




Bulletin No. 1. Indana Departament of Geology and Nitural Resources.

\title{
ON THE COLEOPTERA
}

Known To Occur in Indiana

\author{
$\mathrm{BY}$ \\ W. S. BLATCHLEY, \\ IndianAPOLIS, INDIANA.
}

INDIANAPOLIS .

WM. B. BURFORD, CONTRACTOR FOR STATE PRINTINA AND BINDING 1910 


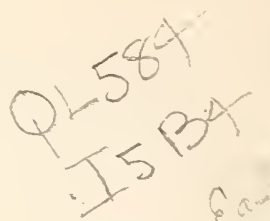

The Department of Geology and Natural Resources was first organized as a Department of Geology and Natural History, its name being afterward changed for political reasons alone. It has therefore been the custom of both the present director of the Department and his predecessors to issue from time to time, in the annual reports, papers on the Natural History of the State. Among the many papers so published have been Jordan's "Fishes of Indiana" in the Sixth Annual Report; Hays" "Reptiles and Batrachians" and Blatchley's "Butterflies" in the Serenteenth Report; Blatchley's "Orthoptera of Indiana" in the Twenty-seventh Report; Cook's "Gall Insects" in the Twenty-ninth Report, and Hahn's "Nammals of Indiana" in the Thirty-third Report.

In accordance with previous custom the following paper on the Coleoptera of Indiana was prepared and offered for publication as a part of the Thirty-fourth (1909) Report. The State Printing Board refused to issue it as a part of said volume, and the paper was therefore withdrawn and is issued as a special bulletin of the Department of Geology, the authority for so doing being embodied in the following section of chapter 181 of the Acts for 1907:

SEc. 2. The director of said Department may, at his discretion, have printed from time to time such matter in bulletin form as he may deem especially important, and the same shall be paid for out of any funds appropriated for the expenses of the Department.

On account of the small sum ( $\$ 3,800$ per year) allotted for the expenses of the Department of Geology, it has been possible to issue but one thousand copies of the bulletin.

W. S. Blatchley.

April 15, 1910.

\section{OF D.}

OCT ह 1910 


\section{An Illustrated}

Descriptive Catalogue

OF THE

\section{Coleoptera or BeEtles}

(EXCLUSIVE OF THE RHYNCHOPHORA)

KNOWN TO OCCUR IN INDIANA

With Bibliography and Descriptions of New Species

By W. S. Blatchley

INDIANAPOLIS, INDIANA 


\section{INTRODUCTION.}

Uf all the many forms of life which exist upon the surface of this old earth of ours, and which are our daily companions for good or ill during our few years' stay thereon, none are more numerous or less known than insects. Not only are they abundant as individuals, but the number of species is many fold greater than that of all other animals taken together. Both on land and in water they occur by millions, yet the life history of even the house-fly is known to but few. Many are the worst enemies with which the farmer hac to contend, while others are to him worth far more than their weight in gold, yet to most farmers the beneficial and the injurious are as one, because he has no way of telling them apart. Not only from his wheat and corn, his grass and trees, his fruit and vegetables do the injurious ones take toll, but on his carpets, his clothes and even his blood they prey. More than six hundred millions of dollars is the average loss they entail to agriculture in the United States alone each year, yet not one farmer in thirty knows the names of a score of different kinds.

The reason of this ignorance is not hard to understand. The first thing which a boy, a girl, or even a man or woman asks about something is, "What is it?" "What is its name?" If nobody can tell them its name or even its position among and relation to the other things about them, they soon forget and ignore it for all time to come, unless by its preying upon them or on their property it causes such harm or loss as to cause them to give it a name of their own. Some of their neighbors may also suffer loss or injury by the same form of life and they may give it a wholly different name. This may continue until the same thing, insect or whatsoever it be, may have half a dozen or more common names. In time, however, a scientist, or one with more knowledge of that particular group of living things, comes along and recognizes that what is known by one name in one place is the same thing called by another name somewhere else. He assigns a technical name, provided one has not already been given it by some other scientist, and shows its place among and relation to all of its kind. If he can do this in such a way that the boy or girl, or the farmer can understand, they will, in future, be able to use the right name when talking or writing about that particular object of nature. 
The name, the place which it holds among other objects of nature, its relation to them and through them to mankind, is therefore the primary or essential knowledge concerning any bird, insect or plant which the true student of nature should desire. He can get the name and its place in nature only through books prepared by the scientist, and if these are lacking his study of nature is most seriously handicapped.

For 25 years the collecting and study of the beetles of Indiana has been one of the hobbies to which I have given much spare time. Happiest those days in which I have wandered far and wide through field and woodland, adding here and there some specimen before unseen, noting now and again some life habit, some food-plant or place of retreat, before unobserved. Ever and always, however, have I felt the need of some one work to which I could refer, some manual or descriptive list by which I could locate the name and place of the specimens at hand. Since the beetles or Coleoptera form one of the most abundant and attractive groups of insects and are easily collected and preserved, they would furnish a favorite subject for study, especially in high schools, could they only be easily named and placed. But the literature through which their original descriptions are scattered comprises hundreds of papers and books, many of which have been out of print for years. The student, therefore, who becomes interested and attempts their study soon gives it up as a hopeless task, unless he has access for reference to some large named collection, or can secure aid from specialists in some locality where such collection is located. Having, as above stated, experienced for years the need of a descriptive work which included the species found in Indiana and adjoining States, and having possessed myself at much cost and labor with most of the scattered literature pertaining to the group, I have prepared the present paper, not for specialists in Coleoptera, but for beginners, a few of whom, I trust, may in time become enough interested to devote their lives to the ever-pleasing, health-giving and inspiring study of Nature. That many mistakes have crept into it there is no doubt, but it is offered as the best that I can give with the faciliiies at hand.

The paper is in very great part based upon species ;which I have seen from Indiana. These are in my private collection, or if not there y uresented, are in the collections of A. B. Wolcott of Chicago, R. L. Wehster of Ames, Iowa, or Chas. Dury of Cincinnati, who have lo aned me specimens from time to time. In a very few in- 
stances, all of which are noted in the text, I have included well recognized species described by Thomas Say from Indiana, examples of which I have not seen from the State. Mr. Say was, from

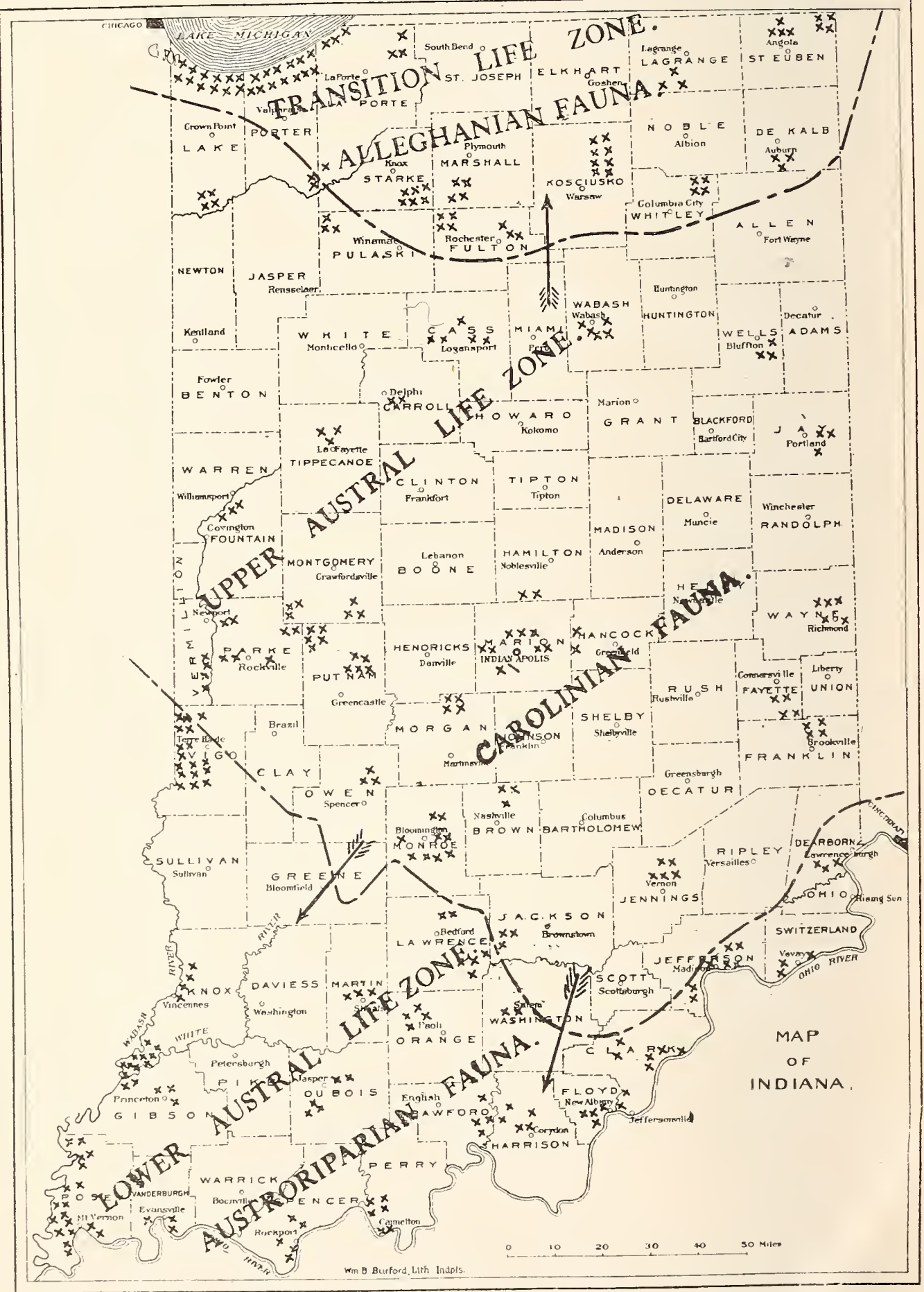

Sketch map of Indiana, showing the life zones of the State and the localities (marked by $x^{\prime} s$ ) in which collecting has been done. The Upper Austral life zone, represented by the Carolinian fauna, covers the entire State, overlapping the Transition life zone represented by the Alleghanian fauna in the north and the Lower Austral !ife zone, represented by the Austroriparian fauna in the south. 
1820 to 1834, the most noted of American Entomologists, and for much of that time resided at New Iarmony, Posey County, Indiana, where much of his writing' was done and where, doubtless, most of his species mentioned as "from Indiana" were taken.

From the accompanying map of the State it will be seen that the collection has been made from so many different localities as to make it a fairly representative one. Wherever a species has been taken in more than five widely separated counties they are not mentioned in detail, but the phrases "throughout the State," "throughout the northern half of the State," etc., are used.

Acknowledgments.-To one situated, as I have been, far from any great reference collection, such a paper would not have been possible had it not been for the aid, usually freely given, * which I have received from noted students and specialists in Coleoptera, throughout the country. To many of these, specimens have been sent for examination, verification or naming. Those to whom especial acknowledgments are due are: Chas. Dury, of Cincinnati, one of the most enthusiastic and successful of naturalists, who has collected beetles for 40 years, and yet seems good for 40 more. He has helped me out with many a species and his collection has added a number to my list from the State. Chas. Liebeck, of Philadelphia, compared and verified many specimens with those in the Horn collection in that city. Frederick Blanchard, of Tyngsboro, Massachusetts, one of the most careful and experienced of American Coleopterists, passed the Haliplidse in review and compared many other species with the Leconte types at Harvard. H. C. Fall and Dr. A. Fenyes, both of Pasadena, California, are specialists, respectively, of Ptinidxe and Aleocharinre, and both have given me much aid in those groups. Mr. Fall has also helped me with some of the Silphidæ and Staphylinidæ. Chas. W. Leng of New York City has passed in review the species of Cychrus and Donacia, and also verified numerous other species which have been sent him from time to time. John B. Smith of New Brunswick; New Jersey, verified all

*An exception must be made of a well known Coleopterist whose collection doubtless contains many specimens from Indians. When $I$ asked the privilege of looking through it for the purpose of making notes on these, he wrote: "I can not admit anyone to my collections for the purpose mentioned, for my specimens are delicately mounted and in places orercrowded, and the resulting damage would be great." When also asked to verify some specimens of Phalacridx, he wrote: "I am too busy to undertake the identification of small species in groups which $\mathrm{I}$ have monographed. I have made my descriptions clear and it seems to me that you can make the identifications with the expenditure of your own time. It is surely not a source of much satisfaction to me to find that a monograph, upon which I have put much time and labor, will not serve the purpose for which it was intended, i. e., to permit others to identify their material." 
doubtful specimens of Mordellidxe, of which family he has made a special study. Frederick Knab of the U. S. National Museum at Washington went over the MSS. and doubtful species of Chrysomelidx, and also compared for me many other species with the types in the museum collection. A. B. Wolcott of the Field Museum of Natural History, Chicago, a specialist in Cleridæ, prepared the MSS. for that family. Mr. Wolcott has also collected for years in the northern part of Lake County. Indiana, especially in the sand-dune region bordering Lake Michigan. All his Indiana material was turned over to me for examination and furnished many species which would otherwise not have been recorded from the State. J. D. Hood of Urbana, Hlinois, who has made a special study of the sexual organs of Lachnosterna, passed in review my species of that genus. Chas. A. Hart of the Illinois Museum of Natural History, has kindly secured for me the loan of numerous volumes from the library of that museum. To Dr. E. A. Schwarz of Washington, D. C., and H. F. Wickham of Iowa City, Iowa, I am also indebted for favors shown.

Nor must I forget the memory of Dr. F. Stein of Indianapolis, with whom I spent many an hour going over and classifying specimens. Dr. Stein had a large and varied assortment of beetles from different parts of the United States, a portion of which came into my hands some years after his death. The pin labels bearing the abbreviation "Ind.' were, however, few, and the dates of capture wholly lacking. For that reason very few, if any, of his specimens have been considered in the present list, though doubtless many of the unlabeled ones came from this State.

Harold Morrison of Indianapolis, C. C. Deam and E. B. Williamson of Bluffton, Dr. Robert Hessler of Logansport, and Mr. and Mrs. Max Ellis of Bloomington, have, from time to time, taken and turned over to me numerous specimens, which have either added to the speries of the collection or aided much in showing their distribution within the State.

\section{RELATION OF A BEETLE TO OTHER ANIMAIS.}

If we compare the body of a beetle with that of any vertebrate animal, as a fish, bird or squirrel, we find at once great and important differences. The vertebrate is an animal with an inner bony skeleton. two pairs of jointed limbs or appendages, and breathes by means of lungs or gills, according as it dwells in air or water. The 
beetle is an animal which has no inner skeleton or bones whatever, but only a hard crust on the surface which surrounds the muscles and vital organs. This crust is composed of separate rings, placed end to end.

Animals whose bodies are thus composed of rings are called $A r$ ticulata. They are in turn divided into two great groups, the Vermes and the Arthropoda. The Vermes (worms) have all the rings composing the body very nearly alike, not hardened into an outer crust or exoskeleton, and without paired limbs which are jointed. The Arthropods have a part of the rings bearing paired jointed appendages, and have the cuticle or outer surface consisting' largely of a peculiar substance called "chitin," which is secreted or exuded by the cells which compose the cuticle. Chitin itself is insoluble and is not composed of cells, but consists of fine, irregular plates. It hardens the cuticle and thus aids the latter in protecting the delicate vital organs within, and also in forming a framework to which the muscles of movement may be attached. Between the joints the cuticle is devoid of chitin and is thin, delicate and flexible, thus allowing the necessary freedom of motion.

The Arthropoda are divided into four classes, as follows:

(a) Crustacea (crayfish, lobster, etc.), mostly aquatic; having the head and thorax usually united and distinct from the abdomen; breathing by means of gills or directly through the skin, the exoskeleton with carbonate and phosphate of lime in addition to chitin.

(b) Arachnida (spiders, mites, etc.), terrestrial; head and thorax usually combined, and bearing four pairs of legs ; breathing by means of tracheæ.

(c) Myriapoda (myriapods, centipedes, etc.), terrestrial; usually worm-like, with only the head distinct; legs numerous ; breathing by means of trachex.

(d) Insecta (grasshoppers, flies, beetles, etc.), in great part terrestrial; legs six; adults usually with one or two pairs of wings ; breathing by a system of tubes called trachere, which branch and ramify through every portion of the body, and which open externally in about ten places on each side of the body instead of at the front end. The rings of the body are grouped in three regions; the head, the thorax and the abdomen. In general it may be said that the head contains or bears the organs of sense and of prehension and mastication of food; the thorax the organs of locomo. tion, and the abdomen those of reproduction. 


\section{THE EXTERNAL ANATOMY OF A BEETLE.}

Having thus seen that a beetle belongs to the class Insecta, it is thought best, before giving its relation to the other orders of that class, to describe briefly the external parts of a typical specimen. The beginner may thus the more readily grasp the name and location of the parts used in classification, as well as the meaning of many of the technical terms which, of necessity, have to be used in such a paper. The three regions of the body, the head, the thorax and the abdomen, will therefore be considered in order.

The Head and Its Appendages.

The front part of the body, the head, is composed of three or more rings or segments, completely fused or compacted into a single hard box or cavity called the epicranium. This contains the brain and accessory ganglia, the mouth cavity and the muscles moving the mandibles, antennæ and other sense organs borne on the outer surface.

The heads of beetles vary great$1 y$ in shape and size, and are joined by a membrane to the thorax. Usually the portion behind the eyes is more or less constricted into a neck, which may be very long and narrow, or short and partly or wholly immersed in the thorax. The upper part of the head is divided into three regions, the back part being called the occiput, the middle part

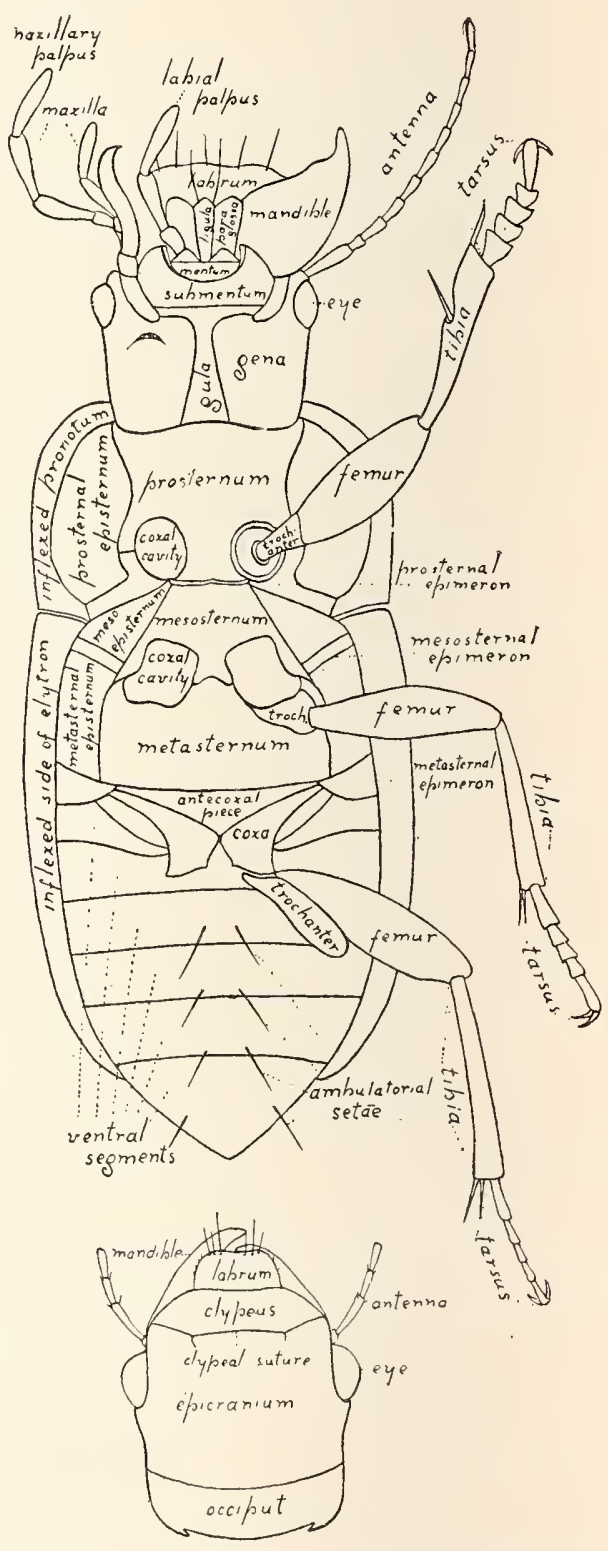

Fig, 1. Under surface and head from above of beetle (Harpalus caliginosus) showing the different parts. (After Smith.) behind the eyes the vertex, while the frontal portion, as far down as a more or less prominent transverse suture between or in front of the antenn:e, is called the front. This suture is known as the clypeal or frontal suture, and its presence or absence, position, depth, etc., is often used in classification. 
Oftentimes, and especially in the greater number of Rhynchophora or snout beetles (not inchuded in this paper), the front is prolonged so that the distance between the eyes and mouth parts is greater in length than the rest of the head. This prolonged portion is called the rostrum or beak, and it usually has on each outer side a groove or scrobe, varying much in length and used for the reception of the long basal joints of the antennæe when in repose.

In most beetles the front is short and the portion in front of the suture is called the clypeus. This varies much in form and size, being sometimes prolonged so as to extend over the mouth. When simall it is by some authors called the epistoma. Its form, texture and the character of its front margin, whether dentate, sinuate, truncate, etc., are much used in classification, especially in the family Scarabæidæe.

The under surface of the head in front is variably excavated to form the mouth. The parts beneath the eyes and behind the mandibles forming the side borders of the mouth are the gene or cheeks. From the opening of the mouth two seams or sutures may usually be observed running backwards. These are the gular sutures, and they often converge at middle but separate at either end.

The Mouth and Mouth Parts. In front of or below the clypens and above the mouth there is usually a small movable flap, called the labrum or upper lip. It is variable in form, is joined to the clypens and is sometimes almost or completely hidden by the latter. In the majority of Rhynchophora the labrum is entirely wanting.

Immediately below the labrum are the jaws or mandibles. They also vary much in shape and size but are usually curved, often toothed on the inner side, and, in certain males, especially those of the Lucanide, are long and often bear prongs, thus resembling somewhat the antlers of a deer. In a number of genera, as those of some Carabidx, the mandibles have a groove or scrobe on the outer side, and this often bears a large puncture from which arises an erect seta or bristle-like hair. The mandibles of beetles are so formed and attached to the epicranium as to move only in and out or to and from a median line. They are used for prehending, cutting, tearing and crushing the food; also often for defense, and rarely as clasping organs. Their range of action is often increased by movements of the entire head, which are permitted by the loose union of the head and thorax.

Attached to the sides of the head just below or behind the mandibles is a pair of aiding or accessory jaws called maxillat. Each 
one consists of two basal pieces and three outer parts. The first or

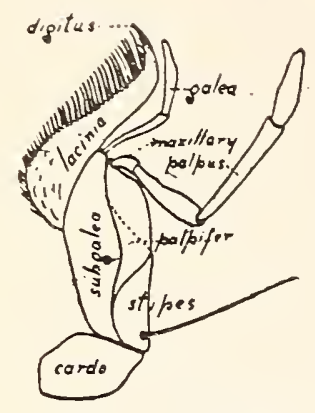

Fig. 2. Maxillæ of Harpalus caliginosus. (After Smith.)

lower one of the former is called the cardo. and is used to hinge the other parts of the maxillix to the head. The second, the stipes, is jointed to the ardo usually at a more or less acute angle. and forms a place of support for the outer parts. These consist of two lobes and one maxillary palpus. The lobes vary much in form and sometimes one or the other is so small as to be indistinct. The outer one, the galea. is often slender and divided into two joints like a palpus. The inner lobe. known as the lacinia, is more or less jaw-like and its inner margin is armed with flexible or stiff bristles. spines or teeth which are rariable in form and often used as brushes by pollen-eating beetles. The maxillary palpus (plural palpi) arises from an upper segment of the stipes. called the palpifer. The palpi are usually t-jointed, rarely 3jointed (in the genus Aleochara alone 5-jointed). The joints vary greatly in size and form and are therefore much used in classification. The fourth one is most variable, sometimes being broad and oral or subquadrate, more often triangular or hatchet-shaped. When suddenly narrowed and more slender than the preceding. the palpi are said to be subulate or awl-shaped. The development and shape of the maxillix of beetles. as of other insects. depend very largely upon the nature of the food, as those organs serve not only to seize and hold the food in the mouth. but also as accessory jaws. aiding the mandibles in rendering the food more suitable for swallowing. Their palpi are not only organs of touch. but in many cases act as hands in prehending and carrying morsels of food to the mouth.

The floor of the mouth beneath and between the maxillix is formed of two small pieces called the mentum and the labium. The mentum is joined to the gula or throat. which is the region behind or below the mouth. the suture between them being the mental suture. The mentum varies greatly in form and size and is often notched or emarginate in front, with a tooth at the middle of the emargination. When deeply notched the side-pieces are called lobes.

The labium is usually in front of the mentum or in the notch between the lobes: rarely it is almost entirely hidden. It is composed of three parts. a central piece. the ligula. and two side-pieces called the paraglossa. The labium is often wholly horn-like in texture, in which case the paraglossa are not distinct. In such case the 
terms ligula and labium are often used stmontmoush. IIowever, in the descriptions which follow. the term ligula is used to designate the piece in front of the mentum bearing the labial palpi. These palpi are usually 3-jointed (in certain Staphylinids 2- or even $t$ jointed). The terminal joint is often of the same form as that of the maxillar' palpi. and offers in many cases important characters used in classification. Both mentum and labium form an under lip which prevents the food from falling backwards ont of the mouth and, with the aid of the maxillæ. pass it formard to be crushed between the mandibles. the two sets of appendages thus acting much as the tongue of vertebrates.

The Eyes. The eyes of beetles rary greatly in size and shape. and each is composed of a large number of facets or simple lenses in each of which a single filament of the optic nerve ends. These lenses also rary much in size. and the terms " coarsely granulated" and "finely granulated" are used to denote this rariation. In the family Grrinida and in the genus Oberea the eres are wholly dirided. two being above and two on the lower surface of the head. thus enabling the beetle to see upward and downward at the same time. In many species of Cerambreida and other families the are often deeply notched or emarginate. either in front or on one or the other of the sides. Rarely ther are wholly wanting: rarely. also, as in certain Staphrlinids. there are one or two simple eres or single lenses called ocelli located on the back part of the rertex. between the compound ones.

In the Cicindelidie and many of the Carabidxe the head bears. in addition to the regular pubescence. rather long. erect setie or bristle-like hairs. which arise from special punctures located abore and close to the inner margin of the exes. These are known as supraorbital setie.

The Antenne. The principal appendages attached to the head are the antennce. Ther rary greatly in form. point of insertion. and number of joints. and these characters are much used in classification. In the true Coleoptera they are inserted in front of or more rarely between the exes. often under the side margin of the front. In the Rhrnchophora they are borne upon some portion of the beak. The number of joints raries from two in Adranes to 25 or 27 in Prionus. the usual number being 11 . The basal joints are usually less pubescent and of a firmer texture than the outer ones. In the latter the surface is usually more or less corered with minute pores which increase greatly the sensitive area. In those genera in 
which the antennx end in an abrupt club the pores are confined to its surface; in most cases, however, they are generally scattered over all except the basal joints.

The principal forms of antennæ are as follows:

(a) Filiform or thread-like, where the joints are cylindrical and the outer ones not or scarcely enlarged.

(b) Setaceous or bristle-like, where the joints are gradually more slender to the tip.

(c) Capillary or hair-like, where the joints are long, slender and very loosely united.
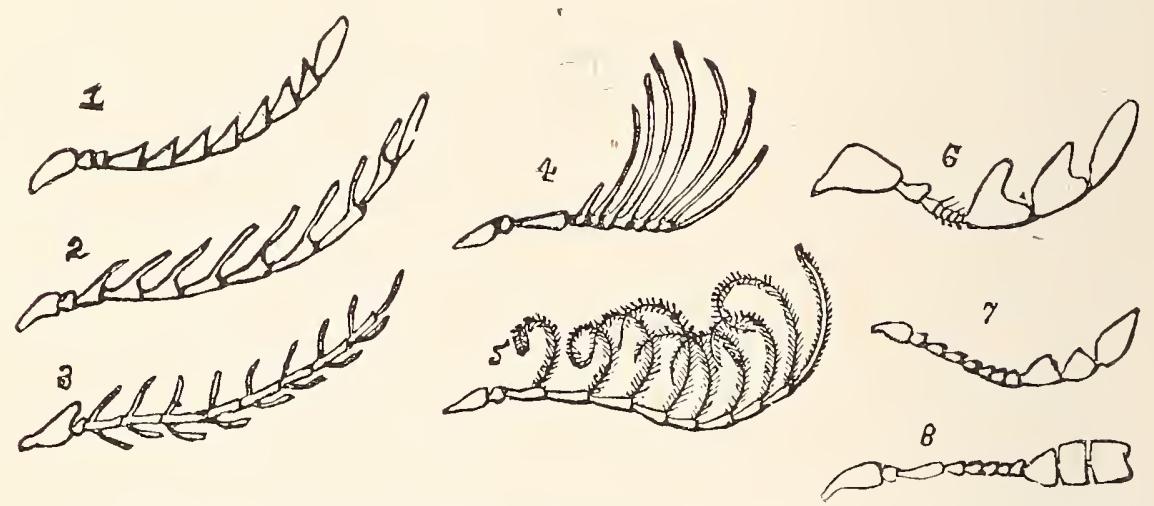

Fig. 3. Serrate antennæ and modifications: 1, serrate; 2 , pectinate; 3 , bipectinate; 4 , flabellate; 5 , plumose; $6,7,8$, irregularly serrate. (After LeConte and Horn.)

(d) Moniliform or bead-like, when the joints are of nearly uniform size and rounded, thus resembling a string of beads.

(e) Serrate or saw-like, when the joints are triangular and compressed, presenting therefore a saw-tooth-like outline on the front margin.

(f) Pectinate or comb-like, when the joints are short, with their front angles much prolonged.

(g) Bipectinate, when each joint has a comb-like tooth on each side.

(h) Flabellate or fan-like, when the prolongations from the joints are very Iong compared with the antennæ, and fold together like a fan.

(i) Plumose or feather-like, when the prolongations are long, slender and flexible.

(j) Clacate or club-like, where the outer joints are more or less enlarged, but not triangular or leaf-like. This is among beetles the most common form of antennæ, and it grades gradually into most of the other types. 
(k) Capitate or head-like, when the outer joints are suddenly larger, forming a compact rounded elub.

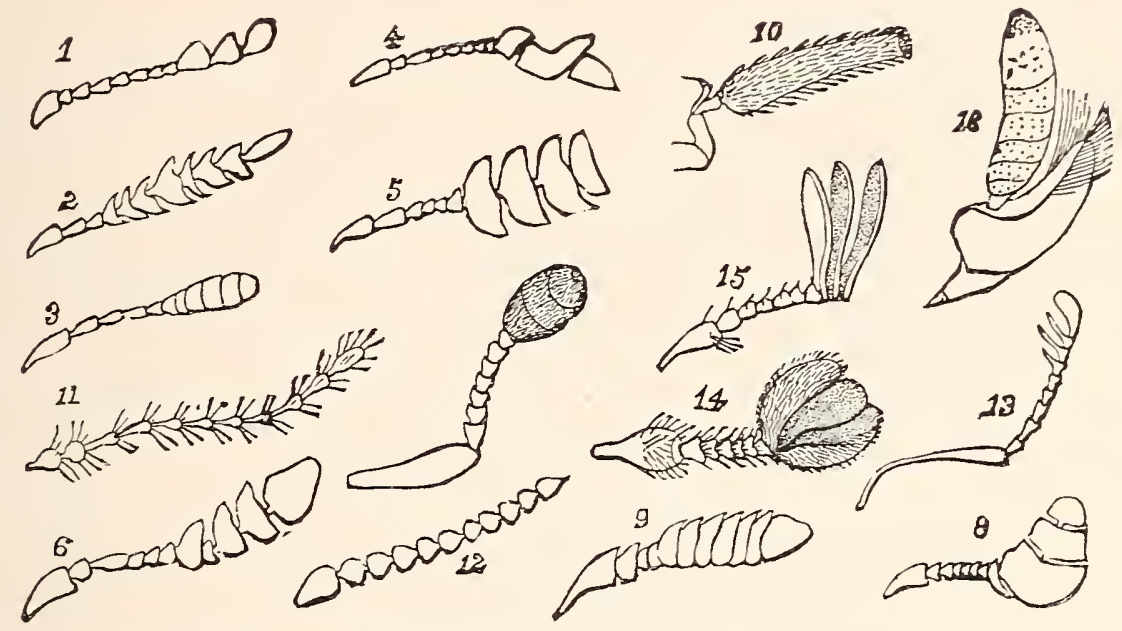

Fig. 4. 1-10, Forms of clavate antennæ; 11, capillary and verticillate; 12, moniliform; 13, 14, 15, lamellate; 16, irregular. (After LeConte and Horn.)

(l) Lamellate, a form of clavate antennæ in which the outer joints are leaf-like plates which may be brought closely in contact, thus forming a transverse or rarely rounded club, supported at one side by the stem of the antennæ.

The antennæ are said to be geniculate or elbowed when the second joint is attached to the first in such a way as to make an obtuse angle, the joints after the second following in the same line as the latter. In this form the first or basal joint is usually much longer and is called the scape. When the antenna is both geniculate and capitate, the joints between the scape and club are together called the funicle.

The antennal grooves are concave. usually elongate and narrow areas on the under side of the head or prosternum, in which the antennæ are concealed or placed in repose. When on the under side of the head they usually are close to the eye and converge on the guta.

The antenna of beetles are supposed to be primarily organs of smell, but also bear nerves of touch. In a number of species they are put to other uses; it being said that certain Cerambycids in walking along a slender twig use them as a rope-walker does his balancing pole; while those of certain aquatic forms are used in connection with respiration, and those of the male Meloe as clasping organs. 


\section{The Thorax and Its Appendages.}

The second division or middle region of the body of an insect is called the thorax and consists of three rings or segments, known respectively as the prothorax, mesothorax and metathorax. Within these rings are located the muscles moving the legs and wings, as well as some of the digestive organs, while attached to their upper surface are the wings and to the lower one the three pairs of legs.

The Prothorax. In the beetles the prothorax or front ring is separated from the other two and is usually freely movable. It consists of a dorsal or upper surface of but one piece and a ventral or lower part of five pieces. The upper part is often called the pronotum, but in this paper it is termed the thorax, since it is the median one of the three body parts visible from above. In the different species of beetles it varies greatly in size and sculpture, and these variations are very extensively used in classification.

The dorsal surface is calied the dist, and this is usually separated from the inflexed portion or flanks by a sharp edge or acute margin. The relative width and length of the disk, the form of its front and hind angles, the presence or absence of a median impressed line and of impressions or fover, the form, size and density of the punctures when present, are but a few of the many points pertaining to the thorax which are used in the description of a beetle.

The Prosternum. The central part of the under surface of the prothorax is the prostermum. It is situated in front of the coxie of the first pair of legs and often has a process or spine which extends backward between these coxæ. its tip sometimes, as in the Elateridie, fitting into a notch or groove in the mesosternum. The prosternum is sometimes prolonged in front to form a prosternal lobe, which more or less conceals the mouth when the head is in repose. On either side of the prosternum and between its side margin and the flank of the pronotum (or thorax), are one or two "side-pieces." When both pieces are present the front one is called the epistermum (plural episterna), and the hind one the epimeron (phural epimera). Most frequently the sutures or seams between these pieces and also between them and the flank of the pronotum are wanting, so that the disk and flanks of thorax form one unbroken piece as far as the side of the prosternum. The sutures separating the prosternum and the side-pieces are more often present and are known as the prosternal sutures.

The cavities in which the first pair of legs are inserted are called 
the front coxal cavities and are either "entire" when they are enclosed behind by the junction of the prosternum and the epimera (the episterna never reaching the coxal cavities proper), or are "open behind" when a space is left protected only by a membrane. They are "separate" when the prosternum extends between them, or "confluent" when it is not visible between them.

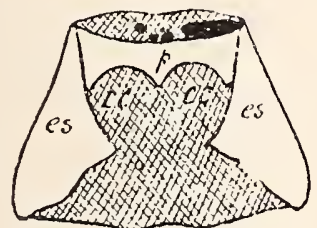

a

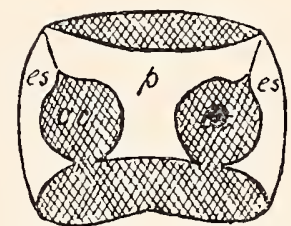

l.

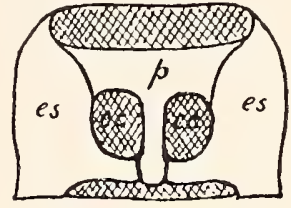

$c$

Fig. 4a. $\quad p$, indjcates the prosternum; $c c$, the coxal cavities; $e s$, the thoracic sidepieces. In $a$ the coxal cavities are widely cpen behind and confluent; in $b$ they are narrowly open behind and separate; in $c$ they are closed behind and separate.

(After Wickham.)

The Meso- and Metathorax. The middle or second thoracic segment is called the mesothorax, and in the beetles is very closely united with the third or hindmost one, the metathorax. These two form the trunk or main body of the insect, and support on their under surface the middle and hirid legs and on the sides above the inner wings and elytra. The upper surface of these two segments is for the most part covered by the elytra and therefore invisible. It consists of four pieces, only one of which, the scutellum, a small, shield-shaped or triangular plate, is usually visible from above between the bases of the elytra. The mesothorax is much reduced in size, its chief function being to support the elytra and to help keep them together by means of its scutellum.

The ventral or lower portions of these segments consist of the same pieces as the prothorax, viz., the mesosternum with its sidepieces or episterna and epimera, and the metastermum, with the same. These pieces are usually distinct, except that the two of each segment are often united to form a single piece. The suture which separates the side-pieces of the mesosternum from those of the metasternum is always present. The form and size of these side-pieces is a character much used in classification.

The Wings. The great majority of adult beetles possess two pairs of wings. The first or onter pair, known as the elytra (singular elytron), or wing covers, are present, except in a few females of the family Lampyridx, are horn-like in texture and vary greatly in shape and sculpture. They are attached to the mesothorax and usually cover the upper surface of the abdomen, but in many genera 
are much shorter, leaving several segments of the abdomen exposed. Almost always they fit closely together in a straight line along the middle, this line of junction being called the suture. Rarely they are somewhat separated near the tips, when they are said to be dehiscent. Their outer front angle or shoulder is known as the humerus (plural humeri). As in the thorax, the sides of the elytra are often separated from the upper portion or disk by an acute margin, beneath which a portion of each elytron is inflexed. Lying next to the edge or margin is a piece of varying width and sometimes extending from base to apex known as the epipleura. The entire inflexed portion is often, but wrongly, called the epipleura.

The tips or apices of the elytra vary greatly in shape, sometimes being truncate, more often rounded and rarely ending in sharp points or even spines. Oftentimes the side margins are more or less deeply sinuate near the tips.

The sculpture of the elytra is much used in classification. Very often the disk is marked with longitudinal impressed lines or fine narrow grooves called strice. An elytron so marked is said to be striate. The space between any two of these strix is termed an interval. When the striæ are fine and shallow, the intervals are usually flat or nearly so; when deep and rather wide, the intervals are more or less convex. Very often the striæ are punctate, i. e., marked by rows of punctures or impressed dots. The intervals are also often punctate or punctulate, the latter term meaning that the punctures are very fine. When the punctures are absent from striæ or intervals they are said to be smooth or impunctate. When the punctures are not in rows but seattered here and there over the surface of the elytron they are termed irregular or confused.

In addition to the ordinary punctures above noted, or often when the elytron is otherwise smooth there may be present one or more larger impressions called dorsal punctures. These are usually somewhere between the suture and the third stria, though they may be anywhere on the disk. Quite often the entire upper surface of the elytra (as well as that of either or both the head and the thorax) may be seen under a lens to be very finely reticulated or covered with minute cracks like the human skin. The surface is then said to be alutaceous. When densely alutaceous the surface is generally more or less opaque. In addition to the forms of sculpture above mentioned the elytra may be granulate, or covered with many minute elevations; tuberculate, or with fewer and larger elevations. They may also be pitted, foveate or impressed in many ways. In addition to the sculpture they, as well as other parts of the body, 
may be either sparsely, moderately or thickly clothed with hairs or pubescence, which may be prostrate, suberect or erect in position. When the pubescence is wholly absent and the surface bare they are said to be glabrous.

The hind pair, known as the inner or true wings, of beetles are membranous and attached to the metathorax. They are usually so arranged as to form a joint near the apex so that the entire wing can be folded under the elytra. In some species with short wingcovers the inner wings extend straight along the dorsal surface of the abdomen. Frequently they are abbreviated or wholly absent, in which case the metasternum is usually short and the elytra closely united or connate along the suturè.

The Legs. As already noted the three pairs of legs possessed by the mature beetle are joined respectively to the under surface of the pro-, meso- and metasterna. The first joint of each leg. or that by which it is attached, is called the coxa (plural coxce). These vary much in shape and size and their. form is therefore of great importance in classification. The front coxal cavities are formed by the prosternum and its epimera or side-pieces. The middle coxæ are surrounded by the meso- and metasterna and, in some Carabidr, by the epimera of the former. The hind coxæ are placed between the metasternum and the first segment of the abdomen.

At the outer end of the coxa and between it and the femur is a small piece called the trochanter. This is usually situated in the axis of the thigh and varies much in form, being more or less obliquely cut off. The first long piece of the leg is the thigh or femur (plural femora); following it is the shank or tibia (plural tibice), the junction of the two being called the inee. Both of these may be more or less toothed or spined and the tibiæ usually bear at their outer or lower extremity one or two movable spines called tibial spurs. Attached to the tibix is the foot or tarsus (plural tarsi), consisting of from one to five pieces placed end to end, though sometimes overlapping. The number and form of these tarsal joints varies exceedingly. The greatest number is five, and when one disappears it is usually lacking on all the tarsi. However, in one large group, the Heteromera,

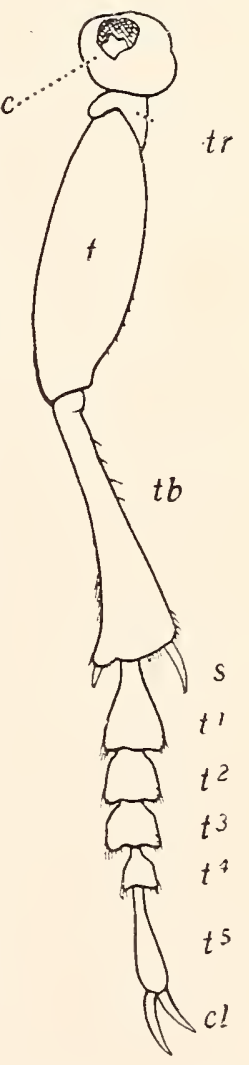

Fig. 5. Leg of a beetle, Calosoma calidum. $\quad c$, coxa; tr, trochanter; $f$, femur; tb, tibia; $s$, tibial spur; $t^{1}-t^{5}$, tarsal joints; $d$, tarsal claws. (After Folsom.) the front and middle tarsi each hare five joints, while the hind ones 
have but four. Sometimes the number of joints varies in the sexes of the same species.

In form the tarsal joints may be slender and cylindrical, compressed, flattened and dilated, globular, triangular or cordiform. Frequently the next to last joint is notched or even bilobed. In some genera the under side of one or more of the joints bear membranous flaps called tarsal lobes. Usually, however, the under side is clothed with spines, hairs, spongy pubescence or small scales. Oftentimes the nature of this lower covering varies according to sex. The front or middie tarsi, or both, are often dilated in the male, and simple, or not dilated, in the female of the same species.

The last joint of the tarsus bears two claws, often called ungues, but in this paper termed tarsal claws. They also vary much in size and shape and the character of their lower edge. They are usually free and independently movable, but are sometimes united at base or even nearly to the tip, when they are said to be comnate. Other terms applied to them are $(a)$ simple, when they have the ordinary pointed form slightly but not suddenly broader at base; $(b)$ divergent, when without being distant at base they diverge slightly; (c) divaricate, when they arise Irom opposite sides of the joint and form a right angle with it; $(d)$ cleft, when each claw is deeply divided into two acute parts which may or may not be of equal length ; (e) bifid, when the tip only is divided; ( $f$ ) appendiculate, when provided with a square dilatation at the base; $(g)$ toothed or serrate, when they bear one or more acute teeth on the lower edge; (7.) pectinate, when the teeth are long, numerous and arranged like those of a comb; (i) chelate, when the claws are capable of being drawn back upon the last tarsal joint and thus enable the beetle to grasp more firmly small twigs or leaves. Between the claws there often occurs a small pad or flap which is more or less retractile. called the onychium. One of the claws is often much smaller than the other and rarely one or even both of them are absent.

\section{THE ABDOMEN:}

The third or hindmost portion of the body is called the abdomen. It consists of nine or ten rings or segments placed end to end, the basal one being attached to the metathorax. Of these but five to seven are usually visible, the others being retracted or coalescent at base and tip. These rings are divided into two portions, the upper or dorsal segments more or less covered by the elytra, and the lower or ventral segments visible beneath. These dorsal and ventral segments are joined by membrane along the sides above, the next to last 
pair being usually more firmly united. On raising the elytra the number of dorsal segments visible is almost always greater than those below, and in most cases their texture is less dense and often membranous.

The breathing pores or spiracles, opening into the trachex or air tubes, are located in the connecting membrane or in the upper inflexed portion of the ventral segments; an additional spiracle is also usually located on the under side of the prothorax behind the outer limit of the coxal cavity.

The anal opening is located between the last dorsal and the last ventral and just below it is the genital opening. Each side of this are horny valves, sometimes of very complex structure, termed the genital armature.

Where the dorsal segments are not covered by the elytra, the last one is called the pygidium and the next to last the propygidium. The ventral segments may be either entirely free, so that the abdomen is flexible, as in the Staphylinidae, or they may be more or less closely united so that the last one alone is movable. The cross sutures connecting them are usually plainly visible. Both they and the dorsal segments are, however, often punctured or otherwise sculptured, and pubescent, as is also the under surface in front of the abdomen.

Stridulating organs, used for producing sound or sexual calls, are present in a number of species, but are much less common and more simple than in the Orthoptera. They usually consist of fine wrinkles or ridges placed side by side, and the sound is produced by rubbing over these some other nearby portion of the body. For the most part these ridges are located upon some one of the abdominal segments and are rubbed by either the elytra or the hind legs.

The above constitute the more important external parts of a beetle, the characters of which are used in determining its name and position among the members of the order Coleoptera. As already seen, these different parts vary much in size and form, but the names above given to them apply as well to the members of one family as to those of another. Many other descriptive terms will also be found in the pages which follow, but they, for the most part, will be self-explanatory, or will be defined in the accompanying glossary. By referring to such figures as are given and by observing very carefully the parts of the specimen in hand, the beginner need have but little hesitation in deciding as to whether the description agrees with that specimen. 


\section{RELATIONS OF THE BEETLES OR COLEOPTERA TO OTHER INSECTS.}

All true insects can be separated into one of two great groups, based upon the kind of changes or transformations which they undergo before reaching the adult or winged stage. To one group, the Heterometabola, belong those insects in which the metamorphosis (or changes which they undergo after hatching from the egg $\mathrm{g}^{\prime}$ is incomplete. In this group the young, when hatched, is of the same general form as the parent, but wholly wingless. As the insect grows it moults its skin a number of times and wings develop gradnally, there being no sharp line defining the larval and pupal stages. The young of all stages are called "nymphs;" they continue active and feed from the time of hatching until they reach the final moult and emerge therefrom mature or in the imago stage. Familiar examples of the Heterometabola are the locust, grasshopper, katydid, dragon-fly, squash-bug and chinch-bug.

The second group, the Metabola, comprises those insects which undergo what is termed a complete metamorphosis. In this group there are four distinct stages-the egg. larval, pupal and imago-in the order named. No insect is hatched from the egr with wings, and when an insect reaches the winged stage it is adult, and never grows thereafter. Thus the gnats and midges are not the sons and daughters of the larger flies, but are full-grown insects of themselves, which are undergoing the fourth or last stage of their lives. The second, the larral or worm-like stage, is the one in which the insect of this group is commonly the most injurious, for then it eats voraciously, and then is the only period of its life when it grows in size. The pupal, or third stage, is usually a quiescent one, the insect eating nothing and not increasing in size, but undergoing great changes of form. Thus the homely and often repulsive grubs, maggots and caterpillars, which are the larval forms of the beetles, flies and butterflies, respectively, enter the third stage as worm-like, crawling creatures, and emerge from it as beautiful winged forms, sometimes glistening and gleaming with all the colors of the rainbow. This change of life and form is undoubtedly of great advantage to most of this group of insects, as it tends to prevent the extinction of the species; since. if at a given moment the parents were swept nut of existence, the roung. living in a different station, would continue to represent the species.

It is to this second group, the Metabola, whose members undergo a complate metamorphosis, that the Coleoptera or beetles belong. 
From the other orders of this group (viz., the Diptera or flies, the Lepidoptera or butterflies and moths and the Hymenoptera or ants, bees and wasps), the Coleoptera may be known by having the front uings or elytra not fitted for flight, but shell-litie, reposing on the back of the body and fitted together along the middle in a straight line or suture; inner wings membranous and folded beneath the clytra; mouth with mandibles; lower lip not divided along the middle.

The name Coleoptera is derived from two Greek words, coleos, a sheath, and pteron, a wing, and refers to the shield-like covering afforded by the elytra. At the present time the Coleoptera are far more numerous in species than any other order of insects, about 150,000 being known and named from the different regions of the earth. Of these about 12,000 species are known from North America. While much more numerous than the flies, bees and butterflies, they are less often seen, as their habits are terrestrial rather than aerial in nature.

\section{THE CLASSIFICATION OF COLEOPTERA.}

As in other classes and orders of animal and plant life, the beetles or Coleoptera of North America have been carefully studied by various students, and to each species has been given a specific Latin name. Each species has also been assigned to a certain gemus. or group of species agreeing in some one character or series of characters, which also bears a Latin name. These two Latin names combined, followed by the name or abbreviation of the person who first recognized the beetle as an undescribed form and gave it a specific name, comprise the name by which the beetle is or should be known whenever it is spoken or written about. For example: one of our common June beetles was first described in 1844, by Dr. F. E. Melsheimer. under the name rugosa. However, he assigned it to the genus Ancylonycha of Dejean. If it had been left in that genus its name for all time should have been written Ancylonycha rugosa Melsh. However, later witers have found that this species, together with a large number of others, belong to a group whose common characters were first pointed out by Rer. F. WT. Hope in 1837. To this group Hope gave the generic name Lachnostema, so that the name of the beetle described by Melsheimer is now recognized as Lachnosterna mgosa Nelsh. The genus. or generic name to which any species is assigned is largely a matter of opinion. but the specific name, if not before used for a member of that genus, is final unless 
changed for some good reason by the describer himself. Of course it often happens that the author of a supposed new species is wrong in his conclusions, and that it has been described before under another name not recognized by him. In such a case his name is but a synonym and has no scientific standing.

In the name Lachnosterna rugosa the specific name rugosa corresponds to the given name as "John" or "James," and the generic term Lachnosterna to the sur- or family name, as "Smith" or "Jones." The name given the beetle is therefore of the same nature as that given a man, but is in Latin and is written backward, as Smith John. There may be any number of species of Lachnosterna, but there can only be one of them named rugosa. The generic name is always begun with a capital letter and the specific name with a small letter, this being the common usage among zoologists in general.

The generic and specific names usually have some well-defined meaning, "Lachnosterna" in the case mentioned, being derived from two Greek words meaning "wool + breast," as most species of that genus have the sternum or breast more or less covered with wool-like hairs. The specific name rugosa means "rough," and was given the beetle on account of the wrinkles on the elytra. After the generic headings in the pages which follow, the date on which the genus was first proposed by its author, and the derivation or meaning of the generic name is, in most instances, given.

A group of genera, having certain characters in common, conprises a "tribe" or "subfamily," and these in turn are merged into larger assemblages called families. Our beetles are so little known that as yet but few of them have common names. When such a name is well established it is mentioned in connection with the specific description. However, the species of each family have usually one or more common names which are applied to them collectively, as "tiger beetles" for the Cicindelidx, and these names are always given under the family heading.

Keys of the Catalogue. In order that the student may determine the more readily the scientific name for himself, "keys" or "tables of determination" are made an important part of the work. These are, when necessary, for families, subfamilies, tribes, genera and species in the order named. When there are but two species belonging to a genus the specific key is usually omitted. These keys contain, for the most part, a few of the more salient or easily recognized characters separating the genera or species. In most instances, to avoid repetition, these characters are not again given in 
the brief descriptions which follow, and the keys should, therefore, always be used in connection with the descriptions. It is also important to bear in mind that the characters used and statements made, both in the keys and descriptions, are to be considered as applying only to the species of the Indiana fauna or those of adjoining States. They may be, and in general are, capable of much wider application, but it is not safe to assume that such is the case.

In the "keys to genera" are included the characters leading up to the names of those genera which, from their known representation in adjoining States, are probably represented in Indiana, even though no species belonging to them has as yet been taken. The same is often true of the "keys to species." Many species are therein included, but not thereafter described, whose known range is such that it is very probable that they occur in some part of the State. The future collector or student will therefore be able to identify almost any species which may come to hand from Indiana or adjoining territory.

The number in parenthesis before the name of each species is that of the Henshaw "List of the Coleoptera of America north of Mexico," or the Third Supplement to the same.

The dates given after the description of each species are only the earliest and latest at which the species has been noted in the State and do not, therefore, necessarily show the actual time of appearance or disappearance. The asterisk (*) preceding the name of a species indicates that the species was taken in the winter season in Vigo County, and was mentioned specifically in my "Notes on the Winter Insects of Vigo County, Indiana,' published in Psyche, vol. VII, 1895-96.

Measurements.-Since the beetles are mostly of small size, the unit of measurement used in the descriptions is the millimetre (mm.) which $=.0394$, or a little more than $-\frac{1}{25}$ of an inch. The smaller divisions of the accompanying scale (Fig. 5a) show, as ac-

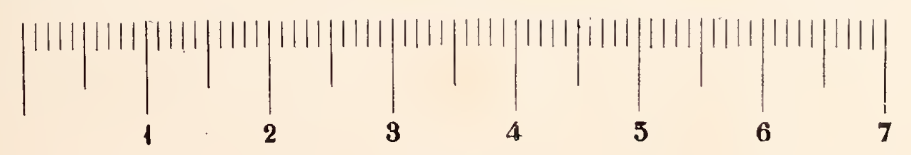

Fig. 5a.

curately as can be represented, the length of a millimetre. For all practical purposes it may be remembered that $2.5 \mathrm{~mm} .=\frac{1}{10}$ inch; $3 \mathrm{~mm}$. $=\frac{1}{8}+$ inch; $4 \mathrm{~mm} .=\frac{1}{8}+$ inch; $5 \mathrm{~mm} .=\frac{1}{5}$ inch; $7.5 \mathrm{~mm}$. = $\frac{3}{10}$ inch $; 10 \mathrm{~mm} .=\frac{2}{5}$ inch $; 12.5 \mathrm{~mm} .=\frac{1}{2}$ inch; $15 \mathrm{~mm} .=\frac{3}{5}$ inch; 17.5 
$\mathrm{mm} .=\frac{\mathrm{T}}{10}$ inch $; 20 \mathrm{~mm} .=\frac{4}{5}$ inch. The divisions of the scale separated by the longer lines 1,2 , 3 , etc., are centimetres.

Bibliography and Synonymy. The titles, with names of the authors, of the principal papers used in the preparation of the "Descriptive Catalogue" are given under each family, tribe or genus. These papers have been used freely, but in general no credit has been given them. This was not from a lack of a sense of "justice due," but solely in order to save space. Wherever possible the species in hand has been studied in connection with the original description and the citation given after the name of each species is to that description alone. However, in the case of species described by Thomas Say, the citation is not only to the place of original description, but after the term "ibid," to the volume and page of the Leconte edition of Say's works, which is the one in common use.

Aside from the papers mentioned in the body of the work there is one to which especial tribute should be paid, and without which the preparation of this or any other paper dealing with the majority of families and genera of North American Coleoptera would be practically impossible. This sine qua non is Leconte and Horn's "Classification of the Coleoptera of North America," published in 1883 as No. 507 of the Smithsonian Miscellaneous Collections. It is a veritable storehouse of knowledge, which is a lasting monument to the fame of the two greatest Coleopterists which this country ever had or probably ever will have. From it have been taken the main facts used in characterizing the families and most of the genera represented in Indiana. The only fault to find with the "Classification" is its extensive use of technical language, which renders it a kind of "bug-bear" to beginners. This I have tried to remedy by simplifying, in many instances, the terms there used, even at the expense of space which could be ill spared.

In addition to the "Classification," LeBaron's "Fourth Annual Report on the Noxious and Beneficial Insects of Illinois," Comstock's "Manual for the Study of Insects," and Sharp's "InsectsPart II," have been the general works most used. 


\section{A DESCRIPTIVE CATALOGUE OF THE COLEOPTERA}

(Exclusive of the Rhynchophora.)

\section{KNOWN TO OCCUR IN INDIANA.}

The insects of the Order Coleoptera, sufficiently defined on a preceding page, are separated into two suborders as follows:

KEY TO SUBORDERS OF COLEOPTERA.

u. Mouth parts normal, rarely unfit for use, never aeparting from the ordinary type; palpi always Hexible, maxillary usually four-jointed, labial three-jointed; gular sutures double, at least before and behind; proster'nal sutures distinct. Suborder I. CoLeoptera (genuina). au. Head more or less prolonged in front to form a beak; palpi usually rigid and not evident; gula not evident; prosternal sutures wanting.

Suborder II. RHYNCHOPHORA.

On account of a lack of time and space, the Rhynchophora of the State are not treated in the present paper. A large collection of them is, however, at hand, and they will, if circumstances allow, be catalogued and described in a future treatise.

\section{Suborder I. COLEOPTERA (genuina.)}

This suborder is divided into the following series or groups of families :

KEY TO SERIES OF COLEOPTERA (genuina).

a. IIind tarsi (except in a few Clavicomia) with the same number of joints at least as the other's.

b. Fourth and fifth tarsal joints not united, the fifth, when present, always distinct.

c. First three ventral segments united, the first divided by the hind coxal cavities so that the sides are separated from the very small median portion; all the tarsi five-jointed; antennæe filiform or nearly so; habits mostly predaceous.

Series I. Adel'haga, p. 26.

cc. First ventral segment visible for its entire breadth (except in Rhyssodidre).

d. Antennæ with the terminal joints not lamellate or leaf-like and capable of separation.

$e$. Antenna clavate or capitate, very rarely serrate; species living for the most part in decaying animal and vegetable matter.

Series II. Clavicornia, p. 242.

ec. Antennæ with joints from the third onward more or less serrate or saw-toothed, very rarely clavate or capitate; food variable, but rarely decaying animal matter.

Series III. Serricornia, p. 686 . 
dd. Antenne with the terminal joints forming a lamellate club composed of movable plates or leaves, capable of separation and usually of accurate apposition; legs more or less fossorial; tarsi five-jointed; food variable, either decaying wood, dung. carrion or foliage.

Series IV. LAMELICORNIA, p. 903.

bb. Fourth and fifth tarsal joints firmly united, the fourth joint very small, the tarsi therefore appearing but four-jointed; sole usually densely pubescent; antennæe filiform, rarely serrate or thickened towards tip; leaf-eater's or wood-borer's.

Series V. Phytophaga, p. 1005. aa. Front and middle tarsi five-jointed, hind tarsi four-jointed, the joints usually slender and bare or at most sparsely haired or spinose; other characters and food habits very variable.

Series VI. Heteromera, p. 1242.

\section{Series I. ADEPHAGA.}

The members of this series always have the mouth parts highly developed, the outer lobe of the maxillæ being nearly always divided into a two-jointed palpus, so that there appear to be six palpi. Abdomen with the exposed segments one more in number at the sides than along the middle, the number usually being five along the middle and six at each side. They are for the most part active, predaceous and carnivorous in habit. Five of the seven families comprising the series are represented in Indiana.

\section{KEY TO INDLANA FAMILIES OF ADEPHAGA.}

a. Terrestrial species; antenne with at least the six outer joints pubescent; metasternum with an antecoxal piece, separated by a well marked suture, reaching from one side to the other and extending in a triangular process between the hind coxie.

b. Antenna inserted on the front above the base of the mandibles; inner lobe of the maxillie ending in a movable hook; eyes large and prominent; head vertical, wider than thorax.

Family I. Cicindelide, p. 27.

66. Antenne arising from the side of the head between the base of the mandibles and the eyes; inner lobe of maxillæe not ending in a movable hook; eyes usually of moderate size; head horizontal or slightly inclined, usually narrower than thorax.

Family II. Carabide, p. 36.

au. Aquatic species; antennæ destitute of pubescence; metasternum (except in Haliplidx) without an antecoxal piece but prolonged behind in a triangular process.

c. Eyes two; antennæe slender and filiform or setaceous; abdomen with six segments.

d. Antemne ten-jointed; hind coxre prolonged as large plates covering the femor:a and a large part of the abdomen; hind legs not formed for swimming.

Family III. Haliplide, p. 200. 
dd. Antennie eleven-jointed; hind coxal plates not covering the femora; lind legs with fringes of long hairs, usually compressed and formed for vigorous swimming.

Family IV. Dytiscide, 1). 204.

cc. Eyes four; antenna irregular, very short; abdomen with seven segments; middle and hind legs forming short, broad paddles.

Family V. GrRinide, p. 236.

\section{Family I. CICINDELID A.}

\section{The Tiger Beetles.}

To this family belong those oblong, predaceous ground beetles which occur for the most part along sandy banks of streams, roadways and woodland paths. They are among the most handsome and agile of our beetles, the legs being slender and adapted to running. Most of the species possess inner wings and when pursued they often run swiftly for several feet, then take a quick flight, but usually alight several rods in advance of where they were flushed. Upon alighting they usually turn so as to face the pursuer.

The antenni are 11-jointed, filiform and slender, inserted on the front above the base of the mandibles, which are long and sharply toothed; terminal hook of the maxillæ movable; eyes prominent; tarsi all 5-jointed; hind coxæ mobile and simple.

The name of the principal genus, Cicindela, is derived from the Latin candela, a candle or taper, and was applied by the ancients to the glowworm. The common name, tiger beetle, portrays well the habits of the mature insect, which is ever eager to seize upon some weaker form of life which will serve it as prey. The name is also suggestive of the stripes or spots with which the elytra of many of the species are marked. The males may be known by their having the sixth ventral segment broadly notched, so as to expose a seventh segment, which is invisible in the female; and by having the first three joints of the front tarsi dilated and densely pubescent on the under side.

The larvæ of the tiger beetle are whitish grubs, with large, flat, nietallic colored heads and long toothed mandibles. They live in vertical burrows in sandy banks, beaten paths and dry plowed fields. These burrows are often a foot or more in depth, and in their upper portion the larva props itself so that the head serves as a plug or stopper for the hole. The prop with which it holds itself in place is a hump on the fifth segment of the abdomen, to which are 
attached two hooks. These are curved in such a way as to prevent the larva from being jerked out of the burrow when it happens to "catch a tartar" in the form of some larger or stronger insect than itself. (Fig. 6.) While waiting for prey its jaws, like those of a steel trap when set, are wide open, ready to seize the first unwary insect that walks Fig. 6. over the living trap. It drags its victim, when captured,

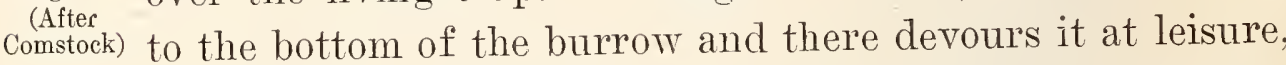
squeezing out the juice and softer parts and rejecting the hard and innutritious portions.

The principal works of reference on the family are as follows:

LeConte.-_"Revision of the Cicindelida,"' in Trans. Amer. Phil. Soc., XI, 1857, 27-63.

Schaupp._- "Revision of the Cicindelidx," in Bull. Brook. Ent. Soc., VI, 1883-84, 73-108; 121-126, Pls. I-V.

Leng._-"Revision of the Cicindelidxe of Boreal America," in Trans. Amer. Ent. Soc., XXVIII, 1902, 93-186, Pls. I-IV.

About 1,400 species of Cicindelidxe are known, 93 species and numerous varieties of which have been described from the United States. These belong to five different genera, only two of which are represented in Indiana.

KEY TO INDIANA GENERA OF CICINDELIDA.

a. Third joint of maxillary palpi longer than the fourth. au. Third joint of maxillary palpi shorter than the fourth.
I. TETRACHA.

II. CicindeLA.

\section{Teтr $\Lambda$ сн $\Lambda$ Hope. 1837. (Gr., "in four parts.")}

This genus is represented in the southern portion of the United States by two rather large metallic green species which are nocturnal in habit, hiding during the day and hunting by night. One of the two occurs in the southern third of Indiana, while the other has been found in southern Illinois and should be looked for in the southwestern counties of this State. They have the head largè, with large circular eyes; mandibles with four teeth; thorax smooth, broader than long, with a large triangular impression at middle; elytra slightly convex, broader than base of thorax, deeply and coarsely punctate. 
1 (13). Tetracha virginica Linn., Syst. Nat., II, 1735,567 .

Dark gold green; elytra blackish at middle, their sides with a broad metallic green stripe; antenne, legs and last ventral segment dull brownish-yellow. Length 20-24 mm. (Fig. 7.)

Vigo, Knox, Crawford and Posey counties; frequent. June 30-September 25. Probably oscurs in most of the counties covered by the Austroriparian fauna. It is found beneath stones,

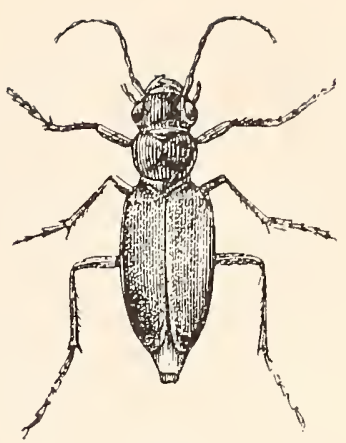

Fig. 7 . wheat shocks and other hiding places, especially along and near streams, and is often attracted by electric and other lights.

The other' species, T. carolina Linn., is slightly larger and of a lighter green hue, with the apical portion of the elytra, legs and antenna yellow.

\section{Cicindela Linn. 1735. (L., "a candle or taper.")}

This genus is represented in the United States by 75 or more species and many varieties. In shape they are very uniform, but differ much in size and color, and have the head large, with prominent eyes; thorax varying from cylindrical to a flattened trapezoidal form and narrower than head; elytra usually quite convex and subparallel at the sides with the tips usually rounded, emarginate in one group.

Unlike most other members of the family the species of Cicindela are diurnal in habit, hiding by night and on cloudy or rainy days in holes dug in the sand, or beneath bark, chips, stones and rubbish. On bright sunny days, however, they are out in numbers, frequenting those haunts for which nature has fitted them. Here, as long as motionless, their hues blend with their surroundings in such a manner as to render them unnoticeable to higher forms. It is very probable that several species which occur in early spring hibernate in the perfect or imago stage. A number of them are double brooded.

Fifteen members of the genus have been taken in Indiana, while two others may occur. These may be distinguished one from another by the following table. Since in it numerous references are made to the white markings on the elytra, the following explanatory terms regarding them are given: 
When the markings are in bands, as in Fig. 8: (C. repanda.)

$1=$ humeral lunule.

$2=$ marginal line.

$3=$ middle band.

4 = apical lunule.

When the markings are in dots as in Fig. 9:

5 (See fig. 23$)=$ basal dot.

$6=$ humeral dot.

$7=$ posthumeral dot.

$8=$ marginal dot.

$9=$ supplementary dot.

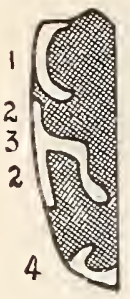

Fig. 8.

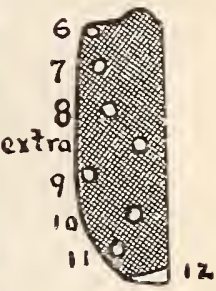

Fig. 9.

(After Leng.)

$10=$ discal dot.

11 = anteapical dot.

$12=$ apical dot.

When these markings are of the style shown in figure (C. hirticolis) they are said to be complete: when lacking in part or broken up into dots, they are called incomplete.

\section{KET TO INDTANA SPECIES OF CICINDELA.}

a. Under side of abdomen metallic blue or sreen.

7. Thorax more or less flattened, its sides margined.

c. Abdomen not hairy; front of head that; elytra flattened and with a white marginal dot.

2. UNIPUNCTATA. cc. Abdomen sparsely hairy: front concare; elytra with a vigue depression on basal third, dull brown or black with humeral. posthumeral and anteapical dots and narrow iniddle band.

LONGILABRIS.

6). Thorax convex, not margined; elytra convex.

l. Pubescence beneath either ercet or lacking; outer margin of elytra in female not angulate.

e. Thorax much narrowed behind; markings incomplete, reduced to dots or spots; colors usually bright.

$f$. Elytra without well defined median band.

g. Thorax quadrate; elytra green or purple; markings distinct.

h. Elytra smooth or nearly so; apical lunule and one or more marginal spots present; color purplish bronze.

3. LECONTEI.

hh. Elytra distinctly punctured; markings reduced to smali smooth.

4. SEXGUTTATA.

gg. Thorax subcylindrical; elytra black or dark bronze; markings very indistinct.

13. PUNCTULATA.

ff. Elytra with well defined median band.

$i$. Color either bright or bluish-green; front of head smooth.

5. Patruela. 
ii. Color coppery or purplish-green; front of head hairy; elytra granulate-punctate.

6. PURPUREA.

te. Thorax slightly or not at all narrowed behind; markings complete or nearly so; color's usually dull.

j. Elytral markings quite broad, connected at margin; humeral lunule obliquely prolonged backward; labrum three-toothed; larger, $16-18 \mathrm{~mm}$.

7. GENEROSA.

ji. Elytral markings narrower, less prominent, complete or incomplete, not wholly connected at margin.

l. Humeral lunule obliquely prolonged backward; middle band not extended along the margin.

8. VULGARIS.

lik. Humeral lunule C-shaped, not prolonged backward; middle band (except in 12-gnttata) more or less extended along the margin.

l. Labrum three-toothed; apical lunule bent forward and inward.

9. ANCOCISCONENSIS.

11. Labrum one-toothed; apical lunule not bent as above.

m. Marginal white line not connected with humeral lunule, the latter not bent upward at posterior end; thorax less hairy.

n. Elytral markings complete.

10. REPANDA.

un. Elytral markings broken into dots; form broader and flatter.

11. 12-GUTTATA.

$m m$. Marginal white line connected with humeral lunule. the latter bent upward at its hind extremity; thorax ver'y hairy.

12. HIRTICOLLIS.

dd. Pubescence beneath prostrate or decumbent; outer margin of elytra in female angulate near apex.

o. Elytra white with a few dark markings.

15. LEPIDA.

ow. Elytra cupreous or bronze; markings complete.

1!. CUPRASCENS.

a1. Under side of abdomen partly red.

p. Elytra dark brown without a marginal white band, the markings normal.

16. RUFIVENTRIS.

111. Elytra greenish or fuscous with a white submarginal band.

MARGINIPENNIS.

2 (17). Cicindela unipunctata Fab., Syst. Ent., 1775, 225.

Dull brown, beneath dark blue; elytra rough with green forea and punctures, and with a triangular marginal white dot. Length 16-18 mm. (Fig. 10.)

Southern half of State: frequent in Crawford and Posey counties, less so in Vigo and Putnam. May 4 September 5. Occurs singly or in pairs on bare spots in upland woods and along woodland paths. Instead of flying when alarmed, it often attempts to hide beneath leaves and stones, and can usually be readily

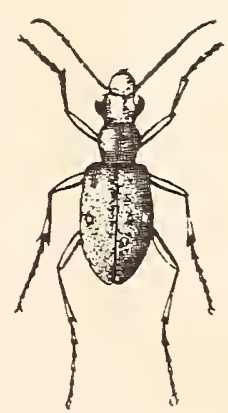

Fig. 10 . (After Leng.) captured with the hand.

[3-23402] 
C. longilabris Say probably occurs sparingly in the northern third of the State, as its range in ludes Michigan and Wisconsin.

3 (19e). Cicindela scutellaris leconter Hald., I'roc. Phil. Acad. Nat. Sci. TI, $1853,361$.

Elytra purplish or coppery bronze with apical lunule, one or two marginal spots and sometimes with a humeral spot. these rarely confuent. Front hairs in male, nearly bald in female.

Fig. 11. Femora, flanks of thorax and front and middle coxie rather dense(After Leng) $1 \%$ clothed with long white hair. Length $12 \mathrm{~mm}$. (Fig. 11.)

This handsome rariety of the western species scutellaris has so far been taken only in Lake and Porter counties, and is probably confined to the sandy areas of the northwestern portion of the State. Where found it is frequent in open sandy spots and along sandy pathways, usually distant from water. April 21-September 9.

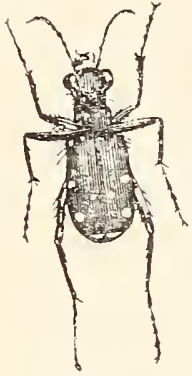

Fig. 12.

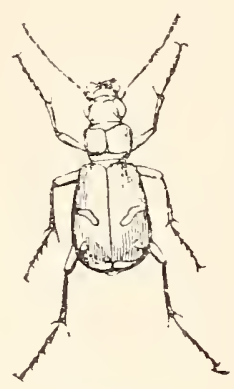

Fig. 13.

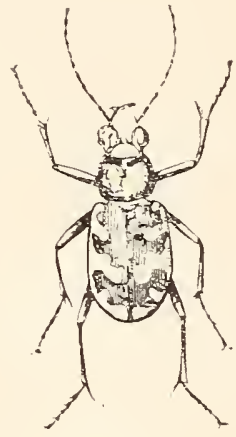

Fig. 14.

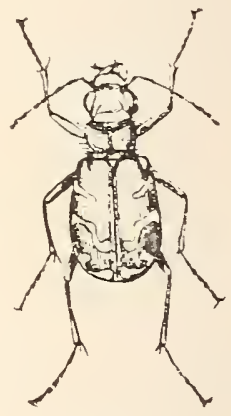

Fig. 15.

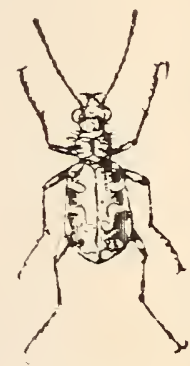

Fig. 15a.

(After Wickham.)

4 (24). Cicindela sexgttiata Fab., Syst. Ent., 176. 2026.

Bright green above often with a strong bluish reflection; each elytron with one to five white d.ts. these sometimes indistinct or even wholly lacking. Front not hiairy; under surface with only a few scattered white hairs. Elytra convex. granulate-punctate. Length 10-14 mm. (Figs. 12 and 16.)

Throughout the State; frequent. April 9-September 15. One of the most attractive of our tiger beetles. It is 1 g. 16 . found most frequently alcng pathways in open woodlands ;

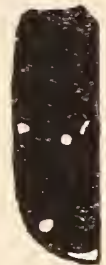
also often on logs, beneath the loose bark of which it hides by night and in cloudy weather. It has been noted on the cement sideralks near the center of Indianapolis.

5 (24b). Cicindela patreeia Dej., Spec., I. 1\$25, 62.

Resembles sexguttata but usually larger and somerhat darker. MIedian band and often the humeral lunule complete: apical and anteapical dots more distinct. Cnder side much more hary. the coxie. -jur- and metisterna heing especially pilose. Length 12-14.5 $11 \mathrm{~m}$. 
Lake and Lawrence comnties; rare. May 7-July 27. Oceurs in shaded pathways on high. dry hills. Usually placed as a variety of sexguttata, but Leng considers them distinct.

6 (25). Cicindela purpurea Oliy.. Ent., II, 1794, 14.

Reddish cupreous, margins and suture of elytra green; markings consisting of a narrow oblique middle band, an apical dot and sometimes an anteapical and humeral dot. Thorax deeply impressed, granulate and rugose. Length 14-16 mm. (Figs. 13 and 17.)

This handsome beetle has so far been noted only in southern Indiana, where it has been taken in a half dozen or more counties. However, it probably occurs through-

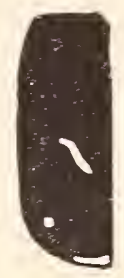

Fig. $17^{\circ}$ After Leng.) out the State, as its general rang'e includes the entire United States. It frequents the grassy margins of roads and meadow pathways. Double brooded and probably hibernates. April 23-October 15.

The variety limbalis Klug., in which the middle band is long and sinuate and with humeral, posthumeral, apical and anteapical dots usually present, probably occurs sparingly in the State, its range being given as "Maine to Colorado and Kansas."

$\tau$ (26a). Cicindela torarosa generosa Dej., Spec. $T, 1831,231$.

Dull reddish cupreous or brownish-bronzed; white markings wide. prominent and connected on margin, the middle band bent backward, then forward and almost reaching the suture. Thorax broader than long, granulate, very hairy on the flanks. Length 16-18 mm. (Fig. 14.)

This eastern form of Say's formosa has been taken only in Lake, Porter, Laporte, Vigo. Perry and Posey counties, where it occurs in numbers on bare sandy spots and along sandy roads. May 13-October 1 . It is more wary and difficult to capture than most of its kind and when flushed often makes a prolonged flight. Generosa and unipunctata are the largest of our tiger beetles, and the former will probably be found over most of the sand covered areas of the State.

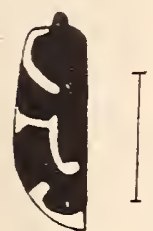

8 (32). Cictindelat rulgaris Say. Trans. Amer. Phil. Soc.. I. 1S1S. 409 ; ibid. II, 422 .

Brownish-bronze abore. dark green beneath; elytral markings consisting of humeral lunule obliquely prolonged; a middle band but slightly expanded on margin, entering obliquely and bent at Fig. 18. an obtuse angle, and an apical lunule. Length $13-16 \mathrm{~mm}$. (Figs. (After Leng.) 15 and 18.) 
Throughout the State; common. April 2-October 9. Occurs usually on sandy or mud flats, 20 and more feet back from running rater; also along sandy roads or on bare spots and pathways in open upland woods. One specimen was taken April 3d on a cement walk in Indianapolis.

9 (31). Cicindela ancocisconensis Harr., Family Visitor, 1853.

No. 3. p. 2.

Brown-bronzed above, bright metallic green beneath; humeral lunule scarcely curved; middle band obtusely bent and extended along the margin toward the apex; apical lunule bent forward and inward. Front hairy ; thorax subquadrate; elytra granulatepunctate. Length 14-16 mm. (Fig. 19.)

Fig. 19. (After Leng.)

Fulton County; scarce. July 14. Taken in small numbers along the borders of Bruce Lake and along ditches in peat bogs and tamarack swamps. Probably occurs sparingly in like situations throughout the northern third of the State, its range being given as "New Hampshire to Illinois."

10 (33). Cicindela repanda Dej., Spec., I, 1825, 74.

Brownish-bronze with a more or less greenish or coppery reflection; humeral lunule C-shaped; middle band rectangularly bent, connected with a marginal white line which nearly but never quite reaches the apical and humeral lunules. Front sparingly hairy. Thorax nearly square, hairy on the sides. Elytra granu- Fig. 20. late-punctate, parallel in the male, suddenly dilated before the middle in the female. Length 12-13 mm. (Fig. 20.)

Throughout the State; frequent. April 18-October 5. Occurs most abundantly on sand banks and gravel bars; also along the borders of roads, fields and railway tracks.

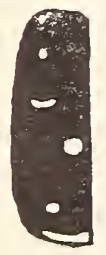

11 (33c). Cicindela 12-gutTata Dej., Spec., I, 1825, 73.

Brownish-bronze; elytral markings consisting of humeral, posthumeral, apical, anteapical and upper discal dots and a very narrow middle band, scarcely reaching the discal dot. From repanda of which it is usually considered a variety, it differs also "br the more flattened form, by the shorter and less convex thorax and Fig. 21. by the elytra of the female being only gradually dilated." (After Leng.) (Leng.) Length 12-15 mm. (Fig. 21.)

Lake, Starke, Fulton, Vigo and Posey counties. May 27-October 10. Occurs sparingly only along the margins of ditches in peat bogs and low, moist grounds. 
12 (35). Cicindela mrticolcis Say. Trams. Amer. Phil. Soc.. I, 181S, 411 ; ibid. II, 2.

Brown blonze above: heneath arleen. very latiry; humeral lunule bent mpward at its himd extremity and commected by al malginal line with midale band, the malginisl line usually broken before the apical lumue. Front hilis. Thorax quadrate, flat. rers hairy. Elytra granulate-punctate, suddenly dilated befores the middle in both sexes. Length 1:3-14 mm. (Figs. 15a and 2.2.)

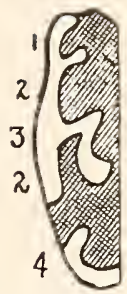

Fig. 22.

Abundant along the shore of Lake Michigan and on the (After Leng.) sand dunes back from the lake; also found on the sandy beaches of other large lakes in northern Indiana. May 13-Sept. 5.

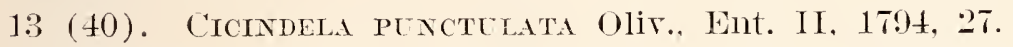

Slender, subcylindricas. Black, dark brown or greenish-bronzed above; greenish-bhue beneath; the whitish markings, except the apical lunule, usually reduced to one or two minute dots, with rarely a broken humeral lunule and interrupted middle band piesent. Front without hairs. Thorax sparsely hairy, very finely granulate. Elytra densely punctured. each with a row of larger green punctures near the suture. Length 11-1t $\mathrm{mm}$.

Throughout the State; one of the most common and widely distributed of tiger beetles. Often found about electric lights and on the walks of the cities; also along dry upland roads and especially pathways in open woods. May 25-November 4.

14 (45). Crcindela cuprascens Lec., Proc. Phil. Acad. Nat. Sci.,

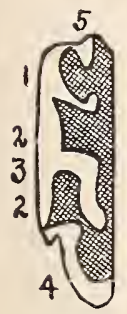
$1852,65$.

Cupreous or greenish-bronzed above: markings complete and connected along the marginal line. Front hairy. Thorax flattened, nearly quadrate, slightly rounded at sides. thinly clothed with white hairs. Outer margin of male elytron slightly sinuate; of female elytron strongly sinuate with a tooth one-fourth from the tip. Length 12-14 inm. (Fig. 23.)

Fig. 23. (After Leng.)

Frequent along the sandy beach of Lake Michigan, near Pine, Lake County and Dune Park, Porter County; also a single example from a sand bar in Putnam County. Probably widely distributed in the State. July 5-September 1.

Those found along the beach of Lake Michigan are more slender, less strongly punctured and with the marginal tooth of the female elytron more obtuse than in the Putnam County form. They are to be referred to the variety macra Lec.

15 (55). Cictrdela lepida Dej.. Spec., r. 1831. 255.

Flat and broad. Hearl and thorax greenish-bronze, hairy; elstra white with a few green or bronze dark lines; under surface densely clothed with white hair. Elytra sinuate at apex. more deeply so in female. Length 9-12 mm. (Fig. 24.)

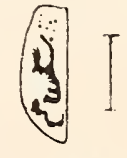

Fig. 24. (After Leng.)

Taken in the State only on the bare white sand along the beach of Lake Michigan near Pine, Lake County, and Dune Park, Porter 
Comnty. Jume 27-September 5. As its color hamonizes so closely with that of its resting place, it nust be marked down and then kept in view until close enough to capture with the net. It is said to $\mathrm{fly}$ to electric light.

1 (6) (64). Cicindela rufirentris Dej.. Spec., I, 1S25, 102.

Dark smoky brown, bronzed above; bluish-green beneath, abdomen red; elytral markings consisting of apical lunule and lumeral, posthumeral, marginal and two discal dots; the latter sometimes wanting. sometimes united to form a short, sinuate middle band. Ilead finely striate, not hairy. 'Thorax subquadFíg. 25. rate with sparse hair's each side. Elytra faintly punctate. Length (After Leng.) 9-12 mm. (Fig. 25.)

This species has so far been taken in Indiana only on bare spots on the slopes and tops of high hills near Wyandotte Cave, Crawford County. Here it is quite common from June 15 to September, and can be readily approached and easily taken with a net. It probably oceurs in like sitnations in many localities in the sonthern third of the State.

Cicindcla marginiponnis De.j. has been taken by Dury on a sand bar of the Little Miami River near Batavia Junction, Ohio. May 17. It therefore very probably occurs along the streams of the southeastern portion of Indiana.

\section{Family II. CARABIDA.}

\section{The Ground Beetues.}

This family has more representatives in Indiana than any other family of Coleoptera. Its members are to be looked for anywhere on or close to the ground, where by day they usually hide beneath whatever cover presents itself. At night they roam about in eager search for anything which will furnish food. All the species have long legs and run with great rapidity. While the inner wings are present in most forms, they seldom attempt to escape by flight; though some of the smaller ones are seen flying in numbers during the first warm days of spring or about electric lights during summer evenings. The principal characters of the family may be briefly diagnosed as follows:

Head narrower than thorax, directed forward; mentum deeply emarginate; maxillo with the outer lobe destitute of a movable hook at the tip; antenne 11-jointed, filiform, inserted under a frontal ridge behind the base of the mandibles, the joints (except 
the basal ones) covered with a minute pubescence; epinera and episterua of thorax distinct; abdomen with six, ravely (Brachinini) with seven ventral segments, the first visible only at the sides; legs slender, the hind ones not very different from the middle pair; front and middle coxe globular, hind coxie dilated on the inner side; tarsi 5-jointed.

The majority of the species of Carabidie are predaceous and beneficial, feeding in part upon the larve and mature forms of other insects; their mouth parts being excellently adapted to catching and masticating such food. Dr. S. A. Forbes examined 175 specimens representing 38 species and 20 genera. Of these 83 specimens, obtained in miscellaneous situations, had derived 42 per cent. of their food from the animal kingdom, while of 70 specimens taken in an orchard where canker-worms were abundant, 77 per cent. of their food was of animal origin, 21 per cent. being canker-worms. Of the 175 specimens examined, 57 per cent. of the food was of animal origin, 36 per cent. being composed of the remains of insects; the other 21 per cent. being made up of mollusks, earthworms, myrapods and arachnidx. The vegetable matter eaten was composed of the remains of eryptogamic plants and the pollen of grasses and Compositæ.*

A few members, especially those belonging to the genera Harpalus, Anisodactylus and Amara, are seed eaters and probably do more damage than good; while the larva of omophrom and some of the species of Clivina have been known to be quite destructive to the soft sprouting grains of corn. However. on account of their great numbers and predaceous habits, both in the larval and perfect stages, our Carabidx doubtless play an important part in holding in check the excessive multiplication of other and more injurious in: sect forms.

The larve of the Carabidic are mostly long, flattened grubs, with the body of nearly pqual breadth throughout. They have sharp projecting mandibles and the hind end of the bodr bears a pair of conical bristly appendages. Tike the adults they are predaceous. living in burrows just beneath the surface of the ground, and feeding upon the soft bodied larra of many leaf eating insects which enter the ground to transform. When fully grown they change to pupa muder armund in small earthen cells which ther form for this purpose. When ready to emerge as imagoes, the color changes

* "The Food Relations of the Carabidæa and Coccinellide," in Bull, No, 6, Ill. Lab. Nat, Hist, 18s3, 
from almost white to that of the perfect insect, and leaving the old pupal skin behind the roung beetle crawls forth to the shelter of some object which will protect it by day, while at night it roams freely in search of food or a mate with which to perpetuate its kind.

About 13,000 species of Carabida are known, more than 1,200 of which have been described from the different parts of the United States. Of these 366 representing 73 genera have, up to the present, been taken in Indiana. The principal papers treating of each genus will be mentioned under the tribal or generic heading. For a general classification of the family the student is referred to the following papers:

LeConte.-"Notes on the Classification of the Carabidx of the United States," in Trans. Amer. Phil. Soc., X, 1853, 363-403.

Horn._- "On the Genera of Carabidie with special reference to the farma of Boreal America," in 'Trans. Amer. Ent. Soc., IX, 1881, pp. 91-196, pls. IIT-X.

By Dr. Horn the Carabide were divided into three subfamilies, two of whirh are represented in Indiana.

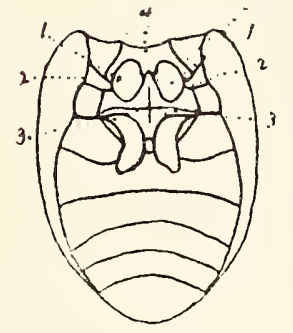

Fig. 26.

(AfteI Leng.)

1. Coxal cavities; 2. Epimeron; 3. Mesosterna; 4. Metasterna.
KEY TO INDIANA SCBFAMILIES OF CARABIDE.

11. Middle coxal cavities not entirely enclosed by the sterna alone, the epimeron of the mesosternum reaching the coxa on the outer side. (Fig. 26.)

Subfamily I. Carabin E, P. 38.

au. Miclale coxal carities entirely enclosed by the sterna, the epimeron not reaching the coxa; head without antennal giooves beneath and with one or more distinct bristly hairs abore the eves.

Subfamily II. HARPALINE, P. 63.

\section{Subfamily I. CARABINAE.}

In this subfamily the epimera of the mesosternum nearly equal the episterna in size and reach the coxal cavities, forming a part of their enclosing walls. The head has one or two large punctures above each eye, each bearing a bristly hair ; sides of thorax usually with two similar punctures. Front tibiæ either entire, obliquely grooved or emarginate. The subfamily is divided into 15 tribes, of which but six ane represented in Tntiana.

KEY TO INDIANA TRIBES OF CARABIN.E.

a. Front coxal cavities open behind.

7. Hind coxie separated; labrum deeply forked.

Tribe II. Crchrini, p. 41. 
b1. Hind roxie not separated; labrum not forked.

c. Mandibles withoui a bristle-bearing puncture on the outer side; size large, $18 \mathrm{or}^{\circ}$ more $\mathrm{mm}$.

Tribe III. Carabint, 1) 44.

$c c$. Mandibles each with a bristle-hearing functure on the outer side; smaller, not over $12 \mathrm{~mm}$.

Tribe V. Nebiand, p. 50.

a11. Front coxal avities closed behinoi.

1. Irosternum frolonged and dilated, entirely andealing the mexissternum ; seutellum invisible.

'Tribe I. GMophronini, p. :i!).

dd. Prosterimun not concealing the mesosternum.

c. Antembe tree all base; hody not pedunculate, the hases of thorax and elytra in contalot: scontellum risible.

'Tribe IV. Llapimini, p. ts. ee. Antemne arising under a frontal plate; body pedunculate, the bases of thorax : mo elytra remote; scutellum not visible; hind coxie contiguous.

Tribe VI. Scaritini, p. $5: 3$.

'Tribe I. OMIOLHRONINI.

Antenna slender, inserted under a slight frontal margim, four basal joints glabrous; mandibles with a bristle-bearing puncture on outer side; second joint of labial palpi with several seta or bristlelike hairs; body not pedunculate; mesosternum covered by the prolonged prosternum. The tribe is represented by the single genus :

\section{Omophron Latr. 1802 (Gr., "savage-like.")}

Form oval, convex; scutellum invisible. The species occupy holes in wet sand along the margins of streams, ponds and lakes. They are also often found under stones or in holes between the roots of plants along the water's edge, and are frequently caught in minnow seines. By throwing water over the sand banks they can be forced out and are then easily captured, as they do not fly. For detailed papers on the genus see:

Horn.-."Synopsis of O mo phron," in Trans, Amer. Ent. Soc., III, 1870, 71 .

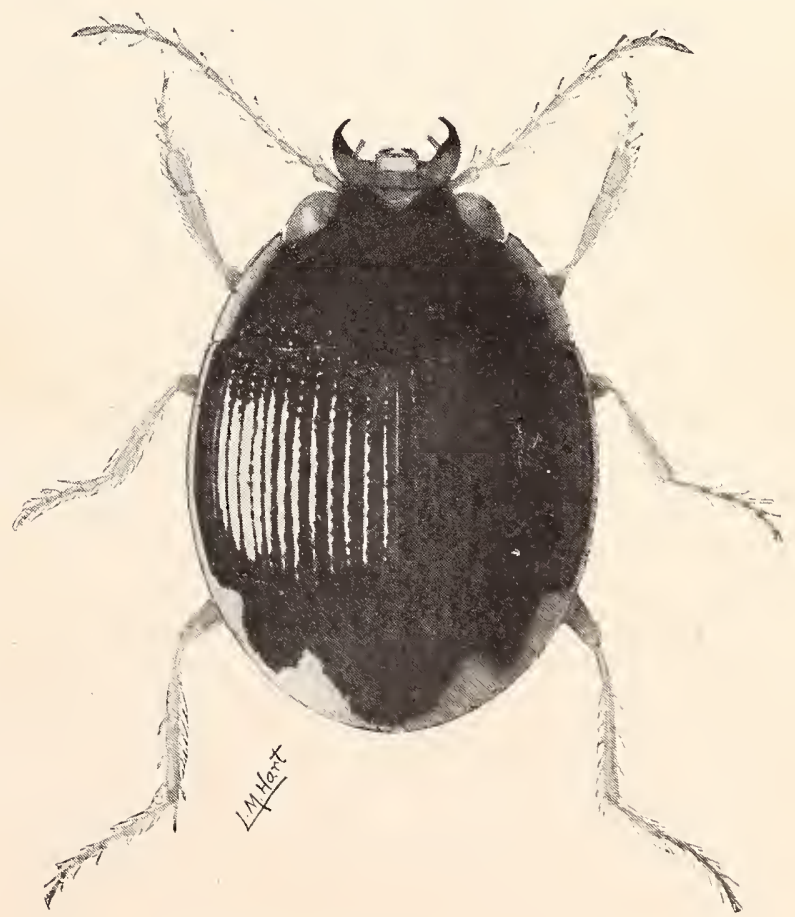

Fig. 27. Omophron labiatum Fab. $\times 9$. (After Forbes.) 
ILom.- "Synoplic table of the genus Omophen," in Bull. Brook. Fint. Sor., I, 1878, 4.

Nine species are known from the United States, of which four have been taken in Indiana, while one other may occur.

KEY TO INDIANA SPECIES OE OMOPHRON.

1. Broadly oval, shining; elytral striæe almost entirely obliterated at apex and indistinct on side, the intervals flat; median line of thorax very faint.

b. Rows of elytral punctures reaching only to middle; color dark brown or nearly black, the side margins of thorax and elytra pale. LABIATUM.

bb. Rows of elytral punctures reaching two-thirds the distance from base to aper; color dark metallic green, pale at sides.

17. NITIDUM.

au. Less broadly oval, less convex and less shining; elytral striæe reach ing to very near the apex, distinct on sides, the intervals convex.

r. Elytra 14-striate; stric shallow, indistinct at apex, punctures large, distint.

r.. Elytra 15-striate; strie deep, distinct at apex.

d. Thorax with side margin only pale.

19. AMERICANUM.

dl. Thor:ax with sides, basal and apical margins pale.

20. TESSELLATUM.

O. labialum Fab. oreurs in the "Middle and Southern States," and should be looked for in southern Indiana. (Fig. 27.)

17 (71). Omophron nitidum Lee., Amu. Lye. Nat. Hist., IV, 1848, 447.

Dark metallic green, shining; thorax and elytra with a narrow, pale margin, that of the elytra with three irregular projections, the first and second of which extend inward to the eighth and sixth striae; the third longer, subquadrate and near the apex. Thorax without punctures on pale margins and at center, coarsely and sparsely punctured near base and apex. Punctures of elytra large, distant. Length 5-6 $\mathrm{mm}$.

Lake County; scarce. Taken by A. B. Wolcott from the beach of Lake Michigan near the station of Pine. April 29-May 28.

is (74). Omophron nobustum Horn, Trans. Amer. Ent. Soc, III, 1870, 73.

Pale brownish-yellow; elytra with broken green cross-markings; the striae with coarse distant punctures. Thorax with a narrow green crossband, which extends forward and backward at the middle, and an oval green spot each side. Length $6.5 \mathrm{~mm}$.

Stein collection from southern Indiana. Probably throughout the State, but scarce. Taken by Dury at Cincinnati.

19 (76). Omophron americanum Dej., sipec.. V, 1831, 583.

Bronzed or greenish-black; head mostly green; thorax and elytra with pale margins, those of the former very narrow. Punctures of elytral stria rather fine, the intervals strongly anrex. Tenoth fi- $7 \mathrm{~mm}$. 
Common throughout the State. April 2:-September 5. Sometimes occurs under rubbish remote from water.

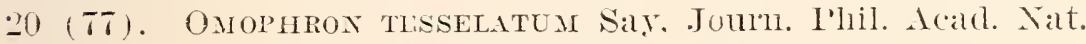
Sci., III, 1s23, 152; ibid. II, 97.

Pale brownish-yellow; head with a green band across the buse; thorax with a small, subquadrate green spot which is prolonged backward and forward along a deeply impressed median line; elytra with cross-markings metallic green, the punctures of the striae close and fine. Thorax contsely punc-

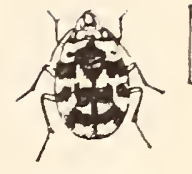

Fig. 28. (After Leng.) tured near base and apex. more finely and rery sparsely at middle and sides. Length 6-T mim. (Fig. 2S.)

Common in the northern part of the State; rare in the southern portion. Nay 22-August 22.

\section{Tribe II. CICHRINI.}

Head more or less constricted; neck often semi-globose; antenna slender, inserted under a feeble frontal ridge; labrum deep ly forked; body not pedunculate; scutellum very small. Prostexnum not prolonged behind the coxx; hind coxx separated by a triangular process of the abdomen. The tribe is represented in the eastern United States by two genera, separated as follows:

KEY TO GEXERA OF CYCHRTXI.

a. Antenne with four basal joints glabrous.

II. Creires. a a. Antemne with two basal joints glabrous.

Nomaretes.

Of these only specimens of Cychrus have as yet been taken in Indiana, though two or three species of Tomaretus should be found here. They are black or violaceous in color and 10-13 $\mathrm{mm}$. in length.

\section{Crchrus Fab. 1794. (Gr., "a ground runner."')}

Beetles of medium or large size, violaceous or brownish-purple in color. having the head elongate. the mandibles long, slender. 'urved and without a bristle-bearing puncture on the outer side: labial and maxillary palpi very long. the last joint hatchet-shaped and concave. The elytra have 14 to 18 very distinct strix. which are sometimes irregular or replaced by tubercles. The spesies live beneath stones and lares. msnally in moist woods. and feed upon snails. their long heads having. in the comrse of time. berome especially adapted to extracting these animals from their shells. For srnopses of the genus see: 
Hor"n.- "Srnopsis of the Species of Cychrus Inhabiting Boreal America." in Trans. Amer. Ent. Soc. VII, 1879, 168-185.

Horn.-Bull. Brook. Ent. Soc., I. 1879, 79-82.

About 30 species of Cychrus are knorn from the United States. Of these but five have so far been taken in Indiana, though two others perhaps occur.

\section{KET TO INDLANA SPECIES OF CYCHRUS.}

a. Smaller. not orer $15 \mathrm{~mm}$. : front tarsi of male broady dilated, those of female not dilated: maxillie hidden beneath the broad cheeks: legs stout.

b. Hind angles of thor:ax rely obtuse: length $12-14 \mathrm{~mm}$.

c. Thoracic punctures very ferw. limited to the basal impressions: elytral strie interrupted only at apex. 21. stexostonus rak. cc. Thorax with numerous punctures between and in the basal impressions: elytial strip interrupted behind the middle.

22. IECONTEI.

bb. Hind angles of thorax rectangular: elytral strie interrupted on sides and apex; length 11-12 $\mathrm{mm}$.

CANADENSIS.

a c. Larger, 18-28 mm ; front tarsi of male but narrowly dilated; maxillie exposed; legs slendel.

17. Thorax nearly as wide as elytra. the sides much elevated, the hind angles prolonged buckirar.

e. Smaller, length less than $20 \mathrm{~mm}$.

ee. Larger, length more than $25 \mathrm{~mm}$.

23. ELETATTS.

24. UNICOLOR.

dd. Thorax much narrowel than elstral. moderatels reflexed. the hind angles not prolonged backward.

$f$. Form robust: margins of thorax rather wide, distinctly reflexed.

ff. Form slender; margins of thorax rery narrow, not reflexed.

VIDUCS.

25. ANDREWSII TAR.

21 (S2). Cratious stenostomés indiana Leng, MS.

Oral. slender. Black; elytra violaceous. their margins bluish. Thorax broader than long. sides curved. strongly conrerging on basal half; hind angles obtusely rounded; disk smooth, the basil impressions linear. deep. with rery few punctures. Elytral intervals slightly interrupted at sides. more distinctly on apical fourth. but not tuberculate. Length 11-12 mm.

Marion. Poser. Crawford and Jennings enmties: scarce. April t-september 20. Мr. Chas. W. Leng. of New York City, who has recently made a special stud! of North American Cychrus. states that this is a distinct variety of slemstomus Web.. which differs from that species by the msually" "total absence of the transverse hasal impression of the thorax." The has given it the varjetal name indiance. 
22 (82a). Cychrus Leconter Dej., Spec. II, 1526, 15.

Oval, rather robust; color of the preceding. Basal impressions of thorax broad, with numerous punctures. Elytra deeply striate with closely placed punctures, the intervals interrupted from the middle to apex, thus forming elongate tubercles. Length 12-14 $\mathrm{mm}$.

Throughout the State; frequent. April 20-November 5. In the north it occurs beneath sphagnum mosses and about the borders of lakes and tamarack marshes, while in the southern counties it is found in lowland woods.

C. canadensis Chaud. has been taken by Dury near Cincinnati. and doubtless occurs sparingly in southern Indiana.

23 (\$6). Cychres envatus Fab., Mant., I, 198.

Oral, robust. Violaceous or cupreous. Antennae slender, three-fourths the length of body, first joint longer than third. Thorax with hind angles prolonged over the elytra, the latter with humeral margins much reflexed. First joint of front tarsi of male spongy pubescent over one-half its lower surtace. Length 18-19 mm. (Fig. 29.)

Fulton County ; rare; one specimen from near DeLong. July 30. Two were in the Stein collec-

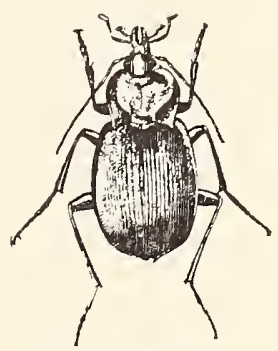

Fig. 29. (After Leng.) Natural size. tion from Indiana, but without definite locality. Our form, according to Leng, is var. flammeus Hald., which "differs from the true elevatus by being broader and flatter."

24 (86a). Crchrus unicolor Oliv., Ent., III. 1795, 47.

Resembles elcvatus but much larger and more robust. Elytra with a slight emargination or sinuation a little behind the middle, which is not present in clevatus. Length 26-28 mm.

Monroe, Lawrence, Knox, Crawford and Harrison counties; one or two specimens from each. Occurs beneath stones in deep ravines. May 3-November 14. This is the form often called elevatus var. heros; the name unicolor, however, has priority. It is undoubtedly distinct from elevatus.

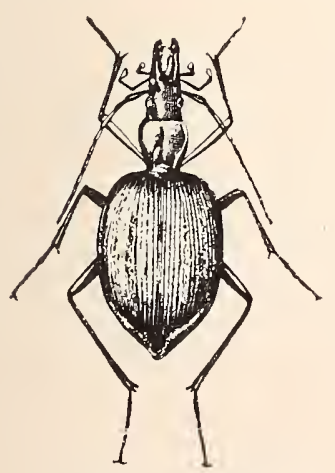

Fig. 30. (After Leng.) $\times 1 \frac{1}{4}$

25 (-). Crchrus andrewsil germari Chaud., Bull. Mosc., II, 1861, 495.

Oval, rather slender. Violaceous above, black beneath. Thorax longer than wide, subcordate, hind angles obtuse; disk almost smooth, punctate along the sides, margins narrow, slightly reflexed. First joint of front tarsi of male as in clevatus. Length 19-22 mm. (Fig. 30.)

A species of southern range. found in small numbers near Charlestown Landing. Clark Comnty; also one specimen from Brown County. May 21-Ortober 1. This is the form often called 
andreusii Harr., but, according to Leng, typical andrewsii occurs only in the mountain region of North Carolina, is smaller, more slender and lacks the intermption of some of the striæ usually noted on the apical third of the Indiana speeimens.

\section{Tribe III. CARABINI.}

Species of medium or large size, for the most part noted for their beauty of form, color or sculpture. Head not constricted behind the eyes; labrum broad and emarginate; mandibles stout, curved and without bristle-bearing puncture on outer side. Body not pedunculate; scutellum small. Prosternum prolonged, the front coxal cavities open behind, the hind coxæ not separated. Males with the front tarsi dilated and densely pubescent beneath. The tribe is represented in the United States and Indiana by two genera, separated as follows:

KEY TO GENERA OF CARABINI.

a. Third joint of antennæ cylindrical.

aa. Third joint of antennie compressed.
III. CARABUS.

IV. Calosoma.

\section{CARABUS Linn. 1765. (Gr., "a horned beetle."')}

Black or brownish-black species above the average in size and with the surface of the elytra more or less sculptured. They occur beneath stones and logs and are nowhere common, not more than 40 specimens having been taken in the State during 25 years' collecting. Nine or ten species are known from the United States. Of these four have been taken in Indiana while another probably occurs. For synoptic tables separating the United States species see:

Crotch.-Trans. Amer. Ent. Soc., V, 1876, 247.

Crotch.-Bull. Brook. Ent. Soc., I, 1878, 66.

\section{KEY TO INDIANA SPECIES OF CARABUS.}

a. Thorax punctate beneath; color brassy-bronze; elytra finely granulate with broken and continuous elevations.

MEANDER,

al. Thorax not punctured beneath.

b. Elytra each with three rows of forere or little pits. 20. Sylvosus.

$6 b$. Elytra without fover but with the fourth, eighth and twelfth interrals broken so as to resemble a series of links.

c. Margin of elytra serrate near the base.

27. SERRATUS.

cc. Margin of elytra not serrate.

d. Elytra black, the margins bluish; intervals equal.

28. LIMBATUS.

dd. Elytra bronzed; four of the interrals elevated so as to form slender ridges.

29. VINCTUS. 
(! mander Fisto is a boreal speries which has been taken by Wolcott near Chicago and doubtless occurs in the northern third of Indiana. Te finds it in spring, early summer and autumn, by tearing the sod away from the large exposed roots of oak and other trees in sparsely wooded pasture land, the beetle oecurring between the sod and the roots.

26 (120). Carabus sylvost's Say, Trans. Amer. Phil. Soce, II, 1823, T5; ibid. II, 492.

Elongate-oral, robust. Black; margins of thorax and elytra blue. Thorax broader than long, slightly punctured, margins reflexed. Elytra elongate-oval, the stria very fine. Lengtl $2 \bar{\tau}-30 \mathrm{~mm}$.

Laporte, Knox and Vigo counties; rare. Nay 12-October 3. Occurs beneath $\log$ s in upland sandy woods.

-7 (1:21). Carabls serratus Say, Trans. Amer. Phil. Soc., II, 1S23, 7 ; ibid. II, 494.

Oval, rather slender. Black with violet margins. Thorax broad, disk smooth, margins punctured and slightly reflexed. Elytra elongate, the nargin with two or three slight notches near the base; striae with distant, deep punctures. Length 20-2t imm. (Fig. 31.)

Lake, Vigo and Posey counties; rare. Taken from beneath logs in damp localities. April 15-May 21.

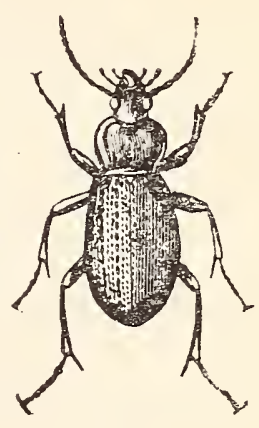

Fig. 31.

28 (122). Carabus limbatus Say, Trans. Amer. Phil. Soc., II, 1823, 7 ; ibid. II, 493.

Oval, robust. Black with bluish margins. Thorax onehalf wider than long, rather spalsely and shallowly punctate. Elytra deeply striate, punctures distinct and regular, intervals convex. Length 25-28 min.

Fulton, Marion, Vermillion, Vigo, Posey, Monroe and Franklin counties; one or two specimens from each. April 10-September 3. Occurs in moist upland woods.

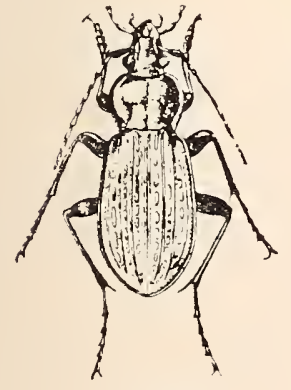

Fig. 32 .
29 (123). Carnbes vinctus Web., Obs. Fint.. 1801. 42.

Elongate-oval, rather slender. Dull black, bronzed: thorax with a greenish tinge at borders, its surface not punctate, but more or less firlely rugose. Broken intervals of elytra more prominent than in the preceding species; the strixe finely and irregularly granulate-punctate. Length 25-30 mm. (Fig. 32.)

Knox, Gibson. Dubois and Spencer counties; scarce. April 23-June 14. Occurs beneath bark and other cover in low, moist woods. 
IV. Calosom Weber. 1801. (Gr.. "beautiful + bodr.")

Large species, green. black or bronze in color, having the tooth of mentum simple and third joint of antennæ strongly compressed. Some of them are rery common beneath logs and stones in open woods and about the borders of cultivated fields. and are often attracted in mumbers hy electic lights. They are among the most bencficial of the Carabidie. feeding almost wholly wom caterpillars, cutworms and other injurious larvex. About 25 species are knom from the Enited States. five of which have been taken in Indiana. while ancther doubtless ocurs. The following papers are the principal ones treating of the genus:

Leconte._" "Notes on the Species of Calosoma Inhabiting the United States" in Proc. Phil. Acad. Nat. Sci.. 1862. 52.

Le Conte._. "Srnoptic Table" in Bull. Brook. Ent. Soc.. I. 1878. 64.

\section{KEY TO INDIANA SPECIES OF CALOSOMA.}

1. Eistra without rows of metallic spots.

b. Elytra black with blue border: lelgth :0 $111 n$.

30. LATERNAI.

b). Elytra metallic green with red margin.

c. Length more than $2.5 \mathrm{~mm}$.

31. SCRETATOR

cc. Length less than $20 \mathrm{~mm}$.

32. WLLCON1. au. Elytra black, each with three rows of golden or metallic green impressed spots.

d. Spots of elytra green.

c. Length $20 \mathrm{~mm}$. front tarsi of males with four joints hairy beneath.

33. FRIGIDCM.

ce. Length 25 or more mim. : front tarsi of male with two joints hair: beneath.

dr. Spots of elstra golden. very rarely green: front tarsi of male with three joints hairy beneath.

34. CALIDïn.

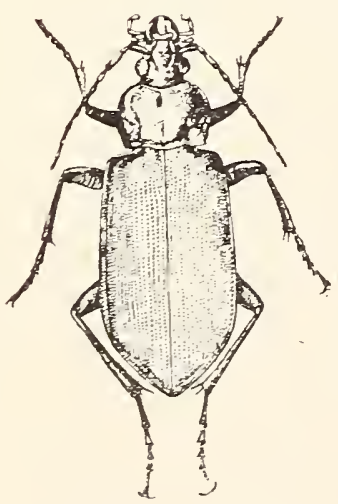

Fig. 33. (After Leng.

30 (121). Calosoma Exterxtar Say. Joum. I'hil. Acad. Nat. Sci.. III. 152:3. 150: inid. II. 96 .

Elongate robust. Black. subopaque: side margins of thorax and elytra blue. Thorax with sides rounded. broadly flattened and reffexed behind: hind angles obtusely rounded. Elytra almost parallel to apicai fourth. the striee with distinct punctures. Lengtli $30 \mathrm{~mm}$. (Fig. :33.)

Throughout the State but nowhere common. Nay 13-O-tober 18. Oecurs singly or in pairs beneath cover in open woods. 
31 (12T). Calosolfa scrutator Fab.. Sys.

Ent., I, 17.5, 239.

Oral, robust. Disk of thorax blue or purplish-black, the margins golden or reddish-bronzed; legs blue; abdomen green and red. Thorax relt short. more than twice as wide as long. nearly smooth. sides and hind angles rounded. Elytra striate punctured. Iriddle tibie of male curved and with it dense brush of hairs on the inner surfacts near the tili. Length $2 S-30 \mathrm{~mm}$. (Fig. :34.)

This large green species is one of the most common and most handsome of the ground beetles. It occurs in all parts of the State and is often attracted by hund-

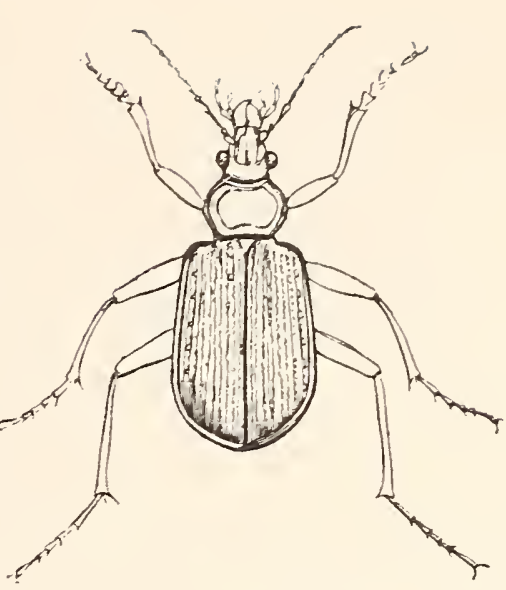

Fig. 34 . dreds to the electric lights of the cities. It is sometimes called the "searcher" or "caterpillar hunter," as it ascends trees in search of caterpillars, catching and feeding upon many injurious forms. Both it and $C$. calidum give off a very disagreeable odor when handled. MIay 11-July 14.

32 (128). Calosoma Wilcoxi Lec., Ann. Lyc. Nat. Hist., Ir. 1S4S, 44 .

Tery similar to scrutator but nuch smaller and with a narrowei thorax. Margin of elstra sometimes green. Middle tibice of male straight: not hairy. Length $15 \mathrm{~mm}$.

Very common along the beach of Lake Michigan in May and June; less frequent in southern Indiana. April 26-June 10. Often attracted by electric light.

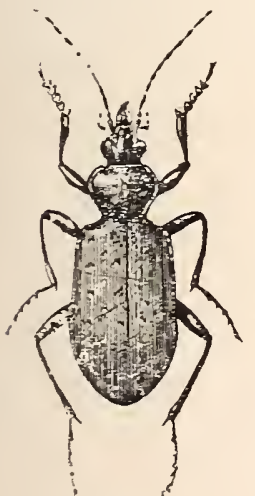

Fig. 35 .

33 (129). Calosoma frigidecar Kirbr; Faun. Bor. Amer.. IT. 1\$37. 19 .

Oral, rather slender. Black above, greenish-black below: thorax and elstra with narrow green margins. Head and thorax sparsely and rugosely punctate. Elytra with fine punctured strize. each with three rows of distant. round. sreen impressed spots. Length $20 \mathrm{~mm}$. (Fig. 35.)

A northern species which has been taken in Indiana only along the beach of Lake Michigan, where it is found in May and June in small numbers. Ma! 27-June 29.

34 (142). Calosoma calidtar Fab., Syst. Ent.. I. 178.j. 237.

Oral. robust. Black abore and below: elstra with three rows of reddish or copper colored pits. Head and thorax finels rugose, not punctate. the latter with broad basal impressions. Elytral striae deep. finely punctured; interrals broad and. as in sereral of the other species, appearing as if composed of orelapping scales. Length 21-23 mm. (Fig. 36.) 


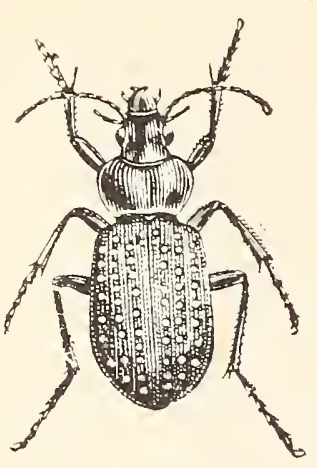

Fig. 36.

Common thronghout the State in meadows. cultivated tields, gardens, etc. It is called the "fiery hunter," as it is often seen in daytime on the search for eutworms and other juicy larva. It is also known to feed upon the young of the Colorado potato beetle. The grubs are called "cutworm lions," as they capture and destroy many of those injurious worms. May 2-July 20.

Tribe IV. ELAPHRINI.

Beetles of small or medium size, blackish or bronze in color, having the eyes more or less prominent, antennæe rarely longer than head and thorax. with three basal joints glabrous; labrum truncate; mandibles stout, concave and with one bristle-bearing puncture on the outer side. Body not pedunculate, scutellum distinct. Elytra not or feebly margined at base. Prosternum not prolonged behind the coxx, the coxal cavities closed. The tribe is composed of three genera, two of which are represented in Indiana.

\section{LEY TO INUTANA GENERA OF ELAPTRINI.}

a. Elytra not striate, but with prominent impressions or pits; eyes prominent; tooth of mentum large, emarginate. V. EuAphrus.

ar. Elytra striate, with small pits beetween the strie; eyes not prominent; tooth of mentum short, bifid at tip.

V. Elaphrus Fab. 1775. (Gr., "light in moving;" i. e., swift.)

Bronzed and metallic beetles, similar in form but much smaller than thcse of the genus Cicindela. They may be found on sunny days running on sand bars and mud flats near streams and lakes, and in cloudy weather hiding under plants and rubbish. Head, in our species, wider than thorax, the latter without marginal bristlebearing puncture. Elytra with rows of large, shallow, orbicular impressions. Eleven species are known from the United States, five of which have been taken in Indiana. For synoptic tables of both this genus and the next, see:

Crotch.-Trans. Amer. Ent. Soc., V, 1876, 246.

Croteh.-Bull. Brook. Entom. Soc., I, 1878, 6-7.

KEY TO INDIANA SPECIES OE ELAPHRUS.

u. Thorax sparsely punctate; front tarsi of males with four joints dilated.

7. Elytra smooth, not punctured. 
c. Under surface of thorax coarsely and sparsely punctate.

35. ClaAtrVILIAL.

cc. Under surface of thorax finely and densely punctate; legs piceoms.

b7. Elytra punctate, at least on sides.

36. LEVIGATUS.

d. Whole surface of elytra sparsely and coalsely punctate; length $7-7.5 \mathrm{~mm}$.

37. CICATRICOSUS.

d.d. Raised portions of elytra between the impressions not punctate; length $8-8.5 \mathrm{~mm}$.

3S. TULIGINOStS.

aa. Thorax finely, evenly and densely punctate; front tarsi of male with three joints dilated; length $6 \mathrm{~mm}$.

39. RUSCARIUS.

3ã (150). Elaphrus clatrvillei Kirby, Faun. Bor. Amer., IV, 1837.

Elongate-oblong. Obscurely bronzed, shining; elytra with a purplis!n tinge; legs paler. Head sparsely punctate, vertex foveate, occiput deeply impressed. Thorax not wider than head, disk with a deep forea each side. the base and apex sparsely punctured on the sides. Elytra with four rows of eye-like fover. Length $8.5 \mathrm{~mm}$.

One in Field Museum collection labelled "Ind." Probably from near South Bend. A member of the boreal fauna.

36 (151). Elaphrus lavigatus Lec., Ann. Lyc. Nat. Hist., V, 1852, 200.

Bronzed, shining, legs piceous. Elytra not punctured, the forear purplish. Length $7-8 \mathrm{~mm}$.

Two specimens in Field Museum labelled "Ind." Ranges from Michigan to California.

37 (153). Elaphrus cicatricosus Lec., Ann. Lyc. Nat. Hist.. IV, 1848, 348.

Elongate-obiong. Dull brassy above; bluish beneath; tibiae and tarsi dull yellow. Thorax with a deep median impression and a small circular fovea each side; the punctures, as well as those of elytra, much more coarse and irregular in size than in mscarius. Length 7-7.5 $\mathrm{mm}$.

Mud flats, border of cypress swamp, Knox County ; frequent locally. June 29-September 2.

38 (155). Elaphrus fuliginosus Siy, Trans. Amer. Phil. Soc., IV, 1S:34.

417 ; ibid. II, 529.

Brassy-black, tinged with green above, metallic green below; tibire and tarsi reddish-brown. Thorax and sides of elytra sparingly punctate; disk of latter in part smooth. Length $8-8.5 \mathrm{~mm}$.

A northern species taken sparingly along the beach of Lake Michigan near Pine, Lake County. May 20-Jume 29.

39 (160). Elaphrus ruscarius Say, Trans. Amer. Phil. Soc., IV, 1834, 417; ibid. II, 496, 530.

Dull brassy above; metallic green beneath; impressions of elytra purplish; Jegs reddish-brown. Thorax conrsely punctate beneath, the disk with a faint median impression. Length (After Leng, ) $6 \mathrm{~mm}$. (Fig. 37.) 
Common along streams and margins of ponds and lakes throughout the State. April 3-December 25. One specimen from Putnam County was taken on the latter date, indicating that the species probably hibernates in the imago stage.

\section{BuEThisa Bon. 1813. (Gr., "to throw.")}

Resembling Elaphrus but much larger, with proportionally narrower head and smaller eyes. Head and thorax parallel, the for- mer with a deep groove each side; last joint of maxillary palpishort. They live during summer near rain pools or small bodies of water. One of the four species known from the United States has been taken in Indiana, while another perhaps occurs.

\section{KEY TO INDIANA SPECIES OF BLETHISA.}

a. Thorax quadrate, smooth above and beneath except in the basal impressions; length $15 \mathrm{~mm}$.

aa. Thorax subcordate, finely and densely punctate beneath ; length $12 \mathrm{~mm}$.

(164). Blethisa quadricollis Hald., Proc. Phil. Acad. Nat. Sci., III, 1847, 149.

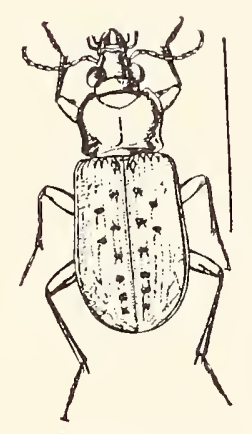

Fig. 38. (After Leng.)

Blackish or coppery bronze above; black beneath. Thorax quadrate, sides feebly curved, margins strongly reflexed, basal impressions sparsely punctate, hind angles obtusely rounded. Elytra striate, punctured, each with about tell furea arranged in three rows. Length $15 \mathrm{~mm}$. (Fig. 3S.)

Represented in the collection by a single specimen, taken August 15 from beneath rubbish near a deep pool in the center of a tamarack marsh, one half mile south of DeLong, Fulton County. Specimens from Lake and St. Joseph counties are in the Wolcott and Field Museum collections at Chicago.

B. multipunctata Linn. has been taken in Michigan and northern Illinois, and doubtless occurs in the northern third of Indiana.

\section{'roibe V. NTRRITNI.}

Species of small or medium size, mostly black in color'; antenna with foul basal joints glabrous; mandibles with bristle-bearing puncture on onter side; elytra margined at base. Prosternum proinged behind the enxie, the cavities open behind; hind coxa tonching. Five genera represent the tribe in the United States, two of which oceme in Jndiana. 
KEY TO INDIANA GENERA OF NEBRIINI.

u. Size small, not orer $5 \mathrm{~mm}$; front tibia very obliquely truncate, the inner spur above the apex; vertex sulcate.

VII. Notiopilile's. ur. Size medium, s or more mm.: front tibie not obliquely truncate. sinus terminal; rertex not sulcate.

VIII. Nebria.

VIII. Notiophilys Dum. 1806. (Gr., "spring + loving."')

Small oblong black $01^{\circ}$ bronzed beetles, having the head horizontal. triangular, striate. and as broad as or broader than the thorax; eyes prominent; elytra with sides almost parallel, but little broader than thorax. They orcur beneath leaves along the margins of open woods and cultivated fields, and in early spring are freruent about the bases of trees and stumps and the sides of logs. Eleven species are known from the United States, three of which have been taken in Indiana. Our species belong to the group having the front 5-striate.

The latest and best paper on the genus is that of:

Fail. H. C." A Review of of the North American Species of Notiophilus.' in Psyche. XIJI, 1906. 79-92.

KEY TO INDLANA SPECIES OF NOTIOPHILUS.

a. Legs and antenaie entirely liale reddish-brown; head much wider than thorax, the sides of the latter deeply sinuate behind the middle.

41. ENEUS.

nu. Legs dark. or with the tibiae alone paler: antennie pale at base only.

b. Elytra each with one apical annulate puncture: second elstral interspace equal to two intervals in width; size larger, form stouter'.

42. SEMISTRIATLS.

b7. Elytra each with two apical anmulate punctures; second elytral interspace broader, equal to three intervals in width; size smaller, more slender.

43. NOYEMSTRIATCS.

41 (173). Notiophilus exeus Hbst., Col., X, 1806. 235.

Metallic bronze, shining. Thorax coarsely punctured near base and apex, disk smooth: hind angles acute. prominent. Punctures of elytral strie deep at base. becoming indistinct behind the midrle: the second elstral interspace as in somistriutus. Fig. 39. Lengtli 5 min. (Fig. 39.)

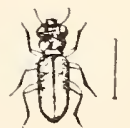

Fig. 39.
(AfterLeng.)

Lake. Vigo and Pusey rounties: smaree. Nay 18-.Jnne 18.

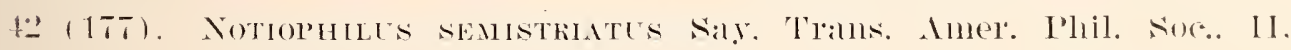
1 s.?. s1; ibid. II, 49т.

Rirther stout. Blackish or purplish-bronze, strongly shining: tibit and foul basil joints of antenne usually pale. Telminal joint of pally dilited and truncate. Thorax coarsely punctite at sides, aper and base. the disk smooth; sides stromgly simuate behind the middle. Elytral striae 
entire, the inner ones faintly impressed at apex, punctures fine. Length $5 \mathrm{~mm}$.

Lake, Vigo, Putnam, Marion and Posey counties; scarce. April 23-Octnber 4. This, according to Fall, is the form usually known as sibiricus, it having been wrongly placed under that name by Leconte.

43 (- -). Notiophinds Novemstriatus Lec., Amn. Lyc. Nat. Mist., IV, 1848,450 .

Shorter, more slender. Mietallic bronze, shining; tibise and four basal joints of antenne pale. Thorax as in semistriatus, the sides less sinuate. Elytral alutaceous at tip, the strixe entire, regularly and distinctly punctured. The second elytral interspace is wider than in either of our other species and, as a consequence, the lateral strix are more crowded. Length $4 \mathrm{~mm}$.

Southern half of State; frequent. March 6-October 9. Probably hibernates as imago. This is the semistriatus of Leconte, nec. Say.

\section{NeBria Latr., 1802.}

Species of medium size, having the antennæ slender, two-thirds or more the length of body, joints cylindrical: maxilla armed beneath with bristles; scutellar strix of elytra always very distinct. About 24 species are known from the United States. Of these but one has been taken in Indiana, though two others may possibly occur. These three species are black and have the elytra truncate at base, the humeri distinct, the third interval with four or five large dorsal punctures. For literature see:

Horn.- "Descriptive Catalogue of the Species of Ncbria of the United States"' in Trans. Amer. Ent. Soc., III, 1870, 97-10t. Horn._- "Synoptic Table"' in Bull. Brook. Entom. Soc., I, 1871, 30 .

KEY TO INDIANA SPECIES OF NEBRIA.

a. Sides of elytra subparallel.

b. Sides of thorax oblique, not sinuate near base; legs black.

SUTURALIS.

b7. Sides of thorax sinuate near base; less brown or piceous, the tibie paler.

SAHLBERGI.

a . Sides of elytra rounded; legs pale yellow.

4. PALLIPES.

N. suturatis Lee., 10-11.5 mm., and N. sahlbergi Fisch., $10 \mathrm{~mm}$. in length, belong to the boreal famna and range from New Hampshire westward. They are likely to be found with other members of that fauna in the northern third of Indiana. 


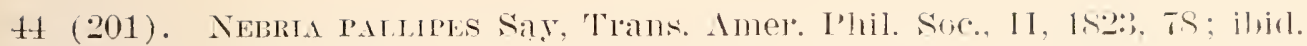
II, 494.

Elongate-oral. Black, shining: legs and antemuce pale yellow. Thorar s'rort, broad, much narrowed behind, margins rather wide. strongly re"exed; hind angles obtuse; disk smoth with a deep median impresterl line. Elytra deeply striate, the strie finely lunctured on the sides; intervals convex, the third with five larger punctures on the outer side. Iength $10-12 \mathrm{~mm}$.

Lawrence. Franklin and Vigo connties; scarce. April 15-July 11. Occurs beneath stones and rubbish close to running water. Probably to be found sparingly throughout the State.

Tribe VI. SCARITINI.

Species variable in size, having the antemne rising from under a frontal plate; head with one or two bristle-bearing punctures above the eyes; mandibles without a similar puncture on the outer side; labrum short, emarginate or sinuate. Body pedunculate, soutellum not visible. Elytra not. or rarely, slightly margined at l:ase; prosternum not piolonged bahind the coxie; front coxal carities closed behind; hind coxie touching; legs stout. more or less adapted to digging. The tribe is composed of six genera, all of which are represented in Indiana.

KEF TO GENELA OF SCARITINI.

a. Species of large or medium size, 15 or more $11 m$. in length; basal joint of antennic long; mentum broad, concealing at the sides the base of the maxillas; one bristle-bearing puncture above the eye and one at hind angles of thorax.

b. Form broad, size large; hind angles of thorax distinct; elçtra rith humeral carina.

IX. PAsmaches.

bъ. Form narrow, size medium; hivd angles of thorix wanting; elytra without humeral carina.

X. SCARITES. ur. Species of small size, less than $10 \mathrm{~mm}$. in length; basal joint of an. temne short; base of maxillixe not corered by the mentum; two bristle-bearing punctures above each eye and two at himl angles of thorax.

c. IIargin of elytria entire; mandibles that and curved.

d. Front tarsi slender in both sexes.

e. Thorax globular or oval; terminal joint of male palpi dilatel and excavated beneath.

XI. Drschmics.

ce. Thorax more or less quadrate: palpi similar in the sexes, not dilated or excavate in male.

Nil. Chitixi.

dd. Front tarsi dilated in botin sexes.

$f$. Head not striate: mentum feebly emarginate.

XII. Aspidogloss.

ff. Head with numerons fine striat or lougitudinal groores: mentum! deeply enarginate.

XIT. Sitizogexits. 
cc. Margin of elytra interrupted behind the middle and with a fold along the suture; mandibles slender. prolonged, not curved: front tarsi dilated.

XV. ARdistonis.

IX. Pasmachus Bon. 1813. (Gr., "all + fight.")

Large, broad species, having the color black, the thorax and elytra msually bordered with blue; thorax broad, with distinct hind angles; elytra rounded or subarute at apex; front tibia palmate. They occur beneath stones, logs and rubbish in open woods and along the borders of cultivated fields, preferably in sandy places, and feed upon larva of various kinds. especially those of the army worm. For this reason they are to be classed among the most beneficial of the Carabida. Eleven species are known from the United States, four of which have been taken in Indiana. The principal papers treating of the genus are as follows:

LeConte.-- "Notes on the Species of Pasimachus"' in Bull. Buffalo Soc. Nat. Sci., I, 1874, 266.

LeConte. "Synoptic 'Table', in Bull. Brook. Ent. Soc., I, 1879. 15.

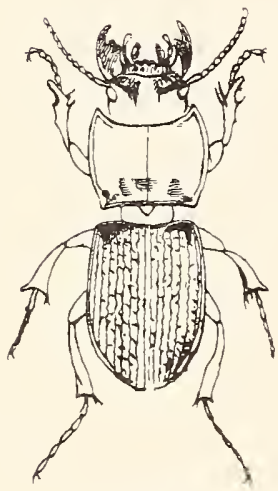

Fig. 40. (After LeConte.)

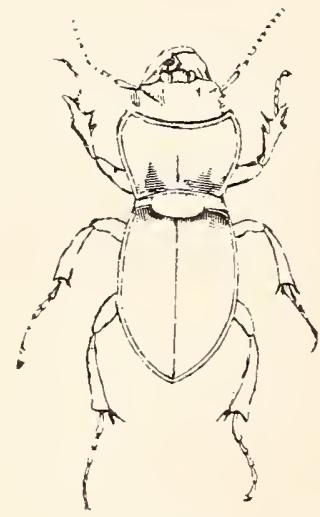

Fig. 41.

(After LeConte.)

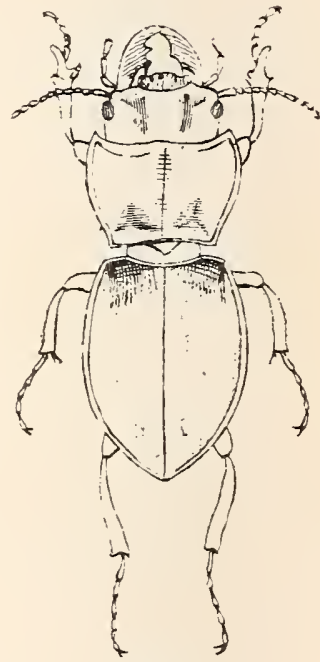

Fig. 42.

(After LeConte.)

JEE TO INDIANA SPECIES OF PASIMACHES.

a. Elytra obtusely rounded at apex, feebly striate; spine of middle tibiar compressed, obtuse at tip; hind angles of thorax obtuse, nat prominent.

45. SUBL.ÆVIS.

a11. Elytra subacute at apex, not striate; spine of middle tibie slender. acute; thniax more or less constricted at base. its hind angles prominent.

b. Hind tibise of male not densely pubescent on inner side; form broad; elytra smooth.

46. DEPRESSTS.

孔. Hind tibise of male densely pubescent on inner side near the tip. 
c. Form elongate; humeral carinal long, curved outward in front; elytra smooth; length $2: 20$ - 6 mm.

47. ELONGATUS.

cc. Form broader; humeral carina short; elytra usually with pairs of punctures; length $28-30 \mathrm{~mm}$.

48. PUNCTULATUS.

45 (210). P'asmachus sublevis Bon., Obs. Eut., 1813, 46.

Elongate-oblong. Black with blue margins. Thorax subquadrate, frout angles prominent, sides feebly curved, suddenly converging at basal third. Elytra with sides parallel, convex; disk with faint rows of small punctures. Length 21-2S mm. (Fig. 40。)

Known from Indiana by a single specimen taken from beneath a $\log$ on the sandy margin of the old canal north of Terre Haute, Vigo County. May 16.

46 (214). Pasmachus depressus Fab., Syst. Ent., I, 1792, 94.

Black, usually with blue margin. Labrum broadly and feebly trilobed; mandibles feebly or not at all striate. Hind tarsi long and slender. Female dull, male shining. Lengtli 24-30 mm. (Fig. 41.)

Common singly or in pairs beneath stones and logs on the slopes of high hills near Wyandotte, Crawford County. May 17-June 26. 47 (217). Pasimachus elongatus Lec., Ann. Lyc. Nat. Hist., IV, 1848. 147.

Black with blue margins. More elongate and less broad than the preceding; hind tibire and tarsi less slender. Labrum broadly trilobed, the middle lobe the wider; mandibles finely but distinctly striate. Length 23-26 $\mathrm{mm}$.

Lake, Marion and Vigo counties; scarce. May 16-August 26. 48 (218). Pasmaches punctulatus Hald., Proc. Plil. Acad. Nat. Sci.. 1. 299.

Allied to $P$. depressus, but differing by the hind tibice and tarsi being less slender and less elongate, and by the hind tibiae of the male being densely pubescent on inner side near tip. Elytra usually with rows of punctures, approximate by pairs. Mandibles deeply and coarsely striate. Length 28-30 $\mathrm{mm}$. (Fig. 42.)

Throughout the State; frequent. April 2-July 6.

\section{Scarites Fab. 1775. (NL., "a scratcher.")}

Narrow, oblong black beetles having the body very plainly pedunculate; hind angles of thorax wanting; elytra parallel, rounded behind and withont humeral carina; front tibia widened, flattened and toothed on outer side.

Two species occur in our faund, and are quite common about gardens and borders of cultivated fields beneath logs, stones and rubbish. They feed upon animal food alone and are very beneficial. 
$49 *(200)$. Scarites subterraneus Fab., Syst. Ent., I, 1785, 124.

Black, shining. Head with two deeply indented parallel lines. Thorax subquadrate, sides nearly straight, finely margined, apex truncate, base angulate. Elytra distinctly striate, the striae without punctures. Length 15-20 $\mathrm{mm}$.

Throughont the State; common. Jantary 1-July 20. Hibernates as imago.

50 (220a). Scarites substriates Hald.. Proc. Phil. Acad. Nat. Sại., II, 1844,54 .

Differs from subtcrancus only in size. I have seen no intermediate snecimens, nor do I find record of any; hence I regard it as a distinct form. Length 25-30 $\mathrm{mm}$.

Common thronghont the State. April 1-.July 7.

Xl. Drscunnus Bon. 1813. (Gr., "bad + hand.")

Small black or bronzed, shining species, having a globular thorax and flat bowed mandibles. They live in burrors in wet sandy places, along streams and lakes and may be taken in the evening, when they run freely about, or at any time by pouring water over their bumows, which causes them to emerge. About 40 species are known from the United States. eight of which have been taken in Indiana, while tro or three others perhaps occur. The principal papers on this and the next three genera are as follors:

Leconte._"Srnopsis of the Species Clivina and Allied Genera Inhabiting the United States" in Proc. Phil. Acad. Nat. Sci., $1857,75-83$.

Leconte._"Synoptjc Tables" in Bull. Brook. Ent. Soc., II, 1879, $17,32,34$.

KEY TO INDIANA SPECIES OF DYSCHIRIUS.

a. Dorsal punctures of elytra, when present, on third interval only.

b. Third interval of elytra with three punctures.

c. Front without a risible transrerse impression; elytral striæe reaching apex; femora black.

51. NIGRIPES.

cc. Front with a deep transrerse impression.

a. Stria extending to base of elytra, obliterated behind the middle. e. Thorax transversely ovate; legs and antennæ wholly reddishbrown.

52. GLOBCLOSTS.

ee. Thorax globular.

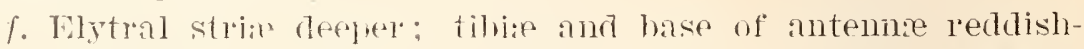
110011.

ai. LONGLLTS.

ff. Flytral strice feeble: legs and antemne black.

秋NEOLUS. 
dd. Striae not extending to base of elytral tip of elytrai rufous.

\%. Elytral stlia strongly punctate; flobax orate, blobler than lo11g.

54. IT EMORRITOHDALS.

gg. Elytral striae feebly punctate; thorax quadrate-globose.

55. TERMINATLS.

bb. 'Third interval of elytra with two punctures or none at all.

7. Apical spur of frout tibiae rery short; elytral striae coarsely punctured, absent on apicai third; thorax longer than wide.

BRETISINL"S:

hh. Apical spur of front tibice long.

$i$. Elytral strise deep, entire; clypens bisinuate and with three teeth.

56. SPHARICOLLIS.

ii. Elytral striae partly abbreviated at base; clypens truncate.

j. Thoiax ovate, broader than long.

$j j$. Thorax oval, not wider than long.

TRENCATES.

57. ERYTHROCERES

a . Elytra with thixd, fifth and serenth intervals each furnished with single rows of seta-bearing punctures; thorax clobose; elytral strix coarsely punctured.

5S. HISPIDCS.

51 (225). Drschirits xigripes Lec., Trams. Mller. Phil. Soc., X, 1S52, 396.

Elongate, slencler. Black, strongly shining; antennie piceous, the basal joint, tibige and tarsi dak leddish-biown. Clypens bidentate. Thoma globose with a very fine, melian inpressed line. Flytrin strice fine, distinctly punctured only on basal half. Length 3-3.2 $1 n u 1$.

Lake County; rare. Nay 5. A member of the boreal fauna.

52 (232). Drschiries globulosts Say, Trans. Amer. Phil. Soc., II, 1S23, 23 ; ibid. II, 452.

Black or dark reddish-brown, strongly shining; legs and antennæe rufous. Thorax orate, broader than long. disk with a median impressed line. Elytral strice extending to base, distinct, coarsely punctate; wholly absent on apical third. Length 2.7-3 mm. (Fig. 43.)

Throughout the State, frequent; much more so northward. March 5-Angust 24. Often taken from beneath the loose bark of logs in low ground woods.

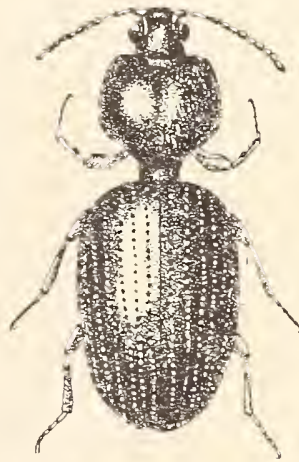

Fig. 43. (Original.) 13.

53 (231). Dyschirius longulus Lec., Agass. Lake Sup., 1850, 204.

Allied to the preceding but a little slualler and luaving the antennc fuscous at apex. Thorax subglobose (the length equal to the breadth) and not narrowed in front. Elytr: more elongate, with deeper strixe, the punctures of which are absent on apical hali. Length $2.5-2.71111$.

Throughout the State; frequent. March 17-October 1.

D. ceneolus Lee. black, shining. and $3.8 \mathrm{~mm}$. in length, is also a member of the boreal fauna and very likely occurs in the northern third of the State. 


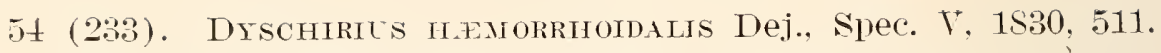

Blackish-bronzed, strongly shining: antemne, legs and tips of elytra pale reddish-brown. Thorax orate, transrerse. Elytral strixe coarsely and deeply punctate, abbreviater at base and obsolete on apical third. Length $2.8-3.3 \mathrm{~mm}$.

Starke, Lawrence and Farette counties; frequent. May 11August 23.

55 (284). Drschirius terminates Iec., Ann. Lye. Nat. Hist., IV, 18t8, 212.

Elongate, slender. Black, slightly bronzed, strongly shining; antenne. legs, abdomen and apical third of elytra obscure reddish. Thorax as broad as long. 'strongly convex, without a longitudinal impressed line. Elytral stria indistinct at base and wholly wanting on apical third. their punctures indistinct; the dorsal punctures of third interval located one on basal third, one near the middle and one slightly behind the middle. Length $3.2 \mathrm{~mm}$.

Posey County ; rare. April 26. Taken from beneath rubbish in cornfield near river bank.

D. brevispimus Lec., black, shining, $3.4 \mathrm{~mm}$. in length, occurs in Michigan and Ohio and doubtless in Indiana.

56 (237). Drschirues sphericollis Say, Trans. Amer. Phil. Soc., II, 1823,23 ; ibid. II, 452.

Black-bronzed; antenne and legs dark red. Thorax ovate, not broade! than long; disk with a median impressed line. Elytra deeply striate, the strix entire, punctures indistinct on apical half. Length $5.5 \mathrm{~mm}$.

Fayette and Posey counties; rare; also two in Webster collection. July 4-August 23. Our largest species.

D. truncatus Lee., blackish-bronzed, $5.5 \mathrm{~mm}$. in length, oceurs in Illinois and Missouri and probably in western Indiana.

57 (240). Drscmirius Erythrocerus Lec., Proc. Phil. Acad. Nat. Sci., $185 \pi$, is.

Elongate. Blackish-bronzed, shining; legs and antennie reddish-brown. Front of head with a transverse impression between the eyes. Thorax suborate, slightly longer than broad, with a fine, median impressed line. Elytral striæ slightly abbreviated at base and absent on apical third, coarsely punctured; dorsal punctures of third interval located one in front of middle, the other, very fine, on apical third. Length $4-5 \mathrm{~mm}$.

Putnam County; rare. July 4.

58 (254). Drschratus mispidus Lec., New Spec. N. Amer. Col., I, 1863. 4.

Blackish-bronzed, strong]y shining: antennæ rellowish; legs reddishbrown. Thorax globose, as broad as long. Clypeus emarginate, twotoothed. Elytral strice impressed and coarsely punctate except on apical 
third; the punctures of the third, fourth and seventh intervals fine but distinct, each bearing a long hair readily risible under a lens when viewer from the side. Length $3 \mathrm{~mm}$.

Posey and Clark comties; rare. April 18-May 6. Taken from beneath boards on the banks of the Wabash and Ohio rivers.

\section{Cimini Lat. 1862. (A proper name.)}

Small black or reddish brown species closely allied to Dyschirius but having the thorax more or less quadrate, the sides either strongly oblique or rounded near base; the disk with a median impressed line. Palpi similar in both sexes, not dilated nor excavated in the male. They occur in damp places, along streams and lakes, and may be captured by throwing water on their burrows and then picking them up as they emerge. Some of the species, as probably some of the Dischirius, hibernate in the perfect stage. Twentytwo species are known from the United States. Of these seven have been taken in Indiana, while three others perhaps occur.

\section{KEY TO INDIANA SPECIES OF CLITINA.}

a. Middle tibire with a spur near the outer tip; clypeus with a lobe each side; dorsal punctures of elytra three or more.

o. Front femora dentate near-the tip; color black. 59. Dentipes.

bъ. Front femora thickened, not dentate; color reddish-brown or piceous. c. Vertex sulcate.

d. Vertical groove deep and long; head sparsely punctate behind the eyes; larger, $6-6.5 \mathrm{~mm}$.

60. IMPRESSIFRONS.

$d d$. Vertical groove shorter, more shallow; head and thorax puncturerl; smaller, 5-5.5 $\mathrm{mm}$.

61. PUNCTIGERA.

cc. Verter not sulcate; head and thorax smooth; basal angle of thorax dentate.

62. RUBICUNDA

a a. Middle tibia without a spur on the outside of tip.

$e$. Clypeus with a lobe each side; front of head with a pit; front femora beneath deeply sinuate near the tip; dorsal punctures three or more.

$f$. Color in part or wholly brownish-red.

g. Elytra entirely light brownish-red.

63. RUFA.

gg. Elytra brownish-red with a broad black suture.

COLLARIS.

ff. Color black; legs dark reddish-brown, antennie paler.

64. AMERICANA.

ee. Clypeus rounded at sides; front femora thickened, not simuate beneath; dorsal punctures two or none.

h. Vertex sulcate; thorax elongate: color reddish-brown. FERreA.

$h h$. Vertex not or faintly sulcate; thorax subquadrate; black, elytra with reddish spots.

i. Thorax nearly smooth.

65. BIPUSTULATA.

ii. Thorax punctate.

POSTICA. 


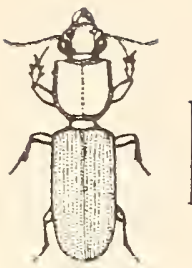

Fig. 44. (After Leng.)

59 (258). Chrina dentreas Dej., Spec. I, $1825,415$.

Elongate, slender. Black, shining; legs piceous; antennæ and tarsi reddish-brown. Elytral striæ distinct, finely punctured. Length 7.5-8.5 nim. (Fig. 44.)

Throughout the State: frequent. April 6-October 9 .

60 (259). Clivins impressifrons Lec., Proc. Phil. Acad. Nat. Sci., II, $1814,50$.

Readily known by its uniform ieddish-brown hue and the deep groore of rertex. Elytral strixe distinct, finely punctured. Length $6-6.5 \mathrm{~mm}$. (Fig. 45.)

Frequent throughout the 'State, beneath stones along the sandy margins of streams and lakes, and in low, damp cultivated fields. April 1-August 30. Said to do much damage to sprouting corn grains.

61 (263). Clivina punctigera Lec., Proc. Phil. Acad. Nat. Sci., 1857 , S1.

Elongate, slender, parallel. Dark reddish-brown; elytra piceous, the antenne and legs a little paler. Vertical groove evident but shallow, with numerous fine punctures near its front

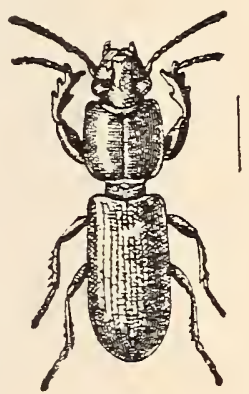

Fig. 45. end and coarser ones on sides. Thorax finely and sparsely punctured. Elytral striæ deep, the punctures fine; the third stria with four dorsal punctures. L ?ngth 5-5.5 mm.

Dubois County; rare. May 11. Resembles impressifrons but smaller, with shorter and more shallow vertical groove and with the outer front angles of the clypeus less advanced. A southern form described from South Carolina.

$62 *(264)$. Clintaxa rubicunda Lec., Proc. Phil. Acad. Nat. Sci, 155i, 81.

Elongate, slender. Head, thorax, antemne and legs reddish-brown; elytra darker. Head smooth, vertex foreate. Thorix with one or two dull teeth on each basil angle. Length $4.8-5.2 \mathrm{~mm}$.

Vigo and Posey counties; scarce. February 10-May 7. Occurs beneath $\log$ and chunks some distance from water. Hibernates as imago. A handsome little species, also of southern range.

0.3 (266). Chmixa Rufa Lec, Proc. Phil. Acad. Nat. Sci., 1857, 81.

Uniform light bromish-red. Elytral strise entire, finely punctate. rength y $\mathrm{mm}$.

Floyd County ; scarce. September 29-October 9.

C. collaris Herbst, an introduced Enropean species, $5.2 \mathrm{~mm}$. in length, has been taken near Cincinnati and probably occurs in southern Indiana. 
64 (269). Clivina americana Dej., Spec., V, 1830, 503.

Elongate, slender. Black; legs and very nurrow onter milrgin of thorax and elytra d trk reddish-brown; antemne paler. Elytral strice entire, finely punctulate. Length $5 \mathrm{~mm}$.

Througliout the State; frequent. April 1-July 23.

$C$. ferrea Lec., $5.2 \mathrm{~mm}$. in lengtl, has been taken in Illinois and perhaps occurs in western Indiana.

05 (275). Clivina bipustulata Fab., Syst. El., I, 1801, 125.

Black, usually with two large, obscure red spots at base of elytra and two near the apex; legs and antemme reddish-brown. Elytral strixe deeply punctate. Length 6-7.5 $\mathrm{mm}$.

Frequent in the southern half of the State; taken in the north only in Lake Cointy. April 4-.July 1.

C. postica Lee., a southern species, $5.2 \mathrm{~mm}$. in length and having the front tibia armed with two teeth, has been taken near Cincimnati and probably occurs in the southern third of Indiana.

XIII. Aspidoglossa Putz. 1846. (Gr., "a shield + tongue.")

Represented in the United States by a single, small, black species having the mentum feebly emarginate; thorax subglobose; head without fine grooves; front tarsi dilated in both sexes.

66 (280). Aspidoglossa subangulata Chaud., Bull. Mose.. IV, $1843,738$.

Black, strongly shining; antenne and legs reddish-brown; elytra with a reddish spot on apical fomptl. Thorax short, subglubose, apex truncate; disk smooth without median line. Elytra deeply striate, the stria coarsely punctate; second interval with seven or eight, the fourth with five or six, dorsal punctures. Length $7.5 \mathrm{~mm}$. (Fig. 46.)

Southern third of State; frequent. April 8-September 19. Occurs beneath the bark of logs in low,

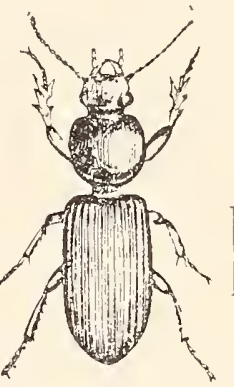

Fig. 46. moist woods; also beneath stones and rubbish near water. Resembles closely Clivina bipustulata and doubtless confused with that species in many collections. Readily distinguished by the shorter, more globose thorax and the numerous dorsal punctures of second and fourth intervals. A member of the Austroriparian fauna.

XIV. Schizogenius Putz. 1846. (Gr., "eleft + chin.")

Small blackish or reddish brown beetles allied to clivina, but having the mentum deeply emarginate: had with mumerous fine. 
lengthwise grooves; thorax subquadrate, apex truncate, sides straight to near base. then strongly oblique or rounded; disk smooth, with an entire median and two shorter impressed lines; front tarsi more or less dilated in both sexes. Like the members of the three preceding genera, they live mostly in damp sandy places. Three of the eight species known from the United States have been taken in Indiana.

\section{KEY TO INDIANA SPECIES OF SCHIZOGENIUS.}

a. Color blackish; elytra somewhat depressed, striae deep. finely and closely punctate.

67. LINEOLATUS.

au. Color reddish-brown.

b. Elytra cylindrical, strice indistinctly punctured. 6S. Ferrugineus.

b. Elytra strongly depressed; hind angles of thorax prominent before the base.

69. AмPнiвIUS.

67 (283). Schizogenius lineolatus Say, Trans. Amer. Phil. Soc., II, 1823, 22 ; ibid. II, 451.

Uniform blackish or piceous above; dark reddish-brown beneath; antennie and legs somewhat paler. Length $3.5-4 \mathrm{~mm}$.

Vigo and Franklin counties; rare. April 1-June 11.

(is (285). Schizogenius ferrugineus Put\%, Mon., 1846, 653.

Color: uniform pale reddish-brown; elytral strixe deep, punctures feeble. Length $3 \mathrm{~mm}$.

Beach of Lake Michigan near Millers, and Pine, Lake County; frequent locally. April 29-.Jujy 23.

(90) (2S6). Schizognerius amphibius Hald., Proc. Phil. Acad. Nat. Sci.. I, 1842. 299.

Dark leddish-brown; elytra darker than the other parts. Hind angles of thol'ax represented by a distinct tooth or cusp before the base. Length 3-3.5 mm.

Fountain, Clay and Owen counties; rare. June 15-August 13. Known from New York and Missouri.

XV. Ardistomis Putz. 1846. (Gr., "high + mouth.")

Small black or greenish shining beetles having the thorax rounded, considerably narrower than cyrad mandibles slender, prolonged, not curved. They occur in low moist woods, beneath bark, stones and rubbish. Five are known from the United States, two of which have been taken in Indiana. 
70 (292). Aruistomis virides Say, Trans. Amer. I'hil. Sor., II. 182:, 21; ibid. II, 451.

Greenish-black, shining; mandibles, antenne and less reddish-brown. Thorax with a median impressed line. smooth except along the margins. Elytra not striate, each with three or four rows of rather fine. scarcely impressed punctures, each puncture bearing a short, erect hair. the hairs plainly visible only from the side. Length $5 \mathrm{nmm}$. (Fig. 47. )

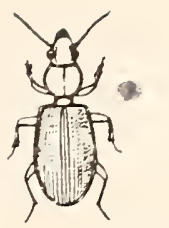

Fig. 47. (After Leng.)

Lake, Larrence and Posey counties; scarce. May 16-August 15.

71 (293). Ardistomis plicticollis Putz. Mon. 15 46.129.

Resembles viridis, but more slender and with the disk of thorax sparsely and coarsely punctured, each puncture baring a bristie-like hair. Punctures of elytra coarser and more numerous. Length $5 \mathrm{~mm}$.

Southern half of State; frequent. Hibernates as imago. February 23-.Tune 93.

\section{Subfamily II. HARPALINAE.}

The members of this subfamily have the epimera of the mesosternum rariable in width but not reaching the coxa, the middle coxal cavities therefore enclosed on the outer side by the junction of the meso- and metasterna: head marked with one or two bristlebearing punctures over each eye; thorax with a similar puncture at the side and another at the hind angle. very rarely without the latter and still more rarely without either; front tibia alwars either obliquely sinuate or deeply emarginate within, the inner spur remote from apex.

For conrenience the subfamily was divided by Horn into two great groups or sections as follows:

KEY TO SECTIONS OF MARPALINA.

a. Head with two punctures above the eye each bearing a single hristly hair.

Section I. HARPALINE BISETOS.玉. 1) 64. au. IIear with but one bristle-bearing puncture abore the eye.

Section II. Habpaline trisetos.e, 1) 156.

When two punctures ocenr. the front one is close to the margin of the eye in front, and the hind one a little remote from the eye, opposite its hind margin. Where there is but one bristle-bearing puncture it is a lithle removed from the margin of the eye, and is situated opposite the middle of the eye or a little behind that point. 
The internal elytral fold mentioned in the key can only be seen by lifting one of the elytra. Its purpose is to afford a means of support to the edge of the abdomen, and at the point of origin of the fold behind, the last ventral segment is held firmly when the insect is in repose.

\section{Section I. HARPALINA BISETOSA:}

This section is divided by IIorn into 24 tribes, of which 12 are known to be represented in Indiana, while members of two others probably oceur.

KEY TO INDIANA TRIBES OF IIARPALINE BISETOSE.

a. Mandibles with a bristle-bearing puncture in the groove (scrobe) on the outer side.

๖. Antenne slender, with at most two basal joints glabrous; abdominal segments entirely corneous or horn-like.

$c$. Last joint of palpi awl-shaped; mesosternal epimera wide; length less than $8 \mathrm{~mm}$.

Tribe IV. Bembidinn, p. 67.

$c c$. Last joint of palpi slender. elongate or subcylindrical: mesosternal epimera narrow.

Tribe V. Pogonini, p. S6.

b). Antennxe moniliform or bead-like, foul basal, joints glabrous; abdominal segments 3,4 and 5 narrowly coriaceous or leather-like on their hind margins.

Tribe II. NomIni, p. 66.

ac. Mandibles without a bristle-bearing puncture in the scrobe.

d. Marsin of elytra interrupted at posterior third and with a distinct internal fold.

c. Four basal joints of antenna glabrous; body slightly pedunculate: antennie moniliform; front tibire dilated; length 12-16 mm.

Tribe III. Mortonini, p. 66.

ce. Three (or fewer) basal joints of antennce glabrous.

$f$. Head constricted behind the eyes, then dilated to a semi-globular neck; last joint of maxillary palpi arising obliquely from the preceding joint.

Tribe I. Panageini, p. 65.

$f f$. Head not constricted behind the eyes; last joint of maxillary palpi arising normally irom the end of the preceding joint.

Tribe VI. Pterostichini, p. $8 S$.

dd. Margin of elytra not interrupted posteriorly and without an intermal fold.

\%. Front of head short; labrum impressed.

Tribe VII. Licinini, 1) 112.

$g g$. Front of head normal.

7. Next to last joint of labial palpi with but two hristly hairs.

i. Head elongate, prolonged behind the eyes: neck constricted and dilated behind into a semiglobular knob.

j. Elytral entire. Tribe X. CTenodactrlint, 1. 137.

ji. Elytra truncate: three basal joints of antenne glabrous.

Tribe XI. Opacanthini, p. 138 . 
ii. Head not prolonged belind the eyes; neck not semi-globose.

l. Elytra rounded at tip; tarsal claws simple.

lik. Listra not roumeled at tip.

Tribe Ix. ANohonomerin, נ) 1:3i.

l. Elytra obliquely simuate at apex.

Tribe VIII. Platynini, p. 119.

17. Elytra truncate at tip.

m. Front tibiæ slender; paraglossie membranous.

Tribe XIII. Lebirni, p. 141.

$m m$. Front tibia rather stout, gradually broader to tip ; paraglossa horn-like. Tribe XIV. Helduonini, p. 155.

$h h$. Next to last joint of labial palpi with a number of bristly hairs in front and always longer than the terminal joint; eyes normal; first antennal joint elongate.

Tribe XII. Dryptini, p. 139.

Tribe I. PANAGEINI.

Head constricted behind the eyes, then dilated to a semiglobular neck; mentum emarginate; labrum with only four setæ; antennæ rising from under a distinct frontal ridge, three basal joints glabrous. Body not pedunculate, scutellum distinet. Elytra not margined at base, their sides narrowly inflexed. Hind coxæ contiguous. Males with the first two joints of the front tarsi dilated and hairy beneath.

The tribe is represented in Indiana by the single genus:

\section{Panagedus Latr. 1802. (Gr., "all-holy.")}

Medium sized black or reddish-brown beetles having the clypeus prolonged beyond the base of the scissors-like mandibles; upper surface coarsely punctured, and clothed with erect hairs; thorax semi-globose, strongly constricted near base, its hind angles rectangular. They occur beneath stones and logs, usually in sandy localities. Three species are known from the United States, two of which occur in Indiana.

72 (295). Panageus crucigerus Say, Trans. Amer. Phil. Soc., II, 1S23, 69 ; ibid. II, 489.

Head and thorax black; elytra each with two large red spots extending from the margin to the first or second stria. Thorax with numerous coarse, deep punctures, its hind angles small, acute; elytral striae and punctures deep. Length $11 \mathrm{~mm}$.

Two in Stein collection labeled "Ind."; probably from Posey County. One in Dury collection from Laporte County, Indiana. Taken also by Dury near Cincinnati. 


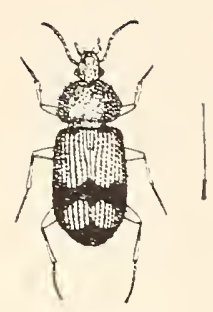

Fig. 48. (After Leng.)

*73 (296). Paxageus faschatus Say, Trans. Amer. Phil. Soc. II, 1823. 70 ; ibid. II. 490.

Heal and thorax resllish-brown; elytra reddish-brown with a black closs-band behind the middle and another at tips: iegs anci abdomen piceous. Thorax and elytra punctured as in the preceding. Length $7.5-8.5 \mathrm{~mm}$. (Fig. 4S.)

Throllohout the State; scarce. January 11-Octopaths; hibernates as imago.

\section{Tribe II. NOMIINI.}

Antenne arising from beneath a distinct frontal ridge. the third joint nearly as long as the two following. Head stout; oval, neck broar; labrum short, broadly emarginate; mandibles curved. with a feeble tooth on inner edge at middle and a bristle-bearing puncture in the outer groove. Bodr pedunculate, scutellum invisible. Elytra slightiy margined at hase. Hind coxa contignous: tarsi not dilated.

The tribe is represented in southern Europe and the United States by a single species. Nomius pygmaus Dej., an elongate-oblong, chestnut brown or piceous beetle, $7 \mathrm{~mm}$. in length, having the apex of thorax nearly twice the width of base and the elytra feebly striate-punctate. While its range is given as "New Jersey, Canada and Lake Superior, southward and westward to California," no verified specimen has been seen from Indiana, though one was in the Stein collection without locality label. It is said to occur under stones in moist places and to exude a very ill-smelling liquid when diśturbed.

\section{Tribe III. MORIONINI.}

Head suddenly narrowed kehind the eyes, neck stout; mentum deeply emarginate, last joint of palpi cylindrical. Elytra feebly margined at base, the disk with a single dorsal puncture on the apical third of third intervai. IInd coxæ contiguous; front tibia triangular, not spinose at the onter apical angle; first three joints of front tarsi slightly dilated in the male.

The tribe is represented in the Southern States by a single species, Morio moniticornis Latr., elongate, shining black. $12-16 \mathrm{~mm}$. in length, the thorax with deep basal impressions. It lives beneath bark, has been taken by Dury near Cincinnati. and very probably occurs in the southern third of Indiana. 
Tribe IY. BEMBIDINT.

Beetles of small size, blark. reddish-brown or bronzed in hue. having the antennæe slender, arising from beneath a slight frontal margin, the first or the first two joints glabrous; mandibles feebly curved, acute at tip; last joint of palpi awl-shaped, the next to last club-shaped and with two setre. Thorax with a bristle-bearing puncture at the side and another at hind angle; prosternum not prolonged. Elytra with sides narrowly inflexed, margin interrupted behind the middle, the disk with dorsal punctures; surface in our genera glabrous.

The tribe is represented in the United States by four genera. three of which occur in Indiana.

REY TO INDIANA GENERA OF BEMBIDINI.

a. Front tibiæ not obliquely truncate at apex; sutural strixe of elytra not recurved at apex; scutellar strix present.

b. Eyes large or moderate.

Ђb. Eyes entirely wanting.

XVII. Benbidiun. XVIII. ANIllus. au. Front tibia obliquely truncate at anex; sutural striæe recurred at apex: scutellar strice absent.

XIX. TACHYs.

XVII. Bembidiun Latr. 1832. (Gr.. "a buzzing insect + little.")

A large genus of small black, greenish, or bronzed beetles, having the characters of the tribe as above given. Elytra glabrous, striate; front tibiæ deeply emarginate, apical angle not obliquely truncate; hind coxæ tonching. Nales with the first two joints of front tarsi dilated, the first joint being slightly elongate and nearly quadrate, the second more or less triangular. with the inner angle usually slightly prolonged.

The Bembidids occur for the most part along the banks of streams, ponds and lakes, especially on mud flats and bars. A few are found in moss and amongst old leares about the trunks of trees and stumps or beneath the bark of logs. Several, perhaps most, of the species hibernate as imagoes.

The principal papers treating of the genus are as follows:

Leconte.- "Catalogue of the Species of Bembidium found in the United States"' in Proc. Phil, Acad. Nat. Sci.. 1857, 2.

Hayuard, Roland.- "On the Species of Bembidium of America North of Mexico" in Trans. Amer. Ent. Soc., XXIV, 1897. $32-143$.

Hayuard, Roland.--"Synonymical Notes on Bembidium and Descriptions of New Species" in Trans. Amer. Ent. Soc.. XXVII, 1901. 156-158. 
About 130 species of Bembidium are known from the United States. Of these 27 have been taken in Indiana, while eleven others perhaps occur. On account of this large number of species the genus has, for convenience, been divided into three groups based upon the position of the dorsal punctures and the form of the humeri of the elytra. The dorsal punctures are located either upon the third interval or the third stria. In two of the species, however, viz., lovigatum and semistriatum, there are irregular rows of small punctures upon all of the intervals. These are placed in their proper sequence in the group having the "dorsal punctures on third interval." The form of the humeri, whether rounded into the sides of the elytra or subangulate with the latter, is also used as a character of importance. The tables which follow have been adapted from those given by Hayward, loc. cit., to fit the species occurring in the State.

\section{KEY TO GROUPS OF INDIANA BEMBIDIUM.}

a. Elytra with two or more dorsal punctures on the third interval.

$b$. Humeri of elytra subangulate; eighth stria distinct from the margin.

bb. Humeri of elytra rounded.

Group $A$.

Group $C$.

aa. Elytra with two dorsal punctures on the third stria.

Group $B$.

\section{Group A.}

In this group the first puncture usually occurs on the third interval just in front of or just behind the middle, the second onethird to one-fourth from apex. The humeri are more or less angulate where they meet the sides of the elytra. It includes the Indiana species of Groups I to IV of Hayward.

\section{KEY TO INDIANA SPECIES OF GROUP A.}

a. Elytral stria more or less abbreviated or indistinct behind the middle; mentum with a short, bifid tooth.

b. Elytral intervals with irregular rows of sparsely placed, setre-bearing punctures; color green or bronzed.

74. LEVIGATUM.

67. Elytra with two dorsal punctures on the third interval; color black, rery shining.

75. NITIDUM.

a a. Elytral striæ entire; mentum with a large entire tooth.

c. Elytra with two quadrate impressions on the third interval, each enclosing a dorsal puncture.

d. Elytra with the fourth stria sinuate.

e. Slender, elongate, convex; thorax as long as wide, not wider at base than apex.

76. IN EQUALE. ce. Broader, less convex; thorax distinctly wider than long, slightly wider at base than apex.

LITTORALE. 
dd. Elytra with the fourth stria straiglit.

f. Broad, slightly depressed; thorax nearly twice as wide as long, not wider at base than apex.

77. CARINUIA.

$f f$. Robust; thorax abolit one-half wider than long, wider at base than apex.

7S. PUNCTATOSTRLATUM.

ce. Elytra without quadrate impressions; two dorsal punctures on the third interval.

9. Thorax wider at base than apex, nearly twice as wide as long; color bronzer, shining.

gg. Thorax not wider at base than apex.

h. Feebly convex; elytral striae deeply punctate, the punctures not greenish; legs bronzed piceous.

79. COXENDIX.

h\%. More robust; elytra less deeply striate, punctures greenish ; legs pale brownish-yellow.

so. CoNfusum.

74 (421). Bemindum refrigatum Say, Trans. Amer. Phil. Soc., II, 182:3, S4; ibid. II, $409,550$.

Robust, convex. Green or bronzed, sliming; antenne fuscous, the basal joints and legs dull yellow, the femora darker; under surface nearly black. Thorax subquadrate, more than one-half wider than long, sides broadly rurved from apex to behind middle, thence sinuate to base, margins reflexed; hind angles rectangular and carinate; disk smooth, the basal inpressions broad and deep. Elytra less than one-half wider than thorax. the stria coarsely punctured but not impressed. Length 5.5-7 $\mathrm{mm}$.

Southern half of the State; frequent in sandy localities. April 15--July 28.

75 (313). Besibidum nitidun Kirby, Faun. Bor. Amer., IV, 1837, 55.

Robust, slightly convex. Black or blackish-bronzed, strongly shining. Thorax subquadrate, about one-lialf wider than long, distinctly wider at base than apex; basal impressions broad, bistriate; hind angles rectangular, finely carinate. Elytra slightly wider than thorax, finely striatelunctate; the first, and sometimes the second strixe entire, the others abbreviated behind; intervals flat. Length $5-6.5 \mathrm{~mm}$.

Taken in small numbers by Wolcott near Indiana Harbor, Lake County. April 23-May 13. A member of the boreal fauna.

76 (30S). Bembidum inequale Say, Journ. Phil. Aaad. Nat. Sci., IIT, 1823, 151; ibid. II, 97, 749.

Bronzed, shining; antenne piceous, the basal joint pale red; legs blackish-green, femora at base and tibie more or less dull yellow. Thorax with sides curved from apex to. behind middle, sinuate in front of hind angles, which are subacute, not carinate; disk finely alutaceous, median line deep, basal inpressions small, deep. Elytra more than onehalf wider than thorax, alutaceus, deecly striate, the strik punctured; intervals convex, the third to sixth more or less sinuate or irregular. I ength $4.7-5.5$ mm. ( Fig. 49.)

Southern half of State: frequent. April 12-Oct. 17.

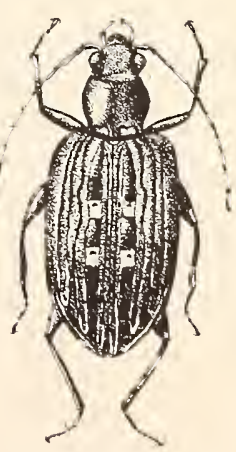
Fig. 49. (Original.)

B. littorale Oliv., coppery or greenish bronze in hue and 5-6.5 
$\mathrm{mm}$. in length. occurs in Canada and Michigan and probably in northern Indiana.

it (305). Bembidiun carinula Chaud. Rev. et Mag. Zool., XX, 1S68, 239.

Broad, slightly depressed. Coppery bronze to black; antennæ and femora bronzed-piceous, the tibixe and tarsi often paler. Thorax with the sides curved in front, deeply sinuate behind; hind angles subacute, carinate; disk alutaceous, finely wrinkled near base and along the median line; basal impressions broad. deep, bistriate. Elytra one-half wider than thorax, alutaceous, finely striate, the strixe finely punctate. Length $5.5-7 \mathrm{~mm}$.

A handsome bronzed form, common along the beach of Lake Michigan and the larger lakes of northern Indiana; also in Crawford County. May 13-October 21.

is (304). Bembidium punctatostriatum Say, Trans. Amer. Phil. Soc., II, 1S23, 83; ibirl. II, 498, 550.

Robust, moderately convex. Bronzed, more or less coppery; antennæ and legs bronzed-piceous, the femora at base and the tibice beneath often reddish-yellow. Thorax with sides slightly curved in front, sinuate behind; hind angles prominent, acute, not cirinate; disk slightly rugose at base and along the median line, the basal impressions broad and deep. Elytrat striæ deep and very distinctly punctate. Length $6.2-7.5 \mathrm{~mm}$.

Crawford County; rare. May 17. The largest species of the grotip.

B. robusticolle Hayw.. 5.7-6.2 mm. in length, is known from Michigan, Iowa and Kansas, and doubtless occurs in northern Indiana.

79 (311). Bembidruar coxendre Say, Joulu. I'lil. Acad. Nat. Sci., III. 1823, 151 ; ibid. II, 97 .

Slightly elongate, rather slender. Greenish-bronze or bluish-black, shining; antemne, femora and tarsi bronzed-picens: tibie, base of femora and two basal joints of antenne reddish-brown. Thorax one-half wider than long, sides moderately curved in front, sinuate behind; lind angles slightly prominent, subacute, very finely carinate: disk minutely alutaceous, the basal impressions broad and deep. Elytra one-third wider than thorax, deeply striate-punctate. Length 5.5-6.5 $\mathrm{mm}$.

Throughont the State; scarce. April 19-September 7. Occurs along moist sand bars of streams. One of the most handsome members of the genus.

so (311a). Bembidiun confusum Hayw., Trans. Amer. Ent. Soc., XXIV, 1897, 52.

Moderately robust, convex. Bronzed, usually coppery, shining; disk of elytra dull brownish-yellow; legs and basal third of antenna pale rellow. Thorax less than one-half wider than long. sides curved nearly to base; hind angles not prominent, subrectangular, feebly carinate; disk 
alutaceons, finely rugose at hase, the basal impressions hoad, deep. bistriate. Elytra about one-half wider than thorax, the intervals less convex than in coxendix. Length 4.5-6.5 $\mathrm{mm}$.

Throughout the State; frequent; more so in the northern counties. May 1-September ${ }^{2}$. Tisted as B. nitidulum Dej., which name was preoccupied. Resembles coxendix, but easily separated by the pale legs and green punctures of elytra.

\section{Group B.}

In this group the dorsal punctures are on the third stria instead of the interval and the humeri are either rounded or subangulate. It includes the Indiana species of Groups V to X of Hayward.

KEY TO INDIANA SPECIES OF GROUP B.

a. Eightl stria of the elytrat moderately near but distinct from the margin. 1). Humeri of elytra subangulate; elytral strixe entire.

r. Elytra with the dorsal punctures large, round impressions; elytra finely striate, shining.

\$1. AMERICANUM.

(c. Elytra with the dorsal punctures normal.

1. Form broad, dilated, depressed; hind angles of thorax obtuse; size larger, (6.5- $-2.2 \mathrm{~mm}$.

DILATATUM.

dr. Form more or less convex and more slender; hind angles of thorax subrectangular; size smalier, 5.5-6.5 mm.

e. Feebly convex; thorax scarcely narrower at base than apex; elytral stria modierately impressed.

82. HONESTUM.

ee. More convex; thorax more narrored behind; elytral strie more deeply impressed, almost crenulately punctate.

S3. CHALCEUM.

b6. IIumeri of elytra rounded; robust. rery conrex; elytral stria dilated, the first and second entire, the others abbreviated behind; blackish-bronzed, the elytra often tinged with green. St. NIGRUM.

"a. Eighth stria of elytra indistinct from margin: humeri rounded.

$f$. Thorax trapezoidal, scarcely convex. the basal forea with either one stria or with two and the outer one very feeble; legs rufous or dull yellow, the femora rarely darker.

g. Basal impressions of thorax with the outer stria small but distinct; size smaller, $4.8-6.2 \mathrm{~mm}$.

h. Elytra with five inner strie only entire; thorax one-half wider than long.

85. GUEXI.

hh. Elytra with six inner strie entire; thorax more than one-half wider than long; the elytra less wide as compared with the thorax; color nearly black. tinged with bronze. Fugax.

gg. Basal impressions of the thorax with the outer stria obsolete: elytra with six inner strie entire, their color rariable. usually dull yellow with darker transrerse bands: size larger. 6-8.5 mm.

TRATSTERSALE. 
if. Thorax cordate, convex, the basal fovea with two striac.

i. Elytra sreenish-black, earlo with a well defined basal and allother subapical spot pale; legs dull reddish-yellow; thorax distinctly narrower at base than apex.

ii. Flytra either withont spots or with a single pale submarginal one neal apex.

j. Head small, narmower than tholax at apex; elytra with all the striae entire, dilated on the disk and nuch finer at sides and tip; brownish-bronzed with a large oblique, submarginal, pale spot one-third from apex.

POSTREMUM。

jj. Head as wide as the thorax at apex; elytra with only the first and second strixe entire, the others abbreviated on apical half.

S6. PICIPES.

S1 (317). Bembidium americanzir Dej., Spec., V, 1S31, $\$ 4$.

Rather broad, subdepressed. Uniform blackish-bronzed, more or less slining. Antennie one-half the length of body, piceous, the first and seconi joints and the tibia dark reddish-brown. Thorax more than one-half wider than long; apex nearly truncate, slightly broader than base; hind angles sulnertangular ; disk finely rugose at base, median line distinct, basal inmessions shallow. Elytra finely alutacenus, about one-halt wider than thorax, finely striate, the strix distinitly punctite to behind the middle. Length $5-6 \mathrm{~mm}$.

Throughout the State; frequent. June 7-September 17.

B. dilatatum Lee, having the sides of thorax strongly curved in front and the legs dark reddish-brown, is known from Pennsylvania and Oklahoma and should occur in Indiana.

S2 (319). Bendidium honestum Say, Trans. Amer. Phil. Soc., II, 1S23, S2; ibid. II, 498-550.

Rather elongate, subdepressed. Bronzed, more or less coppery, rarely bluish or greenish, shining; antemma and legs piceous. Thorax less than one-half wider than long, apex emarginate; sides slightly curved in front. feebly sinuate behind; disk rugose at base, median line deep, abbreviated before and behind. Elytra one-half wider than thorax, deeply striatepunctate, the punctures almost obsolete at tip. Length $5.7-6.7 \mathrm{~mm}$.

Lake, Franklin, Marion and Putnam counties; scarce. April 23-December 7. Listed as B. antirqum Dej., but Say's name has priority.

S3 (320). Bembidiun chalceum Dej., Spec., V, 1831, 89.

More slender and more convex than honestum. Coppery bronze, rarely greenish or bluish-black; legs rufo-piceous, the femora at base and tibie paler. Thorax with sides more strongly curved in front, distinctly more narrowed and deeply sinuate behind than in fonestum, the apex truncate. Elytra oblong-oval, deeply striate; intervals convex. Length 5.5-6.2 $\mathrm{mm}$.

Throughout the State; frequent. June 15-September 4. 
S4 (325). Bembidium nigrum Say, Trans. Amer. Plhil. Soc., II, 182:3, 85 ; ibid. II, 500

Black, feebly bronzed, strongly shining; antemne fuscous, the basal joints and legs reddish-brown. Thorax subquadrate, one-half wider than long, slightly narrower at base than apex; sides curved in front, very feebly sinuate behind; basal impressions broad, deep, bistriate; hind angles rectangular, finely carinate. Elytra one-half wider than thorax, strix coarsely and deeply punctate. Length $3.7-4.5 \mathrm{~mm}$.

Putnam County; rare. July 10. Probably oceurs sparingly throughout the State.

85 (341). Bembidium guexi Chaud., Rev. et Mag. Zool., XX, 1S68, 242.

Moderately elongate, depressed. Head and thorax blackish-bronzed; elytra dark brown or piceous, strongly shining; antennæe fuscous, the basai joints and legs reddish-brown. Thorax one-half wider than long, very slightly narrower at base than apex, hind angles subrectangular, indistinctly carinate. Elytra nearly one-half wider than thorax, the five inner strixe entire, punctate, the sixth and seventh obsolete on apical half, the seventh often wanting. Length $4.7-5.5 \mathrm{~mm}$.

Fulton, Vigo, Jackson and Franklin counties; scarce. April 14-August 20. Listed as B. planum Hald., which name was preoccupied.

B. fugax Lec., 5.5-6.2 mm.; B.transversale Dej.; B. ustulatum Linn., 5.2-6.2 mm., and B. postremurn Say, 6-7 mm. in length, each have a known distribution which might bring them within the limits of Indiana, yet no specimens have as yet been seen from the State.

86 (358). Bembiduum Picipes Kirby, Faun. Bor. Amer., IV, 1837, 54.

Elongate, rather slender, moderately convex. Black, shining, sometimes slightly bronzed or bluish; elytra rarely with a submarginal pale spot one-fourth from apex; antennæe piceous or fuscous, the basal joint and legs reddish-brown. 'Thorax one-half wider than long, narrower at base than apex; sides strongly curved in front, distinctly sinuate behind. hind angles rectangular, carinate; disk with median line fine, basal impressions deep. Elytra about one-half wider than thorax, rather deeply striate, the fifth stria represented by a groove at apex. Length $5-6 \mathrm{~mm}$.

Southern half of State; frequent. April 11-October 6. Occurs beneath stones by running water.

\section{Group C.}

The species belonging to this group have the dorsal punctures on the third interval and the hmmeri rounded into the sides of the elytra. It comprises the Indiana species of Groups XI to XXI, inclusive, of Hayward. 
KEI TO INDIANA SPECIES OF GROUP C.

u. Eyes large or moderately large, convex; outer lobe of maxillie with the two joints distinct.

๖. Dorsal punctures of elytra on the third interval only.

c. Stria on front of head normal; elytra distinctly striate, with at least the first and second strie entire; striee punctate:

d. Thorax nar'rower at base than apex.

e. Form depressed; all the strice of elytra entire.

$f$. Thorax cordate, nearly twice as wide as long, much narlower at base than apex; legs and base of antennie dull brownish-rellow.

S7. CORDATUM.

$f f$. Thorax subquadrate, but slightly narrorer at base than apex: legs dark reddish-brown. SS. Ixteranedicm.

ee. Form more or less convex.

g. Eiytra with all thestriae entire; head alutaceous.

7. Larger, j-6 $11 \mathrm{~m}$.: blackish or piceous. bronzed, the elytra with pale markings.

S9. GRACILIFORME.

h九. Smaller, $4-1.5 \mathrm{~mm}$.

i. Elytra dull brownish-yellow with two fuscous crossbands, one slightly behind the middle and another between this and apex; strice scarcely less deep at tip. OBERTH ÜRI.

ii. Elytra greenish-bronzed with pale markings; striæ much finer at tip.

90. FRATERNUM.

gg. Elytra rith sereral of the strice abbreriated behind.

$j$. Hind angles of thorax distinctly carinate; head rers finely or not at all alutaceous; size rers small, not orer $3.5 \mathrm{~mm}$.

91. TERSICOLOR.

ji. Hind angles of thorax very finely carinate; head distinctls alutaceous; bronzed. tinged with green, elstra with dull sellow markings; size 4.2-5.5 mm.

CONSTRICTUM.

dd. Thorax not perceptibly narrower at base than apex.

h. Thorax squarely truncate at base, the hind angles rectangular; elytra black. with dull yellow markings; length less than $5 \mathrm{~mm}$. 92. VARIEGATUM.

l.F. Thorax slightly obliquely truncate each side at base: elctra dull sellow with a bar behind the middle and tro or three spots blackish : length 5 or more mm. 93. postfasciatra. cc. Stria on front of head double, often conrergent.

i. Frontal strine more or less oblique.

m. Frontal striæ but slightly oblique. the outer one interrupted: size small, not orer $4 \mathrm{~mm}$.

n. Thorax cordate. the base pedunculate or subpedunculate.

o. Moderately convex; thorax scarcely wider than long: elytra brownish-green with a subhumeral and a small submarginal spot dull rellow. 94. PEDICELLATtr.

oo. Slightls depressed; thorax one-half or more wider than Jong; elytral spots as in preceding but larger: punctures of elytra finer. 95. QTADRIMACULATUM. 
III. Thorax cordate, the base truncate.

p. Thorax slightly wider than loig, distinctly nalrower at base than apex; elytra black. slightly bronzed, with

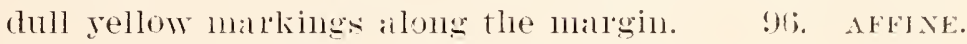

l\%. Thorax one-half wider than long. but shighty narower at base than apex; elytra piceous or neally black. witliont pale spots on margins.

il ciscicolat.

mm. Frontal striae rery oblique, strongly convergent, the onter one the shorter and often rery faint; thorax cordate, trumcate at base.

q. Thorax distinctly witler than long, the hind angles alcute; elytra black. scarcely bronzed, with submalrginal spot and apex more or less dull yellow; linger. $3: 2+$ mm.

97. AXGLLIEERTI

qq. Thorax sancely wider thin long. the hind angles rectangular; elytra brownish-bronzed with subapical spot and apex pale; smaller, $2-2.7 \mathrm{~mm}$. 9S. Assiande.

17. Frontal stria nearly straight, the outer one entire; elytra black or greenish-black. shining, with a submarginal spot and apex dull yellow; length $3.2-3.5 \mathrm{~mm}$.

SCLCATCX.

6). Dorsal punctures of elytra in inregular rows on all the interrals. each puncture bearing a distinct. bristle-like hair; all the strise abbreviated behind the middle.

99. SEMISTRIATUM.

a a. Eyes small, flattened: outer lobe of maxillie with the two joints united; color uniform reddish-brown.

OBLONGULCM.

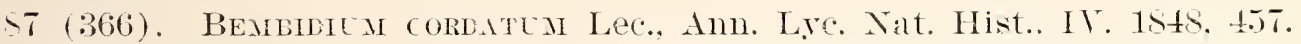

Moderately elongate, depresed. Head and thorax coppery or greenishbronzed, alutaceous; elytra dull brownish-yellow, with a humeral spot, a small oblong spot on third interval and two cross-bands connected by a sutural line. bronzed or nearly black. 'Thorax with sides strongly curved. sinuate near base; hind angles rectungular. finely carinate: basal impressions rather deep, bistriate the outer stria rers feeble. Elstra one-third wider than thorax, strice finely punctate to behind the middle; intervals Hat. Length 5.5-6.2 $\mathrm{mm}$.

Vigo County : rare. Jume 19-July 3.

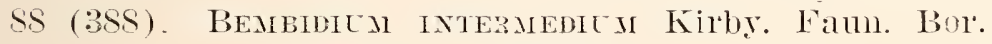
Amel.. IV, 1s:3т, 5s.

Elongate. Slightly depressed. Dark greenish-bronzed: elytral with the apex, a small subapical spot near the margin and rarely a short cross-bind in front of middle. dull brownish-yellow: antemne fuscous, the basal joints 1aler. Head and thorax alutareous. the latter with sirles curred to behind nidtie. thence oblinue to base: hind angles obtuse. carinate: hasil impressions small. rather deep, bistriate. Elytris one-third wider than thor:ax, the striae finely punctured to behind the middle: intervals Hat. Length 3. $6-4.5 \mathrm{~mm}$. (Fig. 50.)

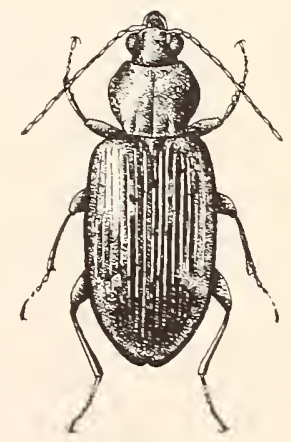

Fig. 50. (Original.) $\times 6$ 
Throughout the State; scarce. February 1-December 25. Hibernates as imago beneath logs, etc., in low, damp places.

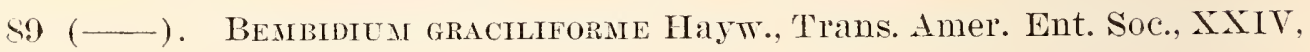
$1897,97$.

Elongate, rather slender, slightly convex. Head and thorax blackishbronzed: elytra bronzed piceous, shining, with a subhumeral blotch, a cross-band behind the middle and sometimes the apex, paler, the markings often indistinct: antenne piceous, the basal joints and legs dull sellow. Thorax subcordate, one-half wider than long, distinctly narrower at base than apex; sides curved nearly to base. deeply sinuate in front of hind angles, which are rectangular and carinate. Elytra slightly wider than thorax, the strixe distinctly punctate to behind middle; intervals convex. Length $5-5.7 \mathrm{~mm}$.

Lake and Vigo counties; scarce. April 25-October 1.

B. oberth ̈̈ri Hayw., 4-4.5 mm. in length. is known from Massachusetts, Illinois and Iowa and should occur in northern Indiana.

90 (37t). Bembidum fraterncar Lec., Proc. Phil. Acad. Nat. Sci., 1857. 6.

Slightly robust, moderately convex. Dark greenish-bronzed; elytra with a narrow transverse band one-third from base, another one-third from apex and an apical spot, paler, the three usually connected along the margin. often indistinct: antenne picesus, paler at base; legs reddish-brown. Thorax slightly subcordate, finely alutaceous, one-half wider than long: basal impressions broad, deep; sides broadly curred, sinuate near base: hind angles rectangular. carinate, the carinse long. Elytra one-half wider than thorax, the striae punctate to behind middle; intervals nearly flat. Length $4-4.5 \mathrm{~mm}$.

Steuben, Fountain and Lawrence counties; scarce. July 6August 16.

91 (391). Bembidich versicolor Lec., Amn. Lyc. Nat. Hist., IV, 1848, 460.

slightly elongate, moderately convex. Head and thorax gresnishblack, slightly bronzed; elytra visually dull yellow, with three cross-bands. more or less connected along the suture. piceous or mearly black; antennie piceous. the basal joints and legs reddish-brown. Thorax subcordate, onehalf wider than long; sides strongly curved in front, deeply sinuate near hase; hind angles rectangular, carinate. Elytra one-half wider than thorax, the strix rather deep, distinctly punctate to behind middle, the outer ones obsolete on apical half. Length 2.5-3.2 $\mathrm{mm}$.

Throughout the State; frequent. March 1-October 11. One of our smallest species.

B. constrictum Lee, has a wide distribution over the Eastern United States and should occur in Indiana. 


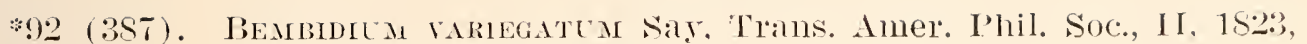
\$!) ; iloil. 11, 499, 5.,0.

Moderately broud. slightly convex. Head and thol:ax blackish-bronzed. alutaceous; elytra black with a few dull yellow malkings. or dull yellow with black markings (for'm patrucle); antenne fuscous, the basal joints baler; legs reddish-brown. 'J'horax subquadrate, as wide at balse as alpex; sides slightly curved in front, distinctly sinuate behind ; basil inplessions

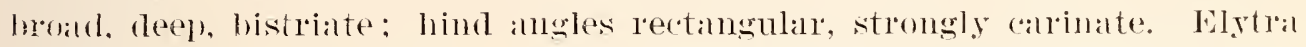
me-half wider than thomat strie entire. distincetly punctate to hohind midalle; intervals conrex. Lengtli $3 . \overline{5}-1 . \bar{i}$ mm.

Throughout the State; common. Hibernates as imago. Often attracted in summer by electric light. February 26-December 25. In the form patruele the ground color of the elytra is dull brownish-yellow with a humeral spot, a narrow line along the suture and three more or less interrupted, sinuous cross-bars, black. In a large assemblage of specimens these dark markings gradually become broader and more extended until the black predominates, the elytra being then spotted and banded with dull yellow as in the typical eariggatum. Both forms are common in Indiana, the dark one being much the more so.

93 (9252). Bexbidich rosteasclatun Mamilton, Can. Ent., XXY., 1898, 305.

Form broad, dilated, slightly convex. Head and thorax coppery-bronze. alutaceous; elytra dull brownish-yellow with a small spot on third interval. a cross-band about the middle and another near the apex blackish ; legs dull yellow. Thorax subquadrate, about one-half wider than long. as widle at base as apex: basal impressions broad. deep, bistriate: hind angles rectangular, carinate. Elytra more than one-half wider than thorax. deeply striate, the strise diated at base, finely punctate; disk with a transrerse depression behind the scutellum. Length 5-6 $\mathrm{mm}$.

Southern fourth of State; frequent. February 11-July 28. Taken along the Wabash and White rivers from beneath the bark of sycamore and other trees; also on low, sandy mud flats. Hibernates as imago.

94 (419). Bembidiuar pedicellatuar Lec., Proc. Phil. Acarl. Nat. Sci., $185 \overline{7}, 6$.

Elongate, moderately convex. Piceous bronzed, elytra each with two pale spots; antenne fuscous, paler at base: legs pale yellow. Thorax cordate. one-half narrower at base than at apex, sides curved in front. sinuate beinind; basal impressions small, hind angles scarcely erident. not carinate. Elytra one-third rider than thorix. the strize distinctly, not closely. punctate: interrals nearly flat. Length 3-3.7 mm. (Fig. 51.)

Southern half of State; frequent. March 25-November 10 .

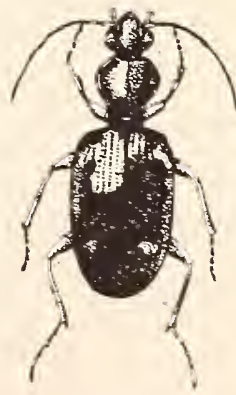

Fig. 51. (Original. $\times 6$ 


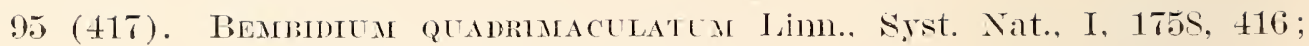
Sily. Ed. Lec., II, 501, , ז.i.

Moderately elongate, slightly depresised. Head and thorax bronzed or blackish-bronzed, shining; elytra brownish or black, with a triangular subhumeral spot and a smaller one behind the middle, dull gellow: antemie piceous, the basal joints and legs dull yellow. Length 2.7-3.7 mm.

Southern half of State; scaree. April 11-December 27. Resembles perticcllatum but is less convex and with punctures of elytra finer and more closely placed; elytral spots more distinct. Hibernates as imago.

mi (407). Rembull a Afrine Sily. Trans. Amer. Plhil. Soc. II. 1823. Sti: ibid. II, 501 .

slightly elongate, conrex. Black or piceous, sightly bronzed. shining: elytra with a small spot near hunerus, a large, triangular submargin 1 one at nilddle. a small one one-fourth from apex and often the apex, dull yellow; antenne tuscons. the basal joints and legs dull yellow. Thorax sightly wider than long. sides curved in front, sinnate behind, hind angles restangular. rely finely carinate. Elytra nore than one-half wider than tholix, stride distinctly bunctate, the first and second only entire. Length $2.5-3.51110 \mathrm{~m}$.

Throughout the State; (ommon. February 20-November 8 . IIibernates as imago.

B. muscicola Hayw. 2.5-3.2 mm. in length, has been taken in Michigan and northern Illinois and should be found in the northern third of Indiana.

97 (410). Bembinfum a vgulfferun Lec., Ann. Lyc. Nat. Hist., Y. 1852. 185.

Slightly elongate. convex. Black, feebly bronzed, shining: elytra with dull yellow markings as giren in key: legs reddish-brown to piceous. Thorax much narrower at base than apex; basal impressions deep, with one stria; sifles curved in front, sinuate behind; hind angles acute. carinate. Elytra one-lialf wider than thorax. strie punctate, feehly impressed. especially on sides: intervals nearly flat. Length $3.2-4 \mathrm{~mm}$.

Lake County ; rare. May 5. A species of northern range, extending across the continent.

as (414). Bembidica assimile Gyll.. Ins. Suec.. II, 1S10, 26.

Moderately robust. Black; elytra piceous or brownish with submarsinal spot and apex paler: antenne fuscous. paler at base: legs dull rellow. Thorax narrower at base than apex. sides strongly curved in tront. distinctly sinuate behind; hind ansles rectangular, disk sparsely and coarsely punctafe at base and apex; basal impressions deep. unistriate. Elytra nearly twice as wide as thorax, coarsely punctate, the punctures obsolete on apical half. Length 2-2.7 $\mathrm{mm}$.

Lake. Laporte and Vigo counties; scarce. Nay 5-October 21. Our smallest species. The subopaque pale spot is ocellate, being 
surrounded by a distinct ring, darker than the remaining surface of elytra.

B. sulcatum Lec., a member of the boreal fauna, has been taken in Nichigan and northern Illinois and should occur in northern Indiana.

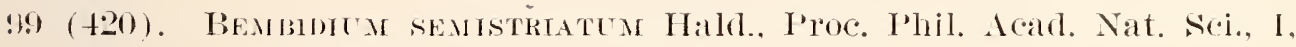
1S4:3. :30:3.

Slightly elongate, convex. Neally black, feebly bronzerl, the elytral often tinged with brownish; antenna piceous, the basal joints and legs dull rellow. Frontal grooves single, straight, parallel. Thorax subcordate, one-half wider than long. distinctly narrower at base than apex; sides strongly anred in front, sinuate behind: basal impressions deep. bistriate; hind angles rectangular, carinate. Elytrat one-half wider than thorax, finely striate, the strix with deep, rather distant punctures, these obsolete on apical half; intervals flat, with punctures as mentioned in key. Length $3.7-4.2 \mathrm{~mm}$.

Putnam County; rare. October 17. Sifted from beneath dead leaves above a hillside spring. The sete arising from the dorsal punctures are very distinct beneath a lens. Occurs from New England to Kentucky.

B. oblongulum Mann. 4.2-5.5 mm. in length, has been taken in Ohio and Michigan. It is a member of the boreal famna and should be found along the northern border of Indiana. Two specimens were in the Stein collection without locality label.

\section{AnILlus Duval. 1851. (Gr., "without+light.")}

Very small brownish species, having the eyes entirely wanting and hind coxx separated. They live in caves or under stones on the slopes of wooded hills. Four species are known from the Inited States, one of which has been taken in Indiana.

100 (429). Anillus fortis Horn. 'Trans. Amer. Ent. Soc., II. 1S68. 127.

Elongate-oblong. Reddish-brown, shining; antenna and legs pale yellow. Head with a shallow groove each side of front. Thorax wider than iong, sides slightly curved to behind middle, thence feebly converging to base, which is narrower than apex and squarely truncate; disk with a single bristle-bearing purcture each side near front angle, median line fine, hind angles rectangular. Elytra with a few discal rows of rery fine punctures, some of which bear single, long. erect hairs; the punctures absent on sides and apex, plainly visible only when viewed from the side. Length $1.7-2 \mathrm{~mm}$.

Rare, or so small as to be overlooked. Two specimens were taken from beneath stones on a wooded slope near Wyandotte Care. Crawford County. May 27. When their cover was removed they ran aimlessly about, instead of seeking some new retreat.

[6-23402] 


\section{Tגenys Schaum. 1860. (Gr., "swift.")}

Very small black or brownish species having the characters of the tribe Bembidiini. Front tibia obliquely truncate at apex; elytra glabrous, either striate or wholly without stria, except that at suture, which is recurved at apex. They occur for the most part in damp places, beneath the bark of partly decayed logs and stumps; also in moss and ant hills and beneath chunks on mud flats. When uncovered they run very rapidly, whence the generic name. About $\frac{15}{5}$ species are known from the United States; of these 15 have been taken in Indiana.

The only paper treating of the genus is by:

Hayuard._" A Study of the Speries of Tachys of Boreal America" in Trans. Amer. Ent. Soc., XXVI. 1899. 191-238.

For convenience Hayward divided the genus into nine groups, his primary division being based upon the presence or absence of punctures on the mentum. Of this character he says: "The mentum varies in the different species being more or less emarginate in front, with a tooth of varying prominence at the bottom of the emargination. In rather more than half of the United States species there may be observed, behind the tooth, two large forameniform punctures which are entirely absent in the other group. These are not difficult to detect, even with a hand lens, and as soon as recognized, their presence or absence can be readily determined. even in the smallest forms." Since only one-third of the species treated by Hayward occur in Indiana, they will be separated into but two groups, and this is done only to lessen the length of the keys to species.
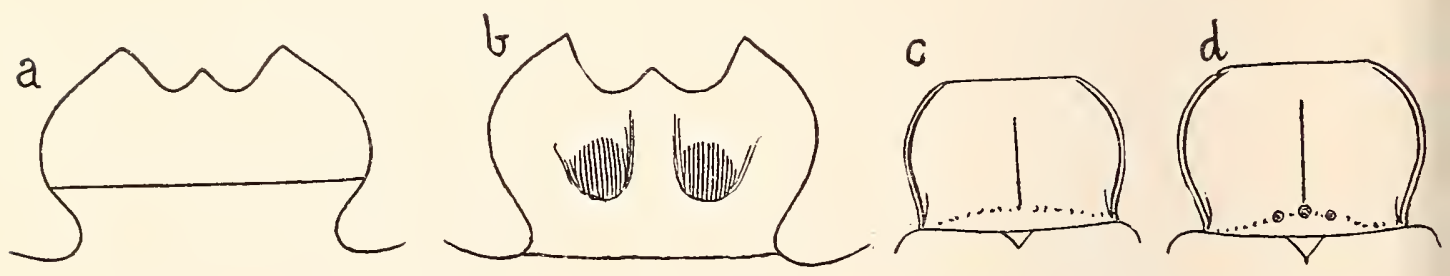

Fig. 52. a, mentum of $T$. vivax; $b$, mentum of $T$. proximus; $c$, thorax of $T$. incervus; $d$, thorax of $T$. irizunctatus. (After Hayward.)

KEY TO GROUPS OF INDLANA TACHYS.

a. Mentum without large punctures behind the median tooth (Fig. 52, a); marginal stria of elytra iriterupted or less deep at middle.

Group 1.

ar. Mentum with two large foraneniform punctures behind the tooth. ( Fig. 52, b.)

Group $B$. 
Group A.

This group includes the Indiana species of Groups I-IV of Hayward.

FEY TO INDIANA SPECIES OF GROUP A.

(i. Thorax broadly margined, the margin translucent; third interval of elytra with two small dorsal punctures very near the third stria; apical third of elytra yellowish.

101. FLAVICACDA.

"a. Thorax narrowly margined, the margin not translucent.

b. Elytra with the recurved portion of the sutural stria parallel to the margin; dorsal punctures two, the first on the fourth stria near the base, the second on the third stria near the apex; color jet black.

102. NANUS.

bb. Elytra with the recurved portion of the sutural stria short, nearly parallel to the suture; dorsal punctures two, placed on the third stria when the latter is present, the second but slightly behind the middle.

c. Elytra with none of the striæ punctate.

d. Thorax with the transverse impression near base not tripunctate at middle (Fig. 52, c) ; elytra with the sutural stria deep, the other strix obsolete.

c. Very convex; thorax scarcely as wide at base as apex, the sides strongly rounded in front, oblique behind.

103. GRANARIUS.

cc. Moderately convex; thorax a little wider at base than apex, the sides slightly curved in front, feebly sinuate behind; elytra distinctly wider than thorax.

$f$. Piceous or dark reddish-brown, the elytra with an ill-defined stripe each side, or with subhumeral and subapical spots, paler; form moderately elongate. 104. Ixcurvus.

ff. Uniform light readish-brown or brownish-yellow, elytra rarely slightly darker on the disk; form very elongate.

105. DOLOSUS.

dd. Thorax with the transverse impression near base with three large punctures at middle. (Fig. 52, d.)

g. Thorax not wider at base than apex; elytra distinctly wider than thorax with a sutural and one to three abbreviated dorsal strize.

106. XANTHOPUS.

gg. Thorax wider at base than apex.

h. Form subdepressed; dark brown or piceous; thorax but slightly wider at base than apex. 107. TRIPUNCTATUs.

hh. Form convex.

i. Reddish-brown or piceous, the elytra paler at sides and tip; thorax distinetly wider at base than apex.

10S. VIVAX.

ii. Plack, very shining: legs pale: sides of thorax rounded to behind the middle. sinuate behind. 109. capax.

cc. Elytra with the sutural stria distinctly punctulate: form robust: reddish-brown; thorax tripunctate at base. 110. FERRGGINeUs. 


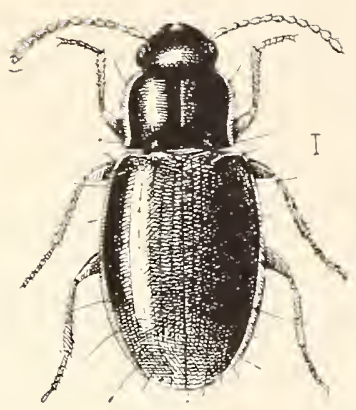

Fig. 53. (Original.)

*101 (450). Tachys flavicauda Say, Trans. Amer. Phil. Soc., II, 1823, S7; ibid. II, 502.

Rather broad, feebly conrex. Dark piceous or nearly black, the apical third of elytra yellowish; antennxe and legs reddish-rellow. Thorax subquadrate, onehalf wider than long: sides feebly curved, base truncate, a little wider than apex; hind angles rectangular, not carinate. Elytra one-half wider than thorax, the five inner strixe moderately distinct. Length $1.5-$ $1.8 \mathrm{~mm}$. (Fig. 53.)

Throughout the State; frequent. January 6-December 25. Occurs beneath bark, especially that of elm and butternut.

*102 (419). Tachys Nanes Gyll., Ins. Suec, II, 1810, 30.

Elongate, depressed. Black, shining, rery finely alutaceous; antennie piceous, the basal joints and tibire and tarsi more or less reddish-brown. Thorax subquadrate, about one-half wider than long, not wider at base than apex; sides rounded in front, slightly sinuate near base, hind angles rectangular, not or but feebly carinate. Elytra subparallel, slightly wider than thorax, the four or five inner strice distinct, without punctures. Length 2.2-3 $\mathrm{mm}$.

Throughout the State; common. January 10-November 20. Occurs beneath bark and leaves.

103 (462). 'Tachys granarius Dej., Spec., V, 18:31, 61.

Robust, convex. Color variable, usually piceous or nearly black ; elytra often more or less brownish and somewhat translucent, sometimes reddishbrown, very shining; antenne fuscous, the basal joints and legs dull yellow. Thorax subquadrate, one-half wider than long; base truncate, hind angles subrectangular with a short, fine carina; transrerse impression near base deep, finely punctulate. Elytra one-third wider than thorax, dorsal punctures small. Length 1.7-2 $\mathrm{mm}$.

Putnam County; scarce. March 5-October 10. Occurs beneath stones and leaves on damp. wooded hillsides.

*10t (461). Tachys incurvus Say, Trans. Amer. Phil. Soc., IV, 1834, 440 ; ibid. II, 554 .

Elongate, moderately convex. Dark reddish-brown to nearly black. shining; the elytra with an indistinct pale yellow stripe reaching from humerus nearly to apex, this often interrupted at middle; antennie fuscous. the basal joints and legs dull yellow. Thorax quadrate, one-half wide: than long; transverse impression near base. deep, finely punctate; hind angles rectangular, with a short carina. Elytra distinctly wider than thorax, with only a moderately deep sutural stria, a second faint one often visible. Length $1.7-2.5 \mathrm{~mm}$.

Throughout the State; common. January 21-October 21. Occurs beneath rubbish in open woodland and often in nests of ants. 
105 (466). 'TAchy's dolosus Lec, Ann. Lyc. Nat. Hist., $1 \mathrm{~V}, 18 \pm 8,470$.

Very elongate, slightly convex. Brownish-yellow or pale reddish-brown. shining; antenna and legs paler. Thorax quadrate, about one-lialf wider than long, slightly wider at base than apex; basal impressions small, moderately deep; hind angles rectangular, finely carinate. Elytra elongate, nearly one-half wider than thorax, with a deep sutural stria which does not reach the base. Length $2.2-2.7 \mathrm{~mm}$.

Lake County ; rare. May 21-June 26. A few specimens taken from beneath cover in sandy places near Pine and Clark Junction.

106 (456). Tachys xanthopus Dej., Spec. V, 1831, 60.

Robust, convex. Piceous or nearly black, shining, the elytra indistinctly paler at tip; antenne piceous, the basal joints and legs dull yellow. Thorax nearly twice as wide as long. sides strongly curved in front, oblique behind; basal impressions broad, deep; hind angles subobtuse, not carinate. Length $1.7-2.2 \mathrm{~mm}$.

Throughout the State; frequent. April 22-October 17 . Often found running about on mud flats in the daytime.

107 (453). Tachys tripunctatus Say, Trans. Amer. Plil. Soc., IV, 1834, 439 ; ibid. II, 553.

Rather elongate, subdepressed. Brown or piceous, shining, the elytra slightly paler at the sides; antenne fuscous, the basal joints paler; legs dull yellow. Thorax subquadrate, one-half wider than long; sides rounded in front, slightly sinuate near base; hind angles rectangular, with a short. fine carina. Elytra with a sutural and three or four abbreviated clorsal stria, the inner three deep, the first only entire. Length 2.7-3.2 $\mathrm{mm}$.

Perry County; rare. May 16. Described from Posey County.

108 (454). Tachys vivax Lec., Ann. Lyc. Nat. Hist., IV, 18 $48,468$.

Rather robust, convex. Reddish-brown, rarely rufo-piceous, slining. the elytra paler at sides and tip: antennie and legs pale yellow. Thorax more than one-half wider than long; sides rounded in front, feebly sinuate behind; hind angles rectangular with a short fine carina. Elytra with three or four inner strise distinct, the inner two deeper. Length 2.2-2.7 mm.

Throughout the State; scarce. April 17-September 9.

109 (455). Tachis capax Lec., N. Sp. N. Am. Col., I, 1863, 20.

Rather elongate, convex. Black, very slining; antenne dark fuscous. paler at base. Thorax one-half wider than long. wider at base than apex. basal impressions broad, deep; sides strongly rounded to behind the middle. sinuate for a short distance in front of hind angles, which are rectangular and finely carinate. Elytra oblong-oval, less than one-half wider than thorax, the two inner strix deep, the third feebly marked. Length 2.3-3 mm.

Knox and Fayette counties; rare. April 25-June 25. A species of southern range, taken from the edge of cypress swamp. 
110 (459). Tachys Ferrugineus Dej., Spec. V, 1831, 59.

Robust, strongly convex. Uniform reddish-brown, shining, often translucent; antenne dusky, paler at base. Thorax one-half wider than long, sides slightly curved in front, feebly sinuate behind; hind angles rectangular, not carinate. Elytra more than one-half wider than thorax, with a deep sutural and a finer abbreviated second stria, rarely with traces of a third. Length 2.5-3.2 $\mathrm{mm}$.

Southern half of State; frequent; much less so northward. April 17-May 28. Occurs usually in the nests of ants, though sometimes beneath chunks in damp localities.

\section{Group B.}

In this group the mentum is marked behind the median tooth with two large deep punctures. Five species are known from the State. They comprise the Indiana species of Groups V-IX of Hayward.
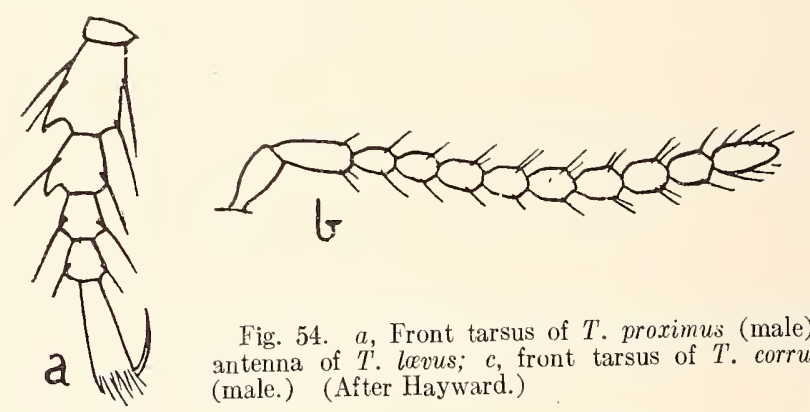

Fig. 54. $a$, Front tarsus of T. proximus (male); $b$, antenna of $T$. leveus; $c$, front tarsus of $T$. corruscus

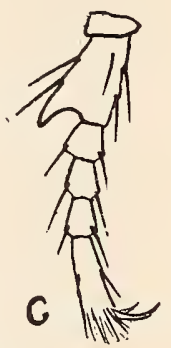
(male.) (After Hayward.)

KEY TO INDIANA SPECIES OF GROUP B.

a. Elytra with the marginal stria broadly interrupted at middle (obsolete in lavus).

b. Recurved portion of the sutural stria very short, parallel with the suture, not hooked at tip; two dorsal punctures on the third interval near the third stria ; form depressed; length $1.2-1.5 \mathrm{~mm}$.

111. LAVUS.

b). Recurved portion of the sutural stria long, nearly parallel to the suture, distinctly hooked at tip ; the first dorsal puncture on fourth interval, the second enciosed within the recurved portion of the sutural stria; lengtl $2.3-3.2 \mathrm{~mm}$.

c. Male witl the first two joints of the front tarsi dilated (Fig. 5t, ( ) ; elytia oblong-oval, pale with an ill-defined dark blotch behind the middle.

112. PROXIMUS.

$c c$. Male with only the basal joint of the frout tarsi dilated (Fig.

$54, c)$.

1. Males with the inner angle of the dilated joint of front tarsi without a spine; colol more reddish than in proximus, with the dark blotch of elytra better defined, frequently extending to the margin.

113. SCITULUS. 
dd. Males with a molonged spiniform process at inner angle of dilated basal joint of front tarsi ; elytrat uniform piceous or dark reddish-yellow.

114. corilisces.

aa. Elytra with the marginal stria deep, entire; two small dorsal punctures on third interval; thorax much narowed at base; elytral stricx inuretate.

115. EPIIIPIATLS.

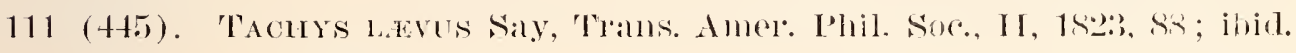
II, 503.

Oblong, subdepressed. Ifead and elytrat piceous; thorax dark redrishbrown; antennæe bead-like (Fig. 54, $b$ ), fuscous, two basal joints and legs pale. Thorax narrowed behind, nearly twice as wide as long; sides strongly curved to near the base, which is slightly narrower than apex; basal impressions small, deep; hind angles obtuse, not carinate. Elytra about onehalf wider than thorax, with a sutural and one to three abbreviated dorsal strix; marginal strixe obsolete. Length 1.2-1.5 min.

Throughout the State; frequent. March 18-June 17. Occurs especially beneath leaves along the borders of marshes. Our smallest Tachys and one of the smallest of our Carabidie.

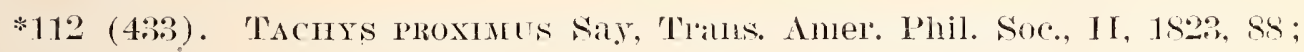
ibid. II, 503.

Elongate, subdepressed. Ifead and thorax piceous; elytra dnll yellow, usually with an ill-defined dusky cloud on the middle of disk, their surface shining with a silken luster; antennie fuscous, the basal joints and legs dull yellow. Thorax subquadrate, one-half wider than long, as wide at base as apex, sides curved in front, more or less sinuate behind; hind angles subrectangular. Elytra with two or three inner striæ distinct, not punctate, the others obsolete. Length 2.7-3.2 $\mathrm{mm}$.

Throughout the State, common in the southern counties; less so northward. February 26-October 31. Hibernates as imago.

113 (435). Tachys scitulus Lec., Ann. Lyc. Nat. Hist., IV, 1848, 471.

Slightly elongate, depressed. Dull reddish-yellow, the head, and rarely the thorax, darker; elytra with a more or less distinct fuscous or piceous cross-band behind the middle; antennæ fuscous, the basal joints and legs dull yellow. Thorax subquadrate, as wide at base as apex, nearly twice as wide as long; sides curved to behind middle, thence oblique to base, hind angles obtuse. Elytra one-half wider than thorax, finely striate. the four or five inner striæ usually distinct, not punctate. Length $2.5-3 \mathrm{~mm}$.

Southern half of State; frequent; much less so northward. April 19-October 17. Occurs on mud flats or beneath rubbish close to water. The females of this species are difficult to separate from the paler ones of proximus. They have the thorax proportionally wider as compared with the length, the sides very slightly if at all sinuate near base. The color is usually more reddish, with the dark discal space forming a transverse band instead of an ill-defined blotch. 
$114(40)$. TAcirs corrisces Lec.. Amm. Lyc. Nat. Hist., IV. 1848, 472.

Rather slender, subdepressed. Uniform black to piceous, rarely dark reddish-yellow; antennæ fuscous, the basal joints paler; legs pale rellow. Thorax subquadrate, about one-half wider than long. as wide at base as apex: sides curred in front. oblique near base; hind angles obtuse, not carinate. Elytra each with a sutural and one to three feebly impressed dorsal strize, and with four to six long. pale. erect hairs near the tip. Length $2.2-2.7 \mathrm{~mm}$.

Southern half of State; frequent; rare in the northern counties. April 18-October 17. The elytra are often more or less iridescent. The uniform dark color and pale legs, taken in connection with the other characters, render its identification easy.

$115(470)$. Tachrs ephipplates Say, Trams. Amer. Phil. Soc.. IV, 1834. 439 ; ibid. II, 553.

Elongate. slender. convex. Pale brownish or reddish-yellow, shining: elytra with a large. common dark brown spot on middle and usually a smaller indistinct one near the scutellum; antennie and legs dull rellow. Thorax subcoldate, narrower at base than apex. widest before the middle: sides curved in front. sinuate behind. hind angles rectangular. Eỳtra onehalf wider than thorax, dorsal stria six. moderately deep, lunctured. Length $2.5-3.2 \mathrm{~mm}$.

Southern half of State; frequent. April 12-September 3. Occurs on damp sandy spots along the margins of streams; also taken by sifting in early spring.

\section{'Tribe T. POGONINI.}

Small or medium sized beetles, having the antenna slender, arising from under a feeble frontal ridge, the first two joints glabrous; labrum short, truncate or broadly emarginate; mandibles feebly curved, with a bristle-bearing puncture in the outer groove; last joint of palpi not awl-shaped, the next to last not pubescent. Thorax with a bristly hair on each side and at hind angles. Body not pedunculate, scutellum distinct. Elytra more or less striate, with dorsal punctures present. Hind coxie slightly separated by the mesosternum. Front tarsi of males with two joints dilated and covered beneath with small scales.

Four genera represent the tribe in the United States, three of which occur in Indiana.

\section{KEY TO INDIANA GENERA OF POGONINI.}

a. Terminal joint of palpi more or less cylindrical and obtuse at tip. that of the labial papi as long as the preceding: head more or less constricted or transrersely impressed behind the eyes.

XX. Patrobus. 
a a. 'Terminal joint of palpi slevder, acute at tip, that of the labial palpi shorter than the preceding.

$b$. Head with distinct eres.

XXI. Treches.

bb. Head without eyes.

xxII. Axophthalie's.

\section{Patrobus Dej., 1825.}

Beetles of medium size. 10 or more mm. in length, having the elytra elongate. not margined at base. their sides subparallel. For literature regarding this and the next genus see:

Horn._" "Srnoptic Tables" in Trans. Amer. Ent. Soc., T. 1874. 130; also in Bull. Brook. Ent. Soc., T, 1882, 47, 48.

Seven species are known from the United States. one of which occurs in Indiana.

*116 (472). Patrobes Loxgicoris Say, Trans. Amer.

Phil. Soc.. II. 1823, 40 ; ibid. II, 466.

Elongate-oral. Black abore. piceous beneath; antennie reddish-brown, half as long as body; legs paler. Last two joints of maxillary palpi equal. Thorax conrex, a little broader than long: sides curved to behind middle. thence sinuate to base; front transrerse impression and median impressed line deel. hind angles rectangular; basal impressions broad. deep, punctured. Elyctral striæe deep and distinctly punctured; interrals convex on disk. flattened on sides. Length 12-14 mm. (Fig. 55.)

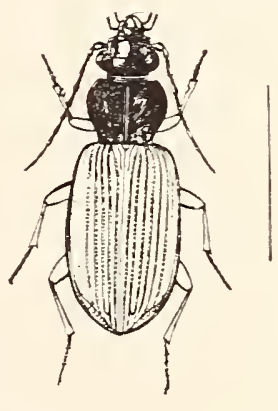

Fig. 55. (After Leng.)

Throughout the State; common. January 1-December 25. Occurs beneath stones and rubbish along streams, lakes. ete; hibernates as imago. Most common in May.

\section{Trechus Clairv. 1806. (Gr.. "a rumner.")}

Elytra oblong-oval. almost twice as long as wide; front tibix slightly broader to tip, the emargination extending nearly to the middle of the tibix; length less than $6 \mathrm{~mm}$. Four species occur in the northern and western parts of North America, one of which extends down into northern Indiana.

117 (483). Trechus chalrbeus Bej.. Spec. T. 1829, 17.

Elongate-oral. Black or dark brown with a bluish gloss: antenni and legs reddish-brown. Thoras subquadrate, one-third wider than long: sides curred to behind middle, thence oblique to base: disk smooth. median impressed line distinct, basal impressions deep, not punctate, hind angles subrectangular. Elstra oblong-oral, with four or fire dorsal strice, the outer two rery faint: strixe finely punctate. Innel wings absent. Length $5 \mathrm{~mm}$.

Steuben County; rare. May 13. One specimen was taken from beneath leares in low moist woods on the eastern edge of Clear Lake. 


\section{Axophthalmes stum. 18t1. (Gr.. "without eres.")}

Small. pale brown. ereless beetles found in caves. Eight species are known from the Tnited States. two of which were described from Trandotte Care. Indiana. For literature see:

Horn.- "Srnoptic Table" in Trans. Amer. Ent. Soc. I. 1883. 270; also in Bull. Brook. Ent. Soc. T. 1882. 18.

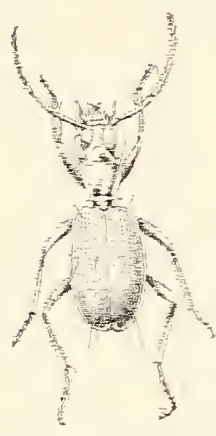

Fiv. 50.03.

11: (189). Axophthaturt: Textis Horn, Trans. Amer. Ent. soc. III. Is71. 327: Geol. surt. Ind. 15:2 179.

Elongate, slender. Pale bromish-Tellow. shining. Head oral. front with two curred immessed lines. Thorax broader than head. slightri: longer than wide: sides curved in front. sinuate behind. medidn line distinctls impressed: hind ansles rectangular. acute. Elitra elongate-oral. two-thirds longer than broad. surface finelr alutaceous: strive faint but erident. with three bristle-bearing punctures along the third.

Cares of Monroe. Lawrence and Crawford counties: frequent in Wrandotte. April 15-September 20. They occur only in the remote parts of the cares. Where the may be found crawling rapidly over mud. sand or rocks in damp localities. Like other Carabids. these small blind beetles are supposed to be camivorous. In Trandotte specimens of mites. spiders, springtails and harrestmen were taken in the same localit as the heetles. and mobabls fumish the latter a scanty supply of food.

119 (491). Axophthalmes erenita Horn. Trans. Amer. Ent. Soc. III.

1571. 325: Geol. SurT. Ind. 1572. 150.

of the same color as tenuis and resembling that species but broader. Thorax wider than Iong and wider than head: hind ancles less prominent. Elytra more distinctir alutaceous. with scarcels ang traces of strice. the surface subopaque. Iength $5 \mathrm{~mm}$.

Tert rare: originally described from a single male specimen taken in Mrandotte Care. Crawford Countr. The trpe is in the Horn collection at the Philadelphia Academt of Natural Sciences.

\section{Tribe TI. PTEROSTICHINI.}

Beetles of medium or large size. having the antenne arising from beneath a distinot frontal ridge. the three basal joints glabrous: mandibles without a bristle-bearing puncture in the unter groove: mentum broad. usuaily deply marginate and tonthed. Thorax with at least one bristle-buring puncture at side and one at hind angle. Bodr not pedunculate. soutellum distinct. Elrtra narromly inflexed. maroin strongly interupted behind the middle and with 
a well-marked internal fold; disk usually with dorsal punctures. Front tibiz broader at tip. deeply emarginate within, the inner spur situated at the summit of the noteh; hind coxie contiguous. Front tarsi of males rather broadly dilated and corered beneath with small scales.

The tribe is represented in the T'nited States by five genera. al! of which oceur in Indiana.

KEY TO GEXERA OE PTEROSTICHINI.

a. Terminal joint of palpi dilated; elstra without dorsal punctures.

SIII. MYAS.

aa. Terminal joint of palpi cyindrical or slightly oral.

b. Front tarsi of male normalls dilated.

c. Last joint of palpi as long as or longer than the next to the last. the latter with two setie (bristly nairs) in front.

IXIT. Pterostichés.

cc. Last joint of palpi shorter than the next to last, the latter with a number of setie in front.

d. Elytra with one dorsal puncture; size larger. 1t or more mm.

XXT. EFARTHRt's.

dd. Elstra rithout dorsal punctures; size smaller, not orer $12 \mathrm{~mm}$.

XXVI. AMARA.

bb. Front tarsi of male obliquely dilated; form oblong. subdepressed: black, rers shining. usually with iridescent reflections; dorsal punctures one.

IIVII. LOXaxDREs.

\section{MIFAs Dej.. 1828.}

Beetles of medium size and broad form, haring the head and thorax black and elytra purplish. Two species oceur in the Lnited States. Of these but one has as ret been taken in Indiana, though Dury has taken the other at Cincinnati. Ohio. They may be separated as follows:

KEI TO SPECIES OF MYAS.

a. Thorax depressed at sides: elytral strice punctured: length $1 \mathrm{~S}-20 \mathrm{~mm}$.

120. CORACINTS.

a $a$. Thorax not depressed at sides: elytral strice not or rery obsoletels punctured; length $13-1.5 \mathrm{~mm}$.

CTANESCEXS.

120 (494). Mras conacires Sar. Trans. Amer. Phil. Soc., II. 1\$23, 59 : ibid. II, 4 S2.

Black, elytra purplish. Thorax broad, transrersels quadrate. froni angles rounded. hind angles rectangular. margin purplish. Elctra broad with acute strie which are finels punctured. Length $18-20 \mathrm{~mm}$.

Throughout the State but scarce: taken in nine widely separated counties. Occurs beneath logs and chunks in open woods with a loose soil. May 21-October 7 . 
XXIV. Pterostichus Bon. 1813. (Gr., "wing + compact.")

Black or greenish-shining beetles of medium or large size, having the characters of the tribe as above given. Form elongate, more or less depressed; head but little constricted behind the eyes; margin of elvtra strongly interrupted posteriorly.

The members of this gents are among the most common of our Carabidx. They are found in woods and along the borders of fields

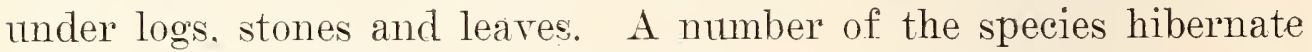
in the perfect stage. Dr. Forbes dissected thirteen specimens of this genus and found that 4.3 per cent. of the food was of insects, canker worms, caterpillars, atc. The vegetable food was of fungi and flowering plants.

The principal papers dealing with the genus are as follows:

LeConte.- "Synopsis of the Species of Pterostichus and Allied Genera Inhabiting Temperate North America,' in Journ. Phil. Acad. Nat. Sci., II, 1852, 225.

Leconte._"The Pterostichi of the Cnited States." in Proc. Phil. Acad. Nat. Sci., 1873, 302.

LeConte._"Srnoptical Table," in Bull. Brook, Ent. Soc.. T. 1882, 15, et seq.

Wickham.-In Journ. N. Y. Ent. Soc., III, 1895, 181.

About 125 species are known from the United States. Of these 24 have been taken in Indiana. while 5 others may occur. For convenience the Indiana species are first arranged in four groups, and these are then treated in order.

\section{KEI TO GROUPS OF INDIANA PTEROSTICHTS.}

a. Dorsal punctures none or one only.

Group d.

aa. Dorsal punctures two or more.

b. Last joint of palpi crlindrical, truncate at tip; size larger, usualls 10 or more min.

c. Side pieces of metathorax short. their length distinctly less than twice their width at base.

Group $B$.

cc. Side pieces of metathorax long. narromed from base to apex. their. length being more than twice the width at base. Groul $C$.

b7. Last joint of palpi elongate-oral, scarcely truncate: size smaller. not over $\$ .5 \mathrm{~mm}$.

Groul) $D$.

Grote A.

To this group belong smali or medium sized species either wholly without dorsal punctures or with one puncture behind the middle on the third interval. close to the second stria. They have the thorax usually rounded or trapezoidal, much narrowed behind, the margin narrow, not reflexed, the base without a marginal line. Six species 
probably ocem in the State, though but three of them have as yet been taken.

IFET TO SPECIES OF GROUP A.

a. Elytra without a dorsal puncture.

b. Head of moderate size; thorax longer than broad, the basal impressions linear, single.

121. ADOXTs.

bu. Head rery large; thorax quadrate, its basal impressions broad; hind trochanters rounded at tip.

ROSTRATCS.

ad. Elytra each with one dorsal puncture behind the middle on the third interval.

c. Basal impressions of thorax double or bistriate.

d. Hind angles rectangular, longer and prominent; elytral strie punctulate.

SUBSTRLATC'S.

dd. Hind angles subobtuse or rery small; elytral strix not punctulate.

APALACHIUS

cc. Basal impressions of thorax single.

$e$. Hind angles of thorix rounded or obtuse; larger, $10 \mathrm{~mm}$; thorax without an impressed line in front.

122. OBSOLETUS.

$e e$. Hind angles of thorax rectangular, prominent; elytral strice deep: small. not over $8 \mathrm{~mm}$.

123. HONESTUS.

121 (519). Pterostichus adoxus Say, Trans. Amer. Phil. Soc. II, 1S23, 46 ; ibid. II, 472 .

Elongate, lather slender. Black; antennæe and palpi dark reddishbrown; legs and abdomen piceous. Thorax widest in front of middle. thence gradually narrowed to base; sides excurred near hind angles. which are rectangular and denticulate; basal lines deep. Elytral strix not punctured, intervals subconvex. Length $13-15 \mathrm{~mm}$.

Throughout the State; frequent. April 18-October 6. Occurs beneath logs and stones on the slopes of deep rooded ravines.

122 (532). Pterostichu's obsoletus Say, Trans. Amer. Phil. Soc.. IV. 1S34, 424; ibid. II, 537.

Elongate, slender, subconvex. Black or piceous, shining; antennæ and legs reddish-brown. Thorax orbicular. sides strongly rounded; basal impressions rounded. deep and small. Elytra a little wider than thorax, the stria punctured, indistinctly so on sides and apex. Length $9.5-10.5 \mathrm{~mm}$.

Described from Indiana; occurs throughout the State. March 21-August 22. Frequent in hilly regions beneath stones and old $\operatorname{logs.}$

129) (539). Pterostichus honestus Say, Trans. Amer. Phil. Soc., II, 1S23. 51; ibid. II. 475.

Elongate-oval. subconvex. Black or piceous; antenna and legs reddish-brown. Thorax scarcely longer than wide. much narrowed behind the middle and sinuate on sides: basal impressions narrow and deep. with the space between them coarsels and sparsely punctured. Elytra. more oral and convex than usual, much broader than thorax, the strixe deep, not punctured. Tength $S \mathrm{~mm}$.

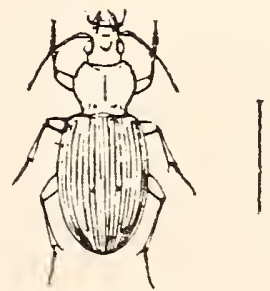

Fig. 57 . (After Leng). (Fig. 57.) 
Fulton, Parke, Vigo, Jackson, Crawford and Posey counties; scarce. Occurs principally beneath logs in deep shaded ravines. April 13-November 4.

P. rostratus Newm., 14-16 mm., P. substriatus Lec., 12-14 mm., and $P$. apalachius Horn, $12 \mathrm{~mm}$. in length, have a known rainge which favors the probability of their oceurring in Indiana.

\section{Group B.}

This group comprises black, medium sized species ranging in length from 10 to $16 \mathrm{~mm}$. They have two or three dorsal punctures on each elytron; thorax narrowed behind and not margined at base, except in permundus; the inner wings lacking except in obscurus. The side pieces (episterna) of the metathorax are short, and nearly as broad at apex as base. Of the seven species whose characters and range are such as to be included in the group, five are represented in the collection at hand, while two others perhaps occur in the State.

\section{KEY TO SPECIES OF GROUP B.}

a. Thorax narrower at base than apex; prosternum not margined behind.

b. Outer stria of elytra indistinct; thorax finely margined; elytral striae not punctured.

124. obscuRus.

bb. Outer strixe of elytra nearly or quite as deep as inner; thorax strongly margined.

c. Dorsal punctures two (rarely three or four).

d. Basal impressions of thorax linear, deep.

LACHRYMOSUS.

$d$. Basal impressions large, broad.

$e$. Hind angles of thorax carinate.

$f$. Basal impressions without a tubercle.

125. CORACINUS. $f f$. Basal impressions with an obtuse flattened tubercle.

126. STYGICUS. ce. Hind angles not carinate; impressions without a tubercle.

127. RELICTUS. SUPERCILIOSUs.
ed behind ; dor-

cc. Dorsal punctures four ; hind ang?es carinate. a a. Thorax broader" at base than apex; prosternum margined behind; dorsal punctures three.

12S. PERMUNDUS.

124 (542). Pterostichus oiscurus Say, Trans. Amer. Phil. Soc., IV, 435; ibid. II, 538 .

Elongate, slender. Black; antenna, tibiae and tarsi dark reddish-brown. Thorax somewhat trapezoidal in shape, narrowed behind; basal impressions short, narrow, punctured, hind angles very obtuse, rounded, Elytra with three dorsal punctures, the first and second on or near the third stria, the third on second stria; intervals flat, stria shallow. Length $10.5-12 \mathrm{~mm}$.

Throughout the State; scarce. April 4-November 17. In one specimen before me there are four dorsal punctures on one side and three on the other. 
125 (545). Pterostrchus coracinus Newm., Entom. Mag., V. $1838,386$.

Elongate-oral. rather robust. Black, shining; antennx and legs piceous. Thorax quadrate. somewhat narrowed behind. sides broadly rounded. hind angles obtuse; basal impressions broad. deep, rugosely punctured. Elytral strice deep, not punctured; interrals flat or nearly so. Length $15-17.5 \mathrm{~mm}$. (Fig. 5S.)

Throughout the State, frequent; more so in the northern counties. May 13-October 3. Occurs beneath logs and stones in open woods. In this and the

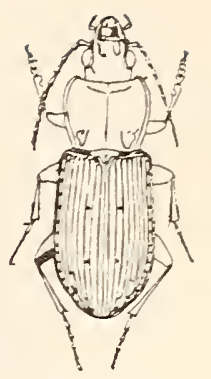

Fig. 58 . (After Leng). next two species the side margins of thorax are wider and more reflexed than in any of those preceding; the two (rarely three or four) dorsal punctures are located on the second stria, one before, the other behind the middle. In one specimen from Cass County there are four distinct dorsal punctures on the second stria. From the keys. as usually given, it was at first referred to supercitiosus Say, but the thorax is not narrored behind as in that species and the elytra are jet black. not purplish. I have concluded, therefore, that it is but a sport of coracimus. with which it agrees in all other respects.

P. lachrymosus Newm. and P. supcrciliosus Say, both $15 \mathrm{~mm}$. in length. very probably inhabit the State. The former has been taken by Dury at Cincinnati and the latter in Michigan.

126 (546). Pterostiches strgicts Say, Trans, Amer. Phil. Soc.. II, 1S23. 41 ; ibid. II, 467.

Closely allied to the preceding. Distinguished principally by the small tubercle in the thoracic impressions; carina of hind angles rery short. Elytral interrals more convex. Length 14-16 $\mathrm{mm}$.

Very common throughout the State beneath logs. etc. in open woods. March 31-October 20. The so-called "tubercle" is only an elerated space between the two stria of the basal impression. It is my opinion that a large series of specimens will show coracinus to be only a form of stygicus, Say's name having priority.

127 (54i). Pterostichés relictl's Nerm. Entom. Mag.. Y. 1S3S, 38 i.

Resembles both coracimus and stygicus. Thorax longer. more distinctly' narrowed behind and without carina at hind angle or tubercle in basal impressions, the latter. therefore. being single. Elytral strit deeper. With narrower, much more convex intervals. Length $16-17 \mathrm{~mm}$.

Putnam. Termillion, Vigo and Knox counties; scarce. May 25September 18. Occurs beneath stones in deep ravines. 
125 (555). Prerostichus permundus Say, 'Trans. Amer. Phil. Soc., IV. 1834, 426 ; ibid. II, 540 .

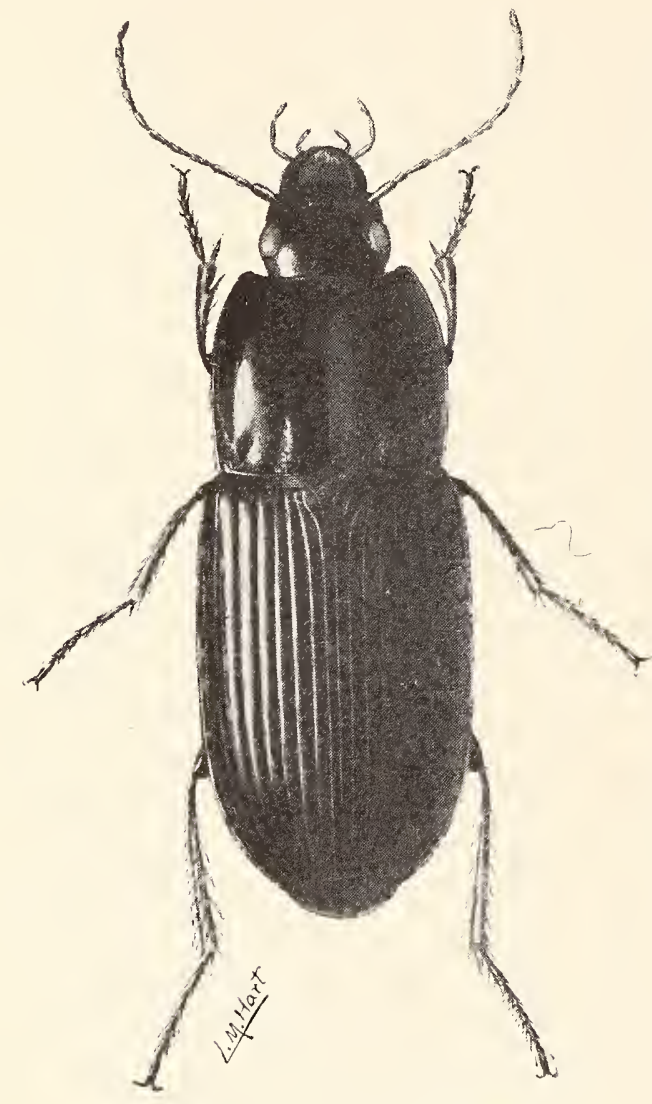

Fig. 59. $\times 5$. (After Forbes).

Elliptical or broadly oval. Black or purplish, shining with iridescent reflection; antenne and legs piceous. Thorax broad, quadrate. a little narrower at front than at base. side margins narrow in front, wider. depressed and punctured behind the middle; basal impressions two on each side, punctured, the outer very short. Elytral strix not or very finely punctured; the first dorsal puncture on the third stria, the other's on the second. Length 12-14 mm. (Fig. 59.)

Described from Indiana. Occurs frequently throughout the southern half of the State beneath logs in open sandy woods. Most common in autumn. March 31-October 20.

Group C.

'T'o this group belong' large or medium sized black, greenish or bluish species having the side pieces of metathorax long and gradually narrowed from base to apex. The thorax varies much in form, and its hind angles are never rounded. The dorsal punctures range in number from three to six, and the inner wings are always present. Thirteen species comprise the group.

KEY TO SPECIES OF GROUP C.

a. Three basal joints of antenne distinctly carinate; basal impressions of thorax double.

๖. Legs black; dorsal punctures two; body above green or bronzed, polished; under surface not punctured.

129. SAYI.

b7. Legs usually reddish; dorsal punctures four; body above green or bluish, not polished; under surface punctured.

130. LUCUBLANDUS. a $a$. Basal joints of antennie simple. not carinate; color black, rarely purplish.

c. Dorsal punctures of elytra three or four.

d. Hind angles of thorax carinate: basal impressions large and dee?. bistriate.

e. Thorax much narrowed behind, the angles rectangulat and prominent. 
$f$. Basal impressions not or very sparsely punctured; elytral ir. descent, the strixe tine; size larger, 14-16 mm.

131. EBENINIS.

ff. Basal impressions distinctly punctulate; elytral strie deeper: smaller, not over $11.5 \mathrm{~mm}$.

132. CAUDICALIS.

ee. Thorax less narrowed behind, the angles small, rectangular, but slightly prominent, impressions punctured.

g. Smaller, not over $10 \mathrm{~mm}$.; form slender.

gg. Larger, 14-15 $\mathrm{mm}$; form broader.

133. LUCTUOSTS. 134. CORVINTS.

dd. Hind angles of thorax not carinate, basal impressions single.

$h$. Basal impressions wide and deep; thorax strongly margined: ligula obtusely carinate.

i. Size very large, 22 or more mm.; surface but little polished. female dull.

135. HALDEMAN1.

ii. Size smaller, not over $20 \mathrm{~mm}$.; surface polished, shining.

$j$. Elytral striæ deep, distinct to apex; surface moderately brilliant; size 16-20 $\mathrm{mm}$.

136. TARTARICUS.

jj. Elytral striæ fine, very faint towards apex; surface very brilliant: size $15 \mathrm{~mm}$.

137. SCRUTATOR.

$h h$. Basal impressions linear; thorax finely margined; ligula not carinate.

k. Color purplish; basal impressions not punctured.

$k k$. Color black; basal impressions punctured.

138. PURPURATUS.

139. MUTUS.

cc. Dorsal punctures of elytra five or six, large, deeply impressed.

l. Hind angles of thorax small, dentiform; elytra black, shining.

140. PENNSYLVANICUS.

7l. Hind angles obtuse; elytra dark reddish-brown, feebly bronzed.

141. LUCZOTII.

129 (564). Pterostichús sayi Brulle., Silb., Rev. Entom., III, 277.

Oblong, somewhat fiattened. Bronzed or green above; sometimes nearly black; basal third of antenna reddish-brown. Thorax a little wider than long, feebly narrowed behind, more so in front; margins not depressed; basal impressions deep. punctate, the outer much the shorter; hind angles rectangular. Elytral strixe deep, punctate. Length 10-12.5 $\mathrm{mm}$.

Throughout the State: common. March 19-October 20. Probably hibernates.

*130 (565). Pterostichus lucublandus Say, Trans. Amer. Phil. Soc., II, 1823. 55 ; ibid. I, 177 ; II, 478.

Resembles the preceding but less flat and without the brilliant polish of surface. Color exceedingly variable, usually green or bluish. Thorax wider, not narrowed behind; margin wider, more reflexed, depressed near the hind angles. Elytral striæ smonth. rarely finely punctate: intervals subconvex, finely alutaceous. Length 10-14 mm. (Fig. 60.)

Very common throughout the State. February 21-September 22. Hibernates as imago. The dorsal punctures are usually four.

$[7-23402]$ 
located on third interval. one near end of scutellar stria. one just behind the middle. the other two on apical third. In one specimen

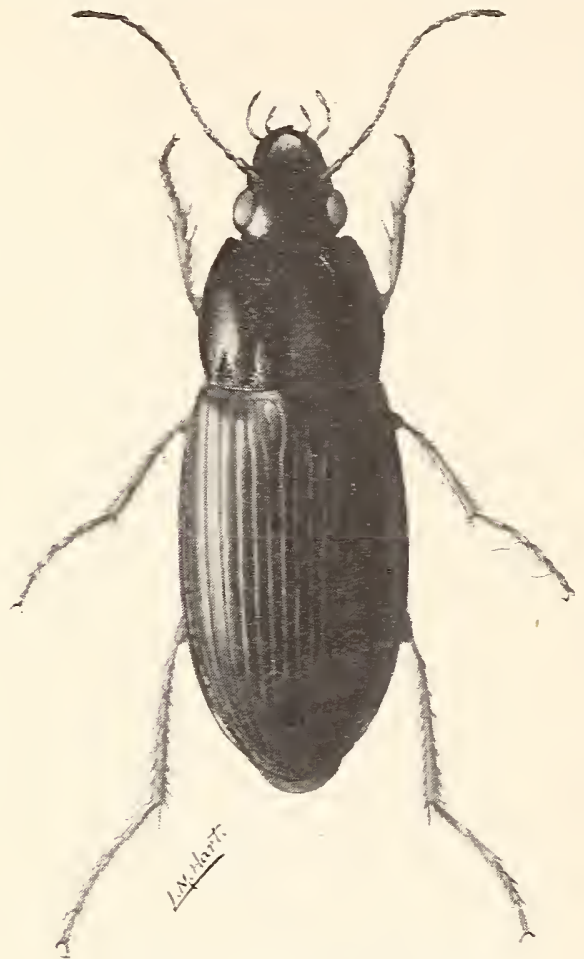

Fig. 60. $\times 5 \frac{1}{2} . \quad$ (After Forbes.) at hand there are six on each elstron. those on the left all on third interval: those on right. four in regular position on third interral and two on fifth. opposite the hinder pair on third.

*131 (56s). PTEROSTICHT'S EBETINT'S Dej.. Spec. III. 152\%. 307.

Elongate-oblong. Black or piceous. shining: elrtra more or less iridescent. Thoras wider at apes than base. sides much rounded. sinuate near hind ansles. Elstral strix shallow. rers fineIr punctured: interrals flat. Length $\div-16 \mathrm{~mm}$.

Lake. Fulton. Nigo and Knox counties: frequent. Esually found heneath $10 \mathrm{grs}$ and rubbish near water. Hibernates. Februar 23October 22. In this and the next three species the scutellar stria is long and the elrtra each hare three dorsal punctures. the first one on the third stria. the other two near the second stria behind the middle.

* 132 (569). Pterostichts catdicalis Sas. Trans. Amer. Phil. Soc.. II. 1523. $56:$ ibid. II, 450 .

Elongate. siender. Black. shining: antemie reddish-brown. legs piceous. Thorax shaped as in ebeninus. the margin more narrow. less reflexed at base: impressions. as rell as the space between them. sparsely and coarsely punctured. Strix of elrtra deeper. finely nunctured. Length 10-11.5 $\mathrm{mm}$.

Throughout the State: commsn. Niarch 19-October 17. Hibernates.

133 (570). Pterostichts Lucttosts Dej.. Snec. III. 1S27. 284.

Resembles caudicalis but smaller and more slender. Thorax more quadrate. less narrowed behind. Elstra but little wider than thorax. the striæ deep. rers finelr punctured. I.ength $\$-9 \mathrm{~mm}$.

Throughout the State: common in the northerm counties. less sn in the southern portion. Occurs beneath rubbish. usually near water. May 10-August 27. 
134 (571). Pterostichus corityes Dej.. Sinec. III, 1827, 281.

Elongate, more robust. Black, antennæe and tarsi piceous. Thords rather short, sides rounded, not sinuate. hind angles very slightly prominent or subobtuse; basal impressions rery deep, sparsely and coarsely punctured. Elytral strixe deep. nrst or very finely punctured. Length $13.5-15 \mathrm{~mm}$.

Frequent about the margins of lakes in the northern half of the State; not yet taken in the southern half. Nay 5-October 29.

135 (5i2). Pтerostichos haldemaxi Lec., Ann. Lyc. Nat. Hist.. IV, 1S4S, 341.

Oblong, rery robust, subdepressed. Black, elstra not shining; antennæe and tarsi piceous. Thorax a little broader than long, narrowed behind, sides scarcely sinuate, basal impressions not punctured. Elytral striæ narrow, deep. not punctured : interrals conrex. Length 22-24 mm.

A southern form, rare in Indiana. Two specimens from margins of cypress swamp. Knox County. April 23-May 25. This species and the next two were formerly classed under the genus Lophoglossus Lec., distinguished by the ligula being obtusely carinate for its whole length. They also have the thorax strongly reflexed, gradually irider behind, the front transverse line deep, distant from margin, the hind angles obtuse; dorsal punctures three.

136 (573). Pterostichus taktarices Say, Trans. Amer. Phil. Soc., II, 1S23, 44 ; ibid. II, 469.

Oblong, depressed. Black, shining, antenne, tibice and tarsi piceous. Thorax with sides distinctly sinuate torards the base. Elytral striæ finely and indistinctly punctate, interrals subconrex. Male with subapical tooth on inner surface of middle tibie short, obtuse; the apical process large, acute. Length $16-20 \mathrm{~mm}$.

Throughout the western half of the State, common; especially so in sandy localities near water. Hibernates. April 17-December 28 .

137 (574). Pterostichus scretator Lec.. Ann. Lyce. Nat. Hist., IV, 1S4S, 342.

Oblong, depressed. Black, rery shining; legs and antennze piceous. Hind angles of thorax less prominent than in tartaricus and elytral strix differing as mentioned in key. Male with subapical tooth of middle tibize long and sharp; the apical mocess not distinct. Length 15-16 $\mathrm{mm}$.

Cass County; rare. September 15. Two specimens taken by Dr. Robert Hessler from a ditch dug about a burning peat bog near Royal Center. 
138 (5Tt). Pterostichus plrperates Lec. Journ. Phil. Acad. Nat. Sci., II, 1853. 242.

Elongate, rather robust. Head and thorax black, shining; elytra and femora with a distinct purplish tinge; antennæ and tarsi piceous. Thorax subquadrate. but little narrowed behind, sides rounded, hind angles obtuse. Elytral strix deep, not punctured : interrals convex. Length $13-14 \mathrm{~mm}$.

Knox and Lawrence counties; rare. August 31-September 26. This and the next species have the hind tarsi with three joints grooved on the outer side: the dorsal punctures three and the front transverse line of thorax short and interrupted.

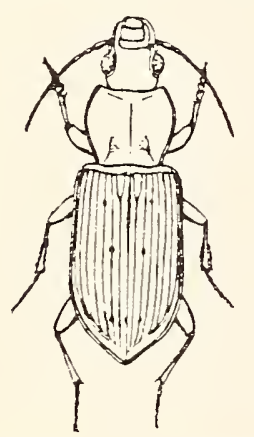

Fig. 60 a. (After Leng).

*139 (578). Pterostichus mutes Say. Trans. Amer. Phil. Soc.. II, 182:3. 44; ibid. II, 470.

Elongate, rather slender. subdepressed. Black, shining; antenne and legs piceous. Thorax more eridently narrored at base, sides less rounded, hind angles distinct. Elytral striæ deep. finely punctured, interrals subconrex. Length 10-12.5 mm. (Fig. 60a.)

'Throughout, the State; common. Hibernates. April 8-December 18.

140 (580). Pterostichus Pennsylanicus Lec., Proc. Phil. Acad. Nat. Sci., 1873, 314.

Elongate, rather robust. Black, very shining; palpi, tibiæ and tarsi dark reddish-brown. Side margins of thorax a little wider toward the base, basal impressions linear with a few punctures. Elytral striæ deep. indistinctls punctured; intervals slightly convex. the third with five large punctures, the basal one near the third stria, the others on or near the second. Length 11-12.5 mm.

A northern species taken in Lake County, near Pine; rare. June 26.

141 (583). Pterostichus Luczotil Dej.. Spec., III, 182て, 321.

Elongate-oral, rather slender. subdepressed. Head and thorax black: antennæ, legs and elytra dark reddish-brown. Thorax narrowed behind: sides oblique. narrowly depressed; hind angles obtuse, basal impressions sparsely punctured. Elytral strix finely punctured, the second and third with fire or six large. indented dorsal punctures placed somewhat alternately; interrais nearly flat. Length 11-12.5 mm.

Steuben County; rare. August 13. Four specimens were taken from beneath leaves in a low wooded tract on the eastern border of Clear Lake. A species of northern range.

Group D.

Three small species comprise this group. In addition to the characters given in key to Groups, they have the side pieces of 
metathorax long; dorsal punctures three; hind tarsi with three or four joints grooved on outer side; basal impressions of thorax deep, single; wings wanting except in erythropus.

$$
\text { KEY TO SPECIES OF GROUP D. }
$$

a. Scutellar stria wanting; thorax subquadrate, hind angles strongly rounded.

a $a$. Scutellar stria long.

142. ERYTHROPL'S.

b. Elytral strice not punctured; hind angles subrectangular, slightly prominent.

148. PATRUELIS.

67. Basal half of elytral striæ puictured ; hind angles obtuse.

144. FEMORALIS.

142 (585). P'Terostichus erythropus Dej., Spec. III, 1827, 240.

Elongate-oral. Black. strongly shining; antennæ and legs reddish-brown. Thorax nearly square, sides feebly curved, widely depressed near the hind angles, which are strongly rounded; basal impressions and elytral striæ not punctured. Length 8-8.5 mm. (Fig. 61.)

Throughout the State, frequent; usually beneath rubbish in sandy localities near water. Probably hibernates. March 19-November 5 .

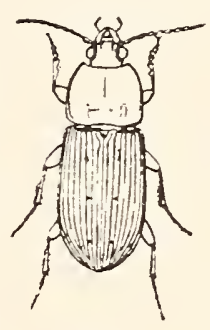

Fig. 61. (After Leng)

143 (587). Pterostichus Patruelis Dej., Spec. V, $1829,759$.

Elongate, slender, subcyindrical. Black, feebly shining; antennæ and legs dark reddish-brown. Thorax feebly narrowed behind, sides moderately rounded, basal impressions sparsely punctured. Elytral striæ deep; intervals nearly flat. Length $7.5 \mathrm{~mm}$.

Throughout the State; more frequent in the northern half. March 26-October 25.

*144 (588). Pterostichus femorai.is Kirby. Faun. Bor. Amer., IV, 1837, 31.

Resembles the preceding, but the form is less slender, the hind angles of thorax more obtuse and the elytral strix finely punctured at least as far as the middle. Length $7.5 \mathrm{~mm}$.

Throughout the State; common. Hibernates as imago. February 6-December 18.

\section{Evarthrus Lec. 1852. (Gr., "good + joint.")}

Black beetles of medium or large size, possessing the characters of the tribe Pterostichini as above given. Last joint of labial palpi shorter than the next to last, the latter with several long setæ in front. Elytra with rounded humeri and one dorsal puncture, located near the third stria just behind the middle. Hind tarsi not grooved on outer side. Wings wanting; mandibles striate. Prosternum not margined behind. 
The members of this genus resemble those of Pterostichus and are found in the same situations though less frequently. Of seven specimens dissected by Dr. Forbes, insects such as canker worms and caterpillars had formed 93 per cent. of the food, so that they may be classed as highly beneficial.

For literature treating of the genus see the first two papers by LeConte mentioned under Pterostichus, also the following:

LeConte.- "Synoptic Table" in Bull. Brook. Entom. Soc., III. 1880, 21, 49, 73.

Wickham.- "Coleoptera of Northeastern America" in Journ. N. Y. Ent. Soc., III, 1895, 189-190.

Thirteen species of Evarthrus are known from the United States. Of these, six have been taken in Iridiana, while another may occur.

\section{KEY TO INDIANA SPECIES OF EVARTIRUS.}

a. Thorax subquadrate, but little constricted at base; prosternum deeply sulcate.

b. Thorax wider than long; scutellar stria wanting.

c. Striae of elytra strongly punctured.

d. Margin of thorax wide, especially at base.

dd. Margin of thorax narrow, nearly uniform.

c. Strix of elytra finely punctured.

145. SEXIMPRESSC S.

146. SIGILLATLS.

147. AMERICANis

b7. Thorax as long as wide; scutellar stria present, rather long.

148. ORBATUS.

aa. Thorax strongly constricted behind; prosternum feebly or obsoletely sulcate.

e. Hind angles of thorax prominent; strixe of elytra fine. colossus.

ee. Hind angles of thorax shorter. less prominent; strix of elytra deep. $f$. Sides of thorax much rounded.

$f f$. Sides of thorax less rounded, more oblique.

149. SODALIS. 150. FERTIVUS.

145 (610). Evarthrus seximpressus Lec., Ann. Lyc. Nat. Hist., IV, 1848 350.

Elongate-oval. Black, head and thorax feebly shining; apical hali of antennæ and tarsi reddish-brown; basal joints of antennæe, femora and tibiæ piceous. Thorax not punctate, sides rounded. Elytra very finely alutaceous, opaque; intervals flat. Length $14.5-15.5 \mathrm{~mm}$.

Southern half of State, frequent; less so in the northern counties. April 29-November 19. Occurs mostly on dry wooded slopes beneath logs and stones. In this and the next three species the thorax has the hind angles obtuse and the sides not sinuate near base. 
146 (611). Evarthrus sigmlatus Say, Trans. Amer. Phil. Soc., II. 182:3, 42 ; ibid. II, 468.

Very close to seximpressus. Thorax with more narrow malsin which is not inflexed or widened near base, the basal impressions more shallow. Female dull black; male often more shining. Length 15-17 $\mathrm{mm}$.

Southern half of State; scarce. Nay 12-October 20.

147 (612). Evarthrus americanus Dej., Spec. III, 1827, 392.

Form proportionally broader than in the two preceding species. Thorax with hind angles less obtuse and elytra more finely punctured. Thorax slightly narrowed in front, the margin fine, not reflexed. Elytra in both sexes subopaque. Length 15-18 mm.

Crawford. Knox and Perry counties; scarce. May 15-September 10 .

148 (613): Evarthrus orbatus Newm., Entom. Mag., V, 1838, 386.

Thorax not broader than long, slightly narrowed behind, the margin narrow and scarcely reflexed; hind angles less strongly carinate. Elytral striæ deeper than in the preceding species, rather finely punctate; intervals more convex. Length 15-17 mm. (Fig. 62.)

Marshall and Posey counties; rare. April 10October 17.

E. colossus Lec., 16-22 $\mathrm{mm}$. in length, has been taken in Kentucky and Illinois, and doubtless occurs in southern Indiana.

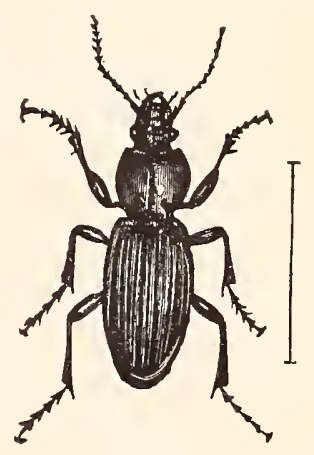

Fig. 62

149 (620). Evarthrus sodalis Lec.. Ann. Lyc. Nat. Hist., IV. $1848,349$.

Elongate-oblong. Dull black, the apical half of antennæ and tarsi reddish-brown. 'Thorax suborbicular, the sides strongly rounded to near base, thein suddenly sinuate, the base much narrower than apex. Elytra finely alutaceous, rather deeply striate, the striæ coarsely punctured; intervals subconvex. Length 15-17 $\mathrm{mm}$.

Southern half of State, frequent; not yet taken in the northern counties. April 3-September 16.

150 (621). Evarthrus furtivus Lec., Journ. Phil. Acad. Nat. Sci., 1852. 233.

Differs from sodalis in having the thorax more broadly and obliquely rounded on the sides, which are but slightly sinuate near the hind angles. Length $15-16.5 \mathrm{~mm}$.

Throughout the State, frequent; less so northward. April 3September 27. 


\section{Amara Bon. 1813. (Gr., "to shine.")}

Black, brownish or bronzed beetles of medium size, possessing the characters of the tribe Pterostichini as previously given. Form usually oval or oblong, convex: last joint of labial palpi shorter than the next to last, the latter with several setæ in front; thorax usually wider than long and in most species as wide at base as elytra, the latter without dorsal punctures. Males with the first three joints of the front tarsi dilated, with two rows of scales beneath.

The genus is a large one and the species very difficult to separate by a table or key unless both sexes are present. Even then a number of the species resemble one another so closely as to be only doubtfully placed. Its members are, according to Dr. Forbes, mainly vegetable feeders, though one of the larger ones, obesa, is known to feed largely upon the eggs of locusts or grasshoppers. They occur mostly in moist situations, beneath logs, stones, etc., and several species are known to hibernate as imagoes.

The following are the principal papers on the North American species:

LeConte.- "Notes on the Amaræ of the United States," in Proc. Phil. Acad. Nat. Sci., VII, 1855, 346.

Horn.- "Synoptic Tables," in Trans. Amer. Entom. Soc., V, 1874, 127.

Horn._- "A Study of Amara," in Trans. Amer. Ent. Soc., XIX, 1892, 19.

Wickham.-In Journ. N. Y. Ent. Soc., IV, 1896, 33.

Hayward.- "Studies in Amara," in Trans. Amer. Ent. Soc., XXXIV, 1908, 13-66.

About 70 species are known from the United States. Of these 19 have been taken in Indiana, while two or three others probably occur. For convenience the Indiana species are separated into three groups, and these in turn into species.

KEY TO GROUPS OF INDTANA AMARA.

a. Thorax distinctly broader in front of than at the base, and usually more or less cordiform.

Group $A$.

ua. Thorax broadest at base, thence gradually narrowed to apex.

b. Hind tibia pubescent on the inner side in the males. Group $B$.

$b b$. Hind tibire not distinctly pubescent on the inner side in the males.

Group $C$.

\section{Group A.}

But five species, whose known range is such as to probably include Indiana, belong to this group. With one exception they are 
our largest species. and are elongate-oblong and conver in form, black or piceous in hue. usually strongly shining, rarely very feebly bronzed. The apical spur of front tibiz is always simple and the elytral striæ are punctured. It includes the Indiana representatives of the subgenera Curtonotus. Leincnemis and Bradytus of Hayrard's paper.

KEY TO SPECIES OF GROLY'd.

a. Prosternum not margined at tip; middle tibie of male with two teeth on the inner side: punctures on base of thorax limited to the impressions.

151. PExNSYLYATICA.

a $\iota$. Prosternum margined at tip: middle tibice of males not toothed.

b. Hind tibire of males not distinctly pubescent on the inner side: thorax punctured from side to side at base. 152 AVIDA.

6b. Hind tibize of males distinctly. usually densely pubescent on the inner side; basal impressions of thorax broad, biforeate, with few or no punctures between them.

c. Scutellar stria rery short or obsolete; side pieces of metasternum punctured.

153. EXARATA.

cc. Scutellar stria long; side pieces of metasternum smooth.

d. Prosternum of male with a shallow sparsely punctured oral space at middle, simple in the female: larger, $8.7-10.5 \mathrm{~mm}$.

154. LATIOR.

dd. Prosternum of male not punctured, but rith a lengthrise groove. more feebly groored in female; smaller. i-s mm. ScHWARzI.

1.51 (6.5). Ajara pexpsylanica Haytrard. Trans. Amer. Ent. Soc. XXXIV, 190s, 34.

Elongate-oblong. moderatels conrex. Black or piceous. shining; antennie and legs rufous. Thorax less than one-half wider than long. slightly wider at base than apex, widest a little in front of middle; hind angles rectangular, carinate; basal impressions broad. deep. indistinctly biforeate. coarsely punctured. Elstral strixe punctured. more finely torard the apex. Length $10-11.5 \mathrm{~mm}$.

Southern half of State: frequent. Hibemates. February 26October 9. Listed as fulcipes Putz. but Hayward shows this name to have been preoccupied.

152 (623). Amara Alina Say. Journ. Phil. Aead. Nat. Sci. III. 1S2:3. 145: ibid. II, 9อ̃, วั41.

Oblong, conrex. Black or piceous. shining: antennæe and legs rufous. Thorax nearly twice as wide as long. widest in front of middle. as wide at base as apex; hind angles rectangular, not carinate. basal impressions ill-defined: disk smooth at middle. sparsely punctate near apex. more densely and coarsely across the base. Elytra scarcely nider than thorax. the strixe deep. distinctly punctured. interrals conrex. Length $\$-9.5 \mathrm{~mm}$. (Fig. 63.)

Tigo and Flnyd comnties: scrarce. April 26-.June 23. 
153 (646). Amara Exarata Dej., Spec., III, 1828, 509.

Oblong-oval, robust, very convex. Blackish-piceous, shining; antenne and legs reddish-brown, the former as long as the head and thorax. Thorax subquadrate, about one-half wider than long, basal impressions broad, double, punctured; hind angles small, acute, very obtusely carinate. Elytra slightly wider than thorax, the strixe deep, closely punctured. Length S-10 mm. (Fig. 64.)

Throughout the State; common. Hibernates. January 13-November 11.
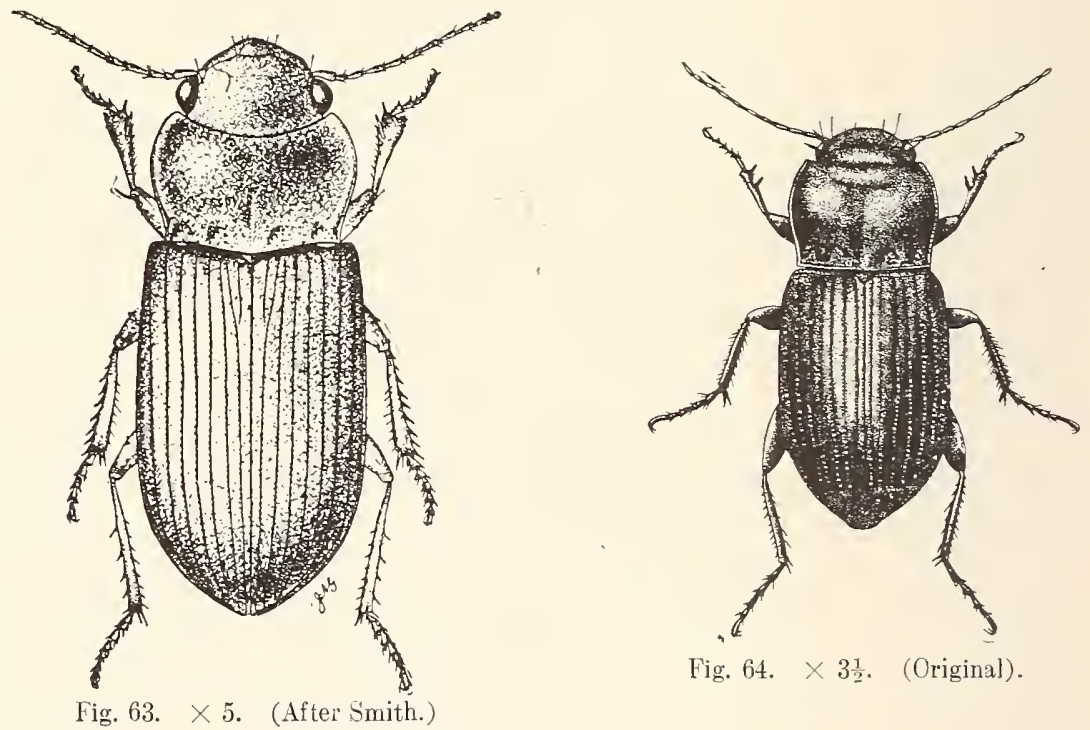

$15 t$ (6ti). Amara lation Kirby, Faum. Bor. Amer., IV, 1837, 36.

Elongate-oblong, feebly convex. Piceons to black, often slightly bronzed. surface finely alutaceous in females. Thorax about one-half wider than long, not sinuate near base; hind angles subrectangular. very obtusely carinate, basal impressions broad, bifoveate, punctate, the inner forea longer than the outer. Elytra sightly wider than thorax, rather deeply striate. the striæ finely punctured, indistinctly so on the apical half. Length 9-10.5 mm.

One specimen from the margin of Lake Michigan near Millers. Lake County. July 29. A member of the Alleghanian fauna which probably occurs throughout the northern third of the State.

A. schuarzi Hayward, usually listed as septentrionalis Lec., was described from Lake Superior and may also occur in northern Indiana.

\section{Group $B$.}

To this group belong nine medium-sized oval, black or piceous, and ustually bronzed-shining species. The antennæ are black or piceous with the two to four basal joints paler. The elytra are rarely, and then only slightly, wiler than the thorax at base and 
their strix are distinctly punctured in but one of the nine, while the hind angles of thorax are never carinate. The group includes the subgenera Tricena and Amara of Hayward's paper.

KEY TO SPECIES OF GROUP B.

a. Apical spur of front tibise trifid; scuteliar stria of elytra terminating in an ocellate (eye-like) puncture at base; antennæ with the three or four basal joints pale.

b. Thorax narrowed from base to apex, its hind angles obtuse; fourth joint of antenne in great part pale.

155. ANGUSTATA.

$b b$. Thorax narrowed from slightly behind the middle to apex, hind angles sharply rectangular ; fourth joint of antennie in great part piceous.

PALLIPES.

a. Apical spur of front tibix simple.

c. Basal joints of antenne not carinate; prosternum of male not punctured.

d. Scutellar stria terminating in an ocellate puncture; femora piceous or dark reddish-brown, tibixe and tarsi paler.

156. IMPUNCTICOLLIS.

$d d$. Scutellar stria without ocellate puncture.

$c$. Elytral st:ice punctured; base of thorax finely punctured.

15\%. BASILLARIS.

ee. Elytral strix not or obsoletely punctured; base of thorax smooth.

$f$. Thorax narrowing from basal angles to apex; form broad, robust: terminal spur of front tibice stouter than usual.

CRASSISPINA.

ff. Thorax narrowing from in front of base; form oblong-oval; terminal spur of front tibia normal.

158. CUPREOLATA.

‘c. Antennæ with basal joints 2 and 3 carinate above.

g. Scutellar stria ending ir an cellate puncture.

$g g$. Scutellar stria without puncture.

h. Basal impressions of thorax rery faint; larger, $7.5-9 \mathrm{~mm}$.

160. PROTENSA.

$h h$. Basal impressions of thorax distinct, the outer oblique; smaller, 6-7 mm.

161. POLITA.

155 (651). Amara angustata Sily. Trans. Amer. Phil. Soc., II, 1823, 36 ; ibid. II. 463. 542 .

Oral. convex. Black, bronzed. shining: legs dull reddish-yellow. Thorax one-half wider than long. hind angles obtusely rounded, outer hasal impression obsolete, the inner small, sparsely or not at all punctured. Elytrit not wider than thorax. gradually narrowed from the base; surface finely alutaceous. the stria not punctured. or sparsely punctate at base: scutellar stria ending in a lirge eve-like puncture. Length 6-7.5 mm.

Common in southern half of the State: less so in the north. April 10-. Tune 20. On the first warm days of early spring this species and the next are often found ruming rapidly about near the bases of trees and stimps in open woodiand pastures. 


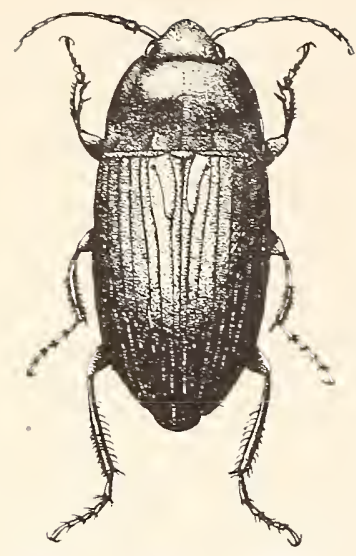

Fig. 65. $\times 4 \frac{1}{2}$. (Original.)

$156(657)$.

Amara impuncticollis Say, Trans. Amer.

Phil. Soc., II, 1823, 36; ibid. II, 463. 542 .

Oral, convex. Blackish-bronzed, often with a faint greenish tinge; femora piceous, tibiæ and tarsi paler. Thorax subquadrate, narrowed from slightly behind middle to apex; surface smooth; inner basal impression often evident. not punctured, outer one obsolete. Elytra as wide at base as thorax, strire shallow, not punctured; a single large puncture at junction of second and sutural striæ. Length $7-9 \mathrm{~mm}$. (Fig. 65.)

Throughout the State; common. Probably hibernates. Narch 12-October 21. The females have the upper surface alutaceous.

*157 (659). Amara basillaris Say, Trans. Amer. Phil. Soc., II. 1823, 35 ; ibiđ̄. II, 462,542 .

Oblong-oval, convex. Blackish-bronzed or purplish-black, shining; legs reddish-brown. the femora darker. Thorax subquadrate, nearly twice as wide as long. narrowed from about the middle to apex; basal impressions double, with numerous distinct punctures, the inner longer than the outer. Elytral strix rather deep, punctured. Length $7-8.5 \mathrm{~mm}$.

Vigo County: rare. January 13. Taken from beneath mullein leaves.

158 (661). Amara cupreolata Putz., Mem. Liege, I. 1866. 180.

Oblong-oral, convex. Bronzed or purplish-black, shining. the females finely alutaceous; antennæ and legs piceous. Thorax one-half wider than long. narrowed from about one-third in front of base and rounded to apex: basal impressions feeble or wanting; hind angles obtusely rounded. the puncture near them distant from side margin and much nearer the basal. Elytra not wider than thorax. subparallel to behind the middle, the strix not or very finely punctured. Length 6-7 mm.

Throughout the State; our most common species. March 4 July 24. Resembles impuncticollis but readily distinguished by the lack of ocellate puncture at base of scutellar stria.

159 (664). Amara fallax Lec.. Ann. Lyc. Nat. Hist., IV, 1848, 362.

Oral. moderately convex. Blackish-bronzed. shining in males, alutaceous in females; under surface and femora black, tibire and tarsi dark reddish-brown. Thorax nearly twice as wide as long. narrowed from slightly in front of base to apex. basal impressions indistinct. hind ancles rectangular. Elytra slightly wider than thorax, striæ not punctured: the ocellate puncture at junction of scutellar and second stria smaller than in impuncticollis. Length $7.5-9.5 \mathrm{~mm}$.

Lake. Laporte. Marion. Vigo and Posey counties; scarce. March 26-May 28. Distinguished from impuncticollis only by carinate basal joints of antennie and the more broadly rounded tip of prosternum. 
160 (66i ). Amara protensa P'ut\%. Mem. Liege, 1, 186;6, $18: 3$.

Oblong-oval, moderately convex. Purplish-black or bronzed, alutaceous in both sexes, more strongly in females; antennie and legs piceous; under surface black. Thorax two-thirds wider than long, very distinctly wider at base than apex; basal impressions very taint, not punctured; hind angles subrectangular. Elytra slightly wider than thorax, finely striate, the strix smooth. Length $7.5-8.5 \mathrm{~mm}$.

Laporte County ; rare. May 20. A species of northern range which probably occurs throughout the northern third of the State. 161 (668). Amara polita Lec., Ann. Lyc. Nat. Hist., IV, 1848, 364.

Oval, moderately convex. Bronzed or blackish-bronzed, shining, often with a bluish tinge; femora black, tibixe and tarsi reddish-brown. Thorax nearly twice as wide as long, narrowed from about one-third in front of base, hind angles rectangular; basal impressions small, deep, not punctured. Elytra very slightly wider than thorax, the strie smooth. Length $6.2-7 \mathrm{~mm}$.

Lake and Pulaski counties; scarce. Narch 26--June 26. Easily recognized by the carinate antennæ, oblique outer basal depression of thorax and smaller size.

A. pallipés Kirby, 5.5-8 mm., and A. crassispina Lec., $7.2-9 \mathrm{~mm}$. in length, are members of the boreal fauna ranging from Massachusetts to Lake Superior and Wisconsin, and probably occur in the northern counties of Indiana.

\section{Grovp C.}

This group of eight species comprises the Indiana members of the subgenus Celia and includes our largest and smallest species of Amara. For the most part they are oval, brown or piceous, rarely bronzed species, having the thorax broadest at base, the hind tibix never pubescent on inner side in males, and the ocellate puncture at base of scutellar stria always lacking.

\section{KEY TO IXDIANA SPECIES OF GROUP C.}

a. Antennæe and legs piceous black.

b. Elytra strongly alutaceous, the intervals more or less uneren.

162. INTERSTITIALIS.

66. Elytra shining; interrals flat, smooth and even.

163. ERRATICA. a a. Antennæe pale. legs usually so.

c. Size very large for the genus, 9-12 $\mathrm{mm}$. ; prosternum with a number of setæ (bristly hairs) at tip.

164. OBESA.

cc. Size medium or small. not over $8 \mathrm{~mm}$; prosternum with either two setæ or none at tip.

d. Prosternum of male with an irregular group of small punctures near the middle.

e. Sides of thorax distinctly flattened: prosternum with two setil: at tip; reddish-brown. the males shinins.

165. REMOTESTRIATA. 
ce. Sides of thorax not flattened; prosternum without seta; piceous, shining.

166. CHALCEA.

dd. Piosternum of male smooth as in the femaies and without setie; sides of thorax not flattened.

i. Elytral striae fine, the intervals flat; thorax distinctly emarginate at apex.

167. SUBжNEA.

$f f$. Elytral striæ deep, the intervals convex; thorax nearly truncate at apex.

g. Form oblong; hind angles of thorax much rounded; sides of metasternum coarsely punctate; larger, 6-7 mm.

168. RUBRICA.

yg. Form more oval: hind angles subrectangular or obtuse; metasternum smooth; smaller, not orer $5.5 \mathrm{~mm}$.

169. MUSCULUS.

162 (670). Amara interstitialis Dej., Sp. Geñ. III, 1828, 472.

Oblong-oval, moderately convex. Color valriable; brownish-bronze to green, cupreous or nearly black. Thorax less than twice as wide at base as long, apex feebly emarginate, hind angles rectangular; basal impressions usually distinct but shallow. the outer oblique, the inner short, not punctured. Elytral strix with very fine, indistinct punctures; intervals more or less convex with undulating surface. Length $\tau_{-9} \mathrm{~mm}$.

A species of northern range, raxe in Indiana. A single specimen was taken in Vigo County from beneath drift in a swamp. Several others were obtained near Hessville and Wolf Lake, Lake County, by Wolcott. March 26-May 26.

163 (669). Amara ERratica Sturm, Deutsche Ins., VI. 55.

Elongate-oval. Bronzed-cupreous or nearly black, slining; antennæe piceous black, the two basal joints often reddish: under surface and legs piceous, shining. Thorax not twice as wide at base as long at middle, sides narrowing to front, hind angles rectangular; basal impressions very feeble, the outer usually the smaller and obliquely placed; surface rarely slightly punctate near the inner depression. Elytra finely striate, the striæ finely but distinctly punctured; intervals flat or slightly convex, alutaceous in female. Length $6-7.5 \mathrm{~mm}$.

Lake County ; scarce. March 26-June 26. A circumpolar species which finds its southern limit in the transition life zone of northern Indiana. Although Horn says in his key that the surface is not alutaceous it is distinctly so in the female.

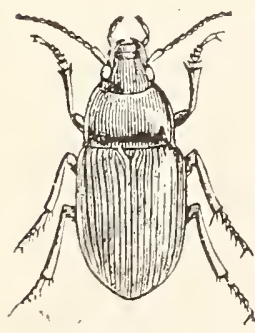

164 (674). Amara obesa Say. Trans. Amer. Phil. Soc., II. 1823. 37 ; ibid. II. 464.

Oblong-oval, lobust. not very convex. Piceous black, shining; elytra opaque in female: antennæe and legs reddishbrown. Thorax one-half hroader than long, hind angles rectangular; hasal impressions double, finely punctate, the onter deeper and with an external carina. Filytral strix more deeply impressed at inex. very finely punctured. Length Fig. 66. $\times 2$.
(After Riley.) 9-12 $\mathrm{mm} . \quad$ (Fig. 66.) 
Lake County, frequent along the south shore of Lake Michigan; also taken in Lagrange and Marjon comnties. June 15-October 28. Probably occurs throughout the state.

165 (678). Amaka remotestriata Dej.. Sp. Gell., ill, 1528, tï.

Oblong-oral, miderately convex. Reddish-brown or slightly piceous, males shining. fenales dull; antennie and legs pale reddish yellow. Thorax one-half broader at base than long, hind angles sharply rectangular; basal impressions double. shailow, sparsely and coarsely punctate, the outer somewhat triangular, the inner linear. Elytral strie fine, smooth or very finely punctate; intervals tlat. Length 6.5-S mm.

Vigo and Crawford counties: rare. Apriỉ 20-September 21.

166 (677). Amara chalcea Dej., Spec. Gen., III, 1828, 476.

Form more broadly oval and more convex than the next. Piceous, shining, surface slightly bronzed; antennæe and legs reddish-brown. Thorax nearly twice as wide at bise as long at middle, hind angles rectangular; basal impressions double, rather large and deep. sparsely and rather coarsely punctured. Elytral striae not punctured : intervals fiat. Length $6.5-7 \mathrm{~mm}$.

Vigo County; rare. April 17.

167 (682). Amara subenea Lec, Agass. Lake Sup., 15.50. 200.

Oblong-oval. P'iceous or dark reddish-brown, faintly bronzed, shining: antennie and legs dark reddish-yellow. Thorax about one-half wider at base than long at middle, distiuctly narrowed at apex, front angles distinct. hind angles rectangular; basal impressions rather deel, the inner larger, sparsely and coarsely punctured. Elytral strie finely and crenately punctured. Length 5.5-6.5 mn.

A northern form, known from Indiana by a single specimen taken by Wolcott near Clarke Junetion. Lake County, June 24.

168 (681). Amara rubrica Hald., Proc. I'hil. Acad. Nat. Sci., I, —_, 301.

Oblong, moderately convex. Reddish to chestnut-brown, shining; antennæ and legs paler. Thorax not twice as wide as long, hind angles rery obtuse; basal impressions shallow. usually punctured. Elytra slightly wider at base than thorax, strie finely. crenately punctured; intervals convex. Length 6-7 $\mathrm{mm}$.

Southern third of State; scarce. May 6-October 9.

169 (683). Amara musculcs Say, Trans. Amer. Phil. Soc.. II, 1823, 35 ; ibid. II, 462.

Oblong-oval. Piceous or dark reddish-brown, shining; antennze and legs pale reddish-brown. Thorax one-half wider than long, distinctly narrored in front; basal impressions almost obliterated. sparsely punctate or smooth. Elytral strie as ill rubrica, which species it closely resembles and from which it is best separated by its smaller size and lack of punctures on sides of metasternum. Length $5-5.5 \mathrm{~mm}$. 
Our smallest member of the genus: common throughout the State. Often found in autumn on flowers of goldenrod (Solidago). April 4-October 27.

\section{Loxandrus Lec. 1852. (Gr., "oblique + male.")}

Flattened, elongate-oblong or oval. black or piceous beetles of medium or small size, possessing the characters of the tribe Pterostichini. Differing from Pterostichus and allied genera by having the front tarsi of males obliquely dilated; mandibles not striate; mentum tooth emarginate. The thorax is scarcely or not at all narrowed behind and has the basal impressions single, linear and straight and the front transverse line distinct, very close to the apical margin. The wings are always present and there is one dorsal puncture on the third interval just behind the middle. Although they are shining and often more or less iridescent, they are rarely with color markings other than the piceous or yellow shades of the antenna and legs, and, as a result, are very difficult of separation. They live beneath stones. logs and bark, especially that of oak, usually in damp locations, and when uncovered run very swiftly. The following are the principal papers treating of the genus :

LeConte._"Synopsis," in Journ. Phil. Acad. Nat. Sci., II, $1852,250$.

LeConte.-_"Synoptic Table," in Proc. Amer. Phil. Soc., XVII.

375 ; and in Bull. Bronk. Entom. Sor.. IIT, 1880, 19.

About twenty species are known from the United States, six of which have been taken in Indiana. while another may occur. They belong to that division of the family in which the side margin of the thorax is not flattened toward the hind angles.

KEY TO INDIANA SPECIES OF LOXANDRES.

॥. Larger, 9-13 $\mathrm{mm}$.

7. Legs, or at least the tibice and tarsi, reddish-brown; elytral strige punctate.

c. Thorax one-half wider than long; length 11.5-13 $11 m$.

170. RECTUS.

cc. Thorax rely slightly wider than long; fenora often picesus; length 9-10 1111 .

17. MINOR.

b7. Legs wholly black or piceeus; elytral stria not punctate.

1. Thorax wider than long. its hind angles rectangular.

d1. 'Thorax longer than wirle, hind angles obtuse.

172. BREVICOLLIS.

17:3. ERRATICLS.

ar. Smaller, not over $7.7 \mathrm{~mm}$.

e. Elytra uniform black or piceous; legs pale to dark reddish-brown.

174. AgILIS. 
ee. Elytra with a common sutuial redrlish sut behind the midrle.

$f$. Legs dull yellow; hind angles romnded at tip).

175. VELOX.

ff. Legs dark; hind angles not rounded.

CELER.

*170 (694). Loxandrus rectus Say, Trans. Amer. Phil. Soc., II, 182:3, 58; ibid. II, 481, 534 .

Elongate-oblong. Piceous blark, shining; antenne, palpi and legs reddish-brown. Thorax nearly as broal as elytral; sides feebly allred; balsal impressions deep, not punctured. Elytral strix deep, finely punctured on their sides; intervals convex. Tength $11.5 \mathrm{~mm}$.

Vigo County ; rare. January 7. A member of the Austroriparian fauna.

$171699)$. Loxandrus minor Chaud., Bull. Mosc., IV, 1843, 766.

Black or piceous, iridescent, shining; antemme, tibice and tarsi dark reddish-brown. Thorax narrower than elytra, very slightly wider than long; sides feebly curved, hind angles obtuse, with the extreme tip rounded. Elytral strix shallow, very finely punctured; intervils subconvex. Length 9-10 $\mathrm{mm}$. (Fig. 67.)

Southern half of State, frequent; Kosciusko County only in the north. April 20-October 20. Occurs in sandy localities near water. The legs of this species vary in hue, being usually wholly reddish-brown; sometimes, however, the femora (and rarely the tibix) are piceous. From brevicollis and

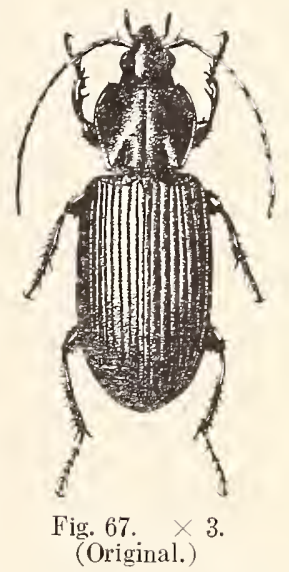
and erraticus the individnals with dark legs can be distinguished by their smaller size and by the minute elongate punctures at the bottom of the strix.

172 (698). Loxandrus brevicollis Lec., Ann. Lyc. Nat. Hist., IV, 1848, 338.

Black, iridescent. shining; antennæ. tibiæ and tarsi dark reddishbrown, femora piceous. 'Thorax subquadrate, nearly as broad as elytra: sides curved to behind middle, thence obique to base; basal impression: wider and more shallow than in rectus. Elytral striæ shallow; intervais flat. Length 11-12 $\mathrm{mm}$.

Cypress swamp, Knox County, and near mouth of White River, Gibson County; rare. April 30-July 6. Also a species of southern range.

173 (700). Loxandrus erraticus Dej. Spee., III, 1828, 240.

Black, shining, iridescent; antenne dark reddish-brown, the two basal joints paler. Thorax subquadrate, slightly longer than wide, basal impressions rather shallow. Elytral strixe not or very obsoletely punctured: intervals subconvex. Cength 9-10.5 mm.

Fulton and Knox counties; rare. May 20-Angust 31.

[8-23402] 
*174 (702). Loxandres AgILIS Dej.. Spec. III. 182S, 244.

Black or piceous, shining. feebly iridescent; antennie dusky. the basal joint paler: legs pale to dark reddish-brown. Thorax subquadrate, as wide as long; sides more strongly curred than in minor; basal impressions large, sparsely and finely punctate, hind angles rounded. Elytral striæ finely but distinctly punctate: intervals subconvex. Length $5.5-7 \mathrm{~mm}$.

Fulton. Vigo and Dubois counties: scarce. .January 7-August 20. Occurs under bark of oak stumps and logs.

175 (707). Loxaxdrus velox Dej.. Spec. III, 1828. 245.

Black or piceous, shining; three basal joints of antennie reddish-yellow, remainder darker. 'Thorax slightly wider than long. sides feebly curved. basal impressions narrow. Elytral strize distinctly punctured; intervals flattened. Length 5-6 $\mathrm{mm}$.

Marion. Vigo. Lawrence and Crawford counties; scarce. Janwary $T$-October 23. The reddish-yellow sutural spot near apex is sometimes indistinct.

L. celer Dej., 6-7 mm. in length, is known from Illinois, Florida and Texas. and probably occurs in the scuthern third of Indiana.

\section{Tribe VII. LICININI.}

Antennæ moderately long. arising from beneath a distinct frontal plate. two or three basal joints glabrous; head short, with two setie above the eyes; labrum short. emarginate, longitudinally impressed: mandibles stout. more or less curved. mentum deeply emarginate. without a tooth. Thorax with one (rarely two) bristle-bearing punctures on the side and one near the hind angles. Body not pedunculate. Elytra striate. margined at base. not interrupted on the margin. Hind coxæ contiguous; front tibiæ deeply emarginate on inner side. Males with two or three joints of front tarsi rather broadly dilated. spongy pubescent beneath and (iliate at the sides.

Four genera represent the tribe in the United States. three of which occur in Indiana.

IET TO INDIANA GENERA OF LICININI.

a. Intennie with three basal joints entirely glabrous; size medium or large. 10 or more $\mathrm{mm}$.

6. Elytra witl one dorsal puncture on the third interval (except in obtusa); eighth and ninth striae very close.

XXVIII. Diplochilat.

60. Elytra without dorsal puncture; eighth and ninth strixe well selıarated.

XXIX. DICALTS. "1r. Antenne with only two basal joints glabrous: size small, not orer $\tau$ inm.; third interval with two dorsal punctures.

SXX. Badister. 
XXVIII. Diplochm.A Brulle. 1835. (Gr., "double + lip.")

Smooth black beetles of small or medium size. Elytra usually with one dorsal puncture near the middle of the third interval, the apex feebly sinuate. They live beneath stones and rubbish, usually in damp places. Three species and two varieties are known from the United States, all of which oceur in Indiana. The following table is based on that of Dr. Horn in Bull. Brooklyn Entomological Society, III, 1880, p. 52 :

\section{KEY TO SPECIES OF DIPLOCHILA.}

a. Hind angles of thorax distinct.

b. Seventh stria of elytra feeble or almost obsolete; base of thorax broader than apex.

c. Smaller, $13-15 \mathrm{~mm}$.

cc. Larger, 18 or more mm.

176. LATICOLLIS.

176a. var. MaJor.

bb. Seventh stria about as distinct as sixth; thorax less narrowed in front, base more narowed, scarcely broader than apex.

d. Elytral intervals all black.

17T. IMPRESSICOLLIS.

dd. Alternate elytral intervals reddish-purple.

177a. Var. ALTERNANS. aa. Hind angles of thorax obtusely rounded; elytral strixe finer, seventh almost obsolete; length 11-12 $\mathrm{mm}$.

178. OBTUSA.

*176 (710). Diplochila laticollis Lec. Ann. Lyc. Nat. Hist., IV, 1848. 319.

Black, feebly shining; antenne and tarsi dark brown, the basal joints of both piceous. Thorax one-half wider than long; sides curved to behind middle, thence oblique to base; hind angles rectangular. Elytra finely alutaceous. the strixe shallow, not or very faintly punctured; intervals flat. Length $13-15 \mathrm{~mm}$.

Throughout the State; frequent. February 6-October 9. Sometimes attracted by electric lights.

176a (710a). Diplochma laticoldrs major Lec., loc. cit., 318.

In addition to its larger size. this form has the basal impressions of thorax broader and more shallow, the elytral striæe finely but distinctly punctate, the serenth fainter, often wholly obsolete. Leugth $18-20 \mathrm{~mm}$.

Throughout the State; common. Narch 18-October 27. Tsually considered a variety of laticollis, but probably distinct.

177 (711). Diplochila mmpressicoldis Dej., spee. V. 1830, 682.

Black. Apex of thorax less narrower than in laticollis. nearly as broad as base. Elytral stria deeper, rather coarsely punctured : intervals nore convex. Length $16-17 \mathrm{~mm}$.

Lake, Laporte and Vigo counties; scarce. March 18-July 7. 
$177 \mathrm{a}$ (- - D). Diplochila mipressicollis alternats CaseJ.

Differs from trpical impressicollis only as shown in table. Size the same.

Vigo and Lake counties; rare. Nay 30-June 7.

178 (712). Diplochila obtusa Lec., Ann. Lyc. Nat. Hist., IV. 1848. 320.

Black, feebly shining: antenne reddish-brown; tibiæ and tarsi piceous. Thorax nearly one-half wider than long, base wider than apex. sides feebly curred, basal impressions deep. Elytral striæ not punctured; interrals feebly conrex, the third rithout dorsal puncture. Length 11-12 mm.

Rare; two specimens from Vigo County. April 11.

XXIX. Dicælús Bon. 1813. (Gr., "two + pitted.")

Black, violet or bronzed-purple beetles of large size, possessing the characters of the tribe Licinini as above given. From allied genera they are separated by the absence of dorsal punctures and by having three joints of the antennæ smooth. In our species the elytra are deeply striate, with the seventh interval carinate from the humerus to a varying distance, and with the eighth and ninth striæ well separated. The generic name refers to the impressions near base of thorax. Their focd has been shown by Dr. Forbes to be wholly of insect origin. thus proving their beneficial habits. They occur beneath logs and stones, usually in high, dry, open woods. Seventeen species are knorn from the United States. Of these nine have been taken in Indiana. while another perhaps occurs. For literature see:

Horn.-"Synoptic Table," in Bull. Brook. Ent. Soc., III, $1880,51$.

Wickham.- "Coleoptera of Northeastern America," in Journ. N. Y. Entom. Soc.. IV, 1896, 44.

KEY TO INDIANA SPECIES OF DICELUS.

a. Elytral interrals rery irregular. interrupted by large punctures.

179. SCULPTILIS.

a $a$. Elytral interrals regular, not interupted.

b. Thorax distinctly narrower at apex than base.

c. Elytra not uniform black: length $18-25 \mathrm{~mm}$.

1. Flytra violaceous or purplish.

180. PURPLRATTS.

dd. Elytra brilliant brassy or cupreous.

SPLENDIDUS.

cc. Elytra black.

e. Intervais of elytra alternately broader and more convex; humeral carina rery long.

181. FURTES.

re. Intervals of elytra equal.

$f$. Two bristle-bearing punctures on margin of thorax near mirldle; form moderately elongate, the elytral intervals equal.

182. ELONGATUS. 
$f f$. One bristle-bearing puncture on margin of thorax near middle. g. Smaller. 15-16 mm. ; basal transrerse impression of thorax feeble.

183. Ovalis.

yg. Larger. 20-25 mm. : basal transrerse impression distinct.

h. Form elongate; margin of thorax reflexed near base.

184. AMBIGẼL's.

$h h$. Form broad; sides of thorax not or but slightly reflexed near base; elstral interrals rather narrow; conrex; humeral carina two-thirds the length of elytra.

br. Thorax as wide or wider at apex than base.

185. Dilatatus.

$i$. Surface scarcels shining; thorax decidedly narrowed behind.

1S6. TETER.

ii. Surface shining; thorax nearly square, not narrowed behind; humeral carina rers short.

187. POLITLS.

179 (722). Dic elus sculptilis Say; Trans. Amer. Phil.

Soc., II, 1823, 68 ; ibid. I, 53.

Broad, subconrex. Black. shining; antennæ piceous, paler at tip. Thorax rers slightls widest at base. the margin broad: disk finels alutaceous. minutely rugose. not punctate. Readily known br the rough upper surface of the elrtra. Length 17-19 mm. - (Fig. 68.)

Southern portion of State. scarce; not taken north of Tryne and Fountain counties. April 17-October 16. Occurs most commonly in low. damp woods.

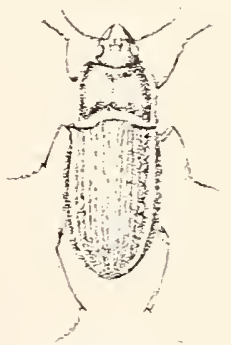

Fig. 68 . (After Say.)

IS0 (718). Diceles plratrates Bon., Mem. Ac. Tor., 1813. 447 ; Say. I, 51.

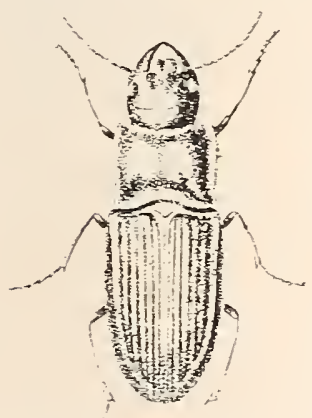

Purplish or riolaceous. without brass tinge; antennæe (as in all the succeeding species) piceous at base, gradually paler to apex; legs black. Thorax with fine. wary transrerse lines. Elytra alutaceous, the striæ deep; intervals rery conrex. Length 20-25 mm. (Fig. 69.)

This large beetle is one of the most handsome of our Carabidæ. It occurs frequently in southern Indiana. but in the north has been taken only in Kosciusko County. April 6-August 11.

Fig. 69. (After Say.) D. splendidus Sar. 18-25 mm. in length. oceurs in Illinois and possibly in western Indiana.

181 (723). Dic.elds Furies Dej.. Spec.. II. 1826. 388.

Short and rather broad. Blackish, opaque or feebly shining. Thorax as in purpuratus. the median line feeble. the margins but slightlr reflexed. Elytra minutely granulate: the interval between the fifth and sixth strie with sereral punctures near the base. Length $15-16 \mathrm{~mm}$.

Putnam. Tigo. Dubois. Posey and Dearborn counties; scarce. March 25-September 16. The humeral carina extends almost to apex and unites at tip with the fifth interval. 
182 (726). Dicklus elongatus Bon., Mem. Ac. Tor., 1813, 447.

Much more elongate. Black, shining. Thorax with deep, distinct median line and two bristle-bearing punctures on sides just in front of the middle. Elytra granulate and punctate as in furvus, the striæ deep; intervals convex; humeral carina reaching beyond middle. Length $15-18 \mathrm{~mm}$.

'Throughout the State; common. April 9-October 17.

183 (725). Diclelus ovalis Lec., Ann. Lyc. Nat. Hist., IV, 1848, 327.

Short, rather broad. Black, feebly shining. Thorax with median line very distinct, deeper near base and apex. Elytral striæ deep; humerai carina reaching two-thirds to apex. Length 15-16 $\mathrm{mm}$.

Kosciusko, Vigo and Crawford counties; scarce. May 17-October 27. This species is of the same form and size of furvus, but is easily distinguished by the equal elytral intervals.

184 (727). Diczles ambigues Laf., Rer. Zool., 1841, 48.

Elongate, subparallel. Black, more or less shining. "Sides of thorax more strongly reflexed than in any of the preceding species. Elytral strix deep: intervals quite convex; humeral carina not reaching middle. Length $19-22 \mathrm{~mm}$.

Frequent in the southern portion of State, as far north as Vermillion County. April 9-October 6.

185 (715). Dicklus dilatatus Say, Trans. Amer. Phil. Soc., II, 1823, 6s; ibid. I, 53.

Hoad, very robnst. Black, dull or very feebly shining.

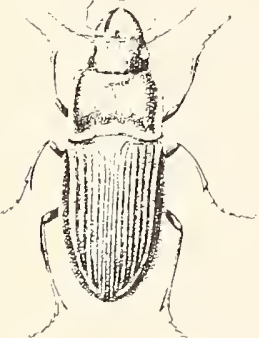

Fig. 70. (After Say.) Thorax with the margins but little reflexed transverse hasal impression rery deep. Elytral strix deep, broad. obsoletely punctured toward the tip: humeral carina reaching two-thirds to apex. Length $20-25 \mathrm{~mm}$. (Fig. 70.)

Southern half of State, frequent; not taken north of Vigo County. April 18-October 21. Our largest member of the genus.

186 (728). Dicklus teter Bon., Mem. Ac. 'Tor., 1813, 449.

Elongate, rather slender. Black, feebly shining. Thorax broadest in front of middle; margins strongly reflexed. transverse basal impression extending almost from middle to base. Elytral strix deep, intervals very convex; humeral carina reaching to middle. Length 20-22 $\mathrm{mm}$.

Crawford County: rare. May 18. On aceount of the form of the thorax, this species has the general appearance of a Pterostichus.

187 (729). Dicalús Politus Dej.. Spec., II, 1826, 391.

Elongate-oblong. Black. strongly shining. Thorax subquadrate, a little longer than wide, apex and base equal. Elytra regularly and deeply striate. Length 11-14 $11 \mathrm{~m}$.

Southern half of State, frequent: Kosciusko County only in the north. April 9-September 6. Our smallest species. Resem- 
bles Pterostichus permundus, but easily distinguished by the lack of dorsal punctures.

\section{BAdister Clairv. 1806. (Gr., "a fast walker.")}

Small piceous, brownish or spotted beetles, possessing the characters of the tribe Licinini. but having only the two basal joints of antennæ entirely glabrous; the elytra with the eighth and ninth striæ well separated and the tips not sinuate. They oceur beneath stones and logs, usually singly and in damp localities, and are comparatively rare. The following papers are eited for students interested in the North American forms:

LeConte.- "Short Studies of North American Coleoptera," in Trans. Amer. Ent. Soc., VIII, 1880, 165.

LeConte.-."Synoptical Table," in Bull. Brook. Entom. Soc., V, $1882,7$.

Eleven species are known from the United States. Of these five have been taken in Indiana. Two others may also oceur, while a new form is herewith described.

KEY TO INDLANA SPECIES OF BAUISTER.

a. Elytral striae deep, the intervais narrow, convex; antenlie and legs reddish-yellow; elytra reddish-brown, darker behind.

1SS. NOTATUS.

a a. Elytral striae shallow, intervals flat or nearly so.

b. Elytra spotted.

c. Thorax. legs and elytra yellow; elytra with a broad middle bind. interrupted at the suture, and an anical spot, black, iridescent.

189. PULCHELLUS

cc. Thorax black, legs and basal third of elytra orange; apical twothirōs of elytra black with an orange spot near apex.

190. MACULATUS.

b7. Elytra not spotted, sometimes bicolored.

d. Thorax and legs dull brownish-yellow; elytra piceous, margined at sides, base and suture, with yellowish-brown; lengtl $5.5-6 \mathrm{~mm}$.

OBTUSUS.

dd. Black or piceous, legs yellow.

$e$. Hind augles of thorax very much rounded; length $6 \mathrm{~mm}$.

FLAVIPES

ee. Hind angles obtuse, not or feebly rounded.

$f$. Head as broad as thorax; margins of latter of same color as disk.

191. LATICEPS.

ff. Head narrower than thorax; margins of latter paler than disk.

g. Larger. 5-6 $\mathrm{mm}$.; margins of thorax narrow, not more reflexed towards the base.

192. MICANS.

gg. Smaller, not over $4 \mathrm{~mm}$.; margins of thorax wider and more reflexed towards the base.

193. REFLEXUS. 
1Ss (731). Badister notates Hald., Proc. Phil. Acad. Nat. Sci., I. 299.

Elongate-oral, slender. Head and thorax black, shining; color otherwise as given in kes. Thorax obcordate; hind angles obtuse; basal impressions deep, linear: median impressed line entire. deep. Length 4-4.5 $\mathrm{mm}$.

Lake, Marion. Crawford and Posey counties; rare. May 5-Norember 8 .

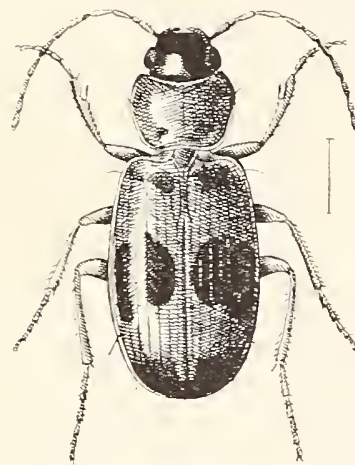

Fig. 70a. (Original.)

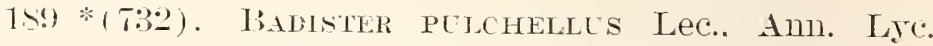
Nat. Hist.. IT, 1848. 418.

Elongate-oral. Head black, antennie dusky, first joint yellow. The two black spots on each elytron are sometimes comnected by a broad stripe. Thorax obcordate, the basal impressions broad and shallow. Length 5.5-6.5 mm. (Fig. 70a.)

Lake, Kosciusko and Vigo counties; scarce. Occurs beneath logs and bark along the margins of marshes and lakes. Hibernates as imago. January 6 -Oetober 29 .

190 (734). Badister macllates Lec. Trans. Amer. Phil. Soc., X, 387.

Elongate-oral. Color as giren in key. Thorax obcordate with a deep. transerse line between the basal impressions, the latter prominent: median impressed line entire. deep. Length $6 \mathrm{~mm}$.

One specimen from Vigo County. Found beneath log in sandy upland woods. October 17. Known before only from Pennsylvania.

B. obtusus Lec. is a boreal species which may yet be found in northern Indiana. B. faripes Lec., is recorded from Cincinnati.

191 (- - ) . Badister LatTCEPS sp. not.

Elongate-oral. Piceous. shining; antemne and legs rellow, the apical halî of former gradually duskt ; narrow margin of elytra and epipleura dull rellow. Head as broad as thorax. faintly alutaceous; eves prominent. Thorax slightly broader than long. narrowed from in front of middle to base: margins narrowly reflexed. searcels mole so near hind angles, which are obtuse; surface finely alutaceous. basal impression deep. median line entire. Elytral striae well impressed on disk, more shallow on sides; interrals subconvex. Lengtho 6 mm.

Vigo. Knox. Clark and Perry counties; scarce. April 15-September 27. Resembles micans closely and confused in my collection with that species until the type was examined at Cambridge. In addition to differences mentioned in key the thorax in laticeps is less transverse and has the basal impressions deeper and better defined. From ferrugineus, a Californian species. to which it is also closely allied. it differs by the less transverse thorax and the pale antennx 
192 (740). Badister micans Lec., Proc. L'hil. Acad. Nat. Sci., II, 1844, 52.

Elongate-oval. Above piceous with a bluish Iuster, the head darker; antennæ dusky brown, the basal joint paler. Thorax one-half wider than long, the basal impressions broader and more shallow than in laticeps. Elytral striæ feebly impressed; intervals ftat. Tength $5.5-6 \mathrm{~mm}$.

Kosciusko County ; rare. October 29.

193 (741). Badister reflexus Lec., Trans. Amer. Ent. Soc., Vili, 1880, 166.

Elongate-oval, slender. Piceous, feebly shining, the narrow margin of thorax and elytra dull yellow, translucent; antennæe dusky. tip of last joint paler; legs dull yellow. Thorax slightly wider than long, trapezoidal, narrowed behind; basal impressions and median line deep; margins wider than in the two preceding species and more reflexed near the hind angles. which are obtuse. not rounded. Elytral strix fine; intervals broad, nearly flat. Length $4 \mathrm{~mm}$.

Laporte, Marshall, Vigo and Knox counties; rare. May 20-September 2.

Tribe VIII. PLATYNINI.

Beetles of medium or small size, having the antennæ slender, arising from beneath a slight frontal ridge, three basal joints glabrous; head oval. rarely elongate. the eyes not very distant from thorax; mandibles moderately prominent, feebly curved, without a seta in outer groove; mentum reeply emarginate, toothed or not. Thorax variable in form with a bristle-bearing puncture at sides and a second at or in front of the hind angle. Elytra margined at base, sides narrowly reflexed, apex obliquely sinuate, disk striate and in our species with dorsal punctures. Prosternum not prolonged at tip; hind coxæ contigucus. Males with three joints of front tarsi feebly dilated and clothed beneath with small scales. Four of the five genera occur in Indiana.

KEY TO INDIANA GENERA OF PLATYNINI.

a. Eighth elytral stria distant from the margin, not deeply impressed; thorax truncate or emarginate at base.

b. Tarsal claws more or less serrate; mentum toothed; tarsi glabrous above.

XXXI. Calathus.

bb. Tarsal claws not serrate.

c. Mentum toothed.

XXXII. Platynus.

cc. Mentum not toothed.

XXXIII. OLIsthopUs.

aa. Eighth elytral stria united with the margin in its basal half, deeply impressed and reaching the suture.

XXXIV. PERIGONA. 
XXX1. Calntuos Bon. 1813. (NI.., "a circular basket" or" "calyx-like."')

Brownish or black beetles of medium or small size, possessing the characters of the tribe Platynini. From allied genera they are separated by the smooth tarsi. the claws of which are serrate. Six examples of our most common species (gregarins) were dissected by Dr. Forbes, who found that two-thirds of their food consisted of caterpillars and other insect larva, and the remainder of the pollen of grasses. Our species occur beneath logs, etc., usually in dry upland woods. They are difficult to separate, and the only papers treating of them are by

LeConte.-In Proc. Phil. Acad. Nat. Sci., VII, 1854, 36; 1860 , 317.

Ten species have been described from the United States, three of which have been taken in Indiana.

KEY TO INDIANA SPECIES OF CALATHUS.

4. Thorax not narrowed behind, its base as wide as base of elytra; basal impressions feeble or wanting.

7. Entire upper suriace polished, shining; sides of thorax moderately reflexed.

194. GREGARIUS.

b). Head and tholax shining, elytra dull, opaque; sides of thorax depressed. broader behind, not reflexed.

195. OPACULUS.

au. Thorax broadest rather before the middle, slightly narrowed toward the base, the latter narrower than base of elytra; basal impressions distinct.

196. IMPUNCTATUS.

*194 (742). Calathus gregarius Say, Trans. Amer. Phil. Soc., II, 1823, 47 ; ibid. II, 472.

Elongate-oval. Dark chestnut or reddish-brown, the margins of thorax paler; antenna and legs reddish-brown. Thorax slightly longer than broad, liind angles rounded. Elytral strix shallow, not punctured. Length 10-11 mm.

Throughout the State; common. January 11-November 17. Gregarious in cold weather.

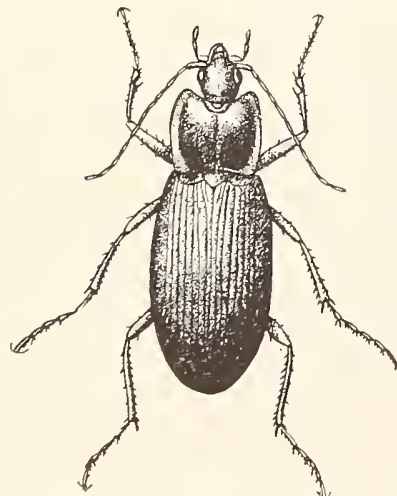

Fig. 71. $\times 3 . \quad$ (Original.)

*195 (744). Calathus opaculus Lec., Proc. Phil. Acad. Nat. Sci., VII, 1854, 37.

Form of gregarius. Head and thorax reddish(.) chestnut-brown; antennae and legs paler; elytra lull piceous or very dark brown. Thorax not longer than wide, slightly narrowed toward apex. Elytra minutely alutaceous, the stria very fine. Length 8.5-10 mim. (Fig. 71.)

Lake, Marion, Putnam and Vigo counties; frequent. January 1-November 24. Probably occurs throughout the State. 


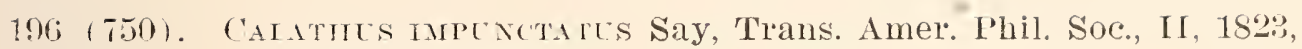
45 ; ibid. II, 471.

Elongate-oral. Black or piceous, shining: antennx and legs pale reddish-brown. Thorax slightly wider than long, sides broadly curved, hind angles obtusely rounded, basal impressions not punctured. Elytral strixe deep. not punctured; intervals convex, the third with two distinct punctures. Length 10.5-11.5 $\mathrm{mm}$.

Northern half of State; scaree. June 17-August 21.

\section{Pratrunus Bon. 1813. (Gr.. "flat or depressed.')}

A large genus of black, green or bronzed beetles of medium size and possessing the characters of the tribe. Palpi slender, with the last two joints subequal; first. third and fourth joints of antennx of about the same length. Body usually somewhat slender with the elytra nearly twice as wide as the head or thorax. Thorax very variable in form, being either oval, cordate, square or rounded; the margin sometimes barely visible. Elytra oval or oblong, sometimes elliptical, usually slightly sinuate at apex, sometimes almost truncate; the interval between the second and third striæ with from three to seven dorsal punctures.

The members of the genus occur beneath cover in all kinds of situations, some species being found only along the margins of ponds, streams and lakes. others in high. dry upland woods, and still others only in sandy locations. A number are known to hibernate as imagoes. The two papers treating of the species of the United States fauna are as follows:

LeConte._"Synopsis of the Species of Platynus and Allied Genera Inhabiting the United States,' in Proc. Phil. Acad. Nat. Sci., VII, 1854, 35.

LeConte.-"Synopsis of the North American Species of Platynus," in Bull. Brook. Entom. Soe. II, 1879, 43-58.

About 90 species of Platynus have been described from the United States. Of these 41 are known to occur in Indiana. Since the number of species is so large. the genus in the table which follows is first divided into groups, and these in turn into species.

KEY TO GROUPS OF INIIANA PLATXNUS.

a. Elytra oval without humeral angles; side pieces of metathorax shirt. not much longer than wide; thorax orate, narrowed behind, usually strongly margined at sides.

Groul) $A$.

a . Elytra with broadly rounded humeral angles; side pieces of metatholax longer than wide.

b. Hind angles of thorax not romnderl.

c. Front tarsi without groves, midlle and hind tarsi with grooves on the sides; tholat narrowed behind.

Group $B$. 
cc. All the tarsi with distinct grooves on the sides; hind angles of thorax obtuse or rectangular.

Group $C$.

67. Hind angles of thorax much rounded, rarely obtuse or somewhat defined.

d. Side margins of thorax wider toward the base and reflexed; tarsi with distinct lateral but no medial grooves.

1d. Side margin of thorax narrow, but little if at all reflexed.

$e$. Dorsal punctures of elytra three; thorax rounded-oval, its basal impressions punctiform; pubescence of antenmæ beginning on fourth joint.

Group E.

- ee. Dorsal punctures 4 to 6 ; basal impressions not punctiform; pubescence of antennæ beginning on third joint; thorax oval, margin narrowly reflexed.

Group $F$.

\section{Group A.}

The species of this group are of a slender form, without inner wings or with feeble ones in quadrimaculatus; legs and antennæ long; thorax usually. elongate; elytra regularly elliptical without distinct humeral angles, sinuate toward the tip and with the lateral margin broader and more reflexed than in the other groups. Four species whose range is such as to include Indiana belong to this group.

\section{KEY TO SPECIES OF GROUP A.}

a. Suture of elytra prolonged and divergent at tips; front tarsi with medial grooves on upper surface.

197. CAUdATUS.

a a. Suture of elytra not prolonged at tips; front tarsi without grooves.

$b$. Hind angles of thorax rounded; elytral striæ deep.

c. Alternate intervals of elytra with numerous punctures; antennæ and legs pale reddish-brown.

198. HYPOLITHUS.

cc. Third interval of elytra with four punctures; antennæ and legs black.

ANGUSTATUS.

$b b$. Hind angles of thorax rectangular; striæ of elytra shallow; thorax, base of elytra and subapical spot yellow.

199. QUADRIMACULATUS.

197 (755). Platynus caudatus Lec., New Sp., I, 1863, 7.

Elongate, narrow. Dark reddish-brown; antennæ and legs paler. Third joint of antennæ nearly twice as long as fourth. Thorax elongate-ovate. side margins strongly reflexed, hind angles obtuse. Elytral margin strongly reflexed, obliquely sinuate near apex; striæ almost obsolete; alternate intervals with an irregular row of rather large shallow punctures. Length $12.5 \mathrm{~mm}$.

Vigo and Lawrence counties; very rare. May 17-May 25. Occurs beneath rubbish or flat stones near water.

198 (759). Platynus hypolithus Say, Trans. Amer. Phil. Soc., II, 1823, 59 ; ibid. II, 482.

Elongate, slender, large for the genus. Black, shining; legs and antennæ pale reddish-brown. Thorax one-half longer than wide, narrowed 
behind, margin strongly reflexed, basal impressions deep. Hiytra elliptical; striæ moderately deep; intervals convex, the alternate oles with a row of rather large punctures on the sides. Length $13-15 \mathrm{~mm}$. (Fig. 72.)

Vigo, Putnam, Monroe and Franklin counties; scarce. May 8October 4. Occurs beneath stones in deep wooded ravines.

199 (762). Platynus quamimaclitas horn, 'Trans. Amer. Enit. Soc.. XII, 1885, 130.

Elongate-oval, slender. Antennæ, legs and thorax reddish-yellow; head and elytra black, the latter with basal third and large rounded subapical spot reddish-yellow. Thorax somewhat cordiform, a little longer than wide, narrowed at base, with an extremely narrow reflexed margin. Elytra oval,

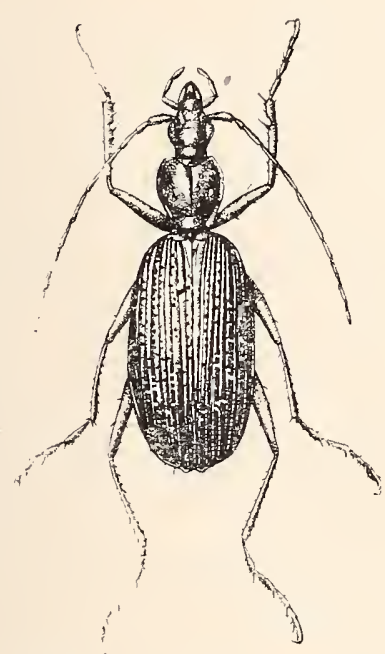

Fig. 72. $\times 2 \frac{1}{8} . \quad$ (Original. $)$

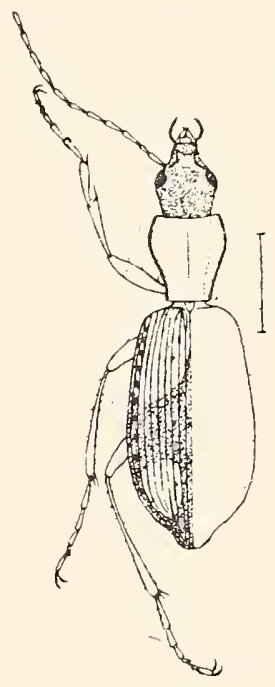

H1g. 73. (After Horn.)

broader behind; intervals flat, the third with three very small dorsal punc tures. Length $7-7.5 \mathrm{~mm}$. (Fig. 73.)

Knox and Posey counties; rare. April 20-April 25. Occurs beneath cover in moist localities. *

$P$. angustatus Dej., $13-14 \mathrm{~mm}$. in length, is said to inhabit the Middle and Southern States, and perhaps occurs in the hilly portion of southern Indiana.

\section{GRouP B.}

Composed of winged species, black or piceous in color, having the thorax strongly margined, basal impressions large and deep. hind angles obtuse or rectangular. Elytra one-half or more broader than thorax, truncate at base, more or less sinuate toward the extremity, the strix fine to deep, the second striæ or third interval with three or four impressed punctures.

*See Can. Ent. XXXVIII, 1906, p. 267. 
KEY TO SPECIES OF GROUP B.

u. Form rather bruad: elytral strixe deep.

๖. Black, shining; elstral intervals convex.

c. Larger: 12-14 mm., more depressed: elstra more deeply sinuate behind: hind angles of thorar obtuse: side pieces of metathorax not punctured.

200. DECENS.

co. smaller, 11 mm. less telressed; hind angles of thurax rectangular; side pieces of metathorix punctured.

201. Sixtates.

67. Subopaque; elytral intervals fiat, the strice less deep; hind angles of thorax obtusely rounded.

202. OPACTLES.

a a. Form slender; antennx and less rery long: elstral strice fine.

d. Elytra each with thiee dorsal punctures; piceous brown. the margin of thorax not paler.

$e$. Hind angles of tborax almost rounded; side margins strongly reflexed only on basal half; elfiral interrals alutaceous.

203. CIXCTICOLIIS.

ee. Hind angles of thorax obtuse, not rounded; side margins strongly reflexed their full length; legs and antenna pale reddish-brown: intervals not alutaceous.

204. REFLENTS.

dd. Elstra each with four or five dorsal punctures; dark reddish-bromn. the margin of thorax translucent.

205. PARMARGIMATLS.

200 (765). Puatryts decexs Say; Trans. Amer. Phil. Soc., II. 1823. 53 : ibid. II, $4 i$.

Rather broad, depressed. Black: legs: antennæ and margin of thorax piceous. Thorax subcordate, narrotred behind, basal impressions punctured; hind angles obtuse, margin of moderate midth, reflexed. Elrtral strire deep. not or rers obsoletels punctured; intervals conrer, finely alutaceous. Length 12-14 $\mathrm{mm}$.

Lawrence and Posey counties; scarce. April 10-August 28. In this and the next two species the median line and front transrerse impression of thoras are rather deep, the elytra more than one-half broader than thorax and slightly sinuate near their tips.

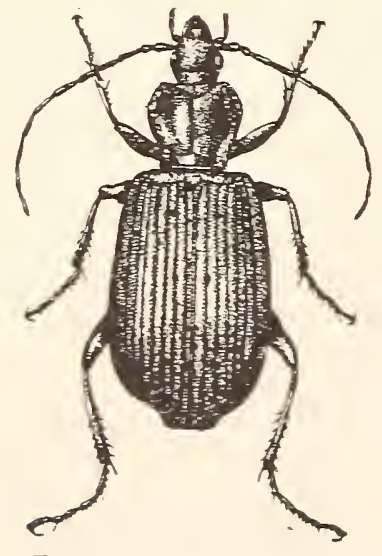

Fig. i4. $\times 3$. (Original.)
201 (766). Platixcs sixuatus Dej., Spec.. III. $10 \mathrm{~s}$.

Resembles decens but smaller, less depressed and more shining. Basal impressions of thoras rider. Elytra less deeply striate, finely punctured: interrals less conrex. Length 10.5-11 mm. (Fig. $7 \pm$.

Throughout the State: scarce. April 10August 13.

202 (767). Platyots opaclles Lec. New Spec. N. Amer. Col., I. 1863. S.

Rather slender, depressed. Dull piceous or submaque. Thorax as wide as long. narrowed in 
front and behind, the margin rather strongly reflexed; basal impressions wide, deep, not punctured. Elytral striae shallow, not punctured; intervals flat, alutaceous. Length $12-13 \mathrm{~mm}$.

Lake and Posey counties; rare. May 14-May 20.

203 (769). I'latynus cincticolris Say, Trans. Amer. Phil. Soc., II, 1823. 52 ; ibid. II, 476.

Elongate, slender. I'iceous black. Thorax widest at middle, more narrowed behind than in front, margins strongly reflexed near the hind angles; basal impressions deep, not punctured. Elytral stria not punctured; intervals slightly convex. Iength $9.5-11 \mathrm{~mm}$.

Throughout the State; common. Hibernates. February 9October 29.

204 (770). Platynus reflexus Lec., Agass. Lake Sup., 1850, 205.

Resembles cincticollis in form. Distinguished readily by the lighter colored antennæ and legs. Thorax longer, more narrowed behind; side margins more strongly reflexed, as wide in front as towards the base; front angles more prominent. Elytral strix deeper; the intervals a little more convex. Length $9.5-11 \mathrm{~mm}$.

Laporte, Lawrence and Owen counties; frequent beneath rocks" along streams, especially those within but near the mouths of caves. April 15-November 8.

205 (9272). Platynus parmarginatús Ham., Can. Ent., XXV, 1893, 305.

Elongate, slender, subdepressed. Reddish-brown; antennæ, legs and margin of thorax lighter brown. Thorax about as wide as long, side margins wide, strongly reflexed their full length; front angles prominent, obtusely rounded, hind angles obtuse; basal impressions deep, finely and sparsely punctate. Elytral striæ deep, not punctured; intervals subconvex, the third with three or four punctures near the third stria and another near the apex of the second stria. Length $8-10 \mathrm{~mm}$.

Crawford and Jackson counties; scarce. Occurs beneath stones in channels or shallow ravines on the slopes of high wooded hills. May 16--September 24.

\section{GROUP C.}

The species of this group are winged, brownish, bluish or greenish in color, with base of antennæ, legs and occasionally the thorax, reddish-yellow. The thorax is longer than wide, the margin less strongly reflexed, hind angles obtuse or rectangular. Elytra elongate. about twice as wide as thorax, scarcely sinuate near apex, humeri broadly rounded. stria deep but fine, the intervals nearly flat, the third with three to seven punctures. 
KEY TO SPECIES OF GROUP C.

u. Color greenish or bluish, base of antennæe, palpi and legs reddish-yellow; base of thorax not cylindrical.

b. Basal impressions of thorax deep.

c. Thorax with the basal half distinctly narrowed, the impressions long, curved; color purplish or dull green.

206. EXTENSICOLLIS.

cc. Basal portion of thorax not distinctly narrowed, the impressions shorter, less curved; thorax and elytra bright green.

206a. var. vIRIDIs.

bb. Basal impressions small, narrow; thorax and scutellum reddish-yellow.

207. DECORUS.

aa. Color piceous or reddish-brown; base of thorax subcylindrical; elytral intervals convex, marked with a row of small punctures, each puncture bearing a fine hair.

208. Pusillus.

206 (772). Platynus extensicollis Say, Trans. Amer. Phil. Soc., II, 1823, 54 ; ibid. II, 478.

Elongate, slender. Head and thorax greenish or bronzed, shining; elytra dull greenish or purplish. Base of thorax finely punctured, the impressions with a small, blunt tubercle on the outer side near the hind angles, the latter obtuse. Elytral strix shallow, not punctured; intervals slightly convex, alutaceous, the third with four or five small, remote punctures. Length $8-9.5 \mathrm{~mm}$.

Shores of Fish Lake, Steuben County; frequent. Lake County by Wolcott. March 26-July 19.

*206a (772b). Platynus extensicollis viridis Lec., Ann. Lyc. Nat. Hist., IV, 1848, 222.

Differs from the preceding mainly as mentioned in key. Head sometimes blackish-green. Thorax with hind angles more rounded and the basal impressions without tubercles. Varies in depth of elytral striæ and convexity of the intervals; in some specimens the striæ are finely punctured.

Throughout the State; rather common beneath rubbish in damp localities. Hibernates. February 21-November 28.

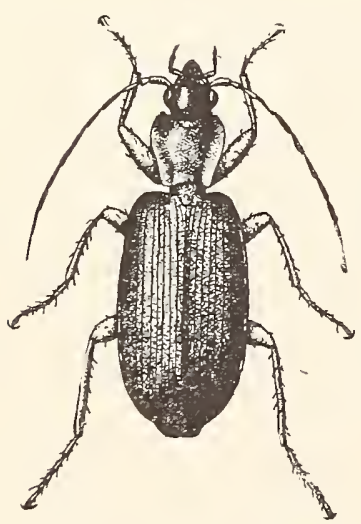

*207 (773). Platinus deconus Say, Trans. Amer. Phil. Soc., II, 1823, 53 ; ibid. II, 477.

Elongate, slender. Head green or greenish-bronze; thorax, scutellum, legs and base of antennæ reddishyeliow; elytra blackish, often green near margins. Thorax a little longer than wide, slightly narrowed at base. hind angles obtuse: elytral striæ shallow, not punctured; intervals slightly convex, finely alutaceous. distinctly punctured, the third with five to seven small dorsal punctures. Length 7.7-8.5 mm. (Fig. 75.)

Throughout the State, but scarce. HiberFig. 75. $\times 4$. (Original.) nates. February 8-October 23. Occurs be- 
neath old logs in Ary. upland open woods. In two specimens the intervals are much more coarsely punctured, more convex and strongly alutaceous.

*208 (784). Platixus pesilles Lec, Proc. Phil. Acad. Nat. Sci., Vil, $1854,39$.

Elongate. very slender. Head and thorax piceous, the elytra usually reddish-brown; antenne and legs light brown. Thorax long and cordate: base much narrowed, subcrlindrical; impressions elongate and narrow. hind angles rectangular; median line deep. surface sparsely and rathel. coarsely punctured. Elstra twice as wide as thorax, tips rounded, strice deep and finely punctured. Length $6-\tau \mathrm{mm}$.

Throughout the State: frequent. Hibernates. January 21September 11.

Grote D.

A large group of winged species. ustally black. the legs and antennæ sometimes of the same hue. more often piceous or reddishbrown. Thorax rounded, the margin usually slightly widened and reflexed toward the base. hind angles very obtuse or altogether rounded. basal impressions variable. either broad and shallow or deep and narrow; sometimes almost obsolete. Elytra often not much wider than thorax. humeri broadly rounded. the base truncate or subemarginate. tips rounded and hardly sinuate; intervals mostly flat. the third with three to seren punctures. Tarsi with distinct lateral but no medial grooves.

\section{KEY TO SPECIES OF GROUP D.}

a. Thorax transrersely oval or rounded. rarels subquadrate; elstra not deeply emarginate at base.

6. Either black (rarely bronzed), or green with disk of elrtra cupreous: hind angles of thorax usially much rounded.

c. Dorsal punctures three.

d. Antennie. and usually the legs. wholly black or piceous.

e. Thorax with side margins wider and strongly reflexed near the base.

f. Elytral strixe fine, the interrals flat.

$g$. Hind angles of thorax obtuse, rather distinct.

211. MIEREXS.

gg. Hind angles of thorax entirely rounded. 212. TExtrs.

ff. Elytral strixe deep, the intervals more or less conrex.

h. Elytral strire strongly punctured: hind angles entirels rounded.

hh. Elytral striæ not or feebly punctulate.

213. COLTatRIS.

$i$. Hind angles of thorax entirels rounded: elvtral interrals distinctly convex.

214. ATRATUS. 
ii. Hind angles rery obtuse but distinct; elctral intervals feebly conrex.

215. MELATARITS.

ce. Thorax with side margins only narrowly reflexed at the edge.

j. All three dorsal punctures on third stria; hind angles entirely rounded.

217. CORTUS.

ji. Second and third dorsal punctures near or on second stria. h. Piceous or black abore.

l. Thorax with hind angles somewhat distinct, basal impressions without a tubercle.

216. AFFIXIS.

7l. Thorax with hind angles more rounded. impressions with a distinct tubercle.

CARBO.

7k. Metallic or blackish-bronzed abore.

$m$. Head, thorax and margin of elytra green, disk of elytra coppery.

218. CUPRIPENTIS.

mm. Blackish-bronzed: dorsal punctures large. foreate.

219. EXCAVATLS.

dd. Four outer joints of antennæ white; thighs dark, tibiæ and tarsi yellowish.

224. ALBICRUS.

cc. Dorsal punctures four to seren: sides of thorax broader and more reflexed behind.

$n$. Dorsal punctures large, foreate: green. with disk of thorax and elytra bronzed. base of antennæ and legs brown.

225. OCTOPUNCTATUS.

$n n$. Dorsal punctures of usual size: base of antennæ brown; sides of thorax rather strongly reflexed.

226. PLACIDUS.

bъ. Either metallic or bronzed green. the elytra uniform in hue.

o. Thorax at least one-third wider than long. the margins on basal half wider and distinctly reflexed.

p. Elytral striæ wholly without punctures; second dorsal puncture near second stria and far behind the middle. 209. ERRAxs.

pp. Elytral striæ finely but distinctly punctulate; second dorsal puncture usually on third stria and near the middle.

210. SUBCORDATUS.

oo. Thorax not or very slightly wider than long, the margins narrow. not reflexed.

q. Basal impressions deep. punctured; elytral striæ strongly punctured; elptra bronzed-black. tibiæ and tarsi light brown.

220. FERREUS.

$q q$. Basal impressions of thorax small.

$r$. Elytral striæ not punctured.

s. Dorsal punctures three: legs rellow.

221. BASALIS.

ss. Dorsal punctures five or six: legs reddish-rellow, thigh: darker.

222. NUTANS.

r. Elytral striæ punctured; dorsal punctures fire.

t. Thorax slightly wider than long. 223. striatopUnctatus.

tt. Thorax longer than wide.

CRENULATUS.

a. Thorax transverse, narrower behind, side margin narrow. basal impressions broad and shallow; elytra deepls emarginate at base. with three small dorsal punctures.

227. BOGEMANNI. 


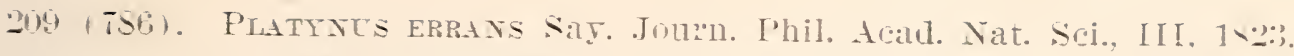
$1 \pm 7$ : ibid. II, 94 .

Elongate-oval, rather broad. Head and thurax bluish-green. elytra with a brassy tinge; under surface black. Thoras one-third wider than long. much narrotred behind. hird angles rounded or obtuse. Elrtral striat narrow, shallow: interrals Hat. Length i-s $1 \mathrm{~mm}$.

Lake Country : rare. Jure 21.

210 ( TStia). Platyos stbcordates Lec., Agas. Lake sup., 1550. 205.

Ditiers from the preceding by the characters giren in key and by having the thorax less narromed behind and the basal impressions more distinctly punctured. The elctra are proportionally broader: the intervals rers slightly convex and mole distinctly alutaceous. Cengrh $7.5-5.5 \mathrm{~mm}$.

Northern third of State. frequent: Knox County, rare. IIay 3-October 17. Occurs beneath rubbish along the borders of lakes and marshes. Appears sufficientlr distinct to take specific rank.

211 (TST). Platymes uerexs Dej., Spec. III. 1527. 152.

Elongate-oral, rather slender. Piceous black. Thorax subrotund. a little wider than long, basal impressions broad, shallow. hind angles obtusels rounded. Elytral stria not punctured, the second puncture on third intertal close to second stria. Length $\mathrm{S}-8.5 \mathrm{~mm}$.

Starke, Vigo and Knox counties : rare. July 6-October 8 .

212 (7SS). Platryes texuls Lec.. Proc. Phil. Acad. Nat. Sci., 1554. ts.

Elongate-oral, rather slender. Piceous or bronzed-black, shining. Thoras subrotund, wider than in the preceding. the margin more narrowly ret distinctly reflexed, the base and hind angles more rounded than in morens. Elrtra one-half wider than thorax. broadly depressed behind the scutellum: strize fine, not or ver indistinctly punctured; intervals fiat or slightly convex. Length $9-9.5 \mathrm{~mm}$.

Laporte, Marshall and Kosciusko counties. scarce; also in Thebster collection. August 17-October 29. In this and the nest three species the second dorsal puncture is on or near the third stria.

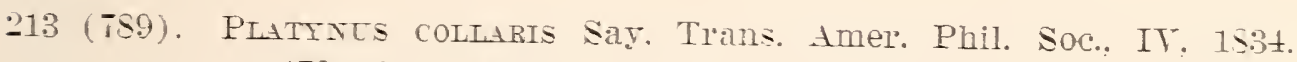
470 ; ibid. II. 534 .

Elongate-cral. Black with a tinge of purple. shining: tibire and tarsi piceous. Thorax subquadrate, wider than long, the margins narrow in flont, broader and strongly reflexed tomard the hind angles, which are rel'r obtuse. Elrtra with acutely impressed strix. strongly and regularly punctured; interrals flat. Length $\$ .7-9.5 \mathrm{~mm}$.

Described from Posey County: more common southward. I have not seen a specimen from the State. 
214 (790). Platyous atrates Lec.. Agass. Lake Sup.. 1S50, 205.

Elongate-oral, rather slender. Black. shining: apical portion of antenne and tarsi piceous. Thoras subrotund. a little wider than long. the reflexed margin but little wider toward the base; basal impressions deep with a small tubercle. Elytra but little wider than thorax, the strixe rer? tinely or olsoletely functate: intelvals distinctly convex. Length $x-!)$ min.

Steuben. Laporte and Kosciusko comties: frequent. Angusi 11-August 28. A member of the boreal fauna.

*215 (791). Platraus melaxarils Dej.. Spec. III. 1S27. 152.

Elongate-oral. rather broad. Black, shining; tibiæe tarsi and basal joint of antennie dark reddish-brown. Thorax subrotund, as wide as long. the margin wider and more strongly reflexed toward the base; depressions large, with a distinct rugosity or tubercle near the angle. Elytra distinctly wider than thorax. the strise of moderate depth. finely punctate. Length S.5-9.5 mm.

Throughout the State; common. Hibernates. Januar' 1October 12 .

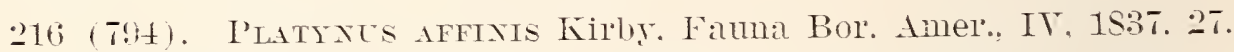

Elongate-oral. rather broad. Black or piceous, shining. Thorax subrotund. a little wider than long. side margins narrow. scarcely retlexed toward the hind angles, which are obtuse: depressions wide, shallow and without a tubercle. Elstra one-half wider than thorix. strie shallow, not punctured, the fifth usualle with a dilated shallow impression near the apex; intervals flat. Length $8.5-9.5 \mathrm{~mm}$.

Lake. Starke and Kosciusko counties; scarce. Occurs along the sandy beaches of lakes. April 9-October 24.

P. carbo Lec., length 8-9 mm.. was described from Lake Superior and may possibly oceur in northern Indiana.

217 (796). Phatryes conves Lec., Proc. Phil. Acad. Nat. Sci.. 1\$60. 319.

Elongate-oral: rather broad. Piceous black, shining. Thorax slightly broader than long. sides rounded into base: margins rather broad. narrowly reflexed: basal depressions wide, shallow. without a trace of tubercles. Elytra oblong. much wider than thorax; strie rather deep, not punctured: intervals slightly convex, alutaceous. Length $9.5 \mathrm{imm}$.

Laporte and Kosciusko counties: rare. October 21-October 22. Taken beneath rubbish along the beach of lakes. Our only species having all three dorsal punctures on third stria. A member of the boreal fauna.

21S (s00). Puatryus cupripexnis Say, Trans. Amer. Phil. Soc. II. 1S23. 50 ; ibid. II, 474.

Elongate. rather broad. Green. strongly polished; disk of elytra cureous; under surface blackish-bronzed. Thorax longer than wide. the 
depressions barruw and shallow. Elytral strite tine, not punctured; in terrals flat. Length $7.5-9.5 \mathrm{~mm}$. (Fig. TS.)

Throughout the northern part of the State; frequent. Not taken south of Vigo Countr. Hibernates. January 6-November 24.

219 (802). Platixts excatatis Dej., Spec. III, 182i, 169.

Elongate. rather slender. Piceous bronzed, shining; base of antenne and legs dull reddish-bromn. Thorax about as long as wide. but slightly narromed behind. sides regularly rounded: basal impressions narrom. deep, punctured; hind angles obtusels rounded. Elytral strie fine, not or indistinctlr punctured: interrals Hat. Length $i-7.5 \mathrm{~mm}$.

Lake, Laporte. Marion. Putnam and Tigo counties; frequent. April 4-October 17. Occurs on sand and gravel bars of lakes and streams. The dorsal punctures are larger than in any of our species except octopunctatus, the first near third stria, the other two near second.

200 (s03). Platryes ferrets Hali. Proc. Phil. Acad. Nat. Sci.. I. 299.

Elongate. slender. Head and thorax greenish-black: antennex piceous. Thorax oral, nearly as long as wide. sides rounded. hind angles obtuse. Elrtral stria deep and strongIr punctured on basal half: more faint and less distinctly punctured torards the aper. Length $7-7.5 \mathrm{~mm}$.

Iarion. Lawrence. Knox and Poser counties: one specimen from each. March 21-August 28. Occurs near water.

221 (S01). Platrites basaits Lec.. Am. Lre. IT. 1S48, 2027.

Elongate, slender. Head and thorax blackish-bronzed: elstra bronzed green, shining; antennie piceous, the basal joints and legs reddish-rellow. Thorax a little longer than wide. narrowed toward the base. hind angle: rounded; basal impressions small. deep, finely punctate. EIstral stria rather deep: interrals moderatels convex. Length $i-7.5 \mathrm{~mm}$.

Tigo and Poser counties: scarce. Hibernates. May 2t-December 18. The dorsal punctures are small and the second and third vare much in position. though LeConte sars they are placed on the second stria. Resembles extensicollis but the basal impressions of thoras much shorter. rounded instead of elongate. the margin not wider at base.

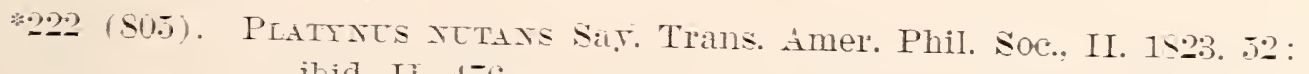
ibid. Ii. 476 .

Elongate, slender. Heal and thorax bronzed green: elstra blackishgreen or cupreous. Thorax oral. a little longer than wide. margin nar. romly reflexed. more strongly tomard the hind angles. which are romded: 
basal impressions rather deep, smooth. Elytral striae very fine; intervals nearly flat, finely alutaceous: fourth and fitth dorsal punctures on or near the second stria, the others near the third. Length $7-8 \mathrm{~mm}$.

Frequent in the northern half of the State; not taken south of Putnam and Vigo counties. Hibernates. January 7-October 26.

.2.:) (so6). I'IATYNus stratropunotates Dej., spec. III, 1S27, 167.

Elongate, rather slender. Bronzed black or piceous, shining; first joint of antenne and legs dark ledaish-yellow. Thorax oral, sides rounded into base; margins slightly wider and more strongly reflexed toward the base than in mutans; impressions deep, finely and sparsely punctured. Elytral strixe moderately deep, distinctly punctured; intervals slightly conrex, alutacesus, the third with five or six punctures. Length 6-7.5 $\mathrm{mm}$.

Lake, Vigo, Knox, Dubois and Posey counties; scarce. April 18-September 3.

232-4 (80 $)$. Platynus albicrus Dej., Spec. III, 1827. 158.

Elongate, slender. Piceous, feebly bronzed, shining. Thorax subquadrate, slightly longer than wide, margin of basal half wider and more reflexed, hind angles obtuse; basal impressions narrow, deep, not punctured. Elytral strife rather deep, not punctured; intervals moderately convex, distinctly alutaceous, the third with three dorsal punctures. Length (0.5- $7.5 \mathrm{~mm}$.

Knox County; rare. Two specimens from the margins of the cypress swamp. July 4-July 9.

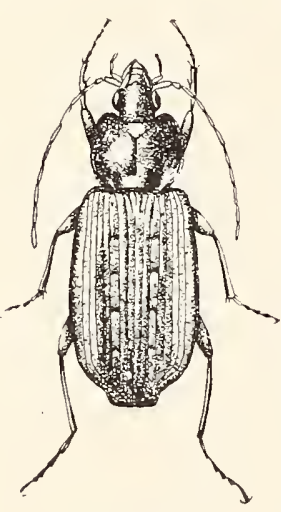

Fig. $76 . \times 4$. (Original.)

*.25 (814). Platyeus octopunctatus Fab., Ent. Syst.. Suppl., 1798, 55; Say, II, 476.

Elongate, rather slender. Color above as given in key; under surface shining blackish-green. Thorax wider than long, sides rounded into base, very finely margined; basal implessions small, deep, not punctured. Elytral striae fine, not or indistinctly punctured; intervals nearly Hat, alutaceous, the third with four (rarely three or five) punctures, each set in a large quadrate impression. Length $7-7.5 \mathrm{~mm}$. (Fig. 76.)

Lake, Porter, Putnam and Dubois counties, rare: Vigo County, frequent. Hibernates. February 14-November 4. Occurs on slopes of sparsely wooded hills. usually in sandy localities.

236; (S15). Platyes placides Say, Trans. Amer. Phil. Soc., II, 1S23. 43: ibid. II, 469.

Elongate, moderately broad. Head and thorax greenish-black; elytral bluish-black, subopaque. Thorax subquadrate, slightly wider than loug: hasal impressions wide and rather shallow. Elytral striæ very fine, not punctured; intervals slightly convex, distinctly alutaceous; dorsal punctures five or six, the apical two on second stria, the others on or near thil. I. Iength $7.5-9 \mathrm{~mm}$. 
Throughout the State: common. Hibernates. Gregarious in cold weather. January 1-November 24.

$P$. cremulatus Lee., 5.5-6 $\mathrm{mm}$. in length, is a nember of the Austroriparian fauna, which may occur in the southern counties.

*227 (821). Platynus bogemanni Gyll., Ins. Suec., III, 1810, 697; obsoletus Say, II, 481.

Elongate, slender. Black or piceous, shining. Thorax heart-shaper, wider before the middle, rounded to a narrow base. Elytra oblong, twice as wide as thorax, strize very fine or obsolete, not punctured: third interval with three rery small dorsal punctures. Length 5.5-6.5 mm.

Lake, Putnam and Vigo counties: scarce. Hibernates. January 14-July 28.

\section{Group E.}

A small group of winged species in which the thorax is rounded oral or slightly cordiform, narrowly margined, hind angles obtuse or rounded, basal impressions usually deep and punctiform; elytra nearly or quite twice as wide as thorax, with punctured striæ and three (rarely four) dorsal punctures placed along the middle of the third interval.

FET TO SPECIES OF GROUP E.

a. Tarsal grooves present.

b. Piceous bronze; strixe of elytra very fine; tarsal grooves on first joint.

228. ERUGINOSUS.

bb. Black, legs brown; strixe feebly punctured; tarsal grooves on first and second joints.

a a. Tarsal groores wanting.

232. PUNCTIFORMIS.

c. Black or dark reddish-brown; base of antennre, palpi, legs and sides of elytra brownish-yellow.

cc. Black, legs reddish-yellow or reddish-brown.

d. Elytral striæ coarsely punctured: larger. $7.5-8 \mathrm{~mm}$.

230. CRENISTRIATUS.

dd. Elytral striæ finely punctured; smaller, $6.2-7 \mathrm{~mm}$.

231. RUBRIPES.

*228 (824). Platýnus aruginosus Dej., Spec. III, 1827. 168.

Elongate. very slender. Head and thorax piceous; antennæ, elytra and legs dark brown, bronzed. shining. Thorax oval, convex. very narrowly margined: basal impressions very small or obsolete. Elytra oval, conrex. emarginate at base; stria finely punctate: intelvals flat. Length $5.5-6 \mathrm{~mm}$.

Throughout the State; common. Occurs in damp localities. Hibernates. April 3-December 18.

229 (825). Platyvus limbates Say. Trans. Amer. Phil. Soc.. II. 1823, 49 : ibid. II. 473.

Elongate, rather robust. Color as giren in key. Thorax subrotund. margin very narrow, hind angles wholly rounded; basal impressions small, 
circular, deep. Elytral strix moderately deep, distinctly punctured; intervals slightly convex. Length $8.5 \mathrm{~mm}$.

Rare. A southern species, one specimen of which was taken near Cannelton, Perry County. May 14.

230 (826). Platynus crenistriati s Lec., New S1. N. Am. Col.. I, 1863, 9.

Elongate, rather slender. Black. shining; base of antennæ and legs reddish-yellow. Thorax oval, a littie longer than wide, narrowed on basal half; basal impressions small, deel. Elytral striæ deep, strongly punctured; intervals one to four distinctly convex. the others nearly flat. Length 7.5-8 $\mathrm{mm}$.

Southern half of State; frequent; scarce in the northern counties. Probably hibernates. March 7-July 28.

*231 (827). Platynus rubripes Zimm., Trans. Amer. Ent. Soc., II, 1869, 244.

Elongate, rather slender. Black, shining; palpi and antennæe brownishyellow; legs reddish-brown. Thorax almost as long as wide, sides rounded into base; impressions broad, shallow with a small deep fovea. Elytral stria deep, finely but distinctly punctured; intervals slightly convex. Length 6.2-7 $\mathrm{mm}$.

Throughout the State; common. Hibernates. January 5-October 1. A smaller species than the preceding with darker legs and more finely punctured striæ.

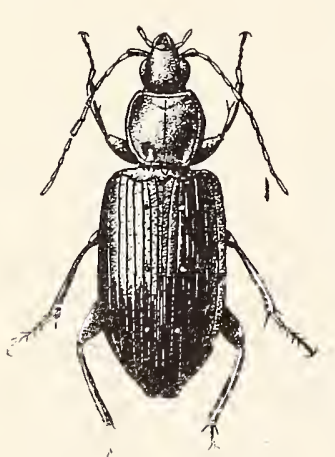

'i

*232 (828). Platynus punctiformis Say, Trans. Amer. Phil. Soc., III, 1823, 58; ibid. II, 481, 536.

Nlongate, rather robust. Black, shining; base of autennæe, tibiæ and tarsi reddish-brown; femora piceous. Thorax subrotund, convex, narrowly margined, hind angles rounded; basal impressions shallow, with a large. round, deep forea. Elytra rather deeply striate, very finely and distinctly punctuate only on basal lis lf ; intervals subconvex, finely alutaceous. Length 7-9 $\mathrm{mm}$. (Fig. 7\%.)

Fig. 77. $\times 4$. (Original.) Throughout the State; frequent. February 13-October 14. Larger and broader than mbripes, with still more finely punctured strix.

\section{Group F.}

Winged species of slender form, black or piceous in color with hase of antenniæ and legs yellow or reddish-brown; thorax oval with margin narrowly reflexed, becoming broader toward the hind angles, which are rounded and indistinct; basal impressions narrow, sometimes nearly obsolete. Elytra elongate-oval, twice as wide as 
thorax,-emarginate at base and obliquely subtruncate at tip, the striæ fine; intervals flat, the third with four to six dorsal punctures. Tarsal grooves indistinct.

KEY TO SPECIES OF GROUP $F$.

a. Thorax narower behind. the side margins more widely reffexed toward the base; antennie with joints 5 to 11 , paler.

2:3. RLFICORXIS.

"t. Thorax elongate-oval, the side margins uniformly narrow.

b. Antennie piceous; size larger. $7-7.5 \mathrm{~mm}$.

236. GEMELLTS.

is. Antenne biownish-rellow: smaller, 5-6.5 mm.

c. Thorax black.

234. PICIPEXXIS.

cc. Thorax brownish-yellow.

235. LUTLLEYTLS.

2:39 (831). Platrixus Ruficonxis Lec., Agass. Lake Sup., 1850, 205.

Elongate. slender. Head and thorax black; elytra piceous. shining: antemne and legs brownish-yellow. Thorax oral. distinctly longer than wide. hind angles rounded: basal impressions broad, rather shallow. Elytrial strie fine. not punctured; interrals flat, the third with fire or six small dorsal punctures, the first three on the third stria, the others on the second. Length $7-8 \mathrm{~mm}$.

Frequent along the margin of Tippecanoe Lake: Kosciusko County ; Lake and Posey counties; scarce. IIarch 26-October 21.

*234 (834). Platrycs picipexyis Kirby, Faun. Bor. Amer.. IT, 1837, 25.

Elongate. rery slender. Head and thorax black; antennæ. legs and elytra brownish-yellow. Thorax oral. about as long as wide; margin narror. hind angles rounded; basal impressions narrow, shallow. Elytra elongate. elliptical. the striee of moderate depth. not punctured: interrals nearly flat, the third with four to six dorsal punctures. Length $6-7 \mathrm{~mm}$.

Lake. Vigo. Posey and Kosciusko counties: frequent. January 1-October 17. Gregarious in winter.

*230 (835). Platrants lutulentes Lec., Proc. Phil. Acad. Nat. Sci. VII. 1854,54 .

Elongate, rers slender. Head black; remainder of body brownish-rellow, shining. Thorax more finely margined. basal impressions smaller and less distinct. and elytral strie finer than in the preceding. Dorsal punctures four, larger than in picipennis. the first two on third stria. the others on second. Length วั.

Throughout the State; frequent. Hibernates. Sometimes attracted by electric lights. January 21-December 23.

236 (833). Platrxes gemeleus Lec.. Bull. Brook. Ent. Soc.. II. 1879. st.

Elongate. slender. Piceous: head and thorax often darker; epipleura. legs and base of antenne dark reddish-brown. Thorax oral. one-third longer than wide. side margins rery narrow. hind angles obsolete: basal 
impressions long. curved and shallow, not punctured. Elytral striae very tine. not punctured; intervals that; dorsal punctures four, the first and second on third stria, the others on second stria. Length $7-7.5 \mathrm{~mm}$.

Lake County; scarce. About twenty specimens taken by Wolrott near Wolf Lake. Narch 26.

\section{OLISTHop's Dej. 1825. (Gr., "slippery+foot.")}

Small piceous or brownish beetles of the tribe Platynini, having the claws of the tarsi entire and the mentum without a tooth. But two species are as ret known in the United States, one of which occurs in Indiana. They are briefly treated by

LeConte.-Proc. Phil. Acad. Nat. Sci., 1854, 58.

Hom.--Brill, Brook. Entom. Soc.. V. 1882, 63.

*2si (839). Olisthopis parmates Say, 'Trans. Amer. Phil. Soc., II, 1823, 49 ; ibia. II, 474. 537 .

Rather broad, subdenressed. Head and thorax black; base of antemne. erige of thorax. legs and basal half of elytra dull brownish-yellow; apical portion of elytrat darker. 'ihorax rounded. one-half wider than long, sides broadiy rounded into base. margin rely narrow, basal impressions small and hirrow. Elytral striae rather fine, not punctured; intervals slightly convex. the third with three rery small dorsal punctures. Length $7-7.5 \mathrm{~mm}$.

Southern half of State, scarce: Lake County only in the north. January 6-November 7 . The elytra are sometimes almost wholly hrownish-yellow.

XXXIV. Perigona Lap. 1837. (Gr., "around + angle.")

Very small piceous or brownish beetles, having the labrum square and flat; mentum deeply emarginate and without a tooth; antennæ rather stout beyond the third joint, which is of the same length as the second. The genus is treated by

Horn.-Trans. Amer. Ent. Soc. XIX. 1892, 44.

One species has been taken in Indiana, while another may occur.

KEY TO SPECIES OF PERIGONA.

a. Head alone piceous: eiytra slightly oblong.

NIGRICEPS.

ur. Head and thorax piceous; elstra oval and more convex.

238. PALLIPENNIS.

P. nigriceps Dej.. length $2.5 \mathrm{~mm}$., is recorded from Cincinnati.

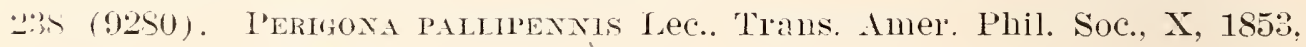
386.

Oblong-oral. Head and thorax piceous; elytra dull reddish-brown; antennie and legs pale yellow. Thorix subquadrate. slightly wider than long; 
sides feebly curved, hind angles obtuse. Fistrit oral. nowe than one-hall wider than thorax, convex, faintly striate, the eighth stria entire; thiro interval with three minute punctures. Length 2.8-2.7 mm.

Southern lialf of State; frergent. April 29-November 28. Occurs beneath rubbish in dry open wordlinds.

\section{Tribe IX. ANCHONODERINI.}

Head oval or rounded, not prolonged or constricted to a narrow neck; antenne slender. Thorax more or less cordiform, the side margins distinct and with a bristle-bearing puncture on each side in front of the middle, and another near the hind angle. Elytra feebly margined at base, rounded at aper. withont dorsal punctures in our species. Scutellum and seutellar stria distinct. Body above pubescent. Hind coxæ contiguous. Two genera may oceur in Indiana. though representatives of but one have so far been taken.

KEY TO INDIANA GENERA OE AXCHONODERINI.

a. Antennie with four basal joints glabrous. Thorax ovate. the second bristle-bearing puncture in front of the hind angle; last joint of palpi conical.

Euphorticus. wa. Antennæe with three basal joints glabrous. Thorax cordate. margin acute. the second puncture in the hind angle. XXXY. ATRAxus.

Euphorticus pubescens Dej. black. shining and $5 \mathrm{~mm}$. in length. has been taken by Dury near Cincinnati and doubtless occurs in the southern third of the State.

XXXV. Atrants Lee. 1848. (Gr.. "dull or indistinct.")

This genus is represented in the United States by a single small species having the thorax slightly broader than head: elytra marcined at base, the tips rounded and surface striate.

239 (S45). Atrixt's pubescexs Dej.. Spec. III. 1827. 122.2.

Elongate. slender. Black or piceous; antenne. mouth parts. legs and abdomen pale reddish-brown. Thorax longer than wide. sides feebls curved. hind angles and median impressed line distinct. Elytral striæe rather deep: intervals conrex. each with two or three irregular rors of minute punctures bearing fine rellow hairs. Length $6-\bar{i} .5 \mathrm{~mm}$.

Vigo. Knox and Posey counties: scarce. April 10-October 20. Occurs beneath cover in open sandy roodland. Resembles Platymus pusillus very much in form. but darker in color and with the elytra rounded. not sinuate at tip.

\section{Tribe X. CTENODACTYLINI.}

Antennæ slender. base free. three hasal joints glabrous. first joint stouter, as long as the next two: joints three to 11 . equal or 
nearly so. Head rhomboidal, prolonged behind the eyes and narrowed to a very slender neck. Mentum deeply emarginate, toothed. Thorax elongate, narrower than head, the margins very feeble; sides with a bristle-bearing puncture near the middle and another at hind angle. Elytra oblong-oval, not margined at base, side margins distinct and entire, tips rounded. Tarsi alike in both sexes, the first joint as long as the next two, which are oval, the fourth broad, deeply bilobed. Males with one seta on each side of apex of last ventral segment; females with two. The tribe is represented in the United States by a single genus.

XXXVI. Leptotrachelus Latr. 1802. (Gr., "slender + tho-
rax.")

Thorax narrow, elongate. Ligula entire, slender, usually narrowed in front. But one species and a variety oceur in the United States. The former is found in Indiana.

240 (S46). Leptotrachelus dorsalis Fab., Syst. El. I, 229 ; Say, II, 447.

Elongate, very slender. Head and usually the thorax piceous; antennæe, legs and elytra brownish-yellow, the latter with a piceous stripe along the suture. Thorax subcylindrical, one-half longer than wide, finely and sparsely punctured near base and apex. Elytral striæ rather deep. with close. distinct punctures; intervals convex, the third with three small punctures. Length $7-8 \mathrm{~mm}$.

Lake, Wells and Spencer counties; one specimen from each. May 14-May 28. Oceurs on low herbs in open woods and probably inhabits the entire State.

Tribe XI. ODACANTHINI.

Antennæ slender. free at base. first joint as long as the next two, three basal joints glabrous. Head oval, elongate, prolonged behind the eyes and narrowed to a neck. Thorax narrow, the margin feeble or entirely obliterated, sides with a seta near the middle and a second, often feeble, at hind angles. Elytra oblong-oval, base not margined, sides narrowly inflexed, apex truneate. Tarsi slender. rarely flattened, the fourth joint entire or feebly emarginate; claws simple. The tribe is represented in the United States by a single genus.

XXXVII. Casconta Latr.
ing.",) (Gr., "to look toward + noth-

Very slender beetles, having the bristle-bearing punctures of the second stria of elytra indistinct and rarely more than four in number. One species occurs in the State. 
*241 (847). Casnonia penisylvanica Linn., Syst. Nat., II, 620 ; Say, II. 447.

Head and thorax black; elytria dull red with three spots, forming an interrupted transverse band, and the apex black; antenne dusky, the three basal joints reddish; legs pale, the knees dusky or black. Thorax cylindrical or nearly so, broader at base than apex. Elytra ovate, the strie coarsely punctured on basal half. Length $7.5 \mathrm{~mm}$. (Fig. S0.)

Throughout the State; common. January 30-October 21. Occurs beneath logs, leaves, etc., along fence rows and borders of woods. A unique and easily known insect.

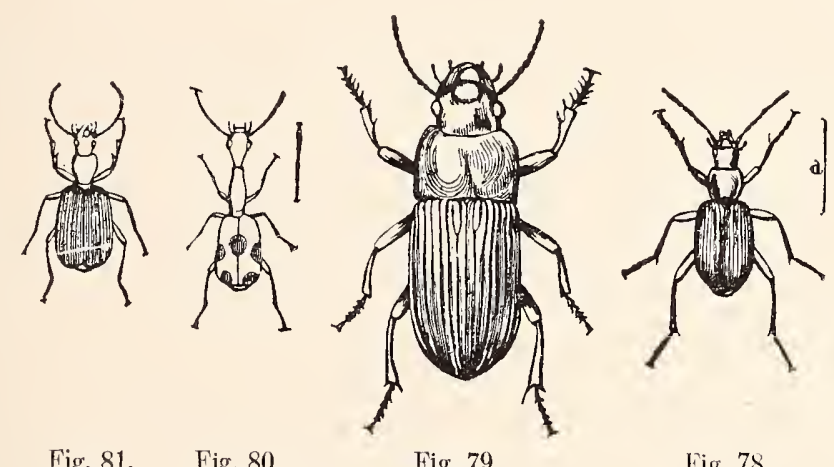

Fig. 81. Fig. 80 Fig. 79 Fig. 78 .

(After Packard.)

Tribe XII. DRYI'TINI.

Antennæ tapering gradually to a point, free at base. Head constricted at a variable distance behind the eyes to a narrow neck; front narrowed before the eyes. Mentum deeply emarginate; maxillary palpi moderately long, the terminal joint more or less triangular. Thorax often moderately long, the side margins acute, the setix at hind angle usually absent. Elytra not margined at base. side margins acute, entire; apex truncate, dorsal punctures absent. Prosternum not prolonged; hind coxæ contiguous. The males have the front tarsi dilated, sometimes very slightly, and densely pubescent beneath. Representatives of one grenus have been taken in Indiana, while a single species of another doubtless occurs in the southern counties.

KET TO INDIANA GENERA OE DRYTTINI.

a. Head elongate-oval, prolonged behind the eyes; neck inserted in thorax by a semigiobular condyle; clypeus with two bristle-bearing punctures each side; larger, $17 \mathrm{or}^{2}$ more $\mathrm{mm}$.

XXXVIII. Galerita.

an. Head triangular, scarcely prolonged behind the eyes. very suddenly constricted to a narrow. cylindrical neck; rypeus with but one puncture on each side, the seta long; smaller, not over 5 nm. Zатныт. 
XXXVIII. G.ilerita Fab. 1801. (L., "a helmet.")

Pubescent beetles of medium size and graceful form, having the head and elytra black or bluish-black, the thorax cordiform, reddish-brown. Head elongate-oval, strongly constricted behind; neck slender; first joint of antennæ elongate. Elytra oval, broadly obliquely truncate behind, finely striate. They occur beneath cover, along fence rows and in open woodlands and are often attracted in great numbers by electric lights. Dr. Forbes dissected 17 specimens of $G$. janus and found that 88 per cent of their food consisted of cankerworms and other injurious forms, the cankerworms alone making up 52 per cent. A sylıptic table of the genus is given by

Leconte.-Bull. Brook. Ent. Soc., II, 1879, 61.

Five species of the genus are known from the United States, two of which occur in Indiana.

KEY TO INDIANA SPECIES OF GALERITA.

a. Head behind the eyes strongly rounded; pubescence of elytra uniform, obliquely decumbent.

242. JANUS.

aa. Sides of head longer behind, oblique and less rounded; pubescence of elytra erect near the scutellum.

243. BICOLOR.

242 (851). Galerita Janus Fab., Syst. Eleut., I, 1801, 36 ; Say, II, 446.

Elongate-oval. Black. densely clothed with short hairs; legs, palpi, tholax and base of antenne reddish-brown. Thorax slightly longer than wide, the margin reflexed at hind angles, which are rectangular. Elytral striie fine. not punctured; intervals flat, finely, transversely rugose. Length $17-22 \mathrm{~mm}$.

Southern half of State; frequent. April 21-August 14.

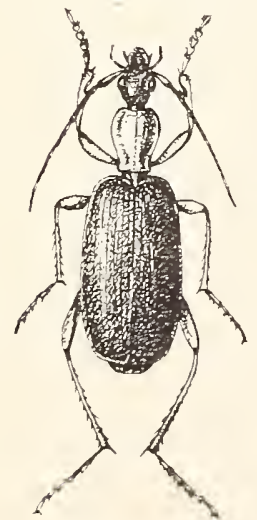

Fig. $82 . \times 1 \frac{1}{2}$ (Original.)
*243 (\$53). Gaierita bicolor Drury, Ins., I. 1770, 94.

Very similar to the preceding. Distinguished by the characters given in key and by its usually smaller size and smonther elytra. 'The latter are more often blue-black than black. Length 17-21 mm. (Fig. 82.)

Throughout the State; common. January 1-October 12. A pair were found mating on May 23.

Zuphium americanum Dej. has been taken by Dury near Cincinnati. It is a small, slender brown form. living under flat stones and runs very rapidly when uncovered. 
Tribe XIII. LABIINI.

Antenne slender, arising from beneath a slight frontal ridge, the three basal joints usually glabrous. Head oval, constricted to a neck or not. Mentum more or less emarginate, toothed or not; palpi variable, the terminal joint equal to or longer than the pre reding, the latter with two setw in front. Thorax variable in form. sides distinctly margined and with a seta on each side and at basal angle. Elytra truncate at tip, the margin acute, entire and narrowly inflexed. Prosternum usually obtuse at tip; hind coxæ contiguous.

The following papers treat of the genera composing the tribe: Horn.- "Revision of the Species of Lebia of the United States" in Trans. Amer. Ent. Soc., IV, 1872, 130-142.

Horn.- "Synoptic Tables" of most of the genera, in Bull. Brook. Ent. Soc., II, 1880, 86 ; IV, 1881, 39-44; 53-55.

Horn._- "Synopsis of the Species of the Tribe Lebiini" in Trans. Amer. Ent. Soc., X, 1882, 126-163.

The tribe is a large one, embracing no less than 21 genera in the United States fauna. Of these, 14 are represented in the collection from Indiana, while another may oceur.

\section{KEY TO INDIANA GENERA OF LEBIINI.}

a. Tibial spur's very long.

b. Head not constricted behind the eyes; tarsal clars in our species with fine, short teeth; tibial spurs with fine teeth.

XXXIX. TeTragonoderus.

bb. Head constricted; tarsal claws with long teeth; tibial spurs simple.

aa. Tibial spurs short or at most moderate in length.

NEMOTARSUS.

c. Mandibles with distinct grooves on outer side.

d. Head constricted behind the eyes.

XL. Lebia.

dd. Head not constricted.

e. Labrum large. prominent, covering in great part the mandibles; antennæ with three basal joints glabrous; elytra dark bluishgreen.

XLI. COPTODERA.

$e e$. Labrum moderate, not large.

$f$. Tarsi slender, fourth joint entire.

g. Labial palpi slender; color black or piceous.

$h$. Thorax truncate at base.

$i$. Mentum not toothed; claws of tarsi serrate; length $6-$ $7.5 \mathrm{~mm}$.

XliI. Dromics.

ii. Mentum toothed: claws of tarsi simple; smaller, not over $4 \mathrm{~mm}$.

XLIII. Apristus.

$h h$. Thorax slightly lobed at base; claws of tarsi serrate; length less than $4 \mathrm{~mm}$.

j. Mentum not toothed.

XLIV. Blechrus. 
i. Mentum with a small emarginate tooth.

XLT. MeTabletcs.

gy. Labial palpi thick, oral; claws of tarsi more or less serrate: length $3 \cdot \mathrm{mm}$.

Xlvi. Axtropalpes.

$f f$. Tarsi with the fourth joint emarginate or bilobed; tarsal claws serrate.

li. Thorax truncate at base; mentum toothed.

l. Tarsi with fourth joint bilobed: elytra blue or green.

xlvit. Callida.

11. Tarsi with fourth joint emarginate.

$m$. Tarsi not hairy above; size medium, $7-11 \mathrm{~mm}$.

$n$. Last joint of labial palpi more or less triangular or hatchet-shaped; thorax with sides rather widely margined near base, which is squarely truncate.

XLVIII. Plochionus.

nn. Last joints of both palpi similar, more or less crlindrical, truncate. XIIX. PINACODERA.

$m m$. Tarsi hairy above; next to last joint of labial palpi usually with more than two setre; length 10-15 mm.

L. Cramndis.

lik. Thorax lobed at middle of base; tarsi hairy above; last joint of labial palpi hatchet-shaped.

LI. Apenes.

cc. Mandibles without grooves on, outer side; mentum not toothed; fourth tarsal joint not dilated; claws simple.

LiI. Pentagontca.

XXXIX. Tetragonoderts Dej. 1825. (Gr.. "four + angled.'")

Small piceous or brownish-yellow beetles, separated from allied genera mainly by the characters given in key. One species has been taken in Indiana, while another may occur.

KEY TO INDIANA SPECIES OF TETRAGONODERES.

a. Elytra in great part piceous; legs and outer joints of antenne piceous: prosternum margined at tip.

INTERSECTUS.

a . Elytra more brownish-yellow than piceous; legs and antennxe wholly brownish-yellow; prosternum not margined.

244. FASCLATUS.

T. intersectus Germ. 5-6 mm. in length, has been taken in Kentucky and the Gulf States, and perhaps occurs in southern Indiana.

244 (S66). Tetragonoderus fasciates Hald.. Proc. Phil. Acad. Nat. Sci.. I. 1842.298.

Orate. subdepressed. Head and thorax piceous, bronzed, minutely alutaceous; elytra grayish or dull yellow. with a semicircular space about the scutellum. a broad irregular broken bind at middle. and the apical fourth piceous. Thorax one-half wider than long. sides curved, hind angles distinct; disk smooth. the median line distinct. Elytra oral, rather deeply striate, the strie not punctured; intervals convex, the third with two small dorsal punctures. Males with three joints of the front tarsi dilated and clothed with small scales beneath; last rentral notched at middle of hind margin. Length $4.5 \mathrm{~mm}$. 
Throughout the State; frequent. April 19-September 27. Occurs beneath logs, chips, etc., only in sandy localities, where its hues blend with the surroundings in surh a manner as to make it visible only when it moves. This it usually does not do for some time after its cover is removed.

Nemotarsus elegans Lec., 5-5.5 mm. in length, brownish-yellow, the elytra piceous with an oval spot near the base and the apex paler, has been taken in Illinois and Maryland and doubtless occurs in Indiana.

\section{Lebia Latr. 1802. (Gr., "shallow or thin.")}

Small, rather broad-bodied beetles, usually prettily variegated in hue, possessing the characters of the tribe and known from allied genera by the short tibial spurs, the groove on the outer side of mandible, and by the head being constricted into a neck. The thorax is but little wider than the head, much narrower than elytra, while the tarsal claws are pectinate or comb-shaped. The elytral strix are, in most species, smooth.

They occur beneath stones and leaves, or in summer upon the foliage and flowers of plants. where they feed upon plant lice and other injurious forms: the pectinate structure of their tarsal claws enabling them to easily cling to the hairs or other inequalities of the foliage.

About 36 species are known from the United States, 15 of which have been taken in Indiana. while four others doubtless occur. For convenience they aro separated into three groups and these in turn into species.

KEI TO INDIANA GROUPS OF LEBIA.

a. Front tarsi of male somewhat obliquely dilated; both head and thorax (except in tricolor) reddish-yellow. elytra wholly dark blue or green.

Group 4.

a . Front tarsi of male not obliquely dilated; both head and thorax not reddish-yellow, or it so, elytra not wholly blue.

b. Mentum with a distinct tooth; elytra without pale stripes.

b. Wroup $B$. Yentum not toothed: elytra with pale stripes (except in abdominalis).

Group $C$.

Group A.

This group, to which the subgeneric name Loxopeza is sometimes applied, includes all the larger species with metallic green or blue elytra. Two of its six forms have been taken in the State and one other perhaps occurs.

[10-_.23402] 
KEY TO INDIANA SPECIES OF GROUP A.

a. Head and thorax reddish-yellow; elytra wholly dark blue.

b. Elytra deeply striate; antennæ pale; length $8.5-9.5 \mathrm{~mm}$.

245. GRANDIS.

bb. Elytra finely striate; three basal joints only of antennæ pale; length 6-7 $\mathrm{mm}$.

246. ATRIVENTRIS.

w.r. Head black, thorax reddish-yellow; elytra greenish-blue, deeply striate; outer joints of antennie darker; length $7-8.5 \mathrm{~mm}$.

TRICULOR.

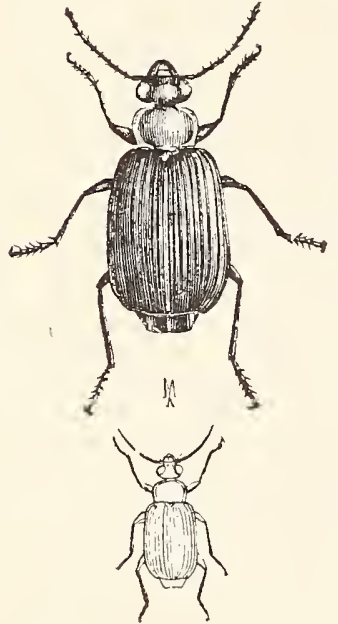

Fig. 83. (Atter Comstock.) *245 (872). Lebia grandis Hentz., Trans. Amer. Phil. Soc., III, 1824, 58.

Orate, subconvex. Color giren in key; under surface and legs pale brownish-yellow; abdomen black. Head finely wrinkled, very sparsely and finely punctate. Thorax nearly twice as wide as long, margin broad; disk with fine transverse wrinkles and distinct impressed median line. Elytra finely alutaceous. Length 8.5-9.5 mim. (Fig. 83.)

Throughout the State, common in the southern half; less so northward. February 8-December 20. Occurs especially in open woodland and with the next hibernates beneath partly

Fig. 83. (Atter Comstock.)
Lower figure shows natural size. buried logs and other cover.

*246 (S73). Imbia atriventris Say, 'Trans. Amel. Phil. Soc., II, 1823, 13; ibid. II, 444.

Resembles the preceding but a third or more smaller. Elytra darker blue; palpi, tarsi and apical two-thirds of antenne piceous. Elytral strix very finely punctured; intervals flat. Length $6-7 \mathrm{~mm}$.

Throughout the State; frequent. April 29-December 29.

L. tricolor Say may yet be found in eastern Indiana, its range being given as Middle States northward to Canada.

Group B.

This group comprises the true forms of Lebia as defined by Latreille. About 17 species and several varieties are known from North America. Of these the following have been taken, or perhaps occur in the State.

\section{KEY TO INDIANA SPECTES OF GROUP B.}

a. Thorax coarsely and rather densely punctured; head, thorax and basal third of elytra reddish-yellow; apical portion of elytra blue; length $8 \mathrm{~mm}$.

DIVISA.

1a. Thorax not, or very linely, punctate; elytra not colored as above; length less than $7 \mathrm{~mm}$.

b. Flytra with fine or very shallow strix. 
c. Tarsal claws serrate rather than pectinate; yalpi stout: elytra brownish-yellow with two bluish bands; length $6-7 \mathrm{~mm}$.

PULCHELLA.

cc. 'Tarsal claws pectinate, their' teeth longer and not directed obliquely outward.

d. Head smooth or very feebly punctured.

$e$. Uniform greenish-black; legs pale yellow; lengtl $5 \mathrm{~mm}$.

ee. Color not black.

247. RHODOPUS.

f. Elytra either wholly blue, sreen or olivaceous.

\%. Head, thorax and elytrat of one color.

h. Greenish or bluish; legs black; length 4.5-5.5 mm.

248. VIRIDIS.

$h h$. Olivaceous green; legs piceous brown or paler; length 3-3.5 mm.

249. PUMILA.

g\%. Body above not unicolored.

$i$. Head and thorax reddish-yellow; abdomen black; length $6.5-7.5 \mathrm{~mm}$.

PLEURITICA.

ii. Head greenish-black; thorax and entire body beneath pale red; elytra bright green.

250. VIRIDIPENNIS.

ff. Elytra piceous, ornate with pale spots. 251. onNata.

$d d$. Head coarsely punctured between the eyes; elytra piceous spotted with brownish-yellow nearly as in ornata; length 3 $3.7 \mathrm{~mm}$.

252. LOBULATA.

bb. Elytra deeply striate; striae not punctured.

j. Head with lengthwise wrinkles or striae; length $4.5-5 \mathrm{~mm}$.

253. ANALIS

$j j$. Head nearly smooth; elytra subovate, broader behind; length 6 $7.5 \mathrm{~mm}$.

254. FUSCATA.

L. divisa Lee., a member of the boreal fauna, has been recorded from Lake Superior and Galesburg, Illinois, and perhaps occurs in the extreme northern part of Indiana.

L. pulchella Dej. has been taken near Cincinnati and its occurrence in the State is more than probable.

247 (882b). Lebia rhodopts Schwarz, Proc. Amer. Phil. Soc., XVII, 1878, 354.

Ovai, slender. Black or rery dark olivaceous green, subopaque, finely alutaceous; antennre dusky, the third joint and legs pale reddish-yellow. Head large, wider than thorax, minutely and sparsely punctate; antennæ more than half the length of body, the outer joints stout. Thorax small, sides feebly rounded, margins less broadly reflexed than in viridis. Elytral striæe very fiue: intervals almost flat. Length $4.5-5 \mathrm{~mm}$.

Jennings and Franklin counties; rare. June 11-July 11. Taken from flowers of wild parsnip. A species of southern range. Listed as a variety of viridis, but in my opinion distinct. 
248 (S82). Lebia rinidis Say. Trans. Amer. Phil. Soc., II, 1823, 14 ; ibid. II, 445 .

Oral, subconvex. Either uniform green or dark purplish-blue, strongly shining; antennie piceous, the basal joints greenish. Head minutely and rery sparsely punctate. Tliorax one-half wider than long, the margin narrow, except at bind angles. which are prominent. Elytral striæ rery fine; intervals flat. Length $4.5-5.5 \mathrm{~mm}$.

Throughout the State; frequent. April 5-October 14. More abundant in May and June on flowers.

249 (S83). Lebia pumila Dej.. Spec. V. 1830. 388.

Oval, slender. Piceous or dark olive-green above. black beneath; antenna piceous, the third joint pale. Thorax subquadrate, but slightly wider than long. Elytra alutaceous, the strix rery faint. Length 3-3.5 $\mathrm{mm}$.

Throughout the State; scarce. May 28-September 16. Our smallest species of the genus.

L. pleuritica Lec, elytra blue tinged with green, is said to oceur sparingly from Canada to Texas.

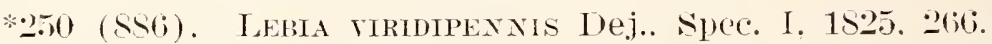

Rather broad. Antennie piceous, the three basal joints paler ; legs and entire body beneath pale reddish-brown. the knees and tarsi darker. Head with a few fine punctures. Thorax one-half wider than long, strongly margined; disk rery finely wrinkled. Elytral strix represented by rows of very fine punctures. Length $5-6 \mathrm{~mm}$.

Throughout the State; scarce. March 9-December'28. Hibernates beneath mullein leaves and logs in upland woods.

251 (889). Lebia oritata Say, Trans. Amer. Phil. Soc., II, 1823, 13; ibid. II, 444 .

Oval, slender. Head piceous, smooth; thorax piceous with pale margin, rarely wholly pale selluw; elytra piceous. with the narrow margin, two large spots on basal half and two small ones at apex. dull rellow; antennæ dusky, the three basal joints pale: bods beneath and legs rellowish. Length $4.5-5 \mathrm{~mm}$.

Throughout the State; common on flowers, especially goldenrod. April 10-September 19.

252 (SS8). Lebia lobulata Lec.. N. Sp. X. Amer. Col.. I. 1963. 5.

Oral. subdepressed. Ifoad black: thorax both above and beneatli piceous. the margin jale; elytra piceous with apical margin and a large oblique subhumeral spot reaching nearly to suture. dull yellow; antenne. under surface and legs pale reddish-rellow. Elytra rather finely striate. Length $3-3.7 \mathrm{~mm}$.

Crawford County: rare. A member of the Austroriparian fauna. Taken at Cincinnati and probably occurs throughout the 
southern third of the State. Very apt to be confused with ornata, but easily distinguished by its punctured head and more deeply striate elytra.

253 (\$92). Lebla Axalis Dej., Spec. I. 1825, 265.

Broadly oral. Head black; antenne piceous the four basal joints paler; thorax reddish-yellow, the margin paler: elstra black. each with the narrow margin and usually a large irregular humeral spot and small apical spot vellowish; under surface and legs pale rellow, abdomen darker. Thorax broadly margined, finels and irregularly wrinkled. Length $4.5-$ $5.5 \mathrm{~mm}$.

Southern third of State; frequent. April 19-November 7 . Taken by sweeping low herbs. Readily known by the longitudinal striæ on head and the deep elytral striæ. The pale markings of eltrra vary greatly in extent and have given rise to a number of synonyms.

254 (\$93). Lebia FL'scata Dej.. Slec. I. 1525, 270.

Broadly oral. subdepressed. Head and disk of thorax piceous; elytra lale brownish-yellow. each with a narrow marginal line, a large scutellal. spot and a spot just behind middle. black; rarels the spots behind middle merge to form a broal cross-bind: antennæe. less and under surface reddish-yellow. Thorax finely wrinkled. margin nioad. Length $6.5 \mathrm{~mm}$.

Known from Indiana by a single specimen taken near Pine. Lake County. by Wolcott. July 23. Resembles closely some of the color varieties of analis, but distinguished by the larger size. smooth head and dark disk of thorax.

\section{Group C.}

This group comprises the Indiana species of the subgenera Dianchomena and Aphelogenia, which are separated only by the head being more strongly constricted behind the eres in the former.

KEY TO INDLANA SPECIES OF GROLP C.

a. Head suddenly and strongly constricted behind the eres: rertex strong15 convex; length $4.5-5.5 \mathrm{~mm}$.

b. Thorax narrowly marcined: head and elstra dull green. thorax reddish-rellow.

255. ABDOMIXALIS.

67. Thorax wideị margined: head strigose at sides: elytra with black and vellow stripes. shining, moderately striate. 256. SCAPULARIS.

ua. Head less constricted; rertex less conrex.

c. Head and thorax reddish-yellow, the latter widely margined.

d. Black stripes of elctra narrow: elytral striæ fine: length 6.5$7.5 \mathrm{~mm}$.

25\%. FURCATA.

dr. Black stripes of elytra hroad: strice distinct: length $5.5-6 \mathrm{~mm}$.

25S. TITTATA. 
cc. Head black; thorax narrowly margined; elytra black, each with two white stripes; abdomen wholly reddish-yellow. 259. BIVITTATa.

255 (894). Lebia abdominalis Chaud., Bull. Mosc., 1843, 104.

Rather slender. Color given in key; antennæ piceous, the three basal joints paler; legs and abdomen pale reddish-yellow, tarsi piceous; mesoand metasterna nearly black. Length $4.5-5 \mathrm{~mm}$.

Perry and Posey comnties; rare. April 18-April 27. Taken from beneath mullein leaves and rubbish. A species of southern range. Resembles viridipennis, but smaller, elytra duller green and body beneath partly black.

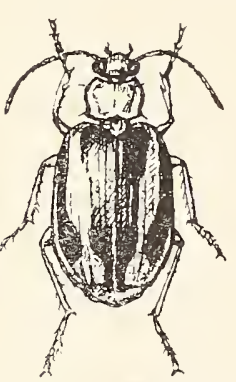

Fig. 84. $\times 4$. (Original.)

\section{6 (S95). Lebia scapularis Dej., Spec. V, 1830, 377.}

Oval, rather slender. Head, thorax and legs pale reddish-yellow; elytra piceous, each with the apical and side margins and a median stripe yellow; antennæ dusky, the three basal joints paler. Thorax nearly twice as wide as long, the margins wider and more reflexed toward base. Elytral striæ rather deep, not punctate; intervals flat. Length $4.5-5.5 \mathrm{~mm}$. (Fig. S4.)

Throughout the State; common on leaves of elder and other plants in summer. April 13-October 11. Takes to wing when disturbed. The pale elytral stripes vary much in width, often occupying more space than the darker ones. The latter are sometimes connected near their tips and the pale stripes reduced to narrow lines, thus forming the variety conjugens Lec.

\section{7 ( 897 ). Lebia furcata Lec. Ann. Lyc. Nat. Hist., IV, 1848. 193.}

Rather broad, subdepressed. Head, disk of thorax and a triangular stripe extending from base half way along the elytral suture reddish-yellow; elytra and margin of thorax pale yellow, the former with a median and two lateral narrow black stripes. the median divided or forked on the basal half to enclose the reddish-yellow stripe; antenne dusky, pale at base; femora and tarsi black, tibi氵e pale. Head and thorax finely and irregularly strigose. Length $6.5-7.5 \mathrm{~mm}$.

Lake, Vigo and Posey counties; rare. April 20-Angust 6.

258 (899). Lebia vitTata Fab., Syst. Eleut., I. 1S01, 202 ; Say, II, 443.

Resembles furcata but smaller and more narrow. The black stripes are wider, the basal fork of the median one much shorter; legs wholly black or with the base of femora alone pale. Thorax more narrow and elytral striae deeper. Length $5.5-6 \mathrm{~mm}$.

Vigo County; rare. March 21. This species also resembles scapularis but is easily distinguished by the broader neck and black legs. 
*259 (902). Lebia bivitTata Fab., Ent. Syst. Supp., 1798, 59.

Oval, rather broad. Thorax reddish-yellow; white striyes of elytr'd narrow, the outer one the shorter; legs black, the tibin pale. Head finely and sparsely punctate. 'Thorax slightly broader than long, sides distinctly curved, apex much broader than base. Lengtlı 5.5-6 $\mathrm{mm}$.

Vigo County; scarce. January 5-December 28. Hibernates beneath chunks in the corners of rail fences about which piles of dead leaves have drifted. A member of the Austroriparian fauna.

\section{COPTODERA Dej. 1825. (Gr., "cut + neck.")}

Small bluish beetles having the mentum deeply emarginate, without a tooth; first joint of tarsi as long as the next two, fourth feebly emarginate; tarsal claws pectinate. But one species is known from the Eastern United States.

260 (904). Coptodera merata Dej., Sp. I, 1S25, $27 \%$.

Rather broad, subdepressed. Head, thorax and under surface piceous: elytra bluish-green; antenna and legs dark brown or piceous. Head finely wrinkled on side near the eyes. Thor:x twice as wide as long; sides distinctly curved, rather broadly margined near the base; hind angles obtuse. Elytral striæ fine, not punctured. Niddle tibie of males distinctly notcher on inner side near tip. Length $5.5-6.5 \mathrm{~mm}$.

Southern half of the State, frequent; Lake County, rare. April 15-October 10. Occurs on vegetation and beneath bark.

\section{Dromius Bon. 1813. (Gr., "a runner.")}

Small piceous beetles, laving the palpi and tarsi slender, the fourth joint of latter not bilobed nor emarginate; tarsal claws serrate; mentum without a tooth. One of the two species is found in Indiana.

261 (906). Dromits piceus Dej., Spec. V, 1829, 363.

Ovate, slender, depressed. Piceous, moderately shining; antennie, mouth parts and legs, and narrow margins of thorax and elytra, pale brownishyellow. Head with lengthwise wrinkles above the eyes. Thorax slightly wider than long, narrower at base; sides curved with a rather wide reflexed margin; disk finely wrinkled, the median line distinct, hind angles obtuse. Elytral strice fine, indistinctly punctured; intervals slightly conrex. Length 6-7.5 $\mathrm{mm}$.

Jennings County; scarce. November 20. Occuss beneath bark.

XLIII. Apristus Chand. 1846. (Gr.. "without+ saw.")

Small black species having the tarsal claws simple; mentum toothed; ligula small, cordiform with four seta in front; thoras 
truncate at base. Four species are known from the United States, two of which have been taken in Indiana. They occur in damp, sandy localities.

262 (908). Apristes condicollis Lec., Ann. Lyc. Nat. Hist., IV, 1848, 190.

Black with slight tinge of blue; antennæ piceous; legs black. Thorax cordate, slightly wider than long, side margins a littie broader and more reflexed near base; median line deep, reaching basal margin; hind angles acute. slightly prominent. Elytral strixe deeply impressed; intervals rather strongly conrex. Males witl three joints of front tarsi dilated and with two rows of small scales beneath. Length $3.5-4 \mathrm{~mm}$.

Marion, Vigo and Morgan counties; rare. April 6-October 15. Larger than the next, the elytra flatter, the intervals more convex.

263 (909). Apristus subsulcatus Dej., Spec. II, 1826. 451.

Piceous, bronzed: elytra often brownish. Thorax with sides less curved in front. less sinuate behind than in cordicollis; hind angles rectangular not prominent. the margins not wider behind: median line fine. usually not reaching the basal margin. Length $3-3.5 \mathrm{~mm}$.

Vigo and Lawrence counties; rare. May 29-.July 20.

\section{Blechrus MIotsch. 1848. (NL., "black.")}

Very small black shining species, differing from those of allied genera by having the base of thorax slightly lobed; mentum not toothed; ligula small with two sete in front; claws of tarsi serrate. Two of the three species have been taken in Indiana.

2lit (911). Blechrt's Nigrixtes Mann.. Bull. Mose. II, 1S43, 184.

Elongate, depressed. Black or piceous, shining. Thorax one-fourth wider than long, broadest one-third from apex; sides moderately curved in front. slightly sinuate near base, hind angles rectangular; disk rery finely wrinkled, median line deeply impressed. Elytral oblong. nearly parallel. one-third longer than head and thorax: faintly striate near the suture. Length $3-3.5 \mathrm{~mm}$.

Vigo County; scarce. April 15. Occurs beneath bark in open woods.

265 (913). Buechrt's Ptsio Lec., New Sp. N. Amer. Col., I, 1863, 6.

Black-bronzed, very shining. Thorax not wider than long, widest just behind the apex. more narrowed behind, the hind angles indistinct. Elytra amost smooth. not Innger than head and thorax, their sides distinctly curved. Length $2 \mathrm{~mm}$.

Marion and Clark counties; scarce. May 5-October 9. Occurs beneath bark on oak logs. One of the smallest of our Carabidx. 
XLV. Metabletus Sch.-Goeb. 1846. (Gr., "changeable.")

Represented in the United States by a single smail, oblong black beetle having the ligula elongate-oval with five short setæe in front, thorax slightly lobed at base, mentum with a small tooth notched at apex.

266 (914). Metabletus americanus Dej., Spec. V, 1829, 361.

Rather slender, subdepressed. Uniform black, shining. 'I'horax nearly twice as wide as long, narrowed behind; median line distinct, deep; margin very narrow, hind angles distinct, not prominent. Elytral striæ very faint. not punctured. Length $3.5 \mathrm{~mm}$.

Lake County; rare. May 14. Taken from beneath bark of pine. Resembles Blechrus nigrimus in form and size. A member of the boreal fauna.

\section{Axinopalpus Lec. 1848. (Gr.. "ax+palpus.")}

Very small beetles having the mentum emarginate, distinctly toothed; labial palpi thick, the last joint oval; maxillary palpi long and slender, the last joint cylindrical and acutely prolonged at tip. One species occurs in Indiana.

267 (915). Axinopalpus biflagiatus Dej., Sper. I, 1825. 243.

Rather broad, subdepressed. Piceous. shining; antennæ dusky, paler at base; legs and an oblique stripe. extending from humerus to middle of elytra, pale yellow. Thorax less than twice as wide as long, slightly cordate; sides curved, sinuate near the hind angles, which are rectangular; median impressed line distinct, entire. Elytra faintly striate on middle of disk. Length $3 \mathrm{~mm}$.

Lake, Marshall and Marion counties; scarce. June 24-November 23. Occurs beneath bark in damp localities.

\section{CALLIDA Dej. 1825. (Gr., "beautiful.")}

Small elongate beetles, usually of bright metallic colors and in our species having the upper side of tarsi convex, not sulcate or impressed. One species has been taken in Indiana, while another should occur.

KEY TO INDIANA SPECIES OF CALLIDA.

a. Body above bicolored; thorax red, elytra blue or green.

268. PUNCTATA. aa. Body bright blue or green; elytra not longer than head and thorax, their strix fine, intervals flat.

PURPUREA.

268 (923). Callida punctata Lec., Ann. Lyc. Nat. Hist., IV, 1S48, 189.

Elongate. narrow, convex. Head usually dark blue; thorax reddishyellow; elytra bright green; legs yellow, the tips of the femora and tarsi 
piceous; antenne piceous, paler at base. Thorax a little longer than wide, widest slightly in front of middle; margin very narrow, hind angles obtuse: disk transversely wrinkled. a few punctures near apex. Elytra oblong. gradually broader behind: the strixe fine, punctate; intervals flat, sparsely punctate. Length $7-7.5 \mathrm{~mm}$.

Northern half of State, frequent; Dubois county only in the south. May 14-October 10. Often found on flowers. One of our most handsome Carabids.

C. purpurea Say, 7.5-9 mm. in length, ranges from Michigan to Georgia. Missouri and Kansas, but has not yet been noted in Indiana.

\section{Plochionus' Dej. 1825. (Gr., "a lock of hair.")}

This genus is very close to Callida, being separated by the characters given in key, and by the ligula having four setæ instead of two, as in Callida. One species occurs in Indiana.

269 (931). Plochones tmmidus Hald. Proc. Phil. Acad. Nat. Sci., I, 1842. 298.

Rather broad, depressed. Uniform dark brown, the margin of thorax and elytra translucent. Thorax broader than long, sides strongly rounded. base wider than apex; margin broad, hind angles rectangular; disk transversely wrinkled. median line distinct. Elytral strix deep, not punctured: intervals convex. alutaceous. Males with the front tarsi narrowly dilated. the first three joints with two rows of small scales beneath. Length $7-7.5 \mathrm{~mm}$.

Marion County; searce. March 16-November 17. Probably hibernates. Occurs in damp places beneath bark and rubbish.

\section{Pinacodera Srhaum. 1860. (Gr., "flat+neck.")}

Oblong, brown or piceous beetles of rather small size, having the tarsi smooth above, the middle pair in male dilated. Hind angles of thorax in our species obtuse, not prominent; inner wings well developed. Two species have been taken in Indiana.

KEY TO INDIANA SPECTES OF PINACODERA.

a. Elytra with pale humeral spot; thorax distinctly narrowed behind, its margin broad and translicent.

270. LIMBATA.

aa. Elytra without pale spot at humerus; thorax very little narrowed behind, the margin narrow, scarcely translucent. 271. PLATICollis.

270 (934). Pinacòdera limbata Dej.. Spec. V, 1829, 320.

Rather slender, depressed. Dark brown or piceous; antennæ, legs. margin of thorax, humeral spot and sicles of elytra paler. Head slightly rrinkled abore the eyes. Thorax one-third wider than long. sides mod- 
erately curved; disk nearly smooth, the median impressed bine fine. Gilytra oval, slightly oblong; strie shallow, rery finely ;unctate; intervals slightly convex, alutaceous, the third with two dorsal punctures. Length 8-9.5 mm.

Crawford and Dubois counties; scarce. April 29-July 2.

271 (935). Pinacodera platicollis Say, Trans. Amer. Phil. Soc., II, 182:3, 14 ; ibid. II, 445.

Resembles limbatu but slightly larger. Thorax with margin more nitrrow and more strongly reflexed; disk often slightly wrinkled and with a few punctures near the hind angles. Alytra with pale margin very narrow and without humeral spot; intervals nearly flat. Length 9-11 mm.

Lake and Pulaski counties; scarce. April 10-October 23. Occurs beneath bark and other cover in sandy regions.

\section{Crmindis Latr. 1806. (Gr., "slender.")}

Slender-bodied beetles of medium size, more or less hairy above, with inner wings absent and tarsi hairy above. Our species have the thorax narrowly margined and the entire upper surface very strongly punctured. The males have the front tarsi with three joints dilated and with two rows of small scales beneath. Two species have been taken in Indiana.

*272 (944). Cymindis americana Dej., Spec. II, 1826, 446.

Rather slender. Piceous, feebly shining; antennæ, legs, humeral spot and narrow side margin of elytra, pale reddish-brown. Thorax slightly longer than wide, narrowed at base; sides curved in front, sinuate behind: disk coarsely and equally punctured. Elytral striæe deep, finely punctured: intervals rather flat, their punctures coarser than those of strix. Length 12-15 $\mathrm{mm}$.

Steuben, Marion, Vigo, Putnam and Knox counties; scarce. July 14-December 25. Hibernates.

273 (946). Crmindis pilosa Say, Trans. Amer. Phil. Soc., II, 1S23, 10 ; ibid. II, 442.

Moderately elongrate. Piceous with faint greenish lustre; surface very distinctly hairy; antenure and legs pale reddish-brown. Thorax about as wide as long, much narrower at base. sides curved, slightly sinuate behind: margin narrow, hind angles rectangular; disk coarsely and deeply punctured. Elytral striæ deep, intervals slighntly convex, irregularly and coarsely punctured. Length $9.5-10 \mathrm{~mm}$.

Lake, Steuben, Marshall, Marion and Putnam counties; frequent. April 12-November 2. Easily known from americana by the lack of humeral pale spot, the shorter and wider thorax and the more sparsely punctate intervals. Occurs usually in dry or sandy localities. 


\section{APENES Lec. 1852. (I., "without wings.")}

Small piceous or bronzed species closely allied to Cymindis, and differing principally in having the thorax lobed at base and the last joint of labial palpi more broadly triangular. One species has been taken in Tndiana. while another doubtless occurs in the southern rounties.

\section{KEY TO INDIANA SPECIES OF APFNES.}

a. Head sulcate lengthwise; surface with metallic bronze luster; length $10 \mathrm{~mm}$.

LUCIDULA.

aa. Head simply and sparsely punctured; elytra shining, striæ distinctly impressed; length $7 \mathrm{~mm}$.

274. SINUATA.

A. lucidula Dej. occurs from "New York to Florida," and has been taken by Dury near Cincinnati.

*274 (950). Apenes sinuata Say, Trans. Amer. Phil. Soc., II, 1823. S; ibid. II, 440.

Elongate-oval. Head and thorax piceous; elytra dark brown or piceous. with a humeral space and two small subapical spots pale; antennæ and legs pale reddish-brown. Thorax one-third wider than long. sparsely punctate, base narrower than apex; sides moderately curved, margin very narrow, reflexed; hind angles distinct. Elytra oblong-oval, striæ finely punctured; intervals slightly convex, minutely alutaceous, the third with two dorsal punctures. Length $6.5-7 \mathrm{~mm}$.

Southern half of State; scarce. February 14-December 7. Occurs in open woodland, about the bases of trees and stumps.

\section{Pentagonica Schm.-Goeb. 1846. (Gr., "five + angles.")}

One small species represents this genus in the United States.

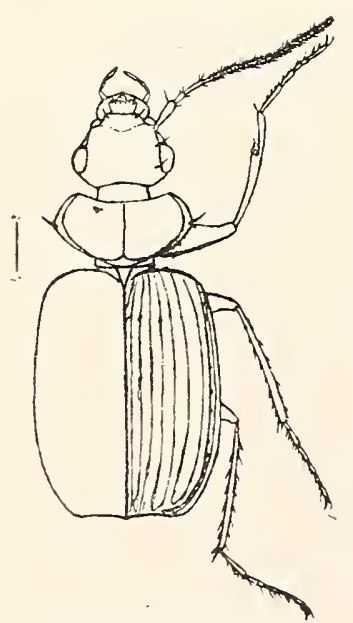

Fig. 85. (After Horn.) Line shows natural size.
275 (954). Pentagonica flavipes Lec., Trans. Amer. Phil. Soc., $\mathrm{X}, 1853,377$.

Rather broad, resembling a small Lebia analis. Head and elytra piceous, very finely alutaceous; thorax, basal portion of antennæ and legs reddish-yellow; sometimes wholly piceous with pale legs. Thorax short, twice as wide as long, sides strongly angulate. base narrowed; median line distinct. Elytra feebly striate without punctures. Length $3.5-4.5 \mathrm{~mm}$. (Fig. 85.)

Rare. Two specimens from Lake County and one from Marion. May 25-October 23. The one from Marion County was found dead in a porch light globe by H. Morrison. 
Tribe NIV. HELLUONINI.

Antennæ rather stout, usually compressed, arising from under a distinct frontal plate, all the joints more or less pubescent, first joint stout, equal in length to the next two. Head broadly oval. not narrowed in front of eyes, with a distinct neck; labrom large and prominent, more or less concealing the mandibles; mentum broad, deeply emarginate. usually toothed; terminal joint of palpi elongate-oval or fusiform and obtuse at tip. Thorax more or less cordate, sides and hind angles each with a distinct bristle-bearing puncture. Elytra oblong, truncate at apex, base not margined. sides narrowly inflexed, disk striate or sulcate without dorsal punctures. Tibiæ compressed and finely bicarinate on the outer edge. Tarsal claws simple. The tribe is represented in the United States fauna by but one genus.

\section{Helluomorphi Lap. 1840. (Gr.. "slender+form.")}

Reddish-brown. strongly punctured. hairy beetles of medium size, having the antenna joints broadly compressed; elytra shorter than abdomen, more or less costate instead of striate, broadly rounded at tip. For synoptic table see-

LeConte.-In Bull. Brook. Ent. Soc., II, 1879, 60.

Six species are known from the United States, two of which have been taken in Indiana. while tro others may occur.

\section{KEY TO INDIANA SPECIES OF HELLUOMORPHA.}

a. Joints of antennæ 5-10 square or broader than long.

b. Thorax longer than wide; elytra more strongly costate; abdomen dark; elytral intervals with three rows of punctures. PRæUSTA.

$b b$. Thorax as wide as long; elytra less strongly costate.

c. Elytra and abdomen usually darker than thorax; elytral intervals with three confused rows of punctures.

276. BICOLOR.

cc. Uniform reddish-brown; elytral intervals with two rows of punctures.

277. TEXANA.

a a. Joints of antennæ $5-10$ oblong; uniform reddish-brown; intervals with three irregular rows of punctures.

FERRUGINEA.

H. prousta Dej., $14 \mathrm{~mm}$. in length. has been taken near Cincinnati and perhaps occurs in the extreme south of Indiana.

276 (959). Hellumorpha Bicolor Harr., New Eng. Farmer, VII, 1820, 117.

Elongate, rather slender. Head, thorax and legs reddish-brown. elytra darker. Thorax as wide as long, subcordate. narrower behind; sides broadly 
curred, sinuate behind; base truncate, hind angles rectangular ; disk coarseIr, sparsely and irregularls punctured. Length $130-16 \mathrm{~mm}$.

Vigo. Poser and Crawford counties; scarce. April 8-MIay 20. Occurs beneath cover in dry upland roods.

27 (960). Heletromorpha texana Lec., Trans. Amer. Phil. Soc.. X. $185 \%$. 374.

Form and structure of bicolor; uniform light reddish-brown: apical half of antennæ and tarsi darker. Length $14-17 \mathrm{~mm}$.

Marshall and Crawford counties; rare. June 29-August 8.

H. ferruginea Lec., $13.5-15 \mathrm{~mm}$. in length. is said to occur from New York to Texas.

\section{Section II. HARPALINE UNISETOSA.}

This section is much smaller than the preceding, the tribes numbering only a third and the genera proportionally less numerous. The essential character is the presence of but one bristle-bearing puncture above each eye. The seta at or near the hind angle of thorax is more often absent than present. Of the eight tribes, but three are represented in the Indiana fama. These may be distinguished as follows:

KEY TO INDIANA TRIBES OF HARPALIN E UNISETOS.Æ.

a. Elytra truncate at apex; mandibles with a bristle-bearing puncture in outer groore; hind coxie often separated, the first rentral segment visible between them; epimera of mesosternum usually wide, sometimes nearly as large as episterna. Tribe I. Brachrnini, p. 156.

a. Elstra alwass entire; mandibles without a bristle-bearing puncture; hind coxæ contiguous; epimera of mesosternum rers narrow and indistinct.

b. Antennæ with three basal joints glabrous; elytral margin more or less interrupted and with an internal fold; front tarsi of male with three, rarely four, joints spongy pubescent beneath.

Tribe II. Chlжnins, p. 162.

bъ. Antennæ with two, rarely (Tachycellus) with three, basal joints glabrous: elstral margin not interrupted, no intermal fold; male tarsi rariable.

Tribe III. HARPALINI, p. 173.

\section{Tribe I. BRACHININI.}

Antennæ slender, the condyle of the basal joint exposed, two basal and a portion of the third joint glabrous. Head gradually narrowed behind the eyes into a neck; labrum broad, truncate; mandibles stout, feebly curved. with a seta in outer groove; mentum moderately broad, emarginate, toothed or not; the second joint of palpi longer than the last. Thorax with short marginal setæ; 
scutellum distinct. Elytra not margined at base, apex truncate and with a membranous border: disk not or very feebly striate and without dorsal punctures. Prosternum not prolonged. Tarsi slender, the front pair in the males with three joints feebly dilated and covered with small scales beneath. The only genus in the United States fauna is-

\section{Brachyyus Web. 1801. (Gr., "short+back.")}

Small or medium sized beetles with broad abdomen and narrow head and thorax. The elytra are of a dark blue, blackish- or greenish-blue color. while the head, thorax and legs are reddishyellow. The generic name refers to the shortness of the elytra.

They occur under logs or stones, usually in damp places. In early spring some of the species are especially abundant and often gregarious in small colonies. When disturbed they emit from a little internal sac near the end of the abdomen a pungent, volatile fluid which serves them as a means of defense. This fluid is ejected with a sound like that of a small popgun, and when it comes in contact with the air it changes to a gas which appears Fig. 86. Brachynus stylike steam. For this reason the members of the

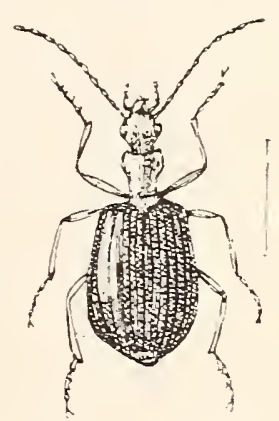
genus are known as "bombardier beetles." When pursued by some larger insect the bombardier discharges a part of the stored liquid into the face of its enemy, the noise and gas so disconcerting the pursuer that the bombardier often has time to escape. Some forms are capable of discharging four or five times in succession.

But one paper has been issued on the United States species of the grenus. viz. :

LeConte.- "Notes on the species of Brachinus inhabiting' the United States," in Proc. Phil. Acad. Nat. Sci., 1862, 523.

This does not include all of the North American species now known, about 26 in number. The distinguishing characters are so few that no satisfactory table is extant. Sixteen different forms have been taken in Indiana. These were submitted to Mr. Liebeck. who wrote me concerning them as follows:

"I assorted your lot of Brachynus and determined them by comparison with the species in the Horn collection, which is the best I could do. There the species are arranged in the order in which they are listed by Henshaw, which differs from the old Le- 
Conte table. They were in all probahility revised by Dr. Horn without publishing the result."

The following table is based largely upon that of LeConte. and was drawn up for the specimens as named by $\mathrm{Mr}_{\mathrm{r}}$. Liebeck and afterward reviewed by Mr. Fall. Comparison was also made with those in the LeConte collection at Cambridge.

KEY TO INDIANA SPECIES OF BRACHYNUS.

a. Larger speries. 10 to $15 \mathrm{~mm}$.

b. Elytra gradually but distinctly widened behind. costate or subcostate.

c. Elytral humeri distinct but rounded; thorax widest just in front of middle.

d. Thorax not longer than wide, the sides in front much rounded.

e. Abdomen fuscous:- antennæ with the fourth and following joints darker.

ee. Abdomen and antennæe pale.

278. ALTERNANS.

279. TORMENTARIUS.

$d d$. Thorax distinctly longer than wide, its sides less rounded.

280. DEYROLLEI.

cc. Humeri of elytra narrow, indistinct; thorax widest one-fourth from apex.

281. AMERICANUS.

bb. Elytra bat slightly widened behind, the sides parallel or nearly so. the humeri distinct.

$f$. Thorax very wide in front, suddenly narrowed behind the middle: elytra blackish-blue.

282. BALLISTARIUS.

if. Thorax much narrower in front. more gradually narrowed behind: elytra paler blue.

283. FUMANS.

a . Medium sized or small species, not over $9.5 \mathrm{~mm}$.

g. Thorax wider than long, strongly constricted behind the middle.

h. Form slender; elytra smooth, feebly widened behind, their sides almost parallel.

284. GRACILIS.

$h h$. Form broader, the elytra gradually but distinctly widened from base to apex.

$i$. Elytra together subquadrate, distinctly costate.

ii. Elytra but faintly or obsoletely costate.

285. QUADRIPENNIS.

$j$. Hind angles of thorax prominent; antennæ and abdomen in part or wholly dark.

286. CORDICOLLIS.

$j j$. Hind angles of thorax very slightly prominent: antennæ and abdomen wholly reddish-yellow.

287. CYANIPENNIS.

$g g$. Thorax as long or longer than wide. the base much less strongly constricted.

li. Joints 3 and 4 of antennie almost black. joints 5 to apex more or less fuscous; abdomen wholly dark.

288. PULCHELLUS.

7\%. Joints 3 and 4 of antennæ not darker than those which follow.

l. Hind angles of thorax not at all prominent; humeri indistinct.

$m$. Abdomen with the sides dark; thorax broadly rounded on the sides in front; larger, 7-9 $\mathrm{mm}$.

289. PERPLEXUS.

$\mathrm{mm}$. Abdomen wholly pale; thorax more strongly rounded on the sides in front: smaller, not over $6 \mathrm{~mm}$.

290. MINUTUS. 
ll. Hind angles of tholax prominent; humeri distinct.

n. Elytra oblong, scarcely widened behind; abdomen wholly pale; size small, not over $7 \mathrm{~mm}$.

291. JANTUINIPENNIS.

$n n$. Elytra gradually but distinctly dilated behind; abdomen dark, at least on sides.

o. Narrow lateral edge and epipleura of elytra pale yellow; knees, sides of abdomen and metathorax dusky.

292. IATERALS.

oo. Lateral edge and epipleura of the same color as the elytra; front angles of thorax obtusely rounded; very small, not over $5.5 \mathrm{~mm}$.

293. MEDIUS.

278 (973). Brachyous alternays Dej., Sp. I, $1825,316$.

Elytra bluish-black; abdomen fuscous. Thor:ax at middle about as wide as long, front margin slightly concave. the angles obtuse but distinct, hind angles rectangular. Elytra distinctly costate, the intervals between the ridges finely and sparsely punctate. Length 14-15 $\mathrm{mm}$. (Fig. 87.)

Southern half of State; frequent, April 6Jily 4.

*279 (975). Brachinus tokmentarits Lec., Ann. Lyc. Nat. Hist., IV, 1848, 200.

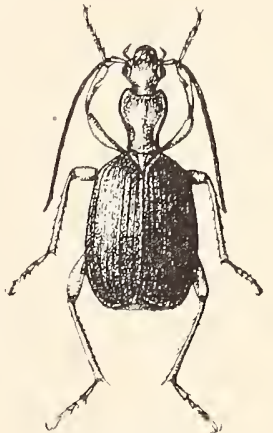

Fig. $87 . \times 1 \frac{1}{2}$. (Original.)

Thorax as wide as long. front angles obtuse but distinct; hind angles rectangular, not prominent. Elytra costate, the humeri distinct, broadly rounded. Length 14-15 $\mathrm{mm}$.

Vigo and Posey countirs; scarce. Hibernates. January 1April 19. Very close to altemans and probably only a variety of that species.

280 (974). Brachynus DeÝrollet Laf., Rev. Zool., 1S41, 42.

Antenna reddish-yellow, the apical portion darker; abdomen piceous. Thorax distinctly longer than wide, slightly narrower than the head; front margin concave, the angles obtuse, hind angles distinct but not prominent. Elytra subcostate, the humeri rounded but evident. Length 14-15 $\mathrm{mm}$.

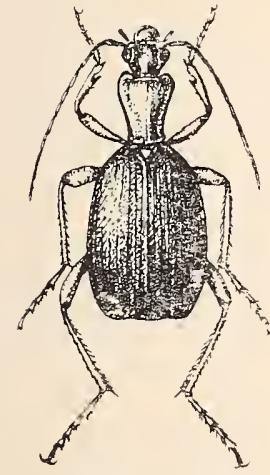

Fig. 88. $\times 2$. (Original.)

Knox County; rare. July 4.

281 (962). Brachynes americanus Lec., Proc. Phil. Acad. Nat. Sci., II, 1844, 48 .

Elytra black, but faintly tinged with blue; four basal joints of antennxe pale, the remainder gladually dusky; abdomen almost black. Thorax wider than long, the base gradually constricted, hind angles rectangular. Elytra distinctly but not strongly costate; intelvals wide and finely punctured; humeri very much sloping, not at all distinct. Length 10-11.5 mm. (Fig. S8.)

Vigo, Knox, Crawford and Perry counties; frequent. April 23-October 21.

[11-23402] 
$2 S 2$ (976). Brachynus ballistarius lec., Anil. N. Y. Lyc. Nat. Hist., IV. 184S, 199.

Elytra blue-black; antennæe reddish-brown at base, gradually dusky to tip; abdomen blackish on sides, usually pale at middle. Thorax slightly wider than long. widest in front of middle, suddenly much constricted behind middle: front margin concave, hind angles prominent. Elytra distinctly costate, intervals sparsely punctulate. Length 11-13.5 mm.

Throughout the State; scarce. April 11-September 7. The margins of the thorax are wider and more reflexed, its sides much more strongly sinuate and its disk more sparsely punctate than in the next speries.

283 (977). Brachynd fumans Fab., Syst. Eleut., 1801, 210.

More narrow and slender than ballistarius. Apical portion of antennie a little darker than the base; elytra more distinctly blue; abdomen reddishbrown, the sides darker. Thorax about as wide as long. widest in front of middle, then gradually narrowed to base. Elytra oblong, the sides nearly parallel, the humeri rounded but evident. distinctly costate. Length 11.5$12 \mathrm{~mm}$. (Fig. S1.)

Vigo and Posey counties; rare. April S-May 12.

284 (一). Brachynts gractlis sp. nov.

Elongate, slender, parallel. Antenne reddish-yellow, joints 3 and 4 darker at tip; abdomen wholly fuscous; elytra blackish-blue. Eyes large. prominent. Thorax wider than long, widest near apex, front margin trumcate, the angles rounded; sides strongly margined, deeply sinuate; hind angles prominent, acute, divergent. Elytra without trace of costa, the humeri distinct. Length $9 \mathrm{~mm}$.

Marshall County; rare. October 14. Resembles cyanipennis, but differs in being nuch more slender, with larger eyes, smooth elytra and dark abdomen.

285 (968). Brachynus quadripennis Dej., Spec. I, 1825, 316.

First two joints of antennæ and part of third pale, the remainder dark reddish-brown; abdomen almost black. Thorax wider than long. convex, front slightly concave, hind angles prominent. Elytra together but little longer than broad. strongly costate; humeri broadly rounded. distinct. Length 9-9.5 $\mathrm{mm}$.

Vigo and Crawford counties; rare. Oceurs in dry or sandy localities. May-12-omne 15.

286 (978). IBRachyous condicolds Dej., Spec. II, 1826, 466.

Elyta blatkish-hlue : mtenne redush-brown at base, the apieal half Ansky; joints 3 and + droker than the others. Thorax wider than long. 
the widest bart nearly twice the wirth of the base, anex slightly cuncalle, hind angles acute, divergent; surface sparsely and finely punctured. Wildra but little widened behind, obsoletely costate. Length 7.5-9 mu.

Thronghout the State; frequent. April 10-October 17.

287 (971). Bhachynus Cyanipennis Siy, Journ. Phil. Acald. Nat. Sci., III, 1823, 143 ; ibid. II, 91.

Elytra blue-black. Thorax shorter than usual, distinctly wider than long, front angles obtusely rounded, hind ones evident, not prominent. Elytra slightly wider behind, the humeri distinct but strongly rounded, the costæe very faint. Length $8-9 \mathrm{~mm}$.

Fulton County; rare. June 20.

2SS (-). Braceirats pulchellus Sp. $110 \mathrm{r}$.

Resembles perplexus in form and size. Elytra distinctly darker, blackish-blue; sides of meso- and metasterna and entire abdomen fuscous. Antennie with joints 3 and 4 almost black. Thorax longer than wide, the base gradually constricted, its disk more convex and hind angles acute and more distinct than in perplexus. Elytra almost smooth, the humeri distinct. Length $7-9 \mathrm{~mm}$.

Vigo and Posey counties; scarce. February 14-April 18. From cordicollis, our only other small species with the third and fourth joints of antennæ dark, it differs in the thorax being much narrower and less constricted, and with less prominent hind angles. This is one of the first species to appear in spring and is the only one besides tomentarius which has been taken in the winter months. It occurs in low, sandy localities.

289 (966). Brachynus perplexus Dej., spec. V, 1829, 426.

Elytra dark blue; antennæe and entire under surface, except the sides of abdomen, reddish-yellow. Thorax longer than wide, the widest part about twice the width of base; front margin truncate, the angles obtuse; hind angles not at all prominent; sides very broadly rounded in front of middle. Elytra but little wider behind, absoletely costate, nearly or quite covering the abdomen; humeri erident but narrow. Length S-9 mm.

Posey County; rare. April 9.

290 (965). Brachynus minutus Harr., N. Eng. Far., VII, 182S, 117.

Smaller and more slender than janthinipenuis, which it resembles closely in form and color. Thorax more narrow, distinctly longer thau wide, much less constricted behind, the hind angles scarcely evident. Humeri narrow, less rounded than in the next. Length $5.3-6 \mathrm{~mm}$.

Narshall, Fulton, Whitley and Kosciusko counties; scaree. June 5-August 17. This is the pumitio of LeConte, which is regarded as a synonym of minutus, though the latter is said by Har- 
ris to have the abdomen and antenna fuscous. In the LeConte collection at Cambridge the single example labeled minutus is similar to the Indiana specimens, as is also the type of pumilio bearing that label and placed at the side of the other specimen. If a comparison with the Harris type shows the two to be different the name pumilio will stand.

291 (963). Brachynus Janthinipennis Dej., Spec. V, 1829, 412.

Elytra dark blue, often with a faint greenish tinge; antennæ, legs and entire under surface reddish-yellow. Thorax slightly longer than wide. hind angles prominent; surface not punctate, faintly, transversely strigose. Elytra parallel, the costæe evident. Length $6.5-7 \mathrm{~mm}$.

Northern half of State; frequent along the shores of lakes. May 20-August 8 .

292 (972). Brachynus lateralis Dej., Spec. V, 1829, 426.

Apical half of antennæ dusky; legs, except the knees, pale yellow; elytra dull blackish-blue with pale lateral margin. Thorax less narrowed behind than in allied forms, hind angles acute, but slightly prominent; elytral costæe obsolete, the humeri distinct. Length $8-9.5 \mathrm{~mm}$.

A species of southern range, known from Indiana by a single specimen taken in Posey County. April 10.

293 (967). Brachynus medius Harr., New Eng. Far., VII, 1828, 117.

Antennæ fuscous; abdomen dark brown. Thorax as long as wide, the front margin concave, the front angles deflexed and obtusely rounded. Elytra slightly wider behind, the humeri rounded but distinct, the costre evident but faint. Length $4.5-5.5 \mathrm{~mm}$.

Vigo County; rare. April 24. Our smallest species.

Tribe II. UHLANIINI.

Antenna slender, arising from beneath a slight frontal ridge, the three basal joints glabrous. Head not narrowed behind the eyes to a neck; labrum transverse, truncate or emarginate; clypeus more or less prolonged between the mandibles which are feebly curved and without a seta on outer side; mentum broad, usually emarginate and toothed. Thorax variable in form, the setæ of the margin either slender or wanting. Body not pedunculate, scutellum distinct. Elytra margined at base, sides narrowly inflexed, surface striate, without dorsal punctures. Prosternum not prolonged; hind coxæ contiguous. Tarsi slender, claws simple. Males with three or four joints of front tarsi dilated and densely spongy beneath. The tribe is represented in the Jnited States fauna by seven genera, six of which occur in Indiana. 
KEY TO INDTANA GENERA OF ('HLANIXNI.

a. Punctures of eighth stria of elytra ristant from the margin. the ninth stria rery distinct; eyes regular in oufline, not truncate hehind: color mostly green or blue-black.

b. Mentum with a distinct lobe each side; leugth $S$ or more $\mathrm{mm}$. c. Mentum toothed in the center of the notch.

LV. Chlexils. cc. Mentum not toothed.

Lit. Axolioglosstis.

bu. Mentum without lobes, truncate in front; leugth $9-9.5 \mathrm{~mm}$.

LVII. Brachylobes.

(11. Eighth stria of elytra rery close to the margin, the ninth indistinct; eres truncate behind; color black or piceous.

1. All the tarsi pubescent beneath; chpeus with a'bristle-bearing puncture each side; labrum with six setie; length 9.5-10 mm.

dd. Hind tarsi not pubescent beneath.

LTIII. LACHNOCREPIS.

c. Front tarsi of males with four joints dilated, the first three spongy beneath; clypeus without bristle-bearing punctures; labrum with six setre; length $5-6 \mathrm{~mm}$.

LIX. ANATRICHIS.

ee. Front tarsi of male with three joints dilated and spongs; second joint of labial palpi without setæe in front: thorax as wide at hase as elytra: length 7.5 or more $\mathrm{mm}$.

r.X. OÖDEs.

\section{LT. CHLwares Bon. 1813. (Gr., "a cloak or mantle.")}

This genus is composed of greenish- or bluish-black oblong beetles of medium or large size. They are mostly finely pubescent, and when handled give off an odor like that of morocco leather. In a number of species the base of thorax is as wide as that of elytra. They live beneath stones. logs. etc.. the majority of the species being found in damp localities. where ther feed largely upon other insects. In 23 individuals dissected by Dr. Forbes. 8.3 per cent. of the stomach content was found to be of animal origin. Of this 65 per cent. was of insects. chiefly cutworms, canker-worms and other injurious forms, so that the genus ranks high among the beneficial Carabidæ.

About 43 species of Chlænius are known from the Cnited States. of these. 16 have been taken in Indiana. while two others perhaps occur. The principal papers treating of the genus are as follows:

Lec'onte.- "Analytical Table of the Species of Chlanins in the 'united States.' in Proc. Phil. Acad. Nat. Sci.. VIII, 1856. 25. Horn._- "Revision of the Species of Chlmnins in the United States," in 'Trans. Amer. Ent. Soc.. T. 1876. 253.

Horn.- "Synoptic Table." in Bull. Brook. Ent. Soc.. 1T. 1882, 3.

For convenience the Indiana speries are first divided into two groups and these in turn into species. 
下FT TO GROTFS OF INDANA SPEITES OT CHT.ENIT S.

a. Third joint of antennic longer than fourth; middle tibiæ of male with a pubescent space near the tip. Group A. au. Third joint of antennie not longer than fourth (except in tomentosus); middle tibire of male without a pubescent space at tip. Group $B$.

\section{Grotp A.}

In this group the males have a pubescent space of greater or less extent near the tip of the middle tibix. 'This is usually on the outer edge, but sometimes in front of the tibiæe. The basal line and side margin of the elytra unite at the humerus to form either a distinct angle or a regular curve; and "basal line angulate at humerus" and "basal line curved at humerus" are terms used to designate the two modes of union.

\section{KEY TO INDIANA SPECIES OF GROUP A.}

a. Abdomen smooth at middle, sparsely and finely punctured on the sides.

b. Prosternum not margined at tip, feebly punctured or smooth in front; male with front femor'a subangulate at base.

c. Color bright greel, shining; length 12-14 mm. 294. solitarius.

cc. Color dark blue; thorax subopaque, elytra opaque; length 13$15 \mathrm{~mm}$.

295. LEUCOSCELIS.

66. Prosternum margined at tip, coarsely punctured in front; color green, the last rentral segment nearly wholly brownish-yellow; length $17 \mathrm{~mm}$.

296. PRASINUS.

a a. Abdomen sparsely punctured at middle. more densely at sides.

d. Episterna (side pieces) of metasternum short, the outer side shorter than the front one; thorax narrower at base than elytra.

e. Thorax greenish-bronzed above, the sides distinctly sinuate near base; front femora of male subangulate at base. 297. 玉sTivus.

ce. Thorax violet or purplish-blue above, not sinuate near base.

f. Thorax wider than long; front femora of male subangulate at base.

PLATYDERUS.

ff. Thorax about as long as wide; front femora of male simple.

29S. DIFFINIS

dd. Episterna of metasternum long, the outer side longer than the front one.

g. Sides of thorax not or feebly sinuate near base.

h. Color bright green to blue, legs pale.

299. SERICEUS.

$h \hbar$. Color blackish or dark blue.

$i$. Smaller, 13-15 mm.; base of thorax as wide as elytra; front femora of male toothed at base.

300. LATICOLLIS.

ii. Larger, 21-23 mm.; base of thorax narrower than elytra; front femora of male simple.

FUSCICORNIS.

gg. Sides of thorax distinctly sinuate near base; color and size of fuscicornis.

301. ERYTHROPUS. 
294 (1009). Chlæanus solttaries Say. Trans. Amer. Phil. Soc., 1I, 182:3. 65 ; ibid. II. 487.

Elongate-oral, rather slender. Above bright green; legs and basal portion of antennæ pale yellow; under surface dark reddish-brown, the last rentral segment margined with dull yellow. Thorax slightly longer than wide, base and apex almost equal and much narrower than elytra; sides rather strongly curved in front, sinuate near base, hind angles rectangular; disk sparsely punctured along the base and apex. Elytral intervals convex. sparsely punctate and pubescent. Length 12-14 mm.

Starke. Vigo. Martin, Posey and Clark counties; scarce. April 15-December 10. Resembles prasimus in color but smaller, brighter green and with much narrower thorax.

295 (1008). Chlænits leucoscelis Cherr.. Col. Mex.. I. 1834. 11.

Elongate-oral. Abore dark violet blue; antennie and legs reddishbrown; under surface piceous. Thorax as in solitarius, the basal impressions and median line deeper. the former long and curved: center of disk each side not punctured. Elytial intervals subconvex, rather densely and finely punctulate. Length $13.5-16 \mathrm{~mm}$.

Clark and Floyd counties: frequent beneath stones along the Ohio River. April 15-October 9.

296 (1007). Chlanius PRasixts Dej.. Spec. II, 1S26, 345.

Elongate oral, robust. Above bright green; legs and antennæe pale: under surface black, the last rentral segment dull yellow. Thorax broader than long; sides curred in front, gradually narrowed from middle to base. which is distinctly narrower than elctra; hind angles obtuse; disk coarsely and sparsely punctate. Eiytral strixe shallow. distinctly punctured; intervals rather densely and finely punctate. Length $17-1 \mathrm{~s} \mathrm{mm.}$

Throughout the State: frequent in damp localities. April 16July 14. In one specimen from Tigo County the elytra are blackishgreen.

297 (1003). Chlexils æstruts Say. Trans. Amer. Phil. Soc., II, 1S23. 62 ; ibid. II, $4 S 4$.

Elongate-oral. Head and thorax green. slightly bronzed; elytra black with bluish tinge; legs and three basal joints of antennie pale; under surface black. Head, except the middle of front, coarsely and deeply punctate. Thorax nearly as long as wide. sides feebly sinuate near base, disk coarsely and densely punctured. Elytral strize finely punctured; intervals finely. densely and indistiuctly punctulate. Length $16-17 \mathrm{~mm}$.

Southern part of State. frequent: much less so in the northern comnties. April 12-.Tune 28.

('. platyderus ('hand. 1t.5 mm. in length. is recoleded form Illi nois and westrard. and possibly occurs in western Indiana. 
298 (1001). Chixicils diffinis Chaud., Buli. Mosc.. III, 1856, 279.

Elongate-oval, robust. Bluish with a tinge of green; elytra darker; antennie brown, three basal joints paler. Head coarsely punctured, smooth at middle and in tront. Thorax with base vers little broader than apex, sides moderately curved in front, slightly converging. not sinuate near base; disk moderately convex, densely and coarsely punctured. Elytral stria with rather distant punctures; intervals flat. rather densely punctulate. Length 13-15 mm.

Throughout the State: frequent. April 11-.July 14.

*299 (996). Chumites sertcets Forst., Nor. Sper. Ins. Cent.. I, 1771, 5s.

Elongate-oral, rather slender. convex. Bright green.

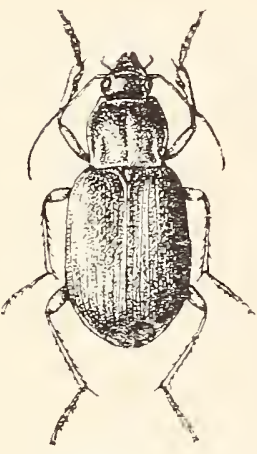

Fig. $89 . \times 12$. (Original.) sometimes with a bluish tinge; antemne usually pale. often with the apical joints darker: under surface black. 'Thorax nearly quadrate, wider at base than apex, densely and rather coarsely and deeply punctate. Elytral strixe tine. with rather fine, distant punctures; intervals flat. densely and finely punctate. Length 13-17 mm. (Fig. S9.)

Throughout the State; common about the margins of ponds, lakes and streams. April 16-December 8 .

300 (1000). Chlæxius raticollis Say, Trans. Amer. Phil. Soc.. II. 1823. 64: ibid. II. 486.

Resembles diffinis very closely. Differs in having the antennae and legs uniform brownish-yellow. Thorax wider. feebly sinuate near the base. which is distinctly wider than apex; disk less densely punctured and more convex. Length 13-15 $\mathrm{mm}$.

Lake and Starke counties; rare. April S-May 28. The longer side pieces of metasternum. broader thorax, short spine near base of male femora and wholly pale antennæ easily distinguish it from diffinis.

C. fusicornis Dej.. antennæ brown. the two basal joints paler. is recorded from the "Gulf States. Mllinois and Missouri."

*301 (994). Chl.xics errthropes Germ., Ins. Spec. Nor., 1824, 11.

Elongate-oral. rery robust. Piceous-black. the thorax with a tinge of blue; legs and antennie uniform brownish-yellow. Thorax slightly longer than wide, base broader than apex; surface densely and rather coarsely punctured. Elytral strie fine. finely punctured : intervals flat. rather densely punctulate. Front femora of male subangulate at base. Length 21$23 \mathrm{~mm}$.

Throughout the State: common. Jannary 1-September 22. Taken in Vigu County in sanuary and Februar but more common jn colonies the first warm days of March, 
(iROEP B.

The species of this gamp are as a mile much smaller than those of Group A. The males are without a pubescent space at tip of middle tibia. and the third joint of antenne is almost alwars equal to or shorter than the fourth.

KEY TO IXDLAXA SPECIES OF GROLP B.

a. Abdomen without punctures and glabrous: thotax as broad at base as elrtra. sides not sinuate, basal impressins relp feeble. surtace dense. Is punctured.

302. TOMENTOSLS.

ar. Abdomen sparsely punctured and pubescent over the entire surface.

7. Sides of thorax not sinuate: prosternum llot maromed at tip.

c. Legs black; thorax as wide at base as elytra. its disk with coars punctures rery irregularly placed.

d. Margin of thorax not thickened: basal line angulate at humerus: purplish or riolet blue abore: length $5.5-9.5 \mathrm{~mm}$.

303. PCRPLRICOLLIS.

dd. Margin of thorax thickened near base; humeri of elytra rounded: black abore: length $11.0 \%-12.5 \mathrm{~mm}$.

304. NIGER.

cc. Legs reddish-yellum: thorax more finely and densely puncturen. naromer at apex than base and with a narow red margin.

305. IMPL NCTIEROAS.

6b. Sides of thorax distinctly simuate: prosternum margined at tip. its side pieces coarsely punctured.

e. Elstral intervals finels muricate: i. e.. with numerous fine. rigid points.

306. PEXXSTLTAXICLS.

cc. Elytral interrals finels and sparsely punctured, not muricate.

$f$. Head and thorax green. Varying to blue. shining.

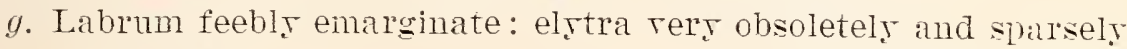
punctate.

g\%. Labrum truncate.

30T. BRETILABRIS.

30S. TRICOLOR.

ff. Head and thorax copder bronze: thorax alutaceous. subopaque. more finely and sparsely punctate.

309. NEMORALIS.

302 (1032). Chemites tomextosts Sar. Trims. Amer. Phil. Soc.. II. 1s23. 60 : ibid. II. 453.

Broady oral. robust. Blackish, purplish or greenish ant feebls bronzed abore; antennæ black. two basal joints pale. the third joint longer than fourth: under surface and legs black. shining. Head nearly smooth. a few wrinkles and punctures above each eye. Thorax gradually broader from aper to base, disk densels and coarsely punctured. with a few irregular smooth spaces. Elitral strix shallow, punctures round. rather coarse: interrals feebly conrex. finels punctulate and pubescent. Length 13.5-15 mm. (Fig. 90.)

Throughout the State: common. March 23-Norem-

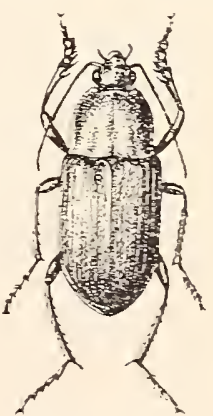

Fig. 90. $\times 1$ 1. (Original., ber 20. Often found at electric light and probably hibernates. The abdomen is sometimes sparsely punctured on the sides. 


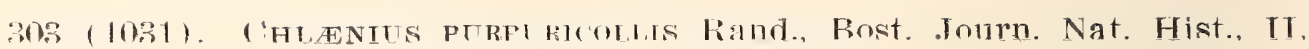
$1838,35$.

Oblong-oval. Dark violet blue above, black beneath; antennæ black. basal joint pale. Thorax gradually narrower from base to apex, surface coarsely and very irregularly punctured. the sides in front of middle almost smooth. Elytral strixe very fine, distantly and finely punctured; intervals flat with numerous rather coarse, simple punctures. Length $8.5-9.5 \mathrm{~mm}$.

Lake and Laporte counties; rare. May 14-August 26. Occurs along the beach of Lake Michigan.

304 (1029). Chlanils Niger Rand., Bost. Journ. Nat. Hist., II, 1838, 34.

Broadly oval. Uniform black throughout; head and thorax shining. Thorax one-third broader than long, apex narrower than base, hind angles obtuse; basal impressions deep; disk coarsely punctured, with irregular smooth spaces each side of middle. Elytral striæ finely punctured; intervals convex, rather densely and roughly punctured. Length $11.5-12.5 \mathrm{~mm}$.

Lake, Vigo and Knox counties; scarce. April 5-July 9.

305 (1025). Chlænius impunctifrons Say, 'Trans. Amer. Phil. Soc., II, 1823, 64 ; ibid. II, 486.

Elongate-oval. Head bright green; thorax blackish-green, subopaque; elytra black; antennæe and legs pale reddish-brown. Thorax broader than long, very flat; base as broad as elytra. hind angles obtuse. Elytral strixe rather deep, finely punctured; intervals flat, finely and roughly punctate. Length $13.5-16 \mathrm{~mm}$.

Throughout the State; scarce. April 16-August 26. Easily known by the very flat thorax with a narrow pale margin.

*306 (1021). Cirlennits Pennsylunanicus Say. Trans. Amer. Phil. Soc., II. 1823, 66 ; ibid. II, 487.

Elongate-oval, slender. Head and thorax bright green; elytra darker green; antennie reddish-brown, three basal joints paler; under surface black, legs pale. Thorax slightly wider than long, sides moderately currert. feebly sinuate near base; disk convex. coarsely and rather sparsely punctate; basal impressions linear, deep. Elytral stria deep, rather cousely punctured; intervals flat. muricate. Length 10-11.5 mm.

Throughout the State; more common in the northern half. where it often occurs in small colonies beneath rubbish along the margins of lakes. .January 3-Octoher 13.

307 (1019). Chlments brevilabris Lec., Amm. Lyc. Nat. Hist.. IV, 1848, 437.

Form and color of penmsylvanicus. Elytra bluish-black, the intervals flat. finely and indistinctly punctured. Length 10-12 mm. 
Northern half of State; scarce. April 26-November 28. Very close to tricolor but narrower and with the labrum feebly but distinctly and broadly arominate, the thorax broader and less narrowed in front and the elytral stria more coarsely punctured.

308 (1018). Chr.entus tricolor Dej., Spec. II, 1826, 334.

Elongate-oval, broader than the two preceding. Head and thorax green, elytra blackish-blue. Thorax narrower at apex than base, broader than long; sides curved and feebly sinuate behind; disk rather coarsely and densely punctured, basal impressions narrow and rather deep. Elytral strix fine, rather deep, finely punctured; intervals flat, finely, sparsely and indistinctly punctate. Length $11.5-13 \mathrm{~mm}$. (Fig. 91.)

Throughout the State; frequent. April $17-$ November 28.

309 (1017). Chlmenus nemoralis Say, Trans. Amer.

Phil. Soc., II, 1823, 65 ; ibid. II, 487.

Form of tricolor. Head and thorax coppery-bronze;

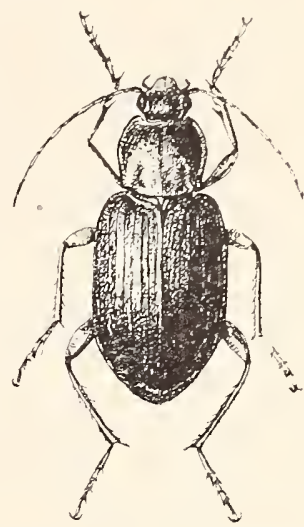

Fig. 91. $\times 2 \frac{1}{3}$. (Original.) elytra black with but a faint bluish tinge; antennæe and legs reddish-brown. Thorax narrower at apex than base; disk alutaceous, finely and rather sparsely punctured; basal impressions narrow, deep; median line distinctly impressed its full length. Elytral striæe narrow, rather coarsely punctured; intervals slightly convex, very finely and sparsely punctate. Length 11.5$13 \mathrm{~mm}$.

Northern half of State; frequent. March 21-October 7. Very close to tricolor but the thorax distinctly alutaceous, subopaque, more convex in front and much more finely punctate.

\section{Anomoglossus Chaud. 1856. (Gr., "irreg"ular + tongue.")}

The members of this genus resemble those of Chlanius, but differ by the entire absence of any mentum tooth and by the mandibles being longer and less curved. The entire surface of the abdomen is punctured and pubescent, the basal line of elytra is angulate at humerus and the labrum is emarginate. Two species occur in Indiana. This genus and the next are treated by:

Horn.-In Trans. Amer. Entom. Soc., V. 1876. 273-274.

Horn.-In Bull. Brook. Fnt. Soc. IT, 1882, 29.

310 (1034). Anomoglosses emarginatus Say, Trans. Amer. Phil. Soc., II, 1823. 62 ; ibid. II, 485.

Elongate-oval, rather slender. Head bright green: thorax green tinged with bronze; elytra dark blue; antenne and legs pale. Thorax slightly longer than wide, broader at hase than apex, sides not at all sinute near hase, hind angles obtuse. disk consely and rathel dosely punctate. libytral intervals flat, densely and coarsely punctured. Length 12-1+ mm. 
Southern half of State, frequent; much less so northward. April 16-October 17. Resembles Chlonius astivus closely in general appearance.

*311 (1036). Axomoglossts pesiluts Say, Trans. Amer. Phil. Soc., II, 1823,63 ; ibid. II, 4S5.

Oblong-oval. Head and thorax bluish-green; elytra dark blue, sometimes black; antennie and legs reddish-brown. Labrum deepls emarginate. Thorax as wide as long. nalrower at base than apex; sides distinctly sinnate, hind angles acute; disk comsely, rather sparsely and deeply punctate. Elytral intervals moderately convex. coarsely and closely punctured. Length $8-8.5 \mathrm{~mm}$.

Throughout the State; sarce. .January 21-August 9. Occurs beneath rubbish in damp localities.

\section{LYII. Brichylosts Chand 1876. (Gr.. "short+lobe.")}

Known fiom allied genera by the mentum being without lobes. transversely trapezoidal. much narrowed and scarcely at all emarginate in front. its sides very obliquely truncate; mentum tooth entirely absent. One species occurs in Indiana.

312 (1037). Brachylobes lithophlles Say, Trans. Amer. Phil. Soc.. II. 1823. 62: ibic. II. 485.

Elongate-oral. Green or blackish-green. liead and thorax shining: elytra thickly clothed with yellowish hairs: antenne fuscous. paler at base; legs pale; under surface black. Thorax one-third broader than long. narrower at apex than base, the latter as broad as elytra: sides broadly curved. not sinnate: disk densely and coarsely punctured, hind angles obtuse. Elytral strixe finely punctured. intervals flat, sparsely and finely punctulate. Pro- and mesosterna coarsely punctured. Length 9-9.5 min.

Throughout the State: frecuent. April 6-September 5. Occurs mostly in damp sandy places about the margins of lakes and streams.

\section{LACHNocrepts Lee. 185., (Gr.. "soft hair + foot.")}

One rather small black species. the male of which has four joints of the front tarsi rather broadly dilated. represents this genus in the United States. 'The principal papers treating of it and the next two are by:

Horn. "On the Species of Oödes and Allied Genera of the T. S.." in T'rans. Amer. Ent. Soc. TII, 1870, 105-109.

Trorn.- "Synoptic Table," in Bull, Brook, Wnt, Sor.. TV. 1882. 29, 30 . 
313 (1039). Lachnocrepis parallelus Say, 'Trans. Amer. Phil. Soc., IV, 1834, 420 ; ibid. II, 532.

Elongate-oblong, parallel, subconvex. Black, shining, very finely alutaceous; antennæ piceous, two basal joints paler; legs and region of hind angles of thorax reddisl-brown, the latter translucent. Thorax slightly wider than long, widest a little behind the middle; apex narrower than base, the latter as wide as elytra; disk not punctured; hind angles obtuse. Elytra seven-striate, the strise parallel their full length, finely and distantly punctate; intervals subconvex, smooth. Length $9.5-10.5 \mathrm{~mm}$.

Lake and Kosciusko counties; scarce. May 6-October 29. Occurs near water.

\section{AnAtrichis Lec. 1853. (Gr., "without + hair.")}

Small oval or oblong black or piceous beetles, separated from allied genera by the characters given in the key. One species occurs in Indiana.

314 (1040). Anatrichis minuta Dej., Spec. V, 1829, 677.

Oval, broader behind. Black, shining; antennæ piceous, the basal joints and legs reddish-brown. Base of thorax as wide as elytra; sides feebly curved, converging gradually to apex; disk finely not densely punctate; basal impressions deep, short. Elytral striæ deep, "serrately punctate; intervals flat, minutely punctulate. Length 5-6 $\mathrm{mm}$.

One specimen taken in Posey County. April 9. A member of the Austroriparian fauna.

\section{OöDEs Bon. 1813. (Gr., "egg + form.")}

Small or medium sized, oval or oblong, black or greenish-black, shining beetles, resembling closely certain forms of the genus Amara. All have the thorax as wide at base as elytra, and the third interval of latter with two dorsal punctures behind the middle. They occur, for the most part, beneath stones, etc., along the margin of lakes and ponds. Five species have been taken in the State.

KEY TO INDIANA SPECIES OF OÖDES.

a. Elytra with seven strixe equally distinct; first joint of front tarsi of male entirely spongy beneath.

b. Thorax broadest at base; length $7.5-9 \mathrm{~mm}$.

315. AMAROIDES.

b). Thorax broadest just in front of base; length $12.5 \mathrm{~mm}$.

c. Elytral striæ distinctly and closely punctured; form very broad.

316. AMERICANUS. cr. Elytral striae finely and distantly punctured; form more narrow.

317. FLUVIALIS 
a a. Serenth elytral stria either entirely obliterated or replace bs fine, distant punctures: first joint of front tarsi of male spongy onls at apex.

1. Flstral striae punctured their entire length; tibire and tarsi pale rellow.

31S. CLPRæUS.

dd. Elstral stria not punctured; tibire and tarsi black or piceous.

319. 14-STRIATLS.

315 (1041). Oödes amaroides Dej.. Spec. T, 1829, 664.

Oblong-oral. Black or piceous, shining: margin and basal angles of thorax often translucent; antennæ reddish-brown. legs piceous. Thorax gradually broader from apex to base, where it is one-half wider than long: sides feebly curred; disk smooth, basal and median impressions obsolete. Elytra with sides subparallel and rery obtuse at apex; striæ finely punctured; interrals flat. Length $7.5-9 \mathrm{~mm}$.

Iake. Kosciusko. Marshall and Knox comties: frequent. June 17 -August 17.

316 (1042). OÖDES AMERICANus Dej., Spec. II. 1826, $37 \overline{7}$

Broadls oral; black. shining. finely alutaceous; legs and antennæe as in amaroides. Thorax gradually broader from apex to base, slightly narrorrer at base than immediateis in front; median line fine but distinct. Elytra subparallel; strixe moderately deep. finels and closely punctured: intervals feebly conrex. Length $12.5 \mathrm{~mm}$.

Knox and Tigo entunties: scarce. April 23-September 2.

317 (1013). Oöbes fltyidis Lec. N. Sp. N. Ameř. Col., I. 1S63, 13.

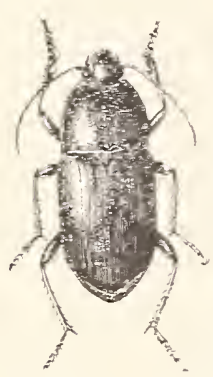

Fig. $92 . \times 1 \frac{2}{3}$.

(Original.)

Resembles the preceding but narrower and more conrex. Thorax less rounded in at base, with more distinct median line. Elytral strise less deep. rery finely. distantly and indistinctly punctured; interrals flat. Length $12.5 \mathrm{~mm}$. (Fig. 92.)

Lake, Marshall. Koseinsko and Marion counties; scarce. May 15-August 27.

318 (1045). OÖDES CUPR 761.

of thorar and elstra often bright oreen shining : antenne and femorin pic eous, the tro basal joints of former paler. Elytral striæ shallor, the serenth wholls absent; intervals flat. Length $10 \mathrm{~mm}$.

Throughout the State; frequent. Argust 17-November 9.

319 (1015). Oöbes 11-stritutes Chand., Bull. Mosc., IV, 1843, 759.

Elongate-oral, robust. Greenish-black. slightl⿳亠 bronzed: antennæ darli reddish-brown. Thorax gradualls broader from apex to base; median line rers faint. Elstra rather deepls striate, the serenth lacking: intervals feebls conrex, finels alutaceous. Length $11.5 \mathrm{~mm}$.

Martin. Clark. Floyd and Posey counties: scarce. April 11Septemher 2-7. Panges from Ohio to Lonisiana and Texas. 
Tribe III. H.IRI'AIAXI.

intenna usually slender, arising from beneath a slight frontal ridge. two basal joints. sometimes a portion of the third. glabrous. Head often large. usually moderate. not narrowed to a neck; labrum moderately prominent. truncate or emarginate; mandibles stout. acute at tip and without bristle-bearing puncture on outer side; mentum broad, emarginate. with or without a median tooth. Thorax rariable in form. with a lateral seta, but none in the hind angles. Body sometimes subpedunculate; scutellum distinct. Elytra usually margined at base. sides narrowly inflexed. surface striate. often densely punctured. either pubescent or smooth. with or without dorsal punctures. Prosternum not prolonged; hind coxre contiguous; front tarsi with the outer apical angle spinous or obtusely prolonged.

The tribe is a large one. being represented in the United States fauna by 17 genera. 14 of. which occur in Indiana. Many of these have been established on trivial or sexulal characters, so that they are difficult to distinguish unless both sexes are at hand. To make shorter an otherwise long generic ker. the genera are distributed by Hor among four subtribes. three of which are represented in Indiana.

KET TO INDIANA SLBTRIBES OF HARPALIXI.

a. Front tarsi of male feeble or not at all dilated. pilose or spinose beneath: eres. except in Agonoderus. small and widely separated from the mouth beneatli: oblong or oral conrex species. usually piceous or brownish-rellow in hue.

Subtribe 4.. p. 173 .

tit. Front tarsi of male dilated: less convex. black. brown or picesus. rarely brownish-rellow species.

b. Dilated joints of front tarsi with two rows of small scales beneath.

Subtribe B. p. 17s.

b7. Dilated joints of front tarsi densely spongs pubescent or brush-iike beneath.

Subtribe C.. 1. 193.

$$
\text { Subtribe A. (DAPTi.) }
$$

To this group belong five Indiana geuera. separated as follows:

KEI TO IXDIAXA GEXERA OF GROLP A.

a. Mandibles prominent. crossing at an angle. deeply strigose at tip: body subpedunculate: front tibia strongls fossorial.

LAI. Geoplits. a a. Mandibles not prominent, at most feehly crossing: bord not peduncrulate. 
b. Outer apical angle of front tibire prolonger; form lobust; length $14 \mathrm{~mm}$.

L.XII. NoTHOPLS.

$b b$. Outer apical angle of tibiæ not prolonged; form less robust; length less than $11 \mathrm{~mm}$.

c. Mentum toothed; hind angles of thorax sharply rectangular; length $8-10 \mathrm{~mm}$.

LixiII. Cratacanthus.

cc. Mentum not toothed; length less than $8.5 \mathrm{~mm}$.

d. First joint of hind tarsi slightly longer than second; outer edge of middle tibia rather flat and with a double row of spinules closely placed; elytra with one dorsal puncture.

LXIV. AgONODERUS.

dd. First joint of hind tarsi nearly as long as the next three; middle tibix with the spinules sparsely placed, in the male curved and serrate on the inner side; three rows of dorsal punctures.

LXV. Discoderus.

LXI. Geopinus Isec. 1848. (Gr., "earth + dirt.")

Represented in the United States by one medium-sized robust species which burrows deeply in damp, sandy localities. The surface is smooth and glabrous, thus favoring its subterranean life. It may often be taken by suddenly turning over an old log partly buried in sand.

320 (1052). Geopinus incrassatus Dej., Spec. IV, 182S, 21.

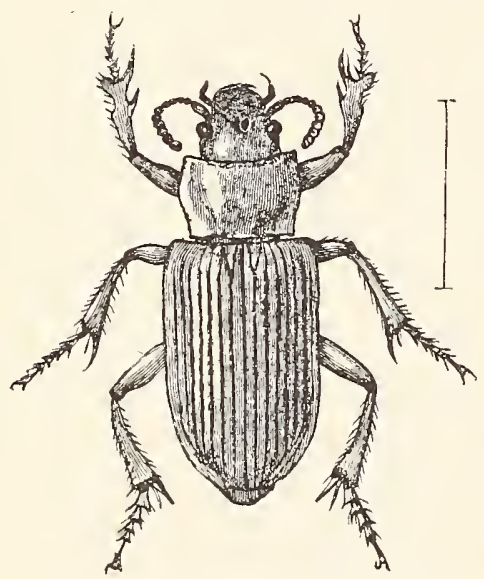

Fig. 93. Line shows natural length.

Oblong, convex. Brownish-yellow ; front and middle of thorax and disk of elytra often more or less piceous. Thorax one-half broader than long, gradually narrowed belind the middle; base a little narrower than elytra, region of the hind angles depressed. Elytra sinuate near apex, strix moderately deep, not punctured; intervals slightly conrex. Length 13.5-15 mm. (Fig. 93.)

Lake, Taporte, Marion and Vigo counties; scarce. April 23-June 15. Four were taken at electric light in Terre Haute on June 9.

\section{Nothopus Lec. 1853. (Gr., "spurious + foot.")}

Represented in the United States by a single rather large, robust black or piceous beetle, having the outer angle of front tibia narrowly prolonged and rather deeply sinuate above the tooth. It occurs from the Rocky Mountains eastward to Tllinois and rarely to northern Indiana. 
321 (1054). Nothopes grosstes Say. T'rans. Amer. I'hil. Soc. IV, 18:34, 4:30. ibid. II. 5 43.

Robust, convex. Black, shining; antennæ and legs piceous. Thorax nearly twice as wide as long, as wide at base as elytra; basal margin depressed, especially so in the region of the hind angles, which are rectangular; disk sparsely but rather coarsely punctured near base and apex. Elytral striae fine. not punctured; third. fifth and serenth intervals each with fire to eight distinct seta-bearing punctures. Length $14 \mathrm{~mm}$.; width $7 \mathrm{~mm}$. (Fig. 94.)

Known from Indiana by a single specimen taken by Wolcott un the beach of Lake Michigan, near Pine, Lake Comnty. July 25. Nr. Wolcott had preriously taken a specimen nea $\mathrm{i}^{\circ}$ Bloomington, Illinois. This is the species usually known as $\mathrm{N}$.

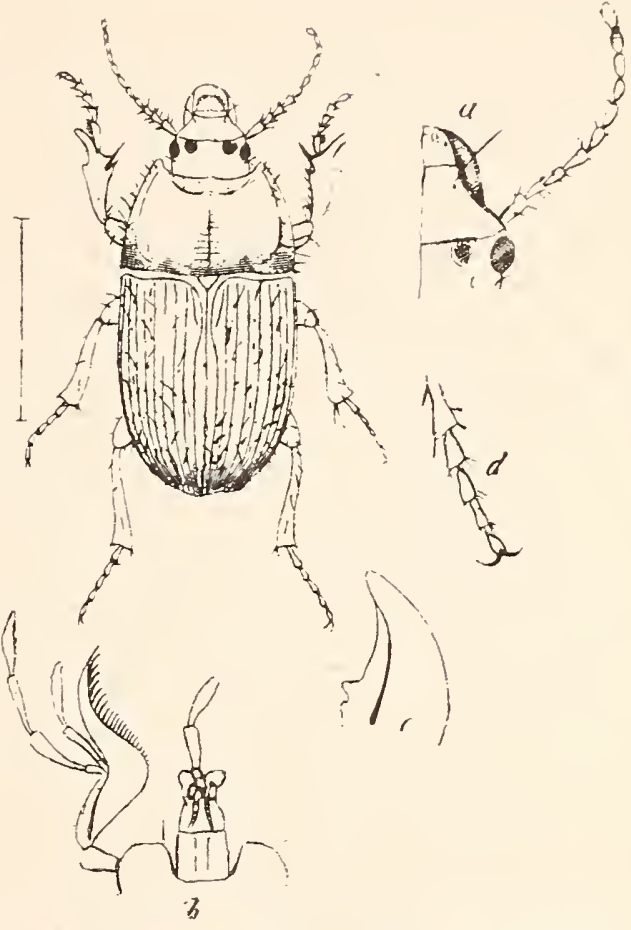

Fig. 94. Yothopus grossus Say; $a$, antenna; $b$, maxilla and palpi; $c$, mandible; $d$, tarsus. (After LeConte.)

zabroides Lec. Sar's description is. howerer. sufficient for determination and has priority.

\section{CRatacin'THUS Dej. 1825. (Gr.. "strong'spine.")}

One medium-sized. oblong. conver beetle represents this genus in the Uniter States. It necurs about gardens and the borders of cultivated fields. and is often thrown out by spading and plowing. It is sometimes attracted by electric light.

32.2 (1056). Cratacanthus dubics Beaur., Ins. d'Amer., 1805. 108.

Oblong, conrex. Piceous, glabrous; legs and antennze reddish-brown. Thorax one-half broader than long; sides broadly curred from apex to behind middle, thence strongly sinuate to base, which is narrowei than apex; basal impressions short. smooth or with a few coarse punctures. Elytral striæ deep, not punctured; interrals slightis convex. Length $8-10 \mathrm{~mm}$.

Throughout the State: frequent. May 14-September 23.

\section{Agonoderus Dej. 1825. (Gr.. "without angle + neck."}

Small brownish-yellow oblong beetles. having the mentum not toothed and the front tarsi alike in form in both sexes. Our species diminish in size in the order given in key. They occur beneath rubbish about qardens and cultivated fields. Several of them hi- 
bernate and are on the wing in great numbers during the first warm days of spring. They are also very common about electric lights in spring and early summer.

The following papers treat of this genus and two of those which follow :

LeConte.-."Notes on the Species of Agonoderus, Bradycellus and Stenolophus inhabiting America North of Mexico," in Proc. Phil. Acad. Nat. Sci., 1868, 373-382.

LeConte.-_"Synoptic Table." in Bull. Brook. Ent. Soc., VI, $1883,13,50,53$.

Five species of Agonoderus have been taken in Indiana. while two others perhaps occur.

\section{KEY TO INDIANA SPECIES OF AGONODERTS.}

a. Body stouter and more convex; thorax transrerse. quadrate-oval: hind angles of thorax strongly rounded; length 6.5-5.5 mm.

6. Pale yellow: two spots on disk of thorax and two stripes on elytra dark: scutellar stria long; one dorsal puncture.

323. LIXEOLA.

bわ. Dark brownish-yellow or piceous, narrow margin of thorax and broader one of elstra pale; scutellar stria shorter; dorsal punctures wanting.

INFUSCATUS.

a a. Body more elongate, less convex; thorax scarcely wider than long. more or less distinctly narrowed behind; elștra with one dorsal puncture.

c. Larger, 5.5- $7 \mathrm{~mm}$; pale, elytra with a wide black stripe. dirided by the suture: disk of thorax often with a large duskr spot: head black.

321. PALLIPES.

cc. Smaller. 2.5-4 mm.

d. Head black: scutellar stria distinct.

e. Thorax pale. without blackish spot: bodr beneath wholly or in part dusky.

f. Basal impressions well marked. with a few coarse punctures: elytra with a broad ill-defined dusky cloud divided by the sutural interval; thorax duskr beneath. 325. PARTIARICs.

ff. Basal impressions less marked. with fer if any punctures: elytra more or less dusky with suture and margin pale: thorax pale beneath. 326. PACPERCULLS.

ee. Thorax with a large blackish spot on disk; elstra blackish with suture and margin brownish-rellow.

IXDISTIXCTLS.

17. Head pale. of the same color as thorax: body beneath rellowish or reddish-brown: scutellar stria short or wanting.

327. TESTACECS.

329 (1059). Agoxodert's LiNeOiad Fab.. Fint. Srst.. I, 1795. 155.

Oblong. convex. Color as given in key; head with a crescent shaped black spot: elrtral dark stripes separated by the sutural interral. Thorax one-fourth broader than long. basal depressions small. finely punctured. hind angles much rounded. Elytra minutely alutaceous: intervals feebls conrex. Tength 7.5-S.5 mm. 
Lake, Vigo and Kosciusko counties; frequent. April 23-June 9. Probably occurs throughout the State.

A. infuscatus De.j. 5-6.5 mm. in length, ranges from New York wolthward and has been reported by Dury from Cincinnati.

*324 (1061). Agonoderus pallipes Fab. Ent. Syst., I, 1795. 159.

Oblong, less convex. Color as given in key, sometimes almost wholly pale; antennæe dark reddish-brown, the basal joints and legs pale. Thorax with hind margin and shallow basal impressions finely punctured. hind angles obtuse. Elytra with deep smooth strix; intervals convex. Length 5-6 mm. (Fig. 95.)

Throughout the State; common. January 21-September 18. Occurs in abundance at electric lights. 'The more northern specimens are larger: 6-7 $\mathrm{mm}$. in length, with head a

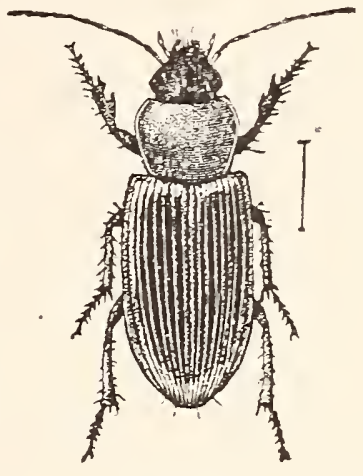

Fig. 95. deeper black. elvtral dark stripe wider and scutellar striæ one-half or more longer. The name comma was given them by Fabricius, and they represent at least a distinct variety.

*325 (1062). Agonoderts partiarit's Say, Trans. Amer. Phil. Soc., II. 1823,90 ; ibid. II, 504 .

Oblong. subconvex. Antennæ brownish, legs pale. Thorax as wide as long. sides broadly curred; disk convex, median impressed line deep, a few fine punctures near apex and coarser ones in the basal impressions; hind angles rounded. Elytral striæ deep; intervals convex. Length $3.5-4 \mathrm{~mm}$.

Throughout the State; common. February 5-November 11.

326 (1063). Agonoderus patperculus Dej., Spec. IV. 1828. 453.

Oblong, slender. Reddish-brown; elytra more or less dusky or piceous. the suture and margins pale. Thorax minutely alutaceous, more narrowed behind; basal impressions more shallow; disk less convex. without punctures near apex. Elytral strire fine, interrals flat. Length $3-3.5 \mathrm{~mm}$.

Throughout the State: frequent. March 20-November 30.

A. indistinctus Dej.. 3-4 mm.. is recorded from New York and New Jersey. and also by Dury from near Cincinnati. I have not seen a specimen from Indiana.

327 (1065). Agoxoderts testacels Dej.. Spec. IV, 182S, 460.

Oblong. subconvex. Uniform reddish-brown abore, disk of elytra sometimes with a faint dusky cloud: antennæ duskr, basal joints and legs pale vellow. Thorax as wide as long. sides broadly curved. hind angles much rounded: basil impressions faint with at few latre punctures: disk convex. sparsely punctate near apex. median line deep. Scutellar stria of elytra punctiform. Length $2.5-3 \mathrm{~mm}$. 
Dubois, Crawford and Jennings counties; searce. May 1May 17.

\section{Discoderus Lec.. 1853. (Gr., "disk + neck.")}

Oblong black or piceous beetles, of small or medium size, having the basal joint of hind tarsi elongate and the second, fifth and seventh dorsal strix each with a number of snall dorsal punctures. The males have but one bristle-bearing puncture on each side of the last ventral segment, while the females have two. The genus is treated by:

Horn.--In Bull. Brook. Ent. Soe., VI, 1883, 52.

One species occurs in Indiana.

328 (1067). Discoderus Parallelus Hald., Proc. Phil. Acad. Nat. Sci., I, $1842,301$.

Elongate-oblong. Black, subopaque, finely alutaceous; antennæ pale reddish-brown; under surface and legs piceous. Thorax as broad as long, slightly narrower at apex than base; disk strongly convex, side margin narrowly depressed toward the base and with numerous minute punctures; hind angles rounded. Elytral strice rather deep, intervals conrex. Lengtlı $7-7.5 \mathrm{~mm}$.

Putnam and Marion counties; rare. September 7-October 1.

\section{Subtribe B. (HARPÁLI.)}

To this group Horn ascribes eight genera, seven of which are represented in Indiana.

KET TO INDIANA GENERA OF GROUP B.

a. Antennæe with only two basal joints glabrous.

b. Last joint of labial palpi shorter than the preceding, the latter with a number of setie in front.

c. Front tarsi dilated in both sexes, the first joint only in the female; body not,pedunculate.

LXVI. GYNANDROPUS.

cc. Front tarsi dilated in the male only.

a. Flytra with at most one dorsal puncture; first joint of hind tarsus not longer than the two following. LXVII. Harpalus.

dd. Elytra with three rows of dorsal punctures; first joint of hind tarsus equal to the next three; length $5-10 \mathrm{~mm}$.

LXVIII. Selenophorus.

bo. Last joint of labial palpi equal to or even a little longer than the preceding, the latter with only two setre.

e. Next to last joint of front and middle tarsi of male bilobed; middle tarsi dilated: length less than $8 \mathrm{~mm}$.

LXIX. S'TENolophus.

ee. Next to last joint simply emarginate; midale tarsi of male not or rery feebly dilated. 
f. Mentum not toothed; elytra frequently with several dorsal punctures; length less than $3.5 \mathrm{~mm}$.

Lxx. Acupalpus.

ff. Mentum toothed; elytra with a single dorsal puncture; length $4.5-5.5 \mathrm{~mm}$.

LXXI. BRADYCELLCS. aa. Antennie with three basal joints glabrous; mentum toothed; middle tarsi of males with two rows of small scales beneath; length 5.5 $7 \mathrm{~mm}$.

LXXII. TACHYCELLUS.

LXVI. Grandropus Dej. 1825. (Gr.. "of doubtful sex + feet.")

Small oblong black beetles having the first joint of front tarsi of males almost as long as the next two. One species occurs in Indiana.

329 (10T4). Griandropls hylacis Say. Trans. Amer. Phil. Soc., II, 1823, 31 ; ibid. II. 459.

Elongate, rather slender. parallel. Black, strongly shining; antenna and legs pale, the former dusky toward apex. Thorax convex. as long as wide. narrower at base than elytra. widest at middle. sides broadly curved; basal depressions distinct. coarsely punctured; hind angles obtuse. Elytral strice moderately deep. the second, fifth and serenth each with a number of fine dor:sal punctures. Length $7.5 \mathrm{~mm}$.

Starke. Marion. Putnam. Jackson and Dubois counties; scarce. March 31--November 23. Occurs beneath bark.

\section{XVII. HARPALtS Lat. 1802. (Gr., "greedy.")}

Large or medium-sized beetles. usually oblong in form and rather Hat. having the thorax nearly sfuare; elytral strix not punetured; first joint of hind tarsi never longer than the next two. The males have the first foux joints of the front and middle tarsi dilated. the dilated joints scaly beneath. 'They occur beneath log's and rubbish, most commonly about the margin of cultivated fields. and for the most part are considered beneficial. though the largest and one of the most common. H. caliginosus, is a seed eater and it is claimed feeds largely upon clover and grass seeds. In 19 specimens dissected by Ir. Forbes, only about 12 per cent. of the food was of animal origin. principally caterpillars and ants, while seeds and other tissues of grasses made up $1 \pm$ per cent. The only paper treating of the genus is by

LeConte._" Notes on the Species of Harpalus Inhabiting' America North of Nexico,' in Proc. Phil. Acad. Nat Sci., 1865, 98-104.

The genus is a ]arge one, about 50 species being known from the United States. Of these 17 have been taken in Indiana. while eight others perhaps occur. For convenience the Indiana species mar be divided into two groups: 
KEY TO GROUPS OF INDIANA HARPALUS.

a. Elytra without a dorsal puncture on the third interval. Group $A$. aa. Flytra with a small dorsal puncture on the third interval behind the middle and near the second stria.

Group $B$.

\section{Group A.}

To this group as defined above belong our largest and most common species. In the keys which follow the "accessory setæ" refer to long bristles located about midway between the ambulatorial setri and the side of the abdomen.

\section{KEY TO INDLANA SPECIES OF GROUP $A$.}

a. Elytra distinctly, sometimes deeply, sinuate at tip; abdomen without accessory setæ.

b. Color above not (or very rarely) black or piceous; thorax distinctly narrower behind the middle; elytra deeply sinuate, outer angle acute in female.

c. Pale reddish-brown above, elytra often darker; body elongate; length 14 or more.

330. ERRATICUS.

cc. Metallic green or coppery (very rarely black) ; length 9.5-10 $\mathrm{mm}$.

VIRIDLANEUS.

6b. Uniform black, piceous or dark reddish-brown above; elytra much less deeply sinuate, the outer angle not acute in female.

d. Mentum not toothed; legs black; length 21-25 $\mathrm{mm}$.

331. CALIGINOSUS.

dd. Mentum toothed; legs and antennæ reddish-brown.

e. Uniform piceous or dark brownish-red above; thorax nearly square, its side margins depressed, scarcely wider behind.

f. Intervals of elytra more or less convex; sides of thorax feebly rounded; length $12.5 \mathrm{~mm}$.

332. FAUNUS.

$f f$. Intervals flat; sides of thorax more rounded in front; length 10.5-12 min.

333. Convivus.

ce. Uniform black above.

\%. All the intervals of elytra of female densely ;un tate; in male those on sides only; length $13.5-15 \mathrm{~mm}$.

334. VAGANS.

$g g$. Discal intervals of elytra of female not or sparingly punctate.

h. Thorax slightly narrowed in front, not narrowed behind; region of the basal angles strongly depressed, densely punctate.

385. PENNSYLVANICUS.

hh. Thorax slightly narrowed behind, not narrowed in front; region of the basal angles feebly depressed.

i. Larger, $13.5-16 \mathrm{~mm}$.

$j$. Thorax one-third or more broader than long; sides of elytra not punctulate.

336. COMPAR.

jj. Thorax nearly as long as broad; sides of elytra finely punctulate.

337. LONGIOR.

ii. Smaller, 10.5 12 mm. : margin of thotax namowly reddishbrown, translucent.

33S. ERYTHROPUS. 
ar. Elytra very slightly or not at all sinuate at tip; abdomen with accessory setæ on sides, arising from distinct punctures; mentum tooth entirely wanting; body oblong-oval; color uniform pale brownish-yellow.

339. TESTACEUS.

330 (1079). IIarpalus erratices Say, Trans. Amer. Phil. Soc.. II, 182:3, 27 ; ibid. II, 455 .

Elongate, parallel. Reddish-brown above; under surface and legs reddish-yellow. Thorax slightly broader than long, basal impressions broad, shallow, rather closely and finely punctate; hind angles obtuse, slightly rounded. Elytra very deeply sinuate at tip, outer angle of sinuation acute and toothed in female; striæ deep; intervals convex. Length $14.5-18 \mathrm{~mm}$.

Throughout the State in sandy localities; frequent. April 10. October 25. Sometimes taken at electric light.

H. viridiremus Beauv., has been taken by Wolcott and others along the beach of Lake Michigan at Chicago. It undoubtedly occurs in Lake and Porter counties, but no authentic Indiana specimen is at hand.

331 (1083). Harpalus caliginosus Fab., Syst. El., I, 1801, 188.

Elongate, robust. Black; antennze and tarsi reddish-brown. Thorax broader than long, as broad at base as elytra, narrower in front; basal impressions broad, shallow, densely and finely rugose-punctate; hind angles rectangular. Elytra deeply striate; intervals moderately convex. Length 21-25 mm. (Fig. 79.)

One of the most common of eur large beetles. Occurs everywhere throughout the State and sometimes attracted by thousands to the electric lights of the larger cities. One of these swarms occurred in Tndianapolis June 14. 1900. Often seen roaming about in daytime in stubble and cornfields. and in early autumn feeding upon the seeds of ragweed. The female of a pair in copulation was noted so feeding September 16. She removed. bit into and devoured a seed kernel every 40 seconds. this being the arerage time during fifteen minntes' observation. April 6-Norember 21.

332 (1084). Harpales faunus Say. Trans. Amer. Phil. Soc. II. 1823. 28 ; ibid. II, 457.

Oblong, parallel. Uniform dark reddish-brown; antenn:e and legs pale. Thorax as broad as long, sides feebly rounded: basal impressions broad. shallow, distinctly punctured, the punctures extending across the base. Elytral striæ moderately deep. intervals alutaceous, the fifth and seventh. and sometimes the apical portion of the third with a row of dorsal punctures in the female. Length 11-12 $\mathrm{mm}$.

Throughout the State; frequent. April 26-September 20.

333 (1085). Harpaius convivus Lec., Proc. Phil. Acad. Nat. Sci.. 1S65. 102.

slightly smaller and more narrow than faumus. which it resembles 
closely in color and structure. Thorax more rounded on the sides in front, distinctly transverse. very slightly narrowed behind and with deeper basal impressions. Length $10.5-11.5 \mathrm{~mm}$.

Marion. Vigo and Crawford counties; rare. May 20-November 8 .

$334(1086)$. Harpalus ragans Lec.. P'roc. P'hil. Acad. Nat. Sci., 1865, 102.

Elongate-oblong. Blackish-piceous: antenne, palpi and legs reddishbrown; under surface reddish-yellow. Thorax slightly broader than long, feebly narrowed behind the middle, hind angles obtuse; basal impressions shallow, rather broad, ill defined, densely and finely punctate. Elytral strix shallow; intervals strongly alutaceous. flat, densely and finely punctate in the female; subconvex. the fifth to eighth sparsely punctate in the male. Length 13.5-14.5 $\mathrm{mm}$.

Southern two-thirds of the State; scarce. April 6-October 17. The females of this species are easily recognized. The males can be told from those of pennsylvanicus by the thorax being narrowed behind, and from those of compar, which they closely resemble, by the punctures of fifth to eighth intervals.

*335 (1087). Harpalls Pennsylvanicus Dej., Spec. IV, 1828, 108.

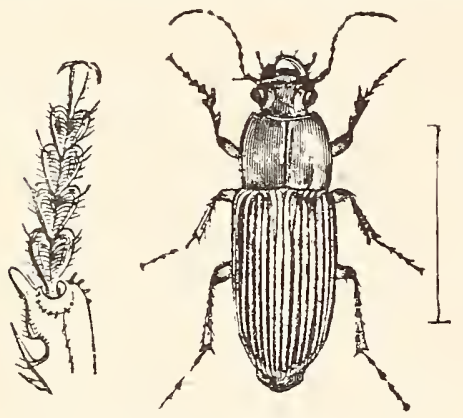

Fig. 96. (After Riley.)

Oblong-robust, subparallel. Black, moderately shining; antennæ and legs reddish-yellow; under surface dark reddish-brown to piceous. Thorax broader than long, sides gradually curved, base as wide as elytra. hind angles obtuse; margin in front of the angles depressed and, together with the large basal impressions, densely and finely punctate. Elytral strixe moderately deep; intervals convex, alutaceous. the fifth to eighth with numerous small punctures in female. very sparsely punctate in male. Length 13-15.5 mm. (Fig. 96.)

Common throughout the State. February 6-October 10. Often seen at electric lights. Feeds on ragweed and other seeds and also on caterpiliars, etc.

\section{6 (1087a). Marpalts compar Iec., Ann. Lye. Nat. Hist., IV, 1S48, 395.}

Resembles pensylvanicus but distinguished by characters given in key. Thorax quadrate, broader in proportion to its length $(5.5 \mathrm{x} 4 \mathrm{~mm}$.), much less depressed in region of hind angles; elytral intervals alutaceous. 5 to $\mathrm{s}$ not punctate in either sex. Length 14-16.5 mm.

Throughout the State; Irequent. April 9-October 17. This and the next two are listed by Henshaw and others as varieties of pennsylvanicus, hut in my opinion are valid species; the separating 
characters. when once rocognized, being more evident than in many of the species of Bembidium. 'hlcrims and other genera of the family.

337 (1057b). Marpalus ronglor Kirby, Faun. Bor. Amer., IV, 1S:38, 43.

Elongate. narrower than the tro preceding. Thorax about as long as broad (4.5 $\mathrm{x} 4 \mathrm{~mm}$.), gradually narrower behind the middle, distinctly marrower at base than in compar: hind angles obtuse; basal impressions wide. shallow, densely punctate. Elytra alutaceous, intervals of male subconrex. the fifth to eighth finely and sparsely punctate. Length 13.5-15 mm.

Marion, Vigo and Floyd counties; scarce. June 2-September 11 .

338 (10S7c). Harpalus nrythropus Dej., Spec. IV, 1S28, 258.

Oblong. Thorax nearly square, slightly narrowed behind, sides feebly curred, hind angles but little rounded; basal impressions broad, shaliow, finely and densely punctate. Elytral intervals alutaceous not punctate. Length $10.5-12 \mathrm{~mm}$.

Southern half of State. common; less so northward. April 27October 5. A pair were taken mating on September 29.

339 (1119). Harpalus testaceus Lec., 'Trams. Amer. Phil. Soc., X, 1853, 385.

Oblong-oral. Color given in key. Thorax one-half broader than lons. sides feebly curved to behind the middle, thence sinuate to base; margin rather broad, depressed, with a row of punctures; hind angles rectangular, basal impressions small, sparingly punctate. Elytral striæ deep; intervals convex. Length 10-10.5 $\mathrm{mm}$.

Starke and Posey counties; scarce. August 23-September 19. Occurs in sandy localities. 'The hind angies are more prominent than in any other species of Harpalus.

\section{GRoup B.}

The species of this group average much smaller than those of Group $A$.

\section{KEY TO INDIANA SPECIES OF GROCP B.}

a. Elytra obliquely but distinctly sinuate at tip; abdomen without accessory setie.

b. Bicolored above; head and thorax reddish-brown, elytra black or piceous.

c. Thorax scarcely narrowed behind; basal depressions shallow, finely punctured.

340. Dichrots.

cc. Thorax distinctly narrowed behind; basal impressions deeper, more coarsely punctured.

341. TULPECTLUS.

bu. Uniform black or piceous abore.

d. Legs reddish-brown; extreme margin of thorax pale. 
c. Thorax distinctly narrowed behind, sides not depressed, base not punctured; elytra not alıtaceous.

$f$. Length $9.5-10 \mathrm{~mm}$.

SPADICEIS.

$f f$. Length $7.5-8 \mathrm{~mm}$.

342. AUTUMNALIS.

ee. Thorax not narrowed behind.

g. Body oblong-oval; thorax not distinctly narrowed in front.

h. Hind angles of thorax obtuse or but vel'y slightly rounded.

$i$. Base of thorax finely punctured; length $8.5-10.5 \mathrm{~mm}$.

FALLAX.

ii. Base coarsely punctured; epipleura reddish-brown; length 7.5-10 mm.

PLEURITICUS.

$h h$. Hind angles distinctly rounded; thorax one-half wider than long; length 8-10 mm.

343. Herbivages.

$g g$. Body nearly elliptical; thorax narrowed in front.

j. Elytra alutaceous; sides of thorax feebly depressed; length $8.5 \mathrm{~mm}$.

OPACIPENNIS.

ij. Elytra not alutaceous; sides of thorax not depressed; length $6-7.5 \mathrm{~mm}$.

344. NITIDULUS.

11. Legs, or at least the femora, black or piceous; margin of thorax not paler.

7. Head decidedly narrower than thorax.

l. Thorax not much wider than long: tibire and tarsi reddishbrown; length 9-9.5 $\mathrm{mmm}$.

IN NOCUUS.

11. Thorax distinctly wider than long; legs wholly black; length 10-11.5 $\mathrm{mm}$.

RUFIMANCS.

Fi: Head very large. scarcely narrower than thorax.

$m$. Sides of thorax distinctly depressed, hind angles rectangular: length $12-14 \mathrm{~mm}$.

345. LATICEPS.

$m m$. Sides of thorax not depressed, hind angles rounded at apex: length 18-14 mm.

346. VIDUUS.

a . Elytra very slightly sinuate at apex; abdomen with accessory setre: piceous, thorax and elytra greenish-bronzed.

GRAITS.

340 (1076). Harpalts dichrous Dej., Spec. IV. 1S2S. 258.

Oblong-oval. Color given in key; elytra strongly iridescent; antenne and legs pale. Thorax broader than long; sides broadly rounded, rather widely depressed; hind angles obtuse, somewhat rounded; base finely punctured. Elytral stria deep; intervals convex. Length 10-11. mm.

Throughout the State; frequent. April 26-November 20. Occurs beneath logs in dry. open woods. Due to its iridescence and bicolored upper surface, this is the prettiest member of the genus.

341 (1077). Harpalis vulpectels Say, Trans. Amer. Phil. Soc., II, 1S23, 30 ; ibid. Il. $458,545$.

Oblong-oval. Color of dichroms, the elytrit ustally paler and less iridesrent. Thorax broader than long. sides rounded in front, oblique and distinctly converging behind; him angles rectangular. Elgtral striat moderately deep; intervals convex. Length $8.5-9.5 \mathrm{~mm}$. 
Throughout the State: frepund in the southern counties. Iess so northward. April 10-September 6 .

H. spadiceus Dej. is said to occur from New Jersey westward.

342 (1075). Harpales autumalis Say. Trans. Amer. Phil. Soc., II, 152:3. 48 ; ibid. II, 473.

Oblong-oral. Black or piceous. shining: antenne, legs and narrow edge of thorax reddish-brown. Thorax mearly square, sides feebly curred to behind middle, thence straight and conrerging to base; hind angles obtuse: basal impressions distinct, small, narrow. Elrtral strie fine; interrals flat. Length $7.5-8 \mathrm{~mm}$.

Lawrence and Crawford counties: scarce. May 11-May 26. Occurs on high dry hills. Resembles herbi?agus but smaller. more shining and with basal impressions of thorax deeper and more narrow.

H. fallax Lec. and $H$. pleuriticus Kirby are both recorded as occurring from "New Tork. New Jersey and westward." The lastnamed is a boreal speries and if found in Indiana it will probably be in the northern counties.

343 (1094). Harpalis herbiyagts Say, Trans. Amer. Phil. Soc., II, 1523. 29; ibid. II, 45 \%.

Oblong-oral. Black or piceous: narrow margin of thorax and elytria reddish. translucent; under surface piceous; antennie and legs reddishbrown. Thorax one-half wider than long; basal impressions rather shallow. ill-defined, sparsely and finely punctured : region of hind angles slightly depressed. Elytra alutaceous, the strice shallow; intervals feebly convex. Length $\mathrm{S}-10 \mathrm{~mm}$.

Throughout the State: common. April 1-October 21.

II. opacipenis Hald. is recorded as occurring from Pennsylrania to Kansas.

$34 t$ (1098). Harpalus ritidulus Chaud., Bull. Mosc. IV, 1st3, iss.

Elliptical. Piceous, strongly shining both above and beneath; marrow margin of thorax reddish; antennie and legs reddish-brown. Thorax quadrate. slightly wider than long. sides feebly curred. hind angles rounded; basal depressions rel⿳亠丷厂 small and shallow. not punctured. Elstral strie lather deep; interrals slightly conrex. Length $5.5-\bar{t}$ mm.

Southern half of State; scarie. April 11-July 2.

$H$. innocuns Lec. and $H$. rufimunus Lec. are both boreal species, described from Lake Superior and since taken in New York and Pennsylvania. which may occur in northern Indiana.

*345 (1107). Harpale's Laticeps Lec., Agass. Lake Sup. 1S50, 20 S.

Oblong-oval, robust. Black, shining: antennce and tarsi reddish-brown. tibix piceous. Thorax one-third broader than long, as broad at base as ely- 
trit, hind angles rectangular: basal impressions distinct, rather broad, finely and sparsely punctured. Elytral striæ rery fine; intervals flat, minutely alutaceous. Length $12-15 \mathrm{~mm}$.

Franklin, Monroe and Vigo counties; scarce. May 8-December 18." Readily known by the black legs and broad head. Occurs in sandy upland woods.

346 (1108). Harpalus viduds Lec., Proc. Phil. Acad. Nat. Sci., 1865, 103.

Oblong-oval. Black or piceous, shining; antennæe and tarsi dark reddish-brown. Resembles laticeps, but the head is not quite so broad, the hind angles of thorax are more rounded and the basal impressions more narrow and deeper. Length $13 \mathrm{~mm}$.

Known from Indiana by two specimens taken in Vigo and Parke counties. May 13-May 24. Described from Rock Island, Illinois.

$H$. gravis Lec., $9 \mathrm{~mm}$. in length, was described from Texas and has been recorded by Dury from Cincinnati.

\section{Selenophorus Dej. 1826. (Gr., "moon or light + bear- ing." )}

Small oblong or oval, black or piceous beetles, closely resembling the smaller forms of Harpalus hut differing by having three rows of dorsal punctures, situated on the second, fifth and seventh elvtral striæ. The males have the front and middle tarsi moderately dilated, with two rows of scale-like papillix on the first four joints. They occur, for the most part, in sandy or dry localities. Four species have been taken in Indiana. while one other perhaps oceurs. The literature treating of the genus is as follows:

Horn.- "Critical Notes on the Species of Selenophorus of the

United States," in Proc. Amer. Phil. Soc., XIX, 1880, 178.

Horn.- "Synoptic T'able," in Buli. Brook. Ent. Soc., V, 1882, 8.

KEY TO INDIANA SPECIES OF SELENOPHORUS.

a. Prosternum obtuse at tip, not margined:

b. Upper surface with a bronzed lustre; elytral punctures very small, the intervals smooth; length $5-6.5 \mathrm{~mm}$.

347. PEDICULARIUS.

6b. Upper surface black, more or less iridescent.

c. Thorax as wide or wider at base than apex.

d. Outer interval not punctulate; length $7.5 \mathrm{~mm}$. 348. Gagatixus. $d d$. Outer interval of elytra finely punctulate; length 9-10 $\mathrm{mm}$.

349. OPALINUS.

cc. Thorax distinctly narrowed at base, hind angles obtuse; marginal intervaì punctulate; length $6.5 \mathrm{~mm}$.

IRIPENNIS.

a . Prosternum horizontal. tip slightly prolonged and margined; thorax broader at base than apex, its sides nearly regularly curved.

350. ELLIPTICUS.

* The H. montanus of my paper, "The Winter Insects of Vigo County, Indiana," Psyche, Feb., 1896339. 
317 (1125). SELExophort's PEDICULARIt's Dej., Spec. W. 1828, 100.

Oblong-oral. Piceous, shining, surface bronzed; antennæ dusky, the basal joints and legs reddish-bromn. Thorax quadrate, slightly broader at base than apex; sides curred. hind angles obtuse, basal impressions scarcely distinct. Elytra alutaceous. finely striate; intervals flat, smooth, the outer one punctulate; apex feebly sinuate. Length $5-6.5 \mathrm{~mm}$.

Lake. Vigo and Crawford connties; scarce. April 5-August 17.

348 (1130). Selexophorus Gagatixus Dej., Spec. IV, 1S2S, 112.

Oblong. Black, iridescent; femora piceous; antennæ, tibiæ and tarsi reddish-brown. Thorax quadrate, slightly broader than long; margin very narrow, not translucent; hind angles obtusely rounded; basal depressions evident but shallow, finely and sparsely punctate. Elytra slightly wider than thorax, the punctures scarcely risible; intervals slightly conrex. Length $7.5 \mathrm{~mm}$.

Crawford County; scarce. May 16. Occurs beneath stones on high, dry hills.

349 (1131). Selexophorus opalixus Lec., List Col. N. Amer., 1S63, 13.

Oblong-oral. Black, strongly iridescent; antennæe and legs reddish-yellow. Thorax one-third broader than long, base as wide as apex, sides feebly: curred; margin narrowly flattened and translucent; basal impressions obsolete, the base finely and sparsely punctate. Elytra rather deeply striate: intervals feebly convex, minutely and sparsely punctate. Length 9-10 mm.

Throughout the State; frequent. April 16-July 25. Our largest species. Oecurs beneath bark.

S. iripennis Say is known from Illinois. Georgia and Texas, and probably occurs in southern Indiana.

350 (1134). Selexophorus Ellipticus Dej., Spec. IT, 182S, 10 S.

Oblong-oral or elliptical. Black, subopaque, alutaceous; antennæ and legs reddish-yellow. Thorax as wide as elytra, their margins nearly continuous; hind angles rectangular, basal impressions indistinct. Elytra finely striate; intervals fiat or nearly so, the dorsal punctures very small. Lengtl $5-6 \mathrm{~mm}$.

Lake, Laporte, Vigo and Crawford comnties; scarce. April 21September 10. Occurs beneath cover in sandy Iocalities.

LXIX. Stenolophus Dej. 1829. (Gr., "narrow+neck.")

Small brownish or piceous oblong beetles having the elytral strix not punctate; third interval with a small dorsal puncture behind the middle and very close to the second stria ; front and middle tarsi of males as in Selenophorus. For literature treating of the genus see above under Agonodems. Our species hibernate beneath 
logs and rubbish in dry or sandy places, and some of them are very common on the wing during the first warm days of March or April. Six species and one variety have been taken in Indiana.

KEY TO INDIANA SPECIES OF STENOLOPHUS.

a. Thorax but little narrower than elytra; body stout; front and midrile tarsi of male broadly dilated.

b. Sides of thorax broadly flattened, scarcely reflexed; black, feebly shining; length $7-7.5 \mathrm{~mm}$.

351. CARBONARICS.

bb. Sides of thorax narrowly margined, the margins not reflexed.

c. Basal impressions of thorax broad and shallow; black, shining. elytra piceous or brownish-yellow, slightly iridescent; length 7 $7.5 \mathrm{~mm}$.

352. FUliginoses.

cc. Basal impressions of thorax small, rounded, not or very sparingly punctured.

d. Thorax with disk distinctly black or piceous, the margin reddishbrown; length $5 \mathrm{or}^{\circ}$ more $\mathrm{mm}$.

e. Pale margin of thorax narrow; elytra wholly black.

353. PLEBEJU'S.

ee. Pale margin of thorax broader; elytra dull reddish-brown, the tips darker.

353a, var. Fuscatus

dd. 'Thorax either uniform reddish-brown or piceous, without distinct blackish discal spot; length not over $4.5 \mathrm{~mm}$.

354. conJunctus.

a . Thorax distinctly narrower than elytra; body more slender ; front tarsi of male moderately dilated, fourth joint deeply bilobed.

f. Thorax and elytra black or piceous, with narrow paler margin; sutural stria long, joining the first dorsal. 355. ochropezus.

ff. Thorax brownish-yellow; elytra iridescent black with brownish-yellow side margins; sutural stria short, not joining first dorsal.

DISSIMILIS.

351 (1135). Stenolophus carbonarius Dej., Sp. Gen., IV, 1828, 398.

Elongate-oblong. Black, feebly shining; first joint of antennæ, tibiæ and tarsi brownish. Thorax as broad at middle as elytra; sides rounded into base; margins flattened, especially near hind angles; basal impressions broad, shallow, sparsely and finely punctate. Elytra alutaceous, the sutural stria long, the others deep. Length 7-7.5 mm.

Putnam County; rare. October 17. Sifted from debris near a hillside spring.

352 (1138). Stenolophus fuliginosts Dej., Spec. IV, 1828, 423.

Oblong-oval. Color given in key; tarsi, base of antennæ and narrow margin of thorax brownish-yellow ; femora and greater portion of antennie darker. Thorax subquadrate; as long as broad, hind angles broadly rounded. Elytral striæ rather deep; intervals moderately convex. Length $7-7.5 \mathrm{~mm}$.

Throughout the State; frequent. Hibernates. January 1-October 21. 
353 (1139). Stenolopily Plebejts Dej., Sper. IV, 1N2\%, 424.

Elongate-oblong. Piceous black, shining; legs. base of antenna and narrow margin of thorax brownish-yellow. Thorax feebly narowed behind; basal impressions small, rounder, each with but two or three punctures; hind angles strongly rounded. Elytra with sutural stria fine, short, cblique, not joining the first dorsal. Length 4.55 nim. (Fig. 97.)

Sontherin half of State; searce. March 21August 17. Closely resembles ochropezus, but

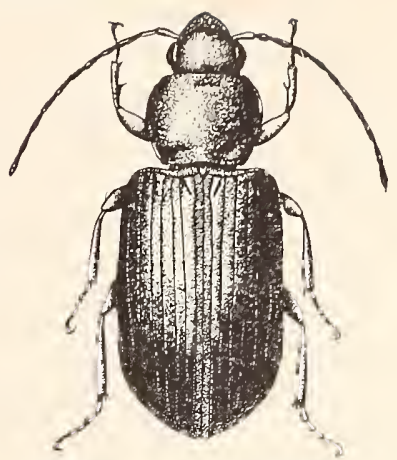

Fig. 97. $\times 6 .^{\circ}$ (Original.) readily distinguished by the comparatively broader thorax and different sutural stria.

353a (- - . Stenolophus plebejus fuscatus Dej., Sp. IV, 1S2S, 426.

A distinct variety of plebejus having the disk of thorax black, with broad, pale margins; elytra dull red, the tips irregularly fuscous. Basal impressions of thorax deeper and without punctures. Length $5.5 \mathrm{~mm}$.

I ale County; frequent, beneath rubbish along the beach of I ake Nichigan. April 29-May 14.

*254 (1140). Stenolophus conjunctus Say, Trans. Amer. Phil. Soc.. II. 1823, 90 ; ibid. II, 504.

Oblong. Piceous, shining; legs and base of antennæ reddish-brown. Thorax broader than long, the sides broadly rounded into base, so that hind angles are wanting. Elytral striæe fine; intervals flat. Length $3.5-4.5 \mathrm{~mm}$.

Throughout the State; common, especially in sandy localities. Iibernates. Abindant on the wing in early spring and at electric lights. February 6-December 3. The smaller size and uniform color cf thorax readily distinguish this species.

*355 (1145). Stenolophus ochropezus Say, Trans. Amer. Phil. Soc.. II,

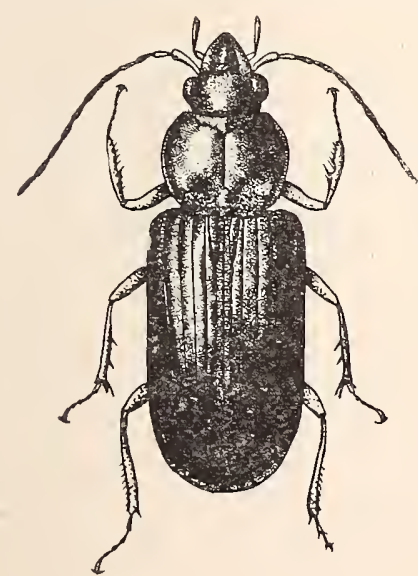

Fig. 95. $\times 6, \quad(0)$ riginal. $)$ 1 S29. 54 ; ibid. II. 478 .

Elongate-oblong, rather slender. Black or piceous, the elytra often iridescent; legs and base of antennae pale. Thorax scarcely wider than long. convex; hind angles obtuse, rounded; basal impressions broad, shallow, sparsely but distinctly punctured. Elytral striae rather deep, especially toward the tip; intervals flat. Length $5.5-6$ mm. (Fig. 9S.)

Throughont the State; common. Hibernates. Jannary T-October 17. 'The sutural stria of elytra is longer and deeper than in the other species. 
356 (1146). Stenolophus dissimilis Dej., Spec. IV, 1824, 424.

Resembles the preceding. Readily distinguished by the black head. yellow thorax and black and yellow elytra. Thorax with narrower margin and more rounded hind angles. Length $6-\tau \mathrm{mm}$.

Posey County: rare. November 8.

\section{Acupalpes Latr. (Gr., "slender + palpus."')}

Very small oblong black or piceous beetles, distinguished from stenolophus, with which they were formerly grouped, by the characters given in generic key. The last joint of the labial palpi is rather stoutly oval, but slender at tip. whence the generic name. For literature see:

LeConte-In Proc. Phil: Acad. Nat. Sei., 1868, 377-378.

Horn.-In Bull. Brook. Entom. Soc., VI, 1883, 15.

Two of the five known species have been taken in Indiana. They have but one dorsal puncture. as ustial, on the second stria; hind angles of thorax obtuse. somerhat rounded; frontal suture more distinct than in the other forms.

KEY TO INDIANA SPECIES OF ACLPALPCS.

a. Head brownish. scarcely narrower than thorax and almost as long; eyes small; elytra oral.

357. HYDROPICUS. a . Head black or piceous, distinctly narrower than thorax; eyes larger, more prominent; elytra oblong-oval, iridescent. 35S. CARUS.

357 (1149). Acupalpus hydropicus Lec., N. Spec. N. Amer. Col., I, 1863, 17.

Oblong-oral, convex. Head and thorax dark brown, strongly shining; elytra piceous, the suture and narrow margins paler; antennæ and legs dull yellow. Thorax trapezoidai, a little broader than long. narrowed behind. rounded on the sides only before the middle; basal impressions broad, distinct, sparsely punctured. Elytral strix rather deep; interrals subconvex. Length $3 \mathrm{~mm}$.

Starke and Narshall counties; scarce. Nlay 20-June 16.

358 (1150). Acupalpus carus Lec., N. Spec. N. Amer. Col.. I. 1863, 18.

Elongate-oral, subconvex. Thorax either dusky yellow or piceous; elytra piceous, iridescent; antennie dusky, the basal joints and legs pale. 'Thorax subquadrate, a little broader than long; sides feebly curred from apex to base; hind angles rounded; basal impressions rather deep, obsoletely punctate. Elytral strix fine; intervals flat. Length 2.5-3 mm.

Throughout the State; frequent. March 26-October 17. Occurs beneath bark and stones in damp localities. Easily distinyuished from hydropicus by the narrower head, dusky antennæ and less narrowed base of thorax. 
LXXI. Bradycelles Er. 18:2. (Gr.. "slow+footed.")

Small brown or piceous bettles known from allied genera by the mentum bearing a rather large acute tooth. The elytra are obliquely but feebly sinuate at tip and the second strix bears a dorsal puncture behind the middle. Two species hare been taken in Indiana. while three others perhaps occur. For literature see above under Agonoderus.

\section{KEY TO IXDIAXA SPECIES OF BRADYCELLCS.}

a. Form rery elongate: thorax with a deep marginal line. its basal impressions long and deep; middle tarsi of male with small scales beneath.

3.59. LINEARIS.

a a. Form much less elongate: thoracic margin narrow; basal impressions short, not deep: middle tarsi of male without scales.

b. Hind angles of thorax broadly rounded. scarcely punctured: length $3.2 \mathrm{~mm}$.

NEGLECTLS

b7. Hind angles of thorax distinct.

c. Thorax without punctures near the hind angles: length $5 \mathrm{~mm}$.

CORDICOLIIS

cc. Thorax distinctly punctured.

d. Basal impressions broad. shallow. strongly punctured: sides obliquels subsinuate near base; length $4.5 \mathrm{~mm}$.

360. RLPESTRIS.

dd. Basal impressions broad. sparsely punctured; sides scarcely sinuate near base: length $3 \mathrm{~mm}$.

TAXTILLES.

359 (1154). Bradrcellts linearis Lec. ‥ Sp. N. Amer. Col.. I. 1S63. 16.

Elongate. subdepressed. Dark reddish-brown to piceous. shining. the margins usually paler: antenne reddish-brown. the two basal joints an! legs dull rellow. Eyes rery small. Thorax much longer than wide. side: curred in front. sinuate behind the middle: base distinctly narrower thin apex: disk with a deep entire median impressed line. a number of coarse punctures near apes and in the basal impressions: hind angles rectangular. Elstra at base wider than thorax. long and parallel: strixe deep. the scutellar one represented by a large puncture: interrals conrex. Length $5.5 \mathrm{~mm}$.

Knox County; rare. April 20. In form of bodr and general appearance it resembles a small Pterostichus.

$B$. neglectus Lec.. black or piceous with legs and antennit pate. and $B$. cordicollis Lec.. black with legs pale. are both boreal species which may occur in northern Indiana. $B$. tantillus Dej.. black or piceous with pale legs and antennæ. mar also occur in the State.

[1:3-23402] 
*360 (1158). Bradjcellts rupestris Say. Trans. Amer. Phil. Soc.. II. 1S23. 91 ; ibid. II. 505. 547.

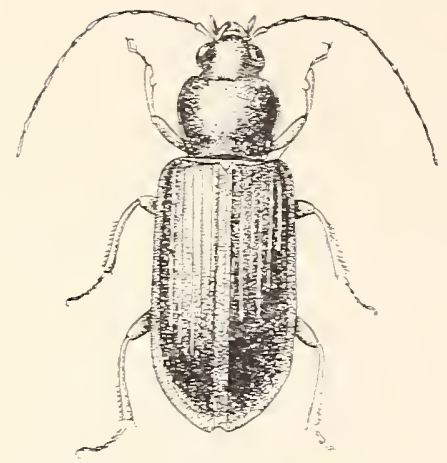

Fig. 99. $\times 6 \frac{1}{2} . \quad$ (Original.)

Oblong. slender. Reddish-bromn, shining: the head and disk of elstra usualls piceous: antennæe dusky, the two basal joints and legs pale. Thorax wider than long. narrowed behind the midale; basal impressions broad. shallow; coarseIs punctured; hind angles distinct but obtuse. Elytral striæe deep: intervals conrex. Length $4.5-5 \mathrm{~mm}$. (Fig. 99.)

Throughout the State: common. January 6-October 5. On the wing with the species of Agnmoderus in early spring.

LXXII. TACHXCELLUS IIorar. 1862. (Gr.. "swift +footed.")

Small oblong brownish or piceous beetles. differing from allied genera in having three joints of the antenna smooth. The joints mas not be entirely hairless. but lack the fine pubescence corering those which follow. Both the front and middle tarsi of the males have two rows of small scales (squamules) beneath: body throughout glabrous: elytra normalle striate and with a single dorsal puncture. Three species have been taken in Indiana. while a fourth perhaps occurs. Ther rrere included with Bradycellus by LeConte in his paper cited under Agonoderus. The following is the latest paper on the genus:

Fall. H. C._ "On the Affinities of the Genus Tachrcellus." in .Journ. N. Y. Ent. Soc. XITT. 1905. 169-178.

KEI TO TMDIANA SPECIES OF TACHYCELLLS.

1. Antemne with two glabrous joints, the third pubescent on apical half: upper surface wholls black.

361. NIGRINCS.

an. Antenne with three basal joints wholly glabrous.

b. Hind angles of thorax rectangular.

c. Thorne wider at base than long. its color piceous with a rery narrow pale edge.

KIRBI.

cc. Thorax not wider at base than long. dull sellow with a large central piceous spot.

362. ATRIMEDICS.

†7. Thorax with hind angles obtuse. its color as in Firbyi.

363. BADIIPEXYIS.

361 (1164). TAChYCELles xtgrixt's Dej.. Spec. Gen.. IT. 1S2S, 399.

Oblong. Black. shining: upper lart of tibie and first joint of antenn ledrlish-yellor. Thorax abuht as wide as long. broadest in front nf middle: siles learly balallel from a little belind the middle to base: hind angles

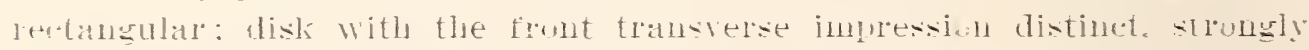

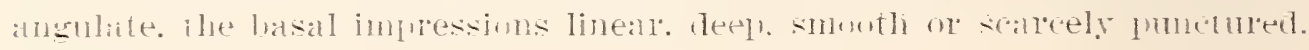
Length $5.5-15.5 \mathrm{~mm}$. 
Lake County ; rare. June ב. I simplespecimen taken he Wol cott near Indiana. Harbor. The therax is less narrowed behind than in the other two species. Previonsly lecorded from "Alaska, Lake Superior, New Mexico and Northern California.",

T. Tivbyi Horn, $6 \mathrm{~mm}$. in length, piceous, with base and sides of elytra paler and hind angles acutely rectangular, is known from Ontario and Ohio.

*362 (1166). Tachrcellus atrimedies Say, Trans. Amer. Phil. Soc. II. 1823, 39 ; ibid. II, 466.

Elongate-oblong. Pale reddish-brown abore, black beneath; head and disk of thorax black; disk of elrtra with an ill-defined blackish or piceous cloud; legs and three basal joints of antenne dull yellow. Thorax subquadrate, distinctly narrowed behind the middle, not wider at base than long; basal impressions broad, rather shallow, coarsely punctured. Elytral stria rather deep; intervals subconvex. Length 6.5-7.5 mm.

Throughout the State; frequent. Janiary 1-October 5.

*363 (1168). Tachycellus badilpenais Hald., Proc. Phil. Acad. Nat. Sci.. I, 1842. 302.

Elongate-oblong, rather slender. Head and thorax black; antennæe and elytra piceous; legs. basal joints of antennæ and edge of thorax dull yellow. femora and tips of tibire often darker. Thorax about as long as broad; sides regularly rounded from apex into base; basal depressions deep, narrow, sparsely punctured. Elytral strixe fine; intervals flat. Length $5.5-$ $6.5 \mathrm{~mm}$.

Throughout the State: frequent. February 24-December $T$.

\section{Subtribe C. (ANISODACTYLI.)}

This group comprises the single genus:

LXXIII. ANisodactruts Dej.. 1829. (Gr.. "unequal-toed.")

A large genus of medium sized black, brownish or piceous beetles having the dilated joints of the tarsi of male spongy pubescent instead of scaly beneath. They occur in various situations, the majority being found in dry, upland. open woods, beneath logs and other cover. A number of our species hibernate and some of them are very common at electric light. Of 31 specimens dissected by Dr. Forbes, 21 per cent. of the stomach content was found to be of animal, and 79 per cent. of vegetable origin, mainly seeds, pollen of grasses, etc.. so that it is very doubtful if this genus can be classed among the beneficial Carabidx. The papers treating of the genus are as follows: 
Horn.- "A Review of the Speries of Anisodactylus Inhabiting" the United States," in Proc. Amer. Phil. Soc.; XIX, 1880, 162-178.

Iorn.-_Synoptic 'T'able," in Mnll. Brook. Ent. Soc., III, 1881, 83.

About 42 species are known from the United States, 19 of which have been taken in Indiana, while one other may occur. For conrenience the Indiana species are separated into three groups or subgenera.

KEY TO GROCPS OF JNDIANA SPECIES OF ANISODACTYLUS.

"a. Terminal spur of front tibice normal, slender; species hairy or glabrous.

a. Terminal spur of front tibise abnormal, either trifid or dilated at middle.

7. Terminal spur trifid. i. e., with a blunt tooth each side near base; species glabrous.

Group A.

b7. Terminal spur dilated at middle, without teeth at base; species usually glabrous.

Group $B$.

Group $C$.

\section{Group A. (T'Riplectus.)}

Oblong-oval species having the hind tarsi slender, as long as the tibiæ, the first joint as long as the next two, the fourth emargirate; elytra striate, intervals smooth, the third with one or more dorsal punctures; tips distinctly sinuate. But two species of this group have been taken, though another may occur.

\section{KEY TO INUTANA SPECTES OF GROUP A.}

a. Prosternum at middle smooth, not pubescent; clypeus with one bristlebearing puncture on each side.

7. Surface shining, black; legs black.

DULCICOLLIS.

b). Surface opaque, distinctly alutaceous; thorax narrowed from base to apex, widlest at base.

364. Rusticus. al. Prosternum at middle punctured and pubescent; clypeus with two bristle-bearing punctures each side; thorax nearly as wide at apex as at base.

365. CARBONARIUS.

A. dulcicollis Laf., $11 \mathrm{~mm}$. in length, is known from the Gult States and Missouri, and may occur in southwestern Indiana.

*36t (1180). Anisodactylus Rusticus Say, Trans. Amer. Phil. Soc., II,

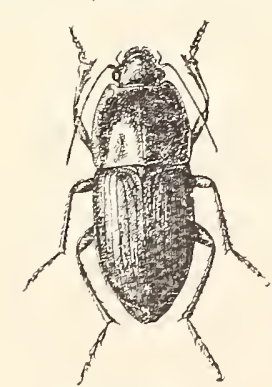

Fig. $100 . \times 2$. (Orıinal.)
1823,32 ; ibid. II, 460.

Oblong-oval. Brownish-black; base of antennie and region of hind thoracic angles reddish-brown; legs piceous. Thorax broader than long, as broad at base as elytra; sides feebly curved, hind angles obtuse; basal impressions rather shallow, not punctured. Elytra rather deeply striate; intervals convex, the third with one to four dorsal punctures behind the middle. Length 914 mnı. (Fig. 100.)

Common throughout the State, especially so in 
sandy localities. Tanuary 10-Norember 24. Gften seen running over plowed ground in early spring.

365 (1181). Axisodactrlus carbonarius Say, Trans. Amer. Phil. Soc., Il, 1823, 32 ; ibid. II, 460.

Elongate-oblong. Male, black, feebly shining; female, rusty, opaque; antennæe and legs piceous, tarsi reddish-brown. Thorax slightly broader at base than apex, sides feebly curved; hind angles obtuse; margins broarly depressed near base, finely and sparsely punctulate. Elytral intervais finely alutaceous, slightly convex in male, flat in female; the third punctured as in rusticus. Length 12.5-13.5 mm.

Throughout the state; common, but less so than musticus. March 19-October 17.

\section{Grocp B. (ANisodactylus.)}

Oblong species usually shining and glabrous; terminal spur, of front tibæ dilated at middle. Elytra striate, the second stria with a distinct dorsal puncture. Males with the front tarsi broadly, the middle tarsi rather feebly, dilated.

\section{KEY TO INDIANA SPECIES OF GROUP B.}

a. Black species; hind tarsi slender, equal to tibiæ, first joint nearly as long as the next two together; male with first joint of middle tarsus pubescent at tip.

b. Clypeus with one bristle-bearing puncture on each side.

c. Elytra opaque, the striæ feeble, especially at tip; hind angles of thorax obtuse, sides regularly curved, base as wide as elytra.

cc. Elytra shining in both sexes, more deeply striate.

366. FURVUS.

c. Elytra oblong, their sides nearly parallel; intervals feebly convex, distinctly but sparsely punctulate, feebly shining.

36\%. INTERPUNCTATUS.

dd. Elytra oral, their sides curved; intervals convex, smooth; form more robust, surface shining.

368. AGRICOLA.

bb. Clypeus with two bristle-bearing punctures each side.

$e$. Hind angles of thorax obtuse.

$f$. Side margin of thorax rery distinctly depressed, and with the base punctulate.

$f f$. Side margin of thorax scarcely depressed.

369. HARRISII.

$e e$. Hind angles of thorax distinct, nearly rectangular.

g. Elytra with sides nearly straight, subparallel; intervals distinctly but sparsely punctulate.

371. NIGRITA.

gg. Elytra with sides distinctly curred; interrals smooth, shining; form more robust.

372. MELATOPUS.

a a. Bicolored or metallic species; hind tarsi slightly flattened, shorter than the tibire, first joint but little longer than second: male with first joint of middle tarsus glabrous beneath.

$h$. Thorax piceous. bromnish-yellow at sides; length $11 \mathrm{~mm}$.

$h h$. Thorax entirely piceous; length 9-10 mm.

373. DISCOIDEUS.

374. BALTIMORENSIS. 
366 (1152). Anisodactirles furves Lec.. N. Spec. N. Amel. Col., I, 186\%. 14.

Oblong-oral. Black, the elytrat olatue; antemne dusky britrm, pale at base. Thorax rery little wider at base than apex, side margins feebly depressed; disk smooth at middle, densely and finely punctured at base. Elrtra alutaceous. only feebly sinuate near tips; finely striate; interrals flat. Length 11-12.5 mm.

Posey County: rare. May 11. A southern species whose range is given as "Georgia to Louisiana."

367 (11S6). Anisonactiles interptratatus Kirbj, Faun. Bor. Amer., IT. $1837,42$.

Oblong. subparallel. Black, shining. female slightly opaque; antennæ and legs piceous: basal joint of former and spot on rertex reddish. Thorax one-fourth broader than long, base and apex equal in width, sides broadly curred. margin narrowly depressed; hind angles lectangular, basal impressions deep; disk densely and finely punctured across the base, more sparse$1 \%$ at apex, the middle smootli. ILength 12-12.5 mm.

Lake. Laporte. Marshall and Tigo counties: scarce. March 26December 18. Occurs in sandr localities. Its general range is northern.

368 (11S7). Anisodactilus agricola Say. Trams. Amer. Phil. Soc., II. 1523. 33 ; ibid. II, 161.

Oblong. moderately robust. Black, strongly shining; antennie and tarsi reddish-brorrn. Therax broadest at midale, base and apex equal, hind angles rectangular; basal impressions distinct, nar'row, rather densely punctured. Elytra deeply striate; interrals convex, not punctulate. Length 12-14 $\mathrm{mm}$.

Tigo and Posey counties: scarce. April 28-July 20. The most robust and convex species of the group.

369 (11S8). Axisodactirts Harrisir Lec. N. Sp. N. Amer. Col.. 1S63. 14.

Oblong-oral. Black. strongly shining; antenna and tarsi reddishbrown. Thorax a little broader than long. distinctly depressed in the region of the hind angles. which are obtuse and rounded; median line distinct, basal impressions rather shallow. finely and densely punctured. Elstral striæ rather deep; intervals finely alutaceous. slightls convex, vel's finely and sparsels punctate. Length 11-11.5 mm.

Porter and Kosciuslio counties; rare. Mar 9-July 24.

370 (1159). Axisodactilts Nigernimes Dej., Spec. T, 1S29, 842.

Oblong-oral. Black, scarcely shining. Thorax broader than long. moderately convex: side margins slightly depressed at middle and not at all at hind angles; basal impressions small. shallow, sparsely and finels punctate. Elytra as in harrisii. Length 11-12 mm.

Southern half of State, frequent; Lake and Laporte counties. only in the north. April 22-October 21. 
371 (1190). Anisodactyuus nigrita idej.. Spec. IV. 1S29, 14!).

Very close to interpunctatus. Dr. Horn states (loc. cil. under gemus) that he could find no difference excejt that in nigritn there are two (clypeal punctures on ench side. while in interpunctutus there is but one. rength $12.5 \mathrm{~mm}$.

Lake and Kosciusko comnties; raxe. Jay 1-.July 5.

372 (1191). Anisodactyles mela xopes Hald., Proc. Phil. Acad. Nat. Sci.. I, 302.

Very similar to 1 . agricola; differs mainly in having two bristle-bearing punctures instead of one on each side of clypeus. This may be a constant difference, but I doubt its specific rank. Howerer, it is much used by Horn in his paper. on which my key is mainly based. rength 13-14 mm.

Kosciusko, Putnam and Knox counties; rare. Narch 25-August 18.

373 (1194). Anisodactylus discombers Dej.. Spec. Y. 1829, $\$ 31$.

Elongate-oblong. Piceous, shining; -antenne. legs and sides of thorax and elytra brownish-yellow. Thorax rery ittle wider than long. narrowed at base; sides curved in front, feebly sinuate behind. rely narrowly depressed; hind angles strongly rectangular, basal impressions short and deep, finely and sparsely punctate. Elytra wider than thorax. rather deeply striate; intervals smooth, slightiy conrex. Length $10.5-11.5 \mathrm{~mm}$.

Throughout the State; frequent in sandy lecalities. April 11July 24.

*374 (1195). Anisodactills batfurorexsis Say. Trans. Amer. Phil. Soc..

II, 1823. 33 ; ibicl. II. 461.

Oblong. rather slender. Pice us. shining; antennse. legs and elytra pale, the latter often with darker discal cloud. Thorax distinctly wider than long. basal impressions more shailow and sides more deeply sinuate behind; otherwise resembles discridcus, than which it is smaller. more depressed and less shining. Length 9-10 $\mathrm{mm}$.

Throughout the State; common. Tanuary 21-! Ingust 26.

\section{GrotP C: (HAPLOCENTRES.)}

This group is composed of species rarring much in size, shape and color and agreeing only in possessing the characters of the genus and in having the front tibial spur slender. and the elytra striate and sinnate at tip.

KEY TO INDINA SPECIES OF GROUP C.

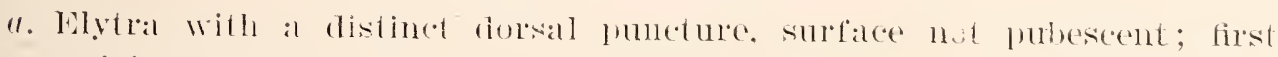

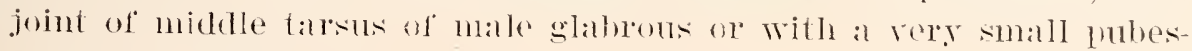
cent space beneath.

b. Interrals of elytria convex, distinctly and finely innctate: rertex with a red spot; length $12.5-14 \mathrm{~mm}$. 
$b b$. Intervals flat or iearly so, not punctate; head without red spot.

c. Species more or less oral. Amara-like, with usually a metallic or bronzed lustre.

d. Thorax widest at middle, the apex almost as wide as base; basal impressions not punctate; legs wholly pale.

e. Margin of thorax more or less flattened in the region of the hind angles; larger, 7.5 or more $\mathrm{mm}$.

$f$. Uniform piceous above; basal impressions rather narrow and shallow.

376. SAYI.

ff. Head and thorax piceous; elytra greenish-metallic; basal impressions distinct, very wide. 377. TERMINATUs.

$e e$. Margin of thorax not flattened; basal impressions indistinct: smaller, not over $7 \mathrm{~mm}$.

378. NITIDIPENNIS.

dd. Thorax widest at base, thence distinctly narrowed to apex: basal impressions distinct, finely and sparsely punctate; femor'a piceous; length $S \mathrm{~mm}$.

379. CEENUS.

ce. Species oblong, black without lustre; hind tarsi long and slender; length 11-12 $\mathrm{mm}$.

3S0. LUGUBRIS.

aa. Elytra without dorsal puncture; surface finely pubescent, densely punctulate; first joint of middle tarsus of male pubescent over half its surface.

g. Wholly black above; tibie and tarsi brown.

381. SERICELS.

gg. Head, thorax, antennæe and legs reddish-rellow; elytra piceous.

382. INTERSTITIALIS.

375 (1198). Anisodactylts verticalis lec., Ann. Lyc. Nat. Hist., IV. 1848,375 .

Elongate-oblong. Black, shining; base of mandibles and a quadrate spot on vertex red; antennæ and legs dull yellow. Thorax more than onehalf wider than long. narrowed behind; sides broadly rounded. margins distinctly reflexed, hind angles obtuse; basal impressions broad, densely and rather coarsely punctate. Elytra deeply striate; intervals convex. finely and densely punctate. Length 12.5-14 $\mathrm{mm}$.

Throughout the State: scarce. April 19-August 20. Occurs in sandy locations near water.

376 (1201). ANisOdaCtylus sayi sp. nov.

Eurytrichus piccus Lec., Ann. Lyc. Nat. Hist., IV, 1848, 388.

Elongate-oval. Uniform piceous, shining; narrow margin of thorax and region of hind angles, reddish, translucent; antennie and legs brownishyellow. Thorax a little broader than long. sides feebly curved; margin depressed behind the middle, hind angles rectangular. basal impressions shallow, ill-defined. smooth. Elytral strix fine; interrals finely alutaceous. flat. Length 10-10.5 mm.

Lake, Marshall. Tigo and Fulton counties; frequent. May 8September 28. This species resembles our common forms of Calathus and is doubtless often confused with them. As the genus Eurytrichus muder which LeConte described this form has been 
merged with Anisodrctylus, the name piceus is preoceupied by a West Coast species, the No. 1176 of the Henshaw Catalogue. I therefore propose the name sayi in honor of Thomas Say of New Harmony, Indiana. who was preëminently the father of American Entomology.

*377 (1202). Anisodactylus terminatus Say, Trans. Amer. Phil. Soc., II, 1823,48 ; ibid. II, 473.

Oblong-oval. Head and thorax dark brown or piceous, the edge of the latter reddish-translucent; elytra with greenish-metallic lustre; antennæe and legs pale yellow. Thorax one-third broader than long, sides regularly curved from base to apex. hind angles rectangular. Elytra as in the preceding. Length $7.5-8.5 \mathrm{~mm}$.

Throughout the State; frequent. April 15-December 25. In September, 1903, this species was noted as very common on the heads of the fireweed (Erechtites hieracifolia L.) in a deadening near Wyandotte Cave. Crawford Comnty, where it was feeding on the seeds.

378 (1204). Anisodactrlus nitmipennis Lec., Ann. Lyc. Nat. Hist., IV. $1848,388$.

Oblong-oval, rather narrow. Color of terminatus. Thorax scarcely broader than long, sides very feebly curved, hind angles subrectangular: disk minutely and very sparsely punctured near base. Elytra alutaceous; intervals almost flat, sometimes very finely and sparsely punctulate. Length $6.5-7 \mathrm{~mm}$.

Throughout the western half of State; frequent in the southern counties, rare northward. April 9-December 25. Occurs beneath cover in sandy localities.

379 (1206). Anisodactylds cernus Say, Trans. Amer. Phil. Soc., II, 1823. 34 ; ibid. II, 461.

Oblong-oval. Piceous, moderately shining; elytra bronzed; tibice, tarsi and base of antenne paler. Thorax as broad at base as elytra, sides feebly curved, margins narrowly depressed from middle to base, hind angles rectangular. Elytral interrals fiat. smooth, more shining in the male. Length $8 \mathrm{~mm}$.

Vigo and Poser counties; rare. April 16-May 11. Easily known by its dark femora and punctured base of thorax.

*380 (1208). Anisodactilts lugubis Dej.. Spec. IV, 1829, 118.

Oblong. rather broad. subdepressed. Black, feebly shining; antennie and legs piceous. the basal joint of former and tarsi reddish-brown. Thorax two-thirds broader than long; sides gradually curred from apex into base. the margins behind the middle tiattened; basal impressions broad, shallorr. rery finely and densely punctate. Elytral strix very fine; interrals flat. alutaceous. Length 11-12 $\mathrm{mm}$. 
Throughout the State; frequent. April 19-December 18.

381 (1209). Anisodactylus sericeus Harr., N. Eng. Far., 1828, 17 .

Oblong. Black, opaque; antennæe reddish-brown; femora piceous, tibiæe and tarsi pale. Thorax broader than long, apex and base equal; sides regulirly curved, hind angles rounded, basal impressions obsolete; surface syarsely punctate, more densely at base and near the sides. Elytral interrals fiat, densely punctulate, each puncture bearing a short, fine hair. Length $10 \mathrm{~mm}$.

Iake, Marion, Vigo and Posey counties; frequent. February 21-November 17 . Noted on stems and burrowing beneath the roots of grasses and sedges about ponds. Also taken at electric light.

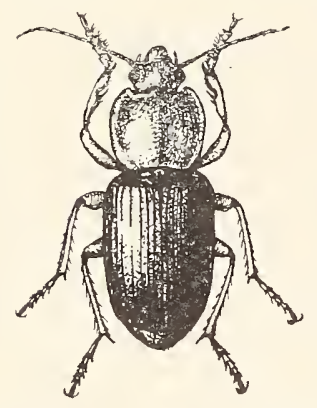

Fig. 101. $\times 2 \frac{1}{2}$. (Original.

*382 (1210). Anisopactylus interstitialis Say, Trans Amel. Phil. Soc., II, 1823, 57 ; ibid. II, 480 .

Form and structure of sericeus. Color as given in key. Thoracic margin broader, more depressed; median line and basal impressions evident, the latter broad and shaliow. Elytral intervals subconvex, densely and rather coarsely punctate. Length 9.5-10 mm. (Fig. 101.)

sandy regions. March 17-December 18. A half dozen just emerged as imagoes were noted on November 28.

\section{Family III. HALIPLID E.}

\section{The Crawling Water Beetles.}

In the North American fauna this family is represented by less than 30 known species of small, very convex aquatic beetles. In color they are light brownish-yellow, more or less spotted with black, while in form they are oval and tapering at each end. The elytra bear rows of punctures and the scutellum is invisible.

They comprise a family intermediate between the Carabidx and Dytiscidx, having the antennæ glabrous, filiform, 10-jointed and inserted on the front before the eyes; thorax with distinct side pieces; hind coxx contiguous at middle and prolonged as broad plates which conceal the basal half of hind femora and from three to six of the ventral segments. The slender but clubbed hind femora move between these plates and the abdomen, and are not adapted to vigorous swimming.

Although aquatic in habit, these little beetles swim but feebly. Where found they usuaily oceur in numbers. They live in shallow watel about the margins of ponds, lakes and pools of streams, where 
they may often be noted crawling slowly over the partially decayed aquatic plants, especially algæ. On account of their feeble swimming powers they may be easily captured by raking the mass of vegetable matter onto the bank, when the beetles, on crawling out to regain the water, may be secured. The name of the family is derived from the Greek and means "sailing the sea," or " covered with water."

The larvæ of the Haliplidæ live in the same places as the adults. They are composed of slender segments, each, except the head, being furnished on the back with fleshy lobes, bearing spiny tips, while the last segment is extended into a long tapering appendage.

The principal paper. including descriptions of the North American species of this family, is by

Crotch._- "Revision of the Dytiscidae of the United States,' in

Trans. Amer. Ent. Soc., IV. 1873. 383-385.

The North American species are divided among three genera. two of which are represented in Indiana.

\section{KEY TO INDIANA GENERA OF HALIPLID E.}

a. Terminal joint of palpi small. awl-shaped; intervals of elytra punctate; thorax without black spots at base.

I. Haliplus.

a a. Terminal joint of palpi conical, longer than the third; intervals of elytra without punctures; thorax with two small round impressed black spots at base.

II. CNemidotes.

\section{Haliplus Latr. 1806. (Gr., "the sea + sail.")}

Of the ten species of this genus known from the United States. six have been taken in Indiana. while another may occur.

KEY TO INDIANA SPECIES OF HALIPLUS.

a. Thorax withont a basal impression.

๖. Prosternum margined at sides; elytral punctures deeper at base than apex.

c. A distinct black spot on middle of front margin of thorax.

383. TRIOPSIS.

cc. Thorax, without black spot, sometimes slightly darkel at apex.

c. Elytra not sinuate near apex.

c. Spots of elytra distinct; size larger. $3.5-4 \mathrm{~mm}$.

FASCIATLS. ee. Spots more or less confluent; size smaller, $2.5 \mathrm{~mm}$.

3S4. LEWISI.

dd. Elytra distinctly sinuate near apex: spots often slightly connected but not confluent.

3S5. BOREAIIS.

b). Prosternum fiat. not margined at sides: elytral punctures not deeper at base than apex: elytra dull brownish-yellow with elongate black spots.

386. CRIBARTIS. 
aa. Thorax with a small impressed fold on each side near base.

f. Pale ochreous yellow; thoracic fold shorter; elytral spots several. more or less distinct.

387. RUFICOLLIS.

ff. Pale reddish-brown; thoracic impression longer; elytral spots very ill-defined.

388. LONGULUS.

383 (1221). Haliplus triopsis Say, Trans. Amer. Phil. Soc., II, 1823, 106 ; ibid. II, 51S.

Ovate. Light brownish-yellow; suture, base, tip and seven slightly connected spots on each elytron deep black, the middle spots confluent. Head and thorax distinctly punctate; punctures of elytral striæ finer toward apex. Length $3.5 \mathrm{~mm}$.

Lake, Laporte and Marshall counties; frequent. May 25-August 15. This is the species usually listed as $H$. punctatus Aube, but that name, according to Blanchard, belongs to a more densely punctate form from the Southern States.

H. fasciatus Aube, with head finely punctate and thorax wholly reddish-brown, is known from the "middle and Western States."

384 (1224). Halipluts lewisir Crotch. Trans. Amer. Ent. Soc., IV, 1873, 384.

Smaller and more slender than triopsis. Head and thorax reddish-yellow without spots; elytra with base and suture black, and a broad black spot on each side, confluent at middle. Punctures of elytral striæ weak; intervals very sparsely punctate. Length $2.5 \mathrm{~mm}$.

One from woodland pond near Broad Ripple, Marion County : June 12.

385 (1222). Haliplus borealis Lec., Agass. Lake Sup., 1850, 212.

Ovate. Dull reddish-yellow; thorax slightly dusky at apex; elytra each with ill-defined basal line and five spots black, the one near humerus and two on apical third rounded, the two on median third placed obliquely, each double, composed of tro partially connected oblong ones. Eyes rery convex. Head rather closely nunctate. Length $3 \mathrm{~mm}$.

Laporte County; scarce. May 26-August 20. A species of northern range. Resembles ruficollis but without the basal impressions.

386 (1225). Haliplus cribarius Lec., Agass. Lake Sup., 1850, 212.

Ovate. Dull bromnish-yellow; head and thorax paler and, in the specimen at hand, without black markings: elytra each with five or six elongate. more or less connected dark spots forming two oblique cross-bands. Head finely punctate. Thorax deeply and coarsely punctate near the hind margin, more finely in front, the disk nearly smooth. Elytra with rows of deep punctures; intervals each with a single row of widely separated punctures. Length $4.2 \mathrm{~mm}$.

A single specimen in the Wolcott collection taken near Pine. Lake County. June 9. A member of the Alleghanian fauna. 
386a (-). Ilahrlu's cribarius subguttates Lec., MS.

A dark variety of the preceding hatring the vertex black; the elytral sprots disconulerted and more distinct. Length $4 \mathrm{~mm}$.

Pine, Lake County; May 12. 'This and rribarius were described from Lake Superior.

387 (1226). Haliplus ruficoldis Der., Mem. IV, 1774, 404.

Ovate. Head and thorax pale dull yellow without spots; elytral spots larger than in borealis, all rounded, the two on median third often more or less confluent. Apex of elytra not sinuate. Length 2.5-3 mm. (Fig. 102.)

Pine and Hudson lakes, Laporte County; ponds near Rirhmond; frequent. May 25August 20. Probably occurs throughout the northern half of the State.

$3 S S$ (1227). Haliples longulus Lec. (Crotch). Trans. Amer. Eut. Soc., IV, 1873, 385.

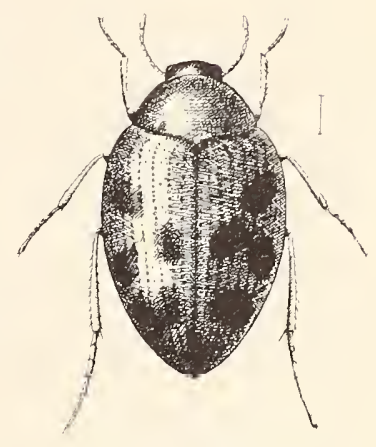

Fig. 102. (Original.) Line shows natural length.

Close to ruficollis but more slender. Elytra with basal spot wanting: the central spot dilated, triangular, the others indistinct. Length $3 \mathrm{~mm}$.

Pine, Lake County; Marion County, from pond near Broad Ripple; scarce. April 3-May 28.

\section{CNemidotus Ill. 1802 (Gr., "wearing leg armor."')}

Our members of this genus are a little larger and more robust than those of Haliplus. All have the thorax marked at base by two round black dots, and the elytral rows of punctures more or less irregular on basal third. Four nominal species have been taken in the State.

\section{KEY TO INDIANA SPECIES OF CNEIIDOTUS.}

a. Hind femora with a broad pale ring near alpex; elytra distinctly obliquely sinuate near tips.

$b$. Head entirely pale.

bb. Head with vertex black.

3S9. 12-PL NCTATL'S. 390. EDENTLLUS.

a . Hind femora wholly dark brown or blackish.

c. Elytra without a subhumeral spot; median subsutural spot contluent with the sutural line to form a discal blotch.

391. MLTICUS.

r. Elytra usualy with a small subhumeral slot; median subsutural spot free or barely touching the sutural line.

392. PEDT NCULATES. 
389 (1231). Cnemidotes 12-pcnctates Say. Trans. Amer. Phil. Soc., II. 1823,106 ; ibid. II. 518.

Orate, rery convex. Dull yellow, each elytron with six

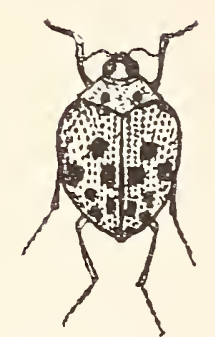

Fig. 103. $\times 4$. (After Tickham.) well defined black spots arranged as in the accompanying figure. Head finely, thorax rather coarsely and sparsely, punctate. Elytra each with eight rows of large black punctures and two rows of finer, paler ones on sides. Hind coxal plates subangulate on hind margin. Length 3.5-4. (Fig. 103.)

Northern half of State, common; less so in the south"rn counties. Often taken in numbers when seining. ILay 25-August 15.

390 (1233). Cnemidote edentults Lec. Yew sp. X. A. Col., I, 1863, 21.

Slightly more elongate and lesś convex than 12-punctatus. Pale straw sellow. Elytra more attenuate behind the middle and with spots larger, often more or less confluent. Length $4 \mathrm{~mm}$.

Lake, Laporte. Marshall and Fountain counties: scarce. April 29-August 15.

391 (1232). Cremidotus muticus Lec., New Sp. ․ Am. Col., I, 1863, 21.

Resembles 12-punctatus in form and sculpture. Differs by haring the hind femora wholly piceous or dark brown, the hind coxal plates broadly rounded, and the elytra subtruncate at apex. The sutural black line is narrowed on basal half and the median subsutural spot is confluent with it to form a rather large irregular blotch. Length $3.5-4 \mathrm{~mm}$.

Throughout the State; common. March 14-October 23. This as well as the other species probably passes the winter as imago.

\section{2 (-). CNemidotes pedunculates Roberts MS.}

Very close to the preceding. Differs mainly in the arrangement of the elytral spots as mentioned in key. The sutural black line is wider, occupying the sutural interval on the basal half. and is not confluent with the median spot. The elstra are feebly sinuate rather than subtruncate at apex. Length $3-3.5 \mathrm{~mm}$.

Taporte. Marshall, Fountain. Marion and Lawrence counties: scarce. Nay 11-October 23.

\section{Family IV. DYTISCIDA.}

\section{The Prediceors Diving Beftles.}

In the quiet. deep pools of streams, and in ponds or stagnant water may often le seen oval. flattened beetles hanging head downward. with the tip of the abdomen at or slightly above the surface of the water. These beetles belong to the family Dytiscidæ, the 
ward being lerived from the Greek Iytiscus, maning a diver. III the species are more or less aquatic in habit and, as a rule, are strong swimmers. Many of them hibernate as imagoes, burrowing in the banks and mud at the bottom or sides of the pools in which they dwell. Dr. Harris kept one for "three years and a half in perfect health, in a glass vessel filled with water, and supported by morsels of raw meat. It was capable of fasting a month; was very sensible to the changes of the weather, which it indicated by the height at which it remained in the vessel." They are often seen beneath the ice in late autumn or early spring. In the mature stage, during the mating season, some of the larger species fly about at night and are often attracted in numbers by electric and other lights.

From the Haliplidæ they may be readily known by having the body less stout and convex and more obtuse at the ends; antennæ glabrous, 11-jointed. usually filiform, and inserted under the front behind the base of the mandibles; middle and hind pairs of legs widely separated, due to the very large hind coxæ, which reach the sides of the body but do not cover the ventral segments. The hind legs are the longest, and are strongly adapted for swimming: being flattened and fringed with long hairs. The spiracles open beneath the elytra on the upper surface of the abdomen. By lifting the elytra slightly an air chamber is formed, from which the beetle draws its supply while. swimming. When the air in this chamber becomes too impure, the insect rises to the surface. forces it out and renews the supply. In color the beetles are usually brownish-black. often with a dull glaucous or sea-green tint, very smooth and shining. Some of them have the thorax and margins of elytra marked with dull yellow.

The sexes of several of the genera possess modifications which are of especial interest and which furnish excellent characters for the separation of groups. In the males of these genera the three basal segments of the fore (and sometimes the middle) tarsi are dilated and form a circular disk on the under side of which are numerous small. cup-like suckers. These serve as clasping organs. (Fig. 104.) The females of certain species also present an interesting dimorphism. in that some of them have the elytra deeply furroved, while others of the same species have them smooth.

The Dytiscidie are among the most voracious of all beetles. They prey not only upon the larva of

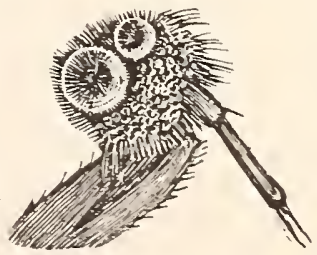

Fig. 104. (After Comstock.) 
other insects. but often upon small fishes, and are sometimes very troublesome in artificial fish ponds. where they attack the young and eat off their fins. Ther also feed upon dead animal matter of any kind which finds its way into the water where they live.

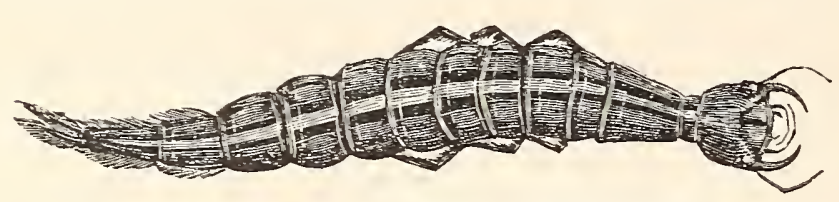

Fig. 105. Larva of Dytiscid. (After Comstock.)

The larvæ of the Dytiscidie are also aquatic and carnivorous, and are known as "water tigers." (Fig. 105.) In form they are elongate. cylindrical or fusiform. with a large oval or rounded and flattened head. The jaws or mandibles are sickle-shaped and hoilow, so that they can easily hold and suck the blood or juice from any prey which they may capture. These grubs remain in the water until full gromn. when they seek out some convenient place beneath a board. stone or tuft of vegetation where, by the squirming motions of the body. a cell is formed in which they undergo the pupal stage. The length of time necessary for this transformation varies greatly with the species and the season.

Nearly 300 species of Drtiscidie are known from the United States. Of these 70. representing 24 genera. have been taken in Indiana. The family does not offer that diversity of color. form and sculpture presented by the Carabidie and other families of terrestrial beetles. hence the number of characters used for the separation of genera and species is limited and the nork. therefore. made more difficult for the beginner. The classification is mainly that of Drs. LeConte. Sharp and Horn and IIr. Crotch. in the following works:

LeConte.- "Analytical Table of the Species of Hydroporus found in the Tnited States. with Descriptions of New Species." in Proc. Acad. Nat. Sci. Phil.. VII. 1855. 290-299.

LeConte.- "Srnopsis of the Species of Colymbetes Inhabiting America North of Trexico." in Proc. Acad. Nat. Sei. Phil. 1862. $521-523$.

Crotch.- "Rerision of the Drtiscidx of the Cnited States." in Trans. Amer. Ent. Soc. IT. 1873. 383-424.

Sharp.-On Aqnatic. Carnivorous Coleoptera or Dytiscidæ. in Trans. Royal Dublin So .. II. Ser. 2. 1882. 179-1003.

Horn.-Miscellaneons Notes and Short Studies of North American Coleoptera. in Trans. Amer. Ent. Soc.. X. 1883, 2†6-284.

For convenience the frmily is first divided into subfamilies and tribes. 
KEY TO SUBFAMILIES OF DYTISCID.E.

a. Episternum of metathorax not reaching the middle coxal cavity. (Fig. 106.)

Subfamily I. Fragarentati, p. 207. aa. Episternum of metathorax reaching the middle coxal cavity. (Fig. 107.)

Subfamily II. Complicati, p. 210.

In the accompanying cuts. Fig. 106 represents a diagram of a portion of the under surface of Laccophilus, which belongs to the subfamily Fragmentati, ec being the middle coxal cavity. It will be seen that the mesosternal epimeron ( $m s$. epm.) articulates at its imner end with the metasternum $(m t$.$) . and thus cuts off the$ metasternal episternum ( $m t$. eps.) from the coxal cavity. In Fig. 107, however. which is a diagram of similar parts of Colymbites of the subfamily Complicati,

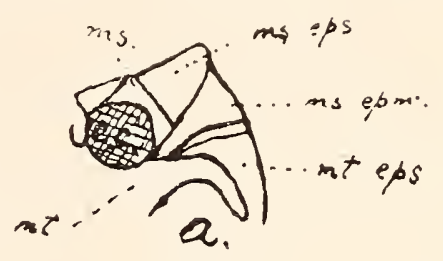
the mesosternal epimeron does not articulate with the metasternum. and thus allows the episternum of the latter to reach the cavity. These features are not, as a rule. difficult to make out. and form the basis of the modern classification of the family. by Dr. Sharp.

\section{Subfamily I. FRAGMENTATI.}

The North American members of this subfamily are divided among two tribes. both of which are represented in the Indiana fauna. In all the species the sentellum is invisible.

KEY TO TRIBES OF FRAGMENTATI.

a. Hind coxie longer near the middle of the body; prosternum dilated behind, truncate or nearly so.

Tribe I. Noterini, p. 20т. a a. Hind coxie longer near the sides of the body; prosternal process compressed. reaching the metasternum.

Tribe II. Laccophilini, p. 209.

\section{Tribe I. NOTERINI.}

The members of this tribe are all small beetles having the body convex. obtuse in front and pointed behind; front and middle tarsi five-jointed; apex of front tibie with a curred spur or hook. Two genera occur in Indiana.

KEY TO INDIANA GENERA OF NOTERINI.

a. Last joint of maxillary palpus bifid or emarginate; prosternal process not broader than long; hind tibiæ less dilated; length less than $3 \mathrm{~mm}$.

[14-23402]

I. CANThydRUs. 
an. Last joint of maxillaly lalpus truncate; prosternal process very broad hehind the coxse; hind tibise broader; length $4-5 \mathrm{~mm}$.

II. Hydrocanthus.

\section{CAnthydrus Sharp. 1882. (Gr., "beetle + water.")}

Small and short, strongly convex species, usually variegated in color above; antennæ very short and slender; pectoral plate coarsely sculptured at middle; hind legs slender, the femora and tibiæ but little flattened, the former contiguous at base. Two species occur in the State.

393 (1237). Canthydrus BIColor Say, Trans. Amer. Phil. Soc., IV, 1834, 447 ; ibid. II, 561.

Ovate, convex. Head, thorax and under parts reddish-yellow; elytra dark reddish-brown, thickly and rather coarsely punctate. Length $2.5 \mathrm{~mm}$.

A small but handsome species, taken in Indiana only from Bass Lake, Starke County, and Hudson Lake, Laporte County. Probably occurs throughout the lake region of the State. May 30-August 20.

394 (1238). Canthydrus gibbulus Aubé, Spec. Gen., Vi, 1838, 414.

Ovate, convex. Head and thorax yellow, the latter clouded with dusky on the front margin ; elytra dark brown or piceous, with an irregular oblique yellowish cross-bar near the middle. Elytra more sparingly punctate than in bicolor, the dorsal rows of punctures more distinct. Length $2.5 \mathrm{~mm}$.

Beneath rubbish on beach of Lake Michigan, near Pine, Lake County; scarce. August 1.

\section{Hydrocanthus Say. 1823. (Gr., "water + beetle.")}

In addition to the characters given in the key, this genus may b? known by having the last joint of the labial palpus very large, triangular and compressed; the front tibix with a strong spur; the hind femora short and stout. their apical margins strongly ciliated; tibiæ short, smooth, claws equal. But one species is known from the United States.

395 (1240). Hydrocanthus iricolor Say, Trans. Amer. Phil. Soc., II, 1823, 105 : ibid. II, 517.

Ovate, convex, attenuate behind. Head, thorax and under parts reddish-yellow ; elytra dark reddish-brown, polished, iridescent. Three irregular dorsal rows of fine punctures visible. Length 4-5 $\mathrm{mm}$.

Throughout the State; frequent. March 16-August 15. Probably hibernates, as one was taken from mud at the bottom of a pond on the earlier date. 
Tribe II. LACCOPHILINI.

This tribe is represented in the Inited States by the single gृentus.

\section{JaccopHLUS Leach. 1817. (Gr., "a pool + loving.")}

Small and very active beetles, ovate and depressed in form, and usually spotted in color; thorax without side margins; scutellum almost concealed; prosternal spine narrow, acuminate and much compressed; hind coxæ expanded into broad processes which are arched in front and almost completely conceal the coxal cavities; hind legs highly developed. The males have the four front tarsi dilated and clothed with spongy hairs beneath. The plates of the hind coxx have a ridge of fine lines, beginning near the middle at the insertion of the femora and extending outward and backward. These ridges, with their file-like arrangement, when rubbed by the hind femora, form a musical or stridulating organ. Four species have been taken in Indiana.

\section{KEY TO INDIANA SPECIES OF LACCOPHILUS.}

a. Elytra without distinct yellow cross-bars: male with a coxal file.

b. Elytra blackish, with one or more greenish-yellow spots.

c. Larger, $6 \mathrm{~mm}$. ; elytra with the margin, four submarginal spots and three basal lines greenish-rellow.

396. MACULOSUS.

cc. Smaller, $4.5 \mathrm{~mm}$; elytra dark reddish-brown, with the subhumeral mark of maculosus present, the others confused.

397. PRoxinus.

b7. Elytra dull yellow, with a distmet blackish bar behind the middle.

398. FASCIATUS.

a a. Elytra black with two cross-bars and apex yellowish; size less than $5 \mathrm{~mm}$; males without a coxal file.

399. UNDATUS.

396 (1242). Laccophiles Maculosts Say, Trans. Amer. Phil. Soc.. II. 1823. 100 ; ibid. II, 514.

Ovate. Head. thorax and under parts reddish-yellow. Elytra as mentioned in kes, the submarginal yellowish spots being in position, subhumeral. median, postmedian and subapical, the second and fourth usually the larger. The yellow basal markings vary much in size and distinctness. Thorax very short, four times wider than long, its surface, as well as that of elytra. rery finely reticulate. Elytra obliquely truncate at apex, with one or two irregular rows of minute punctures. Length $6 \mathrm{~mm}$.

Threughout the State: common. Mareh 16-October 23. Probably hibernates. 
397 (1244). Laccophilus Proxinus Say. Trams. Amer. Phil. Soc., II, 1823, 101 ; ibid. II, 514.

Ovate. Elytra nearly uniform dark reddish-brown, with only traces of the greenish-yellow spots of maculosus. Beneath darker than in that species. Length $4.5 \mathrm{~mm}$.

Laporte, Marshall, Marion and Lawrence counties; frequent. April 11-August 20.

398 (1248). Laccophilus fasciatus Aubé, spec., VI, 1838, 423.

ovate, subdepressed. Head, thorax and under parts dull brownishyellow; elytra greenish-yellow with a broad blackish bar behind the middle. Thorax and elytra finely alutaceous, the latter rounded at apex. Length $5 \mathrm{~mm}$.

Throughout the State; frequent. April 4-August 12. The meso- and metasterna are often fuscons.

399 (1253). Laccophulus undatus Aubé, Spec. Gell., VI, 1838, 435.

Narrowly oval. Head, thorax and under parts reddish-yellow; elytra blackish with a rather broad, irregular basal and a narrower subapical cross-bar, yellowish; also a spot on the margin about the middle and at apex of the same hue. Elytra very finely and rather closely punctate. Length $4.7 \mathrm{~mm}$.

Fountain County and Pine Lake, Laporte County ; scarce. July 21-August 15. The pale basal cross-bar varies in width and usually encloses two small squarish black spots on each elytron.

\section{Subfamily II. COMPLICATA.}

This group contains by far the greater number of the species belonging to the family. All agree in having the middle coxal cavity enclosed by four distinct pieces. The beetles vary much in form and size, and exhibit the most perfect development of the oarlike hind legs. Four tribes occur in the North American fauna, all of which are represented in Indiana.

\section{KET TO TRIBES OF COMPLICATA.}

a. Prosternum deflexed or bent downward between the front coxie, so that the process or spine is on a different plane from that of the prosternum; front and miadle tarsi four-jointed, except in Celina; lengtli less than $6 \mathrm{~mm}$.

'Tribe I. Hydroporini, p. 211.

aa. Prosternum not deflexed; all the tarsi distinctly five-jointed.

$b$. Lower spur of hind tibin not or but little broader than the other.

$c$. Outline of eye in front notched by the free margin of tront of head; front tarsi of males with three (two in Agabinus) basal joints dilated, forming an oblong or elongate surface; length usually 7 or more $\mathrm{mm}$.

Tribe II. Colymbetint, p. 221.

cc. Outline of eye not notched; front tarsi of males dilated so as to form a rounded or triangular disk: hind tarsi (except in $H y$ daticus) with two nearly equal claws; longth $10-40 \mathrm{~mm}$.

Tribe 11 I. Dytriscint, p. 22 ?. 
$b b$. Lower spur of hind tibiæ dilated, much broader than the other ; front tarsi of males as in Dytiscini; hind tarsi with one claw (males) or very unequal claws (females); length 30 or more $\mathrm{mm}$.

Tribe IV. Criststrini, p. 235.

\section{Tribe I. HYDROPORINI.}

Species of small size having the third joint of the front and middle tarsi deeply lobed and concealing the fourth joint, which, however, is often wanting; the fifth joint slender, with claws which sometimes vary in form according to sex. The "elytral ligula" mentioned in the key is a tongue-like process on the inner face of the side margin of the elytra, which must be lifted to show it. Its function is to unite more perfectly the elytra and ventral segments. Seven genera are probably represented in Indiana.

KEY TO GENERA OF HYDROPORINI.

a. Hind coxal cavities widely separated, each with an elongate notch behind.

aa. Hind coxal cavities not notched behind.

IV. Hydrovatus.

b. Size small, 1.5-2 mm.; first ventral segment firmly united to border of hind coxæ.

c. Form rounded, convex; prosternal process rhomboidal, acute at tip.

V. Desmopachria.

cc. Folm oblong, depressed; prosternal process oblong.

VI. Bidessus.

bb. Size larger, 2.5 or more $\mathrm{mm}$; first ventral segment free.

d. Scutellum visible.

VII. Cetina.

dd. Scutellum not visible.

e. Elytral ligula distinct, abrupt.

ee. Elytral ligula wanting.

$f$. Mesosternum not reaching the metasternum.

VIII. CEeLambes.

$f f$. Fork of mesosternum connected with the intercoxal process of the metasternum.

IX. HYDRoporus.

IV. Hydrovatus Mots. 1855. (Gr., "water + old or stagnant.")

This genus includes very small beetles which have the prosternum dilated triangularly behind the front coxæ and the tips of the elytra produced into a sutural point. Two species are known from Indiana.

400 (1257). Hydrovatus pustulatus Melsh., Proc. Phil. Acad. Nat. Sci.. II, $1841,29$.

Form rounded, convex. Head, thorax (except basal cross-blotch) and under parts reddish-yellow; elytra dark reddish-brown with a broad postbasal and a narrow subapical cross-bar orange. Upper surface alutaceous: thorax faintly, elytra distinctly but sparsely, punctate. Length 2-2.5 mm.

Northern two-thirds of State; frequent. Nay 15-Angust 20. 
401 (-). Hydrovatus indianensis sp. nov.

Form of the preceding. Head and under surface reddish-brown; thorax piceous with a median cross-bar reddish-brown; elytra piceous, each with a broad reddish-brown sub-basal spot, a small spot behind middle and the tips also indistinctly reddish. Thorax and elytra sculptured as in pustulatus. Length $3 \mathrm{~mm}$.

Kosciusko County; rare. August 5. A distinctly larger and much darker form than the preceding.

\section{Desmop achria Bab. 1841. (Gr., "band + point.")}

In this and the next genus the hind coxre are united firmly to the ventral segments so that the under surface of the body from the front of the metasternum to the hind margin of the third ventral segment consists of one rigid piece. Desmopachria comprises minute, short, broad species, convex both above and beneath and having the hind coxæ very greatly developed but with the coxal cavities much exposed. The genus is represented in the eastern United States by a single small species.

402 (1262). Desmopachria convexa Aubé, Spec. Gen.. VI, 1838, 479.

Rounded, convex. Uniform brownish-red, shining. Elytra finely but distinctly punctulate, tapering to an obtuse apex. Clypeus with a distinct margin. Length $1.7 \mathrm{~mm}$.

Laporte. Marshall, Wavne and Marion counties ; frequent. Occurs beneath grass roots along the margin of water. May 15-August 15.

VI. Bidessus Sharp. 1892. (Cre., "double + wet.")

This genus contains a number of very small oblong-oval depressed beetles, usually of a brownish color with paler markings. The thorax has a basal groove or longitudinal fold on each side which is often continued onto the elytra. Five species are known from Indiana.

\section{KEY TO INDLANA SPECIES OF BIDESSUS.}

a. Basal grooves of thorax not continued onto elytra; elytra brown, each with two yellow spots.

403. FLAVICOLLIS.

a $a$. Basal grooves of thorax continued onto the elytra.

b. Elytra distinctly pubescent with yellowish hair's. 404. pUlicarius.

7). Elytra not or very finely pubescent.

c. Elytral portion of basal groove distinctly longer than the thoracic portion.

405. LACLSTRIS.

cc. Basal wrouve about equally divided between thorax and elytra, or distinctly longer on the former. 
1. First and second ventral segments smooth or obsoletely punctate; elytra finely punctate.

4U6. AFFINIS.

$d d$. First and second ventral segments coarsely but sparsely punctate; elytra coarsely punctate.

407. IUSCATUS.

403 (1270). Bidessus flavicollts Lec., Proc. Phil. Acad. Nat. Sci., 1855, 295.

Oblong-oval, opaque. Head, thorax, legs and under surface yellow; elytra fuscous or brownish, each with two paler' spots on the sides. Thorax and elytra densely and finely punctate, the basal grooves of the former very short. Hind coxæ not longer than proad. Length 1.2-1.5 mm.

A single specimen from Hudson Lake, Laporte County, July 15. Probably occurs sparingly in the lakes of the northern third of the State. Known from Illinois, Pennsylvania and New England.

404 (1273). Bidessus pulicarius Aubé, Spec. Gen., VI, 1838, 494.

Oblong-oval, opaque. Head, thorax and legs reddish-yellow; elytra dark brownish-yellow, a faint yellow'submarginal spot behind the middle and another near the apex; postpectus and abdomen piceous. Elytra closely punctulate and covered with fine hairs visible only beneath the lens. Length $1.5-1.7 \mathrm{~mm}$.

Laporte, Kosciusko, Marshall and Marion counties; scarce. May 31-August 15.

405 (1278). Bidessus lacustris Say, Trans. Amer. Phil. Soc.. II, 1823. 103 ; ibid. II, 516.

Oblong-oval, shining. Head and thorax dull reddish-yellow; elytra brownish-yellow clouded with darker; under surface usually black. Elytra very finely and indistinctly punctate. Length 1.4-1.8 mm: (Fig. 108.)

Throughout the State; frequent. April 15-August 20.

406 (1275). Bidessus affinis Say, Trans. Amer. Phil.

Soc., II, 1823, 104; ibid. II, 517.

Oblong-oval, feebly shining. Head, thorax and legs reddish-yellow; elytra and under side fuscous brown, the for-

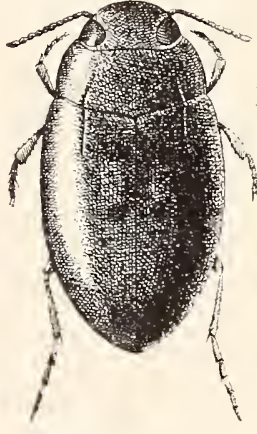

Fig. $108 . \times 18$. mer often with paler elongate markings. Length 1.5-1.5 $\mathrm{mm}$.

Throughout the State, frequent; especially so in the northern lakes. April 4-August 20.

407 (1279). Bidessus fuscatus Crotch, Trans. Amer. Ent. Soc., IV. 1873. 391.

Resembles affinis but darker and more shining. Known by the coarser punctures of elytra and hind coxal plates and the shorter impressed stria at base of elytra. Head and thorax almost smooth. Length 1.7-2 mm.

Starke County ; scarce. Collected by sweeping along the north margin of Bass Lake. May 19. 


\section{Cemina Aubé. 1836. (A proper name.)}

Elongate, glabrous, parallel species having the scutellum distinct; front and middle tarsi with five joints; abdomen terminating in a short spine. One species occurs in the State.

408 (1282). Celina angustata Aubé, Spec. Gen., VI, 1838, 447.

Elongate-oblong, parallel. Brownish-red, alutaceous, shining; elytral disk with a blackish clond. Thorax three times as wide as long, sides feebly rounded, disk very finely and sparsely punctate with coarser punctures along the apical and basal margins. Elytra sparsely, finely and irregularly punctate, with two or three discal rows of larger punctures; their tips ending in fine points. Middle tibixe of male curved and narrowed at middle, the basal portion slender, the apical much broader. Length $4 \mathrm{~mm}$.

This is listed as a southern species, but a single specimen was taken in Lake County, on the shore of Lake Michigan, and another in Kosciusko County. June 9-August 1.

\section{Cermambus 'Thom. 1860. (Gr., "swollen + belly.')}

To this genus belong a number of small, oval or rounded beetles, convex beneath (whence the generic name), and in color either brown or pale with black markings. All are devoid of pubescence, possess the elytral ligula above mentioned and have the humeral or basal portion of the epipleuræ limited behind by a well-marked line. Seven species are known from Indiana.

KEY TO INDIANA SPECIES OF CGLAMBUS.

a. Front of head with a fine but distinct raised margin, the labrum much concealed; under surface of body very convex, usually light brownisllyellow.

b. Elytra without either distinct blackish spots or a carina on the sides. very coarsely and regularly punctured.

409. INAQUALIS.

bb. Elytra each with three or four black spots, and with a carina on the side, the punctures much finer.

410. ACAROIDES.

aa. Front of head without margin, the labrum little concealed; under surface of body less convex, wholly or partly black.

c. Elytra without impressed lines; smaller, $2.5-4.5 \mathrm{~mm}$.

d. Elytra nearly uniform dark reddish-brown, usually with fine and coarse punctures intermingled.

e. Smaller, not over $3 \mathrm{~mm}$.

f. Abdomen wholly black; sides of hind coxæ very coarsely and sparsely punctate.

411. TURBIDUS.

ff. Abdomen in part or wholly pale; sides of hind coxæ finely vinctite.

412. IAACCOPHILINUS.

ee. Larger, $3.5-4 \mathrm{~mm}$; abdomen and metasternum as in turbidus.

41:3. DISSIMILIS. 
dd. Elytra dull yellow, cionded with black streaks, finely, densely and evenly punctured.

414. NUBILUS.

cc. Elytra usually with a sutural and two dorsal impressed lines, deeply and coarsely punctate; larger, 5-5.5 $\mathrm{mm}$.

415. IMPRESSO-PUNCTATUS.

409 (1284). Comambus in equalis Fab., Ent. Syst., I, 1792, 200.

Short, suboval, convex above aud below. Head and disk of thorax dull yellow, the latter with front and hind margins dusky. Elytra dark brown with traces of dull yellow, notable for the deep and regular punctures. Under surface coarsely and rather sparsely punctured. Length $3 \mathrm{~mm}$.

Steuben, Lake, Marshall, Laporte and Marion counties; common in Lake Maxinkuckee. April 4-October 23. Usually listed as C. punctatus Say.

410 (1288). Ceelambus acaroides Lec., Proc. Phil. Acad. Nat. Sci., VII, $1855,294$.

Rounded-oval, subdepressed. Head, thorax and legs dull yellow; elytra yellowish, with a large common sutural spot reaching past middle, and three discal spots on each, blackish; an elevated submarginal carina on middle third. Length $2.5 \mathrm{~mm}$.

Steuben County; rare. July 5. Described from Illinois and Kentucky and probably occurs throughout the State.

411 (1289). Ceflambus turbidus Lec. Proc. Phil. Acad. Nat. Sci., 1855. 298.

Oval, convex. Piceous brown, shiming; head, antennæe, legs and margins of thorax dull brownish-yellow. Thorax finely punctate on apical halt. more coarsely near the base. Punctures of elytra rather dense and moderately coarse. Length $2.8 \mathrm{~mm}$.

Lake and Laporte counties; scaree. May 28-July 21. Resembles $C$. incequalis, but beneath black and much less convex, the elytra with finer punctures and the clypeus not margined in front.

412 (1375). Chelambers laccophilines Lec., Proc. Amer. Phil. Soc., XVII. $1878,595$.

Short, ovate, subdepressed, pointed behind. Head and thorix light brown; elytra darker, the male shining. Thorax of male finely rugose and minutely punctured. Elytra rather coarsely and regularly punctate in male; opaque and very finely punctulate in female. Basal segments of abdomen rather coarsely punctured in both sexes. Length 2.6-3 mm.

Marion and Marshall counties; frequent. March 1t-October 1. The females are minutely alutaçeous and are much less common than the males.

413 (1301). Coerambús dissimilis Harr., Cat. Ins., 18:35, 472.

Oblong-oval, subconvex. Head and thorax dull yellow to brick-red; elytra dark reddish-brown, rather thickly dotted with he and coarse punctures. Kength $3.8-4 \mathrm{~mm}$.

Take, Laporte and Marion counties; scarce. Mareh 14-.Tnly 15. 
414 (1297). Ceflambus nebilts Lec., Proc. Phil. Acad. Nat. Sci., 1855, 298.

Elongate-oral. Head. thorax, legs and antennæ dull yellow; elytra with three or four irregular blackish streaks which sometimes merge to form a fuscous cloud behind the middle; under surface black. Length $4.3 \mathrm{~mm}$.

Known from Indiana by a single specimen taken near Greencastle. Putnam County, by Guy Wilson and presented to the writer. July 9 .

415 (1302). Ceelambus impresso-punctatus Schall., Act. Hal., I, 1783, 312.

Oblong-oval. Legs, head and apical half of thorax reddish-brown; vertex. base of thorax and elytra dark brown, coarsely and deeply punctate. Many of the punctures elongate, confluent; usually three impressed lines on each elytron, reaching to about the middle. Length 5-5.5 $\mathrm{mm}$.

Lake, Laporte and Marshall counties; scarce. April 23-August 16.

Deronectes depressus Fab., dull brownish-yellow, elytra with black lines more or less conflient, length $4.5 \mathrm{~mm}$., and D. griseostriatus, DeG.. black, densely punctate, the elytra often with narrow greenish stripes or even entirely greenish-black, length $4.5 \mathrm{~mm}$., both range from New York and Canada to Nichigan and westward, and perhaps oceur in northern Indiana.

\section{TX. Hydroports Clairv. 1806. (Gr., "water + to walk.")}

T'o this genus belong a large number of small species quite similar in gencral appearance and therefore difficult to distinguish. They are mostly ovate in form. dark brown in color and have the head never margined in front; the prosternum never truncate behind; swimming legs teeble. When captured in a water net. they leap or spring a few inches at a time. much in the same manner as do "click beetles." The following species have been taken or may occur in Indiana:

\section{KEY TO INDLANA SPECIES OF HYDROPORLS.}

a. Hind coxal carities not contiguious.

๖. Elytra rariegated in color.

c. Under surface black or piceous; form oral; length $3.5 \mathrm{~mm}$.

416. CONCINNUS.

r. Fuder suldace reddish-hown: form broader, more olstuse in front. nore acute behind; length ::. $111 \mathrm{~m}$.

I.TYCHER.

b). Eiytra unicolorous.

d. Under surface black or picenus; prosternal spine large. 
6. 'hhorax strongly margined, suarsely but distinctly pumetate.

417. STINATIS

ec. 'Thorax tinely margined, almost smooth.

Ori,ITUS.

dd. Under surface reddish-brown; prosternal process small; head and

thorax darker than elytra. $41 \mathrm{~s}$. VILIs.

al. Hind coxre contiguous.

f. Form elongate, obconic; antennæ of male with joints $3-5$ dilated; length $5.5-6 \mathrm{~mm}$.

419. DIFFORMIS,

ff. Form oral or oblong-oval; antennæe of male not dilated; length not more than $5 \mathrm{~mm}$.

g. Under surface reddish-brown; side margins of thorax generally thickened.

7. Elytra coarsely punctured, with two smooth, narrow lines on each; abore black or piceous. head and elytral markings dull yellow.

420. STRIATOPUNCTATCS.

hh. Elytra without smooth lines.

$i$. Clypeus rounded, broadly margined; elytra blackish with bars or spots of reddish-brown.

$j$. Thorax finely and indistinctly margined. 421. Consimilis.

$j j$. Thorax broadly and distinctly margined. 422. UNdulatus.

ii. Clypeus rounded, not margined.

k. Elytra blackish with yellow markings; form elongate-oval; thorax not infuscate.

MIXTUS.

kik. Elytra reddish-yellow with elongate or oblong black markings.

1. 'Thorax with base and apex fuscous; form convex; surface with dense fine yellow pubescence.

SERICEUS.

17. Thorax narrowly fuscous at base; form subdepressed; pubescence much less distinct. 423. DIMIdiatus.

gg. Under surface (except sometimes the abdomen) black or piceous; side margins of thorax not thickened.

$m$. Thorax evenly and regularly punctate.

$n$. Punctures of elytra distinct; length $4 \mathrm{~mm}$.

424. NIGER.

nn. Punctures of elytra indistinct; length $5 \mathrm{~mm}$. 425. Modestus. $\mathrm{mm}$. Thorax unevenly and irregularly punctate, the disk often smooth, or nearly so.

$o$. Thorax finely and somewhat indistinctly margined at the sides.

p. Abdomen reddish-brown, paler than meso- and metathorax; elytra finely and indistinctly punctured.

q. Elytra piceous; form more slender and parallel; length 3-3.5 $\mathrm{mm}$.

426. PRONIMLS.

$q q$. Elytra reddish-brown; form broader in front, more pointed behind; length $4 \mathrm{~mm}$.

427. DICHROUS.

$p p$. Abdomen black or piceous, not paler than meso- and metithorax; elytra distinctly punctate; length $4 \mathrm{~mm}$.

428. AMERICANUS.

oo. Thorax distinctly margined at sides; black, legs reddish-brown; length $4 \mathrm{~mm}$.

TENEBROSUS. 
416 (1309). Hydropores coxcixyts Lec., Proc. Phil. Acad. Nat. Sci., $185 \overline{ }$ 297.

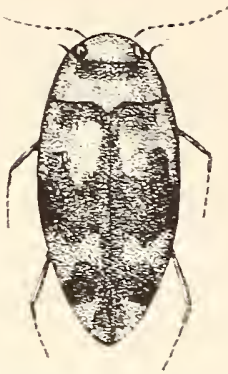

Fig. $109 . \times 7 \frac{1}{2}$ (Original.)

- Elongate-oral. attenuate behind. Head and thorax red. dish-brown. the latter broarly infuscate at apex. more narrowly at base; elytra black with three irregular reddish-bromn cross-bars. interrupted at suturè, one subbasal, one just behind the middle and the third at apex. Upper surface glabrous. rel'y finely alutaceous. Elytra each with two more or less distinct strixe of impressed lunctures and with numerous rery minute, scattered ones. Length 3.5 mm. (Fig. 109.)

Kosciusko, MLarshall, Fountain and Lawrence counties: frequent. June 27-August 15. A handsome species resembling undulatus, but readily distinguished by its glabrous surface.

H. pulcher Lec.; colored above as in concinnus, is reported by Dury from Cincinnati. It is evidently very close to concinnus, and Crotch considered them the same, but Sharp describes them as different.

H. oblitus Aubé, dark reddish-brown, slightly shorter and broader than stagnalis, is also a species which may occur in northern Indiana.

\section{7 (136i). Hrdroports stagralis G. \& H., Cat. Col., 1870, 441.}

Suboral, rather broad, sides parallel, obtusely rounded behind. Uniform dark reddish-brown, glabrous, feebly shining; head and thorax rarying to paler. Thorax short. transverse, thickly margined; disk minutely alutaceous, rer ${ }^{2}$ finely and sparsely punctate at middle, more coarsely along the base and apex. Elytra each with a median discal row of four to six coarse punctures on basal half; elsewhere rather sparsely but distinctly punctate. Length $3.5 \mathrm{~mm}$.

Laporte County; rare. October 21. A member of the boreal fauna. It is the collaris of LeConte, his name being preoccupied.

418 (1370). Hydroports rilis Lec., Ann. Lyc. Nat. Hist., V, 1849, 208.

Elongate-oral, subdepressed. Head and thorax dark brown or piceous; elytra paler reddish-brorn. Upper surface glabrous. minutely alutaceous: both thorax and elstra rery finely, sparsely and evenly punctured. Length $3.3 \mathrm{~mm}$.

Found in numbers in mud and water beneath a stone in a deep ravine fire miles northwest of Terre Haute, Vigo County. October 20. Described Irom California and Oregon. H. terminatus Sharp is a synonym, according to Blanchard. who has compared my specimens with the TeConte type. 
419 (1375). Hydroporus difformis Lec., Proc. Phil. Acad. Nat. Sci., 1855, 298.

Elongate, obconic. Nearly uniform dark reddish-brown, glabrous; antenne and legs paler. Punctures of elytra uniform in size and rather coarse; those of thorax much finer. P'ostermal spine elevated at sides and along the middle. Hind coxal lobes strongly developed. Length 5.5-6.2 mm.

Taken only in Marion County, from woodland pond near Broad Ripple; scarce. March 14. Our largest member of the genus.

420 (132S). Hydroporus striatopunctatus Melsh., Proc. Phil. Acad. Nat. Sci., II, 1844, 28.

Elongate-oval. Thorax and ground color of elytra piceous; elytral markings consisting of a sub-basal curved bar, an indistinct subapical and a distinct apical spot, dull yellow. Upper surface finely and sparsely pubescent. Elytra each divided into three subequal spaces by two smooth impunctured longitudinal lines; the intervals between them coarsely and sparsely punctured. Length $3.2 \mathrm{~mm}$.

Marshall County, near south end of Lake Maxinkuckee; rare. .June 27.

421 (1320). Hydroponus consmmis Lec., Agass. Lake Sup., 1850, 214.

Oval, rather wide, slightly attenuate behind. Head and thorax reddish-yellow, the latter fuscous on base and apex. Elytra blackish, with three irregular reddish-brown spots; one marginal; extending from the humerus back one-third the length of elytron, then across nearly to suture, where it expands; one behind the middle and one near or at apex; these very variable in size and form. Length $4.5 \mathrm{~mm}$. (Fig. 110.)

Northern half of State; frequent. April 4October 23.

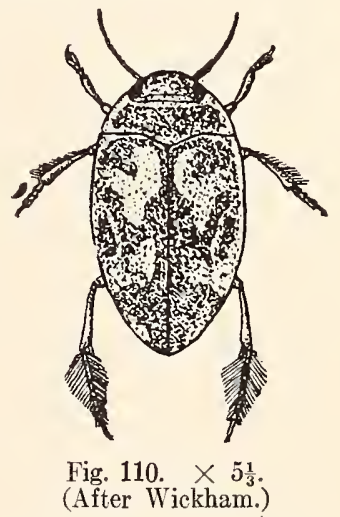

422 (1314). Hydroporus undulatus Say, Trans. Amer. Phil. Soc., II, 1823, 102 ; ibid. II, 99, 515.

In Leconte's table this species is separated from consimilis only by the broader margin of the thorax. In the suecimens at hand the ground color is somewhat paler and the reddish-brown marks of the elytra are smaller and more indistinct than in consimilis. Elytra more sparsely and coarsely punctate than there. Length $4-4.5 \mathrm{~mm}$.

Laporte and Marion counties; scarce. June 12.

$H$. mixtus Lec., $4.1 \mathrm{~mm}$., and $H$. sericeus Lec., $4.5 \mathrm{~mm}$. in length. both have a range which would indicate their presence in northern Indiana.

423 (1327). Hydroporus dimidiatus G. \& H.. Catalog Col., 1870, 432. semirufus Lec., Proc. Phil. Acad. Nat. Sci., 1855, 296.

Oral, moderateiy attenuate behind. Pale brownish-yellow; thorax with a narrow black line on base: elytra each with seven or eight black spots, 
one sub-hasal. three in an irregular row neal the middle, and three sub apical; these often hifirl behind. and sometimes more or less confluent. Sur. face closely and finely punctate. Length $4 \mathrm{~mm}$.

Laporte. Starke. Marshall and Marion counties; scarce. June 9-.June 16 .

424 (1361). Hydroporus riger Say, Trans. Amer. Phil. Soc., II, 1823, 102 ; ibid. II. 515.

Oral, rather conrex. Nearly uniform piceous abore; head, legs and region of humerus obscure reddish-brown; antennæ fuscous. the base paler. Thorax and elytra finely but distinctly and erenly punctured, sparsely pubescent. Sides of meso- and metasterna and base of abdomen coarsely punctured. Length $3.7-4 \mathrm{~mm}$.

Marion County. from woodland pond near Broad Ripple; scarce. April 4-IIay 16.

\section{5 (1366). Hrdroports yodestus dube, spec. Gell. TI. 1S3S, 5 i6.}

Oblong-oral. subdepressed. Piceous; head, sides of thorax and elstra, legs and often the sides of abdomen obscure reddish-bromn. Thorax and elytra finely and indistinctly punctate, rather densely pubescent. Hind coxal plates finely and sparsely punctate; mesosternum coarsels punctured: metastemum and abdomen almost smooth. Prosternal spine with a distinct median carina. Length $5 \mathrm{~mm}$.

Throughout the State: trequent. April 4-October 21. The males are more distinctly punctured and more densely pubescent than the females.

426 (1323). Hýdroports proximes Aubé, spec. Gen. des Hydrocan, 4 S3.

Oval, slightly conrex. Head and thorax reddish-brorn; elytra piceous; sometimes with antennæ. legs and palpi reddish-brown. Thorax with sides feebly rounded, hind angles obtuse, disk sparsely punctate. Length $3-$ $3.5 \mathrm{~mm}$.

Lake County. from small pond near Pine; rare. August 24.

427 (1359). Hrdroporus dichrous Melsh., Proc. Phil. Acad. Nat. Sci., II, 1844, 28.

Broadly огаte, obtuse in front, pointed behind. Uniform reddish-brown above; elytra rather thickls pubescent; legs and often the abdomen reddishbrown; pectus black or piceous. Upper surface, except disk of thorax. rers finels and erenls punctate. Tength $4 \mathrm{~mm}$.

Marion and Putnam counties: scarce. April 4-June 29.

428 (1358). Hydroporus americaxts Aubé, syec. Gen., TI. 1838, כૅ

Elongate-oral, subconrex. Head, legs and disk of thorax pale reddishbrown; remainder of upper surface uniform dark reddish-brown. Disk of thorax almost smooth. Pubescence of eljtia less dense than in allied species, usually distinctly risible only on the sides. Length $4 \mathrm{~mm}$. 
Lake, Laporte and Starke counties; scarce. May 28-August 20.

H. tenebrosus Lec., is known from New .Jersey and Lake Superior.

Tribe II. COLYMBETINI.

This tribe includes diving beetles of medium size or above, having the tarsi distinctly 5-jointed, those of the males with the dilated joints oblong. Nine genera are known to be represented in the State, while a single species of another may occur.

KEY TO INDIANA GENERA OF COLYMBETINI.

a. Semimembranous side pieces of first dorsal segment smooth; smaller, rarely $11 \mathrm{~mm}$.

b. Hind tarsi with unequal claws.

c. Spine of prosteruum not sulcate; elytra with a pale pubescent spot on the inner face at apex.

$\mathrm{X}$. Ilybius.

$c c$. Spine of prosternum deeply sulcate; elytra without pale spot.

XI. Matus.

bb. Hind tarsi with claws equal or nearly so.

d. Last joint of palpi emarginate; prosternal process much swollen along the middle.

XII. CортотомUs.

$d d$. Last joint of palpi normal, not dilated or emarginate.

$e$. Elytra deeply striate; prosternal spine but little swollen at middle.

$e e$. Elytra not distinctly striate.

XIII. Coperatus.

$f$. Thorax not margined; elytra beneath the lens showing numerous very fine elongate strix; prosternum not sulcate.

ff. Thorax margined at sides.

XIV. AgabeTES.

g. Elytra with very fine longitudinal impressions; hind legs short and stout; wing of metasternum linear, strongly curved.

XV. ILyBiosoma.

gg. Elytra without fine strix; hind legs of medium length and size; wing of metasternum wedge-shaped. XVI. Agabus. a $a$. Semimembranous side pieces of first dorsal segment rugose; larger, usually 12 or more mm.

h. Upper surface conspicuously reticulate; thorax not margined on sides.

h./. Upper surface not reticulate.

SCUTOPTERUS.

$i$. Elytra smooth, or in the female with short coarse lines; metasternum with a broad, deep groove; thorax margined.

XVII. RHANTES.

ii. Elytra with fine transverse wrinkles; metasternum with a narrow indistinct groove; thorax not margined. XVIII. Corrmetes.

The rugosities referred to muder an in the above table are near the first spibale, and the dytron must lo raised to see them prop erly. 


\section{Ilymius Er'. 18:32. (Gr.. 'mud + life."')}

Oblong, convex black or metallic beetles of medium size, having the thorax margined and the prosternal spine compressed and acute. The males have the front and middle tarsi compressed. thickly fringed beneath, the claws equal, the anal segment often carinate; female with anal segment emarginate. The upper surface, when viewed with a lens. is seen to be finely reticulate, while beneath they are finely strigose. On the sides of the elytra are two small pale spots, one of which is subapical.

Two species have been taken in Indiana while three others may occur.

\section{KEY TO INDIANA SPECIES OF ILYBIUS.}

a. Hind tarsi of males with the joints margined at the outer lower edge; all four spots of elytra distinct.

b. Last ventral segment of male acutely carinate; above dark reddishbrown.

429. IGNARUS.

bb. Last ventral of male not carinate, its apical portion with coarse lengthwise striæ; upper surface greenish-bronzed, metallic.

SUBÆNEUS.

aa. Hind tarsi of males not margined at the lower outer edge.

c. Last ventral of male carinate; one or both elytral spots very faint.

d. Black, slightly bronzed; elytra without reddish marginal stripe.

430. BIGUTTLLUS.

$d d$. More strongly bronzed; elytra with reddish margins.

FRATERCULES.

cc. Last ventrai of male not carinate; elytra with margin broadly red from the humeri to beyond the middle.

CONELSES.

429 (1385). Ilybius ignarus Lec., Proc. Phil. Acad. Nat. Sci., 1862. 521.

Elongate-oval, not dilated at middle. Dark reddish-brown; margin of elytra slightly paler, the front spot linear; legs piceous. Front tarsal claws of male distinctly sinuate beneath. I ength 8-9.5 $\mathrm{mm}$.

Shore of Lake Michigan near Pine, Lake County; rare. May 25. Also one specimen marked "Ind." in Webster collection.

I. subceneus Erichs., $11.5 \mathrm{~mm}$. : I. fraterculus Lec., $10.5 \mathrm{~mm}$., and I. confusus Aubé, $11 \mathrm{~mm}$. in length, are all members of the boreal fauna which have been taken in Michigan and perhaps occur in northern Indiana.

430 (1389). Ilybius Biguttulus Germ., Ins. Sp. Nov., 1S24, 29.

Oval, convex, slightly dilated at middle. Antenna and front and mid-

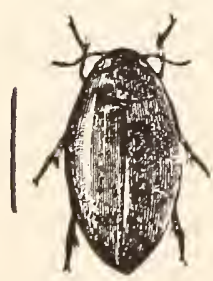

Fig. 111 . dle legs, reddish-brown; under surface and hind legs pireons. Tength 10-11 mm. (Fig. 111.)

Lake, Laporte, Starke, Vigo and Fountain counties; probably throughout the State; frequent. April 23-October 6. When caught with the fingers it exudes from the mnder side a white milky substance. 


\section{Matris Aubé. 1838.}

IIere belongs one medium-sized species having the head very broad; thorax margined; prosternum deeply sulcate; claws of hind tarsi unequal, the outer one being nearly twice as long as inner. 431 (1404). Matus bicarinatus Say, Trans. Amer. Phil. Soc., II, 1823, 98; ibid. II, 512.

Elongate-oval, slightly convex. Unifor'm brownish-red, shining; antemnæ paler. Thorax rounded at sides, front angles acute. Elytra with two or three rows of faint dorsal punctures. Length S-9 mm.

Lake, Marshall, Wells, Marion and Vigo counties; frequent. Hibernates. March 14-December 20. Readily known by the elongate form and peculiar color.

\section{Coptotomts Say. 1834. (Gr., "cut+ joint.")}

Medium-sized oval species having the terminal joint of the palpi somewhat compressed and notched at tip; prosternum with an elevated carina; last joint of hind tarsi equal to fourth; claws equal, pressed together and apparently single. One species occurs in the State.

432 (1396). Coptotomus interrogatus Fab., Syst. Eleut., I, 1801, 267.

Elongate-oval, subconvex. Head, thorax and under parts reddish-brown; vertex black; thorax black at base and apex; elytra pitch-brown, with numerous very small pale markings, a short stripe near the scutellum and an irregular marginal stripe, yellowish. Female with basal portion of elytra less shining than in male and marked with short, dense indistinct striæ. Length $7 \mathrm{~mm}$. (Fig. 111a.)

Throughout the State; frequent. Narch 16-October 28. Probably hibernates. Taken at electric light in June.

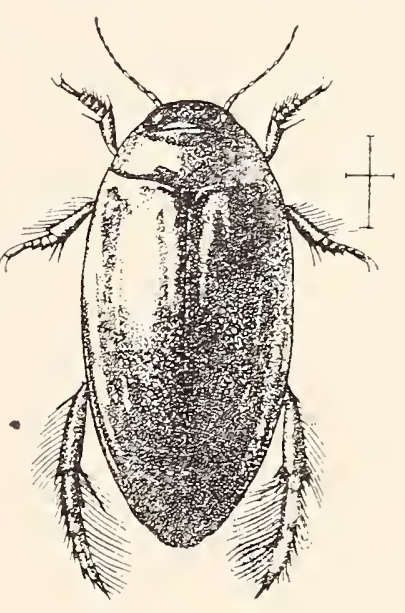

Fig. 111a. (After Sharp.)

\section{Copelates Er. 1839. (Gr., "oar or leg + wide.")}

Rather small beetles having the claws equal in both sexes; prosternum with an acute carina in tront; hind femora not ciliate at apex. The males have the fore and middle tarsi dilated and furnished with small equal disks. One species occurs in Indiana.

433 (1402). Copelatus glyphicus Say, Trans. Amer. Phil. Soc., II, 1823. 99 ; ibid. II, 512.

Oblong-ovate, rather narrow, subdepressed. Dark reddish-brown or piceous; antennæe and legs paler. Thorax almost smooth. Elytra each with ten deeply impressed strice, reaching almost to apex. Length 5-6 mm.

Throughout the State; scarce. April 4-October 21.

[15-23402] 


\section{Agıbetes Crotch. 1873. (Gr., "good + swimmer.")}

This genus contains but one short, broad, depressed species having the head somewhat flattened; thorax very short, with sides rounded, not margined; prosternal spine with an acute carina. The males have the anal segment deeply impressed each side, and the front tarsal claws very long.

434 (1405). Agabetes acuductus Harr.. New Eng. Far., 1S2S, 124.

Oral, subdepressed. Blackish or piceous, feebly shining; head, side margins of thorax and humeri of elytra reddish. Disk of thorax and surface of elytra with very numerous short scratches or impressions. Length $7-7.5 \mathrm{~mm}$. ber 2 .

Lake, Kosciusko and Knox cornties; rare. April 29-SeptemXV. Ilybiosoma Crotch. 1873. (Gr.. "mud or slime + body.")

This genus comprises two medium-sized species having the hind tibia and tarsi very short; first tarsal joint shorter than the tibial spur. The males have the front and middle tarsi compressed, narrowly dilated; claws simple. One of the two, described from Canada and belonging to the boreal fauna, occurs in northern Indiana. 435 (1399). Iltibiosoma bifaria Kirby, Faun. Bor. Amer., IT, 1837. 71.

Oblong-orate, subconvex. Black, shining; head in front, antennie, legs and side margins of thorax reddish-brown. Elytra with numerous minute longitudinal impressed lines which, behind the middle, are transrerse. Length. (i- $7 \mathrm{~mm}$.

Represented in the collection by a single specimen taken near Pine, Lake County. May 3.

XVI. Agubus Leach. 1817. (Gr., a proper name.)

A large number of blackish or more or less metallic. rarely variegated beetles, ranging from 7 to $12 \mathrm{~mm}$. in size and having the thorax margined; prosternum often acutely carinate; claws of hind tarsi equal; elytra usually very finely reticulate or alutaceous. The front tarsi of the males are swollen, the joints beneath being clothed with hairs which are usually tipped with minute disks. The hind legs are rather feebly developed for swimming, and the beetles are therefore often found under stones in wet, grassy places, or about the roots of semi-aquatic plants in marshes and shallow pools. More than 50-species are listed from the Trited States. Of these, 10 are known from Indiana while several others doubtless occur. On account of their close similarity they are difficult to separate unless both sexes are at hand. 
KEY TO INDIANA SPECIES OF AGABUS.

a. Outer front tarsal claw of male elongate and dilated or thickened beneath.

b. Elytra brownish-yellow; length $9.5 \mathrm{~mm}$.

bb. Elytra black, finely and densely reticulate; length $6.5-7.5 \mathrm{~mm}$.

436. ANTHRACINUS.

aa. Outer front claw of moderate length, not dilated beneath.

c. Front tarsal claws of male compressed, obtusely dentate at base.

d. Elytra brownish, more or less pale; inner margin of hind tibia without punctures; prosternal spine acutely carinate along the middle; length $8.5-9.5 \mathrm{~mm}$.

437. CONFINIS.

dd. Elytra black or brassy black; inner margin of hind tibiæ with a row of punctures; prosternal spine broad, nearly flat; length 9 $10 \mathrm{~mm}$.

438. SERIATUS.

cc. Front tarsal claws of male simple or acutely dentate.

e. Front claws of male simple.

$f$. Inner margin of hind tibix without punctures.

g. Prosternal spine rather narrow, convex.

h. Elytra dark reddish-brown, very shining, without a submarginal pale stripe, their surface not coatsely reticulate; length $7.5-8.5 \mathrm{~mm}$.

439. PUNCTATUS.

hh. Elytra fuscous with a reddish-yellow submarginal stripe; their surface coarsely and unequally reticulate; length $8 \mathrm{~mm}$.

RETICULATUS.

gg. Prosternal spine broad, flat, polished; elytra black, each with a dull yellow submarginal stripe.

$i$. Broadly ovate; under surface reddish-brown; length $10 \mathrm{~mm}$.

440. STAGNINUS.

ii. More narrowly ovate; under surface black; length $7.5-8 \mathrm{~mm}$. oBTUSATUS.

ff. Inner margin of hind tibire with a row of deep punctures; thorax finely margined; elytra uniform piceous, shining; length $9 \mathrm{~mm}$.

441. GAGITES.

ce. Outer front claw of maie acutely dentate near the base.

j. Elytra dull yellow with black stripes.

k. Body beneath wholly red; first joint of middle tarsi equal to the next three combined; length $9 \mathrm{~mm}$.

T.AENIOLATUS.

lik. Meso- and metasterna and coxa black; first joint of middle tar:si less elongate; length $7.5-8 \mathrm{~mm}$. 442. Disintegratus.

jj. Elytra not dull yellow.

7. Elytra reddish-piceous with a greenish or brassy tinge, finely punctulate; length $7 \mathrm{~mm}$.

11. Elytra black.

443. ANEOLUS.

$m$. Form broad, subdepressed; elytra with a subapical pale stripe; length $8.5-9 \mathrm{~mm}$.

444. SEMIVITTATUS.

$m m$. Form narrow, convex; elytra without pale stripe but with numerous irregular punctures; length $6-7 \mathrm{~mm}$.

445. SEMIPUNCTATUS. 
A. erythropterus Say, A. reticulatus Aubé and A. obtusatus Say are members of the boreal fauna known from Massachusetts to Lake Superior and perhaps occur in northern Indiana.

436 (1433). Agabus anthracinus Mamm., Bull. Mosc., II, 1852, 304.

Oval, moderately convex. Black, subopaque; antennæ, palpi and legs reddish-brown. Upper surface everywhere finely and densely reticulate. Elytra with a few fine scattered punctures toward apex. Prosternum distinctly widened behind the front coxæ, subcarinate its full length. Front and middle tarsi of male with distinct but small disks. Length 6-7.5 mm.

Kosciusko County; rare. June 1. Taken from border of sphagnum marsh. A boreal species ranging to Hudson's Bay and Alaska.

437 (9300). Agabus confinis Gyll., Ins. Suec., I, 1827, 511.

Oblong-oval, convex. Head, thorax and under surface black; elytra dark brown, polished; antennæe, front legs and margins of elytra reddishbrown; hind femora piceous. Elytra sparingly and irregularly punctate. Lengtlı 8.5-9.5 mm.

Lake and Laporte counties; frequent beneath rubbish along the shores of Lake Michigan. May 5-November 9.

438 (1411). Agabus seriates Say, Trans. Amer. Phil. Soc., II, 1823, 97: ibid. II, 511.

Oblong-ovate, subconvex. Black, slightly bronzed, shining; antennie and legs dark reddish-brown. Elytra rery finely and closely reticulate. with two or three dorsal rows of punctures evident but indistinct. Length 9-10 mm.

Vigo and Posey counties; scarce. April 24-October 20. In Vigo County taken from beneath stone in bottom of deep ravine.

439 (1421). Agabus punctatus Melsl., Proc. Phil. Acad. Nat. Sci., II. $1844,27$.

Short, ovate, convex. Head, antennæe and legs reddish-brown; thorax and elytra darker brown; under surface piceous. Thorax with sides nearly straight, the margin distinct. Elytra with irregular dorsal rows of punctures and numerous additional scattered ones on apical half. Outer spur of lind tibiæ broad and large. Length $7.5-8.5 \mathrm{~mm}$.

Lake and Marion counties. March 14-June 4. Common in woodland pond near Broad Ripple in early spring.

440 (1417). Agabes stagninus Say, Trans. Amer. Phil. Soc., II, 1823, 100 ; ibid. II, 513.

Broadly orate, subdepressed. Black or piceous, slightly bronzed above, shining; under parts reddish-brown; vertex with two small reddish spots. Sides of thorax but little rounded. strongly margined. Elytra very finely reticulate, witl an indistinct submalginal yellowish stripe on apical half and three rows of rather large punctures. Lengtl $10 \mathrm{~mm}$. 
Lake Wawasee, Kosciusko County; rare. June 1. This species is close to semivittatus but is larger, broader, more depressed and the male has simple claws.

441 (1447). Agabus gagates Aubé, Spec. Gen., VI, 1838, 306.

Ovate, subconvex. Piceons, shining; antennæ, legs, head in front, proand mesosterna and sides of thorax more or less reddish brown. Sides of thorax slightly rounded, rather strongly margined. Elytra finely and closely reticulate with dorsal rows of fine but evident punctures. Prosternal spine cariuate. Length 9-9.5 $\mathrm{mm}$.

Laporte and Vigo counties; scarce. August 26-November 4. Those found on the latter date were taken beneath stones in a damp ravine.

A. treniolatus Harr., is recorded from Ohio, New Jersey and Pennsylvania.

442 (1428). Agabus Disintegratus Crotch, Trans. Amer. Ent. Soc., IV, 1873, 416.

Ovate, subconvex. Head and thorax dull reddish, the latter with the front and hind margins black; elytra dull yellow, with three or four narrow black stripes. Surface smooth. Length $S \mathrm{~mm}$. (Fig. 112.)

Marion, Vigo and Lawrence counties; scarce. March 14-October 18.

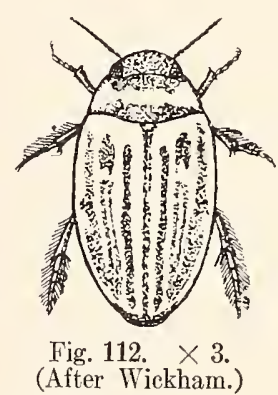

443 (-). Agabus \&eneolus Ciotch, Trans. Amer. Ent. Soc., IV, 1873, 417.

Ovate. Above reddish-brown or reddish-piceous, elytra often with a greenish tinge; beneath black or piceous; antennse and legs paler. Thorax strongly margined and with an angulate row of coarse punctures near the hind angles. Elytra very finely punctate and reticulate, with dorsal rows of coarser punctures which are confused towards apex. Prosternal spine subcarinate. Length $6.5-7 \mathrm{~mm}$.

Lake County; rare. May 29. Taken from the beach of Lake Michigan near Pine.

444 (1419). Agabus semivittatus Lec., Ann. Lyc. Nat. Hist., V, 1849, 204.

Rather broadly ovate, subconvex. Black, shining; elytra with an indistinct submarginal yellowish stripe on apical third; antennæ and legs reddish-brown. Sides of thorax nearly straight. Elytra finely and obsoletely punctate, the dorsal rows of punctures irregular, rather deeply impressed, confused toward the apex. Length $8.5-9 \mathrm{~mm}$.

Lake, Laporte, Putnam, Morgan and Jefferson counties; scarce. May 5-September 5.

445 (1423). Agabus semipunctatus Kirby, Faun. Bor. Amer., IV, 1837, 69.

Oblong-ovate, convex, the sides rather parallel. Black; antemie, mouth parts and legs reddish-brown. Elytra of male shining, very finely reticu- 
late, with the dorsal rows of punctures well marked and additional ones in the intervals: of female opaque, more coarsely reticulate and without punctures. All the tarsal claws short and weak. Length $6-7 \mathrm{~mm}$.

Lake and Laporte counties, beneath rubbish along the shores of lakes; scarce. May 25-October 21.

Scutoptemus angustus Lec., black, length $16 \mathrm{~mm}$., is known from Canada, Lake Superior and Kansas.

\section{Rhantus Esch. 1933. (Gr., "to wet or soak.")}

Medium-sized species having the thorax margined; last joint of hind tarsi as short as fourth, with claws unequal. Males with front and middle tarsi compressed. dilated, and with four transverse rows of disks on under side. The following species have been taken or may oceur in Indiana:

\section{KEY TO INDIANA SPECIES OF RIIANTUS.}

a. Claws of middle tarsi of male unequal, the outer one much longer than the inner.

7. Thorax with hind angles not prolonged; elytra blackish with numerous fine dull yellow markings.

c. Thorax with one or two median black spots; length $11.5-12 \mathrm{~mm}$.

d. Legs dull yellow; discal spot of thorax divided by a narrow line.

BINOTATUS.

d7. Femora black; discal spot entire, transversely quadrate.

FLA VOGRISEUS.

cc. Thorax rellow, its front and hind matroins black; length $10.5 \mathrm{~mm}$.

446. Bistriatus.

67. Thorax with base deeply bisinuate, the hind angles prolonged, acute; elytra wholly black or piceons; length $10 \mathrm{~mm}$.

SINUATUS.

a1. Claws of middle tarsi of male equal; upper surface entirely black; length $12 \mathrm{~mm}$.

447. CONFUSC'.

$R$. binotatus Harr., and $R$. flarogrisens Crotch, both have a range which may inciude northern Indiana.

446 (1466). Rhantes mistriates Bergst., Nom.. I, 42.

Rather shortly orate. Head black, front and rertex dull yellow; thorax yellow, its front and hind margins black; elytra blackish. the margins and many small reticulate marks dull yellow; prosternum and four front legs reddish-brown; remainder of under surface black. Outer middle claw of male very broad, compressed. Length 9-10 $\mathrm{mm}$.

Beach of Lake Michigan. near Pine, I ake County; rare. May 5-June 28.

R. simuatus Lee., is known from New York, Illinois and MichIgan. 
447 (一). Rilintus CONFésus sp. nov.

Elongate-oval, rather robust; subdepressed. Above nuiform black. shining; antennxe and palpi light reddishbrown; tibixe and tarsi dark reddish-brown; under surface piceous. Head smooth, the front with two smail forea between the bases of antenne. Thorax more than twice as wide as long, sides feebly curved. margins distinct; surface with sparse tine punctures near the front and hind margins. Elytra each with four double rows of fine. very confused punctures. Prosternum convex but not distinctly carinate along the middle. Length $12 \mathrm{~mm}$. (Fig. 113.)

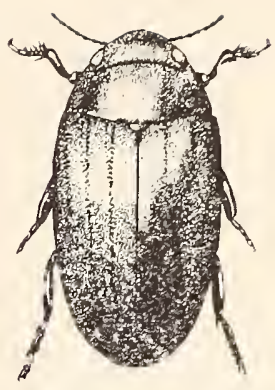

Fig. 113. $\times 2 \frac{1}{4}$ (Original.)

Floyd County; rare. September 28. Described from a single male taken from beneath a stone on the shore of the Ohio River. Under a strong lens the entire upper surface of both this and $b$ isiriatus is seen to be marked with very fine reticulated lines between which are numerous exceedingly minute punctures, giving it the appearance of being alutaceous.

\section{Colymbetes Clairv. 1806. (Gr., "dive+swim.")}

Rather large elongate beetles having the sides of thorax oblique, not margined; scutellum punctate; elytra with very fine transverse stria. The males have the anal segment triangularly emarginate and joints 2 and 3 of front and mirlde tarsi clothed with small cqual disks. One species oceurs in Indiana.

448 (1474). Colrmbetes sculptilis Harr., N. Eng. Far., 1829, 8.

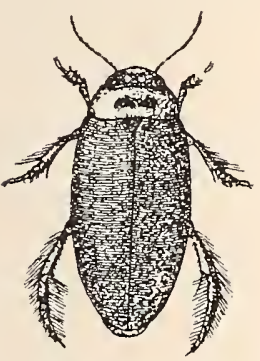

Fig. 114. $\times 1 \frac{1}{3}$ (After Wickham.)

Elongate-oral. Vertex black with two small paler spots; thorax, front of head and margins of elytra dull yellow, the thorax with a black transverse discal bar; disk of elytra darker; under surface black, legs and hind margins of abdominal segments reddish-brown. Length $16 \mathrm{~mm}$. (Fig. 114.)

Occurs sparingly along the shore of Lake Michigan; not noted elsewhere but should occur. May 5-June 26.

\section{'Tribe III. DYTISCINI.}

Diving beetles of large or medium size, easily distinguished by the peculiar dilated form of the front tarsi of the males. In these the first three joints form a circular eushion with small disks on the under side. The middle tarsi are also frequently dilated, the joints being oblong with varionsly arranger disks or suckers beneath. Sometimes, as in Acilius, there are three well-marked sizes of disks on the same foot. The tribe is represented in the Tnited States by six genera, five of which occur in Indiana. 
KEY TO INDIANA GENERA OF DYTISCINI.

a. Length one inch or more; joints of hind tarsi not fringed with flattened hairs on the outer margin, the last one with two claws; front tarsi of males with two large and numerous small disks.

XIX. Drtiscus. a . Length scarcely exceeding one-half inch; joints of hind tarsi fringed on the outer margin.

b. Spurs of hind tibire acute at apex; claws of hind tarsi unequal.

XX. Hydaticls.

67. Spurs of hind tibire emarginate at apex.

c. Elytra either 4-sulcate (female), or with distinct, closely placed. moderate sized punctures (male).

XXI. Acrires.

cc. Elytra not distinctly punctured, sometimes rery finely punctulate or partially aciculate.

d. Middle femora with long conspicuous setre.

XXII. THERMONECTES.

dd. Middle femora with short. stout setie.

TXIII. GRAPHODERES.

The emarginate or bifid tips of the tibial spurs in the last three genera are very fine. and must bo looked for with a good lens.

\section{Dytisct's Linn. 1735. (Gr.. "a diver.")}

T'o this genus belong the largest of our diving beetles. They are of a dark olive-brownish hue. with the clypeus and a stripe along the sides of thorax and elytra dull yellow; front and hind

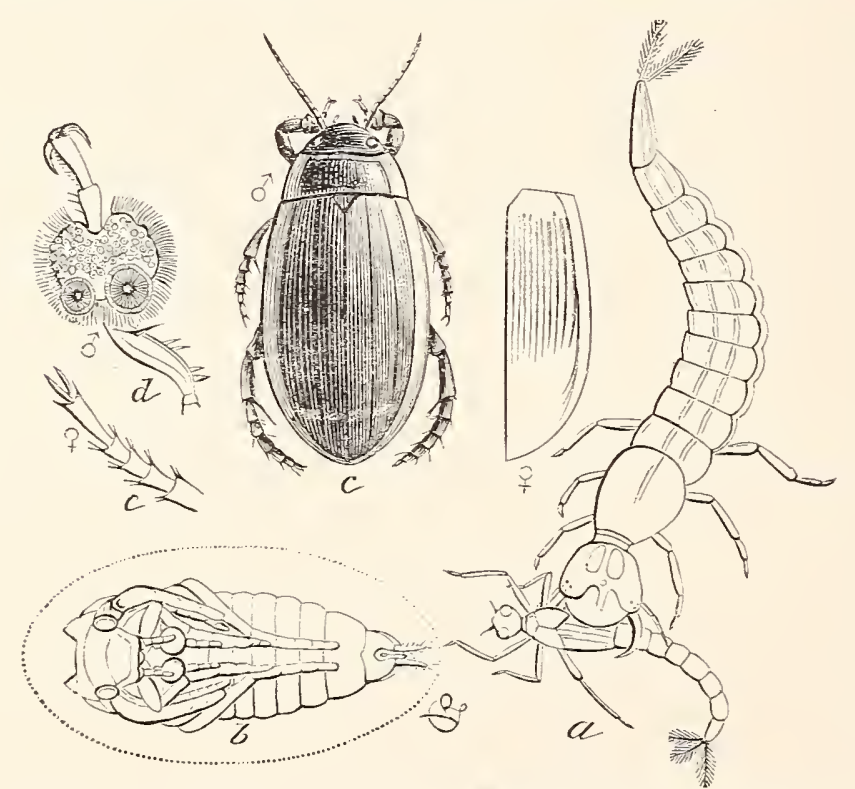

Fix. 115. Dytiscus:- $a$, Larva of $D$. marginalis derouring a larva of Evheinera; $b$, pupz of same: $c, D$. fasciventris Say; grosved elytron of fein lle; $d$, front tarsus of male, under side, showing the suction cups; $e$, sime of fernale. (After Riley.)

some they are always smooth, while in a third group the females are dimorphic, i. e., have either smooth or sulcate elytra. Four species are known from Indiana, while three others perhaps oceur. 
KEY TO INDIANA SPECIES OF DTTISCCS.

u. Labrum distinctly enarginate at middle.

b. Hind coxal processes rounded or acute, not spinose.

c. Thorax with sides yellow base and apex not or only indistinctly so.

d. Abdominal segments reddish-bromn with a piceous hind margin; elytra of female always sulcate.

449. FASCIVENTRIS.

da. Abdominal segments miform black or piceous; elytra of females smooth.

e. Elytra withont a narrow subapical cross-bar of rellow; smaller. $25-27 \mathrm{~mm}$.

450. IIYBRIDUS.

ee. Elytra with a narrow oblique subapical cross-bar; larger, 32 $35 \mathrm{~mm}$.

451. VERTICALIS.

cc. Thorax with base and apex. as well as sides, distinctly and rather broadly yellow; females dimorphic.

f. Hind coxal processes acute; length $33 \mathrm{~mm}$.

ff. Hind coxal processes obtuse: length $30 \mathrm{~mm}$.

MARGINALIS.

SUBLIMBATUS.

$b b$. Hind coxal processes produced, distinctly spinose; thorax with base, apex and sides broadly yellow; length $31-35 \mathrm{~mm}$.

DAURICUS.

a a. Labrum nearly truncate at middle; thorax with all the margins distinctly and broadly yellow; females dimorphic.

452. HARRISII.

449 (14S1). Drtiscus Fascitentris Say. Long's Exped., II, 270 ; ibid. I, $17 \pi$.

Elongate-oval. Greenish-black above; thorax margined with yellow only on the sides. or with a faint trace of sellow at base and apex. Elytra of female each with ten grooves which reach besond the middle; their apical third tinely and rather densely punctate. Length 25-2S mm. (Fig. 116.)

Dekalb and Marion counties; frequent. April 10July 18.

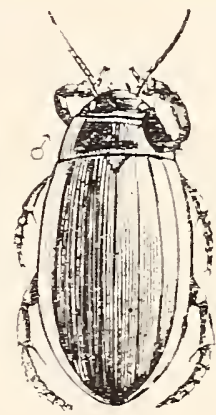

Fig. 116. Natural size.

450 (1782). Dytiscus hybridus Aubé, Spec. Gen., VI, 1838, 116.

Regularly ovate. Thorax shorter than in fasciventris. the apex usually narrowly yellow and sometimes with a faint yellow line at base. Pale margin of elytra of nearly equal width throughout. Length $26-28 \mathrm{~mm}$.

Lake. Laporte, Starke. Vigo and Posey counties; frequent. April 15-September 19.

451 (1483). Dytiscus verticalis Say, Trans. Amel. Phil. Soc. II. 1S:23. 92 ; ibid. II. 506.

Oral, rather broad. Thorax margined with vellow only on sides. Elytra with three rows of well marlied dorsal punctures; the marginal yellow line narrowing on apical half, the subapical line often somewhat indistinct. Length $33-35 \mathrm{~mm}$.

Beach of Lake Michigan near Millers, Lake County; scarce. Мay 28. 
D. marginatis Linn.. D. sublimbatıs Lec. and D. dauricus Gebl..

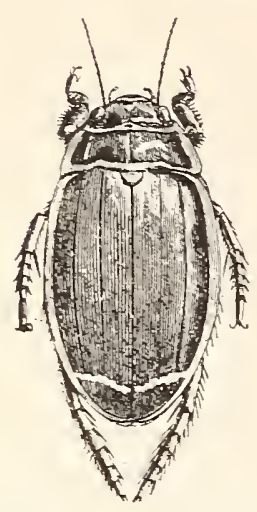

Fig. 117. Tro-thirds natural size. (After Wickham.) are all boreal species which mat occur in northern Indiana.

452 (1491). Drtisct's harrisit Kirbs, Faum. Bor. Amer. 1837. 76.

Broadly oral. Thorax at base. apex and sides broadly bordered with rellow. Elytra with marginal stripe narrowed only near apes. and with a narrow subapical crossbar as in ierticulis. Abdominal segments reddish-yellow marwined with piceous. Length $38-40 \mathrm{~mm}$. (Fig. 117.)

Lake and Marion counties; rare. June 26. On largest and best marked speries. The Marion County specimen is in the Durr collection.

\section{Hrditicts Leach. 1817. (Gr.. "found in the water.")}

Moderate sized, convex. regularly oral species having the thorax not margined; prosternal spine with a rather broad oval expansion, and obtuse $01^{*}$ rounded at apex: hind tarsal claws mequal. the inner one the longer. The dilated front tarsi of males bear numerous subequal disks. the middle tarsi being also broadly dilated and with four rows of disks. Three species have been taken in the State. while another may occur.

\section{KEY TO INDIANA SPECIES OF HTDATICLS.}

a. Rows of punctures on mpper face of hind tibiae distant from one another and parallel with onter border of tibia.

7. Above reddish-brown: sides of thorax dull yellow. 453. PICEcs.

67. Abrve piceous: thorax redish with a black hasal cross-bar.

c. Elytra each with four or five narrow dull sellow lines.

4.5t. STAGNALIS.

cc. Elytra uniform picents. the margin onls paler.

45. L. ETIPENNIS.

at. Rors of punctures on upper fice of hind tibize rather close together and not parallel with hind margins; thorax as in stafnalis: elptria with a submarginal yellow stripe. recurved at the humerus and not reaching apex.

BIMARGINATTS.

453 (1479). Hrdaticts picel's Lec. New Sp. X. Amer. Col.. I. 1863, 23.

Oral. moderately convex. Dark reddish-brown: subopaque. front of head. margins of thorax and elytra paler: front and middle legs pale brown: hind legs and abdomen darker. Dorsal rows of punctures erident but indistinct. Female rith sereral irregular elongate punctures each sicle of micldle of front of thorax. Length 12--13 $\mathrm{mm}$.

Lake and Wells comties; scarce. April 29-.Tune 25.

454 (147T). Hrdatices stigralis Fab.. Mant. I, 191.

Orate. subconrex. Above piceous: thorax and front of hear reddishrellow, the former with a curved black basal cross-bar which does not reach 
the margins; elytra with the margin broadly yellow and usually with a sub-basal rellowish band from which extend backwald four or five nalrow dull sellow lines; under surface dark piceous, the prosternum paler. Length 12.5-14 mm.

Lake and Steuben counties: rare. May 27-Aug'ust 16.

455 (14is). Hydatices Levipexis Thoms., Op. Ent. III. 324.

Elongate-oral, subconver. Piceous abore and beneath; front of head. thorax except a basal cross-bar, front and middle legs and antenne reddishrellow; side margins of elytra dull brownish-yellow; middle tibie piceous. Dorsal rows of punctures distinct. Female with tips of elytra slightly produced and subsinuate. Length $12.5 \mathrm{~mm}$.

One male in Field IIuseum collection from "Ind.." probably St. Joseph County. The dark basal cross-bar of thorax is widest at middle and tapers to a line each side.

$H$. bimarginatus Sar, $12 \mathrm{~mm}$. in length. occurs from Ohio to Georgia and Florida.

\section{Acrlers Leach. 1817. (L.. a Roman name.)}

Medium-sized subdepressed species, slightly obovate in form, and having the upper surface distinctly and regularly punctate; thorax not margined; hind coxæ very large. Females with elytra either sulcate or smooth. Males with front tarsi broadly dilated. with one large and two small disks beneath. the middle tarsi simple. the hind claws equal. (Fig. 11.) Two species have been (After. Comstock.) taken in Indiana, while one other may occur.

KEY TO IXDLANA SPECIES OF ACILICS.

a. Vertex with a distinct M-shaped black mark; sulci of female elytra unequal in length. the outer ones longer and reaching nearly to base.

b. Hind femora reddish-brown; length 12.5-14 $\mathrm{mm}$.

bb. Hind femora black; length $12 \mathrm{~mm}$.

456. SEMISULCATLS. MEDIATUS.

a . Vertex without an M-shaped mark: sulci of female subequal in length and reaching only to middle of elytra: length $13-15 \mathrm{~mm}$.

457. FRATERNCS.

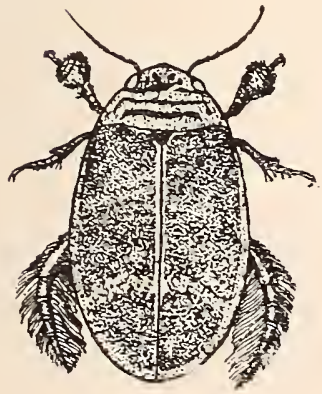

Fig. $119 \times 2$. (After Wickham.)
156 (1492). Acrlits semistlcates Aubé. Spec. Gell.. VI. 1838, 132.

Broadly oral or obovate. Dull brownish-yellow abore; head with base and an M-shaped mark on rertex biack: thorax with two transvelse black lines on disk. the front one the wider; elrtra closely marked with black dots and with subapical yellowish crossbar. Length 12.5-14 1111. (Fig. 119.)

Lake. Marshall. Marion and Vigo counties; frequent. June 12-August 15. 
A. mediatus Say has the sane range as the other two species. and should therefore occur in the State.

457 (1493). Acilius fraterves Harr., New Erig. Far., 1S29, S.

Close to semisulcatus. but a little larger. darker and more densely punctured. Black lines of thorax broader: femora nearls black. Length $13-11.5 \mathrm{~mm}$.

Marion. Putnam and Tigo counties; frequent. March 14-August 12. In coitu on the earlier date. motionless. heads downward and rentral sides together. Then disturbed they dived quickly and hid in the leaves and trash at the botton of the water.

XXII. Thervonectes Esch. 1833. (Gr"., "a warm spring + swimmer." )

Medium-sized, rather convex species resembling Acilius in appearance, but having the upper surface polished, smooth. or with but one to three dorsal rows of punctures: thorax without side margins; prosternal process broad and short; hind tarsal clarrs unequal. The front tarsi of the males bear two or three larger basal and numerous small unequal disks on the lower side. The basal halves of elytra of females are marked with numerous short. deep elongate punctures. Two species occur in the State.

155 (1495). Therioxectes orxaticonis Aubé. Spec. Gen.. VI. 1S3s. 140.

Orate, subconres. Above dull yellow: head with rertex and an IIshaped mark black; thorax with two transverse black lines, the front one the narrotrer; elstra marked with many small black more or less confluent dots. and an indistinct black bar behind the middle; undeĩ surface reddishbrown. Elytra each with two discal rows of rather distinct distant punctures. Length $11.5-13 \mathrm{~mm}$.

Vigo County ; rare. Nay 28.

459 (1496). Thermoxectes basilaris Harr., N. Eng. Far., 1S2S, S.

Orate, subconrex. Abore black; head in front and a transrerse line on the rerter dull rellow: thorax with the sides and a narrow discal bar of the same color; elytra with the margins. a sub-basal cross-bar and some rague markings on the sides yellowish; under surface reddish-bromn or piceous, the front and midale legs paler. Elytra punctate as in ornaticollis. Length $9-10 \mathrm{~mm}$.

Lake. Marshall and Putnam counties; scarce. May 20-Aug'ust 15 .

XXIII. Griptoderes Esch. 1s33. (Gr.. "write+skin.")

This genus is close to Thermonectes. The males have the front tarsi as there, but have also the middle tarsi dilated and bearing two 
rows of disks on under side. The elytra of female are either smooth or rough, with minute tubercles. 'Two species are known from Indiana.

460 (149S). Graphoderes Liberus Say, Journ. L'hil. Acad. Nat. Sci., V, 1825, 160 ; ibid. II, 271.

Slightly obovate; subdepressed. Head and thorax dull reddish-yellow, the latter sometimes piceous at base; elytra blackish-brown, with numerous fine yellow vermiculate marks, these sometimes forming a yellowish margin; under surface reddish-brown, the legs paler. Elytra each with two rows of indistinct dorsal punctures. Length $11.5-12 \mathrm{~mm}$.

Putnam and Lawrence counties; freguent in woodland ponds. August 7-August 12.

461 (1499). Graphoderes fascicollis Harr., N. Eng. Far., VII, 1S2S, 156.

Broadly ovate, subconvex. Head with occiput and an M-like mark black; thorax dull yellow with a rather broad black bar on front and hind margins; elytra blackish. thickly marked with dull yellow dots, the margins and a very narrow sutural line yellow; under surface dull brownishyellow. Length $13.5-14.5 \mathrm{~mm}$.

Lake and Marion counties; scarce. March 23-May 27. This species is said by Sharp to be distinguished from the European $G$. cinereus Linn. by the male having fewer disks on the front and middle tarsi. In one male from Pine. Indiana, the middle tarsi are not at all dilated.

\section{Tribe IV. CYBISTRINI.}

This tribe is represented in the United States by a small number of large species belonging to the single genus Cybister. They have the spiracles very small; hind legs broad and powerful; their tibia short and broad, with the lower one of the two apical spurs dilated; hind claws very unequal, the inner being obsolete or wanting in our species. The front tarsi of the males have joints 1-3 dilated into a large circular disk bearing four rows of equal-sized cupules. In the hollows behind the hind coxæ of the males are four or five deep ridges which, when rubbed by a ridge on the under side of the femur, form a stridulating organ.

XXIV. Cybister Esch. 1833. (Gr., "a tumbler or diver.")

This genus is considered as representing the highest and most completely developed form of Dytiscide. One of the five species known from the United States occurs in Indiana. 
462 (1502). Crbister fimbuiolatus Say, Trans. Amer. Phil. Soc., II, 1823, 9 ; ibid. II, 506.

Orate, more or less wedge-shaped. Above brown with a faint greenish tinge; thorax and elytra with a broad yellow margin; front of head, four front legs and spots at sides of abdominal segments 3 to 6 , also yellow. Thorax and elytra of female, except along the suture, with numerous fine short impressed lines. Length $30-33 \mathrm{~mm}$.

Throughout the State; frequent. May 27-September 20. In autumn sometimes found beneath rubbish on the beaches of lakes.

\section{Family V. GYRINID E.}

\section{'The Whiriligig Beetlaes.}

In the little bays of lakes and ponds and along the quiet places of flowing streams one often sees, close into shore, large colonies of beetles playing and gyrating upon the surface of the still water. These beetles are oval or elliptical in form, somewhat flattened, more or less attenuate at either end and usually of a brilliant bluish-black color. The name of the family is founded upon the principal genus Gyrinus, which in turn is derived from a Greek word meaning "a circle," and given to these insects on account of their habit of moving in little circles upon the surface of the water. They do not swim, as commonly stated, but glide or skate upon the surfacefilm of the water in the same manner as do the wherrymen or waterspiders among the Hemiptera. Except when pursued they rarely dive beneath the surface, and they then carry with them a small supply of air and stay but a short time. Being so agile they are difficult to capture even with a net. When handled they exude a milky fluid which usuaily has a disagreeable odor, but in certain species resembles that of ripe apples, hence they are sometimes called "apple bugs."

Some of the species occasionally crawl out of the water onto logs. stones or other objects, where they bask in the sunlight. If approached when so engaged, they let go all hold and tumble. instead of crawling back into the water, much in the same way as does a basking turtle. When undisturbed, the colonies or groups are usually massed close together, and are sometimes almost quiescent. The least alarm will, however. cause a large. closely bunched assembly to scatter widely in all directions.

From the margins of these groups individuals are continually darting out for a short distance, then back again. These little journeys are probably made in search of prey, as the beetles snap vigor- 
ously at any small insect they meet upon the surface of the water. Sometimes the outsider becomes alarmed and skates back at full speed into the assembly, putting its members into wild stampede.

Although easily recognized by their form and habits, the Gyrinide are distinguished from allied families by having the eyes completely divided by the sides of the head into upper and lower parts, both rounded, so that they appear to have four eyes, two for looking up into the air and two for gazing down into the water. (Fig. 120.) The antennx are very short, thick, inserted behind the mandibles, the third joint enlarged so as to resemble an external ear, the following joints rather broad and

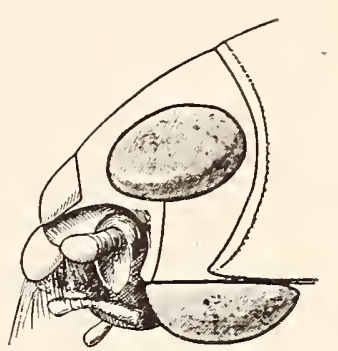

Fig. 120. Head of a Gyrinid beetle, Dincutes, to show divided eye. (After Folsom.) united so as to form a spindle-shaped appendage (Fig. 4, No. 16) ; front legs very long, rather slender, and when at rest placed in oblique grooves between the pro- and mesosterna; middle and hind legs short, broad, very much flattened; tibiæ without spurs; tarsi 5-jointed, the joints in part flattened and triangalar.

The eggs of the Gyrinidxe are laid in parallel rows upon the leaves of aquatic plants. The grubs are long, narrow and much flattened, and breathe by means of tracheal gills attached to the abdominal segments. (Fig. 121.) They are chiefly carnivorous, and when full grown leave the water and spin a gray, paper-like cocoon on some nearby object, in which they undergo the pupal stage.

Only about 40 species of Gyrinidre are known from the United States. These are divided among three genera, two of which are known to occur in the State, while the single species of the third is recorded from Quincy, Illinois, and may yet be found in the western part of Indiana.

The only papers treating of the North American species of the family are as follows:

LeConte.-"The Gyrinida of America North of Mexico," in Proc. Phil. Acad. Nat. Sci., 1868, 365.

Roberts, C. H._"The Species of Dineutes of America North of Mexico,' in Trans. Amer. Ent. Soc., XXII. 1895, 279.

KEY TO GENERA OF GYRINIDE.

a. Last rentral segment depressed, rounded at tip.

b. Scutellum distinct: length less than $8 \mathrm{~mm}$.

I. GrRints.

7). Scutellum invisible; labrum transverse; length 9 or more mm.

II. DINEUTES. 
aa. Last ventral elongate, conical; labrum prominent; scutellum inrisible: length $6 \mathrm{~mm}$.

GyReTES.

I. Gyrinus Linn. 1733. (Gr., "'a circle or ring."')

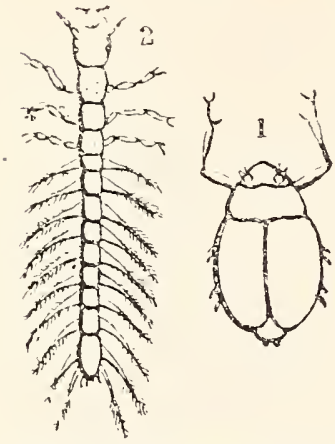

Fig. 121. 1, beetle; 2, larva (After Packard.)

Our members of this genus are smaller, more narrow and more convex than those of the next. They have eleven rows of distinct punctures on each elytron which, when held in a certain light, usually reflect a golden tint; the legs are always reddish-brown or yellowish in hue. (Fig. 121.) On account of the close resemblance between the species, their definition and recognition is quite difficult. The following have been taken or perhaps occur in Indiana.

KEY TO INDIANA SPECIES OF GIRINUS.

a. Scutellum finely but distinctly carinate.

a a. Scutellum flat.

463. MinUtus.

b. Under side margin of thorax and epipleura brownish-yellow.

c. Under surface uniform brown or brownish-yellow.

d. Larger, 6-7 mm.

e. Polished black, not bronzed or iridescent.

464. FRATERNUS.

ee. Black, very highly iridescent, margins and sides bronzed.

$f$. 'Tips of elytra rounded; form broader.

465. VENTRAIIS.

$f f$. Tips of elytra truncate; form more narrow.

dd. Smaller, 4.5-5.5 $\mathrm{mm}$.

AQUIRIS.

g. Form more elongate; tips of elytra rounded, covering only half of last ventral segment.

h. Margins, sides and suture of elytra distinctly bronzed.

hh. Elytra not at all bronzed.

466. ÆNEOLUS.

gg. Form short, broad; tips of elytra nearly truncate, almost wholly covering the last ventral segment. 468. Limbatus.

cc. Under surface black or piceous, bronzed; last ventral segment reddish-brown.

$i$. Upper surface finely alutaceous; length $7-8 \mathrm{~mm}$. 469. AFFinis.

ii. Upper surface not alutaceous; length $5.5 \mathrm{~mm}$. 470. PICEOLUs.

bb. Under side margin of thorax and epipleura metallic black.

$j$. Front margin of mesosternum regular in form.

k. Elytra highly polished, distinctly bronzed.

1. Smaller and more narrow, 5-6 mm.; outer rows of elytral punctures but little stronger than inner.

471. ANALIS.

7.. Longer and broader, $7 \mathrm{~mm}$.; outer rows of elytral punctures distinctly impressed.

472. BOREALIS.

7ik. Elytra black, scarcely polished and not at all bronzed.

473. LUGENS.

ij. Front margin of mesosternum trilobed, with an oblique impression each side; under surface black; length 5-6 $\mathrm{mm}$.

PECTORALIS. 
463 (1505). Grrinus minutus Fab., Syst. Eleut., I, 1801, 270.

Elongate-oval. Above blue-black; sides and margins of elytra bronzed ; beneath brownish-yellow, abdomen black, last rentral segment piceous. Median line of thorax and scutellum with a fine carina; mesosternum with a deep median furrow. Length 4-4.5 $\mathrm{mm}$.

Woodland pond near Broad Ripple, Marion County; scarce. May 15. Readily known by the carinate scutellum and bicolored inder surface.

464 (1508). Grrinus fraternus Coul), Cam. Nat., 2nd Ser., II, 60.

Elongate-oval, rather robust. Above buish-black, polished, not bronzed ; under surface uniform dark reddish-brown. Tips of elytrat broadly rounded. Length $6 \mathrm{~mm}$.

Pine, Lake County and Iudson Lake, Laporte County ; scarce. May 20-August 20. Known by the more robust form and entire absence of bronzed lustre.

465 (1513). Gyrinus ventralis Kirby, Faum. Bor. Amel.. IV, 1837, 80.

Oval. Above black, very highly polished, iridescent; margins, sides and suture of elytra bronzed; beneath readish-brown, sides and tip of abdomen a little paler. Length (6.5-7 mm. (Fig. 122.)

Northern half of State; common. March 1:September 19. A hancisome species, easily known by its larger size and more brilliant iridescent surface.

G. aquiris Lee., $6.5 \mathrm{~mm}$. in length, is recorded from the Middle States and Lake Superior.

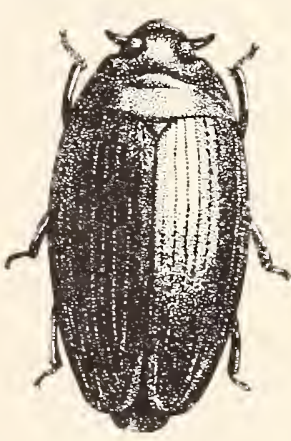

Fig. $122 . \times 5$.

466 (1509). Gyrinus zeneolus Lec., Proc. Phil. Acad. Nat. Sci., 1868, 368.

Elongate-oval. Above uniformly black-bronzed, very shining; beneath dark reddish-brown, the last two ventral segments paler. Elytral punctures in both this and limbatus larger and more distinct than in dichrous. Length 5-5.5 mm.

Low meadow ponds near Bass Lake, Starke County, and Huntingburg, Dubois County; scarce. April 8--May 9.

467 (1511). Gyrixus dichrous Lec., Proc. Phil. Acad. Nat. Sci., 1S6S, 368.

Resembles the next but wholly without bronzed lustre. Punctures of elytral stria smaller, more crowded. Length $4.5 \mathrm{~mm}$.

Lake Maxinkuckee; scarce. Angust 17.

468 (1510). Grrinus indbatus Say, Trans. Amer. Phil. Soc., II, 1S23, 10); ibid. II. 520 .

Short, broad, but little attenuate behind. Above black, shining, distinctly bronzed. especiaily so on margins and suture of elytra and front margin of thorax; beneath reddish-brown. the middle segments of abdo[16-23402] 
men darker. Elytra broad, tapering but little behind. tips subtruncate, outer angle rounded; corering the entire abdomen (male) or leaving only the tips exposed (female). Length $3.8-4.2 \mathrm{~mm}$.

Taken only along the borders of Wawasee and Hudson lakes, where it was found in very large colonies. Juhy 15-July 18.

469 (1519). Grumes affinis Aubé, Spec. Gell., VI, 1838, 669.

Elongate-oral. Black, moderately shining; upper surface minutely alutaceous, margins bronzed; beneath dusky bronzed, the last rentral segment reddish-brown. Elytra with tips more concare than usual, their punctures fine, close-set. Length $6.5-7.5 \mathrm{~mm}$.

Putnam County ; scarce. July 4.

470

Oval. moderately convex." Black, polished, the suture and side marwins of elytra bronzed: under surface black. the last rentral paler; epipleura and legs reddish-brown. Elytral punctures rell marked. the outer two rows coarser. Length $5.5 \mathrm{~mm}$.

Lake County; rare. Maỹ

471 (1521). Grrinus analis Say, Trans. Amer. Phil. Soc., II, 1S23, 108; ibid. II, 520.

Elongate-oral. Black, bronzed both above and beneath; upper surface not highly polished; beneath black, legs and last ventral segment reddishbrown. Elytra with tips broadly but obtusely rounded. Length $5-6 \mathrm{~mm}$.

Throughout the State: common. April 11-October 23.

472 (1527). Grrtnus borkatis Aubé, Spec. Gen.. VI. 1838, 692.

Broadly oral. Abore black, highly polished. margins and sides of elytra bronzed; beneath black. the last rentral segment dark brown. Punctures of elytral striae fine. rather close. Length $\tau \mathrm{mm}$.

Throughout the State; frequent. April 23-August 15. Resembles ventratis but broader and with nnder surface black.

473 (1528). Grrints lugens Lec.. Proc. Phil. Acad. Nat. Sci., 1S6s. 369.

Broadly oral. Resembles boreatis, but above black. slightly polished. not at all bronzed; beneath black, the last rentral segment dark brown. Elytra with tips more rounded and with outer angles less distinct; punctures finer. more distant one from another. Length $6 \mathrm{~mm}$.

Lake and Laporte counties; scarce. May 20-July 15.

$G$. pectoratis Lee., is a boreal species which may occur in northern Indiana.

II. Dinertes MeL. 1819. (Gr., "to whirl or swim in an eddr.",)

The species of this genus are all of fair size. more or less oval and sublepresed. They hare the upper surface usually shining, 
bronzed and finely reticulate; labrum rounded in front and ciliate; scutellum invisible; elytra with nine slightly impressed strix which are sometimes very indistinct. Front tarsi of males moderately dilated and densely clothed beneath with papilla, forming an elongate, narrow brush. Four species are known from Indiana, while another may occur.

KEY TO INDIANA SPECHES OF DHNETTES.

a. Sides of thorax and elytra with a bronzed submarginal stripe; length $12-15.5 \mathrm{~mm}$.

au. Sides without submarginal stripe; length not over $11 \mathrm{~mm}$.

VITTATUS.

b. Under sirface uniform brownish-yellow.

67. Under surface black or bronzed.

c. Sutural angles of elytra rounded in both sexes; femora of male toothed.

475. EMARGINATUS.

ce. Sutural angles distinct in female; femora of male not toothed.

d. Sutural angles of both sexes produced backward; tips of female elytra feebly separated.

476. Assimilrs.

dd. Sutural angles of elytra of male rounded; those of female produced backward with the tips strongly separated.

477. HORNII.

D. vittatus Aubé has a range which probably includes southern Indiana, but it has not yet been taken in the State.

474 (1534). Dineutes discolor Aubé, Spec. Gen., VI, 1S3S, 784.

Oblong-oval, moderately convex, narrowed in front. Above blackbronzed. shining; under surface brownish-yellow to straw color. Elytra with side margins at outer apical angle and tips slightly sinuate, the sutural angles weakly produced; femora of male with a triangular tooth. Length $11.5-13 \mathrm{~mm}$.

Steuben, Kosciusko, Putnam and Martin counties; very common in East Fork of White River. June 26-September 3. Easily known by the narrower Iront half of body and pale under surface.

475 (1538). Dineutes emarginatus Say, Trans. Amer. Phil. Soc., II, 1823. 108 ; ibid. II, 519.

Rather broadly oval, moderately convex. Above black or blackishbronzed, not very shining; beneath black, very shining. slightly bronzed: middle and hind legs, narrow margin and tip of abdomen, paler. Side margins of elytra in male, not in female, slightly sinuate near tips; sutural angles broadly rounded. Length 10-11 $\mathrm{mm}$.

Pond near Tniversity farm, aast of Mitchell, Lawrence County : scarce. August 7. Probably throughout the southern half of State. 
476 (1536). Dineutes assindis Aubé, spec. Gen.. VI. 1S38, Tis.

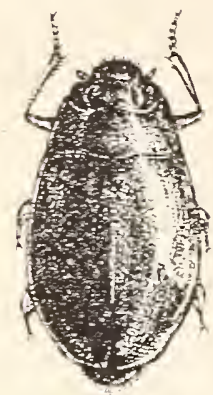

Fig. 123. $\times 2 \frac{1}{2}$ (Original.)

Oblong-oval. distinctly convex. Above black, strongly brouzed; beneath black, rery shining; abdominal segments often tinged with brown; legs brownish-yellow. Elytra of male feebly sinuate near tips, the latter but slightly separated at suture. the angles but little produced backwards: those of female more strongly sinuate both on side margins and near tips. the lattel more widely separated at suture, the angles distinctls produced backwards. Length 10-11.5 mm. (Fig. 12.3.)

Throughout the state: common. May y-September 19. This is the species usually known as the "apple-bug;,' on account of the odor exhaled from the milky fluid exuder from anal segment.

47 (-). Dineutes horit Roberts, Trans. Amer. Ent. Soc., XXII, 1895. 284.

Closely resembles assimitis but usually smaller, more obovate. Distinguished by the elytra of males haring the sutural angles rounded. those of female more widels separated at apex. Length $9.5-11 \mathrm{~mm}$.

Lakes of northerm Indiana; common. May 6-August 20.

Gyretes sinuatus Lec.. elongate-oval. dark bronzed, very shining. sides of thorax and elytra densely punctured and pubescent, has been taken at Quincr, Illinois.

\section{Series II. CLAVICORNIA.}

This is a large and unwieldly group of families having few char acters in common. except that the antennx are enlarged to form a more or less distinct club toward the tip. It is here that the tarsal system has its feeblest vahue. as every possible variation exists from the 5-jointed to the 1-jointed. In the tables which follow certain families (whose numbers are given in parenthesis), and other subdivisions* (whose names are given in italics). rightfully for the most part belong to the Serricornia, but their antennæ are often so obriously clavate as to lead the student amiss. Those which there belong are also included in the Serricornia table. where their aberrant character becomes at once apparent. In order to shorten and simplify the key to families of Clavicornia the Series is first divided into four groups or Subseries. and these in turn into families.

KEI TO SLESERIES OF INDIAXA FAMILIES OF (LATICORXIA.

a. Elrtra short. leaving the sreater part of the abdomen exposed abore; mings usualle present. and when not in use folded beneath the short elytra: dorsil part of the abdomen entirely horn-like in texture; tarsal joints varving in number.

Subseries A. Brachelitra Claticornia, p. 243.

* The number of the family to which these subdivisions belong is also included in parenthesis. 
au. Elytra usually long, covering the greater part of the abdonen; when short the wings wanting or, if present, not folded under the slort elytra when at rest; dorsal part of the abdominal segments partly membranous.

b. Tarsal joints on at least one pair of tarsi. five in number.

Subseries B. Pentamera Clavicorina, p. 243.

bb. Tarsal joints on all the tarsi less than five in number.

c. Tarsi four-jointed (front ones three-jointed in the males of some Mycetophagidæ).

Subseries C. Tetramera Clavicornia, p. 246. cc. All the tarsi three-jointed.

Subseries D. Trimera Clavicornia, p. 247.

\section{Subseries A. BRACHELYTRA CLATICORNIA.}

This group or subseries comprises but two families, whose members subsist for the most part upon decaying animal or vegetable matter, or oceur beneath stones. in rotten wood or in the nests of ants.

\section{KEY TO FAMILIES OF BRACHELTTRA CLATICORNIA.}

a. Abdomen not flexible; rentral segments 5 or 6 ; form short, robust; maxillary palpi usually greatly developed and variable in form; tarsi with not more than three joints; length less than $3.5 \mathrm{~mm}$.

Family X. Pselaphide, p. 305. a a. Abdomen flexible or capable of being curled upward; seren or eight segments visible from below; form usually narrowed and elongated.

Family XI. Staphrlinide, p. 334.

\section{Subseries B. PENTAIERA CLAVICORNIA.}

This group is composed, for the most part, of land and water scavenger beetles whose office it is to hasten the decomposition and remoral of dead organic matter. They occur upon dead animals, mnder the bark of dead trees and on decaving fungi. fruit. ete. Of them Le Baron has written: "The only other insects which can be compared with these in usefulness as scavengers, is the extensive family of Muscidx, in the two-winged flies. It is interesting to observe the order in which these various tribes of scarenger insects perform their respective parts. First come the Iuscidie, which, in the form of carrion fies, deposit their eggs or fly-blows upon dead animal matter at the first moment of decay. and. in very hot weather almost immediately after life has ceased. Soon after these come the carrion beetles, the Silphe and Necrophori. Whose larra. like the maggots of the flesh flies. are seen reveling in the putrescent matter at the most offensive stage of decomposition. When the softer parts have been devoured and only the osseous and liga- 
mentary portions remain, other families of scavengers succeed, namely. the skin-beetles, Dermestidx. and the bone-beetles, Necrobii and Nitidule, which adhere to the dried careass as long as any restige of animal matter remains."

The following families of this subseries are represented in Indiana:

KEI TO FAMILIES OF PENTAMELA CLATICORNIA.

a. Ventral segments all free and morable.

b. Mentum large, the palpi distant at base.

c. Eyes present; habits aquatic or subaquatic; mentum quadrate, its hind angles not prolonged; antennæ short. or less than elevenjointed; maxillary palpi as long as or longer than the antennæe.

Famils VI. Hrdrophilidæ, p. 247.

cc. Eyes wanting; habits terrestrial; mentum transrerse, its hind angles prolonged; antemne rather long. eleren-jointed, its outer joints but slightly thicker. Family rir. LePtixidæ, p. $2 \pi 1$.

b7. Mentum moderate or small, the palpi close together at base.

d. Front coxie conical.

e. Front coxie transversely prolonged at middle. but slightly prominent; thorax (in our species) serrate at margin; abdomen with five risible segments, the first not elongated; antennæ with the last three joints somewhat but not suddenly enlarged; length less than $3.5 \mathrm{~mm}$. Family XXX. Derodontide, p. 670.

ce. Front coxie large. prominent, not transrersely prolonged at middle.

$f$. Hind coxie mole or less conical and prominent.

g. Eyes finely granulated, sometimes absent; hind coxre usually contiguous; antemæe usualls with a compact club. but oftentimes nearly filiform (burying and carrion beetles).

Family VIII. Silphide. p. 22テ2.

gg. Eyes coarsely granulated; hind coxæ separated; length less than $3 \mathrm{~mm}$. Family IX. SCYdiæxid., p. 291.

$f f$. Hind coxie not prominent.

h. Antenne long. slender, sometimes hair-like; elytra shorter than abdomen, the latter thick, conical, and pointed, its last rentral elongate; tarsi long and slender; length less than 5 mm. Family XIII. Scaphidid.e. p. 490.

hh. Antenme moderate in length. capitate; hind coxæ groored for the reception of the thighs in repose; body usually scaly or pubescent; elytra entire; length less than $10 \mathrm{~mm}$.

Famils XXIT. Dermestide. p. jsi.

dd. Front coxæ not conical, not prominent.

i. Front coxie rounded or oral.

$j$. Hind coxie not groored to receire the thighs.

li. Hind coxie contiguous; body very compact and convex, elytra entirely covering it: antenne witl a three-jointed club; length less than $3 \mathrm{~mm}$.

Family XIV. PHalachide, 1). 49T. 
lik. Hind coxie separated.

l. First rentral segment elongated; form elongate, slender; antemnal club two-jointed.

Subfamily (XLIV). Lyctine, 1). s!o1.

11. All the rentral segments subequal.

$m$. Middle coxal carities not closed on the outer side by the meeting of the meso- and metasterna; form very depressed; antennie sometimes clubbed but more often with the outer joints scarcely thickened.

Family XXI. Cucujade, 1). 万(i).

$m m$. Middle coxal cavities closed by the sterna; prostermum prolonged, meeting the mesosternim.

n. Front coxal cavities open behind; antenne with their terminal joints distinctly enlarged; surface pubescent and densely punctate; form oral or elongateoval; length less than $4 \mathrm{~mm}$.

Family XXII. Criptophagide, p. 569.

nI. Front coxal carities closed behind; all the tarsi distinctly five-jointed.

Groul (XYII). Dacnes. 1. .5t4.

$j j$. Hind coxal plates groored to receive the thighs; prosternum prolonged behind and fitting into a notch of mesosternum; antennse with a three-jointed club; length less than $5 \mathrm{~mm}$.

Genus (XXXTII). Throscus, p. тъ.

ii. Front coxie transverse.

o. Hind coxie flat, not grooved.

p. Antennæ straight.

q. Tarsi more or less dilated, first joint not short, the fourth smaller than any of the others; antennie with a threejointed club; elytra usually shorter than the abdomen. the latter with fire segments risible beneath ; color rarely wholly black. FamilyXXYr. Nitidilide. p. 62S.

q. T'ar'si slender, the first joint short.

1. All the tarsi with five joints. the first or basal joint very short; form elongate, usually depressed; length $5 \mathrm{or}$ more $\mathrm{mm}$.

Family XXVitI. Trogositide. p. 661. $\%$. All the tarsi with joints 1 to 4 short; hind tarsi witl but four joints; form convex; length less than $3 \mathrm{~mm}$.

Family (XLTits). Sphindide. p. 901.

mp. Antennse elbowed and with a short compact club; tibise usually all dilated: elytra usually truncate and shorter than abdomen: form short. compact; black, rarely bicolored. Family XXT. HIrsterine, p. 598.

oo. Hind coxie groored to receive the thighs in repose; body rounded or oral, convex; legs retractile.

Family XXXi. Brtrinde, p. 671.

an. Ventral segments 1 to 3 firmly united (not morable), the others free and morable; all the tarsi fire-jointed. 
s. Last joint of tarsi, long, claws lirge; head retractile, the mouth protected by the prosternum; aquatic or subaquatic species.

Family XXXili. Parnide, 1. 675.

ss. Last joint of tarsi moderate, claws normal; thorax (in our species) with deep grooves; mouth parts covered by a large mentum.

Family XX. RHYssodide, p. 558.

\section{Subseries C. TETRAMERA CLATIOORNIA.}

In this group (with the exception mentioned in key to subseries), the tarsi are four-jointed. The species live, for the most part, in fungi, especially those growing on dead trees and logs; some are subaquatic, living in mud or sand along the margin of water.

\section{KEY TO FAMILIES OF TETRAMERA CLAVICORNIA.}

a. Ventral segments all free and movable.

b. Wings fringed with hairs; very small, less than $2 \mathrm{~mm}$.

c. Hind coxæ contiguous, with plates corering the thighs; antennæ nine-jointed, club two-jointed.

Tribe (VIII). Clambini, p. 291.

cc. Hind coxie separate, without plates; tarsi aplarently three-jointed, the basal joint concealed by the notched second joint; mandibles with comb-like teeth. Family XV. Conrlophide, p. 501.

67. Wings not fringed with hairs.

d. Front coxæ transverse; body contractile; lensth less than $2 \mathrm{~mm}$.

Tribe (XXVI). Cybocephatini, p. 64t.

dd. Front coxre not transverse.

e. Front coxre globose.

f. Tarsi slender; length less than $4 \mathrm{~mm}$.

Subfamily (XVII). Myceteince, p. 584.

fi. Tarsi more or less dilated and spongy beneath, the fourth joint united with the fifth, so that only four are visible; antenne strongly clubbed. Family XVIII. Erotrlid A, p. 53:.

ee. Front coxie oval.

g. Front coxa well separated by the horn-like prosternum.

h. Form oval, depressed; head free; surface finely and densely punctured and hairy; length less than $6 \mathrm{~mm}$.

Family XXIII. MrсETophagme, p. 592.

hh. Form cylindrical; thorax prolonged orer the head; length less than $3.5 \mathrm{~mm}$. Family (XLVII). Ciorde, p. 895.

gg. Front coxæ almost contiguous; prosternum semimembranous; form small, rounded, convex; habits subaquatic; length less than $1 \mathrm{~mm}$. Family XXXII. Georisside, p. 675.

a $a$. Ventral segments 1-4 firmly united, the fifth only being movable.

$i$. Antennæ of regular form; tibiæe not dilated, not fitted for digging; front and middle coxx small, globose; length less than $6 \mathrm{~mm}$.

Family XIX. Colydidde, p. 549 .

ii. Antennæ short, the outer seven joints broad and short; tibiæ dilated. armed with rows of spines and fitted for digging; labrum and mandibles projecting forward; length less than $\tau \mathrm{mm}$.

Family XXXiv. Heteroceride, p. 682. 


\section{Subseries D. TRIMERA CLAVICORNIA.}

The members of this group have the tarsi all 3-jointed and the ventral segments free. They live either in fungi or feed upon plant lice. The following families of the subseries are represented in the State :

\section{KEY TO INDIANA FAMILIES OF TRIMERA CLAVICORNIA.}

a. Wings fringed with long hairs; abdomen not prolonged and with 6 or 7 ventral segments; antennæ with the basal and apical joints thicker than the middle ones, the latter with whorls of long hairs; length less than $2 \mathrm{~mm}$.

Family XII. 'Trichopterygide, p. 485.

aa. Wings not fringed.

b. Tarsi with second joint dilited; third joint consisting really of two joints, the small true third joint being inserted at the base of the last joint.

c. 'Tarsal claws dilated or toothed at base; first ventral segment with coxal lines; form usually rounded and convex; head nearly concealed by the thorax; last joint of maxillary palpi usually hatchet-shaped; length less than $8.5 \mathrm{~mm}$.

Family XVI. Coccinelide, p. 506.

cc. 'Tarsal claws simple; first ventral without coxal lines; form oblong or oval, rarely globose; last joint of maxillary palpi oval or triangular; length less than $6.5 \mathrm{~mm}$.

Family XVII. Endomychide, p. 533.

6b. Tarsi with second joint not dilated and without a pseudo fourth joint.

d. Elytra entire; ventral segments nearly equal f front coxal cavities rounded, not prolonged on the outer side; length less than $3 \mathrm{~mm}$.

Family XXVII. Lathridide, p. 651.

$d d$. Elytra truncate behind, leaving the pygidium exposed; ventral segments 1 and 5 longer than the others; front coxie small, rounded; length less than $3 \mathrm{~mm}$. Family XXIX. Момотоміде, p. 666.

\section{Family VI. MYDROPHILID}

\section{The Wa'ter Scavenger Beetles.}

This family comprises, for the most part, oval or elliptical blackish beetles, differing from the Dytiscidr in being more convex, in having the antenne enciing in a distinct club instead of being filiform, and in possessing palpi which are usually longer than the antennæ and are projected forward while swimming, while the antennæ are usually concealed beneath the head. By the inexperienced student the palpi are, therefore, often mistaken for the antennx.

The name of the family is derived from the genus Hydrophilus, a word of Greek origin meaning "a lover of water." As the name 
implies, they are usually found in ponds and streams, but are less active swimmers than the majority of the diving beetles. In swimming they move the hind legs alternately, while the Dytiscidæ strike with them both together, like a frog. Several genera are, however, terrestrial in habit, living in moist earth and in the dung of cattle, where they are said to feed upon the larvæ of dipterous insects.

The principal characters of the Hydrophilidx, briefly stated, are as follows: eyes large; mentum large, quadrate; antennæ with from six to nine joints, the outer ones forming an abrupt club, of which all the joints except the first are pubescent; inserted under the sides of the front behind the base of the mandibles. Thorax with episterna and epimera not distinct. the prosternum very short. Seutellum always present. Metasternum large. frequently carinate and produced into a long spine behind. Hind coxw oblique, flat, extending to sides of abdomen, the latter with five visible segments. Tarsi 5-jointed, the first joint often very small. the middle and hind ones sometimes compressed and fringed for swimming.

As their common name denotes, the water scavenger beetles are supposed to live itpon decomposing arquatic vegetation, but the larve are carnivorous and often eatch and eat living insects and water snails. These larva resemble somewhat those of the diving beetles, but the body is more plimp and the mandibles shorter and usually toother. The eggs of the larger species are encased by the female in a waterproof receptacle, formed of a silk-like secretion. These egg-cases, which sometimes contain 100 or more eggs. are either fastened on the under side of leaves of water plants, or are allowed to float free. In a few instances the cases are carried about by the mother on the under side of her body until the young hatch. The pupal stage is undergone on land, in an underground cell or in a cavity scooped out beneath some object close to the water's edge.

The principal literature treating of the North American species of the family is as follows:

LeConte.-"Synopsis of the Hydrophilidxe of the United States," in Proc. Phil. Acad. Nat. Sci., VII, 1855. 356-375. Horn.- "Revision of the Genera and Species of the Tribe Hydrobiini," in Proc. Amer. Phil. Soc.. XIII, 1873, 118-137.

Horn.- "Synoptic Tables of some Genera of Coleoptera," in Trans. Amer. Entom. Soc. V. 18i6, 251.

IIorn._- "Notes on the Species of Ochthebius of Boreal America," in Trans. Am. Ent. Soc., XVII, 1890. 17-26. 
Horn._"Notes on some Hydrobiini of Boreal America," loc. cit., $237-278$.

Horn._- "A Revision of the Sphreridiini Inhabiting Boreal America," loc. cit., 279-314.

Wickham._"The Hydrophilidx of Ontario and Quebee," in Can. Ent., XXVII, 1895, 181, 213.

About 170 species of Hydrophilidie are known from the United States. These are distributed among four tribes, all of which are represented in Indiana.

KEY TO TRIBES OF HYDROPHILIDE.

a. Thorax narrower than elytra. usually narrowed behind; form elongate; sculpture usually rough; length less than $6 \mathrm{~mm}$.

Tribe I. Helophoriñ, p. 249.

aa. Thorax at base as wide as elytra, narrowed in front; form usually convex, oval or elliptical; sculpture usually weak.

b. Middle and hind tarsi with first joint short.

c. Metasternum prolonged into a distinct spine; tarsi compressed.

Tribe II. Hydrophimtin, p. 254.

cc. Metasternum not prolonged; tarsi not compressed.

Tribe III. HYDRoBIINI, p. $25 \%$.

b7. Middle and hind tarsi with the first joint elongated; length less than $3.5 \mathrm{~mm}$. (except in sphlsitium).

Tribe IV. Spheridint, p. 265.

Tribe I. HELOPHORINI.

Small oblong or elongate aquatic species, gray or brown, more or less tinged with bronze in color. They occur in pools, where they cling to aquatic plants and may be readily taken by stirring up the mud and plants at the bottom, when the beetles will rise to the surface. They swim but poorly and are unable to dive rapidly. Of the five genera into which the tribe has been separated, representatives of four occur in Indiana.

KEY TO INDIANA GENERA OF HELOPHORINI.

a. Elytra with ten strixe or rows of punctures; maxillary palpi moderate.

b. Last joint of maxillary palpi longer than the next to last.

c. Antenna nine-jointed.

I. Hezophorus.

cc. Antemnie seren-jointed.

II. HYDROCHU's.

bb. Last joint of maxillary palpi shorter than the next to last.

III. Ochthebius. a a. Elytra with more than ten rows of punctures; maxillary palpi very long.

IV. HYDRENA. 


\section{Helophorus Fab. 1776. (Gr., "tubercle +bearing."')}

Thorax rough, with granulate depressions, and marked with five longitudinal sulci, of which the intermediate, or those on either side of the middle one, are often very sinuous. Wive species have been taken in Indiana, while one other may occur.

\section{KEY TO INDIANA SPECIES OF HELOPHORUS.}

a. Elytra without tubercles or alternate elevated lines.

b. Larger, 5-7 mm. head and thorax shining. sparsely punctate; intermediate sulcus but slightly undulate.

bb. Smaller, not orer $4.5 \mathrm{~mm}$.

$c$. Thorax with hind angles obtuse, not narrowed at base; color piceous-brown.

a. Thorax with sides feebly rounded in front, nearly straight behind; intermediate sulci strongly sinuate. 478. LACUstris.

dd. Thorax with sides regularly rounded; intermediate sulci nearly straight.

479. Nitidulus.

cc. Thorax with hind angles rectangular.

e. Thorax slightly narrowed at base, its sides subsinuate; color light brownish-yellow with indistinct fuscous markings.

4SO. LINEATUS.

ee. Thorax not narrowed at base, sides nearly straight.

4S1. LINEARIS.

aa. Elytra with tubercles on the third, fifth and serenth intervals.

4S2. TUBERCULATUS.

H. oblongus Lec. was, like lacustris and nitidulus, described from Lake Superior, and like them may occur in northern Indiana.

4is (1543). Helophorus lacustris Lec., Agass. Lake Sup., 1850, 217.

Oblong, subdepressed. Piceous-brown, slightly bronzed; head and thorax tinged with greenish; legs reddish-brown. Thorax two-thirds wider than long, corered with rounded flattened granules; sulci narrow, deep, the intermediate ones strongly sinuate. Punctured strixe of elytra deep. Length $4-4.5 \mathrm{~mm}$.

Lake and Laporte counties; scarce. May 12-August 26.

479 (1545). Helolhorus Nitidulus Lec., Proc. Phil. Acad. Nat. Sci., ViI. $1855,357$.

Elongate, subdepressed. Piceous-brown, shining, distinctly bronzed; legs pale, the femora darker. Thorax one-half wider than long, the sulci broader and more shallow than in lacustris, the intermediate ones but slightly sinuous. Intervals of elytra more narrow, the striae deep. Length 3-3.5 mm.

Lake County, near Osborn and Pine; rare. April 21-May 25. 
$4 S 0$ (1550). Helophorus lineatus Say, Jomrn. Phil. Acad. Nat. Sci., III. 200 ; ibid. II, $12 S$.

Elongate-oblong. Above light brown with a greenish tinge; elytra often with fuscous markings, of which an inverted $V$ on suture behind middle and two spots each side are most obvious; antennze and legs pale. Intermediate sulci of thorax, deep, narrow, rery strongly curved or subangulate near middle. Elytral strixe with deep, dilated transverse punctures. Length $2.5-3.5 \mathrm{~mm}$. (Fig. 124.)

Throughout the State; frequent. April 11-October 17.

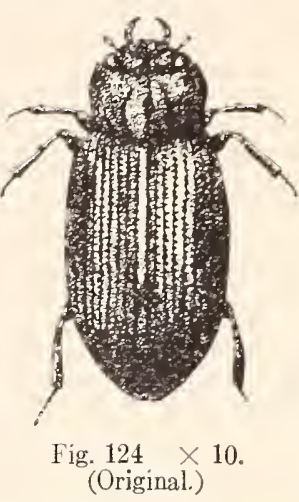

481 (1546). Helophorus linearis Lec., Proc. Phil. Acad. Nat. Sci., 1855, $35 \%$.

Elongate, slender. Dull brownish-yellow; head and thorax tinged with greenish; elytra clouded with fuscous. Thorax one-half wider than long, granulate; intermediate sulci feebly sinuate. Length $3 \mathrm{~mm}$.

Millers, Lake County ; rare. May 25. Recorded from Buffalo, New York, Nebraska and Canada.

$4 S 2$ (1553). Helophorus tuberculatus Gyll., Ins. Suec., 1S27.

Elongate, convex. Dull black, tinged with greenish. Third elytral interval with four elevations, the basal one oblong; fifth and seventh each with three. Length $3.5 \mathrm{~mm}$.

Beneath rubbish close to water on beach of Lake Michigan, near Pine and Millers, Lake County; scarce. April 23-June 24.

\section{Hydrochus Leach. 1817. (Gr., "relating to water."')}

Thorax much narrower than elytra. its breadth being equal to or only slightly exceeding the length; disk usually marked with small cups or fovea. "The following species have been taken or may occur in the State.

KEY TO INDIANA SPECIES OF HYDROCHUS.

1. Larger, $5.5 \mathrm{~mm}$; elytra with intervals flat and much wider than striae. the fourth with large oblique tubercles.

SCABRATUS.

a . Smaller, not over $4.5 \mathrm{~mm}$.; intervals conver.

b. Thorax with five more or less distinct fovese or cup-shaped impressions.

c. Stria of elytra as wide as or wider than intervals; thorax with granules between the punctures.

d. Sides of thorax distinctly sinuate near base, not crenulate; length $3.5-4 \mathrm{~mm}$.

4S3. SQUAMTFER.

Id. Sides of thorax finely crenulate.

$e$. Smaller, not over $3 \mathrm{~mm}$.; sides of thorax subsinuate.

484. INEQEALIS. 
ee. Larger, $3.5-3.8 \mathrm{~mm}$; sides of thorax not sinuate.

4S5. ExCAVATUS,

$c c$. Intervals of elytra wider than strix; thorax without granules between the punctures.

4S6. SUBCUPREUS.

bb. Thorax without distinct forea, its surface densely and finely granulate.

487. GRANULATUS.

H. scabratus Muls. is recorded from New York to Iowa and southward.

483 (1562). Hydrochus squamifer Lec., Proc. Phil. Acad. Nat. Sci., VII, $1855,359$.

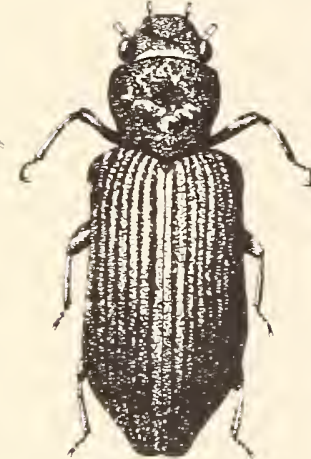

Fig. 125. $\times 9$. (Original.)

Flongate. Abore grayish-bronzed or cupreous; head and thorax tinged with greenish and darker than elytra; beneath dull reddish-brown, legs and palpi paler. Thoras scarcely wider than long. sides sinuate; disk coarsely and rather closely punctate, the intervals with flattened granules. Elytra deeply striate; third interval a little higher than second, fourth elevated from the middle half way to apex, fifth elevated like the third but interrupted orposite the elevation of fourth. Length $3.7 \mathrm{~mm}$. (Fig 125.)

Lake and Marion counties; scarce. May 25-August 20.

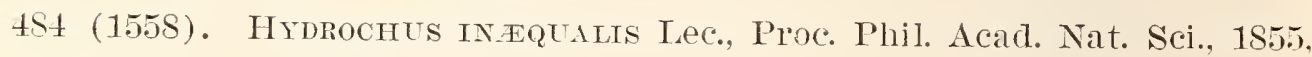
359.

Elongate. Abore dark reddish-brown, slightly bronzed; legs paler. Thorax roughly and densely punctate, slightly longer than wide; dorsal fovere rery distinct. Elytra deeply striate, the fifth, seventh and ninth intervals elevated and interrupted behind the middle, giving the appearance of a transverse impression : fourth elevation opposite break in thilrt. Length $3 \mathrm{~mm}$.

Lawrence County, from pond near University farm; scarce. August 7. A species of southern range.

455 (1559). Hrorochus excaratus Lec., Proc. Phil. Acad. Nat. Sci., MiI, $1855,360$.

Elongate. Blackish-bronzed; legs reddish-brown. Thorax about as wide as long, the forea distinct, the basal ones smaller. Elytral intervals narrow, the fourth, fifth and seventh elevated. the fifth interrupted. Length 3.5-3.9 $\mathrm{mm}$.

Lake and Laporte counties; scarce. May 25.

486 (1560). Hrdrochus scbecpreus Rand., Bost. Journ. Nat. Hist., II. 1838, 40.

Elongate, rather slender. Brown, with a distinct brassy tinge; beneath piceous; legs reddish-brown, knees darker. Thorax subquadrate, not wider than long; disk with fover less distinct than in excavatus; coarsely, deeply. not densely punctate. Elytra with intervals conrex, distinctly wider: than 
striae, fifth slightly elevated and interrupted behind the middle; fomrth elevated opposite the break in fifth; the others alnost mniform. I,ength $3.5 \mathrm{~mm}$.

Starke County ; rare. August 20.

4ST (-). Hydrochus granulatus sp. nov.

Elongate, slender. Above piceous with a greenish or olivaceous tinge; beneath piceous, legs dark reddish- or fuscous brown. Thorax a little longer than widle, sides almost straight; surfice, as well as that of head, finely and very densely granulate-punctate, the forese rely faint. Elytral striae wider than intervals, the latter very narrow. the fourth interrupted behind the middle, fifth almost wholly wanting or not convex. Jeength 3.S-4 $\mathrm{mm}$.

Lake County ; rare. April 29. An nnnamed specimen is also in the LeConte collection at Cambridge, labelled "Illinois."

\section{Ochthebres Leach. 1817. (Gr., "shore + to live.")}

Very small brown. black or piceous species having the thorax narrowed at base, with a transparent side margin, and the disk with impressed lines or fovea, quite similar to those of Helophorus, but interrupted. They occur in or about the edges of small pools and woodland ponds; also on the under side of stones in running water. One undescribed species has been taken in the State, while three described by LeConte have a range which may inchude Indiana.

\section{KEY TO INDIANA SPECIES OF OCHTHEBIUS.}

u. Thorax abruptly sinuately narrowing from in front of middle to bast and with a distinct angulation at middle of sinuation, all the discal impressions well marked.

FOVEICOLLIS.

un. Thorax abruptly sinuate from the middle, or more or less notched near the hind angles.

b. Thorax with well marked discal forere.

c. Form oblong-oval, subdepressed; elytral punctures obsolete near apex.

NITIDUS.

cc. Form short, broadly oral, strongly convex; elytral punctures distinct to apex.

4SS. PUTNAMENSIS.

66. Thorax without discal foreve, coarsely punctate, the lateral fovere deep and broad. CRIBRICOLLIS.

O. foveicollis Lec., 1.2-2.5 mm., O. nitidus Lec., $1.8 \mathrm{~mm}$., and $O$. cribricollis Lec., $2 \mathrm{~mm}$. in length, all piceous-bronzed in hue, may occur in northern Indiana.

4SS (- ). OCHTHEBLS PUTNAMENSIS S1\% noF.

Short: oral, strongly convex. Elytral black, shining; head and thorax bronzed; legs reddish-brown. Thorax twice as wide as long. sides rounded from apex to basal third, thence oblique and feebly simuate to base; disk 
finely and sparsely punctate. its sides broadly flattened; median groore widle and deep, discal forere separated. the hind ones oblique and larger than those in front; lateral ones broad. shallow and but slightly curved. Elytra with rows of large quadrate punctures. Length $1.5 \mathrm{~mm}$.

Putnam County; rare. October 17. Sifted from debris at side of hillside spring. IIr. Blanchard. who compared the specimen with those at Cambridge. writes that "the short convex form is quite different from any of our named species."

\section{HrDRend Kug. 1791. (Gr.. "to wash or bathe.")}

Our single member of this genus is smaller than any of those belonging to the two preceding genera. The thorax is subquadrate, about three-fourths the width of elytra, and the latter are marked with more than ten rows of punctures.

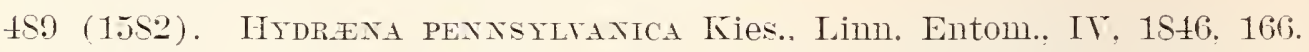

Elongate-oblong. subconrex. Piceous or dark reddish-brown. the palpi. legs and narrow side margins of thorax dull rellow. Thorax narrower at base than aper. side margins sinuate; disk coarsels and densely punctate and with a large impression each side near front angles. Punctures of elytral strixe close, rather coarse, quadrate; intervals narrow. convex. Length $1.8-2.2 \mathrm{~mm}$.

Kosciusko County: scarce. June 21. Sifted from damp, decaring sphagnum moss in tamarack swamp.

\section{Tribe II. HIDROIIIITII.}

Large or medium-sized beetles of an oval or elliptical convex form, olive-black in color. rarely with sides of thorax and elytra rellow. Elytra not striate; antenna 9-jointed: meso- and metasterna forming a continuous keel which is prolonged behind into an acute spine; middle and hind tarsi strongly compressed, fringed on the inner side with long hairs. Three genera oceur in Indiana.

\section{KEY TO GEXERA OF HYDROPHILIXI.}

a. Prosternum sulcate; metasternal spine long.

6. Length 25 or more mm. last joint of maxillary palpi shorter than the preceding.

T. MYDROPHILCS.

6). Length less than $12 \mathrm{~mm}$; last joint of maxillar palpi equal to or longer than preceding.

TI. TropisterTts.

a . Prosternum carinate; metasternal spine short: length 13-16 mm.

VII. HYDROCHARIS.

T. Hrdrophilts Geoff. 1764. (Gr.. "water + loring.")

This genus includes two very large black beetles, the giants of the family as representeil in North America. 
490 (1585). Hydrophilus ovatus Zieg., Proc. Phil. Acad. Nat. Sci., II, 1844,45 .

Less elongate, more convex. Above black with an olive tinge; beneath piceous; antenne and tarsi paler. Abdomen pubescent, the last three segments narrowly smooth at middle, without yellow spots at sides. Prosternal prominence, in which front end of sternal spine fits, open in front. Length $31-33 \mathrm{~mm}$.

Southern half of State; frequent. May 25-October 8. Often attracted by electric light.

491 (1586). Hrdrophilus triangularis

Say, Journ. Phil. Acad.

Nat. Sci., III, 1S23, 201;

ibid. II, 128.

More elongate, less convex. Above of same hue as ovatus; beneath darker. more shining, the abdominal segments with more or less distinct triangular yellow spots at sides. First segment pubescent, the remainder broadly smooth at middle. Prosternal prominence closed in front. Length 34-37 mm. (Fig. 126.)

Throughout the State; common. March 19-October 27. Sometimes attracted by thousands to electric lights in Indianapolis and the larger cities. Hibernates as imago.

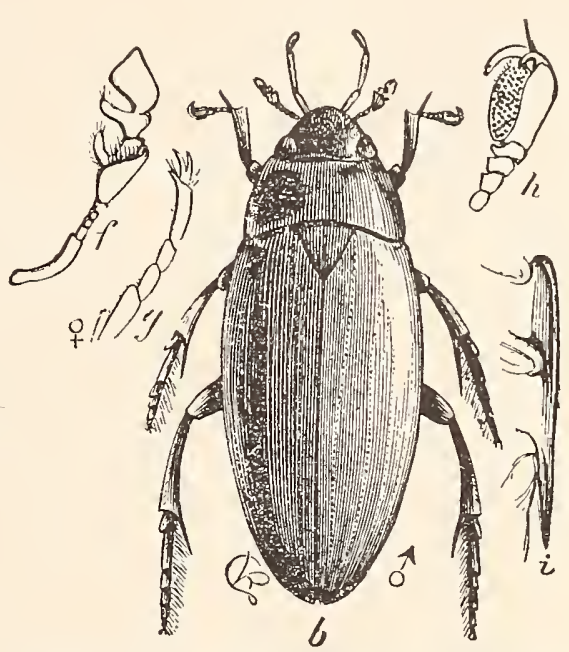

Fig. 126. $b, \mathrm{H}$. triangularis Say natural size; $f$, antenna; $g$, front tarsus of female; $h$, same of male, all magnified; $i$, side view of sternal spine. (After Riley.)

\section{Tropisternes Sol. 1834. (Gr., "keel + breast.")}

Smooth, shining, oval insects, mostly black above; very common in ponds, lakes and slow-flowing streams. Nine species, including Nos. 1588 to 1595 of the Henshaw "Catalogue," belong to this genus, five of which have been taken in Indiana.

\section{KEY TO INDIANA SPECIES OF TROPISTERNUS.}

a. Prosternal prominence or groove closed in front; elytra without yellow stripes.

b. Thorax and elytra narrowly margined with yellow.

bb. Thorax and elytra entirely black above.

492. NMMPATLS.

c. Front part of sternal crest very finely and indistinctly punctured: elytra with very fine and coarser punctures intermixed.

493. MIXTUS.

cc. Front part of sternal crest distinctly punctured; elytral punctures equal in size or nearly so.

d. Form elongate-oral; elytral punctures very minute and indis tinct.

494. SiBLEVIS 
dd. Form more broadls oral; elstral punctures larger and more distinct.

49.5. GLABER.

«a. Prosternal groove open in front; elctra with discal sellow stripes.

496. STRIOLATCS.

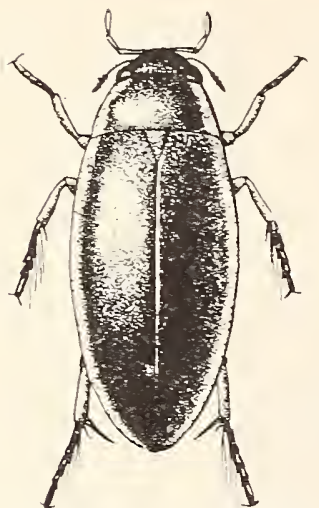

Fig. 127. $\times 4$. (Original.)

192 (1589). Tropisterses ximbatus Say. Journ. Phil. Acad. Nat. Sci.. III, 1823. 205 ; ibid. II, 130.

Elongate-oral. conrex. Oliraceous black. shining; clypeus. thorax and elytra margined with pale sellow; under surface black or piceous; legs sellow. femora black at base. Length $5.2-9$ 11m. (Fig. 12\%.)

Throllghout the State; common. March 14 Sctoler 9. At alectric light in June.

493 (1590). Tropisteryes mixtes Lec.. Proc. Phil. Acad. Nat. Sci.. VII. 1855. 368.

Elongate-oral. conrex. Black. more or less bronzed. shining; antennæe base of paipi and apical holres of femora and tibiæ bromish-vellow. Elytra with coarser and finer punctures intermingled. these risible only under a lens. Length $8.5-9 \mathrm{~mm}$.

I ake. Iaporte. Kosciusko. Putnam and Martin counties; frecuent. MIar 5-October 25.

494 (1593). Tropisterates stbletis Lec. Proc. Phil. Acad. Nat. Sci., VII. 1555.368 .

Elongate-oral. Black, feebly bronzed; antennæ, palpi and legs dull yellow, base of femora piceous. Front half of sternal crest flat, finely but distinctls punctured. Length 9-10 mm.

Putnam County: rare. July 8.

495 (1591). Tropisterixts Glaber Herbst.. Col., VII, 398.

Resembles mixtus but usualls broader and longer. Punctures of elstra rery fine and subequal in size. Front part of sternal crest concare and rel's coarsels punctured. Length $9.5-11 \mathrm{~mm}$.

Throughont the State: common. March 16-October 23. Often found beneath rubbish along the edges of ponds and lakes.

496 (1595). Tropisteryts striolates Lec., Proc. Phil. Acad. Nat. Sci., VII. 1855, 368.

Elongate-отal. convex. Oliraceous black; front of head and sides of thorax rellow; elstra each with sides and six or more narrow stripes on disk rellow; under surface black. prosternum and legs brownish-rellow. Sternal crest sülcate throughout its full length. Length 9-10.5 mm.

A species of southern range, taken only in Vigo and Knox counties; scarce. July 9-October 28. 
VII. Hydrgcharis Latr. 1825. (Gr.. "water + delight.")

The prosternum, instead of heing grooved for the reception of the front end of the sternal crest. is entire and raised into a sharp carina. One species occins in the State.

497 (1597). Hydrocharis obtesates Say, Joull. Phil. Acad. Nat. Sci.. III, 1823, 200 ; ibid. II, 129.

Nale elongate-oral; female oblong-oral, very obtuse behind. Black, shining; under surface dark reddish-bromn, pubescent. Fiytra each with four lows of distinct punctures, the outer row double. Spine of netalsternum not extending beyond hind coxæ. Length 13-16 11111 .

Common throughout the northeln half of State; less so in southern portion. April 6-September 15. Often taken bereath 100 s and stones close to the edge of water; also at electric light.

\section{Tribe III. IIYDROBINI.}

Aquatic beetles of small size and of an oval or hemispherical form, having the thorax at base alwars as wide as the base of elytra, and the metasternal spine never prolonged back of the hind coxw. The tribe is represented in Indiana by nine genera, separated by Dr. Horn as follows :

\section{KEY TO INDIANA GENERA OF HYDROBIINI.}

a. Last rentral segment emarginate; antennze seren-jointed; elytra with ten strix; length $2.5-6 \mathrm{~mm}$.

VIII. Berosts. a a. Last rentral segment entire.

ъ. First and second rentral segments concealed by plates: length less than $2.5 \mathrm{~mm}$.

iX. Chemtarthria.

$b b$. Ventral segments not corered.

c. Antennie eight-jointed; color mostly pale; form rounded, convex: length $2.5-3 \mathrm{~mm}$.

X. Laccobics.

cc. Antennie nine-jointed; color usually dirk.

1. Last joint of maxillary palpi shorter than third; length 3.5$7 \mathrm{~mm}$.

e. Tarsi fire-jointed on all the feet.

$f$. Mesosternum with a longitudinal lamina or plate; second joint of maxillary palpi curved. with the convexity to the front; elytral punctures confused. XI. PHILHydres.

ff. Mesosternum with cinly a slight median tuberosity: conrexity of the curred second joint of maxillary palpi turmed to the back; elytral punctures in rows.

XII. Helochares.

ee. 'Tarsi four-jointed on the middle and hind feet.

g. Mesosternum with a feeble transrerse carina; tarsal clan's simple; elytra not striate.

Xili. Crabiodrta 
.gg. Mesosternum with a compressed conical process; tarsal claws broadly toothed at base in male, less so in female; elytra striate.

XIV. Helocombus.

$d d$. Last joint of maxillary palpi longer than the third.

h. Elytra either with strixe or with punctures arranged in rows; larger species, more than $5 \mathrm{~mm}$.

XV. HYDRoBIL S.

$h h$. Eiytra with confused punctuation; smaller species, less than $4 \mathrm{~mm}$.

XVI. Creniphilus.

\section{Berosus Leach. 1817. (Gr., a proper name.)}

This genus is composed of convex, elongate beetles, usually pale in color with darker spots on thorax and elytra. They may be known also by the 7-jointed antennæ, elongate scutellum and the hind pair of tibiæ and tarsi pilose. Three species are known from Indiana, while two others probably occur.

KEY TO INDIANA SPECIES OF BEROSUS.

a. Elytra with two spines at apex; fifth abdominal segment truncate at middle.

PUGNAX.

aa. Elytra without spines at apex.

b. Fifth segment of abclomen with one tooth at middle of notch.

c. Abdomen of male with segments 2,3 and 4 slightly carinate.

d. Elytra with well defined black spots.

$d d$. Elytra with spots indistinct.

498. PANTHERINUS. 499. PEREGRINUS.

cc. Abdomen of male not carinate; both head and abdomen dull yellow.

EXIGUUS.

bb. Fifth segment of abdomen with two teeth at middle of notch; abdomen never carinate; elytral spots indistinct. 500. striatus.

498 (1608). Berosus Pantherinus Lec., Proc. Phil. Acad. Nat. Sci., VI, $185 \overline{5}, 364$.

Elongate-oval, conver. Pale, dull yellow ; head blackish-bronzed ; thorax with two black spots at middle; elytra each with ten distinct black spots as follows; two near base, four in a sinuous transverse band in front of middle, three in another band behind middle, and one near apex; abdomen reddish-brown. Thorax finely punctured, the sides slightly converging in front. Elytral strie coarsely punctured; intervals rather thickly and irregularly punctate. Length $4 \mathrm{~mm}$.

Posey County; rare. June 3. Known from Illinois, Missouri and Texas.

499 (1609). Berost's perfalint s Herbst., Col., VII, 314.

Oval, convex. Head black with bronzed surface; thorax and elytra light brownish-yellow, the former with two brown spots on disk, the latter with four or five indistinct oblong, double spots. Elytral strixe less distinct on disk than on sides, the intervals finely punctured. Head thickly punctured, with a longitudinal impression between the eyes. Length $4 \mathrm{~mm}$.

Throughout the State; frequent. June 6-August 20. 
*(1614). Berosus striatus Say, Journ. Phil. Acad. Nat. Sci., V, 1825, 188.

Elongate-oval, convex. Head as in peregrinus but without impression between the eyes; thorax and elytra dull greenish-yellow, the former with a double fuscous line on disk; each elytron with eight or ten small, remote, indistinct blackish spots. Elytral striæ distinctly impressed, finely punctate; intervals flat, with rather coarse punctures. Length 4-5 mw.

Throughout the State; common. February 26-October 21. Hibernates as imago, specimens having been taken in February from beneath $\log$ buried deeply in sand. while others were dredged from a pond in early March.

B. pugnax Lec., 5-6 $\mathrm{mm}$. in length, and colored much as in pantherinus, is known from Illinois and Missouri. B. exiguus Say. 2.5 in length, occurs from Pennsylvania to Louisiana.

\section{Chжtarthria Stephens. 1832. (Gr., "bristle + joint.")}

Very small species having the first joint of antennæ long and the body contractile. They occur about the margins of ponds and lakes.

501 (1619). Chжtarthria Pallida Lec., Proc. Phil. Acad. Nat. Sci., 1861, 342.

Hemispherical, very convex, shining. Above dull brownish-yellow; head black, shining; disk of thorax often with a fuscous blotch; beneath black. Elytra very sparsely and finely punctate; sutural striæe distinct. Length $2 \mathrm{~mm}$.

Lakes of Laporte, Marshall, Fulton, and Starke counties; frequent. June 16-August 31. A member of the boreal fauna. This is the form described as nigriceps Lec.

\section{Laccobius Er. 1832. (Gr., "pool or lake + life.")}

502 (1621). Laccobius agiris Rand., Bost. Journ. Nat. Hist., II, 1838, 19.

Subrotund, convex. Head and disk of thorax blackish-iridescent, the margins of latter broadly pale yellow; elytra pale, the striæ dusky; under surface black, legs pale. Head alutaceous, finely and sparsely punctate, the margin in front of eyes yellow. Thorax three times as wide as long. as wide at base as elytra. finely and sparsely punctate. Punctures of elytra very small and close-set in regular rows. Length $2-3 \mathrm{~mm}$.

Throughout the State; common. Nay 26-September 3

\section{Philhydrus Sol. 1834. (Gr., "love+water.")}

Small oblong-oval beetles, piceous or dull brownish-yellow in hue and having the upper surface regularly and rather finely and closely punctured; elytra with four rows of coarser punctures, these 
sometimes indistinct. The beetles usually occur in numbers along the edges of ponds, lakes and streams and rise to the surface when the water is made turbid. Five species have been taken in Indiana, while another may occur.

\section{KEY TO INDIANA SPECIES OF PHILHYDRT'S.}

a. Above paler, brownish-yellow to pale piceous.

b. Irostermum distinctly carinate; length $3.5-1.5 \mathrm{~mm}$.

503. NEBULOSUS.

b). Prosternum not carinate.

c. Smaller, not over $4 \mathrm{~mm}$; mesosternal lamina very feeble, the front edge without distinct angle.

504. OCHRACEUs.

cc. Larger, 4-6 mm.; mesosternal lamina prominent, with a distinct angular projection.

d. Thorax with a large discal piceous space. 505. Hamilton.

dd. Thorax entirely dull yellow.

DIFFCSUS.

a a. Above black or piceous black, the margins sometimes pale.

e. Larger, 6.5-7 mm. ; transtersely very convex.

506. CINCTCS.

ee. Smaller, not over $5.5 \mathrm{~mm}$.; subdepressed.

507. PERPLEXUS.

503 (1626). Philhydrus Nebulosts Say, Long's Exped., II, 1824, 277; ibid. I, 183.

Oval, slightly oblong, conves. Above rariable from pale to dull brownish-yellow, shining; head and under-surface piceous. Thorax and elytra sparsely and indistinctly punctured, the usual rows of coarser punctures scarcely visible. Leigth $3.5-4.5 \mathrm{~mm}$.

Throughout the State; common. Nay 15-October 24.

504 (1630). Philhrdrus ochraceus Melsh., Proc. Phil. Acad. Nat. Sci., II, 1844, 101.

Elliptical, less convex. Above pale piceous or dull

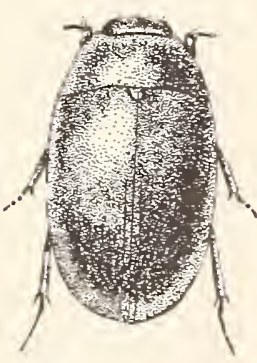

Fig. 128. $\times$ 6. (Original.) smoky brown, shining; head darker, with a pale space in front of each eje; malows of thorax and elytra paler: beneath piceous, the tibire and tarsi paler. Thorax and elytra distinctly and rather closely punctate, the dorsal rows very indistinct. Length $3.5-4 \mathrm{~mm}$. (Fig. 128.)

Northern half of State; common; less so in the southern portion. April 23-October 26. Resembles nebulosus, but smaller: prosternum not carinate and punctures of upper surface more distinct.

505 (9315). Philhydrus hamiltoni Horn, Trans. Amer. Ent. Soc., XVII, $1890,249$.

Oblong-oval, moderately convex. Above piceous-yellow or dull brownish-yellow; head piceous; disk of thorax with an indefinite semicircular space darker. Punctures of thorax not very close; those of elytra a little coarser, the discal rows faint. Length 4.5-5.5 $\mathrm{mm}$.

Lake, Starke and Laporte counties; frequent. April 23-Sep- 
tember 7. A member of the boreal fauna. Next in size to cinctus, but brownish instead of black, more oblong and less convex.

$P$. diffusus Lec., is recorded from Illinois and westward.

506 *(1633). Philhydrus cinctus Say, Long's Exped., II, 1824, 276 ; ibid. I, 182.

Oval, slightly oblong, very convex. Black, shining; entire margin dark reddish-brown. Thorax with basal marginal line very fine and indistinct; its surface finely and evenly punctured. Elytra a little more coarsely and sparsely punctured than thorax, the dorsal rows distinct but feebly impressed. Length $6.5-\tau \mathrm{mm}$.

Throughout the State; common. Hibernates as imago. February 11-December 8.

507 (1636). Philhydrus perplexus Lec., Proc. Phil. Acad. Nat. Sci., VII, $1855,371$.

Oblong-oval, fully twice as long as wide. Above piceous-black, shining; sides of thorax and elytra with narrow paler border. Thorax closely and finely punctate, its basal marginal line always distinct. Elytral punctures coarser than those of thorax, the usual dorsal rows feebly indicated. Length $4-5.5 \mathrm{~mm}$.

Common throughout the northern half of State; less so in the southern portion. April 23-October 23.

\section{Helochares Muls. 1844. (Gr., "marsh + rejoice.")}

Very close to Philhydrus and formerly united with it. One species occurs in Indiana.

508 (1639). Helochares macultcolits Muls., Ann. Sc. Phys. Nat. Lyon., VII, 379.

Oblong-oval, distinctly narrowed in front, subdepressed. Above dull brownish-yellow; occiput and discal spot of thorax piceous; under surface black or piceous. Elytra with ten rather deeply impressed rows of serrate punctures; intervals flat, finely punctulate, the fifth and ninth with a row of coarse punctures. Length $4-5.5 \mathrm{~mm}$.

Lawrence and Dubois counties; scarce. May 9-August 5.

\section{Cymbiodrta Bedel. 1881. (Gr., "boat+dive.")}

Small, oval, piceous or brownish species, formerly included under both Philhydrus and Hydrocombus, but having only four joints on the middle and hind tarsi. In the species occurring in the Eastern United States the elvtra are not striate, but usually have several rows of coarse punctures. One species has been taken in the State, while two others may occur, 
KEY TO INUIANA SPECIES OF CYMBIODYTA.

a. Form oval: elytra with rows of coarser punctures distinct at least on sides.

b. Color wholly piceous.

FIMBRIATA.

b6. Dull brownish-yellow; head black, with a large yellow spot in front of each eye.

509. BLANCHARDI.

a a. Form oblong; elytra without rows of coarser punctures; piceous with a pale border.

LACUSTRIS.

C. fimbriata Melsh., 4.5-5.5 mm. in length, occurs from Canada to Pennsylvania and Texas. C. lacustris Lec., 4-4.5 mm. in length, is a boreal species which may occur in northern Indiana.

509 (9319). Crmbiodyta blanchardi Horn, Trans. Amer. Ent. Soc., XVII, $1890,25 \mathrm{~s}$.

Rather broadly oval, scarcely narrowed in front, moderately convex. Dark smoky brown; margins of thorax and elytra paler; head black with a reddish-yellow spot in front of each eye; beneath piceous or brown, tarsi paler. Thorax and elytra rather closely punctate, the rows of coarser punctures represented only by a few distant punctures, except the outermost row, which is distinct. Sutural stria well impressed and reaching two-thirds to base. Length $4 \mathrm{~mm}$.

Steuben, Putnam and Lawrence counties; scarce. March 25August 11. Taken on the under side of flat stones in swift running water. Resembles Phithydrus ochraceus, but more broadly oval in form.

XIV. Helocombus Horn. 1890. (Gr., "marsh + border."')

Maxillary palpi very long and slender, the last joint distinctly shorter than third; thorax without a basal marginal line; elytra distincly striate. One species is known from the eastern United States.

510 (1629). Hezocombus bifidus Lec., Proc. Phil. Acad. Nat. Sci., VII, $1855,371$.

Oblong-oval, subdepressed. Piceous, shining; tarsi and narrow margin of thorax and elytra paler. Thorax closely and finely punctate. Elytra rather deeply striate, the strixe entire except the inner three; intervals on sides convex, flatter on disk, rather coarsely punctate. Length 5.5-7 mm.

Lakes of northern half of State, frequent; also in Marion and Fountain counties. April 3-August 20.

\section{Mydroвius Leach. 1817. (Gr., "water+life.")}

To this genus, as now limited, belong six of the larger species of the Henshaw list. They have the last joint of the maxillary palpi always longer: than the third, and the elytra with either ten rows of punctures $01^{*} 10$-striate. Three of the species have been taken in the State, while another may occur. 
KEY TO INDIANA SPECIES OF HYDROBIUS.

a. Alternate intervals of elytra, $3-5-7-9$, each with a row of coarse punctures; elytra black or piceous.

b. Elytra with well marked strix; form oblong.

511. FUSCIPES.

bb. Elytra with rows of fine punctures; form short and very convex.

c. Hind femora merely closely punctate near base, not pubescent.

512. TUMIDUS.

cc. Hind femora densely punctulate and pubescent near base and along the upper border.

513. GLOBOSUS.

aa. Alternate intervals of elytra without rows of coarse punctures; elytral strixe deep, the scutellar well marked; elytra pale brown with scattered small dark spaces.

TESSELLATUS.

511 (1653). Hydrobius fuscipes Linn., See Muls. Col. France, Palpic, 122.

Oblong-convex. Above piceous-black, shining; beneath black, the tarsi paler. Thorax finely and closely punctate. Elytra striate the two inner and scutellar striæ indistinct at base; striæ closely punctate; intervals flat, not densely punctulate. Length $6.5-8 \mathrm{~mm}$.

Lake, Starke and Kosciusko counties; frequent beneath rubbish along the beaches of lakes. April 23-August 20. Probably occurs throughout the State. Resembles Helocombus bifidus, but more convex and with shorter maxillary palpi, the last joint longer than the preceding.

512 (1648). Hydrobics tumidus Lec., Proc. Phil. Acad. Nat. Sci., VII, 1855,372 .

Oval, very little longer than wide, rery convex. Piceous-black, shining, slightly bronzed; beneath black, legs piceous, tarsi paler. Thorax rather closely and equally punctate and with coarser punctures in semicircular row on sides. Elytra with ten rows of punctures, the first and second rows not complete; intervals flat, more coarsely punctured than in globosus. Length 8-8.5 $\mathrm{mm}$.

Kosciusko and Marion counties; scarce. April 3-October 22.

513 (1652). Hydrobius globosus Say. Long's Exped., II, 1824, 276 ; ibid. I, 182.

Shorter, broader, more hemispherical than tumidus, which it closely resembles. Surface similarly punctured, but in each part more finely; dorsal rows of punctures more distinct. Hind femora with basal third opaque, punctured and slightly pubescent. Scutellar stria distinct. Length $7.5 \mathrm{~mm}$. (Fig. 129.)

So far taken in Indiana only in swift water at mouth of Donaldson's Cave, near Mitchell, Law-

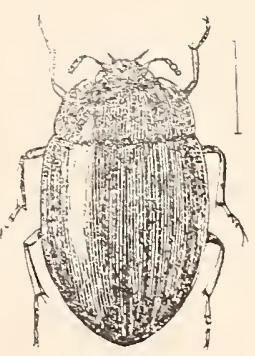

Fig. 129. rence County; scarce. Should occur throughout the State. May 5-September 11.

H. tessellatus Zieg., 7-7.5 mm. in length, is said to occur from Canada to Illinois and southward, but rare in every locality. 
XVI. Creniphilus Mots. 1845. (Gr., "notch or bay+loving.")

Very small, convex elliptical or oblong beetles, having the punctures of elytra confused, thorax without a basal marginal line, and also without the rows of large coarse punctures usually seen in the species of Hydrobius. They usually occur in numbers amongst the decaying aquatic plants along the margins of pools and lakes. Three species have been taken in Indiana, while two others should occur.

\section{KEY TO INDIANA SPECIES OF CRENIPHILUS.}

a. Form oblong, fully twice as long as wide; tarsi slender, the hind pair fully as long as the tibiæ; elytra distinctly narrowed almost from humeri to tips; color piceous, shining, the side margins of both thorax and elytra pale.

SUTURALIS.

aa. Form broadly oval, not much longer than wide, very convex; tarsi stouter, the hind pair shorter than the tibiæ.

b. Prosternum distinctly carinate.

c. Elytra distinctly punctate; antennæ eight-jointed.

514. SUBCUPREUS.

cc. Elytra very indistinctly punctate; antennæ nine-jointed.

515. DESPECTUS.

bb. Prosternum absolutely simple.

d. Black with a bronzed tinge; surface distinctly punctured; hind femora strigose lengthwise and sparsely punctate. DIGEstus.

dd. Dull piceous without tinge of bronze; surface indistinctly punctate; hind femora densely punctulate and pubescent.

516. INEUSCATUS.

C. suturatis Lec., length 1.5-2 mm., and C. digestus Lec., 2.5$3.5 \mathrm{~mm}$. in length, are both said to occur from Canada southward to Georgia and New Mexico.

514 (1657). Creniphilus subcupreus Say, Journ. Phil. Acad. Nat. Sci., V, 1825, 189 ; ibid. II, 293.

E1liptical, convex. Above piceous, distinctly bronzed, the margins of elytra often paler toward apex; beneath dark reddish-piceous, the tarsi paler. Thorax and elytra equally, not closely punctate. Length $1.5-2 \mathrm{~mm}$.

Common along the margins of lakes in the northern part of the State; less so in the southern counties. April 23-August 26.

515 (1658). Creniphilus despectus Lec., New Sp. N. Amer. Col., 1863, 25.

Closely resembles subcupreus, but smaller and transversely more convex. Surface more distinctly brassy, alutaceous with minute punctures, sparsely placed. Length $1.5 \mathrm{~mm}$.

Marshall and Putnam counties; scarce. April 17-October 17.

516 (1655). Creniphilus infuscatus Mots., Bull: Mosc., III, 1857, 177.

Oval, very convex. Piceous or dark fuscous, the margins of thorax and elytra paler. Antennx nine-jointed, the club darker. Thorax very 
finely and indistinctly punctate, more consely at the sides. Filytra more coarsely but less closely punctate than thorax. Femora of all the legs densely punctulate and pubescent. Length $2-2.5 \mathrm{~mm}$.

Marion and Putnam counties: scarce. April 16-October 17. Both this and the preceding were sifted from debris taken from the margins of hillside springs.

\section{Tribe IV. SPHARIDIINI.}

To this tribe belong a number of small, convex, oval or hemispherical beetles, which live in damp places in decaying vegetation or in the dung of herbivorous mammals. The color is usually black or piceous, with the elytra frequently spotted or margined with pale yellow and, in most genera, possessing ten rows of punctures or striæ; legs not fitted for swimming; first joint of middle and hind tarsi elongate. Four genera are represented in Indiana.

KEY TO INDIANA GENERA OF SPHERIDINI.

a. Sides of elytra not extended below the lower surface of body.

b. Elytra not inflexed; epipleura horizontal, distinct; prosternum carinate at middle.

c. Larger species, 5 or more mm.; scutellum elongate; antennæ eightjointed; last dorsal segment visible.

XVII. SPHжRIDIUM.

cc. Smaller species, $3 \mathrm{~mm}$. or less; scutellum equilateral; antennæe nine-jointed; last dorsal segment covered. XVIII. CERcror.

bb. Elytra inflexed, clasping the sides of body, without distinct epipleura; prosternum elevated at middle, forming a large pentagonal area; thorax not margined; length $1.5-2 \mathrm{~mm}$.

XiX. Cryptopleurum. aa. Elytra extended below the lower surface of body, the punctuation confused, without trace of strix; first ventral segment not carinate; length 3-3.5 $\mathrm{mm}$.

XX. Ph⿻上丨оnotum.

XVII. Sphæriduum Fab. 1755. (Gr., "ball or sphere + little.")

517 (1662). Spharidium scarabeomes Linn., Faun. Suec., 1761, 145.

Oval or subglobose, convex. Above black, shining; elytra with a reddish sub-basal spot and the apical fourth yellowish; beneath piceous, the femora spotted with paler. Thorax and elytra finely and evenly punctured, the latter without striæ. Length $5.5-6.5 \mathrm{~mm}$.

A recently introduced European species, taken from beneath rubbish on the beach of Lake Michigan at Pine, and Whiting, Lake County; at Lake Maxinkuckee. Marshall County, and on the shore of the Ohio River at New Albany; scarce. April 16-October 23.

\section{Cerrcyon Leach. 1817. (A mythological name.)}

Small black or piceous beetles with more or less yellow on the tips of elytra. They have the middle coxæ narrowly separated; 
elytra usually striate; mesosternum elevated between and in front of the middle coxæ. About 25 species are known from the United States, many of them being common to this country and Europe. Of these Dr. Horn states that "but a small number owe their presence in our fauna to introduction by human agency. They appear to be rather members of a eircumpolar fauna, equally native in

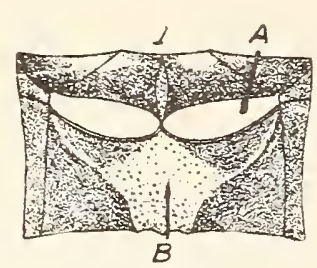

Fig. 130.

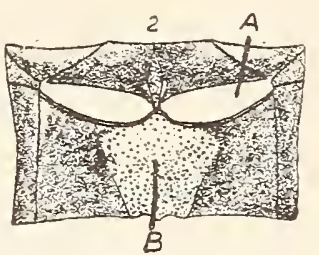

Fig. 131.

$A$, middle coxal cavity. $B$, metasternal area. (After Horn.) either hemisphere, and distributed at a time when continental division was less abrupt than at present." Eieven species $\mathrm{h}$ ave bee $\mathrm{n}$ taken in Indiana and several nthers doubtless occur.

KEY TO INDIANA SPECIES OF CERCYON.

a. Intervals of elytra alternately higher or subcostiform at apex, the striæ deep; surface sparsely pabescent; color pale reddish-brown.

518. PUBESCENS.

aa. Intervals flat or slightly convex; surface smooth.

b. Metasternal area extended on each side by an oblique line. (Fig. 130.)

c. Thorax without basal marginal line, its surface wholly black.

d. Elytra piceous, with pale apex; surface distinctly punctulate; palpi and antennæ piceous.

519. HAMIORRHOIDALIS.

$d d$. Elytra reddish, with a large scutellar triangle and humeral stripe piceous.

e. Elytra very distinctly punctulate; epipleura piceous; palpi pale.

520. MELANOCEPHALUS.

ee. Elytra indistinctly punctulate; epipleura pale; last joint of palpi piceous.

521. PYGMÆUS.

cc. Thorax with distinct basal marginal line, paler at sides; elytra pale with transverse piceous band behind the middle; palpi pale.

522. NIGRICEPS.

b6. Metasternal area median only. (Fig. 131.)

f. Side marginal lines of thorax extending for a short distance along the basal margin: elytra dull reddish-yellow with a large oval piceous spot on suture behind middle which extends narrowly to apex.

UNIPUNCTATUS.

$f f$. Side marginal lines reaching the hind angles only.

g. Interval between the seventh and eighth striæ normally wide, with at least two rows of punctures.

h. Form 'oral, nerer very conrex; head oblique.

$i$. Elytra piceous black, with a sharply limited jellowish apical space extending along the sides torard the base.

523. PRETEXTATUS. 
ii. Elytra piceous, with a common indefinite pale space divided by the suture, but not reaching apex; sides of thorax and humeral umbone pale.

INDISTINCTUS.

$h h$. Form short, very convex; head vertical; punctuation of elytral intervals more indistinct than that of thorax.

$j$. Surface opaque, more or less alutaceous; elytra with distinct striæ; apex with a distinct pale spot.

$k$. Entire surface alutaceous; elytral strix fine. but reaching apex.

524. LUGUBRIS.

$k k$. Flytra alone alutaceous, their striæ very fine and not reaching the apex.

525. TRISTIS.

$j j$. Surface shining; elytral strix replaced by rows of fine punctures; apex with an indistinct rufous space extending slightly along the suture.

526. NAVICULARIS.

$g g$. Interval between the seventh and eighth striæ narrow and with but one row of punctures.

7. Elytra with an indefinite pale space at apex; color piceous or brownish.

527. ANALIS.

77. Elytra with pale space at apex sharply limited by a curved line, not extending along the side margin; color black, shining.

52S. OCELLATUS.

518 (1664). Cercyon pubescens Lec., Proc. Phil. Acad. Nat. Sci.. VII, 1855. 374.

Oval, moderately convex, somemhat attenuate behind the middle. Dull reddish-brown, sparsely pubescent: head piceous. Thorax twice as wide as long, narrowed in front, sides curved from base to apex; surface slightly rugose. without punctures. Elytra with nine rather deeply impressed punctured strix; intervals flat on basal half, convex and alternatels more elevated at apex, very finely and sparsely punctate. Mesosternal eleration elongate-oval, acute in front, truncate behind. Length $1.5 \mathrm{~mm}$.

Lawrence County ; frequent at carrion bait and on fungi. June 10-July 29. Probably throughout the State but overlooked on account of small size. Said to be often abundant in dried horse dung.

519 (1666). Cercyon hæMorrhoidalis Fab.. Syst. Ent.. 1798. 67:

nigricolle Say, Ed. Lec., II, 294.

Oval, moderately convex. Elytra piceous or brownish, their tips slightly paler than disk. Thorax closely punctate. Elytra 10-striate, the striæ distinct at apex, rather closely punctate; intervals flat, densely and rather coarsely punctulate. Length $2.5-3 \mathrm{~mm}$.

Marion, Putnam and Posey counties; frequent. April 6-October 17. This is the species listed as flavines Fab. and nigricolle Say.

520 (1672). Cercyon mran nocephalus Linn., Faun. Suec.. 1761, 144.

Oval, slightly oblong, moderately convex. Head and thorax piceous or black, shining; elytra usually reddish with a triangular piceous space extending from base one-half or more to apex and a subhumeral stripe pic- 
eous: legs, antemnæe and palpi dull reddish-brown. Thorax with sides regularly curred from base to apex. surface rather finels and closels punctate. Elstra 10-striate, the strire punctate and distinctls impressed at apex; intervals finely but aistinctls punctulate. Length $2-2.5 \mathrm{~mm}$.

Marion and Posẹ counties: scarce. April 6-April 13.

\section{1 (16TS). Cerctor Pygmats IHig.. Mag. I, 1802. 40.}

Oral, slightly oblong. Color giren in kes; antennæ dull rellow, club darker: legs and epipleura pale. Thorax with sides regularly curred from base to apex. disk rather closels but not deepls punctate. Elrtra striate. tenth stria indistinct: intervals flat. sparsels and indistinctls punctate. Prosternum distinctly carinate. Length $1.3-2 \mathrm{~mm}$.

Posey County : rare. April 13. Taken beneath bark of funguscorered log. The dark area of elrtra raries much in size.

\section{2 (16 64 ). Cercrox Nigriceps Marsh., Ent. Brit., 1S02, i2.}

Oral. moderatels conrex. Piceous, shining: sides of thorax paler; elstra dull reddish-rellow. with an indefinite common fuscous band behind the middle. Thorax with sides narrored from base to apex, disk finels. not closely punctate. Elytra rather deepls striate. the striæ distinctly punctate; interrals feebls convex, rers minutels punctate. Length $1.2-2 \mathrm{~mm}$.

\section{Marion County: rare. April 2s. Taken by sifting.}

C. unipunctatus Linn.. sides of thorax pale. length $3 \mathrm{~mm}$. is said to range from Canada to Illinois.

523 (1675). Cerctor PR玉textatus Sar. Journ. Phil. Acad. Nat. Sci., T. 1825. 190 : ibid. II, 294.

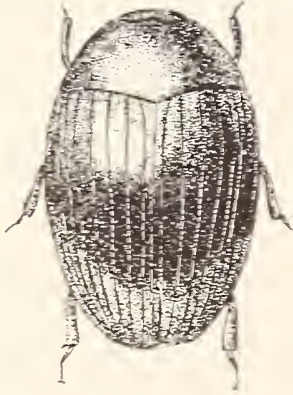

Fig. 132. $\times 8$. (Original.)

Oral. moderatelr conrex. Piceous black. shining; front angles of thorax and a large. sharply defined space at apex and along maroins of elrtra, rellowish; antennœ dull rellow, the club darkel. Thorax transrerse. closels and evenly punctate. Elrtra with ten impressed rors of close-set punctures: interrals closels punctate. more sparsels near apex and on sides. Length $2.5-3 \mathrm{~mm}$. (Fig. 132.)

Throughout the State: frequent. April 15-October 18. Often found in dead fish or beneath rubhish along the sandr margins of ponds and lakes. A large and well marked species.

C. indistinctus Horn, 2.5-3 mm. in length. was described from Canada and Penusylrania.

521 (9334). Cencyor lugtbris Payk. Faun. Suec.. I. 1795, 59.

Oral. conrex, narrorer behind. Piceous black. subopaque: elstra at apex with a well-defined pale space which extends along the side margin. Thorax mith sides regularly curred: disk finels. rather sparsels and erenly 
punctate. Elytra finely striate on disk. more distinctly impressed at sides and apex, the tenth stria wanting; intervals flat, not distinctly punctate. Length $1.5-2 \mathrm{~mm}$.

Kcsciusko County; rare. August j-October 21.

525 (9335). Cercyox tristis Illig., Mag. I. 1802, 109.

Resembles tugubris rery closely but rather smaller and more nariur. Elytral strixe replaced by rows of fine punctures not closely placed. which are nearly obsolete on sides and apex: interrals tiat. punctulate near the base only. Length $1.5 \mathrm{~mm}$.

Pine. Lake County and along margins of cypress stramp. Knox County : scarce. Taken from dead crasfish and at sap. May 1May 28.

526 (1671). Cercrox Navict raris Zimm.. Trans. Amer. Ent. Soc., II, 1869. 250.

Oral, strongly convex. narrower behind the midale. Piceous black. shining: elvtra often slightly paler at tip and along suture; antenne. palpi and legs dull reddish-rellow. Thorax almost smooth, the sides regularly curved from base to apex. Elytra rers convex, their sides rapidly sloping dornward; strixe represented by rows of rers fine punctures which are more distinct at sides and apex; intervals rers sparsely and finely punctate. Body beneath shining. sparsely punctate. Length 1.5-1.i mm.

Starke. Marshall. Kosciusko and Parke counties; scarce. May 2C-July 2. Sifted from masses of damp leares along the borders of pools in low moist roods.

52T (1680). Cercyox axalis Park., Faun. Suec.. I, 179s. 187.

Oral, moderately convex. Piceous black cr brownish, shining: elcira with a pale space at apex which raries much in size. Elytral strixe equal from base to apex. closely but not coarsely punctate. the tenth rery distinct: interrals flat. densely punctate except the eighth, which has but a single row of punctures. Length $2-2.5 \mathrm{~mm}$.

Throughout the State; frequent. April 15-October 17.

528 (167i). Cercyox oceldates Say. Joum. Phil. Acad. Nat. Sci.. V. 1525. 190 ; ibid. II. 294.

Oral. slightly oblong. conrex. Piceous black. shining: elytra witi sharply defined pale apieal space occupring about one-third the surface. the suture piceous to apex. Thorax with sitles regularly curtel from base to apex; surface. as well as that of head. rather coarsely and closely punctate. Elytral striae feebly impressed. but with rather large. closely placei punctures. those of the outer rows the coarser and deeper: intervals flat. distinctly punctulate near the base, much less so on apical third. Metasternal area sbining. sparsely punctate: mesosternal elevation oral: prosternum distinctly carinate. Length $1.5-2 \mathrm{~mm}$.

Kosciusko. Marshall. Tigo. Knox and Jennings counties: common. May 1-October 9. 
XIX. Cryptopleurum Mils. 1844. (Gr., "hidden + breast.")

This genus differs from Cercyon by having the prosternum elevated before the front coxæ to form a rather large, five-sided area widely separating the coxæ; mesosternum with a similar area widely separating the middle coxæ; metasternal area broad, extending across the body; sides of thorax reflexed and angulate near middle, the angle not visible from above. Two species are known, both of which oceur in Indiana.

KEY TO INDIANA SPECIES OF CRYPTOPLEURUM.

a. Elytral intervals distinctly punctate throughout their entire extent; striæe not comspicuously coarsely punctate.

529. мINUTUM.

aa. Elytral intervals feebly punctate on basal half only; striæ coarsely punctured at base.

530. AMERICANUM.

529 (1690). Cryptopleurum minutum Fab., Syst. Ent., 1798, 68.

Rather broadly oval, more narrowed behind than in front, convex. I'iceous black, feebly shining; elytra with an indefinite pale space at tip; antenne and palpi piceous. Thorax narrowed from base to apex, sides feebly curred. surface lather coarsely punctate. Elytra rather deeply striate; intervals slightly convex. closely and distinctly punctulate and sparse15 pubescent. Length $1.5-2 \mathrm{~mm}$.

Kosciusko, Narion and Vigo counties: scarce; April 12-October 9. Taken in decaying fungi and beneath dead turtles and chickens. In one specimen at hand the pale reddish space at apex of elytra extends over three-fourths of the surface.

530 (9339). Cryptopleurum americanum Horn, Trans. Amer. Ent. Soc., XVII, 1890, 311.

Resembles minutum in form and color; antennæ and palpi pale reddish-yellow. Thorax more coarsely punctate than the head. Elytra deeply striate, strix coarsely and closely punctate near base, more finely on apical half; intervals sparsely and finely punctate on basal half only. Metasternal area more coarsely and sparsely punctured than in minutum. Length 1.7$2 \mathrm{~mm}$.

Marion and Crawford counties; scarce. March 23-April 23. Known heretcfore only from Ohio.

XX. Phжnonotum Sharp. 1882. (Gr., "to show + back.")

Rather small black species having the antennæ 9-jointed, the club joints loosely mited; prosternum short. not carinate between the сохæ.

531 (1685). Phжnonotum estriatum Say, Bost. Journ. Nat. Hist., I, 171; ibiā. II, 646 .

Rather broadly oral, strongly convex. Piceous black, shining; antennæ dull yellow, the club fuscous. Thorax very finely punctate. Elytra more 
coarsely punctured than thorax, the punctures not distant one from another more than their own diameter. Length $3-4 \mathrm{~mm}$.

Lake, Marshall, Starke, Kosciusko and Steuben counties; frequent. Мay 20-October 26.

\section{Family VII. LEPTINIDE.}

\section{Mamal Nest Beetles.}

This family is represented in Indiana by a single small, flat beetle. having the antennæ slender and 11-jointed; eyes entirely wanting; thorax with apex truncate, base covering the base of elytra and broadly emarginate, without distinct side pieces beneath; scutellum distinct; elytra rounded at tip, covering the abdomen; front coxæ small, globular, not separated by the prosternum; hind coxæ narrow, transverse. meeting at middle; legs short. tibiæ flattened. tarsi 5-jointed.

But two species of the family are known from North America. One inhabits the Hudson Bay region; the other is common to both Europe and America and lives with small rodents and insectirora, such as mice, moles, shrews, etc., and also in the nests of bumble-bees. If the nest of a mouse or shrew be carefully removed from beneath a $\log$ or other shelter and shaken over a paper, a number of these little beetles will probably be seen scampering away as fast as their legs will carry them. Chas. Dury, of Cincinnati, took 90 specimens of the beetle from one nest and many others es-

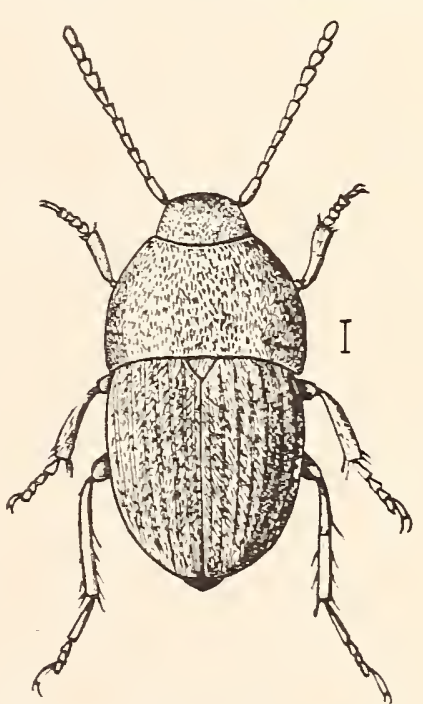

Fig. 133. Line shows natural size. (After Sharp.) caped before he could gather them in. As to whether they are parasites or guests of their hosts is still a mooted question, but Dury states, and my observation bears out his supposition, that he thinks them "only guests' of the animals, as I have found them in nests that have long since been deserted." It is possible that they may live upon the eggs and young of the mites, fleas and other forms of life found associated with them in the nests. It is thought by some that their original home was in the nests of bumble-bees. where they fed upon honey and polien, and that they merely make use of the mice and shrews as a means of getting from one nest of a bumble-bee to another.

[18-23402] 


\section{Leptints MIrll. 1817. (Gr.. “thin or small."')}

592 (1692). Leptixts testacets Mull. Germ. Mag. Ent. II. 1S17, 268.

Oblong-oral. much depressed. Uniform pale sellor. Abore finely and regularly punctured and rather thickls pubescent with golden hairs. Length 2-2.5 mm. (Fig. 133.)

Lake. Marion. Putnam and Perry counties: frequent. March 11-December 1. Evidently hibermates as imago.

\section{Family TIII. SILPHID.E. The Carriox Bentie.}

Thererer decaring animial matter occurs, especially dead birds. mice or snakes. the larger members of this family can usually be found. The smaller species lire more commonly in decaring fungi. while a fert occur onlt in the nests of ants. The name Silphida is founded upon that of the primcipal genus Silpha. a name of Greek origin indicating a foetid odor. The laroer members of the familr. belonging to the genera Tecrophorus and Silpho. range in size between one-half and one and a half inches. Their eggs are deposited in the bodies of small mammals or fragments of putrid flesh. Which are then buried from sereral inches to nearly a foot in the ground. A pair of the beetles will thus bury the bods of a mouse or mole with great rapidity. The larra. on hatching from the eggs. feed upon the decaring flesh. and are said to eren derour the bones of small mammals.

From allied fanilies the members of the silphida mar be knomn br haring the eres finelr granulated. sometimes (in care species) absent: antenna 11-. rarely 9- or 10-jointed. gradually or suddenly clubbed at apes and inserted under the margin of the front. behind the base of mandibles: thorax without distinct side pieces beneath: mesosternum rert short. the side pieces closing the coxal carities 02 the sides: metasternum large. truncate behind: front cosa large. conical. contiguous: hind cosæ contiguous: abdomen with fire or six free rentral segments: legs rariable. sometimes thick and fitted for digging. sometimes slender: tibix with large terminal spurs: tarsi usuall ̦̦-jointed.

The principal literature treating of the North American species is embodied in the two following papers:

LeConte.-. Smopsis of the Silphida of North America." in Proc. Phil. Acad. Nat Sci. TI. 1853. 271-2气т. 
Horn._- Synopsis of the silphide of the Enited states with reference to the Genera of other Comntries." in 'Trans. Amer. Ent. Soc. TIII. 1880. 219-322.

Nearly 900 species of Silphida are known, about 125 of which. distributed among 31 genera. are from North America. Horn. in his Srnopsis. divided the family among six tribes. Four of these are known to be represented in Indiana. While a single species of another mas occur.

KEI TO IXDIAXA TRIBES OF SILPHID王.

a. Hind corie simple.

b. Front coxie more or less transrerse at base and with trochantin.

c. Front coxal carities open behind.

d. Hind coxie contiguous: larger, 10 or more mm.

Tribe I. Silphist. 1). 273.

dd. Hind corie separated: eres ranting: smaller. not orer 2 mm.

Tribe II. Pinoditimi. p. $27 \%$.

ce. Front coral carities closed behind: length less than $5 \mathrm{~mm}$.

Tribe IV. Axisotoumis. p. $2 S_{4}$.

66. Front coxie crlindric-conic. without trochantin. the carities closed behind: length less than $6 \mathrm{~mm}$. Tribe III. CHoletici. p. $27 S$. a a. Hind coxie with laminie or plates; size rery small. not orer 2 mm.

Tribe T. Claмвалt, p. 291.

\section{Tribe I. SILPHINI.}

To this tribe belong all the larger members of the family. the distinctive characters being the open front coxal carities and the contiguous hind coxm. The form is smmetimes elongate. but usually oral or even nearly ciroular: elrtra distinctly. sometimes midely. margined at the sides: abdomen often visible betond the elytra. Of the seren genera comprising the tribe. three are represented in Indiana.

\section{KEY TO IXDIANA GEXERA OF SILPHINI.}

a. Antennie ten-jointed. the last four joints forming an abrupt club: middle cosie midelr separated.

I. Necrophoris. a a. Antenne eleren-jointed, either slender or sradually clarate.

b. Middle coxie moderately separated : front coxal arities widels open behind: elrtral strize, if present. not punctured.

II. Sпिн1.

bb. Middle coxie narrotrly separated or contiguous: front coxal carities narrowl c open: elrtral strixe with distinct impressed punctures.

III. Necrophilts.

I. Necrophorts Fab. 17T. (Gr.. "a dead bodr-bearing." To this genus belong large. elongate. thick-bodied beetles. having 
black elvtra. which are truncate at tip. and ornamented with con-

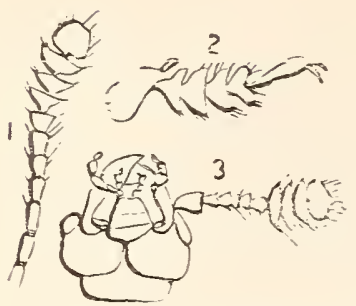

Fig. 134. Necrophorus: 1, antennæ; 2. tarsus; 3, head from beneath.

(After Westrood.)

spicuous reddish-rellow spots. The head is large. suddenly narrotred in front of eyes and also at a little distance behind them. The antennæ are spoken of as ten-jointed. but the true second joint appears as a node at the base of the one usually called the second. (Fig. 134.) They are frequently known as "sexton beetles." on account of their habits of burying small mammals and snakes. Sir species have been taken in Indiana.

\section{KEY TO INDIANA SPECIES OF TECROPHORUS.}

a. Hind, and usually the middle, tibiæ curved or arcuate.

b. Thorax orbicular, its sides and base with wide, flattened margins, disk finely and sparsely punctulate.

c. Disk of thoras red: eljtra without erect hairs.

cc. Disk of thorax black; elstra with erect hairs. 53t. SAII. bъ. Thorax transterselț cordate. its 'sides narromly margined and sinuate at middle; disk smooth; first joint of antennal club red.

535. MARGINATES.

aa. Tibiæ straight. not arcuate.

d. Thorax orbicular as in americanus and sayi.

536. ORBICOLLIS.

dd. Thorax transtersely oral, very little narrowed behind; sides and base broadis margined.

$e$. Disk of thorax glabrous: antennal club orange, the first joint piceous.

537. PUStulates.

ee. Disk of thorax densely pubescent; antennal club piceous.

538. TOMENTOSts.

533 (1695). NeCRopHorts AMERTCANL's Olir.. Ent.. II, 1790. 6.

Elongate, robust. Black, shining; rertex. disk of thorax, epipleural fold and two large irregular transverse spots on each elytron. orange-red; antennæ black, the club orange-red. Thorax wider than long. truncate in front; disk with a ferr scattered punctures along the maroins. Length $27-$ $3.5 \mathrm{~mm}$. (Fig. 135.)

Marion. Tigo and Posey counties: frequent. April 2:3-August 11. Probably occurs throughout the State, Often attracted by electric light. Our largest species. readily known by its size and the color of head and thorax.

534 (1696). Necrophorts say Lap., Hist. Nat. II, $1839,2$.

Elongate. moderately robust. Resembles orbicot-

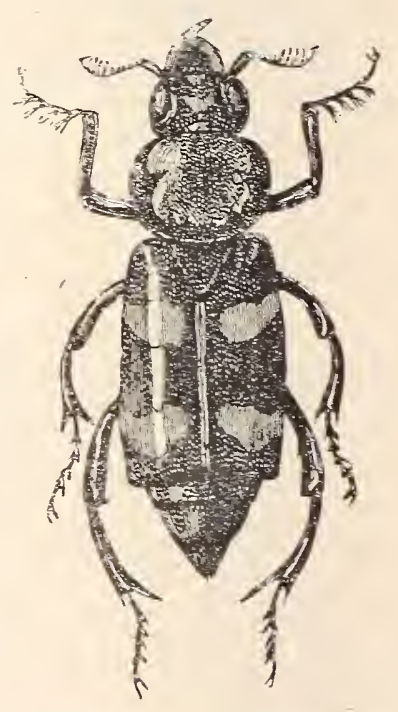

Fig. 135. $\times 1 \frac{1}{3}$. (Original.) 
lis, but smaller. The epipleura fold of elytra is wholly orange-red, the sides of thorax less curved, and the middle and hind tibix are curved in both sexes. Length $16-18 \mathrm{~mm}$.

Lake and Vigo counties; rare. .Tune 4-July 15.

535 (1698). Necrophorus marginatus Fab., Syst. Eleut., I, 1801, 334.

Moderately elongate. Black, shining; antennal club, epipleural fold and two broad dentate cross-bands on elytra, orange yellow; the sub-basal band usually entire, rarely divided at suture; the subapical often reaching the apical margin, the two connected on side margin. Thorax distinctly narrower behind the middle, the disk nearly smooth. Hind tibiæ distinctly curved. Length 20-27 mm.

Throughout the State; frequent. April 23-July 28. Occurs especially about dead snakes.

536 (1697). Necrophores orejcoltis Say, Journ. Phil. Acad. Nat. Sci., V, 1825,177 ; ibid. II, 284.

Elongate, moderately robust. Black, shining; elytra with a sub-basal cross-bar and subapical spot orange-red; epipleural fold black; antennæ piceous, the club orange-red, first joint black. Middle and hind tibiæ in both sexes gradually broader to tip and straight. Length 20-25 $\mathrm{mm}$.

Throughout the State; frequent. April 6-August 20. One just emerged from pupal stage was taken from a little pit beneath a $\log$ on April 17.

537 (1701). Necrophorus pustulatus Hersch., Illig. Mag., VI, 271.

Moderately robust. Black or piceous, shining; antennal club, except the first joint, and two spots on each elytron, orange-red; one of the elytral spots on the side at usual position of sub-basal band. the other, sometimes double, subapical. Thorax transversely oval, very little narrowed behind. Elytra coarsely punctured, each with two faint costre. Length $17 \mathrm{~mm}$.

Posey County; rare. June 18. The color is variable, sometimes wholly black; the epipleural fold usually black, often red or partly so.

538 (1703). Necrophorus tomentosus Weber, Obs. Ent., I, 1801, 47.

Moderately elongate. Black, shining: elytra with two cross-bars and epipleural fold orange-red; the cross-bars resembling those of marginutus. but narrower. Thorax broader than long, very little narrowed behind, the disk clothed with golden yellow hairs. Middle and hind tibix straight. Length 15-20 $\mathrm{mm}$.

Throughout the State; frequent. June 20-October 18.

\section{SILPHA Linn. 1758. (Gr., "a beetle.")}

Strongly depressed beetles of medium or large size, usually rounded in form and with a wide, thin margin to thorax and elytra. 
The antennæ are 11-jointed and never elongate, the terminal joint being flattened and oval at tip; elvtra more or less costate, but not striate, the lateral margins reflexed.

KEI TO INDLANA SPECIES OF SILPHA.

a. Eyes large. prominent; form elongate; hind femora much stouter in males.

539. SURINAMENSIS.

a . Eres not prominent; form oval; hind femora similar in both sexes.

ъ. Labrum broadly emarginate; third joint of antennæ as long or longer than the second.

c. Thorax entirely black.

$540 . \quad$ INAQUALIS.

cc. Thorax with black disk and reddish-yellow margin.

541. NOVEBORACENSIS.

b7. Labrum deeply emarginate; third joint of antennæ shorter than second; form broadly oval.

542. AMERICANA.

*539 (1704). Silpha surinamensis Fab., Syst. Ent., 179S. 72.

Moderately elongate, depressed. Black or piceous; elstra with narrow subapical orange rea cross-bar, often broken into spots, sometimes entirely wanting. Thorax transrersely oval, broadly flattened behind. Elytra gradualls broader behind. apex obliquely truncate; disk flat with three distinct costæ. Length $1 \check{0}-24 \mathrm{~mm}$.

Throughout the State: frequent. Hibernates as imago beneath logs close to carrion. January 19-December 18.

*540 (1708). Silpha INæqualis Fab., Spec. Ins., I, 1781, S7.

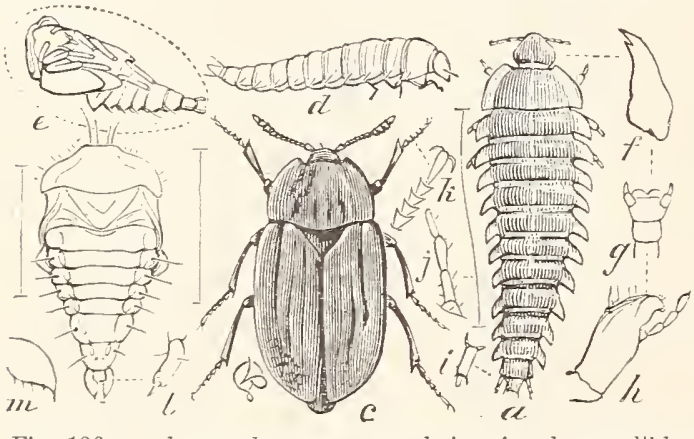

Fig. 136. a, larva; $d$, same, natural size; $f, g, h$, mandible, labium and maxilla of larva; $i, j$. anal process and antennx of same; $m$, one of the lateral processes more highly magnified; $b$, pupa; $e$, same, natural size; $l$, anal process of same; $c$, beetle; $k$, front tarsus of same. (After Riley.)
Oral, slightly oblong, depressed. Black, opaque. Thorax twice as wide as long, narrowed in front. base with a broad truncate lobe at middle; elytra rers little longer than wide, rounded at apex. the disk with three costæ, the outer and most distinct shorter and terminating in a slight tubercle one-third from apex. Length 10-14 mm. (Fig. 136.)

'Throughout the State; common. Hibernates in different stages; gregarioìs. January 16-November 4. 
541 (1709). Silpha noveboracensis Forst., Cent. Ins., I, 1771. 17.

Oral, slightly oblong, depressed. Thorax piceous, broadly margined with reddish-yellow; elytra brownish to piceous. Thorax about one-half wider than long, base truncate at middle, sinuate each side; elytra as broad as thorax, rounded behind, the disk with three costre, the outer one the stronger; surface distinctly and regularly punctate. Length 13-14 mm. (Fig. 137.)

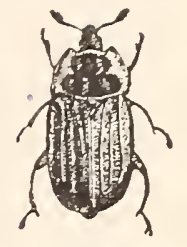

F g. 137. (After Cornstock.)

Marion, Vigo and Posey counties; frequent. April 10-July 2. Sometimes found on decaying fungi; more often on carrion.

542 (1710). Silpha americana Limn., Syst. Nat., II, 1766, 570.

Broadly oral, depressed. Thorax yellow, with discal

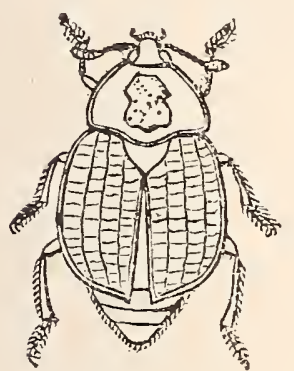

Fig. 138. $\times 1 \frac{1}{4}$ (After Glover.) black spot; elytra brownish, with the elerations darker. Thorax nearly twice as wide as long. much narrowed in front, base broadly lobed at middle, surface densely and equally punctured. Elytra as ride or wider conjointly than long, the disk with three indistinct costie. connected by numerous cross elevations; intervals rather closely punctate. Length 16-20 mm. (Fig. 138.)

Throughout the State; frequent. April 18-July 9. Taken in coitu on June 4. Often found in decaying fungus as well as carrion.

III. Necrophilus Lat. 1829. (Gr., "a dead body+loving.'")

This genus is represented in the United States by only two species, one of which occurs in Indiana.

543 (1714). Necrophilus pettitil Horm, Trans. Am. Ent. Soc., VIII, 1880. 243.

Broadly oval, narrower in front. Dark chestnut brown, shining, glabrous. Thorax nearly twice as wide at base as long at middle, sides curred. apex emarginate, base truncate; margin broadly flattened and recurved, translucent; surface sparsely punctate, the disk nearly smooth. Elytrar suddenly sloping downward near apex, the surface with rows of coarse. deep punctures. Length 10-11 $\mathrm{mm}$.

Two specimens were taken in rery ill-smelling decaring fungi beneath a log in woods near Grand Chain, Posey County: April 10. Dury has taken it in small numbers on sereral occasions near Cincinnati, but it seems to be everywhere scarce.

\section{Tribe II. PINGDYTINI.}

This tribe is represented in North America by three small, blind. oblong. chestnut-colored beetles. One of these. Pinsdytes cryptophagoides Mann., lives in the fine debris of rotten wood and has 
been taken in Alaska, and near Washington, D. C., so that it probably occurs in Indiana. (Fig. 139, a.) Another, P. hamiltoni Horn, occurs near Allegheny City. Pennsylvania.

This tribe comprises insects of small size and usually ovate form, having the front coxæ cylindric-conic and contiguous, the cavities closed behind; abdomen with six distinct segments, except
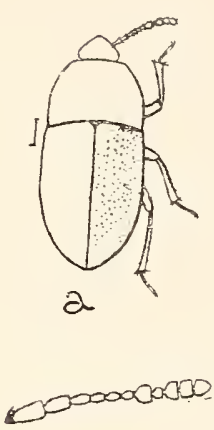

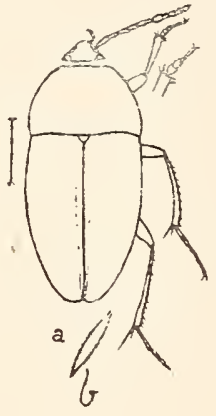

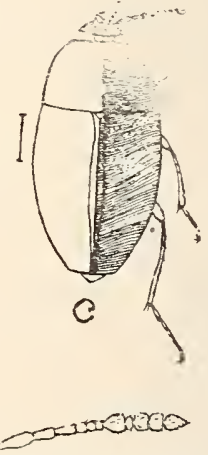

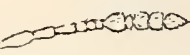

Fig. 139. a, Pinodytes cryptophagoides Mann.; (a) antenna of same; b, Prionochœta opaca Say; (a) tibial spur of same; c, Ptomophagus consobrinus Lec.; (a) antenna of same. (After Horn.)

\section{Tribe III. CHOLEVINI.}

in Colon, and covered by the elytra. Some of the species live on carrion or in Inungi; others in ants' nests. Four of the eight genera are represented in Indiana.

KEY TO INDIANA GENERA OF CHOLEVINI.

a. Abdomen with six segments; hind coxæ contiguous; head suddenly narrowed behind the eyes, forming a neck, the occiput elevated in a ridge.

b. Elytra punctate, not strigose; last joint of maxillary palpi as long as the preceding; mesosternum not carinate, the middle coxæ contiguous.

c. Tibial spurs moderate in length, simple.

cc. Tibial spurs very long, bipectinate. (Fig. 139, b.)

IV. CHOLEVI

\section{Prionocheta.}

bb. Elytra finely and transversely strigose; last joint of maxillary palpi short, awl-shaped; mescsternum carinate, the middle coxæ separated; antenn:e gradually clavate, not longer than head and thorax. (Fig. 139, c.)

VI. Ptomophagus.

aa. Abdomen with five segments (often four in female) ; head oval, not narrowed behind, occiput not elevated; hind coxæ contiguous.

VII. COLON.

IV. Choleva Latr. 1796. (Gr., "to limp or halt.")

Small, usually oval species, narrowed behind and having the surface finely pubescent and the elytra usually finely punctured. The 
antennæ are as long as the head and thorax, the last five joints forming an elongate club, the eighth shorter and narrower than the seventh and ninth. Five species are known from Indiana.

\section{KEY TO INDIANA SPECIES OF CHOLEVA.}

a. Hind angles of thorax rounded or obtuse.

b. Form elongate-cblong, but little narrowed behind; neariy uniform dark brown; cave inhabiting species.

544. ALSIOSA.

bb. Form oval or oblong-oval, distinctly narrowed behind; terrestrial species.

c. Front femora more or less flat on the under edge, usually glabrous and with a tubercle in the male; female with ventral segments not foreate at middle.

545. SIMPLEX.

cc. Front femora with the lower edge rounded. punctate and without trace of tubercle in male.

đ. Form oblong; body distinctly contracted at base of elytra; female with ventral segments $5-6$ deeply longitudinally impressed at middle.

546. BASILLARIS.

dd. Form oral. margins of thorax and elytra nearly continuous; female with rentral segments $5-6$ raguely impressed.

547. CLAVICORNIS.

aa. Hind angles of thorax rectangular, the thoracic and elytral margins continuous; female with abdomen not impressed. 548. TERMinans.

544 (1727). Choleva alsiosa Horn, Trans. Amer. Ent. Soc., XII, 1885. 136.

Elongate-oblong, rather slender, finely pubescent. Dark smoky or sooty bromn. Antennæ rather slender, longer than head and thorax, piceous, the two basal joints paler. Thorax less than twice as wide as long, narrower in front; hind angles rather obtuse, disk densely and finely punctured. Elytra elongate-oval, as wide as thorax at base, rather densely punctate. the punctures coarser than on thorax. Length $4.3 \mathrm{~mm}$.

One specimen from Coon's Cave, Monroe County July 10. Taken from beneath a stone 400 feet from the entrance; also recorded from Marfield's Cave. Monroe County, by Banta. Described from Alaska. but since taken by Garman in caves near Lexington, Kentucky.

545 (1728). Choleva simplex Say, Journ. Phil. Acad. Nat. Sci., V, 1825, 184 ; ibid. II, 289.

Oral, slightly oblong, pubescent. Head and thorax piceous, elytra purplish-brown; antennæ piceous, two basal joints paler. Thorax one-half wider than long. a little narrower in front, surface finely and densely punctate; elytra scarcely wider than thorax, narrowed behind, not striate, rather densely punctate. Length $3.5-4 \mathrm{~mm}$.

Clark and Poser counties; scarce, May 7-May 15. 


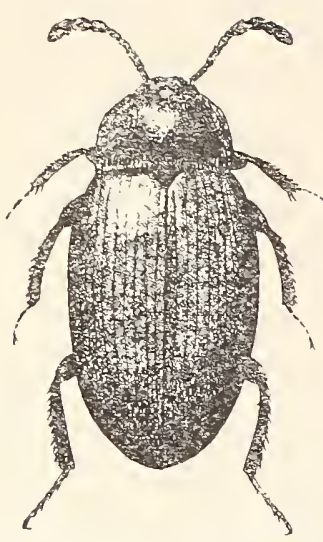

Fig. 140. $\times 8 . \quad$ (Original.)

546 (1729). Choleva Basiliaris Say, Journ. Phi!. Acad. Nat. Sci, III, 1823, 194; ibid. II, 124 .

Oblong, moderately elongate. Head and thorax piceous; elytra dark brown, paler at base, the surface pubescent, moderately shining. Thorax more than half as wide as long, slightly narrowed in front, base feebly curved; elytra very little wider than the thorax, narrower behind, not densely punctured. Length 3-4 mis. (Fig. 140.)

Marion, Clark and Posey counties; scarce. Mareh 25-May 21. Those from Marion County were taken from the nest of a shrew.

547 (1730). Choleva clavicornis Lec., Proc. Phil. Acad. Nat. Sci., VI, $1853,281$.

Oval. slightly oblong. Head and thorax dark brown, or piceous; elytra pale brown, pubescent. Antennæ scarcely reaching hind angles of thorax, piceous, the apical and two basal joints paler. Thorax twice as wide as long, the surface rather densely punctate. Elytra oval, gradually narrower to apex, not wider than thorax. Length $2.5-3 \mathrm{~mm}$.

Kosciusko, Marion, Putnam and Dubois counties; scarce. March 13-August 17.

*548 (1732). Cholfva terminans Lec., Agass. Lake Sup., 1850, 218.

Oblong-oval. Piceous or brownish, finely pubescent. Anteunx as in claticomis. Thorax twice as wide at base as long; sides curved and nar. rowed to front; hind angles rectangular, surface-finely and densely punctr. late. Elytra as wide at base as thorax, gradually narrowing to apex; sutural stria rather deeply impressed; surface not densely punctate. Length $2.5-3 \mathrm{~mm}$.

Throughout the State; frequent. Hibernates as imago. April 12-December 5. Taken in deserted nests of mice; also on dead hens and fungi.

\section{Prionocheta Horn. 1880. (Gr., "a saw + bristle.")}

Here belongs a single medium-sized black species having the antennæ as long as head and thcrax, the last four joints abruptly shorter than those preceding; middle tarsi of male not dilated.

549 (1734). Prionocheta opaca Say, Journ. Phil. Acad. Nat. Sci., V, 1825. 184 ; ibid. II, 289.

Oblong-oval, slightly narrower behind the middle, the thoracic and elytral margins nearly continuous. Black, feebly shining, clothed with short, dark brown hairs; antennæ piceous, the apex and base paler. Thorax less than twice as wirle as long; hind angles obtuse, surface finely and densely 
punctulate. Elytra as wide and a little more than twice as long as thorax. rather densely punctulate, substriate near the tip, the sutural stria distinct. Length $5 \mathrm{~mm}$. (Fig. 139, b.)

Throughout the State, but scarce. April 13-August 12. Usually on fungi. but sifted from nests of rabbits in spring and beaten from vegetation in. June.

\section{PтопорнаGus Illig. 1798. (Gr.. "a corpse-eat.")}

Small oval or slightly oblong-brownish beetles. having the eighth antennal joint always shorter and usually slightly narrower than the seventh and ninth. The surface of elvtra. and often that of thorax, is transversely finely wrinkled instead of being punctate. Four species are known from Indiana.

\section{KEY TO INDIANA SPECIES OF PTOMOPHAGLS.}

a. Eighth joint of antennæe rers short and transterse, somewhat nariurer than the serenth and ninth.

b. Thorax transrersels strigose or finely wrinkled; elytra rer'y oblinitely strigose. (Fig. 139, c.)

550 . COASOBRIXIs.

bb. Thorax punctate, rarely strigose near the margin.

c. Inner spur of hind tibixe as long as the first tarsal joint; thorax of same color as elytra.

551. OBIITS

cc. Inner spur of hind tibize less than half the length of first tarsal joint; thorax distinctly darker than elytra.

552. Pisto.

aa. Eighth joint of antenne at least half the length of the ninth and scarce-

ly narromer; thorax rather densely punctate.

50.3. PARASITLS.

550 (1735). Ptonophagus coxsobrixus Lec., Proc. Phil. Acad. Nat. S.i..

VI, $1553,281$.

Oblong-oral. somerhat wedge-shaped. Dark brown or piceous. feebly shining, pubescent: legs and antenne at base paler. Thorax one-thirt wider at base than long. hind angles acutely rectangular. Llstra gradually narrowing to near apex. the latter suddenly obliquels narrowed. Length $2.5-3 \mathrm{~mm}$. (Fig. 139, c.)

Putnam and Posey counties; scarce. April 17-May T. The fine wrinkles on the surface of both thoras and elytra show verr prettily beneath a lens.

551 (1740). Ptomophagts oblites Lec., Proc. Phil. Acad. Nat. Sci., 155:?, 282.

Resembles the next species. but differs br characters given in kes and by its larger size. Head piceous: thorax and elytra dark reddish-brown. Hind angles of thorax more obtuse and sutural striie of elrtra less impressed than in pusio. Length $2-2.2 \mathrm{~mm}$.

Lawrence County; scarce. June 11. 'Taken from carrionbaited traps. Known from Georgia and Florida. 
552 (1741). Pтоморнagus pusio Lec., Proc. Phil. Acad. Nat. Sci., 1859, 282.

Oval, slightly oblong, narrowed in front and behind the middle. Dark chestnut browr, head and thorax piceous, moderately shining, pubescent. Antennæ piceous, basal joints paler, eighth much shorter than ninth. Thorax twice as wide as long, feebly narrowed in front, sides slightly curved, hind angles rectangular, surface densely punctate. Elytra as wide as thorax, sides feebly curred, tips obtuse; sutural stria deeply impressed, surface transversely strigose. Length 1.5-2 $\mathrm{mm}$.

Steuben and Putnam counties; rare. April 24-May "24. Une specimen on the former date from the deserted nest of rabbit.

553 (1742). Ptomophagus parasitus Lec., Proc. Phil. Acad. Nat. Sci., Vi, $1853,282$.

Oval, narrowed behind the middle. Dark reddish- or chestnut brown, shining, finely pubescent; head and disk of thorax darker. Thorax a little less than twice as wide at base as long, hind angles subrectangular, surface strigose on sides. rather densely punctate on disk. Apex of elytra obtuse.
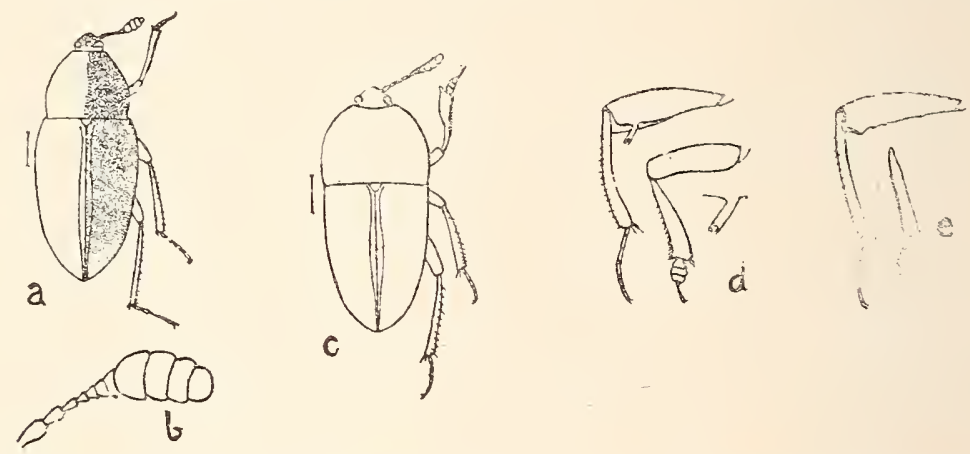

Fig. 141. a, Colon thoracicum Horn; $b$, antenna of same; $c$, Colon magnicolle Mann.; d, front and hind legs of C. hubbardi Horn, male; $e$, front tibiæ and hind legs of C. paradoxum Horn.

the fine wrinkles of surface coarser, more distant and less oblique than in consobrinus. Length $2 \mathrm{~mm}$.

Posey and Putnam counties; frequent in the nests of large black and reddish-brown ants, Camponotus pennsylvanicus DeG., and $C$. fermgineus Fab. March 25-May 12.

\section{COLON Herbst. 1797. (Gr., "a joint or limb.")}

Small, oval, brownish or piceous species, narrowed behind the middle and having the surface punctured and finely pubescent; eyes nearly round, moderately prominent; antennæ rarely passing the middle of thorax, joints 8-11, forming an oblong, rather compact club (Fig. 4, No. 3.) ; middle coxæ separated, the mesosternum not carinate. Males with front spur of front tibiæ short, stout, with the sides dentate or lobed, and with larger spur of middle and hind tibiæ slender but abruptly dilated from the middle to base. The following species have been taken or may occur in the State: 
KEY TO INDIANA SPECIES OF COLON.

a. Hind femora of male with a long tooth on the inner margin near the tip; hind tibiae curved. (Fig. $1 \pm 1$, d.)

HUBBARDI.

a a. Hind femora of male without trace of tooth.

b. Hind angles of thorax distinct. sometimes acutely rectangular.

c. Body broader in front, the elstra rather rapidly narrowing to apex. with feebls curved sides.

d. Surface subopaque, densely punctured; sutural stria entire; larger, 2.5-3 mm. (Fig. 141, c.) MAGNICOLLE.

$d d$. Surface rather shining; thorax sparsely punctate; sutural stria eranescent near base; smaller. not оrer $1.5 \mathrm{~mm}$.

554. PUSILLUM.

cc. Body oblong-oral. not wider in front; elytra behind the humeri usually wider than thorax. the latter with coarse, rather deep punctures, with finer ones in the intervals. (Fig. 141. $a$ and $b$.)

THORACICL II

b6. Hind angles of thorax obtuse or rounded.

d. Color piceous. legs reddish-brown; middle tibiæ of male straight.

ASPERATUM.

$d d$. Color reddish-brown; middle tibiæ of male distinctly curred.

5อ5. OBLONGUM.

C. hubbardi-Horn, piceous to redish-brown in hue and $2.5 \mathrm{~mm}$. in length, is known from Michigan and Ohio. C. magnicolle Mann., piceous in color. oceurs in Michigan and Pennsylvania.

554 (1752). Colon pesilluar Horn. Trans. Amer. Ent. Soc., VIII. 1880. 273.

Oblong-oral, eridently broader in front. Dull reddish-brown, finely pubescent. Antennæ pale, reaching middle of thorax, the last joint as long as preceding and obtuse. Thorax one-half wider than long, sides feebly curred and narrowing to front, disk finely not densely punctate. Elytra as wide at base as thorax, surface rather densely and roughly punctate. Length $2 \mathrm{~mm}$.

Maricn, Lawrence and Posey counties; scarce. April 21-May 16. Taken by sifting debris from about the base of trees. One male has a minute tooth arising trom the midale of hind femora and is to be referred to $C$. putum Horn, which is probably synonymous.

C. thoracicum Horn, reddish-brown, the elytra with a central dark cloud, length $2.5 \mathrm{~mm}$., was described from Missouri and the District of Columbia. C. asperatum Horn, length $2 \mathrm{~mm}$. is known from Nichigan and Illinois.

555 (- $)$. Colon obloxgtar sp. not.

Oblong-oral. Dark reddish-brown. sparsely clothed with fine rellowish hairs. Head densely and finely punctate; antennie reaching middle of thorax, the apical joint paler, not longer and slightls narrower than tenth. 
Thorax one-half wider than long, sides feebly curved, hind angles obtusely rounded; disk coarsely and very densely punctate. Elytra as wide at base as thorax, thence feebly tapering to apex, sides nearly straight; disk densely, finely and rather roughly punctate. Male with three joints of front tarsi broadly dilated, middle tibiae strongly curved, hind ones straight. Length $2.5 \mathrm{~mm}$.

Clark and Posey counties; scarce. April 21-May 6. Taken by sifting.

\section{Tribe IV. ANISOTOMINI.}

This tribe comprises species of smali size, having the body oval, convex, sometimes capable of being contracted into a hemispherical ball; front coxæ conical, contiguous, prominent, with trochantin, the coxal cavities narrowly closed behind; hind coxæ contiguous; abdomen with six segments. They live for the most part either in decomposing fungi or under the bark of dead trees. Seven genera are known to be represented in Indiana, while two others may oceur.

\section{KEY TO INDIANA GENERA OF ANISOTOMINI.}

a. Head without antennal grooves beneath.

b. Hind tarsi five-jointed; mesosternum not carinate; antennal club fivejointed.

HYDNOBIUs.

bb. Hind tarsi with less than five joints: mesosternum carinate.

c. Antennal club five-jointed; length 2.5-4 mm. VIII. Anisotoura. cc. Antennal club three-jointed, elongate, loose; smaller, not orer 2 $\mathrm{mm}$. ; elytra with fine trinsverse wrinkles.

iX. Colenis.

a . Head with distinctly limited antennal groores.

1. Antennal club more than three-jointed.

$\therefore$ Antennal club fire-jointed, elongate. (Fig. 4, Yo. 6.)

f. Form broadly oval or hemispherical, convex; frontal suture well marked; tarsi unlike in the sexes, prosternum short in front of coxie.

$\mathrm{X}$. Liodes.

ff. Form oblong-elliptical. subdenressed; frontal suture wholly lacking; prosternum long before the coxi. XI. Stetholiodes. ce. Antennal club four-jointed; number of tarsal joints the same in both sexes.

XII. Cyrtusa.

dn. Antemnal club three-jointed; tarsi unlike in the sexes.

g. Antennie ten-jointed.

ISOPLASTES.

gg. Antennie eleven-jointed.

h. Hind tarsi four-jointed; mesosternum not carinate between the widdle coxæ; body strongly contractile.

XiII. Agathidium.

hh. Hind tarsi three-jointed; mesosternum strongly carinate.

XIV. Aglyptus. 
Hydnobius substriatus Lec., piceous or dark chestnut brown, labrum deeply bilobed, hind femora of male with a subquadrate tooth, length 2-2.5 mm., is a boreal species which may occur in northern Indiana.

\section{Anisotom Tllig. 1798. (Gr., "unequal + joint.")}

Oval or oblong-oval species having the head short, not prolonged in front of the eyes; antennæ short, 11-jointed, joints 7 to 11, forming an abrupt oblong club, the eighth very short and narrower than the seventh or ninth; last joint of maxillary palpi longer than the third, cylindrical and slightly acuminate at tip; front and middle tarsi in both sexes with five joints, hind ones with four. One species has been taken in Indiana, while three others may occur.
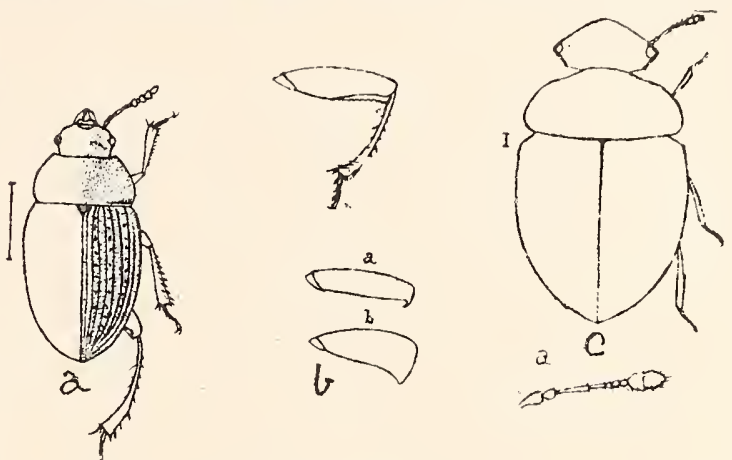

a. Mesosternum oblique between the middle coxie.

b. Punctures of elytral intervals finer than those of strie.

$c$. Hind femora of male obtusely serruiate or crenulate; hind tibice slender and strongly curved. (Fig. 142, b.)

ASSIMILIS.

cc. Hind femora of male simple, neither dentate nor serrulate; hind tibix scarcely longer or more curved than in female.

556. PUNCTATOSTRIATA.

bo. Punctures of elytral intervals and strie equal in size; outer end of hind femora of male forming an acute hook. (Fig. 142 (a).)

CONFERTA.

a a. Mesosternum vertical between the coxæ; elytra without subhumeral striæ. (Fig. $142(b)$ )

OHSOLETA.

A. assimilis Lec., piceous or dark reddish-brown, length 3.5-4 $\mathrm{mm}$., is a boreal species, ranging from New Hampshire to Michigan and westward.

556 (1772). Anisotoma punctatostriata Kirby, Faun. Bor. Amer.. IV. $1837,110$.

Oval, slightly oblong, convex. Dull brownish-yellow, shining. Thorax twice as wide as long, gradually narrower from base to apex, the latter emarginate, base truncate; hind angles rectangular, surface sparsely and finely punctate. Elytra oval, surface with eight rows of coarse, closely placed punctures, the eighth abbreviated at base, also with a rather long 
subhumeral row of punctures; intervals flat, shining. sparsels punctulate. the alternate ones with a fer widels distant, coarser punctures. Length $2.5 \mathrm{~mm}$.

Pine. Lake County, and near Clear Lake. Steuben County; scarce. May 2-May 25. A member of the boreal fauna. Resembles a small Pallodes pallidus, a common fungus beetle of the family Nitidulidæ.

A. conferta Lee., piceous. elytra paler, length $2.5 \mathrm{~mm}$., is known from Illinois. A. obsoleta Melsh. redish-yellow or pale chestnutbrown. length $1.5-2.5 \mathrm{~mm}$. is said to cecur from the Atlantic to Colorado.

\section{Colents Erichs. 1832. (Gr.. "knee.")}

Here belongs one minute pale species having the labrum emarginate; last joint of maxillary palpi crindrical; antennæe 11jointed, joints 9-11 forming a loose. oblong club: tarsi 5-1-4 in both sexes.
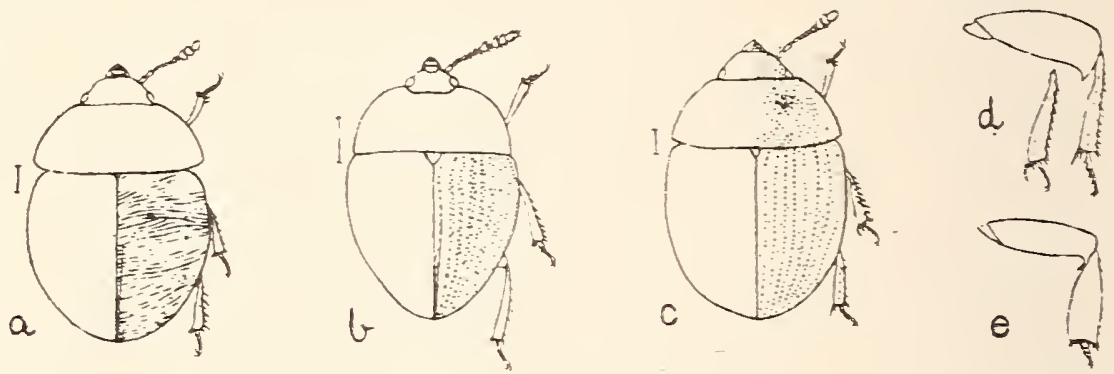

Fig. 143. a, Colenis impunctata Lec.; b, Liodes gcminata Horn; c, Cyrtusn blandissima Zimm.; d, hind leg and middle tibiæ of male of same; $e$, hind leg of $C$. egena Lec., male. (After Horn.)

557 (17S1). Colexis implectata Lec., Proc. Phil. Acad. Nat. Sci.. Ti. 1853, 284 .

Broadly oral. contex, not contractile. Uniform pale reddish-bromn, shining. Thorax more than twice as wide as long. much narrotred in front. apex feebly emarginate, surface smooth. hind angles rectangular. Elytra broadly oral. nearly as wide as long; surface finely transrersel strigose. Length 1.5-2 mm. (Fig. 113, a.)

Throughout the State; frequent. April 22-December 7. Occurs especially in fleshy fungi on beech stumps.

\section{Liodes Latr. 1796. (Gr.. "smooth.")}

Small oval or hemispherical beetles haring trell defined oblique antennal groores on under surface of head; clrpeus slightly prolonged beyond the front; labrum usually truncate: antennæ 11jointed, joints $7-11$ forming an elongate loose club (Fig. 4. No. 6): tarsal joints 5-5-4 in males, 5-4 4 in females. Ther live in patches 
of powderiv fungus on logs and dead trees, and are usually common where found. The following have been taken or probably occur in the State.

KEY TO IXDIANA SPECIES OE LIODES.

a. Elrtra with regular rows of punctures.

b. Ninth row of punctures marginal in the greater part of its length. distant from the margin at base only.

c. Elytra strongly sinuate at sides, the ninth stria very distant from margin at base.

d. Interrals of elytra distinctly punctulate. GLOBOSA.

dd. Interrals smooth or nearly so.

POLITA.

cc. Elytra not sinuate at sides. the ninth stria not rery distant at base; interrals smooth.

อ๊รs. DISCOLOR.

bb. Ninth row of punctures distant from the margin its entire length: elstra not sinuate.

BLATCHARDI.

aa. Elytra with more or less confused rows of punctures.

e. Ninth row distant from margin its entire length.

$f$. Punctures of striæ rather coarse. those of interrals vers fine.

อ๊อ๊. BASALIS.

$f f$. Punctures of stria fine, those of interrals quite erident.

OBSOLETA.

ee. Ninth stria marginal, distant from margin for a short distance at base onls: rows of punctures much confused, forming nearly double striæ. (Fig. 143, b.)

GEMITATA.

L. globosa Iec. and $L$. polita Lec.. both piceous black and 3-3.5 $\mathrm{mm}$, in length. have been recorded from KentuckT.

כ̄5๊ (1784). Liodes díscolor Melsh.. Proc. Phil. Acad. Nat. Sci.. II. 1844. 103.

Hemispherical. rers little longer than wide. Piceous-black abore. reddish-piceous beneath, shining. Thorax mithout punctures, the hind angles rectangular. Eirtra as wide as long, each with eight entire rows of rather coarse punctures. the ninth distant from the margin at base. but joining it slightls behind the middle: interrals flat. smooth. the alternate ones with a rery fer distant coarse punctures. Length $2.5-3 \mathrm{~mm}$.

Marion and Posey counties: scarce. June 6-August 3.

L. blanchardi Horn. Was described from Massachusetts and has been since recorded from Cincinnati.

559 (1787). Liodes basalis Lec., Proc. Phil. Acad. Nat. Sci., VI, 155̌3. 2 S5.

Broadls oral. conrex. shining. Piceous black; elstra with humeral space of rarying width. extending from sides almost to suture, orange-red. Thorax minutely and sparsely punctulate. Elytra with eight entire rors of rather fine. much confused punctures, the rows appearing double. Length $2.5 \mathrm{~mm}$.

Posey and Perre counties: scarce. MIas 1-1Iay 20. 
559a (1787a). Liodes basalis dichroa Lec., loc. cit.

A variety of basalis which differs in having the elytra either entirely orange-red, or the suture and apex only, black.

Jennings and Posey counties: scarce. May 25-July 12.

$L$. obsoleta Horn and $L$. geminata Horn, both piceous black, the former $2-3 \mathrm{~mm}$., the latter $3-3.5 \mathrm{~mm}$. in length, are said to range from New England and Canada to Virginia and Illinois.

\section{Stetholiodes Fall. 1910. (Gr., "breast+smooth.")}

Oblong-elliptical, subdepressed; labrum curved in front with a small, shallow median notch; prosternum as long before the coxæ as the thickness of the latter from front to back; mesosternum strongly oblique; other characters nearly as in Liodes. One species is known.

560 (- - Stetholiodes laticoldis Fall, Can. Ent., XLII, 1910, 4.

Form given above. Dull reddish-yellow, shining. Antennæ reaching hind angles of thorax, third joint as long as the three following, seventh larger than eighth, the latter equal to sixth, ninth to eleventh much larger. Thorax about twice as long as wide, a little wider than elytra, sides broadly curved and gradually narrowed from base to apex, hind angles subrectangular; disk minutely alutaceous, finely and sparsely punctate. Elytra more than twice as long as thorax, each with nine regular rows of punctures. the outer one distant from the margin: intervals nearly flat. sparsely and irregularly punctulate. Length $2.7 \mathrm{~mm}$.

Steuben County; rare. May 25. Sifted from sphagnum moss. The unique specimen is in the collection of Mr. Fall.

\section{CyrTusa Erichs. 1842. (Gr., "to curve or bend.")}

This genus is composed of very small, oval, convex forms (Fig. 143, c.), having the antennæ 10 -jointed, with a four-jointed club and with joints 4 to 6 , very short, together not longer than the third. The front and middle tarsi in both sexes are composed of five joints, while the hind ones have but four.

KEY TO INDIANA SPECIES OF CYRTUSA.

a. Flytra punctured over the entire surface, the rows of punctures often much confused.

561. PICIPENNIS. a a. Elytral intervals smooth and shining, the rows of punctures distinct.

562. EGENA.

561 (1790). Crrtusa picipennis Lec., New Sp. N. Am. Col., I. 1863, 25.

Oval, strongly convex. Uniform chestnut or dark reddish-brown, shining. Thorax more than twice as wide as long, narrowed in front, hind angles distinct but obtuse. surface rather sparsely and very finely punc- 
tate. Elytra broadly oval, continuing the curve of the thorax; surface irregularly punctate, sometimes with larger punctures forming sinucus rows near the sides and suture. Hind femora of male with a broad, acute tooth at apex. Length 1.6-2 $\mathrm{mm}$.

Starke County; rare. June 17. Larger and darker than egena, with the legs less thickened and the tarsi more slender.

562 (1792). Cyrtusa egena Lec., Proc. Phil. Acad. Nat. Sci., 1853, 284.

Oval or subglobose, very convex. Pale brownish-yellow, shining. Thorax more than twice as wide as long, narrowed in front; surface sparsely and very finely punctate. Elytra each with eight somewhat irregular rows of very fine punctures; intervals flat, smooth, or rarely with a few fine punctures. Tarsi very short and much compressed. Length 1-1.5 mm. (Fig. 143, e.)

Marshall, Monroe and Perry counties; scarce. May 16-June 10.

Isoplastus fossor Horn, hemispherical or broadly oval, very convex, reddish-yellow in hue, length $1.5-2 \mathrm{~mm}$., was described from Detroit, Michigan, and the District of Columbia.

\section{Agathidium Illig. 1798. (Gr., "good + little one.")}

Very small black or piceous shining beetles having the labrum short, rounded in front; antennæ with joints 4-8 small, gradually broader, 9-11 forming an oblong rather loose club. They occur beneath bark or in fungi and are more or less contractile, some of them having the power to roll themselves into a very convex rounded mass, with
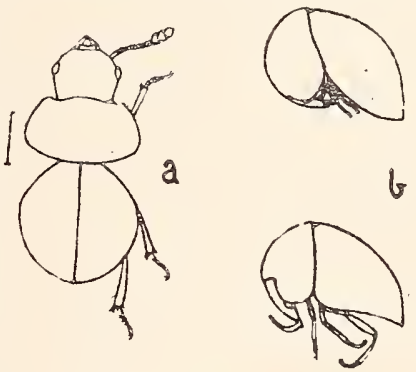

Fig. 144. a, Agathidium oniscoides; $b$, upper, same, contracted; llower, A. politum_(male) contracted; c, Aglyptus lovis; $a$, antenna the legs bent under and lower, $A$.

completely hidden. Three species have been taken in Indiana, while another probably occurs.

\section{KEY TO INDIANA SPECIES OF AGATHIDIUM.}

a. Mesosternum continuous on the same plane with the metasternum, moderately separating the middle coxæ and subcarinate in front; elytra polished, without punctures; third joint of antennæ longer than second.

b. Larger species; sutural striæ very fine.

bb. Smaller species; sutural strix distinctly impressed.

564. ExiguUM.

aa. Mesosternum vertical between the coxæ, which it narrowly separates, not carinate in front; hind angles of thorax broadly rounded; body very convex and contractile. 
c. Surface very smooth, wholly piceous.

565. POLITUM.

cc. Elytra distinctly punctulate, each usually with two large oblique yellow spots.

PULCHRUM.

563 (1794). Agathidic oniscoides Beauv., Ins. Afr. et Amer., 1805, 160.

Body perfectly contractile. Black or piceous, smooth and shining. Thorax nearly twice as wide as long, apex deeply emarginate, front angles broadly rounded. Elytra, viewed from above, almost circular in outline. Length, extended, 3.こ̌-4 mm. (Fig. 144, $a$ and upper b.)

Southern half of State; frerpuent; less so in the northern portion. April 22-November 28. Occuirs beneath bark, especially that of logs bearing fungus growth.

564 (1795̃). Agathidium exiguun Mels., Proc. Phil. Acad. Nat. Sci., II, $1844,103$.

Resembles a small form of the preceding. Distinguished by its smaller size, with the body less perfectly cóntractile; sutural stria distinct under the lens. Length $2-2.5 \mathrm{~mm}$.

Posey and Marion counties; searce. March 17-May 6.

*565 (1S06). Agathidium politum Lec., Proc. Phil. Acad. Nat. Sci., 1866, 370.

Oral, very convex, contractile. Color variable from reddish-brown to piceous, shining. Thorax more than twice as wide as long, narrowed in front, apex rather deeply emarginate, hind angles broadly rounded. Elytra oval, nearly as wide as long, sutural stria rather long, finely impressed; surface either smooth or, in the paler specimens. finely punctate. Length 2-2.5. mm. (Fig. 144, lower b.)

Throughout the State; frequent. April 30-December 25. Hibernates as imago.

A. pulchrum Lec., thorax reddish-yellow with a large rounded discal piceous space; length $2.5-3 \mathrm{~mm}$., has been taken in Kentucky.

XIV. AgLyptus Lee. 1866. (Gr., "without+sculpture.")

In this genus the head is broad and flat, with distinct antennal grooves beneath; antennæ 11-jointed, the last three joints forming an oblong club, the terminal one broarer and longer than the tenth; tarsi slender, the front ones dilated and 4-jointed in the male. 3jointed in the female; middle and hind ones 3-jointed in both sexes. One very small species occurs in the eastern United States, including Indiana.

566 (1809). Agriptus læævis Lec., Phil. Acad. Nat. Sci., VI, 1853, 2 S4.

Oval, strongly convex, very little longer than wide. Piceous, or dark reddish-brown, strongly shining; surface without sculpture. Thorax with margin and base translucent; hind angles rectangular. Length 1-1.5 mm. (Fig. 144, c.) 
Putnam, Monroe and Posey counties; rare. Narch 6--July 10. Taken by sifting.

\section{'Tribe V. CLAMBINI.}

Very small oblong or globose-oval species having the hind coxie contiguous with plates covering the thighs; tarsi four-jointed, tibiæ without spurs. Our only species of the tribe belongs to the genus:

\section{Clanbes Fischer. 1820. (Gr.. "mutilated.")}

The members of this genus have the elytra not margined at the sides and without epipleura; hind coxal plates wide; antenux 9jointed, arising close to the eyes. the club 2-jointed; abdomen with five segments visible. Two species probably occur in the State. though but one has been taken.

KEY TO INDTANA SPECIES OF CLAMBLS.

a. Surface smooth, shining, without punctuation or pubescence.

GIBBULUS.

aa. Surface sparsely pubescent; elytra rather densely and finely punctulate behind the middle.

567. PUBERULUS.

C. gibbulus Lec., globose-oval, piceous-black, length $1 \mathrm{~mm}$., is said to occur from Canada to Texas, but has not yet been recognized from Indiana. (Fig. 142, c.)

567 (1813). Clambus puberulus Lec., N. Sp. N. Amer. Col., I. 1866, 26.

Globose-oval. Piceous or dull sooty brown. finely and sparsely pubescent; elytra paler toward the tips; legs and antennæ dull brownish-yellow. Head and thorax rery finely and sparsely punctulate. Elytra more distinctly punctulate, rery sparsely on the disk, gradually more dense to the tips. Length $1 \mathrm{~mm}$.

Marion and Monroe counties; scarce. April 23-October 15. Taken from window of cellar in which wood had been stored and from debris in beech stump.

\section{Family IX. SCYDMENID 2 .}

The Ant-like Stone Beeties.

Very small, shining, oval, convex species, brownish or piceous in hue and usually having the upper surface rather thickly clothed with erect hairs. They occur beneath bark or stones in moist localities; also often in ants' nests, and are frequently on the wing at twilight. From the smaller Silphidæ. to which they are closely related, they differ by having the hind coxie separated and the facets 
of the eye coarser. In general form and size they resemble the Pselaphide, but the elytra are always entire and the tarsi 5-instead of 3-jointed.

In addition to the characters mentioned, they have the maxillary palpi long, the last joint very small; antennæe inserted upon the front, at the inner margin of the eyes, gradually thickened or slightly chub-shaped toward apex; prosternum not visible between the coxæ; elytra convex, covering the abdomen, the latter with six free ventral segments ; front coxæ conical, promizent, contiguous; middle ones somerhat distant; hind ones small, conical or transverse, often widely separated; tarsi 5 -jointed, claws simple. Nearly 700 species are known, about 175 of which are from the United States. These are treated in the following papers:

LeConte.- "Synopsis of the Scydmænidre of the Tnited States," in Proc. Phil. Acad. Nat. Sci., VI. 1852, 149-157.

Casey.- "Revision of the Scydmænidx of the United States," in Ann. N. Y. Acad. Sci., IX, 1897, 351-548.

In his Revision, Casey divided the family into two subfamilies, only one of which, the Scydmænina, is represented in Indiana. The principal distinguishing characters given of this subfamily are as follows: Antennæ generally distinctly clavate, usually elbowed, but with the basal joint short or moderate in length; hind coxæ transverse or transversely oval; metasternum large; abdomen short; elytra never striate or with rows of punctures. The subfamily is separated into ten tribes, four of which are known to be represented in the State. while two others may be.

\section{KEY TO INDIANA TRIBES OF SCYDMENINE.}

a. Fourth joint of maxillary palpi awl-shaped. finely aciculate and oblique; antennse widely separated at base.

b. Prosternum short and deeply sinuate before the coxæ; neck short and abruptly constricted.

c. Neck narrow; eyes in front of middle of head; scutellum wanting.

Tribe I. Euconsixi, p. 293.

cc. Neck wide; eyes basal or sub-basal in position; scutellum always present.

Tribe II. Sc тDM Exini, p. 301.

bb. Prosternum rather long and pubescent before the coxie; thorax oboral; length less than 8 of a millimetre.

Tribe III. Opresini, p. 302. aa. Fourth joint of maxillary palpi obtuse, never awl-shaped, obscure or fused rigidly to the apex of third, sometimes wanting.

d. Hind coxie transverse. extending to the sides of the body ; antennie widely separated at base. 
$e$. Head deeply inserted and strongly deflexed, the neck invisible; eyes basal, frequently wanting; elytra more oi less rounded at tip; scutellum large and distinct; prosternum very short and deeply emarginate before the coxie.

Tribe IV. Cephenini, p. 302.

ec. Head exserted and but feebly inclined, the neck exposed and constricted; eyes sub-basal; third palpal joint obconic; rosternum rather long and well developed before the coxie.

Tribe V. Eutheinn, p. 303.

$d d$. Hind coxæ oval, not reaching the sides of body; antennæ inserted close together at the apex of the front; neck strongly constricted; hind trochantins elongate: pygidium vertical or greatly inclined.

Tribe VI. Eumicrini, p. 303.

Tribe I. EUCONNINI.

The special characters of this tribe are set forth in the above table. Three of the six genera recognized by Casey are represented in the State.

KEY TO INDIANA GENERA OF EUCONNINT.

a. Thorax with two or more fovere near the basal margin.

$b$. Third joint of maxillary palpi obconic, gradually narrotred toward base; antennal club three- or four-jointed.

I. EUCONNus.

$b b$. Third joint very slender, abruptly clavate in front of middle; brdy glabrous; head large; antennal club four-jointed.

II. Pychopinus.

aa. Thorax without fover, though often more or less transversely impressed near base, conical in form and never narrowed at base nor carinate near hind angles.

III. Connophron.

\section{Euconnts Thoms. 1860, (Gr., "to know well.")}

Head exserted, the eyes in front of middle; thorax oblong, more or less narrowed at base and with at least two fovex or pits near the hind margin. Six species have been recognized from the State, while two others may oceur.

KEY TO INDIANA SPECIES OF ECCONNUS.

a. Antennal club four-jointed.

$b$. Elytra with long, erect and very sparse hairs; head sparsely pubescent; clypeus separated from the front by a fine suture.

c. Head much narrower than thorax; secondary sexual characters of male on third and fourth ventral segments.

d. Carina on side of thorax visible only at base; secondary male characters large and conspicuous; piceous, the disk of elytra reddish.

568. CLAVIPES.

dd. Carina on side of thorax long and distinct; secondary male characters feeble; black, elytra red.

569. SEMIRUB BER. 
cc. Head almost as wide as thorax: secondary male characters confined to the sixth ventral; antennal club stronger, more abrupt and more bead-like.

BICOLOR.

bъ. Elytra very pubescent; head with dense, stiff hairs directed backward; clypeo-frontal suture absent; antennæ with a short abrupt club, the eighth and ninth joints subequal in width.

c. Larger, $1.6 \mathrm{~mm}$; elytra not concave toward base; eighth antennal joint as large as ninth.

570. occultus.

ee. Smaller, not over $1.2 \mathrm{~mm}$; eighth antennal joint distinctly smaller than ninth.

571. SIMILIs.

aa. Antennal club 3-jointed.

$f$. Head and elytra glabrous; thorax with four basal foveæ; antennæ long and slender, the joints all longer than wide.

572. SALINATOR.

ff. Head and elytra distinctly but sparsely pubescent; thorax with a well defined carina each side extending obliquely to base; antennal club darker in color than the stem.

g. Eighth antennal joint fully as long as wide; elytra not inflated.

573. FATUÜs.

gg. Eighth joint distinctly wider than long, the club stouter. DEBILIs.

568 (1838). Euconnus clavipes Say, Long's Sec. Exped., II, 1824, 272 ; ibid. I, 179.

Oval, feebly inflated. Head black; thorax and under surface piceous; elytra dark reddish-brown, shining, the sides and tips blackish; antennæ and legs reddish-brown. Antennæ slender, three-fifths as long as body, the last four joints longer than wide and one-half thicker than those of stem. Thorax as long as wide, narrowed at base, broadly rounded in front, the foveæ deep. distinct. Elytra two-fifths longer than wide, each with a small deep fovea at middle of base and a rather strong humeral fold. Four front femora strongly club-shaped. Length $1.5 \mathrm{~mm}$.

Lake. Marshall and Crawford counties; frequent in Lake, scarce in the others. March 26-May 28. The fourth and fifth ventral segments of males each bear a short, thick discal plate, subdentate on sides.

569 (- ). Euconnus semiruber Casey, Amn. N. Y. Acad. Sci., IX, 1897, 368.

Oval, rather robust. Black, shining, not punctate; elytra dull red; antennæe and legs reddish-piceous. Head not quite as long as wide; antennæ slender, half the length of body, the club loosely formed, its joints gradually larger. Thorax as long as wide, feebly narrowed at base; transverse impression distinct, the fovere minute. Elytra two-fifths longer than wide, twice as wide as thorax; humeral fold long and strong; subhumeral impression long, wide and deep. Length $1.3-1.5 \mathrm{~mm}$.

Marion County; scarce. December 1. Taken in nest of ants from beneath beech log. Described from northern and central Illinois. 
(-). Euconnus occultus Casey, Ann. N. Y. Acad. Sci., IX, 1897, 372.

Rather narrow, feebly inflated. Uniform pale reddish-brown, shining. Head wider than long, broadly rounded at base. Antennie one-lialf the length of body, the club abrupt. its joints wider than long. Thorax as long as wide, but slightly wider than head, sides rounded in front, sinuate behind; disk sparsely clothed with suberect hairs and with two fovere each side near base, the outer one very small. Elytra one-half longer than wide. each with a humeral fold, and a forea near middle of base; disk minutely and sparsely punctate and rather thickly clothed with yellowish suberect hairs. Length $1.6 \mathrm{~mm}$.

Marshall, Putnam and Marion counties: scarce. May 20-November 30 . Taken by sifting decaving vegetable debris.

571 (-). EuconNes similis sp. not.

Shorter and more robust than occultus. Rather dark reddish-brown. shining; antennre and legs paler. Head almost as wide as thorax, its sides with dense, bristle-like hair's directed backward. Antenne short, stout. slightly longer than head and thorax, the joints bead-like, eighth to tenth rounded, less transverse than in occultus; eighth two-thirds the size of ninth, which is equal to tenth; eleventh one-half longer. Thorax as long as wide, sides nearly straight. disk sparsely pubescent and with a deep. transverse impression at base; this, with a rather large forea each side near the hind angles. Elytra ovate, together one-half wider and twice as long as thorax; humeral fold short, feeble; basal forese small, shallow; surface sparsely clothed with fine yellowish pubescence. Length $1.2 \mathrm{~mm}$.

Putnam County; rare. April 17.

572 (1841). Euconnus salinator Lec. Proc. Phil. Acad. Nat. Sci., Ti. $1852,154$.

Rather robust. Blackish-piceous, shining; elytra with a dark reddish tinge; antennæ black, reddish-brown at base. Head nearly as long as wide; occiput with a bristle-bearing puncture each side. Antennæ with joints 3-7 equal, eighth one-half longer, ninth and tenth slightly longer and onehalf thicker than eighth. Thorax as long as wide, but slightly wider than head; disk clothed with erect black hairs and with four forea at base, the inner two the larger. Elytra two-fifths longer than wide, two-thirds wide: than thorax; without humeral fold, but each with a deep forea at middle of base. Length $1.5 \mathrm{~mm}$.

Lake and Posey counties; scarce. March 26-April 27.

573 (1842). Euconnus fatuus Lec., Proc. Phil. Acad. Nat. Sci., VI. 1852. 155.

Rather stout, feebly inflated. Piceous-black, shining, finely and sparsely pubescent; legs and antennx dull brownish-yellow. the club darker. Head rounded, not quite as long as wide; nearly as wide as thorax. Antennie slender, slightly longer than head and thorax; club abrupt and parallel. the ninth and tenth joints nearly twice as wide as eighth. Thorax not quite as long as wide, sides rounded; disk with a transrerse basal impres- 
sion marked with four small foreæ. Elytra nearly three-fourths wider than thorax; the humeral folds rather long and strongly marked, each with a deep forea at base. Length $1 \mathrm{~mm}$.

Kosciusko County ; scarce. June 24. Sifted from moss in tamarack swamp.

E. debilis Casey, deep black, length $.7 \mathrm{~mm}$. was described from Detroit.

\section{Pycrophus Casey. 1897. (Gr. "compact.")}

Head large, truncate at base; neck strongly constricted; antennæ widely separated at base; third joint of maxillary palpi long, the basal half forming a long and slender peduncle.

574 (1834). Prcnophus Rasu's Lec., Proc. Phil. Acad. Nat. Sci., VI, 1852, 153.

Rather stout. Uniform pale reddish-brown, shining, nearly glabrous. Head wider than long, wider than apex of thorax. Antenni longer than head and thorax, the joints of club gradually increasing in size. Thorax slightly longer than wide, sides parallel from base to middle, thence converging to apex; disk somewhat flattened and with a small but deep forea near each hind angle. Elytra twice as wide as thorax, sides broadly and evenly curved; humeral fold short and broad. basal forese small and deep. Length 1.6-1.S mm.

Lake, Starke. Marshall and Marion counties; scarce. May 20December 30. Occurs in nests of ants and beneath $\log$ in sandy places.

\section{Connophron Casey. 1897.}

A large genus of closely allied species having the thorax conical, without basal fover; body rather stout and inflated; head moderate in size, convex; eyes placed in front of middle; maxillary palpi with third joint elongate and obconic, the fourth small, slender and aciculate; femora, especially the front and middle ones, usually strongly club-shaped. Casey has listed 82 species, of which the following have been taken or may occur in Indiana:

\section{KEY TO INDIANA SPECIES OF CONNOPHRON.}

a. Basal joint of hind tarsi not or scarcely longer than second, the first four joints being subequal; hind tibiæ of male rarely with a spur at apex.

b. Antennal club 4-jointed, often gradually formed.

c. Clypeus toothed at middle of apical margin, the tooth sometimes minute; length more than $1 \mathrm{~mm}$.

d. Elytral pubescence long, erect and generally fine. c. Clypeal tooth large or moderate and distinct. $f$. Species more than $1.5 \mathrm{~mm}$. in length. 
g. Elytra strongly impressed each side of suture near base.

$h$. Elytra long, rather acutely pointer behind, fully onehalf longer than wide; blackish-piceous in color; length $2 \mathrm{~mm}$.

LONGIPENNE.

hh. Elytra shorter, more obtuse at apex, less than one-hali: longer than wide, dull red, clouded with blackish behind; length $1.9 \mathrm{~mm}$.

575. FORMALE.

gg. Elytra feebly or not at all impressed on basal half; black, tibiæ paler, tarsi yellowish.

576. FLAVITARSE.

$f f$. Species less than $1.3 \mathrm{~mm}$. in length; thorax shorter than wide, with sides straight; piceous black, the elytra paler.

DENTIGER.

ee. Clypeal tooth very minute.

$i$. Suture not at all elevated or beaded toward base, the subsutural impressions obsolete; black, elytra red, blackish toward tips.

577. FOSSIGER.

$i$. Suture more or less beaded toward base. the impressions long and distinct; body black throughout.

FEMIOPALE.

$d d$. Elytral pubescence coarse, shriter and recurved.

$j$. Antennæ stout, not longer than head and thorax. strongly clatvate, the next to last joints very transverse.

$k$. Larger, 1.4-1.6 mm.; basal foreæ of elytra strong, the outer large.

57S. CLAVICORNE.

$k k$. Smaller, not orer $1.2 \mathrm{~mm}$.; basal tovex small and feeble; antennal club more nearly 3-jointed.

579. ABDUCENS.

jj. Antennæ rather slender, much longer than head and thorax, the next to last joints fully as long as wide; body narrowly oval, pale dull yellow throughout.

FURTIVUM.

cc. Clypeus without trace of median tooth.

7. Thorax without distinct transverse impression at base; elytral suture beaded toward base, the pubescence long, even and suberect; color black.

5SO. INTEGRUM.

ll. Thorax with a distinct interrupted impression near base.

$m$. Body more inflated; elytra always distinctly more than onehalf wider than thorax, the suture with a broad bead which is broadly expanded at base; blackish-piceous. elytra dark reddish-yellow.

IN NOCUÜM.

$m m$. Body narrow and elongate, but convex; elytra almost one-half wider than thorax, the latter with transverse impression strong; head large, nearly as wide as thorax.

5S1. CLAVATUM.

bb. Antennal club :3-jointed. abrupt; length not over $1 \mathrm{~mm}$.

n. Clypeal tooth well developed, narrow and acute; antennse stouter: color dull brownish-yellow.

5९2. DEBILITANS.

$n n$. Clypeal tooth very minute, short and obtuse; antennal funicle much more slender; hind body narrowly oval; pale chestnut brown.

593. FULVU.

aa. Basal joint of hind tarsi elongate, always distinctly longer than second, joints one to four decreasing rapidly in length; hind tibire of male with a slender terminal spur. 
o. Larger, 1.3 or more in length.

p. Color piceous or paler, the elytra generally reddish or dull yellow.

$q$. Length $1.6 \mathrm{~mm}$.; elytra with subhumeral impressions large, deep and conspicuous; dark reddish-brown; elytra paler red.

584. CAPILLOSULUM.

$q q$. Smaller, $1.3 \mathrm{~mm}$; thorax small, not much over one-half as wide as elytra, strongly impressed near base; color piceous.

POLITUM.

$p p$. Black throughout, elytra with at most a faint piceous tinge; legs pale dull yellow, thorax more than half as wide as elytra.

NIGRUM.

oo. Smaller, not over .9 of one mm. in length; basal joint of hind tarsi not as long as the next two combined; color piceous black, the elytra pale reddish-brown.

PUMILUM.

$C$. longipenne and $C$. dentiger were both described by Casey from Iowa.

575 (-). Connophron formale Casey, Amn. N. Y. Acad. Sci., VII, 1897, 402.

Elongate-oval, rather stout. Piceous-black; elytra dark red, blackish behind, thickly clothed with long bristling hairs; abdomen pale at apex; legs and antennæ dark reddish-brown. Head slightly wider than long, clypeal tooth distinct. triangular. Antennæ one-half as long as body, club gradwally formed, the ninth joint but slightly longer than wide. Thorax as wide at base as long, sides feebly curved, base one-fourth wider than head. Elytra twice as long and nearly twice as wide as thorax, humeral fold and subhumeral impression well developed, basal fovere feeble; subsutural impressions distinct. Length $1.9 \mathrm{~mm}$.

Throughout the State; frequent. March 20-October 21. Occurs beneath bark and rubbish. Resembles fossiger but longer and with the joints of antennal club more gradually thickened.

576 (1826). Connophron fravitarse Lec., Proc. Phil. Acad. Nat. Sci., Vi, $1852,152$.

Elongate-oval, rather stout. Black, shining; elytra dull red except near tips and thickly clothed with long fine hairs; legs reddish-piceous, tarsi pale yellow. Head much wider than long, the clypeal tooth broadly triangular. Antennæe less than half as long as body, the joints of club gradually increasing in thickness. Thorax conical, not longer than wide, the base one-fourth wider than head. Elytra one-half longer than wide, humeral fold strong, of moderate length, suture finely elevated toward base, the basal fovea distinct. Length $1.8 \mathrm{~mm}$.

Marion and Posey counties; scarce. April 21-November 28.

*577 (1827). Connophron fosstger Lec., Proc. Phil. Acad. Nat. Sci., VI, $1852,152$.

Rather stout, fusiform. Black; elytra reddish, blackish toward tips, thikkly clothed with long pale hairs; legs and antenne reddish-brown. the femora blackish. Head wider than long. clvpeal tooth small, triangular. 
Antennæ half the length of body, the club abrupt, its joints increasing feebly in thickness, eighth a little longer than wide, as long as tenth but narrower. Tholax slightly longer than wide, the base nearly twice as wide as apex, and one-third wider than head. Elytra one-half longer than wide, three-fourths wider than thorax, each with two small foreæ at base; sides evenly curved, humeral fold and subhumeral impression strong. Length $1.6 \mathrm{~mm}$.

Starke. Vigo and Posey counties; scarce. January 6-June 27. Occurs beneath chips and rubbish, especially in low, sandy, open woods.

C. femorale Casey, $1.5 \mathrm{~mm}$. in length was described from Iowa and Michigan.

578 (-). Connophron clavicorne Casey, Amn. N. Y. Acad. Sci., VII, $1897,417$.

Rather stout, suboval. Uniform pale chestnut brown, polished; pubescence abundant, coarse. pale and conspicucus, that on elytra rather short and suberect. Head semicircular behind the eyes; clypeal tooth elongate and slender. Antennæ stout. shorter than head and thorax, the club large and as long as the other joints together. Thorax conical, slightly wider than long. sides nearly straight, apex more than half as wide as base. Elytra oval, widest near middle; four-fifths wider than thorax; humeral fold short but distinct; outer foveæ strong, subsutural impression faint. Length 1.4-1.6 mm.

Wayne County; scarce. May 26. Occurs in nests of ants and beneath logs.

579 (-). Connophron abducens Casey, Ann. N. Y. Acad. Sci., VII, 1897, 418.

Narrowly suboval. Uniform pale reddish-brown; legs and antennæe paler; pubescence of elytra coarse, stiff and recurved. Head rather small, rounded behind the eyes; clypeal tooth rounded at tip. Antennæ short and stout, club almost three-jointed, the eighth joint only one-third thicker than seventh; ninth and tenth abruptly much wider and strongly transverse. Thorax small, strongly conic; slightly wider than long; apex onehalf as wide as base. Elytra two-fifths longer than wide, three-fourths wider than thorax; humeral fold and usual impression almost obsolete; basal foreæ small, subequal. Length $1.2 \mathrm{~mm}$.

Steuben County; rare. May 25. Sifted from sphagnum moss.

C. furtium, length $1.4 \mathrm{~mm}$., and $C$. innocuum, length $1 \mathrm{~mm}$, were both described by Casey from Illinois, the former from the northern, the latter from the central portion of the State.

580 (- - ). Connophron integrum Casey, Ann. N. Y. Acad. Sci., VII, 1897. 425.

Short, rather stout. Black, shining; elytra often with a feeble piceous tinge, thickly clothed with rather long, suberect pale hairs; legs and antennæ dark reddish-brown. Head wider than long. circularly rounded. An- 
tenna, long, slender, more than one-half the length of body, the club slender and gradually formed; eighth joint only one-third wider than seventh; ninth and tenth one-fifth wider than eighth. Thorax scarcely as long as wide, sides distinctly curved, apex three-fifths as wide as base. Elytra threefourths wider than thorax, humeral fold long and strong, subhumeral impressions large and deep, basal fover large. Length $1.2 \mathrm{~mm}$.

Lake, Starke, Marion, Putuam and Löwrence counties ; frequent. April 17-June 17. 'Taken by sifting damp vegetable debris. The front femora are very much enlarged.

581 (1836). Connophron clavatum Lec., Proc. Phil. Acad. Nat. Sci., VI. $1852,153$.

Elongate, narrow. Dark reddish-yellow; head and thorax darker than elytra, the latter rather thickly clothed with short, pale, recurved hairs; antennæe and legs paler. Head iarge, as wide as thorax. Antennæ as long as head and thorax, slender. the club somewhat abrupt, the eighth joint one-half wider than seventh, ninth and tenth subequal and one-fourth wider than eightl. Thorax as long as wide, sides curved, converging in front. apex three-fourths as wide as base; disk with deep, transverse sub-basal impression. Elytra one-half wider than thorax, sides broadly curved, humeral fold small, the inner basal fovea only distinct. Length $1.2 \mathrm{~mm}$.

Crawford County; rare. May 24. One specimen in Dury collection.

582 (-). Connophron neblltans Casey, Anm. N. Y. Acad. Sci., Vir, $1897,446$.

Rather narrowly oval. Pale chestnut brown, shining; elytra more reddish, dusky toward tips, rather thickly clothed with short, coarse, pale hairs; legs pale yellow. Antennæe stout, as long as head and thorax, club abruptly 3-jointed. Thorax as long as wide, sides nearly straight, apex three-fifths as wide as base. Elytra three-fourths wider than thorax, humeral fold short and feeble; inner fovea distinct, outer one obsolete. Length $1 \mathrm{~mm}$.

Kosciusko, Putnam and Monroe counties; scarce. April 22June 20. Taken by sifting.

583 (1845). Connophron fulvum Lec., Proc. Phil. Acad. Nat. Sci., VI, $1852,155$.

Narrowly suboval. Pale chestnut brown, shining; legs and antennie paler; elytra with numerous short, recurved pale hairs. Antenin as !ong as head and thorax, club abrupt and 3 -jointed, ninth and tenth joints equal and globular, eleventh one-half longer. Thorax as long as wide, sides feebly curved; base one-third wider than head. Elytra oval, one-half wider than thorax, humeral fold very small, basal fovere obsolete. Length .8-.9 mm.

Marion County; rare. December 1 . Taken from nest of ants in low, open woods. 
584 (1827). Conmophron capillosulua Lec., Proc. Phil. Acad. Nat. Sci., VI, 1852, 152 .

Rather stout and inflated. Dark reddish-brown; elytra paler and brighter red, thickly clothed with long, erect, pale hairs; legs paler. Antennæ dull sellow, long and slender, the ciub rather abrupt. Thorax slightly wider than long, sides feebly curred, disk with a distinct sub-basal impression, interrupted at middle. Elytra nearly twice as wide as thorax, humeral fold long and strong, subhumeral impression large and conspicuous, inner forea distinct. Length $1.6 \mathrm{~mm}$.

Marion and Putnam counties; scarce. March 17-April 22.

C. politum Say has been taken in northern Illinois; C. nigrum Casey was described from Michigan and C. pumitum Casey from New York, Canada and Iowa.

In addition to those described, there are in the collection at hand about eight species of Comnophron which I have not been able to identify with Casey's key. Since his collection of types is inaccessible for reference, they are for the present left unnamed.

Tribe II. SCYDMENINI.

As at present restricted this tribe is represented in the United States by only two genera, one of which occurs in Indiana.

\section{Scrdumnus Latr. 1802. (Gr., "sad + colored.")}

The members of this genus are distinguished from those of the preceding tribe by the smaller thorax. which is more dilated in front. narrowed toward base, the sides sinuate behind the middle; more elliptical and convex elytra; wider neck; antennæ enlarged toward apex but never with distinct chub; scutellum usually distinct; legs long and well developed, the femora. especially the front ones, distinctly clarate. But one species has been taken in the State, though two others may oceur.

\section{KEY TO INDIANA SPECIES OF SCYUMIEXUS.}

a. Head not impressed; thorax with four sub-basal forea; scutellum distinct.

b. Elrtra feebly infiated and strongly but gradually narxorred behind: body black.

PERFORATLS.

6b. Elytra strongly inflated, less narrowed behind; piceous. the elytra paler.

5S5. BADIUS.

aa. Head with tro impressions on vertex; thorax with six sub-basal forea; scutellum very minute; length less than $1 \mathrm{~mm}$.

CORPLSCLLTI.

S. perforatus Schaumm. length 1-1.2 mm.. ranges from Massachusetts to Iowa. 
585 (-). Scydmenus badius Casey, Ann. N. Y. Acad. Sci., VII, 1897. 475.

Oval, rather strongly inflated. Piceous, shining; elytra reddish-brown, sparsely clothed with rather long, yellowish recurved hairs; antennæ and legs pale reddish-brown. Head much wider than long; eyes prominent. Antennæ a little less than half the length of body, the joints somewhat beadlike, the outer ones gradually enlarged. Thorax as long as wide, one-fourth wider than head, dilated and narrowly rounded at apical third, the sides thence converging and broadly sinuate to base, the fovere small but distinct. Elytra four-fifths wider than thorax, sparsely and rather finely but distinctly punctate; inner basal fovea large. Length 1.1-1.3 mm.

Wayne County; scarce. May 26.

S. corpusculum Casey is known from Canada and Pennsylvania.

Tribe III. OPRESINI.

Very minute species, chiefly distinguished by the long prosternum in front of the coxæ. To the tribe Casey has ascribed three genera. Of these opresus, having the eyes median, thorax impressed at base and scutellum invisible, is represented by three known species, each less than .7 of one $\mathrm{mm}$. in length, which occur from Pennsylvania to Georgia. Delius, differing in having the scutellum distinct and the elytral suture elevated, is also represented by a single species of the same size in Pennsylvania; while Neladius, having the eyes in front of middle, thorax not impressed at base and scutellum distinct, is also known by one species from Pennsylvania.

\section{Tribe IV. CEPHENIINI.}

Represented by the single genus:

\section{Cephennium Muller. 1822. (Gr., "red or purple color.")}

Small convex species having the head triangular and strongly deflexed, but slightly visible from above; antennæ widely separated, their clubs 3-jointed, the joints increasing rapidly in thickness; thorax with a feeble fovea near each hind angle; scutellum distinct.

586 (1855). Cephennum corporosum Lec., Proc. Phil. Acad. Nat. Sci., VI. $1852,150$.

Oblong-oval, rather robust, strongly convex. Dark reddish-brown, shining, sparsely clothed with rather short, yellowish recurved hairs; antennæ and legs paler, the former one-half the length of body. Thorax nearly twice as wide as long, sides broadly curved; disk convex, with a broad shallow fovea near each hind angle. Elytra together not longer than wide, not wider than thorax, finely and very sparsely punctate; each with a narrow, deep impressed line on basal third just within the humerus and a deep basal fovea near suture. Length $1 \mathrm{~mm}$. 
Putnam and Posey counties; scarce. April 17-April 22. Sifted from damp vegetable debris.

\section{Tribe V. EUTHEIINI.}

This tribe, as characterized in the key, is represented by three genera. No species of the tribe has as yet been noted in Indiana. though all of the genera may occur.

\section{KEY TO GENERA OF EUTHEIINI.}

a. Hind coxæ widely separated; length $1-1.5 \mathrm{~mm}$.

b. Mesosternum broad and flat; antennæ only moderately enlarged at tips.

Eutheia.

bb. Mesosternum strongly carinate; last antennal joint much enlarged.

VERAPHIS.

aa. Hind coxæ very moderately separated; length less than $.7 \mathrm{~mm}$.

EUTHIODES.

Veraphis cristata Brend., black, shining, head with a short carina, length $1.2 \mathrm{~mm}$., was described frrom Pennsylvania. Euthiodes latus Brend.. brownish-yellow, length $.7 \mathrm{~mm}$., is known from Iowa.

\section{Tribe VI. EUMICRINI.}

This tribe, as defined in the key, is composed of three genera, two of which are represented in Indiana.

KEY TO INDIANA GENERA OF EUMICRINI.

a. First joint of hind tarsi only moderately elongate; scutellum visible but minute; body stouter.

VI. Eumicrus. aa. First joint of hind tarsi fully as long as the next two combined; scutellum wholly wanting; body smaller and more slender.

VII. ACHOLEROPS.

\section{Eumicrus Lap. 1840. (Gr., "ggood + small.")}

Stout convex species having the head large and thick; eyes located in front of middle; neck strongly constricted; antennæ rather long, funicle capable of being reflexed into the excavated apex of basal joint, club 3-jointed; thorax usually with two small foveæ each side near base; femora strongly and abruptly clavate. One species has been taken, while three others may occur.

KEY TO INDIANA SPECIES OF EUMICRUS.

a. Front broad and feebly prominent between the antennæ; elytra distinctly impressed at base, their pubescence rather dense, moderately long and recurved.

b. Larger, $2.5 \mathrm{~mm}$.; elytra broadly oval, two-fifths longer than wide; thorax densely punctured toward base.

GROSSUS.

[20-23402] 
bb. Smaller, not over $1.7 \mathrm{~mm}$; femora abruptly clavate; thorax not longer than wide and subglobular; body stout; antemnæ with a strong and gradually formed club.

587. MOTSCHULSKII.

aa. Front strongly prolonged between the antennæ; elytra not at all impressed at base, their pubescence long, sparse, erect and bristiing.

c. Hind femora not dentate on outer side; thorax not quite as long as wide; color pale brownish-yellow.

OCHREATUS.

cc. Hind femora dentate on outer side near the trochanter's; color pale reddish-brown.

CRURALIS.

E. grossus Lec., dark chestnut brown, is a southern species which has been taken near Cincinnati.

587 (1850). Eumicrus motschulskil Lec., N. Sp. N. Amer. Col., I, 1863, 26.

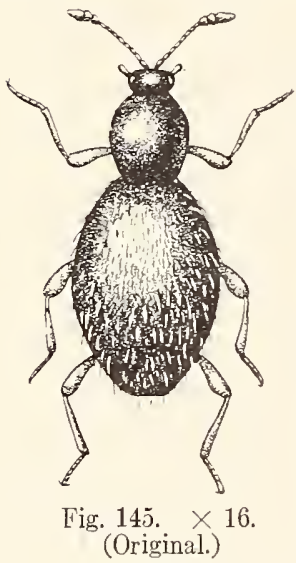

Rather stout; suboral, strongly convex. Dark chestnut brown, rather thickly clothed with recurved sellowish hairs; legs slightly paler. Antennæe three-fifths as long as body, ninth joint as long and twice as wide as the two preceding united; tenth still wider; eleventh as long as ninth and tenth together. Thorax ovate, convex, widest and rounded in front of middle; disk without punctures, but with two distinct foreæ each side near base. Elytra short, broad, very convex, not quite twice as long as and about three-fifths wider than thorax; sparsely but distinctly punctate. Leugth $1.7 \mathrm{~mm}$. (Fig. 145.)

Southern half of State; frequent. April 10-October 31. Forty or more specimens were sifted from decaying woody fungi on a maple log near Broad Ripple on the latter date.

$E$. ochreatus, and $E$. cruralis, each $2 \mathrm{~mm}$. in length, were both described by Casey from Central Illinois.

\section{Acholerops Casey. 1897.}

Narrow-bodied species having the sub-basal foveæ of thorax very faint; scutellum wholly wanting. One of the two recognized species occurs in the State.

588 (1854). Acholerops Zimmermanxi Schaum., Analecta Entom., 1841, 26.

Narrowly suboval, strongly convex. Uniform dark reddish-brown, shining. Head wider than long; eyes placed in front of middle. Antennæ onehalf as long as body, club gradually and feebly thickened, ninth joint obconic, as long and two-thirds as thick as the two preceding united, tenth slightly wider, eleventh still thicker but not as long as ninth and tenth together. Thorax longer than wide, widest and more rounded at apical third, the sides thence oblique and straight to base; disk rather coarsely, 
closely and rugosely punctured near base. Elytra one-half longer than wide, two-thirds wider than thorax, coarsely and rather sparsely punctate, and sparsely clothed with short, stiff recurved hairs. Length $1.5 \mathrm{~mm}$.

Lawrence County ; rare. October 16. Taken from nest of red ants beneath decaying log.

\section{Family X. PSELAPHID A.}

\section{The Antr-Loving Beftles.}

Very small chestnut-brown, dull yellow or piceous species, not exceeding $3.5 \mathrm{~mm}$. in length, having the body usually slightly pubescent, head and thorax mostly narrower than elytra and abdomen; elytra short, truncate; abdomen convex, obtuse at tip and with half its length exposed above. They live for the most part beneath bark and stones, where they feed upon Acarina and other minute animal forms. Others excrete from small tufts of hairs a substance of which ants are very fond, and they are therefore tolerated in numbers in the nests of these insects. They are even said to be fed by the ants and to ride about on the backs of their hosts when so inclined.

The name of the family is from that of the typical genus, Pse laphus, meaning "I feel my way," in allusion to the greatly developed palpi or "feelers," the maxillary palpi being usually 4 jointed, greatly developed and of a variety of remarkable forms.

In addition to the characters mentioned the Pselaphidx have the mandibles usually broad and short, with the tips curved and acute; antennæ usually clavate, rarely bear-like. the number of joints variable, but usually eleven; eyes with coarse facets, sometimes wanting; prosternum almost obsolete between the front coxæ. which are conical, prominent, contiguous, the cavities open behind; middle coxæ rounded, contiguous; hind ones narrow, transverse. usually separated; metasternum very broad, its sidepieces simple; legs long, femora often club-shaped; tibiæ slender and without spurs; tarsi usually 3- (rarely 2-) jointed; claws simple.

Nearly 2.500 species of Pselaphidæ are known, about 275 of which are from North America. The more important papers treating of these are as follows:

LeConte.-_"On the Pselaphidæ of the Tnited States," in Bost. Journ. Nat. Hist., VI, 1849, 64-110.

Brendel, E._-Synopsis of the Gener'a and Species of the Family Pselaphidæ," in Proc. Ent. Soc. Phil., VT, 1866, 31-38. 
Brendel and Wicliham.- "The Pselaphidæ of North America, in Bull. Lab. Nat. Hist. Univ. Iowa, I, 1890, 216-304; II, 1891, 1-84, pls. VI-XII.

Casey.- "Coleopterological Notices, V and VII," in Ann. N. Y. Acad. Nat. Sci., VII, 1893, 433-509 ; IX, 1897, 550-630.

Casey._- "Remarks on Some New Pselaphidæ," in Can. Ent., XL, 1908, 257-281.

The family is divided into two subfamilies, and these in turn into tribes and genera.

KEY TO SUBFAMILIES OF PSELAPHIDA.

a. Antennæ 2-jointed (Fig. 4, No. 10, and Fig. 146, b) ; front coxæ contiguous, hind ones distant. Subfamily I. Clavigerin $\approx$, p. 306. a a. Antennæ 11-jointed (Fig. 146, a), rarely 10-jointed.

Subfamily II. Pselaphinæe, p. 308.

\section{Subfamily I. CLAVIGERINAE.}

The members of this subfamily have the head narrow; palpi rudimentary, of but one joint; three basal dorsal segments of abdomen firmly united and deeply excavated, forming a cavity on the sides of which are tufts of hairs; first and second tarsal joints very short; third long, with a single claw. The species live solitary in ants' nests and the construction and smallness of the mouth is such that their nourishment is supposed to be liquid in form. The ants caress the tufts of hairs on the abdomen of the beetle with their antennæ, causing the exudation of a fluid, which they greedily swallow. Two genera comprise the subfamily, both of which are represented in the State.

KEY TO GENERA OF CLAVIGERIN Æ.

a. Eyes wanting.

aa. Eyes present.

I. AdRANEs.

II. Fustiger.

\section{Adranes Lee. 1849. (Gr., "imbecile.")}

Of this genus only two species are known. One of these has been taken in the State, while the other probably occurs.

KEY TO SPECIES OF ADRANES.

a. Thorax, when viewed from above, conical; head cylindrical; length $1.8 \mathrm{~mm}$.

CECUS.

aa. Thorax bell-shaped; head obconical; length $2.5 \mathrm{~mm}$.

589. IECONTEI.

A. coecus Lec., orange-yellow, elytra with regular rows of short recumbent, stiff hairs, is known from Pennsylvania, Georgia and Illinois. 
589 (1863). Adranes lecontei Brend., Proc. Ent. Soc. Phil., VI, 1865, 255.

Brownish-yellow; pubescence fine, in regular rows. Head twice as long as broad; rertex with two shallow longitudinal impressions. Last antennal joint as long as head, slightly curved, squarely truncate, narrower at its outer end. (Fig. 4, No. 10.) Thorax bell-shaped, slightly longer than head, base twice as wide as neck; disk with an obtuse tubercle behind the middle and a shallow forea each side near base. Elytra triangular, at base scarcely wider than thorax. thence rapidly widening to the truncate apex. Abdomen much wider than elytra, the first dorsal segment very large, broadly and deeply concare, its margin curved and convolute near base. Length $2.5 \mathrm{~mm}$. (Fig. 146, b.)

Posey County; rare. August 3. Taken from nest of the ant, Lasius niger americanus Emery.

\section{Fustiger Lec. 1866.}

Eyes present but very small, having only eight facets each; antennæ with the basal joint small. quadrate; second joint as long as head, gradually broader to apex. which is three times as wide as base.
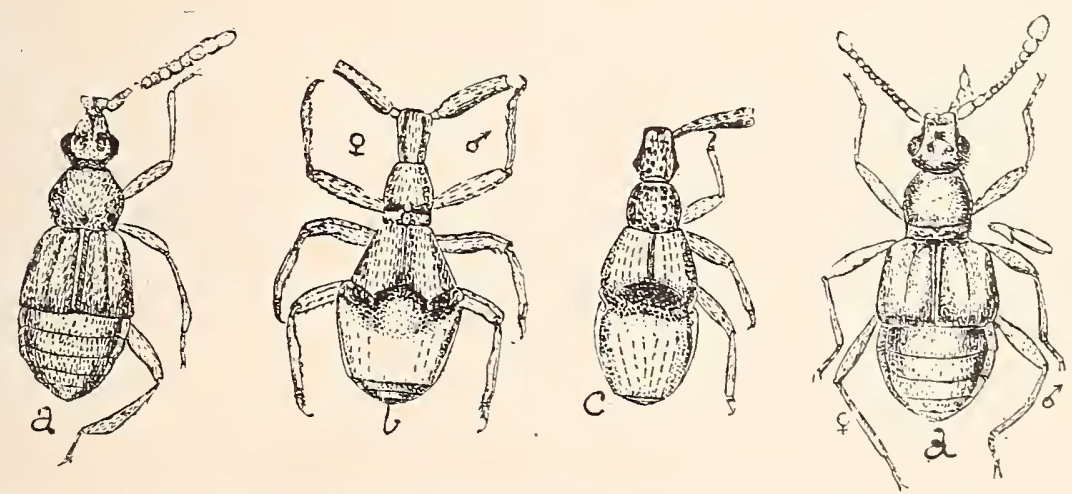

Fig. 146. a, Chennium monilicorne; $b$, Adranes lecontei; c, Fustiger fuchsii; d, Tyrus humeralis. All highly magnified. (After Brendel.)

590 (1864). Fustiger fuchsis Brend., Proc. Ent. Soc. Phil.. VI, 1866, 190.

Dark brownish-yellow, translucent. Head flattened above and, like the thorax, marked with a network of large shallow impressions. Thorax subslobular, equal to the head in length, sides rounded. base and apex truncate. Elytra at base as wide as thorax, thence gradually widening to apex, disk sparsely and rery finely pubescent and behind the middle sloping downward to the deep transverse abdominal forea. Abdomen convex, broader than elytra, the basal segment very large, longer than wide. Length $1.7 \mathrm{~mm}$. (Fig. 146, c.)

Crawford County; scaren. May 17-August 15. Taken from ants' nests beneath stones on slopes of high hills near Nyandotte Cave. 


\section{Subfamily II. PSELAPH:NAE.}

In this subfamily the abdominal segments are all separate and the antennx have 11 (10 in certain species of Bryaxis) joints. Three tribes comprise the subfamily. all of which are represented in the State.

KEY TO TRIBES OF PSELAPHIXE.

a. Antennæ approximate at base, inserted beneath prominent horizontal contiguous tubercles.

Tribe I. Pselaphisi. p. 308.

aa. Antennæ distant, inserted on the sides of the head beneath short. deflexed tubercles.

b. Hind coxre widely separated, transrerse, not prominent.

Tribe II. Brachigletivi, p. 315 .

bb. Hind coxæ approximate or contiguous. conical and prominent.

Tribe III. Euplectixi, p. 328.

Tribe I. PSELAPHINI.

Our species of this tribe are altrays narrowed in front. much broader behind and have the abdomen strongly margined and the hind coxa widely separated. 'The following' g'enera are probably represented in the State:

KEY TO INDIANA GENERA OF PSELAPHIXI.

a. Tarsi with two equal claws.

b. Antenne moniliform or bead-like, without a distinct club.

c. Maxillar palpi rery small, the basal joints hidden. the last two united to form a globular club.

Chennium.

cc. Maxillary palpi with the last two joints rery transrerse. fusiform and compressed.

III. Ceophytuts.

bh. Antenne clarate, the last joint usually gradually larger.

d. Last three joints of maxillary palpi bearing bristle-like appendages on the sides.

e. Appendages of last three joints of maxillars palpi short, the joints triangular; abdomen carinate.

IV. TMesiphorus.

ee. Appendages rery long. the last three joints oral-transrerse.

V. PILOPIUS.

dd. Maxillary palpi without appendages on the sides.

$f$. Last two joints of maxillars palpi lunate, or half-moon shaped. the terminal one longer.

TI. CEDIUS.

ff. Last two joints not lunate.

$g$. Last three joints of antennæe forming a club: last joint of maxillary palpi elongate and with a terminal bristle.

VII. TYRUS.

gg. Last joint of antemnre rery large, rounded: last joint of palpi cylindrical, rounded at tip.

TIII. HAMOTUS. 
aa. Tarsi with a single claw; maxillary palpi very long.

$h$. Last joint of maxillary palpi club-shaped, very long, third small, globular.

Pselaphus.

$h$. Last joint of maxillary palpi long, hatchet-shaped, third triangular.

IX. Trenus.

Chennium moniticorne Lec., reddish-brown, thorax as long as wide, pubescence short, dense, appressed, length $2.8 \mathrm{~mm}$., has been taken near Cincinnati and probably occurs in the hilly regions of southern Indiana. (Fig. 146, a.)

\section{Ceopityluus Lec. 1849. (Gr., "I hide + a leaf.")}

Antennal tubercles wider than long, contiguous; pubescence short, fine, appressed; front femora each with three strong spines near the base. One species is known.
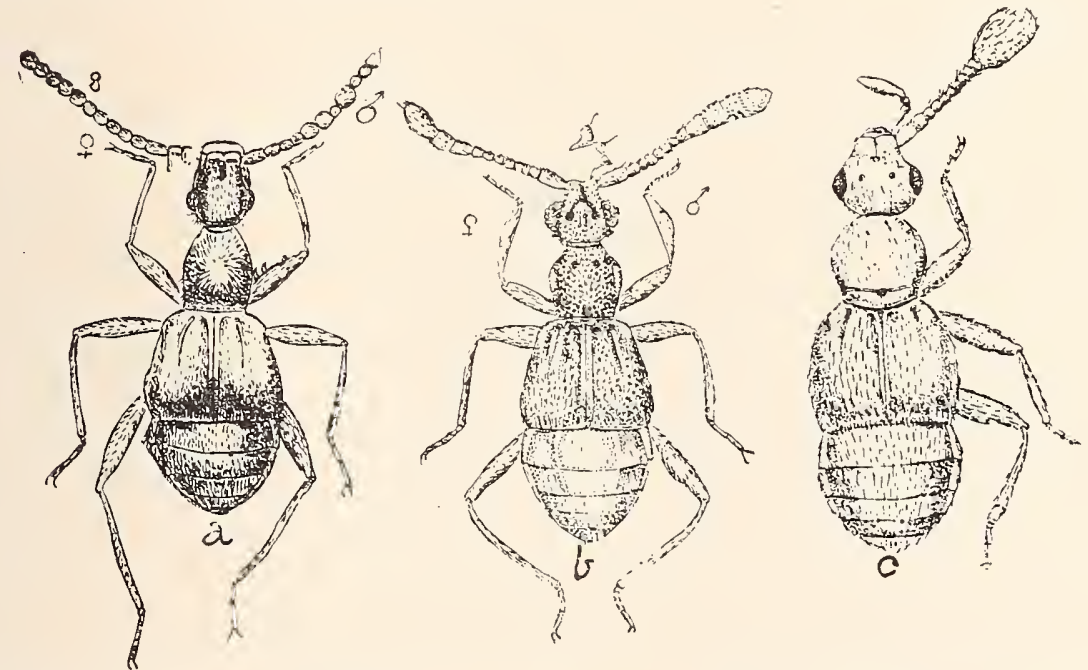

Fig. 147. a, Ceophyllus monilis; b, Tmesiphorus costalis; c, Hamotus tatrisioides. All highly magnified. (After Brendel and Wickham.)

*591 (1866). Ceophyllus monilis Lec., Bost. Journ. Nat. Hist., VI, 1849, 73.

Elongate-ovai. Reddish-brown, not punctate. Head as long and threefourths as wide as thorax. Antennæ stout, half the length of body, male with second joint two-thirds the length of first, third and fourth equal, wider than second; fifth to tenth globose, the eighth largest; eleventh wider and bluntly pointed; female with joints subequal and slightly increasing in size toward tips. Thorax bell-shaped, as long as wide, sides evenly curved; disk with a fine impressed line at base and a fovea each side. Elytra onehalf wider at base than thorax, front half of disk flat with a feebly impressed groove. Abdomen a little narrower than elytra. Length $3.3 \mathrm{~mm}$. (Fig. 147, a.)

Vigo, Franklin, Crawford and Posey counties; scarce. February 28-September 10. Occurs beneath bark of rotten stumps. 
IT. Thesiphorts Lec. 1849. (Gr., "a fissure + to carry.")

Antennæ clarate: frontal tubercles longer than wide: fourth joint of maxillary palpi triangular and emarginate; head and thorax with a network of large rounded punctures. Two species are knomn.

592 (1869). TMesiphords costalis Lec.. Bost. Journ. Nat. Hist. VI, 1849, 7 .

Elongate-oral. Piceous, shining. clothed with short, fine, appressed rellowish hairs. Head two-thirds as long as broad: frontal fissure deep. branching behind the frontal tubercles towards the forea on rertex; eses prominent. Antennie of male more than half the length of bods. second joint crlindrical, one-third as iong and two-thirds as wide as first; third to serenth globular, eighth to tenth gradually larger, obconical. elerenth as long as ninth and tenth together, notched on one side near base: female antennie shorter, less robust and without notch on last joint. Thorax bellshaped, with an obtuse tubercle each side near middle. disk with two forex on apical third and a larger one each side near base. Elstra each with a broad. flat-bottomed sroore on basal half. conrex behind: humeri high.

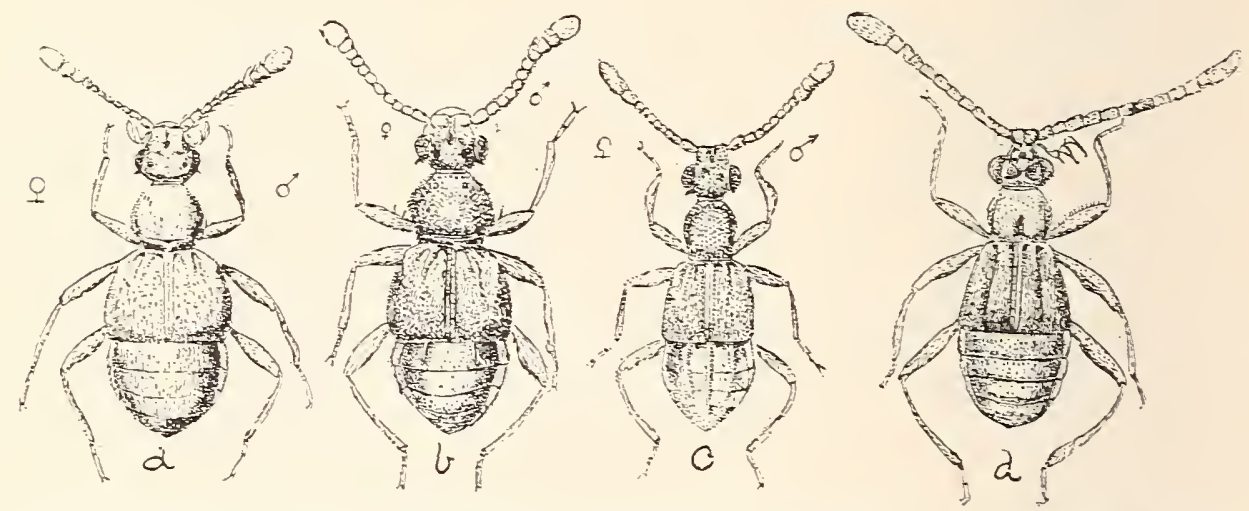

Fig. 148. a. Cedius spinosus; b, Cedius ziegleri; c. Tmesiphorus carinatus; d, Pilopius lacustris. All highly magnified. (After Brendel and Wickham.)

prominent. Abdomen broadly margined. first and second dorsal segments carinate on the sides. Length $3.3 \mathrm{~mm}$. (Fig. 147, b.)

Throughout the State; common. Narch 31-December 29. Occurs beneath stones and bark and in ants' nests. Gregarious in winter beneath half-buried logs in upland woods.

593 (1870). Thestphorus Carixates Sas, Journ. Phil. Acad. Nat. Sci., IT. 1824, 97 ; ibid. II. $2: 35$.

Pale reddish-brom, densels punctate: pubescence short, appressed. Vertex with median frontal groore broader and not connected by branches with the forea. Front forea of thorar wanting. Abdomen with a median carina. as $\pi$ ell as one each side on the second and third dorsal segments. Otherwise as in costulis. Lengtin $2.5 \mathrm{~mm}$. (Fig. 148. c.)

Crawford County; rare. August 13. 


\section{Pilopius Casey. 1897.}

Antennie approximate at base, clavate; joints $2-4$ of maxillary palpi with long bristle-like appendages, the second joint bent and clavate, the third transversely lunate; abdomen with second and third ventrals not much longer than fourth; first four visible dorsals equal in length; front femora with stiff, erect bristles, but without spines. Two species are known from the State and another probably oceurs.

\section{KEY TO INDIANA SPECIES OF PILOPIUS.}

a. Pubescence rather sparse; last joint of antennx as long as the three preceding combined.

b. Tenth antennal joint not at all longer than wide, the sixth joint as long as fifth; body stout; elytra nearly as long as wide.

594. LACUSTRIS.

bb. Tenth antennal joint distinctly longer than wide.

c. Body stout, generally dark in color; abdomen always black or blackish; thorax feebly transverse, never more than one-half as wide as elytra; fifth antennal joint slightly longer than fourth.

IowENSIS.

cc. Body narrower, pale in color throughout, the abdomen nerer blackish; elytra nearly as long as wide, rather longer than head and thorax combined.

595. ZTMMERMANNI.

aa. Pubescence dense, shorter and more scale-like; last antennal joint much shorter than the three preceding combined; elytra as long as head and thorax.

CONSOBRINUS.

*594 (-). Pilopius lacustris Casey, Ann. N. Y. Acad. Sci.. IX, 1897. 619.

Rather stout, subconvex. Dark reddish-brown; elytra, antennæ and legs paler. Head as wide as long; occiput with two large fovea between the eyes. Antenne of male three-fourths the length of body, joints cylindrical, nearly equal; of female, shorter with joints $7-10$ short, transverse. last joint shorter, oblong-oral. Thorax wider than long, disk with an oblong median frivea at base, reaching almost to middle. and a smaller one each side. Elytra slightly wider at base than thorax, thence gradually widening to apex, each with a fine. entire sutural and median stria. Abdomen convex, margin broad, tip rounded. Length 1.8 mm. (Fig. 148. d.)

Southern half of State; common. April 5-December 23. Occurs beneath logs and bark; gregarious in winter. A number were once swept from stems of blue-grass in May. Usually known as $P$. piceus Lec., from which it is distinguished by its more elongate and paler elytra and shorter tenth antennal joint.

$P$. iouensis Casev, length $1.7 \mathrm{~mm}$., was described from Iorra.

595 (1873). P’inopius zinderamanni Lec. Bost. Journ. Nat. Hist., VI. 1849, 79.

Pale brownish-yellow, sparsely pubescent. Head with frontal groore not reaching the oblong frontal fores; occiput elevated, its forere larger. 
farther apart and near the eye. 'Thorax as long as wide, narrower in front than in lacustris, the median foveæ nearly circular, the ones on sides small. Elytra more convex, the lines or striæe less deep. Length $1.7 \mathrm{~mm}$.

Jackson and Crawford comnties; scarce. August 15-October 14.

$P$. consobrinus I.ec., pubescence very dense, giving a very rough appenrance, is said to occur "east of the Mississippi River," but has not yet been taken in the State.

\section{Cindus Lec. 1849. (Gr., "careful.")}

Antennal tubercles wider than long, contiguous; last two joints of maxillary palpi unequal, the fourth oblong, thicker; front femora each with three strong spines on basal half. Two of the three species are known from the State.

KEY TO INDIANA SPECIES OF CEDIUS.

a. Larger and more robust, $2.5-2.7 \mathrm{~mm}$; head transversely excavated between the antennal cavities.

596. ZIEGLERI.

a . Smaller and more narrow, not over $2 \mathrm{~mm}$; head not excavated at apex. 597. SPINOSUS.

596 (1867). Cedies ziegleri Lec., Bost. Journ. Nat. Hist., VI, 1849, 74.

Fuscous-brown, clothed with short dense appressed hairs. Head as long as wide; disk between the prominent eyes convex, punctured and with two circular forex; sides with a spine behind each eye. Antenne nearly half the length of body; joints 2-4 equal, as long as wide, fifth smaller, subglobular; sixth and serenth equal, globular, eight shorter, transverse and in male with its inner side prolonged as a flat tooth; 9-10 wider, elerentl much larger. Thorax convex, as long as wide; disk sparsely and rather finely punctate, with two small forexe near apex and a larger one each side near base, the latter two connected by a curved line. Elytra one-third wider than long, sparsely and rather coarsely punctate; each with a wide shallow groove on basal third. Abdomen slightly narrower than elytra, broadly margined, the first dorsal with a carina each side. Length $2.7 \mathrm{~mm}$. (Fig. 148, b.)

Putnam and Crawford counties; scarce. March 28-May 28. Taken from nests of ants (Formica rufa integra.)

597 (1868). Cedius spinosus Lec., Bost. Joum. Nat. Hist., VI, 1849, 75.

Resembles zicgleri in form and color but smaller and less densely pubescent. Head broader than long. Antemme similar, with the outer joints less enlarged. Thorax very finely and sparsely punctate, without forere on front half, the basal fover smaller and connected by a fine impressed line. Elytra as in ziegleri, but more finely and sparsely punctate. Abdomen convex, the first segment with carinæ. Length 1.8-2 mm. (Fig. 148, a.)

Marshall and Fulton counties; rare. Aprìl 31-May 3. 


\section{Tyrus Aubé. 1833. (Without meaning.)}

Antennx clavate; palpi with first joint minute; second long, curved; third short, obovate; last joint with a needle-like spine at apex; third tarsal joint longer than second. Two species probably occur in the State.

\section{KEY TO INDIANA SPECIES OF TYRLS.}

a. Antenna rather elongate in both sexes, the next to last joint of funicle not transverse; carinæ of abdomen well developed.

598. HUMERALIS. aa. Antennæ shorter and stouter, the three outer joints of funicle transverse in female; thorax a little wider than long; caring of abdomen very short and inconspicuous.

CONSIMILIS.

598 (1875). Tyrus humeralis Aubé, Amn. Lint., II, 1836, 84.

Robust, compact. Piceous-black, clothed with fine, short appressed hairs ; elytra, anteunæ and legs reddish-brown. Head as long as broad, with two small fover between the eyes. Antennæ of male with joints one and two cylindrical ; 3-7 rounded, gradually smaller; eighth and ninth larger, globular; tenth obconical, twice as long and thick as ninth; eleventh largest, ovate; female with joints $3-9$ subequal, tenth larger. Thorax bell-shaped, widest at middle; disk with a median rounded forea and a fine, transverse sulcus near base. Elytra with humeri prominent, disk very finely and sparsely punctate; each with a deep impressed line and fovea on basal half. Abdomen but little longer than elytra, margins very broad, the last dorsal notched at tip in male. Length $1.6 \mathrm{~mm}$. (Fig. 146, a.)

Southern half of State; scarce. April 16-June 18. Taken by sifting and from beneath bark of stumps.

T. consimilis Casey, reddish-brown, elytra paler, length $1.8 \mathrm{~mm}$, was described from Kentucky and Indiana. I have not seen a specimen from the State.

\section{Hamonus Aubé. 1844. (Gr., "like+ear."')}

Head not constricted behind the antennal tubercles; third joint of maxillary palpi very small, subglobular; last joint long and cylindrical; pubescence yellowish, loose, coarse and long; elytra and abdomen very conves; second and third tarsal joints equal. One species is known.

599 (1876). Hamotus batrisioides Lec.. N. Sp. N. Amer. Col., I, 1863, 27.

Elongate-oval, convex. Fuscous-brown, shining. Head as broad as long, very convex; vertex with two small fover. Antennse nearly as long as body; first and second joints cylindrical, thicker than third to fifth. which are quadrate and gradually smaller; sixth to tenth a little wider; eleventh pear-shaped, subcompiessed, half as long as the preceding joints together, somewhat smaller in female. Thorax as wide as long. sides 
evenly curved. disk faintly, irregularly and coarsely punctate, with a small median triangular fovea near base and a smaller rounded one each side. the three connected by a fine curved impressed line. Elytra one-fifth longer than thorax, finely punctate, each with a short basal groove and fovea. Length $1.5 \mathrm{~mm}$. (Fig. 147, c.)

Monroe County; rare. May 13. Sifted from debris of beech stump. Dury finds them at Cincinnati between April 2 and May 2, "in the decayed interior of a standing dead tree."

Pselaphus longiclavus Lec., blackish-brown, elytra blood-red, length $1.8 \mathrm{~mm}$, is known from Towa to Louisiana. P. bellax Casey, dark reddish-yellow, length 1.4 mm.. was described from Michigan.

\section{Tychus Leach. 1817. (No meaning.)}

Antennæ attached to the under side of the frontal tubercles, which are large, close together, separated by a short canal; upper.
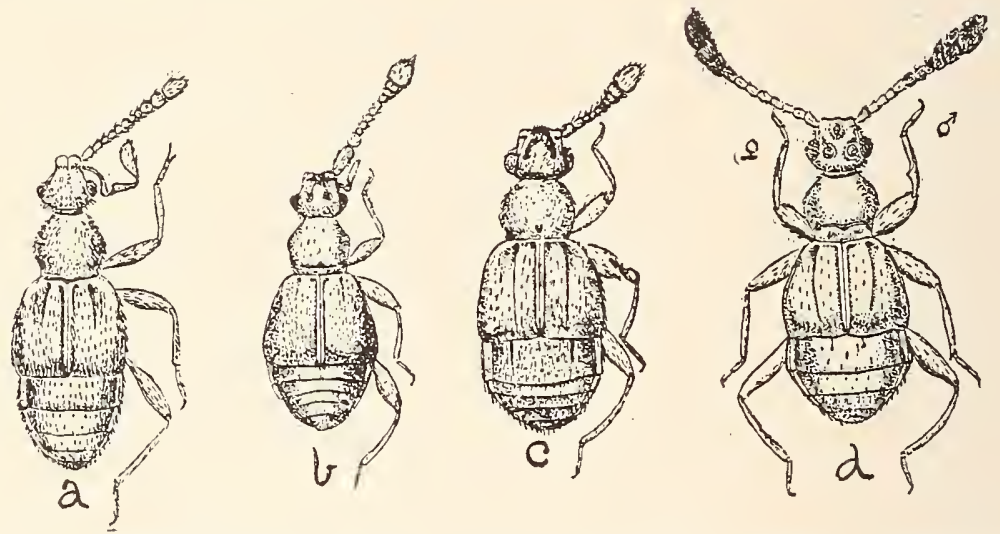

Fig. 149. a, Tychus lonjipalpus, b, Bythinus tychoides; $c$, Decarthron brendeli; d, Rybaxis brendeli. All highly magnified. (After Brendel and Wickham.)

surface of head with a small puncture each side near the front part of eye.

\section{KEY TO INDIANA SPECEES OF TYCHLS.}

a. Thorax with four small fovese at base and a larger one each side; elytra depressed, the sutural lines parallel; third and fourth joints of palpi equal.

600. LONGIPALPUS.

aa. Thorax with five basal fores; elytra more convex, the sutural lines curved; third palpal joint triangular, shorter than fourth.

601. MINOR.

600 (1878). Trchus longipalpus Lec., Bost. Journ. Nat. Hist., VI, 1849, 82.

Pale reddish-brown, subdepressed, sparsely clothed with long, suberect hairs. Head as long as wide. Antennæ longer than head and thorax, first joint twice as long as second, third to eighth subequal; ninth globular, twice as wide as eighth; tenth larger; eleventh ovate, twice as long as tenth. Thorax subglobular, slightly wider than long, widest at middle; basal forea 
very small, rounded. Elytra one-half longer than thorax, sutural lines deep; discal ones fine, limited to basal half. Abdomen narrowly margined. Length $2 \mathrm{~mm}$. (Fig. 149, a.)

\section{Clark County; rare. May 5.}

601 (1879). Trchus minor Lec., Bost. Journ. Nat. Hist., VI, 1849, 82.

Dark reddish-brown, shining, coarsely pubescent; antennæe and legs paler. Head as long as broad, convex, its foveæ very minute. Antennæ slightly longer than head and thorax, first two joints nearly one-half wider than three to seven, which are cylindrical; eighth globular; ninth and tenth larger, widler than long; eleventh rounded-ovate, as long as the two preceding. Thorax wider than long, polished, very convex; basal fovere five, the middle one the largest. Elytra faintly reticulate, sutural lines fine, discal ones deep, reaching beyond the middle. Length $1.5 \mathrm{~mm}$.

Throughout the State; scarce. April 17-October 31. Occurs usually beneath stones on hillsides. One specimen, from Steuben County, sifted from sphagnum moss, is much paler and is to be referred to var. testaceus Casey.

\section{Tribe II. BRACHYGLUTINI.}

The differences between this and the preceding tribe are given in the key. The palpi are less developed and the last joint is oval or fusiform. The following genera are probably represented in the State:

\section{KEY TO INDIANA GENERA OF BRACHYGLUTTNI.}

a. Antennæ 10-jointed, with a three-jointed club; vertex with two foveæ; thorax with sides rounded and with one fovea at base.

X. Decarthron.

aa. Antennæe 11-jointed.

b. Abdomen margined; tarsi with a single claw.

c. Body broad, transversely cylindrical in cross section; margin of abdomen wide.

d. Abdominal margin narrowly retuse; two basal ventrals longer than the others; dorsal segments unequal; last palpal joint pruning-knife shaped.

BrThinus.

dd. Abdominal margin broadly retuse; basal, dorsal and ventral segments much longer than others; elytra flat; last palpal joint fusiform.

e. Vertex without fover; elytra each with two basal fovex; ventral segments four.

Nisaxis.

ee. Vertex with fover.

f. Antennæ with a 3-jointed club; vertex and thorax each with three fover; elytra each with a long discal line.

$g$. Elytra each with two small basal forer; thorax with three nearly equal foveæ. 
h. Three basal fovex of thorax connected by a curved groove; elytra each with a deep subhumeral groove.

XI. Rybaxis.

$h h$. Basal fovere of thorax not connected by a groove; elytra without a subhumeral groove.

$i$. Elytra with margins and sloping sides nearly parallel; male with three of the dorsal segments sculptured.

BRACHYGLUTA.

ii. Elytra with sides diverging; male with not more than two segments sculptured.

XII. Bryaxis.

gg. Elytra each with three small basal fover; thorax with a large pubescent fovea each side of base and a small round median one.

XIII. Reichenbachia.

ff. Antennæe very short, with only the last joint enlarged; vertex with two fòvex; body glabrous.

EUPSENIUS.

$c c$. Body convex; margin of abdomen narrow; thorax with one fovea at base.

ANCHYLARTHRON.

bb. Abdomen not margined; tarsi with two unequal claws; thorax with two or three longitudinal grooves; body elongate, more or less cylindrical, narrow.

XIV. BATRISODES.

\section{Decarthron Brend. 1865. (Gr., "ten + joint.")}

Head with disk of vertex longer than wide, the front fovea wanting; antennæ 10-jointed, the joints, aside from those in ${ }^{*}$ club, rounded; thorax subglobose and with a single funnel-shaped fovea near the middle of the base; elytra hroad, each with two basal foveæ, the humeri prominent; abdomen short and wide, the basal dorsal segment with two distant parallel carinæ. One species has been taken in the State, while three others may occur.

KEY TO INDIANA SPECIES OF DECARTHRON.

a. Form of body broad, robust.

๖. Pubescence long, erect.

$c$. Color black; forea of vertex large and connected with the depressed front by faint converging grooves; length $1.4 \mathrm{~mm}$.

ABNORME.

cc. Color dark red; fovere of vertex small, comnected with the convex front by straight parallel grooves; length $1.6 \mathrm{~mm}$. ExsectuM.

bъ. Pubescence short; occipital fover deep, well separated, not connected with the concave front; length $1.4 \mathrm{~mm}$.

602. BRENDELI. aa. Form slender; elongate; thorax not punctate; color pale reddish-brown; length $1.5 \mathrm{~mm}$.

LONGULUM.

602 (9373). Decàrtirlion brendeli Casey, Bull. Cal. Acad. Sci., II, 1857, 464.

Piceous-brown; elytra dull red; antennx and legs paler brown. Antemnæ scarcely as long as head and thorax, eighth and ninth joints transversely oval, tenth one-half longer than wide and three times as thick as 
eighth, ovate, truncate at base. Thorax finely punctulate, slightly wider than long. Elytra one-half longer than thorax, discal lines parallel. Carinae of first dorsal three-fourths the length of the segment, separated by onehalf its width. Length $1.4 \mathrm{~mm}$. (Fig. 149, c.)

Lake and Putnam counties; scarce. March 26-May 25.

D. abnorme Lec., and $D$. exsectum Brend., both are recorded as occurring in the "Northern States east of the Mississippi River," while $D$. longulum is a southern form which may occur in the southern counties.

Bythinus tuchoides Brend. (Fig. 149, 7.), chocolate-brown, antennæ and legs dark yellow, length $1.2 \mathrm{~mm}$., has been taken at Cincinnati, while Nisaxis tomentosus Aubé, reddish-brown, pubescence long and fine, body coarsely punctate, length $1.2 \mathrm{~mm}$., is recorded from southern Illinois.

\section{Rymaxis Sanley. 1876.}

In this genus the males have a strong tooth on the front tibix. 'Two species have been taken in the State, while another may occur.

KEY TO SPECIES OF RYBAXIS.

a. Median fovea of base of thorax large, pubescent; antennie of male very long, the club slender.

603. VALIDA.

aa. Median fovea small, not pubescent.

$b$. Carina on basal dorsal segment of abdomen including but one-fourth of the width of segment between them; antennal club loose, the next to last joints not elongate or compressed.

CONJUNCTA.

bb. Carinæ on base of abdomen including one-third of width of segment; antennal club dilated and compressed in male, densely clothed with black hairs.

604. BRENDELI.

603 (1914). Rybaxis valida Brend., Bull. Lab. Nat. Hist. Iowa, I, 1890, 273.

Dark piceous-brown; elytra and antennæ red; legs paler. Vertex with a deep impression; antennæ nearly one-half the length of body, first joint almost as long as third and fourth together' second shorter, oblong, rounded; third to sixth narrower; seventh and eighth narrower and shorter; ninth and tenth suddenly increasing in size, wider than long; eleventh as long as the two preceding together. Thorax deeply impressed each side near base. Length $2.2 \mathrm{~mm}$.

Posey County; rare. April 16.

$R$. coninincta Lee., black, elytra red or darker, length 1.8-2 mm., is said to occur "over the territory east of the Mississippi River.",

604 (1916). Rybaxis BRendeli Horn, Crotch's Check List, 1Si3, 36.

Black, shining; elytra ranging to piceous-red; legs, palpi and club of antennæ reddish-brown. Head with two very large fovere between the eyes. 
Antennæe with second joint small, oval; third and fourth smaller, obconical; joints 5-S larger, subglobular, equal; winth to eleventh transverse, forming in male a densely pubescent club, three times as thick as eighth joint and as long as the five preceding together; in female the club is smaller, less pubescent and the preceding joints equal and cylindrical. Thorax subglobular, the basal groove sharply defined. Elytra each with a discal groore on basal two-thirds. Front trochanters with a slender spine. Length $1.8 \mathrm{~mm}$. (Fig. 149, d.)

Lake, Steuben, and Starke counties; scarce. May 25-June 16.

Brachygluta abdominalis Aubé. red-brown, pubescence very fine, length $2 \mathrm{~mm}$., has been taken near Cincinnati.

\section{Bryaxis Leach. 1817. (Gr., "to swarm.")}

In this genus the thoracic fover are not connected by a groove. The following probably occur within the State:

\section{KEY TO INDIANA SPECIES OF BRYAXIS.}

a. Median basal fovea of thorax smaller than those on sides; last three joints of male antennæ contorted.

b. Thorax as long as wide, convex; first dorsal of abdomen without carinæ.

PERPUNCTATA.

bb. Thorax wider than long. less convex; abdominal carinæ present, including between them two-fifths of the width of segment.

605. CAVICORNIS.

aa. Thorax with three large, equal pubescent fover; sexual marks on the abdominal segments of male, the antennæ not modified.

c. Fovere of occiput open toward the eyes, or very near them; thorax finely punctate; male with first dorsal segment acutely bilobed; length $1.7 \mathrm{~mm}$.

606. II.LINOIENSIS.

cc. Forer of occiput distant from the eyes; thorax not punctate; black, legs, antennæ and palpi dusky yellow; length $1.3 \mathrm{~mm}$.

PERFORATA.

B. perpunctata Brend., brown. punctate, sparsely pubescent, length $1.8 \mathrm{~mm}$., is known from Tllinois.

605 (1927). Bryaxis Cavicornis Brend., Proc. Ent. Soc. Phil., VII, 1866. 194.

Elongate-oval. Fuscous-brown, clothed with long, recumbent pubescence; elytra and legs reddish-brown; antennæ dark red. last four joints fuscous. Head six-sided, fover large. Antennæ longer than head and thorax, the last three joints in male each differing in form, ninth wedgeshaped, tenth screw-shaped, elerenth kidney-shaped. Thorax wider than long, finely punctate, the basal foveæ all visible from above. Elytra finely and sparsely punctulate; discal lines straight. colverging. Length $2 \mathrm{~mm}$.

Putnam and Posey counties; rare. September 28-October 10. 
606 (1922). Bryaxis illinorensis Brend., Proce Ent. Soc. Phil., VI, 1866, 195.

Rather broadly ovate. Piceous-black, shining; elytral dark red; antenna reddish-brown, legs and palpi paler. Antennse less than one-half the length of body; joints $2-S$ small, rounded; ninth obconical, longer; tenth twice as wide as eighth; eleventh oblong-oral, twice as thick as ninth. Thorax wider than long, the forese rery large. Elytra one-third longer than thorax, sutural and discal lines distinct, parallel, the latter deep at base and reaching apical fifth. First dorsal of male deeply concave, prolonged behind in two acute triangular lobes; second dorsal with a large merlian fovea. Lengtl! $1.8 \mathrm{~mm}$. (Fig. 150, a.)

Throughout the State; common. March 20-June 24. On May 6 I took scores of this species bneath driftwood on the mud banks of the Ohio River near Charlesten, Clark County.

B. perforata Brend., is said in Brendel \& Wickham's key to oc"ur in "Michigan, Illinois and Iowa," and in the description which follows "in New York, Jersey and Iong Island."
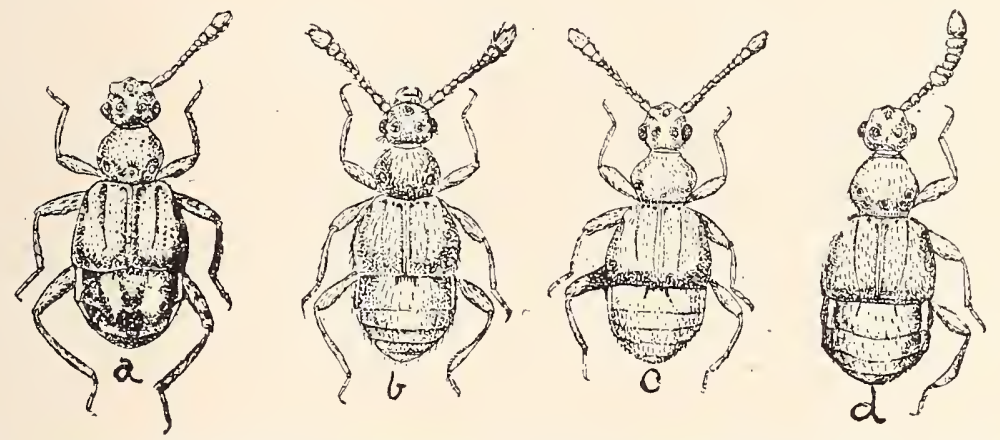

Fig. 150. a, Bryaxis illinoiensis; b, Rcichenbachia yraciis; c, Rcichenbachia congener; d, Reichenbachia propinqua (male). All highly magnified. (After Brendel and Wickham.)

XIII. Reichenbachi Leach. 1826. (Name of a naturalist.)

A large genus of small, broad-bodied species having the base of thorax marked with a large fovea each side and a very small round one on the median line; elytra each with three small basal foveæ, The following species are known from or perhaps occur in the State:

\section{KEY TO INDIANA SPECIES OF REICHENBACHIA.}

a. Carinæ of first dorsal segment of abdomen separated by less than onethird the width of the segment; antenne not modified in the sexes.

b. Carinæ separated by a space not wider than that between the sutural lines of elytra.

c. Thorax punctured.

d. Punctures of thorax fine and sparse; carinie of first dorsal quite short and divergent.

607. GEMMITFER.

dd. Punctures of thorax distinctly coarser and very dense; dorsal carinie one-half the length of segment and less divergent.

60S. CANADENSIS. 
cc. Thorax without functures: abdominal carinie rather long: elytra punctured and subrugose.

609. RADIANS.

bb. Carinie separated by a space wider than that between the suturil lines, but less than one-fourth the width of segment.

c. Thorax distinctly punctate; pubescence short; carinæ of first dorsal nearly one-half as long as the segment, dirergent and separated at tip by one-fourth the width of segment. CRIBRICOLLIS.

ee. Thorax not punctate.

f. Pubescence short and strongly recurved; pale reddish-brown; median forea of thorax very small.

CONGENER.

ff. Pubescence long. bristling and semierect; elytra shorter than wide; piceous, the elytra paler.

g. Abdominal carinæ fully one-half the length of segment, feebly curred and strongly divergent; form less convex.

610. RUBICUNDA.

gg. Abdominal carinæ one-third the length of segment, straight, less divergent; form narrower and more conrex.

611. GRACILIS.

aa. Carinæ of first dorsal separated at base by one-third or more the width of segment; pubescence short and strongly recurred.

$h$. Antennæ similar and ummodified in the sexes.

$i$. Thorax strongly and closely punctured; carinæ of first dorsal short. straight and parallel.

PU XCTICOLIF.

ii. Thorax not punctured; body black or piceous, with bright red elytra; male with last dorsal with a broad rounded notch and last rentral broadly concare. CORPORALIS.

$7: h$. Antenne dissimilar in the sexes, that of male with fifth joint strongly dilated. the sixth scarcely longer than seventh; elytra dark reddish-brown. PROPINQUA.

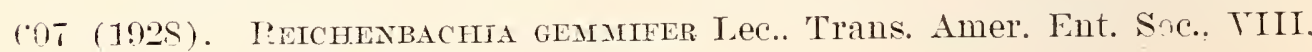
$1880,182$.

Dark reddish-bromn; antennæe. legs and elytra paler; pubescence rers fine and short. Head as long as wide. the three forex circular and equal in size. Antennæ half as long as body; second joint as long but not as thick as first; third to eighth crlindrical and subequal; ninth obconical. slightly longer and thicker; tenth larger, subglobular; eleventh twice as thick as tenth, as long as the three preceding. Thorax subglobular, strongly conrex, median forex small. deep; side ones as large as those of head; disk finely, evenly but distinctly punctate. Elytra at base one-third wider than thorax, smooth except neal tips; each with a wide shallow discal line. Carinæe of first dorsal short and strongly divergent. Iength $1.4 \mathrm{~mm}$.

Putnam County ; rare. April 17. 'Taken by sifting.

608 (9388). Reichexbachia canadexsis Brend., Trans. Amer. Ent. Soc.. $\mathrm{XIV}, 188 \mathrm{i}, 206$.

More slender than gemmifer, with darker body. Thorax one-third broader than long, densely and coirsely punctured, the median forea smaller. Elytra at base not wider than thorax, distinctly but finely am sparsely punctate; discal lines deeper and more distinct. Length $1.5 \mathrm{~mm}$. 
Starke County; rare. May 18-June 17. Sifted from vegetable debris on margin of sphagnum swamp.

609 (1939). Reichendachia radias Lec, Trans. Amer. Ent. Soc., Viti, $1880,182$.

Lniform light chestnut brown; antennæe and legs paler. Head as wide as long; the forere small but deep. Antenne longer than head and thorax, the joints nearly as in gemmifer, the eighth and ninth smaller than there. Thorax subglobose, smooth, the forere on sides one-third larger than those of head, the median one much smaller. Elytra at base one-third wider than thorax, finely, sparsely and somewhat roughly punctate. Carinæ of first dorsal reaching nearly to middle of segment. Length $1.5 \mathrm{~mm}$.

One specimen in Webster collection labeled "Ind.," LeConte's type, came from Illinois and his description is so brief that I am not certain as to the identity of the specimen at hand. However. it runs to radians both in his key and in that of Brendel.

R. cribricollis Brend., piceous-black, elytra dark red, length 1.3 $\mathrm{mm}$., is known from Illinois and Iowa. R. congener Brend. (Fig. $150, c$.). reddish-brown, length $.9 \mathrm{~mm}$., is an eastern species which is recorded from Cincinnati.

610 (1932). Reichenbachia rubricunda Aubé, Anu. Soc. Ent., II, 116.

Piceous-black, not punctured; elytra, legs and antenure dull red. Head wider than long; foreæ large, equal. Antennæ not half as long as body, second joint oblong; third to seventh equal, cylindrical; eighth globular; ninth as long and twice as wide as third; tenth subglobular, one-half thicker than winth; elerenth one-half wider than tenth and longer than the two preceding. Thorix one-third wider than long; forea on sides very large, median one small and deep. Elytra at base as wide as thorax at middle, humeri prominent; discal lines reaching apical third. Length $1.3-1.5 \mathrm{~mm}$.

Throughout the State; common. April 17-June 13. Occurs beneath cover in damp localities.

611 (1935). Rerchenbachia grachlis Casey, Contrib. Desc. Coleop. N. A., I, $1884,32$.

Dark piceous-red; pubescence long, suberect and pale; elytra dull red; autennæ and legs paler.. Head louger than wide; foreæ deep and equal. Antennæ longer than head and thorax, first three joints gradually decreasing in size; fourth to eighth equal, slender, subcylindrical; ninth subglobose, thicker; tenth nearly twice as wide as long; eleventh compressed, as loug as the three preceding together. Thorax wider than loug, strongly con. rex, polished, forex on sides large, median one minute. Elytra rery conrex, discal lines sharp, nearly entire. Length $1.4 \mathrm{~mm}$. (Fig. 150, o.)

Starke and Orange counties: rare. June 2-,June 16. Beaten from hickory. 
R. puncticollis Lec. black with rust-red elytra, legs and antennæ, length $1.4 \mathrm{~mm}$., is recorded as occurring in the "region east of the Mississippi River." $R$. corporalis Casey, length $1.7 \mathrm{~mm}$., was described from Michigan and Canada. $R$. propinqua Lec., piceous-black, elytra dark blood-red. length $1.4 \mathrm{~mm}$., is a boreal species which probably inhabits northern Indiana. (Fig. 150,d.)

Eupsenius glaber Lec., yellow, without pubescence or punctures, length $1 \mathrm{~mm}$., is a southern species which may occur in the Ohio River counties.

Anchylarthron (Terticinotus) cornutus Brend., dark yellow, faintly punctured, sparsely pubescent, is recorded from Ohio and Iowa.
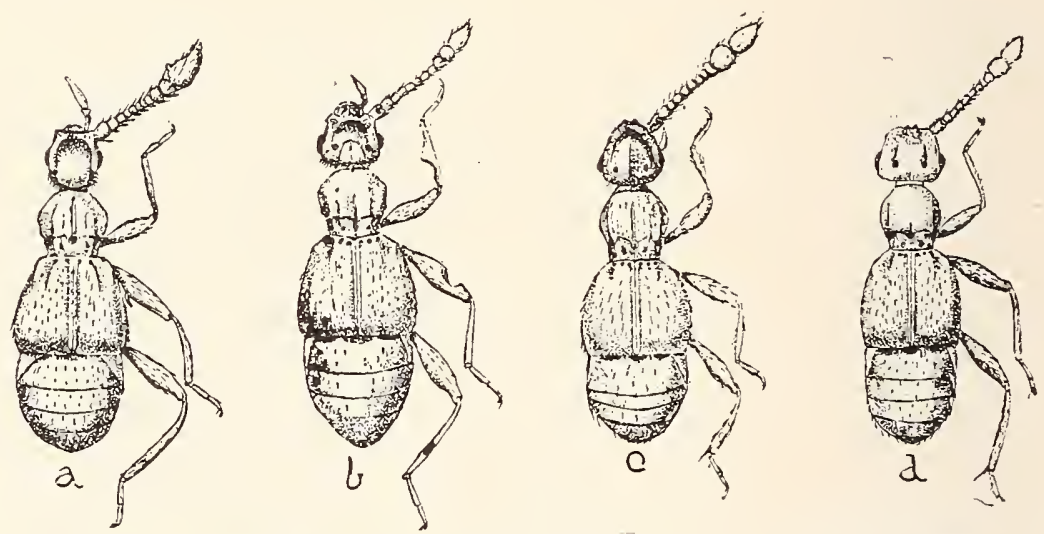

Fig. 151. a, Batrisodes ion $\propto ;$, , Batrisodes ferox; $c$, Batrisodes globosus; d, Batrisodes spretus. All highly magnified. (After Brendel and Wickham.)

\section{BATRISODEs Reitt. 1881. (Gr., "Batrisus + like.")}

A large genus of subcylindrical, rather narrow, elongate species, having the head elongate-oblong, with two foveæ connected by a curved groove on vertex; antennæ with a three-jointed club; last joint of maxillary palpi fusiform, more convex on the outer side; thorax with two or three longitudinal grooves and a transverse curved groove connecting the three basal foveix; elytra very convex. their discal lines confined to basal half; legs long, femora clavate. The species which have been taken or perhaps occur in the State may be separated into two groups as follows:

KEY TO GROUPS OF INDIANA BATRISODES.

a. Hind tibixe without a terminal spur; elytra each with two fovere at base. Group 4 . aa. Hind tibire with a long terminal spur; elytra each with three fovere at base. 


\section{Group A. \\ KEY TO SPECIES OF GliOUY $\Lambda$.}

a. Vertex without a median carina; occiput swollen behind, overlapping the neck; middle femora of male with a curved spine near the trochanters.

612. IONA.

an. Vertex with one or more carinæ.

b. Vertex with three carina converging in front.

r. Front tibia of male with a strong recurved spine near the midnle; mirldle fenora notched above. (Fig. 151, b.)

1. Oeciput swollen above; hind tarsi of male with second joint ailated.

ARMIGE'.

dd. Occiput not swollen; hind tarsi of male simple; elytra punctulate; ninth antennal joint one-lialf the width of tentl, eleventh wider than tenth, ovate.

613. FEROX.

cc. Front tibise of male simple; middle femora not notched above; hind tibia rather suddenly and strongly dilated on the imner side at basal third.

6). Vertex with one median carina.

614. CAVICRUS. 615. CONFINIS.

*612 (1894). Batrisodes ronæ Lec., Bost. Journ. Nat. IIist., VI, 1849, 94.

Uniform reddish-brown, shining, sparsely clothed with long yellowish hairs. Head longer than broad, its surface sloping from the prominent occiput to front margin. Antennie half the length of body, joints 2 to $\mathrm{s}$ subequal, ninth larger, slightly transverse; tenth large, globular; eleventh oblong-ovate, much thicker and toothed on inner side in male. Thorax bell-shaped, widest at middle, slightly narrower at base; disk with three impressed lines, the median one entire and ending at base in a small fovea: sides with a small acute tubercle. Elytra sparsely and distinctly punctate; humeri rounded, not prominent. Abdomen slightly depressed at base, sparsely and finely punctate. Length 2.5-2.7 mm. (Fig. 151, a.)

Vigo and Crawford counties; rare. August 10-December 10. One specimen on the latter date from beneath a partly buried chunk in sandy woods. A species of southern range, described from Georgia.

B. armiger Lec., reddish-brewn, sparsely pubescent, length 2.4 mm., is known from Pennsylvania.

613 (1898:). Batrisodes feiox Lec., Bost. Journ. Nat. Hist., VI, 1849, 95.

Uniform reddish-brown, rather sparsely pubescent. Head quadrate; foves of vertex snall and in a line behind the middle. Antemne lablf the length of body, joints 3-5 cylindrical, 6-9 quadrate or rounded and slightly wider; tenth larger, slobose in male, obconical in remale: elerenth thicker. oblique, truncate at apex, rounded at base, as long as the two preceding. Thorax widest at apical third, sides strongly curved, apex half as wide as base; disk with three inpressed lines, median one obsolete in front; basal forea deep. Elytra one-sixth wider at base than thorax, finely and evenly punctate; humeri with an obtuse spine. Carine of basal dorsal very short, separated by one-fifth the width of segment. Length $2.4 \mathrm{~mm}$. (Fig. 151, b.) 
Throughout the State; frequent. April 9-Norember 2S. Oc(-11t's in nests of red ants. Lasius, heneath stones. Readily known by the notehed aper of middle femora.

614 (9422). Rithisones curicrus Casey, Amn. N. T. Acad. Sci. VII. 159\%. 468.

Reddish-brown. coarsely and sparsely pubescent; elytra, legs and club of antennæ paler. Head wider than long. as wide as thorax. Antennæ half as long as body, second joint longer than third; three to eight equal in width. sradually shorter: ninth and tenth abruptly wider, slightls transrerse; eleventh much larger, subglobular. 'Thorax slightly longer than wide; median sulcus of disk feeble. with two or three acute recurred spines each side; median sub-basal forea large. the side ones distinct. Elytra as long as wide. not punctate: humeri rounded. Carinie of first dorsal separated by one-sixth the width of segment. Male with a rounded subapical impression on last ventral. Length $1.8 \mathrm{~mm}$.

Crawford County; rare. August 15. Described from North Carolina. Dury finds it rather plentiful near Cincinnati.

615 (1896). Batrisodes confinis Lec., Bost. Jouln. Nat. Hist., I', 1849, 96.

Reddish-brown, shining, finely and sparsely pubescent. Head as broad as long, rertex elerated with one median carina. Antennie slender. half as long as body, joints 2-9 suberual, tenth but one-third thicker and not longer than ninth, elerenth oral. acute, twice as long and one-half wider than tenth. Thorax as wide as long, median sulcus fine. entire, basal forere rerr small, side ones distinct. Elytra at base not wider than thorax, smooth. humeri feeble, discal lines very short. Length $2 \mathrm{~mm}$.

Putnam County; rare. April 22.

\section{Group B.}

In this group the hind tibia bear at the outer end a rery fine and slender terminal spur, and the base of each elytron is marked with three small rounded fovex (two in frontalis). The following species are known from or probably occur in the State.

\section{KET TO SPECIES OF GROUP B.}

a. Front of head in either sex not separated by a sulcus or groore from the clypeus; last antennal joint of male with an erect basal tooth: thorax with crests on disk; elytra strongly punctate. scHaUsir. a $a$. Frontal margin in the male separated from the clypeus by a sulcus or excaration; in the female continuous with the clypens.

7. Antenne stout. the joints almost all wider than long. bead-like. serenth and eishth smaller than those preceding or following.

616. CASEII.

bb. Antennal joints. especially those of funicle. more slender, not wider than long, joints 7 and $S$ not smaller. 
c. Frontal margin produced beyond the line between the bases of antennæ.

d. Vertex more or less scabrous gr roughened and carinate.

$e$. Tertex raulted or elerated, feebly scabrous ; last antennal joint of male long. with an erect tooth; elytra punctate, the shoulders not angulate; length $1.5 \mathrm{~mm}$.

617. RIPARIUS.

ce. Vertex not vaulted. coarsely scabrous; last antennal joint of male without a tooth; length $2.2 \mathrm{~mm}$.

$f$. Forea of occiput not pubescent; frontal margin of male notched in middle; shoulders angulate.

SCABRICEPS.

$f f$. Forere of occiput pubescent; head rery flat; frontal margin triangular: thorax with conspicuous discal crests and deel grooves, so that the disk appears to be marked with fire lines.

LINEATICOLLIS.

dd. Vertex smootli; firont more or less elevated.

g. Antenna alike in the sexes; forese of occiput pubescent; rertex not carinate.

$h$. Thorax without crests or spines; sulcus of vertex deep : elrtra not punctate: lengtl $2.2 \mathrm{~mm}$.

FRONTALIS.

$h h$. Thorax with four basal spines; sulcus of rertex shallow; elytra rers finely and sparsels punctate; length $1.9 \mathrm{~mm}$.

SIMPLEX.

gg. Antennme unlike in the sexes, the tenth joint in male globose and very large; in female but one-half thicker than ninth; forer of occiput not pubescent; rertex carinate; length $1.7 \mathrm{~mm}$.

618. GLOBOSUS.

cc. Frontal margin not produced beyond the line between the bases of antennæ; tenth antennal joint of male rers large.

$i$. Humeri blunt rounded; foreæ of occiput not pubescent.

j. Reddish-bromn: tenth joint in male with a small forea at the base; length $2 \mathrm{~mm}$.

619. VIRGIXI.

jj. Black or piceous; antennæ and legs red; tenth joint foreate on under side.

k. Median sulcus of thorax obsolete; length $1.6 \mathrm{~mm}$.

620. SPRETES.

Tik. Median sulcus present: forese on under surface of tenth joint very large.

621. FONEICORNIS.

ii. Humel'i spinous; forea of occiput pubescent; lensth 2 mm.

7. Basal joint of male antemne bluntly toothed below: tenth joint large. with a sinall. round, deep puncture at base on under side.

DEXTICOLLIS.

1l. Basal joint not toothed below; tenth joint not punctate beneath: black. with reddish antennse and less.

$m$. Fiytra smooth. vertex not punctate: thir $\mathrm{j}$ sint of male antemine longer than second or fonth and swollen on one side.

(i2). NIGRICANS.

mm. Elytril indistinctly punctate: letetex with al central transrerse puncture: three basal joints of antennie subequally decreasing in size.

STRIATCS. 
B. schaumii Aubé. piceons-black. length $2.1 \mathrm{~mm}$. is known from Pennsylrania and Illinois.

1516 (—). BatRisodes CASEY DUry MIss.

Lniform reddish or chestnutbrown. sparsely clothed with stiut. suberect rellowish hairs. Mead large, as wide as thorax: reptex stronsly swollen. not carinate: foreie of occiput rery small. Antemne short. stout. reaching base of thorax, joints 2 to 10 wider than iong. 11 oblong-oval. nearly as long as the three neceding. Thorax as wide as long. median sulcus deep. abbreriated in front. basal forese round. deel. Elrtra smonth. convex. humeri not lirominent. Length $2.5 \mathrm{~mm}$.

Posey Countr: rare. April 26. Taken from beneath chunk in open sandy woods. Dury has three or four from Kentucky opposite Cincinnati.

fit (1902). Batrisodes riparits Say. Journ. Phil. Acad. Nat. Sci.. IV. 1524. 95 : ihid. II, 235.

Reddish-brown. sparsely pubescent. Head slightly wider than long. its margin broad. flat. produced in front: the forex small. deep. not pubescent. Antenne of male half the lencth of bods, joints 2 to $S$ gradually smaller and rounded: ninth much larger. transrerse. toothed on outer side: tenth still larger. globose; elerenth not as thick. more than twice as long. with a large tooth inside the base: in female the joints are regular. the last one not as long as the two preceding. acute-orate. Thorax slightly longer than broad. sparsely punctate. the basal forea small, distinct. Elytra rerr convex. strongly punctured: humeri blunt or rounded. Length $1.4-1.6 \mathrm{~mm}$.

\section{Poser Countr: rare. April $18-A p r i 1 ~ 22$.}

B. scabriceps Lec.. piceons. legs and antennæ paler. is said to occur from Pemstrania to Illinois and Iowa. B. lineaticollis Aubé and $B$. frontalis Lec.. have been recorded from Cincinnati. $B$. simplex Lec. is a boreal species which has been taken in northern Illinois.

618 (1903). Batrisodes globosts Lec. Bost. Jourm. Nat. Hist., TI. IS49. 100.

Reddish-brown, shining. slarsely and finely mbescent. Head with rertex roof-shaped, the rest carinate: fore:e small. deep. round, not mulescent: malgin broad, flat. densely functate. Antenne half as long as hodr. second joint obconical. three to eisht globular and of same width as second: ninth thicker. wider than long: tenth in male globular. four times as thick as ninth: eleventh narrower than tenth. orate. acute. obliquely impressed from middle on outer side. Thorax slightly wider than long. median sulcus deel. ending near base in a deep forea from which a transverse groore curves to fovere on sides. Elstra indistinctly punctulate onehalf longer than thorar, each rith three small, rounded forete at base: hiscal lines short. shallow: thuneri tuberculate. Legs lons. thishs charate. Lensth $1.8 \mathrm{~mm}$. (Fig. 151, c.) 
Throughont the State; common. March 5-November 28. ()ccurs in numbers in the large cone-shaped nests of ants and beneath stones on sloping hillsides.

619 (1910). Batrisodes virginiz Casey. Contrib. to Desc. of Coleop. of $\mathrm{N}$. A., II, $1884,90$.

Redhish-brown, shining: elytra dark red: antemne and legs paler. Heand large, quadrate, punctured in front; eyes small; rertex with two small. rounded forea connected by a curved groove. Antenna less tham half the length of body, first joint as long as the next two together, second longer than third; 3 to 8 quadrate, equal; ninth larger, one-half wider than long; tenth large, globular; eleventh as long as three preceding together, obliquely acuminate. Thorax as wide as long, median sulcus narrow, deep, with it small erect tooth each side of the basal median forea. Elytra finely, suarsely and distinctly punctate. Lengtl $2 \mathrm{~mm}$.

Putnam, Fayette and Crawford counties; frequent. April 17August 15.

620 (1906). Batrisones spretcs Lec.. Bost. Jonrn. Nit. Hist., VI, 1849, 100.

Piceous-black; elytia dark red, sparsely and finely pubescent. Head wider than long, wider than thorax, punctulate in front. smooth behind; eyes prominent; weiput elevated, broadly depressed each side; vertex not carinate. Antenne reaching base of thorax, joints 2 to $S$ oblong; ninth longer and wider, transverse; tenth large, quadrate-rounded; eleventh twice as long but narrower than tenth, ovate-acuminate. Thorax slightly longer than wide. widest before the middle. median basal fovea small; basal tubercles minute. Elytra convex, not punctured; humeri without tubercles. Length $1.7 \mathrm{~nm}$. (Fig. 151, $d$. )

Southern half of State; frequent. April 17-October 11. Taken by sifting damp vegetable debris and in nests of white ants.

621 (9414). Batrisones foveicoris Casey, Bull. Cal. Acad. Sci., II, 1S57. 462.

Reddish-brown, not punctate: sparsely clothed with long hairs. Head as wide as long; vertex nearly flat, carinate at middle. Antennie with second joint one-third shorter and narrower than first; third to serenth longer than wide, eighth quadrate; ninth wider than long; tenth much wider, globose, flattened and with a large fovea beneath in male; eleventh wider and as long as the three preceding together. Thorax with forese and sulci deep, the median sulcus obsolete on basil third. Elytra with rounded humeri. Length $2 \mathrm{~mm}$.

Monroe County : rare. May 13. Sifted from debris of beech stump.

B. denticollis Casey, black, elytra dark red, antenna and legs paler. length $1.5 \mathrm{~mm}$., is known from Virginia and Iowa. 
(i22 (1904). Batrisodes NigRiCA xs Lec.. Bost. Journ. Nat. Hist.. VI. 1S49. 99.

Black, shining. sparsely pubescent; antenne, palpi and legs reddish. Ilead as long as broad, front punctate; rertex convex. carinate. Antennie with fourth joint half as wide and about as long as third; fifth to eighth subequal, as wide as long; ninth longer, rounded; tenth nearly twice as thick as ninth, globose; elerenth one-half longer, orate, acute. Thorax with median sulcus rery decp. the basal tubercles acute; forede on sides of base pubescent. Elytra with humeri subacute, discal lines reaching middle. Length $2 \mathrm{~mm}$.

Lake County; rare. May 1.

B. striatus Lee. of which simpler Lec. is perhaps a synonym. is said to occur from Massachusetts to the Missouri Rirer.

\section{Tribe III. EUPLECTINI.}

In this tribe the form is more depressed and linear than in those preceding. thus approaching the Staphylinidx. They have the antenne widely separated at base; abdomen distinctly margined. with six ventral segments: hind coxze conical, prominent and contigunous. The following genera, as limited by Casey, are probably represented in the State.

\section{KEY TO INDLANA GENERA OF ECPLECTINI.}

a. Tarsi with two equal claws; antennæe slender, bead-like, last three joints forming a loose club; first risible dorsal nearly as long as second and without pubescent line.

RAFONUS.

aa. Tarsi with two unequal claws or with but a single claw.

b. Antennre elbowed, the basal joint elongate; thorax twice as wide as long, bilobed, and armed at sides with three inflexed spines.

XV. RHExiCs.

ॐ6. Antennæ straight, first joint not elongate.

c. Tarsi with tro unequal claws, the second in the form of an appendage nearly one-half the length of the principal claw.

d. Thorax with a fine entire median groore, its sides not spinous: body shorter, head more transverse; elstra each with four basal punctures, prolonged backward by a line.

XVI. RHEXIDICS.

dd. Thorax without a median impressed line; body longer, more parallel; head less transrerse.

RAMECIA.

cc. Tarsi with but a single claw. or with the second one rers minute.

c. Antennal club gradualls formed, the last joint only moderate in size.

$f$. Prosternum not carinate along the middle; first dorsal not longer than second.

\%. Thorax with a central discal impression; elytra each with a discal stria. 
h. Head large. Iruncate; antennie rery remote; first dorsill of abdonen with distinct basal carine.

XVII. Euplectus.

$h h$. Head smaller, the front more abruptly and strongly narrowed; antennie less distant; abdomen without basal carinie.

THEsiastes.

gg. Thorax without a discal impression; elytra without discal strix.

Bibloplectis.

ff. Prosternum finely but distinctly carinate throughout the micldle of its length; thorax with a small, subapical impression, its basal forea connected by a transverse sulcr'; antennic less widely separated, the tenth joint larger than usual.

Thesium.

ee. Antennal club consisting almost entirely of the lales? abrupt terminal joint; thorax without discal impressions.

$i$. Ninth and tenth antennal joints very short, distinctly transverse.

j. Elytra with a subhumeral forea from which an acutely elevated carina extends to apex; also with discal stria reaching to middle; head never wider than thorax, the latter with a large fovea on each side connected by a transrerse groove.

Actiun.

$j$. Elytra without trace of a subhumeral forea and without discal striæ, but with an elongate basal impression.

k. First dor'sal segment of abdomen much elongated and without trace of a median impression.

XVIII. TRIMIOMLLBA.

7.\%. First dorsal shorter, equal to second.

XIX. Melba.

ii. Ninth and tenth antennal joints larger, less transrerse; elytra with a discal stria and with two basal fovere but without subhumeral forea; sulcus of thorax not continued down the flanks but ending in small enlargements near the margin.

Trimioplectes.

Rafonus tolulce Lec., dark brown, polished. clothed with long, dense pubescence. antennæ and legs yellowish, length $2.1 \mathrm{~mm}$., occurs rarely near Cincinnati.

\section{RHexius Lee. 1849. (Gr., "I break.")}

Head and thorax each wider than long; tarsi with two unequal claws; antenna elbowed. One of the three species occurs in the State.

62:3 (1957). Rhextes ixscelptes Lec.. Bust. Juuru. Nat. Hist., VI, 1849, 103.

Subcylindrical, depressed. Pale reddish-brown, clothed with short erect hairs. Head twice as wide as long, base truncate. front rounded, concare and with three forea; occiput carinate. Antennie reachirg base of thorax. joints 3 to $S$ transverse, nearly equal; ninth twice as wide as third; tenth 
longer and wider: elerenth conical-orate, as long as ninth and tenth together. Thorax almost as wide as head. sides broady curred: disk with a median groore. and a forea each side near base comnected br a transrerse line. Elrtra as wide as long: discal lines deel. confined to basal third; hmeri prominent. armed with a tubercle: margin with a sharp edge. Abdomen as ride as elctra. the basal segment with two short carine. I.encth $1.2 \mathrm{~mm}$. (Fig. 152. a.)

Monroe. Lawrence and Clark counties: scarce. April 9-May 8. Taken by sweeping blue-grass: also by sifting.
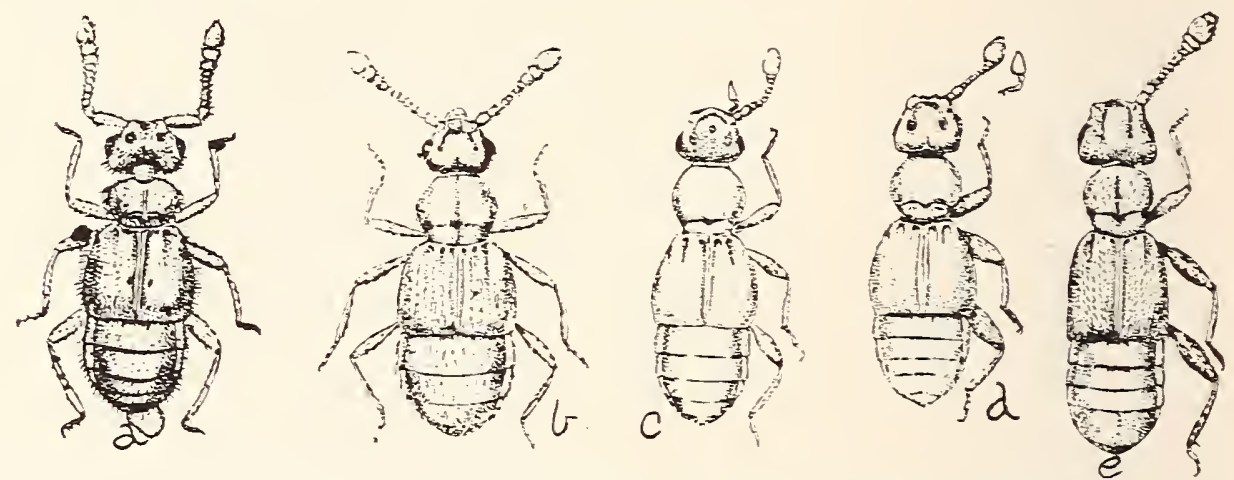

Fig. 152. a, Rhexius insculptus; $b$, Phexidius canaliculatus; $c$, Trimiomeiba dubia; d, Melba parrulu; e. Euplectus confuens. (After Brendel and Wickham.)

\section{XTI. Rhexides Caser. 188T. (Gr.. "a crack or fissure.")}

Head much wider than long: thoras with a median groove: hind coxie contiguous: tarsi with two unequal claws. One species occurs in the State.

(i2t (1971). Rhexidtes caxalictuates Lec.. Bost. Journ. Nat. Hist. YI. 1549. $10 \%$.

Elongate-oral. subconvex. I'ale brownish-rellow. rather densely and finely: pubescent. Head one-half wider than long. front transsersels imn'essed: rertex elerated. feehly sulcate and with a small romd forea each side close to the ere, the two connected by a curred groore. Antenuse short. stout. not reaching base of tholix. joints one and tro subequal. crlindrical. as long as wide: three to eight nitrotrer. rounded. slightly transterse: ninth twice as wide as long: tenth twice as wide as ninth: elerenth wide: than tenth and longer than ninth and tenth together. Thorax widest at middle. sides broadly curred: disk conrex. finels and sparsels punctate. and with an entire median impressed line and a transierse shallow one near base. connecting a forea on each side. Elrtra at base as wide as thorax. cisk minntely punctate. Last rentral of male with a shallow transrerse immession. Length 1.2 mm. (Fig. 152, \%.)

Putnam Coumty : rare. April 17. Sifted from damp regetab?e debris.

Ramecia crimita Brend.. brown. very densely pubescent. length $1.6 \mathrm{~mm}$. is said to occur in the "Northern States:" Ramecia arcu- 
ata Lee. brownish-yellow. legs and antennæ palec. pubescence feeble. length $1.2 \mathrm{~mm}$. is knorn from the Middls and Southerr States.

XTII. Euplectus Leach. 1817. (Gr.. "good + fold."

Depressed. linear: abdomen with three basal segments equal in length. the fourth prolonged. the border wide: ventrals six in female: seren. the last one carinate. in male. The following species have been taken or may occur in the State:

\section{KEI TO IXDIAYA SPECIES OF ELPLECTLS.}

a. Head narromer than thorax: first and second dorsal segments with short carinie: elytra convex: sutural lines deepls impressed. discal ones half the length of elytron.

605. FOSSLLATLS.

aa. Head as wide as or wider than thorax.

b. Forere of head widel distant. situated behind the middle: bodr less slender. more contex.

c. Head not wider than thorax: shotider's wider than head or thorax. d. Sirles of elytra nearly straicht. divergent: sides of thorax broad1s and erenly curred: pubescence feeble; length $1.2 \mathrm{~mm}$.

SPIATEER.

da. Sides of elstra curred: those of thoras sinuate behind middle: length $1.5 \mathrm{~mm}$.

INTERRTPTLS

cc. Head wider than thorax.

e. Shoulders wider than head. thorax narrorel. as wide as long: base of abdomen narromer than elitra.

CONGENER.

ee. Shoulders as mide as head: sides of elctra parillel: form linear. subdepressed: head not punctured.

LINEARTS.

々b. Forese of head smaller. much nearer together. situated in front of middle: head strongls punctured.

626. CONFLIENS.

625 (9442). Euplectes fosstlates Brend.. Bull. Lab. Nat. Hist. Ioma. II. 1591. 59.

Dark brown. shining. sparsels pubescent. Head wider than long. depressed in front: occiput conrex betreen the forere. Antennie as long as head and thorax: joints three to eight very small. wider than long: ninth and tenth each one-half wider than the one preceding: elerenth oralacuminate, longer than ninth and tenth together. Thoris wider than long: disk minutely punctate and with a large fusiform median sulcus. which ends behind in a deep triangular forea. the latter connected br a deep groore with a large forea each side. Elittia with humeri high and prominent: each with three basal punctures. I.ength $1.2 \mathrm{~mm}$.

Lawrence and Crawford connties: l’are. May 11-May 27. Taken by sifting. Caser places this mule The siastes but the tro basal segments of abdomen are distinctly carinate as described by Brendel. 
E. spinife Casey, brown, shining. not punctate, was described from Tllinois; $\bar{L}$ interruptus Lec., r.ust-red, pubescence not dense, and $E$. congener asey. brown, legs paler, pubescence short, dense. conspicuous, are buth recorded from near Cincinnati; $E$. linearis Lec.. brown, length $15 \mathrm{~mm}$.. is said to necur" "east of the Mississippi River."

626 (1981). Euplectes cunfluens Lec., Bost. Journ. Nat. Hist., VI, 1849 , 105.

Elongate, slender. parallel. Uniform reddish-brown. finely pubescent. Head wider than long, with two deep parallel grooves, the intervening space nearly smooth; elsewhere coarsely punctured. Antenna reaching middle of thorax, joints three to eight subequal, wider than long, bead-like: ninth and tenth wider; elerenth orate, wider than tenth. Thorax as wide as long, finely punctate; disk with a deep oblong forea before the middle and a triangular one near base, the latter feebly connected with a large dee one each side. Elytra faintly punctate, densely pubescent, discal lines deep at base, not reaching middle. Abdomen longer than elytra, the first and second dorsals carinate. Length 1.2-1.5 mm. (Fig. 152, e.)

Marion County; rare. May 28.

Bibloplechus mificeps Lec., dark brown, elytra darker, surface not punctate, pubescence short and fine. length $.7 \mathrm{~mm}$., is known from Michigan and Illinois.

Thesium cavifrons Lec., reddish-brown, legs and antennæ paler. pubescence rather dense, pale, length $8 \mathrm{~mm}$., occurs in the "Mississippi Valley."

Actium augustum Casey, pale reddish-yellow, length $1.2 \mathrm{~mm}$.. was described from Pennsylvania.

\section{XviII. Trimiomelba Casey. 1897.}

Differs from Melba in its larger head with more remote fovex; longer first dorsa! and second ventral segments: ninth and tenth antennal joints small, doubly convex: hind tarsi long, slender, ths second joint twice as long as third. One species has been taken. while another may occur.

KEY TO INDTANA SPECIES OF TRIMTOMEJBA.

a. Head not punctate, the front obtusely rounded between the antennit: forex of occiput small and deep: width acoss the shoulders equal to that of thorax.

CONTEXUIA.

aa. Head distinctly punctate. the front more narrowly subangulate; fore:e larger and less separated; width of shoulders less than that of thorax.

627. DUBIA.

T. convexula Lec.. deep yellow, very convex, pubescence not visible. length $7 \mathrm{~mm}$.. is known from Pennsylvania and Illinois. 
627 (1969). 'Trimomelia duria Lec., Bost. Journ. Nat. Hist., VI, 1S4!), 10s.

Dull brownish-yellow, shining, very finely pubescent. IIead slightly wider than long, finely but distinctly punctate. Antennæ reaching middle of thorax, joints 3 to $S$ bead-like, very small, ninth and tenth wider but not longer, eleventh very large, ovate-conical. Thorax as wide as long, widest just in front of middle, disk with a deep transverse sulcus at base, connecting a small fovea each side. Elytra each with two basal fovere, the discal line reaching middle. Length $.8 \mathrm{~mm}$. (Fig. 152, c.)

Putnam County; rare. April 22.

\section{Nenb. Caser. 1897. (A name.)}

Head smaller; last antennal joint large, cone-shaped; oceiput in our species with a median impression; first dorsal not elongate; second ventral shorter than the next two. Males with front and middle femora much swollen. Three spesies perhaps occur in the State.

KEY TO INDIANA SPECIES OF MELBA.

a. Discal striae of elytra short.

b. 'Thorax not punctured, as wide as head.

62S. PARTULA.

bb. Thorax finely and distinctly punctured, wider than head.

THORACICA. a a. Discal striae half the length of each elytron.

629. MAJA.

62S (1966). Melba parvula Lec., Bost. Journ. Nat. Hist., VI, 1849, 108.

Brownish-yellow, shining, finely pubescent. Head one-fifth wider than long, smooth, frontal margin slightly curved; occipital foveæ deep. Antenne as in T. dubia, the last joint larger. Thorax subglobose, narrower at base; disk with a deep transrerse basal groove which is angulate at middle and unites with a small fovea each side. Elytra strongly convex, the discal groove limited to basal fourth. Length $1 \mathrm{~mm}$. (Fig. 152, d.)

Starke and Monroe comnties; rare. Nay 8-May 18.

M. thoracica Brencl., duil yellow, pubescence fine, abundant, length $.9 \mathrm{~mm}$., was described from Illinois and Iowa, and is said to cecur on moist, rotten wood, with ants, and to be abundant in June.

629 (—— Melba ma.ja Brend., Trans. Amer. Ent. Soc., XIX, 1S92, 167.

Differs from parvula in the longer discal stria of elytra and in having the sutural stria punctured on the onter side. Length $1.1 \mathrm{~mm}$.

Putnam County ; rare. April 17.

T'rimioplectus obsoletus Brend., yellow, pubescence fine and sparse, length $1.2 \mathrm{~mm}$., was described from Iowa and may occur in Northern Indiana. 


\section{Family XI. STAPHYLINIDAE.}

The Rove Beetles. The Short-winged Scavenger Beetles.

A very large family of slender-bodied, small or medium-sized beetles having the elytra truncate and very short, leaving always some of the abdominal segments exposed, and covering usually only two or three of them. The abdomen, both above and beneath, is of corneous or horn-like texture, yet very flexible, and when the insect is disturbed it is turned "up over the back as if the beetle were about to sting. However, they are perfectly harmless, though sometimes disagreeable on account of emitting an odorous fluid from the tip of the abdomen. The ventral segments are eight (rarely seven) in number, while there are ten dorsal ones. The wings are usually fully developed, often exceeding the abdomen in length, and when not in use are folded beneath the short elytra.

In addition to the characters mentioned, the Staphylinidx have the labial palpi three-jointed except in Tribe I; maxillary palpi 4jointed (5-jointed in Aleorhara) : mandibles long, sharp and sickleshaped, usually crossing one another at tips when at rest; antennæ variable in insertion and form, 11- (rarely 10-) jointed; mesosternum short, its sidepieces large; metasternum rather large. with narrow sidepieces; front coxre usually large, conical, prominent and contiguous, the coxal cavities rarely closed behind; hind coxa contiguous except in the second subfamily; tarsi usually 5 jointed, rarely 4- or 3-jointed.

In habits the Staphylinids are to be classed as beneficial, as they feed upon decaying animal and vegetable substances, and thus not only act as scavengers. but also aid in reducing the manure heap. and the manure when spread, into a more available form of plant food. The larve, except in the absence of wings, resemble the adults both in structure and habits, and together with them oceur beneath bark, in fungi and in decaying plants, while some are guests in the nests of ants, being reared and attended as carefully while young, as are the young of the ants themselves.

Sharp says that "it is probable that one-hundred thousand species or even more of Staphylinidx are at present in existence." This may be an exaggeration. But 9,000 species are at present described, 1.500 of which are from the United States alone, and many new ones are turning up each vear. As in the other families, the present paper treats only of those which have been taken in the State, or which, from their known range, should occur. It is probable that fully half as many more really occur, many of which are at present unknown to science. The literature treating of the 
known North American species is seattered through many volumes and the more important papers will be mentioned under the respective tribal headings.

The family is divided into eleven subfamilies, nine of which are known to be represented in the State. while the other two may be.

\section{KEY TO SUBFAMILIES OF STAPHYLINID.E.}

a. Antennie 11- (rarely 10-) jointed. without abrupt club and not reseived in carities on the under side of thorax.

b. Antennie inserted upon the front between the eyes. and behind their front margin.

c. Front coxie large, conical: hind coxie transverse, contiguous; fourth joint of maxillary palpi distinct; antenne not at all clavate: thoracic spiracles risible. Subfamily I. Alegcharinde, p. 336. cc. Front coxie small; hind coxie small, conical, widely separaterl: fourth joint of maxillary palpi obsolete: antenne slender, the last three joints suddenly larger ; eyes large and prominent.

Subfamily III. STENIN E. 1. 400.

b). Antennie not inserted mon the front between the eres; hind coxie contiguous.

d. Antenne inserted at the front margin of the front of the head. filiform or aradually thickened : fourth joint of maxillary palpi distinct.

Subfamily II. STaphrlinine, 1. $366^{\circ}$.

dr. Antenne inserted at the sides of the front of the head.

$\therefore$ Front coxie conical, mominent, rarely (Tribe Proteinini) transrerse.

f. Hind coxie conical.

g. Tarsi 5-jointed, rery rarely the middle and hind ones 4 jointed; front coxie long. strongly projecting from the prosternum; eyes not prominent; antennie inserted under a more or less prominent frontal ridge.

Subfamily IY. PÆDERINÆ. p. 414 .

gg. Tarsi 4-jointed: front coxie short; first joint of maxillary palpi at least one-half as long as second.

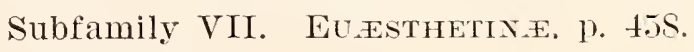

ff. Hind coxie transverse or triangular.

h. Serenth rentral segment retractile and hidden.

i. IJead inclined, narrower than thorax and more or less inserted in the latter; body convex. conical and pointed behind; thoracic spiracles visible; epipleura distinctly limited by a carina.

Subfamily T. TAch IPoRine, p. 441.

ii. Head directed forward: body slender, depressed; epipleura ill defined. not limited by a carina: thoracic spiracles hidden. Subfamily TI. Phlqecharixa, p. 457.

$h h$. Seventh rentral segment exposed: intenne inserted under the widened margins of the front of head. 
j. Middle coxie very widely separated; front of head trumcate just before the eyes; last joint of labial palpi very large, lunate. Subîamily VIII. OXYPorine, p. 459.

$j j$. Middle coxæ contiguous or nearly so; front more or less prolonged before the eyes; labial palpi with last joint normal.

Subfamily IX. OxYteline, p. 461.

fe. Front coxa globose, not prominent; hind coxie transverse; form very elongate, slender, parallel.

Subfamily X. Piestin.e, p. 483. a a. Antennæe 9-jointed with abrupt club, received in cavities on under side of thorax; hind coxie small, rounded and widely separated.

Subfamily XI. Micropeplinæe, p. 484.

\section{Subfamily I. ALEOCHARINAE.*}

Antenna inserted between the eyes and behind their front margin, 11-jointed (10-jointed in the 'Tribe Oligotini); elytra either covering entirely the first two dorsal plates of the abdomen or leaving the apical half of the second plate uncovered; abdomen margined at the sides, the second ventral plate rudimentary; front coxæ conical, prominent, usually shorter than the front thighs; hind coxæ contiguous, with broad, flat external laminæ and with elevated internal laminæ, the latter narrowed behind or subparallel; tarsi variable, 3-, 4- or 5-jointed.

The larva are but little known, greatly resembling in general those of the Tachyporinæ. The species of Aleocharinæ are among the smallest of the family, are very numerous and their life habits are extremely diversified. They occur under stones, on dead animals, in excrement, in mushrooms and toadstools, in decaying vegetable matter, under the bark of various trees, under moss, in old tree trunks and at rumning sap. Some live on the shores of running or stagnant water, some exclusively on the seashore or on the shores of brackish water, while others live in shore sand, in caves, a few in flowers and a great number in the nests of ants and termites. A few are also found in the nests of vertebrate animals, like woodrats, squirrels, swallows, etc. No member of the subfamily is known to have any economic importance except as a scavenger.

The best works of referenee on the American Aleocharinæ are: Erichson.-Kæfer der Mark Brandenburg, Berlin, 1837.

Genera et species Staphylinorum, Berlin, 1840.

Ganglbauer.-Die Kæfer von Mitteleuropa, II. Wien, 1895.

Casey.-- "Observations on the Staphylinid Groups Aleocharinæ, and Xantholinini, chiefly of America," in Trans. Acad. Sci. St. Louis, XVI, 1906, 125-434.

* The outline and keys to tribes and genera of this subfamily were furnished by Dr. A. Fenyes of Pasadena California, through whose hands all the species have passed. The other matter, including keys to species and descriptions, was prepared by the writer.-W.S. B. 
Fenyes._-"A Preliminary Systematic arrangement of the Aleocharinx of the United States and Canada,' in Entom. News. XIX, 1908, 56-65.

The work of Director L. Ganglbauer has been the one principally drawn upon for the present classification of the subfamily.

\section{KEY TO THE INDIANA TRIBES OF ALEOCHARINE.}

a. Head prolonged in a beak in front; inner lobe of the maxillæ entirely corneous or horn-like, its inner side with teeth or spines.

b. All the tarsi with three joints. Tribe I. Dinopsini, p. 337.

bb. Front and middle tarsi with four, hind tarsi with five joints.

Tribe II. MYLLenini, p. 338.

aa. Head not prolonged in a beak in front; inner lobe of the maxillye corneous on the outer side, coriaceous or leather-like on the inner side.

c. All the tarsi with four joints.

d. Antennæ with 11 joints.

dd. Antennæ with ten joints.
Tribe III. Hygronomini, p. 338. Tribe IV. OLIGotini, p. 339.

cc. Front and middle tarsi with four, hind tarsi with five joints.

Tribe V. Bolitocharini, p. 339.

ccc. Front tarsi with four, middle and hind tarsi with five joints.

Tribe VI. Mrrmedonimis, p. $34 t$.

cccc. All the tarsi with five joints.

Tribe VII. Aleocharini, p. 360.

\section{Tribe I. DINOPSINI.}

Head prolonged in a broad and short beak in front. Lobes of the maxillæ very long and narrow, the inner lobe entirely hornlike, its inner side with unequal teeth on apical half. Maxillary palpi very long and slender, apparently only three-jointed, the fourth joint minute, scarcely visible, aciculate. Labial palpi with the basal joint very large, elongate. the second and third joints small. All the tarsi with three joints.

The tribe contains only the single genus:

\section{Dinopsis Matth. 1838. (Gr., "wonderful+face.")}

Antennæ slender, head rather large; thorax transverse, elytra as long as or one-third longer than thorax; abdomen strongly narrowed behind the middle and with two dnal styles.

630 (2088). Dinopsis AMERICANA Kr., Linn. Ent., XI, 1857, 38.

Elongate, slender, depressed. Piceous, subopaque, sparsely clothed with very fine short, prostrate pubescence; antennæe, labrum, palpi and tarsi dull yellow. Thorax convex, more than twice as wide as long, sides rounded on apical half, hind angles rectangular; surface, as well as that of elytra and abdomen, very minutely and densely granulate-punctate. Elytra one-third longer than thorax, the granules arranged in oblique strix. Length $3 \mathrm{~mm}$.

Putnam and Franklin counties; rare. June 11-September 25. 
631 (2089). Dixopsis arrilexomes Kr.. Linn. Ent. XI. 1S57. 38.

Smaller and somewhat paler than americaid. Dull brorn. the thorax and elytra thickly clothed with silken rellowish prostrate pubescence; antennie, legs. front margin of thorax and last rentral and dorsal segments, dull brownish-yellow. Thorax and elytra as in americana, the latter about as long as thorax, the granules finer. Length $2-2.5 \mathrm{~mm}$.

Laporte and Posey counties; scarce. April 18-July 15. Occurs in moist places beneath rubbish.

\section{Tribe II. MILLENINI.}

Head prolonged in a beak in front. Lobes of the maxillæ very long and slender. the inner lobe entirely corneons. its inner side with saw-like teeth. Naxillary palpi very long and slender. Labial palpi rery thin. bristle-like. Front and middle tarsi with four. hind tarsi with fire joints.

The tribe contains only one genus.

\section{NrLliena Er. 1837. (Gr.. "to twist.")}

Antennæe slender. head rather small: elrtra as long as or shorter than the thorax; abdomen strongly narrowed toward the apex.

632 (2086). Mrifexd mixteta Grish, Mon. Col. Micr.. 1S06. 17t.

Dark brown; legs and apical third of antenne dull yellow. Thorax one-half wider than long. sides of disk strongly sloping toward the front angles, which are rounded. Elytra about tro-thirds the length of thorax, its surface, as well as that of the latter, densely and minutely punctate. Length $2 \mathrm{~mm}$.

Putnam Countr; frequent. March 20-October 17. Taken by sifting regetable debris from about a hillside spring.

633 (—). Mrldexa relpixa Brnh., Deutsch. Ent. Ztschr.. 1907. $3 \$ 1$.

Head, thorax and abdomen in great part piceous: legs. basal joint of antennze. tip of abdomen and elytra (in great part) brownish-yellow; anterne and base of elytra fuscous. Thorax one-third wider than long. hind angles obtusely rounded. Elytra as wide and as long as thorax, the surface, as well as that of the latter. minutely and densely punctate; apex notched near the outer angle. Abdomen at base slightly narrower than elytra; densely and finely punctate. Length $2.2 \mathrm{~mm}$.

Laporte Countỵ : rare. Julr 15.

Tribe III. IIYGRONOMINI.

Head not prolonged in a beak in front: antennie with eleven joints; inner lobe of the maxille externally corneous, internally coriaceous; all the tarsi with four joints. 
The only genus of the tribe occurring in Indiana is:

III. Grronycha Casey. 1893. (Gr.. "circle + claw.")

Elongate. linear. depressed; head of moderate size; antenne long. slender. the outer joints usually slightly enlarged; third joint of maxillary palpi but slightly longer than second; thorax oblong; elștra long and well developed: tarsal claws divergent, abruptly bent downward behind the middle.

634 (960S). Grooxycha Fuscteps Caser, Amn. N. Y. Acad. Sci., TII. 1893, 376.

Dull reddish-brorn, head piceous; legs and basil joints of antennie pale yellow. Head about as lons as wide. shorter and slightly narrower than thorax: antenne as long as thorax and elytra. the outer joints feebly but distinctle larger. the third shorter than the second. Thorax slightls longer than wide, sides feebly lounded: disk. as well as that of elytra. faintly alutaceous. minutely and densely punctate. Elytra one-third wider and longer than the thorax. thickly clothed with fine, short rellowish pubescence. Length $2.7 \mathrm{~mm}$.

Putnam County : rare. October 17.

Tribe IT. OLIGOTINI.

Head not prolonged in a beak in front. Antennæ with ten joints only. Inner lobe of the maxilla as in the preceding tribe. All the tarsi with four joints.

Although no representative of the tribe has been found thus far in Indiana, ret it is very probable that one or more members of the iollowing genus oceur :

\section{OL.igota Mannh. 1830. (Gr., "little.')}

Very small; antennæ short. the outer joints much thickened: head rather small, narrower than thorax. base not constricted; thorax very short. much wider than long. as wide at base as elytra which are rather short: abdomen pointed behind.

\section{Tribe T. BOLITOCHARINI.}

Head not prolonged in a beak in front; imner lobe of the maxillxe horn-like or corneous on imner side. leather-like on onter side (in Silusa the whole inner lobe is horn-like). Front and midale tarsi with four. hind tarsi with five joints. The following genera are probably represented in the State: 
KEY TO INDIANA GENERA OF BOLITOCHARINI.

a. Mesosternal process broadly truncate or emarginate behind; middle coxre widely separated; labial palpi with two joints only.

IV. GYROPHÆNA.

a . Mesosternal process more or less pointed behind; middle coxæ moderately separated or contiguous.

b. Labial palpi with two joints only.

c. Hind tarsi with the first joint at least as long as the second and third together; front tarsi with the first joint distinctly longer than the second; ligula very broad and short, very broadly rounded in front; labial palpi short, their first joint swollen.

Placusa.

$c c$. Hind tarsi with the first joint not or only a little longer than the second; front tarsi with the first three joints equally long; ligula very nar'ow; labiai palpi with both joints more or less elongate.

c. Labial palpi moderately long, not bristle-like; ligula moderately narrow, split at tip; body depressed.

V. Homalota.

dd. Labial palpi very narrow, prominent, stiff, bristle-like; ligula very narrow, entire, more or less narrowed toward tip; body rather convex.

SILUSA.

bu. Labial palpi with three joints.

$e$. Ligula entire.

f. Labial palpi with the second joint as long as and scarcely narrower than the first.

VI. Leptusa.

ff. Labial palpi with the second joint longer and narrower than the first; thorax wider than elytra.

ee. Ligula split, or bifid at tip.

VII. Philotermes.

ViII. Bolitochara.

IV. Gyrophena Mannh. 1830. (Gi..." a circle + to show.')

Form short and broad; antennæ rather short; head strongly transverse; eyes prominent; third joint of maxillary palpi thickened; thorax short, broad. distinctly margined; elytra large, abdomen short and broad; surface smooth. shining. almost destitute of hairs or punctures. The species live in fungi and are gregarious.

KEY TO INDIANA SPECIES OF GIROPHANA.

a. Antenn abruptly dilated beyond the fourth joint, the last seven joints forming a loose parallel club.

b. Elỵtral and abdomen almost wholly biack or piceous.

bo. Elytra and abdomen almost wholly pale.

(ii). CORRUSCULA. (636. LOBATA. a a. Antennal joints gradually enlarged from fourth joint to tip; abdomen bicolored.

c. Eyes always separated by more than twice their own width; base and apex of abdomen pale.

637. VINULA.

$c c$. Eyes more convex, separated by not more than their own width; basal half of abdomen pale, apex black.

63S. DISSIMILIS. 
635 (20S0). Grrophexa corm sctla Erichs., Gen. Sp. Staph., 1St0, 1S9).

Short, broald, subparallel. Blackish-piceous, shining; elytra often more or less brownish; antennie and legs pale yellow. Thorax twice as wide as long, slightly wider than head, sides curved, surface minutely and sparsely punctate. Elytra a little wider and longer than thorax. sparsely pubescent; minutely, roughly and sparsely punctate. Length 1-1.5 $\mathrm{mm}$.

Marion. Monroe and Posey comntixs: frepuent locally. .June 2October 31. Oceurs in lathery fungi on sides of oak and beech stumps.

636 (-). Gropitaxa lobata Casey, Trans. Acad. Sci. St. Louis, XVI, 1906. 293.

Rather stout. spindle-shaped. Brownish-yellow, shining; head black, outer apical angle of elytra. disk of thorax and fourth dorsal segment of abdomen more or less fuscous. Antennæ reaching base of elytra, joints $5-10$ brownish, slightly wider than long. Thorax much wider than head, twothirds wider than long. sides broadly rounded into base; disk smooth with the exception of absut ten widely scattered punctures, the post-median pair strong. Elytra a fourth wider and one-half longer than thorax, minutely and sparsely punctate. Length $2.2 \mathrm{~mm}$.

Marion County ; rare. May 22. Taken by sweeping. Described from New York.

637 (207T). Grrophena rixula Erichs., Gell. Sp. Staph., 1S40, 186.

Rather stout, subparallel. Pale reddish-yellow; head, apical third of elytra, except at suture. and fourth and fifth dorsal segments of abdomen black or piceous. Thorax not quite twice as wide as long, parallel and rounded on the sides; surface very sparsely and obsoletely punctate witl two larger punctures behind the middle. Elytra about one-fifth wider and one-half longer than thorax, finely and sparsely punctate. Length 1.5 $2.5 \mathrm{~mm}$.

Southern half of State: frequent. Narch 20-September 25. Occurs on fleshy fungi.

638 (2078). Gyrophæra dissimilis Erichs., Gell. Sp. Staph., 1840, 186.

Form of vinula. Pale dull yellow; head, apical angles of elytra and apical half of abdomen blackish; antennæ and legs yellow. Thorax rider than head, nearly twice as wide as long, otherwise as in vinula. Elytra with the humeri more narrowly exposed than in that species. Length 1.5$2.3 \mathrm{~mm}$.

Southern half of State; frequent. Nay 13-September 25.

$$
\text { Pracrosa Er. 18:37. (Gr.. "plate.') }
$$

Antennx shert, head rather small: thorax broad, strongly transverse; elytra large. abdomen subparallel.

No member of the genus has as ret been recorded from Indiana. but its oceurrence in the state is rerr probable. 


\section{T. Homalot Mannh. 13:30. (Gr.. "a flat surface.")}

To this genus. as characterized in the ker. belongs one Indiana species.

639 (2008). Homalota Plaxa Grilh., Ins. Suec, I. 1810, 402.

Elongate. slender. parallel. Piceous, opaque; antennze, elytra and last doreal segment of abdomen hrownish: legs dull yellow. Head large. its surfilce densely and rather coarsely punctate. Thorax slightly wider than heal. one-fourth nalrower at base than inex; sides rounded. disk finely and densely functate and with a distinct median impressed line. Elytral che-third wider and ahout one-half longer than thorax, densely and rather coarsely punctate. Ablomen as long as the rest of the body. slightly narrower than elytral its sides parallel and of equal width to terminal segment. Length 2.5-2.5 mm.

Naricn and Futnam comties: scarce. February t-December 7 Talen by sifting moist regetable debris.

\section{TI. Leptusa Kr. 1858. (Gr.. "slender.",)}

Elongate. slender parallel forms having the antenne rather short. head moderately large. thorax nsually narrower than elytra and slightly narrower at base than apex.

KEY TO INDIANA SPECHES OF IEPTUSA.

a. Abdomen in great part pale.

b. Thorax and elytra uniform brownish-piceous. much darker than the base of abdomen.

640. CASEYI.

bb. Thorax and elytra reddish-rellow. or of the same hue as the basal portion of abdomen.

6+1. ELEGANS.

a A Abdomen, as well as thorax and elytra. dark brown or piceous.

6+2. OBSCURA

6 fu (-). Leptusa caseyi Feny. Fntom. News. XVIII. 1907. 61; tricolor Cases, Trans. Acad. Sci. St. L. XVI, 1906, 351.

Slender, parallel, convex. Uniform dark brown or piceous, subopaque : abdomen pale reddish-yellow the fourth and fifth dorsal segments in part or wholly piceous: antenne black, paler at base and tips: legs pale. Antenne longer than head and thorax. the second and third joints elongate and subequal. the outer joints broader than long. Thorax a third wider than head and two-fifths wider than long; surface rather coarsels. densely and shallowly punctate. Elytra slightly wider, one-third longer and more deeply and roughls punctate than thorax. Length $2.5-3 \mathrm{~mm}$.

Putnam County : rare. April 22. Taken by sifting. This is Casey's tricolor described from In and Cincinnati. Ohio. Fenves. loc. cit.. showed that Caser's name was preoceupied.

$6+1$ (-). Leptusa Elegans sp. nov.

Form of caseni. but a little more slender. Reddish-yellow, shining. sparsely clothed with very fine prostrate hairs; hear. middle joints of an- 
temme and fourth and fifth segments of abdomen piceous. Antenne shorter than in caseyi. the second and third joints shorter and more narow at base than there. Thorax one-third wider than long; sides strongly rounded into base and apex; disk finely and sparsels punctate and with a distinct impression in front of scutellum. Elytra not wider and scarcely longer than thorax; surface coarsely, roughly and densely punctate. Abdomen not wider. than elytra. parallel to tip ; finely and sparsely punctate. Length 2-2.5 $\mathrm{mm}$.

Described from four specimens taken near San Pierre, Pulaski County. June 19. Occurs beneath cover in dry sandy places. A handsome little species of nearly efual width throughout.

(j42 (-). LEPTESA OBSCLRA SP. nOY.

Form of cosemi. I'jeeous. subopange; thorax and elytrat dark brown: hake of antenne and legs paler. 'Thorax one-haif wider than head, sides rounded into base, disk rather coarsely and densely punctured. Elytra twothirts longel and distinctly wider than thorax; more coarsely and roughly punctate than there. Abdomen distinctly narrower than elytra. Length $2.5-3 \mathrm{~mm}$.

Narion and Putnam counties; scarce. March 17-April 22. A - pair taken in coitu from beneath a chunk in low open roods.

\section{Philotermes Kr. 18.57. (Gr.. "to love + termes.")}

Small and rather broad species having the head large, antennæ stout: abdomen large, flat; legs rather short. The species live with termites or white ants.

643 (2073). Philotermes pilosus Kr.. Linn. Entom., XI. 185T, 14.

Rather broad, depressed, parallel. Reddish-yellow, strongly shining. sparsely clothed with short. erect rellowish hairs: elytra and fourth and fifth abdominal segments indefinitely darker. Head not punctate. Thorax subelliptical, twice as wide as head, truncate in front. sides rounded into base: surface smooth or nearly so. Elytra one-half longer but much narrower than thorax and slightly wider than abdomen, smooth. Abdomen not punctate. Length 2-2.5 $\mathrm{mm}$.

Crawford and Poser counties: scarce. April 19-Мay 26. Occurs in the nests of the white ant or Termite. Termes flacipes Koll. which are usually in rotten or decayed wood. The beetles are very active and often quickly escape when the nest or gallery is uncovered.

644 (2075). Phimotermes fuchsi Kiraitz.. Tinn. Fnt. Zeits.. XI, 1857. 14.

More slender than pilosus. Fuscous or smoky brown. shining. thickly pubescent: antemne and legs paler. Antennic longer thin head and thorax. joints $4-10$ wider than long: eleventh linger. orate-acuminate. Thorax as wide at middle as length of elytrat. all the angles rounded : apex truncate: surface, as well as that of head, finely and rery densely punctate with yel- 
lowish erect hairs on sides and scattered erect black ones on disk. Elytra less densely and less finely punctured. Serenth segment of abdomen closely punctured above and with an inferior lobe in male. Length $1.2 \mathrm{~mm}$.

Marion County; rare. May 15. Taken from anong termites beneath bark. Described from 'Tennessee.

\section{Bolitochara Mannh. 1830. (Gl.." "fungi + to delight in.")}

Rather broad forms having the antenna short. stout, less than half the length of bodr; abdomen somewhat narrowed torard tip ; legs long and slender.

645 (2009). Bolitocinara trimaculata Er., Gen. Sp. Staph., 1S40, 105.

Rather stout and broad, subparallel. Dark brown to piceous, shining, sparsely clothed with short, prostrate yellowish hairs; elytra dull yellow. with the apical half, except at suture, and a common rounded basal median spot, dark brown; legs and basal joints of antennæ vellow; basal half of abdomen often tinged with reddish. Thorax subelliptical, more than one-half wider than long, sides rounded into base; disk rather finely and closely punctate and with a rounded impression in front of scutellum. Elytra slightly wider and two-thirds longer than thorax, coarsely. roughly and shallowly punctate. Abdomen a little narrower than elytra, coarsely and rather closels punctate both abore and below. Length $3-3.5 \mathrm{~mm}$.

Southern two-thirds cf State; scarce. Narch 20-November 5. Taken from beneath debris in damp localities.

646 (9591). Bolttochara bianchardi Casey, Ann. N. Y. Acad. Sci., ViI. $1892,369$.

Rather stout. parallel. Head black; thorax piceous, slightly paler along the basal margin; elytra fuscous, the basal third and often the suture, dull sellow; legs and abdomen reddish-sellow, the last two or three segments of the latter in sreat part piceous. Thorax three-fourths wider than long. sides broadly rounded into base, disk finely, densely and somewhat roughly punctate and with a distinct impression on middle of base. Elstra slightly wider and one-half longer than thorax, impressed along the suture on basal half. rather finely and closels punctate. Abdomen distinctly narrower than elytra. feebly tapering. finely and densely punctate: fifth dorsal segment of male carinate at middle. Length 2.7-3.2 mm.

Fulton. Marion and Putnam counties; frequent. April 30-Norember 28. Taken by sifting damp regrtable debris.

\section{Tribe VI. MIRNEDONIINI.}

Head not prolonged in a beak in front; imner lobe of the maxille with its outer side horn-like, its inner sirle leather-like. Front tarsi with four, middle and hind tarsi with five joints. The following genera are known to be represented in the State. 


\section{KEY TO INDIANA GENERA OF MTRMEDONIINI.}

$u$. Sides of the front dorsal segments of abdomen withont tufts of hair.

b. Maxillary cavity or hiatus only narrowly separated from and not reaching as far behind as the eyes; inner lobe of maxilla with a row of long, curved teeth, or comb-like on the inner margin toward the curved apex; epimera of metasternum as a rule not reaching beyond the hind margin of elytra.

c. Head strongly constricted behind into a neck, the latter only about one-fourth as wide as head.

d. Scutellum not carinate.

dd. Scutellum acutely and strongly carinate.

iX. Chitalia.

X. Falagria.

cc. Head not or only moderately constricted behind.

$e$. Front ventral segments of abdomen at base distinctly transversely sulcate or transrersely constricted.

f. First joint of hind tarsi at least as long as second and third together.

XI. TACHYUSA.

$f f$. First joint of hind tarsi shorter than second and third together.

g. Thorax transversely impressed at base.

XII. Ginypeta.

gg. Thorax not impressed at base.

XIII. Meronera.

$e e$. Front ventral segments oi abdomen at base not transversely sulcate or constricted.

h. Maxillary palpi with five, labial palpi with four joints.

$i$. Seventh segment of abdomen not carinate in male.

XIV. Tinotus.

ii. Seventh segment of abdomen carinate in male.

$j$. First four joints of hind tarsi gradually decreasing in length; elytra simple in male. $\quad \mathrm{XV}$. Platandria.

$j j$. First four joints of hind tarsi equal; elytra carinate in male.

XVI. HOPLANDRIA.

$h \hbar$. Maxillary palpi with four, labial palpi with three joints.

k. Abdomen wholly without punctures; basal joint of hind tarsi as long as the next two combined. XVII. Xesturida.

kk. Abdomen with distinct punctures; hind tarsi with four basal joints equal.

7. Entire body clothed with rather long erect hairs.

XVIII. Trichiusa.

77. Body at most in parts clothed with erect hairs.

XIX. ATHeTA.

b7. Maxillary hiatus or cavity separated from the eyes is rather large cheeks and reaching behind further than the eyes; inner lobe of maxillæ with three or four curved teetl on the inward turned apex and with long and dense pubescence behind these teeth, the outer lobe very long and slender; epimera of metasternum always reaching beyond the hind margin of elytra ; first joint of hind tarsi elongate longer than second and third joints together. XX. Zrras.

aa. Sides of front dorsal segments of abdomen with dense tufts of yell w hairs.

XXI. XeNodusa. 


\section{TX. Chitalia Shp. 1883.}

Rather elongate species having the head large; antennæ long and stout, the last joint much shorter than the two preceding combined: thorax cordate; elrtra with prominent. almost square shoulders; abdomen nearly parallel: middle coxe widely separated; legs long and stout. the basal joint of hind tarsi much shorter than the next three anmbined.

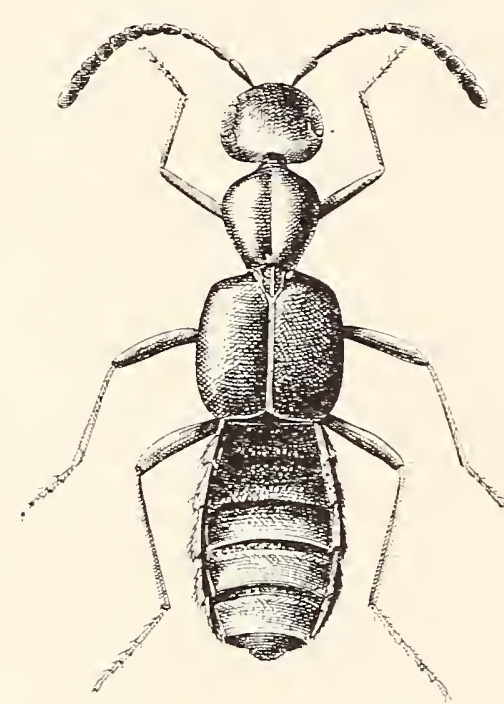

Fig. 153. $\times 15 . \quad$ (Original.)

647 (2002). Cimtalia bilobata Say, Trans. Amer. Phil. Soc., TI. 1836. 156 ; ibid. II. $5 \varsigma 9$.

Elongate rather stout convex. Dark brown to piceous. shining; legs and basal joints of antemne bromnish-yellow. Thorax cordate. slightly wider than head and as long as ride. sides rounded in front, strongly converging behind: disk finely and sparsely punctate and with a wide, deep median groore; scutellum finely and densely granulate and often with a median line. Elytra one-half wider than thorax. as wide as long. finely and sparsely granulate-punctate, more densely so on basal half. Abdomen narrower than elstra, rather closely and roughly punctate. I.ength $3-$ $3.3 \mathrm{~mm}$. (Fig. 158.)

Throughout the State; scarce. April 16-October 31. Taken beneath bark and by sifting regetable debris in moist woods.

\section{Fluigria Mannh. 1830.}

This genus is closely allied to the preceding. differing mainly by having the scutellum distinctly carinate. The meso- and metasterna are on the same plane. whereas in Chitalia the mesosternum is raised above the metasternum.

$6 \pm$ (1996). Falagria cingulata Lec., I'roc. Phil. Acad. Nat. Sci., $1 S 66$. 370.

Elongate, slender. convex. Pale to dark reddish-brown. shining. feebly pubescent: elytra often paler at base; apical half of abdomen blackish : legs dull sellow or in part piceous. Antemie reaching apex of elctra. second and third joints subequal. 'Thorax narrower than head, longer than wide. sides rounded in front. converging and sinuate toward base; disk minutely and sparsely punctate and with a deep median groore. Scutellum finely and sparsely granulate and with a single median carina. Elytra nearly twice as wide but not much longer than thorax. minutely and indistinctly punctate. Abdomen narrower than elytra. slightly widened behind the middle. finels and rather closely punctate. Length $2.5-3 \mathrm{~mm}$.

Putnam. Monroe. Lawrence and Poser counties: scarce. April 18-.June 9. Taken by sifting. Much more slender, with a nar- 
rower and less deeply grooved thorax and a more distinctly punctured head than in Chitalia bilobata.

649 (2003). Falagria dissecta Er., Gen. Spec. Staph., 1840, 49.

Stouter and a little shorter than cingulata. Black or piceous, shining, sparsely clothed with short fine hairs; antenne and elytra often brownish ; legs brownish-yellow. Antenne not reaching middle of elytria. Thorax wider than head and slightly wider than long. sides strongly ronnded in front, thence converging to base; disk finely and sparsely punctate and with a deep median groove. Scutellum with two carinse at middle. Elytra onehalf wider and slightly longer than thorax, finely and sparsely punctate: abdomen parallel. narrower than elytra, finely and closely punctate. Length $2-2.5 \mathrm{~mm}$.

Lake, Marion and Putnam counties; scarce. March 26-December 7 . Taken by sifting. The darker color and the two carinæ of scutellum readily distinguish this from cingulata.

\section{Tachiosa Erichs. 1837. (Gr., "swift.")}

Slender-bodied forms having the antennæ long and slender; middle coxæ almost contiguous ; thorax narrower than elytra; abdomen narrow. usually constricted at base and with the first three dorsal segments deeply impressed at base, the impressions coarsely sculptured and divided on the median line by a fine carina which joins the raised basal margin.

KEY TO INDLANA SPECIES OF TACHYUSA.

a. Abdomen highly polished, almost smooth; larger, $3-3.5 \mathrm{~mm}$.

650. GRACILLIMA. a a. Abdomen alutaceous and pubescent, minutely and closely punctate; smaller, not orer $2.8 \mathrm{~mm}$.

b. Thorax conrex or feebly tlattened; abdomen wholly dark.

65̃1. AMERICANA.

b6. Thorax with a deep median groove; abdomen pale at base.

652. Cavicollis.

650 (2046). Tachyusa gracillima Lec.. N. Sp. N. Amer. Col., I, 1863, 29.

Elongate, slender. Blackish-piceous, shining; antennæ and legs reddish-brown, tarsi vellow; basal segments of abdomen reddish. Antennie reaching tips of elytra, the second and third joints elongate, sub-equal. Thorax about as wide as long, scarcely wider than head; sides feebly rounded in front, almost straight on basal half; disk finely and rathel densely punctate, in female often with a faint median impression. Elytra one-half wider and two-thirds longer than thorax, rather coarsely, sparsely and roughly punctate. Abdomen distinctly narrower at base than middle. Length $3-3.5 \mathrm{~mm}$.

Starke and Lawrence counties; scarce. June 4-June 16. Probably occurs sparingly along shores throughout the State. 
651 (-). Tachyosa americana Casey, Trans. Acad. Sci. St. Lonis. XVI, 1906, 207.

Slender, convex. Blackish-piceous, shining, sparsely clothed with prostrate yellowish pubescence; elytra dark brown, the tips paler; antennæ fuscous or reddish-brown; legs pale yellow, the femora often darker. Antennze reaching middle of elytra, the second joint longer than third. Thorax about as long as wide, distinctly wider than head, disk convex (male), feebly flattened along the middle (female), finely and sparsely punctate. Elytra about one-half wider and a third longer than thorax, minutely, sparsely and roughly punctate. Length $2.5-2.8 \mathrm{~mm}$.

Clark and Posey counties; scarce. May 6-.June 3.

652 (2043). Tachycsa cavicollis Lec., New Sp. N. Amer. Col., I, 1863, 29.

Elongate, very slender, sparsely and finely pubescent. Thorax and elytra reddish-brown, the latter with tips paler; head and apical half of abdomen piceous; antennie and legs pale yellow, the former fuscous at apex; base of abdomen reddish-jellow. Thorax slightly wider than long, sides nearly straight; disk finely and sparsely punctate and with a broad deep groove at middle. Elytra a third wider and one-half longer than thorax, finely, sparsely and roughly punctate. Abdomen distinctly narrower at base than middle. Length $2-2.5 \mathrm{~mm}$.

Lawrence County; rare. August 7.

\section{GNyPETA Thoms. 1857. (Gr., "to fall on the knees.")}

Rather stout species having the middle coxæ well separated, their cavities closed behind; antennæ rather long; neck two-thirds or more as wide as head; thorax with a short transverse impression before the scutellum; abdomen narrower than elvtra, very feebly constricted at base.

\section{KEY TO INDIANA SPECIES OF GNYPETA.}

a. Deep biack; thorax widest at apical third; dorsal basal segments of abdomen coarsely and distinctly punctured.

653. NIGRELLA.

aa. Dark reddish-brown to piceous; thorax widest at middle; basal segments of abdomen without punctures.

654. BALTIFERA.

653 (2044). Gnypeta nigrella Lec., N. Sp. N. Amer. Col., I, 1863, 29.

Deep black throughout, shining, sparsely clothed with fine grayisl hairs; antennæ and legs piceous. Antemnæ reaching base of thorax, the first three joints equal in length. Thorax slightly wider than head, twofifths wider than long, sides broadly rounded in front, thence feebly converging to base; disk almost without punctures, but with a faint median line and a transverse impression at base. Elytra distinctly wider and onehalf longer than thorax, minutely and densely punctate. Abdomen narrower than elytra, parallel to near apex. Length 2.5-3 $\mathrm{mm}$.

Starke and Lawrence counties; scaree. Probably throughout the State. May 11-Augist 22. 
654 (2045). Gnypeta baltifera Lec., N. Sp. N. Amer. Col., I, 186:3, 29.

Head and apical half of abdomen piceous, shining; tholax, elytra and basal half of abdomen dark reddish-brown; legs and antenule somewhat paler. Antennæ reaching middle of elytra, second and third joints equil, longer than first, outer joints gradually larger. Thorax slightly wider than head, a little wider than long, sides rounded, disk minutely punctate and with an elongate, triangular median impression on basal half. Elytra twofifths wider and a little longer than thorax, minutely and sparsely punctate. Length $2.5-2.8 \mathrm{~mm}$.

Lake and Putnam counties: scarce. April 17-May 28. Taken by sifting.

\section{Meronera Shp. 1887. (Gr., "femur.")}

Very small, rather stout species having the neck less than a third the width of head; thorax strongly convex, without basal impression; abdomen as broad as elytra. not constricted at base.

655 (2004). Meronera venustula Er., Gen. Spec. Staph., 1840, 55.

Short, rather stout, subparallel. Head and last three joints of abdomen piceous. Thorax, elytra and apical portion of antennæ brown; legs, base of antennæ and abdomen, dull yellow. Antennæ stouter toward apex, reaching beyond middle of elytra. Thorax slightly wider than long, scarcely wider than head, sides rounded at apical third, thence feebly converging to base; surface, as well as that of head, coarsely and densely punctate. Elytra about one-half wider and but slightly longer than thorax, less coarsely and more sparsely punctate. Length $1.6-1.8 \mathrm{~mm}$.

Throughout the State; frequent. March 5-December 7. Hibernates as imago. Taken by sifting vegetable debris. The elytra are often in part or almost wholly piceous.

\section{XIV. 'Tinotus Sharp. 1883. (Gr.. "stretched or thin.")}

Rather stout species having the antenns short, head small; thorax short, much wider than long. strongly convex and usually impressed.

656 (9523). Tinotus caviceps Casey, Ann. N. Y. Acad. Sci., VII, 1893, 316.

Rather broad, subfusiform, flattened above. Black or piceous, feebly shining; rather thickly clothed with short, pale, recumbent hairs; legs and base of antenne dark reddish-brown. Antennæ reaching base of thorax. second and third joints equal. Head of male broadly and deeply concare. Thorax one-half wider than head, nearly twice as wide as long, sides rounded; disk finely and sparsely punctate and with a large, deep median impression (male) or a broad and feebly impressed median line (female). Elytra equal in length and width to thorax, rather coarsely and rugosely punctate. Abdomen much longer than head and thorax, nearly equall in width to elytra, marked with elongate punctures. Length 2-2.5 $\mathrm{mm}$. 
Putnam County : scarce. October 17. Sifted from debris about a hillside spring.

\section{AT. Platandra Casect. 1893. (Gr.. "broad + male.")}

Rather broad fusiform species, having the antenna rather short and slender. head well inserted, not constricted at base; ligula with a slender process which is deeply forked at apex; thorax elliptical. nuch wider than long: abdomen gradually narrowed from base to tip: hind tarsi neally as long as tibix. the basal joint elongate. the next three decreasing rapidly in length.

6at (9483). Plataxdria mormoxica Ciset. Ann. N. T. Acad. Sci. Til. $1593,3 \pm 5$.

Rather broad. Dark reddish-lnomm. feebly shining. clothed with short sparse rellowish hairs: abdomen black; tibire. tarsi and base of antenn: paler. Antenne slightly shorter than head and thorax. joints 1 to 3 sulyequal. Thorax three-fourths Wider than long: sides rounded into base. which is broadly curred and much wider than apex: disk minutels and erenly punctate. Elytra together one-third wider than long, slightly wider and more coarsels and distinctly punctured than thorax. Abdomen narromer than elytra. finels and closely punctate. Length 2.5-2.8 mm.

Marion and Lawrence counties: common locally on leatherr tungi growing on beach stumps. Mar 11-1Iar 24.

\section{ITI. Hoplatdrit Kr. 1857. (Gr.. "armed-male.")}

Rather robust species, resembling Platandria in general appearance, but having joints 1 to 1 of hind tarsi equal in length.

658 (2006). Hoplaxdria Lateralis Melsin. Proc. Phil. Acad. Nat. Sci.. II. 1S11. 32.

Rather robust. Dark reddish-brown, shiming. sparsels pubescent; head and joints 4 and 5 of abdomen piceous: base of abdomen reddish. legs and base of antennæ pale. Antennæ reaching base of thorax. joints 2 and 3 equal in length. the former stouter. 6-10 also equal and wider than the others. Thorax much wider than head, one-half wider than long: sides rounded into base, apex truncate, disk rather finels and closels punctate. Elytra nearly twice as wide as long. one-fourth wider and more coarsel? punctured than thorax. Length $2-2.5 \mathrm{~mm}$.

Throughout the State, frequent: more so in the southern counties. March 19-September 25. Taken by sifting regetable debris in moist places. The elytra are often marked with fuscous on the sides and near the scutellum.

XVII. Xesturida (asey. 1906. (Gr.. "refuse.")

Closely allied to Trichinsa. but in addition to characters mentioned in ker. differing in its more slender antennæ, broader neck. 
longer and more slender tarsi and less hairy upper surface. One species is known from the Fastern United States.

659 (-). Xesturida lavis Casey, Trans. Acad. Sci. St. L., XVI, 1906, 325.

Short, rather stout. Dark reddish-brown, strongly shining. sparsely and finely pubescent: hear and abdomen piceous; antennæ dusks, theil basal joints and legs dark brownish-yellow. Head wider than long, parallel; antennæ reaching middle of elytra. the second and third joints elongate. subequal. Thorax wider than head, one-third wider than long; sides parallel, rounded into base: surface, as well as that of elytra. finely, sparsely and roughly punctate. Elytra three-fifths wider but only slightly longer than thorax. Abdomen as wide as elytra, feebly narrowed toward the tip, the sides strongly margined. Length $1.7 \mathrm{~mm}$.

Clark County ; rare. May 6. Taken from beneath a log on the muddy banks of the Ohio River. Described from near Vicksburg. Mississippi. The Indiana specimen is in the collection of Dr. Fenyes.

\section{Trichius Casey. 1893. (Gr., "a little hair.")}

Rather stout, convex species. bristling with long hairs and having the third joint of maxillary palpi much longer and thicker than second, fourth small, slender. oblique; head and thorax both rather small; elytra wide. abdomen broad; hind tarsi with four basal joints equal.

\section{KEY TO INDIANA SPECIES OF TRICHIUSA.}

a. Elytra with coarse punctures not bearing hairs, mixed with the smaller, rougher, hair-bearing ones, the intervals polished, not alutaceous; color in great part reddish-brown.

660. PARVICEPS.

aa. Elytra with a single set of minute hair-bearing punctures, the intervals less shining and distinctly alutaceous; color deep black. 661. ATRA.

660 (-). Trichiusa parviccps Casey. Trans. Acad. Sci. St. L., XVI, $1906,329$.

Short, stout, rather convex. Reddish- or chestnut-brown, shining, sparsely clothed with pale, erect, conspicuous hairs; head and indefinite subapical cloud of abdomen black; legs and base and tips of antennæ dull sellow. Antennæ reaching nearly to middle of elytra, the outer joints gradually stout and compact; the second and third ones nearly equal. Thorax onehalf wider than head. two-fifths wider than long, sides broadly rounded, hind angles small but distinct; disk with fine. rather close punctures, with coarser ones intermixed on basal half. Elytra a third wider and longer than thorax, punctured as mentioned in key. Abdomen slightly narrower than elytra, the sides parallel. distinctly and rather closely punctate. Length $2 \mathrm{~mm}$.

Putnam and Monroe counties; scarce. April 17-May 13. Taken by sifting rotten beech wood. 
(i61 (- - ). Trichiusa atra Casey, Trans. Acad. Sci. St. L., XVI, 1906. 329.

Form of the preceding but shorter. Deep black, shining, clothed with sparse erect hairs; legs pale; antennie fuscous, paler at base, reaching base of thorax, more slender than in parviceps, second joint much longer than third. Thorax one-half wider than long, sides rounded into base, surciace minutely and sparsely punctate. Elytra one-half wider and longer than thorax, the punctures more distinct than there. Abdomen parallel, as wide as the elytra. Length $1.5 \mathrm{~mm}$.

Putnam and Lawrence counties; scarce. April 17-May 12. Taken by sifting woody debris.

XIX. АтнетA Thoms. 1859. (Gr., "without place or position.")

A large genus of small brown or blackish species having the head usually narrower than thorax, the latter never wider than elytra; the body not clothed with prominent erect hairs as in Trichiusa. The following species from the State have been identified by $\mathrm{Dr}$. Fenyes or are described as new, and there are also a half-dozen $0 r^{\circ}$ more unidentified ones at hand.

\section{KEY TO INDIANA SPECIES OF ATHETA.}

a. Eyes moderate or rather large in size, separated at most by less than trice their long diameters.

b. Abdomen parallel or only very feebly narrowed behind the middle.

c. Third joint of antennæ not, or only a little, shorter than second.

d. Thorax only very feebly transverse, about one-third wider than long.

c. Middle coxæ almost contiguous; seventh dorsal segment of abdomen in male simple; color mostly black or piceous.

f. Front of head not impressed.

g. Cheeks (genæ) entirely margined.

h. Male with eighth dorsal segment of abdomen simple, the sixth ventral truncate at tip.

662. PALUSTRIS.

hh. Male with hind margin of eighth dorsal quadridentate. the sixth ventral rounded at tip. 663. DICHROA.

gg. Cheeks margined only behind; elytra in part and legs dull yellow.

664. ÆMULA.

ff. Front of head distinctly impressed.

665. CAVICEPS.

cr. Middle coxæ more widely separated; seventh dorsal abdominal segment of male with a blunt tubercle at middle; elytra wholly or in great part pale.

$i$. 'Thorax without a median impressed line; eleventh antennal joint stout, conical, almost as long as joints $S-10$ together.

666. DEN TATA.

ii. Thorax with a distinct median impressed line; eleventh joint not longer than 9 and 10 together.

667. SULCATA.

dr. Thorax strongly transverse. one-half or more wider than long. densely and rather coasely punctate; abdomen pale at base. 
$j$. Seventh dorsal segment of male with a small flat tubercle.

673. UNIGRANOSA.

jj. Seventh dorsal segment of male simple.

(iT4. VIRGINICA. "r. 'hind joint of antennæe at least one-third shorter than second.

1. ' 'olor black and yellow.

1. 'Thorax as broad as elytra; form much stouter than in the next.

668. FLAVEOLA.

1l. 'Thorax distinctly narrower than elytra; form slender.

669. PENNSYLVANICA.

7.7: Color black or piceous, the elytra often slightly paler.

m. Liead and thorax coarsely, evenly and sparsely punctate.

670. PUNCTATA.

$m m$. Head and thorax very finely punctate.

$n$. Antennæ wholly piceous; legs fuscous.

671. POLITA. $n n$. Antennæe with basal joints pale; legs wholly pale.

672. FESTINANS.

1,6. Abdomen narrowed or more or less pointed behind the middle.

o. Antennie long and stout, leaching nearly to middle of elytra; thorax finely, densely but clistinctly punctate; color black.

675. MACROCERA.

oo. Antemn shorter and more slender, reaching only to base of elytra.

$p$. Third joint of antemne distinctly longer than second.

q. Elytra dull yellow with a median black cloud at base; thorax not impressed.

676. SORDIDA.

qq. Elytra uniform brown; thorax with a median impression on basal half.

677. LAURENTIANA.

$p p$. Third joint of antennæ shorter than, or at most as long as second.

$r$ Apical half of abdomen piceous; thorax and elytra coarsely and densely punctate.

678. LUTEOLA.

$r$. Last two joints of abdomen pale yellow; thorax and elytra finely, less densely punctate.

679. SUBPYGM EA.

a . Eyes very small, separated bs three or more times their long diameters.

s. Front of head convex.

680. ANALIS.

ss. Front of head concave.

681. CAVIFRONS.

662 (9503). Atheta Palustris Kiesw., Stett. Ent., Ztg., V, 1844, 31S.

Elongate, rather slender. Head and abdomen black; antennze, thorax and elytra piceous, finely and sparsely pubescent; legs dusky yellow. Head convex, finely and closely punctate; antennæ short, stout. reaching base or thorax, the second and third joints equal. Thorax about as wide as long. sides rounded into base, disk finely and densely punctate. Elytra onefourth wider, one-half longer and nore coarsely and distinctly punctate than thorax. Length 1.S-2 $\mathrm{mm}$.

Marion and Putnam counties; searce. Mareh 25-April 11. 'Taken by sifting moist regetable debris.

663 (2011). Atheta dichroa Grav., Col. Mici., 1802, 186.

Elongate, modelately robust. Black, feebly shining; legs, base of antenmæ, elytra and tip of abdomen dull rellow. Antennxe reaching base of thorax, the third joint slightly longer than second. Thorax" nearly one- 
third wider than long. finely and densely punctate: disk with a very fine median line which expands into a shallow impression at base. Elytra scarcely wider than thorax, densely and finely punctate. Abdomen finely and rery sparsely punctured. Length :3 mm.

Starke and Clark comnties; scarce. May 7-May 19.

(iit (2010). Atmeta æmlla Erichs.. Gen. Spec. Staph., 1840, 102.

Elongate. rather slender. Black, shining; elstra, legs and base of antenne more or less dull yellow. Antemn:e slightly longer than head and thorax. third joint distinctly longer than second. Thorax scarcely onethird wider than long. minutely and rather sparsely punctate; disk with a rather wide. shallow impression at middle of base. Elytra one-third wider and one-half longer than thorax, densely and rather coarsely punctate. Length $2.7-3 \mathrm{~mm}$.

Marion, Putnam and Clark counties; frequent. Narch 6-November 28. Taken by sifting. The sides of elytra are more or less fuscous.

665 (-). АтHeTA CAVICEPS sp. nor.

Elongate, rather stout, parallel. Head, thorax and abdomen piceous. sparsely clother with fine, pale prostrate hairs; elytra dark dull reddishbrown; antennæ piceous, the basal joints and legs dull reddish-yellow. Front of head with a broad shallow impression. Antemme slender, reaching middle of elytra, the third joint slightly longer than second. Thorax one-third wider than long. sides broadly rounded into base, surface finely and sparsely punctate and with a faint median impressed line. Elytra scarcely wider and one-third longer than thorax, finely and roughly punctate. Abdomen equal to elytra in width. Length $2 \mathrm{~mm}$.

Lake. Marshall and Marion counties; råre. May 15-May 20.

(666 (一). Atheta Dextata Brnh., Deutsch. Entom. Ztschr., 1906, 342.

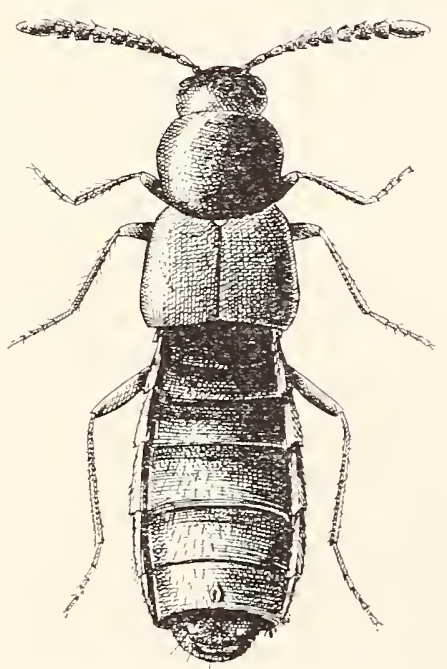

Fig. 154. $\times 16 . \quad$ (Original.)

Elongate, robust. Blackish piceous, shining. sparsely and finely pubescent; elytra dull clay yellow, the humeri, margins and apical angles often darker; legs dusky yellow. Head broad. convex, almost smooth. Antennie stout, reaching beyond base of thorax, second and third joints subequal, eleventh almost as long as $S-10$ combined. Thorax slightly broader than long. sides nearly straight, hind angles rounded, surface sparsely, finely and roughly punctate and with a feeble impression at middle of base. Elytra but slightly wider and one-third longer than thorax, minutely and roughly punctate. Length 3-3.2 mm. (Fig. 154.)

Throughout the State; common in the southern counties; less so northward. Narch 16-November 29. Our largest species; taken by sifting. rarely by beating. and probably hibernates. 
Elongate. robust. Piceous, shining; elytra uniform dull clay yellow: antennie fuscous, the two basal joints and legs pale yellow. Head broad. front subdepressed, finely alutaceous. Antenne as in dentata, the apjical joint shorter. Thorax one-third wider than long, sides rounded on apical third, thence nearly straight to base, hind angles obtuse; disk finely and densely punctate, with a distinct but fine median impressed line and a feeble impression at middle of base. Elytra as in dentata. Abdomen finely and rather closely punctate; under surface much more densely pubescent than in dentata; the apical half of the seventh dorsal segment reddishtranslucent and with a distinct median tubercle in the male. Length $3.5 \mathrm{~mm}$.

Posey County ; rare. April 22.

66s (2015). Atheta flaveola Melsh., Proc. Phil. Acad. Nát. Sci., II, $1844,30$.

Rather stout. Dull reddish-yellow; head, sixth dorsal segment of abdomen and often the tips and sides of elytra black or piceous; legs and base of antennxe pale sellow. Thorax one-third wider than long, sides rounded into base; disk finely and closely punctured. Elytra scarcely narrower than thorax, sparsely and minutels punctate. Abdomen slightly narrower than elytra, sparsely and rather coarsely punctate. Length $2 \mathrm{~mm}$.

Orange County; rare. May 31-June 1. Taken from fleshy white fungi.

669 (一). Atheta pexisslyaxica Brnh.. Deutsch. Entom. Ztschr., 1907, 388.

Elongate, very slender. Reddish-sellow; head and fifth to seventh segments of abdomen black; elytra in part piceous; legs and basal joints of antennæe pale yellow. Thorax scarcely wider than head, about as broad as long, sides rounded into base, disk finely and sparsely punctate. Elytra one-half wider and more coarsely punctured than thorax. Abdomen slightly narrower than eljtra, smooth or nearly so. Length 1.7-2 mm.

Lawrence and Crawford counties; scarce. MLarch 6-July 29. Sifted from rotten fungi.

670 (-). Atheta PUNCTAta sp. nov.

Rather robust. Head, thorax and elytra dark reddish-brown, shining; abdomen piceous; antennæ dusks, the two basal joints and legs dull vellow. Head convex, almost as broad as thorax, coarsely, sparsely and evenly punctate. Antennæ rather slender, longer than head and thorax, second joint obconical, nearly one-half longer than third. Thorax one-third broader than long, sides rounded into base, disk punctured as the head. Elytra slightly wider and scarcely longer than thorax, the punctures a little smaller and more sparse than there. Abdomen as wide as elytra, minutely and sparsely punctate. Iength $2 \mathrm{~mm}$.

Posey County; rare. June 3. Sifted from debris of beech stumps. Very distinct from allied species by the coarse, sparse punctures of upper surface. 
6it (2919). Atheta Polita Melsh., Proc. Phil. Acad. Nat. Sci., II. 1844, 31.

Short and rather robust. Head, thorax and abdomen black, shining; antennie piceous; elytra and legs dusky or fuscous yellow. Head rather hroad, conrex, sparsely and finely punctate; antennie short, stout, reaching base of thorax, the third joint two-thirds the length of second. Thorax suborbicular, scarcely wider than long. sides rounded into base, disk rery finely and sparsely punctate. Elytra one-half longer and one-third wider than thorax; more coarsely and somewhat roughly punctate. Abdomen as wide as elytra, parallel. Length $1.5-1.8 \mathrm{~mm}$.

Marshall, Narion, Putnam, Níonroe and Clark counties; frequent. March 6--October 31. Taken by sifting rotten woody debris and leaves in damp places.

(j72 (2013). Atheta festinans Er., Gen. Spec. Staph., 1840, 112.

More slender than the preceding. Piceous, feebly shining; elytra dark reddish-brown to fuscous; antennæ piceous, the basal joints and legs pale. dull yellow. Antennæ more slender than in polita, reaching middle of elytra. Thorax one-third broader than long, sides rounded into base; disk tinely and rather densely punctate and with a faint median impression on basal half. Elytra slightly wider and one-third longer than thorax, rather coarsely and densely punctate. Abdomen parallel, equal in width to elytra. I.ength 1.7-2 $\mathrm{mm}$.

Marion. Putnam. Vigo, Lawrence, Clark and Posey counties; scarce. January 7-November 8 . Taken by sifting.

673 (-). Atheta unigranosa Brnh., Deutsch. Ent. Zeitsch., 1909, 521.

Elongate, rather slender. Head and middle of abdomen black; thorax, elytra, legs, base and tip of abdomen and base of antennæ dull yellow. Antennæ reaching base of thorax, the third joint a little shorter than second. Thorax one-half wider than long, finely and rather closely punctate; disk with a faint median line and a rounded impression at base. Elytra scarcely wider and one-third longer than thorax, finely and densely punctate. Abdomen slightly narrower than elytra, parallel, finely and rather sparsely punctate. Length $2.7 \mathrm{~mm}$.

Lawrence County ; scarce. July 29. Taken from fungi.

674 (一). Atheta virginica Brnh., Deutsch. Ent. Ztschr., 1907, 393.

Elongate, rather robust. Head, thorax and apical two-thirds or more of abdomen piceous; antennæ and elytra brownish-yellow; legs pale yellow; two basal joints of antennæ and base of abdomen usually reddish-yellow. Front of head with a small round median impression, sparsely and finely punctate; antennæe reaching beyond base of thorax, the third, joint slightly longer than second. Thorax one-half wider than long, sides rounded into base and apex; disk densely and rather coarsely punctate and with a shallow median impression on basal half. Elytra slightly wider, one-half longer and more coarsely, sparsely and roughly punctate than thorax. Abdomen parallel, a little narrower than elytra. indistinctly punctate. Length 2.5-2.8 mm. 
Throughout the State; frequent. April 11-November 21. Occurs beneath regetable debris in low moist woods; also in fungi. This is said by Dr. Bernhauer to be a variety of crassicornis Fab.

675 (-). Atheta macrocera Thoms., Ofo. Vet. AK. Forh.. 1856, 106.

Elongate, rather slender. Head, thorax and abdomen black; elytr:a and antennæ piceous; legs dull yellow. Antennæe long, rather stout, reaching beyond base of elytra, second and third joints subequal. fourth to tenth as wide as long, elerenth equal to ninth and tenth. Thorax as wide as elytra, sides rounded into base, disk finely, evenly and densely granulatepunctate. Elytra scarcely wider than thorax, more sparsely punctate than latter. Abdomen parallel to apical third, minutely and sparsely punctate. Length $2.5 \mathrm{~mm}$.

Marion County; rare. May 15. Taken by sweeping.

676 (2040). AтHeta sordida Marsh, Col. Brit., 1802, 514.

Elongate, robust. Head, thorax and abdomen piceous; antennæ brown; legs dull yellow. Antennæ longer than head and thorax, the second joint one-half the length of third. Thorax as wide as elytra, sides feebly rounded. disk convex, densely and finely granulate-punctate and with a faint median impressed line. Elytra one-third longer and a little more sparsely and coarsely punctate than thorax. Abdomen distinctly tapering from middle to apex, densely and rather coarsely punctate. Length $2.8-3 \mathrm{~mm}$.

Lake. Marion. Putnam and Dubois counties; scarce. May 12November 28. Sifted from moist vegetable debris.

677 (-). Atheta laurentiana sp. not.

Elongate, slender, sparsely clothed with yellowish pubescence. Head, thorax and abdomen dark brown or piceous; antennæe and elytra uniform brown; legs paler. Head convex; antennæ reaching slightly beyond base of thorax, the second joint two-thirds the length of third. Thorax subquadrate, sides nearly straight on basal half, hind angles rounded; surface. as well as that of head, elytra and abdomen, finely and indistinctly punctate and with an oval median depression on basal half. Elytra one-third wider and one-half longer than thorax. Abdomen distinctly tapering from middle to apex. Length $3 \mathrm{~mm}$.

\section{Lawrence County ; scarce. May 11. Taken from fungi.}

678 (2014). Aтheta LUteola Erichs., Gen. Sp. Staph., 1840, 114.

Short. rather robust. Head and apical half of abdomen brownislpiceous; antennæ, thorax. elytra and basal segments of abdomen brownishyellow, sparsely and finely pubescent; legs paler. Antennre shorter than head and thorax, second joint stouter and slightly longer than third. Thora as wide as elytra, twice as broad as long, sides rounded into base and apex: disk convex, with a faint median imjression on basal half. Elytra slightly longer than thorax. Abdomen as wide as elytra, parallel. Length $2 \mathrm{~mm}$. 
Throughout the State, common in the southern counties; much less so northward. Narch 13-November 1. Taken by sifting damp vegetable debris. Probably hibernates as imago.

679 (- - ). Aтheta subpygma Brnh., Deutsch. Entom. Ztschr., 1909, 526.

More slender than luteula. Pale brownish-yellow; head and fifth and sixth segments of abdomen piceous; antennæ dusky except at base, rather slender, reaching middle of elytra. Thorax and elytra as in luteola, but much more finely punctate, the former without median basal impression. Length $2 \mathrm{~mm}$.

Starke and Kosciusko counties; rare. June 18-June 24. Sifted from sphagnum mosses in tamarack swamps.

680 (2022). AтHeta Analis Grvh., Col. Micr. Brunst., 1802. 76.

Elongate, ver'y slender.' Black, shining; thorax and elytra dark brownish-yellow to piceous; antennæe, legs and last one or two abdominal segments brownish or dusky yellow, the tarsi paler. Antennæ reaching base of thorax, the second and third joints equal. Thorax suborbicular, slightly narrower than elytra; sides rounded into base and apex; disk, as well as that of elytra and abdomen, finely and densely punctate and with a small transverse impression on basal third. Elytra one-third longer than thorax. Abdomen as wide as elytra, parallel. Length 1.8-2 $\mathrm{mm}$.

Putnam and Marion counties; frequent. March 20-November 28. Taken by sifting.

681 (9498). Atheta Cayifrons Sharp, Trans. Ent. Soc. Lond., 1869, 33.

Form of analis. Dark reddish-brown, head piceous; antennæ, legs and last two abdominal segments dull yellow. Head with a broad but shallow median groove. Antennæ, thorax and elytra nearly as in analis, the thorax with an entire faint median impressed line in front of the basal impression. Length $2 \mathrm{~mm}$.

Marion County; rare. November 21.

\section{Zyras Steph. 1832. (Gr., "razor.")}

Rather broad species, having the head much wider than long. slightly narrower than thorax; antennæ robust, longer than head and thorax, the third joint longer than second, legs long and slender.

KEY TO INDIANA SPECIES OF ZYRAS.

a. Black, the elytra fuscous; eyes very large, placed less than half their length from base of head; thoracic punctures extremely fine.

682. CALIGINOST'S. a a. Reddish-brown; eyes smaller, placed at nearly their own length from base; thoracic punctures fine but distinct.

683. PLANIFER.

(;82 (952S). Zyras caligtanosus Casey, Ann. N. Y. Acad. Sci., VII, 1893. 323.

Rather stout, parallel. Black; antennæ and legs dark reddish-yellow; elytra dull fuscous, shining. Thorax three-fourths wider than long, sides 
broadly curved, hind angles obtuse and blunt; disk alutaceous, very finely and sparsely punctate, sometimes with a fine median impressed line. Elytra slightly wider and longer than thorax, finely. distinctly and densely punctate. Abdomen slightly narrower than elytra, polished. Length 3 inm.

Putnam County; rare. Octoher 17. Described from Indiana and New York.

683 (9533). Zyras Planifer Casey, Amn. N. Y. Acad. Sci., VII, 1S93, 326.

Rather stout, subparallel. Dark reddish-brown, shining, the elytrat darker except on humeri; abdomen black, the first three segments in part or wholly pale; legs and base of antennæ pale reddish-brown. Antennix leaching middle of elytra, the third joint twice the length of second, obconical. Thorax one-half wider than long, widest at apical third, sides straight on basal half, disk convex, finely and sparsely punctate and with a faint median impressed line. Elytra two-fifths wider and slightly longer than thorax, rather coarsely and roughly punctate. Abdomen one-fourtl narrower than elytra, parallel, smooth or nearly so. Length $3-3.5 \mathrm{~mm}$.

Putnam, Lawrence and Crawford counties; scarce. March 20 May 25. The thorax of male has a large flattened median area and is more coarsely punctate than in female.

\section{Xenodusa Wasm. 1894. (Gr., "strange+guest.")}

Robust brown species having the antenne very slender. head small; thorax wider than elytra, the sides much elevated; abdomen as broad as elytra, parallel, the first four or five dorsal segments with tufts of yellow hairs on the sides.

684 (2041). Xenodusa cata Lec., N. Sp. N. Am. Col., I, 1863, 30.

Elongate, robust. parallel. Red dish-brown, shin ing, sparsely pubescent. Antermie reaching middle of abdomen, the third joint twice the length of second. Thorax nearly four times as wide as long, sides broadly reflexed, hind angles a cute, much prolonged, base bisinuate, dis k minutely and indistinctly punctate. Elytr: one-half narrower and slightly longer than thorax. Length 5-6 mm. (Fig. 155.)

Throughout the State; scarce. April 25-August 17. Occurs in the nests of several kinds of ants. Usually but two or thres of the beetles are found at

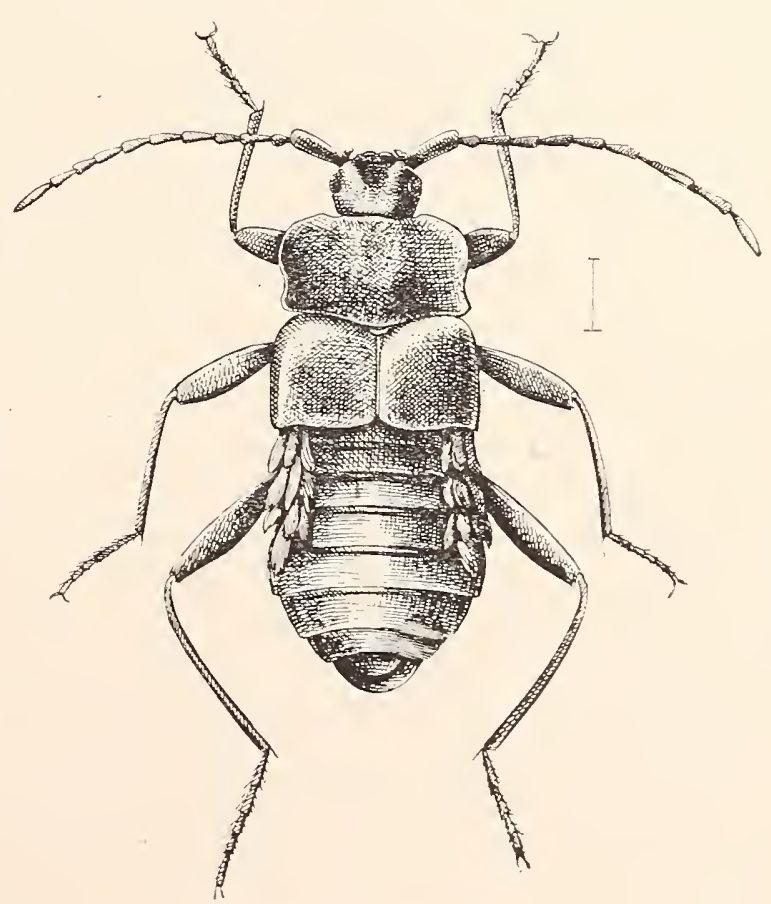

Fig. 155. (Original.) 
a time, but I once took 20 or more from among a colony of the ant Camponotus penusyleanicus beneath the bark of an elm log near Bloomington. It is said that they are fed by the ants and in turn exude a secretion which is much liked by their hosts.

\section{Tribe VII. ALEOCHARINI.}

Usually rather robust species having the head not prolonged in a beak in front; inner lobe of the maxille moderately long, its outer side horn-like, its inner side leather-like, usually with long, thornlike teeth toward the tip, densely hairy behind the teeth; all the tarsi with five joints. The tribe is represented in the State by five genera.

\section{FEY TO INDIANA GENERA OF ALEOCHARINI.}

a. Head prominent, more or less strongly constricted behind; first joint of antennx scapiform, but only moderately long; epipleura of thorax always visible from the side; third to fifth dorsal segments of abdomen always transversely sulcate or constricted.

b. First joint of hind tarsi shorter than the fifth joint and shorter than second and third together; body small, linear; third to sixth dorsal segments of abdomen transversely sulcate. XXII. PHLEopors.

b). First joint of hind tarsi longer than the fifth joint and at least as long as the second and third together.

c. First joint of antennie at most only obliquely emarginate at the very tip. XXIII. Calodera.

cc. First joint of antenna obliquely sulcate or emarginate (for the reception of the second joint) in the apical fourth or fifth.

XXIT. AMAROCHARA.

14!. IIead not $\mathrm{rl}^{\circ}$ only very feebly constricted behind, its base retracted or only moderately prominent; first joint of antennæ never scapiforn!

d. Maxillary palpi with four, labial palpi with three joints.

XXY. OxYPoD.

dd. Maxillary palpi with five, labial palpi with four joints.

XXVI. Aleochara.

XXII. PhL६opora Erich. 1837. (Gr.. "bark + to walk.")

Elongate, narrow forms having the head rather broad. strongly constricted; abdomen elongate and parallel.

685 (—). Phleopora sublevis Casey, Trans. Acad. Sci. St. L., Xr1. 1906,810 .

Elongate, slender, parallel. Dark brown, feebly shining; head and abdomen piceous; antenne fuscous, the basal joints and legs yellow. Antenne reaching base of thorax. the ruter joints transverse. Thorax as long as wide, sides rounded in front of middle. thence nearly straight to base, disk finely and sparsely punctured. Elytra a third wider and a little longer than 
thorax, finely but distinctly punctate. Abdomen slightly narrower than elytra, the first four dorsal segments deeply impressed at base. Isength 1.S $2 \mathrm{~mm}$.

Lake and Marion counties; rare. July 23-December 21. 'Taken from beneath bark of pine.

\section{Calodera Mannh. 1830. (Gr., "beautiful + skin.")}

Head broad, prominent; thorax much narrower and shorter than the elytra; legs rather long and slender.

686 (-). Calodera infuscata sp. nov.

Elongate, rather robust, parallel. Dark brown, feebly shining. sparsely and finely pubescent; head and apical segments of abdomen piceous. Intenna stout, reaching base of thorax, the first joint pale. Thorax slightly wider than head, a little longer than wide. sides parallel behind the middle; surface, as well as that of elytra, finely and densely punctate. Elytra nnehalf wider and one-third longer than thorax. Abdomen narrower than elytra, parallel, the first four dorsal segments rather deeply impressed. Length $1.8 \mathrm{~mm}$.

Marion County; rare. April 4. Taken by sifting.

“XIV. AMAROCHARA Thoms. 1858. (Gr.. "I shine + I am glad.")

Head oval, antennæ rather robust; thorax subquadrate, scarcely narrower than the elytra; abdomen parallel.

687 (--). AMAROCHARA FENYESI sp, nov.

Elongate, slender, parallel. Dark chestnut brown, shining; abdomen piceous; legs dull yellow. Thorax subquadrate, sides nearly straight, rounded into base; disk minutely and sparsely punctate. Elytra but slightly wider" and longer than thorax, more distinctly punctate than there. Abdomew about as wide as elytra, the first three dorsal segments impressed at base. Length $1.8-2 \mathrm{~mm}$.

Lawrence and Clark counties; scarce. May 6-May 12. Taker from beneath rubbish on the muddy banks of streams. Named in honor of Dr. A. Fenyes, of Pasadena. California, the acknowledged. authority on North American Aleocharinæ.

\section{Oxypoda Mannh. 1830. (Gr.. "sharp + feet.")}

Rather robust species clothed with silky pubescence: head narrower than thorax, antennæ elongate: thorax as wide or wider than the elvtra, the latter with the outer hind angles emarginate: abdomen usually narrowed behind the mirdle: legs rather elongate. Five species have been taken in the State. 
KEI TO INDIANA SPECIES OF OXYPODA.

a. Larger. 3-3.2 mm.; dark brown, elștra and legs paler.

688. SAGULATA.

aа. Smaller, not orer $2.5 \mathrm{~mm}$.

b. Thorax subparallel and curved at the sides, the apex almost as wide as the base, the latter as wide as the base of elytra.

c. Dull brownish-rellow; abdomen piceous, pale at tip. distinctly tapeling from base to apex.

689. AMIC.1.

cc. Reddish-brown; abdomen with only the fourth and fifth dorsal segments piceous. its sides nearly parallel. 690. Palustris.

bb. Thorax subconical or with the apex distinctls narrower than base.

d. Bods rather slender: abdomen feebly tapering from base to apex; color chestnut bromn.

691. OBLIQUA.

dd. Bods linear; abdomen straight and nearly parallel; color brownishsellow.

692. PEREXILIS.

bs (2062). Oxypoda sagulata Erich.. Gen. Sp. Staph.. 1S40, 146.

Elongate. rather robust. Dark brown to piceous, sparsely clothed with fine rellowish hairs; elytra reddish-brown; legs and basal joints of antenne fiale rellow. Antennæ reaching base of thorax. the second joint slightly longer than third. Thorax one-half wider than long. the base as broad as the elytra. sides moderately curved; angles rounded. the front ones deHexed; disk finels and rather closels punctate. Elstra one-third Ionger than thorax. more coarsels and densely punctate. Abdomen at base slightly narrower than elctra. distincty tapering behind the middle. densely punctate, the first two segments impressed at base. Length $3-3.2 \mathrm{~mm}$.

Throughout the State; scarce. May 13-October 31. Taken by sifting.

689 (-). Oxypoda Axica Casep. Trans. Acad. Sci. St. L.. XYI. 1906, 312.

Elongate, subfusiform. Dull brownish-rellow. clothed with rather long. shaggr pubescence: head and abdomen piceous. the latter pale at tip: antennæ fuscous. the basal joints and legs pale. Antennæ reaching to basal third of elytra. the second joint one-third longer than third. Thorax threefourths wider than long. sides strongly curred. surface. as well as that of elstra and abdomen. rery finels and rather closely punctate. Elstra about two-fifths longer than thorax. Abdomen at base one-third narrower than elstra. thence feebly tapering to apex. the first three dorsal segments deeply impressed at base. Length 2-2.2 $\mathrm{mm}$.

Throughout the State: one of the most common members of the subfamily. January 18-December 8 . Taken by sifting vegetable debris in low. moist woods. Hibernates beneath mullein leares, bottom rails of fences and other cover.

690 (-). OXYPODA PALCSTRIS SI). nOY.

Rather stont. subfusiform. Dark reddish-brown. shining. sparsely and finely pubescent: head. elstra and fourth and fifth dorsal segments of abdomen piceous. Antenne reaching middle of elytra. second and third joints 
subequal. Thorax twice as wide as long. as wide at base as elytral sides broadly curved, hind angles obtuse; surface, as well as that of elytra, finely and densely punctate. Elytra one-third longer than thorax. Abdonen slightly narionel and more coarsely punctate than elytra. sides parallel to beyond the middle, the first three dorsal segments rather feebly impressed at base. Length 1.S-2 mm.

Starke County ; rare. May 17. Sifted from sphagnum moss of a cranberry bog.

691 (一). Oxypoda obliqua Cases. Trans. Acad. Sci. St. L.. XVI, 1906. 316.

Rather slender, convex. Chestnut brown. feebly shining; head and abdomen piceous; tips of fifth and sixth abdominal segments and a faint, narrow oblique line reaching from humerus to apex of each elytron. reddishvellow; antennæe fuscous. the basal joints and legs pale. Thorax threefifths wider than long. sides broadly and feebly curred from near the base to apex. disk finely and densely punctate and usually with a faint rounded impression at middle of hase. Elytra equal in width to and about onefourth longer than thorax. more coarsely and roughly punctate than there. Abdomen at base slightly narrower than elytra. thence feebly tapering to apex, the impressions of second and third dorsal segments shallow but distinct. Length $2.5-2.7 \mathrm{~mm}$.

Marion. Putnam and Lawrence counties; scarce. April 17-November 21. Taken by sifting.

692 (-). Oxypoda perexilts Casey. Trans. Acad. Sci. St. L.. XVI. 1906. 316.

Linear. convex. Brownish-yellow; head piceous; antennze and apical half of abdomen fuscous, the base of former and the tip of latter paler; legs pale sellow. Antennæ reaching base of thorax. the second joint one-half longer than third. Thorax one-half wider than head. two-fifths wider than long, sides feebly curred. disk rery finely and densely punctate. Elytra slightly narrower and a little shorter, and more coarsely and roughly punctate than thorax. Abdomen evidently narrower than elytra. rather coarsely and roughly punctate. Length 2-2.2 $\mathrm{mm}$.

Marion. Putnam. Clark, and Posey counties : scarce. March 20July 4. Taken by sifting moist regetable debris.

XXVI. Aleochard Grvh. 1802. (Gr.. "warmth + gladness.")

Rather broad and stout species haring the head sniall. much narrower than thorax: eyes large, antennæ usually short and stout: thorax broad, the hind angles almost always rounded: elytra short and broad. their tips not emarginate or sinuate near the outer angles; abdomen usually coarsely and sparsely punctate and with the first three or fom dorsal segments narrowly and acutely impressed at base. Eight species have been taken in the State. 
KEY TO INDLAXA SPECIES OF ALEOCHARA.

a. Form rather broad and stout, rarely parallel; mesosternum without trace of carina at any point.

b. Sixth dorsal segment of abdomen simple and subtruncate at apex in both sexes.

c. Antennæ stout and spindle-shaped, not reaching base of thorax, the joints strongly transverse; thorax wholly black.

d. Elytra wholly black; thorax finely and sparsely punctate; length $5-\tau .5 \mathrm{~mm}$.

693. LATA.

d.d. Elytra in great part red; thorax coarsely and roughly punctate; length $4 \mathrm{~mm}$.

694. RUBRIPES.

cc. Antennæ more slender, reaching middle of elytra, the joints less transterse; thorax wholly black; elytra red, the base and sides narrowly black.

695. PLEURALIS.

1)万. Sixth dorsal segmient of abdomen with a number of sharp, triangular teeth at apex in male, simple in female; thorax with sides dull red; elytra in great part red.

696. LUSTRICA.

aа. Form more slender, linear, parallel; mesosternum carinate.

e. Color in great part black or piceous; first three dorsal segments of abdomen impressed at base.

f. Thorax finely and erenly punctate orer its entire surface; elytra wholly piceous.

697. SCULPTIVENTRIS.

$f f$. Thorax unerenly punctate, the punctures at middle of disk in two uneren rows, the space between the rows smooth.

\%. Dorsal segments of abdomen coarsely punctate. especially so in the basal impressions; elytra each with a large, well defined. rounded. dull yellow spot at inner angle near suture.

698. BIMACULATA.

gg. Dorsal segments of abdomen finely and more densely punctate; elytra each indefinitely dull reddish at apex near suture.

699. BIPUSTULATA.

ce. Color pale reddish-brown: first four dorsal segments of abdomen impressed at base.

700. LUCIFUGA.

693 (20气̄3). Aleochara lata Grvh.. Col. Micr. Biunst.. 1802. 186.

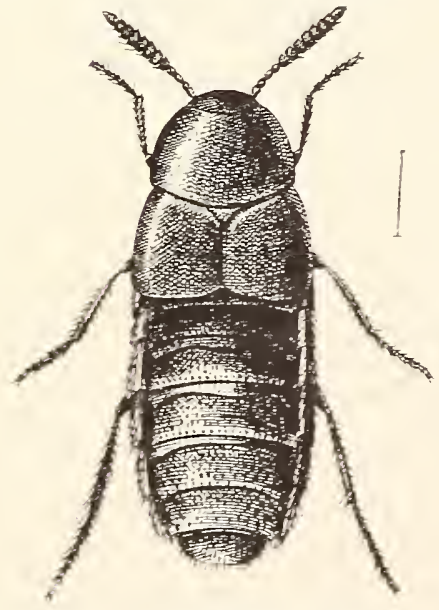

Fig. 156. Line shows natural size. (Original.)

Very stout and broad. Deep black, shining. sparsely clothed with grayish pubescence; tarsi reddish-bromn. Thorax two-thirds wider than long; strongly rounded at base; sides feebly curred, conrerging toward apex, disk minutely and sparsely punctate. Elytra slightly wider and about as long as thorax; coarsely, closely and roughly punctate. Abdomen at base as wide as elrtra. thence feebly but distinctly narrowed to apex, marked with coarse. sparse, oral punctures. Length $5-7.5 \mathrm{~mm}$. (Fig. 156.)

Southern half of State. frequent. March 24-September 25. Occurs beneath carrion. IIating April 29. 
-). Aleochara rubripes, sp. nov

Rather stont. Head. thorax and abdomen blate shining. slatrely (-Inthed with rellowish hair; elytrat dull red, darkel along the base and sides; antennie and legs reddish-brown. Head more than half the width of thorax and, like the latter. coarsely, evenly and rather sparsely punctate. Thorax one-half longer than wide, sides broady rounded into lase. Elytra about as wide and long as thorax, rather (olosely and coarsely mumetate. Abdomen as broad as elytra, sides farallel; mpler surface robatrely and sparsely punctate. Length $4 \mathrm{~mm}$.

Posey County ; rare. April 21.

695

(-). Aleochara pleuralis Casey. Trans. Acad. Sci. St. L.. XVI, 1906, 141.

Rather stout, subparallel. Piceons black, shining; elytra in great part. legs and tip of abdomen dull red; antenne fuscous; paler at base, the second joint nuch shorter than third. Thorax more than twice as wide as head, two-thirds wider than long, sides and hind angles rounded; disk finty and sparsely punctate. Elytra slightly narrower and a little shorter than thorax, rather finely. spalsely and roughly punctate. Abdomen at base as wide as elytra, thence distinctly tapering toward alpex; coarsely and slatriseIy punctate. Length $4-4.5 \mathrm{~mm}$.

I ake. I aporte and Vigo counties: scarce. May 2-July 3. Occurs in fleshy fungi.

696 (- ). Aleochara lustrica Say, Trans. Amer. Ihil. Soc., IV, 1834. 468 ; ibid. II, 585 .

Very close to pleuratis. Differs in having the thorax dull red at sides. the base and sides of elytra more broadly piceous. Elytra and abdomen more coarsely, densely and roughly punctate. Length 4-6 mm.

Throughout the State; scarce. April 15-October 1. Occurs on fleshy white fungi in dense. damp woods; also beneath carrion.

(9548). Alechara scelptiven'tris Casey. Amn. N. Y. Acad. Sci., Vil. $1893,285$.

Rather stout, linear, parallel. Piceous, shining; abclomen black: legs. basal joints of antenne and sometimes the tips of elytra dull brownish-red. Antennæ reaching beyond base of thorax, the second joint shorter than third. Thorax twice the width of head, one-half wider than long, the sides rounded into base. Elytra evidently wider and about the length of thorax, finely, densely and roughly punctate. Abdomen slightly narrower than elytra, parallel; the basal impressions of first three dorsal segments rery large, deep, coarsely and densely punctate. Length $3.8-4.5 \mathrm{~mm}$.

Marion. Orange and Clark counties; scarce. April 25-September 9. Occurs on decaving fungi.

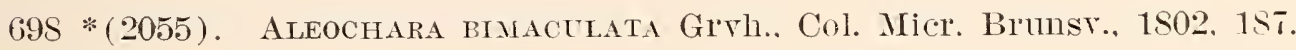

Rather stout. parallel. Black. shining; elytra paler near apex as mentioned in key; tibire. tarsi and tips of lower abdominal segments dull brown- 
ish-red. Antenna reaching base of elytra. Thorax more than twice as wide as head, three-filths wider than long, sides rounded into base; disk rather closely and unevenly punctate on sides and with two elongate, shallow punctured impressions at middle, the space between them smooth. Elytra slightly narrower and shorter than thorax; densely and coarsely punctate. Abdomen as wide as elstra, parallel, densely and coarsely punctate abore. Length $4-6.5 \mathrm{~mm}$.

Southern half of State; scarce. January 1-May 5 . Occurs in horse dung and fungi. Hiberuates beneath logs.

699 (2059). Aleochara Bipustulata Linn., Faun. Suec., 1761, 232.

Rather slender, parallel. Black, strongly shining, sparsely pubescent; elytra with an irregular dull reddish spot at inner angle near suture; legs piceous, tarsi paler. Thorax as wide as elytra, twice as wide as long, sides rounded into base, punctate as in bimaculata, the punctures on sides more coarse and sparse than there. Elytra slightly longer than thorax, rather coarsely, closely and deeply punctate. Abdomen as wide as elytra, parallel. Length 2.5-4 $\mathrm{mm}$.

Beach of Lake Michigan, Lake County ; rare. June 6-June 28. A member of the boreal fauna. A. nitida Grorh. is a synonym, as is probably also A. verna Say.

700 (9551). Aleochara leciftga Casej, Amn. N. T. Acad. Sci., VII, 1893. 288.

Elongate, slender, parallel. Pale reddish-brown, shining; head and dorsal segments of abdomen more or less piceous. Antennæ stout, reaching berond base of thorax, the second and third joints subequal. Thorax about one-fourth wider than long, sides erenly rounded. apex narrower than base: disk finely, sparsely and indistinctly punctate. Elytra rery slightly wider and about as long as thorax, rather coarsely, closely and roughly punctate. Abdomen elongate. slightly narrower at base than elytra, thence feebly tapering to apex; the impressions of basal segments rather coarsely and closely punctate. Length $4.5 \mathrm{~mm}$.

Two specimens were taken in Truett's cave. Monroe County, July 9, about 700 feet from the entrance. They were found beneath some moldy chicken benes left by risitors. Casey, loc. cit., says: "This interesting species is said to inhabit caves. but as the eyes are well developed, it probably only seeks their seclusion and carkness during the day." Garman* says of it and another species: "Both have pretty well developed eyes. and may, therefore. live at times in ordinary situations. but they are perfectly at home in the deepest parts of caves, and are at times very abundant there. In all my collerting in ordinarr situations I have not seen either species out of doors, and am disposed to consider them true cave ciwellers." $\mathbf{M} \mathrm{r}^{\circ}$. Garman is doubtless right. for no beetle is going to

* Psyche, VII, 1894, 81. 
clawl into the deepest recesses of caves each day and emerge again at night. So far liecifuga has only been found in caves. and. like Quedius spelcus Horn, has probably inhabited them too short a time to entirely lose the eyes.

\section{Subfamily II. STAPHYLININAE.}

Rather large or medium-sized black or brown species having the antennæ 11-jointed. situated at the front. margin of the front; spiracles of the thorax visible: front coxæ large and conical; trochanters of hind leg's prominent: abdomen strongly margined. The principal literature treating of the North American species of the subfamily is as follows:

Horn.- "Srnopsis of the Quediini of the United States." in Trans. Amer. Ent. Soc.. TII. 1878. 149-167.

Horn. - "Synopsis of the species of Staphylinus and the more closèly allied Genera inhabiting the United States," in Trans. Amer. Ent. Soc.. VII. 1878, 185-200.

LeConte._"Short studies of North Ainerican Coleoptera," in

Trans. Amer. Ent. Soc.. VIII. 1880. 168-174. Tabulates the genera, Leptacinus. Tanthotimus and Leptotimus.

Horn.- "Synopsis of the Philonthi of Boreal America." in

Trans. Amer. Ent. Soc.. XI. 1884. 17T-244.

Casey.-See above under Aleocharinæ.

Three tribes comprise the subfamily. all of which are represented in the State.

KEY TO TRIBES OF STAPHYLININE.

a. Side margins of the thorax simple.

Tribe I. QCEDIINI, p. 367.

ilı. Side margins of the thorax double.

b. Antenna widely separated at base.

Tribe II. Staphrlixixi. 1). 378.

bb. Antenne rather close together at base: elytra often reddish. and in most species orellapping along the suture.

Tribe III. Xaxtholixixi, p. 394.

Tribe I. QUEDIINI.

The members of this tribe have the antemni inserted at the front point of the side margin of the front: head msually with a distinct suture beneath the eyes: thorax smooth and glabrous with but few dorsal punctures. its side margin single and acute; tarsi in our species 5-jointed. Three of the four recognized genera are represented in the State.

$[2+-23 \pm 021$ 
KEY TO INDIANA GENERA OF QUEDIINI.

a. Antenne elbowed, the first joint elongate; front tarsal claws larger than the others.

XXVII. ACYLOPHORT'S.

a . Antemme straight, first joint not elongate; tarsal claws similar on all the feet.

b. Palpi awl-shaped; length less than $5 \mathrm{~mm}$.

b7. Palpi filiform; length more than $5 \mathrm{~mm}$.

XXVIII. HETEROTHOPS. XXIX. QUEDICS.

XXVII. Acylophorus Nordm. 1837. (Gr., "gland + bearing." )

Rather small, spindle-shaped species having the head oval, with four coarser punctures each side, two over each eye and two behind these; antennæ reaching base of thorax, the second joint longer than third; thorax broader than long, narrored in front, disk with two punctures each side of middle in front. one at front margin, the other one-third behind it.

701 (2091). Acylophorus Flaricollis Sachse., Stettin Zeits., 1852, 143.

Black, shining, elytra and abdomen sparsely pubescent; thorax and legs refldish-yellow; antenne dusky, the basal joint paler. Head behind the eyes with numerous fine punctures and short hairs. Elytra together slightly wider than long, coarsely, rather closely and rery roughly punctate. Abdomen as wide at base as elytra, thence strongly tapeing to apex, coarsely and rather closely punctate. Length 5-5.5 mm.

Kosciusko and Putnam counties; scarce. April 17-October 17. Ocour beneath regetable debris close to water. The fifth dorsal abdominal segment is often pale at apex.

702 (2092). Acylophorus Proxus Erichs., Gen. Spec. Staph., 1840, 521.

Black, shining; antenne piceous, usually paler at base; legs dull yellow, varying to piceous. Otherwise as in flavicollis. Length $4.5-6 \mathrm{~mm}$.

Throughout the State; frequent. March 20-October 31.

XXVIII. Heterothops Steph. 1831. (Gr., "different+eye.")

Small spindle-shaped species having the head with three or four coarse punctures, the frront one nearly at middle of inner margin of eye; thorax as in Acylophorus, the disk with two punctures on middle of apical half and two smaller ones on apical margin. Males with the sixth abdominal segment emarginate. Two of the three species have been taken in Indiana.

\section{KEY TO INDIANA SPECIES OF HETEROTHOPS.}

a. Thild joint of antemse as long as second, eleventh not longer than ninth and tenth together: heald with four punctures each side; length 3.5$4.5 \mathrm{~mm}$.

703. FUSCULCS. 
ul. Third joint of antenna scarcely longer than half the second; eleventh longer than ninth and tenth together; head with three punctures each side; length $2.5 \mathrm{~mm}$.

704. PUSIO.

703 (2096a). Heterothops fusculus Lec., N. Sp. N. Amer. Col, I, 186?, 35.

Head black, elytra and abdomen reddish-piceous; thorax, legs and three basal joints of antennæ paler. Antennæ longer than head and tholix, the last joint obliquely truncate at tip. Thorax as wide as long, narroren in front, sides nearly straight; base broadly curved. Elytra together slightly longer than wide, rather finely, not densely punctate. Abdomen more deuse$1 \mathrm{y}$ and finely punctate. Length $3-4.5 \mathrm{~mm}$.

Wolf Lake, Lake County, March 16. Rare. Listed as a variety of fumigatus, but if the two are distirict the name fusculus has priority.

704 (2097). Heterothops pusio Lec., New Sp. N. Amer. Col., I, 1863, 35.

Head black, shining: thorax piceous; elytra, abdomen and antennie dark reddish-brown, pubescent; legs dull sellow. Antennæe not longer than head and thorax, eleventh joint as long as ninth and tenth united. Thorax as wide as long, narrowed in front, base broadly curved. Elytra slightly wider at base than thorax, rather finely and densely punctate: abdomen at base a little narrower than elytra, thence very feebly tapering to apex. rery finely and densely punctate. Length 2.3-2.5 $\mathrm{mm}$.

Throughout the State. common; especially so beneath the dead leaves surrounding old beech logs in dense lowland woods. April 17-November 28. The basal joints of antennæ and last segment of abdomen are usually pale.

\section{Quedur Steph. 1831. (L.. "filth + to eat.")}

Medium-sized black or brown. Tinear or spindle-shaped species. having the labrum either acutely notched at middle and hence bilobed, or entire and broadly curved or truncate in front; head marked each side with at least four punctures, one at base of antenna, two above and one behind each eye; thorax usually narrowed in front, the disk with sides deflexed toward the front angles and in all species, except ferox and vernix, with a "dorsal row" of three coarse punctures each side of middle of apical half; often also a second row between these and the margin and other smaller ones along the apical and basal margins. Nineteen species are known from the United States, ten of which have been taken in Indiana.

KEY TO INDIANA SPECIES OF QUEDIUS.

u. Tarsi above hairy: thorax with three discal punctures each side.

b. Labrum bilobed.

c. Hind tibire with distinct spinules on the outer side; scutellum sinootli. 
d. Front of head without punctures.

e. Margin of thorax distinctly flattened; color reddish-browu.

705. SPELACS.

ce. Margin of thorax not flattened; color wholly or in great part black or piceous.

$f$. Head broadly oral.

$g$. Second joint of antennæ shorter than third; length 7 $11 \mathrm{~mm}$.

706. FULGIDUS.

gg. Second joint as long as third; length $5-6 \mathrm{~mm}$.

707. SUbLimbatus.

ff. Head elongate, as long as thorax.

708. PEREGRINUS.

dd. Front of head with two punctures; elytra rery irregularly punctured.

709. CAPUCINCS.

$c c$. Hind tibia without spinules; form depressed; elytra without punctures.

710. LEVIGATLS.

bb. Labrum entire, either curved or truncate.

7. Labrum broadly curved; eyes moderate in size; length $7-12 \mathrm{~mm}$.

711. MOLOCHINUS.

hh. Labrum truncate; eyes rery large, prominent; length 5-6 mm.

712. HYPERBOREL'S.

au. Tarsi above glabrous; thorax with two discal punctures each side.

$i$. Form slender; thorax with sides nearly parallel.

713. FEROX.

ii. Form robust; thorax narrowed in front.

714. VERNIX.

705 (2099). QUedius speleus Horn, Trans. Amer. Ent. Soc. 1S71. 332.

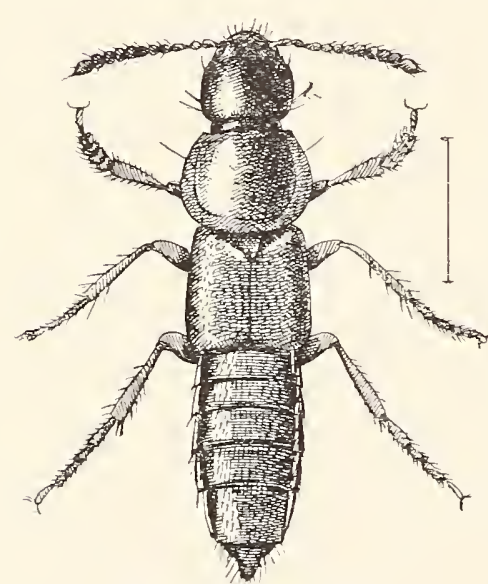

Fig. 157. (Original.)

Elongate, rather slender. Uniform pale reddish or chestnut brown, the elytra sometimes a little darker. Head oval, longer than wide; eyes small, slightly oblique. Antennie reaching base of thorax. the second joint less than one-half the length of third. Thorax broader than long. slightly narrowed in front. sides feebly. base broadly curred; disk highly polished. with small punctures along the marsins and base, in addition to the dorsal rows. Elytra narrower than thorax, together as wide as long: closely and rather coarsely and loughly punctate. sparsely pubescent. Abdomen narrower than elytra, parallel. Length 10-14 mm. (Fig. 15\%.)

Nonroe, Lawrence and Crawford counties; frequent locally in caves. April 15-November 6. Occurs in decaying organic matter. usually the excrement of raccoons and other cave visiting vertebrates, or beneath stones in the ricinity thereof. Although Cope and Packard both refer to this as a "twilight species," all specimens taken were in total darkness. those in Wyandotte Cave being 1,000 feet from the mouth. As the temperature of the cares is very much the same the year round the beetle probably breeds at all seasons, as the larve were always found with the adults. 
706 (2100). Quedius Fulgidus Fab., Mant. Ins.. I, 220.

Moderately elongate. Color variable; usually with head and thorax black, elytra reddish-brown, antennæ, legs and abdomen piceous or dark reddish-brown. Head oval, polished, with four punctures each side. the fourth behind the eye with a few smaller punctures around it. Antenu:c reaching the middle of thorax, joints $4-10$ as wide as long. Thorax slightly wider than long, narrowed in front, sides feebly, base broadly curved; disk with the usual dorsal rows of three punctures, and others along margins of apex and base. Elytra as wide as thorax, together wider than long; surface rather finely, not densely punctate. Abdomen as wide as and more densely and finely punctured than elytra. Length $7-11 \mathrm{~mm}$.

Marion. Putnam, Lawrence and Crawford counties; scarce. June 11-September 22. The specimens from the last two named counties were taken in caves and it has been recorded from caves in Virginia and Kentucky, though it also occurs above ground.

707 (2101). Quenies sublimbatus Makl., Bull. Mosc., III. 1853, 190.

Elongate, slender. Black, shining; antennæ and legs reddish-bĩown; elytra usually with the humeri and a narrow space at apex and along the suture paler. Head oval, with four punctures each side. Thorax wider than long; sides feebly, base more strongly curved; disk with the ustal lows of dorsal punctures and a few very small ones along the margins. Elytra as wide as thorax, together longer than wide, rather coarsely, deeply and closely punctate. sparsely pubescent. Abdomen as wide as elytra. sparsely punctate and pubescent. Length 5-6 $\mathrm{mm}$.

Steuben County ; rare. June 17. Sifted from sphagnum moss in tamarack swamp. A member of the boreal fauna.

708 (2102). Quedius Peregrinus Grav., Mon. Col. Micro.. 1806, 58.

Elongate, slender, parallel. Piceous or dark reddish-brown; legs, antennæe, and often the last two abdominal segments, paler. Head elongateoral, much longer than wide. Antennx reaching middle of thorax, the speond joint less than half the length of third. Thorax broader than long. narrower in front; sides feebly, base broadly curved; disk with the usual dorsal rows of three punctures. Elytra slightly narrower than thorax, a little longer than wide; rather coarsely. sparsely and shallowly junctate. sparsely pubescent. Abdomen a little narrower than elytra. with similil punctures. Length 6-9 $\mathrm{mm}$.

Marion and Vige counties; scarce. October 5-December 25. Occurs in fungi and beneath bark.

709 (2103). Quedius capucinus Grav., Mon. Col. Micr.. 1806. 40.

Elongate, rather slender. Black or piceous. shining: antennie. legs and sometimes the elytra dark reddish-brown. Head orbicular or slightly cral. with the usual four punctures, some smaller ones behind the eye and two on front between the eyes. Antennie reaching the middle of thorax. the second joint one-half the length of third. Thorax as in peregrinks. but 
with a second row of two or three punctures each side of the dorsal rows. Elytra slightly narrower than thorax, together a little longer than wide: very sparsely, finely and irregularly punctate. Abdomen iridescent, rather closely but not coarsely punctate. Length $6-9 \mathrm{~mm}$.

Throughout the State; scarce. March 16-July 16. Occurs in fieshy fungi in low, damp woods.

710 (2106). Quedius Levigatus Gyll., Ins. Suec., II, 1810, 306.

Elongate, subparallel. Black or piceous, shining; elytra and margins of the abdominal segments often reddish-brown. Head broadly oval, punctured as in fulgidus. Antennæ reaching middle of thorax, the third joint twice the length of second. Thorax slightly broader than long. not narrowed in front, sides nearly straight, base broadly curved; disk with a single row of dorsal punctures each side. Elytra as wide as thorax, together a little longer than wide, surface smooth. Abdomen slightly narrower th:m elytra, sparsely and finely punctured and pubescent. Length 5-9 $\mathrm{mm}$.

Marion County ; rare. April 6. Occurs beneath bark.

711 (2107). Quedius molochinus Grav., Mon. Col. Micro., 1806, 4 6.

Elongate, parallel. Head and thorax black, shining; remainder of body dark reddish-brown. Head oval, with a row of five or six punctures each side. Antennæe rather slender, reaching nearly to base of thorax, second joint one-third shorter than third. Thorax slightly wider than long, narlowed in front, sides nearly straight, base broadly curved; disk with the usual rows of dorsal punctures and two others each side, placed transversely. Scutellum punctured. Elytra slightly narrower than thorax, together a little wider than long, densely and rather coarsely punctured and clothed with brownish hair. Length 7-12 $\mathrm{mm}$.

Kosciusko. Vigo and Orange counties; scarce. April 23-December 18.

712 (2108). Quedius hyperboreus Erichs., Gen. Spec. Staph., 1840, 547.

Rather short. robust. Piceous, shining; elytra brownish, often witl a tinge of bronze; antennæ and legs pale. Head orbicular. strongly narrowed behind, smooth, except four punctures each side. Eyes very large, oval, longer than wide. Antennæ slender, reaching basal third of thorax, the second and third joints subequal. Thorax as wide as long, narrowed in front, punctured as in molochinus. Elytra as wide as thorax, together as wide as long, rather densely and finely punctate. Abdomen a little more coarsely and sparsely punctate. Male with sixth ventral triangularly notched and front femora strongly dilated. Length 5-6 mm.

Steuben County; rare. June 17. Sifted from sphagnum moss. A member of the boreal fauna.

713 (2114). Quedius Ferox Lec., Proc. Amer. Phil. Soc. XVII, 1878, 398.

Elongate, slender. Black, strongly shining; antenmæ and legs dark reddish-brown to piceous. Head orbicular, with the usual row of four coarse punctures and numerous smaller ones above and behind the eyes. Antenne slender, reaching base of thorax, the third joint three times the length of 
second. 'Thorax quadrangular, slightly longer than wide, sides nearly straight, base rounded, disk with only two punctures in the dorsal rows, : large one near side margin of apical halt and a few on basal margin. Lilytra slightly wider than thorax, together one-half longer than wide; disk with a median row of four or five punctures; deflexed portion of side margins densely punctate. Abdomen iridescent, rather coarsely and densely princtate. Length 8-11 mm.

Western half of State; frequent. April 1-November 24. Occurs beneath cover, especially in sandy places near water.

714 (2115). Quedius vernix Lec., Proc. Amer. Phil. Soc., XVII, 1878, 389.

More robust. Uniform black, strongly shining. Head oval, with the usual coarse punctures, the small ones only behind and beneath the eyes. Thorax large, broader than long, narrower in front; sides moderately curved, base broadly rounded; disk punctate as in ferox, punctures of basal margin very small. Elytra as wide as thorax, together slightly wider than long, sutural strix deep; disk punctate as in ferox, those on the defiexed sides less numerous. Abdomen iridescent, sparsely punctate. Length 12 $14 \mathrm{~mm}$.

Wester'n half of State, as far south as Vigo County; frequent, especially so along the margins of lakes. April 2-September 27.

\section{Tribe II. STAPHYLININI.}

Head without suture or raised line each side beneath the eyes. Antenna distant from each other at base, never elbowed, inserted on the front margin of the front, inside of the base of the mandibles; labrum always bilobed, thorax more or less convex, frequently densely punctured, with the side margins double, the inflexed portion between the two marginal lines smooth, variable in width; thoracic spiracles visible. The tribe embraces the largest species of the family. They live in decaying fungi, carrion, dung and decomposing organic matter in general.

The North American members of the tribe are at present distributed among 13 genera, seven of which are represented in Indiana.

KEY TO INDIANA GENERA OF STAPHYLININI.

a. Fourth joint of maxillary palpi shorter than third; size large, 10 or more mom.

b. Thorax punctured, densely pubescent. XXX. Listotrophus.

bu. Thorax smooth, pubescent only on front angles; middle coxæ widely separated.

XXXI. Creophilus.

a a. Fourth joint of maxillary palpi equal to or longer than third.

c. Ligula emarginate; size larger, 11 or more mm.; form usually robust.

l. Middle coxie slightly separated; abdomen narrowed at tip; thorax punctured, pubescent.

XXXII. Staphylinus. 
dd. Middle coxre contiguous; abdomen very long, parallel.

XXXIII. Ocrpus.

‘. Ligula entire; size usually smaller, rarely over $10 \mathrm{~mm}$; form more slender.

$\epsilon$. Femora spinous beneath; abdomen bicolored, head and thorax black.

XXXIV. Belonuchus.

ee. Femora unarmed; colors not as above; labial palpi slender.

$f$. First joint of hind tarsi as long as or longer than the fifth; last joint of maxillary palpi slender and needle-shaped.

XXXV. Philonthus.

ff. First joint of hind tarsi shorter than the fifth, joints 1-4, decreasing gradually in length ; last joint of maxillary palpi elongate, conical.

XXXVI. ACTOBIUs.

\section{Listotrophus Perty. 1830.}

Antennæ slender, reaching middle of thorax, not subclavate toward apex as in Creophilus. Side marginal lines of thorax uniting in front. One of the two known species occurs in the State.

715 (2116). Listorrophus cingulatus Grav., Mon. Col. Micr., 1806, 166.

Elongate, robust. Dark brown or piceous, densely clothed with golden. grayish-brown and blackish pubescence, the black hairs forming irregular spots on head, thorax and abdomen; metasternum and tip of abdomen golden; antenne dusky, the basal joints, tibiæe and tarsi reddish-brown. Head as wide as or wider than thorax, densely punctate; eyes large. Thorax as wide as long, widest at apex. sides rounded into base; disk densely and finely punctate. Elytra slightly wider but not much longer than thorax, densely and finely granulate. Abdomen narrower than elytra, sparsely and coarsely punctate. Length 13-1S $\mathrm{mm}$.

Throughout the State; frequent. May 6-September 12.

\section{Creophilus Mann. 1830. (Gr., "flesh + to love.")}

Antennie searcely longer than head, the outer joints gradually broader, the terminal one longer but narrower than the tenth and emarginate at apex; side marginal lines of thorax not uniting in front, the outer one becoming obsolete one-third from the front angle.

716 (2119). Creophilus villosus Grav.. Mon. Col. Micr., 1S06, 160.

Elongate, robust. Black, shining; second and third, and sometimes the fourth abdominal segments in great part densely clothed with yellowish-gray hairs; a broad median. serrate cross-band on elytra composed of similar hairs. Thorax suborbicular, truncate in front, disk wholly smooth. Elytra one-third wider and one-half longer than thorax, finely and sparsely punctate. Abdomen as wide as elytra. Length 12-21 mm. (Fig. 158.)

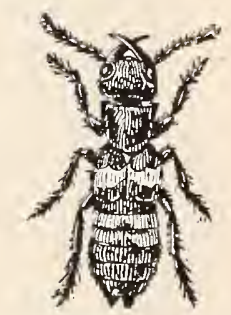

Fig. 158. Natural size. (After Knobel.) 
Throughout the State; frequent. April 6-July 19. Occurs on decaying fungi and carrion.

XXXII. Staphylinus Linn. 1758. (Gr., "a kind of insect.")

Usually large, robust species, having the middle coxal cavities always separated, sometimes very narrowly, by the mesosternum; head as wide as or wider than thorax; abdomen more or less tapering; color brown or dull black. Of the 22 species listed from the United States the following are known from or probably occur in Indiana:

\section{KEY TO INDIANA SPECIES OF STAPHYLINUS.}

a. Head suborbicular, its hind angles rounded; sides of thorax behind the middle sinuate; scutellum pubescent, not velvety.

b. Constriction of neck not deeply impressed above; abdomen entirely black, its segments beneath densely punctured and with golden pubescence along their front margins.

717. BADIPES.

$b b$. Constriction of neck deep above and with golden pubescence; abdomen beneath very sparsely punctate. ERYTHROPTERUS.

a $\alpha$. Head usually subtriangular, suddenly narrowed behind, its hind angles obtusely prominent; sides of thorax curved behind the middle, never sinuate; scutellum velvety.

$c$. Thorax densely and regularly punctured over the entire surface, except at times a smooth median line.

d. Front half of abdominal segments beneath densely and finely punctate and clothed with golden pubescence.

$e$. Abdominal segments above with golden pubescence at base and sides; elytra uniform reddish-brown.

718. VULPINUS.

ee. Abdominal segments above with double row of dark velvety spots at middle; elytra brown with elongate fuscous spots.

719. MaCULOSUs.

$d d$. Front half of abdominal segments beneath not or but little more densely punctate than apical half and without golden pubescence.

$f$. Thorax subopaque, very densely punctate, the pubescence very evident.

g. Elytra brownish or piceous; tip of abdomen always paler.

h. Eyes normal; femora piceous; thorax without smooth median line.

720. MYSTICUS.

$h h$. Eyes large, two-thirds the length of head; femora pale yellowish above, piceous beneath.

FEMORATUS.

gg. Elytra black, sometimes with golden spot; abdomen wholly black.

i. Abdomen above with a double row of small velvety spots; elytra entirely black, simply punctate. 721. Tомеnтosus.

ii. Abdomen above without velvety spots; elytra usually with a large golden pubescent spot, roughly punctate.

722. FOSSATOR. 
ff. Thorax shining. punctures distinctls separate. pubescence scarcels erident.

i. Upper surface brownish or piceous, not metallic.

$k$. Head, thorax and elstra pale reddish-brown.

723. CINXAMOPTERLS.

Fl. Entire upper surface piceous.

724. COMES.

ij. Bods abore with more or less metallic lustre.

l. Legs entirels black; head, thorax and elytra riolet.

725. NIOLACETS.

17. Legs bicolored: head. thorax and elstra bronzed.

VIRIDANUS.

ce. Thoras as mide as long. coarselr and irregularly punctured, with smooth spaces in front on each side and at middle near base; color decidedly bronzed.

EXULANS.

717 (2124). Staphrlinds badipes Lec., N. Sp. N. Am. Col., I, 1863, 36.

Elongate, rather slender. Black or blackish-piceous; antennæ and legs reddish-brown. Head densels punctured; antennæ slightly longer than head. Thoras longer than wide. a little narrower than head: disk densels punctate with a smooth median line. Elstra together slightly wider than long: densels punctate, sparsels pubescent. Abdomen as mide as elrtra. segments one to fire abore each with a small spot of golden pubescence at the middle of the front margin. Length $13-17 \mathrm{~mm}$.

Lake Countr: rare. May 1-Mary 5. Taken from beneath cover on the beach of Lake Michigan near Pine: also near Hessville. A species of northern range.

S. erythopterus Linn.. $13.5 \mathrm{~mm}$. in length. piceous. with elytra and legs pale. has been taken at Detroit. Michigan. and probably occurs in the northern third of Indiana.

718 (2130). Staphylixus vulpixus Nordm., Symb. Mon. Staph., 1837, 53.

Elongate, robust. Head, elrtra and legs uniform pale reddish-bromn: thorax and antennze darker brown; abdomen piceous. the last rentral segment reddish-brown. Antennæ slightly longer than head. Thorax as wide as head, as broad as long, sides nearls straight. base broadly curred, disk densels punctate. With a trace of a smooth median line behind the middle. Elrtra slightlr wider than thorax, as broad as long. rery densely punctured. sparsels pubescent. Abdomen narrower than elstra. finels punctulate. Length $15-18 \mathrm{~mm}$.

Throughout the State: scarce. April 1-September 25. Occurs heneath dead leaves and other cover. especially along the sandy margins of lakes and ponds.

719 *(21:1). Staphilixt's Macclosts Grat.. Mon. Col. Micr.. 1S06, 165.

Resembles vutpinus in form and structure. Color darker bromn: elstra and upper surface of abdomen rariegated with fuscous spots; base of antenne. tibia, tarsi and tip of abdomen pale: femora piceous. with edges paler. Length 18-25 mm. (Fig. 159, a.) 
Throughout the State; frequent. April 28-December 18. Ocrurs in carrion, decaying fungi and dung. Hibernates beneath partly buried logs near a food supply.

720 (2132). Staphrinus mrstices Erichs., Gen. Spec. Staph., 1840, 926.

Moderately elongate, rather robust. Dark brown to piceous, subopaque; tibia, tarsi, basal joints of antemne and tip of abdomen reddish-brown. Thorax not wider than head, slightly longer than wide, sides nearly straight. base broadly curved. Elytra a little wider than thorax, together as wide as long, densely punctate and clothed with brownish hairs. Abdomen as wide as elytra, above densely punctate, sparsely clothed with brownish and yellow hairs; segments two to six with a double row of small velvety spots. Length 16-20 $\mathrm{mm}$.

Throughout the State; scarce. April 15-October 4. Occurs beneath cover in upland sandy woods.

S. femoratus Fab., a southern form, $15 \mathrm{~mm}$. in length, has been taken by Dury near Cincinnati and probably occurs sparingly in southern Indiana.

721 *(2135). Staphylinus tomentosus Grav., Mon. Col. Micr., 1806, 161.

Resembles mysticus in form and structure. Color wholly uniform black. opaque; thorax, elytra and abdomen sparsely clothed with short, black (rarely brownish) pubescence. Antennæ in both species reaching middle of thorax. Head and thorax in both very densely and regularly punctate. the punctures of head coarser than those of thorax. Length 14-16 mm.

Throughout the State; frequent. February 6-October 21. Occurs especially along the beaches of lakes, feeding on decaying fish; also on fungi.

722 (2136). Staphylinus fossator Grav., Mon. Col. Micro., 1806, 164.

Elongate, rather robust. Black, subopaque; antennæ and legs piceous; elytra usually with a large spot of golden pubescence on the outer apical angles. Head, antennx and thorax much as in mysticus, the punctures of head coarser; the thorax with a narrow, smooth median line on basal half. Elytra as wide as thorax, together as broad as long, densely and roughly punctate. Abdomen slightly narrower than elytra, sparsely pubescent, densely and finely punctate. Length 13-17 $\mathrm{mm}$.

Putnam and Lawrence counties; rare. August 5-August 21. Occurs in decaying fleshy fungi.

723 * (2138). Staphylinus cinnamopterus Grav.. Mon. Col. Micl., 1806. 164.

Elongate, rather slender. Head, thorax, elytra, tibiæ, tarsi, apical margins of abdominal segments and entire last segment, brownish-red; antenne. under surface, femora and abdomen in great part piceous. Antemm a little longer than head, slightly paler toward the tip. Thorax as wide as 
head. sides straight or feebl̦ curred. base broadls curred: disk coarsely and rather closely punctate. with a narrow. entire smooth median line. Elytra slightly wider than thorax. densely punctulate, sparsels mubsent. Abdomen eridentls narrower than elstra. slightls iridescent. more coarsels punctate beneath than above. I ength $12-13.5 \mathrm{~mm}$.

Throughout the State: common. February 22-December \&. Occurs on fungi and beneath bark: hibernates beneath logs. mullein leares. etc. The specimens taken in Lake Countr by Wolcott along the beach of Lake Nichigan arerage larger and have the femora wholly reddish-brown. They indicate a distinct race.

\section{4 (2137). Staphilints comes Lec. N. Sp. N. Amer. Col., I. 1863. 36.}

Resembles the preceding in form and size. Piceous, feebly shining: tibiæ. tarsi and tip of abdomen pale. Head broader, more coarsels and confluently punctate and more pubescent than in cinnamopterus. Abdomen with an indistinct double row of relrets spots abore and sometimes with a pale rellowish spot each side on segments one to fire below. Otherwise as in the preceding. Length $11.5-12.5 \mathrm{~mm}$. A member of the Austroriparian fauna.

Lake, Vigo and Posey counties: rare. April 19-June 9. Occurs beneath dung.

\section{5 (2139). Staphylines violaceus Grar.. Mon. Col. Micr., 1S06. 132.}

Elongate, rather slender. Black. shining: head, thorax and elrtra dark riolet blue to cupreous. Antennæ piceous, slightls longer than head. Thoras as wide as head. as wide as long, sides feebly, base more broadly curred: disk coarsely and rather sparsely punctured and with a distinct, smooth median line. Elstra slightly wider than thorax. densely punctulate. sparse15 pubescent. Abdomen narrower than elstra, iridescent. densels and finely punctate at base. more coarsely and sparsely toward apex. Length 12$14 \mathrm{~mm}$.

Throughout the State; frequent. April 9-August 19. Occurs on fungi. at carrion and beneath bark and logs. The base of abdomen abore is sparsely clothed with silver-gray. pubescence which is plainly risible only in a side light.

S. viridanus Horn, 15-16 mm. in length, occurs from New England to Nichigan and has been taken near Cincinnati. S. exulans Erichs., 11-1t mm. in length, is said to range from Canada to Georgia. Both species probably occur sparingly in the State.

\section{OCrPts Kirby. 1837. (Gr., "swift + foot.")}

One elongate. parallel species. having the middle coxæ not separated by the mesosternum and the last joint of the labial palpi oral. dilated, occurs in the Eastern United States and Indiana. 
726 (2144). Ocypes ater Gray.. Mon. Col, Micr'., 1S06, 166.

Black, shining: tibire, tarsi and basal half of antenne piceons. Antemne slender, reaching middle of thorax. Head distinctly broadel than long, finely and sparsely punctate. Thorax longer than broad, slightly narrower than head: sides nearly straight, rounded into base: disk finely and sparsely punctate. Elytra a little wider than thorax, together slightly longer than wide, finely and densely punctate. sparsely pubescent. Abdomen slight-

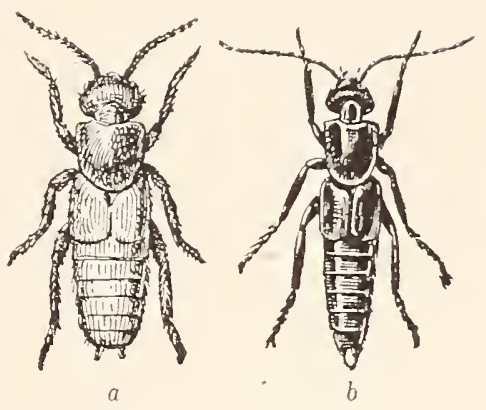

Fig. 159. (After Knobel.) ly narrower than elytra, abore coarsely and rather closely punctate on basal half, more finely and sparsely toward apex. Length $15-17.5 \mathrm{~mm}$. (Fig. 159, 6.)

Vigo and Posey counties: rare. MFay 11-July 5. Occurs beneath stones and other cover near water.

XXXIV. Belonuchus Nordm. 1837. (Gr., "a dart + to have.")

One small black and yellow species having the femora armed beneath with a row of fine. slender spines, occurs in the State.

727 (2146). Belonuchus formosus Grav., Mon. Col. Micr., 1S06, 72.

Elongate, slender. Reddish-yellow; head, thorax and last two segments of abdomen black, shining. Antennæe reaching middle of thorax. fuscous, the three basal joints piceous, apical one paler. Head slightly broader than thorax. coarsely and very sparsely punctate and with a lengthwise impression between the bases of antennæ. Thorax slightly longer than wide, sides nearly straight, rounded into base; disk with a row of five deel' punctures each side of middle, and with about six others between these and margins. Scutellum piceous, coarsely punctured. Elytra one-half wider and slightly longer than thorax, finely and sparsely punctate. Abdomen slightly narrower than elytra, sparsely pubescent, the dorsal segments punctured on their basal halres. Length $6.5-7.5 \mathrm{~mm}$.

Southern half of State; common. April 17-November 10. Occurs at maple and other sap, in decaying fungi and carrion, and rarely on flowers.

XXXV. Philonthus Curt. 1830. (Gr.. "a lover of dung.")

A large group of small, slender beetles distinguished from allied genera only by the characters given in the generic key. The thorax, in the great majority of species, is marked on the middle of the disk with a donble row of dorsal punctures, and the number of punctures in these rors is used in separating the genus into groups. 
The puncture on the apical margin in front of each of these rows is not counted as belonging to the discal or dorsal row, but to the marginal series.

The males in most species have the front tarsi more or less dilated and rather pubescent beneath and the terminal ventral segment always more or less emarginate. For convenience the genus was divided by Horn into five groups, all of which are represented in Indiana.

KEY TO GROUPS OF THE GENUS PHILONTHUS.

a. Thorax with distinct and regular rows of dorsal punctures.

b. Front tarsi more or less dilated and silken pubescent beneath.

c. Three punctures in each dorsal row.

cc. Four punctures in each dorsal row.

Group $A$.

cce. Five punctures in each dorsal row.

Group $B$.

Group $C$.

$b b$. Front tarsi filiform in both sexes and finely spinose beneath; dorsal rows of punctures regular but varying in number. Group $D$. aa. Thorax irregularly punctured, no distinct dorsal rows; front tarsi dilated.

Group $E$.

\section{Group A.}

In this group the front tarsi are dilated and the discal rows contain but three punctures each. The following species have been taken or should occur in the State:

KEY TO INDIANA SPECIES OF GROUP A.

a. 'Thorax not narrowed in front, as wide as long; larger, 6 or more mm.

$b$. Elevated line at base of each of the first three dorsal segments of abdomen in the form of a brace. $\underbrace{-}$; abdomen above coarsely punctured; last ventral of male with a triangular notch.

728. POLITUS.

$b b$. Basal lines of dorsal segments straight.

c. Black or piceous, elytra more or less bronzed.

d. Elytra shining, closely punctured; thorax with a peculiar golden iridescence at base.

SERICINCS.

dd. Elytra rather sparsely and finely punctate; head oval, not wider than long; legs reddish-brown.

729. UMBRATILIS.

cc. Bicolored; black, thorax and base of abdomen red.

730. LETULUS.

aa. Thorax narrowed in front; elevated line at base of dorsal segments straight.

e. Elytra black, distinctly bronzed, roughly punctate.

ASPER.

ee. Elytra dark or dull yellow, not bronzed, simply punctate.

731. HePaticus.

729 (2149). Philonthus politus Limn., Faun. Suec., 1746, 843.

Elongate, rather robust. Black, shining; elytra bronzed, sparsely pubescent. Antennæ piceous, reaching base of thorax, joints 5-10 broader 
than long. Head feebly bronzed, sparsely punctate behind the eyes. Thorax slightly broader than long. sides sinuate behind the middJe, then rounderl into base. Elytra a little wider than thorax, together almost square; sparsely and rather finely punctured. Abdomen slightly narrower than elytra, rather coarsely and closely punctate above, more sparsely beneath; last ventral segment with a small triangnlar notch in male. Length 10 $12.5 \mathrm{~mm}$.

Vigo and Crawford counties; rare. April 17-June 27. Occurs in stable manure.

$P$. sericinus Horn, $11 \mathrm{~mm}$. in length, is known from Canada, Pennsylvania and Texas, and therefore should occur in Indiana.

729 (2156). Philonthus umbratilis Grav., Micr., 1802, 170.

Rather slender, subfusiform. Black, moderately shining; elytra feebly bronzed, sparsely clothed with brownish hairs. Head subquadrate, punctnred near the hind angles. Antenna piceous, slightly longer than head and thorax, joints 5 to 10 a little longer than wide. Thorax slightly longer than wide, sides nearly straight, dorsal punctures deep. Elytra wider than thorax, together nearly square, finely and rather closely punctate. Abdomen more finely and less densely punctate than elytra. Last ventral of male deeply notched. Length $7-8 \mathrm{~mm}$.

Kosciusko County; rare. July 24. Taken from beneath rubbish on shores of Lake Wawasee. A boreal species which also occurs in Europe.

730 (2157). Philonthus Letulus Say, Trans. Amer. Phil. Soc., IV, 1834, 449 ; ibid. II, 564.

Elongate, slender. Head. elytra and thi'ee apical segments of abdomen black; thorax, femora and three basal segments of abdomen dull red; tibiæ and tarsi piceous. Thorax nearly square, narrower than head; sides sinuate behind middle, then rounded into base. Elytra slightly wider and one-third longer than thorax, sparsely and finely punctate, very sparsely pubescent. Abdomen coarsely and sparsely punctate. Length 6-9 $\mathrm{mm}$.

Marion and Lawrence counties; scarce. April 18-September 12. Occurs in fungi.

P. asper Horn, $8.5 \mathrm{~mm}$. in length, has been recorded from Cincinnati and very probably occurs in southern Indiana. It is found in the stems of mushrooms.

731 (2167). Philonthis Hepaticus Erichs.. Gen. Spec. Staph., 1840, 451.

Slender, subfnsiform. Head black; thorax and elytra dark brown, the latter sometimes dull yellow; abdomen and under surface piceous. Antennæ slender, reaching base of thorax, piceous. the two basal joints and legs pale yellowish. Head small, oval, narrower than thorax, with a very few coarse punctures, two of which are on the front between the eyes. Thorax longer than wide, sides nearly straight. Elytra wider than thorax, 
finely but not densely punctured, sparsely clothed with yellowish hairs. Abdomen slightls narrower than elytra. more finels and densely punctate. Male with last rentral acutels and deeply notched. Length $4.5-5.5 \mathrm{~mm}$.

Throughout the State; frequent. April 8-August 15. Occurs on fungi and beneath dead leares and logs. The abdominal segments have their apical margins always paler.

\section{Group B.}

In this group the front tarsi are dilated and there are four punctures in each of the dorsal rows of thorax. The males are readily separated by the notch of the last ventral segment.

\section{KEI TO INDIANA SPECIES OF GROUP B.}

a. Front tarsi of males rers broadly dilated, sometimes plate-like.

b. Thorax oral, distinctly narrowed in front; elytra black or piceous, coarsels not closels punctured; length $6.5-8 \mathrm{~mm}$. 732. uMBRINCs.

bb. Thorax quadrangular. vers little narrowed in front.

c. Elytra clear red, rers sparsels and rather finely punctate.

733. PALLIATLS.

cc. Elytra black or piceous, at least moderately punctate.

d. Black; last rentral of male with a rather deep, lengthwise impression extending nearly to its base.

734. QUADRICOLIIS.

dd. Bromnish or piceous; last rentral of male without a lengthwise impression: legs and basal joints of antennæ pale.

735. DEBILIS.

a . Front tarsi of males moderately dilated, sometimes very little wider than in the female.

e. Larger, 5-7.5 mm.; antennæ slender, the outer joints longer than wide.

f. Elytra rather densels punctured; abdomen rery distinctly punctured.

TARIANS.

ff. Elytra sparsely punctured, slightly bronzed; abdomen rery indistinctly punctured.

736. LONGICORNIS.

ee. Smaller. not orer $5 \mathrm{~mm}$. : antennæ slender. outer joints quadrate.

$g$. Thorax as wide as long; hindmost dorsal puncture distant from the third.

DISCOIDELS.

gg. Thorax longer than mide: punctures equidistant.

THERMARUM.

732 (2169). Philonthus umbrixus Grar., Mon. Col. Micr., 1S06, 169.

Ioderately elongate. rather robust. Body black, strongly shining; legs piceous or dull bromnish-yellow. Antennæ reaching middle of thorax. joints 4-10 gradually shorter and wider than long. Head subquadrate, front with two pairs of punctures abore each eye; hind angles sparsely punctate. Thorax conrex. slightly longer than wide, the hindmost puncture somewhat distant from the third. Elytra slightly wider than thorax. sparsely clothed with bromnish hairs. Abdomen iridescent. sparsely and rather coarsely punctate. Last rentral segment of male deeply notched, the margins of the notch groored. Length 6.5-S mm.

Vigo County; rare. July 1. Taken from decaying fleshy fungi. 
733 (2171). Philonthus pallitatus Grav., Mon. Col. Micr., 1806, 53.

Elongate, slender, parallel. Black, shining; elytra, legs and base of antenna dull reddish-yellow. Antenne piceous, not reaching base of thorax. joints 5-10 nearly square. Thorax slightly longer than wide, dorsal punctures large, deep and equidistant. Elytra scarcely wider and not longel. than thorax, sparsely pubescent. Abdomen a little narrower than elytra, coarsely and sparsely punctate. Male with last ventral broadly and shallowly notched at apex. Length 6-6.5 $\mathrm{mm}$.

Laporte, Starke and Putnam counties; rare. July 10-August 20. Occurs beneath cover near water.

734 (2175). Philonthus quadricollis Horn, Trans. Amer. Ent. Soc., XI, 1884, 194.

Elongate, slender, parallel. Black, shining; antennæ and legs piceous, the former reaching base of thorax. Head with a few coarse punctures behind the eyes and two on middle of front. Thorax slightly wider than head, a little longer than wide. Elytra slightly wider than thorax, finely, not densely punctate; surface feebly bronzed, sparsely pubescent. Abdomen as wide as elytra. above sparsely and finely punctate at base. more densely toward apex. Length 5-7 mm.

Northern half of State, frequent; less so southward. May 8September 17. Occurs in fungi.

735 (2177). Philonthus debilis Grav., Mon. Col. Micr., 1806, 35.

Elongate, slender. Brownish-piceous to nearly black; legs reddishbrown, the tibiæ and tarsi darker; antennæ piceous, reaching middle of thorax, the two basal joints paler. Thorax wider than head, not longer than wide. Elytra slightly wider than thorax, sparsely and rather finely punctate, feebly pubescent. Abdomen above finely and sparsely punctate, beneath more coarsely punctate, the margins of the segments paler; last ventral of male deeply notched. the margins of the notch grooved. Length 5-6 mm.

Lake, Starke and Kosciusko counties; rare. April 7-July 24.

736 (2179). Philonthus longicornis Steph.. Illus. Brit. Ent., V, 237.

Subfusiform, rather robust. Black, shining, sparsely pubescent. Неad oval, hind angles punctured; antenne piceous, as long as head and thorax, joints 4 to 10 slightly longer than broad. Thorax oval, a little longer than wide, distinctly narrowed in front; sides nearly straight; dorsal punctures deep, the hind ones more distant. Elytra wider than thorax, slightly wider than long; rather densely and roughly punctate. Abdomen above finely and densely punctured, more so at the bases of the segments; iridescent and more densely punctate heneath. Length $6-7.5 \mathrm{~mm}$.

Kosciusko County ; rare. October 21. In the only specimen at hand the dorsal punctures of thorax are four on one side and five on the other.

[25-23402] 
P. varians Payk.. 5-6.5 mm.; P. discoideus Grav., 4-5.5 mm.. and P. thermarum Aubé, $3 \mathrm{~mm}$. in length, all have a known distribution which should bring them within the limits of the Indiana fauna. but no one of them is represented in the collection at hand.

\section{Group C.}

In this group the punctures of the dorsal rows of thorax are five in number and the front tarsi of males are rather widely dilated; those of females more narrowly dilated.

KEY TO INDIANA SPECIES OF GROUP C.

a. Males with the last two ventral segments notched at apex; color rariable; surface densely punctate; length $4.5-5.5 \mathrm{~mm}$.

ALUMNUS.

a a. Males with the last segment only notched.

b. Elytra red.

c. Thorax entirely red. distinctly narrowed in front, much wider than head and as broad as the base of elytra.

737. THORACICUS.

cc. Thorax black.

d. Thorax distinctly narrowed in front; bods spindle-shaped.

738. FUSIFORMIS.

$d d$. Thorax scarcely narrowed in front; form parallel; legs and base of antennæ pale yellow.

739. FULVIPES.

bb. Elytra black or piceous.

e. Legs and antennæ wholly black; elytra black; length $10 \mathrm{~mm}$.

740. SCHWARZI.

ce. Legs and base of antennæ paler; general color piceous.

$f$. Head oval, distinctly narrorred behind the eyes.

g. Elytra and abdomen opaque, very densely and finely punctured; antennæ rather short and stout; joints $5-10$ broader than long; length $4.5-5 \mathrm{~mm}$.

741. MICANS.

gg. Elytra more or less shining, neither densely nor finely punctate.

h. Antennæ slender, the joints all longer than wide; length 6.5-8 $\mathrm{mm}$.

i. Basal joint of antennæ pale; abdomen not coarsely punctate.

742. LOMATUS.

ii. Antennæe entirely piceous: elytra more coarsels. abdomen more sparsely, punctate than in lomatus. CUNCTANs.

hh. Antennæ shorter. the outer joints not longer than wide: abdomen quite coarsely punctured; length $5 \mathrm{~mm}$. ÆQUALTS.

ff. Head quadrate, not narrowed behind the eyes; abdomen finels punctulate; elytra brownish; length $5 \mathrm{~mm}$. 743. BRUNNECs.

737 (2184). Philonthus thoracicus Grav.. Mon. Col. Micr., 1806, 170.

Slender, subfusiform. Piceous, shining; thorax and elytra dull red; legs and three basal joints of antennæe brownish-yellow. Antennie reaching beyond base of thorax, joints all longer than wide. Thorax described in key. Elytra together broader than long, not longer than thorax, rather 
densely and finely punctured, sparsely pubescent. Abdomen as wide at base as elytra, thence tapering to apex, less densely and more coarsely punctured. Length 7.5-S $\mathrm{mm}$.

Throughout the State; searee. April 22-August 12. 'T'aken from beneath stones and logs.

738 (2185). Philonthus fusiformis Melsh., Proc. Phil. Acad. Nat. Sci., II, 1844, 38.

Moderately elongate, fusiform. Head and thorax black, strongly shining; elytra dull red; antennæ, under surface and abdomen piceous; legs brownish-yellow. Antennæ reaching base of thorax, all the joints longel than wide, two basal ones paler. Thorax wider than head, not longer than wide. Elytra slightly wider than thorax, together a little longer than wide, rather coarsely and closely punctate, sparsely pubescent. Abdomen as wide at base as elytra, thence feebly tapering to apex, sparsely and coarsely punctate. Length $5-5.5 \mathrm{~mm}$.

Lake and Putnam counties; rare. April 10-June 15.

739 (2186). Philonthus fulvipes Fab., Syst. Ent., I, 1785, 526.

Slender, parallel. Head, thorax and abdomen black, shining; elytra pale red; antennæ and under surface piceous. Antennæ reaching base of thorax, joints 5-10 as wide as long. Thorax slightly wider than head, a little longer than wide. Elytra slightly wider than thorax, together a little wider than long, rather sparsely and finely punctate. "Abdomen as wide at base as elytra, sides almost parallel, surface rather coarsely and closely punctate. Length $6.5 \mathrm{~mm}$.

Starke County; rare. April 26. Taken from beneath cover in sandy woodland pasture.

740 (2188). Philonthus schwarzi Horn, Trans. Amer. Ent. Soc., XI, $1884,201$.

Robust, fusiform. Uniform black, shining. Antennæ slightly longer than head and thorax, joints all longer than wide. Head small, orbicular, sparsely punctured behind the eyes. Thorax much wider than head, not longer than wide, narrower in front; dorsal punctures fine and equidistant. Elytra slightly wider than thorax, together a little vider than long, densely, finely and roughly punctate. Abdomen feebly iridescent, more coarsely and sparsely punctured than elytra. Length 9-10 $\mathrm{mm}$.

Wolf Lake and Pine, Lake County; frequently locally. March 26-May 21. Taken by Wolcott from beneath cover on sandy beaches. One of our largest and most robust species of Philonthus. Recorded heretofore only from Massachusetts and Detroit, Michigan.

741 (2196). Philonthus micans Grav., Mon. Col. Micr., 1806, 25.

Elongate, slender. Head piceous; elytra and abdomen brownish or piceous; legs dull yellow. Antennie reaching base of thorax, piceous, the basal joint paler. Thorax much wider than head, as broad as long, slightly 
narrowed in front. Elytra very little wider than thorax, densely punctured, subopacue, finely pubescent. Abdomen parallel, slightly iridescent, densely and rather finely punctate. Length $4.5-5 \mathrm{~mm}$.

Steuben, Vigo, Lawrence, Posey and Crawford counties; rare. April 22-October 7 .

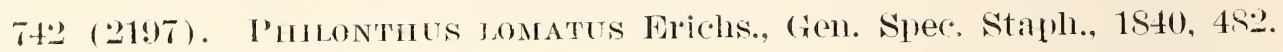

Moderately elongate. more robust than in micans. Head black, shining: thorax and elytra black or dark brown, bronzed; under surface and abdomen piceous. the malrgins of the ventral segments paler; legs dull rellow. Antenne nearly half the length of body. Thorax oval, longer than wide, narrowed in front. Elytra not wider at base than thorax, together one-third longer than wide; rather closely and finely punctate. Abdomen more sparsely punctate and as wide at base as elytra, thence feebly but distinctly tapering to apex. Male with front tarsi rather broadly dilated and last ventral with a triangular notch. Length $6.5-8 \mathrm{~mm}$.

Throughout the State; one of the most common of the Staphylinids. March 17-October 14. Occurs beneath cover, more commonly in low moist places.

$P$. alumnus Erichs. and $P$. cunctans Horn are species of southern range, which may perhaps be found in southern Indiana. $P$. aqualis is a member of the boreal fauna which may inhabit the northern counties of the State.

$743 *(2200)$. Philonthus brunneus Grav., Mon. Col. Micr., 1806, 172.

Short, rather robust. Dark chestuut-brown to piceous, shining; legs and basal joints of antenne dull yellow; apical margins of ventral segments paler. Antennæe reaching middle of thorax, joints $4-10$ as wide as long. Thorax slightly wider than head, longer than wide, feebly narrowed in front. Elytra very little wider than thorax, densely, finely and roughly punctate. Abdomen densely and finely punctate above, more sparsely and coarsely beneath. Apex of last rentral of male with a large oval notch. Length 5-5.5 mm.

Throughout the State; frequent. March 13--December 8. Occurs in fungi and beneath rubbish in damp woods; also at carrion.

Group D.

In this group the front tarsi in both sexes are not at all dilated and the under surface of the tarsal joints bears sparse, short, stiff hairs, while in the preceding groups the under surface is thickly clothed with silken hairs. The dorsal punctures are variable in number.

$$
\text { KEY TO INDIANA SPECIES OF GROUP D. }
$$

a. Dorsal punctures three.

万. Thor:ax wirler than long; elytra metallic blue or green.

744. CYANIPENNIS. 
bb. Thorax oval, as long or longer than wide, not or but slimhtly malrowed in front.

c. Species bicolored.

1. Blue-black; thorax and base of abdomen reddish-yellow.

dr. Piceons: elytra red, nealy smooth.

745. BLANIUUS. re. Species not bicolored.

QUEDINUS.

e. Entirely black, elytra bronzed; abdomen distinctly punctate.

$f$. Notch of last ventral of male oval.

$f f$. Notch of last ventrai triangular.

746. SORDIDUS.

CePHALOTES.

ee. Piceous or fuscous yellow, head black; abdomen sparsely punctured beneath.

au. Dorsal punctures more than three.

INQUIETUS.

g. Dorsal punctures four.

h. Thorax nearly square; length $5 \mathrm{~mm}$.

747. VEnTRALIS.

hi. Thorax longer than wide, its sides parallel; elytra black, as long or longer than thorax, nearly smooth at sides and base.

FALLACIOSUS.

g\%. Dorsal punctures five; tholax oblong, notably longer than wide.

$i$. Piceous or brownish.

$j$. Last ventral of male without a notch but with a channel extending the entire length of the segment.

748. PARVUS.

$j j$. Notch of last ventral distinct, broad, senicircular.

749. MICROPTHALMUS.

ii. Black, shining; notch of last rentral very feeble and with a long triangular smooth space.

ggg. Dorsal punctures seven or eight.

750. NigRiTULUS.

751. MULTIPUNCTATUS.

744 (2201). Philonthus cranipennis Fab., Ent. Syst., I, 1785. 525.

Elongate, robust. Black, shining; elytra metallic blue; antenns and tarsi piceous. Head large, quadrate, as wide or wider than thorax, coarsely punctured behind the eyes. Thorax oval, slightly narrower in front. Elytra slightly wider than thorax, together broader than long, coarsely and rather densely punctate, sparsely pubescent. Abdomen iridescent. more coarsely and sparsely punctured than elytra. Length 12-15 mm.

Throughout the State; frequent. April 27-October 23. Occurs on fleshy fungi.

745 (2202). Philonthus blandus Grav., Mon. Col. Micr., 1806, 72.

Elongate, slender. Head, elytra and apical half of abdomen black. shining, often with a bluish tinge; thorax, base of abdomen and legs reddish-yellow; antenna piceous. Head subquadrate, sparsely punctured behind the eyes. Thorax scarcely wider than head, sides sinuate near base. Elytra slightly wider than thorax, together one-fourth longer than wide. sparsely and finely punctate. Abdomen as wide as elytra, very sparsely punctate. Length $5-5.5 \mathrm{~mm}$.

Throughout the State; searce. May 11-Octoher 31. Occurs in leathery fungi on beech and elm stumps. 
P. qucdimus Horn. $6 \mathrm{~mm}$, in length. was described from Detroit and Kansas and should. therefore. ocom in Indiana.

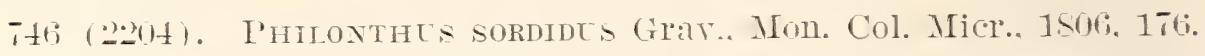

Elongate. slender. Black, shining: elçtra bronzed: antennæe and legs: piceous. the former shorter than head and thorax. joints $5-10$ wider than long. Thorax not wider than head, slightly wider than long, not narrowed in front. Elytra a little wider than thorax, coarsels. roughly and sparsely punctate. Abdomen parallel, more finely and sparsely punctate than elstra. the rentral segments with their apical margins paler. Length $5.5-7.5 \mathrm{~mm}$.

Marion County: scarce. April 12. Taken from beneath carrion.

$P$. cephalotes Grar., length 6-7.5 mm.; $P$. inquietus Erichs.. length $5 \mathrm{~mm}$.. and $P$. fallaciosus Horn. length $4 \mathrm{~mm}$.. all have a range which denotes the possibility of their occurrence in Indiana.

\section{iti (2209). Philonthes textralis Grar. Mon. Col. Micr., 1S06, 17.}

Rather short, robust. Head and thorax black. shining; elytra and abdomen piceous or dart bromm; antennæ piceous. as long as head and thorax. joints \pm-10 as wide as long. the two basal ones and legs dark reddish-bromb. Thorax slightly wider than head, not narrowed in front: dorsal punctures deep. the fourth somerhat distant from third. Elstra slightly wider than thorax, rather finely not closels punctate. Abdomen sparsely and finels punctate. Notch of last rentral of male feeble. Length $5 \mathrm{~mm}$.

Lake and Koscinsko counties; scarce. Mat 5-July 24.

its (2216). Philoxthts pabits Hom, Trans. Amer. Phil. Soc. MI. 1Sit. 214.

Elongate, slender. Piceous. feebly shining: elstra slightly bronzed: antenne duskr. two basal joints and legs dull jellow. Antennæe as long as head and thorax, joints 6-10 as wide as long. Thorax oblong. not wider than head. longer than wide: sides nearly parallel: punctures equidistant. Elytra together distinctly longer than wide, slightly wider and about as long as thorax. rather finely and sparsely punctate. Abdomen slightly iridescent. the punctures finer than on elytra. Length $4.5 \mathrm{~mm}$.

Narion. Putnam and Clark counties; scarce. April 4-October 17. The male is easily distinguished from the next by the entire groove of last rentral: the female has elytra longer. more sparsely punctate and evidently bronzed. Described from Arizona. Specimens were submitted to H. C. Fall for rerification.

749 (2222). Philoxthes microphthalmes Horn. Trans. Amer. Ent. Soc.. II, 1SS4. 216.

Elongate. slender. Head and thorax black: elytra, abdomen. tibia and tarsi piceons: femora dull rellow. Antenna shorter than head and thorax. joints j-10 as wide or wider than long. Thorax scarcels wider than head. sides nearly parallel: punctures equidistant. Elytra sligbtly 
wider than thorax. together a little longer than wide; ratlex roarsely and sparsely punctate. Abdomen parallel, more finely punctate than elytrid. Length $3.5-4.5 \mathrm{~mm}$.

Throughout the State; scarce. April 21-November 28. Taken bre sifting; also sometimes by beating low herbs.

750 (2221). P'Hilonthes NigrtTulus Grar. Micr., 1S02. 41.

Elongate, slender. Black, shining: elytra often feebly bronzed; less piceous or paler. Head oral, its sides parallel , hind angles sparsely punctate. Antennie piceous, as long as head and thorax. joints 7 to 10 not longer than wide. Thorax not wider than head. longer than wide; dorsal punctures equidistant. Elytra slightly wider and a little longer than thorax. sparsely and finels punctate. Abdomen sparsely and more finely punctured than elytra. Length $4.5-5 \mathrm{~mm}$.

Starke County ; scarce. May 18. Sifted from decaying sphagnum moss. A member of the boreal fauna.

751 (- -). Philonthes meltiplnctates sp. nor.

Elongate, slender. Dark chestnut brown. feebly shining: antennie piceous, the two basal joints and legs reddish-brown. Antenne slightly longer than head and thorax, joints $5-10$ as broad as long. 11th rery little longer. Head subquadrate. longer than wide. sides parallel. Thorax rery little wider than head. slightly longer than wide: dorsal punctures eight. the rows diverging toward base. the last puncture nearer the median line. Elctra slightly wider than thorax, together one-fourth longer than wide. rather finely. shallowly and sparsely punctate. Abdomen parallel, as wide as elrtra. abore finely and rather closely. beneath much more sparsely. punctate. Last rentral of male with a broad rounded median notch. Length $44.5 \mathrm{~mm}$.

Lamrence County: rare. May 9. Taken from beneath decaying fleshy fungi.

Group E.

Medium or rather large species. 7 or more mm. in length. having the punctures of dorsal rows irregular or confused. or sometimes the entire thorax with numerous or eren dense punctures. Last ventral of male always emarginate.

KEY TO IXDIANA SPECIES OE GROUP E.

a. Thorax longer than wide, either parallel or narrowed behind.

b. Thorax with rerr few punctures: head oval. nearly smooth, narrowed behind the eyes: length $\$ .5 \mathrm{~mm}$.

SERPENTINTS.

$b b$. Thorax with nmmerous coarse punctures: head transverse or quadrate, not narrowed behind: length $9-13 \mathrm{~mm}$.

c. Head transver'se. wider than long.

a. Antennie bead-like: el̦̣tra red: abdomen brown.

752. BALTIMOREXSIS. 
dd. Antennie of normal form ; tip of abdomen reddish.

753. APICALIS.

cc. Head quadrate, punctured beneath; legs pale yellow; length $7.5 \mathrm{~mm}$.

VIRIDANUS.

au. Thorax oval, as wide as long, distinctly narrowed in front.

c. Thorax densely punctured, a narrow median space only smooth; less pale yellow; length $9.5 \mathrm{~mm}$.

CONFER'TUS.

ee. Thorax coarsely and sparsely punctured; legs piceous; last ventral of male feebly emarginate: length 7.5-9.5 mm. 754. AURULentus.

P. serpentimus Horn, reddish-brown, head and thorax black, was described from a specimen taken in Kentucky. near Cincinnati. It doubtless occurs in southern Indiana.

752 *(2228). Philonthus baltimorensis Grav., Mon. Col. Micr., 1806. 163.

Elongate, robust. Head and thorax black; elytra dull red; legs piceous, the tarsi paler. Antenne reaching middle of thorax, piceous, the apical joint pale. Thorax scarcely as wide as head, slightly longer than wide. distinctly narrowed behind the middle. sparsels and irregularly punctate. smooth at middle. Elytra wider than thorax, its surface, as well as that of abdomen, rather coarsely, not densely punctate. Length 10-13 mm.

Throughout the State; scarce. March 18-December 10. Hibernates beneath logs and rubbish in fence rows.

753 (2229). Philonthus apicalis Say, Trans. Amer. Phil. Soc., IV, 1834, 451 ; ibid. II, 566.

Elongate, rather robust. Black, shining: tar'si, terminal joint of antemmæ and last three segments of abdomen reddish-brown. Antennæe reaching middle of thorax, joints 6-10 as wide as long. Thorax slightly narrower than head, a little longer than wide, feebly narrowed behind, punctate as in baltimorensis. Elytra wider than thorax, together one-third longer than wide; surface as well as that of abdomen. coarsely and sparsely punctate. Length 9-11 $\mathrm{mm}$.

Lake, Marion and Putnam counties; rare. May 3-October 31. Occurs beneath logs on damp wooded hillsides.

$P$. viridanus Horn, occurring "from the Niddle States westward to Missouri," and P. confertus Lec., known from Canada. Iowa. Illinois, and Kansas, probably occur in Indiana but are not represented in the collections.

754 (2234). Philonthis al Rulentus Horn, Trans. Amer. Ent. Soc., XI. 1884, 222.

Elongate robust. Black, feebly bronzed or iridescent. Antennie piceous. slightly longer than head and thorax, joints 8-10 wider than long. Hearl subquadrate. roarsely punctate at sides, smooth at middle. Thorax as wide as long. smooth at mindile. coulsely and lather evenly punctate at sides. Elytral slightly wider than thorax, together a little longer than wide. 
densely and rather finely punctate. Abdomen sparsely and finely punctate above, more distinctly beneath. Length \& $\$ .51111$.

One in Wolcott rollection from beach of I ake Michigan near Pine, Lake Comnty. June 6. Known foom Michigan, Kentucky and the northwest.

\section{Actobus Fauvel. 1875. (Gr., "shore + I live.')}

Small, slender, sparsely pubescent species having the last joint of maxillary palpi conical, acute and longer than the next to last joint; the first joint of hind tarsi equal to or shorter than fifth. The males have the front tarsi more or less dilated and the last ventral emarginate, often feebly so. Twenty-three species are listed from the United States. Of these the following have been taken or probably occur in Indiana:

\section{KEY TO INDIANA SPECIES OF ACTOBILS.}

a. Upper surface black or piceous.

b. Elytra very densely punctured and opique.

$c$. Head opaque, very finely and densely punctured both above and below.

75.5. CINERASCENS.

cc. Head more or less shining, punctures abore coarse and much less dense.

d. Thorax oral, very little longer than wide.

$e$. Elytra longer than thorax, the latter not narrower behind.

756. NANUS.

cc. Elytra not longer than thorax, the latter rery plainly narrowed behind.

INUTILIS.

dd. Thorax oblong, much longer than wide; elytra depressed, parallel, longer than thorax.

75T. FRATERCULUS.

b6. Elytra more or less shining, their punctures distinct.

$f$. Thorax oblong, narrower behind, its punctures numerous, irregularly placed; elytra ristinctly longer than thorax, paler at tips, the punctures sparse and rather coarse.

75.S. SOBRINUS.

ff. Thorax more or less oval, not narrowed behind, the punctures fewer and arranged in three inregular rows each side.

y. Elytra finely and rather densely punctured; larger, 5-6 $\mathrm{mm}$.; piceous, the legs pale.

h. Elytra very densely punctured ; front tarsi of male very broadiy dilated.

PATELLA.

hh. Elytra shining. less densely punctured: front tarsi of male much less dilated.

759. Loxatus.

yg. Elytra conlsely punctured : smaller, not over 3.5 11m.; antemn:e and legs pale.

760. PARCUS.

an. Bicolored species; thorax and legs always rellow.

$i$. Abdomen above and beneath rather densely punctured. feebly or not at all shining. 
j. Apex of elytral with narrow pale border.

761. P.EDEROIDES.

ji. Elytra uniform in color, more elongate.

762. Jocosus.

ii. Alodomen rery sparsely punctured, more strongly shining; head and thorax with numerons punctures.

k. Metatholax nearly black : elytra widely dull yellow at tips.

TERMINALIS.

lik. Metathorax readish : elytri narrowly bordered with paler at tips.

UMBRIPEN NIS.

7.55 (2235). Aстовís cinerascens Grav.. Mon. Col. Micr., 1806, 49.

Elongate, slender. Head and thorax black; elytra and abdomen piceous, opaque; legs dusky yellow, the tibize and tarsi darker ; antennie brownish, paler at base and tip. shorter than head and thorax, the joints all longer than wide. Thorax not wider than head, very little longer than wide, sides sinuate: disk rather closely and coarsely punctate, with a narrow smooth space at middle. Llytra slightly broader than thorax, together one-third longer than wide: surface. as well as that of abdomen, densely and finely punctate. Length $4-5 \mathrm{~mm}$.

Marshall and Putnam counties; frequent. April 17-October 17. Taken by sifting damp regetable debris.

ïn (2236). Астовics raxus Horn, Trans. Amer. Ent. Soc., XI, 1884, 225.

Llongate, slender. Head and thorax black, shining; elytra and ab(1omen piceous, subopaque; antennie and legs dusky yellow. Head coarsely and sparsely punctate above, more finely and closely beneath. Thorax not wider than head. sides siuuate; disk sparsely and coarsely punctate on sides, with a broad median smooth space. Elytra slightly wider and onethird longer than thorax; surface. as well as that of abdomen. densels and finely punctate. Length $4.5 \mathrm{~mm}$.

Steuben and Posey counties; rare. April 21-Nay 25. Taken by sifting. Shorter and slightly stouter than cinerascens, with the head and thorax much more coarsely and sparsely punctate.

7.7 (2928). Actobius fraterculus Horn, Trans. Amer. Ent. Soc., XI, 1 SSt. 226.

Elongate, very slender, parallel. Head and thorax black, shining; elytra. and abdomen brownish-piceous, subopaque: antennie and legs pale brown, the former shorter than head and thorax, joints $8-10$ as long as wide. Head subquadrate, sparsely and coarsely punctured abore, more densely beneath. Thorax not wider than head. one-third longer than wide. rery little narrowed behind: disk coarsely and sparsely punctate, with a rather broad, median smooth space. Elstra slightly wider and one-third longer than thorax: surface. as well as that of abdomen. rather finely and densely punctate. Length $: 3 . \overline{3} \mathrm{~mm}$.

Marion County; rare. Tay 30. Taken from beneath bark of butternut. 
759 (2243). Actobius sobrixes Erichs.. Gell. Spec. Stallh., 1S40, 512.

Elongate, slender. Head and thorax black; elytra and abdomen piceous, shining; antenne brownish. joints $i-10$ as wide as long, the two basal ones and legs pale yellow. Head quadrate, coarsely and rather sparsely punctate on sides and beneath. Thorax not wider than head. coarsely and rather closely punctate except at middle. Elytra described in key. Abdomen sparsely punctate, the segments paler at tip, the first four dorsal ones deeply, transversely impressed at base. Length $4 . \overline{5}$ $5.5 \mathrm{~mm}$.

Throughout the State; frequent. April 9-October 17. Occurs beneath dead leaves and bark.

759 (2246). Aстовius loxatus Morn. Trans. Amer. Ent. Soc., XI, 18st. 229.

Elongate, broader than in the preceding forms. Head, thorax and elytra black, shining; abdomen and legs piceous. the tarsi paler: antennxe brownish, shorter than head and thorax, the joints longer than wide. Heat subquadrate, with a few coarse punctures along the sides. Thorax not wider than head, nearly as wide as long, punctures coarse, sparse. Elytra wider and slightly longer than thorax, together longer than wide. Abdomen subopaque, rather densely and finely punctate; the second and third dorsal segments shallowly impressed at base. Length $5-5.5 \mathrm{~mm}$.

Putnam and Poser counties; frequent. April 22-October 17. Sifted from beneath damp vegetable debris.

760 (2249). Actobius Parcus Horn, Trans. Amer. Ent. Soc.. XI. 1Sst. 234.

Slender, subfusiform. Black. shining; elytra and abdomen with a piceous tinge; legs dull yellow, the tarsi dusky; antennæ brownish, reaching middle of thorax; terminal joints paler. all as wide as long. Head oval, sparsely and coarsely punctate on sides and beneath. Thorax slightly wider than head, rery little longer than wide; the punctures each side of the median smooth space arranged in a regular low of seren. Elytra a little wider and longer than thorax, sparsely and coarsely punctate. Abdomen more finely punctate, the second and third dorsal segments narrowly transversely impressed at base. Length $3.5 \mathrm{~mm}$.

Kosciusko. Starke and Putnam counties; frequent. April 17October 17. Taken by sifting:

761 (2251). AстовIUS Pæderoides Lec.. N. Sp. N. Amer. Col.. I. 1863, 38.

Elongate, slender. Head, meso- and metasterna and tip of abdomen black; tholax, base of abdomen and legs sellow: elytra black with a bluish tinge, the tips paler; antennæ piceous, three basal joints paler. joints 6-10 as wide as long. Head rery coarsely punctate. smooth at middle. Thorax oblong. not wider than head, slightly narrower near base: sides distinctly sinuate: disk coarsely and rather sparsely punctate with a narrow median smooth space. Elytia rather coarsely. not densely punctate. Length $3.5-$ $4.5 \mathrm{~mm}$.

Throughout the State; scarce. May 19-September 4. Oceur's beneath rubbish along the margins of ponds and streams. 
762 (2252). Aстовіus jocosus Horn, Trans. Amer. Ent. Soc., XI, 1SS4, 232.

Elongate, slender. parallel. Color of preceding except that the elytra are wholly black, and the antennæ brown. paler at base. Thorax oblong, slightly narrowed behind. sides almost straight, punctate as in paderoides; elytra much longer and more coarsely punctured than there. one-half longer than wide. Length $4.5 \mathrm{~mm}$.

Lake County ; rare. June 15. Taken from beneath the pricklypear cactus.

A. inutilis Horn. 3.5-4 mm. : A. patella Horn. 5 mm.; A. terminatis Lec.. $4.5 \mathrm{~mm}$. and $A$. umbripennis Lec.. $3.5 \mathrm{~mm}$. in length; all have a known range which might include Indiana in their distribution. but no one of them has as yet been noted within the State.

\section{Tribe III. NANTHOLININI.}

Very slender, small or medium-sized species, having the head usually equal in width to thorax and narrowed behind into a small neck: antennæ elbowed. inserted close together near the middle of the front margin of the front; thorax long and rectangular with rows of punctures of which the outer ones are curred, its side margins double and thoracic spiracles visible. Of the seven genera comprising the tribe. four are represented in Indiana.

FEI TO INDLANA GENERA OF XANTHOLININI.

u. Antennie strongly elbowed; edges of elytra orerlapping at suture; middle coxæ widely separated.

b. Last joint of maxillary palpi long. not awl-shaped.

bb. Last joint of maxillary palpi short. awl-shaped.

XXXVII. Xantholints. c. Front tarsi broadlc dilated: head densels strigose-punctate.

cc. Front tarsi not dilated.

XXXVIII. LEPTOLINTS. XXXIX. LEPTACINUS.

a a. Antemne feebly elborred: elrtra not orerlapping at suture. the sutural stria deep; thorax narrowed in front.

IL. Diochus.

\section{XAntholints Serv. 1825. (Gr.. "Yellow.")}

This genus. sufficiently characterized above. is represented in the State by nine known species. while one other may occur.

KEY TO INDLANA SPECIES OF XANTHOLIXCS.

a. 'pper (onter') marginal line of thorax bent downard and united with the lower-one at middle: thorax with dorsal lows of fire or six fine punctures.

7(ii). CEPHALTS.

a a. Cprer marginal line of thorax separate from the lower one nearly to apex, not bent downard in rront. 
b. Punctures in dorsal rows of thorax four to six in number.

c. Color in great part black or piceous.

d. Thorax and elytra black. legs dark reddish-brown. obsidnaxts.

dd. Thorax and legs reddish-yellow; form rel'y slender.

764. LINEARIS.

cc. Color mostly pale; head usually black or piceous.

$e$. Abdomen wholly pale: punctures of head distinct. coarse and sparse.

$f$. Dorsal rows of thoracic punctures extending but little behind the middle: form more robust; length 5.5-6 $\mathrm{mm}$.

76.5. EMMESTS.

ff. Dorsal rows of punctures extending nearly to base; form rery slender : length $4.5-5 \mathrm{~mm}$.

766. FUSCICEPS.

$c e$. Last two segments of abdomen black: punctures of head rerr minute and indistinct: length $7-7.5 \mathrm{~mm}$. 767 . Ixdiaxexsis.

b). Punctures in dorsal rows of thorax $S$ to 12 in number.

g. Piceous black. thorax not paler.

h. Head beneath feebly punctured. above rers sparsely and coarsely punctured on the sides: elstra dark red. 768 . GULARIs.

hh. Head beneath coarsely and deeply punctured; elytra piceous. legs dull brownish-rellow. 769 . oBsctrus.

gg. Brownish-rellow, head darker: gular sutures deep.

$i$. Head rery sparsels punctate: body moderatels robust.

770. HAMATC'S.

ii. Head more closely punctate. especialls on sides; bods rery slender.

77. PUSILLTS.

*663 (2268). Xaxtholines cephalus Say. Trans. Amer. Phil. Soc., IT, 1834, 452; ibid. II, 567.

Elongate. slender. Black. shining: elytra and legs reddish-yellow: antennæ and under surface dark reddish-bromn to piceous. Head longer tham wide. sparsely and coarsely punctured abore. more finels punctured and alutaceous beneath. Thorax one-half longer than wide. as wide as head in front. gradually narrowed to base. Elstra as long as and scarcels wider than thorax. coarsely. shallomly and sparsely punctured. Abdomen finely and rery sparsely punctate. Length $6.5-7.5 \mathrm{~mm}$.

Tigo and Poser counties: rare. October T-December 25. Occurs beneath bark and rubbish.

X. obsidianus Melsh., $6.5 \mathrm{~mm}$. in length. occurs in Penmstrania and Iowa. and probably inhabits Indiana.

764 (-). Saxtholdxts linearis sp. nov.

Linear. Head black. shining: thorax, less and three basal joints of antennæe reddish-rellow; elvtra reddish-brown. the margins and epipleura pale rellow; abdomen piceous. Antennie stout. but slightly longer than head, pale brown. Head alutaceous. as long as and wider than thorax. coarsely and evelily punctate on sides and base above, sparsely and more 
finely punctate beneath. Thorax one-half longer than wide, gradually but feebly narrowed from apex to base, the dorsal rows with five or six coarse punctures. Elstra scarcely wider and a little shorter than thorax, coarsely and sparsely punctate, the punctures in somewhat irregular rows. Abdominal segments finely and sparsely punctate at base, both above and beneath. Length $5.5 \mathrm{~mm}$.

Putnam County; rare. April 24. Taken by sifting. Liebeck compared this with the specimens in the Horn collection and stated that it was a species near temporalis Horn. That species was described from Florida, has the thorax black, the elytra piceo-testaceous at sides and tip and the inner frontal groove long and deep.

\section{*765 (2274). Xantholints emmesus Grav., Mon. Col. Micr., 1S06, 176.}

Elongate, slender. Head black or piceous, rarely pale; thorax, elytra and legs pale reddish-brown, strongly shining; abdomen usually reddishfuscous; antennæ slightly longer than head, brownish. paler at base. Head a little wider and as long as thorax. sparsely and coarsely punctate above and beneath. Thorax one-third longer than wide, feebly narrowing from apex to base, the dorsal rows with four or five, the rows on sides with fire or six, rather fine punctures. Elytra about as long and wide as thorax. each with three rows of rather coarse punctures, the sutural row irregular. Abdomen very finely and sparsely punctate. Length $5.5-6 \mathrm{~mm}$.

Throughout the State. frequent in the southern counties: much less so northward. January 6-June 27. Occurs beneath bark and logs. When disturbed they and other members of the genus roll themselves into a coil and feign death. In one slender-bodied example from Lake County, the head is concolorous with the remainder of the body.

766 (2274a). Xantholinus fusciceras Lec. Trans. Amer. Ent. Soc. ViII. $1880,173$.

Smaller and distinctly more slender than emmesus; elytra more or less fuscous, both they and abdomen darker than thorax. Punctures of dorsal rows usually six. Length $4.5 \mathrm{~mm}$.

P'utnam and Posey comnties: scarce. April 21-April 22. Occurs in the Ariddle, Southern and Western States.

\section{7 (一). XaNTHOLINTS IndTanensis sp. not.}

Elongate, rather robust. Head and last two segments of abdomen black. shining; scutellum piceous; remainder of body pale reddish-brown. Head one-half longer than wide. sides feebly curved, upper surface almost smooth at middle; sides and under surface minutely and sparsely punctate: antenux darker than thorax, stout. slightly longer than head. Thorax nearly one-half longer than wide. sides almost straight. dorsal lows with six. rows on sides with five or six, minute punctures. Elytra as long as 
thorax, finely and sparsely punctate, the punctures nowhere in regular lows. Abdomen slightly narrower at base than elytra, thence feebly widening to fifth segment, finely and sparsely punctate, minutely pubescent. [uengtls T-7.5 $\mathrm{mm}$.

Porter County; rare. May 21. Larger and more robust than emmesus and very distinct in color of abdomen and punctuation of head.

768 (2275). Xantholinus gularis Lec., Trans. Amer. Ent. Soc., ViII, $1880,173$.

Elongate, slender. Head, thorax and abdomen black or piceous; antennæ, legs and elytra dull red. Thorax elongaté-oblong, feebly narrowed from apex to base; dorsal rows with nine to ten punctures and about the same number in the rows on sides. Elytra one-third longer than thorax, sparsely, finely and irregularly punctured. Abdomen finely and sparsely punctured above, more coarsely beneath, the tip reddish-brown. Length 6.5-7.5 mm.

Lake and Kosciusko counties; rare. July 23-July 24. Occurs beneath bark. especially that of pine. A member of the boreal fauna.

769 (2276). Xantholinus obscurus Erichs., Gen. Spec. Staph., 1840, 330.

Elongate, slender. Head, thorax and abdomen piceous, shining; legs and tip of abdomen dull yellow; antennæe and elytra fuscous-brown, the former one-half longer than head, the second and third joints equal. Head oblong, as wide and about as long as thorax, alutaceous, coarsely and evenly punctate on sides and base. Thorax oblong, feebly narrowed from apex to base; dorsal rows of ten to twelve punctures. the sides with about fourteen. irregularly placed. Elytria a little wider and longer than thorax, each with about four irregular rows of rather coarse punctures. Abdomen finely and sparsely punctate. Length $6-6.5 \mathrm{~mm}$.

Lake, Putnam, Vigo and Franklin counties; frequent in Lake. rare in the others. March 26-October 17. Occurs beneath bark and rubbish in sandy localities.

770 (2279). Xantholinus hamatus Say, 'Trans. Amer. Phil. Soc., IV, 1834, 453 ; ibid. II, 568.

Elongate, slender. Head black, shining: abdomen brownish-piceous: thorax piceous or reddish-brown; antemne. elytra and legs pale reddish-yellow. Head shorter, more convex and much more sparsely and finely punctate than in obscurts. Thorax one-third longer than wide, not narrowed behind. sides parallel: dorsal rows of ten to twelve fine punctures. a short row of four or five and the sides with eight to ten, irregularly placed. with others near the apical angles. Elytra one-third longer and slightly wider than thorax, each with four or five rows of fine. sparse punctures. Abdomen finely. sparsely punctured. the hind margins of the segments paler. Length $5.5-6 \mathrm{~mm}$. 
Southern half of State; scarce. April 22-June 2. Taken by sifting or by beating low herbs.

771 (2278). Xantmolinus pusiluts Sachse, Stett. Ent. Zeit., 1852, 124.

Elongate, rery slender, parallel. Head black; abdomen and under surface piceous; thorax, elytral and legs reddish-brown. Head but little longer than wide; coarsely and rather closely punctate on the sides above, more finely and sparsely beneath. Thorax one-half longer than wide, slightly narrower than head. sides almost straight; dorsal rows with about eight rather fine punctures, the ones on sides with five or six. Elytra slightly wider and one-fourth longer than thorax, each with two discal rows of lather fine punctures and numerous confused ones near the suture. Abdomen finely and sparsely punctate. Length $4-5.5 \mathrm{~mm}$.

Putnam County; rare. April 22.

\section{Leptolinus Kraatz. 1857. (Gr., "slender.")}

Very slender species having the third joint of maxillary palpi swollen and obconical, the last joint very small and awl-shaped. One of the two species occurs in the State.

772 (2282). Leptolinus rubripennis Lec., Trans. Amer. Ent. Soc., Vili. $1880,171$.

Elongate. slender. IIead. thorax and abdomen brownish-black, subopaque; antennie, legs and elytra dull red, the latter dusky about the scutellum. Head nearly twice as long as wide. finely and densely strigosepunctate; antenne reaching middle of thorax, the outer joints nearly twice as wide as long. Thorax as long as and a little narrower than head. finely and densely punctate. with a narrow, smooth median line. Elytra slightly wider and more sparsely and finely punctured than thorax. Abdomen rery finely and densely punctate, wider at apex than base, the tip paler. Male with last rentral acutely notched and sroored lengthwise. Length 6$6.5 \mathrm{~mm}$,

Lake, Posey and Dubois counties; rare. April 19-May 28. Sifted from woody debris. Easily known by the dense sculpture of head and thorax.

\section{Leptacinus Erichs. 1837. (Gr.. "slender.")}

Elongate slender species having the last joint of palpi awlshaped; middle coxæ widely separated; front tarsi not dilated. of the twelve species known from North America, the following have been taken or perhaps occur in Indiana:

KEY TO INDIANA SPECIES OF LEFTACINUS.

a. Fourth joint of maxillary palpi slender, scarcely shorter than third: outer side margin of thorax acute in front of middle. not united with the lower or inner lint.

773. FLATIPES. 
aa. Fourth joint of maxillary palpi very small; outer margin of thorax not acute in front of middle.

b. Thorax elongate-oval, the sides romuded into base and alvex.

31. Thorax with distinct angles.

7T4. LONGICOLLIS.

c. Punctures of thorax confused. and confined to the sides; reddishbrown, elytra piceous with sides and tips yellowish.

775. RUFICOLLIS.

cc. Punctures of thorax in dorsal rows; color piceous or black.

d. Punctures of dorsal rows s-10 in number; legs pale.

NIGRITCLCS.

da. Punctures of dorsal rows 12-14 in number; legs dark.

SERLATCS.

773 (2284). Leptacines flatipes Lec., N. Sp. N. A. Col., I, 1863, 41.

Elongate, slender. Head and abdomen blackish-piceous, shining; thorax and elytra dark reddish-brown; antennæ brown, paler at base; legs reddishrellow. Head longer than wide, with rather dense elongate punctures on sides and base. Thorax oblong-oral, rather sparsely, evenly and finely punctate on the sides, smooth at middle. the dor'sal rows with 12-16 punctures. Elytra as wide and long as thorax. sparsely and finely punctate. Abdomen finely and rather densely punctate. Length 4-4.5 $\mathrm{mm}$.

Putnam County ; frequent locally. March 20-April 22. Sifted from regetable debris.

774 (2287). Leptacinus longicollis Lec., N. Sp. N. Amer. Col.. I, 1863, 41.

Elongate, rery slender. Dark reddish-brown to piceous, shining. sparsely clother with erect hairs: legs and base of antenne paler. Head one-hali longer than wide, its surface, as well as that of thorax and elytra. finely and sparsely punctate. 'Thorax one-half longel than wide. but feebly narrowed behind, disk with a smooth space at middle. Elytra slightly wider and distinctly shorter than thorax. Abdomen slightly narrower at base than elytra. thence gradually broadening, the fifth dorsal distinctly wider than first; surface finely and rather closely punctate. Length $3-3.3 \mathrm{~mm}$.

Clark County; rare. May 6. Occurs beneath stones, often in ants' nests.

775 (2290). Leptactinus puficollis Lec. x. Sp. N. Amer. Col., I. 1863. 42.

Elongate, slender. Head and abdomen piceous; antennæ. thorax and legs pale reddish-brown. Head longer than wide, alutaceous, coarsely and evenly punctate. Thorax one-third longer than wide, with a broad, smooth space at middle. Elytra with four or five somewhat irregular rows of fine punctures. Abdomen very slightly widening from base to apex. finely and sparsely punctate. Length $4-4.5 \mathrm{~mm}$.

Putnam County; rare. April 22. Probably occurs sparingly throughout the southern half of State.

L. nigritulus Lec.. $3.5 \mathrm{~mm}$., and L. seriatus Lee.. $4.8 \mathrm{~mm}$. in length, were both deseribed from Detroit and Canada. and probably occur in the northern third of Indiana.

[26-23402] 
XL. Drochts Erichs. 1840. (Gr.. "to wash awar.")

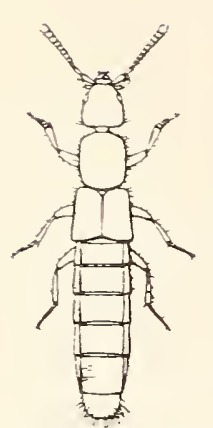

Small. slender species, having the antenne nearly straight and the head oral. much smaller than thorax. the last joint of palpi rery small and awl-shaped. (Fig. 160.) One species occurs in the eastern Lnited States and Indiana.

76 (2299). Dioches schaumi Kraätz., Wien. Ent. Monat. IV. 1860. 27.

Fig. 160. Diochus tongte. slender. Piceous. shining, legs. an nanys Erichs A the thorax and tips of elstra dull sellow: antennre brown. Central American paler at base. Head rers sparsely and finels punctate.

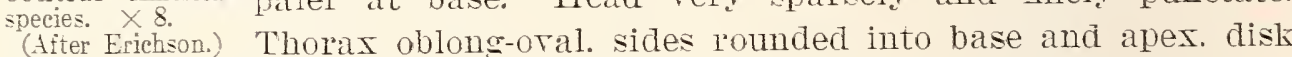
with a row of four or fire punctures on sides and with four to six faint ones on middle. Elstra one-third wider and about as long as thorax. smooth or nearly so. Abdomen minutely and densely punctate, subopaque. the tip paler. Length $2.7-3 \mathrm{~mm}$.

Starke. Kosciusko. Putnam and Poser counties: scarce. April 21-October 17. Sifted from regetable debris in low moist places.

\section{Subfamily III. STENINAE.}

Short. rather robust. subcrlindrical. black or piceous species. having the head large. wider than long. With prominent eres, thus resembling those of the tiger beetles: antennæ straight. inserted upon the front. 11-jointed. the last three joints larger than those preceding: first joint of maxillary palpi nearly as long as second. the fourth obsolete: labrum entire, rounded in front: thorax conrex. usually distinctly longer than wide: elytra wider than thoras: abdomen with seven segments. usually narrowing from base to apex. each dorsal segment with a transterse elerated ridge at base. this usually with sereral cusps or teeth projecting backward: tarsi fivejointed. the fourth joint often bilobed beneath. The thorax and elytra are deeply sculptured. and this character. taken in connection with their large eres and black color render them, as a group. very easy to separate.

The Stenids occur for the most part along the muddr or sandr borders of lakes. pords and streams. where ther run swiftly in the sumshine but hide beneath bark. moss and rubbish in cloudy or cold weather. All are probab? carnirorous. catching their pres alive like most of the Carabida. and not feeding on carrion and excrement as do most other staphrinid forms.

The principal paper treating of the North American species is by 
Casey, Thos. L._"Revision of the Stenini of America North of Mexico," 1884, pp. 1-206. (Published privately.)

Two genera comprise the subfamily, both of which are represented in Indiana.

KEY TO GENERA OF STENINA.

a. Paraglossa not narrowed at base; cheeks prominent; elytra each with a large reddish-yellow spot.

XLI. Dianous. a a. Paraglossa strongly narrowed at base; cheeks very small, usually invisible from above.

XLIT. Stenus.

XLI. Dianous Leach. 1819. (Gr., "to meditate.")

Rather robust species having the eyes smaller and more widely separated than in Stems; antenna long and slender; abdomen strongly margined at the sides. Two species are known from the Tnited States. one of which has been taken in the State, while the other, D. comlescens Gyll, has been taken about the Great Lakes and probably occurs in northern Indiana.

KEY TO SPECIES OF DIANOUS.

a. Elytra scarcely longer than wide; punctuation coarse and sparse.

777. NITIDULUS. a . Elytra distinctly longer than wide; punctuation fine and dense.

CQERULESCENS.

777 (2301). Dianous nitidulus . Lec. Proc. Bost. Soc. Nat. Hist., Xri. $1874,272$.

Black or dark steel blue; elytra each with a large rounded pale spot behind the middle; pubescence very fine and sirarse, visible only on head and abdomen. Head with two wide, shallow grooves between the eyes. separated by a convex ridge; finely and rather closely punctured. Antennæe reaching middle of thorax, third joint one-half longer than fourth. Thorax subcylindrical, widest at middle. narrower at base than apex, without median impression; surface rather coarsely, not closely punctate. Elytra slightly narrower than head, coarsely, rather sparsely and evenly punctate, the punctures separated by twice their own width. Abdomen finely and sparsely punctate. Length $4.5 \mathrm{~mm}$.

Floyd County ; scarce. October 4-October 9. Taken beneath stones on the bank of the Ohio River.

\section{Stencos Lat. 1796. (Gr., "natrow.")}

A very large genus of closely related forms which for convenience are separated into the following groups: 


\section{KEX TO INDIANA GROUPS OF STENUS.}

a. Abdomen strongly and distinctly margined along the sides.

b. Fourth joint of tarsi simple.

Group $I$.

bb. Fourth joint of tarsi bilobed.

Group $I I$.

a a. Abdomen not distinctly margined. faint traces of a marginal line being visible only on first segment.

c. Fourth joint of tarsi simple or but slightly enlarged. Group III.

ce. Fourth joint of tarsi distinctly bilobed.

Group $I T$.

Group I.

This group, on account of its size. Casey also separated into the following divisions :

KEY TO DIVISIONS OF GROCP I.

a. Elytra each with an orange spot near the middle of the disk.

Dirision 4 .

a Elytra without pale spot.

b. Punctures in some portion of the elstra more or less joined or coalescent, sometimes only in tros or threes, sometimes in long channels.

c. The channels or rows of punctures in some one spot on the surface of each elytron arranged in a spiral or whorl which is complete or very nearly closed.

Dirision $B$.

cc. The channels or rows of united punctures often sinuous but nerer forming a completed rortex or whorl.

d. Thorax with a more or less distinct median channel or groore.

Dirision $\dot{C}$.

dd. Thorax without trace of median groore.

Division $D$.

bb. Punctures of elytra all isolated and distinct one from another.

Division $E$.

\section{Division A.}

The species of this division are among the largest in the genus. They are easily recognized by the orange colored spot on each elytron. Two species have been taken in Indiana. while another doubtless occurs.

\section{KEY TO SPECIES OF DIVISION A.}

a. Femora black; length $4.5-5 \mathrm{~mm}$.

7T. BTPUNCTATUS. a a. Femora not black. ranging in color from dark piceous-brown to dull rellow.

b. Head wider than elytra, spot on latter bilobed: length $3.6-4 \mathrm{~mm}$.

779. COLON.

bb. Head equal in width to elytra. spot rounded: ninth and tenth joints of antennie equal; length $3.5-4.4 \mathrm{~mm}$.

SEMICOLON.

778 (2303). Stents bipunctatus Erichs.. Col. Marcll.. 1537. 530.

Rather robust. Black, feebly bronzed, shining. very finely and sparsely pubescent; elytra each with a small. pale. rounded spot just behind the middle. Head less than twice as wide as long. deeply excavated and finely punctured between the eres; antennie reaching middle of thorax. the third 
joint twice the length of fourth. Thorax subcylindrical, widest one-third from base; disk finely, evenly and densely punctate and with a narrow, deep median impression just behind the middle. Elytra at hase as wide as head, slightly longer than wide, coarsely and regularly punctate. Length 4.4-5 $\mathrm{mm}$.

Floyd County; rare. October 9. Taken along the Ohio River; also by Dury at Cincinnati.

779 (2304). Stenus colon Say, Trans. Amer. Phil. Soc., IV, 1834, 458; ibic. II, 574.

Elongate, rather slender. Black, shining; under surface piceous; elytra each with a sublunate or triangular reddish-yellow spot behind the middle; legs dull yellow, the femora fuscous on apical third. Head slightly more than twice as wide as long, deeply excavated and densely punctured between the eyes; antennæe not reaching middle of thorax, the third joint one-half longer than fourth. Thorax widest at middle, densely and rather coarsely punctate and with a short, narrow and deep impression just behind the middle. Elytra at base much narrower than head, densely and coarsely punctate. Length $3.6-4 \mathrm{~mm}$.

Described from Posey County. Known from Michigan, Virginia and other Southern States. Not represented in the collection at hand.

S. semicolon Lec., has the same range as the preceding and doubtless occurs sparingly in Indiana.

\section{Division $B$.}

In addition to the complete spiral or whorl of united punctures, the members of this Division usually have single, more or less isolated punctures on the other parts of the elytra. Four species belonging here may occur in the State, though but three have been taken.

KEY TO INDIANA SPECIES OF DIVISION B.

a. Legs black beneath.

b. Elytra (along the suture) distinctly longer than thorax; head as wide as the elytra at base, deeply excavated between the eyes.

780. JUNO.

6b. Elytra rather shorter than thorax, the latter very robust; body depressed.

AUSTINI.

aa. Legs not black beneath; elytra slightly longer than thorax. the latter widest at or just behind the middle.

c. Median impression of thorax beginning before the midale, narrow. deep. conspicuous; elytra deeply, (dosely and irregularly channeled: fifth rentral of male with a rounded notch at apex.

781. FEMORATUS. 
cc. Nedian impression of thorax beginning behind middle, wider, much more shallow and inconspicuous; elytral surface much less channeled. the punctures distinct over a great part of their area; fifth segment of male not notched at apex.

782. SIMILIATUS.

iso (2311). Stents Juno Fab., Syst. Eleut., II, 1S01, 602.

Elongate, robust. Black, shining, very finely and sparsely pubescent; antennæ, palpi. tibire and tarsi piceous. Head scarcely twice as wide as long, the front coarsely punctate, with a deep groore each side, separated by a strongly conrex ridge. Thorax subcylindrical, slightly longer than wide, widest at middle; coarsely, closely and erenly punctate, the punctures confluent near base and apex; the median impressed line very faint, two-thirds the length of disk. Elytra coarsely, deeply and densely punctured and channeled, the spiral on the side just behind middle. Abdomen one-third narrower than elytra. deeply and rather sparsely punctate, the first four dorsal segments deeply impressed at base, their transverse carinie with three cusps projecting backward. Length $4.5 \mathrm{~mm}$.

Lake. Vigo and Posey comnties; frequent in Lake. scarce in the others. March 26-July 1. Taken from beneath rubbish on the beach of Take Michigan and from under logs on wooded hillsides in the southern counties.

S. austini Casey. 3.5-3.8 mm. in length. a member of the boreal fauna. ranges from New Hampshire to Lake Superior and probably occurs in northern Indiana.

7S1 (2319). Stexts femorates Say. Trans. Amer. Phil. Soc., IV, 1 S34. 459 ; ibid. II. ร74.

Short, rather robust. Black, shining. clothed with short and sparse suberect pubescence. orange-rellow on the abdomen, grayish elsewhere; legs dusky yellow, the femora darker at apex. Head more than twice as wide as long, surface between the eres concare. finely and densely punctate and with a median ridge; antenne reaching middle of thorax, piceous, the third joint less than one-half longer than the fourth. Thorax finely, closely and irregularly punctate and with a narrow. deep impression on median third. Elytra densely and irregularly punctate, the punctures united into channels over most of the surface. the spiral behind the middle. Abdomen narrower at base than eictra. thence distinctly tapering to apex; finely and densely punctate, the transrerse carinx with three cusps. Length $3.5-4 \mathrm{~mm}$.

Marion County: scarce. April 4-April 24. Probably occurs throughout the State.

\section{Ti2 (- - ). STexus smmitates sp. not.}

Short. robust. Black, shining. very finely and sparsely pubescent; anteunre picenus; legs reddish. the femora darker at tips. Head twice as wide as long. surface betreen the eres feebly concare. its median portion slightly convex, rather coarsely and closelp punctate. Thorax slightly longer than wide. widest at middle; coarsely and closely punctate and with a shallow impression on basal half. Elytra as long as wide, one-fifth longer than 
thorax, coarsely and densely punctate and with an almost complete sjiral behind the middle. Abdomen at base slightly narower than elytra, very feebly tipering to apex, finely and rather sparsely punctate, the transverse caringe with three cusps. Length $3.5-4 \mathrm{~mm}$.

Marion. Vigo, Lawrence, Clark, Floyd and Posey counties: scarce. March 1-November 28. Taken by sifting, beneath mullein, etc. Resembles femoratus in form, size and color, but the sculpture is much mole regular. the abdomen less tapering and the median impression of thorax wholly different.

\section{Division $C$.}

Here a part or all of the punctures are united or confluent, but the channels which they form are never arranged in a complete spiral or whorl on any part of the elytra. "The channels or" punctures may be comparatively distant or very closely compacted, and the interspaces correspondingly wide or acute, convex or flat, highly polished or minutely granulose and feebly shining." The thorax is always marked with a distinct impression or canaliculation on some part of the middle of the disk. 'The following species have been taken or probably occur in the State:

\section{KEY TO INDIANA SPECIES OF DIVISION C.}

a. Larger, more than $2 \mathrm{~mm}$. in length; elytral suture not more than onethird longer than thorax; transverse carinse of abdomen with three cusps.

b. Form extremely slender, nearly cylindrical; elytra much shorter than thorax, head much wider than elytra; length $3-3.5 \mathrm{~mm}$.

7S3. STRANGULATLS.

b7. Form much more robust; elytra at most but little shorter than thorax. usually longer.

ત. Larger. 3.7-4.5 mm. : head wide and robust. as broad as or broader than elytra: males (except in neglectus) with the side margins of the impressed area of fifth rentral segment in the form of ridges which terminate behind in acute teeth.

e. Legs black; length $3.7-4 \mathrm{~mm}$.

INTRUSUS.

ce. Legs piceous or paler.

$f$. Head not twice as wide as long, deeply excarate between the eyes; legs pale piceous-brown: length $4-4.8 \mathrm{~mm}$.

784. ERTTHROPTS.

$f f$. Ilead twice as wide as long. feebly excarate between the eyes: legs piceous ; length $3.8-4 \mathrm{~mm}$.

NEGLECTLS.

11. Smaller. not orer $3.5 \mathrm{~mm}$.: males with margins of impressed alea of fifth rentral without ridges or teeth.

\%. Elytral sutme equal in length to thorax. the latter wider hefore the nirlile: form slender: length 2.8 mm.

SIIBTII.IS. 
gg. Elytral suture longer than thorax.

h. Species $3 \mathrm{~mm}$. or more in length.

i. Longitudinal elevation between the eyes indistinct or nearly obsolete; length :3 $\mathrm{mm}$.

j. Thorax with median impression very feeble, extending nearly the entire length.

rICINUS.

jj. Thorax with median impression reduced to a simple erosion just behind the middle.

INGRATUS.

ii. Longitudinal elevation distinct: head wider than elytra at base; length $3.3 \mathrm{~mm}$.

7S5. SCABIOSTS.

$h 7$. Species less than $3 \mathrm{~mm}$. in length.

7. Thorax widest distinctly before the middle.

7. Legs black; length $2.6-3 \mathrm{~mm}$.

INORNATUS.

1l. Legs fuscous: length $2.5-2.7 \mathrm{~mm}$.

PLACIDUS.

1:\%. Thorax widest at or behind the middle; length $2.4-2.6 \mathrm{~mm}$.

ERIENSIS.

a . Minute species. length less than $2 \mathrm{~mm}$.

m. Transverse carinæe of abdomen without cusps; length 1.7-1.9 mm.

NANUS.

mm. Transverse carine with three cusps: form much more slender; length $1.7 \mathrm{~mm}$.

PUMIIIO.

783 (2321). Stenus Strangulatus Casey. Rev. Stell.. 1S84, 39.

Elongate, very slender. Black. shining, very sparsely and finely pubescent; antennie piceous. palpi paler; legs miform dull reddish-brown. Head nearly twice as wide as long: surface between the eyes deeply excavate, finely and rather sparsely punctate, with two groores and a median conrex ridge. Thorax widest before the middle, slightly longer than wide, coarsely and irregularly punctate, the median impression rather wide and shallow, extending two-thirds the length of disk. Elytra at base two-thirds the width of head; coarsely and irregularly punctate. Abdomen long, feebly tapering. coarsely and sparsely punctate. Length $3-3.5 \mathrm{~mm}$.

Lake County; rare. May 2. Known heretofore from New York and Detroit.

iS4 (2928). Stexts ertithropts Melsh., Proc. Phil. Acad. Nat. Sci.. II. 1844. 40 .

Rather robust. Black. shining. sparsely clothed with short. fine grayish pubescence; antennæ piceous, palpi and legs piceous-bromn. Head between the eres distinctly excarate. coarsels, closely and evenly punctate. the median ridge low and subobsolete. Antennze longer than width of head, the third joint one-third longer than fourth. Thorax rery robust, widest at middle, coarsely, closely and mevenly punctate and with a rather narrow shallow impression extending from middle two-thirds to base. Elytra slightly longer than thorax, coarsely. deeply and unevenly punctate. Abdomen at base narrower than elytra, thence feebly tapering to apex, coarsely and rather closely punctate at base. more finely toward apex. Length $4-5 \mathrm{~nm}$. 
Vigo, Orange and Posey counties; scarce. April 13-May 24. In one specimen there is a faint small pale spot on the middle of each elytron.

785 (2342). STenus scabiosus Casey, Rev. Sten., 1884, 60.

Elongate, slender. Black, shining, sparsely clothed with very fine gray pubescence, yellowish on the abdomen; legs fuscous above, reddish-brown beneath. Head twice as wide as long, surface between the eyes excavate, finely and closely punctate. Antennx reaching middle of thorax, third joint one-half longer than fourth. Thorax widest just behind the middle, finely and densely punctate and with a fusiform impression on median third. Elytra slightly longer than thorax, finely, closely and irregularly punctate. Abdomen slightly narrower at base than elytra, feebly tapering to apex, finely, evenly and rather sparsely punctate. Length $3-3.3 \mathrm{~mm}$.

Kosciusko County ; rare. June 24. Two specimens taken while sweeping low herbs in swampy places.

The other species of Division C, briefly characterized in the above key, were with the exception of nanus Steph. and pumilio Erichs., all described by Casey in his Revision, and it is probable that a number of them will prove to be synonymous. His types of these species were from points mostly in Michigan, which would render their occurrence in Indiana, especially the northern portion, very probable, though as yet specimens have not been taken.

\section{Division $D$.}

In this group the elytra are sculptured as in Division C, but the tholax is without an impression along the median line. The beetle, says Casey, "should be held in such a manner that the light will pass obliquely across the highest point of the thorax and perpendicular to its longer axis. If there is no sign of even a narrow longitudinal shade, the species belongs to this division. If there be even a faint shadow extending along the middle of the disk, the insect may be considered as belonging to Division C.',

KEY TO INDIANA SPECTES OF DIVISION D.

a. Transverse caringe of abdomen with cusps.

b. 'Transverse carinae with four cusps.

c. Elytral suture longer than thorax: longitudinal elevation between the eyes almost obsolete: length $: 3-3.4 \mathrm{~mm}$. 786 . coLonus.

cc. Elytral suture equai in length to thorax; longitudinal eleration between the eyes evident. broad ; thorax nore coarsely and roughly punctite; length $3.5 \mathrm{~mm}$.

787. SUSPECTUS.

bb. Transverse carine with three cusps.

d. Elytral suture slightly shorter than thorax; head wider than elytra ; antennal joints three, four and five uniformly decreasing in length ; femora pale beneath; length 2.5-2.9 mm. 788, Humils, 
dd. Elstral suture much longer than thorax; head not wider than elytra; legs piceous; length $2.6 \mathrm{~mm}$.

ANimatus.

aa. Transwerse carine without cusps; thorax with a narrow elerated Iongitudinal carina on its basal half; length 2.3-2.8 mm. CARINICOLLIS.

786 (2376). Stexus colonus Erichs., Gen. Spec. Staph., 1840, 699.

Rather slender. Black, shining, sparsely clothed with fine gray pubescence: legs black; antennæ and tarsi brownish. Head less than twice as wide as long, surface between the eyes flat. finely and densely punctate. Antennie short, not longer than width of head; third joint less than onehalf longer than fourth. Thorax subcylindrical, widest slightly behind the middle. finely and densely punctate. Elytra one-sixth longer than thorax. about as wide at base as head. coarsels, densely and irregularly punctate. Abdomen slightly narrower at base than elstra, thence distinctly tapering to apex, finely and rather closely punctate. Length $3-3.4 \mathrm{~mm}$.

Lawrence County ; rare. May 23.

787 (-). Stenus suspectus sp. not.

Rather robust. Black. feebly shining, sparsely clothed with fine gray hairs; femora black; antennæ, tibiæ and tarsi piceous. Head one-half wider than long. coarsels and closely punctate. Antennæ reaching middle of thorax, third and fourth joints subequal. Thorax narrower than head. widest at middle. slightly longer than wide. coarsely. densely and roughly punctate. Elytra at base one-fourth wider than thorax, punctate as there. the punctures on sides in erident, irregular channels. Abdomen at base slightly narrower than elytra, feebly tapering to apex, rather finely and closely punctate. the transverse carinæ with four fine cusps. Length $3.5 \mathrm{~mm}$.

Lake and Vigo counties; rare. May 28-October 1. Taken beneath bark of elm.

788 (2377). Stenus humitis Erichs.. Col. March., 1837. 554.

Short, rather robust. Black, strongly shining: legs reddish-piceous, the under side of femora and basal joint of palpi much paler. Head twice as wide as long, surface betreen the eyes feebly excavate, coarsely, closely and evenly punctate. the longitudinal elevation rather strongly convex. Antennge dark piceous-brown. slightly longer than width of head. Thorax robust. widest just behind the middle, rather finely. densely and roughly punctate. Elytra at base scarcely wider than thorax at middle. rather coarsely. densely and very roughly punctate. Abdomen as wide as elytra at base. sides nearly parallel, surface rather coarsely and closely punctate. more finely toward apex. Length $2.5-3 \mathrm{~mm}$.

Kosciusko County ; scarce. .June 24. Casey's mammops is said to be a synonym.

S. animatus Casey and carinicallis Caser were both described from Michigan and probably inhabit northern Indiana. 


\section{Division L:}

In this division the pometures of eletra are all separate and distinct one from another. The spreies ale rather small and, except the first two. highly polished.

\section{KEY TO SPECIES OF DIVISION E.}

a. Pubescence rery coarse and distinct, brownish-yellow on the abdomen; punctures crowded. the interspaces not polished.

b. Longitudinal groores between the eyes distinct; form slender.

789. STYGices.

67. Longitudinal groores absent, the surface betreen the eyes flat; form more robust.

790. EGENCS.

a a. Pubescence rery fine and indistinct, rery seldom yellow; punctures rather sparse, their interspaces polished.

c. Transrerse carina of abdomen with four cusps.

d. Thorax with an impression along some part of the median line.

$e$. 'Thorax elongate, slender; punctures separated by at least their' own diameters; length $3-4 \mathrm{~mm}$.

VINNULCS.

ce. Thorax shorter. robust; punctures rery close, never separated by more than one-third their own width; third joint of antennæe much longer than fourth; length 3.2-3.4 mm.

CANALICULATUS.

dd. Thorax without an impression along the median line.

f. First joint of hind tarsi twice as long as second; length $3 \mathrm{~mm}$.

791. ARGTS.

$f f$. First joint scarcely one-half longer than second; antennal joints four and five equal in length, abruptly shorter than third: length $2.3 \mathrm{~mm}$.

MIXOR.

cc. Transrerse carinze of abdomen without cusps; thorax not impressed.

g. Very small, not orer $2.2 \mathrm{~mm}$.

h. Elytra much longer than wide, sparsely punctured, highls polished.

792. JUVENCUS.

hi. Elytra nearly quadrate, rery densely punctured. Pauperculus.

gg. Larger, not less than $2.8 \mathrm{~mm}$; antenmal joints three to six decreasing in length.

793. MORIO.

789 (2383). Stenus strgicus Say. Trans. Amer. Phil. Soc., IV. 1834, 45: ibid. II, 574.

Rather slender. Black. feebly shining; rather thickly clothed with lons. coarse. prostrate grayish-yellow hairs; legs and antennie piceous, tarsi slightly paler. Head rather small, not twice as wide as long; surface between the eyes nearly flat, densely and coarsely punctate. Antennæ slightly longer than width of head, the third joint a little longer than fourth. Thorax subcylindrical. widest in front of middle, one-fourth longer than wide; coarsely, closely and erenly punctured. Elstra at base slightly wider than head, suture one-fifth longer than thorax, punctured like the latter. Abdomen at base narrower than elytra, rery feebly tapering to apex, finely and sparsely punctate, the transverse carinæ with four cusps. Length 3$3.7 \mathrm{~mm}$. 
Laporte. Floyd and Clark counties; scarce. May 6-October 9. The coarse. prostrate hairs often cause the elytra to appear sculptured as in Division $C$.

790 (23S4). Stent's EaEnus Erichs., Gen. Spec. Staph., 1840. 69s.

Rather robust. Black. shining, thickly clothed with short, prostrate sellowish hairs, which give the abdomen a brassy tinge; legs piceous. Head twice as wide as long, surface between the eyes flat, densely and deeply punctate. Antennæ as long as width of head, third joint one-third longer than fourth. Thorax short, robust, widest just before the middle, finely: evenly and rery densely punctured. Elytra at base slightly wider than head, suture one-fifth longer than thorax; deeply, rather coarsely and densely punctate. Abdomen as wide at base as elytra, thence gradually tapering to apex, finely punctate. the carinze with four cusps. Length 2.5$3 \mathrm{imm}$.

Throughout the State: common. February 23-November 8. Hibernates beneath mullein leaves and rubbish. Easily distinguished by the short, robust form. dense. even punctuation, flat vertex and yellow pubescence of abdomen.

S. vimnulus Casey, and S. canaliculatus Gyll, are known from Massachusetts and Michigan; S. minor and S. pauperculus were both described by Casey from Michigan.

\section{1 (2396). Stents ARgCs Grar., Mon. Col. Micr., 1806. 231.}

Short, rather robust. Black, shining; sparsely clothed with short gray pubescence; legs piceous. Head twice as wide as long, surface between the eyes flat, evenly and densely punctate and with a distinct longitudinal carina. Antennie slightly longer than width of head. third joint one-third longer than fourth. Thorax widest a little before the middle, rery slightly longer than wide, closely, rather coarsely and somewhat unerenly punctate. Elytra at base slightly wider than head. sutural line one-fourth longer than thorax; coarsely, deeply and evenly punctate, the interspaces equal in width to punctures. Abdomen finely and rather sparsely punctate. Length 2.5$2.8 \mathrm{~mm}$.

Lake and Starke counties: scarce. Nay 19-June 17. Casey's ageus and rigidus are said to be synonymous.

\section{2 (2401). Stexus Juvexcus Casey, Rer. Sten.. 1884, 12:3.}

Rather slender. Black, strongly shinịng, clothed with long, gray, prostrate hairs; legs piceous, paler beneath. Head twice as wide as long, rertex flat. finely and rather sparsely punctate and with a distinct longitudinal eleration. Anteunx piceous-brown, third joint nearly one-half longer than fourth. Thorax widest at middle, slightly longer than wide, rather coarsely and deeply punctate. Elytra at base slightly narrower than head, sutural line one-fourth Ionger than thorax; finely. rather sparsely and evenly punctate. Abdomen at base as wide as elytra f feebly tapering to apex, coarsely and sparsely punctate. Length 2-2.2 $\mathrm{mm}$. 
Marion County; rare. April 4. Taken by sifting. The small size, highly polished surface and long prostrate hairs of abdomen readily distinguish this form from its allies. Described from Detroit.

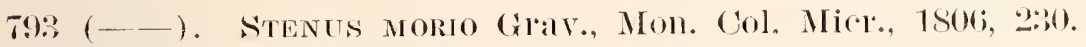

Elongate, slender. Black, strongly shining, very sparsely clothed with fine gray pubescence. Head twice as wide as long, surface between the eyes feebly concave, coarsely and closely punctate. Antennir piceous, reaching nearly to middle of thorax, third joint slightly longer than fourth. Thorax widest just in front of middle, thence distinctly converging and feebly sinuate to base; disk rather coarsely, evenly and deeply punctate. Elytra at base slightly narrower than head, suture one-fifth longer than thorax; disk coarsely, evenly and deeply punctate, the punctures separated by more than their own diameters. Abdomen finely and sparsely punctate, the first four segments as wide as elytra with distinct border, then distinctly tapering to apex, the border very narrow. Length $2.8-3 \mathrm{~mm}$.

Marion County ; searce. May 22-June 12. Taken by sweeping. Ranges from Michigan to California.

\section{GROUP II.}

In this group the abdomen is margined and the fourth joint of tarsi bilobed. Of the four species recognized by Casey, but one has a known distribution which would bring it within the limits of Indiana. This is S. crocentus Casey, $3.7-4.5 \mathrm{~mm}$. in length, and having the legs pale brownish-yellow, darker at the knees. Its range is given as New England to Nebraska, but no specimen has as yet been taken in Indiana.

\section{GROUP III.}

This group comprises species having the abdomen cylindrical, without a margin along the sides and with the fourth joint of hind tarsi simple. Three species may occur in the State, though but one has as yet been taken.

KEY TO SPECIES OF GROUP III.

a. Elytral punctures isolated and distinct.

b. Robust, very convex, nearly cylindrical; densely pubescent, very coarsely punctate; length $2.5-2.7 \mathrm{~mm}$.

GRATIOSUS.

b b. Much more slender, depressed; very sparsely pubescent, finely punctate; elytral suture one-third longer than thorax; length $2 \mathrm{~mm}$.

CURTYS.

aa. Elytral punctures more or less confluent, the surface very rough; first joint of hind tarsi more than twice the length of second; length $3.5 \mathrm{~mm}$.

794. ALACER. 
794 (2415). Stexc's Alacer Casey, Rer. Sten., 1SS4. 135.

Elongate. slender: Black, shining, rery finely and sparsely pubescent: legs dull yellow. very long and slender, the femora piceous at tips; palpi pale yellow. Head two-thirds wider than long. surface betreen the eres deeply excalvate. siarsely and unerenly punctured and with a distinct median carina. Antennie brownish. one-half longer than width of heat. the third joint one-third longer than fourth. Thorax subcylindrical. widest slightly behind the middle. one-sixth longer thau wide, coarsely. densely and roughly punctite. Elytra at base as wide as head. suture slighty longer than thorax: rery roughly. densely and coarsely punctate. Abdomen much narrower than elytra. tapering from base to apex; coarsels and closely punctate near base. finely and sparsely toward apex. Length 3.2$3.7 \mathrm{~mm}$.

Posey County; rare., April 22. Taken from beneath mullein leaves on a sandy hillside. A member of the Austroriparian fauna. known from Florida. Texas and southern Illinois.

\section{Group IV.}

The members of this group differ from those of the preceding only in having the fourth joint or tarsi distinctly bilobed beneath. The abdomen is subcylindrical, usually tapering from the base and without distinct side margins. The following species have been taken or may occur in the State:

KEY TO SPECIES OF GROUP IT.

a. Fourth and fifth abdominal segments wider than the first; length 4 $4.4 \mathrm{~mm}$.

ADTEXA.

a a. Abdominal segments decreasing regularly in width from the base, the fourth not wider than first.

7. Large species, $3.6 \mathrm{~mm}$. or more in length.

c. Femora and tibive not black throughout.

r. Legs and antenne almost wholly pale dull yellow. the tips of hind femora alone darker; head slightly broader than elytra.

795. FLATICORNIS.

dd. Legs black, the femora reddish-yellow at base. 796 . Axxularis.

cc. Femora and tibiæ wholly black, the tarsi pale.

$e$. Thorax equally wide at base and apex.

TARSALIS.

ee. Thorax distinctly wider at apex than base.

797. CANADEXSIS.

h). Smaller species, not exceeding $3.4 \mathrm{~mm}$. in length.

f. Legs pale yellow, the femora darker at tip; length $3-3.2 \mathrm{~mm}$.

79S. CALLOSTS.

ff. Legs dark fuscous brown in color throughout.

g. Thorax distinctly longer than wide.

$h$. Elytra very slightly longer than thorax. their punctures very coarse; length 2.8-3.4 $\mathrm{mm}$.

799. ARCLLTS.

$h \hbar$. Elytra one-third longer than thorax, their punctures fine and close; length $3-8.3 \mathrm{~mm}$.

800. PUNCTATUS.

gg. Thorax as wide as long: length $2.8-3 \mathrm{~mm}$.

HUBBARDI. 
795 (2443). Stenus flavicorinis Erichs., Gen. Spec. Staph., 1840, 73:3.

Elongate. rather slender. Black, shining. sparsely clothed with fine gray hairs. Head nearly twice as wide as long. surface between the eyes feebly (oncave, finely, closely and deeply punctate. With a groove each side of a slightly convex ridge. Antenne long and slender, third joint two-thirds longer than fourth. Thorax widest in front of middle, slightly longer than wide, closely, rather coarsely and deeply punctate. Elytra distinctly longer than the width at base, punctures round, rather small and deep, separated by more than twice their width. Abdomen narrower than elytra, the first four segments equal in width, finely, closely and evenly punctate. Length $4.6-4.8 \mathrm{~mm}$. (Fig. 161.)

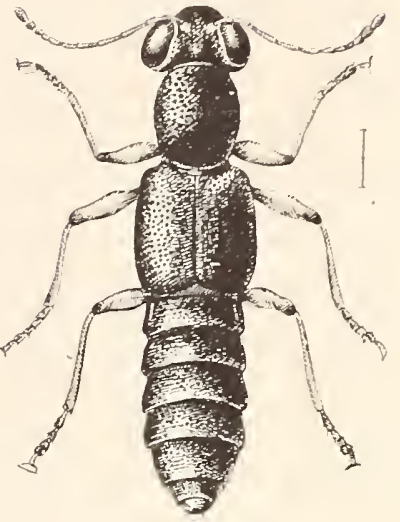

Fig. 161. (Original.)

Throughout the State; common. March 13-November 28. First described by Say under the name S. geniculatus, which name was preoccupied.

*796 (2444). Stents annularis Erichs., Gen. Sp. Staph.. 1840, 735.

Elongate, robust, subcylindrical. Black, strongly shining, sparsely clothed with grayish pubescence. Head small, much less than twice as wide as long, surface between the eyes nearly flat, coarsely and irregularly punctate, convex at middle. Antennæ longer than the width of head, piceousbrown, the club darker, third joint two-thirds longer than fourth. Thorax about as wide as long, widest just in front of middle, coarsely and irregularly punctate, with sereral small smooth spaces at middle. Elvtra at base slightly wider than head, a little longer than thorax. punctured as in flavicornis. Abdomen at base slightly narrower than elytra. thence feebly tapering to apex. finely, closely and evenly punctate. Length $5-5.5 \mathrm{~mm}$.

Lake, Kosciusko, Marion and Vigo counties; scarce. January 7-June 25. Hibernates beneath logs and rubbish.

797 (2451). Stenưs Canadensts Casey, Rev. Sten.. 1884, 175.

Elongate, rather robust. Black, shining, sparsely and finely pubescent. Head twice as wide as long; surface between the eyes feebly convex, finels. evenly and densely punctate. Antennæ as long as width of head, reddishbrown, the club darker; third joint one-half longer than fourth. Thorax widest distinctly behind the middle. slightly longer than wide; rather coarsels, densely and somewhat unerenly punctate. Elytra at base equal in width to head, one-third longer than thorax; punctures round, deep. evenly distributed, separated by about their own width. Abdomen as wide at base as elytra, thence gradually and feebly tapering. rather coarsely. densely and erenly punctate. Length $4.7-5 \mathrm{~mm}$.

Starke and Kosciusko counties: scarce. May 19-June 25. Taken by beating low herbs on borders of marshes. Known from Ontario and northern Illinois. 


\section{8 (2460). Stenus callosus Errichs., Gen. Spec. Staph., 1840, 737.}

Rather slender, subcylindrical. Black, shining; sparsely pubescent; palpi and legs dull yellow, the femora dusky at tips. Head slightly wider than thorax, surface between the eyes flat, rather coarsely, closely and irregularly punctate, the middie portion slightly convex and almost smooth. Antennæe one-half longer than width of head, reddish-yellow, the clul darker; third joint one-half longer than fourth. Thorax subcylindrical. slightly longer than wide, densely and rather finely punctate, with a small. fusiform smooth space at middle. Elytra at base a little wider than head. the suture one-fifth longer than thorax, finely, evenly and densely punctate. Abdomen distinctly narrower than elytra at base, gradually tapering to apex, finely and rather sparsely punctate. Length $3-3.2 \mathrm{~mm}$.

Kosciusko County; rare. June 24. The thorax is nearly of the same width throughout. Probably occurs throughout the State.

\section{9 (2462). Stenus Arculus Erichs., Gen. Spec. Staph., 1S40, 744.}

Subcylindrical, rather slender. Black, shining, sparsely clothed with grayish hairs. Head a little wider than thorax, surface between the eyes almost flat, rather coarsely, densely and evenly punctate. Antennæ scarcely longer than width of head, dull brownish-yellow, the club darker, third joint one-half longer than fourth. Thorax widest just behind the middle, rather coarsely, densely and unevenly punctate, the interspaces finely rugose. Elytra at base as wide as head, suture very little longer than thorax. surface densely, coarsely and deeply punctate. Abdomen distinctly narrower than elytra, rather coarsely and closely punctate. Length $2.8-3.4 \mathrm{~mm}$.

Lake and Marion counties; scarce. May 24-May 30.

800 (2463). Stenus punctatus Erichs., Gen. Spec. Staph., 1840, 744.

Subcylindrical, rather robust. Black, shining, rather thickly clothed with grayish hairs. Head slightly wider than thorax, surface between the eyes feebly convex, withont grooves, finely and densely punctate. Antennæ as long as width of head, joints two to six reddish-brown, the others darker, the third one-third longer than fourth. Thorax about as wide as long, widest at middle, finely and densely punctate. Elytra at base as wide as head, suture one-third longer than thorax, surface convex, deeply, densely and rather coarsely punctate. Abdomen much narrower at base than elytra, very gradually tapering to apex, deeply, coarsely and evenly punctate. Length $3-3.3 \mathrm{~mm}$.

Throughout the State; frequent. May 12-October 17.

\section{Subfamily IV. PAEDERINAE.}

Medium sized or small Staphylinids having the antennæ widely separated at base and inserted at the sides of the front, above the base of the mandibles, under a more or less prominent ridge; maxillary palpi with the last joint usually very small and awlshaped; head narrowed suddenly behind into a distinct neck; front coxre conical and prominent; hind coxx also conical and contiguous. 
The following papers treat of the North American speries of the subfamily :

LeConte._"Synoptic Tables of Lathrobium, Stilicus and s'unius," in Trans. Amer. Ent. Soc. VIIT. 1880. 174-180.

LeConte.-"Synoptic Tables of Cryptobium, Paderus and Palaminus," in Proc. Amer. Phil. Soc., XVII. 1878, 390-397.

Hor".-_ A Study of the Species of Crrptobium of North America." in Trans. Amer. Entom. Soc., XII, 1884. 85-106.

Casey._-"A Revision of the American Prederini," in Trans. Acad. Sci. St. L.. XV. 1905, 17-248.

As above defined, the subfamily is represented in Indiana by two tribes:

KEI TO INDIANA TRIBES OF PRDERINE.

u. Last joint of maxillary palpi very smail, awl-shaped.

Tribe I. P'EDERINI, 1. 415. au. Last joint of maxillary palpi as large as the third, obliquely hatchetshaped.

ribe II. Pinophilini, D. 440.

Tribe I. PADERINI.

This tribe as above limited is composed of a large number of genera, the following of, which are known to oceur in Indiana:

KEY TO INDIANA GENERA OF PEDERINI.

a. Fourth joint of hind tarsi not lobed beneath.

$b$. Antennæe elborred at the end of the long basal joint; front tarsi not dilated.

c. Mandibles each with three teeth on the inner side; males with last ventral not notched, the second and third rentrals each with a fold or pit at middle.

xtiti. Criptobium.

cc. Mandibles each with two teeth: males with the last rentral notched, the second and third withont folds or pits.

XLiv. Hesperobium.

bb. Antemne straight or nearly so, the basal joints not greatly elongated.

d. Prosternum shortened between and under the front coxie, ending in an acute point which does not reach the mesosternum.

c. Labrum bilobed; sculpture never very dense, the surface more or less shining; front tarsi strongly dilated in both sexes: ligula bilobed at tip.

NLY. LATHRoBím.

ee. Labrum with a distinct median tooth; sculpture rery dense, the surface subopaque; front tarsi rariable; ligula with a dense fringe of hairs at tip.

f. Front tarsi morlerately dilaterl, densely parderl beneath ; first joint of hind tarsi one-half longer than second: length $6.5 \mathrm{~mm}$.

XIVI. Aderocharis.

ff. Front tarsi not dilated; first joint of hind tarsi only slightly longer than second; length $3.7 \mathrm{~mm}$.

LITHOCHARIS.

[27--23402] 
ad. Prosternum prolonged behind so as to reach the mesosternum.

g. Sides of prosternum not dilated under the coxie.

h. Neck never very slender; ligula loosely fringed at tip.

i. Labrum with teeth.

$j$. Teeth of labrum two in number.

$k$. Antenne with the two basal joints thick, the others slender, filiform; basal joints of hind tarsi distinctly longer than second; length less than $3.5 \mathrm{~mm}$.

7. Gular sutures moderately separated, gradually conrerging and most narrowly separated at base; front tarsi more or less dilated; surface distinctly punctuled.

XLVII. Sciocharis.

71. Gular sutures rery widely separated and nearest together in front, thence widely diverging to base of head: front tarsi not at all dilated; surface not distinctly punctured.

XLNIII. Sciocharella.

1.\%. Antenne with the basal joints of equal thickness with the others, the apical ones feebly enlarged: teeth of labrim very small; prosternum not carinate.

$m$. Basal joints of hind tarsi equal in length to second. the first four joints short and subequal; sul:ur sutures most narrorly separated a little before the middle.

Xlix. Trachisectes.

$m$. Basal joints of hind tarsi distinctly longer than second. the tarsi more elongate; front tarsi strongly dilated, especially in the male; gular sutures most narrowly separated at base; neck wide, almost half as wide as head. L. PARAmedon.

ji. Labrum with four teeth, the inner ones long. acute, and prominent, the outer ones rery small; gular sutures widely separated at base.

Piatimedon.

ii. Labrum without teeth: body very slender, finely and vers densely punctate: gular sutures as in Platymedon: first joint of hind tarsi longer than second.

LI. Pseudomedox.

hh. Neck. in our species rery slender; ligula tricuspid at tip; labrum with four teeth.

LII. Scop.eus. gg. Sides of prosternum broadly dilated under the coxie, reaching the inflexed sides of thorax; neck rery slender.

11. Intennæ distinctly longer than head; length 3.5 or more mm.; hind tarsi with joints 1 to 4 gradually decreasing in length.

o. Form rather slender: labrum broadly rounded or subtruncate at apex, the teeth usually acute; front tarsi finely and densely pubescent beneath.

LIII. Stilicts.

m. Form rery stout; labrum sinuate-emarginate at apex. the tro teeth short. obtuse; lront tarsi not at all dilated, haring long coarse hairs beneath; head orbicular, the surface minutely punctate or alutaceous. LIV. Megastilicus. 
nn. Antennie shorter than head; length less than $2 \mathrm{~mm}$.; basal joint of hind tarsi equal in length to the next two together; third joint of maxillary palpi more or less hatchet-shaped, the fourth rery minute; fifth rentral not elongated, wider than long.

LV. LePtogeNit's.

a $a$. Fourth joint of hind tarsi bilobed.

p. Last joint of maxillary palpi obtuse and pubescent; reddish-yellow. elytra dark blue, head and tip of abdomen black. LVI. P无DERTs.

$p p$. Last joint of maxillary palpi slender, very minute.

$q$. Thorax oval, usually longer than wide; elytra usually longer than thorax; form linear; neck moderately narror; length not orer $5 \mathrm{~mm}$.

LVII. Sunius.

$q q$. 'Thorax almost circular, distinctly longer than elytra; neck ver $y$ slender; color uniform pale rellow; length less than $3 \mathrm{~mm}$.

LVIII. STILICOPSIS.

\section{Cryptobium Mann. 1830. (Gr., "hidden+life.")}

Rather large, elongate, parallel species having the gular sutures separated; elytra with a fold or raised line near the side margin, extending from the humeri to the outer spical angle; neck distinctly and abruptly constricted above; basal joint of antennæ greatly elongated; front tarsi not dilated. The males always have a fold at the middle of the second, and a pit or fovea on the third ventral segment, and the last ventral is unmodified. In some of the species the males are of two forms; one having. in addition to the fold and forea. the third segment prolonged backward in a lobe which varies much in length. (Fig. 162.) Caser has created a new name, "Gastrolobium," for' the species possessing the characters above mentioned, but I

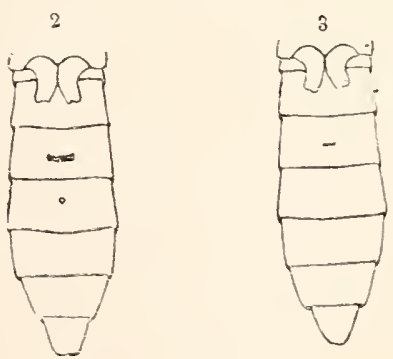
have retained the older and better known name. The following species have been taken or probably oecur in the State:

KEI TO INDIANA SPECLES OF CRYPTOHIUN.

u. Second rentral of female with a pit or short transverse forea near its middle. (Fig. 162, No. 3.)

6. Abdomen uniform dark brown or piceous: third joint of antemue distinctly longer than second; length 10-12 mm.

S01. BaDIUM.

67. Abdomen bicolored, piceous, with the last two segments pale reddishbrown; length $\mathrm{S}-10 \mathrm{~mm}$.

a a. Second rentral of female simple. without pit or forea.

SO2. BICOLOR.

c. Abdomen bicolored, the last two segments paler.

d. Head and meso- and metasterna pale reddish-brown.

TEXANUM. 
dd. Head and meso- and metasterna piceous.

S03. CAROLINUM.

cc. Abdomen uniform pale reddish-brown; head darker than thorax and elytra; length $8.5-11 \mathrm{~mm}$.

PIMERIANUM.

*S01 (24S4). Cryptobluar badiun Grav., Mon. Col. Micr., 1806, 53.

Uniform reddish-brown, shining, the head slightly darker. Head oblong-oval, sides nearly parallel, coarsely and rather closely punctate, the front smooth. Thorax much narrower than head, one-fourth longer than wide, sides feebly curved; disk sparsely. coarsely and shallowly punctate, with a median smooth space. Elytra one-third longer and nearly one-half wider than thorax, coarsely, rather closely and irregularly punctate. Abdomen rather finely, not densely punctate. Length 10-12.5 mm.

Southern half of State, common: much less so in the northern counties. February 10-November 17. Occurs beneath bark and hibernates in small colonies beneath partly buried logs. About onethird of the males have the third ventral prolonged backwards in a lobe, with parallel sides and rounded tip. This bears a fringe of long, stiff hairs and sometimes reaches nearly to the end of abdomen. (Fig. 162, No. 1.) This lobe is also present in some of the males of the next two species. but its function is as yet unknown.

*S02 (2490). Criptobiua bicolor Grav.. Mon. Col. Micr., 1806, 179.

Head black; labrum, antennæ, thorax, elytra and last two segments of abdomen pale reddish-brown; legs pale sellow. Head oblong-oval, coarsely, not densely punctate. Thorax narrower than head, one-fourth longer than wide, sides parallel; disk smooth at middle, coarsely and rather closely punctate on sides. Elytra one-third wider and longer than thorax, rather coarsely, closely and irregularly punctate. Abdomen slightly narrower than elytra, sparsely and finely punctate. Males of two forms, one with, the other without, a prolongation of third rentral. Length $7.5-10 \mathrm{~mm}$.

Throughout the State; common. January 5-October 28. Occurs beneath cover and on fungi, especially in wooded pasture land. Hibernates beneath mullein leaves, logs, etc.

C. texanum Lec., 8-11 mm. in length. has been recorded from near Cincinnati, though its range is usually given as Texas to New Mexico.

S03 (2491). Criptobium carolinum Erichs., Gen. Spec. Staph., 1840, 563.

Piceous, moderately shining; thorax, elytra and last two abdominal segments rather dark reddish-brown; antennæe brownish. two basal joints and legs dull yellow. Head broadly oral, as wide as or wider than (male) elytra, coarsely and rather sparsely punctate. Thorax as in bicolor. Elytra one-fourth wider and one-third longer than thorax. very coarsely, closely and roughly punctate. Abdomen as wide as elytra, coarsely and rather sparsely punctate. Males as in badium. Length $8.5-10.5 \mathrm{~mm}$.

Kosciusko, Marion. Knox and Posey counties; scarce. March 21--June 22. Occurs on fungi and carrion. The females are easily 
separated from those of bicolor by the lack of fovea on second ventral. The males have the thorax and elytra darker reddish-brown, and the latter much more coarsely puuctate.

$C$. pimerianum Lec., $8.5-10.5 \mathrm{~mm}$. in length, is recorded by Casey from Indiana. I have not seen a specimen from the State. Its usual range is Texas to California.

\section{XTIV. Hesperobum Casey. 1905. (Gr.." "western+life.")}

This genus was created by Casey to include those species hitherto ascribed to Cryptobium which have the first and second ventrals of male without a trace of pit or fovea and the last rentral distinctly notched at apex. I include with them serpentinum LeConte, as the characters separating it are not sufficient to erect a new genus.

\section{KEY TO INDIANA SPECIES OF HESPEROBIUM.}

a. Elytra black or piceous; hind angles of head distinct.

$b$. Head distinctly broader than thorax, its sides curved behind the eyes; form robust.

S04. PALLIPES.

bb. Head scarcely wider than thorax, its sides straight for some distance behind the eyes; form more slender.

S05. CINCTUM.

aa. Elytra wholly or in great part reddish-yellow; head obliquely narrowed from the eyes to the neck, its hind angles wholly wanting.

$c$. Head. wholly smooth or with very few punctures.

d. Piceous; elytra pale reddish-brown, coarsely and deeply punctate.

S06. CRIBATUM.

dd. Reddish-yellow; front of head, thorax, two basal and two apical segments of abdomen black.

SERPENTINUM.

cc. Head distinctly punctured on basal half; color biack; elytra reddishyellow with a sutural black stripe, broader at apex and reaching to apical third.

SOT. SELLATUM.

*804 (2502). Hesperobium paldipes Grav., Mon. Col. Micr., 1S06, 179.

Piceous or nearly black, shining; antenne dusky; legs dull yellow. Head oval, slightly longer than wide, coarsely and rather sparsely punctured. Thorax slightly narrower than head, one-fifth longer than wide, sides feebly curved; disk with a well defined smooth median area, its sides coarsely, regularly and rather sparsely punctate. Elytra one-third wider and a little longer than thorax, rather finely, closely and roughly punctate. Abdomen as wide as elytra. finely and very densely punctate; last rentral of male with a triangular notch, much deeper than wide. Length $\mathrm{S}-11 \mathrm{~mm}$.

Throughout the State; frequent. February 8-October 17. Occurs especially beneath cover on sandy banks of streams. ponds, etc.

S05 (2502a). Hesperomiun cinctum Say. Trans. Amer. Phil. Soc., IV. $1 \$ 34$. 454 ; ibid. II, 569.

Elongate, slender. Black or piceous, feebly shining; antemne dusky. paler at tip; palpi and legs reddish-yellow. Head oblong-oral, much nar- 
romer than elytra. rather coarsels and closely punctate. Thorax slightly longer than wide. sides feebly curred; disk sparsely and rather finely punctate. Elstra one-third longer and one-half wider than thorax, coarsels and closely punctate. Abdomen as wide as elstra, rather finels and densels punctate. the hind margins of the segments paler. Last rentral of male with a triangular notch. about as wide as deep. Length $S-9.5 \mathrm{~mm}$.

Porter. Marion and Putnam counties: scarce. March 6-December 25. Listed as pallipes rar. latebricnta. but in my opinion distinct. Say's name has priority.

\section{S06 (2507). Hesperobitar cribatua Lec., N. Sp. N. Am. Col., I, 1S63, 46.}

Elongate, rather slender. Black, shining; antennæ, mouth parts and elrtra reddish-rellon: suture dariel on basal third; legs dull sellow. Head elongate-oral, slightly mider than thorax, with a fer coarse punctures behind the eres. Thorax subcrlindrical, one-fourth longer than wide, sides nearly straight: disk smooth at middle with a row of seren to nine coarse punctures each side the smooth area and a few others betreen these and margin. Elytra one-third wider and slightly longer than thorax, with about nine irregular roms of coarse, sparse punctures. Abdomen rather finely and closely punctate. Male with the last rentral with a deep, triangular notch. Length $8.5-10 \mathrm{~mm}$.

Vigo and Posey counties: rare. Nay j-June 11. Easily known by the long. sparsely punctured head and red elytra.

sot (2508). Hesperobiuy sellatuar Lec., N. Sp. N. Am. Col., I, 1S63, 46.

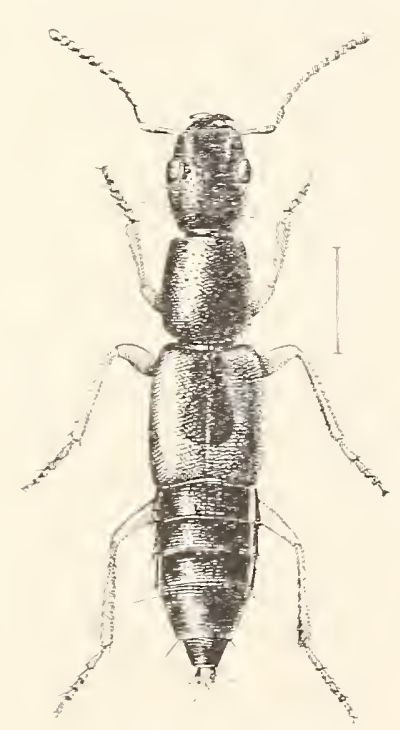

Fig. 163. (Original.)

Rather stout, subfusiform. Black, shining; color. of elytra given in key; antennie and mouth parts reddish-bĩown; legs dull sellow. Head elongateoral. coarsely and rather closely punctate behind the eyes. the front almost smooth. Thorax subcrindical. slightly narrower than head, one-third longer than wide. coarsely and rather sparsely punctures each side of a median smooth space. Elytra one-third longer and distinetly wider than thorax. surfice. as well as that of abdomen. finely and l'ather densels punctate. Length $\$$-9 mm. (Fig. 163.)

Lake County ; frequent beneath cover, especially the clumps of prickly-pear cactus. in the sand dune region; Posey County; rare. Irarch 26-September 25. A handsome spe(ies. readily known by the wedge-shaped black sutural stripe of elytra.

C. scrpentinum Lec. $9.5-10 \mathrm{~mm}$. in length. is a rare species known from Pennsylrania, North Carolina. Alabama and Kansas, and therefore should occur in southern Indiana. 
XLV. Lathrobum Grav. 1806. (Gr., "hidden+life.")

Medium or small sized Staphylinids having the prosternum shortened and acute between the frront coxx ; front tarsi strongly dilated and densely clothed beneath with large whitish pads composed of flattened hairs; fourth joint of maxillary palpi conical and pointed or needle-shaped.

Casey, in his "Revision," has divided the old genus Lathrobium as recognized by LeConte, Horn and other authorities, into 19 genera, ten or eleven of which are probably represented in Indiana. His distinguishing characters are, in many instances, of minor importance and I prefer to rank his genera as groups or subgenera, thus placing all species under the well-known name of Lathrobium. The following is a modification of the ker or table of genera as proposed by Casey :

KEY TO INDLANA GROUPS OR SIBGENERA OF LATIROBITM.

a. Elytra without a fold or raised line on the deflexed portion.

b. Neck broad, half. or more than halt the width of head.

c. Hind tarsi longer and more slender, the basal joint much shorter than second, the fifth much shorter than the first four combined.

d. Elytra rery short, from one-half to two-thirds the length of thorax, their basal angles obsolete; inner wings wanting; abdomen rather coarsely and sparsely punctate.

Group A. Apteralium.

dd. Elytra varying in length from a little shorter to decidedly longer than thorax, basal angles distinct; inner wings present; abdomen minutely punctate.

Group B. Lathrobiun.

$c c$. Hind tarsi shortel and stouter, the first and second joints subequal, the first four differing but iittle among themselves and together often but little longer than fifth; gular sutures parallel and curred, rather widely separated, nearest together near the middle of the surface behind the mouth.

Group C. Lathrobioma.

bb. Neck narrow, about one-third as wide as head; gular sutures nearly straight, feebly converging behind, nearest together near the base of the head.

Group D. Tetartopets.

a a. Elytra with a longitudinal fold or raised line on the deflexed portion. the line parallel with the side margin.

e. First joint of hind tarsi equal to or slightly longer than second.

f. Four basal joints of hind tarsi subequal; front tarsi feebly dilated; gular sutures rery widely separated, being separated at base by one-third the width of head; body rery small and slender, not over $4 \mathrm{~mm}$. in length.

Group E. Psecdolathri.

ff. First and serond joints of hind tarsi each longer than the third or fourth. 
y. Form larger, more robust, length 6 or more mm.; neck broad, more than half as wide as head; elytral punctures in rows.

Group F. Lathrotaxis.

gg. Form small. slender, length less than $5 \mathrm{~mm}$.; neck distinctly less than half as wide as head; elytral punctures coarse and sparse, arranged in rows.

Group G. Linolathra.

ce. First joint of hind tarsi distinctly shorter than second.

7. Body large. stout. parallel; length 9 or more mm.; gular sutures less separated. nearest together at base of head.

Group H. Eulathrobius.

h $h$. Body slender, less than $6 \mathrm{~mm}$. : gular sutures widely separated. nearest together in front, farthest apart at base of head.

i. Elytra longer and wider than thorax; head small and, in our species, dark: body more or less fusiform.

Group I. LATHRobIELLA.

ii. Elytra small. shorter than thorax; head larger, as wide as elytra and pale in color: body parallel.

Gromp J. MicroLATHRA.

Group A. (APTERALiti.)

To this group Casey ascribes two species. one of which occurs in Indiana.

SoS (2521). Lathrobium brevipenne Lec.. N. S1. N. Am. Col.. I. 1S69. 44.

Elongate, rather slender. Dark reddish-brown to piceous. shining; legs and antenne reddish-brown. Head as wide or slightiy wider than thorax. sides parallel. base truncate. hind angles rounded; surface coarsely and rather closely punctate behind the eyes, smooth at middle. Antennæ rery stout, the joints obconical. the basal joint robust. Thorax oblong, onefifth longer than wide, sparsely and coarsely punctured. with a broad median smooth space. Elytra but slightly more than half the length of thorax. rather coarsely and sparsely punctate. Abdomen as wide as elytra. Length 7.8-9 $\mathrm{mm}$.

Putnam County: rare, March 25. Known heretofore from Illinois, Iowa and Missouri.

\section{Group B. (Lathrobium.)}

Rather stout, usually large or medium-sized species, having the thorax miformly punctured, with distinct smooth dorsal line; elytra without a fold or raised line on side; basal joint of hind tarsi distinctly shorter than second. The following species have been taken or probably oceur in the State:

REY TO INDIANA SPECIES OF GROLP B.

a. Bicolored; black, antenne, legs and elytra wholly reddish-brown; length less than $5 \mathrm{~mm}$; fifth ventral of male with a round discal impression. sixth deeply notched at tip.

BICOLOR. 
a a. Color nearly uniform, the elytral not distinctly baler except toward the tip ; larger, 7 or more num.

b. Antennie rery stout, more slender toward apex. the middle joints rounded, never longer than wide.

c. Flytra bicolored, black basally and reddish on apical third, as long as thorax; length $10 \mathrm{~mm}$.

S09. Proceruar.

ce. Elytra wholly black or piceous.

1. Elytra much longer and wider than thorax, a fourth longer than wide; legs and antennik dirk reddish-hrown; length $\tau$ mm.

SPISSICORNE.

dd. Elytral equal in length to thorax; Jegs wholly pale reddishbrown; length \&-10 $\mathrm{mm}$. ; sixth ventral of male with a lengthwise groove near base, not notched at tip. S10. ARmatur.

bb. Antemie only moderately stout, the joints at least one-half longer than wide, obconic; sixth ventral of male more or less notched at tip.

$e$ Elytra not longer, and often distinctly shorter than thorax.

$f$. Antennx not longer than head and thorax, the joints less than twice as long as wide; gular sutures straight, nearest together at base of head.

\%. Punctures of elytra rather fine, sparse and inconspicuous; notch of last rentral of male wide and deep, distinct; length $7.5-9 \mathrm{~mm}$.

h. Head and thorax sparsely and rather finely punctured.

\$1. SIMILE.

hh. IIead and thorax densely and rather coarsely punctured.

S12. INSANTS.

gy. Punctures of elytra coarse. uneven and conspicuous; last rentral of male truncate. the notch rery small; length 6.5$7.5 \mathrm{~mm}$.

SIMPLEX.

$f f$. Antennie slender, longer than head and thorax, the middle joints fully twice as long as wide; gular sutures curved, nearer together at middle of area behind the mouth; color black, legs and antennie paler ; length $6.7-7.5 \mathrm{~mm}$.

CRURALIS.

ce. Elytra much longer than thorax; abdomen narrower than elytra. the last rentral of male broadly and semicircularly notched: black, antennie and legs bromn ; length $6.5-7.5 \mathrm{~mm}$. coxcolor.

L. bicolor Lec., was described from Detroit. Michigan, and $L$. spissicorne Casey from Massachusetts and Detroit, so that one or both of them are apt to be found in Indiana.

SO9 (- ). Tathrobity procerua Casey, Trans. Acad. Sci. St. L., IV, 1905. S2.

Elongate. rather slender. Black, shining; elytra becoming gradually but distinctly reddish on apical third; legs reddish-brown: antennie piceous. with a reddish tinge. Mead equal in width to thorax, sides parallel, sparsely. rather finely and irregularly punctate. Thorax oblong. sides nearly straight. feebly convelging toward base. finely and rather sparsely punctate. Elytra rather closely and finely pumctate. Abdomen as wide as elytril. mimntely and rather densely punctate. Length 9-10 $\mathrm{mm}$. 
Laporte County'; rare. July 25. Described from New York, Ontario and Illinois.

*S10 (2522). Lathrobitur armatelu Say, Trans. Amer. Phil. Soc., IV, 1834, 453 ; ibid. II, 568.

Elongate, rather robust. Black or piceous, feebly shining; palpi, antennie and legs reddish-brown. Head as wide as elytra, its sides rounded into base; surface finely and sparsely punctate. Thorax oblong, nearly equal in width to head and elstra; surface, as mell as that of elytra, roarsely, erenly and sparsely punctate; the median smooth line rery narlow. Abdomen as wide as elytra, parallel, finely and rather closely but not densely punctate. Length $\mathrm{S}-10 \mathrm{~mm}$.

Southern half of State. frequent: less so in the northern counties. February 11 september 22. Occurs especially in low, damp sandy places: taken also at sap of soft maple.

S11 (2524). Lathrobium simile. I.ec., N. Sp. N. Am. Col., I, 1863, 43.

Elongate, rather slender. Black. shining; elstra and abdomen piceous; antennie and tip of abdomen reddish-brown; legs paler. Head subquadrate, sparsely and finely punctate. Thorax oblong, as wide or' slightly wider than head, scarcely longer than wide, rather coarsely and sparsely punctate. Elytra as long and slightly wider than thorax. Abdomen as wide as elytra, minutely and rers densels punctate. Fifth rentral of male narrowly and deeply impressed along the middle; sixth also with a lengthwise groove and a wide, deep notch at apex. Length $7.5-9 \mathrm{~mm}$.

Vigo and Marion colinties; scarce. February 11-October 4.

S12 (- ). LATHROBILAI INSANUS s]). HOY.

Elongate, slender. Dark reddish-brown; elytra tinged with red; legs and antennæ paler. Head subquadrate, narrowed in front, its surface, as well as that of thorax, closely and rather coarsely punctate. Antemne slender, the cuter joints obconical, as wide at apex as long. Thorax longer than wide, its sides straight, feebly converging from apex to base. Elytra as long as thorax. finely and much more sparsely punctate than there. Abdomen finely and densely punctate. Notch of last rentral of male distinctly wider and less deep than in simile. Length $8.5 \mathrm{~mm}$.

Laporte County; rare. July 25.

L. cruralis Casey was described from New Jersey, Ohio and Iowa. L. concolor Lec., is said by Casey to occur in "Indiana and westward."

\section{Group C. (LAthrobiona.)}

This group is composed of rather small. slender species which resemble those of Group B. in their large head and thick, bead-like antennæ. but the joints of the hind tarsi are subequal. Casey has placed in the gromp 11 species. two of which may occur in the State, though neitler is in the collection at hand. 'They are: 
L. othoides Lee., having the head parallel at the sides. color deep' shining black. legs reddish-brown, antennu dusky; sixth ventral of: male with a square notch; length $5-5.4 \mathrm{~mm}$. It has been taken in New England and Iowa. L. teme Lec., very slender, with head broadest near the base; color similar; sixth rentral of male semicircularly emarginate; length 4.6-5 mm., known from New England, Canada and Nichigan. and probably oecurs in northern Indiana.

\section{Group D. (Tetartopeus.)}

This group is chiefly distinguished from other species of Lathrobium by the very narrow neck. The antennie are rather slender and filiform and the body is usually more or less fusiform rather than parallel in outline. The following species have been taken or' perhaps occur in the State:

\section{KEY TO INDIANA SPECIES OF GROLP D.}

a. Elytra reddish, sometimes clouded with black on suture near base.

b. Thorax deep black.

c. Head parallel or only very feebly and gradually nar'rowed behind the eyes; thorax strongly and coarsely punctate, the punctures rather dense.

S13. PUNCTULATUM. $c c$. Head very obriously narrowed behind the eyes in bath sexes.

6b. Thorax dull reddish, similar in color to elytra.

RUBRIPENNE. aa. Elytra not red.

d. Elytra black with the outer apical angles. or sometimes the whole apex, more or less abruptly pale; length $i-\tau . S \mathrm{~mm}$.

ATGULARE.

dd. Elytra and entire body black. the legs dark; length $5.3-5.5 \mathrm{~mm}$.

NIGRUM.

S13 (2512). Lathrobiun Punctulatum Lec., N. Spec. N. Amer. Col., I. $1863,42$.

Elongate, slender. Black, shining; antenne and elrtra dull red. the former dusky toward apex; legs dull yellow. Ilead semicirular behind the eyes. finely and rather sparsely punctate. Thorax oblong. slightly Ionger" than wide, distinctly wider than lead; surface as well as that of elytrat. rather coarsely, not closely punctate, the median smosth line rery nalrow. Elytra one-third wider and distinctly longer than thorax. Ablonen as wide as elytra. minutely and densely punctate. Males with the third to fifth rentral segments feebly impressed along the middle. the sixth acutely and deeply notched. Length 6-i mm.

Throughout the State; scarce. February 26-October 17. Occurs beneath corer in open upland woods.

L. rubripenne Caser, $6 \mathrm{~mm}$. in length, is said to range from Nassachusetts to Iowa. 
S14 (- ). Latimobium Semiruber Casey, Trans. Acad. Sei. St. L., XV, $1905,107$.

Elongate, rather slender, nearly parallel. Black; thorax and elytra dark dull reddish, the elytra clouded with blackish toward the base; antemne piceous, paler at base; legs dull yellow. Head orbicular, finely and sparsely punctate; antenne slender, reaching middle of elytra. Thorax oblong, distinctly wider than head, coarsely, rather sparsely and unevenly punctate. Elytra one-fourth wider but very slightly longer than thorax, coarsely, rather closely and roughly punctate. Abdomen as wide as elytra, finely and densely punctate. Males with fourth and fifth ventrals feebly flattened, sixth with a minute median notch, deeper than wide, and narrower than in punctulatum, almost concealed by dense hairs. Length 7 $7.5 \mathrm{~mm}$.

Putnam County; rare. October 17. Taken by sifting damp vegetable debris. Described from Iowa.

L. angulare Lec., 7-7.8 mm., and L. nigrum Lee., 5-5.8 mm. in length, both have a range which favors their occurrence in the State. The latter is a boreal species, known from Massachusetts, Michigan and Wisconsin.

\section{(Group E. (PSLUdolattira.)}

Small, slender, subdepressed species having the head small. broadly rounded and subtruncate at base; maxillary palpi short and stout; gular sutures widely separated and strongly divergent; antennx reaching middle of elytra, rather stout, the joints obconic; neck half as wide as head; thorax with median smooth area, defined by impressed rows of punctures. The two known species occur in the State.

S15 (2540). Lathrobium anale Lec., Trans. Amer. Ent. Soc., VIII, 1S80, 177.

Elongate, very slender. Head black; antenne, thorax and elytra pale reddish-brown, shining; legs yellow; abdomen piceous, paler at apex. Head rather coarsely and very sparsely punctate. Thorax as wide or wider than head. slightly longer than wide; sides straight, feebly converging from apex to base, disk with a row of close set punctures each side of median line, those on sides few and finer. Elytra slightly wider and but little longer than thorax, with rows of very fine. shallow, indistinct punctures, confused near tips. Abdomen a little nilrower at base than elytra, minutely and very densely punctate. Sixth rentral of male with a small triangular notch. Length $3.4-3.7 \mathrm{~mm}$.

Lake, Dubois and Posey counties; scarce. April 21-May 19. Sifted from damp vegetable debris.

S16 (-). Lathrobium Laviceps Casey, Trans. Acad. Sci. St. L., XV. $1905,129$.

Slender, subparallel. Dark piceous; head black; antenna and legs dull reddish-brown. Heat rather coarsely and sparsely muctate, Thorax ob- 
long, wider than head, sides nearly straight, disk rather coarsely and sparsely punctate. Elytra one-third longer and two-fiftlis wider than thorax, finely, rather closely punctate, the rows uneren. Abrlomen finely and densely punctate. Length $3.8 \mathrm{~mm}$.

Described by Casey from Indiana and Mississippi.

\section{Group F. (Lathrotaxis.)}

Rather large, parallel and subdepressed species, having the upper surface except the abdomen coarsely and sparsely punctate; head usually narrower than elytra, its sides broadly rounded into base; labrum with a large triangular notch; antennæ rather long and slender, filiform; elytral punctures sparse and in distinct rows.

*817 (2534). Iathrobie a longetisculum Grar., Mon. Col. Micr., 1806, 181.

Elongate, slender. Head and thorax black; elytra dull red, dusky at middle of base; antenne and legs reddish-brown; abdomen piceous. Head coarsely and rery sparsely punctate. Thorax oblong, slightly longer than wide, a little wider than head, sides straight; disk with a wide smooth median space bounded each side by an irregular row of close-set punctures, elsewhere coarsely, very sparsely and irregularly punctate. Elytra onefourth wider and slightly longer than thorax, each with about six rows of rather coarse, feebly impressed punctures. Abdomen slightly narrower than elytra, finely and rather closely punctate. Sixth rentral of male with a shallow, broadly rounded notch at apex. Length 6.5-7.5 mm.

Throughout the State; frequent. February 14-November 28. Hibernates beneath bark and logs in upland woods.

\section{Grove G. (Linolathra.)}

Small, slerder. subparallel polished species having the head narrower than elytra; labrum short. broadly emarginate; thorax small. oblong, the angles distinct; elytra wider and never shorter than thorax, their punctures in rows. One of the four species has been taken in the State.

818 (2543). Lathrobium dimidiatum Say, 'Trans. Amer. Phil. Soc., IV, 1834, 455; ibid. II, 570.

Elongate, vel'y slender. Head and abdomen black; thorax and elytra dull red, the latter often blackish at base; antemne reddish-brown, legs paler. Head coarsely and very sparsely punctate. Thorax slightly narrower than head, a little longer than wide, sides straight; disk with a single row of seren to nine rather coarse punctures each side of the median smooth space; punctures on sides very fine and sparse. Elytra a fourth wider and slightly longer than thorax, each with two or three rows of rather coarse, distant, shallow punctures. Abdomen slightly narrower than elytra, finely but not very closely punctate. Sixth ventral of male with a shallow rounded notch at apex and with a deep, triangular impression before the notch; fifth rentral also with a slight noteh. Length $3.8-4.5 \mathrm{~mm}$. 
Southern half of State, frequent; much less so northward. March 6-October 10. Occurs beneath bark, vegetable debris, etc.

\section{Group H. (Eulathrobium.)}

This group is represented by one species which is the largest of the genus.

S19 (2511). Lathrobium grande Lec., N. Sp. N. Amer. Col., I, 1863, 42.

Robust, parallei. Black, shining, finely pubescent; antemnæ and legs dark reddish-brown. Head wider than long, rather finely, not densely punctate, its sides rounded into the subtruncate base. Thorax oblong-oval, slightly narrower than head, a little longer than wide; disk coarsely, deeply, rather closely punctured, with a narrow median smooth line. Elytra slightly wider and distinctly longer than thorax, coarsely and densely punctate. Abdomen as wide as elytra, finely and rather closely punctate. Sixth rentral of male with a small triangular tooth at apex. Length 10-11 mm.

Steuben and Kosciusko counties; rare. June 26-August 13. A member of the boreal fauna.

\section{Group I. (Tathrobiella.)}

Rather small. more or less fusiform species having the head small, its sides rounded-into base; neck half as wide as head; thorax rather large, oblong; elytra with the punctures in rows; abdomen minutely and densely punctate.

The following species have been taken or probably occur in the State :

KEY TO INDIANA SPECIES OF GROUP I.

a. Form more convex, less slender; head narrower than thorax; elytra piceous or dark reddish-brown.

b. Fifth ventral finely and densely punctate like the fourth; elytral punctures finer, more close set; sixth rentral of male with a broad triangular notch.

VENTRATE.

bb. Fifth and sixth rentrals less densely punctured; elstral punctures coarser. in more regular impressed rows; sixth rentral of male with an acute triangular notch.

S20. COLLARE.

a a. Form more slender and depressed; head erual in width to thorax; ely-

tra pale, distinctly longer and wider than thorax.

c. Eyes of normal size and prominence, situated at distinctly less than twice their own length from base of head; elytra pale reddish-yellow, with a piceous cloud near scutellum.

RUBIDA.

cc. Eyes notably smaller, situated at twice their own length from base: elytra pale dull yellow.

821. AMBIGUUM.

$L$. ventrale Lec., $4 \mathrm{~mm}$. in length, was described from Pennsylvania, Florida and Kansas, and therefore probably occurs in Indiana. 
*820 (2537). Lathrobium collare Frichs., Gen. Spec. Staph., 1840, 599.

Elongate, slender. Head black, antennse and thorax reddish-brown; legs paler; abdomen piceous, the apex paler. Head as long as wirle, coarsely and very sparsely punctate. 'Thorax slightly longer than wide, much wider than head, sides feebly curved; disk with a smooth median line, bounded each side by an irregular row of fine punctures, and with a few scattered ones each side. Elytra distinctly longer and a little wider than thorax; abdomen slightly narrower than elytra, densely and finely punctate. Length $4.5-5.5 \mathrm{~mm}$.

Southern half of State, frequent; less so northward. February 10-November 1.

L. rubida Casey was described from Pennsylvania, Indiana and Mississippi. I have not seen a specimen from the State.

821 (2538). Lathrobium ambiguum Lec., Trans. Amer. Ent. Soc., VIII, $1880,177$.

Elongate, very slender, subdepressed. Head and abdomen piceous or paler; remainder of body dull brownish-yellow. Head rery sparsely punctate; antennæ rather thick, reaching middle of elytra. Thorax oblong, sides straight; disk with a row of fine punctures each side of a smooth median line, and with a few scattered ones on sides. Elytra slightly wider and one-third longer than thorax, with rows of fine, close-set punctures. Abdomen narrower at base than elytra, thence feebly widening to fourth segment; densely and finely punctate. Sixth ventral of male with a small triangular notch at apex. Length $3.5-4.5 \mathrm{~mm}$.

Lake, Kosciusko, Marshall. Posey and Perry counties; scarce. April 19-July 24. Occurs beneath bark and rubbish in damp places.

\section{Group J. (Microtatitra.)}

One small, pale species represents this group in the State.

S22 (2541). Lathrobium paldidulum Lec., 'Trans. Amer. Ent. Soc., VIII, 1880,177 .

Elongate, very slender. Pale reddish-yellow, strongly shining. Head as long as wide, finely and sparsely punctate, the base truncate; antenne reaching base of thorax, joints short, rather stout. Thorax slightly longer than wide, with a row of fine punctures along each side of a smooth median line. Elytra one-fourth shorter and slightly wider than thorax, with indistinct rows of fine, sparse punctures. Abdomen at base as wide as elytra. feebly widened toward apex, finely not densely punctate. Sixth ventral of male with a small, broad triangular notch at apex. Length $3.8-4 \mathrm{~mm}$.

Marshall, Putnam and Clark comnties; scarce. March 25-May 20. Occurs beneath stones in open woodland pastures, often in company with ants. 
XLVI. AdErocharis Sharp. 1886. (Gr., "eating enough t to delight in.' ')

Rather stout, parallel species, having the head broadly sinuatetruncate at base; third joint of maxillary palpi elongate-oval; antennæ slender, reaching beyond middle of thorax; neck two-fifths as wide as head; thorax subquadrate, the apex somewhat produced forward at middle. One speries occurs thronghout the Eastern United States.

S23 (2559). Aderocharis corticlna Grav., Mon. Col. Micr., 1806, 184.

Rather broad, moderately convex. Dark reddish-brown, the entire upper surface minutely and densely punctate; antennie and legs paler; head blackish. Head a little wider than long, its sides feebly curved. Thorax slightly wider than long, a little narrower than head, sides straight, feebly converging from the distinct apical to the broadly rounded basal angles. Median smooth line very narrow. Elytra together quadrate, a little longer and wider than thorax. Abdomen slightly narrower than elytra; the sixth ventral of male broadly and shallowly emarginate. Length $6-\tau \mathrm{mm}$.

Marion and Monroe counties; rare. June 9-June 12. Taken by sifting decaying maple logs. Described by Say from Posey County under the name Lathrobium millepunctatum.

\section{XLVIT. ScIOCInARIS Arrib. 1884.}

Small, rather stout brown or piceous species having the two basal joints of antennie much thickened, the second in our species longer than third; gular sutures but slightly separated. closest together at base; neck less than half as wide as head; front tarsi more or less dilated; basal joint of hind tarsi distinctly longer than second, joints two to four decreasing in length. One of the three United States species occurs in Indiana.

S24 (-). Sciocharis carolinensis Casey, Trans. Acad. Sci. St. L., XV. $1905,157$.

Parallel, moderately convex. Head piceous; antennæe, legs and abdomen pale reddish-brown; thorax and elytra darker. Head as wide as elytra, its sides feebly curved, finely and densely punctate. Thorax subquadrate, wider than long, widest at apex, its sides straight and feebly converging to base; disk finely and rather densely punctate, with a very narrow smooth median line. Elytra one-third longer, slightly wider and a little more coarsely and sparsely punctate than thorax. Abdomen as wide as elytra, minutely and rather closely punctate. Sixth rentral of male with a broad notch at apex. Length $3 \mathrm{inm}$.

Orange County; rare. June 2. Sifted from decaying beech stump. 


\section{XIVIII. Sciocharital Casey. 1905.}

Closely related to Sciocharis, but differing by the smaller size and in the characters mentioned in the generic key. One species belongs to the Austroriparian famna.

S25 (-). Sciocharella delicatela Casey, Trans. Acad. Sci. St. Lomis, X V, $1905,159$.

Slender, parallel. Pale to dull brownish-yellow, very minutely punctate, alutaceous; legs and antemie paler. Head piceous, as long as wide. widest at the truncate base; eyes situated iwice their length from base. Second antennal joint as long as the next two combined and much thicker. Thorax as long as wide, scarcely narrower than head, sides nearly straight, angles scarcely rounded. Elytra quadrate, parallel, much wider than head, a fifth wider and one-fourth longer than thorax. Length $1.8 \mathrm{~mm}$.

Crawford and Posey counties; rare. May 26-June 3. Described from Alabama.

\section{XliX. Trachysectus Casey. 1886.}

Represented east of the Rocky Mountains by one small piceous species having the gular sutures narrowly separated and nearest together in front of middle; neck half as wide as head; third joint of antenna distinctly longer than second, the outer joints bead-like; prosternum not carinate; upper surface coarsely and densely punctured.

S26 (2560). Trachysectus confluens Say, Trans. Amer. Phil. Soc., IV, 1834, 456 ; ibid. II, 571.

Rather stout, parallel, subconvex. Dark reddish-brown to piceous. feebly shining; legs, tips of elytra and base of antenne paler. Head wider than long, as wide as elytra, its hind angles broadly rounded; densely, coarsely and strigosely punctured. Thorax narrower than head, wider than long; disk with fine, lengthwise wrinkles. Flytra slightly wider and one-third longer than thorax, finely, rather closely and roughly punctate. Abdomen at base slightly narrower than elytra. thence feebly widened to near apex, finely and densely punctate. Sixth ventral of male with a small median notch. Length $3.5 \mathrm{~mm}$.

Throughout the State; frequent. March 17-October 17. Occurs beneath loose bark and dead leaves and in fungi. When uncovered they run very rapidly. The elytra are not always paler at tips and the thorax is often reddish on the sides.

\section{Paramedon Casey. 1905. (Gr., "orel" provider.")}

The principal distinguishing characters of this genus are the strongly dilated front tarsi and the sexual characters of the males. Its members hitherto known have all been from the Pacific or Southwestern States. 
$\$ 27$

( PARAMEdon falli sp. nov,

Elongate, rather slender, parallel. Dark reddish-brown. finely and sparsely pubescent; antennie, legs and last two segments of abdomen paler. Head subquadrate, sides straight and parallel behind the eyes; surface finely and rather densely punctate above, more sparsely beneath, the gular sutures very close together. Antennæe reaching almost to base of thorax. basal joint as long as the next three; two to five oval, subequal, longer than wide; six to ten transverse, eleventh slightly longer. Thorax nearly square, sides almost straight, angles rounded, disk finely and rather closely punctate. Elytra slightly wider and one-fourth longer than thorax, finely and densely punctate. Abdomen very finely and more densely punctate. Hind margin of fifth ventral of male with a broad and shallow rounded emargination. on each side of which is a tuft of short stiff black bristles. Length $4 \mathrm{~mm}$.

Steuben County; rare. May 25. Sifted from a nest of mouse at border of sphagnum marsh. Named in honor of H. C. Fall of Pasadena, California.

\section{Pseudomedon Rey. 1879. (Gr., "false + provider.")}

Small, slender species, with the entire upper surface very finely and densely punctate, subopaque; head small; gular sutures very fine, widely separated, nearest together in front, thence widely diverging to base; neck two-fifths as wide as head; front tarsi strongly dilated in both sexes. Two species have been taken in the State.

Sas (- - Pseudomedon ruficolle Casey, Trans. Acad. Sci. St. L., XV, $1905,18 S$.

Elongate, slender. Head, elytra and abdomen dark reddish-brown; thorax pale dull red; antennie and legs paler. Head as long as wide, threefourths as wide as thorax, its sides behind the eyes parallel and rounded into base. Thorax subquadrate, as long as wide, sides feebly curved, the angles broadly rounded. Elytra one-third longer and slightly wider than thorax. Abdomen at base as wide as elytra, thence distinctly tapering to apex. Sixth ventral of male with a small rounded emargination at apex. Length $4 \mathrm{~mm}$.

Steuben, Starke, Marion. Putnam and Posey counties; scarce. April 23-October 17. Taken by sifting regetable debris.

S29 (-). Pseudomedon tronacicum Casey, Trans. Acad. Sci. St. L., XV, $1905,18 S$.

Form of preceding. Uniform black or very dark piceous; antennæe and legs paler. Head almost as wide as thorax, the latter slightly wider than long, as wide almost as elytra; otherwise as ruficolle. Length $3.5 \mathrm{~mm}$.

Marshall County ; rare: May 20. Taken from beneath rubbish at margin of lake. 


\section{Scopæus Erichs. 1840. (Gr., "a dwarf.")}

Very small and delicate species having the labrum short, transverse and toothed; last joint of maxillary palpi acute, distinct; ligula tricuspid; antennæ filiform, subacuminate toward apex, the first joint moderately elongate, second and.third obconic, the remainder oval; thorax oblong, more or less narrowed in front. Casey has subdivided the genus as defined by Erichson into a number of genera, herewith treated as groups or subgenera, three of which are perhaps represented in Indiana, though members of but two have as yet been taken.

KEY TO INDIANA GROUPS OF SCOPAUS.

u. Neck extremely slender.

b. Hind tarsi rather short, the basal joint never more than slightly longer than second; body minute in size, more or less alutaceous; gular sutures rather widely separated. Group A. Scopeus.

$b b$. Hind tarsi long, slender, the basal joint always distinctly longer than second; body subparallel, strongly convex, very minutely punctulate and pubescent; gular sutures virtually united from a short distance behind the mentum.

Group B. Scoperopsis.

a a. Neck moderately narrow, varying from a fourth to nearly a third as wide as head; gular sutures more or less widely separated, farthest apart at base; labrum with four teeth; hind tarsi short, the basal joint but little longer than second; color black, polished, more or less sparsely punctate.

Group C. Pycnorus.

\section{GroUp A. (SCOPAUS.)}

Of the 20 or more species ascribed to this group by Casey, but one has as yet been taken in the State.

S30 (2546). Scopeus Exiguds Erichs., Gen. Spec. Staph., 1840, 608.

Slender, parallel. Head and elytra blackish piceous; thorax dusky yellow; abdomen blackish, paler at tip; antennæe and legs pale yellow. Head slightly longer than wide. minutely and densely punctate above, more sparsely beneath, truncate-sinuate at base. Thorax oblong, slightly longer than wide, but little narrower and less densely punctate than head; sides obliquely truncate on apical third, thus narrowing to apex. Elytra distinctly wider than head and thorax, but slightly longer than the latter, finely and densely punctate. Abdomen at base slightly nilrower than elytra, minutely and densely punctate. Length $2.4 \mathrm{~mm}$.

Marion and Putnam counties; scarce. March 6-June 12. Taken by sifting damp vegetable debris.

\section{Group B. (SCOPAOPSIS.)}

S. duryi Caser, 4 mm. in length. piceous black, head, thorax and antenna dusky yellow, was described from Cincimnati and was 
sifted from a patch of withered fungus. Very probably occurs in southern Indiana.

\section{Group C. (Prchorus.)}

Body rather thick and convex; legs stout, the front tarsi dilated; front angles of thorax obliterated. One of the three species ascribed to the group has been taken in the State.

S31 (2548). Scopeus dentiger Lec., Trans. Amer. Ent. Soc., VIII, 1S80, 179.

Elongate, convex. Black, feebly shining, thinly clothed with very fine gray pubescence; antennæ and tarsi dark reddish-brown; legs and abdomen piceous. Head longer than wide, truncate at base, very minutely and sparsely punctate above, more distinctly beneath. Antennæ reaching base of thorax, the outer joints scarcely thicker. Thorax elongate-oval, onethird longer than wide, sides feebly curved, converging from middle to base and apex; disk, as well as that of elytra, finely and sparsely punctate. Elytra as long and scarcely wider than thorax. Abdomen as wide as elytra, minutely and densely punctate. Length $3-3.2 \mathrm{~mm}$.

Kosciusko County; rare. June 24. Sifted from sphagnum moss at edge of tamarack marsh. The males have the femora thicker, the hind ones bent, concave beneath. the curved edge finely serrate and with a tooth near trochanter.

\section{Strilicus Latr. 1829. (Gr.. "a style.")}

Small slender species having the labrum broadly rounded or subtruncate at apex; second joint of maxillary palpi much shorter than third; head rounded or subtmucate at base; surface usually coarsely punctured. The head is narrowed behind and the thorax in front, the two parts being united by a mere point, giving to them the aspect of small ants. The following species have been taken or probably occur in the State:

\section{KEY TO INDIANA SPECIES OE STILJCUS.}

a. Under surface of head densely punctured.

b. Upper surface finely and densely punctate; head subquadrate, truncate at base; elytra with the outer apical angles broadly pale.

OPACULUS.

67. Upper surface of head and thorax coarsely, elytra finely and sparsely punctured; tips of elytra pale; head rounded at base; thorax without a smooth median line.

RUDIS.

aa. Under surface of head sparsely punctured.

c. Labrum with two acute teeth at apex; sculpture above not very fine and dense.

d. Head not strigosely punctured above; thorax with a broad, smooth dorsal line; elytra distinctly wider than head. S32. ANGUharis.

dd. Head and thorax strigosely punctured above. 
e. Elytra bronzed brown, the tips narrowly pale, more widely toward sides; wider than head, finely and very sparsely punctate.

S33. Dentatús.

ce. Piceous black; elytra scarcely at all paler at tip, not wider than head, rather closely punctate.

834. BIARMATUS.

cr. Labrum with four teeth, the outer pair very small, the inner pair short, broad and widely separated; surface very finely and densely punctate; head rounded behind: prosternum strongly carinate.

TRISTIS.

S. opaculus Lec. $4 \mathrm{~mm}$. in length, has been taken at Cincinnati, and $S$. rudis Lec., $4.5 \mathrm{~mm}$. in length, in Illinois.

832 (2554). Stmorcus axgularis Erichs., Gen. Spec. Staph., 1S40. 634.

Dark reddish-brown, shining; elytra with tips pale; abdomen piceous; legs pale yellow. Head as wide as long, broadly rounded and subtruncate at base, coarsely and densely punctate. the punctures rounded, shallow, each bearing a minute hair. Thorax but little longer than wide, three-fourths as wide as head. the obtuse angles at apical third distinctly rounded; disk sparsely and coarsely punctured on sides with a broad smooth median line. Elytra one-half wider and one-third longer than thorax, finely and sparsely punctate. Abdomen narrower at base than elytra, minutely and rather closely punctate. Fifth ventral of male feebly flattened, its apex truncate without a tooth. Length 3.8-4 mm. (Fig. 164.)

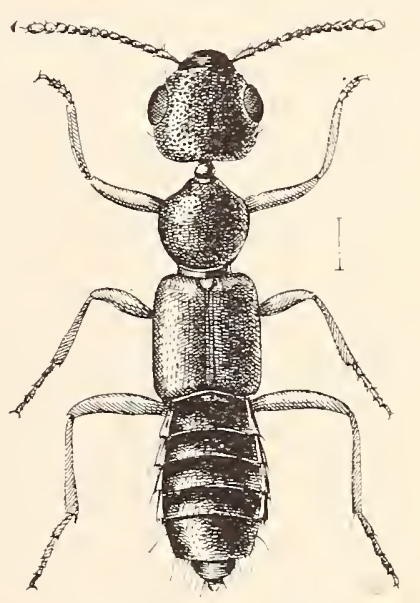

Fig. 164. (Original.)

Marion, Monroe. Lawrence and Spencer counties; scarce. April 12-July 29. Occurs beneath carrion and leaves.

S33 (2556). Strlicus dentatus Say. 'Trans. Amer. Phil. Soc., IV, 1834. 457 ; ibid. II, 573.

Head, thorax and elytra dark reddish-brown, the elytra strongly shining; abdomen black; antennæ reddish-brown; legs and tips of elytra pale yellow. Head longer than wide, strongly rounded at base, its punctures elongate and dense. Thorax three-fifths as wide as head; disk with lengthwise wrinkles, the median smootl line very narrow, forming an obtuse carina. Elytra three-fourths wider and a third longer than thorax. Abdomen at base uarrower than elytri. thence gradually widening, surface shining. finely and sparsely punctate. Fiftl rentral of male with a median tooth. Length $3.7-4 \mathrm{~mm}$.

Putnam, Marion and Poser counties; scarce. March 20-Norember 28. Taken by sifting damp leaves and in fungi.

S34 (2557). STrlicts biarmatus Lec. Trans. Amer. Ent. Soc., YIII, 1SS0, $17 S$.

Piceous black. Elytra scarcely at all palel at tip: antennie and legs duskr yellow, Head as wide as long, its base broadly rounded. surtace, as 
well as that of thorax, densely and strigosely punctate. Thorax threefifths as wide as head, median smooth line narrow. Elytra one-third wider but not longer than thorax. Abdomen at base as wide as elytra. Fifth ventral of male with two small tubercles on hind margin. Length $3.7-4 \mathrm{~mm}$.

Kosciusko County; rare. June 25. Sifted from vegetable debris at edge of tamarack swamp. A member of the boreal fauna.

S. tristis Melsh., 5.5-7 mm. in length, has been taken near Cincinnati and ranges from Pennsylvania to Arizona. It doubtless occurs in southern Indiana.

\section{Megastilicus Casey. 1889. (Gr., "large + style.")}

This genus was erected by Casey upon a very stout form with a small orbicular head, having the body, especially the margins, thickly clothed with short, stiff bristles.

S3e (9650). Megastilicus formicarius Casey, Entom. Amer., V, 1889, 183.

Dark reddish-brown, opaque; head and abdomen piceous. Head nearly circular, not punctured but coarsely alutaceous; neck exceedingly small; antenne reaching base of thorax, stout, the joints closely united. Thorax slightly longer than wide, widest one-third from apex, the sides thence rapidly converging to apex, nearly straight to base; disk coarsely alutaceous, the median line smoother. Elytra three-fourths wider and onethird longer thain thorax, finely, sparsely and roughly punctate. Abdomen short and broad, strongly margined, less than one-half longer than elytra, finely and densely punctate. Length $5 \mathrm{~mm}$.

Putnam and Spencer counties; rare. April 9--June 13. Occurs in the large cone-shaped nests of ants, especially those of Formica exsectoides.

\section{Leptogenius Casey. 1905.}

Minute reddish-brown species having the eyes very small; labrum with four teeth; antennæ extremely short, not longer than head; neck about one-fifth as wide as head; thorax obliquely narrowed in front. Two species ocenr in the Eastern United States, one of which has been taken in Indiana.

S36 (9657). Leptogenius breviconnis Casey, Thans. Acarl. Sci. St. Lonis, $\mathrm{XV}, 1905,247$.

Slender, subparallel, feebly convex. Pale reddish-brown, closely, coarsely and rugosely punctate; elytra somewhat darker. Head longer than wide, its sides parallel. Thorax three-fourths the width of head, about as long as wide, base twice-as wide as apex, median line feebly carinate Elytra together as long as wide, one-third wider and a fourth longer than thorax. Abdomen as wide as elytra. Length $1.7 \mathrm{~mm}$. 
Southern half of State; frequent. March 25-May 11. Taken by sifting and from decaying fruit. One of the smallest of Staphylinids.

\section{Paderus Grav. 1806. (Gr., "a precious stone.")}

Small, slender, convex species, sparsely clothed with erect hairs and having the prosternum shortened between and under the coxix, not reaching mesosternum ; neck one-third the width of head, labrum emarginate at apex; last joint of maxillary palpi obtuse ; tarsi with the fourth joint bilobed beneath. Three species are known from the State, all colored alike, being reddish-yellow, shining, with the head and last two segments of abdomen black; elytra dark blue.

\section{KEY TO INDIANA SPECIES OF PADERUS}

a. Elytra much shorter than wide; distinctly shorter than thorax, sparsely, coarsely and deeply punctate.

837. PALUSTRIS.

aa. Elytra subquadrate, at least as loug as wide, and as long, as or longer than thorax.

Ђ. Thorax ovate; elytral punctures coarse, deep, rather close-set throughout.

S38. LITTORARIUS.

b). Thorax elongate-oval; elytral punctures shallow, much less coarse and very sparse, obsolete toward apex.

839. OBLITERATUS.

S37 (2572). Pederus Palustris Aust., Proc. Bost. Soc. Nat. Hist., XiX, 47.

Elongate, slender. Antennæe piceous, the apical and four basal joints pale, the outer joints gradually thickened. Head suborbicular, as wide as long, rather coarsely and sparsely punctate. Thorax elongate-oval, slightly narrower than head, very sparsely punctate. Elytra as mentioned in key. the basal angles very broadly rounded. Abdomen as wide as elytra, minutely punctate. Length $4.5-5 \mathrm{~mm}$.

Starke, Knox and Posey counties; scarce. April 18-June 17. Sifted from debris along the margins of ponds and lakes.

838 (2573). Paderus littorarius Grav., Mon. Col. Micr., 1S06, 142.

Elongate, slender, subparallel. Antennæe piceous at middle, the base and two or three apical joints pale, the outer joints not enlarged. Head slightly longer than wide, base broadly rounded; surface, as well as that of thorax and abdomen, finely and very sparsely punctate. Thorax convex. slightly longer than wide, a little narrower than head; sides feebly curved. Elytra equal in length to and one-fourth wider than thorax. Abdomen a little narrower than elytra, parallel. Male with the slit of the sixth ventral three times as deep as wide. Length $4.2-5.5 \mathrm{~mm}$.

Throughout the State; common. February 14-November 10. Oceurs especially in open woodland. Hibernates beneath and between the leaves of mullein. 
S39 (2575). Paderus obliteratus Lec., Proc. Amer. Phil. Soc., XVII, 187s, 395.

Elongate, rery slender. Head as broad as long, slightly wider than thorax and, like the latter, very finely and sparsely punctate. Thorax elongate-oval, sides feebly curved. Elytra distinctly longer than wide, a fourth wider and slightly longer than thorax. Abdomen as wide as elytra, minutely and sparsely punctate. Male with the sixth rentral cleft nearly to base. Length $4.7-5.2 \mathrm{~mm}$.

Kosciustio County ; rare. October 26. Occurs along the borders of the laroer lakes and the seacoast of the Eastern Cnited States.

\section{Sunius Steph. 1831. (Gr., "to be together.")}

Elongate, very slender species having the labrum short. truncate. bidentate; prosternum carinate; base of head more or less broadly curved and truncate; basal joint of hind tarsi much elongated, the fourth joint of all the tarsi bilobed beneath. The following species have been taken or probably occur in the State:

KET TO INDIANA SPECIES OF SUNIUS.

u. Head black or piceous.

b. Elytra in part, sometimes almost wholly, black.

c. Abdomen wholly dark; elytra pale at apex.

d. Elytra distinctly longer than thorax; head more densely punctured beneatl.

CINCTUS.

d. Elytra equal to or shorter than thorax; head less densely punctured beneath.

S40. LINEARIS.

cc. Abdomen reddish-yellow, usually black at tip; elytra subequal in length and width to thorax, with a large dark spot on outer side behind the middle.

S41. BINOTATUS.

bb. Elytra wholly pale, small, equal to ox shorter than thorax; body wholly pale except the head and last two segments. BRETIPENNIs. at. Head and entire body except the last two segments pale; elytra distinctly longer than thor:ax.

812. DISCOPUNCTATUS.

S. cinctus Say, 3.5-4.5 mm. in length, occurs from New York to Iowa. It is moually listed as prolixus Erichs. but Say's name has priority.

S40 (-). Sunits minearis Erichs., Gen. Spec. Staph., 1840, 639.

Elongate, parallel. Black or piceous, subjpaque; legs, antenna and apical third of elytra pale yellow. Head as wide as long, slightly wider than thorax, its surface, as well as that of the latter, coarsely and densely punctured, the punctures elongate. Thorax oval, as wide as long. sicles feebly curved, base slightly marrower than apex. Elytra a little wider. about as long and more coarsely punctate than thorax. Abdomen at base slightly narrower than elytra, gradually and feebly widening toward apex. finely and densely punctate. Length $4.4 \mathrm{~mm}$. 
Throughout the State; frequent. March 20-May 19. Taken by sifting. Probably hibernates as imago. 'This, as well as the other species, runs with great rapidity when disturbed.

S41 (2579). Sunicis minotatus Say, Proc. Phil. Acad. Nat. Sci., III, 1S28, 154 ; ibid. II, 99.

Very slender, parallel. Head, a large spot on elytra and tip of abdomen black; thorax, base and suture of elytra and base of abdomen reddishyellow; antennx, legs and tip of abdomen pale yellow. Head longer that wide, wider than thorax and elytra. Thorax elongate-oval, the sides feebly converging from apical third to base; surface, as well as that of head and elytra, punctured as in lincaris. Abdomen slender, gradually broader behind. Length $3.5-4 \mathrm{~mm}$.

Marion and Putnam counties; starce. April 4-October 10. Taken by sifting damp vegetable debris.

S. brevipenuis Austin, 3-3.7 mm. in length, oceurs from Massachusetts to Iowa and doubtless inhabits Indiana.

*S42 (- ). Sunies discopunctatus Say, Trans. Amer. Phil. Soc., IV, 1834,457 ; ibid. II, 572.

Very slender. subparallel. Pale reddish-yellow, last two ahdominal segments black. Head rather small, narrower than elytra. Thorax oval, narrower than head, slightly longer than wide, sides rounded at apical fourth, thence feebly converging to base; punctate as in lincuris. Elytra a third longel and distinctly wider than thorax. Abdomen at base slightly narrower than elytra, its sides almost parallel. Length $3.8-4 \mathrm{~mm}$.

Throughout the State; frequent. February 20-November 28. Occurs especially beneath stones, bark, etc., in high, open woodland. Listed as longiusculus Mann., of which it is usually considered a synonym, but Casey says the latter is a Pacific Coast species, with much larger elytra.

\section{STILICopsis Sachse. 1852. (Gr., "style + face.")}

Ninute pale species having the thorax almost circular, its median line finely elevated; elytra short with diverging sides; abdomen broad, convex.

S43 (2582). Stilicopsis paradoxa Sachse., Stett. Ent. Zeit., 1852, 144.

Short, parallel. Pale yellow throughout. Head scarcely as long as wide, coarsely and densely punctate. its sides rounded into the slender neck; eyes prominent, coarsely granulate; antenne reaching middle of thorax, the outer joints somewhat thickened. Thorax equal to head in width, nearly circular, rather densely sianulite-punctate. Elytra distinctly wider and shorter than thor:ax, coarsely, closely and rugosely punctate. Abchmen at middle wider than elptri. finely. densely and roughly punctate. Length 2.5-2.7 $\mathrm{mm}$. 
Putnam County; scarce. March 26-October 10. Sifted from damp vegetable debris.

\section{Tribe II. PINOPHILINI.}

Elongate, slender, subcylindrical species having the fourth joint of maxillary palpi as long as the third and obliquely hatehet-shaped. Two genera compose the tribe, both of which occur in Indiana.

\section{KEY TO GENERA OF PINOPHILINI.}

a. Abdomen distinctly margined; species black or piceous.

Lix. Pinophilus. au. Abdomen not margined; species usually pale yellow.

Lx. Palaminus.

\section{Pinopinuos Grav. 1802. (Gr., "filthiness + loving.")}

Rather large blackish species having the head short, wider than long, about as wide as thorax, its base truncate; neck one-half the width of head; antemnæ very slender, reaching nearly to base of thorax; mandibles long, strongly curved, each with a blunt median tooth which is notched at apex; eyes large, very close to base of head; basal joint of hind tarsi as long as the next three, fourth joint bilobed. Only isolated descriptions of the five North American species are extant. Two are known from Indiana.

S44 (2585). Pinophilus latipes Grav., Mon. Col. Micr., 1806, 202.

Elongate, parallel. Black, feebly shining, sparsely clothed with grayish hairs. Antennæ, legs and hind margins of abdominal segments pale reddish-yellow. Head very finely and sparsely punctate, with a number of coarse, deep punctures above and behind the eyes. Thorax slightly longer than wide; base and apex truncate; sides nearly straight, feebly converging from apex to base; disk coarsely, rather sparsely and irregularly punctate. Elytra slightly wider and nearly one-half longer than thorax, coarsely, deeply and densely punctate. Abdomen at base a little narrower and more finely and sparsely punctate than elytra. Front tarsi of male short, very strongly dilated, the joints membranous and overlapping. Length 13-15 mm.

Southern half of State; scarce. March 8-December 3. Occurs singly beneath logs and stones in upland woods. One of the longest of our Staphylinids.

845 (2588). Pinophilus opacus Lec., N. Sp. N. Amer. Col., I, 1863, 49.

Smaller and more slender than latipes. Black, subopaque, head and thorax feebly shining; antennie, palpi and legs pale yellow. Elytra much more finely and deeply punctate, but slightly longer than thorax. Abdomen more finely punctate. Length 8-9 $\mathrm{mm}$.

Lake County ; rare. May 30. One specimen from the beach of Lake Michigan. 


\section{Palaminus Erichs. 1840. (Gr., "hand.")}

Small, slender, subcylindrical species, having the head broader than long, its base truncate immediately behind the eyes; antennæ slender, longer than head and thorax; last joint of maxillary palpi relatively shorter and broader than in Pinophilus. Abdomen cylindrical, narrower than elytra, its sides not margined.

846 (2592). Palaminus testaceus Erichs., Gen. Spec. Staph., 1840, 683.

Elongate, very slender. Pale reddish-yellow, shining, sparsely clothed with long yellowish hairs; abdomen reddish-brown; antennæ and legs pale yellow. Head rounded in front, coarsely and sparsely punctate. 'Thorax subquadrate, slightly wider than long, sides rounded into base, which is but slightly narrower than apex; disk convex, coarsely and rather sparsely punctate. Elytra slightly wider and twice as long as thorax, rather coarsely, not densely punctate. First four segments of abdomen with coarse overlapping, scale-like granules; the fifth and sixth smooth. Last ventral of male with middle lobe curved, bent to one side and obliquely truncate at tip. Length 3.5$4 \mathrm{~mm}$. (Fig. 165.)

Throughout the State; frequent. April 18-

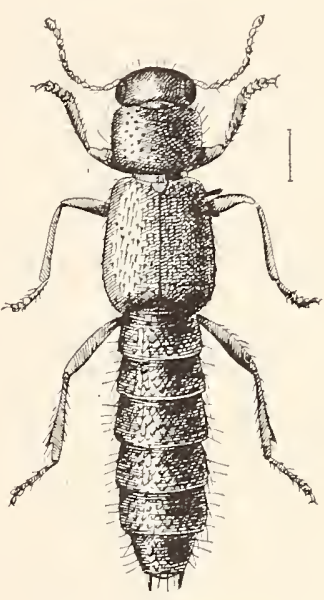

Fig. 165. (Original.) June 21. Taken by sifting; also on fungi and beneath bark. Their motion is wriggling or vermicular, like that of a worm or snake.

S47 (2597). Palaminus larvalis Lec., N. Sp. N. Amer. Col., I, 1S63, 49.

Elongate, very slender. Color of testaceus, the head darker and shorter. Thorax obcordate, much narrower at base than apex, coarsely and very sparsely punctate. Elytra slightly narrower and not longer than thorax, coarsely, deeply and sparsely punctate; abdomen as in testaceus, the imbricated scales extending to middle of fifth segment. Length $3.2 \mathrm{~mm}$.

Starke County ; rare. May 19. Sifted from sphagnum moss.

\section{Subfamily V. TACHYPORINAE.}

Rather short and broad convex Staphylinids, having the body conical and pointed behind; antenma widely separated at base, inserted at the sides of the front above the base of mandibles, usually beneath the side margin of the front, sometimes free, but never beneath a projecting ridge as in the Prederinie; head narrower than thorax, its base not constricted but covered by the front of thorax; front coxæ large, conical and prominent, their trochanters very distinct; spiracles of thoras distinct; hind coxæ transverse or triangular; tibiæ with numerous spines; abdomen conical, often bordered and terminated with divergent spines. 
The one paper treating of the North American species of the subfamily is by

Hom._ "Srnopsis of the Genera and Species of the Staphrlinid Tribe Tachrporini of the United States,' in Trans. Amer. Ent. Soc. TI, ist7, 81-128.

The subfamily is separated into fire tribes. and these in turn into genera.

KEY TO TRIBES OF TACHYPORIX.E.

a. Hind coxie transrerse. reaching the side pieces of the metathorax.

b. Antenni 10-jointed; tarsi 4-jointed.

bъ. Antenne 11-jointed; tarsi 5-jointed.

c. First joint of hind tarsi nearly as long as tibix; hind coxie apparentls united with the metasternum.

Tribe II. Trichopisi, p. 442.

cc. First joint of hind tarsi moderate or short; hind coxie free.

d. Head not margined on the sides beneath the eres; elytra distinctly longer than the thorax, minutels and irregularls punctate.

Tribe III. TAchYporixi, p. 443.

dd. Head margined on the side beneath the eyes; elytra sabout as long as thorax, smooth or with three or more rows of punctures.

Tribe IV. BoLtтoвIINI, p. 452.

a a. Hind coxæ triangular. prominent: antennie 11-jointed; tarsi 5-jointed; head not margined.

Tribe V. Habrocerini, p. $45 \bar{i}$.

\section{Tribe I. HIPOCIPTINI.}

Tery small, broadly oral pubescent species, which occur for the most part in the nests of ants. When disturbed they bend the head under the bodr which. together with their conrex forms. gives them the appearance of little globes m balls. No representative of the tribe has been taken in the State. though Dury has taken Microcyptus testacrus Lee. from the nest of a small black ant near Cincinnati. It is reddish-yellow. with the middle coxie narrowy separated: mesostermm carinate; length $8 \mathrm{~mm}$.

Hypocyptus longicomis Park. black. legs and antenna pale rellow. middle coxie widely separated. mesosternum flat. length $1 \mathrm{~mm}$. may occur in the southern half of the State.

\section{Tribe II. TRICHOPIINI.}

Two genera represent this tribe in the Eastern United States, both of which occur in the nests of white ants (Termes). Both genera have a southern range and both are perhaps represented in southern Indiana. though only the single species of one has as ret been taken. 
KEI TO GENERA OF TRICHOPYIXI.

a. Body broad, narrowed behind. clothed with lons. sparse. bristly hairs: thorax narrowed in front. not impressed. LXI. 'TrICHOPSEXIS. aa. Bods narrower; thorax not narwowed in front, with an apical impression, the bottom of which is membranous. Nexistesi.

LXI. Trichopsentes Horn. 18it. (Gr... "little hair + like.")

Represented in southern Indiana and southward by one small form having the tibia distinctly spimmlose. middlo (oxar rontiguous; abdomen and elẹtra not margined.

S4S (2602). Trichopsenits depresst's Horn, Trans. Amer. Ent. Soc., TI. $187 \pi, 88$.

Oblong, depressed. Bromnish-rellow, glabrous, rery shining and without punctures. Thorax nearly twice as wide as long. sides slightly curred. base truncate, hind angles acute. Elytra each quadrate, as long as broad. together not wider and a little shorter than thorax. and with three transrerse rows of erect yellowish hairs. Abdomen conical and bearing numerous sparse, erect hairs. Length $1.2 \mathrm{~mm}$.

Cranford County. Mas 15. Four or fire specimens were taken in the nests of Termes flaripes Koll., beneath flat stones near the mouth of Wyandotte Care.

\section{Tribe III. TACHYPORINI.}

Rather short. broad species. With a conical abdomen. which is never turned upward when disturbed. as is the habit of most other Staphylinids. Ther occur-in fongi, dung and other decaring matter.

\section{KEY TO INDHAXA GENERA OE TACHYPORIXI.}

a. Abdomen with a narrow margin; tibire with a fringe of uneren spinules at tip.

7. Mesosternum not carinate.

c. Maxillary palpi filiform; body oblong. somewhat depressed, morteratels tapering: lencth $3-6 \mathrm{~mm}$.

TAII. TACHIXTs.

cc. Naxillary palpi awl-shaped : body short. conrex, abruptly tapering: length less than 3 mm.

LNIII. TACHYPORLS.

b). Mesosternum carinate: maxillary palpi filiform; front tarsi of male simple.

a. Elytra not extended at sides below the bods.

Cilea.

ad. Elytra projected at the sides belor the body. LXIT. Erchours. a a. Abdomen not margined: surface finely pubescent; tibia with a fringe of equal spines at tip.

LXT. Coxosoma.

LXII. Tichines Grav. 1802. (Gr.. "swift.")

A large genus. the species of which are very difficult to separate, unless both sexes are present. The males have the front tarsi almars dilated and the last or serenth ventral segment deeply divided. form- 
ing processes or laciniæ of varying shape, frequently long and slender and decurved, resembling somewhat the forceps of an earwig, often broader in the form of triangular plates. The sixth segment varies also in form and sculpture, the hind margin being notched in most species and the surface concave or impressed, the impression often wholly or partly filled with very short, stout bristles, thus forming a "spongy space." The hind margin of the sixth ventral in part of the species is also pectinate or fringed on each side with stiff, close-set spinules, thus forming a comb-like structure.

In the female the front tarsi are not dilated and the last ventral is (a) either entire and fringed behind with short equal spinules (flavipennis and circumcinctus only) or (b) divided into six rather long and slender processes. In the latter case the last dorsal is trilobed, with the middle lobe either entire, emarginate, bifid or trifid at apex. In the key the characters given pertain only to the male, unless the female be mentioned specifically.

\section{KEY TO INDIANA SPECIES OF TACHINUS.}

a. Sixth ventral pectinate on its hind margin.

b. Sixth ventral with a spongy space on the center of the impression; female with middle lobe of last dorsal shorter than the side lobes, slender and feebly notched at tip.

849. MEMNONIUS.

bb. Sixth ventral without a spongy space at middle, very deeply emarginate, the angles prolonged.

c. Spinules on hind margin of sixth ventral bordering the entire emargination; female with middle lobe of last dorsal as long as the side lobes, deeply divided to form two slender processes; piceous, the sides and base of thorax piler.

S50. REPANDUS. $c c$ Spinules divided into three groups; pale reddish-yellow; length 3.511111 . SCRUTATOR.

al. Sixth ventral segment not pectinate on hind margin.

(. Form parallel; ablomen not narrowed exrept at tip; female as in repandus.

del. Alidomen gradially narrowed from base to tip.

c. Sixth ventral with a spongy space on its middle.

f. Abdomen rather coarsely punctured; elytrat clay-yellow; female with last ventral entire, last dorsal with the three lobes united.

851. FLAVIPENNIS.

ff. Abdomen very obsoletely punctured; female with middle lobe of last dorsal as long as and broader than the side lobes, the tip notched one-third toward base.

S52. LURIDUS.

ec. Sixth rentral without a spongy space on its middle.

g. First two ventrals strongly carinate at middle.

h. Processes of last ventral long and curved; last dorsal with four acute teeth; elytra pale brown, their tips piceous; female with middle lobe broad, shorter than side ones, and triangularly notched at tip.

S53. FIMBRIATUS. 
hh. Processes shorter, straight; last dorsal with short teeth; female as in parallelus.

PICTPES.

$g g$. First two ventrals not or feebly carinate.

$i$. Sixth ventral concave, emarginate behind.

$j$. Hind margin of sixth ventral emarginate at middle and sides; female with middle lobe broad, as long as the side ones, its tip broadly triangularly notched.

SCHWARZI.

ij. Hind margin emarginate at middle only.

k. Thorax entirely dull yellow; female with middle lobe shorter than side ones, broadly oval, rarely with a feeble notch at tip.

LIMBATUS.

7.li. 'Thorax piceous with narow pale border; elytra distinctly punctate; female as in luridus.

854. PATLIPES.

ii. Sixth ventral not concave or emarginate.

1. Last dorsal with four teeth; elytra coarsely and irregularly punctured; female as in flavipennis. crrcumcrnctus.

11. Last dorsal with three teeth; elytra coarsely and evenly punctured; female as in turidus.

NITIDULOIDES.

S49 (2608). 'Tachinus memnonues Grav., Mon. Col. Micr., 1806, 192.

Uniform piceous, moderately shining; legs and antennac reddish-brown. 'Thorax one-half longer than wide, sides broadly curved, hind angles obtuse; disk minutely alutaceous. Elytra together one-third longer than wide, finely alutaceous, very finely and sparsely punctate. Length $5.5-7.5 \mathrm{~mm}$.

Southern half of State, frequent; probably throughout. October 4-November 8 . Occurs in decaying fungi.

850 (2613). Tachinus repandus Horn, Trans. Amer. Ent. Soc., VI, 1S77, 97.

Piceous, shining, very finely alutaceous; sides and base of thorax reddish-yellow; antennæe long, slender, piceous, the two basal joints paler; legs dull yellow. Head, thorax and elytra very minutely punctulate. Elytra as broad as long. Abdominal segments wrinkled at middle. Last ventral of male deeply divided, the lobes straight. Length $4.5-5 \mathrm{~mm}$.

\section{Putnam County; rare. September 25.}

T. scrutator Horn, dark reddish yellow, $3.5 \mathrm{~mm}$. in length, was described from Illinois, while $T$. parallelus Horn, 6-6.5 mm. in length, piceous, with thorax, elytra, legs and antennæ reddishbrown, is recorded from Illinois and Canada.

S51 (2619). Tachunus flavipennis Dej., Cat., 1836.

Head and thorax black, shining; elytra pale clay yellow; antennæe dusky, the basal joints and legs reddish-brown; abdomen and under surface piceous. Head and thorax very finely and indistinctly punctate. Elytra together scarcely longer than wide, minutely punctate. Abdomen finely punctured above, more coarsely beneath. Length $6 \mathrm{~mm}$.

Kosciusko County; frequent locally. June 24. Taken from white fleshy fungi. 
852 (2620). Tachines lurides Erichs., Gen. Spec. Staph., 1S40, 920.

Head black; legs, sides of thorax. basal two-thirds, sides and tip of elytra dull yellow: antennie reddish-brown, the four basal joints paler; under surface and abdomen piceous. Hear and thorax minutely alutaceous. very finely and indistinctly punctate. Elytra together one-third longer than wide, more distinctly alutaceous, sparsely and finely punctate. Abdomen punctured as elytra, almost smooth beneath. Length $5-5.6 \mathrm{~mm}$.

Laporte County ; rare. May 7.

S53 (2621). Tachinus Fimbriates Grav., Mon. Col. Micr., 1806, 191.

Hend and thorax black, shining: elytra pale chestnut brown, tip narrowly piceous; antenna black, four basal joints and the last one pale; abdomen. under surface and legs piceous. Head and thorax finely alutaceous, minutely punctate. Elytra together as wide as long, minutely alutaceous, rather coarsely and irregularly punctate, some of the punctures in evident rows. Abdomen shining, sparsely punctulate above, more coarsely beneath. Length $7-9 \mathrm{~mm}$.

Throughout the State; common. April 11-October 6. Occurs in fleshy fungi. Onx largest and broadest species. The first two ventrals of both sexes are carinate between the hind coxæ.

T. picipes Erichs, uniform piceous, 7-8 mm. in length, oceurs from Canada to Virginia; Th. schwarzi Horn. also piceous and $8 \mathrm{~mm}$. in length, has been taken at Detroit and near Cincinnati; T. limbatus Melsh., $7-7.5 \mathrm{~mm}$. in length, is known from the Middle States and near Cincinnati.

854 (2626). Tachinus Pallipes Graly., Mon. Col. Micr.. 1806, 20.

Piceous black, shining; legs, margin of thorax, base and sides of elytra and four basal joints of antenne. reddish-yellow. Head and thorax finely alutaceous, minutely and sparsely punctulate. Eiytra slightly longer than wide, finely but distinctly punctured, finely alutaceous. Abdomen more finely punctured than elytra. Length $5-6 \mathrm{~mm}$.

Thioughout the State; common. February 21-October 4 . Occurs beneath bark and on fungi. Also taken in numbers Mạch 16 from beneath a mass of old honeveomb.

T. circumcinctus Makl., piceous, elytra chestnut brown, length $4.5 \mathrm{~mm}$., is a boreal species recorded from Michigan and Kansas; T. nitiduloides Horm, piceous with sides of thorax and tips of elytra paler, length $3 \mathrm{~mm}$., is said to be found from Canada to Maryland, and is reported from Cincinnati by Dury.

\section{TXIII. "Tachyporus Grav. 1806. (Gr..,"swift + to walk.")}

Short, broad, convex speries having the abdomen abruptly tapering and beset with bristly hairs. The males have the front tarsi distinctly dilated, the sixth ventral triangularly notched and the 
last dorsal with entire hind margin. The females have the front tarsi feebly or not at all dilated. last ventral semi-circular and the last dorsal with four equal acnte teeth.

KEY TO INDIANA SPECIES OF TACHYPORLS.

a. Form convex and rather robust.

$b$. Color in great part pale reddish-brown or reddish-yellow.

c. Elytra bicolored.

d. Under surface piceous.

e. Elytra with sides and an oblique discal spot on each black; abdomina! segments piceous at base. 85.5. MActlipexais.

ce. Elytra with basal half or two-thirds shining black; abdomen abore reddish-rellow, the last two segments black.

S56. PULCHRTS.

du. Under surface, except last two segments, pale; elytral with scutellar blotch only black.

85T. ELEGANS.

cc. Elytra uniform in color or slightly darker around the scutellum; thorax and clytra paler than abdomen.

f. Thorax not broader than elytra, rapidy narrower to apex.

S.5. Jocost's.

ff. Thorax broader than elvtra, ìts sides strongly curved.

S5.). CHRYSOMELINUS.

67. Color pitchy black; apex of elstra paler; femora and coxre piceous.

u $\boldsymbol{u}$. Form more or less depressed. slender.

NANLS.

g. Color dark fuscous brown to pitchy black: elytra in part or wholly paler; third joint of maxillary palpi normal. 860. SCITULUS.

gg. Color reddish-yellow; third joint of maxillary palpi stout.

S61. BRUNNECS.

*855 (2632). Tachypores maculipexis Lec., Proc. Phil. Acad. Nat. Sci., 1866.374.

Head black. smooth: thorax and elytra dark reddish-brown. strongly shining; elytra each with an oblique spot near middle and an oblong one on side. black, these sometimes united; basal portion of abdominal segments and under surface piceous; legs and antenne pale. Thorax smooth. nearly twice as wide as long. not wider than elytra, sides curved. hind angles obtuse. Elytra together wider than long. slightly longer than thorax. both they and abdomen very finely and sparseiy punctate and pubescent. Length $3.5-4 \mathrm{~mm}$.

Southern two-thirds of State; irequent. February 10-December $\tau$. Hibernates beneath mullein leaves and rubbish. The thorax often has a dusky spot on disk.

856 (-). 'TACHYPORUS PLLChrt's sp. nor.

Reddish-yellow. strongly shining. Head, hasal fourth of tholax. bisal lialf or two-thirds of elytra and last two segments of abdomen. black: undel surface piceous. Elytra without visible punctures very sparsely and tinely pubescent. I.ength :3 111ill.

[2!-23402] 
Lake. Marion and Putnam counties; rare. March 13-December 7. A handsome species which may prove to be the European obtusus.

S5T (2633). Tacmypores elegaxs IIorn. Trans. Amer. Ent. Soc. VI. 1Sit, 103.

Reddish-yellow, strongly shining; head. last two segments of abdomen and a circumscutellar spot of elytra black. Antenne slightly longer than head and thorax, the latter as in maculipemis. Elytra and abdomen rers finely and sparsely punctate and pubescent. Under surface of abdomen more distinctls punctured than abore. Length $3.5 \mathrm{~mm}$.

Putnam County; rare. Narch 20.

858 (2634). Tachrporus Jocosts Say, Trans. Amer. Phil. Šoc., IV, $18: 34$. 460 ; ibid. II, 552.

Piceous, shining; head black; tholix, elytra and legs reddish-yellow; antenna dull yellow, the onter joints dusky. Thorax smooth. twice as wide as long. lind angles rounded. Elytra together as long as wide; surface, as well as that of abdomen, sparsely punctulate and pubescent. Length 3-4 mm.

Lake. Starke and Marion counties; rare. Nay 5-November 28. Described from Posey County and taken by Dury at Cincinnati. so that it probably occurs througheut the State.

*S59 (2685). 'TAchyport's chrrsomelixes Tinn.. Faun. Suec.. 1746, S55.

Head black; thorax, elytra and legs reddish-yellow. polished; antennie dull yellow, outer joints darker; abdomen, under surface and often a space about scutellum piceous. Thorax smooth. not twice as wide as long. Elytra and abdomen as in jocosus. Length $4 \mathrm{~mm}$.

Throughout the State; common. February 21-November 17. Occurs beneath logs, bark and other cover. especially in low open roodland. The thorax is often marked with an ill-defined dusky diseal spot.

T. nanus Erichs., $3-3.5 \mathrm{~mm}$. in length. occurs from Canada to Pennsylvania and has been taken near Cincinnati.

S60 (2638). Tachyports sctiults Erichs. Kafer Mark Brand., I, 1S39, 395.

Elongate. subdepressed. Dark fuscous or pitchy black, shining; antennæ and legs pale; elytra usually paler at tips, sometimes almost wholly dull yellow. Thorax smooth, slightly broader than elytra, the sides and apical margins narrowly pale. Elytra together slightly broader than long. finely punctulate and pubescent. Tength 2.5-3 $\mathrm{mm}$.

Marion and Putnam counties; frequent locally. July 4-Norember 22. 'Taken by sifting damp regetable debris.

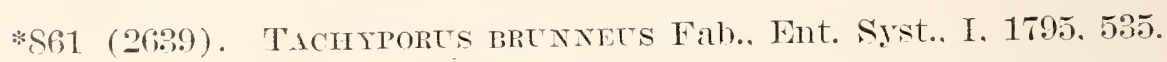

Elongate, depressed. Reddish-rellow; head piceous; antennæe and legs dull yellow; abdomen darker than elytra. Thorax twice as wide as long, 
not wider than elytra, sides gradually narrowing from base to apex. Elytra as wide as long, both they and abdomen sparsely punctulate and pubescent. Length $2.5-3 \mathrm{~mm}$.

Throughout the State; common. January 7-November 1. Occurs beneath bark, dead leaves, etc., in open woodland.

\section{Erohomus Mots. 1858. (Gr., "to enter.")}

Very small black or piceous species, having the mesosternum carinate, and front tarsi of male simple. Two of the four known species occur in the State.

*862 (2644). Erchomus ventriculus Say. Trans. Amer. Phil. Soc., IV, 1834, 466; ibid. II, 582.

Short, broad, convex, narrowed behind. Black, strongly shining; elytra and abdomen with a reddish-piceous tinge; antennæe and legs dark reddishbrown. Thorax twice as wide as long, as wide at base as elytra ; very finely and sparsely punctate. Elytra together one-third longer than wide, onehalf longer than thorax, finely but distinctly punctate. Abdomen, as exposed, shorter than elytra, minutely punctulate. Last rentral of male with a semicircular notch. Length 2-2.5 $\mathrm{mm}$.

Throughout the State; common. April 5-December 25. Occurs in colonies beneath bark, especially that of elm and red oak.

863 (2645). Erchomes letis Lec., N. Sp. N. Amer. Col., I, 1S63, 31.

Similar to ventriculus in form and color. Differs in having the upper surface wholly smooth and last ventral of male triangularly notched. Length 2-2.5 $\mathrm{mm}$.

Posey County; rare. April 15. Occurs beneath dead leaves. A member of the Austroriparian fauna.

LXV. Conosons Krä̈tz. 1858. (Gr., "cone+body.",

The lack of a margin on the sides of the abdomen especially distinguishes this genus from all others of the tribe. The species are of small size, brown, piceous or black in color, and the segments of the abdomen are in death usually telescoped so that the abdomen as exposed exfends but little beyond the elytra.

KEY TO INDIANA SPECIES OF' CONOSOMA.

a. Mesosternum not carinate but obtusely elevated; body subdepressed.

b. Thorax piceous, hind angles broadly reddish-yellow.

LITTOREUM.

bb. Thorax dull yellow, apical half or third piceous.

S64. KNOxII.

a. Mesosternum distinctly carinate.

c. Middle tibire with only one terminal spur.

d. Body robust, convex; hind angles broadly rounded; elytra piceous. usually narrowly paler along the base.

S6.5. CRASSUM. 
dA. Body more elongate. subdepressed; lind angles of thorax acute; color wholly piceous.

S66. ELONGATA.

cc. Middle tibiae with two distinct terminal spurs.

$c$. Elytra without a row of bristle-bearing punctures along the margin.

$f$. Abdominal segments without long setre along the sides.

g. Elytra densely punctulate, as long as wide; length $4 \mathrm{~mm}$.

S67. PUBESCENS.

gy. Elytra smooth, each with three or four very fine raised lines; length $2 \mathrm{~mm}$.

868. CARINULA.

ff. Abdominal segments with long setre at the sides, arising from rather large deep punctures; elytra more or less reddish at base.

h. Thorax with minute transverse striga'between the punctures; elytra with entire basal margin red.

869. OPICUM.

hh. Thorax very finely punctate, not strigose; elytra with a red spot on base nearer the suture than the margin.

870. BASALE.

ee. Elytra with a row of bristle-bearing punctures along the sides; abdomen with setre at the sides; pale reddish-yellow, elytra with tip and discal spot piceous.

871. SCRIPTUM.

C. littoreum Linn.. a European species, 3.5-4 mm. in length, is known from Massachusetts and Canada, and has been recorded by Dury from Cincinnati.

S64 (2647). Conosoma knoxir Lec.. Proc. Phil. Acad. Nat. Sci., 1866, $37 t$.

Oval, subdepressed. Head and apical third or more of thorax black. slining; basal portion of thorax, a large oval space on each elytron, legs and base and apex of antennse dull yellow; abdomen reddish-yellow, its last three segments, the sides and apex of elytra, and the under surface piceous. Thorax broader than elytra, hind angles subacute. disk finely alutaceous and, as well as elytra, densely and rery finely punctate and pubescent. Elytra one-third longer than wide. Length $3.5-4 \mathrm{~mm}$.

Marion and Putnam counties; scarce. September 25-November 28. Taken by sifting damp vegetable debris.

*S65 (264S). Conosoma crassum Grav., Mon. Col. Micr.. 1S06, 190.

Oval, convex. Piceous, sparsely clothed with fine pale brown pubescence; thorax and elytra usually with a narrow reddish space at base of each; antennæ dusky, the apical joint paler; under surface reddish-brown. the legs paler. Thorax slightly wider than elytra, sides regularly curved: hind angles broadly rounded; disk finely and densely punctate. Elytra together as long as wide, densely and more distinctly punctate than thorax. Length $3-5 \mathrm{~mm}$.

Throughout the State; common. January 21-November 17. Occurs beneath bark and on fungi. Our largest species.

S66 (-). CoNosoma elongata sp. nov.

Elongate-oral, subdepressed. Piceous, shining, sparsely clothed with fine brownish-yellow pubescence; antenna and legs reddish-browl. Thorax 
slightly wider than elytra, sides very feebly curved; hind angles acute, slightly prolonged; disk finely alutaceous, minutely and densely punctate. Elytra together distinctly longer than wide, finely, densely and somewhat roughly punctate. Abdomen minutely and closely punctulate on basal portion. Length 3-4 mm.

Lake, Starke, Marion and Lawrence counties; scarce. March 26-November 17. Taken by sifting. The depressed form, much less curved sides and acute hind angles of thorax readily distinguish this from crassum, with which it has heretofore been confused.

867 (2651). Conosoma pubescens Payk., Monog. Carab. App., 1790, 138.

Oral, robust, convex. Dark chestnut brown, moderately shining. sparsely clothed with silken pubescence; antennæe and legs somewhat paler. Thorax slightly wider than elytra, sides feebly curved, hind angles subacute, slightly prolonged; disk very minutely punctulate. Elytra rather densely and minutely punctulate. Length $4 \mathrm{~mm}$.

Lawrence County; scarce. July 29. Taken from decaying fleshy fungi.

S68 (-). CoNosoma carinula sp. nov.

Broadly oral. Uniform piceous, highly polished, smooth and glabrous; antennæe and legs reddish-brown. Thorax as wide as elytra, sides feebly curved, hind angles rectangular. Elytra together wider than long. wholly without punctures, each with three or four fine, straight rugie or raised lines on disk and a fer oblique ones on sides. Length $2 \mathrm{~mm}$.

Vigo County; rare. October 6. Taken from beneath bark of red oak.

S69 (2654). Conosoma opicum Say. Trans. Amer. Phil. Soc., IV, 1S34, 467; ibid. II, 583.

Oval, conrex. Piceous, shining, finely pubescent; elytra each with a broad reddish basal cross-band; abdominal segments paler at apex; antennæ and legs reddish-brown. Thorax slightly wider than elytra, sides regularly curved hind angles rectangular; disk sparsely and finely punctate, minutely strigose or alutaceous between the punctures. Elytra slightly broader than long, rather densely and finely punctulate. Abdominal segments each with a seta from the sides of the upper surface and two at the margin. Length 3-3.5 mm.

Throughout the State; frequent. May 6-Norember 17. Occurs beneath the bark of fungus covered logs.

870 (2653). Conosoma basale Eirichs., Gen. Spec. Staph., 1840, 225.

Form and color of opicum. Thorax not strigose or alutaceous between the punctures. Reddish basal cross-band of elytra not reaching the side margins, the humeri piceous. Length $3-3.5 \mathrm{~mm}$.

Throughout the State; frequent. April 15-October 31. Probably only a variety of opicum. 
871 (2655). Conosoma scriptum Horn. Trans. Amer. Ent. Soc., VI, 1S77, 112.

Broadly oval. Pale reddish-yellow, sparsely pubescent; thorax with a basal spot each side of middle and elytra with sides near apex and discal spot behind the middle, piceous; antennæ, legs and under surface reddishyellow. Thorax slightly wider than elytra, sides regularly curved, hind angles obtuse; disk almost smooth. Elytra as long as wide, sparsely punctulate and with a row of about six larger punctures bearing stiff black hairs along the sides. Length $2-2.5 \mathrm{~mm}$.

Putnam, Monroe and Lawrence countięs; scarce. May 13-July 29. The color is variable, the thorax sometimes wholly piceous or wholly pale, and the spots of elytra may be united and enlarged. Occurs in fungi.

Tribe IV. BOLETOBIINI.

Elongate, slender, glabrous forms, having the head margined beneath, the color often variegated and the elytral punctures, when present, in rows. Three genera represent the tribe, all of which occur in the State.

\section{KEY TO GENERA OF BOLETOBIINI.}

a. Elytra each with three rows of punctures.

b. Maxillary palpi usually filiform; size larger, 4-8 $\mathrm{mm}$.

LXVI. BoletobiUs.

7b. Maxillary palpi awl-shaped; size smaller, not over $4.5 \mathrm{~mm}$.

LXVII. MYCETOPORUS. aa. Elytra each with about seven rows of punctures; maxillary palpi with last joint conical, acute; length $4.4 .5 \mathrm{~mm}$.

LXVIII. BRYOPORUS.

\section{Boletobius Steph. 1832. (Gr., "boleti + living in."')}

In this genms the middle and hind tibix are fringed at tip with unequal and rather coarse spinules. The thorax is punctured on the margins with disk smooth; rows of elytral punctures arranged one near suture, one on disk and one near margin.

KEY TO INDIANA SPECIES OF BOLETOBIUS.

a. Maxillary palpi elongate, slender, glabrous.

b. Head oval or moderately elongate, never widest at base.

c. Abdomen of one color.

d. Joints 5-10 of antenna distinctly wider than long.

e. Elytra uniform black or piceous.

NIGER.

ee. Elytra black, the apex and broad dorsal stripe dull sellow.

AXILLARIS.

$\bar{d} d$. Joints $5-10$ of antennæe distinctly longer than wide; elytra with black spots.

f. Thorax in part piceous or black; head oval. 
9. Disk of thorax entirely piceous, the side and balsal marans narrowly pale.

S7:2. CIXCTICOLLIS.

99. Thorax with a large black spot in each front ancle, the two rows united at middle.

ST: ANTICTS.

ff. Thorax wholly reddish-brown or reddish-rellow.

h. Dorsal row of elstra with few punctures: male with a distinct tubercle on the sixth rentral.

S74. PYGMEUS.

hi. Dorsal row of elytra with numerous punctures.

6.5. TRIXOTATLS.

cc. Abdomen bicolored. red. the last two segments black: dorsal row with few punctures.

ST6. CIXCTES.

b7. Head rery elongate. twice or more longer than wide, widest at base; thorax entirels black: legs piceous.

QLESITOR.

ua. Maxillary palpi short. stout. third joint sometimes pubescent.

i. Antenme with joints 5-10 wider tỉan long.

j. Elytra bicolored. black. the basal half red.

STi. DIMIDIATLS.

jj. Elytra wholly dull reddish.

STS. INTRESLS.

ii. Antennie slender, the joints longer than wide: black. the eletra and often the thoris reddish-bown. lecs pale.

Si?. CINGULATES.

B. Miger Grar. T-11 mm. and B. ariltaris Grav. 5-T mm. in length. have both been taken by Dury at Cincinnati. The latter is a southern species which will be found. if at all. only in the southern third of the State.

Si2 (2661). Boletobils cincticolits Sas, Trans. Amer. Phil. Soc.. IT. 1\$34, 465; ibid. II, 5\$1.

Piceous, shining; legs and base and sides of thorax dull rellow: elytra reddish-rellow with a large black spot near outer apical ansle: antennie with three basal joints pale. Thorax not broader than elytra, hind angles obtuse. Elytra slightly longer than wide; the sutural and marginal rows of punctures fine. distinct. dorsal row rery faint. Abdomen sparsels punctate, the hind margins of the segments paler. Length $3.5-5.5 \mathrm{~mm}$.

Throughout the State: frequent. Mar 11-October 10. Occurs beneath bark, dead leaves and rotten wood.

Si3 (2662). Boletobies anticts Horn, Trans. Amer. Ent. Soc. TI. 1Sit. 117.

Piceous or duskr yellow; base of thorax and elrtra pale reddish-rellow: apical portion of thorax, a large spot at the outer apical angle of each elrtron and often a scutellar spot black: antennie piceous. the apical and four basal joints of former and the legs paler. Thorax slightly broader at base than elytra, hind angles obtuse. Elytra slightly longer than wide. discal row of punctures distinct, the other two rows faint. Abdomen is in cincticollis. Length $4-5 \mathrm{~mm}$.

One in Wolcott collection from Millers. Lake County. July 13. A member of the boreal fauna. 
Sit (2663). Boletobits Prguıts Fab., Spec. Ins., 17S1, 339.

Resembles anticus. Thorax entirely pale. Elstra with a triangular scutellar spot and a larger one near the outer angle black. Thorax at base slightly narrower than elstra, hind angles obtuse, not broadls rounded. Elytra as wide as long. the sutural and marginal punctures rers faint. Length $3.5-4 \mathrm{~mm}$.

Kosciusko and Lawrence counties: rare. Jume 19-July 29.

875 (2664). Boletobits Trixotatus Erichs., Gen. Spec. Staph., 1840, 279.

Color and form of pygmous. Elytra eách with a sutural. discal and submarginal row of numerous punctures. Length $3.5-4 \mathrm{~mm}$.

One species labeled "Ind." in the Wehster collection. Ranges from Massachusetts to Nichigan and has been recorded from Cincimmati. The dark scutellar spot of elytra is often absent.

Sig (2666). Boletobils cixctes Grar., Mon. Col. Micr., 1S06, 193.

Reddish-rellow, shining: head, under surface, a large spot near outer apical angle of elstra and last two segments of abdomen black. shining: antennie piceous. the apical and four basal joints and the legs dull rellow. Thorax as broad at base as elstra, hind angles broadly rounded. Elstra as broad as long, discal rom with three or four punctures. those of the other rows very faint. Abdomen rery sparsely punctate. Length $4 . \overline{-}-\overline{\mathrm{mm}}$.

Throughout the State; common. March 6-October 6. Occurs on fungi. especially that growing in chumps at base of cak stumps.

B. quasitor Horm. 7-10 mm. in length. was described from New Tork and Illinois and is recorded from Cincinnati.

si (265s). Boletobits dimidates Erichs., Gen. Spec. Staph.. 1840. 270.

Piceous, shining: antenne piceous. the basal joints paler: basal half and vers narrow apical border of elstra dull red: legs dull sellow. Thorax slightly broader than elrtra at base; sides broadls curred. hind angles rounded. Elytra together as long as wide, the punctures rery faint. Abdomen sparsely and coarsels punctate. the hind margins of segments paler. Length 4-5 $\mathrm{mm}$.

Lamrence County; rare. Nar 11. Taken from fungi. In one specimen the pale portion of elytra is extended along the suture to apex.

sis (2660). Boletobils intruses IIolm. Trans. Amer. Ent. Soc.. VI. 1Sit. 115.

I'iceous. shining: elstra dull led: thorax eithel black or duskr red: antenn:e duskr. the basal joints pale: legs dull rellow. Thorax as wide at base as elstra, the hind angles broadly rounder. Elytra together longer than wide: sutural and dorsal rows of punctures distinct. marginal row faint. Abdomen sparsels and coarsely junctate. Length $5-6 \mathrm{~mm}$.

Mariou. Lawrence and Posey counties: rare. April 11-December 7 . Occurs beneath bark of fungus covered logs. 
879 (2659). Boletobius cingulatus Mann., Nour. Arrang. Brachl., 18:30, 64.

Black, shining; elytra and often the thorax dull red; legs reddish-yellow; antennæ piceous, the terminal and two basal joints pale; abromen piceous, the apical half of fifth and sometimes the sixth segment reddish. Thorax slightly broader at base than elytra, hind angles rounded. Elytrat slightly longer than wide, sutural and marginal rows of punctures fine, dorsal row obsolete. Ahdomen sparsely and coarsely punctured and pubescent. Length $7 \mathrm{~mm}$.

Lake and Steuben comties; rare. May 21-.July 6. A northern species ranging from Pennsylvania to Canada and Oregon. Resembles intrusus but larger, the elytra more distinctly red and the antennal joints mostly longer than wide.

\section{LXVIT. Mrcetoports Mann. 1830. (Gr., "mushroom + to walk." )}

Small, slender species having the elytra smooth and shining. with three (rarely four) rows of punctures bearing fine setæ, these placed one row in the sutural channel, one extending from humerus to tip, the third along the side margin. The thorax always has four punctures along the apical margin, two basal, three on each side margin and two, one behind the other, between the middle of disk and side margin. "Two of the species have two additional "discal" punctures.

KEY TO INDIANA SPECIES OE MICETOPORUS.

a. Thorax with two discal punctures slightly behind the middle.

b. Elytra with one discal row of punctures.

bb. Elytra with two rows of discal punctures.

an. Thorax without discal punctures.

c. Middle and hind tibire with coarse unequal spinules at tip; third joint of maxillary palpi slender, similar to second.

SS2. HUMIIDUS.

ce. Middle and hind tibire with a dense fringe of equal spinules at tip.

d. Abdomen reddish-yellow, each segment paler at tip; elytra not distinctly bicolored.

SS3. SPLENDIDUS.

dd. Abdomen reddish-brown, its last two segments black; elrtra bicolored, piceous at base, apical third red.

880 (2674). Mrcetoporus AMericants Erichs., Gen. Spec. Staph., 1S40. 285.

Elongate. slender. Dark reddish-brown to piceous, shining; elytra sometimes piceous with only a small humeral spot and narrow apical space reddish-brown, more often wholly reddish-brown except a dark scutellar space: legs and basal joints of antenne paler. Thorax with two small punctures just behind the middle in addition to the usual marginal ones. Elytra as long as wide. with the usual rows of punctures and one to three additional punctures near apex inside of the humeral row. Abdomen sparsely pubes- 
cent and coarsely and sparsely punctured, the hind margins of the segments paler. Middle and hind tibiæ with spinules as in humidus. Length 2.5$3.2 \mathrm{~mm}$.

Throughout the State; frequent. March 26-November 26. Taken by sifting. This species is usually known as lucidulus.

881 (2673). Mrcetoporus consons Lec., X. Sp. N. Amer. Col., I, 1863, 34.

More robust than americanus, which it resembles in color, the elytra piceous with an oblique reddish spot on basal third. Punctures of elytra in four rows; the sutural row faint, the discal and dorsal rows distinct with ten to twelve punctures in each, the submarginal row with five or six. Length $3.5 \mathrm{~mm}$.

Starke County ; rare. Nay 19. A single specimen sifted from sphagnum moss. Known heretofore only from Michigan.

SS2 (2671). Mrcetoporus humidus Say, Trans. Amer. Phil. Soc., IV, 1834, 465 ; ibid. II, 581.

Elongate, slender. Color variable; either (a) dark reddish- or chestnut brown with elytra darker at sides and along the suture, the abdominal segments reddish-piceous, paler at tips; or $(b)$ reddish-yellow with the abdomen reddish-piceous; legs reddish-brown or paler. Thorax smooth, shining, slightly broader than base of elytra, disk with the usual punctures. Elytra as long as wide, shining, the three rows of punctures feebly impressed. Abdomen sparsely pubescent, sparsely and finely punctured above, more coarsely beneath. Length $3-4.5 \mathrm{~mm}$.

Lake, Posey and Jefferson counties; scarce. March 26-June 5. Described from Posey County.

S83 (2676). Mrcetopords splendides Grar., Mon. Coi. Micr., 1806, 24.

Elongate, rather robust. Head piceous; thorax and elytra reddish-yellow, strongly shining; abdomen reddish-brown, the segments paler behind: antennæ and legs dull yellow, the former with middle portion dusky. Thorax slightly broader than elytra, without discal punctures. Elytra together slightly longer than wide, sutural row of punctures distinctly-impressed, the humeral row very faint. Abdomen coarsely and sparsely punctured, sparsely pubescent. Length $3-3.5 \mathrm{~mm}$.

Pulaski, Starke and Marion counties: scarce. April 28-June 19.

$M$. flavicollis Lec., length $4 \mathrm{~mm}$., is known from Michigan, Georgia and Florida.

LXVIII. Bryoporus Kraätz. 1856. (Gr., "moss + to walk.")

Small. slender speries having the last joint of maxillary palpi as wide at base às second and distinctly conical; elytral punctures in about seven rows; front and middle tibiæ with a dense fringe of spinules at apex; hind tarsi longer than in Bolitobius; thorax with the marginal punctures as in Mycetoporus, the apical and basal ones more distant from the margin. 
884 (2670). Bryoforus rufescens Lec., N. Sp. N. Amer. Col., I, 1863, 33.

Elongate, rather robust. Head, under surface and abdomen piceous; antennæ, thorax, elytra and legs dark reddish-brown, shining. Thorax wider at middle than elytra, hind angles broadly rounded. Elytra together longer than wide, with seven rows of coarse, shallowly impressed punctures. Abdomen sparsely pubescent, sparsely and rather coarsely punctured, the last two segments and the hind margins of the others paler. Length $3.5-4.5 \mathrm{~mm}$.

Throughout the State, frequent; more so in the southern counties. March 20--June 17. Occurs beneath bark and rubbish. Much more robust than the next species, with the elytral punctures much coarser and in regular rows.

885 (- - . Bryoporus testaceus Lec., N. Spec. N. Amel. Col., I., 1863, 33.

Elongate, very slender. Head and thorax piceous; elytra reddishbrown, often with an indefinite sutural blotch darker; under surface and abdomen dark reddish-brown, the segments of latter paler at apex; antennæ dusky, paler at base; legs pale reddish-brown. Thorax as wide at base as elytra, smooth, strongly shining. Elytra distinctly longer than wide, the punctures of sutural row distinct, the others small, faint and in somewhat irregular rows. Abdomen pubescent, rather finely and sparsely punctate. Length $2.7-3 \mathrm{~mm}$.

Marion, Putriam and Posey counties; scarce. March 20-October 14. Taken by sifting. Resembles Mycetoporus americanus but without the discal punctures of thorax. This species was suppressed by Horn, and afterward redescribed as parvulus by Casey.

\section{Tribe V. HABROCERINI.}

This tribe is represented in the United States by a single genus, Habrocems, having the hind coxæ broadly triangular, concealing a part of the femora in repose; head deflexed, antennæ slender, hairlike; abdomen margined. One small piceous form, $H$. schwarzi Horn, $2 \mathrm{~mm}$. in length, having the elytra pale clay yellow, finely and very sparsely punctate, was described from Detroit and probably occurs in northern Indiana.

\section{Subfamily VI. PHLOEOCHARINAE.}

Slender, depressed species having the antennie inserted under the sides of the front, 11-jointed, straight, the outer joints but little thicker; head without ocelli; prosternum behind the front coxæ membranous; abdomen elongate, margined, with but six ventral segments visible, the second with a longitudinal elevation at middle; tarsi 5-jointed. The subfamily is represented in Canada, Michigan and perhaps northern Indiana by two genera. 
KEY TO GENERA OE PILGOCHARINA.

u. Thorax not cirinate; maxillary palpi filiform; mandibles simple.

OLISTH ERUS.

au. Thorax with four carinz; maxillary palpi, awl-shaped; mandibles toothed.

Pseudopsis.

Pseudopsis columbica Fauv., reddish-brown, 2.5-3.5 mm. in length has been taken in numbers near Detroit.

\section{Subfamily VII. EUAESTHETINAE.}

Small, rather slender species having the antenna inserted before the eyes at the base of the labrum; tarsi four-jointed; eyes moderate in size, convex, coarsely gramulated, located very close to the base of head; labrum usually denticulate in front; antenna, month parts and thorax much as in the subfamily Steninæ. Three genera represent the subfamily in the United States. Specimens of but one of these have been taken in Indiana, though those of the others may oceur. The only paper treating of the subfamily is by:

Casey._- Contributions to the Descriptive and Systematic Coleopterology of the United States," Part I, 1884 (published privately). The genera Eucsthotus and Edaphus are treated on pp. 18-31.

\section{KEY TO GENERA OF EUAETHETIN E.}

a. Abdomen margined.

b. Labrum with a row of comb-like teeth in front; head between the eyes convex; thorax without fovea near base; first dorsal segment of abdomen without a carina.

LXIX. EUAsthetus.

bわ. Labrum without teeth; head bi-impressed between the eyes; thorax with several deep fover along the base; first dorsal with a median carina.

EDAPHUS.

a a. Abdomen not margined.

STICTOCRANIUS.

\section{EuRustinter Grav. 1806. (Gr., "easily perceived.")}

Ten species of this genus are listed by Casey, loc. cit.; nine of which he describes as new. Two of the ten have been taken in the State.

\section{KEY TO INDIANA SPECIES OF EUESTHE'TUS.}

a. Elytral suture distinctly shorter than thorax; color pale reddish-brown; length $1-1.2 \mathrm{~mm}$.

886. FLORID E.

a a. Elytral suture as long as thorax; color piceous; length 1.2-1.5 mm.

887. AMERICANUS.

886 (2474). Eu esthetus floride Casey, Contrib. Coleop., I, 18S4, 21.

Elongate, slender. Pale reddish-brown; funely and sparsely pubescent. Elead slightly wider than long. rather coarsely, not closely punctate. Tho- 
rax widest just behind the middle. whele it is a little broader thatu lons and slightly broader than head; dikk. as well as that of elytra, coalsely and rather sparsels punctate. Elytra at base equal in width to thol:ax, the slltural striae deep. Abdomen smooth, stromgly malgined tomand the base. Length 1-1.2 $10 m$.

Floyd County; rare. May 2t. Two specimens taken by Dury while sifting. and now in his collection.

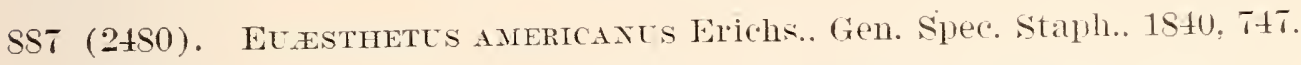

Elongate, rather robust. Piceous or rery dark reddish-brown; antemne and legs paler. Head slightly wider than long. neally as wide as thorax, coarsely and lather closely punctate. 'Thorax one-third broader' than long; sides broadly rounded to behind middle. thence rapidly converging to base: disk coarsely and closely punctate. Elytra at base one-half wider than thorax, finely, evenly and rather closely punctate. Abdomen at base as wide as elstra. lather finels punctate. Length 1.2-1.5 mm.

Lake and Kosciusko counties; rare. Nay 25-June 25. Taken by sifting debris from margins of sphagnum begs.

One species of Edaphus is known from near Tashington. D. C.. Alabama and Lonisiana, and one of Stictocranius. from the former locality. They resemble members of the family Pselaphidie very closely and occur under old leaves and in nests of ants.

\section{Subfamily VIII. OXYPORINAE.}

Elongate. robust species having the antennæ i1-jointed. inserted under the side margin of the front: head very large. usually wider than thorax; eres small. not prominent: mandibles long. crossing at an angle; mentum with a bifid tooth at middle: last joint of labial palpi very large, lmuate: middle coxæ at the sides of the breast: tarsi five-jointed; abdomen strongly margined. The subfamily is represented by the single genus:

\section{Oxyports Fab. 1792. (Gr.. "to min.")}

This genus. sufficiently characterized above. is represented in the Tnited States by 13 nominal species. eight of which have been taken or probably ocenr in Indiana. All of the species feed upon fleshy fungi. They are treated by :

LeConte.-In Trans. Amer. Ent. Soc. VI. 187T. 21t-215: VIII. 1880. 180.

KEI TO INDIANA SPECIES OF OXYPORLS.

a. Elytra with the sides finels lugose: black: elytra lalle. sutule and sides black; tibia and tarsi pale.

FEMUIIALIS. au. Elytra polished, with the usual stritie and punctures. 
b. Legs black.

c. Sides of thorax feebly rounded; elytra pale, with suture, sides and a narrow stripe black.

cc. Sides of thorax much rounded; elytra wholly black.

MAJOR.

SSS. STYGICUS.

bъ. Legs yellow.

d. Color abore wholly or in great part black or piceous.

e. Elytra in part at least dull yellow.

$f$. Suture and sides of elytra black.

$f f$. Suture and outer apical angles black.

SS9. vitTatus.

FASCIATUS,

ee. Elytra wholly black; under surface pale yellow.

$d d$. Color above reddish-yellow.

$g$. Sides of elytra fuscous.

BICOLOR.

gg. Spot on head, two on thorax and part of dorsal surface of abdomen, black.

S91. occipitalis.

O. femoralis Grav., 7-7.5 mm. and O. major Grav., $9 \mathrm{~mm}$. in length, have both been recorded by Dury from Cincinnati.

SSS (2692). Oxrpolus strareus Siy, Trans. Amer. Phil. Soc., 1V, 183t, 459 ; ibid. II, 575.

Elongate, rather robust. Black, strougly shining; antennæ piceous, joints 2 to 5 and the tarsi reddish-brown. Thorax widest at middle, thence much narrowed to base, sides strongly rounded; surface, as well as that of head, smooth. Elytra together one-half wider and one-third longer than thorax, each with a subsutural and two discal striae, the former finely, the latter more coarsely punctate, and with a number of coarse, scattered punctures intervening. Abdomen at base slightly narrower than elytra, smootl. Length 6.5-8.5 $\mathrm{mm}$.

Southern half of State; frequent. June 11-November 4.

SS9 (2693). Oxxporus vytTatus Grav., Mon. Col. Micl., 1806, 195.

Oblong, robust. Black or piceous, shining; elytra dull clay yellow, the suture and a stripe on sides, gradually widening from humerus to apex, black; legs and base of antennie reddish-yellow. Head slightly wider than thorax, the base very finely and sparsely punctate. Thorax one-half wider than long. sides strongly curved, the base much narrower than apex, disk smootl. Elytra one-third wider and distinctly longer than thorax, with a sutural and two discal rows of rather fine punctures and a number of coarser scattered ones. Abdomen as wide as elytra, smooth, the tip of the last segment pale. Length $5.5-6 \mathrm{~mm}$.

Lake and Vigo counties: frequent. July 2-October 9. Occurs especially in chumps of overlapping fungi at base of stumps.

O. fasciatus Melsh. and O. bicolor Fauv., are in all probability only color varieties of vittatus. I have inclided them in the key. that the variation may be noted, though authentic specimens of neither are in the collection at hand. 
(2696). Oxyporus lateralis Gray., Mon. Col. Micr., 1806, 195.

Elongate-oblong, robust. Reddisll-yellow; sides of elytra with a black or fuscous stripe, starting one-third behind humerus and gradually widening to apex; legs pale yellow. Ifead of male slightly narrower, of female as wide as, thorax; surface, with that of latter, very finely alutaceous, not punctate. Thorax slightly wider than long, sides broadly rounded. Elytra one-half longer and distinctly wider than thorax, with a sutural and one discal row of fine punctures with seattered coarser ones intervening. Length $6.5-7.5 \mathrm{~mm}$.

Lake and Putnam counties; searce. October 7-November 9. Taken on the latter date beneath partly buried logs, and probahiv hibernates.

\$91 (2692). Oxyporus occipitalis Fauv., Mars. Abeille, I, 1S64, 369.

Form of lateratis. Color in part given in key. Elytra black, each with a triangular basal spot reddish-yellow; abdomen with a small black spot on middle of second and third, and a much larger one on fourth and fifth, dorsal segments. Thorax one-third wider than long, sides strongly curved. Elytra with numerous very coarse punctures between the sutural and discal strix. Length $6 \mathrm{~mm}$.

Lake, Marion and Vigo counties; scarce. October 7-October 20. The elytra are sometimes colored very nearly as in lateralis, but are much more coarsely punctured than there. This may also prove to be only a color variety of vittatus.

\section{Subfamily IX. OXYTELINAE.}

Small, usually slender species having the antennx 11- (rarely 10-) jointed, inserted mider the sides of the front, the latter more or less prolonged before the eyes; front coxa usually large, conical and prominent; middle coxr contignous (separated in Oxytelus). The subfamily as above defined is separated into six tribes, font of which are represented in Indiana.

KEY TO INDIANA TRIBES OF OXYTELIN E.

a. Front coxie conical, prominent.

b. Head without ocelli or simple eyes.
c. Abdomen margined.
Tribe I. Oxvereini, p. 46\%.

cc. Abtomen not margined; form cylindrical.

Tribe II. OsoRIINI, p. 473.

bb. Head with two ocelli usually placed on a line joining the hind margin of the eyes; form broad and depresced; elytra usually corering half or more the length of abdomen. Tribe iII. Omanini, p. 47 . an. Front coxie transverse; head without ofelli: prosternum horn-like behind the coxie.

Tribe IV. Proteinini, 1. 4S.2. 
Tribe I. ONYTELINI.

In this tribe the antennix are more or less elbowed; first joint of maxillary palpi short; second ventral without ridges; tarsi in all of our genera but one. three-jointed. The following genera are known to be or are probably represented in the State:

KEY TO INDIANA GENERA OF OXYTTELINT.

a. Antennie 10-jointer ; eyes very large: tarsi j-jointed.

a a. Antennie 11-jointed: tarsi :-jointed.

IXXI. MEGALOPS.

b. Front tibie more or less spinous on onter nuargin.

c. Front tibie with two rows of spines; body subcrlindrical; antennie strongly elbowed.

LXXII. BLEDIUS.

cc. Front tibice with a' single row of spines; bods depressed.

d. Middle tibie also with a single row of spines. Platrstethus. dd. Middle tibice without spines; middle coxie not contiguous.

77. Tibire all pubescent and without spines.

LXXIII. OXYTELLS.

e. Scutellum not visible.

ce. Scutellum visible.

$f$. Head strongly constricted behind; bods glabrous.

LXXY. Apocellus.

ff. Head not constricted behind; bodr pubescent; last joint of maxillary palpi awl-shaped.

THINobius.

LXXI. Megrlops Dej. 1833. (Gr., "big + eye."

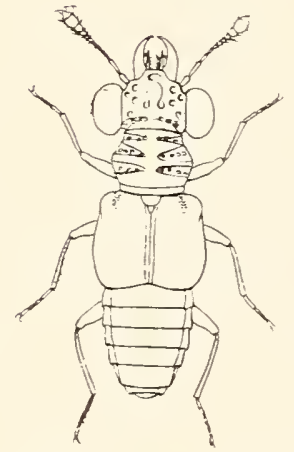

Fig. 166. Megnalops cephalotes Erichs. $\times 8$. (After Erichson.) A South American species.

Short robust species. resembling those of $O x y$ porus in form. having the eves larger than in Stenus; thorax coarsely and irregularly punctured and marked with a few transverse furrows on the sides. (Fig. 166.)

S92 (2685). Megalops c.elatés Grav.. Mon. Col. Micr.. $1806,197$.

Elongate-oblong, robust. Black, shining; e lytra with an oblique reddish stripe, extending from humerus to suture at apex; legs and antennie reddish-brown. the latter shorter than head, the last joint very large. fuscous. Head wider than thorax. coarsely, sparsely and rugosely punctate. Thorax subcylindrical. as wide as long; disk with a number of large tubercles in addition to the coarse punctures. Elytra one-third wider and slightly shorter than thorax. rely coarsely, roughly and irregularly punctate. Abdomen slightly narrower than elytra, almost smooth. Length $4.4 .5 \mathrm{~mm}$.

Posey County : rare. May 7 . Occurs beneath bark of fungus covered beech logs. 
S93 (2686). Megalops rufipes Lec. N. Spec. X. Amer. Col., I, 1869, 51.

Resembles colatus. Elytra each with a small red spot on lumerus and another at the inner apical angle. Head and thorax punctate as in cclatus, the thorax with two impressions each side. Elytra much smoother, the disk with two abbreviated rows of coarse deep punctures. Length $3 \mathrm{~mm}$.

Knox County; rare. June 9. One specimen from beneath bark at edge of cypress swamp. Described from Georgia.

\section{Buenus Leach. 1832. ( $\$ proper name.)}

Elongate, slender. subcrindrical species having the tarsi 3jointed; head smaller and narrower than thorax, base scarcely constricted; middle coxa contiguous : front tibie with two rows of fine spines on onter side. The genus is a very large one, and the species exceedingly difneult to separate. The great majority of the North American species of this and the other genera of Oxytelini are treated in the following papers:

Leconte._"On certain Genera of Staphylinidx, as represented in the Fauna of the United States,' in 'Trans. Amer. Ent. Soc.. VI, 1877, 21:3-248.

Casey._- "Coleopterological Notices," in Ann. N. Y. Acad. Sci.. V. 1889, 41-89; VII, 381-398.

LeConte divides the species into five groups, four of which are probably represented in Indiana.

KEY TO INDIANA GROUPS OF BLEDIUS.

a. Thorax without an edge on sides or prosternal sutures beneath.

Group 1.

a a. Thorax with the edge on sides well defined.

b. Prosternal sutures distinct.

c. Fissure at side of front coxal cavities short, closed. Group $B$.

rc. Fissure of front coxal carities open and large, extending twothirds the distance from the coxa to the side. Group $C$.

b). Prosternal sutures obliterated: fissures of front roxal cavities short. rlosed: hind angles of thorax obtuse.

Groulp $D$.

GROUP A.

Rather large brownish-yellow species, not shining. finely granulate. not strongly punctured. Thorax broader than long. truncate in front. sides parallel. suddenly and strongly narrowed from middle to base; hind angles wanting. disk with a distinct median line. Two of the seven species recognized by LeConte have been taken in Illinois and doubtless occur in Indiana. They are:

B. gularis Lec. $7.5 \mathrm{~mm}$. in length, having the head, suture. diagonal tip of elytra and last two abdominal segments blackish: gula [30-23402] 
with a very deep triangular excavation, and $B$. pallipennis Say, 9 mm. in length, with head blackish, suture and tips of elytra fuscous; gula with a shallow excavation.

\section{Group B.}

Small or medium-sized species having the side margins of thorax acute, the flanks concave; mandibles stout, strongly toothed near the tip; rows of spines on front tibia widely separated.

\section{KEY TO INDIANA SPECIES OF GROLP B.}

a. Side pieces of prosternum rery distinctly triangular. the sutures directed to the front angles of the thorax.

b. Head coarsely punctured; chestnut brown. shining; elytra and legs paler.

SEMIFERRUGINEUS.

b). Head not or obsoletely punctured; thorax not wider than long. coarsely punctured; chestnut brown, elytra and abdomen reddishbrown.

894. FUMATUS.

a a. Side pieces of prosternum not triangular, the sutures parallel with the side margin of the under surface or flank of thorax.

c. Reddish-brown; head and thorax darker; tip of abdomen black.

895. ANALIS.

cc. Blackish-brown; elytra, antenne and legs brown; dorsal impressel line of thorax wanting.

NITIDICOLLIS.

$B$. semiferrugineus Lec., 4.5 in length, occurs from Michigan to Florida and has been taken near Cincimnati. No authentic specimen has been seen from the State.

\$94 (2719). Bledius funatus Lec., ․ Sp. ․ Amer. Col.. I, 1863, 52.

Elongate, robust, subcylindrical. Dark chestnut or reddish-brown, shining; head and thorax piceous, legs and tip of abdomen paler. Head finely srinulate. sparsely and indistinctly punctulate. Thorax not wider than long, sides strongly rounded into base; disk coarsely and rather closely punctate, the median line deep. Elytra slightly wider and more finely punctate than thorax. Abdomen at base narrower than elytra, sparsely punctate above, more finely beneath. Length 5.5-6.5 mm.

Lake, Kosciusko and Vigo comnties; rare. May 30-July 18.

$\$ 95$ (2723). Bledius axalis Lec. N. Sp. N. Amer. Col., I. 1863, 52.

Elongate, slender. subcylindrical. Pale reddish-brown; head, thorax and tip of abdomen black; elytra fuscous about the scutellum and along the suture to middle. Head finely granulate. sparsely and finely punctate. Thorax as wide as long, sides straight to behind middle, thence strongly rounded into base: disk not granulate, coarsely and rather closely punctate, the median line fine but distinct. Elytra deeply and rather closely punctate. Abdomen nearly smooti above. sparsely punctulate beneath. Length $4 \mathrm{~mm}$.

Lake, Putnam and Dubois comnties; scarce. Nay 12-July 10. Occurs under cover along the banks of streams and lakes. 
B. nitidicollis Lec., $3 \mathrm{~mm}$. in length. is recorded from New York, Michigan and Missouri.

Group C.

Small or medium sized forms having the side margin of thorax acute: prosternal sutures straight: mandibles with two acute teeth on the inner side; fissure of front coxal cavities open and large.

IEY TO INDIANA SPECIES OF GROUP C.

a. Head and thorax finely granulate, the former flattemed.

b. Size larger. 6-6.5 mm.; median forea of head very large; elytra reddish-brown. fuscous near scutellum.

S96. BOREALIS.

bb. Size smaller, not over $4 \mathrm{~mm}$.

c. Head not punctate; elstral piceous; lelıtlı $3.5 \mathrm{~mm}$.

S9T. STABILIS.

cc. Head punctate; elytra reddish-brown.

d. Thorax with hind angles distinct, its disk less densely granulate; tip of abdomen darker than base. S9S. Axwelaris.

dd. Thorax with hind angles indistinct. rounded, its disk rery densely granulate; abdomen black tliroughout. 899 . confusus. au. Ifead and thorax polished, the former convex, the latter without hind angles; piceous, elstra dull yellow, the suture fuscous.

900. EMARGINATUS.

S96 (- ( ) . Bledits Borealis sp. nor.

Elongate, robust. subdenressed. Black, shining; legs and elytra chestnut brown, the latter fuscous at middle of base. and for a short distance along the suture; antennie dusky toward apex, slender. Head much narrower than thorax, rery finely granulate, coarsely and sparsely punctate, the median forea large and deep, the suture distinct. Thorax at apex slightly wider than long, sides straight and parallel for twothirds their length, thence rapidly converging to base, the latter one-half as wide as apex; disk conrex. finely and densely granulate. coarsely and sparsely punctate, smooth along the middle and on apical third. median line fine: hind angles small but distinct. Elytra scarcels wider and but slightly longer than thorax, finely and

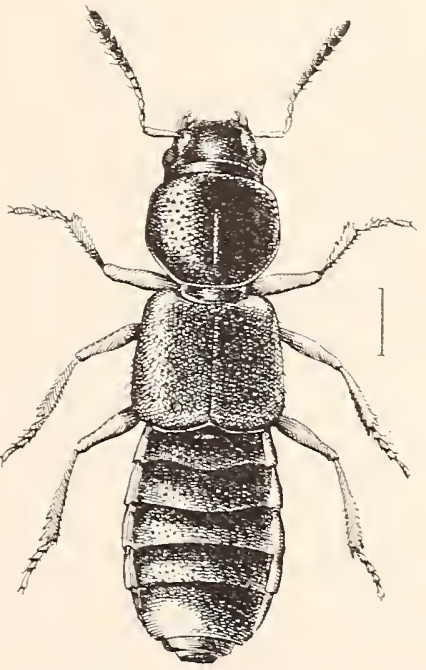

Fig. 167. (Original.) rather sparsely punctate. Abdomen above and beneath finels granulate. rery sparsels and finely punctate. Length 6-6.5 mm. (Fig. 167.)

Lake County: rare. May 19-May 28. Three specimens from near Pine. beneath clumps of cactus.

S97 (9696). Bledies stabilis Casey, Ann. N. Y. Acad. Sci.. T, 1S59, 61.

Elongate, rather robust, depressed. Black; thorax and elytra piceous: legs and antennie toward base, dull yellow. Head distinctly narrower than 
thorax, densely granulate. not punctate; rertex with a distinct but not large median forea. Thorax nearly as broad as base of elytra. one-third wider than long; sides parallel and feebly curved for two-thirds their length, thence converging and feebly sinuate to base; disk convex. finely and sparsely punctate, median line fine but distinct, hind angles obtuse. Elytra one-half longer and at apex one-fourth wider than thorax: finely. deeply and rather closely punctate. Abdomen finely granulate, finely and rery sparsely punctate above, more coarsely and somewhat closely beneath. Length $3.5 \mathrm{~mm}$.

Marion County ; rare. May 15. Described from Pennsylvania.

S9S (2730). Bledius anvularis Lec., x. Sp. N. Amer. Col.. I. 1863. 53.

Elongate, slender. Head, thorax and tip of abdomen black: elytra, base of abdomen and antenne reddish-brown; legs dull yellow. Head finely granulate, sparsely and finely punctate. with a small fovea on rertex. Thorax not wider than long. sides rounded to behind middle, thence oblique and slightly sinuate to base; disk finely granulate, sparsely, erenly and shallowly punctate, median line fine. Elytra finely. deeply but not closely punctate. Abdomen at base narrower than elytra, finely and rery sparsely punctate. Length $3.8-4.5 \mathrm{~mm}$.

Marion County; rare. April 16. The hind margins of the dorsal segments of abdomen are often darker. thus causing it to appear indistinctly fasciate.

S99 (2731). Buedils confusus Lec., Trans. Amer. Ent. Soc.. VI, 1S7т, 228.

Elongate, slender. Head. thorax and abdomen black; elytra and legs reddish-brown, the former fuscous in the region of the scutellum; antennæ piceous. the base paler. Head less finely granulate. sparsely and finels punctate, with a small rertical forea. Thorax one-fourth wider than long, sides straight to middle, thence rounded to base. the hind angles rery obtuse; disk sparsely and rather finely and irresularly punctate, the median line fine. Elytra deeply, rather finely and somewhat densely punctate. Abdomen as in ammularis. Length 3-3.5 mm.

Narshall and Miarion counties; scarce. April 17-August 15.

900 (2741). Bledius emarginates Say. Trans. Amer. Phil. Soc., IV, 1834. 461 ; ibid. II. 57 .

Elongate, rery slender. Black; antenne, legs and elytra prale, the latter with suture dusky. Head convex, coarsely, deeply and sparsely punctate. Thorax a little wider than long, sides rounded into base; disk punctate like the head, the impressed median line evident but fine. Elytra finely and rather sparsely punctured, the sutural angle rery widely rounded. Abdomen very sparsely and finely punctate. Length $2-2.3 \mathrm{~mm}$.

Southern third of State; frequent. May 1-August 17. Occurs along the sandy marginis of streams. 


\section{Groul’ D.}

Small, slender species having the side margin of thorax acute, the flanks deeply but narrowly concave; prosternal sutures wanting; coxal fissures short and closed; hind angles of thorax obtuse. 901 (2745). Bledius condatus Say, Trans. Amer. Phil. Soc., IV, 1S34, 461; ibid. II, 576.

Eiongate, very slender. Black; elytra dull yellow with a wide fuscous sutural stripe; antennæe and legs dull yellow, the former dusky at tip. Head broad, flat, finely granulated. Thorax one-third wider than long, sides subparallel, rounded behind; disk finély granulate, very sparsely and irregularly punctate, the median line distinct. Elytra slightly wider and onethird longer than thorax, finely and rather densely punctate. Abdomen at base narrower than elytra, finely granulate, neariy smooth above, distinctly punctate beneath. Length $4 \mathrm{~mm}$.

Lake County; rare. May 21. A sea-coast species which will probably be found all along the shore of Lake Michigan.

Platystethus americamus Erichs., $3 \mathrm{~mm}$. in length, black, shining, elytra fúsco-piceous, tibix and tarsi pale, is recorded from Cincinnati, and very probably occurs in southern Indiana.

\section{OXYT̄elus Grav. 1806. (Gr.. "a pointed end.")}

Small, depressed black or piceous species having the head usually as wide as thorax, the middle cox: somewhat separated and the front tibiæ with a single row of spines.

KEY TO INDIANA SPECTES OF OXYTELUS.

a. Thorax coarsely sculptured, more or less shining.

b. Head rounded immediately behind the eyes, which are large and prominent; thoracic grooves deep; length $3.5-4 \mathrm{~mm}$.

902. SCULPTUS.

$b b$. Head prolonged behind the eyes, the latter moderate in size.

c. Sides of thorax crenulate; piceous, legs and base of antennæe dull yellow; front flat; length $4.2-5 \mathrm{~mm}$.

RUGOSUS. $c c$. Sides of thorax entire.

d. Front of head concave, its apical margin elevated ; onter thoracic groove feeble; length $3.5-4.5 \mathrm{~mm}$. 90:3. PENNSYLVANICUS.

dd. Front of head flat, not margined at apex.

e. Vertex flat, not channeled; thorax strongly punctured; male with apical margin of front extended forward in a short. sharp process; length $2.5-3 \mathrm{~mm}$.

904. INSIGNITUS.

ee. Vertex convex, feebly channeled.

$f$. Front polished; dorsal grooves of thorax distinct; length $1.7-2 \mathrm{~mm}$.

905. SUSPECTUS.

ff. Front opaque; dorsal grooves obsolete; length $2.3 \mathrm{~mm}$.

906. PLACESINUS, 
ac. Thorax rery finely strigose, quite opaque.

g. Dorsal segments of abdomen densely punctate; front tibix obliquely emarginate on the outer side; length $1.7 \mathrm{~mm}$.

TETRACARINATUS.

gg. Dorsal segments smooth; front tibix slender, truncate at tip; grooves of thorax feeble; length 1.5-1.8 mm.

907. EXIGUUS.

902 (2749). Oxytelts sculptus Grav., Mon. Col. Micr., 1S06, 191.

Elongate. subdepressed. Piceous; legs and base of antennæ dull yellow. Head small, narrower than thofax, finely and densely punctate and with a slight median groove on rertex. Thorax elliptical, angles all rounded; disk rather closely punctured and with three entire grooves, the sides somewhat concare. Elytra slightly wider and one-half longer than thorax, rather coarsely and roughly punctate. Abdomen very finely and densely punctate. Serenth rentral of male with two narrow, deep notches, the median lobe broad, truncate. Length $3.5-4 \mathrm{~mm}$.

\section{Marion County; scarce. April 14.}

O. rugosus Erichs. ocenrs in Canada, Massachusetts and Pennsylrania, and probably in northern Indiana.

903 (2752). Oxytelus Pexnsyluanict's Er., Gen. Spec. Staph., 1S40, 792.

Elongate. depressed. Dark reddish-brown to piceous, shining; elytra dull clay yellow; legs and basal joints of antenne paler. Head slightly narrower than thorax, finely and rather closely punctate, the rertex rugose; frontal margin broadly curved and elevated. 'Thorax three-fourths wider than long. sides rounded into base; disk finels and rather sparsely punctate, the median groore distinct, the two outer ones faint. Elytra slightly wider and one-third longer than thorax, finely, sparsely and rugosely punctate. Abdomen at base narrower than elytia, almost smooth. Male with two slight tubercles on hind margin of seventh rentral and head wider and more quadrate behind the eses than in female. Length $3.5-4.5 \mathrm{~mm}$.

Marshall, Putnam and Clark counties; scarce. April 17June 24.

\section{4 (2755). Oxyteles insignitus Gray., Mon. Col. Micr., 1S06, $18 \mathrm{~s}$.}

Elongate, subdepressed. Black or piceous, shining; thorax dark reddish-brown; elytra and base of antennæ dull sellow; legs paler. Head of male wider than thorax, quadrate. nearly smooth, strigose each side behind the eyes; of female. not as wide as thorax. rounded behind the eres, sparsely and finely punctate. Thorax truncate at apex, front angles almost rectangular, sides rounded into base; disk rather coarsely and sparsely punctate, with three deep grooves, its sides concare. Elytra slightly wider and distinctly longer than thorax, finely and rather closely punctate, and finely longitudinally rugose. Abdomen minutely granulate, not punctate. Length 2.5-3 mm.

Throughout the State; trequent. January 5-October 4. Occurs in fungi, beneath bark and dead leares. The mandibles of the male are very long. slender and scythe-shaped. 


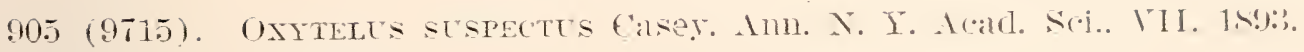
395.

Elongate, slender. parallel. Blakk. shining; elytrat picenus; less fuscous rellow. Head about as wide as thorax. male, distinctly nalrower. female, finely and sparsels punctute. the rertex with three slightlc impressed groores. Thorax one-half $\pi$ ider than long. sides rounded into base; disk coarsels, rather closels and roughly punctate. with three groores. the median one narrow. the others broad and shallow. Elytra slightly wider and one-third longer than thorax. sculptured as in insignitus. Abdomen smooth. polished. Length $1 . \bar{i}-2 \mathrm{~mm}$.

Kosciusko. Marion and Putnam comnties: scarce. March 17July 10. Sifted from damp regetable debris.

906 (2759). Oxytelts plactsixts Lec. Trans. Amer. Phil. Soc. TI, 1STi. $23 \pi$.

Elongate, slender. depressed. Head and abdomen fusco-piceous: thorax and elstra pale reddish-brown: legs pale sellow. Head narrower than thorax, as long as wide, finels and densels rugosels punctate behind. front nearly smooth. Thorax one-half wider than long, sides nearls straight; apex truncate, hind angles obtuse: disk densels and rugosels punctate, the median groove faint. the others obsolete. Elstra distinctly wider and longer than thorax. punctured as there. Abdomen smooth abore. finels and densely punctate beneath. Length $2-2.3 \mathrm{~mm}$.

Poser County: rare. April 19-April 21. Sifted from ants' nests.

O. tetracarinatus Block. (depressus Grar.), a European species. is said by LeConte to oceur in Indiana. but I have seen no specimens.

907 (2762). Oxyterts Exiguts Erichs., Gen. Spec. Staph.. 18t0, 798.

Elongate. parallel. Black. opaque; elrtra fuscous; legs pale sellow. Head slightly narrower than thorax. densely and finels strigose. Thorax one-half wider than long. sides and apex feebls curred; disk with rers fine. dense lengthwise strige. the usual groores rers faint. Elstra flat. onethird longer and a little wider than thorax. more coarsels strigose with fine punctures between the strigie. Abdomen smooth. polished. Length 1.5 1.S $\mathrm{mm}$.

Putnam and Lamence counties: scarce. April 17-.July 29.

LXXIT. Trogophlets Mann. 1830. (Gr.. "to gnaw + bark.")

Elongate slender forms having the front tibire not spinose: second joint of tarsi with a long. slender spine or stout sata extending beneath as far as the end of the third or last joint: tarsal claws large: scutellum invisible: middle coxp contiguons. The following paper is the only one treating of the genus as a whole: 
Casey.- "A Preliminary Monograph of the North American Species of Trogophlous,"' in Ann. N. Y. Acad. Sci., IV, $1889,322-383$.

The following species have been taken or perhaps occur in the State.

\section{KEY TO INDIANA SPECIES OF TROGOPHLCEUS.}

a. 'Thorax with a deep transverse curved or lumate groove near the base.

b. Color dark reddish-brown; legsapale.

90S. ARCIFER.

b7. Color black; legs and antenne black; thorax widest before the middle.

ANTHRACINUS.

aa. Thorax without a curved groove near base, but usually with a length-

wise groove on basal half each side of a slightly raised median line.

$c$. Eyes large, convex and prominent, the distance from their hind margin to base of head less than one-third their diameter.

1. Thorax subhexagonal, widest one-third behind apex, the sides thence converging and nearly straight to base; its disk broadly impressed on side; length $3-3.2 \mathrm{~mm}$. 909. QUADRIPUNCTATUs.

$d d$. Thorax rounded in front, widest just in front of middle, sides thence converging to base; disk not flattened on the sides; length $2.5 \mathrm{~mm}$.

910. MEMNONIUS.

co. Eyes small, much less prominent, the distance from their hind margin to base nearly as long as or longer than the eyes.

e. Elytra chestnut brown or paler.

$f$. Larger, $2.6 \mathrm{~mm}$; thorax coarsely and sparsely punctate.

$f f$. Smaller, not over $2 \mathrm{~mm}$. ; thorax densely and finely punctate.

PHLAOPORINUS.

911. POSEYENSIS.

ee. Elytra black or piceous.

g. Elytra distinctly longer than thorax; surface not opaque; antennæe shorter than head and thorax; length $1.8-2 \mathrm{~mm}$.

912. AGONUS.

gg. Elytra not longer than thorax; surface strongly granulate and oparue: length $.6 \mathrm{~mm}$.

BRACHYPTERUS.

gos (2770). Trogophnots arcifer Lec., Trans. Amer. Phil. Soc., VI, 1877. 245.

Elongate, rather robust, convex. Uniform dark reddish-brown; legs and antenne slightly paler. Head three-fourths as wide as thorax, coarsely. deeply and rather sparsely punctate. Antennse longer than head and thorax, the outer joints thickened. Thorax one-half wider than long, widest just in front of middle. the sides thence curving to base; disk coarsely. deeply and rather closely punctate. Elytra one-third wider and one-half longer than thorax, coarsely but not densely punctate. Abdomen almost as wide as elytra, rather finely and sparsely punctured. Length $2.8 \mathrm{~mm}$.

Fountain County ; rare. August 17. The specimen at hand has the legs, antenn:e and abdomen but slightly paler than elvtra ; otherwise it agrees with the description of the type. 
T. anthracimas Casey. $2.8 \mathrm{~mm}$. in length, was described from Kentuck ve and Tirginia.

909 (27i3). Trogophleus quadriplyctates Say. 'Tlans. Amer. Phil. Soc, IV. 1834,459 ; ibid. II, 575.

Elongate, rather robust. convex. Black, strongly shining; antenne and legs piceous; knees and tarsi paler. Head one-third narrower than thorax. finels and rather densely punctate. Antenne longer than head and thorax. second and third joints equal. Thorax two-thirds wider than long: disk finely and densely punctate. Hattened on the sides and with four distinct impressions on basal half. Elytra distinctly wider and one-half longer than thorax. coarsely. rather sparsely and deeply punctate. Abdomen slightly narrower than elstra. minutely granulate. Lengtl $3-3.2 \mathrm{~mm}$.

Kosciusko, Starke. Narshall and Lawrence comties; suaree. June 2t-Angust 22. Taken by sifting damp regetable debris.

910 (2776). Trogophlets mempoxtes Erichs., Gen. Spec. Staph.. 1sto. So6.

Elengate, slender. Black. shining: antenne piceous. the two basal joints and legs reddish-brown. IIead slightly nalrower than thorax, minutely and densely punctate. Antenne as long as head and thorax. joints two to four decreasing in length. 'Thorax one-half wider than long. base much narrower than apex; disk finely and densely punctate. the impressions on basal half shallow. Elytra slightly wider and one-half longer than thorax, deeply, rather coarsely. not closely punctate. Abdomen narrower than elytra, very finely granulate. minutely and sparsely punctate. Length $2.5 \mathrm{~mm}$.

Marshall and Putnan counties : rare. March 20-May 20. Taken from beneath dead leares at margin of lake. The impressions of thorax are somewhat interrupted at middle so as to appear four in number.

T. phlooporimus Lec., a very slender. coarsely and sparsely punctate species, is kuown from Illinois and Iowa.

911 (-). Trogophlets poserexsis sp. nor.

Elongate-oblong. rather slender. Reddish or fuscons brown, the head and apical half of abdomen darker; elytra dark clay sellow; antennæ piceous, the basal joint and legs pale yellow. Head as wide as thorax. conrex. very finely and densely punctate. Antennie longer than head and thorax, the outer joints distinctly thickened. 'Thorax scarcely wider than long. widest one-third from apex, thence feebly curred to base; disls finely and densely punctate, flattened on sides and with four rounded impressions on basal half. Elstra together broadel than long. one-third wider and onehalf longer than thorax. very finely and rather closely punctate. Abdomen distinctly naromer than elrtra. minutely and sparsely punctate. Length $1.8 \mathrm{~mm}$.

Poser Countỵ; rare. Jume 3. Taken bỹ sifting a decaỵing beech stump. 
912 (9744). Trogophlet's Agoxt's Casey. Ann. N. I. Acad. Sci.. IV, 1589 356.

Elongate. slender. Piceous. feebly shining; abdomen black; legs and antenmie dark piceous brown. Head scarcels narrower than thorax, wider than long, rather finely, deeply and densely punctate. Thorax one-half wider than long, widest just before the middle, sides feebly curred, apex much rider than base; disk densely and somewhat coarsely punctate and with two distinct parallel impressions on basal half. Elstra together about as long as wide, one-fourth wider and three-fourths longer than thorax. rather coarsely, not closely punctate.' Abdomen minutely granulate, very finely and sparsel $\bar{y}$ punctate. Length 1.S-2 $\mathrm{mm}$.

Starke and Putnam comties: scarce. March 20-May 19. Sifted from damp regetable debris.

T. brachypterus Lec., wholly dull black in hue and one of the smallest of the genus. occurs in numbers at Detroit. Michigan, and probably inhabits northern Incliana.

LXXT. Apocelles Erichs. 1840. (Gr.. "to withdraw + wild
animal.")

Rather slender glabrous forms having the head equal to or wider than the thorax; antemne arising from beneath distinct elevated frontal ridges; abdomen vervy broad.

913 (2782). Apocellts sphertcollis Say. Trans. Amer. Phil. Soc., IV,

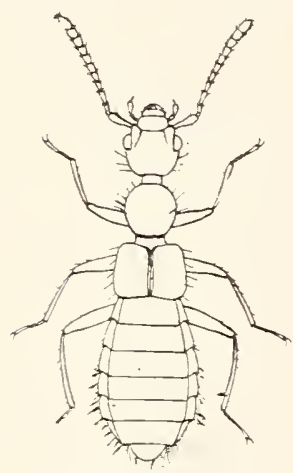

Fig. 168. $\times 9 \frac{1}{2}$. (After Erichson.) 1834, 455: ibid. II. 570.

Elongate, slender. widest across the abdomen. Dark reddish-brown. strongly shining; head and abdomeu usually darlier ; antennie fuscous, the first three joints and legs paler. Head wider than thorax. its sides oblique and rounded into a distinct neck; surface smooth. Fyes rery small; antennæ longer than head and chorax. the outer joints much enlarged, the second one-half the length of third. Thorax subglobular. conrex; its surface. as well as that of elytra, with a few scattered minute punctures bearing short black erect hairs. Elytra together wider than long, one-third wider and slightly longer than thorax. Abdomen at base as wide as elytra, thence gradually widening to the fourth and fifth segments: surface smooth, highly polished. Length 2.7-3 mm. (Fig. 168.)

Southern half of State; frequent. April S-May 13. Occurs beneath stones. logs and damp decaying leaves. The thorax varies much in color and size.

\section{Tmmobuts Kies. 18t4. (Gr.. "shore + to live.")}

Tery small linear depressed, pubescent species having the scutellum visible; the inner apical angles of elytra broadly and obliquely 
rounded so as to leave an angle in which the wings are visible; fourth and sixth joints of antenne smaller than the fifth and seventh. No species is at hand from the State. T. fimbriatus Lec. $.7 \mathrm{~mm}$. in length, dark reddish or chestnut-brown, legs slightly paler, probably occurs in the northern counties.

\section{Tribe II. OSORIINI.}

Rather stout, black or piceous, more or less cylindrical species having the middle coxæ contiguous; tarsi 5-jointed; mandibles stout, not toothed; abdomen not margined. Our two genera are treated by :

LeConte.-In Trans. Amer. Ent. Soe., VI, 187T, 215-216.

KEY TO GENERA OF OSORIINI.

a. Front tibiæ armed with spines; body cylindrical, pubescent.

LXXVI. OsORIUS.

aa. Front tibiæ unarmed; body subcylindrical, glabrous.

IXXVII. Holotrochus.

\section{Osorius Latr. 1829.}

Head almost as wide as thorax, the front more or less flattened and sloping toward mouth; eves small; antennx short, reaching middle of thorax, first joint loug, the others bead-like, gradually larger. This genus is represented in the state by two of the three known North American species.

914 (2701). Osorius Planifrons Lec., Trans. Amer. Ent. Soc., VI, 1S77, 215.

Elongate, cylindrical. Black, shining; antennce, legs and elytra dark reddish-brown. Head as wide as thorax, minutely granulate, finely and sparsely punctate, front distinctly flattened. Thorax widest at apex, sides straight and distinctly converging to base; disk sparsely and coarsely punctate, with a wide, smootl median stripe. Elytra narpower at base than thorax at apex, sparsely, coarsely and shallowly punctate. Abdomen as wide as elytra, finely granulate, sparsely and coarsely punctate. Length 7-S $\mathrm{mm}$.

Lawrence and Crawford counties; rare. May 17-May 23. Occurs beneath stones and logs in damp places. A member of the Austroriparian fauna.

915 (2702). Osorius latipes Grav., Mon. Col. Micr.. 1S06, 19S.

Elongate, cylindrical. Blackish-piceous, shining, rather thickly clothed with yellowish hairs; antenne and legs pale reddish-brown; thorax and elytra often chestnut brown. Head as wide as thorax, rather coarsely and more closely punctate; front less flattened. Thorax as in planifrons but 
more closely punctured. the median smooth space more narrow. Elstra and abdomen rather closely and coarsely punctate. Length $4-5.5 \mathrm{~mm}$.

Throughout the State; frequent in the southern counties, much less so morthward. March 23--July 1f. Tsually found burrowing in the ground beneath stones. The smaller size. paler antennæ and legs and more closely punctate upper surface readily distinguish it from planifrons.

\section{HoLotrochus Erichs. 1840. (Gr., "whole + ring or circle.")}

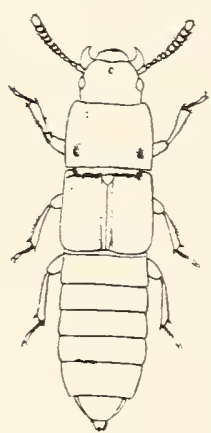

Fig. 169. Holotrochus volvulus Erichs. A Porto Rican species. $\times 6$. (After Erichson.)

Small subeylindrical glabrous species having the head narrower than thorax, antennæ slender with short basal joint: front tibia not spined. (Fig. 169.) 916 (2704). Нодотrochus laticauda Lec., Proc. Phil. Acad. Nat. Sci., 1866, 376.

Elongate, slightly depressed. Dark reddish-bromn to piceous: antemne and legs paler. Head and thorax rery finely and sparsely punctate, the latter subquadrate; slightly wider than long: sides almost straight; hind angles rectangular. Elytra slightly wider and almost one-half longer than thorax, finely and sparsely punctate. the sutural strix distinct. Abdomen vers minutely punctate abore, more distinctly so beneath. Length $3.5-4 \mathrm{~mm}$.

Putnam and Tarion counties: rare. March 20-November 22. Taken by sifting.

\section{Tribe III. OMALIINI.}

Small depressed brown or piceous forms having the prosternum menbranous behind the coxa: tarsi 5-jointed; second ventral segment carinate at base and the head with two simple eyes (ocelli). Our species are in part treated in the following papers:

Faurel. Albert.- "Les Staphylinides de l'Amerique du NordHomalini." in Bull. de la Soc. Limn.. 3rd ser.. vol. II. 1878. $196-255$.

Casey.- "Coleopterological Notes. Y," in Ann. N. Y. Acad. Sci. VII. 189:3. 398-433.

The following genera are probably represented in the State:

KEY TO INDIANA GENERA OF OMALIINI.

a. Last joint of maxillars palpi not awl-shaped.

7. Hind tarsi with joints $1-4$ unequal.

c. First joint of hind tarsi much longer than second.

d. Fourth joint of maxillary palpi not longer than third, pearshaper.

LXXVIII. GEODROMICUS 
dd. Fourth joint of maxillary palpi longer than third.

e. Maxillary palpi with fourth joint four times longer than tinirt.

f. Elytra short, quadrate; antennie without club.

LXXIS. LESTEN.

$f f$. Elytra long, extending to the apex of the third rentral; antenne with last three joints longer and thicker, forming an elongate and slender club.

TEVALES.

ee. Maxillary palpi wide, short, fourth joint stout; tibiæe with spinules.

\%. Antennie nearly filiform, the outer joints gradually and slightly thickened.

h. Hind tarsi with first joint only elongated.
i. Iandibies short. without teeth.
LXXX. ACIDOTA.

ii. Mandibles short, the right one toothed at middle.

IXXXI. ARPEDIUY.

$h h$. Hind tarsi with fourth joint rery long. the second elongated but shorter than first.

AMPHichroum.

gg. Antennie with joints $5-11$ suddenly thicker; front of head but slightly prolonged.

TRIGONODEXIS.

cc. First and second joints of hind tarsi equally elongated.

j. Front coxie large. conical and prominent.

k. Antenne thickened towards apex; tibire with spinules.

7.7. Antennie slender" tibire pubescent. . IXXXII. OLophrum. jj. Front coxie small, transverse, not prominent; fifth joint of hind tar'si equal to the other's united.

PrCNoglipta.

bb. Hind tarsi with joints 1 to 4 rers short and equal; elytra long.

l. Tibiæ with fine spinules; right mandible with a tooth.

LXXXIII. Homaliuar.

7l. Tibiæ pubescent; mandibles not toothed. LXXXIV. Aхтновгол.

aa. Last joint of maxillary palpi rery small and narrow, awl-shaped, the third joint long. obconical: antennce slightly and gradually thickened; first joint of hind tarsi slightly longer than second.

LAXXY. EPHELIS.

IXXVIII. GEodrommcts Redt. 1858. (Gr.. "the earth + running" over." )

Rather large flattened species having the antennæ long and slender; elytra covering half the abdomen: hind tarsi with joints 1 to 4 rather short. mequal. the first joint distinctly longer than second.

917 (2799). Geobromicts Bruxnets Say, Journ. Phil. Acad. Nat. Sci., III, 158 ; ibid. II, 102.

Elongate-oral, strongly depressed. Dark reddish-brown; antemne. abdomen and legs reddish-yellow: elytra and abdomen both clouded with piceous near their tips. Head narrower than thorax. strongly excarate between the eyes, finely and rather sparsely punctate. Thorax oblong-oril, 
widest at middle; sides strongly rounded, sinuate near base, hind angles rectangular; disk coarsely and rather closely punctured, with a deep median impressed line and a forea at middle of base. Elytra at base slightly wider than thorax, reaching to fourth segment of abdomen, coarsely and rather densely punctate. Abdomen rather finely and sparsely punctate. Length $6.5-8 \mathrm{~mm}$.

Southern half of State, scarce; Lake County only in the north. May 11-October 20. Occurs beneath stones, moss and leaves in damp places. Usually listed as cosus Erichs., but Say's name has priority. The thorax varies much in size and in the depth of the sinuation behind middle.

918 (9789). Geodromicus stictus Fauv., Rev. Ent., 1889, 126.

Form of brunneus. Black, shining; antennx and legs and often the tip of abdomen, reddish-brown. Head narrower than thorax, front triangular, narrowly impressed between the eyes, finely and sparsely punctate. Thorax subcordate, wider than long, sides strongly rounded, deeply sinuate behind, the base much narrower than apex; disk finely and rather closely punctate, the median line shallow. Elytra at base equal in width to thorax; surface, as well as that of abdomen, finely and rather closely punctate. Length $5.5-6 \mathrm{~mm}$.

Fulton County; rare. August 20. A species of northern range.

\section{Lesteva Latr. 1796. (Gr., "a robber.")}

Small, flattened species, having the third joint of maxillary palpi very small, not longer than wide, the fourth joint very long; thorax (in our species) not flattened on the sides; first joint of hind tarsi not quite as long as second.

919 (2803). Lestena pallipes Lec., N. Sp. N. Amer. Col̈, I, 1863, 55.

Elongate-oval, depressed. Blackish-piceous to dull brownish-yellow, feebly shining, sparsely clothed with yellowish hairs; elytra when piceous each with an oblique pale spot extending from humerus to suture. Head with two deep, oblique impressions, rather densely and finely punctate. Thorax subcordate, slightly longer than wide, widest in front of middle, the sides thence oblique and sinuate to base; disk finely and sparsely punctate and with two distinct, shallow oblong impressions on basal half. Elytra at base one-half wider than thorax, thence feebly widening to apex, covering one-half or more of abdomen, finely and sparsely punctate. Abdomen as wide as elytra, broadly margined, very finely punctate. Length 3-4 $\mathrm{mm}$.

Marion, Putnam and Crawford counties ; frequent locally. May 11-October 17. Taken by sifting vegetable debris from about hillside springs. Probably occurs throughout the State. One specimen was found crawling on the floor of Wyandotte Cave nearly one mile from the mouth. 
Tevales cribatulus Casey, $2.7 \mathrm{~mm}$. in length and pale uniform brownish-yellow throughout, was described from Pennsylvania.

LXXX. Acivors Steph. 18:1. (Gr., "sharp.")

Small elongate, subconvex species having the fourth joint of maxillary palpi scarcely longer than third; mandibles without teeth; elytra reaching middle of abdomen, their onter apical angle rounded. One species has been taken in the State, while another may oceur.

KEY TO INDIANA SPECIES OF ACIDOTA.

a. Elytral punctures coarse, arranged in regular rows; length fi-7 1111 .

CRENATA. a a. Elytral punctures finer, more or less irregularly placed; length 4.5$5 \mathrm{~mm}$.

920. SUBCARINATA.

A. crenata Fab., piceous or dark chestnut-brown, antenne and legs paler, occurs in Canada and at Detroit, and probably in the northern comties of Indiana.

920 (2806). Acrmota subcarinata krichs., Gen. Sprec. Staph., 1S40, S6:3.

Elongate, subdepressed. Dark reddish or chestnut brown, shining; head, thorax and dorsal segments of abdomen often more or less fuscous. Thorax subquadrate, a little broader than long; sides feebly curved, depressed near hind angles, which are obtuse; disk rather coarsely, deeply and sparsely punctate. Elytra at base scarcely wider than thorax, the punctures fine, deep and arranged in irregular double rows with fine raised lines between. Abdomen as wide as elytra, finely and sparsely punctate. Length 4.5-5 $\mathrm{mm}$.

Martin and Posey counties; rare. April 21-May 6. Beaten from apple blossoms.

\section{ARPEDIUM Erichs. 1838. (Gr., "flat.")}

Oblong, subdepressed brownish or piceous species having the antennæ filiform, longer than head and thorax; right mandible toothed at middle; elytra reaching usually to or beyond middle of abdomen. Two species have been taken in the State and two others may occur.

\section{KEY TO INDIANA SPECIES OF ARPEDIUM,}

a. Thorax and elytra distinctly punctate.

b. Winged species; elytra long, not obliquely truncate at tips.

$c$. Disk of thorax even, densely and rather finely punctate.

921. CRIBATUM.

cc. Disk of thorax uneren, widely and deeply impressed each side.

922. SCHWARZIT. 
bb. Wingless species; elytra rery short, obliquely truncate at apex.

ANGULARE.

aa. Thorax very sparsely and obsoletely punctate; winged species: elytra much longer than thorax.

TENUE.

921 (2S08). Arpediun cribatuni Faur., Bull. Soc. Linn.. II. 187s. 224.

Elongate-oval, depressed. Head black; disk of thorax and elytra dark reddish-brown; legs and narrow margins of thorax and elytra paler; abdomen, under surface and antenne, except the base, piceous. Head about onehalf the width of thorax, sparsely and finely punctate. Thorax subquadrate, sides feebly curved, front angles rounded, hind ones obtuse, base almost as wide as apex. Elytra at base but slightly wider than thorax. reaching almost to fourth segment of abdomen, coarsely. somewhat roughly. not densely punctate. Abdomen smooth. Length $4.5-5 \mathrm{~mm}$.

Marion and Vigo connties; frecuent locally. March 1-October 5. Occurs beneath bark of logs and dead leaves in damp places.

922 (2S09). Aripdium scinwarzit Faur., Bull. Soc. Limn.. II, 187s, 225.

Elongate-oval, depressed. Dull brownish (or fuscous) rellow. moderately shining; legs. sides of thoras and elytra slightly paler: antenn: dusky, paler at base and apex. Thorax quadrate, scarcely wider than long: sides feebly curved; disk finely and irregularly punctate, nueren, with three or four smooth raised spaces near middle and a deep impression each side. Elytra distinctly wider and more than twice as long as thorax. coarsely. deeply, not closely punctate. Length $3.5-3.7 \mathrm{~mm}$.

Throughout the State; frequent. February 23-October 21. Occurs beneath cover in damp places. The Acidota subcarinata of my "Winter Insects."

A. angulare Fauv., color and size of schuraii and A. teme Lec.. blackish piceous in hue and $4-4.5$ in length, are both boreal species. taken in Michigan and probably oceur in northern Indiana.

Amphicroum levicolle Lec.. blackish to dull reddish-yellow in hue, $3.7-5 \mathrm{~mm}$. in length. occurs in abundance on flowers of $\mathrm{Cra}$ tagus in Pennsylvania.

Trigonodemus striatus Lec. is a southern form, also blackish piceous, smooth, shining. length $4.5 \mathrm{~mm}$., which has been recorded from Cincinnati:

Lathrimum sordidum. Erichs.. dull rellow, with piceous abdomen, $2.7 \mathrm{~mm}$. in length, is also recorded from the same locality.

\section{Olophrum Erichs. 1838. (Gr.. "bold.')}

Oblong-oval, convex, black or piceous species having the mandibles and tibia without teeth or spines; antenna slender. as long as head and thorax; elytra covering two-thirds of abdomen. One species has been taken and another perhaps occurs in the State. 
KEY TO INDIANA SPECIES OF OLOPIIRUM.

a. Thorax twice as wide as long, sides broadly rounded into base and apex; length $5-6$ mm.

92:3. OвTLCTUM.

aa. Thorax subquadrate, sides subparallel, the front allgles obliquely trun-

cate; length $4.5-5 \mathrm{~mm}$.

ROTUNDICOLLE.

923 (2828). Olophrum obtectum Erichs., Gell. Spec. Stilph., 1840, 865.

oblong-oval, convex. Uniform piceous. shinimg; antennx, legs and very narrow margin of thorax reddish-brown. Head rather coarsely and closely punctate, with two shallow triangular impressions on vertex. 'Thorax coarsely, evenly, not densely punctate, often with a faint rounded impression at middle of base. Elytra scarcely wider and nearly three times longer than thorax, densely, rather coarsely and evenly punctate. Abdomen smooth, 'its apex paler. Length 5-6 $\mathrm{mm}$.

Throughout the State; common. April 7-November 28. Occurs on fungi and beneath bark and leaves.

O. rotundicolle Sahlb., is a boreal species reported from Cincinnati.

Pycnoglypta lurida Gyll., oblong, convex, brownishpiceous, $2.8 \mathrm{~mm}$. in length, is also recorded from the same locality.

\section{Homalium Grav. 1802. (Gr., "even or smooth.")}

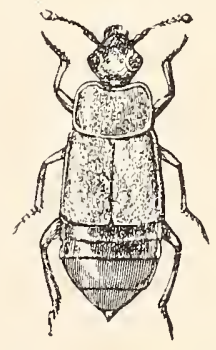

Fig. 170. Homalium

Small elongate or oblong, subdepressed species (Fig. diffusum Fauv. $\times 10$.

Small elongate or oblong, subdepressed species ( $F$ ig. diffisum Fauv. $\times 10$ 170), having the joints of hind tarsi very short and cies. equal, tibiæ with fine spines; maxillary palpi with last joint longer than third; "elytra reaching to or beyond the middle of abdomen. The following have been taken or perhaps occur in Indiana.

\section{KEY TO INDIANA SPECIES OF HOMALIUM.}

a. Thorax eren, or sometimes with two more or less obsolete impressions on the disk.

b. Sides of thorax not angulate at middle.

c. Thorax very even, strongly convex; length $2.3 \mathrm{~mm}$. 924. hamatum. cc. Thorax with a faint impression each side of disk.

d. Elytral convex.

$e$. Smaller, :3 mmlm; black or piceous: abdomen almost smooth; elytra not striolate.

HUMEROSUM.

ee. Larger, 4 mun.; reddish-hrown; abdomen strongly and densely punctate; elytra striolate.

PUNCTIVENTRE.

$d d$. Elytra subdepressed; thorax short, hind angles obtuse.

925. FLORALE.

bb. Sides of thorax angulate at middle; head and thorax shining. distinctly punctate.

920. FRACTUM.

aa. Thorax uneven, the disk with two distinct fovese.

[31-23402] 
f. Head distinctly narrower, than thorax, the latter, as well as the legs and border of elrtra. reddish-brown.

927. REPANDUM.

ff. Head only slichtly narrower than apex of thorax. the latter black.

FORAMINOSTM.

924 (2551). Homaluu Hamatem Faur.. Bull. Soc. Linne., II. 1578. 209.

Oblong-oral. Dull reddish or dusky rellow. sparsely pubescent: head and tips of elrtra fuscous. Antenne shorter than head and thorax: the latter one-half wider than long. widest at base. sides feebly curred. disk finely and sparselr punctate. Elrtra slightly wider and one-half longer than thorax. more coarsely and closely punctured than there. Hind tibiae deeply emarginate on the outer side. Sixth secment of male feebly sinuate at apex. Length $2.3 \mathrm{~mm}$.

Marion and Fountain counties: scarce. Jume 12-.June 17.

$H$. humerosum Faur. and $H$. punctiventre Fanr.. described from Pennstrania and Missomi. doubtless occur in Indiana.

925 (2854). Homatitar florale Pạk. Mon. Staph.. 1789. 67.

Elongate-oblong. Tniform black or piceous. feebly shining: antenne and legs reddish-brown. Thorax one-third wider than long. sides feebly 'urred. narrowly depressed near hind angles: disk finely. rather densely and erenly punctate. Elytra slightly wider and more than twice longer than thorax. densely and finely punctate and faintly strigose. Abdomen minutely and sparsely punctate. Length $3-3.5 \mathrm{~mm}$.

Lake and Marion counties : scarce. Mat 22-Norember 1. This is the species usually known as mfipes Faur.

926 (25.5). Homalium fractrar Faur. Bull. Soc. Linne.. II. 1sts. 212.

Oblong. contex. Dark reddish-brown, shining: disk of elitra often piceous. Head three-fourths as wide as thorax, finels and sparsels punctate. Thorax one-half wider than long, conrex. hind angles obtuse: sides curred in front of middle. thence feeble sinuate to base: disk rather coarsely. not densely punctate. Elstra slightly wider. twice longer and more coarsels and sparsels punctate than thorax. Abdomen smooth. Length $2.3 \mathrm{~mm}$.

Fountain and Tigo counties: scarce. Februart 23-June 17. Occurs beneath bark in moist places.

927 (2S42). Hodralita RePaxdur Erichs. Gen. spec. Staph.. 1S10. Sis.

Elongate. slender. depressed. Head. abdomen and disk of elrtra piceous, opaque; thorax. antennze legs and sides of elctra reddish-brown. Antenne longer than head and thorax; head coarsels and densels punctured. Thorax slichtly broader than long. sides feebly curred. sinuate behind: disk flattened on sides. finely. rather densely punctate. with two oblong impressions on hasil two-thirds. Elytril slightly wider and two-thirds longer than thorax. coarsely. densely and roughly lumatite: Ahdomen minutely sranulate-punctate. Length $3.54 .5 \mathrm{~mm}$.

Southerm half of State: frequent. April 18-Norember 22. Ocoms beneath lead leaves. 


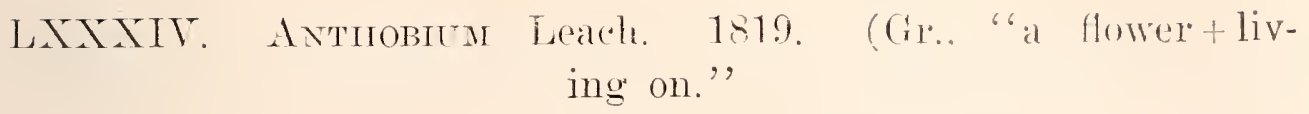

Short and rather broad. subdepressed species having the elytra usually reaching nearly to or beyond the tip of abdomen; last joint of maxillary palpi longer than the third; tibia pubescent; hind tarsi as in Homalium. Two species have been taken and one other perhaps occurs.

KEX TO INDIAXA SPECIES OF ANTHOBICM.

a. Body distinctly convex: thorax not groored; elytra as long as or longer than abdomen. acuminate in female.

928. CONTEXUM.

a a. Bodr feebly convex or subdepressed.

b. Thorax not groored. sparsely and finely punctate; elytra of female truncate. not covering tip of abdomen.

929. HORNI.

bb. Thorax distinctly grooved: elstra of female truncate, not reaching much berond the nuiddle of abdomen. pothrs.

92S (2S68). Axтhobila convexum Faur., Bull. Soc. Limne.. II. 1S7s. 201.

Oblong-oral, convex. Dull reddish-yellow; head and thorax alutaceous: elytra shining; base of abdomen black in male. Head as broad as apex of thorax. flattened and minutely and sparsely punctured betreen the eres. Antennie not reaching base of thorax, joints $i-11$ forming an elongate club. Thorax distinctly wider at base than apex. sides feebly curred; disk conrex. flattened near hind angles, sparsely and rers finels punctate. Elytra feebly widened from base to apex. their tips rounded in male. acute in female; surface more coarsely and closely punctate than thorax. Length 2-2.5 $\mathrm{mm}$.

Steuben. Fountain. Marion and Martin counties; frequent locally. April 28-June 16. Occurs on flowers of black haw; especially abundant on those of the red-berried elder in the marshes of Steuben County. Our only species of the subfamily with the elytra longer than the abdomen.

929 (2Si0). Axтhobius Horxi Faur., Bull. Soc. Linne., II, 1Sis, 202.

Short, rather broad. subdepressed. Dull reddish-rellow. shining: abdomen of male in great part piceous. of female piceous at apex. Head finely and sparsely punctate; antenne shorter than head and thorax. joints i-10 broader than long. forming a loose club. Thorax more than twice as wide as long: sides rounded into base and apex: disk finels and sparsely punctate. Elytra more than twice as long as thorax. their tips truncate. Length $:-2.4 \mathrm{~mm}$.

Martin. Posey and Crawford counties: scarce. May 6-May 25.

A. pothos Mann. reddish-yellow, abdomen black, 2.5-2.5 mm. in length. is a boreal species which may occur in northern Indiana.

\section{LXXXY. Ephelis Faur. 187s. (Gr.. "on + a nail or stud.")}

Rather elongate. feebly convex. strongly punctate species having the head not constricted at base. eyes large: third joint of maxil- 
lary palpi truncate at apex, fourth very short, slender; antenna short; thorax subeylindrical; hind tarsi with joints one and two slightly longer than three and four, which are equal.

930 (2876). Ephelis notata Lec., N. Sp. N. Amer. Col., I, 1S63, 5 S.

Elongate-oval. Black, feebly shining; legs and base of antennæe reddisll-yellow; elytra each with the apical margin and a small rounded spot at middle reddish-yellow. Thorax subquadrate, widest at apical fourth. the sides thence almost straight and slightly converging to base; disk densely and rather coarsely and roughly punctate. Elytra at base onethird wider than thorax, feebly widening to tips, which are truncate; surface coarsely and densely punctate. Length $2.5-2.7 \mathrm{~mm}$.

Lake County; rare. May 25.

\section{Tribe IV. PROTEININI.}

Species not exceeding $3 \mathrm{~mm}$. in length, having the antennæ inserted under the sides of the front; head without ocelli; prosternum horn-like behind the front coxa, which are transverse and somewhat prominent; hind coxæ transverse; tarsi 5-jointed. Two genera represent the tribe in the Tnited States. The species of this tribe are treated by

Fauval._-“'Les Staphylinides de L'Amerique du Nord,' in Bull. Soc. Linne., II, 1878, 190-196.

KEY TO GENERA OF PROTEININI.

a. Antennæ with only the last joint larger; thorax always with a median impressed line.

LXXXVT. MEgarthrus.

a a. Antemnæ with the last three joints larger.

Protinus.

\section{MEgAR'THRUs Steph. 1831. (Gr., "big + joint."')}

Small, broad subdepressed species, having the head much narrower than thorax, constricted at base; maxillary palpi short, the fourth joint slender and acuminate; antenna short, the last joint very large, subglobose; elytra truncate, covering more than onehalf of abdomen; hind tarsi with first four joints short, equal. One species has been taken and another perhaps occurs.

KEY TO INDTANA SPECIES OF MEGARTHRUS.

a. Thorax black, the sides slightly angulate.

EXCISUS.

aa. Thorax dull yellow, the disk brownish.

931. AMERTCANUS.

M. excisus Lec., piceous, narrower than americanus, $2.5 \mathrm{~mm}$. in length, is recorded by Dury from Cincinnati.

931 (2883). Megarthrus americanus Sachse., Stett. Ent. Zeit., 1852, 149.

Oblong-oval, depressed. Dusky or fuscous yellow; head black; legs dull yellow. Head narrower than thorax, finely rugose. Thorax as wide 
as elytra, more than twice as wide as long, base and alpex truncate; sides rounded, widely depressed: mangins with a small bhunt tooth in front of

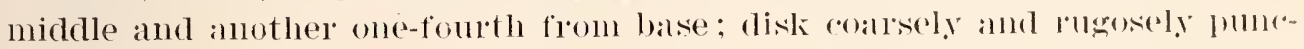
tate and with a deep entire median wloove. Elytrat more than twide as long as thorax, densely, coansely and rugosely punctate. Aludomen finely and rather closely punctate. Length $2.3-2.7 \mathrm{~mm}$.

Crawford County; rare. May 26. Occurs in fungi.

Protimus atomarius Erichs., black or brownish-black, antennix dull yellow, length $1-1.3 \mathrm{~mm}$., has been recorded from near Cincinnati and Detroit.

\section{Subfamily X. PIESTINAE.}

Elongate, slender, parallel species, resembling Cucujids in general appearance and, like them, living beneath bark. They have the antenne inserted under the sides of the front, straight, with the outer joints slightly thickened; thoracic spiracles covered; prosternum wholly of a horn-like texture; front coxie globular. The North American species of this subfamily and the next are treated by

LeConte.-In Trans. Amer. Fnt. Soc., VI, 1877, 249-252.

Fauvel.-In Bull. Soc. Linne., II, 1878, 167-188.

The following genera of the subfamily are probably represented in the State:

KEY TO INDIANA GENERA OF PIESTIN.E.

a. Abdomen not margined.

b. Tarsi 5-jointed; front coxa separated. LXXXYI. Lispinus.

bb. Tarsi 3-jointed; front coxie contiguous. LXXXVIII. GLypoma. aa. Abdomen margined; tarsi 5-jointed; front coxæ contiguous.

c. Front tibia not spinose.

d. Abdomen widely margined.

'TRIGA.

da. Abdomen very timely margined.

ELEUSIS.

cc. Front tibiae with spinules; body much flattened; front impressed, horned in male.

Siagonium.

LXXXVII. Lisprets Erichs. 1840. (Gr., "clean.")

Very slender species having the head directed forward; antenne not longer than head and thorax; mandibles small, not toothed: thorax subquadrate; elytra truncate. (Fig. 171.) One species has been taken and another may occur in the State.

KET TO INDIANA SPECIES OF LISPINUS.

a. Black or piceous, shining: legs reddish-brown; front not implessedi ; length 4.3-4.5 $\mathrm{mm}$.

LINEARIS. Fig. 171. Lispinus

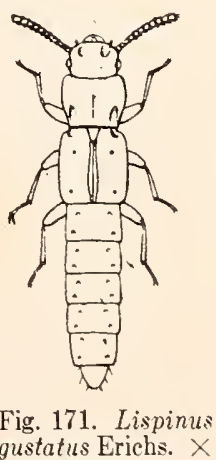
ar. Chestnut brown; front with two shallow impressions; 7 . A Madagascar spelength $2.5 \mathrm{~mm}$.

932. Exigü̈s. cies. 
L. Tincaris Erichs. is a southwestern species which has been recorded from Cincinnati.

932 (285). Lispines exigtïs Erichs. Gen. Spec. Staph., 1S40, $\$ 30$.

Linear. parallel. Lniform chestnut brown. shining, not punctate. Head almost as ride as thorax. Thorax subquadrate. narromed at base: disk deepls impressed each side in front of hind angles. which are rectangular. Elrtra together as wide as and one-third longer than thorax. each with a distinct dorsal puncture near middle. Abdomen narrower than elctra. minutely alutaceous. Length $2-2.5 \mathrm{~mm}$.

Parke County: rare. IIạ 13.

LXXKTII. GLYptoma Erichs. 18t0. (Gr.."sculpture+ joint.")

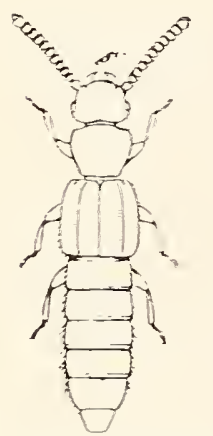

Fig. 172. Glyptomg crassicorne Erichs. $\times 10$. A South American species(After Erichson.)

Small elongate bromnish forms having (in our spe(cies) the thorax and elytra carinate; abdomen not margined: tarsi three-jointed. (Fig. 172.)

928 (2\$93). Glyptoma costale Erichs. Gen. Spec. Staph.. $1 \$+0,009$.

Elongate. slender. parallel. Dark chestnut brown, opaque. Antenme reaching middle of thorax. Head margined, the rerter with elerated lines. Thorax subquadrate, front angles prominent, disk with six carince, the outer ones close to margin. Elytra slightly wider: scarcels longer than thorax, each with four carinz: intervals minutels punctate. First fire segments of abdomen with elongate granules on their hind margins. Length 2-2.5 $\mathrm{mm}$.

Throughout the State: frequent. March 23--June 16. Taken by sifting decaring wood.

Triga picipemis Lec.. hlackish-piceous. antennæ and legs paler. length $3 \mathrm{~mm}$., is known from near Detroit. Michigan and Kansas.

Eleusis pallidus Lec. reddish-brown and shining. length $3.5 \mathrm{~mm}$., lives in ants' nests at rarious points in the Eastern United States and doubtless occurs in the State.

Siagonium americanum Melsh. reddish-rellow, feebly shining. head and thorax very finely punctate. length $\pm-6.5 \mathrm{~mm}$., and $S$. punctatum Tec.. \$-6 mm. black or dark chestnut-brown. head and thorax con punctate. also have a range which includes Indiana.

\section{Subfamily XI. MICROPEPLINAE.}

Small subquadrate species haring the antenna 9-jointed. inserted under the sides of the front and in repose received in prosternal carities: front coxre transrerse, not prominent; hind coxie 
rounded. widely separated by the broadly dilated second rentral segment; tarsi three-jointed.

Several species of the genus Micropeplus have a range which may include Indiana. They have the abdomen margined and head, thorax and elytra costate. much as in GTyptomu. 1 . cribatus Lec.. blackish with the next to last segment of abdomen carinate above; the costre of elrtra sinuate, intervals coarsely punctured, length 2 mm., has been taken near Cincinuati. M. tesserula Curtis, sixth segment not carinate. body black. shining. length $1.5-2 \mathrm{~mm}$. is a boreal species known from Michigan.

\section{Family XII. TRICHOPTERYGID无.}

\section{The Feather-ininged Beetles.}

This is a small family of minute beetles, the largest of which scarcely exceeds a pin-head in size. They lire in rotten wood and dung, on fungus covered logs and in ants' nests, and comprise the smallest of known beetles. The name is derived from that of the typical genus, Trichopteryx, a term meaning "hairy-winged," the inner wings. when present, being long. narrow and fringed with long hairs. or feather-like in appearance.

The members of the famil y have the maxilla exposed at the base, which is large. with two lobes, the onter one hooked: palpi 4-jointed, the last joint needle-shaped; antennie usually 11-jointed, inserted on the margins of the front, the joints with whorls of long hairs, joints 3 to 7 slender. $8-11$ thicker, forming a loose elongate club; thorax with the side pieces distinct; elytra often abbreviated; inner wings as above described: abdomen with sir or seven free ventral segments : front coxx subglobular, prominent. contiguous: middle coxæ oval. separated; hind ones transverse. more or less separated; tarsi 3-jointed, the last joint with two equal simple claws.

About 75 species, distributed among 18 genera, are known from North America. Of these but $s$ have been taken in Indiana, though a number of others doubtless occur, and the gener: are therefore included in the key which follows: The principal me retically the only reference works are as follows:

Matheus. Rer. A.- "Trichoptergeia Illustrata et Descripta." London. 1872.

Ibid._"Synopsis of North American Trichoptergrgida." in Trans. Amer. Ent. Soc. XI, 188t. 113-156. 
KEY TO INDIANA GENERA OF TRICHOPTERYGIDA.

a. Elytra entire.

b. Thorax widest at base.

c. Pygidium invisible; form oval, rery convex; color darti.

I. Nossidium.

cc. Pygidium risible beyond the elytra; hind angles of thorax not elongate; form elongate; color pale.

Nanosella.

b7. Thorax widest before the base.

d. Pygidium visible beyond the elytra.

P'tilitur.

dd. Pygidium invisible.

il. Ptenidiun.

a a. Elytra truncate.

e. Antenna very short. 9-jointed; eyes wanting; thorax larger than elytria.

III. Limulodes.

ee. Antenne elongate. 11-jointed.

f. Thorax widest at the base.

g. Abdomen with seven rentral segments.

PTERYX.

yg. Abdomen with six rentral segments.

h. Hind coxie very widely separated; mesosternum scarcely carinate; color pale.

PTINELlodes.

hh. IInd coxa moderately separated; mesosternum distinctly carinate.

IV. TRICHOPTERYX.

$f f$. Thorax widest before the base.

i. Elytra long; mesosternum carinate; color dark. Y. SMicrus.

ii. Elytra short; mesosternum not carinate.

j. Body opaque; abdomen moderate: hind coxie with plates.

NePHANes.

ji. Body translucent; abdomen very long; color pale.

Vi. Ptinelia.

I. Nossiduum Erichs. 18ł5. (Gr., "nest + formed.")

Small oval, convex species having joints 1 and 2 of antennæ very large, 3-8 slender. 9-11 much thickened; abdomen with seven segments, entirely covered by elytra: metasternum not reaching the sides of the body. One of the two known species occurs in the State.

934 (2914). Nossidien americantum Mots., Bull. Mosc.. 41, 1S66, 191.

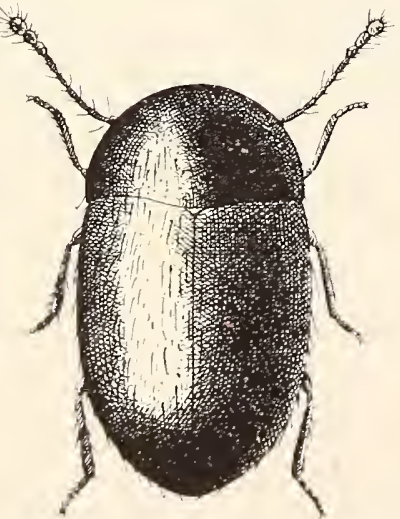

Fig. $173 . \times 34 . \quad$ (Original.)

Oblong-oval, rely convex. Head and thorax piceous, strongly shining; elytra reddish-brown. rather thickly clothed with long rellowish hairs: legs and antenne yellow. Thorax more than twice as wide as long. hind angles rectangular: sides rounded, distinctly margined. surface very fincly and sparsely punctured. Elytra not wider than thorax, surface with rather deep, rugose punctures in sinuate trinsverse rows; tips broad. much rounterl. Length $1 \mathrm{~mm}$. (Fig. 173.)

Monroe County ; frepuent. May 13-June 9. Taken by sifting debris of beech stump. Probably oceurs throughout the State. 
Tanosella fungi Lec., elongate, reddish-rellow. leg's and antenna paler, length .3 of one mm., has been taken near Cincinnati. It is the smallest of North American beetles and occurs in powdery fungi. Ptilium collani Makl., oblong, pitchy-black, length .7 of one mm., may also occur.

II. Potendum Erichs. 18t5. (Car.. "provided with little feathers.')

Small elongate or oblong-oral species having the club of antennæ formed of three joints ; thorax small, narrower at base than middle: elytra entire, concealing all seven segments of the abdomen; metasternum large. quadrate. extending to the sides of the body. Two have been taken in the State. and another may occur.

KEY TO MNDIANA SPECIES OF PTENIUILII.

a. Thorax with tro distinct forese on each side near the base; color pale chestnut brown.

FOYEICOLLE.

a . Thorax with but one forea on each side at base, or none.

7. Color black. shining. the tips of elytra rellowish. 935. pusillor.

bb. Color dull yellow. shining: elytra each with two blackish stripes.

936. LINEATCM.

935 (2929). Ptenidiun Pusilluni Gyll., Ins. Suec., I, 1808, 189.

Rather broadly orate, convex. Black or piceous, shining, very sparsely clothed with long whitish hairs; tips of elytra more or less widely reddishyellow; legs and antenne dull yellow, the club of the latter dusky. Thorax much wider than long. widest just behind the middle, sides rounded. hind angles obtuse; disk deeply and sparsely punctured and with a deep transrerse impression each side at base near the angles. Elytra orate. widest before the middle, with very fine remote punctures in rows. Length 1$1.5 \mathrm{~mm}$.

Putnam County ; rare. March 25. Taken by sifting dead leares. 936 (2934). Ptenidium lineatum Lec.. N. Sp. N. Amel. Col.. I. 1S63. 63.

Elongate-oblong, convex. Color given in key. Thorax slightly wider than long, a little narrower at apex than base, very finels punctate. Elytra oral, sparsely clothed with fine silken hairs. Length $4 \mathrm{~mm}$.

Clark County ; rare. May 6. Taken from fungi on beech log. A member of the Austroriparian fauna.

\section{Lmilodes Míathews. 1867.}

One small reddish species belongs here. It has the antenne very short and thick, joints 1 and 2 large, 3-6 very small. $7-9$ very large and forming an elongate club; head small. deflexed; elytra truncate, short and narrowed toward the apex; abdomen short. with six 
segments. three of which are exposed abore: prosternum produced behind into a long. broad plate, bifid at apex : mesosternum strongly carinate. produced into a broad. spoon-shaped process which covers the hind coxi.

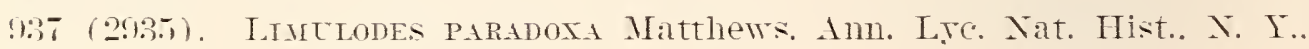
TIII. 1SGT. 400 .

Conic. widest in front. rers conrex. Reddish-rellow. shining. thickly clothed with a silk crayish phescence. Thorax rers large and convex. widest at base. sides circulinls romded in front. hind angles acute and slightle produced: surface alutaceous. Elytra shorter and narrower than head and thorax, surface rery finely and prettily gramulate. Length $1 \mathrm{~mm}$.

Clark County: scarce. Mar 5. Three specimens from ants. nests beneath flat stones. Occurs throughout the Lnited States.

Pteryx brunea Lec.. chestnut-brown. thorax with sides widest at the base. length $.9 \mathrm{~mm}$. and P. balteata Lec. bright rellow. thorax with sides slightly rounded and widest before the base. length $.6 \mathrm{~mm}$. . mar occur in sonthern Indiana.

Ptinellodes Tecontei Matth.. elongate-oblong. rellow. translucent. length $1 \mathrm{~mm}$. mar also occur.

\section{Trichopterix Kirby. 1819. (Gr.. "feather"+ming.")}

A large genus of small oblong or orate species. haring the antennæ 11 -jointed. the last three joints forming a bead-like club: head large. rather deffexed: elytra truncate. usually short: abdomen with six rentral segments: hind coxe moderately distinct. the outer edge expanded into a broad plate. Of the 30 or more species known from North America but two have as ret been taken in the State. though sereral others doubtless occur.

KEY TO IXDLAXA SPECIES OE TRICHOPTERTY.

a. Thorax distinctly wider than elretra.

b. Thorax smooth: elrtra liot attenuate: color dark chestnut brown. shining: length .9 $\mathrm{mm}$.

GLABRICOLLTS.

67. Thorax with small. rather remote tubercles or granules.

c. Head and thorax black. the latter dilated: elstra dark chestnut brown: form elongate-oblong.

935. HALDEMAXXI.

c. Entirels black but thickly clothed with long reddish hair: thorax ridest before the base: lensth .9 $\mathrm{mm}$.

ABRTPTA.

a a. Thorar scarcely or not at all wider than elrtra.

a. Hind angles acute. often produced.

e. Head. thorax and abdomen black, elstra dark reddish-brown: length $.9 \mathrm{~mm}$.

PARALLELA.

ee. Entirely black or fuscous black.

f. Eirtra midest at apex: length s $\mathrm{mm}$.

A SPERA. 
ff. Elytra with the sides nearly straight: thoriar whlest before the base: color tuscous black: leligtl .9 $\mathrm{mm}$.

SERICANS.

dd. Hind angles of thorax not alcute or produced.

():3!) MUERES.

988 (2966). Trichopterix haldeanaxi Lec.. List of Col. of X. All.. 146.3. 29.

Elongate-oblong. convex. Color given in key: surface sparsely clothed with short, pale hairs: antenne and less reddish-yellow. Thorax more than twice as wide as long. Widest before the base: sides strongly rounded. hind angles broad. acute and much prolonged; surface corered with small. rather remote granules aringed in transerse rows. Elrtra as lous as but narrower than head and tholax. rather closels and irregularly alsperate or roughened with small gramules. Length 1-1.2 $11 m$.

Kosciusko. Marion and Putnani comnties: frequent. April 17October 17. Taken by sifting leares and sphagnum moss in damp places.

939 (2942). Trichoptersx yegrexs Matthers. Cist. Ent. 11. 1874. 298.

Oblong. conver. Black. strongly shining: sparsels clothed with pale hail: antennie and legs rellow. Thorax twice as wide as long. widest neal the middle. sides moderately rounded. hind ancles rectangular; surface smooth. polished. Elytra about as long and wide as head and thorax. rery faintly and transrersely granulate or asperate: tips broad. the extreme edge rellowish. Length $.6-.7 \mathrm{~mm}$.

Steuben and Putnam counties: scarce. May 25-October 17. Taken by sifting damp debris. Differs from the preceding by its smaller size. smoother surface and form of hind angles of thoras.

The range of the other species of Trichoptery mentioned in the key is given by Matthews as "Tnited states."

\section{T. Suicrus Matthews. 1si2. (Gr.. "small."}

Elongate-oblong species. having the antenma long and slender. reaching nearly to middle of elytra. 11-jointed. the last three joints forming an elongate. bead-like chb: head large and broad: hind coxre rather distant and with wicie plates. One species is known.

940 (2969). SuIterts filicorais Fairm.. Faun. France. I. 15.54, 338.

Oblong. subparallel. Black. sparsely clothed with short rellow hairs: antenne and tips of elçtra pale: legs rellow. Thorax short. quadrate. widest in front. feebly narrowed toward the base. hind angles acute: disk closely corered with mimute tubercles. Elrtra as long and nearly as wide as head and thorax. closely and minutely punctate: tips squarely truncate. learing one-third of abdomen exposed. Length $1.2 \mathrm{~mm}$.

Marion County: rare. October 31. Taken by sifting.

Tephanes Taviusenlus Natth.. short. broad. convex. dark chestnut-brown. legs rellow. length $6 \mathrm{~mm}$.. may oceur in southerm Indiana. 
TI. Ptinella Mots. 1845. (Diminutive of Ptimus.)

Terr small. elongate or oblong forms having the head large and prominent: eres often wanting in male: antemne long and slender. each joint ornamented with long hairs; thoras small. usually more or less constricted at base: elytra short. truncate. leaving five or six joints of the long abdomen exposed: hind coxie widely separated. One of the three species listed, has been taken in the State.

941 (2970). P'TIXella quercts Lec.. New Sp. X. Am. Col.. I. 1S63. 63.

Moderately elongate. narrow. Male pale rellow. female pale chestnut brown: sparsely clothed with yellowish hairs. Eres of female rather large. those of male wanting. Thorax more than trice as wide as long. widest before the middle. constricted near base. hind angles acute, surface alutaceous. Elytra shorter and rather narrower than head and thorax together. widest townd the apex: surface remotely asperate or roughly grimulate. Length .5-.6 mm.

One specimen taken by Dury while sifting dead leaves near New Albany. Floyd County. Nay 25. A southern form. described from Georgia.

\section{Family XIII. SCAPHIDIID.E.}

\section{The Shining Futgets Beetles.}

Small. oral. convex. very shining beetles which live in fungi. in rotten rood. dead leaves. or beneath the bark of logs. But little is known regarding their life history. althongh some of them are rer! common in everr piece of woodland. When exposed br remoring their corer of bark or other material. they either remain quiescent or move rapidly with an uneren, skipping gait. The name of the family is based mpon that of the genus Scaphidium, a name meaning "a little skiff or boat." on account of the fancied resemblance in form of the beetles to that of a boat. being thickest and arched in the middle and narrowed toward each end. the head small and the abdomen more or less conical and pointed.

They have the mentum large. quadrate: palpi short. fourjointed. the last joint conical: front of head contracted and prolonged into a short beak: antennæ either hair-like or slightly clavate. inserted at the margin of the front: thorax closely applied to the after bodr: presternum not prolonged. the coxal carities widely open behind: elytra broady truncate. not covering the tip of the conical abdomen. which has six or seven risible ventral segments. The front coxe are rather large. conical and contiguous: middle 
coxæ small, rounded and widely separated; hind ones oval or: transverse, also widely separated; tarsi 5-jointed, long and stender.

About 200 species of Scaphididar are known, 41 of which have been described from the United States. The principal literature treating of the family is as follows:

LeConte._. "Symopsis of the Scaphidiida of the U. S.," in Proc. Phil. Acad. Nat. Sci., 1860, 321-324.

Casey.- "Synopsis of the Scaphidiidx," in Ann. N. Y. Acad.

Sci., VII, 1893, 510-533; Journ. N. Y. Entom. Soc., VIII. $1900,55-60$.

Representatives of four of the seven genera comprising the family have been taken in Indiana, while those of two others may occur.

KEY TO INDIANA GENERA OF SCAPHIDIIDE.

a. Scutellum distinct; antenne with a broad, abrupt and somewhat flattened 5-jointed club; elytral punctures in rows.

$b$. Hind tibia not spinous; eyes emarginate; lind angles of thorax acute and somewhat prolonged backward.

I. Scaphidium.

bb. Hind tibiae with rows of snilll spines; eyes entire; hind angles of thorax not prolonged.

Cxparium.

aa. Scutellum minute or wanting; antennse slender, without distinct club; elytral punctures. when present, scattered.

c. Third antennal joint elongate and cylindrical; scutellum usually invisible. when present transrerse.

d. Body oral; sutural stria of the elytra reaching the base; hind coxie widely separated.

II. B.EOCERA.

$d d$. Body narrowed. more or less compressed; sutural stria not reaching the base; hind coxa less separated.

III. Toxidius.

$c c$. Third antennal joint rery short, wedge-shaped or triangular. narrowed to the base; scutellum present, minute, triangular.

$e$. Length 1.5 or more mm.; hind coxal plates very short and their curve developed only on the inner side.

IV. SCAPHISOMA.

ee. Length less than $1 \mathrm{~mm}$. hind coxal plates semi-elliptic; antenne shorter and stouter.

SCAPHIOMICRUS.

\section{Scaphidium Oliv. 1791. (Gr.. "tub or boat + small.")}

Here belong our most common members of the family, readily distinguished by the larger size, emarginate eyes and produced hind angles of thorax. The male is known by having a large, depressed, punctate and pubescent area on the middle part of the metasternum. One species and two varieties have been laken in the State.

KEY TO INDIANA SPECIES OF SCAPHIDTCM.

a. Elytra each with two to four short rows of laned pumctures.

b. Elytra each with two transverse, reddish spots which extend inward two-thirds the width.

942. QUADRIGUTTATUM. 
bb. Elytra black without spots.

942a. var. PICEUM. aa. Elytra without coarse discal punctures, each usually with two marginal spots of pale yellow.

942b. var. OBLITERATUM.

*942 (2975). Scaphidium Qúadriguttatum Say, Journ. Phil. Acad. Nat. Sci., III, 1823, 198; ibid. II, 126.

Oval, convex, glabrous. Black, strongly shining; elytra with spots as mentioned in key. Thorax with a bisinuate row of coarse punctures near' the base. Elytra with a row of similar punctures on inner half of base and two to four short rows before the middle and nearer the suture than the sides. Length $3.8-4.5 \mathrm{~mm}$.

Frequent throughout the State. February 23-November 8.

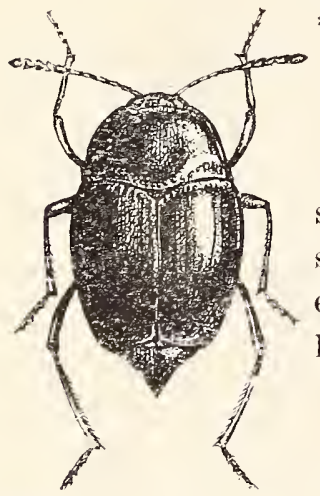

$* 942 \mathrm{a} \quad(2975 \mathrm{c})$

Scaphidium QUadrigutTatum PICEUM

Mẻlsh., Proc. Phil. Acad. Nat. Sci., II, 1S44, 103.

A color variety of quudriguttutum which is wholly shining black above. It is found associated with that species and in winter is even more frequent, being found especially beneath the bark of old, fungus-covered beech logs. (Fig. 174.)

Throughout the State. JJanuary 24-December 25.

Casey's amplum, described from Indiana, is eviFig. 174. $\times 6$. (Original.) dently based on an immature piceum.

$942 \mathrm{~b}$ (2975a). Scaphidfum quadriguttatum olimteratum Lec., Proc. Phil. Acad. Nat. Sci.. 1860, 322.

The absence of coarse punctures on the disk of elytra and the small size of the elytral spots are the only characters given by LeConte and Casey to distinguish this form from quadriguttatum.

In my collection are several specimens taken in Vigo County. which have the elytra wholly devoid of discal punctures and yet. like piceum, are entirely black. I have not seen the spotted form from the State, but the type of LeConte came from near Evansville, Indiana. In all probability Horn was right in regarding both piceum and obliteratum as varieties, *Casey to the contrary notwithstanding. ** *

Cyparium flavipes Lec., chestnut-brown, legs and antennæ paler, length $3.5 \mathrm{~mm}$., is a southern form which Dury records from Cincinnati.

\section{Beocera Erichs. 1845. (Gr., "small+horn.")}

Small black or piceous species, having the third joint of antenna slender and cylindrical, the outer three joints somewhat

\footnotetext{
*Trans. Amer. Ent. Soc., V, 1875, 132.

**Journ. N. Y. Ent, Soc., VIII, 1900, 55 .
} 
enlarged, forming a loose, slencier club; scutellum usually wanting but when present broadly triangular. Thirteen nominal species from the United States are recognized by Casey. Of these six are known from Indiana.

KEI TO INDIANA SLECTES OF BHECHA.

a. Soutellum not visible.

b. Larger species, not less thitn 2 nnm. in length.

c. Sides of thorix feebly and evenly curved when viewed from the side; basal mirginal strial of elytra entire.

d. Third antennal joint very long. slender, subequal to fourth; elytra sparseiy but distinctly punctate.

943. CONCOLOR.

dd. Third joint much shorter and thicker; form less broadly oval; elytral smooth.

944. CONGENER.

cc. Sides of thorax strongly bent downward behind the middle; basal stria of elytra broadly interrupted; third antennal joint long and slender.

94.5. DEFLEXA.

bb. Smaller species, nerer much exceeding $1.5 \mathrm{~mm}$. in length; narrowly oval; third antennal joint not longer than fourth.

c. Elytra not punctate.

f. Length $1.6 \mathrm{~mm}$; epimera of mesosternum extending two-thirds to coxie.

SPECULIFER.

$\mathrm{ff}$. Length not over $1.3 \mathrm{~mm}$; mesosternal epimera longer and narrower.

946. APICALIS.

ce. Elytra sparsely. coarsely and shallewly punctate.

947. PUNCTIPENNIS

aa. Scutellum risible, very minute and transverse; length less than $1.3 \mathrm{~mm}$.

$g$. Hind angles of thorax normally acute; color reddish-brown to piceous.

94. PICEA.

$g g$. Hind angles of thorax obtusely truncate; color deep black. NANA.

943 (2978). Bæocera concolor Fab., Syst. Eleut., II, 1801. 576.

Oblong-oval, broad, strongly conrex. Black, highly polished; legs, antenne and tips of elytra and abdomen reddish-piceous. Thorax three-fourths wider than long. apex one-third as wide as base. Scutellum wanting. Elytra barely as long as wide. scarcely twice as long as thorax, broadly truncate at apex; sparsely and coarsely punctate. Length $2 . \overline{\mathrm{mm}}$. (Fig. 175.)

Thronghout the State; frequent. March 25September 25. Occurs on fungi.

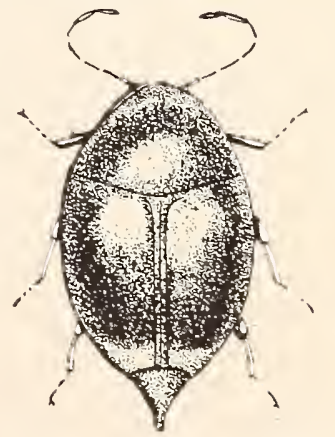

Fig. 175. $\times$ 10. (Original)

944 (9554). B.eocera congener Casey, Amm. N. Y. Acad. Sci.. VII, 1893. 517.

Rather stout, oral. Black; legs and antenne pale reddish-brown. Antennæe shorter than head and thorax. third joint much shorter than second, three-fourths the length of fourth. Thorax and elytra much as in concolor. from which it differs chiefly by its smaller size and antennal structure. Length $2 \mathrm{~mm}$. 
Southern half of State; frequent. April 17-July 29. Taken by sifting rotten wood and vegetable debris; also on fungi.

945 (9S55). Beocera deflexa Casey, loc. cit., 1) 517.

Stont, broadly oral. Black; antennie and under surface paler, rufopiceous. Antemne rery slender. not quite as long as head and thorax, third joint distinctly longer than second, scarcely as long as fourth. Fiytra fully as long as wide, twice as long as thorax; sutural and maroinal strie deele. the basal broadly interrupted. Length $2.5 \mathrm{~mm}$.

Lake, Vigo and Putnam counties; frequent. February 16-September 25. One of Casey's types came from Indiana.

Beocera speculifer. Casey, black, shining, legs, tips of elytra and abdomen paler, was described from Iowa.

946 (2979). Beocera apicalis Lec. Proc. Phil. Acad. Nat. Sci., 1S60, 323.

Narrowly oval. Piceous-black or dark reddish-brown, polished. without punctures or hairs. Antenme short, not as long as head and thorax: third and fourth joints subequal, the former not quite three times as long as wide. slightly shorter than sixth. Thorax short. more than one-half wider than long. Scutellum wholly obsolete. Elytra longer than wide. rather more than twice as long as thorax, widest at basal third, their tips obliquely truncate. Length $1.3 \mathrm{~mm}$.

Kosciusko County ; scarce. June 24. Taken in sifting damp leaves in low moist ground.

947 (-). BAOCERA PUNCTIPENNis sp. nov.

Form and color of apicalis. Elytra pale at tips and distinctly but sparsely and coarsely punctate; legs pale reddish-brown. Antennæe piceous, the basal joints paler. as long as head and thorax, the second, third and fourth joints subequal. Thorax as in apicalis. Basal marginal line of elytra wholly wanting. Length $1.2 \mathrm{~mm}$.

Wells, Marion, Lawrence and Crawford counties; scarce. May 12-November 28. Occurs on the large yellow fungus Clytocybe illudens Schw.

948 (9S59). Beocera picen Casey, Amn. N. Y. Acad. Sci., VII, 1S93, 520.

Rather broadly oral. Dark reddish-brown to piceous; highly polished. not punctate; legs, antenne and tip of abdomen rufous. Antennæe shorter than head and thorax; third joint two-thirds the length of fourth. four ts six slender, subequal; serenth and eighth longer and thicker. Thorax three-fourths wider than long, apex less than one-half as wide as base. Elytra as long as wide, twice as long as thorax, the basal marginal stria broadly interrupted. Length $1.2 \mathrm{~mm}$.

Kosciusko, Putnam, Lawrence and Posey counties; scarce. April 17-July 10. Taken by sifting leaves in low moist places.

B. nana Casey, length $1 \mathrm{~mm}$., is known from Rhode Isiand, Michigan and Texas. 
III. Toxidum Lee. 1860. (Gr.. "a bow+small.")

Small black or brownish beetles having the body compressed and narrowed behind the middle; seutellum absent; hind coxa narrowly separated. One of the two species occurs in the State.

949 (29s ). Toxmina complessum Zimm., Trams. Aner. Ent. Sor., II, $1869,251$.

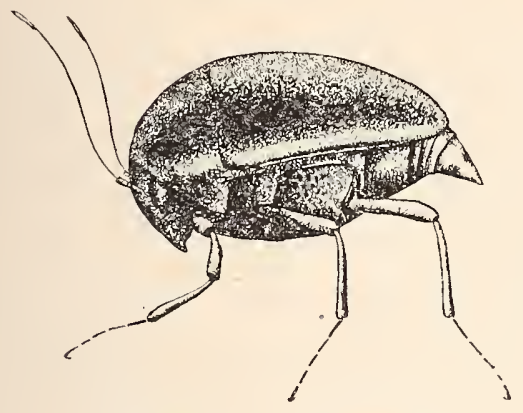

Fig. 176. $\times 15, \quad$ (Original.)

Dark reddish-brown, highly polished; antemie, legs and tip of abdomen paler. Antenne slender. about as long as head and thorax. Side margin of thorax prominent and carinate in front, but rapidly deflexed and pressed against the sides just behind the middle; hind angles obtusely romuled. Metasternum coarsely and deeply junctured throughout. Length $1.4-1.7 \mathrm{~mm}$. ( Fis. 170$.

'Throughout the State; frequent. March 17-November 14. Probably hibernates. Taken by sifting in late autumn and early spring.

\section{Sc.mHisoma Leach. 1812. (Gr., a bow + body."')}

Species resembling those of Brocera, but having the third antennal joint short and narrowed on basal half. and the scutellum always present but minute. (Fig.

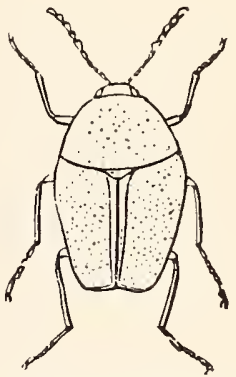

Fig. 177. Scaphisoma agaricinum $\times$ 7. A European spe177.) They are of small size and occur beneath bark, in fungi, and can also be taken by sifting in late autumn or early spring. The following species have been taken or probably occur in Indiana:

\section{KEY TO INDIANA SPECIES OF SCAPHISOMA.}

a. Metasternum strongly but sparsely punctate orer most of its surface: length $1.7 \mathrm{~mm}$.

REPANDA.

aa. Metasternum almost smooth or only punctured over part of its area.

b. Larger species, never much under $2.3 \mathrm{~mm}$. in length.

c. Form elongate-oval; elytra finely, rather closely and uniformly punctate; the punctures twice as numerous as in comera.

950. PUNCTCLATA.

ce. Form broadly oral; elytra distinctly but less densely punctate: metasternum between the middle and hind coxie coarsely and strongly punctate.

951. CONVEXA.

b7. Smaller species, seldom more than $1.7 \mathrm{~mm}$. in length.

1. Flytra not paler at apex, except feebly and gradually from semitranspanency.

e. Elytria slarsely but strongly punctate; length $1.8 \mathrm{~mm}$.

952. SUTURALIS. 
ee. Elytra wholly smooth; length $1.2 \mathrm{~mm}$.

953. DISTINCTA.

dd. Elytra with a broad and rather distinctly defined pale apical margin; metasternum strongly punctured at base. 954. тERmixata.

S. repanda Casev, black. shining. legs and antennæ pale, is known from Massachusetts and Iowa.

950 (2982). Scaphisona punctulata Lec. Pro. Phil. Acad. Nat. Sci., 1860. 323.

Elongate-oral, convex. Bhck. shining: antenne, legs and tip of abdomen reddish-brown. Antenne long and slender, reaching base of thorax. Thorax two-thirds wider than long. rery finely and indistinctly punctured. Sutural striae of elytra deep. Basal joint of hind tarsi as long as the next three. Length 2-2.2 $\mathrm{mm}$.

Vigo County ; rare. May 2. A species of southern range.

951 (2981). Scaphisoma convexa Say, Journ. I'hil. Acad. Nat. Sci., T, 1825, 183; ibid. Il. 289.

Black or dark chestnut-brown. shining; antennæ, under surface and tips of elytra paler. Thorax three-fifths wider than long. rers finely punctate. Elstra three-fourths longer than thorax, the punctures ferer and coarser than in punctulata. Length $2.2-2.7 \mathrm{~mm}$.

Throughout the State; frequent. May 26-November 30. Occurs on fungi on oak and other logs.

952 (2983). Scaphisona suturalis Lec., Proc. Phil. Acad. Nat. Sci., 1860. 323.

Rather narrowly oral. Dark chestnut brown to black, highly polished. Thorax three-fourths wider than long, one-half as long as elytra. rery finely punctate. Elytra a little longer than wide. strongly but remotely punctate. the sutural stria deep. Length $1.7 \mathrm{~mm}$.

Marion, Putnam and Monroe counties; frequent. March 20September 21. Sifted from dead leaves and debris of beech stumps.

953 (- ). Scaphisoma distixcta sp. nor.

Elongate-oral, subparallel. conrex. Uniform dark chestnut-brown. strongly shining; antennxe. legs and abdomen paler; surface both abore and beneath wholly smooth. Antenna reaching base of thorax, seventh and eighth joints but slightly wider than sixth: ninth and tenth distinctly longer, obconical; elerenth oblong. Thorax two-thirds wider than long. Sutural stria rery fine. Length $1.2 \mathrm{~mm}$.

Putuam. Posey and Dubeis counties; scarce. April 21-MIay 11. Taken by sifting.

954 (2984). Scaphisoma terminata Melsh., Proc. Phil. Acad. Nat. Sci., II. 1S44, 102.

Oval. strongly convex. Black, highly polished, the tips of the elytra margined with rellowish: legs and antennre pale. Sixth antennal joint rery long. more than equal to the three preceding. Thorax one-half the length 
of elstra. scarcely punctate. Elytra distinctly but sparsely punctate, the punctures finest toward the base; sutural stria deep, a little curved. I iength $1.8 \mathrm{~mm}$.

Southern half of State; frequent. May 1-September 20.

Scaphiomicrus flavescens Casey, pale brownish-yellow, length $.9 \mathrm{~mm}$., was described from Michigan.

\section{Family XIV. PHALACRIDA.}

\section{The Shining Flower Beetles.}

To this family belong a small number of oval or rounded-oval, convex, shining beetles, having the body very compact; antennæ inserted under or at the sides of a slight frontal margin. 11-jointed. the last three joints forming an oval club; thorax with the side pieces not distinct; prosternum prolonged, entering the emarginate mesosternum behind. the coxal carities open; metasternum large, produced in front; scutellum large, triangular: elytra rounded at tip and entirely covering the abdomen, which has five free ventral segments. (Fig. 178.) The front coxie are rather small and globular: middle coxæ transverse. separated by the sternum; hind coxi contiguous, $\begin{gathered}\text { Fig. } 178 . \text { Olibrus } \\ \text { bicolor. A European }\end{gathered}$ transverse and flat; tarsi 5-jointed, the fourth joint speries. (After usually small and obscure.

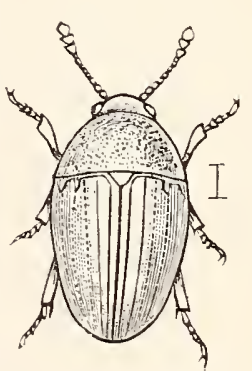

From the Scaphidiidx the members of this family may be known by their broadly rounded instead of truncate elytra and by the smaller and less prominent front coxæ. They are less than $3 \mathrm{~mm}$. in length and live principally on flowers, the larvæ living in the heads of flowers, especially those of Compositie. The adults may be taken in summer by beating or in autumn and spring by sifting. Some species, however. oceur only beneath bark. The name of the family is based upon that of the oldest genus. Phalacrus, a word meaning bald-headed and suggested probably by the rounded shining aspect of these beetles.

The principal literature relating to the family is as follows:

LeConte.- "Synopsis of the Phalacridx of the United States," in Proc. Phil. Acad. Nat. Sci., VIII, 1856, 15-17.

Casey._."Synopsis of Phalacride," in Ann. N. Y. Acad. Sci.. $\mathrm{V}, 1890,89-144$.

About 300 species of the family are known. $4 \bar{\tau}$ of which. distributed among ten genera, being listed from the United States. 
Of these nine species. belonging to five genera. have been taken in Indiana, while one additional genus and two species may occur.

\section{KEY TO INDIANA GENERA OF PHALACRIDE.}

a. Antenne inserted under the sides of the front. their base entirely concealed from above; scutellum large: front and hind tarsi of the same length ; spurs of hind tibiae very short.

I. PHALACRE'S

aa. Antennie inserted at the sides of the front. their base risible from above: scutellum small or moderate: hind tarsi elongated.

b. Basal joint of bind tarsi shorter than the second joint.

c. Apex of prosternal spine inflexed, without an acute and free edge: elytra with one or two discal strice. the suture beaded: second joint of hind tarsi of moderate length.

II. Olibrts.

cc. Apex of the prosternal spine with an acute free edge, and bearing a transverse row of spinules: elctra with a single discal stria, the suture not beaded.

d. Second joint of hind tarsi elongated. very much longer than first joint. spongy pubescent beneath in male: hind tibial spurs long, rery unequal.

III. ACYLOMES.

da. Second joint of hind tarsi moderate. not more than twice as long as first. finely pubescent beneath in both sexes: hind tibial spurs small and inconspicuous.

IV. Eustilbts.

$b b$. Basal joints of hind tarsi longer than second; elytra with two discal striæ.

e. Prosternal spine inflexed at apex and without terminal spinules: basal joint of hind tarsi much longer than all the other joints together.

LitTochRLs.

ee. Prosternal spine not inflexed, the edge free and acute; basal joint of hind tarsi subequal in length to the next two together.

T. OCHRolites.

\section{Philicrus Payk. 1798. (Gr.. "bald + head.")}

Besides the characters above mentioned. the members of this genus have a single discal stria on each elytron and the head is marked with four or five minute forea each side near the eye.

*955 (2998). Phalacres polites Melsh. Proc. Phil. Acar. Nat. Sci.. II. 1814,102 .

Broadly oral. Black, moderately shining: legs and antennie paler. Antenne slender, the third joint equal in length to the two following united. Thorax twice as wide at base as apex. feebly reticulate in wary lines. rers finely and spinsely punctate. Elytra not narrowed toward tips. which are rery broadly and evenly lounded: sutural stria complete. rely fine: discal stria fine distinct: disk with rows of fine. feeble punctures. Metastermal process wide, romden at apex and projecting far in adrance of middle coxie: prostemal process nearly one-half as wide as metasternal. Length $1.8-2.2 \mathrm{~mm}$. 
Common throughout the State; hibernates. January 7-October 6. Frequent on leaves of skunk cabbage, sedges. Peltandra. etc., in moist places in early spring.

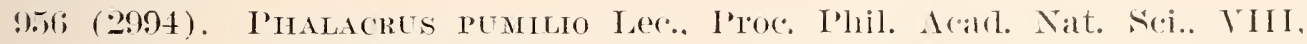
$1856,16$.

Resembles politus but smaller and more narrowly oval. 'Third joint of antemie notably shorter than fourth and fifth togetler. P'rosternal process much narrower. not orel one-third as wide as the metasternat. Elytral punctures more distant and less distinct. Length $1.4 \mathrm{~mm}$.

Lake, Fountain and Lawrence counties; scarce. May 1īJuly 1.

\section{OuIBRus Erichs. 18t5. (Gr., "slippery.')}

The mode of antennal insertion and the size of scutellum distinguish this genus from Phalacrus. In our two species the elytra are of one color and have two discal strixe on each. one near the suture extending to basal third and joining the suture at apex. the second closely parallel and a little shorter.

957 (3000). Olibrus semistriatus Lec, Proc. Phil. Acad. Niat. Sci., VIII. 1856. 16.

Oblong-orate, strongly convex. Above dark chestnut-brown, highly polished: beneath pale reddish-yellow, antennic and legs of the same hue. Thorax rery sparsely and feebly punctate. Elytra with two discal strixe near the suture and with feebly impressed lines along the very fine rows of punctures. Length $1.8-2.2 \mathrm{~mm}$.

Southern half of State, frequent; less so in the northern counties. March 27-October 1. Occurs on fiowers of Eupatorium and Solidago (thoroughwort and goldenrod). Taken in spring by sifting.

958 (3002). Olibres pallipes Say, Journ. Phil. Acad. Nat. Sci., IY. 1825. 90 ; ibid. II, 230.

Elliptical, very convex. highly polished. Above dark piceous-brown. the head and thorax a little darker than elytra; antenne and under parts pale brownish-yellow. Thorax with minute obsolete punctures on each side. Elytra with discal strixe and rows of fine punctures as in scmistriatus but without the accompanying inpressed lines along the row of punctures. Length 2.5-2.5 $\mathrm{mm}$.

Lake and Knox counties; scarce. July 30-August 31. Longel and more narrowly oval than the prereding:

III. ACrmonts Sharp. 1888. (Gr.. "an acorn.")

Small oval, more or less conver beetles. haring the serond joint of hind tarsi very much elongate and in the male spongy pubescent. as in the males of the gemus Anisorlactylus of the family Carabida. 


\section{9 (9881). Acylomus ergoti Casey, Ann. N. Y. Acad. Sci., V, 1890, 119.}

Strongly convex, almost evenly elliptical, not at all narrowed behind the middle. Above black or dark chestnut-brown, strongly shining; beneath pale brownish-yellow. Elytra with one discal stria, this obsolete on basal third, and with rows of punctures which, near the suture, are rery minute and feeble, slightly larger on the sides. Hind tarsi three-fourths as long as tibire, the second joint between three and four times as long as the basal one. Length 1.8-2.2 $\mathrm{mm}$.

Frequent throughout the 'State. April 26-October 1. Occurs on leaves of skunk cabbage in early spring.

960 (9882). Acruonus piceus Casey, 7oc. cit., p. 120.

Broadly oval, distinctly nar'rowed behind the base of elytra. Piceousbrown, shining. Otherwise as in ergoti. Length $1.8 \mathrm{~mm}$.

Posey and Martin counties; rare. Nay 16-June 6.

\section{Eustilbus Sharp. 1888. (Gr., "good + shine.")}

Small oval, convex species differing from those of allied genera by the characters given in generic key. Two species have been taken in the State, while a third may occur.

KEY TO INDIANA SPECIES OF EUSTILBUS.

a. Spinules at apex of prosternal spine long and conspicuous; elytra either entirely pale or distinctly paler at apex.

b. Elytra highly polished, not reticulate, abruptly and distinctly paler at apex.

bb. Elytra finely reticulate and pale throughout. 961. APICALIS. 962. NITIDUS. a a. Spinules at apex of prosternal process short; body narrowed behind from base of elytra; color dark reddish-yellow throughout.

ATTENUATUS.

961 (3005). Eustilbes apicalis Melsh., Proc. Phil. Acad. Nat. Sci., II, $1844,102$.

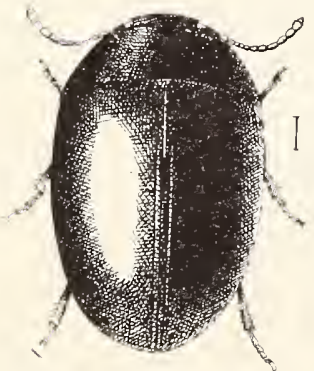

Fig. 179. (Original.)

Oral, strongly convex, rery feebly narrowed behind the middle. Above piceous or dark chestnut brown, highly polished; apical fourth of elytra rather abruptly pale brownish-yellow; beneath reddishbrown; legs and antenna paler. Elytra distinctly longer than wide, the discal stria very deep, strongly impressed, uniting with the suture near apex; the rows of punctures rery fine, scarcely visible. Length 2-2.3 $11 \mathrm{~m}$. (Fig. 179.)

Throughout the State; frequent. Hibernates. March 9-December 7. Taken by sifting in early spring and by sweeping goldenrod and other herbage in summer. Listed by Henshaw as Olibrus consimilis, a European species, but since shown to be distinct. 
962 (3007). Eustilbus nitidus Melsh., Proc. Phil. Acad. Nat. Sci., II. 1844.102.

Oval, strongly convex, distinctly narrowed behind the middle. L'ale reddish-yellow throughout, very shining. Elytra narrowly rounded at apex. the discal stria less impressed and not uniting with suture at apex; wholly without rows of punctures. Length $1.3-1.5 \mathrm{~mm}$.

Thronghout the State; frequent. Taken by sifting in rarly spring. so that it probably hibernates. Nareh 5-July 6.

E. attemuatus Casey, $1.6 \mathrm{~mm}$. in length, was described from New York, Michigan and Texas.

Litochrus immaculatus Casey, piceous, the suture paler. length $1.5 \mathrm{~mm}$., is a southern form which may occur in the Ohio River counties.

\section{Ochroutwus Sharp. 1889. (Gr.., "pale yellow + shine.")}

A single species represents this genus in the State.

963 (3001).. Ochrolites rebexs Lec., Proc. Phil. Acad. Nat. Sci., VIII, $1856,16$.

Rather broadly oval, strongly convex. Pale reddish-yellow throughout, highly polished. Thorax a little more than twice as wide as long. very smooth. Discal strize of elytra well impressed. obsolete on basal fifth, the second uniting with the first near the apex. Length $1.5 \mathrm{~mm}$.

Kosciusko, Marion and Posey counties; scarce. June 21-December 7 .

\section{Family XV. CORYLOPHTD E.}

\section{The Fringe-winged Funges Beetles.}

Here belong a number of minute oval or rounded beetles, which occur under damp bark or in decaying fungi and other vegetable matter. At times they fly about in large numbers by twilight. They have the antennie 9- to 11-jointed, ending in a loose club and inserted on the front; palpi short and fonc-jointed; mandibles small. with comb-like teeth on the imner margin; front coxe globose. prominent, contiguous or nearly so: middle coxæ also globose and separated by the mesosternum; hind coxæ transverse, widely distant; tarsi 4-jointed. the third joint small, concealed in a notch of the second joint; ventral segments six; scutellum distinct, though small: wings wide, fringed with long hairs which, however, are shorter than in the family Trichopterygide. In many species the body is clothed with a grayish pubescence. 
The members of this family hare been by most authors considered as belonging to a subdivision of the Coccinellidx, but the form cf the mandibles and the structure of the tarsi are sufficient to separate them. MLoreover, they differ widely in food-habits. However. they are related closely in structure not only to the Coccinellidie but also to the Silphide. so that they are assigned a place between those two families.

The principal literature treating of the family is as follows:

Leconte- "Synopsis of the Corylophi," in Proe. Phil. Acad. Nat. Sci., VI. 1852. 141-145.

C'asey.-." "Synopsis of the Corylophidx," in Journ. N. Y. Ent. Soc. VIII. 1900, 60-75.

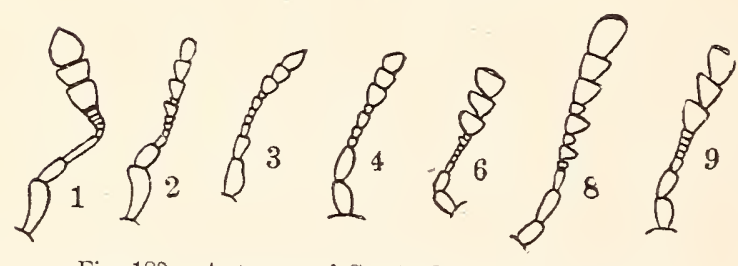

Fig. 180. Antennæ of Corylophid . (After Casey.)

About 200 species of the family are known. Casey in his Synopsis lists 54 species, divided among ten genera, from the United States. Of these eight species, belonging to five genera. have been taken in Indiana, while a number of others may occur.

KEY TO INDIANA GENERA OF CORYLOPHID.E.

a. Antennie 10- or 11-jointed; tholax hood-like. completely concenling the head.

b. Body rounded. convex, glabrous; front coxie long and narrow, enclosed within deep carities; antemne 11-jointed, the third joint elongate but shorter than the second.

c. Head very deeply inserted within the thorax, the front margin oc which is evenly rounded and strongly descending; post coxal plates large with rounded outline: labrum rounded and subquadrate.

I. CoRYlophodes.

cr. Head less concealed by the orelhanging margin of the thorax. but not visible from above; post coxal plates rery short: labrum small. triangular. its apex acuminate: tarsi short. dilated: hind angles of thorax acute, feebly prolonged. II. Groverts.

bわ. Body oblong or oval and pubescent: front coxie oblong or globular.

d. Hind angles of thorax distinctly prolonged backwards and acute: antemne 10-jointed (Fig. 180. No. 3) ; front coxie short, oblong.

III. SERICoderus.

dd. Hind angles of thorax not prolonged backwards. rectangular : front coxie larger. less deeply imbedded : globular.

e. Antennie 11-jointed: lnostelnum well developed in front of coxie. f. Body elongate. subdepressed. the sides sublarillel: basal joint of hind tillsi short. scincely as long as the next two combined.

SACIUMr. 
ff. Body oval with the sides more curved; basal joint of hind tarsi nunch longer than the next two combined.

IV. NOLANBA.

ec. Antenne 10-jointerl. the elongate third joint followed by foul small subequal ones (Fig. 180, No. 9) ; Hosternum very slort in front of coxie; body oval or oblong-oval, more convex.

Arthrolips.

a . Antennie 9-jointed (Fig. 180. No. 4); thorax emarginate in front, the head in great part exposed; body very minute.

V. ORThoperes.

\section{Corylophodes Matthews. 1885. (Gr., "helmet + crest.")}

Small rounded species having the hind angles of thorax slightly prolonged; front tarsi feebly dilated in males; antennæ as in Fig. 180, No. 1, except that the third joint is shorter than second.

964 (3023). Corilophones marginicolis Lec., Proc. Phil. Acad. Nat. Sci., VI, 1852, 143.

Rounded, strongly convex. Blackish-piceous, shining; legs and antennie paler. Thorax semicircular, the margin broadly transparent, and therefore appearing rellowish; base obtusely angulated at middle. Elytra with sparse, deeply impressed punctules. Length $.9 \mathrm{~mm}$.

Throughout the State; frequent. April 17-October 17. On leaves or fungi in summer. Taken by sifting in spring and fall.

\section{Gronevus Casey. 1900.}

'T'o this genus, as defined in key, Casey ascribed five species. The antenna are shown in Fig. 180, No. 2. One has been taken in the State, while two others may occur.

KEY TO INDTANA SPECIES OF GRONEYUS.

a. Elytral punctures strong. especially on the sides; blackish, thorax paler, its margins transparent: length $8 \mathrm{~mm}$.

STICTICUS.

aa. Elytral punctures minute and indistinct.

b. Antennal club blackish; body black, thorax piceous, with narrow transparent margins; length .9 mm. Fetscicornis.

bb. Antennal club pale; body dark reddish-yellow, thorax still paler: length $1 \mathrm{~mm}$.

965. HESPERUS.

G. sticticus Casey was described from Iowa and G. fuscicornis Casey, from Ottawa, Canada.

965 (-). Gronevos hesperuts Casey, Journ. N. Y. Ent. Soc, VIII. $1900,64$.

Elongate-oval, convex. Reddish-yellow tinged with piceous, shining. Elytra more than twice as long as thorax. its punctures very fine, almost affaced belind the middle. Length 1 min.

Monroe Comnty; rare. June 9 . Sifted from debris of beech stump. Known heretofore from Iowa and Nebraska. 
III. Sericoderus Steph. 1829. (Gr.. "silken + skin.")

Small oblong or ovate pubescent species having the antennal club 3-jointed (Fig. 180. No. 3) ; elytra narrowed behind, their tips truncate; tarsi slender in both sexes. One species has been taken in the State, while two others mar occur.

KEY TO INDIANA SPECIES OF SERICODERUS.

a. Elytra more strongly narrowed from base to apex.

b. Color pale dull yellow; thorax with a fuscous spot at apex; length $.9-1 \mathrm{~mm}$.

FLAVIDUS.

bb. Elytra piceous. yellow at tips: thorax dull yellow, the subapical spot darker; length .S mm.

966. OBSCURC'

a a. Elytra feebly narrowed, the form more quadrate; color pale dull rellow; length .8 mm.

SUBTILIS.

S. flaridus Lec., was described from New York and Lake Superior and probably occurs in the northern counties. S. subtilis Lec. is known from southern Illinois and Florida.

966 (3026). Sericonerts obscrruts Lec. Proc. Phil. Acad. Nat. Sci., VI, $1852,143$.

Oblong. quadrate. Thorax broadly rounded in front, dull yellow with a piceous spot at apex. Elytra finely and rather densely punctate. dark reddish-brown or piceous, the truncated apex yellowish. Length $.8 \mathrm{~mm}$.

Marion. Putnam and Vigo counties; scarce. March 5-May 2.

Sacium lugubre Lec.. thorax as long as wide, elytral punctures and pubescence sparse, color piceous, length $1.7 \mathrm{~mm}$, and $S$. obscurum Lec., thorax wider than long, elytral punctures and pubescence dense, color piceous-brown. length $1.6 \mathrm{~mm}$.. both have a range which may include Indiana. The antenna of Sacium is shown in Fig. 180, No. 8.

\section{Morambi Casey. 1900.}

Small oval species having the antennæ rather short with a stout. compact club, the serenth joint enlarged. the fifth normal. (Fig. 180, No. 6.) They were mostly formerly classed under Sacium. Three have been taken in Indiana.

\section{KEI TO INDIANA SPECIES OF MOLAMHA.}

a. Elstra each with a transserse rellow spot or band just behind the middle.

7. Yellow markings of elytra an entire crossbar located behind the middle; pubescence coarse, distinct.

96iT. FASCIATA.

孔. Yellow markings of elytra a subiuadrate spot located very little behind the middle. 968. ORNATA. 
au. Elytra each with a small yellow spot, much behind the midnle; pubesrence fine, less distinct.

9(j). LUNATA.

967 (3015). Molamba fasclata sag. Jomm. Phil. Acarl. Nat. Sci., Y. 15206. 259 : ibid. II, 320.

Broadly oval, subdepressed. Piceous; antennie and legs yellowish; thorax reddish-yellow with a dark spot in front of mirlde; elytra with il crossbar behind the middle, the tips edged with dull yellow. Thorax hoodlike. sides regularly curred. apex rounded; disk, as well as that of elrtra, densely and finely punctate. Length $1.4-1.7 \mathrm{~mm}$.

Kosciusko and Perry counties ; rare. May 20-June 20. Taken from beneath bark of locust. also by sifting the debris of beech stumps.

968 (-). Molamba orNata Ciaser. Journ. N. Y. Ent. Soc., VIII, $1900,71$.

Resembles fusciata but having the pale crossbar of elytra reduced to a quadrate spot and located a little nearer the middle. Males narrower than females and with the elstra shortened. exposing two segments of the abromen. Length 1.3-1., mm. (Fig. 181.)

Kosciusko, Putnam. Orange and Posey counties; scarce. April 24 June 22. Probably only a variety of fasciata. Taken by sifting.

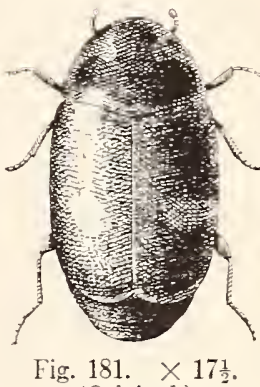

Fig. 181. $\times 17 \frac{1}{2}$ (Original.)

969 (3017). Molamba LrxatA Lec, Proc. Phil. Acad. Nat. Sci.. TI, 1852. $1 \pm 4$.

Resembles fasciata but smaller and broader. Thorax mostly black with narrow dull rellow margins and apex. Elytra with a small lunate rellow spot on apical third; their tips broadly rounded and margined with rellow, which extends a short distance along the sides; surface finely and densely punctate. Length 1-1.3 nm.

Narion and Perry counties; rare. April T-May 20.

Arthrolips decolor Lec.. pale dull yellow. elytra minutely reticulate, length $.8 \mathrm{~mm}$., and $A$. misellus Lec.. blackish, thorax paler. elytra highly polished and distinctly punctate. length $1 \mathrm{~mm}$. both hare a range which may inchde Indiana. For shape of antenna of Arthrolips see Fig. 180. No. 9.

\section{T. Orthoperts Steph. 1829. (Gr., "straight + pouch.")}

The members of this genus are among the smallest of Coleoptera. and may be recognized by their oral. moderately convex form, exposed head and 9-jointed antennie. (Fig. 180, No.4.) Two species have been taken in Indiana, while a third may oceur. 
KEI TO INDIANA SPECIES OF ORTHOPERU'S.

a. Elytra not punctate. but marked with small V-shaped scratches; length $.7 \mathrm{~mm}$.

SCUTELLARIS.

aa. Elytra distinctly but linely and sparsely punctate; length not orer $.6 \mathrm{~mm}$.

b. Form oblong-oral: length $.6 \mathrm{~mm}$.

970. GLABER.

bb. Form erenly oval, the sides more curved; length $.5 \mathrm{~mm}$.

971. MICROS.

O. scutellaris I ec. black, legs and antenna paler. is known from Ohio and northern Illinois.

970 (3029). Orthoperts glaber Lec.. Proc. Phil. Acad. Nat. Sci., VI, 1852. 142.

Oblong-oral. Piceous-black, glabrous, shining. Thorax twice as wide as long, narrowed in front, emarginate at apex. hind angles rectangular. Elytra very sparsely and obsoletely punctured. Length .6 mm.

Southern two-thirds of State; frequent. NIarch 20-November 8. Taken by sifting.

971 (—). Orthopertis micros Casey, Journ. N. Y. Ent. Soc. VIII, 1900. 66.

Rounded-oval. I'iceous-black, glabrous, shining. Reticulations of surface distinct beneath the lens. Eyes separated on the front by but little more than twice their own width. Lèngth $.5 \mathrm{~mm}$.

Throughout the State; scarce. May 19-.July 4.

\section{Family XVI. COCCINELLID}

\section{The Lady Bugs. The Pliant-louse Beetles.}

This family comprises a moderate number of rounded or hemispherical, rarely oblong, convex beetles, the larger members of which are well known under the common name first mentioned. In color they are generally red or rellow, with black spots, or black with white. red or yellow spots. The name coccinella is derived from the Coccus, which produces the cochineal dres so extensively

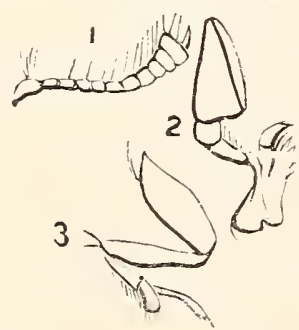

Fig, 182, Coccinella 1 Antenna; 2, maxillary palpus; 3 , tarsus. (After Westwood.)

\section{.} used before the aniline dres were discovered, and was suggested by the prevalence of red in the coloration of many of these insects. In most cases the surface is glabrous, but in some of the swaller forms it is plainly pubescent.

The most distinctive characters of the family are the three-jointed tarsi and the broad, hatchetshaped terminal joint of the maxillary palpi. (F'jg' 152.) In addition they have the antenna 11-jointed, terminating in a more or less distinct 3-jointed club and inserted at the inner front margin of the eves; head deeply immersed in the thorax. which is transverse, rather 
small. and strongly emarginate in front: elrtra convex. not truncate at tip : front coxa transverse. separate. the coxal carities r. losed behind. except in roccidula: middle coxe rounded; hind coxiu transrerse. widely separated: abdomen with five free ventral segments. the dorsal portions of which are partially membranous; tarsi 3jointed, the second joint dilated and spong: beneath.

Taking into consideiation the foregoing characters, LeBaron has well said that: "In a sistematic point of view the Coccinellida occupy a remarkably anomalous and isolated position. Whilst haring the rounded form of the plant beetles. the clavate antennie of the scarengers. and the dilated palpi of the fungus beetles. they agree in food and habits with none of these. but resemble, in their predaceous habits. the ground beetles and the soft winged carnirora. all of which have their bodies more or less elongated. their tarsi 5 jointed, their antenna filiform, and their paipi slender or but moderately dilated."

The Coccinellidx are among the most beneficial of insects, being. with rery few exceptions. predaceous in both the larval and adult stages. Ther seem to be especially adapted to keeping in check the extensive families of plant lice. both the leaf-lice (aphids) and the bark-lice (coccids) upon which they feed roraciously. It is not uncommon to find in an orchard branches of trees thickly corered with the scales of bark-lice. almost every one of which has been torn open and its occupant deroured by these ladr-beetles. Ther are also known to feed upon the eggs of many forms of larger insects, upon chinch bugs and upon spores of the lower cryptogams and pollen grains. After examining the stomach content of 39 specimens. Dr. S. A. Forbes states that "the function of the beetles of this family of limiting the multiplication of plant-lice is expressed by the fact that these insects compose a fourth of the food of this entire collection. The pollen of grasses and Compositit make $1 \pm$ per cent. the spores of lichens four per cent.. and those of fungi t5 per cent., or nearly half the whole." Chinch bugs made up 10 per rent. of the entire food eaten by nembers of the genus Hipporlamia, taken in a cornfield where such bugs were abundant.*

The larra of the Coccinellida are oblong. blackish grubs. and are usually beset with spines. which are in turn armed with smaller spines or prickles. giving them. when magnified. a formidable appearance. (Fig. 183.) In many cases the larrie are spotted or banded in reds. black and rellows. They bear some-

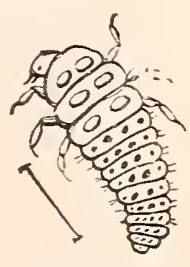

Fig. 183. (After Forbes.)

* "The Food Relations of the Carabidæ and Coccinellidæ" in Bull. No. 6, Ill. Lab. Nat. Hịst., 1883. 
what a resemblance to a minute alligator in shape, and are known under that name by children in some parts of the country. As is the case with other grubs, they are much more voracious than the perfect beetles. When full grown the larva suspends itself by the hinder end to some convenient leaf or branch and either pushes the larval skin upwards. where it remains in a little wad about the tail. or remains within it until ready to emerge, when it bursts the skin open along the back and emerges a perfect beetle.

The principal literature treating of the North American members of the family is as follows:

LeConte.--"Remarks upon the Coccinellidx of the United States," in Proc. Phil. Acad. Nat. Sci., VI, 1852. 129-141.

Crotch.- "Revision of the Coccinellidæ of the United States," in Trans. Amer. Ent. Soc.. IV, 1873. 363-382.

LeConte- "Short Studies of North American Coleoptera (Hyperaspis)," in Trans. Amer. Ent. Soc., VIII. 1880. 186-188.

Horn.- "Studies in Coccinellidx." in Trans. Amer. Ent. Soc.. XXII, 1895, 81-114.

Casey.- "A Revision of the American Coccinellidx," in Journ. N. Y. Entom. Soc., VII, 1899, 71-163.

Leng._-"Notes on Coccinellidx." in Journ. N. Y. Ent. Soc.. XI. 1903. 35-45. 193-213; XVI, 1908, 33-44.

About 150 members of the family are listed by Henshaw as belonging to the North American fauna. To these Caser added in his Synopsis 179 new names. a number of which are evidently based on geographic races or varieties, while many of them will doubtless proye good species. Altogether it is probable that about 250 known species occur in this country.

For convenience the family. as represented in the State, is first divided into eight tribes by the following table. modified from that used by Maj. Casey:

KEI TO IYDAXA TRIBES OF COCCINELLIDE.

a. Middle coxæ narrowly separated; body elongate-oral. glabrous: legs long. free, the femora extending beyond the sides of the bodr: abdomen with sixth segment visible in both sexes; head not deeply inserted. the thorax stronglr sinuate but not corering the eres.

Tribe I. HIPpodanimin. p. 509.

a. Middle coxre Nidely separated: legs shorter. the femora generalls not extending beyond the sides of the body: head deeply inserted, the thorax covering a large portion of the eyes.

b. Front coxal carities closed behind; eses finels faceted. 
c. Body loosely jointed. generally rounded in form; epipleuria wirle. concare. strongly descending externally.

c. Frontal plate narrowed from the base. not corering the base of antennæe.

e. Lpper surface of bods glabrous.

Tribe II. Coccinellixi, p. J12.

ee. Upper surface of body pubescent: antemne long. with loosely articulate club; thorax deeply emarginate at apex: mandibles bifid at tip and denticulate within.

Tribe TiI. Epilachisist, p. 532.

dd. Frontal plate broadly dilated. concealing the base of antenne and subdividing the eres: upper surface glabrous: body rounded. rery conrex: legs free or feebly retractile.

Tribe III. Chilocostrit. 1).

cc. Bodr compact. generally oral in form: epiplenra nar 1 u, gentrialls horizontal. Hat or feebly concare.

$f$. Abdomen composed of only fire segments. the fifth triangular and longer that the three preceding combined: eyes entire; base of antennx exposed: size minute. Tribe IT. CExersi, p. 519.

$f f$. Ablomen with the sixth segment well dereloped. the fifth shorter. g. Body glabrous.

gg. Body pubescent.

Tribe T. Hrperaspixi. p. 519. Tribe Ti. Scrmaxist. p. 524.

bb. Front coxal carities open behind: eyes coarsely faceted: body oblong-oral. pubescent: abdomen with six segments: antenne long. the club loose: length less than $3.5 \mathrm{~mm}$.

Tribe NiII. Coccidelisi. p. 533.

Tribe I. HIPPODAMIINI.

The members of this tribe are easily recognized from those which follow by having the antennæ very short: body more elongate and loosely formed; up-
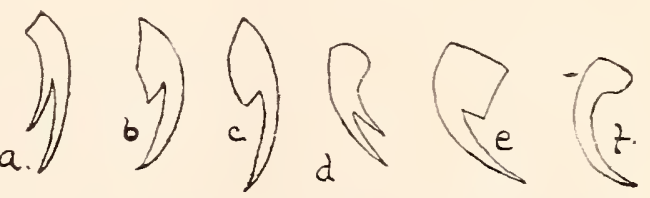
per surface glabrous; legs longer and less retractile. The tribe is represented in the State by three genera.

\section{KEY TO IXDIANA GENIRA OE HIPPODAMIINI.}

a. Tarsal claws simple (Fig. 1S4. $f$ ) : bodr oral: hind angles of thorax obtuse but not rounded : length less than $3.5 \mathrm{~mm}$.

I. Axisosticta.

aa. Tarsal claws either with a large tooth at base or bifid: length $4.5 \mathrm{~mm}$. or more.

b. Claws witl a large quadrate basil tooth (Fig. 14t. e) : thorax witl a narrow but distinct marcin along the base.

II. NEgilla.

ъb. Claws bifid. the two lobes medual in length and acutely pointed (Fig. 1S4, d) ; thorax not margined at base.

iII. Hippodalis. 
I. Anisosticta Duponchel. 1842. (Gr., "unequal + spot.")

One of the three recognized North American species occurs in the State.

972 (3033). Axisosticta strigata 'Thunb.. Ins. Suec., IX. 1794. 113.
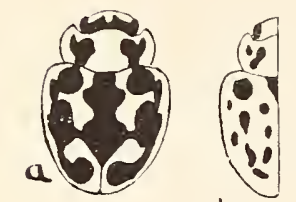

6
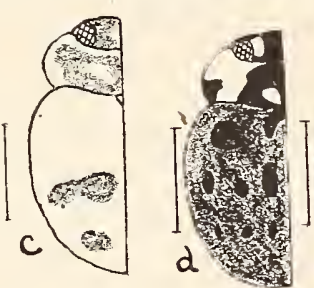

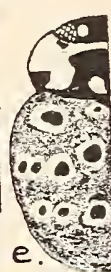

e.

Fig. 185. a, A nisosticta stri7ata; $b$, var. of same; $c$, Hiprodamia glacialis; $d, A$ natis 15-punctata;, e, same var. mali. (After Leng.)

\section{rion and usululy eicht others on each black:} (these often more or less united to form fewer and larger spots. Beneath black; legs, antenne, sides of abdomen and last rentral sesment yellow. Length $3.3 \mathrm{~mm}$. (Fig. 185, $a$ and $b$.

Beneath rubbish on beach of Lake Nichigan near Pine and Millers, Lake County; scarce. March 26-.Tune 29. A species of northern range.

\section{Megrlua Muls. 1851. (A mythological name.)}

In this genus the thorax is subquadrate with the base sinuate, rounded and finely but distinctly margined. One species occurs in the State.

*973 (3036). Megilla maculata DeGeer, Mem. V, 1775, 392.

Oral, subconvex. Head black with at triangular red spot on front; thorax and elytra reddish, the former with an obtriangular black spot on each side of median line; elstra with two blick spots on suture and four (the second the largest) arranged longitudinally near the outer edge of each. Beneath black, the prosternum and a row of triangular spots on each side of abdomen. reddish. Tength $j-\tau \mathrm{mm}$. (Fig. 1S6.)

Throughout the State; common. January 12-November 5. Gregarious in winter. During October it congregates beneath rubbish and

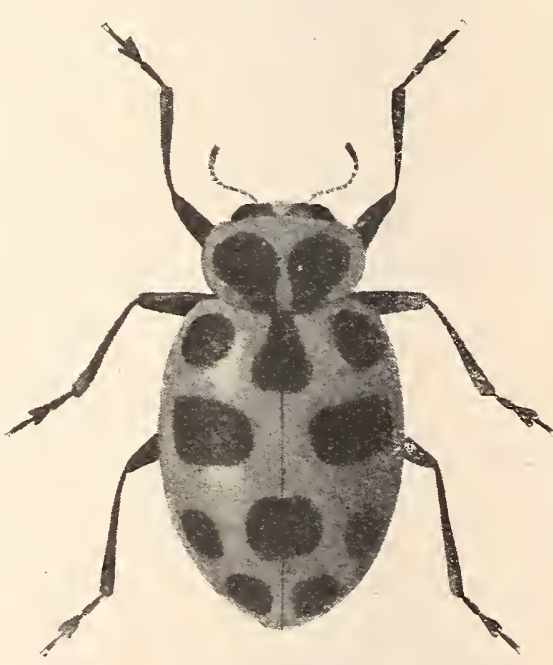

Fig. 186. $\times 6 . \quad$ (After Forbes.) logs, mullein leaves, etc. On several occasions I have found them in midwinter by thousands, huddled together beneath piles of the 
stems of the larger ragweed (Ambrosia trifida L.) in the low bottom lands of the Wabash River.

III. Hippodama Muls. 1546. (A mythological name.)

Thorax subtransverse, not margined at base; claws bifid; hind tibial spur's distinct. Casey (loc. cit.) lists 27 species of the genus from the United States, while Leng, in a later paper (loc. cit.), reduced these to ten, the others being regarded as either geographical races or synonyms. Of these four and one variety are known from Indiana.

KEY TO INDIANA SPECIES OF IIIPPODAMIA.

a. Thorax black with broad pale lateral margins within each of which is a black dot; tibire and tarsi pale.

974. 13-PUNCTATA.

aa. Thorax with a narrower white lateral margin, without distinct dot, but usually intruded upon by a more or less pronounced angulation of the central black area; legs black throughout.

b. Black disk of thorax nearly divided by a white quadrate spot at the middle of base, and an elongate triangular spot at apex.

975. PARENTHESIS.

bb. Black disk of thorax without white spot at base and apex, but with two discal divergent white dashes.

c. Front half of elytra without markings or with only a humeral black dot.

976. GLactalis.

cc. Elytra each with six small spots, three of which are on the front half.

d. Spots of elytra all small and widely separated.

977. CONYERGENS.

dd. Spots much larger, the front one near suture apparently double.

97 Ta. VAR. 15-MACULATA.

*974 (3050). Hippodama 13-pc nctata Limn.. Syst. Nat.. X. 1765, 336.

Oblong-oval. Head black at base; thorax described in ker and without discal divergent bars; elytra each with six rounded black spots and a small common scutellar spot. Readily known by the pale tibire and tarsi and the markings of the thorax. Length $4.5-5.2 \mathrm{~mm}$. (Fig. 187.)

Frequent throughout the northern half of State; (After Riley.) less so southward. February 23-December 25. In one specimen from Laporte County the black area embraces nearly the entire upper surface of thorax and the spots of elytra are nearly double the usual size.

*975 (3051). Hippodanima Parenthesis Say, Journ. Phil. Acad. Nat. Sci.. IV, 1824, 93 ; ibid. II, 232.

Oblong-oval. Head black at base and apex; thorax described in key; elytra reddish-yellow, with a large triangular common scutellar spot, a round spot ou humerus, and a strongly curred subapical lunule on each. black. Length $4-5 \mathrm{~mm}$.

[33-23402] 
Throughout the State; frequent. April 1-December 18. The black subapical lunule varies much in size and form, being sometimes a large irregular blotch.

976 (3044). Hippodama claciatis Fabr., Syst. Eit., 1775, so.

Oblong-oval. Head black with a triangular yellow spot on center; thorax with the pale side malrgins wider in front and behind, the anguiar extension of the black area well mirked, the discal dashes distinct; elytra reddish with an oblique band behind the middle, and a latge subapical spot. black; rarely also a small black dot on the humerus. Beneath black, the rentral segments with a triangular redulish spot on each side. Length 6 $7.5 \mathrm{~mm}$. (Fig. 185, c.)

'Thronghout the State; scarce. Narch 28-November 9. Probably hibernates. Several specimens were taken beneath rubbish on the beach of Lake Michigan in May.

*977 (3046). Hippodania convergens Guel', Icon. du Reg., An., 1846, 321.

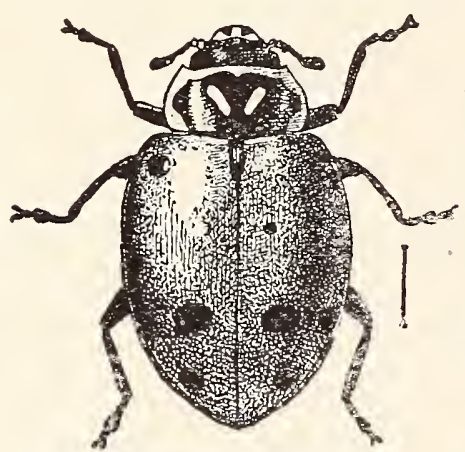

Fig. 188. (After Chittenden.)

Oblong-oval. Head black, the pale spot on center transverse, reaching the eyes; thorax with a narrow, nearly uniform pale border and two distinct discal bars; elytra reddish with a common scutellar spot, and six small spots (sometimes partly or wholly obsolete), on each, black. Beneath uniform black. Length 4.S$6 \mathrm{~mm}$. (Fig. 18S.)

Throughout the State; common. April. with 13-punctata and parenthesis, beneath chunks and mullein leaves along the borders of cultivated fields.

$977 a$ (3045). Hippodamia convergens 15-maculata Muls., Spec., 1851, 20.

A variety of the preceding, distinguished by having all the spots of elytra enlarged and partly coalescent, and the black disk of thorax with a distinct angulation on the side as in glacialis. Length $6.5 \mathrm{~mm}$.

Laporte County; rare. August 26. Known heretofore only from Missouri, Kansas and Arkansas.

\section{Tribe II. COCCINELLint.}

The members of this tribe have the front coxal cavities closed; middle coxa widely separated; base of antennie exposed; body loosely articulated, not very contractile; form nsually rounded, sometimes oblong, and the surfare never pubeseent. It includes those lady-bugs most commonly met with, as the two-spotted ladybug, Adalia bipunctata, often found in houses, and the nine-spottea 
lady-bug, Cocrinella 9-notata. common in wartens. Most of the species resemble these common forms in size and shape, being rounded and convex. The tribe. as divided by Casey. comprises ten North American genera. In order to aroid the division into so many groups I have followed Leng by including the single genus Psyllobora of the tribe Psylloborini and combining certain genera with Coccinclla. This gives in our fama representatives of five genera.

\section{KEY TO INDLANA GENERA OF COCCINELLINI.}

a. Body larger, 1-7.5 mm.; antennce shorter with last joint truncate.

b. Antenna onls slightls longer than head; epipleura not extending to the sutural tip.

c. Body usually rounded, strongly convex; elstra reddish, without spots or with more than two black spots on each; tarsal claws with a large subquadrate tooth at base. (Fig. 184, c.)

IV. Coccinella.

cc. Body oral. less convex; elytra reddish with one or tro black spots on each; tarsal claws as in Fig. 184, $b$.

V. ADALIA.

bb. Antennre longer, extending at least to middle of thorax; epipleura entire.

d. Tarsal clams bifid (Fig. 1S4, a) ; prosternal process compressed in front: elstra without spots.

TI. NEOMYSIA.

dd. Tarsal claws as in Coccinella; prosternal process broad, strongly conver in a transrerse direction and prominent at aper; elytra with numerous spots.

VII. AxATIS.

a a. Body small. 2-2.5 mm. : antennie slender with last joint elongate.

VIII. PsTlloborA.

\section{Coccinelua Linn. 1758. (Gr.. "scarlet + insect.")}

Rounded, very convex forms having the front margin of the thorax more or less emarginate. They vary considerably in the black markings of thorax and elytra. and among them are some of the most common and best known of the "lady-bugs." The genus. as usually defined. was divided by Casey into four. viz. Coccinella. Neoharmonia. Cycloneda and Otla. and to them he ascribed 27 species. Leng reunited the four and rednced the number of species to 12. Of these the following are known from the State:

KEY TO INDLANA SPECIES OF COCCINELTA.

a. Thorax black with narrow apical margin and a large subquadrate spot at each apical angle, pale.

b. Elytra together normally with nine spots, without trace of sub-basal crossbar.

978. 9-xotATA.

bb. Elytra with three black crossbars, the one near base common, the others interrupted at suture.

979. TRIFASCIATA. 
aa. Thorax black, rariegated with pale markings, or red or yellow with, black spots.

c. Body somewhat dejressed; thorax red with four distinct black spots, the two hind ones oblique, elongate. 9S0. rexusta. ce. Body strongly convex.

d. Elytra reddish without spots; mesosternum truncate in front.

981. SANGUINEA.

dd. Elytra pale brownish-yellow, each with eight small black dots; mesosternum broal̨ly and rather feebly sinuate in front.

982. ABDOMITALIS.

9 is (3058). Coccinella 9-мотата Herbst., Kafer, V, 1793, 269.

Hemispherical. Head pale, black at base; thorax described

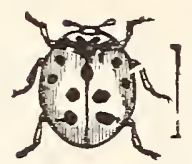
in kes; elstra with one common scutellar spot, and each with four others black, the two front ones the smaller; the spots sometimes united into two oblique curred bars. Under surFig. 189. face and legs black. the meso- and meta-epimera white. Length (After Riley.) $5.5-7 \mathrm{~mm}$. (Fig. 189.)

Throughout the State, frequent; especially so in cultivated grounds. January 7 -Norember 30. Hibernates beneath logs and mullein leaves.

979 (3056). Coccixella trifasciata Linn., Syst. Nat., Ed. X, 1758, 365.

Smaller and more narrowly oval than 9-notata. Head of male white. of female with two white spots; thorax black at base, the apical margin and a broad space at each apical angle. whitish; elstra orange, the subbasal black band not reaching side margins, the others interrupted at suture and each encircled with a narrow pale ring; legs and under surface black, the side pieces of meso- and metasterna white. Thorax finely and sparsely, elytra more coarsely, deeply and closely punctate. Length 4.5$5 \mathrm{~mm}$. (Fig. 191, c.)

A boreal form of which a single specimen was taken by sweeping near Clear Lake. Steuben County. Nay 25. Probably occurs sparingly throughout the northern third of the State.

980 (305̃a). Coccinelta rexusta Melsh. Proc. Phil. Acad. Nat. Sci., III. 1846. 175 .

Broadly rounded, feebly convex. Head black, yellow near the eres: thorax described in key; elytra red or reddish-yellow, each with five black spots. riz. two sub-basal, two median and one large subapical, the latter prolonged forward to form a common sutural stripe extending nearly to middle. Length 5.5-6 mm. (Fig. 191, d.)

A southern species taken in Jennings. Floyd and Crawford counties; scarce. June 23-July 12. The name affinis Rand.. of the Henhaw list was cited in error. and venusta is therefore a distinct species, not a variety. C. notulata Tuls., black above and beneath. thorax with an oblique pale border. elytra each with a transverse 
reddish cross-bar, is a color variety of vemusta which has been recorded from near Cincinnati.

*981 (3064). Coccinella sanguinea Linn., Cent. Ins., 1763, 11.

Rounded-oval, somewhat convex. Head black, white in front (male), or with two white spots (female); thorax black with the front, sides and hind angles bordered with white, the front margin sending back three white spurs, the lateral ones sometimes reaching the base; elytra dull reddish-yellow, without spots, the refiexed margins paler. Be-

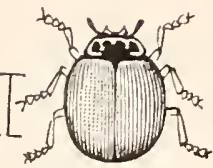

Fig. 190. (After Forbes.) neath black, the tibiæ and tarsi usually paler. Length $4-5 \mathrm{~mm}$.

(Fig. 190.)

Throughout the State; frequent. February 23-October 16. Hibernates in small numbers. Common on flowers of goldenrod in autumn. Our form described above is the var. munda Say.

982 (3065a). Coccinella abdominalis Say, Journ. Phil. Acad. Nat. Sci., IV, 1S24, 95; ibid. II, 233.

Pale reddish-yellow; thorax with seven black dots, five of which form an M-like mark on the disk; elytra described in key. Length 4.2-5 $\mathrm{mm}$. (Fig. 191, e.)

A southwestern species listed by both Casey and Leng from "Indiana," without definite locality. I have not seen a specimen from the State, and it occurs probably only in the lower Wabash Valley.
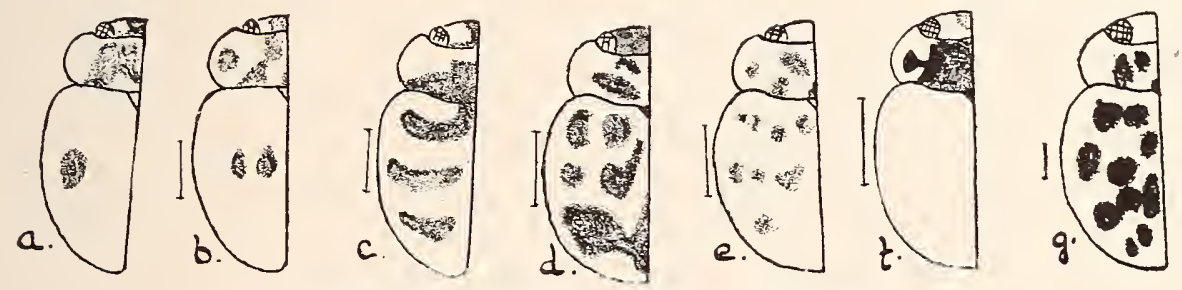

Fig. 191. Figures of Coccinellini. (After Leng.)

V. AdıLiA Mruls. 1851. (NL., an invented name.)

Two species, both introduced by commerce, occur in the State.

*9S3 (3067). Adalia Bipuncrata Limn., Syst. Nat., 175S, 364.

Oval. Head with two yellow frontal marks; thorax with an M-shaped black mark on disk, the broad pale margins without a spot; elytra reddish with a round black spot near center of each. Beneath black, the tarsi and sides of abdomen reddish-brown. Thorax finely and indistinctly punctate; elytra more coarsely punctate. Length 4-5 $\mathrm{mm}$. (Fig. 191, a.)

Frequent throughout the State. Jannary 1-December 7. Often passes the winter in houses, being found on the walls and windows in late autumn and early spring. Very beneficial and should be protected and allowed to escape in spring: 


\section{St (3066). Adulta frigida Schneid. Neu. Mag. Ent.. 1792. 172.}

Differs from bipunctate in haring a black point at center of broad yellow margin of thorax, or thorax black, with front, sides and basal bilobed spot sellowish; elytra reddish, usually with two small spots near middle (var. ophthatmica MIuls.), sometimes with two black bands (rar. disjuncte Rand.), rarely wholly without black markings. Elytra rather coarsely and densely punstured. Length $3.5-4.5 \mathrm{~mm}$. (Fig. 191, b.)

One specimen (var. ophthatmica) in Webster collection labeled "Ind." Ranges across the northern part of North America, as far south as Ohio and Missouri.

\section{Neonirsia Casey. 1899. (Gr., "new +Mysia.")}

This genus replaces Mysia of the Henshaw list. It is represented in the State by the single species:

9S5 (3073). Neomrsia puldata Say, Journ. Phil. Acad. Nat. Sci., V. 1S25, 301 ; ibid. II, 346.

Oral, strongly convex. Head black with two spots on sides of front yellow; thorax of male with disk black, the front margin narrowly, the sides broadly yellow, the latter enclosing a black spot; a small yellow spot in front of scutellum, which is. sometimes extended into a median pale space; in female the disk brown; elstra uniform dull reddish-brown. Under surface black, paler along the middle. Length 6-7 mm. (Fig. 191, $f_{\text {. }}$ )

Lake and Posey counties; scarce. May 20-July 8. Closely resembles Coccinella sanguinea but larger and with different markings on thorax.

\section{Anatis Muls. 1846. (Gr., "harmless.")}

Broadly oval or rounded convex species, above the medium in size and having the thorax less transverse than usual and the punetuation rather coarse and mequal. One species and a variety occur in the State.

$9 S 6$ (3075). ANATIS 15-PUnCTATA Oliv., Ent., VI, 1S0s, 1027.

Oral, rery broad, rathel convex. Fead black with two triangular yellow spots on front; thorax with disk black. enclosing two pale spots at base; side margins broadly pale, with a marginai black spot near base; elytra yellow or reddish-brown, each with eight black spots. one scutellar. one on the humerus, three forming a median band and three subapical. Beneath black, the tibix, tarsi and sides of abdomen pale l'eddish-brown. Length 6.5-8.5 mm. (Fig. 185, a.)

Throughout the State; frequent. April 18-October 22. Mates about mid-April and is then found in numbers on the flowers of the red haw (Cratcogus). In rery dark specimens the spots of elytra are indistinct. 
$986 a$ (- - ). Anatis 15-PUnctata mali Say, Journ. Phil. Acad. Nat. Sci., IV, 1824, 93; ibid. I, 192.

A variety of 15-princtata having the ground tint reddish-brown and each elytral spot surrounded by a broad pale border; the marginal spot of the median row dirided or geminate. Length $8-9 \mathrm{~mm}$. (Fig. 185, e.)

A single specimen was taken from beneath a chunk on the beach of Lake Michigan, near Tillers, Lake County, on May 13; 15-punctata being common along the beach on the same date.

\section{Psyllobora Chevr. 1806. (Gr., "a flea + to eat.")}

Small oval or rounded convex species, having the upper surface pale, spotted with a darker tint; scutellum minute; mesosternum truncate; tarsal claws with a large quadrate tooth on inner side near apex. One species occurs in Tndiana.

987 (307S). Psyllobora 20-macutata Say, Journ. Phil. Acad. Nat. Sci., IV, 1824, 96 ; ibid. II, 234.

Rounded or broadly oral, convex. Yellowish-white; thorax with five black or brownish spots, the one in front of scutellum the smaller; elytra each with nine spots, the two discal usually merged and sometimes joining the others partly together. Beneath pale brownish-yellow, the sternum and middle of rentral segments black. Thorax finely, elytra more strongly and closely, punctate. Length 2-2.5 mm. (Fig. 191, g.)

Frequent throughout the State. April 5-October 20. Probably hibernates. Occurs in early spring in numbers about the base of skunk cabbage and on leaves of various surubs.

\section{Tribe III. CHILOCORINI.}

Antennie very short, compact. narrowly clavate and inserted under a broadly dilated frontal plate. thus concealing their base; thorax very small. deeply emarginate in front and rounded behind; epipleura very broad, concave, strongly descending on the outer side; legs short, femora not extending beyond sides of body; tarsi beneath densely; spongy pubescert. Three genera compose the tribe, all of which are represented in Indiana.

\section{KEY TO INDLANA GENERA OF CHILOCORINI.}

a. Front tibia with a small tooth on outer margin near base; thorax pubescent toward sides; length less than $6 \mathrm{~mm}$.

IX. CHILOCORUS.

aa. Front tibia without a tooth; thorax not pubescent toward the side margins.

b. Body convex, not compressed nor excavated beneath; size small, not over $3.5 \mathrm{~mm}$.

X. Exochomus.

bb. Body very convex, subcompressed above, excavated beneath for the femora; size large, 6 or more mm.

XI. AxIoN. 
IX. Chiloconus Leach. 1817. (Gr., "lip or labrum + shield.")

Abdomen and epipleure concave for the femora; tarsal claws toothed.

*988 (3080). Chilocorus bivulnerus Muls., Spec. des Col. Trim., 1851, 460.

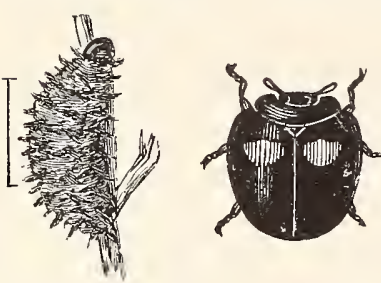

Fig. 192. Larva and adult. (After Forbes.)

Broadly oval, very convex. Black, shining; elytra each with a rounded red spot near the center; beneath black, the ventral segments red. Elytra finely but distinctly punctured. Length $4-5 \mathrm{~mm}$. (Fig. 192.)

Frequent throughout the State. January 8-November 20. Hibernates beneath rubbish, and on the wing on the first warm days of spring, when it is often to be seen resting on the sunny sides of rails, fence posts, trunks of trees, etc. A little later often found on the flowers of the red haw (Cratcogus).

\section{Exосномus Redt. 1843. (Gr., "prominent+shoulder.")}

Small rounded convex species having the tarsal claws toothed, hind legs not retractile and color of elytra variable. One species is known from the State.

989 (30S3). Exochomus marginipennis Lec., Amn. Lyc. Nat. Hist., I, 1824, 170.

Broadly oval, convex, glabrous, shining. Head and thorax black in female, the latter with sides reddish-yellow in male; elytra reddish-yellow with black markings, which, in the male at hand. consist of two large black spots on each. Elytra sparsely and finely punctulate. Male with fifth ventral segment truncate, disclosing a small sixth segment. Length $3 \mathrm{~mm}$.

Orange County; rare. June 2. Peaten from foliage of oak. The specimen belongs to Casey's variety latiusculus, in which the black spots of elytra are sometimes distinet, sometimes united at suture to form transverse bands. A member of the Austroriparian fauna.

\section{Axion Muls. 1850. (Gr., a classical name.)}

The species of this genus are the largest of the tribe and are strongly convex and subcompressed. They are colored nearly as in Chilocorus, having the upper surface deep black with one or two red spots on each elytron; very nearly without punctures, the thorax being very feebly punctate near the side margins and having the apical margin near the angles always more or less pale. 
990 (一). Axion plagiatum Oliv., Ent. VI, 1808, 1044.

Broadly oval, very convex. Black, strongly shining; head and narrow space near apical margins of thorax reddish; elytra each with a large round, brick-red spot on sides in front of middle. Beneath reddish-yellow, the middle of abdomen black. Length $6.5 \mathrm{~mm}$.

Known from the State by a single male taken by Wolcott near Pine, Lake County. May 20. Resembles Chilocorus bivuluerus, but much larger, more convex and with smooth upper surface. The head is usually wholly black and the red spot of elytron is said to be much larger in female than in male.

\section{Tribe IV. GENEINI.}

The principal characters of this group are set forth in the tribal key. 'The species are glabrous or nearly so and are among the most minute members of the Coccinellidx. The tribe is represented in North America by the single genus:

\section{Delphastus Casey. 1899.}

Antennæ well developed, with a compressed elliptical club; thorax as wide as elytra, short and transverse; scutellum well developed, a little longer than wide; coxæ all remotely separated; front femora greatly dilated; when in repose completely concealing the tibiæ and tarsi.

991 (3088). Delphastus pésillus Lec., Proc. Phil. Acad. Nat. Sci., Vi, $1852,135$.

Oblong-oval, when in repose almost globose. Black, very shining; head, legs and sides of thorax pale in the male. Head and thorax finely, sparsely punctate; the latter distinctly margined. Length $1.3-1.5 \mathrm{~mm}$.

T'hroughout the State; frequent. April 28-August 11. Beaten from vegetation or taken from beneath stones.

Trine V. HYPERASPINI.

Species below the medium in size, and having the body oval or hemispherical, compact and usually contractile; antennæ short and 11-jointed; epipleurx, in our genera, hollowed out for the reception of the knees of middle and hind legs; scutellum well developed and triangular; legs short, stout and strongly retractile; front coxæ narrowly separated; prosternum flat. Two genera are represented in Indiana.

KEY TO INDIANA GENERA OF HYPERASPINI.

a. Front tibixe with a strong spine on outer edge near middle; eyes with a small emargination in front.

XIII. BRachYacaNtha.

aa. Front tibia without spines; eyes entire; elytral spots well defined and usually fewer in number.

XIV. HYPERASPIS. 
XIIT. Brachracantha Cher. 1834. (Gr., "short+spine.")

Oval, strongly convex, black beetles, in our species having each elytron marked with either two or five distinct, rounded yellow or orange spots. Four species occur in the State.

KEY TO INDIANA SPECIES OF BRACHYACANTHA.

a. Elytra each with five clearly defined yellow spots, one humeral, one larger basal, two near the middle and one subapical.

b. Elytral spots, except the humeral, well developed and subequal in size.

c. Larger, 2.5-3 mm.; basal spot never much more than semicircular. broadly truncated by the basal margin.

992. URSINA.

ce. Smaller, 2-2.2 mm. ; basal spot almost fully circular.

993. STELLATA.

bb. Elytral spots smaller and unequal, the two median much smaller than the other's.

994. 10-pustulata.

aa. Elytra each with two spots, one basal, one subapical.

995. QUADRIPUNCTATA.

992 (3095). Brachyacantha Uksina Fab., Mant., 1798, 61.

Elongate-oval, convex. Black, shining; head yellow; thorax with apical margin yellow in male, the region of apical angles only. yellow in female; elytra with spots as described in key. Beneath black; legs pale, the base of femora darker. Thorax and elytra both finely but distinctly and evenly punctate. Length 2.7-3.5 $\mathrm{mm}$.

Throughout the State; frequent. May 21-July 20. Occurs especially on the leaves and flowers of the common milkweed ( $A s$ clepias syriaca L.)

993 (- - ). Brachyacantua stfllata Casey, Journ. N. Y. Ent. Soc., VII, $1899,117$.

Close to ursina and perhaps only a variety. Color nearly the same, the spots proportionally larger. Punctures of elytra coarser and sparser; surface more shining. Length 2-2.2 $\mathrm{mm}$.

Putnam, Lawrence, Orange. Posey. Perry and Crawford counties; frequent. May 11-.June 1. The legs are not always "pale throughout' ' as mentioned by Caser, the basal half of femora being sometimes dark.

994 (3095a). Brachyacantha 10-pustulata Mels., Proc. Phil. Acad. Nat. Sci., III, $1847,179$.

Resembles ursina but smaller. Pale frout border of thorax wider in male; head of female sometimes black with an orange spot on vertex. Punctures coarser and much less numerous. Length 1.8-2.3 mm.

Throughout the State; scarce. May 31-June 24. Usually given as a variety of ursina, but the differences are sufficient to justify its hoiding specific rank. 
995 (3096). Brachyacantha quadripunctata Melsh., Proc. Phil. Acad. Nat. Sci., III, 1847, 178.

Broadly rounded. Black, shining, coarsely and rather sparsely punctate; head yellow in miale, black with a yellow V-like mark in female; thorax with front margin narrowly yellow in male, the region of apical angles broadly yellow in that sex, narrowly yellow in female; elytral spots large, rounded. Beneath black, the tibia and tarsi paler. Length $3-3.5 \mathrm{~mm}$.

Vigo, Posey and Jackson counties; scarce. Occurs especially on maple trees infested with plant lice. May 20-July 8. Casey calls it basalis Melsh. The two names were proposed by Melsheimer at the same time, 4-punctata on page 178, and basalis on page 179, the former therefore having priority.

\section{Hyperaspis Redt. 1843. (Gr., "above + a shield.")}

Small, oval or rounded, black beetles having the elytra margined or spotted with paler, often both. Distinguished from Brachyacantha by having the outer margin of front tibiæ unarmed. Eight species and one variety are known from Indiana.

KEY TO INDIANA SPECIES OF HYPERASPIS.

a. Side margins of elytra with a reddish or yellow stripe, this rarely broken so as to folm a subapical spot.

b. Elytra without a second stripe, but often with a red or yellow spot on side of disk.

c. Discal spot of elytra, if present, comnected with marginal band.

d. Stripe on side of elytra expanding into a large rounded discal spot a little behind the middle.

996. BOLTERI.

$d d$. Stripe only feebly undulating on the inner margin, its hind portion often separated as a distinct oval subapical spot.

997. FIMBRIOLATA.

cc. Discal spot of elytra distinct from marginal band, the latter sometimes broken into separate spots; side margins of thorax yellow in both sexes.

998. UNDULATA.

bb. Elytra with a second yellow stripe on side of disk. 999. 4-vittata.

aa. Side margins of elytra without a reddish or yellowish stripe.

e. Elytra black with one or two lounded red or yellowish subapical spots and usually with a large discal spot.

f. Side margins of elytra without a spot; legs in part or wholiy black. g. Subapical spot single.

h. Larger discal spot present, subapical small; sides and apical margin of thorax yellow in male.

1000. SIGNATA.

7h. Discal spot absent, subapical larger; sides of thorax with a large rounded orange spot.

1001. BIGEMINATA.

gg. Subapical spots two, discal spot present; sides of thorax yellow in both sexes.

1000b. var. PROBA.

$f f$. Side margins of elytra with a spot opposite the discal spot; legs yellow.

1002. PRATENSIS.

cc. Elytra black without subapical spots but with a large round spot near the center of disk; thorax as in signata.

1000a. Tal*, BINOTATA. 
996 (3100). Hyperaspis bolteri Lec., T'rans. Amer. Ent. Soc., VIII, 1880, 186.

Broadly rounded, strongly convex. Black, shining; head and sides of thorax of male pale; elytra with a pale red margin, reaching nearly to apex, this expanded into or confluent with a large discal spot a little behind the middle; front and middle legs pale. Upper surface strongly and rather closely punctured. Length $3 \mathrm{~mm}$.

Taken in small numbers by Wolcott near Pine, Lake County. April 29-June 4. Described from Illinois.

*997 (3101). Hrperaspis fimbriolata Mels., Proc. Phil. Acad. Nat. Sci., III, 1847, 180.

Rounded, subconvex. Black, shining; elytra with a narrow yellow marginal stripe; this often broken on apical third, leaving a free, oval subapical spot (var. dissoluta Cr.). Male with head and thorax in front and on sides, yellow. Upper surface coarsely and rather sparsely punctate. Length $2.5 \mathrm{~mm}$.

Lake, Vigo, Dubois and Perry counties; rare. May 14-December 10. Hibernates beneath mullein leaves and other rubbish; taken in spring by sweeping.

*998 (3105). Hyperaspis undulata Say, Journ. Phil. Acad. Nat. Sci., IV, 1824, 92 ; ibid. II, 231.

Elongate-oral; subdepressed. Black, shining; male with head, narrow apical margin and sides of thorax yellow; female with only the sides of thorax yellow; elytra with an ovai spot near center and a narrow threelobed band on sides, yellow. Length $2.3-2.5 \mathrm{~mm}$.

Throughout the State; frequent. March 20-December 7. Occurs on herbage in low, moist ground.

999 (3122). Hyperaspis 4-vittata Lec., Proc. Phil. Acad. Nat. Sci., Vi, $1852,133$.

Broadly ovate, subdepressed. Black, shining, finely punctate; side margins of thorax narrowly yellow; elytra with a narrow marginal and a wider dorsal stripe pale yellow, the latter not reaching base or apex. Head and thorax of male reddish-yellow. Length $2.5 \mathrm{~mm}$.

Taken by Wolcott near Pine, Lake County; scarce. May 21June 4.

1000 (3110). Hyperaspis signata Oliv., Ent., VI, 1801, 92.

Rounded, strongly convex. Black, shining, thickly and rather strongly punctate. Male with head and narrow apical and side margins of thorax. yellow; female with head and thorax wholly black. Subapical spot of elytra about one-fourth the size of one on disk. Length $2.5-2.7 \mathrm{~mm}$.

Marion County; scarce. April 25. In two specimens at hand one has the subapical spot red and situated about as far from the 
hind margin as from the suture; the other has the spot yellow and located much farther from the suture, in msual situation of second spot in proba.

1000a (-). Hyperastis signata motata Sily, Jomrn. Ihil. Acial. Niat. Sci., V, 1826, 302 ; ibid. II, 346.

A variety of signata having the subapical spot lacking. Color and structure otherwise exactly as in that species ; the females a little larger. Length 2.3-3.5 $\mathrm{mm}$. (Fig. 192a.)

Throughout the State; frequent. Hibernates beneath chunks and rubbish in waste places. January 6-October 17. Usually regarded as a mere form of signata. Caser, however, gives it specific rank.

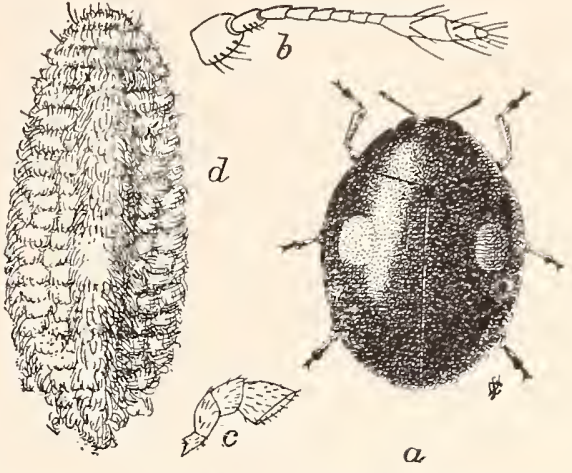

Fig. 192a. $a$, beetle; $b$, antennæ: $c$, maxillary palpi $d$, pupa. (After Forbes.)

1000b (3112). Hyperaspis signata Proba Say, Journ. Plil. Acad. Nat. Sci.. V, 1S26, 303; ibid. II, $34 \mathrm{~T}$.

Resembles signata but smaller and less conrex. Head and thorax of male as in that species; elstra with two small subapical reddish-yellow dots and a much larger and deeper red discal spot. Surface more finely punctured. Length $2.3-2.7 \mathrm{~mm}$.

Lake, Steuben, Knox and Crawford counties; scarce. May 16July 10. A large series of specimens will doubtless show signata, binotata and proba to be color forms of one species.

1001 (3114). Hyperaspis bigeminata Rand., Bost. Journ. Nat. Hist. II. 32.

Rounded, convex. Black, shining; head with a large sellow frontal spot in male, wholly black in female; thorax with a large internally rounded orange spot each side; elytra with a similar circular spot just before the apex. Elytra strongly, thorax more finely punctured. Length 2.5-2.8 $\mathrm{mm}$.

Lake, Marshall, Kosciusko, Putnam and Marion conties; scarce. May 25--July 4.

1002 (3115). Hyperaspis pratensis Lec.. Proc. Phil. Acad. Nat. Sci.. VI. 1852, 154 .

Broadly oral, subconvex. Black, shining; male with head and broad side margin of thorax yellow; elytra each with three rellow spots, the largest on middle of disk, a marginal one opposite this and one subapical. Thorax finely and closely, elytra more coarsely and sparsely punctate. Length 3-3.5 mm.

One in Webster collection labelled "Ind." Recorded heretofore only from Kansas. 


\section{Tribe VI. SCXMNINI.}

This tribe embraces a large number of small species readily recognized by the distinct pubescence of the upper surface. The genus Smilia, though composed of apparently glabrous forms, is combined with the other genera on account of a similarity in structure. In all our forms the antennæ are scarcely as long as the head, thorax deeply emarginate in front and rounded behind; front and middle legs more or less contractile, with the thighs sulcate beneath for the reception of the tibix. Casey separates the tribe into six genera. four of which are represented in Indiana.

\section{KEY TO INDIANA GENERA OF SCYMNINI.}

a. Thorax not deeply emarginate; antenne apparently 11-jointed, free; front coxæ moderately sepurated.

b. Thorax with a fine, obliquely impressed line behiud the front angles; body apparently glabrous, yet finely pubescent under high power; tarsal claws simple.

XV. SuILIA.

bb. Thorax without an oblique line near the front angles; body always distinctly pubescent; tarsal claws bifid.

$c$. Clypeus prolonged for a considerable distance before the eyes, the sides converging; antennæ inserted in small shallow emarginations just before the eyes; prosternum flat, not at all deflexed toward the tip, generally bicarinate.

XVI. Scruires.

ce. Clypeus extremely short before the eres, truncate with rounded angles, the antenna inserted under its sides adjoining the eyes; prosternum transrersely convex, not carinate, broadly and gradwally deflexed, forming a protection to the mouth in repose.

XVII. Stethorus.

a a. Thorax very short and broad and deeply emarginate in front; antennse apparentls 9-jointed; front coxie very widely separated.

XVIII. CEphaloscruxus.

XV. Samla Weise. 1891.

Here belong very small rounded species formerly classed under the genus Pentitia. Of the six listed from the United States, one is known from Indiana.

1003 (3090). Smilia misella Lec., Proc. Amer. Phil. Soc., XVII, 187S, 400.

Oral, convex. Uniform black, shining. Thorax nearly smooth, the impressed line near the front angles fine and indistinct. Elytra rather coarsely, sparsely and somewhat unerenly punctate. Length $.8-1 \mathrm{~mm}$. (Fig. 193.)

Throughout the State; frequent. April 13-May 29. Occurs especially on fruit trees -infested with San José scale and one of the most beneficial beetles preving upon that injurious insect. 
XVI. Scrmnus Kug. 1794. (Gl"., "a cubor whelp.")

This gemus comprises a very large number of minute, pubescent forms which occur on foliage in spring and summer and are readily taken by beating. Horn, in his "Studies' in 1895, listed and described 45 species from the United States. Casey, in his Revision in 1899, increased this number to 118 and left the genus, as Bowditch has well put it, "a wilderness." Thirteen species have been recognized among those collected in Indiana, while several others doubtless occur.

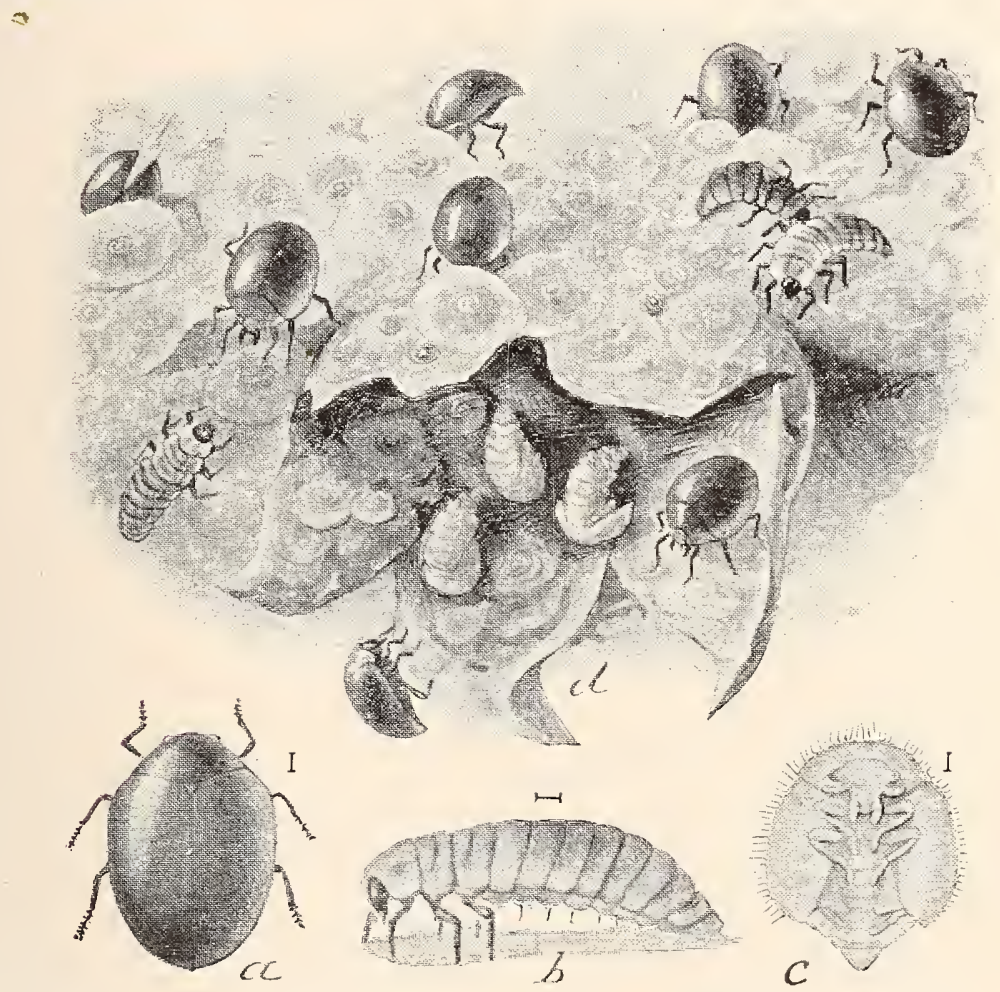

Fig. 193. Smilia misella; $a$, adult; $b$, larva; $c$, pupa; $d$, all stages, larva and adults feeding on San José scale in calyx cup of pear. All much enlarged. (After Howard and Marlatt.)

As the term "metacoxal line" is used extensively in the key, I quote from Dr. IIorn's Revision of the genus as follows: "The first ventral segment exhibits the character of greatest value in the division of species. Behind the coxal cavity is a slightly elevated line beginning at the inner edge of the cavity passing more or less obliquely and curved toward the first suture, sometimes joining the suture and continuous with it (Fig. 194. No. 1), or running parallel with the suture (Fig. 194, No. 2). or recurving to the front and when entire ending near the front angle of the segment. (Fig. 194, No. 4). In the present essay this line is called the "metacoxal line.', Casey calls the lines "abdominal lines." To see them plainly the hind femora must be litted up or pushed to one side and 
the specimens should be so mounted that this can be readily done. For convenience the Indiana species are first separated into two groups.
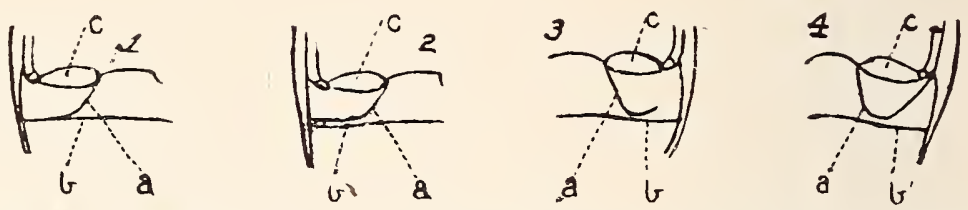

Fig. 194. a, metacoxal line; $b$, first ventral suture; $c$, hind coxal cavity. (After Horn.)

KEY TO GROUPS OF SPECIES OF INDIANA SCYMNUS.

a. Metacoxal line incomplete, gradually curring into the first rentral suture and forming a part thereof, or not joining said suture. (Fig. 194. Nos. 1, 2 ánd 3.)

Group $A$.

a a. Netacoxal line forming an entire arc beginning at the inner border of the coxal carity and ending at or near the outer front angle of the first segment. (Fig. 194, No. 4.)

Group $B$.

Group A.

This group incluries the Inciana species belonging to Groups 1. B and C of Morn's "Studies in Coccinellide," and in addition a few that have since been described.

KEY TO SPECIES OF GROUP A.

a. Metacoxal line passing in an oblique curve from the hind coxal cavity to the first ventral suture and joining the latter. (Fig. 194, No. 1.)

b. Elytra piceous, each with two pale spots.

c. Head and thorax yellow, the latter sometimes with piceous basal spot.

1004. LIEBECKI.

cc. Head and thorax black: form oval; elytral spots small and oval.

MYRMIDON.

bb. Elytra piceous with a large yellow spot at apex, but without spots on disk.

d. Thorax black with the apex narrowly, the front angles more broadly yellow.

dd. Thorax yellow with a black basal spot.

1005. TERMINATCS. 1006. PARTITUS.

a . Metacoxal line not joining the first rentral suture.

c. Metacoxal line extending outward, parallel with the suture and at a slight distance therefrom. (Fig. 194, No. 2.)

f. Elytra wholly reddish-brown or dull brownish-yellow.

ff. Elytra black or piceous. marked with rellow spots.

1007. INTRUSCS.

$g$. Each elytron with one rounded yellow spot behind the middle; thorax black.

gg. Each elytron with two oval spots.

1008. FLAVIFRONS.

ORNATUS.

ce. Metacoxal line recurved at the outer end (Fig. 194, No. 3) ; elytra black, narrowly tipped with red; thorax with black disk and red margins.

1009. AMERICANUS. 
1004 (-). Scrmpus liebecki Horn, Trans. Amer. Ent. Soc, XXIt, $1895,89$.

Oval, convex. Head and thorax yellow, the latter darker in front of scutellum; elytra piceous with a narrow apical borter, a small round spot in front of middle, nearer the suture than the side, and a slightly sinuous crossbar one-third from apex. yellow. Abdomen reddish-yellow, punctate. Legs yellow. Length 1.2-1.5 min. (Fig. 19., a.)

I have not seen this species from the State. Part of Horn's types came from near Elkhart. Indiana, and were probably collected by R. J. Weith; others were from southern New .Jersey.

S. myrmidon Muls., length $1.5-2 \mathrm{~mm}$.. is known from Pennsylvania and Maryland.
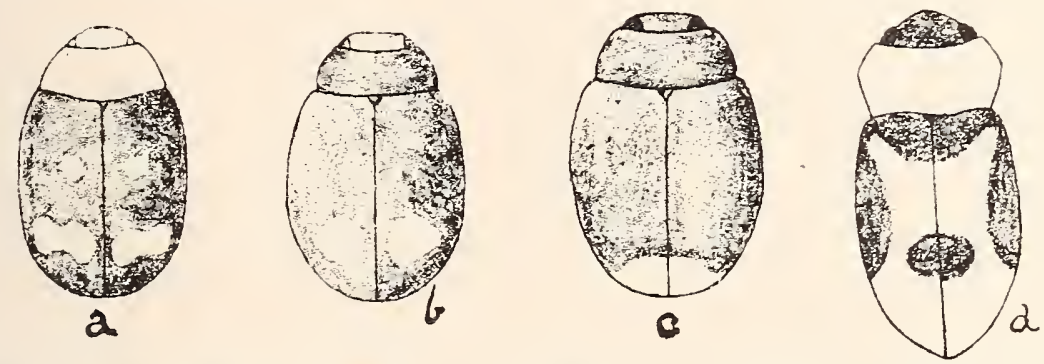

Fig. 195̃. a, Scymnus liebecki; b, S. flavifrons; c, S. terminatus; d, Coccidula lepida. All greatly enlarged. (After Horn.)

1005 (3135). Scymnus terminatus Say, Bost. Journ. Nat. Hist., I, 1835, 203 ; ibid. II, 671.

Oval, very little longer than wide. Piceous; head, narrow side margins of thorax, legs and apex of elytra reddish-yellom. Thorax distinctly narrower in front, the disk rather closely punctate. Elytra one-third longer than wide, a little more coarsely but less closely punctate; abdomen yellow, piceous at base or wholly piceous; legs reddish-yellow. Length $1.5-1.8 \mathrm{~mm}$. (Fig. 195, c.)

Lawrence. Clark. Perry and Posey comnties; scarce. April 22October 16.

1006 (-). Scrandes partitus Casey, Journ. N. Y. Ent. Soc.. VI. 1899. 158.

Resembles terminatus but differs in color of thorax. Elytra broadly oral, together scarcely longer than wide. the punctures closer than in terminatus and the pubescence less conspicuous. Length $1.5-1.7 \mathrm{~mm}$.

Knox and Poser counties: rare. April 21-September 2. Described from Texas.

1007 (-). Scrmats intrusus Horn, Trans. Amer. Ent. Soc. XXII. 1895. 93.

Oval, rery little longer than wide. moderately convex. Dull brownishyellow throughout, or slightly darker along the suture. Thoracic disk

$[34-23402]$ 
sparsely and indistinctly punctate. Elytra longer than wide, rather closely. not coarsely punctate; pubescence coarse and conspicuous. Length 1.5 $2 \mathrm{~mm}$.

Starke, Putnam and Posey counties; a single specimen from each. March 20-December 6. One was taken from beneath chunk in a fence row on the latter date.

S. ormatus Lee. length $2-2.5 \mathrm{~mm}$., is a boreal species which may occur in northern Indiana.

1008 (3133). Scranus flarifrons Melsh., Proc. Phil. Acad. Nat. Sci., III, $1847,181$.

Oval. Black; an oval yellow spot on each elytron one-third from apex and equally distant from side and suture; head often. tibise and tarsi always, yellow. Thorax narrower in front, the surface sparsely punctate. Elytra rather coarsely punctate. Length 1.5-2 mm. (Fig. 195, b.)

Steuben, Vermịthion. Marion and Martin counties; scarce. Probably hibernates. Narch 14-June 15. Those on the former date were taken from a freshly cut maple stump where they were feeding on sap. Our form is the one commonly called bioculatus Muls., which both Horn and Casey place as a small variety of flavifrons.

1009 (3138). Scymnes animicands Muls. Spec. Sec., 1850, 965.

Broadly oval, rather strongly convex. Piceous black; thorax usually orange red with a central piceous space, sometimes black throughout; elytra narrowly margined with red at apex; legs yellow or piceous. Thorax narrowed in front, sides feebly curved, disk sparsely punctate. Elytra coarsely and sparsely punctate. the pubescence coarse, rather long, ashy and conspicuous. Length $2-2.5 \mathrm{~mm}$.

Throughont the State; common. Nay 5-December 25. IIibernates beneath $\operatorname{logs}$ and rubbish. Taken while sweeping grass or beating foliage.

\section{Group L:}

This group corresponds to Group I). of Horn's paper, the metacoxal line forming a complete are beginning at the inner edge of the hind coxal cavity. sometimes touching, at the apex of the curve. the first suture and ending nearly at the outer front angle of the segment. (Fig. 194. No. 4.)

KEY TO SPECIES OF GROUP B.

a. Form broadly oval, the margins of thorax and elytra continuous; elytra uniform in coloration on the disk, not considering the apex.

b. Elytra pale at apex, either merely bordered with yellow or with an apical area of that color.

c. Elytra with a wide, pale, common area at apex. 
d. Form broadly oval; apical spot not extending over one-fifth the length of suture.

c. Apex of elytra dull yellow; thorax sparsely and obsoletely punctate throughout. (Fig. 196, c.) 1010. Fraterisus.

ee. Apex of elytra reddish; thorax distinctly and coarsely punctate at middle, more finely and sparsely at sides.

1011. CACDALIS

dd. Form oblong-oral; apical spot comprising nearly a third of the rpper area; last three segments of abdomen sellow.

1012. RUBRICAUDA.

cc. Elytra narrowly pale at apex.

f. Thorax partly black.

g. Legs entirely reddish-rellow; first rentral segment of male without pubescence. (Fig. 196, a.) 1013. CoLlaris.

gg. Legs pale, the femora piceous; first rentral segment of male with a median smooth area surrounded by short pubescence.

1014. PUXCTICOLLIS.

ff. Thorax entirely sellow.

1015. CERHCALIS.

bb. Elytra entirely black.

h. Species larger. 2-2.5 $\mathrm{mm}$; thorax entirely black.

1016. TENEBROSTS.

hh. Smaller. not orer $1.5 \mathrm{~mm}$; front angles of thorax usually pale.

NATCS.

a1, Form oblong; thorax narrorer at base than base of elytra; elstra black, each with a small oral red spot at center of disk. (Fig. 196, b.)

PUNCTATUS

1010 (3145). Scrancs fraterixts Lec., Proc. Phil. Acad. Nat. Sci., VI, $1852,138$.

Broadly oral. Piceous black; head black or yellowish; thorax reddishrellow at sides. with a central piceous spot $\pi$ hich is variable in size; elytra with a sellowish area at apex which nerer extends along the suture more than a fifth of its length. Abdomen piceous, paler at sides and apex; legs reddish-yeliom. Thorax and elstra punctate but not closely nor densely. Length 2-2.5 mm. (Fig. 196, c.)

Our most common species; found throughout the State. Hibernates. January 6-Norember 1. This species includes the form generally listed as hamor hous Lec. the types showing. as stated by Horn, "that they were established on uniques. the differences being merely individual, fratemus having the greater extent of yellow on the thorax." **

1011 (3149). Scrmxus catdalis Lec., Agass. Lake Sup.. 1850, 238.

Broadly oral. Black; head. side margins of thorax, tibiæ and tarsi and large. often somerhat indistinct spot on apex of elstra, dull reddish: femora piceous. Thorax but little more than twice as wide as long, sides moderately convergent. erenly curved. Elytra quite coarsely and closely but not densely punctate. First rentral segment of male rith a large median area at apex glabrous and impunctate. Length $2-2.3 \mathrm{~mm}$.

*Trans. Amer. Entom. Soc., XXII, 101. 
Taken by Wolcott near Pine. Lake County; rare. May 20. Described from Lake Superior and Genrgia. Resembles the preceding but more robust, with larger spot on apex of elytra and with piceous spot on thorax reaching nearly to apex.

1012 (- - ). Scymnus rubricauda Casey, Journ. N. Y. Ent. Soc., VII, $1899,141$.

Oblong-oval, subconvex. Black; sides of thorax and a large apical elytral space reddish-yellow; head piceous or yellow; antennæ, legs and last three segments of abdomen reddish-yellow. Elytra rather closely and distinctly, thorax sparsely and indistinctly, punctate. Length $1.8-2 \mathrm{~mm}$.

Throughout the State; frequent. Hibernates. January 7-July 12. Known from fraternus by its smaller size, more narrow and less convex form and the larger relative area of yellow spot at apex of elytra.
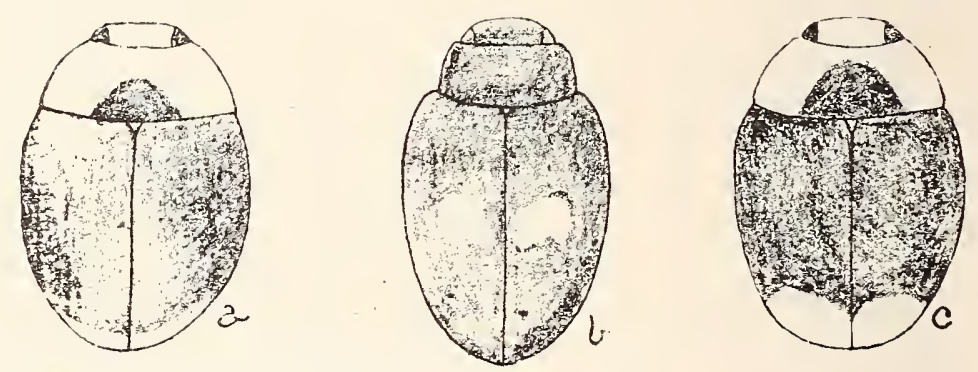

Fig. 196. a, Scymnus collaris; b, S. punctatus; c. S. fraternus. (After Horn.)

1013 (3148). Scrmnus collaris Melsh., Proc. Phil. Acad. Nat. Sci., III, $1847,180$.

Regularly oval, convex. Piceous, rather shining; head and thorax reddish-yellow, the latter with a median piceous spot of variable size; apex of elytra narrowly pale red; abdomen piceous, the last three segments usually yellowish; legs entirely reddish-yellow. Thorax more distinctly punctate at middle than at sides. Length $2-2.2 \mathrm{~mm}$. (Fig. 196, a.)

Martin County; scarce. July 13.

1014 (3152). Scymnus puncticoltis Lec., Proc. Phil. Acad. Nat. Sci., Vi, $1852,139$.

Broadly oval, convex. Biack, rather dull; head piceous; thorax black with the sides indefinitely yellow, usually with the apical angles alone pale; apex of elytra narrowly reddish; tibixe and tarsi pale, femora piceous. Thorax more closely punctate toward the sides. Elytra rather closely and more coarsely punctured than thorax. Length $2-2.5 \mathrm{~mm}$.

Southern half of State, frequent; Steuben County, rare. April 21-December̀ 23.

1015 (3153). Scrmaus cervicatis Muls., Spec. Sec., 1850, 984.

Oval, convex. Head, thorax and legs reddish-yellow; elytra piceous, at apex very narrowly margined with reddish-yellow; abdomen black, the 
terminal segments pale. Thorax very sparsely punctate, the basal marginal line distinct. Elytra rather coarsely but not closely punctate. Length $1.8-2.2 \mathrm{~mm}$.

'Throughout the State; frequent. May 11-November 28.

1016 (3156). Scymnus Teneirosus Muls., Spec. Sec., 1850, 989.

Broadly oval, strongly convex. Uniform black, shining; sparsely pubescent; legs red or reddish-brown. Thorax narrowed in front, sides feebly curved, surface finely, equally and sparsely punctate. Elytra much more coarsely and closely punctured than thorax. Length $1.8-2.3 \mathrm{~mm}$.

Three specimens from near Pine and Hessville, Lake County, and one from Warren County. May 11-July 14. Should occur throughout the State.

S. nanus Lec., legs reddish, length $1.3-1.5 \mathrm{~mm}$., is known from Michigan and Florida. S. punctatus Melsh., length $1.5 \mathrm{~mm}$., is recorded from Canada, Pennsylvania and Texas.

\section{STEThorus Weise. 1891. (Gr., "breast + margin.")}

The members of this genus are nearly as small as those of Smitia. They differ from Scymnus, as shown in the generic key, mainly in the structure of the front of head and prosternum.

1017 (3160). Stethorus punctum Lec., Proc. Phil. Acad. Nat. Sci., VI, $1852,141$.

Broadly oval, convex. Black, shining; antennæ and legs yellow, the femora black, with the apex pale. Thorax narrowed in front, the surface sparsely punctate at middle, more densely and coarsely at sides. Elytra sparsely but distinctly punctate; covered with a sparse and fine pubescence. Length $1.2-1.5 \mathrm{~mm}$.

Throughout the State; frequent. April 17-October 17. Taken by sifting rubbish from damp hillsides and borders of marshes.

\section{Cephaloscymnus Crotch. 1873. (Gr., "head + cub.")}

Small, oblong-oval, rather depressed pubescent species, having the front coxal cavities open behind; head large, front vertical; last joint of maxillary palpi long, slender, pointed; thorax at base narrower than elytra; prosternum short and broad.

1018 (3169). Cephaloscrmeus zimmermanni Croteh, Trans. Amer. Ent.

$$
\text { Soc., IV, 1S73, 3S2. }
$$

Broadly oval, feebly convex. Black, slightly bronzed, sparsely clothed with gray pubescence; legs piceous, tibir and tarsi paler. Thorax three times as wide at base as long at middle, coarsely and closely punctured: front angles prominent on account of the deeply emarginate apex. Elytra more sparsely and coarsely punctate than thorax. Length 1.5-2.2 $\mathrm{mm}$. 
Knox County; rare. July 2. A southern form known heretofore from Maryland, South Carolina and Ohio.

\section{Tribe VII. EPILACHNINI.}

This tribe is represented in the United States by two or three large pubescent species. belonging to the single genus Epilachna. They have the margin of the elytra rather strongly reflexed; epipleuræ horizontal. broadly concare; legs moderately retractile; tarsal claws cleft, the lower cusp being nearly as long as the upper one. One species occurs sparingly in southern Indiana.

\section{Epilachia Cher. 1844. (Gr., "abote + woolly hair.")}

1019 (3171). Epilachna borealis Fab., Srst. Ent., 1775, S2.

Ters broadly oral. Pale orange sellow. shining. the pubescence short, rather abundant. Thorax with an apical and basal black spot on the me-

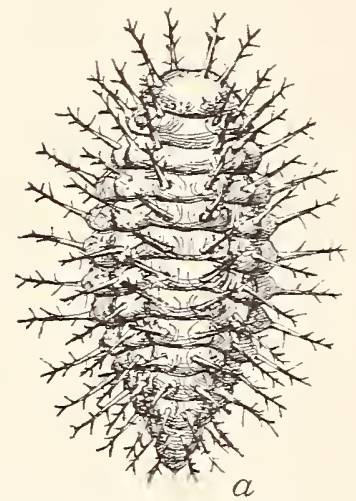

a

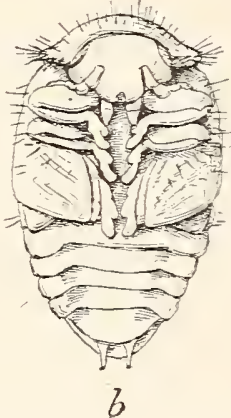

b

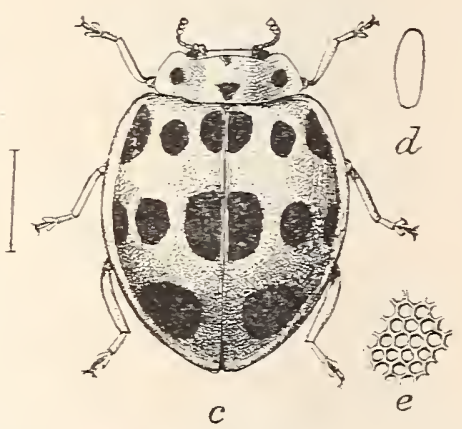

$c$

Fig. 197. Epilactina borealis: $a$, larva; $b$, pupa; $c$, adult beetle; $d$, egg; $e$, surface of same. All highly magnified. (After Chittenden,"Bull. XIX, Dir. Ent., U. S. Dep. Agr.)

dian line, the basal the larger. and one at each side near the margin. Elytra each with seren black spots, three sub-basal, three median and one subapical, the last named the largest; the inner sub-basal and median on each side uniting to form two common sutural spots. Metasternum blackish, legs pale. Length i-S mm. (Fig. 197.)

Orange, Perrer. Crawford and Poser counties; frequent. April 9-November 9. Taken beneath bark in early spring and late fall. and at other times on foliage. Hibernates in large colonies beneath leares in low ground. This insect. known as the "squash ladybird." presents a remarkable exception in food habits to other members of the Coccinellidæ. the larræ being herbivorous and feeding upon the leaves of pumpkin. squash and allied plants. It is rellow, armed with forked spines. and feeds upon the lower side of the leaf. while the adult usually feeds upon the upper surface. They first mark out a circle or semicircle on the leaf and then feed within 
this and nowhere else, consuming the epidermis and parenchyma and leaving the reins and nerveres almost intat. Haud picking of the adults and large ego-clusters is the best remedr, if done when ther first appear: arsenites. either dry or in solution. can also be applied with snceess.

Tribe VIII. COCCIDULINI.

Small pubescent species having the antenne long and slender, with loose. serrate. 3-jointed club: thorax narrowed at base, feebly sinuate at apex: prosternum bicarinate. rather widely separating the coxie; legs free, rather stout: claws feebly bifid. One genus is known.

XX. Coccidul Kug. 179s. (Gr.. "scarlet berry.")

$1020(3170)$. Coccidula lepida Lec., Proc. Phil. Acad. Nat. Sci., VI, 1852. 132.

Elongate-oral. Head and part of under surface black; thorax dull yellow with a transrelse black spot near apex; elytra dull rellow, black at base and along sides to behind the middle and with a common transrerse sutural black spot at apical third. Punctures of elytra rather coarse, deep and uneren, the larger ones in somerhat irregular rows. Length $3 \mathrm{~mm}$. (Fig. 195, d.)

One specimen in Field Inseum collection labelled "Ind." Probably from St. Joseph County. A species of northern range which is said by LeConte to occur on plants near water.

\section{Family XVII. FNDOMTCHIDEE.}

\section{The Hindone Fungtés Beetles.}

To this family belong a limited number of small-sized, oval or oblong beetles. which occur on woody fungi. in decaying wood or beneath $\operatorname{logs}$ and bark. Some of them are very prettily marked with black or red. and most of them feign death or "play possum" when first uncovered. The name of the typical genus. Endomychus. is derived from two Greek words, meaning" "within" and "a concealed place," and probably refers to the concealed habitations of the beetles and their larræ in the substance of tree fungi, rotten wood, etc. They difier from the Coccinellidx. to which they are the most closely allied. by having the form usually less conver and more elongate. in haring much longer antenne. and by the termina? joint of the maxillary palpi being oral or triangular instead of securiform or hatchet-shaped. 
In addition to the characters mentioned they have the antennx situated upon the front, usually about half the length of the body, 9-, 10- or 11-jointed, the last three joints forming a

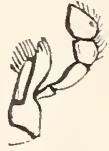
distinct club; head moderate in size, prolonged in front into a short muzzle; thorax usually nearly square, trisuleate at base, often with distinct wide thin palpus Endomychus. margins turned up at the sides; elytra rounded at tip (After LeBaron.) and covering the dorsal segments; front and middle coxie globose, hind ones transverse; front coxal cavities open hehind; abdomen with five free ventral segments; legs of moderate length. not retractile; tarsi either 4-jointed or apparently 3-jointed, but then with a smali concealed joint at the base of the terminal one; tarsal claws simple.

The larvæ are usually moderately elongate, only slightly convex, scaly above and with the sides of the body bearing a number of appendages. While not injurious, the larvæ cannot be said to be especially beneficial, their food consisting principally of fungi and perhaps the juices of decaying wood. Fully 500 species of the family are known, less than 30 of which have been described from the United States. Of these ten are known from Indiana, while a few others doubtless occur.

The principal literature treating of the North American species of the family is as follows:

LeConte.-"Synopsis of the Endomychidi of the United States.' in Proc. Phil. Acad. Nat. Sci., VI, 1853. 357-360.

Crotch.- "Synopsis of the Endomychidæ of the United States," in Trans. Amer. Ent. Soc., IV. 1873, 359-363.

Wickham._- "The Endomychidx and Erotylidæ of Ontario and

Quebec,' in Can. Ent., XXVI. 1894, 337-339.

Our representatives of the family may be divided among two subfamilies, separated as follows:

\section{KEY TO SUBFAMILIES OF ENDOMYCHIDA.}

a. Tarsi distinctly 4-jointed; size smaller. less than $4 \mathrm{~mm}$.

Subfamily I. Mrсetæixæ, p. 534. aa. Tarsi dilated, apparently 3-jointed, the third joint minute and hidden between the lobes of the second; larger, usually more than $4 \mathrm{~mm}$.

Subfamily II. FNdomrehinæ, p. 537.

\section{Subfamily I. MYCETAEINAE.}

Very small species having the tarsi narrow, the third joint distinct, though shorter than second. The following genera are perhaps represented in the State: 
KEY TO INDIANA GENERA OF MYCETAENAE.

a. Body lounded or oral, pubescent.

b. Antenna 10-jointed; thorax with well marked basal lines. extending half the length.

I. Rirymbes.

bb. Antennæ 9-jointed; thorax with a iarge, finely margined basal lobe and a basal line each side rumning forward and then curving inwards.

ANAMORPIUCS.

a a. Body oblong or elongate.

$c$. Pubescent; base of thorax not, or rer's feebly, nar'orel than middle, but slightly narrower than base of elytra.

II. Srarbiotes.

cc. Glabrous; base of thorax distinctly narrowed, that of elytra rery eridently the wider.

d. Thorax unspotted. with deep basal impressions and lines extending from base half the length.

III. RHaxis.

dd. Thorax with black spot on center and with deep impressions, without lines; antennal club of male rery large. (Fig. 4, No. 8.)

IV. Phymaphora.

\section{Rhymals Gerst. 1858.}

Very small, convex. pubescent species, having the thorax deeply impressed on each side; labrum prominent and truncate: antennal club abruptly 3-jointed and sides of thorax strongly margined. They resemble the members of the genus Scymmus of the Coccinellidx, but are readily distinguished by the narrow, t-jointed tarsi. Two species and one variety oceur in the State on old fungus-corered logs.

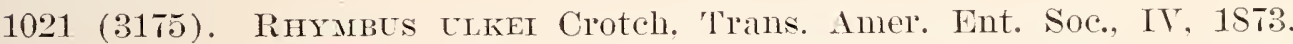
362.

Subhemispherical, globose: strongly pubescent. Disk of thorax and elstra dark reddish-brown, the margins and suture narrowly paler; antennal club black. Thorax obsoletely punctulate; elstra finely and rather sparsely punctate. Length $1.7 \mathrm{~mm}$.

Vigo. Poser. Crawford and Dubois counties; frequent. April 18-August 10.

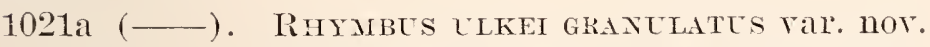

Differs from ulkei in haring the elptra densely granulate-punctate and the pubescence a little more sparse. Iength $1.6 \mathrm{~mm}$.

Lake County; rare. April 15.

1022 (3176). RHYmbUs yiNor Crotch loc. cit.

Smaller and less globose than ulkci. Uniform light reddish-brown throughout. Length $1.3 \mathrm{~mm}$.

Monroe. Dubois. Posey, Clark and Perry counties: scarce. April 20-October 10 .

Anamorphus pusillus Zimm., pale reddish-brown. length 1-1.2 mm., has been taken by Dury near Cincinnati. 


\section{Srmbiotes Redt. 1849. (Gr.. "living together.")}

Snrall, elongate-oval species, having the body pubescent with recumbent hairs: antenna 11 -jointed, first two joints thick, 3 to 8 subequal, 9-11 forming a prominent club; thorax with a prominent transverse basal impression, from which a narrow impression or sulcus extends forward on each side nearly one-half the length of thorax; elytra with puncthres arranged irregularly or in rows; sutural stria distinct. One species has been taken in Tndiana.

\section{3 (-). SYMBIOTES DURYT Walton MS.}

Oblong-oval, subconvex. Uniform dull brownish-yellow, sparsely pubescent with bright yellow hairs. Thorax twice as broad as long, sides evenly curved on apical two-thirds, parallel on basal third, apex truncate; disk with an oblique carina on each side extending from middle to near hind angle, this the outer boundary of the lateral sulcus extending forward from the basal impression: margins reflexed but not flattened; surface finely and evenly punctate. Elytra with sides nearly parallel to beyond middle, thence narrowing to a rounded apex. margins distinctly reflexed; surface with rows of very fine punctures. Length $2.2 \mathrm{~mm}$.

One specimen in Wolcott collection from near Battle Ground. Tippecanoe County. July 4.

\section{Rhanis Lec. 1853. (Gr., "a spot.")}

Here belongs one narrow, elongate, nearly glabrous species, having the last joint of the maxillary palpi cylindrical; prosternum obsolete between the front coxæ.

1024 (3178). Rhanis unicolor Ziegl., Proc. Phil. Acad. Nat. Sci., II, 1844, 272.

Elongate, subparallel. Reddish-brown, shining; elytra usually black with the shoulders often indistinctly and the apex very broadly, reddish; sometimes uniform reddish-brown throughout. Upper surface rather finely and sparsely punctate. Length $3.5 \mathrm{~mm}$.

Throughout the State; frequent. April 4-September 21. Sometimes found in autumn on the flowers of thoroughwort (Eupatorium); more often sifted from the debris of beech stumps.

\section{Phymaphora Newm. 1838. (Gr., "tumor + bearing.")}

Small elongate species having the prosternum narrow but distinct between the front coxr ; mesosternum bicarinate; antennal club of male very large, perfoliate, its basal joint as large or larger than the head. (Fig. 4, No. 8.) One species occurs in the State. 
1025 (3179) Pfymaphora pélmelta Newm., Fintom. Mag.

$\mathrm{V}, 1837,389$.

Elongate-oblong. Thorax red with black spot on disk; elytra reddish with two black crossbars, the front and broader one near the middle, the other, less distinct, subapical. Length $3.8 \mathrm{~mm}$. (Fig. 199.)

Posey County ; scarce. May 11. Occur's usually on

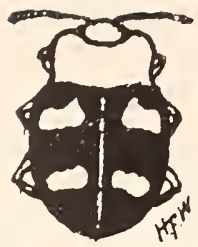
old beech logs.

Hig. $199 \times 41$ (After Wickham.)

\section{Subfamily II. ENDOMYCHINAE,}

The species of this subfamily are larger and broader than those of the preceding group, though none of them exceed $6.5 \mathrm{~mm}$. in length. The following genera are known from the State:

KEY TO INDIANA GENERA OF ENDOMYCHIN E.

a. Ligula oblong, rounded at tip; thorax black, elytra red, each with two black spots.

V. ENDomychus.

aa. Ligula transverse, emarginate or truncate; color not as above.

b. Prosternum not prolonged behind; front coxre contiguous or nearly so; thorax and elytra nearly uniform piceous black above.

VI. LYCOPERDINA.

bъ. Prosternum prolonged behind, partly covering the mesosternum ; front coxæe separăted.

c. Prosternum narrow between the coxæ; elytra in our species with lengthwise stripes.

VII. APHORISTA.

cc. Prosternum wide, margined; elytra without stripes, either unicolorous or with spots.

d. Thorax without an impressed submarginal line; body glabrous.

VIII. MYCETINA.

dd. Thorax with an impressed submarginal line; body pubescent.

IX. Stenotarsus.

V. Endomychus Panz. 1795. (Gr.. "within + nook or corner.")

Antennx elongate, with a loose, not large club; sides of thorax feebly sinuate, strongly but narrowly margined; longitudinal basal impressions deep, the usual transverse line represented only by a

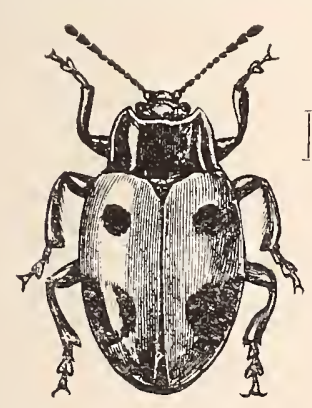

Fig. 200.

very fine basal margin; prosternum flat, spoonshaped, not marginerl. One species represents the genus in North America.

*1026 (3198). Endomychus biguttatus Say, Journ. Phil. Acad. Nat. Sci., IV, 1824, 96 : ibid. II, 234.

Oblong-oval. Head, antennæ, thorax, legs and scutellum black, shining; elytra red with two black spots on each, the larger subapical, the smaller before the middle. Length 3.5-4.2 mm. (Fig. 200.) 
Throughout the State; frequent. January 8-November 14. This and the next species hibernate, passing the winter months beneath logs, rails and chunks, especially those deeply covered with dead leaves in fence corners or along the margins of upland woods.

VI. Lycoperdina Lat. 1807. (Gr., "a wolf + to break wind.")

Here belongs a single oblong species haring the front coxæ contiguous; thorax subquadrate. feebly narrowed behind, its base with a deep transverse line and a short longitudinal one each side, the sides sinuate and margined; elytra convex, the suture very finely margined; scutellum broad and semicircular.

*1027 (3181). Lycoperdixa ferrdginea Lec., Ann. Lyc. Nat. Hist., I, 1824, 172.

Oblong-oral. Piceous-black, shining; antennæ, head, legs and narrow margins of thorax and elytra brownish-red. Length 4.5-5.2 mm.

Throughout the State; frequent. April 22-December 28. Occurs most abundantly inside the little round fungus Lycoperdon pyriforme Schæff., which groms on old logs, where it feeds upon the spores. By squeezing the ball, the beetle, if present, can be readily felt.

VII. ApHoRIsta Gorh. 1873. (Gr., "to mark off by boundaries.")

Differs from Lycoperdina mainly by having the front coxæ narrowly separated, the prosternum being distinctly prolonged between

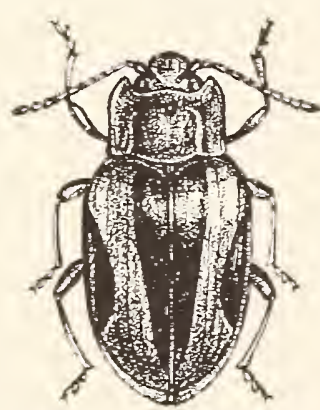

them. One species occurs in the State.

*102S (3186). Aphorista vittata Fab., Mant., I, 44.

Oblong-elongate. Brownish-red, shining; antennæ piceous, the terminal joint paler; thorax with an indistinct dusky spot each side of disk; eljtra with a common sutural stripe, and each with a shorter one on side, blacts. Length 5.5-6.2 mm. (Fig. 201.)

$A$ handsome and rather common species; found Fig. 201. $\times$ 5. (Original.) throughout the State. January 31-November 20.

\section{Mrcetina Muls. 18t6. (Gr.. "fungus.")}

In this genus the prosternum extends behind the coxæ, but is wider than in Aphorista and distinctly margined; thorax with deep transverse impression near base from each end of which a lengthwise one extends forward to middle. One of the three North American species oceurs in Indiana. 
*1029 (31Si). Mrceitixa Perpulchra Newm., Ent. Mag., V, 183S, 390.

Oblong. Piceous-black, shining; thorax reddish-yellow, sometimes with a blackish discoidal stripe; elytra each with two reddish-yellow spots, the larger subhumeral, the other subapical. Male with front and hind tibice angulate within. Length $4 \mathrm{~mm}$.

Steuben, Hancock. Tigo and Crawford counties; scarce. May' 17-December 3.

\section{Stenotinsts Perty. 1831. (Gr.. "narrow + tarsus.")}

One species, listed as Hycetina testacea Zieg., but evidently belonging to this genus. has been taken in the State. while another may occur.

\section{KEY TO IXDIATA SPECIES OF STEXOTARSUS.}

a. Prosternum spoon-shaped and prolonged orer the mesosternum; elstra wholly dull sellow.

1030. TESTACELS. a . Prosternum dilated. not spoon-shaped, not prolonged orer the mesosternum; disk of elytra usually black.

HISPIDUS.

*1030 (3189). Stenotarse's testaceus Ziegl., Proc. Phil. Acad. Nat. Sci., II, $1845,272$.

Elongate-oblong. Reddish-yellow, shining, sparsely pubescent with prostrate sellow hairs; head and sides of thorax often paler; club of antennie piceous. Thorax subquadrate, widest before the middle; hind angles prominent, somewhat prolonged and excurved; disk, as well as that of elytra, finely and sparsely punctate. Length $3.5-4 \mathrm{~mm}$.

Starke, Vigo, Posey and Crawford counties; scarce, except locally. March 9-December 11. Occurs beneath logs in upland sandy roods. In such a locality I found it on a number of ocaasions in Vigo County. always beneath the same log and nowhere else. When I first took it the log was so large that I had to use great exertion to turn it part way orer. Returning after ten rears' absence I found the same log, reduced to a chunk, easily orerturned by one hand, and beneath it I took twenty or more of the beetles.

S. hispidus Herbst.. length $4-4.5 \mathrm{~mm}$.. is recorded from the middle and southern States and has been taken near Cincinnati.

\section{Family XVIII. EROTYLID E.}

\section{The Plejsing Fungts Beethes.}

A family of moderate extent. comprising. for the most part. beetles elongate or oval in form. and of medium or small size. Many of them are very prettily bicolored. possessing a red thorax. with black or black and red elytra, or the reverse. A number. howerer. 
are of one hue. The name is based upon the typical genus Erotylus, a Greek word meaning "Ioriendly" or "pleasing." probably in aliusion to the contrasted color's of many of the species. They occur for the most part upon fleshy fungi growing upon logs or trees, though the members of the genus Languria are found upon plants and are more or less injurious in habit.

The Erotylidx are most closely allied to the Endomychidæ and differ mainly in having the tarsi 5-jointed, but with the fourth joint usually very small, the first three more or less broad and pubescent beneath. The thorax has not the deeply impressed sub-basal and longitudinal lines so often seen in the Endomychidæ, and the form is usually more élongate and more convex. They have the mentum of variable form, its front margin bisinuate; maxillary palpi 4jointed, the fourth joint usually broadly triangular; antennæ 11jointed, inserted at the sides of the front, on the inner front margin of the eyes, the last three or four joints forming a distinct club; head small, immersed in the thorax to the hind margin of the eyes; thorax with side margins distinct; front coxal cavities usually closed (open in Languria), always separated by the prosternum; elytra entire, covering the abdomen, the latter with five nearly equal segments ; tarsi claws simple.

The larvæ of but few species of the family are well known. That of Languria mozardi, which bores into and feeds upon the stems of clover, is elongate and subcylindrical, about $8 \mathrm{~mm}$. in length, the anal segment slightly narrower than the preceding. In color it is light yellow, the mandibles and anal appendages brown. The larra of a common fungus feeding form. Tritoma humeralis, is moderately elongate. nearly cylindrical but tapering to each end. the ninth segment bearing two short, erect. slightly recurved hooks. In color it is nearly white. the head yellowish. When full fed it pupates beneath the ground, the pupal stage lasting eight days.

The principal literature treating of the North American species of Erotylide is cmbodied in the following papers:

LeConte.- "Synopsis of the Erotylidx of the United States," in Proc. Phil. Acad. Nat. Sci.. VII. 1854, 158-163.

Crotch.- "Synopsis of the Erotylidx of Boreal America," in Trans. Amer. Ent. Soc., IV. 1873. 349-358.

Wickham.- "The Endomychidæ and Erotylidæ of Ontario and Quebec." in Can. Ent.. XXVI, 1894, 337-339.

Schaffer.-_"Synoptic Table of Languria." in Journ. N. Y. Ent. Soc., XII. 1904, 198-200. 
Nearly 1,800 species of Erotylida are known, most of which are exotic and tropical. Only about 50 species, distributed among two tribes, are listed from North America. Of these 22, belonging to seven genera, have been taken in Indiana.

\section{KEY TO TRIBES OF NORTH AMERTCAN EROTYLIDA.}

1. Front coxal arities open behind; epimera of metathorax not distinct; form very elongate, subcylindrical, the sides parallel; antennal club gradually formed, 5- or (i-jointed.

Tribe 1. Langetrint, p. 541. au. Front coxal cavities entire; phimera of metathorax separated from the episterna by a distinct suture; form more robust, usually oval; antemill (dul) 3- or 4-jointed, more abruptly formed.

Tribe II. Erotylini, p. 54:3.

Tribe I. LANGURINI.

This tribe is represented in North America by the single genus:

I. Languria Latr. 1802. (L., "a kind of lizard.")

Long, narrow insects, somewhat resembling certain click beetles (Elateridx) in form, and of shining black and red colors. They occur upon the leaves and stems of plants, especially Mesadenia, Lactuca and other genera of Compositx, and upon the flowers of Umbelliferæ. Several of the species hibernate as imagoes and in early spring are to be found beneath logs and stones. Fifteen are known from the United States; of these six have been taken in Indiana, while two others may occur.

\section{KEY TO INDIANA SPECIES OF LANGURIA.}

a. Abdomen in great part red.

b. Head red.

c. Antennal club distinctly 6-jointed; under side red, the last ventral segment black; thorax red, usually with a black discoidal spot.

1031. BICOLOR.

cc. Antennal club 5-jointed; last three ventral segments black.

d. Thorax red, shining, without spot.

1032. MOZARDI.

dd. Thorax alutaceous, or with a greasy aspect, its disk with a large elongate black blotch.

DISCOIDEA.

Ђъ. Head either entirely or in great part black.

$e$. Antenna wholly black.

f. Metasternum blue; epipleura and sides of elytra at middle red.

1033. ANGUSTATA.

ff. Metasternum red; knees, tarsi and tips of tibiæ black.

var. THLERIT.

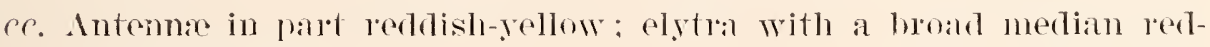
dish crossbar.

10:34. TRIEASCIATA.

a $a$. Abdomen entirely black. 
g. Head black; thorax oblong, its sides nearly parallel, disk with a large greenish-black spot.

1035. LECONTEI.

gg. Head more or less red; thorax elongate, distinctly narrowed behind the middle, its disk with a greenish-black stripe. 1036. GRACILIs.

1031 (3199). Languria bicolor Fab., Ent. Syst., Suppl., 1798, 50.

Elongate. Head and thorax reddish, the latter with a black spot on disk; scutellum and elytra bluish-black, shining; beneath reddish-yellow, legs, last abdominal segment ànd antennæ, black. Thorax quadrate, obsoletely punctate, rather narrowed in front, the sides rounded. Elytral striæ not impressed but marked by rows of punctures. Length $5.5-12 \mathrm{~mm}$.

Throughout the State; more frequent southward. May 1-June 25. Occurs especially on the leaves of the pale Indian Plantain (Mesadenia atripticifolia L.) in the stems of which the larvæ live.

*1032 (3200). Languria mozardi Lat., Gen. Crust., III, 1S07, 66.

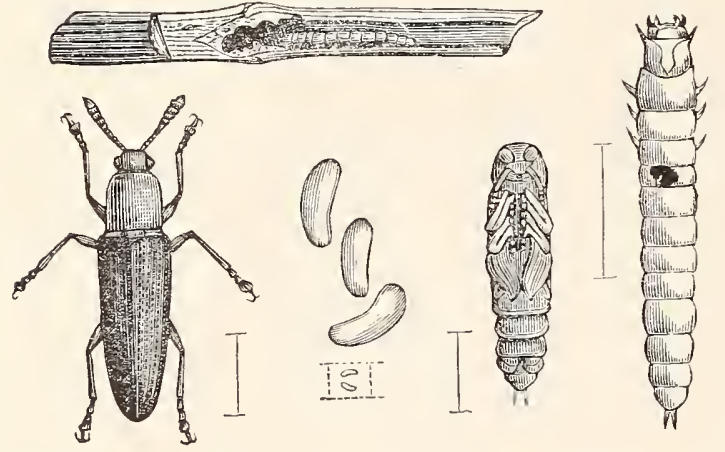

Fig. 202. Languria mozardi. $a$, egg; $b$, larva in clover stem; $c$ larva; $d$, pupa; $e$, adult. (After Comstock.)

pecially on wild lettuce (Lactuca.) "clover-stem borer," live in the stems of clover and often do much injury to that crop.

L. discoidea Lec., length 7-8 mm., is known from the southern States and may oecur in southern Indiana.

1033 (3204). Languria angustata Beauv., Ins. d'Afr., 1805. 125.

Elongate, rather narrowed behind. Head, antennie and elytra bluishblack, the latter narrowly reddish, near middle of sides; scutellum black; thorax reddish-yellow; beneath reddish-yellow, the last two abdominal segments, tarsi and tips of femora, black. Thorax sparingly and indistinctly punctate, the base strongly margined. Elytra punctate as in bicolor. Length 6-7.5 $\mathrm{mm}$.

Marion, Orange and Posey counties; scarce. April 26-October 6. Taken from flowers of Ranunculus and goldenrod. The specimens at hand belong to the color variety uhlerii Horn. 
1034 (3204a). Languria trifasciata Say, Journ. Phil. Acad. Nat. Sci., III, 1823, 462; ibid. I, 86.

Elongate; the elytra tapering to an obtuse point. Head, basal and apical thirds of elytra bluish-black; thorax, a broad median band of elytra and joints two to six inclusive of antennæ, reddish-yellow; beneath as in angustata. Length 6-7.5 $\mathrm{mm}$.

Throughout the State; frequent. March 16-Nay 29. Usually regarded as a variety of angustata. but in my opinion specifically distinct. Occurs especially on the foliage of the wild lettuce, Lactuca canadensis L., but often found on fiowers of buttercup ( $R a$ nunculus).

1055 (3207). Languria Leconter Crotch, Trans. Amer. Ent. Soc., IV, 1873, 351.

Elongate, parallel. Nearly unifor'm greenish-black: th rax reddish-rellow with a large greenish-black spot on center of disk. Head and thorax sparsely but distinctly punctate. Flytral punctures in rows, with a few finer ones on intervals. Length $10.5 \mathrm{~mm}$.

Vigo County ; rare. March 12. Described from Illinois.

1036 (3209). Languria gractitis Newm., Ent. Mag., Y. 1S3S, 390.

Resembles lecontci, but more narrow. Head. at least in part, red; greenish-black mark on thorax extended into a stripe reaching from base to apex. Varies with the thorax entirely greenish-black. Length $8.7-10 \mathrm{~mm}$. (Fig. 203.)

Southern half of State; frequent. Nay 21-October 28. Occurs on ragreed (Ambrosia), fleabane (Erigeron) and other low herbs from which it is taken by sweeping.

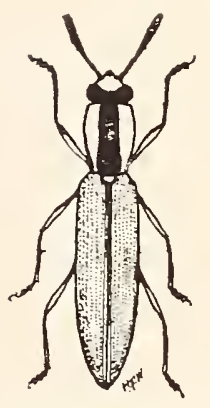

Fig. 203. $\times 2 \frac{2}{3}$. (After Wickham.)

Tribe II. EROTYLINI.

To this tribe. as defined in the ker. belong the following genera from Indiana:

KEY TO INDIANA GFNERA OF EROTYLINI.

a. Tarsi distinctly 5-jointed. (Group Dacnes.)

Ђ. Tarsi narrow, not dilated; size smail. not over $3.5 \mathrm{~mm}$.

c. Form oral. the sides curved; elytra unicolored; antennie with 10th and 11th joints united.

II. PLEOSOMA.

cc. Form oblong, the sides nearly paraliel; elytra bicolored; antennie distinctly 11-jointed.

IIT. DACNE.

bъ. Tarsi dilated, spongy beneath; size larger, 5-20 mm.

IV. MEGATODACNE. aa. Tarsi apparently 4-jointed, the fourth joint rery small, united with the fifth.

$[35-23402]$ 
d. Last joint of palpi widely hatchet-shaped; thorax yellow with four black spots; length $7-8 \mathrm{~mm}$.

$\mathrm{V}$. IschYRUS.

dd. Last joint of palpi oral or slightḷ triangular; thorax yellow or black. rarely with two spots; length less than $6 \mathrm{~mm}$.

$e$. Middle area of mentum large, transverse.

ce. Middle area of mentum small, triangular.

VI. MYCOTRETLS. VII. Tritoni.

\section{Pléosonia Woll. 1854.}

This genus is represented in the eastern United States and Indiana by a single very small brown species.

1037 (3212). Plogosoma punctata Lec.. Trans. Amer. Ent. Soc.. T, 1St5. 171.

Oral, rather stronsly convex. Uniform dirk chestnut-brown; antenne and legs paler. Thorax twice as wide as long, finels and sparsely punctate. Elytra distinctly but rather sparsely and irregularly punctate and narrowed to a rounded apex. Length $2-2.5 \mathrm{~mm}$.

Southern two-thirds of State: common. Hibernates. April 9December 3. Gregarious in winter and carly spring beneath bark. especially that of elm and willow.

\section{TII. D.ICNE Latr. 1796. (Gr.. "bite or sting.")}

This genus is represented in the Tnited States by three small species. one of which occurs in Indiana.

1038 (3213). Dacde 4-maculata Say. Bost. Journ. Nat. Hist.. I, 1835, 169: ibid. II, 645 .

Oblong. parallel. Black: elytra each with a round reddish-yellow spot on humerus and another at apex: beneath piceous or dark reddish-brown. the antenna. legs and clypeus paler. Head and thorax closely but sparsely punctate; elytra with numerous rows of fine punctures. Length $2.5-3.2 \mathrm{~mm}$.

Throughout the State, frecuent in the southern counties; less so northrard. April 15-September 21. Occurs in fungi.

\section{Megalodicate Crotch. 1873. (Gr.. "large + bite.")}

Here belong the largest species of the family, handsome black and yellow forms, having the fourth joint of tarsi smaller but distinet: last joint of palpi suberlindrical and the mentum triangular. Three species are known from the United States, all of which occur in Indiana.

KEY TO INDIANA SPECIES OF MEGALONACNE.

a. Elytra without rows of punctures; length $18-21 \mathrm{~mm}$.

aa. Elytra with rows of fine punctures.

1040. IIEROS. 
b. Head and thorax nearly smooth; elytra with black crossbars; length $12-15 \mathrm{~mm}$.

1089. FASCIATA.

$b b$. Head and thorax very coarsely and distinctly punctured; elytra each with four black spots; length less than $6 \mathrm{~mm}$.

1041. ULKEI.

*1039 (3216). Megalodacne Fasciata Fab., Ent. Syst., II, 1798, 511.

Oblong-ovate. Black, shining; elytra with two reddish crossbars, the basal one irregular in form and enclosing three black spots, one small round, near each humerus, the other large, quadrate behind the scutellum; the subapical bar narrower and interrupted at suture. Thorax short, transverse, very finely and obsoletely punctulate; sides straight, broadly margined; base with a punctured impression each side. Length 9-15 $\mathrm{mm}$.

Throughout the State; common in fungi. February 14-September 21. Hibernates with the next in dry rotten wood beneath loose bark. Gregarious at all seasons but especially so in winter.

*1040 (3217). Megalodacne heros Say, Journ. Phil. Acad. Nat. Sci., III, 1823, 196 ; ibid. II, 125.

Resembles fasciata very closely in form and color but much larger. Thorax longer with narrower side margins and elytra without rows of punctures. Black spot at scutellum smaller and more nearly enclosed by the red basal crossbar. Length 18-21. (Fig. 204.)

Frequent throughout the State. February 3-December 10. Much less common than fasciata and seldom more than two or three found together.

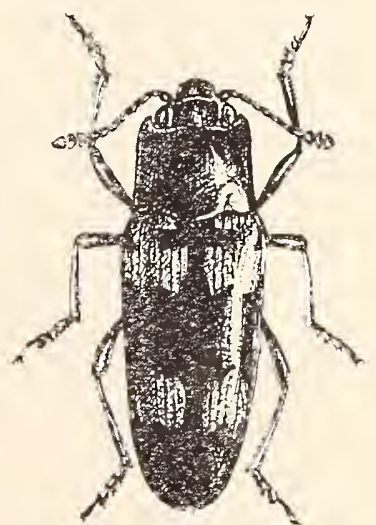

Fig. 204. $\times 2 . \quad$ (Original.)

1041 (3218). Megalodacne ulker Crotch, Trans. Amer. Ent. Soc., IV, 1873, 353.

Elongate-oval, rather narrowed behind. Head and thorax black, shining; elytra brownish-red, each with four black spots, one near the liumerus, two before the middle, and one, the largest; subapical; beneath black, the sides of abdomen reddish. Thorax coarsely and sparsely punctate, with a smooth space before the scutellum; elytra with rows of fine but distinct punctures. Front coxa widely separated, the prosternum forming a broad triangle with distinct margins. Length 5-5.5 $\mathrm{mm}$.

A prettily marked species of southern range, taken only in Jackson, Crawford and Posey counties; searce. April 12-June 7. Occur's in dense woods, especially on the fungus Polyporus cuticularis, which is usually found on beech or hickory logs.

$$
\text { V. Ischyrts Lac. 1842. (Gr., "robust.") }
$$

One medium sized species, having the antennal club 3-jointed and the eyes coarsely granulate, represents this genus in Indiana. 
*1042 (3219). Iscitrous Qundripunctatus Oliv., Enc. Meth. Ins., VI, 1808,

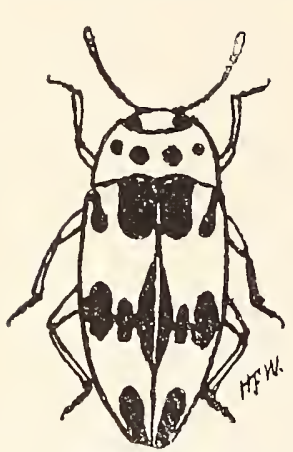

Fig. $205 . \times 3$.

(After Wickham.) 437.

Ovate, subelongate, convex. Heat black; thorax yellow, with four black dots in a row across the middle; elytra yellow, with a large common scutellar spot, a smaller one on humerus, a deeply dentate median band and an oblong spot on each at apex, black; beneath black, the sides of abdomen yellow. Head and thorax sparsely and coarsely punctite; elytra with rows of distinct punctures. Length $7-8 \mathrm{~mm}$. (Fig. 205.)

Frequent throughout the State. January 21December 8. Gregarious in winter, hibernating beneath bark and logs. In early spring often found at sap; in summer on fungi.

VI. Mycotretus Lac. 1842. (Gr., "fungus + to perforate.")

Small oval, red or black insects, having the last joint of palpi oval, antennie abruptly 3 -jointed and eyes finely granulated. Two species are known from Indiana, while a third may occur.

KEY TO INDIANA SPECIES OF MTCOTRETUS.

a. Thorax black; elytra wholly or' in great part dull red.

b. Elytra and scutellum wholly dull red.

1043. SANGUINIPENNIS.

bb. Elytra partly black; scutellum black.

1044. PULCHRA. $a a$. Thorax reddish-yellow with two black spots; elytra wholly black.

DISSIMULATOR.

1043 (3222). Mrcotretus Sanguinipennis Say, Journ. Phil. Acad. Nat. Sci., IV, 1825, 89 ; ibid. II, 229.

Broadly ovate. Head and thorax black, shining; scutellum and elytra pale red; beneath black, abdomen red. Head and thorax finely and sparsely. punctured, the latter more coarsely near base, which is sinuate each side. Elytral strixe with deep, rather close punctures; intervals finely but distinctly punctate. Length $4-4.5 \mathrm{~mm}$.

Frequent in southern half of State; less so in the northern counties. April 25-October 20. Occurs most commonly on fleshy fungi. 1044 (3223). Mrcotretus Pulchra Say, Jourix. Phil. Acad. Nat. Sci., V, 1826, 301 ; ibid. II, 345.

Ovate. Head, thorax and scutellum black; elytra red with the apical third obliquely black, the biack space extending on side nearly to humerus. Surface punctate as in the preceding, but the punctures of elytral strixe finer. Length $3.5 \mathrm{~mm}$.

Marion, Vigo, Knox and Posey counties; frequent. April 9.J une 19.

M. dissimulator Crotch, length $4.5 \mathrm{~mm}$., was described from Illinois. 


\section{Tritomi Fab. 17\%5. (Gr., "three + joint.")}

Small oval or oblong species, black or red and black in color, having the antennal club 3 - or 4 -jointed, the last joint of maxillary palpi broadly dilated and the middle area of mentum small and triangular. Some of the species are to be found by hundreds in fungi during the summer and antumm, having resorted thereto to deposit their eggs. which hatch into maggot-like larva which feed upon the juices of the fungi. About 15 species are known from the United States, eight of which have been taken in Indiana. while two others may occur.

\section{KEY TO INDIANA SPECIES OF TRITOMA.}

a. Elstra more or less red.

b. Red of elytra limited to spots on humerus.

c. Under side piceous-black, the apex of last segment alone pale.

1045. HUMERALIS.

cc. Under side entirely pale.

1046. BiguTtATA.

ఒb. Elstra nearly entirely red or with broad central reddish-sellow band. a. Form oval; elytra red with outer margins black.

1047. MILETICA. dd. Form oblong; elytra with broad central band of reddish-yellow.

1048. FESTIVA.

u1. Elytra wholly black.

$e$. Head and thorax of same color as elytra.

$f$. Beneath piceous, the legs and palpi brownish-yellow.

1049. ANGULATA.

ff. Beneath black, the tarsi and palpi piceous.

1050. UNICOLOR. ec. Head or thorax or both, paler than elytra.

$g$. Head reddish-yellow, thorax and elytra concolorous.

ERYTHROCEPHALA.

gg. Head and thorax both rellow.

h. Body beneath reddish-yellow.

$i$. Antennæe entirels black; elytral intervals obsoletely punctulate.

MACRA.

ii. Antennæ black, red at base; elstral intervals sparsely but distinctly punctate.

1051. THORACICA.

$h \hbar$. Body black beneath.

1052. FLAYICOLLIS.

1045 (3225). Tritoma humeralis Fab., Syst. Eleut., II, 1801, 571.

Broadly oval. Black; antenme, legs and a subquadrate spot near the humerus of each elytron, reddish-yellow. Head and thorax distinctly and rather closely punctate. Elytra with rows of fine punctures, the intervals rery obsoletely punctulate. Length $3-4 \mathrm{~mm}$. (Fig. 206.)

Sonthern half of State; frequent. Not yet taken in the northern counties. April 22-September 29.

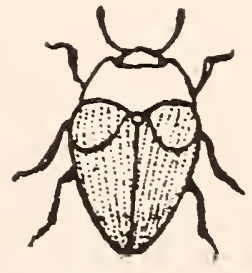

Fig. $206 . \times 4 \frac{1}{4}$. (After Wickhan.) 
*10t6 (3226). Tritoma biguttata Say, Journ. Phil. Acad. Nat. Sci., IV, 1825,59 ; ibid. II, 229.

Resembles humcralis, but more narrowly oval. Entirely pale beneath and with the reddish-yellow spot of elytra larger, triangular, reaching nearly from scutellum to humerus. Elytra more deeply striate, the punctures of intervals more distinct, especially at base. Length $34 \mathrm{~mm}$.

Lake, Vigo, Lawrence and Crawford comties; common locally on decaying Agaricus. Hibernates. March 9-December 25.

1047 (3227). 'Tritoma mmetica Crotch, Trans. Amer. Ent. Soc., IV, 1873, 355.

Rather broadly ovate. Head, thorax and club of antennæ black; elytra pale red, with the outer margins nearly to humeral angle and apex, black; beneath black, legs, sides of abdomen and sternum, reddish. Head and thorax finely but distinctly punctate. Elytra striate with rows of fine punctures; intervals rather thickly and finely punctulate. Length $4-4.3 \mathrm{~mm}$.

Vigo, Marion and Posey counties ; scarce. April 18-October 11. Resembles Mycotretus pulchra but readily distinguished by the larger size and red scutellum.

*104S (3234). Tritona festrua Lac., Monog. des Lrot., 1842, 208.

Elongate-oblong, subconvex. Black; thorax, scutellum and a broad median band on elytra reddish-yellow; antennæe black; beneath reddishyellow. Head and thorix sparsely but distinctly punctured. Elytra with rows of rather deep punctures which do not extend onto the humeral region. Length $5-6 \mathrm{~mm}$.

A handsome and well marked species of southern range, taken only in Marion, Vigo and Knox counties: scarce. April 18-December 10 . Hibernates.

1049 (3230). Tritoma angulata Say, Journ. Phil. Acad. Nat. Sci., V, 1826, 300 ; ibid. II, 345.

Rather narrowly ovate, convex. Head dark piceous-red; thorax and elytra uniform black; beneath piceous, the legs, antennse and palpi brownish-yellow. Head and thorax finely and rather closely punctate. Elytra with rows of fine, close punctures; intervals finely and sparingly punctulate. Length 3-4 $\mathrm{mm}$.

Vigo and Lawrence counties; scarce. Taken on decaying fleshy fungi (Boleti). July 2-July 29.

*1050 (3231). Tritoma unicolor Say, 7oc. cit.

Broadly orate. Entirely black, somewhat shining. Head closely, thorax more coarsely and deeply, punctate. Elytra with rows of distinct punctures which become finer toward the tips; intervals smooth. Length $4-5 \mathrm{~mm}$.

Frequent throughout the State. March 7-October 9. Probably hibernates. Ocours beneath logs in early spring; in fleshy fungi in summer. 
T. erythrocephala Lac., length $3.5-4 \mathrm{~mm}$., is known from near Washington, D. C., Georgia and Missouri, while T. macra Isec.. length $5.5 \mathrm{~mm}$, has been recorded from Illinois and near Cincinnati. Ohio.

1051 (3236). Tritoma thoracica Say, Journ. Phil. Acad. Nat. Sci., IV 1825,89 ; ibid. II, 229.

Oblong-oval. Head and thorax yellow; elytra and apical half of antennie black; beneath reddish-yellow. Head and thorax distinctly and closely punctate. the latter with the sides rounded and somewhat narrowed in front. Elytral strice scarcely impressed. finely punctured; intervals sparsely but distinctly punctate. Iength 3.5 5 1mm. (Fig. 207.)

Common on fleshy fungi and beneath bark, in sonthern half of State; less so in the northern counties. March 12-September 21.

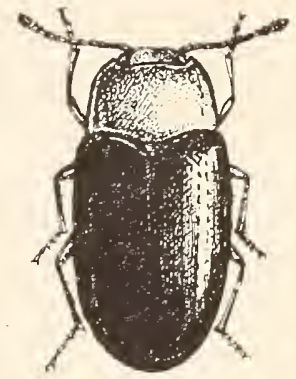

Fig. 207. $\times 5 \frac{1}{2}$. (Oririall.)

1052 (3239). Tritoma fravicollzis lac., Monog. des Erotyl., 1842. 218.

Oblong-orate. Hearl. thorax, antenne and legs yellow; antennal club, elytra and body beneath black. Head and thorax distinctly and rather (losely punctate. Elytral strixe finely. the intervals sparsely and obsoletely. punctate. Length $3-4 \mathrm{~mm}$.

Solihern half of State, common; not noted in the northern counties. April 12-October 9.

\section{Family XIX. COLYDITD A.}

\section{T'he Cylindricil Bari Beetles.}

This family includes a limited number of small beetles of an elongate or cylindrical form, which live beneath the bark of trees. in fungi or in the ground. They are closely allied to the Cucujidix and by Casey have been included as one of nine subfamilies of that family.*

From their near allies they may be known by the following combination of characters: antenux 10- or 11-jointed. rarely 8-jointed. inserted under the margin of the front. sometimes gradually thickened, but usually terminated by a small one- or two-jointed club: elytra entire, always covering the abdomen; front coxal cavities either open or closed behind, the coxæ small, globular; hind coxie transverse, not prominent; abdomen with five ventral segments, the first three or four grown together; legs short, tibia not dilated; tarsi four-jointed, claws simple. The small globular front and middle coxa, the four-jointed tarsi and the entire elytra, form a trio of characters which readily distinguish the group.

*Ann. N. Y. Acad. Sci., V, 1890, 496. 
In habits the Colydiidx are in part carnivorous. as the larvæ of certain genera are known to feed upon those of other small, woodboring forms. About 600 species are known, 70 of which are from North America. These are divided among numerous tribes and genera, many of the latter containing but a single species. The only paper which treats of the family as a whole is by

Horn.-- "Synopsis of the Colydiidxe of the IT. S.," in Proc. Amer. Phil. Soc., XV11, 1878, 555-592.

Other short papers by Casey on isolated species have appeared in the Annals of the N. Y. Academy of Science. Fourteen species of the family, distributed among 11 genera, have been taken in Indiana. Several other genera are doubtless represented in the State, and are included in the generic keys which follow:

\section{KEY TO INDIANA TRIBES OF COLYDIIDE.}

a. Antennze inserted under a distinct frontal ridge; front coxie distant from the mesosternum.

b. Last joint of palpi not needle-shaped.

c. Front coxre slightly separated.

d. First joint of tar'si short; form elongate or oral.

Tribe I. SrNchitlis, p. 550. dd. First joint of tarsi longer than the second ; form cylindrical.

Tribe II. Colydini, p. 553.

cc. Front coxie widely separated; form elongate, subdepressed.

c. Antenna arising under a frontal margin: first rentral segment not elongate; trochanters free.

Tribe III. Pycnomerini, p. 555.

$c e$. Antennie free at base: first rentral segment elongate; trochanters closely united to the femora.

Tribe IV. Botmriderixi, p. 556.

6b. Last joint of palpi needle-shaped: antennæe free at base; form short, oval, depressed.

Tribe V. Cerrlonini, p. 557. a a. Antennse inserted on the front: front coxie inclosed behind by the mesosternum.

Tribe VI. MURMIDIINI. p. 557.

Tribe I. SYNCHITINI.

Elongate or oval species having the surface often ribbed and more or less bristly; tarsi short, the first three joints subequal and together not longer than fourth. 'The following genera are known to be or should be represented in Indiana:

\section{KEY TO INDIANA GENERA OF STNCHITINT.}

a. Front coxal arities open behind.

7. Antennse 10-jointer. club solid.

c. Head beneath without antennal groores.

I. SYNChitA 
$c c$. Head with distinct grooves.

II. HUCICONAS.

bb. Antennse 11-jointed, club 2-jointed.

d. Head without antennal grooves.

III. IITOM

dd. Ilead with distinct antemnal grooves; tibiae with terminal spurs.

Fudesma.

au. Front coxal arvities closed behind.

d. Antenna with a two-jointed club; tibiae withont spurs.

IV. Coxents.

er. Antenne with a :-jointed club; tibiar with small sums.

IASCONOTTS.

I. Srnchita Hellw. 1792. (Gr., "together + skin or cover."')

Antenna 10-jointed, terminating in an abruptly larger club joint, which is smooth at base and pubescent at tip; first three joints of tarsi very short, together but little longer than half the fourth. Of the seven known species, two have been taken in Indiana, while two others should occur.

KEY TO INDIANA SPECIES OF SYNCHITA.

a. Elytral with fine costar: thorax with an elevited line each side.

IATICOLIIS.

a. Elytria not costate.

b. Eilytrat variegated with lialer markings. 1053. PARvira.

bb. Elytra unicolorous.

c. Thorax with a fine subapical impressed line, its disk finely granulate; length $2.5 \mathrm{~mm}$.

FULIGINOSA.

rc. Thorax without impressed line, its disk coarsely granulate; lengtl $4 \mathrm{mml}$.

1054. GRANULATA.

S. laticollis I ec, piceous, elytra with humeri and a spot near apex reddish, length $2 \mathrm{~mm}$., is a southern form which has been recorded from Cincinnati.

1053 (3247). SYNCHita PARvula Guer., Icon. Regu. Ins., 1S30, 1S9.

Oblong, subdepressed. Piceous brown; elytra variegated with paler crossbars. Thorax wider than long, sides feebly curved, margin finely serrulate, base slightly wider than apex, sufface granulate. Elytra with rows of rather small, close-set punctures; intervils granulate. Length 2-2.5 1 m.

Marion County; rare. December 8. Taken from dry fungi on a dead beech tree.

S. fuliginosa Melsh., rusty red-brown, antennie, under surface and legs paler, is also known from near Cincinnati.

1054 (3249). Srnchita granulata Say, Journ. Phil. Acad. Nat. Sci., Y. 1826,266 ; ibid. II, 326.

Oblong, parallel, moderately convex. Uniform dull reddish-brown, subopaque. Third joint of antenme as long as the three following together. Thorax wider than long, sides feebly curved, margin distinctly serrate, base 
slightly narrower than apex. Elytra coarsely granulate with traces of strice between the rows of granules; sparsely pubescent on the sides. Length $4 \mathrm{~mm}$.

Posey County; rare. April 12. Taken beneath bark of honey loenst. Occurs from Missouri to Pennsylvania and Georgia.

\section{Eucicones Sharp. 1894. (Gr., "beautiful + Cicones."')}

Differs from Synchita only in possessing distinct, deep antennal grooves along the lower margins of the eyes. One species is known from the State.

1055 (3251). Eucícones marginalis Melsh., Proc. Phil. Acad. Nat. Sci., II, $1844,112$.

Oblong-oval, depressed. Piceous, opaque; antenne, legs and margin of thorax reddish-brown; elytra each with three or four small spots and a narrow undulate crossbar at apical third, also reddish-brown. Thorax more than twice as wide as long, sides curved; margins wide and flat, edges finely serrate; disk granulate and finely pubescent. Elytra with indistinct rows of punctures; intervals flat, with two irregular rows of punctures, each puncture bearing a short, seni-erert bristly hiair. Length $2.5-3.5 \mathrm{~mm}$.

Marion and Monne comnties; scaree. March 2:3-. June 9. Taken from beneath the bark of old maple and beech stumps.

\section{Diтома Ill. 1807. (Gr., "two + joint.")}

Oblong flattened beetles having the antennæe 11-jointed, inserted under the margin of the front, the last two joints forming an abrupt club. Eyes rather large and convex, coarsely granulated. One of the six known North American species has been taken in Indiana, while another is herewith described for the first time.

1056 (3254). Ditoma Quadriguttata Say, Journ. Phil. Acad. Nat. Sci., V, 1826,260 ; ibid. II, 326.

Oblong-elongate. depressed. Blackish-brown, subopaque; elytra each with three dull reddish spots; one oblique, elongate, extending from humerus to suture, a round one behind middle and a snialler subsutural one near apex; antenne and legs reddish-brown. Thorax broader than long, sides nearly straight, disk finely granulate and with four elevated lines, each curved inwards in front, the two median ones united, forming an arch. Elytra slightly wider than thorax, each with four discal ridges, the broader intervals with two rows of coarse punctures. Yength $2.5-3 \mathrm{~mm}$.

Throughout the State; frequent. April 9-.June 5. Occurs beneath bark and logs.

\section{7 (- - ). DitOMA GRANULATA Sp. nov.}

Elongate-oblong, subdepressed. Uniform piceous brown; antenne and margins of tholax reddish-brown. Ninth joint of antenne not wider than 
eighth. 'Thorax one-third broader that long, sides feehly curved, front angles prominent, hind ones rounded; margins flattened, finely crenate; disk coarsely and roughly granulate and with four raised lines, the outer one on each side curving aromnd the apex, the inner ones joined to the curve but not to each other, the interval between them wider than in quarriguttata. Elytra not wider than thorax, each with four.discal ridges, intervals not punctate but each with two or three rows of small oblong granules. Length $3.4 \mathrm{~mm}$.

Marion Connty ; rare. May 29. Described from a single specimen taken by $\mathrm{H}$. Morrison from beneath bark. Broader than quadriguttata, elytra not marked with red as there, and with the intervals granulate instead of coarsely punctured.

D. quadricollis Iorn, narrower than quadriguttata, dark brown, length $2.5 \mathrm{~mm}$., is listed by Dury from Cincinnati.

Eudesma undulata Melsh., elongate, subcylindrical, piceous, length $5 \mathrm{~mm}$., has also been taken by Dury. who found them running up and down and burrowing in the bark of a buckeye log.

\section{Coxelus Latr. 1829. (L., "coxa.")}

Antennæ as in Ditoma but received in grooves beneath the eyes; front coxal cavities closed behind. One species occurs in Indiana.

*1058 (3261). Coxelus gutrulatus Lec., New Spec. N. Amer. Col., 1863, 65.

Elongate-oblong, subconvex. Piceons-black; antennæe, legs and margins of thorax and elytra dull reddish-brown. Thorax twice as wide as long. apex deeply emarginate, front angles prominent; sides broadly curved; margins wide and flat, edges finely serrulate; surface coarsely granulate. Elytra with rows of coarse granules, and each also with spots of coarse gray pubescence forming an interrupted sinuous band near middle and another subapical. Length $4-5 \mathrm{~mm}$.

Southern half of State; frequent. February 10-November 19. Occurs on dry fungi and beneath close fitting bark of beech, maple and other trees,

Lasconotus boreatis Horn, thorax wider than long, elytra equally costate, piceous, length 2.5-3 mm., is known from Michigan, while L. pusillus Lec., thorax longer than wide, elytra broadly channeled. fifth interval strongly elevated, color and size the same. has been recorded from Cincinnati.

Tribe II. COLYDIINI.

Elongate, cylindrical beetles having the head horizontal; antennx capitate, retractile; front coxal cavities narrowly closed behind; first joint of tarsi as long or longer than the next two together, the three longer than the fourth. They ocur beneath bark. Two genera are represented in the State. 
KEY TO INDIANA GENERA OF COLIDIINT.

a. Front tibice finely denticulate at outer apical angle; form rather robust.

V. Auloxicis. a a. Front tibia with outer apical angle prolonged; form rery slender.

VI. Colipitur.

\section{Aulonium Erichs." 1832. (Gr., "pipe or channel.")}

Antenni 11-jointed. the last three joints forming a rather loose club; inserted in front of the eyes. which are emarginate in front by the sides of the clypeus; hind cox: separated by a triangular. acute abdominal process. Two of the four known species occur in Indiana.

1059 (3272). Aulonium Parallelopipedta Sas. Journ. Phil. Acad. Nat. Sci., V, 1S26. 263 ; ibid. II, 324.

Elongate, subcylindrical. Piceous-black, rather shining; legs and antemmæ reddish-brown. Head with two, often indistinct. tubercles on rertex. Thorax quadrate, the disk with a raised line on each side which curves and unites on front margin. and two obtuse tubercles in front of middle; sides feebly curved, surface finely punctate; hind angles rectangular. Elytra slightly wider than thorax. with rows of rather fine, close set punctures. Length $4.5-6 \mathrm{~mm}$.

Southern half of State; frequent. Not yet noted in northern counties. Probably hibernates. March 17-November 22. Occurs beneath bark.

1060 (3274). Aulonium tubercllatum Lec., Nem Spec. N. Am. Col., 1863,67 .

Elongate, subcylindrical. Reddish-brown, rather shining, the apical half of elytra piceous. Thorax longer than wide. sides nearly straight. hind angles obtuse: disk with two raised lines on each side, one of which is near the margin. surface finely and sparsely punctate. the male with two tubercles near front margin. Elytra not wider than thorax, the rows of punctures rery fine. Length $5.5 \mathrm{~mm}$.

Lake County: rare. June 6-October 13. Known from the State by two specimens taken from beneath the bark of the northern scrub pine, Pinus divaricata Ait.

VI. Colydum Fab. 1792. (Gr., "sheath.")

This genus is represented in the United States and Indiana by the single species: 
1061 (3276). Colyotum lineora Say, Journ. Phil. Acad. Nat. Sci., V, 1826, 264 ; ibid. II, 324.

Elongate, cylindrical, slender. Piceous black, moderately shining, legs and antenne paler. Thorax much longer than wide, the disk with a deep impressed line at center and another abbreviated one on each side, surface rather coarsely punctured. Elytra not wider than thorax, each aiternate interval finely ribbed, the interspaces with two rows of punctures. Length 4-6.5 mm. (rig. 208.)

Throughout the State; frequent. April 9-October 23. Occurs especially beneath bark of linden and locust $\log \mathrm{s}$.

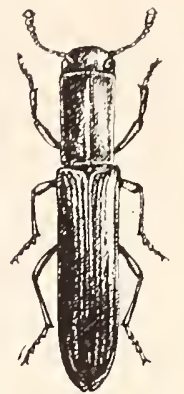

Fig. 208. $\times 6 \frac{1}{2}$. (Original.)

\section{Tribe III. PYCNOMERINI.}

Elongate, somewhat flattened species, covered with coarse punctures and having the elytra marked with rows of very large punctures; hind coxa small, oval. widely separated; first joint of tarsi longer than either of the next two, the third longer than fourth. Two genera are known.

\section{KEY TO GENERA OF PYCNOMERINI.}

a. Antennæ 11-jointed, the club 2-jointed.

ViI. PENThelispa. a a. Antennæ 10-jointed, the club composed of a single joint.

VIII. Pycnomerus.

VII. Penthelispa Pase. 1861. (Gr., "sorrow+smoeth.")

Two species belong here, both of which may occur in the State.

KEY TO SPECIES OF PENTHELISPA.

a. Thorax slightly wider than long, not narrowed behind; hind angles prominent.

a $a$. Thorax longer than wide, slightly narrowed behind; hind angles not prominent.

1062. REFLEXA.

$P$. homatodes Fab., brownish, shining, length $3.5 \mathrm{~mm}$., is said to occur rarely from Penmsylvania to Texas.

1062 (3285). Penthelispa reflexa Say, Journ. Phil. Acad. Nat. Sci.. V, 1826, 262 ; ibid. II, 322.

Elongate, subdepressed. Dark reddish-brown, shining. Antennie stout. shorter than thorax, the latter with disk deeply and coarsely punctured. Elytra slightly wider than thorax, disk tlattened, deeply and broadly striate, the strixe coarsely and closely punctured; intervals very narrow. Length $4-5 \mathrm{~mm}$.

Marion, Perry and Posey counties; searee. May 13-Norember 28. Occurs on trunks of dead locust. 


\section{Pycnomerus Erichs. 1832. (Gr., "close + joint." )}

In this genus the eleventh joint of the antennæ is closely united to the tenth, so that the elub is solid and apparently one-jointed. It is represented in the United States by the single species:

1063 (3286). Pycnomerus sulcicollis Lec., N. Spec. N. Amer. Col., 1863, 69.

Elongate, subconvex. Dark reddish or chestnut-brown, shining. Thorax slightly longer than wide, base rery little narrower than apex, disk with two broad grooves at middle which do not reach the apex or base, margin slightly reflexed, surface sparsely punctate. Elytra slightly wider than thorax, the strixe with coarse, deep, elongate punctures. Length 5$5.5 \mathrm{~mm}$.

Putnam Counity; scarce. June 29.

\section{Tribe IV, BOTHRIDERINI.}

Somewhat flattened, oblong or elongate beetles, having the antennæ short, 11-jointed, received in ohlique antennal grooves, club 2-jointed; all the coxæ widely separated; first ventral segment elongate; first joint of tarsi longer than either the second or third. Both genera are probably represented in the State.

\section{KEY TO GENERA OF BOTHRIDERINI.}

a. Head horizontal or nearly so; front coxæ very narrowly enclosed behind; outer apical angle of tibia not prolonged. IX. Bothrideres. a . Head deflexed; front coxa very distinctly closed; outer apical angle of tibiæ prolonged.

Erotylathris.

IX. Bothrideres Erichs. 1832. (Gr., "a small trench + neck.")

One of the two known species occurs in Indiana.

*1064 (3287). Bo'fhrideres geminatus Say, Journ. Phil. Acad. Nat. Sci., V, 1826, 262 ; ibid. II, 323.

Oblong, subdepressed. Dark reddish or chestnut-brown, moderately shining, sparsely pubescent. Thorax longer than wide, narrowed behind, apex feebly emarginate; sides slightly curved with a small tubercle on middle of margin; disk raguely concave, coarsely and rather densely punctured. Elytra slightly broader than thorax, striate, the strix finely punctured; intervals alternately wider with a single row of punctures, the narrower ones smooth. Length $3-4.5 \mathrm{~mm}$.

Southern half of State; frequent. February 25-November 24. Occurs beneath bark, usually that of living hickory, maple and other trees.

Erotylathris exaratus Melsh., oblong, black, opaque, length 4-6.5 mm., is a southern form which has been taken at Cincinnati. Dury finds it beneath the bark of dead elm. 
rribe V. C'LRILONINI.

Small oblong or oval flatened bestes having the last joint of palpi small and pointed, next to last thick, oval; middle and hind coxæ widely separated; first ventral segment as long as the three following; first three joints of tarsi short. together shorter than fourth. Two genera are represented in Tndiana, each by a single species.

\section{KEY TO GENERA OF CERYLONINI.}

a. Antenne 10-jointed, club composed of a single joint; front coxal cavities closed behind; tibie with small terminal spurs. $\mathrm{X}$. Ceryon. au. Antennæ 11-jointed, club 2-jointed; front coxal cavities open behind; tibiæ without terminal spurs.

XI. Philothermus.

\section{Cerylon Latr. 1802. (Gr., the name of a bird.)}

Head small, deeply inserted; front coxe widely separated, prosternum broad.

*1065 (3290). Chrylon castaneum Say, Jomm. Phil. Acad. Nat. Sci., V, 1826, 259 ; ibid. II, 321.

Oblong-elongate, depressed. Dark reddish or chestnut-brown, shining. 'Thorax nearly square, hind angles rectangular, disk with a slight impression on each side at base, rather coarsely but not densely punctured. Elytra scarcely wider than thorax, surface striate, the strixe punctured. Length $2-3 \mathrm{~mm}$.

Frequent in the southern half of State; less so in the northern counties. March 25-December 28. Occurs in winter on the under side of deeply buried logs, and also then and at other seasons beneath bark of elm and other trees.

\section{Pinlothermus Aubé. 1838. (Gr., "love + heat.')}

*1066 (3291). Pimlothermus grabriculus Lec., N. Spec. N. Amer. Col.. $1863,69$.

Elongate-oval, subdepressed. Dark reddish or chestnut-brown, shining. Thorax broader than long, broadest at base; sides regularly curved from apex to base, margin distinctly reflexed; disk sparsely and finely punctate. Elytra not wider than thorax, with rows of rather coarse punctures which are less distinct toward apex. Length $2-3 \mathrm{~mm}$.

Throughout the State; common. Narch 12-December 25. Occurs beneath bark and rarely beneath stones.

Tribe VI. MURMIDIINI.

The principal distinctive characters of this tribe, in addition to those given in the key, are the very small oval body, the 10 -jointed 
antennæ, usually received in a cavity at the apical angle of the thorax, and the widely separated coxx. Five genera are recognized by Casey.* While no member of the tribe has as yet been noted from Indiana, two of the genera, each of which contains a single species, may be represented in the State.

KEY TO INDLANA GENERA OE MURMIDIINI.

a. Antennal cavities visible from above; prosternal lobe large, completely concealing the labrum and mouth parts in repose; legs strongly retractile.

MURMitdius.

a . Antemnal cavities visible in front. but not from above; prosternal lobe truncate, not concealing the mouth parts; legs free. Mrchocerus.

Murmidius ovalis Beck., brownish, shining, elytra with rows of distant punctures, length $1.3 \mathrm{~mm}$., is widely dispersed by commerce.

Mychocerus depressus Lec., reddish-brown, depressed, length 1 $\mathrm{mm}$., is a rare southern species which has been taken near Cincinnati.

\section{Family XX. RIYSSODID A.}

\section{The Wrinkled Bark Beetles.}

This family comprises only four North American species, two from each side of the continent. The name of the family is founded upon that of the typical genus Rhyssodes, meaning "wrinkledform," and doubtless refers to the deep grooves of head and thorax. They are narrow, elongate, somewhat flattened brown beetles having the head strongly constricted behind into a neck, and furrowed by two deep grooves; antennæ composed of 11 nearly equal rounded joints (Fig. 4, No. 12), inserted under the frontal margin; thorax long, deeply grooved; scutellum wanting; elytra rounded at tip. covering the abdomen; front coxal cavities widely separated, closed hehind; abdomen with six ventral segments, the first broadly triangular, widely separating the coxæ; legs short, the front tibixe terminated by two hooks; tarsi 5 -jointed, very slightly pubescent beneath.

The principal paper treating of the family is the following:

LeConte._"Notes on the Rhyssodida of the U. S.," in Trans. Amer. Ent. Soc., V, 1875, 162-168.

The two species of the Atlantic slope both occur in Indiana, living under bark of decaying logs. They belong to different genera, separated as follows:

*Ann. N. Y. Acad. Sci., VIII, 1895, 451 
KEY TO GENERA OF RIISSSOIDE.

u. Elytra not grooved, hut with distinct rows of punctures.

I. RHYssones.

aa. Elytra deeply grooved, without punctures.

II. Clinidium.

\section{RHyssodes Dalman. 1825. (Gr.." "wrinkled + form.")}

In this genus the thorax has three deep, antire grooves and one finer line on each side. The eyes are rounded. distinctly granulated and situated on the sides of the head; the middle and hind tibix have one terminal spur.

*1067 (3295). Rhyssodes americanus Tap., Silberm. Rev., IV, 1836, 58.

Elongate, narrow. Uniform dark reddish-brown, shining. Thorax one-half longer than wide, broally rounded on the sides; furrows rery deep, the two outer ones dilated behind. Elytral strix composed of large punctures, the inner ones rather deeply impressed. Front femora of male armed with a distinct tooth. Length $6-7.5 \mathrm{~mm}$. (Fig. 209.)

Frequent throughout the southern half of the State; less so in the northern counties. April 14-December 18. Both this species and the next hibernate singly or in small colonies beneath the close fitting bark of beech, oak and elm logs, rarely beneath mul-

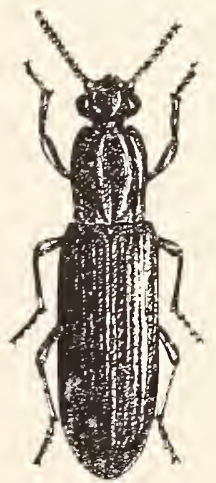

Fig. 209. $\times 4 \frac{1}{2}$. (Original.) lein leaves. One of these colonies containing 18 specimens was noted on November 28, beneath the bark of an elm log. This is the species usually called exaratus Serv., which name was preoccupied.

\section{Cumidum Kirby. 1829. (Gi'., "a slope + little.")}

In addition to the deeply grooved elytra devoid of punctures. this genus may be known by the thorax having one entire dorsal line, two short, deep basal impressions and a double line on each side; eyes narrow, scarcely granulated, confined to the upper side of the head; middle and hind tibix, with two terminal spurs.

*1068 (3297). Chinidium sculpitle Newm., Nat. Hist., 1838, 666.

Form and color as in $R$. americumus. Thorax oblong, nearly twice as long as wide, sides broadly rounded. Elytra with the intervals narrower than the deep intervening groores. Front thighs of male distinctly toothed. Length $5.5-7.5 \mathrm{~mm}$.

Throughout the State: frequent. February 21-November 8 Mating on April 9.

[36-23402] 


\section{Family XXI. CUCU.JID A.}

\section{'The Flat Bark BeEtles.}

The Cucujidre constitute a small family of very depressed elongate beetles. As Mr. Dury has well said: "The members of the family are striking examples of forms modified for an existence under the loose, close-lying, bark of trees, enabling them to squeeze into crevices, where they find food for their larva. and which the eternally vigilant ant cannot penetrate." The name "Cucujus" is of South American origin, and its meaning is not certain. It is said to be applied by the natives to a luminous snapping beetle (Elater noctitucus L.) of Brazil and adjoining countries.

From allied families the Cucujidx may be distinguished by having the antennx 11-jointed, inserted at the margin of the front, sometimes long and slender, sometimes with the outer joints slightly enlarged; scutellum distinct; elytra rounded at tip and covering the abdomen, usually flat and strongly margined; front coxal cavities widely separated, usually closed behind, though open in some subfamilies, the coxæ rounded or subglobular, not prominent; middle coxæ small, subtriangular, not prominent; hind coxæe nearly contiguous, transverse; abdomen with five free ventral segments, equal in length; legs rather short, femora large; tibie slender, terminated by two spurs.

The larvæ of the Cucu,jidie, as far as known, are flattened grubs with distinct antennæ and several simple eyes, the terminal segment ending in hooks or tubercles. Like the mature beetles they live under bark, and some of them are carnivorous, feeding upon mites, podurids and small larvæ of wood-boring beetles, so that in general they may be regarded as beneficial. However, two of the beetles, Sitvanus surinamensis, and Cathurtus advena, infest stored grain, dried fruits and other stores, and are therefore often quite injurious.

The principal literature treating of the North American forms is as follows:

LeConte.-- "Revision of the Cucuiides of the United States," in Proc. Phil. Acad. Nat. Sci., VII, 1854, 73-79.

Casey.- "Revision of the Cucujidxe of America North of Mexico," in Trans. Amer. Ent. Soc., XI, 1884, 69-112.

Wickham.-."The Cucujidx of Ontario and Quebec," in Can. Ent. XXVII, 1895, 25-29. 
Almost 400 species of the family are known, about 60 of which. distributed among 17 genera. are from the United States. These are divided among five subfamilies. foum of which are represented in Indiana.

KEI TO INDIANA SUBFAMILIES OF CUCUJIDE.

a. Front coxal carities closed behind.

b. Tarsi not lobed beneath, the fourth joint small; antennæe with distinct club, their third joint nerer longer, usually shorter than the second.

Subfamily I. Siltaxixe, p. 561.

66. Tarsi with the third joint lobed beneath; fourth tarsal joint rery small; antenne long and slender, filiform; last joint of maxillary palpi in our species large, hatchet-shaped.

Subfamily IV. TelePhaxix.e. p. 569.

aa. Front coxal carities open behind; antennæe usually without club; the third joint longer than second (except in some Lromophtous).

c. Maxille concealed by horny plates which extend out from the sides of the mouth; thorax as long or longer than broad.

Subfamily II. Passandrixæ, p. 564.

cc. Maxillie not concealed.

Subfamily III. CucuJixe, p. 565.

\section{Subfamily I. SILVANINAE.}

Elongate, depressed brownish forms, less than $5 \mathrm{~mm}$. in length, having the tarsi 5-jointed in both sexes; the maxilla exposed. Three genera occur in the State.

\section{KEY TO IXDIANA GENERA OF SILTAXIXE.}

a. Club of antemne formed by abrupt enlargement of last three joints; form rer's slender: length less than $3 \mathrm{~mm}$.

b. The three joints of the club subequal.

I. Silvaxts.

60. The middle joint of the club slightly larger than either of the other two.

II. Cathartis.

a a. Club formed by gradual enlargement of the joints; form broader; length $3.5-5 \mathrm{~mm}$.

iII. Nausibics.

I. Silvantes Lat. 1S0T. (L.. "pertaining to a wood or forest."')

Small oblong or elongated species having the head subquadrate. last joint of palpi obconical; antennx with joints one and tryo larger. three to seren smaller. subequal: eighth smallest; nine to eleren forming an abrupt loose club. Flytra with large round punctures arranged in rows. They occur beneath bark. more especially that of oak. elm or poplar. or in grain. Four species are known from the State. 
KEI TO IXDIANA SPECIES OF SILTANUS.

a. Thorax suboral, its sides each with six teeth.

1069. SURINAMENSIS.

a . Thorax elongate, the sides not toothed.

b. Thorax strongly narrowed behind, the sides more or less sinuate; head with a small tooth behind each eye.

c. Thorax with a sharp divergent tooth at each front angle; elytra very opaque. strongly punctured.

1070. BIDENTATUS.

cc. Thorax with teeth less dereloped; elytra somewhat shining, less densely punctured.

1071. PLANATUS.

bb. Thorax rery feebly narrowed behind, the sides nearly straight; head without a tooth behind the eye.

1072. IMBELLIS.

*1069 (3299). Silyanus surinamexsis L., Syst. Nat., II, 1767, 565.

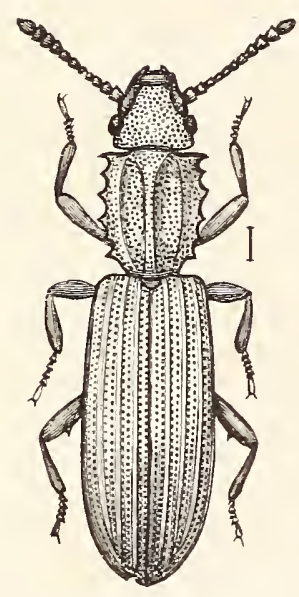

Fig. 210. (After Chittenden. Far. Bull. 45, U. S. Dep. Agr.)

Elongate, depressed. Dark chestnut brown clothed with lighter pubescence. Antennx slightly longer than thorax. Thorax longer than wide, the disk with three raised lines; sides evenly curred and provided with six distinct teeth. Elytra each with four costæ, the intervals granulate-punctate. Length $2.5 \mathrm{~mm}$. (Fig. 210.)

Marion and Vigo counties: common. Probably throughout the State, as it has been carried by commerce all over the globe. On account of damage done to stored grain. corn in particular, it is known as the "corn silvanus." It also feeds on dried fruits. By closing the bin or fruit receptable airtight. or as nearly so as possible, and pouring in bisulphide of carbon, a gill for each bushel capacity. and allowing it to evaporate for twenty-four hours, both beetles and larve will be killed without leaving any odor or flavor behind. Hibernates as imago. April 25-December 28.

1070 (3300). Silmayus Bidentatus Fab., Syst. El., I, 1S01, 317.

Elongate, subdepressed. Dark reddisin-brown, very opaque, densels punctured. Front angles of thorax sharply toothed the disk somewhat convex and with traces of the raised lines seen in surinamensis. Length $2.7 \mathrm{~mm}$.

Marion. Putnam. Jackson. Lawrence and Crawford counties: frequent. March 20-. Tune 12. Taken beneath bark and by sifting. 1071 (3301). Sildaxus plaxatts Germ., Ins. Spec. Nor., 1824, 466.

Elongate, depressed. Dark chestnut bromn, less densely punctured. Thorax broader than in bidentatus; sides parallel from apex to middle. thence distinctly converging. Length 2.2-2.7 $\mathrm{mm}$.

Throughout the state: commion. April 16-Norember 30. It is possible that this is the female of bidentatus. They often occur in company and Linell stated (Entom. Amer. III, 171), that he had taken the two in coitu. 
1072 (3302). Silvanus mmeltis Lec, Proc. Phil. Acad. Nat. S'ci., VII, 1854, 7 .

Elongate, rather narrow, depressed. Dark reddish-brown, subopaque, very deeply and densely punctured. Thorax slightly longer than wide, the teeth of front angles but slightly developed; disk finely and densely punctate; hind angles obtuse. Length $2.5 \mathrm{~mm}$.

Throughout the State; frequent. February 4-November 8. Occurs in damp localities, often beneath the bark of sycamore.

\section{CatharTus Reiche. 1854. (Gr., "to cleanse.")}

Small brown forms very close to silvamus but having the middle club joint larger than either of the others; thorax broader than long except in quadricollis. T'wo species have been taken in the State, while two others may occur.

KEY TO INDIANA SPECIES OE CATHARTUS.

a. Thorax either subquadrate or longer than wide, its sides nearly straight; body very feebly punctate. (Fig. 211.)

QUADRIC OLLIS.

a a. Thorax broader than long.

b. Front angles of thorax each with a distinct tooth.

$c$. Second and third joints of antenne subequal;

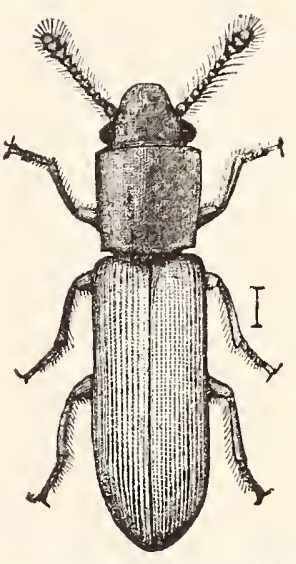

Fig. 211. (After Chittenden, Far. Bull. No.45.) head and thorax minutely and densely punctate; form broader and more conver.

1073. ADVENA.

$c c$. Second joint of antemine distinctly longer and stouter than third; head and thorax densely granulate-punctate; form more slender.

1074. LONGULUS.

b7. Front angles of thorax not toothed.

RECTUS.

C. quadricollis Guer., elongate, slender, pale reddish-brown. shining, length 2.4-3 mm., is known from Pennsylvania and Georgia. 1073 (3305). Cathartus advena Waltl., Silb. Rev. Ent., II, 256.

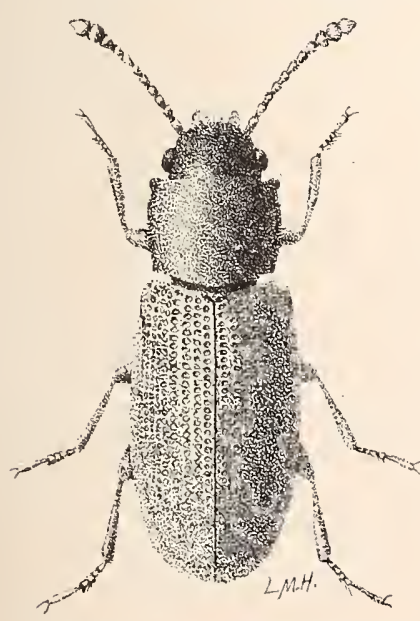

Fig. 212. $\times$ 20. (After Forbes.)

Oblong, subconvex. Rather pale chestnut brown, shining, finely pubescent. Thorax quadrate, one-third broader than long. sides feebly curved, front angles with minute blunt teeth. hind ones rectangulir. Elytra with rows of rather coarse punctures. I.ength $1 . \overline{7}=2 \mathrm{~mm}$. (Fig. 212.)

Southeru half of State; frequent. January 24-November 12. Probably occurs thronghont the State, as it feeds on varions articles of commeree, especially damp flour. meal, rice, figs, beans. apples, etc. If these articles be stored in a clean, dry. well-ventilated place the damage will not be serious. 


\section{4 (-). Cathartus longulus sp. nov.}

Elongate, slender, subdepressed. Head and thorax dark reddish-brown, subopaque; elytra, antennæ and legs paler brown, more shining. Antennæ slender, longer than head and thorax, joints $3-8$ subequal, ninth two-thirds the width of tenth. Thorax slightly wider than long; sides almost straight, the margins flattened; front angles with an obtuse tooth. hind ones acute; disk with dense elongate granules. Elytra scarcely wider at base than thorax, with rows of rather fine, close-set punctures. Length $2 \mathrm{~mm}$.

Starke County ; rare. June 16. Sifted from borders of sphagnum marsh.

C. rectus Lec., pale chestmut-brown. length $2 \mathrm{~mm}$., is known from Penusylvania, Illinois and southward.

\section{Nausibius Redt. 1858. (L., "disgust+life.")}

Broader and more depressed than in Sivvanus, the elytra costate and covering the entire abdomen. One species is known from the State.

1075 (3308). Nausibius clavicornis Kug., Schneider’s Magaz., I, 1794, 511.

Elongate, depressed. Dark chestnut brown, deeply and densely punctured. Antemme robust, rather short, placed on the front angles of the head in front of eyes. Thorax quadrate, disk with two indentations behind the middle; sides rith six obtuse teeth. Elytra each with four slightly elevated lines. Length $3.5-4.5 \mathrm{~mm}$.

Vigo County; rare. September 17. T'wo specimens were taken with a dozen other species at sap beneath the bark of a soft maple tree. LeConte states that it occurs usually in rice. sugar and other articles of commerce throughout the United States. Listed as $N$. dentatus Marsh.

\section{Subfamily II. PASSANDRINAE.}

Elongate, slender. depressed or subcylindrical species, having the tarsi 5-jointed in both sexes; elytra covering the entire abdomen; head quadrate; eyes coarsely granulated. One of the three genera is represented in the State.

\section{Catogenus Westw. 1835. (Gr.. "inferior + chin.")}

This genus is represented by a single species of wide distribution which is very variable in size. It has robust, bead-like antennæ, joints one to ten subglobular, first largest, second smallest; the last joint compressed and carinate.

*1076 (3310). Catogents rufus Fab. Ent. Syst. Emend., 1798, 123.

Elongate, depressed. Dark reddish or chestnut brown. Head with a transverse groove behind the eyes. Thorax narrowed behind, ristinctly 
punctured but with a faint smooth median line on basal half. Ealytra deeply striate, not punctate. Eyes almost invisible from above. Length j-11.5 mun.

Throughout the State; common. February 2-October 13. Hibernates in numbers beneath bark. especially that of sugar maple.

\section{Subfamily III. CUCUJINAE.}

The absence of the horn-like plates concealing the maxillae is the rhief distinction between this and the preceding subfamily. The following genera are known to be represented or may occur in the State.

KET TO INDIANA GENERA OF CUCUJINE.

u. Head widest behind the eres; color bright red.

V. CUCUJUS.

a a. Head widest across the eyes.

b. Body elongate, cylindrical; thorax margined.

NarTHEClCS.

ъ7. Body depressed.

c. Antenne shorter than head and thorax, the latter not margined.

Pediaces.

r. Antemne longer than head and thorax.

a. Thorax not serrate at sides, sometimes with a single tooth at front angles.

e. Elytral rery short: thorax not margined.

INo.

ee. Elytra long: thorax marginer.

$f$. First antennal joint about as long as head. Dendrophagus.

if. First joint much shorter than head; thorax with an impresserl line each side of disk.

g. Spurs of front tibire unequal in length.

TI. L.EMOPHLEUS.

$g g$. Spurs of front tibire equal.

LATHROPC'S.

dd. Thorax distinctly serrate at sides; first joint of antennie nearly as long as the head.

VII. Brontes.

V. Cucutus Fab. 1775. (NL., a word of South American origin.)

To this genus belongs our largest and most brilliantly colored member of the family.

*1076 (3316). Cucujes claripes Fab., spec. Ins. I. 17S1, 257.

Elongate. very depressed, sides parallel. Above bright scarlet red; beneath duller red; tibice and tarsi darker. Antenne black. equal to head and thorax in length. Head broadest behind the eres. the hind angles being produced outward and backward. Thorax coarsely punctate; disk with three broad, slightly elerated ridges. Elytra finely punctate. Length 10-13.5 mm. (Fig. 213.)

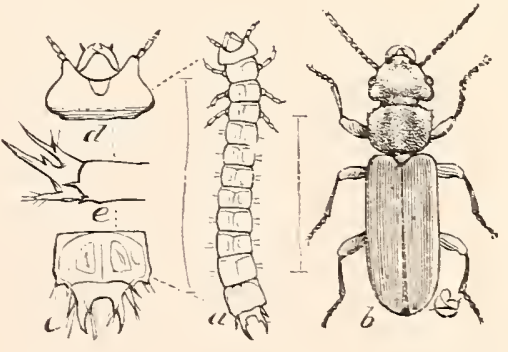

Fig 213. $a$, larva; $c$ and $e$, enlarged back and side views of its anal joint; $d$, view of

Southern half of State, frequent; less its head; $b$, imago. (After Riley.) 
so in the northern counties. March 17-December 20. Occurs beneath bark, especially that of freshly felled ash and poplar logs. Sometimes gregarious in colonies of twenty or more.

Narthecius grandiceps Lee, dark chestnut-brown, thorax narrowed behind, length $3 \mathrm{~mm}$., is known from Pennsylvania and Nebraska, but is very rare.

Pediacus depressus Tlerbst., recidish-brown, strongly punctured, length $3.3 \mathrm{~mm}$., is a cosmopolitan species which has been taken by Dury near Cincinuati. The also records an undescribed species of Ino from the same locality.

Dendrophagus glaber Lee., black, shining, elytra sometimes brown, length 6-7 mm., is a boreal species which may occur in the northern counties.

\section{Limoptumus Lap. 13:37. (Gr., "to eat + bark.")}

Smail, flattened or subeonver species, usually much broader proportionately than in siluams, the antennæ frequently elongate. especially in the males; eyes rather small, near the front edge of thorax; labrum large, transverse, rounded in front; middle and hind tarsi 4-jointed in the males. 'The following have been taken or perhaps occur in the State.

KEY TO INDIANA SPECIES OF LEMOPHLEUS.

a. Second joint of antennæ shorter than third.

$b$. Labrum enrarginate; elytra with a pale spot before the middle of each; length 2.S-4 min.

c. Elytral spot nearly circular, well defined; surface densely punctate. 107s. BIGUTTATLS.

cc. Elytral spot ill-defined, irregular in form; surface finely and sparsely punctured.

1079. FASCIATUS.

bb. Labrum entire; elytra without spots; length $1.5-2 \mathrm{~mm}$.

d. Body convex.

e. Front angles of thorax toothed.

CONVEXULU'S.

$e e$. Front angles of thorax rounded.

d d. Body depressed; elytra shorter than abdomen.

10S0. ADUSTUS. MODESTC'S.

a a. Second joint of antenne equal to third; pale reddish-brown. elytra without spots; length $1.5-2 \mathrm{~mm}$.

f. Head with transverse groore behind the eyes; male without deep notch in front of base of antenne.

10S1. TESTACECS.

ff. Head without transverse groove; male with head deeply notched near base of antenne and first joint of the latter as long as the three following.

1082. PUNCTATUS. 
*1078 (3320). Lemophr.dens biguttatus Say, Journ. Phil. Acarl. Nat. Sci., V, 1826, 267; ibid. II, 326.

Oblong, depressed. Dark chestnut brown; legs and antennie slightly paler. Thorax narrowed behind; sides much curved, the margins obsoletely crenate. Elytra striate, twice as long as head and thorax together, strongly margined. Length $3-4 \mathrm{~mm}$.

Southern half of State; frequent. May 1-December 18.

1079 (3321). Læmophleus fasciatus Melsh., Proc. Phil. Acad. Nat. Sci., II, 1844, 113.

Oblong, depressed. Pale reddisll-brown; elytra somewhat darker. Antennæ slightly longer than head and thorax, the last three joints broadest and flattened. Thorax slightly nurowed behind, sides curved and feebly sinuate. Elytra as in biguttatus, but only lightly punctured. Length $3-$ $3.5 \mathrm{~mm}$.

Kosciusko, Marion, Lawrence and Posey comnties; scarce. March 24-November 23. 'Taken in spring at sap on maple and beech stumps.

L. convexulus Lec, dark brownish-yellow. length 2-2.4 mm., is known to occur from Michigan and near Cincinnati.

1080 (3327). Lemophlzus adestus Lec., Proc. Phil. Acad. Nat. Sci., VII, $1854,74$.

Oblong, subconvex. Head and thorax reddish-brown, thickly and coarsely punctured; elytra darker, shining, glabrous. Ifead as wide as thorax; antenne two-thirds the length of body. Thorax twice as wide as long, narrowed at base, sides strongly rounded, sinuate near hind angles. which are sharp and prominent. Elytral striae fine, punctured. Length $2 \mathrm{~mm}$.

Iake. Kosciusko. Marion and Posey counties; scarce. Nareh 27-.Tune 20. Occurs on beech logs.

L. morlestus Say, dark brownish-yellow, sparsely and rather deeply punctate. length 1.8-2.3 mm., is known from Canada and Georgia.

1081 (3328). Lemophleus testaceus Fab., Ent. Syst. Emend., I, 1798, 96.

Elongate-oblong, depressed. Uniform light reddish-brown. Antennre of male nearly as long as body ; of female equal to elytra. Head and thorax sparsely and rather finely punctured; the latter quadrate, sides almost parallel, front angles plainly toothed, hind ones rectangular, lateral grooves distinct. Length $1.5-2 \mathrm{~mm}$.

Throughout the state: frequent. January 5-June 20. Found mating in April. Hibernates; gregarious in winter. 
1082 (3330). Lemophlæus punctatus Lec., Proc. Phil. Acad. Nat. Sci., VII, 1854. 75.

Form and color of testacens. Head and thorax more coarsely punctured, the latter not as wide and feebly narrowed toward base. Elytra shorter, more distinctly striate, the outer stria deeper; intervals each with two rows of fine punctures. Length $1.6 \mathrm{~mm}$.

Crawford County; rare. August 10. Hitherto recorded only from the southern states.

Lathropus vernatis Lec., dark chestnut-brown, legs, antennæ and front of head paler, head and thorax covered with small elongate granules, length 1.3-1.7 mm., occurs in the "Atlantic and Mississippi regions."

\section{VIT. Bronies Fab. 1801. (Gre., "thunder.")}

Rather broad and very flat species having the sides of thorax finely and acutely serrate, the front angles strongly toothed and the mesosternum emarginate in front. Two species occur in Indiana.

*10S3 (3349). Brontes dubius Fab., Syst. Eleut., II, 1S01, 97.

Moderately elongate, rery depressed. Nearly uniform brownish-black; legs and margins of elytra paler; head and thorax often paler than elytra, their surface coarsely and densely punctured. Antennæ as long as body, densely pubescent. 'Thorax one-half broader than long; front angles very prominent and toothed, hind ones broady rounded. Elytra broader at base than thorax, with a distinct costa from humerus to apex; sides strongly margined. Length $4.5-5.5 \mathrm{mmm}$.

Throughout the State; common beneath bark. February 21November 17. The mandibles of male are armed with a slender curved horn which is turned upward to meet the one of the opposite side.

1084 (3350). Brontes debiuls Lec, Proc. Phil. Acad. Nat. Sci., VII, 1S54, 76.

Elongate, slender, depressed. Uniform piceous-black, clothed with short, sparse yellowish hairs; antenne and legs reddish-brown, the former as long as thorax and elytra together. Thorax about as long as wide, distinctly narrowed behind the middle, sides finely and evenly serrate; front angles acute, hind ones obtusely rounded; surface densely and coarsely punctured. Elytra costate as in dubius and as there with a row of minute granules along each interval, the sides between the costre and margin almost perpendicular. Length $4-5 \mathrm{~mm}$.

Marion Comnty; rare. November 1. Taken by sifting. The narrower and less serrate thorax, more slender form and darker color easily distinguish this from dubius. 


\section{Subfamily IV. TELEPHANINAE.}

Two genera comprise this subfamily, one of which is represented in the State by a single species:

\section{VIIT. TELephanis Erichs. 1892. (Gr.," distant + glitter.")}

Elongate, slender, sublepressed species, having the first joint of antenux long, spindle-shapeci clytra broader than thorax, their tips rounded; hind femora swollen; tarsi 5 -jointed, the last joint bilobed.

*1085 (3353). Telephanus velox Hald., Proc. Phil. Acad. Nat. Sci., III, 1846, 127.

Pale brownish-yellow, closely and coarsely punctured; rather coarsely pubescent; head and often the apical third of elytra fuscous. Antennæ as long as elytra; apical half, except the last one or two joints, darker. Thorax one-half longer than wide, narrowed behind the middle. Length $4 \mathrm{~mm}$.

Throughout the State; common. February 27-November 27. Occurs more often beneath stones, chunks and dead leaves than beneath bark. When exposed it usually remains quiescent with antennæ folded against sides, but if touched it runs with great swiftness, whence its specific name.

\section{Family XXII. CRYPTOPHAGIDA.}

\section{The Silken Fungus BeEtles.}

Belonging here are a number of beetles of small size, oblong or oval in form and never very depressed. They are usually less than $2.5 \mathrm{~mm}$. in length and often of a light yeilowish-brown color, with a silken lustre produced by a very fine pubescence. Their habits are exceedingly variable, some living in fungi, others about wood and chip piles or in cellars, beneath dead leaves, in rotten logs or on flowers. They are to be taken in early spring by sifting and in summer by beating vegetation or examining fleshy fungi. The name Cryptophagidæe implies that the insects comprising the family feed upon cryptogamous plants, which include the mushrooms and fungi; however, they are much less fungivorous in habit than the members of the next family.

The principal distinguishing characters of the family, briefly stated, are the 11-jointed antennæ, with joints 9 to 11 larger, forming a loose club; thorax nearly or quite as wide as elytra, often with distinct basal impiessions and usually with the lateral edges modified by serrations or nodular

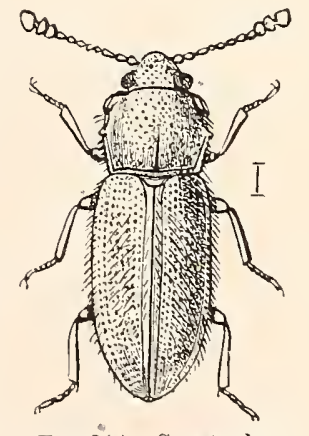

Fig. 214. Cryptophagus dentatus. A European species. (After Sharp.) 
thickenings; elytra rounded behind, entirely covering the abdomen, the latter with five free ventral segments, the first usually somewhat longer than the others; front coxæ oval, moderate in size, separated by the prosternum, the coxal cavities usually widely open behind; legs short, tarsi 5-jointed, the hind ones 4-jointed in the males of certain genera, the joints clothed beneath with long hair. (Fig. 214.)

The family is closely allied to the cucujide, but the broader and shorter convex body, the oval front coxæ and the usually greater length of the first ventral segment are sufficient to distinguish the two. The principal, and practically the only, paper treating of the North American representatives of the family is that of:

Casey.- "Review of the American Cryptophagidx," in Journ. N. Y. Ent. Soc., VIII, 1900, 75-128.

In it he has placed the genus Diplocchus, assigned by LeConte and Horn to the Mycetophagidx, and has listed and described from North America 127 species, distributed among 16 genera. For convenience the family is first divided into two subfamilies as follows:

\section{KEY T'O SUBFAMILIES OF CRYPTOPHAGIDE.}

a. Antenna remotely separated at base, inserted under the sides of the front; palpi dissimilar, the maxillary elongate and slender, with the fourth joint elongate and more or less acuminate at tip, the labial short with the last joint oval or hatchet-shaped.

Subfamily I. Criptophagin e, p. 570.

ar. Antennie close together at base, inserted on the front; palpi similar, short, stout and acuminate, the last joint of both small, narrow and awl-shaped.

Subfamily II. ATomarima, p. 578.

\section{Subfamily I. CRYPTOPHAGINAE.}

The species of this subfamily are generally larger, more oblong. less convex and more pubescent than in the Atomariinæ. Of the 127 species accredited the family by Casey, 59 belong here.

KEY TO INDIANA GENERA OF CRYPTOPHAGTNE.

a. 'Thorax with two fine raised lines on each side of the disk; antennal grooves before the eyes narrow and deep; trochanters moderate in size, very obliquely attached at the side of the base of the femora.

I. Diplocalés.

aa. Thorax without raised lines on the disk (except in Crosimus); antennal grooves obsolete; trochanters elongate, bearing the femora obliquely attached to their outer ends; antennal club always loosely :-jointed

b. Front coxil carities completely closerl behind ; first ventral segment but little longer than second and with two straight raised lines 
diverging from the inner margin of the hind coxal cavities; first joint of hind tarsi as long as the next two combined; eyes with coarse facets.

II. Cryptophilus.

bb. Front coxal cavities broadly and completely open behind; basal segments of abdomen variable in length.

c. Tarsi with third joint strongly and second joint less strongly lobed beneath, the fourth joint very small; 5-jointed in both sexes.

a. Body distinctly, rather densely pubescent, closely and irregularly punctured; ninth joint of antenna very little wider thin eighth; sides of elytra not margined at base; prosternal process acute at tip.

iII. Telmatophimus.

dd. Body sparsely and feebly pubescent; ninth antennal joint as wide as the tentlı; sides of elytra margined at base; prosternal process truncate at tip.

$e$. Punctures of elytra in rows; thorax transversely impressed at base.

IV. LOBERUS.

ee. Punctures of elytra few and irregularly distributed; thorax not impressed at base.

V. 'Tomarus.

$c c$. Tarsi filiform, simple, and never lobed beneath, 5-jointed in the females, the hind ones 4-jointed in the males; sides of elytra never margined at base and elytral punctures never in rows.

f. Mesosternum deeply emarginate, receiving the prosternum; eyes situated in front of base of head, small, not prominent; body large, for the family, oblong, densely clothed with yellow liair.

VI. Antherophagus.

$\mathrm{ff}$. Mesosternum not emarginate; eyes situated at base of head, convex, prominent.

g. Sides of thorax with three undulations-at the apex and near apical and basal thirds-the apical angles not more thickened; body short, broadly oval and convex, with long hairy covering.

ViI. Crosimus.

gg. Sides of thorax not undulated.

7h. Thorax with apical angles thickened and obliquely truncate, the lateral edges even except a minute tooth near the middle; basal fovese very small and feeble.

Vili. Cryptophagus.

hh. Thorax with apical angles not thickened, the lateral edges serrulate with very fine teeth.

$i$. Body oval, convex; thorax with a distinct transverse basal groove.

IX. Henoticus.

ii. Body oblong, parallel, rather strongly depressed; thorax without a basal groove, but with two small distinct basal fovere.

X. Pteringium.

I. Diplockivs Guer. 18t6. (Gr.." "double + cavity.")

This genus, formerly placed in the next family. comprises small elongate or oblong subdepressed beetles, most easily distinguished by the fine raised lines on the sides of the disk of thorax. The anten- 
nal club is 3-jointed, the ninth joint slightly smaller than tenth, the. eighth small and similar to seventh. Three species are known from the United States, two of which are known from Indiana, while the other mar occur.

\section{KEY TO SPECIES OF DIPLOCELL'S.}

a. Raised lines on sides of thorax well marked.

b. Thorax narrowed in front, its sides nearly straight, hind angles prominent, externally corering the base of elytra. Axgcsticollis.

bb. Thorax not narrowed in front, its sides regularly curved.

10S6. BRCNNELS.

a a. Raised lines of thorax almost obsolete.

10ST. RUDIS.

D. angusticollis Horn, piceous, length $4.5 \mathrm{~mm}$., was described from Marquette, Michigan.

1056 (3414). Diplocelds brexyeds Lec., New Spec. N. Amer. Col., I. $1 S 63,73$.

Elongate-oral, slightly convex. Dull blackish-brown or piceous, feebly shining, rather sparsely pubescent. Thorax closely punctured, sides nearly parallel, disk with three elevated lines on each side, of which the inner is feeble and incomplete. Elytra with feebly impressed rows of close-set punctures, intervals each with a row of short, rery fine, suberect hairs. Length $3-3.5 \mathrm{~mm}$.

Marion. Putnain, Lawrence, Jemnings and Posey counties ; frequent. April 22-November 20. Probably hibernates. Taken in summer from fungi on beech and maple logs and in spring by sifting from about the roots of such trees.

1057 (3415). Diplocelus rudis Lec, loc. cit.

Elongate-oral. slightly convex. Dark reddish-brown to fuscous, shining. Thorax coarsely punctured, with only traces of raised lines on the disk; hind angles rectangular. acute. Elytra with rows of rery coarse punctures; intervals polished, each with a single row of rery long suberect hairs. Length $2-2.5 \mathrm{~mm}$.

A southern species taken in Perry County; rare. Мay 1.

\section{Cryptophiles Reitt. 1874. (Gr., "a concealed place + loving.' ')}

A single, small oblong: piceous-brown species, introduced from Europe, represents this genus in the State. It resembles sereral of our species of Cryptophagus but does not have the apical angles of thorax thickened.

$10 S S$ (-). Cryptophilts integer Heer. Famm. Helret., I, 1840, 426.

Elongate-oblong. subparallel. feebly convex. I'iceous or dark reddishbrown, sparsely clothed with suberect yellowish hairs. Antemne nearly 
half the length of body, the club loosely three-jointed. Head coarsely and rather closely punctured. Thorax one-half wider than long, sides feebly curved, margins rather wide and distinctly reflexed; front angles rather prominent, hind ones obtuse; disk convex, rather closely and coarsely punctate. Elytra a little wider at base than thorax, feebly narrowed from middle to the rounded tips; each with numerous closely placed rows of rather coarse slightly impressed punctures. Length $3 \mathrm{~mm}$.

Marion and Hancock counteis; frequent. April 6-October 15. Taken by Harold Morison from a cellar in which wood had been stored. Resembles Typho fumata L., but more coarsely punctate and less pubescent.

\section{Temmatopumber Heer. 1841. (Gr., "swamp + loving." )}

In this genus and the next two the thorax has two small, deep and widely separated fover or pits near the basal margin. The genus is represented by the single species:

1089 (3355). Telmatopinlus americants Lec., N. Sp. N. Amer. Col., I, $1863,70$.

Elongate-oval, convex. Dark reddish-brown to piceous, rather shining, the pubescence yellowish to ashy gray; antennie and legs reddish-brown, the former scarcely as long as head and thorax. Thorax a third wider than long, finely and densely punctate, sides evenly curved, the edges rery finely serrulate; apical angles obtusely rounded. hind angles acute. Elytra slightly wider than thorax, the punctures nuch less dense. Length 2.5$3 \mathrm{~mm}$.

Northern half of State; locally common on the flowers and leaves of the semi-aquatic plant, arrow-arum, Peltandra virginica L. May 20-June 25.

\section{Loberus Lec. 1861.}

Small oblong species resembling, at first sight, certain "fleabeetles" of the family Chrysomelidæ. From the members of allied genera they may be most readily known by the elytral punctures being arranged in rows, and bearing very short, fine, recurved hairs. One of the five known species oceurs in Indiana.

1090 (3356). Loberus mpresses Lec., N. Sp. N. Amer. Col., I, $1863,70$.

Elongate-oral, convex. Dark reddish-brown to blackish, shining; sparsely pubescent. Antemne slightly ionger than head and thorax, paler than body. Thorax narrower than elytra, nearly twice as wide as long; sides feebly curved, disk sparsely and rather coarsely punctate, basal depression broadly impressed. Flytral three and a lalf times as long as tholax, the apex rather nalrowly rounded; intervals smooth and without punctures. Length $2-2.3 \mathrm{~mm}$. 
Throughout the State; frequent. May 6-July 15. Occurs beneath bark and on foliage of plants usually near water. Common at Hudson Lake July 15, on the louse-wort, Pedicularis lanceolata Michx.

\section{Tómarus Lec. 1861. (Gr., "to cut.")}

Smaller and shorter than in Loberus. Elytra irregularly punctured; thorax not impressed at base; basal joint of antennal club about as large as second. One species occurs in Indiana.

1091 (3357). Tomarus pulchellus Lec., N. Sp. N. Amer. Col., I, 1863. 71.

Elongate-oval, convex, nearly smooth. Brownish-yellow

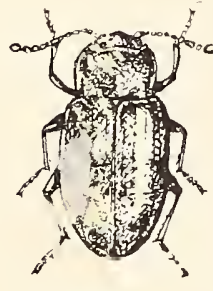

Fig, 215. $\times 12$. (Original.) to piceous; legs and basal half of antennæ paler; elytra each with a large liumeral space and a wide subapical crossbar yellow. Antenne slightly longer than head and thorax. Thorax finely but distinctly punctured, narrower than elytra; sides parallel and curved; apex as wide as base. Elytra widest just before the middle, then gradually narrowed to the rather acute apex, finely and sparsely punctured. Length 1.3-1.6 mm. (Fig. 215.)

Throughout the State; frequent, especially in spring, when it occurs in dead leaves and beneath mullein, stones and chunks. Hibernates. Narch 19-December 7 .

\section{Antherophagus Lat. 1806. (Gr., "blossom + eating.")}

This genus comprises the largest members of the family, distinguishrod by having the eyes placed on the side of head; male with clypeus deeply emarginate, and antennæ thick and closely jointed; the body in both sexes densely clothed with short, appressed pubescence.

1092 (2359). Antherophagus ochraceus Melsh., Proc. Phil. Acad. Nat. Sci., II, 1844, 115.

Oblong, subconvex. Pale brownish-yellow throughout; antennæe and base of tibia blackish in male. Thorax transverse, sides parallel and almost straight, the punctures fine and dense. Elytra as wide as thorax. very de:isely and finely punctate. Length 4-4.5. $\mathrm{mm}$.

Southern half of State, frequent; less so in the northern counties. Occurs on flowers, especially those of the wild hydrangea, $H y$ drangea arborescens L. June 24-September 21.

\section{Crostmets Casey. 1900.}

In addition to the chararters mentioned in generic key, the members of this genus have a fine raised line on each side of the thorax, extending from base to apex; and also have the basal fovæ of thorax 
connected by a deep channel along the basal margin. Two species are listed by Casey. one of which occurs in Indiana.

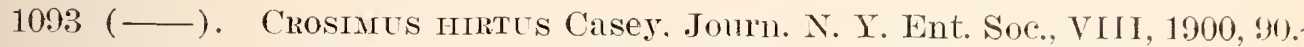

Broadly oral. Piceous or black; legs and antennie somewhat paler; clytra dark red. black at apex, on middle of side margins and transversely behind the base near the suture. Thorax nearly twice as wide as lons. the sides feebly conrerging from base to apex, not continuing those of the elytra: surface finely, deeply and densely punctate, the subminginal line parallel to the edge. Elytra with long, rather dense pubescence and with long. erect luairs in addition; surface irregularly, sparsely and rather coarsely punctate. Length $1.5-1.8 \mathrm{~mm}$.

Putnam and Posey counties; scarce. April 6-April 25. 数aken from a large yellow well-decayed fleshy fungus. and by sifting. Known from Ohio and Iowa.

VIII. Cryptophagus Hbst. 1792. (Gr.. "eryptogam + eating:")

This genus comprises numerous oblong or oblong-oval speeies. distinctly though not densely pubescent, having the thorax transverse and bearing a short tooth on each edge near the middle; the apical angles thickened and base with two small fover or pits connected by a fine groove; front not margined. Casey lists 32 species of the genus, 25 of which he describes as new. Of these five have been taken in Indiana, while one or two others doubtless occur.

KEY TO INDIANA SPECIES OF CRIPTOPHAGUS.

a. Sides of the thorax distinctly angulate at about the middle, the spicule or little point at apex of the angle therefore more prominent and separated from the thickened node of front angle by a rounded notch.

1094. ACUTANGULUS. a $a$. Sides of thorax broadly and evenly curred from base to apex, the spicule near middle rery small and indistinct.

b. Disk of thorax with four more or less evident smooth elerations and a short elerated ridge at middle of base.

c. Thickened portion of front angles of thorax with a broadly oral. sharply defined tlat or feebly concare disk, having a large central puncture.

d. Dark reddish-brown; disks of front angles of thorax large, as long as the distance thence to the median spicule.

1095. CROCELS.

dd. Pale brownish-yellow; disks of front angles smaller. distinctly shorter thim distance thenere to the spirenles.

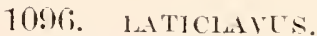

re. Thickened portion of front angles of thorax smill, irrecular. nalrrow and withont a puncture-bealing disk.

C. Antemie long. rither stout, about half as long as body; length $1.8 \mathrm{~mm}$.

ANTENRATLS.

[37-23402] 
ee. Antenne much less than half as long as body; length $2.2 \mathrm{~mm}$.

1097. FUNGICOLA.

bb. Disk of thorax evenly convex without elevations or ridges; thickened node of front angles not flattened but protuberant.

109S. NODA NGULUS.

1094 (9923). Criptophagus acutangulus Gyll., Insect. Suec., 1827.

Oblong-elongate, subdepressed. Pale brownish-yellow; head and thorax slightly darker; eyes large, more than one-

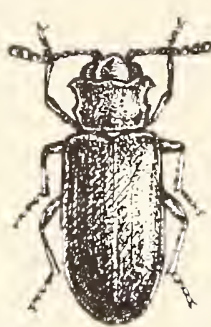

Fig. $210 . \times 1 \mathrm{~J}$ (Original.)

half the length of head. Thorax wider in front than at middle, finely and densely punctate; nodes of the front angles prominent. slightly hooked behind; sides distinctly angulate at about the middle. Elytra three and a half times as long as thorax, more finely and less densely punctate than the latter. Length $2.3 \mathrm{~mm}$. (Fig. 216.)

Throughout the State; frequent. January 24-June 15. A boreal species, common to northeru Europe and America.

1095 (3372). Criptopinaus croceus Zimm., 'Trans. Amer. Ent. Soc., II, 1869, 257.

Oblong, the sides parallel. Dark reddish-brown, rather strongly pubescent. Thorax scarcely narrower than elytra (male) or distinctly narrower (female), strongly and closely punctured, the thickened nodes of apical angles conspicuous. Elytra about three times as long as thorax, less closely but equally coarsely punctured. Iength 2-2.3 $\mathrm{mm}$.

Throughout the State; scarce. January 24-November 12. I'aken on the wing and by sifting rubbish; also feeding on apples in cellar.

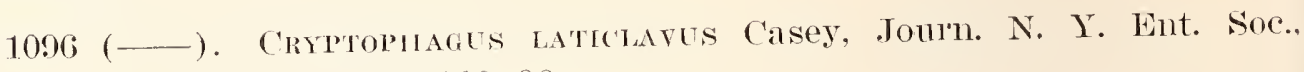
VIII, 1900, 96.

More oval and rather more convex than croceus. Pale brownish-yellow throughout. Thorax smaller and more rounded at the sides; punctures rather coarse and close-set. Elytra three-fifths longer than wide, rather strongly rounded at tip. punctures moderately coarse, deep and close-set; pubescence shorter and less conspicuous than in croceus. Length $2 \mathrm{~mm}$.

Posey and Dubois counties; scarce. May 11-June 4 . Taken by sifting damp leaves and rubbish.

C. antennatus Casey, oblomg-oval, pale reddish-brown, was described from Michigan.

1097 (3374). Criptophagus fungicola Zimm., Trans. Amer. Ent. Soc., II, 1869, 257.

Oblong. moderately convex. Dark brownish-yellow or reddish-brown, shining. Thorax but little narrower than elytra, the nodes of front angles small, feehle, oblique; submedian spicule minute, slightly behind the middle and separated from the nodes by two to three times the length of the latter; punctures small, deep, rather close-set. Elytra oval, obtusely rounded at tip, finely, deeply and not rery closely punctate. Length 2.2-2.4 mm. 
Throughout the State; frequent. January 24-October 21. Occurs in fungi.

1098 (3375). Cryptophagus nodangulus Zimm., 'Trans. Amer. Ent. Soc., II, $1869,25 \pi$.

Elongate-oblong. Dark reddish-brown, strongly shining. Antennæe reaching base of thorax, the club less stout than in fungicola. Thorax finely, equally and rather closely punctured. Elytra more coarsely punctate. Length $2 \mathrm{~mm}$.

Marion County; rare. April 7.

\section{Henoticus Thom. 1870. (Gl.., "in unity.')}

Resembles Cryptophagus very closely, but is distinguished by the thorax having the edges finely toothed and withont thickened apical space at front angles, and by the front above the base of antenna being finely margined. One of the two known species occurs in Indiana.

1099 (3363). Henoticus serratus Gyll, Insect. Suec., 1S27.

Oblong, subconrex. Dark reddish-brown to blackish, sparsely pubescent with yellowish hairs, the legs and antennze paler. Thorax transrerse, deeply and rather closely punctured, the sides nearly parallei, the edges with eight to ten fine teeth. Elytra distinctly wider than thorax, obtusely rounded behind, sparsely and coarsely punctured. Length $1.7-2 \mathrm{~mm}$.

Marion and Posey counties; scarce. April 23-May 11. Oceurs in dry fungi about the stumps of oak.

\section{Pteryngium Reitt. 1887." (Gr., "wing + little.")}

The species of this genus are readily recognized by the rather narrow, strongly depressed, finely pubescent body. The basal segment of the abdomen is as long as the next three combined. Of the two species known, one occurs in Indiana.

1100 (-). Pteryngium malacum Casey, Journ. N. Y. Ent. Soc., ViII, $1900,102$.

Oblong, parallel, depressed. Pale reddish-yellow, shining. Antennse as long as head and thorax, rather slender. Thorax one-third wider than long, finely and closely punctured; sides distinctly curved. hind angles rounded. Elytra scarcely wider than thorax and about three times as long. finely and sparsely punctured; pubescence scarcely evident. Length $1.7 \mathrm{~mm}$.

Vigo County; rare. February 10. One specimen taken from beneath a $\log$ in upland sandy woods. 


\section{Subfamily ATOMARIINAE.}

The members of this subtamily are most readily distinguished by the position of the antema. these organs being inserted upon the front and having their bases close together. The body is smaller. as a mle, than in the Crytophagine. The following genera are known to be represented or probably ocenr in the State:

\section{KEI TO INDIANA GENERA OF ATOMARIINE.}

a. Prosternal spine free. the tip passing over the edge of the flat or feebly concave surfice of the mesosternum; antennx free. the grooves before the eres wholly obsolete, club loosels three-jointed; scutellum of moderate size.

7. Spine of prosternum prolonged and acute at tip: side margin of thorax double: hind tar'si of male 4-jointed: form elongate. pubescent.

XI. Canoscelis.

b7. Spine of prosternum shorter and truncate at tip; thorax with a single lateral edge; hind tarsi 5-jointed in both sexes; form rariable. c. Elytra not margined at base; body always distinctly pubescent.

d. Body elongate and parallel; thorax angulate and foreate close to the edge far behind the middle; antennie rery close at base. the basal joint obconical.

AgATHENGIS.

dd. Pody oval, more convex; thorax rounded or angulate at or before the midrle; antenno less close at base. the basal joint shorter and oblong.

XiI. ATOMaria.

ce. Elytra with a beaded margin at base; body minute and nearly glabrous.

XiII. Tisactia.

au. I'rostermal spine broader and flatter, the tip broadly curred and received closely within a depression at the apex of mesosternum; scutellum cordate, very minute; body broadly oral, convex and almost glabrous.

XIV. Ephistenus.

\section{Cenoscelis Thom. 1870. (Gr.. "common+tibia.")}

Rather elongate, stronghy punctured and pubescent beetles, possessing the characters mentioned in key and having the thorax broadly impressed at base; antennie stont. with the basal joint unusually large and obconic. Three species have been taken in Indiana. while one other may oceur.

KEX TO INDIANA SPECIES OF CENOSCELIS.

a. Color pale reddish-brown.

b. Thorax one-third wider than long, strongly curved at sides, basal impression median and feeble; body narrow and rather elongate.

1101. FERRLGINEA.

b). Thorax two-thilds widler than long: body stouter and more oval in form.

TESTACEA.

a 
r. Antemae distinctly longer than head and thotax, with joints fomp, six and eight longer than wide.

1102. Bongats.

ce. Antenna scarcely longer than head and thorax, the fourth, sixth and eighth joints not longer than wide.

110:. SUBFuscata.

1101 (3380). Cxnoscelis ferruginea Sahlb., Ins. Femnica, I, 1817, 58.

Nilongate-oral. Pale reddish-brown, the pulsescence distinct, fine "and sparse on elytrat. Antenne stout, reaching base of thorax, the first joint of club much smaller than the other two. Thorax convex, finely and closely punctured, the apex narrower than base. Flytra oval, two-thirds longer than wide. Length $1.8 \mathrm{~mm}$.

Marion County; scarce. June 4-October 31. 'Taken beneath bark of oak logs in low moist woods.

C. testacea Zimm., length 1.5-1.8 mm., is known from Kentucky. 1102 (- C). Canoscelis elongata Casey, Journ. N. Y. Ent. Soc., VIII, $1900,107$.

Oblong-oval. Dark reddish-brown. Antenna stout, not quite half the length of body. Thorax more than one-half wider than long, strongly and rather densely punctured. Llytra distinctly wider than, and three times as long as thorax, finely, ratler sparsely and irregularly punctured. Length 1.S-2 $\mathrm{mm}$.

Marion and Putnam rounties: frequent. March 6-April 28. Taken by sifting'.

1103 (一). Cæenoscelis subfuscata Casey, Jomrn. N. Y. Ent. Soc., VIII, 1900, 107.

Elongate, slender, parallel. Reddish-piceous or fuscous. Antennse reaching base of thorax, the first joint equal in length to next two. Thorax one-half wider than long, finely and densely punctate. Elytra slightly wider and more coarsely punctate than thorax. Length $1.8 \mathrm{~mm}$.

Marion County; rare. April 28.

Agathengis subnitens Casey, piceous, elytra paler, length 1.2$1.4 \mathrm{~mm}$. was described from Nichigan; while A. pumilio Casey, thorax more distinctly impressed at base, piceous, elytra brownish. yellow, length $1.3-1.5 \mathrm{~mm}$., is known from Massachnsetts to Iowa.

\section{XIT. Aтomaria Steph. 1830. (Gr., "an atom."')}

Very small. shining, oblong-oval, sparsely pubescent beetles, having the first two joints of antennal club about as long as wide; thorax narrowed in front and concave at base. Five species have been taken in Indiana.

\section{KEY TO INDIANA SPECIES OF ATOMARLA.}

1. Elytra unicolorous or only slightly darker towards the base.

b. Second and third antemal joints elongate, subequal; base of thorax straight or feebly curved. 
c. Thorax rather rounded than angulate at the sides at or before the micldle.

1104. OCHRACEA.

$c c$. 'Thorax conspicuously though broadly angulate at the sides at or slightly before the middle, where it is distinctly wider than at base.

1105. GONODERA.

$b b$. Second antennal joint distinctly longer and thicker than third.

d. Thorax dilated at or a little before the middle, narrowed toward base and still more strongly toward apex; color dull yellow, elytra gradually blackish toward base.

1106. pusilla.

$d d$. Thorax parallel at the sides from the base to or beyond the middle, then strongly narrowed to apex; color black or piceous.

1107. ovalis.

aa. Elytra pale with a dark crossbar (often broken) just before the middle. 1108. EPHIPPIATA.

1104 (338S). Atomaria ochracea Zimm., Trans. Amer. Ent. Soc., II, 1869, 258.

Elongate-oval, convex. Dark reddish-brown to piceous, moderately shining; antennx and legs paler. Antennse slightly longer than head and thorax, the joints of club equal in size. Thorax three-fourths as wide as elytra, strongly narrowed at apex, deeply and closely punctate, the sides rounded. Elytra widest before the middle, acutely rounded at tip, finely and sparsely but distinctly punctured. Length $1.5-1.8 \mathrm{~mm}$.

Throughout the State; common in spring beneath mullein, in decaying leaves, etc. April 18-November 8.

1105 (-). Atomaria Gonodera Casey, Journ. N. Y. Ent. Soc., VIII, 1900, 122.

Rather broadly oval, moderately convex. Reddish or chestnut-brown. polished. Thorax small, at its widest part not equalling the base of elytra. nearly two-thirds wider than long. angulate at middle, the sides thence to base distinctly converging, disk finely and rather closely punctate. Elytra, near the middle, about one-third wider than thorax, finely but sparsely punctate. Length $1.5 \mathrm{~mm}$.

Lake and Marion counties; scarce. March 26-April 16.

1106 (-). Atomaria pusilla Payk., Faun. Suec., I, 1798, 295.

Elongate-oblong, parallel. Dull reddish-yellow, shining; basal third of elytra blackish. Antennie slender, nearly half the length of body. Thorax short. convex, about as wide as elytra, disk finely and densely punctate and with a distinct basal impression. Elytra three times as long as thorax, obtusely rounded at tips, very finely and closely punctate. Length .8-1 mm.

Steuben, Kosciusko, Marion, Hancock and Putnam counties; scarce. May 25-November 8. Sifted from borders of sphagnum marsh and other damp vegetable debris. A European species hitherto recorded only from the Pacific slope in the United States. 
1107 (-). Atomarta oralis Casey; Journ. X. Y. Ent. Soc. TiII, 1900, 124.

Oral, rapidy attenuate at each end. strongly convex. Black or piceous, shining; legs and antennie dull brownish-rellow. Antennix stout, one-half length of body in male. Thorax one-half wider than long, sides strongly converging on apical half, apex two-thirds as wide as base; disk rather coarsely and densely punctate. Elstra widest a little in front of middle where, together, thes are one-third wider than thorax. thence narrowing to a rounded apex; surface rather sparsely and finely but distinctly punctured. Length $1.3-1.5 \mathrm{~mm}$.

Steuben, Kosciuskc and Marion comties; frequent. April 11July 11. Taken by sifting and on the wing in early spring.

1108 (3389). Atomaria ephippiata Zimm., Trans. Amer. Ent. Soc., II, 1869. $25 \mathrm{~S}$.

oblong-oval. strongly convex. Head and thoras piceous: antennie, legs and elytra reddish-rellow, the latter with a piceous crossbar before the middle, this sometimes reaching from side to side. sometimes broken into spots. Thorax strongly conrex. sides rounded. minutely and sparsels punctured. Elstra distinctly rider. and two and a half times as long as thorax. finely but distinctly punctate. Length 1.5 mm. (Fig. 217.)

Throughout the State: frequent. March 17June 22.

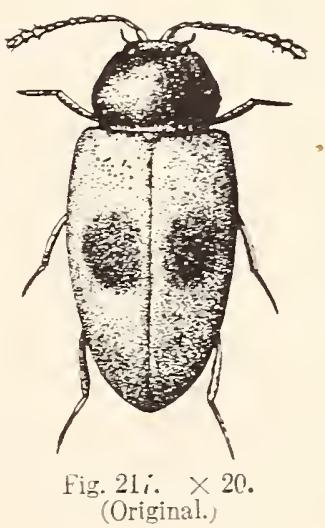

\section{Tisnctin Casey. 1900.}

Small. oral. convex species. having the thorax eren and unimpressed at base: antennæ more widely separated than in Atomaria. the club parallel and loosely 8 -jointed: prosternal spine broad. sharply margined each side.

1109 (一). Tisactla stbglabra Casey. Journ. X. I. Ent. Soc., TIII. 1900. 126.

Oblong-oral. strongls conrex. Blackish-piceous. glabrous. shining; elytra (in specimen at hand) indistinctly reddish near humeri and on apical third; legs and antennre paler. 'Thorax one-half wider than long. rer's conrex. wider at base than apex. sides feebls curred. strongly margined: disk. as well as that of elytra. finely and rather sparsely punctate. Elytra widest before the middle. as wide at base as thorax. Length 1-1.2 $\mathrm{mm}$.

Steuben County : rare. June 16. Sifted from sphagnum moss. Described from Indiana.

\section{Ephistexics Steph. 1829. (Gr.. "upon + to place.")}

Tery small species. having the body erenly oral and rather pointed behind: sides of thorax and elrtra continuous, their margins not interrupted at the contiguous bases. 
1110 (3390). Ephistemus apicalis Lec., N. Sp. N. A. Col., I, 1S63, 72.

Oral, conrex. Black or piceous-black, shining, without punctures; elytra gradually feebly paler on apical half; legs and antenne paler. Thorax transrerse, the sides evenly curved. Elytra one-third wider than thorax and about three times as long, the tips narrowly rounded. Length $1 \mathrm{~mm}$.

Lake, Parke and Marion counties; scarce. April 23-July 1.

\section{Family XXIII. MYCETOPHAGIDA.}

\section{'The Ilitr Fungus Beetles.}

To this family belong a limited number of small, oval, slightly convex beetles. which live on fungi and beneath bark. They have the upper surface hairy and densely punctured and the elytra are brown or blackish. usually prettily marked with vellow spots or bands, or yellow with black spots. The name, Iycetophagide, is from two Greek words meaning "fungus" and "to eat," and is indicative of the habits of the insects.

The principal distinguishing characters of the

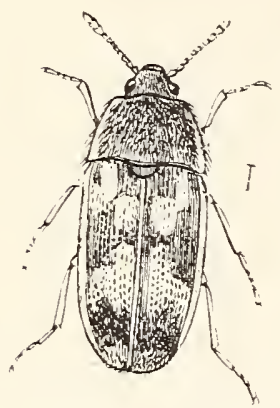

Fig. 218. Litargus bifasciatus. A European species. (After Sharp.) Mreetophagids are the 11-jointed antennx. inserted immediately in iront of the eyes, the outer joints gradually or suddenly enlarged; eyes rather large, with coarse facets; thorax as wide as elytra at base; elytra covering the abdomen and rounded at tip; front coxa oval, rounded, narrowly separated, the cavities either widely open or closed; middle coxæ rounded. narrowly separated; hind coxæ transverse; abdomen with five free and equal ventral segments: legs slender, tibia nearly linear, with small terminal spurs; tarsi filiform, t-jointed, the front ones of the males 3-jointed, more or less dilated and pubescent beneath. (Fig. 218.)

As already noted under the family Cryptophagidx, the genus Diplocolus has been transferred trom this family to that; while the species listed by Henshaw under the genus Triphyllus have been shown by Casey to belong to the family Melandryidx, and the one under Berginus to the Ptinidx. 'This leaves but five genera. and, according to Casey's list, about 25 species of Mycetophagide from North America. Only about 100 species are known from the entire irorld.

The principal literature treating of the North American species is as follows: 
LeConte. "Srnopsis of the Mycetophagida of the United states." in Proc. Phil. Acad. Nat. Sci.. VIII, 18.56, 12-15.

Horn._ "Tables of the Species of Mrcetophagus and Litargus,"

in Proc. Amer. Phil. Soc.. XVIT, 1878, 603--608.

Casey._"Review of the American Tritomider (Mycetophagides).' in .Journ. N. Y. Ent. Soc. YTIT. 1900, 128-138.

Of the five North American genera. four are represented in Indiana.

\section{KEY TO INDIANA GENERA OF MYCETOPHAGIDE.}

a. Basal angles of thorax rell defined; length 1.5 or more mm.

๖. Eres transverse, sinuate in front: antennie gradually enlarged, usualis without distinct club: epipleura horizontal and flat.

I. MYCETOPHAGL'S.

7). Eyes more rounded. not sinuate; antennæe with joints 9-11 suddenly larger.

c. Clypeal suture not deeply impressed : body much smaller and more oral : epipleura concare. rapidly descending.

II. LITARGTS.

cc. Clrpeal suture deep: epipleura horizontal and flat.

III. TYPh.е. ur. IIind angles broadly rounded: length less than $1 \mathrm{~mm}$.

IV. THRIMOLTS

I. Mrcetophagus Hellw. 1792. (Gr.. "mushroom + eating.")

Oblong-oval, moderately convex insects, clothed rather sparsely with short. stiff. reclined hairs. Six species have been taken in Indiana.

\section{KEY TO INDIANA SPECIES OF MYCETOPHAGU'S.}

a. Antennie gradually larger tomard tips; bods broadly oblong-oral; subbasal forese of thorax deep and distinct.

b. Thorax widest at base.

$c$. Tast joint of antennie elongate, distinctly longer than the tro preceding combined: size larger, 4.5 or more $\mathrm{mm}$.

1111. PUNCTATCS.

$c c$. Last joint of antenne shorter, nerer longer than the two preceding combined: size smaller, not orer $4 \mathrm{~mm}$.

d. Prosternum nearly smooth at middle. 1112. FLExuosus. dd. Prosternum densely and coarsely punctured; antenne with a feeble, parallel 4-jointed club.

1113. BIPUSTULATUS.

67. Thorax narrower at base than at middle; antennal club 5-jointed.

c. Margin of thorax entire. the disk coarsely and deeply punctured.

1114. MELSHEIMERI.

ec. Margin of thorax serrulate: elytra with numerous small rellow spots.

1115. PLURIPUNCTATLS.

au. Antenure with last three joints rather suddenle larger; thorax without sub-basal forea; elrtra piceous spotted witl rellow.

1116. OBSOLETUS. 
1111 (3391). Mroetopiagus punorates Say, Jomm. I'hil. Acad. Nat. Sci.,

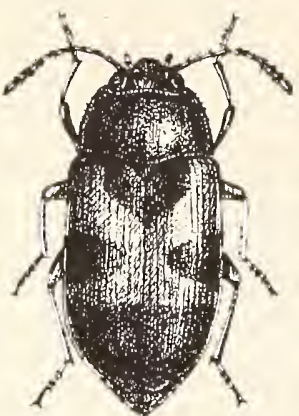

Fig $219 . \times 5 \frac{1}{2}$ (Original.)

V, 1826, 260; ibid. II, 321.

Oblong-oval, sublepressed. Head and thorax blackish; elytra reddish-yellow with black spots; one large. common, surrounding the scutellum; another smaller on each at middle, usually confluent with the lateral margin and extending narrowly along it, and a third forming a common subapical crossband; antennie reddish, the apical half more or less fuscous. Thorax coarsely and evenly punctured. Length $4.5-5.5 \mathrm{~mm}$. (Fig. 219.)

Southern half of State, frequent; less so in the northern counties. April 6-September 29. Probably hibernates. Occurs beneath loose bark and in fungi, especially in low moist woodlands.

1112 (3393). Mrcerophagus flexuosus Say, loc. cit.

Resembles punctatus but much smaller. Elytral markings very rariable, usually nearly as in punctutus, but the middle and subapical black shots are larger, with their edges very meven, and there is usually a small romut spot on humerus. Length $2-4 \mathrm{~mm}$.

Throughout the State; frequent. April 11-October 6. Occurs in fungi and in spring sometimes at sap.

Casey's subdepressus is only a color variety of Rexuosus in which the black spots have become enlarged so as to cover the greater part of the elytra, leaving only a narrow oblique reddish line composed of two or three spots on basal third, another similar line behind the middle and a spot near the apex. It occurs commonly with typical flexuosus, and individuals showing the gradual merging of one color variety into the other are frequent, several of them being in the collection at hand.

1113 (3394). Mrcetopingus mipustulatus Melsh., Proc. Phil. Acad. Nat. Sci., II, 1844, 114.

Oblong-oval, moderately convex. Dark reddish-brown; elytra each with an irregular subhumeral yellowish spot which sometimes extends nearly to suture, and also a transverse oblong one on apical third; antennæe and palpi dull brownish-yellow. Thorax three-fourths wider than long; sides slightly curved, surface coarsely, densely and unequally punctured. Elytral strix feebly impressed, finely punctate; intervals densely punctulate, each with a single row of suberect yellowish hairs. Length $3-3.5 \mathrm{~mm}$.

Marion County ; scarce. April 16. Four specimens collected by $\mathrm{H}$. Morrison from the window of a cellar in which wood had been stored.

1114 (3396). Mrcetophagus melshemmeri Lec., Proc. Phil. Acad. Nat. Sci.. VIII, 1856, 13.

Elongate, parallel. I'iceous brown; legs and basal half of antennie dull yellow; elytra each with a large oblique spot reaching from humerus 
nearly to suture; another broader, behind the middle, and usually a smaller one on each side, dull yellow; these sometimes confluent so as to make the larger portion of the surface yellow. Thorax one-half wider than long. sides strongly curved, disk sparsely, coarsely and equally punctured. Flytral strix with deep, coarse punctures. Length $4-4.5 \mathrm{~mm}$.

Posey County ; rare. April 9. Readily known by its elongate form, parallel sides and evenly punctured thorax.

1115 (3397). Mrcetophagus pluripuxctatus Lec., Proc. Phil. Acad. Nat. Sci., VIII, 1856, 13.

Elongate, narrow, parallel. Piceous-black; elytra with numerous small reddish-yellow spots, often more or less confluent into oblique bands and sometimes covering the greater part of the surface; under surface. legs and basal half of antenne pale. the last fire joints of the latter dusky and slightly larger. Thorax distinctly narrowed at base, the margin finely serrate. Elytral strie finely punctured, indistinctly so at tip. Length 3.5$4 \mathrm{~mm}$.

Vigo County ; scarce. October 21. Occurs in fungi, especially that growing on hickory logs and stumps.

1116 (3400). Mrcetophagus obsoletus Melsh., Proc. Phil. Acad. Nat. Sci., II, 1844, 113.

Oral, rather strongly convex. Piceous black: legs and antenns paler; elytra each with two irregular oblique reddish-rellow stripes, one extending from humerus nearly to suture, the other behind the middle; an oral submarginal spot between the two and another at apex. Thorax less than twice as wide as long, widest at base. hind angles obtuse, disk coarsely and erenly punctate. Elytra with impressed, entire rows, of coarse deep punctures. Length $4.5 \mathrm{~mm}$.

Kesciusko, Vigo. Dubois and Pcsey counties; rare. April 13Dotoler 21. Taken from fungi on hickory stumps and by sifting debris.

\section{Litargus Erichs. 1832. (Gr., "swift of foot.")}

The species belonging here are much smaller and more narrowly oval than in Mycetophagus. The antennæ end in a 3-jointed club and the epipleurx are concave. Four species have been taken in the State, while a fifth probably occurs.

\section{KEY TO INDIANA SPECIES OF LTTARGL'S.}

a. Thorax without basal impressions.

b. Elytra with the pubescence short and stiff, arranged in distinct rows; last antennal joint short, rounded.

1117. TETRASPILOTUS.

$b b$. Elytra with pubescence irregularly arranged.

c. Last antennal joint short. not as wide as preceding. broadly rounded at tip; thorax convex, coarsely punctured.

111S. DIDESMUS. 
$c c$. Last antennal joint longer and broader than the preceding, obliquely truncate at tip.

NEBULOSUS.

aa. Thorax with distinct basal impressions.

d. Last joint of antenna nearly as long as the two preceding together, its tip truncate; form depressed.

1119. BALTEATUS.

dd. Last antemnal joint short. narrowly rounded at tip; thorax depressed and finely punctured.

1120. SEXPUNCTATUS.

1117 (3406). Litargés tetraspilotes Lec., Proc. Phil. Acad. Nat. Sci. VIII, 1S56. 14.

Oral. subconvex. Piceous-black. shining: elytra each with two reddishyellow spots, one slightly in front of middle. the other one-third from apex. Thorax less coarsely punctured than elytra, the basal margin sinuate each side of middle. Léngth 1.8-2 mm.

Throughout the State; scaree. May 16-July 9.

1118 (3407). Litargés didesires Say, Journ. Phil. Acad. Nat. Sci., V, 1826, 261 ; ibid. II, 322.

Narrowly oblong-oval, rather convex. Piceous, shining; elytra with a narrow crossband behind the middle and each with an oblique humeral spot, yellow. Thorax rather coarsely punctate, the base squarely truncate. Elytra coarsely punctate. the punctures not in rows. Length $2-2.2 \mathrm{~mm}$.

Frequent in southern half of State; much less so in northeru counties. April 10-.June 15. Taken in spring by sifting; latel' beneath bark.

L. nebulosus Lec., dull yellow with a piceons dentate band behind the middle and another near apex. length $1.5-2 \mathrm{~mm}$. ranges from New York to Mexico, and doubtless occurs in the State.

1119 (3405). Litargus Balteatus Lec.. Proc. Phil. Acad. Nat. Sci., ViII, $1856,14$.

Oblong-oval, moderately convex. Piceous, feebly shining; thorax with patches of yellowish pubescence; elytra each with an irregular basal spot. widest along the suture, and a narrow oblique crossbar behind the middle. dull yellow. Thorax nearly twice as wide as long; narrower at apex than base. sides rouncied; disk densely and finely punctured and with a feeble basal impression each side. Elytra as wide as thorax and less distinctly punctate. Length $1.8-2 \mathrm{~mm}$.

Putnam County ; rare. Ápril 22. Taken by sifting.

1120 (3404). Litarges sexpunctatus Say, Journ. Phil. Acad. Nat. Sci., V. 1s26, 261: ibid. II, 322.

Elongate-oral. depressed. Piceous, moderately shining: elytra each with three yellow spots, one sub-basal and two close to suture; one of these before the middle, the other one-third from apex. Thorax finely but not densely punctate. Elytra closely punctate, the pubescence fine and dark, and with widely separated rows of longer, semi-elect hairs. Length $2.2-$ 2. $7 \mathrm{~mm}$.

Throughout the State; frequent. Tray 11-December 7. Occurs 
beneath bark of beech in late antumn and winter; sometimes on foliage in spring. Hibernates.

\section{TrPHA Steph. 1830. (Gr..,"smoky or fuscous.")}

To this genus belongs a single small brownish beetle which has been distributed by commerce to all parts of the world.

1121 (3409). Typhea fumata Linn., Syst. Nat., II, 1766, 654.

Narrowly oblong-oval, slightly convex. Dull reddishyellow, elytra rarely piceous. Antemure distinctly shorter than head and thorax, the club 3 -jointed. Thorax about twice as wide as long, the apex but slightly narrower than base, finely and rather closely punctured. Elytra with rows of fine punctures which become obsolete toward the tip: pubescence short, moderately dense. Length 2.3-2.7 $\mathrm{mm}$. (Fig. 220.)

Throughout the State, but scarce. Jamuary 11-Au-

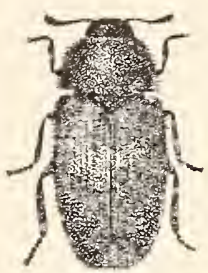

Fig. 220 (After Forbes.) wnst 7. Beaten from vegetation; said to often occur in louses and where flour and grain are stored.

\section{Thrmolus Casey. 1900.}

Here belongs a single minute species having the head large, transverse; eyes basal; antennal club cylindrical, stout, 3-jointed; thorax broadly curved and finely beaded at base; scutellum well developed; front coxie large, obliquely suboval, rather widely separated by the prosternum.

1122 (-). Thrmolus minutus Casey, Joum. N. Y. Ent. Soc. VIII, $1900,137$.

Oblong-oval, moderately convex. Dark brownish- or clay-yellow; legs and antennse paler. Head and thorax without punctures, the latter more than twice as wide as long, the disk without basal impressions. Elytra one-third longer than wide, much wider than thorax; finely, sparsely and somewhat roughly punctate. Length .7-.9 $\mathrm{mm}$.

Marion County; rare. October 31. Two specimens sifted from woody fungi on side of maple log. Described from Texas; known also from near Cincinnati.

\section{Family XXIV. DERIIESTID F.}

\section{The Srin BeEThes.}

Among the small beetles which prey upon dead or decaying animal matter those belonging to the family Dermestidae are the most important; many of the species being exceedingly destructive to skins, furs and other dried animal substances. In form they are usually oval and plump, and in color dark, often having the surface 
partly covered with pale gray or brown spots composed of minute scales or hairs which are easily rubbed off. When disturbed they usually "play possum," folding back their leg's and rolling over on their backs, where they remain quiescent for some time. The name of the typical genus, Dermestes, is derived from two Greek words meaning "a skin" and "to devour,"' whence the common name of skin-eaters or skin beetles.

The principal distinguishing characters of the family are the small deflexed head; eyes rounded, with small facets, the front usually with a third simple eye or ocellus; antennæ short, inserter in front of eyes, ustually 11-. sometimes 9- or 10-jointed, the last two or three joints forming a large club; thorax short, in the majority of species excavated beneath for the reception of the antenna ; elytra covering the abdomen, not striate; abdomen with five free ventral segments; front coxx rather long, conical or oblique, the cavities open behind except in Byturus; middle coxæ oval, oblique; hind coxa slightly separated. usually dilated into a plate partly protecting the femora and formed to receive the latter in repose; legs short, tibia with distinct spurs; tarsi 5-jointed, claws usually simple.

The larva of the majority of Dermestids are brown, active grubs clothed with long hairs and usually with a brush of similar hairs at the end of the body. Nany of them have a peculiar gait, running for a short distance, then stopping and vibrating the hairs with great rapidity. They are much more destructive than the adult beetles, but at times appear to be able to live for long periods with little or no food.

Between 300 and 400 species of Dermestidae are known, about 85 of which, with numerous varieties, are from North America. The principal literature treating of these is as follows:

LeConte._"Synopsis of the Dermestida of the United States," in Proc. Phil. Acad. Nat. Sci., VIIT, 1854, 106-113.

Jayne._"Revision of the Dermestidx of the United States," in Proc. Amer. Phil. Soc., XX, 1882, 343-377.

Casey. - "Review of the American Dermestida," in Journ. N. Y. Ent. Soc., VIII, 1900, 138-165.

The members of the family which have a range including Indiana are distributed among eight genera.

KEY TO INDIANA GENERA OF DERMESTID.E.

a. Tarsi with second and third joints lobed beneath; front coxal carities closed behind; claws, armed with a large basal tooth. (Fig. 221.)

I. BYTURUS, 
au. Tarsi simple; front coxil carities open behind farsal chas simple.

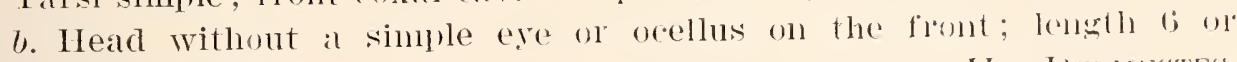
more mm.

II. IERMLSTES.

bb. Head with a distinct ocellus ; length not orer 5 mm., usually less.

c. Body either pubescent or covered with small scales; mosternum visible between the front coxil.

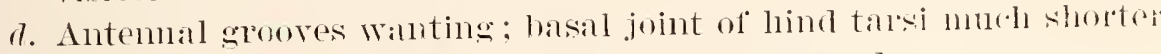
than second; midule coxie namowly seplatrited.

c. Antemna 11-jointed: hind coxal plates nallow; mesosternum deeply emarginate in front.

III. ATtAGENTS.

ce. Antennie 9-jointed: hind coxal plates short and wide; mesosternum sulcate its full length.

IV. Dearthrus.

dr. Antennal grooves or pits distinct; basal joint of hind tarsi but little shorter than the next two combined; midnle coxie widely separated.

f. Body pubescent.

9. Antemne stout. subserrate, the club 6 - to 8-jointed in male. 4-jointed in female: mandibles and labrum not corered by prosternum in repose.

r. T'Rogoneria. gg. Antennie with a large compact :-jointed clnb, received in a deep pit beneath side margin of thorax: mandibles cor ered, labrum not covered by prosternum.

TI. ('RYPTORHOPALUM.

ff. Pody covered with small scales; antemnal chb received within a deep pit at the apical thoracic angles. VII. Anthrents.

rc. Body glabrous; the mouth in repose covered by front legs; prosternum not visible between the front coxie. TiII. Orphilus.

\section{Brturus Latr. 1796.}

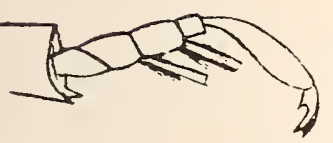

Fig. 221. Tarsus of Bytunus showing lobes of tarsal joints and basal tooth of claw. (After Jayne.)

1123 (3416). Bytures unicolor Say. Journ. Phil. Acart. Nat.

Head very large. front as ride as long without ocellus; eves prominent. coarsely granulated: antennæ 11-jointed, club 3-jointed. not received in pits or grooves; scutellum large. quadrate. One species occurs in the State. Sci., 111, 152:3. 197; ibid. II, 126.

Oblong-oval. convex. Uniform reddish-yellow or pale brown, rarely piceous, thickly clothed with fine, paler silky pubescence. Thorax one-third wider than long. coarsely and densely punctate; sides regularly curred. margins broadly depressed, base slightly broader than apex. Elytra three times as long as wide, rather coarsely and densely punctured. Length $3 . \bar{\tau}-4.5 \mathrm{~mm}$. (Fig. 222.)

Throughout the State; frequent. May 16-July 6. Oceurs on the flowers of blackberry and raspberry. on which it feeds. The fruit is also often infested with the larva, a small white worm known as the "raspberry fruit worm," which clings to the inside of the berry. 


\section{DERMEstes Linn. 1767. (Gr., "skin + devour.")}

Oblong or elongate black or piceous species having the front coxi contiguous; head capable of retraction within the thorax; antenna 11-jointed with a 3-jointed club; body clothed with short hairs. On the carcasses of dead animals, after the soft parts have been devoured by other scavengers and only the bones and skin remain, they can usually be found in numbers; while one or two are common household pests, found about refuse lard. bacon. feathers and cheese. Five species have been taken in Indiana. while another doubtless occurs.

\section{KEY TO INDIANA SPECIES OF DERMESTES.}

a. Abdomen thickly corered with long whitish pubescence and with a row of black spots on each side; front portions of side margins of thorax not visible from above.

b. I'ubescence of thorax densely corering the entire surtace. rariegated with small spots of black, gray and reddish-brown.

c. Thorax with three small. widely separated spots of pale pubescence, arranged transrersely at about the middle of its length; form more lobust; pubescence of scutellum not conspicuously pale.

1124. CANINCS.

cc. Thorax without the three pale pubescent spots: form more slender and parallel: pubescence of scutellum dull yellow.

112.5. TALPINUS.

bb. Pubescence of thorax gray and limited to the margins. the disk with

a large triangular, nearly smooth spot, black. 1126. TULPINUS.

a $a$. Abdomen without whitish pubescence or rows of black spots; side margins of thorax entirely risible from abore.

a. Thorax and basal fifth of elytra corered with uniform reddish-brown pubescence; abdomen reddish-brown.

112-. PLLCHER.

dd. Thorax without trace of reddish pubescence; abdomen black.

c. Basal two-fifths of each elytron gravish-rellow. enclosing three black spots.

1128. LARDARIUTS.

ee. Elytra black. sparsely and uniformly clothed with paler pubescence. and with feeble but risible strice: body subcrlindrical.

ELONGATUS.

*1124 (3420). Dermestes canints Gelm. Ins. Spec. Nor.. 1\&24, \&4.

Elongate-oblong. Thorax with dense. rariegated pubescence; elytra black. mottled, especially on basal half, with fine black and coarse grat pubescence, the latter often corering the greater part of the surface; middle and hind femora with rings of white pubescence. Male with a median pit on the third and fourth rentral segments, from which arises a bunch of erect brown hairs. Length $7-8.2 \mathrm{~mm}$.

Throughout the State; frequent. January 6-October 20. Hibernates. Gregarions in winter beneath mullein leaves, bark and logs. 
1125 (3421). Demanestes talphes Mamm. Bull. Mosc.. II. 194:3, 25.

Elongate. subcrlindrical. Thorax densely clothed with valriegated hairs: elytra black. clothed with dark bluish-gray. clay-yellow and black hairs; antennæ fuscous; femora with white rings at middle. Length $5.5-6.5 \mathrm{~mm}$.

Lawrence Counț: scarce. May 9. Known heretofore from Idaho and Nevada. westward. Terified by HI. C. Fall.

*1126 (3t2S). Dermestes vulpixus Fab., spec. Ins.. I. 17S1, 64.

Elongate. subconvex. Elstra piceous. uniformly and rather sparsely elothed with a mixture of black and grarish-rellow hairs; last rentral segment brown with two white spots at base. Fourth rentral segment of male with a median pit bearing a bunch of brown hairs. Length $6-9 \mathrm{~mm}$.

J ake. Yigo. Putnam and Monroe counties: frequent. January 13-December 12. Hibernates.

1127 (3424). Dermestes pulcher Lee., Proc. Phil. Acad. Nat. Sci.. Vit. 1554,108 .

Oblong-oral, subdepressed. Head. thorax and basal fifth of elytra uniform pale reddish-brown; remainder of elytra black. Length $6-6.5 \mathrm{~mm}$.

Marion County: scarce. Hibernates. March 20-December 11. Taken from beneath bark of ash logs.

*112S (3425). Dermestes lardarics Limn. Faun. Suec., 140.

Elongate. moderately conrex. Black or piceous; elctra with base marked as shown in Fig. 223; under surface and legs black with fine, sparse rellowish pubescence. Thorax black with a few small isolated tufts of yellowish pubescence, finely and densely punetate. Length 6-7.5 mm. (Fig. 223.)

Throughout the State; frequent. February 7-July 21. This species, known as the "ham beetle., the "larder beetle," etc.. has been widely distributed by commerce and is often a household pest. especially where bacon and hams are stored. It is said that they can be attracted by baits of old cheese and then gathered and destroyed. Where a smoke-house or storeroom is

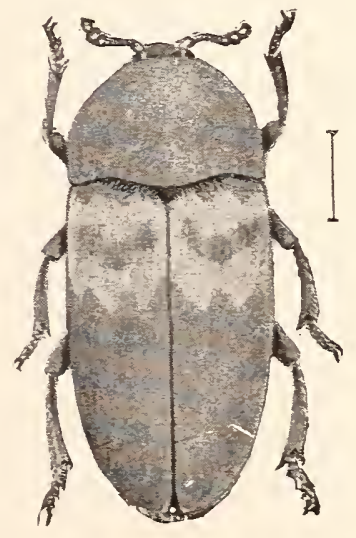

Fig. 223. (After Howar', Bull. 4 X. Ser. Div. Ent. L' S. Dep. Agr.) overrun with the beetle. its contents should be cleared out and the room either sprayed with benzin or subjected to strong fumes of bisulphide of carbon. Where a ham or other object is alreadr infested. the affected portion should be cut away and the surface of the remainder washed with a rery weak solution of carbolic acid. If thereafter the windows are scleened with fine wire gauze and the doors kept tightly closed. the contents will probably be 
safe. It is said that an entire generation of the beetle may be developed in six weeks, so under proper conditions of warmth and food supply the increase of the insect will be very rapid.

$D$. elongatus Lec.. length $9 \mathrm{~mm}$., is a southern and western species which has been recorded from near Cincinnati.

\section{Attagenes Latr. 1802. (Gr., "a woodcock.")}

Small oblong species clothed with rather sparse, dark pubescence, having the antennæ 11-jointed; hind coxal plate long. narrow and prominent; mesosternum narrow and emarginate.

1129 (3434). Attagents PICEUs Oliv., Ent. Hist. Nat., II, 17S9, 9.

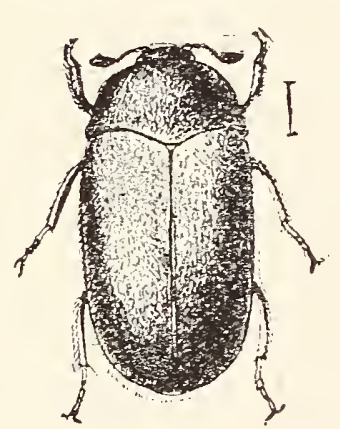

Fig. 224. (After Howard, Bull. 4, N. Ser. Div. Ent., L?. S. Dep. Agr.)

Oblong, subconvex. Head and thorax black; elytra dark reddish-brown to piceous or black, clothed with short. sparse pubescence. Thorax coarsely punctate. base bisinuate with a slight impression before the scutellum. Elytra more finely and densely punctate. Last joint of male antemnal ciub as long as the entire remainder of antemie. pointed at the end. Length 3.55 $111 \mathrm{~m}$. ( Fig. 2.24.)

Thoughont the State; frequent in the southern counties, less no northward. Narch 16-August 26. A common museum and household pest often found on windows while trying to escape. It is known as the "black carpet beetle," and the larræ often do much damage to carpets. silk and woolen goods, feathers, etc. The same remedies may be used as are given for the Buffalo carpet beetle on a succeeding page. Taken also on flowers of wild parsnip in July.

\section{DEARTHUS Lec. 1861.}

One small oblong black species represents this genus in the State. 1130 (3438). Dearthrus loxgulus Lec., New Spec. N. Amer. Col., I. $1863,73$.

Narrowly oblong-oval. moderately convex. Black or piceous, clothed with short dark pubescence; under surface and legs dark reddish-brown to piceous, clothed with sparse gray hairs. Thorax nearly twice as wide as long, distinctly narrowed from base to apex, sides erenly and feebly curved, base broadly and feebly lobed and bisinuate; disk rather coarsely but not densely punctate and with a short, fine median line. Elytra coarsely but not closely punctate. Last joint of male antennx almost three times as long as the two preceding united. obtuse at end. Length $2.5 \mathrm{~mm}$.

Narion and Posey counties: scarce. May 3-May 8. Beaten from flewers of the red haw. Cratugus punctata. Jaed. 
V. Trogoderma Lat. 1829. (Gr., "to gnaw + skin.")

Small, oblong-oval species, having the antennal club 4 - to 7 jointed and the antennal grooves occupying the entire space between the prosternum and the lateral margin of thorax; elytra with narrow, oblique crossbars formed by variegated pubescence. Three species are known from Indiana.

\section{KEY TO INDIANA SPECIES OF TROGODERMA.}

a. Eyes entire, the inner frontal margin not emarginate; antennse of male serrate, the third and fourth joints equal. (Fig. 225.)

b. Thorax strongly and rather closely punctate, especially toward the sides; pubescence persistent.

1131. ORNATUM.

bu. Thorax very minutely and sparsely punctate throughout; pubescence easily denuded.

TARSALE.

a a. Eyes feebly notched or emarginate at abont the middle of their inner frontal edge; male antennie compact, not serrate. (Fig. 226.)

c. Elytra black with reddish bands.

1132. INCLUSUM.

cc. Elytra brown or piceous with dull faint yellow bands.

1133. OBSOLESCENS.

1131 (3442). Trogoderma ornatum Say, Journ. Phil. Acad. Nat. Sci., V, 1825, 186; ibid. II, 290.

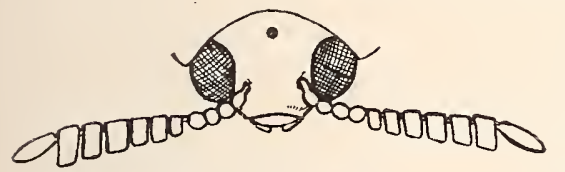

Fig. 22.5. Head and antennæ of Trogoderma ornatum. (After Jayne.)

Oblong-oval. Black, rather shining, thorax variegated with reddish and gray hairs; elytra with three irregular confluent reddish bands bearing gray pubescence; beneath piceous brown. Apex of elytra obtuse and as broad as base. Prosternum long and rather broad at tip, subcarinate. Club of male antennix formed of joints 6 to 11 , which are strongly pectinate. Length $3-4.5 \mathrm{~mm}$.

Vigo, Marion and Posey counties: scarce. "March 23-October 19. Found about houses and cellars; the larva occurring. though rather rarely, as a museum pest in insect collections.

O. tarsale Melsh., length 1.8-2.5 mm., has been recorded from near Cincinnati.

1132 (-). Trogoderma incutsum Lec. Proc. Phil. Acad. Nat. Sci., 1854. 110.

Oral, somewhat oblong. Black; thorax with lines of gray hairs; elytra with four marow, simuous, more or less confluent real dish bands bearing gray pubescence, the subapical band enclosing a trinsterse rhombus on the suture. Thorax of the female twice as wide as long. finely and sparsely punctate. Jayne.)

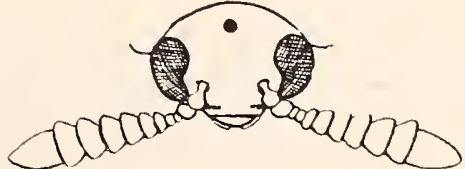

Fig. 226. Head and antennæ of Trogoderma. inclusum, showing notched eyes. (After

Elytra more coarsely punctate: scarcely narrowed from base to apex. Joints of male antennal club not pectinate. Length $2-3.5 \mathrm{~mm}$. 
'Throughout the State; scarce. May 11-.July 30. Resembles the preceding but usually smaller. Readily distinguished by the emarginate eyes.

1133 (-). Trogoderma obsolescens Casey, Journ. N. Y. Ent. Soc., VIII. 1900. 154 .

Narrower and more elongate than inclusum. Head. thorax and under surface dull black or piceous: elytra brownish with a faint dull rellow band bearing gras pubescence near base and another near apex; also a spot of similar pubescence on each at middle near suture and a second on side slightly behind the middle. Thorax twice as broad as long, its surface, as well as that of elytra, rery finely and rugosely punctate. Length $2-3 \mathrm{~mm}$.

Lawrence Comnty; scarce. May 11. Beaten from flowers of red haw. Cratagus.

\section{Cryptorhopilum Gner. 1838. (Gr., "hidden + club.")}

Small black or piceous. sparsely pubescrunt species having the antennal club 2-jointed, the deep groores beneath the margin of the thorax; prosternum covering all the month parts except the labrum. its process with broad tip widely dividing the mesosternum.

1134 (3449). Criptorhopalca hamorrhomale Lec. Ann. Lyc. Nat. Hist., I. $1824,170$.

Elongate-oral, moderately convex. Head black: thorax and elytra dark reddish-brown or piceous. the latter with apical third dull sellow and with two transrerse bands of short, rather sparse rellow hairs. Head coarsely and densely, thorax more finely, punctate; the latter with pale hairs on the sides and basal lobe. Beneath, black with long, sparse rellow pubescence. Joints of antennal club of male subequal, oval, together twice as long as the preceding joints united. Length 2-2.5 $\mathrm{mm}$.

Tippecanoe, Marion. Oren. Vigo and Posẹ counties; frequent. May 3-June 23. Taken on flowers of the panicled cornel or dogwood, Cormus candidissima Marsh.

1135 (3452). Cryptorhopalum triste Lec., Proc. Phil. Acad. Nat. Sci.. VII, $1854,111$.

Rather narrowly oval. subconvex. 'Tniform black or piceous, clothed with sparse rellowish, semi-erect pubescence; antemne reddish-brown to piceous. Thorax finely and rery densely punctured, the lobe at middle of base narrow, truncate; hind angles acute. Elytra more coarsely and less densely punctured. Antennal club of male of two unequal joints, the terminal one being only half as long as the preceding. Length $2-3 \mathrm{~mm}$.

Throughout the State; common. April 27-September 19. Oc. curs in spring on the flowers of red haw. yellow puccoon and other plants, and on those of goldenrod in antumn. Whenever the plant 
is touched or jarred they feign death and fall off. The proper name of this speries is somewhat in doubt. C. lriste was described from California and picicorne from "Pennsyivania to Georgia" by LeConte on the same page. Jayne says the two are synonyms. Casey says triste is a rest coast species and that he has not seen picicorne, but that it is probably a valid species. If the two are distinct, our species should bear the latter name.

\section{AnTHRenus Geoff. 186t. (Gr., "a buzzing insect.")}

Short, compact species, readily known by having the thorax broad at base and narrow in front, its lateral margins bent under the body and divided by a deep groove or pit for the reception of the antennal club; the mouth parts except labrum covered by the projecting prostermum, and surface covered by small. variegated scales instead of the usmal hairy pubescence. They are the worst of museum pests. being especially destructive to dried insects. Five or six species are known from the United States, four of which oceur in Indiana.

\section{KEY TO INDIANA SPECTES OF ANTHRENUS.}

a. Antennie 11-jointed, the club 3-jointed.

b. Eyes emarginate; scales of surface coarse, large, triangular, as wide as long; antennal club oral.

c. White scales on elytra in two or three narrow. sinuous bands or spots; these usually comected with projections from a stripe of orange scales along the suture.

1136. SCROPHULARIE. c. White scales of electra confluent into a broad median or sub-basal band.

113\%. THORACICUS.

bb. Eyes entire; scales fine, elongate, three times as long as wide; antemnal club oblong.

113S. VERBASCI. aa. Antennæe S-jointed, club 2-jointed; eyes entire; scales small, triangular. 1139. CASTANEE.

1136 (3444). Antmrenus scrophulariz Limn., System Nat., II, 1766. 56 s.

Ovate, rather convex. Elytra marked with a longitudinal sutural stripe and an apical spot of brick red or dull yellow scales, the stripe with three equidistant lateral projections of the same color, the first two of which join narrow, sinuous white bands. Body beneath black, corered with white and orange scales. Length 2.2-3.5 mm. (Fig. 227.)

Lake, Cass. Wabash and Marion counties; scarce. April $27-$ December 26 . This is the carpet

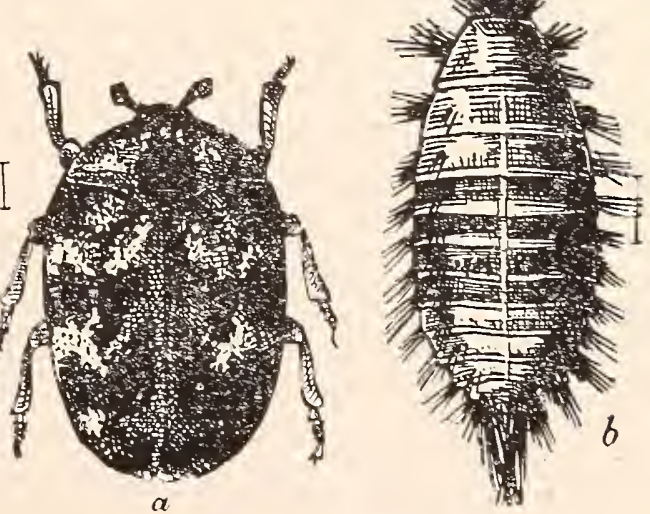

Fig. 227. (After Riles.) 
beetle, the larva of which is known as the Buffalo moth. It is a European species, which made its appearance in the eastern United States about 1874, and has sinee been widely distributed, becoming one of the worst of household pests. In the larval stage it feeds upon carpets and woolen goods, furs and feathers. The larva is a short fat grub about one-fifth of an inch in length, clothed with stiff brown hairs, with short tufts of similar hairs on the sides of each segment and a longer tuft at the extremity, forming a tail-like projection. (Fig. 227, b.) It oceurs all the year round in well-heated houses, but more frequently in summer and fall, in the cracks of floors near the edges of rooms and beneath furniture. It feeds upon the wovlen fibres of the carpet, often following the line of a floor crack and cutting long slits. When full grown it contracts, sheds its skin and becomes a quiescent pupa. In this stage it remains for several weeks, or even months, the length of time depending upon the temperature and surroundings. The mature beetles begin to appear in October and are found about the house in winter, being most abundant in spring when they are mating, and may be often taken at the windows while trying to escape.

Where it his once become installed nothing but the most thorough and long-continued measures will eradicate this beetle. Dr. L. O. Howard, in writing of the known remedies says: "In Europe it is not especially noted as a household pest, and this is doubtless owing to the fact that carpets are little used. In this country carpets once put down are seldom taken up for a year, and in the meantime the insect develops uninterruptedly. Where polished floors and rugs are used, the rugs should be taken up and beaten, and in the same way woolens and furs should never be allowed to remain undisturbed for an entire year. It is a well-known fact that the carpet habit is a bad one from other points of view, and there is little doubt that if earpets were more generally discarded in our more northern States, the Buffalo bug would cease to be the household pest that it is today."

"Where convenience or conservatism demands an adherence to the old custom, however. we have simply to insist upon extreme thoroughness and a slight variation in the customary methods. The rooms should be attended to one or two at a time. The carpets should be taken up, thoronghly beaten, and sprayed out of doors with benzine, and allowed to air for several hours. The rooms themselves should be thoroughly swept and dusted, the floors washed down with hot water, the cracks carefully cleaned out and kerosene or benzine poured into the cracks and sprayed under the baseboards. 
The extreme inflammability of benzine. and even its vapor. When confined, should be remembered and fire carefully guarded against. Where the floors are poorly constructed and the cracks are wide it will be a good idea to fill the cracks with plaster of paris in a liquid state; this will afterwards set and lessen the number of harboring places for the insect;. Before relaying the carpet tared roofing paper should be laid unon the fioor, at least around the edges. but preferably over the entire surface, and when the carpet is relaid it will be well to tack it down rather lightly. so that it can be occasionally lifted at the edges and examined for the presence of the insect." ${ }^{*}$

1137 (3444a). Axthrexts thoracices Melsh., Proc. Phil. Acad. Nat. Sci.. II, 1844,117 .

Resembles the preceding in form but smaller. The reddish sutural stripe is rarely present: the first and second crossbars of white are wide, merging on the sides only. or throughout their entire extent. when they form a wide sub-basal or median crosshand. Inder surface corered with white scales. Length $2.5-3 \mathrm{~mm}$.

Posey County; rare. Beaten from fiowers of Cratcogus. This species is placed as a synonym of scrophularice by Jayne and Henshaw. but is very distinct. It was described from the "middle and southern States', 30 years before the European species was known from the eastern United States.

*1138 (345). Axthrexts verbasci Olir.. Entom.. IT, 1795, $\mathbf{~}$

Oblong-oral, moderately convex. Thorax black. the disk sparsely clothed with rellow scales, the sides more densely with white ones; elytra black, with a large basal ring and two transterse zigzag bands of white scales, bordered by rellow ones. Under surface clothed with fine, long grapishyellow scales. Length 2-3 $\mathrm{mm}$. (Fig. 22S.)

Marion, Tigo and Knox counties. common; probably throughout the State. February 12-June 16.

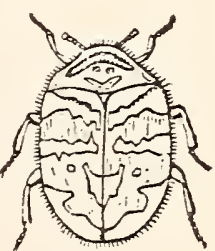

Fig. 228. $\times 7$. (After Gloter.) Occurs especially on the flowers of the wheat-or corn-cockle. Lychnis githago Linil. It is also the most common and destructive of museum pests. being especially injurious to skins of birds, mammals and dried insects. If once infested, the only remedy is a teaspoonful or two of bisulphide of carbon poured into the boxes or drawers containing the specimens. They should then be closed as tightly as possible. Naphthaline flakes, kept in liberal quantities in or about the cabinet. will disguise the odor of the dried insects and repel the pests, but they serve only as a preventative and not as a remedr

* "Principal Household Insects of the U. S." in Bull No. 4, New Ser., U. S. Dir. Entomology, 1896, 59-60. 
for boxes already infested. In heated buildings it begins to emerge from the pupal stage about February 15 th; in open air probably not until spring.

1139 (3446). Antmrenus castaned Melsh., Proc. Phil. Acad. Nat. Sci.. II, $1844,116$.

Oblong-oval, moderately convex. Head and thorax black; the latter with the disk sparsely, the base and sides narrowly and densely, covered with small triangular yellow scales; elytra chestnut-brown. sparsely clothed with similar scales arranged in three narrow zigzag crossbands, with a few scattered ones between. Under surface piceous-brown, the sternum densely, the abdomen sparsely, corered with yellowish scales. Length 2$2.5 \mathrm{~mm}$.

Throughout the State; frequent. May 3-July 13. Occurs on the flowers of Hydrangea, Cratagus and Ceanothus. I have followed Casey in giving the name castanere to the species commonly listed as muscomum. He states that the latter is much larger and differs especially in the structure of the antennal joints. I have never seen castanea about houses or musenm collections.

\section{ORPhILus Erichs. 1846. (Gr., "a sea fish.')}

Small, compact, oblong-oval black beetles having the surface nearly smooth; spine of prosternum short, reaching, but not passing between the front coxie; front legs large, protecting the mouth parts; thorax as wide at base as the elytra, its base with a broad lobe at middle, the side margins beneath with a pit behind the antennal grooves for the reception of the front knees in repose. One species occurs in Indiana.

\section{0 (3455). OrPhilus ater Erichs. Nat. Ins., III, 1S46, 463.}

Oblong-oval, moderately conrex. Black, shining. without pubescence. Antenine reddish-brown, 11-jointed. the club 3-jointed. Entire upper surface coarsely punctate. Elytra somewhat rugose, the punctures of the basal region coarser and densely crowded. Scutellum large, oval, with a few punctures. Length 2.3-2.5 $\mathrm{mm}$.

Southern half of State, frequent; not taken north of Fountain County. May 3-July 11. Occurs on the flowers of the Jersey tea. Ceanothus americanus, L., on those of the red haw, Cratcegus, and other plants. Listed by Jarne and Henshaw as O. glabratus, a European species. but Erichson. LeConte and Casey claim it is ristinct.

\section{Family XXV. MISTERTD.F.}

THE MISTER BEETLES.

A family of medium size. eomprising small, usually black. shining beetles having the elytra truncate behind, learing two segments 
of the abdomen uncovered. In form they are variable, either oblong and flat or, more usually, round, oval, globose or cylindrical. All are very compact, have a very hard surface and the elytra are usually marked with a number of stria. According to speries, these vary much in number, length and connection and are therefore much used in classification. The beetles Jive for the most part under the bark of logs, in decaying fungi, carrion, animal excrement or ants' nests. They were formerly thonght to be scavengers, but it is now believed they are predaceots in all stages, and devour the larvæ of Diptera and other forms which are feeding upon the decaying matter.

The name Hister is usually supposed to have been derived from the Latin histrio, meaning a clown or mimic, and to have been applied to these insects by Limmeus on account of their habit of retracting the antennx and legs and feigning death when disturbed. However, LeConte states * that as a vast number of other insects feign death in the same manner, this derivation appears inappropriate. He therefore snggests that as the Roman poet Juvenal, in one of his satires, mentions a filthy fellow of the name of Hister. Linnæus, who was fond of alluding to the classic writers of Rome. on finding these beetles living in the most filthy conditions, in the midst of excrements and putrefaction, probably, and very properly, gave this name to them.

In addition to the characters mentioned, the members of the family have the antennæ elbowed or abruptly bent and retractile (Fig. 229), the first joint long, the eighth and following joints forming a com-

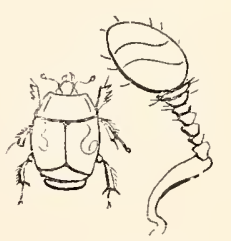

Fig. 229. (After LeBaron.) pact, rounded or rarely triangular club; thorax closely applied to the elytra, usually with cavities beneath the side margins to receive the clubs of the antennx; prosternum frequently lobed in front and prolonged between the front coxie, the latter transverse or globose. the cavities open behind; middle and hind coxæ rounded or subquadrate, widely expanded; abdomen with five free ventral segments, the first very large, the fifth very short: legs short, retractile; tibix compressed, front ones toothed and more or less fitted for digging; tarsi slender, short, 5-jointed (except in Acritus and Eletes, where the hind ones are 4-jointed), the front ones usually received in grooves on the front face of the tibia.

The principal literature treating of the North American members of the family is as follows:

\footnotetext{
*Proc. Phil. Acad. Nat. Sci., XI, 1859, 310.
} 
LeConte, John E.-."A Monograph of the North American Histeroides,' in Bost. Journ. Nat. Hist., V, 1845, 32-86, pls. I-VI.

Horn.- "Synopsis of the Histeridie of the United States," in Proc. Amer. Phil. Soc., XIII, 1873, 270-363.

Casey._- "Descriptions of isolated Genera and Species of Histeridx," in Ann. N. Y. Acad. Sei., VII, 1893, 533-578.

Nearly 2,000 species of the family are known, about 260 of which are from North America. Of these 68, distributed among 13 genera, have been taken in Indiana. The family is first divided into three tribes, and these in turn into genera.

\section{KEY TO TRIBES OF HISTERIDA.}

a. Head stretched out forward or horizontal; mandibles very prominent; form rery much depressed.

Tribe I. Hololeptini, p. 600.

a a. Head retracted, bent downward; mandibles not very prominent; form convex, usually rounded, oval or cylindrical.

7. Prosternum distinctly lobed in front (the lobe very short in Tribalus.) Tribe II. Histrini, p. 601.

67. Prosternum not lobed in front. Tribe III. Saprini, p. 617.

\section{Tribe I. HOLOLEPTINI.}

This tribe contains in our fauna the single genus :

\section{Hololepts Payk. 1811. (Gr., "all + thin.")}

Medium-sized, oblong or nearly square, very flat and thin beetles which live usually beneath the close bark of freshly felled poplar, tulip and elm trees. They have the labrum deeply and broadly grooved, its apex triangular and strongly bent downward; front tibix dentate on the inner edge; antennal club without distinct cavity for its lodgment, being merely received in a slight depression on the under side of thorax. Two species are known from the State.

1141 (3460). IIololepta lucma Lec., Bost. Journ. Nat. Hist., V, 1845, 37. pl. I, fig. 2.

Subquadrate, depressed. Thorax transverse, apex widely emarginate, base truncate, hind angles obtuse; disk punctured at the sides, the marginal stria entire; apical angles of male with a deep pit. Elytra with first dorsal stria entire; the second rery short, basal; third a mere puncture at base; subhumeral deep, abhreviated at both ends. Length $8 \mathrm{~mm}$.

Marion and Posey comnties; scaree. Narch 10-April 21. Taken from beneath cottonwood bark in low damp woods. 
1142 (3461). Hololepta fossuraris Say, Journ. Phil. Acad. Nat. Sci., V, 1825, 47: ibid. II, 271.

Resembles closely the preceding, differing only in the striation of the elytra. The first stria is short, extending not over a fourth of the elytra, the second still shorter and the third merely a trace. Males with a deep pit near the front angles of thorax, this lacking in females. Length 7 $9.5 \mathrm{~mm}$. (Fig. 230.)

Southern half of State; frequent. April 6-June 27. Appears to be much more common in spring. This and the preceding are very close and time will

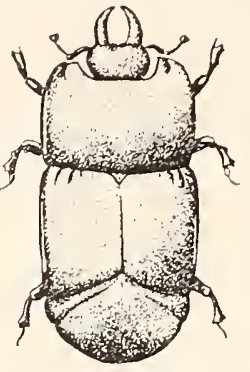

Fig. $230 . \times 3$. (Original.) doubtless prove that they are the same, Say's name having priority.

\section{Tribe II. HISTRINI.}

To this tribe belong a number of genera, which live mainly in excrements or beneath bark. They vary much in form and have the mandibles capable of being applied to the front edge of the prosternum so as to conceal the mouth. Between the prosternal lobe and the prosternum proper is a suture, so that the former appears to be a distinct piece. In a number of genera the lobe is very wide, extending to the under edge of the thorax and forming the floor of a cavity which holds the antennx when the beetle is in repose. When so extended, the widened portion is called the "pectoral plate." Six of the twelve known genera of the tribe are represented in Indiana, while a seventh probably occurs.

KEY TO INDIANA GENERA OF HISTRINI.

a. Antennal cavities beneath the front angles of the thorax, open in front, but closed more or less completely beneath by the pectoral plate.

b. Club of antenne more or less oval, pubescent, and distinctly ringed or annulate; therax without a lobe on the side.

c. Nandibles rather prominent, upper edge rounded; labrum trapezoidal; antennal club broadly oval; elytra distinctly striate.

II. Hister.

cc. IIandibles retracted, upper edge acute; labrum short, very transverse.

d. Form ovate; elytra scarcely striate; prosternum broad, the lobe short; antennal club truncate.

III. Tribalus.

dd. Form more oblong; elytra distinctly striate; prosternum of moderate width, the lobe distinct; antemnal club rounded.

IV. Epierus.

67. Club of antenne obconical. solid, slabrous; thorax with a distinct lobe on each side; clypeus truncate.

V. HET ERIUS.

aa. Antennal cavities beneath the middle of the inflexed sides of the thorax. in front of the outer portion of the coxa, not closed beneath by a pectoral plate. 
c. Tibia all dilated, the front ones with lange terminal sums.

ce. Middle and lind tibie slender.

VI. Dexdrophiles.

$f$. Front tibise dilated, with large terminal spur.

ff. Front tibice feebly dilated, with small spur.

ViI. Paromalus. Axapleus.

\section{Hister Limn. 1765. (1.. " a clown or mimic.")}

A very large genus, comprising about 84 of the known North American species. Many of them are nominal only, being separated by characters which are variable or unstable, such as the length of the outer thoracic stria and the length and connection of certain of the elytral strix. Since these strix are so much used in the separation of species in almost all of the genera, the following brief description of them is given:

Near each side margin of the thorax there are usually tro strix, known as the "onter and inner thoracic strix." The first of these is often very short or wholly wanting and in the same species is often variable in length. The strix of each elytron are normally nine in number, but several of them are more or less abbreviated, so that the number apparent is much less. Six of these, when present, are found on the disk, and beginning near the margin, are called "first dorsal," "second dorsal," etc.; the sixth one, nearest the suture. being' known as the "sutural." The fourth. fifth and sixth are often very much abbreviated. On the margin of the elytron, outside of the first dorsal. there may be three other strize known as the "inner, outer and oblique subhumerals," or if only one be present, as the "subhumeral." The two dorsal segments left exposed by the truncate elytra are known as the "proprgidium" and the "prgidium." and the character of their punctuation is also often used in the separation of species. To obviate the necessity of a rery long key. the species of the genus Hister have been divided into six or seven groups or subgenera: four of which are represented in Indiana.

KEY TO INDIANA SUBGENERA OF HISTER.

a. Front tibix with the tarsal groove bady defined. straight; middle and hind tibiæe with small spines.

b. Mesosternum truncate or emarginate at apex; inner thoracic stria always present, usually entire.

Subgenus I. Hister.

bb. Mesostermum more or less produced in front; inner thoracic stria entirely absent.

Subgenus II. Phedister.

at. Fromi tibia with the tarsal groove well defined; middle and hind tibie subdentate; imer thoracic stria absent.

c. Front tibia without a tooth on the inner side near the base; spine of prosternum flattened at apex.

Subgenus III. Platrsoma. 
ce. Front tibia with a small tooth on the inner side neal the hase; spine of prosternum conver.

Sulgenus IV. CYLISTRIX.

\section{SUbGents I. (Histel.)}

Rounded or oval, convex species, having the elytra always striate; thorax nearly always with two marginal striæ, the onter. often short; hind tibiz narrower at base than at apex, and with two rows of spines. Since the number of species and varieties of the subgenus taken in the State is 22. while five others may occur, they are for convenience arranged in four groups, separated as follorrs:

KEY TO GROUPS OF INDIANA SPECIES OF THE SUBGENUS HISTER.

a. Margin of thorax fringed with short hairs; antennal cavities shallow.

Group A.

aa. Margin of thorax not fringed; antennal carities deep.

b. Prosternum convex without striae on the sicies.

c. Mesosternum emarginate in front.

Group $B$.

cc. Mesosternum truncate in front.

Group $C$.

6b. Prosternum more or less flattened mith a stria on each side; mesosternum rery feeblọ emarginate; outer thoracic stria usually entire.

Group $D$.

Grottp A.

Tho this groun belong two rather robust species having the entire margin of the thorax fringed with short yellowish hairs. One of the two has been taken in the State, while the other probably oceurs.

\section{KEY TO SPECIES OF GROUP A.}

a. Front tibiæ bidentate; outer marginal stria of thorax entire; color black and red.

1143. BIPLAGIATUS. aa. Front tibiæ not dentate; outer marginal stria abbreriated; color wholly black.

LATIPES.

1143 (3472). Hister Biplagiatus Lec., Bost. Journ. Nat. Hist.. V, 1845. 55 , pl. 3, fig. 4 .

Broady oval. Black; elytra each with a large curved red space on the center. Thorax with two entire strixe, its surface smooth or nearly so. Elytra without trace of subhumeral stria; each with three entire dorsal strix and a trace of fourth at base and apex, the sutural extending from apex one-third to one-half towards base. Pygidium sparsely and rather finely punctured. Length $5 \mathrm{~mm}$.

Cass County; rare. One specimen dug from a burrow in a sand bank by Dr. Robert Hessler. April 17. Probably occurs sparingly throughout the southern two-thirds of the state.

H. laripes Germ., length $3.5-4.5 \mathrm{~mm}$. is said to occur from Pennsylvania to Georgia. 


\section{Group B.}

All the members of this group have the mesosternum distinctly emarginate in front and the thorax without cilix on the front and side margins. The following species have been taken or may occur in the State.

KEY TO SPECIES OF GROUP B.

a. Subhumeral stria entire; elytra with four dorsal strixe, the fourth sometimes abbreviated at base.

b. Outer thoracic stria entire.

$c$. Surface above sparsely but distinctly punctured. 1144. HARRISII. cc. Surface smooth.

d. Apical tooth of front tibiæe more prominent than the second; length $5-5.5 \mathrm{~mm}$.

1145. MERDARIUS.

dd. Apical tooth much less prominent than the second.

$e$. Sutural stria long; extending in front of middle.

$f$. Size larger, $5-\tau$ mm.

1146. INTERRUPTUS.

$f f$. Size smaller, not over $3 \mathrm{~mm}$.

114t. STYGICUS.

ee. Sutural stria very short, apical ; length $5 \mathrm{~mm}$.

1146a. var. IMMUNIS.

67. Outer thoracic stria much abbreriated or entirely absent.

g. Outer stria entirely obliterated; prosternal lobe margined.

h. Thoracic margin thickened; inner stria entire; length $4.5 \mathrm{~mm}$.

1145. MARGINICOLLIS.

hh. Thoracic margin not thickened; inner stria abbreriated behind; length $2.5-3.5 \mathrm{~mm}$.

COGNATUS.

gg. Outer thoracic stria visible, usually forming a short arc near the front angle; inner stria slightly abbreviated at tip; length 3.5$5.5 \mathrm{~mm}$.

1149. FCEDATUS.

a $\iota$. Subhumeral stria interrupted at middle, or often entirely obsolete.

$i$. Front tibiae serrulate with several spinules or small sharp teeth.

$j$. Both outer and inner subhumeral stria present, the latter apical, deeply impressed; elytra with four entire dorsal striæ; length $3.5 \mathrm{~mm}$.

1150. ABBREviatus.

ji. Subhumerals entirely absent or with only a mere trace; elytra with three dorsal strix; length $4 \mathrm{~mm}$.

1151. CIVILIS.

ii. Front tibire tridentate, the teeth being processes of the tibir itself.

k. Thorax with but one marginal stria.

l. Elytra with three dorsal strixe.

$m$. Epipleura with one stria; front tibire 4-dentate; length $5 \mathrm{~mm}$.

SEMISCULPTUS.

$m m$. Epipleura with two strixe; front tibire 3-dentate; length 3$4 \mathrm{mmm}$.

DISPAR.

11. Elytra with four entire dorsal striae; epipleura unistriate; length $5.5 \mathrm{mmll}$.

1152. OSCULATUS.

k.k. Thorix with two striae.

n. Elytra with three entire strixe.

o. Inner subhumeral present at apex, moderately impressed; epipleura with two striac; length $5.5 \mathrm{~mm}$.

1153. DEPURATOR. 
oo. Subhumeral striac wholly absent.

p. Apex of prosternal lobe truncate; epipleura with two strice; length 5-5.5 mm.

1154. FuRTIVUS.

pp. Apex of prosternal lobe rounded; epipleura with three stria; length 4-6 mm.

1153a. INCERTUS. $n$. Elytra with four entire strix; outer thoracic stria abbreviated; form oblong; length $4.5 \mathrm{~mm}$. CURTATUS.

1144 (3475). Hister harrisi Kirby, Fauna Bor. Amer., IV, 1837, 124.

Rounded-oval, convex. Surface sparsely and equally punctured. Thorax with two strixe, the outer entire and slightly curved at base, the inner often slightly the shorter. Elytra with four entire striæ, fifth extending to middle, sutural longer, than fifth. subhumeral entire. Front tibiæe with four or five teeth, the apical shorter than the second. Length 4-5 $\mathrm{mm}$.

Lake, Laporte, Pulaski, Cass and Marion counties; frequent. April 10-June 26. Occurs principally in cows' dung. Frequent beneath chunks on beach of Lake Michigan.

1145 (3479). Hister merdarús Hoffm., Ent. Hefte., I, 39.

Oblong-oval, convex. 'Thorax with two entire strixe which usually unite at the base, the inner somewhat sinuous, a few sparsely placed punctures along the sides. Elytra with four entire strie or with the fourth slightly abbreviated at base, fifth and sutural extending to middle, subhumeral entire, nearly straight. Front tibise with four teeth, the apical one more prominent than the second and slightly notched at tip. Propygidium rather sparsely. pygidium more densely punctured. Notch of mesosternum deep and broadly rounder. Length 5.5-7 $11 \mathrm{~m}$.

Throughout the State; frequent. April 25-October 24.

1146 (34S0). Histek interruptus Reany., Ins., 1805, 180.

Broadly ovate. convex. Thorax with two entire strie, not united at base, the inner rarely sinuate, surface without punctures. Elytra with three entire striæ, fourth slightly abbreviated at base, fifth very short, sutural extending in front of middle. Pygidium rather finely and sparsely punctured. Front tibire with five teeth. the apical one shorter than the second and bificl. Notch of mesosternum broad but very shallow. Length 5.5-7 mm.

Common beneath rubbish along the beach of Lake Michigan; taken elsewhere only in Vigo County, where it is scarce. May 6October 11.

1146a (3482). IIster interruptus maunis Erichs., Kl. Jahrbuch, 1834. 143.

Close to interruptus and, in my opinion. only a variety of that species. Differs by being shorter and proportionally broader, and by having the sutural stria very short or often entirely obsolete. Front tibix with five suhequal teeth. Length 5 - $8 \mathrm{~mm}$. 
Common along the beach of Lake Michigan in company with interruptus; not noted elsewhere in the State. May 20-June 10. The length of the sutural stria, the only character used by Horn in separating several species, is often uncertain and variable in the same species.

1147 (3481). Histen stranes Lec., Post. Joum. Nat. Hist., V, 1S45, 48.

Resembles interruptus in almost every particular except size. Form more broadly oval ; thorax with striae entire. parallel, equidistant from each other and from the margin; disk rery minutely punctulate. Propygidium coarsely but very sparsely punctulate; pygidium finely and sparsely punctate. Length $2.5 \mathrm{~mm}$.

Putnam County; rare. April 24. Taken by sifting about a deserted mouse's nest.

114S (348:3). IIIster marginicollis Lec., Bost. Joullu. Nat. Hist., V, 1S45, 5S, pl. 3, fig. 11.

Broadly oblong-oval, subconvex. Thorax with margin thickened, conrex; outer stria wholly absent; inner one entire, close to margin; surface very finely punctulate, sides more coarsely punctate. Elytra with subhumeral and three dorsal strixe entire, fourth abbreviated at base sometimes only on apical half, fifth short, apical; sutural extending beroni middle. Epiplenra with one stria. Front tibiae with five rather acute teeth. Notch of mesosternum very shallow. Length $3.5-4.5 \mathrm{~mm}$.

Lake, Marion and Posey counties; scarce. March 13-August 26. Those on the earlier date were taken in company with several other beetles beneath honey-comb on the ground in dense woods.

$H$. cognatus Lee., is said to occur in the Middle States, Illinois and Wisconsin.

1149 (3486). IIIster FGDates Lec., loc. cit., 50, pl. 2, fig. S.

Broadly oval, subconvex. Thorax with outer stria short, but variable in length; inner stria usually abbreviated at tip, surface minutely punctulate, more coarsely on sides between the strix. Elytra with subhumeral and three dorsal striae entire, fourth slightly abbreviated at base, fifth usually one-third, sutural one-half, the length of elytra. Front tibiae with six or more teeth. Tength 4-6.5 $\mathbf{m m}$.

Marshall, Marion, Vigo and Putnam counties; frequent. May 6-October 11. Ocenes beneath carrion. The outer thoracic stria varies from a mere are at anterior angle to half the length of the inner stria. The fifth dorsal is also variable, the basal portion often being present either as a line or disconnected punctures. 
1150 (3490). Hister ABbreviates Fab. Syst. Ent., 17!8, 5.\%.

Broadly oval, convex. Thorax with inner strial en. tire, outer usually extending to middle, often shorter: surface finely punctulate. Elytra with two subhumerals, the inner apical, the outer basal, the two with their end; overlapping near middle; entire dorsal strice, four, strongly punctured, fifth short, apical, sutural reaching middle. Pygidium finely and sparsely punctate. Front tibia with four feeble teeth, the apical one bifid. Iength $3.5-5.5 \mathrm{~mm}$. (Fig. 231.)

Throughout the State; frequent. April 12-Oc-

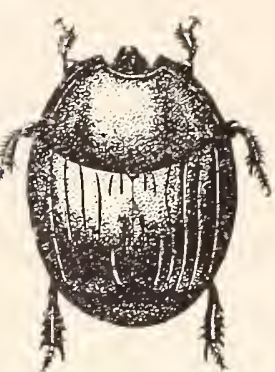

Fig. 231. $\times 5$ (Original. tober 9. Occurs especially beneath dead fish and turtles along sandy margins of lakes and ponds; also rarely in fungi, cow dung, ete.

1151 (3491). Hister crvilis Lec., Bost. Journ. Nat. Hist., V, 1845, 55, pl. 3 , fig. 5.

Oblong-oval, subdepressed. Thorax with inner stria entire. the outer represented only by an arc at front angle. Elytra without subhumeral and with only three dorsal striae. the fourth existing merely as a trace at apex. Propygidium coarsely and rery sparsely, pygidium more finely, punctured. Front tibix with very fine teeth or none at all. Length $4 \mathrm{~mm}$.

Vigo Countr: rare. June 11. One specimen from beneath a chunk in dry upland woods.

$H$. semisculptus Lee., form oblong, is known from Illinois. $H$. dispar Tec., also with three dorsal strix, occurs in Georgia, Illinois and Kansas.

\section{2 (- - ). Hister osculates sp. nov.}

Broadly oral, convex. Thorax with inner stria entire, close to margin. outer one wholly absent; disk coarsely and rather sparsely punctate on sides, smooth at middle. Elytra with four entire dorsal strie, a trace of fifth near apex, sutural on apical third but not reaching apex; inner subhumeral deeply impressed on apical third. outer absent. Propygidium and prgidium sparsely and finely punctate. Front tibise with three teeth. the middle one the largest. Notch of mesosternum rather deep and broadly rounded. Length $5.5 \mathrm{~mm}$.

Posey County; rare. May 28 . The absence of outer thoracic stria, the coarse punctures on sides of thorax and the presence of four entire dorsals, readily distinguish this from all other members of the depurator group of Horn.

115.3 (3494). Mrster perulator Sily. Journ. Phil. Acald. Nat. Sci. T. 1S2. 33 ; ibid. II, 201.

Broadly ovate, convex. Thorax with the inner stria entire, outer variable, usually reaching middle or beyond. Elytra with three entire dorsal striae, fourth alpical, rarely half the length of elytra, fifth a mere trace, sutural reaching middle; inner subhumeral moderately inpressed at apex,

[39-23402] 
outer with only a trace. Propygidium coarsely and sparsely, pygidium more finely, punctured. Front tibiæ with three teeth, the apical prominent and slightly bifid at tip. Length $5-6.5 \mathrm{~mm}$.

Throughout the State; more frequent in the northern counties. June 10-September 18. Occurs in putrid fungi and excrement. The subhumeral. fourth. fifth and sutural stria are often partially represented by detached punctures and the sutural rarely reaches apex.

1153 a (3496). Hister depurator incertus Marsuel, Mon. Hist., 1854, 269.

A variety of depurator without trace of subhumeral stria and with the epipleura tri-striate. Length 5-6 $\mathrm{mm}$.

Vigo County; scarce. June 11.

1154 (3495). Hister furtivus Lec., Proc. Phil. Acad. Nat. Sci., 1859, 313.

Resembles depurator, differing only in having the subhumeral stria wholly absent and the apex of the prostermal lobe truncate or faintly emarginate, with the sides of the emargination slightly prominent. Tength ј-6 mm.

Wells, Vigo and Jennings counties; scarce. June 11-September 24.

H. curtatus Lec., without trace of subhumeral strix, but with a short humeral appendix, is known from Pennsylvania and Illinois.

Group C.

In this group the front margin of the mesosternum is truncate and the side pieces of meso- and metasterna grooved. Seven species oceur in the State.

KEI TO SPECIES OF GROLP C.

a. Elytra bicolored, black and red; epipleura very narrow with one stria. 1155. BIMACULATUS.

an. Elytra wholly black: epipleura broader, with two strix.

b. Elytra with two subhumeral strixe, the outer entire; thorax with but one marginal stria.

1156. SEDECIMSTRIATCS.

bb. Elytra without subhumeral stria.

c. Elytra with five entire dorsal striæe.

d. 'Thorax with two marginal strix, the outer one short.

$e$. Surface smooth.

1157. AMERICANUS.

ce. Surface distinctly punctured.

1158. PERPLEXUS.

rd. Thorax with only the inner stria present.

1159. FXARATCS.

ce. Elytra with four entire dorsal strix or less.

f. Four entire dorsal strix present; epipleura with two strix.

1160. NEBILTS.

ff. 'Three entire dorsal stria lresent. the fourth short. basal; epipleura with three striae.

1161. POLLUTUS. 
1155 (3507). Hister Bmaculatus Linn., Syst. Nat., XI, 567.

Oblong-ovate, convex. Elytra black, with the outer diagonal half orange red. 'Thorax with one fine marginal stria, abbreviated at tip; disk minutely punctulate and with a broad shallow impression on each side near the front angles. Elytra with five entire striæ, the sutural extending in front of the middle; the subhumeral absent. Front tibia with three teeth; mesosternum truncate. Length $4.5 \mathrm{~mm}$.

Vigo County; rare. April 13.

1156 (3505). Hister sedechistriates Say, Journ. Phil. Acad. Nat. Sci.. T. 1825, 36 ; ibid. II, 263.

Rounded-oral. conrex. Thorax with inner marginal stria entire. outer' wholly absent. Elytra with five entire dorsal stria, the fifth arching at base and joining the sutural, and with two subhumerals, the outer entire, the inner on apical half only. Front tibia with three teeth, the apical one finely bifid. Length $4-5 \mathrm{~mm}$.

Southern half of State; frequent. May 2-September 10. A prettily and well marked species, common locally beneath carrion and in excrement.

*115i (3507). Hister americaxcs Payk., Monograph Hist., 1811, 31.

Rounded-oral, moderately convex. Thorax with inner stria entire, the outer varying from a mere are at front angle to nearly entire. Elytra with fire entire strixe, the fifth curved at base and often joining the sutural; subhumeral absent. Upper surface smooth. Front tibiæ with three teeth. the apical one prominent and finely bifid. Length $3-4 \mathrm{~mm}$.

Throughout the State; one of the most common of the family. Iribernates. January 6-October 9. Occurs usually beneath logs or bark in low moist woods. Horn says that the fifth dorsal very rarely joins the sutural but in one-third of the 25 or more specimens at hand the two are united. while in one specimen they unite on one side and not on the other.

1158 (3508). Hister perplexcs Lec., New Spec. N. Amer. Col., I, 1S63, 61.

Closely allied to americanus but larger, more oblong and distinctly but sparsely and finely punctured. Elytral striæ more strongly impressed and punctured, the fifth joining the sutural. rength 4-5 $\mathrm{mm}$.

Lake. Laporte. Kosciusko, Marion, Putnam and Posey counties: scarce. April 18-June 9. Occurs in same localities as americamus and, as Horn suggests, it will probably prove only a better developed geographical race of that species. In one specimen at hand, with surface distinctly punctured, the elytral stria are not punctured and the fifth does not join the sutural. In another the outer thoracic stria is very fine and entire. 
1159 (3509). Hister Exaratus Lec, Bost. Journ. Nat. Hist., V, 1845, 59 ; 1)l. III, fig. 12.

Also closely allied to americamus, but differing by having the outer thoracic stria wholly absent; the elytral strive finer, the fifth joining the sutural; surface smootlı. Length $3.5 \mathrm{~mm}$.

Vigo and Lawrence counties; scarce. July 1-July 29. Taken from decaying fungi. Agurices.

1160 (3510). Hister xubilus Lec, Col. of Kansas, 1859, 7.

Broadly oral, subconvex. Thorax with inner stria entire; the outer. short, apical. Elytra with four entire strix; fifth short, apical; sutural extending in front of middle. Front tibise with four teeth, the apical one slightly bifirl. Length 5 mun.

A well marked species described from Kansas and represented in the collection by a single specimen taken in Vigo County, June 7, from beneath the carcass of a dead hen.

1161 (3511). His'ter pollutus Lec., Col. of Kansas, 1S59,.

Resembles nubilus, but difters by being less broad and by having the fourth dorsal short, basal only, or with a few disconnected punctures at apex. Epipleura with three strix. Apical tooth of front tibix larger. Iength $5 \mathrm{~mm}$.

Lake and Crawford counties; rare. May 13-May 25.

\section{Group D.}

To this group belongs a single small species, separated from its allies by the characters mentioned in key.

1162 (3502). Hister serves Erichs.. Jahrbuch, 1834, 147.

Oval, convex. Thorax with two marginal stria, the outer usually entire, sometimes abbreviated to one-half or three-fourtins. Elytra with four entire stria, fifth short. apical; sutural hilf the length of elytra; subhumeral entirely absent. Pygidium convex, coarsely and rather densely, propygidium more densely and more coarsely, punctured. Front tibixe with three teeth. the apical one deeply bifid. Length $3.5-4.5 \mathrm{~mm}$.

Vigo County ; scarce. May 20-June.11. H. defectus Lec., is probably a synonym of servus, as the two are separated on the length of the thoracic stria, which varies exceedingly in the specimens of servus before me.

\section{Subgenus II. (Phelister.)}

Very sinall, oval species, having the inner thoracic stria absent. the outer sometimes present and then very close to margin ; prosternum with a stria on each sice; mesosternum prominent in front. Of the six species known from the United States, two oceur in Indiana. 
KEY TO INDLANA SPECIES OF THE SUBGENUS PIELISTER.

u. Thorax with distinct submarginal stria; elytra with five entire dorsal strix.

1163. SUBRoTUNDUs. aa. Thorax with no submarginal stria; elytra with four entire dorsal striæ. 1164. VERNUS.

*1163 (3515). Hister subrotundus Say, Journ. Phil. Acad. Nat. Sci., V, 1825, 39 ; ibid. II, 265.

Broadly rounded-oval, convex. Dark reddish-brown to blackish, shining; antenne and legs reddish-brown. Thorax finely punctulate on the disk, more coarsely on the sides; the stria distinct but very close to margin. Sutural stria of elytra extending in front of middle. Pygidium sparsely and minutely punctulate. Front tibixe with a number of fine teeth. Length 2-2.5 $\mathrm{mm}$.

Throughout the State; common beneath bark and often in fungi on oak stumps and logs. Hibernates. March 12-December 10.

*1164 (3516). Hister vernus Say, loc. cit., 40 ; ibid. II, 266.

Oblong-oval, convex. Black, shining; antennæ and legs reddish-brown. Disk of thorax sparsely and finely, the sides much more coarsely, punctate; marginal stria absent. Elytra with four entire dorsal striæ, the fifth and sutural extending from apex to middle. Front tarsi with eight or nine teeth, the apical three larger, subequal. Length $2.5 \mathrm{~mm}$.

Southern half of State; frequent. Hibernates. Occurs most commonly beneath logs and bark, in low, moist, sandy places. January 6-October 9 .

\section{Subgenus III. (Platysoma.)}

Small oval, oblong or cylindrical, often much depressed species, having the front tibise with a deep, sinuate tarsal groove; thorax without inner marginal strix; middle and hind tibiæ armed with two to four teeth or short spines; front tibix. without a tooth on the inner side near the base; prosternum without striæ. Six species of the subgenus have been taken in Indiana, while another may occur.

\section{KEY TO INDIANA SPECIES OF SUBGENCS PLATYSOMA.}

a. Body broad, not twice as long as wide, more or less depressed; elytra with not more than three entire dorsal strise.

b. Sutural stria well marked ; front tibiae with five teeth.

1165. CAROLINUS.

bb. Sutural stria either obsolete or wholly absent; front tibise with four teeth.

c. Sides of thorax punctured.

1166. LECONTET.

ce. Sides of thorax smooth.

1167. AURELTANUS.

a . Rody elongate, always as long or longer than twice the width, either cylindrical or depressed; elytra with more than three entire dorsal strixe. 
d. Sutural stria entire.

c. Ferm subcylindrical; all the dorsal striae entire.

PARALLELL'S.

c. Form depressed; fifth dorsal abbreviated at base.

116S. 玉QUT'S.

dd. Sutural stria abbreriated at base; form crlindrical.

f. Thorax evenly punctured; mesosternal stria entire.

1169. COARCTATCS.

ff. Thorax nearly smooth at middle; mesosternal stria broadly interrupted.

1170. BASALIS.

*116. (9519). Hister Carolixt's Payk., Monog. Hist., 1S11, 45.

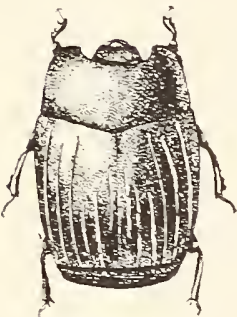

Fig. $232 . \times 7$.

(Original.)

Broadly orate, subdepressed. Black or piceous, shining: legs reddish-brown. Thorax with outer marginal stria present, vers fine; disk smooth. Elytra with three entire dorsal strix, fourth and fifth apical. reaching the middle, sutural somewhat longer. Front tibixe with fire rather fine teeth: middle tibiæ with four, hind tibiæ with three, short spines. Length 3-3.S mm. (Fig. 232.)

Probably our most common species of Hister: found throughout the State. especially in low, moist woods beneath bark and logs. January 11-Norember 30. Often gregarious in winter.

*1166 (3520). Hister Lecoxtet Marsuel, Monog. Hist., 1S53, 273. pl. †. fig. 17 .

Oblong-oral, strongly depressed. Thorax smooth at middle; sparsely and rather coarsely punctured on sides, the marginal stria entire. Elytra with three entire dorsal striae, fourth apical, extending to middle or besond. fifth short. apical: sutural often wanting, sometimes as long as fifth. Propysidium coarsels but rery sparsely punctured. Front tibiæ with four teeth: middle tibire with three. hind tibire with two, short spines. Length $2.5-3 \mathrm{~mm}$.

Throughout the State: common. February 14-December 29. Occurs beneath the close-fitting bark of logs and stumps. especially that of oak and elm; rarely on fungi or at sap.

1167 (3521). Hister alreliaxts Holn, Proc. Amer. Phil. Soc., IiII. 1873. 297.

Resembles lecontei but more depressed. Thorax almost smooth at sides. Elytra with three entire dorsals, fourth rers short, apical; fifth and sutural wanting. Length $3 \mathrm{~mm}$.

Lawrence County : rare. May 23. Taken from decaring fungi. Described from T.ouisiana. but since taken by Dury near Cin. cinnati.

II. parallelus Say, length $2.5 \mathrm{~mm}$.. is known from Georgia southward, but may occur in southern Indiana.

1168 (3523). Hister 玉quUs Lec., N. Sp. N. Amer. Col., I, 1S63, 61.

Oblong. strongly depressed. Black or piceous-brown, shining. Thorax finely and rather densely punctured. Elytra with four entire dorsal striæ, 
fifth abbreriated at base, sutural entire or nearly so; intervals sparsely but distinctly punctured. Mesosternum deeply emarginate, its striæ interrupted at middle. Front tibise with four teeth; middle tibixe with three short spines. Length $2-2.5 \mathrm{~mm}$.

Known from Indiana by three specimens taken by A. B. Wolcott from beneath bark of pine near Clark Junction, Lake County. July 23. Described from Georgia, where it is said to be rare.

1169 (3524). Histfr. coapctates Lec., Bost. Journ. Nat. Hist., V, 1845, 41, pl. I, fig. 6 .

Elongate, parallel, cylindrical. Black, shining; legs and antennæ reddish-brown. Thorax evenly but not densely punctured. Elytra with four entire dorsal striæ, fifth one-half and sutural two-thirds the length of elytra; a rery short basal subhumeral. Propygidium coarsely and sparsely, prgidium finely, punctured. Length $2.5-3 \mathrm{~mm}$.

\section{Marion County; rare. May 17.}

1170 (3526). Hister basalis Lec., Proc. Phil. Acad. Nat. Sci., 1861, 343.

Elongate, subcylindrical. Black, shining; antennæ reddish-brown; legs piceous. Thorax minutely punctulate on disk; rather coarsely and sparsely punctured at apex and on sides. Elytra with four entire dorsal striæ, fifth and sutural subequal, one-half the length of elytra; a rery short humeral. Propygidium and prgidium rather coarsely and sparsely punctured. the latter nearly smooth at apex. Middle and hind tibire each with three acute teeth on outer edge. Length $4.5-5.5 \mathrm{~mm}$. (Fig. 233.)

Marion County : rare. November 22. Two speci-

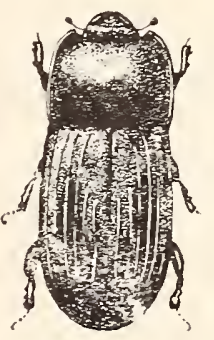

Fir. ?3?. $\times 5$. (Origine 1.) mens from the roots of a hackberry tree in low, open woods. Nuch more robust than coarctatus.

\section{Subgenus IV. (Crlistirix.)}

Small. elongate. cylindrical beetles. having the inner marginal stria of thorax absent. outer stria entire and close to the margin: front tibia spinose as mentioned in key. One of the three known species has been taken in Indiana.

1171 (3529). Hister gracilis Lec, Bost. Journ. Nat. Hist., V, 1845, 41, pl. I, fig. 7 .

Elongate, crlindrical. Piceous black, rery shining; antennæe and legs reddish-brown. Head sparsely punctured; clypens concare. Thorax longer than wide. sparsely punctured with fine and coarse punctures intermingled. Elytra with four entire strix. the fifth apical, extending to middle, sutural slightly longer. Pygidium nearly smooth. Marginal stria of prosternal lobe obliterated. Front tibiæ four-, middle three-, hind two-toothed. Length $2.5-3 \mathrm{~mm}$.

Vigo and Marion counties: scarce. May 1-May 21. Occurs beneath bark of elm and other trees in low, moist woods. 
JII. Tribiul's Erichs. 1834. (Gr., "worthless.")

This genus contains two small. dull blackish. ovate species, having the antennæ inserted under the margin of the front, their cavities at the front angles of thorax open both in front and on sides. One of the two occurs in Indiana.

1172 (3531). Tribalus americanus Lec., Bost. Journ. Nat. Hist., T, 1845, 64, pl. IV, fig. 7 .

Broadly oval, conver. Black or piceous, feebly shining, densely punctured. Thorax without striæ. Elytra with four ill-defined dorsal stria. the first and second apical, third and fourth basal. Pygidium and propygidium finely and densely punctured, the former vertical. Length 2.3$2.8 \mathrm{~mm}$.

Southern half of State; scarce. Apri] 24-June 16. Occurs beneath bark of hickory, black gum and elm.

\section{EPIERUS Erichs. 183t. (Gr., "pleasing.")}

Small, oblong-oval forms, easily distinguished from Tribalus by the distinct elytral strix. As there, the antennal cavity is partly concealed by the pectoral plate and is open in front and on the side. Our two species have all the dorsal striæ entire.

1173 (3533). Epieres regularis Beaur., Ins.. 1805, 180.

Oblong-oval, convex. Black. shining; legs piceous. Thorax rather sparsely punctate with larger and smaller punctures intermingled. Elytra each with six entire punctured dorsal strix; intervals sparsely and minutely punctulate; subhumeral entire; epipleural fold coarsely punctured and with two deep, distinct striae. Length $2.5-3 \mathrm{~mm}$.

Throughout the State; frequent. April 9-September 10. Occurs usually in fungi.

*1174 (3535). Epierc pultcarius Erichs., Jahrb., 1834, 162.

Oral, moderately convex. Dark reddish-brown or piceous, shining. Thorax finely and sparsely punctured. Elytra with six entire dorsal stria; subhumeral entire. Epipleura with one fine stria. Length 1.5-2 $\mathrm{mm}$.

Southern half of State. common; less so in the northern counties. February 23-October 4. Gregarious in winter beneath bark and logs in low. moist ground. Easily distinguished from regularis by the smaller size, lighter color and one stria of epipleura.

\section{Het жrius Erichs. 1834. (Gr., "friendship.")}

Readily known by the peculiar lobe on each side of thorax. Four species are listed from the Inited States, one of which occurs in Indiana. 


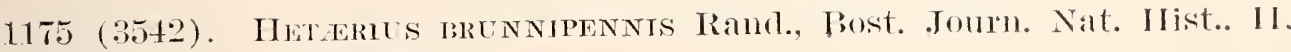
1838. 40.

Broadly oral, subdepressed. Pale chestnut brown, shining. Thorax with a groove on each side separating the disk from the lobe, the latter divided by a shallow transrerse groove slightly behind the middle. Elytral with subhumeral and first dorsal entire; second dorsil three-fourths, third two-thirds, the length of elytrai, with erect fine yellow is h hairs sparsely placed along the strise. Length $1.5 \mathrm{~mm}$. (Fig. 234.)

Marion and Lawrence counties; rare. April 28-May 11. Occurs in nests of large

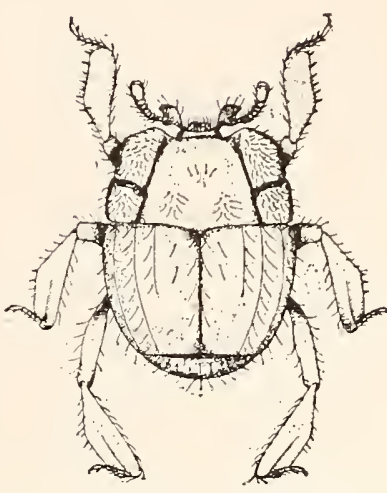

Fig. 234. $\times 12 . \quad$ (After Wheeler.) brown ants, a variety of Formica rufa.

VI. Dendropintes I weach. 1817. (Gr.. "tree + love.")

In this and the next two genera, the antennal cavities, instead of being beneath the front angles of the thorax are beneath the middle of its sides. and the lobe of the prosternum does not form a floor for them as in the preceding genera of the subfamily. Dendrophilus is represented in the eastem Lnited States and Indiana by the single species:

1176 (3551). Dendrophilus punctulatus Say, Journ. Phil. Acad. Nat. Sci.s V, 1825, 45 ; ibid. II, 269.

Rounded-oval, moderately convex. Piceous black, shining; sparsely, evenly and rather coarsely punctured; malginal line of thorax finely impressed on basal half. Elytra with outer subhumeral entire; dorsal strie faintly impressed, one and two nearly entire. three and four gradually shorter, basal; fifth and sutural absent, or the former represented by punctures only. Notch of mesosternun deep. Prosternum with a stria on each side, the apex rounded. Tibire all dilated in the middle. Length $3 \mathrm{~mm}$.

Fulton, Marion and Crawford counties; rare. April 14-July 22. Beneath bark.

VII. Paromales Erichs. 1834. (Gr., "almost flat.")

This genus comprises about 20 small oval or oblong species with the antennal cavities located as in the preceding, but having only the front tibix dilated at middle. Five of them are known to occur in Indiana.

KEI TO INDIANA SPECIES OF PAROMALUS.

a. Form oblong, strongly flattened; elytra without entire striae.

117\%. EQUALIS.

a a. Form more or less convex.

b. Flctra with entire striae; prosternum with a stria on each side. 
c. Fourth dorsal stria joining the sutural by an arc; elytra with deeply inpressed striæ, the intervals concave.

1178. GEMINATUS.

cc. Fifth dorsal stria joining the sutural, the fourth not arched at apex.

1179. 14-STRIATUS.

b6. Elytra without entire strix; prosternum without strix.

1. Elytra without trace of sutural stria; form oblong, subdepressed. 1180. BISTRIATUS.

dr. Elytra with a distinct abbreviated sutural stria ; form oval, more convex.

1181. SEMINUTuM.

*1176 (3552). I'aromales equalis Say, Jomrn. Phil. Acad. Nat. Sci., Y, 1825, 44 ; ibid. II, 269.

Oblong, strongly depressed. Black, shining, sparsely and minutely punctulate. Elytra either wholly without striæ or with traces at base or middle of two or three dorsals; a deep, oblique humeral stria often present. Front tibix 5-dentate. Length 2.5-3 mm.

Throughout the State; common beneath bark and logs, especially that of cottonwood and poplar. Hibernates. January 21-December 8. LeConte's estriatus is a synonym, the third dorsal varying from a mere trace to nearly half the length of elytron.

1178 (3555). Paromalus geminatus Lec., Proc. Phil. Acad. Nat. Sci., 1859, 314.

Oval, moderately convex. Piceous black, shining. Thorax evenly and finely punctulate. Elytra with a fine subhumeral, extending from apex three-fourths to base and with dorsal striæ one to four entire, the fourth broadly arching at base to join the sutural; fifth abbreviated at base; intervals slightly concare, sparsely and finely punctate. Front tibiæ with two teeth. Length 2-2.5 $\mathrm{mm}$.

Putnam and Marion counties; rare. March 25-May 10. Takea while sifting leaves from fence corners. Readily known by the peculiar striation of the elytra.

1179 (3557). Paromalus 14-Striatus Steph., Illust. Brit. Entom., V, 1S32, 412.

Oblong-oval, rather strongly convex. Piceous black, shining. Thorax sparsely punctulate, more distinctly so at sides. Elytra with a fine subhumeral and dorsals one to five entire, the fifth arching and joining the sutural; the intervals flat, finely and sparsely punctulate. Front tibiæ with two teeth. Length 2-2.5 $\mathrm{mm}$.

Posey County; rare. May 6. Said to occur in Europe and to be widely distributed throughout the United States.

\section{*11S0 (3564). Paromalus bistriatus Erichs., Jahrb., 1834, 171.}

Oblong-oval, subdepressed. Piceous black, shining; legs and antennæe reddish-brown. Thorax rather finely and densely punctate, the marginal stria entire, very close to edge. Elytra more coarsely and sparsely punc- 
tate. the first and second strie rere short. basal. Front tibia with four teeth. Length $2 \mathrm{~mm}$.

Throughout the State: frequent. IIibernates beneath the bark of walnut. poplar and elm logs: on tree fungi in sumer. February 10-September 21.

$11 S 1$ (3565). Parouralts semintetur Elichs.. loc. cit.

Oral, rather conrex. Picens black, shining. Thoras as in bistriatus. Elytra more coarsely punctured than thorax, with traces of two strice at base, and a short. faintly impressed sutural stria at middle. Length $2 \mathrm{~mm}$.

Southern haif of State: scarce. Occurs with the preceding and may be sexually different only. Hibernates. February 10-October 4 .

Anupleus marginatus Lec. broadly oral. piceous. coarsely punctured. elytra with traces of thiral dorsal stria at base. length 1.5 mm.. is known from Illinois and the District of Columbia.

\section{Tribe III. SAFRINI.}

The different genera of this tribe vary much in size and form. but all agree in lacking a lobe on the front of the prostermum. The members of the largest genus. Saprims. live mostly in carcasses. especially those of dead fish along the shores of rivers and lakes. The others occur mostly beneath bark and stones. Six of the seren genera are represented in the State.

KEY TO THE IXDIATA GENERA OF SATRINI.

a. Antenni inserted under the margin of the front, in repose receired in carities at the sides of the prosternum: size larger, 2.5 or more $\mathrm{mm}$.

VIII. SAPRINLS.

aa. Antennie inserted on the front. in repose receired in carities beneath the sides of the thorax in front of the coxie; size usually rerry small.

b. Eres finely granulated. not prominent; length $1.5-2 \mathrm{~mm}$.

c. Thorax with deep lateral groore; prosternum deeply bisulcate: tibix not toothed.

ix. Plegaderts. c. Thorax without deep lateral groore; form crlindrical; tibia toothed.

r. Teretrits.

6b. Eres coarsely gramulated and rery conrex; form oral: length less than $1.5 \mathrm{~mm}$.

d. Hind tarsi 5-jeinted: scutellum invisible.

NI. Bacavits.

dd. Hind tarsi t-jointed.

e. Scutellum distinct.

NiI. Acrites.

ce. Scutellum invisible.

XIII. Eletes.

\section{TIII. S.APRrute Erichs. 1834. (Gr.. "rotten.")}

The members of this genus resemble in form those of the larger species of Hister. but almost all of them have the thnas and eltra. in part, at least. more coarsely punctate. The fifth dorsal stria 
is usually wholly absent and the other striæ are not as well developed as in Hister. As noted above, our species mostly oceur along shores beneath dead fish, though several of them may be found anywhere beneath carrion. The genus is a large one, 79 species being listed from the United States, while three others are herewith described. Since the form of and characters pertaining to the prosternum are much used in classification, the under part of the body should be clean, and if too small to mount on a pin, the specimen should be set with the card point attached to the abdomen so as to expose fully the front of the under side.

For convenience the Indiana species are separated into two groups :

KEY TO GROUPS OF INDTANA SAPRINUS.

a. Front of head not margined.

aa. Front of head distinctly margined.

Gronp $A$. Group $B$.

Group A.

To this group belong the Indiana species of Groups II, IV, V and VI of Horn. his Groups I, III and VII not being represented in the State.

KEY TO SPECIES OF GROUP A.

a. Prosternum flat, its marginal striae horizontal and united in front; sutural stria very short, basal; length 2.5-3.5 mm. 1182. RoTUNDATUs.

aa. Prosternum at least moderately convex, distinctly striate.

z. Striæ of prosternum parallel, horizontal, abbreviated in front; internal subhumeral stria represented by a row of rather coarse, disconnected punctures; length 3.5-4 mm. 1183. Posthumus.

b7. Strire of prosternum divergent in front and ascending.

c. Prosternum without a pit or forea on each side near the front margin; head with a distinct stria extending slightly along the front above the eye.

d. Fourth dorsal stria feebly arched at base, not joining the sutural, the latter short; area between the dorsal stria coarsely and densely punctured; length 4-6 mm. 1184. Lugens.

17. Fourth dorsal strongly arched at base, usually joining the sutural; area between the dorsal striae very little or not at all punctured; length 4.5-5.5 $\mathrm{mm}$.

r. Sutural stria wanting at basal and apical portions, visible for a very slight extent at middle only. 1155. IMPERFEcTus.

ce. Sutural stria distinctly impressed at apical portion and joining the apical marginal stria; surface brilliant metallic green or bronze.

1186. PENNSYLVANICUS.

cc. Prosternum with a small but distinct fovea on each side in which the stria ends; stria on front above the eye rarely present.

f. Pygidium with a deep marginal groove at apex.

1187. ASSIMILIS. 
ff. Pygidium not groored.

y. Fourth dorsal and sutural united, the latter stromgly impresserl at base.

h. Outer subhumeral stria short, distinct. 11S8. coxfoksus.

hh. Outer subhumeral stria entirely absent.

i. Fourth dorsal strial nearly as long as first; lengtl $t$ $4.5 \mathrm{~mm}$.

1189. SIMLLATCS.

ii. Fourth dorsal distinctly shortel than first; length less than $2.5 \mathrm{~mm}$.

1190. MIXTTS.

y. Fourth dorsal arched at base: sutural stria rery feeble, interlupted at base and apex: length 3.2 11m. 1191. oriforass.

1182 (3571). SAprixus rotundates Kugel, Schneidel Mag.. III. 1792, 304.

Broadly oral. Piceous or black. shining: legs and antenne brownishrect. Thorax rather coarsely punctate orer its entire surface. Elytra with first dorsal entire but rery fine beyond the middle: second, third and fourtl nearly equal. reaching middle: fifth represented only by a short basal arc. sometimes uniting the fourth and sutural, the latter vers short. on basal fourth only: surface sparsely punctured on sides and base. mole densely on apical third. Front tibixe with fire teeth. Length $2.5-3.5 \mathrm{~mm}$.

Marion. Vigo and Crawford counties; rare. Nay 15-October 9. 'Taken from decaring fungi at base of oak stmmps.

1183 (3579). Saprixus posthumes Mars. Monog. Hist. 18ti2. 460.

Broadly oral. Black, strongly shining. Thorax with middle sparsely. sides and base more densely and coarsely, punctured. Elytra with first dorsal extending three-fourths to apex. second. third and fourth subequal. reaching middle, the fourth arched at base and joining the sutural. which extends nearly to apex: surface of apical third coarsely but rather sparsely punctured, the punctures extending from the first stria to the suture. Front tibir with a number of fine teeth. Length $3-3.5 \mathrm{~mm}$.

Marshall. Tippecanoe. Putnam andi Posey connties: scarce. May 8-October 17.

1184 (3593). SAPRINUS LCgExs Erichs. Jahrb.. 1\$34. 181.

Broadly oral. Black. moderately shining. Thorax feebly impressed on each side near the front angles. disk smooth. sides with punctured sparee broader in front and at base, narrower along the basal margin. Elytra with a large. well defined scutellar space and a much smaller subhumeral one smooth: remainder of surface densely punctured: first and second dorsal strixe extending tro-thirds to apex. third and fourth a little shorter and nearly equal. the fourth slightly arched: the sutural absent on hasal thirk. Front tibie with a number of fine teeth. Tength $t-6 \mathrm{~mm}$.

Lake Countr: rare. Tune t. Not before recorded east of the Mississippi River. but said to be abuncant at the eastern base of the Rocky IIountains and westward. 
118.5 (3.54). Saprinus miperfectus Lec., Bost. Journ. Nat. Hist., V, 1845. 70, pl. 5 , fig. 3.

Broadly oval. Black, strongly shining. Thorax smooth at middle, the sides broadly and coarsely, the base narrowly and coarsely, punctured. Elytra sparsely punctured on apical third, the punctures extending to the base on the interval between the first and second dorsal strix, this interval slightly rugose near base; oblique humeral stria bifid at tip, the outer branch joining the internal subhumeral, which is longer than the first dorsal; dorsals one. two and four, subequal, extending slightly beyond middle. the third shorter, the sutural represented by a few close punctures at middle. Front tibire finely denticulate. Length 5-5.5 mm.

Marion and Hamilton counties. rare; a single specimen having been-taken in each from beneath dead turtles. May 29-June 7 . Known heretofore only from Pennsylvania.

1186 (3585). Saprixes Penxsyluaxicts Payk., Monog. Hist., 1S11, 62.

Broadly oval, robust. Brilliant metallic green to bronze. Thorax smooth. with a few rather coarse punctures along the sides and a double row of coarse ones on basal margin. Elytra coarsely and sparsely punctured on apical half, between first dorsal and suture; humeral stria fine. oblique. not joining internal subhumeral, which is longer thin first dorsal; the latter extending two-thirds to apex, second shorter. third rery short. fourth shorter than second. broadly arching to join the sutural, which is entire. Front tibix coarsely serrate. Length $4.5-5 \mathrm{~mm}$.

Lake and Poser counties; scarce. Probably throughout the State, as it is said to occur "ever'yhere east of Rocky Mountains." May 7 -June 29.

1187 (3590). SaPrinus assimmlis Payk. Monog. Hist., 1811, 63.

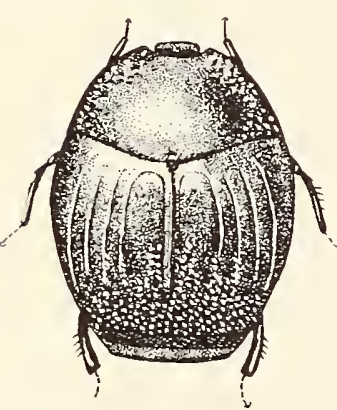

Fig. 235. $\times 5$. (Original.)

Broadly oral. Black, shining. Thorax impressed near the front angles, the disk smooth, sides coarsely and densely punctured, the base with a few punctures and a distinct impression in front of scutellum. Elytra coarsely punctured on apical third; humeral stria oblique. indistinct, not joining the interual subhumeral which is represented by punctures at apex; first dorsal extending three-fourths to apex. second, third and fourth gradually shorter and terminating in coarse punctures, the fourth joining the sutural, which is Front tibir with a number impressed at base, but does not reach apex.

Throughout the State; frequent on carrion, especially that of reptiles and fishes. April 13-August 23.

1188 (3592). Saprinus conformis Lee. Bost. Journ. Nat. Hist., V, i2. pl. $V$, fig. $\tau$.

Broadly oral. Black, shining. Thorax with disk smooth, rather finely and densely punctured on the sides, one low of coarse punctures along the 
base and a single larger one in front of scutellum. Elytra witl an irresulall triansular space of rather (oarse and sparse punctures on alpical third: humeral stria very fine; internal subhumeral, short, subapical; first dorsal extending four-fifths to apex, second. third and fourth gradually shorter. the fourth arched to join to sutural. which extends two-thirds to apex and thence continued by punctures. Front tibire finely denticulate. Length $3 . \bar{x}$ 4.5) 111111 .

Lake. Marshall. Tippecanoe and P'utnam counties: scarere. Ma!" ?T-September 1:3.

11S9 (—). SAPRIXES SIMLATLS S1) not.

Oblong-ovil. Black, shining; antenne and legs picentus. Head minutely and rery indistinctly punctured. Thorax rather finely and densely punctured at the sicies and with a single row of coarse punctures along the base. Elytra rather sparsels and finely punctured on apical iourth, with a few scattered ones extending betreen the sutural and fourth dorsal to midrle or beyond: internal subhumeral short, subapical; dorsal strice deeply impressed. obsoletely punctured. the first extending four-titths to apex; second, third

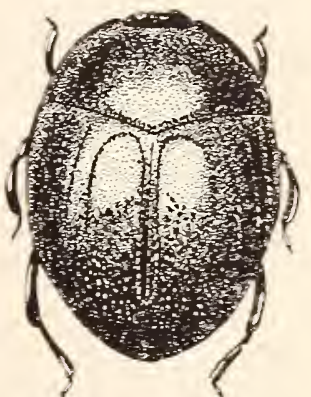

Fig. $236 . \times 6 \frac{1}{2}$. (Origiaul.) tirst. the fourth arching at base and joining the sutural, which extends three-fourths to apex. I'roproidium and prgidium rather finely and densely munctured. Front tibiae with fire distinct teeth. Length $4.5 \mathrm{~mm}$. (Fig. 236.)

Tigo and Crawford counties: rare. April 2-15ay 11. According to Horn is ker. this runs to vescus Mars., but comparisons with examples of that species at Cambridge show rescus to be a smaller and much nore shining species. with thorax more uniformly and pygidium much more sparsely punctate.

1190 (3597). Saprixts mixutus Lec., Bost. Journ. Nat. Hist., T. 1St5, 73. pl. T. tig. 9.

Broadly ovate. Piceous-black tinged with bronze: legs reddish-brown. Thorax smooth at midlle. finely and sparsely punctulate on sides. Elytra sparsely and coarsely punctate on apical third. the punctures extending along suture beyond the middle; oblique humeral continuous with internal subhumeral which, with first and second dorsals, extends three-fourths to apex: third dorsal reaching slightly besond middle, fourth extending to middle only and joining the sutural. which is abbreriated at aper. Front tibix finely denticulate. Jength $2 \mathrm{~mm}$.

Termillion County: rare. August 11. The smallest species of the genus in the State. Horn in his Monograph states that the sutural stria of mimutus attains the apes and joins the apical marginal line, but LeConte in his original description says that it is "postice abbreviata" and figures it so. It reashes only three- 
fourths to apex in the specimen at hand, and it is my opinion. julging from descriptions only. that concexiusculus and minutus are stmonymous, the latter name having priority.

1191 (—). SAPRINCS OVIForMis sp. nor.

Oral, conrex. Black. shining; legs piceous. Head finely and sparsely punctate. Thorax with a large area near front angles. narrowing to base, l'ather coarsely and densely punctate, disk almost smooth. Elytra with alical third coarsely and sparsely punctate; oblique numeral distinct, subhumeral absent; first dorsal extending three-fourths to apex; second. third and fourth subequal, reaching but little besond middle; sutural represented by a row of punctures from slightly in front of middle to apical fourth. Propygidium and prgidium coarsely and rather densely punctate. Front tibice with six or seren sharp teeth. Length $3.2 \mathrm{~mm}$.

Lawrence County: rare. June 10. Taken at carrion. Allied to wacoensis Horn. but differs by the larger and much more coarsely punctured area of elytra and less miformly punctate thorax.

GrotP B.

This group comprises the Indiana species of Groups VIII and IX of Horn. They are robust. rombed or oval species. having the front of head wider than long, distinctly margined and usuaily marked with one or two short curved grooves.

KEI TO SPECIES OF GROCP B.

a. Prosternum compressed. its strise entire or nearly so, convergent in front: hind tibixe with two rows of fine spines.

b. Elytra with distinct sutural stria.

c. Sutural stria entire; punctured space at apex of elptra of small extent. not entered by the dorsal strise.

1. Thorax sparsely punctured in front and at sides. its disk smooth : surface bronzed; length 2.5-3.5 mul. 1192. spH.玉roides.

dd. Thorax rather sparsels and evenly punctured orer its entire surface; black. strongly polished ; length $4.2 \mathrm{~mm}$. 1193. LAKExsis.

cc. Sutural stria abbreriated at apex, or confused with the punctures.

e. Flytral punctures apical only, the basal region smooth: thorax with strigose punctures at sides and apex; surface bronzed: length $3 \mathrm{~mm}$.

1194. SEMINITEXs.

ce. Elytral punctures dense. extending to base between the strire.

f. Mirror. or shining smooth space about the scutellum. sharply defined: sutural stria entire. confused at tip; length 3.5$4 \mathrm{~mm}$.

1195. FRATERXLS.

ff. Mirror not rell defined: sutural stria obsolete at apex; length 3-4 $\mathrm{mm}$.

1196. MAxCLs.

bb. Elstra with sutural stria wanting; scutellar mirror well defined: length 2.5-3.2 $\mathrm{mm}$.

1197. FITCHII.

ad. Prosternum compressed and carinate. its strixe short, united in front: hind tibire with three rows of long spines: sutural stria entire; elytral punctures coarse.

119S. PATRLELIS. 
1192 (3614). Saprinus sphamoldes Lec., Bost. Joul. Nat. Iist. V, 1S45, is. pl. VI, fig. 5 .

Rounded-oval. Bronzed or cupreous, shining. Thorax sparsely punetured in front and at the sides; basal margin more coarsely punctured, disk smooth. Elytra finely punctured on apical third in space between the fourth dorsal and sutural ; external subhumeral rather long. humeral fincly impressed, not uniting with the internal subhumeral; first dorsal stria extending four-fiftls to apex and sinuite at tip; second, third and fourth gradually shorter, the fourth arching to join the sutural, which is entire. Front tibiac coarsely denticulate, the apical three teeth longer than the other's. Length $2.5-3.5 \mathrm{~mm}$.

Beneath rubbish on beach of Lake Michigan, near Millers, Lake County; scarce. May 12-June ?.

\section{3 (-). SAPRINUS LAKENSis sp. Hov.}

Broadly oblong-oval, convex. Black, strongly shining. Ilead distinctly margined, nearly smooth, rugose in front. Thorax with the disk sparsely and evenly punctured, the sides and apex with strigose punctures. Elytra rery finely and sparsely but distinctly punctured near the suture on apical third, elsewhere wholly smooth, polished; external subhumeral short, indistinct; humeral finely impressed, not joining the internal subhumeral, which is obsolete towards apex; dorsal stria very fine, the first extending fourfifths to apex, second, third and fourth gradually shorter, the fourth arched at base and joining the sutural, which is entire. Pygidium and propygidium finely, densely and evenly punctured. Front tibixe with five or six teeth, the apical three broader and more flattened. Length $4.2 \mathrm{~mm}$.

Described from a single specimen taken from beneath a $\log$ on the beach of Lake Michigan near Millers, Lake County. July 25. It is readily known from sphreroides by its larger size, its polished black hue, by having the entire surface of thorax punctured, and by the much smaller and more finely punctured space of elytra.

1194 (3615). Saprinus seminitens Lec., New Spec. N. A. Col.. 1863, 61.

Resembles sphrroides but the punctured space of thorax is larger and more distinctly strigose on sides and in front; that of elytra is also larger with coarser punctures and the sutural stria reaches only two-thirds to apex. Length $3-3.5 \mathrm{~mm}$.

Beneath rubbish and dead fish on beach of Lake Michigan near Pine and Millers, Lake County; scarce. May 14-July 27. Recorded heretofore only from Nebraska.

1195 (3617). Saprinus fraternus Say, Journ. Phil. Acad. Nat. Sci., Y. 1825, 40 ; ibid. II, 266.

Broadly oval. convex. Black tinged with bronze, subopaque. Thorax rather densely punctured, the punctures on sides somewhat strigose, a broal triangular space on disk nearly smooth. Elytra everywhere densely punctured except on a well defined, shining scutellar space which is limited at

$\left[\begin{array}{ll}40-23402\end{array}\right]$ 
the sides by the fourth dorsal; internal subhumeral entire, external obsolete; first dorsal long, curved at tip, second, third and fourth gradually shorter, extending nearly to middle, fourth joining the sutural, which is entire. Front tibiæ with seven or eight teeth. Length 3-4 $\mathrm{mm}$.

Lake, Laporte and Vigo counties; common on dead fish and turtles along the beach of Take Michigan. Probably occurs on sandy beaches throughout the State. April 29-3nue 26.

1196 (3618). Saprinus mancus Say, loc. cit., p. 41 ; ibid. II, 267.

Resembles fraternus in form, color and size. Thorax rather densely punctured over its entire surface. Elytra densely, strigosely punctured. the scutellar mirror ill-defined and sometimes almost obliterated; sutural stria basal, extending to middle only. Front tibiæ with six teeth. Length 2.S $-4 \mathrm{~mm}$.

Occurs with the preceding along the beach of Lake Michigan. but much less common. May 20-June 25.

1197 (3620). SAPrinus Fitchit Mars., Mon. Hist., 1862, 494.

Oblong-oval, convex. Black, distinctly bronzed, shining. Thorax with a broad space at sides and apex coarsely punctured, finely strigose near margin; base narrowly and coarsely punctured; disk smooth, polished. Elytra everywhere densely and coarsely punctured except a well defined scutellar mirror; first dorsal nearly entire; second and third shorter, indistinct; fourth very short, curved at base; sutural entirely absent. Length 2.S-3.2 $\mathrm{mm}$.

Lake County; rare: Five specimens were taken from beneath the carcass of a dead hen near Hammond. May 27.

1198 (3625). Saprinus Patruelis Lec., Bost. Journ. Nat. Hist., V, 1845, 76 , pl. VI, fig. 2.

Broadly oval, robust. Surface shining, with a bluish-green or slightly bronzed lustre. Thorax with a narrow band of coarse punctures along the sides and apex, distant from margin except at base; disk smooth. Elytra very coarsely and sparsely punctured on apical half, the punctures extending along the suture two-thirds to base; humeral oblique, fine and long, not uniting with the short internal subhumeral ; dorsal strie subequal, reaching slightly beyond the middle. the fourth arched to join the sutural, which is entire. Front tibie with six teeth, the apical three much coarser. Length 3-4.2 $\mathrm{mm}$.

I ake. Starke, Vigo and Posey counties; scarce. May 13-September 20 .

IX. PLEGADERT' Erichs. 1834. (Gr., "a blow + neck.")

Small oblong species having a broad prosternum with a deep channel on each side extending from the lobe to the tip, and also a broad transverse groove which divides the median convex portion of the prosternum into two unequal portions. The thorax has a deep 
groove on each side aud also, usually, a transverse impression which divides it into two unequal parts. Of the nine species known from the United States, one has been taken in Indiana, while another may oceur.

KEY TO INDIANA SPECIES OF PLEgADERUS.

u. Elytra with strigose confluent punctures.

1199. TRANSVERSUS.

aa. Elytra with coarse rounded punctures; body beneath coarsely and rather closely punctate.

SAYT.

1199 (3633). Plegaderus thansversus Say, Journ. Phil. Acad. Nat. Sci., V, 1825, 45; ibid. II, 270.

Oblong-oval, subdepressed. Brownish-black, moderately shining. Thorax slightly broader than long, the side margins convex with a narrow and deep marginal stria on outer side and a deep lateral groove on inner; the disk divided unequally by a moderately impressed transverse groove, the front portion smaller and more closely punctured than the hinder. Elytra with elongate, confiuent punctures and a short, moderately impressed, oblique humeral stria. Length 1.:-1.5 mm.

Taken in small numbers by Wolcott from beneath the bark of the Norway pine, near Clarke Junction, Lake County, and Dune Park, Porter County. June 27-July 23. Occurs from Canada to Texas.

$P$. sayi Mars., brownish, length $1.5 \mathrm{~mm}$., is recorded from the "Middle States."

X. Teretrius Erichs. 1834. (Gr., "cylindrical + form.")

Small subcylindrical beetles having the prosternum emarginate at tip, receiving the mesosternum, the tibir toothed. Three species are known from the United States, one of which occurs in Indiana. 1200 (3640). Teretrius americanus Lec., Proc. Phil. Acad. Nat. Sci., XI, $1859,316$.

Oblong, subcylindrical. Piceous-black, shining, the narrow margin of efytra reddish. Thorax longer than wide, finely punctured; marginal stria entire but fine and very close to the margin. Elytra without strix, sparsely and rather coarsely punctured, the punctures coarser at base; truncate at apex. Front tibix with five or six fine teeth. Length $1.5 \cdot 2 \mathrm{~mm}$.

Dubois and Posey counties; rare. May 5-May 1t. Taken beneath the bark of soft maple and by sifting rottea ciebris. Widely distributed but scarce.

\section{Bacanius Lee. 1853. (Gr., "radish seed.")}

Minute brownish-red species possessing. the characters given in generic key and having the first joint of antenna gradually thicker to tip, second joint broader than long, third longer than the two 
following; prosternum broader than long, truncate at tip; mesosternum truncate; front tibix dilated and two-toothed. Six species are listed from the Enited States, two of which have been taken in Indiana, while another perhaps occurs.

KET TO INDLANA SPECIES OF TACANIU'S.

a. Pro- and mesosterna smooth or rery sparsely punctured; elytral punctures simple, rounded.

b. Subhumeral and first dorsal striæ of elytra both entire, the latter not arching at base; prgidium rery minutely punctulate. JHsElcts.

bb. Subhumeral striae abbreriated at apex, first dorsal short; pygidium distinctly punctured.

1201. TAXTILLTS.

a a. Pro- and mesosteina coarsely punctate; first dorsal striae entire, broadly arching at base; elytral punctures elongate, substrigose.

1202. PLNCTIFORMIS.

B. misellus Lec., brownish-red. length $.8 \mathrm{~mm}$. is recorded from "the Middle States region."

1201 (3645). Bacanius tantileus Lec. Proc. Phil. Acad. Nat. Sci.. 1853. 291.

Broadly oral, convex. Dark leddish-brown, shining. Thorax distinctly but not densely punctured. Elytra more coarsely punctured than thorax; the subhumeral stria abbreriated at base and apex. Pygidium strougly inHexed, rather coarsely and distinctly punctured. Length 1-1.2 mm.

Monroe County ; scarce. June 9. Sifted fron debris of beech stump. Larger and less convex than the next species.

1202 (3646). Bacanius puxctiformis Lec., Proc. Phil. Acad. Nat. Sci.. $1853,288$.

Rounded-oral, subglobose. Dark brownish-red, moderately shining. Thorax finely and sparsely punctured. Elytra with dense aciculate, elongate punctures. Length $0.75 \mathrm{~mm}$.

Marion. Putnam, Dubois and Poser counties; scarce. March 25-July t. Taken while sifting in early spring and also beneath bark of half decayed elm logs. Probably mole common than indicated. but overlooked on account of minute size.

\section{Acritus Lec. 1853. (Gr.. "indistinguishable.")}

'The species of this genus are very minute and may be known by the four-jointed hind tarsi and distinct scutellum. As in the two preceding and the following genera, the scape of the antennæ is lodged, when at rest. in a deep groove in front of the eve. Eleren species are listed from the trited States, two of which have been taken in Indiana. 
KEY TO INDIANA SPECIES OF ACRITUS.

a. 'Thorax without a row of punctures across the base.

1203. EXIGUUS. aa. Thorax with a row of punctures across the base; prosternum much longer than wide, its striae not more divergent in front than at base.

1204. STRIGOSUS.

1203 (3649). Acrite's Exiguus Erichs., Jahrb., 18:34, 208.

Broadly oblong-oval, slightly convex. Dark reddish-brown, shining. Thorax rather coarsely and sparsely punctured. Elytra more coarsely but not more densely punctured than thorax, the marginal stria rather deep, entire. Prosternum more than twice as long as wide, its surface with very few punctures. Front tibia slender. Length $1 \mathrm{~mm}$.

Southern half of State; frequent beneath bark of elm and other logs. Gregarious and probably hibernates. April 9-November 22.

1204 (3654). Acritus strigosus Lec., Proc. Phil. Acad. Nat. Sci., 1853, 289.

Rounded-oval, moderately convex. Dark brown, shining. Thorax sparsely and rather finely punctured, the basal row of punctures sightly curved and not extending on either side beyond the middle of the base of elytra. Elytra coarsely punctured, less distinctly on basal third. Metasternum coarsely and rather sparsely punctured. Length $0.8 \mathrm{~mm}$.

Marion County; scarce. Taken by H. Morrison from the sides of a bridge abutment on which they had alighted to bask in the sunshine; also by sifting. April 23-November 8.

\section{XIIT. Eletes Horn. 1873.}

The species of this genus are separated from those of Acritus only by the absence of a scutelium. In such minute forms this charactel is very difficult to distinguish except under very high power. Four species are known from the United States, two of which have been taken in Indiana.

1205 (3657). Aletes politus Lec, Proc. Phil. Acad. Nat. Sci., 1S53, 290.

Rounded-oval, convex. Brown, shining. surface wholly deroid of punctures. Prosternum twice as long as wide; mesosternum with longitudinal grooves. Length $0.8 \mathrm{~mm}$.

Throughout the State; frequent. Occurs beneath bark and in dead leaves and other rubbish about the base of trees where it may be taken by sifting. April 9-November 28.

1206 (3660). Aletes simplex Lec., Bost. Journ. Nat. Hist., V. 1S45, S4.

Oval, moderately convex. Reddish-brown, shining. Thorax and elytra very sparsely and finely punctured. the former with a basal row of coarser punctures the middle ones of which are linear or sulciform. Prosternum nearly as broad as long. Meso- and metasterna smooth. the suture coarsely punctate. Length $1 \mathrm{~mm}$. 
Putnam Countr: rare. April 17 . Sifted from debris near a hillside spring:

\section{Family XITI. NITIDLLID.E.}

\section{The SAP-EEEDING BEETLES.}

This is a family of medium size. comprising small and usually somewhat flattened beetles. In most species the thorar has wide. thin side margins and the elstra are often truncate at aper. thus leaving the end of the abdomen exposed. In food habits they rars much. a few being found on fiowers and others on fungi or carrion. The great majority: howerer. feed on the sap or juices of rarious trees and firuits. especialle that which has begun to ferment or sour. They can be found in numbers in early spring whererer sap exudes from trees, especially those of maple.

Dury says that he has trapped hundreds by laying chips on top of a freshly cut mapie stump. Under these chips. in a dar or two, were congregated twenty or more species and hundreds of individuals. A mixture of vinegar with bromn sugar or molasses will also attract them if spread on a log in the roods and then corered with chips. In late summer and early autumn certain species. especially those of Ips. are often found in or under partially decared apples, pears or melons. Ther are therefore to be classed as innoxious. rather than either beneficial or harmful in habit: though the larra of the genera Ips. Carpophitus and Rhizophagus have been shown to be. in part at least. carnirorous. subsisting upon the soft bodied larra of other beetles which live mder bark.

The name Titidula, applied by Fabricius to the trpical genus. is rer. inappropriate for the family. since it literally means shining or elegant. Whereas the great majority of the species are clothed with a fine pubescence which does not permit of their shining to any great extent.

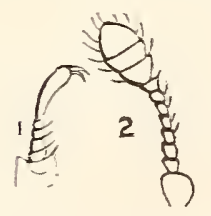

The principal characters distinguishing the Nitidulidie are: Antenne 11- rarely 10-jointed. teminating: in a round or oval club of three. rarels tro. joints and inserted under the margin of the front: thoras with base sometimes closely uniting with that of elrtra. Fir. 237. Titidula. sometimes passing orer the base of the lattel (Fig. 1. iront tarsis 2, an- 237 ) : elrtra usually truncate. sometimes entire: front wood.) core transrerse. separated, not prominent: middle and hind coxe transverse. flat. widel separated. the latter extending almost to the margin of the bodr: abdomen with fire free ren- 
tral segments; legs short, somewhat stout, retractile or partly so: tarsi short, usually dilated and hairy beneath, usually five-jointed, with the fourth joint very small. rarely four- or three-jointed.

Practically the only available paper treating of the North American species of the family is that of

Horn.-." Revision of the Nitidulidx of the United States," in

Trans. Amer. Ent. Soc., VII, 1879, $267-336$.

About 120 species of the family, divided among 32 genera, are known from North America. Of these 49 species, belonging to 22. genera, have been taken in Indiana. For convenience the family vas first divided by Horn into eight tribes, seven of which are represented in the collection at hand.

KEY TO INDIANA TRIBLS OF NITIDL LIDE.

a. Antenna 11-jointed, ending in a three-jointed club;: all the tarsi similar in both sexes.

b. Tarsi 5-jointed.

c. Labrum free, more or less visible; color rarely shining black.

d. Maxillæ with two lobes; antennal club elongate, loose.

Tribe I. Brachypterint, p. 629.

$d d$. Maxillæ with one lobe; antennal club rounded, compact.

e. Thorax not margined at base; head horizontal.

$f$. Abdomen with two or three segments exposed.

Tribe II. Carpophilini, p. 631.

ff. Abdomen wholly covered or with but one segment exposed.

Tribe III. Nitidulini, p. 635.

ce. Thorax margined at base, covering the base of elytra; head more or less bent downward.

Tribe IV. Cychramini, p. 645.

cc. Labrum united with the front or lower part of face; color usually shining black or piceous with reddish or yellow markings.

Tribe VI. IPINI, p. 648 .

$b b$. Tarsi four-jointed; body contractile; thorax margined at base, covering the base of elytra.

Tribe V. Crbocephalini, p. 647. aa. Antennæ 10-jointed, the club two-jointed; hind tarsi of males 4-jointed.

Tribe VII. Rhyzophagini, p. 650.

\section{Tribe I. BRACHYP'TERINI.}

The members of this tribe necur usually on flowers and have the antennal club gradually formed and not of compact construction; maxillie with two lobes; labrum distinct, usually small, often deeply emarginate. The males have a small additional apical dorsal segment. Four genera constitute the tribe, two of which are represented in Indiana.

*In some species of Cercus the club has but two joints. 
KEY TO INDIANA GENERA OF BRACHYPTERINI.

a. Tarsal claws distinctly toothed at base.

I. Brachypteris.

a a. Tarsal claws simple or very nearly so.

II. Cercus.

I. BRACHYPTERT'S Kug'. 1794. (Gr.. "short+wing.")

This genus is represented in the eastern United States and Indiana by one species. which was probably introduced from Europe.

1207 (3661). Brachypterus urtic. Fab., Ent. Syst., I, 179s, 235.

Oval, contex. Piceous with a tinge of bronze, shining and rery sparsely pubescent: anfennie and legs reddish-brown. Thorax nearly twice as wide as long. convex, coarsely and rather densely punctured; sides curred and feebly sinuate near base. Elytra a little more coarsely but less densely punctured than thorax, truncate at apex. Length $2 \mathrm{~mm}$.

Steuben, Marshall and Narne counties; scarce. May 25-July 15. Occurs usually un flowers of nettle, whence the specific name: also sifted from sphagnum moss.

\section{Cercts Latr. 1796. (Gr.. "tail of a beast.")}

Two species represent this genus in the eastern Tnited States, both of which oceur in Indiana.

1208 (3664). Cercus abdominalis Erichs. Germ. Zeits., IT. 1S43, 229.

Oral, convex. Metallic blue or greenish, shining; legs and abdomen red; antenna reddish-brown. the club piceous, three-jointed. Thorax convex, one-third wider than long, rather coarsely and evenly, but not densels punctate; base a little wider than ajex, hind angles rectangular. Elytra. together, a little longer than wide, rather more coarsels punctured than the thorax. Length 2-2.5 $\mathrm{mm}$.

Throughout the State; frequent. April 11-.July 6. Occurs on flowers of blood root (Sanguinaria) in early spring and later on foliage of rarious shrubs and trees, especially those in low ground.

1209 (3665). Cercts penxatus Murr.. Trans. Linn. Soc., XXIV, 235.

Oral. subconvex. Light bromnish-yellow to piceous. feebly shining. sparsely pubescent. Antennal club two-jointed. Thorax nearly twice as ride as long. apex feebly emarginate. sides regularly curred and hind angles obtuse in male; sinuate behind and hind angles distinct in female; disk conrex, rather densely punctate. Elstra. together. longer than wide, apex rounded-truncate, surfice rather coarsely but not densely punctate. Tength $2.3 \mathrm{~mm}$.

Steuben. Whitley, Marion and Jackson counties; scarce. June 19-July 19. Occurs on flowers of elder and wild hỵdrangea. 


\section{Tribe II. CARPOPHILINI.}

Small oval or elongate subdepressed species haring the antennw ending in an abrupt 3-jointed club and, in repose, received in distinct grooves. Males with a small sixth dorsal segment attached to the abdomen. The species live on flowers or rarely beneath bark. of the four genera composing the tribe, three are represnted in Indiana.

KEY TO INDIANA GENERA OF CARPOPHILINI.

a. Form not especially elongate; last rentral segment not long and conical.

b. Second and third rentral segments short, first, fourth and fifth longer.

iII. Carpophills.

bb. First to fourth rentral segments short, fifth as long as the other's united.

IV. Colastus.

aa. Form elongate; last rentral segment long and conical. $\quad \mathrm{V}$. Conotelus.

III. Cinpophmus Stephens. 1830. (Gr., ' 'fruit + loving.',)

The members of this genus have the labrum bilobed; club of antennæ flattened and oval; tarsi dilated, with simple claws. About 15 species are known from the United States, seven of which have been taken in Indiana, while one or two others doubtless occur.

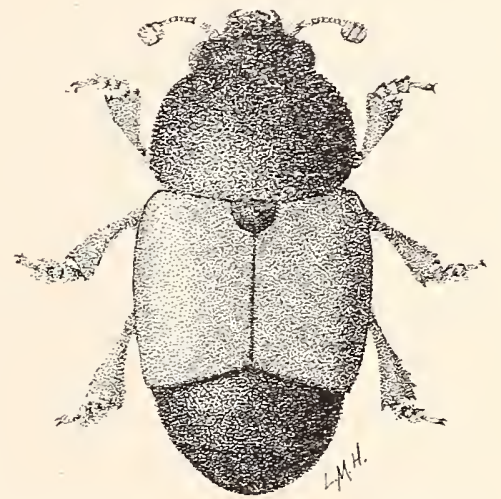

Fig. 238. Carpophilus pallipennis Say. $\times 11$. (After Forbes.)

\section{KEY TO INDIANA SPECIES OF CARPOPHILUS,}

a. Hind angles of thorax broadly rounded or very obtuse.

$b$. Thorax narrowed in front, its front angles rounded; elytra piceous, with yellow basal and apical spaces.

1210. HEMIPTERUS.

bb. Thorax quadrate, its front angles distinct.

1211. DIMIDIATUS.

aa. Hind angles of thorax distinct but sometimes retracted.

c. Elytra wholly different in color from head and thorax; surface finely and densely punctured.

1212. MELA NOPTERTS.

$c c$. Elytra, at least in part, of same hue as head and thorax.

d. Thorax distinctly narrower at apex than base.

e. Sides of thorax curved; surface opaque, piceous or black.

1213. NIGER.

ee. Sides straight; surface feebly shining, dark reddish-brown.

MARGINATUS.

dd. Thorax subquadrate, not or rery feebly narrower' at apex.

\section{$f$. Surface densely punctured. opaque.}

1214. CORTICINLS.

ff. Surface sparsely or inconspicuously punctured. moderately shining.

g. Elytra uniform piceous or nearly black; prosternum in front nearly smooth.

1215. BRACHYTERUS. 
gg. Elytra bicoiored, the base reddish-brown, apex piceous; prosternum in front densely and rather coarsely punctured.

1216. ANTIQUUS.

1210 (3672). Carpophilus hemipterus Linn., Syst. Nat., I, 1766, 565.

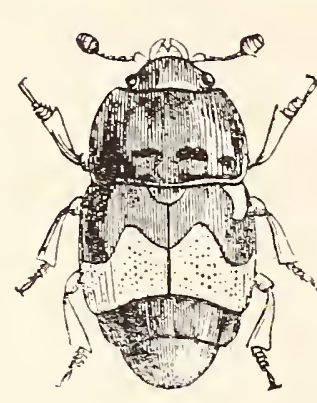

Fig. $239 . \times 6 \frac{1}{2}$. Fig. 239. Smith.)

Oblong. Piceous, feebly shining, sparsely pubescent; elytra each with a humeral spot and large irregular apical space dull yellow; legs pale. Thorax one-third wider than long, narrowed at apex, sides feebly curred. hind angles obtuse; surface sparsely punctured at mirlde, more densely near sides. Elytra and abdomen above and below sparsely and finely punctate. Prosternum coarsely and sparsely punctured. Length $4 \mathrm{~mm}$. (Fig. 239.)

$$
\text { Posey County ; rare. May } 25 .
$$

1211 (3674). Carpophilus dimidiaus Fab., Ent. Syst., I, 1795, 261.

Oblong. moderately robust. Pale brownisln-yellow to piceous; feebly shining. spirely pubescent. Thorax slightly wider thim loug. sides curved on apical third, thence nearly straight to base, hiud angles obtuse, surface rather densely punctured, more so on sides. Elytra together longer tham wide. more sparsely and finely punctured than thorax. Abdomen abore and below finely and sparsely punctured. Prosternum coarsely and densely punctured. Length 3-3.5 mm.

Wells and Vigo counties; rare. July 21-September 23. Taken on rotten melon.

1212 (3675). Carpophilus melanopterus Erichs., Germ. Zeitschr., IV. $1843,262$.

Oval, moderately robust. Uniform pale reddish-yellow, abore and below, except the elytra, which are black or piceous. Thorax one-third wider than long, narrowed in front, sides feebly curved, hind angles small, retracted; disk convex, together with the elytra rather finels and densely punctured. Prosternum coarsely but not densely punctured. Length 4 $4.5 \mathrm{~mm}$.

A southwestern species, collected in Marshall and Putnam counties; scarce. June 4 -October 15.

1213 (3678). Carpophilt's Niger Say, Journ. Phil. Acad. Nat. Sci.. III. 1823,195 : ibid. II, 124.

Oval, slightly oblong. Uniform browuish-black or piceous, sparsely pubescent; legs. scape of antennie and abdomen reddish-brown. Thorax one-half wider than long. sides regularly curved. hind angles rectangular: disk, as well as that of elytra, slightly flattened, densely punctured. Humeral angles of elytra prominent. Length 3.5-4.2 $\mathrm{mm}$.

Stemben and Vigo comnties. suarce; at sap of soft maple. Probably occurs throughout the State. June 18-September 22. 
1214 (3680). Carpophilus corticinus Erichs., Germ. Zeitschr., IV, 1843, 263.

Oral, slightly oblong. P'iceous, feebly shining, minutely alutaceous, sparsely pubescent; legs and antennæ dark reddish-brown. Thorax onehalt wider than long, as broad at apex as at base, sides feebly curved, hind angles rectangular; surface, as well as that of elytra, rather densely but not coarsely punctured. Prostermum densely and rather coarsely punctured. Length $3 \mathrm{~mm}$.

Southern half of State; scarce. April 4-October 17. Resembles a small niger but known by the form of thorax and more shining surface. Taken from beneath leaves of mullein and beaten from flowers of linn.

C. marginatus Erichs., length 1.5-2 mm., with sides of thorax and elytra continuous, has been taken near Cincinnati.

1215 (3681). Carpophilus brachypterus Say, Journ. Phil. Acad. Nat. Sci., V, 1S25, 1S3; ibid. II, 288.

Oblong-oval, subdepressed. Piceous, very finely and sparsely pubescent; legs and antenn:e reddish-brown. Thorax nearly twice as wide as long, apex and base equal, sides moderately curved, punctures of the disk rather coarse and not dense, those of sides finer and denser. Surface of elytra more finely punctured than thorax. Prosternum nearly smooth. Length $2.5 \mathrm{~mm}$.

Throughout the State; frequent. March 20-October 17. Occurs on flowers of cherry, apple, black haw and other shrubs and at sap. Resembles the preceding, but distinguished by its smaller and broader form and smooth prosternum.

1216 (3683). Carpophilus antiques Melsh., Proc. Phil. Acad. Nat. Sci., II, 1844, 105.

Oblong. Piceous, moderately shining; base of elytra reddish-brown, gradually passing to piceous. Thorax one-third wider than long, base and apex equal, sides feebly curved, hind angles rectangular; surface sparsely punctured at middle, more finely and densely on sides. Surface of elytra coarsely but sparsely punctate. Prosternum coarsely and rather densely punctured on sides. Hind tibixe of males suddenly dilated at apical half. Length $2.5-3 \mathrm{~mm}$.

Southern half of State; common. Hibernates beneath mullein and rubbish in fence corners. Taken by sifting in early spring; also at sap. Narch 17-December 7 .

IV. Cousstus Erichs. 1843. (Gr., "to mutilate.")

The members of this genus are broadly oval or oblong, strongly flattered and sparsely pubescent beetles, which live beneath bark and feed upon sap. The males have the last ventral segment emar- 
ginate and a small additional segment visible. Five are known from the eastern Tnited States. all of which may occur in Indiana, though but three have as yet been taken.

TEE TO THE SPECIES OF COLASTUS.

a. Hind angles of thorax distinct.

b. Scutellum smooth at tip.

c. Form broady oral.

d. Thoras with an oblique pit or forea in each hind angle.

1217. MORIO.

dd. Thorax without forea; elstra each with four reddish spots.

MACULATLS.

cc. Form oblong. much depressed; elstra dull yellow, the sides and apes narrowly piceous.

121S. SEMITECTLS.

46. Scutellum densels punctured; color uniformly piceous. Sxicolor. a $a$. Hind angles of thorax obtuse, rounded; form oblongroral, depressed.

1219. TRENCATLS.

1217 (3685). Colastes yonio Erichs., Germ. Zeitschr., IT: 1S43, 242.

Broadly oral, depressed. Piceous black, shining, sparsely pubescent; under surface piceous; antemne and legs reddish-brown, the club darker. Head coarsely and densely punctate. Thorax more than twice as wide as long, sides broadly curred, apex emarginate; base bisinuate, twice as wide as apex; disk coarsely and rather closely punctured, with a rague depression each side of scutellum and a distinct oblique one near each hind angle. Elstra together wider than long, with somewhat irregular rows of coarse. close-set punctures. Length $4-5 \mathrm{~mm}$.

Putnam Countr; rare. March 6. Taken from under surface of hickory slab.

1218 (3687). Colastes semitectus Say, Journ. Phil. Acad. Nat. Sci., V, $1 S 25,182$; ibid. II, $2 S S$.

Elongate-oral, much depressed. Piceous, moderately shining; elytra dull reddish-rellow, narrowly piceous on sides and apex. Thorax one-hálf wider than long. apex narrower than base, surface coarsels but not densely punctate. Elstra rather densels punctate. the punctures near suture in illdefined rows. Prosternum rer sparsely punctate. Length $3-4.5 \mathrm{~mm}$.

Lake. Crawford and Posẹ counties: scarce. Nay 21-July 3.

1219 (36S9). Colastes trexcates Rand. Bost. Jour. Nat. Hist.. II, 1S3S, 1 S.

Oval. slightly oblong. strongly depressed. Dull reddish-brown; head usually piceous. Thorax nearly twice as wide as long. narrowed in front. width of apex equal to length. disk feeblr conrex; surface, as well as that of elytra. rather densely munctate. Apex of elytra broady emarginatetruncate. Prosternum nearls smooth. Length 2-2.5 $\mathrm{mm}$. 
Starke. Marshall. Marion and Clark connties; scarce. April 9July 30. Occurs in spring at sap of maple and other trees; in summer on flowers.

$C$. maculatus Erichs.. and $C$. unicolor Say, both $4.5 \mathrm{~mm}$. in length and piceous in hue, are of wide distribution in the Atlantic region. The first named has been taken at Cincinnati.

\section{T. Conoteuts Frichs. 1813. (Gr., "cone + end.")}

The members of this genus hare an elongate form. and resemble those of Trogophlous of the Staphylinida. This is due to the abdomen being much elongated. three joints being exposed abore. Beneath. the first two segments are short and equal; the third and fourth are of equal length. each as long as the first two together; fifth elongate, flattened conical. longer than the preceding two together. The males have the terminal dorsal segment truncate and feebly emarginate. with a small additional segment exposed. Three species are known from the United States, one of which occurs in Indiana.

1220 (3692). Conotelts obscrres Erichs., Germ. Zeits., IV, 1843, 252.

Elongate, subdepressed. Black or piceous. opaque, sparsely pubescent; legs and antenne brownish-rellow; the club piceous. Thorax one-third wider than long, slightly narrowed in front, hind angles obtusely rounded; surface finely rugulose, sparsely punctate. Elytra together nearly square, usually less black than thorax. surface finely granular, with numerous irregular rors of obsolete punctures. Length $3.5-4 \mathrm{~mm}$.

Tippecanoe, Putnam. Marion. Tigo and Posey counties; scarce. June 15-July 15. Occurs on flowers of dogrrood (Comus) and hollỵhock.

Tribe III. NITIDULINI.

This tribe is the largest of the family and is composed of elliptical. usually depressed and often widely margined. species. The elrtra cover the entire abdomen or leave only the pyoidium exposed. Its members live on sap. on flowers. in fungi, under bark or on dried animal matter. Twelve genera comprise the tribe, nine of which are represented in Indiana.

\section{KEI TO INDIANA GENERA OF NITIDULINI.}

a. Prosternum depressed behind the frout coxie, not prolonged.

7. Tarsi very distinctly dilated on all the feet: tips of elstra usualls truncate.

c. Apical segment of abdomen usualḷ exposed; elotra without costat 
or rows of punctures; antennal grooves strongly convergent.

d. Labrum bilobed; males with a sixth dorsal segment; length $2-4.7 \mathrm{~mm}$.

VI. EPUR瓜A.

dd. Labrum feebly emarginate; males without sixth segment; length 3.5-5.5 $\mathrm{mm}$.

VII. Nitidula.

cc. Abdomen wholly covered; elytra with either costæe or rows of punctures; antennal grooves parallel, passing directly backwards; length $2.3 \mathrm{~mm}$.

VIII. Stelidota.

bb. Tarsi not dilated or very feebly so; tips of elytra rounded, wholly covering the abdomen.

$e$. Mentum broad, covering the base of the maxillæ; margin of thorax and elytra very wide and flat, translucent; length 5-6 mm.

IX. Prometopia.

ee. Mentum not covering the maxillæ.

$f$. Front not lobed over the antennæ.

g. Elytra subcostate; mandibles with tip slightly bifid; length more than $5.5 \mathrm{~mm}$ :

X. Phenolia.

gg. Elytra without trace of costre; mandibles not bifid at tip; length less than $4 \mathrm{~mm}$.

XI. Onosita.

$f f$. Front lobed orer the insertion of antennæ; margin of thorax and elytra as in Prometopia; length 4-5 $\mathrm{mm}$.

XII. Soronia.

aa. Prosternum elevated behind the front coxæ, often prolonged.

h. Mesosternum not carinate; body oral or rounded, convex, pubescent; tarsi not dilated; length $3-4 \mathrm{~mm}$.

XIII. Pocadius.

hh. Mesosternum carinate; body oblong, subdepressed; tarsi all dilated; length 2-2.5 $\mathrm{mm}$.

XIV. Meligethes.

VI. EPURAa Erichs. 1843. (Gr.., "npon + tail.)",

This is the largest genus of the family and is composed of small depressed species very difficult to separate. They have the labrum bilobed; antennæ with an abrupt 3-jointed club and elytra either truncate or entire. The males possess an additional anal segment. and often have the middle and hind tibiæ dilated at tip. Ther must be mounted with legs spread and the hind coxæ visible, else they cannot be classified at all. Horn divides the species into three groups, two of which are represented in the State.

KEY TO INDIANA GROUPS OF EPURAA.

a. Middle tibire dissimilar in the two sexes, that of the male sinuate within and thickened at tip; that of the female slender. Group $A$.

a a. Midd]e tibiæ similar in the two sexes, slender; hind tibiæe of both sexes similar and slender.

Group $B$.

\section{Group A.}

The greatest number and the largest of our species belong here. In the male the middle tibiæ are sinuate on the inner margin, the apex being prolonged inward to a greater or less extent. The following species have been taken or probably oceur in the State: 
KEY TO INDIANA SPECIES OF GROUP $\Lambda$.

a. Process of abdomen between the hind coxæ broad, truncate.

$b$. Sides of thorax moderately curved, gradually broader to base; form broadly oval, color yellow; length $4.4 .5 \mathrm{~mm}$.

HORNII.

$b b$. Sides of thorax strongly curved, at base narrowed or sinuate, hind angles acute; color dark reddish-brown.

c. Form broadly oval; elytra narrower at tips.

1221. HELVOLA.

cc. Form more oblong; elytra scarcely narrowed at tips. 1222. RUFA.

a a. Process of abdomen between the hind coxie narrow, acute; metasternum usually acutely notched behind for its reception; elytra truncate at tip.

d. Form oblong-oval.

e. Midcle tibise of male strongly sinuate within, the inward prolongation of tip well marked.

f. Thorax broadest at base, hind angles rectangular; color pale reddish-yellow.

1223. ERICHSONII.

ff. 'Thorax slightly nar'owed at base.

\%. Sides of thorax simply curved; hind angles not prominent; color uniform dull reddish-yellow.

1224. RUFIDA.

$g g$. Sides of thorax sinuate near hind angles, which are rather acute; color dull reddish-brown, the disk of elytra cloudet with fuscous.

1225. CORTICINA.

ec. Middle tibia of male feebly sinuate. the tips merely thickened.

h. Color reddish-yellow; sides of thorax obliquely narrowed near the base.

AVARA.

h7. Color pale yellow; sides of thorax slightly curved near the base.

i. Hind angles of thorax obtuse, margin not flattened.

FUIVESCENS

ii. Hind angles acute and mominent, malrgins flattened and reflexerl.

1226. vURII.

dત. Form elongate-parallel; color piceous, feebly shining; thorax sinuate behind.

1227. TRUNCATELLA.

E. hornii Crotch is known from Grimsby, Canada, and probably occurs in northern Indiana.

1221 (3696). Epurea helvola Erichs., Germ. Zeits., IV, 1843, 273.

Broadly oval. Dark reddish-brown, feebly shining, sparsely pubescent: the margins often paler. Thorax rather more than twice as wide as long, apex deeply emarginate; sides strongly curved. slightly narrowing at base, hind angles subacute; margin broadly flattened, slightly reflexed: surface, as well as that of elytra, finely granulate, rather densely punctate. Elytra oval, together a little longer than wide, margin reflexed. Iength $3 \mathrm{lnm}$.

Steuben, Laporte, Lawrence, Vigo and Crawford connties. frequent; probably throughout the State. May 26-A ugust 11. Occurs in summer in decaying fleshy fungi; in spring at sap. 
1222 (3697). Epurad rufa, Journ. Phil. Acad. Nat. Sci., V. 1S25, 1S0; ibiđ̄. II, 286.

Resembles helrola in color and size, and often confounded with that species. It is, howerer. more oblong, with longer elytra, which are scarcely narrowed from base to apex and rery narrowly margined. Thoracic margins not at all reflexed. Length $3-3.5 \mathrm{~mm}$.

Throughout the State; common. March 6-October 17. Occurs in early spring beneath leaves, mullein and other rubbish. from whence it is taken by sifting; also at sap and in fungi.

1223 (3700). Epur玉a ERichsonir Reitter, Verhandl. Nat. Verein. 1Sit, 35.

Oblong-oral. - Dull clay yellow. sparsely clothed with yellowish pubescence. Thorax less than twice as wide as long. slightly narrowed in front. apex feebly emarginate; sides feebly curved and subparallel behind, margin slightly reflexed; surface, as well as that of elytra, rather densely and coarsely punctate. Elytra one-third longer than wide, slightly narrower to apex. Length 2.5-3 $\mathrm{mm}$.

Throughout the State; frequent. March 31-August 25. Probably hibernates. Occurs beneath bark and at sap in early spring; later on flowers of huckleberry and other marsh plants.

1224 (3701). Epurza rufida Melsh., Proc. Phil. Acad. Nat. Sci.. II, 1844, 106.

Oblong-oral. Dull reddish-yellow. Thorax less than twice as wide as long, slightly narrower-at apex than base: sides moderately curred, narrowed obliquely for a short distance in front of base, hind angles rectangular; margins rather widely flattened. slightly reflexed; surface, as well as that of elytra, densely punctured. Elytra one-half longer than wide. sides parallel in front. slightly curved and narrowing on apical third. Length $3.5-4 \mathrm{~mm}$.

Throughout the State: frequent. April 11-July 11. Occurs beneath bark of oak and on flowers of linden.

1225 (3703). EPUr.a corticina Erichs., Germ. Zeitsch.. IV. 1843, 270.

Oblong-oral. Dull reddish-brown; disks of thorax and elytra clouded with darker; legs paler. Thorax one-half wider than long; sides rather strongly curved, sinuate near base: hind angles acute. margin narrowly reflexed; surface, as wefl as that of elytra, rather densely granulate-punctate. Elytra one-third longer than wide. sides feebly curved and slightly narrower toward the tips. Length $3.5 \mathrm{~mm}$.

Orange County : rare. September 9. Taken beneath oak bark. "Occurs especially in the Gulf States."

$E$. avara Rand., dull reddish-yellow, length $3-3.5 \mathrm{~mm}$, is said to occur all over the Linited States and Canada. but has not yet been noted from Indiana. E. fulvescens Horn. pale yellow, length 3-3.5 mm. was described from Canada and is recorded from near Cincinnati. 
1226 (-). EPUR.A DURYI sp. nor.

Broadly oral, subdepressed. Uniform pale sellow, sparsel pubescent, distinctly shining. Head finelr and sparsely punctate. Thorax two-thirds wider than long. widest at middle. the sides thence converging and nearls straight to apex, feebls curred to base; disk finelr and rather sparsely punctate, broadlc and shallowly impressed near the hind angles. Elctra together a little longer than wide. tips subtruncate; disk finely and rather sparselr punctate. Abdomen finelr granulate-punctate. Intercoxal process rather broad, but acute at apex. Length $3.5-4.7 \mathrm{~mm}$. (Fig, 240.)

Cramford Countr: rare. June 27-June 28. Taken also by Chas. Dury near Cincinnati and named in his honor. The largest species taken in the State.

1227 (3709). Eptrea trexcatella Mann., Bull, Mosc, II, 1846, 511.

Elongate, parallel. Piceous-brown to nearls black, sparselr pubescent. Thorax one-third wider than long. sides feebly curred and obliquels narrowed on basal third: hind angles subrectangular, margins narrowlr flattened: surface densel punctate. Elytra slightly narrowed near tips. less denselr punctured than thorax. Length $2.5-3 \mathrm{~mm}$.

Lamrence County: rare. April 13. Taken from decaring fing $g^{2}$.

\section{Grote B.}

In this group the tibix present no sexual characters whaterer. Two of the seren species comprising the group have been taken. while another mar occur.

\section{KET TO IXDIANA SPECIES OF GROCP B.}

a. Process of abdomen between the hind coxie. broad. obtuse.

ъ. Elrtra narromlı margined; hind femora of male simple; color dark reddish-brown, the margin of thorax rellowish translucent.

122S. OTATA.

66. Elstra widely margined; hind femora of male obtusely subangulate: picecus. the elctra each with four paler spots.

PELTOIDES.

a a. Process of abdomen triangular. more or less acute: color pale reddishrellor.

1229. IABILIS.

122 (3711). Epur.et orata Horn, Trans. Amer. Ent. Soc. TII, 1S79, 295.

Broadly oral. Piceous. moderately shining; margins of thorax and elctra paler. Thorax twice as wide as long: aper narrower than base and deeply emarginate: sides strongl $c_{c}$ curred, suddenls sinuate near the hind angles, which are rectangular: margins widels flattened and moderatels reflexed: surface, as well as that of elitra. rather densely punctate. Elytra rerp little longer than wide at base: sides curred and gradualls narroming to the tips. which are rounded: margin narrowlr reflexed. Length 2.5-3 $\mathrm{mm}$.

Steuben. Kosciusko, Putnam and Narion counties; scarce. [41-23402] 
April 22-June 19. Taken from beneath dead leaves by sifting; also beneath bark of beech. Described from Michigan and Canada. Resembles helvola but readily distingiuished by the smaller size and rounded tips of elytra.

E. peltoides Horn, $2.5 \mathrm{~mm}$. in length, was described from Michigan and Maryland.

1229 (3714). Epuraa Labilis Erichs., Germ. Zeitschr., IV, 1843, 272.

Oval. Dull reddish-yellow, rather shining, sparsely pubescent. Thorax twice as wide as long; sides regularly curved and gradually narrowing from base to apex, which is feebly emarginate; margin narrowly reflexed, hind angles rectangular; surface, as well as that of elytra, coarsely and rather denselý punctured. Elytra one-third longer than wide, tips truncate, sides feebly recurved and slightly narrowing behind the middle. Length 2-2.' $\mathrm{mm}$.

Throughout the State; frequent. May 16-August 29. Resembles erichsonii, but smaller and the males distinguished by characters given in key. Occurs on flowers of elder, dogwood, etc.

\section{Nitidula Fab. 1775. (L., "shining or bright.")}

The members of this genus are known as "bone beetles" and are distinguished from Epurcea by their larger size and by the labrum being feebly emarginate instead of bilobed. They have the antennæ 11-jointed, the club abrupt and 3-jointed; abdominal segments 2 to 5 equal, the first very little longer. Three species occur in the United States, all of which are found in Indiana. The first two have been introduced from Europe.

\section{KEY TO THE SPECIES OF NITIDULA.}

a. Thorax coarsely and rather densely punctured.

b. Piceous; elytra each with a rounded reddish spot on disk.

1230. BIPUNCTATA.

1231. RUFIPES.

ъb. Piceous; elytra without spots.

aa. Thorax sparsely and rather finely punctured; elytra usually with irregu-
lar dull yellow spots. lar dull yellow spots.

1230 (3719). Nitidula BIPUnctata Linn., Fauna Suec., 1758, 148.

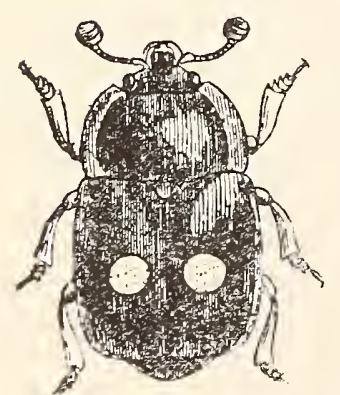

Fig. 241. $\times 5$ (After Smith.)

Oval, feebly convex. Piceous black, finely pubescent; each elytron with a round reddish spot near. the middle. Thorax twice as wide at base as long, narrower at apex; margins moderately flattened, hind angles nearly rectangular. Elytra together longer than wide, rather sparsely and finely punctured. Length 4.5-6 mm. (Fig. 241.)

Vigo, Tawrence and Knox counties; scarce. April 15-July 11. Occurs on or beneath bones and skins of dry carcasses, and probably to be found throughout the State. 
1231 (3720). Nitidula rufipes Linn., Syst. Nat., II, 1766, 573.

Oval, slightly oblong. Piceous, subopaque, pubescent; antennæe (except clubs) and legs reddish-brown. Thorax less than twice as wide as long, apex but little narrower than base; sides moderately curved, margin narrowly flattened; surface, as.well as that of elytra, densely and rather coarsely punctured. Length 3.5-4 mm.

Lake, Vigo, Crawford, Posey and Lawrence counties; frequent. March 26-August 7. Occurs with preceding on bones of carrion; also on foliage.

1232 (3721). Nitidula ziczac Say, Journ. Phil. Acad. Nat. Sci., V, 1825, 179 ; ibid. II, 285.

Oblong-oval. Piceous, subopaque, pubescent; elytra usually with basal spots and a median S-shaped spot dull yellow. Thorax a little less than twice as wide as long, apex slightly narrower than base; sides feebly curved, surface rather sparsely and finely punctured. Length 3-4 mm.

Lake, Lawrence and P'osey counties; rare. April 13-August 7. Occurs on dead birds and reptiles. Varies to the elytra wholly devoid of spots.

\section{Stelidota Erichs. 1843. (Gr., "a column.")}

The members of this genus resemble those of Epurcea, but have the elytra subcostate or with rows of punctures and covering the abdomen, so that, looking from above, no segment of the latter is visible. The antennæ end in an abrupt club, and when folded back repose in rather deep, subocular grooves which are parallel. Three species are known, two of which oceur in Indiana.

1233 (3722). Stelidota geminata Say, Journ. Phil. Acad. Nat. Sci., V, 1825, 181 ; ibid. II, 287.

Oval, narrower behind. Piceous or dark reddish-brown, the margins paler; elytra with two crossbars of indistinct paler spots, one basal, the other behind the middle. Thorax twice as wide as long, broadest at base, apex deeply emarginate; sides regularly curved from base to apex, margin broad, flattened; hind angles rectangular, disk coarsely and densely punctured. Elytra as wide at base as thorax, gradually narrowed to apex; tips rounded; disk subcostate, the ridges with a single row of fine punctures, each bearing a short hair, the grooves closely punctured. Length 2-2.5 mm.

Throughout the State; frequent. April 22-September 23. Occurs in spring at sap and beneath leaves; in autumn on decaying fruit and melons.

1234 (3723). Stelidota octomaculata Say, loc. cit.

Resembles the preceding, but a little larger and darker. The thorax with sides more curved at base, so that the latter is narrower than a little 
in front. Elytra with the ridges less distinct, but with the rows of fine hair bearing punctures, between which are rows of larger round, shallow punctures. Length $2.5-3 \mathrm{~mm}$.

Starke. Marion. Putnam. Crawford and Posey counties; less frequent than geminata. April 10-June-18. Occurs beneath chips. stones and decaying fruit. The spots on elytra are reddish and usually located two at base, one on sutural margin near middle, another behind the middle and one on tip.

IX. Pronetopla Erichs. 1843. (Gr.," before + spot.")

This genus is represented in the eastern United States and Indiana by a single species having the thorax deeply emarginate in front, with sides broadly flattened; mandibles prominent and bifid at tip; antennæ slender, first joint stout, third rery long; club elongateoval.

*1235 (3725). Prometopia sexmaculata Say, Journ. Phil. Acad. Nat. Sci., V, 1825, 179 ; ibid. II, 285.

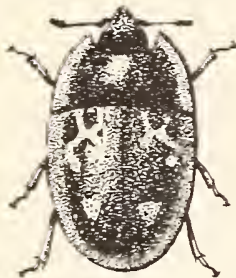

Fig. $242 . \times 3 \frac{1}{2}$

Broadly oval, depressed. Piceous, with the margins, under parts, an irregular humeral band and a spot on apical third of each elytron, pale reddish-brown. Thoras twice as wide as long, narrower in front, sides feebly curved, hind angles rectangular; disk rather sparsely punctate with coarse and fine punctures intermingled. Elytra as wide as long (male) or longer than wide (female), the surface sparse$1 y$ and coarsely punctate. Length $5-6 \mathrm{~mm}$. (Fig. 242.)

Southern half of State, frequent; much less so in the northern counties. Hibernates with the next species beneäth logs and bark and remains motionless, adhering closely to logs when shelter is removed; in spring at sap. January 18-December 20.

\section{Pнenolia Erichs. 1843. (Gr., "a cloak.").}

This genus is also represented over the same range as the preceding by a single species, one of the largest of the family.

*1236 (3726). Pherolta Grossa Fab., Syst. Eleut., I, 1801, 347.

Elongate, oral. Piceous, feebly shining; elytra each with seren indistinct reddish spots, arranged one on each side of scutellum, an oblique row of three between humerus and suture and a second oblique row of three near the middle. Thorax twice as wide as long, apex a little nạrrower than base, deeply emarginate; sides moderately curred, sinuate near the hind angles, which are subacute; surface coarsely but rather sparsely punctate. Elytra as wide as thorax; disk feebly costate, each ridge with a row of fine punctures bearing a short hair; the groores with three illdefined rows of punctures. Length $6.5-\mathrm{s} \mathrm{mm}$. 
Throughout the State; common. Hibernates. January 1-November 25. Occurs beneath bark and in fungi.

XI. Omosta Erichs. 1843. (Gr., "wild.")

To this genus belong two small, piceous beetles, distinguished by characters given in generic key. Both occur also in Europe. One of them inhabits Indiana.

1237 (3727). Oмоsita colon Linn., Faun. Suec., 151.

Oblong-oval. Piceous, the margins of thorax dull yellow; elytra each with three or four small dull yellow spots on basal half, and a large common yellowish space on apical portion enclosing on each side a piceous dot. Thorax nearly twice as broad as long, sides regularly curved, surface somewhat rugose and rather coarsely punctate. Length $2-3 \mathrm{~mm}$.

Throughout the State; common. March 24-October 9. Probably hibernates. According to field notes, it was found on flowers of skunk cabbage in April; beneath bones and skin of dead calf in June and July, and on dry fungi in autumn, so that it may be said to be omnivorous in taste. An introduced European species.

\section{Solonin Erichs. 1843. (Gr., "old oak.")}

Five species of this genus are listed from the United States. Our single species resembles Prometopia sexmaculata in form but is smaller, differently colored and the side of the head in front of the eyes bears a distinct lobe.

*1238 (3730). Soronia undulata Say, Journ. Phil. Acad. Nat. Sci., V, 1825, 179 ; ibid. II, 286.

Broadly oval, depressed. Under surface and margins above dull yellow; disk of thorax piceous with pale spots; that of elytra piceous with a zigzag band behind the middle and numerous small spots, paler. Thorax more than twice as wide as long at middle, narrower in front, apex deeply emarginate, sides moderately curved, hind angles obtuse; surface rather densely punctured at middle, more sparsely on sides. Elytra slightly wider than base of thorax, the disk a little more coarsely punctured. Length 4-5 $\mathrm{mm}$.

Lake, Marion, Putnam and Vigo counties; scarce. Hibernates. February 25-September 22. Occurs beneath logs in winter, at sap in spring and autumn.

XIII. Pocndius Erichs. 1843. (Gr., "the hair.")

This genus belongs to that division of the Nitidulini having the prostemum convex between the front coxæ, the tip with a conical 
protuberance. Head with distinct antennal grooves; tarsi slender on all the feet; the claws simple. Two species are known from the United States, one of which occurs in Indiana.

1239 (3734). Pocadius helrolus Erichs., Germ. Zeitsch., IV, 1843, 320.

Broadly oral, convex, robust. Dark reddish-brown, sparsely pubescent; sides of elytra often darker. Thorax more than twice as wide as long, narrowed in front, apex emarginate; base and sides curved, the latter harrowly margined; disk convex, coarsely and irregularly punctured. Elytra as wide as thorax, tips rounded-truncate; disk of each with ten rows of slightly impressed punctures; intervals with two irregular rows of fine punctures, each bearing a short yellowish hair. Length 3-4 mm.

Southern half of State; frequent. April 5-September 1. Occurs in the "giant puff ball," Lycoperdon giganteum.

\section{Meligethes Steph. 1830. (Gr., "honey+rejoice.")}

Small, subdepressed, black or bronzed species, having the labrum nearly concealed; antennæ with an abrupt 3-jointed club; point of prosternum enlarged, free and overlapping the mesosternum; elytra truncate at apex, exposing the tip of abdomen. They feed on various flowers, eating the pollen and nectar. Five species are listed from the United States, two of which have been taken in Indiana. Both have the front tarsi finely toothed and tarsal claws simple.

1240 (3738). Meligethes æexeus Fabr., Syst. Ent., 1775, 78.

Obiong-oval. Head and thorax bronzed; elytra black with a bluish tinge, sparsely and finely pubescent; antennie and legs piceous, the front tibiæ often paler. Thorax twice as wide as long, sides feebly curved, margins narrowly flattened their full length, hind angles obtusely rectangular; surface finely and rather densely punctate. Elytra as in the next species; intervals between the punctures not alutaceous. Length $2-2.5 \mathrm{~mm}$.

Monroe and Lawrence counties; rare. MIay 11-May 13. Sifted from debris of beech stumps. Nore oblong and less convex than mutatus and with the flattened margins of thorax extending the full length instead of only to the basal fourth. M. rufimamus Lec., is a synonym.

1241 (3739). Meligethes mutatus Harold, Col. Heft., IV.

ruficornis Lec., Col. Kans., 1859, 6.

Oral, subdepressed. Black, tinged with bronze, sparsely pubescent. Thorax twice as wide as long, narrower in front; sides moderately curved, margin flattened from in front to near the basal fourth; hind angles obtusely rectangular, disk convex, rather.densely punctured. Elytra onefourth longer than wide, slightly narrowed to apex; rather finely and sparsely punctate, the intervals between the punctures finely alutaceous. Length 2-2.5 $\mathrm{mm}$. 
Franklin County; scarce. May 13. Occurs on flowers of nettle and other plants.

Tribe IV. CYCHRAMINI.

Rounded or oval convex species, living mostly in fungi and having the thorax margined at base and covering the base of elytra, which in turn cover the abdomen, so as to leave only the tip of the terminal segment exposed; head more or less deflexed; labrum distinct; prosternum more or less prolonged at apex. Four of the six genera composing the tribe have been taken in the State.

KEY TO INDIANA GENERA OF CYCHRANINI.

a. Mesosternum protuberant in front; middle coxie widely separated.

b. Body glabrous; punctures of elytra in rows; prosternum prolonged, broadly dilated at tip, covering entirely the mesosternum.

XV. Psiloptiga.

bb. Body pubescent; punctures of elytra confused; prosternum less prolonged, feebly dilated at tip, not covering entirely the mesosternum.

XVI. Ampitcrossus.

aa. Mesosternum small, oblique, not protuberant in front; middle coxie narrowly separated.

c. Body glabrous; hind tarsi longer than the others.

cc. Body pubescent; all the tarsi equal in length.

XVII. PAllodes.

XVIII. Cychramus.

\section{Pshopyga Liec. 1853.}

Labrum prominent, deeply bilobed; antennal club abrupt, oval, three-jointed, the grooves deep, subocular; base of thorax with a short truncate lobe; scutellum large, broadly triangular; elytra truncate; front tarsi dilated. Males with a small additional segment. The genus Psylopyga is said by Dr. Sharp to be distinct from Oxycnemus Er.

1242 (3742). Psilopyga histrina Lec., Proc. Phil. Acad. Nat. Sci., VI, $1853,287$.

Broadly oval, robust. Black, shining. Head coarsely punctured. Thorax more than twice as wide as long. narrowed in front, apex broadly emarginate; base curved, sinuate each side of median lobe; disk sparsely, rather finely punctured, with a double row of larger punctures near the apex. Elytra as broad as long, each with ten rows of rather coarse punctures; intervals slightly convex, sparsely and irregularly punctate. Length $5 \mathrm{~mm}$. (Fig. 241a.)

Montgomery County; rare. July 4. Occurs

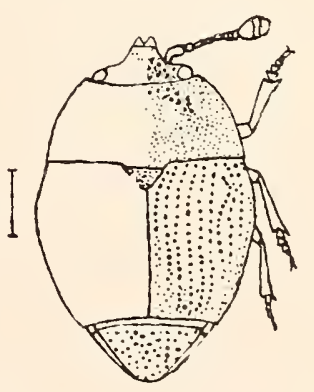

Fig. 241a. (After Horn.) in the stink-horn fungus. 
1243 (3743). Psilopiga nigripennis Lec., N. Sp. N. Am. Col., I, 1863, 64.

Form of histrina. Reddish-yellow; elytra alone black, shining. Disk of thorax more sparsely and less coarsely punctured than in histrina, without coarse punctures near apex. Elytral striæ less deep, the punctures smaller; intervals flat. Length $4-4.5 \mathrm{~mm}$.

Montgomery County; rare. July 4. Both this and the preceding were taken by Earl Grimes of Russellville, Indiana, from the same stink-horn fungus. As stated by Horn, this may prove to be but a variety of histrina. Both resemble species of Hister very closely and are usually placed with that genus by beginners.

\section{Amphicrossus Erichs. 1843. (Gr., "on both sides + fringe."')}

Oval, brownish or piceous species having the labrum bilobed; front tarsi distinctly dilated, hind ones simple; claws not toothed. One species occurs in the State.

1244 (3744). Amphicrossus ciliatus Oliv., Encyc. Meth., ViII, 210.

Broadly oval. Piceous, subopaque, pubescent; thorax with margins and a spot in front of scutellum paler; elytra each with three paler spots at base and sometimes a fourth near apex; legs yellowish. Thorax more than twice as wide as long, narrowed in front, apex deeply emarginate; sides feebly curved, hind angles broadly rounded; surface rather closely punctate. Elytra as long as wide, surface more finely and less densely punctured than thorax. Males with a small tuft of stiff hairs, resembling a spine, near the middle of the suture. Length $3.5-4.5 \mathrm{~mm}$.

Marion, Putnam and Knox counties; frequent. April 7-September 21. Occurs at sap in spring; on flowers of Eupatorium and allied plants in autumn.

\section{P.LLODEs Erichs. 1843. (Gr., "a ball + like.")}

In this genus the prosternum is but slightly prolonged and not dilated at tip; mandibles bifid; front and middle tarsi dilated. But one species is known.

1245 (3747). Pallodes palimdus Beauv., Ins. Afr. et Amer., 1805, 157.

Oval, convex. Dull reddish-brown, shining; elytra somewhat iridescent. Thorax more than twice as wide as long, much narrowed in front, apex emarginate. sides curred. hind angles rectangular; surface sparsely and finely punctate. Scutellum large, sparsely punctate. Elytra longer than wide, each with nine rows of fine punctures; intervals each with a single row of very fine ones. Length $3-4 \mathrm{~mm}$.

Throughout the State; frequent on fleshy fungi. May 2-September 29. 
XVIII. Cychramus Kug. 179-. (Gr., "name of a bird.")

The members of this genus resemble those of Amphicrossus in form and pubescent surface, but differ in having the labrum feebly emarginate instead of bilobed; prosternum not prolonged at tip; metasternum bent upwards at tip between the coxæ, but not protuberant; thorax not lobed at middle of base and scutellum of medium size. One of the two known species occurs in Indiana.

1246 (3748). Crchramus adustus Erichs., Germ. Zeitsch., IV, 1S43, 346.

Broadly oval, conrex. Reddish-brown, opaque, pubescent; elytra with the sides usually piceous, or rarely wholly black; legs paler. Thorax twice as wide as long, narrower in front, apex deeply emarginate, base truncate; sides curved, hind angles obtuse or rounded; surface rather coarsely and closely punctate. Elytra as broad as long, slightly narrower behind the middie; tips obtusely truncate; disk with fine elongate punctures arranged in quite regular rows. Length $3-4 \mathrm{~mm}$.

Near Mitchell. Lawrence County ; rare. June 4-July 28. Taken from fleshy white fungi. Ranges from Virginia and Pennsylvania to Georgia and Missouri.

\section{Tribe V. CYBOCEPHALINI.}

This tribe is represented in our fauna by the single genus:

XIX. Cybocephalts Erichs. 1814. (Gr., "inflected +head.")

It comprises two minute species, the smallest of the family, having the tarsi 4-jointed; antennæ scarcely longer than the width of head; prosternum acutely carinate in front, not prolonged behind the front coxæ; thorax margined at base, covering the base of elytra; body retractile and when so bent, ovate and very convex. One of the two occurs in Indiana.

1247 (3750). Cxвocephalus xigritulus Lec., x. Sp. N. Amer. Col., 1863, 64.

Orate, conrex. Black or piceous. strongly shining, rerg finely alutaceous; legs piceous. Thorax with margin not flattened, narrowly translucent, surface smooth. Elytra with rery fine. sparse punctures in basal area. Length 1-1.5 $\mathrm{mm}$.

Dubois County; scarce. April 29. Probably throughout the State, but overlooked on account of small size, as the range is given as "Michigan to Georgia." Occurs in colonies on fung'us covered lngs. Resembles in form the species of Agathidium of the family Silphidx. 
Tribe VI. IPINI.

Medium-sized species having the labrum firmly united with the front of head, the suture more or less distinct; antennæ 11-jointed, club 3-jointed. Three genera compose the tribe, two of which are represented in Indiana.

KEY TO INDIANA GENERA OF IPINI.

a. Body pubescent; thorax margined at base, slightly orerlapping base of elytra.

aa. Body glabrous; thorax not margined at base.

XX. Cryptarcha. XXI. IPS.

\section{Cryptarcha Shuck. 1839. (Gr., "hidden + anus.')}

Oval, piceous or reddish-brown species having the labrum indistinct; prosternum prolonged and plate-like at tip, partly concealing the mesosternum. Two species are known from the State.

KEY TO INDIANA SPECIES OF CRYPTARCHA.

a. Punctures of elytra in ill-defined rows; length $6-7 \mathrm{~mm}$. 1248. AMPLA. a a. Punctures of elytra all confused; length less than $4 \mathrm{~mm}$. ; sides of thorax flattened, those of elytra rather widely reflexed.

1249. CONCINNA.

1248 (3752). Criptaricha ampla Erichs., Germ. Zeitsch., IT, 1S43, 356.

Oval, more obtuse in front. Uniform piceous or dark reddish-brown, sparsely pubescent. Thorax feebly emarginate and but little narrowed in front, margin not flattened, narrowly reflexed, hind angles obtuse; surface rather closely punctate. Elytra gradually narrowing behind, margin narrowly reflexed, the tips separately rounded. Length $6-7 \mathrm{~mm}$.

Lake, Marion and Vigo counties; scarce. June 13-September 28. Taken in Vigo but once, when a number were found at sap of soft maple in a swamp.

1249 (3754). Cryptarcha concinsa Mels., Catalogue, 1806, 41.

Oval. Piceous, moderately shining, sparsely pubescent; margin of thorax, two narrow transrerse, sinuous bands and a scutellar spot on elytra, dull yellow. Thorax nearly twice as wide as long. sides gradually curved, hind angles rectangular; surface, as well as that of elytra, sparsely punctate and with short, erect, stiff hairs, those on elytra in seven rows. Length 2.5-3 mm.

Marion and Putnam counties; rare. March 20-April 22. Taken by sifting; also occurs at sap.

XXI. IPs Fab. 1776. (Gr., "a worm that eats horn and wood."')

Smooth, shining black beetles, having the elytra marked with reddish or yellowish spots. They occur at sap or in decayed fruits, 
and among them are one or two of the most common and best known species of the family. Six species are listed from the United States, four of which oceur in Indiana.

\section{KEY TO INDIANA SPECIES OF IPS.}

a. Thorax broader at base than aper; hind tarsi nearly as broadly dilated as those in front.

$b$. Larger, length $S$ or more mm.; middle and hind tibia of males suddenly broader at apical half.

1250. овтLSUS.

bb. Smaller, length not orer $7 \mathrm{~mm}$.; middle and hind tibiæ not different in the sexes.

c. Body wholly black beneath.

1251. QUADRIGUTTATLS.

cc. Abdomen and metasternum red.

1252. SANGLINOLENTUS.

a a. Thorax narrower at base; hind tarsi slender; elytra with large dull sellowish space enclosing black spots.

1253. CONFLUENTUS.

1250 (3755). IPs obtuscs Say, Bost. Journ. Nat. Hist., I, 1S35, 15s; ibid. II, 644 .

Oblong-oral, subconrex. Piceous black, shining; elytra each with two rounded, reddish-yellow spots, one at middle of base, the other slightly behind the middle. Entire upper surface rather finely and regularly punctured. Tips of elytra slightly oblique in both sexes. Length S-12 mm.

Vigo and Floyd counties; rare. May 3-September 29. Occurs in the middle and southern Atlantic States.

*1251 (3756). IPs quadriguttatus Fab., Syst. Eleut., II, 1S01, כS0.

Oblong-oral, subconrex. Black or piceous, shining; elytra usually with broad, irregular yellowish humeral spot and another smaller one behind the middle, these often reduced and rarying much in size, becoming at times mere rellow points. Upper surface finely and sparsely punctured. Tips of male elytra oblique; those of female rounded. Length 4-7 mm. (Fig. 243.)

Throughout the State; common. Hibernates beneath logs, chips, etc. Hundreds sometimes accumulate in a small space at sap of oak or maple. February 14-Sep-

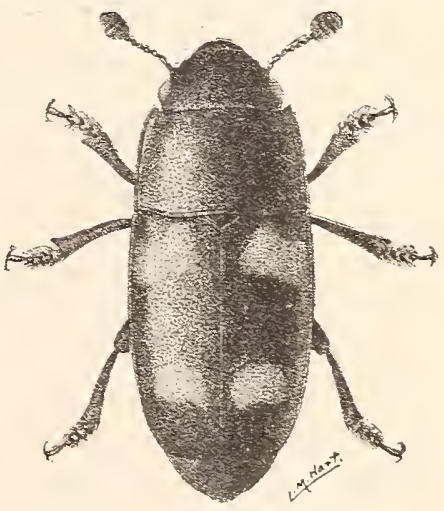

Fig. 243. $\times 7$. (After Forbes.) tember 22. Listed as $l$. fasciatus but the name here given has priority.

1252 (3757). IPs sangunolentus Olir., Ent., II, 1791, S.

Oblong-oral. Black, shining; elytra in great part bright red; the tip. a small humeral and larger round discal spot black; abdomen red. Tips of elytra of the two sexes as in the preceding. Length $4.5-5.5 \mathrm{~mm}$.

Lake. Vigo. Putnam, Crawford and Poser counties; scarce. March 20-September 22. Taken at sap and on decaring fleshy fungi. 
1253 (375s). Ips conflentes Say, Journ. Phil. Acad. Nat. Sci., III, IS23. 195 : ibid. II, 125.

Elongate-oblong. Head and thorax piceous black; elstra largely dull rellow: the tips. an oblique humeral spot; a small spot on each side of scutellum, the suture at base, and a large discal spot connected with the margin, piceous. Surface coarsely punctured. Sexual characters as in quadriguttatus. Length $4.5-5 \mathrm{~mm}$.

Marion. Tigo. Crawford and Posey counties; scarce. June 2iDecember 8 .

Tribe VII. RHIZOPHAGINI.

This tribe is represented by a single genus of small. slender, elongate species which live beneath bark. Ther have the antennæ 10-jointed with two-jointed club; prosternum not prolonged at tip ; abdomen with the first and fifth segments long. the intermediate three. short. equal: elrtra truncate. exposing the last segment of abdomen. and tarsi 4 - and 5-jointed in the males, 5-jointed in the females.

XXII. Rhizophigus Herbst. 1793. (Gr., "root + eat.")

Nine species of this genus are listed from the United States. only two of which have been taken in the State. though three others may occul'.

KEI TO INDIANA SPECIES OF RHIZOPHAGL'S.

a. Thorax longer than wide.

b. Elytral rows of punctures distinctly impressed and reaching the tips: length $3-3.5 \mathrm{~mm}$.

1251. SCAIPTCRATLS.

67. Elstral rows of punctures not impressed.

c. Thorax beneath nearly smooth: in male vers decidedls narrotred from apex to base, its sides nearly straight; length $4.5 \mathrm{~mm}$.

CILITDRICES.

cc. Thorax beneath distinctly punctured, scarcely or not narrowed behind in male, sides feebls curred in both sexes: piceous. elrtra each with two red spots.

1255. BIPUXCTATES.

a a. Thorax as wide or wider than long: length $2.5 \mathrm{~mm}$.

d. Elstra pitchr black.

REMOTLS.

dd. Elytra each with two oblique reddish spots.

MINUTUS.

1254 (3765). Rihizophages scalpterates Manm., Bull. Mosc.. II, 1552. 362.

Elongate. slender. subcrlindrical. Dark reddish-brown or piceous. Thorax longer than wide, sides feebls curred. gradualls narrowed to base: disk at middle subdepressed. sparsely and coarsely punctured. sides more finely punctured. Elytra not wider than apex of thorax. the strice rather coarsels punctate; intervals flat. Length $3-1 \mathrm{~mm}$. 
Lake and Vigo counties; rare. March 11-May 20. Occurs in sandr localities, beneath logs or bark. Probably hibernates.

$R$. cylindricus Lec.. rufo-piceous in hue, is known from Tennessee and Georgia, and may occur in southern Indiana.

1255 (3770). Rhizophages bipuxctatus Say, Journ. Phil. Acad. Nat. Sci., III, 1S23, 324; ibid. II, 1 S3.

Elongate, crlindrical. Black, shining; antennie and legs reddish-brorn; elytra with usually two reddish spots, one oblique behind the base, the other smaller, oral, at apical third. Thorax longer than wide, its disk convex. sparsely punctured. Elytra not wider than thorax, sides parallel, surface not striate but with rows of punctures which become finer toward apex. Length 2.5-3 mm.

Lake, Marion, Putnam, Floyd and Harrison counties ; frequent. April 9-Norember 1t. Occurs most frequentir beneath bark of maple. The basal spots on elrtra are often obsolete.

$R$. remotus Lec.. and $R$, minutus IIann. are both boreal species known from Canada and Nichigan. and may oceur in northern Indiana.

\section{Family XXVII. LATHRIDIIDA.}

\section{The AIntte Bromi Scatenger Beetles.}

Tery small oral. oblong or linear beetles, usually of a reddishvellow or brownish hue. rarely black or with distinct markings and never metallic. They are of a graceful form. the elvtra being usually wider than thorax. and a number of them have the thorax prettily marked-with elerated lines. They occur for the most part under bark and stones or in regetable debris. especially decaying leares, but some species are also found in drugs and other commercial products, and some on the flowers or foliage of certain plants. The larræ have not been studied. and their food habits are. therefore, practically unknown. The name of the typical genus. Lathridius, is derived from a Greek word meaning" "secret or hidden," and ras probably giren these beetles on account of their living. for the most part, in concealed places. About 700 species are known, scarcely any of which are more than one-tenth of an inch (2.5 mm.) in length.

The most prominent and distinguishing characters of the family are: the 9- to 11-jointed antennie. terminating in a club of three. rarely two. joints. and inserted at the sides of the front; eyes usually laro and prominent. but small and minute in certain genera: thorax of rariable form. but rarely as wide as elrtira. the margin often finely toothed. especially near the hind angles, the disk usually with either a transterse impression or a forea at base; 
elytra entirely covering the abdomen, or very rarely slightly truncate and with the punctures usually arranged in six to eight rows; prosternum more or less visible between the front coxæ, the side pieces not separate, the coxal cavities usually enclosed; abdomen with five, rarely six, free ventral segments which are subequal in length; front coxæ conical, prominent, usually more or less separated; middle coxæ rounded and less prominent; hind coxæ transverse, widely separated; legs moderate, tibire slender without terminal spurs; tarsi 3-jointed, the third joint equal in length to the other two; claws simple.

The most important papers treating of the North American members of the family are as follows:

Horn.- "Synopsis of the Lathridiides of the United States and

Northern Contiguous Territories," in Proc. Phil. Acad. Nat.

Sci., VII, 1855, 299-305.

Fall.- "Revision of the Lathridiidæ of Boreal America," in

Trans. Amer. Ent. Soc., XXVI, 1899, 101-190.

According to the latter paper, this family is represented in North America by 103 species, distributed among 13 genera. The family is divided by Fall into four tribes. Two of these are known to be represented in Indiana, while a third probably occurs.

KEY TO INDIANA TRIBES OF LATHRIDIIDA.

a. Front coxal cavities open behind, the coxæ separated by a prosternal plate; antennæ clavate; body not costate.

Tribe I. Merophysini, p. 652.

aa. Front coxal cavities closed behind.

b. Body often costate, glabrous or virtually so, the hairs, when present, sparse and erect; epistoma or lower face on a lower plane than the front and separated from it by a deep suture:

Tribe II. Lathridini, p. 653.

$b b$. Body never costate, always pubescent, the hairs more or less inclined or recurved; epistoma on the same plane as the front, separated from it by a distinct but scarcely impressed suture.

Tribe III. Corticariini, p. 656.

\section{'Tribe I. MEROPHYSIINI.}

One genus, Holoparamecus, represents this tribe in the United States. Belonging to it are six species, two of which may occur in Indiana. They have the antennæ 9-jointed in the male, 10-jointed in the female; thorax bistriate at base, hind angles without fovea; elytra with an entire sutural stria but without rows of punctures.

H. ragusce Reitt., dull yellow, 1-1.2 mm. in length, eyes small, distant about their own diameter from the antennæ, thorax without discal fovea, is known from P'ennsylvania and Missouri. 
H. Kunzei Aubé, dull reddish-yellow, 1-1.2 mm. in length, eyes larger, distant by only half their diameter from the antennæ, thorax with small discal fovea, is recorded from New York and California.

\section{Tribe II. LATHRIDIINI.}

In addition to characters given in above key, the members of this tribe have the thorax with pronounced sculpture, often costate, and usually with impressions or fover, the side margins without teeth but often lightly crenulate; elytra each with six or eight rows of punctures, the intervals often more strongly elevated; front coxæ distinctly separated, and abdomen composed of five segments in both sexes. Eight genera are recognized as composing the tribe, four of which should be represented in Indiana, though specimens of but three have as yet been taken.

\section{KEY TO INDIANA GENERA OF LATHRIDIINI.}

a. Disk of thorax marked with costæ or ridges; eyes on sides of head; elytra not connate.

b. Prosternum not reaching the hind border of the prothorax, the epimera uniting on the median line.

I. LATHRIDIUS.

$b b$. Prosternum reaching the hind margin of the prothorax and thus separating the epimera.

Coninomus.

aa. Disk of thorax without costæ.

c. Eyes large, not very distant from antennæ; scutellum distinct.

II. Enicmus.

cc. Eyes small or miuute, remote from antennæ; scutellum indistinct; middle coxæ separated.

III. CARTODERE.

I. Lathridius Herbst. 1793. (Gr.., "secret or hidden.")

Small, glabrous, shining brown species, having the front angles of thorax more or less lobed and the sides sinuately convergent to a point near the middle, thence divergent to base. Elytra fully twice as wide as thorax, broadly ovate with the apex somewhat pointed. Seven species are recognized by Fall as belonging to the North American fauna. Of these one occurs in the eastern United States and Indiana, while another, brevirlavus Fall, known by the 2-jointed club of antennæ, was described from Michigan and may inhabit the northern part of the State.

1256 (3779). Ilathrimits liratus Lec., N. Spec. N. Amer. Col., I, 1863, 72.

Oblong. Dark reddish or chestnut brown, shining; legs and antennæe slightly paler. Antennx reaching hind angles of thorax, rather slender. Thorax a little longer than wide, margin reflexed; disk with two entire longitudinal ridges which are nearly parallel on basal two-thirds, diverging 
toward apex; sub-basal depression distinct and divided by the costre into three portions; surface rather coarsely and irregularly punctate. Elytra broadly impressed behind base; striæe coarsely and distinctly punctate; intervals convex, the third slightly, the seventh more prominently, elevated at base. Length $2 \mathrm{~mm}$.

Steuben, Putnam and Marion counties; scarce. Taken while sifting. April 22-June 18.

Coninomus Thom. 1863.

Small, glabrous species, having the sides of thorax deeply notched behind the middle and usually with a semi-transparent whitish margin.

C. constrictus Gyll., having the elytra without tubercles, antennal club 2-jointed, length 1.3-1.8 mm., is a cosmopolitan species known from Michigan, Illinois, etc.

\section{Enicmus Thom. 1859. (Gr., "in + moisture.')}

Small brown, black or piceous species having the eyes of normal size; thorax without ridges or costæ; prosternal spine reaching the hind margin of the thorax, completely separating the epimera; first and second tarsal joints of equal length. The body is somewhat broader than in Lathridius and the thorax much wider in proportion to the width of elytra. But two species have as yet been taken in the State, though a number of others doubtless occur.

\section{KEY TO INDIANA SPECIES OF ENICMUS.}

a. Prosternal spine not elevated into a crest, the coxæ more prominent.

b. Color usually black, legs and antennxe brownish; elytral intervals nearly equal; thorax transverse, front angles not lobed; length 2 $2.2 \mathrm{~mm}$.

1257. CoNsIMILIS.

bb. Color usually brown; alternate elytral intervals more convex, at least on sides; thorax larger, more transverse, front angles lobed; length $1.2-2 \mathrm{~mm}$.

1258. MINUTUS.

aa. Prosternal process elevated into a crest which reaches above (or below) the tips of the coxæ.

c. Antennal club abruptly formed, the ninth joint nearly or quite as wide as the eighth and but slightly narrower than eleventh.

d. Elytra black or reddish-brown.

$e$. Rows of elytral punctures equidistant.

ATERRIMUS.

$e e$. Rows of elytral punctures in pairs, each pair separated by a wider interval.

DUPLICATA.

dd. Elytra dull yellow with black markings.

MACULATUS.

cc. Antennal club much more gradually formed, ninth joint elongateobconic, scarcely wider at base than eighth and decidedly narrower than eleventh; elytra distinctly impressed behind the base; head with median longitudinal sulcus.

TENUICORNIS. 
1257 (一). Enicmus consinulis Mamn., Germ. Zeitschr., V, 99.

- Moderately elongate, feebly convex. Color given in key. Thorax nearly square, sides feebly convergent behind the middle; surface with a shallow median channel, its sides or carinæe distinctly cutting the sub-basal transrerse depression, an additional impression on each side near the front angles. Elytra striate with rows of coarse, subquadrate punctures; intervals slightly convex, each with a row of very fine punctures. Length 2-2.2 mm.

Marion County; scarce. Several specimens were taken by Harold Morrison from a cellar in Indianapolis in which wood was stored. January 11-January 24. A European species, known in this country heretofore only from Michigan.

1258 (3781). Enicirus minutus Linn., Syst. Nat., II, $1766,675$.

Orate, subconvex. Usually brown, rarely blackish or brownish-yellow. Thorax larger, subquadrate, sides distinctly converging from front angles to base, disk finely and thickly granulate. Length 1.5-2 mm. (Fig. 244.)

Marion County ; scarce. June 3. Collected by Harold Morrison. Also in Webster collection from Indiana. Occurs throughout the United States.

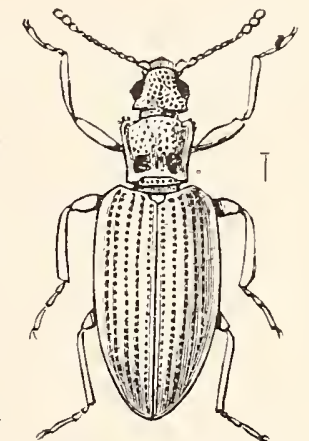

Fig. 244. (After Sharp.)

$E$. aterrimus Mots., length 1.6-1.9 mm. and $E$. duplicatus Lec., length $1.9 \mathrm{~mm}$, are both known from Illinois and Michigan.

E. maculatus Lec., 1.9-2.1 mm., occurs in Ohio and Michigan; $E$. tenuicornis Lec., length $1.6-1.9 \mathrm{~mm}$., is also recorded from New York and Michigan westward.

\section{CARtodere Thom. 1859. (Gr., "strength $\vdash$ neck.")}

Small, narrow, often depressed beetles, having the antennæ shorter than head and thorax, their clubs abruptly two- or threejointed; eyes small, situated far behind the base of antennæ; thorax without costæ, more or less deeply and transversely impressed near base; elytra each with six to eight close set rows of large, rounded punctures; front coxa distinctly, hind ones widely, separated. One species has been taken in the State and four others perhaps occur but have been overlooked on account of their small size. They live about dwellings, stores or barns in ground cereals, vegetable drugs, or decaying and dust-like vegetable matter.

\section{KEY TO INDIANA SPECIES OF CARTODERE.}

a. Antennal club three-jointed.

b. Thorax much narrower than elytra, the latter each with seven rows of punctures.

1259. RUFICOLLIS.

[42-23402] 
$b b$. Thorax but slightly narrower than elytra.

c. Eyes minute, situated at about their own length from the hind angles of the head.

d. Elytral intervals 3, 5, 7 higher than the others.

dd. Elytral intervals subequal; form more narrow.

COSTULATA. cc. Eyes much larger, occupying the hind angles.

FILIFORMIS.

ARGUS.

aa. Antennal club two-jointed; thorax with a large rounded fovea on front of disk.

FILUM.

1259 (3786). Cartodere ruficollis Marsh., Ent. Brit., I, 111.

Elongate, slender, subconvex. Pale reddish-brown, elytra darker. Antennal club rather abruptly three-jointed, its first joint large, orbicular; second less thick, elongate-oval; third small and subglobular. Thorax subcordiform, sides rather strongly rounded in front of middle, deeply constricted near base; surface densely and rather finely punctate. Elytra elongate-oval, each. with seven rows of coarse, closely-set punctures ; intervals narrow, very feebly convex except the sixth, which is more prominent. Length $1-1.3 \mathrm{~mm}$.

Howard County; frequent locally about a barn. June 24. An introduced species widely distributed throughout the United States.

C. costulata Reitt. and C. filiformis Gyll., both reddish-yellow and 1-1.5 mm. in length, are known from Michigan and near Cincinnati; C. argus Reitt. and C. filum Aubé, also dull reddish-yellow, length 1.3 to $1.6 \mathrm{~mm}$., range from Canada, Michigan and westward.

\section{Tribe II. CORTICARIINI.}

This tribe has the thorax without distinct sculpture, its sides more or less crenulate or denticulate, the disk with nearly always a rounded or transverse impression before the base; front coxæ usually continguous or nearly so; abdomen with five or six ventral segments; elytra without costæ but with hairs arranged in rows. Three genera compose the tribe, two of which are represented in Indiana.

KEY TO INDIANA GENERA OF CORTICARIINI.

a. Abdomen of female with five segments, a sixth usually visible in the males; form more elongate.

IV. CORTICARIA. aa. Abdomen of both sexes with six segments, except in picta, where the male has but five; form more oval.

V. Mela Nophthalma.

IV. CORTiCaria Marsh. 1802. (Tat., "bark.")

Small elongate or oblong-ovate species liaving the pubescence more or less long and conspicuous, that on the elytra arranged in rows; eyes large and rather prominent; antennse usually not quite reaching the hind angles of thorax, 11-jointed, the club 3-jointed; thorax usually subcordate, with front and hind angles obtuse, sur- 
face without carinæ and disk with a distinct rounded or transverse fovea before the base; elytra each with eight rows of punctures which are moderately large toward the base but become finer apically. The males have the first joint of the front tarsi distinctly dilated. Of the 26 species of the genus listed from the United States, the following have a range which may include Indiana:

\section{KEY TO INDIANA SPECIES OF CORTICARIA.}

a. Pubescence more conspicuous, the hairs of elytral intervals longer, more erect and bristling than those of the striæ; middle coxæ separated by less than one-third their own diameters; form moderately convex.

b. Punctures of strix and intervals not rery different in size, somewhat confused; front and middle tibiæe of male not bent at tip; length $2.3-3 \mathrm{~mm}$.

PUBESCENS.

6b. Punctures of elytral intervals distinctly finer than those of striæ, not confused; front and middle tibiæ of male bent and mucronate on the inner side at tip.

c. First joint of antennal club not distinctly longer than wide; thorax cordate; color pale brownish-yellow; length 1.7-2 mm.

FULVA.

cc. First joint of club distinctly elongate; thorax feebly cordate; color piceous brown, the elytra often paler; length 2.1-2.3 $\mathrm{mm}$.

VARICOLOR.

aa. Pubescence shorter, more appressed and uniform; middle coxæ separated by nearly one-half their own diameters; form often depressed.

d. Metasternum subequal to or shorter than first rentral; joints of antennal club all longer than wide; thorax without forea; length $2.3-2.6 \mathrm{~mm}$.

VALIDA.

dd. Metasternum distinctly longer than first rentral.

e. Size larger, 2-2.5 mm.; sculpture of both upper and lower surface coarser and closer; margin of thorax distinctly serrate.

1260. SERRATA.

ee. Size smaller, always less than $2 \mathrm{~mm}$.

f. Fifth rentral segment not longer than fourth, the sixth usually distinctly risible; last three joints of antennal funicle transverse.

BREVICORNIS.

ff. Fifth rentral at least one-half longer than fourth, the sixth not risible; outer joints of funicle not eridently transverse.

g. Color yellowish to dull reddish-yellow; elytral intervals with a single regular row of punctures. 1261. ELONGATA.

gg. Color reddish-brown; elytral intervals more or less irregularls punctulate; form less parallel and less depressed.

1262. FERRUGINEA.

C. pubescens Gyli., fuscous to fuscous-rellow in hue, is known from Michigan and northern Illinois; $C$. fulva Com., is recorded from Kentucky and Michigan; C. varicolor Irall was described from Michigan, Dakota and restward; while $C$. vulida Fall has been taken in northern Illinois. 


\section{0 (3S05). Cor'́tcaria serrata Payk., Faun. Suec., I, 1798, 300.}

Oblong-oval, moderately convex. Dull reddish-yellow to dark reddishbrown; pubescence grayish, recumbent. Thorax distinctly wider than head, three-fourths as wide as elytra, transverse, sides rounded in front of middle, moderately convergent behind, surface closely and rather coarsely punctate; sub-basal fovea rounded, moderately impressed. Elytra with sides subparallel, apex broadly and rather obtusely rounded, striæe feebly impressed; punctures rather coarse toward the base, those of intervals finer. Length 2-2.2 $\mathrm{mm}$.

Throughout the State, frequent in the northern counties; much less so southward. April 7-November 1. Occurs in fungi and about houses and electric lights in May. Dury reports the taking of 31 from the deserted nest of a wild rabbit.

C. brevicornis Fall, elongate, depressed, dull reddish-yellow, length 1.6-1.8 mm., is known from Michigan and near Cincinnati.

\section{1 (3S06). Corticaria elongata Gyll., Ins. Suec., IV, 1827, 130.}

Elongate, parallel, subdepressed. Light brownish or reddish-yellow; elytra faintly clouded with fuscous each side of scutellum; pubescence pale, rather long, recumbent. Thorax transversely quadrate, sides feebly rounded in front, slightly convergent behind; surface finely and sparsely punctate; basal fovea rounded, moderately deep; side margins finely crenulate in front, denticulate behind. Elytra oblong, parallel, obtusely rounded at apex; the rows of punctures fine, those of intervals still finer. Length 1.4$1.8 \mathrm{~mm}$.

Northern half of State; frequent. April 17-November 18. Taken while sifting dead leaves and other vegetable debris in damp localities.

1262 (-). Corticaria Ferruginea Marsh., Ent. Brit., I, 111.

Oblong, subconvex. Dark reddish-brown; head often darker; pubescence short, sparse, appressed. Head sparsely and finely punctate; antennæ reaching base of thorax, the ninth and tenth joints wider than long. Thorax slightly wider than long, base and apex equal, sides broadly rounded, margin feebly serrate; disk finely and sparsely but deeply punctate; basal forea round and rather deep. Elytra oblong-oval, striæ shallow, finely punctate; intervals with two irregular rows of minute punctures. Length 1.5-1.8 $\mathrm{mm}$.

Starke, Putnam and Lawrence counties; scarce. May 11-October 17 .

\section{Melanophthimia Mots. 1866. (Gr., "black + eye."')}

The members of this genus have the antennal club 2- or 3jointed; when the latter, the abdomen with a sixth segment more or less distinctly visible in both sexes. Twenty species are listed by Fall, of which the following may occur within the State: 
KEY TO INDIANA SPECIES OF MELANOPHTHALMA.

a. Antemnal club 2-jointed; first and second joints of tarsi subeguil ; elytra yellowish or reddish-yellow, usually with a median crossbir, and often a basal and apical cloud, piceous; pubescence short.

126:3. P'IC'TA.

a . Antennal club 3-jointed; pubescence longer and more conspicuous.

$b$. Second joint of tarsi as long as or slightly longer than the first; male with tips of front tibix provided with a longer, denser and more bristling fringe of hairs.

$c$. Claw-joint of front tarsi toothed beneath in the male.

d. Tips of elytra slightly sinuate and minutely toothed near the sutural angles, which are slightly prolonged; length $1.6-$ $1.9 \mathrm{~mm}$.

VILLOSA.

dd. Tips of elytra not sinuate or finely toothed before the sutural angles, which are not at all produced; eyes large, separated on the front by less than one and one-half times their diameter; elytra nearly always darker than thorax.

1264. DISTINGUENDA.

ce. Claw-joint of front tarsi not toothed beneath in the male; prosternum swollen before the coxie and armed with a spine at tip in the male; color reddish-yellow throughout. 1265. pumila.

bb. Second joint of tarsi distinctly shorter than first; front tibia of male with a short acute tooth on inner side beyond the middle.

$e$. Thorax scarcely more than half as wide as elytra and with a deep, sub-basal transverse impression extending from side to side; color brown. 1266. GIBBosA.

$e e$. Thorax distinctly more than half as wide as elytra, the sub-basal impression confined to the disk.

$f$. Sides of elytra nearly straight behind the middle, their tips distinctly truncate; color pale yellow. 1267. Longmennis.

$f f$. Sides of elytra curved throughout, their tips feebly or scarcely truncate.

g. Color usually dull reddish-yellow; elytra less broadly ovate, widest at middle, relatively longer and more obtuse at apex.

1268. AMERICANA.

$g g$. Color usually dull sooty brown, the thorax often paler; elytra shorter and more broadly ovate, widest a little before the middle.

1269. CAVICOLLIS.

1263 (3826). Melanophthalma picta Lec., Proc. Phil. Acad. Nat. Sci., $1855,303$.

Oval, rather robust. Dull reddish-yellow: elytra rarying as mentioned in key, rarely fuscous with only a pale spot near base and tip; pubescence whitish, very fine, soft and indistinct. Thorax slightly wider than head, subquadrate; sides feebly angulate at middle; surface finely and sparsely but distinctly punctulate and without basal forea. Elytra one-half wider than thorax, rather short. ovate, the sides curved; surface finely striate. the striae with widely separated fine punctures; intervals minutely punctuiate. Length $1.3 \mathrm{~mm}$.

Lake and Starke counties; searce. May 5-June 3. Taken by sifting damp leaves. 
M. villosa Zimm., dull reddish-yellow, larger than distinguenda, with eyes smaller and more widely separated and pubescence longer and more bristling, occurs throughout the northern United States.

*1264 (9992). Melanophthalma distinguenda Com., Coleop. Prov. Novoc., 38.

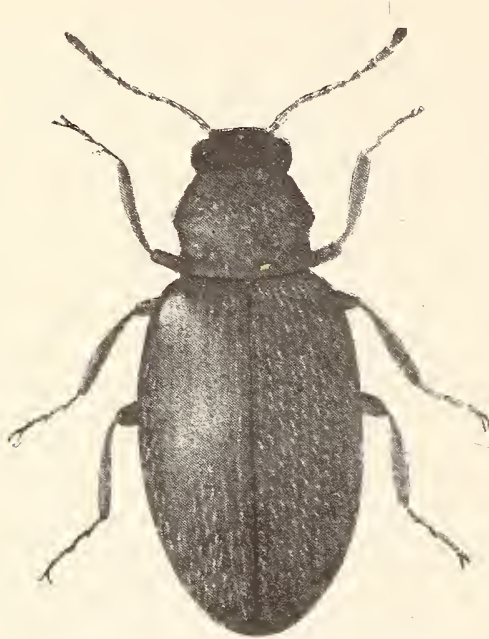

Fig. 245. $\times 24 . \quad$ (After Forbes.)

Elongate-oval, moderately convex. Dull fuscous or brownish-yellow, the elytra usually darker. Thorax transverse, sides angulate at middle, margin obsoletely crenulate; surface rather strongly punctate, the sub-basal impression moderately deep, extending nearly from side to side. Elytra elongate-oval; strix not impressed. punctures coarser at base than behind the middle; pubescence yellowish, long and conspicuous, the hairs arising from the intervals more erect than those from the strix. Length 1.5-1.S mm. (Fig. 245.)

Throughout the State; common. Hibernates. January 6-November 28. Occurs in winter beneath bark and $\log$; taken by sifting in spring and in summer often from flowers of the black haw (Viburmum prunifolium L) and allied shrubs.

1265 (3823). Melanophthalma pumiua Lec., Proc. Phil. Acad. Nat. Sci., VII, 1S55, 302.

Resembles the preceding but more parallel. Pubescence rather long and bristling. Punctuation of thorax and elytra coarser. Different otherwise as mentioned in key. Length $1.5-1.6 \mathrm{~mm}$.

Marshall and Putnam counties; scarce. March 20-June 24. Taken by sifting.

1266 (-). Melanophthalma gibbosa Herbst., Kaf., V, 5, pl. 44, fig. 2.

Oval, convex. Uniform piceous brown, rarely paler; antennæ and legs reddish-brown; pubescence short, appressed. Head rather coarsely and closely punctate; eyes large and prominent. Thorax slightly wider than head, very little wider than long; sides rounded in front, then feebly convergent and nearly straight to base; disk closely and rather finely punctate. Elytra with rows of rather coarse punctures; intervals more finely punctate. Length 1.1-1.5 mm.

Steuben and Floyd counties; frequent locally. April 16-May 25. Beaten from flowers of swamp huckleberry. Occurs from New Hampshire westward across the northern border of the United States.

1267 (3808). Melanophthalma longipennis Lec., Proc. Phil. Acad. Sci., VII, $1855,300$.

Elongate-oval. Uniform pale yellow, the club of antenuxe darker; pubescence short, recumbent. Thorax broad, sides rather strongly rounded, 
margins very finely crenulate, hind angles with a distinct denticle; surface sparsely and finely punctate, the basal fovea a little transverse and somewhat shallow. Elytra elongate, tips broadly truncate, exposing the tip of abdomen in male; punctures of strixe rather coarse. Length $1.5-1.8 \mathrm{~mm}$.

Putnam County; scarce. Taken by sifting dead leaves. April 22.

1268 (3810). Melanophthalma americana Mann., Germ. Zeitschr., V, 50.

Resembles the next species but more elongate and usually paler in color. Elytra widest at middle in both sexes, and longer in proportion to length of thorax; the latter more transverse and more regularly rounded at the sides, with the basal fovea less deeply impressed. Length 1.5-1.8 mm.

Marion and Posey counties; scarce. March 20-May 11. Widely distributed throughout the United States and probably occurs throughout the State.

*1269 (3818). Melanophthalma cavicollis Mann., loc. cit., p. 57.

Short, ovate, convex. Color variable, but usually with head and thorax dull reddish-brown, the elytra darker sooty brown; tip of abdomen, legs and base of antennæ paler; pubescence rather short, recumbent. Thorax transverse, subcordate, strongly rounded in front; hind angles ending in a distinct denticle; surface evenly and rather finely punctate; basal fovea rounded, deep.- Elytra rather broadly ovate, base but slightly wider than that of thorax, tips rounded; strix but slightly impressed, the punctures moderate, those of intervals finer. Length $1.2-1.5 \mathrm{~mm}$.

Throughout the State; frequent. Iibernates. March 20-December 23. Taken by sifting in early spring and beneath logs in winter.

\section{Family XXVIII. TROGOSTIIDA.}

\section{The Grain and Bark-gnawing Beetles.}

A family of small size, which includes medium or small oblong or oval, usually somewhat flattened beetles of a black or reddishblack hue which live, for the most part, under bark, though some inhabit granaries and have been widely distributed by commerce. They have the maxillæ 2-lobed, the inner lobe sometimes very small; antennæ short, 11-jointed, inserted under the margin of the front, the last three joints widest, forming a loose club of varied form; thorax with its hind margin not overlapping the base of elytra; the latter never truncate, always covering the abdomen, which is composed of five free ventral segments; front coxie transverse, separated by the prosternum, the cavities usually closed behind; middle and hind coxæ transverse, flat, the former separated, the latter contiguous ; tarsi 5-jointed, not dilated, first joint very short, second slightly longer, fourth very long; claws simple. 
The name of the typical genus, Trogosita, derived from two Greek words meaning "to gnaw" and "corn or grain," was given a common European species which occurs in great numbers in worminfested granaries. Recent observations, however, go to show that its larvæ probably live upon the larvæ of more injurious insects which do the real damage to the grain. The larvæ of the members of the principal genus, Tenebroides, are whitish flattened grubs with a pair of black spots on the top of each of the first three segments, and with the last segment ending in two horny points. That of $T$. corticaria was observed by Le Baron to feed upon the larve of the coddling moth:

The only paper treating of the family is that of

Horn.- "Monograph of the Species of Trogosita (Tenebroides) Inhabiting the United States," in Proc. Phil. Acad. Nat. Sci, 1862, 82-88.

It embodies but one of the nine genera among which the 30 or more known species from North America are at present distributed. Three of these genera are known to be represented in Indiana, while members of four others may occur.

KEY TO INDIANA GENERA OF TROGOSITIDA.

a. Form elongate, margins not flattened; head relatively large, eyes not prominent; frout coxal carities closed.

b. Ejes rounded.

NeMosoma.

bb. Eyes transverse.

c. Tibire with spines; form cylindrical.

I. Alindria.

cc. Tibire without spines.

d. Thorax truncate at apex, the side margin bent downward at middle.

Trogosita.

dd. Thorax emarginate at apex, the side margin not bent downward.

II. Tenebrotdes.

aa. Form oval, margins flattened; head small, eyes prominent; mentum transverse, emarginate; front coxal cavities open behind, except in Calitys.

e. Mentum transterse, emarginate; antennal groores feeble.

$f$. Front tibiæe with terminal hook,

Peltis.

ff. Front tibire without terminal hook.

g. Front coxal cavities closed.

CaLITYS.

gg. Front coxal cavities open behind.

III. Grynocharis.

ee. Nrentum minute, orai; antennal grooves deep; front tibiæ without hook.

Thymalus.

Nemosoma cylindricum Lec., linear, cylindrical, black, the base of elytra, antennæ and legs reddish, length $4.5 \mathrm{~mm}$., has been taken near" Cincinnati. 
I. Alindria Erichs. 1844. (Gr., "to roll or turn.")

This genus is represented in the eastern United States by two species, one of which occurs in Tndiana.

1270 (3831). Alindria cylindrica Geoff., Encyc. Method., X, 719.

Elongate, subcylindrical, convex. Uniform dark reddish-brown or piceous. Thorax subquadrate, slightly and gradually narrowed from apex to base, hind angles obtuse, surface finely, sparsely and evenly punctate. Elytra with base well separated from that of thorax, sides nearly parallel, tips rounded; surface striate, the strixe with rather fine serrate punctures; intervals very finely punctulate. Length $5-14 \mathrm{~mm}$.

Southern half of State; frequent. April 14-September 20. Occurs beneath bark of hickory, elm, ete. There is a wide variation in size between the sexes, the males being much the smaller.

Trogosita virescens Fab., greenishblack, $12 \mathrm{~mm}$. in length, occurs beneath bark of pine, etc., and has been taken at Cincinnati.

II. Tenebroides Pillar \& Mett. 1783. (Gr., "Tenebrio + resemble.")

Oblong, subdepressed species having the thorax widely emarginate at apex, narrowed behind the middle and somewhat distant from elytra: front of head trisinuate or emarginate in front; tibiæ without spines. Twelve species and a number of varieties are listed from the United States. Of these the following have been taken or perhaps occur in Indiana:

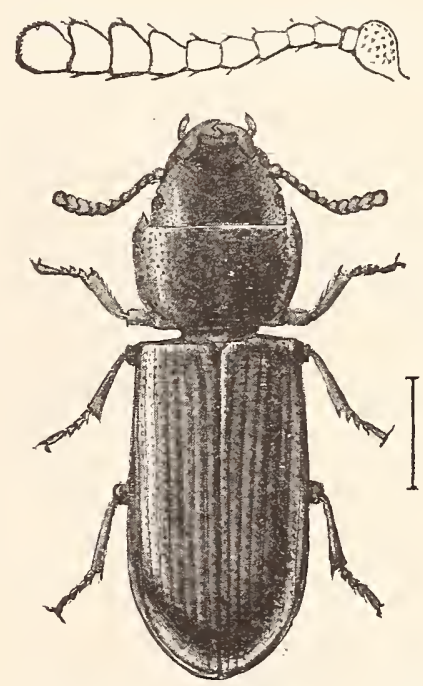

Fig. 246. T. mauritanica L. Adult beetle with antenna, the latter greatly enlarged. Bull. 4, U. S. Div. Ent. (After Howard.)

KEY TO INDIANA SPECIES OF TENEBROIDES.

a. Eighth joint of antennæ equal to the ninth; length $9.5 \mathrm{~mm}$. (Fig. 246.)

MAURTTANICA.

aa. Eighth joint much smaller than the ninth.

b. Thorax subquadrate, but little broader than long. sides feebly rounded, hind angles acute.

c. Color black or piceous; sides of thorax sinuate near base; form more convex.

d. Size larger, $7.5-8 \mathrm{~mm}$; sides of thorax more rounded than in the next.

1271. CORTICALIS.

dd. Size smaller, not over $6.5 \mathrm{~mm}$; sides of thorax feebly rounded.

1272. DUBIA.

cc. Color reddish or chestnut brown; sides of thorax not sinuate; form more depressed.

1273. NANA. 
aa. Thorax nearly twice as broad as long, sides much rounded, hind angles small, obtuse.

d. Elytra unicolorous without spots.

e. Size larger, 10-11 mm.; intervals of elytra subconvex, minutely rugulose.

1274. AMERICANA.

ee. Size smaller, not over $8.5 \mathrm{~mm}$; intervals of elytra nearly flat.

f. Dark reddish-brown to piceous.

1275. LATICOLLIS.

ff. Light reddish or brownish-yellow.

1276. OBSCURA.

$d d$. Elytra each witli an irregular shaped yellowish spot in front of middle.

1277. BIMACULATA.

T. mauritanica Linn., blackish-piceous and easily known by having the joints of antennæ gradually increasing in width, is a cosmopolitan species which has been taken near Cincinnati. (Fig. 246.) It is commonly known as the "cadelle."

1271 (3S38). Tenebroides conticalis Melsh., Proc. Phil. Acad. Nat. Sci., II, $1844,109$.

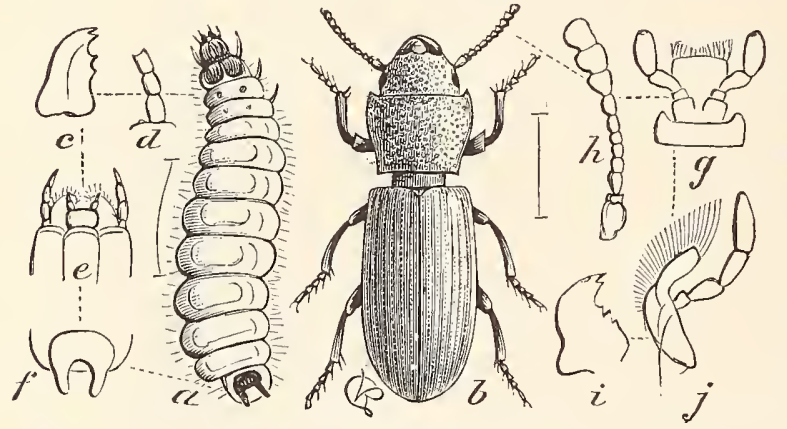

Fig. 247. $a$, larva; "c, its mandible; $d$, antenna; $e$, under side of head; $f$, the 2-horned anal plate; $b$, the beetle; $h$, its antenna; $i$, mandible; $g$, labium and its palpi; $j$, one of the maxillæ and its palpus. (After Riley.)

lose, each with two irregular rows of very tures. Length 7.5-8 mm. (Fig. 247.)

Southern half of State: scarce. April 18-October 10.

Elongate-oblong, su b convex. Black or piceous, feebly shining; antennæ and legs piceous. Head and thorax coarsely punctate, the latter narrowed, with sides sinuate behind the middle, margins reflexed, base subtruncate. Elytra shallowly striate, the strix with rows of rather coarse, deep, oblong punctures; intervals nearly flat, slightly ruguminute, oblong, distant punc-

1272 (3838b). Tenebromes dúbia Melsh., Proc. Phil. Acad. Nat. Sci., II, 1844, 110.

Resembles corticalis but smaller. Thorax more quadrate, sides scarcely at all rounded; punctures more sparsely placed and coarser; those of intervals of elytra distinctly larger and in more regular rows. Length 5-6.5 mm.

Throughout the State; frequent. February 14-November 8. Oceurs beneath bark and logs, where it hibernates.

1273 (3839). Tenebrotdes nana Melsh., Proc. Phil. Acad. Nat. Sci., II, 1844, 10.

Elongate-oblong, subdepressed. Dark reddish or chestnut brown. Thorax more depressed, slightly broader than long; sides moderately rounded and feebly converging, but not sinuate behind the middle; punctures, as 
well as those of head, rather fine and sparse. Elytra twice as long as wide, slightly broader behind the middle, intervals subconvex, each with two rows of distinct punctures. Length $6 \mathrm{~mm}$.

Vigo County; rare. February 14.

*1274 (3843). Tenebroides americana Kirby, Faun. Bor. Amer., 1837, 166.

Oblong, moderately depressed. Black or piceous, shining; under surface and legs dark reddish-brown. Head and thorax finely alutaceous, rather sparsely and finely punctate; the latter two-thirds wider than long, the margins reflexed, sides sinuate near base, hind angles acute. Elytra elongate-oval, the striæ shallow and rather finely punctate; intervals slightly convex, densely and distinctly rugulose, each with two rows of fine punctures. Length 9-10 $\mathrm{mm}$.

Throughout the State, frequent; more so in the southern half. February 4-September 5. Gregarious in winter. This is the species usually listed as castanea, Kirby's name having priority.

1275 (3843a). Tenebroides laticollis Horn, Proc. Phil. Acad. Nat. Sci., $1862,86$.

Form of americana. Dark reddish-brown to piceous. Thorax twice as wide as long, strongly depressed; sides feebly curved, not sinuate, hind angles more obtuse, less distinct. Elytral intervals very finely rugose. Length T. $5-8 \mathrm{~mm}$.

Posey County; rare. April 27. Listed as a variety of americana but the much wider and shorter thorax, with smaller hind angles, shows it distinet.

1276 (3843b). Tenebroides obscura Horn, Proc. Phil. Acad. Nat. Sci., $1862,86,87$.

Oblong, depressed. Pale brownish-yellow, shining. Head and thorax sparsely and rather coarsely punctate; the latter twice as wide as long, sides feebly curred, but little narrowed behind the middle. Elytra oblongoval, the strix more strongly impressed and with coarser punctures than in any of the preceding species; intervals almost flat, very finely punctulate. Length $5 \mathrm{~mm}$.

Harrison County; rare. November 14. Usually considered a variety of americana but appears to be very distinct.

1277 (3845). Tenebroides bimaculata Melsh., Proc. Phil. Acad. Nat. Sci., II, $1844,110$.

Oblong, subdepressed. Black, tinged with bronze, shining; elytra each with an irregular yellowish spot slightly in front of middle; club of antennæ and tarsi yellowish. Thorax transverse, finely and densely punctate; sides rounded, margin slightly reflexed. Elytral striæ shallow, their punctures obsolete on apical third. Length $5 \mathrm{~mm}$. 
Putnam County; rare. September 7. Readily known by the brassy tinge and the yellow spot on elytra. Occurs on foliage of the laurel or shingle oak, Qucrcus imbricaria Michx.

Peltis fermginea Linn. and Calitys scabra Thunb., both members of the boreal famna, have been recorded from Michigan.

\section{GRYNocharis Thom. 1859. (Gr., "fire-brand + rejoice.")}

Oval, subdepressed beetles, having the margins of thorax and elstra flattened: front truncate; antennal grooves feeble; front tibiæ without a terminal hook. Three species are known from the United States, one of which has been taken in Indiana.

1278 (3851). Grinocharis 4-Lineata Melsh., Proc. Phil. Acad. Nat. Sci., II, 1844, 104.

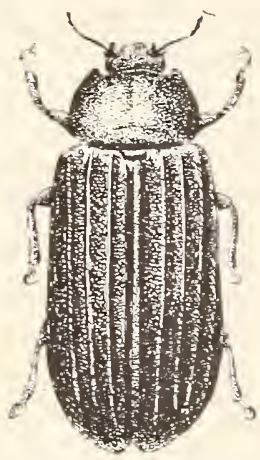

Fig. 248. $\times 5 \frac{1}{2}$.

Oblong-oval, subdepressed. Black, feebls shining; antennæ and under parts piceous. Thorax twice as wide as long. slightly wider at base than apex, hind margin truncate; sides nearly straight, margins reflexed, hind angles obtuse; disk alutaceous, finely and sparsely punctate and with a transverse impression behind the middle. Elytra oblong. sides parallel, each with four narrow costr; intervals each with three or four rows of coarse punctures. Length $6 \mathrm{~mm}$. (Fig. 248.)

Lawrence County; rare. April 13. Occurs beneath loose bark of walnut and oak.

\section{Family XXIX. IIONOTOMID}

\section{The Monotomid Beetles.}

To this family belong a fer small, depressed beetles, resembling rather closely those of certain genera of the family Cucujidæ and also those of the genus Rhizophagus of the Nitidulidx. They live beneath the bark of trees or in the nests of ants. The word Monotoma means literally "a single cut," and probably refers to the small subapical tooth of the mandibles.

From closely allied families they may be separated by having the antennæ 10-jointed. inserted mnder the sides of the front, the last one or two joints enlarged to form a club; front coxæ small and round. the cavities widely closed behind; elytra truncate behind, leaving the last dorsal segment exposed; abdomen with five free ventral segments, the first and fifth elongated. the others shorter and equal; tarsi three-jointed, the last joint longer than the others united. 
The principal paper treating of the family is by

Horn._"Synopsis of the Monotomidxe of the United States," in Trans. Amer. Hnt. Soc., VIT, 1879, 257-267.

In Henshaw's list the genera are (by mistake?) combined with those of Trogositida. Eighteen species, distributed among five genera, represent the family, as far as known, in the United States.

\section{KEY TO INDIANA GENERA OF MONOTOMIDE.}

a. Head slightly prolonged behind the eyes, then suddenly narrowed.

b. Process of abdomen between the hind coxæ broad, feebly rounded in front.

c. Terminal joint of antennæ suddenly broader, joint nine not wider than eight.

I. Monотома.

cc. Last two joints of antennæ enlarged, ninth joint not as wide as the tenth; punctures of elytra in rows.

Hesperobanus.

$b b$. Process of abdomen between the hind coxæ triangular, acute; ninth joint of antennæ as wide as the tenth; elytral punctures in rows.

EURops.

aa. Head parallel behind the eyes, not at all narrowed; last joint of antennæ suddenly enlarged, ninth not wider than eighth.

II. Bactridium.

\section{Monotoma Herbst. 1793. (Gr., "one+cut.")}

In addition to the distinctly larger terminal joint of antennæ, the members of this genus have the head and thorax usually densely punctured and the elytra with rows of punctures, each bearing a short hair. The surface has a tendency to become coated with foreign matter, which adheres to the minute hairs and renders the sculpture difficult to study. Of the nine species known from the United States five have been taken in the State, while two others perhaps occur.

\section{KEY TO INDIANA SPECIES OF MONOTOMA.}

a. Antennæ slender, joints 4 to 9 longer than wide.

PRODUCTA.

aa. Antennæ stouter, joints 4 to 9 bead-like or submoniliform.

b. Metasternum densely punctured at middle and sides; thorax densely punctured.

c. Head with a rather deep oblique impression on each side of vertex. 1279. PICIPES.

cc. Head regularly convex, vertex not impressed.

d. Thorax longer than wide.

1280. FULVIPES.

dd. Thorax nearly square, or even slightly wider than long.

$e$. Thorax with four rather deep impressions. QUADRIFOVEoLATA. ee. Thorax at most with two feeble impressions near base. 
f. Thorax distinctly wider behind the middle, its hind angles prominent.

1281. AMERICANA.

ff. Thorax parallel, its hind angles not prominent.

1282. PARALLELA.

bb. Metasternum nearly smooth; thorax sparsely punctate, narrower near base.

1283. LONGICOLITS.

M. producta Lec., black, opaque, sparsely clothed with whitish hairs, antennæ and legs paler, length $3 \mathrm{~mm}$., is recorded from near Cincinnati.

1279 (3856). Молотома Picipes Hbst., Kafer, V, 1801, 24.

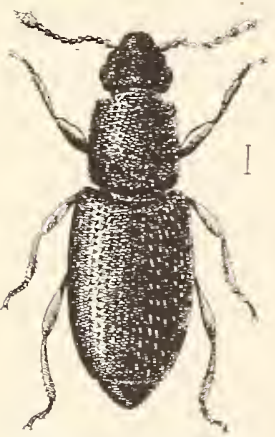

Fig. 249. (Original.)

Elongate-oblong, subconvex. Black or brownish, opaque; antennæ and legs reddish-brown. Thorax slightly longer than wide, sides finely crenate, front angles obtusely prominent, hind ones indistinct; disk coarsely and densely punctured and with a distinct fovea on each side near base. Elytral striæ rather coarsely punctured, the hairs yellowish in hue. Length 2-2.3 mm. (Fig. 249.)

Marion County; frequent. January 17-October 15. Taken by Harold Morrison from the windows of a barn and cellar in which wood had been stored.

1280 (3857). Monotoma fulvipes Melsh., Proc. Phil. Acad. Nat. Sci., II, 1844, 111.

Moderately elongate, rather slender, subconvex. Black to piceous, subopaque; legs and antennæ reddish-brown. Head coarsely and denseìy punctured, not impressed. Thorax longer than wide, narrower in front, sides straight and finely crenate; front angles prominent, obtusely rounded, hind angles broadly rounded; disk coarsely and densely punctured with two faint impressions on basal third. Elytra with rows of fine punctures. Length 2-2.5 $\mathrm{mm}$.

Marion County; frequent. April 11-June 7. Taken with the preceding:

M. quadrifoveolata Aubé, reddish-brown, length 2 mm., is known from the District of Columbia.

1281 (3859). Молотомa Americana Aubé, Ann. Ent. Soc. Fr., VI, 461.

Elongate-oblong. Black, subopaque; antennæ and legs reddish-brown. Head as in fulvipes. Thorax distinctly wider than long, front angles obtuse, hind ones rectangular ; sides subcrenate, straight; disk convex, coarseIy and densely punctured, the basal impressions almost obsolete. Elytra rather coarsely, densely and roughly punctured. Last ventral of male with an oval flattened space. Length $2.2 \mathrm{~mm}$.

Narion and Posey counties; rare. April 17-June 2. Sifted from decaying fleshy fungi; also on flowers of Amorpha fruticosa. 
1282 (3860). Monotoma Parallela Lec., Proc. Phil. Acad. Nat. Sci., 1855, 305.

Elongate-oblong, subdepressed. Piceous, opaque; antennx and legs reddish-brown. Head coarsely and densely punctured, not impressed on the sides. Thorax nearly square, sides parallel, front angles not prominent, hind angles rounded; disk coarsely and densely punctured and with faint basal impressions. Elytra with striæ of rather fine punctures. Body beneath densely and rather coarsely punctured. Length $2 \mathrm{~mm}$.

Jackson County; rare. September 9.

1283 (3863). Mомотома Longicollis Gyll., Ins. Suec., 635.

Elongate, subcylindrical. Dark reddish-brown, feebly shining; legs and antennæ paler. Head coarsely, not densely punctate, its hind angles ending in a tooth. Thorax slightly longer than wide, front angles distinct, hind ones obtuse, sides almost straight; disk finely and rather sparsely punctate and with two distinct forex near base. Elytra with rows of fine simple punctures; intervals alutaceous. Length 1.5-1.7 mm.

Webster collection from "Indiana." Known from all others by the finely punctured and shining thorax.

Hesperobcenus rufipes Lec.. piceous, antennæ and leg's reddishbrown, length $3 \mathrm{~mm}$, is known from Illinois and Missouri.

Europs pallipennis Lec., piceous, elytra dull yellow, thorax as wide as long with a curved basal impression, length $2.8 \mathrm{~mm}$., is known from Pennsylvania.

\section{Bactridium Lec. 1861. (Gr.. "a stick + little.")}

Besides the distinctive characters given in the key, the members of this genus have the intercoxal process of abdomen rather broad, truncate in front and the elytra with rows of punctures. Four species are known from the United States, two of which have been taken in Indiana.

1284 (3869). Bactridium ephippigerum Guer., Icon. Reg. Anim., 1830, 190.

Oblong, depressed. Piceous, shining; antennæ, legs and elytra reddishbrown, the sides and tips of the latter usually darker. Thorax slightly wider than long, sides feebly curred and somewhat narrowed to the base, margin with two small teeth behind the middle; surface vaguely concave, sparsely punctured at middle, much more densely at sides. Elytra slightly wider than thorax, finely striate, the striæ at sides closely and finely placed, those of disk with fine, rather closely placed punctures. Length $2 \mathrm{~mm}$.

Marshall, Starke, Jennings and Crawford counties; scarce. May 20-November 20. Taken by sifting the mold and leares about the roots of trees; also beneath bark of honey locust. 
1285 (3871). Bactridium striolatum Reitt., Verhand. des Nat. Vereins in Brunn., XII, 1S72, 14.

Moderately elongate, subdepressed. Uniform piceous or dark reddishbrown, antenne and legs paler. Thorax slightly wider than long, sides feebly curved and gradually narrowed behind the middle; disk rather coarsely but not densely punctured, punctures of the middle forming a vague U-shaped mark. Elytra slightly convex, surface striate, the striæ at sides replaced by sparse punctures, those on disk with fine, not closely placed punctures; intervals finely wrinkled. Length $2 \mathrm{~mm}$.

Putnam, Posey and Jennings counties; scarce. April 13-November 20. Darker than the preceding, elytra more convex and with the strix on sides semi-obsolete.

\section{Family XXX. DERODONTID E.}

The Tooth-necked Fungus Beetles.

This is a very small family comprising only three known North American species. They are small brown or dull brownish-yellow beetles, in our species having the head deeply impressed, and with a small, smooth tubercle on the inner side of each eye. This at first sight resembles a large ocellus or simple eye. The name of the typical genus, Derodontus, is derived from two Greek words meaning "neck" and "toothed," and was applied to these beetles on account of their having the thorax much narrower than the elytra, resembling a neck, and with the lateral margins strongly toothed.

From allied families they are chiefiy distinguished by having the front and hind coxæ transverse; the former conical, somewhat prominent and contiguous; the latter slightly separated and dilated on the inner side to form a small plate which protects the insertion of the thigh. In addition they have the head suddenly but not strongly constricted behind, the antennæ 11-jointed, inserted before the eyes upon the side of the front, joints nine to eleven somewhat larger than those preceding, except the first and second, which are thicker; abdomen with five free, equal ventral segments; tarsi 5jointed, clothed beneath with long, gray hairs, the fourth joint somewhat smaller than those preceding.

Two genera comprise the family. One of these,

\section{Derodontus Lee., 1861. (Gr., "neck+tooth")}

is represented in the eastern [nited States and Indiana by the single species : 
*12S6 (3S73). Derodontus maculates Melsh., Proc. P'hil. Acarl. Nat. Sci..

II, $1814,115$.

Oblong-oval. convex. Dull brownish-yellow; elytra with a number of irregular, indistinct, more or less connected, darker spots. Thorax about as wide as long, disk coarsely granulate and with a deep median impression; margins flattened and armed with three or four uneven teeth. Elytra slightly wider behind the middle, tips rounded, covering the abdomen; each with ten rows of large, quadrate punctures. Length 2.5-3 mm. (Fig. 250.)

Throughout the State; common on fungi and beneath bark of fungus-covered logs. Hibernates. April 11-December 10.

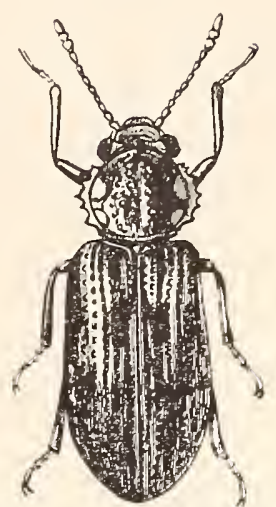

Fig. 250. $\times$ 10. (After Sharp.)

\section{Family XXXI. BYRRHID E.}

8

\section{The Pill Beetles.}

Included in this family are short, very convex beetles of small or medium size, having the upper surface more or less clothed or ornamented with hairs or minute scales. The legs of most of the species are very contractile, being capable of being folded up so closely against the body that it is with difficulty that they can be seen. The name Byrrhus, that of the typical gerus to which the larger species belong, is derived from the Greek word "bursa," a "hide," and was given the genus by Linnæus, probably on account of some fancied resemblance in texture of their upper surface. He also gave the specific name pilutus, meaning "a little pill," to a European species, on account of its resemblance to a pill or little ball, and the name "pill-beetle" has been since applied to the members of the family. The beetles are most common in sandy localities, where they are usually found upon the ground, either beneath cover or burrowing about the roots of the tufts of coarse grasses which grow in such places. The beach of Lake Nichigan is a favorite locality for them, and along it most of the spacies known to occur in the State have been taken. However, one or two species live beneath bark and probably occur throughout the State.

The principal characters distinguishing the family are the transverse mentum; the 11- (rarely 10-) jointed antennæ, the outer joints usually forming an elongate club; prosternum short, truncate in front, slightly prolonged and fitting into the mesosternum behind; elytra covering the abdomen, which has five ventral segments; front coxa transverse, separated by the prosternum, the [43-23402] 
coxal cavities open behind; hind coxp extending to the margin of the body, transverse and dilated into a plate partly protecting the hind thighs: tarsi short. five-jointed. last joint nearly as long as the others united.

The literature treating of the North American species is as follows :

LeConte.-"Synopsis of the Byrrhidxe of the Tnited States," in Proc. Phil. Acad. Nat. Sci.. VII. 1854, 113-117.

Horn._- "Table of Species ố Limnichus," in Bull. U. S. Geol. Survey, V, 1879, 514.

Casey._-_Limnichus." Synopsis of," in Ann. N. Y. Acad. Sci.. V, 1890, 145-160.

Forty-six species, distributed among 11 genera, represent the family in the United States. Of these 8 species, belonging to four genera. have been taken in Indiana.

\section{KEY TO INDIANA GENERA OF BYRRHIDE.}

a. Ifead prominent; mentum large, elongate. semi-elliptical. coilsely punctate, entirely closing the mouth below.

I. Nosodendron. a. Head retracted: mentum small, quadrate, largely exposing the base of the maxillie.

b. Antenne 11-jointed. clavate; lowel face or epistoma not distinct ; size medium, 5 or more mm.

c. Front tarsi only retractile.

ce. All the tarsi retractile.

II. Crtilus.

III. BYRRHUS.

bb. Antennie 10-jointed: epistoma corneus, separated by a fine suture; size small, less than $3 \mathrm{~mm}$.

IV. Limnichus.

I. Nosodendron Lat. 1807. (Gr.. "disease + tree.")

This genus comprises two oval, convex beetles, having the head advanced in front; mentum as described in key; antennse 11-jointed, situated under the side of head. They live beneath the bark of trees. One of the two occurs in Indiana.

1257 (3976). Nosodendron unicolor Say, Long's Exped. to St. Peter's Riv., II, 274 : ibid. I, 180.

Rounded-oval, strongly convex. Black, somewhat shining; autennie piceous. Above uniformly, rather densely and coarsels punctate, more sparingly and coarsely beneath. Elytra not striate but with rows of short, stiff, erect-yellowish hairs, plainly visible only in side light. Length 5$5.7 \mathrm{~mm}$.

Lake, Putnam. Crawford and Posey counties; scarce. April 22-July 4. 
II. Cytulus Erichs. (Gr., "covering + mud.")

In this genus and the next the head is rertical or bent downward, the labrum distinct and fitting close to the front, and the body covered with a fine, easily removed pubescence forming varied patterns. Two species of Cytilus are known. both of which occur in Indiana.

1288 (3SS7). Crtilus sericeus Forst., Nor. Spec. Insect., 1771.

Subovate, narrowed in front, strongly convex. Bronzed black, shining; densely covered with a fine pubescence which. on head and thorax, is nearly uniform bronzed; on elytra the four or five inner intervals are alternately narrow and uniform metallic green, and wider, slightly elevated, and green tesselated with black. Head and thorax rather finely and densely, elytra more sparsely and coarsely, punctate; the punctures visible only after the pubescence is remored. Length $5 \mathrm{~mm}$.

Lake and Warren counties; frequent along the beach of Lake Michigan. May 28-July 28.

1289 (3SSS). Crtilus trivitTatus Melsh.. Proc. Phil. Acad. Nat. Sci., II, $1844,117$.

Resembles the preceding in form and structure but a little larger. Uniform dull bronze; thorax with a patch of golden hair at middle of base; elytra with the alternate intervals slightly elevated and tesselate with squarish black spots. Tength $5.5-6.5 \mathrm{~mm}$.

Lake and Laporte counties. beneath rubbish along the beach of Lake Michigan; scarce. Taken with sericeus, and may eventually prove to be the female of that species. May 20-May 28.

\section{Byrrhus Linn. 1766. (Gr., "a hide.")}

To this genus belong the largest members of the family. They resemble closely those of Cytilus, but have all the tarsi strongly retractile. Two of the eight known species from North America have been taken in the State. Byrrhus. 251 pilum L L. (Fig. 251.)

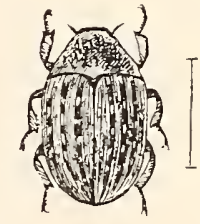

Byrrhus pilulus I.
A European species.

1290 (3SS9). Brrrhus americanus Lec., Agassiz Lake Sup., 1S50, 224.

Oral, strongly convex, narrowed in front. Black, densely covered with fine grayish pubescence; thorax indistinctly marked with gray; elytra each with three or four narrow interrupted black lines and a double. narrow. sinuous gray crossbar at middle. Length $8.5-9.5 \mathrm{~mm}$.

Lake and Laporte counties, along the beach of Jake Michigan: scarce. May 20-June 10.

1291 (3895). Brrrhus murinus Fab., Syst. El., I, 1S01, 104.

Roundert-orate, strongly convex. Black, closely pubescent and corered with numerous short, erect, bristle-like hairs; elytra each with four or five 
narrow, black, slightly elevated lines and a double row of small grayish, spots arranged crosswise, just behind the middle. Length $4.5-5 \mathrm{~mm}$.

Crawford County; rare. July 25.

$$
\text { IV. Lmmichus Latr. (Gr., "a pool or marsh + love.") }
$$

Here belong nearly a score of very small species having the labrum distinct; antennx inserted at the sides of the front; head strongly retracted, the eres, labrum and mandibles concealed in repose. They are found along the borders of streams and lakes, where they burrow in the ground and emerge when water is thrown on the banks.

\section{KEY TO INDIANA SPECIES OF LIMNICHUS.}

a. Body beneath densely and coarsely punctured; blackish-bronzed, densely clothed with yellowish pubescence.

1292. PUNCTATUS.

aa. Body beneath finely, in part sparsely punctured.

b. Under surface shining; above black, shining, rery sparsely clothed with grayish pubescence.

1293. Nitidulus.

6b. Under surface opaque; above dark brown to piceous, rather densely clothed with pale brown or rellowish pubescence. 1294. oratcs.

1292 (3901). Limeiches punctatus Lec., Proc. Phil. Acad. Nat. Sci., ViI, $1854,116$.

Oval, convex. Blackish-bronzed, densely covered with golden gray pubescence. Thorax more than twice as wide as long, sides feebly and evenly curved; surface, as well as that of elytra, coarsely and densely punctate; median groove fine, distinct. Prosternum coarsely punctate, and with a wide and deep longitudinal groove. Abdomen coarsely and densely punctured. Length 1.S-2 $\mathrm{mm}$.

Throughout the State; frequent. Hibernates. May 5-December 7. In October I once found a number of this species sunning themselves on the vertical cliffs of sandstone along the Ohio River at Cannelton, Perry County.

1293 (3907). Limnichus nitidulus Lec., loc. cit.. p. 117.

Oval, narrowed before and behind. Black, shining, rery sparsely clother with yellowish pubescence. Thorax sparsely and finely punctate, median groove short but distinct; scutellum one-third longer than wide at base. highly polished. Elytra sparsely and feebly punctured, the punctures on side and near suture semi-obsolete. Prosternum sparsely punctate, median groove distinct except on apical fourth. Abdomen finely and rather sparsely punctate. Length $1.7 \mathrm{~mm}$.

Shores of Bass Lake, Starke County; frequent locally; also in Webster collection from Indiana. Nay 18-August 20. Known heretofore only from Georgia. 
1294 (3909). Limnichus ovatus Lec., Proc. Phil. Acad. Nat. Sci., VII, $1854,117$.

Orate, rather acutely pointed behind. Above dark brown to piceous, shining, conspicuously clothed with pale brownish-yellow pubescence; antemnæe and legs dark reddish-brown; under surface paler piceous. Thorax more than twice as wide as long, sides straight, disk sparsely and very finely punctate, without median groove. Elytra nearly four times as long as thorax and one-fourth wider, very finely and sparsely punctate. Prosternum with a deep median groove, which reaches neither base nor apex. Length 1.2-1.5 mm.

Putnam Cointy; scarce. April 17-October 17. A half dozen specimens were sifted during a severe drouth from debris just above a hillside spring. Known heretofore only from the "Southern States."

\section{Family XXXII. GEORYSSID Æ.}

\section{The Minute Mud-ioving Beetles.}

A very few minute, rounded, convex species comprise this family. They have the surface roughly sculptured; antennæ short, 9jointed, inserted under the sides of the front, the last three joints forming an oval club; head deflexed, eyes rounded; prosternum very small; mesosternum short and wide, sloping downward in front; elytra entire; abdomen with five free ventral segments; front coxæ rather prominent, with a deep fissure between them; middle coxæ oval, well separated; legs short, slender, tarsi 4-jointed, claws simple.

They live on the margins of streams and cover themselves with a coating of mud or fine sand, so that they can be detected only when they move. One genus represents the family.

\section{Georyssus Lat. 1807. (Gr., "earth + dig up."')}

This genus, sufficiently characterized above, is represented in the United States by two known species. One of these, G. pusillus Lec., black, thorax rugosely punctate, strongly margined, with an interrupted elevated line on side, elytra with rows of rather coarse punctures, length $1.7 \mathrm{~mm}$., doubtless occurs in the State. but no verified Indiana specimen has been seen.

\section{Family XXXIII. PARNIDAE. \\ T'he Long-Toed Water Beetles.}

This is a small family of aquatic beetles which live for the most part in swift running water, where they cling to flat stones, log's or 
aquatic plants. They feed upon decomposing matter in the water and thus form one of the agencies which nature has provided for purifying streams. The legs are not fitted for swimming. but the fifth or last joint of the tarsi is ionger than the other four mited. and is armed with long. simple clars. whence the common name above girell. This structure of the tarsus is the principal distinguishing character of the family and enables its members to grasp firmly objects resting in strong currents of water. By taking an old limb or rough stone from the water at a suitable locality and placing it in the sun. the insects will more as the water dries. though at first nothing ean be seen of them, so perfectly do they resemble the surface on which ther rest. The surface of the bodr is clothed with fine sillen hair's which have the property of repelling or shedding water and enabie the insect to surround itself with a film or globule of air while clinging to objects beneath the water.

The larva of our largest species. Psephonus lecontci. resembles in appearance a trilobite. being flat and nearly circular in outline. and measuring about $S \mathrm{~min}$. in length. It is found clinging to stones in rapid water or in muck near springs or ponds. The larrie of the genera Elmis and Stenetmis are said to be similar in form. except that the segments are not united to the margin, which thus appears notehed or incised.

Among the more distinctive characters of the family are the usually retractile head, with distinct labrum and small mandibles: prosternum distinct in front of the coxæ. usually elongate behind and forming a process receired into a definite carity in the mesosternum : front coxal cavities widely open: lind coxa transverse and usually dilated into a plate. which partly protects the thighs: elytra entire: abdomen usually with fire rentral segments, the front ones connate or firmly united.

Nearly 400 species of the family are known, about 50 of which occur in North America. The principal literature treating of these is as follows:

LeConte.- "Srrmopsis of the Parnida of the Tnited States." in Proc. Pliil. Acad. Nat. Sci.. VI. 1552. 41-44.

Horn.- "Srnopsis of the Parnidx of the Tnited States." in Trans. Amer. Ent. Soc. TII, 1870. 29-42.

The North American species are distributed among three subfamilies. all of which are represented in Indiana. 
KEY TO SUBFAMILIES OF PARNIDA.

a. Abclomen with more than fire rential segments; front coxie with very large trochantin; body subdepressed.

Subfamily I. Psephexinæ, p. 67T. a a. Abdomen with only five rentral segments; body convex.

b. Front coxæ transrerse, with distinct trochantin; body clothed with a dense silky pubescence. Subfamily II. Parixixe, p. 678. bb. Front coxre rounded without trochantin; body feebls pubescent.

Subfamily III. Elinxæ, p. 679.

\section{Subfamily I. PSEPHENINAE.}

In this subfamily the head is free, not retractile; labrum broad, entirely covering the mandibles; maxillary palpi elongate, the last joint wide. hatchet-shaped: antennæ widely separated, serrate, 11jointed. longer than head and thorax; prosternum carinate, prolonged behind into an acute point which fits into a narrow groore extending the full length of the mesosternum; abdomen of male with seren ventral segments, the first and second united. fifth broadly emarginate. sixth deeply bilobed. visible only around the notch of the fifth; serenth rounded, entire. filling the notch of the sixth; female with the segment corresponding to the sixth in male absent. The subfamily is represented by the single genus

\section{Psephents Hald. 1863. (Gr.. "dark or obscure.')}

Four species represent the genus in the United States. one of which occurs in Irdiana.

1295 (3914). Psephexts Lecoxtei Lec.. Proc. Phil. Acad. Nat. Sci.. Ti, 1852. 41.

Oral. subdepressed, narrowed in front, obtusely rounded behind. very finely punctate and pubescent. Black or dull bromish-black; head and thorax usually darker, alwass deep black in the female. Base of thorax trice as wide as apex, bisinuate, distinctly lobed at middle; hind angles acute. sides regularly curved. Length 4.5-6 mm. (Fig. 252.)

Hudson Iake, Laporte County and pool near Delong, Fulton County; scarce. August 20. Probably occurs throughout the lake region of

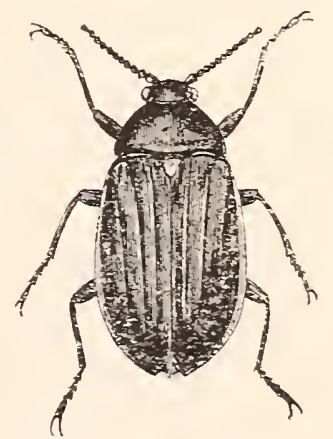

Fig. 252. $\times 5$. the northern third of the State. LeConte sars that "the perfect insect lives on bushes over the surface of rumning water and is also found creeping over wet stones in the torrents." 


\section{Subfamily II. PARNINAE.}

In our genera of this subfamily the head is retractile and protected beneath by the prosternum. which is lobed in front; antennæ short. 11-jointed. the first and second joints enlarged: prosternal spine wide: mesosternum broad. emarginate: hind coxr dilated into a plate. Four genera are known. three of which may occur in the State.

KEI TO INDIANA GENERA OF PARNIXE.

a. Bods rounded; eres not hairy; last joint of maxillars palpi hatchetshaped; length $3 \mathrm{~mm}$.

LUTROCHLS.

aa. Bods elongate; last joint of maxillars palpi elongate; larger. $5-6.5 \mathrm{~mm}$.

7. Antemna close together at base, their clubs pectinate; eres hairs.

PELOTOMTS.

66. Antennæ $\pi$ idels separated. their clubs lamellate; eres glabrous.

II. DRIOPS.

Introchus lutens Lec.. oral. bronzed. densely clothed with clarrellow hairs. has been recorded br Dury from Cincinnati.

Pelonomus obscurus Lec. subcrlindrical. piceous. denselr clothed with erect hairs. length $6.5 \mathrm{~mm}$.. is recorded from the "Southern and Western States."

\section{Drsops Oliv. 1790. (A mythological name.)}

Oblong species of medium size, haring the head retractile and when bent dommard protected beneath by the lobe of the prosternum: joints 4 to 11 of antennæ distinctly lamellate: prosternal spine wide. Fire species are known from North America. two of which have been taken in Indiana. while a third probablr occurs.

\section{KEY TO INDIATA SPECIES OF DRYOPS.}

a. Bods finels and densels clothed with silks pubescence.

1296. ITTHOPHILLS.

aa. Bods coarsels pubescent.

b. Base of thorax and space along elytral suture without pubescence.

1297. FASTIGIATUS.

bb. Surface erersthere pubescent: altemate intervals of elvtra more contex.

STRIATLS.

1296 (3921). Driops LIthophitts Germ.. Ins. Spec. Nor.. 1s2t. s\&.

Oblong. subconrex, ererrwhere corered with a dense and erenls distributed silky pubescence which has a slichtly bronzed lustre. Thorax broader than long. disk convex. base bisinuate, front and hind angles acute. Elytra rapidy narrowed behind the middle to an acute apex: last abdominal segment, as in the next species. nearlo deroid of nubescence and reddish in hue. Length $5-5.5 \mathrm{~mm}$. 
Lake, Laporte, Lawrence and Putnam counties; frequent. .July 21-August 20.

1297 (3922). Dryops fastigiatus Say, Long's Exped., II, 1824, 275 ; ibid. I, 181.

Similar in size and form to the preceding. Differ's in having the basal region of the thorax rather suddenly depressed, smooth, shining and wholly without pubescence. Sides of elytra densely pubescent, but a space on each side of the suture, reaching the second or third row of punctures on basal half and widening to the fourth row on apical half, with only a few scattered hairs; punctures large, coarse. Length 5-5.5 $\mathrm{mm}$.

Wells. Hancock, Vigo and Poser counties; scarce. August 10October 20. The Vigo County specimen was taken from beneath a $\log$ in a deep ravine.

D. striatus Lec., elongate. blackish-olivaceous, $6 \mathrm{~mm}$. in length, is a boreal species extending across the continent.

\section{Subfamily III. ELMINAE.}

Here the front coxre are rounded without trochantin; abdomen with five ventral segments, the fifth rounded at tips; antennæ simple, inserted upon the front near the eyes; middle coxæ widely separated; hind coxw separated. not dilated into a plate, protecting the thighs. Four genera are known, ali of which may oceur in Indiana.

\section{KEY TO INDIANA GENERA OF ELMINÆ.}

a. Head protected beneath by a prosternal lobe.

\section{Antennæ 11-jointed.}

c. Front tibire pubescent on the inner side; thorax in our species without median groove.

III. ELMIS.

ce. Front tibiæ glabrous on the inner side; thorax with a distinct median groove.

bb. Antennæ 6-jointed.

IV. Steneluis. MaCRONYCHUS. a . Head free; prosternum not lobed; antennæ 11-jointed. Ancronony.

\section{Elums Latr. 1802. (Gr., "I drive.")}

This genus comprises about 20 small, elongate or oval species (Fig. 253), of which the following may oceur in Indiana:

KEY TO INDIANA SPECIES OF ELMIS.

a. Thorax with even surface; i. e., without elevated lines or folds.

b. Thorax more or less reddish-brown, slightly narrorrer from base to apex.

bb. Thorax black, slightly bronzed. a a. Thorax with more or less uneven surface.

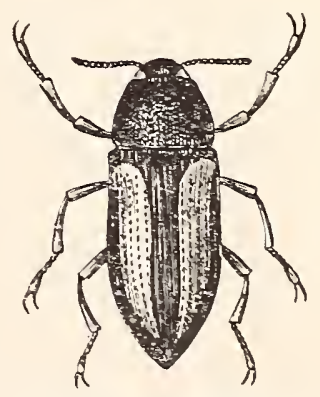

Fig. 253. Elmis bivittatus Lec. 129S. vitTates. QUADRINOTATCS. 
c. Thorax with a short elevated line each side at base; elytra each with an oblique clay-yellow stripe.

d. Elytral intervals distinctly punctured ; oblique pale stripe entire, extending from humerus nearly to apex. FAsTIDITUS.

dd. Elytral intervals scarcely punctured; oblique pale stripe broken.

1299. OVALIS.

ce. Thorax with oblique folds converging backward, its sides sinuate.

PUSILLUS.

129 (3925). Elmis vittatus Mels., Proc. Phil. Acad. Nat. Sci., II, 1844, 99.

Elongate, subcylindrical, convex. r'iceous black, shining; elytra each with a yellowish stripe, broadest at base, extending from humerus nearly to apex; antenne, tibize and tarsi reddish-brown. Thorax slightly broader than long, gradually narrower from base to apex, sides feebly rounded; disk convex, finely and rather sparsely punctate. Elytral striæe feebly impressed, the punctures fine, separated one from another by a space greater than their own diameters. Length $2.5-3 \mathrm{~mm}$.

Marshall and Kosciusko counties; rare. June 16-August 5.

$E$. quadrinotatus Say, elytra with a pale spot at base and another behind middle, length $2.3 \mathrm{~mm}$. is known from the Middle States and Canada. E. fastiditus Lec., bronzed black, elytra with an entire reddish-yellow stripe. length $4 \mathrm{~mm}$., is a boreal species which may oceur in northern Indiana.

1299 (3931). Elmis ovalis Lec., N. Sp. N. Amer. Col., I, 1S63, 74.

Oval, convex. Blackish-bronzed, finely and sparsely pubescent; elytra each with an oblique narrow, dull yellow, usually interrupted, stripe reaching from humerus to apex; tarsi and antennse reddish-yellow. Thorax with an elevated line each side at base; sides feebly curred; disk convex, densely and finely punctate. Flytra deeply striate, strice with coarse punctures; intervals very finely punctulate. Iength 2.5-2.8 $\mathrm{mm}$.

Kosciusko, Fountain, Starke and Knox counties, rare; Lawrence County, frequent in the swift stream emerging from Hamer's Cave, east of Mitchell. June 8-September 7.

E. pusillus Lec., black, elytra each with a humeral and subapical yellowish spot and with the second, fourth and sixth intervals carinate, length $2 \mathrm{~mm}$., is known from the Middle States and Canada.

\section{Stenetmis Dufour. 1835. (Gr., "narrow + Elmis.")}

Elongate, subcylindrical species, very closely allied to Elmis. Six are listed from the United States, three of which may occur in the State, while a fourth is herewith described.

KEY TO INDIANA SPECIES OF STENELMIS.

a. Second elytral interval not elevated at base; elytra black with a broad yellow stripe; length $2-2.5 \mathrm{~mm}$.

LINEARIS.

a a. Second elytral interval elevated on basal third. 
๖. Form subdepressed; thorax with sides strongly rounderl, its disk with three oblique tubercles each side of the median channel.

CRENATLS.

ఒъ. Form elongate, conrex; sirles of thorax less rounded. more or less sinuate at middle.

c. Thorax scarcely broader at base than apex; pale stripe of elytra alwars entire.

1300. BICARINATU's.

cc. Thorax distinctly wider at base than apex; pale stripe of elytra broadls interrupted at middle.

1301. stLCATCS.

S. linearis Zimm. and S. crenatus Say hare both been recorded from Cincinnati by Durv.

1300 (3949). Stezelans bicarixatus Lec., Proc. Phil. Acad. Nat. Sci., TI, $18.52,4$.

Elongate, subcylindrical. Dull black: thorax tinged with bronze; elytra each with a rather broad sellow stripe extending from humerus sereneighths to apex; tarsi and antennze reddish-bromn. Thorax with the sides parallel in front of and behind the middle, scarcels broader at base than apex; the dorsal channel and an oblique groore each side distinct. Second elytral interral distinctly but feebly carinate near base, the fifth carinate its full length: strice rather deeplr and coarsels punctured on base, more faintly near apex. Length $3.5- \pm \mathrm{mm}$.

Spencer Countr: rare. June 13. Described from Ohio.

1301 (-). STExeluis sticates. sp not.

Broader. more robust and less conver than bicarinatus. Deep black; elstra each with an oblong rellow spot behind humerus and a more elongate one on apical third: antennze and tarsi reddish-brown. Thoras finely and sparsely granulate and with a deep median groore extending from base three-fourths to apex. the sides of groore conrergent near base; disk also with two oblong oblique tubercles each side of groore, the hind one separated from the latter by an oblique depression. Elrtra with second interval elerated on basal third. fifth carinate its full length; strize coarselr: shallowly and rather closely punctate. Length $3.5 \mathrm{~mm}$.

Lake Maxinkuckee. Marshall County: frequent. October 26. Specimens were sent me br H. Walton Clark. of the T. S. Fish Commission. who reported it as "apparently spending its life in the intervals of the marler growth on mussels. etc.. at the bottom of the lake. and can usually be procured in numbers by examining the concretions of marl." From the descriptions I at first thought it to be quadrimamlatus Horn. but comparison with cotrpes of the latter at Cambridge. shows the sculpture of thorax to be wholly. different. Several unnamed specimens of sulcatus from Ner York were in the Cambridge collection. 
Macronychus glabratus Say, blackish, antennæe pale reddishbrown, seventh interval carinate, length $3-3.5 \mathrm{~mm}$., is known from Pennsylvania.

Ancyronyx rariegatus Germ., black, elytra with yellow stripes, length 3-3.5 mm., is recorded from the Middle States and Tennessee.

\section{Family XXXIV. HETEROCERID AE.}

\section{The Varifgated Mud-loving Befites.}

To this family belong a small number of subdepressed, oblong or elongate, semi-aquatic beetles which live in galleries which they excavate in the sand or mud along the borders of streams and lakes. When disturbed they run from their galleries and take flight, as do certain species of Bembidium. They are of a brownish or blackish color, usually variegated with undulated bands or spots of dull yellow, and have the body very finely punctate and densely clothed with short, silky pubescence. From the Parnidæ, with which they were formerly grouped, they differ mainly in having the front and middle tibir widened and armed with spines on the outer edge, thus enabling them to burrow in the wet sand which they and their larvæ inhabit.

The name Heterocerus, that of the typical and only genus, comes from two Greek words meaning "different" and "horn," and was so given from the irregularity of the 11-jointed antennæ, joints 5 to 11 of which form an oblong, serrate club (Fig. 4, No. 9).

In addition to the characters mentioned, the nembers of the family have the mentum large, oblong. deeply emarginate in front; thorax transverse with rounded angles; prosternum lobed in front, acute behind; mesosternum very short, deeply emarginate; elytra entirely covering the abdomen, which is composed of five nearly equal ventral segments, the fifth only being movable, the others connate; front coxæ oval, transverse, the cavities widely open behind; tarsi 4-jointed, the second and third joints shorter than the others.

The only paper treating of the North American species is that by Horn.-- "The Species of Heterocerus of Boreal America," in Trans. Amer. Entom. Soc, XVII, 1890. 1-16. pl. I.

\section{Heterocerts Bose. 1792. (Gr... "different+horn.")}

In the paper above cited, Dr. Horn reduced the 16 species of the genus listed by Henshaw to nine, and added two new ones. One of the princinal characters used by him in separating the species is the 
presence or absence of the post-mesocoxal lime. This is an clevated line on the metasternum which "begins at the middle of the hind border of the middle coxe and extends obliquely backward, joining the suture between the metasterumm and its episternum.' 'The first ventral segment bears a stridilating organ in the shape of an elevated curved ridge which is finely striate transversely, and when rubbed by the hind legs. produces a quite distinct sound. Of the 11 species recognized by Horn, seven have been taken in Indiana. while another may occur.

\section{KEY TO INDIANA SPECIES OF HETEROCERUS.}

a. Thorax with a pale median stripe; stridulating ridge of first ventral segment complete, forming nearly a semicircle; an elevated oblique line on the epipleura near the base. (Fig. 256, c.)

1302. AUROMICANS.

aa. Thorax without a pale median stripe; stridulating ridge of first rentral incomplete, extending from the front angle in a curved line to hind border; epipleura without an oblique elevated line near the base.

b. Metasternum without a post-mesocoxal line; elytra never with a spot at base near suture.

c. Labrum of male narrowed at tip and prolonged forward in a process; size larger, $6 \mathrm{~mm}$.; elytra obsoletely substriate.

1303. VENTRALIS.

cc. Labrum of male not prolonged forward in a process; size smaller, not over $4.5 \mathrm{~mm}$. ; elytria usually distinctly substriate.

1304. UNDATUS.

66. Metasternum with a post-mesocoxal line.

d. Elytra usually brownish or piceous, always with more or less distinct dull yellow spots or markings; mandibles of male without basal lobe extending over the labrum.

$e$. Elytra without a pale spot at base near suture.

$f$. Elytra usually substriate, the pale markings much broken; legs more or less piceous; larger, 3.5-4 mm.

1305. BRUNNEUS.

ff. Elytra not substriate, the markings well defined and broad: legs wholly pale; length not over $3 \mathrm{~mm}$. scHwarzl.

ce. Elytra with a pale spot at base near suture.

g. General color of upper surface brownish or pale; thorax merely slightly darker at middle; mandibles of male with an angulate basal lobe on outer side.

1306. COLLARIS.

gg. General color piceous; thorax piceous, often sharply bordered with pale; mandibles of male not prominent at hase.

1307. TRISTIS.

dd. Elytra pale without yellow marks, often with a broad fuscous sutural space; mandibles of male with a basal lobe extending over the base of labrum.

130S. PUSILLUS. 
1302 (3958). Heterocerus auromicans Kies., Rev. Linn. Ent., V, 1851. 287.

Oblong, convex. Piceous, sparsely clothed with golden, short, scalelike, recumbent hairs; sides and median stripe of thorax pale. Elytra with sides, two sinuous entire bands and short subapical lunule, yellow; femora and tarsi reddish-yellow, tibia piceous. Elytra parallel, faintly substriate. Labrum of male, transverse, narrowed in front, apex emarginate-truncate. Length $3.5-4.5 \mathrm{~mm}$. (Fig. $256, c_{\text {. }}$ )

Starke, Fountain and Vigo counties; frequent. April 26-August 20. Easily known by the pale median stripe of thorax, and the entire stridulating ridge on first ventral segment.

1303 (3957). Meterocerus ventralis Melsh., Proc. Phil. Acad. Nat. Sci., II, $1 S 44,9 S$.

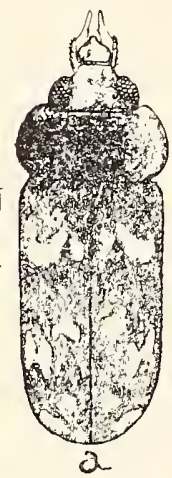

Fig. 254. H. ventralis, $a$, male; $b$, female, var. (After Horn.)

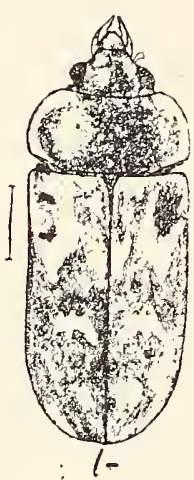

Oblong, feebly convex. Piceous, clothed with short, semi-erect yellowish or brownish pubescence; front angles of thorax yellow; elytra with three sinuous bands of dull yellow spots, which are interrupted on the disk and not united at the margin by a pale border; rarely a basal spot near scutellum; femora reddish-yellow, piceous at base, tibie piceous, tarsi pale. Thorax of male slightly wider than elytra. not narrowed in front: that of female distinctly narrowed in front. not broader than elytra. Elytra parallel in both sexes, faintly substriate. Length 66.5 mm. (Fig. 254.)

I.awrence County ; scarce. Angust 18. Our largest species.

1304 (3970). Heterockrus undatus Melsh., Proc. Phil. Acad. Yat. Sci., II, $1844,9 S$.

Oblong, moderately convex. I'iceous or brown; thorax often with the front angles yellow, or the sides narrowly yellow; elytra with two sinuate bands more or less interrupted (often united at the margin by an entire pale border), a rounded subapical spot and an apical lunule, yellow; body beneath piceous, the sides of abdomen narrowly yellow. Elytra usually substriate. Length 4-4.5 mm. (Fig. 255,

Throughout the State; common. April 6-October 21. Resembles the next species very closely, but distinguished by the absence of post meso-coxal lines, and by having the front angles or sides of thorax reddish-yellow.
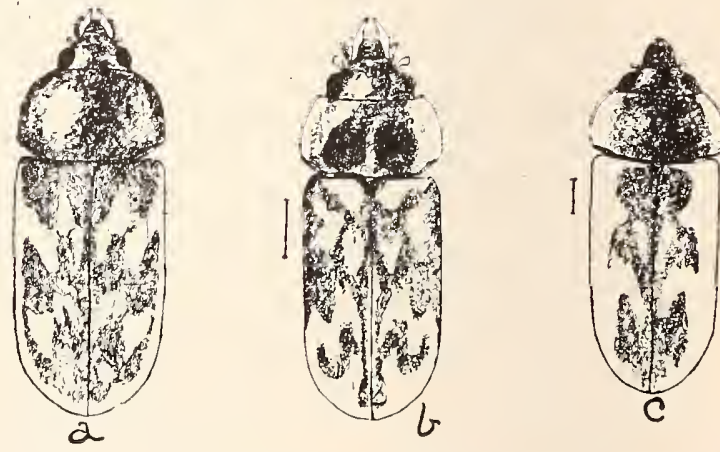

Fig, 25j. a, H. undatus, female; $b, H$. collaris, male; $c, H$. collaris, small var. (After Horn.) 
. Heterocerts bruxneus Melsh., Proc. I'hil. Acad. Nat. Sci., II. $1 S 44.99$.

Oblong, moderately convex. P'iceous, slightly shining; elytral with the usual three sinuous bands of dull rellow. often broken into spots. sometimes scarcely distinct; the front band usually with a dash projected forward from the middle: the hind one usually forming two rounded spots near apex but not touching marain: body beneath entirely piceous. Elytra more distinctly substriate than in the other species. Length : $-4 \mathrm{~mm}$.

Frequent about the lakes of northern Indiana; elsewhere taken only in Marion and Lawrence counties. Nay 11-December 7 .

H. schuarzi Horn, is known from Pennsylvania, Lake Superior and Texas. (Fig. 256. b.)

1306 (3965). Heterocerts collaris Kies., Revis. Linn. Ent., V. 1851, 292.

Oblong. moderately convex. Dull sooty brown or piceous, clothed with brownish hair; sides of thorax pale; elytra each with an indistinct spot near scutellum and two sinuous bands, often more or less interrupted and sometimes indistinct. yellow: body beneath piceous, sides and apex of abdomen rellowish; legs entirely reddish-yellow. Thorax twice as wide as long. sides and hase curred, the lattel bisinuate. Length $2.5-4 \mathrm{~mm}$. (Fig. $25.5, b$ and $c$ )

Throughout the State; frequent. June 11-August 17.
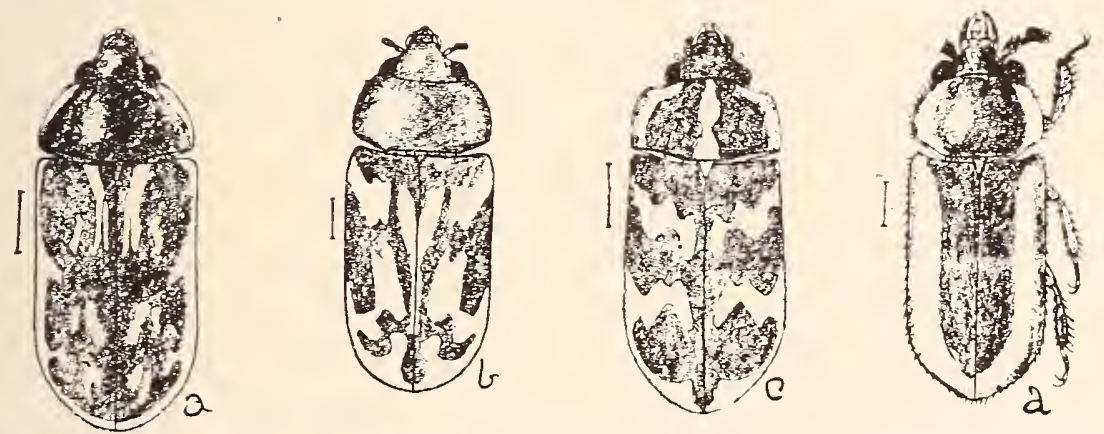

Fig. 256. a, H. tristis, female; b, H. schwarzi, female; c, H. auromicans; d, H. pusillus. (After Horn.)

1307 (3960). Heteroceres tristis Mann., Bull. Mosc., III, 185:, 21 .

Oblong, subdepressed. Piceous, sparsely clothed with short. brownish pubescence; sides of thorax indistinctly paler; elytra with the side margins entirels but narrowly pale. the usual sinuous bands broken into short longitudinal lines as follows: an oblique stripe on each side of scutellum, on each side of this one-third from base a short stripe; behind this near middle a pair of oblong spots. and another pair on apical fourth: beneath piceous. the sides of abdomen narrowls pale. Elytra raguels substriate, epipleura pale. Length $3.54 \mathrm{~mm}$. (Fig. 256. a.)

Lake. Starke and Kosciusko comnties: scarce. July 18-Angust 25 . 
1308 (3969). Heterocerus pusiluus Say, Journ. Phil. Acad. Nat. Sci., III. 1S23, 200 ; ibid. II, $12 S$.

Oblong, moderately convex. Dull yellow to pale sooty-brown, either uniform in color or with a broad darker median band extending from base of head to tips of elytra; epipleura and legs pale. Elytra parallel, not substriate. Length 2-2.5 mm. (Fig. 256, d.)

Putnam and Crawford counties, scarce; frequent on border of pond near University farm east of Mitchell. July 10-August 7. Readily known by its small size and absence of usual yellow spots on elytra.

\section{Series III. SERRICORNIA.}

This series is primarily distinguished, as its name indicates, by the serrate or saw-tooth character of the antennæ. The serrate antenna is, like the filiform, usually slender and of nearly the same width throughout, but differs in having each joint project more or less inwards, this projection being sometimes so long as to form what is called the pectinate or comb-toothed antenna. As we have already noted, some of the families connect so closely with those of the Clavicornia that they are included in both tables. In all but two the tarsi are 5-jointed.

Their food is variable in character, but consists for the most part of either living or decaying wood or other vegetable matter, or in those species with soft body covering, mainly of larvæ, small worms, snails and other living matter. All the families of the series are represented in Indiana.

KEY TO FAMILIES OF SERRICORNIA.

a. First and second ventral segments firmly united; antennæ serrate, never elongate (pectinate in the male of Xenorhipis); tarsi with membranous lobes beneath; prosternal spine received in a cavity of the mesosternum; thorax fitting closely to the elytra.

Family XXXix. Buprestide, p. 776.

a $a$. Ventral segments all free and movable.

b. Tarsi 4-jointed; antemnæ short, terminal joints thicker (flabellate in Rhipidandrus) ; form cylindrical; length less than $3.5 \mathrm{~mm}$.

Family XlviI. CIOIde, p. 895.

bъ. Tarsi in part or wholly 5-jointed.

c. Hind tarsi 4-jointed, the others 5-jointed; form oval, convex; length less than $3 \mathrm{~mm}$. Family XlviII. SPHindide, p. 901.

cc. Tarsi all 5-jointed.

d. First joint of tarsi very short and imperfectly separated from the second; antennal club 3- or 4-jointed, first ventral segment not elongated (subfamily Bostrichince) ; antennal club 2jointed, first ventral elongated (subfamily Lyctinx).

Family XLIV. Bostrichide, p. SS6.

ar. First joint of tarsi distinct (except in some Cleride), often longer than the second ; first ventral not elongate. 
c. Hind coxal plates with gronves for the reception of the femolia in repose.

$f$. Front coxie globose.

\%. Thorax loosely jointed, its hind angles usually molonged backwards: prosternal spine loosely received in a notch in mesosternum. so as to admit of a springing motion: front coxal carities entirely surrounded by the prostermm. Family XXXYil. Futeride. 1) (is).

9\%. Thorax firmly attached to the remainder of the bods: prosternal spine prolonged but not morable; front coxal carities closed behind by the mesostemum: length less than 5 mm. Famils XXXTin. Throseme. 1\% 7T:?.

ff. Front coxie transrerse.

h. Onfchium (pad between the tarsal claws) large and hairs: antenne of males usually flabellate; length 11 or more mm. Family XXXTI. RHIPICERId.e, p. 69\%.

7h. Onschium small or wanting.

i. Head constricted behind: eses smooth: flanks of thorax (in our species) excarated for the reception of the front legs; body corered with small scales.

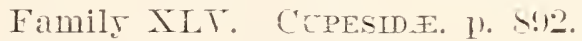

ii. Iear not constricted behind; eres granulated.

j. Fpimera of mesothorax reaching the middle coxie: bods corerings rather soft and flimss; form usually oral or hemispherical, conrex: length less than

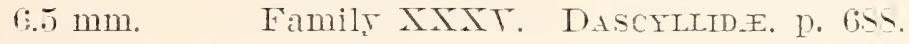

ji. Epimera of mesothorax not reaching the coxie; prosternum rery short: thorax usually extending as a form of hood abore the head. the latter bent under and rarels risible from above; length less than $7 \mathrm{~mm}$. Famile Xliil. Ptixid.玉. p. S6j2.

ee. Hind coxal plates not groored.

i. Hind coræ flat.

1. Prosternum not prolonged behind: tarsal joints $1-4$ with membranous lobes beneath, the first joint often indistinct. Family XIII. Cleride. p. $\varsigma_{44}$.

17. Prosternum prolonged behind.

m. Front coxal carities entirels surrounded by the prosternum: hind coxie without plates: trochanters of middle and hind legs rers long.

Subfamily (XXXTI), Cerophytines. p. Tis.

mm. Frent coxal carities partly formed by the mesosternum: autemne witheut club: length less than $4.5 \mathrm{~mm}$.

Genus rXXTTII). Drapetes. p. itt.

lik. Hind coxæ prominent.

n. Front corre conical. prominent. Without trochantin; tarsi slender; form elongate. narror: length $10 \mathrm{or}^{\mathrm{r}}$ more mm. (onls $2.2 \mathrm{~mm}$. in Hicromathus).

Famils ILVI. Tranexiloxide. 1). S!). 
nn. Front coxie long with distinct trochantin; body and elytra softel than usual. flexible, the parts not well coadapted; thorax usually with a broad, thin margin.

o. Tisible rentral segments seren or eight, some of them often with light-giring power; fourth joint of tarsi more or less bilobed.

Family Xl. Lampromide, p. SOT. 6o. Visible rentral segments fire or six, none with lightgiving power: fourth joint of tarsi entire; elstra more or less truncate and ridest near their tips; length less than if 1 mon. Family XLI. Malachimde. p. 839.

\section{Family XXXY. DASCYLLIDE.}

\section{The Soft-bonied Pinint Beetres.}

A family of small size. composed, for the most part. of small. hemispherical or oval, subconvex species of rather soft texture and dull color. They oceur mostly on plants near water, though some are found on dead timber, a few in running water and others in rotten wood. The name of the trpical genus. Dascyllus, comes from the Greek words meaning "thick" and "shaded." and probably refers to the dusky or piceous hue of many of the species. or perhaps to the shaded places along streams which they inhabit.

The most important characters possessed by the family are the widely separated. 11-jointed, more or less serrate antennie which are inserted beneath a slight ridge immediately in front of the exes; head sometimes prominent but isually deflexed; elytra covering the abdomen. which has five free ventral segments, the fifth rounded at tip; front coxie transverse. either with large trochantin or none at all, the cavities widely open behind; middle coxæ smaller, subtransverse; hind coxa transverse. nearly contiguous. dilated into a plate partly covering the thighs; tarsi 5-jointed, claws simple or pectinate.

The principal literature treating of the North American species is as follows :

LeConte.- "Synopsis of the Atopidæ and Cyphonidx of the United States." in Proc. Phil. Acar. Nat. Sci.. VI. 1853. $350-357$.

Horn.- "Synopsis of the Dascyllidæ of the United States," in

Trans. Amer. Ent. Soc.. VIII, 1880, 76-114.

Only about 400 species of the family are known. 50 of which are listed from the Inited States. These are distributed between two subfamilies. 
KEY TO SÜBFAMILIES OF DASCYLLIDE.

a. Front coxie with large and distinct trochantin; covering of body usually firm.

Subfamily I. Dascrldixe, p. 6:59. a a. Front coxie without trochantin; covering of body usually soft and thin. Subfamily II. Helodice, 1). 690 .

\section{Subfamily I. DASCYLLINAE.}

In addition to the distinct trochantin. the mandibles are more prominent than in the Helodina: tibiæ never bicarinate on outer side and bearing smaller spurs. The following' genera are perhans represented in the State:

KEY TO IXDIANA GENERA OF DASCYLLIXE.

a. Hind coxie narrowly separated; lower face prolonged, concealing the mandibles and most of the labrum.

b. Antennæe slender, elongate, joints 2-3-4 rery short, subequal, together not longer than fifth.

MACROPOGON.

67. Antennie subserrate. joints 2 and 3 only short, together equal to fourth.

I. Eurypogox.

au. Hind coxre contiguous: lower face short. labrum and mandibles risible.

c. Claws pectinate; thorax acutely margined.

Odoxtonix.

ce. Claws simple; thorax not acutely margined; middle coxæ not more widels separated than the front ones.

Axchytarses.

Macropogon rufipes Horn, oblong. piceous. legs and antennæ reddish-brown. length $5.5 \mathrm{~mm}$., is recorded from Illinois.

\section{Eurrpogox Motsch. 1859. (Gr.. "wide $\div$ beard.")}

Head free. slightly deflexed and received in the thorax as far as the eres; antennæ stender. more than half the length of body. joints 4-11 slender. subequal; prosternum prolonged. meeting the mesosternum. carinate on each side. Two species are known. one of which occurs from Pennsylrania to Kansas. including Indiana.

1309 (3974). Ecrypogon niger Melsh.. Proc. Phil. Acad. Nat. Sci., II, 1St4, 309.

Oblong, convex. Black. shining. sparsely pubescent. Thorax one-half broader than long. slightly broader at base. sides straight. surface sparsely and coarsely punctate. Elytra oblong. parallel. slightly wider than thorax. with rows of coarse. closely placed punctures; intervals much narrower than the strix, each with a row of vers fine punctures. Length $44.5 \mathrm{~mm}$.

Marshall. Tigo. Orange. Floỵd and Posey counties : rare. May 30-June 23. Beaten from leaves of hickory and oak.

Odontonyx trivittis Germ.. oblong-oval. piceous. thorax reddishrellow with two large black spots. length $8-9 \mathrm{~mm}$. occurs in the Middle States. 
Anchytarsus bicolor Melsh.. oblong-oval. piceous. femora paler, length 5-6 mm.. ranges from New York to Georgia.

\section{Subfamily II. HELODINAE.}

Species less than $6 \mathrm{~mm}$. in length. occurring on plants near water. The following genera are probably represented in the State :

KET TO IXDIANA GEXERA OF HELODIX.E.

a. Tarsi with the fourth joint rers small, the third lobed beneath; form more elongate; antennal joints of male with an articulated appendage.

II. Ptilodactila.

a a. Tarsi with the fourth joint as large or larger than the third; form usually oral or hemispherical.

b. Hind coxie rer's large; form elongate-oral.

III. Etcinetus.

bъ. Hind coxie at most dilated on the inner side.

c. Front narrotred by the insertion of the antennx; prosternum distinct before and betreen the front coxie.

d. Tarsi slender,: fourth joint smaller than third and not prolonged beneath the fifth.

IV. ECTOPRIA.

dd. Tarsi slightly dilated, joints 2-3-4 feebly emarginate, the fourth slightls prolonged beneath the fifth.

DicRaxopselaphts.

cc. Front moderatels broad; prosternum rers short before and rery narror betreen the coxie.

$e$. Third joint of labial palpi arising from the side of the second.

$f$. Hind femora normal; tibial spurs moderate; hind tarsi flat above and bicarinate: color usually rariegated.

g. First joint of antennxe expanded. V. Prioxocrphox.

$g g$. First joint of antennie not expanded.

h. Hind tarsi conrex above. liot carinate, third joint normalls risible: color brownish-rellor.

MIICROCARA.

$h \hbar$. Hind tarsi flat and bicarinate abore, third joint in great part concealed by the prolonged upper edge of the second joint.

VI. Helodes.

$f f$. Hind femora broad, fitted for jumping; spurs of hind tibire long: color usually dull, uniform.

TII. SCIRTES.

ee. Third joint of labial palpi arising from the end of the second ; tarsi convex abore. not carinate; color usually duli.

riII. Crphor.

II. Ptilodactrla Latr. 1829. (Gr.. "wing +toed.")

Head deflexed and partially concealed from above by the thorax: antenne of female simple. those of male with joints $t$ to 10 each furnished with a slender. articulated crindrical appendage arising from the base and as long as the joint itself: prostermum narrowly 
prolonged between the front coxac tarsal claws with a broad, rectangular tooth at base.

1310 (39S6). Ptrlodactyla serricollis Say, Journ. Phil. Acad. Nat. Sci., III, 1823, 186; ibid. II, 119.

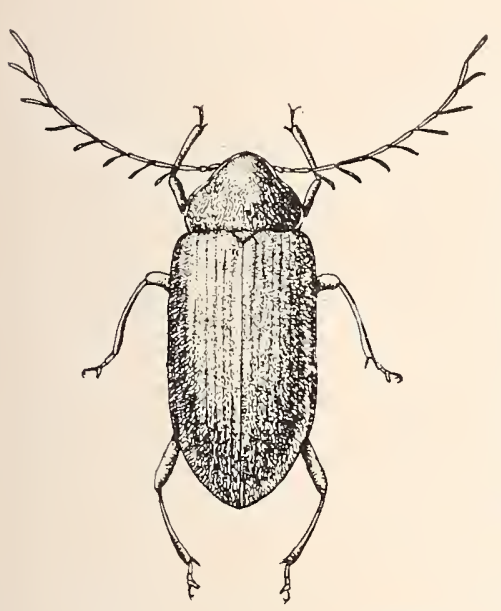

Fig. 266. Male. $\times 5$. (Original.)

Oblong-oval. Chestnut brown to piceous. moderately shining, sparsely pubescent; legs and antennie pale. Thorax viewed from above, nearly semicircular, apex slightly prolonged over head, lateral margin acute; basal margin with three small teeth opposite scutellum; surface coarsely and rather densely punctured. Elytra not wider than thorax, with strix of rather coarse punctures; intervals sparsely punctulate, scutellar stria long. Tooth of tarsal claw basal, not reaching the middle of claw. Length 4-6 mm. (Fig. 266.)

Throughout the State, frequent in the northern counties; less so in the southern portion. May 29-July 5. Beaten from vegetation about the border's of lakes and marshes.

\section{Eucinĕtus Germ. 1818. (Gr.," "well + moving.")}

Head strongly deflexed, resting on the front coxæ, the front prolonged in a feeble beak; thorax short, narrowed in front; prosternum very short in front of the coxæ. which are long and conical; hind coxæ formed of broad oblique plates which reach the side margin of the body and cover the greater part of the first ventral segment; tarsal claws small, simple. The following species may occur within the State:

\section{KEY TO INDIANA SPECIES OF EUCINETLS.}

a. Elytra punctured; hind tibix with two spurs.

b. Punctures rather coarse; body orate, convex.

c. Elytra substriate near the tip; color piceous.

OVIFORMIS.

cc. Elytra without strix except the sutural; color dull brownish-yellow.

TESTACEL'S.

bb. Punctures dense and rather fine; elytra with sutural stria only: brownish or piceous.

PUNCTULATUS.

aa. Elytra not punctate but with fine transverse wrinkles or strigie.

d. Hind tibia with two spurs; nearly black.

1311. MORIO.

dd. Hind tibix with one long spur.

e. Tips of elytra reddish; strigie very close.

1312. TERMINALIS.

$e e$. Tips not reddish; strigæ much farther apart, surface more shining. 
E. oriformis Lec.. length $4 \mathrm{~mm}$. is known from Illinois and Ohio: E. testaceus Lec., more slender, length $3.5 \mathrm{~mm}$., is said to occur from Canada to Pennsylrania: E. punctulatus Lec., length 2.5 mm. is recorded from Michigan and Tirginia.

1311 (3992). Eucinetus yorio Lec. Proc. Phil. Acad. Nat. Sci., VI, 1553. $35 \%$

Elongate-oral. narrower behind, conver. Blackish-piceous, sparselr pubescent; head and thorax with a reddish tinge. Thorax wider than long. the sides strongly sloping dommard. disk finely and sparsely punctulate. Elytra distinctly substriate. their surface densely transrersely strigose. Sixth segment, of abdomen risible in female, a small serenth segment in male. Length $2.5-3 \mathrm{~mm}$.

Kosciusko and Knox counties: searce. Mar 1-June 25. Taken from beneath bark and in a hasd. wood r. rellowish fungus on oak stumps. Narrower than teminalis and more acutely attenuate behind.

1312 (3993). Etchetes terminalis Lec.. Proc. Phil. Acad. Nat. Sci.. TI, 1553. 357 (no name): List Col. X. Amer.. 1565. 50.

Form and sculpture of morio. Piceous or black. finely pubescent: elstra with a well defined rufous spot at tip: antemne and legs pale. Head and thorax finely and sparsely punctate. Length $2.5-3 \mathrm{~mm}$.

Lake and Marion counties : rare. April 10-Mar 2s. One specimen was taken from beneath a log close to a dead shrew. It leaped like a flea very rapidly sereral times in succession, then buried itself in the dirt.

E. strigosus Lec.. black. legs and antenna reddish-brown, length $2.5 \mathrm{~mm}$., is recorded from Ohio.

\section{Fotopria Lec. 1553. (Gr., "'outside--to make a harsh sound."}

Head small. nearly rertical. receired in the thoras as far as the eyes. which are partly concealed: antenne half the length of bodr. distinctly serrate in the male: tarsal claws with a broad basal tooth in both sexes. those of male bifid at tip. One species is known from the easterin Lnited States and Indiana.

1313 (3995). Ectopria rertosa Melsh., Proc. Phil. Acad. Nat. Sci.. II. 15.4. 222.

Oral. broadest behind the middle, moderately conrex, sparselr pubescent. Color rariable. usualls piceous: thoras often with pale lateral margins; elytra of female often paler than thorax and with three dark lines which unite before the apex. Thorax twice as wide as long. much narrowed in front; aper truncate, haif as wide as base, hind angles subacute; 
surface finely and sparsely punctate. Elytra not wider at base than thorax, gradually broader to apical third, surface sparsely punctate. Length 3-5 $111 \mathrm{~m}$.

Vigo County; rare. June 19. Beaten from foliage in low ground.

Dicranopselaphus variegatus Horn, broadly oval. brownish, thorax darker, elytra clonded, length $3 \mathrm{~mm}$., is recorded from Illinois.

\section{Prionocypion Rect. 1858. (Gr., "a saw + bent.")}

Head deflexed; antenna slender, longer than half the body. Prosternum very short in front of coxre, prolonged in a slender plate between them; hind coxæ sudrenly dilated into an oval plate on inner side; tarsal claws simple.

1314 (3998). Prionocyphon discombeus Say. Jouln. Phil. Acad. Nat. Sci., V. 1825, 161 ; ibid. II, 272.

Oral, slightly oblong, moderately convex. Iellow; elytra with a large discal black spot of variable size, sometimes covering three-fourths of the surface. Antennæe yellow, those of the males bipectinate, joints 4 to 10 , each being furnished with a cylindrical appendage on each side at base, this longer than the joint itself (Fig. 3, No. 3). Thorax short, transverse, very little narrowed in front, base bisinuate, surface sparsely punctulate. Elytra coarsely and rather densely punctate. Length $3.5-4.5 \mathrm{~mm}$.

Orange, Ferry and Posey counties; rare. May 12-June 1. Taken by beating foliage, and at electric light.

Microcara explanata Lec., elongate-oval, brownish-yellow. length 5-5.5 mm., is known from Canarla and Michigan.

\section{Helodes Payk. 1798. (Gr.," "marshy.'”)}

Head deflexed, usually concealed from above by the prolonged thorax; antennæ slender, first joint oval, second round, scarcely half the size of first; third minute, fourth as long as the preceding three; 5 to 11 equal, a little shorter than the fourth. Prosternum not prolonged between the coxæ, which are prominent and contiguous; second joint of tarsi with two dentiform projections which nearly conceal the small third joint; claws simple. Two species have been taken in Indiana, while another perhaps occurs.

KEY TO INDIANA SPECIES OF HELODES.

a. Form oval, longer than broad.

b. Elytra yellow with two black spots on each.

1315. PULCHELLA.

60. Elytra entirely black. FUSCIPENNIS. aa. Broadly ovate, nearly as broad as long; elytra entirels black.

1316. THORACICA. 
1315 (4003). Helones pulchelda Guer., Spec. et Icon., III, 1845, 13.

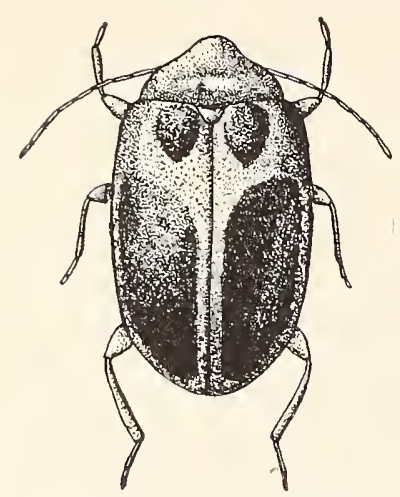

Fig. 267. $\times 7$. (Original.)

Elliptical, finely pubescent. Yellow; elytra each with an oval basal piceous spot, and another much larger, reaching from before the middle to apex. Thorax semicircular, base bisinuate, entire margin slightly reflexed, disk sparsely and finely punctate. Elytra rather densely punctured. Length $3.5-5 \mathrm{~mm}$. (Fig. 267.)

Orange, Posey and Crawford counties; scarce. April 18-. June 1. Wight or ten speeimens were secured on the former date by sifting the rotten debris from the center of an old oak stump.

H. fuscupemis Gurer., yellow, elytra black or piceous, length 4.5$5 \mathrm{~mm}$, ranges from Pennsylvania to Texas.

1316 (4005). Helodes thoracica Guer., loc. cit., p. 14.

Broadly oval, nearly as broad as long. Black, thorax and antenne yellow; body beneath and femora piceous, tibire and tarsi paler. Thorax as in pulchella. Elytra not densely punctured. Last ventral segment of male emarginate. Length $2.5-3.5 \mathrm{~mm}$. (Fig. 26S.)

Marshall and Vign counties; rare. June 10September 28.

\section{ScIRTES Illig. 1807. (Gr., "'a dancer.")}

Tread deflexed; antennx slender, half as long as

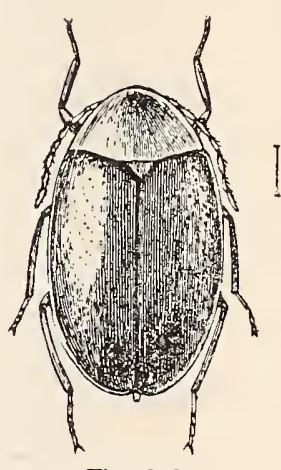

Fig. 268 . body; prosternum short, not prolonged between the coxæ, which are prominent and contiguous; hind coxæ suddenly dilated on inner side into a small plate; hind femora oval, very much enlarged, the tibiæ with one long and a shorter spur; tarsi with fourth joint bilobed, the first joint of the hind ones as long as the other joints combined.

1317 (4006). Scirtes orbiculatus Fab., Syst. Eleut., I, 1S01, 503.

Broadly oval, sparsely pubescent. Black or piceous, shining; elytra with an oblong-oval reddish-yellow spot on middle of suture; thorax with sides usually broadly reddish-yellow; femora piceous, tibiæ, tarsi and antennæ paler. Head and thorax sparsely, elytra more densely and coarsely punctate. Length $2.5-3 \mathrm{~mm}$.

Steuben County; rare. Beaten from plants near margin of water in Clear Take. June 17.

1318 (4007). Scirtes tibialis Guer., Spec. et Icon., III, 1845, 3.

Broadiy oval. Uniform piceous or nearly black, moderately shining. sparsely pubescent; antennse, tibiæe and tarsi paler. Head and thorax nearly smooth. Elytra rather densely punctulate. Length $3-3.5 \mathrm{~mm}$.

Common on vegetation about the borders of lakes and marshes in 
the northern half of the State; taken only in Knox County in the southern portion. June 3-August 31.

\section{Cyphon Payk. 1798. (Gr., "bent or sloping.')}

The species of this genus are distinguished from those of Helodes only by having the third joint of the labial palpi arising from the end instead of the side of the second. Five species are known from the State.

\section{KEY TO INDIANA SPECIES OF CYPHON.}

a. Joints 2 and 3 of antenne short, their united length less than that of the fourth.

b. Form oblong, subparallel; thorax reddish-yellow, with the center of disk piceous.

1319. RUFICOLLIS.

bb. Form oval, moderately robust; thorax and elytra uniform piceous.

1320. OBSCURUS.

aa. Joints two and three of antenne together always longer than the fourth, the third a little longer and more slender than the second.

c. Bicolored, thorax reddish-yellow; elytra piceous or black; sides of thorax flattened.

1321. COLLARIS.

cc. Thorax and elytra of the same color, the sides of the former not or very feebly flattened.

d. Thorax more densely punctured at the sides than middle; color usually pale brown.

1322. VARIABILIS.

$d d$. Thorax not more densely punctured at the sides; color piceous, the tips of elytra yellow.

1323. PADI.

1319 (4010). Cyphon ruficollis Say, Jourm. Phil. Acad. Nat. Sci., V, 1825, 162 ; ibid. II, 273.

Oblong-oval. Piceous, finely pubescent; thorax reddish with a piceous spot on disk, rarely wholly piceous or wholly yellow; three basal joints of antennæe pale; the second and third short, together scarcely longer than half the fourth, the third much shorter than second. Thorax nearly three times as wide as long, slightly narrowed in front, base bisinuate; surface sparsely punctate, more coarsely near the sides. Eiytra slightly wider than thorax, coarsely and rather densely punctured. Length 3.5-4 mm.

Throughout the State; frequent. April 4-July 6. Taken by beating leaves of shrubs and trees.

1320 (4014). Crphon obscurus Guer., Spec, et Icon., III, 1845. 4.

Ovate, moderately convex, sparsely pubescent. Black or piceous, shining. Antennæ, tibiæ and tarsi usually entirely pale, the former sometimes with terminal joints darker. Thorax nearly three times as wide as long. front angles distinct, side margins gradually sloping downward: surface sparsely punctate. Elytra vaguely tricostate, not very densely punctate. Length 3-3.5 $\mathrm{mm}$.

Steuben, Kosciusko and Wayne counties; scarce. May 25-August 21. Swept from grass in low ground. 
1321 (4015). Crphox collaris Guer., spec. et Icon., III, 1S45. 4.

Oblong-oral. Piceous black, shining, finels pubescent:

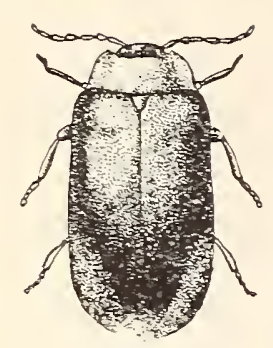

Fig. 269. $\times 6$. (Origina!.) thorax, tibire, tarsi and base of antennæ reddish-rellow. Thorax nearly three times as wide as long, front angles rounded, sides distinctly flattened. especially torards the hind angles, which are rectangular; surface sparsely and finely punctate. Elytra one-third wider than thorax. surface rather coarsely and moderately densels punctate. Females with a large oral flattened or slightly depressed space behind the scutellum. Thich is rery feebly punctured. Length $3.5-4 \mathrm{~mm}$. (Fig. 269.)

Steuben. Marshall and Orange counties: scarce. June 2-July 6. Taken by sweeping herbage at edges of woods and br beating limbs of tamarack. Resembles ruficollis closely. but with basal joints of antennæ longer and never with central black spot on thorax.

1322 (4016). CrPhon Valiabius Thunb. Mus. Cps., IT. 54.

Oral, slightly oblong, moderately conrex, pubescent. Color uniform but variable from piceous to pale brown or dull yellow. Antemne slightly longer than half the body, the outer joints darkel. Thorax twice as wide as long. margin not flattened. Elytra a little wider than thorax. about a third longer than wide, surface rather finely and densely punctured. Length 2.5-3.5 $\mathrm{mm}$.

Throughout the State; common in the northern half: much less so in the southern portion. April 8-September 19.

1323 (4017). C'Phox Padi Linn.. Syst. Nat., II, 1766. 585.

Orate. moderately convex. finely pubescent. Piceous or black: elytra with the tip yellow. the spot sometimes well defined, often extending forward in an irregular stripe; antennse piceous. the basal joints pale: femora piceous, tibire pale. Thorax more than twice as wide as long, slightly narrowed in front. surface evertwhere very finely and sparselr punctulate. Elytra wider than the thorax at base, rather densely punctate, vers sparsely pubescent. Length $2 \mathrm{~mm}$.

Lake. Steuben. Knox and Tanderburgh counties; scarce. Мay 25-August 12. Known by its small size. nearly smooth thorax and rellow tips of elytra. Those from the nor thern counties were beaten from the fiowers of the tall swamp huckleberry.

\section{Family XXIVI. RHIPICERID E.}

\section{The Cedar Beetles.}

This is a family comprising only two genera and fire species, all of medium or large size. elcngate form and black or chestnut-brown in color. They are found on plants, the species of Sandalus especially on cedars. The name of the typical genus Rhipicera is derived from tro Greek words meaning "a fan" and "horn." the antenni of certain males having long, flat processes, which fold like a fan. 
The members of the family are mainly characterized by having the antennx 11-jointed, inserted before and on the inner side of the eyes, serrate in the females and with fan-like processes (flabelkate) in the males of Sandalus; elytra covering the abdomen, which has five free ventra! segments; front and middle coxæ conical, prominent, the former with large trochantins; hind coxa transverse, dilated into a small plate partly covering the thighs; tarsi 5-jointed. claws simple, each pair with a long. hairy pad or cushion (ony(chium) between them.

The only literature dealing with the North American species is as follows:

Haldeman._"Observations on the Genus Sandalus," in Proc. Phil. Acad. Nat. Sci., VI, 1853, 362.

Horn.- "Notes on Rhipiceridae" in Trans. Amer. Entom. Soc., IX. 1881, 85-86.

\section{KEY TO GENERA OF RHIPICERIDA.}

a. Joints of tarsi not lobed: antenna moderately long, serrate in both sexes.

I. ZENOA. a . Joints of tarsi lobed: antenne short. serrate in the female, flabellate in the males.

II. SANDALUS.

\section{Zenoa Say. 1835. (Gr.." "a stoic.")}

In addition to the characters above mentioned this genus may be known from Sandalus by having the mandibles much smaller. emarginate or bifid at tip; the side pieces of metathorax much narrower. the epimera not visible. One species occurs in the eastern United States.

1324 (4020). Zexod picea Beaur. Ins. Africa and America. 1805, 7.

Elongate-oblong. Uniform dark reddish-or blackishbrown. Antennæe reaching to or slightly bejond the base of thorax, the joints wide, serrate on the inner side. Thorax one-third wider than long. front and hind angles prominent; disk with a small rounded impression on each side of the middle and another much larger irregular one at base; surface finely and erenls punctate. Elytra each with four raised lines, the first uniting with the second on apical third, the others uniting near apex; intervals between the lines marked with large, more or less confluent punctures; a short, oblique raised line on each side of scutellum. Length 11-15 mm. (Fig. 270.)

Vigo, Putnam and Poser counties; scarce. May 2-August 3. Occurs beneath logs and bark in dre Fig. 270. (After Horn.) upland roods. 
II. Sandalus Knoch. 1801. (Gr.," slipper or sandal.")

Mandibles large, stout, prominent and toothed on the inner side near base; antenna but little longer than head; metasternum short, with wide side pieces and large epimera. Four species are known, two from Indiana.

KEY TO INDIANA SPECIES OF SANDALUS.

a. Thorax obtusely subangulate behind the middle; elytra but little wider than thorax.

1325. PETROPHYUS.

aa. Thorax regularly conical; elytra distinctly wider than thorax.

1326. NIGER.

1325 (4021). Sandalus Petrophyus Knoch., Nene Beytr., 1801, 131.
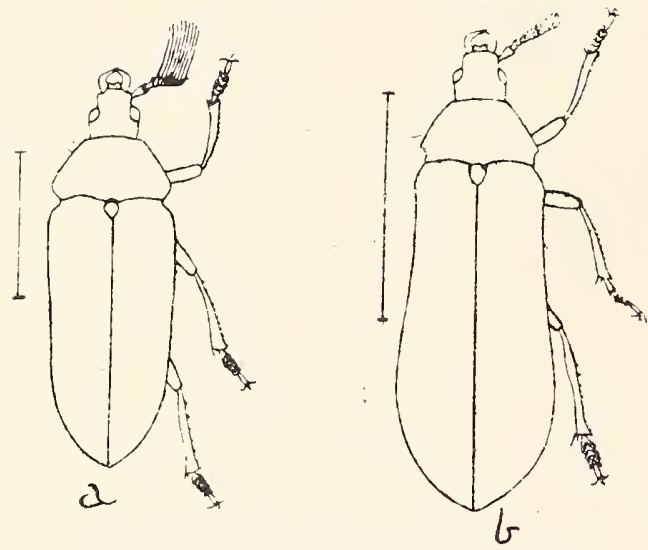

Fig. 271. $a$, male; $b$, female. (After Horn.)

Elongate, subconvex. Dark chestnut brown to black. Thorax about twice as wide as long; sides with distinct, rather sharp edges, subangulate on basal third; surface densely punctate with fine and numerous coarse punctures intermingled; median dorsal line fine, slightly impressed. Elytra each with three faint costre or raised lines; intervals very coarsely and reticulately punctured. II a le one-third or more smaller than female and with the elytra narrowing, instead of slightly widened behind the middle, as in the latter sex. Length $12-17 \mathrm{~mm}$. (Fig. 271.)

Marion and Putnam counties; rare. May 31-August 2. Occurs beneath bark or on trunks of trees near clumps of red cedars. Ranges from Pennsylvania to Tllinois.

1326 (4023). SANDalus Niger Knoch., 7oc. cit., p. 140.

Elongate, convex. Black, somewhat shining. Thorax conical, much narrowed in front; base bisinuate, sides rounded without distinct edges; median dorsal line distinct; disk with a basal and two lateral impressions, finely and densely punctulate with very few coarser punctures intermingled. Flytra nearly twice as wide as thorax, the costa very faint or obsolete; punctured as in petrophyus. Length $21-24 \mathrm{~mm}$.

Marion,. Putnam and Pusey counties; scarce. Occurs on cedar or beneath cover in their vicinity; also on the lower trunks or about the roots of ash trees in late summer. Jaly 14-October 1. 


\section{Family XXXVII. ELATERID AE.}

Click Beetles. Spring Beetles. Snapping Bugs. Skrpjacks.

Every country boy in Indiana has found beneath the bark of logs or stumps either a big grayish-black beetle an inch or more in length, or smaller, slender brown ones. which feign death when first picked up, but, when placed on their backs, after a few seconds give a click, and spring several inches into the air, turn over in their descent, alight on their feet and crawl rapidly away. These beetles are typical representatives of the great family Elateridx. This power of springing into the air when placed on the back is effected by bending back the head and thorax, thus bringing the prosternal spine to and slightly above the front edge of a cavity in the mesosternum (Fig. 272,e), and at the same time raising the base of elytra slightly above the surface upon which the beetle is resting; then by suddenly relaxing the muscles the spine descends with force into the cavity, causing the base of elytra to strike violently against the supporting surface, and by their elasticity the whole body is propelled upwards. To bring about the motion in the manner indicated there must be a loose articulation, so as to give free movement between the pro- and mesosternum, and this character is a prominent one in the majority of the genera of Elateridxe. The hind angles of the thorax are prolonged backward into a point so as to embrace the base of the elytra, and as the bases of the thorax and elytra slope downwards toward each other, a slight separation between them is sufficient to permit the freedom of motion necessary to the upward movement.

The great majority of Elateridx are small or medium in size; elongate in form, tapering more or less toward each end; dull brown or blackish in color and have the surface clothed with a fine pubescence. They occur beneath bark, logs and stones, or on the foliage of various plants, most commonly in dry upland localities. The word "Elater" means literally a "driver or hurler," and refers to the elastic power of motion possessed by these beetles.

The principal distinguishing characters of the family are the 11-jointed, more or less serrate (rarely flabellate or pectinate) antenna,

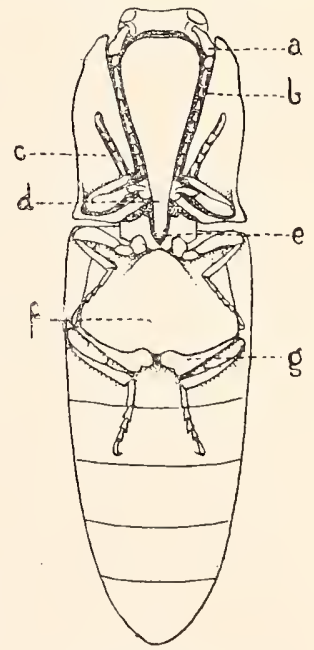

Fig. 272.

$a$, antenna in repose; $b$, antennal groove: $c$, tarsal groove; $d$, prosternal spine; $e$, mesostemal carity; $f$, metasternum; $g$, hind coxal plates. (Original.) 
which are inserted in groores on. or under the margin of the front; the frequently retracted. sometimes advanced head; elytra covering the abdomen, which has five free ventral segments; prosternum long. usually lobed in front. prolonged behind into an acute spine moving in the mesosternum. the latter short, with a cavity in the middle for the reception of the prosternal spine (Fig. 272, $d$ and e); front coxæ small rounded. without trochantins, the cavities open behind; middle coxæ small. rounded with distinct trochantins; hind coxæ transverse. oblique, contiguous, dilated (except rarely) into a plate covering in part or entirely the thighs (Fig. 272, g): tarsi 5-jointed, simple or lobed beneath; claws simple, toothed or pectinated.

All the species of Elateridæ are vegetable feeders. and are hence to be classed as injurious, though many of them feed upon the juices of rotten wood. The larve are long. narrow, worm-like crea-

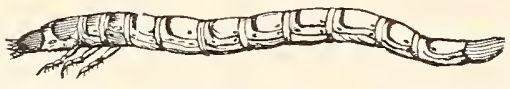

Fig. 273. (After Forbes.) tures. very even in width and with a hard, brownish or yellowish-white body covering. (Fig. 273.) They are commonly known as "wire-worms," and those species which live in the ground feed upon seeds and the roots of grasses and grain. and often do much damage, especially to sprouting corn and other cereal crops. Working as they do beneath the surface of the ground, they are exceedingly difficult to destroy. In many of the more injurious species the larva requires several years to complete its growth, and when full grown usually changes in late summer into a pupa in a little cell in the ground. Either the pupa or adult beetle remains in this cell until spring, and it has been found that much can be done towards keeping them in check by fall plowing. which breaks up these cells and exposes the pupæ or young adults to the rigors of winter.

About 7.000 species of Elateridx are known, more than 560 being listed from the United States.

On account of the large size of the family and the strong general resemblance of many of the species, their classification is very difficult, especially to beginners. The genera belonging to the principal subfamily, the Elaterinæ, have, for the most part. been treated in special synopses or monographs, which will be mentioned under the proper generic headings. The principal works dealing with the family or the other subfamilies of the North American forms are as follows :

LeConte.--"Synopsis of the Eucnemides of Temperate North America," in Proc. Phil. Acad. Nat. Sci., VI, 1852, 45-49. 
LeConte._ "Revision of the Elateridxe of the United States," in Trans. Amer. Philos. Soc., X, 1853, 405-508.

Horn._"A Monograph of the Species of the Subfamilies Eucneminx, Cerophytinx and Perothopinx inhabiting the United States,' in 'Trans. Amer. Entom. Soc., XIII, 1886, 5-58.

For convenience the family is first divided into subfamilies, and these, in turn, into tribes and genera. Of the five subfamilies recognized, representatives of three have been taken in Indiana. while those of a fourth perhaps occur.

\section{KEY TO INDIANA SUBFAMILIES OF ELATERIDA.}

a. Hind coxie dilated into plates which cover in part or entirely the thighs; trochanter's of middle and hind légs very small.

b. Labrum concealed; antennie somewhat distant from the eyes, their insertion narrowing the front.

Subfamily I. EUCNEMINA, p. 701.

b6. Labrum visible.

c. Labrum free; antennie arising near the eyes nnder the frontal margiil.

Subfamily II. Elaterind, 1). T13.

cc. Labrum transverse, connate with the frout; ventral segments five; claws serrate.

Subfamily III. I'ERothopin.e, p. 772.

a . Hind coxie not dilated into plates; trochanter's of middle and hind legs very long; labrum short, transverse, connate with the clypeus; tarsal claws serrate.

Subfamily IV. Cerophitine, P. 773.

\section{Subfamily I. EUCNEMINAE.}

Head convex, deflexed, and resting against the sternum in repose; labrum absent or very slightly visible; antennx inserted upon the front at the inner extremity of transverse grooves; prosternum movable, but less so than in the Elaterina, without a lobe in front. The majority of the species are rare, and the larva have a striking resemblance to those of the family Buprestidx, both in form and habits, being abruptly enlarged in front, and usually occurring in wood which has just begun to decay. Representatives of twelve of the 22 genera are known from Indiana, while those of four others perhaps occur.

KEY TO INDIANA GENERA OF EUCNEMINA.

a. Last joint of maxillary palpi acute; prosternal sutures and side margin parallel; bases of antenne moderately distant.

b. Tibia broad, compressed; length (i-S mm.

bъ. Tibiæe slender; length 4- $\mathbf{\tau}$ mm.

I. Melasis.

II. Tharops.

ua. Last joint of maxillary palpi dilated; prosternal sutures and margin converging; bases of antennæ close together. 
c. Under side of thorax with antennal grooves usually sharply limited, and close to the lateral margin.

d. Prosternal sutures strongly curved; length 6-9 mm.

III. STEThoN.

dd. Prosternal sutures straight.

$e$. Antennal grooves continuing directly from the thorax to the head.

f. Metasternum with a fine groove, limited by finely elevated lines, prolonged backnard from the outer side of the middle coxr; length $6 \mathrm{~mm}$.

EUCNEMIS.

ff. Metasternum without groore.

g. Antennal grooves of thorax wide, usually wider behind; length 3-5 $\mathrm{mm}$.

IV. Deltometopes.

gg. Antennal grooves narrow, not wider behind; length 5.5$8.5 \mathrm{~mm}$.

V. Dromæolus.

ec. Antennal groores more or less interrupted by the eyes; antennie slender; fourth joint of tarsi emarginate and slightly lobed beneath; length $7-17 \mathrm{~mm}$.

VI. Fornax.

cc. Under side of thorax without marginal antennal groores.

h. Antennal grooves present on under side of thorax close to suture; side margin of thorax formed by two finely elevated lines, the one starting from the front margin and prolonged backward. the other from the hind angles becoming inferior.

i. Antennal groores near the suture rery short, merely slightly indicated in front; length $3.5-4 \mathrm{~mm}$.

ADELOTHYREUS.

ii. Antennal groores near the suture entire; length $3-6 \mathrm{~mm}$.

$j$. Second joint of antennie alone small.

VII. Microrhagus.

$j j$. Joints two and three of antennx small, moniliform.

ENTomophthaLMUS.

$h \hbar$. Under side of thorax without antennal grooves; side margin of thorax single or sometimes nearly obsolete.

7. Hind coxal plates either parallel or wider on the outer side.

1. Antennæe slender, filiform. the third joint much longer than second; length \&-9 $\mathrm{mm}$.

VIII. HrLochares.

71. Antennæ biserrate in the female, bipectinate in male; length $6.5 \mathrm{~mm}$.

SARPEDON.

$k \%$. Hind coxal plates narrower on the outer side.

$m$. Mandibles stout, rugose.

n. Last rentral segment prolonged in a point; length 6-9 $\mathrm{mm}$.

IX. Nencatodes.

$n n$. Last rentral segment obtuse at tip; length $4-5.5 \mathrm{~mm}$.

$\mathrm{X}$. Hrpocelus.

$\mathrm{mm}$. Mandibles slender, not rugose; side margins of thorax distinct.

o. Clypeus very deeply sinuate each side, so as to appear trilobed; length $8 \mathrm{~mm}$.

XI. SChIzophiLds.

on. Clypeus regularly curved in front; coxal plates gradually broader on inner side; last three joints of antennæ abruptly longer; length $9.5-11 \mathrm{~mm}$.

Xit. Phlegon. 


\section{Melasis Oliv. 1790. (Gr., "black.")}

Elongate, crlindrical beetles haring the antenne distinctly pectinate in male. feebly so in female: prosternal sutures distant and parallel; no antemnal groores on under side of thorax; hind coxal plates very broad on inner side. narrow externally: last rentral segment prolonged. with a slight elevation before the apex. One of the two known species occurs in Indiana.

1327 (4025). Melasis Pectiniconnis Melsh., Proc. Phil. Acad. Nat. Sci., II, 1S44. 14S.

Elongate, subcrlindrical. Piceons or black. opaque: sparsely clothed with rery short grayish pubescence: antenne reduish-brown. barely reaching middle of thorax. Thorax broader than long. slightly narrowed behind: sides rather deeplr sinuate in front of hind angles, which are acute and divergent. male; or faintly sinuate. the angles not dirergent. female; disk with a distinct median impressed line. coarsely punctured and with elevated sranules. Elstra slightly narrowing behind the middle. the tips acute: surface with rather deep. punctured strixe: intervals slightly conrex. granulate and rugose. Length $6-8 \mathrm{~mm}$.

Poser County scarce. April 9-April 15. Emerging from bark of standing beech on the former date: beneath bark of soft maple on latter. Occurs from Pennsylrania to Texas, but usually rare.

\section{Tharops Cast. 1835. (A mrthological name.)}

This genus comprises two small species. one of which was decribed by Say from Indiana.

$132 S$ (4027). Tharops reficorxis Say, Journ. Phil. Acad. Nat. Sci.. III. 1§23. 166 ; ibid. II, 107. 626 .

Subcrlindrical. slender, slightly narrowed behind the middle. Piceous black; elytra usually with an elongate. triangular sutural rellowish space. Antennæ and legs reddish-brown, the former not passing the hind angles of thorax; those of male with joints $t$ to 10 each furnished with a branch as long as the entire antennie. elerenth joint as long as the branch of the tenth. but stouter. Thorax longer than wide, sides nearly parallel. hind angles short; disk moderately convex. rather denseis punctured. Elstra striate, lather densely and roughly punctured. Last rentral segment acute at tip. Length 4-7 mm. (Fig. 274.)

Kosciusko. Lamrence. Dubois and Perry coun- Fig. 2it. Female. $\times 6$. ties: scarce. Mar 12-.June 20. Occurs on beech and soft maple. Say. after describing this species from Arkansas. found other specimens near New Harmony. Posey County. and re$[45-23402]$ 
described it under the name of Eucnemis obliquus. The males are rare, but three of the 21 specimens taken being of that sex.

\section{Sтетном Lec. 1866. (Gr., "breast.")}

Medium-sized cylindrical species, having the head convex, deeply inserted in thorax; antennæ reaching base of elytra, their grooves deep, narrow, marginal, closed behind; last ventral segment more or less prolonged at apex.

1229 (4n29). Stethon pectorosus Lec., Proc. Phil. Acad. Nat. Sci., 1866, 386.

Cylindrical, robust, slightly narrower behind the middle. Uniform brown or piceous, subopaque. Antennæ flattened, first joint stout, as long as the next three; joints 4 to 10 gradually very little shorter. Head coarsely and densely punctured. Thorax slightly longer than wide, sides curred in front, straight and parallel behind the middle, hind angles obtuse; disk strongly convex, densely and rather rugosely punctured. Elytra striate; intervals convex, densely and roughly punctured. Hind tarsi with the first joint as long as the next four. Length 6-9 $\mathrm{mm}$.

Posey and Crawford counties; rare. June 4-July 1. Occurs beneath bark of hickory. Known from Ohio, Illinois and Missouri.

Eucnemis americana Horn, obleng, piceous-black, antennæ and legs brownish, is known from Kentucky and Ohio.

IV. Deztonetopus Bonv. 1871. (Gr., "triangle + forehead.")

Small, slender-bodied, black species, having the elytra gradually narrower to apex and first joint of hind tarsi as long as the next three. One of the two species has been taken in the State, while the other doubtless occurs.

1330 (4030). Deltometopus Amenicornis Say, Trans. Amer. Phil. Soc., VI, 1836, 189; ibid. II, 628.

Elongate, moderately convex. Piceous, feebly shining, sparsely clothed with grayish pubescence; legs and two basal joints of antennæ reddishbrown. Antenne not quite as long as half the body; joints 5-10 pectinate in male, serrate in female, the groove distinctly wider behind the middle. Thorax a little wider than long, narrower in front; sides straight, male, or widest behind the apex with sides in front curved, female; disk convex, rather densely punctate. Elytra striate, intervals slightly convex, rather densely rugosely punctate. Length $3-4.5 \mathrm{~mm}$.

Throughout the State; scarce. June 5-July 25. Beaten from vegetation; more frequently in damp localities.

D. rufipes Melsh., brown or piceous, antennæ longer than half the body, male, filiform in both sexes, length $3.5-5.5 \mathrm{~mm}$., is recorded from Canada and Ohio. 


\section{Drom rolus Kies. 1858. (Gr., "to run.")}

Antennæ filiform or very feebly serrate; head convex, deeply inserted in the thorax; mandibles robust, the exposed surface large and rugose; antennal grooves deep, sharply limited, open behind. One species has been taken in the State, while two others perhaps occur.

\section{KEY TO INDIANA SPECIES OF DROM AOLUS.}

a. Clypeus at base half as broad as the apical margin; body above black.

b. Elytra faintly striate; abdomen rather densely and finely punctured; pubescence conspicuous.

HARRINGTONI.

$b b$. Elytra without strix; abdomen coarsely punctured; pubescence very sparse.

1331. CYLINDRICOLLIS.

aa. Clypeus at base very narrow; color above piceous; antennæ half as long as body; elytra not striate.

PUSILLUS.

D. harringtoni Horn, elongate, length 5.5-6 mm., is recorded from Ohio; D. pusiltus Horn, oblong, length $3.5 \mathrm{~mm}$., was described from northern Illinois and Texas.

1331 (4033). Dromæolus crlindricoluis Say, Trans. Amer. Phil. Soc., VI, 1835, 188; ibid. II, 627.

Elongate, moderately convex, slightly narrower behind the middle. Black, shining, sparsely clothed with inconspicuous yellow hairs. Antenna piceous, subserrate, not extending beyond hind angles of thorax. Head coarsely and deeply punctured. Thorax longer than wide, sides straight and parallel behind the middle, obliquely converging on apical third; median line deeply impressed on basal third; surface rather densely punctate on sides, less so at middle. Elytra without striæ, except the sutural, which extends two-thirds from apex to base; surface rather coarsely but not very densely punctured. Length 7-8.5 mm.

Kosciusko and Posey counties; rare. June 11-August 11.

\section{Fornax Lap. 1835. (L., "a furnace.")}

Beetles of small or medium size, having the head convex, deeply inserted; prosternal sutures distinct, slightly divergent; antennal grooves deep, sharply limited on each side; elytra striate; last ventral segment obtuse; hind tarsi with the first joint as long as the others combined, the fourth broader, excavated above and slightly lobed beneath. Three species have been taken in Indiana, while two others probably occur.

\section{KEY TO INDIANA SPECLES OF FORNAX.}

a. Second joint of antennae as long, or very nearly as long as fourth.

b. Color pale chestnut brown; front without trace of carina between the eyes. 
b7. Color piceous; front with a transverse carina between the eyes.

1332. HORNII'

au. Second joint of antenne small, not half as long as fourth.

c. Size smaller, not over $6 \mathrm{~mm}$; front with a distinct transverse carina between the eyes; color piceous.

1333. CALCEATUS.

cc. Size larger, 10 or more $\mathrm{mm}$. ; carina wanting.

a. Joints 4 to 8 of antennx serrate, the last three more slender and not serrate. MOLESTUS.

dd. Joints 4 to 10 serrate, the last joint alone slender.

1334. ORCHESIDES.

F. badius Melsh., length 8-11 mm., is said to occur from Pennsylvania to Illinois; F. molestus Bonv., dark reddish-brown, length $13 \mathrm{~mm}$., is recorded from Cincinnati.

1332 (4042). Fornax hornit Bonv., Eucn., 1875, 891.

Elongate-oblong, rather robust. Dark chestnut brown to piceous, feebly shining, the thorax usually darker than elytra. Antennæ feebly serrate, a little longer than head and thorax, which are coarsely and densely punctured. Base of clypeus less than a third the width of its apex and less than half the distance to the eyes. Thorax as long as wide, sides parallel on basal half, areuate and narrowing in front of middle. Elytra striate, faintly at middle, more deeply at sides, densely and subrugosely punctate. Hind coxal plates abruptly broader at middle. Length 7-8 mm.

Marion and Posey counties; scarce. May 1-May 18. Occurs in half rotten wood of elm and other logs. Resembles calceatus but more robust, with larger second joint of antennæ and more abruptly dilated hind coxal plates.

1339 (4041). Fornax calceatus Say, Trans. Amer. Phil. Soc., VI, 1836 , $18 S$; ibid. II, 626.

Oblong, moderately convex. Daris brown or piceous. feebly shining, sparsely pubescent with yellow hairs. Antenna nearly half as long as body, slender, the grooves deep and sharply limited. Head and thorax coarsely, deeply and roughly punctured; the latter longer than wide, distinctly narrower in front, sides straight behind the middle. Elytra narrowed at apical third, faintly striate, coarsely and rather densely punctate. Hind coxal plates gradually but rather widely dilated. Length 5-6 mm.

Marion and Posey comnties; scarce. April 16-May 29. Beneath bark of beech and oak.

1334 (4044). Fornax orchesides Newm., Ent. Mag., V, 1838, 384.

Oblong, moderately elongate, slightly narrower behind, convex. Dark reddish-brown to piceous, feebly shining. Antennæ slightly compressed, extending a little beyond the hind angles of thorax. Head and thorax coarsely and densely punctured; the latter as long as wide, sides feebly narrowed behind the middle, obliquely narrowed to the front on apical 
half; median impression distinct on basal third, a small fovea each side of scutellum on basal margin. Elytra distinctly striate, intervals slightly convex, punctuation dense, finer than on the thorax; epipleura flat, roughly punctate. Length 11-16 mm.

Wells County; rare. July 14 . Collected by E. B. Williamson. Our largest species of the subfamily.

Adelothyreus dejeani Bonv., elongate, slender, piceous, was described from Maryland, and has been recorded from near Cincinnati.

\section{Microrhagus Esch. 1836. (Gr., "small + fissure.")}

Small elongate beetles having the body sparsely clothed with short yellowish or brownish pubescence; antennæ at least one half as long as body, second joint small, third nearly as long as the next two, 4 to 10 serrate, sometimes pectinate in the male; antennal grooves entire, located near the middle of under side of thorax. Nine species are known from North America, five of which have been taken in Indiana, while two others perhaps occur. They live on dead timber, where they are to be found running about in the sunshine or resting in crevices during cloudy or stormy weather. The "posterior supplementary carina" mentioned in the key to species is a raised line beginning at the tip of the hind angles of thorax beneath, and extending forward more or less sinuously.

KEY TO INDIANA SPECIES OF MICRORHAGUS.

a. Hind coxal plates parallel, not dilated near the coxa; posterior supplementary carina nearly entire.

b. Prosternum prolonged and acute at tip; outer carina of antemual groove obliterated behind the middle; elytra usually reddish at base.

1335. HUMERALIS.

bb. Prosternum obtuse at tip; outer carina of antennal groove entire; elytra uniform black.

1336. BONVOULOIRI.

a . Hind coxal plates dilated near the coxre, narrow on the outer side.

c. Thorax with a fine raised line beginning on the apical margin near front angles, and extending obliquely backward, but not reaching the middle; antenna of male not pectinate.

a. Posterior supplementary carina very short; outer carina of antenual groove much abbreviated behind; disk of thorax not impressed at middle.

1337. IMIPEREECTUS.

ad. Posterior carina extending at least to the middle of thorax, sometimes longer.

e. Episterna of metathorax rery narrow in front, broader behind. $f$. Thorax without a carina in front of scutellum, the median line impressed on basal half. SUBSINUATUS. 
ff. Thorax with a distinct though fine carina in front of scutellum, without median impressed line, the sides parallel or slightly wider in front.

1338. TRIANGULARIS.

ee. Episterna of metathorax broad and parallel; disk of thorax deeply impressed at middle.

IMPRESSICOLLIS.

cc. Thorax with raised line reaching the middle; antennæ of male pectinate; posterior supplementary carina entirely wanting.

1339. PECTINATUs.

1335 (4049). Microrhagus humeralis Say, Trans. Amer. Phil. Soc., VI, 1836, 189 ; ibid. II, 628.

Cylindrical, moderately robust. Piceous, subopaque; elytra reddish at base; antennæe and legs reddish-brown. Antennæ half as long as body and serrate, male, shorter and not serrate, female. Thorax longer than wide, sides parallel, curved near front angles; hind angles short, carinate; disk with a faint median line, coarsely, densely and roughly punctate. Elytra vaguely striate, intervals slightly convex, surface punctured like thorax. Length 4-6 $\mathrm{mm}$.

Posey County; rare. June 26. Probably throughout the State. The extent of red at base of elytra varies from a narrow space to one third or more. The front and hind margins of the thorax are often reddish.

1336 (10,029). Microrhagus Bonvouloiri Horn, Trans. Amer. Ent. Soc., XIII, 1886, 35.

Moderately elongate, rather slender. Piceous black, moderately shining; antennæ, tibiæ and tarsi reddish-brown. Antennæ more than half the length of body, slightly serrate in the male. Thorax as long as wide, sides parallel, rounded near the front angles, hind angles carinate; surface coarsely, densely and roughly punctured. Elytra vaguely striate, punctures as on thorax but less dense. Length $3-4.5 \mathrm{~mm}$.

Kosciusko County; scarce. July 11. Smaller and more slender than humeralis, and with a longer thorax.

1337 (4051). Microrhagus imperfectus Lec., Proc. Phil. Acad. Nat. Sci., VI, 1852, 48.

Elongate-oblong. Dark reddish-brown or piceous, feebly shining; antennæe and legs reddish-brown, the tarsi paler. Thorax as long as wide, sides parallel behind, curved at apical third; disk coarsely but not densely punctured, with a median impressed line on basal half. Antennal groove deep, the outer carina reaching barely more than one-half from apex to base. Elytra substriate, coarsely and rather closely punctured. Length 5-5.5 $\mathrm{mm}$.

Vigo and Jefferson counties; rare. June T-July 15. One of the two specimens at hand was taken from the leaves of milkweed. Both have a distinct rounded fovea on each side of thorax near the middle. 
M. subsinuatus Lec., piceous or nearly black, posterior supplementary carina very long, length $3.5-5 \mathrm{~mm}$., is recorded from Canada, Ohio and Virginia; M. impressicollis Bonv., reddish-brown, length 5.5-6.5 mm., is a southern species recorded by Dury from near Cincinnati.

1338 (4055). Microrhagus triangularis Say, Journ. Phil. Acad. Nat. Sci., III, 1823, 170 ; ibid. II, 110, 628.

Elongate-oblong, slender, narrower behind the middle. Piceous or black, feebly shining; antennæ and legs brownish. Antennæ feebly serrate, one-half, female, or three-fourths, male, the length of body. Thorax nearly as wide as long, sides straight and parallel, hind angles carinate, disk rather coarsely and densely punctured. Posterior supplementary carina reaching the middle of thorax. Elytra obsoletely striate, closely and roughly punctate. Length $3-4 \mathrm{~mm}$.

Koscuisko, Marion and Posey counties; scarce. May 1-July 11. 1339 (4054). Micrormagus pectinatus Lec., Proc. Phil. Acad. Nat. Sci., $1866,38 \pi$.

Elongate-oblong, slightly narrowed behind the middle. Piceous, moderately shining; legs brownish, tibiæe and tarsi paler. Antennæ two-thirds the length of body and pectinate, male; one-half the length of body, acutely serrate, female. Thorax wider than long, sides parallel, rounded in front, hind angles finely carinate; surface rather coarsely but not densely punctured. Antennal grooves slightly wider behind, the outer carina entire, extending to hind angles of thorax. Elytra as wide at base as thorax, vaguely striate, densely and coarsely punctured. Length $4.5-5 \mathrm{~mm}$.

Marion and Crawford counties; scarce. April 20-May 1. Occurs in partially rotten elm and other logs.

Entomophthalmus rufiolus Lec., pale reddish-brown, antennæ nearly as long as body, second and third joints very small, together shorter than fourth, length $4 \mathrm{~mm}$., is known from Ohio and Illinois.

\section{Hylochares Latr. 1834. (Gr., "forest + rejoice.")}

Small robust species, having the antennæ short, not passing hind angles of thorax, joints $4-10$ equal, as broad as long; clypeus narrowed at base, trilobed in front; hind coxal plates parallel; first joint of hind tarsi as long as the next two, lobed beneath.

1340 (4067). Hylochares nigricornis Say, Journ. Phil. Acad. Nat. Sci., IIT, 1823, 165 ; ibid. II, 107.

Subcylindrical, robust. Black, feebly shining; apical and sometimes basal margins of thorax reddish. Head and thorax coarsely, densely and deeply punctured. Thorax broader than long, sides curved on apical half; disk with a deep and broad median line and an oblique impression near hind angles. Elytra deeply striate, stria coarsely punctured; intervals finely and rugosely punctate. Length 8-9 $\mathrm{mm}$. 
Crawford County; rare. June 5. Taken from decaying beech log. Known heretofore only from Ohio.

Sarpedon scabrosus Bonv., black. apical margin

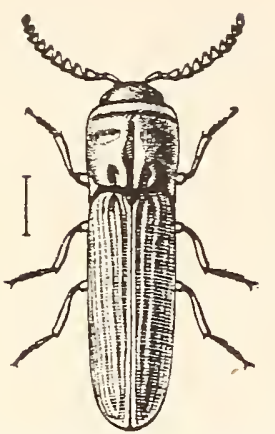

Fig. 275. Sarpedon scabrosus Bonv. (After Horn.) of thorax reddish, length $6.5 \mathrm{~mm}$., is known from Canada, Tennessee and Nebraska. (Fig. 275.)

IX. Neniatodes Latr. 1825. (Gr.." "thread-like.")

Elongate, cylindrical species, having the antennæ filiform; mandibles rather broad and coarsely punctured; prosternal sutures straight; hind coxal plates widely dilated on inner side; fourth joint of tarsi excavate-emarginate and slightly lobed beneath.

KEY TO INDIANA SPECIES OF NEMATODES.

a. Joints 4,5 and 6 of antenne distinctly longer than wide, and rery little shorter than the following joints.

1341. AтROPOS.

aa. Joints 4 and 5 small, not longer than wide, $\tau$ to 11 equal, rather abruptly longer.

7. Sixth joint of antennse not longer than fifth, distinctly shorter than the serenth; size smaller, not over $6 \mathrm{~mm}$.

1342. PENETRATS.

67. Sixth joint of antennæ as long as serenth, distinctly longer than fifth; size 8 or more $\mathrm{mm}$.

1343. COLLARIS.

1341 (405S). Nematodes atropos Say; Trans. Amer. Phil. Soc., VI, 1836. 157 ; ibid. II, 626.

Elongate, subcrlindrical. Dark bromn, almost black, subopaque; antennæ and legs reddish-browu. Antennæ slightly less than half the length of body, second joint longer than fourth, third nearly equal to the next two, 4 to 11 gradually longer, each longer than wide. Thorax distinctly longer than wide, widest one-third from apex. hind angles acute; disk slightlr flattened at middle. median line impressed nearly to apex. a more or less distinct forea on each side; surface densely and rugosels punctate. Elytra gradually narrowed from base to apex, surface striate; interrals flat, densely but less coarsely punctate than thorax. Length $6.5-9 \mathrm{~mm}$.

Wells County; scarce. Collected by E. B. Williamson. July 1. Described from Posey County.

1342 (4059). Nematodes pexetraxs Lec., Proc. Phil. Acad. Nat. Sci., VI, 1852,47 .

Elongate, subcrlindrical, slender. Dark brown or piceous. feebly shining; antennæ and legs reddish-brown. Antenne less than half the length of body, second joint longer than fourth, third as long as the next two, four, fire and six, short; seren to eleren each as long as third. Thorax distinctly longel than wide. sides at apical third narrowing to the front. basal two-thirds straight and parallel; disk with a distinct median impression 
extending two-thirds from base to apex and a subobsolete fovea on each side slightly in front of middle. Elytra distinctly striate; intervals flat, densely but not rugosely punctate. Length $6 \mathrm{~mm}$.

Posey County ; rare. May 27. Occurs from Canada to Georgia.

1343 (-). Nedratodes collaris Bonv., Monog. Eucn., 1875, 663.

Elongate, subcylindrical, moderately robust. Piceous, feebly shining; legs paler. Antennie slightly more than one-third the length of body; second and fourth joints subequal, third slightly longer, double the length of fifth; sixth to eleventh equal, slightly longer than third. Thorax and elytra nearly as in penetrans, the former with median line more deeply impressed and visible nearly to apex, the fovea each side deep, distinct; surface more coarsely punctate. Length $9 \mathrm{~mm}$.

Posey County; rare. May 1. This species was named for me by Chas. Dury, who has taken nine of them near Cincinnati. It was not included in Horn's Monograph of the Subfamily and was described from Brazil, South America, by Bonvouloiri, who also gave "La., N. A.," as a doubtful locality. Mr. Dury identified it from a translation of the original description and.his identification was afterwards verified by comparison with the type.

\section{Hrpocelus Esch. 1836. (Gl'., "beneath + hollow.")}

Small oblong species having the antennæ filiform; elytra striate; first joint of hind tarsi as long as the next three, the fourth joint not dilated or lobed beneath. One of the two known species was described from Indiana and the other probably occurs.

1344 (4056). Hxpoccelus Frontosus Say, Trans. Amer. Phil. Soc., VI, 1836, 187 ; ibid. II, 625 .

Oblong, slightly attenuate behind. Piceous black, antennæe and legs reddish-brown. Antennæe less than half the length of body, second joint shorter than fourth, third longer. fourth to tenth very gradually longer and slightly broader, eleventh oval, acute at tip, very little longer than tenth. Front of head with a distinct transverse ridge, clypeus concave. Thorax a little wider than long, median line distinctly impressed its entire length, surface very densely and rugosely punctate. Elytra distinctly striate, intervals flat, punctured as the thorax. Length $4.5-5.5 \mathrm{~mm}$.

Say's types came from near New Harmony, Posey County. Dury has taken it and also the other species, terminalis Lec., near Cincinnati. The latter is distinguished by having the terminal joint of antennæ longer than the preceding, the front with a fine longitudinal carina. clypens flat, median thoracic line less impressed. Both species occur on dead hickory. 


\section{Schizophilus Bonv. 1875. (Gr., "cleare + love.")}

The only member of this genus has the antennæ passing but slightly the base of thorax, first joint stout, second one-third as long, third one-half longer than second and nearly equal to the next tro, four to ten very gradually longer and broader. 11th one-half longer than tenth and acute at tip; prosternal sutures straight, well marked; hind coxal plates broad. triangular: first joint of hind tarsus as long as the next three.

1345 (4061). Schizophilts stbrufts Rand., Bost. Jour. Nat. Hist., II. $1838,38$.

Oblong, narrot, subdepressed. Pale reddish-brown, feeblc shining. sparsely pubescent. Thorax as wide as long, slightly narrorred in front, sides straight, hind angles acute, not carinate, surface coarsely and densely punctate. Elstra finels striate; interrals flat, each with two roms of rugose punctures. Length $8 \mathrm{~mm}$.

A single specimen in Dury's collection from Marion County. Taken from the trunk of a beech. A rare species, known only from Nerr York and Canada.

\section{Phlegon Lap. 1835. (A mrthological name.)}

Oblong brown beetles having the antennæ slightly shorter than half the body; with second joint small. third shorter than half the first and nearly as long as the next two, four to eight small, last three joints much longer and broader. the eleventh longest; antennal grooves absent; hind coxal plates rery broad on inner side; tarsi slender, first joint of middle and hind pairs as long as the next three; the joints not lobed beneath. One of the trro species has been taken in Indiana. The other. P. ulkei Horn, dark brown, with thorax parallel behind, length $9.5-10 \mathrm{~mm}$.. was described from Ohio.

1346 (4063). Phlegor heterocerts Sas, Trans. Amer. Phil. Soc., VI, 1836, 186 ; ibid. II, 624.

Oblong-elongate, more obtuse in front, gradually narrowed behind. Light reddish-brown, feebly shining. Head coarsely and densels punctured. Thorax one-third wider than long, gradually narrowed from base to apex; disk convex with a rague median line on basal half; surface rather closely but not coarsels punctate. Elstra distinctly but finels striate; interrals slightly conrex, densels but more finely and roughly punctate than thorax. Length 10-11 mm.

Representèd by a single specimen taken from beneath bark near Fountain. Fountain County. Described from Posey County. Knorn elsewhere only from Maryland and Pennsylyania and very rare in collections. 


\section{Subfamily II. ELATERINAE.}

The click beetles belonging to this subfamily have the antennx widely separated and inserted in small pits before the eres and under the margin of the front: head usually horizontal. with the mouth in front: mandibles small and retracted: middle coxre with a small but distinct trochantin: tibire slender in all the genera. The subfamily is dirided into fire tribes, three of which are represented in Indiana, while a single species of another probablr oceurs.

\section{KET TO INDIANA TRTEES OF ELATERITE.}

a. Antenna in repose receired in deep groores on the under side of thorax. (Eig. 2i2, b.)

Tribe I. Agriprini, p. 713 .

aa. Antenne not received in groores on prosternum.

b. Meso- and metasterna firml united without visible suture; size rert large.

Tribe II. CHaICOLEPIDIIII, p. 716.

七万. Mesosternal suture distinct.

c. First joint of antennze rert long.

Tribe III. HEMIRHIPINI. p. i1s. cc. First joint of antennze moderate: apes of mandibles obtuse or emarginate.

Tribe IT. Eisiterici, p. iIS.

Tribe I. AGRIPNINI.

Medium sized elongate-oblong: subdepressed beetles. usualls occurring beneath the bark of dead trees. Ther are easily recognized by the distinct antemal groores lring alongside the prosternal sutures. The base of under side of thoras is also deeply groored for the reception of the front femora. In front of these is often an additional groove for the tarsi. When the three sets of groores are present the prosternum presents a rer remarkable sculptured appearance. (Fig. 272. $b$ and $c$ ) The mandibles are emarginate or toothed at tip: antennæ serrate: tarsal joints slightly dilated beneath but not lobed. Two of the four genera are represented in Indiana.

\section{KEY TO INDIANA GENERA OE AGRIPNINI.}

a. Antennal groores occupring the whole or nearle the whole of the prosternal suture (Fig. 272, b) : third joint of antennze equal to the fourth.

XIII. ADELOCERA.

aa. Antennal groores much abbreviated behind: front tarsi receired in sroores; third joint of antennie smaller than fourth. XIT. LAcox.

KIII. Adelocers Latr. 1829. (Gr.: "invisible + horn.")

The principal characters of this genus hare been set forth under the tribe heading and in the abore key. Our species are coarselr punctured above and beneath and have a portion or all of the upper 
surface covered with small oblong seale-like hairs. Five species have been taken in the State, while two others perhaps occur. For a table separating the North American species see:

Horn.-T'Trans. Amer. Ent. Soc., VII, 1879, Appendix, XIV-XV.

KEY TO INDIANA SPECIES OF ADELOCERA.

a. Front tarsi in repose received in grooves on the under side of the thorax. (Fig. 272, c.)

b. Tarsal grooves deep, oblique, distinctly limited, uniting behind with the antennal grooves. (Fig. 272, $b$ and $c_{\text {. }}$ )

c. Punctures of elytra in regular rows; impression of thorax shallow.

1347. IMPRESSICOLLIS.

cc. Punctures of elytra dense, not in rows; impression of thorax distinct; surface of elytra irregularly spotted with brown and dull yellow scales.

1348. MARMORATA.

bb. Tarsal grooves feebly impressed, neither distinctly limited nor joining the antennal grooves.

d. Head and sides of thorax densely covered with closely appressed golden yellow scales.

1349. DISCOIDEA.

dd. Head and thorax without yellow scales; elytra spotted with brown and dull yellow.

MACULATA.

aa. Tarsal grooves entirely absent.

e. Disk of elytra convex; thorax feebly channeled; antennal grooves long, reaching the coxæ.

1350. AVITA.

$e e$. Disk of elytra depressed; thorax broadly channeled; antennal grooves abbreviated behind.

f. Impression of thorax entire, extending from base to apex; hind angles divergent.

1351. OBTECTA.

$f f$. Impression of thorax limited to basal half; hind angles not divergent, compressed and feebly carinate; antennæ very short.

BREVICORNIS.

1347 (4071). Adelocera impressicollis Say, Ann. Lyc. Nat. Hist., N. Y., I, 1825, 260 ; ibid. I, 394 ; II, 619.

Elongate, slender, subdepressed. Dull reddish-brown, sparsely covered with short, curved yellow hairs. Thorax oblong, disk convex, with an indistinct median sulcus and two shallow fovere each side near base, sides nearly parallel, sinuate near hind angles, which are oblique and rather short; surface densely, coarsely and deeply punctured. Elytra with regular rows of coarse, close, deep punctures. Under surface punctured like the thorax. Length 9-11.5 $\mathrm{mm}$.

Southern half of State, frequent; Fulton County, scarce. April 12-November 10.

1348 (4072). Adelocera marmorata Fab., Syst. Eleut., II, 1801, 227.

Elongate, robust, rather strongly depressed. Dark reddish-brown, subopaque; sparsely covered with dull yellow scales which, on the elytra, form irregular blotches. Thorax as long as wide, disk subconvex, with a 
deep median sulcus; sides nearly straight. surface densely and coarsely punctured. Elrtra gradually but feebly narrowed from base to tip. densely and rather coarsels punctate. Length $15-17.5 \mathrm{~mm}$.

Throughout the State; frequent.

Occurs beneath bark of dead trees, usually in low; damp wouds. Often gregarious. April 4 August 10. Our largest and broadest species of the genus.

*1349 (40T6). Adelocera discoidea Teb.. Obs. Ent.. 1S01, Tт.

Oblong. subdepressed. Black. feebly shining: head and broad margin of thorax densely coreled with narrow golden sellow scales. Thorax oblong. with a rather deep median sulcus: sides nearly straight, curred on apical fourth: surface. as well as that of elrtra. densely and coarsely punctured. Tarsal groore long. shallow. parallel to the antennal groore. Length S-11 mm.

Throughout the State: frequent. January 18-December 20. Hibernates beneath bark and logs: most common in April and Mar.

A. maculata Lec.. black. length $13 \mathrm{~mm}$. is recorded from near Cincinnati. Dury has also mrongly recorded A. aurorata Say from there. the specimens being avita. A. brevicornis Lec. sootr-bromn, thickly and irregularly blotched with whitish scalas. length 14-17 $\mathrm{mm}$.. is known from Michigan and Wisconsin.

1350 (40S0). Adelocera arita Say. Trans. Amer. Phil. Soc., TI, 1S36, 1S2; ibid. II, 620.

Elongate. slender. subconvex. Dark reddish-brown. sparsely corered with elongate rellow scales; legs and antenne paler. Thorax oblong. conrex, sides sinuate in front of hind angles, thence slightls curred to aper: disk distinctly sulcate on basal half. often with a shallow rounded forea each side near base. Elytra conrex, irregularls and densely but less coarsels punctate than thorax. Length 12-14 mm.

Putnam and Crawford counties: scarce. July 1-July 2. Described from Poser County. Resembles impressicollis but larger, more convex, and with tarsal grooves wholly absent.

1351 (40S1). Adelocera obtecta Say. Trans. Amer. Phil. Soc., TI, 1S36. 1S1; ibid. II. 61 s.

Elongate. subdepressed. Piceous or rery dark reddish-bromn. with sparse. widely scattered pale scales. Thorax oblong. sides feebly curred from near hind angles to apex. margins lather broadly flattened: disk with a wide and deep median groore. hind angles rather broad and distinctly dirergent. Elrtra with two indistinct elerated lines on basal half. one of which extends beyond the middle: surface. as that of thorax. densels and coarsels punctured. Length $15 \mathrm{~mm}$.

Steuben and Marshall counties: rare. I northern species which belongs to the Transition life zone of the State. July 6-July 30. 
Readily known by the dark color. distinct ridges on each side of median groore of thoras. and absence of tarsal grooves. Knomn only from Maine, Termont and Pennsylvania.

IIT. Lacox Lap. 1836. (Gr.. " short." referring to the antennal grooves.)

This genus differs from Adelocer br its shorter and proportionally broader form and by haring the antennal grooves rerr much shortened behind; second and third joints of antennæ subequal and much smaller than those which follow: tarsal grooves oblique, shallow and subobsolete.

*1352 (4085). Lacon rectangularis Say, Ann. Lyc. Nat. Hist., I, 1825, 263 ; ibid. I, 397.

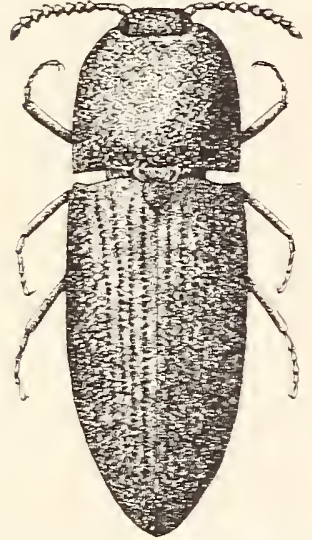

Fig. 276. $\times 5$. (Original.)

Oblong. subdepressed. Dull sootr brown, sparsely clothed with short. suberect. stiff whitish hairs, those of the elytra in a double row on each interval. Antennie paler, reaching onls two-thirds to base of thorax; legs reddish-brown. Thorax subquadrate. conrex. rapidly narrowing before the middle, hind angles rectangular. sides rounded. front margin finels crenate: disk convex. Without trace of a median impressed line, densels and coarsely punctured. Elytra with rows of rather distant medium sized punctures: intervals flat, wider than the strix. Length $\$-9.5 \mathrm{~mm}$. (Fig. 276.)

cept locally in Tigo County, where it was found rather abundantly on the slope of a high sandr ridge. fire miles north of Terre Haute. Here it hibernated beneath chips and chunks. January 1-December 12 .

\section{Tribe II. CHALCOLEPIDIINI.}

To this tribe belong our largest click beetles. In addition to the characters mentioned in tribal ker. they have the hind coxal plates gradually dilated on imer side and strongly toothed at the insertion of thighs; mandibles with tips entire. but not prolonged: tarsi not lobed but vere densely pubescent beneath and claws simple. Two genera compose the tribe, one of which is represented throughout Indiana, while the single species of the other perhaps occurs in the southern portion. 
KEY TO GENERA OF CHALCOLEPIDIINT.

a. Thorax without large relrety black spots; scutellum obcordate; margin of elytra obsolete on basal half; antennie of male pectinate.

Chalcolepidits. aa. Thorax with two large velrety black spots on disk; scutellum oral; elytra strongly margined.

XV. AlAUS.

Chalcolepidius viridipilis Say. black, densely clothed with minute olive-gray scales, length $22.5 \mathrm{~mm}$., occurs in the Middle and Southern States and is recorded from Cincinnati.

\section{Aluts Esch. 1836. (Gr.. "wander.")}

The characters of this genus are sufficiently set forth above. Two of the five known North American species occur in Indiana.

1353 (4093). Alaus oculates Linn., Syst. Nat., II, 1766, 651.

Elongate, subconrex. Black, shining; marked with small, irregularly disposed blotches of pale silvery scales; each side of thorax with a large rounded black ere-like spot surrounded bs a ring of pale scales. Elstra distinctly striate: intervals conrex, finels and sparsely punctulate. Length $28-45 \mathrm{~mm}$. (Fig. 27亍.)

Throughout the State; frequent in the southern portion; less so in the northern counties. March 16-October 21. This is the best known member of the family in the State. The adult usually begins to occur in numbers about midApril and is then to be found beneath the loose bark of half-rotten stumps or logs. in orchards or dry. open woodland. I once took a single

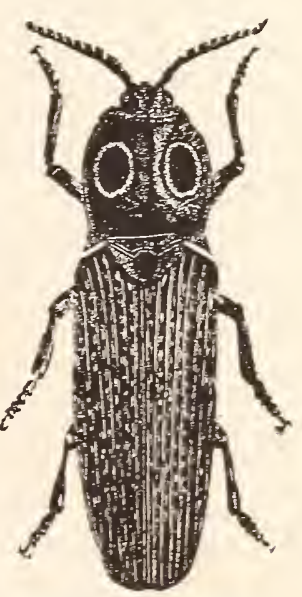

Fig. 27i. (After Harris.) male from beneath some honercomb in a dense roods in Marion County on March 16. It was as lively as though it were midsummer. though the mercury had been far below the freezing point only two days before. The larva, when nearly full grown, is a smooth cylindrical worm nearly two and a half inches long and four-fifths of an inch wide across the middle of the body; of a creamy yellow color. with the head and one or two front segments brown and the last segment black. with a semicircular notch at end. It lives upon ard in decaring rood and is often to be found in the trunks of old apple trees.

1354 (4094). Alats myops Fabr.. Syst. Elent., II. 1S01, 222.

Elongate, subconrex. Black, feebly shining. sparsely clothed with irregular pubescence. Thorax longer than wide. feebly convex. slightly wider in front; disk with eye-like spots narrow, elliptical, black, smaller 
than in oculatus, their margins of grayish hairs indistinct. Elytra finely but distinctly striate, densely and finels granulate-punctate. Length 243S $\mathrm{mm}$.

Pine. Lake County: rare. June 6. One specimen taken by Nolcott from beneath bark of pine. Common in the Southern States; rare north of the Ohio River.

\section{Tribe III. HEMIRHIPINI.}

This tribe is represented in the eastern United States by the single species Fremirhipus fascicularis Fab.. a large black beetle. haring the elytra dull rellow. varied with small dusky spots and densely clothed with short brown pubescence: length $19 \mathrm{~mm}$. It has been taken near Cincinnati and should be looked for in southern Indiana.

\section{Tribe IT. ELATERINI.}

By far the larger number of our native click beetles belong to this tribe. The 38 genera which compose it differ widely in rarious peculiarities of structure. but all agree in having the prosternum deroid of antennal groores: mesosternal suture distinct; side pieces of metathorax narrow and the mandibles short, never extending far beyond the labrum. In order to shorten the generic kevs, the tribe is divided into two subtribes, defined as follows:

\section{KEY TO SLBBTRIBES OF ELATERINI.}

a. Hind coxal plates suddenls dilated about the middle, the outer part much narrower than the inner. Subtribe A. Elaterixi, p. is. a a. Hind coxal plates gradualls, sometimes scarcels, dilated on the imner' side.

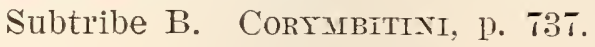

\section{Subtribe A. (Eliterini.)}

In addition to the suddenly dilated plates of hind coxæ. the nembers of this subtribe have a strong tooth at the insertion of the thighs; the prosternum lobed in front; mandibles emarginate or toothed at tips; tarsal claws rery rarely ser'rate. Of the 19 genera composing the subtribe representatives of fourteen hare been taken in Indiana. while those of one other donbtless occur.

KET TO IXDIANA GENERA OF ELATERINI.

a. Margin of the front elerated behind the labrum: size small or medium, rarely orer $14 \mathrm{~mm}$.

ъ. Prosternal spine truncate at apex, fitting like a redge into the deepls cleft notch of mesosternum; scutellum heart-shaped.

c. Tarsi simple. not lobed beneath.

d. Marginal line on side of thorax becoming inferior, not risible from abore; bodr winged, elstra free. XVI. Cardophorts. 
dd. Marginal line of thorax, strictly lateral, visible from above throughout its full lengtlı; elytra yellow, with black crossbar; length less than $5 \mathrm{~mm}$.

XVII. HORISTONOTUS.

cc. Tarsi with fourth joint lobed beneath; length $7 \mathrm{~mm}$.

XVIII. EsTHESOPUS.

6b. Prosternal spine acute at apex; scutellum oval.

$e$. Prosternun very broad, sutures single, straight or convex on outer side.

f. Tarsal claws simple; tarsi of moderate length, clothed witlı stiff: hairs.

g. Prosternal sutures straight, either parallel or converging very little behind the middle; side pieces of mesothorax reaching the middle coxis length over $5 \mathrm{~mm}$.

XIX. Cryptohypnus.

gg. Prosternal sutures curved and very evidently converging behind the middle; side pieces of mesothorax not reaching the coxæ; smaller, less than $5 \mathrm{~mm}$; elytra usually with yellow spots.

XX. Hypnoidus.

ff. Tarsal claws with a tooth at middle; tarsi long, pubescent; uniform piceous black.

XXI. CEDostethus.

ee. Prosternum of moderate width, sutures double, either straight or concave on outer side.

7. One or more of the tarsal joints lobed beneath.

$i$. Second joint of tarsi without lobes.

j. Third joint alone lobed.

$j j$. Fourth joint alone lobed.

XXII. Anchastus.

XXIII. MonOCREPIDIUS.

ii. Second and third joints of tarsi with long lobes; color brown; length 10 or more $\mathrm{mm}$.

k. Mesosternum horizontal ; front of head with two crests uniting above with frontal margin.

XXIV. DICREPIDIUS.

k\%. Mesosternum oblique; front of liead not crested.

hh. Tarsal joints not lobed beneatl.

XXV. Ischiodontus.

l. Prosternal sutures excavated in front; joints 1 to 4 of tarsi gradually increasing in length, ciliate beneath; color usually variegated.

xxVI. ËLAter.

ll. Prosternal sutures not excavated in front.

m. Third joint of antennie longer than second.

XXVII. DRasterius.

$m m$. Second and third joints of antennie small, equal.

MEgapenthes.

aa. Margin of the front not elevated behind the labrum; size larger, 15 or more $\mathrm{mm}$. in length.

$n$. Sides of mesosternal cavity sloping downward, not prominent; elytra black.

XxVIII. Ludius.

$n n$. Sides of mesosternal cavity protuberant, prominent; color brown.

[46-23402]

XXIX. Orthostethus. 


\section{Cardiophorus Esch. 1836. (Gr., "heart+ bearing.')}

Small convex species. clothed with more or less abundant, prostrate pubescence. The antennx usually vary considerably in the two sexes, those of the male longer and with joints 3 to 10 broader in the middle than in the female; scutellum distinctly heart-shaped, emarginate at base. The North American species are treated by

Blanchard._."Revision of the species of Cardiophorus Esch. of America North of Mexico," in Trans. Amer. Ent. Soc., XVI, $1889,1-27$.

In this paper 31 species are recognized, three of which have been taken in Indiana, while two others may occur.

\section{KEY TO INDIANA SPECIES OF CARDIOPHORUS.}

a. Thorax with hind angles obliquely truncate; elytra each usually with two yellow spots; hind margin of side pieces of prosternum straight.

1355. CARDISCE.

aa. Thorax with hind angles produced and carinate; elytra without spots; hind margins of side pieces of prosternum with a deep notch next to the outer angle.

b. Sides of mesosternal carity prominent and nearly rertical in front; upper surface densely covered with short prostrate yellowish hairs ; legs reddish-yellow.

135̄6. CONVEXUS.

bb. Sides of mesosternal cavity not prominent, oblique in front.

$c$. Second joint of antennie longer than wide and more than one-half as long as third.

d. Prosternal process margined behind the coxie; pubescence of upper surface sparse; legs wholly black.

135\%. GAGATES.

$d d$. Prosternal process not margined behind the coxie; tarsi reddishbrown.

CONVEXULUS.

cc. Second joint of antennæ small, one-half as long as third; prosternal spine distinctly margined; surface feebly bronzed.

ROBUSTUS.

1355 (4104). Cardiophorus cardisce Say, Trans. Amer. Phil. Soc., VI, 1836, 169 ; ibid. II, 604.

Elongate, conrex. Black, rather thickly clothed with short grayish pubescence; elytra each with a yellow spot before the middle and another before the apex; these variable in size and shape, sometimes wholly lacking, the front one sometimes extending obliquely forward to the humerus; legs black, knees and tarsi reddish-yellow. Thorax very convex, slightly longer than wide, sides rounded, less narrowed behind than in front. Elytral stria punctate; intervals feebly convex, punctulate. Body beneath shining, punctulate with finer and coarser punctures intermingled. Length $5.5-7.5 \mathrm{~mm}$.

Frequent beneath rubbish along the beach of Lake Michigan. IIay 13-June 15. 
1356 (4097). Cardrophorus convexus Say, Journ. Phil. Acarl. Nat. Sci., III, 1S23, 169; ibid. II, 110.

Elongate, subconvex. Dark sooty brown or piceous, shining; legs and two basal joints of antenne reddish-yellow. Thorax longer than wide, widest at middle, strongly convex, narlowed in front; hind margin with a short groove each side, tridentate at middle; disk rery finely and evenly punctate. Elytra wider than thorax, gradually tapering from base to apex, striate, the strix punctate; intervals slightly convex, very finely punctulate. Body beneath clothed with fine brownish pubescence, closely punctulate. Length 8-10 $\mathrm{mm}$.

Throughout the State; common. April 7-July 26. Frequents leaves and branches of various shrubs in May and June, and then one of the most common Elaters taken by beating.

1357 (4109). Cardiophorus gagates Erichs., Zeitschr., II, 297.

Oblong, rather stout, convex. Black, shining, sparsely clothed with fine grayish pubescence. Antenn:e stout, strongly serrate in male, joints 3 to 6 one-half longer than wide. Thorax very convex, slightly longer than wide, sides strongly rounded; base tridentate at middle and with a short groove each side; surface densely and finely punctate. Elytra either subparallel or narrowed and rounded from the humeri, striate, punctate; intervals convex and finely punctulate. Length.5.5-7.5 mm.

Northern half-of State, frequent; Lawrence and Posey counties only in the south. April 21-August 15.

C. convexulus Lec., black, shining, length $7.2-10 \mathrm{~mm}$., is known from Canada, New England and Ohio; C. robustus Lee., stout, black, feebly bronzed, legs reddish-brown, length $7-10 \mathrm{~mm}$., ranges from Massachusetts to Texas.

\section{Honistonous Cand. 1860. (Gr., "defined + back.")}

Small slender species, having the margin of thorax well defined, the edge running along the suture which divides the dorsal from the pectoral region.

1358 (4129). Horistonotus curiatus Say, Trans. Amer. Phil. Soc., VI, 1836, 173; ibid. II, 609 .

Elongate-oblong, subconvex. Piceous, feebly shining; legs, antennie and elytra dull reddish-yellow, the latter with a blackish crossbar at middle which extends narrowly along the margin to apex. Antenna slender, very little longer than thorax, feebly serrate. Thorax slightly longer than wide, narrower at apex than at base, sides feebly curved, disk convex, sparsely punctate, hind margin with a short groove each side near the spines. Elytra not wider at base than thorax, feebly narrowing to apex, deeply striate, strix punctate; intervals convex, sparsely punctulate. Tarsal claws dentate from the middle to the base. Length $4-4.5 \mathrm{~mm}$. 
Southern tro-thirds of State; frequent. April 22-Norember 20. On leaves of IIar apple. Podophyllum peltatum L.. and other herbs in May and June.

\section{Esthesopts Esch. I856. (Gr.. "vestiture + foot.")}

Side maroin of thoras acute from base nearly to apes; the fourth tarsal joint dilated and somewhat lobed beneath; tarsal claws dentate from middle to base. Of the six species known, one was described from Indiana.

1359 (4134). 'Esthesopus clabicoldis Sas, Trans. Amer. Phil. Soc., TI, 1\$86, 179; ibid. II, 616.

Oblong. moderately robust. Piceous black. shining, sparsels clothed with grayish pubescence: antennæ and legs reddish-rellow. Thorax slightly longer than wide, narroter in front: sides nearly parallel behind the middle, curved on apical third; hind angles not dirergent, obtusely rounded. without carina; basal folds small but distinct; surface finels and rather densely punctate. Elytra not wider than thorax. sides feebly curred, narrowing on apical third. striate. the strix rather coarsely and closely punctate; interrals slightls conrex, finels and closels punctulate. Length $7 \mathrm{~mm}$.

Described from Poser County : taken by Dury near Cincinnati. "Occurs from Virginia to Indiana and Texas."

\section{Criptohrpxus Esch. 1836. (Gr.. "hidden + sleep.")}

But one Indiana species belongs to this genus as now restricted. It is an oblong piceous form having the side pieces of mesothorax. together with the meso- and metasterna uniting to close the middle coxal cavities on the outer side. The principal papers treating of the North American species of this and the next genus are by

Horn. - A Ionograph of the Species of Cryptohrpnus of Boreal America," in Trans. Amer. Ent. Soc., XVIII. 1891. 1-29.

Horn._"A Note on Crrptohypnus." in Entom. Ners, T. 1894. $6-7$.

1360 (4149). Criptohypres abbreviatus Sag, Journ. Phil. Acad. Nat. Sci.. III. 1823, 173 ; ibid. II. 112.

Oblong, moderately conrex. Piceous with greenish-bronze lustre; elstra often dark reddish-brown, sparsels clothed with brownish or rellowish pubescence. more conspicuous on scutellum and on sides of elrtra behind the middle: legs reddish-rellow. Head coarsely. not closels punctate; frontal margin depressed, scarcely distinct from that of labrum. Thorax slightly broader than long, narrowed on apical two-thirds, sinuate in front of hind angles, which are acute, carinate. scarcels dirergent; disk conrex, 
with usuaily a distinct median impression extending from base to apex, deeper behind; surface rather coarsely not closely punctate. Elytra widest one-third from base, thence gradually narrowing to apex; disk striate, strice finely but indistinctly punctured; intervals flat, rather sparsely and finely punctate. Length $5.2-6.5 \mathrm{~mm}$.

A species of northern range taken in Lake, Laporte and Starke counties. April 16-June 4. Occurs especially beneath rubbish and bark of trees along the dune region bordering Lake Michigan.

XX. Hrpnoidus Steph. 1830. (Gr., "sleep + form.")

Small species readily known by the broad prosternum, with the sutures single and convex on the outer side; the simple tarsal claws and stiff hairs of the tarsal joints. The epimera of the mesothorax do not reach the middle coxæ and the latter are therefore closed on the outer side only by the meso- and metasterna. About 20 of the species formerly listed under Cryptohypnus belong here. Of these eight have been taken in the State, while another may occur.

KEY TO INDIANA SPECIES OF HYPNOIDUS.

a. Elytra with all the strix entire.

- b. Form depressed, the dorsum quite fiat; opaque, densely punctulate and pubescent; color uniform piceous.

b7. Form convex.

c. Thorax coarsely granulate, often in part or wholly finely, longitudinally rugose or strigose.

d. Apical margin of thorax truncate at middle.

$e$. Base of thorax strigose like apex; a distinct, smooth elevated median line; larger, 3 or more $\mathrm{mm}$.

f. Elytra yellow with two sinuous blackish crossbars; apical third more or less attenuate; legs wholly pale.

1362. CHORIS.

ff. Elytra piceous, each with two yellow spots; apical third scarcely attenuate; femora fuscous or piceous.

1363. ExIGUUS.

ee. Base of thorax smoother than aper; median line indistinct; size smaller, not over $2.5 \mathrm{~mm}$.

1364. MELSHEIMERI.

dd. Apical margin of thorax curved at middle, slightly prolonged over the head.

CUCULLATUS.

cc. Surface of thorax equally punctate, not finely strigose.

g. Elytra each with trio yellow spaces, humeral and subapical; elytral humeri obtuse, strixe scarcely more punctate than the intervals.

1365. EsTIVUs.

gg. Each elytron with a humeral spot only; humeri rounded, strice more coarsely punctate than the intervals. 1366. PERPLExUs.

aa. Elytra with the strix wholly obliterated.

h. Surface subopaque, distinctly punctate, especially on the thorax: color variable from dull yellow to piceous.

136T. PECTORAIIS. 
hh. Surface moderately shining, very indistinctly punctate; each elytron with an oblique yellow band at middle, not reaching the suture, and an oral apical spot.

1368. OBLIQUATULUS.

1361 (4154). Hrpxoidus striatulus Lec., Trans. Amer. Phil. Soc., X, $1853,485$.

Oblong, subdepressed. Piceous black, opaque, finely pubescent with sellowish hairs; legs pale, the femora darker. Head densely rugosely punctate. Thorax slightly wider than long, narrowed in front, sides curred, slightly sinuate in front of hind angles, which are stout and with a short carina; disk feebly conrex, densely and finely punctate. Elytra as wide as thorax; sides nearly parallel to apical third, thence curred to apex; disk rather flat, striate, striæ punctate; intervals feebly convex, densely and finely punctate. Length $3-4 \mathrm{~mm}$.

Marion and Franklin counties; rare. June 11-June 20. Described from Lake Superior region and probably occurs sparingly throughout the State.

1362 (4157). Hypxoidus choris Say, Trans. Amer. Ent. Soc., VI, 1836, 172 ; ibid. II, 608.

Elongate-oblong, subconver. Black, opaque, sparsely

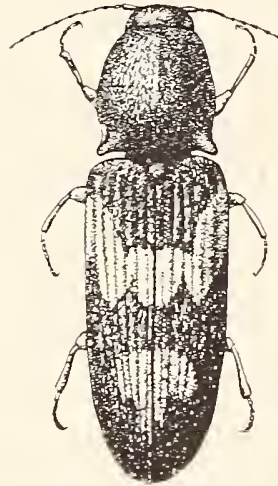

Fig. $278 . \times 9$. (Original.) clothed with yellow hairs; elytra dull yellow with a black spot each side of scutellum, and two black crossbars, often interrupted on suture and with rery sinuous edges; one median, the other subapical, these connected on sides with a marginal line extending nearly from base to apex. Thorax slightly ionger than wide, sides feebly curved, narrowed in front, nearly straight on basal half; hind angles divergent, the carina long, extending three-fourths to apex; disk conrex, coarsely and closely rugose. Elytra widest in front of middle, thence gradually narrowed to apex: disk deeply striate, striæ punctured; interrals conrex, roughly and sparsely punctate. Length $3.5-5 \mathrm{~mm}$. (Fig. 278.)

Throughout the State; frequent. May 25-June 28. Occurs especially in sandy localities near ponds and streams; also beaten from flowers of swamp huckleberry.

1363 (10,051). Hypxoidus exiguus Rand., Bost. Journ. Nat. Hist., II, $1838,35$.

Oblong, subconvex. Black, subopaque; elytra each with two dull yelIow spots, one subhumeral, oblique-oblong, the other subapical, rounded. Thorax slightly longer than wide, narrowed on apical third; sides on basal two-thirds parallel, hind angles slightly divergent, the carina extending three-fourths to apex; disk densely covered with oblong granules. Elytra widest slightly behind the middle, thence feebly narrowed to apex, which is broadly rounded; disk rather deeply striate, the striæ very indistinctly punctate; intervals convex their entire length, sparsely and roughly punctate. Length 2.5-3.5 $\mathrm{mm}$. 
Marion, Putnam and Lawrence counties; rare. May 24-.June 29. Beaten from vegetation near water.

1364 (10,053). Hypnoidus melshemeri Horn., Trans. Amer. Ent. Soc., XVIII, 1891, 19.

Oblong, moderately convex. Piceous black, shining, sparsely and finely pubescent; elytra each with a humeral and subapical yellow spot; antennæe fuscous, joints 2 and 3 paler; legs reddish-yellow. Thorax wider than long, narrowed in front; sides curved, straight on basal third; hind angles broad, acute at tip, the carina long; disk convex, quite smooth near the base. Elytra as wide at base as thorax, sides neariy parallel, narrowed on apical third; disk striate, striæe very finely punctured; intervals slightly convex, sparsely and minutely punctulate. Length $2-2.5 \mathrm{~mm}$.

Putnam County; rare. Narch 20-April 11. Taken by sifting the debris of a locust stump.

H. cucullatus Horn, black, elytra feebly bronzed, length $3.5 \mathrm{~mm}$., is recorded from Ohio, Texas and Ttah.

1365 (4164). Hyproidus Æstirus Horn, Trans. Amer. Ent. Soc., 1871, 304.

Elongate-oblong, subconvex. Piceous, moderately shining, sparsely pubescent; basal joints of antennæ, hind angles of thorax, legs, a humeral and subapical spot on each elytron, dull yellow. Thorax not longer than wide, slightly narrowed in front, widest a little in front of middle; sides curved, distinctly sinuate in front of hind angles, which are slender, acute and distinctly divergent, "with short carina; disk sparsely and finely punctate. Elytra with sides feebly curved, disk striate, striæ punctured; intervals slightly convex, punctured as the thorax. Length 4-5 mm.

Floyd and Posey counties; scarce. May 30-.June 23.

1366 (4165). Hxpnoidus perplexus Horn, Trans. Amer. Ent. Soc., 1871, 304.

Resembles astivus but smaller, with the thorax distinctly longer than wide, the median smooth line more evident. The elytra have only a humeral pale spot, and are more distinctly striate. Length $3-3.5 \mathrm{~mm}$.

Vigo County; rare. Nay 14.

*1367 (4161). Hyproidus pectoralis Say, Trans. Amer. Phil. Soc., VI, 1836, 173 ; ibid. II, 60 S.

Oblong, feebly conrex, subopaque, sparsely and finely pubescent. Color variable from entirely dull yellow to wholly piceous; often piceous with a humeral space on elytra paler, or dull yellow with a transverse fuscous band behind the middle of elytra and extending narrowly along the suture to apex; antennæe and legs pale yellow. Thorax as wide as long, slightly narrowed in front, widest at middle, sides curved; hind angles small, acute. not divergent, the carina short; disk convex, very distinctly and rather closely punctate. Elytra slightly wider than thorax, sides curved, disk without striæ; surface less distinctly punctate than thorax. Length $1.5-2.5 \mathrm{~mm}$

Lake, Vigo and Harrison counties: scarce. January 7-June 24. Hibernates beneath chunks and bark. 
*1368 (4162). Hypnoidus obliquatulus Melsh., Proc. Phil. Acad. Nat. Sci., II, 1844, 214.

Resembles pectorulis but usually a little larger and more conrex; thorax more distinctly sinuate in front of hind angles, which are slightly dirergent. Color piceous, each elytron with an oblique median yellowish band, reaching the margin but not the suture, and an oral apical spot of variable size, also yellow. 'Length $2.3-2.7 \mathrm{~mm}$.

Marion, Putnam, Vigo and Posey counties; frequent. January 3-May 30. Occurs in sandy localities where it libernates beneath partially buried logs and clunks. Taken in early spring by sifting.

\section{XXI. 'Edostethus Lec. 1853. (Gr., "swollen + breast."')}

Thorax distinctly margined. without basal fissures; mandibles prominent; antenna long, the third joint one-half longer than second; tarsi long, slender, pubescent. One species only is known from the eastern United States.

1369 (4166). CEdostethus femoralis Lec., Trans. Amer. Phil. Soc., X, $1853,489$.

Elongate-oblong, subconvex. Piceous-black, very sparsely pubescent with yellowish hairs; two basal joints of antennæ, base of femora, tibiæ and tarsi yellow. Thorax as wide as long, conrex, narrowed at apex and in front of hind angles, which are small, acute, diverging and with a long (arina; surface very finely and sparsely punctate. Elytra with sides parallel to apical third, thence rounded to apex; strix indistinct on disk, wholly wanting on sides. Length $4.5-5.5 \mathrm{~mm}$.

Marion, Posey and Franklin counties; scarce. April 28-June 10.

\section{Anchastus Lec. 1853. (Gr.. "to strangle.")}

Third joint of tarsi furnished beneath with a membranous lobe; fourth joint small and received upon the third; front very convex, its front margin rounded; hind coxal plates very narrow on the outer side, suddenly dilated and strongly toothed on the inner; tarsal claws simple.

1370 (4174). Axchastus binus Say, Trans. Amer. Phil. Soc., VI, 1836.

177 ; ibid. II, 614.

Elongate-oblong, subconvex. Black, pubescent with short rellowish hairs; elytra each with a large dull yellow spot extending from base nearly to middle, not reaching the suture, and another, smaller, on apical fourth: antennæ and legs reddish-yellow. Thorax longer than wide, narrowed on apical third; sides parallel and straight on basal two-thirds; hind angles acute, the carinæ long. Elytra striate, the striæ deeply punctate; intervals densely and rugosely punctulate. Length $7-7.5 \mathrm{~mm}$. 
Described from New Harmony, Posey County. One dead specimen taken near there by Wolcott; also taken by Dury near Cincinnati. Should occur sparingly throughout the southern third of State.

XXIII. Monocrepidius Esch. 1829. (Gr., "single + little shoe.")

Fourth joint of tarsi obliquely prolonged into a membranous lobe; first joint of antennæ longer than usual; hind coxal plates suddenly dilated on the inner side with the angles rounded and a tooth at the origin of the thighs.

\section{KEY TO INDIANA SPECIES OF MONOCREPIDIUS.}

a. Lobe of fourth tarsal joint very broad.

b. Size larger, 12 ol $^{*}$ more mm. ; color uniform brown. 1371. LIvidus.

bb. Smaller, not over $7.5 \mathrm{~mm}$; elytra dull reddish-brown with a broad fuscous stripe along the suture.

1372. SUTURALIS.

u⿰. Lobe of fourth tarsal joint narrow.

c. Length 5 or more mm.

d. Form elongate, slender; thorax distinctly longer than wide.

1373. VESPERTINUS.

dd. Form short, oblong, robust; thorax about as wide as long.

1374. AURITUS.

cc. Length not over $4 \mathrm{~mm}$; elytra reddish with narrow black lines.

1375. BELLUS.

1371 (4181). Monocrepidius Lividus DeGeer, Mem.

Hist. des Ins., IV, 1763, 162.

Elongate, subconvex. Dull brown, densely covered with short, prostrate hair; antenna reddish brown; legs yellow. Thorax one-fourth longer than wide, slightly narrowed in front, sides feebly curved; hind angles prominent, acute, divergent, with a short and rather feeble carina. Elytra gradually tapering from base to apex, striate, the strixe with close set, oblong punctures; intervals flat, finely punctulate. Length 14-17 mm. (Fig. 279.)

Southern two-thirds of State; frequent probably throughout. May 30-August 11. Beaten from branches of trees and shrubs, especially those of walnut and hickory.

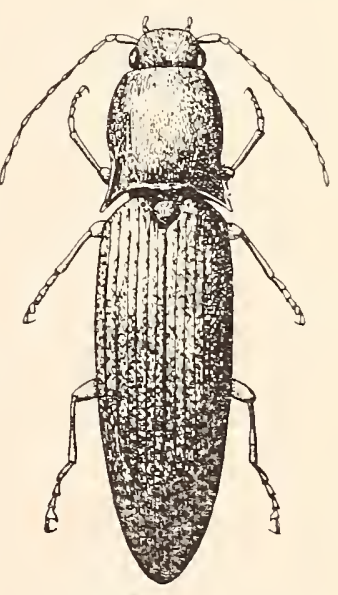

Fig. $279 . \times 3$.
(Original.)

1372 (4183). Monocrepidius suturalis Lec., Trans. Amer. Phil. Soc., X, $1853,482$.

Elongate-oblong, subconvex. Above dull reddish-brown, finely and sparsely pubescent with grayish hairs; head, median line on thorax and sutural stripe on elytra, expanding at base and on apical third, sooty brown or fuscous; beneath fuscous, the prosternum and inflexed portion of thorax reddish-yellow; antennæ and legs pale brownish-yellow. Thorax one-half longer than wide, sides broadly rounded, hind angles finely carinate; sur- 
face sparsely but distinctly punctate. Elytra with sides parallel to apical third, thence feebly converging to a rounded apex; striæ indistinctly punctate; intervals rery finely punctulate. Length $6.5-7 \mathrm{~mm}$.

Dubois County; rare. May 27. Beaten from oak. A member of the Austroriparian fauna, described from Alabama.

1373 (4185). Monocrepidius vespertinus Fab., Syst. Eleut., II, 1801, 200.
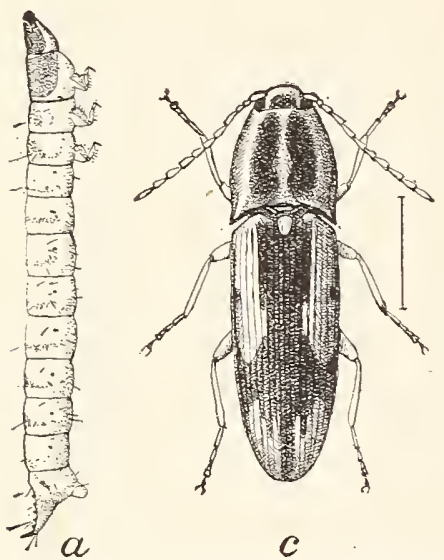

$c$

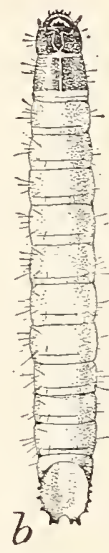

Fig. 280. Monocrepedius vespertinus. a, larva,
side view; b, larva, dorsal view; $c$, beetle-all three times natural size.. (After Chittenden, Bull, 33, N. Ser. Div. Ent., U. S. Dep. Agr.)

Elongate, slender, subconvex. Color variable, usually yellow beneath and dark reddish-brown above, with middle and sides of thorax and a broad stripe from humerus two-thirds to aper of elytra and a spot on the latter, yellow; rarely nearly black with one or two small spots, tips and humeri of elytra, yellow; scutellum always yellowish. Thorax one-fourth longer than wide, narrowed in front; sides feebly curved, sinuate in front of hind angles, which are rather long, acute and with a feeble carina close to edge. Elytra striate, the striæ indistinctly punctate; intervals nearly flat, rery finely punctulate. Length $7.5-10 \mathrm{~mm}$.

Throughout the State; frequent. June 22-Aug'ust 11. Occurs on mullein and foliage of various trees. (Fig. 280.) The larva is said to prey upon beans, and is also injurious to cotton in the Southern States.

*1374 (4190). Monocrepidius auritus Hbst., Kafer, X, 1806, 145.

Oblong, robust. Color above exceedingly variable, three distinct types being usually present. These are (a) uniform piceous or piceous with only a median stripe on thorax reddish; (b) dull red, with two small spots on thorax, one on elytra surrounding scutellum, and a subapical crossbar, black; (c) red, with two stripes on thorax, margin. suture and apex of elytra black; beneath piceous or fuscous, legs and two basal joints of antennæ yellow. Thorax convex, scarcély longer than wide, sides obtusely rounded, hind angles nearly straight, finely carinate; surface densely, deeply and rather coarsely punctate. Elytra with sides parallel to apical fourth, thence slightly curred to a broadly rounded apex; disk striate, striæ punctured; intervals subconvex, finely but roughly punctulate. Length $5-\tau \mathrm{mm}$.

Throughout the State; common. March 4-December 25. Hibernates beneath mullein leaves. logs and rubbish along fence rows and on side hills, especially in sandy localities. Mates in May and June.

*1375 (4191). Monocrepidius bellus Say, Journ. Phil. Acad. Nat. Sci., III, 1823,168 ; ibid. II, $10 \mathrm{~S}$.

Oblong, subconvex. Black, sparsely pubescent; thorax with a median line and hind angles reddish; elytra dull red, each with two or three black 
lines, these often connected at middle and near apex by two narrow and sinuous black crossbars; antennre and legs yellow. Thorax slightly longer than wide, convex, narrowed in front, sides feebly curved on apical half; hind angles short, obtuse, divergent; surface densely and rather coarsely punctured. Elytra gradually tapering from base to apex, striate-punctate. Length $3.5-4 \mathrm{~mm}$.

Southern half of State; frequent. January 19-December 25. Hibernates beneath rubbish in damp localities. At electric lights in summer.

XXIV. Dicrepidius Esch. 1829. (Gr., "two + little shoes, i. e. lobes."')

Elongate brown hairy insects separated from the next genus only by the characters given in the key. The hind coxal plates in both are strongly dilated inwards and toothed. One of the three recognized species has been taken in the State.

1376 (4195). Dicrepidius Palmatus Candez., Mon. de Elat., II, 1859, 146.

Elongate, very slender. Dark reddish-brown to piceous, very sparsely pubescent with yellowish hairs. Antennæ of male branched or pectinate; second joint (in both sexes) globular, one-sixth the length of third, the latter as long as fourth. Thorax distinctly longer than wide, sides feebly rounded; disk sparsely and rather coarsely punctate; hind angles long, strongly carinate. Elytra gradually attenuate from middle to apex, strice coarsely punctate; intervals subconvex, finely and sparsely punctulate. Length 14-16 $\mathrm{mm}$.

Lake County; rare. July 21. Taken from beneath the bark of pine.

\section{Ischiodon'tus Cand. 1860. (Gr., "coxa + tooth.")}

Clypeus strongly margined but not crested; prosternal sutures excavated in front and concave on outer side; tarsi with lobes beneath both second and third joints.

1377 (4197). Ischiodontus soleatus Say, Trans. Amer. Phil. Soc.; VI, 1836, 176 ; ibid. II, 612.

Elongate-oblong, slender, convex. Dark chestnut brown; sparsely pubescent with short, suberect hairs; antennæ and legs reddish-brown. Antennæ strongly serrate, second joint not more than one-third the length of third, the latter as long as fourth. Thorax slightly longer than broad, sides nearly straight, feebly divergent from near apex to tips of hind angles, which are prominent, subacute and finely carinate; surface rather densely and coarsely punctured. Elytra feebly tapering from near base to apex; disk with coarsely punctured striæ; intervals slightly convex, finely and irregularly punctate. Length $10-11 \mathrm{~mm}$. 
Lake, Posey and Crawford counties; rare. May 10-July 21. Probably occurs throughout the State, as it is known from Michigan and Ohio.

\section{Elater Linn. 1748. (Gr., "to drive or set in motion.")}

This, the typical genus of the family, comprises about 50 known North American species having the body more or less wedge-shaped and pubescent; front convex, distinctly margined, base of labrum on a lower level; antennæ serrate, third joint frequently but little wider than second, though often as long as fourth; thorax narrowed in front, hind angles long, acutely carinate: prosternal sutures double and excavated near the front lobe, which is rounded and moderately long; scutellum rounded; elytra strongly striate; tarsi as long as the tibire, joints 1 to 4 gradually shorter, the 5th long; claws simple.

For a synoptical table of the North American species see

LeConte.- "Short Studies of North American ColeopteraElater,' in Trans. Amer. Ent. Soe., XII, 1884, 8-15. State.

The following species have been taken or perhaps occur in the KEY TO INDIANA SPECIES OF ELATER.

a. Hind angles of thorax with two carinæ; thorax rather densely and coarsely punctured.

b. Third joint of antennæ shorter than fourth; uniform chestnut-brown ; length $9 \mathrm{~mm}$.

1378. HEPATICUS.

bb. Third joint of antenne as long as fourth; color piceous-brown; length $14 \mathrm{~mm}$.

aa. Hind angles of thorax with but one carina.

INSIGNIS.

c. Antennæ feebly serrate, joints longer than wide, their outer angles not acute.

a. Dark brown, coarsely pubescent; thorax equally, deeply and rather coarsely punctate.

1379. MANIPULARIS.

dd. Black, finely pubescent; thorax more finely and sparsely punctured on basal half; third joint of antennæ shorter than fourth.

1380. PEDALIS.

cc. Antennæ strongly serrate, joints not longer than wide, their outer angles acute.

e. Antennæe with third joint triangular in both sexes.

$f$. Legs pale; elytra pale, dull yellow, margins blackish near tips.

ff. Legs black.

1381. NIGRICOLLIS.

g. Elytra in great part black or fuscous.

h. Basal and lateral margins of elytra scarlet.

DISCOIDEUS. 
hh. Base of elytra and sides for one-fourth the length red.

LESUS.

$g g$. Elytra pale dull yellow.

$i$. Narrow sutural margin and tip black. 1382. LINTEUs.

ii. Broad sutural stripe and narrow lateral margin black.

1383. SAYI.

ee. Antennæ with third joint not triangular or very feebly so in male.

$j$. Third joint of antennæ very nearly equal to fourth and much longer than second.

l. Pubescence of thorax rather long and coarse; legs reddishbrown.

IMPOLITUS.

7kk. Pubescence of thorax very short.

l. Thorax red.

1384. RUBRICOLLIS.

ll. Boơy uniformly dark brown, nearly black; length 11-16 mm.

1384a. var. SOCER.

$j j$. Third joint of antennæ very little longer than second and distinctly shorter than fourth.

$m$. Black, legs and antennæ alone reddish-brown; thorax finely and sparsely punctate; joints 2 and 3 of antennæ together scarcely longer than fourth.

1385. sUBTILIS.

$m m$. Black; thorax or elytra in part or wholly red or brownish-red.

$n$. Size larger, more robust; length 6.5 or more $\mathrm{mm}$.

o. Thorax wholly or partly red.

p. Apex of thorax black, base and sides red.

pp. Thorax wholly red.

1386. RUBRICUS.

1387. COLIARIS.

oo. Thorax black, elytra scarlet or dull red.

138S. SANGUINIPENNIS.

$n n$. Size smaller, slender; length less than $5 \mathrm{~mm}$.

$q$. Elytra blackish with large oblique basal spot and sometimes the tip dull yellow; thorax often yellow.

1389. AREOLATUS.

$q q$. Elytra dull brownish, the thorax paler. 1390. PUsio.

1378 (4200). Elater mepaticus Melsh., Proc. Phil. Acad. Nat. Sci., II, 1844,160 .

Elongate-oblong, subconrex. Uniform dark brown, sparsely clothed with coarse yellowish pubescence. Antennse with second and third joints together a little longer than fourth. Thorax wider than long, sides rounded; hind angles acute, straight, finely bicarinate. Elytra with punctured strix; intervals flat, wrinkled, sparsely and finely punctulate. Length 9-10 mm.

Lake, Kosciusko, Marion and Posey counties; scarce. April 11June 22. Occurs beneath bark and on vegetation. Resembles a small form of the common Melanotus communis Grll., but readily known by the form of the hind coxal plates.

$E$. insignis Lec., antennæ and legs dull red, length $14 \mathrm{~mm}$., is recorded from Ohio and Texas. 
1379 (4214). Elater manipularis Candez., Mon. Elater, II, 1860, 478.

Oblong, subconrex. Uniform dark reddish-bromu; rather sparsely but coarsels pubescent with yeliowish hairs. Antenne as long as thorax, second joint small, one-half length of third, the two together equal to fourth. Thorax wider than long, sides rounded on apical half; hind angles rather short, dirergent, with distinct oblique carina. Elytral striæ feebly impressed with fine, oblong punctures; intervals flat, rather densely and roughly punctulate. Length $8.5-10 \mathrm{~mm}$.

Lake, Marshall and Fulton counties; scarce. April 21-August 15. Taken beneath cacti and rubbish in sandy localities. Resembles hepaticus but more slender; hind angles of thorax shorter and with but one carina.

1380 (4217). Elater Pedalis Germ., Zeitsch., V, 1844, 176.

Elongate-oblong, convex. Black, shining, sparsely clothed with brownish pubescence; three basal joints of antennæe and legs reddish-brown, the tarsi paler. Thorax scarcely longer than wide, conrex, widest at base, sides feebly rounded; hind angles straight, subacute, finely and obliquely carinate; surface rather finely and sparsely punctured. Elytra with the punctures of striæ longer than broad; intervals nearly flat, transversely wrinkled. Length $6.5-8 \mathrm{~mm}$.

Steuben, Starke and Posey counties; scarce. June 16-July 5. Beaten from vegetation, especially that of tamarack.

\section{1 (4221). Elater Nigricoldis Herbst., Kafer, X, 1806, 73.}

Oblong, subdepressed, sparsely pubescent with yellow hairs. Head, thorax, scutellum and under surface, black; elytra and legs dull whitish yellow; antennæ fuscous, the two basal joints paler; third joint shorter than fourth, much longer than second. Thorax as broad as long, broadest at base, sides rounded on apical third, straight and slightly divergent on basal two-thirds; hind angles acute, carinate; surface densely and coarsely punctate. Elytral strix feebly impressed with rather coarse punctures; intervals subconvex, finely punctulate. Length $8.5-10 \mathrm{~mm}$.

Throughout the State; frequent. April 6-November 17 . Occurs beneath bark and in rotten willow, ironwood and other logs in

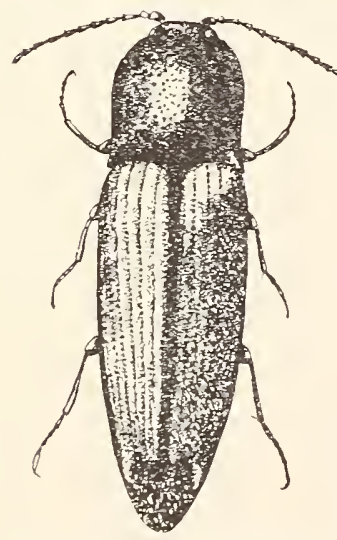

Fig. 281. $\times 5$. (Original.) low. damp woods. Probably hibernates.

E. discoideus Fab., length $10 \mathrm{~mm}$., is known from Canada, Ohio and Georgia; E. lessus Lec. dull black, opaque. length $12 \mathrm{~mm}$.. is recorded from Massachusetts, Ohio and Georgia.

1382 (4222). Elater linteus Say, Trans. Amer. Phil. Soc., VI, 1836, 168; ibid. II, 114, 603.

Resembles nigricollis and mentioned by Say as a variety of that species. Differs in haring the legs, narrow sutural margin of elytra and small space at apex, black. Head and thorax more roughly punctate. Third antennal joint of male as long as fourth. Length 7.5-S.5 mm. (Fig. 281.) 
Frequent throughout the State. April 11-June 2. Occurs beneath bark of red oak and other logs, usually in dry, sandy localities.

1383 (4226). Exater sayi Lec., Trans. Amer. Phil. Soc., X, 1853, 465.

In form, size and general color this species resembles the two preceding. E!ytra with a broad black stripe along the suture gradually narrowing near the scutellum, and a narrow black marginal one reaching from apex three-fourths to base. Third joint of antenna distinctly narrower than fourth in both sexes. Length 11-12.5 mm.

Marion County; rare. A single specimen taken from a hollow in an ash tree. April 22. Recorded only from New York.

E. impolitus Nelsh., black, legs reddish-brown, length $12 \mathrm{~mm}$., is known from Pennsylvania and Ohio.

1384 (4229). Elater Rubricollis Herbst., Kafer, X, 1806, 49.

Elongate-oblong, subconvex. Black, feebly shining, rather densely clothed with short yellowish pubescence; thorax, except the apex and hind angles, and front of head, dull red. Third joint of antennæ more than twice the length of second. Thorax slightly broader than long. widest at base, hind angles feebly divergent, surface rather densely and coarsely punctate. Elytral strix with fine punctures; intervals convex, rather densely and coarsely punctured. Length $12.5-14 \mathrm{~mm}$.

Crawford County; rare. Мay 26. Taken from stem of wheat. 1384a (4228). Elater rubricollis socer Lec., Trans. Amer. Phil. Soc., X, 1853, 467.

Resembles rubricollis in form and structure but has the entire upper surface black, sparsely clothed with short grayish pubescence. Thorax slightly longer than wide, with a faint median impression on basal half. Length 11-16 mm.

Lake and Laporte counties; rare. May 20-June 12. Taken from beneath the bark of pine. A female from Laporte County measures $16 \mathrm{~mm}$. Blanchard claims that socer and rubricollis are synonyms, Herbst's name having priority, but I prefer to retain socer as a variety.

1385 (4232). Erater subtilis Lec., Trans. Amer. Ent. Soc., XII, 1S\$4, 12.

Elongate, slender, subconvex. Black, clothed with fine, short, brown pnbescence; antennæ not longer than thorax, the second and third joints very short, nearly equal. Thorax slightly longer than wide, feebly narrowed from base to apex, slightly rounded on the sides. Elytra with punctured'strix; intervals subconvex, finely punctate. Length $7 \mathrm{~mm}$.

Lake County; rare. June 12. Described from Lake Superior. 1386 (4236). Elater rubricus Say, Ann. Lyc. Nat. Hist., I, 1825, 261; ibid. II, 395.

Oblong, subconvex. Black, sparsely pubescent with yellow hairs; thorax and sides of prosternum red, the former with a broad, polished black spot extending from apex to middle; tarsi and three basal joints of an- 
tennæ paler. Thorax nearly as broad as long, sides feebly curred; surface finely and sparsely princtured. Elstral strix with rather coarse, closels placed punctures; inter'rals nearly flat, rery sparingly and finely punctulate. Length $7-9 \mathrm{~mm}$.

Northern half of State. scarce: not taken south of Marion County. May 30-July 29. Occurs on flowers of Tiburnum and foliage of rarious plants.

1387 (4239). Elater coltaris Say, Amn. Lyc. Nat. Hist., I, 1S25, 26S; ibid. I, 400.

Oblong, rather slender, subconrex. Black, shining, sparsels clothed with grarish pubescence; thorax abore and its sides beneath bright red; antennæ and legs dark reddish-brown. Thorax slightly longer than wide. sides feebly curred on apical half, hind angles acute, scarcely dirergent: surface rers finely and sparsely punctate. Elytral striæ feebly impressed. punctured; intervals sparsely and rather coarsels punctate. Length $\mathrm{S}-$ $8.5 \mathrm{~mm}$.

Marion. Putnam. Vigo. Posey and Crawford counties; scarce. Iarch 3-.June 6. Taken in early spring beneath partly buried logs and stones on wooded hillsides; later on foliage.

*13Ss (4242). Elater sajgetimenxis Sas. Journ. Phil. Acad. Nat. Sci., III, 1823. 177 ; ibid. II, 115 .

Elongate-oblong. subconrex. Black. shining, sparsels clothed with rellowish pubescence; elytra uniform pale brick red; tarsi reddish-bromn. Thorax as broad at base as long, feebly tapering from base to apex, hind angles short, acute; surface sparsely and rather coarsely punctured. Elytral striæ feebly impressea with rather coarse distant punctures; interrals rather flat, finels and sparsels punctate. Length $7.5-8.5 \mathrm{~mm}$.

Throughout the State: frequent. Februars 6-June 28. An easily recognized species which occurs beneath loose bark, usually in damp. low wooảs.

1389 (4247). Elater areolates Say, Joum. Phil. Acad. Nat. Sci., III, 1S23. 167 ; ibid. II, $108,610$.

Elongate-oblong. slender. subconrex. Piceous or dark reddish-brown. sparsely clothed with rather long sellowish hairs; elstra each with a large oblique subhumeral spot. and often a common space near tip dull sellow: sides, and often the disk, of thorax sellowish. Thorax as broad as long. sides feebly rounded, hind angles short, acute; surface finely and sparsels. punctate. Elytral striæ feebly impressed with large punctures: interrals sparsels and finels punctured. Length $4.5-5 \mathrm{~mm}$.

Throughoint the State. frequent: less so in the northern commties. April 17--July 24. Beaten from regetation. usually about the margins of low woods. This is the species commonly known as 
obliquts say. described in 18:36. The form with rellow space at apex of elytia was described by him as areolatus 13 years previous. and hence that name has priority.

1390 (4248). Elater pesio Germ.. Zeitschr.. V. 1\& 4 . 169.

Elongate-oblong. subconvex. pubescent with rather long yellowish hairs. Head. thorax and under parts dull reddish-yellow: elytral reddish-brown. Thorax broader than long. but slightly narrowed in front: hind angles short. acute. feebly divergent: surface very finely and spresc puncturert. Elrtral strie feebly impressed with rather coarse punctures; intervals finely and sparsely punctulate. Length 3-3.5 $\mathrm{mm}$.

Kosciusko. Posey and Cianford connties; scarce. June 24 July 11. Beaten from regetation. Our smallest species of the gentus.

XXTII. Drasterits Esch. 1829. (Gr.. "active.")

In this gemus the dilated part of the hind coxa is truncate and not emarginate in front of the trochanter: antennæ feebly serrate. the third joint longer than second. the two together longer than the fourth. For a stmoptical table and notes on the eight known North American species. see

LeConte.--Trans. Amer. Ent. Societr. XII. 1884. 16.

But one species has been taken in Indiana. though another one probably recurs.

1391 (4253). Drasterit's elegaxs Fab. Ent. Srst.. I, 179s, 230.

Elongate-oblong, subconrex. Dull reddish-bromn, finely and sparsely pubescent;

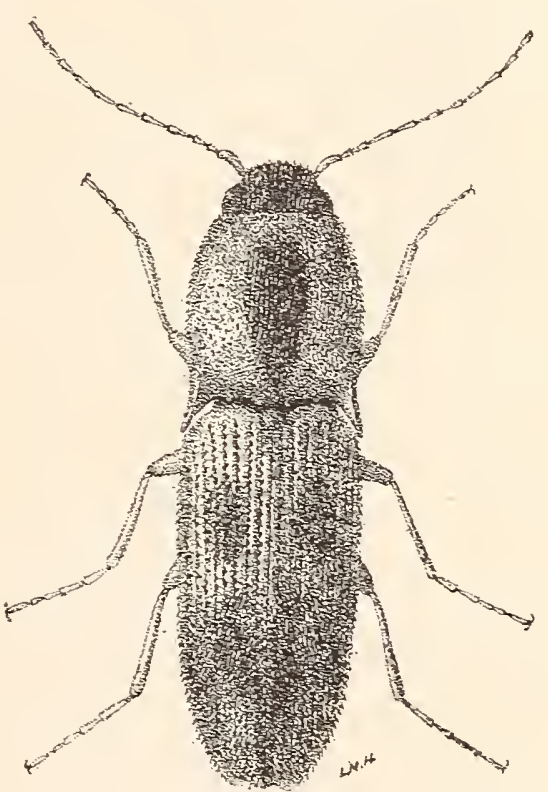

Fig. 2\$2. $\times 7 \frac{1}{2} . \quad$ (After Forbes.) head. median spot or stripe on thorax, scutellum. spot before the middle on each elctron and subapical crossbar. black. Thorax slightly longer than wide, feebly narrowed in front: hind angles acute. prominent; surface rather finely but rery distinctly punctured. Elytral strice with lather coarse punctures: intervals slightly convex. sparsely and finely punctulate. Length 6-т mm. (Fig. 2S2.)

Throughout the state: frequent. February 12-December 26. Hibernates beneath rubbish in same localities as IIonocrpidius auritus and eften confused with that spoeies. The black discal spot of thorax is sometimes reduced to a more point.

[47-23402] 


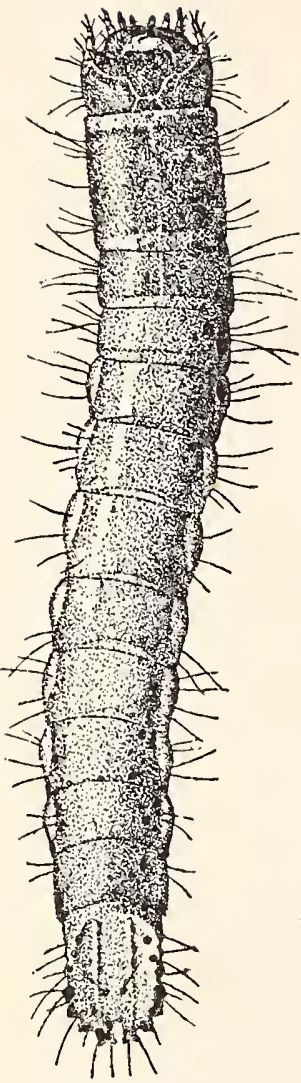

Fig. 282a.

$\therefore \leq$

(After Forbes.)

The larva is one of the smaller injurious wire worms, often doing much damage to corn and wheat. It is of a light waxy yellow color, nine to $12 \mathrm{~mm}$. in length, sparsely hairy and considerably flattened in form; the last segment is nearly tlat, rugose above, without bristle-bearing tubercles and with an acute apical notch. (Fig. 282 a.) It attacks sprouting corn and wheat, especially that planted on sod, eating part of the softened grain and boring up into the tender stem. No effective remedy has yet been discovered, though fall plowing for corn will greatly lessen their numbers.

D. amabilis Lec., color of elegans, length 3 mm., is recorded from Maryland, Ohio and Texas.

Megapenthes limbalis Herbst, black, disk of thorax (in great part) and sides of elytra reddish-yellow. length 8-11 mm., occurs in the Middle and Southern States and has been reer rod from Cincinnati.

XXVIII. Ludius Esch. 1829. (Gr., "a stage player or gladiator." )

I. alge black or dark reddish-brown Elaters, having the prosternal sutures concave on the outer side; tarsi simple, pubescent beneath; hind coxal plates less suddenly dilated on inner side and strongly toothed at insertion of the thighs; second and third antennal joints always small, third a little shorter than second, the two together shorter than fourth, the terminal joint suddenly narrower near apex. presenting the appearance of a false joint. (Fig. 3, No. 1.) For a synopsis of the genus see

LeConte.-Trans. Amer. Ent. Soc., XII, 1884, 45-49.

1392 (4271). Ludius attenuatus Say, Ann. Lyc. Nat. Hist., N. Y., I, 1825, 257 ; ibid. I, 392 ; II, 600.

Elongate, moderately robust, gradually narrower behind the middle. Dark reddish-brown or black, feebly shining, clothed with very fine silky pubescence; thorax usually reddish with elytra black. Thorax as long as wide, or longer in the male, gradually narrower from base to apex, sides feebly curved; hind angles rather short, strongly carinate; disk coarsely but not densely punctate. Elytra not wider than thorax, rapidly narrowing to apex, tips acute; surface obsoletely substriate, densely and rather roughly functate. Cavity of mesosternum into which prosternal spine fits with sides parallel and elevated. Length 14-22 $\mathrm{mm}$. 
Throughout the State; frequent. June 30-September 26. One was noted emerging from pupal stage on the former date. Occurs beneath bark of decaying walnut, mulberry and other stumps and $\log s$.

1393 (4275). Lunius abruptus Say, 7oc. cit., 253; ibid. I, 399.

Elongate, moderately robust. Black, shining, clothed with fine black, silky pubescence; antenne and legs piceous, the former reaching tips of hind angles of thorax in male, shorter in female. Thorax as wide as long, female, somewhat narrower, male; sides curved and narrowing to the front; hind angles scarcely divergent, carinate; disk convex, shining, rather coarsely, not closely punctate. Elytra not wider than thorax, sides gradually curved and narrowing to apex, the tips together rounded; surface substriate, finely and densely punctured. Sides of mesosternal cavity strongly convergent behind, not elevated. Length $15-20 \mathrm{~mm}$.

Starke, Putnam and Lawrence counties; rare. July 4-August 7.

XXIX. Orthostethus Lac. 1857. (Gr., "straight + breast.")

This genus is represented in the southern Atlantic States and southern Indiana by the single large species:

1394 (4278). ORthostethus infuscatus Germ., Zeitschr., V, 1S $\mathbf{4}, 183$.

Elongate, strongly attenuate behind the middle. Uniform dark reddish or sooty brown, densely clothed with brownish-yellow prostrate hairs. Antenne with second joint less than half the length of third, the latter shorter and much narrower than fourth. Thorax slightly longer than wide, subconvex, sides rounded on apical third, straight and parallel on basal twothirds; hind angles long, acute, divergent, strongly and obliquely carinate; surface rather densely and finely punctate. Elytra gradually tapering from base to apex, obsoletely striate, more densely punctate than thorax. Length $26-30 \mathrm{~mm}$.

Lawrence and Crawford counties; scarce. July 2-July 26. Occurs beneath loose bark of old snags, on high wooded hills. A typical example of the Austroriparian fauna of the southern third of the State.

\section{Subtribe B. (Corymircini.)}

In this subtribe the hind coxal plates are gradually, sometimes scarcely, widened on the inner side, the hind margin being nearly straight, and often not toothed over the insertion of the thighs. The claws are serrate or pectinate in several of the genera. Of the 20 North American genera composing the subtribe 14 are known to be represented in Indiana, while two others perhaps occur. 
KEY TO INDIANA GENERA OF CORTMITINI.

u. Front or clypeus conrex, its edge higher than the labrum; mouth inferior and applied to the prosternum in repose.

b. Front truncate, not margined behind the labrum. though higher than it; tarsal claws simple; size $\tau$ or more $\mathrm{mm}$.

c. Sicle margins of thorax bent downward in front.

cc. Side margins of thorax straight.

XXX. Agriotes.

XXXi. DoLopies.

bb. Front margined behind the labrum: tarsi slightly lobed, the clatrs with comb-like teeth: size small. not more than $6 \mathrm{~mm}$.

XXXII. Glyphoryx.

aa. Front flattened; mouth horizontal or anterior (except in sericus).

d. Front margined.

e. Tarsal claws with comb-like teeth; color usually dull reddishbromrn or piceous.

XXYIII. MELANOTLS.

ee. Tarsal claws simple.

$f$. Hind tarsi with first joint scarcely longer than second; color dull soots brown.

XXXIY. Limonits.

ff. Hind tarsi with first joint elongate.

\%. Prosternal lobe rers short.

h. Antennre 11-jointed; metasternum acute.

CAMPILCS.

hh. Antenna 12-jointed: metasternum obtuse.

Pitrobies.

gg. Prosternal lobe long.

$i$. Sutures of prosternum single; thorax usually distinctly longer than wide.

XXXY. Атног'

ii. Sutures of prosternum double; thorax scarcely longer than wide. more convex.

XXXTI. Leptoscheni.

dd. Front not margined; usualls slightly concare.

j. Sides of mesosternal carity not protuberant; size usualle medium or small; color rarely uniform black.

li. Tarsi simple, filiform.

1. Prosternum not lobed in front. the sutures straight; third joint of antennie small; length $6.5-7 \mathrm{~mm}$. XXXTII. Buadus.

17. Prosternum lobed in front.

$m$. Lobe of prosternum short. the sutures excarated in front: elytra striate; length 11-12.5 mm. XXXVIII. Nothodes.

$\mathrm{mm}$. Lobe of prosternum long.

n. Front conrex; hind coxal plates scarcels narrower at the outer end: length $6.5-7.5 \mathrm{~mm}$. XXXIX. SERICLS.

m. Front more or less flattened; coxal plates distinctls narrower at outer end.

o. Tarsal cilars simple; color often rariegated.

XL. Corymbites.

on. Tarsal claws with a broad tooth at base; piceousbronzed. elstra reddish-brown. XLI. Oxygoxts.

hli. Tarsi with the second and third joints lobed beneath.

XLII. Asaphes.

$j j$. Sides of mesosternal carity motuberant: size large, 18 or more mm.. color uniform black.

Xliti. Melanactes. 
XIX. Agroter Exh. 1829. iGr'. "will,."

Moderate sized oblong species. having the prosternum lobed.in front. its sutures double: antennix slender. scarcely serrate. the first joint a little longer than usual: hind coxal plates but slightly broader on the inner side. and with a large tooth abore the insertion of the thighs. For a srnoptical table of the North American species with notes. see

LeConte.- - Short Studies of North American ColeopteraAgriotes." in Trans. Amer. Ent. Soc.. XII. 158t. 15-19.

Six species have been taken in Indiana. While another probably nceurs in the northern counties.

KEY TO INDIATA SPECIES OF AGRIOTES.

a. Hind coxal plates rere gradually dilated from without to inner side and not twice broader at imner third than at outer end.

b. Form robust: mandibles thick. the tips broad. chisel-shaped: thorax rers conver. coarsele and densely punctate. 139.5. MAXCLS.

bъ. Form more slender: mandibles much more slender, tips subacute.

c. Thorax coarsely punctured in front. verr finely and densels punctured behind the middle.

1396. STABILIS.

cc. Thorax similarls. usually coarsely. punctured orer the entire surface.

d. Antenne with joints tro and three each distinctly shorter than fourth : side margin of thorax distinct in its entire length.

c. Hind angles of thorax not risibls carinate: color pale bromn with dense grarish pubescence: smaller. i-s mm.

1397. IXSAYTS.

ec. Hind angles of thorax rerp distinctle carinate; color rariable: larger. :-12 mm.

ELCOSTS.

d. Antennie with joints two and three each equal in length to, and sarcely narromer than. joint four: sicte marcin of thorax indistinct in the middle of its length and rerr much deflexed in front: color clark fuscous.

139S. PCBESCENS.

an. Hind coxal plates rather sudtenls dilated within. more than trice as broad at immer third than at outer end.

$f$. Joints two and three of antenne each shorter than fourth. the third shorter than second; thorax distinctly longer than wide.

1399. OBLONGICOLLIS.

ff. Antennie with joints two. three and four rerr nearly of equal length: thorax scarceer longer than wide. coarsely and deeply punctate.

1100. ArLLSLS 
1395 (4279). Agriotes mancus Say, Journ. Phil. Acad. Nat. Sci.. III. 1\$23. 171: ibid. II, 111.

Oblong. subconvex. Dull brownishrellow. dusky beneath, sparsely clothed with short yellowish pubescence: head and thorax often fuscous; tibiae and tarsi paler. Thorax slightly wider than long, sides regularly curved from base to apex; hind angles short, feebly dirergent; disk with a shallow median line on basal half. Elytra with sides parallel on basal half, thence gradually rounded to apex; striate, the stria finely punctate; intervals nearly flat, finely and transversely wrinkled. Length $7.5-$ $8.5 \mathrm{~mm}$. (Fig. 283.)

Lake County ; frequent. March 26-June 24. Should be found throughout the State. The larva is known as the "wheat wireworm,",

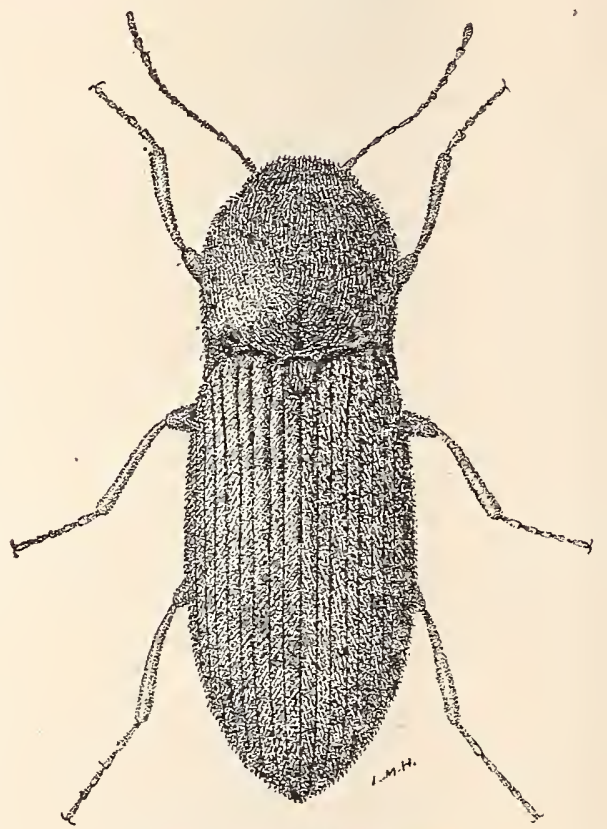

Fig. 283, $\times 7$. (After Forbes.) and is injurious to corn, wheat and other cereals espec ally those growing in low, wet lands. It is a cylindrical, pale brownish-yellow species, having two conspicuous black circular pits near the front

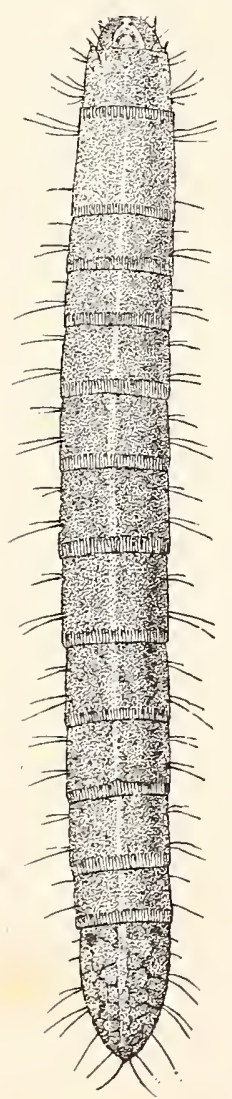
margin of upper surface of last segment. (Fig. 28t.) It bores into the stems of corn from the time the latter appears above the ground until it is a foot or more high, causing the infested stalks to wither and die. About three years are necessary for the larva to reach maturity, when it pupates in earthen cells. If disturbed by fall plowing, many of the pupx or matured beetles are killed. As yet no other effective remedy has been discovered.

1396 (4280). Agriotes stabilis Lec., Trans. Amer. Phil. Soc., $\mathrm{X}, 1853,457$.

Elongate, rather robust. Color rariable, head and thorax usually piceous; elytra often dull red, pubescent: antenne and legs reddish-brown. Thorax one-third longer than wide, sides nearly parallel, rounded in front; hind angles feebly divergent, not, or very obtusely, carinate; surface distinctly but finely punctate in front, very densely and finely punctate behind the middle. Elytral strix finely and deeply punctured; intervals flat. minutely punctulate and with fine transverse wrinkles. Length $9-11 \mathrm{~mm}$.

Lake and Steuben counties; rare. June 17. Beaten from sassafras. A member of the AlleFig. 284. (After Forbes.) ghanian fauna. 
1397 (4281). Agriotes insayes Cand., Elat., IT, 376.

Elongate-oblong; slender. convex. Pale dull brown; head and thorax somewhat darker: legs paler. Thorax slightly longer than broad: sides rounded on apical third; hind angles feebly diverging. subacute. not visibly carinate; disk with a median impressed line on basal half, rather densely and finely punctate. Elytral strixe rather finely punctate; intervals densely and roughly punctulate. Length $i-S \mathrm{~mm}$.

Marion, Lawrence and Posey counties; frequent. April 16June 6. Oceurs on flowers of the red haw. Cratagus, and later on the foliage of the horseweed. Ambrosia trifida.

A. fucosus Lec., piceons or with the sides of thorax dark red. sometimes with elrtra or even entire upper surface reddish-brown, is a northern species ranging from New England to California.

1395 (4286). Agriotes pubescexs Melsh., Proc. Phil. Acad. Nat.

Sci., II, 18 15.217.

Elongate, convex. rather densely clothed with grayish-yellow pubescence. Dark fuscous or sooty brown; antemnæ and legs dull reddish-brown. Thorax distinctly longer than wide, sides parallel and straight from base to apical fourth, thence suddenly rounded to apex; hind angles slightly divergent, carinate; surface deeply. rather densely and equally punctate. Elytra with sides parallel to beyond the middle, thence gradually narrowed to tips. which are acuteis rounded; strixe with fine punctures : intervals nearly flat. densely and roughly punctulate. Length $9 \mathrm{~mm}$. (Fig. 2S5.)

Lake and Wells comnties: scarce.

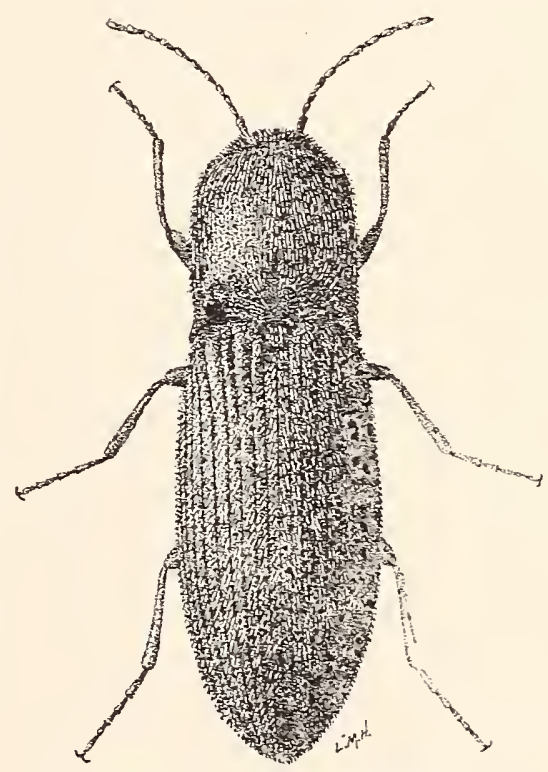

Fig. $285 . \times 5 \frac{3}{4}$. (After Forbes.) May 17-June 24. Recorded from Pennsylrania and Ohio.

1399 (4290). Agriotes oblongicollis Melsh.. Proc. Phil. Acad. Sci.. II. $1845,218$.

Elongate, slender. convex. Dark redish- to fuscous-brown. sparsely clothed with rellowish pubescence; antennie and legs pale reddish-brown. the former longer than head and thorax. Thorax subcylindric, convex; sides nearly straight to apical fourth. then curved to apex; hind angles acute, dirergent. feebly carinate; surface finels and densely punctate. Elytral stria fine. impressed with oblong punctures: intervals minutely and rather densely punctulate, appearing as if transrersely wrinkled. Lengtl 6-9 $\mathrm{mm}$.

Throughout the State; frequent in the southern half. less so northward. April 17-August 13. Occurs in April and May on 
flowers of Cratagus, and later on foliag of raricus plants. Noted as mating on April 26.

1400 (4293). Agriotes avulsus Lec., Trans. Amer. Phil. Soc., X, 1853, 457.

Elongate-oblong; convex. Piceous-black, shining; sparsely clothed with yellowish pubescence; legs and antenn:e pale reddish-brown. Thorax slightly' longer than wide, sides rounded on apical thind ; hind angles feebly diverging, strongly carinate; surface rather sparsely and very coarsely punctate. Elytral strixe rather coarsely punctate; intervals nearly flat, sparsely and loughly punctulate. Length $8 \mathrm{~mm}$.

Vigo County; scarce. May 24-June 9. Beaten from foliage. Known heretofere only from New England and Pennsylvania. Resembles pubescens but readily distinguished by the form of hind coxal plates, more shining surface and more coarsely punctured thorax.

XXXI. DoLopius Esch. 1829. (Gr., "crafty.")

Differs from Agriotes only in having the side margin of the thorax straight instead of being bent downward in front. One species only is known from North America.

1401 (4297). Dolopius lateralis Esch., Thon. Archiy., Ent. II, 1S29, 34.

Elongate, slender, subconvex. Piceous or sooty brown, sparsely clothed with short yellowish pubescence; apex and hind angles of thorax, more or less distinct subhumeral stripe of elytra. legs and basal joints of antenne. yellowish. Thorax slightly longer than wide, sides parallel, rounded on apical fourth; hind angles acute. prominent. not divergent; disk densely and rather finely punctate, and with a faint median impressed line on basal half. Elytral strixe with distinct, close-set punctures; intervals flat, finely, densely and rugosely punctulate. Length $7-S \mathrm{~mm}$.

Northern half of State; frequent. April 15-October 12. Beaten from foliage, especially that of tamarack; often occurs on flowers of blackberry. In some specimens the yellow on elytra is reduced to a mere trace on humeral angles.

\section{Glyphonyx Cand. 1863. (Gr., "carve + claw.")}

Small, slender, brownish bestles, attenuate behind the middle and having the clypens more or less angulate; hind angles of thorax not carinate; third and fourth joints of tarsi slightly lobed beneath. Five species are known from the United States, four of which occur in Indiana. 
KEY TO INDIANA SPECIES OF GLYPHONYX.

a. Front of clypeus distinctly angulated.

b. Head at least, and usually the sutural line, dusky.

c. Larger, more robust; third and fourth talsal joints lobed beneath; length $5.5-6 \mathrm{~mm}$.

1402. REC'TICOLLIS.

ce. Smaller, more slender; fourth tarsal joint only lobed beneath; length $4.5-5 \mathrm{~mm}$.

1403. INQUINATUS.

bb. Color unifor'm dull reddish-yellow or "rufo-testaceous"; length 4$5.5 \mathrm{~mm}$.

1404. TESTACEUS.

a a. Front of clypeus rounded or very obtusely angulated; color sooty or blackish-brown; length $4.5-5 \mathrm{~mm}$.

1405. QUIETUS.

1402 (4299). Glyphonyx nectrcoldis Say, Journ. Phil. Acad. Nat. Sci., III, 1823, 168; ibid. II, 109, 622.

Elongate-oblong, slender. Dull brownish-yellow; head, disk of thoras and sutural margins dusky; legs and antennie paler. Clypeus strongly descending with the apex almost rectangular. Second and third joints of antenure short, subequal, together one-half longer than fourth. Thorax as broad as long, sides straight, rounded on apical fourth; disk rather sparsely and finely punctulate; hind angles not carinate, scarcely divergent. Elytral stria punctate; intervals subconvex, with numerous minute punctures. Length $6 \mathrm{~mm}$.

Southern two-thirds of State; frequent. March 8-November 1. Readily known from the next three by its larger size.

1403 (4302). Glyphonyx inquinatus Say, Trans. Amer. Phil. Soc., Vit, 1S36, 175 ; ibid. II, 611.

Elongate-oblong, slender. Pale brownish-yellow, rather densely pubescent with long yellowish hairs; head and often a narrow sutural line dusky. Thorax slightly broader than long; sides nearly straight, slightly rounded on apical fourth, hind angles acute, not carinate, feebly divergent; surface finely and densely punctate. Elytra with finely punctured strixe; intervals nearly flat with minute punctures. Length $4.5-5.5 \mathrm{~mm}$.

Southern half of State; frequent. January 5-December 25. Hibernates beneath iubbish along fence rows and in dry, open woods; most frequent in June on vegetation.

1404 (4300). Gryphonyx testaceus Melsh., Proc. Phil. Acad. Nat. Sci., II, 1S45, 219.

Resembles recticoltis but smaller and entirely dull reddish-yellow in color. Thorax with sides straight except immediately at apex, where they are rounded; hind angles not divergent. Clypeus acutely angulated at apex. Length $4-5.5 \mathrm{~mm}$.

Throughout the State; frequent. April 6-December 23. Occurs in spring beneath chunks and stones in sandy localities; in summer on foliage. 
1405 (4301). Glyphonyx Qutetus Say, Trans. Amer. Phil. Soc., VI. 1836, 184 ; ibid. II, 622 .

Elongate. slender. conrex. Blackish-brown or piceous, rather densels clothed with short rellowish hairs: antennie reddish-brown: legs pale rellow. Clypeus obtusely rounded in front. Thorax as in recticollis, the hind angles scarcels direrging. Tarsal claws with few rather robust teeth. Length $4.5-5 \mathrm{~mm}$.

Southern half of State. Narshall County only in the north: frequent. Narch 25-June 10. Beaten from vegetation.

XXXIII. NELANoTts Esch. 1829. (Gr.. "black+ back.")

This génus contains a number of small or moderate-sized clickbeetles, usually uniform dull brown in color and having the clypeus margined in front; antennx serrate, with the first joint broad. the second and third rariable; prosternum lobed in front, the sutures double and concave on outer side; hind coxal plates gradually dilated inwards and toothed above the insertion of the thighs: tarsi not lobed beneath, the claws with distinct. comb-like teeth. The males usually have the antennal joints pilose or clothed with erect bristling hairs.

The larva of three or four of the species are among the most destructive of the wireworms. The adults usually occur beneath bark or on the foliage of trees, to which their pectinate claws enable them to readily cling. They are so similar in form and hue that they are very diffeult to separate. There is no special literature on the genus, the descriptions being widely scattered and many of them doubtless synonymous. and the group has given me more trouble than any other genus treated in the paper. All the Indiana specimens have been compared with such types and named species as are in the Horn collection at Philadelphia and the LeConte and Neisheimer collections at Cambridge. Of the 45 species listed from the Enited States, 19 have been taken in Indiana. while 9 others are herewith described for the first time. For convenience they are first separated into two gromps and these in turn into species.

KEY TO GROUPS OF INDLANA SPECIES OF MELAXOTUS.

a. Third joint of antemne but little if ans longer than second. the two together almost always shorter than fourth.

Group 1 .

aa. Third joint of antenne at least one-half longer than second, the two together equal to or longer than fourth.

Group $B$.

\section{Grotp A.}

This group comprises seven of the 28 species. The third joint of antennx may be slight!y longer than second. but never one-half longer. 
KEY TO SPECIES OF GROUP A.

a. Size la rger, 14.5 or more nmm.

7. Sides of thorax straight or nearly so ; those of elytra distinctly converging on apical half.

c. Thorax distinctly narrower at apex than base, the sides straight from base to apex; last ventral of male very coarsely punctate; length $15-16 \mathrm{~mm}$.

1406. CORTICINUS.

cc. Thorax very slightly narrower at apex than base, the sides distinctly rounded near apex; length $17.5-18 \mathrm{~mm}$.

1407. GLA NDICOLOR.

b7. Sides of thorax feebly but distinctly rounded, slightly sinuate in front of hind angles; those of elytra parallel or nearly so; color darker; lengtl 18-21 mm.

140S. CASTANIPES.

aa. Size smaller, not over $12.5 \mathrm{~mm}$.

d. Disk of thorax evenly and rather coarsely punctate; carinie of hind angles acute, distinct, close to and parallel to outer edge and reaching beyond the middle of thorax.

1409. IGNOBILIS.

dd. Disk of thorax unevenly and sparsely punctate; carince of hind angles more or less oblique, not reaching middle.

$c$. Thorax more densely and coarsely punctured on sides than on middle, its sides straight or nearly so from base to apex; antenna of male very long.

1410. LONGICORNIS.

ce. Thorax rather finely and sparsely punctured on both sides and middle, its sides distinctly rounded on apical half.

$f$. Ventral segments of abdomen, except the last. finely and rather sparsely punctate; reddish or chestnut brown; length $7-9 \mathrm{~mm}$.

1411. AMERICANUS.

$f f$. Ventral segments with coarse, dense, elongate, more or less confluent punctures; piceous or dark fuscous-brown; length 10 $11 \mathrm{~mm}$.

1412. CRIBRIVENTRIS.

1406 (4304). Melanotus cortrctes Say, Jouril. Phil. Acad. Nat. Sci., III, 1823, 174 ; ibid. II. $113,621$.

Elongate, subconvex. Chestnut or dark reddish-brown, sparsely clothed with long grayish hairs. Second and third joints of antennie small, rounded, subequal; together much shorter than fourth. Thorax one-fourth longer than wide; disk with a miedian impressed line on basal half; surface rather sparsely and coarsely punctate. more densely on sides; hind angles feebly diverging, strongly carinate. Elytral strixe feebly impressed with rather large, close-set punctures; intervals sparsely and finely punctulate. Length $14.5-15.5 \mathrm{~mm}$.

Knox, Orange, Crawiord and Fosey counties; scarce. May 15June 8. The seven specimens at hand are all males.

1407 (4321). Meranotus glandicolor Melsh., Proc. Phil. Acad. Nat. Sci.. II, $1 S+4,152$.

Elongate, the sides straight and parallel from near the front angles of thorax to beyond the middle of elytra. Chestnut-brown; sparsely pubescent with grayish-yellow hairs. Second and third joints of antemle sub- 
equal, together a little shorter than fourth. Thorax subquadrate, convex. rather sparsely punctate at middle, very coarsely and closely on sides and with a faint median impressed line near base; hind angles strongly and acutely carinate. Elytral strixe with crenate punctures; intervals flat, finely and sparsely punctulate. Length $17.5-1 \mathrm{~s} \mathrm{~mm}$.

Orange and Crawford connties; rare. June 1-June 26. This species may prove to be the female of corticinus. The single type at Cambridge is a female, as are also both of my specimens.

1408 (4320). Melanotus castanipes Payk., Faun. Suec. Insect., III, 1S00, 23.

Elongate, the sides parallel. Tery dark reddish-brown, sparsely pubescent. Second and third joints of antenna subequal, together slightly shorter than fourth. Thorax a little longer than wide, distinctly narrower at apex than base, sides feebly but distinctly rounded from base of hind angles to apex; disk coarsely and densely punctured, the median impressed line distinct on basal third; hind angles elongate, acute, divergent, strongly and obliquely carinate. Elytra with sides straight and parallel from base nearly to apex; striæe feebly impressed with elongate punctures. Length $18-21 \mathrm{~mm}$.

Laporte County; rare. May 20. Taken from beneath the bark of pine, and probably oceurs on!y in the northern counties.

1409 (4312). Melanotus ignobilis Melsh., Proc. Phil. Acad. Nat. Sci., II, 1844, 152.

Elongate, slender. Piceous or very dark reddish-brown, sparsely pubescent. Antemne elongate, joints broader and more strongly serrate than usual, the third one-fourth longer than second. Thorax subquadrate, slightly longer than wide, a little narrowed in front, sides straight; carinse of hind angles continued onto elytiral humeri. Elytra feebly but distinctly narrowed from base to apex, marked with rows of large, round, deep punctures; intervals minutely and sparsely punctate. Length $10.5 \mathrm{~mm}$.

Fountain County; rare. June 16. Described from Pennsylvania. The long parallel carina of hind angles, carinate humeri of elytra and broad antennal joints make this an easily distinguished species.

\section{0 (- ). MELANOTUS LONGICORNIS Sp. nov.}

Elongate, slender. Chestnut or reddish-brown, sparsely clothed with prostrate grayish hairs. Antenne of male reaching middle of elytra. of female one-fourth shorter; joints 2 and 3 subglobular, the third one-fourth longer than second, together much shorter than fourth. Clypeus concare. coarsely and densely punctate, its front margin feebly angulate at middle. Thorax one-fourth longer than wide, sides straight and diverging from apex to base; disk very sparsely and rather finely punctate at middle, more coarsely and closely on sides. Elytra with rows of coarse, close-set punctures; intervals smooth or nearly so. Abdomen coarsely and rather densely punctate. Length $9.5-10 \mathrm{~mm}$. 
Kesciusko. Vigo, Orange and Posey counties; frequent. May 31-June 6. This species oceurs in collections under the name corticimus, but is very distinet in size, length of male antennix and punctuation of thorax, from that species as above described.

1411 (4336). Melanotus americands IHbst., Káafer, 10, 1806, 74.

Elongate-oblong, slender. Dull reddish-brown, sparsely pubescent with grapish hairs. Second and third joints of antenne slort, subequal. together about equal to fourth. Thorax not longer than wide, distinctly narrower at apex than base, sides feebly rounded on apical half; disk finely and sparsely punctate, with a faint median impression on basal third. Elytral strixe rery feebly impressed with large oblong punctures; intervals finely and sparsely punctulate. Length $7-9 \mathrm{~mm}$.

Throughout the State; frequent. April 27-August 11. The thorax is more convex and rounded on sides in female than in male.

1412 (-). Melanotus cribriventris sp. nor.

Elongate, rather robust. Uniform piceous. sparsely clothed with grayish pubescence; antennæ and legs reddish-brown. Antennæe slender, reaching basal fourth of elytra, second and third joints subglobular, subequal, together one-third shorter than fourth. Clypeus feebly concare, coarsely punctate, its front margin rounded. Thorax slightly longer than wide, sparsely and rather finely punctate; disk with a distinct median impression on basal two-thirds: hind angles rather short, scarcely divaricate. strongly carinate. Elytra very slightly tapering from the base, the punctures small, close-set; intervals smooth or nearly so. Length 10-11 $\mathrm{mm}$.

Kosciusko County; rare. July,11.

Group B.

In this group the third antennal joint is always fully one-half longer than second and sometimes more than as long again. The following species, except one, are represented in the collection at hand:

KEY TO SPECIES OF GROUP B.

a. Hind angles of thorax with two carina, the inner one much less distinct than the onter.

b. Thorax with a more or less distinct median impressed line.

c. Fourth joint of antennie nearly or quite double the length of third: thorax slightly longer than wide; last rentral of male distinctly tumid or convex at middle; larger, 15 or more $\mathrm{mm}$.

1413. DECUMANUS.

cc. Fourth joint of antenne but little if any longer than third: thorax not longer than wide: smaller, not orer $14 \mathrm{~mm}$.

1414. COMMUNIS.

bb. Thorax without a median impressed line. 
d. Clypeus flat or slightly concare; thorax slightly wider at middle than elytra, strongly narrowed in front; length 14-17 mm.

1415. FISSILIS.

dd. Clypeus strongly concare; thorax not wider at middle than elytra; length $15-17 \mathrm{~mm}$.

1416. CANADENSIS.

aa. Hind angles of thorax with but one carina.

$e$. Fourth joint of antennx at least one-third longer than third.

$f$. Size larger, 12.5 or more mm.; form rather robust.

g. Surface of thorax sparsely and rather finely punctate, the sides straight from base to near apex; clspeus subangulate at apex; length $12.5-14 \mathrm{~mm}$.

1417. SAgITTARIUS.

$g g$. Surface of thorax, at least on sides, coarsels and rather densely punctured; sides more or less rounded toward apex; clypeus broadly rounded; elștral intervals coarsels and distinctly punctate; length 14-15 $\mathrm{mm}$.

141S. DIFEICILIS.

$f f$. Size smaller, not over $12 \mathrm{~mm}$; form usually much more slender.

h. Thorax very finely and so densels punctate as to make the surface dull; pubescence short, erect; length 10-11 mm.

OPACICOLLIS.

hh. Thorax normally punctate, the punctures either much more sparse or much coarser.

$i$. Surface closely pubescent with long gray prostrate hairs; elytra but slightly narrowed from base to apex; length 10 $11.5 \mathrm{~mm}$.

1419. PILOSUS.

ii. Surface sparsely pubescent with much shorter hairs; elytra (except in macer) distinctly narrowed behind the middle.

j. Carinæe of hind angies rery long, and close to margin; third joint of antennæ one-half longer than second, the two together slightly shorter than fourth; length $11 \mathrm{~mm}$.

1420. CARINUS.

$j j$. Carinie of hind angles not reaching middle of thorax; third joint more than one-half longer than second.

k. Length not more than $9 \mathrm{~mm}$; form rery slender.

1. Clspeus rounded in front, convex; thorax short, not longer than wide.

1421. TRAPEZOIDEUS.

17. Clypeus subtruncate, concare; thorax more slender. longer than wide.

1422. PRASIXUS.

7ik. Length 10-12 $\mathrm{mm}$. ; form more robust.

$m$. Clrpeus strongly concave; sides of thorax straight; elytra parallel or nearly so.

1423. MACER.

$m m$. Clypeus flat or subconvex; sides of thorax more or less rounded; elytra distinctly narrowing behind the middle.

n. Dark reddisin-brown or fuscous; disk of thorax coarsely and rather sparsely punctate.

1424. TERBERANS.

nn. Pale reddish-brown; disk of thorax rery finely and more sparsely punctate.

1425. ANGUSTATUS.

e. Fourth joint of antennæe but little, if ans. longer than third. 
o. Punctures on basal half of thorax minute. rery dense and sontewhat rugose; those on apical laalf much coalser; lengtl 1:3$1+11111$.

1426. GRADATCS.

ov. Punctures on basal and apical halves of thorax not valying greatly in density and coarseness.

p. Carine of hind angles very distinct, and strongly diverging from apex to their bases, the space between carina and side at base with three or four rows of coarse punctures; length 12$14.5 \mathrm{~mm}$.

1427. DIVARCARINUS.

pp. Carinie of hind angles less distinct and much less divergent. not over two rows of punctires between their bases and sides of thorax.

\%. Larger and more robust species; length 11 or more mm.

$r$ : Thorax very sparsely punctured, finely on the middle of disk. a little more coarsely on the sides; length 11-12 $1 \mathrm{~mm}$.

1428. PARAMPUNCTATI'S.

r. Thorax coarsely and closely punctured on sides.

s. Clspeus broadly but not deeply concave; color dark reddish-brown; length $15 \mathrm{~mm}$.

1429. LIXUS.

ss. Clypeus subconrex; color fuscous or smoky brown; length $13.5 \mathrm{~mm}$.

1430. DEBILIS.

qq. Smaller and much more slender species; length not orer $10.5 \mathrm{~mm}$.

t. Punctures of elytral intervals rery fine and indistinct.

u. Reddish or sooty brown; clypeus subconvex; thorax as long as or slightly longer than wide, rery finely and sparsely punctate at middle, more closely on sides.

1431. DEPRESSUS.

uu. Piceous-black; clypeus subconcave; thorax slightly wider than long. its punctures coarser. 1432. PERTINAx.

tt. Punctures of elytral intervals almost as coarse as those of stria: form ver:y slender; color piceous ; length $7.5-8.5 \mathrm{~mm}$.

1433. TENAX.

141: (4307). Melanotus decumanus Erichs., Germ. Zeitschr., III, 1842, 104.

Elongate, robust. Piceous or dark reddish-brown, sparsely clothed with grayish hairs. Clypeus feebly concave, coarsely and densely punctate. Antennie slightly longer than head and thorax. third joint twice the length of second, three-fifths as long as fourth. Thorax slightly longer than wide, sides sinuate near base of hind angles, distinctly curved in front of middle: disk very coarsely and densely punctate on sides, more sparsely at center and with a smooth. more or less impressed line on basal two-thirds. Elytral stria feebly impressed. rather finely punctate; intervals finely and sparsely punctate. Length 14-18 $\mathrm{mm}$.

Throughout the State; frequent. April 8-July 14. Beaten from pine and beech foliage; also beneath bark. The sides of thorax are more broadly rounded in females than in males. 
*1414 (4323). Melanotus communis Gyll., Schon. Syn. Ins., III, 1S17, 135.

Resembles fissilis but more slender

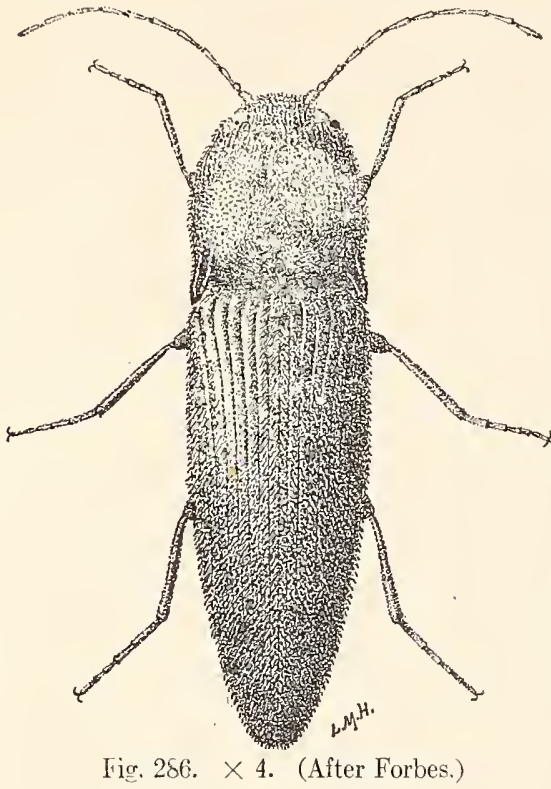
and paler brown in color. Thorax not wider than elytra, not longer than wide and with a distinct median impressed line on basal half; disk less densely and more inely punctured than in fissilis or decumanus. Length 11.5-14 mm. (Fig. 286.)

The most abundant click beetle in the State. Hibernates in the same places as tissilis and often occurs in company with that species. January 14-December 25. Both this species and fissitis are attracted by electric light in May and June. Their larva are among the most injurious wireworms preving upon corn. The larval stage extends over three or four years and the change to a pupa takes place in .July or August. From these pupx the hibernating beetles begin to emerge in about one month.

*145 (4322). Melanotus fissilis Say, Trans. Amer. Phil. Soc. Vi. 1S:36. 183 ; ibid. II, 621.

Elongate, rather robust. Dark smoky brown or piceous, sparsely pabseent. Third joint of antenna mie than twice the length of second, one thind shorter than fourth. Thorax slightly wider than long. widest at middle. sides rounded; basal fissures rery distinct; surface coarsely punctured, more densely on sides. Elytra gradually attenuate from base to apex, strix with crenate punctures; intervals flat, sparsely and finely punctulate and transversely wrinkled. Length $13-17 \mathrm{~mm}$. (Fig. 287.)

Throughout the State, common: more so in the southern countiss. January 5-November 23. Hibernates heneath loose bark, mullein leaves and rubbish and in cracks of logs in dry localities; usually three to a dozen or more close together. The females are

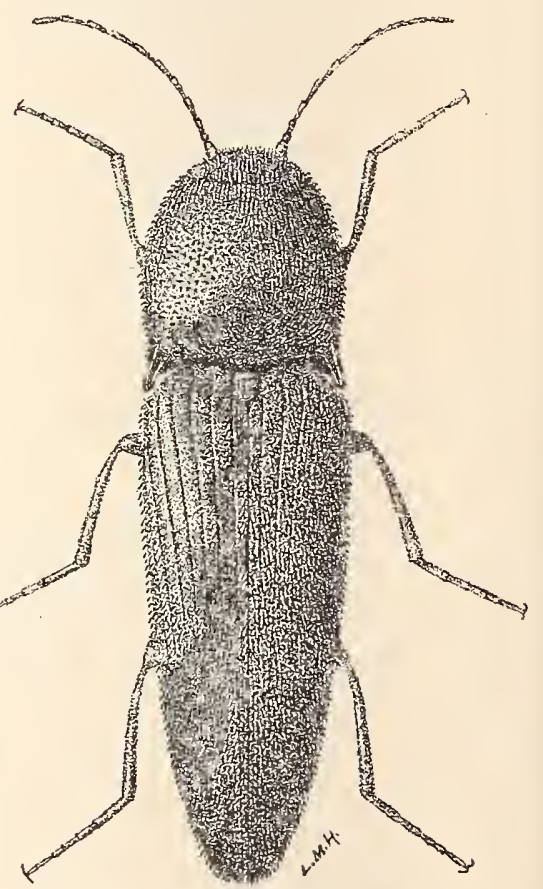

Fig. 287. $\times$ 4. (After Forbes.) much larger and have the disk of thorax more coarsely and densely punctate than the males. 
1416 (4308). Melanotes caxamensis Cand., Monog. Elat., III, 1S60, 342.

Elongate, rohust. I'iceous or dark chestnut brown, sparsely puhescent. Antennie slightly longer than head and thor:ax, third joint double the length of second, one-lialt as long as fourtl. Thorax slightly longer than broadl. apex distinctly narrower than base, sides rounded on apical half; disk coarsely and densely punctate. Elytra feebly but distinctly tapering from base to apex, strice coarsely punctate. Length 15-15.5 $\mathrm{mm}$.

Posey County; rare. June 2. Resembles both fissitis and decumanus. Differs in the strongly concare clypeus and in having the prosternum much more coarsely and closely punctured than in either.

1417 (4343). Melaxotus sagittaries Lec., Trans. Amer. Phil. Soc., X, $1853,480$.

Elongate, slender. Duil sooty or reddish-brown, sparsely clothed with grayish hairs; legs paler. Second and third joints of antenne together distinctly shorter than fourth. Thorax but slightly convex, a little longer than wide, feebly narrowed from base to apex, sides slightly rounded on apical third; disk sparsely and rather coarsely punctate, with an impressed line on basal half. Elytra with rows of rather coarse, feebly impressed punctures; intervals sparsely and finely punctulate. Length 12-13 mm.

Steuben and Kosciusko counties; rare. June 17-July 10. Beaten from elm.

1H1S (-). Melayotus difficilis sp. nor.

Elongate, slender, parallel. Pale reddish-brown, sparsely pubescent. Clypeus short, coarsely punctate. Antenne slender, third joint twice the length of second. one-half as long as fourth. Thorax slightly wider at base than long. narrowed in front; disk, viewed from above, with sides obviously sloping downward toward front angles, coarsely, evenly, not closely punctate; carinie of hind angles piominent, strongly diverging from their tips. Elytra almost parallel, strix feebly impressed, finely punctate. Length $14-$ $15 \mathrm{~mm}$.

Knox and Posey counties; rare. July 2-July 8. Resembles corticinus and sagittarius in form. Elytral intervals more coarsely punctate than in any of cur species except tenax.

11. opacicollis, Lec., fuscous, third joint one-half longer than second. was described from Rock Island, Illinois.

1419 (-). Melayotus pilosus sp. nov.

Elongate-oblong, slender. Pale reddish-brown, densely clothed with long grayish prostrate hairs. Third joint of antenne in male two-thirds longer than second. one-half the length of fourth; in female trice as long as second. two-thirds the length of fourth. Thorax slightly longer than wide. sides nearly straight. feebly rounded on apical half; disk densely and rather coarsely punctate, a faint median impressed line behind the middle. Elytra with sides parallel from base to apical fourth, thence converging to il rounded apex; punctures of strize large, feebly impressed; interrals $[4-23+02]$ 
sparsely and finely punctulate. Prosternal flanks sparsely and finely punctate. Length 10-11.5 $\mathrm{mm}$.

Vermillion, Vigo, Knox and Posey counties; scarce. Juue 6-July 24. More denscly pubescent than any other member of the genus taken in the State. Occurs on regetation, especially that of milkweed.

\section{0 (-). Melanotus carinus sp. not.}

Elongate, rather robust. Fuscous or dark reddish-brown, sparsely pubescent with long gray hairs; antenne and legs paler. Clypeus feebly concave, coarsely punctate. Third joint of antennæ much narrower than and one-half the length of fourth. Thorax subquadrate, scarcely narrower at apex than base, sides almost straight, the punctures very coarse, rather dense at sides, sparse at middle; disk with a vague median impression on basal third. Elytral stria feebly impressed, coarsely punctate; intervals minutely and indistinctly punctate. Last ventral of male with coarse, dense, elongate punctures. Length $12 \mathrm{~mm}$.

\section{Lake County; rare. June 4.}

1421 (4315). Melanotus trapezoideus Lec. Trans. Amer. Phil. Soc., X, 1853. 475 .

Elongate, slender. Dark chestnut or sooty brown, sparsely pubescent with long grayish hairs; antemne and legs paler. Third joint of antennæe twice the length of second, one-third shorter than fourth. Thorax slightly longer than wide, sides nearly straight, feebly rounded on apical third. disk very sparsely and rather coarsely punctate; carina of hind angles long. close to the margin. Elytra subparallel to apical third, thence gradually narrowed to tips; punctures of strixe feebly impressed. Length S-9 mm.

Throughout the State; scalce. March 21-July 3. Probably hibernates. Resembles dcpressus, but the thorax is shorter, and in that species the third joint of antenne is more nearly the length of fourth.

1422 (-). Meianotus prasinus sp. nov.

Elongate, slender, subcylindrical. Reddish-brown, shining, sparsely pubescent. Clypeus subconcave, coarsely punctate. Third joint of antenna twice as long as second, one-third shorter than fourth. Thorax distinctly convex, slightly longer than wide, sides straight to apical third, thence feebly rounded to apex, disk everywhere very finely and remotely punctate. Elytra strongly tapering from base to apex; stria rather coarsely punctate; intervals finely and sparsely punctate. Length $8.5-9 \mathrm{~mm}$.

Vermillion and Posey counties; rare. June 15-July 3. Resembles depressus, but readily distinguished by the shorter, nearly truncate clypeus, narrower and more convex thorax and shorter third joint of antennie.

1423 (4306). Melanotus macer Lec., Trans. Amer. Phil. Soc., X, 1S53, 473.

Elongate, slender, parallel. Rather pale reddish-brown, sparsely clothed with grayish hairs. Clypeus concave, coarsely and densely punctate. An- 
tenna reaching basal third of elytra in male, third joint one-half longer than second, the two together slightly shorter than fourth. Thorax a little longer than wide, sides nearly straight, disk rather sparsely and finely punc- tate. Elytra very little or not at all narrowed from base to apex, striac feebly impressed, rather finely punctate; intervals finely, sparsely and somewhat roughly punctate. Length 10.7-12 mm.

Lake County; rare. June 7-July 11. The slender, parallel form, strongly concave clypeus and straight sides of thorax easily distinguish this species.

1424 (4327). Melanotus verberans Lec., Trans. Amer. Phil. Soc., X, 1853, 478.

Elongate, subdepressed. Dark reddish or fuscous-brown, sparsely clothed with grayish pubescence; antemne and legs smoky reddish-brown. Third joint of antenna twice the length of second, one-third shorter than fourth. Thorax about as wide as long; sides nearly straight on basal two-thirds, thence distinctly rounded to apex; finely and sparsely punctured on disk, more densely and coarsely on sides; hind angles sometimes with a faint inner carina. Elytra feebly attenuate from base to apex, punctures of strix slightly impressed; intervals subconvex, finely and rery sparsely punctulate. Length 10-11.5 $\mathrm{mm}$.

Orange and Knox counties; scarce. June 1-June 6. Resembles communis, but the punctures of thorax much finer on disk and without trace of median impressed line.

1425 (4314). Melanotus angustatus Erichs., Germ. Zeitschr., III, 113.

Elongate, slender. Pale reddish-brown, sparsely pubescent with pale yellowish hairs. Clypeus feebly convex, coarsely and closely punctate, its front obtusely rounded. Third joint of antenna double the length of second, one-third shorter than fourth. Thor'ax a little wider than long, sides straight from hind angles to middle, thence strongly rounded to apex; disk rather sparsely and finely punctate, more closely on sides, the carinæ of hind angles close to and parallel with margins. Elytra finely striate-punctate; intervals very minutely punctate. Length $9 \mathrm{~mm}$.

Steuben and Fulton counties; rare. May 6-eJune 16. A member of the Alleghanian fauna.

1426 (4338). Melanotus gradatus Lec., Proc. Phil. Acad. Nat. Sci., 1866. 390.

Elongate, rather robust. Reddish-brown, sparsely clothed with short pubescence. Third joint of antenne twice as long as second, but little shorter than fourth. Thorax convex, distinctly longer than wide, sides rounded in front of middle; punctures tine and very dense on basal half, gradually becoming sparse and coarse near front margin; disk feebly channeled behind the middle. Elytral strixe with rather distant moderately impressed punctures. Length 13-14 mm.

Vermillion, Lawrence, Clark and Spencer counties; scarce. May 24-June 21. Beaten from foliage of elm. Known elsewhere only 
from Ohio and Maryland. Easily recognized by the peculiar sculpture of thorax.

\section{7 (-). Melanotus divarcarinus sp. nor.}

Elongate, slender. Dull reddish or fuscous-brown, sparsely pubescent. Clypeus feebly concare, coarsely and densely punctate. Antennie of male reaching middle third of elytra, third joint more than twice as long as second, nearly equal in length to fourth; of female, reaching base of thorax, third joint slightly longer than fourth. Thorax as wide at base as long. sides feebly curved and distinctly converging to apex. disk coarsels, erenly and rather closely punctate and with a distinct median impression on basal half; hind angles feebly inflexed rather than dirergent at tips. Elytra gradually tapering from base to apex, the strixe with rather coarse, well impressed, close-set punctures; intervals very sparsely and finely punctate. Length 12-14.5 $\mathrm{mm}$.

Vermillion, Knox and Posey counties; frequent. April 23July 6. Resembles communis in general appearance, but darker. and with a single strongly diverging carina on each hind angle.

1428 (4325). Meranotus Parampunctatus Melsh., Proc. Phil. Acad. Nat. Sci., II, 1S44, 151.

Elongate, rather slender. Chestnut brown, sparsels pubescent; antenure and legs reddish-brown. Clypeus subconvex. coarsely and densely punctate. Antenne slightly longer than thorax, third joint twice the length of second, nearly as long as fourth. Thorax subquadrate, distinctly narrowed toward apex, sides nearly straight from base to middle. feebly curved to apex: disk punctured as mentioned in key and with a faint median impressed lipe on basal two-thirds. Elytra gradually tapering from base to apex, the strixe with feebly impressed punctures; intervals rery sparsely, minutely and roughly punctate. Length 10.5-11.5 mm.

Throughout the State; irequent. May 2-July 4.

1429 (-). Melanotus lixus sp. nov.

Elongate, robust. Dark reddish-brown. sparsely pubescent. Clypeus broadly rounded, coarsely punctured. 'Third joint of antennie twice or more longer than second. as long as fourth. Thorax convex, distinctly longer than wide; sides sinuate near base of hind angles, thence nearly straight to apical fourth. where they are feebly rounded into apex; disk sparsely and rather finely punctate at middle, densely and coarsely on sides. Elytra feebly tapering from the base, strixe rather coarsely and closely punctate; intervals very finely and sparsely punctate. Length $15 \mathrm{~mm}$.

$$
\text { Posey County ; rare. July } 6 .
$$

1430 (-). Mela Notus Debilis sp. nor.

Elongate, robust. Dark smoky or fuscous brown. sparsely pubescent; antenne and less paler. Clypeus less broadly rounded. coarsely punctate. 'Third joint of antennie three-fourths longer than second, slightly shorter than fourth. 'Thorax a little longel' than broad, sides feebly rounded: disk finely and sparsely punctate at middle, more densely and somewhat more 
coarsely on sides and with a rague median impression on basal half; hind angles slightly divergent. Elytra as in Tixus. Length $13.5 \mathrm{~mm}$.

\section{Marshall County; rare. Jurie 26.}

1431 (4313). Melanotus Depressus Melsh., Proc. Phil. Acad. Nat. Sci., II, 1844, 151.

Elongate, slender. Fuscous or dark reddish-brown, sparsely pubescent; antennæ and legs paler. Third joint of antennæ more than twice as long as second, subequal to fourth. Thorax as long as wide, sides straight almost to apex, then feebly rounded; median line obvious from base to middle; carine of hind angles long, parallel and close to margin. Elytra distinctly narrowed from base to apex; the striæ feebly impressed, finely punctate. Abdomen coarsely and rather densely punctate. Length $9-10 \mathrm{~mm}$.

'Throughout the State, frequent; much more so in the northern counties. April 17-July 6. Beaten from vegetation. Close to both trapezoideus and perlinax. From the former it may be known by the longer thorax and the more nearly equal third and fourth ioints of antenna; from pertinax by the paler color. less rounded sides, and finer punctures of thorax.

1432 (4333). Melanotus pertinax Saj, Trans. Amer. Phil. Soc., V'I, 1S36, 185 ; ibid. II. 623.

Elongate, slender. Black or piceous, sparsely clothed with rery fine pubescence; antennæe and legs much paler. Third joint of antennie twice as long as second, slightly shorter than fourth. Thorax slightly wider at middle than long, thence strongly rounded to apex; disk rather coarsely and rery sparsely punctured, a faint median impression on basal half. Elytra gradually attenuate from near middle to apex; strire with feebly impressed punctures; intervals sparsely punctulate, transrersely wrinkled. Length 10-10.5 mm.

Starke and Marshall counties: scarce. May 9-June 26.

1433 (4335). Melanotus tenax Say, Trans. Amer. Phil. Soc., VI, 1836. 185 ; ibid. II, 623.

Elongate, slender. Blackish-piceous; legs and antennæe paler. Third joint of antennæ one-half longer than second, a little shorter than fourth. Thorax slightly longer than wide, sides almost straight to apical fourth. thence rounded to apex; disk rather finely and erenly. not closely punctate, with a vague median impression on basal third. Elytra feebly narrowed from the base; punctures of strixe rather fine, feebly impressed. Length 7.5-8.5 mm.

Steuben County ; rare. May 16-July 8 . Fasily known by the distinct and numercus punctures of elrtral intervals.

XXXTV. Lmonum Esch. 1829. (Gr.. "found in meadows.")

Small or medium-sized rather slender click beetles. usually dul! sooty-brown in color and having the front margined. the mouth anterior; first joint of tarsi scarcely longer than second: tarsal claws simple. In some of the species the margin of the clypens is 
almost obsolete at the middle. No synopsis of the 30 or more species listed from the United States has been published. They begin to reach maturity in May and are most common from then until about August 1, when they mostly disappear.

\section{KET TO INDLANA SPECIES OF LIMONIUS.}

a. Clypeus strongly and deeply emarginate in front; head and thoras rather densely covered witl golden yellow hairs. 1434. AdripILIs.

a a. Clypeus not, or broadiy and shallowly, emarginate in front.

b. Legs and antenna black; thorax brilliant metallic purple, very sparsely pubescent.

1435. AURIFER.

bb. Legs and antennse reddish-brown or piceous; thorax more or less densely pubescent, not metallic.

$c$. Hind angles of thorax distinctly produced and rather strongly carinate.

d. Color dull sooty brown; length 9 or more mun.

$e$. Front of clypeus broadly emarginate, indistinctly margined in the nindale.

f. Form slender; antenna distinctly paler than the body, the third joint notably longer than the second; thorax longel than broad. its hind angles straight and median impressed line indistinct; smaller, 10-14 $\mathrm{mm}$.

1436. GRISEUS.

$f f$. Form broader; antenna fuscous or sooty brown, the third joint scarcely longer than second ; thorax as broad as long, hind :angles slightly but evidently divergent, median impressed line distinct; larger, 12.5-17.5 $\mathrm{mm}$.

1437. INTERSTITIALIS.

$e e$. Front of clypeus broadly rounded or truncate, not emarginate, distinctly margined.

\%. Clypeus rounded in front; antenne entirely black; thorax with a median impressed line.

1438. confusus.

gg. Clypeus truncate in front; antenna with basal joints reddislı; tholax without median impressed line.

1439. PLEBEJUS.

da. Color black; length not orer $7.5 \mathrm{~mm}$.

$h$. Second and third joints of antenna together longer than fourtl ; hind angles of thorax not paler.

1440. QUERCINUS.

$h h$. Second and third joints of antennie small. rounded, together

distinctly shorter than fourth; hind angles of thorax pale reddish-yellow.

1441. BASILLARIS.

cc. Hind angles of thorax short, scarcely produced, feebly and indistinctly carinate.

$i$. Elytra uniform sooty brown or piceous; length 9-11 mm.

AGONUS.

ii. Elytra bicolored, piceous and dull reddish-brown; length 5$6.5 \mathrm{~mm}$.

1442. ORNATIPENNIS.

1434 (4348). Tmmonius Auripitis Say, Journ. Phil. Acad. Nat. Sci., III, 1823. 172 ; ibid. II, $112,602$.

Elongate-oblong. Piceous black; head and thorax densely, elytra sparsely, clothed with yellow hairs; basal joint of antenne, legs, narrow basal 
mal'gin of elstra and epiplenra, reddish-yellow. Third joint of antennit as long as fourth and more than trice as long as second. Thorax slightly longer than broad. sides rounded; disk strongly convex, densely and l’atlel' coarsely punctured; hind angles very short. feebly arinate. Flytral witl punctured strice; interrals flat. densely and coasely punctulate. Lengtli $9-10.5 \mathrm{~mm}$.

Steuben. Kosciusko and Starke counties: scarce. June 1-July ๖. A handsome and easily recognized species.

1435 (4353). Lmonics Acrifer Lec.. Trans. Amer. Phil. Soc., X. 1853. 429.

Elongate-oblong. slender. Black. sparsely clothed with grasish hairs: head and thorax shining metallic purple. Second and third joints of antenna small, rounded, equal, together slightly shorter than fourth. Thorax slightly longer than wide, sides feebly rounded; disk strongly convex. rather sparsely and coarsely punctured. Elytral intervals with punctures almost as large as those of the strixe. Length $6-7.5 \mathrm{~mm}$.

Marion. Jackson and Lawrence counties; scarce. May 20-July 20. Beaten from vegetation.

1436 (4355). Limoxits griseus Beaur.. Ins. Afr. et Amer.. 1805, 214.

Elongate. rather slender. Dull grayish or sooty brown. head and thorax densely. elytra more sparsely. clothed with grayish-rellow pubescence: legs and basal joints of antenne brownish-red; epipleura, inflexed portion of thorax and narrow apical and side margins of thorax and side margins of elytra, often dusky reddish. Third joint of antennie nearly one-third longer than second. the two together Ionger but narrower than fourth. Thorax slightly longer than wide. distinctly narrower at apex than base, sides feebly rounded; disk strongly conrex. densely and rather coarsely punctured. Elstral strice feebly impressed with rather large punctures; interrals flat, each with three irregular rows of smaller distinct punctures. Length $10-14 \mathrm{~mm}$.

Throughout the State; common. May 12-July 12. Taken by sweeping grass and beating regetation.

1437 (4356). Iimoxics ixterstitialis Melsh.. Proc. Phil. Acad. Nat. Sci.. II, $1845,215$.

Elongate. robust. subdepressed. Dull sooty brown. sparsely clothed with yellowish hairs. more densely on head. Third joint of antenne scarcely one-fourth longer than second. slightly shorter than fourth. Thorax as wide as long. sides nearly straight on basal half. feebly rounded in front of middle: disk rather densels and coarsely punctate. a median impressed line on basal two-thirds : hind angles acute. strongly carinate. Elytral striæe with fine punctures; intervals subconrex, distinctly and rather coarsels punctate. Length 13.5-17.5 mm.

Southern half of the State. frequent: much less so in the northexn counties. Mar 16-September 18. Occurs on regetation and beneath corer. Our largest species of the genus. 
1438 (4357). Limonius confusts Lec., Trans. Amer. Phil. Soc., X, 1853, 430.

Elongate-oblong, slender. Dull sooty brown or piceous, slightly bronzed, sparsely pubescent; antennæ entirely piceous; legs and margin of epipleura reddish-yellow. Second and third joints of antennæ short, subequal, together about as long as fourth. Thorax slightly longer than wide, sides feebly rounded; disk convex, densely and rather finely punctured, an impressed median line on basal half; hind angles short, feebly carinate. Ely. tral striæ feebly impressed with close-set punctures; intervals flat, densely punctulate. Length 9-9.5 $\mathrm{mm}$.

Marion, Lawrence, Monroe and Posey counties; scarce. April 12-September 20. Occurs beneath bark of oak and other trees.

1439 (4358). Limonius plebejus Say, Ann. Ljc. Nat. Hist., I, 1S25, 263 ; ibid. I, 396.

Resembles the preceding, but the clypeus is truncate in front; three basal joints of antennæ dull red, the second and third together longer than fourth; thorax without a median impressed line and with the sides (especially in the female) more broadly rounded. Length $\$ .5-9.5 \mathrm{~mm}$.

Posey County; scarce. April 18-May 21.

1440 (4363). Limonius quercinus Say, loc cit.

Elongate-oblong, slender. Black, sparsels clothed with grayish pubescence; antennie piceous, three basal joints reddish; legs reddish-yellow. Clypeus broadly emarginate. Thorax slightly longer than wide, strongly convex, sides feebly rounded; disk finely and rather densely punctate; hind angles short, subacute, feebly carinate. Elytral striæ finely impressed, deeply punctate; intervals finely and sparsels punctulate. Length $4.5-6 \mathrm{~mm}$.

Throughout the State; common. May 16-August 11. Occurs most frequently on the leaves of oak and hazelnut.

1441 (4366). Limonius basillaris Say, Journ. Phil. Acad. Nat. Sci., III, 1823,172 ; ibid. II, 111.

Closely resembles quercinus but usually a little smaller, with the hind angles of thorax more obtuse and always reddish-yellow. Antennæ with joints one and two often reddish-brown. Lobe of prosternum and legs reddish-yellow. Length 4.2-5.5 $\mathrm{mm}$.

Throughout the State; common. May 19-October 12. Beaten from vegetation.

L. agomus Say and L. maculicollis Mots. have both been recorded from near Cincinnati. I have seen no specimen or description of the latter, and hence have not included it in the key.

1442 (4376). Limonius ornatipennis Lec., New Sp. N. Am. Col., I, 1S63, S4.

Elongate-oblong, slender. Black or piceous, finely pubescent with sellowish hairs; elytra each with an oblong, oblique spot reaching from humerus to middle, a common crossbar behind the middle and a narrow space on tips, dull reddish-yellow; hind angles of thorax, legs and basal joints of antennæ also reddish-yellow. Clypeus truncate; second and third joints of 
antennæ short. nearly equal, together a little longer than fourth. Thorax slightly longer than wide, convex. narrowed on basal third; hind angles short. obtuse. not carinate; surface finely and rather densely punctate. Elytra striate, the striae punctate. Length $5.5 \mathrm{~mm}$.

I awrence Comnty : rare. Jume 5. Beaten from sasafras. Deseribed from Pennsilvania.

Cempylus denticomis Kirby. black with paler margins. elytra bronzed-picens, length $11 \mathrm{~mm}$. is recorded from Pennsylrania and Ohio.

Pityobius anguims Lec.. lono. parallel, blackish-piceous, tholas with a deep median groove. length $20-25 \mathrm{~mm}$.. accurs on pine in the Southern States and New Hampshire.

\section{IXIT. Атнот' Esch. 1829. (Gr.. "slow.")}

Differs from Limonius in having the first tarsal joint much longer than second. In all of our species but one, the second and third tarsal joints are slightly lobed beneath and the thorax is distinctly longer than broad. Fonr species have been taken in Indiana. while two others perhaps oceur.

KEY TO INDIANA SPECIES OF ATHOUS.

1. Second and third tarsal joints lobed beneath.

b. Hind angles of thorax not carinate, the apex rounded.

c. Pale chestnut brown : size larger, 11-14 mm. 1443. BRIGHTWELL.

cc. Dark sooty brown or piceous; thorax sometimes pale with darker median stripe; smaller, not orer $10 \mathrm{~mm}$. 144. Acaxthus.

67. Hind angles of thorax distinctly carinate.

d. Second joint of antenne much smaller than third. the latter equal to fourth.

e. Dull reddish- or sooty-brown.

145. CUCULlates. ee. Black, the bases of thorax and elytra narrowly yellow.

1446. SCAPULARIS.

dd. Second and third joints of antennæe small, equal: black, base of thorax reddish-brown.

aa. Second and third tarsal joints not lobed beneath.

POSTICUS.

RUELFRONS.

1443 (43St). Athous brightwelli Kirby. Faun. Bor. Amer.. 1S37. 146.

Elongate. slender. Pale dull brown. sparsely pubescent with yellowisin hairs. Third joint of antennie more than twice the length of second, nearly equal to fourth. Thorax one-half longer than broad. narrower than elytra: sides straight. feebly rounded at middle. margin flattened at front angles: Lind ansles compressed, obtusely rounded. with marcin slightly reflexed: disk densels. rather finely punctate, nsually with a median transverse line on basal half. Elptral striae deeply and rather coarsely punctured; interrals subconvex. finely punctate. transversely rugose. Length 11-1s mm.

Throughout the State: scarce. May 12-July j. Occurs on grass and foliage of oak. beech and hickory. A single specimen 
from Kosciusko County is $4 \mathrm{~mm}$. larger than any others in the collection, measuring $18 \mathrm{~mm}$. in length.

1444 (4385). Athous acanthus Say, Trans. Amer. Phil. Soc., VI, 1836, 178 ; ibid. II, 615.

Differs from the preceding only in its smaller size and usually darker color and in having the thorax more convex and more finely punctured. Rarely the thorax is reddish-yellow, with a narrow discal black spot. Length 7.5-10 $\mathrm{mm}$.

Southern half of State, frequent: Kosciusko County, scarce. Mạy 20-June 24.

1445 (4390). Athous cucullatus Say, Ann. Lyc. Nat. Hist., I, 1825, 264; ibid. I, 397 ; II. 613.

Elongate, slender. Dull reddish or sooty-brown, sparsely pubescent with short, suberect yellowish hairs. Clypeus obtusely rounded and with a large triangular impression. Thorax one-third longer than wide, sides straight, male; broadly rounded on apical half, female; disk convex, densely and rather finely punctured; hind angles obtusely rounded and with a distinct oblique carina. Elytral striae feebly impressed with somewhat distant punctures; intervals subconvex, finely and sparsely punctulate, transversely wrinkled. Length $10.5-11.5 \mathrm{~mm}$.

Lake, Kosciusko, Putnam and Posey counties; scarce. May 12 September 30. The species in hand is the one recognized by LeConte as Say's cucullatus. In the original description Say states that the "second joint of antennx is not much shorter than third," whereas it is not more than one-third the length of third. It is possible that Say meant that the "third joint is not much shorter than fourth." Otherwise LeConte was wrong in his determination, as the comparative length of these antennal joints seldom varies.

1446 (4395). Athous scapularis Say, Trans. Amer. Phil. Soc., VI, 1S36, 178 ; ibid. II, 615.

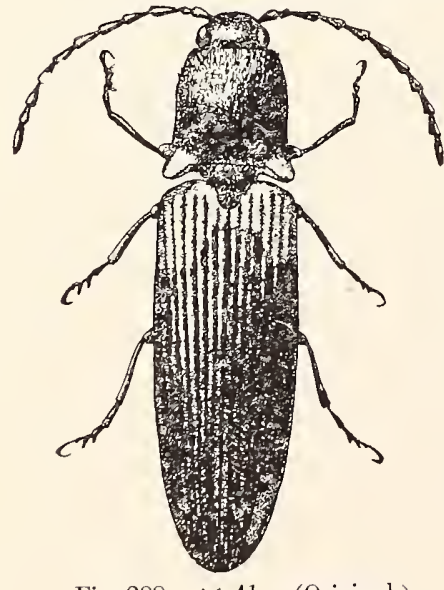

Fig. 288. $\times 4 \frac{1}{2}$. (Original.)

Elongate, slender, subdepressed. Black, opaque, finely and sparsely pubescent; hind angles of thorax and a rather broad humeral iunule on each elytron reddish-yellow; legs piceous. Antenna longer than head and thorax, second joint one-third the length of third. Thorax longer than wide, sides feebly curved, disk densely and finely punctate; hind angles short, obtuse, with a distinct but fine carina. Elytral intervals subconvex, densely and roughly transversely wrinkled. Léngth $9.5-10.5 \mathrm{~mm}$. (Fig. 2SS.)

Kosciusko, Knox, Lawrence, Posey and Crawford counties; scarce. May 28-July

4. Beaten from vegetation, especially that of oak. 
A. posticus Melsh.. length $12 \mathrm{~mm}$., and A. rufifrons Rand., thorax reddish with black conter. elytra brownish with paler sides. length $15 \mathrm{~mm}$. have both been recorded from near Cincinnati.

XXXTI. Leptoschema Horn. 1885. (Gr.. "slender-form.")

Differs from Athous only in having the prosternal sutures double. The antenne are as long as hear and thorax : first joint of hind tarsi much longer than second. the joints not lobed beneath. Three species are listed from the Lnited States, two of which have been taken in Indiana.

144 (4109). Leptoscheja ricolor Lec. Trans. Amer. Phil. Soc., X, 1853. 428.

Elongate-oblong. broadest behind the middle. Abore black or dark reddish-brown. sparsels clothed with short, suberect, grarish-rellow pubescence; beneath miform pale reddish-brown. Clrpeus of female obtusely rounded in front. impressed abore. Antenne with second and third joints each nearis as long as fourth: this and the following joints without prominent angles in either sex. Thorax one-third longer than wide, strongly conrex, sides feebly rounded. disk finels. erenly and densels punctured: hind angles slightly diverging. strongly carinate. Elytral strix fine, the punctures small. close-set: interrals flat. rather densels and roughls punctulate. Length $8.5-12 \mathrm{~mm}$.

Putuam Countr: rare. August 12. A single female taken from beneath the bark of a maple log. It is more robust. less shining and more densely punctured beneath than the single male type in the Cambridge collection.

1ttS ( $\$ 10)$. Leptoscheja discaiceatey Sar. Trans. Amer: Phil. Soc.. II, 1\$36. 169: ibic. II. 604.

Elongate. rather slender. Reddish or pale chestnut-brown. rerr sparseIs clothed with fine rellowish pubescence: beneath pale. dull bromnish-rellow. Clrpeus prominent. subtruncate. Second and third joints of antenne shorter than in bicolor, the outer joints broader: with the angles better defined, thus causing them to appear more serrate. Thorax slightly longer than broad, sides broadly rounded on apical half: disk more sparsels. coarsely and unerenls punctured than in bicolor: hind angles slightly diraricate, strongly and obliquels carinate. Elrtra with sides parallel to apical fourth, thence conrerging to a broadly rounded apex; strixe finely punctate; interrals subconrex. sparsely punctulate. Length $11.5-13 \mathrm{~mm}$.

Laporte and Fulton counties: rare. Nay 26-August 3. Taken from beneath bark of dead tamarack and pine.

\section{IXITII. Biddes Lee. 1861.}

Front not margined behind the labrum : tarsi not lobed beneath: prosternum not lobed in front. the sutures straight and excavated in front. But one species is known and was described from Indiana. 
1449 (4411). Blades quadricollis Say. Trams. Amer. Phil. Soc.. VI, 1836. 1 S6; ibid II, 624 .

Elongate-oblong. Piceous-black, sparsely clothed with sellowish hairs. second and third joints of antennie equal. each nearly as long as fourth. the second more robust than third. Thorax transversely quadrate, sides nearly parallel; disk densely and coarsely punctured; hind angles nearly rectangular, not extending backmard behind the line of base. Elytral strix punctate; interrals minutely punctured. Length $6.5-7 \mathrm{~mm}$.

Described from Posey County. One specimen taken by Dury near Cincinnati. Not seen by me from the State.

\section{Nothodes Lec. 1861. (Gr., "false+appearance.")}

This genus is represented by a single species which resembles so closely Limonius griscus that it can with difficulty be separated. The clypeus is truncate. suddenly deflexed at tip and not margined at middle; prosternum with a short lobe. the sutures feebly excarated in front.

1450 (441S). Nothodes pubitans Lec., Trans. Amer. Phil. Soc.. X, 1853. 433.

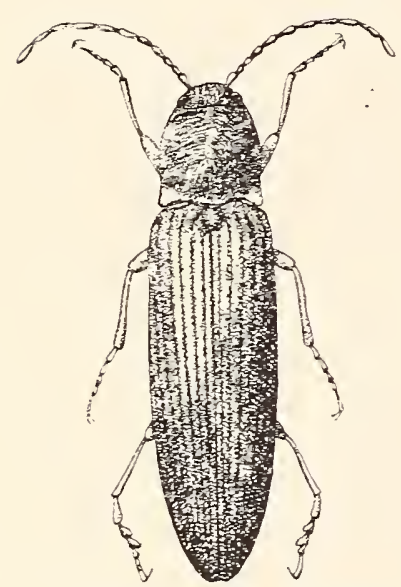

Fig. 289. $\times 3 \frac{1}{2}$. (Original.)

Elongate-oblong. rather robust. Dull sootybrown or piceous, tinged with bronze; rather densely clothed. especially on head and thoriax. with rellowish hairs: legs and antemue paler. Second and third joints of antennic subeciual, together longer than fourth. Thorax nearly as broad as long. strongly convex, scarcely narrower in front than at base, sides feebly rounded; disk rather densely and finels punctate, with a feebly impressed median line: hind angles short. subacute, but faintly carinate. Elytra with sides parallel to apical third. thence rounded to apex, striee with punctures; intervals nearly flat, densely punctulate. Length 11$12.5 \mathrm{~mm}$. (Fig. 2S9.)

Southern half of State; frequent. May 14-June 20. Taken by sweeping grass and low herbs; also especially on leares of the greater ragweed. Ambrosia trifia $\mathrm{L}$. One specimen was taken from the clutches of a large bumble-bee like fiy. Hallophora sp.? which had just captured it and settled down for a feast.

XXXIX. Serrots Esch. 1829. (Gr.. "silken.")

Slender. fusiform species having the front convex, not margined; prosternal lobe long; hind coxal plates scarcely narrower on outer end. Sericosomus Steph. is a strnonym. 


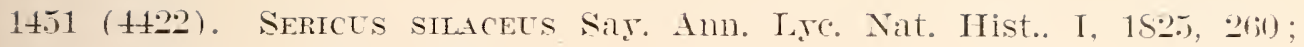
ibid. I. 395.

Oblong. slender. Dull reddish-yellow to sooty-brown, rather densely clothed with rellow hairs: head and thorax often paler than elytra. Serond and third joints of antenne subequal. together sliglitly longer than fourth. Thorax one-half longer than broad, scarcely narrowed in front: sides rounded on apical third: disk densels and finely punctate; hind angles long. distinctly diverging. not carinate. Elytra with sirles parallel to apical third: the strice with rather large moderatels impressed punctures: intervals subconrex, sparsels punctulate, transrersely wrinkled. Length 6.5- $.5 \mathrm{~mm}$.

Putnam. Knox and Posey counties: scarce. Mar 22-June 11.

1452 (442t). Sericts flatiperits Mots. Bull. Soc. Mosc., $1 S 43$.

Elongate, slender. Fiscous- or dusky-bromn, sparsely clothed with rellomish hairs; legs and basal half of elstra dull yellow. Second and third joints of antennie short, equal, together one-third shorter than fourth. Thorax two-thirds longer than broad. sides nearly straight. disk finely and rery densely punctate: hind angles long. feebly dirergent. finely but distincty carinate. Elytra with sides attenuate behind the middle. strix punctate; intervals rather densely and loughly punctulate. Length $6.5-7 \mathrm{~mm}$.

Larrence Counț: rare. Mạ̦ 23.

Xl. Confubites Lat. 1834. (Gr.. "a brush or pencil.")

This genus comprises a large heterogeneous group, into which have been shifted species widely different in form. size and color. They all agree in haring the clrpeus more or less flattened and not margined in front: tarsal joints without lobes. the clars simple: prosternum with a long lobe: hind coxal plates narrow on the outer end. The genus is badly in need of revision. and no literature except the widely scattered descriptions is arailable. About 80 species are known from the Enited states. of which the following have been taken or perhaps occur in Indiana:

\section{KEI TO IXDIANA SPECIES OF CORTMBITES.}

a. Joints three and four of antennæ subequal. or joint three rarely slightly longer than four.

๖. Antennie serrate; joints 4 to 10 more or less triangular.

c. Thir joint of antemme triangular. not much narrower than fourth: form not strongly robust.

d. Color abore not uniform brown or piceous.

e. Elytra rellow. thorax black.

f. Elstra with a common sutural spot and two spots on each. black.

1453. VERTALIS.

$f f$. Elytra dull rellow, withont spots.

145t. TARSAIIS. ee. Elytra black or piceous. 
g. Thorax red with a black stripe on disk.

1455. SIGNATICOLLIS.

$g g$. Thorax piceous with hind angles dull yellow; tips of elytra dull yellow.

COPEI.

d. Color above uniform dull brown or piceous.

h. Form elongate, slender, subcylindrical; elytra with sides parallel to apical fourth, thence rounded to apex; length 11$12.5 \mathrm{~mm}$.

1456. CYLINDRIFORMIS.

hh. Form shorter, more robust; elytra distinctly attenuate behind the middle; length $9-10 \mathrm{~mm}$.

145\%. DIVARICATUS.

cc. Third joint of antenne cylindrical, distinctly narrower than fourth ; form robust.

i. Color black, shining; length $15-23 \mathrm{~mm}$.

ii. Color not black; length $8-12 \mathrm{~mm}$.

$j$. Elytra dull yellow with two undulated darker bands; form subdepressed.

1459. HIEROGLYPHICUS.

$j j$. Uniform bronzed piceous; form much swollen.

b6. Antenne not distinctly serrate; joints 3 to 10 generally drical.

k. For'm elongate, slender; thorax distinctly longer than wide.

7. Elytra uniform dull reddish-brown; length 15 or more mm.

1461. PYRRHOS.

17. Elytra with alternate narrow stripes of brown and dull yellow; length $8-10.5 \mathrm{~mm}$.

1462. BIVITTATUS.

7.7. Form oblong, rather robust; thorax as wide as long; color dark chestnut brown.

1463. ROTUNDICOLLIS.

at. Joint three of antenne distinctly shorter and more narrow than joint four.

m. Elongate, parallel; uniform chestnut brown, shining.

$m m$. Oblong, dilated behind the middle.

1464. SULCICOLLIS.

n. Elytra dull yellow, each with a single dusky hooked line on apical half.

1465. HAMATUS.

nn. Elytra uniform cupreous or brownish-bronzed. SPLENDENS.

1453 (4427). Corrmbites vernalis Hentz., Journ. Phil. Acad. Nat. Sci., V, $182 \pi, 374$.

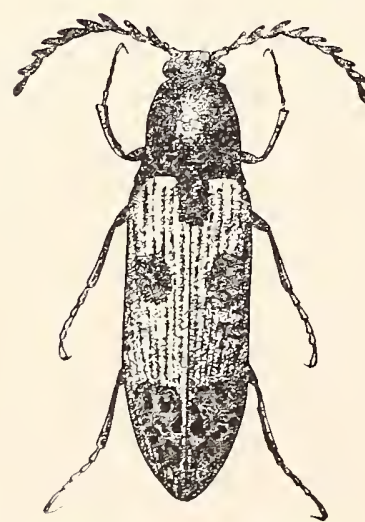

Fig. 290. $\times$ 4. (Original.)

Elongate-oblong. Color given in key Antennie strongly serrate, subpectinate in male, third joint as long as fourth, its outer angle not as much produced. Thorax slightly longer than wide, sides feebly curved, disk densely and finely punctate, a basal median impressed line; hind angles short, divergent, faintly carinate. Elytra strougly attenuate on apical third, strise punctate; intervals flat, minutely punctulate. Length $8-10.5 \mathrm{~mm}$. (Fig. 290.)

Posey County; frequent in spring on a perpendicular loess bank one-half mile south of New Harmony. April 22-April 26. Taken 
at the same place on three different years, only on sunny days, when they flew to the face of the bank and often crawled into small openings. They evidently pupate in burrows in such banks and in the earth clinging to the roots of uprooted trees.

1454 (4450). Cormamites tarsalis Melsh.. Proc. Phil. Acad. Nat. Sci., II, 1844 , p. 157 .

Elongate. rather slender. Black, sparsely and finely pubescent; elytra, except the very narrow sutural and side margins, dull yellow; legs reddishbrown. Antenne half the lengtl of body, second joint very small, obconic, third as wide as and slightly longer than fourth. Thorax one-half longer than wide; sides nearly straight, feebly curred on apical third; disk moderately convex, rather densely and finely punctured; hind angles obtuse, slightly excurved and divergent, not carinate. Elytra with sides nearly parallel to apical third, thence converging to the acute tips; strie feebly impressed, punctate; intervals subconvex, densely punctulate. Length 10.5$11 \mathrm{~mm}$.

Starke and Posey counties; scarce. May 19-June 11. Beaten from blossoms of cherry trees.

1455 (4448). Consmbites signaticollis Melsh.. Proc. Phil. Acad. Nat. Sci., II, $1845,216$.

Oblong, rather siender. Black, shining: labrum and thorax red, the latter with a broad median black stripe. Antenne strongly serrate, with second joint small, obconic; third as long and nearly as wide as fourth. Thorax slightly longer than wide. sides feebly rounded; disk sparsely and rather coarsely punctate; hind angles moderately dirergent. with a distinct oblique carina. Elytral strixe with deep. coarse punctures; interrals subconvex, sparsely and roughly punctulate. Length $7.5-9.5 \mathrm{~mm}$.

Orange and Crawford counties; May 26-June 12. Twenty or more specimens were taken from stems of wheat in an upland field near Wrandotte Cave, and a few beneath logs and stones along the margin of the same field.

C. copei Horn, length $12 \mathrm{~mm}$., was described from Virginia and has been taken near Cincinnati.

1456 (4434). Coryamites cylindriformis Herbst., Kafer, X. 1806. 93.

Elongate, slender, subcylindrical. Dull sooty-brown or piceous, faintly bronzed, sparsely pubescent; legs. epipleura and often the very nar'row margins of thorax and elytra and suture of latter dusky reddish. Third joint of antemne three times as long as second. Thorax one-half longer than broad, male, one-fourth, female; sides nearly straight, disk densely and finely punctured, witl a median basil impression ; hind angles rather strongly diverging, indistinctly carinate. Elytral strice finely punctate: intervals flat, rather̈ coarsely and densely punctulate. Length 11.5-16 $\mathrm{mm}$.

Porter. Marion, Lawrence and Vigo counties; frequent. March 22-May 6. Oceurs on vegetation, usually close to the ground. The females are s arce and much larger than males, with shorter antennx and thorax. 
1457 (4437). Cormartes priartcates Lec. Trans. Amer. Phil. Soc., I. 1ร53. 146.

Oblong. robust. Dull sootr-bromn or piceous. sparsels and finels pubescent. Third joint of antenne slightly longer than fourth. much longer than second. Thorax of male subquadrate. feebly convex, sides nearls straight. disk coarsels and densely punctate. hind angles strongls direlging: that of female wider than lons. strongls conrex. sides broadls rounded. a deep impression each side along front margin. Elstral striae feebls impressed with rather coarse punctures: intervals of male fiat, densels and roughly punctulate; of female subconrex. finels and sparsely punctulate. Length 9-12 $\mathrm{mm}$.

Crawford County; scarce. June 25-June 28. Beaten from foliage of oak. The so-called female is rerr different in appearance from the male. In addition to the distinctions above giren. the body is much more robust. dark shining chestnut-brown in color and much less pubescent. It was described as C. crassus Lee. and may ret prove to be a distinct species. The mere fact that two beetles widely different in appearance are sometimes found in company. or even rarely in coitu. does not furnish absolute proof of their identity.

\section{8 (1468). Cormaites ethiops Herbst., Kafer. X. 1S06, 70.}

Elongate, broad. subdepressed. Black, shining. finels and rerr sparsely pubescent; legs and antennie piceous or dark reddish-brown. Third joint of antennie trice the length of second, slightls shorter and much narrorer than fourth. Thorax a little longer than broad, narrowed in front, sides feebls rounded; disk finels and sparsels punctate on middle. more densels on sides. with a faint median impressed line: hind angles slightle direrging. distinctls carinate. Elstra with sides parailel to apical third. thence strongly conrerging to apex: strixe finels and closels punctate: interrals subconrex. sparsely and rather coarsels and roughls punctulate. Length $15-23 \mathrm{~mm}$.

Throughout the State. frequent: more so in the southern counties. May 10-June 26. Occurs usually beneath stones and rubbish on high. dry hills: also on Tirginia creeper. Parthenocissus quinquefolic Michx. Om largest species of the genus.

1459 (4482). Corratbites hierogliphices Say. Trans. Amer. Phil. Soc.. NI. 1S36, 172; ibid. II. 607.

Oblong, robust. Head and thorax piceous, bronzed. densels clother with rerp fine, silks gravish-reilow pubescence: elytra dull rellow, with an oblique undulated blackish band from the humerus. comnected br a narrow sutural stripe with another similar but broader band behind the middle. the latter with a sutural spur nearly to apex: antemie and hegs reddislybrown. Tholax as in hamatus. the carine of hind angles indistinct. Elytra with punctures of the strie smaller than in hamatus, otherrise similar. Length 11-12.5 mm. 
Northern third of State; scarce. June 7-June 27. Beaten from foliage of shrubs and trees about the margins of lakes and marshes.

1460 (4496). Cormabites inflatus Say, Ann. Lyc. Nat. Mist., I, 1825, 25S; ibid. I, 392 ; II, 609.

Oblong, vers robust or swollen. Black, bronzed, rather densely clothed with short, prostrate grayish and sellow hairs; antennæe and legs dull reddish-brown. Third joint of antennæ more than twice the length of second. slightly longer but more slender than fourth. Thorax convex, as broad as long, sides rounded; disk densely and rather finely punctured, with an impressed line on basal half; hind angles short, feebly divergent, distinctly carinate. Elytral striæ faintly impressed with fine punctures; intervals subconvex, male, flat, female, rather densely and very minutely punctulate. Length $8.5-11 \mathrm{~mm}$.

Marion and Posey counties; frequent. April 23-June 19. Taken by sweeping grass or beating foliage; usually in low, open woods.

1461 (4443). Corymbites pyrrhos Hbst., Kafer, X, 1806, 30.

Elongate, slender. Dark reddish brown, finely and rather sparsely pubescent with yellowish hairs. Third joint of antennæ equal to fourth and nearly three times as long as second. Thorax narrower than elytra, twothirds longer than wide, subconrex, sides nearly straight; disk rather densely and coarsely punctate; hind angles moderately diverging, finely carinate. Elytra with sides parallel to apical third, thence converging to apex; strie finely punctate; intervals nearly flat, finely and rather sparsely punctulate. Length $15-19 \mathrm{~mm}$.

Lake. Starke and Steuben colinties: scarce. June 7-July 12.

1462 (4444). Cormabites Bivittatus Melsh., Proc. Phil. Acad. Nat. Sci.. II, $1815,219$.

Elongate, slender. Piceous black or dark sooty brown, sparsely pubescent with yellowish hairs; legs, hind angles of thorax, and intervals 1 to 3 and 5 to 7 of elytra, dull sellow. Antennæe as in pyrrhos. Thorax narrower than elytra, one-half longer than wide, sides nearly straight; disk denseḷ̦ granulate-punctate; hind angles elongate, moderately divergent, indistinctly carinate. Elytra with sides parallel to apical fourth; striæ punctate; interrals flat, roughly punctulate. Length $\$-10.5 \mathrm{~mm}$.

Jefferson and Posey counties; scarce. June 4-June 15. The dull yellow on upper surface varies in extent. Sometimes the entire elytra except a nerrow sutural line and side margin are of this hue and it often forms a narrow median line on thorax.

*1463 (449S). Coryarites rotundicoldis Say, Ann. Lyc. Nat. Hist.. I. 1S25. 259 ; ibid. I, 394.

Elongate-oblong, rather robust. Dark chestnut-brown, shining. not pubescent; thorax often reddish-brown. Thir joint of antennie slightly shorter'

[49-23402] 
than fourth. Thorax rounded, subquadrate, strongly convex, sides rounded; disk sparsely and finely punctate; hind angles short, acute, divergent, strongly carinate. Elytra parallel, male, or slightly dilated behind the middle, female; strix deeply impressed without punctures; intervals convex, sparsely and very finely punctulate. Length 9.5-10.5 mm.

Vigo County; rare. September 29-December 12. Hibernates beneath $\log _{\mathrm{s}}$ on sandy hillsides. Occurs on foliage of Virginia creeper, Parthenocissus quinquefolia Michx.

1464 (4466). Corymbites sulcicollis Say, Ann. Lyc. Nat. Hist., I, 1825, 256 ; ibid. I, 391 ; II, 602.

Elongate, rather slender. Uniform chestnut-brown, shining, not pubescent. Third joint of antenne twice as long as second, nearly one-third shorter and slightly narrower than fourth. Thorax one-third longer than wide, widest at the front angles, slightly convex; disk finely and rather densely punctate, with an entire and deeply impressed median line; hind angles acute, slightly divergent, distinctly carinate. Elytra with sides parallel to apical third, thence rounded to apex, strix punctured; intervals subconvex, finely and densely punctulate. Length 14-16 mm.

Whitley, Marion and Lawrence counties; frequent. March 14 August 7. On the earlier date a half dozen or more were taken from beneath the loose bark of an ash snag, so that the species probably hibernates as imago.

1465 (4479). Conxmbites mamatus Say, Trans. Amer. Phil. Soc., VI, 1836. 170 ; ibid. II, 605.

Oblong, robust, dilated at middle. Head, thorax and under parts dark reddish-brown to piceous; thorax densely clothed with yellow hair; elytra dull yellow, with a brownish stripe on onter side from tip to near middle. where it curves inward and backward. Second and third joints of antenne small, subequal, together scarcely as long as fourth. Thorax convex, scarcely longer than wide, sides broadly rounded; disk finely and densely punctured, with a faintly impressed median line on basal half, hind angles feebly divergent, distinctly carinate. Elytral strix deeply impressed with rather coarse punctures; intervals subconvex, densely punctulate. Length 9.5$11 \mathrm{~mm}$.

Posey County; rare. June 1. Taken by Dury near Cincinnati from foliage of honey locust.

C. splendens Zieg., hind angles of thorax and epipleura reddish, length 10-13 mm., has been recorded from New England, Pennsylvania and Ohio.

\section{Oxygonus Lee. 1863. (Gr., "sharp + angle.")}

Differs from Corymbiles only in having the tarsal claws armed with a broad tooth near the base. Of the two speries known, one occurs in Indiana. 
1466 (4499). Oxygonus obesus Say, Journ. Phil. Acar. Nat. Sei., I I, 182:), 168 ; ibid. II, 109, 603.

Oblong, rather robust. Antenne, head and thorax piccons, bronzed; densely clothed with fine yellowish hairs; elytra and under parts dull reddish-brown, more sparsely pubescent; legs and two basal joints of antennic paler. Third joint of antenne twice as long as second, shorter than fourth. Thorax as wide at base as long, narrower in front; sides feebly rounded; disk finely and densely punctate; hind angles divergent, not carinate. EIytra slightly widest behind the middle, then strongly attenuate to acute tips; strix with indistinct punctures; intervals subconvex, minutely punctulate. Length $10 \mathrm{~mm}$.

Kosciusko County; rare. June 5.

\section{Asaphes Kirby. 1837. (Gr., "obscure.")}

Differs from Corymbites only in the structure of the tarsi which have the first joint as long as the next two together; the second and third joints each dilated beneath into a short spongy lobe; fourth joint small and narrow, received upon the third; fifth joint elongate with simple claws. The known North American species are treated in the following paper:

Horn._- "Notes on the Species of Asaphes of Boreal America," in Trans. Amer. Ent. Soc., VIII, 1880, 69-75.

Three species have been taken in Indiana, while two others probably oceur.

KEY TO INDIANA SPECIES OF ASAPHES.

a. Hind angles of thorax carinate, basal margin with short, more or less distinct fissures.

๖. Hind angles not divergent; prosternal spine curved.

c. Third joint of antennæ shorter than fourth.

d. Thorax very sparsely and indistinctly punctured. InDIsTinctus. dd. Thorax rather finely but distinctly punctured.

cc. Third joint of antennæe equal to fourth.

1467. BREVICOLLIS.

1468. MEMNONIUS.

bb. Hind angles of thorax divergent; prosternal spine horizontal. (Fig. 291.)

DECOLORATUS.

a . Hind angles of thorax not carinate; basal margin without fissures.

1469. BILOBATUS.

A. indistinctus Lec., piceous, length $11 \mathrm{~mm}$., is a southern species recorded from Cincinnati.

1467 (-). Asaphes Brevicollis Cand., Mon. Elat., IV, 212.

Elongate, rather robust. Piceous-black or dark reddish-brown, shining. sparsely clothed with grayish pubescence; antenna paler, third joint twothirds the length of fourth. Thorax longer than wide, sides feebly curved. 
male; subquadrate, more convex, sides more distinctly curved, female; disk rather finely punctured, more densely and coarsely on sides; median impressed line distinct on basal half. Elytral striæ finely punctured; intervals subconrex, rather sparsely punctulate. Length 11-14 mm.

Lake County : scarce. July 1-July 11. Horn placed this as a depauperate form of memnonius, but the latter always has the third and fourth joints of antennæ equal. Blanchard. who has given much study to the Elateridx, considers the two distinct.

*1468 (4510). Asaphes inemnonius Hbst.. Kafer, X, 1806, 29.

Elongate, robust. Piceous to paìe brown, sparsely pubescent; legs paler. Thorax as long as broad, sides nearly straight, less convex, male; broader than long, strongly convex, sides moderately curred, female; disk densely and coarsely punctate; hind angles with carina parallel with the margin. Elytral stria moderately deeply impressed with coarse shallow punctures; intervals subcontex, rather densely punctulate. Length 15-22 mm.

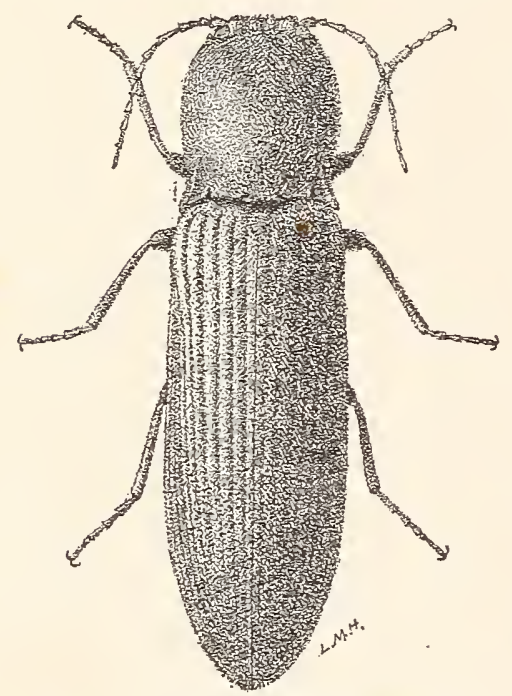

Fig. 291. $\times 4 \frac{1}{2}$. Asaphes decoloratus Say. (After Forbes.)

Throughout the State, frequent; less so in the southern counties. June 8-December 27. Occurs beneath stones and rubbish in dry localities. Taken in winter from beneath the bark of red oak $\log \mathrm{s}$.

A. decoloratus Say, piceous, black, often feebly bronzed, legs paler, length $9-15 \mathrm{~mm}$., is said to occur in the "Atlantic region as far west as Missouri." (Fig. 2.91.)

1469 (4511). Asaphus bILobatus Say, Trans. Amer. Phil. Soc., VI, 1836 , 174 ; ibid. II, 610.

Elongate, rather slender. Dark chestnut to paler brown, shining; finely and rery sparsely pubescent; antennæe and legs paler. Thorax of male longer than wide, sides straight, convergent in front; of female, nearly square, sides more or less curved, rarely slightly sinuate behind the middle; disk in both sexes moderately conrex, finely and rather sparsely punctate; hind angles obtuse, not carinate. Elytra striate, the striæ coarsely punctured; those nearest the suture much less deep in female; intervals subconvex, each with two rows of fine punctures. Length 13-16 $\mathrm{mm}$.

Laporte and Posey counties; rare. June 25-August 20.

\section{Melanactes Lec. 1853. (Gr.. "black + shining.")}

Large. smooth, shining black beetles, distinguished from allied genera by having the sides of the mesosternal cavity raised and swollen so as to be protuberant, and the tarsal joints furnished be- 
neath with a dense brush of hairs. The antenne are serrate with third joint usually a little longer than fourth and the hind ancles of thorax are prominent and strongly carinate. Four of the seren species known from the Tnited States hare been taken in Indiana.

\section{FEI TO INDIANA SPECIES OF MELANACTES.}

a. Stria on disk of elytra not at all impressed. their punctures rerr fine and separated one from another bs more than their arm diameters: interrals flat. rers minutels and indistinctls punctulate.

1士70. PICEL's. a a. Strie of elrtra more or less impressed. the punctures more distinct and not separated br more than their own diameters: intertals distinctly punctulate.

๖. Elrtral stria deeplo impressed. coarsels punctate: interrals strongl conver.

14i1. MORIO.

ఒ6. Elytrai stria feebly impressed. finely punctured: interrals nearls flat.

c. Thorax rather sparsels and finely punctured.

1472. PUNCTICOLLIS.

ce. Thorax rers densels and coarsely punctured. 1473. corsors.

1470 (4511). Metakactes piceus DeGeei2. Ins. IT. 1775, 162.

Elongate, subdepressed.

Black, strongly shining: antennæ and tarsi piceous. Thorar a little longer than broad, slightly narrowed in front and at base of hind angles; sides feebly curred. strongls margined; disk finels; sparsels and shallowls punctate. more densely at sides. Elrtra with sides parallel to midale. thence feebly narrowed into a rounded apex. Length $23-32 \mathrm{~mm}$.

Throughout the State: scarce in the northern counties: frequent in the southern part. Mari 18-July 23. Occurs beneath stones and rubbish in dry localities. (Fig. 292.) The supposed larra, when full grown, is
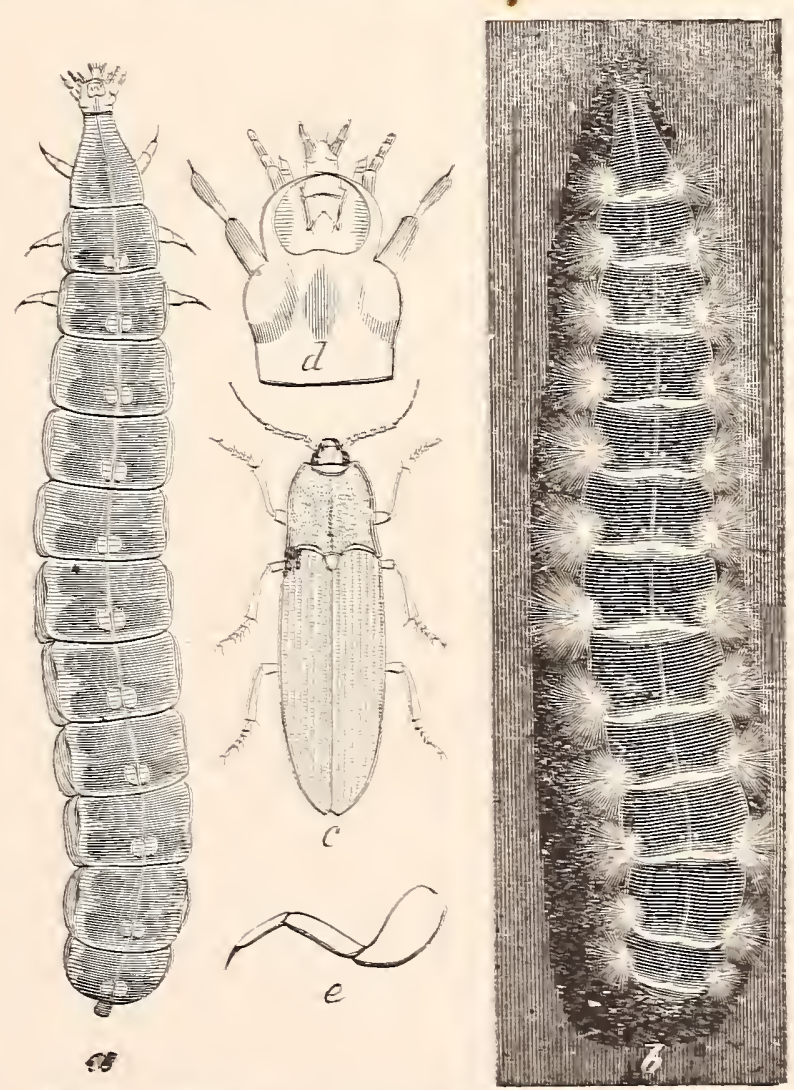

Fig. 292. Melanades piceus DeG-a, larra as seen br dar: b, sare as seen by night; $c$, beetle: d. enlarged heed and parts of larta; $\dot{x}_{\text {, en- }}$ larged leg of sanie. (After Riley.) 
about three inches in length, subdepressed, and has a row of pale rellow spots along middle of back and another each side. In the dark these glow very brilliantly with a greenish-yellow phosphorescent light. Henshaw claims that this is not the larva of $I$. piceus, but that of a species of Phengodes.

1471 (4516). Melanactes morio Fab., Ent. Syst., Emend. Suppl., 1798, 138.

Resembles piceus in form and structure; differs mainly by characters given in key. The thorax is proportionally shorter, being as broad as long and is somewhat more coarsely punctured. Length $22-26 \mathrm{~mm}$.

Vigo and Parke counties; rare. June 12-June 17.

1472 (4517). Melanactes puncticollis Lec., Proc. Phil. Acad. Nat. Sci., VI, 1852,68 .

Elongate, rather slender. Black, shining. Thorax longer than wide, somewhat narrowed in front, slightly rounded on sides, which are less strongly margined than in the two preceding species; disk rather finely and sparsely punctured, more densely on the sides; hind angles slightly divergent. Elytral intervals subconvex, finely and rather densely punctulate. Length 18-21 mm.

Marion, Vigo and Knox counties; scarce. May 23-June 25. Occurs beneath rubbish.

1473 (4518). Melanactes consons Lec., Trans. Amer. Phil. Soc., X, 1853, 495.

Elongate, robust. Black, not very shining. Thorax not longer than wide, as wide at middle as at hind angles, more convex than in any of the preceding species; sides broadly rounded, strongly margined; disk densely and coarsely punctured, median dorsal line not distinct, somewhat smooth. Elytra slightly narrower than thorax, more obtusely rounded at apex than in any except piceus; strie distinctly punctured; intervals slightly convex, finely punctulate, transversely wrinkled. Length $23 \mathrm{~mm}$.

Vigo County; rare. June 19. A single specimen taken from a blackberry bush. Described from Nebraska.

\section{Subfamily III. PEROTHOPINAE.}

In this subfamily the antenin are well separated at base and arise from small pits beneath well-marked frontal ridges, at a distance in front of the eyes; the mouth is inferior; labrum transverse. curved in front, closely united with the clypens; prosternum slightly lobed in front, the spine very short; front coxæ small, globular, without trochantin; middle coxæ oval with a small trochantin; hind coxæ transverse, the plates broadly dilated on the inner side; tarsal claws with comb-like teeth. The subfamily is represented by the single genus : 
XLIV. Perotilops Erichs. 1842. (Gr., "to pieree+face.")

To this genus belong two medium-sized, oblong, robust species having the first joint of antenna elongate, conical, second one-third as long, third twice the length of second and one-half longer than fourth. One of the two occurs in Indiana.

1474 (4538). Perothops mucida Gyll., Schon. Syn. Ins., 15:7, 133.

Oblong, parallel. Piceous, male; reddish-brown, female; feebly shining; sparsely clothed with very fine grayish pubescence. Thor:ax short, wider than long, narrower in front, sides feebly curved, male, more strongly, female, slightly sinuate in front of hind angles, which are short, subacute, feebly diverging, not carinate; disk very finely punctate, with sparse and coarser punctures intermixed, a feebly impressed median line on basal half. Elytra striate, the stria indistinctly punctate; intervals flat and equal, male, or alternately slightly narrower and more convex, female, finely punctulate. Length 11-18 $\mathrm{mm}$.

Monroe, Posey and Crawford counties; scarce. May 12-June 11. Occurs on the trunks and branches of old beech trees.

\section{Subfamily IV. CEROPHYTINAE.}

While no member of this subfamily has been taken in Indiana, it is doubtless represented in the southern third of the State by a rare species, Cerophytum pulsator Haid.. a single specimen of which was taken by Dury near Cincinnati. It is an oblong black beetle, 7.5-8.5 mm. in length, with the hind coxal plates wholly wanting; tarsal claws pectinate on basal half; antemnx pectinate in male, serrate in female; elytra deeply striate, the strix coarsely and closely punctate.

\section{Family XXXVIII. THROSCID A.}

\section{T'he Pseudo Click Beetles.}

This family contains only a few small oblong black or brownish beetles which resemble the Elaterids, and the next family, the Buprestids, in form and in having the prosternum prolonged behind into a spine which fits into a cavity in the mesosternum. They differ from the Elateride in having the pro- and mesosterna firmly joined, thus preventing the power of leaping possessed by most click beetles. From the Buprestide they are distinguished by having the ventral abdominal segments all free. The adult beetles are found on flowers. while the habits of the larvie are as yet almost unknown.

In addition to the characters above mentioned, the Throscids have the antennæ 11-jointed, inserted on the front, and in repose 
received in groores along the inner margins of the inflexed portions of thorax: head immersed in thorax to the exes: mouth inferior: applied in repose to the prostermum: thoras deeplr sulcate on under side along the sutures for reception of antennx: prosternum with a rounded lobe in front which protects the mouth: front and middle cosa small, rounded. without trochantins, the carities of the former closed behind by the mesosternum: hind coxæ transrerse and dilated into a plate partly covering the thighs: tarsi short. fire-jointed. joints 1 to 4 being furnished beneath with long membranous lobes: clatss simple.

The name Throscus. that of the trpical genus. is ill-suited to these beetles. since it is derived from a Greek word meaning "to leap upon." The fixity of the thorax upon the trunk precludes any such motion. The family is represented in the Lnited States by three genera and 18 species. Of these five species. belonging to two genera. have been taken in Indiana. The principal paper on the North American forms is by

Horn.-"Srnopsis of the Throscidæ of the United States." in Trans. Amer. Ent. Soc.. XII, 1885. 198-208.

KEI TO INDIANA GENERA OF THROSCIDE.

u. Antennie serrate, their cavities on prosternum short. straight: no tarsal srooves.

I. DRAPETES.

a a. Antemne terminating in a three-jointed club, their carities long and curred: tarsil groores present on metasternum.

II. THRoscts.

\section{Drapetes Relt. 1819. (Gr.. "to run awat.")}

To this genus belong four species. one of which has been taken in the State. while two of the others mar in time be found. Since the table by which ther are separated is brief. it is herewith given.

KEY TO SPECIES OF DRAPETES.

a. Thorax black.

万. Elrtra red and black.

c. Elrtra with a broad sub-basal red crossbar.

cc. Elytra with humeral and subapical red spots.

67. Elytra wholly black.

1475. GEMINATUS.

QLADRIPESTULATLS. XIIIDCS. a a. Thorax red. eletra black. RUBRICOLLIS.

1475 (4512). Drapetes gemixatus Sar: Ann. Lrc. Nat. Hist., I, 1S25, 264: ibid. I, 398.

Oblong. convex. Black. shining. rery sparsely pubescent. Elytra with a broad sub-basal red crossbar. this sometimes divided at the suture or refluced to a round spot on each side. Thorax as wide at base as Iong. grad- 
ually narrowing to front, surface sparsely and rather coarsely punctured; carince of hind angles extending two-thirds to apex. Elytra slightly wider than thorax, not striate, sparsely, finely and irregularly punctate. Length $4 \mathrm{~mm}$.

Southeru half of State; frequent. May 25-June 26. Oceurs especially on flowers of milkweed.

D. quadrpustulatus Bonv., more robust, thoracic caring shorter, length $4 \mathrm{~mm}$., ranges from Wisconsin to Florida and has been recorded from Cincinnati. D. nitidus Melsh., wholly piceous black, length $4 \mathrm{~mm}$, is known from Pennsylvania.

\section{Throscus Lat. 1796. (Gr., "to leap upon."')}

In this genus the antenne vary in the two sexes. In the male the club is one and a half times the length and three times as broad as all the preceding joints together; in the female it is very little longer than the six preceding joints and not more than twice as wide as they. The eyes of the male are larger and less separated in front. Four species have been taken in the State.

\section{a. Eyes entire.}

$$
\text { KEY TO INDIANA SPECIES OF THROSCUS. }
$$

ъ. Striæ of prestērnum much shortened.

c. Hind angles of thorax without trace of carina. 1476. PUNCTATUs.

cc. Hind angles with a distinct but short carina close to the side margin.

1477. INvisus.

$b b$. Striæ of prosternum entire or nearly so; hind angles not carinate.

1478. CONSTRICTOR.

aa. Eyes with a narrow oblique impression very nearly dividing them into two equal portions; strixe of prosternum entire; elytral intervals with two rows of punctures.

1479. Chevrolati.

1476 (4547). Throscus punctatus Bonv., Monog. Throscidæ, 1859, 15.

Oblong, convex. Dark brown, moderately shining, sparsely and very finely pubescent. Thorax nearly twice as wide as long, sides strongly converging from base to apex, disk distinctly depressed on basal third, coarsely, equally and rather closely punctate. Elytra not wider than thorax, striate, striæ rather closely punctate; intervals flat, each with two rows of closeset punctures which are almost as large as those of striæ. Length $3-3.5 \mathrm{~mm}$.

Vigo County ; rare. May 28, In a specimen at hand the elytra are reddish-brown and the thorax piceous.

1477 (4548). Throscus invisus Horn, Trans. Amer. Entom. Soc., XII, 1885, 201.

Resembles punctatus but somewhat larger, darker and more robust, with the basal region of thorax less impressed, the punctures of disk more widely separated and a fine but distinct carina close to the margin on hind angles. Length $3.5-4 \mathrm{~mm}$. 
Owen and Posey counties; scarce. April 29-June 15. One specimen on the later date from flowers of Cormus.

1478 (4549). Throscus constrictor Say, Trans. Amer. Phil. Soc., VI, 1836, 189 ; ibid. II, 629.

Oblong, convex. Reddish-brown to piceous, moderately shining, sparsely pubescent. Thorax nearly twice as wide as long, rather strongly narrowed in front, sides feebly curved; surface coarsely and rather closely punctate, and strongly depressed each side on basal third. Elytra not wider than thorax, finely striate, strice punctate; intervals flat, each with two rows of sparse, rather fine punctures. Length $2.5-3 \mathrm{~mm}$.

Marion and Perry counties; rare. June 12. Occurs from Canada to Georgia on flowers and leaves of May-apple and other low herbs.

*1479 (455.3). Throscus chevrolati Bonv., Monog. Throscidæe, 1859, 21.

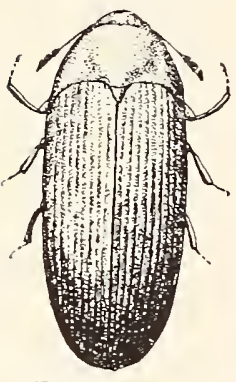

Fig. 293. $\times 11$

Oblong, convex. Reddish-brown, clothed with rather coarse, yellowish pubescence. Clypeus with two distinct parallel carinse. Thorax nearly twice as wide as long, much narrowed in front, widest in front of hind angles, which are prolonged and indistinctly carinate; surface rather finely and sparsely punctate, the basal region not depressed. Elytra slightly narrower than thorax, somewhat narrower behind the middle; surface with distinctly impressed and punctate strig; intervals each with two rows of fine punctures. Length 2.5-2.8 mm. (Fig. 293.)

Throughout the State; frequent. January 21-November 18. Hibernates beneath rubbish. Readily known by its obliquely impressed eyes and bicarinate front.

\section{Family XXXIX. BUPRESTID E.}

\section{The Metallic Wogi-boking Beetles.}

A family of moderate extent, comprising beetles which vary much in shape and size. The larger ones are usually oblong elliptical and somewhat fiattened, while many of the smaller species are either elongate and subcylindrical or short and ovate. Their bodies are hard and inflexible, with usually a bronzed or méallic sarface. The antenna are short. rather slencier and finely but distinctly serrate. Nany of them resemble the click beetles in general form, but have the thorax and abdomen firmly united. so that they have no power of leaping.

The Buprestidxe are preéminently a tropical family, and in the torrid regions reach a large size and reflect the light from their polished bodies with an almost dazzling brilliancy. The adults of 
our Indiana species are usually found upon flowers or upon the trunks and limbs of trees, basking in the sunshine. When disturbed they drop to the ground and feign death. The name of the typical genus, Buprestis, is from two Greek words meaning "ox" and "to blow up or swell," and was applied by the ancients to an insect whose sting caused a swelling in cattle, or which being eaten by cattle in the grass caused them to swell up and die." 'The name was afterward applied by Linnæus to the members of the present family.

The principal characters, other than those above mentioned. which distinguish the family are the 11-jointed antennæ inserted upon the front, the outer joints furnished with pores; head immersed in the ihorax to the eyes; prosternum prolonged behind, fitting into mesosternum, the latter short, divided into two portions, which complete the front coxal cavities; elytra covering the abdomen or leaving but one segment exposed; abdomen with five ventral segments, the first and second united, the others free; front and middle coxæ globular, with distinct irochantin; hind coxæe transverse, concave behind, dilated into a plate partially covering the femora: tarsi 5-jointed, the first four joints each with more or less developed membranous lobes beneath.

The larve of the larger Buprestids are wood borers, usually living under the bark of trees which are just beginning to decay, though some of them penetrate the solid wood. They are somewhat flattened in form, wholly destitute of legs, and have the head small and the first two or three thoracic segments very much broadened, so as to give the grubs a hammer-like form. For that reason they are known as "hammer heads" or "flat-headed borers," and some of them do much injury to orchards. Their burrows are broad and shallow, corresponding with the shape of the larger part of the body. These larger Buprestids are usually the first insects to attack trees which have been injured by sun scald, forest fires, or which have otherwise had their vitality weakened. They therefore occupy a position intermediate between the genuine wood borers, the Cerambycidxe and Scolytidx, which bore into the solid wood. and those other wood beetles, like some of the Elaterida and Lucanidx, which inhabit only wood and bark in an advanced stage of decay.

The larva of some of the smaller Buprestids, notably those of the slender-bodied species of Agrilus, are shaped like the "flatheads" above mentioned, and inhabit the stems of small trees and shrubs. One of the best known of these is the "raspberry cane borer," which causes galls on the stems of blackberry and raspberry. The larva of other small, short-bodied forms, are slender 
and cylindrical, with three pairs of short, widely separated leys. These live in leaves and soft twigs and are known as leaf miners.

The two principal papers treating of the North American forms are as follows:

LeConte._-"Revision of the Buprestidx of the United States," in Trans. Amer. Phil. Soc., XI, 1859, 187-258.

Crotch, G. R.- "Notes on the Species of Buprestidx found in

the United States,' $n$ Proc. Phil. Acad. Nat. Sci., 1873, 84-96.

In addition to these, monographs or synopses of several of the principal genera have appeared and will be mentioned under the proper heading.

Nearly 5.000 species of Buprestida are known, only about 300 of which are from the United States. For convenience the family is first divided into tribes, and these, in turn, into genera. Of the six tribes recognized in the North American fauna, representatives of four oceur in Indiana.

KEY TO INDIANA TRIEES OF BUPRESTIDA.

a. Hind coxie with the plates distinctly dilated near base, cut off on the outer end by the prolongation of the abdomen; their front margin straight, hind margin oblique; fourth tarsal joint not lobed.

Tribe I. Buprestini, p. Tis.

a a. Hind coxal plates scarcely dilated internally or near base.

b. Thorax lobed at the base; front narrowed by the insertion of the antennæ.

c. Mesosternum emarginate, not divided; species larger, 5-11 mm.

Tribe II. JULOdiNI, p. 792.

cc. Mesosternum scarcely visible; species smailer, not over $3 \mathrm{~mm}$.

Tribe III. Mastogenint, p. 795.

66. Thorax truncate at base; clypeus not narrowed by the insertion of the antennz; form slender.

Tribe IV. Agrilini, p. 795.

\section{Tribe I. BUPRESTINI.}

'To this tribe belong our largest and also some of the smaller species. They are more or less flattened in form and are distinguished by the characters given above and by the mesosternum being always divided so that the cavity for the reception of the prosternal spine is formed both by the meso- and metasternum. Nine genera are known to be represented in Indiana, while another may occur.

\section{KEY TO INDIANA GENERA OF BUPRESTINI.}

a. Prosternat spine obtusely angulated behind the front coxæ; epimera of metathorax triangular, uncorered; scutellum small.

b. Mesosternum and metasternum closely united; antenmal pores scattered over the sides of the joints; size large, 19 or more mm.

I. Chalcophora. 
67. Mesosternal suture distinct; pores of antemme in small pits on the under side of the joints; size medium, rarely over $17 \mathrm{~mm}$.

c. Prosternal spine obtusely rounded at apex.

a. Mentum entirely horn-like; elytra without yellow markings.

e. Scutellum small, rounded; tarsi broad, shorter than the tibic.

II. Dicerca.

ce. Scutellum mich broader than long. truncate behind.

iII. Peeciloxota.

dd. Mentim membranous in front; elytra usually marked with rellow.

IT. Buprestis.

cc. Prosternal spine acute at apex; form rery slender. T. Cirrrs. u( Prosternal spine acutely angulated behind the coxie, acute at tip; epimera of metathorax partly corered by abdomen.

$f$. Clypeus not contracted by the insertion of the antennie; size small, usually flattened.

g. Mentum leather-like in front; base of thorax sinuate.

VI. Melanophila.

yg. Mentum entirely horn-like.

h. Base of thorax truncate; antennce serrate in both sexes.

VII. Anthaxia.

$h \hbar$. Base of thoras sinuate; antennie pectinate in male, serrate in female.

Xenorhipis.

ff. Clypeus contracted by the antemne being inserted at the inner extremits of short oblique groores; size medium; form rather broad and flat.

$i$. Third joint of tarsi truncate; hind tarsi with first joint elongate; scutellum large, acuminate.

VIII. CHRYsobothris.

ii. Third joint of tarsi much prolonged at side; hind tarsi with first and second joints equal; scutellum small. IX. ACTExodEs.

\section{ChalcophonA Sol. 1833. (Gr., "copper + bearing."')}

Here belong the largest of our Buprestids. having the antenna inserted in small forea: mentum broarly emarginate in front; hind tarsi with first joint elongated. The males have a distinct sisth rentral segment.

\section{KET TO IXDIANA SPECIES OF CHALCOPHORA.}

a. Mitrgins of elytra entire or rery finely serrate; median dorsal impression of thorax broad, more or less irregular.

๖. Sutural stria of eịtra on apical half only; color dull black, feebly bronzed.

14S0. TIRGIXIENSIS.

67. Sutural stria of elytra entire; coppery or brassy yellow.

14S1. LIBERTA.

a . Margins of elstra strongly serrate on apical third; median impression of thorax deep, narror.

14S2. CAMPESTRIS. 


\section{0 (4569). Chalcophora rirginiexsis Drury, Ins. I, 1770, 66.}

Elongate-oral, robust. Dull black, feeble bronzed, the impressions of thorax and elstra often brasss. Head with a deep, median groore, this broader and deeper in front. Thorax one-third wider than long, sides rounded on apical third, disk with a broad median impression and two others each side, in the regions of the front and hind angles. Elstra each with four to sis elongate impressed spaces which are finely and rather densely punctate. Length 23-30 $\mathrm{mm}$.

Clark County; rare. June 30. Said to be common in the Middle, Eastern and Southery States. Occurs usually on pine.

\section{1 (45\%0). Chalcophora liberta Germ., Ins. Sp. Nor., 1824, 38.}

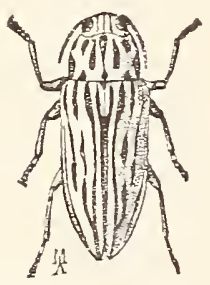

Fig. 294. Tatural size. (After Packard in Fitth Rep. U. S. Ent. Comm.)

Elongate-oral. Bright copper or brassy sellow; antennæ, legs and raised lines of thorax and elytra piceous brown. Thorax transverse, sides broadls rounded, disk with three broad raised lines, the middle one entire, the others interl'upted at base, the interrals between them, as well as the sides. rery coarsely and irregularly punctured. Elstra each with four raised lines, the second of which is wider than the first, or one next the suture, and broadly interrupted before and behind the middle by two impressed spots; stria between the suture and first raised line entire. Length 19$24 \mathrm{~mm}$. (Fig. 294.)

Frequent on the scrub pines, Pinus banksiana Lamb, in the dune region of Lake, Porter and Laporte counties; not noted elsewhere in the State. Nay 28-September 19. The aduits feed upon the roung buds and leaves of pine, while the young live as borers in the decaying rood.

1482 (4573). Chalcophora Campestris Say, Journ. Phil. Acad. Nat. Sci., III, 1S23. 165 ; ibid. I, 60.

Elongate-oral. Uniform grasish bronzed above; polished cupreous beneath. Thorax broader than long. narrowed in front. sides nearly straight: disk with a deep median channel, sides roughls and unerenly punctured. Elytra each with four narrow and somewhat interrupted raised lines. the broader intervals transrersely roughened. a large slightly impressed spot before and another behind the middle. Length 22-2s $\mathrm{mm}$.

Throughout the State: scarce. April 11-July 7. Occurs on beech. oak and other trees.

\section{Dicerca Esch. 1829. (Gr.. "two + tails.")}

Dull bronzed species of medium size. which, in addition to the characters mentioned in generic key, hare the tips of elytra more or less prolonged and tapering. thus forming a kind of tail. About 20 
species are known from the United States, five of which have been taken in Indiana, while one other perhaps orcurs.

KEY TO INDIANA SPECIES OF DICECA.

a. Elytra much prolonged at apex.

b. Tips of elytra entire.

14S3. DIVARICATA.

bb. Tips of elytra bidentate.

PUGIONATA.

a a. Elytra not much prolonged at apex, the tips bidentate.

c. Thorax and elytra uniform without elevated smooth ridges.

d. Thorax narrowed from the base; impressions of thorax and elytra distinct.

14S4. OBSCURA.

dd. Thorax narrowed from the niddle; impressions indistinct.

14S5. LURIDA.

cc. Thorax and elytra uneven, the latter with short elerated smooth ridges.

e. Front of head with a transverse carina; middle tibice of male dentate.

14S6. SPRETA.

ee. Front not carinate; middle tibix of male simple.

1457. ASPERATA.

1483 (4577). Dicerea divaricata Say. Journ. Phil. Acad. Nat. Sci., III, 1823,163 ; ibid. II, $105,590$.

Elongate-oval. Above brassy brown or grayish-cupreous; beneath cupreous. Thorax nearly twice as wide as long, side margins subangulate at middle; disk with a median impressed line and an indentation before the scutellum, its sides roughly, coarsely and unevenly punctured. Elytra with tips much prolonged and usually somewhat divergent; surface substriate, coarsely and irregularly punctate and with numerous raised reticulate smooth spaces. Length 16-21 mm. (Fig. 295.)

Throughout the State; scarce. May 2t-June $\begin{gathered}\text { Fig. 295. (After. Pack- } \\ \text { ard in Fifth Rep. U. S. }\end{gathered}$

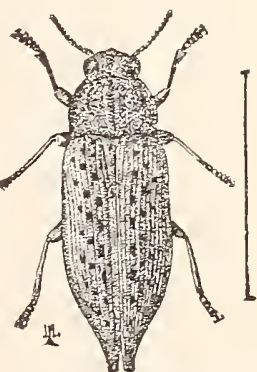
27. The larve burrow in the wood of beech and cherry and the beetles are usually found on the trunks or branches of these trees, though sometimes on apple, maple and oak, all of which have light colored bark, thus serving to protect the basking beetle from its enemies. One specimen was taken on June 12 from the clutches of a large bumble-bee-like fly, Hallophora sp.?

D. cauciata Lec. is a small variety, more convex in form and having the thorax feebly narrowed from base to apex instead of widest at middle. A single specimen was taken from the flowers of willow near Pine, Lake County, May 30.

D. pugionata Germ., bronzed-eupreous, length $11-13.5 \mathrm{~mm}$. is known from Pennsylvania and Maryland. 


\section{St (4579). Dicerca obscura Fab., Ent. Syst., I, 1798, 190.}

Resembles closely the next species. Distinguished by its duller color, more depressed form, and by liaving the punctured impressed spaces of elytra larger and more distinct. The thorax is feebly narrowed from base to apex, not broadest at middle, as in lurida, and has a large oblique impression on each side. Jength 16-18 $\mathrm{mm}$.

Posey County ; rare. Novenber 9. One in Webster collection labeled "Ind.",

1485 (4579a). Dicerca LURIDA Fab., loc cit.

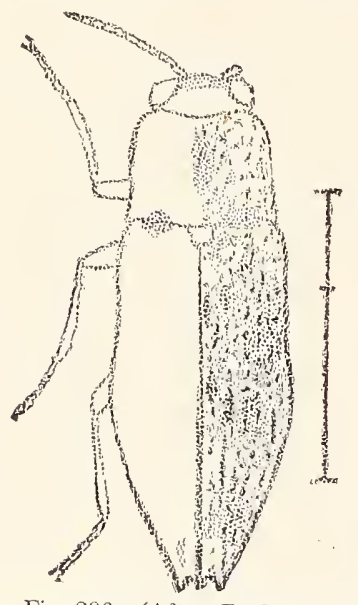

Fig. 296. (After Packard in Fifth Rep. U. S. Ent. Comm.

Elongate-oval. Grayish-bronzed above, dull cupreous beneath. Thorax one-half wider than long; side margins broadly rounded on apical two-thirds; surface rather evenly and coarsely punctured on the sides, the disk smoother. Elytra striate, the intervals coarsely punctate; surface with a number of small, densely punctate impressions; apices but little prolonged, the tips bidentate. Length 14-19 $\mathrm{mm}$. (Fig. 296.)

Throughout the State; frequent. May $20-$ August 16. Occurs on hickory, in the wood of which the larva live; also beneath stones. Listed as a variety of obscura, but probably a valid species.

\section{6 (45S1). Dicerca spreta Gory, Mon. Buprest., IV, 1837, 108.}

Oblong-oval. Above brassy-bronzed, beneath cupreous. Front concave, with a transverse carina between the bases of antennæ. Thorax one-half wider than long, sides rounded in front, parallel on basal half; disk with four elevated smooth lines, between which and on the sides are a number of irregular and deep punctured impressions. Elytra with interrupted coarsely punctured striæ and with a number of small scattered, elevated, polished brown spaces; tips short, bidentate. Apex of abdomen emarginate in male; tridentate in female. Length $17 \mathrm{~mm}$.

Crawford County; rare. September 9. Taken from trunk of oak tree.

\section{7 (45S2). Dicerca asperata Lap. \& Gory, Mon. Buprest., 1837, 105.}

Elongate-oval. Brassy-bronzed above, cupreous beneath. Front of head concave, coarsely and rugosely punctate, without transverse carina. Thorax one-half broader than long, sides rounded to near base; disk with two wide, smooth, flattened ridges separated by a narrow punctured median line, and also an irregular narrow, smooth ridge each side, the impressions deeply and coarsely punctured. Elytra each with a number of elongate smooth elevations, these more prominent near the suture; the depressions each side coarsely punctate; tips short, bidentate. Length 14$16 \mathrm{~mm}$. 
Lawrence County ; rare. May 11. Beaten from blossons of wild crab-apple.

III. Predilonota Fsch. 1829. (Gr., "variegated+bark.")

Eiffers from Dicerea in having the sentellum very transverse and truncate behind, with its hind angles well marked. The third joint of antenne is twice as long as second; fourth triangular and nearly as broad as the fifth.

$148 S$ (4594). Pecilonota Cyanipes Say, Journ. Phil. Acad. Nat. Sci., III, 1S23, 164 ; ibid. II, 106.

Elongate-oval. Greenish-brassy above, dark cupreous beneath; antennæe and tarsi bluish-green. Thorax one-third wider than long, side margins feebly rounded, disk with an elevated smooth median line, sides very coarsely and irregularly punctured. Elytra with numerous short, irregular, elevated smooth spaces, between which are coarsely punctured brassy depressions; tips prolonged, somewhat divergent, either entire and finely serrate, or with two teeth at apex. Length 11-15 $\mathrm{mm}$.

Northern half of State, scarce; not taken south of Marion County. May 28-July 29. Occurs on pine, sycamore and oak trees.

\section{Buprestis Linn. 1735. (Gr., "ox + swell."')}

Medium-sized species, having the front portion of mentum membranous; scutellum small and rounded. The elytra are mcderately narrowed behind and are often very prettily marked with yellow. Four have been taken in Indiana, while one other may oceur.

KEY TO INDIANA SPECIES OF BUPRESTIS.

a. Prosternum not or indistinctly sulcate.

$b$. Elytra with distinct spots.

c. Elytra green with yellow spots.

d. Elytra each with a basal stripe, two spots behind the middle, and the apex yellow.

1489. RUEIPES.

dd. Elytra with a common yellow crossbar behind the middle, and a yellow spot on each midway between the bar and apex. (Fig. 297.)

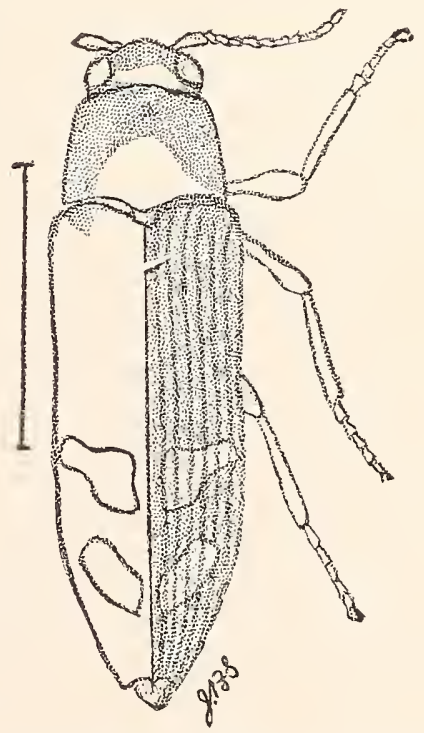

Fig. 297. Buprestis fasciata Fab. (After Packard in Fifth Rep. U. S. Ent. Comm.)

FASCIATA.

cc. Elytra brassy black, each with four often more or less connected yellow spots.

1490. LINEATA.

bb. Elytra brassy black without spots.

1491. MACULIVENTRIS. aa. Prosternum distinctly sulcate throughout its full length; bright green, the suture and sides of elytra cupreous.

1492. STRIATA.

[50-23402] 
1489 (459S). Buprestis rufipes Oliv., Nat. Hist. des Ins., II, 1801, 16.

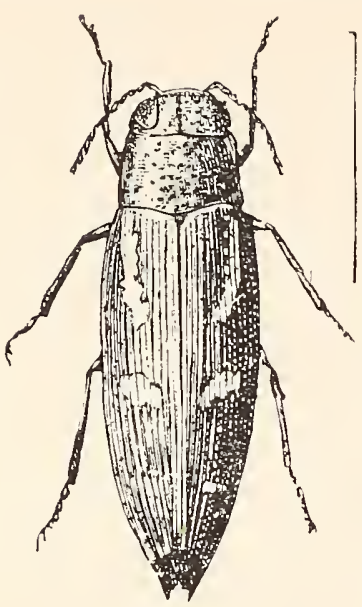

Fig. 298.

Eiongate. Above green, tinged with brassy, shining; elytra spotted as described in key; an oblique yellow stripe near margin of thorax. Beneath green, with a median stripe extending from mouth to second ventral segment and a row of small spots along the sides, bright yellow; legs and last three ventral segments purplish-red. Thorax one-third wider than long, disk sparsely and coarsely punctured; an impressed spot before the scutellum. Elytra with narrow, deeply punctured strise; tips bidentate. Length 1S-25 mm. (Fig. 29S.)

Southern half of State; scarce. June 10July 4. One of the most brilliantly colored and handsome of our native beetles. Usually occurs on old beech or maple trees and logs, in the wood of which the larve live.

B. fasciala Fabr, length $20-23 \mathrm{~mm}$, is a sonthern species recorded from Cincinnati.

\section{0 (4601). Buprestis lineata Fab., Ent. Syst., I, 1798, 192.}

Elongate-oval. Above black, with a brassy tinge; elytra each with four yellowish spots, one sub-basal, one before and another behind the middle. the fourth and smallest subapical; these spots sometimes united to form two broad stripes; beneath dull bronze, the head and front margin of prosternum yellowish. Thorax strongly narrowing from base to apex, disk sparsely, irregularly and coarsely punctured. Elytra striate, the striæe finely punctate; intervals subconvex, very sparsely and coarsely punctate; tips bidentate. Length 11-15 $\mathrm{mm}$.

Lake County ; rare. June 29-July 25.

1491 (4606). Buprestis maculiventris Say,

Long's Exped. to St. Peter's Riv., II, 1S24, 272 ; ibid. I, $17 \mathrm{~S}$.

Elongate-oval. Black, tinged with brassy ; front angles of thorax, a small spot above base of antennie and a row of spots along the sides of abdomen, reddish-yellow. Thorax at base one-half wider than long, sides rounded and suddenly curved downward in front of middle; disk coarsely, sparsely and unevenly punctate. Elytra with finely punctured strix; intervals subconvex, more coarsely punctate. Length $16 \mathrm{~mm}$.

Putnam County ; rare. June 18. Presented by Guy Wilson.

1492 (4609). Buprestis striata Fab., Syst.

Eleut., II, 1S21, 192.

Elongate-oval. Above brilliant green, the

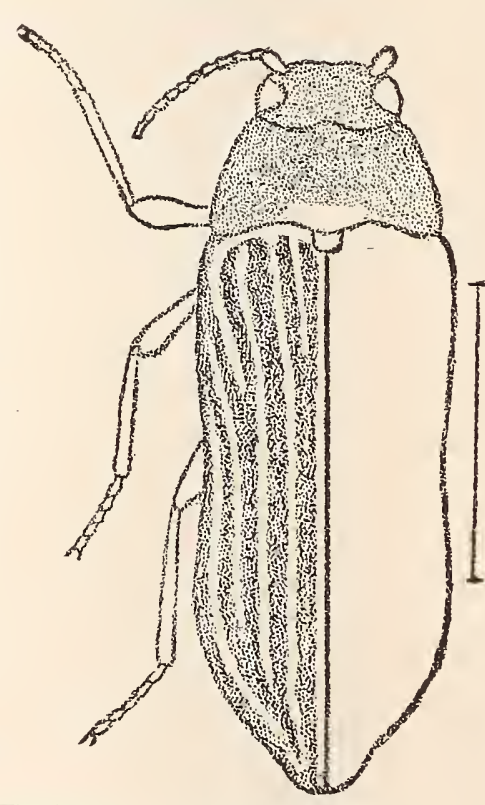

Fig. 299. (After Packard in Fifth Ren. $\mathrm{C}$ S. Ent. Comm.) 
dorsal median space of thorax. suture and narrow side margins of elrtral cupreous: beneath greenish, tinged with cupreous. Thorax one-third wider than long. sides nearls straight. disk coarsels. densely and unerenlr junctured. Elytra each with four sparsels punctured narrow raised lines, the noader interrals denselז and reticulatels punctured. Tips together rounded, not dentate. Length 13-17 mm. (Fig. 299.)

Putnam and Lake counties; scarce. February 16-.June 21.

T. Cintra Lap. \& Corry 183T. (Gr.. "the lyre.")

To this genus belongs a single rather small oblong species, haring the pores of the antenne in pits on the end of the joints and the prosternal spine acute at aper.

1493 (4615). Cirirat gracilipes Melsh. Proc. Phil. Acad. Tat. Sci., II, 1St4. 145 .

Elongate-oblong. slender, subdepressed. Abore dull fuscous. obscurely bronzed; beneath cupreous. Thorax quadrate. a fourth wider than long. sides straight. apes truncate: disk coarsels and roughIs punctured and with a distinct median groore. Scutellum triangular. Elrtra feebls striate. the strie punctate. disk with tro subobsolete impressions. one before and the other behind the middle: interrals alternately a little elerated: tips narromed but not prolonged. feeblז bidentate. Length 10-11 mm.

Marshall. Marion and Posẹ̦ counties: scarce. June 6-June 12. Eeaten from branches of oak along the border of low woods.

TI. Nel.tophild Esch. 1829. (Gr.. "black+lore.")

This genus is separated from Antharia only by the characters giren in kes to genera. One species has been taken in the State and two others perhaps occur.

FEY TO INDIAXA SPECIES OF MELAXOPHILA.

a. Elytra acute at tips: first joint of hind tarsi equalling the next three in length.

๘. Front sparsels punctured : elrtra with reliow spots. 1494. xotaTA,

bð. Front densels punctured: elstra without spots: sides of thorax oblique behind. the disk widest in front of middle. APPExDICtrata. a a. Elytra rounded at tips: first joint of hind tarsi not longer than the next two: thorax coarsels punctured orer its entire surface; tip of prosternum broadle triangular.

ENEOTA.

1494 ( 4617 ). Melaxophita xotata Lap. \& Gory. Mon. Buprest., I, 1537. 4.

Elongate. denressed. Black: head and thorax shining: elrtra less shining. each marked with sellow as follows: a short stripe near middle of base which curves inward and terminates near suture in a rounded spot. the latter sometimes separated: a short bar on apical third and often a small spot on middle near margin. Thorax one-half wider than long. sides 


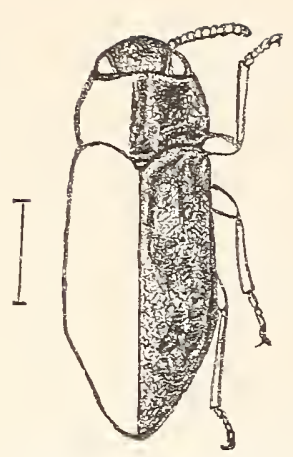

Fig 300. Melanophila appendiculata Fab. (After Packard in Fifth Rep. U. S. Ent. Comm.)

regularly curred; disk evenly granulate-punctate with a small impression in front of scutellum. Elytra with margins serrate near tips, disk granulate-punctate. Length 3-12 $\mathrm{mm}$.

Marion County; rare. June 22. One specimen taken from window of street car. Recorded from Georgia and Florida.

I. appendientata Fab. (longipes Say.) (Fig. 300), black, length $7-13 \mathrm{~mm}$. has been recorded from Cincinnati; $M$. cheola IIelsh., convex, bronzed. length $4.5-6.5 \mathrm{~mm}$. occurs in the "Middle and Southern States.',

\section{ANThuxi Esch. 1829. (Gr., "a flower+ worthy of.")}

Small flattened species, having the mesosternum narrowly divided and separated from the metasternum by a distinct suture; antenne serrate in both sexes. the pores at the ends of the joints; head and thorax marked with shallow punctures with the intervening lines forming a fine network. The genus has been monographed by

Horn.- "Revision of the species of some Genera of Buprestidx." in Trans. Amer. Ent. Soc., X, 1882, 106.

Of the eight species recognized by Horn, four have been taken in Indiana. while another mar ocenr.

KEY TO INDIANA SPECIES OF ANTHAXIA.

a. Body depressed, oblong-oral; last ventral segment punctured like the ones preceding.

b. Tarsal clans simple or merely a little broader at base.

c. Elytra roughls granulate.

1495. ÆNEOGASTER.

cc. Elytra feebly sculptured, at most with small raised points.

d. Body above and beneath uniform brownish-bronze, feebly shining; elytra with fine raised points.

1496. VIRIDIFRONS.

dd. Body nearly black with a slight purplish lustre; front and sides of thorax broadly cupreous or bronzed; elytra scarcely wrinkled.

1497. VIRIDICORNIS.

67. Tarsal claws broadly toothed at base; color bright green, bluish or purple. shining.

1498. QUERCATA.

a a. Body slender, wedge-shaped; last rentral segment much more coarsely punctured than those preceding.

FLAVIMANA.

1495 (4628). Anthaxia enecgaster Lap.. Mon. Buprest., I, $1837,32$.

Rather broad, depressed. Abore piceous or black, the surface with faint bronze lustre; beneath. bronzed, more shining. Head densely punctate, reticulate, front concave. Thorax nearly twice as broad as long. sides feebly curred in front, slightly sinuate behind; disk coarsely reticulate. usually with four shallow foveæ arranged in a curred transrerse row. Ely- 
tra gradually narrowed on apical third, the tips obtuse; surface rather coarsely granulate, each with a shallow oblique impression from humerus towards middle of suture. Length $4-6.5 \mathrm{~mm}$.

St. Joseph County; scarce. June 1. A boreal species which will probably be found throughout the northern third of State.

1496 (4630). Anthaxia viridifrons Lap., Mon. Buprest., Supp., 1837, 284.

Oblong, feebly convex. Dark coppery bronze, more shining beneath, head and narrow front margin of thorax often green. Front slightly convex, reticulate. Thorax one-half broader than long, sides irregularly curved, disk regularly reticulate, usually with two shallow transverse depressions on each side. Elytra shaped as in cneogaster, the surface distinctly rugulose and subopaque. Length 4-5 mm.

Throughout the State: frequent. April 18-July 7. Beaten from vegetation; often attracted by light.

1497 (4631). Anthaxia viridicornis Say, Journ. Phil. Acad. Nat. Sci., III, 1823, 162 ; ibid. II, $105,594$.

Oblong, moderately depressed. Above purplish-black, sides of thorax broadly cupreous; beneath bluish, shining. Front cupreous or brassy, slightly depressed at middle. Thorax nearly twice as broad as long, sides feebly curved, disk with a transverse depression each side, surface very regularly reticulate. Elytra with surface opaque, finely wrinkled. Length 5-6.5 mm.

Throughout the State; frequent. May 15-August 9. Often found in company with the preceding and perhaps will prove to be the female of that species. If so. Say's name has priority.

1498 (4633). Anthaxia quercata Fab., Syst. Eleut., II, 1801, 216.

Oblong, parallel, subdepressed. Color variable, uisually bluish or purple, shining, often bright green with the middle of thorax and a broad stripe on each elytron brown. Front flat. often impressed at middle, surface coarsely punctured. Thorax nearly twice as wide as long, sides straight at middle, curved at either end; disk with a deep impression each side. Elytra obtuse at tip, surface smoother on apical than on basal half. Length 4-6 $\mathrm{mm}$.

Vermillion, Marion Knox and Crawford cornties; scarce. May 19-July 2. A. cyanclla Gory is the female of this species.

A. flarimana Gory, greenish-bronzed, thorax purple-black at middle, length $3-5 \mathrm{~mm}$., occurs in the Middle and Southern States and has been recorded from Cincinnati.

Tenorhipis brendeli Horn. dull black. feebly hronzed, length $5 \mathrm{~mm}$, a very rare form, is known from New York, Peoria, Illinois, and Texas. (Fig 301.)

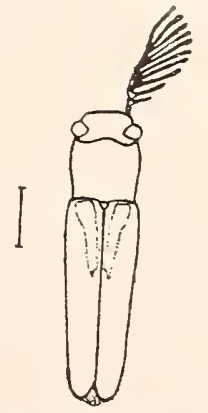

Fig. 301. Aenorhipis brendeli Horn. Male. (After Horn.) 
VIII. Chrysobothris Esch. 1829. (Gr., "gold + a pit.")

A large genus of rather broad and flattened beetles, small or medium in size and having the antennæ inserted at the inner end of short oblique grooves by which the front is narrowed; mentum horn-like at base, membranous at apex; prosternum acutely angulated on the sides behind the coxæ and acute at tip; scutellum large and acuminate; front femora strongly toothed; first joint of hind tarsi always as long as the next three, often much longer.

The principal paper treating of the genus is by

Horn.- "A Monograph of the species of Chrysobothris inhabiting the United States," in Trans. Amer. Ent. Soc., XIII, 1886, 65-124, pls. II-VII.

The following species have been taken or may occur in the State:

KEY TO INDIANA SPECIES OF CHRYSOBOTHRIS.

a. Side margins of last ventral segment with fine teeth.

b. Disk of thorax even, without pits or elevations.

c. Sides of abdomen densely punctate and clothed with fine recumbent white pubescence; sides of thorax narrowing to base; elytra with first costa faintly indicated and with indistinct fover on the disk.

DEBILIS.

cc. Abdomen sparsely punctate and not pubescent; sides of thorax straight and almost parallel; elytra without trace of costre or foves; color blue or green, with a median purple black stripe, surface shining.

1499. PURPUREOVITTATA.

b7. Disk of thorax irregular, median line more or less sulcate, often with small elevations.

d. Front tibia of male curved and with numerous fine teeth on the inner edge; clypeus acutely notched at middle, semicircularly curved on each side.

1500. FEMORATA.

dd. Fiont tibia of male curved but with not more than one tooth on inner side; clypeus not as above.

e. Front tibia of male with a single acute tooth one-third from apex; clypeus with a short truncate median lobe.

1501. FLORICOLA.

ee. Front tibiae of male dilated at tip and without teeth.

$f$. Prosternum without trace of Iobe in front; color dark bronze; disk of thorax with median groove.

$g$. Joints 4 to 11 of antenne more or less brownish-yellow.

gy. Joints of antennæ wholly metallic bronzed; hind tibiæ straight in both sexes.

TRINERVIA.

ff. Prosternum distinctly lobed in front, the lobe short.

$h$. Median groove of thorax well marked, the elevated smooth spaces conspicuous; front tibia of male abruptly dilated at tip; first elytral costa sinuous, especially near apex; length $10-12.5 \mathrm{~mm}$.

1502. BLANCHARDI. 
hh. Median groove of thorax feeble; ventral segments without lateral smooth spaces, the last one without a submarginal ridge; length $5.5-7 \mathrm{~mm}$.

PUSILIAA.

ur. Side margins of last ventral segment without teeth.

$i$. Elytra with more or less distinct costie or elevated lines; disk of thorax uneven.

j. Color above dark bronze; tooth of front femur serrulate.

1503. SEX-SIGNA'TA.

$j j$. Color violaceous or coppery; tooth of front femur not serrulate.

1504. AZUREA.

ii. Elytra without trace of costre; thorax one-half wider than long.

1505. SCITULA.

$C$. debilis Lec., dark brownish-bronze, sides of thorax cupreous, length 5-8 mm., is known from Ohio and T'exas.

1499 (10,071). Chrysobothris purpureovittata Horn, Trans. Am. Ent. Soc., XIII, 1SS6, 76.

Moderately elongate, feebly depressed. Bright blue or green, varying to violet or coppery bronze; elytra each with a moderately broad purple black stripe, reaching from humerus nearly to tip, indistinct on the violet or bronze forms. Third joint of antenne very little longer than fourth. Clypeus broadly triangularly emarginate, the notch oval at bottom, curved on each side. Thorax one-half wider than long, sides nearly straight, surface sparsely punctate at middle, more densely and slightly strigose near the sides. Elytra a littie wider than thorax, parallel, margins rather coarsely serrate, tips obtuse; surface with only the usual basal forea and a depression between the humeri ; rather finely, spar'sely and evenly punctate. Length $5.5-7.5 \mathrm{~mm}$.

Horn's types came from "Indiana, Illinois and Texas,' no special location indicated. I have not seen examples from the State.

\section{0 (4639). Chrisobothris femorata Fab., Syst. Eleut., II, 179S, 208.}

Oblong or elongate-oblong, subdepressed. Color usually dark bronze, sometimes slightly brassy or cupreous; antennæ greenish or cupreous, the third joint a little longer than the next two. Clypeus described in key. Thorax more than twice as wide as long, widlest slightly behind the apex; disk irregular, with an indistinct median depression, and a deeper one each side behind and parallel with the apical margin, with other irregular ones near the

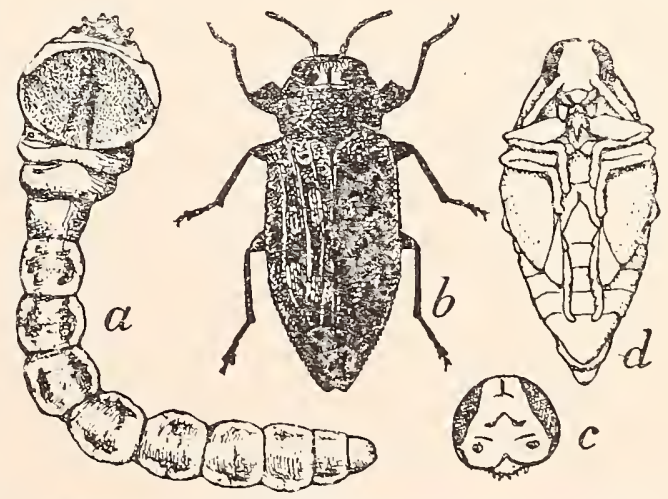

Fig. 302. $a$, larva; $b$, beetle; $c$, head of male; $d$, pupa, all twice natural size. (After Chittender.) sires; surface rather coarsely punctured, more densely on the sides. Elytra a little wider than thorax, sides nearly parallel, gradually narrowed on apical third, margin serrate, tips obtuse; sculpture of disk rery variable. 
usually with first and second costie distinct near apex, and with two transrerse-depressions on eacl side, the first a little in front of middle, second one-third from apex, the basal depression ratlier feeble; surface coarsely and, on the sides, confluently punctured. Length $7-16 \mathrm{~mm}$. (Fig. 302.)

Throughout the State; frequent. Nay 15-June 28. Mating on .June 7. Occurs especially on the trunks of white oak, peach and apple trees, in the wood of which the larva bore. The grubs are known as the "flat-headed apple borer," and often do much damage to orchards where the trees are not in healthy condition.

1501 (4640). Chrysobothris floricola Gory, Mon. Buprest. Suppl., 1837, 179.

Oblong, subdepressed. Dark bronze, with slight cupreous tinge; antennie bronzed, male, greenish, female. Thorax more than twice as wide as long, sides nearly parallel at middle, narrowed at apex and base; disk with a distinct median channel and some irregular depressions near the side; surface coarsely punctate, less densely at middle. Elytra wider than thorax, usually widest slightly behind the middle, gradually narrowed at apical third, margin serrulate, tips obtusely rounded; first costa moderately elevated from apex to middle, the other's indistinctly defined; basal and humeral depressions not deep, the one behind the middle double; surface densely punctured between the elevations, more sparsely at base. Prosternum distinctly lobed in front. Length 8.5-12 mm.

Posey County; rare. June 11. Occurs from the Middle States to Florida.
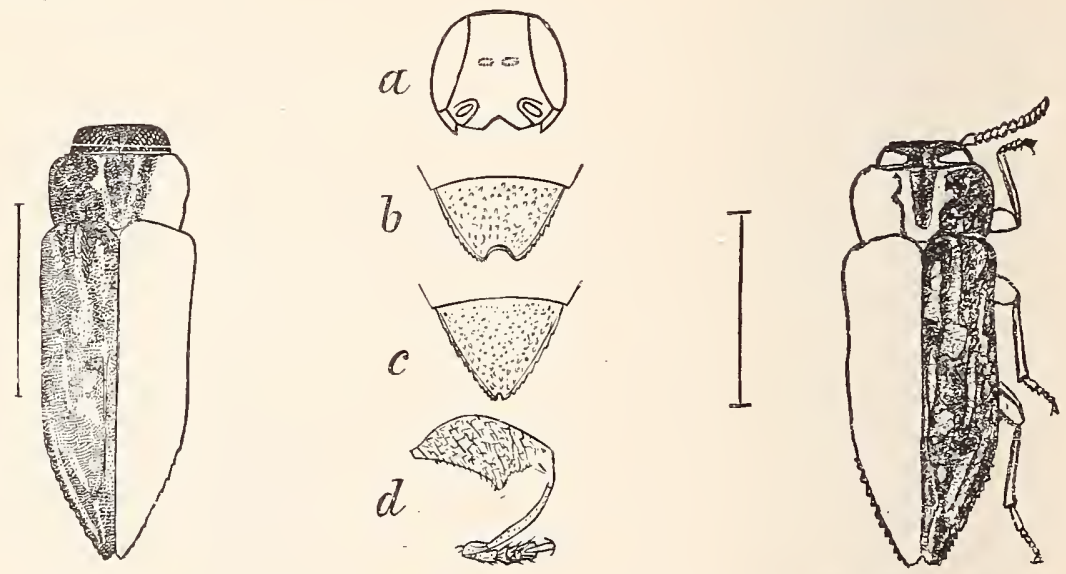

Fig3. 303-305. Chrysobothris dentipes. $a$, head, front view; $b$, last male ventral segment; $c$, last female ventral segment; $d$, front leg of male. (After Packard in Fifth Rep. U. S. Ent. Comm.)

C. dentipes Germ. (Figs. 303-305), length 10-16 mm., is said to cceur throughout the area east of the Mississippi River, but has not yet been noted from Indiana.

1502 (10,077). Chrysobothris blancinardi Horn, Trans. Amer. Ent. Soc., XIII, 1886, 93.

Moderately elongate, depressed. Dark bronze, shining; antennæ of male greenish, of female bronzed, third joint as long as the next two. Clypeus 
broadly but not deeply triangularly notched at middle. Thorax twice as wide as long, narrowed at apex and base, sides regularly curved; disk with a vague median densely punctured sulcus, wider in front, limited on eachls side by an elevated smooth space, between which and margin the surface is irregularly and densely punctate. Elytra wider than thorax, gradually narrowed from middle to apex; margins feebly serrate, tips obtuse; first costa distinct on apical half, the other's replaced by broad smooth spaces of irregular shape, the surface between them densely punctate. Body heneath very shining. the last ventral with submarginal serrate ridge. Length $10-16 \mathrm{~mm}$.

Lake and Knox counties; scarce. June 6-July 28. Occurs on scrub pine in the former county. Ranges from Massachusetts to Lake Superior.

C. trineria Kirby, piceous, bronzed, elytra and abdomen more or less cupreous, length 9-14 mm., is said to occur from the Middle States westward; $C$. pusilla Lap., dark coppery-bronze, length 5.5$7 \mathrm{~mm}$., occurs from Massachusetts to Wisconsin and has been taken near Cincinnati.

1503 (4657). Chrysobothris sex-signata Say, Trans. Amer. Phil. Soc.

VI, 1836, 158; ibid. II, 103, 591.

Elongate-oblong, subdepressed. Piceous with faint bronzed lustre; elytra each with three rounded brassy spots, one basal, one in front of middle on second costa, the other one-third from apex; beneath bright green, the sides cupreous; antennæ green in both sexes. the third joint as long as the next three. Clypeus triangularly emarginate at middle, curved on each side. Thorax twice as wide as long, abruptly narrowed in front, sides slightly curved, hind angles obtuse; disk with a vague median impression on basal half and a subapical oblique one each side, coarsely and densely

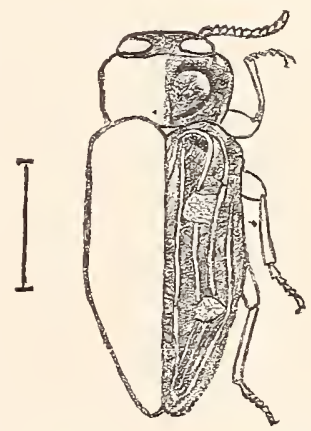
Fig. 306. (After Packard in
ifth Rep. U. S. Ent. Comm.) punctured, transversely strigose. Elytra wider than Fifth Rep. U. S. Ent. Comm.) thorax, sides nearly parallel in front, obliquely narrowed behind the middle; surface with first costa nearly entire, the other's represented by faintly elerated smooth lines, coarsely and closely punctate. Prosternum not lobed in front. Length 6.5-11 mm. (Fig. 306.)

Marshall, Putnam. Perry, Vigo and Knox counties; scarce. May 21-July 25. A handsome and easily recognized species.

1504 (4660). Chrssobothris azurea Lec., Trans. Amer. Phil. Soc. XI. $1859,239$.

Oblong, rather broad, subdepressed. Color variable from blue to greenish-blue, riolet or cupreous; beneath blue, the sides sometimes cupreous; antennæe greenish, male, bronze. female. the third joint nearly as long as the next three. Clypeus broadly, not deeply, triangularly emarginate at middle. 'lhorix twice as wide as long, without well marked depressions; 
surface coarsely punctate, much more densels on sides. Elytra wider than, thorax, gradually wider to apical third. thence narrowing to apex, margins serrate; surface sparsely punctate and with a faint trace of first costa and a basal and two discal impressions, one in front of middle, the other onethird from apex. these often bright blue or green. Prosternum rery faintly lobed in front. Length $G-S \mathrm{~mm}$.

Lake and Posey counties; scarce. Mị 20-June 7.

150.5 (10,091). Chrs sobothris scitela Gory. Mon. Buprest.. Supp.. 153 . 169.

Rather elongate, convex. Dark cupreous or (leep riolet. elytra each witl three more brilliant blue or green spots: antenne piceous, the three basal joints greenish or cupreous, third joint as long as the next three. Clrpeus with a small triangular notch at middle. Thorax with sides straight, rounded near front angles: disk without depressions. coarsely punctate and finely transrersely strigose. Elytra wider than thorax. coarsely. deeply, not densely punctate, the colored spots in the position of the usual foreæ. Length $\overline{5} . \overline{-}-\bar{\imath} \mathrm{mm}$.

Starke and Perry counties: scarce. May 20-June 27.

IX. Acterodes Lac. 1857. (Gr., "without + a comb or crest.")

Buprestics of small or medium size having the antenna inserted at the end of short grooves as in Chrysobothris, but differing from the latter genus by the small scutelinm. the equal first and second joints of hind tarsi and the rery narow vertex between the eres.

1506 (4666). Actexodes Acoris Say. Trans. Amer. Phil. Soc., VI, 1S36, 159 ; ibid. II, 592.

Broadly oblong, subdepressed. Brass black above, dull cupreous beneath; scutellum green. Antennie short, the third joint as long as the next three; clypeus almost truncate. Thorax twice as broad as long, with a transrersely sub-basal impression; surface densely and coarsely punctured. transversely strigose. Elstra broader than thorax; surface without costie or distinct impressions but densely and roughly transversely wrinkled; margins serrate from near the humerus. Length 10-13 $\mathrm{mm}$.

Lake. Märshall. Orange and Vigo counties; frequent in Lake. scarce elsewhere. Beaten from regetation. June 2-June 28.

\section{Tribe II. JULODNI.}

Our species belonging to this tribe are conver and subcrlindrical in form. narrowed behind and clothed with suberect pubescence. The front is not contracted by the insertion of antenna; thorax truncate behind and closely applied to the elrtra: mesostemum deeply enarginate; first joint of hind tarsi elongate. The tribe is represented br four genera. two of which oceur in Indiana. 
KEY TO INDINNA GENERA OF JULODINI.

a. Scutellum indistinct; side pieces of metathorax partly risible.

X. ACM.EODERA. a . Scutellum risible; side pieces of metathorax corered by the elytra.

XI. PTOSIMA.

\section{ACM EODER Esch. 1829. (Gr.. "in full bloom + skin.")}

This genus, as characterized above, is represented in the United States by 70 species, only three of which occur in the eastern United States. including Indiana. The others are found mostly in the Southwestern and Pacific States. The two principal papers treating of the genus are by

Horn._- "Revision of the Species of Acmaodera of the United States," in Trans. Amer. Ent. Soc.. VII, 187 s, 2-27, Pl. I.

Fall. H. C._ "Synopsis of the Species of Acmrodera of America North of Mexico," in Jonin. N. Y'. Entom. Soc., VII, 1899. $1-37$.

KEY TO INDIANA SPECIES OF ACMEODERA.

a. Sides of thorax with an elongate yellow spot near hind angles.

1507. PULCHELLA.

a a. Sides of thorax without trace of yellow.

b. Larger, S.5-11 mm.; bluish-black, elstra with a number of small. more or less connected yellow spots.

150S. ORNATA.

bb. Smaller, 5-7.5 mm.; blackish-bronzed, spots smaller, distinctly separated and usually in two rows.

1509. TYBULCS.

1507 (4699). Acmemodera pulchella Herbst., Col. IX, 1805, 211.

Elongate-oblong or subcylindrical, convex. Thorax and under surface bronzed, the former with an oblong yellow spot in front of hind angles; elytra black with rariable yellow markings, these usually a small sub-basal spot, an elongate marginal spot reaching from humerus to beyond middle, this with an inward prolongation near middle, and two crossbars, interrupted at suture, on apical third. Thorax conrex, nearly twice as wide as long, apex and base truncate, sides narrowing from base to apex; disk without distinct impressions, but with a small basal forea on each side; suríace densely, evenly and rather coarsely punctured. Elytra as wide at base as thorax, margin seirate; surface striate, the strice rather finely punctured: intervals flat, each with a single row of punctures, bearing short brownish hairs. Length $5.5-10 \mathrm{~mm}$.

Throughout the State; frequent. June 11-July 25. Occurs on flowers, especially those of Jersey Tea. Ceanothus americanus I. The rellow spot on side of thorax is sometimes reduced to a mere point and in one specimen at hand is wholly lacking. 
$150 S$ (4692). Acm eodera ornata Fab., Syst. Ent., 1798, 220.

Robust, subcylindrical, moderately depressed. Bluish-black, sparsely, clothed with erect black hairs, each elytron with usually six or eight irregular small yellow spots on the sides. Thorax twice as wide as long, apex emarginate, base truncate; sides rapidly converging from behind the middle to apex; disk with distinct median triangular impression and oblique lateral impression, the latter terminating in a pit at base; surface coarsely and deeply punctured, more densely on sides. Elytra narrower at base that thorax, gradually narrowing from base, more rapidly on apical third; margins serrulate; disk with coarsely punctured striæ; intervals flat, each with a single row of punctures. Length $8.5-11 \mathrm{~mm}$.

Knox County; rare. June 24. Probably occurs sparingly throughout the southern half of the State.

1509 (4707). Acm жodera tubulus Fab., Syst. Eleut., II, 1801, 200.

Subcylindrical, convex. Black bronzed, with sparsely placed short erect whitish hair; elytra each with a dorsal row of four or five, and a marginal row of three or four small yellow spots, these rarely connected to form an irregular stripe. Head densely punctured, front feebly impressed. Thorax convex, nearly twice as wide as long, sides curved and widest in front of base; disk with three small basal fover, coarsely and densely punctured. Elytra as wide at base as thorax, gradually narrowed and finely serrate on apical third; striæ with rather coarse punctures; intervals coarsely punctate. Length 5-7.5 mm.

Throughout the State; common. April 13-June 24. Occurs especially on the flowers of the wild cranesbill, Geranium maculatum L., the red haw, Cratrgus, and other low herbs and shrubs. Mating May 27. Listed as A. culta Web.

\section{Prosima Sol. 1833. (Gr.., "to fall down.")}

The members of this genus are readily distinguished from Acmaodera, which they resemble in form, by the presence of a distinct sentellum. One of the two known species occurs in Indiana.

1510 (4713). Ptosima gibicollis Say, Journ. Phil. Acad. Nat. Sci., III, 1S23, 161; ibid. II, 104, 591.

Subcylindrical, robust. Bluish-black, shining, finely and sparsely pubescent. Elytra each with a large oblong spot on side, reaching from base to beyond middle and a smaller transverse one on apical third, bright yellow. Front concave. Thorax convex, with an obtuse subapical elevation each side, sides strongly deflexed, base truncate; surface rather densely and coarsely punctate. Elytra without striæ, margin sinuate, serrate on apical third, disk rather finely and sparsely punctate. Length 6-7.5 mm.

Marion and Vermillion counties southward; frequent. May 11July 22. Beaten from foliage of red bud, Cercis canadensis L., in the wood of which the larva bores; also occurs frequently on sassafras. A prettily marked species. 
Tribe III. MASTOGENINI.

This tribe is represented in North America by the single genus

XII. Mastogentus Sol. 1851. (Gr., "mother + chin.")

It in turn is represented in the eastern United States by one of the smallest Buprestids known, subcylindrical in form and having the antennæ inserted in large cavities, narrowing the front, which does not expand again in front of the cavities as in Agrilus; mouth small, deflexed but not applied to the prosternum; thorax truncate at base, closely fitting against the elytra; prosternum truncate before and behind, with the lateral sutures parallel; scutellum small. triangular; legs not contractile, claws broadly toothed.

1511 (4717). Mastogenius subcyaneus Lec., Trans. Amer. Phil. Soc., XI, $1859,254$.

Subcylindrical. Bluish-black, shining. Head with a lengthwise groove. Thorax one-half wider than long, slightly wider than elytra, convex, sides strongly rounded; surface, as well as that of elytra, finely and rather sparsely punctate. Elytra with a deep but narrow transverse impression at base, sides parallel, tips obtusely rounded. Length $2-2.5 \mathrm{~mm}$.

A single specimen taken by sweeping on University farm near Mitchell, Lawrence County. May 11. LeConte states that it occurs rarely on leaves and flowers in the Middle, Southern and Western States.

\section{Tribe IV. AGRILINI.}

Small-sized, usually slender, though sometimes short, broad and flat species, having the body narrowed on apical third. Their chief structural characters are the front strongly narrowed by the insertion of antennæ, then expanded, thus forming two diverging lobes; front part of head vertical, the month inferior and applied to the prosternum in repose; thorax lobed at base, receiving the convex bases of the elytra; legs contractile; tarsal claws strongly toothed. Six genera are recognized as composing the tribe, four of which are known to be represented in Indiana, while another perhaps occurs.

KEY TO INDTANA GENERA OF AGRILINI.

a. Antennæ free, in repose not received in grooves on the under side of thorax.

b. Hind tarsi with first joint scarcely elongated.

Eupristocertis.

bb. Hind tarsi with first joint as long as the three following.

XIII. Agrilus.

aa. Antenna received in grooves on under side of thorax near the margin.

c. Scutellum small; tibiæe linear. 
d. Body elongate; prosternum pointed behind. XIV. Taphrocerts.

dd. Body broad, orate; prosternum obtuse behind. XV. Brachrs.

cc. Scutellum large; body triangular; prosternum rery broad, almost truncate behind; tibire dilated.

NYi. Pachiscelts.

Eupristocerus cogitans Weber. head and thorax obscure supreous, elytra black, with crossbars of grayish hairs. length $8-9 \mathrm{~mm}$. is known from the "Middle. Southern and Western States."

\section{Agrilus Steph. 18:30. (Gr., "field.")}

Small. slender, elongate forms, having the prosternum pointed behind; the scutellum transverse and acuminate. The larvæ live in slender stems and twigs of shrubs and trees, and often do much damage. especially to blackberry and raspberry canes. The genus has been monographed by

Horn.- "The species of Agrilus of Boreal America," in Trans. Amer. Ent. Soc., XVIII, 1891. 277-336. PI. VIII.

In this paper Horn recognizes 54 species. 18 of which have been taken in Indiana. while sereral others doubtless oceur. On account of the large number of species the Indiana members of the genus are classed in three groups.
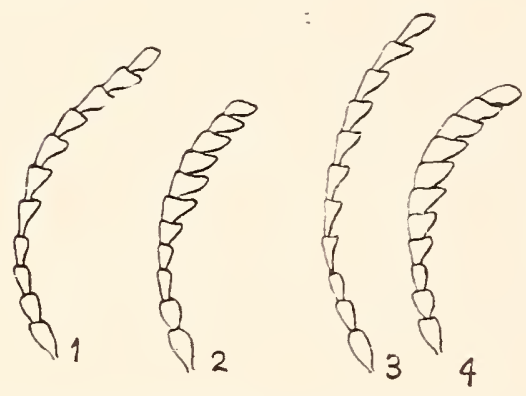

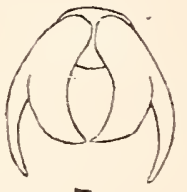

5

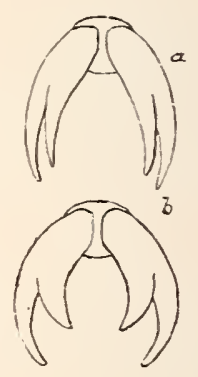

6

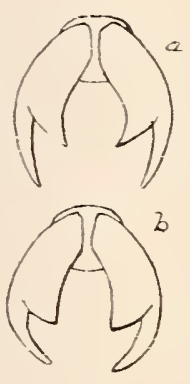

7

Fig. 307. 1, Antenna of Agrilus egenus; 2, of A, imtellis: 3, of A. obsoletoguttatus; 4, of A. ruicullis; 5 , tarsal claws of A. ruficollis: 6 , claws of A. bilineatus, $a$, male; $b$, female; $r$, claws of $A$ leconte $i$, $a$, male; $b$, female. (After Horn.)

KEY TO GROUPS OF INDIANA AGRILLS.

a. Antemne serrate, beginning at the fourth joint. (Fig. 307, Nos. 3 and t.)

b. Tarsal claws cleft in such a manner that the lorer portion is turned inward, nearly or quite touching that of the opposite side. (Fig. 307. No. 5.)

Group $A$.

b7. Tarsal claws simply cleft, or almost bifid, the lower portions not turned inrard. (Fig. 307, Nos. 6 and T.) Group $B$. aa. Antenne serrate, beginning at the fifth joint. (Fig. 307. Nos. 1 and 2.)

Group A.

Group $C$.

Whenever the tourth joint of antennæ resembles the fifth more than it does the third (Fig. 307, Nos. 3 and 4). the species comes 
under $a$ of the above key. If the lower lobes of the tarsal claws are bent inward as shown in No. 5 of Fig. :307, the insect belongs to Group $A$.

KEI TO INDIANA SPECIES OF GROLP A.

a. Prosternum parallel between and behind the front coxie, the apex obtuse or truncate; thorax not impressed at middle, carina of hind angles distinct; length $S$ or more mm.

b. Thorax without a white pubescent space on sides; tips of elytra erenls serrate.

1512. DIFFICILIS.

7b. Thorax with elongate space of dense whitish pubescence on sides; tips of elytra ending in a short. sharp spine, merenly serrate.

1513. FERR1S1.

u . Prosternum gradually narrowing, the apex acute.

c. Last dorsal segment carinate, the carina prolonged at tip ; length $5.5-$ $7 \mathrm{~mm}$.

d. Front with a deep median furrow; hind angles of thorax not carinate in either sex.

1514. RCFICOLLIS.

dd. Front feebly impressed; hind angles of thorax slightly carinate in female onls.

LATERALIS.

cc. Last dorsal segment not carinate.

$e$. Male with inner apical angle of tibiæ on all three pairs of legs terminating in a sharp incurred spine; form slender; length less than $5.5 \mathrm{~mm}$.

f. Antennæe rery slender with a fringe of long hairs on the outer side; color olire-bronze.

CRINICORNIS.

ff. Antenne stouter. not pilose on the outer side; front of head and sides of thorax greenish.

1515. отIOSLS.

$e e$. Hind tibire of males not terminating in a spine; head not or feebly impressed; length $5-9 \mathrm{~mm}$.

g. Males with a denseị pubescent space on middle of prosternum: color uniform dull olive-green or slightly brasss.

1516. IASCELINUS.

gg. Males with prosternum but slightly pubescent; head and thorax brassr or slightly greenish.

1517. ARCTATLS.

1512 (4725). Agrilts difficilis Gorr, Mon. Buprest., Supp., 1837, 224.

Elongate. Piceous with a greenish or cupreous lustre, metallic beneath: abdomen with two rows of rellowish pubescent spots on each side, one row abore the lateral suture and partly risible from abore. Front flat. occiput slightly impressed. Thorax broader than long, sides slightly curved, disk with a feeble oblique depression on sides and another in front of scutellum; surface rather finely transversels strigose. punctate at apex; hind angles with a rather strong curred carina. Elștra with tips rounded. fineIs toothed. basal forer feeble, disk with faint coste, surface with imbricated scales. Prosternal lobe rounded. acutely emarginate. Length 9-13 $\mathrm{mm}$.

Marion and Poser counties; scaree. June 19-.July 21.

1513 (-). Agrilts ferrisi Dur

Resembles difficilis. Differ's by haring the front of head and sides of under surface densels corered with white, wool-like pubescence. that on ab- 
domen being in triangular spots on sides of ventral segments. Occiput with a more distinctly impressed median line. Elytra with an indistinct costa, between which and suture the surface is broadly grooved; tips ending in a short, sharp spine and unevenly toothed. Length $8-12 \mathrm{~mm}$.

Warren and Posey counties; scarce. June 9-July 23. Occurs only on the hackberry, Ccllis occidentalis $\mathrm{I}_{\text {., }}$ in the twigs of which the larve bore.

1514 (4721). Agrilus ruficollis Fab., Ent. Syst., I, 1798, 214.

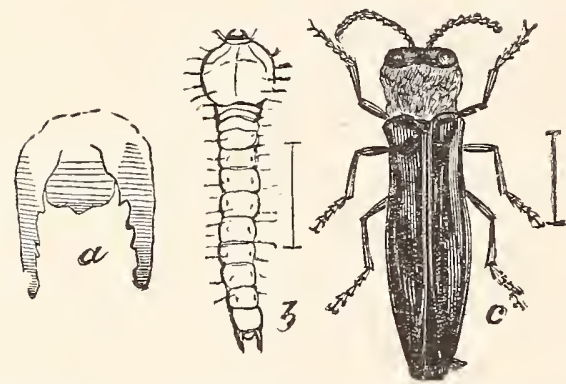

Fig. 308. $a$, anal end of body of larva; $b$, larva; $c$, beetle. Lines show natural size. (After Riley.)

Elongate. Black or bluish-black; head and thorax usually bright cupreous. Occiput with a deep median furrow, somewhat strigose. Thorax broader than long, apex slightly wider than base; disk with a rather deep oblique depression on each side, and a feeble one in front of scutellum; surface faintly strigose and rather densely punctate. Elytra a little broadened behind the middle, nearly concealing the sides of abdomen from above, tips rounded, distinctly serrulate; disk flat, a basal depression on each side; surface without trace of carinæ, closely granulate. Prosternum obtusely lobed in front. Length 5.5-7 mm. (Fig. 308.)

Throughout the State; common. May 18-July 22. Occurs on the foliage and stems of blackberry and raspberry bushes, in the canes of which the larvæ bore, forming galls on some varieties. These should be cut out in winter and burned with the enclosed grub; or the shoots made up to the first of July should be cut off at the surface, because in them the larva of a new brood are contained. The shoots formed later in the season will be sufficient for the next year's crop of fruit.

A. crinicornis Horn. length $4.4 \mathrm{~mm}$., is known to occur in Ohio and Illinois: A. lateralis Say, head and thorax cupreous, elytra black, with slight bronzed lustre, length 6-7 mm., is known from New England, Mllinois and Missouri.

1515 (4724). Agrilus otiosus Say, Trans. Amer. Phil. Soc., VI, 1836, 163 ; ibid. II, 597.

Elongate, slender, male sometimes linear. Dull greenish or slightly cupreous; front of head, sides of thorax, antennæ and under surface usually bluish or greenish. Occiput with a slight impression; lower part of front usually with dense whitish pubescence. Thorax a little wider than long; hind angles indistinctly carinate, male, or with a well defined carina, female; disk with an oblique depression each side and two on median line. the hind one the larger; surface transversely strigose with fine punctures between the wrinkles. Elytra with a vague costa from the humeri to be- 
hind the middle, between which they are slightly flattened; tips rounded, finely serrulate; basal depressions distinct, surface densely covered with scales. Prosternal lobe obtuse, faintly emarginate. Length 4-5.5 mm.

Throughout the State; common. May 13-August 13. Occurs especially on foliage of oak and hickory.

15016 (10,112). Agrilus masculinus Horn, Trans. Amer. Enit. Soc., XVIII, 1891, 295.

Rather slender, more robust than otiosus. Dull green or slightly brassy, feebly shining; antennæ greenish. Occiput feebly impressed, male; distinctly so, female; front densely punctate. Thorax slightly wider than long, a little narrowed at base. side margin sinuate; hind angles with a distinst carina; disk with an oblique depression on each side and two faint ones on median line; surface finely, transversely strigose, punctate. Elytra obtuse at apex, finely serrate; disk with an indistinct costa on each side; basal depressions shallow; surface with close scales. Prosternal lobe broadly and rather deeply emarginate. Length 6-7 mm.

Kosciusko and Marion counties; scarce. May 23-June 8. Occirrs on foliage of buckeye.

1517 (4720). Agrilus arcuatus Say, Ann. Lyc. Nat. Hist., I, 1825, 251; ibid. I, 387; II, 596.

Moderately elongate, rather robust. Dark olivaceous; head and thorax brassy or cupreous; sometimes (var. coryli) the whole upper surface uniform bright brassy. Front moderately impressed from occiput nearly to base of clypeus, coarsely and rather closely punctate. Thorax one-fourth wider than long, not narrowed at base; disk with two depressions on median line and a large oblique one each side; hind angles with a curved carina, more distinct in female; surface transrersely strigose with punctures in depressions. Elytra dilated behind the middle, tips separately rounded, finely serrulate, sutural edge elerated behind the middle; surface rather densely scaled. Prosternal lobe broadly emarginate. Length 5-9 mm.

Throughout the State; frequent. May 23-July 21. Occurs on foliage of oak and other trees, usually along the margins of marshes and lakes; var. coryli on hazelnut.

Group B.

In this group the antennæ are serrate as in Group $A$, but the tarsal claws are cleft or almost bifid, with the inner portion not recurved. (Fig. 307, Nos. 6 and 7.)

KEY TO INDIANA SPECIES OF GROUP B.

a. Last dorsal segment with a projecting carina.

b. Front deeply impressed; head and thorax coppery red, elytra black; hind angles of thorax not carinate; coxal plates not pubescent.

$b b$. Front convex or feebly impressed; color uniform.

VITTATICOLIIS.

[51-23402] 
c. Sides of thorax with yellowish pubescence; elstra each with a rellow pubescent stripe; hind angles of thorax not carinate.

151S. BILINEATCS.

cc. Elytra without a sellow pubescent stripe.

d. Elytra with more or less erident pubescent spots; last rentral segment obtuse or truncate at tip; first two rentrals of male groored.

GRA NULATLS.

dd. Elytra without pubescent spaces

$e$. Last rentral segment obtuse or truncate; first and second rentrals of male with a smooth deep groore.

BLA XCHARDI.

ee. Last rentral segment oral at tip.

$f$. Hind angles of thorax carinate in both sexes; first rentral of male broadly groored.

1519. Axxius.

$f f$. Hind angles of thorax not carinate; first rentral of male nearly flat.

1520. ACUTIPEXNIS.

ut. Last dorsal segment without a projecting carina.

y. Elytra without pubescent spaces; prosternal lobe truncate or feebly emarginate.

1521. POLITCS.

gy. Elitra with pubescent spaces.

h. Prosternal lobe entire; middle pubescent space of elrtra rounded. 15:2. FALKAX.

hh. Prosternal lobe deeply emarginate; first joint of hind tarsi longer than half the tibia; middle pubescent space of elstra elongate.

1523. OBSOLETOGETTATCS.

A. vittaticollis Rand., length $8-9.5 \mathrm{~mm}$., is said to occur from "Massachusetts :restward to Illinois."

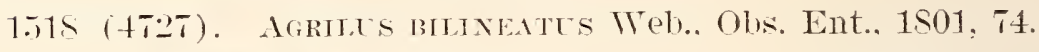

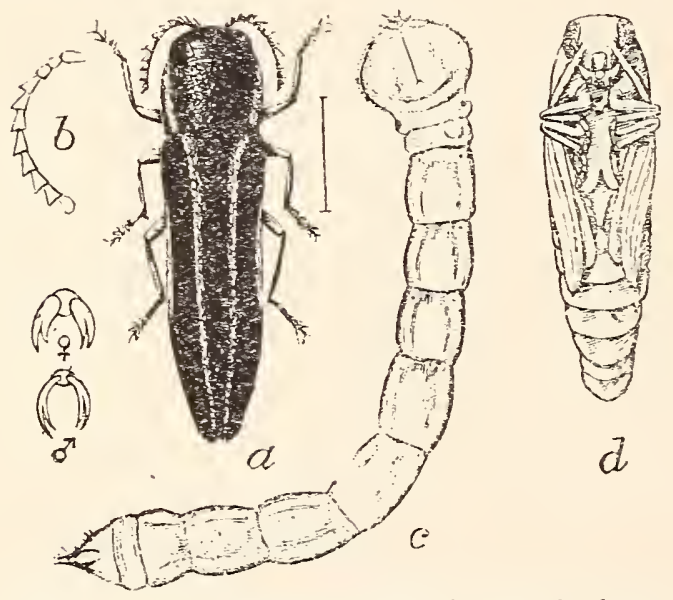

Fig. 309. $a$. adult beetle; $b$, antenna of same; $q$, claws of hind tarsi of female; $d$, same of male; $c$, larva; $d$, pupa. ( $1 f-$ ter Chittenden.)

Elongate, moderately robust. Abore black, with often a slightly greenish tinge; sides of thorax and a narrow stripe reaching from humerus to beyond middle of each elytron clothed with dense rellow pubescence; beneath more shining and greenish. Thorax one-third wider than long. distinctly narrower at base; sides nearly straight on apical half. sinuate near the hind angles. which are rectangular; disk with a vague median and a short lateral oblique impression each side. finely transtersely strigose-punctate. Elytra broadened behind the middle. tips rounded. serrulate; surface densely granulate. Prosternal lobe truncate in front. Length 6-9 mm. (Fig. 309.)

'Throughout the State; frequent. June 1-July 2. Occurs on oak, honer locust and chestnut. A handsome and easily recognized species. 
A. gramulatus Say, brassy-bronze, elytra each with two or three pubescent spots, length 7.5-9 mm., occurs from the New England States westward to Missouri; A. blanchardi Horn, olivaceous-bronze, length $9 \mathrm{~mm}$., is known from Massachusetts, New York and Lake Superior, and may oecur in northern Indiana.

1519 (4739). Agritus Anxius Gory, Mon. Buprest. Suppl., IV, 1897, 226.

Elongate, moderately robust. Abore olivaceous. bronzed, subopaque. Occiput with an impressed line; front roughly punctured somewhat strigose. Thorax one-third wider than long, not narrowed at base, sides regularly curved; disk with a rague median depression, on each side of which in front of middle is often a circular forea, also a moderate depression each side; surface indistinctly strigose punctate. Elytra slightly broader behind the middle, tips subacute, serrulate; disk slightly flattened, with a rague costa, sutural edge elerated behind the middle; surface with close granulate scales. Prosternal lobe distinctly emarginate at middle. Length $7.5-11 \mathrm{~mm}$. (Fig.

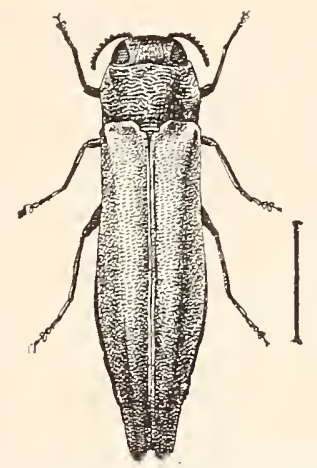

Fig. 310. Female. Bull. 18, Div. Ent. U.S. Dep. Agr. (After Chittenden.)

\section{Lake County; rare. `June 29-July 12.}

\section{0 (473S). Agrilus Acutipennis Mann., Bull. Mosc., 1837, 109.}

Elongate, moderately robust. Blue or bluish-black to olivaceous, feebly shining. Occiput with a median impressed line extending to middle of front. Thorax one-fourth wider than long, not narrowed at base, sides curved, hind angles not or very obtusels carinate; disk with a vague median depression divided at middle; lateral depressions well marked; surface finely transversely strigose, with small punctures between the wrinkles. Elytra as in anxius. Prosternal lobe subtruncate or faintly emarginate. Second rentral of male with a deep median groore. Length $S-10 \mathrm{~mm}$.

Crawford County ; rare. May 16. Occurs on oak.

1521 (4742). Agriles polites Say, Ann. Lye. Nat. Hist., I, 1825, 251: ibid. I. 3ST; II, 596.

Moderately elongate, subdepressed. Color variable from bright brassy to purplish or greenish, moderately shining. Antennze short, not reaching middle of thorax. Occiput strigose and with a feeble median depression. Thorax one-third wider than long, sides slightly curred. hind angles feebly carinate; disk with two faint median impressions, the smaller one in front, rather coarsely, transversely strigose-punctate. Elstra dilated behind the middle, more notably in female. tips rounded and serrulate; disk slightly flattened. basal depressions feeble; surface closely corered with granulate scales. First two rentral segments finely transrersely strigose on the sides. Front and middle tarsal claws of male cleft near apex. nearly bifid; hind claws cleft at middle, forming a broad tooth. Length $5-8.5 \mathrm{~mm}$. 
Throughout the State; frequent. Niay 24-August 11. Occurs on oak and willow. The short, robust antennæ, lack of projecting carina of last dorsal segment and lack of pubescent spots on elytra are the principal distinguishing characters of this species.

1522 (4731). Agrilus fallax Say, Trans. Amer. Phil. Soc., VI, 1836, 163 ; ibid. II, 596.
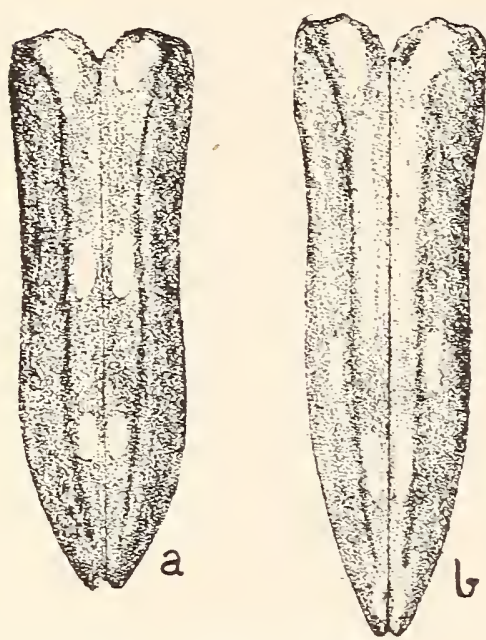

Fig. 311. a, Elytral markings of $A$. fallax; $;$, same of $A$. obsoletoguttatus; $c$, same of lecontei. (After Horn.)

Moderately el ongate, slender. Dark oliraceous, often with a greenish tinge; each elytron with three small round pubescent spots, one basal, one before the middle and one on apical third. Antennæ long. slender, reaching hind angles of thorax. Occiput with a feeble median impression. Thoras very little wider than long, sides curred in front, slightly sinuate near hind angles, which are acutel 5 rectangular and with a sharpls defined straight carina; disk with a vague median depression on basal half and two lateral depressions; surface transversely strigose-punctate. Elytra gradually narrorred at apical third, tips rounded and serrulate; disk slightly flattened with a rague costa each side. Length 4-6 mm. (Fig. 311, u.)

Throughout the State; frequent; more so in the southern counties. Nay 17-October 17. Occurs on locust and oak.

1523 (4732). Agrilus obsoletoguttatus Gorj, Monog. Buprest., IV, 1S37, 256.

Elongate, slender. Brassy black or dark olivaceous, feebly shining; each elytron. With three pubescent spaces, the middle one elongate; often also a small spot on side near the end of the middle one. Front flat, with a depression at its upper part. Thorax rery little wider than long, slightly narrowed at base, sides feebly curred, hind angles with a well defined straight carina; disk with a median depression near apex, lateral depressions feeble; surface transrersely strigose-punctate. Elytra as in fallax, the basal impressions deeper. Length 6-8 mm. (Fig. 311, b.)

Northern half of State, frequent; Perry County in the south. May 29-June 19. The greater length, elongate middle spot of elytra and notched front margin of prosternum readily distinguish this species from fallax. 


\section{Group C.}

In this group the fourth joint is slender and very similar to the third, the fifth broader (Fig. 31)T, Nos. 1 and 2). The species are, for the most part. smaller and more slender, rarely over $6 \mathrm{~mm}$. in length.

KEY TO INDIANA SPECIES OF GROUP C.

a. Hind angles of thorax not at all carinate.

b. Elytra with pubescent spots or spaces forming a distinct design; length 4-4.5 $\mathrm{mm}$.

1524. sUBCINCTUS.

bb. Elytra without pubescent spaces, vaguely costate; thorax transversely strigose and punctate; scutellum carinate; length $3 \mathrm{~mm}$.

a $a$. Hind angles of thorax distinctly carinate.

1525. PUTILLUS.

c. Elytra with pubescent spots; lateral margin of thorax as seen from the side, sinuous; length 4.5-6 mm.

d. Front convex, not impressed; prosternal lobe deeply emarginate.

1526. LECONTEI.

dd. Front more or less concave and distinctly impressed; prosternal lobe very feebly emarginate; last dorsal segment without a carina; head roughly strigose.

1527. ADDENDUS.

cc. Elytra without pubescent spots; lateral margin of thorax straight, deflexed only in front.

e. Male with under surface distinctly pubescent, the first two ventral segments deeply channeled; thorax without lateral impressions.

LACUSTRIS.

ee. Male with first two ventral segments flat or feebly channeled, not pubescent; length $3-5 \mathrm{~mm}$.

f. Antennæ slender, joints longer than wide. 1528. EgEvus.

ff. Antennæ shorter, the serrate joints wider than long; prosternal lobe emarginate.

1529. PUSILLÚS.

1524 (4734). Agrilus subcinctus Gory, Mon. Buprest., IV, 1837, 252.

Elongate-oblong, moderately robust. Piceous, with faint bronze lustre; elytra with two yellowish pubescent spaces, one extending from humeri to middle, with two interruptions, then turning obliquely outwards; the second oblique, one-fourth from apex. Occiput strigose and with a deep median impression. Thorax one-fourth wider than long, sides regularly curved; disk with a rather broad but shallow median groove extending the full length and a well marked depression each side; surface transversely strigose at middle, obiiquely so on sides. Elytra somewhat dilated behind the middle, tips rounded and serrulate; disk slightly flattened with a vague costa, surface with coarse scales. Prosternal lobe broadly emarginate. Length 4-4.5 mm.

Vermillion, Narion and Vigo counties; searce. May 30-July 21. Taken by beating. 
1525 (tits). Agribus puthlu's sily, Trans. Amer. Phil. Soc, TI, 1836. 163 ; ihid. II. 597.

Elongate-oblong, slender. Dark olivaceous bronze, moderately shining. Antennie scarcely reaching the middle of thorax. Occiput with a feebly impressed line. Thorax one-third wider than long, sides regularly curred, hind angles rectangular: disk with a feeble linear median impression, lat. eral depressions deep along the sides; surface transrersely strigose. punc. tured near apex. Elytra very little sinuate at middle, tips rounded, serrulate; disk slightly depressed at middle, basal forea feeble; a shallow groove between the suture and a rague costa on each; surface covered with scales, but not closely. Prosternal lobe truncate or slightly emarginate. Length 3-4 min.

Kosciusko County ; rare. June 3. Our smallest species. Described from Posey County.

1526 (4730). Agrilus iecontei Saunders, Cat. Buprest. 1ST1, 117.

Elongate, rather robust. Dull oliraceous bronze, sometimes slightly brassy; elștra with a space on each basal depression. an indistinct, broad curved band at middle and another on apical third. whitish pubescent. Thorax a little wider than long, sides feebly curred: disk with a deep median depression composed of two foreie united by a groore, the lateral oblique depressions moderately deep; surface coarsely punctate. Elytra slightly broadened behind the middle. tips together rounded, serrulate; disk slightly depressed at middle with a rague costa each side; surface subgranulate. Tarsal claws cleft at middle, forming a broad tooth. Length 4.5-5.5 mm. (Fig. 311, c.)

Lake, Vermillion, Marion and Knox counties; scarce. May 17July 10.

A. Tacustris Lee., dark bronze. green or blue, length $4-7.5 \mathrm{~mm}$., is known from Illinois. westward.

1527 (4737). Agrilus addendus Crotch, Proc. Phil. Acad. Nat. Sci.. 1S73, 95.

Moclerately robust. Dull coppery or olivaceous bronze, subopaque : each elytron with three pubescent spots, as in fallax, these sometimes very faint. Antenne reaching the middle of thorax. Head from above concare, a rather deep impression from the occiput to clypeus. Thorax a little wider than long, sides feebly curved and slightly sinuate in front of hind angles; disk with a faint median and a moderately distinct lateral impression each side. closely transrersely strigose. Elytra but slightly broadened behind the middle, the tips rounded, feebly ser'ulate; disk slightly flattened and with a rague channel each side of suture. Length $5-6 \mathrm{~mm}$.

Posey and Perry comnties; scarce. April 21-Nay 31. Taken Irom peach trees in blossom and by sweeping herbage. A southwestern form, described from Texas.

1528 (4746). Agritus Eqexus Gory, Mon. Buprest.. IV. 1S37, 258.

Moderately elongate, rather slender. Olive bronze, sometimes greenish. Antennse reaching middle of thorax, the third joint shorter than fourth. 
Occiput strigose and with a feeble median impression. Thorax one-fourth wider than long, hind angles with a distinct, slightly oblique carina; disk without a median depression, those on sides well marked, transversely strigose with small punctures between the wrinkles. Elytra slightly broader behind the middle; tips rounded, serrulate; disk slightly depressed; surface with imbricate scales. Prosternal lobe truncate, more or less emarginate; tarsal claws broadly toothed. Length $3.5-5 \mathrm{~mm}$.

Throughout the State; common. May 24-.July 25. Ocenrs on foliage of various trees, especially the black locust, in which the larva dwell.

1529 (4724a). Agrilus pusildus Say, Ann. Lyc. Nat. Hist., I, 1825, 252; ibid. I, $38 S$.

Elongate-oblong, rather-robust. IIead and thorax brassy or hronzed: elytra purplish-black. Antenne reaching middle of thorax. Occiput witl a feeble median impression. Thorax one-fourth wider than long, slightly narrowed at base; sides curved in front, slightly sinuate near hind angles. which are distinctly carinate; disk with a broad transverse depression in front of base, so that when viewed from the side the front half is more convex; lateral depressions moderate; surface coarsely transversely strigose with coarse punctures between the wrinkles. Elytra distinctly dilated behind the middle; disk with a vague costa on each side and concave each side of suture; surface with sparse, smooth scales. Length 3.5-4.5 mm.

Vermillion, Knox and Posey counties; frequent. .June 8-July 7.

\section{TAPHrocerus Sol. 1833. (Gr., "pit+horn.")}

In this and the remaining genera of the family the under side of the thorax is deeply grooved near the margin for the reception of the antennæ in repose; the legs very retractile, the tibix being usually sulcate for the reception of the tarsi, which are short. In Taphrocerus the body is elongate and the prosternum narrow and pointed behind.

1530 (4755). Taphrocerus gracilis Say, Ann. Lyc. Nat. Hist., I, 1825, 253 ; ibid. I, 389 ; II, 599.

Elongate-oblong, strongly tapering on apical third. Blackish-bronzed, shining. Occiput with a broad but shallow median depression. Thorax one-half wider than long, very meven, a transverse, slightly impressed line near apex and a triangular indented space on each side of basal half; surface very finely and densely punctate and with scattered shallow punctures of much larger size. Elytra with sides strongly sinnate; disk with rows of rather large deeply inpressed punctures which become obsolete on apical third; usually with rague patches of whitish pubescence arranged in two crossbars on apical half. Length $3.5-5 \mathrm{~mm}$.

Throughout the State; frequent. May b-August 21; mating on May 21. Occurs on the flowers and leaves of the button bush.

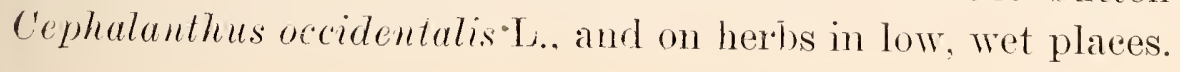




\section{Brachys Sol. 1833. (Gr., "short.")}

In this genus the body is broadly ovate and subdepressed; the prosternum obtuse behind. Five species are listed from the United States, three of which have been taken in Indiana.

KEY TO INDLANA SPECIES OF BRACHYS.

a. Larger, 5-6.5 mm.; pubescence of elytra white and reddish-yellow; arranged in three sinuous crossbars; last ventral segment truncate.

1531. OVATA.

aa. Smaller, not over $4.5 \mathrm{~mm}$.; last ventral segment rounded.

$b$. Pubescence of elytra mostly fulvous or reddish-yellow, that on apical third more dense than elsewhere.

1532. ÆROSA.

$b b$. Pubescence of elytra mostly whitish and arranged as in ovata, that on apical third not more dense than in middle crossbar.

1533. ARUGINOSA.

1531 (4758). Brachys ovata Web., Obs. Ent., 1801, 76.

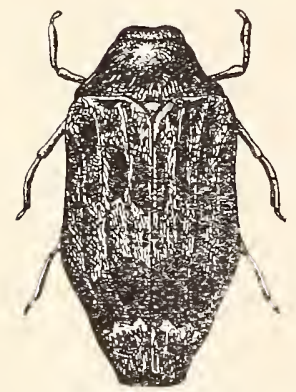

Fig. 312 (Original.)

Broadly ovate, obtusely triangular in front, narrowed behind. Blackish or purplish-bronzed, head and thorax sparsely, elytra more densely clothed with prostrate hairs; those on elytra in three irregular bands, one subbasal, one median and one subapical; the latter forming two crescents; the outer hairs in each band usually white. Occiput and front with a broad and shallow median groove. 'Thorax more than twice as broad as long, finely and densely punctate. Elytra with widely separated rows of shallowly impressed punctures, and each with a sinuous raised line or narrow carina extending from humerus almost to apex. Length 5-6.5 mm. (Fig. 312.)

Throughout the State; frequent. May 16-July 13. Occurs on oak, in the leaves of which the larvæ dwell.

1532 (4761). Brachys frosa Melsh., Proc. Phil. Acad. Nat. Sci., II, 1844, 148.

Resembles ovata in form and distinguished mainly by the characters given in key. On the apical third of elytra the pubescence covers the entire surface and is orange red or fulvous at center and yellowish on the edge. The punctures of elytra are more numerous and irregularly placed. Length $4-4.5 \mathrm{~mm}$.

Throughout the State, frequent; less so in the southern counties. Nay 16-June 18. Occurs on oak. hickory and elm.

1533 (4762). Brachys emuginosa Gory, Mon. Buprest., IV, 1837, 335.

Differs from cerosa only in its smaller size and in the arrangement and color of the pubescence. That of elytra is in irregular, sinuate transverse bands as in ovata, and is mostly whitish-yellow in hue. That on head and thorax is shorter and more sparse. Punctures of elytra less numerous. Length $3.5-4 \mathrm{~mm}$. 
Starke, Pulaski and Marshall comnties; rare. .June 11-.June 19. Beaten from foliage of oak.

\section{PAChrscelus Sol. 1833. (Gr., "thick+leg.")}

This genus is distinguished from Brachys by the characters given in generic key. Of the four species known from the United States. two have been taken in Indiana.

1534 (4764). Pachyscelus purpureus Say, Trans. Amer. Phil. Soc., VI, 1836, 164 ; ibid. II, 599.

Orate or triangular, subconrex. Head and thorax black, shining; elytra purple. Thorax more than twice as wide as long, sides broadly curved, disk without depressions; surface with a number of large shallow discoidal punctures, more numerous near hind angles. Elytra each indented at middle of base and behind the humerus; surface with rows of large. feebly impressed punctures, which become obsolete towards the tips. Abdomen with a deep marginal groove; last segment rounded, not serrate on edge. Length $3.5 \mathrm{~mm}$.

Lake. Marshall and Starke counties; rare. June 11-July 4. Described from Posey County. Beaten from vegetation in marshy places. The larrae live in the leaves of the bush (luver (Lespedeza).

1530 (4766): Pachyscelus levigatus Say. Ann. Lye. Nat. Hist., I, 1825, 252 ; ibid. I, 388 ; II, 598.

Broadly ovate. Black, shining. Thorax twice as wide as long; sides less curved; disk with a depression each side, punctured as in purpureus. Elytra with sides more rounded, less attenuate behind the middle; surface irregularly and shallowly punctate. Length $2.5-3 \mathrm{~mm}$.

Througheut the State: common. June 2-August 11. Mating June 11. Occurs on the foliage of the black gum and the flowers of black haw. milk-weed, etc.

\section{Family XL. LAIIPYRID.W.}

\section{'The Fireflies or Lightixing Bigs.}

The firefly in June-time doth glow at eventide. In central Indiana, during the dusk of the last days of May or first week in June, the signal lamps of these curiously formed beetles begin to appear. A fortnight later the r are here by myriads, illumining by their flashes of light the gloom that orerhangs low. moist meadows and the darker spots along the banks of streams and ponds or the borders of woodlands. Silently and slow y they wing their way. lighting their signals every few seconds in order to attract mnto themselves another of their kind, or as an incitement to rivalry amongst the males when both sexes are winged. 
The fireflies are medimm or small-sized, elongate or oblong. beetles of soft structure. mostly plain black or brownish in color and often having the thorax bordered with red or yellow and expanding into a thin projecting margin which, in many species. covers the head. They have the maxillie exposed at the base and bearing two ciliate lobes. the inner of which is sometimes obsolete; antennie serrate, usually 11 -jointed and inserted on the front; elytra thin, flexible, sometimes short and never strongly embracing the sides of abdomen, the latter with seven or eight free ventral segments; front coxal cavities large, transverse, the coxæ conical, with large trochantins; middle coxæ oblique, usually contiguous; hind coxæe transverse and prominent́; legs long, slender, often compressed; tarsi 5-jointed, not lobed beneath, the fourth joint more or less bilobed.

The name "Lampyrida" is derived from a Greek word meaning "to shine," and refers to the preperty above mentioned which many of the larger forms possess, viz., that of emitting a phosphorescent or luminous glow. This light-giving apparatus is located on the under side of one or more segments of the abdomen and is composed of a specialized portion of fatty tissue, situated directly under the soft chitinous cover and thickly supplied with nerves and fine tracheal branches. "The cells of this luminous organ secrete, under the control of the nervous system, a substance which is burnt during the appearance of the light; this combustion takes place by means of the oxygen of the air conveyed to the cells of the huminous body by the trachex, which branch profusely in it and break up into capillaries." The burning takes place without producing sensible heat, is controlled by the will of the insect and is intermittent, being exhibited by flashes. It is a vital phenomenon and ceases after death, but the luminous segments can be recognized in dried specimens by their yellow hue.

That the light-giving power is of especial importance to the true fireflies, which all belong to the subfamily T ampyrinæ, is shown by the fact that they usually have the eyes largely developed, and that they are nocturnal insects, being sluggish by day, when they rest upon the ground, the trunks of trees or the foliage of herbs or grasses. The property of emitting light is possessed both by the perfect insect and the larva, the latter, as well as the wingless females of certain species. being known as "glow-worms." Those belonging to the other" subfamilies are diurnal in habit and are usually foumd mpon fiowers or running activoly abont over leaves in 
search of their prey. All are for the most part carnivorous in diet, especially in the larval stage, feeding mostly upon small worms, larve of other insects, and snails, and are therefore to be considered among our more beneficial beetles. The larva are alongated, flattened, usually a little tapering toward each end, of a tough or leathery texture and often clothed with sholt hairs. They are furnished with sharp, slender projecting jaws with which they seize their prey. They occur usually beneath rubbish on the ground, or under the bark of logs and dead trees, where they lie in wait for small wood-eating larva.

The principal literature treating of the North American species of the family is as follows:

LeConte-_"Synopsis of the Lamprrides of Temperate North America," in Proc. Phil. Acad. Sci., T, 1851, 331-347.

LeConte._-"Srnopsis of the Lamprxida of the I. S.," in Trans. Amer. Entom. Soc., IX, 1881, 15-72.

Nearly 1,500 species of Lampyridx are known, about 230 of which, distributed among 42 genera, are from the United States. Of these, 68 species, belonging to 25 genera. have been taken in Indiana. For convenience the fanily is divided into three subfamilies, all of which are represented in the State.

\section{KEY TO SUBFAMILIES OF LAMPYRIDE.}

a. Middle coxie separated; elytra for the most part reticulate; epipleura wanting; abdomen without phosphorescent organs.

Subfamily I. Lrcixæ. p. 809.

a . Middle coxæ contiguous; elytra not reticulate; epipleura distinct.

b. Head nearly or quite corered by the thorax; episterna of metathorax sinuate on the inmer side; epipleura usually wide at the base of the elytra; phosphorescent organs usually present.

Subfamily II. LAMPYRIN.e, p. S16.

bb. Head wholly uncovered by the thorax; episterna of metatlorax not sinuate on the inner side; epiplenra narrow at the base; phosphorescent organs absent. Subtamily III. Telepmorine. p. S.5.

\section{Subfamily I. LYCINAE.}

The members of this subfamily are diumal and occur usually on the leaves and flowers of plants, where they soek insect food. The have the epipleura raduced to a narrow thickened marginal line. and the middle coxw rather widely separated by the mesosternm. The elytra are usually costate and coarsely reticulate, with fine elevated lines forming a conrse network. The head is sometimes prolonged in front of the eyes into a long. narrow beak. To the 
subfamily belong eleven genera, five of which are represented in the collection at hand, while members of three others probably occur within the State.

\section{KEY TO INDIANA GENERA OF LYCINE.}

a. Under side of thorax (except in Cœnia) with a prominent tubular spiracle behind and at the outer extremity of the front coxæ.

b. Front prolonged into a beak; mouth anterior; antennæe with third joint scarcely as long as fourth.

LYCOSTOMUS.

Ђb. Front swollen betreen the antennæ, the beak wanting; mouth deflexed, inferior.

c. Antennx much compressed.

I. Calopterox.

cc. Antennæ pectinate.

d. Intervals of elstra with double rows of coarse quadrate reticulations; spiracle of thorax not tubular and prominent.

CoENia.

dd. Intervals with single rows of quadrate impressions; spiracle of thorax prominent.

II. Celetes.

aa. Under side of thorax without a prominent tubular spiracle.

e. Elytra costate, cross-barred or reticulate.

$f$. Disk of thorax strongly carinate, its sides also dirided by an oblique ridge from the hind angles.

LOPHEROS.

$f f$. Disk of thorax scarcely or not carinate.

g. Thorax many celled, the sides divided by a strong transrerse ridge.

III. Eros.

gg. Thorax without distinct cells, feebly channeled behind the middle, its sides not divided by a transrerse ridge.

IV. Plateros.

ee. Elytra substriate, not costate or cross-barred; beak short and broad; thorax with thickened sides and short cblique ridges.

V. Calochromus.

Lycostomus lateratis Melsh.. black. apex and sides of thorax and sides of elytra as far as middle. dull yelior, length 8-10 mm., has been recorded from near Cincinnati.

\section{Calopteron Guer. 1830. (Gr.. "beautiful+wing.")}

This genus comprises our largest species of the family. In them the elytra gradually widen from base to apex and are each marked by six costæ with rows of transverse cells in the intervals. The antennæ are long and strongly compressed, with the outer joints frequently broader than the others. Disk of thorax rather strongly carinate. the sides reflexed. Tro species are known from Indiana.

1536 (4775). Calopteron termixale Say, Journ. Phil. Acad. Nat. Sci., III. 1823, 178 ; ibid. I, 45, pl. 21.

Elongate, triangular, depressed. Black, sides of thorax and basal trothirds of elytra rellow; apical third of elytra purplish-black. Thorax 
small, not longer than wide; elytra and wings extending much beyond the end of abdomen, the former about four times wider near apex than at base. Length 11-17 $\mathrm{mm}$.

Throughout the State, but scarce. August 6-October 23. Occurs on foliage of plants usually near water.

1537 (4776). Calopteron Reticulatum Fab., Syst. Ent., 1798, 203.

Resembles in form the preceding, but usually more slender. Elytra dull yellow, with a broad black transverse band just in front of the middle, which sometimes extends along suture to base, and another on apical third. Elytra but three times wider near apex than at base, their first and third costæ finer and less elevated than second and fourth. Length 11-19 mm. (Fig. 313.)

Throughout the State; frequent. May 31-November 30. Occurs on flowers of wild hydrangea, goldenrod, and leaves of various shrubs. The

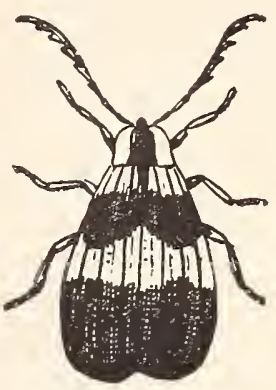

Fig. 313. $\times 1 \frac{1}{4}$. (After Knobel.) specimen taken on November 30 was found beneath a piece of rail in a fence corner, where it was evidently attempting to hibernate.

Conia dimidiate Fabr., black, sides of thorax and front half of elytra, except scutellar black spot, dull yellow, length $10 \mathrm{~mm}$., is said to occur in the "Atlantic region."

\section{Ceueres Newm. 1838. (Gr., "a swelling.")}

Represented in the Atlantic region of the United States by a single species having joints four to ten of antennæ each with a long basal process in the male or shorter and broadly triangular with acute angle in the female. Elytra gradually becoming twice as wide behind as at base; each with six acutely elevated costæ, with a single row of quadrate cells in each interval.

1538 (4779). Celetes basatis Lec., Journ. Phil. Acad. Nat. Sci., 1847, 76.

Elongate, rather slender. Black or piceous; sides of thorax and line along humerus on basal half of each elytron dull yellow; base of femora yellowish. Thorax variable in size and form, the disk strongly carinate, the sides reflexed. Length $6-8.5 \mathrm{~mm}$.

Lake County; rare. July 15. Taken from the foliage of the thorn or honey locust.

Lopheros fraterius Rand, black. thorax with a large orange spot behind middle, length 9-11 mm, has been recorded from Cincinnati. 
III. Eros Newm. 1838. (Gr.. "the God of love.")

The species of this genus are of medium size and have the last joint of maxillary palpus longer than the preceding: and acute at tip; antennx moderately compressed, with the second joint at least half as long as third. which is not longer than fourth. Elytra never widely dilated behind. the intervals usually with double rows of small quatrate depressions. Ten species of Eros are listed from the United States. six of which have been taken in Indiana.

KEI TO INDLANA SPECIES OF EROS.

a. Thorax with fire well defined cells, the median one rhombic, not carinate.

b. Upper surface black; humeral spot on elytra and sides of thorax dull yellow.

1539. THORACICUS.

bъ. Upper surface scarlet.

c. Under surface of bods black,

1540. AURORA.

cc. Under surface red.

1541. MUNDUS.

au. Thorax with six cells. sometimes ill defined; the middle one of front row more or less carinate.

d. Head strongly margined in front of antenne; front middle cell of thorax with sides distinct.

1542. SCULPTILIS.

dd. Head not margined before the antenna; front middle cell of thorax with sides indistinct or wanting.

$e$. Base of elytra and each side of thorax yellowish; transrerse carine between the front and hind rows of cells strong, sinuate.

1543. HUMERALIS.

ce. Elytra wholly black or piceous: transverse carinze separating the front and hind rows of cells indistinct at middle.

1544. TRILINEATUS.

1539 (4783). Eros thoracices Rand., Bost. Journ. Nat. Hist., II, 1838, 14.

Elongate-oblong, depressed. Black; sides of thorax and humeral spot on elstra dull reddish-yellow. Antenne with elongate slender joints, the second and third together about equal to the fourth. Length $5-8 \mathrm{~mm}$.

Vigo Countr; rare. Nay 31. Beaten from foliage of elm.

1540 (4787). Eros ACrora Herbst., Nat. Insect.. 1789.

Elongate, depressed. Head, antennie and under surface black or piceous; thorax and elytra bright scarlet, the depressions of the former and the scutellum dusky. Thorax with two elerated lines, distant in the middle and meeting on the front and hind edges, enclosing a rhomboidal cell; also with two cells on each side. Length $7-11 \mathrm{~mm}$.

Vigo and Posey counties; scarce. September 22-Norember 4.

Those taken in Vigo County were found in dry upland woods beneath logs which had been partially burned. three beneath one log. six beneath another. They feigned death when the logs were overturned. 


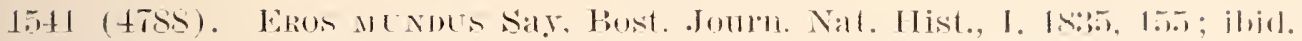
II, 633.

Resembles the preceding but much smaller and with under side of body red or scarlet; antennie black. the two basal joints scarlet; rentral segments and tarsi often dusky. Length $6 \mathrm{~mm}$.

A species of southern range described by Say from Posey County. Taken by Dury near Cincinnati; not represented in the collection at hand.

1542 (47S9). Eros scclptilis Say. loc. cit., 15t; ibid. II, 633.

Elongate, slender. subdepressed. Black or piceous: thorax reddish-yellow, usually with a blackish spot on disk. Antennæe elongate, slender, third joint but little shorter than fourth, second minute, about one-third the length of third. Front middle cell of thorax quadrate, carinate; hind middle cell narrow. Elytra each with four strong discal costre; the lateral edge and sutural line raised: intervals each with a double row of alternating irregular cells. Length $5-\tau \mathrm{mm}$. (Fig. 314.)

Tigo and Posey counties; scarce. June 3-June 22. Beaten from leaves of hickory and ironweed.

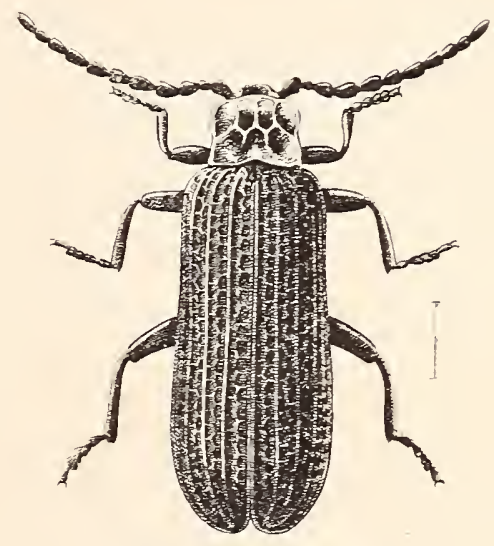

Fig. 314. (Original.)

$1543(4790)$. Eros humeralis Fab., Syst. Eleut., II, 1801, 111.

Resembles thoracicus in color. but distinguished by having six cells on thorax. the middle front one with sides indistinct but with a strong central carina; hind middle cell narrow like a channeì ; second joint of antemie more than half as long as third. Length $8-10 \mathrm{~mm}$.

Lake. Kosciusko and Posey counties: rare. May 28-.June 3. Described by Say from Posey County under the specific name obliques.

1544 (4791). Eros trilineatus Melsh., Proc. Phil. Acad. Nat. Sci.. II. $1845,303$.

Elongate-oblong, depressed. Black or piceous. often with a rustr or reddish-brown tinge; sides of thorax dull sellow. Walls of front row of thoracic cells obliterated, only the median carina remaining; hind row of cells consisting of a verr narrow median and two large lateral ones, the latter defined in front by the usual oblique transrerse ridge, which is not (omplete. Elytra each with three coste; the lateral edge and suture raised. the usual first costa of disk indistinct; intervals each with a double row of quadrate cells. Length $5-7.5 \mathrm{~mm}$.

Jackson. Crawfind and Poser comnties: scarce. June 24 July 20. 
IV. Plateros Bourg. 1879. (Gr., "broad + Eros.")

In this genus the sides of thorax are strongly reflexed; the disk without the transverse ridge seen in Eros, and consequently without cells. The elytra have nine narrow and usually equal slightly elevated lines, separated by rows of fine quadrate cells. Sometimes the alternate lines are a little stronger, so that the elytra become feebly 4-costate. The species are very difficult to separate. Eight are known from the United States, five of which have been taken in Indiana.

KEY TO INDIANA SPECIES OF PLATEROS.

a. Antennæ broad, not strongly serrate.

b. Elytra with alternate lines distinctly more elevated, the intermediate ones very feeble.

1545. MODESTUS.

$b b$. Elytra with all the lines equal or nearly so.

c. Thorax with a small notch at middle of base, the discal black spot with a pale margin on all sides.

1546. SOLLICITUS.

cc. Thorax not notched at base, the discal spot reaching the base and usually the apex.

d. Median impressed line of thorax distinct, reaching from base to middle.

1547. CANALICULATUS.

dd. Median impressed line of thorax obsolete, represented only by a small roundish impression in front of scutellum; antennæ shorter; form more narrow.

1548. FLORALIS.

aa. Antennæ strongly serrate; thorax with a median impressed line on basal third.

1549. LICTOR.

1545 (4794). Plateros mouestus Say, Bost. Journ. Nat. Hist., I, 1835, 153 ; ibid. II, 631.

Elongate-oblong, subdepressed. Black, sides and apical margin of thorax reddish-yellow. Third joint of antennæ one-half the length of fourth, the second much smaller. Thorax with sides strongly elevated, apex rounded, hind angles somewhat prolonged. Elytra as mentioned in key, the more elevated lines with two rows of cells in intervals, these rows separated by the finer lines. Length 6-7.5 mm.

Crawford County; rare. June 8. A broader species than those which follow.

1546 (4796). Plateros sollicitus Lec., Journ. Phil. Acad. Nat. Sci., 2d Ed., I, 1847, 83.

Elongate, subdepressed, narrower than canaliculatus. Dull black; thorax reddish-yellow, with a large square, central, shining black spot. Thorax with sides strongly reflexed, the median impressed line extending from base to beyond middle, deepest on middle third. Elytra with well marked equal intervals and strongly cross-barred interspaces. Antennæe of male long, the fourth joint twice as long as third, fifth twice as long as wide, outer ones narrower, with angles acute. Antennæ of female shorter, seventh joint twice as long as wide. Length 6-7.5 mm.

Starke County; scarce. July 27. The thorax is narrower, with 
apex much more rounded and hind angles less prominent than in the next.

1547 (4795). Plateros canaliculatús Say, Bost. Journ. Nat. Hist., I, 1835, 154 ; ibid. II, 632.

Elongate, depressed. Black; thorax with yellowish side margins; elytral with humeri sometimes reddish-yellow. Thorax with a narrow basal channel extending almost to middle. Second joint of antennæ minute, third half the length of fourth. Length $5-8 \mathrm{~mm}$.

Throughout the State; frequent. May 10-.July 27. Occurs on leaves of milkweed and rarious shrubs.

1548 (4798). Plateros floralis Melsh., Proc. Phil. Acad. Nat. Sci., II, $1845,302$.

Elongate, slender. Black, the side margins of thorax broadly yellow. Antennæe compressed, shorter and much less serrate than in lictor. Thorax with apex more broadly rounded and sides straighter than in the next. Length 5-6.5 $\mathrm{mm}$.

Throughout the State: frequent. June 2-August 11. Beaten from vegetation.

1549 (4797). Plateros lictor Newm., Entom. Mag., V, 1838, 382.

Elongate, more slender than the preceding, with which it agrees in color. Antennæ of male long, strongly serrate, third joint triangular, as wide as long, fourth longer, not wider; those of female broader, less serrate. Thorax subpentagonal, with the front margin raised and less broadly rounded; the disk with an elongate channel on basal half, this extending to middle in male, shorter and broader in female. Elytra with well marked equal lines and more finely cross-barred interspaces. Length 5-7 mm.

Throughout the State; frequent. MIay 30-July 15.

V. Calochromus Guer. 1833. (Gr., "beautiful + color."')

This genus is mainly disting'uished by the pubescent velvety surface and feebly striate, not reticulate, elytra. They have the head ending in a short, broad beak; antennæ rather widely separated, subserrate, with joints thicker and less compressed; thorax with an entire median groove, toward which a short, oblique ridge runs from the middle of the thickened margin.

1550 (4805). Calochromus perfacetus Say, Amer. Entom., II, 1825, 46 ;

ibid. I, 46, pl. 21.

Elongate, depressed. Black, velvety with fine pubescence; sides of thorax broadly reddish-yellow. Antennæ with second joint one-third the length of third, the latter as long but not as wide as fourth. Side margin of thorax impressed at the middle, the basal lateral impressions deep. Middle and hind tibiæ curved. Length 6.5-9.5 mm. (Fig. 315.)

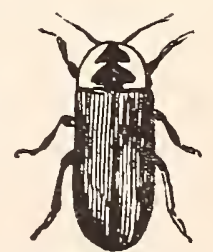

Fig. $315 . \times 2$. (After Kinobel.)

[52-23402] 
Putnam and Gibson counties: rare. July 4-September 1. Beaten from flowers of the linden, Titia americana L.

\section{Subfamily II. LAMPYRINAE.}

The members of this subfamily have the middle coxæ contiguous and the epiplenre wide at the base of elytra. They are divided into two tribes, both represented in the State.

FEY TO TRIBES OF LAMPYRINE.

a. Head more or less concealed beneath the thorax; antennxe usually approximate at base; epimera of metathorax long.

Tribe I. Laniprrini, p. 816.

aa. Head exposed; antennæ widely separated at base; epimera of metathorax wide.

Tribe II. Phengodini. p. \$24.

Tribe I. LAMPYRINI.

'To this tribe belong our true fireflies, most genera possessing a light-giving apparatus on the hind abdominal segments. The head is deeply immersed in the thorax, the edges of which are usually expanded into a wide, thin margin. The tribe is separated into twelve genera, representatives of eight of which have been taken in Indiana.

\section{KEY TO INDIANA GENERA OF LAMPYRINI.}

a. Antennæe with second joint small, usually transverse; head completely covered by thorax.

7. Antennæe bipectinate, somewhat distant at base. last joint simple; margins of thorax not flattened.

VI. Polyclasis.

66. Antennie not pectinate, approximate at base.

c. Last joint of antennie elongate, simple.

a. Eyes small ; light organs feeble; rentral segments without stigmalike pores.

e. Antenne rery much compressed, not serrate; second joint rery short, transverse.

VII. LeCIDOTA.

ee. Antemne with second joint one-half as long as third, or nearly so.

f. Last dorsal segment of male rounded; light organs wanting.

VIII. Ellichnia.

ff. Last dorsal segment of male bisinuate and truncate.

IX. Pyropyga.

dd. Eyes large, but larger in male than female; light organs well developed; male with strongly marked stigma-like pores.

g. Thorax subcarinate: female with light organs on the sides of abdomen.

$\mathrm{X}$. Prractomena.

g\%. Thorax not carinate, frequently grooved; female with light organs on the middle of abdomen.

XI. Photincs. 
cc. Last joint of antemne bearing a small. jointed, needle-shaped a1pendage; female with short elytra.

XII. Lamprohiza. a a. Antennie with second joint not transverse; head exserted, narrowed behind the eyes.

XiII. Photuris.

\section{Powyclasis Nerm. 1838. (Gr.. "many + branches.")}

Antenn: moderately separated at base. and strongly bipectinate from the third to tenth joint in the male. less so in female; second joint small, third not shorter than fourth. The two processes spring from the base of the joints in male and from the middle of the sides in female. One species occurs in the eastern United States.

1551 (4809). Polyclasis bifaria Say, Bost. Jouln. Nat. Hist. I. 1S35, 157 ; ibid. II, 635.

Elongate-oral, densely and roughly punctured. Black; thorax with sides and apex reddish-yellow and with a median impressed line. Male with serenth and eighth rentral segments dull yellow, serenth with a small triangular notch, eighth narrow, parallel. Female with sixth and serenth segments sellowish, the serenth triangular. rounded behind. Length 9 $10 \mathrm{~mm}$.

Marshall and Crawford counties; scarce. June 2-June 15. Occurs out trumks of trees in upland woods.

\section{Lictuot` Cast. 1833. (L.. "shining.")}

This genus and the next four are grouped by LeConte under the name Photimi. All fire genera have the head covered by the hood-like thorax. The elytra vary in color. but in all our species without well developed light organs they are black. Of the group he says: "There are in many families of Coleoptera strong resemblances between species of different genera. but I know of none more deceptive than those presented by this group of Photini. The inexperienced student shouk, therefore, always ascertain the genus to which his specimen belongs before attempting its specific determination." The genus Lucidota is easily known by the rery broadly compressed antenni which are not serrate. but gradually narrowed externally, with the second joint ver'y short and transrerse. The light organs are feebly developed and indicated by rellow spots on the last rentral of the female or last two rentrals of male. The two species belonging to it are diumal and frequent shady places.

1552 (4810). Lucidota Atra Fab., Ent. Sist.. I. 179§. 101.

Elongate-oblong, depressed. Black. sides and apex of thorax dull rellow, with a reddish or orange spot next the black median space. Thorax 
triangular, the apex rounded. Elytra finely granulate, with four or five longitudinal, slightly raised lines, which are abbreviated on apical third: Length 8-11 $\mathrm{mm}$.

Throughout the State; common. June 4-July 7. Occurs on low herbage and trunks of trees in woods. Also often noted in flight. When captured it exudes from the joints of the legs and sides of abdomen a milky fluid having a disagreeable odor.

1553 (4811). Lucidota punctata Lec., Proc. Phil. Acad. Nat. Sci., V, 1851, 333.

Oblong, narrow, subdepressed. Black, opaque, sparsely clothed with grayish pubescence; thorax with dorsal spot and basal margin black, the spot often almost disconnected from the base, and with a reddish or orange spot each side; hind angles usually dusky. Elytra coarsely granulate-punctate. Length $5.5-6 \mathrm{~mm}$.

Kosciusko County; rare. Probably throughout the State. June 25. Taken by sweeping low-ground herbage.

\section{Eltychnia Lee. 1851. (Gr., "a lamp-wick.")}

Antennæ narrow, strongly compressed, with the second joint but little wider than long and about one-third as long as third, which is not longer than fourth; dorsal segments not acutely lobed at sides and, except the next to last, not produced backwards. The light organs are lacking and the species therefore diurnal. Two species and one variety occur in Indiana.

1554 (4815). Eldychnia corrusca Iinn., Syst. Nat., Ed. XII, II, 1785, 644.

Oblong-oval. Black or rusty black; thorax with disk

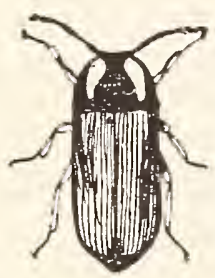

Fig. 316. $\times 1 \frac{2}{3}$ (After Knobel.) and side margins black; between these is a reddish and yellow space or line. Third joint of antenmæ longer than wide. Thorax semi-oval, its apex regularly rounded. Elytra finely granulate and thinly covered with a fine, prostrate yellowish pubescence; each with three or four rather indistinct costæ. Leugth 10-14 mm. (Fig. 316.)

Throughout the State; common. April 1-October 21. Occurs in spring on trunks of trees in open woodland, especially on those oit maple at or near flowing sap; in autumn on fiowers of goldenrod and asters. Noted mating on April 26 and May 28.

$1554 a$ (4815a). Eldichira corrusca autumnalis Melsh., Proc. Phil. Acad. Nat. Sci., II, 1845, 303.

Much smaller and relitively broader than corrusca. More brownish in hue and with the raised lines of elytra almost obsolete. Length 7-7.5 mm. 
A well-marked variety of corrusca taken by Wolcott near Clarke, Lake County. and by myself in Steuben County; scarce. Nay 25-June 12.

1555 (4815b). Ellychnia lacustris Lec., Proc. Phil. Acad. Nat. Sci., V, $1851,334$.

Elongate-oblong, narrow, parallel. Dull sooty-black. Thorax semielliptical, its edges only indistinctly paler and sparsely punctate. Elytra finely granulate, with one costa only fairly distinct, the others obsolete. Length $5 \mathrm{~mm}$.

Lake County ; rare. July 2. Smaller and much narrower than autumnatis and probably a distinct species. though classed as a variety of corrusca by LeConte in his Srnopsis. A northern form described from the Lake Superior region.

\section{Pyropyqa Miots. 1853. (Gr.. "fire+rump.")}

Rather narrow forms, having the antennæ moderately wide and compressed, with second joint transverse. one-third as long as third. the latter in our species longer than fourth; last dorsal segment in both sexes broadly truncate with rounded angles: segments lobed at the sides, with the angles but feebly produced backwards; light organs but slightly developed.

\section{KEY TO INDIANA SPECIES OF PYROPYGA.}

a. Thorax with black disk and narrow piceous or dusky edges.

乙. Elytra costate; length $6.5-S \mathrm{~mm}$.

1556. FENESTRALIS.

bb. Elytra not costate; length 4.5-6 mm.

155\%. NIGRICANS. a . Thorax with black disk and reddish-rellow sides.

15อ๊S. DECIPIENS.

1556 (4817). Pyropyga Fenfstralis Melsh., Proc. Phil. Acad. Nat. Sci., II, $1845,304$.

Elongate-oval, slender. Black or blackish-brown; thorax with a large reddish-yellow subtriangular space on each side of the black central disk. Elytra finely granulate and with two or three rather indistinct costre. Length 6.วั-8 $\mathrm{mm}$.

Laporte, Steuben. Marshall and Vigo counties; frequent. June 19-August 17. Taken hy sweeping grass and low herbage, usually in moist meadows.

1557 (481S). Prropiga xigricaxs Say, Journ. Phil. Acad. Nat. Sci., III, 1823, 179 ; ibid. II, 116.

Resembles the preceding in form and in color of thorax. Differs mainly in its smaller size and lack of raised lines on elytra. Length $4.5-6 \mathrm{~mm}$.

Steuben, Starke and Marshall counties; frequent about tamarack marshes. June 17-Juị 15. 
155 (4820). P'ropyga deciptexs Harris, Trans. Hartford Soc., 1536, it.

Elongate-oral. Black or rusty black; thorax with a wide pale reddishyellow margin. Antennie less slender than in the other two species, the joints one-half longer than wide. Elytra each with two subobsolete costie and with surface more coarsely sranulate than in nigricans. Tength $5-$ $7 \mathrm{~mm}$.

Northern half of State; frequent. June 17-July 24.

\section{Princtoment I.ec. 1851. (Gr.. "to set on fire.")}

Antennix narrom. not serrate: the thorax subcarinate with sides broadly reflexed. Iight organs are well dereloped in both sexes; those of the male being located on the fifth and sixth ventral segments and marked each side about half war between the middle and side by a large round stigma-like pore or spot; those of fenrale are at the sides of the segments, which are dusky or piceous at middle, and are also accompanied by distinct pores. The males have the last dorsal segment emarginate. serenth ventral truncate, and the eighth small. Three of the four known species have been taken in the state.

\section{KET TO INDLANA SPECIES OF PIRACTOMENA.}

a. Elytra witl wide side margins.

1559. ANGLLATA. aa. Elytra with nar'ow side margins.

b. Antennie shorter than thorax.

1560. BOREALIS.

b7. Antenne longel than thorax.

1561. LUCIFERA.

1559 (4823). Pyractomexa axgclata Say, Journ. Phil. Acad. Nat. Sci.. I. 1825, 162 ; ibid. II, 273.

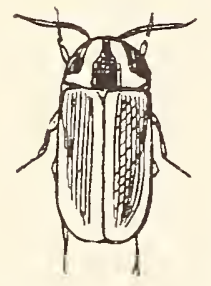

Fig. 317. $\times 1 \frac{1}{2}$. (After Lingbel.)

Elongate, depressed. Blackish-brown; thurax with a dark median space and dusk tateral margins, between which the area is sellow tinged with reddish on basal half; elytra with suture and narrow side margins pale. Thorax with front margin obtusely angulate. Elytra finely granulate, not punctured. each with two or three well marked costie. Tentral segments of female dull rellow spotted with dusky. Iength $\mathrm{S}-15 \mathrm{~mm}$. (Fig. 817.)

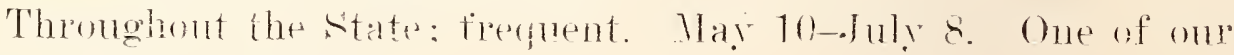
most common fireflies.

1560 (4824). Prkactodera boreatis Rant.. Bost. Journ. Nat. Hist. II, $1539,16$.

Resembles angulate closely in form and general appearance. The margins of both-thorax and elytrat are narrower and those of the former are yellow instead of dusky as in angulata. The central black spot is usually smaller and the red one each side larger. Antenne stout and shorter than thorax. Abdomen of female in great part dark. Length 10-15 $\mathrm{mm}$. 
Marshall and Orange counties; rare. May 228-Jume 10. A species of wide distribution, but everywhere much less common than angulaia.

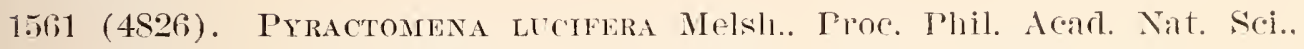
II. 1845,304 .

Elongate, narrow, parallel. Colors as in angulate except that the dusky spot on margins of thorax is more distinct, and occurs only on middle third of the margin. Iellow margin of elytra much narrower and more parallel tham in angulatu. Male with rentral segments 1-4 piceous, serenth with a piceous spot; female with fifth and sixth also piceous at middle. Length S-14 mm.

Lake and Kosciusko counties; scarce. June 3-June 24. Probably throughout the northern half of state.

\section{Photrots Lap. 18:3:. (Gr., "shining."')}

Hood-like thorax not at all carinate, usually slightly grooved and more obtusely romided in front. The light organs are always the larger in the male, where they oceupy all the ventral segments behind the third or fourth and are accompanied by stigmatic pores on the fifth and sixth segments. In the female they occur on the middle part of the vontral segments. but the stigma-like impressions are barely or not visible. Five have heen taken in Indiana, while one other perhaps occurs.

\section{REY TO INDIANA SPECTES OF PHOTINUS.}

a. Fourth rentral segment dark.

b. Thorax with a black stripe and two roseate spots; elytra with wide sicle margins.

1562. CONSANGUINEUS.

bъ. Thorax with a dusky cloud or black spot; elytra with narrow side margins: form more narrow.

c. Thorax with hind angles acute, somewhat produced, its disk smooth. margins punctate.

1563. ARDENS.

ce. Thorax with hind angles not produced, its disk finely, margins densely and rather coarsely. punctate.

all. Fourth ventral segment pale. at least in part.

d. Large species (9 or more $\mathrm{mm}$.) : disk of thorax roseate with a large black spot; rentral impressions of male rery distinct.

1.)64. PIRALIS.

dd. Small species (less than \& mm.) : ventral impressions of male obsolete.

c. Elytra pale, widlely mircined female with long elytra and wings.

1565. MARGINELLTS.

rc. Elytra dusky with pale margins, narrowly margined: female without wings, elptra short. widely separated at suture.

1566. SCINTILLANS. 
1562 (4S27). Photrnts consanguneus Lec, Proc. Phil. Acad. Nat. Sci., $\mathrm{V}, 1851,335$.

Elongate, rather slender. Dusky or piceous; thorax yellow, with a black median bar on basal half, this bordered with pinkish on each side: elytra with suture and side margins pale. Surface of elytra finely granulate, with one or two subobsolete carinze. Female with sixth ventral segment dark piceous. Length $8-12.5 \mathrm{~mm}$.

Porter, Narshall and Koscinsko counties; scarce. June 3June 19.

1563 (4829). Photinus ardens Lec., Proc. Phil. Acad. Nat. Sci., V, 1851, 334.

Elongate, slender. Fuscous or piceous; thorax with side margins and apex pale; elytra with suture and narrow side margins sellowish. Antennie very slender. Thorax semicircular, base truncate, margins wide, translucent, feebly refiexed. Elytra finely and densely granulate. Length 6-11 mm.

Kosciusko and Posey counties, scarce; also two Indiana specimens in Nebster collection. June 22-.June 25.

$P$. punctulata Lee., fusco-piceous, thoras dusky with sides dusky, length 10-11.5 mm., is known from Illinois and Kansas.

1564 (4835). Photinus pyralis Linn., Syst. Nat., Ed. XII, 1785, 644.
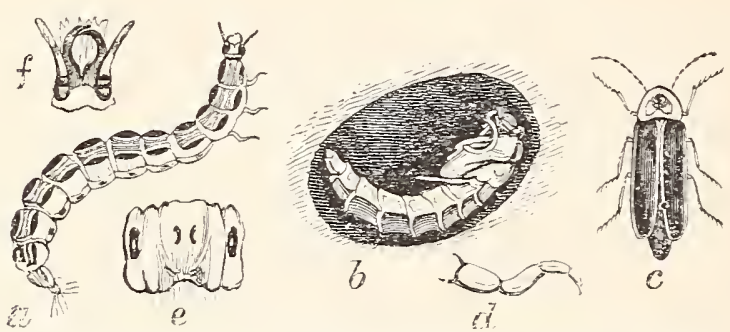

Fig. 318. $a$, larva; $f, e, d$, head, under side of segment and leg of same; $b$, pupa in its earthen cell; $c$, beetle. (After Riley.)

Elongate-oblong, rat he 1 robust. Piceous-brown; thorax with margins dull yellow, the convex disk roseate and with a central black spot. Elytra with suture and narrow side margins pale. Thorax with a short dorsal chanuel. Male with hind margin of fourth and whole of the succeeding ventral segments yellow; female with dusky spots at base of fifth segment; sixth dusky, margined with yellow. Length 10-14 mm. (Fig. 318.)

Tippecanoe, Madison, Vigo, Narion and Lawrence counties: frequent. June 8-July 29.

1565 (4836). Photinus margineluus Lec., Proc. Phil. Acad. Nat. Sci., V, $1851,335$.

Elongate, slender. Pale, dull yellow; disk of thorax roseate without or with only a trace of a black spot; antennæe and legs dusky. Elytra finely granulate and pubescent. Length $6-8 \mathrm{~mm}$.

Kosciusko, Crawford and Pnsey counties; scarce. June 2-August 11. The form here described is the pale variety casta Lec. The typical form is colored similar to scintillans. 
1566 (4837). Photinus scintillans Say, Journ. Phil. Acad. Nat. Sci., V, 1825, 163 ; ibid. II, 275.

Elongate, slender. Dusky brown; thorax rosaceous with a yellowish margin and central black spot; elytra with suture and side margins pale; antennæ dusky. Elytra finely and almost indistinctly granulate; those of female not more than one-third the length of abdomen. Length 5.5-8 mm.

Martin County; scarce. July 13. Said by Say to be "our very abundant firefly and familiar to every inhabitant of the country," but this does not hold good in Indiana.

\section{Lamprohiza Mots. 185:3. (Gr.., "to glow + a root.")}

Antennæ simple with quadrate joints, the eleventh with a small jointed needle-shaped appendage near the tip. The females have short elytra and the males transparent spots on the thorax. One species has been taken in the State, while another may occur.

1567 (4843). Lamprohiza inaccensa Lec., Proc. Amer. Phil. Soc., XVII, $1878,611$.

Elongate, gray, slightly pubescent.- Thorax wider than long, semicircularly rounded at tip and sides, the latter strongly incurved at base, hind angles dentiform; disk dark, convex, smooth, sides very widely flattened, scabrous, pale gray; near the apex (in male) are two large colorless, transparent spots. Elytra reticulate-punctate, with the longitudinal raised lines very faint, sides rather strongly margined. Beneath densely punctured, gray; abdomen piceous, wholly without phosphorescent spots; antennæ and legs gray. Length $6.3 \mathrm{~mm}$.

A speries of the Alleghanian fauna described from Marquette. Michigan. One specimen in the Dury collection is from near Michigan City, Laporte County. Probably occurs sparingly in the nortirern third of the State.

L. splendidula Linn., fifth and sixth ventral segments yellow. thorax wider than long, length $8.5 \mathrm{~mm}$., is a European species recorded from Maryland and Illinois.

\section{Photuris Lec. 1851. (Gr., "light+tail.")}

Eyes large, convex and widely separated; head rounded, narrowed behind, not retractile and not entirely covered by the hoodlike thorax; antenna longer than one-half the body, filiform, slender, not compressed, the second and third joints about equal and, together, as long as each of the following joints. Tho light organs in both sexes occupy the whole of the fith and following segments.

1568 (4847). Photuris pennsylvanica Deg., Mem. Hist. des Ins., IV, 1768, 52.

Elongate, slender, subdepressed. Head and thorax dull

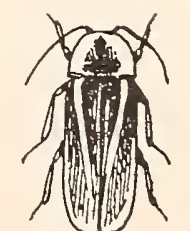

Fig. 319. $\times 1 \frac{1}{3}$. (After Tinobel.) 
sellow, the latter with disk red with a narrow median dark stripe; elytra brown or piceous. with the suture. narrow side margins and a narrow stripe on disk pale. Labrum tridentate. Thorax and elytra densely and rather roughly punctured. Length 11-15 mm. (Fig. 319.)

Throughont the State: our most common firefiy. Nay 23-August 6.

\section{Tribe II. PHENGODINYI.}

In this tribe the thorax, though rounded in front. does not corer the head. The eres are conrex, prominent and widely separated; antenne not approximate, plmmose or with fan-like processes in male; middle coxa contiguous. T'wo genera are represented in the State.

KEY TO INDIAXA GENERA OF PHEXGODINI.

a. Prosternum rely short; front flat, labrum large; elytra short, awlshaped; tarsi with fourth joint Iobed.

XIT. Phexgodes.

a a. Prosternum well dereloped; front conrex, labrum small; antennie serrate.

XV. Tуттнохт.

\section{XIT. Phengodes Illig. 180T. (Gr.. "shining.")}

Medium-sized species. having the head deeply and transversely excarated behind the eyes: gular region deeply excavated. the sutures confluent. One species is known from the State.

1569 (4S52). Phexgodes Pltalosa Oliv., Ent. II, 1790, 26.

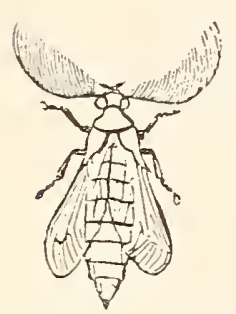

Fig. $320 . \times 1 \frac{1}{2}$. (After Glover.)

Elongate, robust, depressed. Dull yellow, finely pubescent; head, antenne, tips of elytra and dorsal surface of abdomen fuscous. Antennis of male feather-like, the third and following joints emitting long flexible branches. Thorax more than twice as wide as long, almost smooth. Elytra one-third the length of abdomen, very widely separated at tips. Length 11-12 mm. (Fig. 320.)

One in Webster collection lablod "Ind." Seems to be everyhere rare. though Say says: "Not uncommon for a short period in autumn when, attracted br candles. they enter the house in the evening and fy repeatedly against the ceiling in their efforts to escape."

XV. Tұтthorr Lec. İכi. (Gr.. "small + claw.")

Eyes small, rotuded. ronvex: antemne nearly as long as the body. broadly compressed, strongly serrate. joints triangular, the second but one half as Iong and one half as wide as third; the outer joints of male longer. narrower and more prolonged at tip than the joints prececiing. One specjes is known. 


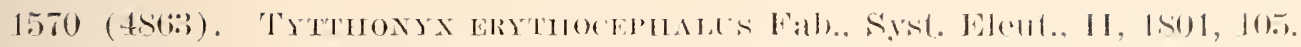

Oblong, compressed. Blatek, opalure, spratrely and fincly jubescent; front, occipnt and under surface of head reddish-yellow. Thorax transrerse, truncate in front, broadly rounded behind, the sides short. inflexerl. Elytra one-half as long as abdomen. rounded at tip ; wings straight. extending along the dorsal surface of the abdomen. Iength $4 \mathrm{~mm}$.

Marion and Poser counties: scarce. May 17-ouly ?. Occurs on leares of rarious shrubs.

\section{Subfamily III. TELEPHORINAE.}

The members of this subfamily differ from those of the two preceding by having the mouth orgais more strongly developed; eyes smaller; antennæ more widely separated at base and by the straight or nearly straight outline of the inner side of the metathoracic episterna. Light organs are wholly lacking and the sexes are quite similar in form and the development of the wings. The subfamily is separated into three tribes, all of which are represented in Indiaua.

KEY TO TRIBES OF TELEPHORINE.

a. Tarsi with joints three and four lobed beneath; mentum short.

Tribe I. OMethiNi, p. \$25. al. Tarsi simple or with the fourth joint only lobed beneath.

b. Mentum rery long, wider in front; prosternum feebly developed, separated by a membrane from the surrounding parts.

Tribe II. Chauliograthini, p. S26.

bb. Mentum small, quadrate, often semimembranous; prosternum normal, fully dereloped.

Tribe III. Telepilorini, p. S2S.

Tribe I. OMETHINT.

This tribe comprises two genera of small oblong beetles possessing the characters of the tribe Telophorini as set forth on a succeeding page, but having the third and fourth joints of the tarsi prolonged or lobed beneath. The typical genis, Omethes, is represented in the eastern United States by a single species, O. marginatus Lec., which has been taken bỹ Dury near Cincinnati and therefore probably ocems in the southern third of the State. The other genus is established for a new speries, closely allied to Omcthes, which has been taken in three of the southern counties.

KET TO GENERA OF THE TRIBE OMETHIXI.

a. Elytra with finely impressed striae; clypens truncate; antennie alike in the sexes.

OMETHES.

aa. Elytra wholly without striae; clypens broadly emaloginate; antennge unlike in the sexes.

XVI. Biancharda. 


\section{Blanchardi Gen. Nov.}

This genus differs from Omethes in the characters above given and in having the head broacier, more finely and densely punctured on front and vertex; eyes smaller and less prominent; tarsal claws much smaller and more slender, with a smaller tooth at base. In the male the antennse are geniculate at the end of the fourth joint; the basal joint is large, strongly and distinctly clavate; second and fourth subequal in length, the latter much more robust and closely united with the shorter third, the two appearing like one clavate joint; fifth shorter than sixth to tenth, which are subequal; eleventh longer, a little stouter and subacuminate. In the female the basal joint is less stout and not clavate; joint two is a little shorter than three to ten, which are equal. The genus is named in honor of Frederick Blanchard, of Tyngsboro, Massachusetts, a well-known Coleopterist who has shown me many favors during the preparation of the present paper.

\section{1 (-). Blanchardia gracilis sp. nov.}

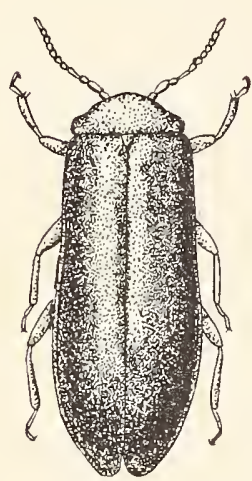

Fig. 321. $\times 7 \frac{1}{2}$. (Original.)

Elongate, slender, clothed with fine, sparse, suberect yellowish hairs. Head, thorax, antennæ, legs and under surface; except the abdomen, pale reddish-yellow; elytra and abdomen piceous, the humeral angles of former and tip of latter reddish-yellow. Thorax transversely elliptical, more than twice as wide as long, sides rounded into base and apex; margins, except the apical, distinctly reflexed; surface minutely and very sparsely punctured. Elytra not wider at base than thorax, their margins slightly flattened and reflexed along their apical two-thirds, thus causing them to appear wider toward the apex; surface finely, sparsely, shallowly and somewhat rugosely punctured, each puncture bearing a suberect yellowish hair. Length $4-4.5 \mathrm{~mm}$. (Fig. 321.)

Lawrence, Crawiord and Perry counties; one specimen from each; one male, two females. May 20-June 5. Taken by sweeping roadside herbage.

\section{Tribe II. CHAULIOGNATHINI.}

Head prolonged before and behind the eyes; maxillary palpi long and but slightly dilated; mentum elongate and wider in front; prosternum small, broadly triangular ; middle coxæ separated, mesosterum membranous; tarsal claws simple. The tribe is represented by the single genus 


\section{Chauliognathus Hentz. 1830. (Gr., "with exposed+ jaws or maxillæ."')}

The species of this genus are known from all others by the elongate head, and by the singular structure of the maxillary lobe, which has a long, extensile, pilose, thread-like process which can be pushed out and used to gather food. In this respect it is somewhat similar to the tongue or proboscis of a moth or butterfly. The mature beetles are said to feed solely upon the honey and pollen of various flowers. The larvæ are, however, strongly carnivorous, those of our more common species being very beneficial in that they feed upon the larve of the plum curculio and other injurious forms. The last ventral segment of the male is elongate-oval, convex and more horn-like in texture than the other segments; the next to last is broadly and deeply emarginate; the males are also furnished with a pair of slender, curved clasping organs hooked at the end and fringed with hairs on the inner margin. Two species occur in Indiana.

\section{KEY TO INDIANA SPECIES OF CHAULIOGNATHUS.}

a. Thorax wider than long; head black.

1572. PENNSYLVANICUS. aa. Thorax longer than wide; head yellow with black spots.

1573. MARGINATUS.

1572 (4875). Chauliognathus pennsylvanicus Deg., Mem. Hist. des Ins., IV, $1768,78$.

Elongate, slender, parallel. Head and under parts black; thorax yellow with a broad black spot on basal half ; elytra yellow with an oblong-oval blackish spot on apical third, this sometimes prolonged to cover two-thirds or more of the surface; ventral segments margined behind with yellow. Thorax with margin rather widely flattened and reflexed. Length 9-12 $\mathrm{mm}$. (Fig. 322.)

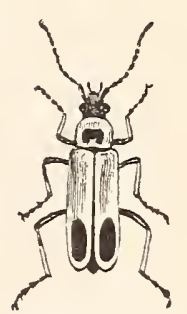

Throughout the State; common. June 30-Septem- Fig. $322 . \times 1 \frac{1}{3}$. ber 30. Occurs most abundantly in autumn upon the flowers of goldenrod and allied plants. Riley says that the larvæ pass the winter in a nearly fuil grown stage; feed ravenously in the spring and appear in the mature stage during August, September and October. I have taken them mating in Putnam County on June 30, so that a few, at least, become mature by that date.

1573 (4876). Chauliognathus marginatus Fab., Syst. Ent., 1798, 206.

Resembles pennsylvanicus in form, but usually smaller and more narrow. Head in great part yellow; thorax with a broad black median stripe reaching from base to apex; blackish spot on elytra very variable in size, 
sometimes extending nearly their full length, rarely wholly lacking; base of femora and greater part of abdomen yellow. Sicles of thorax narrowly margined. Length $8-11 \mathrm{~mm}$.

Throughout the State, common in the southern counties; much less so in the northern portion. June 3-July 28. Occurs by thousands on the florers of the linden; also abundant on those of wild hydrangea, Jersey tea and other shrubs.

\section{Tribe III. TELEPHORINI.}

Head but slightly prolonged before the eyes; maxillæ moderate in size, their palpi rather long and of variable form; front coxæ contiguou's; prosternum distinct in front of coxi ; middle coxæ contiguous; mesosternum horn-like in texture. Eight of the nine recognized genera are known to be represented in the State.

KEY TO INDIANA GENERA OF TELEPHORINI.

a. Elytra entirely covering the wings.

b. Thorax truncate in front; head entirely exposed; gular sutures confluent.

XVIII. Podabrus.

$b b$. Thorax rounded in front; head partly covered; gular sutures separate.

$c$. Last joint of maxillary palpi dilated, hatchet-shaped.

d. Hind angles of thorax of male notched; head short and broad.

dd. Hind angles of thorax rounded.

XIX. SILIS.

e. Head moderately long: sides of thorax not notched.

XX. Telephores.

$e e$. Head short and broad: sides of thorax in male nicked at the midtlle.

XXI. Polemits.

cc. Last joint of maxillary palpi subeval, obliquely truncate; sides of thorax in male distinctly notched at the middle and behind; antennce strongly serrate.

XXII. DITEMINUS.

a . Elytra abbreviated; wings exposed; gular sutures confluent.

f. Maxillary palpi with the last joint elongate, hatchet-slanped; side pieces of metathorax wide in front, strongly triangular ; claws with broad tooth near base.

XXIII. Tripherus.

ff. Maxillars palpi with the last joint oval, pointed; side pieces of metathorax narrow; claws simple.

g. Mandibles toothed; head wide, narrowed behind.

gy. Mandibles simple; head not narrowed behind.

XXiv. Maltimes.

XXV. MaLthodes.

XVIII. Podibrers Fisch. 1839. (Gr.. "foot+delicate.")

Head prolonged and narrorred behind the eyes, so as to form a distinct neck which is not covered by the thorax; the latter nearly 
truncate or even somewhat emarginate in front; seventh ventral segment of male truncate, the eighth exposed. The tarsal claws of all our known Indiana species are armed with a long acute tooth, causing them to appear broadly cleft. In another group, which may yet be found to be represented in the State, the claws are armed with a broad, nearly rectangular, basal tooth. Fight sneries have been taken in the State.

KEY TO INDIANA SPECIES OF PODABRUS.

a. Eighth ventral segment of male triangular, flat, rounded at tip.

b. Elytra distinctly dilated on the sides, their elevated lines strongly marked; antennie stouter.

c. Size larger, 11-13 mm.; thorax more than twice als wide as long.

1574. TRICOSTATUS.

cc. Smaller, T-S mm.; thor:ax not much wider tham long, distinctly narromed in front.

157\%. RUGOSULC'S.

bb. Elytra not or scarcely dilated on the sides, their elerated lines indistinct.

d. Elytra rather coarsely rugose.

e. Thorax twice wider than long; color smoky brown or dull black.

1576. BASILARIS.

ee. Thorax but little wider than long; color, except sides of thorax, shining black.

157\%. FRATER.

dd. Elytra finely rugose; thorax but little wider than long.

f. Elytra black without pale mirgins; median impressed line of thorax distinct.

I) DAEMA.

ff. Margins and suture of elytra nallowly pale; median line of thorax feeble or wanting; second and thiud joints of antenna subequal.

1578. MODESTUS.

aa. Eighth ventral of male oblong with sides parallel, obtusely rounded at tip.

y. Head suddenly narrowed behind the eyes, neck short; head and thorax uniform reddish-yellow.

1579. TOMENTOSUS.

gg. Head much prolonged behind the eyes, neck long.

$h$. Head sparsely punctured behind; thorax feebly punctured.

15SO. PROTENSUS.

$h h$. Head and thorax both coarsely, the latter sparsely punctured.

15S1. BRUNNICOLLIS.

1574 (4879). Podabrus tricostatus Say, Bost. Journ. Nat. Hist., I, 1835. 158 ; ibid. II. 635.

Elongate, robust. Black; front of head and sides of thorax reddish-yellow. Antennæ about half the length of body, joints two to four increasing in length. Head and middle of thorax densely punctured, the sides of latter broadly flattened and reflexed. Elytra very broadly dilated on middle third, densely rugose, each with three strongly elevated lines. Male elytra less dilated and antennæ longer than in female. Length 11-13 mm. (Fig. 323.)

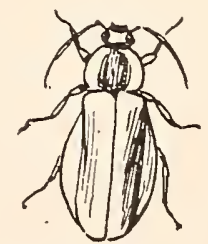

Fig. $323 . \times 1 \frac{1}{2}$. (Atter Kinobel.)

Lawrence and Perry counties; rare. May 31-June 17. 
1575 (4880). Podabrus rugosulus Lec., Agass. Lake Sup., 1850, 229.

Elongate, the sides of elytra less broadly dilated than in tricostatus, Black; front of head and sides of thorax yellow. Head coarsely, thorax less coarsely punctured, the latter narrowed in front of middle, side margins broad, deeply impressed before and behind, dorsal line well marked. Elytra densely rugose. Length 7-8 mm.

Throughout the State; common. May 31-July 4. Occurs on the leaves and flowers of various shrubs and herbs. One was noted feeding on a winged plant louse. In one specimen at hand the thorax is wholly black.

1576 (4882). Podabrus basilaris Say, Journ. Phil. Acad. Nat. Sci., III, 1823,181 ; ibid. II, 117.

Elongate, parallel. Blackish or piceous; front of head and margins of thorax reddish-yellow; narrow side margins and suture of elytra pale; antennæ and legs piceous. Second joint of antennæ shorter than third, the two together scarcely longer than fourth. Thorax with sides rounded, broadly flattened and reflexed; dorsal line distinct; disk sparsely punctured. Length 8-13 $\mathrm{mm}$.

Lake, Kosciusko, Starke and Tawrence counties; rare. May 23-June 27. One of the largest species of the genus, which probably occurs sparingly throughout the State. The thorax is much wider in proportion to its length than in modestus.

1577 (4881). Podabrus Frater Lec., Proc. Phil. Acad. Nat. Sci., V, 1851, 344.

Slightly larger than rugosulus, which it closely resembles. Head black, the mandibles and a narrow line between the eyes yellowish, coarsely and closely punctate behind the eyes. Thorax quadrate, apex truncate, front angles rounded, the convex portion of disk almost smooth. Length 9 $10 \mathrm{~mm}$.

Steuben. Marshall, Starke and Vigo counties; scarce. June 6. Tune 17. Taken by sweeping herbage in low, moist grounds.

$P$. diadema Fab., black, front of hear and sides of thorax pale, length 9-11 mm., is recorded from the Atlantic region and Lake Superior.

1578 (4886). Podabrus modestus Say, Journ. Phil. Acad. Nat. Sci., III, 1823,179 ; ibid. II, 116.

Resembles basilaris very closely. Black or dusky black; front of head, broad margins of thorax and femora in great part sellow; antennæ and tibiæ dusky. Thorax nearly one-half wider than long, hind angles rectangular, front ones rounded; margins reflexed. disk finely and sparsely punctate. Length 9-13 $\mathrm{mm}$. 
Throughout the State; frequent. June 3-.June 27. One species with thorax wholly pale is referred to var. flavicollis Lee.; this heing a variety of modestus and not of basilaris, as the form of the thorax and relative length of antennal joints plainly show.

1579 (4889). Podabrus tomentosus Say, Journ. Phil. Acad. Nat. Sci., V, 1825, 165 ; ibid. II, 275.

Elongate, slender, parallel. Head, thorax, two basal joints of antennæ, abdominal margin and femora reddish-yellow; remainder of antennæ, tibiæ and tarsi dusky; elytra black with fine grayish pubescence. Thorax quadrate; disk finely and sparsely punctate, with distinct median line. Length 9$12 \mathrm{~mm}$. (Fig. 324.)

Thronghout the State; common. May 21October 15. Occurs most abundantly on the greater ragweed, Ambrosia trifida L., along

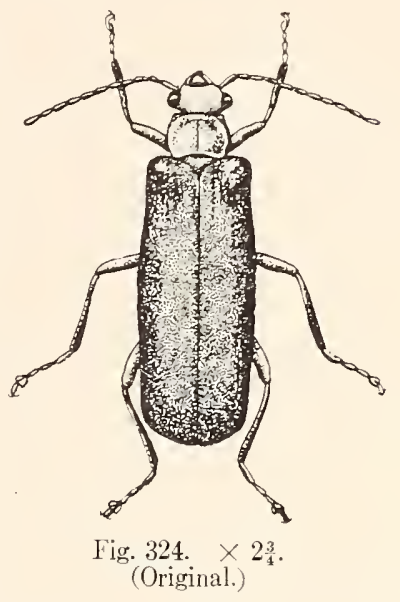
the borders of streams; also noted at electric light.

1580 (4890). Podabrus protensus Lec., New Sp. N. Am. Col., 1866, 91.

Elongate, slender. Blackish; front of head, thorax, legs, basal fifth and outer margin of elytra as far as middle, reddish-yellow. Thorax slightly longer than wide, sides feebly curved; disk very finely and sparsely punctate; dorsal line deep. Second and third joints of antennæ nearly equal and together longer than fourth. Length 11-14 mm.

Clark, Jefferson and Perry counties; scarce. Tray 21-June 17. In some specimens, var. fayi Lee., the elytra are wholly dull yellow.

1581 (4891). Podabrus brunnicollis Fab., Syst. Eleut., I, 1901, 298.

Resembles the preceding but more slender. Front of head, sides of thorax, margins of elytra, legs and base of antennæ yellow. Back of head and disk of thorax coarsely punctured. Thorax longer than wide, the sides parallel, not rounded. Length $7-10 \mathrm{~mm}$.

Orange County ; scarce. May 28-5une 2. Beaten from foliage of oak, hickory and wild grape.

\section{SiLis Latr. 1829. (Gr., "pug-nosed.")}

Small oblong species having the thorax broader than long and, in the male, notched near the lind angles and bearing two processes on each side near the base.

KEY TO INDIANA SPECIES OF SILIS.

a. Base of thorax lobed, deeply foveate inside of hind angles; notch near the base deep, the appendage behind notch long. compressed and rounded at tip.

15S2. PERCOMIS.

[53-23402] 
aa. Base of thorax not lobed; process behind the notch not ante-basal but proceeding from the base itself by an extension of the hind angles; both processes narrow, parallel, compressed and obtuse at tip.

1583. SPATHULATA.

1582 (4920). Silis perconis Say, Bost. Journ. Nat. Hist., I, 1835, 159 ; ibid. II, 636.

Oblong, depressed. Black, often with a bluish tinge; thorax reddishyellow. Thorax wider than long, obtusely rounded in front, the sides of female with a slight notch near hind angles; those of male deeply notched as noted above; surface of elytra finely granulate and pubescent. Length $5 \mathrm{~mm}$.

Lake County; searce. May 28.

1583 (4924). Silis spatilulata Lec., Trans. Amer. Entom. Soc., IX, 1SS1, 5 T.

For'm and color of percomis. Thorax strongly margined but not lobed at base, the basal margin blackish. Antennæe of male nearly as long as body, joints 4-10 about four times longer than wide, slightly broader at tip, therefore subserrate; those of female one-half length of body, not serrate. Length $4.5-5 \mathrm{~mm}$.

Lake, Marshall and Fountain counties; scarce. May 12-May 28. LeConte's types were from Illinois. Occurs especially on the flowers of the wild cranesbill, Geranium maculatum L.

XX. 'Telephorus Schäff. 1766. (Gr., "afar + bearing," i. e. of wide distribution."

The species belonging here are small or medium, soft-bodied forms, which are very difficult to separate. From allied genera they are distinguished only by the characters given in the generic key. They occur mostly on the foliage of low herbs and shrubs, especially in moist lowlands. About 36 species are known from the United States, 12 of which have been taken in Indiana.

\section{KEY TO INDIANA SPECIES OF TELEPHORUS.}

a. Claws of tarsi either in part or wholly toothed or cleft.

b. Tarsal claws similar, all being toothed or cleft.

c. All the claws appendiculate or broadly toothed at base.

d. Thorax one-half wider than long; last joint of maxillary palpi dilated, triangular.

15S4. DENTIGER.

dd. Thorax not wider thin long; last joint of maxillary palpi elongate, triangular.

15.5.5. EXCAVATUS.

cc. All the elaws cleft or acutely toothed.

c. Size larger, 9-10 $\mathrm{mm}$.

15S6. CAROLINTS.

ce. Size small, not over $7 \mathrm{~mm}$.

f. Elytra rather andrsely and densely rugose-punctured; thorax rellow with a wide dorsal stripe black.

1587. LINEOL.A. 
$f f$. Elytra finely or sparsely rugose-punctured.

g. Legs piceous or dull yellow; length 4.5-6 mum.

gg. Legs bright yellow.

1588. RECTUS.

h. Black; thorax and base of antenne orange yellow, the former often with a black dorsal line.

15S9. FLAVIPES.

hh. Piceous; thorax and margins and suture of elytra yellow.

$i$. Thorax wider than long.

j. Form slender; thorax but little wider than long, its sides nearly parallel; elytra usually pale with dusky stripes.

1590. SCITULUS.

j.. Form more robust; thorax one-half wider than long, its sides rounded.

1591. LUTEICOLLIS.

ii. Thorax not wider than long, sides subsinuate; elytra piceous with narrow pale stripes.

1592. PUSIrLUS.

66. Tarsal claws unlike; the outer claw of all the tarsi toothed at base, entire at tip, the inner claw simple.

li. Eyes large and prominent; size larger, 12-14 mm.; thorax not wider than long.

ROTUNDICOLLIS.

ki. Eyes smaller, not prominent; size less, not over $7 \mathrm{~mm}$; thorax wider than long.

l. Thorax yellow with a broad black dorsal stripe.

1593. TUBERCULATUS.

7l. 'Thorax reddish-yellow with two oblong-oval blackish spots.

1594. BILINEATUS.

a.a. Claws of tarsi simple, slender, not toothed or cleft; thorax semiorbicular. with a dorsal black stripe.

1595. SIMPLIU NGUIS.

1584 (4926). Telephorus dentiger Lec., Proc. Phil. Acad. Nat. Sci., V, $1851,341$.

Elongate-oblong, rather robust. Dusky black, clothed with fine grayish pubescence; thorax rellow with a transverse angulated central dusky spot; mouth and side margins of abdomen, and sometimes the margins of elytra, dull yellow. Head and elytra densely and roughly punctured. Thorax more sparsely and coarsely punctured, median impressed line distinct, front angles broadly rounded. Length $8-9 \mathrm{~mm}$.

I ale. Wayne and Marion counties; searce. May 6-May 28.

$15 S 5$ (4927). Telephorus excayatus Lec., loc. cit., 342.

Elongate, slender. Black; thorax reddish-yellow with a narrow dorsal black stripe, this sometimes wanting; narrow side margins of elytra, tibiæ, tarsi and basal third of antennæe, sometimes dull yellow. Head finely and densely punctured. Thorax as long as wide, nearly smooth, slightly narrowed in front, sides straight, exca vated about the middle; median line wide and deep, channel-like; thorax of female wider and less excarated at sides than in male. Length 5-6 mm.

Throughout the State; frequent. May 11-June 25.

1586 (4932). Telephorts carolinus Fabr., Syst. Eleut., I, 1S01, 296.

Elongate, robust, subdepressed. Black, finely pubescent; thorax reddish, with a large shining black spot at center; mouth parts, three basal 
joints of antennie and narrow margin of abdomen dull yellow. Thorax broader than long, sides and front angles broadly rounded. Tarsi broad. those of male broader than in female. Length 9-11 $\mathrm{mm}$.

Throughout the State; common. April 26-.July 9. On flowers and leaves of Cratogus and other shrubs.

\section{7 (4933). Telephorus lineola Fab., Syst. Ent., I, 1798, 219.}

Elongate, slender. Black, with sparse grayish pubescence; thorax yellow, with a wide median black stripe; front of head and legs sometimes yellow. Thorax wider than long, its front and hind angles rounded; side margins rather strongly reflexed, median line obsolete or indistinct, but usually a broad, shallow depression on middie of basal half. Length 4-6.5 mm.

Throughout the State; common. NIay 24-July 4 . Occurs on the flowers of blackberry and on the foliage of many shrubs. In several speeimens at hand the thorax is wholly piceous or dusky.

1588 (4936). Telephorus rectus Melsh., Proc. Phil. Acad. Nat. Sci., II, $1845,305$.

Elongate, parallel, slender. Black or piceous, sparsely clothed with grayish pubescence; sides of thorax, mandibles, tibiæ and tarsi dull yellow; epipleura and sutural line of elytra whitish. Second joint of antennæ onefourth the length of third, the latter nearly as long as fourth. Thorax subquadrate, front angles obtusely rounded, side margins narrow, scarcely reflexed, nearly straight. Length $4.5-6 \mathrm{~mm}$.

Throughout the State; frequent. May 24-June 16.

1589 (4939). Terephorus flavipes Lec., Proc. Phil. Acad. Nat. Sci., V, $1851,341$.

Elongate, slender. Black; front of head, base of antennæ, legs and thorax orange yellow; the thorax with or without (var. dichrous Lec.) a black median stripe. Antennæ but little shorter than body, second joint one-third as long as third (male) ; or two-thirds as long as body, second joint nearly half as long as third (female). Thorax slightly wider than long, disk broadly concave each side in front of middle, front and-side margins strongly reflexed. Length 5-6 $\mathrm{mm}$.

Throughout the State; scarce. Nay 16-June 12.

1590 (4940). Tetephorus scitulus Say, Journ. Phil. Acad. Nat. Sci., V, 1825, 168; ibid. II, 278.

Elongate, slender. Piceous or dusky, disk of thorax with or without a piceous cloud. Elytra with wide marginal and sutural stripes pale yellow, that along the suture widest at base, often occupying half or more the width of elytra. Second joint of antennæ more than half the length of third. the latter equal to fourth. Thorax wider than long, broadly concare on each side, the margins strongly reflexed. Length 4-6 $\mathrm{mm}$.

Throughout the State; common. June 2--July 5. 
1591 (4942). Telephorus luteicollis Germ., Ins. Nov., 1824, 70.

Oblong, rather robust. Piceous; front of head, thorax, legs, narrow marginal and sutural lines of elytra and basal half of antennæ, yellow. Thorax one-half wider than long, sides rounded, margins narrowly reflexed. Length $5 \mathrm{~mm}$.

Lake County; scarce. May 24.

1592 (4941). Telephorus pusillus Lec., Proc. Phil. Acad. Nat. Sci., V, $1851,343$.

Elongate, slender. Black or piceous ; front of head, sides of thorax and legs yellow; elytra with narrow sutural and marginal lines pale yellow. Thorax not wider than long, sides nearly straight, not strongly reflexed. Elytra sparsely clothed with semi-erect grayish hairs, the marginal and sutural pale stripes much narrower than in scitulus. Length 4-6 mm.

Throughout the State; common. May 12-July 5. Very close to scitulus and probably merges into that species.

T. rotundicollis Say, yellow, elytra and ventral segments often piceous, is recorded from Illinois and Lake Superior.

1593 (4953). Telephorus tuberculatus Lec., Proc. Phil. Acad. Nat. Sci., $\mathrm{V}, 1851,341$.

Elongate, rather slender. Black, shining; mouth and thorax yellow, the latter"with a broad, black dorsal stripe which, in some specimens, is wider along the basal and apical margins. Antennæ of male two-thirds as long as body, subserrate; those of female half as long as body. Thorax quadrate in male, wider in female, disk with a deep median impressed line and a transverse impression each side. Elytra coarsely rugose-punctate. Length 5-7 mm.

Lake, St. Joseph, Kosciusko and Wayne counties; common on the foliage of alder (Alnus incana Willd.) and other shrubs along the borders of marshes. May 12-June 1. Resembles lineola and rectus, but readily separated by the form of the tarsal claws.

1594 (4955). Telephorus Bilineatus Say, Journ. Phil. Acad. Nat. Sci.. III, 1823, 182 ; ibid. II, 118.

Oblong, robust. Dull reddish-yellow; back of head, elytra, two oblong spots on thorax, antennæ, except the basal joint, and tibiæ and tarsi, black. Thorax suborbicular, widely margined, sparsely punctured. Length $6-8 \mathrm{~mm}$. (Fig. 325.)

Throughout the State; common. April 22-June 11. Mating May 3. Oc-

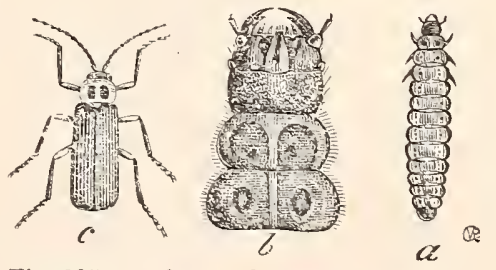

Fig. 325. $a$, larva; $b$, head of same; $c$ beetle. (After Riley.) curs abundantly on flowers of the red haw, Crategus, and the foliage of many shrubs. 
1595 (- $)$. 'lelephorus smipliunguts sp. nor.

Elongate-oblong, rather robust. Piceous black; thorax yellow, with a rather broad median stripe black, this wider near apex and base; front of head yellow, antennæ piceous. Thorax suborbicular, one-half wider than long, more convex on basal half; sides broadly rounded into base and apex; margins narrow, not reflexed; median impressed line deep, entire; disk with a feeble impression each side near middle. Elytra finely rugose, sparsely and finely pubescent. Second joint of antennæ nearly half the length of third, the latter equal to fourth. Length $6 \mathrm{~mm}$.

Described from a single specimen taken near Pine, Lake County. May 26. Beaten from the foliage of sand cherry, Prunus pumila L. Belongs in the group with marginellus Lec., in which the tarsal claws are simple and elytra finely scabrous. The shape of thorax, which is that of bilineatus, and the lack of pale margins of elytra distinguish it from marginellus.

\section{Porenues Lec. 1851. (Gr., "war-like.")}

This genus is intermediate between Silis and Telephorus and is separated mainly by the characters given in the table. The antennæ are compressed, more or less serrate. with second joint less than one-third the length of third. which is equal to fourth. Tarsal claws simple. the outer one of hind pair with a blunt tooth at base.

1596 (4966). Polemius Laticornis Say, Journ. Phil. Acad. Nat. Sci., T, 1825. 168 ; ibid. II. $27 \mathrm{~S}$.

Elongate-oblong, rather robust. Black or piceous black, finels hirsute; side margins of thorax and humeri (sometimes basal third) of elytra dull orange yellow. Antenne long and strongly serrate (male); shorter and less serrate (female). Thorax as broad as long, front angles obtusely rounded. side margins slightly notched a little before the middle and narrower in front of notch; disk impressed each side near the margin. Elytra densely and finely scabrous, obscurely three-costate. Length 6.5-S mm.

Vigo County; rare. June 17. Occurs on the greater ragweed, Ambrosia trifida L., in low. moist grounds. Also in Webster collection from Indiana and Illinois.

1597 (4967). Polemius undulatus Lec., Proc. Phil. Acad. Nat. Sci., Y, $1851,341$.

Oblong, rather robust. Piceous; thorax rosaceous and sellow, with a dark dorsal stripe; base of femora, margins of abdomen and elstra, and sutural line of latter dull yellow. Thorax as wide as elytra, front angles obtusely rounded, hind ones rectangular; side margins wide, notched at middle, bisinuate. Elytra finely and densely scabrous. Length 6-7 mm.

Steuben and Marshall counties; rare. August 11-August 15. Say described a beetle from Posey County, Indiana, under the name Cantharis invatida (LeConte Ed. Say's works. II, 636), which is 
at present unrecognized by entomologists. but which is probably this species. He gives the length as less than one-fourth of an inch and there are some minor details of color which do not agree with the specimens at hand.

\section{Ditemnes Lec. 1861. (Gr., "twice + to cut or split."}

Antenna stout. compressed and serrate; sides of thorax lobed in such a manner as to present two notches, one near the tip formed by the thickened apical margin. the other between two narrow lobes or processes which extend outward near the base. In our species the base of thorax is strongly margined and its disk excavated.

\section{KEY TO INDIANA SPECIES OF DITEMNUS.}

a. Hind lobe at side of thorax rery little wider than the one before it; smaller, not over $3.5 \mathrm{~mm}$.

1598. BIDENTATLS. a $a$. Hind lobe at side of thorax more than twice the width of the one before it; larger, $4.5-5.5 \mathrm{~mm}$.

1599. LATILOBUS.

1598 (4969). Ditemncs Bidentatus Say, Journ. Phil. Acad. Nat. Sci., V, 1825, 169 ; ibid. II, 278.

Oblong, sparsely clothed with grayish pubescence. Black; thorax dull sellow. Second joint of antennæ not dilated, about one-third as long as third. which is equal to fourth. Thorax slightly wider than long, the apical lobe of sides well defined, middle and hind lobes narrow, parallel. Length $3.5 \mathrm{~mm}$.

Lake, Laporte. Spencer and Dubois counties; scarce. May 12July 25. Occurs on low herbs along roadsides. 1599

1599 (-). Ditemats latilobl's sp. nor.

Elongate-oblong. Black or piceous, feebly shining; thorax reddishrellow. Second joint of antennze rounded, not pubescent, less than one-fourth the length of third, the latter equal to fourth. Thorax onethird wider than long. the base more strongly margined than in bidentatus; basal side lobes prominent, the front one narrow, its apical half a little wider and bent slightly downmard and backward, the tip obliquely truncate; the hind one more than

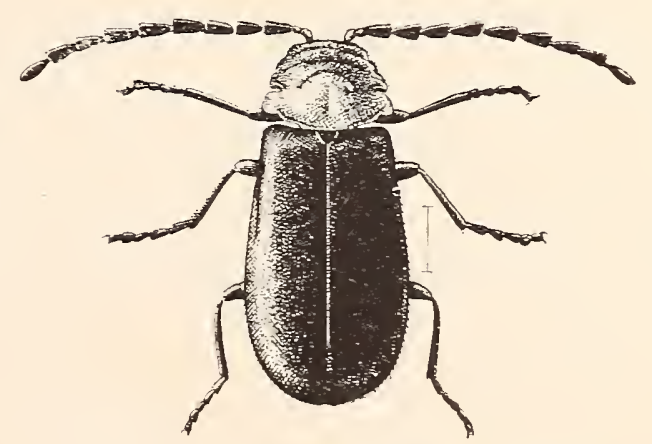

Fig. 326. Lite shows natural length. (Original.) twice as broad and a little shorter, concave, its apex rounded and bent forward or slightly toothed so as to touch the front lobe, learing only a small lounded notch between the two, its hind margin overlapped at base by the hind angles of thorax; median impression of disk distinctly larger than in bidentutus. its limits marked by fonr slight tubercles, its margins indistinct. Elytra finely scabrous, sparsely and rery finely pubescent. Length $4 . \overline{0}-$ $5.5 \mathrm{~mm}$. (Fig. 326.) 
Lake, Marion. Putnam. Vigo and Cratrford counties: scarce. April 20-July 30. Occurs on the flowers and foliage of black haw and other shrubs; also on tall blue grass in open roods. Described from eleven specimens. all haring the characters above giren. and therefore all males. if that sex only has the thorax lobed.

\section{Tripherts Lec. 1851. (Gr.. "weak.")}

Here belongs a single elongate species, having the elrtra abbreviated as in the Staphylinidx, the inner wings much longer and corering the surface of the abdomen in repose. Exes large and prominent in the male. which has also the middle femora decidedly thicker than in femaie.

1600 (4972). Tripherts Latipexis Germ.. Ins. Sp. Nor., 1824, 72.

Elongate. slender. Dull rellow beneath; piceous abore, the margins of thorax and tips of elytra dull rellow. Antennæ dusky, slender, one-half as long as body; third joint equal to second, a little shorter than fourth. Thorax slightly wider than long, transrersely oral, broadly rounded in front, truncate behind. Elytra nearly twice as long as thorax, rugosely punctured, tips rounded. Female with last dorsal segment trilobed at tip. Length 6-7 mm.

Throughout the State: frequent. April 22-Jume 28. Occurs especially on catnip and flotrers of red haw: also on foliage of various plants.

\section{MLlthinus Lat. 1806. (Gr.. "soft wax.")}

Head large. narrowed behind the eres into a neck: antenna slender. with second joint equal to those which follow; elytra threefourths as long as abdomen. marked with rotrs of punctures. One of the two known North American species occurs in Indiana.

1601 (4975). Malihixes occipitalis Lec., Proc. Phil. Acad. Nat. Sci., V, $1851,345$.

Elongate, slender. Dull rellow; head. middle of thoras and an irregular space behind the middle of elrtra piceous; tips of elstra lemon-yellow: apical half of antennæ dusky. Thorax as wide as long. sides rounded; disk sparsels and finely punctured and with a deep median impression on basal half. Length $3 \mathrm{~mm}$.

Tipperanoe. Orange and Flord counties: scarce. MIar 25-June 29. Hitherto recorded only from the Southern States. Occurs on grasses in low. moist places.

\section{Malthones Kies. 1852. (Gr.. "soft + form.")}

Species of small size and weak structure. haring short elytra which leate the inner wings partly exposed and folded along the 
dor'sal surface of the abdomen; head not narrowed into a neck and mandibles not toothed. But two species have been taken in Indiana, though others doubtless occur.

KEY TO INDIANA SPECIES OF MALTHODES.

a. Thorax piceous; next to last ventral segment of male inflated, deeply and broadly excavated, its side lobes large, broad, triangular.

1602. CONCAVUS.

aa. Thorax yellow or reddish-piceous; last ventral of male with long complex processes.

b. Last ventral of male narrow, prolonged, cleft or nicked at tip ; thorax yellow.

1603. EXILIS.

$b b$. Last ventral wider, parallel, channeled its full length, curved upward and forked at tip; thorax rufo-piceous.

CURVATUS.

1602 (4979). Malthodes concavus Lec., Proc. Phil. Acad. Nat. Sci., V, $1851,346$.

Elongate, slender. Piceous; head blackish; base of antennæ and part of abdomen dull yellow. Head wider than thorax; eyes rery large, convex, prominent. Antennæe rather stout, reaching beyond tips of elytra, second and third joints equal. Thorax one-half wider than long, sides narrowly margined, impressed near front angles, which are rounded. Elytra twothirds as long as wings. Iast ventral elongate, slightly nicked at tip. Length $2-3 \mathrm{~mm}$.

Dubois County; rare. May 12.

1603 (4981). Malthodes exilis Melsh., Proc. Phil. Acad. Nat. Sci., II, 1845 , 305.

Elongate, slender. Dull brown; thorax and front legs yellow; head black; antennæ dusky, with two basal joints paler. Thorax one-third wider than long, finely margined, front and hind angles obtusely lounded, apex subtruncate, base feebly rounded. Elytra two-thirds the length of abdomen, separated at apex, surface finely rugulose; a small rounded smooth spot at tip of each. Antennæ of male two-thirds, of female half the length of body, the fourth and following joints longer than second or third. Length 2.5$3 \mathrm{~mm}$.

Kosciusko, Knox, Dubois and Perry counties; scarce. Nay 12June 8. Beaten from bushes along the margins of marshes.

M. curvatus Lec., piceous, head black, Iegs dull yellow, length $3 \mathrm{~mm}$. , was described from Illinois.

\section{Family XLI. MALACHIID 尼.}

The Soft-winged F'Lower Beetles.

A family of small extent, comprising small, soft-winged species which bear a general resemblance to the Lampyridx, but are shorter, and have the elytra more or less truncate and broadest near the 
tips. From the Lampyrida they are distinguished chiefty by having the antennæ inserted upon the front at the sides, generally before the eyes; by the presence of a separate piece between the labrum and the front and by the fourth joint of the tarsi not being bilobed. The great majority of our Indiana species also have the power of protruding from the sides of the abdomen a number of soft, orangecolored vesicles which are supposed to be scent organs used in defense.

In addition to the characters mentioned, the Malachiidæ have the mentum smail, quadrate and horn-iike; antennæ 11-jointed, usually serrate and often curiously knotted in the male; head exserted and prolonger into a short, broad beak; elytra usually entire, sometimes slightly abbreviated; abdomen with six free ventral segments; prosternum short, not extending between the front coxæ, which are large, conical, contiguous, with distinet trochantins, the coxal cavities large, transverse, open behind; tarsi 5-jointed, filiform; claws usually with a large membranous appendage between them.

The larvæ of the Malachiidx are, so far as known, carnivorous. 'The mature insects oceur on flowers or herbage, some only in low, moist places, and are said to feed on insect eggs, larvæ and small, soft-bodied insects, so that on the whole they may be elassed as beneficial.

The principal literature treating of the genera occurring in Indiana is as follows:

LeConte.- "Catalogue of the Melyrides of the United States, with Descriptions of New Species,' in Proc. Phil. Acad. Sei., VI, 1852, 163-171.

Horn.- "Synopsis of the Genus Collops," in Trans. Amer. Entom. Soc., III, 1870, 79-84.

Horn.- "Synopsis of the Malachiidæ of the United States," in Trans. Amer. Entom. Soc., IV. 1872. 109-127.

Casey.- "Synopsis of the Melyridæ of North America," in Ann. N. Y. Acad. Sci., VIII, 1395. 456-606.

About 140 species, distributed among 20 genera, are listed by Henshaw from the United States, most of them inhabiting the region west of the Rocky Mountains.

KEY TO THE INDIANA GENERA OF MALACHIID E.

a. Sides of body with extensible vesicles, the front pair proceeding from a fissure beneath the front angles of the thorax; last joint of tarsi with two membranous appendages beneath the claws.

b. Antennæe apparently 10-jointed.

I. Collops. 
64. Antennæe distinctly 11-jointed.

c. Front tarsi simple, joint two not prolonged.

d. Flytra similar in both sexes.

II. Axthocosius.

dd. Elytra of male prolonged at tip and bearing a hook-like appendage.

III. Pseudebeus.

cc. Front tarsi of male with second joint prolonged over the third (Fig. 328) ; elytra similar in both sexes.

IV. AtTalis.

a a. Sides of body without vesicles; angles of thorax not fissured beneath: first joint of tarsi shorter than second; claws without appendages; edge of thorax and elytra serrate.

V. ALYMIERIS.

\section{Collops Erichs. 1840. (L., "embrace + eye or face.")}

To this genus belong our largest members of the family, yet none of them exceed $7 \mathrm{~mm}$. in length. The antennæ are apparently 10jointed (the true second joint being very small and concealed); second joint (really the third) of male much enlarged and bearing near the base a curious slender articulated appendage furnished at the tip with a brush of stiff. curred hairs. This extends forward and is usually concealed in a deep cavity on the upper surface of the joint. It is supposed to be used in clasping the antennæ of the female during mating.

1604 (4994). Collops tricolor Say, Journ. Phil. Acad. Nat. Sci., III, 1S23, 182 ; ibid. I, 107 , pl. 48.

Oblong-oral, broadest behind the middle. Head, legs and under surface, except abdomen, black; palpi, thorax, abdomen and basal third of antennæ, reddish-yellow; elytra blue or bluish-black. Thorax much wider than long, nearly oral, sides broadly rounded; surface, as well as that of elytra, sparsely clothed with black, erect hairs. Elytra densely punctured. Length 4-5 $\mathrm{mm}$.

Lake and Marshall counties; rare. June 28-August 27. The figures of pl. 48, LeConte's edition of Say, are wrongly named, Fig. 3 being this species.

1605 (5004). Collops quadrimaculatus Fabr., Ent. Syst. Suppl., 1798, 70.

Oblong-oval, widest behind. Ifead, abdomen and femora black; thorax and elytra reddish-yellow, the latter each with a large basal and anteapical spot blue or bluish-black; tibire, tarsi and apical portion of antennæ dusky or piceous. Otherwise as in tricolor. Length 4-6 $\mathrm{mm}$. (Fig. 327.)

Throughout the State; frequent. Mar 30-September 8. Taken by sweeping and beating grasses and foliage in damp localities.

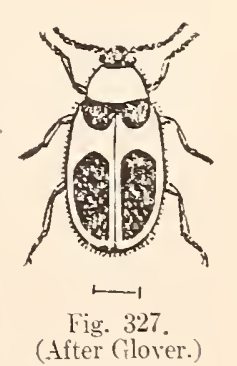




\section{Anthoconus Erichs. 1840. (Gr., "flower + to revel.")}

Our two members of this genus may be known by having the 11-jointed antennæ inserted at the sides of the front nearly or quite at the front margin; tarsi simple and similar in both sexes.

1606 (5038). Anthocomus Erichsoni Lec., Proc. Phil. Acad. Nat. Sci., Vi, 1852,165 .

Oblong-subdepressed, but little wider behind the middle; sparsely clothed with grayish hairs. Head, under surface and femora black; thorax reddish-yellow, the disk with a broad median black stripe; elytra black with a bluish tinge; tibiæ, tarsi and front coxre piceous. Front of head with a wide, shallow impression. Thorax broader than long. sides and angles strongly rounded, surface sparsely punctulate. Elytra parallel, finely punctured and ruguiose. Length $3.5-4 \mathrm{~mm}$.

Putnam, Vigo and Posey counties: scarce. April 18-May 26.

1607 (5039). Anthocomus flavilabrus Say, Journ. Phil. Acad. Nat. Sci., V, 1825, 169 ; ibid. II, 279.

Resembles the preceding in form and size. Black; thorax narrowly margined with reddish-yellow, sometimes wholly black; front part of head, prosternum, front and middle legs and basal third of antennæ bright yellow; front coxæ and femora often with a dilated black line; elytra tinged with purplish. Length $3.5-4 \mathrm{~mm}$.

Southern half of the State, frequent; Marshall County, rare. May 18-June 26: Occurs on fllowers of dogwood, red bud, wild rose, ete.

\section{Pseudebmets Horn. 1872. (Gr., "false + ebæus.")}

Very small species having the elytra in the male obliquely prolonged, tipped with yellow, and with a hook-like process above. Three species have been taken in Indiana, while one other may occur.

KEY TO INDIANA SPECIES OF PSEUDEBAUS.

a. Last ventral segment of male yellow, deeply grooved lengthwise and deeply notched at tip.

b. Thorax yellow.

1608. APICALIS.

bb. Thorax black.

1609. oBLITUS.

aa. Last ventral of male black, not grooved, slightly emarginate at tip.

c. Thorax yellow.

1610. BICOLOR.

cc. Thorax black. PUSILLUS.

1608 (5041). Pseudebeus ApICAlis Say. Journ. Phil. Acad. Nat. Sci., V, 1825. 170 ; ibid. II. 279.

Oblong, rather broadly expanded behind the middle. Black, slightly tinged with bluish; tholax and legs pale dull yellow; antennæ with terminal joints piceous or dusky. Thorax broader than long, sides and angles rounded. Elytra slightly broader at base than thorax, gradually widened 
behind, sinuate near the tip and prolonged in the male; broadly dilated and obtusely rounded in the female. Length $1 . i-2.2 \mathrm{~mm}$.

Marion and Posey counties: scarce. May 24--June 5.

1609 (5045). Pseddebecs oblitus Lec., Proc. Phil. Acad. Nat. Sci., 1852, 167.

Form of apicatis. Colcr above wholly black; antennæ at base and legs pale dull yellow. Male characters as in apicalis. Length 2-2.5 mm.

Steuben County ; rare. June 17. Swept from herbage in tamarack swamp. Ranges from Canada to Georgia.

1610 (5042). Pseudeb eus Bicolor Lec., Proc. Phil. Acad. Nat. Sci., VI, 1852, 167 .

Similar to apicatis but with the thorax shorter and more rounded on the sides. Head reddish-yellow but darker than thorax. Male with elytra sellow at tip. Length $1.8-2 \mathrm{~mm}$.

Throughout the State; scarce. May 1t-June 2t. Occurs on soft maple and allied trees.

$P$. pusillus Say, bluish-black. length $1.5 \mathrm{~mm}$., occurs in the Southern States.

IV. Attalus Erichs. 1840. (Gr., after King Attalus.)

Species of small size. having the second joint of front tarsus of male prolonged over the third and grooved beneath. (Fig. 328.) Nine species and two varieties hare been taken in Indiana. The species are based mostly on color Fig. 328. Front male tarsus of Attalus as and merge into one another. so that a

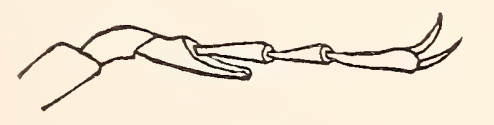
number of them will, in time, probably have to be suppressed or listed as varieties.

KEI TO INDIANA SPECIES OF ATTALUS.

a. Head, thorax and elytra black or nearly so.

b. Apical margin of elstra in male bordered narrowly with sellow; female wholly black.

1611.' TERMITALIS.

bb. Apical margin of elytra not pale.

c. Legs all pale; broadly oval; length 1-1.5 mm. 1612. GRANULARIS. cc. Middle and hind legs black; larger. 2.5-3.5 $\mathrm{mm}$.

đ. Head wholly black; elytra black. shining. 1613. rorults. dd. Clrpeus and front legs pale; elytra sooty. opaque.

1614. PALLIFRONS.

aa. Body abore bicolcred. the head. thorax or elstra in part nọ wholly yellowish or reddish-yellow.

e. Head and thorax both mholl r reddish-yellow. 
f. Elytra entirely black. shining; legs wholly sellow.

161อ̆. MELATOPTERTS.

ff. Elsctra not wholly black.

g. Tips of elytra marrowly reddish-yellow: tibie and tarsi rellow. femora marked with black. 1615a. Tar. MARgrMIPExxis.

gg. Elrtra reddish-yellow with one or two black spots.

h. Elytra each with one small black spot on humerus.

HCMERALIS.

7h. Elstra each with two black spots. one basal, one anteapical.

1616. PETTITI.

ee. Head and thorax not of one color.

i. Thorax reddish-rellow: elstra sooty; front and middle tibia pale. 1617. otiosts.

ii. Thorax with discal black spot, the margins broads pale.

j. Elstra with suture and side margins narrowly pale: abdomen black.

161S. CIRCLMSCRIPTT'S.

i. Elytra either nearly wholly pale or black without pale side margins.

k. Suture and marsin of elstra often black, the remainder dull reddish-rellow.

1619. SCIXCETLS.

lik. Entire elytra except tips black or piceous.

1619a. Tar. COXfests.

1611 (50.52). ATtales terdixalis Erichs.. Entom.. I. 1S40, 108.

Oblong. depressed. dilated hehind the middle. Black. shining. sparsely pubescent; tips of the male elstra and a nar'row margin along their sides to besond the middle pale rellow: front and middle tibia duslis or dull sellow. Length $2.5 \mathrm{~mm}$.

Throughout the State: frequent. June 2-July 20.

1612 (5054). AtTalts GRaxtlaRis Erichs., Entom., I, 1St0, 112.

Broadly oral. much dilated behind the middle. Piceous black: less all dull rellow. Elstra of female nearis as broad as long. Length $1.5 \mathrm{~mm}$.

Steuben and Kosciustro counties: rare. June 1T-June 20. Taken by sifting dehris in low. moist woods.

1613 (505.5). AtTalts yortlt's Lec.. Proc. Phil. Acad. Nat. Sci.. TI. 15.2. 167.

Oblong. feebly dilated behind. Wholly black, shining. rers sparsely pubescent; legs piceous or dusks. Length $2.5 \mathrm{~mm}$.

Martin County : scarce. Ju! r 13. The females of this species are almost inseparable from those of teminatis.

1611 (5056). AtTalts pallifroxs Motsch.. Bull. Mosc.. IT. 1S59. 408.

Elongate-oblong. neariy larallel. Piceous black: clypeus. front less and sometimes the narrow front margin and hind angles of thorax. dull yellow; elctra subopmue with a sooty mpearance. sparsely and finely pubescent; middle and hind femera dusky. their tibice paler. Length :$3.5 \mathrm{~mm}$.

Knox and Posey counties: scarce. May 11-.July 10. 


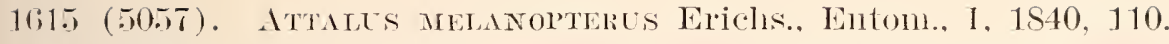

Oblong, rather broadly dilated behind. Head, thorax, abdomen and legs, pale or leddish-yellow; elytrat and body beneath black; hind femola piceous at tip. Surface shining and scarcely pubescent. Length $2.5 \mathrm{~mm}$.

Crawford and Jenuings counties; scarce. June 26-.July 10. Ilso a species of southern range.

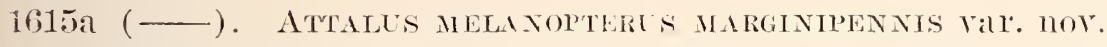

Oblong, rather broadly dilated hehind. Head, thorax, mostermm and ablomen reddish-yellow; artra black or bluish-black, their tips narrowly hordered with orange or reddish-yellow: front and middle logs rellow, the femora with blackish lines: hind femoral and tibie hlackish, the tarsi yellow; antenna blackish, their hasal joints reddish-yellow. Surface shining. finely pubescent. Length 2.S-3 mm.

Crawford County; scarce. June 26-July 5.

A. humeralis Horn, length $3 \mathrm{~mm}$, was described from Illinois.

1616 (5060). Attalus pettiti Horm, Trans. Amer. Entom. Soc., IV, 1Si2. 124.

Oblong. rather broadly dilated behind. Head. thorax, prosternum and ahdomen reddish-yellow; elytra dull orange yellow, reddish at tips, each with a humeral and larger anteapical spot black; legs pale reddish-yellow. lind femora, except at tips. piceous. Length $2-2.5 \mathrm{~mm}$.

Kosciusko and Putnam counties; rare. July 4-July 24. Known heletofore only fiom Canada.

1617 (5063). Atrales otrosts say. Amer. Fnt., I. 152S, 109, pl. 4S; ibid. I, 109 .

Oblong-oval. Head black, pale rellow in front; thorax dull yellow, rarely with a nedian black stripe: elytral sooty-black with a bluish tinge; hind legs more or less piceous. Length $2.5-3 \mathrm{~mm}$.

One specimen in Webster collection labelled "Ind." Said to be widely distributed over the dtlantic region.

1618 (5064). Attalus circumscriptus Say, Jourm. I'hil. Acad. Nat. Sci., III. 1823,185 ; ibid. II, 119.

Oblong. robust for the genus, rather feebly dilated behind. Mead black, labrum dull yellow; thorax with a black median stripe. the side margins broadly pale; elytra black with lateral and apical margins and suture dull rellow; beneath black, the rentral segments edged behind with rellow; legs dusky varied with dull yellow. Length 3 inm. (Fig. 329.)

Crawford County ; not rare about Wyandotte Cave. May 12-Nay 27. A well marked member of the Austroliparian fauna. Horn says "it ap-

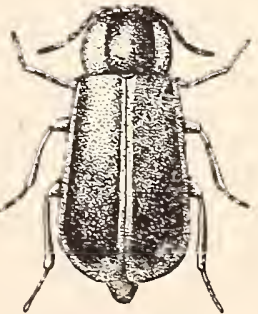

Fig. 329. $\times 7 \frac{1}{2}$. (Original.) peurs to be almost entirely confined to the extreme Southem States.' 'Taken also by Dury near Cincinnati. 
1619 (5068). Attalus scincetus Say, Jomm. P'hil. Acad. Nat. Sci., V, 1825, 170 ; ibid. II, 279.

Oblong, feebly dilated behind. Abore, usually dull yellow; occiput, a broad median stripe on thorax, scutellum and sutural stripe on basal half of elytra, blackish; under surface, antennæ and legs yeliowish ; metasternum black. Length $3 \mathrm{nmm}$.

Throughout the State; common in the southern portion; less so in the northern counties. April 21-June 13. Occurs on flowers of dogwood, red and black haw, wild hydrangea, wild rose, ete., in company with several other members of the genus. The sides of elytra are rarely dusky or brownish.

1619a (- - Attalus scincetus confests var. nor.

A color variety of scincetus in which the elytra, except the tips, are wholly piceous black and the median black stripe of thorax usually a little broader. Length $3 \mathrm{~mm}$.

Knox and Posey counties; scarce. Nay 11-June 9.

\section{Alymeris Casey. 1895.}

Small or moderate-sized species, having the upper surface very coarsely, closely and deeply punctate; last joint of maxillary palpi cone-shaped and gradually pointed; epiplenræ rather wide and almost equal in width from base to sutural angles of elytra, flat and finely punctate, their lower edges strongly serrulate; last joint of hind tarsi as long as the three preceding together. One species occurs in Indiana.

1620 (5123). Alymeris cribata Lec., Proc. Phil. Acad. Nat. Sci., VI, 1852, 171.

Elongate-oval, moderately convex. Uniform piceous black, shining; clothed with short, sparse, scarcely evident pubescence. Thorax one-half wider than long, sides strongly curved, margins serrate, surface coarsely and densely punctate. Elytra three-fourths longer than wide, distinctly wider than thorax, coarsely and closely punctured. Length 2.2-2.5 mm.

Posey County; rare. Tune 2 . Three specimens beaten from flowers of the false indigo, Amorpha fruticosa I. A species of southerm range belonging to the Austroriparian fauna.

\section{Family XLTI. CLERID 正.* \\ The Checkered Beetres.}

The Cleridx comprise a rather large family, over one hundred and sixty species being known from the United States. The adults

* The manuscript and illustrations for this family were prepared by Mr. A. B. Wolcott, of the Field Museum of Natural History, Chicago, Illinois, who is the leading authority on North American Cleridæ. I have added some additional characters to Mr. Wolcott's keys to render them more easily followed by beginners.-W. S. B. 
are handsome in color and raried in form, being for the most part elongate, graceful and pubescent. The thorax is generally elongate and often much narrower than the elytra and head; this, together with the rather long legs, short antennæ and more or less cylindrical form, gives to many of the species a very ant-like appearance. Others, especially some of the members of the tribe Enopliini, strongly resemble some of the Lampyridæ or fireflies.

From allied families the Cleridx may be known by having the antennæ 11-, rarely 10-jointed, inserted at the sides of the front, generally serrate, the outer joints larger, forming an open. or, less often, a compact club; elytra usually entire or nearly so; tarsi of all the legs 5-jointed, the first and fourth joints often very small and inconspicuous, and all but the fifth furnished with membranous appendages ; front cox:e prominent, usually contiguous, rather large. the cavities usually open behind; hind coxæ flat; ventral segments free (mobile), the first ventral not elongate; prosternum not prolonged behind.

The Cleridx occur chiefly on flowers, recently cut timber, trunks and foliage of trees and low shrubs. The species are predaceous in both the larval and adult stages, wood-boring species (Scolytidx, etc.), such as burrow in the sap-wood, being especially to their liking. The slender form and short legs of the larvæ enable them to enter the bores of their prey to feed on the early stages, and the adults are sufficiently active to capture and devour the perfect stage of various xylophagous Coleoptera. Some of the species are found in the nests and ill-kept hives of bees. The genus Necrobia, which has been generally supposed to be a carrion feeder, is probably also carnivorous, as the investigations of Perris make it likely that they infest such refuse to capture and eat the Dipterous larvæ which are so numerous in such situations.

The principal synoptic paper dealing exclusively with the North American species is out of print and very difficult to procure. It and others treating of the family, are:

LeConte.- "Synopsis of the Coleopterous Insects of the Group Cleridie which inhabit the United States," in Ann. N. Y. Lyc. Nat. Hist., V, 1849, 9-35.

Wickham.-_"The Coleopter'a of Canada-The Cleridæ of Ontario and Quebec," in Can. Ent., XXVII, 1895, 247-253.

Horn._- "Synopsis of the species of Cymatodera and Trichodes of the United States,' in 'Trans. Amer. Ent. Soc.. V. 1876. $220-232$.

[54-23402] 
"Tolcott.- "The North American Species of Chariessa," in Ent. News, XIX, 1908, 70-72.

About 161 species of Clerida. belonging to 27 genera, are known from America north of Mexico. Of these 28 species and one rariety. representing 14 genera. have been taken in Indiana. LeConte and IIorn divide the family into two tribes. Woth of which are represented hy species taken in the state.

KEY TO TRIBES OF THE FAMILY CLERID.E.

a. Tarsi with fourth joint of normal size; disk of thorax continuous with the flanlis.

Tíibe I. Clerini. p. Sts. ur. Tarsi with the fourth joint rely small and indistinct; disk of thorax separated from the flanks by a marginal line.

Tribe II. Exoplimis. p. S5T.

\section{Tribe I. CLERINI.}

This tribe. which contains more than two-thirds of the Indiana species, is sufficiently characterized by having the fourth joint of the tarsi about equal in size to the third and the flanks of thorax continuous with disk: middle coxa scarcely prominent. moderatey distant, except in H!idnocera, where they are but slightly separated; body alwars elongate. Of the $1+$ genera belonging to this tribe eight are known from Indiana. while two others mar oceur.

\section{KEY TO INDIANA GENERA OF CLERINI.}

a. Fire joints of tarsi risible from above.

b. Terminal joint of antennae as long or longer than the preceding joints combined; elytral punctures confused; thorax with a discal black spot.

I. МолорНГLLA.

b2. Terminal joint nerer exceeding the four preceding joints combined in length; elytral punctures in rows.

c. Eyes finely granulated; tarsal claws bifid at apex.

Tillts.

cc. Eres coarsely gramulated, tarsal claws simply toothed.

II. CrMatonera.

a . Four joints only of tarsi risible from above, the first joint rers small, corered by the second; tarsal claws toothed.

d. Eyes emarginate in front.

e. Antennse without distinct club, serrate.

f. Eyes coarsely granulated: head and thorax dark reddish or chestnut-brown.

III. PRIOCERA.

ff. Eyes finely granulated.

CIERONOMTS.

ee. Antennie with distinct club of three joints; eres finely granulated.

\%. Last joint of maxillar' palpi slightly broader than the preceding joint: antennal club triangular: head and thorax dark blue.

IT. TRICHODES.

go. Last joint of maxillary palpi slender. 
h. Hind tarsi rather broadly dilated; thorax with at nust a nalrow shallow groove near apex, and without a median line.

Y. ExOCLERLS.

$h$. Hind tarsi slender and longer: thorax with a rery deep subapical groove and with a median impressed line.

VI. Thixismes.

dd. Eres entire.

i. Antemnal club gradually formed. :3-jointed: elytra bright red.

VII. Zexodoses.

ii. Antennal club small, subglobose, 2-jointed; elytra black or black and dull sellow.

TIII. HYDXOCERA.

I. Moxophyli. Spin. 18t1. (Gr., "single+leaf.")

Eyes deeply emarginate in front. nearly dirided; maxillary palpi crlindrical : last joint of labial palpi strongly dilated, hatchetshaped; tarsi elongate. distinctly fire-jointed: claws bidentate. Antennæ with terminal joint large, compressec. about equally as long (female) or very much longer (male) than all the preceding joints combined. Three species are known from North America. one of which occurs in Indiana.

1621 (5127), Moxophylda termixata Say. Bost. Jouln. Nat. Hist. I. 1535. 160 ; ibid. II, 63i.

Elongate, subcyliudrical. Black: moderately shining: thorax yellow with a large or small discal black spot: elytral flanks from humeri to middle and a transrerse spur at middle (the latter sometimes wanting) sellow; abdomen entirely yellon, male, the apical ( sixth) rentral segment black, female. Pubescence of elytra and abdomen grayish. moderately sparse, of thorax sellowish; that of discoidal spot and of occiput of head black, moderately long. dense and erect. Thorax cylindrical. longer than wide: its disk and that of elytra lather coursely, densely punctate. Length $4-$ 7 mm. (Fig. 330.)

Posey County; rare. June 4-June 6.

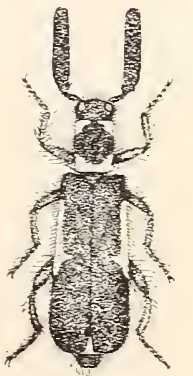

Fig. 330. Male. (Original.)

Tillus collaris Spin.. is known from Georgia and Texas. and has been taken by Dury near Cincimati. It is black. the thorax entirely or with disk red: length $5-5.5 \mathrm{~mm}$.

\section{Cruatoder Gray. 1832. (Fr.. "ware + neck.")}

Eyes moderately emarginate in front: maxillary palpi cylindrical : last joint of lahial palpi strongly dilated. hatchet-shaped : tarsi elongate, distinctly 5-jointed: antennir more or less serrate. Fifty species are known from North America. three of which have been taken in Indiana. while another may occur. 
KEY TO INDIANA SPECIES OF CYMATODERA.

a. Last ventral segment in both sexes smaller than last dorsal and never deeply emarginate in the males.

b. Body black, thorax (except apex and base) and legs reddish-yellow; last dorsal segment of male broadly emarginate. 1622. BICoLor.

bb. Uniform dark brown above.

c. Last joint of antennæ longer than joints 9 and 10 (female), or T, 8, 9 and 10 (male); legs unicolorous with elytra; last dorsal segment of male rounded at apex.

BRUNNEA.

cc. Last joint of antennie shorter than joints 9 and 10 in both sexes; legs paler than elytra; last dorsal segment of male feebly notched at apex.

1623. INORNATA.

aa. Last ventral segment broader than the last dorsal, the sides of the former reflexed, partly enclosing the latter; last ventral emarginate; elytra brownish, with from one to three pale undulating crossbars, sometimes in great part dull yellow.

1624. UNDULATA.

1622 (5136). Cymatodera bicolor Say, Journ. Phil. Acad. Nat. Sci., V, 1825, 174 ; ibid. II, 282.

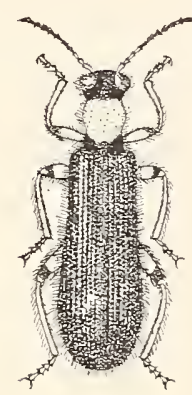

Fig. 331.

$\times 3 \frac{1}{2}$
(Original.)

Elongate, subcylindrical. Black, feebly shining; thorax (except apical and basal margins), legs (except knees and apical fourth of femora), labrum, palpi and first two joints of antennæ reddish-yellow; under surface piceous. Antennæ feebly subserrate, joint two slightly shorter than three, three to ten similar, elerenth longer. Thorax bell-shaped, onehalf longer than wide, strongly constricted behind the middle, finely and sparsely punctate. Elytra at base twice as wide as thorax, rarely with a more or less distinct undulate crossbar, the punctures coarse, deep and close-set. Length 5.5-10 mm. (Fig. 331.)

Starke, Marshall and Crawford counties; scarce. May 28-June 18. Beaten from foliage of oak.

C. brunnea Melsh., dark brown, abdomen paler; elytra very coarsely and densely punctured, length $7.5-15 \mathrm{~mm}$, ranges from New Jersey and Ohio to 'Texas and Arizona.

1623 (5137). Cyamatodera inornata Say, Bost. Journ. Nat. Hist., I, 1835, 161 ; ibid. II, 638.

Elongate, subcylindrical, broader behind. Uniform dark brown, rather thickly clothed with suberect yellowish hairs; antennæ and base of femora reddish-brown, the former with last joint scarcely longer than the tenth. Thorax cylindrical, more than twice as long as wide; sides feebly contracted before and behind the middle; disk finely and rather sparsely punctured and with a small fovea at middle of base. Elytra at base one-half wider than thorax, thence gradually but distinctly widening to apical fourth; the punctures rather coarse and reep. Tength $7-8.5 \mathrm{~mm}$.

Lake County; rare, June 28, Described from Posey County. 
1624 (5147). Cymatodera undulata Say, Journ. Phil. Acad. Nat. Sci., V, 1825,174 ; ibid. II, 282.

Elongate, slender, subcylindrical. Brownish, sparsely pubescent; legs and abdomen dull yellow; elytra either largely dull yellow or with from one to three pale, dentate crossbars. Antennæ reddish-brown, their form as in bicolor, but slightly longer. Thorax cylindrical, one-half longer than wide, rather coarsely and densely punctate. Elytra nearly twice as wide as base of thorax, the punctures coarse, deep and rather distant. Length 9-12 $\mathrm{mm}$.

Elkhart, Wells and Marion counties; scarce. August 18-November 23. Those on the latter date were found beneath the bark of a soft maple tree.

\section{Priocera Kirby. 1818. (Gr., "serrate+horn.")}

Eyes emarginate in iront, coarsely granulated; maxillary palpi cylindrical; last joint of labial palpi dilated, scarcely transverse; tarsi short, apparently 4-jointed, claws simple. 'Two species are known from within our faunal limits, one of which is found in Indiana.

1625 (5152). Priocera castanea Newm., Ent. Mag., Lond., V, 1837, 380.

EIongate, subcylindrical. Head, thorax and legs dark chestnut-brown. rery shining, pubescence long and sparse; elytra reddish-brown with a broad, irregular blackish crossbar behind the middle, each also with two yellow spots, one of which is near the suture and just behind the middle, the other in front of this and near the flank; a third yellow spot often also on base near scutellum. Thorax conrex, bellshaped, strongly constricted near base, sparsely and finely punctate. Elytra with rows of rather coarse punctures, these gradually obsolete toward apex. Length 6.5-10 mm. (Fig. 332.)

Kosciusko, Marion and Hancock counties; rare. July 11-July 20.

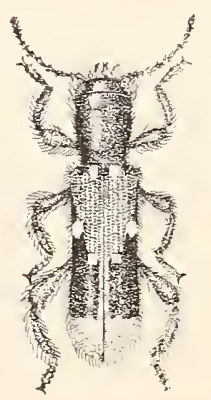

Fig. 1332

(Original.)

Cleronomus melanopterus Dury. black, shining, front of head dull yellow, thorax pink, with a broad black furcate mark, length $8 \mathrm{~mm}$, was described from Cincinnati.

\section{IV. 'Trichodes Herbst. 1792. (Gr., "hairy or shaggy.")}

Eyes deeply emarginate in front, finely granulated; maxillary palpi subcylindrical, last joint longer and slightly broader than the preceding; labial palpi strongly dilated; tarsi apparently fourjointed; antennal club 3-jointed, triangular. Ten species are known from North America, one of which occurs in Indiana. 
1626 (5159). Trichodes nuttalli Kirbs, Trans. Linn. Soc. Lond., XII, 1818, 394.

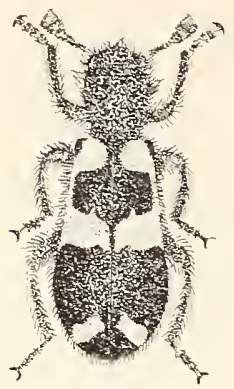

Fig. 333 . $\times 2 \frac{3}{4}$.

(Original.)

Elongate, subcylindrical. Head, thorax, legs and under surface dark blue, sometimes purplish or greenish-blue; elytra blackish-blue. with basal, median and subapical crossbars, interrupted at suture, and also with the margin from humerus to middle. reddish-yellow, the humeral umbone blue. Thorax bell-shaped, coarsely, sparsely and shallowly punctate. Elytra coarsely, shallowly and irregularly punctate. Length S-10.5 mm. (Fig. 333.)

Porter, Kosciusko, Elkhart and Crawford counties; scarce. Tune 28-August 6. The Porter County specimens were taken from blossoms of Opuntia.

\section{Enoclerts Gahan. 1910. (Gr.. "in +insects noxious to hives."')}

Eyes distinctly emarginate in front, finely granulate; maxillary palpi slender; labial palpi dilated; tarsi apparently 4-jointed, claws broadly dentate; antennal club 3-jointed, rather abruptly enlarged, conical. About 30 species of this genus are known from North America, six of which have been taken in Indiana. One additional species and one variety may also occur.

KEY TO INDIANA SPECIES OF ENOCLERUS.

a. Elytra more or less broadly red at base.

b. Median pale elytral crossbar very broad, not lunate; larger, 8-12 mm. $c$. Width of median pale crossbar less than one-fourth the length of elytra; body beneath usually red.

1627. QUADRISIGNATUS.

cc. Width of median pale crossbar about one-third the length of elytra: meso- and metasterna usually dark. 162S. ICHNEUMoNeus.

bъ. Median pale crossbar narrow, lunate on each elytron; smaller species, $4-\tau \mathrm{mm}$.

d. Abdomen red.

1629. QUADRIGUTTATUS.

dd. Abdomen black.

e. Shining. slender; elytral sculpture finer.

1630. NIGRIFRONS.

ce. Subopaque, rather robust; elytral sculpture coarse.

$f$. Disk of elytra without trace of costæ, their tips black; antennæe entirely red.

ANALIS.

$f f$. Disk of elytra obsoletely costate, the tips pale; antennie red. club dusky.

1631. ROSMARUS.

a. Elytra black at base.

g. Elytra entirely black: abdomen black.

1632. THORACICUS.

gg. Elytra with pale median crossbar; abdomen red. rar. RUFIventris.

1627 (5165). Exocleres quadrisignateis Say, Bost. Journ. Nat. Hist. I, 1835,162 ; ibir. II, 638.

Elongate, moderately robust. strongly conrex. Head, thorax, basal third of elytra and under surface dull red; apical tro-thirds of elytra 


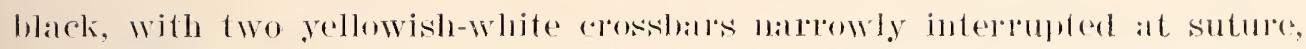
the broader one at middle, the narrower one on apical fourth ; antennæ and legs black. Thorax bell-shaped with a faint transverse groove in front of middle, sparsely and finely punctate. Elytra rather coarsely and very densely punctate. Length $8-12 \mathrm{~mm}$.

Crawford County; searoe. June 25-September 4.

1628 (5171). Enocherts ichneumoneus Fabr., Gen. Ins. Mant., 1757, 230.

Elongate, robust, convex, feebly shining. Head and thorax pale brick red: antennar, legs. pro-, meso- and metasterna black. Elytra black with a very broad median yellowish crossbar, their basal margin narrowly and suture before the crossbar red. 'Jhorax as in the preceding, the transverse groove less evident. Elytra coarsely and densely punctate, their apical fourth densely clothed with grayish hairs. Length S-11 mm. (Fig. 334.)

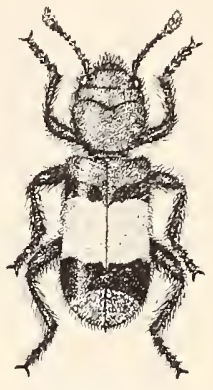

Fig. 334 .

$\times 2 \frac{1}{2}$.

(Original.)

\section{Clark County; rare. May 15.}

1629 (5167). Fnoclerus quadriguttatus Oliv., Ent., IV, 1795, No. 76, 18. pl. 2, fig. 23, $a, b$.

Elongate, moderately robust, subdepressed, subopaque. Head, thorax and basal two-fifths of elytra dull red; antennæ, legs, meso- and metasterna. spot on head (often wanting) and apical three-fifths of elytra black; black portion of elytra with a narrow crossbar very near its front edge and a crossbar or spot (rarely wanting) on apical fourth, whitish. Thorax as in cuadrisignatus. Elytra rather coarsely and densely punctured, the pale crossbar and apex clothed with dense grayish pubescence. Length 4.5$7 \mathrm{~mm}$.

Wells, Putnam and Posey counties; frequent. March 23-November 7 . The var. rufiventris Spin. has a range which should include northern Indiana.

1630 (—). Enoclerus nigrifrons Say, Journ. Phil. Acad. Nat. Sci., III, 1823, 190 ; ibid. II, 121.

Elongate, subdepressed, very shining. Black or fuscous, legs in part and basal third of elytra dull red. Upper surface more finely punctate than in quadriguttatus, which it otherwise resembles. Length $4.5-6.5 \mathrm{~mm}$.

Laporte County; rare. June 27. Two specimens beaten from pine limbs near Dune Park. Iisted as a synonym of quadriguttatus, but now regarded as a distinct species.

$E$. anatis Lee., red, muder surface in great part and legs black; elytra, excent base, black with two whitish erossbars, length 5.5-7 $\mathrm{mm}$. is known from Ohio. Mllinois and westward. 
1631 (5169). Enoclerus rosmarus Say, Journ. Phil: Acad. Nat. Sci., III, 1823, 190 ; ibid. II, 121.

Elongate, convex, slightly wider behind. Dull red, subopaque; elytra with a narrow crossbar in front of middle and a much broader one on apical third, black, the two separated by a curved yellowish-white bar, apex also yellowish-white or pale red; tibiæ and outer joints of antennæ fuscous; abdomen black, polished. Thorax bell-shaped, finely and densely punctate. Elytra with coarse, dense confluent punctures, arranged in very irregular rows; intervals subcostate, especially at base, the pale crossbar and apex clothed with rather dense whitish hairs. Length 4-7 $\mathrm{mm}$.

Southern two-thirds oí State, common; not taken north of Marion and Vermillion counties. May 21-September 16. Occurs especially on the foliage of the greater horseweed.

1632 (5180). Enoclerus thoracicus Oliv., Ent., IV, 1795, No. 76, 18, pl. 2, fig. $22, a, b$.

Elongate, slightly wider behind, subdepressed. Black, often with a bluish or violaceous tinge; thorax and sometimes the front of head reddishyellow, the former with a large black discal spot on basal half (this rarely extending to front margin); legs and antennæe very rarely dusky yellow. Elytra rather coarsely and very densely punctate, obsoletely costate. Length 5-7 $\mathrm{mm}$.

Throughout the State; frequent. May 4--June 28. Occurs on foliage in damp meadows.

\section{Thanasimus Latr. 1806. (Gr., "'mortal.")}

Eyes emarginate in front, finely granulated; maxillary palpi slender; labial palpi dilated; antennal club loosely 3-jointed, very gradually enlarged; tarsi apparently 4-jointed, slender, elongate, claws broadly toothed. Four species are known from America north of Mexico, one of which occurs in Indiana.

1633 (5184). Thanasimus dubius Fabr., Gen. Ins. Mant., 1777, 229.

Elongate, depresseci, subopaque, somewhat wider behind.

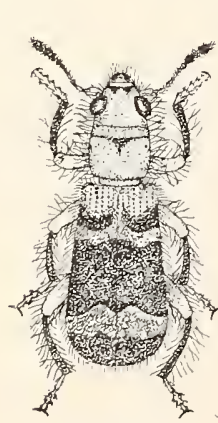

Fig. $33 \tilde{\text {. }}$

$\times 3$.

(Original.) Head, thorax, under surface and base of elytra dull red; antennæe and legs varying from red to pitchy black, the legs usually red, the tibix black; elytra in great part black, with a narrow angulate crossbar in front of middle and a broader sinuate one near apex formed of dense recumbent grayishwhite hairs. 'Thorax bell-shaped, finely and densely punctate and with a deep curved transverse groove in front of middle and a median impressed line behind the groove. Elytra with rows of coarse punctures on basal half, these gradmally indistinct toward apex. Length 7.5-9 mm. (Fig. 335.)

Lake and Elkhart entinties; rare. July 23-Auguist 9 . 
VII. Zenodosus Wolcott. 1910. (Gr., a proper name.)

Eyes small, entire, finely granulated; maxillary palpi moderately compressed; labial palpi triangular, moderately dilated; antennæ stout, club loosely and gradually formed, 3-jointed; tarsi apparently 4-jointed, rather slender, claw joint as long as those preceding united, claws simple. 'The only known species is North American.

1634 (5186). Zenodosus sanguineus Say, Bost. Journ. Nat. Hist., I, 1835, 162 ; ibid. II, 639.

Elongate, rather slender. Head, thorax and under surface fuscous-brown; apical joints of antennse, legs and abdomen usually dull red; elytra bright crimson or blood-red, feebly shining. Head and thorax densely and confluently punctate. Elytra coarsely, densely and rather deeply punctate, the sides subparallel. Length 4.5-6.5 mm. (Fig. 336.)

Kosciusko. Marion, Putnam and Dubois counties; scarce. April 17-December S. Occurs beneath bark and moss.

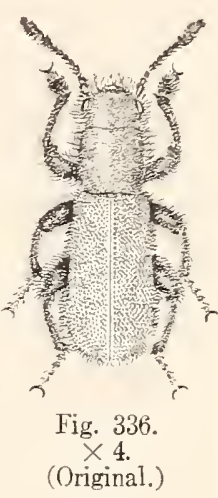

VIII. HydNocera Newm. 1838. (Gl., "swollen+horn.")

Eyes entire, finely granulated; maxillary palpi cylindrical. smaller toward apex of terminal joint; labial palpi elongate, strongly dilated; antennæ rearly filiform. club abruptly formed, compact, subglobose, 2-jointed, the terminal joint very small; tarsi apparently 4-jointed, rather slender, short, claws broadly toothed at base. About 45 species of this genus are known from America north of Mexico. Six of these have been taken in Indiana, while three or four others perhaps oceur.

KEY TO INDIANA SPECIES OF HYDNOCERA.

a. Thorax broader than long or the length and width subequal.

b. Elytra entirely covering the abdomen.

c. Very elongate, strongly convex: black, elytra with a whitish crossbar just behind the middle.

1635. UNIFASCIATA.

cc. More robust and less convex; elytra without crossbar.

d. Flanks of thorax distinctly tuberculate; elytra not densely pubescent, the humeri usually red.

1636. HUMERALIS.

d.d. Flanks of thorax broadly rounded; elytra rery densely clothed with short grayish pubescence.

bb. Elytra shorter than abdomen.

$e$. Head including the eyes narrow; elytra parallel.

PEDALTS.

$e e$. Head including the eves broad; elytra more or less narrowing toward their tips. 
f. Head black, feebly shining, finely rugose; elytra coarsely, dense$1 y$, somewhat confluently punctate.

1637. PALLIPENNIŚ.

ff. Head in part pale, very shining, nearly smooth, not rugose; elytra coarsely, less densely, not confluently punctate.

1638. VERTICALIS.

aa. Thorax conspicuously longer than broad; elytra shorter than abdomen (except in tricondyle).

g. Elytra at base narrower than at apical third.

TRICONDYLE.

gg. Elytra at base as wide or wider than at apical third.

h. Thorax fully one-half longer than broad.

$i$. Flanks of elytra parallel, only slightly abbreviated. SCHusteri.

ii. Flanks of elytra convergent behind, but slightly more than onehalf the length of abdomen.

1639. LONGICOLLIS. $h h$. Thorax very nearly twice as long as wide. 1640. TABIDA.

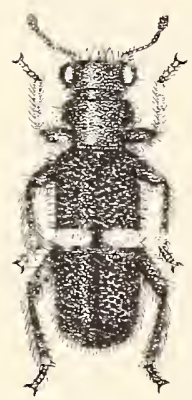

Fig. 337. $\times 5 \frac{1}{4}$
(Original.)

1635 (5189). Hydnocera unifasciata Say, Journ. Phil. Acad. Nat. Sci., V, 1825, 176 ; ibid. II, $2 S 4$.

Elongate, rather strongly convex. Bluish-black; sparsely clothed with erect yellowish hairs; antennæ and tarsi dull sellow. Thorax one-fourth wider than long, sides tuberculate. Elytra coarsely, deeply, closely punctate, the narrow post-median crossbar interrupted at suture and densely clothed with prostrate whitish hairs. Length $3.5-4.5 \mathrm{~mm}$. (Fig. 337.)

Orange and Crawford comties; rare. May 30June 2. Beaten from foliage of oak and hickory.

1636 (5193). Hydnocera humeralis Say, Journ. Phil. Acad. Nat. Sci.. III. 1823,192 ; ibid. II, 122.

Elongate, less strongly convex. Violaceous or bluish-black; elytra dark blue, humeri usually red; antennæ and legs, especially the front pair, usually in great part reddish. Thorax one-third wider than long, constricted near base and apex, the sides moderately tuberculate. Elytra parallel, more finely and densely punctate than in unifasciata. Length $3.5-5.5 \mathrm{~mm}$.

Lake, Starke, Elkhart and Crawford counties; scarce. June 1June 24. The tips of elytra are sometimes dull yellow. In var. difficitis Lee. the elytra are unicolorous.

H. pubescens Lec., dark blue, antennæ and front legs dull yellow, length 3.5-4.5 mm., and $I$. peclatis Lee., black, with a bluish tinge, elytra only slightly shorter than abdomen, $4.5 \mathrm{~mm}$. in length. are both known from Illinois. The latter has also been taken in Ohio.

1637 (5199). Hydnocera Pallimennis Say, Journ. Phil. Acad. Nat. Sci., V, 1825, 176 ; ibid. II, 283.

Elongate, subdepressed. Black, with a tinge of bronze; antennæe and legs pale; elytrat dull rellowish, the side margins, apex, suture and a median crossbar browish or black, the markings often reduced in extent. 
Thorax fully as long as wide, the sides feebly tuberculate. Elytra as described in key. Length $3-5 \mathrm{~mm}$.

Iake Countr ; rale. July 13. One specimen taken near Millers. 1638 (5203). Hyomocera rerticalis Say, Bost. Journ. Nat. Hist., I, 1835, 164 ; ibid. II, 640.

Elongate, moderately conrex. Black, sparsely clothed with suberect hairs; head pale vellowish, with a black oblong spot (often wanting) on rertex; antennæ and legs pale; thorax often with a pale stripe or triangular spot each side; elytra with base dull yellow, rarely entirely black, sometimes entirely pale with tips only black. Thorax cylindrical, as wide as long. Elytra strongly narrowing from base to apex, two-thirds the length of abdomen; coarsely, not densely punctate. Length 3.5-4.5 $\mathrm{mm}$.

Throughout the State; frequent. May 17-July 4 . Beaten from hickory limbs.

H. tricondyl wec, greenish olive-bronz, antennx piceous, legs and paipi dull yellow, length $4-4.5$ mm., and $H$. schusteri Lee., 5-5.5 mm. in length, black, antennæ rale yellow, legs and elytra in part redish-yellow, are both known from Illinois.

1639 (5206). Hydnocera lonatcollis Ziegl., Proc. Phil. Acad. Nat. Sci.. II, $1844,44$.

Elongate, moderately convex. Bluish-black; antennæe and legs and often the front of head, pale rellow; elytra usually with a pale subsutural stripe at base, this sometimes dilated so as to leave only the extreme tips black. Thorax cylindrical. one-half longer than wide. Elytra rather closely but not rery coarsely punctate, the sides conrerging towards apex. Legs elongate. Length $3.5-4.5 \mathrm{~mm}$.

Steuben, Lawrence, Dubois, Perry and Posey counties; scarce. May 23-June 17. Taken by sreeping low herbage, especially in moist places. Said to breed in hickory and witch-hazel.

1640 (5205). Hydnocera tabida Lec., Ann. N. Y. Lyc. Nat. Hist., V, $1849,29$.

Very elongate, subdepressed. Bluish-black; antennie, mouth parts and legs pale reddish-yellow. Thorax subcylindrical, nearly twice as long as wide. Elytra paralleil, distinctly shorter than abdomen, widely dehiscent at suture, coarsely and rather densely punctate. Legs very elongate. Length $5-\tau \mathrm{mm}$.

Dubois County; rare. Мay 24-May 25.

Tribe II. ENOPLIINI.

The members of this tribe are easily recognizable by having the fourth joint of the tarsi atrophied. the tarsi thus appearing. when viewed from above, to be 4 -jointed, except in Orthoplewra. where but three joints are visible. The flanks of thorax are separated from the disk by a more or less distinctly elerated marginal line. In 
the males of most genera the inner angles of the first two joints of the antennal club are much prolonged. Ten genera are represented in America north of Mexico, six of which are known from Indiana, while another may occur.

\section{KEY TO INDIANA GENERA OF ENOPLIINI.}

a. Three outer joints of antennie very large, flat, dilated; six segments of abdomen visible.

b. Eyes emarginate on inner side; antennæ 10-jointed.

c. Last joint of both pair of palpi elongate-triangular; eyes broadly emarginate.

IX. PhyllobanUs.

$c c$. Last joint of labial palpi obconic; last joint of maxillaries subcylindrical, truncate at apex; eyes narrowly but deeply emarginate; body very elongate.

ELIIPoToMA.

bb. Eyes emarginate in front.

d. Basal joint of tarsi not smaller than second, visible from above.

e. Antennæ 11-jointed, joints 2 to 8 distinct.

$f$. Sides of thorax rounded, not constricted before the base; form rather broad, resembling that of certain fireflies.

X. Chariessa.

$f f$. Sides of thorax sinuate, angulately enlarged behind the middle, constricted before the base.

XI. Cregra.

ee. Antennæ 10-jointed, joints 2 to 8 indistinct. XII. PYTICERA.

dd. Basal joint of tarsi small and short, covered by the second; black, thorax yellow.

XIII. Orthopleura.

aa. Three outel joints of antennæ forming a small compact club; five segments of abdomen visible.

XIV. NECROBIA.

\section{Phyllobænus Spin. 1844. (Gr., "leaf + to go.")}

Eyes emarginate on inner sides; last joint of both pairs of palpi very elongate, triangular ; labial palpi a little larger than the maxillary; antennæ 10-jointed, joint 7 very small, joints 8,9 and 10 much larger than the preceding, depressed, last joint ovate, club shorter than funicle; tarsi slender, short, fourth joint rudimentary, claws strongly toothed at base. Two species are known from the United States, one of which occurs in Indiana.

1641 (5210). Phyllobenus dislocatus Say, Journ. Phil. Acad. Nat. Sci.,

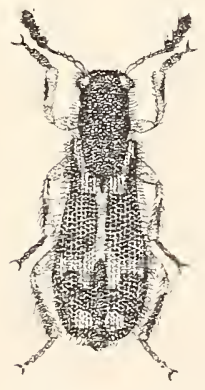

Fig. 338. $\times 4$. (Original.)
V, 1825, 176 ; ibid. II, 284.

Elongate, subcylindrical. Black, moderately shining; antennæ, mouth parts and legs yellow, often more or less fuscous; elytra each with an oblique pale yellow stripe extending from humerus to suture at basal third, thence along suture to just behind middle, where it usually connects with a narrow undulate yellow crossbar; also usually a small yellow subapical spot. Thorax subcylindrical, widest near base; surface, as well as that of head, densely and rather finely punctate. Elytra with rows of very coarse, quadrate, deep and closely placed punctures. Length $3.5-6 \mathrm{~mm}$. (Fig. 338.) 
Kosciusko, Marion, Vermillion, Perry and Posey counties; searce. March 31-June 20. Has been bred from twigs of butternut.

Ellipotoma laticornis Say, very elongate, slender, black, with each sicle of thorax and a broad, lengthwise median stripe on head, orange-yellow, length $5-6.5 \mathrm{~mm}$., ranges from Ohio and Illinois eastward.

\section{Chariessa P'erty. 1830. (Gr., "pleasing.")}

Eyes emarginate in front; palpi subequal, last joint triangular, slightly longer than wide; antennæ 11-jointed, joints 9, 10 and 11 together as long or longer than the funicle, very large, dilated, triangular, first two joints of club more or less prolonged at inner angles; tarsi dilated, first three joints distinctly lamellate, fourth joint very small, claws simple. Five species are known from America north of Mexico, one of which and its named variety are found in Indiana.

1642 (5215). Chariessa pilosa Forst., Nov. Spec. Ins., 1771, 49.

Elongate, subdepressed. Black, subopaque; thorax reddish, with two wide black stripes which are convergent and usually connected at base. Elytra rather finely, densely and somewhat roughly punctate. Length 7.5-13 mm. (Fig. 339.)

Lake, Marshall, Kosciusko and Perry comntios; scarce. May 30-June 24. Has been bred from the twigs of hickory and butternut.

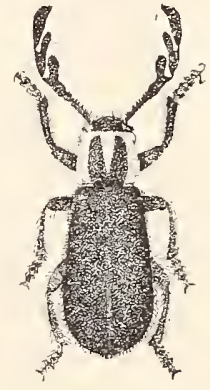

Fig. 339. $\times 2$. Male. (Original.)

1642a (5215a). Chariessa Pilosa onusta Say, Amer. Ent., III, 1828, pl. 41 ; ibid. I, 89.

Differs from the typical form only in having the suture and side margins of elytra yellowish, the femora usually pale at base.

Crawford and Posey counties; rare. May 16-June 4.

\section{Cregra Lee. 1861. (Gr., "charming.")}

Eyes emarginate in front; both pairs of palpi hatchet-shaped, the last joint of labial pair larger; antennæ 10- or 11-jointed, club 3 -jointed, about equal in length to funicle, first two joints triangular, last joint elongate-ovate; tarsi short, rather broad, first joint equal to second, fourth very smail, first three joints distinctly lamellate, claws thickened or feebly toothed at base. Of the seven species known from North America one has been taken in Indiana, while two others may occur. 
KEY TO INDIANA SPECIES OF CREGIA.

a. Antennie 11-jointed; surface of thorax very uneren; elytra coarsely; sparsely punctate at apex.

aa. Antenna 10-jointed.

LEUCOPHÆA.

b. Thorax with longitudinal area on disk, sparsely and rather finely punctate; elytra pitchy black, the sutural and side margins pale.

1643. OCULATA.

bb. Thorax with discal area coarsely, rather densely and somewhat irregularly punctate; elytra pale yellowish, with black markings.

MIXTA.

C'. leucophara Klng. (retusta Spin.), elongate; piceous, legs annulate with yellow; elytra white. base and apex widely brown; length 7.5-11 mm., has been taken at Lexington, Illinois.

1643 (5218). Cregra oculata Say, Bost. Journ. Nat. Hist., I, 1835, 163; ibid. II, 639.

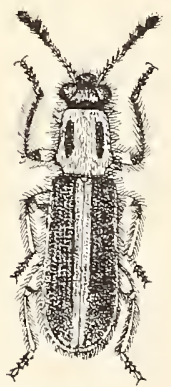

Fig. $340 . \times 4$ (Original.)

Elongate, subcylindrical. Black or piceous, shining; thorax pale yellowish with an oblong black spot each side; spot on front between the eyes, mouth parts, sutural and side margins of elytra, pro- and mesosterna and legs yellow; knees, front tibice and all the tarsi often piceous. Elytra nearly parallel, with rows of coarse, deep, quadrate punctures, these gradually smaller and becoming obsolete at apex. Length 4-6.5 mm. (Fig. 340.)

Starke. I arrence and Posey counties; rare. June 4-July 3. Beaten from the foliage of wild grape.

C. mixta Lee., $3.5-4.5 \mathrm{~mm}$. in length, is known from Maryland. Kentucky and Ohio, and probably oceurs in southern Indiana.

\section{PrTtCerd Spin. 1844.}

Eyes finely granulate, often deeply emarginate; palpi elongatetriangular; antemna 10-jointed, joints 8 to 10 forming a large dilated club, longer than the funicle; tarsi short and broad, four joints visible from ahove, the first three lamellate; claws at base with a tooth-like thickening.

1644 (5220). Pyticera Quadripunctata Say, Jomrn. Phil. Acad. Nat. Sci..

III, 1823, 18S; ibid. I, 90.

Elongate-oval. Black, shining; elytra bright red, each with two large rounded black spots, the first of these before, the other just behind the middle. Thorax subcylindrical. finely and sparsely punctate. Elytra gradually widened from base to apex, rather finely, shallowly and roughly punctate. Club of antennæe in male three times as long as funicle, the inner angles of joints 8 and 9 produced into very long stout branches; club shorter in the female and rami wanting. Length 5-6.5 mm. (Fig. 341.)

Posey County; one specimen from near New Har- Male and antennæ of mony. May 6. Beaten from the flowers of Cratcous.

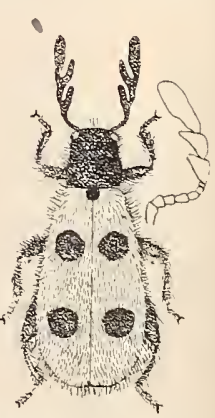
female. (Original.) 


\section{Orthoplemen Spin. 1844. (Gr., "straight+side.")}

Eyes coarsely granulate, emarginate in front; palpi subecpual. cylindrical or obconic; antenna 11-jointed, joints 9 to 11 forming a large club, internal angles of joints 9 and 10 more or less produced, club much longer than funicle; tarsi rather short, first joint covered by the second, second and third furnished with lamellæ, the fourth invisible, the fifth nearly as long as preceding joints combined, claws toothed. One of the two known North American species occurs in the State. 1645 (5225). Orthopleura damicornis Fabr., Ent. Syst. Suppl., 1798, 117.

Elengate, subcylindrical. Black; thorax red, its base and apex usually black or infuscate; elytra often with a more or less distinct pale crossbar at middle. Thorax cylindrical, sides sinuate, hind angles obtuse, disk finely and densely punctate. Elytra parallel, rather coarsely and densely punctate. Length 3.5-8.5 mm. (Fig. 342.)

Kosciusko, Monroe, Isawrence. Orange, Knox and Posey counties; scarce. June 2-August 7.

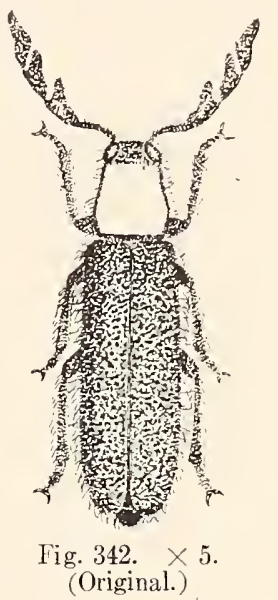

XIV. Necrobía Latr. 1796. (Gr., "corpse + to live.")

Eyes entire, coarsely granulate; last joint of palpi nearly cylindrical, slightly dilated; antennx 11-jointed, club rather small, compact, 3 -jointed; tarsi moderately short and broad, fourth joint very inconspicuous. claws toothed at base. Three cosmopolitan species represent this genus in North America, all of which occur in Indiana.

KEY TO INDIANA SPECIES OF NECROBIA.

a. Red; head, antennæ and abdomen black; elytra blue or green, base broadly red.

1646. RUFICOLLIS.

aa. Dorsal surface blue of green.

$b$. Legs and basal joints of antenmæ red.

bb. Legs and antemnæ dark.

1647. RUFIPES. 1648. VIOLACEA.

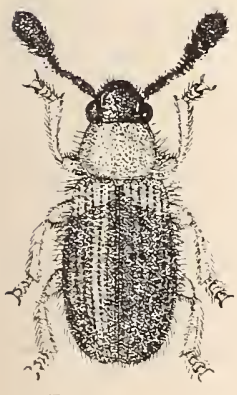

Fig. 343 (Original.)

1646 (5231). Necrobia Ruficollis Fabr., Syst. Ent., 1775, 57.

Oblong-oral, robust. Colol given in key. Head and thorax at sides densely, rather coarsely punctate. Elytral with rows of fine but very distinct punctures, becoming gradually finer behind but evident nearly to apex. Length $4-5 \mathrm{~mm}$. ( Fis. : it:3:)

Lndiand, Stein collection; frequent.

1647 (5230)). Necrobia rugupes Deg., Mem. Ins., V, 1765, 165, pl. 15, fig. 4 .

Elongate-oblong, robust. Color given in key. Head and thorax rather coarsely and sparsely punctate. Elytra finely 
transversely rugose with rows of rather coarse punctures at base. Length 3.5-6 mm.

Indiana, Stein collection; frequent.

1648 (5232). Necrobia violacea Linn., Syst. Nat. (ed. 10), 1758, 356.

Elongate-oblong, robust. Uniform dark blue or green. Head and thorax rather coarsely and densely punctate. Elytra with rows of rather coarse punctures, becoming fainter behind the middle; intervals irregular. finely punctulate. Length $3.2-4.5 \mathrm{~mm}$.

Lake. Vigo. Dubois, Crawford and Posey counties; frequent. April 11-May 17. This and the other two species occur together with Dermestids and certain Nitidulids on the bones and skins of old carrion. The Dermestids are known as "skin beetles" and the species of Necrobia and the Nitidulids which occur with them as "bone beetles."

\section{Family XLIII. P'TTNID E.}

\section{The Deıth-watch Beetles. The Dreg Store Beetles.}

A family of medium size containing speries rarely exceeding one-fourth of an inch in length, which live for the most part on dry vegetable or animal matter, usually the former, which is just beginning to decay. Many of them are therefore found about cellars, old houses and outbuildings, into the woodwork of which they bore, making meanwhile a ticking sound that gives them the name of "death-watch." Others occur in drug and grocery stores, where they feed upon cayenne pepper. cigars, dried roots, etc., and still others in the forest and open woodland beneath the bark and dead leaves. They vary greatly in form, so that no general popular description is possible, and only the fact that the thorax extends forward in a hood-like fashion over the head is of general application. The head is usually well bent under, and not visible from above, and the general color is either cinnamon-brown or black. The name Ptimus, that of the typical genus upon which the family name is based, is from a Greek word meaning "to decay" or "destroy," and applies to the habits of the best known species. which have been carried by commerce over the entire globe.

The principal character's of the Ptinidx, briefly stated, are as follows: MTaxillæ exposed at base, with two ciliate lobes, the palpi short, four-jointed; antennæ inserted upon the front (Ptininæ) or at the sides of the front in the other subfanily, variable in form, 
9 to 11-jointed; head retractile, usually protected by the thorax; labrum distinct; thorax with the side pieces not separate; elytra entire, with distinct epipleuræ: abdomen with five free ventral segments f front and middle coxæ cylindrical or sub-globose, the coxal cavities rounded, open behind; hind coxæ transverse; tarsi fivejointed.

The larvæ of the Ptinidæ occur with the adults, and are white, soft, grub-like creatures, covered with short, stiff hairs or bristles, and when at rest lie in a curved position like the common white grubs of the genus Lachnosterna. They have six legs, but usually move by drawing themselves along on their sides. Only a few species, comprising those feeding upon drugs and upon the wood of living trees, are economically important and injurious. The others may be classed as innoxious.

The principal literature treating of the North American forms is as follows :

LeConte.--"Prodromus of a Monograph of the Species of the Tribe Anobiini, the Family Ptinidx innabiting North America," in Proc. Phil. Acad. Nat. Sci., 1865, 222-244.

Fall, H. C.-_Revision of the Ptinidx of Boreal America," in Trans. Amer. Ent. Soc., XXXI, 1905, 97-296.

Casey._- "Studies in the Ptinida: Cioidxe and Sphindidxe of America," in .Journ. N. Y. Ent. Soc., VI, 1898, 61-93.

LeConte and Horn, in their "Classification," and Henshaw, in his Check List, recognize four subfamilies of Ptinidæ. Fall, in his latest work, recognizes but two, viz., Ptinince and Anobiince, relegating the Lyctince to the family Cucujidæ, as proposed by Maj. Casey, and proposing a separate and independent family for the subfamily Bostrichince. Sharp regards these two subfamilies as forming the family Bostrichidx, and they are so recognized in the present paper.

Fall, in his Revision, records 53 genera and 259 species of Ptinidx as belonging to the North American fauna.

\section{KEY TO SUBFAMILIES OF P'TINID E.}

$a$. Antenna inserted upon the front of head and rather close together at base; thorax without side margin.

Subfamily I. PTINinæe, p. S64. aa. Antennze inserted on the sides of head in front of eyes and usually distant at base; thorax usually margined at sides.

Subfamily IT. Anobirs e, p. 866 .

$[55-23402]$ 


\section{Subfamily I. PTININAE.}

Our members of this subfamily are small-sized species having the antenna inserted on the front and more or less approximate at base, rather long and moderately stout. filiform or feebly serrate. 11-jointed. Head and thorax small, the latter without side margins, the disk frequently swollen or tuberculate. Elytra much wider than thorax. usually oral or globose. Legs long. not contractile. with trochanters in the axils of the thighs; tibix with two small or minute terminal spurs; tarsal claws simple, strongly divergent. Representatives of but two of the eight genera have as yet been taken in Indiana, though those of one other should occur.

\section{KET TO INDIANA GENERA OF PTINTNE.}

a. Elytra not punctured, polished, widely embracing the abdomen at the sides; ventral surface about one-third the width of elytra.

b. Head and thorax entirely glabrous; eyes subfrontal; rentral segments four.

Grbetur.

67. Head and thorax densely covered with small scales and scile-like hairs; eyes on sides of head; thorax tuberculate; rentral segments five.

I. Mezius.

a a. Elytra with rows of punctures, pubescent, much less widely embracing the abdomen, parallel in males, oral in some females; rentral surface nearly equal in width to elytra; eyes large; thorax strongly constricted behind.

II. Ptincs,

Gibbium psylloides Czemp., upper surface glabrous, under surface with dense short, rellowish hairs, ocenrs in houses from Virginia to California.

\section{MeZIUM Curtis. 1828.}

Small species having the eyes rery small, elliptical. flat and widery separated; entir surface except the elytra densely clothed with pale yellow scales and scale-like hairs; elytra smooth, much inflated, highly polished; last antennal joint but little longer than tenth, oval, pointed; ventral surface greatly contracted, segments one to four short; fifth equal to all the preceding united. One species occurs throughout the Tnited States.

1649 (5236). Mezium Americanum Lap., Hist. Nat. des Coleop., I, 1537, 297.

Oral, the elytra subglobose. Dull sellow; elytra piceous, shining. Thorax subcylindrical, sulcate on middle of disk, sides with obtuse tubercles. Elytra very smooth, highly polished. Length $2.5-3 \mathrm{~mm}$.

Marion County; rare. June 26. A single specimen from box which had contained dried insects. Gecurs in houses, where it is said to breed in all sorts of dried animal substances. 


\section{PTINes Linn. 1767. (Gri., "to decay or destroy.")}

Antenne filiform, first joint robust, second smallest, 3 to 11 elongate, subequal; elytra variously clothed with reeumbent hairs or scales and erect bristles. 'Two species are in the collection from the State, and four others probably occur, two of them having been taken by Dury at Cincinnati.

\section{KEY TO INDIANA SPECIES OF PTINUS.}

a. Elytra dissimilar in form in the sexes; elongate, subparallel in male; oval, more or less swollen in female; fourth rentral segment short; female without imner wings.

b. Setre of elytral interrals equal or subequai in length.

c. Erect hairs of elytra shorter; sub-basal and subapical patches of pale scales on elytra conspicuous, especially in the female; head alutaceous.

1650. FUR.

$c e$. Erect hairs of elytra longer" sub-basal and subapical spots of scales wanting on male elytra, represented on those of female by coarse appressed hairs on the humeral region only; surface of head polished.

1651. BRUNNEUS.

67. Alternate elytral intervals with longer erect hairs; length $2.5-3.5 \mathrm{~mm}$.

VILLIGER.

a a. Elytra oblong, more or less elongate, in both sexes; fourth rentral segment longer; both sexes winged.

d. Elytra without recumbent hairs in addition to the erect ones; color black, head, thorax and sometimes base of elytra rufous. FALu.

dd. Elytra with pale recumbent hairs in addition to erect ones.

e. Black, the humeri and apex of elytra bright rufous; elytra with post-humeral and anteapical bands of white recumbent hairs conspicuous.

BIMACULATCS.

ee. Rufous; elytra with a broad black or piceous median band, interrupted at suture; male with form rery elongate and antennæe as long as body; thorax not swollen.

QUADRIMACULATUS.

1650 (5239). P'TINUS Fur Linn., Syst. Nat., II, 1766, 566.

Elongate-oral, male; oval, more robust, female. Pale brown or dull reddish-yellow, male; darker brown, female. Thorax a little narrower than head, nearly as wide as long, sides parallel in front, strongly constricted behind; disk feebly tuberculate and with a tuft of yellowish hairs each side of median impressed line. Elytra elongate, parallel, with prominent humeri. male; elongate-oral without humeri, female: strie slightly impressed. coarsely punctate; surface with patches of pale scales behind the humeri and on apical third, these conspicuous, especially in female. Length 2.S$3.5 \mathrm{~mm}$.

Tamilton and Posey counties; scarce. Jume 7-July 12. Probably thronghout the State. An Old World species, widely disseminated by commerce. Said to be often injurious to museum specimens. 
1651 (5240). Ptixus BRUraxeds Duft. Faun. Austral.. III. 65.

Very similar to fur. from which it is dis-

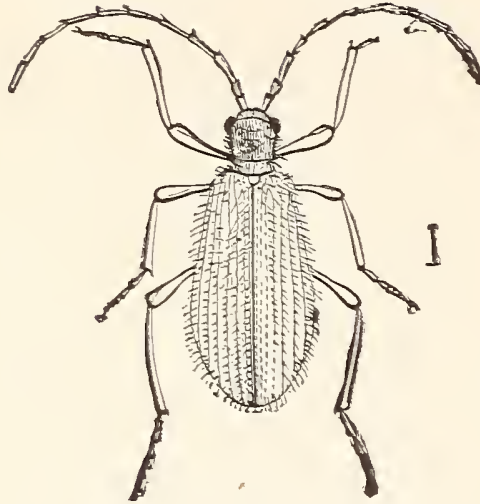

Fig. 344. Male. (After Forbes.) tinguished mainly by characters giren in kes. Color more often pale brown in both sexes. Elytra without trace or patches of recumbent scales except near humerus in the female, and these often lacking. Head behind the antennæ polished and with strong punctures, these visible only when the scales are removed. Length 2.7-3.5 mm. (Fig. 344.)

Hamilton, Marion, Putnam. Crawford and Poser counties: frequent. April 24-December 22. Occurs in old buildings and outhouses. Also an intro-

duced species.

$F$. villiger Reit., is known from New England. Nichigan and westward; P. falti Pic., length 2.3-3 mm.. is recorded from Ohio and Kentucky; $P$. bimaculatus Melsh., length $2-2.8 \mathrm{~mm}$. is recorded from Michigan, Pennsylvania and Missouri, while P. quadrimaculatus Melsh., length 3-3.2 mm., is reported from Ohio.

\section{Subfamily II. ANOB!INAE.}

The insects of this subfamily are mostly of a slightly depressed. subcylindrical form. but varey to broadly oval or nearly globular. The antenna are distant at base and inserted just in front of the eyes, which are rounded and usually prominent. Head deflexed and nearly or quite invisible from above. Hind coxæ. except in the first tribe, more or less sulcate for the reception of the femora. Fall divides the subfamily into six tribes, all of which are represented in Indiana.

\section{KEI TO TRIBES OF ANOBINA.}

a. Front of head not margined, nor with impressed line over the base of antemm; hind coxæ not groored for the reception of thighs: thorax not margined at sides.

Tribe I. Henomisi, 1). Ait.

aa. Front of head margined more or less acutely or with an impressed line above the antenne; hind coxa more or less distinctly groored; thorax margined at sides, except vers rarely.

b. Antennæ of male never fan-shaped, at most pectinate: front tibiw not toothed and denticulate on the onter side; form and sculpture similar in both sexes.

c. Head in repose receired upon the under surface of the thoriax. d. Thorax not excarated beneath, the head free.

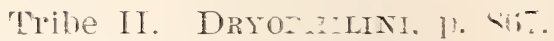
dd. Thorax excarated beneath for the reception of the head. 
cc. Head very strongly deflexed and retracted, the mandibles nearly or quite reaching the metasternum.

e. Metasternum and first ventral segment not grooved for the reception of middle and hind legs; form oblong or elongate-oval; head impressed or excavated beneath for the reception of the antenna.

Tribe IV. Xyletinini, p. S7:3.

ee. Middle and hind legs received in excavations on metasternum and first ventral segment; form varying from elongate-oval to globose; antennæ usually received between the front coxæ.

'Tribe V. Dorcatomini, p. Sti;.

bъ. Antennæ of male strongly fan-shaped; outer margin of front tibiae prolonged at tip in a horizontal tooth, the margin above the tooth finely denticulate; form and sculpture varying in the sexes, the former usually cylindrical; thorax not distinctly excavated beneatll.

Iribe VI. PTILINiNi, p. SS5.

\section{Tribe I. HEDOBIINI.}

The two genera comprising this tribe were placed by LeConte and Horn in the subfamily Ptininæ, but were transferred by Fall to the Anobina. One of the two is represented in the eastern United States, including Indiana, by a single species.

\section{Eucrada Lec. 1861. (Gr., "good + rust.")}

Antennæ widely separated at base, being inserted near the inner margin of the eye, pectinate in male, quite strongly serrate in female; elytra with somewhat irregular rows of punctures.

1652 (5245). Eucrada humeralis Melsh., Proc. Phil. Acad. Nat. Sci., II, 1845,310 .

Oblong, moderately elongate. Dull black; thorax, except basal and apical margins, and humeri of elytra, reddishyellow. Head granulate, densely clothed with grayish-yellow hairs. Thorax about as long as wide, sides rounded, surface granulate, disk obtusely elevated. Elytra with close rows of rather coarse punctures ; intervals narrow, feebly convex, pubescent, the humeral one more conspicuously pubescent, giving the appearance of

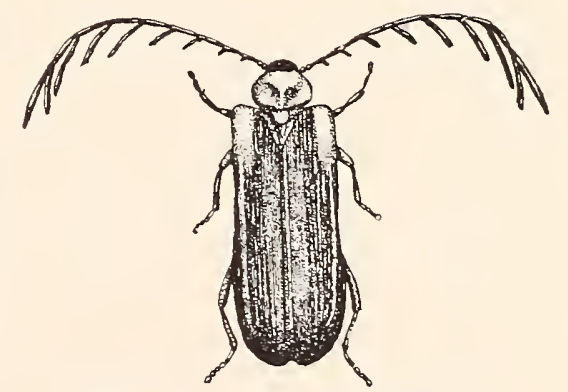

Fig. 345. $\times 5$. Male. (Original.) a costa or raised line along the sides. Length 4-5.5 mm. (Fig. 345.)

Marion, Dubois and Posey counties; scarce. March 23-May 11. Occurs on trunks of dead beech or beneath rubbish in open woodland.

\section{Tribe II. DRYOPHILINI.}

The members of this tribe agree in having the head only moderately deflexed, the thorax not excavated beneath for its reception; 
legs not received in cavities; antenna in repose resting loosely upon the front coxi, usually 11-jointed, the three outer joints more or less dilated and elongated. Two genera are probably represented in Tndiana.

IEY TO INDIANA GENERA OF DRTOPHILINI.

a. Front coxie only moderately prominent, distinctly separated by the process of prosternum ; intermediate joints of antenna subequal.

IV. Xestobium.

aa. Front coxæe conical, very prominent and contiguous; thorax with sharply defined side margins; fourth tarsal joint short, emarginate.

ERNOBIUS.

IV. Xestopinm Mots. 1845. (Gr.. "smooth or dry + live.")

This genus comprises two oblong, moderately stout beetles, having the elytra parallel and irregularly punctate; joints 9 to 11 of antenna longer than those preceding; front coxæ distinctly but narrowly separated, the prosternum short before them, and tarsi wide and densely pubescent beneath. One of the two occurs in Indiana.

1653 (5261). Xestomida ruformlosum DeG., Ins., IV, 1774, 230.

Elongate-oblong, rather stout, parallel. Dark brown. marked with small patches of sooty and rellowish hairs. Antenne a little longer than head and thorax, second joint much narrower than and half as long as first, third twice as long as wide, third to eighth subequal in length and gradually wider. Thorax two-thirds as long as wide, margin rather broadiy flattened and slightly reflexed, angles all rounded; surface, as well as that of head and elytra, densely granulate-punctate. Length 6-7.5 mm.

Fall says of this species: "Rather common locally from the New England States to Illinois," and mentions Indiana as one of the States from which the specimens examined by him were taken. Not seen by me from the State.

Ernobius mollis Linn., ninth joint of antennæ shorter than the three preceding united, brown, Iength $4-5.5 \mathrm{~mm}$, is recorded from Cincimmati; E. lacustris Fall, ninth joint as long as the five or six preceding united, piceous-brown, length 4.8-5.5 mm., was described from Michigan, while E. luteipcmis Lec., ninth joint equal to all preceding in male. reddish or brownish-yellow, length $2.5-4 \mathrm{~mm}$., is known from Ohio and Michigan. All occur on pine.

\section{Tribe III. ANOBIINI.}

Species of parallel and moderately elongate form in which, during repose, the head is received on the under side of the thorax, which is distinctly excavated for its reception; mandibles not reach- 
ing metasternum. the latter never groored for the reception of the legs. The contractile or "doubling-under" power is therefore much less than in the tribes which follow. Eight genera are either represented in the collection at hand or shonld occur in the State.

\section{KEY TO THE IXDIAXA GENERA OF AXOHIXI.}

a. Front coxie contiguous or narrowly separated rexcept in oligomerus sericans); process of prosternum usualls ending in a sharp point.

b. Last joint of both labial and maxillary palpi elongate. spindle-shaped: antennie usualiy 10-jointed.

r. Oligomert's.

66. Last joint of maxillary palyi parallel and obliquely truncate: last joint of labial palpi broadly triangular: antennie 11-jointed.

YI. STTODREPA.

a a. Front coxie distinctly or even widely sepalated : nosteminl process with parallel sides: antennie usually received between the coxie in repose.

c. Antemne not serrate. joints a to 11 long.

d. Tarsal claws with a broad basal tooth: form oblong. densely pubescent and ornamented with tufts of erect hairs.

TII. TRICHODESIA.

di. Claws not toothed.

e. Tentral segments free. sutures distinct: tarsi narrom.

f. Metasterum deeplý excarated in front.

A XOBICM.

ff. Metasternum not deeply excarated in front. at most a little concave.

\%. Third rentral segment short: tibise not moduced on the outer side at apex.

TIII. HADROBREGMTS.

yg. Third ventral segment long: tibia acutely produced on the outer side at apex.

Mírobregira.

ec. Ventral segments firmly united. their sutures. except the first faint or obliterated at middle: tarsi stouter and broader.

Colostethes.

cc. Antennie serrate. joints 9 to 11 not conspicuously longer than those preceding; elstra with rows of punctures: ventral segments united at middle.

IX. TRIPopitis.

\section{T. Oligonerts Redt. 18t5. (Gr.. "small + femur.")}

Front and middle coxæ without an intervening carity for the reception of the antennx: first. third and fourth rentral segments nearly equal and shorter than second and fifth. One species has been taken in Indiana. while another may ocenr.

TEY. TO IXDIAXA SPECIES OF OLIGOAERTS.

a. Front coxie distinctly sepaliated: pubescence of head and thorax erect.

1654. SERICAXS. a. Front coxie contiguous or irtually so: pubescence entirely recumbent. 
1654 (5264). Oligomerus sericans Melsh., Proc. Phil. Acad. Sci., II, 1845, 309.

Elongate, cylindrical, slightly depressed. Piceous brown; head and thorax shining with small scattered granules and clothed with short, erect fuscous hair. Elytra finely scabrous, feebly striate, the striæ with rows of punctures, the inner rows irregular and more feebly impressed; surface clothed with fine inclined hairs. Length $3-4.5 \mathrm{~mm}$.

Marshall, Steuben and Putnam counties; rare. June 11-July 5. Beaten from foliage of oak and linden.

O. obtusus Lec., reddish-brown, length $4.8-7.2 \mathrm{~mm}$., has been recorded from Ohio and Michigan.

\section{Sitodrepa Thom. 1863. (Gr., "food + pluck.")}

The single member of this genus has the antennæ less than onehalf as long as body, 11-jointed, the first joint elongate, rather stout; joints three to eight small, ninth equal to the five preceding, tenth and 11th each equal to ninth; the last three united much longer than all preceding; front coxæ separated by a triangular intercoxal process.

1655 (5267). Sitodrepa Panicea Linn., Syst. Nat., II, 1766, 564.

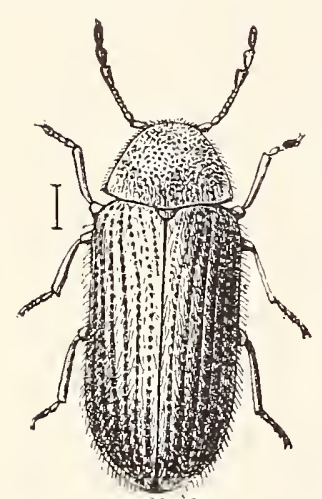

Fig. 346 . (After Sharp.)

Oblong, moderately robust. Reddish-brown, with rather long and somewhat bristling yellowish pubescence. Thorax as wide as elytra, a little narrowed from the base, side margin narrow in front, finely serrate; front angles somewhat rounded, hind ones broadly rounded, surface sparsely granulate. Elytra finely striate, the strix with rows of punctures; intervals with a single line of punctures bearing semierect hairs. Length $2.5-3.5 \mathrm{~mm}$. (Fig. 346.)

Kosciusko, Marion, Vigo and Knox counties; frequent. June 15-November 7. A cosmopolitan species which has been widely diffused by commerce. Usually found in drugs of various kinds, such as ginger, rhubarb, chamomile. boneset, licorice, peppermint and seeds of every description; hence the common name "drug store beetle." It is also often called the "biscuit weevil," being found in households. where it feeds upon flour, meal, breakfast foods, dried beans and peas, chocolate, black pepper, coffee, etc., and is sometimes injurious to manuscripts and books. Its injuries are to some extent limited by the attacks of a small mite and a chalcis fly, which are parasitic upon its larve. The best remedy for it is the subjection of the object attacked to the fumes of bisulphide of carbon. 
VII. Trichodesma Lec. 1861. (Gr., "hair+band.")

The members of this genus are readily known from all other Ptinidx by their oblong, convex bodies, which are densely pubescent and ornamented with tufts of erect hairs. 'The antennæ are 11jointed, the three outer joints large, elongate and together as long. as the preceding united; front and middle coxæ widely separated, the prosternum broadly truncate behind. One species is frequent in Indiana, while another may occur in the southern counties.

1656 (5277). Trichodesma gibbosa Say, Journ. Phil. Acad. Nat. Sci., V, 1825. 171 ; ibicl. II, 280.

Oblong, moderately robust, densely clothed, except on basal thirds of thorax and elytra, with grayish-white recumbent hairs. Thorax slightly narrower than elytra, sides feebly curved and couvergent near hind angles, which are broadly rounded; disk strongly swollen, surface densely granulate, each granule bearing a long, fine erect hair; the summit of the disk with a divided tuft of brown and brownish-yellow hairs, and in front of this two smaller similar tufts. Elytra with coarse punctures arranged in somewhat irregular rows and numerous small granules which are more conspicuous on basal third the grayish-white appressed hairs form a broad oblique band just behind the middle; each elytron with two elongate tufts of brownish hairs in front of middle and four smaller tufts in a curved row on apical fourth. Length 4.5-6.5 $\mathrm{mm}$.

Throughout the State; frequent. May 26--July 5. Occurs most commonly on foliage of hickory, maple and redbud.

T. Klagesi Fall, having the pubescence of elytra less dense and hairs of elytra tufts uniformly blackish-brown, is known from Ohio and Kentucky.

Anobium striatum Oliv., elongate, subcylindrical, brown, opaque, length 2.7-4 mm., is a true "death-watch beetle" which is common to Europe and America.

\section{Hadrobregmus Thom. 1859. (Gr., "thick+head.')}

Elongate, subcylindrical species covered with fine, short, recumbent pubescence; front and middle tarsi widely separated, the antennæ in repose received between them. Our species have the antennæ 10-jointed, the three outer joints elongate, together longer than all the preceding. Two species have been taken in Indiana, while another doubtless occurs.

KEY TO INDIANA SPECIES OF HADROBREGMUS.

a. First ventral suture straight, the second segment not quite as long as fifth; size larger, $3.5-7 \mathrm{~mm}$.

b. Disk of thorax slightly gibbous or humped, compressed behind, sides converging and usually feebly sinuate behind the front angles.

1657. Carinatus. 
bT. Inisk of thorax strongly whbous or raised into an obtuse cone. sides nearly straight and parallel for more than tro-thirds their length.

165S. LINEARIS.

ad. First rentral suture bisinuate. broadly curred backirard at middle. the second segment a little longer than fifth; smaller, not orer $2.5 \mathrm{~mm}$.

PESILLTS.

1657 (5271). Hadrobregarts carinates Say, Journ. Phil. Acad. Nat. Sci.. III. 1S23, 1ST: ibid. II. 120.

Elongate. subcrlindrical. Reddish- to piceous-brown. Thorax nearly equal to elrtra in width; sides rounded. conrergent: hind angles undefined: disk slightly swollen, finely granulate-punctate, compressed a little behind the middle and often with a median carina on basal third. Elrtra with moderatels impressed. strongly and closely punctate strix. Length 3.5$6.5 \mathrm{~mm}$.

Throughout the State: frequent. May 21-July 21. Occurs on soft maple and beech logs in low. moist woods: taken also at light. 165s (52i2). Hanrobregres linearis Lec.. Proc. Phil. Acad. Tat. Sci.. 1ธ65. 232.

Resembles carinatus. from which it is distinguished mainly by characters giren in kes. Color blackish-brown. Punctures of elytral strice obsolete $0 \mathrm{r}^{2}$ very indistinct. Length $4.5 \mathrm{~mm}$.

Steuben Countr: rare. June 17. Taken from the split trunk of an oak. A northern species known from the Hudson Bar Region and near Detroit. Michigan.

H. pusillus Fall, reddish-bromm. disk of thorax strongly swollen and compressed behind, was described from Ohio and Wisconsin.

Hicrobregma emarginatum Duft. brown, thorax not as wide as elvtra, length $1-5 \mathrm{~mm}$.. is known from ilichigan.

Colostethus notatus Sar. dark brown, pubescence of elrtra rariegated, length $3.2+1 \mathrm{~mm}$. is said to ocen from New England to Tissouri on old oak branches.

\section{Tripopitrs Redt. 18ts. (Gr.. "to bore+ pine.")}

Antenna more or less serrate, the three outer joints not conspicuously longer than those preceding: sutures of rentral segments obsolete at middile. the median area of abdomen rather densely punctate. the large punctures with an encircling ring. One of the two known species occurs in Indiana.

1659 (5281). Trypopitys sericers Saj. Journ. Phil. Acad. Nat. Sci.. T. 1ร25. 172 : ibid. II. $2 \subseteq 0$.

Oblong. subcrlindrical. Scoty brown. sparsely clothed with short brownish-rellow recumbent hair's. Head deeply sunk within the thorax. the eres almost corered in repose. Thorax not quite as wide as elrtra, about as 
long as wide, sides parallel, broadly sinuate at middle; hind angles nearty rectangular, sharply defined; disk erenly convex, with an impressed line at middle and a transverse impression each side on basal third. Elytra with regular rows of close-set, rather deep. quidrate punctures; intervals sighthtly convex, not much wider than the punctures. Length $5-6.2 \mathrm{~mm}$.

Starke, Putnam, Vigo and Tawrence counties; scarce. June 12-October 12. Occurs beneath bark and on old branches of wild cherry and oak.

Tribe IV. XYLETININI.

Usually elongate-oval species having the contractile power fairly well developed; thorax excarated beueath for the head, which is strongly bent under in repose, and more or less impressed or exeavated on the under side, the antenne curving into the cavities and resting against the front coxæ. The antennx are 11-jointed and variable in form. Two of the six genera comprising the tribe are represented in Indiana, while another may occur.

KEY TO INDIANA GENERA OF TILETININI.

a. Elytra striate; head merely broadly impressed beneath in front, not distinctly excavated for the reception of the antenne, the latter strongly serrate, the three outer joints not elongate; metasternum not sloping downward in front.

$\mathrm{X}$. Irtetinus.

a a. Elytra not striate; head deeply excavated beneath for the antenne.

b. Antennie serrate, the outer joints not elongate; metasternum strongly sloping domnward in front.

XI. LASIODERMA.

bъ. Antenna not serrate. joints 9-11 elongate; metasternum more gradually sloping downward.

MEgORAMA.

\section{Xyletnes Tat. 1829. (Gr.. "wood + destroy.")}

Oval to oblong species, having the thorax wider than long, the hind angles broadly rounded and undefined, the front angles nearly rectangular and scarcely rounded; elytra striate, the outer and inner striæ uniting on apical third; rentral seginents nearly equal, the first, second and fifth somewhat longer than the third and fourth. Three of the nine known species have been taken in Indiana.

KEY TO INDIANA SPECIES OF XTLETINLS.

a. Form cylindrical; eyes. especially those of male, linger and more convex; width of front about twice as wide as that of eye when riewed from the front; color brown or reddish-brown.

b. Last joint of maxillary palpus elongate, feebly triangular ; thorax more parallel, the side marcins rery narrow and not at all reflexed. 
67. Last joint of maxillary palpus broadly triangular; thorax less parallel, the side margins narrowis but eridentls reflexed; form more robust.

HARRISII.

a a. Form more oral; eyes small, not rery conrex, scarcely larger in the male: width of front fire or six times that of eye as seen from front: color piceous or dark brorrn.

c. Antenne acutely serrate; first two rentrals of male without line of erect hairs; sides of thorax flattened.

1661. FCCATCS.

cc. Antennie subpectinate in the male; first two rentral segments of male with a median line of short, dense, erect hairs; sides of thorax not flattened.

1662. LLGLBRIS.

1660 (5292). Nreetixts peltatus Harris. Trans. Hartf. Nat. Hist. Soc., I, $1836,75$.

Elongate-oblong. Bromn or reddish-brown, clothed with fine. silky rellowish pubescence. Antenne moderately serrate, joints 3 to 10 triangular, terminal joint elongate-oral or nearly spindle-shaped. Head finely and densel $\Sigma$ punctate. feebl $y$ obtusels carinate at middle. Thorax moderately narrowed in front, disk conrex, broadly impressed each side on basal third. learing the median line ver's convex, resembling a carina : surface finelr and sparsely punctate. Elytra with narrow, lightls impressed strix. which are finely. not closely punctate. Length 3.5-5 mm.

Putnam and Kosciusko counties: rare. July 4-September 7. Beaten from the foliage of the Tirginia Creeper.

I. harrisii Fall, length $3.7-5.5 \mathrm{~mm}$, was described from Ohio, Kentuck and Michigan.

1661 (5295). Arletixus fucatus Lec., Proc. Phil. Acad. Nat. Sci., 1S65, 238.

Elongate-oral, conrex. Black or piceous black, clothed with fine, short and rather sparse pubescence. Antennxe with joints 3 to 9 almost trice as wide as, long, male. or slightly wider than long. female. Eres small, separated on the front br about fire times their longest diameter. Thorax strongly transrerse. median line feebly elerated at base. sides flattened but scarcely refiexed, surface densely, finels punctured and with larger shallow punctures on the sides. Elytra finely rugose-mrinkled, deeply and finely striate, the strix rers feebls punctate; intervals nearly flat. Length $3-$ $5 \mathrm{~mm}$.

Marion County, scarce. May 28-May 29. Taken from the side of stone abutments. where they were basking in the sunshine.

1662 (5296). Xrletixts legubris Lec, Proc. Amer. Phil. Soc, XVII. 1sis, 612.

Resembles fucatus, but smaller and more elongate. Antennæ subpectinate in male, acutely serrate in female, where the intermediate joints are about as wide as those of male fucatus. Sides of thorax less flattened and more strongls sloping downward on basal half. Length $2.5-3 \mathrm{~mm}$.

Starke, Marion and Poser counties: scarce. March 23-June 18. Beaten from foliage of oak. Probably hibernates beneath bark. 


\section{Lasionerma Stephens. 1832. (Gr., "hairy + skin.")}

Oval, more or less elongate, moderately convex, species having the body clothed with recumbent pubescence; antennx serrate, but not strongly so, the outer joints not more elongate; elytra not striate; metasternum short, suddenly sloping downward in front from side to side, the declivity limited behind by a transverse raised line extending across the body. Two of the five known species occur in Indiana.

1663 (5299). Lasioderma serricorne Fab., Ent. Syst., I, 1798, 241.

Elongate-oval, inoderately convex. Uniform dull reddish-yellow or brownish-red. Head broad, eyes small. Antenne rather narrow, second and third joints smaller than first, the third distinctly triangular; fourth to tenth about as wide as long; eleventh oval. Thorax strongly convex, front angles

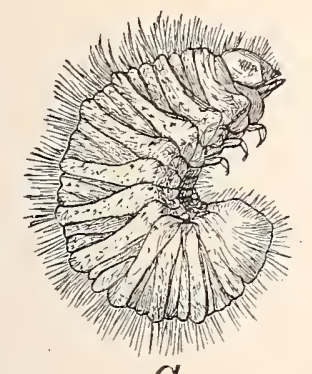

a.

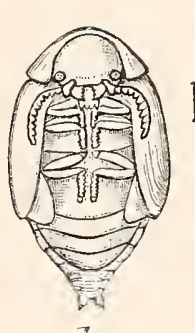

b

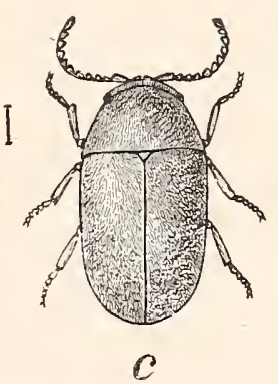

c

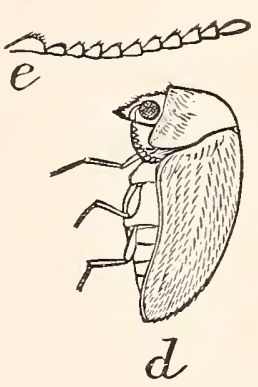

$d$

Fig. 347. $a$, larva; $b$, pupa; $c$, beetle; $d$, same, side view, $e$, antenna. All enlarged. (After Howard and Marlatt, in Bull. IV, Div. Ent., U. S. Dept. Agr.)

acute, hind angles wanting. Punctuation of entire upper surface fine, uniform, not dense. Length 2.2-3 mm. (Fig. 347.)

Howard, Vigo, Marion, Putnam and Lawrence counties; frequent locally. April 10-November 7. Specimens in all stages were found in smoking tobacco put up in tin boxes on the earlier date. Widely distributed over the world by commerce and feeds on a variety of dried vegetable products, such as cayenne pepper, ginger, rhubarb, rice, figs, yeast cakes and prepared fish food. 'Tobacco it devours in every form, in the leaf and when made up into chewing plug, cigarettes and cigars. It is, therefore, often known as the "cigarette beetle." Both it and the larvæ may be destroyed by submitting them to the fumes of bisulphide of carbon, or by steaming the substance in which they are found. Drugs which are badly infested should, however, be burned.

1664 (--). Thasioderma semirufum Fall, Trans. Amer. Ent. Soc.. XXXi, $1905,205$.

Elongate-oral. Head. thorax. under surface and appendages reddishhrown; elytra dark chestnut or piceous brown. Sculpture as in serricorne, 
the pubescence a little shorter and more recumbent and the punctuation a little sparser. Metasternum with a fine raised line extending from the side margin obliquely inward and backward. Length $1.5 \mathrm{~mm}$.

Lawrence County; rare. June 6. Swept from vegetation at side of wagon road. Known heretofore from New Jersey to Ohio. The small size, more elongate form and bicolored upper surface readily distinguish it from serricorne.

Megorama simplex Lec., elongate-oval, blackish-brown, with fine recumbent grayish-yellow pubescence, length $3.5-4.5 \mathrm{~mm}$., was described from Kentucky.

\section{Tribe V. DORCATOMINI.}

The members of this tribe are distinguished from all others of the family by their highly developed contractile power. The antennæ and mouth organs are completely hidden in repose, the head being strongly reflexed and received into a deep cavity on the under side of the thorax and the legs withdrawn into suitable excavations in the meso- and metasternum and first ventral segment. In form they are usually broadly oval, varying to elongate-oval or even globose; and all are less than $3.5 \mathrm{~mm}$. in length. Fall in his Revision removes to this tribe a number of genera placed by LeConte and Horn in the Anobiini and Yyletinini, so that the elassification and arrangement of the Henshaw List is much broken up. In all the genera so removed, the metasternum and first ventral segment are deeply excavated for the middle and hind pairs of legs, these excavations forming the principal characters upon which the tribe Dorcatomini is based. Of the eleven genera recognized by Fall, representatives of seven have been taken in Indiana. The genera, as well as the species of each, are very difficult to separate unless they are clean and opened up so that the under parts can he readily studied with a lens.

\section{KEY TO INDIANA GENERA OF DORCATOMINI.}

a. Front coxæe expanded at apex into transverse horizontal plates which are not concealed in repose; trochanter joined to the coxa from behind.

b. Metasternum with broadly expanded front lobe which covers the mouth in repose; hind coxal plates wider on the inner side; form elongate-paxallel.

XII. Petalium.

bb. Metasternum with a short front lobe which does not reach the mandibles; form elongate-oral.

c. 'Two outer joints of antennre closely united; front coxre widely separated; hind coxal plates wider on the outer side; mesosternum depresser.

XIII. Eupactus. 


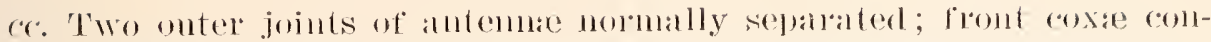
tignous; hind coxal plates nalrow and palabllol; mososternum strongly elevated into a central keel which is horizontal and attains the level of the metasternum.

'THEC'A.

aa. Front coxie not expanded into apical plates, entirely slunt in in refose : trochanter joined to the alpex of the coxa.

d. Front coxa contiguous or nearly so; head innpessed or excavated beneath for the antennie.

c. Punctures of elytra confused. not in rows; metasternum not lobed in front; epiplenre without small pits for the reception of hind knees ; antennie 10-jointed.

XIV. Catorama.

ec. Punctures of elytra in rows; metasternum apparently broadly lobed in front, on account of deep and narrow excavations for middle tarsi; epipleura with small pits for the hind knees; antennse 9or 11-jointed; pribescence more or less bristly. XV. Pкотнeca.

dd. Front coxie widely separated, antenna received between then.

f. Prosternum produced behind into two long, slender, horn-like processes; antemme 10-jointed ; form oval, moderately elongate.

XVI. DoRcatoma.

ff. Prosternum truncate and emarginate behind; antennæ 8-, 9- or 10jointed.

\%. Eyes minutely emarginate; elytra without strise on the disk; form broadly oval.

XVII. Eutruistus.

yy. Hyes deeply and acntely incised, the notch extending to or beyond the middle; form nearly globose. XVIII. Cenocara.

\section{Petalium Lec. 1861. (Gr., "a leaf.")}

Small, parallel, more or less elongate, rather strongly convex species, having the antenna 11-jointed, about one-third the length uf body, joints 9 to 11 together as long or slightly longer than all preceding; thorax as wide as elytra and with a short curved, deeply impressed tine on sides behind the front angles; strongly excavated beneath for the reception of the heal: prosternum short, front coræ widely separated; second ventral sogment as long as the three following united.

\section{KEY TO INDIANA SPECIES OF PETALIUM.}

a. Punctures of elytral rows strong, close-set and distinct quite to apex, the two lateral lows not much deeper than those on disk.

1665. SERIATUM.

aa. Punctures of elytral strixe finer, less close-set and becoming nearly obsolete on apical third, the two lateral rows conspicuously deeper.

1666. BISTRIATUM.

1665 (-). Petalmu seriatum Fall, Trans. Amer. Ent. Soc. XXXI. 190.5. 215.

Moderately elongate. Brown. distinctly though sparsely pubescent. Head and thoras densely punctate throughout; the latter with disk a little prominent, with well-defined oblique impressions each side. its front malogin 
thickened and reflexed. Elytra punctate as mentioned in key, the intervals with fine, confused punctures. Width of front of head less than the vertical diameter of the eye in male; a little greater in female. Length 2$2.3 \mathrm{~mm}$.

Vigo and Orange counties; scarce. May 14-June 1. Taken by sweeping vegetation in low ground. Larger and a little stouter than the next, always brown, never black as there, with the eyes relatively larger and the front narrower than in the corresponding sex of bistriatum.

1666 (5283). Petalium bistriatum Say, Journ. Phil. Acad. Nat. Sci., V, 1825, 172 ; ibid. II, 281.

Moderately elongate, sides parallel. Black or dark reddish-brown, feebly shining, pubescence fine and sparse, legs and antennæ usually paler. Thorax with disk slightly elevated at middle, and with oblique impressions each side; front margin thickened and evidently reflexed, surface finely and densely punctured, hind angles sharply defined. Elytral striæ not impressed except the two marginal ones, which are deeply so; intervals very finely and sparsely punctulate. Length 1.7-2 $\mathrm{mm}$.

Throughout the State; frequent. June 1-July 12. Taken by sweeping or beating low vegetation.

\section{Eupactus Lec. 1861. (Gr., "well + joined.")}

Elongate-oval, very convex species, either glabrous or with very fine, short, appressed pubescence. Antennæ 11-jointed, first joint large, curved; second scarcely narrower and much smaller; third much narrower, elongate-triangular; fourth to eighth as wide as third; ninth much wider, compressed and equal to 3 to 8 united; tenth and eleventh closely united, forming an oblong mass, rounded at apex. Thorax narrowed in front, deeply excavated beneath, side margins very narrow, not visible from above; elytra irregularly punctate, very rarely with discal strix; first ventral segment deeply excavated throughout, segments 2 to 4 gradually decreasing in length, fifth longer.

1667 (5286). Eupactus nitidus Lec., Proc. Phil. Acad. Nat. Sci., 1865, 236.

Elongate-oval, strongly convex, not quite twice as long as wide. Black or dark reddish-brown, polished, surface entirely glabrous. Thorax strongly narrowed in front, sides nearly straight; punctuation simple, sparse and rather fine on disk, closer and coarser on sides. Elytra wholly without strix. Last ventral segment with a deep marginal impressed line or groove. Length 2-3 $\mathrm{mm}$.

Knox and Posey counties; rare. July 2-July 3. 
1668 (-). Eupactus obsoletus Fall, Trans. Aner. Ent. Soc., XXXi, $1905,220$.

Narrowly oval, nearly two and a halt times as long as wide. Brown, subopaque, finely and feebly pubescent. Thorax rather coarsely and closely punctate on sides, more finely at middle. Elytra with obsolete rows of closely placed punctures on disk; marginal striæe two, feebly impressed and marked by punctures toward the base, with a short inner third stria composed of punctures. Length $2-3.5 \mathrm{~mm}$.

Posey County; rare. July 9. A species of southern range.

Theca profunda Lec., elongate-oval, piceous, antennx, legs and abdomen reddish, length 2-2.5 mm., is known from Michigan.

\section{Catorama Guer. 1850. (Gr., "downward + to view.')}

A large genus of sma!l, broadily to narrowly oval, convex species, clothed above and below with short appressed pubescence. Antennæ 10-jointed; first joint larger, second much smaller, obconic; third to seventh very small, about as long as wide; eighth large, triangular, as long as the six preceuing united; ninth similar to but slightly smaller than eighth; tenth longer, oval. 'Thorax evenly convex; moderately strongly curved each side at middle, sinuate each side, front angles acute, hind ones broadly rounded; elytra irregularly punctate, usually with two marginal striæ extending from middle to apex, one or both of these often lacking. Metasternal process produced into a stout acuminate hook, curved backward and clasped by the mandibles in repose; first ventral segment excavated for the reception of the hind feet and nearly concealed by them; segments $2-4$ decreasing a little in length, the fifth longer. Seven species have been taken in Indiana, while three additional ones may occur.

KEY TO INDIANA SPECIES OF CATORAMA.

a. Front tibiæ with only a single well-defined groove on the outer face; metasternum not carinate; color varying from red-brown to piceous brown.

VENTRALE.

aa. Front tibiæ with two grooves on the onter face.

b. Middle tibiæ with an evident marginal groove.

c. Metasternum carinate; form strongly elongate; color brown.

1669. PUNCTATUM.

cc. Metasternum not carinate.

d. Punctuation of upper surface fine and close throughout, coarser punctures absent; elytra piceous, head, thorax and under surface reddish-brown.

1670. DICHROUN.

dd. Punctuation of elytra of two kinds, the surface finely punctulate with coarser punctures intermixed.

[56-23402] 
c. Color blalck on neally so; punctuation relatively sparse; surface shining.

1671. NIGRITLLLM.

ec. Color rufous to piceous. usually some shade of brown; punctuation closer; surface less shining.

f. Form more elongate, twice as long as wide; pubescence finer and shorter; profile not in the least gibbous.

1672. VEXATLM.

ff. Form more oral. about three-fifths as wide as long; pubescence more conspicnons.

67. Middle tibia without marginal groore.

1673. GRATE.

g. I'ubescence exceedingly short. sparse and indistinct; color chestunt

brom to blackish.

1674. CASTANEL

gg. Pubescence normalls dereloped.

h. Form evidently gibbous in profile. elytra not parallel; coarser punctures scarcely risible on any part.

BOREALE.

h.h. Form not gibbous in profile. elytra parallel.

i. Inner lateral stria of elytra feeble or indistinct; size smaller. under 2 mm.. and more elongate; coarser punctures lacking.

GRACILE.

ii. Lateral strixe of elytra well dereloped; size medium, 2-2.7 mm. ; coarser punctures evident on elytra and sides of thorax.

1675. CONFLSUM.

C. ventrale Lec., parallel, twice as long as wide, length 2-2.4 mm., has been recorded from Cincinnati.

1669 (5309). Catorana plictatear Tec.. Proc. Phil. Acad. Nat. Sci., 1S65, 240.

Elongate. subcrindrical. more than twice as long as wide. Uniform reddish-brown. rather finely and sparsely pubescent. Elytra densely and rather finely punctured. Front tibice with two deep groores, middle tibia with one. Length 2.1-2.5 mm.

Marshall and Narion countios; rare. Nlay 22-June 10. Ranges from Indiana south and southwestward.

1670 (- -). Catorama dichrous Fall, 'Trans. Amer. Entom. Soc. XXXI. 1905, 240.

Oblong-elliptical. twice as long as wide. Piceous brown; head. thorax and rentral surface reddish-bromn. Upper surfice finely. erenly and rather closely punctulate throughout. Eighth antennal joint broady subquadrate. triangular, nearle as wide as long. Metasternum with coarser and fine punctures intermingled. the former reaching the sides. Length 1.S-2.5 1 mn.

Marion County: scarce. April 6.

1671 (5318). Catorain migrtecruar Lec., Proc. Phil. Acad. Nat. Sci.. 1865. 241.

Elongate-oral, moderately robust, less than twice as long as wide. not narrowed behind. Black or piceous; pubescence sparse and rery fine. Head and thorax finels. closely and erenly punctulate without intermixed coarser punctures. Elytra finely punctulate with scattered larger punctures. Eighth antennal joint broadlỵ triangular. Length 1.7-2.4 $11 \mathrm{~m}$.

Vermillion and Larrence counties; scarce. May 24-June 13. 
Catorala rexatuar Fall, Trans. Amer. Ent. Soc, XXXI. 1905,245

Oblong-elliptical. twice as long as wide: pubescence fine and rather sparse. Bromn, nearly uniform. Coarsel punctures variable, but usually moderate in size and not prominent. Eighth antennal joint slishtly longer than wide. quadrate-triangular. Metasternum punctured from side to sirle. Length $2.5-3.5 \mathrm{~mm}$.

Knox. Orange and Crawford counties: scarce. Mlay 23-July 26. Resembles grave closely. but distinctly more elongate. with sparser. shorter pubescence. less flattened eres and without impressed front.

1673 (5309). Catoraya Grate Lec. Proc. Phil. Acad. Nat. Sci.. 1s5s. 72.

Oblong-elliptical, quite robust. slichtly less than three-fifths as wide as long. [niform dark bromn: pubescence rather plentiful but not concealing the punctuation: coarser punctures distinct throughout. moderate in size. Eighth antennal joint triangulax. a little longel than wide. Length 2.5$3.5 \mathrm{~mm}$.

Poser County: rare. May 11-June 4. Onl largest and most robust species of the genus. It and the other species are mostly taken by beating regetation.

167 (10.155). Catoraya castatecar Hamilton. Cam, Ent. 1593. 30 i.

Oblong-ellintical, distinctly mole than half as wide as long. Dark reatdish or chestnut bromm. highly polished: pubescence of elrtra rerr short and sparse. Thorax finels and sparsels punctulate at middle. more coarsely on sides. Elrtra mith coarser punctures erenly distributed on disk but showing a tendencr to be in rows on sides. Eighth antennal joint triangular and as wide as long in female. transterse and subquadrate in male. Length 1.5-2.5 $\mathrm{mm}$.

Lake. Fosciusko and Tippecanoe counties: scarce. June $11-$ July 12. Readily known by its rolor and shining surface. Occurs on huckleberry (Taccinium) and other low bushes.

C. boreate Lec.. piceous. length $2.3-3$ mm.. is recorded from Michigan and Ohio. and C. gracile Fall. reddish-brown. length 1.i mm. was described from near Cincinnati.

1675 (一). Catorana coxfestar Fall. Trans, Amel. Ent. Soc. XXXI. 1905. 252 .

Oblong-elliptical, about three-fifths as wide as long. Dark piceous bromn, pubescence medium in length: coarser punctures numerous and rather large at the sides of the thorax and on the elrtra. Eighth antennal joint quarlute-triangular. little more than one-fourth longer than wide. Metasternum rather strongly punctate at midale. the sides without punctures. Length 2-2.7 mm. (Fig. 345$.

Throughout the State: frequent. April

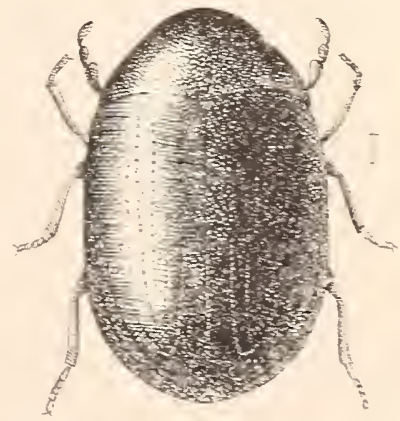

Fig. 31s. $\times 10 \frac{1}{2}$. (Original.) 26-July 4. Beaten from low regetation along roadsicles. 
XV. Protheca Lec. 1865. (Gr., "first+case or box.")

Oblong-oval species clothed with semierect pubescence; thorax wider than long, gradually narrowed in front, sides nearly straight, hind angles rounded, front angles rectangular and sharply defined. 'Two species are known, one of which has been taken in the State, while the other probably occurs.

\section{KEY TO SPECIES OF PROTHECA.}

a. Antennæ 9-jointed; punctures of elytral series coarser, distinct to apex.

1676. PUBERULA.

aa. Antennæ 11-jointed; punctures of elytral rows fine, obsolete behind the middle.

HISPIDA.

1676 (5319). Protheca puberula Lec., Proc. Phil. Acad. Nat. Sci., 1865, 241.

Oral, less than twice as long as wide. Dark brown, moderately shining; pubescence inclined, fine and rather sparse. Antennæ 9-jointed, the serenth to ninth joints forming a broad club, longer than the preceding united. Thorax rather coarsely but not deeply punctate, the punctures closer on the sides. Scutellum as long as wide. Elrtra feebly striate, the punctures of the strixe rather coarse and close. Length 1.7-2.2 $\mathrm{mm}$.

Marion and Knox counties; rare. June 8-November 17. Taken on the later date by sifting.

P. hispida Lec., brown, length 1.6-2.4 mm., is recorded from Ohio and Michigan.

\section{Dorcatoura Herbst. 1792. (Gr., "deer+joints.")}

Small oval or moderately elongate convex species, having the antennæ 10-jointed, the first joint large, ear-shaped; second much smaller, dilated at middle; third to seventh narrower and very small; eighth to tenth forming a broad club, much longer than all the preceding; the tenth oval, one-third longer than ninth, more or less curved and rounded at tip. (Fig. 3, No. 6.) Thorax evenly convex, sides nearly straight. Prosternum short, concave, produced behind into two long more or less widely separated hornlike processes which tit into cavities in the mesosternum, these visible only when insect is unfolded. Flytra with two nearly entire marginal strix and sometimes a short basal third stria. Two of the three known species ocsur in Indiana.

\section{KEY TO INDIANA SPECIES OF DORCATOMA.}

a. Pubescence erect; size smaller. not orer 2 mm.; elytra finely punctate.

1677. SETULOSUM.

aa. Pubescence of upper surface recumbent; size larger, 2.5-3 mm.; elytra more coarsely punctate.

1678. DRESDENSIS. 
1677 (5321). Dorcatoma setulosum Lec., Proc. Phil. Acad. Nat. Sci., 1865, 242.

Oval, moderately elongate. Black, shining; pubescence sparse, short, erect; antennæ and legs paler. Head and thorax finely and sparsely punctate. Elytra with somewhat coarse punctures in more or less regular rows; submarginal strixe two. Under surface finely punctate. Length 1.7-2 mm.

Throughout the State; scarce. June 3-July 2.

167 (5323). DoRcatoma dresdensis Herbst., Kafer, IV, 17792, 104.

Oral, moderately elongate, convex. Black, shining, clothed with fine. recumbent grayish pubescence; tibix more or less reddish; antennæ and tarsi paler. Joints of antennal club emarginate on their apical edge in female, so deeply emarginate as to become branched in male. Thorax short, with sides strongly convergent and nearly straight; surface finely punctate. Elytra with well marked trace of third lateral stria; surface with punczures distinctly coarser and usually closer than those of thorax. Length $2.5 \cdot 3 \mathrm{~mm}$.

Knox County; rare. June 9-July 9.

XVII. Eutristus Fall. 1905.

Form more broadly oval than in Dorcatoma, the prosternum broadly truncate and notched behind and the fifth ventral segment relatively longer. The antenna vary in the number of joints present, there being from eight to ten, according to species. But one species has been taken in Indiana, though another probably occurs.

1679 (5330). Eutylistus intermedius Lec., Proc. Phil. Acad. Nat. Sci., XVII, 1S7S, 411.

Broadly oral. Black, shining, sparsely clothed with suberect grayish pubescence; mouth and legs more or less reddish-brown. Head sparsely punctulate; thorax finely but more closely punctate. Elytra with irregular row's of rather strong punctures and with two entire lateral strix, which are nearly equally deep from base to apex. Tentral segments finely and rather closely punctate, their sutures deep and scarcely or feebly curved at middle. Length 1.7-2.2 $\mathrm{mm}$.

Vermillion, Putnam, Knox and Lawrence counties; scarce. June 8-July 4. Antennæ 8-jointed.

$E$. incomptus Lec., brown or piceous, elytra finely and closely punctate in longitudinal bands, length 2.2-2.5 mm., is known from Michigan and Illinois. Antenno 10-jointed.

XVIII. Canocıri Thom. 1859. (Gr., "ordinary+beetle."'

Easily separated by their more globose form, deeply incised eyes and second joint of antennal club, which is here narrow and but 
feebly dilated at apex instead of broadly triangular. The lateral strie of elytra consist of two nearly complete outer and a third inner basal stria which scarcely reaches the middle: antennæ 9jointed. But two have been taken in the State. though two others perhaps oceur.

\section{KEY TO INDIANA SPECIES OF C.ENOCARA.}

a. Pubescence relatirely short and much inclined; antemul club in male blackish. in female pale.

SCYMNOIDES.

a $a$. Pubescence longer and erect: antennie pale in both seres.

b. Eres of male but little larger than in female, deeplr, acutely incised or nearly divided in both sexes : last joint of palpi broadly triangular: punctuation rather sparse and coarse.

16SO. OCLLATA.

b7. Eres of male larger than in female. the front narrower than longest diameter of the eye.

c. Last antemnal joint of male scrthe-shaped, the tip acutely pointed: color black, head and thorax dark rufous.

16S1. BICOLOR.

cc. Liast antemnal joint of male not curved; last joint of maxillary palpi slender. subparallel.

TEXIIPALPA.

C. scymmoides Lec., black, length $1.8-2.3 \mathrm{~mm}$.. ranges from New Fngland to Montana.

1680 (5326). Cexocara octhata Say. Long's Exped. St. Peters, II. 1S24, 273 ; ibid. I. 180.

Rounded-oral. strongly conrex. Black, polished; head frequently rufous; antennie and legs reddish-brown: pubescence grayish-rellow. Serenth joint of male antemne as long as the fire preceding. strongly produced on its inner side; eighth nearly as long as the width of serenth: ninth four times as long as ride. its outer edge broady curved. Thorax sparsely and finely punctate at middle. more coarsely and densely at sides. Elytral punctures coarser than those of thorax. Fifth rentral segment as long as third and fourth united. Length $1.7-2.2 \mathrm{~mm}$.

Throughout the State; frequent. May 29-August 10. Oceurs on low vegetation in damp localities; also in small puffballs ( $L y$ coperdon).

1681 (-). CENoCARA BiCOLOR Gelm.. Ins. Sp. Not.. 1S24. 19.

Form of oculata. pubescence less distinctly rellowish. Black; head and thorax dark reddish-brown. Male with serenth antennal joint nearly as strongly produced as in oculatu. the terminal joint scimetar-shaped; eyes larger, the front of head less than their longest diameter, cleft only to middle. Female with serenth joint triangular. the terminal one scarcelr curved : eses smaller. widely separated and nearly divided as in oculuta. Length $1.5-2 \mathrm{~mm}$.

Lake and Knox counties; rare. Mray 29-July 2. Occurs throughout the eastern United States.

C. tenuipalpa Fall, form and color of oculata. length 1.3-1.8 mm., nas described from Michigan and Illinois. 
Tribe VI. P'TILININI.

This tribe is composed of a single genus, seperated from those preceding mainly by the characters given in the tribal key. The head is deflexed. less retractile than in the preceding group: antenne 11-jointed, serrate in female and branched in male.

\section{Pthmirs Geoft. 176t. (Gr., "feather.")}

Small crindrical species, covered with short, fine appressed pubescence. The antenna of male have the third joint elongateryindrical, with a basal process as long as the joint itself, and joints $t$ to 10 strongly flabellate or with long flat processes folding like a fan; tarsi as long as the tibix, with the first joint as long as the two or three following. Tro species have been taken in Indiana, while another probably occur's.

\section{KEI TO INDIAXA SPECIES OF PTIIIXUS.}

11. Side margin of thorax fine but well defined and eren throughout; sub-

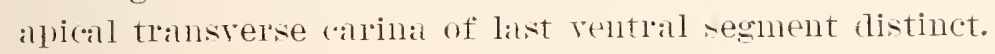

16S2. RLFICORXIS.

au. Side margin of thorax irregularly granulate-serrate and not well defined; subapical rentral carina nearly or entirely wanting.

6. Thorax equal to the elstra in width; branch of fourth antennal joint of male scarcely three times the length of joint: scutellum elongate. finely and densely rugose.

LOBATUS.

46. Thorax a little narrower than elytra; branch of fourth joint nearly five times the length of joint; scutellum cuadrate. coarsels rugose.

1683. PREINOSLS.

16is2 (5332). Prilixts RCFicorxis Say. Jouln. Phil. Acad. Nat. Sci.. III. 1523. 1so; ibid. II. 119.

Cylindrical. elytral not wider than thorax. Black or piceous. opaque. usually paler in female; antenne and legs reddish-yellow, thighs often darker. Branch of fourth joint of male antemne six or seren times the length of joint. Thorax slichty wider than elytra. widest before the base. sides broadls curved, hind angles rounded. front ones rectangular. front margin rather strongly rounded, narrowly reflexed at middle; surface finely granulose at base, more coarsely in apical hall: median line feebly impressed. terminating at base in a feeble. smooth protuberance. Elytra a little more than twice as long as thorax and a little less than trice as long as wide, finely scabrous and rather closely and distinctly punctured. Length 3- $4.5 \mathrm{~mm}$.

Throughout the State: frequent. May 11-December 25. Occurs on dead branches of oak and maple, into which the larre bore.

P. lobatus Casey. dark piceo-castaneons, antennie paler. length 3-5 $\mathrm{mm}$. is recorded from Ohio. 
1683 (-). Ptilinus pruinosus Casey, Journ. N. Y. Ent. Soc., VI, 1898, 63.

Form of ruficornis. Uniform black, opaque, antennæe and legs reddishbrown. Branch of third antennal joint one-half longer than the joint. Thorax a little narrower than elytra, the side margins plainly serrulate throughout, median line finely impressed its full length, the small basal smooth protuberance obsolete. Elytra three-fourths longer than wide, male, or scarcely three-fifths longer than wide, female. Length $3-3.5 \mathrm{~mm}$.

Lake County ; rare. May 20. Casey's types were from "Indiana" and Fall recognizes the species from Ontario.

\section{Family XLIV. BOSTRICHID Æ.}

\section{The Powder-post Beetles.}

This family, as here limited, consists of elongate, robust or slender species having the antennæ 9- to 11-jointed, inserted at the sides of the front; eyes small; labrum distinct; elytra entire; abdomen with five free ventral segments ; front coxæ prominent, contiguous, but little extended transversely; tarsi 5-jointed, the first joint very short and imperfectly separated from the second. All the species live in dry wood, either in cylindrical burrows or beneath the bark, and sometimes in such numbers that the timber is wholly destroyed by them. About 45 species of the family are known from North America. These are divided among two subfamilies, both of which are represented in the State. They differ widely in character and are placed together more for convenience and similarity of habits than on structural grounds.

The principal papers treating of the North American species of these subfamilies are as follows:

Horn.- "Revision of the Species of the subfamily Bostrichidæ of the United States," in Proc. Anier. Phil. Soc., XVII, $1878,540-555$.

Casey._ "Coleopterological Notes-III," in Ann. N. Y. Acad. Sci., VI, 1891, 12-16. A synoptical table of the genus Lyctus is given.

KEY TO SUBFAMILIES OF BOSTRICHID A.

a. First ventral segment scarcely longer than those which follow; antennal club 3- or 4-jointed. Subfamily I. Bostrichinж, p. SS6. a . First ventral segment much longer than the others; antennal club twojointed.

Subfamily II. LYCTINÆ, p. 891.

\section{Subfamily I. BOSTRICHINAE.}

Rather robust, oblong or elongate species, having the head usually deflexed and protected by the thorax; antennæ widely separated and inserted immediately in front of the eyes, upon or under 
the frontal margin, the three outer joints always larger; front coxæ large, globose. subconical; spurs of middle and hind tibiæ distinct; front tibiæ usually serrate and terminated by one long spur; first joint of tarsi short, sometimes obsolete: fifth joint long, with simple clars. Four genera are represented in the collection at hand, while another probably occurs in the State.

\section{KEY TO INDIANA GEXERA OF BOSTRICHIX.E.}

a. Thorax with distinct and entire side margins; head covered in part by the thorax.

I. ExDECATOMCS.

an. Thorax without side marrins: liead entirely covered by the thorax, the latter usually roughened in front by small elevations.

b. Intermediate joints of antennie shorter than the first and second: tarsi long, slender, first joint rery short.

II. SixostLox.

bb. Intermediate joints of antenne longer than the first and second.

c. Tarsi as long as the tibire, slender, second joint long.

d. Front margined, at the sides at least.

dd. Front not margined.

cc. Tarsi short. second joint not elongated.
III. BOSTRICHĹs.

IT. AMPHICERT'S.

T. DIXODERES.

\section{Exdecatonus Mellié. 18ti. (Gr.. "eleren - joint.")}

Head in great part corered by the thorax, the latter margined from base to tip ; antennæ 11-jointed, with a loosely united 3-jointed club; terminal spur of front tibiæ large and hooked; last joint of tarsi very long. Two species are known from the Eastern United States, both of which oceur in Indiana.

\section{KEY TO SPECIES OF ENDECATOMIS}

a. Under surface conspicuously granulate; male with two small tubercles in front.

1681. RETICLLATTS. aa. Under surface obsoletely granulate: male without frontal tubercles.

16S5. RLGOSES.

$16 S 4$ (5336). Exdecatojts Retictlates Hbst., Kafer. T. 70.

Elongate, rather slender. Dull reddish-brown. rather thickls clothed with rellowish hair. Thorax broadly arched. sides rounded. disk with a median impressed line, both it and the elrtra granulate and pubescent as in rugosus. Tength $4.5 \mathrm{~mm}$.

Two in Webster collection labelled "Ind." Said to be an introduced European species. Paler and more slender than rugosus. and less densely pubescent above.

*16S5 (5337). Exdecatones Rtgosts Rand., Bost. Journ. Nat. Hist.. II, $1835,26$.

Elongate-oblong. Dark or piceous bromn, opaque, corered with tufts of pale brown, wool-like hairs. Thorax rather closely and coarsely granu- 
late. Elytra with snall granules arranged in a network of lines, the spaces between them smooth. their summits with pale brown hairs. Length 4 $4.5 \mathrm{~mm}$.

Southern half of State; common. Narch 9-December 21. Hibernates. Oceurs on woody fungi and beneath bark of trees and shrubs; also at maple sap in spring.

\section{Sinoxyluon Dufts. 1825. (Gx., "harm + wood.")}

Cylindrical beetles having the head completely concealed from above by the thorax, which is truncate in front, with the apical half covered with small tubercles; elytra obliquely truncate behind, their surface punctate. One of the eleven species occurs in the eastern United States and Indiana.

16 S6 (5339). Styoxylox basilare Say, Journ. Phil. Acad. Nat. Sci., III. 1823, 121 ; ibicl. II, 181.
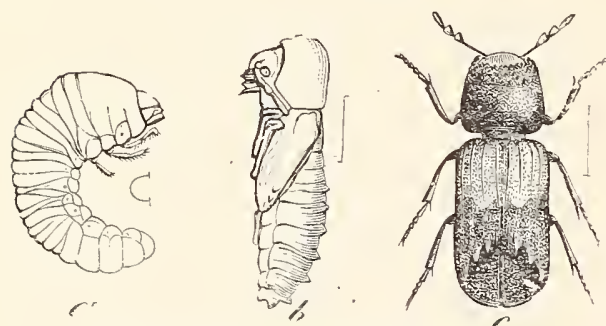

Fig. 349. $a$, larva; $b$, pupa; $c$, beetle. (After Riley.)

Cylindrical. Black; elytra dull reddish-yellow on basal third. Antenuie 10-jointed : last two joints of maxillary palpi equal. Thorax rery convex, sloping downwald on apical half, angles rounded: surface densely punctate, and with numerous small tubercles in front. Elytra bent downward nearly at right angles on alpical fourth, with three tubereles on each side of the declivity, the latter coarsely punctured. Length 5.5-6 mm. (Fig. 349.)

Fayette, Lawrence and Poser counties; scarce. May 23-August 23. Occurs beneath the bark of hickory, to the wood of which it is said to be very destructive.

\section{Bostrichts Geoff. 176i. (Gr., "hooked + hair.")}

Elongate, subcylindrical species, having the joints of the antennal club short, subglobose; hind angles of the thorax acute and prominent. Three of the five known species have been taken in the State.

KEY TO INDIANA SPECIES OF BOSTRICHUS.

a. Thorax with two hooked processes in front.

b. Elytra with two costre, the surface clothed with patches of small appressed scales.

1687. BICORNIS.

bb. Elytra with one short basal costa, the surface clothed with hilis which are mevenly disposed in clusters.

168S. ARMIGER.

an. Thorax in front simply truncate; pubescence of elytra in spots irregulatrly arranged; elytria without traces of ridges.

1689. TRUNCATICOLLIS. 
1687 (5350). Bostrictics bicornis Web., Obs. Lint., 1801, 91.

Elongate, subcylindricil. Piceous, subopaque, clothed with yellowish scales arranged in irregular patches. Thorax prolonged in front in two hooked processes which are serrate, the apex between them truncate; apical region roughly granulate, basal half with smaller granules, median line distinctly inplessed. Filytra bicostate, the inner costa stronger; surface densely and coarsely punctured and clothed with rellowish sales in patches; tips in male with an acute subsutural spine. Length i12 min. (Fig. 350.)

T'hroughout the State; frequent. June 4-Sep-

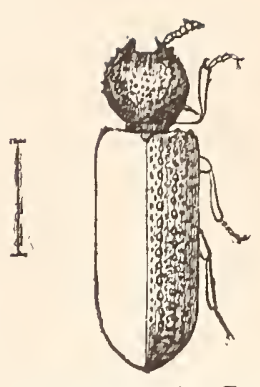

Fig. 350. (After Packard in Fifth Rep. U. S. Ent. Comm.) tember 20. Occurs beneath bark and in oli fungi.

1688 (5351). Bostrichus armiger Lec., New Spec. N. Am. Col., 1866, 100.

Form of bicornis, which it closely resembles. Elytra with trace of inner costa at base; intervals tuberculate. especially near the suture; surface clothed with longer hair-like scales arranged in patches. Length $7.5-$ $9 \mathrm{~mm}$.

Lake County; rare. July 21. Taken by Dury at Cincinnati. Probably throughout the State.

1689 (5352). Bostriciuts truncaticollis Lec., New Spec. N. Am. Col., I, 1S66, 101.

Elongate, subcylindrical. Piceous, subopaque. Thorax slightly longer than wide, apex seen from abore, truncate, without processes; otherwise as in bicornis. Elytra without costx or tubercles, surface densely and coarsely punctured and clothed with patches of yellowish appressed hairs. Length $7.5-10 \mathrm{~mm}$.

Wells, Marion and Putnam counties; scarce. Tune 4-July 5. Occurs beneath bark, especially that of sycamore.

\section{Amphicerus Lec. 1861. (Gr., "on both sides + horn."')}

This genus differs from Bostrichus by having the front of head not margined; joints of antennal club strongly compressed and deeply bistriate from the apical margin; hind angles of thorax rounded. One of the seren species occurs in Indiana.

1690 (5356). Amphicerus Bicaudatus Say, Jomrn. Phil. Acad. Nat. Sci., II I, 1823, 320 ; ibid. II, 180.

Cylindrical, moderately elongate. Piceons-brown, sparsely clothed with recumbent pubescence. Thorax as long as wide, strongly sloping before and behind, the front portion with many small tubercles and with two larger hook-like processes; the basal half gramulate. Elytra rather coarsely and irregularly punctured. strongly sloping on apical fourth, the declivity oblique, coarsely punctured. With moderately long processes each side in male. Length $6.5-9 \mathrm{~mm}$. 
Casey mentions Indiana as one of the localities from which his specimens came. Horn states that it occurs "everywhere east of the Rocky Mountains." I have not seen it from the State. The mature beetle is said to bore for feeding purposes in living twigs of fruit trees and grape vines, never, however, ovipositing in such twigs, but living as larvæ in the dead and dry wood of forest trees.

\section{Dinoderus Steph. 1830. (Gr., "huge + neck.")}

Species of cylindrical form having the tarsi short, the four basal joints each about the same length and together nearly equal to the fifth. The declivity of the elytra is normally convex, though sometimes flattened. Four of the eight known species may occur in Indiana, though but two of them have been taken.

KEY TO INDIANA SPECIES OF DINODERUS.

a. Declivity of elytra convex, not acutely margined.

$b$. Margin of thorax coarsely serrate.

c. Head shining, smooth, granules small, flat; elytra polished or strongly shining.

cc. Head opaque, rather roughly granulate; elytra opaque. SUBSTRIATUS.

1691. PORCATUS.

b7. Margin of thorax feebly serrate; elytral punctures in regular rows; color pale reddish- or chestnut-brown.

PUSILLUS.

aa. Declivity of elytra more or less flattened and acutely margined, the marginal ridges short; second joint of antennæ as slender as the third.

1692. PUNCTATUS.

1691 (5358). Dinoderus porcatus Lec., New Spec. N. Amer. Col., 1866, 101.

Elongate, cylindrical. Brownish, opaque, sparsely clothed with short erect hair. Front opaque, roughly granulate. Thorax as long as wide, slightly narrowed in front, margin conspicuously serrate; disk in front with spiniform tubercles; its basal half rather densely tuberculate and with a fine, smooth median line. Flytra with tubercles in rows. Length $3.5 \mathrm{~mm}$.

Lawrence County; rare. May 23. Probably throughout the State.

1692 (5363). Dinoderus punctatus Say, Journ. Phil. Acad. Nat. Sci., V, 1826, 25 ; ; ibid. II, 320.

Elongate, cylindrical. Piceous or blackish-brown, sparsely pubescent. Thorax a little longer than wide. narrowed in front, margin very feebly serrate, tuberculate as in porcatus. Elytra densely and irregularly coarsely punctate; intervals not elevated: declivity feebly convex, acutely margined at sides of aipex. Length $4.5 \mathrm{~mm}$.

Taken by Dury at Cincinnati. Casey's specimens were in part from Indiana. Notrepresented in the collection at hand. 
D. substriatus Payk., piceous, length $4-4.5 \mathrm{~mm}$., is said to occur in the Northern States and Canada; D. pusillus Fab., length $3 \mathrm{~mm}$.. is an introduced species which probably occurs throughout the United States.

\section{Subfamily II. LYCTINAE.}

Elongate slender species, having the head prominent, somewhat narrowed behind the eyes, not covered by the thorax, which is trapezoidal in form and has fine side margins; antennæ 11-jointed, with rounded club composed of two joints; front coxrentirely enclosed and separated by the prosternum; hind ones widely separated; first ventral segment much longer than any of the others. The subfamily is represented by but one genus, Trogoxylon Lec. having been merged with Lyctus by Casey.*

\section{Lyctus Fab. 1792. (A proper name.)}

The characters of the subfamily Lyctince as above given apply to the members of this genus. Four of the nine known North American species have been taken in the State.

\section{KEY TO INDIANA SPECIES OF LYCTUS.}

a. Elytra with rows of large rounded, rery shallow punctures; intervals with a single row of punctures bearing Jellowish hairs, which form slightly raised lines; thorax with an elongate-oral median impression.

1693. STRIATES.

aa. Elytra with smaller deeper punctures, usually arranged in more or less distinct rors; thorax rarely with a median impression.

b. Thorax longer than wide, the front angles rounded.

1694. OPACULUS.

bъ. Thorax not longer than wide.

c. Front angles of thorax rounded; punctures of elstra in rows; color piceous black.

1695. PLAXICOLLIS.

cc. Front angles of thorax not rounded; punctures of elytra vers fine and dense, arranged irregularly.

1696. PARALLELOPIPIDUS.

1693 (5374). Lyctes striatus Melsh., Proc. Phil. Acad. Nat. Sci., II, 1S44, 112.

Elongate, slender. Dull redaish-brown, sparsely clothed with rellowish pubescence. Thorax nearls square, slightly narrowed behind, sides straight nearly to apex; front angles rounded, hind angles distinct, surface coarsely punctate, with a smoother median impression. Surface of elytra as described in lies. Length $3.5-5 \mathrm{~mm}$.

Marion and Vigo counties; freriuent. April 25-May 22. Bred from stems of hickory. Probably occurs throughout the State.

*Ann. N. Y. Acad. Sci., VI, 1S91, 12. 
1694 (5:375). Ixctus ophoutus Lec., New Sp. N. Im. Col., 1866, 103.

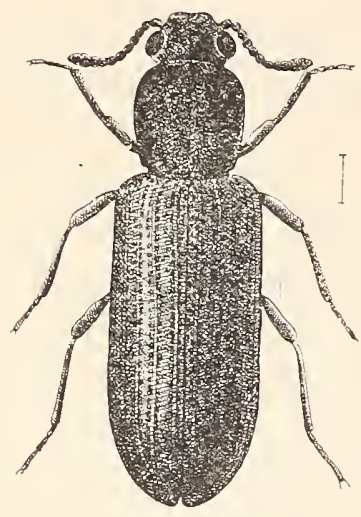

Fig. 331. (Original.)

Elongate, slender, subcylindrical. Blackish-piceous or dark reddish-brown, very sparsely clothed with rellowisl hairs; head and thorax usually darker than elytra. Thorax distinctly longer than wide, much nalrower than elytra, densely and coarsely punctate; sicles neally straight, evenly rounderl into the front margin. Elytra with rather coarse deep punctures arranged in regular rows. Length $3.5-4.5 \mathrm{~mm}$. (Fig. 351.)

Throughout the State; frequent. May 11June 17. Occurs on dead limbs of oak and other trees.

1695 (5:36). Lyctus Pla nicolis Lec., Proc. Phil. Acad. Nat. Sci., 1858, 7.

Elongate, slender, subdepressed. Piceous-black, very sparsely and finely pubescent. Thorax as wide as long, slightly narrowed behind the middle, front angles rounded, hind angles rectangular, side margins rery finely serlate; disk densely punctate, with an indistinct elongate median impression. Elytra witll rows of fine punctures. Length $4.5-5.5 \mathrm{~mm}$.

Posey County; rare. May 11. The thorax is wider, flatter and with a less distinct median impression and the punctures of elytra much finer and deeper than in striatus.

1696 (5376). Tyctus Parallelopipidus Melsh., Proc. Phil. Acad. Nat. Sci., II, 1844, 112.

Elongate, subparallel. Dull reddish-brown, clothed with fine yellowish pubescence. Thorax nearly quadrate, a little wider at apex thin base, sides almost straight, front angles subsulcate, hind angles rectangular; surfice, as well as that of head and thorix. very finely and densely punctured. Elytra nearly three times as long and but little wider than thorax, the sides nearly parallel. Length $3.5-4 \mathrm{~mm}$.

Orange and Perry counties; frequent. May 16-June 1. Taken while boring into the skinned portion of the trunks of living honeylocust, Gleditschia triacanthos I. Smaller and much more slender than any of the other species.

\section{Family XLY. CIPESIDA. \\ The Cupesid Beetres.}

This small family is represented in the United States by but two genera and five species of elongate and somewhat fiattened betles, having the elytra entire, with rows of large square punctures and intermediate ribs. and the body covered with small scales. They occur beneath bark and about old frame or log houses.

The principal cistinguishing characters of the family are the 11-jointed filiform, rigid antenne inserted rather close together 
upon the front; the tubereulate head, stretched out forward and suddenly constricted behind and attached to the thorax by a distinct neck; thorax small, quadrate, the side margins well defined; prosternum well defined with a slight point behind fitting into the mesosternum ; front coxæ small, not prominent, their cavities transverse, open behind; mesosternum with the side pieces excavated for the middle legs; hind coxæ transverse, flat, sulcate behind, receiving the thighs in repose; abdomen with five free ventral segments; legs slender, contractile; tibia without terminal spurs, tarsi 5-jointed, spongy beneath, their claws simple.

The name of the family is based upon that of the typical genus, Cupes, which is derived from the Latin word of the same form meaning "dainty" or "fond of delicacies." Why Fabricius gave such a name to these beetles is not manifest, as the larva are said to breed in decaying wood.

The principal literature treating of the family is as follows:

LeConte.--"On the Cupesidx of North America," in Trans. Amer. Entom. Soc., V, 1874, 87-88.

Casey.--"Synopsis of the Genus Cupes." in Ann. N. Y. Acad. Sei., IX, 1897, 637-638.

One of the two genera is represented in the eastern United States by three species, one of which oceurs in Indiana.

\section{Cupes Fab. 1801. (N1.., "fond of dainties.")}

This genus has the flanks of the thorax excavated for the reception of the front leogs and the eves strongly convex.

1697 (5382). Cupes concolor Westwood. Zool. Journ., V. 440.

Elongate. slender, subdepressed. Pale brownish or ashy gray. densely covered with small scales; elytra with darkel brown oblong dashes or blotches, which form three indistinct undulated bands. Antenme nearly as long as the body. Head with four feebly separated tubercles, with a narrow impressed line between them. Thorax wider than long, about half the width of elytra; disk with a median longitudinal carina and a deep impression each side; side margins abbreviated near the front and hind angles. Elytra with rows of large quadrate punctures; intervals convex, the alternate ones higher. Length $7-11 \mathrm{~mm}$.

Lake, Wells, Putnam, Vigo and Posey counties, one specimen from each. June 22-July 25. One was taken from the cavity of a ripe apple, the others beneath bark. Say deseribed it as C. cinerea, stating that he had obtained mmerons specimens in the vicinity of New Harmony, where it was common about old frame houses. 
Casey, loc. cit., described as new C. oculatus from Indiana, stating that it "differs from concolor by having the punctures of elytra" narrow and elongate. antennæ less elongate and elytra more depressed, with subobsolete first costa." It is probably to be ranked as a variety only.

\section{Family XLVI. ITMEXYLONID A.}

\section{The Ship-timber Beetles.}

This is another small family represented in North America by only three known species. They are elongated, narrow beetles with short serrate antennæ, which are 11-jointed and inserted at the sides of the head. Our species have the head deflexed, narrowed behind, the eyes large; maxillary palpi four-jointed, stout, very large and flabellate in the male: thorax with the side margins well defined; prosternum short; mesosternum large, flat; metasternum long, with narrow side pieces; elytra entire; front and middle coxæ conical, large, prominent, contiguous, their cavities open behind; hind coxw transverse, prominent on the inner side; legs slender, moderately long. tibiæ with small terminal spurs; tarsi five-jointed, filiform, their claws simple.

The name of the iypical genus, Lymexylon. is derived from two Greek words meaning "to ruin" and "wood," the larvæ of the best known European species, $I$. navale, causing great damage by boring small roind holes in ship timber. The genera being monotypic, there is no literature other than the isolated descriptions of the species, two of which have been taken in Indiana, while another may occur.

KEY TO INDIANA GENERA OF LYMEXILONIDE.

a. Elytra entire; length 10 or more mm.

b. Top of head with a small deep line at middle; abdomen with six ventral segments.

I. Hrleccetus.

bb. Top of head without visible line; abdomen with five rentral segments.

II. LyMexYLON. aa. Elytra a little shorter than abdomen; length less than $3 \mathrm{~mm}$.

Micromalthus.

I. Hylecetus Lat. 1806. (Gr., "wood + bed.")

This genus is represented in the eastern United States, including Indiana, by the single species:

1698 (5384). Hyleccetus lugubris Say, Bost. Journ. Nat. Hist., I, 1835. 166 ; ibid. II, 642.

Elongate, slender: Head, thorax and prosternum rufous; elytra and mesosternum black; abdomen and legs sellow; antennæ black, one to three 
of the basal joints dull yellow. Body punctured, with short hairs; thorax with an indented line; scutel glabrous and carinate in the middle; elytra with slightly elevated lines. Length 10-12 mm.

The above is a modification of Say's original description. He took it from the vicinity of New Harmony, where he "observed it in considerable numbers on the 16th of April, flying about a prostrate sugar maple and running briskly upon it. It is infested by ‘ species of "Gamasus," (mite). A variety has the elytra dull yellowish on the basal half. Not represented in the collection at hand.

\section{Lymexylon Fab. 1775. (Gr., "iestroyer+wood.")}

This genus is also represented in the eastern United States by but one species.

1699 (5385). Lymexilon sericeum Harr., Ins. Mass., 1838, 52.

Elongate, slender, subcylindrical. Piceous brown, clothed with very fine, silky, yellowish pubescence; antennæ, under surface, tibiæ and tarsi, paler. Antenmæ short, half the length of head and thorax; third joint longest, 5th to 10 th bead-like. Thorax twice as long as wide, broadly rounded in front, hind angles rectangular'; disk strongly convex on basal half, surface densely and rather coarsely punctured. Elytra with sides nearly parallel, their surface finely, densely and irregularly punctate. Length 11-13.5 $\mathrm{mm}$. (Fig. 352.)

Irake and Crawford counties; rare. June 29-July 21. Taken from beneath loose bark of oak logs.

Micromalthus debilis Lec., elongate,

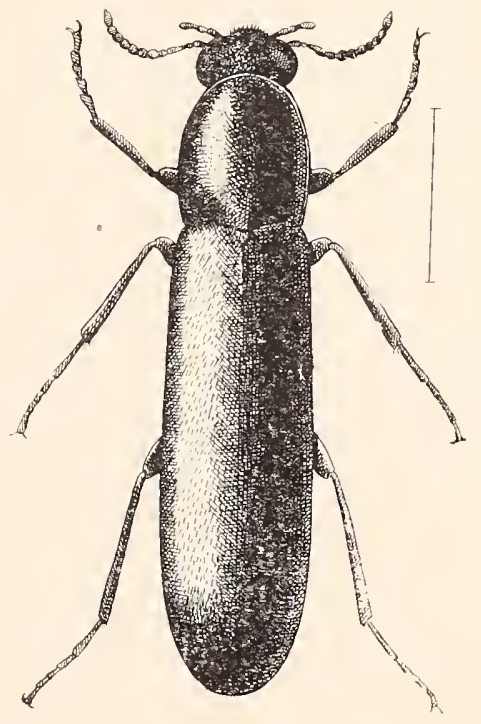

Fig. 352. (Original.) piceous, shining, antennæ and leys yellow, length $2.2 \mathrm{~mm}$., was described from Detroit, Michigan, where it occurred in August in decaying wood.

\section{Family XLVII. CTOIDA.}

The Minute Tree-fungus Beetles.

Very small, subeylindrical black or brownish beetles, rarely exceeding $3 \mathrm{~mm}$. in length, and having the head retracted, but not entirely concealed by the prolonged thorax. In the males of some species the head and front margin of thorax are ornamented with small, horn-like processes. The family name comes from that of the 
typical genus, Cis, which is from a Greek word meaning "a worm in wood or grain." The beetles are mostly found under the bark of trees and in dry and woody species of fungi, and are usually gregarious. Some species oceur in houses and are injurious in the larval stage to books, furniture and old woodwork, which they pierce with small round holes. The grubs which prey upon books are known as "book-worms."

The principal characters by which the Cioidx may be known are the 8- to 10-jointed antenne (11-jointed in one genus), inserted at the front margin of the eyes, the last three joints larger, forming a loose club; eyes rounded, somewhat granulate; thorax with side margins distinct, cylindrical, rounder in front, and frequently prolonged over the head. Elytra entirely covering the abdomen, the latter with five free ventral segments, the first longer than the others; front and midale coxa oval, not prominent, without trochantins, the cavities small, separate, narrowly closed behind; legs moderately short; tarsi four-jointed, joints 1-3 very short, equal, fourth long with simple claws.

The principal available paper treating of the North American species is that by

Casey.-"Studies in the Ptinidx, Cioidx and Sphindidx of America," in Journ. N. Y. Entom. Soc., VI, 1898, 61-93.

Of the nine genera recognized by Caser, representatives of seven have been taken in Indiana.

KEY TO INDIANA GENERA OF CIOIDA.

a. Antenna with last three joints larger, forming a loose club.

b. Antennæ 10-jointed.

c. Prosternum simple or nearly so.

d. Body with distinct erect bristly hairs; front tibiæe usually produced and toothed on outer side at apex.

I. Cis.

dd. Body glabrous or minutely pubescent; front tibire not toothed or produced; body elongate; head and thorax simple in male.

II. ORTHOCIS.

cc. Prosternum carinate along the middle; body either glabrous or with short decumbent pubescence.

III. Xestocis.

b7. Antennæ 8- or 9-jointed; body glabrous.

e. Front tibiæ thickened and rounded on the outer side.

f. Antennir ?-jointed; body narrow, cylindrical.

ff. Antennæe 8-jointed.

IV. EnNearthron. V. Ceracis.

ee. Front tibice narrowly triangular, the outer edge straight and minutely spinulose; antennse S-jointed.

VI. OCTOTEMNes.

at. Antenne with joints 5 to 11 forming a lirge pectinate mass, 11-jointed; elytra sulcate.

VII. RHIPIDANDRUS. 


\section{Cis Tatr. 1798. (Gr., "a worm in wood.")}

This genus is sufficiently characterized in the above table. Casey recognizes 22 species, mostly from the Western and Southern States, 19 of which he describes as new. Of these but four have been taken in Indiana, while three others are herewith described for the first time.

\section{KEY TO INDIANA SPECTES OE CIS.}

a. Hairs of elytra stiff and bristle-like, sometimes very short and subdepressed.

b. Elytra deeply punctured throughout, some or all of the punctures arranged in rows; apical augles of thorax obsolete; body narrow, parallel.

c. Elytral punctures deep, nearly uniform in size, all bearing hairs; color dark reddish-brown or piceous. 1700. cReberrimus.

cc. Elytral punctuation dual, consisting of finer, deeper, seta-bearing punctures, with larger shallow nude punctures intermixed; color black, shining.

1701. FALLI.

$b b$. Elytra with none of the punctures arranged in regular rows; usually with larger shallow ones mingled with smaller and deeper ones, which bear the setre.

d. Elytra with distinct stiff yellowish bristle-like hairs arranged in rows; body stouter, more convex.

e. Thorax of male without a prominent suberect lobe in front.

f. Elytra rugulose, the punctures indistinct; third joint of antennæe longer than fourth.

1702. FUSCIPES.

ff. Elytra but slightly rugulose, the large shallow punctures very evident; third joint of antennse equal to the fourth.

1703. CHEVROLATII.

ee. Thorax of male with a prominent suberect lobe in front; clypeus with two distinct triangular teeth.

1704. CORNUTUS.

dd. Elytra with very short, scarcely evident, bristles; body narrow, parallel.

1705. CONFUSUS.

aa. Hairs of elytra long, slender, not bristle-like, but erect and conspicuous; elytral punctures confused; last joint of maxillary palpi acutely pointed.

1706. URSULINA.

1700 (5388). Cis creberrimus Mellié, Ann. Ent. France, Vi, 1848, 357.

Oblong, subcylindrical, narrow, parallel, more or less depressed. Dark reddish-brown; antennæ and legs dull brownish-yellow. Thorax wider than long, sides feebly rounded into the front margin ; surface densely and rather coarsely punctate. Elytra with prominent stiff and bristle-like yellowish hairs, arranged in rows; densely punctured, the punctures nearly uniform in size. Length $1.5-2 \mathrm{~mm}$.

Southern half of state, frequent; Isake County, rare. March 4-October 1. Oceurs on fungus-covered stumps beneath bark; taken also by sifting. 
1701 ( - $)$. Cis FalLi sp. not.

Broader: more conrex than crebrimus. Black, shining; antennre and legs reddish-brown. Thorax with front margin broadly rounded and slightly prolonged, the surface much more coarsels punctate than in crcberimus. Elytra with pubescence shorter and much less distinct than in that species: the punctures differing in size, the larger ones, especialls those close to the suture, forming indefinite rors. Length 2-2.2 mm.

Marion and Posey counties; scarce. April 11-September 20. Taken beneath bark of wild cherre stmp in open pasture: also in woody fungi. and debris of beech stumps.

1702 (53S9). Cis ftsctpes Mellié, Ann. Entom. France. TI, 1StS, 271.

Oblong, subcjlindrical, contex. Piceous black to dark reddish-brown. feebly shining, antennie and legs paler. Thorax one-half wider than long. the apex prolonged and broadls rounded orer head, surface finels and erenly punctured. Elytral bristles moderate in length and in distinct rows: punctures fine, rather sparse and indistinct, being hidden by the small transterse wrinkles. Length 2.5-3 mm.

Southern half of State, common: less so in the northern counties. January 11-November 28. Occurs beneath bark of logs and in fungi.

1703 (5393). Cis chetrolatir Mellié, Amn. Entom. France, TI, 1S48, 249.

Form and size of fuscipes. Dark chestnut brown, feebly shining: legs and antenne paler. Thorax with front angles distinct but less prominent than in fuscipes. surface finely and denselø punctured. Larger punctures of elytra distinct, not in rows, the pubescence shorter and less prominent than in fuscipes. Length $3 \mathrm{~mm}$.

Vigo Countr; rare. January 7 . One specimen from beneath a chunk near the border of a swamp.

$1704(-)$. Cis corntet's sp. not.

Oblong, subcylindrical, robust. Dark reddish- or chest-

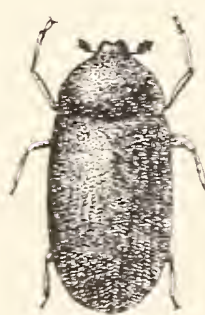

Fig. $3.53 . \times 11$ (Original.) nut-brown. Tery thickly clothed with stiff, erect rellowish hairs; beneath piceous, the legs and antennæ paler. Front concare; clypeus with two prominent triangular teeth, their tips obtuse. Thorax one-third broader than long. sides rounded: hind angles obtuse. front ones distinct. acute; disk conrex, finely and rather sparsely punctured, and with a broad, slightly recurred and notched horn-like lobe arising from the front margin. Elytra with rather coarse deep punctures. none of them in rorss. Length $2.2 \mathrm{~mm}$. (Fig. 35.)

Described from a single male taken from a fungus-corered stump near Grand Chain, Posey Countr. April 9. More robust but a little shorter than fuscipes. with longer and more dense pubescence, and remarkable for the processes of clrpeus and thoras. 
1705 (-

Resembles creberimus in form and size. Piceous, the head and front of thorax tinged with reddish; legs, mouth parts and antennæe reddishbrown. Thorax rery slightly broader than long, narrowed in front, sides strongly lounded into the base, front angles obtuse, disk coarsely, deeply and erenly punctured. Elytra more finely punctured than thorax, the punctures deep and evenly distributed, but not in rows; the bristles very short, scarcely distinct. Length $2 \mathrm{~mm}$.

Marion and Perry counties; rare. April 4-October 31. Taken by sweeping low herbage. The front angles of the thorax are less prominent, its surface more coarsely punctured and the elytra are less rugose than in the common fuscipes.

1706 (-). Cis ursulina Casey, Journ. N. Y. Entom. Soc., VI, 1898, 83.

Oblong, subcrlindrical, robust. Uniform chestnut brown, shining, sparsely clothed with long, slender hairs. Thorax conrex, one-half wider than long; sides broadly rounded; disk finely and rather sparsely punctate, and in male bearing a short, emarginate lobe at apex. Elytra slightly wider and more than twice as long as thorax; more coarsely and sparsely punctured than there. Front tibire simple at apex, not dilated or produced. Length $1.5 \mathrm{~mm}$.

Crawford County; rare. May 25. Described from Alabama.

\section{OrThocis Casey. 1898. (Gr., "straight + Cis.")}

Flongate, parallel, glabrous species having the elytral suture impressed and margined toward the tip; antennal club 3-jointed rather small and loose.

1707 (5400). Orthocis penctates Mellié, Ann. Entom. France, VI, 1848, 337.

Elongate, subcylindrical. Black, shining; legs and antennæ reddishbrown. Thorax one-half wider than long, sides almost straight, distinctly margined; angles all rounded, apex broadly curred; disk finely, deeply and rather closely punctate. Elytra nearly twice as long as wide, finely, irregularis and rather sparsely punctate, each puncture mith a rery minute silrers hair. Length $2.5 \mathrm{~mm}$.

Marshall County; rare. June 12. Sifted from debris of oak $\log$.

III. Xestocis Casey. 1898. (Gr., "smooth or dry + Cis."')

To this genus Casey ascribes inve species, having the prosternum carinate and the front tibire strongly oblique and acute on the outer side at apex. One of the five was described from Indiana.

1708 (-). Xestocis Levettei Casey, Journ. N. Y. Entom. Soc., VI, 1898,85 .

Suboral, glabrous. Very dark reddish-brown, polished. Thorax twofifths wider than long. simple and rounded at apex in both sexes; sides 
rather distinctly and evenly curved, feebly convergent from base to apex, the margins very fine; surface minntely and rather sparsely punctured. Elytra less than one-half longer than wide, narrowly rounded at apex, very feebly rugulose, minutely and sparsely punctate. Length $1.5-2 \mathrm{~mm}$.

Marion and Dubois counties; rare. April 4-October 31.

\section{Ennearthron Meilié. 1847. (Gr., "nine + joints.")}

Small, smooth, cylindrical species having the antennæ slender, with feeble club. The thorax of the male is armed at apex with two small, horn-like processes. Two species occur in Indiana.

1709 (5404). Ennearturon thoraciconne Ziegl., Proc. Phil. Acad. Nat. Sci., II, 1845, 270.

Oblong-cylindrical, robust. Dark reddish-brown, rather strongly shining; mouth parts, antennæ, tibiæ and tarsi paler. Front of clypeus in male elevated, slightly recurved and broadly emarginate. Thorax of male convex, sides rounded, surface finely and sparsely punctured; distinctly impressed behind the processes, which are rather short and divergent; of female less convex, more broadly rounded in front, slightly prolonged over the head. Elytra very finely punctured and rugulose. Length $1.5 \mathrm{~mm}$.

Steuben, Marion, Jackson, Crawford and Posey counties; frequent. Apxil 6-September 3. Occurs beneath moss and bark.

1710 (-). ENNEArTHRon oblongus sp. nov.

More slender and parallel than the preceding. Piceous black, strongly shining. Thorax of male feebly impressed behind the processes, the latter longer and less divergent than in thoracicome; thorax of female more strongly extended over the head; disk in both sexes finely alutaceous and more evenly and coarsely punctate than in thoracicorne. Elytra more coarsely and rugosely punctured. Length 1-1.5 mm.

Marion County; frequent locally. October 31-December 8. Taken in numbers from beneath dry, leathery fungi on dead beech trees.

\section{Ceracis Mellié. 1848. (Gr., "horn + worm.")}

The members of this genus are very similar to those of Ennearthron, but the antennæ are only 8-jointed, one of the small joints near the middle being absent. One of the two species occurs in the State.

1711 (5406). Ceracis sallei Mellié, Ann. Entom. France, VI, 377.

Oblong-cylindrical. Dull reddish-yellow; basal half of elytra blackish. Thorax slightly wider than long, sides broadly curved from base to the obtuse apical angles; disk rather finely and sparsely punctured and, in the male, armed with a moderately long process which is deeply sinuate at apex. Elytra as wide at base as thorax, about one-half longer than wide, finely, sparsely and irregularly punctured. Length $1.3 \mathrm{~mm}$. 
Jackson County; rare. April 12. Taken by Dury at Cincinnati and probably occurs sparingly throughout the southern third of the State, on fungus-covered logs.

\section{Octotemunus Mellié. 1847. (L., "eight + cut or joint.")}

Differs from Ennearthron by the characters given in generic key and also by the more oval outline of body and absence of male sexual characters of head and thorax. One of the two species occurs in Indiana.

1712 (—). Остотемnus i.жvis Casey, Journ. N. Y. Ent. Soc., VI, 1898, 91.

Rather short and broadly oval, polished. Dull reddish-brown to blackish. Thorax but little wider than long, circularly rounded at apex, the sides feebly diverging to base; front and hind angles broadly rounded; surface finely, sparsely but distinctly punctured. Elytra one-half longer than wide, distinctly wider than thorax and barely twice as long; surface with a few scattered erect hairs on apical half, minutely and sparsely punctate. Length $1.3-1.6 \mathrm{~mm}$.

Marion, Putnam and Posey counties; scarce. March 6-November 10. P'robably hibernates. Taken from beneath moss on trunks of beech stumps.

\section{RHipidındrus Lee. 1862. (Gr., "a fan + male.")}

This genus is represented in the eastern United States and Indiana by a single speeies, readily separated from other members of the family by the characters given in the key.

1713 (5407). Rhipidandrus Paradoxus Beauv., Ins. Afr. et Amer., 1S05, 173.

Oblong-oval. Blackish or piceous brown; antennæe and legs yellow. Antennx with joints 5-11 strongly pectinate in male; gradually thickened on the outer side, with the middle portion subserrate in female. Thorax one-half wider than long, hind angles rectangular, front angles rounded, surface densely and coarsely punctate. Elytra finely but distinctly ribbed or sulcate, the depressions with coarse subquadrate punctures. Length 2$2.8 \mathrm{~mm}$.

Putnam County; rare. June 28. Occurs beneath bark of oak stumps.

\section{Family XLVIIT. SPHANDTDA.}

\section{The Sphindus Beet'leis.}

This family is represented in the United States by only three small species, which occur in dry fungi on the trunks of trees and logs. They have the head short, prolonged into a short, broad muzzle; labrum distinct; antennæ 10-jointed, inserted near the 
front margin of the eyes, the first joint large and stout, 3 to 7 slender, small, the third as long as the two following, 8 to 10 forming an oval, bifoliate club as long as the stem; thorax truncate before and behind, with distinct side margins; prosternal sutures deep for the reception of the antennæ, which in repose are folded with the club bent suddenly outward, behind the front leg; front coxæ transverse, small, the eavities separated by the prosternum, narrowly closed behind; elytra entire, epipleura narrow; abdomen with five free ventral segments; front and middle tarsi 5-jointed, hind ones 4-jointed; claws small, simple.

The three species comprising the family represent as many different genera, and all probably oceur in the State, though but one has been taken.

KEY TO GENERA OF SPHINDID

a. Sides of thorax with six or seven teeth, its flanks not concave; body smooth.

ODONTOSPHINDUS.

aa. Sides of thorax entire.

$b$. Body finely pubescent; flanks of thorax slightly concave.

I. Sphindus.

$b b$. Body broadly oval, clothed with erect hairs; flanks of thorax deeply concave.

Eurysphindus.

\section{Sphindus Chev. 1833. (NL., a made word.)}

This genus, sufficiently characterized above, is represented by the single species :

1714 (5409). Sphindus adiericanus Lec., New Sp. N. Amer. Col., I, 1866, 104.

Oblong, convex. Piceous-black, the elytra often dark brown; antennæ and legs reddish-brown. Thorax one-half wider than long, sides strongly rounded, disk convex, finely and rather closely punctate. Elytral striæ feebly impressed, coarsely but shallowly punctate; intervals finely punctulate; umbone prominent. Length 2-2.5 mm.

Marshall and Marion counties; rare. May 20-June 7. Taken from fungus on beech and sifted from decaying linn stump. Probably occurs throughout the State.

The other two species of the family are Eurysphindus hirtus Lec., $1.6 \mathrm{~mm}$. in length, blackish-brown, pubescent with erect hairs, and Odontosphindus denticollis Lec., elongate, subcylindrical, brown, and $2.7 \mathrm{~mm}$. long. Both were described from near Detroit and have been recorded by Dury from Cincinnati. 


\section{Series IV. LAMELLICORNIA.}

All members of this series have the tarsi 5-jointed and the antennæe with three to seren of the terminal joints broader on one side, so as to form a peculiar club, the parts of which are movable. The front tibia are dilated and strongity toothed or scalloped on the outer edge. The larva hive on decaying vegetable matter, roots or dung. Two families comprise the series, both of which are represented in the State.

\section{KEY TO FAMILIES OF LAMELITCORNIA.}

a. Antenne usually elborred. the outer joints or lamella not flattened, but prolonged on the inner side to form a pectinate club, the joints of which cannot be brought closely together (Fig. 4, No. 13); elytra entirely corering the dorsal surface of the abdomen, the latter with fire rentral segments risible at the sides.

Family Xlix. ILecanide, p. 903. a . Antennie not elbowed, the lamellie flattened and capable of forming a compact club (Fig. 359); elytra usually leaving the pygidium uncorered; six or seren rentral segments visible on the sides.

Family L. Scarab.eide, p. 909.

\section{Family XLIS. LUCANID正.}

\section{The Stag Beetles. "Pinching Bugs."}

A small family of large or medium-sized beetles distinguished by having the outer joints of antennæ leaf-like but not capable of being opposed or folded together into a compact club, as in the next family, the Scarabæidæ, to which they are otherwise closely allied. The ciuhs of the antennæ are therefore pectinate, or combtoothed, rather than lamellate. In the majority of species the antennæ are elborred or crooked, the second and following joints forming an angle with the first. The common names, "stag beetles" and "pinching bugs." are given them on account of the great development of the mandibles, which, in the males of some species, are branched like the antiers of a stag.

In addition to the characters above mentioned the Lucanidæ have the mentum large, horn-like. quadrate (triangular in $\mathrm{Nica}$ gus) : maxillæ usually corered and with two lobes, one or both of which bears a fixed. horn-like terminal hook: antennæ 10-jointed, inserted under the margin of the front: elytra rounded at tip, covering the abdomen. which has five free rentral segments; legs 
fitted for digging; front coxæ large, transverse, without trochantin, the cavities closed behind; front tibie more or less toothed on the outer side; middle and hind lioiæe each with two teeth on the outer side; tarsi slender, 5-jointed; claws simple, with a short bristle-bearing pad between them.

The name Lucanidx is from that of the typical genus Lucanus, which is derived from a Latin word meaning "to shine" or "sunrise," in allusion to the flistening surface of the elytra in the members of that genus. The adult beetles live by day in or beneath decaying logs or stumps, and some of them take flight at dusk, when they are often attracted in large numbers by electric and other lights. Some of them are said to feed upon honey dew, or the exudations of the leaves and bark of trees. They lay their eggs in crevices in the bark of trees, especially near the roots, and the larvæ feed upon the juices of wood in various stages of decay. In form the larva resemble the ordinary white grubs of the genus Lachnosterna and they mature slowly, some of the large ones requiring six years to complete their spowth.

The principal literature relating to the North American species is as follows:

Fuchs, Chas:- "Synopsis of the Lucanidæ of the United States," in Bull. Brook, Entom. Soc., V, 1882, 49-60.

Wickham, H. F.- "The Lucanidæ of Ontario and Quebec," in

Can. Ent., XXXI, 1899, 21-25.

Between 500 and 600 species of stag beetles are known. Of these only nineteen species and several varieties, distributed among eight genera, are recognized as belonging to the North American fauna. Eight species, representing six genera, have been taken in Indiana.

KEY TO INDIANA GENERA OF LUCANIDA.

a. Antennæ elbowed at end of first joint, which is nearly or quite as long as all the other's united. (Fig. 4, No. 13.)

b. Elytra smooth or nearly so; front tibir with large teeth on outer edge; size large, $20-35 \mathrm{~mm}$.

I. LUcANus.

bb. Elytra striate and punctate.

c. Eres strongly notched by the margin of the head; front tibiæ serrulate; size larger, $15-25 \mathrm{~mm}$.

II. Dorcus.

cc. Eyes entire or nearly so; size smaller, 10-12 mm.

III. Pratycerts.

aa. Antennæ straight (not elbowed).

d. Form oblong or elongate, sides parallel or mearly so; elytra striate, glabrous.

e. Front of head simply excavated or with a depression; size smaller. not over $15 \mathrm{~mm}$.

IV. Ceruchus. 
ce. Front of head with a short bent horm, pointing forward; larger, 30 or more mm.

V. Passalus.

dd. For'm short, oval. convex, the sides not parallel; elytra coarsely punctured, not striate, pubescent.

VI. NiCAGUS.

\section{Ludontus Linn. 1763. (L., "to shine.")}

Large, smooth, brownish species with very prominent mandibles, which are most strongly developed in the males. The mentum, as in the next two genera, is very broad, completely covering the maxillie. Three of the four known species occur in Indiana.

KEY TO INDIANA SPECIES OF LCCANUS.

a. Mandibles of male as long as abdomen; female with black legs and chestnut brown elytra.

1715. ELAPHUS.

a a. Nandibles of male as long as thorax.

b. Mandibles each with one tooth on the inner side; head of male broader than thorax; femora light brown.

1716. DAMA.

bb. Mandibles straight, with sereral teeth on inner side in male, two ill-defined ones in female; head of male not broader than thorax; femora dark brown or nearly black.

1717. PLACIDUS.

1715 (5411). Ltcaxus Elaphus Fab., Syst. Ent.. 179s, 2.

Dark chestnut-brown, shining; legs and antennæe black or nearly so. Head of male much wider than thorax. with a strong crest abore the eyes; mandibles rery long. widely forked at apex. the inner edge with numerous small teeth; mentum of female comparatively longer, much more quadrate and with front angles much less rounded than in those of female of dama. Antennæ of male more slender than in the other species. Length of male (not including mandibles) $31-40 \mathrm{~mm}$; of female $28 \mathrm{~mm}$. (Fig. 354.)

A species of southern range. represented in the collection by five males and one female, taken in Vigo, Mionree and Crawford commties. May 20-August 21. Occurs

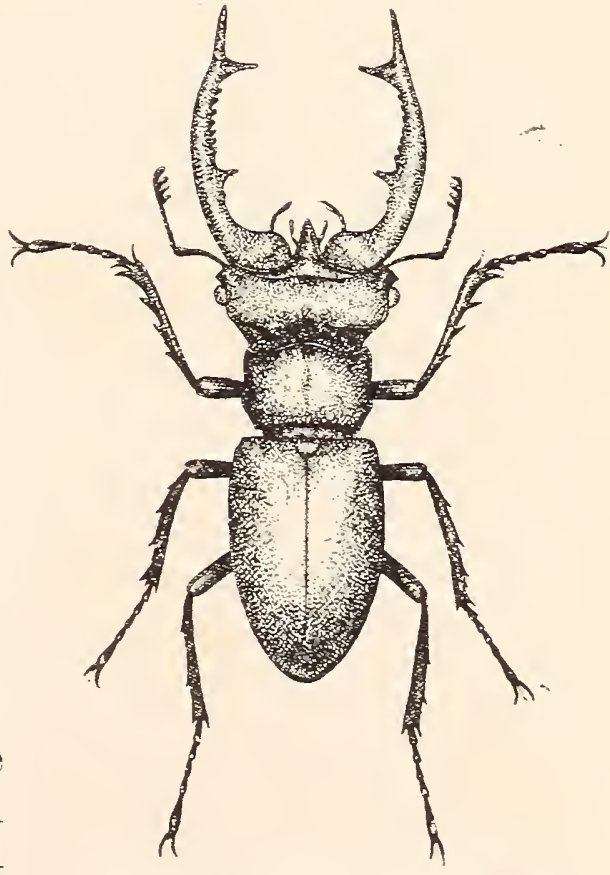

Fig. 354. Natural_size. (After Fuchs.) about old oak stumps, though sometimes in gardens. The females are very rare.

1716 (5412). Lucaxtes DaMa Thunb. Memr. Mosc. 1S06. $19 \mathrm{~S}$.

This species is sufficiently distinguished by the characters given in ker. It is the onily one of the three which has light brown femora. The 
elytra are smooth or very finely punctulate and the antennæ of male stouter and comparatively shorter than in elaphus; mandibles of male twice the length of those of female. Length 22-35 mm. (Figs. 355-356.)
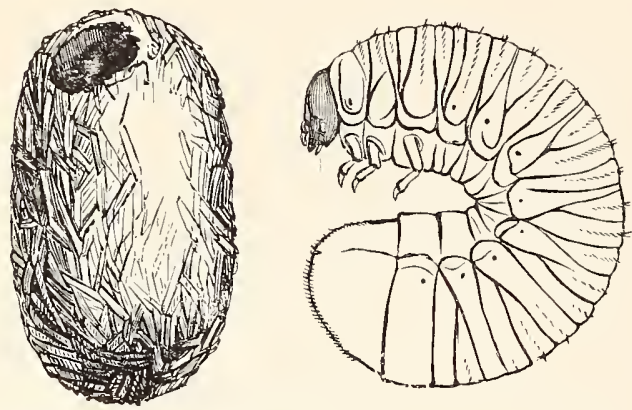

Fig. 355. Lucanus damu Fabr. Larva and cocoon. (After Packard.)

'Throughout the State; frequent. May 10-July 16. It flies by night with a loud buzzing noise

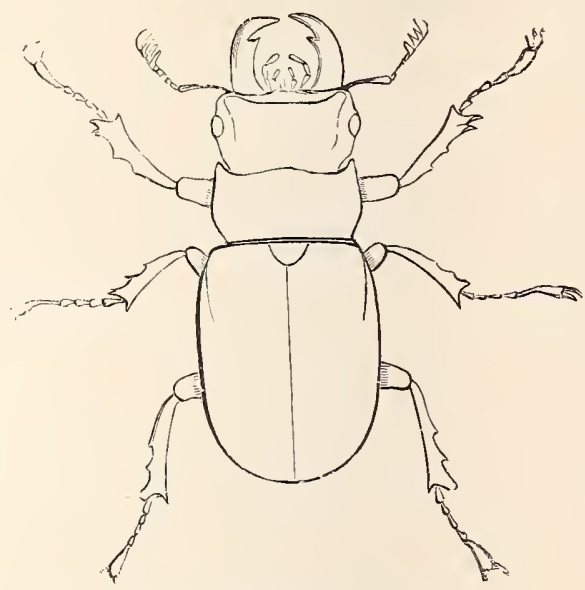

Fig. 356. Natural size. (After Packard.) and is attracted by electric or house lights. The larvæ live in old oak, beech, apple, willow or oak snags, and the freshly matured beetles are often found about the roots and beneath the bark of these trees in May and June. This and the next species are the ones commonly known as "pinching bugs," as when picked up they often grab the fingers with their protruding jaws and hold on with a strong grip.

1717 (5414). Lucanus Placidus Say, Journ. Phil. Acad. Nat. Sci., V, 1825, 202 ; ibid. II, 302.

From dama this species is known by the characters given in key and by its piceous or very dark reddish-brown color. The mandibles are curved only at tip, and they, as well as the entire upper surface, are more coarsely and distinctly punctured. Length 19-32 mm.

Throughout the State; more common than dama. May 1-June 20. Occurs at electric lights and is abundant in season along the beach of Lake Michigan.

\section{Dorcus McLeay. 1819. (L., "antelope.")}

Smaller, more parallel, and with the body more distinctly pedunculate than in Lucamus. One species and two varieties are known from the United States.

*1718 (5415). Dorcus Parallelus Say, Journ. Phil. Acad. Nat. Sci., III, 1823, 248; ibid. II, 146.

Oblong, parallel. Dark brown, nearly black. Head and thorax shining, finely and sparsely punctulate. Mentum strongly transversely striate, male; rugose, female. Males with head nearly as broad as thorax; mandi- 
bles with a large median tooth which points oblignely inward and upward. Elytra deeply striate, both striae and intervils finely and rather closely punctured. Length $15-26 \mathrm{~mm}$.

Throughout the State; frequent. April 27-December 8. Hibernates beneath old, partly burned logs. Occurs most commonly in June and July about the roots of oak, linn and maple trees and stumps, in the decaying wood of which the larvæ bore. The word Dorcus means antelope, and this spocies is sometimes called the "antelope beetle."

\section{Platycerus Geoff. 1764. (Gr., "broad + antennæ.")}

Small oblong beetles having the eyes nearly entire instead of being notched in front by the sharp side margin of the head; sixth ventral segment visible; front tibix armed on the outer side with numerous fine, saw-like teeth. The mandibles of the males incline upward and are larger than those of the females.

1719 (5416). Platycerus quercus Web., Obs. Ent., 1S01, 55.

Oblong, subdepressed. Blackish or dark reddishbrown, often tinged with brassy or greenish, shining. Mandibles of male as long as head and about 6-toothed at tip; of female, much shorter. Thorax one-half wider than long. sides rounded, hind angles obtuse; surface sparsely punctured, male; more densely and coarsely, female. Elytra with three or four subobsolete strie next to suture, deeply and rather sparsely punctured. Length 10-12 $\mathrm{mm}$. (Fig. 35\%.)

Throughout the State; common. March 25October 29. Occurs beneath bark and logs, es-

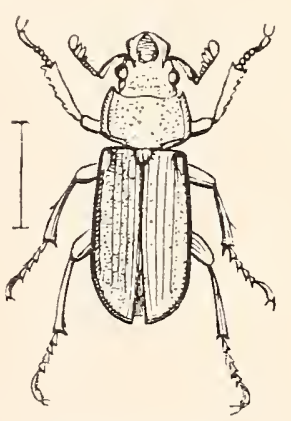

Fig. 357. Line shows natural size. pecially those of oak. Begins to emerge as imago the latter part of March. Mates about May 1st.

\section{Ceruchus MeLeay. 1819. (Gr., "bearing a horn.")}

Larger and more convex than Platycerus, with antennæ straight; body subcylindrical and front coxa contiguous. The head of the male is much broader and longer than that of female, and bears a deep frontal excavation.

1720 (5422). Ceruchus Piceus Web., Obs. Entom., 1801, S4.

Subcylindrical, convex, highly polished. Piceous or dark reddish-brown. Male with mandibles as long as head and with a rery large median tooth on inner side; head deeply striate on the sides; thorax and elytra finely and rather sparsely punctate. Female with mandibles half the length of head, with three or four blunt teeth on imner side: thorax and elytra more coarsely and densely punctured. Elytra shallowly striate in both sexes. the striae subobsolete on the sides. Cength 10-15 mm!n. 
Throughout the State; frequent. April 10-October 25. Occurs in and about decaying beech, oak and other logs.

\section{Passauds Fabr. 1792. (Gr., "a post or peg.")}

Mentum deeply emarginate, the notch being filled by the large horn-like ligula; antenna stout, not elbowed, but in repose so curved as to appear so; body distinctly pedunculate, the scutellum in front of the base of elytra. One species occurs throughout the United States.

*1721 (5424). Passalus connutus Fab., Syst. Eleut., II, 1801, 256.

Elongate, somewhat flat-

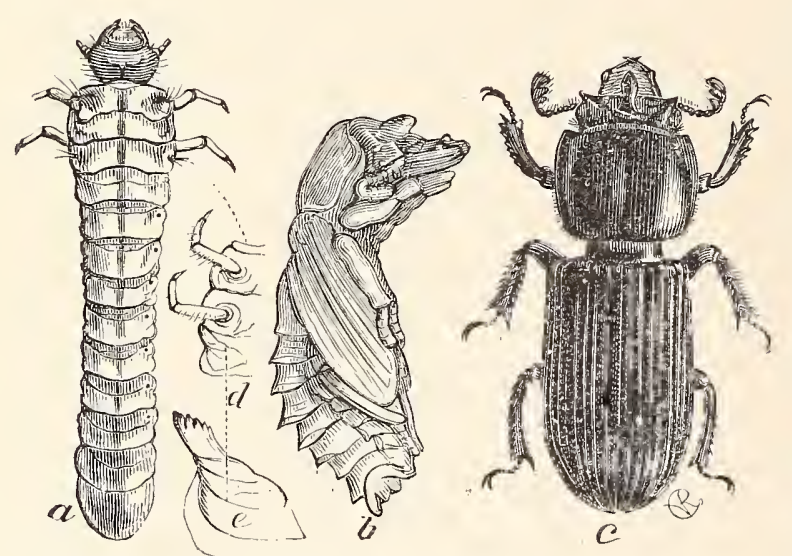

Fig. 358. $a$, larva; $b$, pupa; $c$. beetle; $d$, hind leg of larva, showing atrophied joints; $e$, same, enlarged. (After Riley.) tened, parallel, robust. Black, shining. Head armed with a short, bent hook. 'Thorax quadrate, angles rounded; disk smooth, with a deep median impressed line. Elytra deeply striate, the strixe finely punctured. Length 32-36 mm. (Fig. 35s.)

This well-known species, commonly known as the "horn" or "bess-beetle," oceurs abundantly throughout the State. It hibornates in its usual abiding places, the juicy depths of half-decayed logs and stumps. They are often utilized as horses by country children, the horn furnishing an inviting projection to which may be fastened, by a thread or cord, ehips and pieces of bark to be dragged about by the strong and never-lagging beast of burden. When tired of "playing horse" they can make of the insect an instrument of music; for, when held by the body, it emits a creaking, hissing noise, produced by rubbing the abdomen up and down against the inside of the hard, horny wing covers. The larva is remarkable in having only the four front legs of normal size. the hind pair being aborted. .Jannary 11-November 26.

\section{Nicagus Tiec. 1861. (Gr., "to lead in victory.")}

The only member of this genus, usually placed among the Scarabæidx, has been recently transferred to the present family. It differs widely in appearance from the other Lucanidx, more resembling a nearly smooth Trox. The joints of the antennal-elub 
are, like those of the other Lucanide, pectinate and not opposable, but the triangular mentum, the small size of the month organs and the form of body are distinctly Searabiad. The antennæe are 10jointed, the club three-jointed, longer in the male than in female.

1722 (5611). Nicagus obscurus Lec., Jomm. Phil. Acad. Nat. Sci., Ser. 2, I, 86 .

Oval, convex. Piceous or dark brown, sparsely clothed with very short, pale suberect hairs; entire uper surface coarsely and rather densely punctured. Thorax one-half broader than long, widest at middle, apex onehalf narrower than base. margins finely crenate, front angles prominent, hind ones obtuse. Liytra not striate, the pubescence more dense than on thorax. Length $7-9.5 \mathrm{~mm}$.

Vigo and Narion counties; scarce. May 1-. June 7. Occurs about piles of drift in damp, sandy localities. In the East it is said to frequent the vicinity of dead mussels (Unios).

\section{Family T. SCARABAID, E.}

The Lamelticorn Befties.

A verr large family, complising beetles that vary greatly in size, form and habits. All agree, however, in having the antennæe and in an oval club, composed of three to seven leaves or "Iamelææ." (Fig. 359.) These leaves can be folded closely together so that in repose the club appears solid. It is this form of antennal club which gives rise to the common name "lamelli"orn beetles." Another character possessed by all members of the family is the form of the front tibix, which are fossorial, or fitted for digging in the ground, being almost always broad, coinpressed and strongty toothed or scalloped on the outer edge. The tarsi of the middle and hind legs are generally long and always fivejointed. For the most part the beetles are short, convex and stout-bodied, the well-known "June bugs" or Nay beetles heing familiar examples. Taking this form in connection with the lamellate antennæ and fossorial legs, the members of

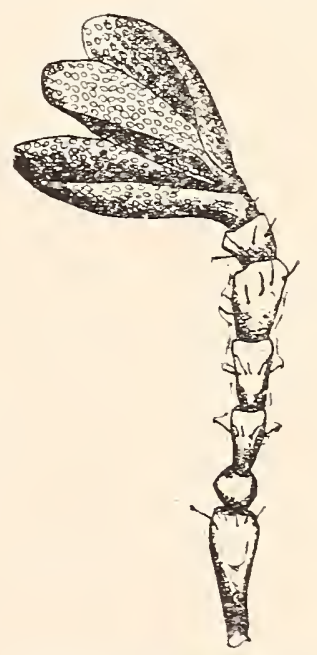

Fig. 359. Antenna of a Lamellicorn beetle, showing the structure of club. (After Smith.) the family are easily recognized.

In addition to the characters mentioned, the Scarabæidie have the antennx 7 - to 11-jointed, usually 10-jointed, and inserted before the eyes under the sides of the front; abdomen with six (rarely five) ventral segments; front and middle coxæ large, transverse, 
the front eavities very large and closed behind; hind coxæ flat, transverse; front tibiæ palmate; tarsal claws generally equal, rarelý wanting.

According to habits the adults of the Scarabæids are popularly separated into two well-marked groups, known as the dung beetles, or scavengers, and the leaf-chafers. The former have the legs stout, the hind ones set far back behind the middle of the hind-body. They live upon putrefying or decomposing matter, such as the dung of animals, decaying fungi and carrion. Of this group the common "tumble-bugs" and skin beetles (Trox) are well-known examples. The leaf-chafers have the legs rather slender and with the hind legs attached at or before the middle of the hind-body. They feed either upon the leaves of trces or the pollen and petals of flowers, the "rose-bugs" and May-beetles being familiar forms.

The larva or grubs of the lamellicorns are either white or yellowish in hue, with a brown, horny head bearing prominent mandi. bles. They are usually much wrinkled and enlarged toward the hinder end, and when at rest lie partly coiled up, the tip of the abdomen almost touching the long spiny legs. They live in the ground, in decaying wood or in excrement. Those which live in the ground are known as "white-grubs," and often do much damage to the roots of grass, corn and other plants. They will be more fully mentioned in connection with their adults on later pages. Those which live in dung and other refuse matter render man much valuable aid by removing from sight and smell a great deal of filth.

The family Scarabæid $x$ comprises about 13,000 described species, among them the largest beetles known, and is best represented in warm or tropical countries. The name of the family is from the Latin Scarabceus or Scarab, meaning "a beetle." The Scarab of the ancient Egyptians was a sacred beetie belonging to this family, which they held in high veneration. It was placed by them in the tombs with their dead. Its picture was often painted on their stone coffins or sarcophagi and its image was carved in stone and precious gems. The name scarab was also given by them to a gem, usually of emerald, grecn feldspar or obsidian, cut in the form of a beetle and engraved on the under face.

About 600 species of the family are known from North America. These are divided among three subfamilies, and these in turn into tribes and genera. The literature is scattered among many papers, mostly by Drs. LeConte and Horn, and will be mentioned under the tribal or generis headings. 
KEY TO SUBFAMI1,IES OF SCARAIBEII)A.

a. Abdominal spiracles situated in a line on the membrane connecting the dorsal and ventral horn-like plates, the last one, like the others, covered by the elytra; upper surface of head usually much dilated on the front and sides; dung eating or skin beetles.

Subfamily I. Laparostrotr, P. !11.

a a. Abdominal spiracles, except the front one or two, not situated on the membrane above mentioned, the last one usually visible behind the elytra; upper surface of head ranely dilated; regetable feeding species.

b. Abdominal spiracles in part situated on the superior portion of the ventral segments, the rows of spiracles feebly diverging.

Subfamily II. Melolonthine. p. 947.

bb. Abdominal spiracles (excepting the three front ones) situated on the dorsal portion of the ventral segments, forming two rows which diverge strongly.

Subfamily III. Pleurostict1, P. 980.

\section{Subfamily I. LAPAROSTICTI.}

In addition to the characters above given the Laparosticti, or Coprophaga, as they are sometimes called, are distinguished by having the suture separating the clypeus from the head distinct, and not transverse but extending npward toward the vertex; chub of antennæ consisting of only three joints. They all live on decomposing matter, most of them in dung or fungi. 'The subfamily is divided into eight tribes, six of which are represented in Indiana.

KEY TO INDIANA TRIBES OF IAAPAROSTICTI.

a. Abdomen with six visible ventral segments.

b. Antennæe with eight to ten joints; mandibles concealed by the clypeus except in the genera Aigialia and Ochodceus.

c. Hind tibia with a single terminal spur (except in Canthon nigricornis) ; form shorter, rounded; end of the abdomen exposed.

Tribe I. Coprini, p. 912.

c. Hind tibise with two spurs; abdomen wholly covered by elytra; size usually small.

1. Antemne 9-jointed; form oblong-convex or subcylindrical.

Tribe II. Apiodint. p. 920.

dd. Antennie 10-jointed; form oral, convex.

Tribe III. Orphnini, p. 935.

bb. Antenni 11-jointed; mandibles prominent, visible from above.

Tribe IV. Geotrupini, p. 936.

a . Abdomen with five visible ventral segments.

$e$. Body partially contractile, rounded, smooth. shining; scutellum relatively large.

Tribe V. ACanthocerini, p. 940. ce. Body not contractile, oblong, convex, roughly sculptured; scutellum small.

Tribe VI. Trogini, 1). 941.

[58-23402] 
Tribe I. COPRINI.

Beetles of rounded form and variable size, which live almost exclusively in excrement or decaying fungi. They have the clypeus expanded so as to cover entirely the mouth organs; the mandibles principally membranous, with only the outer margin horn-like; middle legs widely separated; elytra subtruncate at apex, leaving the pygidium exposed. The tribe is subdivided into seven genera, five of which are represented in Indiana. The principal literature treating of the North Ainerican genera is by

Horn.-- "Notes on Some Genera of Coprophagus Scarabæidæ of the Tnited States," in Trans. Amer. Ent. Soc., III, 1870, $42-51$.

Horn.- "Synonymical Notes and Descriptions of New Species of North American Coleoptera,'" in Trans. Amerr. Ent. Soc., V, 1875. Whe genera Choridium and Onthophagus are treated on pp. 137-144.

Blanchard, Frederict.--"On the Species of Canthon and Phanæus of the T'nited States, with Notes on other Genera,' in Trans. Amer. Ent. Soc., XII, 1885. 163-172.

Schceffer, Chas.- "On Bradrcinetus and Bolboceras of North America, with Notes on other Scarabieide," in Trans. Amer. Ent. Soc., XXXII, 1906, pp. 219-278.

\section{KET TO INDIANA GENERA OF COPRINI.}

a. Middle and hind tibix, slender, curred, but little enlarged at tip; head and thorax nerer horned in either sex.

I. Canthon.

a a. Niddle and hind tibiæ much expanded at tip; males usually with horns on the head or thorax.

b. Third joint of labial palpi distinct.

c. Size small, not orer $7 \mathrm{~mm}$; front coxie rery transrerse, not prominent.

II. Cherintur.

cc. Size larger, 10 to $27 \mathrm{~mm}$; front coxie short. lrominent.

d. Front legs with tarsi; tarsal claws distinct: color black.

III. COPRIS.

dd. Front legs of males without tarsi; all tilsal claws wanting; colors metallic and green.

IV. PHANæUS.

bb. Labial palpi 2-jointed; scutellum invisible; size small. not orer $8 \mathrm{~mm}$.

T. ONTHOPHAGTS.

\section{CANTHON Hoffm. 1817. (Gr., "a kind of beetle.")}

Black or bronzed insects often seen along country roads and pathways, rolling balls of dung from place to place, hence popularty known as "tumble-bugs." The halls are rolled often to a consider- 
able distance, the long, slender, slightly curved hind tibir having berome modified and well adapted for this work. The beetles work in pairs, a male and a female together, and the ball which they roll is often several times as large as their combined size. (Fig. 360.) They finally bury the ball in the ground and the female then deposits an egg in one side of it, thus insuring the future larva a suitable supply of food. Comstock says that "this is one of the instances, rare among insects, where the male realizes that he has some responsibility as a father, and assists the female

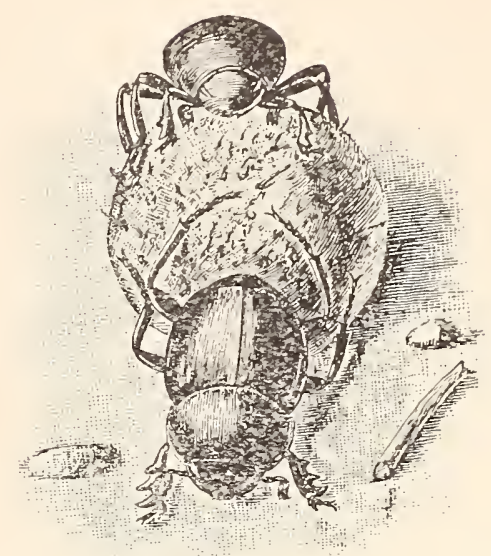
in providing for the young. This strange habit of rolling these balis has occasioned much speculation as to its object, and has been the source of many superstitions, especially in ancient times. The only reasonable theory that we have met is that, as many predaceous insects frequent the masses of dung from which the balls are obtained, in order to prey upon the larvæ which live there, the more inteliigent tumble-bugs remove the food for their larre to a safe distance." The sexes of Canthon are alike in appearance and the clypeus has prominent teeth at the middle. Fire species have been taken in Indiana, while four others may occur.

KEY TO INDIANA SPECIES OF CANTHON.

a. Sides of thorax beneath without an entire transverse carina.

b. Clypeus with four to six teeth; hind thighs not margined in front: size small or medium. 6 to $10 \mathrm{~mm}$.; color black.

c. Hind tibia with two spurs.

1723. NIGRICORNIS.

cc. Hind tibixe with one spur.

d. Subhumeral stria not carinate; surface coarsely granulate.

$e$. Hind femora with bristle-bearing punctures; thorax more coarsely granulate.

EBENLS.

ce. Hind femora with fine setie, sparsely punctate; thorax more densely. much less coarsely granulate.

DEPRESSIPENNIS.

dd. Sublumeral stria carinate; surface not granulate, very smooth, almost shining.

PROBUS

b7. Clypeus with two teeth; hind thighs margined in front; size larger. $11-2.2 \mathrm{~mm}$.

f. Eyes larger; antenne reddish-brown.

VTGILANS.

ff. Eyes smailer: antenne dark brown.

g. Thorax distinctly granulate; prgidium and last rentral segment grimulate.

1724. L.玉VIS, 
gg. Thorax finely rugose without distinct granules; pygidium and last ventral smooth.

1725. CHALCITES.

aa. Sides of thorax beneath with an entire transverse carina; size small, 4-6 $\mathrm{mm}$.

h. Clypeus with two teeth; bright bronze or greenish. 1726. viridis. $h \hbar$. Clypeus with four distinct teeth; brown, bronzed, shining; eyes larger. 1727. PERPLEXIS.

1723 (5425). Canthon nigricoris Say, Jomrn. Phil. Acad. Nat. Sci., III, 1S23, 207 ; ibid. II, 133.

Broadly oral. Black, subopaque, sparsely and finely granulate; head and thorax often with a purplish reflection. Clypeus six-toothed, the two front ones more prominent, flattened and slightly recurved, the others smaller. Elytra with subobsolete striæ. Length 6-9 $\mathrm{mm}$.

Two specimens from near North Judson, Starke County. July 13.

C. ebenus Say, deep black, length $7-10 \mathrm{~mm}$., is known from Maine and Pennsylvania to Kansas and Texas; C. depressipennis Lec., greenish-black, length $7-10 \mathrm{~mm}$., has been recorded from Cincinnati; C. probus Germ., dull black, length $6 \mathrm{~mm}$., occurs in Kentucky and southward; C. vigilans Lec., length 17-22 mm., occurs from Pennsylvania and Ohio westward.

1724 (5435). Cantion LæuIS Drury, Exot. Ins., I, 1770, 79.

Broadly oval. Usually dull black, tinged with cupreous; sometimes (south and west) varying to deep blue and bright green. Readily known by its larger size and distinct and rather dense granulations of thorax and elytra. The teeth of clypeus are blunt and but little prominent. Length 11-19 mm. (Fig. 360.)

Throughout the State; common. April 23-Septeniber 29. This is our most abundant and best known "tumble-bug." 'From midApril until after heavy frosts it can be found along every roadside or pathway where horses or cows have dropped their dung.

1725 (5436). Canthon chalcites Hald., Proc. Phil. Acad. Nat. Sci., I, 1843,304 .

Form somewhat more robust, shorter and broader than levis. Upper surface distinctly and uniformly bronzed; under surface and legs black, moderately shining. Thorax finely and intricately rugose, not granulate. Elytra granulate, but much more sparsely than in lavis. Male with front tibiæ much longer and more curved and middle tibiæ distinctly longer than in female. Length 13-20 $\mathrm{mm}$.

Vigo, Knox and Posẹ counties; frequent. April 23-September 2.

1726 (5438). Canthon viridis Beauv., Ins. Afr. et Amer., 1805, 23.

Broadly oval or subrotund. Bronzed, strongly shining. Thorax very finely punctured. Elytra smooth or nearly so, obsoletely striate. Hind tibiæ slightly curved. Length $4-5 \mathrm{~mm}$.

Lawrence and Crawford counties; scarce. May 11-July 1. Oc- 
curs beneath flat stones on hillsides near Wyandotte Cave. This and the next are the smallest species of the genus.

1727 (5439). Canthon Perplexus Lec. Joum. Phil. Acad. Nat. Sci., Ser. 2 , I, 1847,85 .

Broadly oral or subrotund. Brown bronzed, shining. Thorax rather coarsely punctured. Elytra more finely punctured, each puncture bearing a rery small, recumbent, scale-like hair. Hind tibiæ slightly curved. Length 4.5-5.5 $\mathrm{mm}$.

Knox County; rare. July 8. A single specimen from border of cypress swamp. Known from Illinois and westward.

\section{CHeridum Lep. 1825. (Gr., "a young pig.')}

This genus contains two small, rounded species resembling Hister in general appearance. They have the under side of thorax transversely carinate and, as in the next three genera, the middle and hind tibire much expanded at apex. By this character they may be readily separated from the small species of Canthon. One of the two has been taken in Indiana.

*172S (5441). Chœridiua histeroides Web., Obs. Ent., 1S01, 37.

Rounded. conrex. Bronzed abore; dark chestnut brown beneath, strongly shining. Clypeus emarginate or two-toothed. Thorax with a feeble median impressed line on basal half and a small, deep rounded impression on each side; surface sparsely and shallowly punctured. Elytra finely striate. the strixe indistinctly punctured. Male with spur of front tibia dilated in the form of a small, circular sessile disk. Leugth 6-7 mm. (Fig. 361.)

Throughout the State; common in the southern, scarce in the northern counties. Occurs most abundantly in half-dried cow dung, and

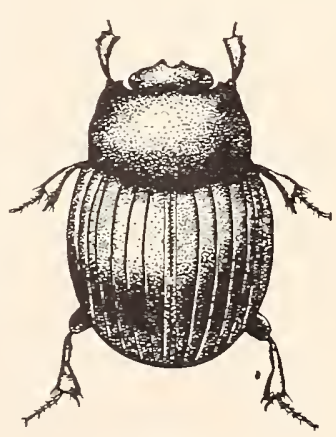

Fig 361. $\times 4$. hibernates sparingly beneath this and logs. February 23-Norember 17.

\section{Copris Geoff. 1762. (Gr., "dung." )}

Medium or large-sized species having the labial palpi broad. compressed and 3-jointed; the front coxæ conical, large and prominent; all tarsal claws distinct but without a bristle-tipped process (onychium) between them. The males have the head or thorax or both either tuberculate or horned. The species of Copris do not transport excrement in balls any great distance, but bury it in burrows on or near the spot.

\footnotetext{
KEI TO INDIANA SPECIES OF COPRIS.
}

a. Elytra each with eight strix; front of head semicircular; thorax with a transverse carina on sides beneath. 
6. Clrpeus densely punctured at sides, nearly smooth at middle; size small, $\mathrm{S}-11 \mathrm{~mm}$.

1729. mixutus.

bb. Clspeus erenly and densely punctured orer its entire surface; larger, 13-18 mm.

1730. AxAgLTPTICUS.

aa. Elytra each with seren strix; front of head elongately rounded; thorax without carina beneath; still larger, 20-28 mm.

1731. CAROLIXA.

*1729 (5443). Copris minutus Drury, Exot. Ins., I, 1770, 78.

Broadly oral, conrex. Black, feebly shining. Clypeus acutely and rather deeply notched, its median portion nearls smooth; its sides, as well as surface of thorax, rather densely and coarsely punctured. Tertex in male with a short and slender horn. Elytral strix punctate. Length S$11 \mathrm{~mm}$.

Southern half of State, frequent: less so in the northern counties. February 28-September 9. Hibernates sparingly beneath corer of logs, ete.

1730 (5444). Copris Axaglipticts Say, Journ. Phil. Acad. Nat. Sci., III, 1S23, 204 ; ibid. II, 131.

Broadly oral, convex, robust. Black, feebly shining. Clrpeus acutely notched at middle. Tertex of head of male armed with an obtuse horn; tuberculate in female. Thorax densely and coarsely punctured; its crest with three tubercles, the mediar one deeply emarginate; these much less prominent in female. Elytral strix broad, the punctures transrerse. Length 13-1S mm.

Throughout the State; frequent. Tay 23-October 21. The spine on head of male varies much in length.

\section{1 (5448). Copris Carolixa Limn., Syst. Nat., II, 1766, 545.}

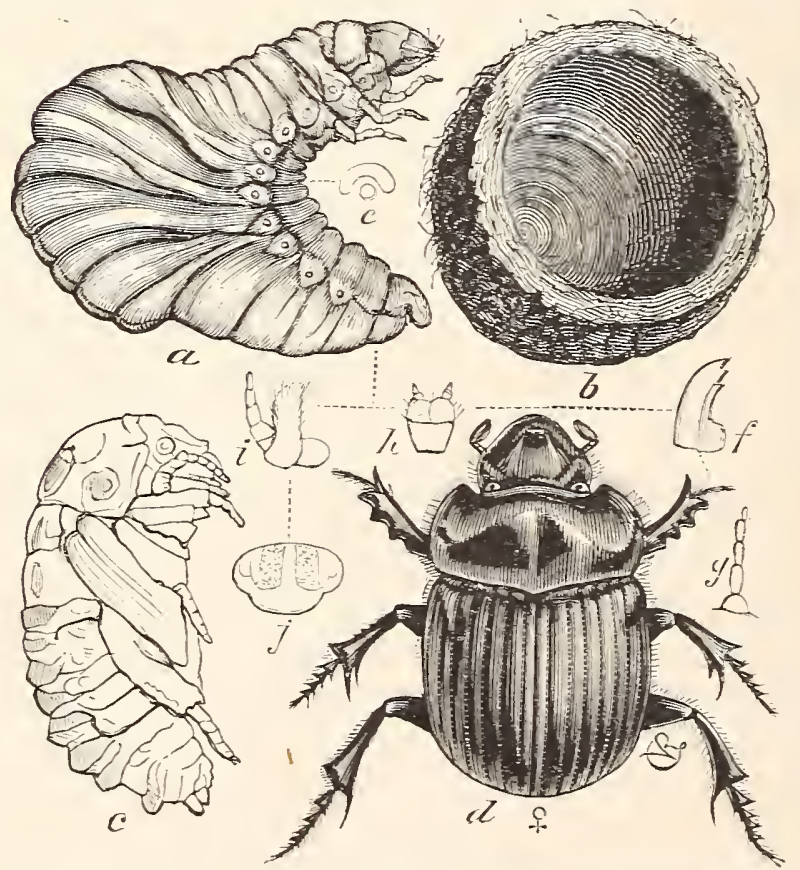

Fig. 362. $a$, larra; $b$, section of hollow ball of dung in which the larra undergoes its changes; $c$, pupa; $d$, female beetle; $e$, spiracle or breathing pore of larra; $f$, mandible; $g$, antenna; $h$, labium; $i$, maxilla and maxillary palpus; $j$, swelling on under side of anal segment. (After Piley.)

Broadly oval, rere robust. Black, shining. Clypeus finely rugose, not punctate, the horn of male short, blunt. Under side of thorax with a rather deep excavation near the front angle for the reception of the antennal club in repose. Elytral strixe shallow, feebly punctate. Length 20$25 \mathrm{~mm}$. (Fig. 362.)

Southern half of State. frequent; noted only in Lake County in the north. April 25August 23. Often attracted by electric lights in the cities. Onr largest species of the tribe Copmini. 


\section{Phinats MacLeay. 1519. (Gr., "light bearer.")}

Robust, brilliantly colored forms, the males of our species with head armed with a horn; first joint of antennal club hollowed out to receive the others; front tarsi of males wholly absent; those of females present, but very small and slender. Two species occur in Indiana.

1732 (5452). Phaneus carnffex Linn., Syst. Nat., I, 1767. ihti.

Broadly oval, somewhat flattened above. Head bronzed; thorax bright cupreous; elytra green, often tinged with bluish. Clypeus entire, armed in male with a long curred horn, in female with a short blunt tubercle. Thorax of male with disk flat and hind angles much more prominent than in female; surface very rough. Elytra striate; interrals broad, finely and intricately rugose, deeply punctured and more or less costate. Length 14$22 \mathrm{~mm}$. (Fig. 363.)

Throughout the State; frequent. May 10-Oc-

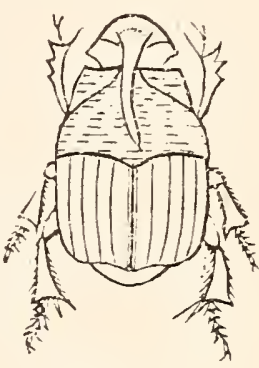

Fig. $363 . \times 1 \frac{1}{4}$. (After Glover.) tober 21. Notwithstanding its clisgusting habits this is one of our most beautiful and interesting beetles.

1733 (-). Phanees torkexs Tec., Journ. Phil. Acad. Nat. Sci., I, Ser. 2, $1847,85$.

Form of carnifex. Uniform coppery above; piceous, feebly bronzed beneath; palpi, stem of antennie and tarsi reddish-brown; club of antennie darker. Clypeus rounded, margin elevated; vertex in female transrersely elevated, in male armed with a short, compressed acute horn. Thorax of male with disk flattened and triangular, finely scabrous; sides deeply sinuate near base, hind angles obtuse; in female more convex, with a transverse eleration near apex, disk with small, triangular, scale-like granules and with a median impression oli basal half. Elytra deeply striate, the strie dilated at base; intervils strongly elevated. minutely and sparsely punctate. Length $15-18 \mathrm{~mm}$.

Monroe County; rare. June 9. A single female collected by Max Ellis. Described from St. Louis, Nissouri. After describing this form as distinct, Dr. LeConte in 1863 placed it as a variety of triangularis Say. In this he was followed by Blanchard. Chas. W. Leng, to whom the specimen was sent for identification, takes the ground that the original name torrens should be restored until the relationship of the beetle to triangularis is settled.

\section{Onthopmigrs I.at. 1807. (Gr., "dung'+eating."')}

Small oral beetles having the front coxie large. conical and protuberant; third joint of labial palpi obsolete: tarsal clars distinct, with a long setre-bearing process betreen them. In some of the 
species the thorax bears a process or protuberance in front, this being most prominent in the male, where it varies greatly in development, even in the same species. The clypeus and vertex usually each bear a transverse carina, these being more strongly marked in the females. In all the males the front tibia are much longer, more slender and more curved than in the females. Five species and three varieties have been taken in Indiana.

KEY TO INDIANA SPECIES OF ONTHOPHAGUS.

a. Thorax of male protuberant in front, frequently with a long process more or less deeply emarginate at tip; protuberance in female very short but evident.

b. Body black, opaque; thorax finely granulate; elytral intervals each with two rows of fine granules.

1734. HECATE.

67. Body bronzed or greenish, shining; thorax punctured; elytra not granulate.

1735. JANUS.

a a. Thorax of male not differing from the female, both simply convex.

c. Margin of clypeus distinctly notched, more acutely in female than in male.

a. Base and apex of elytra with small paler patches; thorax sparsely granulate punctate.

1736. TUBERCULIFRONS.

dd. Elytra uniform purplish-bronzed; thorax coarsely and deeply punctate.

1737. CRIBRICOLLIS.

cc. Margin of clypeus feebly truncate at middle; elytra wholly black.

173S. PENNSYLVANICUS.

1734 (5458). Oxthophagus mecate Panz, Fam. Ins. Amer. Bor., 1794, 5, pl. I, fig. 2.

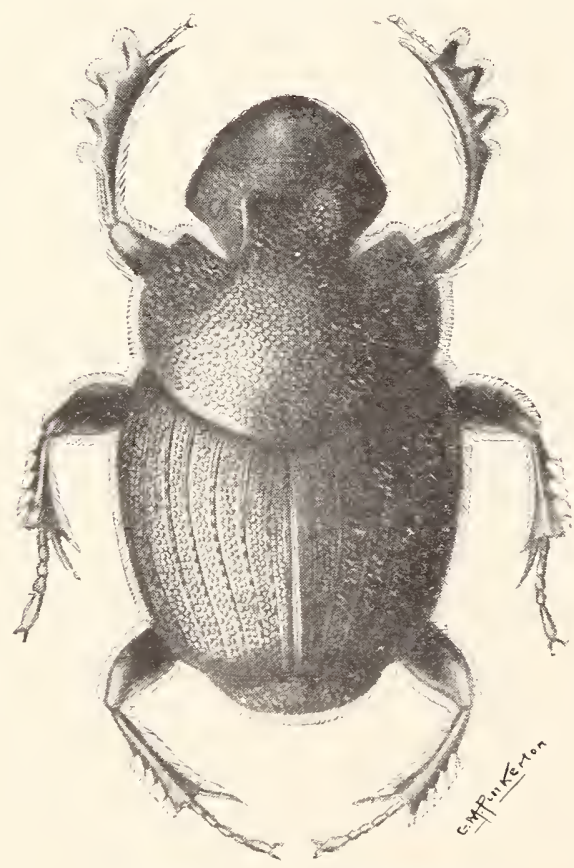

Fig. 364. $\times 5 . \quad$ (After Forbes.)

Broadly oral. Black, opaque; sparsely clothed with short, grayish hairs. Thorax rather densely granulate. Elytra finely striate, the interrals with two or three rows of fine granules. Males with margin of head moderately reflexed, and elevated in front in a slender triangular process; the carini of clypeus and vertex feeble or absent; thoracic process variable in form and length, often as long as the thorax itself, broadly emarginate at tip and with two small teeth extending downtard from the middle of the emargination. Female without the slender process on front of clypeus; the clypeal and vertical carinæ strongly developed, the thorax slightly protuberant at middle or with a feeble depression each side of the middle of the front margin. Length $6.5-9 \mathrm{~mm}$. (Fig. 364.) 
Throughout the State; common. April 24--September 28. Occurs beneath dead birds, snakes and other carrion, and in dung.

1735 (5459). Onthophagus Janus Panz., loc. cit., 5, PI. I, fig. 3.

Broadly oval. Color exceedingly variable, bronzed, green or cupreous, shining; sparsely pubescent. Thorax sparsely and coarsely punctured, with a tendency to granulation on front half. Elytra finely striate, the intervals with two or three rows of punctures. Body beneath green or bronzed, sparsely punctured. Length $4-7.5 \mathrm{~mm}$.

Throughout the State; frequent. April 13-September 18. Occurs most commonly in decaying fungi (Boletus). The following three well-marked varieties occur in the State.

1735a (5459a). Onthophagus Janus orrheus Panz., loc. cit., 5.

Metallic green or bright bronze, shining; elytra sometimes bluish. Male with the clypeal margin moderately reflexed, slightly elevated and subtruncate at middle, the carina nearly obliterated; vertical carina feeble at middle, elevated at each end in an acute tubercle. Thorax with rather long process which is broader and deeply emarginate or forked at tip, the sides diverging. Female with carinæ of head more strongly developed, the protuberance of thorax feeble.

Lake, Putnam and Posey counties; frequent. April 15-June 30. In fungi and at carrion.

1735b (5459b). Onthophagus Janus striatulus Beauv., Ins. Afr. et Amer., 1805, 92.

Brownish or piceous, often bronzed, shining; elytra sometimes paler at base and apex. Male with clypeus as in orpheus. Vertical carina at each end elevated into a slender horn nearly as long as the height of the thorax; protuberance of latter very small. Length 5-7 mm.

Steuben, Marshall, Putnam, Lawrence and Vigo counties; frequent. June 24-August 11. Occur's mostly in fungi.

1735 c (5459c). Onthophagus Janus subæneus Beanv, loc. cit., 105.

Thorax and elytra metallic green or bronze, the elytra yellowish at base and apex. Male with clypeal margin slightly elevated at middle and not truncate. Vertical carina with a short horn at each end. Thoracic process short, broadly but not deeply emarginate at middle.

Vigo, Putnam and Lawrence counties; searce. July 1-July 29. In fungi.

1736 (5462). Onthophagus tuberculitrons Harold, Coleop. Hefte., VIII, 115.

Broadly oval. Piceous or very dark brown; base and apex of elytra with small, dull brownish-yellow patches; feebly bronzed, very sparsely pubescent. Clypeus acutely notched at middle in female, less deeply in male; 
rertical carina divided at middle, thus forming two short tubercles. Tholax minutely roughened, sparsely granulate-punctate. Elytra finely striate; intervals each with two rows of punctures, each puncture bearing a short hair. Length $3.5-5 \mathrm{~mm}$.

Lake and Vigo counties; frequent locally. April 29-June 10. Occurs beneath bones and skin of carrion and in fungi.

1737 (5464). ONthophagus cribricollis Horn, Trans. Kans. Acad. Sci., VII, 1881, 76.

Rounded oral. Dark purplish, bronzed, feebly shining; sparsely pubescent with short erect hairs. Head with two feeble transrerse carina, the shorter one on the frontal suture, the other between the eyes. Clypeus coarsely punctured, its front broadly and rather deeply emarginate, with a triangular tooth each side of notch. Thorax broadest at middle, sides oblique on basal half; surface coarsely, deeply and rather sparsely punctate. Elytra finely striate; intervals each with two irregular rows of rather dense punctures. Front tibia with four teeth, the second from apex the longest. Tength $3.5 \mathrm{~mm}$.

Lawrence County; rare. June 6. 'Taken from beneath horse manure in wagon road, tro miles east of Mitchell. Described from Douglas County, Kansas and Texas, and not since recorded elsewhere. Resembles a small form of janus, but the clypeus is distinctly two-toothed and the thorax is without sign of protuberance.

\section{8 (5463). ONThOphagus penNsYlanicts Harold. loc. cit.. 115.}

Form of tuberculifrons. Black, feebly shining, sparsels pubescent. Clypeus entire or feehly truncate at middle, rather densely and coarsely punctured in female. 'Thorax rather finely, not densely punctate. Elstra finely striate, interrals each with two rows of punctures. Length $3.5-5 \mathrm{~mm}$.

Throughout the State; commion. Narch 6-September 28. Occurs in carrion. dung and fungi. All the species of this genus burrow under the material in which they feed in the same way as Copris.

Tribe II. APHODIINI.

Small, oblong, subcrlindrical beetles. which live chiefly in dung. They have the clypeus expanded so as to cover the mouth parts (except in Egialia); middle coxæ oblique and contiguous, so that the legs are close together; elytra entire, always striate and covering the abdomen; ventral segments six, all free; tarsi with distinct rlaws, with a small process bearing two setw between them. 'The tribe is divided into nine genera, of which representatives of five 
have been taken in Indiana, while those of two others may occur. The following is the principal literature treating of the North American representatives of the tribe:

Horn.- "Description of the species of Aphodius and Dialytes of the United States," in Trans. Amer. Entom. Soc., III, 1870, 110-134.

Horn.- "Synopsis of Aphodiini of the Inited States," in Trans. Amer. Ent. Soc., III, 1871, 28t-297.

Horn.- "A Monograph of the Aphodiini inhabiting the United States," in Trans. Amer. Ent. Soc., XIV, 1887, 1-110.

\section{KEY TO INDIANA GENERA OF APHODIINI.}

a. Mandibles visible beyond the clypeus.

VI. Rgtalia.

aa. Mandibles concealed beneath the clypeus.

$b$. Hind tarsi with triangular joints.

VII. Psammodius.

bb. Hind tarsi with elongate, usually cylindrical, joints.

c. Head roughily granulate; thorax transversely grooved.

d. Thorax without a marginal fringe of hairs, the grooves short, confined to the sides; one or more of the rentral segments carinate.

VIII. PleUrophorus.

$d d$. Thorax with scale-like marginal hairs, the grooves entire; ventral segments not carinate. RHyssemus.

cc. Head punctured or slightly rugose; first five strixe of elytra not reaching apical margin.

e. Outer apical angle of hind tibix prolonged, spiniform; color black.

IX. Atenius.

ee. Outer apical angle of hind tibiæ obtuse.

$f$. Front tibiæ with upper teeth of outer margin obsolete.

Dialytes.

$f f$. Front tibire strongly toothed on the outer margin; elytra simply striate; color usually variegated.

X. Aphodius.

\section{Egralia Lat. 1807. (Gr., "shore.")}

In this genus the mandibles and labrum are visible beyond the clypeus when viewed from above; head more or less granulate or roughened with small tubercles; legs stout and strongly fossorial; front tibiæ broad and with large teeth on outer side.

1739 (5469). Egtalia conferta Horn, Trans. Amer. Ent. Soc., III, 1Si1, 294.

Oblong, convex, slightly broader behind. Piceous, the elytra sometimes reddish-brown; antennæe paler. "Head with rather coarse, close granules. Thorax twice as wide as long, narrower in front, hind angles very obtuse; base curved, its marginal line distinct; surface coarsely and sparsely punctured, the sides smoother and with a small rounded pit. Elytra as wide at 
base as thorax, the strix rather deep, with moderately fine, not crenate, punctures; intervals flat, smooth. Spurs of hind tibia short, broadly expanded, obtuse at tip, their margin translucent. Length 3.5-4.5 mm.

Lake. Tigo and Posey counties; frequent along the beach of Lake Michigan; scarce in the other counties. April 25-May 24. Occurs most frequently in sandy places near water, beneath dung or rubbish.

\section{Psamirodics Gyll. 1825. (Gr., "sand + through.")}

In this genus the mandibles are hidden beneath the clypeus and semimembranous, the base and tooth horn-like; head granulated, deflexed, with the eres hidden in repose; thorax transversely grooved and coarsely punctate; leg's never rery stout; joints of hind tarsi flattened, the first elongate triangular, the last very short and small. One species ras described from Indiana, and another perhaps occurs.

KEY TO INDIANA SPECIES OF PSAMMODIUS.

a. Disk of thorax with transterse grooves; elytral intervals with a row of faint flattened tubercles; length $3.5 \mathrm{~mm}$.

1740. INTERRUPTUS.

aa. Disk of thorax coarsely, irregularly and sparsely punctate; intervals smooth; length 2-2.5 $\mathrm{mm}$.

NATUS.

1740 (5455). Psamarodits interreptes Say, Bost. Journ. Nat. Hist., I, 1835, 178 ; ibỉd. II, 651.

Oblong, nearly parallel, moderatels conrex. Thorax piceous; head and elytra brown; under surface and legs reddish-brown. Head rather closely granulate; clypeus broadly triangularls emarginate. Thorax one-half wider than long. margin crenulate. hind angles obtuse; disk conrex. with four indistinct transcerse ridges: the first entire, the others interrupted by a rather broad and deep median depression. Elytra as wide as thorax, the striæ indistinctls punctured; intervals flat, with inner side feebls crenulate and outer side with a row of indistinct, elongate flattened tubercles. Length $3.5 \mathrm{~mm}$.

Described from Posey County. Horn says it "occurs in the Middle States, Dakota and Texas, but rare." Not represented in the collection at hand.

P. namus DeG., bromnish, head and thorax piceous, leg's pale, is known from Massachusetts, Michigan and westward.

VIII. Pletrophort's Muls. 1842. (Gr., "the side+bearing.")

This g'enus is not well defined. In the "Classification" when but one species was considered it was separated by having the "head roughly granulate or vermucose; thorax transversely grooved. 
not fimbriate, grooves short, lateral." Another species has been since described by Horn and ascribed to the genus, in which the head is finely and sparsely pructate and the thorax not grooved. Both species occur in Indiana.

\section{KEY TO SPECIES OF PLEUROPHORUS.}

a. Clypeus granulate; thorax sparsely, irregularly and coarsely punctured; front femur emarginate beneath.

1741. CÆSUS. a a. Clypeus finely and sparsely punctate; thorax rery regularly, not densely punctured; front femur entire.

1742. ventralis.

1741 (5479). Pleurophorus cesus Panz., Fauna Germ., 35.

Elongate, subcylindrical, slender. Piceous black, shining; legs reddishbrown, antennæ paler. Clspeus broadly emarginate at middle, sparsely and rather coarsely granulate-punctate in front. Thorax one-fourth wider than long, slightly broader in front, hind angles distinct but obtuse; median impressed line with deep, coarse punctures; a large rounded pit at middle of each side, smooth between the pit and margin. Elytra a little narrower than thorax, sides parallel; striæ deep, punctate, the first three only entire and reaching apex; intervals slightly conrex, crenate on their inner border. Second rentral segment carinate at middle. Length $3 \mathrm{~mm}$.

Lake and Posey counties, rare; a single specimen from each. April 25-July 4. Taken from a pathway along the border of woods. Occurs abundantly in Europe and probably introduced.

1742 (10,181). Pledrophorus ventraits Horn, Trans. Amer. Ent. Soc., XIV, 1S87, 92.

Elongate, parallel, semicylindrical. Piceous, shining; legs reddish-brown, antennæ pale. Clypeus broadly truncate. Thorax one-fourth wider than long, margin narrowly flattened, hind angles obtuse, surface sparsely and regularly punctured, the punctures gradually finer towards sides and apex. Elytra a little narrower at base than thorax; strixe broad and deep, with large shallow punctures; intervals strongly convex, smooth. First three rentral segments plainly carinate at middle; fourth and fifth emarginate at middle of front margin. Length $4 \mathrm{~mm}$.

Narion and Posey counties; scarce. April 22-November 17. Probably hibernates beneath partly buried logs in low open woods, as specimens were taken on the later date in such situations. Readily known from all others of the tribe by having the first five strix of the elytra reaching the apical margin and by the carinate and emarginate ventrai segments.

Rhyssemus scaber Fald, oblong, piceous, legs brownish, antennæ pale, intervals of elrtra with a row of small tubereles on the inner side, lenglh 3.5-4 mm.. "ocenis at the margin of streams from the Middle States to Texas." 


\section{ATraxits Harold. 1867. (Gr.. "without a fetter.")}

Small, siender, blackish insects resembling Aphodius, but usually smaller and more elongate. The head is conrex, not tubereulate; eres usually concealed: hind tibir simple. straight, the outer apical angle more prolonged than in A phodius and often ending in a spine. The strix of elytra often apnear more coarsely punctured than they really are, dine to the sides of the intervals being crenate, this rrenation being entirely independent of the punctures of the strix, which are fine and distant. The "accessory spinule" of the hind tibir mentioned in the key below is a prolongation of the apical margin on the under side near the spurs. Seven species have been tal:en in Indiana, while two others perhaps occur.

\section{KEY TO INDIANA SPECIES OF ATENIUS.}

a. Clspeus feebly emarginate at middle, broadly rounded on each side. nerer dentate nor subangulate.

6. Opaque species; thorax without basal marginal line; head densely and finels punctured, not wrinkled; hind tibiæe without accessory spinule.

c. Elytral interrals flat.

1743. IMBRICATCS.

cc. Elstral interrals altermately more elerated. 1744. AITERxATUs.

66. Shining species; thorax with basal marginal line.

d. Hind tibize without accessory spinule.

e. Elstra oblong-oral, base slightly emarginate; form rather robust; thorax unequalls and irregularly punctured. oratuLUs.

ce. Elstra elongate, parallel, base truncate; form slender, elongate; thorax erenls and densely punctured.

1745. GRACILTS.

dd. Hind tibiæ with accessors spinule.

$f$. Clrpeus finels punctured without traces of wrinkles; occiput with coarse punctures.

STRIGATUS.

ff. Clspeus more or less Trinkled and coarsely punctured; thorax with coarse and fine punctures intermingled. 1746. cogratcs.

a a. Clypeus subangulate. or sometimes denticulate each side of the median emargination.

g. Thorax nearly smooth in front, coarsely and rather sparsely punctured behind the middle. more densely at sides; interrals of elstra conres: marginal line of hind femur deep and entire.

1747. LECONTEI.

gg. Thoras nearly erenly punctured from base to apex; marginal line of hind femur rers short or absent.

h. Piceous species; first joint of hind tarsus as long as the long spur; thorax densels punctured.

1745. ABDITCS.

$h h$. Reddish-brown; first joint of hind tarsus shorter than the long spur; thorax regularly not densels punctured, the punctures a little finer in front.

1749. IXYPS. 
1743 (5486). Atemius mabricatus Melsh., Proc. Phil. Acad. Nat. Sci., II, 1S44, 136.

Oblong-oval, moderately conver. Piceous, opaque, the surfice usually covered with a brownish-gray coating; legs brownish, antennæe and palpi paler. Clypeus broadly but feebly emarginate, its sides broadly curved, nearly smooth at middle; rertex densely punctate. Thorax nearly twice as wide as long, slightly narrower behind; sides in front curved, hind angles rery obtuse, base broadly curved; surface with rather coarse and closely placed punctures, which are but faintly risible on account of coating. Elytra as wide at base as thorax, humeri acutely dentate; strie rather deep, with coarse, not closely placed indistinct punctures; interrals flat, each with a single row of fine punctures bearing a small, scale-like vellowish hair. Length 4-4.5 $\mathrm{mm}$.

Lake County; rare. May 25-July 12. Two specimens only from beneath rubbish; one from the lake beach near Pine; the other from Hessville by Wolcott. Occurs from Massachusetts to Texas.

1744 (54S7). Atwentus aiternatus Melsh., loc. cit., p. 137.

Resembles imbricatus in form and color. Head densely punctured, the punctures equal, at sides more rugose. Thorax similar to that of imbricatus, the base undulate, not regularly curved. Elytral striae fine, with rather distant inconspicuous punctures, often hidden br the surface coating; intervals slightly convex, the alternate ones. 1-3-5- $\overline{-}$, more acutely elevated along the middle. Length $3.5-4.5 \mathrm{~mm}$.

Posey County; rare. June 5. Occurs from Pennsylvania to Texas.

A. ovatulus Horn, piceous-black, legs and antennie paler, length $3.5 \mathrm{~mm}$, is known from Pennsylvania to Lonisiana.

1745 (5491). Atemius gracilis Melsh., loc. cit., p. 137.

Elongate, slender, parallel, subdepressed. Piceous black, moderately shining; legs brownish; tarsi, palpi, antennse and rery narrow front margin of thorax, paler. Clypeus rather smooth in front; rertex rather closely and coarsely punctate. Thorax one and a half times wider than long, hind angles broadly rounded. base curved, its marginal line rery distinct; disk with a distinct impression near front angles and a feebler one at middle of sides, surface rather coarsely and closely punctate. Elytra as wide as thorax, striæ deep and broad. not distinctly punctured; intervals strongly conrex, almost like carinx, each with a row of slight elongate elerations on the sides below the summit. Mesosternum opaque. coarsels punctured. strongly carinate between the coxre. Length 3-4 mm.

Throughout the State; frequent. April 23-October 10. A prettily marked and very distinct little species, widely distributed over the United States.

A. strigatus Say, piceous-black, legs and antennie paler, length $4.5-5 \mathrm{~mm}$., is said to oceur fịom the Mriddie. States westward and southward. 
*1746 (10,190). Atæenies cognatus Lec., Proc. Phil. Acad. Nat. Sci., 185S, p. 65 .

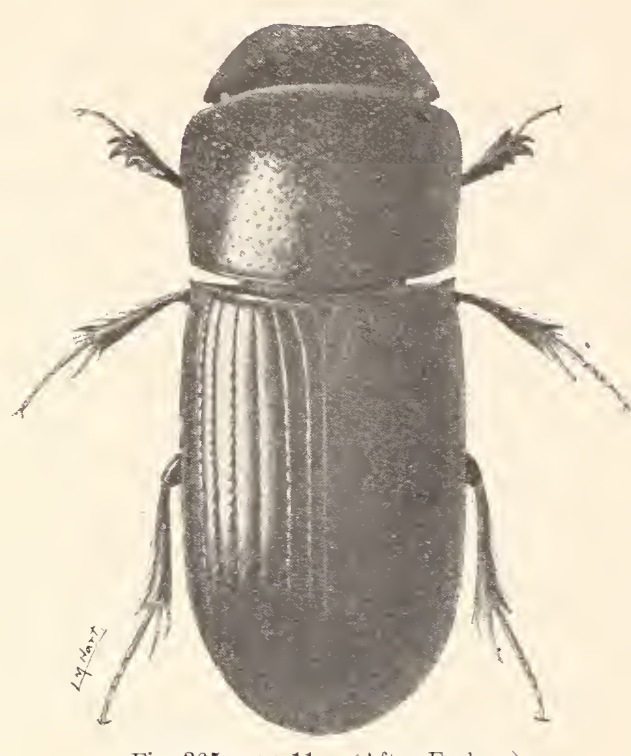

Fig. 365. $\times$ 11. (After Forbes.)

Oblong, parallel, conrex. Piceous-black, shining; legs, sides of clypeus and very narrow front margin of thorax reddish-brown. Clypeus moderately impressed in front. sides broadly rounded, their surface with numerous fine wrinkles; rertex coarsely and sparsely punctured at base. more finely in front. Thorax one and a half times as wide as long. sides feebly curred, himd angles rounded, base curved with deep marginal line; disk with sparse, coarse punctures, with finer ones everswhere intermingled. Elytra as wide at base as thorax, humeri dentate. sides nearly parallel. strire punctured; intervals very finely punctate. crenate on the inner side. Length $4.5-5 \mathrm{~mm}$. (Fig. 365.)

Throughout the State; common. February 8-November 20. Our most robust species of Atrenius resembling Aphodius in general appearance; readily known by the finely wrinkled clypeus and coarse and fine punctures of thorax. They hibernate in large numbers in dry cow dung and beneath it, and on warm sunny days in winter are on the wing. In early spring they and some species of Aphodius fly by thousands and are attracted by electric lights in great numbers. Also frequents fungi.

\section{7 (10,183). Atжenius Lecontei Harold, Col. Hefte, XII, 1874, 19.}

Elongate-oral, moderately convex. Piceous or black, shining; legs reddish-brown, antenne paler. Clypeus impressed in frout, broadly but feebly emarginate, slightly angulate each side, finely and obsoletely punctured; vertex coarsely punctate. Thorax about one and a half times as wide as long, sides feebly curred; apex and base equal, base curred at middle, oblique each side near the hind angles, which are obtuse. Elytra oblongoval, strix deep and rather broad, with coarse, not serrate punctures; intervals convex, subcarinate at apex. each with a row of indistinct punctures on the inner side. Length $3.5-4 \mathrm{~mm}$.

Crawford County; rare. June 1S. A southern form, whose range was given by Horn as "District of Columbia to Louisiana." Taken by Dury near Cincinnati.

1748 (5499). Atenius Abditus Hald.. Jouln. Phil. Acad. Nat. Sci.. 1848. 106.

Elongate, parallel, subdepressed. Piceous, moderately shining; legs pale reddish-bromn; antenme and palpi paler. Clypeus broadly but feebly 
emarginate. a distinct angulation or small denticle each side, its surface roughly punctured or subgranulate; rertex densely punctured. Thorax not quite twice as wide as long. slightly narrower behind, hind angles broadly rounded, surface densely and rather coarsely punctured. Elytra as wide as thorax, the strix rather deep and coarsely crenate-punctate; intervals nearly flat, each with one or two rows of fine but distinct punctures. Length $3.5-4 \mathrm{~mm}$.

Northern half of State, frequent: not taken south of Marion County. May 5-November 28.

$17+9$ (10,155). Atæxius txops Horn. Trans. Amer. Ent. Soc. XIV, 1SS7, 73

Rather elongate. parallel. feebly convex. Reddish-brown, shining; head and thorax a little darker than elytra. Clypeus broadly and feebly emarginate, with a small acute tooth each side of the notch; the entire front granulate. Thorax one and a half times as wide as long. sides regularly curved, hind angles broadly rounded. punctuation as given in key. Elytra as wide as thorax, strixe indistinctly punctured; intervals convex. crenate on their inner edge and each with a row of minute punctures on the outer side. Mesosternum opaque. finely strigose-punctate, carinate between the coxæ. Length $3.5-4 \mathrm{~mm}$.

Marion County ; rare. November 28. Described from Arizona and Texas.

Diaiytes striatulus Say, elỹtral intervals strongly elevated, color piceous-brown, antenne paier, length $4.5 \mathrm{~mm}$., ranges from New England to Illinois and has been taken near Cincinnati.

\section{ApHodivs Iliiger. 1798. (Gr., "excrement + way."')}

The species of this genus bear a close resemblance to those of Atcmius, but are usually hroader, stouter and variegated with black and dull red or yellow. They are separated from Atchius by haring the outer apical angle of the hind tibia obtuse. In mounting specimens of the entire tribe of Aphodiini care should be taken to stretcin out the hind legs so that they may he easily examined. The known species of North American Aphodius number more than 80, and are among our most aumerous scavengers. They occur in great abundance in the dung of horses and cows, into which they burrow almost as soon as dropped from the animals. None of them construct balls for transportation. and the larvie go through their (hanges on the spot. On the first warm days of early spring they are on the wing by myriads along every roadside and in and about harnyards, and thousands meet their death about the electric lights of cities. Serenteen species have been taken in the State and three others perhaps necur.

[59-23102] 
In using the following table the student must, at all times, be careful that the specimens are perfect; that is, that the spinules at the tips of the tibiæ are not worn or accidentally reduced to an equal size, or that the long hairs fringing the sides of the tibix do not, by crossing the field of vision, deceive into the belief that the spinules are unequal. In those that are pubescent, various accidental causes may have removed the hairs. In old specimens of those species in which the clypens is denticulate, the teeth are apt to be worn down, as also the spurs of the tibix and the large teeth of the front tibiæ.

KEY TO INDIANA SPECIES OF APHODICS.

a. Scutellum long, one-fourth or one-fifth the length of the elytral suture; front tibire not serrate above the upper tooth.

1750. HAMATCS.

a a. Scutellum short, not more than one-eighth to one-tenth the length of suture.

b. Apex of hind tibire fringed with short, equal spinules; head with three small tubercles on the rertex.

c. Thorax with distinct basal marginal line.

a. Mesosternum not carinate between the coxie.

$e$. Elytra clear red; thorax dissimilar in the sexes. inlressed in front in the male.

1751. FINETARIUS.

ce. Elytra piceous or dull red; thorax similar in the sexes.

f. Color wholly piceous black, front angles of thorax never paler ; first joint of hind tarsus very little longer than the next two; form small, robust.

1752. RURICOLA.

ff. Front angles of thorax paler; first joint of hind tarsus as long as the next three; elytra uniform reddish-brown, the first interval narrower than second.

FETIDUS.

dd. Mesosternum distinctly carinate.

g. Color entirely black or piceous; first joint of hind tarsus not longer than the next two; first or sutural interval of elytra as wide or wider than second.

1753. GRANARIUS.

gg. Elytra reddish-brown, the suture and side margins piceous; first joint of hind tarsus equal to next three.

1754. VTTTATUS.

cc. Thorax without trace of basal marginal line; color dull brownishyellow, with hind portion of head, large spot on thorax and sutural line of elytra dark brown or piceous.

1755. LIVIDUS

7)6. Apex of hind tibire fringed with unequal spinules; head rarely with tubercles.

h. Elytra opaque; color reddish-brown, head and thorax slightly darker"; size small, 3.5-4 $\mathrm{mm}$.

1750. LENTTS.

h\%. Elytr:a more or less shining.

$i$. Thorax not narrower at base than apex, not simuate at sides near hind angles. 
j. Elytra not pubescent; clypeus without a transverse ridge.

li. Mesosternum distinctly arinate between the coxie; ront tibia punctate on front fare f lirst tarsal joint longer than second.

7. Uniform reddish- or pale chestuut-brown; first joint of hind tarsus not as long as the next three.

1757. RUBEOLUS.

ll. Dull brownish-yellow, head and thorax darker, elytra often clouded; first joint of hind tarsus longer than the next three.

1758. STERCOROSUS.

7\%. Mesosternum not carinate; basal marginal line rarely absent; front tibixe smooth in front.

m. Color reddish-brown or dull brownish-yellow, never in any part black.

n. Thorax not fringed with long hairs; color dull yellow, thorax and suture darker; larger, 4.5-5 mm.

CONSENTANEUS.

mn. Thorax fringed with conspicuous hairs; color pale, dull yellow, elytra with an oblique fuscous bar on basal half; smaller, not over $3.5 \mathrm{~mm}$. 1759. woLcotт.

$m m$. Color in great part piceous; head and thorax always black or piceous.

o. Clypeus angulate each side of middle notch.

p. Elytra entirely piceous or often with the alternate intervals marked with small reddish spots; body beneath and legs pale yellow. 1760. BICOLOR.

pp. Elytra dull yellow, with black spots; sides of thorax paler.

1761. SERVAL.

oo. Clypeus very obtusely rounded each side of middle notch.

q. Elytra dull yellow, with black spots; thorax with front angles paler.

1762. INQUINATUS.

qq. Elytra black, apex dull red; thorax entirely black; elytral intervals very tlat.

1763. TERMINALIS.

i. Euytra more or less pubescent, fuscous, the sides paler.

$r$ Sides of thorax not fringed; teeth of front tibiæ normal; punctures of elytral strix very distinct.

1764. FEMORALIS.

$\%$. Sides of thorax with a fringe of rather long hairs; front tibixe with upper tooth small or wanting; punctures of elytral striae indistinct.

1765. WALSHII.

i. Thorax narrower at base thin apex, distinctly sinuate at sides near hind angles; color black or piceous.

s. Elytra oblong with a small tooth on each humerus; length i$9 \mathrm{~mm}$.

1766. OBLONGUS.

ss. Elytra oval withont a tooth on humerus; length $3.5 \mathrm{~mm}$.

HUMERALIS. 
1750 (5510). Aphodius hamatus Say, Long's Exped., II, 1824, 27 ; ibid. I, 183.

Oblong-oval, moderately robust. Piceous or black; elytra varying to brown, and often with a paler suture and margin. Head smooth; clypeus truncate or very feebly emarginate. Thorax large, not wider than elytra; surface with a few coarse punctures on the sides, disk almost smooth. Elytral striæ sparsely punctured; intervals nearly flat, with a few fine punctures. Length 6-9 $\mathrm{mm}$.

One specimen in Stein collection marked "Ind." without date. Probably from near Michigan City. Its range is given "from Maine to Oregon in the region north and a little south of the great lakes.' Readily known by its large size and long scutellum.

*1751 (5517). Aphodius fmmetarius Linn., Syst. Nat., 1766, 348 .

Oblong-oval, very convex. Black, shining; elstra brick-red, rarely clouded with piceous; thorax reddish-yellow near front angles. Head sparsely, rather finely punctulate, with three distinct tubercles in male. Clypeus broadly but very feebly emarginate with a slightly elevated transverse carina. Thorax with coarse, very irregularly placed punctures, intermingled with finer ones. Elytra as wide as thorax, the striæ with crenate punctures; intervals slightly convex, finely and sparsely punctate. Length 6.5-8.5 $\mathrm{mm}$.

Throughout the State; common. February 11-October 12 . Hibernates in large numbers in or beneath half dry cow dung; also beneath logs on sandy banks. In three specimens at hand the disk of elytra is in large part piceous. The tubercles on head are much more distinct in the males. Introduced from Europe and widely distributed.

1752 (5523). Aphodius ruricola Melsh., Proc. Phil. Acad. Nat. Sci., II, 1844,136

Oblong-oral, often slightly wider behind. Piceous-black, shining, usually with sides and tips of elytra paler than disk. Head with three small but distinct tubercles, sparsely punctate. Clypeus broadly emarginate at middle, the angles on each side obtuse. Thorax narrower in front, hind angles distinct, rather obtuse; disk finely and rather sparsely, sides more coarsely, punctured. Elytra slightly wider than thorax, the strix deep with rather coarse crenate punctures; intervals convex, very finely and sparsely punctate. Length $4.5-5.5 \mathrm{~mm}$.

Lake, Poser and Crawford counties; scarce. April 28-1Iay 30.

A. foetidus Fab., head and thorax black, length $4-5 \mathrm{~mm}$., is a European species said to be "widely distributed in our country." 
1753 (5528). Aphontus graxartus Limn.. Syst. Nat., II, 1766. 547.

Oblong, subcylindrical. Piceous, shining; legs reddish-brown, antennie paler. IIead with three distinct tubercles; sparsely punctured at midale. more densely and rugosely at sides; clypeus rather feebly emarginate. the sides broadly rounded. Thorax with coar'se and fine punctures intermingled in female, almost smooth in male. Elytra parallel. the strize finely and serrately punctured: intervals feebly convex and with few very minute punctures; the first as wide, or even wider than second. Length 4-6 mm. (Fig. 366.)

'Throrighout the State; common.

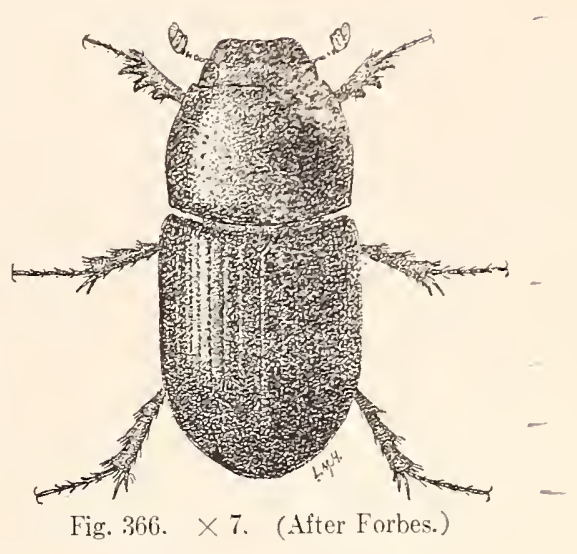
April 8-June 3. Occurs in dung and on fungi.

1754 (5529). Aphodres vittates Say, Journ. I'hil. Acad. Nat. Sci., T. 1525. 191 ; ibid. II. 295.

Oblong, subcylindrical. Piceous or black; elytra each with a basal and apical reddish-brown spot more or less united; rarely with the elrtra, except margin and suture, entirely reddish-bromn, or entirely black; legs reddishbrown, tarsi paler. Head with three tubercles; surface sparsely punctate; clypeus feebly truncate or broadly rounded. Thorax slightly narrower in front, hind angles obtuse; surface finely, regularly and rather densely punctate. Elytral strice fine, crenately punctate; intervals flat with numerous fine punctures. Length $4-5 \mathrm{~mm}$.

Lake County ; rare. May 12. Probably occurs throughout the State.

1755 (5533). Aphodius lividus Oliv.. Ent., III. 1798, 86.

Oblong-convex. Color giren in key. Head sparsely punctate. tuberculate. Clypeus always paler than rertex, feebly emarginate, sides rounded. Thorax with rather coarse, sparse punctures, intermingled with finer ones. Elytra parallel, the striæ finely and crenately punctured; intervals nearly flat with a few very minute punctures. Length 4.5-5 mm.

Putnam and Posey counties; scarce. February 8-May 30. Introduced from Europe. Probably thronghout the southern half of the State.

1756 (5544). Aphodius Lextus Horn, Trans. Amer. Ent. Soc., III, 1870, 125.

Elongate-oblong, convex. Color given in key. Head finely and rather closely punctate. Clypeus hemihexagonal, feebly emarginate in front. sides oblique, angles rounded. Thorax with sides feebly curved, hind angles obtuse, disk finely and rather densely punctate. smoother at middle. Elytra not wider than thorax; stria rather coarsely punctate: intervals conrex. each with two rows of punctures. nearly as coarse as those of strice. each puncture bearing a rery short suberect rellowisin hair. Mesosternum finely carinate between the coxie. Length $3.5-4 \mathrm{~mm}$. 
Hessville, Lake County ; rare. Nay 30. Ranges from Massachusetts to Illinois and Georgia.

\section{7 (5545). Aphodius rubeolus Leauv., Ins. Afr. et Amer., 1805, 90.}

Moderately elongate, convex. Reddish or pale chestnut brown, shining. Head sparsely and finely punctate; vertex not tuberculate; clypeus feebly emarginate, angles each side obtuse. Thorax very sparsely and finely punctate at middle, more coarsely aud densely on sides; basal marginal line fine but distinct. Elytral strixe fine and very feebly punctured; intervals flat, smooth. Length $3.5-4.5 \mathrm{~mm}$.

Southern half of State, scarce; Lake County only in the north. April 7-October 9. T'aken at dung, heneath leaves and at electric light. Horn states that the thorax is without basal marginal line, but all Indiana specimens examined have that line fine but distinct.

1758 (5546). Aphodius stercorosus Melsh., Proc. Phil. Acad. Nat. Sci., II, $1844,136$.

Oblong, parallel, convex. Color given in key; surface smooth, shining. Head sparsely punctate, female, nearly smooth, male; clypeus truncate, the sides curved. Thorax with hind angles distinct, obtuse; basal marginal line wholly absent; surface punctate as in rubeolus. Elytra finely striate, the striæ very finely punctate, male, more coarsely so, female; intervals flat, smooth. Length 3.5-4.5 $\mathrm{mm}$.

Southern half of State, frequent; Lake County, scarce. Febpuary 8-September 8. Occurs cverywhere east of the Mississippi.

A. consentaneus Lec., occurs "from Canada to Missouri, Kansas and New Míexico.

\section{9 (—). ApHodics wolcotTi sp. nov.}

Elongate, feebly convex. Pale yellowish, shining; head and thorax faintly clouded with fuscous; elytra, in one of the two specimens at hand. each with an indistinct fuscous bar extending oblicquely from humerus to suture in front of middle. Head without trace of tubercies, rery sparsely and finely punctate; clypeus broadly and feebly emarginate at middle, angles rounded, sides oblique, divergent. Thorax one-half wider than long. sides broadly curved into the base; marginal line of base fine but distinct, slightly sinuate; surface nearly smooth at middle, coarsely and sparsely punctate on sides. Elytral strix deep, not punctured; intervals convex, very finely wrinkled, each with a few fine, shallow punctures. Front tibie with three teeth on outer side, the middle and apical ones equal, the upper one much smaller. First joint of hind tarsi as long as the next three. Length $3-3.5 \mathrm{~mm}$.

Pine, Lake County; scarce. July 23. 'Two specimens taken by A. B. Wolcott from beneath rubbish on white sand of Lake Nichigan beach. Named in honor of the collector, who has shown me many favors lluring the premaration of the present paper. 

212 ; ibid. II, 136.

Oblong, slightly wider behind. subiepressed. Color given in key. Hear without tubercles, rather densely and coarsely punctured; clypeus broadly emarginate, the angles each side of notch well marked. Thorax nearly twice as wide as long. hind angles broadly rounded; basal marginal line distinct; surface rather closely punctate with coarser and finer punctures intermingled. Elytra as wide at base as thorax; the strix rather deep. finely and crenately punctured; intervals convex, sparsely and irregularly punctate. Length $4.5-6 \mathrm{~mm}$.

Vigo, Orange, Crawford and Posey counties; frequent. May 1-October 3. Probably throughout the State. A rather large, bulky species, readily known by the pale under surface and leg's.

1761 (5535). ApHodies servat, Say, Bost. Journ. Nat. Hist., I, 1835, 177; ibid. II, 651.

Moderately elongate, parallel. Head and thorax piceous, their margins paler; elstra dull sellow, with quadrate black spots arranged in an oblique row extending from base of fifth interral to near the suture and in a sinuous band one-fourth from apex; sides also with a rather broad black stripe on the seventh, eighth and ninth intervals. Heat coarsely and roughly punctured; clypeus rather deeply emarginate, the angles each side of notch distinct. Thorax nearly twice as wide as long, sides nearly parallel; surface with coarse and fine punctures intermingled. Flytra finely striate, the strix fine. not punctured; intervals flat. sparsely and indistinctly punctulate. Length 4.5-5 mm.

Throughout the State; freifuent. March 11-November 23. ProbabIy hibernates beneath leaves and rubbish. The black spots of elytra are sometimes so enlarger as to cover the greater part of the surface.

*1762 (5256). Aphodies inquixates Herbst., Hissl. Arch., 1784. II. 6.

Oblong. conrex. Color as in servat, except that the black spets of elytra are often united and more elongate. the middle one of basal half occupying parts of the second, third and fourth intervals. Head sparsely punctate, more roughly on sides; rertex with three blunt tubercles; clypeus rers feebly emarginate, obtusely rounded each side of notch. Thorax rers sparsely punctate in male, more densely in female. Elytra parallel, striate. the striæ finely and crenately punctured; intervals feebly conrex in male. more strongly in female, very finely punctate near the strix. Length 4.5$5.5 \mathrm{~mm}$.

Throughout the State; common. February 12-November 8. Hibernates with and in same places as $A$. fimetarius and Atcenius cognatus. On the wing by thousands in late autumn and early spring. Tntrodiced from Furope and widely distributed.

*1763 (5563). Apmoduts Terminatis Say, Jomm. Phil. Acad. Nat. Sci., III, 1823,213 ; ibid. II,。137.

Oblong-oval, moderately convex. Black, shining; apex of elytra reddish-brown. Head often with three small tubercles, coarsely punctate. 
slightly rugose at sides and in front; clypeus feebly emarginate in front. the angles each side of notch obtuse. Thorax with distinct basal marginal line, hind angles nearly rectangular; disk finely and sparsely punctured at middle. more coarsely and densely on sides. Elytra as wide at base as thorax. a little broader behind the middle: strix fine, deep, closely but not coarsely punctured: intervals rery flat, each with two indistinct rows of fine punctures. Length $4-5 \mathrm{~mm}$.

Henry and Vigo counties, scarce. January 13-March 10. Hibernates beneath cow dung and party buried logs. Horn says the elypeus is without tubercles. Sar, in his original description. makes the "trituberenlate clypens" one of the principal distinguishing chararters. Traces of the tubercles are present in all specimens at hand and in some of them they are quite distinct.

1764 (5569). Aphodius fexroralis Say. Journ. Phil. Acad. Nat. Sci., III. 1823, 215 : ibid. II, 139.

oblong, nearly parallel. moderately convex. Head and thorax piceous black. shining. sides of latter dull rellow: elștra smoky brown. opaque. pubescent, the base and often entire margin paler; antennæe and legs reddish-brown. Head with three feeble tubercles, surface finely and sparsely punctate. male. more coarsely. and densely, female; clypeus truncate or faintly and broadly emarginate. the angles each side broadly rounded. Tholax nearly twice as wide as long. basal marginal line distinct: surface sparsely and finely punctate, male, more coarsely and closely, female. Elytral strixe rather deep, finely punctured; intervals convex, with a row of distinct punctures each side. Length $4.5-6.5 \mathrm{~mm}$.

Throughout the State; common. April 18-October 11. Readils known by the pubescence and dull sooty-yellow hue of elytra.

$1765(5570)$. Aphodius walshit Horio, Trans. Amer. Ent. Soc., III. 1870. 132.

Resembles femoratis in form and color. Sides of thorax more widely and distinctly yellow. Head sparsely and finely punctate in both sexes. Thorax with a marginal row of bristly yellow hairs. hind angles rounded. Elytral strix very finely punctured; intervals convex, alutaceous. with a few rers fine punctures, the three outer ones more distinctly punctate. Length 5-6 mm.

Lake County ; rare. May 27. Taken from the carcass of a hen. Known heretofore from Tllinois and Kansas.

1766 (5572). Aphoduts oblongt's Sar, Journ. Phil. Acad. Nat. Sci.. III. 1S.23. 215 ; ibid. II. 135 .

Oblong, moderately elongate. slightly broader behind. Piceous black. shining: antennie and legs brownish. Head without tubercles. sparsely and rather finely punctate at middle. more coarsely at sides: clipeus broadly and rather feebly emarginate, a small reffexed tooth each side of notch. Thorax nearly twice as wide as long, distinctly narrower behind middle. base curred at middle. oblique near hind angles; surface coarsely and 
sparsely punctate with finer punctures intermingled. Elytra as wirle at base as thorax, with a distinct tooth on each humerus; strie deep and subcrenately punctite; intervals nearly fiat, sparsely : ind finely punctate. Iength 7 $-9 \mathrm{~mm}$.

Orange County ; sarce. September 9.

A. humeratis Lec., black, shining, dytral strie fine with large round distant punctures, is known from Detroit, Michigan, and Maryland.

\section{Tribe III. ORPIININI.}

'This tribe is represented in the United States by a single genus comprising oval, convex species, covered above with short, erect hairs. They have the mandibles and labrum of horn-like texture, not covered by the elypeus, which is not expanded as in the two preceding tribes; antenna 10-jointed, club three-jointed; eyes not emarginate; front coxæ prominent: middle coxæ oblique, contiguous; elytra striate. covering the abdomen; ventral segments six, not firmly united; tarsi with a small seta-bearing process between the claws. The principal papers treating of the North American species are as follows:

Horn._- Ochodxus-Synoptical Table of,"' in 'Trans. Amer. Ent. Soc., II, 1868, 50-52.

Horn.-_"Revision of the U. S. Species of Ochodeus and other Genera of Scaraheicie,' in Trans. Aner. Ent. Soc., V, 1876, $177-197$.

\section{OCHODfus Serv. 1827. (Gr., "to carry + tooth.")}

To this genus, as characterized above, belong eight species, only one of which occurs east of the Mississippi.

1767 (5578). Ochodeus musculus Say, Bost. Journ. Nat. Hist., I, 1835. 178 ; ibia. II, 652.

Oval, convex. Uniform reddish- or chestnut-brown, sparseìy clothed with short erect hairs. Head coarsely punctured; clypeus with a double margin, the upper one forming a curved carina ; vertex with a feeble transverse carina. Thorax three times as wide as long, sparsely punctured in male, more densely in female; a rounded impression on the middle of each side. Elytral strix rather closely punctured: intervals subconvex, each with two cr three irregular rows of small punctures. Length $5-6 \mathrm{~mm}$.

Two specimens from near Hessville. Lake County. June 13June 17. Say deseribed the species from a single female taken near New Harmony, Posey County. Horn records it from Michigan. Dakota and Nebraska. 
Tribe IV. GEOTRUPINI.

Rounded, convex beetles having the mandibles and labrum prominent, of horn-like texture; antennæ 11-jointed, club 3-jointed, variable in form; elytra usually strongly striate, covering the abdomen; the middle coxæ, ventral segments and tarsal claws as in Tribe III. The thorax of some males, and more rarely the head, is armed with horns or tubercles. Nost of the species live in excrement; others, according to Horn, are veritable hoboes, "wandering about without visible means of support." The principal literature treating of the North American members of the tribe is as follows:

Horn.- "Notes on Genera of Coprophagus Scarabæidæ of the U. S.," in Trans. Amer. Ent. Soc., III, 1870. The genera Pradycinetus, Bolboceras and Odontcus are treated on pp. $48-50$.

Horn.- "Geotrupes of Boreal America," in Trans. Amer. Ent. Soe., I, 1868, 313-322.

Horn.- "Synopsis of the Geotrupes of the U. S.," in Trans. Amer. Ent. Soc., VITII, 1880, 145.

Blanchard, Frederick.- "Some account of our Species of Geotrupes," in Psyche, V, 1888, 103-110.

Scheffer, Chas.-: "On Bradycinetus and Bolboceras of North America, with Notes on other Genera," in Trans. Amer. Ent. Soc., XXXII, 1906, 249-278.

Of the five genera of Geotrupini recognized from the United States, representatives of iour have been taken in Indiana:

KEY TO INDIANA GENERA OF GEOTRUPINI.

a. Club of antennæe large, round, convex on both sides. (Fig. 4, No. 14.)

$b$. Eyes only partially divided by a process from the side of head.

bъ. Eyes entirely divided.

XII. Rolboneras.

c. Color above black and reddish-brown; process between the middle coxie with an erect tooth-like elevation.

XIII. Bolbocerosoma.

cc. Color above uniform chestnut brown; process between the middle coxie without a tooth-like elevation. XIV. ODontæus. a a. Club of antennæ smaller, composed of leaf-like plates. XV. Geotrupes.

\section{Bolbocerts Kirby. 1818. (Gr., "bull + horn.")}

This genus is principally distinguished by having the eyes only partly divided and by the middle coxe being continguous or ver? close together. 
1765 (5591). Bolboceras lazares Olir.. Ent. IIist. Nat. des Ins., I, 17s9, 63:3.

Broadly oval, robust, convex. Uniform chestunt-brown, shining; margins of head, thorax and legs fringed with long brownish-yellow hairs. Irales with a flattened, slightly recurved. truncate or emalginate holn on clypens and a transrerse ridge on rertex; females with clypeal horn reduced to a ridge and rertical ridge higher than in male. Thorax of male with a transterse ridge and a prominent tubercle each side ou apical half; these reduced in female to a blunt crest: median lengthwise groove wide and deep behind the crest, with one or two coarsely punctured, cibliduely transrerse groores each side. Eiytra with fire coarsely punctured strie between the suture and humeral ridge and four or fire additional ones on the side. Length 6-12 $\mathrm{mm}$.

Throughout the State; scarce. Nay 19-July 1. Two of the fire specimens in the collection were taken at electric light; the others beneath rubbish

\section{Bolbocerosoma Schreffer. 1906. (Gr., "bull +horn + body.")}

In this genus the eyes are completely dirided and the middle coxæ are very narrow separated, with a tooth-like elevation arising from a process betrieen them. One species is known from the United States.

1769 (5590). Bolbocerosoma Farctuar Fab., Spec. Insect., I, 17S1, 14.

Broadly oral, rery robust, strongly conrex. Reddish-yellow; head. narrow basal line (and sometimes a discal spot) on thorax, sutural and marginal lines and apical third of elytra, black. Males with front edge of clypeus and angles in front of eyes, acute, elerated and slightly reflexed; also with a short, acute horn arising from the middle of the clypeus; females with the horn reduced to a transrerse ridge. Thorax of male with a deep pit each side of apical half; between these a ridge with an acute tooth at each end and a similar tosth outside each pit; in female the pits are absent. the front half bearing only an elerated ridge. Elytra with fire or seren coarsely punctured strix between the suture and humerals. Length $S_{-}$ $12 \mathrm{~mm}$.

Throughout the State; scarce. June 6-.June 15. Occurs beneath logs, most frequently in sandr Iocalities: also along pathways in woods. The black area of the upper surface varies greatly in size. A female from Lawrence County has three black spots on apical half of thorax. one median and a smaller one each side, and the pale portion of elytra limited to a small rounded spot on basal third. The specimens with seven strixe between the suture and humeral prominence are usually listed as rar. tumefactus Beaur. All but one of the Indiana specimens are of this form. 


\section{ODONTEES Neg. 1521. (Gr., "a tooth.")}

Eyes completely divided; midule coxe contiguous without a tooth-like eleration on the process between them. The males have a long. slender. curved horn arising from the clrpeus. Two of the three known North American species have been taken in the State.

1770 (5592). Odontels filtcorsis Say, Journ. Phil. Acad. Nat. Sci., III. 1ร23, 211; ibict. II, 136.

Broady oral. convex. Cniform pale chestnut-brown, male; brownislrellow. femile. clipens with a slender. curred. morable horn. longer than the greatest width of head. Thorax of male with a deep median groore on basal two-thirds. a broad pit each side, bordered externally by a sharp longitudinal ridge. the groove and pits sparsely and coarsely punctured: female with median groore less wide and deep. the pits obsolete: the sides more densely and coarsely punctured than in male. Elstra each with 11 or 12 shallowly impressed, coarsely punctured strix. Length 6$8.5 \mathrm{~mm}$.

Frequent about Hessrille, Lake County: one specimen from Vigo County. May 9-july 16. Oceurs beneath logs and other cover in sandy localities.

1771 (5593). Odoxteus conxigeres Melsh., Proc. Phil. Acad. Nat. Sci.. II. 1S44, 135.

Resembles fiticorris but larger and more robust. Horn of clrpeus of male stouter and not movable. Thorax of male with median groore shorter and wider, the pits on each side rery large. reaching nearly to base. their onter margin not limited by a sharp ridge: a stont reflexed horn in front of each pit. Elytra as in filicomis. Length $10 \mathrm{~mm}$.

One male from Tigo County. September 28. Taken from beneath a partly buried log in upland. sandy moods. Female not seen and, as far as I can ascertain. not described.

\section{Geotrupes Fab. 1798. (Gr.. "the earth + bore.")}

Medium-sized, broadly oval species, rarring in color from black to dark mietallic green or purple. They have the antennal club small, with the plates of equal thickness. Some of them are rery common species, occurring under cow dung, in pastures, often burrowing into the ground beneath. Of the 11 species known from North America, three have been taken in the State. while another doubtless occurs.

KEI TO INDIANA SPECIES OF GEOTRTPES.

a. Body abore shining. more or less metallic: elytra distinctly striate.

b. Strise of elstra without punctures: head without tubercles: basal malginal line of thorax absent. SEMIOPACE'S. 
b7. Striac of elytra punctured; head with a median tubercle; batsil malginal line of thorax present.

c. First joint of hind tirsus shorter than the next three together; claws of midale tarsi chelate in the male.

1772. SPLENDIDLS. cc. First joint of hind tarsus equal to the next three; claws of middle tarsi of male not chelate.

17T4. MEACKBURNIT. a . Body above opaque, black; elytra not striate, but with rows of punctules.

177:3. OPACL'S.

G. semiopacus etekl, has been taken near Cincinnati.

*1772 (5596). Geotrupes splendiuus Fab., Syst. Ent., 1798, 18.

Broadly ovate. Color very variable; brilliant metallic green, purple or bronze. Clypeus rounded in front, surface coarsely and roughly punctate and with a distinct median tubercle. Thorax twice as wide as long, surface finely and sparsely punctured, more coarsely and densely on sides. Elytra deeply striate. the stria with well-defined punctures; intervals smooth, flat or subconvex. Male with middle tarsus short and thick. Length 12-17 mm. (Fig. 367.)

Throughout the State; common. March 16-

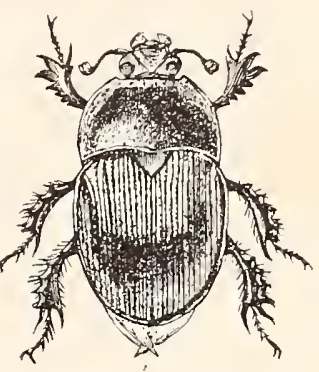

Fig. 367. $\times 1 \frac{2}{3}$.

December 20. A pair were found mating beneath a $\log$ on the latter date. They evidently sometimes feed upon carrion as a pair, also mating, were taken beneath the bones of a dead horse on May 6 .

1773 (5601). Geotrupes opacus Hald.. Proc. Phil. Acad. Nat. Sci., VI, 1S53, 362.

Broadly oval. Above black, opaque, often with a purplish tinge; under surface and legs bluish. Clypeus rounded, rough, with few punctures and with a distinct tubercle near the frontal suture. Thorax with fine, irregularly scattered punctures, more coarse and numerous on the sides. Elytra smooth, not striate, each with about 16 somewhat irregular rows of fine punctures. Length 12-15 $\mathrm{mm}$.

Lake and Vigo counties; rare. May 19-October 11. Occurs in sandy localities.

1774 (5602). Geotrupes blackburnit Fab., Spec. Insect., I, 1781, 20.

Broadly oval. Black, feebly bronzed. Clypeus rounded in front, finely and densely punctate, with a slight tubercle behind the middle. Thorax with the center of disk nearly smooth, the sides with fine and sparsely placed punctures; a feebly impressed median line on basal half. Elytra deeply striate, the strice finely punctured. Front tibice of male with a short spur. Length 13-16 $\mathrm{mm}$.

Very common in the southern half of the State; much less so in the northern counties. Narch 11-October 17. Often seen on the wing. The surface is less shining and the color not variable as in splendidus: the average size is also smaller. 
Tribe V. ACANTHOCERINI.

To this tribe belong three small, oval, convex, smooth, shining beetles, living under bark and in rotten wood. They have the mandibles and labrum of horn-like texture and prominent; the antenne 10-jointed, club 3-jointed; front coxa conical, prominent; middle coxæ transverse, contiguous; ventral segments five, loosely united; pygidium entirely covered by the elytra; tarsi with slender claws without a process between them. One of the two genera comprising the tribe is represented in Indiana. No papers treating of the tribe as such have been published, the descriptions of the species being isolated.

\section{Cheotus Germ. 1842. (Gr., "girdled.")}

This genus contains two smail species having the middle and hind tibiæ thick; body partially contractile, so that it may be rolled up into a somewhat henispherical mass, much in the same manner as in the members of the genus Agathidium of the Silphidx. The scutellum is large, triangular and attenuate behind and the elytra are not striate.

\section{5 (560S). Crafotis aPHonloides Ill., Germ. Zeitsch., IV, 1805, 137.}

Short, oval or subglobose. Blackish or purplish-bronzed. polished. Clypeus rounded in front, finely and sparsely punctate. Thorax about twice as broad as long, sides nearly straight; hind angles rectangular, disk finely and sparsely punctured and with two impressions each side near the margins. Elytra with the side margins entire, surface with rows of long, deeply impressed, rather close punctures, and with three or four elevated lines on apical third, the outer one longer. Length 4-4.5 $\mathrm{mm}$.

Southern half of State; frequent. April 9-November 22. Occurs beneath bark, especially that of oak and hickory. Easily distinguished from the next species by its smaller size and the more closely placed punctures and entire side margins of elytra.

1776 (5609). Cleotus globosus Say, Bost. Journ. Nat. Hist., I, 1835, 179; ibid. II, 653.

Form and color of the preceding but slightly larger. Clypeus finely rugose. Thorax much more densely punctate. Elytra with the side margins finely denticulate; the punctures oblong, separated from each other by a distance about equal to their length; apical half with four or five slightly elevated lines, the two outer ones extending toward the humerus. Length $5-5.5 \mathrm{~mm}$.

Throughout the State; scarce. March 20-November 30. Probably hibernates as inago. The specimens taken on November 30 
were from the half-dried carcass of a dog. It seems, therefore, that this species sometimes has the habits of Trox, a genus with which it is closely allied and in which it was placed by Say.

\section{Tribe VI. TROGINI.}

Oblong, convex, dirty-looking brown betles, which occur under or about the skins and bones of carrion, old hides or feathers. The surface is usually roughly sculptured and covered with a crust of earth which is difficult to remove. From the preceding tribe they differ in form and by having the side pieces of mesothorax not reaching the rounded middle coxæ. They possess a distinct stridulating organ in the form of an elliptical plate with pearly reflections, located on the upper part of the outer face of the first ventra! segment, and covered by the elytra. A small oval polished space on the inner surface of the elytra near the margin and about opposite the plate serves as an aid in producing the sound. All of our species belong to the single genus Trox. The following are the principal papers treating of the North American forms:

LeConte._- Descriptions of the species of Trox and Omorgus inhabiting the United States,' in Proc. Phil. Acad. Nat. Sci., VII, 1854, 211-216.

Horn.- "Revision of the Species of Trox of the United States," in Trans. Amer. Entom. Soc., V, 1874, 1-12.

\section{Trox Fab. 1792. (Gr., "a gnawer.")}

Twenty-one species of this genus are recognized from the United States, 14 of which have been taken in Indiana, while one other perhaps occurs. Sometimes a half dozen or more species are found in company in or beneath the same old skin or other remains of carrion. Unless cleaned of their nsual encrusted coat of dirt, the specimens are very dificult to classify.

KEY TO THE INDIANA SPECIES OF TROX.

a. Scutelium spear-shaped, i. e., narrowed strongly near the base, its sides at middle angulate: larger species. 12 or more $10 m$.

b. Elytra with rors of tubercles rery distinct and tomentose, or corered with fine hairs.

c. First joint of antenne with dark brown hairs; club dark.

1TT. SCABROSCS. cc. First joint of antennxe with reddish-brown hairs: chub reddishbrown or ash-giat.

d. Elytral tuberdes round, their cntire surface tomentose.

17TS. MONACHIS. 
$d d$. Elytral tubercles oblong, the front portion of each without hairs.

1779. ASPER.

bb. Elytra with rows of tubercles much less distinct, wholly without hairs.

$e$. Sides of thorax near the hind angles rather deeply notched; elytra not distinctly tuberculate.

1780. SUBEROSLS.

ce. Sides of thorax not or rery feebly notched; elytra with well marked rows of smooth tubercles.

PUNCTATUS.

aa. Scutellum oval, never spear-shaped; size smaller, not over $12 \mathrm{~mm}$.

$f$. Tip of prosternum behind the front coxie not spiniform; hairs of elytral intervals, when present, in tufts, never in single row.

$g$. Hind femora with a row of small spines along the hind margin; thorax with a median groore, limited on each side with an obtuse ridge; elytral tubercles with erect setæ or bristle-like hairs; length 9-10 $\mathrm{mm}$.

gg. Hind femora without spinules.

h. Elytral tubercles with black setæ.

$i$. Tubercles elevated, the setre erect, moderately long; length 6- $7 \mathrm{~mm}$.

1782. ERINACEUS.

ii. Tubercles indistinct, setae very short; length 9-10 $\mathrm{mm}$.

1783. CAPILLARIS.

hh. Elytral tubercles with reddish-brown or pale hairs or scales.

j. Elytra distinctly tuberculate; thorax with well marked ridges.

li. Thorax sulcate at middle, the ridges straight or nearly so.

l. Elytral margins entire at base; length 10-12 $\mathrm{mm}$.

1784. UNistriatus.

1l. Elytral margins crenulate or with small teeth at base; length 6-8 $\mathrm{mm}$.

1785 . SORDIDUS.

kik. Thorax with the median groove divided into two fovere or pits, the ridges very sinuous; length 5-6 mm.

$m$. Tubercles of elytra with erect brownish setre.

$m m$. Tubercles with pale yellowish scale-like hairs.

17S6. INSULARIS.

17ST. TERRESTRIS.

ji. Elytral tubercles very indistinct, being replaced by patches of setre.

n. Front tibiæe without fine teeth above the tooth on side; tufts of setre on elytra of equal size in all the rows; length 6$6.5 \mathrm{~mm}$.

17SS. ÆQUALIS.

$n n$. Front tibix with fine teeth near the base; tufts of setre on elytra much smaller on the alternate rows; length 5-6 mm.

17S9. SCABER.

ff. Tip of prosternum spine-like behind the coxæ; elytral intervals with

a single row of short, erect setr; front tibia bidentate on the outer" side and cremulate near the base.

1790. ATROX.

1777 (5613). Trox scabrosus Beaur., Ins. Afr. et Amer., 1805. 175.

Oblong-oval, robust. Dull blackish-brown or piceous ; labrum and mandibles and basal joint of antenna clothed with stiff brown hairs. Thorax with sides rounded, deeply-and broadiy notched near hind angles, the lat- 
ter in the form of a rounded lobe; base rather acutely lobed at mirlle: alisk

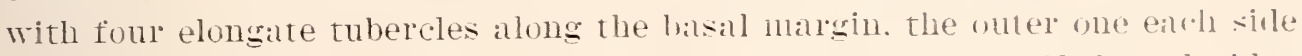

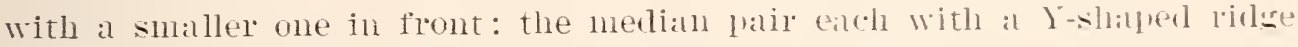
in front. these ridges forming the sides of a median sroore. Elytria with rors of moderitely elerated. oblong. tubercles. tomentuse at smmit: between the rows of large tubercles is a row of smaller ones. also tomentose at top. and on each side of the smaller tubercles is a row of rumded sranmlar elevations: the surface hetween all tubercles and elevations. smooth. Length $15-15 \mathrm{~mm}$.

Lake Countr: rare. September 3. I hare seen but a single specimen. taken by J. D. Hood on the beach of Lake Michigrn. near Pine. It occurs on the sandy shores of lakes and rivers and is said to be abundant in the Gulf states. The rows of three different sizes of tubercles on the elrtra readily distinguish this from our other large species.

17is (5614). Trox moxachts Herbst.. Kafer, III. 17ธ9. 25.

More oblong and less robust than scabrosus. Dark brown or fuscous. Thoras mith sides subangulate in front of notch near hind angles: basal margin deepla sinuate near the angles: tubercles as in scabrosus. Elrtra each with fire rows of rounded or oral tubercles. tomentose at tip. rather distantly placed one from another. those of

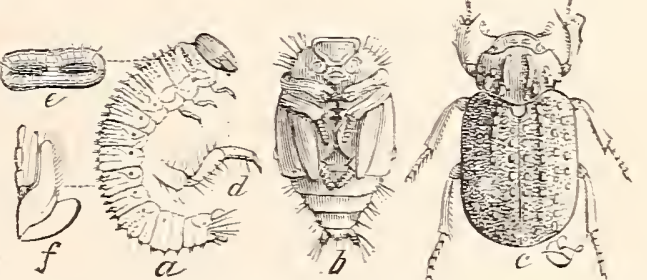

Fis. 33\&. a, larva: $b$, pupa: $c$, beetle; $d, e, \dot{T}$, leg, cervical plite and masilla of larva. (After Ri'ey.) one row alteruating with those of the next: the spaces between the tubercles finely and sparsely granulate. one of the tubercles of third row on apical fourth of elrtra is much enlarged. the corresponding one in the fourth and fifth row also enlarged. but smaller than that of the third. Length 13-16 mm. (Fig. 36s.)

Southern half of State: frequent. June T-October 6. Mating on the former date.

1779 (5615). Trox Asper Lec.. Proc. Phil. Acad. Tat. Sci.. TII. 1S5t. 215.

Oblong. robust. Purplish or gravish-bromm: the first joint of antennie and club as in monachus. Thorax as in monachus. except that the notch near hind angles is less deep. the angular lobe less prominent. and the sinuation of basal margin less marlied. Elytra with roms of oblong or elongate, tomentose tubercles. their front ends smooth and shining. Intel'rals between the larger rows of tubercles each with a rom of small ones. on each side of which is a row of rather deeply impressed punctures. Length $13-15 \mathrm{~mm}$.

Putnam County: rare. June 11. Probably occurs sparingly throughout the southern half of State.

[ $60-23102]$ 
1780 (5616). Trox suberosus Fab., Syst. Ent., 1798, 31.

Oblong, robust. Dull grayish-brown, elytra mottled with piceous, sontetimes almost black and shining. Thorax with sides rounded, the notch in front of hind angles broad and shallow, the basal tubercles as in monachus. but much less elevated and therefore less distinct, the Y-shaped ones forming the median groove almost obsolete except at middle. Elytral tubercles feeble or obsolete, with very small tufts of hairs between them. In those specimens in which the elytral tubercles and surface coating are wholly absent, the elytra are marked with rows of large rounded or subquadrate punctures, and appear black and shining. Length 12-17 $\mathrm{mm}$.

Throughout the State; frequent. May 30-September 6. Often attracted by electric lights of the cities.

Trox punctatus Germ., length $12-17 \mathrm{~mm}$., is a southern species which is recorded from near Cincinnati.

\section{1 (5618). 'Trox tuberculatus DeGeer, Mem. Ins., IV, 17is, 318.}

Oblong, slightly broader behind. Black or piceous black. Head usually with four small tufts of hairs in a transverse row. Thorax twice as wide as long, sides feebly rounded, basal margin sinuate; disk with a wide and deep median groove, bordered each side by an entire ridge, rarely interrupted at middle by a transverse elevation. Elytra with rows of rather distinct, feebly elevated tubercles, covered with brownish, suberect setre intervals with much smaller tubercles, each of which, in perfectly clean specimens, is seen to be surrounded by three or four minute granules set in large shallow punctures or depressions. Front tibia with one small marginal tooth and above it subserrate. Length 9-10 $\mathrm{mm}$.

Lake, Putnam, Vigo and Posey counties; scarce. April 30June 9. This and the next three species are of medium size and have the margins of thorax ciliate with short flattened hairs. The scutellum in it and all the remaining species is oval instead of spear-shaped.

1782 (5621). Trox erinaceus Lec., Proc. Iliil. Acad. Nat. Sci., VII, 1854, 212.

Oblong-oval, shorter than tuberculatus. Dull black, shining when clean. Clypeus more distinctly angulate at middle, the front with two small tufts of hairs. Thorax as in tuberculatus, the median sulcus more shallow and often feebly interrupted at middle. Elytral tubercles in first and third rows more or less connected on basal half, the others rounded, clothed with short, erect black hairs: intervals with smaller tubercles and small granules as in tubcrculatus. Hind femora without spinules on hind margin. Length 6-7 $\mathrm{mm}$.

Putnam County; mare. August 12. Taken from the skin of a dead squirrel. Probably occurs throughout the southern half of the State. 
17S3 (5622). Trox capiliaris Say, Journ. Phil. Acar. Nat. Sci., III, 1S:4, 238 ; ibid. II, 139.

Oblong-oval. Grayish or fuscous; when clean often purplish. Clypeus broadly rounded; front with four small tufts of brownish hairs. 'Thorax with sides feebly curved, gradually wider to base, the median groove shallow but entire, surface each side roughly punctured. Elytral tubercles reebly elevated, widely distant; intervals with minute tubercles or granules, these subobsolete on the sides; intervals one to three each with four slightly elevated broken lines. Length $9-10.5 \mathrm{~mm}$.

Southern half of State; frequent. April 12-December 25. Clean specimens can be quickly recognized by the fine "capillary lines" on the intervals near the suture. Say's specific name was based on the presence of these lines.

1784 (5623). Trox unistriatus Beauv., Ins. Afr. et Amer., 1805, 175.

Elongate-orate. Dull brownish-black. Clypeus rounded. Thorax onehalf broader than long, sides nearly straight, curved on apical fourth, hind angles rectangular, median groove feeble; surface coarsely punctured and with a large irregular depression each side near the groove and another near the margin, these usually concealed by dirt. Elytral tubercles elongate, slightly separated, thus forming elevated interrupted lines, each of these with two rows of very short brown, scale-like hairs; intervals each with a row of minute brownish tufts of hair and two rows of large, transverse, shallow punctures. Length $9.5-11.5 \mathrm{~mm}$.

Southern half of State; frequent. May 2-June 10. Larger than capillaris, and readily distinguished by the carina-like lines of elytral tubercles and the larger and more distinct rows of punctures.

1785 (5624). Trox sondidus Lec. Proc. Phil. Acad. Nat. Sci., VII, 1854, 211.

oblong-oval, broader behind. Dull black. Clypeus broadly rounded. Thorax two-thirds wider than long, sides nearly straight, ciliate with very short hairs; median groove slightly interrupted, its sides somewhat sinuous; surface roughly punctured and with a rounded impression each side on basal half. Elytra each with four rows of tubercles, those on basal half of first and second rows more elongate; intervals each with a single row of small distant tubercles. Front tibiæ finely toothed above the median tooth. Length 6-8 $\mathrm{mm}$.

Jennings, Putnam, Dubois and Posey counties; scarce. April 24-May 12. This and the remaining five species are all small in size and difficult to separate. This is the largest of the six, more robust and broader behind the middle. It resembles tuberculatus in form and sculpture, but is distinctly smaller and has the scales of the tubercles much paler.

1786 (5625). Trox insularis Chev., Col. Mex., 1835.

Ovate. Dull piceous or blackish-brown. Clypeus subangulate at middle; front with four obtuse tubercles. Thorax with sides feebly curred. margins ciliate; disk with the median ridges strongly sinuous, converging 
at middle and united by a transverse ridge, thus dividing the groove into two forea or depressions, the hinder one of these with a large rounded fovea on each side; apical half with a transverse fovea each side. Elytra with rows of small but distinct tubercles, bearing short, erect brownish hair's; intervals with a few very small tubercles and scattered granules. Front tibix with a small marginal tooth near the angle. Length 5-6 $\mathrm{mm}$.

Putnam, Vigo, Lawrence and Posey comnties; frequent. June 2-Septrmber 26. Resembles closely the next and probably confused with it in many collections. Known by the erect brownish hairs of the elytral tubercles, which can he readily seen by viewing the specimen from the side. Listed as $L$. foreicollis Har.

1787 (5626). Trox terrestris Say, Joulll. Phil. Acad. Nat. Sci., V, 1S25, 192 ; ibid. II, 295.

In form, color and sculpture of thorax this species very closely resembles insularis. Thorax with sides a little less rounded, and more convergent in front. Tubercles of elytra with yellowish scale-like hairs which are semi- or wholly prostrate. Length 5-6 $\mathrm{mm}$.

Southern half of State; scarce. February 14-November 30. This species and the next hibernate beneath rails and chunks in fence corners where dead leaves have accumulated. It is possible that all species of Trox so hibernate, as several others have been taken very early in spring or late in antumn. When touched or uncovered all the species "play possum" or simulate death.

*178s (5627). Trox æequalis Say, New Spec. Ins. Lonisiana, 1832, 5 ; ibid. I, 301.

Elongate, subovate. Dull brownish-black. Clypeus rounded, densely punctured; front with minute tufts of reddish-brown hairs arranged in a transverse sinuous line. Thorax twice as wide as long, sides feebly and evenly curved, ciliate; dorsal groove very feeble, surface finely and evenly punctate, sparsely clothed with short, erect brownish hairs. Elytra without tubercles, but with numerous tufts of reddish-brown, scale-like hairs arranged in regular rows. Hind tarsi with joints $2-4$ longer than wide. Length 6-6.5 $\mathrm{mm}$.

Throughout the State; frequent. March 20-December 12. Occurs often distant from carrion beneath bark and about the roots of trees.

\section{9 (5629). Trox scaber Linn.. Syst. Nat., Ed. Xil, 1785, 573.}

Form of aqualis. Black, somewhat shining, when clean. Thorax with median groove a little more distinct and a shallow impression each side near base, the surface less covered with bristly hairs, otherwise as in rqualis. Elytra with rows of oblong, shallow punctures, the alternate intervals more elevated and bearing oblong tufts of brownish hairs; the intervening intervals with minute rounded tufts of similar hairs. Hind tarsi 
longer than in aqualis. Front tibise with two tecth on the onter margin near the tip and with several small blunt teeth neal the base. Iength 5 $7 \mathrm{llm}$.

Frepuent beneath dead fish and other carrion and rabbish along the beach of Lake Michigan in Lake and Porter counties; not noted elsewhere in the State, though probably occurs throughout, as Dury records it from Cincinnati. April 9- July 3.

$1790(5630)$. 'Trox atrox Lec., Proc. I'hil. Acad. Nat. Sci.. VII, 1S5t, 2214.

Elongate-ovate. Black, surface without coating. 'Thorax transversely quadrate, sides moderately curved in front, slightly sinuate at base; hind angles acute, surface sparsely punctured, median groove wholly obliterated except a slight impression in front of scutellum. Elytra with broad, shallow striæ, bearing transverse rather distant punctures; intervals feebly convex and with a single row of small punctures each of which bears a short, erect brownish hair. Hind femora with a row of spines along the hind margin. Length $8 \mathrm{~mm}$.

Known from Indiana by two specimens taken near Lafayette, one each in the collections of Dury and Webster. Recorded heretofore only from Illinois and Kansas.

\section{Subfamily II. MELOLONTHINAE.}

The members of the subfamily are mainly distinguished by the position of the abdominal spircicles, which are in part placed on the superior portion of the ventral segments, the rows feebly diverging, the last spiracle usually visible behind the elytra. They are usually of looser, more slender build, with longer legs than the members of the preceding subfamily. The clypeal suture is transverse; club of antennx often elongated in males; tip of the abdomen usually visible beyond the elytra; color in general some shade of brown. In all of our genera the mandibles and labrum are beneath the clypeus and not visible from above. In habits they are entirely vegetable feeters, occurring on leaves and flowers, or flying about in the evening, and are oiten attracted in great numbers to electric and other lights.

But six of the 21 genera into which the subfamily is divided are represented in the state. The following papers treat of these genera and to them the sperial student is referred for more detailed descriptions :

LeConte.--"Synopsis of the Melolonthidie of the United States." in .Tourn. Phil. Acad. Nat. Sci., New Ser., III, 1856, $295-258$. 
LeConte._"Short Studies of N. Amer. Coleoptera," in Trahs. Amer. Ent. Soc., VIII, 1880. A synopsis of the genus Hoplia is given on pages 191-194.

Horn._- "Revision of the U. S. Species of Ochodrus and other Genera of Scarabaidre," in T'rans. Amer. Ent. Soc., V, 1876. The genera Macrodactylus and Dichelonycha are treated on pages 183-192.

Horn.- "Revision of the Species of Lachnosterna of America North of Mexico," in Trans. Amer. Ent. Soc., XIV, 1887, 209-296.

Smith, Iohn B.-_Notes on Lachnostema fusca," in Insect Life, I, 1889, 180-185.

Smith, John B._- "Some New Species of Lachnosterna," in Ent. Amer., V, 1889, 93-99.

Smith, John B._ 'Notes on the Species of Lachnosterna of T'emperate North America with Descriptions of New Species,' in Proc. U. S. Nat. Mus., XI, 1888, 481-525, Pls. XLVIII-LX. Fall, H. C.- "Notes on Dichelonycha and Cantharis with Descriptions of new Species in other Genera," in Trans. Amer. Ent. Soc., XXVII, 277-292.

Fall, H. C._'Revision of the Species of Diplotaxis of the United States,' in Trans. Amer. Ent., XXXV, 1909, 1-97.

KEY TO INDIANA GENERA OF MEIOLONTHINA:

a. Middle and hind tibix with only one spur, this sometimes obsolete; tarsi without seta-bearing process between the claws; hind tarsi with a single claw; body scaly.

XVIII. HopLIA.

aa. Middle and hind tibire with two spurs; all tarsi with two equal claws and a distinct setr-bearing process between them.

b. Form elongate, slender; colors metallic green or bronzed (at least in part) or dull yellow.

c. Elytra pubescent, not densely scaly; claws chelate, i. e., capable of being folded along the last joint of the tarsi.

XIX. Dichelonycha. cc. Elytra densely covered with elongate yellowish scales; tarsal claws not chelate.

XX. Macrodactylus.

67. Form robust, heavy; color brownish, sometimes iridescent.

d. Ventral segments five; elytra either uniformly and rather finely punctured, or with punctured strix.

XXI. Diplotaxis.

dd. Ventral segments six.

$e$. Elytra with rather indistinct but regular sulci or grooves on the disk; ventral segments free; size small, not over $10 \mathrm{~mm}$.

XXII. SERICA.

ce. Elytra without strix or grooves orer the great portion of the disk; rentral segments comnate; size larger, 11.5 or more mm.

XXIII. LaCHNOSTERNa. 


\section{XVIIT. Hopuis Illiger. 1803. (Gr., "arms.")}

Oblong, more or less flattened insects, living on flowers by day, beneath cover at night, and having the body entirely or in part covered with flat scales of a yellowish, brownish or silvery hue; claws of front and middle tarsi chelate and unequal, the outer one being larger and bifid at tip; scutellum small; club of antenns threejointed. The two sexes often differ much in size and color and the males have the hind tibixe and tarsi stouter.

KEY TO INDIANA SPECHES OF HOPLIA.

a. Claw of hind tarsi not cleft.

$b$. Sexes dissimilar in color, male black, hairy with grayish pubescence; female brown with pale brown and yellowish silvery scales; thorax wide, narrowed in front, its sides subangulate and rounded.

1791. TRIFASCIATA.

bb. Both sexes dull black, thinly clothed with elongate grayish scales; thorax with sides oblique, slightly rounded; clypeus more strongly margined in front.

1792. TRIVIALIS.

ua. Claw of hind tarsi cleft near the tip.

c. Sides of thorax strongly angulated; black, sides of thorax, suture and margins of elytra and two oblique branches with silvery scales.

1793. LIMBATA.

cc. Sides of thorax either broadly rounded or nearly straight.

d. Brown, clothed with very small scales, these oval on thorax, narrow and hair-like on elytra.

1794. MODESTA.

dd. Dull brownish-yellow, very densely clothed with silvery scales, these circular on thorax, broadly oval on elytra.

1794a. var. BARBATA.

1791 (5650). Hoplia trifasciata Say, Journ. Phil. Acar. Nat. Sci., III, 1823,200 ; ibid. II, 301.

oblong. Male dull black; thorax and elytra rather densely clothed with elongate grayish-yellow prostrate hairs or hair-like scales; pygidium and abdomen densely covered with silvery scales; these replaced by erect gray hairs on front of under surface and legs. Female with head black; thorax and elytra reddish-brown, covered with yellowish scales, some of those of elytra usually more densely placed so as to form three irregulitr. undulated bands, one at base, another at middle and a third near apex; entire under surface clothed with silvery scales. Head and thorax in both sexes with numerous erect grayish or yellowish hairs. Clypeus truncate, the front edge reflexed. Length $6.5-9 \mathrm{~mm}$.

Lake, Starke and Vigo counties; scarce. April 8-May 27. Occurs on flowers of Cratagus, ete. Passes the winter in pupal stage beneath half-buried logs and other cover. The black males appear to be rare, but one having been taken in the State. 
1792 (5651). Hopla trivialis Harold. Col. Hefte. V. 1869.

Elongate-oblong. Dull black; upper surface clothed

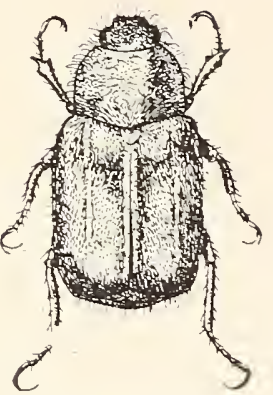

Fig. $369 . \times\left\{\frac{2}{3}\right.$. (Original.) with lanceolate. hair-like scales, those on elytra usually so placed as to form two indistinct bands, one at middle, the other at apex; prgidium and abdomen rather sparsely covered with flat, silvery scales; front portion of under surface, legs and thorax with erect gray hairs. Elytra at hase a little wider than base of thorax, the humeri prominent. Length $6-7 \mathrm{~mm}$. (Fig. 369.)

Starke, Fultom and Putnam counties; frequent beneath boards, etc., in sandy localities about the borders of lakes. April 8--May 9.

1793 (5653). Hoplia limbata Lec., Journ. Phil. Acad. Nat. Sci., New Ser.. III. $18556,286$.

Elongate. Black; above with scales as mentioned in key; pygidium and under surface densely clothed with rounded. silrery scales. Claws of hind tarsi cleft near the tip. Length $7.5-8.5 \mathrm{~mm}$.

LeConte described this from "two specimens found at Evansville, Indiana." Of it he says: "The dilatation of the white suture at the middle forms an oblique fascia reaching tro-thirds way to the suture; the posterior dilatation is a spot connected both with the suture and tip. The thoras is hardir narrower at tip than at base. The legs are black, with the thighs sparsely sprinkled wit' silvery scales.' Not represented in the collection at hand.

1794 (5654). Hoplia rodesta Hald.. r'roc. Phil. Acad. Nat. Sci., I. 304.

Oblong. Black or dull reddish-brown; head and thorax fuscous. Epper surface with scales as noted in key: pygidiun and under surface ratle ${ }^{*}$ thickly corered with larger oval, iridescent silvery scales. Clypeus narrower than in the other species, truncate, its front margin feebly reflexed. Thorax flattened with oblique but slightly rounded sides. Elytra obsoletely costate. Hind tarsal claws finely cleft near the apex. Length $6-7.5 \mathrm{~mm}$.

Lake, Putnam, Owen and Knox counties: scarce. May 25June 26.

\section{4a (-). HOPLIA MODESTA BARBATA Var. HOr.}

More robust than modesta. Color as giren in key; pygidium and under surface reddish-brown, shining. rery densely clothed with oral silvery scales. Thorax one-half wider than long. sides nearly straight. subsinuate near hind angles. Elytral withont trace of costre. IInd tibia and tarsi of males very much larger than in modesta. Length $8-8.5 \mathrm{~mm}$.

Vigo and Owen counties; raxe. May 31-Jine 15. Taken from the flowers of the climbing bitter-sweet. Celastrus scandens L. The shorter, wider and more densely placed scales of the elytra readily separate this from modesta. The scutelium is also longer and more narrow than there. 


\section{Dichelonycha Kirby. 1837. (Gi., "("left + "aw.")}

Elongate, parallel, subdepressed species, usually pireous of brownish-yellow in hue, with a distinct greenish, purplish or bronze lustre. They are covered with a fine silky pubescence, have large, prominent eyes. the first ventral segment in great part visible, the claws cleft at tip. The males have the club of antenne nearly as long as the remaining portion and the middle line of abdomen, when viewed from the side, more or less concave. They often occur in numbers on the young shoots or leaves of trees and shruhs. Five species have been taken in Indiana, while another probably occuss.

\section{KEY TO INDIANA SPECIES OF DICHELONYCHA.}

a. Thorax without a well defined median groove.

b. Prevailing color dull brownish-yellow, the elytra usually with faint greenish or bronzed surface lustre; tibine and tarsi entirely pale.

c. Suture between clypeus and front indistinct. not impressed.

d. Subapical marginal grooves of thorax distinct: front margin of clypeus narrowly reflexed; elytra with a darlier narrow stripe on the sides which is more distinct at its extremities.

1795. sUBVTTTATA.

dd. Subapical and basal marginal grooves obsolete: clypeus rather broadly reflexed; elytra without trace of darker lateral stripe.

TESTACEA.

cc. Suture between clypeus and front distinct. rather deeply impressed; clypeus rather strongly reflexed: subapical marginal line of thorax deeply impressed; elytra pale. feebly tinged with green.

1796. DILTTA.

bъ. Prevailing color dark: elytra in fully colored species more or less brilliant green or bronze.

$e$. Suture between clypeus and front indistinct; surface lustre greenish or purplish : apex of hind tibire and tarsi piceous.

1797. ELONGATA. cc. Suture between clypeus and front deeply impressed; elytra piceous with bronzed lustre; legs wholly redtish-brown or piceous.

1798. FUSCCLA.

a a. Thorax with a rather broad and deeply inmpressed median line or groove; elytra with distinct greenish lustre.

1799. ALBICOLLIS.

1795 (5657). Dichelonycha subvittata Lec., Journ. Phil. Acald. Nat. Sci.. III, $1856,279$.

Resembles clongata in form but stouter. Dull reddish-brown or brownish-yellow. with a hronze or areenish tinge: elytral with a fuscous or dark greenish stripe on sides. often obsolete except on the humeral and alical elevations. Ilead coarsely and rugosely punctured. Thorax with a faint median line; less densely and more coarsely punctured than in clom!ate. its surface sparsely pubescent in both sexes. Elytra rather coarsely punctured and wrinkled. rery sparsely pubescent. Length $10-11.5 \mathrm{~mm}$. 
Marshall, Marion and Tawrence counties; scarce. May 26-June 24. Occurs on hazel and oak foliage.

D. testreea Kirby is a boreal species which may occur in northern Indiana.

1796 (- - ). Dichelonjcha diluta Fall, Trans. Amer. Ent. Soc., XXVI, $1901,283$.

Elongate, parallel. Pale, dull yellow; front and thorax sometimes fuscous; elytra feebly tinged with green. Clypeus more strongly reflexed, less densely and more deeply punctate than in clongata, the sutural line distinctly impressed. Thorax rather sparsely and coarsely punctate, sparsely pubescent, its sides strongly subangulate. Elytra coarsely and roughly punctulate. Inner spur of hind tibix of male distinctly broader and more obtuse than in elongata. Length $8.5-9.5 \mathrm{~mm}$.

Starko and Crawford counties; scaree. May 25-.June 27. Boaten from oak shrubs. 'The clypeus in all the four specimens at hand is distinctly and abruptly paler than the vertex.

1797 (5656). Dichelonycha elongata Fab., Syst. Fint., I, 1798, 170.

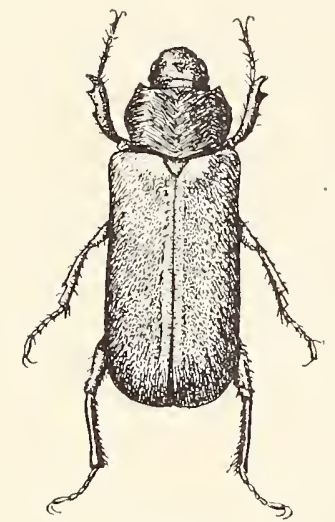

Fig. $370 . \times 3$.

Elongate. parallel. Head and thorax piceous or dark reddish-brown. Elytra dull brownish-yellow or darker, more or less tinged with greenish, purplish or bronzed lustre; antemne and legs pale, the apex of hind tarsi and tibice piceous. Head densely and rather coarsely punctured. Thorax with sides sinmate behind the middle, hind angles prominent; surface densely punctured, sparsely pubescent. male; densely pubescent, female. Elytra rather coarsely punctured, sparsely and finely pubescent. Prgidium and sides of abdonen rather densely clothed with long. silvery, scalelike hairs. Length $8-10 \mathrm{~mm}$. (Fig. 370.)

Throughout the State; frequent. April 18July 5 . Oceurs on flowers of wild plum, wild rose, ete, and on leaves of oak and willow.

1798 (5663). Dichelonycha fuscula Lec., Journ. Phil. Acad. Nat. Sci., III, $1856,281$.

Elongate, slender, parallel. Dark reddish-brown or piceous; elytra with a pale marginal stripe, their surface otherwise uniformly and distinctly bronzed. Clypeus concave, the margin moderately reflexed, rather densely and coarsely punctured. Thorax sparsely and rather deeply punctured, the intervals between the punctures shining; sparsely pubescent. Flytra rery coarsely punctured, sparsely pubescent. Length $7 \mathrm{~mm}$.

Putnam and Crawford counties; rare. May 27-June 20. Probably oecurs throwshont the southern half of State. Readily known by its smaller 'size and dark bronzed elytra with paler margin. 
1799 (5667). Dicheloxycha a bicoldis Burm., Handib. Ent., IV, 1842, 74.

Elongate, parallel, rather robust. Dull brownish or luscons yellow, sparsely clothed with short pubescence. Elytra with greenish lustre, the suture and margins paler. Head coarsely and densely punctured; suture feebly impressed; clypeal margin moderately reflexed. Thorax coarsely and spar'sely punctured, sides obtusely angulite, oblique near hind angles, which are broadly rounded. Elytra coarsely punctured. Males with outer spur of hind tibice much broader than inner, truncate at tip and distinctly twisted. Length 11-12.5 $\mathrm{mm}$.

Porter County: starce. June 27-June 28. Beaten from pine near Dune Park. Easily distinguished by jts larger size and deep median groove of thorax.

XX. Macrodactrues Lat. 1825. (Gr., "long + toe or claw.")

The member's of this genus are commonly known as "rose-bugs" and are elongate, rather slender beetles having the elytra densely covered with yellowish scales; tarsi very long and bearing long, slender diverging claws cleft at tip, more deeply in the female; labrum not united with clypeus ; front coxa prominent and conical. Males with front and hind tibiæ without spurs; prosternum elevated in a vertical spine behind the front coræ; pygidium elongate instead of triangular as in the female. Two of the three known North American species have been taken in Indiana.

1800 (5690). Macrodactrlts subspinosus Fab., Syst. Ent., 1798, 39.

Eiongate, slender. Dull brownish-yellow or reddish-brown, densely covered with yellow scales or hairs; head, thorax and under surface usually darlier; tarsi and apex of tibiae black. Thorax convex, a little longer than wide, much wider at middle and rapidly narrowing thence to both base and apex; surfice with short, recumbent rellow hairs, male, or with recumbent hairs and short, rertical setie intermingled, female. Flytra indistinctly striate. Nale with prosternal spine as long as coxx and visible from the front, the rentral segments each with two to five slender bristles on each side; rentral segments of female with a few median erect hairs. Length $8-10 \mathrm{~mm}$. (Fig. 371.)

Throughout the State; very common. June 5-July 5. Noted especially on wild grape vines about the borders of marshes and lakes in northern Indiana. This is the

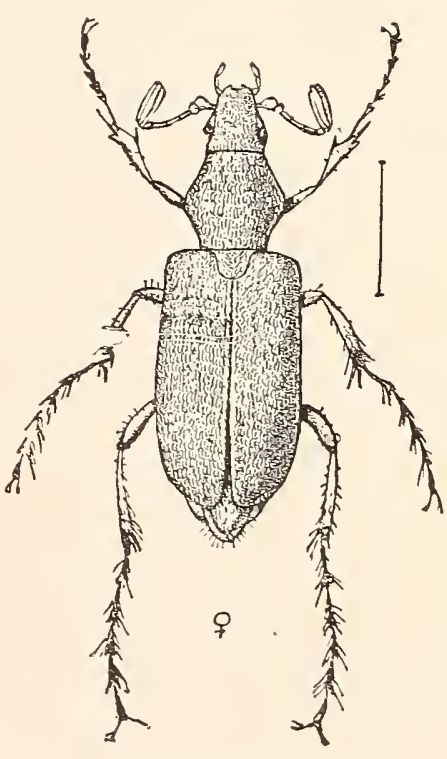

Fig. 371. Line shows natural size. (After Forbes.) best known rose chafer or rose beetle, and is very destructive in the 
imago stage. It sometimes appears in immense numbers on roses and various flowers and also on leaves and blossoms of grape, often. completely ruining the crop of the latter. Bordeaux mixture is a repellant, but in addition to its use, until after the grapes are set, the beetles should be beaten into umbrellas and burned.

$1 S 01$ (5691). Macrodactrles axglistates Beaur., Ins. Afr. et Amer., I. $1505,30$.

Form of the preceding but somerhat larger. Uniform dull brownishsellow except the apex of tibire and apical halves of tarsal joints. which are piceous. Iale with prosternal spine short, not visible from the front. the bristles of rentral segments very short. Female with all the hairs of disk of thorax erect, those of the margins recumbent; abdomen with numerous erect hairs along the middle. these arising from strong punctures. Elytra with erect hairs near the base. Length 9-11 mm.

Crawford and Perry counties: rare. May 21-June 25. A species of southern range, belonging to the Austroriparian fauna of the State.

\section{Diplotaxis Kirby. 1837. (Gr., "double + order.")}

Small, oblong, convex species, brown or piceous in color and having the elytra not sulcate but simply and irregularly punctate or with the punctures of feeble costar arranged in rows, the wider intervals being irregularly punctured. The antennæ are 10-jointed and only five ventral segments are visibie. The body is not broader behind, as in Serica, and the tarsai claws are cleft or toothed. They occur beneath flat stones, bark and logs, usually in drer, hilly localities. Three species have been taken in Indiana, while two others may occur.

KEY TO INDIANA SPECIES OF DIPLOTAXIS.

a. Bodr pubescent; elstra without distinct rows of punctures.

1SO2. SORDIDA.

aa. Body not pubescent abore; elstra with some of the punctures arranged in rows.

b. Thorax with a distinct impression near front and hind angles.

c. Disk of thorax merenls punctured. leaving smooth spaces near the middle.

LIBERTA.

cc. Disk of thorax densels and more finely punctured.

TRISTIS.

b7. Thorax without distinct impressions near the angles.

d. Clrpeus semicircular, its front broadly and regularly rounded.

1S03. HARPERI.

dd. Clrpens hemihexagonal. its front subsuleate or slightly emarginate.

1SO4. FRONDICOLA. 
1802 (5699). Diplotaxis sordida Say, Joum. Plil. Acad. Nat. Sci., V, 1825. 197 ; ibid. II, 299.

Oblong, robust. convex. Reddish-brown to black or picenus. subnginue: upper surface clothed with fine. short, suberect, yellowish hairs, those on thorax dense and more erect. Clypeus short, broadly but not deeply emarginate; its surface, as well as that of thorax and elytra, densely, rather finely and more or less confluently punctured. Thorax with a deep impression near the front angles and a distinct but more shallow one near the hind ones, the middle portion more convex; sides subangulate behind the middle. margin crenate. Elytra with very fine transverse wrinkles between the punctures. Length 11-12 $\mathrm{mm}$.

Lake County ; rare. Julr 28-September 3. Two specimens from beneath drift on the beach of Lake Michigan near Millers and Pine. It is known only from Michigan, Pennsylvania and Georgia, and seems to be everywhere rare.

1803 (5716). Diplotaxis harperi Blanch., Cat. Col., Mus. Hist. Nat. Paris. $1850,171$.

Oblong. feebly convex. Reddish-brown or piceous, shining. Clypeus semicircular, narrowly margined. slightly reflexed, surface rather coarsely and densely punctate. Thorax twice as broad as long, sides feebly rounded; surface coarsely but not densely punctate. Elytra each with three indistinct costr, each of which bears a single somewhat irregular row of punctures with a more distinct row on each side; the much broader interrals with numerous coarse, irregular punctures. Length $8.5-9.5 \mathrm{~mm}$.

Throughout the State; common in the southern half, much less so in the northern counties. March 21-October 1 . Occurs in early spring and late autumn beneath logs, leares and stones, where it probably hibernates sparingly as imago, and commonly in the pupal stage. Also occurs at electric light and sparingly on foliage.

1804 (5717). Diplotaxis frondicola Say, Journ. Phil. Acad. Nat. Sci., V, 1825, 198 ; ibid. II, 299.

Oblong-oral, conrex. Pale to dark chestnut brown, feebly shining. Clypeus subtruncate at apex, its margin more strongly reflexed and surface more finely punctate than in harperi. Thorax two-thirds wider than long. sides broadly rounded, surface rather finely and somewhat densely punctate. Elytra each with three feeble costie, each bearing a single regular row of punctures and a row each side; the intervals with the punctures more regularly placed than in harperi. Length $7-S \mathrm{~mm}$.

Larrence, Crawford and Poser counties; frequent. May 10. Inly 3. Occurs beneath stones and logs. A shorter and more conrex species than harperi, easily distinguished by the form of the clrpens. Probably occurs throughout the State. 


\section{Seric Macleay. 1819. (Gr., "silken.")}

Robust, oblong, convex species of a brown color, often covered with soft silken pubescence and with iridescent reflections. They are of small size, and the body, especially that of female, is broader behind; labrum united firmly with the under surface of clypeus, and therefore indistinct; elytra feebly sulcate; hind coxæ flat and broadly dilated into a plate, as wide as any two ventral segments, which covers the base of the abdomen.

The beetles fly about chiefly in the evening and by day are to be found beneath leaves, logs and bark in orchards and woods. Five species have been taken in the State, two of which are herewith described as new, while two others may occur.

\section{KEY TO INDIANA SPECIES OF SERICA.}

a. Clypeus with an acute notch each side; body smooth, shining, not iridescent.

$b$. Notch of clypeus deep, distinct, the margin in front of notch strongly reflexed; surface of front and clypeus coarsely, confluently punctured, with wrinkles between the punctures. 1805. vespertina.

bb. Notch of clypeus small and indistinct, margin less strongly reflexed; surface finely punctured, without wrinkles or rugosities.

c. Suture between clypeus and front with a distinct carina; surface of clypeus and thorax finely and densely punctured.

1806. CARINATA.

cc. Suture between clypeus and front impressed, without carina; surface of clypeus and thorax finely and sparsely punctured.

1S07. INTERMIXTA.

aa. Clypeus without a notch on sides; body usually silky-pubescent and more or less iridescent.

d. Head and thorax with numerous short, erect yellowish hairs:

dd. Head and thorax not distinctly hairy.

IRICOLOR.

e. Size larger, $\mathrm{S}$ or more mm.; body above unicolored.

f. Upper surface black, feebly shining, scarcely iridescent; clypeus densely and rather coarsely punctured.

TRISTIS.

ff. Upper surface purplish-brown or piceous, distinctly iridescent; clypeus more sparsely and finely punctate.

180S. SERICEA.

ee. Size smaller, not over $6 \mathrm{~mm}$; head and thorax black or piceous, elytra usually reddish-brown.

1S09. TROGIFORMIS.

1805 (5674). Serica vespertina Gyll., Schönh. Syn. Ins., I, 1S17, 94.

Oblong-ovate. Chestnut brown to piceous, smooth, shining. Clypeus short, truncate, coarsely, densely and rugosely punctate, the notch deep, distinct; frontal suture impressed. Thorax twice as wide as long, sides 
feebly curved, hind angles rectangular; surtace rather finely and rogularly punctate, more densely and roughly on the sides. Elytra broadly not deeply sulcate, the grooves with two rows of coarse, confluent punctures; intervals feebly convex, sparsely punctate. Length 8.5-11 mm.

Starke, Jackson and Dubois counties; scarce. April 12-June 27. 1806 (-). SErica cariNata sp. nov.

Oblong-oval, subdepressed. Piceous-brown, feebly shining; antennæ, legs and under surface reddishbrown. Clypeus and front very densely and finely punctate, the notch minute, not more than one-third the depth of that of vespertina; frontal suture riewed from the side, with a distinct transverse raised line or carina; front with a longitudinal carina connecting that of suture with hind margin of head. Thorax two-thirds wider than long sides nearly straight, feebly curved on apical third, hind angles rectangular; disk densely and finely punctate at middle and on sides, more sparsely and coarsely near front and hind mar-

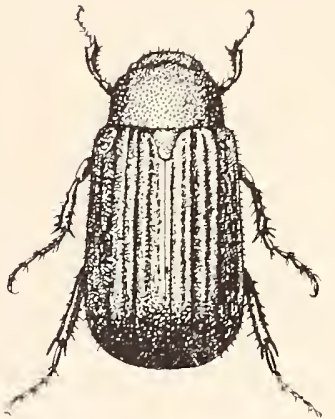

Fig. 372. $\times 2 \frac{3}{4}$ (Original.) gins and in a space near front angles, a very small smooth area near the middle. Elytra less deeply sulcate than in vcspertina, the grooves broader, each with two or three irregular rows of finer, more or less confluent punctures. Metasternum, hind coxal plates and first five segments of abdomen coarsely and rather sparsely punctate; sixth ventral segment smooth. Iuength S-10 $\mathrm{mm}$. (Fig. 372.)

Described from eight specimens taken in Fountain, Marion, Vigo, Crawford and Posey counties. April 9-October 6. Taken from beneath bark of oak. Those taken on October 6 were in mud or dirt cells beneath deeply buried logs on wooded hillside in Vigo County, and were just emerging as imagoes. Probably confused with vespertina in most collections, but readily distinguished by the carinate suture of clypeus and close, irregular punctuation of thorax. The color in all specimens at hand is uniform and not variable as in respertina or the next.

$1807(-)$. SERica intermixta sp. nov.

Oblong, convex, smooth, shining. Dull brownish-yellow, sometimes chestnut-brown or even black. Clypeus longer than in vespertina, the notch smaller, one-half as deep; surface finely and sparsely punctate; front more coarsely and sparsely punctate. Thorax more convex than in vespertina, sides feebly curved, surface finely and rather sparsely but evenly punctate. Elytra moderately deeply sulcate, the grooves each with two or three irregular rows of rounded, more or less confluent punctures; intervals subconrex, sparsely punctured, the punctures as large as those of the groores. Length $7.5-9.5 \mathrm{~mm}$.

Lake, Vigo, Marion, Tawrence and Jennings counties; frequent. April 12-June 26. Occurs heneath bark. Specimens just emerging as imagoes were taken in Vigo Comnty on April 12 and in Lake 
on May 13. The longer, more finely and less roughly punctured clypens, with shallow notch, distinguishes this species from vespertina. LeConte's texana is a smaller, paler form, with the notch and surface of the clypeus nearly as in vespertina.

S. iricolor Say, is a species of wide distribution which should occur in southern Indiana; $S$. tristis Lec., length $8 \mathrm{~mm}$., was described from Lake Superior and may occur in the northern third of the State.

1808 (5681). Serica sericea Ill., Mag. fur Insect., V, 1805, 75.

Oblong, convex, nearly parallel. male; broader behind, female. Purplish-brown or piceous, strongly iridescent. Clypeus feebly emarginate, its margin rather strongly reflexed; surface densely and rouglily punctate: rertex finely and sparsely punctate. 'Thorax two-thirds wider than long. sides feebly rounded; surface finely, sparsely and shallowly punctate. Elytra of male rather deeply, of female more shallowly, sulcate, the grooves with fine, irregular punctures; intervals convex. male, subconvex, female. sparsely punctate. Length $8-9.5 \mathrm{~mm}$.

Throughout the State; common. March 20-July 12. Occurs beneath shelter of various kinds; hibernates in pupal stage beneath partly buried logs.

1809 (5689). Serica trogtronmits Uhler, Proc. Phil. Acad. Nat. Sci., VII, $1855,415$.

Orate, convex, nearly smooth, feebly shining. Head, thorax aud under surface black or piceous; elytra reddish-brown, the sides margined with piceous; sometimes wholly piceons; antennse. tibire and tarsi reddish-brown. Clypeus feebly emarginate, densely and coarsely punctate. Thorax conrex. sides slightly rounded. disk coarsely and rather densely punctured, with a median impression on basal half. Elytra feebly sulcate, the grooves sparsely punctured; intervals subconvex, rery sparsely punctured. Length $5-6 \mathrm{~mm}$.

Posey County; rare. April 25. One specimen beaten from wild rose bushes in woods. A southern form described from Baltimore.

\section{ILACHNOS'ERNA Hope. 1897. (Gr., "wool + breast.")}

A large genus of robust, pale reddish- or yellowish-brown to piceous beetles, familiarly known as "May beetles" or "June bugs.' They have the front coxa transverse not prominent, but contained entirely in the coxal cavities: ventral segments six, firmly united yet with sutures visible; the tarsal claws never serrate, but with a single tooth beneath. All the species have long and numerous, often very dense, hairs on the meso- and metasterna, hence the 
generic name Lachnostcme, meaning "wool" and "breast." 'They are abundant everywhere in early summer, hiding by day and beginning to fly at dusk, when they settle upon the foliage of low shrubs and trees, especially those of lawns and other grass-covered areas, to which they often do much damage by devouring the leaves. The best method of collect. ing them is to go out with lantern and umbrella just after dusk
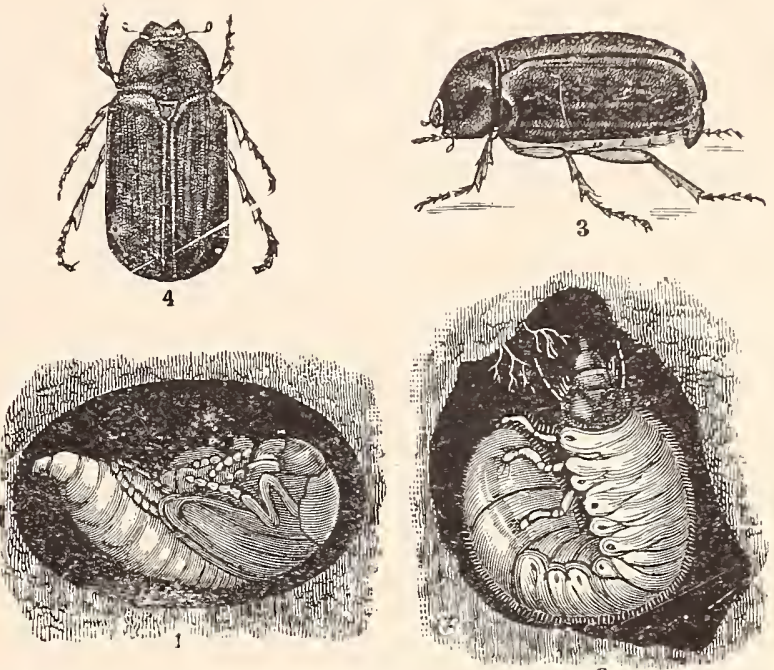

Fig. 373. Lachnosterra fusca Froh. 1, pupa, in its earthen cell; 2, larva; 3, 4, beetle, side and back views. (After Riley.) and beat the branches upon which they are feeding. In this way hundreds or even thousands can be collected in a single evening. If the damage to shrubs or small trees is too great the beetles may be easily gathered by shaking them onto sheets.

The larva of the May beetles are those large, bulky forms commonly known as "white grubs." (Fig. 373.) They often do much damage to the roots of grass, corn and allied plants. Lawns and strawberry beds are sometimes wholly ruined, the grubs gnawing off every root at a certain depth. Living as they do, underground. they are very difficult to combat. If the field is badly infested an? not in cultivation, hogs may be turned in to root them out, as they are very fond of the grubs. Fall plowing turns out pupx and recently matured beetles and greatly lessens the damage to corn and other crops the ensuing year. In lawns and small areas of grass lands a kerosene emulsion, washed down by an abundance of water. often destroys many of the larve.

On account of the great similarity in form, color and size, the May beetles are difficult to determine, and for a long time were often jumbled together in collections without specific names. However, Dr. ITorn, in his Revision, furnished tables by which, with a little patience and close observation, the males can he readily recognized. The females are more difficult and can only be determined by careful comparison with the males, which they most resemble.

[61-23402] 
or with which they are found in company. The two sexes may be distinguished by the male being the less robust, less widened behind and less convex: and in our species by having the antennæe usually longer and the club distinctly longer than in the female, except in cremulata and albina. In most males the abdomen is more or less flattened and the last two ventral segments are more or less modified, the next to the last often bearing a transverse "ventral ridge," and the last segment a hollow depression or concavity.

The sexual organs have been shown by Smith (Proc. U. S. Nat. Mus., loc. cit.) to possess a certain and unvariable form in each species, and in the future they will doubtless be largely relied upon to furnish distinguishing characters. In fresh or relaxed specimens they can be easily pressed out by squeezing the abdomen, or removed by a pair of forceps. The nane "clasper" has been given to the horn-like organ whose variations form the specific differences in the male, while those of the female consist of a pair of broad "inferior plates." above which are a pair of "superior plates," generally smaller, narrower and much more variable than those below. When the organs are most fully developed the superior plates are notched at their point of union and are surmounted by a "pubic process" very variable in shape in the species and therefore furnishing important distinguishing characters. In the figures of these sexual organs in the plates which follow, the letters throughout have the same meaning, viz. $a$, claspers of male from front or above; $b$, right clasper; $c$, left clasper ; $d$, female organs ; $e$, ventral characters of male. These are always sublettered as follows: $i$, inferior plates; $s$, superior plates; $p$, pubie process.

The spurs of the hind tibix of the males are also much used in classification. In one division the two spurs are both free or movable, being united to the tibir by a membranous hinge, and usually inclined at an angle, as they are in all females. In the other and larger division the inner. spur is a fixed prolongation or part of the edge of the tibiæ itself. A little practice will soon enable the beginner to readily see the rigidity or fixedness of the inner spur, without attempting to move it.

Much care must be taken in counting the joints of the antennæ, which are either nine or ten in number. The club is always composed of three elongate joints, resting at right angles to the others. (Fig. 4, No. 15.) Joint 7 or 6 , as the case may be, is very thin, triangular in form and elosely appressed against the base of the inner joint of the club, and is therefore liable to be overlooked. 
Moreover, specimens which normally have 10-jointed antennæ, sometimes, but rarely, have two of the joints united, so that the number is reduced to nine. 'The 9-jointed species, however, never have the number of joints increased to ten.

In the papers by Drs. Horn and Smith, 93 species of Lachnosterna are recognized from the United States. Of these 26 have been taken in Indiana, while nine others perhaps occur. Since the number of species is so large the genus is first divided into six groups, and these, in turn, into species.

\section{KEY TO GROUPS OF INDIANA LACHNOSTERNA.}

a. Hind tibiæ of male with one spur fixed.

b. Fixed spur of hind tibiæ of male very short; form oblong or elongate, subcylindrical.

Group A, p. 961.

bb. Fixed spur of hind tibire of male at least moderately long; usually half or more as long as the other.

c. Apex of hind tibir of male with a distinct sinuation or notch on inner edge at base of fixed spur.

Group B. 1).962.

cc. Apex of hind tibix of male squarely truncate.

d. Antennæ 10-jointed.

e. Body above glabious.

Group $C$, p. 96.5.

ee. Body above pubescent.

Group E, p. 976.

dd. Antemie 9-jointed; body sometimes hairs.

Group D, p. 974 .

aa. Hind tibix of male with both spurs free and slender. Group F, p. 97s.

Group A.

Our three species classed in this group are oblong or elongate and subcylindrical in form, pale brownish-rellow in hue, and have the inner spur of hind tibire of male short or wanting, the outer long and slender.

KEY TO INDIANA SPECIES OF GROUP A.

a. Antennæ 10-jointed; clypeus feebly emarginate.

$b$. Inner spur of hind tibiæ of male distinct.

1S10. EPHILIDA.

$b b$. Inner spur of hind tibire of male wholly absent; form more slender.

GLABERRIMA.

aа. Antennæ 9-jointed; clypeus deeply emarginate.

1811. LOXGITARSIS.

1810 (5749). Lachnosterna ephilida Saj, Journ. Phil. Acad. Nat. Sci.. V, 1825, 196 ; ibid. II, 298.

Moderately elongate, subcylindrical. Pale brownish-yellow, shining: head and thorax darker. Clypeus broadly rounded or very feebly emarginate, coarsely but less densely punctured than the front, the border reflexed. Thorax short, narrowed in front. rather coarsely, not closely punctate. Elytra more coarsely and deeply punctured, the submarginal costa 
obsolete. Metasternum closely punctate, the hair sparse and long. Tarsal claws with a strong median tooth. Male with antennal club a little shorter than stem; the next to list rentral segment feebly and broadly emarginate. the last one more deeply emarginate and abruptly concave; both roughened or granulate in front of the emarginations. Length 14-18 mm. (Plate I, fig. 377.$)$

Clark County; rare. July 22. A species of southern range.

L. glaberima Blanch., length 13-15 mm., is known from Illinois, New York and southward.

1 S11 (5744). Lachnosterna longttarsis Say, Journ. Phil. Acad. Nat. Sci.. III, 1824, 241 ; ibid. II, 141.

Elongate, slender, subcylindrical. Pale straw yellow; front of head piceous. Clypens concave, coarsely and very sparsely punctured; front coarsely and densely punctured. Thorax short, strongly curved in front of middle, margin entire, surface somewhat irregular, rather coarsely, shallowly and closely punctate. Elytra coarsely and shallowly punctured, the submarginal costa rather well defined. Metasternum closely but indistinctly punctate, the hairs rather long, sparse. Male with antennal club a little longer than stem; abdomen slightly flattened at middle, last segment irregularly concave. Length $10.5-13 \mathrm{~mm}$. (Plate I, fig. 379.)

Vigo County ; rare. July 28. One specimen in Wolcott collection taken at light in the city of Terre Haute. A western form whose range is given as Illinois to Kansas, Montana and southward.

\section{Group B.}

The essential characters of this gromp are the sinuation of the apex of the hind tibix, together with the more or less emarginate clypeus and the 10-jointed antennx. The inner spur of the hind tibix is long, fixed and usually more or less curved or contorted. Three species ascribed to the group have heen taken in the State.

KEY TO INDIANA SPECIES OF GROUP B.

a. Form slender, subcylindrical; color pale reddish- or brownish-yellow; tooth of tarsal claws small, placed slightly below the middle.

1812. GRACILIS.

a a. Form oblong-oval, more or less robust; color reddish-yellow to dark brown; tooth of claws strong.

b. Inner spur of hind tibire of male curved at middle and angularly bent at tip; color pale chestnut brown; length $12-16 \mathrm{~mm}$.

1S13. GIBBOSA.

76. Inner spur not angularly bent, usually nearly as long as the outer spur; color dark reddish or chestunt brown, the surface more or less hoary or pruinose.

1S14. PRUNINA. 

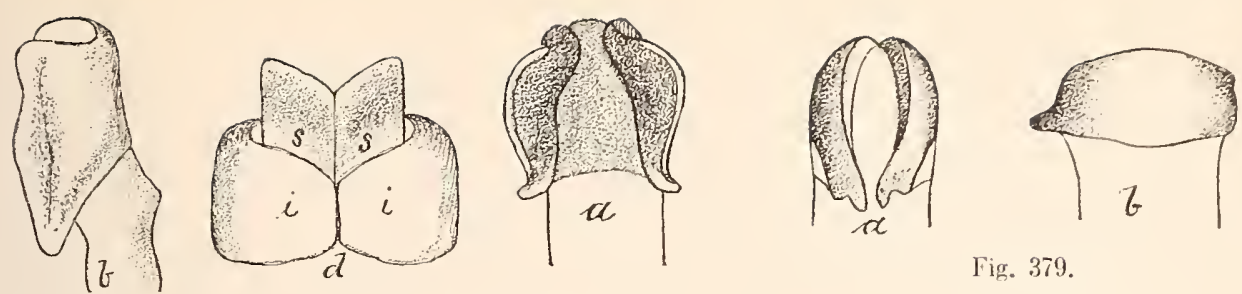

Fig. 379 .

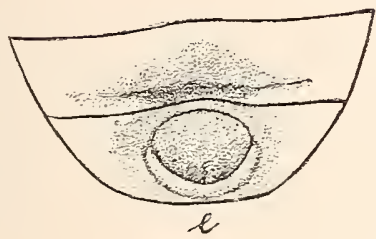

Fig. 376 .
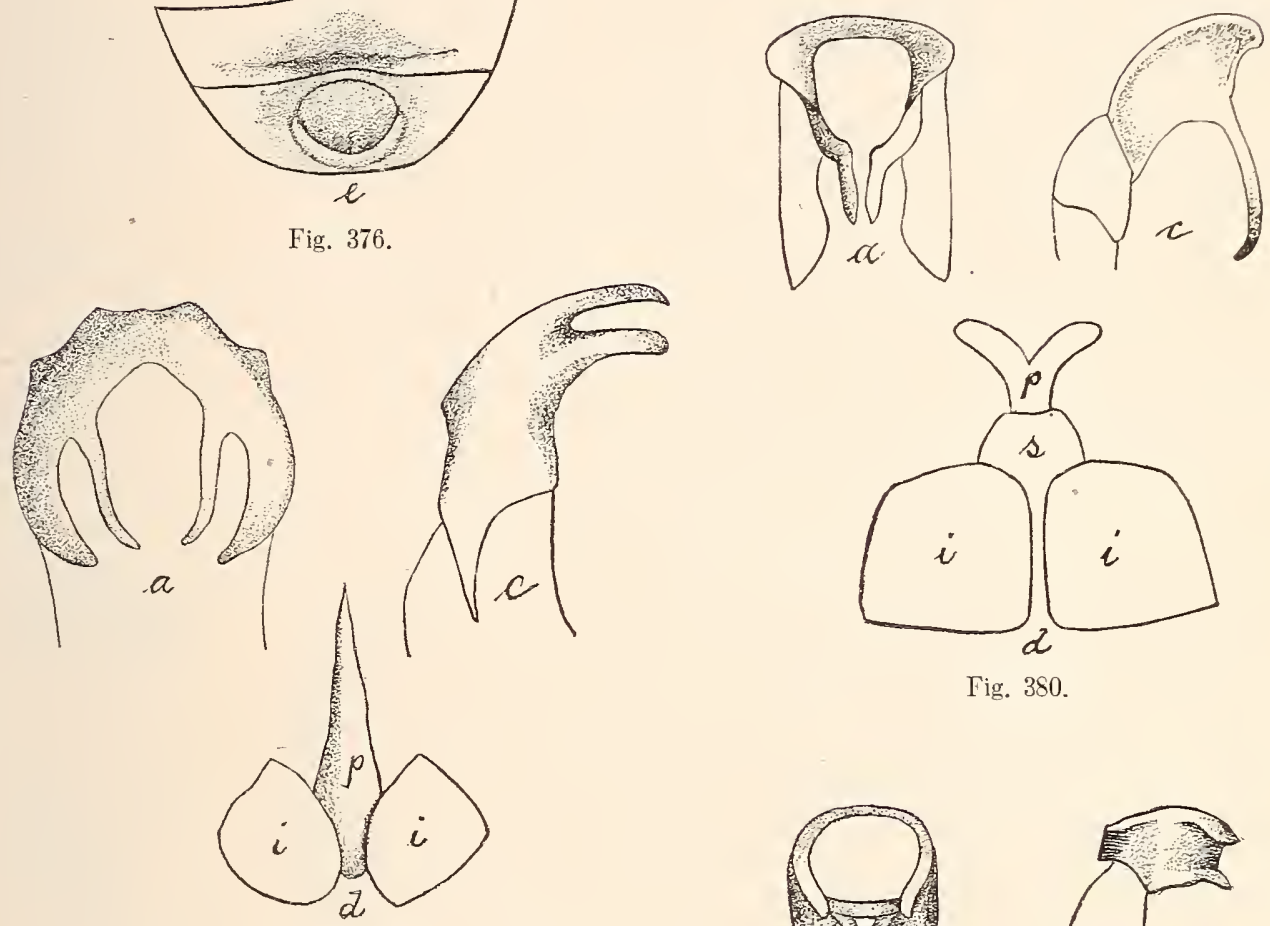

Fig. 377 .
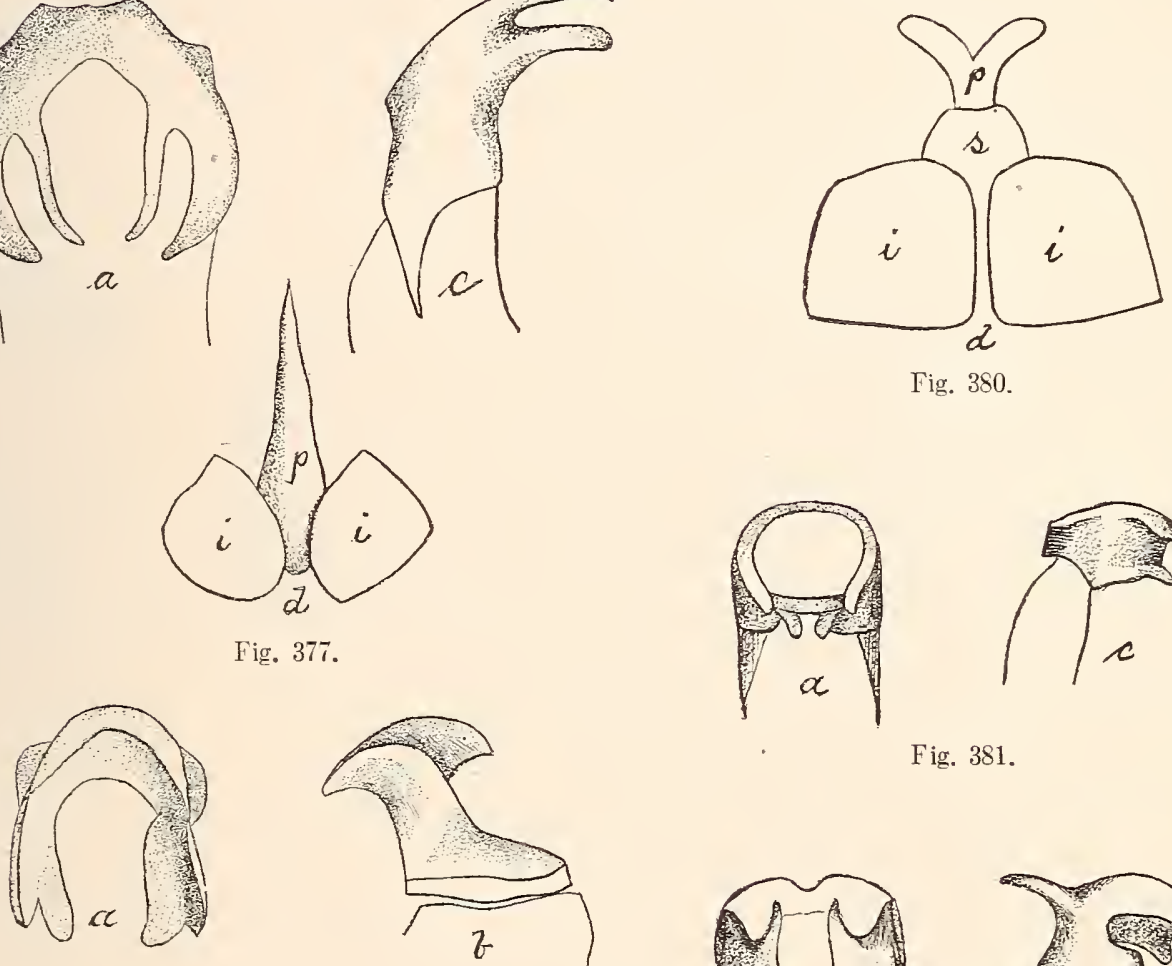

Fig. 380.
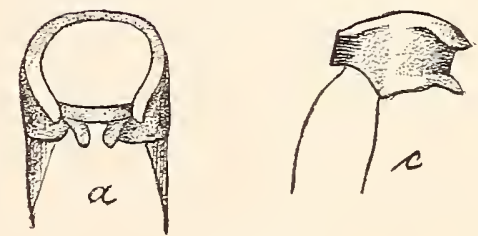

Fig. 381 .
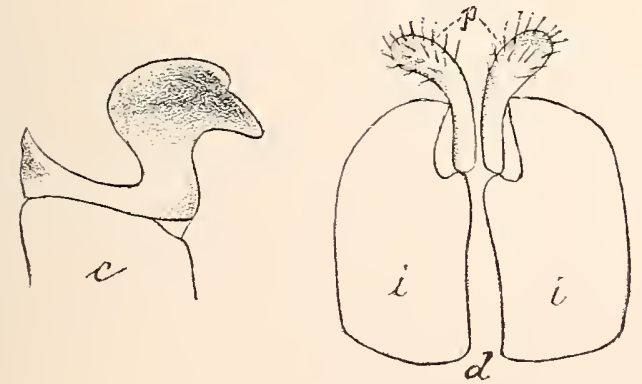

Fig. 378.
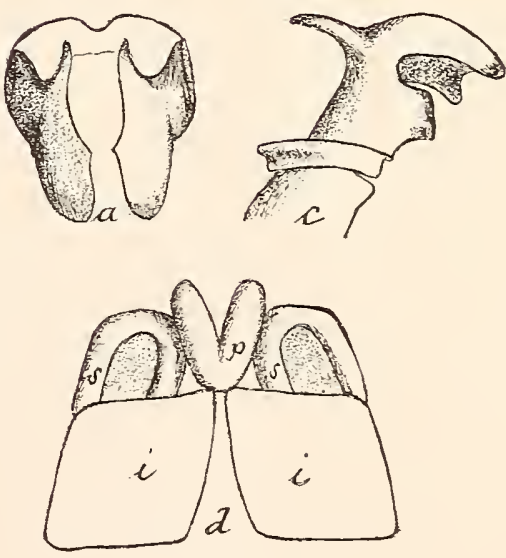

Fig. 382.

Sexual Organs of Lichnosterna. (After Smith in Proc. U. S. Nat'l Museum, Yol. XI, 188S.)

F'g. 376, L. gibbosa (4 ïgs.); Fig. 377, L. ephilida (3 figs.); Fig. 378 L. prunina (4 figs.); Fig. 379, L. longitarsis (2 figs.); Fig. 380 L. gracilis (3 fig..); Fig. 381, L. tristis (2 figs.); Fig. 382, L. micans (3 figs). 
1812 (-). Lachiosteria gractlis Burm., Handb. Entom., IV, 1855, 361.

Elongate, subcylindrical. Pale reddish-yellow, thorax somewhat darker: head fuscous or piceous. Clspeus short, broadly, not deeply emarginate. rather closels, not coarsely punctate. Antennal joints either 9 or 10 in number. Thorax short, sides strongly curved in front of middle, nearly straight behind, surface sparsely and rather coarsely punctate. Elytra more coarsely and closely punctate than thorax, the costre almost obsolete. Metasternum sparsely punctured, the hairs short and sparse. Male with antennal club as long as stem; abdomen slightly flattened, fifth segment sloping downward, last segment feebly concave. Length 10.5-13 mm. (Plate I, fig. 380.)

One specimen taken by Wolcott near Hessville, Lake County. July 25. Occurs from Canada to North Carolina and Texas.

1813 (-). Lachiosterna gibbosa Burm., Handb. Ent., IV, 1855, 324.

Oblong, convex, slightly broader behind. Pale chestnut or dark reddish-brown, smooth, moderately shining. Clypeus very feebly emarginate, more deeply in female, both it and the front rather sparsely and coarsely punctured. Thorax rather short and conrex, margin slightly crenate, ciliate with long hairs; disk coarsely and rather sparsely punctate, usually with a smooth median space. Elytral punctures as coarse as those of thorax; the submarginal costa faintly risible on apical half. Metasternum densely punctured, the hair long and close. Male with antennal club a little

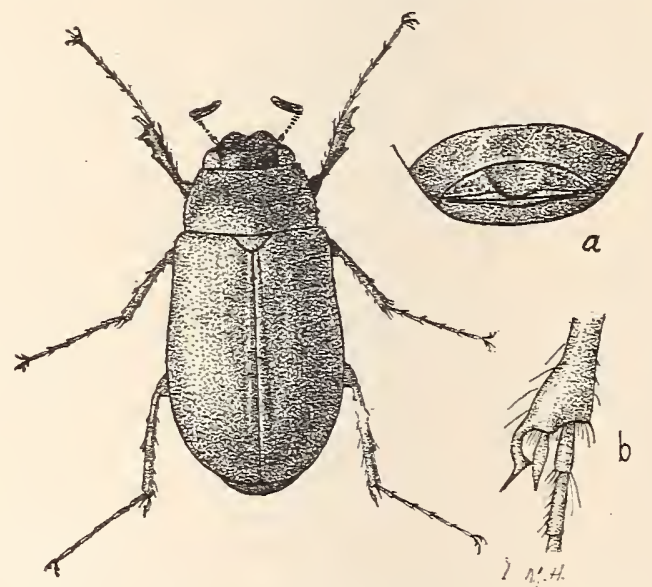

Fig. 374. $\times 2 . \quad a$, ventral characters of male; $b$, apex 0 hind tibia of male, showing the form of spurs. (After Forbes.)

shorter than stem; abdomen broadly impressed, fifth segment feebly conrex and granulate at middle, last segment deeply concare; inner spur of hind tibix somewhat S-shaped. Length 12-16 mm. (Fig. 374 and Pl. I. fig. 376.)

Common in the southern half of State; much less so in the northern portion. April 3-August 22. Specimens on April 3 and April 12 were taken beneath cover and had just emerged as imagoes. Others were taken at light on April 18th and 19th. Readily known by the pale color, long cilix of thorax and peculiar inner hind tibial spur of male. I. futitis Lec. of the Henshaw Catalogue, is the male of gibbosa and L. serricomis Lee. the female. 


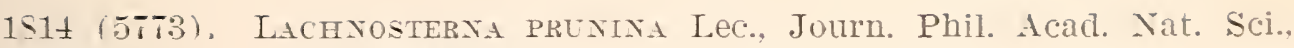
III. $1856,251$.

Oblong-ovate. moderatels robust. Dark reddish- or chestnut-brown to piceous, the surface usually with a purplish or hoary coating. Clrpeus broadly emarginate, densely punctured, the front more coarseily and roughly punctured. Thorax with marcin serrate. sparsels ciliate: disk with rery coarse, closely placed punctures, dense near the front angles, the median line usually smooth. Elytral punctures fine, indistinct, sparsely placed: all the costre moderatel distinct. Metasternum densely punctured, the hair long and dense. male: sparser and much shorter, female. Male with antennal club a little longer than the funicle: abdomen flattened at middle, fifth segment with a strongl elerated, rugose ridge behind which the segment is rather deeply impressed: last segment irregularly concave. with small granulations. Length 17-21 mm. (P1. I, fig. 378.)

Lake and Tigo counties: scarce. June T-August 11. A number of specimens have been taken along the beach of Lake Nichigan. Said to occur on raspberry bushes. Ranges from Ohio and IIichigan to Kansas and Texas.

Grotp C.

To this group belong a number of our best known and most common species. All agree in having the body not pubescent above. usually shining, rarely pruinose or iridescent: antennæ 10-jointed: clypeus usuafly emarginate; hind tibire truncate at apex, without trace of sinuation at the base of the fixed spur. this spur usually long and straight. Trelve species have been taken in the State. while four others perhaps occur.

\section{KEF TO INDIAYA SPECIES OF GROLP C.}

u. Clypeus not densely punctured. its margin moderatels reflexed. feebly emarginate: side margins of thorax not serrate. disk never very coarsel punctured.

b. Last rentral segment of male with a distinct cup-shaped depression : fifth segment with a relr feeble transverse ridge near the hind border; form short and robust; color pale chestnut brown.

CRASSISSIMA.

63. Last rentral segment of male without any mell defined concarits: clrpeus distinctị emarginate.

c. Fifth rentral segment of male with a semicircular. slightly rugulose depression. Without a transrerse ridge. 1515. Ixrenst.

cc. Fifth rentral segment of male with a transverse, more or less sinuous ridge in front of the hind margin of the segment.

d. Surface with a conspicuous hoar's or pruinose coating.

1S16. MICATS.

d7. Surface not at all pruinose. 
c. Form oblong, depressed; punctuation of thorax and elytra relatively very coarse.

DIFEINIS.

ee. Form larger, more robust; punctuation not conspicuously coarse.

$f$. Fixed spur of hind tibire of male long, feebly curved, and with a slight hook at tip.

1817. VEHEMENS.

$f f$. Fixed spur of hind tibix of male moderate in length and straight.

g. Ventral riage of fifth segment of male more or less curved.

h. Ventral ridge with the ends only overhanging behind, the curre but slight, the middle of the ridge lower and sloping gradually downward behind; last rentral segment of female not emarginate.

181S. FC'SA.

$h \hbar$. Ventral ridge orerhanging its full length behind, shorter and more decidedly curved; last rentral segment of female emarginate.

$i$. Ends of ventral ridge at the extreme hind margin of the fifth segment and somerhat overhanging the last segment.

1819. ARCUATA.

ii. Ends of rentral ridge at some distance frow the hind margin of the fifth segment.

1S20. DUBIA.

gg. Ventral ridge straight, not orerhanging behind.

1821. GRA NUIS.

a a. Clypeus densely punctured, its margin narrowly reflexed, rather deeply emarginate; side margins of thorax more or less ser'rite.

j. Thorax not angulate at the sides, usually broader at base than middle.

k. Submarginal costa of elytra well marked, reaching very nearly the humeral prominence; thorax with scattered coarse punctures and smooth spaces of variable size.

1S22. MARGINALIS.

7.\%. Submarginal costa rery feeble, visible only on apical third.

1. Antennal club of male nearls a third longer than the entire stem: last rentral without a deep cup-shaped impression. SPRETA.

17. Antennal club of male rery little longer than the funicle; last rentral with a deep impression.

$m$. Thorax rather erenly punctured, its margin not distinctly crenate; fifth rentral segment of male impressed at middle and slightly granulate, with a feebly oblique ridge each side.

1823. FRATERNA.

$m m$. Thorax sparsely and rery irregularly punctured, with large smooth spaces near the center, its margin distinctly crenate; fifth ventral segment of male with a distinct curved granulate ridge. behind which the segment is deeply impressed.

1S24. Nora.

ij. Thorax angulate at the sirles, broader at middle than base.

$n$. Thorax densely and confluently punctured and with an elevated smooth median line; elytral costie feeble but distinct.

KNOCHII. 
mu. Thorax less densely and not confinently punctured, withont an elevated median line.

o. Fifth ventral of male deeply concare and gramulate behind the middle, with an oblique ridge each side; thorax coarsely and rather closely punctate, the median line smootl.

1825. RUGOSA.

oo. Fifth ventral of male with a strongly elevated, orerhanging curved lidge, sometimes divided at middle; thoriax more finely and irregularly punctured. having smooth spaces but no smooth median line.

1826. HORNII.

L. crassissima Blanch., length $15-21 \mathrm{~mm}$, is known from New York, Illinois, Kansas and Texas.

1815 (10,235). Lachnosterna inrersa Horn, Trans. Amer. Ent. Soc., XIV. $1857,241$.

Oblong-oral, scarcely broader behind. Reddish-or chestnut-brown, moderately shining. Clypeus feebly emarginate, rather closely punctate. Thorax with sides nearly parallel behind. slightly curved in front of middle. margin entire. sparsely ciliate; surface with moderately coarse punctures not closely placed. Elytral punctures more closely placed than those of thorax, distinctly rugulose along the middle; discal and submarginal costre very feeble. Male with antemal club nearly as long as the stem; last ventral segment broadly and transversely impressed; inner spur of hind tibire broad, short and obtuse. Length 15-18 mm. (PI. II, fig. 383.)

Vigo and Knox counties; searce. May 9-May 29. Taken at clectric light. Resembles fusca but shorter, more slender and with the elytra more distinctly rugulose or wrinkled; the male ventral characters also widely different.

\section{6 (5761). Lachnosterna micans Knoch., New Beytr., 1801, 7 .}

Oblong, slightly broader behind. Brownish-black, surface with a hoary coating. Clypeus concare, very slightly emarginate, its surface rather coarsely, not closely punctate. Thorax with margins entire or nearly so; surface rather coarsely, sparsely and irregularly punctured. the median line smoother. Elytra punctured similarly to thorax. Metasternum densely punctured, the hair rather long and dense. Male with antemal club shorter than stem; fifth rentral with a feebly elevated curved ridge at middle; last segment irregularly concare; inner spur of hind tibiae half the length of cuter, slender and slightly curved outwardly. Length 15-17 mm. (Pl. I. fig. 382.)

Monroe, Lawrence, Gibson and Perry counties; frequent. May 16-June 21. One of our smaller species, easily known by the hoary coating. When this is removed the color is dark reddish-brown. 
L. diffinis Blanch., dark reddish-brown, length $15 \mathrm{~mm}$., is a southern species which has been taken near Cincinnati.

1817 (10,237). Lachiosterna rehemens Horn, Trans. Amer. Ent. Soc., XIV, 185T, 244.

Oblong-oval, moderately robust. Liceous or dark reddish-brown. strongly shining. Clypeus very slightly emarginate, somewhat concave, its surface rather finely, not closely punctate. Thorax narrowed toward base, its sides behind middle nearly straight, curved in front; margin entire with short ciliæ; disk relatirely finely and sparsely punctured. Elytral punctures indistinct except at base and sides, rugulose at middle; submarginal costa well dereloped. Male with antennal club shorter than stem; fifth segment with a curved ridge overhanging or projecting in the manner of a ledge. except at middle; last segment broadly and transversely impressed, its apex broadly emarginate; hind femora broadly angulate at middle. Length 21.5$23 \mathrm{~mm}$. (Pl. III, fig. 394.)

Vigo and Knox counties; scarce. April 16-May 1. Specimens which had just emerged were taken on the two dates named. It occurs more commonly in damp localities and is one of our largest species.

$1 S 18$ (5757). Lachosterna Fusca Froh., Naturforscher, 1792, 99.

Oblong, robust. Light to dark chestnut brown or piceous, shining. Clypeus slightly emarginate, its surface rather finely and closely punctate; front a little more coarsely and less closely punctate. Thorax always widest at base, usually feebly curred from middle to apex; margin entire, with short cilise: surface never very closely or coarsely punctate, usually with a smooth median line. Elytra more closely punctate than thorax, the submarginal costa distinct on basal half. Metasternum densely punctured, the hair long and dense. Male with antennal club as long as or slightly longer than stem; abdomen flattened at middle, the fifth segment as described in key; last ventral feebly concave. Pubic process of female a single cylindrical rod, terminating in an obtuse point. Length $17.5-21 \mathrm{~mm}$. (Pl. III, fig. 391; pl. IV, fig. 39S.)

Throughout the State; common. March 25-June 19. Our most abundant and injurious member of the genus, occurring by thousands at electric lights during its season. As usually knorn, and as described by Horn, several species were confused which were afterward separated by John B. Smith in the papers; loc. cit. All of these have the thorax rather finely and sparsely punctate. The form fusca is generally smaller than these species, except arcuata. and in the male the ventral ridge is lower in the middle than on either side. The female is readily distinguished from its allies by not having the last ventral segment emarginate. 
Plate II.
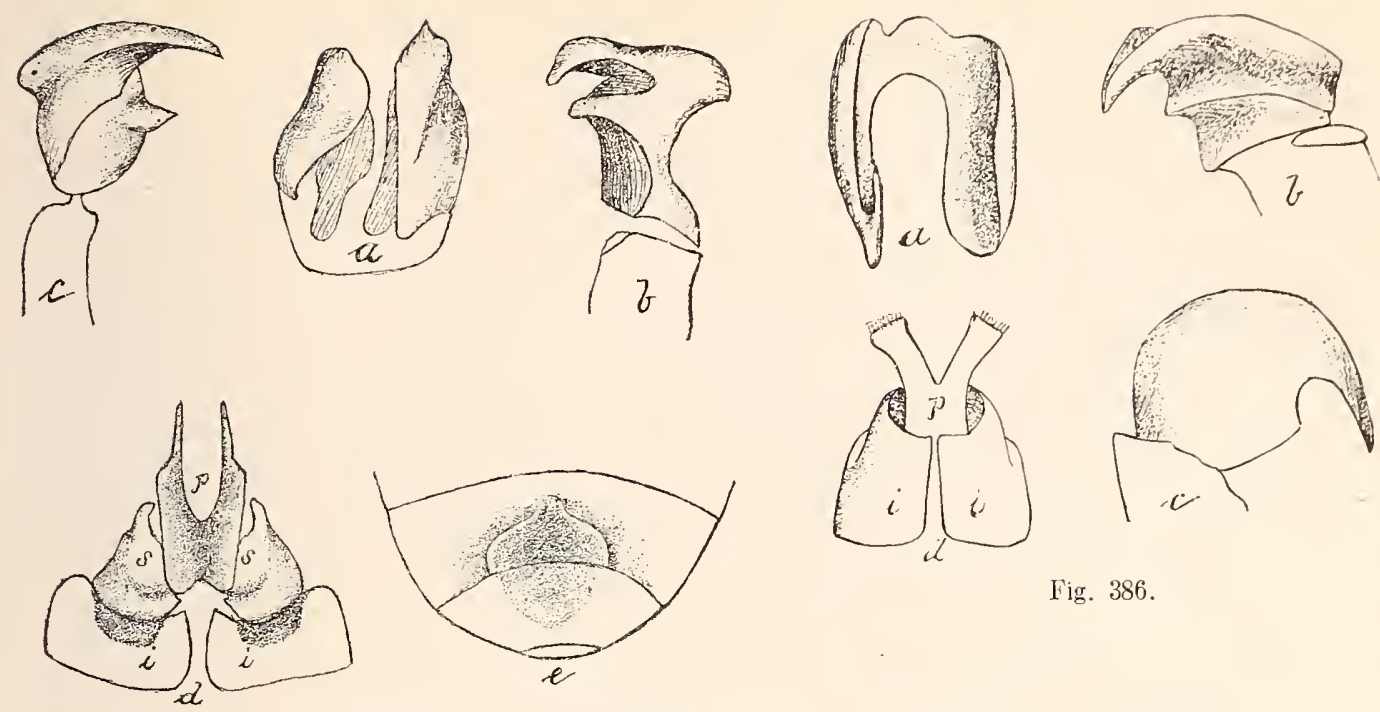

Fig. 383.
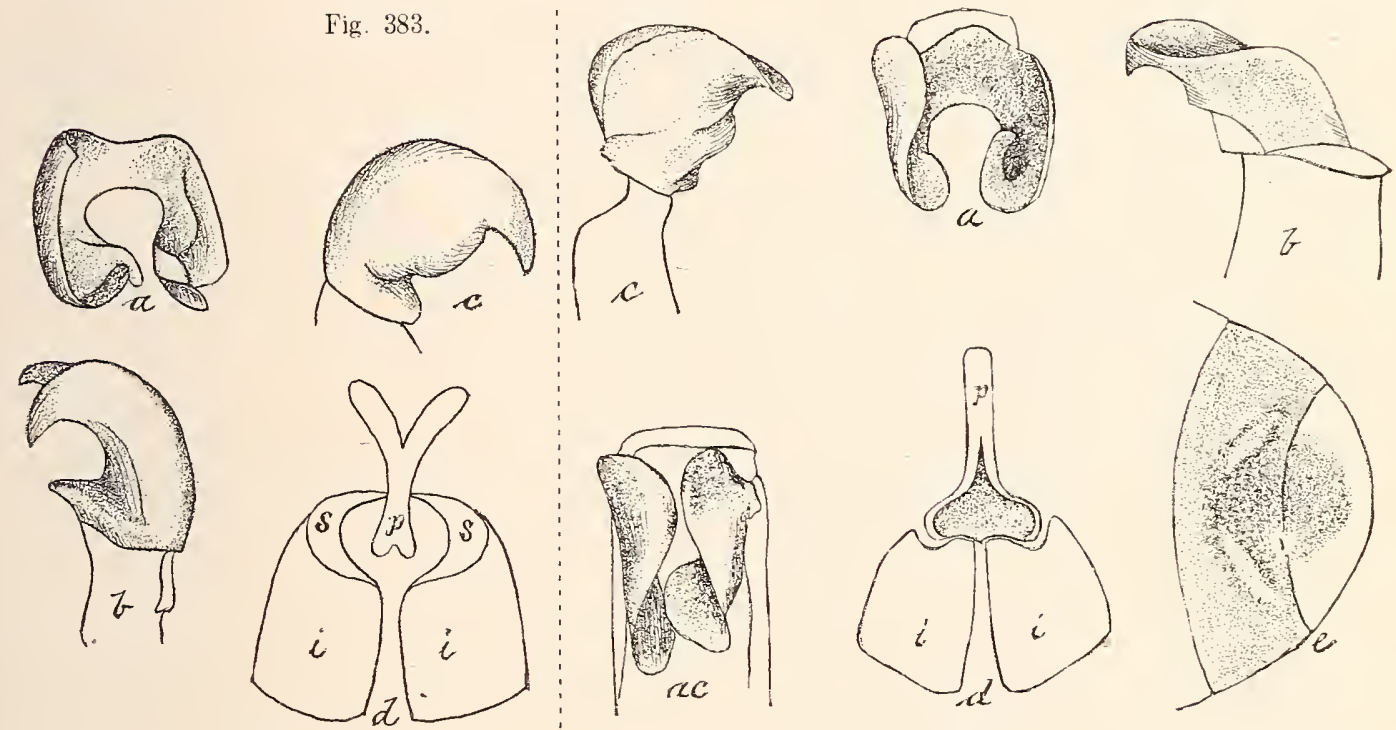

Fig. 384 .

Fig. 385 .
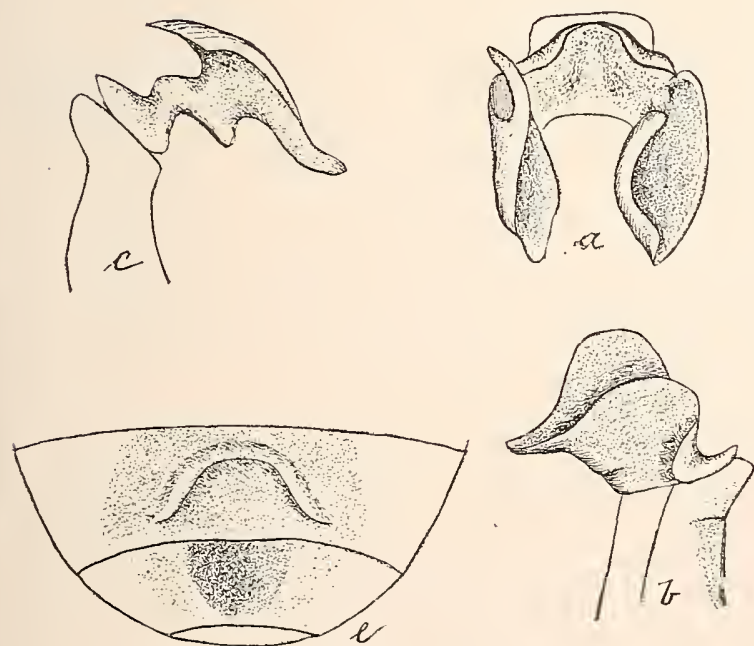

Fig. 387
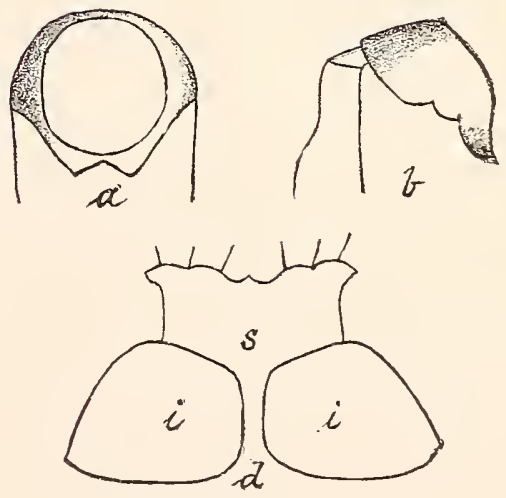

Fig. 388 .

Sexdal Organs of Lachnosterna. (After Smith in Proc. U. S. Nat'l Museum, Vol. XI, 1Sss.)

F:g. 383, L. inversa (5 figs.); Fig. 384. L. balia (4 figs.); Fig. 385, L. fraterna (6 figs.); Fig. 386, L. muryinulis (4 figs.); Fig. 387, L. nova (4 figs.); Fig. 38S, L. crenulatu (3 figs.). 


\section{9 (10,238). Lachoosterna arcuata Smith, Insect Life, I, 18s8, 183.}

Resembles fusca in form, size and color. The males can be easily separated by the ventral characters, the ridge of the fifth segment being very mucl curved, very much overhanging, the ends reaching the apical margin of the segment, while the arch, combined with the depression of the last segment, forms a perfect oval. The space included by the arch of the ridge is smooth, in dubia it is punctured. The females are distinguished from those of fusca by having the last ventral segment emarginate. From those of dubia they can be known only by the genital structure, the "superior" plates" being large and quadrate, while those of dubia are narrow and linear. (Pl. III, fig. 3S9.)

Porter, Monroe and Posey counties; scarce. May 13-June 29.

\section{0 (10,240). Lachnosterna dubia Smith, loc. cit., p. 183.}

Resembles fusca in all outward appearance, the ventral characters of the male alone separating that sex. The ventral ridge is decidedly less curved than in arcuata and more curved and in every way more distinctly marked than in fusca, overhanging or projecting like a ledge behind for its full length. Female with the pubic process broad, stout and forked at apex, as in arcuata, but twice as long as there, the branches broad, somewhat flattened and obliquely truncate; the superior plates narrow and linear. Length 17.5-23 mm. (Pl. III, fig. 390.)

Lake, Kosciusko, Vigo and Crawford counties ; frequent. May 10-June 19. Probably throughout the State. The clypeus is more distinctly emarginate than in fusca.

\section{1 (10,241). Lachnosterna Grandis Smith, loc. cit., p. 181.}

Resembles fusca, but usually larger and more robust. Sides of thorax more subangulate before the middle and upper surface much smoother, the carinæ of elytra being less distinct and the punctures finer, so that it has a glossy or satiny appearance. Male with ventrai ridge without a perceptible curve, not overhanging; last ventral granulate-punctate. Female with last segment emarginate and the middle of abdomen, especially toward the base, distinctly punctate; pubic process deeply forked, the branches much more slender than in the two preceding species. Length $21-23 \mathrm{~mm}$. (Pl. V, fig. 400.)

Steuben, Putnam and Vigo counties; scarce. April 18-June 16.

1822 (5771). Lachnosterna malgina Lis Lec., Jomm. Phil. Acad. Nat. Sei., VII, $1856,250$.

Oblong, rather slender, slightly broader behind. Reddish- or chestnutbrown to piceous, shining. Clypeus moderately emarginate, its surface deeply and rather coarsely, the front more coarsely punctured. Thorax broadest at base, sides curved from middle to apex, margin slightly irregular, with short cilire; surface very coarsely, sparsely and irregularly punctured, with large smooth places on each side slightly in front of middle. Elytral punctures rather fine and moderately close, the costre distinct, but narlow and feebly elevated. Male with antennal club a little longer than 

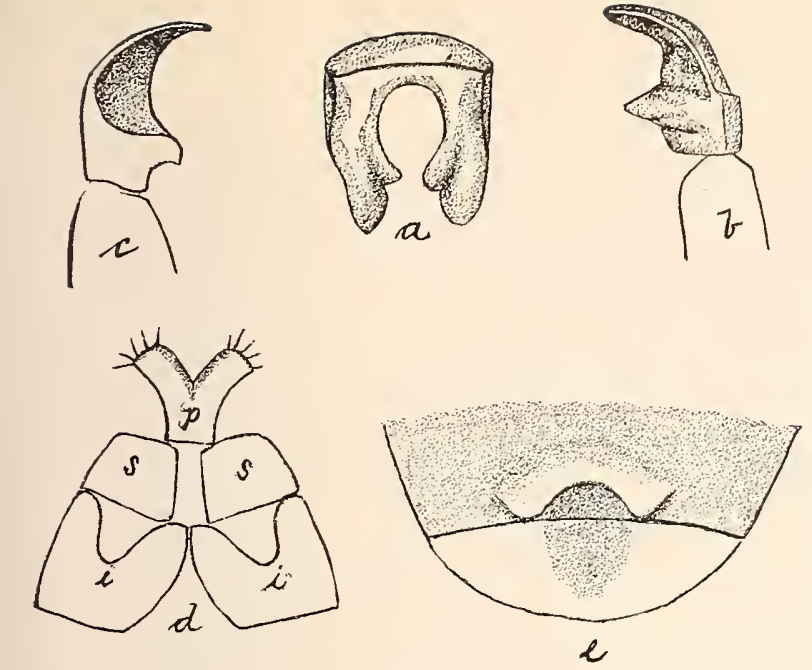

Fig. 389 .
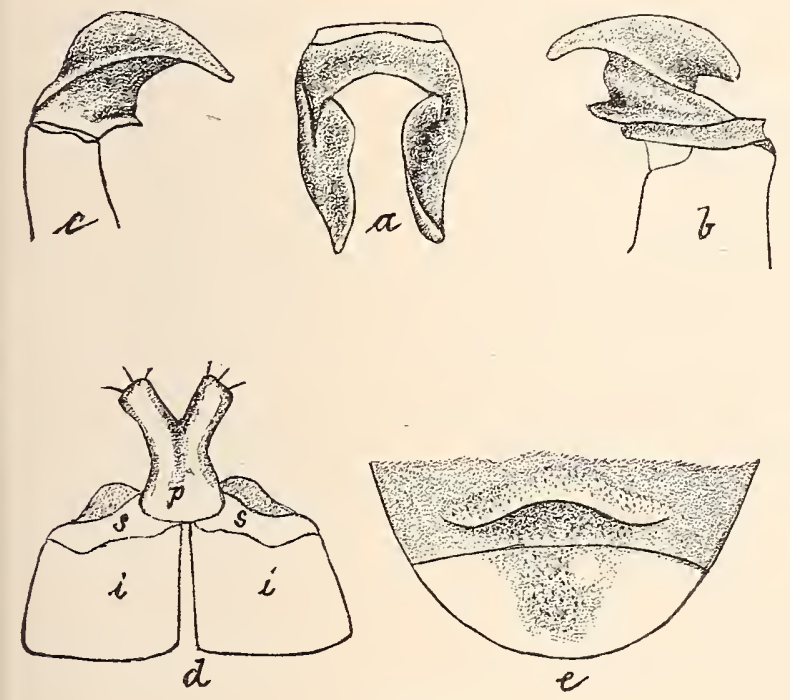

Fig. 390
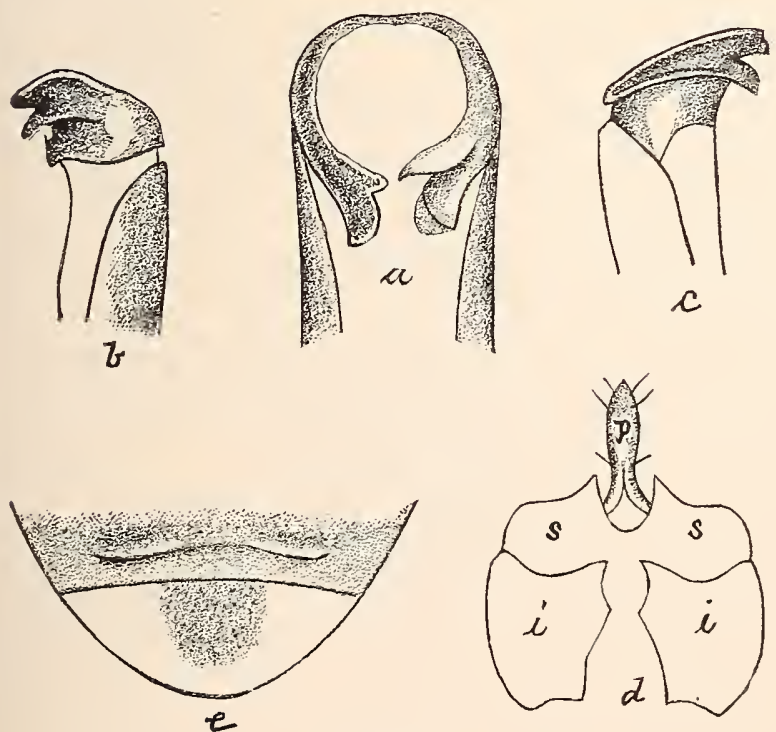
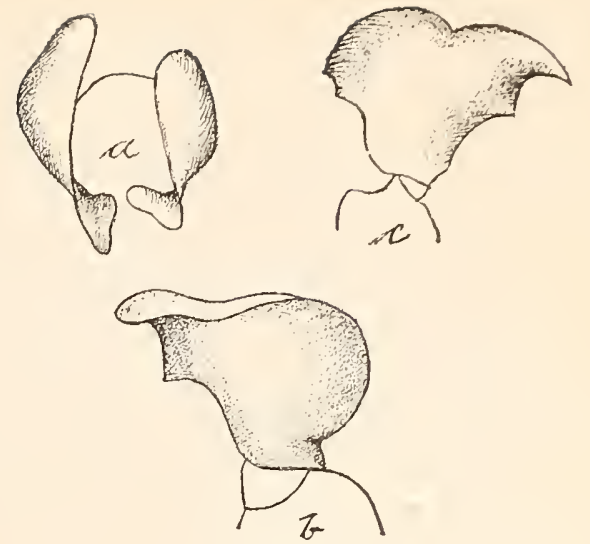

Fig. 392.

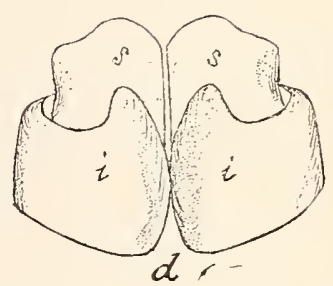

Fig. 393.
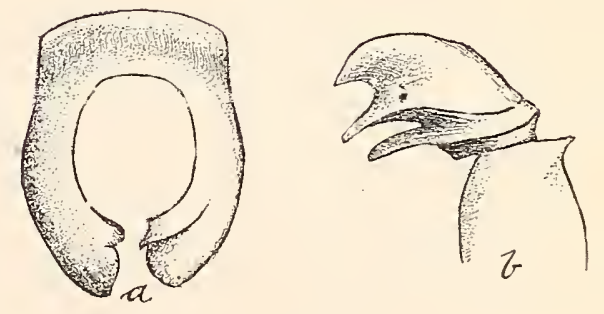

Fig. 391.

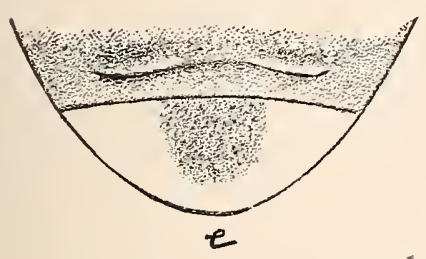

Sexual Organs of Lachnosterna. (After Smith in Proc. U. S. Nat'l Museum, Vol. XI 1S88.)

Fig. 389, L. arcuata (5 figs.); Fig. 390, L. dubia (5 figs.); Fig. 391. L. fusca (5 figs.); Fig. 392, L. delata (3 figs.); Fig. 393, L. albina (1 fig.); Fig. 394, L. vehemens (4 figs.). 
stem; abdomen flattened at middie. the fifth segment with a semicircular rugulose eleration in front of a rather deep, smooth depression; last segment raguely and transversely impressed. Female with pubic process long. deeply forked. the branches truncate at tip. Length 16-20 mm. (Pl. II, fig. 386.)

Lake, Porter, Putnam and Perry counties; scarce. April 22July 16. Ranges from New York to Illinois and southward. The more slender, oblong body, distinct submarginal costa and coarsely and irregularly punctured thorax should readily distinguish this species.

L. spreta Horn, oblong, chestnut-brown or fuscous, length 16.5$18 \mathrm{~mm}$., is a rare species described from Miarvland and Iowa.

1823 (5767). Lachiosterna Fraterna Harr., Insects Injur. to Veg., 1841, 29.

Obloug. scarcely broader behind. Reddish-brown. fuscous or piceous, shining. Clypeus broadly emarginate, its surface densely punctured; front more coarsely and less densely punctured. Thorax gradually narrowed from base to apex, sides feebly curved, margin entire or slightly irregular; surface rather coarsely and erenly punctured, a narrow median line smooth. Elytral punctures finer and more dense than those of thorax, somewhat rugulose on the sides; the costie usually rery feeble. Metasternum densely punctured, the hair not long or dense. Male with antennal club equal to or slightly longer than the funicle: abdomen feebly flattened at middle, rentral ridge as described in key; last segment deeply concare and smooth. Female with pubic process long, somewhat flattened, expauded at base. the superior plates wholly lacking. Length 15-18 mm. (Pl. II, fig. 385.)

Crawford County ; rare. May 24. Will probably be found to occur throughout the southern third of State.

1824 (10,247). Lachnosterna nova Smith, Proc. U. S. Nat. Mus.. XI, 1888. 509.

Oblong, slightly broader behind. Chestnut-brown. shining. Clypeus moderately emarginate, its surface densely and coarsely punctured; front léss densely so. Thorax as in fraterna. except as mentioned in key. Elytral punctures inner and much more closely placed than those of thorax, the costre feeble but evident. Nale rentral surface as in fraterna except as noted in key ; the claspers not more than half as large and quite different in structure. (See plate.) Length 14-18 mm. (Pl. II. fig. 38т.)

Vigo and Lawrence counties; rare. April 25-July 29. The male is easily distinguished from fraterna by the distinct curved ventral ridge.

L. hnochii Gyll., elongate-oval, reddish-brown to piceous, length $21.5-23.5 \mathrm{~mm}$, is said to occur from Massachusetts to Georgia.

1825 (5774). Lachosterna rugosa Melsh., Proc. Phil. Acad. Nat. Sci.. II, $1844,140$.

Oblons. rather robust; broader behind. Dark reddish- or chestnutbrown to piceous, shining. Clypeus acutely and rather deeply emarginate, 

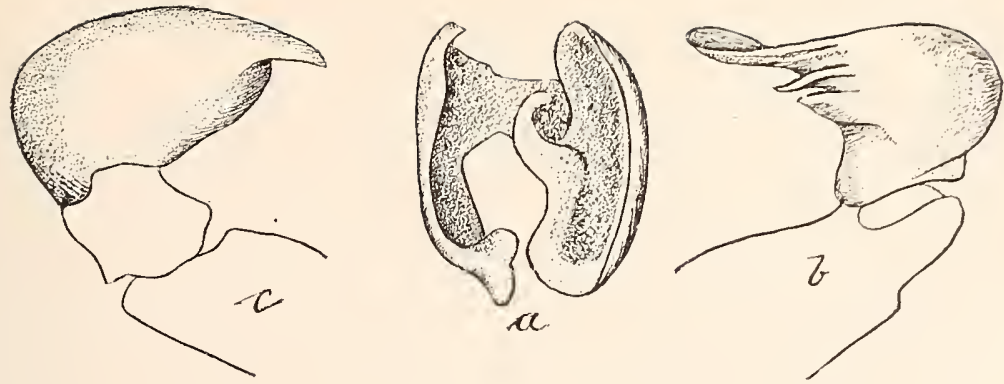

Fig. 395.
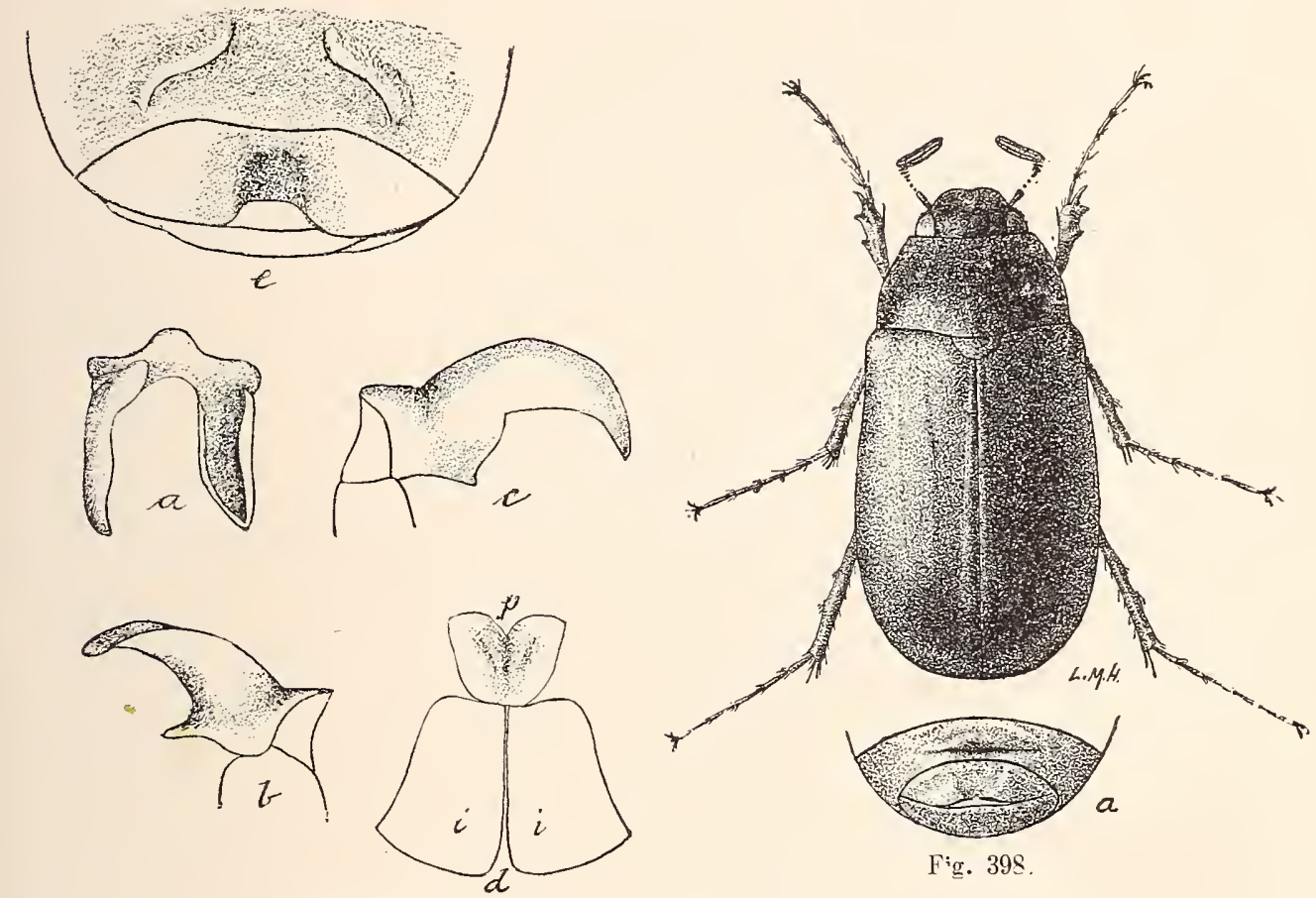

Fig. 396 .

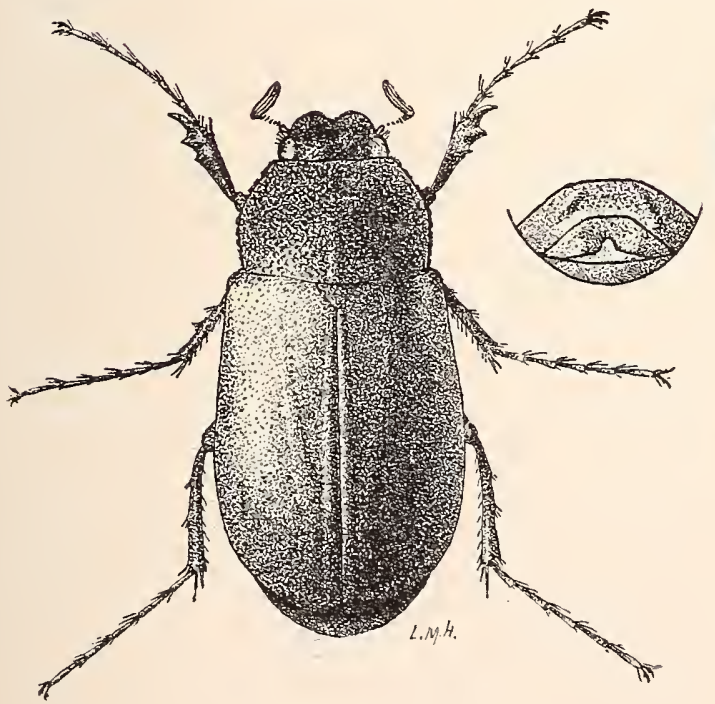

Fig. 397 .
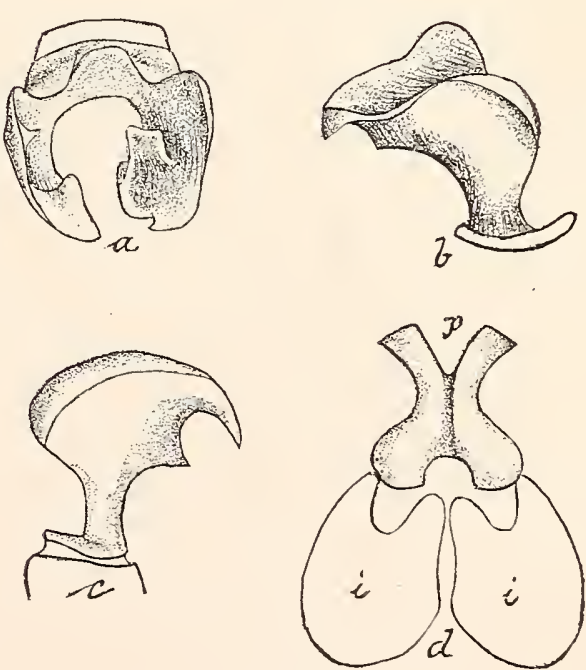

Fig. 399 .

Sexual Organs of Lachnosterna. (After Smith in Proc. U. S. Nat’l Museum. Vol. XI, 1858; Fiøs $\$ 97$ and 398 after Forbes.)

Fig. 395, L. hornii (4 figs.); Fig. 396, L. implicita (4 figs.); Figs. 397 and 399, L. rugosa (6 figs.); Fig. 39S' L. fusca (2 figs.). 
densely and moderately coarsely punctate; front more coarsely punctate. Thorax widest at middle, obtusely angulate, distinctly narrowed at base; margin crenate, sparsely ciliate, punctured as described in key. Elytral punctures finer than those of thorax, very dense, rugulose near the suture; submarginal costa distinct on apical half. Hair of metasternum long and dense, male, very short, female. Male with antennal club a little longer than stem; fifth rentral deeply and transversely depressed behind the middle, with an oblique elevation each side of the concavity; last rentral concare, smooth, the apex broadly and triangularly emarginate, the notch filled by a membrane. Lengtl $18-22 \mathrm{~mm}$. (Pl. IV, figs. 397, 399; pl. V, fig. 404. larva.)

Throughout the State; frequent. May 19-October 15. Smaller and usually paler than the next species.

\section{6 (10,252). Lachnosterna horni Smith, Entom. Amer., V, 1889, 95.}

Oblong-oval, robust, not broader behind. Deep blackish-brown or piceous, shining. Clypeus rather deeply emarginate, more acutely in female, its surface coarsely and densely punctured. Thorax distinctly narrower in front, the sides obtusely angulate, widest just behind the middle, thence narrowed to base, margin feebly crenate, surface punctured as described in key. Elytral punctures finer, much more dense, somewhat rugulose, the costre narrow but distinct. Male with antennal club slightly longer than funicle; last ventral with a quadrate punctured impression, the hind margin with a small, deep notch; fixed spur short, less than half the length of outer. Length 19-21 mm. (P.l. IV, fig. 395.)

Vigo, Lawrence and Crawford counties; scarce. May 1-June. 19. A species of sonthern range. Near Wyandotte Cave it was locally common on May 17, beneath logs on wooded slopes. Known from Tennessee, Ohio and Virginia.

\section{Group D.}

Small or medium-sized species having the antennæ nine-jointed; clypeus emarginate; inner spur of hind tibix of male fixed and at least half as long as the outer one. Three species have been taken in Indiana, while two others perhaps occur.

\section{KEY TO INDIANA SPECIES OF GROUP D.}

a. Body with erect hairs lather sparsely placed; form moderately elongate. the sides parallel.

b. Inner spur of hind tibire of male distinctly shorter, and stouter than the outer one. HIRSUTA.

bb. Inner spur of hind tibise of male fully as long and scarcely stronger than the outer; elytra with distinct lines of longer hair.

LONGISPINA.

aa. Pody above entirely glabrous, with the exception of erect hairs on the head. 
c. Form more or iess orate; front without erect hairs; last ventral of male convex; fifth ventral concave, with a short oblique ridge each side.

1527. TMPLICTTA.

cc. Form more elongate, parallel; front with erect hairs.

d. Last segment of male with a cup-shaped impression ; clypeus broadly not deeply emarginate; pubic process of female slender and bific at tip.

1S2S. BALIA.

dd. Last segment of male broadly and slablowly concalve, with a longitudinal impression at middle; dyjeus deeply emarginate; pubic: process of female bifid but short, broad and stout.

1S29. VILLIFRONS.

L. hirsuta Knoch, reddish-brown to piceous, length 15-18 $\mathrm{mm}$., and L. longispina Smith, reddish-brown, margins of thorax crenulate, length $17 \mathrm{~mm}$, are both known from Michigan.

1827 (10,255). Lachosterna mplicita Horn, 'Trans. Amer. Entom. Soc., XIV, 1SS7, 262.

Oblong-oval, moderately robust. Elytra brown. head and thorax alwars darker, more nearly piceous, body beneath paler than abore. clypeus rather deeply and acutely emarginate, its surface closely and rather coarsely punctate. Thorax widest at middle, the margin feebly crenate. with short cilice surface coarsely and regularly but not closely punctate, the median line usually smoother. Punctures of elytra more shallow and dense than those of thorax, somewhat rugose; coste feeble, the submarginal more distinct. Male with antennal club longer than stem; rentral characters as given in key. Length 14-17 mm. (Pl. IV, fig. 396.)

Southern half of State, frequent; Lake County, rare. May 6June 9. Occurs abundantly at electric light in Vigo County. Readily distinguished from the next two by the broader form, difference in color and convex last ventral segment of male.

1928 (5782). Lachnosterna balia Say, Jomn. Phil. Acad. Nat. Sci., T. 1S25, 194 ; ibid. II, 297.

Oblong, slightly broader behind. Chestnut brown, moderately shining. Head coarsely and rather densely punctured f front convex, with erect hairs. Thorax narrowed in front. widest at middle, rery slightly narrowed behind. margin entire with rather long cilia; surface coarsely, not closely and somewhat irregularly punctured. usually with a smooth median space. Fylytra more finely and rather densely and roughly punctured. Male with club of antennie as long as stem; abdomen broadly flattened at middle. the fifth segment with a curved tramsverse elevation in front of a slight concarity. Length $15-16 \mathrm{~mm}$. (Pl. II, fig. 384.)

Southern and western portions of the State north to Fountain County ; frequent. April 18-May 27. Occurs beneath leaves along the borders of woods and also at electric light.

[62-23402] 
1829 (5783). Lacmnosterna imlifions Lec., Journ. Phil. Acad. Nat. Sci., VII, 1856, 255.

Oblong, moderately elongate. Dark reddish or chestnut brown, shining. Head coarsely and densely punctured. Thorax narrowed in front, sides regularly curred, margin not crenate and with short cilix; surface coarsely. deeply and sparsely punctured. often with large smooth spaces. Elytral punctures coarse and very dense, the discal costie indistinct. Nale with antennal club as long as stem; abdomen broadly flattened at middle, the fifth segment with a feeble curved elevation. Length 14.5-16 mm. (PI. V, fig. 402.)

Posey County ; scarce. April 15-May 10. Those on the earlier date were taken from beneath bark of oak stmmps and logs.

\section{Group E.}

All the memhers of this group are more or less hairy and have the antennie 10-jointed, the chb of male shorter than in the preceding groups; clypeus emarginate; inner spur of hind tibiæ of male fixed and rather long; claws armed with a strong median tooth. Three of the four known species have been taken in Indiana, while the other probably occurs.

\section{KEY TO SPECIES OF GROUP E.}

a. Basal margin of thorax with an impressed line reaching from hind angles nearly to middle; sides of thorax not subangulate.

b. Elytra with rows of erect hairs.

1S30. HIRTICULA.

bb. Elytra with fine scattered suberect hairs.

1831. DELATA.

a . Basal margin of thorax without impressed line, the median line usually finely carinate; sides subangulate.

c. Surface of elytra more or less hoary or pruinose; pubescence fine, uniform and recumbent.

1832. ILICIS.

ce. Surface not pruinose; elytra with rows of short erect hairs in addition to the recumbent ones.

CIIIATA.

\section{0 (5780). Lach nosterna mirTicuta Knoch., Neue Beytr., 1S01, 79.}

Oblong, slightly broader behind. Reddish-brown to dark chestnut-brown. shining; head and thorax with erect hairs. Elytra with five lines of erect hairs along the usual costie. Clypeus rather deeply emarginate, surface coarsely and very densely punctured. Thorax narrower at apex, sides usually entire, with short cilix; surface with coarse, rather sparse variolate punctures. Elytra with much finer, rather dense, feebly impressed punctures, the margin fringed with long hairs. Male with antennal club a little longer than the funicle; abdomen ftattened at middle, the fifth segment more depressed behind the middle, with a short oblique ridge each side, sometimes with a well marked transverse ridge in front of middle. Length $16.5-19 \mathrm{~mm}$. ( Pl. V, fig. 403.)

Throughout the State; common in the southern counties, less so in the north. Narch 25-July 1. Those on the earlier date from beneath stones. Quite variable in form and size, but readily known by the lines of erect elytral hairs. 
Plate V.
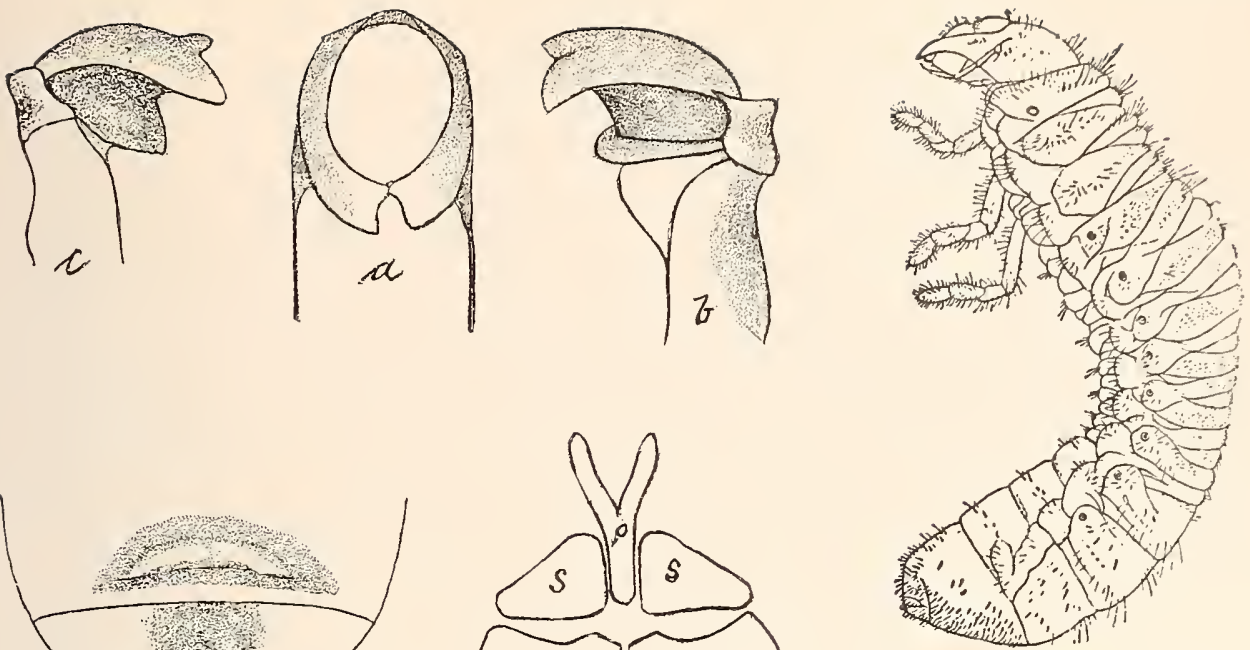

Fig. 404.
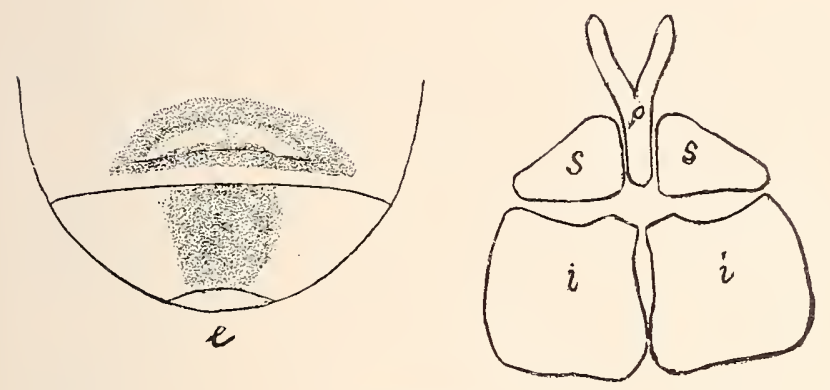

Fíg. 400.
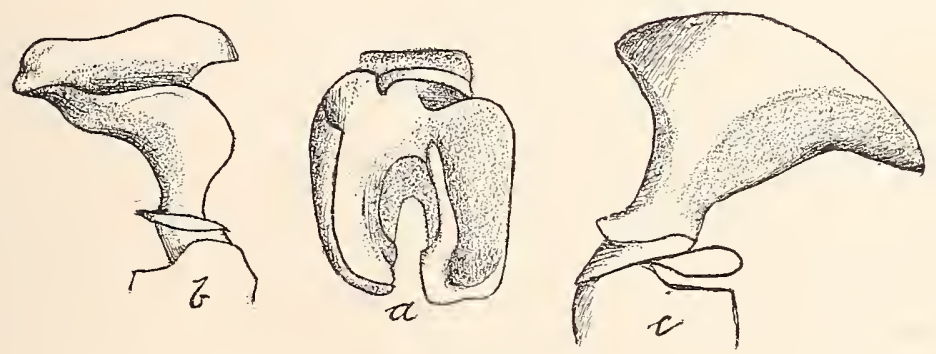

Fig. 401.
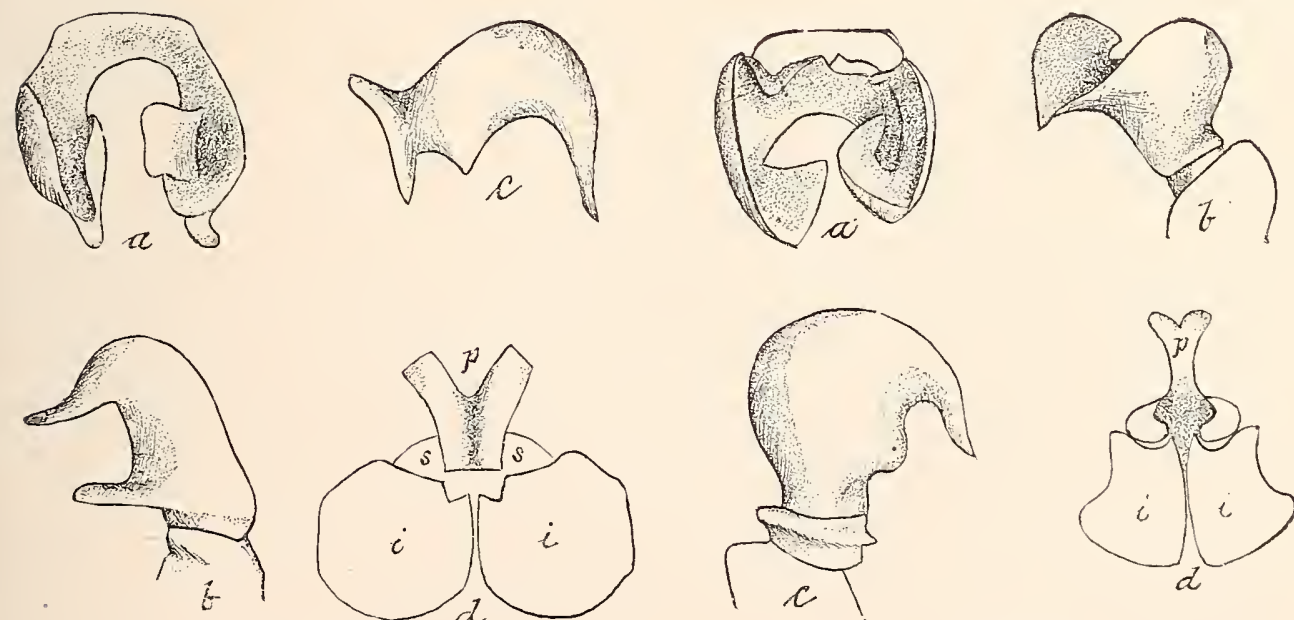

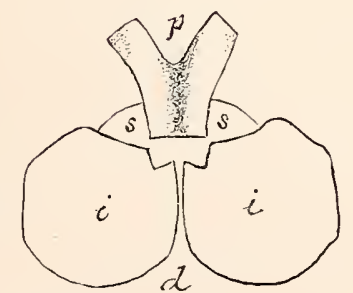

Fig. 402 .
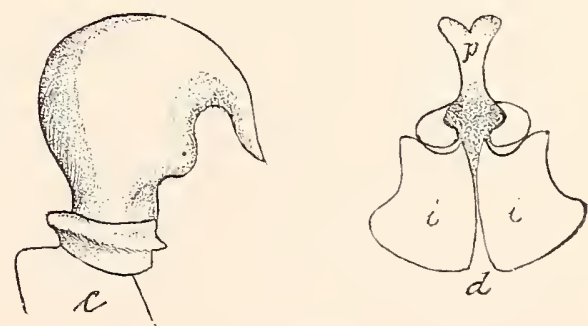

Fig. 103.

Sexual Organs of Lachnosterna. (After Smith in Proc. U. S. Nat'l Museum, Vol. XI, 18SS; Fíg. 404 after Forbes).

Fig. 400, L. grandis (5 figs.); Fig. 401, L. ilicis (3 figs.); Fig. 402, L. villifrons (4 figs.); Fig. 403, L. hirticula (4 figs.); Fig. 404, larva of $L$. rugosa. 
1831 (10,25S). Lachnosterna delata Horn, Trans. Amer. Ent. Soc., XIV, 1857, 267.

Oblong. slightly broader behind. Piceous brown, head and thorax more shining; sparsely clothed with short, semi-erect grayish hairs. Clypeus rather deeply and broadly emarginate, its surface densely and coarsely punctate. Thorax with margin subcrenate and ciliate; surface with coarse, deep punctures not closely placed, each with a short, semi-erect hair. Elytra finely and rather closely punctate, the costre indistinct. Male with abdomen feebly flattened at middle, the fifth segment broadly and rather deeply depressed behind the middle, with an oblique fold each side; last segment acutely notched at apex and with a shallow concavity marked with a longitudinal line. Length $15-17 \mathrm{~mm}$. (Pl. III, fig. 392.)

Orange County ; rare. May 28. Two specimens taken at electric light. Known only from Kentucky and Illinois. Resembles hirsuta but more oval, less hairy and with 10-jointed antennæ.

1832 (5777). Iadmosterna ilicis Knoch., Nene Beytrage zur Insect, 1S01, 79.

Oblong, slightly broader behind. Brown, more or less opaque; head piceous; elytra pruinose. Clypeus rather deeply emarginate. surface very densely and coarsely punctured. Thorax widest at middle, slightly narrowed at base, side margins crenate and ciliate; surface densely granulatepunctate, covered with a rather close, recumbent pubescence; usually with a slightly elevated smooth median line. Elytra densely punctate and finely rugulose; discal costæ indistinct, submarginal moderately distinct. Male with abdomen flattened at iniddle, the fifth segment broadly transversely impressed with an oblique ridge each side; last segment irregularly concave, distinctly emarginate at apex. Length 19-23.5 mm. (Pl. V, fig. 401.)

Throughout the State; frequent. April 22-July 24. Our largest hairy species.

L. ciliata Lec., length $20-21.5 \mathrm{~mm}$., is known from Wisconsin, Illinois, Missouri and Georgia.

\section{Group F.}

In this group the spurs of hind tibixe of male are both free, movable and slender. The species vary much in form and size and comprise the Indiana species of Groups XIT, XV, and XVI of Iorn. Three have been taken in the State, while two others perhaps occur.

KEY TO SPECIES OF GROUP T.

a. Antenna 10-jointed; body more or less hairy.

b. Clypeus more or less emarginate, extended on to the eye at base.

c. Margin of thorax strongly crenate; pubescence of upper surface yellowish.

1833. CRENULATA.

cc. Margin of thorax entire; pubescence rather dense, white.

1S34. ALBINA. 
67. Clypeus entire, rather deeply concave, not extented on to the eye at base; elytra with abundant erect hair; color pale brownish- or reddish-yellow.

18:55. TRISTIS.

aa. Antenna 9-jointed; hind angles of thorax distinct; clypens emarginate.

d. Surface shining.

INEI'TA.

ad. Surface subopaque or iridescent.

QUERCUS.

1833 (5789). Lachosterna crenulata Frohl., Naturforscher, 1792, 94.

Oblong, robust, very little wider behind. Brown, feebly shining, surface clothed with rery short yellowish recumbent hairs, often with erect hairs intermingled. Clypeus feebly emarginate, surface coarsely and closely punctate, with short, erect hairs. Thorax with side margins coarsely serrate; surface coarsely and rather densely punctate, with rather long, erect yellowish hairs and with the median smooth line interrupted. Elytral punctures much finer than those of thorax, evenly and rather closely placed; submarginal costie well marked and entire. Male with antemnal club as long as funicle; fifth rentral segment vaguely concare at middle; hind tibia with both spurs free. Length 17-20 mm. (Pl. II, fig. 38S.)

Lake, Porter, Owen and Vigo counties; frequent. Probably occurs throughout the State. May 7-June 29. A more narrow and parallel form than ilicis, with the hairs of thorax erect and not recumbent as there.

1834 (5790). Lachiosterna albrixa Burm., Handbuch Entom., IV, 1855, 328.

Oblong-oval, distinctly broader behind. Brown, moderately shining. rather densely clothed with white hairs. Clypeus emarginate, densely punctured and with short, erect hairs, which become longer on the front. Thorax with sides obtusely angulate, the margins entire; surface rather closely and coarsely punctate. withont smooth median line. Elytra nearly as coarsely but less densely punctured than thorax; costie well marked, the whitish pubescence with a few erect hairs. Male with antemnal club a little longer than the funicle; rentral segments slightly flattened at middle. Female with club distinctly shorter than funicle. Length 15-1S mm. (Pl. III, fig. 393.)

Marion County; scarce. May 22. Oceurs on the flowers and leaves of the red haw, Cratrgus, in low, open woods. A rare form, known only from Ohio, Indiana and Mississippi. Easily recognized by the conspicuous white pubescence of the surface.

1835 (5796). Lach vosterna tristrs Fab.. Spec. Ins., I, 1781, 39.

oblong-elongate, or slightly oral, a little broader behiud. Iight to dark, dull brownish-yellow, sparsely clothed with short. semi-erect hairs on elytra, with longer; erect reliowish hair on thorax and base of elytra. Clypeus entire, concare, coarsely and sparsely punctured, not prolonged at sides on the eyes. Thorax with margins entire. fringed with long hairs. disk coarsely and rather closely punctured. Elytra evenly and rather closely punctured. the costre obsolete. Male with antennal club slightly longer than stem; abdomen flattened at middle; fifth sesment with a short. transverse acute ridge near the front

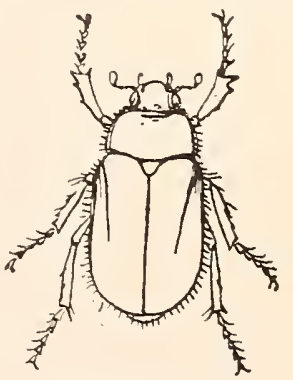

Fig. $375 . \times 1 \frac{3}{7}$ (After Knobel.) 
border; last segment with the front margin elerated and a ridge prolonged backward at middle. Length 11.5-14.5 mm. (Fig. 375 and Pl. T. fig. 3S1.)

Throughout the State; common. April 8-June 9. Readily known by the small size, pale color and erect hairs of thoras, taken in connection with the other characters mentioned in key.

L. inepta Horn, oblong, subcylindrical, reddish-yellow, length 15 mm., was described trom Ohio. L. quercus Knoch, oblong, cylindrical, reddish-yellow: head darker, elytra paler, length 14.5-16 $\mathrm{mm}$, oceurs from the Middle States sonthward to Georgia.

\section{Subfamily III. PLEUROSTICTI.}

The members of this subfamily are mainly distinguished by the position of the abdominal spiracles, the second pair being located in the membrane connecting the dorsal and rentral segments, the third on the outer limit of the membrane and the others in the upper or dorsal portion of the rentral segments. The last two pairs diverge strongly and are usually visible on the sides of the abdomen below the elytra, which do not corer the last dorsal segment or pygidium. They are more closely and hearily built insects than the Nelolonthinæ, and like them are, for the most part, regetable feeders or "leaf chafers." 'The general color is lighter and often variegated; the antennæ 9- or 10-jointed, with the club three-jointed and rarely elongated in the males, and the ligula is always horn-like and firmly united with the mentum. For convenience the subfamily is subdivided into three tribes, all of which are represented in Indiana.

KEY TO TRIBES OF PLEUROSTICTI.

a. Claws of the tarsi unequal in size, the inner one usually much more slender than the outer.

aa. Claws of the tarsi equal in size.

Tribe I. Rutelixi, p. 980 .

b. Front coxæ transrerse, not prominent; body abore convex (except in Philcurus).

Tribe II. Drxastixi. p. 9ss.

bb. Front coxæ conical, prominent; bods abore somewhat Hattened or nearls level.

Tribe III. Ceтoxinis. 1. 995.

\section{Tribe I. RUTELINI.}

Oblong, convex, usually robust species, having the labrum short, horizontal and sinuate; mentum quadrate; scutellum usually rounded behind; tarsi short. with crlindrical joints; side pieces of metathorax narrow with the epimera visible. Ther live for the most part on the leares of trees and vines and some of them are very injurious, especially to the foliage of the graje. 
The following papers embrace the principal literature treating cf the North American genera:

Horn. " "Totes on the Species of Anomala inhabiting the United States." in Trans. Amer. Ent. Soc.. XI. 1884. 157-164.

Horn.- "Table of Species of the Genus Cotalpa." in Trans. Amer. Fintom. Sor., IIT, 1871, 338.

Wirkham. H. F._"The North American species of Cotalpa," in Journ. X. Y. Enton. Soc. XIII. 1.205, 1-4.

schaffer. rhas.- "Notes on some Speces of the Genus Anomala with Descriptions of New Speries," in Journ. N. Y. Entom. Soc.. XIT. 1906, 1-5.

Tbid.-"New Scarabaidx," lor. cit.. XT. 1907. 60-75. Tables of the U. S. species of the genera Anomala and strigoterma are given on pages 69-73.

The descripticns of the species of the other genera are scattered through various publications. Five of the seven genera of the tribe are represented in Indiana.

\section{KET TO INDIANA GENERA OF RUTELIXI.}

«. Elytra with a-membranous margin; antennie 9-jointed: mandibles in repose not projecting beyond the clrpeus.

b. Elstra conrex. not notched at base, shallowle striate and punctate; thorax not haire.

XIT. Aromala.

67. Elytra flattened, notched at base. deeply striate. not punctate; thorax hairs and sulcate or impressed.

XXT. STRIGODERMA. a . Elctra without membranous margin: antennæe 10-jointed; mandibles more prominent, usually risible besond the clypeus.

c. Thorax with marginal line at base: color sellow or brom nish-rellom. a. Clspens without a suture betreen it and the front; elytra with black spots.

TITI. PELIDNOTA.

ad. Clrpeus distinctly separated from the front: elstra without spots.

IXTII. COTALPA.

ce. Thorax withont a marginal line at base: color dark bromn.

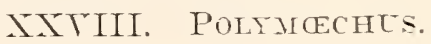

SXIV. Axomal Samouelle. 1819. (Gr.. "unlike.")

Small or medium convex forms, distinguished mainly by the characters given in key. The color is extremely variable. often ranging from dull rellow to biack in the same species. In all but one of the Indiana species the outer or larger claws of the front and middle tarsi are distinctly cleft or divided for one-fourth or more of their length. About 20 are recognized from the Tnited States. 7 of which have been taken in Irdiana. 
KEY TO INDIANA SPECIES OF ANOMALA.

a. Middle coxre narrowly separated and without a tubercle or protuberance between them; basal marginal line of thorax present.

b. Outer or larger claw of front and middle tarsi very distinctly cleft at tip; body beneath with only a few scattered hairs.

c. Claw-bearing joint of front tarsi distinctly toothed on under side. d. Thorax wholly reddish-yellow; clypens distinctly concave, the margin widely reflexed.

1836. FLAVIPENNIS.

dd. 'Thorax either bicolored or entirely piceous; clypeus flat, the margin narrowly reflexed.

e. Larger, 10-11 $\mathrm{mm}$. ; sides of clypeus nearly parallel.

1837. BINOTATA.

ee. Smaller, not over 8 mm.; sides of clypeus divergent behind the middle.

183S. INNUBA.

cc. Claw-bearing joint of front tarsi not toothed on under side.

f. Form elongate, paraliel; thorax with disk dark, side margins paler.

1839. UNDULATA.

$f f$. Form shorter, broader behind the middle; thorax uniformly black or piceous.

1839a. var. DUBIA.

67. Outer claw of front tarsus scarcely cleft, the small division being much below the tip; body beneath, including the legs, distinctly pubescent.

1840. PUBESCENS.

an. Middle coxæ more widely separated and with a distinct tubercle or prominence between them; thorax without basal marginal line.

g. Pygidium sparsely punctured, with little or no pubescence; size smaller, not over $10 \mathrm{~mm}$.

1S41. LUCICOLA.

gg. Pygidium rather densely punctured and distinctly pubescent; size larger, 11-15 mm.

1842. MARGINATA.

1836 (5830). Anomala flavipennis Burm., Handb. Ent., IV, 1855, 247.

Oblong, moderately robust. Elytra pale dull yellow, with or without darker blotches; head, thorax and under surface reddish-yellow, the thorax sometimes with a faint metallic or greenish lustre. Thorax nearly twice as broad as long, sides regularly curved; surface sparsely and rather finely punctured and with two or three small, irregular impressions on the sides. Elytra each with three or four indistinct costæ, the intervals between them broad and marked with several irregular rows of punctures. Pygidium rather coarsely punctured. Length 10-11 $\mathrm{mm}$.

Putnam and Vigo counties; scarce. June 29-July 5. Taken at light. Occurs in the Southern States, Putnam County being its most northern record.

1837 (5831). Anomala Binotata Gyll., Schonh. Syn. Ins., I, 1S27, 106.

Oblong, robust. Head, thorax and scutellum dark greenish-bronze, shining. Elytra dull yellow, the suture, narrow side margins, and usually a rounded spot and short subhunieral stripe, piceous; legs and under surface piceous. Head rather densely and finely punctured. Thorax twice as broad as long, narrowed in front, sides curved; surface finely and sparsely punctured. somewhat more densely on sides. Elytra with rows of coarse punctures and three slightly elevated costæ. Pygidium rather densely rugulose and with short hairs. Length $9.5-11.5 \mathrm{~mm}$. 
Throughout the State; common. April 23-June 15. Occurs on foliage of various shrubs and at light. One specimen at hand has the elytra wholly piceous except a small space each side near the scutellum.

1838 (5S33). Anomala invuba Fab., Mant. Ins., I, 22.

Oval, rather robust. Color very variable, usually dull yellow with the front, a large spot on thorax and one to three transrerse rows of spots on elytra, piceous; sometimes wholly black or piceous, shining. Head rather densely and finely punctured; clypeus nearly semicircular in outline, the sides divergent behind the middle. Thorax one-half wider than long, sides curved; surface coarsely and rather deeply but not densely punctured. Elytra with rows of coarse, deep, closely placed punctures the rows near suture very irregular. Pygidium rugulose at base, smoother at apex. Claw joint of front tarsus distinctly toothed beneath when riewed from side. Length 6-7.5 mm.

Throughout the State: common. April 23-July 21. Occurs especially on the flowers of wild rose and Jersey Tea and at electric light. Specimens occur in which the elytra are wholly pale, dull yellow. According to Dr. F. Ohaus, who examined the type of Fabricius, inmuba is the species commonly listed as minuta Burm. Dr. Horn gave inmuba as a doubtful synonym in his bibliography, p. 164, loc. cit. Dr. Ohaus shows the true minuta Burm. to be a small form from the Southern States, belonging to the subgenus Rhombonyx, in which the tarsal claws are not cleft.

1839 (5S34). Anomala undurata Melsh.. Proc. Phil. Acad. Nat. Sci., II, $1844,140$.

Elongate-oral. Dull brownish-yellow, head darker; disk of thorax piceous with a greenish tinge. Elytra usually with a curred row of oblong piceous spots (these often confluent) across the middle and another on apical third; abdomen and tarsi partly or wholly piceous. Head depressed at middle of front, the anterior flattened portion and clypeus densely and rugosely punctured; clypeus twice as broad as long, its margin narrowly reflexed. the angles broadly rounded. Thorax with sides regularly curved. surface finely and rather sparsely punctured. Elytra with rows of rather coarse punctures, the rows somewhat irregular near the suture; intervals equal and nearly flat. Prgidium rugulose and coarsely

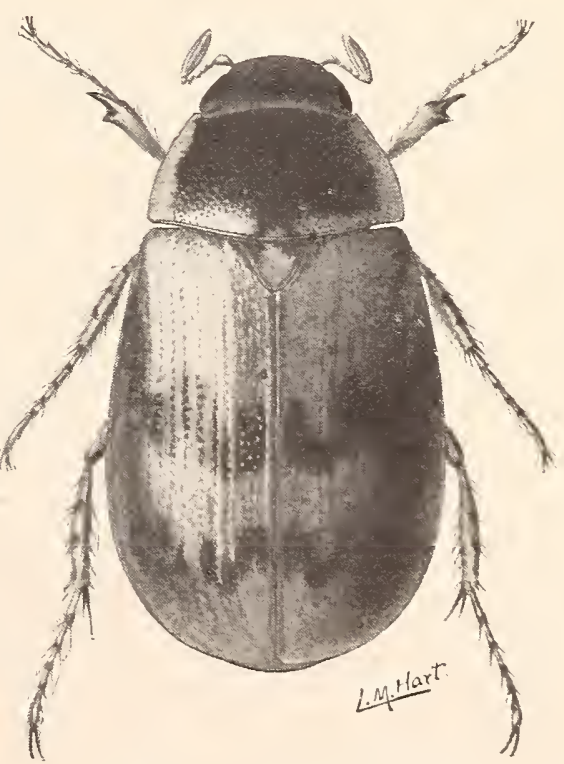

Fig. 405. $\times 5 \frac{1}{2} . \quad$ (After Forbes.) punctured. Length S.5-9.5 mm. (Fig. 405.) 
Throughout the State; frequent. April 23-June 26. Occurs on vegetation, beneath cover and at light. The above is a description of the typical undulata known to Nelsheimer. Confused with, it or immba almost in every collection are shorter, darker specimens which also have the front tarsal claw joint wholly without teeth. These I regard as a distinct variety, if not species, and describe as follows:

$1839 a$ (一). Anomala undulata dubia var. nov.

Oral, broader behind. Usually dark reddish-brown or piceous, feebly shining; elytra often with irregular paler blotches. Clypeus somewhat longer and narrower than in undulata, the sides more divergent behind. Thorax narrower, more convex, and much more coarsely and densely punctured. Elytra more closely and coarsely punctured, the punctures distinctly wider than the intervals, the latter narrower and more convex than in undulata. Meso- and metasterna more coarsely and densely punctured than there. Length $7-7.5 \mathrm{~mm}$.

Throughout the State; less frequent than undulata. April 2:July 13. This form resembles the black color variety of immba, but has the thorax more coarsely and densely punctured. It may be a variety of that species without teeth on the front tarsal claw. If so the main character usually used in separating the two species is of no value. The short, syuat body, taken in connection with the other differences mentioned, at once separate it from undulata. Since both it and that species oceur throughout the State it cannot be classed as a climatic variety.

\section{0 (-). Anomala pubescens su. nov.}

Oblong-oval. Head. thorax and scutellum dark reddish-brown or piceous; elytra dull yellow, the side margins narrowly brownish or piceous; under surface and legs dull brown or piceous. everywhere sparsely clothed with long grayish hairs, these more dense on the meso- and metasterna and covering the pygidium. Clypeus concave, the margin broadly reflexed, more so than in flaripennis; surface, as well as that of lower part of front. roughly, coarsely and confluently punctate, sides broadly and evenly rounded. Thorax one-half broader than long, narrowed in front, widest at middle, sides curved thence to base; front angles acute, hind angles obtuse; surface rather finely, sparsely and irregularly punctate, with a small rounded forea and one or two inpressions on the sides; basal marginal line present. Elytra very irregularly and unevenly punctate, the punctures on sides only being in somewhat distinct rows, many of those on middle of disk confluent in short, broken, deeply impressed lines which are darker than the remaining portion of the disk. Pygidium rugulose. Claw joint of front tarsus toothed beneath; the outer claw of both front and middle tarsi unequally and finely cleft. the small, slender division being near the middle on the front tarsi and distinctly beiow the tip on the middle one. Length 8 $8.5 \mathrm{~mm}$. 
Lake and Vigo counties; rare. June 27-July 7. Of the Vigo County specimen my notebook says, "several burzing close to ground in cornfield on high land southwest of St. Mary's-ouly one taken.' This specimen, together with the one since taken in Lake County, have heretofore been among my innuba labeled as a variety, but a critical examination shows the form of clypeus, cleft of tarsal claws, pubescence of under surface and punctuation of elytra to be wholly different and presenting a combination of characters found in no other described North American species.

1841 (5838). Anomala lucicola Fab., Ent. Syst., 1798, Suppl. 132.

Oval, robust. Color variable from entirely dull yellow to wholly black; thorax often with a discal piceous space, this sometimes divided at middle. Clypeus nearly twice as broad as long, rather densely punctured, its front broadly rounded, sides very little divergent, margin narrowly reflexed. Thorax convex, sides regularly curved; surface rather coarsely but not densely punctured. Elytra with double rows of rather coarse, closely placed punctures, those near the suture confused; intervals broad, feebly convex, finely punctulate. Length $8.5-10 \mathrm{~mm}$.

Throughout the State; frequent in the southern counties, much less so in the north. June 12--July 11. Occurs most commonly on the foliage of the wild grape and Virginia ereeper. Sometimes does much damage to cultivated grapes. These can be sprayed with a solution of Paris green, as the poison will be washed off between the time of the beetles' appearance and the ripening of the fruit.

1842 (5840). Anomala marginata Fab., Ent. Syst., I, 1798, 164.

Oval, robust. Pale dull yellow, with shining bronzed lustre; head and disk of thorax reddish-brown, narrow side margin of latter paler. Clypeus short, broader at base, margin narrowly reflexed, its surface and lower part of front densely and rugosely punctured. Thorax narrower in front. sides curved, surface rather coarsely and sparsely punctured, with minute shallow punctures between the larger ones. Elytra with somewhat irregular rows of coarse, closely placed punctures, the intervals equally convex. Length $12-15 \mathrm{~mm}$.

Knox, Crawford and Posey counties; scarce. June 25-July 10. Our largest, least variable and most handsome form. A member of the Austroriparian fauna which. according to Horn, "occurs in the Southern States.'

XXV. Strigoderma Burm. 1814. (Gr., "stria + skin.")

This genus differs from Anomala mainly by the characters given in key. The thorax is impressed on the sides and the outer front and middle tarsal claws are cleft at tip. 
$1 S 43$ (5842). Strigoderma arboricola Fab., Syst. Eleut., II, 1S01, 174.

Oral, subdepressed. IJead. thorax and scutellum dull blackish-green, shining; sides of thorax usually in part or wholly pale; elytra dull brownish-yellow, often suffused with fuscons or piceons, especially on the sides and along the sutme; under surface and legs piceous, sparsely clothed with long grayish hairs. Head coarsely, roughly and confluently punctured. Thorax one-half broader than long. sides feebly curved, hind angles rounded, front ones acute: surface coarsely. shanlowly and lather sinrsely punctate. with an impressed median line on middle third and two irregular depressions on each side. Elytra with ail the strice distinct, entire and deeply impressed. Length 10-12 $\mathrm{mm}$.

Throughout the State: freguent. May 25-July 9. Occurs most commonly on the flowers of wild rose, blackberry and the water willow, Dianhera americana Linn. In two specimens the thorax, elytra and legs are wholiy reddish-yellow. On the other hand, four Lake County specimens have the thorax wholly bluish black.

\section{Pelinnota MacL. 1817. (Gr., "to make livid.")}

Belonging here we have in Indiana one large, convex, robust species, readily distinguished by the characters given in key.

1844 .(5S44). Pelidnota punctata Linn., Syst. Nat., 1758, 350.

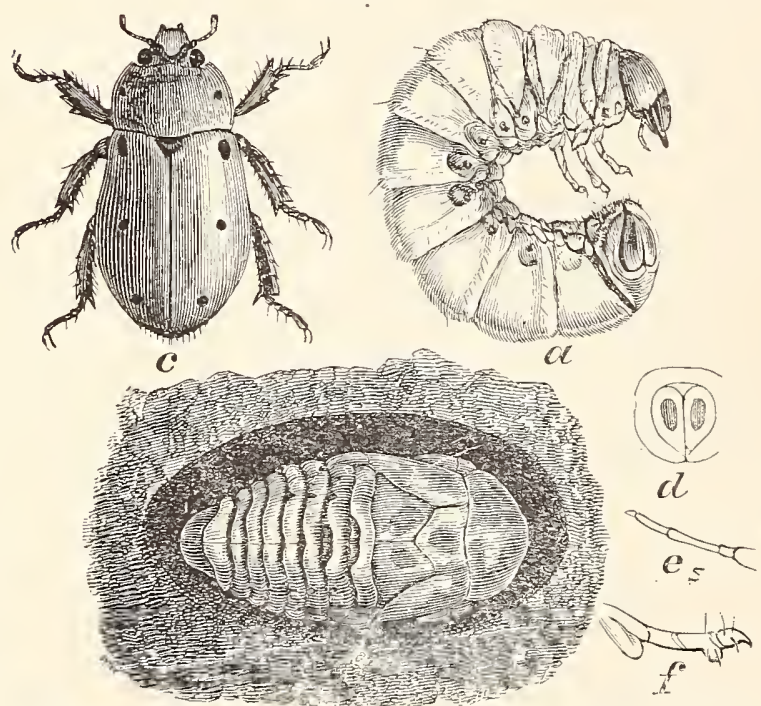

Fig. 406. $a$, larva; $e$, leg of same; $d$, tip of abdomen of same; $b$, pupa in its cell; $c$, beetle. (After Riley.)

Broadly oval, convex. Abore dull reddish-brown or brownish-sellow; under surface and legs, top of head and scutellum black tinged witl greenish: thorax with a small round black dot each side and elytra each with two or three similar dots on the side. Entire upper surface finely, sparsely and irregularly punctured. Length 20-25 mm. (Fig. 406.)

Throughout the State, frequent; less so in the northern counties. Occurs on the grape, both wild and cultivated. The larva live upon decaying roots and stumps of various trees.

\section{COT_LPA Bum. 1844. (T_., "with + mole.")}

The characters separating this genus from its allies are sufficiently set forth in the key. One of the seren known North American species occuts in the eastern United States and Indiana. 
1845 (5S5̆1). Cotalpa LANigERA Limn., System Natura (10th Ed.), 1760, 350.

Broadly oval, robust. Head, thorax and scutellum greenish or yellowish with a strong metallic lustre; under surface piceous, bronzed, rather densely clothed with long. wool-like hair, the legs sometimes paler: elytra yellowish, feebly shining. Thorax trice as broad as long, sides broadly rounded, surface rery finely and spirsely punctate. Elytra with a depression each side near the humerus, their punctures coarser than those of thorax, and arranged in rows which are visible only beneath a lens. Length 20-26 mm. (Fig. 407.)

Throughout the State but searce. April 4-Argust 26. Often foind in the rashup

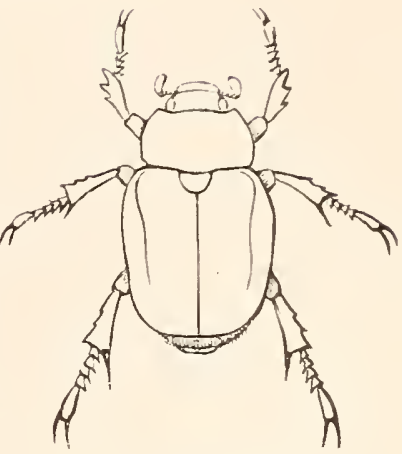

Fig. 40\%. Natural size. (After Forbes.) along the beach of Lake Michigan. One specimen from Putnam County presents a curious color variation. The top of head and thorax is dark green. One of the elytra is almost wholly fuscous, only a small space in the outer apical fourth being yellow; the other one has a broad, fuscons sutural stripe extending from apex to base and along the latter to the humerus, where it is recurved. Otherwise it agrees with the common forms of the species and is therefore to be recorded only as a sport.

\section{Pourncents Lee. 1858. (Gr., "much + adulterous.")}

This genus comprises a single species which, in addition to the characters given in key: has the elypeus somewhat trilobed and separated from the front by an elevated carina, which is interrupted at middle; mandibles with outer edge entire, the tips turned upward; legs short and stout, tibia not longer than the femora, tarsi as long or longer than tibia; tarsal elaws dissimilar in the sexes, those of the female simple, feebly curved and alike on all the legs; those of male, with outer claw of front leg with a trace of tooth at middle; outer claw of middle and hind legs deeply divided, the lower division forming a tooth as long as the upper; the other claws simple.

$1 S 46$ (5S5T). Polyacechts brevipes Lec. Proc. Phil. Acad. Nat. Sci.. VIII, $1856,24$.

Oblong-oval, convex. Dark chestnut-brown to piceous. Head coarsely. rugosely punctate; clypeus two-toothed. its margin reflexed. Thorax onethird wider than long. strongly convex. sides rounded: surface sparsely and finely punctate. more closely and coarsely on sides. Elytra striate, the stria coarsely punctate; the outer ones regular, those next the suture much 
confused, especially toward the base. Antennal club as long as stem in female, one-half longer in male. Length 14-17 mm.

Lake, Laporte and Posey counties: rare. June 6-August 10. Oceurs in sandy localities.

\section{Tribe II. DYNASTINI.}

Medium-sized to very large robust forms, having the labrum usually invisible; mentum narrored and subacuminate, rarely truncate, in front; tarsal slars equal, not toothed. In some genera the males have the head and often the thorax armed with horns. To the tribe belongs our largest Indiana beetle and in the tropics the largest of known beetles. Seven of the eleven genera comprising the tribe are represented in Indiana.

The most arailable literature relating to the North American genera is as follows:

LeConte._"Notice of three genera of Scarabæidæ found in the Tnited States," in Proc. Phil. Acad. Nat. Sci., VIII, 1856, 19-24. Treats of the genera Ligmms and Aphonus.

Horn._-"Descriptions of New Coleoptera of the United States with Notes on Known Species," in Trans. Amer. Ent. Soc., III. 1871. The genus Cyclocephala is treated on pp. 334 337.

Horn.- "Synonymical Notes and Descriptions of New Species of North American Coleoptera," in Trans. Amer. Ent. Soc., V, 1875, 126-156. Sinnopses of the genera Ligyrus and Stratregus are given on pages 143-147.

Horn.- "Contributions to the Coleoptera of the United States, III," in Trans. Amer. Ent. Soe., VIII, 1880, 139-154. This includes a table of species of the genus Phileurus, pp. $14 \bar{i}-148$.

KEX TO INDLANA GENERA OF DYNASTINI.

a. Body convex, usually more or less oval; labial palpi inserted at the sides of mentum.

๖. Head and thorax unarmed in both sexes.

c. Mandibles narrow, scarcely curved; color pale brownish-yellow.

XXIX. Crclocephata.

cc. Mandibles broad, rounded on the outer side and curved; color piceous or black.

XXX. Discinetus.

bb. Head or thorax (sometimes both) armed, or at least bearing a tubercle, in both sexes.

d. Size orer $30 \mathrm{~mm}$; color piceous or dark reddish-brown; males with the front feet not elongater. 
e. Head with a low. transrerse callina; hind tibiae troncate at til and fringed with hairs.

$f$. Mandibles toothed on the outer side: clrpeus bidentate at tip (unidentate in one species).

XXXi. LigYRLS.

ff. Mandibles not toothed; clypeus with an elerated three-toothed process just before the tip.

XXYII. ApHoxus.

ee. Head with a long horn, male, or tubercle, female, on the rertex; hind tibire with sereral blunt, rounded teeth at tip.

XXXIII. Irlorictes.

dd. Size 40 or more mm.: color greenish-gray with black spots (rarely wholly piceous); males with the front feet elongated.

XXXIT. DYXastes.

a a. Body elongate. flattened; labial palpi inserted behind the mentum.

XXXY. PHILELRL'S.

\section{Crelocephat Latr. 1329. (Gr., "circle-head."')}

Both this genus and the next have the head and thorax entirely destitute of tubercles: clypeus flat, elongately rounded, finely margined; mandibles projecting but slight!y and not toothed on outer side; basal marginal line of thorax not entire. In the males the fifth joint of front tarsi is much enlarged and the antennal club is usually longer than in the female. Three of the nine species of Cyclocephala occur in the eastern L'nited States and Indiana.

$$
\text { KEY TO INDLAYA SPECTES OF CYCLOCEPHALA. }
$$

a. Outer front tarsal claw of male not cleft at apex: 1rosternum convex, not carinate; last joint of maxillary palpus cylindrical; head blackish.

1St7. NIGRICOLLIS.

u. Outer front claw of male cleft (sometimes rery slightly) at apex.

b. Body smooth abore; antennal club of male shorter than the other joints together.

1StS. IMMACULATA.

b7. Body pubescent abore: antennal club of male longer than the other joints together.

1St9. NILLOSA.

1847 (5S61). Crclocephala xigricollis Burm.. Handb., T, 50.

Oblong-oral, robust. Pale brownish-yellow; shining: head blackish. Clrpeus dull reddish. rounded in front, the margin reflexed. Thorax twice as wide as long, sides broadly rounded, surface coarsely and rather sparsely punctate. Elytra glabrous. coarsely and somerhat confluently punctate. Length 11-13 mm.

Putnam and Clark counties: scarce. Tuly 5. Described from Texas. Comparatively shorter. more robust and more shining than our other two species.

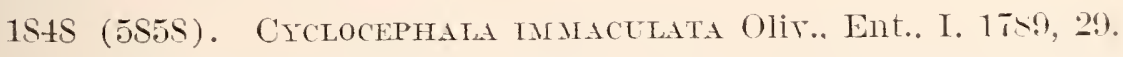

Oblong-oral, moderately robust. Dull brownish-rellow, shining; front black, clypeus reddish-yellow. Thorax one-half broader than long. sides 
broadly rounded, hind angles rounded, surface finely and sparsely punctate. Elytra with rows of very fine, feebly impressed punctures; the side margins in female often thickened near middle. Cylindrical elevation of prosternum behind the front coxse distinctly visible when viewed from the front. Length 12-14.5 $\mathrm{mm}$.

Vigo, Putnam and Posey counties; scarce. May 12-July 30.

1849 (5862). Crclocephala villosa Burm., Handb. Ent., V, 1856, 54.

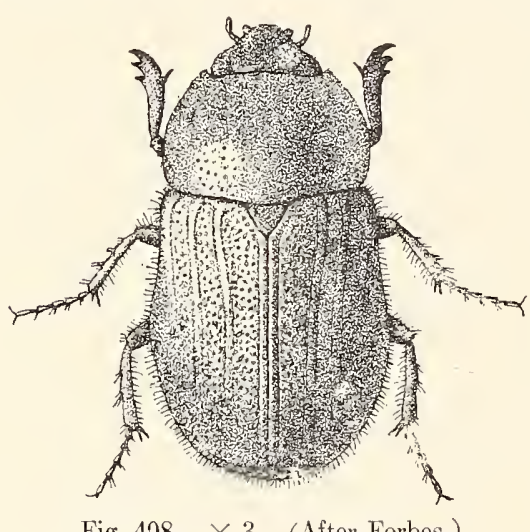

Fig. 408. $\times 3 . \quad$ (After Forbes.)

Resembles the preceding but more convex. Color pale dull yellow, front piceous; clypeus reddish-yellow. Thorax as in immaculata. Elytra more coarsely and roughly punctate, the rows of punctures ill-defined; surface viewed from side finely and sparsely pubescent. Prosternal elevation scarcely visible. when riewed from the front. Length 11-14 mm. (Fig. 408.)

Marion and Putnam counties; scarce. July 1-July 30. The longer antennal club of male, paler color and more roughly punctured elytra distinguish this species. It and the preceding fly after dusk and are attracted by light, being seldom seen by day.

\section{Drscinetes Harold. 1869. (Gr., "bad + moving.'”)}

The characters of this genus have been sufficiently set forth in the key and the remarks under Cyclocephala. One of the two known North American species occurs in the State.*

1850 (5868). Dyscinetus trachypygus Burm., Handb. Ent., V, 1856. 79.

Elongate-oblong. Piceous-black, shining; antennæe and legs dark reddish-brown. Clypeus almost truncate in front, sides diverging, surface sparsely, shallowly and rather finely, front more coarsely, punctate. Thorax one-half wider than long, sides feebly curved, hind angles rounded, front ones acute; surface coarsely, sparsely and irregularly punctate. Elytra each with four feebly raised lines, these with a row of fine, variolate punctures each side; intervals broader, with three or four very irregular rows of similar punctures. Length $15-18 \mathrm{~mm}$.

Occurs beneath rubbish along the sandy shores of lakes and larger streams throughout the State; frequent. April 8-October

*Dyscinetus barbata Fab., Mant. Ins., I, 1787, 10.

Elongate-oval. Uniform mahogany-brown, shining. Head and thorax very finely and very sparsely punetate, the latter otherwise as in trachypygus. Elytra minutely alutaceous, wholly without punctures. Length $18 \mathrm{~mm}$.

This is a West India species, one specimen of which was taken by Max Ellis at porch light on the State Forestry Reservation near Henryville, Clark County. It was evidently introduced by commerce, and as only a single specimen was taken it is not included in the regular list. Identified for me by Frederick Blanchard. 
21. Often attracted in large numbers to electric light; evidently pupates in moist places, as a number were thrown up in plowing a recently drained marsh. Listed under Chalepus, which name was preoccupied.

\section{XXXT. Lrgveus Burm. 1847. (Gr., "flexible.")}

This genus and the next are composed of moderate-sized, robust convex species, having the head armed with small tranverse toothed ridges, alike in both sexes; clypeus rather triangular, always toothed; first joint of hind tarsi more or less elevated at its upper end. In Ligyrus there are small stridulating organs or rugose spaces on the inner surface of the elytra near the outer hind margin. Two of the four known species liave been taken in the State, and a thire probably occurs.

\section{KEY TO INDIANA SPECIES OF LIGYRUS.}

a. Thorax impressed in front and with a small tubercle on the front niargin ; front tibiae with three teeth.

b. Clypeus with two teeth.

1851. GIBBostes.

bъ. Clypeus with one tooth at mislle.

RUGTNASTS.

au. Thorax not impressed nor tuberculate; front tibic with four teetle, the upper one small; mesotholax hairy.

1S52. RELICTUS.

1851 (5869). Ligrrus gibbosus DeG., Mem. Mist. des Ins., IV, 1768, 322.

Oblong-robust, slightly broader behind. Reddish-brown to dark chestnut-bruwl above, paler beneath. Thorax one-half wider than long, strongly convex, sides regularly cul'ved from base to apex; surface rather finely, sparsely and unevenly punctate. Elytral punctures much coarser than those of thorax, those on disk in somewhat regular rows; those on sides confused. Length 11$16 \mathrm{~mm}$. (Fig. 409.)

Throughout the State; common. April 18-September 27. Sometimes very abundant at electric lights.

L. vuginasus Lec., reddishbrown, length $16.5 \mathrm{~mm}$., is a

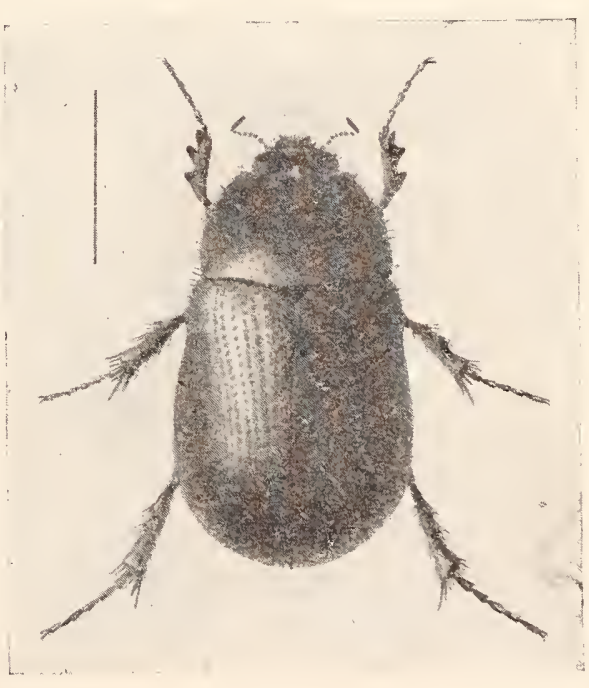

Fig. 409. $\times 2 \frac{1}{2}$. (After Forbes.) southern specieș which has been recorded from near Cincinnati.

[63-23402] 
1852 (5871). Ligyrus relictus Say, Journ. Phil. Acad. Nat. Sci., V, 1825, 194 ; ibid. II, 296.

Oblong, very robust. Piceous black, shining. Transverse carina of head interrupted at middle; clypeus with two teeth. Thorax strongly convex, hind angles broadly rounded, surface finely and sparsely punctured. Elytra with rather fine punctures, those of - center of disk arranged in three double rows; those on sides and near suture much confused. Male with inner claw of front tarsi thickened, dilated and abruptly curved. Length 1S-23 $\mathrm{mm}$. (Fig. 410.)

Throughout the State, frequent; more so about the sandy lake shores of the northern counties. May 26-August 26. Occurs at electric light and beneath rubbish. The larvie live in old,

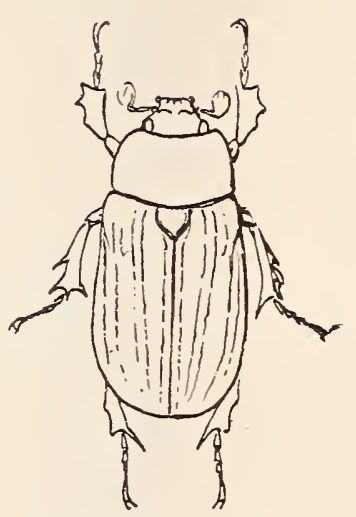

Fig. $410 . \times 1 \frac{1}{4}$. (After Knobel.) well-rotted manure piles.

\section{ApHonus Lec. 155S. (Gr., "without+voice.")}

The untoothed mandibles and the lack of stridulating organs on the under surface of the elytra are the principal characters separating this genus from Ligyrus. In our species the tip of the clypeus is elevated, and immediately behind it is a sharp, transverse elevated line which bears three blunt teeth. One of the four recognized species has been taken in the State.

1853 (5S74). Aphonus tridentates Say, Journ. Phil. Acad. Nat. Sci., III, 1823, 209 ; ibid. II, 134 .

Oblong-orate, robust. Black or piceous-black. shining; beneath dark reddish-brown. Thorax about one-third wider than long, strongly convex, sides feebly curved, hind angles obtuse, basal margin sinuate; surface finely and sparsely punctate. Elytra striate, the stria with rows of rather fine punctures; intervals subconrex. irregular in width and with scattered coarse punctures. Length $13-16 \mathrm{~mm}$.

Putnam, Vigo, Floyd and Posey counties; scarce. May 10July 29. Occurs about old decaying stumps in which the larvæ live; also at light.

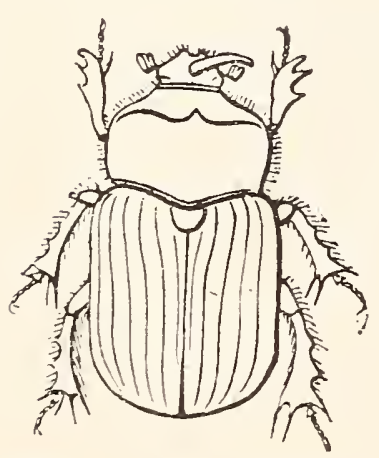

Fig. 411. Male. Natural size. (After Glover.)
XXXIII. Xrioryctes Hope. 1837. (Gr. "wood + a digger.",

This genus contains a single large bulky form, having the mandibles prominent, not toothed on the outer side; the male with a long curved horn arising from the middle of the head, whence the common name of "rhinoceros beetle."

1854 (58S0). Xyloryctes satirus Fab., Syst. Eleut., I, 1801, 15.

Oblong, robust. Dark chestnut to piceous brown. 
shining; under surface paler and rather thickly clothed with reddish-brown hairs. Male with the front half of thorax almost perpendicular, the slope with irregular transverse rows of oblong punctures; basal half convex, rery finely and sparsely punctured; sides rounded, thickly fringed with brown hairs; female with thorax strongly convex, but slightls sloping in front of middle. Elsctra striate, with rows of rather fine, feebly impressed punctures; the strixe deeper and punctures larger in female. Length 25-2s mm. (Figs. 411-411a.)

Wells, Marion, Monroe and Posey coun-

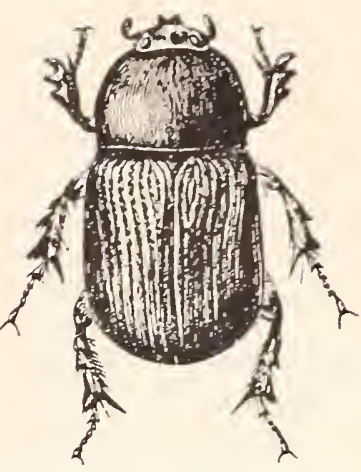

Fig. 411a. X Xyloryctes satyrus. Female. Natural size. ties; scarce. June 3-September 8. Probably occurs sparingly over the southern two-thirds of the State. The larvæ are said to be injurious to ash trees by feeding upon their roots, and the adults are usually found in the vicinity of these trees.

\section{Drnastes Kirby. 1825. (Gr., "a ruler.")}

To this genus belong the largest of known beetles, some of the tropical species being nearly three inches in length and more than an inch in thickness. In the southern United States and extending northrard over the southern third of Indiana is one species, sometimes called the "unicorn beetle." The generic name Dynastes having the same origin as the English "dynasty,' and meaning sovereignty, has been given to these heetles on account of their large size and imposing appearance.

\section{5 (5SS6). Dynastes tityus Linn., Syst. Nat., 1766.}

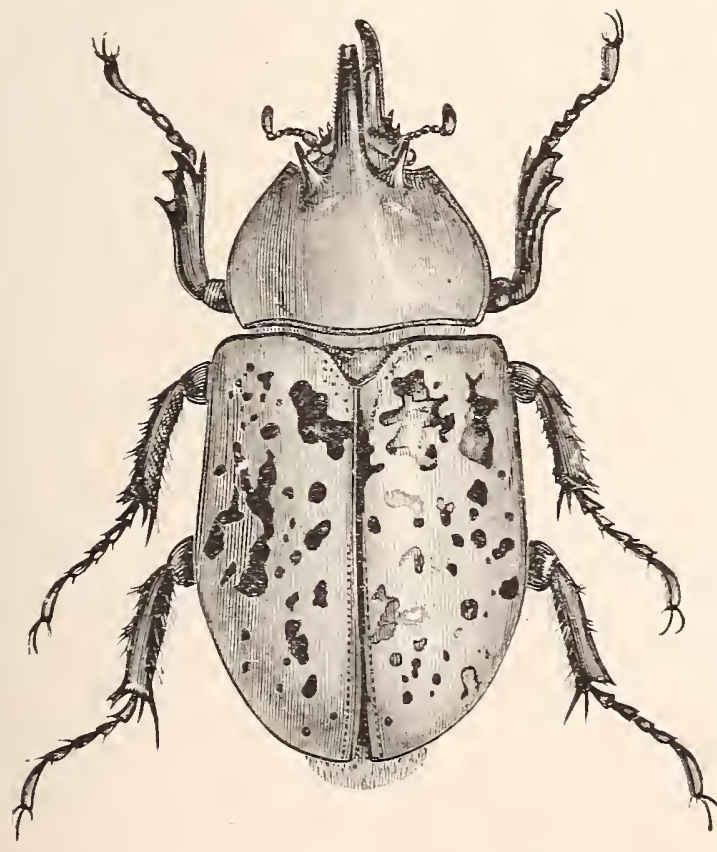

Fig. 412. Natural size. (After Riley.)

Broadly oral. Usually greenish-gray, with brownish or piceous spots scattered irregularly orer the elytra; rarely uniform dark chestnut-brown. Nale with thorax three-horned, the ones on sides short and curred, the median one bearded with yellowish hair beneath, bifid at tip and projecting forward to meet a long curved horn arising from the head. Females with only a slight tubercle on middle of head. Entire upper surface of male almost wholly smooth; female with thorax sparsely and finely punctate. more densely and coarsely on sides and near front angles; elytra with coarse and rery fine punctures intermingled on basal half, apical half smooth. Length of male 40 to $50 \mathrm{~mm}$., exclusive of horns; of female, $45 \mathrm{~mm}$. (Fig. 412.) 
Of the eight specimens in the collection, three are from Crawford County, the others from Bartholomew, Greene, Sullivan, Orange and lefferson counties. All but two are males. July 25September 4. One of the females is wholly chestnut-brown above; while one of the males has one elytron almost wholly chestnutbrown, the other one being of a normal hue. The species probably occurs sparingly over the area covered by the Austroriparian fauna of the State. It is said to live in the larval stage in old rotten wood.

\section{Phileurus Lat. 1807. (Gr.. "love+ well.")}

This genus is characterized by having the labial palpi inserted behind the mentum; mandibles prominent; head and thorax alike in both sexes, the former with two short horns or tubercles, the thorax with one tubercle on apical half. Stridulating organs are found on the under surface of the elytra, along the side margins. One of the four known species has been taken in the State.

\section{6 (5890). Phileurts valgus Linn., Syst., Nat., 175s, $3 \pm 7$.}

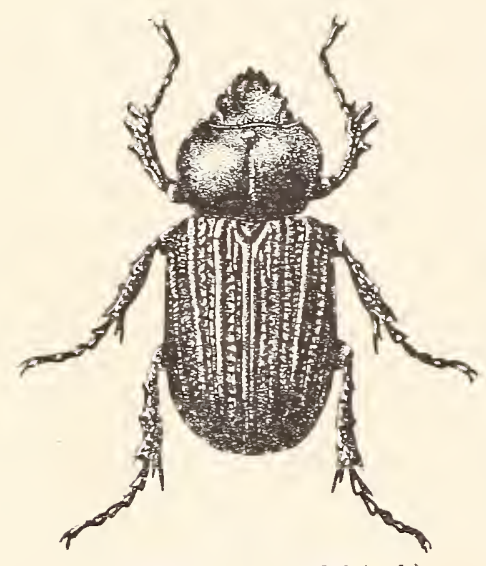

Fig. 413. $\times 1 \frac{1}{2}$. (Original.)

Elongate, subdepressed. Abore black, shining; beneath piceous. Head deeply concave, with two blunt conical tubercles in front of eyes; tip of clypeus tooth-like, recurred. Thorax transverse, with sides broadly rounded; surface sparsely and rather finely punctured and with a deep median groore, terminated in front by a short, blunt tubercle near the margin. Elytra striate, the strix with rows of rather coarse variolate punctures, the altermate interrals more elerated. Outer apical angles of hind tibire and basal joint of tarsi each with a distinct spine. Length 19-22 $\mathrm{mm}$. (Fig. 413.)

Southern portion of the State, from Monroe County southward, scarce; specimens from seren different counties having been taken. April 16-November 10. Occurs beneath bark of decaying trees; also at light. A true member of the Austroriparian fauna. Horn mentions it as from 'Texas only, but states that it is also found in South America. In general appearance it recalls a small form of the common "bess-bug," Passalus cornutus Fab. Probably hibernates as imago, as a freshly moulted specimen was taken on November 7 . 
Tribe III. CETONIINI.

In addition to the flattened form and prominent conical front coxie, the members of this tribe have the antenne always 10-jointed; scutellum usually triangular and pointed; pygidium visible and tarsal claws equal and simple. In some gennera the side pieces or epimera of the mesothorax are continued upward so as to form a little piece which is easily seen at the shoulders between the thorax and elytra. In flying. the true Cetonix do not raise the elytra, as most beetles do, but the inner wings pass out from the side under the elytra, which are a little narrower at the tips than the base and do not at all embrace the sides of the body. The members of this tribe differ from the other "leaf chafers" in being for the most part flower beetles, the mouth organs being furnished with a brush of hairs with which they collect the pollen. They are therefore mostly diurnal, flying about from flower to flower during the heat of the day. At night and in cloudy or rainy weather they are to be found beneath bark or other cover. Seven of the nine genera comprising the tribe in North America are represented in the State.

The following literature treats of three of these, the descriptions of the species of the others being widely scattered:

Horn.- "Synopsis of the Euphorix of the United States," in Proc. Amer. Phil. Soc., XVIII, 1880, 397-408.

Horn.- "Descriptions of Ner Coleoptera of the United States, with Notes on Known Species," in Trans. Amer. Ent. Soc., III, 1871. The genus Cremastochitus is treated on pp. 339-341.

Horn:- "A Monographic Revision of the Species of Cremastochilus of the United States." in Proc. Amer. Phil. Soc., XVIII, 1880, 382-397.

Horn._- "Revision of the United States Species of Ochodeus and other Genera of Scarabxidx," in Trans. Amer. Ent. Soc., V, 1876. The genus Trichius is monographed on pp. 194-197.

KEY TO INDIANA GENERA OF CETONIINI.

a. Side pieces or epimera of the mesothorax risible from abore; elytra more or less sinuate on the sides behind the humeri.

b. Thorax lobed at the base, the lobe corering the scutellum; head of both sexes with a more or less distinct frontal and clrpeal spine.

XXYVI. Cotinis.

bb. Scutellum not corered by a lobe of the thorax. 
c. Mentum normal in shape; clypeus narrow, feebly reflexed; thorax triangular ; color never uniform black. XXXVII. EupHoria.

cc. Mentum cup-shaped; clypeus broad, strongly reflexed; thorax quadlate with prominent angles; color uniform black or piceous.

XXXVIII. Cremastochilus.

a $a$. Epimera of mesothorax not visible from above; elytra not sinuate behind the humeri; middle coxre without an elevation between them.

d. Hind coxæ contiguons; thorax without median groove; size 9 or more $\mathrm{mm}$.

e. Body almost glabrous; color uniform; size large, 18 or more mm. XXXIX. OSMODERMa.

ee. Body pubescent; color variegated; size less than $13 \mathrm{~mm}$.

$f$. Elytra longer than wide; thorax sinuate at base; elytra yellowish with black spots.

XL. GNorimus.

$f f$. Elytra not longer than wide; thorax rounded at base.

XLI. Trichius.

dd. IIind coxa widely separated; thorax with a deep median groove; size small, not orer $7.5 \mathrm{~mm}$.

XliI. Valgus.

XXXVI. Cotrnis Burm. 1842. (Gr., "oleaster," the wild olive tree.)

In this genus the elypeus is armed in front with a short, erect horn. One of the two known species occurs in the State.

1857 (5894). Cotinis 'nitida Linn., Mus. Ludov. Ulrich., 1764, 26.

Elongate-oblong, somewhat pointed in front. Dull

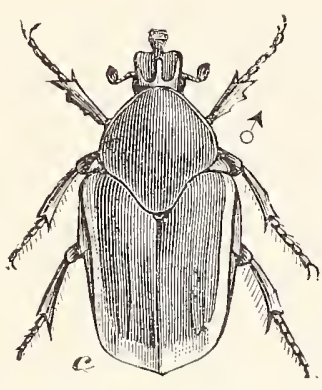

Fig. 414. Natural size. (After Riley.) velvety green above, sides of thorax and elytra brownish-yellow; head, middle of metasternum, tibire and sometimes the abdomen, brilliant metallic green; femora and usually the abdomen reddish-yellow. Head deeply excavated, the front with a horizontal spine extending forward nearly to the upturned spine of clypeus. Thorax triangular, the apex truncate, less than half the width of base, the latter with a triangular lobe covering the scutellum. Upper surface wholly smooth. Length 20-23 mm. (Fig. 414.)

Knox and Posey counties; frequent. July 24-Angust 2. Probably occurs over the area covered by the Austroriparian fauna, of which it is a striking member. It is commonly known as the "fig-eater," and in the South often flies in great numbers by night, especially in sandy districts, making a loud buzzing noise similar to that made by the May-beetles (Lachnosterna). The larvæ feed upon the roots of grass and sometimes are harmful to strawberry and other plants. When they move they crawl upon their backs, making no use of their short legs. Allorhina Burm., to which the species is usually ascribed, is a South American genus. 
XXXVII. EUpHoria Burm. 1842. (Gr., "well + bearing.")

Rather broad, bulky, more or less hairy species, having the tho. rax triangular and nearly as wide at base as elytra. (Fig. 415.) Scutellum distinct; middle coxa with an elevation or protuberance between them; mandibles feeble, in great part membranous; last spiracle placed midway between the front and hind margins of the segment. Three species have been

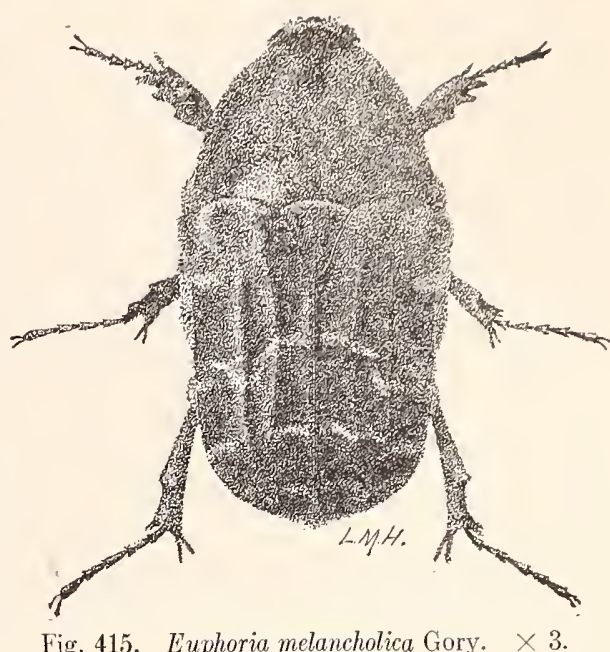

Fig. 415. Euphoria melancholica Gory. $\times 3$. (After Forbes.)

taken in the State, while two others perhaps oceur.

\section{KEY TO INDIANA SPECIES OF EUPHORIA.}

a. Clypeus with four teeth in front; black; elytra yellowish with black spaces at the humeri and along the suture.

AREATA.

a a. Clypeus entire or feebly emarginate, its angles rounded.

๖. Elevation between the middle coxie oval or semicircular.

c. Thorax either shining or punctured and pubescent.

d. Thorax densely punctured, its surface pubescent; color dark brown, feebly bronzed, with narrow white markings.

1S5S. SEPULCHRALIS.

dr. Thorax sparsely punctate, its surface shining, not pubescent; color green tinged with brownish.

1859. FULGIDA.

cc. Thorax opaque, scarcely punctured, not pubescent; color dull green to opaque brown.

HERBACEA.

67. Elevation between the middle coxie transverse; elytra brownish-yellow with numerous small black spots.

1S60. INDA.

$E$. areata Fab., length 12 mru., is said to occur from the Middle States westward to Kansas and Texas.

1858 (5904). Euphoria sepulchralis Fab., Syst. Eleut., II, 1S01, 156.

Oblong-oval. Beneath, bronzed, shining, with a violaceous tinge; above, dark brownish-bronzed, feebly shining; elytra with numerous short, sinuous transverse, whitish lines. 'Thorax triangular', base emarginate at middle; surface coarsely punctured, more densely on sides, clothed with short, erect. persistent pubescence. Elytra each with two costre; intervals with numerous coarse punctures, these changing on sides to short, deep, transverse wrinkles; tips subtruncate, distinctly sinuous. Pro- and mesosterna, femora and sides of abdomen hairy. Length $9-13 \mathrm{~mm}$.

Throughout the State; frequent. May 6-September 30. Occurs at sap, also on flowers of various kinds, especially goldenrod (Solidago) in autumn. Sluggish and feigns death when touched. 
1859 (5909). Euphoria fulgida Fib., Syst. Ent., 1798, 48.

Oblong-oval. Head and thorax usually brilliant green, the latter margined at the sides with yellow; elytra green. usually with a reddish-brown tinge, sometimes marked with chalk-white spots; abdomen green, the sides with whitish spots; pygidium with four similar spots on base; legs reddish- or brownish-yellow. tinged with green. Entire upper surface sparsely and rather finely punctate; elytra with only faint traces of costre. Length $13-18 \mathrm{~mm}$.

Throughout the State; frequent. Nay 10-September 29. Usually pupates beneath logs in damp places; common in June in the washup along the shore of Lake Michigan. Occurs also on flowers.

$E$. herbacea Oliv., longth 14-16 $\mathrm{mm}$., occurs in the "Middle States Remion.",

1860 (5911). Euplokia inda Linn.. Syst. Nat., Ed. X, 1766, 352.

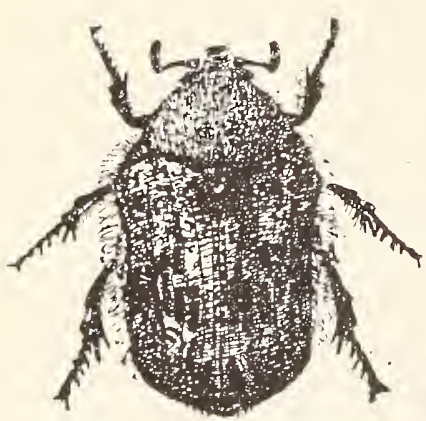

Fig. 416. $\times 2 . \quad$ (After Forbes.)

Broadly oral. Head and thorax piceous, feebly bronzed, the latter often witl yellowisl spots; elytra brownish-yellow, mottled witl black spots, which often tend to form crossbands; beneath piceous, the legs and hind margins of abdominal segments often paler. Vertex. thorax. pro- and mesosterna, femora and sides of abdomen usually densely hairy. Elytra each with two rather broad and feeble costre which unite at apex. Length $13-16 \mathrm{~mm}$. (Fig. 416.)

Throughout the State; frequent. March 20-August 17. On the first warm, sunny days of spring this "bumble flower-beetle" comes forth in numbers and flies close to the ground with a loud buzzing noise like that of a bumble-bee, for which it is often mistaken. When captured it defends itself by emitting a strong, pungent chlorine-like odor. A second brood is said to appear in September. The larva live in rotten wood, beneath ehips and other woody debris. The adults are often found sucking the juices of roasting ears, peaches, grapes and apples, and sometimes do much damage.

XXXVIII. CREmastochules Knoch. 1801. (Gr., "hanging + lip.' ')

Rather elongate, dull black, coarse!y punctured species, known from their allies by the characters given in key, and by having the outer portion of mandibles thickened and horn-like; last spiracle near hind margin of the segment; middle coxa without a protuherance between them. The mouth is peculiarly constructed, the clypeus being thickened and turned up, and the mentum much en- 
larged and projecting forward so as to almost close the oral cavity, its sides hanging down like two curtains, whence the generic name. They usually oecur beneath stones and chunks in of about ants' nests. The great majority of the 21 species lister have the mentum entire and pointed behind, and ocemr from Kansas and Nebraska westward. Seven, most of which have the mentum deeply concave and notched behind, occur east of the Tississippi. Of these four have been taken in Indiana, while another probably oceurs.

KEY TO INDIANA SPECIES OF CREMASTOCHILUS.

a. Mentum plate acutely angulate and entire behind; legs not fossorial, tarsi as long as the tibix; hind angles of thorax triangular, smooth. continuous with the side margin; front angles continuous with the disk, punctured.

1S61. KNOCHII.

all. Mentum plate distinctly notched or with a deep emargination behind.

7. Notch on hind border of mentum plate small, acute; front angles prominent and distinct from the disk; hind angles not continnous with the disk.

VARIOLOSUS.

67. Notcll of mentum plate wide and deep.

c. Disk of thorax coalsely and densely punctured.

r. Front angles of thorix continuous with the disk; hind angles continuous with the outer margin of the disk.

1S62. CANALICULATUS.

dd. Front angles separated from the disk by a transverse impression: hind angles completely separated by a groove and depressed below the surface of the disk. 1863. Castaxe玉.

cr. Disk of thorax shining, sparsely and irregularly punctured; front angles short, obtuse. hind angles retracted and slightly depressed.

1S6t. HARRISII.

1861 (5925). Cremastochilus kxochir Lec., Proc. Phil. Acad. Nat. Sci., $1853,231$.

Elongate-oblong. Black, feebly shining. Mentum plate flat at bottom. angulate and entire behind. Thorax one-half wider than long, base not wider than apex. sides broadly curved; front angles feebly prominent, not limited behind by a line; hind angles triangular, smooth, limited on inner side by an oblique impression; disk moderately convex, coarsely but not densely punctured; median line evident but faint. Elytra with oral, shallow, often more or less confluent, punctures. Length 10-13 mm.

Lake, Laporte, Marshall and Kosciusko counties; rather frequent beneath rubbish along the beach of Lake Michigan; only one each from the other tro counties, these also beneath chunks on borders of lakes, one of them with a colony of small brown ants. April 25-August 26.

C. variolosus Kirby, length $9 \mathrm{~mm}$., occurs in the "Middle States region," and has been recorded from Cincinnati. 
1862 (5929). Cremastochilus canaliculatus Kirby, Zool. Journ., III, 151.

Elongate-oblong. Black, feebly shining. Mentum plate deeply concare, its hind margin widely reflexed and with a deep, wide notch. Thorax one-third wider than long, sides moderately curved; front angles obtuse, feebly prominent, limited on their inner side by a deep fovea, punctured and continuous with the disk; hind angles triangular, nearly smooth, tips slightly turned outward, limited within by a moderately deep groove, but not depressed below the surface of the disk; disk slightly convex, coarsely and densely punctured. Elytra flattened on the disk, vaguely grooved and with rather dense, oval, shallow punctures. Length 11-12.5 mm.

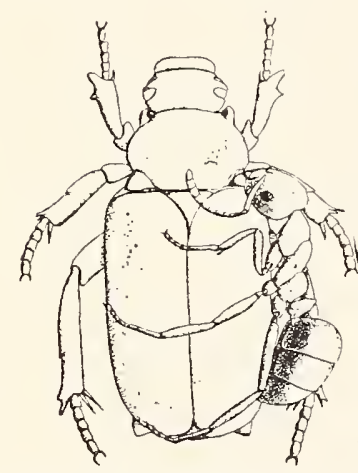

Fig. 417. Ant sucking at glands of Cremastochilus. (After Wheeler.)

Vigo, Putnam, Monroe and Crawford counties; scarce. May 10-May 17. Of the ten specimens at hand, nine were found in ants' nests beneath logs or flat stones, all singly but two. Although taken in six different years, they were all collected between the two dates above mentioned. On this and most other species there are pubescent depressed spaces near the front angles and beneath or near the hind ones which are supposed to be glandular and to excrete a liquid very palatable and attractive to the ants, with which they are found in company. LeConte records* several instances in which specimens have had the projecting portions of the hind angles fall off on account of the continual gnawing or sucking of the ants at the glands. (Fig. 417.) The beetles are sluggish insects which feign death when touched, and seem to be held in captivity by the ants. which pull them back into the vicinity of the nests whenever they attempt to escape.

1863 (5931). Cremastochilus castanem Knoch., Neue Beitr., 1S01, 115.

oblong. Piceous, feebly shining. Mentum plate deeply cupped, the margin widely reflexed except in front, and with a rather deep U-shaped notch behind. Thorax nearly twice as wide as long, sides moderately curved ; front angles in the form of tubercles, limited on the inner side by the usual deep forea and behind by an impressed line; hind angles triangular, punctured at base, separated completely from the surface of the disk by a deep impression, their tips turned outward; disk moderately convex, coarsely and closely punctured; median line sometimes feebly impressed. Elytra moderately flat, with rather sparse, shallow, oval impressions; those on the sides, as usual in the

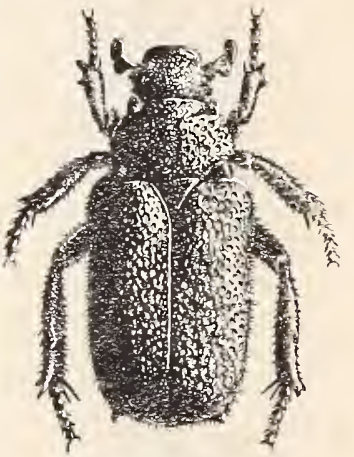

Fig. $418 . \times 3$. (After Wheeler.) other species, smaller, rounded and deeper. Pygidium very coarsely punctured. Length $9.5-10 \mathrm{~mm}$. (Fig. 418.)

*Entom. Amer., I, 188. 
Crawford and Perry counties; rare. May 10-1lay 16. The larve of this species are said to live on the trunks and roots of the chestnut, whence the specific name. As these trees grow indigenously only in the southern third of the State, it is probable that the beetle will be found to be confined to that area. Both it and canaliculatus often have a small transverse hoary white spot formed of exuded matter near the margin and just behind the middle of the elytra. Castanece is shorter and has the upper surface more distinctly pubescent with short erect yellowish hairs than in either the preceding or the next species.

$1 S 64$ (5932). Cremastochilus Harrisil Kirby, Zool. Journ., III, 152.

Elongate-oblong. Piceous, rather strongly shining. Mentum plate deeply concave, margins reflexed, more strongly at the sides and behind, its hind margin broadly and deeply notched. Thorax more than one-half wider than long, sides feebly curved; front angles short, obtuse, limited within by a deep impression and behind by a finely impressed line; hind angles somewhat triangular, smooth, separated from the disk by a rather deep impression; disk rery sparsely and irregularly punctured and with distinct patches of stiff hairs near the hind angles. Hlytra rery coarsely. deeply and densely punctured. Length 10-11 mm.

Lake, Starke and Vigo counties; scarce. April 24 -October 6 . Occurs usually in nests of large reddish ants in sandy localities. Readily known by its more shining surface, more coarsely and roughly sculptured elvtra and larger tufts of hairs near hind angles of thorax.

\section{XXX1X. Osaloderma Lep. 1825. (Gr., "odor + skin.")}

Large, broad, dark brown species, having the thorax distinctly narrower than elytra and rounded on the sides; last spiracle nearer the front than hind margin of the segment. Two of the three known species occur in Indiana.

1865 (5933). OsModerua EReMiçora Knoch., Neue Beitr., 1S01. 105.

Broadly oral, depressed above. Dark chestnut or mahogany blown, shining. Head deeply excavated between the eyes in both sexes, the edge with a tubercle above the base of antennie. Thorax with a deep impressed median line on basal half, in front of which is a broad, deep excaration. bordered in front by a sharp elevated line. Surface of both thorax and elytra rery finely and sparsely punctate. Length 25-29 $\mathrm{mm}$. (Fig. 419.)

Taken only in the southern half of State, but probably occurs throughout; scarce. July 4-August 12. Found at electric light and about the borders of open woods. Both it and the next emit, when captured, a strong odor of russia leather,

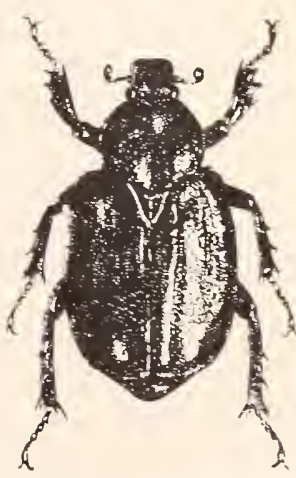

Fig. 419. Natural size. (After Harris.) 
whence the generic name, meaning "scented skin." On account of this one being usually found singly it is called the "hermit flowerbeetle."

1866 (5934). Osmoderma scabra Beaur.. Ins. Af. et Amer., 1S05. 58.

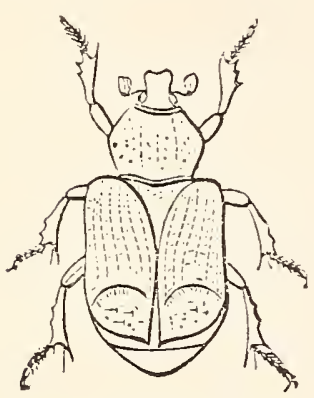

Fig. 420. Naturil size. (After Glover.)

Form of the preceding but usually smaller. Pur1)lish-black, bronzed. Head of male as in eremicola. the clypeus more strongly reflexed in front; of female nearly flat with clypeus narrowly reflexed. Thorax with a rather deep median groove. its surface densely, deeply and coarsely punctured. Elytra rery rugosely and irlegularly sculptured. Length $18-25 \mathrm{~mm}$. (Fig. +20.)

Throughout the State: scarce. May 27-August 19. It is nocturnal and occurs about orchards and open woods, the larve living in the hollows of bcech, cherry and apple trees and feeding upon the juices of their rotten wood. Harris speaks of them" as being "whitish, fleshy grubs, with a reddish, hard-shelled head closely resembling the grubs of the common dor-beetlc. In the autumn each one makes an oval cell of fragments of wood strongly cemented with a kind of glue; it goes throngh its transformations within this cell and comes forth in the beetle form in the month of July.' In southern Indiana, as the above dates show, ther begin to appear a month earlier.

\section{Gronmets Serv. 1825. (Gr., "known.")}

Medium-sized robust beetles, having the thorax broader behind, the base bisinuate; elytra longer than wide, their tips rounded; prgidium exposed, similar in the sexes: middle tibix of female straight, of male nore slender and suddenly curred at base. One specics is known from North America.

\section{7 (5936). Grommus mactrost's Knoch. Neu. Beytr., 1801. 109.}

Oral, robust. Dull black, lather thickly clothed with long rellowish hairs; elytra clay-rellow. glabrous. each with three vague, more or less interrupted costre; the seren to nine oblong elerations or tubercles so formed. shining black. the ones at umbone and near apex the larger; prgidium pruinose. Length 12-14 $\mathrm{mm}$.

Narion County ; rare. July 4. One specimen taken by Harry Dietz from the flowers of a tulip tree (Liviodendron). Knom from New England to Ohio. 


\section{Trichius Fab. 1775. (Gr., "hairy.")}

Medium-sized beetles having the thorax rounded, narrower than elytra, the latter short, almost truncate; pygidium prominent in both sexes, that of male more convex than that of female and with the tip somewhat inflexed. They occur upon flowers during the day and readily take to flight when disturbed. 'Three of the six known species have been taken in Indiana.

KEY TO INDIANA SPECIES OF TRICHIUS.

a. Elytra with white transverse bands and relrety spots on the sides.

ъ. Elytra with third and fifth intervals distinctly more convex than second and fourth, the latter two rather densely punctate; front tibix of male without spur.

1S68. PIGER.

66. Elytra with third and fifth intervals but slightly convex, second and fourth rery sparsely punctured; front tibiæ with spur in both sexes, that of male more slender and straight than in female.

1869. AFFINIS.

a a. Elytra reddish-brown. tinged with green. without transverse whitish bands or velrety spots on the sides.

1870. BIBENS.

1868 (5937). TrichuUs Piger Fab., Syst. Ent., 1798, 40.

Oblong-oral. Head and thorax piceous. tinged with greenish; elytra reddish-brown to piceous, sparsely pubescent. each with two short, oblique whitish bars, one slightly in front of, the other slightly behind the middle. and reaching from the margin to the fifth, rarely the third. interval; sides with a black or reddish relrety space reaching from the margin to the fifth interval behind the front bar and divided by the hind one; body beneath and femora piceous-bronzed, clothed with long. white, silken hairs; abdomen, tibire and tarsi reddish-brown. Head and thorax densely punctate. usually thickly clothed with short, erect, yellowish hairs. Pygidium finely rugose, sparsely pubescent, often with a whitish scaly space on the sides. Length 9-11 $\mathrm{mm}$. (Fig. 421.)

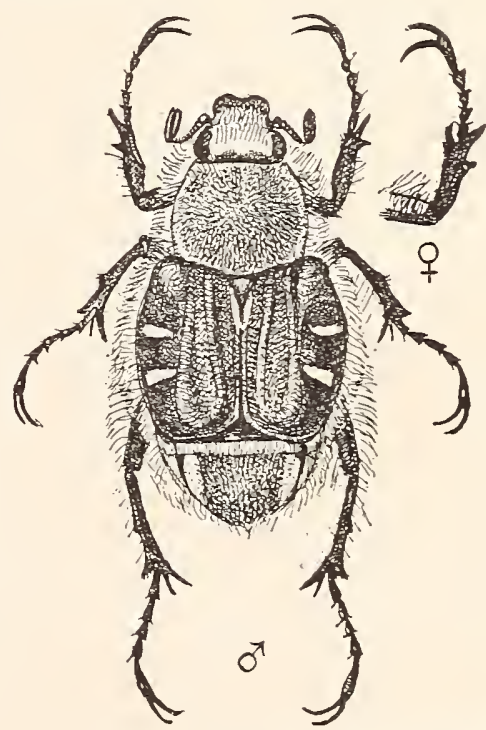

Fig. 421. Male? and foreleg iof female. (After Chittenden in Bull. XXVII, New (After Chittenden in Bull. A 1 II, New

Throughout the State; frequent. June 3-July 2t. Occurs on flowers of rarious kinds, especially those of Jersey tea (Ceanothus), and wild hydrangea. The clypeus of male is longer and the thorax much more densely pubescent and more narrowed in front than in female. 
1869 (5939). Trichius affinis Gory, Mon., 93.

Form of piger but usually smaller. Head, thorax, body beneath and legs greenish-black, shining; elytra of the same hue with the second and fourth intervals often reddish-brown, the sides with whitish transverse bars and velvety space as in piger; also frequently with a short whitish bar next the suture just behind the scutellum. Pygidium with white space on sides densely pubescent. Length 9-10 $\mathrm{mm}$.

Throughout the State; scarce. May 29-July 6. Occurs with piger, which it closely resembles, but is more shining, with smaller. and less punctured thorax and much more sparsely punctured second and fourth elytral intervals.

1870 (5940). Trichius bibens Fab., Syst. Ent., 1798, 49.

Oblong-oval. Head, thorax, body beneath and legs bright metallic green; elytra reddish-brown, shining, usually with a strong greenish or brassy lustre. Head densely punctured; thorax more coarsely but less densely punctured, both rather thickly clothed with short, erect, yellowish hairs. Elytra with shorter, sparser hairs and with the intervals very nearly equal, the second and fourth more densely punctured than the others. Pygidium with an oblong white space on each side. Under surface and femora with long, white, silken hairs. Front tibiæ of male with a slender, straight spur. Length 11-12 $\mathrm{mm}$.

Throughout the State; scarce. May 27-October 15. Occurs especially on the flowers of different species of dogwood (Cormus). Pupates beneath loose bark and flat stones. 'Taken in Marshall County in October. A more robust species than either of the other two.

\section{VaLgus Scriba. 1790. (L., "bow-legged."')}

Small brownish, strongly flattened species, having the hind coxæ widely separated; elytra short, exposing two dorsal segments; body more or less covered with whitish scales instead of hairs. Two of the three known species occur in the State.

KEY TO INDIANA SPECIES OF VALGUS.

a. Front tibire with three or more slender, widely separated teeth on outer side; size smaller, not over $6 \mathrm{~mm}$.; color brown.

1871. CANALICULATUS. aa. Front tibixe with five or six closely placed, stout, rounded teeth; size larger, 6.5-7.5 mm.; color usually piceous.

1872. SQUAMIGER.

*1871 (5943). Valgus canaliculatus Fabr., Syst. Eleut., II, 1801, 132.

Oval, flattened. Reddish-brown, feebly shining; sides of thorax, base, middle and apex of elytra and pygidium sparsely clothed with yellowish scales. Thorax longer than wide, narrowed in front, sides feebly curved; margin denticulate nearly to base; surface with a deep median groove, 
which is wider at base and with an impression on the middle of each side. Elytra with disk feebly but evidently concave; intervals each with two rows of shallow punctures. Under surface and femora rather densely clothed with yellowish scales. Length $5-6 \mathrm{~mm}$.

Southern half of State; frequent. February 21-December 10. Both this and the next hibernate in colonies beneath mullein leaves and half buried logs and chunks and in old trees in dry, upland woods. They oceur in spring and summer on fiowers, especially those of the red haw (Cratregus) and dogwood (Cormus). One specimen at hand has the pygidium terminating in a sharp tapering spine $3 \mathrm{~mm}$. in length, and grooved its full length above and beneath.

*1872 (5944). Valgus squamiger Beauv., Ins. Af. et Amer., 1805, 59.

Resembles the preceding but larger and usually dark piceous-brown in color. Thorax more coarsely punctate, with fewer and larger teeth along the sides, the median groove less distinct on basal half and often with a short oblique ridge each side. Teeth of front tibise broader, triangular and more rounded or blunt at apex. Surface of elytra and pygidium densely granulate; under surface less densely scaly. Length $6.5-7.5 \mathrm{~mm}$. (Fig. 422.)

Southern half of State; frequent. April 13-December 10. Occurs in the same places

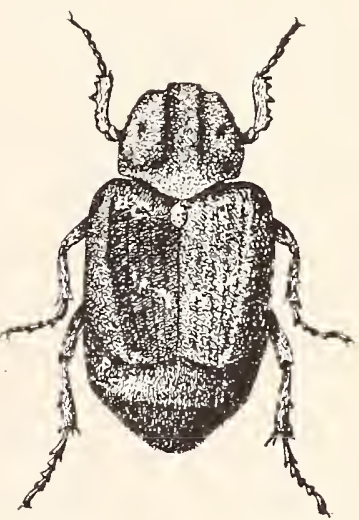
and often with canaliculatus.

\section{Series V. PHYTOPHAGA.}

The members of this series have the tarsi apparently 4-jointed, rarely (Spondylidae), the fifth joint distinct, the three basal joints almost always densely set with cushion-like pubescence beneath ; third joint grooved on its upper surface or divided into two lobes, so as to allow the insertion of the fourth joint near its base instead of in front; head not forming a prolonged beak; labrum always visible. About 35,000 species of Phytophaga are known, almost all of which, in the larval stage, are vegetable feeders, either devouring the foliage or boring into the wood, stems, seeds or roots of plants. Four families are recognized by most authorities, all of which are represented in the State.

KEY TO FAMILIES OF PIIYTOPHAGA.

a. Tarsi distinctly 5-jointed, not dilated nor pubescent beneath: sensitive surface or pores of antenna in deep impressions; form elongate.

Family Li. SPONDYlide, T. 1006. 
aa. Tarsi dilated and spongy pubescent beneath (except in H(rmonia) : sensitive surface of antenure widely diffused.

b. Submentum not pedunculate; front not or rery rarely prolonged in a short beak.

c. Antennx usually long or greatly developed, their iusertion much embraced by the eyes and usually upon frontal prominences; form usually oblong, with sides paraliel; front often large, vertical and quadrate; thorax rarely margined; tibial spurs distinct; upper surface usually hairy.

Family LII. Ceranbycida, p. 100 t.

cc. Antennæ moderate or short, their point of insertion rarely or not at all surrounded by the eyes and not upon frontal prominences; front small, oblique or inflexed; thorax most frequently margined; tibial spurs usually wanting; upper surface usually glabrous, frequently brightly colored and shining.

Family Lili. Chrysomelina, p. 10\%).

7b. Submentum pedunculate; front prolonged into a broad quadrate beak; antenne inserted in front of the eyes, serrate or pectinate: prosternum extremely short; hind femora more or less thickened; latre living upon seeds.

Family LIV. Bruchid.e, p. 1233.

\section{Family LI. SPONDYLID正。}

\section{The Aberrant Long-Horned Beetles.}

This family comprises but four known North American species, closely allied to the true long-horned beetles of the next family, but differing in the form of tarsi and structure of antennæ. They have the antennæ short, the scape very short, much constricted at base, inserted at the sides of head near the base of the mandibles, the second joint rather large, though smaller than third; mentum transverse; elytra parallel, rounded at tip, covering the abdomen, the latter with five ventral segments; legs rather short, compressed; tarsi 5-jointed without brush or hairs beneath, the fourth joint distinct, fifth long, with slender claws.

The name Spondylis, that of the typical genus, is derived from a Greek word meaning "a vertebra joint," and was probably applied by Fabricius on account of the joints of the antennæ having deep pits or grooves on one side, in which organs of special sense are supposed to be located. The North American species live beneath bark, principally that of pine. The family is divided into two subfamilies. one of which is represented in Indiana by the single genus : 


\section{Parandra Lat. 1802. (Gr., "erm!al +male.")}

Oblong, brown beetles having the head broad, the eyes transverse, feebly notched; antennx reaching the base of thorax, second joint half as long as third, joints 3-10 subquadrate, equal, flattened, each with two deep grooves on the mder or onter surface; eleventh ioint longer, obliquely truncate and pointed; mandibles toothed. longer in male than female; thorax margined; prosternum distinct between the front coxre, which are large, not prominent, transverse and enclosed behind. Two species are known, both of which have been taken in Indiana.

KEY TO SPECIES OF PARANDRA.

a. Thorax distinctly wider than head. punctured. a a. Thorax not wider than head, not punctured.

187:3. BRUNNEA. 1ST4. POLITA.

1873 (5946). Parandra Brixnea Fab., Ent. Syst., Supp., 1798, 49.

Elongate-oblong. subdepressed. Pale reddish to mahogany bromn, shining, the mandibles darker. Head wide, horizontal and, with the thorax. sparsely and rather finely but distinctly punctured. 'Thorax subquadrate, widest at apex, the sides nearly straight, gradually converging to base; hind angles obtuse. Elytra parallel, margined, rounded at tip, not striate: surface more finely punctured than thorax. Length 9-18 $\mathrm{mm}$.

Throughout the State; rather scaree. Angust 20-September 27. Occurs in late summer and fall beneath bark of soft maple, red oak, etc., usually in damp localities. The larve live in the trees about which adults are found.

1874 (5947). Paraxdra polita Say, Bost. Joum. Nat. Hist., I, 1835, 192; ibid. II, 662.

Form and size of brunnea. Differs in having thorax more slender, not widler than head, often "blackish-ferruginous;" hind angles almost rounder. Head and thorax not punctured. excepting the former just behind the eres. where the punctures are numerous. Elytra minuteiy punctured.

Described from Indiana, probably Posey County. Not seen by me from the State. Dury chopped three from the heart of a dead beech tree near Cincinnati in August. Probably ocenrs thronghout the sonthern third of State, but everrwhere rare.

\section{Family LII. CERAMBYCID X.}

\section{The Long-Horned Wood-Boring Beetles.}

A family of large size, comprising beetles usually of an oblong or elongate, more or less cylindrical form, but sometimes rery much

$[64-23402]$ 
flattened, with only the thorax eylindrical. All agree in having the antenne very long, these organs being with few exceptions much longer than the head and thorax and often longer than the entire body. However, in but one genus (Priomus) are they more than 11jointed, the great length of the individual joints causing the increase in length of the organ. The family name is from the generic name Cerambyx given by Linnæus, which is from the Greek and means "a beetle and horn," and the Latin word Longicornes, often given to the family, means also "long-horns."

The color is variable, often very handsome, and the beetles are therefore great favorites among collectors. They are usually strong fliers and swift runners; but many of them have the habit of remaining motionless, as if dazed. upon the trunks or limbs of trees and ean then be readily picked up by the fingers. When so caught they generally vent their anger by making a peculiar squeaking or stridulating noise by rapidly moving the pro- upon the meso-thorax. Many species of the family may be taken by carefully beating branches (especially if partially dead) and flowers, over a sheet or an umbrella. Dead logs should be searehed, on both the upper and under surfaces, and particularly freshly eut timber or sawed lumber. A morning spent in a woodyard will often repay one richly in rare specimens. Some are to be found eommonly under bark and may be trapped by loosely fastening picces of bark to a tree over night and exaniining the under side of the bark in the morning. A great number fly to lights after dusk. Dead twigs and branches may be sawed or cut off, preferably during the autumn months, and kept in large boxes or in an empty room until the beetles are disclosed through the development of the larvæ contained therein.

The principal characters of the Cerambycidx, briefly stated, are as follows: Labial palpi three-jointed; maxilla with two lobes, clothed at the tip with bristles; mandibles ustially curved and acute at tip, sometimes, though rarely, very long; eyes usually transverse, frequently deeply emarginate or even entirely divided; antennæ inserted either in front of or between the eyes, often borne on large frontal tubercles, their sensitive surfaces differing in the tribes; thorax not margined except in the first subfamily; elytra usually with distinct epipleurse and covering the abdomen, the latter with five free ventral segments, the sirth visible in many males and occasionally in both sexes; legs msually slender, hind coxa transverse; tarsi apparently 4 -jointed, joints one to three furnished beneath 
with brushes of hair, third joint emarginate or bilobed, fourth small, rounded, united with the fifth; claws simple, rarely cleft.

The larva or grubs of the Longicornes are white or yellowish borers, with body tapering slightly from head to tail and possessing powerful jaxs which enable them to penetrate the solid or heart wood of trees or shrubs. Only a few of them live in the sap wood, but on dead or dying trees or in stumps they occur beneath the bark and wood, often in such numbers as to completely detach the bark. They are more or less cylindrical, the joints well marked, the thoracic joints enlarged. They resemble the grubs of the Buprestids, but are not flattened, hence are called "round-headed borers.' 'The larval state usually lasts two or three years and the pupal stage is passed within the burrow made by the grub; usually within a small cavity partitioned off by a plug of chips or within a crude cell formed of minute gnawed fragments of wood.

The literature treating of the North American species of the family is extensive and widely scattered. The principal papers treating of the family as a whole are herewith mentioned. Others dealing with isolated tribes or genera will be mentioned in their proper sequence.

Haldeman, S. S.- "Materials towards a History of the Coleoptera Longicornia of the United States,' in Trans. Amer. Phil. Soc., X, 1845.27-66. Corrections and additions to same in Proc. Amer. Phil. Soc., IV, 1847, 371-376.

LeConte.- "An Attempt to Classify the Iongicorn Coleoptera of America North of Mexieo,' in Journ. Phil. Acad. Nat. Sci., I, 1850, 311-340 ; II, 1851, 5-38; 1852, 99-112, 139-178. Leng, C. W._-“Synopses of Cerambycidx," in Bull. Brook. Ent. Soc., VII, 1884-85, and Entom. Amer., I, II, III and VI, 1885-1890.

Wickham, H.F._"'The Cerambycidæ of Ontario and Quebec," in Can. Ent., XXIX, 1897 ; XXX, 1898.

Nearly 13,000 species of Cerambycidm are known, about 620 of which are from the United States. The family is divided into three subfamilies, separated by character's pertaining to the thorax, palpi and front tibix. The thorax may be one of two types, viz., $(a)$ "'margined," when it is liattened with the edges sharp and thin for almost the whole length, at the same time being usually toothed; or ( b ) "not margined," when it is cylindrical or rounded on the sides, which may be spined, tuberculate or plain. The palpi may (a) have the terminal joint more or less compressed and subtriangular, 
or $(b)$ cylindrical and pointed at the tip. The front tibiæ may have an oblique sulcus or groove on the inner surface, or this groove may be lacking. By combinations of two or more of these characters the subfamilies are separated by the following:

KEY TO SUBFAMILIES OF CERAMBYCID

a. 'Thorax margined; labrum firmly united with the clypeus; body usually broad and depressed.

Subfamily I. Prionine, p. 1010.

aa. Thorax not margined; labrum free; body usually oblong, more or less cylindrical.

7. Front tibire not grooved; last joint of palpi not acute at tip, often subtriangular.

Sublamily II. Cerambicine, p. 1013.

bb. Front tibire with an oblique groove on the inner side; palpi with last joint cylindrical, pointed at tip.

Subfamily III. Lamina, p. 1060.

\section{Subfamily I. PRIONINAE.}

Large-sized brown or blackish beetles having the elytra usually leather-like in appearance; mandibles strong, frequently elongated in the males; last joint of palpi triangular; front coxæ transverse, with distinct trochantin. The mesosternum is without stridulating surfaces, but some of the species produce a noise in the same way as do certain grasshoppers, i. e., by rubbing the hind femora against the edge of the elytra. They are slow-moving insects, flying only in the evening. Some of the tropical forms are the longest of beetles, measuring five to six inches in length. The larva are broad, somewhat flattened and have six very small but distinet feet. The subfamily is separated into ten genera, only three of which are represented in Indiana.

KEY TO INDIANA GENERA OF PRIONINAE.

a. Sides of thorax with two or three distinct teeth; eyes strongly granulate.

b. Form elongate, parallel; antenna 11-jointed, more slender, the joints not overlapping.

I. OrThosoma.

bb. Form stout, broad; antenna (in our species) 12-20-jointed, more or less overlapping, especially in the male.

II. PRionus.

au. Sides of thorax with one small, obtuse tooth near the base; eyes finely granulate.

III. Sphenostethus.

I. Orthosoma Dej. 1834. (Gr., "straight + body.")

This genus is represented by a single large species having the hind femora not deeply sulcate beneath and with several short, elevated ridges on the inner side. 
1575 (59.5). Orthosoma brUxneuar Forst., Not. Spec. Ins., 1771, 37.

Elongate. parallel. Uniform light chestnutbrown, shining. Head with a deep impression between the antenne. Thorax more than twice as wide as long. each side with three sharp teeth. Elytra each with three fine raised lines. surfice finely and rather thickly punctured. Fifth rentral segment rouncled in female. broadly truncate in male, learing the sixth risible. Length $22-40 \mathrm{~mm}$. (Fig. 423.)

Throughout the State; frequent. June 29August 14, Often enters houses to which it is attracted by light. The larve are supposed to live only in pine, but evidently feed on oak

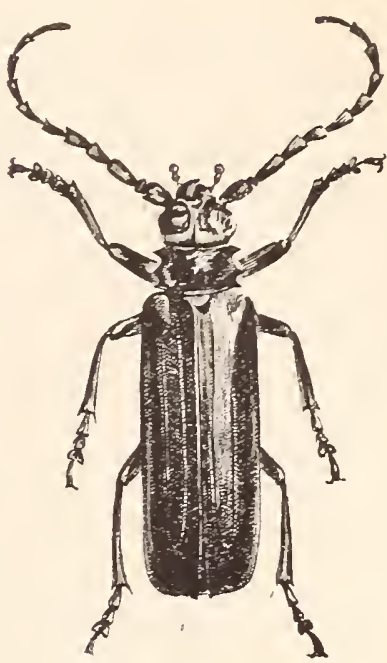

Fig. 423. Natural size. (After Riley.) and walnut trees in Central Indiana, where pine are absent.

\section{Prionus Geoff. 1764. (Gr., "a saw.")}

Very large, broad forms having the antennal joints conical, stout and overlapping in male; more slender and subserrate in female; the surface of the fourth and following joints covered with fine, reticulate, elevated lines bearing special sense organs; thorax armed each side with two or three sharp teeth; elytra broadly rounded at apex. punctate and ornamented with raised lines. Three of the six resognized species occur in the State.

\section{KEY TO INDIAXA SPECIES OF PRIONC'S.}

(t. Antennal joints 12; soles of hind tarsi densely pubescent.

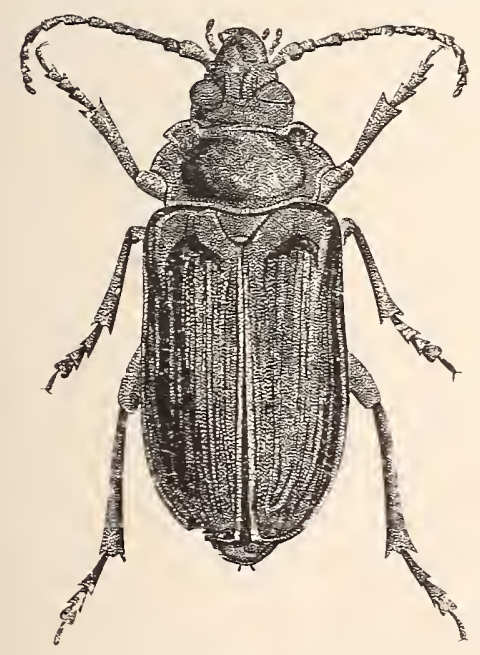

Fig. 424. Female. Natural size. (After LeBaron.)

b. Elytra at base not wider than tholax; all joints of hind tarsi densely pubescent beneath.

1876. LATICOLLIS.

b0. Elytra at base wider than thorax; basal joint of hind tarsi nearly smootl.

1ST. POCLLARIS.

au. Antennal joints 16-20; soles of hind tarsi with scattered hairs. 1Sis. mabriconsis.

187G (7959). Prones laticollis Drury. III. Nat. Hist.. II. 1778. 83.

Broad, stout. Piceous black, shining. Antennie of male longer than bods; of female about one-half the lengtin. Thiolax almost or quite as broat as the base of elrtra. sides with three teeth. the hindmost one often indistinct: these sometimes slightly reflexed. Elytra broader at base than apex; each with three slightly elevated lines; surface roughly, coarsely and rers irregu- 
larly punctured. All the joints of hind tarsi densely pubescent beneath, with a smooth median channel. Length 22-47 mm. (Fig. 424.)

Southern half of State; scarce. Sune 20-August 7. The females are always much larger than the males. The beetle is known as the "Broad-necked Prionus" and the larve are said to injure the grape, apple, poplar and pine by boring into the roots.

187 (5960). Prioxus pocularis Dalm., Scheenh. Syst. Ins., I, 1817̄, 148.

More slender and parallel and with antennæ more slender than in laticollis. Dark reddish-brown, shining. Thorax narrower than base of elytra, the teeth never reflexed. Elytra with sides straight, almost parallel; surface more sparsely and much less roughly sculptured than in laticollis. Length $25-45 \mathrm{~mm}$.

Lake County; rare. June 20. Said to occur in the Middle and Southern States.

1878 (5962). Prionts mabriconxis Linn., Syst. Nat., XII, 17S0, 622.

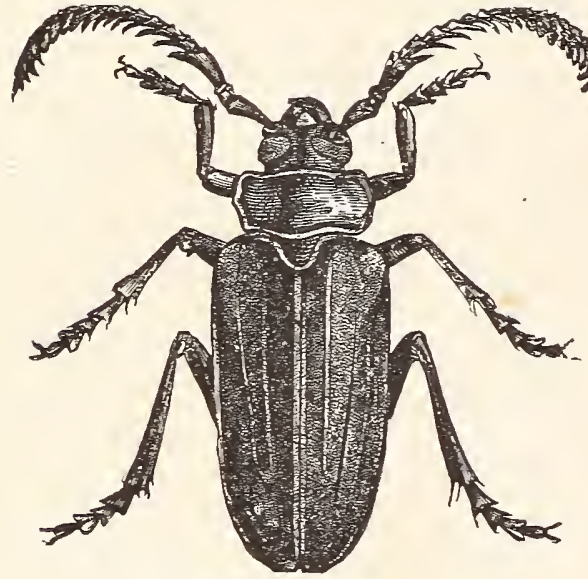

Fig. 425. Male. Natural size. (After Forbes.)

Broad, stout. Dark reddish-brown. shining. Antennæ 18-20-jointed, male; 16-18-jointed, female; the joints of male conical, each one hollowed to receive the next and with the lower edge prolonged; those of female more slender and simply serrate. Thorax rery short and broad, the hind tooth indistinct. Elytra of female more conrex than male; surface roughly and rather densely sculptured. Length $22-4 \mathbf{~ m m}$. (Fig. 425.)

Knox and Crawford counties; scarce. July 4-July 9. Known as the "Tile-horned Prionus" on account of the joints of antennie overlapping like the tile of a roof. The larvie infest the roots of the grape and pear and also feed upon the roots of herbaceous plants. A member of the Austroriparian fauna.

\section{Sphenastemuls Hald. 1845. (Gr., "wedge + breast.")}

Head small. much narrower than thorax; the latter larger. trapezoidal, smooth; prosternum deeply emarginate behind for the reception of the mesosternum.

1879 (5968). Sphenostethes taslei Buq., Ann. Fr., 1S11, 39.

Elongate, tapering behind. Black, feebly shining; elstra often more or' less reddish-bromn. Antennze slender, about one-half length of bods. slightly. compressed and serrate. Thorax narrower at apex, subconvex. obtusely. toothed near base. surface finely and sparsely punctate. Elytia tapering. separated near alex. tips finely ser'rate; surface finely and rather sparsely punctate. Length $27-29 \mathrm{~mm}$. 
Montgomery County; rare. Aagust 26. Taken from hemlock at Bloomingdale Glens.

\section{Subfamily II. CERAMBYCINAE.}

The only character's available for separating this subfamily are those given in the key, viz., thorax not margined; labrum separate from the front; front tibiæ not olliquely sulcate; palpi never acute at tip; antenna always pubeseent. The subfamily is of great extent, embracing many genera which are very difficult to separate in easily understood terms. The first distinguishing character used, viz., the "enveloping of the base of the antennæ by the eyes," is apt to cause trouble if not properly understood. To make it plain, the antenna should be extended forward from the head. In this position it will be seen that in thuse genera where the "base of the antenna is partially enveloped by the eyes,' a line passing from the front or inner border of the upper lobe of the eye to a corresponding spot on the lower lobe will pass through the antennal socket, whereas in the genera where "not enveloped," this line would run behind the socket. All genera in which the eyes are entire are of course "not enveloped," while those in which the eyes are emarginate may be partially enveloped or not. The subfamily is first separated into four Divisions, all of which are represented in Indiana, and these in turn into tribes and genera.

\section{KEY TO DIVISIONS OF CERAMBYCINE.}

a. Base of antennæ not enveloped by the eyes.

b. Front coxæ transverse, not prominent; antennae with second joint rather large, one-third or more the length of third; head inserted in the thorax.

Division I. CALlidiotDES. P. 101:?.

67. Front coxic conical (globose in Distenia), prominent; second joint of antennæ small; head usually attached to thorax by a neck; elytra usually tapering behind the middle.

Division IV. LAPTUROIDES, P. 104:. ar. Base of antennie partly enveloped by the eyes; head inserted in the thorax.

c. Second joint of antennae small, not over one-fourth the length of third (except in Microclytus) ; front coxie not conical, though sometimes prominent.

Division II. Cerambrcomes, 1). 1020.

ce. Second joint of antennae about one-third the length of third joint; front coxse globose, widely separated.

Division III. ITHMOLES. P. $10+1$.

\section{Division I. CALTIDTOIDES.}

This division is separated into two tribes, both of which are represented in Indiana. 
KEY TO TRIBES OE C.ALLIDIOIDES.

a. Ligula horn-like; eyes variable; second joint of antenna more than onethird as long as third.

'ribe I. AsEMINI, 1) 1014. aa. Ligula membranous; eyes tinely granulate; second joint of antennæ not more than one-third as long as third.

Tribe II. CAllidint, 1) 1016.

Tribe I. ASEMINI.

In this tribe the antennæ are densely punctured and pubescent, with the second joint nearly half the length of third and the 11th simple; front coxi transverse, with distinct trochantin, the cavities open behind; scutellum rounded behind; males with fifth ventral segment transverse and sixth segment visible; females with fifth segment prolonged, sixth invisible. In this and many of the following tribes the character of the granulation of the eyes is much used in separating the genera. In those which are "coarsely granulate" the lines between the facets are deeply impressed. In the second group the granulations are much fincr, the lines feebly impressed, the surface of the eye appearing almost plane. Representatives of three of the seven genera comprising the tribe have been taken in the state, while those of another prohably occur.

KEY TO INDIANA GENERA OF ASEMINT.

a. Color black or dark brown; form cylindrical, scarcely depressed; epimela of mesothorax truncate at inner end.

7. Eyes not wholly divided, often deeply emarginate.

c. Eyes moderate in size, transrerse, finely granulated and hairy; antennie finely pubescent.

A SEMUM.

cc. Eyes large, coarsely granulated, not hairy. IV. Criocephalus. 7). Eyes divided, apparently four in number, rather finely granulated.

V. TETROPITM.

at. Color pale rellowish; form depressed : epimera of nesothorax narowed and acutely pointed at inner end.

VI. SMODICUM.

Asemum mostum Hald, black, opaque, thorax rounded at sides, length 12-15 mm., ranges from "Lake Superior to Fiorida and eastward."

\section{Criocephalus Muls. 1839. (Gr., "a ram+head.")}

This genus comprises seven rather large, subcylindrical species, having the eyes coarsely granulated, not hairy and the thorax with two to four large and shallow depressions on the disk. One of the seven has been taken in Indiana and another may oceur. 
KEY TO INDINA SPECIES OF CRIOCEPHALCS.

a. Third joint of hind tarsi emalrginate for half its length, two-thirds longer than wide; elytra finely punctured.

AGRESTIS.

a a. Third joint of hind tarsi bilobed. cleft nearly to base. rery little longer than wide; elytra more coarsely punctured.

1S:0. OBSOLETLS.

$C$. agrestis Kirby, piceous, length $22-27 \mathrm{~mm}$. is said to inhabit "the United States east of Rocky Mountains."

$1 S S 0$ (59-S). Criocephales obsoletes Rand.. Bost. Joum. Nat. Hist. II, 1 1ระ. 27.

Elongate, subcrindrical. Dark sooty or smok brown. Front of head with an impressed line. Thorax subrotund. sides rounded. alvex and base truncate. the latter more narrow; disk finely and densely punctate and with a distinct oral impression each side of middle. Elytra euch with two finely elerated lines. surface more coarsely punctate than thorax. Length 20 $24 \mathrm{~mm}$.

Lake Countr: rare. Nay 25. Taken from the washup of Lake Nichigan. Occurs in "restern New York and Canada." its larre feeding upon pine.

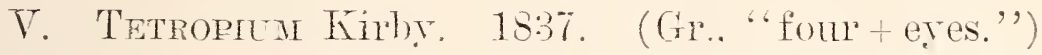

Oblong. sulcylindrical speries having the eyes divided by a deep emargination into an upper and lower portion; these parts connected along the hind maroin by a narrow hand on which the facets or granulations are obsolete.

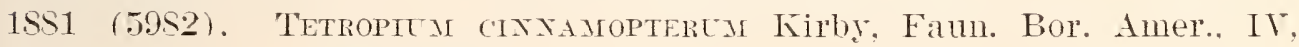
15:37. 174.

Oblong. subeslindrical. Dull sooty or slaty brown: under surface, legs and often the sides of elytra reddish-brom. Head and thorax slightly shining. closely but distinctls punctured: the latter subrotund without discal impressions. Elytra opaque. more finely punctured than thorax, each with two feeble raised lines. Length $12-14 \mathrm{~mm}$.

I aPorte County: scarce. June j. Two specimens beneath bark of pine.

\section{Siromeru Hald. 184.5. (Gr.. "with protuberances.")}

Front broad. short and perpendicular: the eves coarsely granulated and rery deeply emaroinate: antenne scarcely as long as hody. male: shorter and more slender. fenzale: the joints polished. sparsely punctured and pilose. One species occurs from Nerr England to Texas. 
1882 (59S5). Smodicum cucujfforme Say, Journ. Phil. Acad. Nat. Sci., V. 1826, 277 ; ibicl. II, 334.

Elongate, narrow, depressed. Pale, dull yellow, shining; antennre slightly darker. Thorax longer than broad, slightly contracted before the middle; surface, together with that of elytra, rather sparsely, finely and irregularly punctured. Femora much dilated. Length $7-8 \mathrm{~mm}$.

Throughout the State; frequent. July 2-November 24. Occurs beneath the close fitting bark of dead poplar, oak, locust and linn trees. Has the form and habits of a number of the Cucujidx, whence the specific name.

\section{Tribe II. CALLIDIINI.}

The species of this tribe are more or less flattened, but not very slender in form, and the thorax and elytra are never armed with spines. The eyes are finely granulate and deeply emarginate; head small with the front short and perpendicular; front coxal cavities transverse, open behind, the coxie with large trochantin. Males with antennæ usually longer than body and thicker at base than in females; the fifth ventral segment short, subemarginate. Four genera are known. to be represented in the State, while two others probably occur.

KEY TO INDIANA GENERA OF CALLIDIINI.

a. Elytra with narrow raised white lines; thorax with rery deep median groove; thighs strongly clubbed.

VII. PHTsocnenuM.

a a. Elytra without distinct raised white lines.

b. Thorax very short. strongly rounded on the sides; upper surface entirely opaque; black, thorax red.

RHOPALOPUS.

bb. Thorax not very short, the width not much exceeding the length; upper surface more or less shining.

c. Front coxæ contiguous, the prosternum very narrow and pointed.

d. Palpi unequal, the labial much the shorter; thorax rounded.

ViII. Phimatodes.

dd. Palpi about equal; mesosternum obtusely triangular.

IX. Callidium.

cc. Front coxæ at least moderately separated.

e. Dorsal surface of thorax with narrow median elevation and moderate or small ones on the sides; prosternum broad; hind coxa inclosed.

HyLOTRUPEs.

ce. Dorsal surface of thorax with a broad, smooth, shining median space on basal half; elytra with more or less distinct but broken whitish markings.

X. Merium. 


\section{Physocnemum Hald. 1847. (Gr., "bladder+leg.')}

To this genus belong two species having the femora strongly club-shaped; antenna 11-jointed, longer than the body and tapering to the end in male; as long as body and almost filiform in female, the humeri prominent and rectangular. One of the two occurs in Indiana.

1883 (59S8). Physocnemum brevilineum Say, Journ. Phil. Acad. Nat. Sci., III, 1S24, 413; ibid. II, 194.

Elongate-oblong. Black; elytra bluish-black, shining, each with three short raised whitish lines on middle third placed side by side, the inner one slightly oblique, usually a fourth line in front of the middle one of these. Thorax subglobose, with a rounded tubercle each side near the middle; apical half and sides covered with dense, short, velvetlike hairs. Elytra granulate-punctate, sparsely pubescent. Length 12.5-16 mm. (Fig. 426.)

Madison, Putnam and Posey counties; scarce. June 11-July 1. Occurs about elm trees, in the wood of which the larvæ bore.

Rhopalopus sanguinicollis Horn, length 15-19 mm., is known from New York and (ihio.

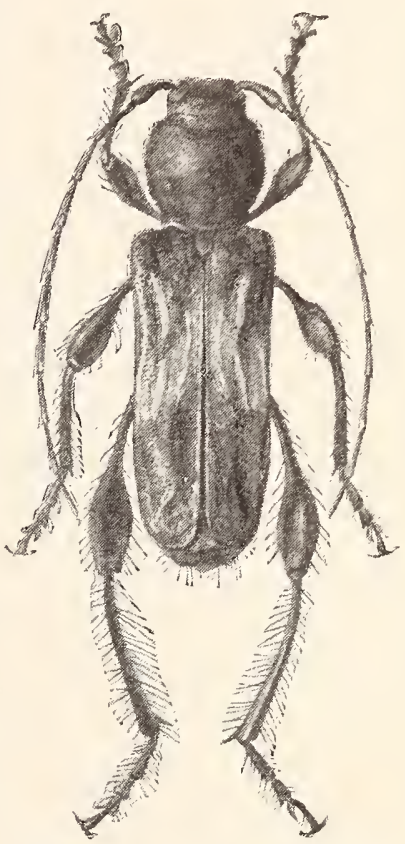

¿ Fig. 426. $\times 2 \frac{1}{2}$. (After Forbes.)

VIII. Phymatodes Muls. 1840. (Gr., "ggrowth + similar.')

To this genus belong 16 species, all of rather small size, usually bright in color and having the prosternum very narrow and pointed; hind coxa not promiment and not enclosed; thorax rounded, usually sparsely punctured and shining. Three have been taken in Indiana, while two others perhaps occur.

\section{KEY TO INDIANA SPECIES OF PHYMATODES.}

a. Elytra without narrow cross-bands.

b. Thorax yellowish; surface metallic.

c. Larger, 12-13 mm.; elytra and legs yellow more or less marked with blue.

1SS4. VARIABILIS.

cc. Smaller, 5-9 mm.

d. Flytra blue, antennæ dark.

18S5. AMGENUS.

dd. Elytra piceous.

LIVIDUS.

bb. Thorax dirk; elytra of lighter shade before the middle; length 9 $12.5 \mathrm{~mm}$.

DIMIDIATUS.

aa. Elytra with two narrow white or yellowish cross-bands; length 6$9 \mathrm{~mm}$.

1SS6. VARIUS. 


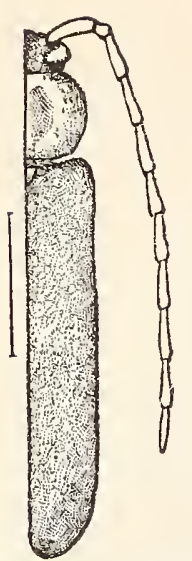

Fig. 427. (After Smith in Fifth Rep. U. S. Ent. Comm.)

1884 (5993). Phymatodes variabilis Fab., Faun. Suec.; 192.

Elongate-oblong. Head blackish; thorax reddish-yellow, the disk often darker; elytra yellow, or blue with yellow along sides; femora usually yeliow, often blue. Thorax sparsely and rather coarsely punctate, both it and elytra with scattered pubescence. Length 12-13 mm. (Fig. 427.)

Monroe, Posey ant Dubois counties; scarce. May 11-June 17. Probably throughout the State. The larva breed in oak.

1855 (5996). Phymatodes amánus Say, Bost. Journ. Nat. Hist., III, 1823, 413; ibid. II, 193.

Oblong, slender, subdepressed. Reddish-yellow; elytra cylindrical, sparsely and rather coarsely punctured. Elytra parallel, tips rounded, surface with rather coarse punctures, each bearing a stiff, short hair. Length 5-8 $\mathrm{mm}$. (Fig. 428.)

Throughout the State; frequent. May 11-June 5. Beaten from wild grape, in the stems of which the larva bore; also occurs on flowers of yarrow and other herbs.

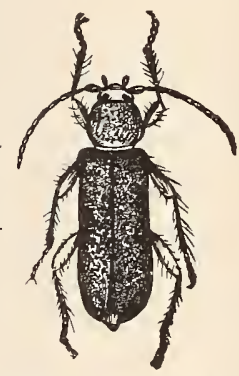

P. lividus Rossi., thorax yellowish, darker at sides, Fig. 428 . (After length $9 \mathrm{~mm}$., is known from "Canada and the Middle U. S. Ent. Comm.) States." P. dimidiatus Kirby, is said to inhabit the "United States."

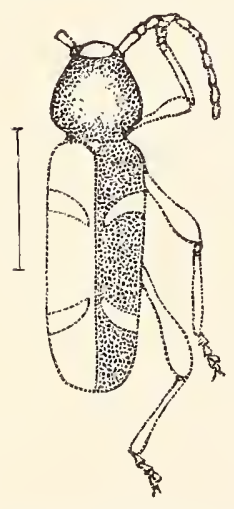

1Ss6 (6004). Phymatodes varius Fab., Spec. Ins., I, 1781, 241.

Elongate, rather slender, subcylindrical. Black, pubescent with prostrate hairs; thorax at least in part and basal portion of elytra often reddish-brown. the latter each with two narrow whitish crossbars, one curved in front of middle, the other nearly transverse, on apical third. 'Thorax rounded. rather sparsely and coarsely punctured. Elytra finely granulilte-punctate. Length 6-9 mm. (Fig. 429.)

Marion County; rare. January 17-January 24. Fig. 429. (After Two specimens presented by Harold Morrison; taken Smith in Fifth Rep. from cellar where wood was stored.
U. S. Ent. Comm.)

\section{Callidium Fab. 1775. (Gr., "beautiful + little.")}

To this genus belong six species having the palpi about equal in size; mesosternum obtusely triangular; form flatter than in Phymatodes and with stouter antenne, especially in male. Three species may be looked for in Indiana, though but one has been taken. 
KEY TO INDIANA SPECIES OE CALLIDIUM.

u. Thorax and elytra blue.

b. Thorax finely punctured and impressed.

bb. Thorax deeply punctured, not impressed.

1SST. ANTENNATUM. a. Thorax and elytra dull brownish-yellow.

1897 (600S). Callidium antennatum Newm.,

Ent. Mag., V, 1838, 393.

Elongate-oblong, subdepressed. Deep blackish-blue. Antennie longer than body, thickened at base, each joint in male clubbed at outer end. Thorax wider than elytra in male, about as wide, female; sides broadly rounded, surface finely and densely punctate, and with a rounded impression each side of middle. Elytra deeply and roughly punctate. Length 13-14 mm. (Fig. 430.)

Laporte County; scarce. June 21. Breecis in pine, about which the adults are usually found.

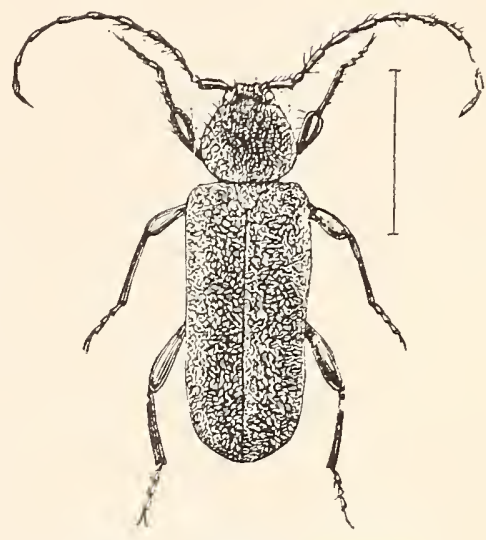

Fig. 430. Callidium antennatum.

C. janthinum Lec., length 10-13 mm., was described from Texas and has been recorded from Cincinnati. C. creum Newm., length 8.5-12 mm., is said to inhabit the Atlantic States.

Hylotrupes ligneus Fab. (Fig. 431), black, elytra yellow or red with black markings, length 7-12 mm., occurs from Maine to Cali-

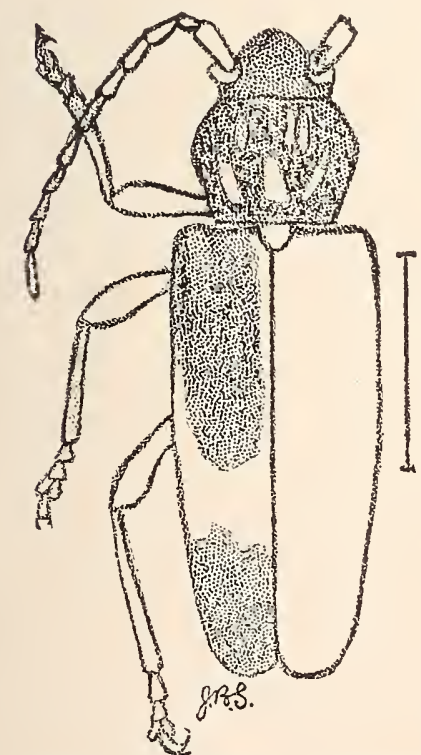

Fig. 431. (After Smith) in Fifth Rep. U. S. Ent. Comm.)

fornia and has been recorded from Cincinnati; $H$. bajalus Linn., elytra black with gray pubescence, length 19-23 mm., inhabits the "Ynited States."

\section{Mertum Kirby. 1837. (Gr., "the hip." )}

This genus contains but the single species :

$1 S 8 S$ (600T). Meriuar proteus Kirby, Faun. Bor. Amer., IV, 1S37, 172.

Oblong-subdepressed. Head and thorax dull blue; elytra greenish-yellow with nodules or broken lines of ivory white on basal half; femora reddish-yellow; antemne, tibice and tarsi dusky. Thorax short, broad, sides rounded; surface densely punctured, except the shining. smooth space on basal half, which bears a few coarse punctures each side. Elytra coarsely and roughly punctate. Length 11-14 mm.

Marion County; rare. May 25. A northern species. 


\section{Division II. CERAMBYCOIDES.}

This division, distinguished only iy the characters given in the key, is divided into 12 tribes, seven of which are represented in Indiana.

KEY TO INDIANA TRIBES OF CERAMBYCOIDES.

a. Eyes coarsely granulated.

b. Front coxal carities open behind. Tribe i. Ceranbrcini, p. 1020.

bb. Front coxal cavities angulated, closed behind; length less than $7 \mathrm{~mm}$. Tribe II. OBRtini, p. 1027.

aa. Eyes finely granulated.

c. Elytra either only about as long as thorax or elongated and awlshaped.

Tribe III. Stenoptini. p. 1028.

cc. Elytra normal, not abbreviated nor awl-shaped.

d. Scutellum either rounded behind or broadly triangular.

$e$. Tibial spurs small; legs long and slender; thighs very slender at base, strongly and suddenly club-shaped at apex; front coxal carities open belind. Tribe IV. Rhopalophorini. p. 1029.

ee. Tibial spurs large; thorax never with tubercles or spines.

f. Tibiæe strongly carinated; form slender; punctuation sparse and coarse. Tribe VI. Stenospuenini, p. 1031.

ff. Tibiæ not carinated; form usually stouter; punctuation fine.

Tribe VII. Clrtini, p. 1032.

dd. Scutellum acutely triangular; front coxal cavities open behind.

Tribe V. Trachiderini. p. 1029.

\section{Tribe I. CERAMBYCINI.}

This tribe embraces all genera of the subfamily having the eyes strongly granulated; front coxal cavities open; abdomen normal in both sexes; antenna with the second joint small. The scutellum is rounded behind, except in Chion; antennæ long without distinctive sensitive spaces; mandihles acute at tip; elytra not abbreviated; etres not divided, though always deeply emarginate. About 25 genera belong to the tribe, seven of which are known to be represented in Indiana, while four others may oceur.

\section{KET TO INDIANA GENERA OF CERAMBICINI.}

a. Body with six cross-bands of yellow pubescence; ligula more or less horn-like; palpi unequal, dilated.

XI. Dryobius.

aa. Body with not more than one yellow cross-band.

๖. Ligula more or less horn-like.

c. Epimera of mesosternum large; front trochantins not visible: length $16 \mathrm{~mm}$.

ACHRYSON.

cc. Epimera of mesosternum small; length $6-S \mathrm{~mm}$.

GRACILIA.

bb. Ligula membranous.

d. Front coxal cavities angulated; antennæ, thighs and elytra not spinose; length $14.5 \mathrm{~mm}$.

Stromatium.

dd. Front coxal cavities rounded. 
e. Scutellum acute, triangular; antennie very long, sulcate; thorax with spine on each side.

XII. CIIION. ee. Scutellum rounded behind.

f. Elytra with elliptical, elevated ivory-like spots in pairs.

Xiti. Eburia.

ff. Elytra without raised ivory-like spots.

g. Femora not strongly clubbed; antennal joints and elytra with spines.

h. Larger species (19-2S mm.); side pieces of metathorax narrower behind.

XIV. Romaleum.

hh. Smaller species $(\mathrm{S}-19 \mathrm{~mm}$.) ; side pieces of metathorax parallel.

XV. Elaphidion.

gg. Femora strongly clubbed; elytra without spines at tip.

$i$. Antenne bisulcate on outer side.

XVI. TYLONOTUS.

ii. Antenne not sulcate nor hairy.

j. Middle coxal cavities rounded; length $7.5-11 \mathrm{~mm}$.

XVII. HeTERACHTHES.

jj. Middle coxal cavities angulated; length $13 \mathrm{~mm}$.

ZAMODES

XI. Dryobius Lec. 1850. (Gr., "oak + live.")

Antennæ 11-jointed, much longer than body in male, and densely pubescent on under side with long brownish hair ; thorax depressed, with obtuse tubercles; elytra subtruncate or broadly emarginate at apex. One species occurs in the Mississippi Valley.

1889 (6022). Dryobius sexfasciatus Say, Journ. Phil. Acad. Nat. Sci., III, 1824, 415; ibid. II, 195.

Elongate, subdepressed. Black, shining; thorax with two and elytra with four conspicuous crossbands of bright yellow pubescence; top of head, clypeus and scutellum also yellow; antennæ and legs reddish-brown. Thorax with sides rounded, surface coarsely and sparsely punctured, with three smooth, blunt tubercles. Elytra with the smooth black spaces finely and sparsely punctured. Length 19$27 \mathrm{~mm}$. (Fig. 432.)

Putnam, Posey and Crawford counties; scarce. June 13July 4. Occurs beneath the loose bark of dead beech and

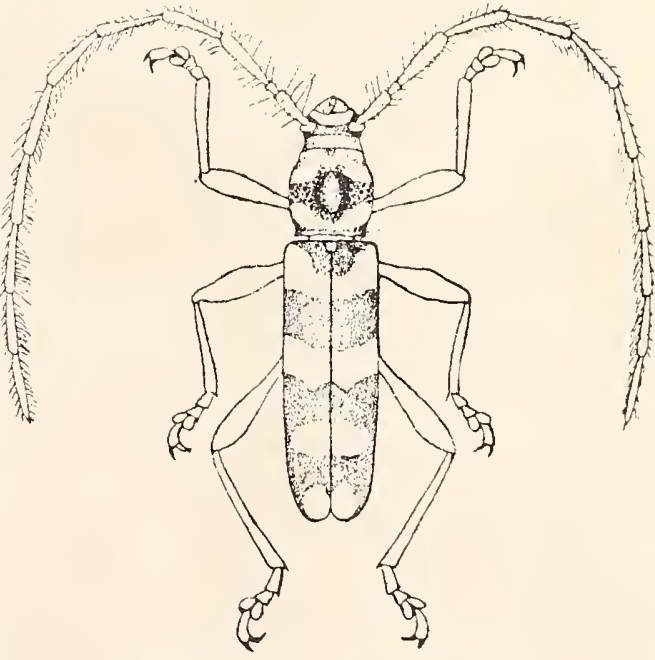

Fig. 432. $\times 1 \frac{1}{2}$. (After Smith.) maple, in the wood of which the larvæ bore. One of the most handsome members of the family. The antenne of female are but little longer than the body; those of male nearly twice as long.

Achryson surinamum Linn., reddish-brown, elytra with a few 
oblong black points, lerigth $16 \mathrm{~mm}$., ianges from the Middle States to Mexico.

Gracilia minuta Fab., piceous, length $6 \mathrm{~mm}$., is an introduced European species which occurs in the Atlantic States.

Stromatium pubescens Hald., pale yellowish-brown, length 14.5 mm., is known from Pennsylvania.

\section{Chion Newm. 1841. (Gr., "snow.")}

To this genus belongs the single species:

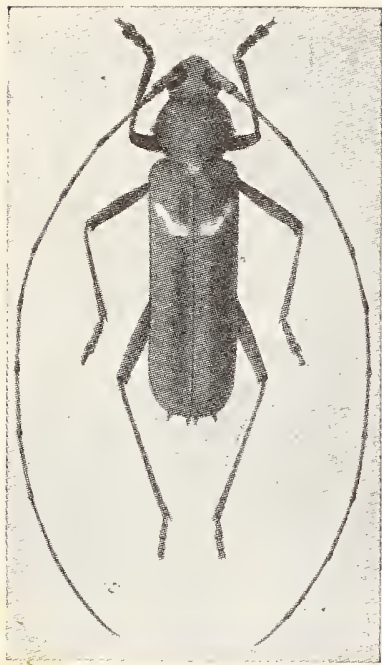

Fig. 433. Natural size. (After Forbes.)

1890 (60:35). Chion cinctus Druly, Ill. Nat. Hist., II, 1773, S5.

Elongate, slender, subcylindrical. Brownish, sparsely clothed with fine grayish pubescence; elytra usually with an oblique yellow blotch in front of middle. Antemne of male much longer than in female, about the length of body. Thorax cylindrical with a short, sharp spine each side. Elytra finely and rather densely punctate. each with two short spines at apex. Length 16$32 \mathrm{~mm}$. (Fig. 433.)

Throughout the State; scarce. April 25-June 18. Occurs beneath bark, most commonly that of hickory, in the wood of which the larve dwell; also taken at light. The form with yellow spot on elytra, which is of most frequent occurrence in the State,

is the one usually listed as var. garganicus Fab.

\section{Eburta Serv. 1834. (Gr., "ivory.")}

The members of this genus are readily distinguished by the two pairs of ivory-white spots on each elytron. But one of the eleven known North American species occurs in the State.

1891 (6042). Eburia Quadrigeminata Say, Joum. Phil.

Acad. Nat. Sci., V, 1826, 275 ; ibid. II, 333.

Elongate, slender, subcyindrical. Pale brownish-yellow; elytra each with two nearly equal oblong whitish spots at base, and a second pair just hehind the middle. the outer one of which is nearly double the size of the inner. Thorax crlindrical, with two minute blackish tubercles on disk and a short, sharp spine each side. Elytra parallel, surface finely and rather densely punctured: tips each with two spines, the onter one of which is the longer. Middle and hind femora each with two spines at apex. Length $14-24 \mathrm{~mm}$. (Fig. 434.)

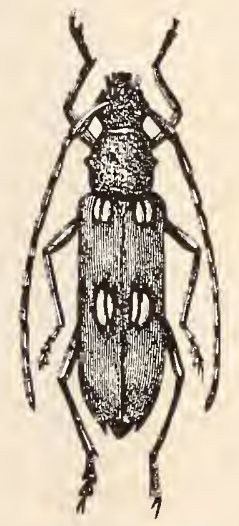

Fig. 434. Eburia quadrigeminata. Natural size. Breeds in hickory, ash and honey locust. 


\section{Romaleum White. 1855. (Gr., "strong of body.")}

The species of this genus differ from the next, with which they are most closely allied, by their larger, more robust form and by the episterna of the metathorax being distinctly though slightly wider in front and gradually narrowed behind. The femora are not spinose and the spines of antennx are never long. The males have the antennæ longer than body, the thorax densely and finely punctured with a median channel on basal half and a small rounded tubercle each side of middle. In the females the antennx are, shorter, thorax more coarsely punctured with a median and two dorsal raised spaces.

1992 (6050). Romaleum atomarium Drury, Ill. Nat. Hist., II, 1778, 93.

Elongate, subcylindrical. Piceous brown with irregular spots of short grayish pubescence. Thorax cylindrical without spines on side. Elytra deeply, rather coarsely and densely punctured, each with two spines at apex. Length 19-28 $\mathrm{mm}$.

Throughout the State; frequent in southern portion, scarce in northern counties. July 2-September 10. Occurs beneath bark of walnut, hickory and hackberry.

1893 (6051). Romaleum rufulum Mald., Trans. Amer. Phil. Soc., X, $1847,32$.

Resembles atomarimm in form and size. Reddish-brown with uniform pubescence of the same color. Thorax with a small tubercle each side of the median line, the latter widening into a triangular smooth l'aised spot on basal half. Length 22-2S $\mathrm{mm}$.

Marion, Putnam and Spencer counties; rare. July 4-August 17. The Spencer County specimen was sent in as a supposed "kissing bug." Occurs on oak and at light. The paler and uniform colored pubescence readily distinguishes this from the preceding.

XV. Elaphidion Serv. 1834. (Gr., "a deer + little.")

Rather slender subcylindrical species, having the episterna of the metathorax scarcely wider in front than behind; antennæe longer than body in male, shorter in female, and without distinct sensitive spaces. Four species have been taken in the State, while one other perhaps occurs. 
KEY TO INDIANA SPECIES OF ELAPHIDION.

a. Antennæe and elytra with long spines; thighs spinose at tip; thorax of male and female similar with sereral small, smooth elerated spaces.

b. Above glabrous with patches of white hair.

IRRORATUM.

bъ. Abore clothed irregularly with grayish pubescence.

1S94. MUCRONATUM.

aa. Antennal spines small; thighs not spinose at tip; thorax of male finely, female more coarsely punctured.

c. Thorax lounded on sides, its disk with several smooth elerated spaces.

1S95. INCERTUM.

cc. Thorax scarcely rounded on sides, nearly cylindrical.

d. Body with distinct mottled pubescence; legs densely punctured and pubescent.

1S96. VIllosum.

dd. Bodr shining reddish-brown, scarcely pubescent; form rery elongate.

1897. UNICOLOR.

E. irroratum Linn., piceous, with patches of white hair, length $19 \mathrm{~mm}$. has been taken in Illinois and Ohio.

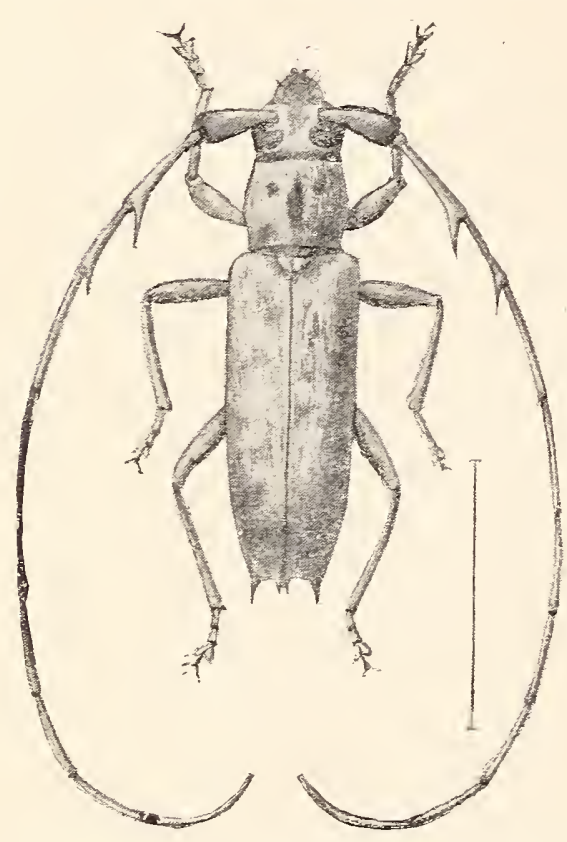

Fig. 435. $\times 2 \frac{1}{2}$. (After Chittenden in Bull. No. 18 , New Ser. U. S. Div. Ent.)

1894 (6056). Elaphinion mucronatum Say, Journ. Phil. Acad. Nat. Sci., III, 1S24, 427; ibid. II, 201.

Elongate, slender, subcylindrical. Dull leddish-brown, irregularly clothed with grayish-yellow pubescence. Antennæ with joints $3-5$ each with a distinct spine, that of the third joint one-half or more the length of the fourth joint. Thorax nearly cylindrical, sides feebly rounded; disk coarsely and sparsely punctured, with the median line and two small rounded spaces each side smooth and slightly elerated. Elytra irregularly and somewhat coarsely punctured, the tips each with two spines, the outer one the longer. Length 15-19 $\mathrm{mm}$. (Fig. 435.)

Knox, Posey and Crawford counties; scarce. June 9-August 29. Occur's on or about oak, hackberry, beech, sugar maple and dogwood, in the wood of which the larvæ bore.

1895 (605S). Elapphidion incertuan Newm., Entomologist, 1840, 28.

Elongate, subcylindrical, rather robust. Dark reddish-brown, mottled with small patches of gravish-brown pubescence. Antennæ with joints $3-5$ armed with rely short spines. Thorax subglobose, wider than long, sides rounded; median line smooth, polished, widest behind the middle and with 
two small, smooth elevations each side, the front one rounded, the other oblong, the two sometimes connected. Elytra deeply, rather sparsely and finely punctured, the tips each with two short spines. Length 14-17 mm.

Throughout the State; much more frequent in the southern counties. June 25-September 20.

1896 (6062). Elaphidion villosum Fab., Ent. Syst., I, 1798, 302.

Elongate, slender, subcylindrical. Dark brown, clothed with grayish-yellow, somewhat mottled pubescence; antennæ and legs reddish-brown. Antennæ of female shorter, those of male longer, than body, joints $3-5$ armed with short spines. Thorax cylindrical unarmed, surface coarsely, deeply and rather lugosely punctured. Elytra parallel, deeply and rather coarsely punctured, the tips each

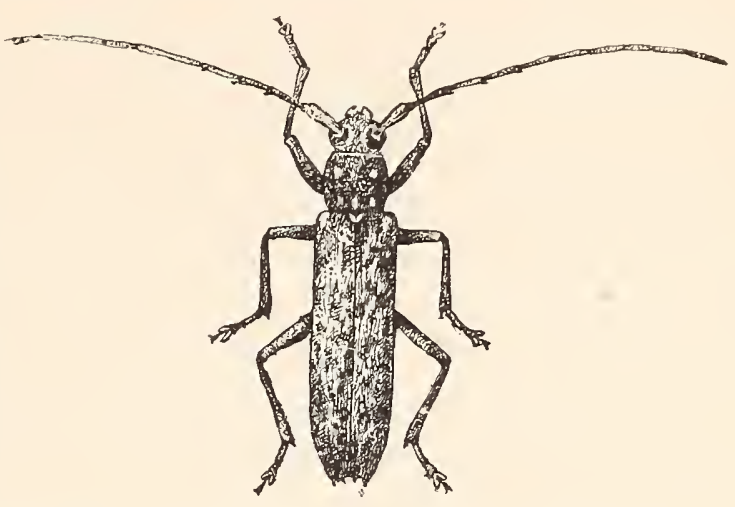

Fig. 436. $\times 2$. (After Chittenden in Bull. No. 18, New Ser., U. S. Div. Ent.)

with two short spines, the outer one the longer. Length 11.5-17 mm. (Fig. 436.)

Throughout the State; common. May 11-July 11. This species is the well-known "oak-pruner," which does much damage to oak and other trees by cutting off the small leaf-bearing twigs. According to Chittenden* it attacks almost every woody plant that grows, including all the more common forms of fruit trees. The severed twigs vary in lerrgth from a few inches to two or three feet and sometimes are more than an inch in diameter. An examination of one, and sometimes of both ends of one of the twigs will show a smoothly cut surface, near the center of which will be seen a more or less oval opening plugged up with a wad of a material composed of fine shavings and sawdust. If one of these limbs be split open a larva or pupa will be found. The larva is subcylindrical, soft and fleshy, and of a whitish or light-yellowish color. It is provided with legs which are, however, somewhat rudimentary and of little service to the creature as organs of locomotion.

"The pruning process is not always in itself especially injurious, but the ultimate effects are apt to be more serious. The fallen twigs serve as a breeding place for hosts of other wood borers, many of which are injurious to timber. Among these are some which do not hesitate, in default of an abundance of dead wood, to attack and injure living trees. In case this beetle becomes injuriously abun-

*Bull. 18, New Ser., U. S. Div. Ent., 1898, 37. 
dant, it may be readily controlled by gathering the infested twigs during the winter and burning them before the following spring.'

E. parallelum Newm. of the lists, formerly separated from villosum by having the "thorax distinctly longer than wide," is now considered a synonym, as the differences are indistinguishable in a large series.

1897 (6069). Elaphidion Unicolor Rand., Bost. Journ. Nat. Hist., II, 1838, 42.

Elongate, very slender, subcylindrical. Uniform light reddish-brown, very sparsely pubescent. Joints 3 and 4 of antennæ each with a short spine at apex. Thorax cylindrical, nearly one-half longer than broad, sparsely and irregularly punctate. Elytra deeply and rather closely punctured, the tips each with a short spine on outer side. Length 8-12 $\mathrm{mm}$.

Throughout the State: scarce. June 1-July 29. Occurs about red-bud and wild plum, in the twigs of which the larvie dwell; also taken at light.

\section{Tylonotus Hald. 1847. (Gr., "a knot+back.")}

This genus is represented in the eastern United States and Indiana by a single medium-sized species having the femora strongly clubbed; antenmæ as long as body, compressed and with two graoves or sulci on the outer side, these more noticeable on the third and fourth joints.

1898 (6079). Trlonotus Bimaculatus Hald., Trans. Amer. Phil. Soc., X, 1847,38 .

Elongate, rather robust, subdepressed. Dark brown or piceous; elytra each with two rather large, somewhat rounded yellow spots, one near middle, the other near apex; femora yellowish except at base and apex. Thorax short, nearly cylindrical, thickly punctured; median line and two small raised spaces smooth. Elytra coarsely and rather sparsely punctured, not spined at tip. Length $12-16 \mathrm{~mm}$.

Putnam County; rare. July 8. The larvæ bore in ash wood and the adults usually occur about these trees.

\section{Heterachthes Newm. 1840. (Gr., "different+load.")}

Very elongate species having the eyes large and coarsely granulated; femora strongly clubbed; antennæ of female slender; of male with joints $3-6$ thickened throughout their full length; second joint very minute in both sexes. One of the three known species occurs in Indiana. 
1899 (6084). Heterachthes quamimaculatus Hald., Trans. Amer. Phil. Soc., X, 1847, 43 .

Elongate, slender, subcylindrical. Dull brownish-yellow, shining; elytra each with two circular paller spots, one in front of and one just behind the middle. Thorax cylindrical, narrowed in front, disk with a wide, shallow median groove interupted at middle; surface, as well as that of elytra, very sparsely punctured. Icength S-11 $\mathrm{mm}$.

One in Dury collection from Isaporte County. Occurs from Pennsylvania to Missouri. The larve live in the wood of hickory.

Zamodes obscurus Lec., black, opaque, clothed with dense brown pubescence, length $13 \mathrm{~mm}$., is known from New Jersey and Pennsylvania.

\section{Tribe II. OBRIINI.}

Small species having the front coxæ prominent, contiguous, conical and enclosed behind; palpi slender, with the last joint triangular; first segment of abdomen very long, the second and following irregular in length, hairy and excavated or deformed in female ; thorax constricted and pedunculate at base and narrower thąn elytra; femora strongly clubbed; first joint of hind tarsi as long as the next two. But two of the seven genera are represented in the eastern United States and Indiana.

KEY TO INDIANA GENERA OF OBRIINI.

a. Thorax much narrower at base than at apex.

XVIII. Phiton. aa. Thorax dilated at middle, equally narrowed at base and apex, tuberculate at sides.

XIX. ObriuM.

\section{Phyton Newm. 1840. (Gr., "plant.")}

This genus contains but two small species, one of which occurs in Indiana.

1900 (6090). Phyton pallidum Say, Journ. Phil. Acarl. Nat. Sci., III, 1S24, 412; ibid. II, 193.

Elongate, slender, subcylindrical. Dull, pale yellow; thorax with three dusky lines and elytra each with four oblique brownish bands, of which the one just behind the middle is broad, the others narrow. Thorax broad in front of middle, narrowed on apical fourth, much narrowed on basal third. Length 5.5-6.5 mm.

Knox County ; rare. July 2. Should occur sparingly throughout the State. The larvie live in red-bud, hickory and osage orange.

\section{Obritin Serv.}

Two small species having the thorax equally narrowed at base and apex belong here. One has been taken in the State and the other probably occurs. 
KEY TO SPECIES OF OBRIUM.

a. Head and thorax piceous, coarsely and closely punctate; elytra pale reddish-brown, very sparsely punctate.

RUBIDUM.

aa. Body uniformly reddish-yellow; thorax not closely punctate; elytra more closely punctate.

1901. RUBRUM.

1901 (6092). Obrium ruberum Newm., Ent. Mag., V, 1838, 393.

Elongate, subcylindrical. Pale reddish-yellow, shining. Head broader than thorax, the latter with an obtuse tubercle each side near middle. Elytra rather coarsely punctate, each puncture bearing a yellowish hair. Femora rather strongly clubbed. Length 5.5-6.5 mm.

Posey, Putnam and Crawford counties; scarce. June 24-June 28. Beaten from vegetation.

Tribe III. STENOPTINI.

In this tribe the front coxal cavities are widely angulated on the outer side, but entirely closed behind; abdomen normal in both sexes; head extended forward, the front large and oblique; eyes finely granulated and deeply emarginate; hind tarsi with first joint twice as long as second; legs and thorax sparsely clothed with long flying hairs. Two genera, each represented in Indiana by a single species, compose the tribe.

KEY TO GENERA OF STENOPTINI.

a. Elytra scarcely longer than thorax, their tips separated and rounded; mesosternum triangular and truncate.

XX. Molorchus.

a a. Elytra elongate, gradually awl-shaped and widely separated at apex; mesosternum broad, widely emarginate behind. XXI. Callimoxys.

\section{Molorchus Fab. 1792. (A mythological name.)}

1902 (6100). Molorchus bimaculatus Say, Journ. Phil. Acad. Nat. Sci., III, 1S24, 428; ibid. II, 202.

Elongate, subdepressed. Dull black, sparsely pubes-

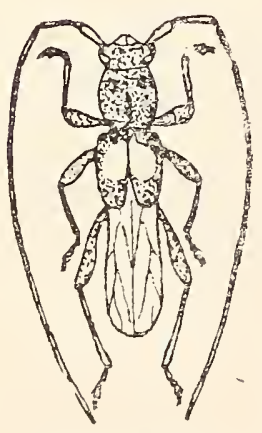

Fig. 437. $\times 4$. (After Wickham.) cent with long grayish hairs. Elytra dull yellow, blackish at tip and margin; antennæe and legs reddish-brown. Thorax subcylindrical, rounded at sides, much narrowed at base, surface coarsely and rather densely punctate. Length 5-7 mm. (Fig. 437.)

Throughout the State, common; less so in the northern counties. April 12-May 27. Often abundant on the flowers of the red haw (Cratagus)." Mating April 26 and May 27. Breeds in hickory, maple, ash and dogwood. 
XXI. Callimoxys Kraätz. 1863. (Gr., "beautiful + sharp.")

1903 (6101). Callimoxys Sanguinicoldis Oliv., Ent., IV, 180S, 74.

Elongate, slender. Dull black; thorax of male red, with narrow black apical and basal margins; elytra brownish; hind legs yellow, the tips of joints black. Thorax subcylindrical, its disk with four obtuse tubercles. Elytra sparsely and rather coarsely punctate. Hind tibix of males long and curved, with numerous teeth on the outer margin. Length 8.5-10 mm. (Fig. 438.)

Laporte and Kosciusko counties; rare. June 6-.June 24. Occurs on flowers of Jersey Tea.

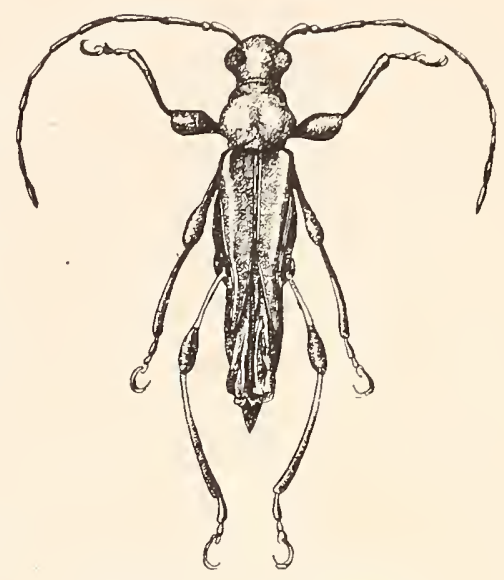

Fig. 438. $\times 3 \frac{1}{4}$. (Original.)

'Tribe IV. RHOPALOHIORINI.

This tribe is composed of a singie yenus of small, slender beetles having the head elongate; eyes finely granulated and deeply emarginate; antennæ slender, as long as body in male, shorter in female, the fourth joint shorter than the third or fifth; hind tarsi with first joint twice as long as second.

XXII. Rhopalophor Serv. 1834. (Gr., "a club + bearing.")

This genus comprises three species, two from Texas, the other from the eastern United States, including Indiana.

1904 (6105). Rhopalophora rongipes Say, Journ. Phil. Acad. Nat. Sci., III, 1824, 426; ibid. II. 201.

Elongate, very slender, subcylindrical. Bluish-black, the thorax red. Thorax cylindrical, with a slight obtuse tubercle each side, rery finely and obsoletely punctate. Elytra with basal fourth flat and suddenly sloping downward, the humeri prominent: surface deeply, coarsely and rather densely punctured, the tips subtrun:ate. sometimes with two short spines. Length $7-8 \mathrm{~mm}$.

Western and southern Indiana from Vermillion County southward; scarce. May 30-June 30. Beaten from the foliage of oak and the flowers of wild hydrangea.

\section{Tribe V. TRACHYDERINI.}

A large tribe containing, as great a variety of forms as Tribe I, Cerambycini. The distribution of the genera is, however, mostly to the south and southwestward, representatives of but three of the 
16 having been taken in the State. They are distinguished by the finely granulated eyes, acutely triangular scutellum, and by having the front coxal cavities open behind.

KEY TO INDIANA GENERA OF TRACHYDERINI.

a. 'Thorax opaque, its sides with a spine or large tubercle; size larger, 13$25 \mathrm{~mm}$.

b. Body pubescent.

bb. Body not pubescent.

Xxili. Tragidion. a . Thorax shining. sides unarmed; size much smaller, not over $S \mathrm{~mm}$.

XXY. BATYLE.

XXIII. Tragidion Serv. 1834. (Gr., "a young goat.")

Large or needium-sized species having the scutellum small, broadly triangular; thorax densely punctured, both it and elytra with black pubescence concealing the punctures; antennæ filiform, joints 5-11 carinate on outer side.

1905 (6127). Tragniox coqués Linn.. Syst. Nat., Ed. X. 393.

Elongate, robust, subcylindrical. Black; elstra each with a large, rounded orange spot near base; antennie wholly black. Thorax as wide as long. sides rounded, armed with a small spine behind middle. Elytra each with three raised lines on disk. Length 16-25 $\mathrm{mm}$.

One specimen in each of the Webster and Field Museum collections labelled "Ind." Occurs in the "Atlantic and Southern States."

XXIV. Purpuricenes Serr. 1833. (L., "purple.")

Medium-sized, handsome black and searlet or black and yellow species, having the thorax with a small spine each side, the seutellum broadly triangular and acute at tip. and the elytra not pubescent. Two of the three species occur in Indiana.

1906 (6129). Purpuricenus humeralis Fab., Ent. Syst., Supp., 179S, 143.

Elongate, robust. subcrlindrical. Black, opaque, the legs alone feebly shining; elytra each with a large, triangular. scarlet humeral spot, defined by an oblique line, running from scutellum to middle of outer margin. Antemng of male two-thirds longer than body; of female about the length of body. Thorax coarsely, densely and roughly punctured. Elytra deeply and rather coarsely punctured on basal half. more finely and densely toward the apex. Length $14-1 \mathrm{~s} \mathrm{~mm}$.

Taken only in Lake County in the wash-up along the beach of Lake Michigan where, at times, it is frequent. June 15-July 13. Said to occur elsewhere on oak and hickory. 


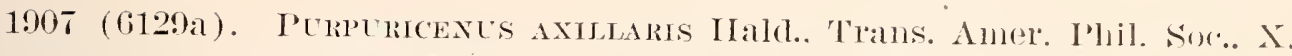
$1847,31$.

Resembles humeralis in form. Black; elytra from base to middle orange yellow. Elytra much less coarsely and less deeply punctate than humeralis; those of females emarginate and somewhat toothed at apex. I, fingth 12 $19 \mathrm{~mm}$.

Lawrence and Crawford counties; rare. June 9-.July 1. Beaten from the foliage of hickory. Listed as a variety of humeralis, but in my opinion wholly distinct.

\section{Batrie 'Thom. 1864.}

Small, slender forms. having the front of head short, not abruptly defined each side; antennx a little shorter than body, the latter pilose; scutelium small : thorax margined at apex. One of the three recognized species occurs in the State.

1908 (6141). Batrle suturalis Say, Jomm. Phil. Acad. Nat. Sci., III, 1S24. 411 ; ibid. II, 192.

Elongate, slender. Dark red; antenne, legs and often the suture of elytra varying from dusky red to black; surface sparsely clothed with long blackish hairs. Thorax subglobose, rery sparsely and finely punctured. Elytra coarsely and sparsely punctured, the tips rounded. Length 6.5$7.5 \mathrm{~mm}$.

Throughout the State; frequent. June 16-July 29. Occurs in numbers on flowers of Jersey Tea (Ceanothus), dogwood (Cormus), meadow-sweet (Spircea) and other plants. Mating June 25.

\section{Tribe ri. STExOSPHENINI.}

This tribe is represented by a single genus having the eyes finely granulated and deeply emarginate; the head, in our species, neary vertical; antenne as long as body in female, somewhat longer in male, tapering, punctured and pubescent, second joint small, third longer than fourth, 3-7 armed with short apical spine on the inner side; scutellum rounded behicd; elytra truncate at tip and armed with two apical spines; tibia strongly carinated and the first joint of tarsi as long as the two following mited.

\section{S'TEnosphents Hald. isti. (Gr., "narrow + wedge.")}

This genus, possessing the characters of the tribe as given above, is represented by six species, all but one of which oceur in the southwestern United States. The exception is 
1909 (6161). Stexosphexts yotates Olir. Ent.. IT, 1795, 61.

Elongate, nearly parallel. Black: thorax reddish with a central black spot; under side of head and thorax reddish. Thorax wider than long, not narrorred at apex: surface, as well as that of elytra, sparsels and coarsely punctured, each puncture bearing a gras hair. Length 9-12 $\mathrm{mm}$.

Lake. Poser and Crawford counties: probably throughout the State: frequent. especialiy in the wash-mp of Lake Michigan: also beneath bark of hickory. In the rood of which the larva bore. April 17-May 30 .

\section{Tribe VII. CLITINI.}

Our members of this tribe have the elytra banded with yellow or white and black pubescence; eyes finely granulated and deeply emarginate, the lower lobe alwars large; antennæ usually shorter than bodr in both sexes. joints rarely spined; front coxal cavities rounded, open behind, not angulated on the sides; legs long, usually slender, femora sometimes clubibed, tibire not carinated. hind tarsi with first joint very elongate. Representatives of 9 of the 14 genera, comprising the tribe have been taken in Indiana, while those of three other's perhaps occur:

\section{KET TO INDTAXA GENERA OF CLTTINI.}

a. Head small, front short. oblique: process of first rentral segment between the hind coxie rounded.

7. Thorax transrersels excarated at sides near the base; prosternum perpendicular at tip; thoras with three rellow crossbands.

XXTiI. CrlleNe.

66. Thorax not excarated at sides. which are rounded and constricted at base; prosternum sloping downmard at tip; thorax without sellow crossbands, but sometimes with rellow oblique bars each side.

c. Antennæ compressed. subserrate; colors notably contrasted, with black and rellow bands: length $23-25 \mathrm{~mm}$.

IXViII. Plagionotes.

cc. Antemnæ filiform.

๙. Large species. 20 or more mm. : thorax entirels black. much rounded on the sides.

rXIX. Calloines.

dr. Smaller. not orer $18 \mathrm{~mm}$; thorax with central black spot. the sides much less rounded and clothed with grarish pubescence.

IXI. ARHopalts.

na. Head large, front long: process between the hind coxæ acute.

e. Elytra flat on basal third: size moderate. $s-18 \mathrm{~mm}$.

$f$. Front of head with one or more caring of rariable form.

XXII. IYLOTREchts.

ff. Head without carince. 
g. 'Thorax with short, transverse dorsal raised lines or ridges.

XXXII. Neoclytus.

gg. Thorax without transverse ridges.

h. Episterna of metathorax narrow.

XXxili. Clytanthus.

hh. Episterna of metathorax wider.

Clytus.

$e e$. Elytra swollen on basal third; small, ant-like species, not over $10 \mathrm{~mm}$.

$i$. Elytra without a transverse oblique, ivory-like band.

$j$. Eyes oblique, emarginate.

$k$. Second joint of antennse as long as fourth; antenne without spines.

Microclytus.

$k k$. Second joint of antennie distinctly shorter than fourth; third joint with a spine.

jj. Eyes rounded, entire.

XXXIV. Cyrtophorus.

TIILOMORPHA.

ii. Elytra each with a transverse, oblique, ivory-like band.

XXXV. EUdERCES

XXVII. Crulene Newm. 1840. (Gr., the name of a mountain in Greece.)

Medium-sized robust species having the body densely clothed with short prostrate hair. In our species the thorax and elytra are conspicuously banded with yellow. Three of the five known species occur in the State.

KEY TO INDIANA SPECIES OF CYLLENE.

a. Second joint of hind tarsus glabrous at middle; antennæ of male longer than body; prosternum between the coxre longer than wide.

1910. PICTLS.

a a. Second joint of hind tarsus densely pubescent; antennæ not longer than body.

b. Basal third of elytra with three narrow yellow bands, the hindmost one W-shaped; prosternum as wide as the coxal cavity.

1911. ROBINIE.

bb. Basal third of elytra orange yellow; prosternum not as wide at middle as coxal cavity.

1912. DECORTS.

1910 (6170). Crllene Pictus Drury, Ins., II, 1773, 91.

Elongate, rather robust. Velvety black; liead, thor'ax and elytra with narrow yellow crossbands, the third one from base of elytra W-shaped, the three behind it sinuous; legs reddish-brown. 'Thor:ax wider than long, sides rounded. Prosternum longer than wide, truncate at tip. Elytra tipering behind the middle, obliquely truncate at tip but not prolonged. Length 12 $20 \mathrm{~mm}$.

Southern half of State; frequent. April 18-April 28. Occurs on elm and hickory logs in spring. The larve bore in the rood of these trees and are often very destructive to the hickory. 
1911 (6171). Crllene robiniz Forst., Nov. Sp. Ins., 1771, 43.

Resembles $p$ ict $u s$ so closely that

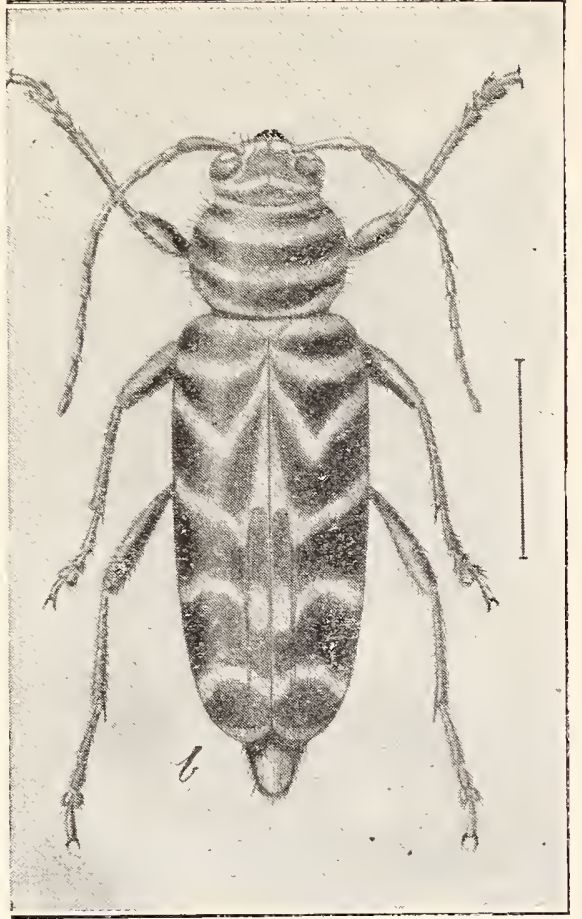

Fig. 439. Female. $\times 2 \frac{1}{2}$. (After Hopkins in Circ. No. 83. Bur. Ent. U. S. Dept. Agr.) only an expert can tell them apart. The characters given in the key are those usually relied upon. The elytra are less tapering and more broadly rounded at apex, thus giving it a more robust appearance, and the hind femora and antennæ of male are distinctly shorter than in pictus. Length 14-20 mm. (Fig. 439.)

Throughout the State; common. August 21-October 9. Oceurs abundantly in autumn on goldenrod and about the trees of the biack lomust (Robinia). The wood nf this tree is often injured by the lal"va, which is known as the "locust borer."

1912 (6172). Cyllene Decorus Oliv.. Ent., IT, 1795, 63.

Elongate, robust. Head black ; clypeus and a narrow transverse band behind the eyes, yellow; thorax yellow with three short and narow. black crossbar's; elytra black, the basal third, a band behind the middle and the tips rellow; under surface yellow. Length 14-20 $\mathrm{mm}$.

Knox County; rare. October 11. One specimen from near the border of the tamarack swamp. A southern species, which in Indiana reaches its most northern and eastern range. Our form is the var. charus Say described from Posey County. Say's specimen being taken "near the end of August."

XXVIII. Plagionotes Muls. 1842. (Gr., "oblique+back.")

This genus contains only a single large species, distinguished from its allies by the heavier compressed antennæ.

1913 (6173). Plagionotus speciosus Say, Amer. Entom.. III. 182S. 118.

$$
\text { pl } 53 \text {; ibid. T. } 11 \mathrm{~s} .
$$

Elongate, robust. Black; densely clothed with yellow pubescence, this covering the greater part of head and forming two short oblique bands on each side of thorax and five on elytra, arranged as follows: one forming an arch diverging from scutellum, behind this a second $W$-shaped band: a third nearly transverse one across the mintle; a fourth curved each side from the suture obliquely backward and separated narrowly from the fifth and broadest upon the apex. Length 23-25 mm. (Fig. 440.)

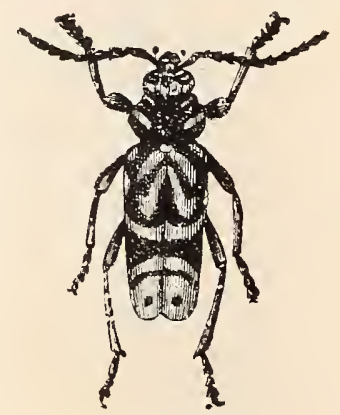

Fig. 440. Natural slıt (After Saunders. , 
Known from the State by a single specimen in the Dury collection from Laporte County. Occurs in the vicinity of the soft maple (Acer saccharinum L.) to the wood of which the larva often do much injury. A species of northern range, probably oecurring only in the Transition life zone of the State.

\section{Calloides Lee. 1873. (Gr., "beautiful + form.")}

Here belong two large species distinguished by the form and color of thorax and by having the mesosternum sloping downward. One of the two occurs in Indiana.

1914 (6174). CAlloides noblus Harris, Trans. Hartford Soc. Nat. Hist., I, 1836,84 .

Elongate, robust. Brownish-black, opaque, densely clothed with very short, velvet-like pubescence; elytra each with a rounded yellow spot at base, a minute submarginal one behind the humerus, a larger one before the middle, and two narrow, transverse, sinuous bands on apical half; these spots and bands often almost or wholly obsolete. Antenna short, onehalf the length of body. Thorax globose, sides much rounded, surface densely and finely granulate. Tips of elytra rounded, without spines. Length 20-23 $\mathrm{mm}$.

Lake County; frequent in the wash-up along the beach of Lake Michigan; Starke and Clark counties; rare. May 27-June 28.

XXX. Arhopalus Serv. 1834. (Gr., "without+club.")

This genus is represented east of the Rocky Mountains by the single species :

1915 (6176). Arhopalus furminans Fab., Syst. Ent., 179S, 192.

Elongate, rather slender, subcylindrical. Black; head and thorax covered with grayish pubescence; the latter with a large black spot on center of disk, and a small round one each side. Elytra marked with ill-defined zigzag bands of grayish pubescence. Length 12-1S mm. (Fig. 441.)

Crawford and Posey counties; scarce. May 15-June 26. Breeds in oak, hutternut and chestnut, the adults oceurring beneath the bark of these and neighboring trees.

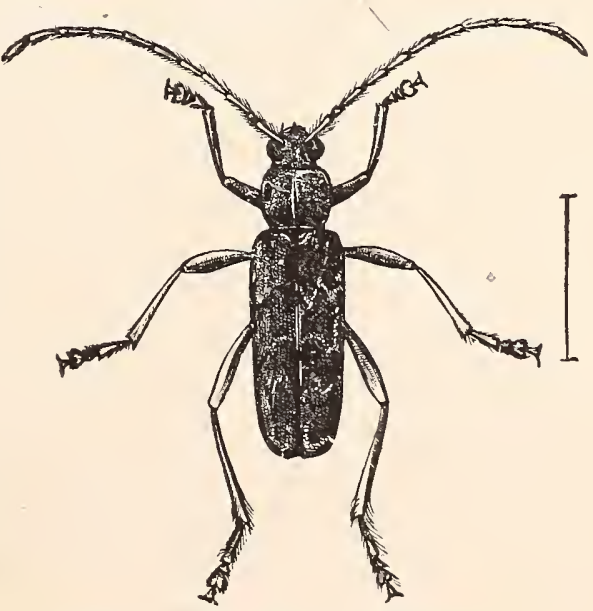

Fig. 441. (After Packard in Fifth Rep. U. S. Ent. Comm.) 
XXXI. Xylotrechus Chev. 1860. (Gr., "wood + a runner.")

Medium-sized, slender species, having the front of head marked with a carina or elevated ridge of variable form, which is best seen by holding the insect with the front uppermost. In part of the species the ridge is a smooth line starting below the eyes and running a little past them, dividing at about the middle into two $\mathrm{V}$ or $\mathrm{Y}$ shaped lines diverging toward the sides of the head. In the remainder of the species the diverging lines are absent, the division being only represented by an impressed space. Six species may occur in Indiana, though but three of them have as yet been taken.

\section{KEY TO INDIANA SPECIES OF XYLOTRECHUS.}

a. Frontal carina reduced to an elongate space.

b. Carina scarcely divided; black, shining, with narrow yellow margins.

bb. Carina divided or impressed longitudinally.

NITIDUS.

c. Thorax with four spots of rellowish pubescence; elytral markings white, indistinct.

1916. QUADRIMACULATUS.

cc. Thorax marked with lines; elytral pubescence yellow, the lines connected at suture.

CONVERGENS.

aa. Frontal carina V-or Y-shaped.

d. Elytra obliquely truncate at apex, the outer angle with a spine; sides of thorax regularly curved.

SAGITTATUS.

$d d$. Elytra obliquely truncate but without distinct spine at outer angle.

$e$. Thorax without apical and basal margin of paler pubescence; elytral bands about as broad as their intervals. 1917. colonus.

ee. Thorax with apical and basal margin of yellow or white pubescence; median elytral band angulate or undulatory.

191S. UNDULATUS.

$X$. nitidus Horn, length $12 \mathrm{~mm}$, is known from New Jersey, Pennsylvania, Ohio and Texas; $X$. convergens Lec., length 8-11 mm., is recorded from Ohio and Iowa; X. sagittatus Germ., brownish with more or less white pubescence, length 15-18 mm., ranges from Massachusetts to Arizona.

1916 (6181). Xrlotrechus quadrimaculatus Hald., Trans. Amer. Phil. Soc., X, 1847, 41.

Elongate, moderately robust, subcylindrical. Dull black; thorax with a spot of yellowish pubescence in each angle; elytra with the sutural line and three oblique processes therefrom dull yellow and sparsely clothed with whitish hairs; hind margins of meso- and metasterna and three or four segments of abdomen also with transverse bands of whitish pubescence. Thorax cylindrical, largest at middle; surface with minute, irregular transverse wrinkles. Elytra finely rugosely punctate on the sides. Length 12 $13 \mathrm{~mm}$.

Monroe County; rare. June 9. Taken from trunk of beech; said to occur usually on the black alder. 


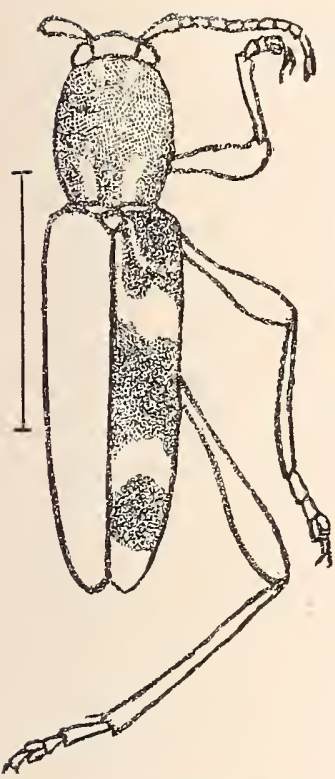

Fig. 442. (After Gissler in Fifth Rep. U. S. Ent. Comm.)
1917. (6179). Xraotriches colones liab., Sist. Eint. 1798, 91.

Elongate, slender, subcylindrical. Black or brown, pubescent above and beneath witl yellowish or whitish hairs; these arranged to form very variable markings. Those on thorax are usually four or six small spots. two on base, two near apex and often two near niddle; those on elytra consisting of a semicircular, subhumeral line enclosing a brown humeral spot, two broad, pale crossbars and a smaller spot at apex. Thorax cylindrical, longer than wide, roughly and coarsely punctate. Length $8-16 \mathrm{~mm}$. (Fig. 442.)

'Throughout the State; common. .June 3-October 15. Beaten from vegetation. Breeds in oak, maple and beech.

1918 (6183). Xrlotrechus undulatus Say, Lollg's Exped., 1I, 1824, 291; ibid. I, 119.

Elongate, rather slender, subcylindrical. Black or dark brown; elytra marked with yellow pubescence as follows: a narrow stripe extending from scutellum along the suture to middle, thence curving and angulate to outer margin, a short crossbar near humerus, a subapical band and an apical curved line; these markings often broken into dots. Length 11-21 mm.

One specimen in Webster collection labelled "Ind." Its range is given as the entire United States. Var. fuscus Kirby has the sides of thorax covered with pubescent blotches and the elytral bands wavy. In var. interrupius Lap. the bands of elytra are greatly obscured by a sprinkling of white hairs.

\section{Neochytus 'Thom. 1860. (Gr., "new + noisy.")}

Slender bodied, subcylindrical species of medium size having the thorax, with short transverse riciges or with a broad, longitudinal ridge, composed of many minute cross-ridges; antennæ short, usually less thar half the length of body. Four species have been taken in the State, while two others perhaps oceur.

\section{KEY TO INDIANA SPECIES OF NEOCLITUS.}

a. Middle and hind femora spinose at apex.

b. Thorax with a longitudinal elevated ridge. minutely rugose on its crest; antennæ filiform.

c. Thorax with apical basal and middle pubescent yellow bands; scutellum elongate-triangular, the apex rounded.

1919. SCUTELLARIS. cc. Thorax with apical and basal bands only; scutellum transverseoval.

1920. LUSCTS. 
67. Thorax with a few distinct transterse ridges arranged in median row: antennie thickened towards apex: head and thorax reddislbrown.

1921. ERYTHROCEPHALUS.

aa. Niddle and hind femora not spinose: antenne filiform; thorax with a number of distinctly elerated but more or less confused transterse ridges.

d. Elrtra rounded at tip: each with an oral or rounded pubescent figure at base and two oblique bands behind the middle. 1922. CAPr.玉A.

dd. Elytra truncate at tip : bands of elstra angulate or curred.

e. Thorax wider than long.

MLRICATLLES.

ee. Thorax longer than wide.

LONGIPES.

1919 (6195). Neoclitus scutellaris Oliv.. Enctci. Meth.. T. 1790. 266.

Elongate. subcylindrical. Blackisin. densely clothed with fine gracishpurple pubescence and marked with narrow sellow bands as follows: two rertical ones on front of head; three transrerse ones on thorax. one on front and hind margin, the third on center extending only to middle of sides; elytra with the base reddish-brown. the scutellum and three narrow bands yellow, one curving backward from scutellum. then forward to margin: one curving forward from middle of suture. then backward to margin. the third oblique on apical fourth. Elstra tapering from base to aper. their tips obliquely truncate with a distinct spine at outer angle. Length $\mathrm{S}-$ $15 \mathrm{~mm}$.

Narion Comnty; rare. June - Ranges from New Tork to Kansas and southward.

1920 (6196). Neoclitus Lescts Fab. Ent. Srst. Suppl.. 179s. 152.

Resembles the preceding closely. Thorax less narrowed in front and with the median yellow band lacking. the sides often marked with a reddish spot, which, hotrerer, is not one of pubescence, but is a color of the chitin itself. Antennæ with joints 6 and $i$ fuscous. Length $s-17 \mathrm{~mm}$.

Marion County : rare. September 20. Taken from an elm log in which probably the larra breed. The range is the same as that of scutellanis.

1921 (6201). Neoctitts ERrthrocephalus Fab.. Ent. Srst., I, 179s, 335.

Elongate, slender, cylindrical. Reddish-brown; elstra blackish behind the first band and with four nearly straight. narrow crossbars of bright rellow pubescence. the one at base less distinct. Thorax crlindrical. coarsely granulate-punctate. the central ridge with four to six short transrerse ridges. Elytra obliquely truncate with a spine or blunt tooth at outer angle. Length $\mathrm{S}-1 \mathrm{~s} \mathrm{~mm}$.

Throughout the State: frequent. May 10-August 13. Beaten from foliage-especially that of hickory. The larva bore in the wood of elm. soft maple, black locust and hickory. The spines of hind femora are often ver small. 
(619S). Neoclytes Capli.ea Say, Journ. Phil. Acad. Nilt. Sci.. III. 1824, 424; ibid. I, 120. 1)1. 53.

Elongate, subcylindrical. Black, thorax and under surface pulvescent with long whitish hairs; thorax with front margin narrowly yellow or whitish: elytra each with whitish or sellow lines as follows: one curring from scutellum backward. then forward along the margin to humerus. thus forming nearly a circle; a second inverted W-shaped one just behind tle midile and a third oblique one on apical fourth: tips usually narrowly edged with white or yellow. I.ength 12-20 $\mathrm{mm}$.

Southern two-thirds of State, Irequent: probably throughout. April 23-October 11. The larve breed in ash, elm and hickorv, and the adults occur on the trunks of these trees or on flowers. Say in his original description says that the "tips of elytra are emarginate with a prominent spine at the external angle." which is not true of any specimen I have seen, nor is this character shown in his figure. In all Indiana specimens at hand the pubescent lines of thoras and elotra are white, not yellow.

N. muicatulus Kirby. black or brown with white markings. length $7-10 \mathrm{~mm}$. ranges from New England to Louisiana and California. T. longipes Kirby, more slender, black with white markings, more distinct on base of elytra. length 9-11 mm., is known from Virginia, Texas and Canada.

\section{XXXIF. CLFThinhes Thom. 186t. (Gr., "noisy.")}

In this genus both the frontal carina of head and the transverse ridges of thorax are lacking: the side pieces of metathorax are narrow and the color black banded with white or yellow. Two species are known from the eastern United States and Indiana.

1923 (6207). Clytaxthes rericola Olir. Ent. IY. 1805. 70.

Elongate, rather robust. subcrlindrical. Black; thorax with a rellow marginal line, interrupted at middle of base: scutellum and markings of elytra bright rellow: the latter consisting of an oval oblique spot on basal third, a strongly angulated band extending from suture backrard to middle. thence forward and outward to near the margin. and an oblique bar behind the middle: antenne and legs reddish-brown. the clubs of femori blackish. Thorax subslobose, finely granulate. Elrtra rounded at tips. n t spinose. Length $\mathrm{S}-14 \mathrm{~mm}$.

Throughout the State: scarce. May 10-July 1. Beaten from elm.

1924 (620S). Clytaxthes albofasctates Lap.. Mon.. 1S37. 96.

Elongate, slender. subcrlindrical. Blackish-brown; elytra each with a narrow oblique line on basal half. a long. curred. narrow band behind the middle and the apex. whitish pubescent: antenne and legs dark reddishbrown. Length $8-10 \mathrm{~mm}$.

[66-23402] 
Posey County; rare. July 6. Known from Pennsylvania, Illinois and Ohio. Occurs about wild grapevines, in the wood of which the larvæ live.

Clytus marginicollis Lap., elytra black, pale at base and with yellow crosshands, length $8-10 \mathrm{~mm}$., is known from Massachusetts, Georgia, Pennsylvania and Nevada.

Microclytus gazellula Hald., thorax above and elytra black, the latter with pale markings, legs and antennæe pale, length 6-7 mm., is recorded from the "Middle States to Canada and Lake Superior.',

XXXIV. Crrtophorus Lec. 1850. (Gr., "curve+bearing.")

The two species of this genus have the elytra swollen or elevated on basal fourth and the third joint of antennæ with a distinct spine at apex. One of the two occurs in the State.

1925 (6210). Cirtophorus verrucosus Oliv.. Encycl. Meth., VII, 1792, 458.

Elongate, slender, subcylindrical. Black; femora and basal three-fifths of elytra reddish-brown, the latter marked with three narrow oblique lines of whitish pubescence and separated from the black portion by a transverse line of similar pubescence; antennæe. tibia and tarsi dusky. Thorax compressed, with a rather prominent median crest. Length $6-10 \mathrm{~mm}$.

Throughout the State; scarce. April 26-June 11. Taken from beneath bark of walnut and on flowers of wild plum; apple and wild cherry, the larvæ living in the wood of these trees.

Tillomorpha geminata Hald., head and thorax black, elytra reddish, marked with lines of silver-white pubescence, length 6-8 mm., is known to occur from Massachusetts and New York to Pennsylvania and Georgia.

XXXV. Euderces Liec. 1850. (Gr., "beautiful + to look at.')

The members of this genus resemble black or brown ants and are readily known by the ivory-white bar on each elytron. Three of the four known species have been taken in the State.

KEY TO INDIANA SPECIES OF EUDERCES.

a. Irory bar of elytra oblique; thorax striate with raised longitudinal lines.

b. Eyes nearly divided, the two parts connected with a narrow horn-

like line; thorax uniformly rounded at the sides. 1926. PICIPES.

bb. Eyes completely divided: thorax distinctly depressed each side near the front margin and subangulate at sides.

1927. PINI.

a a. Irory bar of elytra exactly transierse; thorax punctate, not striate.

1928. REICHEI. 
1926 (6212). Euderces picipes Fab., Mant. Ins., I, 1781, 157.

Elongate, slender, cylindrical. Black, rarely dark reddish-brown, shining; sparsely pubescent with grayish hairs. Elytra each with an oblique raised ivory-like bar at middle; antennæe and legs usually dark reddishbrown. Length $5-8 \mathrm{~mm}$.

Throughout the State; frequent. May 27-July 5. Beaten from foliage of buckeye, honey-locust, hazel, oak, etc.

1927 (6213). Euderces prini Oliv., Ent., IV, 1795, 70.

Form of picipes. Reddish-brown, shining; elytra with apical third black, each with a slightly oblique irory-white line at middle and also an oblique line of whitish pubescence on the black portion. Length $6.5-9 \mathrm{~mm}$.

Posey and Dubois counties; scarce. April 29-May 11. Beaten from foliage of wild grape.

1928 (6215). Euderces reichei Lec., New Sp. N. Am. Col., II, 1873, 202.

Form of picipes but smaller and more slender. Dark reddish-brown or piceous, very sparsely clothed with long, erect hairs; antennæ and legs paler; elytra each with a narrow, transverse. ivory white band near middle. Thorax cylindrical, longer than wide, smooth near the front margin, thence granulate-punctate to base. Elytra with granulate punctures from base to beyond ivory bar, the apical third smooth, polished; the sub-basal tubercles less prominent than in the other species. Length $4-5 \mathrm{~mm}$.

Posey County; rare. June 2. Beaten from blossoms of the false indigo, Amorpha fruticosa I. Known heretofore only from Illinois and 'Texas.

\section{Division III. ATIMIOIDES.}

This group is represented by the single genus Atimia, distinguished by the characters given in key and by having the head broad and short, the front perpendicular; eyes large, almost divided, not very finely granulated; palpi unequal, truncate at tip, the maxillary about one-half longer than labial; antennæ slender, shorter than body, 11-jointed; scutellum subquadrate, rounded behind; legs short, thighs moderately clubbed, hind tarsi with first joint equal to second and third united.

\section{Aтimia Hald. 1847. (Gr.," “contempt.")}

This genus, as above characterized, is represented by two species, one of which occurs in the eastern United States, including Indiana. 
1929 (6218). Atmita coxflsa Sag, Journ. Phil. Acad. Nat. Sci., V, 1826, 276 ; ibid. II, 333 .

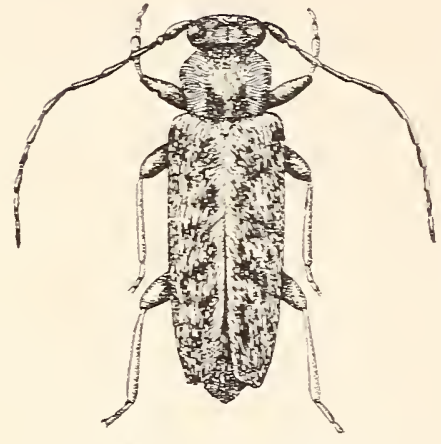

Fig. 443. $\times 4$. (Original.)

Short. rather stout. subdepressed. Dull black. clothed with rather long rellowish pubescence, which is irregularls disposed so as to leare abraded smooth spots. Thorax quadrate. broader than long. sides feebls rounded. surface coarsels and rather sparsely punctured. Elrtra broader than thorax. truncate at tips, surface with sparse, fine punctures intermingled with larger distant ones. Length i-9 mm. (Fig. 143.)

Crawford County: rare. May 16. Occurs on the red cedar. Juniperus rirginiana $\mathrm{L}$.

\section{Dirision IT. LEPTTROIDES.}

This division comprises those members of the subfamily Cermabycinæ, in which the base of antennæ are not enreloped br the eres, which are usually rounded, sometimes entire, but more often with a small notch or emargination, and almost alwars finely granulated; front cosæ conical. except in the first tribe: head narrotred behind the exes and the thorax narrowed in front, the union of these tro parts giving the appearance of a neck of greater or less length. The name of the trpical genus. Leptura. is derived from a Greek word meaning "slender or attenuated," in allusion to the usually tapering form of the elrtra, which also often have their base more or less elerated abore the level of the thorax. As a general rule the species are more active than those of the preceding groups and many of them fiy by day and occuir upon flower's rather than upon the trunks and about the roots of trees, where the members of the preceding genera are usually found.

The division is separated into fire tribes. all probably represented in Indiana. though four of them each only by a single genus and species.

KET TO TRIBES OF LEPTLROIDES.

a. Front coxie slobose: mandibles chisel-shaped. not fringed on the inner margin: thorax spined on the sides and elstra at apex.

Tribe I. Disteximi. p. 1048.

aa. Front coxiè conicai.

b. Joints 3 to 5 of antenne much thickened at tips: mandibles simple. not fringed: elrtra bluish-black. the basal third orange-rellor.

Tribe II. Desuocenisi. p. 1043. 
bb. Joints 3 to 5 of antenne normal, usually slender;'mandibles acute, fringed on the inner margin; elytra not colored as above.

c. Elytra short, not corering the wings.

Tribe IJI. Necrodenis. D. 1044.

cc. Elytra of normal length.

d. Front nearly vertical; body elongate, slender, parallel; color dark blue.

Tribe IV. Excrelopixi, p. 1045.

dd. Front oblique or horizontal; elytra usually tapering to apex.

Tribe V. Lepturixi, p. 104.

\section{Tribe I. DISTENIINI.}

In addition to characters given in key, the single genus of this tribe may be known by having the body elongate; lead large, horizontal; eyes transverse, large, feebly emarginate; antennæ long, tapering, first joint as long as head, second very small, third and following equal, nearly as long as first; legs long, slender, hind pair longest; first joint of hind tarsi as long as the two following united.

XXXVII. Distenid Serv. 1825. (Gr., "two+band.")

This genus, sufficiently characterized above, is represented by the single species:

1930 (6220). Distenia undata Oliv.. Ent., IV, 1795, 25.

Very elongate. slender, subdepressed. Dark brown to piceous. densely clothed with short, gray, prostrate pubescence; elytra marked with three serrate crossbands of darker pubescence, one on base, one just in front of middle, the other on apical third. Thorax subcylindrical, base and apex truncate, sides with a prominent. acute tubercle; surface with a short median line and four obtuse elerations, smooth, shining. Elytra gradually tapering from base to apex, each with five somewhat irregular rows of coarse punctures; intervals with distant scattered punctures; tips each with two sharp, slender spines. Length 17-26 $\mathrm{mm}$.

Lake, Vigo, Jackson and Crawford counties ; scarce. June 25September 28. Occurs beneath bark of hickory and oak and on foliage of wild grape. When disturbed feigns death and falls to the ground, where it is difficult to see on account of the protective coloration.

Tribe II. DESMOCERINI.

This tribe is represented in the United States by four species belonging to the genus Desmoccms. They are large insects having the eyes finely granulated, nearly rounded, suddenly and deeply emarginate; antenni 11-jointed, with joints 3 to 5 thickened at the 
end, the outer ones velvety black; vertex prominent, deeply sulcate; front horizontal; prosternum very narrow between the front coxæ, which are large and conical, the cavities open behind; legs slender, tarsi broad, the first joint of hind ones scarcely equal to the two following united.

\section{Desmocerus Serv. 1835. (Gr., "band + horn.")}

One of the four species occurs in the eastern United States, the other three on the P'acific slope.

1931 (6221). Desmocerus palimatus Forst., Nov. Spec. Insect., 1771, 40.

Elongate, robust. Dark blue; basal third of elytra orange-yellow. Thorax bell-shaped, widening gradually from apex to base, hind angles acute, disk with transverse wrinkles. Elytra parallel, tips obliquely rounded; surface densely and rather coarsely punctured, each with three fine raised lines. Length 17-23 $\mathrm{mm}$.

Posey County; scarce. July 6. Occurs on the flowers and foliage of elder, Sambucus canadensis L., in the stems of which the larvæ bore.

\section{Tribe III. NECYDALINI.}

Readily known by the short elytra, which are scarcely longer than the thorax, separated near apex and rounded at tip. The eyes are finely granulated, Iarge, oblique and deeply emarginate; antennæ filiform, second joint small, third and following equal in our species ; scutellum elongate, triangular ; front coxæ conical, prominent, the cavities closed behind; legs slender, hind pair much longer, first joint of hind tarsi much longer than all the others together. One of the two genera is represented in the State.

\section{Necydalis Linn. 1758. (Gr., "chrysalis of the silk worn." $)$}

In this genus the third and fourth antennal joints are together longer than the fifth and the last joint of palpi is bell-shaped.

1932 (6225). Necydalis mellitus Say, Bost. Journ. Nat. Hist., I, 1835, 194 ; ibid. II, 664.

Elongate; slender. Black; abdomen, front and middle legs and basal joint of antennæ dull yellow; elytra reddish-brown, often with paler spot at tip, sometimes dull reddisll-yellow with darker apex; hind legs dusky. Head sulcate between the antennæ, coarsely and densely punctate. Thorax subcylindrical, constricted in front of middle and with a blunt tubercle each 
side; its surface finely and sparsely punctate. Elytrat reaching only to base of abdomen, obliquely impressed on inner side, finely and densely punctate with larger scattered punctures intermingled. Length 13-21 mm.

Putnam County ; rare. June 25. Described from Posey County. The upper surface of the abdomen is sometimes black.

Tribe IV. ENCYCLOPLI.

In this tribe the head is quadrate, suddenly but not strongly narrowed and constricted far behind the eres so that the neck is very short; eyes finely granulated, obliquely emarginate; antennæ 11-jointed. the first five joints punctured; thorax constricted before and behind, wider at base, tuberculate on sides, scutellum small, triangular; elytra elongate, parallel rounded at tips; legs slender, hind pair longer, first joint of hind tarsi much longer than the others combined and, in Encyclops, the only one of the three genera occurring in the eastern United States, cylindrical. One species, Encyclops coruleus Say, green or blue, shining. coarsely punctured, length 7-8 mm. should be looked for in southern Indiana, having been taken by Dury at Cincinnati.

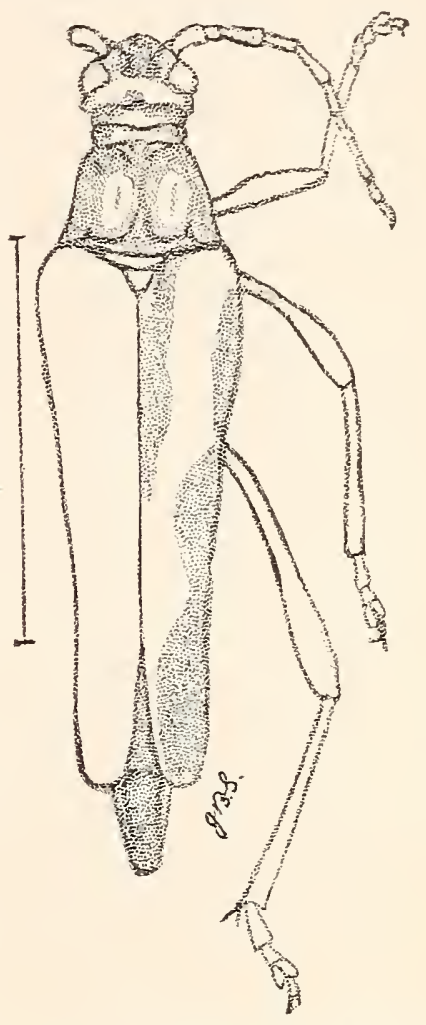

Fig. 444. Bellamira scalaris Say. (After Smith in Fifth Rep. U. S. Ent Comm.)

\section{Tribe $\mathrm{T}$. LEPTURINI.}

This tribe contains numerous species, all possessing the characters of Division IV, as given above, and also having the palpi unequal, the maxillary elongated, the last joint cylindrical or triangular; neck long; thorax usually wider at base; elytra usually narrowed from base, sometimes acute and separated near apex, but more often rounded and separated (Fig. 444); legs slender and never rery short. The species occur, for the most part, on flowers, are usually prettily colored and clothed with fine pubescence. The tribe is divided into 11: genera, eight of which are known to be represented in Indiana, while members of three others may occur.

KEY TO INDLANA GENERA OF LEPTURINT.

a. Spurs of hind tibire not terminal, but borne at the base of a deep excaration; thorax tuberculate at the sides.

XL. Tохотеs. aa. Spurs of hind tibire terminal. 
b. First joint of Lind tarsi with the usual brush of hair beneath; thorax, with rare exceptions, distinctly tuberculate or spined at sides; head obliquely narrowed behind the eyes.

c. Antennie short, joints 5-11 wider; thorax with heary spine at sides; elytra strongly costate.

Xli. Ritagiudr.

cc. Antennie long or moderate, the joints not thickened; elytra nerer strongly costate.

1. Eyes large or moderate: thorax with a short, acute tubercle on side.

e. Eyes coarsely granulated, rery prominent; elytra almost parallel.

XliI. Centrodera.

ee. Exes finely granulated; body narrowed behind.

$f$. Eyes feebly emarginate.

PACHYTA.

$f f$. Eyes more strongly emarginate.

ANThophilax.

dd. Eyes small, not emarginate; thorax angulated or rounded on sides.

g. Body above more or less pubescent. opaque or moderately shining; mesosternum not protuberant.

XLIII. ACMEOPS.

gg. Body above brilliant metallic green; mesosternum protuberant.

Xliv. Gaurotes.

bb. First joint of hind talsi without brush-like sole; thorax with few exceptions broadest at base. its sides never spined or tuberculate: head constricted close behind the eyes.

h. Last ventral of male deeply excarated ; form very slender, strongly tapering behind.

i. Elytra strongly sinuate on the sides; size larger, 20 or more $\mathrm{mm}$. : antennie without poriferous spaces.

Bellamira.

ii. Elytra less sinuate on the sides; smaller, not orer $18 \mathrm{~mm}$.; antenne with poriferous spaces on the outer joints.

XLV. Straxgalia.

hh. Last ventral of male not excarated; form less slender and less tapering behind.

j. Antemie with poriferous spaces.

XLVI. TrPocerés.

jj. Antenuie without poriferous spaces.

XLTII. Leptura.

XI. Toxotus Serv. 1835. (Gr.. "a bow + carrying.")

Species of medium or rather large size, having the spurs of the hind tibire inserted at the base of a deep excavation instead of at the extreme end; thorax constricted before and behind and tuberculate or spined at the sides; elytra strongly tapering from base to tips, which are obliquely truncate: sinuate at sides on basal third. Three species have been taken in the State and another probably occurs.

KEY TO IXDIANA SPECIES OF TOXOTUS.

a. Third joint of antennse rery decidedly longer than fourth.

b. Elytra of one color.

c. Flytra black; body either yellow or black; legs bicolored.

1933. SCHAUMIT. 
cc. Elytra reddish-brown, sometines varying to blackish; legs of one color.

19:34. CINNAMOPTERLS.

6b. Elytra bicolored, black, with marginal and discal stripes yellow.

TRIVTTTATLS.

aa. Third joint of antenne rery little longer than fonrth; elytra black or dark reddish-brown, tips obliqueiy emarginate and bidentate.

1935. CYLINDRICOLLIS.

1933 (6238). Toxotus schaumi Lec., Journ. Phil. Acad. Nat. Sci., I, 1850, 320.

Elongate, robust, tapering behind. Male black, finely pubescent; central part of femora yellow ; female, body yellow except the tibix, tarsi and antennæ, which are black. Antenne with third joint elongate, fourth shorter than fifth. Thorax narrowed in front, finely and sparsely punctured, sides with acute tubercle. Elytra with humeral angles prominent, surface finely rugose-punctate. Length $19-25 \mathrm{~mm}$.

Crawford County; rare. May 19.

1934 (6245). Toxotus cinnamoptekus Rand., Bost. Journ. Nat. Hist., II, $1838,45$.

Elongate, slender. Pale reddish or cinnamon brown, densely clothed with fine, silky pubescence: head and thorax darker. Eyes large, proninent, blackish. Antenure about as long as body, male; two-thirds the length. female. Thorax as in cylind!icollis, the basal transverse impressed line less strong. Length 10-13 $\mathrm{mm}$.

Southern two-thirds of State; scarce: May 12-June 7. Occurs on the foliage and flowers of various shrubs, especially wahoo and wild hydrangea. In two specimens the general color is dark reddish-brown.

1935 (6243). Toxotus cylindricollis Say, Journ. Phil. Acad. Nat. Sci.. III, 1823, 417 ; ibid. II, 196.

Form of schaumii. Varies from dull blackish, female, to reddish-brown, male, densely clothed with silky pubescence; pro- and metasterna and antennæ, at least in part, reddish-brown; legs and abdomen of male often partly of same hue. Thorax cylindrical, wider at base, with two transrerse impressed lines, one near base, the other in front of middle, these with a rather deep longitudinal groove between them; sides swollen but not tuberculate. Length 17-22 $\mathrm{mm}$.

Putnam and Crawford counties; scarce. June 27-July 10 . A pair were taken from hickory while mating on the former date, the male being wholly reddish-brown except the elytra, tibia and tarsi.

T. trivitatus Say, length 15-17 mm., a member of the Transition life-zone, is recorded from northern Tllinois. 


\section{Rhagicm Fab. 1775. (Gr., "to tear.")}

Antennæ short, scarcely reaching the hase of elytra; eyes rather small. oblong. slightly emarginate: prosternum prominent between the front coxæ. One species occurs throughout the northern United States.

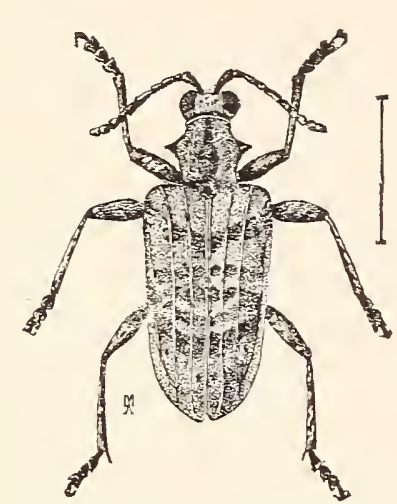

Fig. 445. (After Marx in Fifth Rep. U.S. Ent. Comm.)

1936 (6232). RHAgIUM LINeAtum Olir.. Ent., IV, $1795,69$.

Elongate, rather robust. Black, mottled with brown and grayish pubescence; elytra with reddish-brown spots. Thorax cylindrical, much narrower than elytra. armed each side with an acute tubercle. Firtra feebly narrowed from base to apex. each with three smooth, rather strongly elerated lines: intervals coarsely and sparsely punctate. Length 1:-1s mm. (Fig. 445.)

Laporte County; scarce. June 11. Occurs beneath the bark of pine and in lumber yards.

\section{Centrodera Lec. 1850. (Gr., "spine +neck.")}

Eyes large. globose and prominent; antenne slender, as long as body, male; one-third shorter, female; second joint rery small, fourth intermediate in size between the third and fifth; body elongate, sides nearly parallel. One species has been taken in the State, and two others may occur.

\section{KEY TO INDIANA SPECIES OF CENTRODERA.}

a. Tubercles on sides of thorax acute.

b. Elytra uniform reddish-brown, truncate at tips. 1937. DEcolorata.

bb. Elytra ciay-yellow with irregular brown stripes and blotches, the tips rounded and slightly separated.

PICTA.

aa. Tubercles of thorax obtuse: pubescence of elytra arranged in lines.

SUBLINEATA.

1937 (6233). Centrodera decolorata Harr.. Injur." Ins., 1841. 93.

Vely elongate, subcylindrical. somewhat flattened abore. Reddish-brown, sparsely pubescent. Thorax cylindrical, constricted and much narrowed before the tubercle, the disk with a wide but shallow median groore. Elytra at base about twice as wide as thorax, feebly narrowed to apex, coarsely and somewhat confluently punctured on basal half, more finely towards apex. Length $27 \mathrm{~mm}$. (Fig. 4t6.)

Kosciusko Countr: rare. June 1. Occurs on beech and maple.

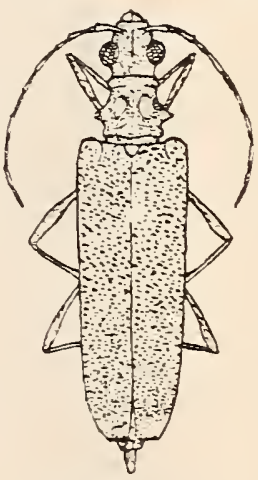

Fig. 446. $\times 1 \frac{1}{4}$. (After Wickham.) 
C. picte Hald, length $13 \mathrm{~mm}$, is known from New York, Pennsylvania and South Carolina. C. sublineatu Lec., dark piceous, length $14 \mathrm{~mm}$., has been recorder from Cincinnati.

Pachyta monticolia Rand., black, elytra dull yellow with tips and four black spots in a line near suture, length $9 \mathrm{~mm}$., and $P$. liturata Kirby, elytra entirely black, or dull yellow with black spots, length 15-18 mm., are both members of the Transition life-zone and may occur in the northern counties.

Anthophilax viridis Lec., elytra greenish-blue, legs black, and A. malachiticus Hald., eupreous-bronzed to blue, legs pale, length $13 \mathrm{~mm}$. , may also occur in the northern third of the State.

\section{AcM fops Lee. 1850. (Gr., "point + eye.")}

Species of small or medium-size, having the eyes small, not emarginate; antennæ about the length of body, the fourth joint slightly shorter than third; thorax variable in form, the disk either distinctly angulated or rounded, not tubereulate. Many of the species vary much in color, so that the synonymy is very much mixed. But two species have been taken in the State, though three others perhaps occur.

\section{KEY TO INDIANA SPECIES OF ACM FOPS.}

a. Front and mouth not greatly prolonged.

b. Form short, stout; hind tarsal joints stout, equally pubescent beneath; antennæe stout; sides of thorax concave behind the middle, the angle distinct.

1938. BIVITTATA.

bb. Form slender; hind tarsal joints slender, the last one only pubescent beneath; antennie slender.

c. Disk of thorax convex, not channeled, sparsely and finely punctured; elytra rounded at tips, dull yellow with suture, dorsal stripe and side margin black.

1939. DIRECTA.

cc. Disk of thorax flattened behind and prolonged each side into a tubercle; elytra truncate at tips.

d. Black; elytra opaque, base, side margins and sometimes the suture, bright red; tubercles of thorax conical and on the sides.

DISCOIDEA.

dd. Black; elytra shining, black striped with dull yellow or fuscous; tubercles of thorax obtusely rounded and on disk. PRoteus.

aa. Front and mouth greatly prolonged; black, elytra black, fuscous or dull yellow, sometimes with dorsal stripe and tips fuscous. 
1938 (6259). Aculaops bivititata Say, Journ. Phil. Acad. Nat. Sci., III, 1824, 416 ; ibid. II, 195.

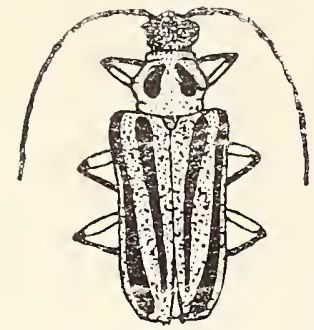

Fig. 447. $\times 3 \frac{1}{2}$. (After Wickham.)

Elongate-oblong, rather robust. Usually dull brownisli-yellow; thorax with two black spots and elytra each with a narrow dorsal and a broader black lateral stripe; varies from entirely black to almost wholly dull yellow. Antenne about as long as body. Thorax much broader at base than apex, with a transverse impressed line in front of middle and another near base; sides angulate, the angle forming an oblique tubercle; surface finely and sparsely punctate. Elytra much broader than thorax, closely and rather coarsely punctate, the tips rounded.

Length 6-9 mm. (Fig. 447.)

Wells, Lawrence and Crawford counties; scarce. May 11-June 26. Occurs on the flowers of Anemone pennsylvanica L. According to Leng the form nigripennis Lec. has black elytra with thorax more or less yellow; the form varians Lee. is entirely black, while fuscipes Lec. is entirely dull yellow except the dusky head.

1939 (6271). ACג Aor's directa Newm., Entomologist, 1842, 71.

Elongate, slender, parallel. Head, thorax, legs and under surface yellow; elytra as described in key; antemnal joints yellow at base, dusky at tips. 'Thorax subcylindrical, convex, broader at base, narrowed in front, sides rounded, not tubercilate. Elytra coarsely and deeply punctured. Length $6-8 \mathrm{~mm}$.

Marion, Lawrence, Crawford and Posey counties; scarce. June 4-June 27. Beaten from shingle oak, Quercus imbricaria Michx.

A. discoidea Hald., length 6.5-8 mm.; A. proteus Kirby, length 6-9 mm., and $A$. pratensis Laich, length 6-8.5 mm., are all recorded from Michigan and may occur in northern Indiana.

\section{Gaurotres Lee. 1850. (Gr., "superb.")}

This genus is readily known by the shining green elytra. Three species are recognized, one of which has been taken in the State.

1940 (6276). Gaurotes Cyanipennis Say, Journ. Phil. Acad. Nat. Sci., 1II, 1824, 423 ; ibid. II, 200.

Elongate-oblong, rather robust. Head, thorax and under surface black; elytra bluishgreen, shining; antenne and legs pale brownishyellow. Antenna a little shorter than body. Thorax bell-shaped, narrowed and constricted on apical half; surface smooth, shining. Elytra twice or more broader than thorax, rather sparsely and finely punctured, humeri prominent, tips subtruncate. Length 9-10 mm. (Fig. 448.)

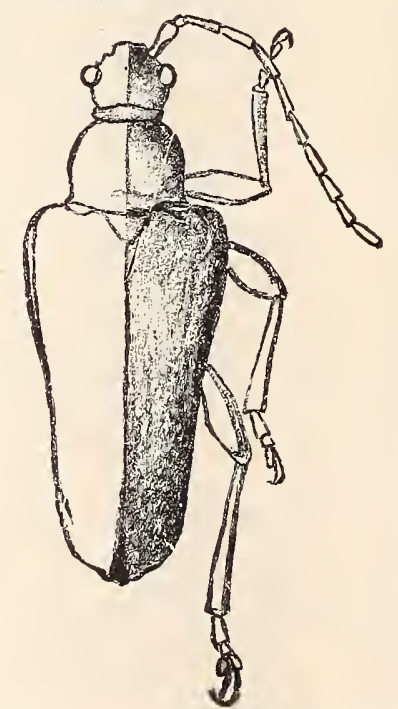

Fig. 448. (After Smith in Fifth Rep. U. S. Ent. Comm.) 
Vigo, Lawrence and Craw ford conntics; frequent. May 19-.July 22. Oecurs on flowers of sumac and wild hydrangea.

Bellamira scalaris Say, chestnut-brown to black in hue, elytra marked with paler, is shown in Fig. 444, 20-27 mm. in length, ranges throughout the Eastern I'nited States and has been recorded from Michigan and Ohio.

XLV. Strangalia Serv. 1835. (Gr., "a rope or halter.")

The very slender form, with elytra tapering greatly from base to tips will serve to separate the members of this genus. In our species the last ventral segment of the male is strongly excavated and the sixth and following antennal joints have small oval, depressed poriferous spaces near the tips. Thorax bell-shaped, much narrowed in front, hind angles prominent, acute, base bisinuate. Four species have been taken in the State. They oceur especially on the flowers of wild rose, wild hydrangea and other summer blooming plants.

KEY TO INDIANA SPECIES OF STRANGALIA.

a. Head and thorax wholly black; elytra dull yellow, with margin and suture blackish.

1941. ACUMINATA.

aa. Head and thorax not wholly black.

b. Elytra not wholly black.

c. Elytra dull brownish-yellow, with black spots on sides; antennæ black.

1942. FAMELICA.

cc. Elytra reddish-yellow, with three black crossbars; antennæe reddish-yellow.

1943. LUTEICORNIS.

ъъ. Elytra wholly black.

1944. BICOLOR.

1941 (6282). Strangalia acuminata Oliv., Ent., IV. 1795, 73.

Elongate, very slender. Uniform black except the elytra, which are dull yellow with black suture and side margins; under surface rather densely, upper more sparsely, clothed with yellowish prostrate pubescence. Thorax finely and rather densely punctate, the median lobe of base smaller than in famelica. Elytra sparsely and rather coarsely punctured, tips less acuminate and more distinctls truncate than the next. Length $\mathrm{S}-10 \mathrm{~mm}$.

Crawford County; scarce. June 26-June 28. MItuch smaller and more slender than famelica.

1942 (6281). Strangalia Famelica Newm., Entom., 1841, 68.

Elongate, slender. Above dull brownish-yellow, clothed with brighter yellow pubescence; antennæ. two broad stripes on thorax and usually some spots on sides and a band near apex of elstra, black; under surface usually dark; abdomen, sometimes. and legs partly dull rellow. Thorax with surface, as well as that of elytra, rather sparsely and coarsely punctate. Hind tarsi with third joint strongly emarginate. Lèngth 12-14 $\mathrm{mm}$.

Throughout the State, frequent; more so in the southern counties. May 30-July 27. 
1943 (6284). Strangalia Luteicornis Fab., Syst. Ent., 1775, 197.

Elongate, slender. Reddish-yellow; thorax with two stripes and elytra with three crossbars black; hind femora black at tips. Thorax densely and rather finely punctate. Elytra more sparsely punctate, their tips acute. Length 9 13 mm. (Fig. 449.)

Throughout the State, frequent; more so in the southern counties. May 31-July 27.

1944 (62S5). Strangatia Bicolor Swed., Vet. Ac. Nya. Handl., VIII, 17ST, 197.

Elongate, very slender. Reddish-yellow; elytra black; tibiæ and tarsi dusky. Thorax finely

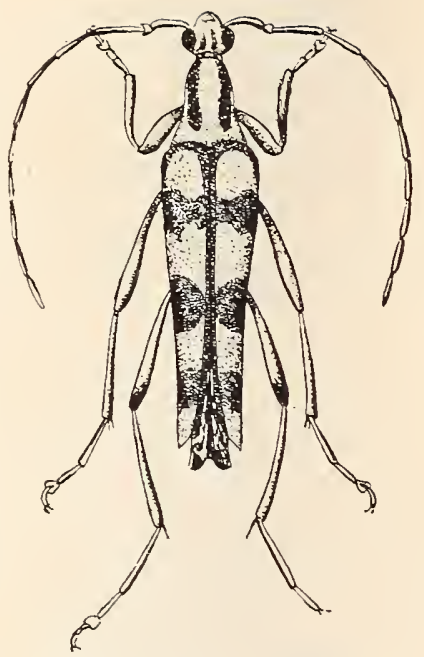

Fig. 449. $\times 3 \frac{1}{2}$. (Original.) and rather densely punctured; hind angles very acute, strongly diverging. Elytra more sparsely punctate, their acute tips widely separated. Length $12-14 \mathrm{~mm}$.

Starke, Putnam, Lawrence and Crawford counties; frequent. June 9-June 28.

\section{Typocerus Lee. 1850. (Gr., "impression + horn.")}

The members of this genus are more robust than those of Strangalia, but have the same tapering form. From the species of Leptura they are distinguished by the large impressed poriferous spaces on the antennæ. These are near the bases of the sixth or seventh and following joints and appear as elliptical or elongate smooth spots. Three species have been taken in the State, while another perhaps occurs.

\section{KEY TO INDIANA SPECIES OF TYPOCERUS.}

a. Antennæe black, the sixth and following joints with impressed spaces; thorax bell-shaped, not strongly rounded on the sides.

b. Elytra never entirely black, usually banded with yellow.

c. Legs black; elytra black with basal spot and three transverse bands yellow, the two front bands sometimes united at suture.

SPARSUS.

cc. Legs reddish-brown; elytra redidish-brown, with four yellow bands, these frequently imperfect or obsolete.

6b. Elytra, legs and antennae entirely black.

1945. VELUTINUS. 1946. LUGUBRIS. aa. Antennre brown, joints 3-5 longer, sixth without impressions in either sex; thorax strongly punctured, much rounded on the sides before the middIe; elytra with four yellow bands more or less confluent.

1947. SINUATUS.

T. sparsus Lec., length $9-10 \mathrm{~mm}$., is known from Wisconsin, Michigan and Ohio. 
1945 (6292). Trpocencs velutixus Oliv.. Ent. IY. 1795. 73.

Elongate, robust, strongly tapering behind the middle. Head, thorax and antennie black: under surface usually black, the rentral segments reddish-brown, often blackish at base. Elrtra rather finely and evenly punctured, each puncture bearing a prostrate yellow hair ; tips subobliquely truncate, each with two short spines. Length 10-14 mm.

Throughout the State; frequent. June 2--July 21. Occurs on flowers, especially those of wild hydrangea and Jersey Tea. By the elimination of the rellow crossbars the elvtra are sometimes almost or wholly reddish-brown.

1946 (6293). 'T'Ypoceres Lt'gubris Say, Journ. Phil. Acad. Nat. Sci., III, 1S24. 419 ; ibid. II. $19 S$.

Elongate. rather slender. tapering behind. Uniform deep black; elytria rery rarely with a reddish spot near humerus. Upper surface with prostrate black hairs: under surface with yellowish ones. Tips of elstra subemarginate, the outer angle acute. Length 9-11 $\mathrm{mm}$.

Crawford and Posey counties: scarce. June 25-July 7. Occurs with the preceding.

1947 (6296). Trpocert's sintates Nerrm.. Entomologist, 1841, 70.

Elongate, rather slender. tapering behind. Black with rather dense yellowish pubescence; elytra with yellow bands, the three basal ones frequently connected near suture. tips black. Thorax conrex, suddenls narrowed in front, sides strongly rounded. Tips of elytra subtruncate. not spined. Length 10-13 $\mathrm{mm}$.

Two specimens in Dury collection from northern Indiana. Should oceur throughout the State. The bands of the elytra are sometimes reduced to spots near the margins.

\section{LEPTURA Linn. 1758. (Gr., "slender.")}

A genus of large size containing about 70 known North American species. It is separated from Typocerus only by the absence of poriferous impressed spaces on the antennæ. Sixteen species have been taken in the State, while six others perhaps occur. For convenience, the species, whose range is such as to include Indiana. are arranged in three groups.

\section{KEI TO GROLPS OF INDIANA LEPTURA.}

a. Thorax more or less triangular, or bell-shaped. widest at base.

$b$. Hind angles of thorax prolonged.

$b b$. Hind angles not prolonged.

Group $A$. Group $B$. aa. Thorax nearly quadrate, more or less rounded or sub-bell-shaped. nsually constricted in front and behind. hind angles not prolonged.

Group $C$. 


\section{Grotp A.}

Nine species of this group have been taken. While the range of two others is such that ther may be looked for in the State.

KEI TO SPECIES OF GROUP A.

a. Size very large, 28-30 mm.; black with relrety jellow pubescence; elytra red, apex black.

1948. exiRgiNata.

a a. Size moderate or snall, not orer $15 \mathrm{~mm}$.

b. Thorax with transrerse basal impression present, often deep; elytra usually narrowed behind, often rer'y much so and frequently spotted. striped or banded.

c. Thorax with sides not much rounded in front of middle.

d. Elytra black or dull brownish-yellow with black tips; abdomen with the third. fourth and base of fifth segments red.

PLEBEJA.

dd. Elytra with black and red or sellow markings.

c. Outer joints of antennæ annulate at base with dull rellow.

$f$. Female reddish-rellow raried with black beneath: male black. elytra with rellow stripes; form more robust.

1949. SLBHAMATA.

ff. Blackish: legs and elytra yellowish, the latter with suture. discal stripe and side margins black; form much more slender.

1950. LINEOLA.

ce. Antennie not anuulate; black: sides of elytra. metathorax and abdomen red; elytra not narrowed behind. much separated at tips.

19.51. CRUENTATA.

cc. Thorax convex. with sides much rounded in front of middle and a transterse depression at hase: black with dense golden pubescence forming four elytral bands.

1952. NITEXS.

67. Thorax without distinct transrerse basal impressions; size small; elrtra subparallel at sides, not spotted or banded but uniformly dark.

g. Elyctra margined and usually rounded at tips.

h. Black: elstra blue, polished. coarsels and sparsels punctured; antenne and legs either black or sellow. 1953. chalsBæa.

h九. Black or piceous: head and thorax often reddish.

$i$. Elstra shiming, rather coarsels punctured.

j. Thorax without impressions; hind angles not prominent; tips of elstra subtruncate.

1954. CAPITATA.

ji. Thorax impressed near the hind angles, which are rery prominent: tips of elstra rounded. 1955. AMERicAxA.

ii. Elrtra more finelr punctured, pubescence fine white; thorax either dull red or rellow:

EXIGUA.

gg. Elstra not or scarcely margined at tips; dull black, with fine white pubescence; head, legs and first antenmal joint sometimes reddish or partly so.

1956. SUBARGENTATA. 
1948 (6297). Leptura exarginata Fab., Ent. Syrst. Il. 1775. :341.

Elongate, robust. Color giren in ker. Antenne feebly serrate. Thorax strongly narrowed from the base. which is broadly but deeply bisinuate: surface sparsels punctured. Elytra widest at base. gradually narrowed behind, truncate and emarginate at tijis. Length 27-30 $\mathrm{mm}$.

One specimen in Dury collection from northern Indiana. Taken by him also near Cincinnati. Of it he sars: "This fine large species emerges from dead beech timber in .June: the holes are perfectly round and some of them one-half inch in diameter. Many come from a single tree. ret it is rery difficult to get specimens."

L. plebeja Rand., length $13 \mathrm{~mm}$. is a member of the Alleghanian fauna, recorded from Michigan.

1949 (6304). Leptera śtbhanata Rand., Bost. Journ. Nat. Hist.. II. 1S3S. 44.

Elongate, rather slender. Male. head and thorax black; base of legs and discal elrtral stripe (often interrupted) rellow. Female. reddish-yellow. the top of head, a discal spot on thorax. scutellum, sutural and side margins and transrerse median elytral band black. Antennæ filiform. Thorax as in emarginata. Fifth rentral of male broadly truncate-emarginate and bidentate. Length 12-11 mm. (Fig. 450.)

Steuben Countr: rare. June 16. Taken from flowers of wild hrdrangea. A species of northern range.

1950 (630s). Lepttra lixeola Say, Bost. Journ. Nat.

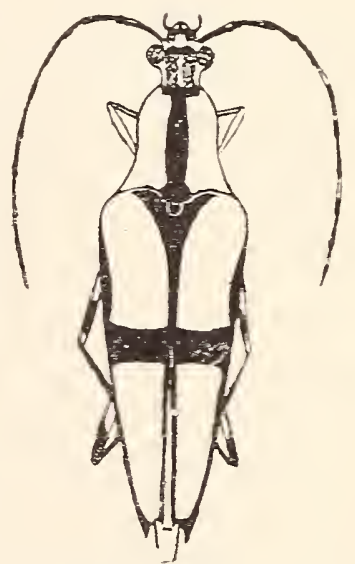

Fig. 450. Female. $\times 3$ (Original.)

Hist.. III. 1S24. 421 ; ibid. II. 199.

Elongate, slender. Black. finely pubescent: legs (except tarsi) and elstra dull sellow, the latter with narrow sutural line, a narrow stripe on disk, and a broad one. sometimes broken into spots on sides black. Thorax densely and finely punctured. feebly impressed, not sinuate on sides. Elstria with sides subparallel; surface coarsely, deeply and rather closely punctured; tips truncate, subemarginate. Length $\mathrm{s}-12 \mathrm{~mm}$.

Southern half of State: frequent. May 17-August 13. Oceurs on flowers of rarious kinds, especially wild rose and Jerser Tea.

1951 (6310). Leptura creentata Hald., Trans. Amer. Phil. Soc. I. $184 \bar{i}, 64$.

Elongate-oblong, slender. Color giren in ker: femora red. their tips black. Thorax nearly smooth, strongls and gradually narrowed from the base, which is bisinuate. the transrerse basal impression deep. Elytra scarcels narrowed behind, coarsely punctured: tips rounded. Widely separated and margined. the outer' ancle subaruminate. Length $9 \mathrm{~mm}$.

Tigo County: rare. June 15. Taken from flowers of the redosier dogrtrood (Comus stolonifera Michs.)

[67-23402] 


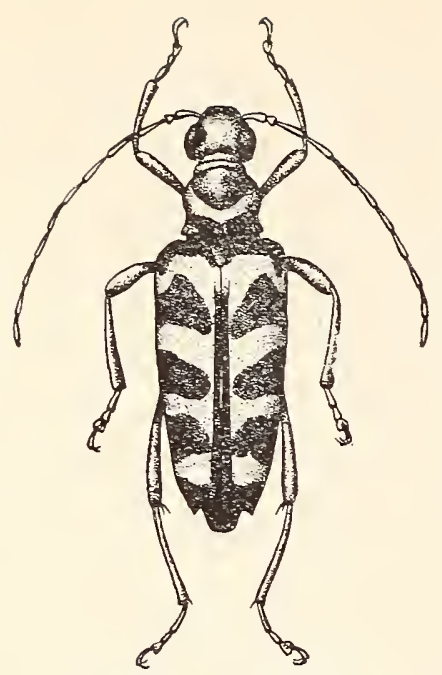

Fig. 451. $\times$ 3. (Original.)
1952 (6319). Leptura nitens Forst.. Nor. Spec. Ins., $1771,45$.

Elongate, robust. Black; body beneath, margins of thorax and four elytral bands densely clothed with golden sellow pubescence; antennæ dark reddish-brown; legs pale reddish-yellow. Thorax convex, with transverse impressed lines before and behind. Elytral bands broader at the suture, the basal one curring outward and forward to enclose the humerus; tips of elytra obliquely truncate and subemarginate. Length 10-13 mm. (Fig. 451.)

Lake and Marshall counties; scarce. June 11-June 15. Beaten from foliage of oak. Iisted as L. zebra Oliv.

1953 (6311). Leptura chalybæa Hald., Trans. Amer. Phil. Soc., X, 1847, 60.

Elongate, rather slender. Black; elytra steel blue, shining. Thorax subquadrate, convex, not much broader at base than apex; hind angles small ; surface finely punctured. Flytra parallel, rather coarsely and sparsely punctured; tips rounded, not widely separated. Length $6-7 \mathrm{~mm}$.

Posey Countỳ; rare. June 25. Ranges from New York and Pennsylvania to Iowa.

1954 (6312). Leptura capitata Newn1., Entomologist. 1S41, 71.

Elongate, slender, parallel. Black; head and thorax red. Thorax convex; sides rounded, narrowed in front, hind angles small; surface finely and rather sparsely punctate. Elytra much more coarsely and sparsely punctured, the tips subtruncate. Length $6.5-9 \mathrm{~mm}$.

Lawrence and Posey counties: scarce. April 26-July 10. Taken from flowers of wild plum.

1955 (6313). Ieptura americana Hald., Trans. Amer'. Phil. Soc.. X. $1847,63$.

Form of capitata. Black; head and thorax red, with fulvous hair. Thorax convex, strongly widened behind the middle. finely and sparsely punctate. Elytra parallel, densely not coarsely punctured. Length $8-9 \mathrm{~mm}$.

Recorded by Leng from Indiana, Ohio and southward; also by Dury from Cincinnati.

L. exigua Newm., black, legs in part pale, thorax sometimes yellow with a black discal spot, length $5.5-7 \cdot \mathrm{mm}$., is a member of the Alleghanian fauna recorded from northern Illlinois.

1956 (6916). Ifeptura subargentata Kirby, Faun. Bor. Amer., IV, 183T, 184.

Elongate, slender; parallel. Color given in key. Thorax bell-shaped, more elongate and slender than in capitata, its surface densely, rather finely punctate. Elytra more coarsely and sparsely punctate, the tips rounded. Length $6-7.5 \mathrm{~mm}$.

Marion and Crawford counties: scarce. June 1-June 8. Our 
form is var. ruficeps Lec., having the head red, or partly so, the front legs and base of middle and hind thighs reddish-yellow.

Grour B.

In this group the species are usually of larger size with the hind angles of thorax not prolonged; the antenna with joints one to four and half of the fifth, punctured, the remainder covered with very fine, dense silky hairs. Four species have been taken in the State, while another may occur.

\section{IKEY TO SPECIES OF GROUP B.}

a. Antenna annulate with yellow (except in male of canadensis).

b. Tips of elytra truncate and dentate.

$c$. Elytra deeply truncate-emarginate at tips; antennie of male serrate; black, elytra more or less red.

1957. CANADENSIS.

cc. Elytra truncate at tips, those of male sometimes feebly emarginate; black, elytra reddish; abdomen red, male, black, female.

195S. RUBRICA.

bb. Tips of elytra nearly rounded, widely separated; black, elytra with reddish or yellowish submarginal stripe, rarely wholly dull yellow or wholly black.

aa. Antennæ not annulate.

VAGANS.

a. Black; elytra dull yellow except at tips, which are truncate and rather broadly and obliquely marked with black. 1959. Proxima.

$d d$. Black; elytra black, each with four triangular yellowish spots, their tips scarcely truncate.

1960. остоNOTATA.

1957 (6332). Leptura Canadensis Oliv., Ent.

$$
\text { IV, } 1775,73 .
$$

Elongate, rather slender, elytra tapering behind. Black; elytra usually with a large basal reddish spot, which rarely (var. erythroptera) extends over the whole surface. Antennæ with 11th joint distinctly divided; unicolorous, male; joints 3 to 9 yellow at base, female. Thorax elongate, narrowed in front, deeply constricted behind; surface, as well as that of elytra. coarsely and closely punctured. Length 13$17 \mathrm{~mm}$. (Fig. 452.)

Several in Dury collection from Laporte County, taken by G. M. Levette. Probably to be found throughout the northern third of the State. Occurs about pine and hemlock.

1958 (6333). LePtura RUbrica Say, Journ. Phil. Acad. Nat. Sci., III, 1824. 418 ; ibid. II, 197.

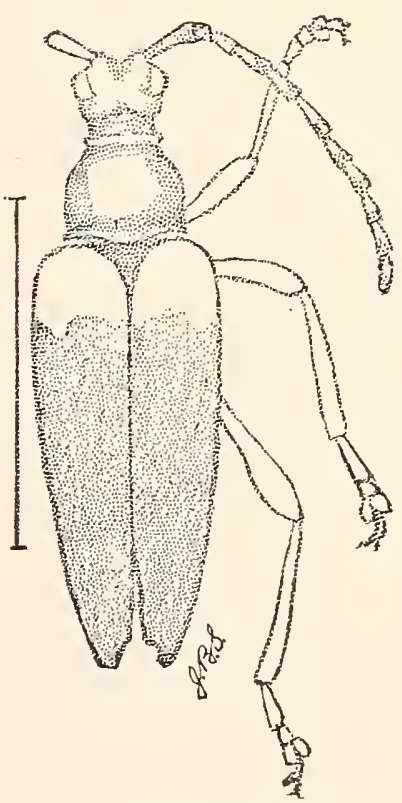

Fig. 452. (After Smith in Fifth Rep. U. S. Ent. Comm.)

Elongate, robust. Color given in key; under surface rather densely clothed with fine yellow pubescence. Antennx with 11th joint scarcely di- 
vided, joints 1 to 5 in both sexes black, remainder annulate at base with yellow. Thorax short, convex, bell-shaped, constricted behind; surface coarsely and densely punctured. Elytra tapering from the base, coarsely and somewhat sparsely punctured, more finely toward tips, which are separated. Length $10-16 \mathrm{~mm}$.

Throughout the State; scaree. June 11-July 4. Occurs in the sand dune region of Lake and Porter counties on the blossoms of the prickly pear cactus, Opuntia rafuesquii Engelm; elsewhere on foliage of oak and wild grape.

L. vagans Oliv., length 9-12 mm., occurs throughout the eastern United States.

1959 (6344). Leptura proxima Say, Journ. Phil. Acad. Nat. Sci., III, 1824, 420 ; ibid. II, 198.

Elongate, robust. Color given in key; surface sparsely pubescent with short, yellowish hairs, those on thorax longer and erect. Thorax rounded or subglobose, constricted before and behind; disk with a broad and shallow median channel, rather coarsely and densely punctured. Elytra rather densely, not coarsely punctured, their tips truncate and subemarginate. Length 14-15 mm.

Marion and Posey counties; scarce. June 6--July 1. Occurs on foliage of maple and on flowers.

1960 (6351). Leptura oстоnotata Say, Journ. Phil. Acad. Nat. Sci., III, 1S24, 419 ; ibid. II, 197.

Elongate, rather robust. Color given in key; hind tarsi and base of hind femora pale. Body pubescent with long, whitish, suberect hairs. Thorax subcylindrical, feebly rounded on the sides, rather finely and densely punctured. Length $10-12 \mathrm{~mm}$.

Putnam County ; rare. Tune 5. Two specimens in Dury collection taken by Levette in northern Indiana. The spots of elytra are equidistant, the front one on base.

\section{Group C.}

To this group belong medium-sized or small species in which the elytra are nearly parallel and the thorax as described in key. Six species are ascribed to the group, three of which have been taken, while the others probably oceur within the State.

\section{KEX TO SPECIES OF GROUP C.}

a. Thorax much, often suddenly, narrowed in front; elytra parallel from near base to tip.

b. Thorax feebly or not constricted but with an impressed line at base; elytra protuberant at base.

c. Head prolonged behind the eyes; black, shining; elytra each with a yellow stripe, rarely wholly black.

1961. VITTATA. 
cc. Head not prolonged; black, without markings.

1962. PUBERA. 66. Thorax deeply constricted at base, the sides strongly rounded; elytra not protuberant.

d. Thorax not densely punctured or clothed with yellow pubescence.

e. Black; legs more or less yellow; thorax sometimes (var. ruficollis Say) red, nearly smooth except at base. SPHARICOLLIS. ee. Black or piceous; elytra brown, each with side margin and a long, narrow stripe on disk dull yellow; thorax sparsely and finely punctured, more coarsely at base.

1963. VIBEX.

dd. Thorax densely punctured and clothed with yellowish pubescence; dull yellow, the elytra with black stripes.

AURATA.

aa. Thorax quadrate, hardly narrowed in front and not constricted behind; elytra feebly narrowed from the base; black, the elytra sometimes dull yellow or with the tip alone dark.

MUTABILIS.

1961 (630̃3). Leptura vittata Oliv., Encyc. Meth., VIr, 523.

Elongate, slender. Black; elytra usually with a yellow stripe, broader at base, extending to beyond middle; rarely wholly black or dull yellow. Head densely punctured and with a distinct neck. Thorax elongate, subcylindrical ; surface, as well as that of elytra, sparsely and rather coarsely punctured. Elytra wider on basal third, the sides thence parallel to tips, which are subtruncate. Length 10-13 $\mathrm{mm}$.

Throughout the State; frequent. May 25-June 28. Occurs on foliage of Virginia Creeper and other shrubs.

1962 (6354). Leptura pubera Say, Journ. Phil. Acad. Nat. Sci., V, 1826, 279 ; ibid. II, 336.

Elongate, slender. Black, feebly shining. Head densely punctured, neck short. Thorax bell-shaped, base bisinuate, surface densely and rather coarsely punctured with a smooth median line and with numerous erect black hairs. Elytra sparsely and coarsely punctured, the tips truncate and feebly emarginate. Length 9-10 $\mathrm{mm}$.

Kosciusko and Starke counties; scarce. June 5-July 1. Occurs on the flowers of meadow-sweet (Spircea). The base of thorax is more deeply bisinuate and not at all constricted in pubera, whereas in vittata the constriction is evident though feeble.

L. sphcericollis Say, length $7-8 \mathrm{~mm}$, is known from Ohio, Kentucky and Michigan; L. aurata Horn, length $9 \mathrm{~mm}$, and L. mutabilis Newm., length $8-15 \mathrm{~mm}$, have both been recorded from Cincinnati; the latter also from Michigan.

1963 (6356). Leptura vibex Newm., Entomologist, 1841, 72.

Elongate, slender, parallel. Head and under surface black; thorax reddish; elytra as mentioned in key; front of head and legs, except tips of femora, dull yellow. Antennie with tips of joints reddish-yellow. Thorax convex, deeply constricted before and behind. Elytra ratler coarsely, not densely punctured, the tips rounded. Length $7-10 \mathrm{~mm}$.

Posey County ; scarce. June 11. Occurs throughout the eastern United States. 


\section{Subfamily III. LAMIINAE.}

The members of this subfanily are rery numerous and vary greatly in size, color and general appearance. The three characters in which almost all agree are the small, ohligue groove of the outer side of the front tibir, the lack of side margins of the thorax and the cylindrical pointed or spindle-shaped terminal joint of the palpi. In the tribe Methiini alone the tarsal grooves are absent. In addition the front of the head is vertical, so that, riewed from above, the face cannot be seen and is usually large and flat; front coxæ rounded, never transverse, the cavities rarely open behind; ventral segments always five. 'The tarsal claws are either "divaricate," i. e., extending in a plane at right angles to the length of the last tarsal joint, or "divergent," not in the same plane but forming an angle. The "cicatrix" is a sort of scar seen near the tip of the scape or first antennal joint in certain genera.

The species generally remain stationary by day upon the trunks and branches of trees, and often escape detection by the resemblance which they bear, in the hues and sculpture of their bodies, to the color and inequalities of the bark on which they repose. Their colors are, therefore, as a general rule less vivid than those of the Cerambycinæ, the prevailing tints being brown and gray.

The larva resemble those of the Cerambycinæ in being of a nearly cylindrical form, but a little tapering behind, and considerably swollen at the front extremity, with a small head, which is retractile within the enlarged tront segment. These larvæ differ, however, from those of nearly all other Longicorns in being wholly destitute of leg's.

The principal literature relating to the North American forms of the subfamily, aside from the general works on the family already cited, are as follows:

Horn.- "Notes on some Genera of the Cerambrcidx of the United States," in Trans. Amer. Ent. Soc., VII, 1878, 41-50.

Horn._-_Notes on some Genera of Cerambycidæ with Descriptions of New Species," in Trans. Amer. Ent. Soc., VIII, 1880, 115-138.

Horn._"Descriptions of some Nèw Cerambycidæ with Notes," in Trans. Amer. Ent. Soc., XIT, 1885, 173-197.

Leng, Chas. IT. \& Hamitton. John._"The Lamiinæ of North America," in 'Trans. Amer. Ent. Soc., XXIII, 1896, 101-17£. Felt, E. P. \& Joutel, L. H._-Minograph of the Genus Saperda," in Bull. 74. N. Y. State Mis., 1904, 1-86, pls. 1-14. 
Fall, H. C._ "New Species of Pogonocherus with Synoptic Table," in Ent. News, XXI, 1910, 5-9.

The subfamily is divided by LeConte and Horn into 16 tribes, eight of which are known to be represented in Indiana, while members of two others may oceur.

KEI TO INDIAXA TRIBES OF LAMIINE.

a. Elytra entire; front tibie sulcate.

b. Elytra with a spine or protuberance near the scutellum; size small. not orer $6 \mathrm{~mm}$.

c. Humeri rounded; elytra convex with large spine near the scutellum; front coxal carities rounded.

Tribe I. CrRtixisi, p. 1062.

cc. Humeri distinct; elytra less conrex with oral protuberance near scutellum; front coxal carities angplated.

Tribe II. Psexocerixi. D. 1062.

bb. Elytra not spinose or protuberant at base; size usually larger or moderate (over $6 \mathrm{~mm}$. except in some Liopus of Tribe IT).

d. Scape of antennie with an apical cicatrix (except in Dorcaschema) ; bods elongate. subcyindrical; mostly large species with antenne sometimes greatly elongate in male.

'Tribe III. Молонамmisi. p. 1063.

dd. Scape of antennie without apical cicatrix.

e. Tarsal claws (at least those on front tibiæ) diraricate.

$f$. Front coxal carities rounded; middle coxal carities closed or nearly so: body usually broad; antennæe usually rery long in males. Tribe IV. Ac.xthoderixi. 1) 1069.

ff. Front coxal cavities angulate; middle carities open.

g. Tarsal claws simple (except the outer one of front and middle tarsi in some males of saperda).

h. Smaller, somerhat flattened species; thorax with a spine or tubercle on sides.

Tribe T. Pogoxocherixi, p. 1080.

hh. Larger cylindrical species; thorax never armed with spine or tubercle.

Tribe Tirt. Stperdixi, p. $10 \varsigma 4$. gg. Tarsal claws cleft or appendiculate.

Tribe IX. P'HYtecins. p. 1089.

ee. Tarsal claws dirergent.

i. Front large, flat; front coxie angulated.

Tribe VI. Oxchderixi. p. 1083.

ii. Front inflexed; form rery slender and elongate.

Tribe TiI. Hippopsixi, p. 1083.

aa. Elytra about half the length of abdomen: front tibire not sulcate; front coxal cavities angulated, widely open behind; eyes rery large, divided.

Tribe X. Мethins, p. 1095. 
Tribe I. GYRTININI.

This tribe is represented in the eastern United States by a single genus containing one species, which is the smallest member of the subfamily :

\section{Crrtints Lec. 1850. (Gr., "convex.")}

Head broad; eyes small, divided, coarsely granulated; antennæ a little longer than body, scape slender withont apical cicatrix; the joints each with one or two hairs near tip: legs stout, femora strongly club-shaped.

1964 (6383). Crrtixes prgareus Hald. Trans. Amer. Phil. Soc., X. 1S47, 42.

Elongate, subcylindrical. Dark brown: antemal joints ammlate with sellow; elytra with a transverse blotch of white pubescence before the middle. Thorax subcrlindrical, constricted at base. very convex, smooth. Elytra convex, wider behind, nearls smooth. each with a large acute spine near the scutellum. Length $2-3 \mathrm{~mm}$.

Posey County ; rare. June 5. Occurs on dead branches of oak and is probably frequent throughout the State, but overlooked on account of its small size.

Tribe II. PSENOCERINI.

Also represented by a single genus and very small species oceurring from the Atlantic States to Nebraska.

\section{Psenockrts Lee. 1850. (Gr., "crnips + horn."')}

In addition to characters giren in key this genus may be known by having the antenne shorter than body, scape rather stout, without cicatrix; third and fourth joints equal, longer than the others: tarsi wider than in Cyrtinus, the last joint rather long; claws widely diverging, not divaricate.

1965 (63S4). Psenocercs suphotatus Sar, Jouru. Phil. Acad. Nat. Sci.

II, 1S24, 425 ; ibid. II. 200.

Elongate, cylindrical. Dark reddish-brown or blackish. densely and rather coarsely punctured; scutellum. a narrow oblique band about the middle and a wider curved band. not reaching suture, on apical third, clothed or composed of white pubescence. Thorax crlindrical, convex, constricted at base. Elytra crlindrical. each with an oral obtuse eleration

Fig. $453 . \times 2$. (After Wickham.) near the scuteilum. Length $:-6 \mathrm{~mm}$. (Fig. 453.)

Throughout the State: common. April 23-July 29. The larre dwell in the stems of grape, currant, gooseberry 
and sometimes in twigs of apple. The adult is called the "currant tip borer" and is often beaten from the flowers or foliage of the various species of red-haw (Cratogus) and other shrubs.

\section{Tribe III. MONOHAMMINI.}

In this group of genera the front is large, vertical, quadrate, flat; eyes somewhat finely granulate, emarginate; antenna longer than body, very long in male, except in Goes and Cacoptia, scape rather stout; elytra narrowed behind or cylindrical; front coxal cavities angulated. Five of the seven genera comprising the tribe are known to be represented in the State, while a sixth probably oceurs.

KEY TO INDIANA GJNERA OF MONOHAMMINI.

a. Legs long, the front pair elongate in maie; antemne much longer than body.

7. Thorax with spines on the sides.

LI. MonoHamate.

b7. Thorax cylindrical without spines.

(. Elytra rounded at til; black or srayish-brotirl.

LII. DORCASCHEMA.

cc. Elytra pointed at tip; color uniform ash gray. LIII. IIETenis.

a $a$. Legs equal, not elongate.

d. Scape of antennie with a distinctly limited cicatrix.

e. Thorax cylindrical; color gray.

CaCOPLIA.

cc. Thorax with a spine each side; color brown or gray. LIV. Goes. dd. Scape of antemne with the cicatrix not sharply defined; thorax with a strong lateral spine; color black and white. ISV. Plectrodera.

\section{Li. Monohammus Serv. 1835. (Gr., "one+band or fetter.")}

Here belong large species with long legs, which oceur upon pine. The antennæ of the males are very long, quite roughly punctured and without pubescence; those of females shorter, very much smoother and clothed with a fine ash-colored pubescence on the basal half of each joint from the third; except in confusor, in which the whole of each joint is pubescent; thorax with a robust spine each side. Two species and one variety have been taken in the State, while another may oceur.

KET TO INDLANA SPECIES OF MONOHAMMTS.

a. Tips of elytra rounded, the sutural angle acute or projecting as a short spine.

b. Larger, 20-32 mm.; elytra darker: antennæ of male longer.

1966. TITILLA TOR. 
bb. Smaller; 13-18 mm.; elytra paler; antemne of male not more than twice the length of body.

1966a. var。CAROLINENSIS.

aa. Tips of elytra rounded, the sutural angle not prolonged, usually rery obtuse.

c. Surface color black, distinctly bronzed, the elytra with rery small or no patches of white and brown pubescence.

1967. SCUTELIATUS.

cc. Surface color brown; elytra sparsely mottled with small patches of gray and brown pubescence; antenna of female uniformly pubescent.

CONEUSOR.

1966 (6385). Moxohamies titillator Fab., Syst. Ent., 1775, 279.

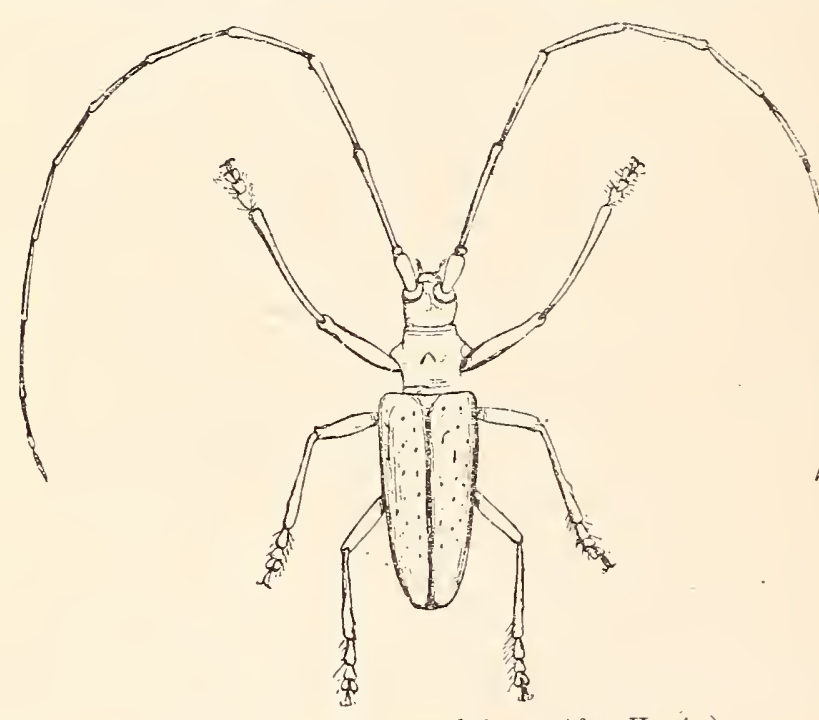

Fig. 454. Male. Natural size. (After Harris.)

Elonga te, robust, subcylindrical. Brownish, the elytra irregularly mottled with patches of brown, piceous and gray or white pubescence. Antennæ of male sometimes four and a half times, those of female never more than one and a half times, the length of body. Punctuation of thorax rariable from very sparse to dense. Length 20-30 mm. (Fig. 454.)

Marion County; scarce. July 2--July 28. Probably introduced in pine lumber.

1966 a (-). Monohamiles tituldator Carolinensis Oliv., Entom., IT, 1795, S5.

Form of titillator but smaller and more cylindrical. Color much paler. the pubescence ash gray variegated with brown, the piceous spots of tititlator almost wholly absent. Thorax coarsely and roughly punctured on center of disk; finels, transversely wrinkled near base and apex. Elytra coarsely and rather closely pinctured on basal half, more finely and sparsely toward tips, which in both sexes are rounded, the sutural angle evident but obtuse. Length 13-18 mm.

Lake and Porter counties; scarce. May 25-June 29. Occurs on the Northern scrub pine, Pimus banksiana Lam. Usually considered a synonym of titillator, but in my opinion a distinct rariety. It is the same as LeConte's minor. 
(6357). Молонammus scutellatus Say, Long's Exped., II, 1824, 289 : ibid. I. 192.

Elongate, subcylindrical; color given in key; scutellum clothed with white pubescence, its median line often smooth. Antennie of male twice as long as body; of female, one-fourth longer than body, and sometimes annulate. Thorax transrersely wrinkled, especially so near front and hind margins. Elytra coarsely and rugosely punctured, more so in male. Length 15-2s mm. (Fig. 455.)

Lake and Porter counties: frequent beneath bark of pine. June 15July 3.

H. confusor Kirbr, length 28-31 mm., occurs in "Canada. New England and the Middle States."

I.II. Doncischma Lec. 1850. (Gr.. "a deer + form.")

This genus comprises three medium or small-sized species, differing from their allies by the lack of cica-

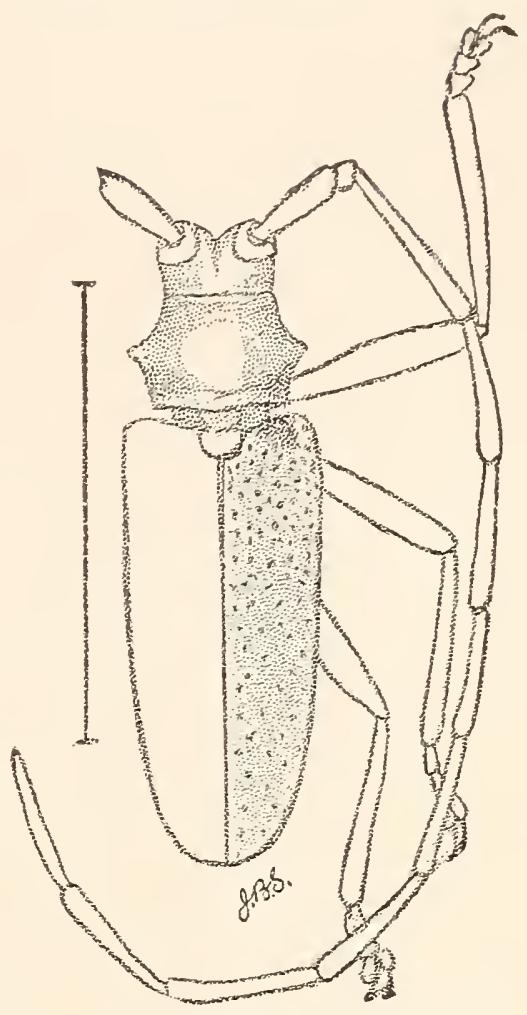

Fig. 45j. (After Smith in Fifth Rep. U. S. Ent. Comm.) trix on basal joint of antennx, the smooth sides of thorax and the rounded tips of elytra. All three occur in the State.

KEY TO SPECIES OF DORCASCHEMA.

a. Thorax truly cylindrical, longer than wide; brown with grayish pubescence.

b. Thorax transversely wrinkled, indistinctly punctured; larger, 15 $22 \mathrm{~mm}$.

1968. WILDII.

bb. Thorax not wrinkled: punctuataion distinct; smaller, S-12 mm.

1969. ALTERNATUM.

a . Thorax slightly narrowed behind the middle, nearly as wide as long: color black.

1970. NIGRUM.

1968 (6391). Dorcaschema wildit Uhler, Proc. Phil. Acad. Nat. Sci., VII. $1855,217$.

Elongate. slender, subcylindrical. Brown, densely clothed on disk of thorax and elytra with yellowish-gray pubescence, this bordered on sides with light gray pubescence; elytra with numerous small. rounded, bare spots and a large, irregular one behind the middle; often also with a stripe of clay sellow pubescence on sides, extending from middle to apex. Thorax with median line smooth and with numerous fine transverse raised lines or wrinkles. Length $15-22 \mathrm{~mm}$.

Marion and Fountain counties: scarce. June 3-June 17. This and the next breed in mulberry and osage-orange and the adults are usually found on the trunks or foliage of those trees. 
1969 (6392). Dorcaschema alternatum Say, Journ. Phil. Acad. Nat. Sci., III, 1S:2, 405; ibid. II, 1 SS.

Elongate, slender, cylindrical. Brown, sparsely clothed with prostrate gray pubescence; thorax with four narrow stripes of clay yellow pubescence; elytra each with three rows of irregular spots of similar pubescence, those of middle row the larger. Thorax sparsely and finely punctured, with an elongate median smooth space. Elytra more coarsely punctured; each with an irregular bare space behind the middle, this densely and confluently punctured. Length $\mathrm{S}-12 \mathrm{~mm}$.

Southern two-thirds of State; frequent. May 24-July 7.

1970 (6393). Dorcaschema nigrum Say, Journ. Phil. Acad. Nat. Sci., V, 1S27, 272 ; ibid. II. 330.

Elongate, slender, cylindrical. Uniform duil black. Head with a narrow raised line. Thorax finely granulate-rugose. Elytra minutely granulate, sparsely, rather finely and deeply punctate. Length S-10 mm.

Throughout the State; frequent. June 5-July 8. Breeds in hickory, in the dead twigs of which it occurs in numbers.

\section{HeTcims Hald. 1847. (Gr., "in sight" or "at hand.")}

Differs from the preceding by having the elytra narrowed and pointed at tip. The antennx are slender, tapering, double the length of the body, the third joint longest, twice the length of fourth, fifth slightly longer than fourth. One species is known from the eastern United States.

\section{1 (6394). Hetemis cinerea Oliv., Ent., IV, 1795, 68.}

Elongate, slénder, cylindrical. Black, densely clothed with short, grayish, prostrate pubescence. Antenne naked, black. Thorax cylindrical, slightly longer than wide, narrower than elytra, the middle third with a smooth dorsal line. Elytra rather densely and coarsely punctured, the punctures hidden by the dense pubescence. Length $\mathrm{S}-12 \mathrm{~mm}$.

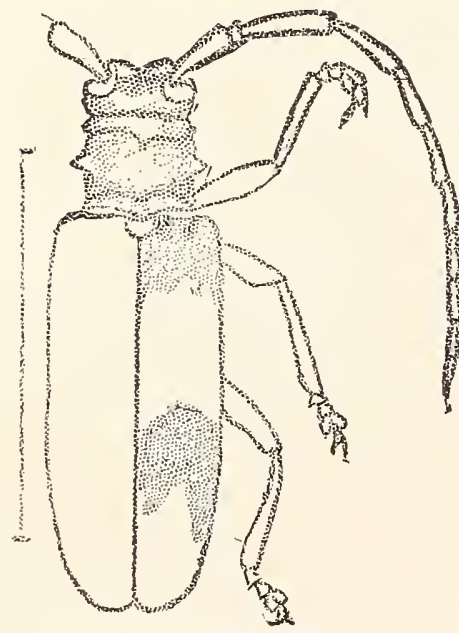

Fig. 456. Goes pulchra Hald. (After $\mathrm{S}$ mith in Fifth Rep. U. S. Ent Comm.)

Throughout the State; frequent. Nay 16-July 7. Breeds in walnut, mulberry, osage orange and hickory, about the dead limbs of which it may be found.

Cacoplia pullata Hald, clothed with soft gray pubescence, length 10-16 mm., is known from New York, Pennsylvania, Ohio and southward.
LIV. Goes Lec. 1852. (Gr., "mag- ical."')

Robust species, having the legs rather short and subequal in size; scape of antennæ with a distinct sear-like impression near apex; thorax cylindrical with 
a short, obtuse spine each side. (Fig. 456.) Hour of the six species are known from the state, and the others probably oceur.

KEY TO STECIES OF GOES.

a. Surface color of body brownish; antenne of male not nole than one and a fourth times the length of body.

b. Elytra each with a conspicuous space on apical half, which is not pubescent.

c. Size larger, 22 or more $111 m$.

d. Pubescence of surtace white.

19T2. TIGRINA.

dd. Pubescence clay-yellow, the basai region of elytra darker, less pubescent. (Fig. 456.)

PULCHRA.

cc. Smaller, not over $15 \mathrm{~mm}$.; pubescence marbled with whitish and dark clay-yellow.

1973. DEBILIS.

bb. Elytra without conspicuous bare space on apical half.

e. Pubescence clay-yellow or pale brown, inconspicuously mottled with paler spots.

1974. TESSELATA.

ee. Pubescence grayish or almost white, uniform; elytra usually with two crossbars of darker pubescence.

1975. PULVERULENTA.

aa. Surface color of body black, shining; antenne of male twice as long as body; elytra coarsely punctured.

OCLLATA.

1972 (6396). Goes tigrina Degeer, Ins., V, 1775, 113.

Elongate, robust, subcylindrical. Dark brown, rather densely clothed with prostrate white pubescence. Thorax short, wider than long; disk with three obtuse tubercles, sides with a much longer one. Elytra finely and sparsely punctate, the basal third roughened with small, black, elevated points. Length $25-30 \mathrm{~mm}$.

One specimen in Webster collection labelled "Ind." Ranges from Pennsyivania and Canada westward and southward.

G. pulchra Hald (Fig. 456), length 23 mm., breeds in hickory and is known from the Eastern and Southern States and Ohio.

1973 (639S). Goes debilis Lec., Journ. Phil. Acad. Nat. Sci., II, 1852, 150.

Elongate, rather robust, subcylindrical. Brown; head, thorax and apical third of elytra clothed with reddishyellow or fulvous pubescence; basal half of elytra mottled with grayisi pubescence. Thorax cylindrical, wider than long, coarsely and sparsely punctured. Elytra sparsely and rather coarsely punctured on basal half, more finely toward tips. Which are rounded. Iength 11-15 mm. (Fig. 45\%.)

Lake, Steuben, Starke and Marshall counties: frequent. June 13-July 5. Beaten from hickory and black or yellow-barked oak, Quercus velutina Tiam.

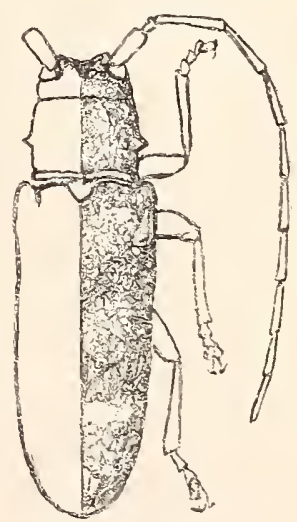

Fig. 45i. (After Smith in Fifth Rep. U. S. Ent. Comm.) 
1974 (6399). Goes tesselata Hald.. Trans. Amer. Phil. Soc., X. 1S47. 51.

Elongate, robust, subcrlindrical. Dull brown; ererywhere clothed with rerr short, prostrate, brownish hairs; elstra with small spots of rellowish hairs arranged in irregular rows. Thorax finels punctured and more slenderly spined than in debilis. Elytra punctured as in that species. Length $20 \mathrm{~mm}$.

Marshall County: rare. June 12. Known from New York, Georgia and Louisiana.

1975 (6400). Goes pulverulexta Hiald., Trans. Amer. Phil. Soc., X. 1S47. 51.

Form of tessclata. Brown; uniformls clothed with short. prostrate. whitish hair: elytra indistinctly cross-barred at base and again behind the middle with darker pale brown pubescence; scutellum sometimes clas-rellow. Thorax and elritra punctured as in tesselata. Length 19-23 mm.

Lake, MIarshall. Madison and Marion counties: scarce. June 10July 15. Beaten from foliage of black oak. Said to breed in beech and wild cherrer.

G. oculata Lec.. pubescence whitish. elrtra each with a small black spot one-third from apex. length 10-11 mm., is known from New York, Ohio and Wisconsin.

\section{Plecthodera Lec. 1852. (Gr., "spur+neck.")}

Body stouter than in Goes. with stronger thoracic spines: lower margin of head behind the mentum straight, not rounded as there: antennre of males but little longer than bodr. One species occurs in the eastern Tnited States.

1976 (6102). Plectrodera scalator Fab. Sisst. Ent., II, 1775, 27.

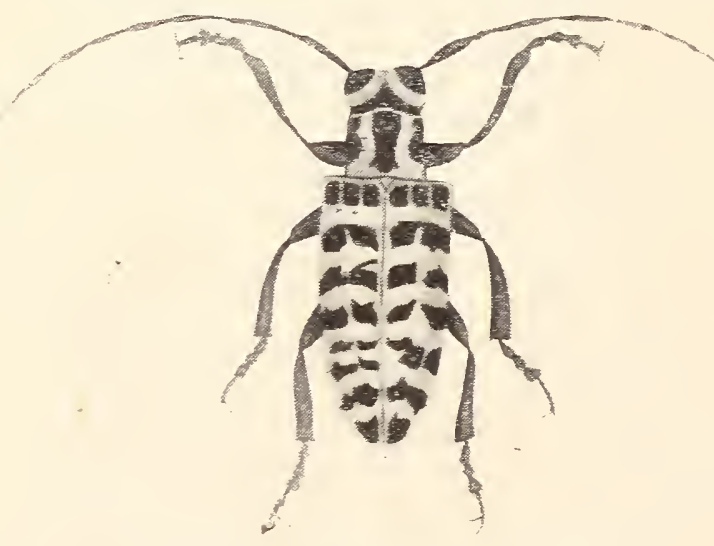

Lig. 458. Natural size. (After LeConte.)

Elongate subcrlindrical, very robust. Black. shining; elrtra with conspicuous, dense white pubescence arranged in irregular transterse rows. Thorax with similar pubescence arranged so as to leare a large dorsal spot and a space around the base of spines bare. Legs and antennæ sparsely clothed with fine gras-

ish pubescence. Elstra rery finely and sparsely punctate. Length 25$32 \mathrm{~mm}$. (Fig. 45s.)

Lake and Porter counties: scarce. August 6-September 19. Occurs in the sand dune region. where it probably breeds in the 
quaking aspen and cotton-wood (I'opulus), both of which are fairly common in that area. One of the largest and most striking members of the family in our fauna.

\section{Tribe IV. ACAN'THODERINI.}

Small or medium-sized, rather broad and usually somewhat flattened species, having the front lirge, quadrate, vertical; palpi slender; elytra rounded or truncate at tip ; front coxal cavities rounded, closed behind; legs moderate, femora usually strongly club-shaped, middle tibiæ with a tubercle on the outer margin; tarsal claws divaricate. The color is dull, usually black marked with gray, and the beetles are found on the trunks or limbs of trees. Of the $1: 3$ genera composing the tribe, eight are known to be represented in the State, while another probably occurs.

KEX TO INDIANA GENERA OF ACANTHODERINI.

a. Basal joint of antenne club-shaped; thorax with dorsal tubercles and large acute spine near the midnle of each side.

LVI. ACANTHODERES.

a a. Basal joint of antennx cylindrical; spine on side of thorax, if present, behind the middle.

b. Females without elongated ovipositor.

c. Thorax feebly tuberculate or angulate at the sides a little behind the middle; mesosternum broad.

LVII. Leptostylus.

$c c$. Thorax distinctly angulate, or more frequently with an acute tubercle or short spine behind the middle; mesosternum triangular or narrow.

d. Antennæ without traces of fringed hairs beneath; first joint of hind tarsi as long as the next two.

c. Form somewhat flattened; prosternum narrow but not linear; body without erect hairs.

LVIII. Litopes.

ee. Form cylindrical; prosternum linear; elytra with erect hairs.

LIX. Dectes.

dd. Antennæe distinctly fringed beneath with hairs; first joint of hind tarsi as long as the next three.

$f$. Elytra without a carina on each side, usually with transrerse angulated markings.

LX. Lepturges.

$f f$. Elytra each with a distinct carina on the side, their surface marked with numerous small black spots.

LXI. HYPERPlatys.

bb. Females with elongated ovipositor.

g. Body above with erect hairs mixed with the pubescence.

h. Antennæ not much longer than the body and withont fringed hairs beneath except feebly on the first joint; mesosternum broad.

I.XII. Graphisures. 
hh. Antemic of male twice as long as body and very slender, with fringed hairs beneath; mesosternum narrow.

LXIII. Ceratographis.

gg. Body above pubescent without intermixed erect hairs; antennæ very long. with at least joints 3 and 4 densely fringed with short hair's beneath.

Acanthocinets.

\section{AC八NThoderes Serv. 1835. (Gr., "spine+neck.")}

Medium-sized rather robust and somewhat flattened species, having the antennx not or very slightly longer than body, the first joint shaped like an Indian club; thorax tuberculate above and on sides; femora much swollen towards the tips. The front tarsi of male are broader than in female and fringed at the sides with rather long hair. Two of the five known species have been taken in the State, while a third may occur.

KEY TO INDIANA SPECIES OF ACANTHODERES.

a. Elytra each with a rather broad, oblique crossbar of white in front of middle and with a feeble costa on middle third near suture.

1977. QUADRIGIBBUS.

aa. Elytra without distinct whitish crossbar or costa, but each with an indistinct M-shaped black mark behind the middle.

b. Base of elytra with an oblong, obtuse raised space at middle; smaller, 11-12 $\mathrm{mm}$.

1978. DECIPIENS.

b). Base of elytral regularly convex without raised space; larger, $20 \mathrm{~mm}$.

MORRISII.

1976 (6404). Acanthoderes quadrigibeus Say, Bost. Journ. Nat. Hist., I, 1835, 195; ibid. II, 665.

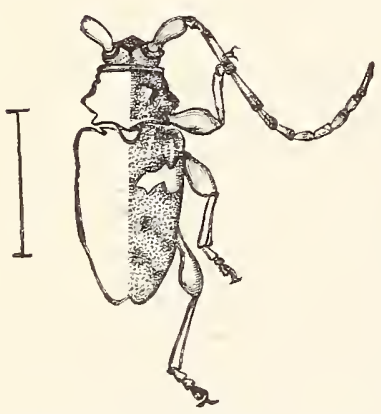

Fig. 459. (After Smith in Fifth Rep. U. S. Ent. Comm.)

Elongate-oblong, rather robust. Dark brown, lather thickly clothed with yellowish-brown prostrate pubescence; elytra each with a large undulated white crossbar near middle and a row of small alternate brown and white spots along the suture; antennæ annulate with gray. Thorax wider than long; surface, as well as that of elytra, rather finely, deeply and sparsely punctured. Elytra each with two elevations near base. Length 10-13 mm. (Fig. 459.)

Clark and Posey counties; scarce. July 5-July 22. The larve live in oak, hickory, beech and hackberry.

1978 (6406). Acanthoderes decipiens Hald., Trans. Amer. Phil. Soc., X, $1847,45$.

More slender than the preceding. Dark brown, densely clothed with short, prostrate, yellowish and gray pubescence in about equal proportions, the gray on elytra in three obscure, ohlique, subparallel bands. Thorax 
and elytra each with punctures and elevations as in quadrigiblus. from which it is separated mainly by characters given in key. Length 10$13 \mathrm{~mm}$.

Crawford and Posey comnties; scarce. Jnly 2-.July 5. Occurs on the trunks of white oak trees.

A. morrsii [hler is known from Missomri, Pennsylyania and Canada.

\section{Leptostýt's Lec. 1852. (Gr., "slender+point.")}

Oblong, rather robust species, closely related to the next, but differing by having a very obtuse tubercle on the side of thorax a little behind the middle; proster'num broad and channeled; mesosternum broader than long, more or less emarginate at tip and slightly dilated behind the coxæ; anteninx less slender and shorter than in Liopus, the outer joints becoming rapidly shorter than the third and fourth; first joint of hind tarsi not longer, if as long, as the next two. Four species have been taken in Indiana, while three others may occur.

\section{KEY TO INDIANA SPECIES OF LEPTOSTYLUS.}

a. Elytra without small elerations bearing short black scale-like hairs.

b. Elytra slightly truncate at tip; prosternum as wide between the coxre as the width of a coxal carity.

1979. MACULA.

bъ. Tips of elytra separately rounded; prosternum narrower than a coxal carits; thorax rather densely punctured on flanks as well as disk.

COLLARIS.

a a. Elytra with small tubercular elevations, each bearing on its summit short, black, scale-like hairs.

c. Thorax densely punctured: elytra with densely placed coarse, deep punctures.

1980. SEXgutTatu's.

cc. Thorax not densels punctured; elytral punctures not closelș placed. often inconspicuous or concealed; legs not hairs.

d. Surface of thorax eren, not tuberculate, regularly punctured.

e. Elytra rery indistinctly punctured. especially at apex, the disk with an angulate white band behind the middle, the tips ieebly and obliquely truncate. BIUSTLS.

ce. Elytra distinctly punctured over the entire surface. the tips slightly prolonged. not obliquely truncate. 19S1. PARrcs.

dd. Surface of thorax more or less tuberculate, the punctures irregularly placed and rugose.

f. Antennie in both sexes longer than bods: elytra feebly or not roughened with acute tubercles.

PIAXIDORSES.

$f f$. Antenna scarcely longer than body. even in male. the third joint distinctly longer than fourth: elytra with acute tubercles or ridges.

19S2. ACULIFERL'S.

[68-23402] 
1979 (6423). Leptostrues macula Say, Journ. Phil. Acad. Nat. Sci., V, 1826,268 ; ibid. II, 327.

Oblong, convex, robust. Brownish; thorax with whitish pubescence forming a broad stripe each side, banded within by a narrow blackish stripe which is formed by a row of elongate bare tubercles; the central area brownish. Elytra each with a broad, irregular white blotch behind the middle and with six lines of minute hlack spots. Thorax deeply and densely, elytra more sparsely punctate. Length 4-9 $\mathrm{mm}$.

Southern halî of State; scarce. Nay 27-June 24. Taken from beneath walnut bark and beaten from oak. Breeds in beech, hickory, black walnut and butternut.

L. collaris Hald., dull clay-yellow, elytra sprinkled with minute black spots and irregular patches of dark and gray, length $10 \mathrm{~mm}$., is known from Kentucky eastward and southryard.

1980 (6420). Leptostylus sexguttatus Say,

Journ. Phil. Acarl. Nat. Sci.,

V, 1826, 269 ; ibid. II, 328.

Elongate-oblong, robust. Brownish, irregularly mottled with grayish pubescence; elytra with an elongate dark spot behind base. another behind middle, sometimes becoming a bar, and a third near apex; antennæe and tibice annulate. Thorax finely, densely and deeply punctured, the disk with five small, blunt, rounded elevations. Elytra each with two or three finely elevated costie, each of which, together with suture, bears a row of distantly placed black points. Length 7 $10 \mathrm{~mm}$. (Fig. 460.)

Kosciusko County; rare. June 7. Said to breed in pine. Listed as commixtus Hald., but Say's name has pri- Fig. 460. (After Smith in Fifth Rep. U. ority.

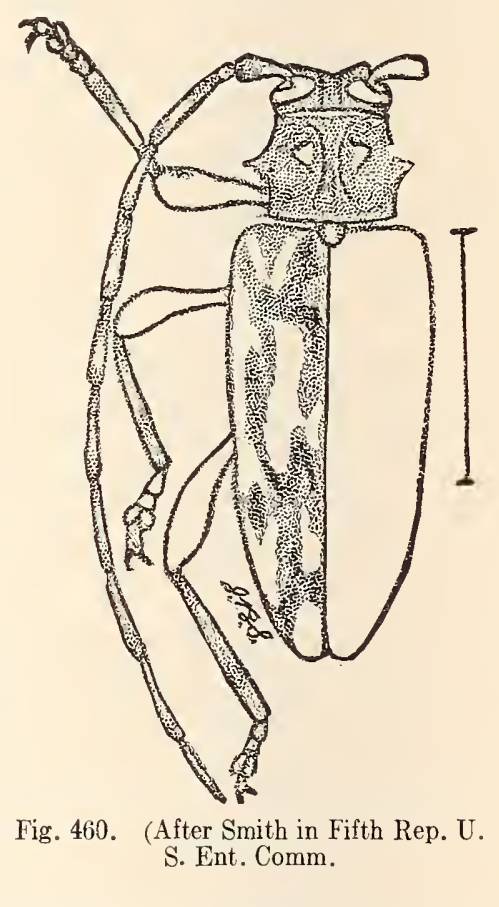

L. biustus Lee., elongate, narrow, dull brownish-yellow, sides ci thorax and elytra to middle black, length 4-6 mm., is known from New York, Illinois and southward.

1981 (6417). Leptostylus parvus Lec., New Spec. N. Am. Col., II, 1S73. 234.

Elongate-oblong, moderately robust. Brownish, clothed with very fine, dense, dark gray pubescence; elytra with an acutely angulate, oblique white band behind the middle; antennse and tibire annulate. Disk of thorax without tubercles, but often with four or five minute flat facets. Elytra with an oblique impression in front of middle and each with four irregular, somewhat broken costre, each of these with a row of small tubercles bearing short, erect black scales. Length 4-6 $\mathrm{mm}$. 
Lawrence County; rare. June 5. Beaten from limbs of dead oak. Ranges from Canada and Pennsylvania to Kansas and Texas.

L.planidorsus Lec., densely clothed with gray hairs, elytra with interrupted dark crossbar, length $9 \mathrm{~mm}$., is known from Michigan, Louisiana and Texas.

1982 (6411). Leptostylus aculiferus Say, Journ. Amer. Phil. Soc., III, 1823,329 ; ibid. II, 186.

Elongate-oblong, robust. Blackish-brown, densely clothed with short, prostrate, grayish pubescence; elytra with a whitish band behind the middle, this broad at suture, narrowing toward the sides, and edged with a black line behind which the surface is fuscous or smoky brown; joints of basal half of antenne spotted, those of apical half, annulate at tips with brown. Disk of thorax with

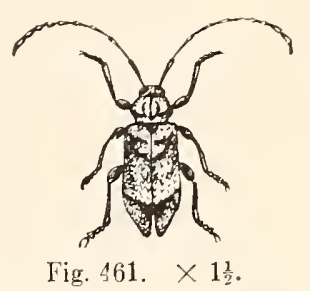
five blunt tubercles. Male with hind trochanters ending in a short, acute spine. Length $7.5-10 \mathrm{~mm}$. (Fig. 461.)

Southern half of State, frequent; probably throughout. April 22-September 20. Breeds in a variety of trees, especially sycamore, oak, apple and osage orange. The larva mine under the bark and are usually found in diseased or recently cut trees.

\section{Liopus Serv. 1835. (Gr., "smooth + foot.")}

Species usually smaller than those of Leptostylus and differing by having an acute spine behind the middle on each side of thorax; prosternum usually narrow; mesosternum gradually narrowed behind, truncate at tip and not dilated; antennæ always longer than body, joints 5 to 11, very nearly equal in length. Five species are known from the State.

\section{KEY TO INUIANA SPECIES OF LIOPUS.}

a. Front flat, mouth in the same plane as the front; elytra without an angular mark behind the middle; sides of thorax curved, the spine small and acute.

1983. VARIEGATUS.

aa. Front convex, mouth slightly retracted; spine on side of thorax rather distant from base.

b. Elytra with distinct tufts of small, black, erect scales.

c. Form robust; pubescence pale ash-gray; elytra with one broadly angulated band.

19S4. CRASSULUS.

cc. Form slender; pubescence brown; elytra with one band forming a broad angle, and a second less distinct band behind it.

19S5. FASCICULARIS.

bb. Elytra without tufts of erect scales.

d. Elytra with an acutely angular blackish band behind the middle.

19S6. ALPHA.

dd. Elytra without an angular band but often with a feebly marked transverse band of whitish pubescence.

19S7. PUNCTATUS. 
1983 (6424). Liopes rariegatus Hald., Tr. Amer. Phil. Soc., X, 1Stī, $4 \bar{\imath}$.

Elongate, rather robust. Purplish-brown, mottled with black, clothed with rers fine and short pubescence. Elytra with numerous small, irregular black spots. and a dark blotch behind the middle; which is bordered behind by gras; antenne and tibie annulate with gras. Thorax sparsely and deeply punctured. Elytra each with two costre. which unite near apex; coarsels and rather densels punctured. more sparsely and finels on apical third. Length S-12 $\mathrm{mm}$.

Marshall. Starke and Posey counties: scarce. June 15-July 2. Breeds under bark of the box-elder (Negundo aceroides Mren.), and the honey locust.

1984 (6426). Liopts crassulus Lec.. N. Sp. N. A. Coleop., II, 1S73, 235.

Elongate. convex, robust. Piceous brown, clothed with short. gray pubescence: elytra with the suture, three slightly elerated lines and margin each bearing a row of sparsels placed black tufts of hairs; humeral angles black, polished; a large bare blackish space each side in front of middle and a curved, bare. black band behind middle. Antennæ one-half longer than bods. annulate. first, third and fourth joints subequal. Thorax nearly twice as wide as long. feebly punctulate. Elytra rather coarsely punctured, tips obliquely truncate. Length $6-\overline{\mathrm{mmm}}$.

Floyd Countr: rare. June 23. Breeds in the twigs of hackberrer.

1955 (642S). Ltopes Fasctctlaris Harr.. Trans. Hartf. Soc. Nat. Hist., I, $1 S 36 . S S$.

Elongate. rather slender. Pale brown: disk of thorax with an oral spot near base and two obliquely placed ones near apex, dark brorn. Elytra with a black spot near scutellum. a much larger one on sides behind the humerus and with a number of small black ones scattered irregularls: also with an angulated black band, bordered widely in front by grar pubescence, just behind the middle: back of this a second rathel indistinct black band usualls risible. the pubescence between this and apex brown. Thorax rers finels and sparsels punctate. Elstra each with three slightly elerated lines. the inner and onter uniting before the aper; surface rather coarsely and closels punctured. Length 5-6.5 $\mathrm{mm}$.

Southern half of State. frequent: not noted north of Wells and Termillion counties. Mar 19-July 8. Breeds in prickly ash.

$19 S 6$ (6429). Liopes alpha Sas, Journ. Phil. Acad. Nat. Sci. T. 1S26. 270; ibid. II. 329.

Elongate. slender. Tsually dull reddish-brown, rather sparsels clothed with grarish pubescence: elrtra usualls with four rows of small black dots and with an acute, angular black band behind the middle. Thorax with three small blackish spots: finely and densels punctured. Elytra rather 
finely punctured, the anical third almost without punctures; or often coarsely, with apical third distinctly. punctured (var. cinereus Lec.). Length $5-\pi \mathrm{mm}$.

Throughout the State, frequent; more so in the northern counties. May 12-July 8. Breeds in apple, hickory and locust. 'This species and the preceding are very closely related. Say in his original description of alpha says: "Elytra irregularly punctured with a few black dots consisting of tufts of hairs, chiefly along the suture; region of the scutel dusk : a blackish marginal abbreviated line from the humerus;" all of which is true of fascicularis as above described.

19S7 (6431). Liopus purctatus Hald., Trans. Amer. Phil. Soc., X, 1S47, 49.

Smaller than atpha and distinguished chiefly by the absence of the angular black line of the elytra, which is replaced by an obscure transrerse band of gray. The black dots are also fewer in number and smaller. Length 4-5 $\mathrm{mm}$.

Throughout the State; rather frequent in the northern counties. June 5-August 9.

\section{Dectes Lec. 1852. (Gr., "given to biting:" )}

To this genus belongs a single species ranging from New England to New Mexico and Colorado.

$19 S 8$ (6433). Dectes spinosts Say. Journ. Phil. Acad. Nat. Sci., T, 1S26, 271 ; ibid. II, 330.

Elongate. cylindrical. Piceous. densels clothed throughout with short. prostrate, ash-gray hairs; antenne longer than body, the joints black at tips. Thorax with an acute spine each side near base; surface finely and rather closels punctate. Elytra finely and rather sparsely punctate, each puncture bearing a short, suberect, blackish hair, these plainly risible only when viewed from the side. Female with a short, black, exserted oripositor. Length $8-10 \mathrm{~mm}$.

Warren, Marion, Vigo and Poser counties, frequent; probably throughout the State. June 10-July 28. Breeds in the greater horseweed and common ragweed, Ambrosia trifida L. and A. artemisicefolia L., in the stems of which the larvæ hibernate. On the horseweed the beetle is usually to be found resting in the angles between the leaves and stem.

\section{Lepturges Bates. 1863. (Gr., "slender + to make.")}

Small somewhat flattened species, having the sides of thorax angulate near or close to the base: antenna fringed beneath with 
very short hair; pro- and mesosterna both very narrow, barely wide enough to separate the coxæ; hind tarsi with first joint as long as all the others united. Five of the six recognized species have been taken in the State.

\section{KEY TO INDIANA SPECIES OF LEPTURGES.}

a. Spine on side of thorax rather broad and very close to the base.

1989. SYMMETRICUS.

a a. Spine on side of thorax more slender and acute, less close to base, the tip recurved.

b. Elytra with a black crossbar behind the middle.

c. Crossbar of elytra incomplete, broadly interrupted by the suture.

1990. SIGNATUS.

cc. Crossbar of elytra complete, broad.

d. Apex of elytra not black; crossbar oblique on each elytron.

1991. QUERCI.

$d d$. Apex of elytra black; crossbar transrerse.

1992. FACETUS.

bb. Elytra without a crossbar, but each with six round black spots; thorax with four spots.

1993. REGU LARIS.

1989 (6435). Lepturges symmetricus Hald., Trans. Amer. Phil. Soc. X, 1847,50 .

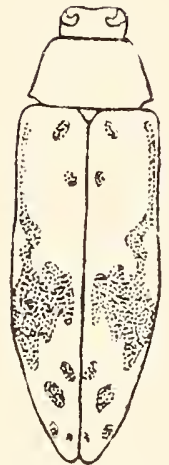

Fig. $462 . \times 4$. (After Horn.)

Elongate, slender, subdepressed. Pale brown, rather densely clothed with purplish-gray pubescence; thorax usually with four rounded dark brown spots. Elytra marked with darker, as shown in Fig. 462. Antennæe one-third longer than body. basal joint dark brown. Thorax and elytra sparsely and rather finely punctate. Length $7-9 \mathrm{~mm}$. (Fig. 462.)

Southern two-thirds of State; scarce. July 2-August 13. Occurs on foliage of wahoo (Euonymus) and other shrubs. The form as above described is that of var. pictus Lee. The markings there given vary in both directions, so that specimens may be nearly dark brown or entirely pale.

1990 (6436). Lepturges signatus Lec., Journ. Phil. Acad. Nat. Sci., II, $1852,171$.

Elongate, rather slender. Pale reddish- or fuscous-brown, sparsely clothed with grayish pubescence; elytra each marked with darker brown as shown in Fig. 463, a. Thorax finely and densely punctured. Elytra rather coarsely and sparsely punctured on basal half, more finely toward tips. Length 6-6.5 $\mathrm{mm}$.

Marion County; rare. July 7. Ocenrs on sumach, Ranges through the Eastern United States. 


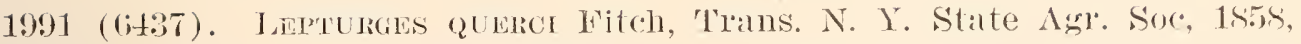
796.

Elongate-oblong, subdepressed. Head and tholax very dark brown, the latter often with a narrow discal line of gray pubescence and a broad one on the sides; elytria pale purplish-brown, marked with dark brown as shown in Fig. 463, b. Antenne more than twice as long as body. Thorax densely and finely, elytra rather coarsely and sparsely, punctured. Tength 3.5-6 mm. (Fig. 463b.)

Throughout the State; frequent. June 3July 8. Taken from flowers of wild hydrangea of L. signatus; $b$, of $L$. querci; and beaten from elm and oak. Breeds in oak, $c$, of $L$ facetus. (After Horn.) hickory and butternut.

1992 (6438). Lepturges Facetes Say, Jonrn. Phil. Acad. Nat. Sci., V, 1826, 271 ; ibid. II, 329 .

Elongate-oblong. Black; elytra each with a broad, oblique, I-shaped whitish mark extending from humerus inward to suture, thence ontward nearly to side margin, and a whitish bar on apical fourth. Antemie and tarsi dark brown, the former more than twice the length of body. Thorax finely and densely, elytra more coarsely and sparsely, punctured. Length 3-4 mm. (Fig. 468, c.)

Kosciusko and Marion counties; scarce. Inne 20-June 25. Occurs on trunks of beech, cedar and hickory, in the rood of which the larvæ dwell.

1993 (6439). Lepturges regularis Lec, Proc. Phil. Acad. Nat. Sci., 1862, 39.

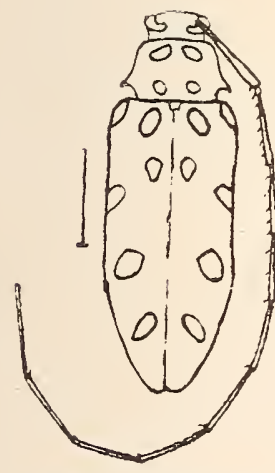

Fig. 461. (After Horn.)

Elongate, slender. Dark brown, densely clothed with purplish-gray pubescence; thorax with four rounded dark brown spots, two near apex and two near base; elytra each with six similar spots arranged in two oblique rows, the outer row of four spots extending from humerus to near apex, the inner row of two spots on basal third; antenuæ, under surface and femora reddish-brown; tibiæ and tarsi black. Thorax and elytra both coarsely and rather sparsely punctured. Length $7-9 \mathrm{~mm}$. (Fig. 464.)

Fountain and Marion counties; scarce. June 14- June 17. Occurs on the foliage of wild grape.

\section{Hrpenplatrs Haid. 1847. (Gr., "over+broad.')}

This genus differs from Lepturges by having the elytra more flattened on the disk, sides abruptly sloping downward and separated from disk by an acute ridge or carina, tips each obliquely emarginate, the outer angle more or less spiniform; antennie more 
distinctly fringed beneath; first joint of hind tarsi as long as the three following united. Two of the three recognized species have been taken in the State.

1994 (6440). Myperpiatrs aspersus Say, Journ. Phil. Acad. Nat. Sci., III, 1S24, 330 ; ibid. II, 187 .

Elongate, slender. Reddish-brown, densely clothed with grayish pubescence; thorax with four small, round, black spots arranged in a transverse row, the two imner ones the larger ; elytra each with three irregular rows of similar spots and usually a large black blotch behind the middle. Antenne of both sexes more than twice as long as body. Thorax wider than long, constricted near base, finely and sparsely punctate. Elytra twice as long as wide at base, more coarsely punctured than thorax. Length 4-6 mm.

Posey County ; scarce. June 28. Breeds in the twigs of cottonwood and quaking asp (Populus) ; also in those of apple.

1995 (6441). Hrperplatys maculatus Hald., Trans. Amer. Phil. Soc., X, $1847,49$.

Resembles the preceding closely. Elytra more sparsely pubescent, the spots much larger and more irregularly arranged, the biotch behind the middle absent; femora "red at base. Antenne of male about twice as long as body; of female shorter. Elytra not twice as long as wide, much more distinctly punctate. Length 4-6 mm.

Kosciusko, Wells, Perry, Spencer and Posey counties; scarce. May 12-June 17. Bẹaten from foliage of shrubs.

LXII. Graphisurus Kirby. 1837. (Gr., "a pencil + tail.")

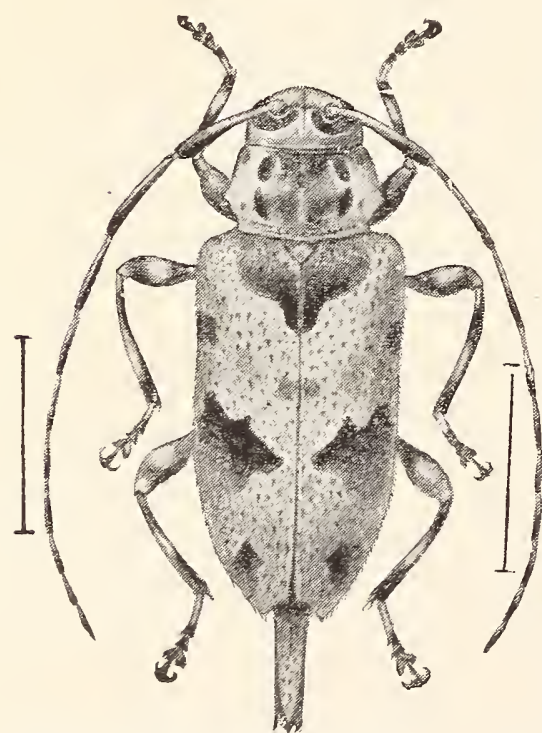

Fig. 465. Graphisurus triangulifer Hald. (After Smith in Fith Rep. U. S. Ent. Comm.)

occurs in the sonthern third.
Here belong two rather robust elongate species, listed under the name Urographis Horn, and having the antennæ nearly equal in the sexes, joints 3-11 gradually decreasing in length; prosternum of moderate width, with a median groove; elytra emarginate at tip; thorax with a blunt tubercle at the sides a little behind the middle. The ovipositor is much prolonged and the fifth ventral segment is also nearly equally prolonged to form a shield on its under side. One of the two has been taken in the State and the other, triangulifer Hald. (Fig. 465), a member of the Austroriparian fauna, probably 
KEY TO SPECIES OF GRAPHISLRUS.

a. Prolonged fifth ventrai of female emarginate at tip ; talsi equal in width in both sexes; pubescence of upper surface mostly clay-yellow; length $13 \mathrm{~mm}$.

TRIANGULIEER。

aa. Fifth ventral of female deeply cleft at tip; front and middle tarsi of male broader than in female; pubescence of upper surface chiefly grayish.

1996. FASCIATUS.

1996 (6443). Graphisurus Fasciatus DeG., Mem., $\mathrm{V}, 1775,114$.

Elongate, rather slenđer. Thorax grayish with black dots; elytra thickly sprinkled with small black spots, and usually with two irregular blotches, one in front of, the other behind the middle; antennæ and legs annulate. Thorax finely and indistinctly, elytra rather coarsely and sparsely, punctured. Length $8-14 \mathrm{~mm}$. (Fig. 466.)

Throughout the State; frequent. May 11-July 22. Found especially beneath bark of beech and hickory; numerous pupe under the former on June 9 ; also breeds in oak and maple.

\section{liNiII. Ceratographis Gahan.} (Gr., "horn + pencil.")

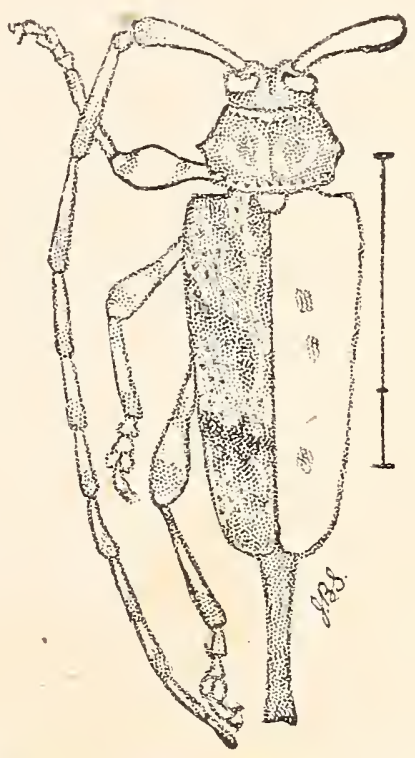

1888

Fig. 466. (After Smith in Fifth

This genus, sufficiently characterized in the generic key, is represented in the eastern United States, including Indiana, by a single species.

1997 (6444). Ceratographis biguttatus Lec., Journ. Phil. Acad. Nat. Sci., II, $1852,172$.

Elongate, slender, slightly depressed. Dull brownish-yellow, rather densely clothed with brownish pubescence; elytra indistinctly mottled with grayish, each with an oblique black band behind the middle and a short, elevated blackish line on base. Thorax rather finely and densely punctured, with a sharp, obliquely placed spine each side behind the middle. Elrtra rather coarsely, deeply and somewhat closely punctate. tips rounded. Oripositor of female one-half the length of the preceding species; all the femora clavate. Length $9 \mathrm{~mm}$.

Lake County ; rare. July 23. A species of northern range.

Acanthocinus obsoletus Oliv., dull whitish-yellow, elytra with some small blotches and three indulated cross-bars, length 10-15 mm., is known from Wisconsin and Ohio, eastward and southward. 


\section{Tribe V. POGONOCHERINI.}

The genera comprising this tribe are represented by small, somewhat flattened species, having the tarsal claws divaricate; scape of antennæ short and stout without cicatrix; thorax with a spine or tubercle each side. They usually bear long, erect (flying) hairs in addition to the ordinary pubescence, and the antennæ are only a little longer or shorter than the body, the outer joints gradually shorter. Three of the eight genera composing the tribe are known to be represented in the State, while a member of another probably occurs.

KEY TO THE INDIANA GENERA OF POGONOCHERINI.

$a$. Thighs club-shaped; rertex concare; antennal tubercles prominent.

b. Lower lobe of eyes elongate; spines on sides of thorax large, median; pubescence mottled, gray and black mixed with short, scattered hairs on elytra.

Hoplosta.

77. Lower lobe of eyes as wide as long, subquadrate or subtriangular.

c. Thorax with spines on sides; flying hairs long.

LXIV. Pogonocheris.

cc. Thorax with feebly rounded sides; pubescence short.

LXV. Ecrrus.

a a. Thighs not club-shaped; vertex flat or convex; antennil tubercles not prominent; eyes coarsely granulated, lower lobe as wide as long.

LXVI. Eupogonies.

Hoplosia mubila Lec, length 9-12 mm., is said to breed in twigs of dry beech and linden and is recorded from Michigan, Illinois and New York.

LXIV. Pogonocmerus Latr. 1829. (Gr., "beard + to enjoy.")

In this, as well as the next genus. the eyes are not coarsely granulate; thorax with faint dorsal tubercles, elytra feebly carinate on sides ; femora club-shaped; hind tarsi short, the first and second joints equal. Two species may occur in the State, though but one has been taken.

KEY TO INDIANA SPECUES OF POGONOCHERUS.

a. Elytra with weil marked costre on the sides and with a row of five or six tufts of erect black hair's.

PENICILLATUS.

a a. Elytra without costie or tufts of hairs. 1998. MIXTUS.

$P$. penicillatus Lec., piceous, elytra behind the base densely clothed with gray pubescence, length $6 \mathrm{~mm}$, ranges from Maine to Michigan and Lake Superior. 
1998 (6453). Pogonocherus mixtus Hald., Trans. Amer. Phil. Soc., X. $184 \pi, 50$.

Elongate-oblong. Head and thorax piceous black; elytra blackish, variegated with dull brownish-yellow, bearing sparse, erect black hairs, and each with a broad, oblique band of white pubescence extending from side behind the humerus nearly to suture; antenne and base of femora dull reddish-brown. Thorax with two dorsal tubercles; surface smooth in lemale, densely and finely punctured in male. Elytra rather coarsely and closely punctate, the tips subemarginate. Length $4-7 \mathrm{~mm}$.

Lake, Porter and Kosciusko counties; frequent beneath the bark and on the dead limbs of pine. June 15-July 23. Said to occur also on pear trees and in dead branches of willow.

\section{Ecyrus IeConte. 1852.}

This genus differs from the preceding by having the antennæ very hairy; front tibir suddenly thickened at apex; thorax cylindrical and unarmed; pubescence of elytra more dense and close with a few erect short hairs proceeding from rows of granules. Three species are known, two of which may occur in Indiana, though but one has as yet been taken.

\section{KEY TO INDTANA SPECIES OF ECIRUS.}

a. Thorax moderately punctured; elytra each with four rows of small, distant tufts of black hairs.

1999. DASYCERUS.

aa. Thorax with only a few coarse punctures on sides; elytra variegated with brownish spots.

ExIGUUS.

1999 (6456). Ecrrus dasycerus Say, Journ. Phil. Acad. Nat. Sci., V, 1826, 270 ; ibiđ. II, 328.

Elongate, robust. parallel. Pale grayish-brown; elytra with a common. narrow, curved band on basal third reaching to middle of sides and each with four lows of minute tufts of blackish hairs, one on the suture, the others on slightly raised lines. Antennæ a little longer than body, annulate. Occiput deeply impressed. Front margin of thorax with two small tubercles at middle; disk with two black facets, surface rather closely and finely punctured. Elytra coarsely and sparsely punctured, the tips subtruncate. Length 6-S mm.

Throughout the State; frequent. June 1-July 2. Beaten from foliage of elm and wild grape and from limbs of dead oak.

E. exigurs Lec., antennx dull yellow, not annulate, length 4.5 mm., is known from Ohio, Georogia and Kansas. 
LXVI. Eupogonius Lec. 1852. (Gr., "well + bearded.")

Eyes very coarsely granulated; antennæ not longer than body, thickly clothed with long flying hairs, scape feebly club-shaped, shorter than third joint, joints 5-10 equal: thorax densely punctured without dorsal tubercles, armed on the side with a small spine; legs short, equal; first joint of hind tarsi a little longer than second. Four species are known, all of which may occur in Indiana, though but one has been taken.

\section{KEY TO SPECIES OF EUPOGONICS.}

a. Spine on side of thorax acute, well marked.

b. Elytra pale chestnut brown, the punctuation feeble, almost obsolete near apex; pubescence ash-gray or yellowish, forming more or less transverse reticulations.

TOMENTOSUS.

bb. Elytra piceous, the punctuation coarse, gradually finer but distinct at tip; pubescence pale clay-yellow arranged in irregular small patches.

2000. VESTITUS.

aa. Spine on side of thorax small, obtuse.

c. Elytra nearly black, punctuation rather coarse, finer but distinct at apex, the pubescence ash-gray, fine and rery erenly disposed; thorax sparsely and erenly pubescent.

PUBESCENS.

cc. Elytra black, coarsely punctured even to the apex, the pubescence black and inconspicuous; thorax with a broad line of yellowish pubescence each side.

SUBARMATUS.

E. tomentosus Hald., length $7-\& \mathrm{~mm}$., occurs on pine and is known from Nichigan, Wisconsin, Pennsylvania and Florida; $E$. pubescens Lec., length $7-8 \mathrm{~mm}$., is recorded from Ohio and northern Illinois; E. subarmatus Lec., length 7-8 mm., breeds in elm and occurs throughout the eastern United States.

2000 (6459). Eupogonius vestitus Say, Journ. Phil. Acad. Nat. Sci., V, 1826, 273 ; ibid. II, 331.

Elongate, convex, parallel. Piceous brown, everywhere sparsely clothed with erect hairs; elvtra marked with numerous small, irregular patches of clay-yellow pubescence. these sometimes (form pauper) becoming narrow transverse lines. Thorax densely, deeply and rather conssely punctured. Elytra rounded at tips. Length 6-8 $\mathrm{mm}$.

Throughout the State; frequent. Nay 21-June 25. Beaten from foliage of oak, beech and wild grape; said to breed in dead hickory limbs. 


\section{Tribe VI. ONCIDERINI.}

Front coxal cavities angulated on the outer side and closed behind; antennie longer than body in male, as long as body in female, the scape stout, without cicatrix; legs rather stout, equal; claws slightly divergent. One genus of the tribe is represented in New York, Pennsylvania, Louisiana, Texas and probably southern Indiana by the "hickory girdler,' Oncideres cingulaia Say, length 14 $17 \mathrm{~mm}$., smoky or reddish-brown to clay-yellow in hue, with the pribescence usually forming a broad median band on elytra, thorax with or without a spine on sides, the disk usually with three small black facets. The female beetle deposits her eggs in

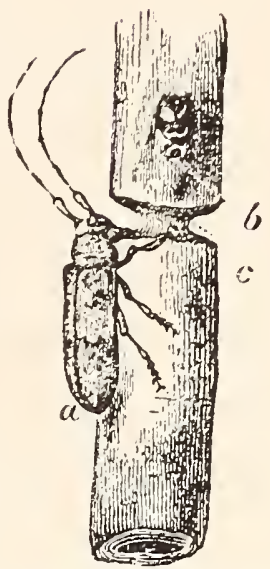

Fig. 467. Oncizieres cingulata Say. $a$, beetle; $b$, hole made in depositing egg; $c$, girdle cut by female. (After Riley.) twigs of trees and then cuts a girdle about the twig below the eggs. (Fig. 467.) 'The twig dies and is broken off by the wind, falling to the ground where the larvæ mature. The beetle occurs in August and September and not only girdles the young twigs of hickory, but also those of pear, apple, plum, elm, linden, and other trees.

Tribe VII. HIPPOPSINI.

Body very slender; front long and inflexed so that the mouth is near the prosternum; palpi not slender, the last joint almost conical and pointed; eyes coarsely granulated; front coxæ annulated; legs rather short, equal; tarsi as long as the tibix, first joint of hind pair slightly elongated, last joint rather long, claws divergent. One of the four genera is represented in the State.

\section{Hippopsis Serv. 1825. (Gr., "horse + face.")}

This genus, sufficiently characterized above, is represented in the eastern United States by a single species.

2001 (6472). Hippopsis lemiscata Fab., Syst. Eleut., II, 1801, 330.

Elongate, very slender, cylindrical. Dark reddish-brown; thorax with two whitish lines each side; elytra each with three whitish lines; antenne pale brown, darker at base, more than twice as long as body, fringed with hairs beneath. Thorax much longer than wide, cylindrical, rather coarsely and densely punctured. Elytra with coarse, deep punctures arranged in rows, the tips rather acute. Length 10-13 $\mathrm{mm}$.

Tarion, Vigo and Orange comnties: scarce. May 28-June 7. Breeds in stems of ragweed (Ambrosia); also in those of tickweed 
and bur-marigold (Coreopsis and Bidens). Taken by sweeping these plants.

\section{Tribe VIII. SAPERDINI.}

Large or medium-sized, cylindrical species having the front flat, quadrate and vertical; eyes finely granulated, deeply emarginate; paipi rather stout, last joint more or less

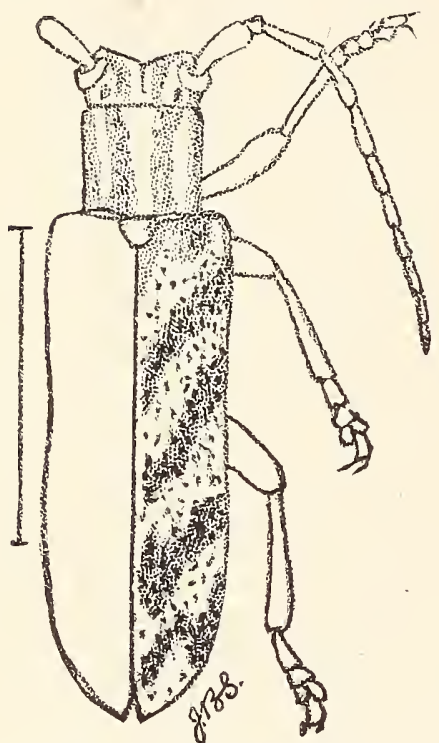

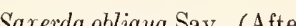
Smith in Fifth Rep. U. S. Ent. Comm.) oval, truncate at tip; antennæ as long as body or a little shorter, scape nearly cylindrical, without cicatrix ; thorax cylindrical, without spines or tubercles; elytra wider than thorax, rounded (rarely spinose or acuminate) at tip; legs moderate, thighs not club shaped; hind tarsi with first joint much elongated; tarsal claws divaricate. All of our species belong to the single genus:

LXVIII. SAPERda Fab. 1775. (Gr., "a kind of fish."')

To this genus, as characterized above, 15 North American species have been ascribed by Messrs. Felt and Joutel, ${ }^{*}$ of which eight have been taken in Indiana, while six others may occur. Among them are beetles of much economic importance, several being very injurious to apple trees, while others prey upon the elm, hickory, linden and poplar.

KEY TO INDIANA SPECIES OF SAPERDA.

a. Antennæ plainly annulate.

b. Head deeply impressed between the eyes.

c. Elytra obliquely narrowed, ending in a spine at tip ; color yellowish-brown with four oblique darker bands. (Fig. 468.)

OBLIQUA.

cc. Elytra slightly narrowed at tip and without a spine; thorax with three orange yellow lines.

2002. MUTICA.

bb. Head rounded in front.

d. Thorax with a dense line of gray pubescence each side; black, coarsely punctured, thinly clothed with fine ash-gray pubescence.

MOESTA.

dd. Thorax with pubescence uniform, black, more finely punctured, densely clothed throughout with gray pubescence.

2003. CONCOLOR.

aa. Antennæ unicolored, not annulate.

*Their monograph is a model of its kind, giving full description, life history and colored figure of each species and its markings. 
c. Elytra rounded at tip with spine at suture, very rarely with the apex acute and without sutural spine; gray with yellow patches.

2004. CA LCARA'TA.

ec. Elytra rounded at tip without spine at suture.

$f$. Elytra with marginal or submarginal stripes.

g. Thorax and elytra not black.

h. Pubescence silvery white; thorax and elytra brown or yellowish-brown with two white stripes. (Fig. 470.) CANDIDA.

7ih. Pubescence ash-gray.

$i$. Thorax yellow with four black spots on disk and one on each side; elytra with broad marginal and sutural stripes bright yellow.

PUNCTICOLIIS.

ii. Thorax and elytra gray, each with an orange stripe on sides.

$j$. Second and third crossbands on elytra oblique, a small dark spot usually on each side of first and one behind the third.

2005. TRIDENTATA.

$j j$. First and second crossbands on elytra oblique; small dark spots wanting.

2006. IMITANs.

g!. Thorax and elytra black, with orange stripes on sides, rarely a sutural orange stripe present; surface coarsely punctured.

2007. LATERALIS.

ff. Elytra without stripes, usually with spots, rarely unicolored.

k. Elytra with white pubescent spots; thorax with two white stripes; sides and under surface white.

l. Humeri of elytra not white; two large white spots on each elytron, reaching neither margin or suture. (Fig. 472.)

CRETATA.

71. Humeri white; two white spots near the suture on each elytron.

FAYI.

lik. Elytra without white pubescent spots.

$m$. Cimnamon or reddish-brown, sometimes nearly black; male smaller, $10 \mathrm{~mm}$., with elytra unicolored; female, larger, 15 mm., with a transverse undulated yellowish crossbar at middle.

200S. DISCOIDEA.

$m \mathrm{~m}$. Olive yellow, with three small black dots near middle of each elytron, these sometimes wanting. 2009. VESTITA.

S. obliqua Say (Fig. 468), length 16-19 inm., is known from New England to Michigan and Wisconsin. It is found on black alder (Alnus sermulata Willd.) in June and very probably occurs in northern Indiana. S. moesta I.ec., length $8-9$ mm., breeds in poplars and is known from New England, Northern Ohio, Michigan and westward.

2002 (6479). Saperda mutica Say, Journ. Phil. Acad. Nat. Sci., III, 1S24, 409 ; ibid. II, 191.

Elongate, robust. Black, sparsely clothed with gray and yellow pubescence. Thorax with an orange median stripe extending onto the head and a similar stripe each side; elytra with numerous patclies of denser yellow 
pubescence; antemnse shorter than body, anmulate with gray and black. Thorax and elytra rather coarsely and sparsely punctate, the punctures showing as bare round dots. Length $9-15 \mathrm{~mm}$.

Kosciusko and Marshall counties; searee. June 5-August 17. Beaten from foliage of black oak. Occurs near lakes and possibly breeds in willow.

2003 (64S9). SAPERd concolor Lec., Journ. Phil. Acad. Nat. Sci., II, 1852, 163.

Elongate, slender, cylindrical. Black, everywhere densely and evenly clothed with fine, prostrate, gray pubescence; antennie annulate. Thorax and elytra rather finely and sparsely spunctured, the latter with tips rounded. Length 10-12 $\mathrm{mm}$.

Lake County; rare. June 16. Breerts in the stems of willow (Salix longifolimm Muhl.), and in the base of sapling poplars. Probably occurs throughout the State.

2004 (647S). Saperda calcarata Say, Jouln. Phil. Acad. Nat. Sci., III, 1S24, 40S; ibid. II, 190.

Elongate, robust, subcylindrical. Reddish-

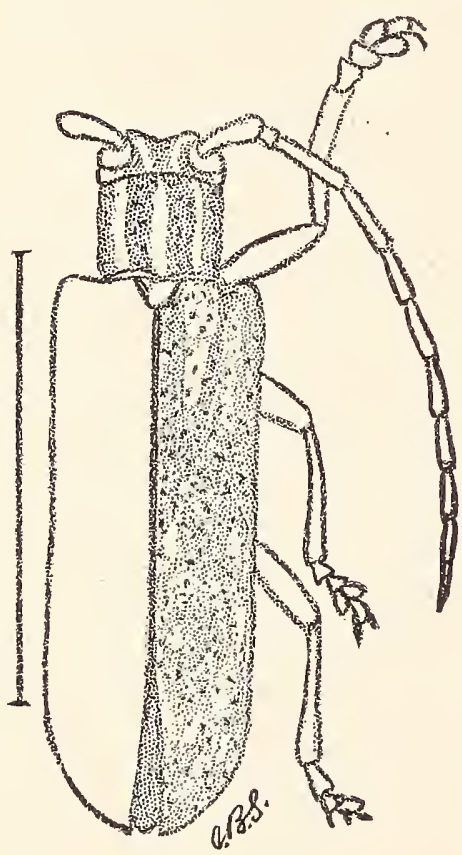

Fig. 469. (After Smith in Fifth"Rep. U. S. Ent. Comm.)

brown. densely clothed with prostrate gray and yellow pubescence. Front of head, three stripes on thorax, scutellum and numerous lines and blotches on elytra, orange yellow. Thorax sparsely, elytra more closely, marked with small. round, black, bare dots or punctures. Length 21-30 1mm. (Fig. 469.)

Lake. Porter, Marion and Vigo counties, frequent; probably throughout the State. May 31-July 16. This beetle, known as the "poplar borer," is our largest member of Srperda. It breeds in cottonwood, quaking ash, lombardy poplar and other members of Populus, to which it often does great damage. Three years are probably required to complete its lifo changes. Where trees are badly infested the most obvious signs are the numerous blackened, swollen scars alnng the surface of the trunks and limbs. Sometimes these are open, and in early summer large quantities of borings are expelled from the inhabited galleries, and frequently occur in considerable piles about the base of the trees. It is impossible to atiempt to control this insect on other than valuable shade or park trees. In such situations, digging out 
the borers, with possible recourse to the use of repellant washes, is about all that can be done and in the majority of instances should afford considerable protection. In one specimen from Porter County the tips of elytra are acute and divaricate.

S. candida Fab. (Fig. 470), length 15-20 mm., has the same range as meesta. Its larva is known as the "apple tree borer" and is sometimes very destructive to apple, crab-apple, June berry and Fig. 470. Saperda canred-haw. It attacks the tree near the base, and dida Fab. Natural size. several thicknesses of newspaper, loosely tied, or a wire netting kept at a distance of half an inch from the trunk for a height of three feet above the ground from May till September, will serve as a protection. A heary coating of whitewash with Paris green to the same height will also often prevent the beetle from depositing eggs.

S. puncticollis Say, length 9-10 mm., breeds in the poison ivy, Rhus radicans L., and occurs about the middle of June on that plant.

2005 (6485). Saperda tridentata Oliv., Ent., IV. 1795, 30.

Elongate, slender, subcylindrical. Blackish-brown to piceous, rather densely clothed with fine, gray, prostrate

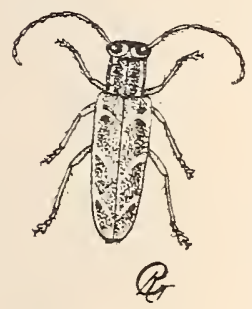

Fig. $471 . \times 1 \frac{1}{4}$ (After Riley.) pubescence, that on under surface longer and more conspicuous; thorax with an orange stripe each side extending onto head, where it divides and encircles an eye. usually with two black dots each side below the stripe; elytra each with a narrow, submarginal, orange stripe from which proceed three bands, the first nearly transverse except at tip, the other two oblique and usually joining those from opposite side at suture. Thorax and elytra rather coarsely and sparsely punctate, the latter with tips subtruncate. Length 9-14 mm. (Fig. 471.)

Throughout the State; frequent. Tray 20-.July 10. This beetle is commonly known as the "elm borer," as the larva are very injurious to the white and slippery elms, especially to the former when planted as a shade tree. The first signs of its attack are usually seen in the lighter, thinner foliage, followed by a deac limb here and there. Indications of boring soon appear, and the dark sawdust collects in crevices of the bark, and, after the attack has progressed for some time, large portions of the bark may be easily pulled from the tree. The inner portion of the bark may be hiterally a mass of mines or burrows, and if the work has not gone too far, numerous whitish, flattened, legless gruhs may be found in the channels they have excavated.

[69-23402] 
Badly infested trees should be cut and burned before the beetles have had an opportunity to emerge in the spring or, in Indiana, before the middle of May. Infested portions of other trees should also be cut away and burned. Removing portions' of the bark has also been recommended. The badiy infested portions should be cut away and the grubs destroyed and, where a few are working in living bark, it might be well to remove the upper layers until the grubs are nearly exprsed and then brush over the shaven surface with strong kerosene emulsion or whale oil soap solution, finally covering the wound with a paste formed of a mixture of fresh cow dung and lime or with a coat of cheap red paint.

2006 (-). Saperda imitans Felt \& Joutel, Bull. 74, N. Y. St. Museum, $1904,5 S$.

Resembles tridentata, but more slender. General color darker; first crossbar of elytra oblique without spots on each side; second crossbar usually not connected with marginal stripe, the tip more pointed and rarely reaching suture; third crossbar usually rudimentary and transverse. Elytra with humeral angle less pronounced and tips rounded. Length 11$13 \mathrm{~mm}$.

Crawford and Posey counties; scarce. May 12-May 15. Beaten from foliage of hickory, in the wood of which the larvæ are supposed to live.

2007 (64S6). Saperda lateralis Fab., Syst. Ent., 1775, 185.

Elongate, rather robust. Piceous black; pubescence beneath gray and dense; above blackish-brown, very sparse and intermixed with short semierect black hairs; thorax and head marked with orange as in tridentata; elytra each with a submarginal orange stripe connecting with that of thorax at humeral angles and often also with a very narrow sutural stripe of same hue. Males with a tooth or process on all the claws. Length 9 $15 \mathrm{~mm}$.

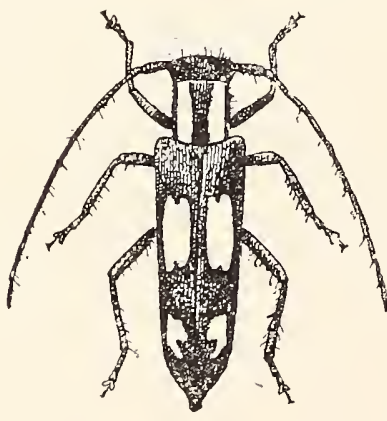

Fig. $472 . \times 1 \frac{1}{2}$ (After Chittenden.)

Throughout the State; frequent. May 30 July 2. Beaten from hickory and elm. Breeds in the former, but rarely abundant enough to do much damage.

S. cretala Newm. (Fig. 472), length $12-20$ mm., and S. fayi Bland., length 10-12 mm., both breed in the red-haw (Cratcegus) and emerge in Sune. The former ranges from New England to Michigan, Illinois and Iowa, while fayi is known from Ohio eastward. 
2008 (6484). SAPERda discoidea Fab., Ent. Syst. Supp., 1798, 147, female; fuscipes Say, Journ. I'hil. Acall. Nit. Sci., V, 1827, 279, male.

Elongate, subcylindrical. Male, slender, usually blackish or piceous; above sparsely clothed with grayish pubescence, which forms a whitish line on disk and sides of thorax; that of under side more dense, longer and silvery white; femora reddish-brown, tibia and tarsi often darker. Female more robust, dark reddish-brown, the pubescence olive or grayish-yellow; head, thorax and scutellum more densely clothed with yellow hairs; elytra each with a small spot on basal third, another on apical third and a rather broad, crescent-shaped bar at middle, composed of dense yellow hairs; under surface light yellowish-gray. Length, male, 10-11 $\mathrm{mm}$; female, 14 $16 \mathrm{~mm}$.

Marion, Putnam and Lawrence counties, scarce; probably throughout the State. June 6-July 15. The sexes ale so unlike in size and appearance that they were long mistaken for distinct species. It breeds in hickory and butternut, usually confining its attacks to diseased or dying trees.

2009 (6483). SAPERDa vestita Say, Long's Exped., 1824, 29 ; ibid. I, 193.

Elongate, robust, cylindrical. Dark reddish-brown, everywhere clothed with dense, olive-yellow, prostrate pubescence. Elytra each usually with three small black dots, two placed obliquely in front of and one, more distant, behind the middle. Length 12-21 mm. (Fig. 473.)

Throughout the State; frequent. June 3-August 20. A large and handsome beetle known as the "linden borer," as the larva live in the wood of the linden ('Titia), often proving very destructive to those set out for shade. Remedies the same Rep.U. S. Ent. Comm.) as those above given for the "poplar borer."

\section{'Tribe IX. PHYT(ECINI.}

Medium-sized cylindrical or rather robust forms, having the tarsal claws cleft or toothed in both sexes; front moderately convex, broader than long; eyes finely granulate, emarginate or divided; palpi slender, last joint elongate-oval, nearly pointed; antennæ not longer than body, scape cylindrical; thorax either cylindrical or with an obtuse tubercle on sides; ely tra cylindrical, rounded or truncate at tips; front coxre conjcal, cavities angulated, closed behind; legs short, thighs not chub-shaped; hind tar'si with first joint not elongate, last joint rather long. The tribe is composed of five genera, all of which are represented in Indiana. 
KET TO GENERA OF PHITECIINI.

a. Exes deeply emarginate but not divided; thorax cylindrical.

乙. Antemie not pilose: form elongate. slender, crlindrical.

c. Bods abore nearly uniform gras: tarsal clatrs feebls tootled or cleft.

LIIX. MECAS.

cc. Body abore nerer uniform gray, usualls bicolored, with small black spots ou thorax: tarsal claws broadly toothed. LNX. ObEREA.

66. Anteme thickly pilose with long black hairs; form shorter, elongateoblong.

LXXIIT. AMPHIONтсHA.

aa. Eres completely dirided, the upper and lower portions widels separated; thorax dilated or tuberculate on the sides.

d. Form slender: head and thorax red, elrtra black: tarsal claws broadls toothed.

LXXI. Tetrops.

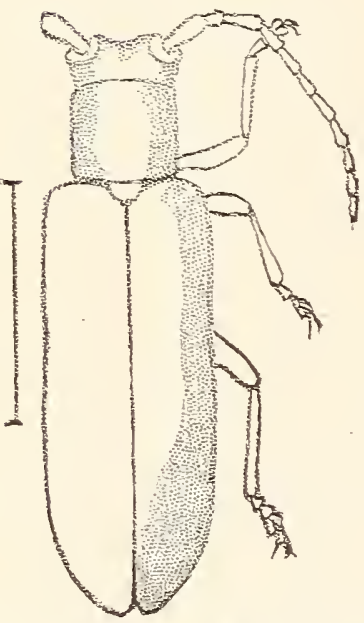

Fig. 474. Mecas inomata Say. (After Smith in Fifth Rep. U. Ent. Comm.) dd. Form robust; color red with black spots; tarsal clars cleft.

LXXII. TETRAOPES.

Our members of this genus are slender. black species, clothed with gray pubescence. Ther resemble small Saperdas, but have the front short and subconvex instead of flat and quadrate, and the tarsal claws cleft. Their habits are. moreorer. different, as they do not breed in rood. but in the stems of herbs or weeds. One of the fire known species has been taken in the State. while two others may occur.

KET TO INDIATA SPECIES OF MECAS.

a. Legs black.

7. Bods abore uniformly clothed with ash-gras pubescence: thorax usualls with a bare eleration each side of disk; tarsal claws deepls cleft, the inmer portion broad and lobe-like.

IXORYATA.

77. Body above sparsels clothed with ash-gray pubescence; thorax at sides and middle. elrtria at suture and sides more densels clothed with sellowish-white pubescence: thorax without bare elerations.

MARGITELIA.

ua. Legs, or at least the femora, red; thorax with four or fire slightly elerated. hare, ronnd spaces.

2010. PERGRATA.

H. inomata Say (Fig. $17 \pm$ ), Jength $\$-15 \mathrm{~mm}$. is recorded from Cincinnati. Wisconsin and westrard: W. marginclla Lec., length T-E mmi. is known from Illinois. Texas and Kansas. 
(6492). Mecas Pergrata Say, Journ. Phil. Acad. Nat. Sci., III, 1824, 408 ; ibid. II, 190.

Elongate, slender, cylindrical. Black, above sparsely clothed with rlark ash-gray hairs ; suture and margins of elytra more densely and conspicuousls clothed with whitish pubescence; under surface thickly clothed with pale gray hairs; femora reddish; antennæ annulate. Thorax with two round black spots placed obliquely on each side of median line and another behind them on the line; surface, as well as that of elytra, rather coarsely and sparsely punctured. Length $8-10 \mathrm{~mm}$.

Knox, Dubois, Spencer and Posey counties; scarce. May 24 July 10. Swept from low herbage along roadsides. Resembles Saperda concolor, but readily disting mished by generic characters, paler suture and redilish femora.

\section{Oberea Muls. 1839. (A proper name.)}

Very slender elongate species, having the tarsal claws broadly toothed; eyes not divided; middle tibire sinuate on outer edge; thorax without tubercles. The females have the last ventral segment impressed lengthwise and feebly emarginate and the last dorsal (pygidium) sometimes projecting in an obtuse conical protuberance. Five species and one variety have been taken in the State. and one or two others probably occur.

KEY TO SPECIES OF OBEREA.

a. Thorax marked with small, rounded, black elevations or callosities.

b. Thorax with four callosities; pygidium of female strongly protuberant.

2011. SCHAUMII.

bb. Thorax with two callosities and often a third spot black; pygidium of female feebly protuberant.

c. Elytra truncate at tips.

d. Color entirely black except the thorax. 2012. BIMACCLATA.

dd. Legs, elytra and abdomen usually in part sellow.

2013. TRIPUNCTATA.

cc. Elytra rounded at tips; abdomen red, elytra black.

2014. OCELLATA.

ar. Thorax without callosities.

c. Elytra not pubescent: pale dull sellow with a fuscous stripe on sides.

GRACILIS.

ce. Elytra closely clothed with prostrate pubescence; pale red, antennie and elytra black.

2015. RTFICOLLIS.

2011 (649S). Oberea schat'mi Lec., Journ. Phil. Acad. Nat. Sci., II. 1552.2. 153.

Elongate, robust for the genus. Color rariabìe, usually pale, dull yellow; elytra, antennie and tarsi of ten nearly black. Thorax nith four round. black. smooth spots arranged in a curved line; in tlie darker specimens the 
basal half often black; disk sparsely and rather finely punctate. Elytra more coarsely and closely punctate, the tips rounded or feebly subtruncate. Length 11-16 mm.

Throughout the State; scarce. May 24-June 23. Breeds in the living twigs of cottonwood, Populus monilifera Ait. A number of the specimens in the collection were taken from sidewalks in Terre Haute and Indianapolis.

2012 (6496). Oberea bimaculata Oliv., Ent., IV, 1795, 21.

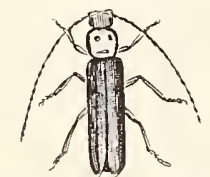

Elongate, slender, cylindrical. Black, shining; thorax yellow, with two round black spots on disk and often with a small black one in front of scutellum; the lower portion of sides also black. Thorax and elytra punctured as in ocellata. Length S-12 mm. (Fig. 475.)

Fig. 475. Natura
size. (After Forbes.)

Throughout the State, frequent; more so in the northern counties. June 4--June 26. Often taken by sweeping low herbage along the borders of marshes. Breeds in the canes of raspberries and blackberry. In var. basalis Iee. the thorax has two discal spots and the entire basal margin black.

2013 (6503). Oberea tripunctata Swed., Ac. Nya Handl., 1787, 197.

Elongate, slender, cylindrical. Color exceedingly variable. In typical tripunctata the body beneath is usually in great part yellow, sometimes wholly black; head fuscous, rarely yellow; thorax yellow, with two spots on disk and another in front of scutellum black; elytra each with a wide discal stripe dull yellow, the suture and margins blackish. Thorax sparsely and rather shallowly punctured. Elytra coarsely, densely and deeply punctured, the punctures in rows. Length $\mathrm{S}-16 \mathrm{~mm}$.

Throughout the State; frequent. May 24--June 24. Breeds in the twigs of cottonwood; also in those of blackberry.

A number of color varieties of this and bimaculata have been named, and the two species probably merge. Among the varieties are myops Hald, having the head yellow, the sutural black stripe of elytra and black spot before scutellum of thorax wanting, and $f a$ vipes Hald., black, with legs yellow and thorax almost wholly black.

2014 (6501). Oberea ocellata Hald., Trans. Amer. Ent. Soc., X, 1847, 56.

Elongate, subcylindrical. Under surface and femora entirely red; head and thorax usually red, rarely more or less black, the latter with two small, black, rounded spots on disk; elytra, and usually the tibiæ and tarsi, black. Head and thorax rather sparsely, deeply and coarsely punctate, the latter somewhat constricted at base. Elytra with rows of coarse punctures which are less dense than in allied species. Length 13-14 $\mathrm{mm}$.

Lake and Lawrence counties; rare. June 9-July 4. Probably breeds in blackberry stems, as the two specimens at hand were taken hy sweeping about a cluster of these bushes. 
O. gracilis Fab., antennæ fuscous, legs pale, tips of tibix and tarsi darker, length 10-13 mm., is known from New York, New Jersey and southward.

2015 (6505). Oberea ruficoldis Fab., Ent. Syst., II, 1775, 311.

Elongate. subcylindrical, rather robust. Pale reddish-yellow; antennie, elytra. tibiæ and tarsi nearly black. Thorax short, about as broad as long. without discal black spots. Elytra rather densely clothed with gray pubescence and with irregular rows of moderately fine oblong punctures; tips subtruncate. Length $15-18 \mathrm{~mm}$.

Vigo County; rare. June 19. One specimen taken on the wing.

LXXI. Tetrops Steph. 1839. (Gr., "four + eyes.")

This genus, sufficiently characterized in the key, is represented in the State by a single species.

2016 (6507). Tetrops joxostigua Hald., Trans. Amer. Phil. Soc., X. $185 \pi, 57$.

Elongate, slender, cylindrical. Black. shining; elstra with black. recumbent and erect hairs; head and thorax red, the latter with black spot on disk; femora reddish-yellow; antennal joints paler at base, pilose with long hairs. Thorax feebly constricted before and behind, sparsely and rather coarsely. punctured. Elytra with rows of rather closely placed. coarse and deep punctures; tips rounded. Length $7-9 \mathrm{~mm}$.

Dubois and Spencer counties; scarce. May 22--15ay 24. Taken by sweeping low herbage along roadsides. The middle trochanters of male are very strongly dereloped. T. jucunda Lec. is doubtless a synonym, the legs in the specimens at hand varying from wholly black to almost wholly reddish-yellow.

\section{Thtraopes Serville. 1835. (Gr., "four + eyes.")}

Medium-sized, stout-bodied species, having the antennæ shorter than body; thorax armed with a blunt tubercle each side and, in our species, marked with four round black spots. They occur altogether on the different species of milkweed (Asclepias), in the stems and roots of which they breed. Four of the eight known species have been taken in the State.

KEI TO IXDLANA SPECIES OF TETRAOPES.

a. Elytra with a common median and apical heart-shaped black space; disk of thorax red, regularly conrex.

2017. CANTERIATOR.

a a. Elytra with romided or elongate black spots; disk of thorax distinctly elerated.

Ђ. Antennæ black, not annulate: abdomen rery sparsely punctulate; larger median spot of elytra oblong.

201S. TETRAOPHTHALMTS. 
6. Antenne more or less distinctly annulate; abdomen densels but rery finely punctulate.

c. Median eleration of thorax oblong. suddenlr elerated, its sides rertical; usually four rounded spots on each elitron.

2019. FEMORATCS.

cc. Median eleration of thorax rounded, gradually conrex; elstra each with two spots and tip black.

2020. QUIXQUEMACLLATLS.

2017 (6510). Tetraopes Canterlator Drap.. Anm. Gen. des Sc.. II, 1S19. 47.

Elongate-oblong. Black. clothed with sparse. suberect, black hairs: head and thorax red. the latter with four round spots on disk; elctra red. black from in front of middle to apex, the black space nearly dirided near its middle, the front portion sometimes small: scutellum and a small spot on each humerus also black. Thorax almost smooth. Elytra rather coarsely and closely punctate. Length $\mathrm{S}-12 \mathrm{~mm}$.

Posey County; rare. Jult 9. Ranges from New England to Iowa and southward.

2018 (6511). Tetraopes tetraophthalmes Forst.. Cent. Ins., 1ii. 41.

Elongate, robust. Black; head. thorax and elytra red; thorax with four spots on disk and sometimes a blotch on front angles and basal margin black; elstra each with a spot on humerus and three on disk black: the first rounded and near suture, second oblong. near middle, third rounded on apical third; scutellum black. Thorax with median eleration rounded, its sides merging gradually with area of disk; surface sparsely and finely punctate. Length 9-14 $\mathrm{mm}$.

Throughout the State: common. June 8-August 3.

2019 (6513). Tetraopes femorates Lec., Journ. Phil. Acad. Nat. Sci.. I, 154T. 93 .

Resembles the preceding closely in form. size and color. Antennre usually distinctly but marrowly annulate with gras at apex and base of each joint: elytra each usualls with four smaller spots as follows: one on humerus; two on basal third, one near suture. the other submarginal; the fourth behind the middle. Thorax with median eleration and tubercles on sides more prominent than in the other species. Length 12-16 mm.

Lake, Fountain, Knox and Tigo counties; frequent. July 2-August 17. Those specimens haring the scape of antenne and femora red are known as rar. basatis Lec.

2020 (6514). Tetraopes qumquemactlates Hald. Trans. Amer. Phil. Soc.. X. 1847.53.

Elongate-oblong. robust. Thorax with usual spots; elrtra each with a round spot on humerus, another on apical third, and the tips. black. Antemnal joints indistincty annulate at hase. Nedian eleration of thorax as in tetraophthatmus. Length $9-11 \mathrm{~mm}$.

Throughout the State: scarce. June 18-July 20. 
LXXIII. Amphionveha Lee. 1852. (Gr., "on both sides + claw.")

This genus comprises two small species having the antenne strongly pilose, the third and fourth joints elongated, outer joints suddenly shorter; eyes not divided; tarsal claws cleft. One of the two oceurs in Indiana.

2021 (6516). Amplionycha Elamata Newm., Entom., 1840, 1:3.

Elongate-oblong. Black, feebly shining; hispid with fine, erect, black hairs; vertex of head, a stripe each side of thorax, and often the margins of elytra nearly to apex, yellowish; onter joints of antennie feebly annulate. Thorax rather finely, elytra more closely and coarsely, punctate. Length 6-9 $\mathrm{mm}$.

Kosciusko County ; rare. July 11. Probably occurs throughout the State. In the specimen at hand the elytra are wholly black.

\section{Tribe $\mathrm{X}$. METHIINI.}

While no menher of this tribe has as yet bcen taken in the State, one, Dysphaga laeis Lec., probably occurs, having been described from Illinois. It is a small black or piceous species, with thorax cylindrical and elongate; elytra a little more than half the length of abdomen, narrowed and dehiscent behind the middle, their tips rounded, surface roughly punctate; legs yellow. Length $7 \mathrm{~mm}$. It is supposed, like allied species, to breed in hickory twigs.

\section{Family LIII. CHRYSOMELID.E.}

\section{THE LehH BeETLES.}

A very large family of medium- or smail-sized beetles, usually short-bodied and more or less oval in outline, with the antennie of moderate length, usually filiform, the joints often comparatively stouter towards the tips. In color the beetles are often prettily variegated, though some are wholly of a brilliant metallic blue or green, while others are dull black or brown. All have the legs short, with the tarsi of the same type as in the Cerambycidx, viz., the fourth and fifth joints grown together, the fourth usually very small and concealed in a notch in the third segment. (Fig. 498.)

In addition to the general characters above given, the species agree in having the labial palpi 3-jointed; mentum transverse and not large; maxillary palpi 4-jointed, cylindrical, rarely dilated or elongate. Head either prominent and more or less constricted behind (Eupoda) or inserted to the eses ; in the Cassidini usually concealed under the shield-like thorax; eyes entire or feebly emarginate 
on the inner side, finely granulated; mandibles usually short and robust, labrum transverse, usually romnded in front. Antennæ variable in position and form, serrate or lamellate in certain Clythrini, clavate in many Hispini, not inserted upon frontal prominences, usually 11-jointed. Thorax often margined at the sides, the side pieces not separate from the prosternum, which is not prolonged. Elytra usually covering the abdomen, sometimes leaving the last dorsal segment exposed; rarely (in some Galerucini and Chrysomelini) smaller and not covering the greatly enlarged abdomen of female; abdomen with five ventral segments. Legs usually short, hind thighs often enlarged for jumping; tibiæ never serrate, usually without spines; tarsi (except in H(emonia) with joints one to three broad and covered beneath with a brush of hair, fifth with two equal claws of variable form.

The name of the family is from that of the typical genus, Chrysomela, which is derived from two Greek words meaning "gold" and "fruit," and probably refers to some of the member's of the genus Cassida, which are often of a brilliant golden hue. They are called leaf beetles because they feed upon the leaves of plants, the Colorado potato beetle and striped cucumber beetle being familiar examples. All the species are diurnal in habit and move slowly over the surface of plants, to which they adhere by means of the dense brush of hairs upon the under side of the tarsi. "As the function of the Cerambycidx is to hold the vegetable world in check by destroying woody fiber, the Bruchidæ effect a similar result by attacking the seeds and the Chrysomelidx by destroying the leaves. As the cellular and succulent-leaved plants have succeeded the drier and more woody forms of early geological time, so have the Chrysomelidx probably attained their highest development in the more recent periods. ${ }^{\prime} *$

On account of their leaf-eating habits the family comprises some very injurious forms, which will be mentioned in their proper sequence. The eggs are usually yellowish and elongated and are generally laid upon the leaves or stems of the plants upon which the larvæ feed. The latter are of varying form, but for the most part are fleshy convex or chunky hump-backed "slugs" or grubs, a familiar example being that of the Colorado potato beetle. Many of them live on the leaves of the plants, where they feed often in company with the mature insects. Those that live exposed to the light differ from the great majority of Coleopterous larvæ in being

*LeConte and Horn, Classification, p. 335. 
more or less highly colored. Some of them are flattened and curiously armed with spines, while others are partially covered with their own excrement. A few are leaf miners or stem borers, and these are long and slender and without the conspicuous markings of those which feed in the open. The larve of one large group (Camptosoma) are case-bearers; others, including an entire tribe (Eumolpini) are root-feeders. When ready to transform, many of the leafeating larvæ fasten themselves by the tail or last abdominal segment to a leaf and enter the chrysalis stage, while others go into the ground when about to change to a pupa. The case-bearers pupate within the sealed-up larval case.

About 18,000 species of Chrysomelidx are known, 750 of which are from North Anerica. These are arranged in twelve tribes, all of which are represented in Indiana. The literature pertaining to the different tribes is widely scattered, and the more important papers will be noted under the respective tribal headings. Two which attempt to treat of the United States or Canadian species of the family as a whole are as follows:

Crotch, G. R.- "Materials for the Study of the Phytophaga of the United States," in Proc. Phil. Acad. Nat. Sci., 1873, 19-83.

Wickham, H.F.—"The Chrysomelidie of Ontario and Quebec," in Can. Ent., XXVIII, 1896; XXIX, 1897.

The different forms of tarsal claws are much used in the classification of genera, and the beginner is urged to familiarize himself with these as described on page 18 .

\section{KEY TO TRIBES OF CHRYSOMELIDA.}

a. Head produced, constricted or neck-like behind the eyes; thorax much narrower than elytra and without lateral margins (raised edges); mandibles simple, pointed (Eupoda).

b. First rentral segment about as long as all the others united; form elongate; prosternum very narrow; tarsal clars simple, divergent.

Tribe I. Donacinn, p. 1098.

$b b$. First ventral about as long as or somewhat shorter than the two following.

c. Elytral punctures irregular; tarsal claws cleft or toothed; prosternum distinct.

Tribe II. SAgrini, p. 110 .

cc. Elytral punctures in rows; tarsal claws simple, dirergent; prosternum very narrow. Tribe III. CrIocerixi, p. 1110.

a a. Head inserted in the thorax to the eyes; thorax as broad, or but little narrower, than elytra, usually margined on the sides; mandibles with several teeth.

d. Thorax and elytra without broad, expanded margins; head usually plainly visible from above. 
$c$. Front of head normal, not inflexed, nouth anterior:

f. Last dorsal segment of abdomen not exposed; middle ventral segments not narrowed.

\%. Antennie widely separated at base, usually more so than the length of first joint.

h. Front coxre rounded; third tarsal joint bilobed.

Tribe VII. Eumolpint, p. 1134.

hh. Front coxa transverse; third tarsal joint usually entire.

Tribe Tim. Chrsomelini, p. 114!)

yy. Antenne rather ciose together at base, inserted on the front; front coxse conical and prominent.

$i$. Hind thighs slender, adapted for walking.

Tribe IX. Galeructat, 1) 116?.

ii. Hind thighs thickened, adapted for leaping.

Tribe $\mathrm{X}$. Halticini, 1. 1177 .

$f f$. Last dorsal segment of abdomen exposed and sloping downward; form of body robust, compact, subcylindrical.

$j$. Surface of body coarsely tuberculate above; antennæ received in marginal grooves on the lower side of thorax.

Tribe V. Chlamyorri, p. 1114.

$j$. Surface of body not tuberculate; antennæ not received in grooves.

k. Prosternum not separating front coxæ; antennæe short and serrate.

Tribe IV. Clythrint, p. 1112.

kk. Prosternum extending between front coxæ; antennæ usually long and slender. Tribe VI. CRYPtocephalini. p. 1116.

$e e$. Front of head inflexed, mouth inferior; form oblong, wedge-shaped, broad and truncate behind; surface usually strongly pitted or reticulated.

Tribe XI. Hispini, p. 1223.

dd. Thorax and elytra with broad, expanded margins; head (in our species) concealed; outline of body elliptical or nearly circular.

Tribe XII. Cassinini, p. 1228.

Tribe I. DONACIINI.

Oblong, graceful beetles of medium size which occur upon the leaves and stems of water-lilies, arrowhead, pond-weed, skunk cabbage, pickerel weed, reeds, sedges and other water-loving plants, and hence are semiaquatic in habit. In form and general appearance they resemble certain Cerambycidx and constitute a connecting link between that family and the present. The larvæ live on the outside of the submerged roots of the plants above mentioned, and obtain their supply of air through the tissues of the plant. When about to change into pupæ, they enclose themselves in silken cocoons, a number of which are often found fastened in a row to the stems or roots of the aquatic plants. The mature beetles are more or less gregarious, and fly about on bright sunny days, alighting on the leaves or flowers in numbers. 
They have the head prominent, somowhat narowed bohind the eyes; antenna filiform. slender, at least half as long as body ; thorax quadrate withont side margins, not wider than head. Elytra wider than thorax, depressed, cylindrical or somewhat triangular, usually narrowed toward the tips, and each marked with ten rows of cuadrate, rarely rounded, punctures. In color they are usually more or less metallic, of a greenish, bronze or purplish hue. The under side is paler and densely clothed with a fine silky pubescence, which enables them to shed the water when the plants upon which they alight happen to be submerged.

The principal papers treating of the tribe are as follows:

LeConte._"Synopsis of the Species of Donacia Inhabiting the United States,' in Proc. Phil. Acad. Nat. Sci., T, 1851, 310-316.

Long, Chas.--"Review of the Donacia of Boreal America," in

Trans. Amer. Ent. Soc., XVIIT, 1891, 159-176.

The tribe comprises but two genera, both of which are represented in Indiana.

KEY TO GENERA OF DONACIINI.

a. Elytra simple at tip; tarsi dilated. spongy beneath.

I. DONACIA. a a. Elytra distinctly spinose at tip; tarsi narrow. smooth beneath, last joint very long, claws large.

II. HÆMONIA.

\section{DonACIA Fab. 1775. "(Gr., "a reed.")}

Belonging to this genus, as characterized above, Leng, in his latest synopsis, recognized 20 speries and a number of varieties. Eighteen species have been taken in Indiana, while four others may occur.

In those species having the "sutural margin sinuate behind the middle," there is an apparent second margin, starting not more than one-fourth the length from the tip---often less-which is sinuate, or curved more or less, aray from the suture. Thus a space somewhat elliptical in shape is formed, sometimes depressed. sometimes in the same plane with the rest of the elvtron. and alwars destitute of punctuation.

The males are narrower than the females and usually have the hind femora more strongly toothed and the last dorsal segment shorter and either truncate or emaroinate, never rounded. Last dorsal of female more or less elongate, always rounded. For convenience the Indiana species are separated into three groups and these in turn into species. 
KEY TO GROUPS OF INDIANA DONACIA.

a. Head and thorax evidently pubescent above.

Group $A$.

a $a$. Head occasionally, thorax never pubescent.

b. Elytra truncate or subtruncate at tip.

Group $B$.

bb. Elytra rounded at tip; sutural margin of elytra sinuate behind the middle.

Group $C$.

Group A.

But two Indiana species belong to this group. They are widely different in size and general appearance and, except in the pubescence of head and thorax, have little in common.

KEY TO SPECIES OF GROUP A.

a. Elytra without pubescence; hind femora slender, without a tooth.

2022. PUBICOLLIS.

a a. Elytra evidently pubescent; hind femora swollen, toothed.

2023. PUBESCENS.

2022 (6523). Donacia pubicollis Suffr., Stett. Zeit., 1S72, 21.

Elongate, rather robust, convex. Brown, bronzed; antennæ, tibiæ and tarsi dusky; femora reddish-yellow. Head, thorax, scutellum and under surface clothed with short gray, but not dense, pubescence. Third joint of antennæ nearly twice longer than second. Thorax longer than broad, median line distinct on basal half; sides with an obtuse tubercle in front of middle; disk finely and densely punctate. Elytral punctures small, rounded, rather close set in more or less irregular rows; intervals rugulose; tips rounded. Mesosternum narrower than coxæ. Length 10-12 $\mathrm{mm}$.

Lake County ; rare. May 20. A few specimens taken by Wolcott along the beach of Lake Michigan, near Pine. Known heretofore only from northern Illinois, where it occurs on water-lilies.

2023 (6538). Donacia pubescens Lec., Trans. Amer. Ent. Soc., II, 1867, 55.

Elongate, slender, subconvex. Pale reddish-brown, everywhere rather densely clothed with short, silky, golden hairs. Antennæe piceous, rather stout, third joint one-half longer than second. Thorax slightly longer than broad, feebly constricted near middle, broadly channeled on median third; feebly and obtusely tuberculate each side. Elytral punctures coarse, intervals nearly flat; tips subtruncate. Mesosternum narrower than coxæ. Length 7-9 $\mathrm{mm}$.

Lake, Kosciusko and Marion counties; rare. June 9-June 16. Known only from Canada, Illinois and Michigan. Occurs on pickcrel weed.

Group B.

This group comprises 14 species, among them the most common ones occurring in the State. All agree in having the elytra more or less truncate at apex. The form in a number of them is flattened 
above, but in subtilis the male is convex and the female flattened. But two, distincta and lorosa, have the sutural margins sinuate.

\section{KEY 'TO SPECIES OF GROUP B.}

a. Body broad, distinctly flattened above: middle coxie separated by about their own width.

b. Third joint of antennie about one-half longer thin second.

c. Thorax finely and indistinctly punctate.

d. Color brownish or fuscous yellow; form more slender; hind tibice of male curved, serrate; elytral punctures finer.

2024. CINCTICORNIS.

dd. Color purplish-black; form broader, more robust; hind tibia straight; elytral punctures coarser, subquadrate.

2025. PROXIMA.

cc. Thorax coarsely punctate over its entire surface.

MAGNIFICA.

bb. Third joint of antenna more than twice the length of second.

e. Elytra truncate at tips; first ventral segment of male simple, convex.

f. Front tarsi of male dilated; color greenish-bronzed; larger, 9 $11 \mathrm{~mm}$.

2026. PALMATA.

ff. Front tarsi of male simple; color brownish-yellow; smaller, 68 m111.

2027. RUFESCENS.

ce. Elytra subtruncate at tips, form more convex; first ventral of male concave at middle; sides of thorax strongly tuberculate.

2028. PISCATRIX.

a a. Body narrower, more convex above; middle coxse separated by less than their own width.

g. Thorax with disk even, punctate, not or scarcely tuberculate on sides.

h. Punctures of thorax very fine, confused and confluent; third joint of antennæe one-third longer than second.

2029. CURTICOLLIS.

hh. Punctures of thorax larger and distinct.

$i$. Antenne and $\operatorname{legs}$ pale reddish-brown, the former very stout, the second and third joints subequal; thorax with coarse, transverse wrinkles in addition to punctures. 2030. MEGACORNIS.

i1. Antenne and legs dark reddish-brown to piceous, the former much more slender, third joint distinctly longer than second.

i. Punctures of thorax coarse, uniform in size.

$k$. Third joint of antennse one-half longer than second; thorax straight on sides.

2031. subtilis.

k\%. Third joint of antenna twice the length of second; thorax constricted at middle.

2032. REGOSA.

ji. Punctures of thorax not uniform, finer mixed with the coarser ; third joint of antennie one-half longer than second.

POROSICOLLIS.

!/g. Thorax with disk uneven, the sides tuberculate; elytra with two transverse depressions.

l. Sutural margin of elytra straight.

2033. EQUALIS.

ll. Sutural margin of elytra sinuate. 
$m$. Coppery-bronzed; third joint of antennæ longer than second; head not torose.

2034. DISTINCTA.

$\mathrm{mm}$. Blackish-violet; second and third joints of antennæ subequal; head torose, i. e., with knots or elevations.

TOROSA.

2024 (10,334). Donacia cincticonisis Newm., Ent. Mag., V, 1838, 391.

Elongate, rather slender, subdepressed. Above brownish-yellow strongly shining, often with a greenish tinge; head and thorax darker; beneath clothed with dense gray pubescence; antenna and legs reddish-brown to piceous, the tips of joints of former often darker. Thorax wider than long, slightly narrowed near base; disk nearly smooth, median line distinct; sides finely and somewhat rugosely punctured, with an irregular depression in front of middle. Disk of elytra with two feeble transverse impressions; punctures large, subquadrate; intervals flat, nearly smooth. Hind femora swollen and armed with one to three teeth. Length $7-11 \mathrm{~mm}$.

Northern half of State; common. Not taken south of Vigo County. May 17-August 22. Occurs on the yellow water-lily. Nuphar advena Ait., and the leaves of Potamogeton.

2025 (65.34). Donacia Proxima Kirby, Faun. Bor. Amer., IV, 1837, 225.

Elongate, robust, depressed. Blackish-riolet, head bronzed; antennæ and legs black. Thorax quadrate; disk with a median impressed line, punctate at base and apex, nearly smooth at middle. Elytral intervals not rugose. Hind femora less developed than in cincticomis. Length 8-11 mm.

Wells County ; rare. August 1. Ranges from New England to Oregon and probably occurs oniy in the northern part of Indiana.

$D$. magnifica Lec, violaceous, margined with golden yellow, length 8-9 mm., is known from Canada and Michigan.

2026 (6526). Donacia Palmata Oliv., Ent., IV, 1795, 75.

Elongate, slender, subdepressed. Purplish-green to brownish-yellow above, strongly shining; densely whitish pubescent beneath; joints of antennie and femora reddish-brown at base, blackish at apex. Thorax broader than long, very finely punctulate, sides with a rounded tubercle in front of middle. Elytra coarsely punctate; intervals subconvex, distinctly rugose. Length 9-11 $\mathrm{mm}$.

Starke, Marshall, Kosciusko and Vigo connties; scarce. June 20-August 20. Occurs on both white and yellow pond-lilies.

2027 (6527a). Donacia rufescens Lac., Mem. Soc. Liege, III, 1845, 112.

Elongate-oblong, subdepressed. Brownish-yellow, feebly shining. Antenna with third joint twice as long as second, the other joints scarcely thickened at apex. Thorax quadrate, very finely wrinkled, not punctured. scarcely tuberculate on the sides. Elytra depressed without transverse impressions, punctures small, feebly impressed; intervals flat, not rugulose; tips squarely truncate. Length $6-\dot{S} \mathrm{~mm}$.

Kosciusko and Starke counties; rare. August 20-August 26. Listed as a variety of $D$. Typolenca Lac. 
2028 (6529). Donacia piscatrix Lac., Mem. Soc. Liege, III, 1845, 113.

Elongate, rather slender, subconvex. Color abore variable, bronze, green or brownisli-yellow, strongly shining; gray ish pubescent beneath; antenna and legs reddish-yellow, femora in part darker. Antenne stouter than in the two preceding, the second joint about half the length of third. Thorax quadrate, sides each with two rounded tubercles, the front one more proninent; disk finely alutaceous, sparsely, fineIy and shallowly punctate. Elytrai punctures rather coarse; intervals nearly flat, finely, transrersely rugose. Length $6.5-10 \mathrm{~mm}$. (Fig. 476.)

Throughout the State; common. Mav 15-August 20. Occurs mainly on the flowers and foliage of the yellow water-lily, rarely on those of the white. The stouter

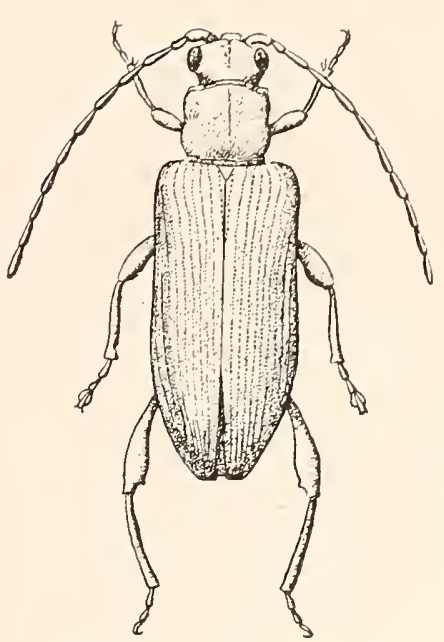

Fig. 476. $\times 4 . \quad$ (Original.)

antennx, more distinct tubercles of thorax and less squarely truncate tips of elytra readily distinguish this from palmata, with which it is most apt to be confused.

2029 (-). Donacia curticolis Knab, Proc. Ent. Soe. IVash., VII, $1906,122$.

Rather slender, convex, male; broader, subdepressed, female. Reddish- or brownish-yellow; head and basal joint of antennse greenish; under surface, tibix and tarsi with a greenish tinge. Head with a deep median groove. Thorax one-half broader than long, sides straight, without tubercles; disk very finely wrinkled, confusedly punctate and with a deep median groove reaching to basal fourth. Elytra with a shallow oblique depression just in front of, and another behind, middle; striæ deeply, closely and coarsely punctate; intervals finely wrinkled. Length 9-10 mm.

Laporte, Marshall and Whitley counties; scarce. July 15-August 15. Knah's types were from Illinois and Indiana. Occurs on bullrushes.

2030 (-). DONACIA MLGaCORNis sp. nov.

Elongate, slender. Cupreous, bronzed; antennæe and legs reddish-brown. Antennæ much stouter than in subtilis. half the length of body, the second and third joints nearly equal. Thorax longer than wide, feebly tuberculate on the sides; disk with sides rugose, with fine punctures between the wrinkles; median line distinct on basal half. Elytra each with two distinct impressions, the hind one with an elongate extension reaching nearly to apex; punctures rather coarse, oblong; intervals flat, densely rugose. Length $7.5 \mathrm{~mm}$.

Lake County ; rare. May 28.

2031 (6536). Donacia subtilis Kunz, Mon. Neu. Schrift. Ges. Malle, II, 1818, 14.

Elongate, slender, subconvex. Color brassy bronzed to purplish-black; rarely bluish, shining; antenne and legs reddish-brown to piceous. Tho-

[70-23402] 
rax slightly longer than wide, sides almost straight, disk transversely rugose, with punctures between the wrinkles; median line shallow but distinct. Elytra each with two shallow impressions near middle; punctures oblong, intervals nearly flat, transversely, densely rugose; tips more narrowed than in the preceding species, squarely truncate. Length $7-10 \mathrm{~mm}$.

Lake, Marshall, Kosciusko and Vigo counties; common. May 12-August 20. Occurs on leaves and stems of sedges and arrowalum along borders of ponds and lakes. Mating May 21 and June 20. In a form from Lake County the females are much more robust, more convex, and more shining, with shorter thorax than in typical subtitis. They are probably to be referred to var. fulgens Lec.

2032 (6537). Donacta rugosa Lec.. Proc. Amer. Phil. Soc., XVIII, 187s, 415.

Resembles subtitis closely in form and color. The antennæe are longer and more slender, with the third joint distinctly longer than second. Thorax slightly constricted at middle, surface more densely and finely punctured. Length $8.5 \mathrm{~mm}$.

Two specimens taken at. Bass Lake and Lake Maxinkuckee, August 15 and 20 were submitted to Leng, who pronounced them this species. He writes that he now considers rugosa a distinct species instead of a variety of subtilis, and that it has been found to live on pickerel weed, whereas subtitis lives on reeds and sedges.

D. porosicollis Lac., coppery-bronzed, length $10 \mathrm{~mm}$., is recorded from Michigan and Pennsylvania.

2033 (6539). Donacra Equalis Say. Journ. Phil. Acad. Tat. Sci.. III. 1823, 42S; ibid. II, 202.

Elongate-oblong, rather slender, subconvex. Bronzed, shining; tibiæe. tarsi and base of femora reddish-brown. Second and third joints of antenne equal. Thorax as long as broad, median line distinct, sides with a rounded tubercle before the middle; disk somewhat uneren, finely and densely punctate. Elytra with two shallow, subsutural, transrerse impressions near the middle; intervals flat. feebly rugulose; tips obliquely truncate. Length $5.5-7 \mathrm{~mm}$.

Lake, Wells and Jackson counties; scarce. May 27-October 14. Occurs on reeds and sedges along the borders of marshes and streams.

2034 (6525). Donacia distincta Lec.. Agass. Lake Sup., 1850, 236.

Elongate, slender. Cupreous, bronzed; head. antennæ and legs clothed with very short, fine, whitish pubescence. Antennæ rather slender, the third joint nearly one-half longer than second. Thorax quadrate, narrowed near base, angles prominent, sides with blunt tubercles; disk sparsely. irregularly and rather finely punctate, the median line distinct for nearls 
its entire length. Elytra depressed, the punctures rather fine and deen; intervals flat, finely, transversely wrinkled; sutural margin sinuate for only about one-tenth its length near apex. IIind femora armed with an acute tooth. Length $7-9 \mathrm{~mm}$.

Starke County; rare. May 19. Taken irom leaves of the yellow water-lily. A northern form, known heretofore from Wisconsin, Michigan and Massachusetts.

D. torosa Lec., thorax nearly smooth, length 6-7 mm., is known from Massachusetts, Illinois and Iowa.

\section{Group C.}

Our six members of this group agree in having the elytra rounded at tip and their sutural margin distinctly sinuate near apex. The form is always convex and the middle coxa are separated by less than their own width.

KEY TO SPECIES OF GROUP C.

a. Eyes small; size larger, 10-11 mm.; strongly convex. 2035. HARrisir.

a a. Eyes of normal size; smaller, not orer 8.5 mm.; less convex.

b. Thorax depressed, without basal or median line; hind femora toothed in both sexes.

PUSILLA.

$b b$. Thorax convex, punctured; basal line distinct, median one usually so.

c. Thorax closely punctulate; hind femora club-shaped.

d. Legs dark.

e. Hind femora toothed in both sexes; coler usually dark blue.

2036. EMARGINATA.

ce. Hind femora toothed in male only; color metallic green or blackish.

2037. METALLICA.

dd. Legs reddish-yellow; hind femora toothed in both sexes.

2038. FLAVIPES.

cc. Thorax sparsely punctured; hind femora elliptical; legs reddishyellow.

2039. RUFA.

2035 (6524). Donacia hamisit Lec., Proc. Phil. Acad. Nat. Sci., V, 1851, 316.

Elongate, robust, convex. Piceous bronzed; head and thorax often with a cupreous tinge. Antenne slender, piceous, joints often paler at base; third more than one-half longer than second. Thorax distinctly longer than wide, scarcely narrowed behind, tubercles on sides rery feeble; disk densely and finely strigosely punctate. Elytra with tips rounded or very slightly subtruncate; punctures comparatively fine and deep; intervals subconvex, densely rugose. Length 10-11 $111 \mathrm{~m}$.

Lake and Kosciusko counties; rare. Trmne 3-June 23. Srept from sedges in low moist meadows. The large size, small eyes and sinuate sutural margin of elytra distinguish this species. Leng places it in the group with truncate tips of elytra, since he "includes thus all forms that are in the least truncate or even doubt- 
fully so," but the beginner will evidently class the tips as rounded, and I have therefore placed it in the present group.

D. pusilla Say, greenish or coppery-bronzed, second and third antennal joints equal, length $6-8 \mathrm{~mm}$., ranges across the northern United States, has been recorded from Michigan and perhaps occurs in northern Indiana.

2036 (6541). Donacia emarginata Kirby, Faun. Bor. Amer., IV, 1S37, 224.

Elongate, slender, conrex. Dark metallic blue, rarely purple or bronzed; antennie black, the joints often reddish at base, second and third joints nearly equal. Thorax longer than wide, median line distinct, sides with a rounded tubercle on apical half; surface minutely rugose, finely and densely punctate. Elytra with an impression in front of middle, rounded at tip; sutural margin strongly sinuate on apical fourth; interrals feebly convex, transversely rugose. Last dorsal segment of male emarginate. Length 6 $7 \mathrm{~mm}$.

Lake County ; frequent locally. May 15-June 15. Taken by beating tall sedges along sloughs near Pine.

2037 (6545). Donacia metaldica Ahrens, Neu. Schrift. Ges. Halle, I. $1810,33$.

Elongate. rather slender, convex. Color variable, usually greenish or bronzed, sometimes blackish, strongly shining. Second and third antennal joints subequal. Thorax longer than wide, narrored near base, tubercles on sides evident but feeble, median line fine; disk minutely rugulose, finely and rather densely punctate. Elytra convex, tips rounded, punctures rather coarse; intervals almost flat, nearly smooth. Length $5.5-7 \mathrm{~mm}$.

Lake County, scarce; Marion County, frequent at Crow's Nest, near Broad Ripple, on the base of the leaves of skunk cabbage, Symplocarpus footidus Salisb., April 26-1Tay 15.

2038 (6546). Donacia flavipes Kirbs, Faun. Bor. Amer., IT, 1837, 223.

Elongate, rather slender, convex. Bronzed coppery, rarely dark blue, shining; antennæ and legs reddish-rellow. Antemnæe rather robust. third joint one-third longer than second. Thorax one-half longer than wide, median channel wide, rather deep; tubercles on sides large. rounded, somewhat prominent; surface finely transversely rugose. densely and minutely punctate. Elytra usually with two shallow transverse impressions near middle; punctures coarse. quadrate: intervals strongly transversely rugose; distinctly sinuate near the tips, which are rounded. Mesosternum narrower than coxæ; first rentral segment shorter than metasternum. Length $7-8.5 \mathrm{~mm}$.

Northern half of State, common; not taken south of Vigo and Wayne counties. May 5-June 15. Oceurs on reeds, rushes and the aprow-alum, Peltandro undulata Raf. Mating May 21. 
2039 (10,336). Donacta ruth Say, Jomm. Phil. Acad. Nat. Sci., V, IS27, 283 ; ibid. II, 339).

Elongate, convex, subcylindrical. Dalk leddish-bown, shining; antemure and legs reddish-yellow. Third joint of anteuna one-half longel than second. 'Thorax one-third longer than wide, broadest near apex; tubercles on sides not prominent, median line very distinct; surface convex, shining, marked with minute seattered punctures. Elytra with two shallow impressions near middle; intervals nearly flat, almost smooth. Length $7-7.5 \mathrm{~mm}$.

Throughout the State; rather scarce. April 21-October 18. Occurs on leaves and aboit roots of skunk cabbage. The more conrex, shining and sparsely punctured thorax, wider in front; and the smoother intervals of elytra rearily distinguish this from flavipes.

\section{Hemonia Lat. 1829. (A geographical name.)}

This genus is represented by a single species resembling Donacia in form, but distinguished by the narrow tarsi and the distinct spine at outer angle of tips of elytra.

2040 (6549). Hzmonia nigricornis Kirby, Faun. Bor. Amer., IV, 1837, 222.

Elongate, slender, subconvex. Thorax, elytra and legs brownish-yellow; head, antennæe, tarsi and under surface black. Thorax subquadrate, constricted at middle, front angles rounded, prominent; surface smooth, with a few coarse punctures at base. Elytra each with ten long rows of punctures and a shorter sutural row; alternate intervals wider and subconvex. Length 5.5-8 $\mathrm{mm}$.

Lake County; scarce. May 20-May 28. Taken from pondweed (Potamogeton) in the Calumet River near Pine; also in the washup of Lake Michigan. Probably oceurs in lakes and streams throughout the northern half of State.

\section{Tribe II. SAGRINI.}

Small or medium-sized, oblong or elongate, roughly punctured species having the head prominent, not narrowed behind; eyes very convex, entire; antennæ filiform, rather widely separated at base; thorax not wider than head. Elytra entire, wider than thorax, strongly and irregularly punctured f front coxir conical, transverse, usually prominent and contiguous; middle and hind coxie narrowly separated; tarsal claws (in our species) toothed or cleft.

The principal paper treating of the genera comprising both this tribe and tribe IV, Ciythrini, is by

Horn.- "Studies in Chysomelida," in Trans. Amer. Ent. Soc., XIX, 1892, 1-18.

Three of the four known genera are represented in the state. 
KEY TO INDIANA GENERA OF SAGRINI.

a. Thorax somewhat bell-shaped, the sides much rounded, without teeth or tubercle; front coxæ not prominent, separated. III. OrsodacNa. aa. Thorax with a tubercle or angulate at the sides; front coxx prominent, contiguous.

b. Eyes emarginate; thorax with a large, distinct tubercle on sides; front coxal cavities closed; claws toothed.

IV. ZeUgOPHORA.

bb. Eyes entire; tholax angulate or toothed at sides; front coxal cavities open; claws cleft.

V. Syneta.

\section{Orsod ACNA Lat. 1802. (Gr., "bud+gnawer.")}

This genus, as characterized above, contains a single species of such variability in color, that it has been described under six or seven different names. It occurs on willow blossoms in the spring, several color varieties often being found on the same tree. All intergrades are known, from those entirely piceous to those almost wholly pale brownish-yellow.

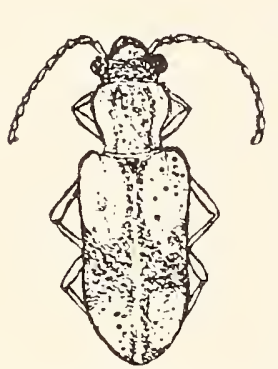

Fig. $477 . \times 4 \frac{1}{2}$ (After Wickham.)

2041 (6550). Orsodacna atra Ahrens, Nov. Act. Halens, I, 1S10, 46.

Elongate, rather slender, subconvex. Color given in varietal key below. Antennæ less than half the length of borly, the joints subequal in length, bell-shaped, much narrowed at base. Thorax longer than wide, distinctly narrowed behind the middle; surface coarsely, roughly and rather sparsely puncturer. Elytra one-half wider than thorax, coarsely punctate, tips rounded. Length 4$7 \mathrm{~mm}$. (Fig. 477.)

KEY TC COLOR VARIETIES OF O. ATRA.

a. Elytra wholly blackish or piceous.

b. Thorax black or piceous.

c. Legs wholly piceous.

$c c$. Tibiæ and femora brownish-yellow.

ATRA Ahr. TIBIALIS Kirby.

bb. Thorax more or less reddish.

d. Thorax reddish with central dark spot.

LUCTUOSA Lac. dd. Thorax entirely reddish-yellow. HEPATICA Say,

a a. Elytra more or less brownish-yellow.

e. Elytra with stripes.

f. Piceous, thorax reddish-yellow; elytra each with one yellow stripe on disk.

vitTata Say.

ff. Dull yellow; elytra each with sutural line and stripe on side dark. TRIVITTATA Lac. ee. Elytra dark, with large humeral and apical yellow spot. (Fig. 477.) CHILDRENI Kirby. 
Southern half of State; rather scarce. April 3-May 26. Four of the varieties have been taken, viz, alra in .Jennings and Putnam counties; hepatica in Hancock, Jackson, Crawford and Posey counties; vittata in Jackson and Posey and trivillata in Posey.

\section{Zeugophok Kunze. 1818. (('l?., "a yoke + bear.")}

The members of this genus are smaller, being proportionally shorter and more robust, than those of Orsodacna.. The punctuation is very coarse and the thorax has a large blunt tubercle on sides. Three species have been taken in the State and another probably occurs.

KEY TO INDIANA SPECIES OF ZEUGOPHORA.

a. Elytra entirely black.

b. Head wholly yellow; punctures of elytra large, more distant one from another than their own diameter's.

2042. SCUTELLARIS.

bb. Occiput black; elytral punctures close. aa. Elytra bicolored.

c. Thorax entirely yellow; onter half of antenna piceous; elytral punctures very close.

PUBERULA.

ce. Thorax with a piceous discal spot, divided at middle by a yellow line; antenne pale; elytral punctures more distant.

2044. VARIANS.

2042 (6551). Zeugophora scuteldaris Suff 1 .. Ent. Zeit. Stettin, 1S40, 99.

Elongate-oblong, convex. Head, thorax, legs, pro- and mesosterna clear yellow; elytra and abdomen black, shining, very sparsely pubescent. Antennæ less than half the length of body, rather stout, joints 1 to 3 yellow, the remainder piceous. Thorax longer than wide, strongly convex, tubercles prominent, surface sparsely and coarsely punctate. Length $3.5-4 \mathrm{~mm}$.

Starke and Wells counties; rare. June 18. Beaten from leaves of hickory.

2043 (6556). Zeugophora consanguinea Croteh, Proc. Phil. Acad. Nat. Sci., $1873,23$.

Elongate, slender, parallel. Resembles scutellaris in color, except that top of head is black and antennie wholly yellow. Thorax as broad as long, the tubercles less prominent. Length $3-3.5 \mathrm{~mm}$.

Lake and Starke counties; scarce. May 9--July 4. Known heretofore only from northern Illinois.

Z. puberula Crotch, dark reddish-brown, abdomen, metasternum and apical half of antenna black, length $3.5 \mathrm{~mm}$., was described from Illinois. 
2044 (6554). Zetgophora varians Crotch, Proc. Phil. Acad. Nat. Sci., 1S73, 23.

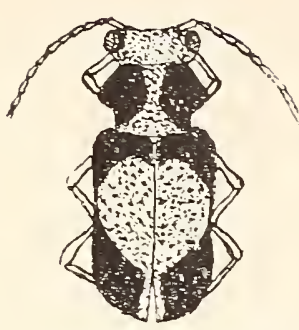

Fig. $478 \times 8$ (After Wickham.)

Elongate-oblong, subconvex. Top of head and disk of thorax black, the latter with a yellowish median stripe, which widens on basal half. Elytra piceous, with a large oral or heart-shaped yellowish spot on center of disk: front of head. antenne and legs dull redtish-yellow. Thorax as in the preceding, the tubercles more blunt. Length $3 \mathrm{~mm}$. (Fig. 4is.)

Lake and Posey comties; scarce. May 11June 24. Occurs on foliage of poplar.

\section{Srneta Lac. 1845. (Gr.," "sagacious.")}

One species of this genus occurs in the eastern United States, including Indiana.

\section{5 (055i). Syxeta ferrugixea Gelm., Nor. Act. Halens, I, 1S10, 36.}

Elongate, subcslindrical. Head, thorax and antennæe reddish-yellow; elytra, legs and under surface paler sellow. Antemnse slender, half the length of body; joints $t$ to 10 rery nearly equal in length. 11th longer than 10th. Thorax slightly longer than wide; rather broadls angulate and obtusely three-toothed at sides; surface coarsely and densely punctate. Elytra each with four raised lines or costre of rarions degrees of distinctness; the broad intervals each with 3 to 5 imegular rows of coarse. close-set punctures. Hind tibice of male slightls broader at tip and with terminal spurs, the inner edge sinuate below the middle. Length $7-\mathrm{S} \mathrm{mm}$.

Southern two-thirds of State; scarce. May 12-June 2. Beaten from the foliage of scrub oak and hazel.

\section{Tribe III. CRIOCERINI.}

Oblong or elongate beetles of rather small size and graceful form, having the thorax much narrover than elytra, usually strongly constricted near middle; elrtra with punctures in regular rows; antennæ widely distant at base, inserted in front of eyes, 11 jointed and rather stout; front coxr conical, prominent and nearly contiguous, the cavities closed behind; first rentral segment as long as the two following; tarsal claws simple and approximate at base. Two genera compose the tribe.

\section{KET TO GENERA OF CRIOCERINT.}

a. Thorax with a constriction about the middle. a . Thorax cylindrical, not constricted.

TI. LEMA. Crioceris.

\section{VT. Lexa Fabr. 1798. (NT., meaning unknown.)}

This genus, sufficiently characterized above, is represented in the State by fire species.*

\footnotetext{
*A synoptical table of most of the species is given by Crotch, Proc. Phil. Acad., 1573, 24
} 
KEY TO INDIANA SPECIES OF LEMA.

a. Elytra with the ninth stria entire.

b. Elytra wholly dark blue.

c. Head red. with two tubercles on rertex; antenne, legs and abdomen black.

2046. BRLNNICOLLIS.

cc. Head black, without tubercles; thorax red.

2047. COLLARIS.

bu. Elytra reddish-yellow, with three black stripes. 2048. TRILINEATA.

aa. Elytra with the ninth stria interrupted.

d. Elytra reddish-yellow, spotted with black.

$e$. Larger, $6 \mathrm{~mm}$.; spots on the disk of elytra.

6-PLXCTATA.

ee. Smaller, 4.5-5 mm.; spots common, crossing the suture.

dd. Elytra blue; thorax red, with a central black spot.

2049. ALBINI.

2050. SAYI. 2046 (6565). Lema Bruxicollis Lac., Moll., I, 1801, 382.

Elongate-oblong. Head, thorax and under surface, except abdomen. red; color of other parts giren in kes. Thorax very finels punctulate. with a few coarse punctures on sides near apex and on median line. Length $4-4.5 \mathrm{~mm}$.

Lake, Steuben and Marshall counties; rare. June 12-June 27. Taken by sweeping herbage in tamarack swamp. Crotch records it from the Southern States, so that it probably occurs throughout Indiana.

2047 (6567). LeMA coliaris Say, Journ. Phil. Acad. Nat. Sci., III. 1S23. 430 ; ibid. II, 203.

Elongate-oblong. Black; thorax red; elytra dark greenish-blue. Antennie shorter than in the preceding; rertex with a median groore. Thorax short, rery finely and sparsely punctate. Length $4.5-5 \mathrm{~mm}$.

Throughout the State; frequent. May 11-.July 1. Occurs especially on the spiderwort. Tradescantia rirginiana L; also on other low herbs in moist, sandy localities.

2048 (6573). Lexa trilineata Oliv., Ent., VI. 1808, 739.

Elongate-oblong. robust for the genus. Reddish-yellow; elytra somewhat paler. with sutural margin and rather wide stripe on sides black; antennæe (except basal joints), tips of tibix and tarsi, blackish. Thorax usually with two black spots on disk. strongls constricted at middle. smooth except a fer coarse punctures on sides near apex. Inner rows of elytral punctures indistinct on apical half. Length $6-\bar{t}$ mm. (Fig. 479.)

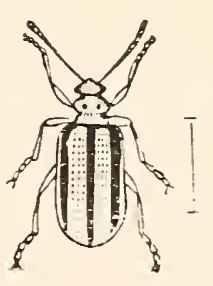

Fig. 479

Throughout the State; frequent. April 19-July 25. Occurs on the foliage of various Solanaceous herbs, especially that of potato. Sometinies called the "old-fashioned potato beetle.' bat that name in Indiana is usually applied to "hlister beetles" of the genus Epicauta. Mating .June 8 .

2049 (6575b). Lfim ALBiNA Lac., Mon.. I. 1845. 492.

Elongate-oblong. Reddish-yellow; antennæ. legs (except base of femora) and sides of metasternum, blackish; elytra with a small spot on 
humerus and two large, heart-shaped common ones, black. Thorax nearly smooth. Elytra with humeri prominent; punctures rery coarse on basal half, becoming finer toward apex. Length 4.5-5 $\mathrm{mm}$.

Knox, Dubois, Posey and Crawford counties; scarce. May 8June 26. Taken by sweeping herbage along roadsides. This species is listed as a variety of 6 -punctata Oliv. The range of both is southern and the typical species may be found in the southern third of the State.

2050 (6576). Lema sayi Crotch, Proc. Phil. Acad. Nat. Sci., 1873, 26.

Elongate-oblong. Dull red; antennr, legs, small spot on head and larger one on center of thorax, black. Thorax longer than in collaris, finely and rather closely punctate. Ninth stria of elytra narrowly interrupted near middle. Femora clavate, pubescent. Length $5-6.5 \mathrm{~mm}$.

Dinbois County; rare. May 12. A southern

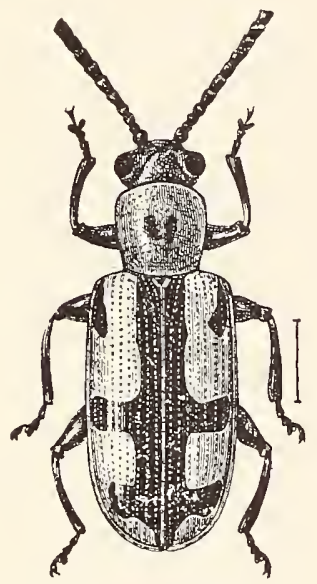

Fjg. 480 .

(After Chittenden.) form found on the spiderwort or day-flower Tradescantia virginiana $\mathrm{L}$.

Crioceris Geoff. 1764. (Gr., "a ram + horn.'”)

To this genus belong two introduced species which prey upon asparagus. C. asparagi L. (Fig. 480), the common asparagus beetle, is about $7 \mathrm{~mm}$. in length; bluish green, thorax red with two green spots; elytra with three or four yellow spots on sides which merge into a yellow margin. It has been taken near Cincinnati and Cleveland, Ohio, and very probably occurs in Indiana.

\section{Tribe IV. CLITHRINI.}

Compact, stont, subcylindrical species of medium size, having the head large, deflexed; antennæ short, widely separated, 11jointed, serrate; thorax margined on sides, fitted closely to the elytra; front coxæ transverse, more or less prominent, the cavities closed behind; elytra lobed on sides, not covering the pygidium; legs short, stout, tarsi broad; claws either simple or toothed. Four genera are represented in the State. The larva are case-bearers and, as far as known, live in ants' nests, where they feed upon vegetable debris.

KEY TO INULANA GENERA OF CLTTHRINI.

a. Tarsal claws simple.

b. Front coxie contiguous; form elongate; color mostly yellow.

VII. ANOMGa. 
bb. Front coxæe separated by the prosternum; form short, robust; eyes oval, not emarginate; color (in our species) miform blackish.

VIII. COSCINOPTERA.

aa. Tarsal claws appendiculate; eyes emarginate; color black witl red or yellow elytral spots.

c. Epipleura broad in front; elytra (in our species) each with humeral and apical reddish spots.

IX. ВАВiA.

cc. Epipleura narrow; elytra each with humeral spot only.

X. Saxinis.

VII. Anomen Lac. 1849. (Gr., "unlike.")

One species occurs east of the Mississippi. The male has the antennæ more deeply serrate and front tibiæ longer than in female.

2051 (6579). Anomea ratictavia Forst., Nov. Spec. Insect., 1771, 27.

Elongate, subcylindrical. Head, thorax and femora reddish-yellow; elytra paler yellow, the suture and outer margins narrowly bordered with black; antennx, tibixe and tarsi usually blackish; under surface, except prosternum, black, densely clothed with gray pubescence. Thorax more than twice as wide as long, sides rounded, hind margin sinuate, surface smooth. Elytra finely and indistinctly punctate. Length 7-S mm.

Southern two-thirds of State; frequent. May 19-June 26. Occurs on ragweed ( $A m b r o s i a)$; also on flowers of Jersey tea and other herbs.

\section{Coscinoptera Lac. 1849. (Gr., "a sieve + wings.")}

Of the North American species of this genus all but two occur in the western and southwestern states. One of these is found in Indiana.

2052 (6590). Coscinoptera dominicana Fab., Syst. Eleut., II; 1S01, 34.

Oblong, robust. Black, densely clothed on under surface, more sparsely above, with short, prostrate ash-gray pubescence; labrum usually yellow. Thorax evenly and regularly convex, as broad at base as elytra, more than twice as wide as long, sides rounded; surface densely and rather finely punctate, median line smooth. Elytra more coarsely and less densely punctate than thorax. Length 4.5-6.5 mm. (Fig. 4S1.)

Throughout the State; frequent. May 31-July 5. Occurs on the foliage of the sour or

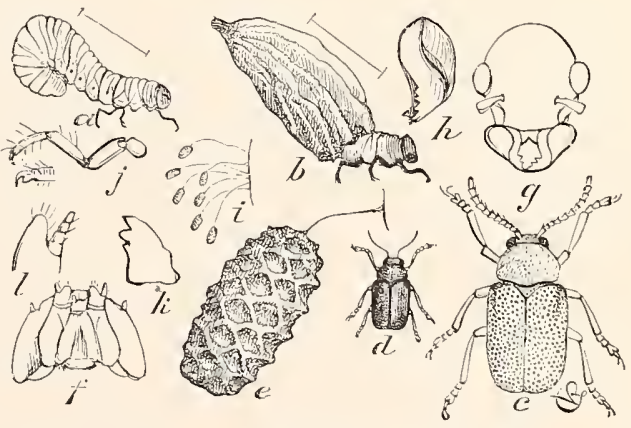

Fig. 481. a: larva extracted frcm case; $b$, same with case; $c$, beetle, showing punctures; $d$, same natural si $\prec e$ $e$, egg enlarged; $f$. head of larva, under side; $g$, head of male; beetle; $h$, mandible of same; $i$, eggs, natural size; $j$, leg of larva; $k$, mandible of same. (After Riley.)

black-gum, Nyssa syluatica Marsh; also on oak and wild grape. The larva are said to oceur in ants' nests. Mating June 11. 


\section{Bıbia Chev. 1834. (NL., "a baboon.")}

Two species and two nominal varieties of this genus occur in the United States. One of the two necurs in Indiana.

2053 (6596). Babia Qvadriguttata Oliv., Encyc. Method. Ins., VI, 1796, 37.

Oblong, convex. Black, shining; elytra each with a large humeral and smaller apical reddish-yellow spot. Thorax a little narrower than elytra, finely and rather sparsely punctate. Elytra with irregular rows of larger punctures; intervals with numerous scattered punctures. Length $3.5-4 \mathrm{~mm}$.

Throughout the State; common. Nay 16-August 15. Occurs on milkweed and other plants along roadsides. The short, stout, subserrate antennæ will readily distinguish it from other black and red species of following genera. The elytra are not striate nor coarsely punctate, as stated by Crotch and others.

\section{Sıxinis Lac. 1849 .}

Here, again, most of the seven species are from the western and southwestern states, only one being found east of the Mississippi.

2054 (6598). Saxinis omogera Lac., Mon., II, 1842, 482.

Oblong or subcylindrical. Bluish or greenish-black, shining; finely pubescent beneath; elytra each with a large reddish-yellow spot on humerus. Thorax convex, as wide as elytra, sparsely and rather finely punctured. Elytra with rows of coarse, close-set punctures, the rows on disk somewhat irregular. Length $3-3.7 \mathrm{~mm}$.

Southern half of State, frequent; not taken north of Vermillion. County. May 17-July 21. 'Taken by beating or sweeping foliage along roadsides, ete.

\section{Tribe V. CIILAMYDINI.}

Short, robust, cylindrical or subquadrate beetles of a dull metallic or blackish hue, having the eyes large, emarginate; thorax and elytra covered with wart-like tubereles; antenna widely separated, short, serrate and received in grooves on the side of prosternum; scutellum truncate behind and with a median tooth in front which fits into a notch in base of thorax; elytral suture with minute teeth cach side which dove-tail between one another. The legs are closely contractile and when disturbed the beetles draw them and the antenne in and feign death. They then resemble the excrement of certain caterpillars so elosely as to render their detection difficult, unless the collector is in especial search for them, and it is said that birds will not pick them up for the same reason. The larva of this and part of the next tribe live upon the surface of leaves, and have 
the curious habit of enclosing themselves in compact cases, composed of their own exerement, which they mould into shape by means of thcir mandibles. They carry their cases about with them by protruding the front part of their bodies through the open extremity. (Fig. 4\&2, b.) When abont to transform they attach their cases to the twigs, and elose the opening, thus making them answer the purpose of a cocoon.

'Two genera compose the tribe. The latest paper treating of them is by

Linell, Martin L.- "New Species of Coleoptera of the Family Chrysomelidx with a Short Review of the Tribe Chlamydini," in Proc. U. S. Nat. Mus., XX, 1897, 473-485.

KEY TO GENERA OF CHLAMYDINI.

a. Antenne serrate from the fourth or fifth joint.

aa. Antenna serrate from the sixth joint.

XI. Chlamis. XII. Exema.

XI. Chlamys Knoch. 1801. (NL., "A cloak or mantle.")

Two species probably oceur in the State.

KEY TO INDIANA SPECIES OF CHLAMYS.

a. Elytral intervals not or obsoletely punctate; length 4 mm.

2055. PLICATA. a . Elytral intervals closely and deeply punctate; length not over $3 \mathrm{~mm}$.

CRIBRIPEN NIS.

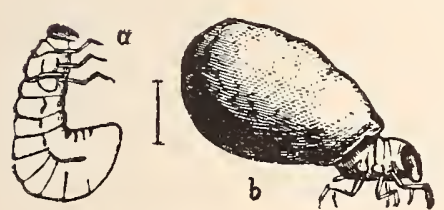

2054 (6601). Chlamys plicata Fab., Ent. Syst. Supp., 1798, 111.

Short, robust, oblong-quadrate. Brown, bronzed; elytra and legs sometimes blackish. Thorax with surface finely and densely strigose; disk with a large central tubercle which is

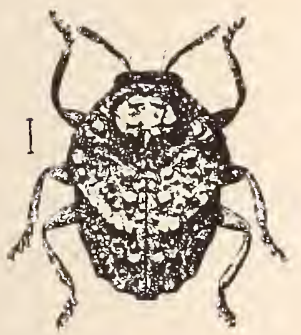

Fig 482. $a$, larva: $b$, same with body protruding from case; $c$, beetle. (After Marlatt.) sparsely and coarsely punctured in front and bifid at summit. Elytra each with 12 to 15 tubercles, the four largest of which are arranged in an oblique row extending from humerus to suture; intervals between the tubercles sparsely punctate, either flat or covered witl smaller tubercles. Length $4 \mathrm{~mm}$. (Fig. 4S2.)

'Throughout the State, frequent; more so in the southern counties. May 16-September 22. Occurs on foliage of various kinds, usually that of roadside weeds.

C. cribripennis Lee., length $3 \mathrm{~mm}$., was described from Detroit, Michigan, and may oceur in northern Indiana. 


\section{Exema Lac. 1849.}

Two very small species represent this genus in the eastern United States, both of which occur in Indiana.

\section{KEY TO THE SPECIES OF EXEMA.}

a. Dark cupreous, bronzed: thorax strigose.

2056. DISPAR. aa. Black without metallic lustre; thorax punctate.

205\%. GIBBER.

2056 (6605a). Exema dispar Lac., Mon., II, 1848, S50.

Oblong, subquadrate. Blackish, feebly bronzed; antennæe and labrum usually dull yellow. Thorax finely strigose, the crest of the median tubercle sulcate but not bifid. Elytra with tubercles as in C. plicata; intervals with coarse, deep, rather close-set punctures. Prosternum concave. Length $2.5-3 \mathrm{~mm}$.

Throughout the State; frequent. June 9-September 25. Taken by sweeping herbage along roadsides.

2057 (6604). Exema Gibber Fabr., Suppl. Ent. Syst., 1798, 112.

Oblong-quadrate. Black, without lustre, often more or less spotted with yellow; labrum and legs sellow. Thorax densely punctate. the crest with a shallow median groore. Elytra with oblique oblong tubercles; intervals coarsely and rather closely punctate. Prosternum flat. Length $2-2.5 \mathrm{~mm}$.

Starke, Marshall, Putnam and Posey counties; rare. May 11June 18. Taken by sweeping.

\section{Tribe TI. CRYPTOCEPHALINI.}

To this tribe belong numerous small, robust, more or less cylindrical species having the antennæ slender, filiform, longer than head and thorax, rarely (Honachus) shorter and subserrate; thorax margined, as wide as elytra and closely applied to the latter; eyes large, more or less emarginate; elytra not tuberculate, marked with rows of punctures, rather short, leaving the tip of abdomen exposed; prosternum wide, separating the front coxx, which are rounded, not prominent, their cavities enclosed behind; middle and hind coxæ each widely separated; tarsi dilated, claws usually simple, rarely broadly dilated at base. The tribe is founded upon the genus Cryptocephatus, of Geoffroy, a term meaning "concealed head," and given to these insects because the head is so deeply immersed in the strongly convex thorax that it can be scarcely or not at all seen when viewed from above. In color they are usually variegated with various combinations of spots or stripes which are sometimes very inconstant, so that numerous varieties have been named.

Seven genera compose the tribe, all of which are represented in the State. In addition to the papers cited under the family heading, the following treat especially of these genera: 
Haldeman, S. S._ "Cryptocephalinorum Borealis-America diagnoses cum speciebus novis Musei Lecontiani,' in Journ. Phil. Acad. Nat. Sci., I, 1849, 245-265.

Suffrian, E._-"Monog'raphie und Kritsches Verzeichniss der Nordamerikanischen Cryptocephali," in Linnea Entomlogica VI, 1852, 198-318; VII, 1855, 1-238; XII, 1858, 343409.

LeConte. "Contributions to the Coleopter'a of the United States, ' in 'Trans. Amer. Ent. Soe., VIII, 1880, 195-209.

KEY TO GENERA OF CRYPTOCEPHALINI.

a. Tarsal claws simple; larger, 3 or more mm.; surface sculpture rougher. b. Thorax not margined but crenulate at base; front femora not evidently stouter than hind ones.

c. Front edge of flank of thorax, beneath the antenni, toothed or sinuate.

XIII. Bassareus.

$c c$. Front edge of flanks of thorax straight. XIV. Cryptocephalus.

bb. Thorax margined at base, not crenulate; front femora distinctly stouter than hind ones.

d. Prostermum flat in front, depresced behind. XV. Griburios.

$d d$. Prosternum feebly channeled; rows of punctures of elytra usually much confused.

XVI. Pachybrachys.

$a$ a. Tarsal claws appendiculate, $i$. e., with a square dilatation at base; smaller. less than $2.5 \mathrm{~mm}$. (excejt in Monuchus); surface much smoother.

e. Prosternum wider than long; form robust, rounded; antennæ stout, rather short.

XVII. Monachus.

ee. Prosternum longer than wide; form more elongate, cylindrical or oval.

f. Antennal joints 6 to 11 wider; form cylindrical.

XVIII. Diachus.

ff. Antennal joints 7 to 11 wider ; form oval, convex.

XiX. Triachus.

\section{Busstreus Hald. 1849. (Gr., "a fox.")}

The members of this genus are separated from those of Cryptocephatus, which they most closely resemble, by the character given in key. The males have the prosternum armed at middle with a large, erect compressed process; first ventral with a large flat plate at middle, the hind angles of which rise into acute processes or spines; fifth ventral broadly concave, with a crest of curved erect hairs each side of middle. Female with forea of fifth ventral large, deep and circular. The following species and varieties have been taken or should occur in the State. 


\section{KEY TO INDIANA SPECIES OF BASSAREUS.}

a. Elytra with either spots or stripes.

b. Elytra each with two or more reddish, black, or yellow spots.

c. Spots on each elytron four or more.

d. Edge of thoracic flanks, beneath the antenna, acutely toothed.

2058. Clathrates.

dd. Edge of thoracic flanks only feebly sinuate.

$e$. Elytra black or piceous, the spots yellow. 2059. Formosts.

ee. Elytra yellow, the spots smaller, black.

2059a. var. SULPHURIPENxIS.

cc. Elytra each with two reddish spots.

$f$. Thorax uniform dull red, elytra darker.

DETRITLS.

$f f$. Thorax black, sometimes, with yellow spots.

g. Elytra without a basal row of small, oblong, pale spots.

2060. SELLATLS.

gg. Elytra with a basal row of small, oblong yellow spots, the outer two connected with the larger discal spot.

2061. MAMMIFER.

67. Elytra with black and yellow stripes or with a single yellow spot near apex.

h. Thorax in part or wholly black; upper surface dull.

$i$. Elytra with discal yellow stripes.

2062. LITURATUS.

ii. Elytra without discal stripes.

j. Thorax and elytra with reddish-yellow margins.

2062a. var. RECTRVTS.

ji. Thorax black with two red basal spots; elytra with small apical pale spot.

rar. CAsTLS.

jjj. Thorax wholly black; elytra as in rar. castus.

2062b. var. NIGER.

$h h$. Thorax wholly reddish-yellow, sometimes teebly infuscate at mid-

dle of disk; surtace polished; elstra with two yellow stripes which unite at apex.

2063. LATIVITTIS.

a a. Elytra wholly yellow without spots or stripes.

2061a. rar. LUTEIPENNIS.

2058 (6606). Bassarecs clathratus Melsh. Proc. Phil. Acad. Nat. Sci. III, $1547,173$.

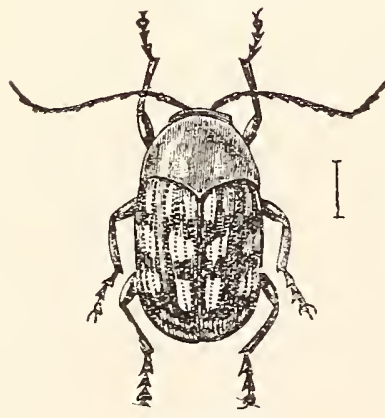

Fig. 483

Short. robust. subcylindrical. Head and thorax dull red, each with paler sellow spots, those on thorax near tront and hind angles (often confluent) and two larger oblique basal ones; elytra blackish or piceous-hrown. each with alex and three cross rows of spots. yellow. the spots in basal row elongate, the others irregular or subquadrate; femora and base of antenne red: apical half of antennze. tibia and tarsi blackish. Thorax finely and sparse-

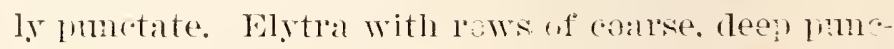
tures, the fifth and sixth rows much confused near middle; alternate intervals wider and more convex. Length $3.5-5 \mathrm{~mm}$. (Fig. 4S3.) 
Lawrence, Martin and Knox counties; frequent. July 13-August 2. This species is usually considered a synonym of congestus Fab., but according to Knab the latter is a larger species with rough thorax, found in Georgia and Florida.

2059 (6608). Bassareus formosts Melsh., Proc. Phil. Acad. Nat. Sci., III, $1847,173$.

Resembles the preceding very closely, and probably only a variety of it. Distinguished by the absence of a tooth on the front edge of the side pieces of prosternum. The color in trpical specimens is black spotted with yellow, exactly as in clathratus. In most specimens, however, the color is dull red spotted with yellow, as there. The punctuation of elytra is finer, the rows on sides less confused. Length $3.7-5 \mathrm{~mm}$.

Lake, Fountain, Putnam and Knox counties; scarce. June 15August 2. Beaten from the foliage of wild grape and elder.

2059a (6608a). Bassarees formosus sulphurtpennis Melsh., Proc. Phil. Acad. Nat. Sci., III, 1847, 173.

Form of clathratus. Head and thorax black, marked with yellow as in that species. Elytra pale rellow, each with a basal and median cross-row of three oblong black spots, and two similar spots near apex, the inner basal and median spot sometimes connected; under surface black: legs and base of antennæ dull red. Thorax and elytra punctate as in clathratus. Length $3.5-4.5 \mathrm{~mm}$.

Lake, Starke and Kosciusko counties; scarce. June 17-July 8. B. detritus Oliv., is recorded from the "Atlantic States."

2060 (6610a). Bassareus sellatus Suffr., Limn. Ent., VI, 1852, 307.

Robust. subcylindrical. Black, feebly shining; elytra each with a median and apical reddish spot. the former extending from margin nearly to suture; head of female spotted with white; antenne dull yellow at base. Thorax finely and sparsely punctate. Elytra with impressed rows of coarse punctures, the 5th, 6 th and 7 th rows confused on the front pale spot. Length $4.5-5.5 \mathrm{~mm}$.

Lake, Steuben, Blackford and Lawrence counties; scarce. June 24-July 29. Occurs on the flowers of Jersey tea.

2061 (6610). Bassareus Mammifer Netrm.. Entom. Mag.. IV. 1840, 250.

Form of sellatus. Head black, with yellow spots; thorax black, with narrow front margin, wider side margins and two rounded spots near base. yellow; elytra black, each with a basal row of small oblong spots, a large spot near middle, reaching nearly to suture and connecting with outer two basal spots, and an apical spot. reddish-yellow; under surface black: legs piceous. Elstral punctate as in sellatus, but the punctures less coarse. Lellsth $3.5-4.5 \mathrm{~mm}$.

Steuben, Laporte, Vigo and Harrison counties : scarce. June 11July 15.

[71-23402] 
2061a (6610c). Bassareus mammifer luteipennis Melsh., Proc. Phil. Acad. Nat. Sci., III, 1847, 172.

A rariets of mammifer in which the elstra are wholls dull sellow, with the exception of a minute dot on humerus and a rery narrow sutural line which are black. Length $3.5 \mathrm{~mm}$.

Known from the State Ijy a single specimen in the Wolcott collection, taken near Hessville, Lake County. Juls 4.

2062 (6612). Bassarets lituratus Fab., Syst. Eleut., II, 1S01, 50.

Short, robust, subcrlindrical. Head black; thorax reddish-yellow, with three black spots, the middle one larger; elytra each with a rellow stripe along the broad third interval, which unites at apex with another similar submarginal stripe, and a short stripe at base on fifth interral. Thorax smooth. its flanks obtusely toothed under the antennie. Elstra with regular rows of deep punctures, the fifth and sixth confused near middle. Length $3.5-4 \mathrm{~mm}$.

$$
\text { I ale County ; rare. May } 29 .
$$

2062a (6612a). Bassareus lituratus recurtes Say, Journ. Phil. Acad. Nat. Sci.. III, 1823, 439 ; ibid. II, 210.

A color variety of lituratus having the head black; thorax with a large black spot on disk which reaches base but not apex; elytra black with only a small reddish spot near afex or with the outer margins als narary leddish-rellow. Length $3-3.5 \mathrm{~mm}$.

Throughout the State; frequent. Nay 12-August 2. Taken by sireeping roadside herbage and beating hickory. Forms occur haring the body wholly black except the small reddish spot at aper of elytra. These may be known as var. niger (2062b).

2063 (6612b). Bassareus latitittis Germ.. Ins. Spec. Nor.. 1824. 55 S.

Form of lituratus. Head and thorax wholly reddish-rellow; elstra with stripes as in lituratus; under surface, legs and antennæ black. Length 3- $1 \mathrm{~mm}$.

Throughout the State, frequent. May 28-June 26. Occurs on flowers of yellow puccoon, Jersey tea and foliage of hickory. Said by Knab to be a distinct species, but the differences, except in color of head and thorax, between it and ituratus are rery slight.

XIV. Cryptocephatus Geoff. 176t. (Gr., "concealed + head.")

A large genus of compact. subcylindrical forms having the thorax not margined at base, the front edge of its flanks or deflexed portion straight: head in repose wholly hidden within the thorax: male without the modifications of prosternum and first ventral as mentioned under Bassareus; tarsal claws simple. The following speries and rarieties have been or should be found in the State. 
KEY TO INDLANA SPECIES OF CRYPTOCEPHALUS.

a. Elytra black, each with a humeral and apical reddish spot.

b. Surface finely pubescent above and beneath.

2064. BASALIS.

bb. Surface above glabrous and shining.

c. Larger, 4-5 mm.; humeral spot of elytra usually extending nearly or wholly across the base.

2085. QUADRIMACULATLS.

cc. Smaller, 2.5-3.5 1mm. ; humeral spot oblong, a little wider belind.

2060. QUADRUPLEX.

aa. Elytra not black, or if so without distinct humeral and apical spots.

d. I'rosternum with an apical lobe or cusp, longer in male than in female.

e. Elytra with numerous spots.

f. Thorax reddish; elytra each with seven spots.

2067. GUTTULATUS.

ff. Thorax yellow, with black or brown stripes; elytra with spots more or less united to form bands.

ec. Elytra without distinct spots.

2068. LEUCOMELAS.

g. Elytra yellow, each with two broad, oblique black or brown stripes, one of these sometimes absent. 2069. venustus.

gg. Elytra black with sides and apical margin yellow.

2069a. val. CINCTIPENNIS.

fil. Presternum broadly truncate in front in both sexes.

h. Thorax smooth or finely punctured.

i. Elytra with three narrow. sometimes ill-defined, stripes.

j. Thorax densely punctured, marked with three brown stripes or spots; length $3.5-4.3 \mathrm{~mm}$.

2070. TRIVITTATUS.

ji. Thorax sparsely punctured, usually without spots; length $3-$ $3.5 \mathrm{~mm}$.

INSERTUS.

ii. Elytra with spots or cross-bands.

k. Larger, 4-7 mm.; elytra pale yellow, with three interrupted brown bands.

2071. MUTABILIS.

lik. Smaller, 3-4.2 $\mathrm{mm}$. ; elytra brown with yellow spots.

hh. Thorax very coarsely punctured.

2072. BADIUS.

1. Dull yellow; elytra with three broad, ill-defined reddish bands; larger, 3-4.5 mm.

2073. TINCTUS.

11. Dull reddish-yellow; elytra with dusky suture; smaller, 2 mm.

STRIATULUS.

2064 (6613). Cryptocephalus basalis Sufirl., Linnea. Entom., VII, 1853, 54.

Robust, cylindrical. Black, shining; elytra with a red spot on humerus which extends across the base and along the sides to middle and another on apex. Thorax finely and densely punctured. Elytra with ten regular rows of large punctures. Hind margin of prosternum nearly truncate. Length 5.5-6.5 mm.

Spencer County; rare. May 24. Beaten from oak shrubs. Known heretofore only from Kansas and Texas. Listed as $C$. mucoreus Lee. Resembles quadrimaculatus, but larger and distinguished by the pubescence of elytra and the dense punctures of thorax. 
2065 (6614). Cryptocephalus quadrimaculatus Say, Journ. Phil. Acad. Nat. Sci., III, 1824, 441 ; ibid. II, 210.

Robust, cylindrical. Black, shining: elytra with an ohlong reddish humeral spot often extending across the base and along the sides to middle. and another rounded one (rarely wanting) at apex; base of antenna pale. Head coarsely and sparsely punctate. Thordx rery finely and sparsely punctured. Elytra with ten regular rows of coarse punctures. Length 4 $5.5 \mathrm{~mm}$.

Throughout the State; common. March 11-July 21. Occurs on flowers of Jersey tea and foliage of various shrubs. Varies with the humeral spot extending along the sides to join the one at apex; also with the humeral spot small, the apical one wanting, and rarely (fulvipennis Hald.) with the elytra wholly orange yellow. Our most common form, with red spot extending across the base, is var. notatus Fab., and should, according to priority, bear that specific name.

2066 (6617). Cryptocephalus quadruplex Newm., Entom., 1840, 78.

Smaller and more slender. Humeral spot oblong, a lit-

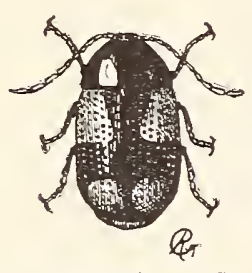

Fig. $484 . \times 5$. (After Riley.) tle wider behind. (in var. quadriguttulus Suffr. reaching to middle of sides), apical spot rounded; antennæ dusky, base yellowish. Elytral rows of punctures very coarse. Length 2.5-3 mụ. (Fig. 484.)

Throughout the State; frequent. May 12-July 6. Taken by sweeping and beating various plants. The variety mentioned is much the more common in the State.

2067 (6619). Cryptocephalus guttulatus Oliv., Ent., VI, 1808, S15.

Short, robust, cylindrical. Reddish; elytra blackish or reddish-brown. each with seven rounded yellow spots, arranged $2,2,2,1$, the last one at apex; sometimes a small additional spot on humerus; apical portion of antennæ black. Thorax smooth. Elytra with rows of rather coarse, distant punctures, the 6 th and 7 th rows confused near the middle. Length $4-$ $5.5 \mathrm{~mm}$.

Lake and Laporte counties; scarce. June 17-July 4. Beaten from white oak. The male is much the smalier and has the ground color of elytra black.

2068 (6020). Criptocephall's leucomelas Suffr.. Limnea. Entom., VII. $1853,36$.

Short, robust, subcylindrical. Abore rellow: thorax with four black or dark brown-stripes; elytra with three dark cross-bands, the front one the broader, the other two broken into spots; under surface and legs blackish or reddish-brown. Thorax finely and rather closely punctate. Elytra with rows of coarse punctures, the sixth and serenth much confused in front of middle. Length 4-5 $\mathrm{mm}$. 
Wells, Putnam. Knox and laosey counties; saree. June 1tSeptember 11. Occurs on poplar.

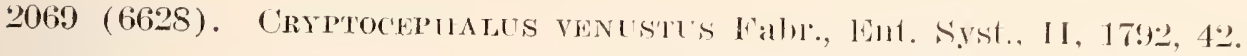

Robust, subcylindrical. Ilead and thorax redelish-bown. the latter with sides narrowly and two oblique basal spots yellow; color of elytra as given in key; under surface and legs reddish brown. Thorax finely and rather closely punctate. Elytra with regular rows of rather fine punctures. Length $4.5-5.5 \mathrm{~mm}$. (Fig. 485.)

Throughout the State; common. May 25-August 2. Occurs on the flowers of "white-top" (Erigeron) in timothy meadows, also on those of ironweed, wild sweet potato, etc. Varies greatly in color, the thorax

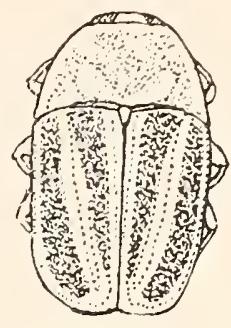

Fig. $485 . \times 5$. (After Wickham.) being often entirely reddish (var. ornalus Fab.) or the elytra black with sides, narrow line at suture and basal spot yellow (var. hamatus Melsh.)

2069a (6628c). Cryptocephalus venustus crnctipennis Rand., Bost. Journ.

Nat. Hist., II, 1838, 45.

A color variety of venustus having the elytra black, with narrow marginal line, apex, and rarely the suture, yellow. Length 4-5 mm.

Northern half of State; frequent. June 16-August 12. Occurs especially on foliage of dwarf birch, Petula pumila L., along the borders of marshes.

2070 (6637). Cryptocephatus trivittatus Olir., Ent., VI, 1S0S, S24.

Smaller, subcylindrical. Rerldish-brown; thorax yellow, with three rather wide brown stripes; elytra brownish-yellow, each with an oblique stripe on side and rery narrow margin brown; also with a common sutural stripe and a short stripe or oblong spot at base of fourth interval. brown. Sixth and seventh rows of elytral punctures interrupted and confused. Prosternum nearly flat, strongly margined at sides, acutely bilohed behind. Length $3.5-4 \mathrm{~mm}$.

Lake County ; rue. July 30. Occurs on hazel.

$C$. insertus Hald, thorax reditish-brown with sides yellow; elytra yellow, with two broad ollique black stripes; length $4.2 \mathrm{~mm}$., is a southern form recorded from Cincinnati.

2071 (6640). Cryptocephalus mutabilis Melsh., Proc. Phil. Acad. Nat. Sci., III, 1S47, 172.

Robust, subcylindrical. Reddish-brown, shining; thorax with apical and side margins narrowly yeliow, with or without two oblique basal spots: elytra pale yellow with a large, common brown spot extending backwaril along the suture; each also with six or seren small brown spots arranged three in a basal row, one or two near middle and two near apex. Thorax 
finely, sparsely and shallowly punctured. Elytral punctures rather fine and distant, the sixth and seventh rows more or less confused. Prosternum emarginate and acutely toothed behind. Length $4-6 \mathrm{~mm}$.

Throughout the State; frequent. May 10-August 21. Occurs on foliage of birch and hazel, on flowers of spirrea, Jersey tea, etc. The male has the spots of thorax and elytra black.

2072 (6642). Cryptocephalus badius Suffr., Linnea. Entom., VI, 1852, 315.

Smaller, robust, subcylindrical. Reddish-brown, shining; thorax sometimes with apical and side margins and hind angles yellow; elytra darker brown marked with yellow as follows: a basal band of confluent spots reaching to sixth stria, a submarginal spot at middle, an interrupted subapical band and an apical spot. Thorax very finely and sparsely punctate. Elytra with rows of rather coarse impressed punctures, the sixth to eighth interrupted and obliquely connected. Prosternum deeply emarginate and acutely lobed behind. Length $3-4.2 \mathrm{~mm}$.

Posey County ; scarce. July b-July 9. Known from Pennsylvania and Kentucky.

2073 (664t). Criptocephalus tinctus Lec., Trans. Amer. Ent. Soc., VIII, $1880,203$.

Small, subcylindrical. Dull brownish or reddish-yellow; elytra with three broad, reddish cross-bands, narrowly and vaguely separated by paler yellow. Thorax very. coarsely and densely punctured. Stria of elytra deep, conrsely punctured, the seventh and eighth slightly irregular near middle. Length $3-4 \mathrm{~mm}$.

A single specimen in Wolcott collection taken near Hessville, Lake County. September 25. Ranges from Massachusetts to Texas and Florida.

C. striatulus Lee, elytral strice regular, was described from northern Illinois.

\section{Griburius Hald. 1849.}

Rather robust species resembling the preceding in form and general appearance, but having the thorax distinctly margined behind, the prosternum lat in front and depressed behind, and the front thighs distinetly stonter than the hind ones. One species has been taken in the State and another probably occurs.

2074 (6649). Griburius scutellaris Fab., Syst. Eleut., II, 1801, 54.

Robust, subcylindrical. Black, shining; side margins and small spot on disk of thorax, scutellum, median transverse and rounded apical spots of elytrat yellow; base of antenne, spot on sides of first, fourth and fifth ventral segments and legs also yellow. Thorax coarsely and sparsely punctured, and with an obliqne impression each side near base. Elytra with rows of fine, rather distant and feebly impressed punctures. Length $5.5 \mathrm{~mm}$. 
Vigo County; rare. June 11. Taken from flowers of olusey tea. Dury has taken $G$. comeshis Oliv. near Cincinnati. It has the elytra yellow, with black spots and the thorax sparsely punctured.

\section{Pacmybrachys Chev. 1834. (Gr., "thick+short.")}

'To this genus belong a large number of small, compact, subcylindrical species having the basal marginal line of thorax distinct; prosternum feebly channeled; imner rows of elytral punctures usually completely confused, the outer ones tortuous or irregular, separated by more or less interrupted ridges; front thighs distinctly stouter than hind ones. A number of the species vary greatly in color and merge from one form gradually into another, so that they are very difficult to classify. Of the 50 or more species known from the T'nited States, the following have been taken in Indiana:

KEY TO INDIANA SPECIES OF PACIIYBRACIIYS.

a. Upper surface miform black, densely punctured.

b. Upper surface pubescent; punctures of elytra ererywhere much confused; size larger, 4 - $4 . \overline{\mathrm{m}} \mathrm{mm}$.

bb. Upiner surface glabrous.

207.). NIOROSUS.

c. Punctures of elytra mostly in distinct rows: smaller, 2.5 $3.5 \mathrm{~mm}$.

2076. CARBONARTUS.

cc. Punctures confused orer the greater part of surface: length $3.2-$ $4 \mathrm{~mm}$.

u. Tpper surface not uniform black.

2086a. val. Nigrinus.

a. Colors of upper surface definitely arranged.

$c$. Thorax and elytra black, each with narrow iror.w-wite morcinal lines.

ce. Disk of thorax or elytra with spots or stripes.

207\%. FLEGANS.

$f$. Wlytra with stripes; colors yellow and black or brown.

g. Elytra with rows of punctures in great part well defined.

h. Thorax yellow with an M-shaped brown spot (rarely black with narrow, pale margins); elytra with suture and two broad stripes on each, black. 2078 . Litigiosts.

7h. Thorax black with margins and narrow median line from front edge to midile, vellow. 2079. OTHONus.

$g g$. Elytral punctures confused, the two outer rows ristinct; elytra yellow with suture, broad oblique stripe, narrow outer margin and three spots on sides, black. 2080. BIritTATts.

ff. Thorax or elytra with spots.

$i$. Colors black and red; rows of elytral punctures very irregular at sides and behind middle; thorax black, usually with marsins and two basal spots red.

ii. Colors black and yellow.

20S1. TRINOTATUS. 
j. Thorax black with margins and three discal spots sellow; 1.11 gel. $3.5-\frac{1}{4} 111111$.

20S‥ M-MIGRLM.

ij. Thorax yellow with either a Y-shaped or an entire oblong median spot and a smaller lounded one each side, black; smaller, not orer $3 \mathrm{~mm}$.

20S3. TRIDENS.

dd. Colors of upler surface irlesularly mottled.

li. Elytra with well defined though simous rows of punctures orer most of the surface.

1. Outer three or four elytral intervals entire, whitish, in strong contrast with the rows of black punctures; thoracic punctures each side of middle separated by more than their orn diameters, their intervals not alutaceous. 2084. ABDomisalis.

17. Onter intervals broken into oblong whitish spots; thoracic punctures cromded, their interrals finely alutaceous.

20S5. ATOMARILS.

7.T. Elytral punctures mostly confused, complete strixe visible only on the sides.

m. Sides of thorax strongly rounded and incurved near the base, the hind angles obtusely rounded: brosternum deeply concare lengthwise; upper surface densely and rery strongly punctured.

n. Thorax usually with margins and median line red; elytra mottled with small, white dots. the punctures confused over most of the surface; legs black with yellow spots; size $3.2-4 \mathrm{~mm}$. 20S6. LLRIDL's.

11n. Thorax black with narrow margins sellow. its punctures fine and dense; legs and last rentral wholly yellow; smaller. $2.5 \mathrm{~mm}$.

205T. STICTICTS.

mm. Sides of thorax obliquely, broadly rounded or straight, not incurved behind: prosternum flat, scarcely concare, not narrower behind.

o. Punctures of elptra unitorm in size; two striæ visible at sides: dull clay sellow clouded with brown. 20Ss. HEPATICLs.

no. Punctures of elstra more or less irregular; striæ risible at sides and behind.

p. Colors red and black.

q. Elytra black with a broad. irregular band from the side almost to suture. red.

2059. SLBFASCIATLS

qq. Elytra with broader and paler red band extending from side to side.

20S9a. Val. DILATATCS

121. Colors yellow. brown or black. mottled.

$\therefore$ Upper surface black with scattered white or rellow markings.

s. Thoracic punctures each side of middle coarse, separated by more than their diameters. their intervals distinctly alutaceous: legs wholly pale.

2090. PECCAXS.

s. Thoracic punctures arowded, their intervals not or ver? finely alutaceons.

t. I'unctures of thorax coarser and more uneven : elytra without an isolated round white spot at middle near suture. 
11. Elytra with rery few white dots: less wholly birck. 2051. INFACSTIS.

uu. Elytra with numerous oblong white spaces, arranged in two nllore or less evident crossbars; legs in part pale.

200.2. FEMORATES.

1t. I'muctures of thorax rery fine and eren, their intervals ninutely aluticeous; elytra with rounded white spot at midlle near suture.

2093. CONECSES.

r. Iner surface in sreat part brownish-yellow with black markings: punctules of thorax fine and dense.

209) t. SPLMARILS.

2075 (6655). Pachybachys morosts llalde, Jomrn. Phil. Acad. Nat. Sci. I, 1S+9, 260.

Subcrlindrical, robust. Black. subopaque; antennie and legs reddishbrown. Thorax with dense. coarse. sieve-like punctures. Elytral punctures everwhere confused; humeral umbone prominent. nearly smonth; surface pubescent in fresh specimens. Length $+4.5 \mathrm{~mm}$.

\section{St. Joseph County: rare. June 1.}

2076 (66S3). Pachrbrachys carboxaries Mald. Journ. Phil. Acad. Nat. Sci., I, 1849,260 .

Smaller and less robust than morosus. Uniform black, opaque; antemne and tarsi sometimes piceous. Thorax finely, densely and deeply punctate: hind angles obtuse. not rounded. Elytra with distinct rows of coarse punctures, except near scutellum, where they are somerhat confused. Length 2.5-3.5 $\mathrm{mm}$.

Lake, Yigo, Lawrence, Martin and Orange counties, scarce; probably throughout the State. June 2-July 11. Taken in beating oak and sweeping herbage.

207 (-). PACHYBRACHYS ElEgaxs sp. not.

Subcylindrical, robust. Black, shining; thorax with a narrow ivory white line neal the side margins. the edge black; elstra each with a similar line. and also with the margin or upper portion of each epipleural lobe white from humerus to middle. Thorax with dense oral, rather coarse punctures which are substrigose on the sides. Elrtra with regular rows of deep. rather coarse punctures. those near the suture confused. Under surface. except abdomen, coarsely and rather closely punctured. Length $3.5 \mathrm{~mm}$.

\section{Tarshall County : rare. June 24. Beaten from hazel.}

2078 (6659). Pachrbrichys litigiosts Suffr., Linn. Entom., VII, 1853. 217.

Subcrlindrical. robust. Brown or black: legs. thorax and elytra rellow; thorax with brown spots. the middle one divided in front and united with the ones on sides to form a dark $\mathrm{M}$ : elotra with sutural and two discal stripes on each dark, the inner one the shorter: these may he confluent and so widened that the light color is reduced to mere lines. in which case 
the tholax is usualiy wholly black except narrow pale margins. Thorax closely and finely punctured. Rows of elytral punctures distinct on middle and sides, confused near suture. Length 2.5-3.5 $\mathrm{mm}$.

Floyd County ; rare. June 23.

2079 (6662). Pachimrachys othoncs Say, Amer. Ent., II, 1S25, Pl. 28; ibid. I, 66 .

Subcylindrical, robust. Black; head with labrum and three spots on front yellow; elytra with a common sutural stripe and two broad ones each side, black; legs and ventral margins yellow; antennæ dusky. Thorax nearly three times wider than long, densely and rugosely punctured. Length $3.5-4 \mathrm{~mm}$.

Throughout the State; frequent. June 1-July 30. Taken by sweeping herbage along roadsides.

2080 (—). Pachybrachys bivittates Say. Amer. Ent., I, 1824, 65; ibid. I, 65.

Subcylindrical, robust. Head, thorax, legs and under

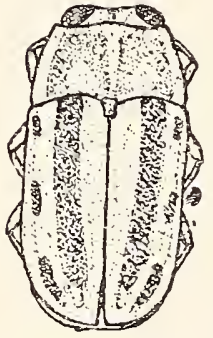

Fig. $486 . \times 6$. (After Wickham.)

2081 (66it). Pachybrachys trinotates Melsh., Proc. Phil. Acad. Niat. Sci., III, $1847,170$.

Short, subcylindrical, robust. Black, opaque; head with tro red spots between the eyes; thorax with narrow front and side margins, two large basal spots, and a median line from apex to near middle, reddish. Thorax strongly convex, rery erenly, deeply and rather coarsely punctured. Elytra coarsely and very irregularly punctured. Length $4-5 \mathrm{~mm}$.

Putnam and Posey counties; rare. June 24-July 9. Occurs on formers of Jersey tea.

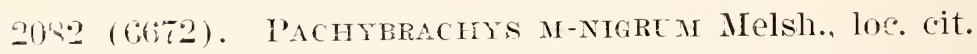

Subcylindrical, robust. Black, opaque; thorax with front and side margins, median line or spot near apex, and two basal spots, yellow; elytra with basal and apical margins, a space around humerus, two small smooth spots near suture and a large submarginal space on sides, pale rellow: legs spotted with yellow. Thorax rather densely and coarsely punctured. Elytra with humeral umbone, prominent, smooth; rows of punctures very irregular, excepting behind the middle. Length $3.5-4 \mathrm{~mm}$.

Lake and Taporte counties; rare. June 4-June 24. Taken by swepping herbage. The black markings on thorax resemble the letter M. 


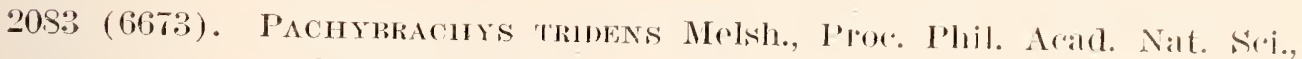
III. $1847,172$.

Short, subcylindrical, less robust. IJead yellow; vertex, and often a spot on front, black; color of thorax given in key; elytra yollow, with a large, common, black cruciform spot on disk, this wider at base, much narrowed at middle, and again widened on apical third, so as to form a common crossbar; each also with narrow marsinal line and hmmeral spot, black; under surfice black; antemne and legs yellow, the hind thighs often with black spot. Thorax sparsely and rather coalrsely punctured. Elytar with well defined though sinuous rows of coarse punctures. Length 2-3 mm. (Fig. 4S7.)

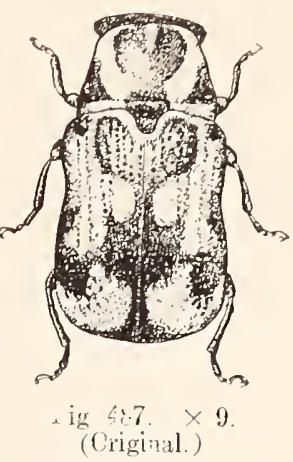

Throughout the State; common. May 25-August 2. Occurs on foliage of hickory and elm and on that of many herhs along roadsides. The color varies greatly. The yellow is sometimes pale, sometimes dirty brownish in hue; the dark spots vary from black to dull brown. The median spot of thorax is sometimes Y-shaped, again oblong, and rarely more or less merged with those on sides; while the elytra may be black with only a narrow median line of yellow, or yellow with only the discal spot and three spots on side; black. The sparsely punctured thorax and yellow legs will serve to distinguish it from spumarius and other closely allied forms.

$20 S 4$ (6660). Pachybachis abdominalis Say, Journ. Phil. Acad. Nat. Sci., III, 1S24, 437 ; ibid. II, 263.

Form and size of the preceding. Head and thorax dull grayish-yellow. irregularly clouded with markings formed by black punctures. Elytral intervals grayish-white and prominent on the sides, the rows of punctures black; the latter confused and intervais much broken on disk near suture; under surface black; sides of abdomen and pygidium marked with paler; legs pale, the femora with a dark spot on middle. Thorax rather coarsely and irregularly punctate, the raised, smooth, gray or dull yellow spaces varying much in size and shape. Length $2-3 \mathrm{~mm}$.

Northern third of State, frequent; not taken south of Marsha!l and Kosciusko counties. May 12-June 30. Taken by sweeping herbage in low, moist places.

2055 (6690). Pachybachys atomarius Melsh., P'oce. Phil. Acid. Nilt. Sci., III, $1847,170$.

Subcylindrical, robust. Black, mottled with whitish ; front mostly white: antennæ fuscous, the three basal joints paler; thorax black, with the narrow margins and three or four small, scattered spots, whitish; elytra with numerous elongate spaces of the broken intervals whitish; under surface black, the legs varied with white. Length 2.5-3 mm.

Lake, Marshall and St. Joseph counties; scalce, May 29June 11. 
2086 (6689). Pacmymacitys luridus Fabr., Syst. Elent., II, 1801, 45.

Subcylindrical, robust. Black, subopaque; thorax with sides and a narrow median line usually red; elytra with a line at base and usually a number of oblong spaces on the broken intervals dull yellow; antenne reddish-brown at base. dusky at apex; femora often with a rellow spot. Thorax densely, coarsely and deeply punctured, often with a portion of a smooth median line; hind angles obtusely rounded. Elytra with coarse, confused punctures over the wreater part of the surface, the rows visible only on sides and behind middle. Length $3.2-4 \mathrm{~mm}$.

Throughout the State; scarce. June 1-July 9. Occurs on Howers of Jersey tea and on foliage of the false indigo, Baptisia lencantra 'T. \& G. The elytra, and sometimes the entire body, are wholly black. In the latter instance the name var. nigrinus (2086a) is herewith given to distinguish them from the other black species, morosus and carbonarius. The punctures of thorax are much coarser than in the latter.

\section{7 (-). Pachytrachis sticticl's sp. nov.}

Slender, subcylindrical. Dull black, mottled with yellowish ; front dull yellow, with a median black line; antenne yellow, the onter joints fuscous; thorax with rery narrow margins, a median elongate dash and three or four minute spots each side dull yellow; elytra with a narrow basal line. extending from humerus to and back of scutellum and two backward spurs from same, dull yellow; also with numerous elongate marks on apical third and a larger spot at apex, yellowish; under surface black, the legs and last rentral yellow. Elytral intervals very narrow and much broken; punctures minute, crowded, their intervals finely alutaceous; humeral umbone prominent, shining black. Length $2.5 \mathrm{~mm}$.

Floyd County ; rare. June 28.

2088 (6697). Pachyraders yepatrces Melsh., Proc. Phil. Acad. Nat. Sci.. III, $1847,171$.

Subcylindricail, moderately robust. Above dull day yellow, more or less clouded with brownish : elytra usually with a brown spot on each humerus and four or five similar spots on apical third, of which a common sutural one is the largest; under surface reddish-brown. Thorax rather coarsely. closely and evenly punctured. Elytra coarsely and erenly punctate without strice except two near margin each side. Prosternum flat, truncate at apex. Length $2.5-3 \mathrm{~mm}$.

Lake County; rare. July 14. Probably oceurs throughout the state, as it has reen taken at Cincimmati.

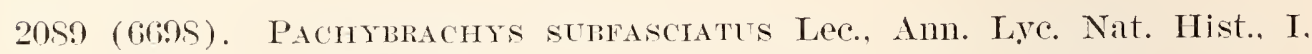
$1824,173$.

Short, subcylindrinal. Black. feebly shining: thoriax with sides and often a dorsal spot reddish; elytra with a median angulate reddish band extending from sides almost to suture and often a smaller spot near apex. 
'Thorax densely punctured, the hind angles almost lounded. Elytra with sinuous rows of punctures and convex intervals at sides and behind middle, confusedly punctured on basal half. Length $2.5-3.5 \mathrm{~mm}$.

Marshall, Vermillion and Tawrence counties; scarce. May 11 June 14.

2089a (6701). Pacmibrachys sumasciat's didatates Suffr., Timea. Entom. VII, 1S53. 162.

Very similar to the preceding but broader. Elytra with median band covering more than one-third the length and often sending a spur forward to the scutellum. Punctures of elstra almost everywhere confused; intervals nearly obsolete except on apical third. Length 3-3.5 mm.

Orange and Posey counties; scarce. May 13-.June 4. Taken by sweeping herbage in low places.

\section{0 (6691). Pachrbrachy's Peccaxs Suffr.. Limn. Ent, VII, 1S53, 192.}

Short, subcylindrical. Black, shining; head with three or four spots and labrum yellow; thorax with narrow marginal line and two or three irregular smooth spots yellow; elytra with a line at base and along sides. an irregular space at apex and a number of scattered dots, pale sellow; pygidium in great part sellow. Thorax sparsely and coarsely punctured. Elytra with three or four irregular rows of coarse punctures, the others much confused. Length $2.5-3 \mathrm{~mm}$.

Marshall and Crawford counties; rare. May 26--June 10. Occurs on leaves of hickory. Its general range is southern.

2091 (6692). Pachybachys infaustus Hald.. Journ. Phil. Acad. Nat, Sci., I, 1849, 262.

Short, subcylindrical. Black. feebly shining; head often with labrum and a curved line in front of each eje dull yellow; thorax wholly black or with a few minute, smooth whitish dots; elytra usually with a number of smooth, oblong yellowish spaces, these sometimes reduced to mere white dots or points; front and middle femora with a white spot at apex. Thorax with rough, coarse, sieve-like punctures. Elytra with coarse punctures, confused except on apical third. Length 2-3 $\mathrm{mm}$.

Throughout the State; common. April 26-August 2. Occurs on foliage of the greater ragreed, wahoo and other plants.

\section{2 (6691). Pachybrachys femorates Oliv., Ins., VI. 1S08, 810.}

Robust, subcrlindrical. Black, with numerous dull yellow marks ; front black, with a narrow rellow line near the eves; thorax with three or foul large, irregular rellow blotches: elstra with intervals broken near middle and at apical third into oblong white spaces which form two crossbars, also with similar spaces near apex; proidium with white marks: under surface black. Elytral punctures everywhere confused. Length 2.6-3 $\mathrm{mm}$.

Throughout the State; scarce. July 4-July 29. 
2093 (-). Pachybrachys confusus Bowd., Can. Ent., Xli, 1909, 320.

Rather robust. Black with yellow markings; front black with two yellow triangular spots between the eyes and an irregular quadrate spot between the antennæ; thorax with front angles, narrow marginal line, a median line to middle and a small spot each side at base, yellow; elytra with basal line as in sticticus and numerous rounded, scattered raised spaces, whitish; under surface and legs black, spots on thighs and rings on tibix pale. Thorax with surface very smooth and even, the punctures and intervals as described in key. Elytral punctures everywhere confused. Length $2.5-2.7 \mathrm{~mm}$.

Knox County ; scarce. August 2. Swept from vegetation near margin of cypress swamp. Described from Mississippi and Virginia. A member of the Austroriparian fauna.

2094 (6695). Pachybrachys spumarius Suffr., Linn. Ent., VII, 1853, 179.

Short, robust; subquadrate. Head black, with labrum and two curved lines between the eyes brownish-yellow; thorax and elytra brownish-yellow, irregularly clouded with markings formed by black punctures; the black on thorax forming a vague $\mathrm{Y}$-shaped figure on disk, with an irregular space each side. Punctures of elytra in sinuous rows on apical half, elsewhere much confused; the ridges broken and irregular, the remnants in part dull yellow. Length $3-3.5 \mathrm{~mm}$.

Throughout the State; frequent. June 24-August 3. Occurs on flowers of wild hydrangea and Jersey tea.

\section{Mondchus Chev. 1834. (Gr., "single.")}

Small, broadly oval and convex species, having the eyes strongly emarginate; antennæ rather long with joints 6-11 broader; scutellum elongate, acutely triangular, not elevated behind; prosternum flat, broader than long, slightly rounded behind. The females have the fifth ventral segment impressed with a large, circular, rather deep fovea. Two of the five species occur in the State.

KEY TO TIE INDIANA SPECIES OF MONACHUS.

a. Thorax smooth, opaque; color nearly black.

2095. ATER. aa. Thorax with punctures near the base; color steel blue.

2096. SAPONATUS.

2095 (6702). Monachus ater Hald., Journ. Phil. Acad. Nat. Sci., I, 1849, 264.

Oral. Black, shining; thorax very dark blue; labrum and base of antennæ dull yellow. Elytral rows of punctures less distinct than in the next. Length 2.5-3 mm.

Throughout the State, frequent; less so in the southern counties. June 16-August 15. Cceurs on foliage of milkweed and other herbs. 
2096 (6703). Monachus saponatus Fabr., Syst. Eleut., II, 1801, 55.

Ovate. Dark steel blue, shining; labrum and four basal joints of antennæe dull yellow. Thorax with scattered shallow punctures near the base. Elytral punctures coarse on basal half, finer and subobsolete near apex. Length $2-2.5 \mathrm{~mm}$.

Throughout the State; frequent. May 29-August 15. Taken by beating and sweeping foliage.

\section{Dinchus Lee. 1880.}

Very small, subcylindrical oval species, having the tarsal claws broader at base; antenna not more than half the length of body, with joints 6 to 11 broader; eyes feebly enarginate; thorax as wide is elytra; prosternim usually quadrate and flat.

KEY TO INDIANA SPECIES OF DIACHUS.

a. Head and thorax dark metallic; scutellum obtusely triangular.

b. Upper surface not uniform blue.

c. Scutellum flat; head and thorax dull reddish-brown; elytra brassy green; legs yellow.

2097. AURATUS.

rc. Scutellum elevated behind; upper surface dark bluish-green; antennie and legs reddish-brown.

6ъ. Upper surface uniform blue; antenne and legs yellow.

209S. CATARIUS.

2099. PALLIDICORNIS.

aa. Head and thorax yellow; elytra metallic green; scutellum acutely triangular.

2100. CHLORIZANS.

2097 (6707). Diachus auratus Fabr., Syst. Eleut., II, 1801, 57.

Oval, subcylindrical. Head and thorax reddish-brown, bronzed; elytra brassy green or brownish; antennæ, legs, sides and under surface of thorax dull yellow; abdomen black. Thorax very finely alutaceous. Rows of elytral punctures fine but complete. Length $1.5-2 \mathrm{~mm}$.

Throughout the State; rommon. May 31-August 7. Taken by sweeping and beating.

2098 (6712). Diachus catarius Suffr.. Linnea. Entom., VII, 1853, 68.

Form of auratus. Dark bluish-green, shining. Antenna, legs and prosternum dull yellow. Thorax distinctly alutaceous. Punctures of elytra coarser than in auratus. Length 2-2.5 $\mathrm{mm}$.

Marshall, Starke, Kosciusko and Knox counties; scarce. June 11--July 15.

2099 (6713). Diachus Pallidicornis Suffr., Limnea. Entom., rit, 1853.

Oral, subcylindrical. Dark steel-blue, shining; antennie and legs rellow. Thorax finely alutaceous, not punctured. Elytral punctures rather coarse. Length 2-2.5 $\mathrm{mm}$.

Throughout the State; frequent. May 11-July 6. Taken by heating and sweeping foliage. 
2100 (6714). Diachus chlorizaxs Sutfr., Limnea. Entom., VII, 1853, 76. Oral, subcylindrical. Head, thorax and legs sellow, shining. Elytra metallic green. Rors of elytral punctures entile. Length $2 \mathrm{~mm}$.

Lawrence and Harrison counties; rare. June 24.

XIX. Trilchus Lec. 1880.

Here belong the smallest of Chrysomelids, none of them being over $1.5 \mathrm{~mm}$. in length. They are oval in form and have the claws widely dilated; antennæ about half as long as body, with the last five joints wider; eyes feebly emarginate; prosternum flat, quadrate, margined at sides, truncate behind; elytral strix consisting of small punctures. Tro of the four known species occur in the State. 2101 (6715). Triachts atomes Suffr., Linnæa., Entom., VII, 1553, 74.

Oral, conrex. Piceous-brown, thorax slightly paler; legs yellow. Thorax smooth. feebls punctured at sides. Rows of elytral punctures obsolete except on sides. Length 1.2-1.5 mm.

Crawford Countr; scarce. June 2t--July 25. Taken by sweeping huckleberry bushes.

2102 (6717). Triachus racuts Lec., Trans. Amer. Entom. Soc., VIII, 18s0, 197.

Oral, convex. Dull sellow, the elytra often clouded with darker. Thorax sparsels and finels punctured, more deepls at sides, not margined at base. Rows of elytral punctures rery fine but distinct on disk. Length 1$1.3 \mathrm{~mm}$.

Throughout the State; common. Nay 16-June 29. Beaten from regetation.

Tribe VII. EUMOLPINI.

A large group of medium or small-sized oblong, convex (rarely rounded or oral) species, usually uniform metallic, though sometimes dull yellow or spotted in hue. They have the head plainly risible, moderate in size and deflexed: eres more or less emarginate; antennæ usually long, filiform, widely separated at base; thorax margined at base, except as mentioned in key to genera; elytra rounded at tip, entire; front coxæ globose, separated by the prosternum, the cavities closed behind; tarsi broad, the third joint deeply bilobed, the claws toothed or cleft.

The following paper. in addition to those mentioned under the family heading. treats especially of the genera composing the tribe:

Horn._-"The Eumolpini of Boreal America," in Trans. Amer.

Ent. Soc., XIX. 1892, 195-234.

Of the 19 genera ascribed to the tribe by Horn, 14 are known to be or should be represented in the State. 
KEY TO INDIANA GENERA OF ELMUIPIN.

a. Front margin of thorax beneath curred, forming lobes behind or below the eyes.

b. Body above pubescent or scaly.

c. Thorax without distinct margins on sioes; form subquadrate; elytral brown or blarelk.

ce. Thorax with distinct sicle margins.

XX. InOACS.

d. Margins of thorax dentate; front tibie toothed on inner side near apex.

XXI. Mrochrot's.

dd. Mirgins of thorax entire; front tibixe simple.

b\%. Body above not pubescent or scaly.

NAII. Girposceis.

c. Elytral punctures in distinct, regular rows; middle and hind tibie emarginate on outer edge near apex. (Fig. 490.)

XXIIL. TYPopHores.

r. Elytral punctures confused ar iregular; tibia all entire.

f. Bluish-green, shining; tarsal claws divergent: legs dark.

XXIT. Chrisochus.

ff. Brom; tarsal claws divaricate; legs pale. XXY. Trunes.

a1. Front margin of thorax beneath straight.

g. Thorax without distinct margins on sides.

$h$. Body abore not metallic: head without a groore above the eyes.

$i$. Thorax transverse; front thighs with a small tooth; third joint. of antenne not longer than second.

XXVi. Xaxthoxia.

ii. Thorax cylindrical; thighs not toothed; third joint of antenne longer than second.

XXVII. Fidia.

hh. Body above metallic green or bronzed; head with a groore abore the eyes; length less than $4.5 \mathrm{~mm}$.

gg. Thorax margined on the sides.

xitili. Graphops.

$j$. Head with distinct groores above the eyes; middle and hind tibive emarginate near apex.

XXix. Metachroma.

jj. Head without groores above the eyes.

l. Side margins of thorax irregular or undulating.

l. Prosternum narrow, contracted between the coxæ.

7l. Prosternum wide, its sides nearly parallel.

XXX. COLASPIS.

lik. Side margins of thorax regular and entire.

XXXI. RHABDopteres.

$m$. Third joint of antennse distinctly longer than second, the outer' five joints not abruptly wider.

XXIII. NODONOTA.

$m m$. Joints 2 to 5 of antenne very nearly equal in length. the outer five joints rather abruptly wider: form nearly globose: thorax without basal marginal line.

CHRYSODINA.

XX. Adoxus Kirby. 1837. (Gr., "without + glory.")

A single species represents this genus in Europe and the northern United States.

[72-23402] 
2103 (67:6). Anoxts obscures Limn. Srst. Nat., Ed. X, 1758, 375.

subquadrate. Head, thorax, under surface and femora dark brown or black: elytra. tibie and basal half of antennæe brown or bromnish-yellow. sparsely clothed with prostrate yellowish pubescence. Thorax subglobose. much narrorer than elștra, densely and rather finely punctured. Elstrar with numerous irregular rows of fine punctures. Length $5-6 \mathrm{~mm}$.

Steuben County; scarce. July 4. Our form is the variety ritis Fabr.. distinguished by the paler elytra. In the typical species they are of the same color as the thorax. It is a species of northern range and probably occurs only in the Transition life zone of the state.

\section{Mrochrocs Erichs. 1S47. (Crr., "mouse + color.")}

In this genus the form is oblong, and the upper surface is rather thinly clothed with hair-like scales. One of the three species occurs in the State.

*2104 (6735). Mrochrots Dexticollis Sar. Journ. Phil. Acad. Nat. Sci.. III, 1824, 448 ; ibid. II. 215.

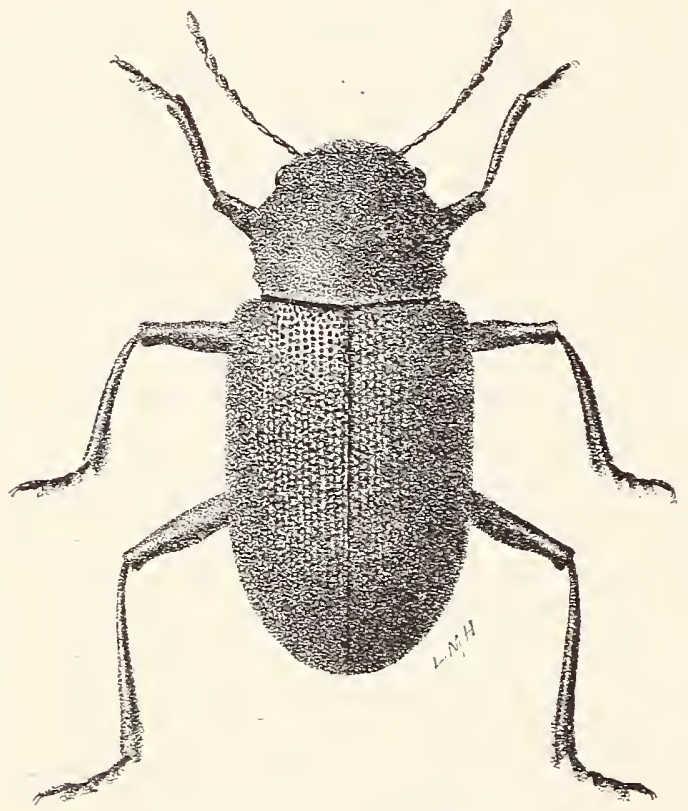

Fig. 485. $\times 6 . \quad$ (After Forbes.)

Oblong, conrex. Brown. bronzed; base of antennie dull red. Thorax wider than long. side margins with three blunt teeth near the middle; surface densely clothed with grayish-yellow scales. Elytral margins feebly dentate; surface with rows of deep, close-set punctures. sparsely clothed with rellowish scales. Last ventral of male with a small forea. Length $5-\tau \mathrm{mm}$. (Fig. 4SS.)

Throughout the western half of State, frequent: more so in the southern counties. February 2-October 9. Hibernates beneath rubbish in open woods. Taken in spring by sweeping herbage.

\section{Gurptoscells Lec. 1859. (Gr.., "carved + tibia.")}

Species above the average in size for the tribe, brown in color and haring the bodr more or less densely clothed with prostrate 
scaly hairs or seales. Two species have been taken in the State and two others perhaps oceur.

KEY TO INDIANA SPECIES OF GLIPTOSCELIS.

a. Tarsal claws cleft.

b. Surface clothed with prostrate hairs.

c. Elytra with a distinct depression surrounding the scutellum; surface sparsely but equally clothed with gray and brown hairs.

cc. Elytra convex at base; surface hairs all brownish.

PUBESCENS.

2105. BARBATA.

bb. Surface clothed with hair-like whitish scales.

2106. LIEBECKI. aa. Tarsal claws simple; elytra acute at tip and slightly prolonged; surface clothed with scale-like hairs.

CRYPTICA.

2105 (6730). Glyptoscelis barbata Say, Journ. Phil. Acad. Nat. Sci., V, 1S26, 296 ; ibid. II, 341.

Oblong, convex, robust. Bronzed, feebly shining; rather thickly clothed with prostrate reddish-brown hairs; antennæ and tarsi dull reddish-brown. Thorax narrower than elytra, widest at middle, slightly narrowed at base, coarsely and closely punctured. Elytra finely and irregularly granulatepunctate. Length $5.5-7.5 \mathrm{~mm}$.

Southern third of State; scarce. May 16-June 6. Occurs on the foliage of wild grape and hickory.

G. pubescens Fab., length 8-9.5 mm., occurs in the "Niddle States Region." G. cryptica Say, length 7.5-9 mm., is known from Missouri, Kansas and Dakota.

2106 (- $(-$ ). GLYPToscelis LIEBEcki sp. nov.

Longer and less convex than barbatus. Reddishbrown, shining, feebly bronzed; thickly clothed above and beneath with prostrate, whitish, hair-like scales. Thorax about as broad as long, sides nearly straight, not narrowed at base, rather coarsely, closely and deeply punctured. Elytra finely and rather densely punctured, the punctures not in rows. the tips not prolonged. 'Tarsal claws deeply cleft, the inner lobe the shorter. Length $T$ $9 \mathrm{~mm}$. (Fig. 4S9.)

Knox, Martin and Poser counties; scarce. Miar 16-June 9. The thorax is sometimes darker than

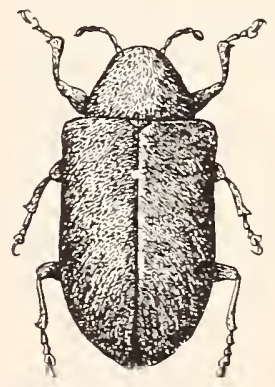

Fig $459 . \times 3$ (Original.) elytra and the surface is more distinctly bronzed in male than in female. Named in honor of the well-known Coleopterist, Chas. Liebeck of Philadelphia, Pa., who has shown me many favors during the preparation of this paper. 
XXIII. T'Ypophorts Erichs. 1847. (Gr., "impression + bear-

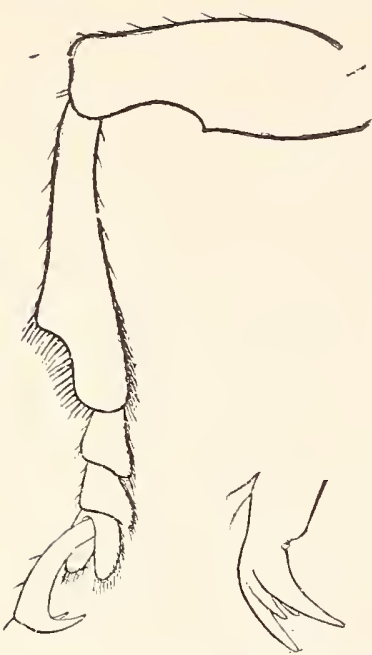

Fig. 490. Leg of Typophorus canellus, showing emarginate hind tibia, tarsal joints, and cleft tarsal claw. (After Forbes.)

$$
\text { ing.") }
$$

'T'o this genus belong the species listed by Henshaw under the name Paria. They have the eyes surrounded by a rather deep groove; tarsal claws bifid: elytra with rows of punctures; antenne with second joint thicker but shorter than third. Three species and a number of varieties comprise the genus.

KEY TO SPECIES OF TYPOPHORUS.

a. Bright blue; size larger, $5.5-7 \mathrm{~mm}$.

2107. VIRIDICYANEUS. au. Reddish-yellow, usually with black markings; sometimes wholly black; smaller, not over 411111 .

b. Elytra without a large, com $\mathrm{mon}$, saddleshaped black mark. 210S. CANELLUS.

bb. Elytra, with a 1arge, median, saddle-shaped black space. 2109. sELlatus 2107 (6751). Typophonls vimicraneus Croteh., Proc. Phil. Acad. Nat. Sci., $1873,40$.

Oblong-oral, strougly conver. Dark greenish-blue, shining; antennae reddish at base, the five outer joints blackish. Head and thorax finely and rely sparsely punctate, the latter narrower than elytra, its sides feebly curved. Elytra with regular rows of rather fine. shallow punctures; sides with a fold or costa extending from the humeral elevation obliquely backward toward the margin. Length 5.5-7.5 $\mathrm{mm}$.

Southern third of State; scarce. June 15August 2. Oecurs on the foliage of the hedge bindweed, Conrolvulus sepium $\mathrm{L}$.

2108 (6747-6750). TYPOPHORUS CANELLCS Fib. Sist. Elent., II, 1801, 52.

Ohlong-oval, convex Color exceerlingly va $r^{\circ}$ able, as noted in the color rarietal key below; surface shining. Thorax nar-

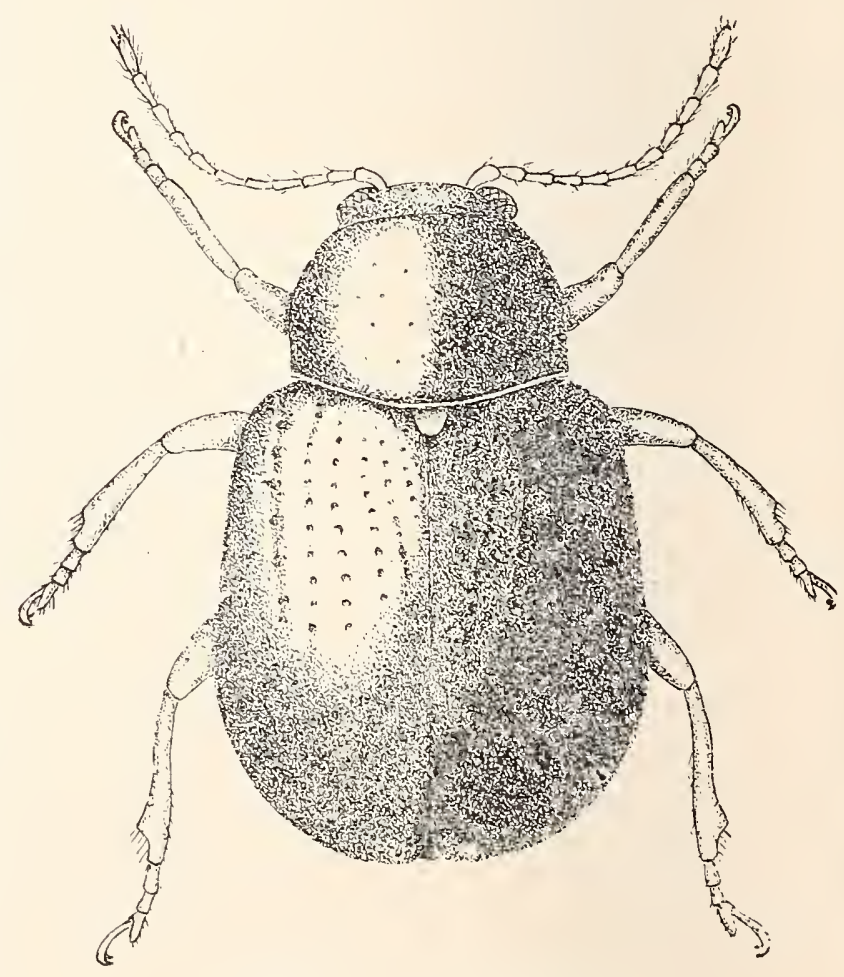

Fig. 491. $\times$ 14. (After Forbes.) 
rower than elytral. Taldably punctured, sometimes neally smoroth, often, ill

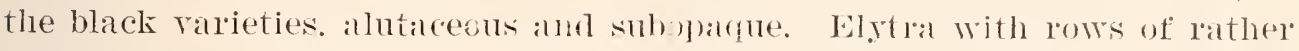
fine punctures. these often indistinct on sides and anicall thind. I.ength :;4 mm. (Figr. t!)1.)

One of the most common of the Chrysomelidie. oceurring in large numbers thronghout the State. Taken by beating or sweeping vegetation.

KEL TO (OROL VARETIES OF T, CANELI,LS.

u. Elytrad wholly black.

b. Thorax black.

(. Legs black.

¿10Sa. ATERRIILS.

( $\%$ Legs pale.

GILTIPES.

b). 'Thorats reddish- reliom.

உ10Sb. THORACICLS.

uu. Elytra pale or spotted.

d. 'Thorax black, elytral syots larger.

dd. Thorax yellow or slightly redelish.

e. Elytra with black spots.

$f$. Spots of elytra confluent to form a black stripe on each.

ff. Spots of elytra separate.

210Sd. VITTATCS.

g. Two spots on eaclu elytron; suture often piceous.

y9. Three spots on each elytron.

210Se. QUADRIGUTTATES. ce. Elytrat pale, without spots.

210Sf. SEXNOTATCS. 210Sg. PUMILUS.

210Sa (6745). TYPOPHORLS CANELLCS ATERRIMLs Olir.. Ent., TI, 1S0S. 913.

The head of this variety is often reddish and not always black, as stated by Horn. The subrariety gilvipes Dej. differs only in the legs and antennie being wholly pale.

Throughout the State; common. April 12--Tuly 13. Occurs especially on foliage of wild grape. Taken in earty spring by sifting and probably hihernates.

210sb (-). Trpophores caxelles Thoracicts Melsh., Proc. Phil. Acad. Nat. Sci., III, 1S47, 16 S.

Head and thorax and usually the legs, reddish or reddish-yellow. Examples in which the thorax is partly black and partly red, thus connecting it with aterimus, are often met with.

Occurs throughout the State. Mar 20-Angust 17. Mating June 22.

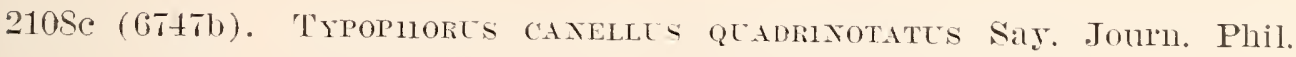

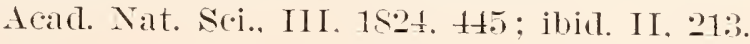

Head either black or reddish ; back spots of elstra located on the middle of the base and behind the niddle and sometimes confluent: legs and antenna usually pale. It seems to vary mole in size than the other forms. 
More common in the southern counties. April 20-August 2. Occurs beneath bark in early spring and on foliage of linn, redbud, etc., in May.

2108d (-). Typophorus canellus vittatus Horn, Trans. Amer. Ent. Soc., XIX, 1892, 208.

In this rariety the black spots on each elytron are merged to form a narrow stripe.

Lake and Vermillion counties; saarce.

2108e (6747a). Trpophorus canelrets Quadriguttatus Lec., Proc. Phil. Acad. Nat. Sci., 1858, S6.

The black spots of elytra are usually rounded and somewhat indistinct; the color otherwise is wholly dull reddish-yellow.

Throughout the State; frequent. April 29-July 26. Occurs mostly in sandy localities. The typical cancllus differs only in having the suture dark.

2108f (6747). Trpophorus canellus sexnotatus Say, Journ. Phil. Acad. Nat. Sci., III, 1824, 445; ibid. II, 213.

Form somewhat more elongate than in the others. Color wholly pale, dull yellow, with three black linear spots, one near base, the other two on middle, parallel, the inner one the longer.

Lake. Clark, Vigo and Posey counties; scarce. April 16-June 17. Occurs on horseweed and juniper.

2108g (6750). Typophorts canellus pumilus Lec., Col. Kans., 1S59, 23.

Thorax either black or dull reddish-yellow; elytra wholly of the latter hue.

Throughout the State; scarce. April 23-September 9.

2109 (-). Typophorus seliatus Horn, 'Trans. Amer. Ent. Soc., XIX, $1892,208$.

Oblong-oval, strongly convex. Reddish-yellow; elytra with a very shining black discal space extending from base two-thirds to apex and on sides to fifth or sixth row of punctures. Thorax more than twice as wide as long, sides feebly curved, hind angles rounded; disk finely alutaceous, finely and sparsely punctured. Elytral punctures distinct but more shallow on sides and near apex, the first and scutellar rows often more or less confused. Length $3-4.5 \mathrm{~mm}$.

Throughout the State; more common northward. May 9-July 21. Occurs espccially on the shrubby St. Johnswort, Hypericum prolificum L. Described as a variety of cancllus, but the color is not or very little variable. 
XXTV. Curroctits Cher. 18:, (Gr., "goldsmith.")

This genus is represented in the eastern Inited States by a single large polished green speeies which lives upon the foliage of milkweed (Asclepias).

2110 (6741). Chrysocius auratus Filb., Ent. Syst., 17ti, 101.

Oblong, convex. Green, brilliantly polished; elytra often with a coppery or brassy tinge; antenne, legs and under surface bluish-black. Head and thorax with coarse, rery sparse, deep punctures intermingled with minute ones. Elytra finely and irregularly punctate. Length $\mathrm{S}-11 \mathrm{~mm}$.

Throughout the State; common. Jnne 11-August 10. Occurs on dogbane or Indian hemp (Apocynum) as well as milkweed.

\section{NXV. Tymnes Chap. 1874.}

Here belong three medium-sized oblong forms, two of which have been taken in Indiana, while the other, riolaceus, perhaps occurs, having been described from Pennsylvania. The key is that of Dr. Horn.

\section{KEY TO SPECIES OF TYMNES.}

a. Sides of metasternum comparatively smooth.

b. Color variable, green, brouze or cupreous; elytra coarsely punctate even to the apex; apical angle acute, rery slightly prolonged in the male. 2111. TRICOLOR.

bb. Color deep blue with violaceous reflections; elytra not coarsely and rather sparsely punctate, at apex quite smooth; apical angle not acute.

VIOLACEUS.

a $u$. Sides of metasternum densely and coarsely punctured; color piceous. slightly bronzed; elytra moderately coarsely punctured even to the apex; sutural angle well defined, not acute. 2112. metasternaris.

2111 (6744). Trmas tricolor Fab., Ent. Syst., I. 1775. 316.

Oblong, conrex, subparallel. Bronzed or greenish. shining; brown beneath; antennx and legs pale reddish-bromm. Thorax rather closely and finely punctured on sides, nearly smooth on middle and toward base. Elytra irregularly and rather coarsely punctate. Male with last rentral segment broadly emarginate and with a transverse depression. Length 6$7.5 \mathrm{~mm}$.

Throughout the State; frequent. June 1-July 21. Taken by beating hazel, oak, wild grape and ironweed.

T. violaceus Horn, was described from Alleghenỵ. Pennsylvania.

2112 (6745). Trmases metasternalis Croteh., Proc. Plil. Aead. Nat. Sci., $1873,38$.

For'm and color of the preceding, but shorter and less shining. Ifead and thorax more closely and evenly punctured. Elytral somewhat more sparsely punctured and with traces of costie. Length $5-4 ; \mathrm{mm}$. 
Throughout the State; common. May 1-June 17. Occurs with tricolor.

XXVI. XANTHonta Baly. 1863. (Gr., "yellow.")

Three small oblong brownish species having broad elytra, narrower thorax and pubescent surface belong here. Two of the three oceur in the State.

\section{KEY TO INDINNA SPLCIES OF XANTHONIA.}

a. Punctures of elytra rery confused; color usually dull reddish-brown or clay-yellow with piceous spots; sometimes wholly reddish-yellow.

2113. 10-NOTATA.

1a. Punctures of elytra much finer and arranged in quite regular rows, but slightly confused near the suture: color usually pale reddish-yellow, often dark, nerer spotted.

2114. villosula.

2113 (6720). Xanthonia 10-Notata Say, Jouln. Phil. Acad. Nat. Sci., III, 1S 24,445 ; ibid. II, 213.

Oblong or subquadrate. Brownish-red. sparsely clothed with suberect brownish pubescence; elytra each usually marked with eight or ten irregular piceous spots, sonietimes wholly dull pale yellow; antenne and legs pale reddish-yellow. Head and thorax densely punctate. Front femur of male with a small tooth. Length $3 \mathrm{~nm}$.

Throughout the State; common. April 26-October 10. Occurs on oak, beech and elm.

2114 (6721). Xaxthonia villosula Melsh., Proc. Phil. Acad. Nat. Sci.. III, $1847,169$.

Form of the preceding. Dull reddish-brown or pale rellow, pubescent; head and thorax usually darker than elytra; antennie and legs dull yellow. Thorax wider at base than apex, sides rounded, densely and coarsely punctured. Elytra with distinct rows of rather fine punctures. Length 3 $3.5 \mathrm{~mm}$.

Throughout the State; common. May 21-August 11. Beaten from hazel and oak.

\section{Fidia Baly. 1863. (NI,., a nonsense name.)}

The species of this gemus resemble those of Adoxus in form, but differ by having the front margin of thorax straight, the sutures separating the side pieces of prosternum wholly obliterated, and the legs much longer. From Tanthonia they may be known by the cylindrical thorax and larger size. The males have the front tibiæ curved inwards near the tip. 
KEY TO INDIANA SPECTES UF FIDIA.

u. Piceous or nearly black; punctures of elytral strix coalse and deep; intervals flat, punctures not dense.

2115. IONGIPES.

an. Reddish to pale brown; punctures of elytral strix not very coarse; intervals flat, densely punctured.

2116. VITICIDA.

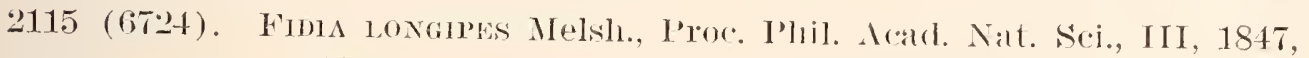
169.

Elongate, subcylindrical. Fuscous or smoky to piceous, rather densely clothed with ash gray lorostrate hairs; tibire, base of antenna and femora paler. Thorax longer than wide, much nalrower than elytra; coarsely. densely and deeply punctured. Length 5.5-6.5 $\mathrm{mm}$.

Western and southern portions of the State; frequent. Not taken north of Vermillion County. May 24-August 11. Occurs on the foliage of wild grape.

2116 (6725). Fidia viticida Talsh, Pract. Entom.. II, 1S67, s7.

Elongate, subcylindrical. Dull leddishbrown, rather thickly clothed with short grayish-yellow pubescence; antenne and legs paler'. 'Thorax wider than long in female. often longer than wide in male, widest at or just behind the middle, finely and densely lunctate. Length 6-7 mm. (Fig. 492.)

Southern two-thirds of the State, common; probably throughout. May 27-July 21. Ocenrs on the wild grape and occasionally does much damage to the cultivated varieties. The adult beetles may be killed by the use of an arsenical spray with lime, at a strength of Fig. 492. one pound to 150 gallons of water. The

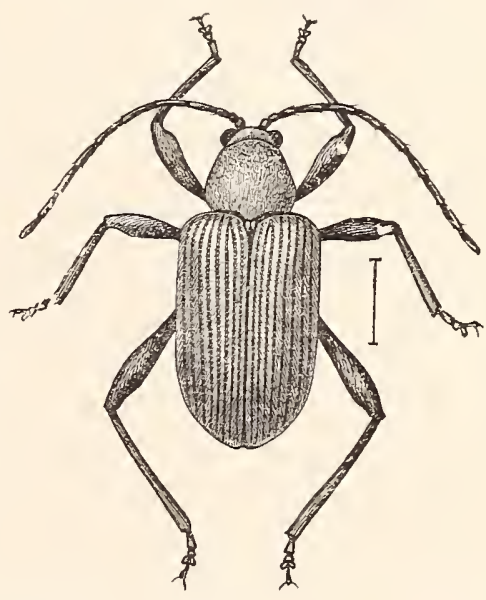

(After Marlatt in Far. Bull. 70, U. S. Dep. Agr.) larvæ about the roots may be destroyed by bisulphide of carbon or by wetting the soil before the end of June with a kerosene emulsion diluted nine times with water, a gallon or two being poured about the base of the vine.

XXVIII. Graphops Lec. 1884. (Gr., "to mrite or carve + eye.")

Here belong small subcylindrical pubescent, metallic species, having a deep groove partly surrounding the eyes. Three species have been taken in the State and two others prohably oceur.

KEY TO INDIANA SIPCIES OF GRAPEOPS.

a. 'Thorax strongly margined at base.

b. Clypeus truncate.

c. 'Thorax punctured on disk, rugose on sides; longer. $4 \mathrm{~mm}$.

2117. PLBESCENS. 
ce. Thorax l'ugose vrer entire surface; smaller. 2-2.5 mm.

211S. CURTIPENis.

61). Clypens emarginate.

d. Coppery ; head and thorax regularly punctured. not rugose.

2119. MARCASSITUS.

dd. Green or coppery; thorax irregularly punctured and with indistinct smooth spots.

a a. Thorax feebly margined at base; clypeus emarginate.

NEBULOSTS.

TARIANS.

2117 (6767). Graphops pebescens Melsh.. Proc. Phil. Acad. Nit. Sci.. III.

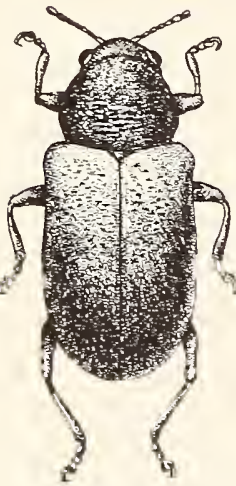

Fig. $493 \times 5 \frac{1}{2}$ (Original.) $1847,169$.

Oblong, subcylindrical. Coppery-bronzed, sparsely clothed with ash-gray pubescence. Thorax slightly wider than long, not margined at sides, finely and sparsels punctured, densely and finely wrinkled on sides and often cn basal half. Eistra one-half wider than thorax. disk with rows of fine punctures, becoming obsolete behind, and a sutiral stria on apical half. Length $3.5-4 \mathrm{~mm}$. (Fig. 493.)

Throughont the State: frequent. March 27-Auyust \&. Probably hihernates. Taken in May by steeping and in summer on evening primtose.

2115 (676s). Graphops ctrtipennis Melsh., Proc. Phil. Acad. Nat. Sci., III, 1S47, 169.

Shorter and stouter than mbescens. Coplery-brown, sparsely clothed with rery short gray hairs. Thorax as wide at middle as elytra; entire surface rugulose and minutely punctate. Elytra finely punctate, with subobsolete rows of larger punctures. Length $2-2.5 \mathrm{~mm}$.

One in the Webster collection labelled "Ind." Ranges from New York to Texas and Florida.

2119 (6769). Graphops marcassites Crotch. Proc. Phil. Acad. Nat. Sci.. 1873.35.

Resembles mucscons closely in color and general appearance. The form is shorter and lnoportionally broader, the clypens deeply emarginate; thorax not rugose; punctures of elytra larger, more distant one from another, and obsolete on apical half. Length $3-3.5 \mathrm{~mm}$.

Marshall, Tippecanoe and iloyd counties: scarce. June 12. July 5.

$G$. nebulosus Lec.. length $4 \mathrm{~mm}$., is known from Ohio. Wisconsin and Kansas ; G. varians Lec.. coppery-green or blackish, length 4-4.5 mm., was described from Illinois.

XXIX. Metachroma Lee. 1858. (Gr.. "after +color.")

Thorax without a lobe behind the eves. the latter surrounded in front and above by a deep groove; middle and hind tibix emarginate on outer edge near the tip; antennit with second and 
third joints equal, the fourth as long as fifth. Fach elytron has eleven strix, seven of which are between the suture and the umbone, while two run parallel with the side margin. Between these two sets, that is, just ontside the seventh, are two short strix which begin from a common point behind the umbone. These are the socalled "short stria" of the key. The species resemble the common and variable Typophorus canellus, but are mostly larger and much more constant in color. Five species have been taken in the State, while one other perhaps oceurs.

\section{KEY TO INDIANA SPECIES OF METACHROMA.}

a. Thoracic punctures, when present, round, not strigose.

b. Suture between the clypeus and front obliterated, the groove above the eye not extending on the front.

c. Head and thorax more or less punctate.

a. Form more or less oval; thorax with very distinct side margins which, when viewed from the sides, are convex downward.

$e$. Sixth to eleventh strixe of elytra much confused; thorax onehalf wider than long, sides feebly curved; elytra dull yellow.

2120. ANGUSTULUM.

ee. Striae of elytra regular except the two short ones; thorax nearly twice as wide as long, its sides strongly curved; elytra dull yellow with oblong dark spaces.

2121. INTERRUPTUM.

dd. Form parallel; thorax very feebly margined on sides, the margins straight; color mainly piceous.

cc. Head and thorax almost entirely smooth; color dull yellow.

L.EVICOLLE.

bb. Suture between clypeus and front distinctly grooved and formed by the oblique extension of the groove above the eye; color dull yellow; elytral punctures coarse and in regular rows.

2123. PALLIDUN. aa. Thorax densely and strigosely punctate; color mostly piceous, elytra sometimes with reddish spots; elytral punctures fine and more or less in'regular.

2124. QUERCATUM.

2120 (6753). Metachroma angustulum Crotch, Proc. Phil. Acad. Nat. Sci., $1873,41$.

Oblong-oval. Upper surface, legs and base of antenne dull yellow; under surface piceous; outer six joints of antennie black. Head sparsely punctate, more coarsely and closely on clypeus. Thorax one-half wider than long, slightly narrowed in front; disk convex, sparsely and rather finely punctate. Elytra with the first three to five rows of punctures regular or nearly so, the others much confused, especially toward the apex; intervals smooth. Length 6-6.5 mm.

Iake, Porter, Starke and Posey counties; scarce. June 5-July 8. Beaten from dead willow. A species of restern range, therefore probably to be found only in the western portion of the State. 
2121 (6757). Metachroma interruptum Say, Journ. Phil. Acad. Nat. Sci., III, 1824, 44s; ibid. II, 215.

Oblong-oval. Pale redlish-brown; thorax with a large piceous spot each side; elytral each usully with the umbone, a sutural line and two oblong discal spots piceous; under surface reddish-brown to piceous. Thorax nearly twice as wide as long, sides strongly curved. surface sparsely and rather finely punctate, more densely on sides. Length 5.5-6.5 $\mathrm{mm}$.

Vigo County; rare. June 16. Two specimens from willow. Not before recorded east of Kansas.

*2122 (10,359). Metachroma Parallelum Horn, Trans. Amer. Entom. Soc., XIX, 1892, 217.

Elongate, parallel, slightly depressed. Piceous black, shining; legs, epipleura, base of antennie, front of head and sometimes the suture of elytra yellow. Thorax about one-fourth wider than long, scarcely narrower in front, sides curved, the margins very narrow; disk convex, very sparsely and finely punctate. Elytra parallel, narrower only near apex, the rows of punctures all more or less irregular, those outside of third rery much so. Length 5-6 mm.

Lake, Vermillion and Vigo counties ; frequent. February 12August 10. A specimen was taken on the former date hibernating between mullein leaves. Occurs in summer on the flowers of dogwood and Jersey tea; also at electric light. The thorax is sometimes partly or wholly dull yellow.

M. lavicolle Cr., length $3.5 \mathrm{~mm}$., is a Southern form which may occur in the southwestern part of the State.

2123 (6763). Metachroma pal.lidum Say, Journ. Phil. Acad. Nat. Sci., III, 1S24, 446; ibid. II, 214.

Oblong-oval. Dull yellow; head and thorax often reddish-yellow. Ifead with median frontal impression and suture between ciypeus and front distinct. Thorax nearly twice as wide as long, sides strongly curved, surface distinctly and rather closely punctate. Elytral rows of punctures, moderately coarse, obliterated behind the middle, the two short rows somewhat confused. Length $3-4 \mathrm{~mm}$.

Iake and Porter counties; rare. June 15-.Tune 28. Beaten from wild grape.

2124 (6759). Metachroma Quercatum Fibr., Syst. Eleut., I, 1801, 417.

Oblong-oval, subdepressed. Dull black or piceous; legs and basal twothirds of antenne yellow; head often in part or wholly, and elytra sometimes with a humeral and apical spot, dull red. Thorax nearly twice as wide as long, angles pominent, sides strongly curved, disk convex, opaque. rather densely marked with elongate punctures. Elytra finely alutaceous. the punctures-fine and obliterated on apical third, the rows all slightly irregular. Length $3-3.5 \mathrm{~mm}$.

Lake and laporte counties; lrequent. Nay 28-June 15. Beaten from hazel. 
XXX. Colaspis Fabr. 1801. (Gr., "mutilated+shield.")

Small, oblong or oval species, having the thorax not lobed behind the eyes; tarsal claws broadly appendiculate; tibia entire.

\section{5 (6774). Colaspis brunNea Fabr., Ent. Syst. Supl., 1798, 94.}

Oblong-oval, moderately convex. Dull brownish- or reddish-yellow, legs always pale; outer joints of antenne often dusky. Ilead rather coarsely and sparsely punctate. 'Thorax about one-half wider than long, sides rathel' broadly curred, angles prominent, aisk rather closely and evenly punctate. Elytra with intervals more or less costate, between which are two or three irregular rows of coarse, deep punctures. Male with first joint of front tar'si dilated. Length $4.5-6 \mathrm{~mm}$.

Throughout the State; frequent. June 4-August 11. Occurs on various wild and cultivated plants, among the latter, grape, beans, strawberries, etc. The larva are said to feed on the roots of grapes. Variety flavida Say is wholly dull yellow, while in the typical brunnea the epipleural margin and under surface are brownish, often with a metallic iustre. In var. costipennis Dej., the head and thorax are brightly metallic and the elytra brown, with yellow. costæ.

\section{Rhabdopterus Lef. 1885. (Gr., "a rod + wing.")}

A single species, formerly listed as Colaspis protexta Say, has been ascribed to this genus by Horn. From Colaspis it is separated only by the shape of the prosternum as mentioned in generic key.

2126 (6775). Rhabdopterus picipes Oliv., Ent., VI, 1806, S\$6.

Oblong-oval, convex. Brown, bronzed, strongly shining, the elytral margins often greenish-bronzed; antennæe and legs reddish-yellow, the outer joints of former often dusky; under surface of body greenish, abdomen brown, its tip paler. Head coarsely and sparsely punctate, clypeus more closely punctate. Thorax nearly twice as wide as long, narrowed in front, sides strongly curved, hind angles prominent; disk rather sparsely and finely punctate. Elytra coarsely but not closely punctate, the punctures irregular on the disk, a line representing the third interval smooth. Length 4-5 mm.

Throughout the State; scarce. June $2 \pm$-August 11 . Occurs on linn, wild grape, etc. Resembles Tymnes metastematis very closely: separated by the absence of thoracic lobes behind the eres, the more sparsely punctured thorax and smooth metasternum.

\section{Nodonota lut. 1885. (Gr., "knot+back.")}

Small, oval, convex, greenish-bronzed or bluish forms, having the thorax with side margins entire and basal marginal line present: third antennal joint distinctly longer than second, the sixth joint 
shorter than either the fifth or serenth. All four of the forms recognized by Horn cecur in Indiana. They were formerly included under the genus Colaspis.

KEY TO SPECIES OF NODONOTA.

a. Clrpens much contracted between the bases of the antennas surface above finely punctate, beneath not or but little punctate.

2127. CLYPEALIS.

a a. Clypeus broad between the antennie.

b. Form short, oval; punctuation of thorax simple; elytra without a costil behind the umbone.

r. Ipper surface shining; metasternum not punctate on sides.

212S. TRISTIS.

re. Upper surfice dull; metasternum coarsely punctate on sides.

2129. CONTEXA.

bb. Form oblong, subparallel; punctuation of thorax substrigose; elytra with distinct costa behind the umbone, this sometimes absent in female.

21:30. Puxcticolis.

2127 (10,371). Nononota clypealis Horm. Trans. Amer. Entom. Soc., XIX. $1892,231$.

Resembles tristis closely in form, size and general appearance. Color usually bronzed, shining. Readily separated by the form of the clypeus. which is distinctly narrowed between the insertion of antenne. Punctures of upper surface less distinct and more sparse. Cength $3.5-4 \mathrm{~mm}$.

Southern half of State; frequent. June 17-Angust 9. Occurs with tristis.

2128 (67Ts). Nodonota tristis Oliv.. Ent. VI, 1806, 8S9.

Oval, conrex. Color variable, dull bronze. bluish or bluish-green : antemne pale at base, the fire outer joints and legs piceons. Thorax more than twice as wide as long, front angles prominent, sides regularls curred, finely and rather sparsely punctate. Elytra oral, conrex, the umbone distinct; surface more coarsely punctate than thorax, the punctures in irregular rows. two or three of which occur between each interval. Males with first joints of front and middle tarsi distinctly dilated. Length $3-4 \mathrm{~mm}$.

Throughout the State; common. May 24 August S. Occurs on various herbs and shrubs in dry upland localities. The legs are sometimes dull yellow.

2129 (6678a). Nodonota contexa Say, Journ. Phil. Acad. Nat. Sci.. III. 1824. 443 ; ibid. II. 212.

Oral, convex. Color bronzed, rarely blue, or slightly greenish. Thorax as in tristis, the punctures more sparse, the median line lisually smother. Elytra much more coarsely punctate than thorax, the punctures ererswhere confused except near apex. Length $4-4.5 \mathrm{~mm}$. 
Southwestern portion of the State; scarce. fune 12. .uly 28. Occurs on the greater ragweed, Ambrosin trifida L, in low, moist places. The larger size, more truly oval form and coarsely punctured sides of metasternum readily distinguish this from tristis.

2130 ( $5778 b)$. Nodonota punctrcoldis Say, Jomin. Phil. Acad. Nat. Sci., III, 1826, 444; ibia. II, 212.

Oblong, nearly parallel. Bluish, greenish or bronzed, moderately shining; basal joints of antenna, and rarely the legs, reddish-yellow. Head and thorax distinctly alutaceous, the latter more than twice as wide as long, sides feebly curved, front angles acute; surfice with rather. dense, elongate punctures. Elytra coarsely and irregularly punctate, the punctures in rows near apex. Umbone marked with a distinct impression and with usually a short raised line or costa behind it. Length $3.5-4.2 \mathrm{~mm}$.

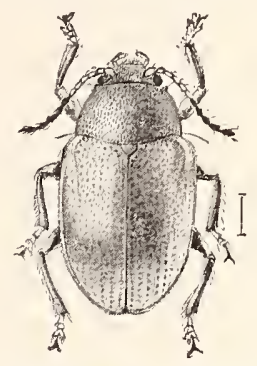

Tig. 494. (After Chittenden in Bull. VII, New Eer., U. S. Dir. Ent.)

Southem half of state; frequent. May 28-July 4. Ocours on the flowers of wild rose and the foliage of various herbs.

Chrysodina globosa Oliv., broadly oval, convex, bronze-blue or brassy, length $2.5 \mathrm{~mm}$, is said to occur from the "Middle States to Colorado and Arizona.',

\section{Tribe VIII. CHRYSOMELINI.}

Oval, convex, rarely oblong beetles of moderate, rarely small size, usually variegated in color. They have the antenni of moderate length, widely separated at base, the outer joints somewhat enlarged; eyes feebly emarginate, not prominent; thorax with welldefined side margins; front coxæe transverse and widely separated; elytra with distinct epipleurx and covering the abdomen; third tarsal joint entire (except in Gastroidea and Lina). Representatives of nine of the 13 genera composing the tribe have been taken in the State, while those of one other may occur.

The only papers treating especially of the North American genera comprising the tribe are as follows:

Rogers, W. F.- "Synopsis of the Species of Chrysomela and Allied Genera Inhabiting the U. S.,' in Proc. Phil. Acad. Nat. Sci., VIIT, 1856, 29-39.

Linell, Martin L.-"A Short Review of the Chrysomelas of North America,' in Journ. N. Y. Entom. Soc., IV, 1896, 195-200. 
KEY TO INDIANA GENERA OF CHRYSOMELINI.

(1. Tarsal clars simple.

b. Thirci joint of tarsi entire or scarcely emarginate (except in l'rosocuris, where it is bilobed).

c. Thorax not margined at base; species mostly rather elongate, slightly conrex, striped.

XXXIII. Prasocuris.

cc. 'Thorax margined at base; species larger, more robust and convex.

d. Last joint of palpi short, truncate.

e. Mesosternum prominent, forming a blunt tubercle between the middle coxse; front femora of male strongly toothed.

XXXIV. LABIDOMERA.

ec. Mesosternum not raised abore the level of the prosternum; femora simple.

XXXY. LEPTINOTARSA.

dd. Last joint of palpi not shorter than next to last.

f. Tarsal claws parallel, mited at base; claw joint dentate beneath.

XXXVI. ZIGOGRAMMA.

ff. Tarsal claws direlgent; claw joint simple.

g. Sides of thorax not thickened; elytra with darker markings limited by impressed punctures.

xyxVit. Calligrapha.

gy. Sides of thorax thickened; elstra without spots.

xxyViII. Chrisomela.

bb. Third joint of tarsi emarginate or bilobed.

h. Sides of thorax not thickened; elytra unicolored.

$i$. Punctures of elytra in regular rows; tibir not grooved on the outer side.

Plagiodera.

ii. Punctures of elytra dense and confused; tibire grooved on onter side.

IXXIX. Gastroidea.

hh. Sirles of thorax thickened; elytra often spotted or spotted and striped.

XI. LixA.

al. Tarsal claws toothed or bifid: tibire not dilated and not toothed.

Xli. Phyllodecta.

XXXIII. Prasocuris Lat. 1802. (Gr., "leek-green + a spear."')

Rather small, elongate or oval, feebly convex species having the upper surface brassy-green or bronzed-black and striped with dull rellow. The three known species have been taken in the State. while a fourth is herewith described for the first time.

KEY TO SPECIES OF PRASOCURIS.

a. Yellow stripes of elytra not united at base.

b. Form elongate, parallel : length 5 or more min.

2131. PHELLANDRII.

b7. Form short-oval; fength not orer 4 mm.

2132. OTAIIS. 
au. Yellow stripes of elytra united at base.

c. 'Thorax a little wider than long.

cc. Thorax nearly twice as wide as long.

21:3:3. VIT'TATA.

21:34. OBLIQUATA.

2131 (6782). Prasocuris Pliellandri Linn., Syst. Nat., ed. 10, 175s, 376.

Elongate, slender, parallel. Piceous or blackish, feebly bronzed. Thorax broadly margined each side. and elytra each with a discal and marginal stripe. united at apex, dull yellow. Thorax quadrate, sides almost straight, surface coarsely and sparsely punctate. Elytra with regular rows of rather fine. closeset punctures. Length 5-6 $1 \mathrm{~mm}$. ( Fig. 495.)

Lake Comty; frequent. April 2:3-1 Iay 28. Occurs in the sand dune regions on ox heneath the prickly-pear cactus (Opunlia rafinesquii Engelm). The larva is said to bore in the stems

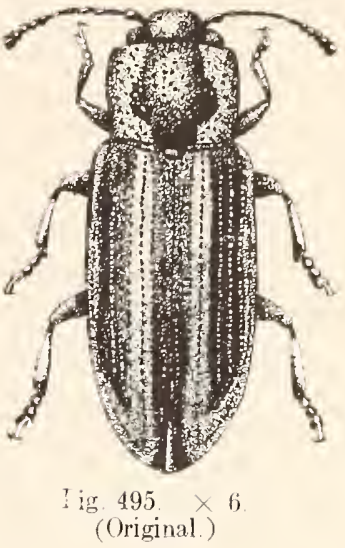
of marsh marigold (Caltha) and other semiaruatic plant:

\section{2 (—). Prasoculis oralis spr. not.}

Short, oral, feebly convex. Phackish, slightly bronzed; thorix narrowly margined with dull yellow; elytral each with a nallow malrainal and discal yellow stripe, uniting at apex. the latter oblique neal base but not merging with the former. Thorax one-half wider than long, sides rurver in front of middle, surface sparsely and rather coarsely punctate. Elytra oval, with regular rows of rather fine punctures, those of the fifth to seventh rows widely separated. Length $3.5-4 \mathrm{nmm}$.

Lake, Welìs and Vigo counties; scarce. TLay 20-.July 10. Occurs on the leaves of sedges in low, moist places.

2133 (6783). Prasocuris vittata Oliv., Entom., Y. 1S07. 595.

Elongate, narrow. Greenish-black, shining; thorax broadly marginel on sides with reddish-yellow: elytra each with a reddish-yellow marginal stripe and a narrow paler one on disk, the two united at base and apex; under surface, legs and antenne black, the tibise sometimes pale. Thorax but slightly wider than long, apex deeply emarginate, disk sparsely, unevenly and finely punctate. Elytra parailel, umbone carinate; punctures rather fine and deep, those of the first row somewhat confused. Iength $3.5-4.5 \mathrm{~mm}$.

Lake County ; scarce. May 5-May 21. Readily known from the next by the more slender form and narrower thorax.

\section{4 (6784). Prasocuris obliquata Lec., Pract. Entom., II, 1S66, 9.}

Elongate-oral. Black, tinged with sleenish; thorax with broad malginal stripe, and elytra each with discal and marginal stripe, miting at

[73-23402] 
both base and apex. yellow. Thorax nearly twice as wide as long, finely and sparsely punctate. Elytra with somewhat irregular rows of close-set fine punctures. 'Length $4.5-5.5 \mathrm{~mm}$.

Lake Conntỹ scarce. May 5-.June 24. Taken by sweeping marsh regetation.

XXXIV. Labidomeri Chev. 183t. (Gr., "forceps + femur.")

The old genus, Doryphora Ill., was discarded by Linell in his paper, loc. cit., and the North Anerican species were distributed among this and the next genus, the two being separated only by the characters given in the generic key. To Labidomera, as characterized, belongs only a single species and a western variety.

*2135 (6755). Labidomera clivicollis Kirby, Faun. Bor. Amer., IV, 1S37, 213.

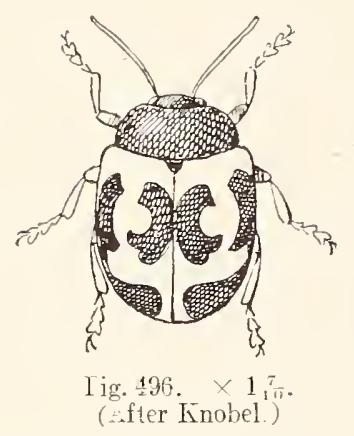

Oval. convex, robust. Dark blackisll-blue: elytrat range yellow with a large, black, cruciform common sot in front of middle, each with a triangular spot behind the humerus, and a V-shaped one near apex; these spots sometimes in part or all confluent to form one or two broad transrerse bands. Thorax three times as wide as long. sparsely and finely punctate. Elytral punctures fine, ar ranged in irregular double rows. Length S-12 $\mathrm{mm}$. (Fig. 496.)

Throughout the State; frequent on the foliage of the common milkweed, Asclepias syriaca L. January 5-August 3. Hibernates beneath logs partly buried in sand, mullein leaves, etc. One of the largest and most handsome of our Chrysomelids.

\section{Leptinotarsi Stal. 1858. (Gr., "slender+tarsi.")}

Two of the 12 species recognized by Linell occur in Indiana, the others being found in the Western and Southwestern States. One of the two is the common injurious "Colorado potato beetle" and the other is very similar in appearance.

KEY TO INDLANA SPECIES OF LEPTINOTARSA.

a. Elytria with double rows of confluent punctures, the suture and fire narrow stripes on each black: epipleura pale. 2136. DecemLixeata. a a. Elytra with single rows of regular punctures; each with five narrow black stripes, the third and fourth usually united at base and apex.

2137. JUNCTA. 


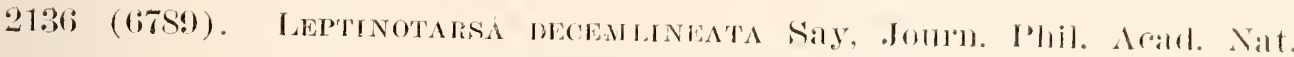
Sci., III, 18:4, 45:3; ibiol. II, 218.

Oral, robust, convex. Dull yellow; thorax with two short, divergent lines on disk and six small spots each side, black; elytra with suture and five narrow lines on each side, black, the second and third united near apex; knees and tarsi blackish. Length 5.5-11 mm. (Fig. 497.)

The original home of this well-known beetle was Colorado, Say having described it from the Upper Missouri River, where it fed upon the sand nettle, Solamum rostratum Dunal. It made its way oradually eastward, migrating from one potato patch to another, aided, doubtless, by railways and eommerce, until it has spread over the whole of the eastern United States. It first appeared in numbers in Indiana about 1868 , and the first beetles ever collected by

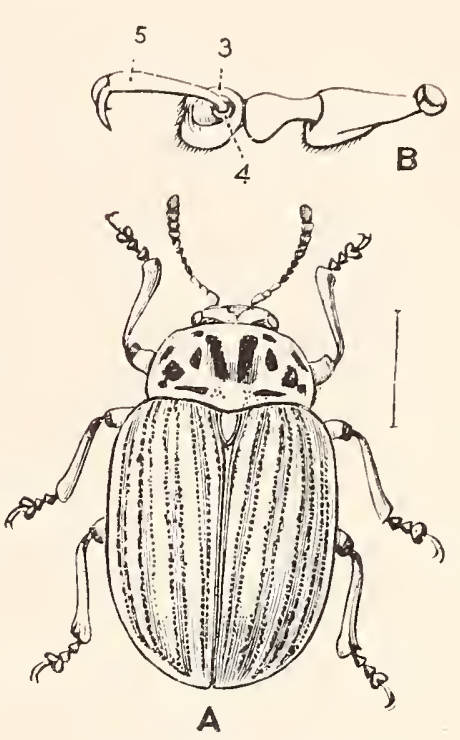

I ig. 4.7. A, adult beetle; $B$, hind tarsus of sane; 3, third tarsal joint; 4 , true fourth joint; 5 , so-called fourth joint. (After sharp.) the writer were these "new-fashioned" or "Colorado potato bugs," an old tin basin and a stout stick being the paraphernalia used. Suffice it to say they were not taken for a collection, but at a fixed sum per hundred, paid to the children to clear the patch of the pests. Afterwards the discovery that a solution of Paris green "would fix 'em" put the tin hasin method of collection out of vogue.

For a number of years the potato industry in the State was almost destroyed by this beetle, but its damages gradnally lessened, until now they appear much fewer in numbers than between the years 1870 and 1890, and are readily kept in check by Paris green and other arsenites. The beetle hibernates in the ground, both as pupa and imago, and begins to mate about May first, each female producing 750 to 1,000 eggs, these being laid at intervals through forty days. Under normal conditions it requires but about 36 days from the laying of the eggs to the perfecting of the imago, and in about 14 days after emerging, the beetle begins to lay a second generation of eggs. The first or spring brood heeomes fertile, therefore, about July 1st, and the second generation by September 1st. It attacks not only potatoes, but egg plant and other members of the Solanacee or potato family. The rose-breasted grosbeak, yellow-billed enckoo or rain-crow, and the quail feed upon the larvar of the beetle, as do also turkeys and occasionally chickens. 
2137 (6790). Leptinotarsa Juncta Germ., Ins. Sp. Nov., 1824, 590.

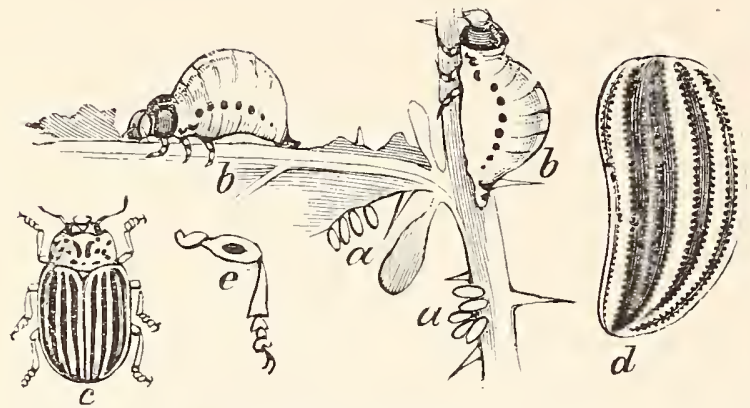

Fig. 498. $a$, eggs; $b$, larva; $c$, beetle; $d$, elytra; $e$, front leg of beetle. (After Riley.)

Form of the preceding. which it resembles rery closely. Distinguished mainly by the characters given in key. The femora are marked on the outer side near apex with a black spot. Length 10-12 $\mathrm{mm}$. (Fig. 49S.)

Putnam, Lawrence, Knox, Crawford and Posey counties: scarce. June 10September 21. Feeds on

the horse-nettle, Solanum carolinense I. and different species of ground-cherry (Physatis). A member of the Austroriparian fauna.

XXXVI. Zygogramma Chev. 1831. (Gr., "yoke + together.')

To this genus, as at present limited, belong about a dozen of the species formerly listed under Chrysomela. All of these but one occur in the Western and Southwestern States. They are oval, convex forms of medium size, having the elytra marked with spots or stripes; last tarsal joint toothed beneath; tarsal claws narrowly separated and connate at base, whence the generic name.

*2139 (6799). Zygogramma suturalis Fabr., Syst. Ent., 1775, 95.

Oral or subglobose, convex. Brown, feebly bronzed; elytra yellow, with the first and second intervals and a broad discal stripe dark brown; epipleura pale with dark margins. Thorax three times wider than long, sparsely and coarsely punctured. Elytra coalsely puncturet on disk, more insel on sides, the punctures bordering the sutural brown stripe in rows, the others scittered. Length $5.5-6.5 \mathrm{~mm}$.

Throughont the State; frequent. April 18-Decenber 10. Occurs in spring on ragreed in low moist

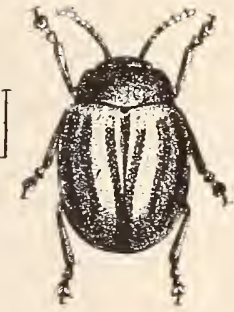

rig sco (After Rogers.) places and on flowers of goldenrod in autumn. In var. casta Rogers (Fig. 499), the subsutural dark stripe is often divided to behind middle and the discal stripe wholly, or to near apex.

XXXVIT. Calugripha Frich. 18+7. (Gr., "beautiful + writing."

Form oval or rounded, convex; size medium or rather small; last tarsal joint not toothed beneath: claws widely separated. Eight 
species and two varieties have been taken in the State, while two others perhaps occur. All were formerly listed under chrysomelu.

KEY TO INDIANA SPECIES OF CALLIGRAPHA.

a. Elytra with brown and yellow stripes.

b. Thorax wholly browl ; epipleura dark.

c. Last joint of palpi strongly dilated; discal brown stripe of elytra more or less divided by yellow.

LUNATA.

cc. Last joint of palpi normal; discal brown stripe of elytra entire, notched on outer side.

bb. 'horax in part yellow; epipleura pale.

2139. SIMIRIS.

d. Oval, strongly convex; discal brown spot of thorax large, quadrate, reaching to base.

2140. PRÆCELSIS.

dd. Elongate-oval, much less convex; discal spot of thorax irregular, not reaching base.

2141. ELEGANS.

au. Elytra with irregular spots, the suture usually dark.

e. Epipleura of thorax not impressed; legs reddish-brown.

$f$. Thorax wholly dark green or olive green.

\%. Elytra with a dark double sutural stripe, to which is joined on median third a heavy curved line, the sutural stripe thus appearing to bear three or four short side branches or spurs.

h. Form elongate-oval, subdepressed; thorax and elytral markings metallic green or blue-green. 2142. SCALARIS.

hh. Form short, oval, convex.

$i$. Thorax and elytral markings dark olive green; small discal spots of elytra ten or more in number.

$j$. Third side branch of suturai stripe (representing the lower part of annexed curved line) heavy, unbroken and curved forward as in scalaris. 2143. RHODA.

$j j$. Third side branch of sutural stripe slender and directed obliquely backward.

2143a. var. WALSHIANA.

ii. Thorax and elytral markings dark blue-green; small discal spots of elytra tinree to eight in number; third side branch of elytral suture usually represented by a detached curved spot.

2144. ROWENA.

gy. Elytra without a sutural stripe but with a narrow subsutural line.

$f f$. Thorax in part or wholly pale.

2145. PHILADELPHICA.

li. Thorax pale with reddish-brown discal spots; elytra with numerous small black spots.

2146. MULTIPUNCTATA.

k. Thorax olive green or brown with pale apical and side margins; elytra with numerous small greenish spots: moler side of body greenish.

21 16ia. vall. BIGSBIANA.

e. Epipleura of thorax grooved or impressed; legs black; elytra with a broad, black sutural stripe and with about nine large pale spots surrounded by black rings. 
C. Innata Fab., form of precelsis, reddish-brown, elytra yellow with the usual brownish stripes, is said to occur "east of the Rocky irountains.'

*2139 (6801). Calimgrapha similis Rogers, Proc. Phil. Acad. Nat. Sci., VIII, 1856, 35.

Oval, convex. Brown, feebly bronzed; elytra pale with a broad sutural stripe and a discal stripe brown, the latter broadly notched near middle on outer side. Thorax nearly three times as wide as long, very roarsely and sparsely punctured. First four rows of elytral punctures mostly regular, the others confused. Length $5.5-7 \mathrm{~mm}$.

Throughout the State; frequent. February 21-July 29. Hibernates beneath partly buried logs and rubbish. More common in sandy localities. Often noted crawling over the ground in cultivated fields and, like other members of the genus, feigns death when disturbed. Resembles $Z$. suturais very closely; distinguished by its more oval form and notched discal stripe of elytra.

*2140 (6804). ('alifgrapia precelsis Rogers, Proc. Phil. Acad. Nat. Sci.. VIII, 1856, 35.

Oval, convex. Dark reddish-brown, bronzed; thorax

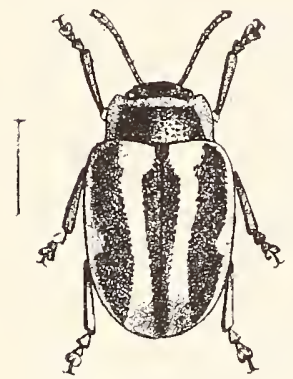

Fig. 500. (After Rogers.) with sides and front margin reddish-yellow; elytra pale with sutural and one discal stripe on each brown, the latter much narrowed behind and broathy emarginate on onter side. Thorax a little nore than twice as wide as long, sparsely and coarsely lunctured. Elytra punctured as in similis. Length $7-8$ mm. (Fig. 500.)

Vermillion, Vigo and Posey counties; scarce. April 6-Decenber 21. Occurs on white top in timothy meadows. Hibernates. Larger and more robust than either simitis or Z suturalis.

2141 (6805). Calitgrapha elegans Oliv., Entom., V, 1807, 583.

Elongate-oval, less convex. Blackish bronzed; thorax reddish-yellow with dark inverted W-shaped or transverse spot near, but not reaching, base; elytra pale yellow with a common sutural and discal stripe on each bronzed black. Whorax and elytra punctured as in similis, the yellow stripes with finer and more numerous scattered punctures. Length 5-6 mm.

Throughout the State; frequent in the northern counties, less so southward. March 14-August 26. Probabiy hibernates. Occurs beneath rubbish and on varions plants, especially thoroughwort and goldenrod, usually in moist localities. 
2142 (6S08). Callighapia scataris Lec., Am. Tyc. Nat. Hist., I, 1824, 173.

Oval, convex. Dark metallic green, shining; elytra creamy white with a broad, greenish, common sutural stripe, which projects three short spurs each side, and each with a large, curved humeral lunule double to near middle and enclosing a round greenish spot; behind the lunule 12 to 15 smill greenish spots; antenna and legs reddish-brown. Thorax more than twice as wide as long, coarsely and sparsely punctate and with an irregular impression each side. Iilytra finely, sparsely and irregu-

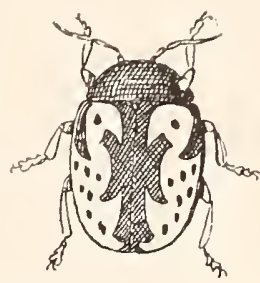

lig. 501. $\times 2$. (After Knobel.) larly punctate. Length $8-10$ mm. (Fig. 501.)

Lake and Laporte countios; scarce. June 10-June 12. Beaten from foliage of linden and elm.

2143 (- ). Calligrapita rhona Knab, Proc. Eut. Soc. IVash., XI, 1909, S:.

Subovate, convex. Darlí olive green, subuetallic; legs, antemie and balpi reddish-brown; elytra creamy white, of often with the apical twothirds dull reddish-yellow; a common sutural stripe and lumelal lumble much as in scularis, the latter enclosing two small spots which are often confluent; disk behind lumule with about 11 small spots. Head and thorax finely alutaceous, coarsely, sparsely and irregularly punctate, the thorax with an irregular impression each side. Pale area of elytra more coarsely and closely punctate than in scalaris. Length $7-8 \mathrm{~mm}$.

Lake, Marshall, Marion and Lawrence counties; frequent. April 29-July 15. Knab says of it: "This species feeds exchusively upon the hazel, both in the imago and larval stages, and, as far as known, it is the only species of Calligrapha found upon this plant." It will probably be found throughout the State, wherever hazel oceurs.

$2143 a$ (- ). Caldigrapita RHODA walshiana Kllab, Mas.

A valiety of rhoda in which the annered stripe (united with the usual double sutural stripe on median third of elytra) is very slender, less curved than usual and with its front and hind portions lirected obliquely forward and backward. Discal elytral spots 15 or 16 in number. rength $7-8 \mathrm{~mm}$.

Lake County; rare. May 25-June 3. Knab's specimens are from Missouri, and he thinks this may be the form mentioned by Walsh as a variety of $C$. scalaris oecurring upon the wild phum.

2144 (- ). Calligrapha rowena Knab, Proc. Ent. Soc. Wasli., XI, 1909, 85.

Differs from rhoda principally as mentioned in key. In mature specimens the greater part of elytral disk is bright orange red, the basal third and broad outer margin golden. Punctuation of elytra distinctly coarser than in rhoda and the surface therefore more mneven. Tarsal claws more divergent. Length 6.5-S.5 nmm.

Marshall County; rare. June 26. Originally described from Canada, New England and Pennsylvania. While the three forms 
described by Knab are undoubtedly distinct from scalaris, it is rerr probable that a large series will show them to he varieties of one species, rhoda.

2145 (6S09). Calligrapha philadelphica Linn., Syst. Nat., ed. 10, 175 s. $3 \pi 2$.

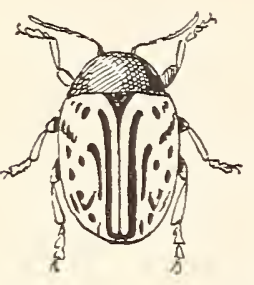

Fig. 502. $\times 2$ (After Knobel.)

Resembles rhoda closely in form and general color. The pale area of elytra is much greater. the suture being pale with a narrow subsutural black line each side on basal half and with two or three elongate dark spots which represent the spurs or branches of scataris. The humeral lunule is much more narrow and less curved than in rhoda and encloses both a shorter lunule and a small spot, while the other discal spots are smaller and more numerous. Length $8-9 \mathrm{~mm}$. (Fig. 502.)

Lake, Marshall, Starke, Kosciusto and Steuben counties: scarce. May 25-July 11. Occurs with the preceding.

2146 (6810). Calligrapha multiputctata Say, Journ. Phil. Acad. Nat. Sci., III. 1824, 450; ibid. II, 216.

Resembles philadelphica very closely. Thorax rellow with sereral small reddish-brown spots arranged in an irregular curred line near the middle and often a darker. narrow, transverse basal spot. Elytra with narrow, dark sutural and subsutural stripe separated by a sellow line and with numerous blackish or greenish spots. Thorax more sparsely and finely punctate than in scalaris and without the depression each side. Length 6.5S.5 $\mathrm{mm}$.

Vigo, Martin and Poser counties : frequent. April 25-October 1. Beaten from foliage of thorn and red haw (Cratcegus).

$2146 a$ (6810a). Calligrapha multipunctata bigsbiana Kirby, Faun. Bor. Amer., IV, 1837, 212.

Oral, convex. Reddish-brown or greenish, feebly bronzed: thorax with a large brown or greenish spot on basal half. the apical and side margins pale; elstra pale with narrow sutural and subsutural dark stripes sometimes confluent, and numerous small spots greenish or reddish-brown. Length $6.5-8.5 \mathrm{~mm}$.

Northern half of State; frequent. May 21-October 1. Beaten from vegetation of various kinds. Feeds on willow and poplar.

C. multiguttata Stal, is a western form which has been recorded from Cincinnati.

SXXVIII. Chryomel Limn. 1735. (Gl., "golden + fruit.")

This genus, as now limited, contains oval convex species of medium size having the elytra of one color and, in our species, the margin of the thorax distinctly and abruptly thickened. 
2147 (6821). Chrysomela nuripenvis Sily, Journ. Phil. Acad. Nat. Sci., III, 1824, 452; ibid. II, 218.

Oblong-oval. Head, thorax, scutellum and umder sulface latk violaceous blue; elytra coppery red or brassy green, strongly shining. Thorax twice as wide as long, finely and sparsely punctate. Elytral with somewhat regular rows of distant, rather coarse but not impressed punctures. Length S-11 $\mathrm{mm}$.

Lake County; scarce. April 15-August 24. Occurs in the sand dune region, usually about the prickly-pear cactus. Linell gives its range as Texas to Nebraska.

2148 (6824). Chrysomela subopaca Rogers, Proc. Phil. Acad. Nat. Sci., VIII, 1856, 36.

Oblong-oval. Uniform purplish-black, feebly bronzed, subopaque and above finely alutaceous. Thorax nearly twice as wide as long, disk finely and sparsely punctate, and with a few coarse punctures along the inner side of the thickened margin. Elytra with irregular rows of rather fine, scarcely impressed punctures. Length $7-9 \mathrm{~mm}$.

Vigo and Crawford counties; rare. June 28-November 9. Occurs from New York to Texas.

Plagiodera viridis Melsh., greenish to finscous or brassy, shining, length $3 \mathrm{~mm}$, was described from Pennsylvania.

\section{Gastronden Hope. 18t0. (Gr., "belly +form,' i. e., pot-bellied.)}

Small, oblong-greenish forms having the punctures of elytra dense and confused and the sides of thorax not thickened. The females have the abdomen very inuch swollen before their eggs are laid, making it difficult for them to move about.

2149 (6830). Gastroidea Polygoni Limn., Syst. Nat., el. 10, 1758, 370.

Oblong-oval. Head, elytra and under surface brilliant green or blue; thorax, legs, base of antennse and tip of abdomen reddish; tarsi and apical two-thirds of antennæ black. Thorax twice as broad as long, sides rounded, surface finely and sparsely punctate. Length 4-5 mm. (Fig. 503.)

Southern half of State, frequent; probably throughout. April 29-October 6. Occurs on the knotgrass, Polygonum aviculare $\mathrm{J}_{\mathrm{s}}$ in yards and along pathways.

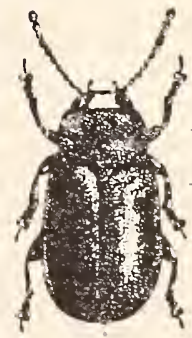

Fig. 503 (After Harris.)

2150 (6832). Gastroidea cranea Melsh., Proc. Phil. Acad. Nat. Sci., III. $1847,175$.

Oblong-oval. Uniform brilliant green or blue; antennse, legs and under surface purplish-black. Head and thorax finely and sparsely punctate; elytra densely and rather ronghly punctate. Length 4-5 mm. 
Southern half of State; frequent. April 18--June 15. Occur's on various species of dock ( $R$ mmex).

\section{Lina Meg. 1823. (Gr., "flax.")}

Oblong, feebly convex species, having the sides of thorax thickened and the elytra usually spotted or striped. Three species are known from the State and another may occur.

KEY TO INDIANA SPECIES OF IINA.

u. Thorax with sides rellow and disk dark metallic green.

b. Elytra reddish-yellow with rounded black spots, which are sometimes merged into transverse bands.

2151. INTERRUPTA.

b6. Elytra dull reddish or greenish-yellow, with elongate black spots.

2152. SCRIPTA.

a a. Thorax green or yellow, the sides not paler.

c. Elytra dull yellow without spots; thorax green.

TREMULE.

cc. Elytra purplish-black, narrowly margined with rellow.

2153. OBSOLETA.

2151 (-). Lina interrupta Fab., Syst. Eleut., I, 1801, 438.

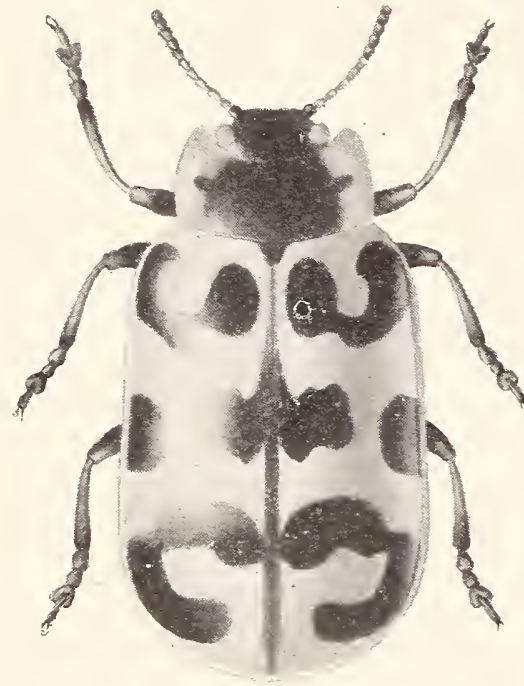

Fig. 504. $\times 6 . \quad$ (After Forbes.)

Oblong-oral. Black; thorax with a rellow margin enclosing a small black dot; elytra dull yellow with usually six spots on each. more or less confluent; base of antenne and tibise reddish. Thorax with the black center very finely, the thickened yellow sides coarsely, punctate. Elytra with numerous rather coarse, scattered punctures. Length 6.5- $8.5 \mathrm{~mm}$. (Fig. 504.)

Throughout the State; common on willow, cottonwood, etc. April 2August 11. The dull yellow of elytra is red in life. 'The spots of elytra vary much in shape and are sometimes absent, except the two median ones on each. Known as lapponica Limn. in most collections, but the latter is a Furopean species with thorax wholly metallic.

2152 (6839). Lina scripta Fabr.. Srst. Elent., I, 1801, 438.

Nore elongate and parallel than the preceding. Thorax and under parts usually similar in color to those of intermpta, but the former sometimes red dish with rour small black spots in a curved line at centel. Elytra with the suture and seven elongate
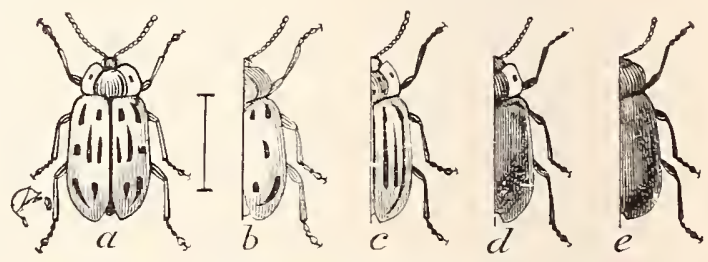

Fig. 505. $a$, beetle, normal form; $b, c, d, e$, rariations of elytra. (After Riley.) 
spots on each blatk, the outer ones sometimes confluent to form a malginal stripe. Upper surface punctured as in interupta. Length $7-9.5 \mathrm{~mm}$. (Fig. 505.)

Throughout the State; frequent. April 15-September 18. Lives on the foliage of cottonrood, Carolina poplar and other members of the genus Populus.

L. tremule Fabr., is an introduced Enopean species which is known to occur in Massachusetts and Michigan.

2153 (6840). Lina onsoleta Say, Journ. Phil. Acad. Nat. Sci., III, 1S24, 453 ; ibid. II, 218.

Oblong-oral. Head, elytra and under surface purplish-black; thorax with reddish margins enclosing a rounded black spot, or reddish with three or four blackish spots at center: elytra with the margins, tips and often two short, indistinct lines on basil half, reddish-yellow. Elytra more coarsely and densely punctured than in scripta. Length $\tau-S \mathrm{~mm}$.

Lake County ; rare. 'Two specimens taken by WVolcott near Hessville and Pine. May 2-June 30 .

\section{Xli. Phyllodecta Kirby. 1837. (Gr., "leai + to bite.")}

This genus is represented in the State by one oblong, convex species having the front coxal cavities open; front tibiæ slender, neither toothed nor produced at tip; tarsi with third joint much wider and longer than first and second and deeply bilobed; tarsal claws toothed.

2154 (—). Phyllonecta vitellin 370.

Oblong, convex. I'urple, shining; under surface piceous, bronzed. Antennæ slender, less than one-half the length of body; third joint longer than second and one-half longer than fourth. Thorax one-third broader than long, front angles prominent, hind ones rectangular, base without a marginal line; surface sparsely and irregularly punctured, the punctures on sides coarser than those on disk. Elytra with rows of moderate sized punctures, those on the sides coarser and more or less irregular. Length 4 $5 \mathrm{~mm}$.

Steuben County; rare. June 17. Taken by sweeping herbage in tamarack swamp. Occurs on the willow, Salix longifolia. A European species introduced by commerce. Of it Knab rrites me: "Generally passes in collections as P. vulgatissima L.. but Teise states that the latter species has the thorax finely margined behind. I have seen no American specimens with this character." 
Tribe IX. GALERUCINI.

Small or medium-sized leaf-eating beetles, having usually a somewhat oblong form and a softer body covering than in those tribes already treated. All of them agree in having the head exposed; antennæ placed upon the front between the eres and therefore close together at base, the third joint usually smaller than fourth; eyes not emarginate, finely granulate; thorax truncate or emarginate in front, with the sides distinctly margined; elytra longer than abdomen; prosternum very narrow, usually invisible between the front coxie, which are therefore contiguous; hind femora slender, adapted for walking; hind tibir usually without terminal spurs; tarsi slender, not retractile.

Many members of the tribe are very injurious to vegetation. among them being the striped cucumber beetle, the long-horned corn beetle and the imported elm-leaf beetle. The principal papers treating especially of the genera comprising the tribe are as follows:

LeConte.- "On the Species of Galeruca and Allied Genera inhabiting North America," in Proc. Phil. Acad. Nat. Sci.. 1865, 204-222.

Horn.- "The Galerucini of Boreal America," in Trans. Amer. Ent. Soc., XX, 1893, 57-136.

Horn, in the paper last cited, recognized 20 genera as belonging to the tribe. Of these 12 are known to be or should be represented in the State.

KEY TO INITANA GENERA OF GALERLCINI.

a. Front coxal carities closed behind.

b. Tarsal claws appendiculate, i. e., with broad expansion at base; tibix with spurs; smaller, not orer 7 .mm.

c. First joint of antennæ longer than fourth, third joint elongate: elstra dull red or sellow with black spots. XLII. CERotoxa.

cc. First joint of antennæ not longer than fourth, third joint shorter; elytra metallic blue or greenish.

AgELASA

bb. Tarsal claws bifid; front and hind tibire without spurs; larger, 9 or more $\mathrm{mm}$.

aa. Front coxal carities open behind.

XliII. GalerUCa.

d. Claws of tarsi bifid or simple.

$e$. All the tibiæ without terminal spurs.

$f$. Epiplemre short. scarcely passing the middle of elçtra: elstra metallic blue with a dull rellow median crossbar. Morocesta.

ff. Epiplemre Jong. reaching nearly to tips of elytra.

g. Antennx longer than half the body; tarsal claws deeply bifid in both sexes. 
h. Third joint of antenna shorter than fourth; size larger, $7 \mathrm{or}^{\circ}$ more min.

Xliv. 'Trirhabin.

hh. Third joint of antenne longer thin fourth; smaller, not over $6.5 \mathrm{~mm}$.

xis. Galerucella.

yy. Antemne not reaching middle of body, third joint longer than

fourth; tarsal claws narrowly bifid in males. simple in females.

NOXOXIA.

ec. Tibie. in part at least, with terminal spurs.

$i$. Middle and hind tibixe with terminal spurs: antennie similar in the sexes; elytra greenish or greenish-yellow, usually with black spots or stripes; tholax usually with two forese or pits.

XLVI. DMnRotTCA.

ii. Ill the tibire with minute terminal spurs; fifth to seventh joints of antenne broadly dilated in male; elytra shining bluish-green with a narrow yellow border.

Xlvil. Paratriares.

dd. Claws of tarsi appendiculate.

j. Epipreura not distinct; tibia without spurs; color black and yellow.

XlVIII. PHYllobrottca.

ji. Epipleura well defined.

li. Tibire with spurs; elytra black or blue. XLIX. Luperones. 7.k. Tibiæe without spurs; elytra black and yellow.

L. Phyllecthres.

\section{Cerotona Chev. 1834. (Gr., "horn joint.")}

To this genus belongs a single rather small, oval species, having the antenne slender, first joint rather long, second short, third nearly as long as first, fourth shorter, 5-11 nearly equal ; first joint of hind tarsus as long as the following joints together.

*2155 (6845). Cerotoma trifurcata Forst.. Nor. Sp. Ins., 1771, 29.

Oval, narrower in front, moderately convex. Body beneath and head black; above dull yellow. rarely reddish, the elytra usually with black basil and side margins, the latter extending nearly to apex and with three black spots on each side of and close to suture, the hind one the smaller; the spots and border often in part lacking. sometimes to such an extent as to leave only the scutellum black; antennie and legs yellow, the tibix and often the femora in part black. Thorax nearly twice as wide as long. slightly narrowed in front, margin broader near base; disk very finely and sparsely punctate. Elytra with irregular rows of fine, rather distant punctures. Length $3.5-5 \mathrm{~mm}$. (Fig. 506.)

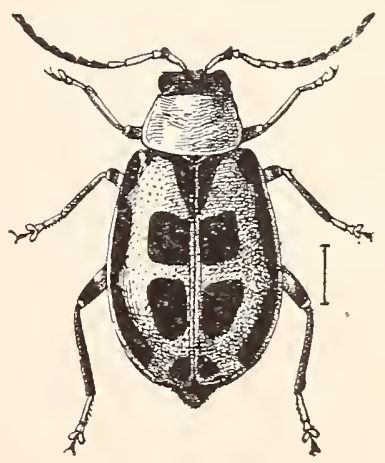

Fig. 506. (After Chittenden in Bull. IX, New Ser., U, S. Div. Ent.)

Throughout the State: frequent. February 21-October 18. Hibernates in small numbers beneath logs and other cover in low, moist places. Oceurs in summer on bush-elover (Lespedeza), tick 
trefoil, heans and other leguminous plants. Listed as C. caminea Fals. In one specimen at hand the dorsal spots of elytra are merged to form a stripe each side of suture. If destructive to bean leaves, hand picking early in the season and spraying with arsenicals later will serve as remedies.

Agclasa halensis Linn., oval, convex, dull yellow, elytra blue or greenish, length $5-7 \mathrm{~mm}$., is known from Connecticut and Wisconsin, and may yet be found in Indiana.

\section{Galereca Geoff. 1764. (L., "a helmet + caterpillar.",)}

Broadly oval, subconvex species having the head moderately large, not deeply inserted; front grooved between the antenna, which are rather stout, not longer than half the body, joint three nearly twice as long as the second, three to ten gradually decreasing in length, eleventh longer; seutellum nearly semicircular; epipleure entire; tibia carinate on onter edge, the middle pair with one terminal spur; first joint of hind tarsi nearly as long as the next two, the claws cleft slightly bohind the middle, the inner lobe much the smaller. Two species are known from the United States. One of them, introduced from Europe, has been taken in Indiana.

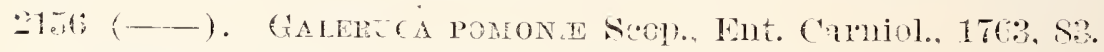

Broadly ovate, subconvex. Dark piceous brown above, black beneath, feebly shining; elytral narrowly margined with dull yellow. Thorax more than twice as wide as long, rery cuarsely and densely punctured; disk with a broad but shallow median groore and with an irregular depression each side. Elytra each with three or fonr smooth raised lires, the broald inteivals with dense, coarse, confluent punctures. Length 8.5-11 mm.

Laporte and Kosciusko comnties; rare. July 1-Augast 26. The larva feed on the foliage of Phlox divaricata and Dentaria laciniata. The species was first taken in this country by Dury near Cincinnati in 1878 and probably occurs sparingly throughout the State.*

Moncesta coryli Say, dull yellow, e! ytra metallic blue, length 10-16 mm., occurs on hazelnut and is known from Virginia, Illinois and Kansas.

\section{Trirhabdi Iee. 1865. (Gr., "three+rod.")}

Medium-sized elongate-oblong, feebly convex species with usually opaque, finely punctured and pubescent surface; antennæ slender, two-thirds the length of bedy; thorax much broader than long. widest at middle, the angles distinct and more or less prominent;

*A full account of its habits and life history, by J. J. Davis, is given in Entomological News, July, 1907. 
elytra elongate, parallel, distinetly margined at sides, the epipleurar narrow; color in our species brown with dull yellow stripes; tarsal claws of males narrowly bifid at lip, of females more broadly bifid behind the tip. Three speeies have been taken in the state, while another perhaps occurs.

KEY TO INDANA SPECIES OF TRIRIIABHA.

a. Thorax more than twice as wide as long; epiplema of female piceous. 2157. BREVICOLLIS.

au. 'Thorax not twice as wide as long; epiplemia always pale.

b. Elytra very densely and finely punctured, the punctures so dense as to be indistinct as such; black stripes of elytria united near tips.

c. 'The yellow discal stripe of elytra broader at bise, gratually narrowed to tip, and extending only three-fourths to anex.

TOMENTOSA.

c. 'The yellow stripe broad, parallel and entire. 215s. canabensis.

6b. Elytra closely punctate but the punctures distinctly seluated; black stripes of elytra not mited near tips.

2159. VIRGATA.

2157 (6897). Trirhabda brevicollis Lec., Proc. Phil. Arad. Nat. Sci., 1S65. 221.

Elongate-oval. IIead and thorax dull yellow, the former with a small black spot on vertex; the batter with three irregular fuscous spots, the middle one often forked or cordate, sometimes wanting; elytra dull yellow with a common sutural piceous stripe, broad at base and gradualiy narowing to apex, each also with a piceous stripe extending from humerus nearly to tip, then curving, and joining the sutulal in the male; antennie piceous, the three basal joints in part pale; femora yellow, tibia on outer side and tarsi piceous. Thorax with sides obtusely angulate; disk with a rather deep oblique innression each side. Elytra closely and finely punctate. Length S.5-9.5 $\mathrm{mm}$.

Dekalb, Vigo, Putnam and Narion counties; frequent locally. June 23-September 21. Occurs especially on leaves of prickly as?, Yanthoxylum americamm Mill.

T. tomentosa Linn., length 8.5-10 mm., occurs abundantly on the Atlantic coast from Long Island to Florida. It is herewith included as the range of brevicollis was given "Sea coast Florida to Texas," and one is as likely to occur in Indian? as the other.

2158 (6892b). 'Trirhabda canadensis Kirby, Famm. Ror. Mmer., IV, 1S:3. 219.

Elongate-oblong, slightly broader behind. IJead and thorax dull yellow, the former with a black spot on vertex: the latter with all oval centtral spot and a round one eacle side : elytra with margins and a broad discal stripe dull yellow, the black stripe on side broader behind the middle. then narower at apex and incurving to join the sutural: antemse piceons. the basil joints partly dull yellow; legs bale yellow, the talsi dusky. Tho- 
lax two-thirds wider than long, slightly narrowed in front, sides sinuate; disk with a vague oblique impression each side, sparsely and coarsely punctate. Elytra sparsely and finely punctate. Length $7.5-10 \mathrm{~mm}$.

Lake and Marshall counties; scarce. July 4-July 30. The larvæ are said to feed on goldenrod (Solidago).

2159 (6892a). Trirhabda virgata Lec., Proc. Phil. Acad. Nat. Sci., 1865, 220.

Oblong-oval. Color nearly as in canadensis but the yellow stripes narrower, so that the elytra are more black than yellow, and the spots on thorax are usually larger. Antemnc piceous, the basal joints dull yellow beneath, the fifth much longer than third, the second and third together but little longer than fourth. Thorax with sides less sinuate than in the preceding, the surface sparsely and irregularly punctate. Length $7-9 \mathrm{~mm}$.

Throughout the State; frequent. June 25-September 7. Said by Horn to "occur on the Atlantic coast from Massachusetts to Florida."

\section{XIN. Galerucella Croteh. 1873. (Gr., "diminutive of Gale- ruca.',)}

Small oval brownish or reddish species, having the head usually with a distinct median impressed line; antennæ as long or longer than half the body, the third joint longer than fourth; thorax with a median and two lateral impressions; elytra irregularly punctate, the epipleuræ extending three-fourths to apex; front coxal cavities open behind; tibix carinate on the outer side and without terminal spurs ; first joint of hind tarsi not longer than the next two; tarsal claws bifid in both sexes. They occur for the most part on herbs growing in low, moist places, on the flowers of water-lilies, or on the foliage of trees and shrubs bordering marshes. Ten of the eleven species recognized by Horn probably occur in the State, while luteola, an introduced species, has also been taken. They were formerly classified under the genera Adimonia and Galeruca.
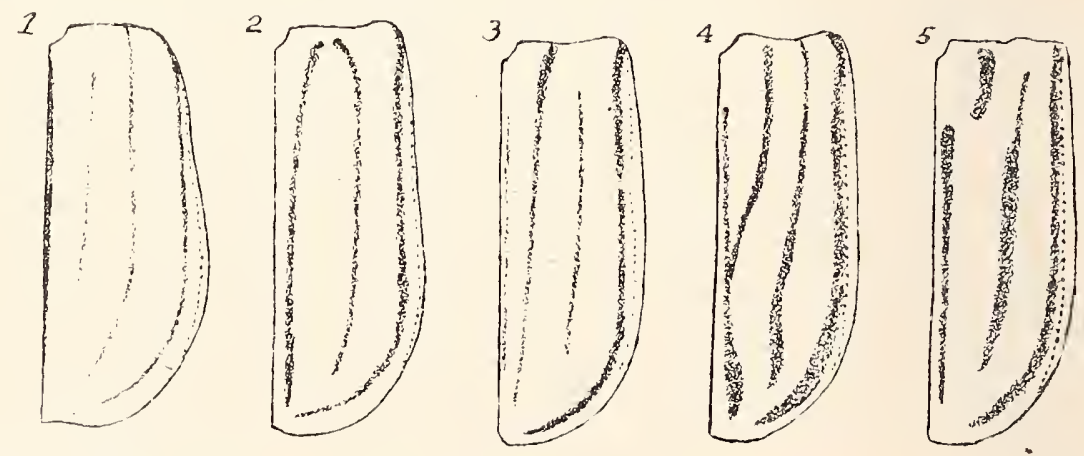

Fig. 507. 1, Elytral markings of Golerucella americana; 2, of G. sexvittata; 8 , of $G$. integra; 4 , of $G$. notulata; 5, of $G$. notata. (After Horn.) 
KEY TO INDTANA SPECIES OF GALERUCELLA.

u. Antennie sinilar in color above and beneath ; elytra coallsely punctate, more finely towards apex.

b. Elytra with elongate black markings or narrow stripes.

$c$. Side margins of elytra not at all flattened; middle coxie separated by the mesosternum.

d. Elytra very coarsely punctate; thorax more or less shining, the black spots often indistinct.

2160. AMERICANA.

dd. Elytra less convex and less coarsely and more closely punctate; thorax opaque, the spots distinct.

2161. SEXVITTATA.

cc. Side margins of elytra distinctly tlattened; middle coxie contiguous.

c. Sutural dark line indistinct or absent, the next inner line long, nearly reaching the apex. (Fig. 50T, No. 3.) INTEGra.

ee. Sutural dark line distinct.

$f$. Sutural dark stripe joined by the next at or behind the middle. (Fig. 50 5 , No. 4.)

2162. NOTULATA.

1i. I ark stripe next to the sutural one very short. basal. (Fin. 507 , No. 5.)

2163. NOTATA.

64. Llytra without elongate dark marks, the side margins often paler.

\%. Color dull brick red; head red.

7. Elytra more coarsely punctured, the intervals between the punctures distinct: surface shining.

2164. CAVICOLLIS.

hh. Elytra finely and densely punctured; surface subopaque.

RUFOSANGUINEA.

gg. Color dull yellow, brownish or piceous; occiput usually piceous.

$i$. Form convex, elytra coarsely punctate.

ii. Form subdepressed.

2160a. Var. AMERICANA.

j. Middle coxie separated by a prolongation of the mesosternum; thorax angulate at middle, subsinuate behind, hind angles obtuse.

216ว. NYMPHE.

ji. Middle coxie contiguous; hind angles of thorax distinct.

li. Thorax irregularly punctate, with smooth areas along the apex and near the front angles; elytra dull reddish-brown.

2166. TUBERCULATA.

lik. Thorax densely and evenly punctured and opaque; elytra dull brownish-yellow to piceous.

2167. DECORA.

au. Antenne piceous abore, pale beneath: elotra rather finely and equally punctate.

216S. LUTEOLA.

2160 (6899). Galerucella Americaxa Fabr., Syst. Eleut., I, 1801, 489.

Oral, more convex than in the other species. Dull yellow, sparsely pubescent: elytra each with three piceous lines. these often indistinct or even ranting (Fig. 507. No. 1) : apical half of antennse. and sometimes the metasternum and abdomen. piceous. Thorax more than twice as ride as long. Wider at base than apex, sides curved, surface sometimes sparsely (female). more usually rather coarsely and closely punctate. Elrtra oval with rounded humeri, sides not flattened. surface rery coarsely. deeply and rather closely punctate. Length 4-6 $\mathrm{mm}$. 
Lake, Laporte, Clark and Knox counties; scarce. May 25July 25. The variety without spats (2160a) occurs with the type.

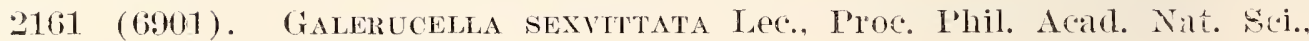
$1865,215$.

Oblong-oval, subdepressed. Dull yellow or pale brown, opaque; pubescence sparse, prostrate; thorax with three distinct black spots; elytra each with three narrow piceous lines (Fig. 507. No. 2) ; antennie and scutellum entirely black. Thorax twice as wide as long, distinctly narrower in front; sides curved, hind angles distinct; disk densely punctured. Elytra slightly broader behind, tips obtuse; surface rather finely and densely punctured. Length $5-6 \mathrm{~mm}$.

Throughout the State; frequent. April 9-August 2. Taken by sweeping herbage in low, moist lands.

G. integra Lec., dull yellow, elytra each with a sabsutural and three dorsal lines, length 4-5 mni, oceurs from Pennsylvania to Florida and 'Texas.

*2162 (6909). Galertcella notulata Fabr., Syst. Elent., I, 1S01, 489.

Oval, slightly oblong. moderately convex. Dull dusky yellow, sparsely clothed with fine, prostrate, silken lubescence; thorax with three black spots; elytra each with fonr narrow blark lines (Fig. 507, No. 4), viz.. a sutural rarely reaching the base, a secont oblique one on basal half, joining sutural at middle; a third, often entire, sometimes wanting on basal half, the fourth starting at umbone and often joining the sutural; apical half of antenne and metasterinum piceous. Thorax nearly twice as wide as long, narrower in front, sides strongly curved, base on each side oblique, surface coatsely, not closely punctate. Elytra scarcely wider behind, surface closely punctate, more coarsely on basal half. Length $3.5-5 \mathrm{~mm}$.

Southern half of State; frecuent. January 15-December 10. Hibernates beneath logs and mullein leaves in sandy localities. Rarely the second dark stripe does not join the satural at middle, though reaching the usual point of rnion.

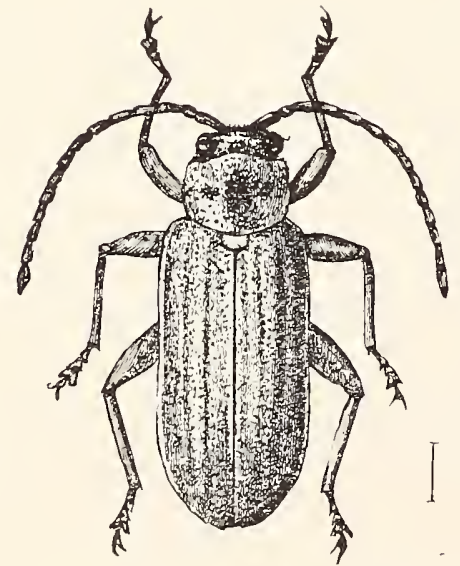

Fig. 508. (Line shows natural size.)

2169 (6910). Galeritcella notata Fiar., Syst. Eleut., I, 1801, 4\$8.

Resembles the preceding, lut the pubescence is more sparse and the general color usually paler. Each elytron is marked with a sutural and three disal lines (Nig. 507, No. 5) : of thesp the sutural and the second discal reach neither base nor apex, the first discal being short and confined to the hasal fomth, while the outer line is entire. I'unctuation of uprer surface somewhat finer than in notulatu. Length $3.5-5 \mathrm{~mm}$. (Fir. 508.)

Throughout the State; rather frequen on the Howers of boneset, Eupatorium perfoliatum L. May 1t-October 16. 


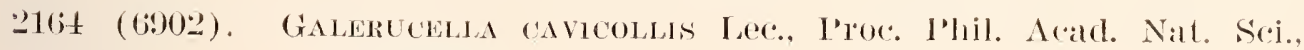
$1865,216$.

Oral, nalrower in fromt, subdepressed. Dull red, moderately shining, very sparsely and finely pubescent; antenne black; legs dull red to piceons. Thorax neally twice as wide as long, nalrower in front, sides curved or obtusely subangulate, hind angles distinct; disk with a broad median depres-

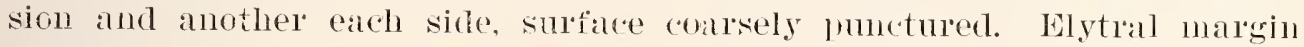
Hattened; disk with coalse, dcep, not crowded punctures. Lengtl 4.5$5.5 \mathrm{~mm}$.

Taken in numbers by Wolcott noar Pine, Lake County. May 21. Oceurs from Canada and the New England states westward to Wisconsin. Probably to be found throughout the northern third of the State.

G. mfosanguinca Say, length 4.5-5.5 mm., is known from Pennsylvania southward.

2165 (6906). Galerucelda nymphä Linn., Syst. Nat., 1758, 376.

Oblong-oval, narrower in front, subdepressed. Piceous brown, finely pubescent; thorax dull yellow. usually with three piceous spots; side margin, apex and epipleura of elytra yellowish: under surface and antenne piceous, the basai joints of the latter partly dull yellow; legs pale. Thorax twice as wide as long. sides rather strongly angulate; front angles suall, prominent, hind angles nearly obsolete; disk with nedian narow depression and a larger one ench side which is densely punctured and piceous; surfare otherwise sulootl or with a few coallse punctures. Elytral slightly broader behind, malgins distinctly fiattened, surface coalsely and l'ather (closely punctate. Length 4.5-6 1mm. (Fig. 509.)

Nor thern half of State, frequent; Knox and Lawrence counties only in the south. March 26-September 29. Probably hibernates. Ouurs on the pads and flowers of the white and yollow water-lilies.

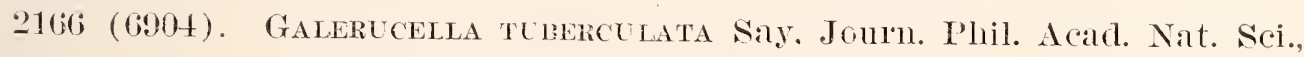
III, 1S24, 456 ; ibid. II. 2200.

Oblong-oral, subdepressed, opaque, finely pubescent. Color rariable. duil reddish-brown to piceous; antennxe black; legs pale or party piceous. Thorax nearly twice as wide as long, sides rounded or obtusely subangulate. hind angles distinct, base sinuate each side: surfice coarsely and closely punctured, smoother near the front angles and along the aper. Flytra somewhat wider behind the middle: disk coarsely and deaply punctured. more sparsely and finely at sides and apex. Length $5-6$ mm.

Wayne and Marion counties; rare. May 26-June 18. The usual black spots of thorax are often wanting. 
2167 (6907). Galerdcella decora Say, Long's Second Exped., II, 1S24, 294 ; ibid. I. 195.

Oblong, scarcely wider behind, subdepressed. Dull yellow or dusky brown clothed with fine, short, yellow, silken pubescence; antennæe wholly piceous or with the basal joints partly dull yellow; legs pale. Thorax twice as wide as long, narrower in front, sides curved, hind angles slightly prominent, base oblique each side; disk with a vague median impression and a large, shallow one each side. marked with piceous. Elytra scarcely widened behind, surface coarsely, deeply and rather closely punctate. Length 4.5$5.5 \mathrm{~mm}$.

Lake County ; scarce. May 21-June 30. Occurs on willow. Has the same range as cacicollis and, like it, probably confined to the northern third of the State.

2168 (6912). Galertcelda luteola Mull., Melanges Soc. Roy. Turin, 1766, III, 187 .

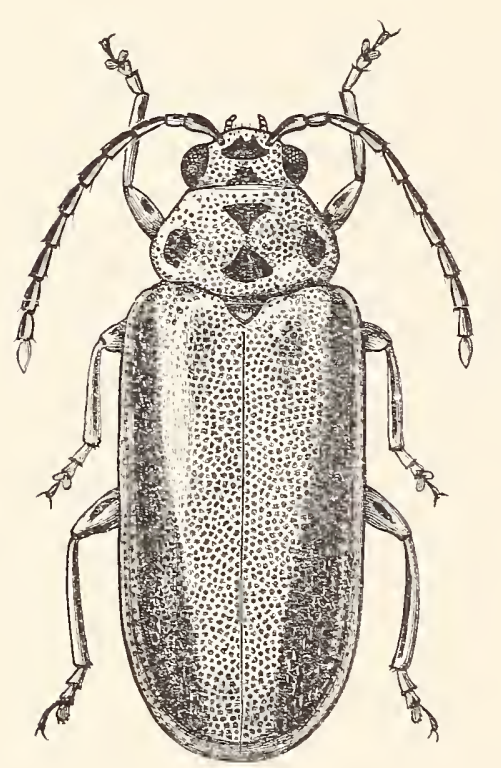

Fig. 510. (After Howard in Far. Bull. 99, U. S. Dep. Agr.)

Oblong, subdepressed. Dull olive or greenish-yellow. finely pubescent; head with a black spot on vertex and another between the eyes: thorix with three black spots; elytra with a stripe on sides and a narow, short line on middle of base, black; abdomen piceous. Thorax more than twice as wide as long. slightly narrowed in front; disk with an oblique depression each side and a shallow pit on median line near apex; surface rather sparsely punctate. Elytra with sides nearly parallel. margins flattened, surface $r$ at the $r$ finely and erenly punctate. Length $5-\bar{t} \mathrm{~mm}$. (Figr. 510.)

This is the injurious "elm-leaf beetle, " introduced from Europe into the Enited States near Baltimore about $183 \bar{i}$. Since then it has gradually spread southward and westward and reached Harrison County, Indiana, about 1905, probably by way of the Ohio River. It is abundant on the elms of Laconia, Elizabeth and Corydon in that county. from which the specimens in the collection were obtained. The beetle hibernates as imago beneath bark, in cracks of wood and other shelter, and emerges to feed on the first opening buds in spring. The egos are laid in clusters of five to $20 \mathrm{or}$ more on the lower side of the elm leaves and hatch in about a week. The larve feer on the under side of the leaf, gradually skeletonizing it. They reach îll growth in 15 to 20 days, and then eraw or fall to the ground and change to pupa. 
from which they emerge as imagoes in six to ten days. 'There are usually two broods each season, those of the second hibernating.

The only remedy is the spraying of the trees with an arsenical solution two or three times a year; once just after the buds have opened, to kill as many of the mating insects as possible; a second time two or three weeks later to kill the larvie, the majority of which have hatched by that time. A third spraying about June first will also be found beneficial. The crushing of the larvx at the surface of the ground when they are about to transform is also recommended. With the foothold that it has gained the beetle will undoubtedly spread over the southern third of the State and ultimately do much damage to the many noble elms of that section.

Monoxia puncticollis Say, pale yellow to entirely black, or elytra with stripes, length 7-8.5 mm., is known from Massachusetts and Florida westward.

\section{Diabro'tica Chev. 1850. (Glo., "through + gnaw.")}

Small or medium-sized, oval or oblong beetles having the head not inserted as far as the eyes, which are broadly oval and entire; antennce slender, longer than half the body, second and third joints often very small; thorax broader than long, sometimes nearly square, the disk usually with two pits or foveæ; elytra with a very distinct and slightly reflexed side margin; front coxa contiguous, the cavities open behind; tibia slender, the middle and hind pair with terminal spurs, the outer edge usually carinate from knee to tip; first joint of hind tarsus as long as the next two; tarsal claws bifid. Three species have been taken in the State, and a fourth prob-

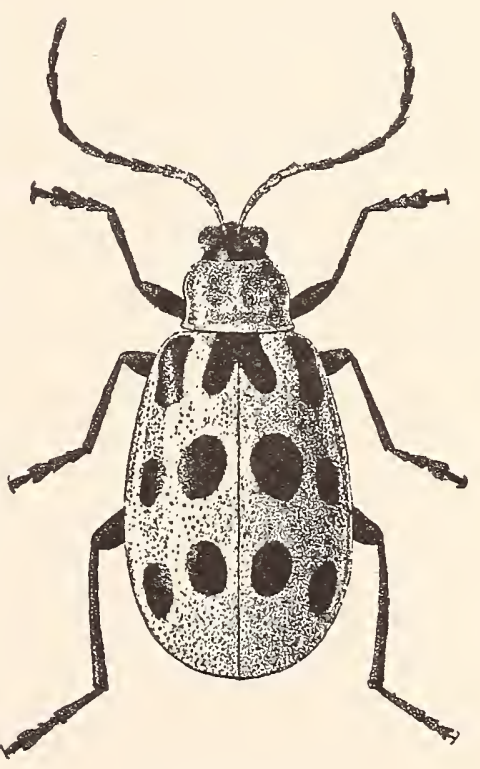

Fig. 511. $\times 5 \frac{1}{2}$. (After Forbes.) ahly occurs.

\section{KEY TO INDIANA SPECIES OF DIABROTICA.}

a. Tibixe carinate along the outer edge; elytra without black stripes.

b. Elytra each with six black spots; abdomen and base of femora pale.

br. Elytra unicolorous without spots. 2169. 12-PUNCTATA. 
c. Head and legs in part piceous: elrtra black.

cc. Head and less pale: elctra green or rellow.

ATRIPENTIS.

2170. LONGICORXIS. a a. Tibire not carinate along the outer edge; elrtra rellow with black stripes.

2171. пITTATA.

2169) (6.911. Diabrotica 1.2-pextata Fabr.. Syst. Ent. 17\%. 108.

Oblong-oral. narrower in front, moderatels conres. Pale greenish-rellow: head and mostelnum black: elstra each with six black spots, as shown in Fig. 511; antenme dark, with three basal joints pale, the second and third together about as long as fourth: less except base of femora piceous. Thorax wider than long. surface smooth; disk conrex with a rather deep pit each side of middle. Elytra sparsely and rery finely punctate. Length 6-7.5 mm. (Fis. 511.)

Throughout the State; common. MIar 30-October 21. Oceurs on the foliage of cucumber. melon and allied plants. but is much less injurious to them than is D. vittata: found also on goldenrod, corn and many plants. The larre feed on the roots of corn and grasses.

D. atripennis Sar, entirely black. or with thoras and abdomen in part or wholly yellow. length $t-5 \mathrm{~mm}$. is said to cecir from Massachusetts to Kansas and Dakota. but no specimens have as ret been noted in Indiana.

2170 (bsse). Diabrotica loxgromats siy. Jomm. Phil. Acad. Nat. Sci.. III. 1S24, 460 : ibid. II. 223 .

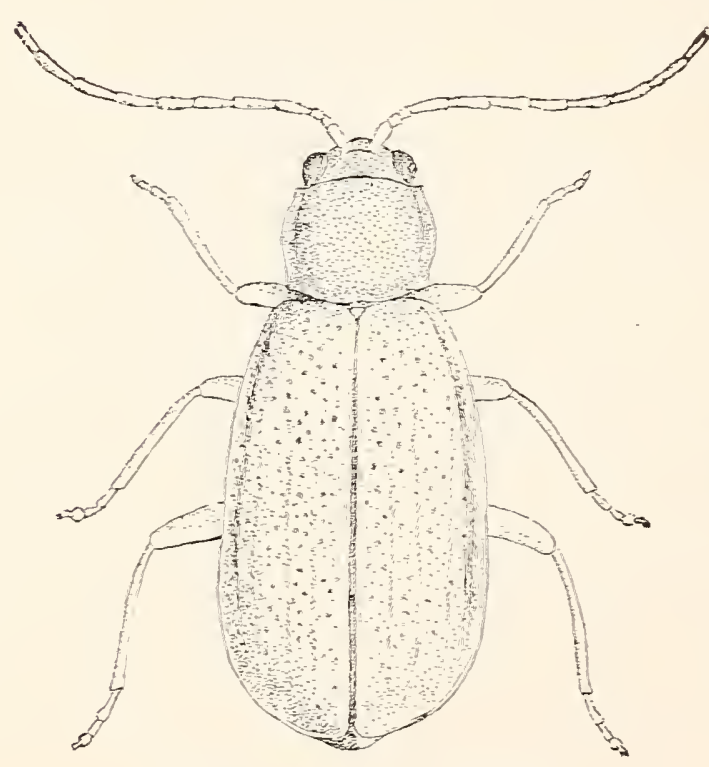

Fig. 512. $\times$ 10. (After Forbes.)

Elongate-oblong. Greenish or sreenish-rellow: antennz. and sometimes the head and thorax. rale reddish-brown. Thorax nearly quadrate. sides curred in front. slightls sinuate behind; disk convex, smooth, with a rather deep forea each side. Antemne two-thirds the length of bodr. Elctra distinctly wider behind the middie. surface raguels subsulcate, rather coarsely and closeIy punctate and with a raised line from umbone tro-thirds to apex. Length $5-5.5 \mathrm{~mm}$. (Fig. 512.)

Throaghout the State, frecuent: more so in the southern counties. June -2-Octoter 5 . Most abundant in early autumn on the silk and leaves of ripening com and on the flowers of wild sunflower and goldeniod. 
*2171 (68S5). Diabrotica vittata Fabr., Syst. Ent. 1775, 122.

Oblong-oral. Pale yellow above; head, scutellum, one common sutural and a discal stripe on eatch elytron, black; under surface, antennie, excent the three basal joints, knees, front tibie, tips of middle and hind tibice and tarsi piceous. Thorax one-fourth wider than long, sides curved in front; disk smooth but with two deep fover. Elytra rather broadly striate, the striee each with two rows of punctures, intervals convex, subcostate. Length 4.5-6 mm. (Fig. 513.)

'Throughout the State: common. Known as the "striped cucumber beetles," and very injurious to cucumber and melon rines. Hibernates beneath rubbish in the vicinity of gardens

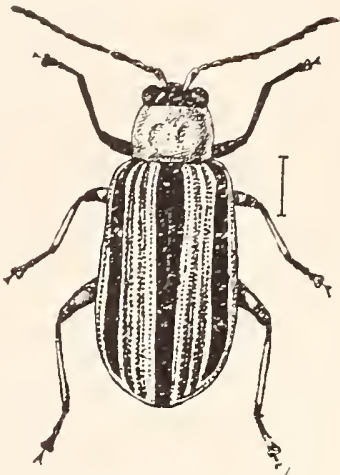

Fig 513. (After (hittenden.) and melon patches. February T-December 11. Nating April 26 in numbers on the flowers of crategus and wild plum; also taken at sap. The beetle eats into the stems of the melon vines at the surface and the larve mines in them a little under ground. "Remedial measures vary and generally result in an effort to keep away the beetles until the vines are well established. This is sometimes accomplished by planting an excess of seed so as to allow the insects to kill a number of the plants and yet leave enough for the farmer: sometimes ground tobaceo at the base of the plant is used as a repellant, and this is good if it be ground fine. The beetles may also be driven away with air-slaked lime or plaster. Occasionally carbolized lime or plaster is used, and sometinies kerosene or turpentine is mixed with plaster. All these are good, and the hest is that which succeeds best with the individual farmer." *

\section{XlVII. Paratriarius Schf. 1907. (Gr., "near + Triarius.")}

This genus was established to embrace the long lost Galeruca dorsata Say which was rediscovered by Dury near Cincinnati in 1903. It is a small-sized oblong-oval species having the antenna longer than half the body, first joint stout, slightly larger than fourth, second small, third and following subequal, the fifth to seventh broadly dilated on outer side in male; elytral punctures confused; legs slender, all the tibia with minute spurs; first joint of hind tarsi as long as the next three together ; claws deeply bifid, the inner lobes convergent and tonching.

2172 (-). Paratriaries dorsata Sily, Journ. Plil. Acad. Nat. Sci.. III, 1824,456 ; ibid. II, 2221.

Oblong-oral. Front of head, thorax, under surface, legs and narrow border of elytra pale sellow; vertex black: elytra bluish-green, shining; an-

*J. B. Smith, Cat. N. J. Insects, 1\$99, 310. 
tennæe and a line on outer side of tibire and tarsi, brownish. Thorax twice as broad as long; disk with a shallow fovea each side, very sparsely and finely punctate. Elytra slightly widening from base to apex, rather coarsely and closely punctate and with an irregular depression near the suture on apical third. Length $6-6.5 \mathrm{~mm}$.

Vermillion County; rare. July 21. Dury has taken this handsome beetle in numbers near Cincinnati on the spiderwort, Tradescantia virginiana $\mathrm{L}$. He states that it is the most active Chrysomelid known to him, flying like a Cicindela 50 to 100 feet before alighting, and that it occurs only in late June and July, the males disappearing by July 15th. It probably occurs throughout the southern third of Indiana.

\section{XlViII. Phyllobrotica Redt. 1849. (Gr., "leaf + gnaw.")}

Elongate-oblong, black and yellow beetles, having the head transversely grooved between the eyes, which are nearly round and prominent; antennæ slender, longer in the female, the third joint longer than second; thorax transversely quadrate, sides nearly straight, disk usually with depressions; elytra parallel without side margins or separate epipleuræ; tibiæ without spurs; first joint of hind tarsi scarcely as long as the next two; claws appendiculate and divaricate. Five species have been taken in the State.

\section{KEY TO INDIANA SPECIES OF PHYLLOBROTICA.}

a. Head black, front pale.

b. Elytra yellow, with two piceous spots on each.

bb. Elytra each with two black stripes.

2173. DECORATA. 2174. VITTATA. aa. Head entirely yellow.

c. Last rentral of male with a shallow longitudinal impression; elytra piceous, with suture and sides yellow; abdomen black, sparsely pubescent.

2175. DISCOIDEA.

cc. Last ventral of male with a deep cup-shaped cavity.

d. Abatomen dull yellow, sparsely pubescent; elytra as in discoidea.

2176. LIMBATA.

dd. Abdomen black, densely pubescent; elytra yellow with a subsutural and short subapical marginal stripe black.

2177. LENGI.

2173 (6847). Phyllobrotica decorata Say, Journ. Phil. Acar. Nat. Sci., III, 1824, 459 ; ibid. II. 223.

Elongate, parallel. Front of head, thorax and legs yellow; elytra yellow with two black or piceous spots, one at base smaller and oval, one behind middle oblong; under surface and antennæ piceous, the three basal joints of latter yellow. 'Thorax broader than Iong; disk smooth, basal edge sinuate. Elytra very finely and sparsely punctate. Length 5.5-7 mm.

Lake, Steuhen, Starke, Kosciusko and Crawford counties; scarce. June 5-.July 2. Occurs on foliage of various kinds along the edges of marshes. 
2174 (10,379). Phịllobrotica vitutata Horn, 'Trans. Amer. Entom. Soc., XX, 1893, 100.

Elongate-oblong. Head black, front yellow; thorax, legs and under surface yellow; elytra piceous, the side margin and suture yellow and a median yellow stripe extending partly or wholly from umbone to apex; antennæe dusky, the basal joints yellow. Thorax one-half wider than long, sides nearly straight; disk smooth, with a shallow transverse depression on basal half. Elytra sparsely and finely punctate. Fifth rentral segment of male with a deep, cup-shaped carity as in limbata. Length $4-5 \mathrm{~mm}$.

Spencer County; rare. May 24. Taken by sweeping herbage along roadsides.

2175 (6845). Phyllobrotica discoidea Fab., Syst. Elent., I, 1801, 485.

Elongate, parallel. Head, thorax, legs and under surface, except the abdomen, yellow; elytra piceous or bluish-black, with a sutural line, wider at base, and narrow side nargins, yellow; antenna piceous, the three basal joints indistinctly paler; tips of tibire and tarsi piceous. Thorax wider than long, slightly wider at apex; disk smooth, with a rather deep fovea each side of middle. Elytra sparsely and rather finely punctate. Length $4-6.5 \mathrm{~mm}$.

Western half of State; scarce. May 27-July 25. Occurs on the arrow alum (Peltandra undulate Raf.) and other plants about the margins of marshes.

2176 (10,378). Phyllobrotica rimbata Fab., Syst. Eleut., I, 1801, 486.

Resembles discoidea very closely in form and color. The basal joints of antennse are more distinctly paler and the body beneath is wholly dull yellow. Thorax with a broad but shallow transverse depression on basal half. Elytra more finely, sparsely and indistinctly punctate; abdomen very sparsely pubescent. Length 4-6 imm.

Northern half of State, scarce; Knox County only in the south. June 25-August 9. In similar localities with the preceding. The males are easily separated from those of discoidea by the deep pit of last ventral segment.

\section{7 (-). Phillobrotica Lengi sp. nov.}

Form of discoidea. Color of head, thorax and under surface as there; color of elytra given in kcy; legs yellow, tarsi fuscous. Thorax as wide as long, slightly wider at apex; disk smooth, with a median and two lateral sub-basal impressions. Elytra finely alutaceous, sparsely and finely punctate. Length $5.5-6 \mathrm{~mm}$.

Perry County; rare. May 16. Swept from roadside lrerbage. The last ventral of male is like that of limbata, convex in front, with deep, cup-shaped cavity behind, this prolonged at middle by a short truncate lobe limited each side by a noteh. The dark, strongly pubescent abdomen and different color of elytra readily distinguish it from timbata, while the former character and yellow head separate 
it from rillata. According to Knab there are, in the U. S. Museum collection, two males of 7 engi, placed as males of vittata, while there is no true rittata male prosent. Named in honor of Chas. W. Leng, of New York City, who has shown me many favors during my work on this paper.

\section{Luperodes Motsch. 1858. (Gr., "troublesome.")}

This genus comprises the majority of the species formerly listed under Luperus. 'They are oblong, small-sized beetles, having the bead transversely grooved between the eyes and carinate between the antennæ; the latter slender, longer than half the body, joints 2 and 3 small, together not longer than fourth; thorax variable in form, transverse to quadrate, the disk never distinctly impressed; elytra with epipleuræe extending nearly to apex; front coxal cavities open behind, the coxa often separated by a narrow prolongation of the prosternum; tibixe with a terminal spur, that of the hind pair the longer; claws appendiculate and divaricate. But one species has been recognized from the State, though two others may oceur.

KET. TO INDLANA SPECIES OF LUPERODES.

a. Thorax yellow, twice as wide às long; form oral; elytra black or piceous, sparsely punctate; legs yellow.

aa. Thorax blue or black: antenne yellow.

THORACICUS.

b. Elytra punctate and aluticeous; hind angles of thorax dentiform; all the fenora more or less piceous.

MERACA.

bb. Elytra very obsoletely punctate, scarcely alutaceous; hind angles of thorax not dentiform; middle and hind femora often partly piceous.

2178. CYANELLUS.

L. thoracicus Melsh., length $4.5-5 \mathrm{~mm}$., and L. meraca Say, length $5 \mathrm{~mm}$., both range from Pennsylvania to Kansas; the latter has been recorded from Illinois.

217 (6865). Luperodes craneluts Lec., Proc. Phil. Acad. Nat. Sei., 1865. 209.

Elongate-oblong. Above dark blue, strongly shining, beneath piceous; antennie and legs usually entirely yellow, the middle and hind thighs sometimes piceous near base. Thorax a little wider than long, sides slightly curved. hinf angles distinct, not prominent: disk convex, smooth, sparsely punctured at sides and base. Elytra sparsely and finely punctate, feebly alutaceous. Lèngth $3.5-4.5 \mathrm{~mm}$.

Marion, Jackson and Crawford counties: scarce. May 17--June 24. Occurs on the fiowers of wild rose. 
L. Phyllecthrus Liec. 1865. (Gr., "leaf + eating.")

Small, elongate, nearly smooth species having the eyes oval, distant from the margin of the thorax; antenne slender, 10-jointed in the male of gentilis, 11-jointed in the other species; thorax broader than long, sides distinctly margined, base curved; elytra with very distinct side margins and epiplenræ, the latter narrow; front coxæ contiguous; tibire slender, without spurs; first joint of hind tarsi longer than the next two together; claws broadly appendiculate at base. One of the four species has been taken in the State and another probably oceurs.

KEY TO TNDIANA SPECIES OF PITYLLETIIRUS.

a. Antennæ piceous and 11-jointed in both sexes, thickened toward the tip. male, or filiform, female; elytra but slightly wider than thorax.

DORSAIIS.

aa. Antennse filiform and piceous in both sexes, but 10-jointed, male, 11 jointed, female; elytra distinctly wider than thorax.

2179. GENTILIS.

$P$. dorsalis Oliv., head, thorax and under side of body yellow, elytra and abdomen black, length $6 \mathrm{~mm}$., occurs "from Washington, D. C., to Missouri and Texas."

2179 (6S53). Phytlecthros gentilis Lec., Proc. Phil. Acad. Nat. Sci., $1865,208$.

Elongate-oblong, parallel. Head, and often the thorax, entirely yellow, the latter, howPver, usually with a broad black stripe each side with the extreme margin pale; elytra sometimes wholly black, more often with the suture, side margins and apex yellow; under surface and legs yellow, the former sometimes piceous; antenn re piceous, the three basal joints partly yellow. Thorax slightly wider than long, sides nearly straight; disk smooth, convex and with a vague impression behind the middle. Elytra very finely alutaceous, without pnnctures. Length 2.5-4 mm. (Fig. 514.)

Southern third of State, scarce; Koseinsko County only in the north. May 19-June 23. Occurs on bush-clover (Lespedeza) along roadsides.

Tribe $x$. IALTICINI.

A large group of small or medimm-sized, leaf-eating forms, distinguished from the preceding tribe mainly by the fact that the hind thighs are greatly enlarged and thickened for leaping. As a conse- 
quence they are known as "flea-beetles" or "jumping" beetles," this term being especially applied to the small black species of Haltica and Epitrix, which are very injurious to vegetation in the mature or adult stage.

In addition to the thickener hind femora, most of the species are distinguished from the Galerucini by having the front coxi separated by a prolongation of the prosternum, and the hind tibiæ provided with a terminal spur which gives them a point of resistance in the act of leaping. The third joint of the antennæ is, in most species, equal to or longer than the fourth, whereas in the preceding tribe it is usually smaller. The identification of some of the members of the group is among the most difficult in the family, yet most of the genera have a peculiar facies or general appearance which, once learned, leads readily to the proper placing of additional species. The principal paper treating of the North American forms is by

Horn.- "A Synopsis of the Halticini of Boreal America," in Trans. Amer. Ent. Soc., XVI, 1889, 163-320.

Of the 33 genera recognized by Horn as comprising the tribe, 22 are known to be or should be represented in the State. For convenience, and to avoid a long generic ker, these are first divided into two subtribes.

KEY TO SUBTRIBES OF HALTICINI.

a. Front coxal cavities open behind.

a a. Front coxal cavities closed behind.

Subtribe A. 1. 117s.

Subtribe B. 1) 1205 .

\section{Subtribe A. (HaLticini.)}
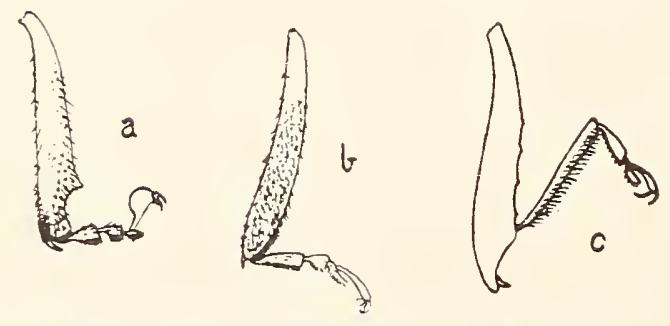

As mentioned above, the division of the Halticini into two subtribes is for convenience only and is wholly arbitrary. Aside from the open coxal cavities on which the first division is based, Fig. 515. a, Hind tibia and tarsus of Edionychis; b, our member's of it are for the
same of Disonycha; c. same of Longitarsus. (After Horn.) mcst part larger than those of the second, being usually 3.5 or more $\mathrm{mm}$. in length. They are also mostly more ornate or variegated in color. Twelve of the 22 genera belong to this group. 
KEI TO THE INDIANA GLNELA OF MALTICINI, SUBTRIBE A.

1. Last joint of hind tarsi globosely swollen (Fig. 515, a); punctures of elytra confused; surface glahrous: thorax very little nurower than clịtra.

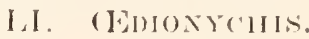

ur. Last joint of hind tarsi not inflated, usually slender, sometimes thickened when viewed from the side.

7. Mesosternum always visible, usually moderately long.

c. 'Thorax without a transrerse inpression near the base; hind tibixe faintly or not grooved.

d. First joint of hind tarsus short, as compared with the tibiæ, and rather broad; claws appendiculate ( Fig. 515, b) ; size medium, 4.5 or more mun.

LII. Disonycha.

dd. First joint of hind tarsus long and slender; claws simple; size smaller, less than $4 \mathrm{~mm}$.

$e$. Hind tibiae grooved above or on the outer edge, at least near apex; elytra without rellow stripes or spots.

$f$. Hind tibire with the apex entire, the spur placed in the middle in front of the tarsus.

g. Punctures of elytra confused; first joint of hind tarsus nearly or quite as long as half the tibia (Fig. 515, c).

LIII. Longitarsus.

gg. Punctures of elytra in regular rows; first joint of hind tarsus not more than one-third the length of the tibix and sarcely as long as the three following joints united.

LiV. Glyptina.

$f f$. Hind tibie deeply groored abore, with the apex notched or bilobed, the spur placed on the outer lobe; reddish-brown, shining.

LV. Арнтнола.

ee. Hind tibire not groored on the outer edge, slightly excavated near the tip, the spur at middle beneath; elytra each usually with a yellow stripe or spots.

LVI. Phyllotreta.

cr. Thorax with a transverse impression on basal half.

11. Transverse impression of thorax usually feeble, not distinctly fimited at each end; elytral punctures, when present, confused.

i. Hind tibia each with a short terminal spur. LriI. HaLtica.

ii. Hind tibize wholly without spurs. LXIII. Luperatrica.

h\%. Transverse impression deep. limited at each end by a longitulinal fold; above bicolored.

j. Elytra nearly smooth, the punctures, when present, extremely fine and scattered.

LIX. LACTICA.

j). Elytra with distinct punctures in rows.

li. Form oval; surface without erect hairs.

DIPHALLACA.

hi. Form oblong, parallel; elytra with short hairs arising from punctures on the intervals.

ia. Trichaltica. 
6). Mesosternum rery short, nearly concealed by the close approach of the pro- and metasterna ; form orbicular or hemispherical antennie slender, but slightly thickened externally ; color piceous black, shining.

SPh.eroderia.

\section{EDionychis Lat. 1829. (Gr., "swollen + joint.")}

A large genus of oval, small or medium-sized species having the head inserted in the thorax to the eyes; thorax always much broader than long, deeply emarginate in front, the margin more or less dilated, base curved, usually obliquely sinuate near the hind angles; elytra oval, humeri not prominent; prosternum moderately wide between the front coxw, the cavities open behind; side pieces of metathorax rather wide, parallel and roughly punctured; legs short and robust, front and middle tibie slightly broader at apex, the outer edge deeply grooved; hind femora very stout and thick, deeply grooved beneath for the tibix, which are short and feebly grooved; tarsi with first joint oblong, triangular, second smaller and narrower, last joint of hind pair globular; claws divaricate and dilated at base. Males with the first joint of front tarsus more broadly dilated and last ventral segment with a deep sinuation each side, the space between forming an oval lobe with a finely impressed line at middle. Eleven species have been taken in the State, while two others may occur.

KEY TO INDIANA SPECIES OF GDIONYCHIS.

a. Antennie stonter, scarcely half the length of body; species larger (4.5 or more mm.) and more convex; front of head oblique; elytral margins not flattened.

b. Elytra wholly of one color.

c. Elytra brilliant blue or green; thorax smooth; body beneath entirely pale.

2180. GIBBITARSA.

cr. Elytra dull blue or greenish-black; thorax more or less punctate; body beneath in great part dark.

r. I'unctures of elytria distinct, often coarse and close; thorax bordered with pale.

21S1. VIANS.

dd. Punctures of elytia almost obsolete; thorax black.

2182. CONCINNA.

6b. Elytra bicolored, either with a pale margin or with stripes on the disk, rarely dull reddish-yellow, with the suture black.

e. Elytra bluish, the margin fale; thorax and elytra coarsely and closely punctate.

2153. THORACICA.

ee. Elytra dull yellow, with or withont hlack stripes.

$f$. Elyta wholly dull yellow except a sntural black line.

ff. Elytra yellow with dirk stripes. 21Sta. val. FIMrbriata. 
g. 'Three stripes on each elytron, silulat, modian and submargillal.

h. Form oblong-oval; foont angles of tholax not denfifolmo; body beneath and legs bale.

21S4. FMBRIAT.

hh. Form oval; front angles of thorax dentiform; clytral dalle stripes broad.

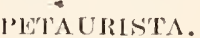

yy. 'Two stripes ou each elytron. sutulal and nedian; oval or oblong-oval; fourth joint of antennie distinctly longer than third.

218.5. MINIATA.

ar. Antennat slender, as long as or longer than half the body; sivecies smaller (usually loss than t.5 num.), much depressed ; fromt vertical; elytral margins usually Hattened.

i. Elytra with narrowly flattened margins; rellow with all oral discal black space; head yellow; nmbone indistinct.

21S6. THYAMOLHES.

ii. Jiytrat matrins broally fiattened, the epiplentio wite and horizontal.

j. Elytra broadly oval, sides munch curved, coalsely punctate; dirty yellow with indistinct blarck lines.

2157 . LAIIALLIS.

ji. Elytra with sicles feehly culved or nearly pallallel, entirely piceous or yellow witī piceous suots.

k. Thorax rely coarsely punctured; elytra with a nore or less evident costa from the humeri to apex. 2185. SExMACULATA.

7ik. Thorax finely and smarsely punctured or smooth; elytra without costa on the side.

l. Head coarsely and closely punctate; elytra with base, suture and often two suots on each, brown.

SUTURALIS.

17. Head sparsely punctate or almost smooth.

m. Smaller, not over $4 \mathrm{~mm}$; elytral usually in great part piceous; mmbone prominent.

2189. QUERCATA.

$m$. Larger, 4.5 $5 \mathrm{mmm}$; elytril dull yellow oruanented with black spots tending to form trausverse bands.

2190. SCALARIS.

*2180 (6928). (Enhon rehis qubitaksa say. Jomm. Phil. Acad. Nat. Sci., IV, 1824,$83 ;$ ibid. II. 205.

Oral, slightly oblong, moderately convex. Head, under surface and fentora yellow or reddish-yellow; thorax yellow with four piceous spots, the two median ones often more or less confluent; elytra brilliant green or cobalt-blue; tibixe, tarsi and antenna piceous; scutellum black. Thorax more than twice as wide as long, margins moderately flattened, not translucent. Elytra sparsely and indistinctly punctulate. Length 5-T $\mathrm{mm}$.

Throughout the State: frequent. February 21-September 29. IIibernates beneath logs, bark, mullein leaves, etc. Occurs in summer on flowers of yarrow, wild hydrangea and other plants. The only blue specimens taken were in Lake County. 


\section{*21S1 (6932). CEdonychis vians 111., Mag. fur Insect.. VI. 1807, 83.}

Oblong-oval, moderately convex. Black, usually with a slight violet or greenish lustre; thorax reddish-yellow with an inverted W-shaped black spot (var. scripticollis Say) or with a large transrerse Cliscal spot, so that the margins only are pale; til and sides of abdomen yellowish. Antemnx about half the length of body, third joint longer than fourth. Thorax twice as wide at base as long, narrowed in front, sides nearly straight, angles prominent; surface finely alutaceous, rather coarsely and sparsely punctate. Elytra a little wider at base

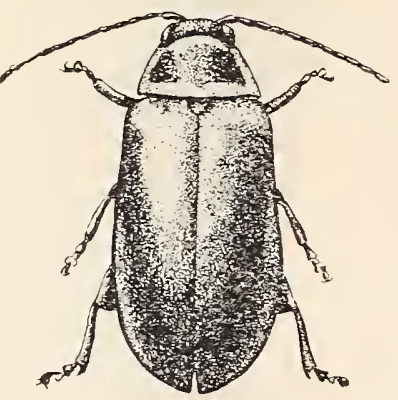

lig. 516. $\times 5 . \quad$ (Original.) than thorax, surface alutaceous, closely and finely punctate. Length $4.5-$ $7 \mathrm{~mm}$. (Fig. 516.)

Throughout the State; frequent. February 14-October 6. Hibernates with the preceding.

2181a (6932a). CEnionychis vians scripticoldis Say, Journ. Phil. Acad. Nat. Sci., IV, 1824, S4; ibid. II, 226.

Form and general appearance of vians. The head has a transrerse reddish spot between the eyes and another smaller one at the base of each antenna; thorax with the black discal spot in the shape of an inverted $\mathrm{W}$. Elytral punctures distinctly coarser, deeper and more dense. Length o$7 \mathrm{~mm}$.

Lake and Lawrence counties; scarce. May 14-June 12. Horn makes this a synonym of vans, but the different punctuation of the elytra is sufficient to make of it at least a distinct variety.

2182 (6932c). CEdonychis concinna Fabr., Syst. Eleut., I, 1S01, 499.

Oblong-oval, moderately convex, feebly shining. Black, except the elytra, which are dark blue or with a greenish tinge; tip and sides of abdomen yellowish. Antenne not half the length of body, third joint longer than fourth. Thorax twice as wide at base as long. sides straight or feebly curved; base deeply sinuate near hind angles. which are prominent; surface alutaceous, sparsely and rather coarsely punctate. Elytra alutaceous, sparsely and very finely punctate. Length $6.5-7.5 \mathrm{~mm}$.

Lake County ; rare. May 21. Recorded before only from Georgia and Texas.

2183 (6935). CEdonychis thoracica Fabr., Syst. Eleut., I, 1S01, 498.

Broadly ovate, feebly convex. Head. thorax and under surface reddish-yellow; thorax with seren black dots forming a curved front row and three just behind them. these often more or less confluent: elytra dark blue with a narrow margin on basal half and epipleuræe reddish-rellow; antennæe and tarsi piceons, the former half as long as body, third and fourth joints equal. Thorax slightly more than twice as wide as long, sides nearly straight, angles acute; disk rather coarsely and closely punctate. Elytra at little wider at base than thorax, surface rather coalsely and densely punctate. Length $5.5-7 \mathrm{~mm}$.

Southern half of State: scarce. April 15-October 1. Often taken on the wing. 
2184 (6936). Cefonichis finmerata Forst., Nov. Sp. Ins., I, 1771, 25.

Oblong-oval, moderately convex, feebly shining. Dull reddish-yellow; thorax with five piceous spots, usually more or less confluent; elytra with only a narrow sutural line black, or with three piceous stripes, with intergrades; femora and under surface, except the metasternum, reddish-yellow; antennæe, tibixe and tarsi piceous. Thorax more than twice as wide as Iong, feebly narrowed to front, margins narrow, surface finely alutaceous, rather coarsely and sparsely punctate. Elytra scarcely wider than thorax, surface closely punctate, more finely at apex. Length 5-7.5 mm. (Fig. 517, a.)

Lake and Dubois counties; rare. May 13--May 21. Taken by sweeping herbage.
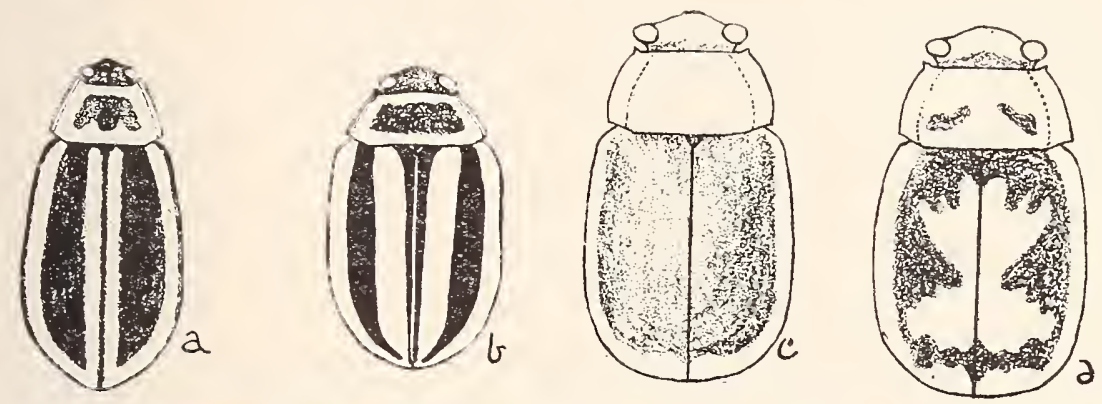

Fig. 517. a, Edionychis fimbriata; b, O. miniata; $c$ and $d, 0$. quercata and variety. (After Horn.)

O. petaurista Fabr., length 5.5-8.5 mm., ranges from North Carolina to Texas and has been recorded from Cincinnati.

*2185 (6939). CEdonychis miniata Fabr., Syst. Eleut., I, 1801, 495.

Oval, slightly oblong, convex, feebly shining. Reddish-brown beneath, dull yellow above; thorax with a transverse brownish spot; elytra with a sutural and each with a median discal stripe blackish; antennæ, except the base, front and middle tibiæ, and all the tarsi, piceous. Thorax three times as wide as long, sides curved and narrowed to the front; disk sparsely and finely punctate. Elytra variably, usuaily finely and rather closely, punctate. Length $5-6.5 \mathrm{~mm}$. (Fig. 517, b.)

Throughout the State; frequent. February 14-October 1. Hibernates beneath rubbish in sandy localities. Taken in May by sweeping.

2186 (6941). CEdonychis thyamoldes Crotch, Proc. Phil. Acad. Nat. Sci., $1873,63$.

Oval, subdepressed, moderately shining. Above pale yellow; elytra with a broad, oval, common spot, black, tinged with greenish; under surface and legs reddish-yellow: head yellow, sparsely punctate. Antennie longer than half the body, piceous, three or four basal joints paler. Thorax twice as wide as long, distinctly broader at base than apex, margins broadly flattened; disk finely alutaceous, sparsely and indistinctly punctate. Elytra

[75-23402] 
with humeri rounded, margins narrowly flattened, surface coarsely and closely punctate. Length $44.5 \mathrm{~mm}$. (Fig. 518, $d$. .)

Southern half of State; frequent. April 11-June 1t. Taken by sweeping and beating low shrubs along roadsides. The black discal space of elytra is sometimes so narrow as to occupy but half the space between the suture and margin. More often it is so broad as to leare only a pale margin and the species then resembles closely o. quercata. The more oval form, indistinct umbone and paler under surface will serve to distinguish it from the latter.
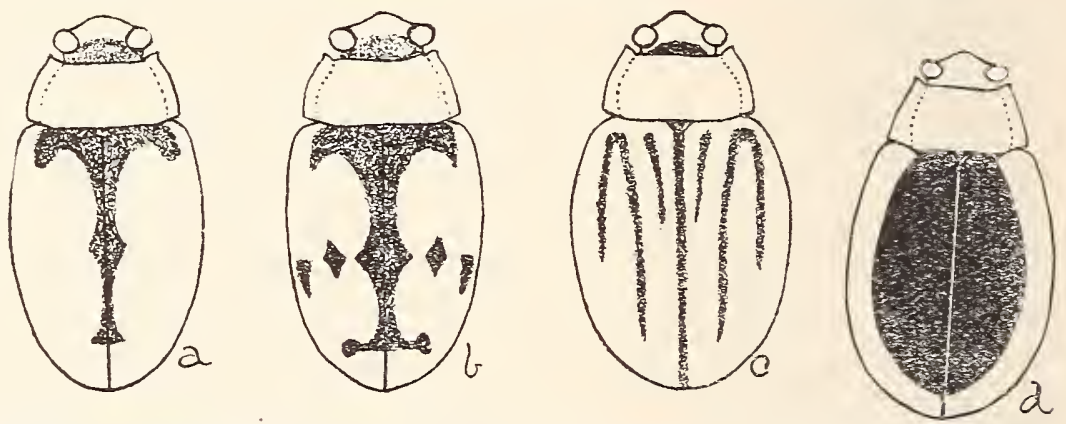

Fig. 518. a, Edionychis suturalis; b, same var.; c, O. limbalis; d, O. thyamcides. (After Horn.)

2187 (6945b). CEdonychis mimbalis Melsh., Proc. Phil. Acad. Nat. Sci., III, $18 \pm \bar{\tau}, 162$.

Broadly oral, subdepressed. Dull brownish-yellow; elytra each with four narrow fuscous or piceous lines or stripes as follors: one sutural, not reaching base. a second each side of scutellum. extending nearly to middle; a third slightls oblique. extending from nmbone tro-thirds to apex. and a fourth short one reaching from the umbone parallel with the side margin; these stripes may be one or all absent. or ralely all confluent into a larce discal piceous space: head paie. sparsely punctate. Antemne longer than half the body, fuscous. the basal joints paler, third and fourth equal. Thorax nearly three times as wide as long, margins broadly flattened, front angles not dentiform. surface alutaceous. sparsely and obsoletely punctate. Elytra broadly oral. umbone moderately prominent; surface rather coarsely and closely punctate. Length $3.5-5 \mathrm{~mm}$. (Fig. 518, c.)

Throughout the State, frequent; much more so in the northern

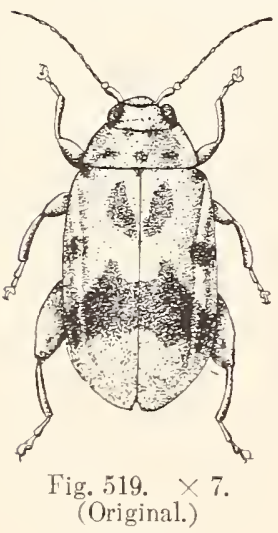
counties. May 12-.July 1t. Taken by sweeping and beating foliage, especially that of oak. Listed by Henshaw as a variety of quercata, but distinct.

21SS (6944). CEdoxychis sexacacllata Ill., Mag. fü Insect. VI. 1807, 104.

Oblong-oral, depressed, subopaque. Abore reddish or brownish-rellow marked with piceous as follows: spot on occiput, an indistinct irregular space on thorax, a broad common band belind the middle and three spots on each elytron. riz.. one at umbone. a second near the side mar- 
grims and one between these near the suture, the latter set obliquely so as to

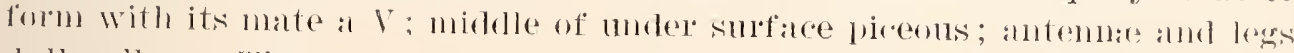

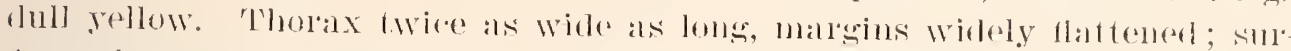

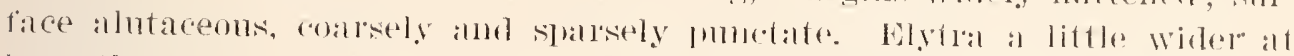

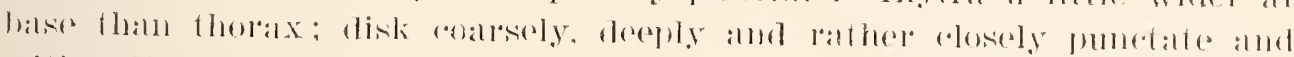

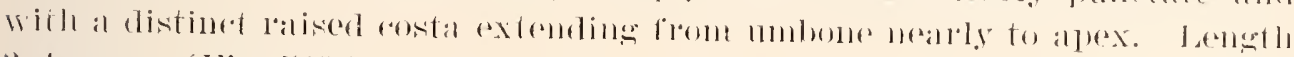
3- 4 mul. (Fig. 519.)

Southern half of State, common; much less so in the northern counties. May 11-July 6. Taken by heating oak and sifting woody debris.

O. suturalis Fab. (Figs. 518, $a \& b$ ), pale yellow with brown spots as shown in figure, length $3.5-4 \mathrm{~mm}$., is a southern form which may occur in the Lower Austrai life zone of the State.

2189 (6945). CEdonychis quercata Fabr., Syst. Eleut., I, 1801, 495.

Oval, depressed. Front of head, thorax, legs, epipleura and narrow margin of elytra yellow; disk of elytra and under surface piceous. Antennæe longer than half the body, outer joints piceous. Thorax more than trice as wide as long, margin widely flattened, iront angles dentiform; surface finely alutaceous, very finely and sparsely punctate. Elytra not wider at base than thorax, umbone distinct, sulcate within; surface finely but distinctly and rather closely punctate. Length 3.5-4 mm. (Fig. 517, $c$ and $\left.d_{.}\right)$

Throughout the State; frequent. April 22-June 18. Oceurs on oak, red-haw and other foliage. Mating .June 7. The sides of elytra are more parallel than in thyamoides and the next.
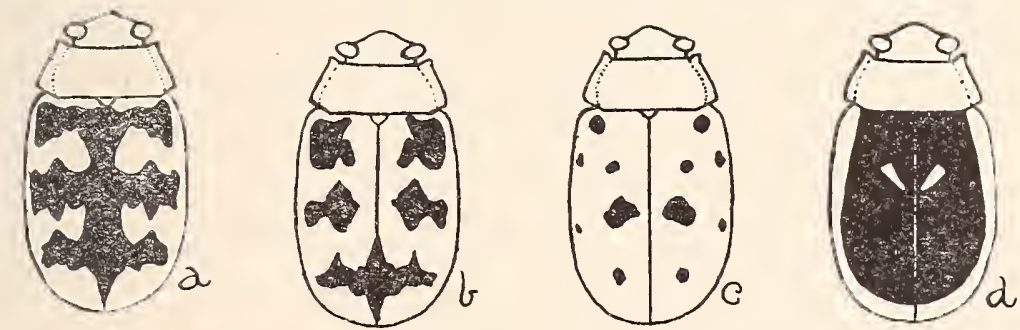

Fig. 520. Edionychis scalaris and its varieties. (After Horn.)

2190 (6946). CLdonychis scararis Melsh., Proc. Phil. Acad. Nat. Sci., III, $1847,163$.

Oval, slightly oblong, depressed. Above dull yellow; occiput piceous; thorax with a blown ol piceous spot each side, sometimes merged to form a discal space: elytra with three broad, black, common crossbars, confluent along the suture, these sometimes broken into spots; under surfice piceous, legs pale. 'Thorax as in quercata. Elytra not wider at base than thorax, umbone distinct, surface lather coarsely punctate near base, smoother at tip. Length 4.5-5 mm. (Fig. 520.)

Lake, Marion, Knox, Posey and Dubois counties; scarce. April 19-July 9. Occurs on the foliage of plants along marshes. The black of elytra varies much in extent, the spots or crossbars being sometimes so merged as to cover nearly the entire surface. 


\section{Disonycha Chev. 1834. (Gr., "two + claw.")}

Oblong or oval beetles of medium size, having the head inserted as far as the eves, front with distinct carina and two tubercles; antennæ slender, rarely

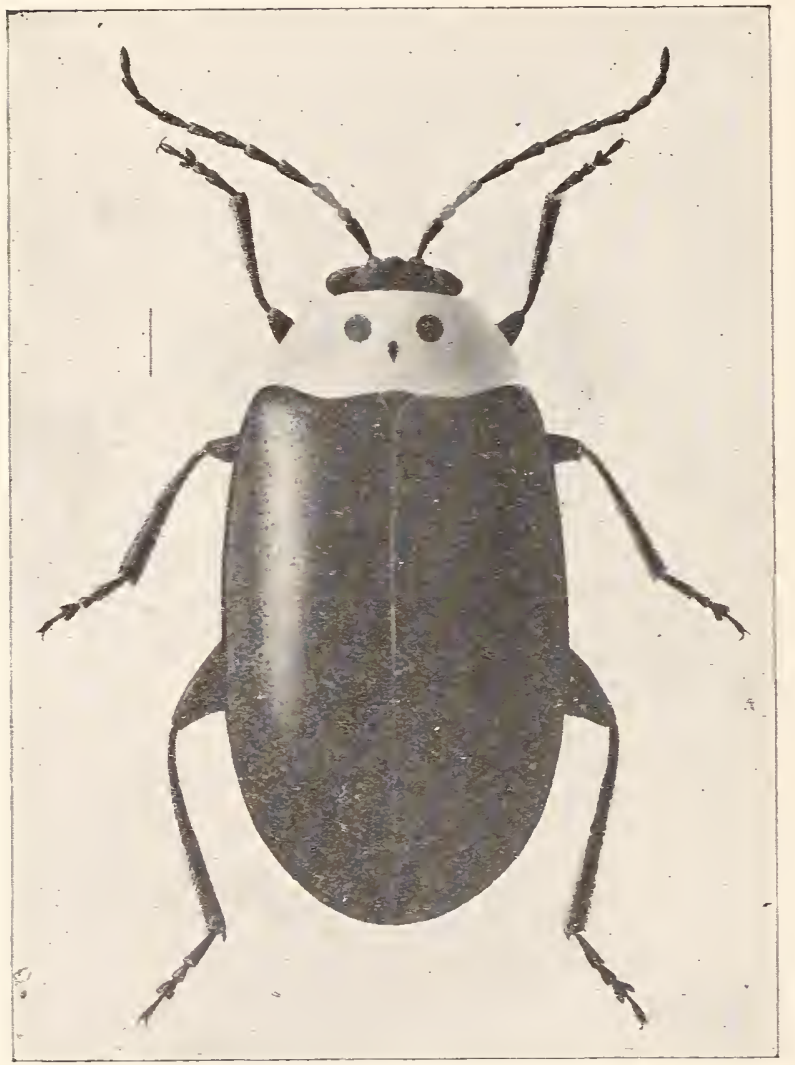

longer than half the body, the fourth joint longer than third, except in the species with blue elrtra, where the two joints are equal; thorax as wide at base as elytra, narrowed in front, sides obliquely sinuate, disk convex without transverse basal depression; elytra oblong or oral, the epipleuræ gradually narrower from base; front coxal cavities open behind; hind thighs much enlarged, grooved beneath; tibiæ more or less bisulcate on outer face, terminated by a moder-

Fig. 521. Disonycha triangularis.jay. $\times$ 10. (After Forbes.), ate spur; first joint of hind tarsi as long as the next two; claws dilated at base. The males have the last rentral segment truncate, the proidium rertical and convex; in the females the last rentral is oval and the pygidium horizontal.

The species feed upon herbs of various kinds and often do much damage to sugar beets and allied plants. They feign death when disturbed, falling to the ground. where ther remain quiet for several minutes. Of the 18 species ascribed to the genus by Horn, eleven have been taken in the State.

\section{KEY 'TO INDIANA SPECIES OF DISONYCHA.}

a. Form elongate parallel: elptra rellow with black stripes, subsulcate on the sides: thorax with an irregular impression each side.

2191. PENNSTLTANICA.

a rex.

b. Elytra with black and rellow stripes, or yellow with only a narrow sutural and submarginal black line. 
c. Elytra with a submarginal black stripe.

d. Abdomen deinsely and finely punctured, subojantue and clothed with distinct pubescence.

c. Iread coarsely punctured from side to side; occiput pireous or brown.

2192. QUINQLEVTTATA.

ce. Head smooth at middle.

$f$. Discal black stripes of clytra narrower tlan yellow one each side; head and body beneith always pale yellow; labrum pale.

2193. CAROLINIANA.

$f f$. Discal black stripes of elytra as wide or wider than the yellow one each side; head and metasternum usually more or less fuscous or piceous; labrum piceous.

2194. CRENICOLLIS.

dれ. Abdomen very sparsely punctured and shining, its pubescence scarcely risible; thorax smooth; head rough; epipleuræe black.

2195. GLABRATA.

cc. Elytra without a submarginal black stripe, the median stripe broad; thorax without spots.

2196. ABBREVIATA.

bb. Elytra without black and yellow stripes.

g. Elytra reddish, with a large discal black spot. 2197. DIScoIdEa. gg. Elytra blackish-blue or green.

h. Body beneath and legs entirely black; thorax with three spots arranged in a triangle; elytra punctate. 2198. TRIANgULARIS.

hh. Body beneath and legs, in part at least, jellow.

$i$. Hind femora entirely or in part piceous ; abdomen alone wholly sellow; elytra blue-black; head wholly piceous.

2199. XANTHOMELÆNA.

ii. Hind femora entirely yellow; abdomen piceous, its apex and sides rellow; head bicolored.

$j$. Elytra blue or violet; body oral.

jj. Elytra bright green; form more oblong.

2200. MELLICOLLIS.

2201. COLLATA.

2191 (6950). Disonycha Pennsilvanica fllig.. Mag. fur Insect., YI, 1S07, 146.

Oblong. nearly parallel. Head black, front rellow; thorax pale rellow. usually with three black spots, the central one larger, truncate in front, gradually narrowed behind; elytra whitish-yellow with the suture, a submarginal stripe and a median stripe not reaching the apex, black; antenne and under surface, except the prosternum and sides of abdomen, black: femora redtish-yellow; tibize and tarsi usually black or piceous. Thorax more than twice as wide as long, side margins rather wide, surface shining. nearly smootli. Elytra alutaceous, sparsely and finely but distinctly punetate, and in the female often feebly sulcate between the discal stripes. Length 6.5-7.5 $\mathrm{mm}$.

Throughout the State, common; more so in the northern counties. February 11-Octoher 29. Ocerrs on sedges and mints in moist meadows. Hihernates beneath corer along the borders of marshes and lakes.

The common form, as above described, was named uniguttata 
by Say. Along the margin of a cypress swamp in Kinox County there occurs a distinct variety, which differs from that above mentioned in having the head, antennx, legs and under surface (except the tip of abdomen) wholly black; thorax with only the median spot present; elytra with the black stripes proportionately wider, the disk not alutaceous, strongly bisuleate along the median stripe and very minutely and indistinctly punctate. Length $5-5.5 \mathrm{~mm}$. As the fauna about the swamp is largely Austroriparian in character, this may be the form mentioned by Horn (p. 203 of his Synopsis) as occurring in Florida and Ionisiana. According to Knab, it is the typical pennsyluanica as described by Illiger.

2192 (6949). Disonycha quinquerittata Say, Journ. Phil. Acad. Nat. Sci., III, 18:4, 85; ibid. II, 227.

Oblong-oval. Ifead yellow, occiput piceous; thorax yellow with normally five romided blatk spots arranged in a front row of two and a hind one of three, often with only the two-spot row present; elytra yellow with a narrow sutural stripe, a submarginal line, often incomplete at base and not joining the sutural at apex, and a narrow median stripe (often wanting), black; antennie piceous, the under side of the first three joints pale; under surface and legs reddish-yellow, the metasternum and tarsi piceous. Thorax twice as wide as long. front angles distinctly prominent, disk very finely and sparsely punctured and usually with a slight umbone on the outer dark spot. Elytra distinctly wider at base than thorax, surface finely and sparsely punctate. Length $6-9 \mathrm{~mm}$.

Throughout the State, frequent in the northern counties; Vigo and Clay only in the south. Nay 6-September 7. In Lake and Porter counties the form with the discal black stripe lacking occurs in numbers in the sand chune region on the leaves and flowers of a dwarf willow and the quaking asp. Almost all those from the northem part of the State are of this variety, while those from the south have the normal elytral markings. Listed as alternata Illig. 2193 (6918). Disonycila caroliniana Fibr., syst. Ent., 1775, 122.

Oval, slightly narrower in front. Head and thorax rellow, the latter with two piceons spots of variable size (rarely absent) on apical half; elytra rellow with a narrow sutural stripe and a marginal line not covering the-edge, black. these rarely united at apex; also with a median darls stripe narrower than the rellow spaces each side and not leaching apex; antennie piceous, the under side of three basal joints pale; under surfice and legs reddish-yellow, the tarsi and tips of tibise piceous. Thorax convex. more than twice as wide as long, sides feebly curved, margins narrow; surfice smootl. polished or very indistinctly and sparsely punctured. Elytra scarcely wider at base than thorax, surface rery finely alutaceous, finely and sparsely punctured. Length $5.5-6.5 \mathrm{~mm}$.

Lake County; rare. May 21. One in Webster collection labelled "Ind." 
$2194(10,416)$. Disonycha crenicoldess Say, Bost. Jouln. Nat. Ilist. I, 1485, 200 ; ibid. II, 66s.

Very similar to curolinimna. Ifead with occiput ustally in part jireous; thorax reddish-yellow with three piceous spots, aranged in il triangle, the front pair larger: elytral as in corolininna, the median blalck stripe as wide or wider than the yellow one cach side, the sutulal and mallginal ones joining at tip. Tlorax not more tlan twice as wide as long. jts surface, as well as that of elytra, nore distinctly alutaceous and more evidently punctate than in caroliniana. Length $5-6$ mm.

Vigo County; scarce. Hebruary 21-Nareh 18. Mibernates beneath partly huried logs in open woods.

2195 (6951). Disonycha glabrata Fabr.. Spec. Ins., I, 1781, 156.

Oblong-oral, surface rery shining. als if rarnished. Head often entirely black except the front. sometines nearly wholly yellow; thorax yellow, usuilly with a narrow median spot, sometimes an indistinct spot each side; elytra yellow, the suture, margins and a median stripe black: under surface and legs usually rellow, tips of tibiae and tarsi, and sometimes the hind portion of metasternum. piceous. Thor:ax more than trice as wide an long. malrgins hilrow, sulfalce smooth, shining. Elytral a little wider at base than thorax, very finely and sparsely punctate. Lengtl $5-5.5 \mathrm{~mm}$. (Figr. 522.)

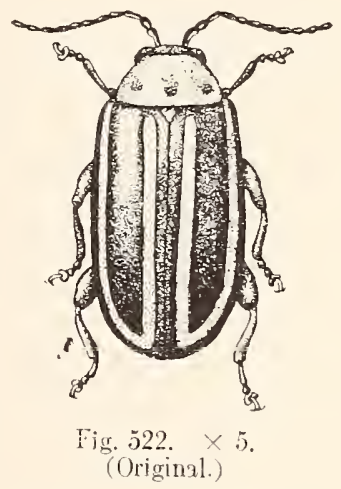

Throughout the State. common; more so in the southern counties. April 6-July 8. Taken by sweeping roadside herbage, especially the pigweel, Amarantus retroflexus L. Resembles pennsylranica, but smaller and more shining. The black median stripe of each elytron is distinetly wider than the yellow ones each side.

2196 (6954). Disonicha abbreriata Melsh., Proc. Phil. Acad. Nat. Sci.. III, 1847.163.

Oral, slightly oblong. Head, thorax, scutellum, under surface and femora, reddish-yellow: elytra paler yellow with a sutural stripe and a median one on each, both rather wide. black; antenne piceous. the two basal joints and the apical one paler: tibie and tarsi rellow, with a black line on outer side. Thorax nearly twice as wide as long. narrowed in front. sides curved, margins narrow. surface smooth. Elytra slightly widel at base than thorax, umbone distinct. surface finely alutaceous. very tinely and sparsely punctate. Length 6-8.5 $\mathrm{mm}$.

Southern half of State; scarce. April 9-September 29. Probable hibernates, as most of the specimens were taken heneath logs in the spring.

\section{7 (6955). Disonycha miscoidea Fab., Syst. Ent., II, 1798, 25.}

Oral. slightly depressed. Reddish-yellow; antenne. tibie and tarsi piceous; elytra with a broal oral sutural spot black, shining. Thorax 
twice as wide as long, narrowed in front, margins narrow; disk convex, smooth, shining. Elytra slightly wider than thorax, humeri almost obliterated; surface distinctly, finely and rather closely punctate. Length $5.5-7 \mathrm{~mm}$.

Dubois, Crawford and Spencer counties; scarce. May 10-June 22. Swept from low herbs along roadsides and from flowers of wild hydrangea. Horn gives its range as North Carolina to Texas. A member of the Austroriparian fauna.

2198 (6957). Disonicha triangularis Say, Jourm. Phil. Acad. Nat. Sci., IV, 182t, S4; ibid. II, 226.

Oval, rather depressed. Black: thorax above and beneath yellow, with the front pair of spots round, the hind one linear; elytra with a faint bluish tinge; antenne piceous, the three basal joints pale beneath. Thorax more than twice as wide as long. sides feebly curved, margins very narrow, surface alutaceous, rather finely, not closely punctate. Elytra a little wider at base than thorax, surface rather closely but distinctly punctate. Length 5-6.5 mm. (Fig. 521.)

Throughout the State, frequent; more so in the northern counties. April 17-October 23. Occurs beneath logs in spring. Adults said to be injurious to beets and spinach. Occurs especially on Chenopodium and other herbs in moist places.

*2199 (6958). Disonycha xanthoner ena Dalm., Analecta Ent., 1523, 79.

Resembles the preceding but

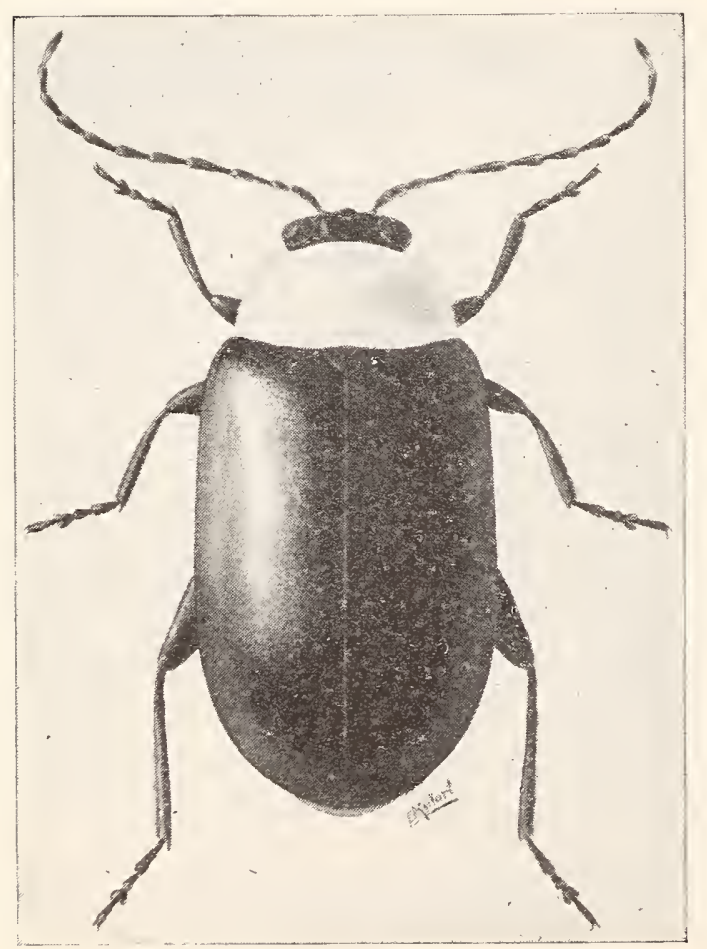
“ chickweed, Stellaria. Listed as collaris Fabr. usnally smaller and more oblong. Thorax entirely yellow; elytra black with faint greenish tinge; abdomen wholly yellow, mesoand metasterna black; femora usually yellow on basal half, sometimes wholly black; tibiæ and tarsi piceous. Thorax not twice as wide as long, surface almost smooth. Elytra wider at base than thorax, surface finely alutaceous, obsoletely and rery finely punctate. Length 4.5$5.5 \mathrm{~mm}$. (Fig. 523.)

Throughout the State; frequent. February 14-November 8 . Hibernates beneath mullein leaves and rubbish. Known as the "spinach fleabeet]e" on account of its injury to that plant. Feeds also on Chenopodium and 
200 (6958c). Disontera mellicolles Say, Bost. Jomrn. Nat. Mist., I, 18:55, 199 ; ibid. II, 66S.

Resembles closely the preceding. Oiffers by having the head blue-black and coarsely punctured between the eyes, the front yellow; femora entirely yellow; abdomen piceous at middle. with the apical segment and wide side margins yellowish. The elytra are sometimes nearly black, nore often with a distinct bluish tinge. Length t.j-.i minl.

Vigo, Marion, Perry and Posey counties, scarce; probably throughout the southern half of state. February 8-November 17. Hibernates beneath logs in low, moist places.

*2201 (6958a). Disonycha col.lata Fabr., Syst. Elent., I, 1801, 463.

Oblong-oral, subdepressed. Tertex and occiput black with faint greenish tinge, front yellow; thorax yellow above and beneath, without spots; elytra blue-green, shining; metasternum black; abdomen piceous, the last segment and the sides broadly yellowish; femora pale sellow, tibia at tips and tarsi piceous. Thorax and elytra rely finely alutaceous, the former minutely and sparsely punctate; the latter with fine, distinct, sparsely placed punctures. Length 4-4.5 $\mathrm{mm}$.

Fulton, Vigo and Posẹ counties; scarce. February 6-July 31. Hibernates with the preceding, which it closely resembles. Distinguished by its smaller size, more elongate form and more distinctly

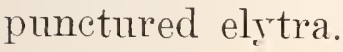

\section{Longitinsers Latr. 1829. (NL., "long + tarsus.")}

This and the three succeeding genera belong to a group, Aphthonce of the Halticini, having the form oval; antennæ 11-jointed; front coxal cavities open behind; thorax without trace of basal impressions; hind tibix grooved, at least near the apex, and terminated by a rather long spur; hind tarsi with last joint not inflated, the claws simple. The members of the genus Longitarsus are very small oral or oblong convex species, usually uniform dull rellow, brownish or piceous in hue, with the elytral punctures much confused; tarsi slender, the first joint of the hind pair nearly or fully half the length of tibir and as long as all the following joints united. The following species have been taken in the State:

\section{KEY TO INDIAYA SPECIES OF LONGITARSLS.}

a. Antennæe with joints 2.3 and 4 successively longer; inner wings always present.

b. Reddish-yellow, shining: thorax rery plainly broader than long; punctuation distinct. 
7b. Brownish or piceous, with a faint brouzed lustre; punctures of elytrat in rague rows.

2203. TURBATUS.

ua. Antennie with joints 2. . and 4 of equal length, or with the fourth not longer than second.

c. Surface entirely shining, not alutaceous; elytral punctures rather coarse; for'm robust; humeri well marked.

1. Color reddish-brown : form oblong-oval ; legs pale.

2004. ALTERNATUS.

dl. Color piceous, shining: form shorter, oval; legs piceous.

2205. ERRO.

cc. Surface more or less distinctly alutaceous; form rather elongate; humeri not prominent.

c. Color pale reddish-yellow; elytra not shining, the punctures rery indistinct.

2206. TESTACEL $S$.

ee. Color dark reddish-yellow to piceous; elytra shining, the punctures coarse and well marked.

2207. MELANERLS.

2202 (7011). Longitarsus subrufus Lec., Col. Kam., 1859, 26.

Oblong-oval, convex. Reddish-yellow, shining; antemne and legs pale reddish-yellow, the onter fire joints of former and hind femora slightly darkel. Thorax one-third wider than long, not namowed in front; disk convex. shining, rery sparsely and finely punctate. Flytra wider at base than thorax, umbone rather prominent; disk convex, punctures rather fine, not closely placed. Length 2.5-3 mm.

Vigo County; common locally on the stems and leaves of the false gromwell, Onosmodium carolinianum DC. June 15. Deseribed and known heretofore only from Kansas. Our largest species of the genus.

2203 (10.434). Longitarsus turbatus Horn, 'Trans. Amer. Ent. Soc, XVI, $1889,279$.

Oblong-oval, subconvex. Piceous or chestnut-brown, feebly bronzed; antemne piceous, the four basal joints pale; front and middle legs and hind tibia rellowish; hind femora brown. Thorax nearly one-half wider than long, slightly narrowed in front, sides feebly curred. surface smooth or nearly so; basal marginal line wanting. Elytra wider at base than thorax. umbone distinct, punctures rather coarse and close. Length $2.5 \mathrm{~mm}$.

Lake, Marion and Dubois countios; scarce. May 12-June 11. Resembles melanurus, but differs in the length of basal antennal joints, in the surface not being at all alutaceous, and in the much more prominent shouiders.

2204 (7015). Longrtarsus alternates Zieg., Proc. Phil. Acad. Nat. Sci..

II, $1846,271$.

Oblong-oval, moderately convex. Dark brick-red, shining. Antennie three-fourths the length of body. piceous, the four basal joints paler. Thorax one-thind wider than long. sides curved; disk convex, nearly smooth 
except along the base, where there are a few fine punctures. lintral wider at base than thorax, monbone feeble; punctures coarse, much ronfused, finer neal the sides. Length $2.5 \mathrm{~mm}$.

Taken only near Pine, Lake County, where it occurs beneath clumps of the prickly pear cactus. Nay 15-ilay 20.

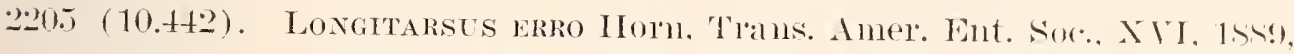
284 .

Oral, convex, rather robust. l'iceous. shining: antemie blakk, the hasal joints piceous. Thorax one-half wider than long, not narrowed in front, sides nearly straight: disk rely finely and slatrely punctate, the apjical region and a broad median space without punctures. Elytra widel at base than tholax. umbone prominent. surface coarsely and rather closely punctate. Length 1.S-2 mill.

Lake County ; rare. Mia! 1t. A member of the boreal fauna, described from White Fish Point, Isake Snper.ior.

*206 (7008). Longltarst's testacets Melsh. Proc. Phil. Acad. Nal. Sci., III, $184 \pi .166$.

Oblong-oral, moderately convex. Dull brownish-yellow. surface finely alutaceous and with a greasy aspect: antennie and legs pale brownish-rellow. Thorax one-third wider than long, not narrowed in front; disk moderately convex, very distinctly alutaceous, finely, sparsely and indistinctly punctate. Elytral rery little wider at base than thorax, umbone distinct. not prominent; surface finely and sparsely punctate. Length $2 \mathrm{~mm}$.

Throughout the State; conmon. February 10-November 28. Hibermates beneath logs. mullein leaves. etc. Taken by sifting in early spring and antumn and by sweeping roadside herbage.

2207 (7007). Loxgitarses melanures Melsh., Proc. Phil. Acad. Nat. Sci., III, $184 \pi, 166$.

Oblong-oral, moderately convex. Dark reddish-brown to piceous, alutaceous. shining; antenur red d is hbrown, apical half darker; front and middle legs dull yellow, hind femora brown. Thorax slightly wi d e r than long, not narrowed in front, sides feebly culved; disk convex, slightly wrinkled near base, sparsely and rather coarsely punctured. Elytra evidently wider at base than thorax, umbone distinct, the punctures coarse, deep and rather close. Length $2-2.5 \mathrm{~mm}$. (Fig. .54$.

Throughout the state, frecpuent

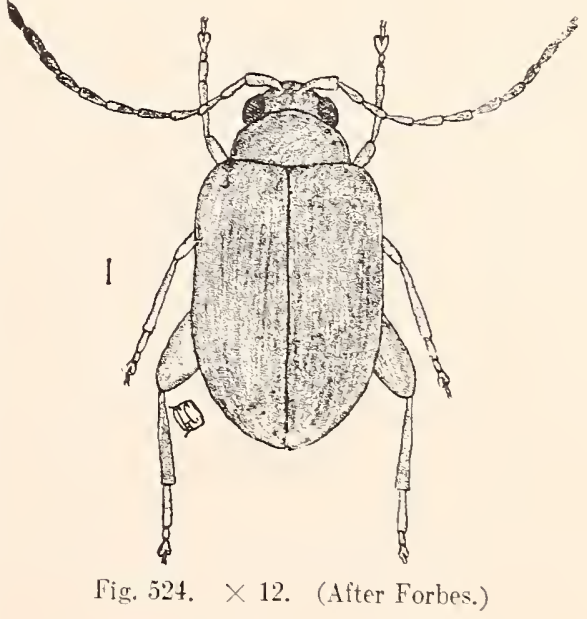
in the southern portion: rare in the northern counties. March 20 - July 8. Taken by beating and sweeping roadside regetation. 


\section{Glyptina Lee. 1859. (Gr., "seulptured.")}

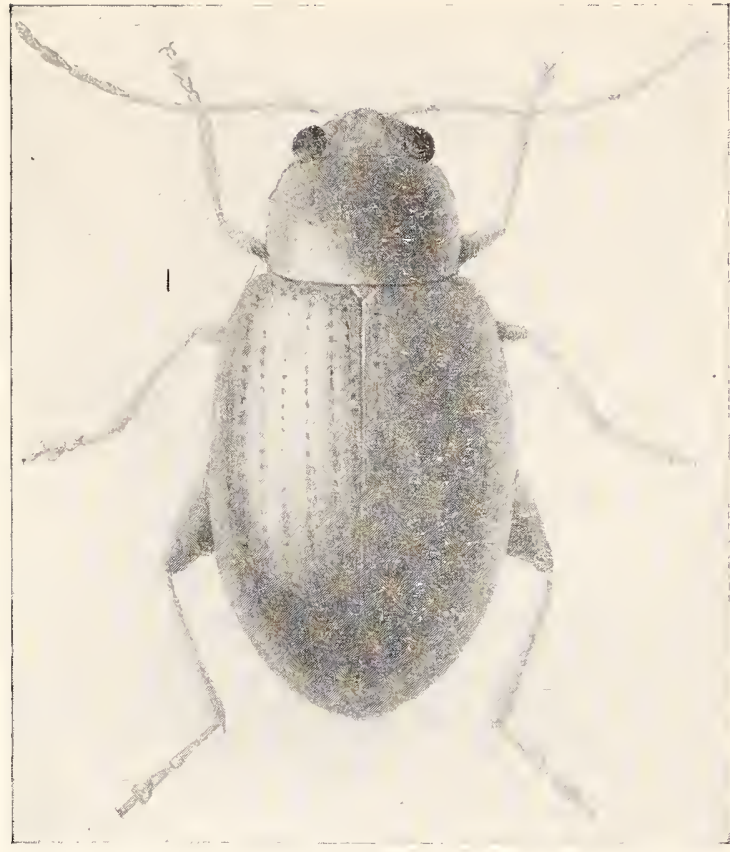

Fig. 525. Glyptina brunnea Horn. $\times 25$. (After Forbes.)
Small oblong or oval, dull yellow or blue and yellow species, resembling Longilarsus in general appearance, but having the elytral punctures in distinct rows on base and sides, often confused at tip ; the first joint of hind tarsi not more than onethird the length of tibix; antenne siender, as long as half the body, first joint cylindrical, second conical, more than half the length of first, joints 3 to 7 gradually increasing in length, 8 to 10 shorter, 11 th longer Four of the seven species and acute at tip; tarsal claws simple. Four of

KEY TO INDIANA SPECIES OF GLYPTINA.

a. Elytra yellowish or reddish-yellow.

$b$. Strix on sides of elytra, especially the ninth, deeper than those of the disk; body beneath brown. (Fig. 525.) BRUNNEA.

bb. Strix on sides faint; body beneath brownish-piceous, very rarely pale.

2208. SPURIA.

a . Elytra blue, with metallic lustre; head and thorax reddish-yellow.

$c$. Thorax somewhat wrinkled, vaguely punctate; elytral striæe much confused at apex.

2209. BICOLOR.

ce. Thorax smooth, or rery finely and sparsely punctate; elytral striæ entire, not confused.

2210. CYANIPENNIS.

Glyptina brumea Horn, reddish-brown, legs and antennx paler, length 1.8-2 mm., is known from Wisconsin, Georgia and Texas.

2208 (7016). Glyptina spuria Lec., Col. Kan., 1859, 26.

Oblong-oval, moderately convex. Above pale brownish-yellow, shining; beneath piceous; antennic reddish-yellow, outer joints darker; legs pale. Thorax one-half wider than long, not narrower in front, sides obliquely truncate near front angles and angulate in front of middle; disk rather coarsely and sparsely punctate. Elytra distinctly wider at base than thorax, feebly striate, the stria coarsely and closely punctate; intervals wider than strix, slightly convex, each with a low of minute punctures. Length $1.5-1.7 \mathrm{~mm}$. 
Throughout the State; common. March 2(). July 2. Taken by sifting in early spring and later by sweeping roadside herbage.

2209 (10,449). Glyptina Bicolor Horn, 'Trans. Amer. Ent. Soc., XVI, 1SS9, 289.

Oblong-oval, somewhat narrowed in front, convex. Head, thorax and legs pale reddish-brown; elytra rather dark metallic blue; under surface piceous; antenne with basal joint brown, next three reddish-yellow, outer joints piceous. Thorax one-third wider than long, narrower at apex, the punctures fine and very indistinct. Elytra not wider at base than thorax, with regular rows of coarse, dcep, rather close-set punctures, except at apex. Length 2.5-3.5 mm.

Lake and Martin counties; frequent in the former, scarce in latter. April 30-July 30.

2210 (7018). Glyptixa cranipennis Crotch, Proc. Phil. Acad. Nat. Sci., 1873,65 .

Oblong-oval, convex. Resembles the preceding in color, the antennie but little darker towards tip. Tholax as in bicolor, the front angles more obliquely truncate, sides angulate in front of middle; disk with a few fine, scattered punctures. Elytra slightly wider at base than thorax, umbone feeble; stria rather coarsely and closely punctured; intervals slightly conrex, punctate as in bicolor. Length $2 \mathrm{~mm}$.

Posey County ; rare. April 18-June 3. Known heretofore from Florida and Texas. Beaten from foliage of the Virginia creeper (Parthenocissus quinquefolua L.)

\section{Aрнтнемл Chev. 1834. (Gr., "smperabundant.")}

This genus is represented in Indiana by a very small, oblongoval, reddish-brown species, having the antenne rather stout, longer than half the body, third joint more slender and a little longer than second, 4 to 7 gradually longer, 8 to 10 slightly shorter, 11th suddenly constricted and arute at tip; apex of hind tibiæ modified as mentioned in generic key.

2211 (6992). Aphthora msolita Melsh., Proc. Phil. Acad. Nat. Sci., III, $1847,168$.

Oval, the elytra nearly quadrate, conrex. Brownish-red, strongly shining; sixth to ninth joints of antennæ fuscous, the others dull sellow. Thorax one-fourth wider than long, not narrowed in front, front angles obliquely truncate, sides nearly straight, with distinct angulation in front of middle; disk smooth and polished. Elytra distinctly wider at base than thorax. humeri and umbones prominent, surface with faint rows of rery minute punctures. Length 2 mm.

Dubois and Posey counties; rare. April 12-1Гay 13. Beaten from Indian currant, Symphoricarpus vulgaris, Michx. 


\section{Phrllotreta Cher. 183t. (Gr.. "leaf+bore.")}

Small elongate-oval or oblono-oral subconrex species, separated from allied genera br characters pertaining to the hind tibiæ as mentioned in the generic ker. Ther have the head small. deeply inserted in the thorax: antenna half as long as bodr, or slightly longer; thoras broader than inng and somerhat narrowed in front: elytra oral, the humeri nerer prominent. usually marked with a rellowish white sinuous stripe; first joint of hind tarsus about onethird the length of tibie and ernal to the other three: claws simple. The males hare the last rentral more or less impressed at tip. The following species have been taken or should occur in the State. All feed upon cruciferous plants, both cultivated and wild:

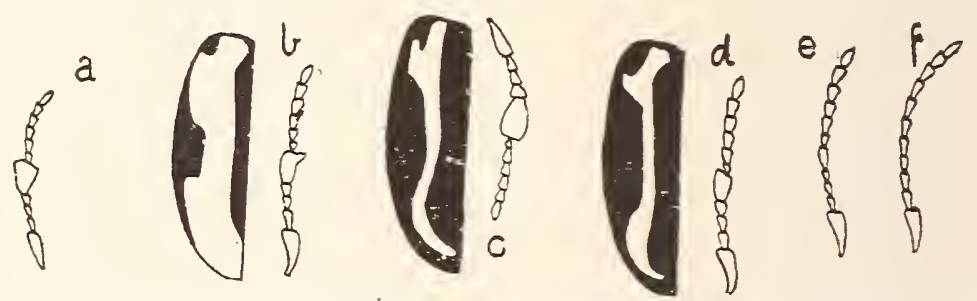

Fig. 526. a, Antenna of Phyllotreta ulkei, male: b, P. robusta and antenna of male; $c, P$. sinuata and an tenna of male; $d, P$. vittata and antenna of male; $e$, antenna of female of $P$. robusta. sinuria and vittata; $t$, antenna, male and female of picta, bipustulata, etc. (After Horn.)

\section{KEY TO INDIANA SPECIES OF PHTLLOTRETA.}

a. Fifth joint of antenna longer than either the fourth or sixth; the male with the fifth joint always, and sometimes the fourth, thickened and elongate.

b. Elrtra piceous, without stripes; sixth joint of male antennæ as long as the fourth and celindrical. (Fig. 520, $a_{0}$ )

bъ. Elstra piceous, each with a rellowish stripe.

c. Elstral stripe narrower; lower angle of fifth joint not prolonged.

d. Stripes of elytra parallel with the suture on the basal half. (Fig. 526, c.)

2212. SINUATA.

dd. Stripes of elytra incurred at base, approaching the scutellum.

(Fig. 526. d.) 2213. пIтTATA.

cc. Elstral stripe broad, at its apical third reaching side, apex and suture: lower angle of fifth antennal joint distinctly prolonged. (Fig. 526, 万.)

2214. ROBUSTA.

a a. Fifth joint of antenne nerer longer than sixth; antennæ not different in the sexes. the joints gradually but slightly stouter from second to tip. (Fig. 526, f.)

e. Elytra black and rellow.

f. Elstra each with two oral rellow spots. one on humerus, the other subapical.

2215. BIPL'STLLATA.

ff. Elstra dull rellow with a common sutural stripe and narrow marginal line. black.

2216. ARMORACI.玉.

ee. Elytra unicolorous. 
y. Elytra binish-green, metallid: head and thorax bright reddish-yellow.

2217. PJCTA.

9y. Elytral and thorax halck or piceons, with or without metallic lustre.

h. Elytril whth fine and coalse punctures, the latter arrangent in rows near the suture and within the humeri.

hh. Flytral uniformly punctate.

221S. ENEICOLLIS.

$i$. Color black; thorax aluticeous.

LINDA HLI.

ii. Color dark blue; thorax not alutaceous.

2219. LEWISII.

I'. ulkei Horn, piceons-blaci, shining, legs, except the hind femora, reddish-brown, length $2.5 \mathrm{~mm}$, was described from Ohio.

*2212 (7022). Phyllotreta sinuata Steph., Iilust. Brit. Entom., IV, 297.

Elongate-oral, subconvex. Piceous. shining; elytra each with a narrow, dull yellow stripe. parallel with the suture at base, and with a short, broad branch behind the humerus, the apical third strongly sinuate; antenlie piceous, the three or four basal joints paler. Thorax nearly twice as wide at base as long, distinctly narrowed in front; disk convex. surface finely alutaceous, rather coarsely and sparsely punctate. Elytra slightly wider than thorax, with the punctures coarser and more close-set than on the latter. Length $2.5 \mathrm{~mm}$. (Fig. 526, c.)

Throughout the State; coinmon. Narch 19-November 1. Probably hibernates. Taken by sifting in early spring and late autumn and by beating hickory and sweeping grass in summer.

2.213 (7023). Phyllotreta vittata Fabr., Syst. Eleut., I, 1801, 469.

Smaller than simuata and with the yellow stripe of elytra narrow at middle, incurved at base, broader and slightly incurved at tip; legs piceous, tibire and tarsi brownish-yellow. In the males the fourth joint of antenne is broader than the third, fifth a little broader and nearly equal in length to third, wherens in simuata the fourth is much broader than the third, and the fifth longer than the two preceding together and much dilated. Length $2 \mathrm{~mm}$. (Fig. 526, d.)

Throughout the State; frequent. May 12-September 25. Taken by sifting and sweeping. Occurs on cabbage and other cruciferous plants, as the turnip, radish, mustard, shepherd's purse, pepper grass, etc.

2214 (7031). Phyllotreta robusta Lec., Proc. Amer. Phil. Soc., 1Sis, 614.

Oblong-oral, similar in form and size to rittuta. Piceous, shining; elytra each with a broad yellowish stripe parallel with the suture for most of its length, dilated at base to form a broad process behind humerus and incurred towards scutellum, the apical third broadly expanded. Thorax nearly twice as wide as long, coäsely, deeply and closely punctate. Elytra slightly wider and more coarsely punctured at base than thorax, more finely punctured towards apex. Fourth and fifth antennal joints of male much broader than third, the fifth as long as the two precedi, $\mathrm{g}$. its apical free angle prolonged. Length $2 \mathrm{~mm}$. (Fig. $52 \%$; ) 
Lake County; rare. May 12-May 30. Described from Garland, Colorado.

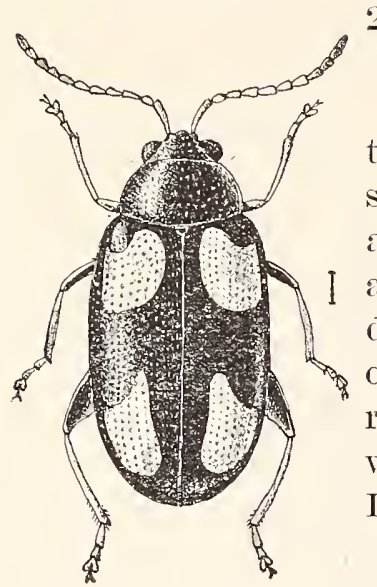

2215 (7026). Phyllotreta bipustulata Fabr., Syst.

Eleut., I, 1801, 464.

Oblong-oval, rather robust. Piceous without metallic lustre; elytra each with a large oval humeral spot, touching base but not including the umbone, and a subapical more elongate and narrower spot, yellow; antenne piceous, the basal five joints paler; legs reddish-yellow, the hind femora darker beneath. Thorax one-third wider than long; disk finely alutaceous, rather finely and sparsely punctate. Elytra distinctly wider at base than thorax and with coarser punctures. Length 2-2.5 mm. (Fig. 527.)

Throughout the State, frequent; more so in Fig. 527. (After Chittenden the southern counties. April 14-July 13. Taken in Bull. 33, N. Ser., U. S. Div. Ent.)

by sweeping and sifting.

2216 (一). Phyllotreta armoracie Koch, Eint. Heft., II, $1803,75$.

Elongate-oval, convex. Head, thorax and under surface black, shining; elytra dull yellow, with a common sutural stripe and very narrow side and apical margins, black; antennæe and femora piceous, the basal three joints of former and tibise and tarsi dull brownish-yellow. Thorax one-third wider than long, sides curved and rounded to apex; surface finely and sparsely, that of elytra more coarsely and densely, punctate. Length 3-3.5 mm. (Fig. 52S.)

A recently introduced European species, several specimens of which have been taken by Wolcott in the washup of Lake Michigan, near Pine, Lake County.

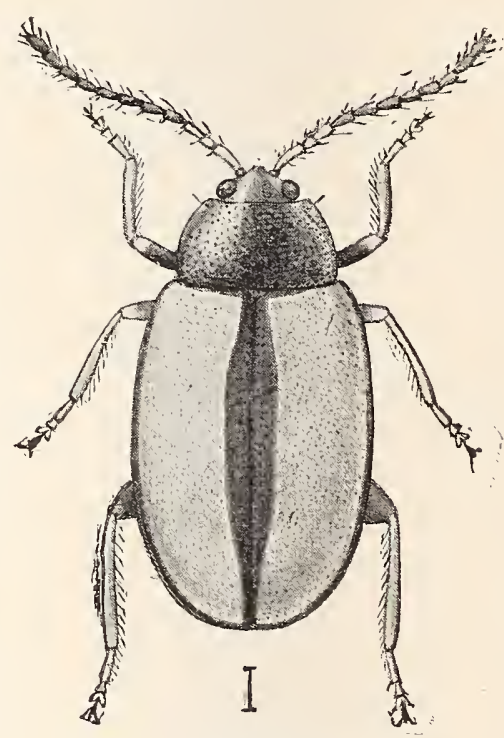

Fig. 528. (After Chittenden in Insect Life VII.) May 28. From its specific name I judge that it preys upon horseradish.

2217 (7019). Phyllotrena picta Say, Journ. Phil. Acad. Nat. Sci., IV, 1824, S7; ibid. II, $22 \mathrm{~S}$.

Oval, slightly oblong, feebly convex. Head and thorax pale reddishyellow; elytra bright bluish-green, shining; antennæ pale, the outer joints fuscous; abdomen and metasternum piceous; legs yellowish, the hind femora often darker. Thorax nearly twice as wide as long, surface very finely, sparsely and indistinctly punctured. Elytra slightly wider at base than thorax, umbone rather prominent, smooth; surface finely, closely and indistinctly punctured on disk, smoother at sides and apex. Length 2 $2.5 \mathrm{~mm}$. 
Tippecanoe, Vigo, Orange and Crawford counties; scarce. .Tune 1-June 25. Taken by sweeping roadsicle herbage.

2218 (7029). Phrllotreta aneicollis Crotch., Proc. Phil. Acad. Nat. Sci., $1873,67$.

Elongate-oval, rather slender. Piceous; head and thorax with a cupreous lustre; elytra with a greenish tinge; legs piceous. tibia and tarsi paler. Antennie half as long as body, joints 2-5 reddish-yellow. Thorax one-hall wider than long, narrowed in front; disk alutaceous, rather finely and closely punctate. Elytra wider at base than thorax, punctate as mentioned in key. Length 2-2.5 $\mathrm{mm}$.

Narion Country ; rare. July 14. Swept from herbage along the margin of a woodland pond. Known from Kansas and Texas.

$P$. lindahti Dury, last ventral of male with a deep, rounded depression which extends forward in triangular shape through the next to last rentral, length $2.5 \mathrm{~mm}$., was described from Cincinnati.

2219 (7028). Phrllotreta lewisil Crotch., Proc. Phil. Acad. Nat. Sci., $1873,66$.

Elongate-oval, moderately convex. I'iceous; elytra with a bluish tinge; antennæ piceous, the basal joints pale; tibise and tarsi brown. Thorax twothirds wider than long. narrowed in front. sides broadry curred. surface rather finely and sparsely punctate. Elytral punctures coarser than those of thorax. Last rentral of male with a broad, triangular impression. Length $2-2.5 \mathrm{~mm}$.

Two specimens in Webster collection labelled "Ind." Known heretofore from Illinois westward.

\section{Hatíca Geoff. 1764. (Gr., "leaping.")}

Oblong or oval, medium-sized, blue, green or bronzed, rarely reddish-brown, species, having the head short, usually deeply inserted; antennæ half as long as body, joints 2,3 and 4 gradually longer except in rufa; thorax usually one-half wider than long, broadest at base, which is curred and with a more or less distinct transverse line just in front; side margins slightly thickened near front angles; elytral punctures confused; front coxal carities open behind, the prosternum rather narrow between the coxæ; hind tibiæ not or feebly sulcate, terminated by a short spur; tarsal claws broadly dilated at base.

The genus is a difficult one, and the species can never be determined with any degree of certainty withont a fair number of specimens, some of which must be males. Unfortunately, this sex is much less abundant than the females. The following species have been found or probably occur in the State:

[76-23402] 


\section{KEI TO INDIANA SPECIES OF HALTICA.}

u. Body above reddish-rellow. broadly oral: elstra smooth. 22:0. RUFA.

a . Body above blue, bronze. green or cupreous, more or less metallic.

b. Elçtra with a longitudinal fold or costa along the sides: color dark blue.

2221. BIMARGIXATA.

67. Elytra without fold.

$\therefore$ Antenmir and legs ficeous. more or less metallic.

1. Thorax with a deep groove in front of base which extends cumpletcly across the thorax.

c. Larger slecies. $4-5.5 \mathrm{~mm}$ : usually blue : form robust; thorax rery distinctly wider at base.

2202. CHALTBEA.

ce. Smaller. 3-3.5 mm. : color distinctly metallic brass green, blue or bronze: form more elongate: thorax scarcels wider at base.

2223. IGNITA.

d1. Thorax with a moderate. sometimes obsolete. groove near base. which is nerer entire.

f. Humeral angles of elrtra well marked, the umbone moderately prominent with a depression behind it: transrerse imiression of thorax deep at middle. eranescent on sides.

(\%. Brilliant cupreous with violet or purplish reflections.

4\%. Blue, head more prominent: form more robust.

CARINATA.

TICARIA.

$\mathrm{ff}$. Humeral angle of alstra rounded, the umbone feeble: transverse impression of thorax faint.

h. Color brilliant coppers red: larger. more robust. more broadIT oral.

2024. CLPRASCEXS.

h/. Color greenish or brasse black; smaller. more slender, elongate-oblong.

2205. ENESTEXS.

c. intenne and legs in great part reddish-rellow. in striking contrast with the color of the upper surface.

i. Fntire upper surface uniform in color and with metallic lustre.

j. Form oblong-oral. rery conrex: elstra scarcely alutaceous. the punctures distinct on basal half.

2226. FLSCO.EXEA.

ii. Form elongate-oblong. much less conrex; elstra distinctle alutacenus, the punctures minute and indistinct throughout.

2227. KरABII.

ii. Head and thorax reddish-rellow. elstra metallic blue: thoracic impression deep and entire.

BLRGESSI.

\subsection{0 (6959). HALTICA RCFA I11. Mag. fur Insect. VI. 1507. 153.}

Oral, broader behind. moderately convex. Dull reddish- or orange-rellow abore. piceous beneath: antenne and legs piceous. the hind femora paler at base. Autenne half as long as body. third joint distinctly longer than fourth. Thorax neary twice as wide at base as long. feebly narrowed to the front. margins rery naror: ante-basal impression brand and shallow: surface sparsely and finels punctate. Elstra slightls wider at base than thorax: umbone feeble. surface indistinctly and sparsels punctate. Length +.5 $\mathrm{mm}$.

Lake and Dubois counties: rare. May 26--15ar 30. Beaten from ash. 
2202 (6960). Ilaltica bimargixata Say. Jomm. Phil. Acad. Nat. Sci., IV, 1824,85 ; ibicl. II, 226.

Oblong, subparallel. Abore dark blue. moderately shining; under surface and legs blue-black, antenne piceous. Thorax one-halt wider than long, margins rers narrow, the ante-basal depression deep, reaching the sides and joining the marginal depression : surfice distinctly alutaceous. sparsely punctate. Elytra wider at base than thorax. with a prominent fold extending from umbone to near apex; surface finely, rather sparsely and indistinctly punctate. Length $5-6 \mathrm{~mm}$.

Northern half of State, frequent; not taken south of Vigo Countr. Nay 20-August 26. Occurs on knotweed or smartreed in moist localities.

\section{*22022 (6961). Haltica chalybea Ill. Mag. fur Insect. VI. 1807. 115.}

Oral, rather robust. Metallic blue, shining. rarely cupreous or greenish: under surface and legs blue-black: antemie piceous, the basal half with metallic lustre. Thorax a little more than half wider than long. margins narrow, slightly thickened in front; disk conrex, the ante-basal impressed line rather deep, extending from margin to margin; surface with minute scattered punctures. Eistra scarcely wider at base than thorax, umbone rather prominent. smooth;

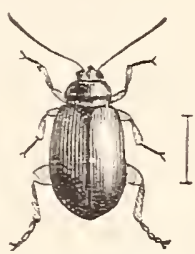

Fig. 529

(After LeBaron.) surface sparsely punctate, nearly smooth near apex. Length $4-5 \mathrm{~mm}$. (Fig. 529.)

Throughout the State; common. Narch 1t-December 10. Hibernates beneath bark and rubbish; mating April 12. Occurs on the wild grape and poison iry and known as the "grape fleabeetle," often doing considerable clamage to the cultirated rine. Readily controlled by spraying with arsenites when the larvie are discovered.

2223 (6963). Haltica Igrita Ill. Mag. fur Insect., VI, 1807, 11 .
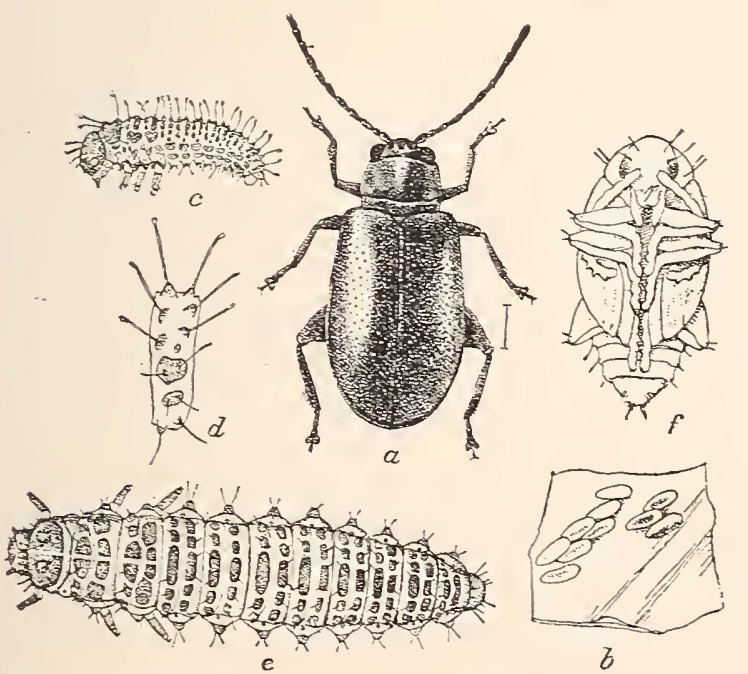

Fig. 530. $a$, Beetle; $b$, egg mass on bit of leaf; $c$, newly hatched larra; $d$, first abdominal segment of same; $e$, larra; $f$, pupa: all $x$ S. (After Chittenden in Bull. 23, X. Ser., U. S. Dir. Ent.) apex. Length $3-4 \mathrm{~mm}$. (Fig. 5̄30.)
Oral, slightly oblong. subdepressed. Color exceedingly variable from a coppery golden lustre. through greenish to dark blue: under surface and legs colored as above. Thorax one-half wider than lons. rery little narrowed in front, sides feebly curred. ante-basal impression deep. extending from margin to margin: surface minutels and sparsels punctate. Elrtra distinctlr midel at base than thorax, umbone rather prominent. limited within by a delnession: surface distiuctIy and sparsely punctate near base, gradually smoother to 
Throughout the State; common. May 11-October 6. Occurs by thousands on the foliage of the water purslane, Ludwigia palustris Ell.; also on foliage of many other plants. Said to attack strawbery and rose-bushes.

H. carinata Germ., length $3.5-4.5 \mathrm{~mm}$., and H. vicaria Horn, length $4.5-6 \mathrm{~mm}$., last ventral of males in both with a deep elongate impressed line, ale said to occur from New England westward to Arizona. The former has been recorded from Cincinnati.

2024 (-). HALTtCA CUPRAscexs sp. nor.

Oral. strongly convex. Coppery red, strongly shining: antenne. legs and under surface piceous-bronzed. Thorax about one-third wider than long. scarcely nilrowed in front. sides feebly curved, margin narrow, thickened at the front angles; disk finely alutaceous, sparsely and minutely punctate, the ante-basal impression rery shallow, evident only at middle. Elytra one-third wider at base than thorax, sides broadly curred; surface finely and sparsely punctate, very indistinctly so on apical third. Length $3.5-$ $4 \mathrm{~mm}$.

Three specimens from beneath rubbish on beach of Lake Michigan, near Pine, Lake County. May 5-May 21. Probably occurs on cottonwood.

2025 (6972). HALTICA ENESCENS sp. nor.

Elongate-oblong. conrex. Uniform brassy-greenish abore and beneath; antenne piceous-bronzed, third and fourth joints subequal. Thorax onethird wider than long; sides feebly curved. slightly sinuate near hind angles; disk minutely and sparsely punctate, the ante-basal impression very faint, extending almost from side to side. Elstra together one-third wider than thorax, their sides parallel to apical fourth. then rounded to tips; surface finely and sparsely punctate. Last rentral of male with an elongate impression extending from apex half way to base. Length $3-3.5 \mathrm{~mm}$.

Starke County ; rare. June 18.

2296 (-). Haltica fuscomena Melsh., Proc. Phil. Acad. Nat. Sci., III, 1847,165 .

Oblong-oral. convex. Olivaceous green or bronzed, strongly shining: under surface and hind femora piceous with bronzed lustre; antennæ and legs reddish-yellow, the former with apical half darker. Thorax subquadrate, very little wider than long. not narrower at apex than base: sides very feeblr curved; disk convex, rery finely alutaceous, sparsely and minutels punctate. Elytra slightly wider at base than thorax, less than trice as wide as long, umbone not distinct; surface distinctly and sparsely punctate near base, smoother near apex. the punctures sometimes in more or less evident rows. Length 2.5-3 $\mathrm{mm}$.

Lake. Koscinstro, Putnam and Jefferson counties; scarce. April 22-September 25. Occurs on the evening primrose, Enothera biennis L. 
22027 (-). HALTICA KNABIL SI\%. HOV.

Elongate-oblong, subparallel. Metallic olivaceous, notlerately shiuing; under surface and hind femora piceous, bronzed; antenne, front and middle legs, hind tibise and tarsi reddish-yellow, the outer joints of antennit fuscous at tips. Thol'ax one-half wider than long. sides moderately curved; ante-basal impression narrow but deep, extending from side to side; sulface distinctly alutaceous, finely and slarsely punctate. Flytra more than twice as long as wide, sides paratlel to apical third. thence rounded to tips; surface sculptured as mentioned in key. Length $3-3.5 \mathrm{~mm}$.

Described from eleven specimens taken in Lake and Starke counties. May 19-September 27. Occurs on low herbs in damp, sandy localities. From fuscornca this may be at once separated by the much longer, more parallel and less convex elytra, which are at the same time less shining, more strongly alutaceous and much more finely punctuate on basal half. The thorax is wider, with deeper ante-basal impression. Named in honor of Frederick Knab, of Washington, D. C., who has given me much aid in my study of the Chrysomelidx.

H. burgessi Crotch, length $1.5-1.8 \mathrm{~mm}$, is a southern form which has been recorded from Cincinnati.

\section{Lumperaltica Crotch. 1873. (Gl., "wolf + leaping.",).}

This genus contains two small species, one of which has been taken in the State, while the other doubtless occurs. They have the front carinate between the antenns and with flattened tubercles between the eyes; antennæ slender, longer than half the body, first joint stout, second small, oval, third twice as long, joints 3 to 10 equal; thorax convex with a vague transverse basal impression; epipleura reaching nearly to sutural angle; front coxal cavities open behind; first joint of hind tarsi as long as the next three.

\section{KEY TO SPECIES OF LUPERALTICA.}

a. Elytra very indistinctly punctate; color above varying from dull yeilow to dull blue; front coxie contiguous.

FUSCULA.

aa. Elytra ver'y evidently punctate, bright metallic blue; front coxie separated.

222S. SENILIS.

L. fuscula Lec., length 2.5-4 mm., is said to occur" from Pennsylvania and Virginia to Iowa and Kansas."

$222 S$ (7005). Ifperaltica senilis Say, Jomrn. Phil. Acad. Nat. Sci., IV. 1824. S 7 ; ibid. II. 228.

Elongate-oblong. subconvex. I'ale dull yellow, the head and thorax sometimes clouded with fuscous; elytra metallic blue, the suture and epi- 
pleur:e yellow; antennxe usually fuscous, the basal joints pale. Thorax nearly twice as wide at middie as long; surface finely alutaceous, minutely and sparsely punctured. Elytra one-half wider at base than thorax, umbone distinct; surface rather closely and irregularly punctate. Last ventral of male Hattened, truncate at apex and with a short, acute process at middle. Length $3.5-4 \mathrm{~mm}$.

Putnam County; scarce. July 25. Swept from flowers of the darkey-head, Rudbectia triloba L. Ocenes from Pennsylvania to Illinois.

\section{LACTica Er. 1847. (L., "milk.")}

Small oval yellow or blue and yellow species having the head inserted in the thorax as far as the eyes; antennæ longer than half the body, third joint shorter than fourth, joints 4 to 10 equal, 11th very little longer. Thorax with a deep, transterse impression noar the base, which is bent at each end abruptly toward the base; front coxal cavities open behind; tarsi more than half the length of the 1ibix, the claws appendiculạte.

\section{9 (6976). LAC'TICA iris Oliv., Ent., VI, 1808, 702.}

Oval, slightly oblong, moderately convex. Head and tholax yellow: elytra deep violet blue, shining; antenne piceous, three basal joints pale; thorax beneath and front and middle legs pale yellow: metasternum, abdomen and hind legs piceous. Thorax about twice as wide as long, margins nariow; disk convex, not risibly punctate. Elytra not wider at base than thorax, umbone rather prominent, surface very finely punctate. Length 3.5$4 \mathrm{~mm}$.

Posey County; rare. Septomber 5. One of the prettiest of our small Chrysomelids.

Diphaulaca bicolorata Horn, head, thorax and legs reddish-yellow, elytra and abdomen piceous-purple, length $2 \mathrm{~mm}$., is known from Michigan, Georgia. Kansas and Lonisiana.

\section{LX. 'Trichaltica Harold. 1876. (Gr., "hair + leap.")}

This genus comprises one small, oblong reddish-yellow and blue species, differing fron Lactica mainly by the elytral punctures being much coarser and arranged in ten distinct rows. Front of head with two distinct tubercles; outer joints of antenne slightly thicker, joints 1. 4, 5 and 11 loneer than the others, which are equal. 


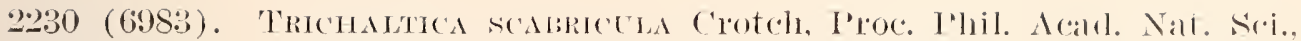
$187: 31$.

Oblong, nearly parallel, moderately ronvex. Reddisl-yellow; elytra blue; antennze piceous. Thorax more than one-half wider than long, not nanowed in front. hind angles distinct; disk convex, shining. very sparsely and coarsely punctured. Elytral wider at base than thorax: disk slightly flattened at midlle. with a short scutellan and ten long lows of coallse, deep. rlesely placed punctures; intervals malower than the striae and hearing sparse, short, semiereet hails. Lemeth 2.5-3.5 mm.

Southern third of State; fresuent. May 6-June 24. The thorax and under surface are sometimes of a Vandrke brown, and the hairs of elytra are so small as to be visible only from the side with a strong lens. Oecurs irom Ohio to Texas.

Sphrerodermu opima Lee., tihie and tarsi redaish-brown, length $2.5 \mathrm{~mm}$, occurs in Illinois, North Carolina and Texas.

\section{Subtribe B. (CHжTocnemini.)}

The members of this subtribe are separated from the preceding only by the closed cavities of the front coxæ. They are, for the most part, very small oval or oblong species, with the upper surface usually uniform in color. Although the two subtribes are each probably represented in the State by about the same number of genera, the present one has much the fewer species.

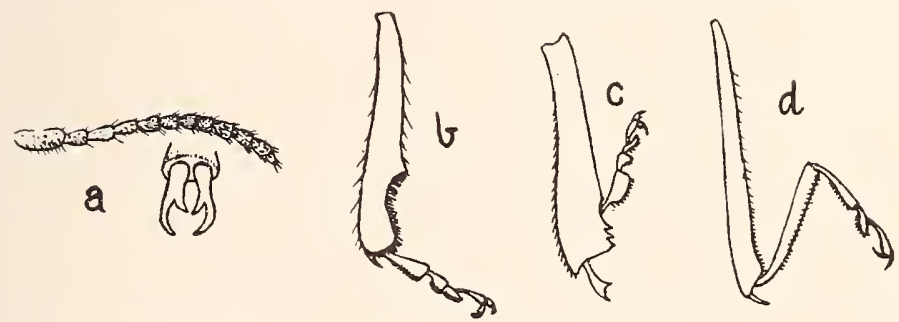

Fig. 531. $a$, Antenna and claws of Blepharida; $b$, hind tibia and tarsus of Chatocnema; $c$, same of Dibolia; $d$, same of Psylliodes. (After Horn.)

KEY TO INDIANA GENERA OF HALTICINI, SUBTRIBE B.

a. Last joint of hind tarsi globosely swollen; elytra with punctures in rows; hind tibire with one spur.

b. Thorax not impressed; body hairy; hind tibia with but one carina.

LXI. HYPOLAMPSIS.

bb. Thorax with a transverse impression near base: body glabrous; hind tibiæ with two earine on the outer side. LAII. PAchroxychus. aa. Last joint of hind tarsi not inflated, usually slender. sometimes thickened when viewer from the side.

c. Antenn: 11- or 12-jointed: hind tarsi inserted at the end of the tibire. 
d. Antenne 12-jointed, distant at base; tarsal claws bifid (Fig. 531, a) ; form robust, Chrysomela-like, larger. 5-6.5 mm.

LXIII. BLEPHARIDA.

dd. Antennæ 11-jointed, close together at base; claws simple or dilated; smaller, not orer $4.5 \mathrm{~mm}$.

$e$. IIind tibice sinuate near apex and with a distinct tooth on the outer margin (Fig. 531. b) ; thorax without an impression in front of base; first and second rentral segments closely united; elytral punctures in regular rows.

LAIV. Ch.etocnema.

ce. Hind tibiac without sinuation or tooth.

$f$. Thorax with distinct transrerse impression in front of base; elytral punctures in rows.

g. Elstra without hairs.

h. Form more or less orate; antennæe shorter than bods: transverse groove of thorax limited on each side by a lengthwise impression.

LAVi. CREPIdodera.

hh. Form elongate, parallel; antenna as long as or longer than body ; thoracic groore not limited.

LXVil. Orthaltica.

gg. Elytra with rows of stiff hairs (setie) on the intervals; form short, orate.

LXYIII. EPITRIX.

ff. Thorax withont a tiransverse impression in front of base.

$i$. Hind tibial spur small and slender; form elongate or elongate-oral.

j. Thorax with a short, deep longitudinal impression each side near base; elytral punctures in rows.

LAix. Mantura.

ji. Thorax without any impression; elytral punctures confused.

IAX. Srstena.

ii. Hind tibial spur broad, emarginate or bifid at apex (Fig. $531, c)$ : elytral punctures in rows; form oval or oblongoval, convex.

LXXI. Dibolia.

cc. Antenm 10-jointed; hind tarsi inserted on the outer side of the tibire abore the apex (Fig. 5:1. d) ; elytral punctures in rows.

LXXiI. PSYLLIODES.

\section{Hypolamesis Clark. 1860. (Gr.," "sub + red.")}

Small oblong-cval, convex, brown or piceous hairy species, having the antennæ half the length of body, the second joint oblongoval, as stout as the first but shorter, third more slender and longer than second, 4, 5 and 6 gradually shorter, 7 to 11 abruptly broader; prosternum narrow between the coxie, dilated behind them; hind tarsi nearly as long as tibix, first joint obconical, very narrow at base, fourth abruptly inflated at apex, the claws toothed at middle: claws of front and middle tarsi bifid. 
*2231 (6920). Hypolampsis phosa Illig., Mag. fur Insect., VI, 1S67, 105.

Oblong-oval, convex. Dull brownish-yellow to piceous, oparque; surface with prostrate gray and brown pubescence and sparse erect labirs; antenno reddish or brownish-yellow, the onter five joints darker. Thorax quadrate, very little wider than long, sides nearly straight; disk convex, coarsely and closely punctate and with two feeble elevations slightly in front of middle. Elytra wider at base than thorax; disk with a falint oblique impression from humerus to suture near middle, ending in a shallow black fovea on first and second strix; punctures coarse, close-set and deep, arranged in regular rows; intervals not wider than the distance between the punctures. Length $2.5-4 \mathrm{~mm}$.

Lake, Wells and Vigo comnties; scarce. January 1-July 21. Occurs mostly in sandy localities, beneath rubbish, where it hibernates as imago.

\section{Pacliyonychus Chev. 1834. (Gr., "thick + joint.")}

Represented in the castern United States and Indiana by a small, oblong, parallel smooth species, having the antennx a little longer than half the body, the second and third joints short, nearly equal in length, together longer than first but shorter than fourth, joints 5 to 10 equal, not thickened as in the preceding genus; hind tarsi moderately long, the first two joints triangular, the fourth inflated at apex.

2232 (6924). Pachronychus paradoxus Melsh., Ploc. Phil. Acad. Nat. Sci., III, $1847,163$.

Oblong, nearly parallel. Reddish-yellow; elytra piceous, the suture narrowly reddish-yellow; antennse black, the three basal joints paler. Thorax convex, more than one-half broader than long, not narrowed in front, sides feebly curved, margins thickened at front angles, hind angles dentiform; surface sparsely and deeply punctate, the impression near base deep and extending from side to side. Elytra wider at base than thorax, the punctures of strixe coarse and closely placed; intervals slightly convex, each with a row of very fine punctures. Length $3-4.5 \mathrm{~mm}$.

Southern half of State; searce. May 12-June 26. Occurs on the greenbrier (Smilax).

\section{Blepharima Rogers. 1856. (Gr., "eye-lid.")}

Here belongs a single robust, oval species having the antennat rather widely separated at base, half as long as body, first four joints smooth, the second half as Iong as first; third and fourth slender, each longer than second; 5 to 10 hroader than fourth, gradwally very slightly shorter and pubescent, 11th longer and with a 
very small conical terminal joint; lind tibi: sinuate and deeply grooved on outer edge near apex; tarsi stout, first joint broadly triangular, fourth slender.

2233 (6919). Blepharida Rhois Forst., Nor. Spec., Ins., 1771, 21.

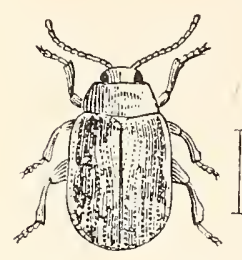

Fig 532 .

Short, robust, oval, convex. Under surface and legs reddish-brown; above dull yellow, the elytra paler, irregularly variegated with dark reddish-brown; antennæe piceous, the four basal joints paler. Thorax more than twice as wide as long, narrowed in front, sides regularly curved, front angles prominent, hind ones obtuse; disk sparsely and finely punctured and with a row of coarser punctures around the margins. Elytra scarcely wider at base than thorax, each with nine feebly impressed rows of coarse, deep. distant punctures. Length $5-6.5 \mathrm{~mm}$. (Fig. 532.)

Throughout the State; rather common on sumac. May 19-Oetober 1. The elytra vary greatly in the proportion of reddishbrown markings, these sometimes covering the entire surface except the sides and apex. Known as the "jumping sumac beetle."

\section{Chжtocnema Stephens. 1831. (Gr., "spine + tibiz.")}

Small elongate or oval, black or brown, usually faintly bronzed species having the head immersed in thorax to eyes, the front not carinate; antennx slender, at least half the length of body, second joint elongate-oval, 3 to 6 slender and longer, 7 to 11 gradually hroader and flattened, the 11th nearly as long as the two preceding, acute at tip; thorax always broader than long, narrowed in front, base regularly curved, without an impression in front; elytra at most but little wider than thorax, their punctures in rows; hind tibiæ sinuate near apex, with a triangular tooth above the curve, grooved at apex on the outer side and terminating in a rather long, stout spur; tarsal claws simple. The following species have been taken or probably oceur in the State:

\section{KEY TO INDIANA SPECIES OF CHATOCNEMA.}

a. Sides of thorax regularly curved from base to apex, the front angles not obliquely truncated.

7. Head punctate, sometimes indistinctly so.

r. Rows of elytral punctures confused or irregular at base.

d. Punctures of elytral strice 1 to 8 much confused to beyond the middle.

CRIBATA.

d1. Punctures of elytral strix 1 to 3 irregular near the base only; punctures of tholax coilse. 
C. Form elongate, subcylindrical.

SUIBCYLINIMICA.

ee. Form regularly oval.

cc. Rows of elytral punctures regular.

IRREGULARIS.

$f$. Form eloninalte-oval, nore than twice als long as wirle; piceons. surface bronzed; apical portion of antenne and all the femora piceous.

2:2:4. PROTENSA.

$f f$. Form oval, not twice as long as wide.

g. Punctures of heal distinct.

7. Punctures of the front and dypeus dense and rugulose; surface subopaque.

22:5. DENTICULATA.

7hl. Punctures of the front and clypeus coarse, well sepalrated; surface shining.

2236. CRIIRIFRONS.

gy. Punctires of head small, indistinct.

i. Punctures of elytral striae well impressed to apex; thorax with a distinct basal row of punctures. 2237. MINUTA.

ii. Punctures of elytril strice feebly impressed, nearly obsolete at apex; basal row of thoracic punctures very feeble.

2238. PINGUIS.

bb. Head absolutely without punctures.

$j$. Thorax with an entire basal marginal line, which is not defined by punctures; color brassy bronze; scutellar stria regular.

2239. OPULENTA.

$j$. Thorax with a basal marginal row of punctures.

l. Thorax shining, minutely alutaceous.

2240. PARCEPUNCTATA.

kl. Thorax subopaque, distinctly alutaceous.

2241. PULICARIA.

aa. Sides of thorax obliquely truncate at the front angles and with an angulation in front of middle; thorax without basal marginal line.

2242. CONFINIS.

C. cribata Lec., brassy-bronzed, antennre, tibixe and tarsi reddishyellow, length $2 \mathrm{~mm}$, is known from Massachusetts and Oregon. $C$. subcylindrica Lee., piceous, feebly bronzed, length 2-2.5 mm.; and C. irregularis Lee, piceous, distinctly bronzed, length $2 \mathrm{~mm}$, are known to oceur in Michigan.

22:34 (6042). Chetocnema protensa Lec., Proc. Amer. Phil. Soc., Xvit, $1878,417$.

Form given in key. Piceous, distinctly brassy-bronzed; tibiae tarsi and basal half of antenue reddish-yellow. I Iead coarsely, not closely punctate. Thorax one-third wider at base thin long, sides regularly curved, feebly narrowing to apex; disk minutely alutaceous, rather finely and sparsely punctate. Elytra slightly wider al base than thorax, with regular rows of rather coarse, close-set punctures: intervals flat, wider than strie. without punctures. Length 2.5-2.8 mm.

Lake County ; rare. October 6. Ranges from Maryland and Michigan westward to Colorado. 
*2235 (7010). Chetocrema dexticulata Ill.. Mag. fur Insect., VI, 1S07, 163.

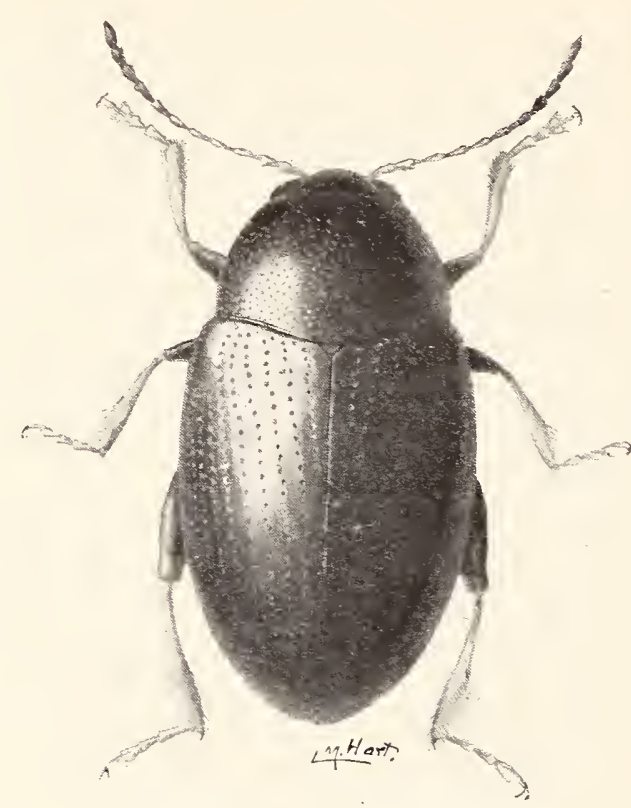

Fig. 533. $\times$ 18. (After Forbes.)

Oblong-oval, robust. Piceousbronzed, slightly brassy; a n tennx reddish-yellow at base, the outer fire or six joints piceous; front and middle femora brown, hind ones piceous bronzed; tibix and tarsi reddish-rellow. Head and thorax alutaceous; the latter nearly trice as wide at base as long. sides regularly curred to apex; surface rather coarsels and regularls but not densely punctured. the basal marginal line feeble at the sides. Elstra not wider at base than thorax, the punctures coarse and deep, not closely placed ; intervals nearls flat on disk, subconrex on sides, each with a row of rers fine punctures. Length $2.3-2.5 \mathrm{~mm}$. (Fig. 533.)

Throughout the State; frequent. January 5-October 24. Occurs on sedges and grasses in moist meadows. Hibernates beneath leaves and rubbish in fence corners.

2236 (7043). Chetocnema cribrifrons Lec., Bull. U. S. Geol. Suìt., 1879, 517.

Oral, but proportionatels more elongate than denticulata. Dark bronze, moderately shining; antenne brownish at base, outer joints piceous; legs as in denticulata. Thorax also as in that species but with basal marginal line distinct at the sides. Length 2.2-2.7 $\mathrm{mm}$.

Lake, Marshall, Putnam and Orange counties; scarce. April 10September 9. Resembles denticulata very closely, but less broad and with the punctures of the clypens rery coarse, deep and well separated.

2237 (-). ('h жетоcnema mintta Melsh.. Proc. Phil. Acad. Nat. Sci., III, $1847,167$.

Oral, robust. Piceous. distinctly bronzed, shining; antennie with four basal joints brownish-rellow. the remainder piceons; legs piceous. the tibize and tarsi sometimes paler. Iead distinctly alutaceous, indistinctly punctate. Thorax twice as wide as long. widest at middle. disk faintly alutaceous, finely and sparsely punctured; basal row of punctures distinct and coarse. Elytra distinctly wider at base than thorax, punctures coarse. lather closels placed, slightly broader than long: intervals feebly conrex. without punctures. Length $2 \mathrm{~mm}$. 
Lake, Starke and Marshall counties; frequent along the marshy margins of lakes. May 18-May 30 .

2238 (7041). Chetrocnema pinguis Lec., Proc. Amer. Phil. Soc., 1878, 417.

Short, oval, robust. Piceous-bronzed, shining; antenna witlı five basal joints reddish-yellow, the remainder bronzed; middle and hind femora bronzed, front femora and all the tibia and tarsi reddish-yellow. Head very finely alutaceous, minutely and sparsely but distinctly punctate. Thorax nearly twice as wide as long, sides more curved than in minuta; surface faintly alutaceous, very finely and sparsely punctate. Elytra but slightly wider than thorax, widest at middle; surface distinctly alutaceous, umbone not prominent; strix feebly impressed, more deeply on sides, their punctures fine and well separated; intervals smooth. Length 1.8-2 mm.

Lawrence County; scarce. May 11. Resembles minuta in form, color and size, but differs in the basal punctures of thorax and in the less impressed and more finely punctured elytral strix and the more distinctly punctate head. A member of the Austroriparian fauna.

2239 (10,462). Chætocnema opulenta Horn, Trans. Amer. Ent. Soc., XVi, $1889,264$.

Oval, moderately convex. Brassy-bronze, not alutaceous; antennæ reddish-yellow at base, gradually darker to tips; femora bronzed, tibi氵e and tarsi reddish-yellow. Head finely wrinkled, not punctured. Thorax nearly twice as wide as long, sides regularly curved, basal marginal line deep, entire; surface coarsely, deeply and closely punctate. Elytra slightly wider at base than thorax, strixe feebly impressed, punctures very coarse, deep and closely placed intervals feebly convex, finely but distinctly punctulate. Length 2-2.5 $\mathrm{mm}$.

Starke and Wayne counties; scarce. May 19-May 26. Swept from the foliage of mint in low, moist places. Known heretofore only from California, Nevada and New Mexico.

2240 (7050). Chжtocnema parcepunctata Croteh, Proc. Phil. Acad. Nat. Sci., $1873,74$.

Oval, robust. Piceons-bronzed. shining; tibia, tarsi and base of antennæ pale1. Thorax twice as wide as long, sides curved; disk finely alutaceous, sparsely and rather finely punctate. Elytra one-fourth wider at base than thorax, stria feebly impressed, the rows of punctures large. round and rather close-set; intervals narrow, not punctate. Length $1.5 \mathrm{~mm}$.

Marion County; rare. June 12. Swept from low-ground herbage. Known from Massachusetts, Pennsylvania, Ohio and southward. 
2241 (7053). Chetocnema pulicaria Melsh., Proc. Phil. Acad. Nat. Sci., III, $1847,167$.

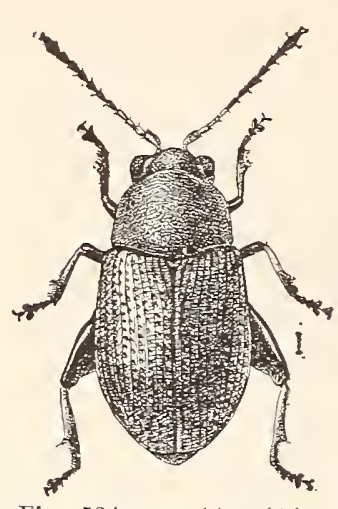

Fig. 534. $\times$ 14. (After Chittenden in Bull. 33 N. Ser., U. S. Div. Ent.)

Oral, slightly oblong. convex. Black, shining with faint greenish or bluish-bronzed lustre; antenne with three or four basal joints reddish-yellow, the remainder piceous; femora piceous, tibiæ and tarsi brownish-rellow. Head and thorax alutaceous, the latter one-half wider at base than long, distinctly narrowed in front, basal marginal line punctured to near middle; surface very finely, sparsely and shallowly punctured. Elytra a little wider at base than thorax, umbone smooth, distinct, punctures rather coarse and closely placed; intervals slightly convex, each with a row of minute punctures. Length 1.5-1.S mm. (Fig. 534.)

Southern half of State, frequent; Starke County only in the north. March 25-July 1. Taken by sifting in early spring. Said to be sometimes injurious to corn and millet.

2242 (7055). Chetocnema confinis Crotch, Proc. Phil. Acad. Nat. Sci., $1873,74$.

Broadly oval, robust. Pi ceous, slightly bronzed; antennæe and legs reddish-yellow; hind femora piceous. Head finely alutaceous, not punctured. Thorax.twice as wide as long. distinctly narrowed in front; disk alutaceous, rather coarsely and regularly but not closely punctured. Elytra scarcely wider at base than thoria, the strice more deeply impressed on sides, punctures rather coarse. close and deep; intervals slightly convex, minutely punctate. Length 1.5-1.8 11m. (Fig. 535.)

Throughout the State; common. April 18-October 27. Probably hibernates. Oc-

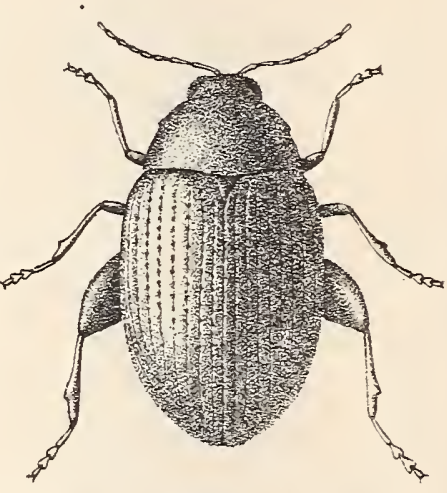

Fig. 535. $\times 17 \frac{1}{2}$. (After Forbes.) curs in gardens and often damages young sweet potatoes by eating channels along the veins of the leaves. The leaves (not the roots) should be dipped in a strong solution of arsenate of lead before being set out.

\section{Crepidoderi Chev. 1934. (Gr., "a half boot + neck.")}

Small oval or oblong-oval brownish, greenish or blackish-bronzed species, having the front more or less triangular, inserted in thorax to the eyes; antenna half as long as body, second joint half as lono as first, 3 to 10 subequal, a little longer than second and gradually slightly broader to eleventh, which is longer and acute at tip ; thorax broader than long, the ante-basal impression limited at each end 
by a longitudinal one; first ventral segment as long as the next three; hind tibiac obliquely truncate and with a small spur. Six of the seven species recognized by Horn have heen taken in the State.

KEY TO INDIANA SPECIES OF CREPIDODERA.

11. Form oblong-oval or elongate.

b. Head and thorax yellow, elytra blue; thorax and prosternum smootli.

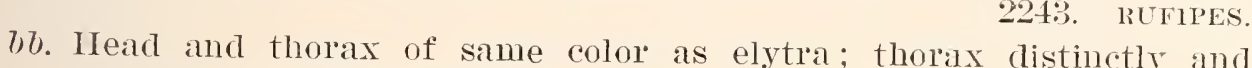
rather coarsely punctured.

c. Elytra uniform in coloration; posternum smooth or rery sparingly punctate.

d. Form narrow, elongate; reddish-yellow with greenish surface lustre.

2241. LONGCLAd.

dd. Form more oral ; surface metallic blue, bronzed or green; thorax with fine and coarse punctules mixed. 2245. Hexxines.

cc. Elytra more or less dull yellow on apical third; prosternum densely punctate.

2246. MODEERI.

a a. Form broally oval or ovate.

e. Reddish-yellow, without metallic lustre; thorax not distinctly punctured; abdomen piceous.

2247. ATRIVENTRIS.

ee. Piceous black. shining; thorax coarsely and rather closely punctate; elytra each with a small eleration at middle of base.

22tS. NITENS.

$2243(6979)$. Crepidodera rufipes Linul. Syst. Nat.. X, 1765, 373.

Oblong-oval, nearly parallel. Head, thorax and legs dull reddish-yellow; elytra dark blue, shining; metasternum and abdomen piceous. Thorax nearly twice as wide as long, sides straight and parallel hehind the middle, rounded to apex in front; disk ('onvex, sulooth. Elytra a little wider at base than thoridx, umbone rather prominent and smooth ; each with a long scutellar low and nine discal rows of coarse, closely placed punctures; intervals narrower than the striae, slightly convex. Length 2.5-3 $\mathrm{mm}$. (Fig. 536.)

Southern half of State; frequent. April (After Howard in Insect Life, V.) 24-June 6. Taken by sweeping roadside herbage. Introduced from Europe. Occurs on black locust, Robinia, and sometimes injurious to peach and apple foliage.

2244 (10.428). Crepidodera Longula IIoln. Trans. Amel. Fut. Sor.. XYi. $1889,240$.

Elongate-oval, nearly parallel. Pale readisll-yellow. surfice with a distinct greenisl lustre; suture narrowly piceous. more broadly so near base. Thorax nearly twice as wide as long, very litłle narrowed in front, sides feebly curved; disk conrex, with ratlier coarse. irlegulal and unequal punc- 
tures. Elytra rery little wider than thorax, umbone not prominent, disk with scutellar and nine discal strice of coarse, rather closely set punctures; intervals flat, each with a single row of fine punctures. Length $2.5 \mathrm{~mm}$.

Jackson, Spencer and Dubois counties; rare. May 13-May 24. Occurs on willow.

\section{5 (69S0). Crepidodera helxixes Linn., Syst. Nat., X, 1765, 373.}

Oblong-oral, moderately conrex. Metallic bronzed, blue or green; antennie and legs reddish-yellow: hind femora often darker; under surface piceous. Thorax more than half wider than long, not narrowed in front, sides rery feebly curved; inte-basal impression deep and at each end suddenly bent towards base. surface coarsely and unequally punctate. Elytra distinctly wider at base than thorax, umbone rather prominent, punctures rather coarse, becoming finer towards apex: intervals very minutely punctate. Length $2.5-3.3 \mathrm{~mm}$.

Throughout the State; common. April 16-July 14. Occurs especially on the foliage of elm, thorn, willow and poplar, and sometimes attacks that of apple and pear. A handsome little species exceedingly variable in hue.

\section{6 (69S2). Crepidodera yodeeri Limn. Faun. Suec, 1761, 167.}

Oblong-oral. rather robust. narrowed in front. Piceous with a shining bronzed lustre; apical third of elstra indistinctly dull sellow; antennæ brownish or piceous. the four basal joints pale; legs brown. the front and middle pairs paler. Thorax one-half wider than long, sides nearly parallel behind the middle; disk convex. the ante-basal impression more shallow than in helxines. the impressions at each of its ends deeper, surface coarsely and rather sparsely punctate. Elytra distinctly wider at base than thorax, umbone prominent. punctures coarse and close-set on base, finer and more distant towards apex. Length $2-2.5 \mathrm{~mm}$.

Lake and Kosciusko counties: scarce. May 30-June 29. Occurs on the arrow alum and other semiaquatic plants about the margins of lakes. A member of the Transition life zone. Our form is rar. mancula Lec.

2247 (69S1). Crepidoderi Atrivextris Melsh., Proc. Phil. Acad. Nat. Sci., III, $18 \pm 7,165$.

Short. broadly ovate. conrex. Dull reddish-yellow; antennæ and legs paler. Thorax twice as wide as long, sides feebly curred, obliquely truncate near front angles and with a slight angulation one-third from apex; disk convex. not punctured. Elytra wider at base than thorax, umbone distinct; punctures coarse. rather closely placed on base. finer torard apex. Length 1.5-1.8 $\mathrm{mm}$. 
Throughout the State; common. March 20-September 5. Occurs on leaves of May-apple and beneath rubbish in moist, grassy places. Our smallest species.

2248 (10,429). Crepidonera nitens Irorn, Trams. Amer. Ent. Soc., XVI, $1889,243$.

Ovate, robust. Black, shining; antenna pale rerldish-yellow; femora piceous, tibixe brown, tarsi paler. Thorax twice as wide as long, distinctly narrowed in front, obliquely truncate near front angles; disk convex, antebasal impression feeble, surface rather coarsely, deeply and closely punctured. Elytra scarcely wider at base than thorax, umbone rather feeble; disk convex with a vague transverse depression one-third from base and along the suture, causing an apparent feeble elevation on each elytron; punctures small, not closely placed; intervils flat, wider than the strise, smooth and shining. Leingth $2 \mathrm{~mm}$.

Marion, Dubois and Perry counties; rare. April 12-June 12. Taken by sweeping roadside herbage. Resembles the black species of Epitrix but devoid of hairs.

\section{LxVII. Orthaltica Crotch. 1873. (Gr.. "straight+ jump.")}

Small, elongate, parallel, brownish or piceous beetles, having the antenne nearly as long as body, male, shorter in female, the second joint half as long as first; the others dissimilar in the sexes. Thorax broader than long, scarcely wider at base, apex truncate, sides and base curved, disik with a rather deep antebasal impressed line, not limited at the ends, which gradually approach the base; first ventral segment as long as the next three; hind tibix with a short spur. Two species are known, both of which oceur in the State.

\section{KEY TO SPECIES OF ORTHALTICA.}

a. Antennae stout in both sexes; elytral rows of punctures confused on each side of scutellum; antebasal impression of thorax rather deep but not sharply impressed; front punctate.

2249. COPALINA.

aa. Antennxe slender; elytral punctures not confused near scutellum; antebasal impression deep, sharply defined; front smooth.

2250. MELINA.

2249 (6993). ORthaltica copalina Fabr., Syst. Eleut., I, 1801, 466.

Elongate-parallel, subconvex. Brownish or piceous, shining; when piceous the head and thorax paler; antennre and legs reddish-yellow. Antennie of male with third and fourth joints equal, a little longer than second, fifth longer than either fourth or sixth, 6 to 10 gradually shorter and stouter. 
11th one-half longer than 10th and acuminate at apex; in female joints $t$ to 10 are equal. shorter than third and slender. 'Thorax one-half wider' than long, base scarcely broader than apex, margins finely serrate; surface rather sparsely but deeply and coarsels punctate. Elytra distinctly wider than thorax, umbone prominent: disk with nine rows of coarse, closely placed punctures, those of the inner rows confused at base ; intervals slightly convex. Length $2-3 \mathrm{~mm}$.

Throughout the State; frequent on sumac and Hercules' club. MIay 20-.Tuly 7.

2250 (10.431). Orthaltica melixa Horn, Trans. Amer. Ent. Soc., XVI, 1859, 249.

Elongate, parallel. Pale reddish-yellow, shining. Thorax one-half wider than long. widest in front of middle, sides curred, slightly oblique in front of base, margins entire; disk convex, rather coarsely, sparsely and irregularly punctate. Elytra wider at base than thorax, umbone distinct; disk with feebly impressed rows of rather distant moderate punctures; intervals flat. smooth. Length $1.52 \mathrm{~mm}$.

Floyd County ; scarce. June 28. Known heretofore only from Kansas and Texas.

\section{LIVITI. EpITrix Foud. 1859. (Gr., "upon + hair.")}

Very small conves species, differing from Crepidodera in the upper surface bearing short, semierect hairs, sparsely placed over the thorax and arranged in a single row on each interval of the elytra. The head has an oblique ridge each side, extending from the end of the frontal carina to the exe and limited abore by an impressed line, the two forming together a broad $T$. The front angles of the thorax are obliquely truncate with a small tooth behind the truncation. Five species are known from the State, while another may occur.

KEY TO INDIAXA SPECIES UF EPITRIS.

a. Tpper surface piceous.

b. Thorax very densely and coarsely punctate; antebasal impression rers feeble.

2251. Físctul.

66. Thorax not densely punctate. the punctures well separated.

c. Antebasal impression well marked.

d. Elytral strie rather deep. the punctures coarse, close and quadrate; punctures of thorix close, though separated. Lobata.

da. Elytral strice, especially those nearest the suture, very feeble, the punctures round, not crowied.

2252. CLCUMERIS.

ce. Antebasal impression rery leeble: species smiller, not over $1.5 \mathrm{~mm}$.

2253. BRETIS. 
a . Upper surface reddish-brown; legs always pale.

c. Thorax rather closely punctate, the antebasal impression scarcely risible.

2.254. PARVUTA.

ce. Thorax sparsely punctate, the antebasal inmression distinct.

2.55. HE MERAISS.

2251 (6989). Epitrix fuscula Crotch, Proc. Plit. Acad. Nat. Sci.. 1573. 72.

Ovate, rather robust, convex. Piceous, feebly shining; antennie reddish-yellow, often darker towards apex; femora all piceous, tibie and tarsi dull reddish-yellow. Thorax twice as wide as long, slightly narrowed in front; antebusal impression narrow, sinuate, often almost obsolete: surface coarsely, densely and deeply punctured. Elytra scarcely wider at base than thorax. umbone rather prominent, punctures on middle round, not erowded, those on sides deep. more closely placed; intervals as wide as or wider than striae, each with a single row of minute setre bearing punctures. Length $2 \mathrm{~mm}$. (Fig. 537.)

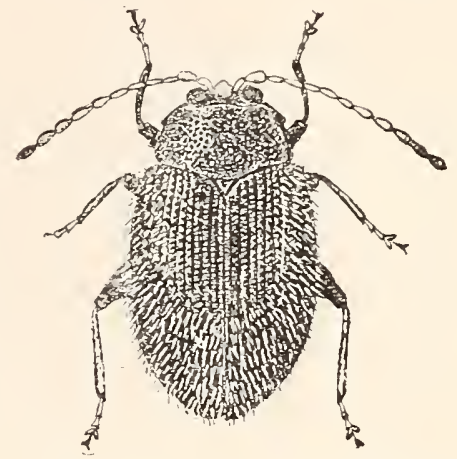

Fig. 5:7. $\times$ 14. (After Chittenden. in Bull. 33. N. Fer. U. S. Div. Ent.)

Throughout the State; common. Narch 20-November 20. Doubtless hibernates beneath dead leaves in fence corners along cultivated fieids, as large numbers were taken by sifting on the dates above given. Noted especially on hazelnut, pokerreed and, in July, by hundreds on egg-plant, to which it was doing much damage.

E. lobata Crotch, length $1.5-2 \mathrm{~mm}$., is a southern species which has been recorded from Cincinnati.

2252 (698

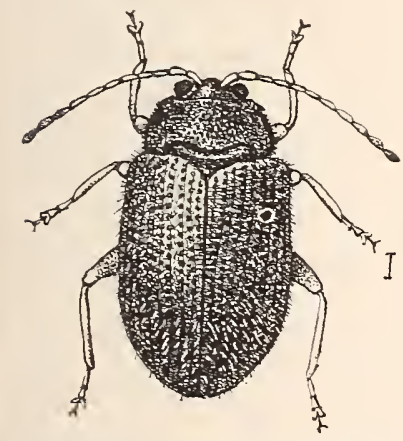

Fig. 538. $\times$ 13. (After Chittenden in Bull. 19, X. Ser., U. S. Dir. Ent.)

Ovate, slightly oblong. Piceous, shining: antennze and legs reddish-yellow, the hind femora only piceous. Thorax nearly twice as wide as long. slightly narrowed in front, antebasal inpression deep and slightiy curved toward the base, the longitudinal impressions at its ends well marked; surface much more finely and sparsely punctured than in fuscula. Elytra slightly wider at base than thorax, umbone rather prominent, strice feebly inpressed, the punctures large and closely placed. Length 1.5-2 1mm. (Fig. 538.)

Throughout the State: much less common than fuscuia. April 19-Oetober 1. Oecurs on a variety of field and garden products. Sail to injure potatoes by eating small round holes in their leares. Pemedies: Bordeaux mixture and Paris green. 
2253 (69S6). Eprtrix brevis Schwarz, Proc. Amer. Phil. Soc., 1S78, 367.

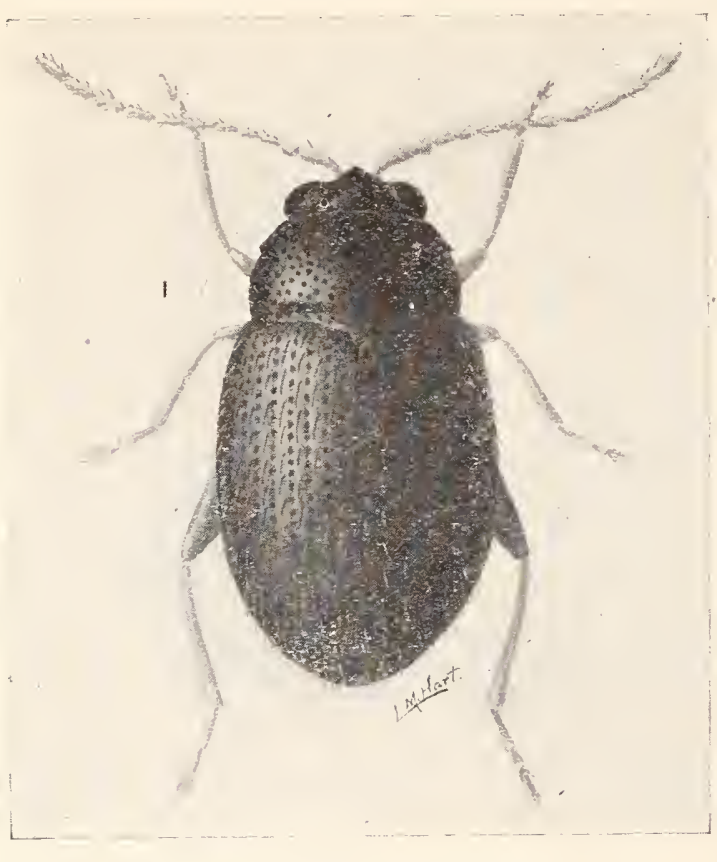

Fig. 539. $\times 28 . \quad$ (After Forbes.)

Broadly ovate. Piceous, shining; antenure and legs pale reddish-brown; hind femora piceous. Thorax twice as wide as long, slightly narrowed in front, sides distinctly curred; punctures moderate in size, close but not crowded; antebasal impression scarcely evident, the longitudinal ones not visible. Elytra a little wider at base than thorax; striæe feebly impressed on disk, deeper on sides, the punctures of former rounded and distinct, those at sides more quadrate and closer. Length $1.5 \mathrm{~mm}$. (Fig. 539.)

'Throughout the State; scarce. April 22-September 25. Shorter and more convex than cucumeris, from which it is easily separated by the lack of antebasal impression.

2254 (6991). Epttrix paryula Fabr., Syst. Eleut., I, 1801, 468.

Oblong-oval, subconvex. Dull reddish-yellow; elytra often with a fuscous transverse cloud at middle; abdomen brown; antennæ and legs pale reddisli-yellow, the four outer joints of former and hind femora of latter often darker. Thorax convex, shining, nearly twice as wide as long, not narrowed in front; antebasal impression evident but not deep; surface distinctly but rather finely and sparsely punctate. Elytra very little wider than thorax, umbone feeble, punctures rather coarse and not crowded on disk; finer and more close-set on sides. where the intervals are subconvex. Lengtlı 1.5-2 $\mathrm{mm}$.

Southern half of State; Irequent. April 18-November 22. Taken by sifting and sweeping.

2255 (-—). Epitrix numeralis Dury, Journ. Cin. Soc. Nat. Hist., XX. $1906,253$.

Ovate, rather robust. Head, thorax and legs reddish-brown; elytra darker brown, the umbones paler. Thorax fully twice as wide as long, sides broadly rounded. surface finely and sparsely punctate; antebasal inpression well marked. Elytral strixe feebly impressed, the punctures large, round, deep and closely placed. Length $2.5 \mathrm{~mm}$.

Wayne, Marion, Putnam, Dubois, Posey and Perry counties; scarce. April 22-September 5. Taken by sweeping herbage. Described from Cincinnati, Indiana and Kansas. 


\section{LXTX. Mantura Stephens. 1831. (A mythological name.)}

To this genus belongs a single small, elongate-oval, brownish species, having the antenna slender, half as long as body, the outer five joints abruptly broader ; thorax with a deep longitudinal basa! impression each side opposite the middle of each elytron and extending neariy half way to apex; first ventral segment nearly as long as all the others; tibixe each with a small terminal spur; claws simple.

2256 (7032). Mantura froridana Crotch, Proc. Phil. Acad. Nat. Sci., $1873,73$.

Elongate-oval, moderately convex. Brownish, with a bronzed Iustre; elytra indefinitely paler on apical third; antennæ brownish, the basal joints paler; legs reddish-yellow, the hind femora darker. Thorax nearly twice as wide as long, widest at base, gradually narrowed in front; surface coarsely, deeply and rather closely punctate, more sparsely between the basal depressions. Elytra scarcely wider at base than thorax, umbone not prominent, disk with ten rows of rather fine, deep punctures; intervals broader than strix, smooth. Length $2 \mathrm{~mm}$.

Steuben, Marion, Putnam, Orange and Posey counties; scarce. April 22-July 14. Taken by sifting and sweeping.

LXX. Systena Cher. 1834. (Gr., "compressed.' ')

Small elongate, usually subdepressed species, having the antennx slender, half as long as body, slightly thicker toward the tip, the fourth joint longer than the third or fifth. Thorax broader than long, very little narrowed in front, margins Fig. 540. Systena taniatu
very narrow, hind angles acute, disk but vaguely Chittenden in Bury. (After impressed in front of base; front coxæ narrowly Div. Ent.)

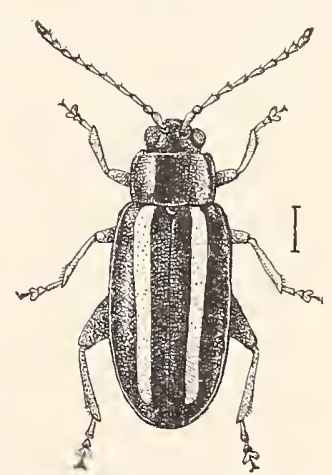
Fig. 540. Systena taniata
Say, dark variety. (After Div Ent.) separated, the cavities closed behind; hind tibiæe grooved on the outer edge and carinate, terminated by a single spur; claws appendiculate. Five species have been taken in the State.

KEY TO INDIANA SPECIES OF SYSTENA.

a. Elytra wholly piceous or dark brown, slightly bronzed.
b. Head entirely black.
b7. Head dull reddish-yellow.
2257. HUDSONIAS.
225S. FRONTALIS.

aa. Elytra dull yellow or with yellowish stripes.

c. Elytra piceous, with a yellow stripe reaching nearly to apex; gense (cheelis) very coarsely punctate.

2259. ELONGATA. cc. Elytia pale, dull yellow, sometimes with a paler median stripe; gence
smooth. 
d. Surface shining, the punctuation never very coarse; elytra each with a paler median stripe.

2260. TANIATA.

dd. Surface subopaque, the punctuation coarse, close and reep; elytra without a paler median stripe.

2261. MARGINALIS.

2257 (6995). Systena hudsonias Forst., Nov. Sp. Ins., 1771, 26.

Elongate, subdepressed. Pic-

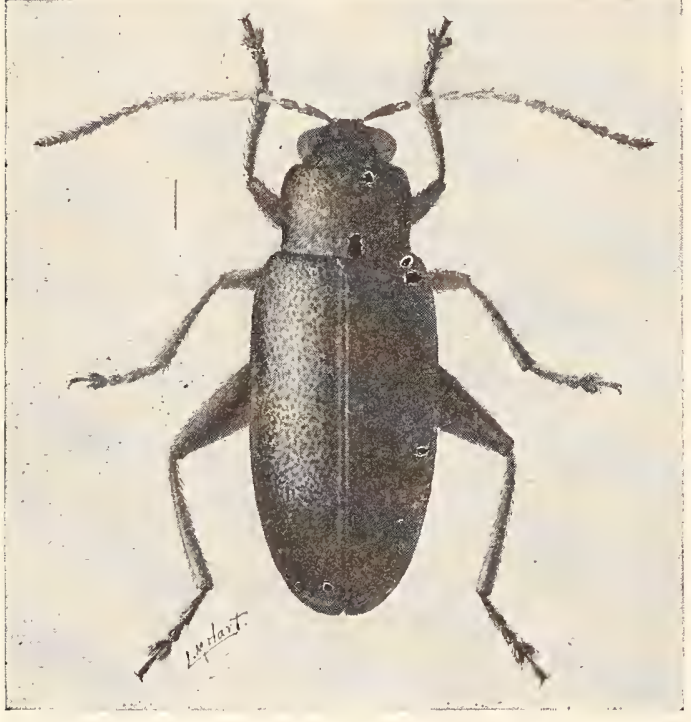

Fig. 541. $\times$ 10. (After Forbes.) eous black, shining; antennæ with joints 3,4 and 5 dull yellow, the others more or less piceous; legs black. Thorax about one-third wider than long, sides feebly curved, front angles obliquely truncate; surface finely alutaceous, indistinctly punctate, minutely wrinkled. Elytra wider at base than thorax; disk coarsely and closely punctate, somewhat rugose. Length 4-4.5 mm. (Fig. 541.)

Throughout the State; frequent in the southern, scarce in the northern counties. May 21-August 20. Occurs on the greater ragweed, Ambrosia trifida $\mathrm{L}$.; also on elder and other weeds.

*2258 (6996). Systena Frontalis Fabr., Syst. Eleut., I, 1801, 300.

Resembles hudsonius very closely. Usually a little broader and less shining, the head reddish or reddish-yellow; antennæe and legs mostly pale. Thorax more distinctly and elytra less coarsely punctate. Males in both species with the last ventral segment notched each side, the middle lobe with a deeply impressed triangular median line. Length 3.5-4.5 10m. (Fig. 542.)

Throughout the State; less common than hudsomias. Hibernates beneath bark of soft maple and mullein leaves. February 14-September 22. Occurs most frequently on smartweed (Polygonum), the

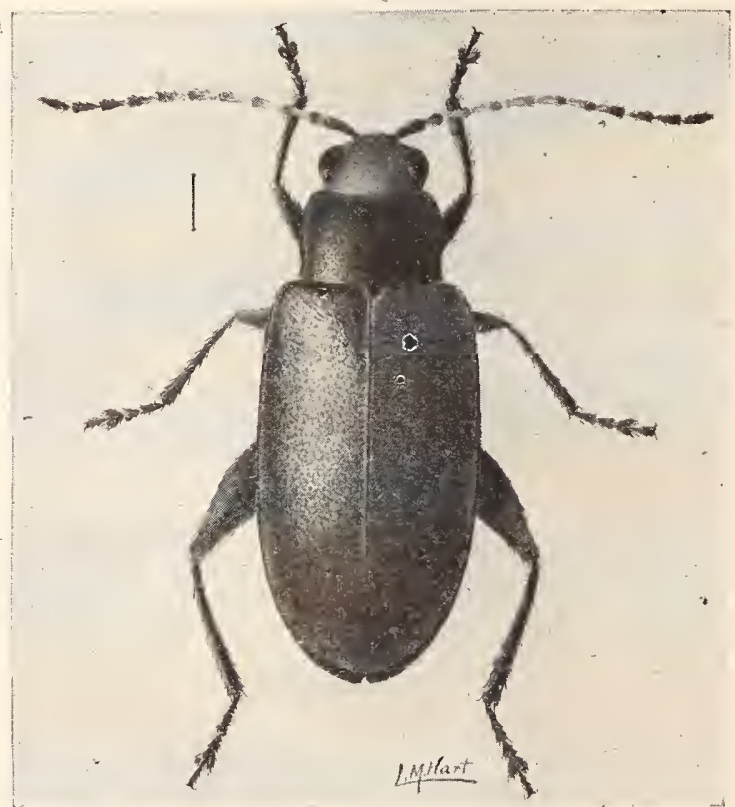

Fig. 542. $\times$ 10. (After Forbes.) greater ragweed and pigweed (Chenopodium). 
22.259 (7000). Systena Elongata Fibr., Ent. Syst., Supp., 1798, 99.

Elongate-oval, moderately convex. Piceous with a slight bronzed lustre; elytra each witl a yellow stripe on middle reaching nearly to apex; antennæ brownish; legs reddish, hind femora piceous. Head coarsely and closely punctate. Thorax one-fourth wider than long, sides feebly curved; disk convex, coarsely and closely punctate. Elytra distinctly wider at base and more finely and sparsely punctate than thorax. Length $3-4 \mathrm{~mm}$.

\section{Posey County; rare. April 12. Beaten from wild grape.}

2260 (7003). Srstena treniata Say, Long's Sec. Exped., 1824, 294 ; ibid. I, 195.

Elongate-oval. Color variable, usually reddish or brownish-yellow, shining; elytra each always with a paler median stripe; under surface and narrow margins of thorax usually piceous: antennæe and legs reddishbrown. 'Thorax one-fourth wider than long, sides feebly rounded, surface finely and sparsely punctured. Elytra distinctly wider. than thorax, finely, shallowly and rather densely punctate. Length $3-4.5 \mathrm{~mm}$. (Fig. 543.)

Throughout the state; frequent. May 16-July 25. - Occurs on ragweed, horseweed, flowers of Cornel, etc. The

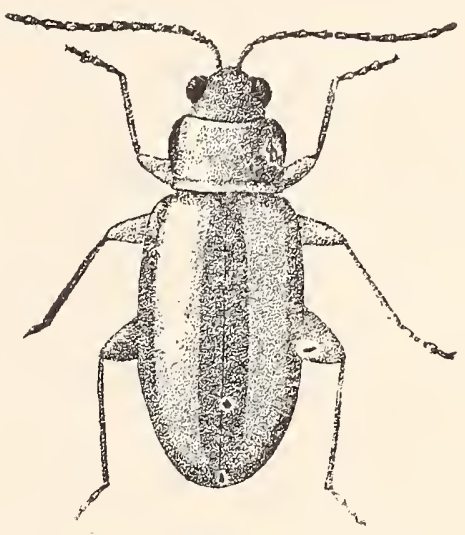

lig. 543. × 9. (After Forber.) form above deseribed is var. blanda Melsh., the only variety so far noted in the State. A variety with median pale stripe of elytra much narrower is also known. (Fig. 540.)

2261 (7002). Systena marginalis I11., Mag. fur Insect., VI, 1S07, 150.

Elongate-oval, subdepressed. Pale dull yellow, scarcely shining; sides of thorax and elytra rery narrowly piceous; antennse with the terminal halves of the outer joints piceous. Head alutaceous, sparsely and regularly punctate. Thorax one-third wider than long, not broader at base than apex, sides regularly curved; disk coarsely, not closely punctured. Elytra distinctly wider at base than thorax, rather densely and coarsely punctate. Kength $3.5-4 \mathrm{~mm}$.

Lake and Marshall counties; scarce. July 11-August 21. Oceurs on oak.

\section{LXXt. Dibotis Chev. 1834. (Gr., "two + spine.")}

Small oval or oblong species having the head rounded, retracted within the apex of thorax; front carinate with distinct tubercles; antennæ at least half as long as body, the outer joints a little stouter; thorax broader than long, much narrowed in front; elytra oval, not wider than base of thorax, with regular rows of punctures; hind femora strongly dilated, tibiæ slender, broader and 
denticulate at tip, terminated by a rather long and broad spur, which is deeply emarginate at tip ; first joint of tarsi one-third the length of tilire; claws appendiculate.

2262 (7057). Dibolia borealis Cher., Guer. Icon. Regne Anim., 1845, 307.

Oral, slightly oblong, conrex. Piceous bronzed, usually cupreous or bluish; antennæ and legs reddish-yellow, hind femora piceous, bronzed. Thorax twice as wide at base as long, apex but little wider than the length, sides curved; disk closely punctate with fine and coarse punctures intermingled. Sides of elytra continuous with those of thorax, umbone prominent; disk with rows of rather fine, close-set punctures, the third and sixth rows often in part confused; intervals broad and flat, the second, fourth and sixth with coarser punctures than the others. Length $3 \mathrm{~mm}$.

Throughout the State; frequent. April 15-June 2. Occurs on plantain (Plantago major L.) in the leaves of which the larvæ breed.

\section{Psylumodes Latr. 1825. (Gr., "flea + like.")}

Head oval, deeply inserted; front nearly vertical without carina or distinct tubercles; antennæ 10-jointed, separated at base, joints 2, 3 and 4 nearly equal, 5 to 9 gradually slightly shorter, tenth longer, acute at tip. Thorax broader than long, narrowed in front, base broadly curved and with a distinct marginal line; hind femora much thickened, sulcate beneath for the tibiæ; hind tibiæ broader toward the apex, ending in a short spur, the tip prolonged beyond the union of the tarsi and with a border of short hairs; hind tarsi slender, first joint more than half the length of tibiæ; claws simple. Two of the four known species have been taken in the State.

KEY TO INDIANA SPECIES OF PSYLLIODES.

a. Elytral stria feebly impressed. the punctures closely placed; last rentral segment of male distinctly impressed.

2263. PUNCTCLATA. aa. Elytral strire not impressed, the punctures rell separated; last rentral of male convex, not impressed.

2264. CONVEXIOR.

2263 (705S). Psrlilodes PUnctulata Melsh., Proc. Phil. Acad. Nat. Sci., III, $1847,166$.

Elongate-oral. little narrower in front, convex. Piceous or dark bronzed, shining; antennre with three basal joints pale, the remainder brownish; front and middle femora piceous. the hind ones bronzed; tibire reddish-rellow, darker at middle. Thorax one-half wider at base than long. obliquely truncate at front angles; disk alutaceous, rather coarsely but not densely punctate. Elytra not wider at base than thorax, punctures rather coarse: interrals slightly convex. each with a single row of fine punctures. Length $2.8-2.7 \mathrm{~mm}$.

Lake, Starke and Posey counties; scarce. June 2-July 21. Said to occur on rhubarb and garden weeds. 
2264 (7059). Psylliodes convexior Lec, Pac. R. R. Rep., 185̃ , 69.

Oblong-oval, moderately conrex. Piceous, shining and distinctly bronzed; antennie piceous, three basal joints paler; legs as in punctulata. Thorax nearly twice as wide at base as long. surface finely punctate at middle, a littie more coarsels at sides. Elytra not wider at base than thorax; punctures rather coarse, well separated, becoming gradually finer toward apex; intervals flat, the inner three with numerous fine punctures, the outer ones each with but a single row. Length 2-2.5 $\mathrm{mm}$. (Fig. 544.)

Northern half of State: frequent. Not taken south of Marion County. April 25October 23. Occurs on grasses and sedges in low, moist meadows.

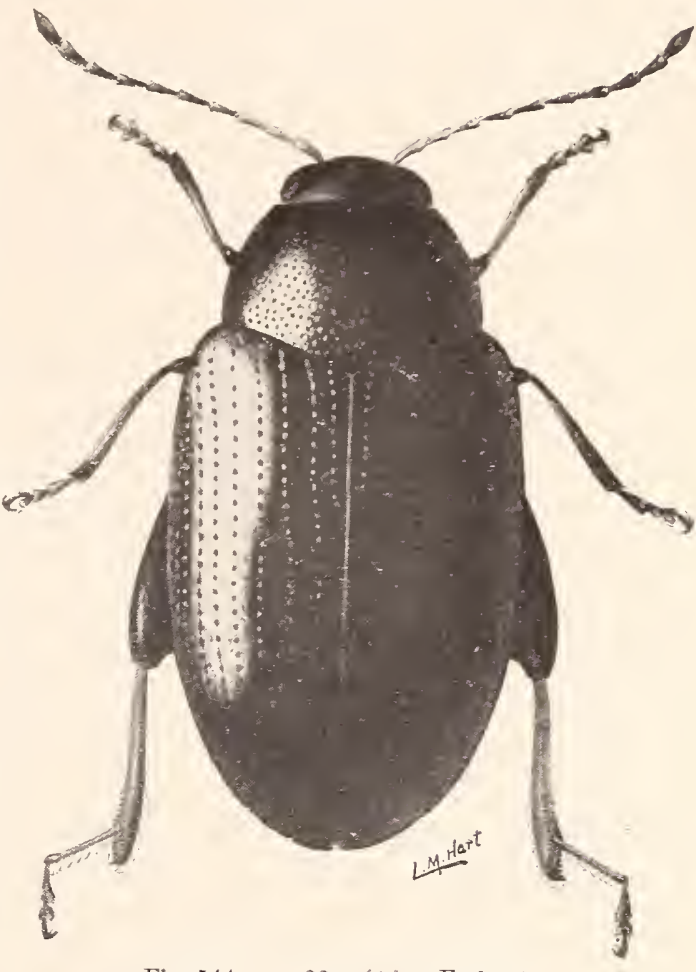

Fig. 544. $\times 22$. (After Forbes.)

Tribe XI. HISPINI.

Small or medium-sized wedge-shaped (elongate in genus Stenispa) species having the elytra often broadly and squarely truncate behind, with rows of deep punctures, and sometimes raised lines or costre. The front of head is prominent, the mouth being confined to the under surface, and the head is never covered by the thorax, which is emarginate or truncate in front. The antennæ are short, straight, compact and close together at base. The larræ are mostly leaf-miners, feeding between the upper and lower surfaces of leaves, and have the head much narrower than the body and the first three segments wider than those behind. Those that feed on the surface of leaves corer themselves with a shelter or protection of their own excrement. The following paper deals particularly with the genera comprising the tribe.
Horn.- "Miscellaneous Notes and Short Studies of North Amer- ican Coleoptera." in Trans. Amer. Entom. Soc., X, 1883. 290-303.

Five of the six genera recognized by Horn are probably represented in the State. 
KEI TO INDIANA GENERA OF HISPINI.

a. Antennæ 8- or 9-jointed.

b. Antennæ filiform or fusiform, the last four joints being united into an oblong mass; elytra oral, convex, not or feebly costate.

LXXIII. MicrorhopaLA.

6). Antennæ clavate, the last two joints forming an elongate-oral club; elytra with short, oblique folds, the intervals punctured.

LXXIT. OсTоTOMa.

aa. Antennæ with 11 distinct joints.

c. Elytra costate, the striæe coarsely punctate.

d. Middle tibix straight.

LXXY. Chalepts.

dd. Niddle tibiæ strongls curred.

Charistent.

cc. Elytra not costate, striæe finely punctate; body elongate.

LAXTI. STENispa.

LXXIII. Microrhopala Cher. 1834. (Gr., "little+club.")

In addition to characters given in key this gemus has the thorax usually broader than long and wider at base; legs short, tibiæ straight; third tarsal joint deeply bilobed. Six of the 12 species recognized by Horn should occur in the State.

KEY TO INDIANA SPECIES OF MICRORHOPALA.

a. Elytra with only eight rows of punctures; last joint of tarsi very little or not longer than the lobes of the third joint.

b. Joints 2 to 6 of antenne nearly smooth and without hairs; elytria black, with the second costa and a narrow line at side red.

2265. VITTATA.

bb. Joints 2 to 6 of antennæe roughly sculptured and somewhat hairy.

c. Body abore bicolored, black, with the sides of thorax and elytral stripe reddish-yellow.

2266. XERENE.

cc. Body above entirely dark blue or slightly greenish.

d. Punctures of the outer rows on elytra much larger and of more irregular size than the inner.

2267. EXCAVATA.

dd. Punctures of all the rors equal and distinct. CrANEA.

aa. Elytra with at least ten rows of punctures on the apical half.

e. Black; interval between the third and fourth costre with four rows of punctures near apex; form slender, parallel. PoRCATA.

ee. Reddish-yellow: elytra with small black spots and with ten entire rows of punctures: last joint of tarsi nearly twice as long as the lobes of the third.

MELSHEIMERI.

2265 (7060). Microrhopala vittata Fabr., Ent. Syst. Supp., 1798, 117.

Oblong-oral, subdepressed. Black or bluish-black, feebly bronzed; head. thorax, second costa and narrow marginal line of elytra, and often the base of femora, red. Thorax twice as wide as long. sparsely, coarsely and rather shallowly punctured. Elytra with eight rows of oblong punctures arranged in pairs; alternate intervals broader and a little more conrex. Length 5 $6.5 \mathrm{~mm}$.

Lake County ; rare. May 20. 
2266 (7062). Microrhopala xereni: Newni., Entom. IIag., V, $1838,390$.

Oblong-oval, subdepressed. Black, sometimes feebly bronzed; thorax with a narrow reddish stripe on sides which continues along the second costa of eiytra to near apex; tip of first costa also reddish. Front of head coarsely punctured or with lengthwise grooves. Thorax one-half wider at base than long, much narrowed at apex; surface coarsely, densely and deeply punctured. Elytra with eight rows of coarse, deeply impressed punctures; intervals slightly alternating, the second or l'ed one inuch the widest. Length $4-5.5 \mathrm{~mm}$.

Steuben County ; rare. Jun 15 -June 16. Taken by sweeping herbage in a tamarack marsh. The larvie of both this and vittata are said to mine the leaves of goldenrod (Solidago).

2267 (7067). Microrhopala excavata Oliv., Ent., VI, 1808, 775.

Oblong-oval. Uniform bluish-black, moderately shining. Front sulcate. Thorax slightly broader than long, widest at base, coarsely and irregularly punctured. Elytra with eight rows of coarse, deep punctures, those of the two inner rows smaller and less deep; intervals often slightly elevated; margins of elytra with minute, distant teeth. Length $5 \mathrm{~mm}$.

Lake County ; rare. July 30.

$M$. cyanea Say, bluish-black, elytral intervals equal, length 6 mm., is known from New York and Missouri; $M$. porcata Mels., black without lustre, length $3 \mathrm{~mm}$, is said to oceur rarely from Pennsylvania to Illinois; $\boldsymbol{M}$. melsheimeri Crotch, length $3 \mathrm{~mm}$., "occurs in the Atlantic region and California."

\section{Octoтома Suffr. 1868. (Gr., "eight+ joint.")}

Small wedge-shaped species having the antennæ as long as head and thorax, 8-jointed, the last two joints forming an elongate oval club; elytra with short oblique folds or reticulated carinæ, the intervals punctured; tarsal claws divergent.

2268 (7090). Oстотоліа Plicatula Fabr., Syst. Fleut., II, 1801, 63.

Oblong, wider behind. Piceous black, feebly bronzed, opaque; front of thorax, scutellum and base of femora dull redrish-yellow; antennæ reddish-brown, club darker. Thorax one-half wider than long, front angles prominent, sides nearly straight, sinuate in front of middle; disk coarsely punctured and with a 'I'-shaped elevation on the middle. Elytra oblong, each wider and obliquely truncate at apex; disk flattened and with numerous short, oblique, acutely elevated and reticulate carina, the intervals or depressions sparsely and coarsely punctate; margins and apex serrulate. Length 4.5-5 mm. (Fig. 545.)

Southern half of State; scarce. May 11-October 18. Occurs on bush-clover (Lespedeza)

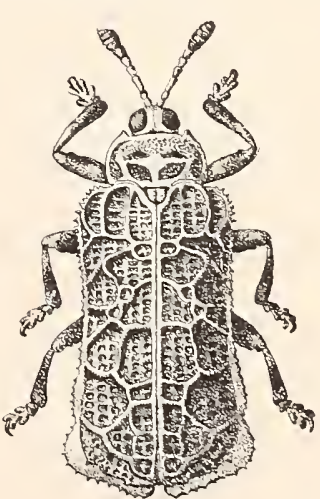

Fig. $545 . \times 6 \frac{1}{2} . \quad$ (After Chittenden in Bull. 3S, N. Ser., U. S. Div. Ent.) and the trumpet creeper (T'ecoma radicans Juss.) 


\section{ChalepUs Thumb. 1805. (Gr., "difficult.")}

The members of this genus resemble those of the preceding in form, but differ by having all the joints of the antenna distinct, the elytra with the alternate intervals usually costate and the middle tibia straight. Six species have been taken in the State, while another probably occurs. They were listed by Henshaw under Odontota.

\section{KEY TO INDIANA SPECIES OF CHALEPUS.}

a. Elytra with ten rows of punctures.

b. Elytra not costate; form narrow, parallel; thorax red, elytra blue.

bb. Elytra costate.

COLLARIS.

c. Elytra with three entire costr only.

d. Elytra black, or at most with reddish humeri.

$e$. Body beneath black; thorax red with discal dark space; humeri of elytra red.

2269. SCAPULARIS.

ee. Body beneath red; thorax wholly red; elytra wholly black.

da. Elytra mostly red.

2270. BICOLOR.

f. Elytra with a very narrow black sutural line, which does not reach apèx.

2271. HORNII.

ff. Elytra with a black sutural stripe which broadens gradually from hase to apex.

2272. DORSALIS.

$c c$. Elytra with three entire costæ, and a fourth represented at base and apex between the second and third; color reddish-yellow, with darker spaces on elytra; length 6-6.5 mm. 2273. RUBRA. aa. Elytra with eight rows of punctures; color reddish with dark markings; length $3.5-4 \mathrm{~mm}$.

2274. NERVOSA.

C. collaris Say, length 5.5-6 mm., is known from Colorado and Illinois.

2269 (7075). Chalepus scapularis Oliv., Ent., VI, 180S, 766.

Wedge-shaped, robust. Black, feebly shining; a broad stripe each side of thorax, humeral angles of elytra, and sometimes the base of femora, dull red. Thorax widest at base, sides subangulate at middle; disk depressed near base, coarsely and deeply punctured. Elytra each with three costre, the second and third separated by four rows of punctures; apex serrulate. Length $5.5-7 \mathrm{~mm}$.

Steuben, Starke, Narshall and Vigo counties ; scarce. June 15September 18. Occurs on the hog-peanut, F'alcata comosa L.

\section{0 (7077). Chalepus ricolor Oliv., Encyc. Method., VII, 1792, 96.}

Elongate, nearly patallel. Black, subopaque; thorax, scitellum, under surface, and often the base of femora, bright red. Vertex sulcate. Thorax very little wider at base, sides obtusely angulate; disk very coarsely, densely and deeply punctured. 'Elytra with sides and apex serrulate; disk punctured and costate as in scapularis, except that the four rows of punctures 
between the second and thixd costie are merged into two at middle. Length $6 \mathrm{~min}$.

Dubois, Perry and Spencer countios; scarce. May 12-May 24. Taken by sweeping roadside herbage.

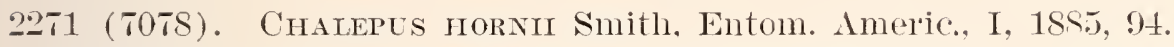

Elongate, slightly wider behind. Bluish-black, shining; thorax and elytra scarlet red, the latter with a blackish sutural line reaching three-fourths to apex. Vertex sulcate. Thorax one-half broader than long, sides distinctly subangulate near middle; surface coarsely and densely punctate. Elytra each with three costre, the first and second indistinct behind the middle; the four rows of punctures between the second and third regulal. Length $5-6.5 \mathrm{~mm}$.

Lake and Marshall counties; scarce. Nay 21-August 1. Occurs on the hog-peanut, Folcata comoss L.

2272 (7079). Chalepus Dorsalis Thumb., Götting., Gel. Anz., 1S05, 282.

Wedge-shaped, rather broad. Color of hornii except that the black sutural stripe of elytra becomes sradually much broader and extends to apex. Vertex coarsely punctate. Thorax wider at base, sides regulirly curved; disk coarsely and densely punctate, feebly depressed near base. Elytra costate and punctate as in scrpularis, the margins and apex serrulate. Length 6-6.5 mm. (Fig. 546.)

Throughout the State, frequent; much more so in the southern counties. March 20-December 25. Occurs on the flowers of black locust (Robinia), in the leaves of which the larve mine; also on pokeweed and clover. Hibernates

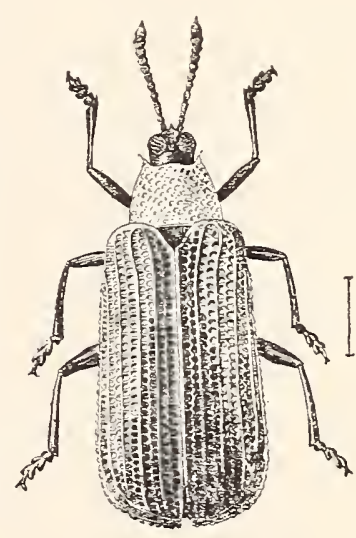

Fig. 546. (After Chittenden in Bull. 38 , N. Ser., U. $\$$. Div. Ent.) beneath locust bark.

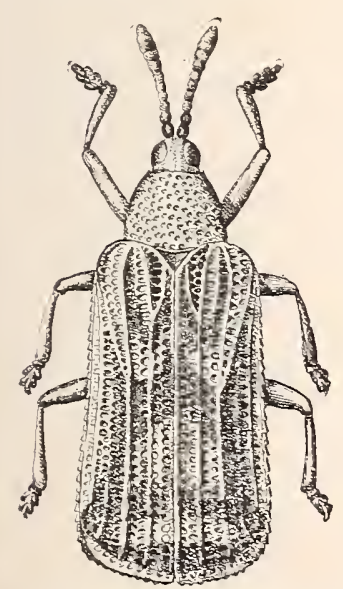

Fig. 547. $\times 6 . \quad$ (After Chittenden in Bull. $38, \mathrm{~N}$. Ser., U. S. Div. Ent.)
2273 (7080). ChalePus rubra Weber, Obs. Ent.. 1801.

60.

Broadly wedge-shaped. depressed. Rose red or reddish-yellow, the elytra with indistinct diarker malkings along the sides and on apical half; under surface pale red to piceous, legs sellow. Terter punctured. 'Thorax much broader behind, sides nearly straight: disk coarsely and deeply punctured. Elytra much broader at apex. the margins thattened and serrate: disk with three entire costre, a shorter oblique one from umbone to second and another from apex of third for a short distance formard. Length $6-6.5 \mathrm{~mm}$. (Fig. $5+7$.

Throughout the State: frequent. Mar 6July 21. Occurs on locust, oak, soft maple and linn. 


\section{4 (7082). Chalepus nervosa Panz., Ed. Voet., IV, 1798, 92.}

Elongate-oblong, nearly parallel. Color variable from nearly uniform rose red to nearly piceous, with a few indistinct reddish or yellowish spots; legs pale. Vertex with a median groove. Thorax one-third wider at base than apex, sides nearly straight, front angles often prominent and dentiform; disk coarsely and deeply punctured. Elytra each with three entire acute costie, the first broader, and but eight lows of punctures; margins and apex serrulate. Length $3.5-4 \mathrm{~mm}$.

Throughout the State; common. March 8-.June 28. Occurs on weeds and bushes of many kinds. Mating May 28.

Charistena nigrita Oliv, rather elongate, black, with faint bluish lustre, length $3.8 \mathrm{~mm}$., is said to be widely distributed over the Atlantic region.

\section{Stenispa Baly. 1858. (Gr., "narrow or straight."')}

Elongate, subcylindrical, black or bluish-black species, having the antennx 11-jointed, the third joint cylindrical, nearly as long as the first two; 4 to 10 subequal, 11th longer and subacute at tip ; front concave with a carina between the antennæ; thorax quadrate; tarsi dilated, densely puipescent beneath, first joint triangular, third deeply bilobed; tarsal claws divaricate. One of the two species has been taken in the State, while the other may occur.

KEY TO SPECIES OF STENISPA.

a. Black with a slight bronze tinge.

a a. Black with a bluish tinge; thorax red.

2275. METALLICA. COLLARIS.

2275 (7093). Stenispa metaldica Fabr., Syst. Eleut., II, 1801, 66.

Elongate, subcylindrical. Uniform black, shining, with a slight bronzed tinge. Thorax a little longer than wide, sides nearly straight, feebly curved near front angles; surface very sparsely and finely punctate. Elytra slightly wider than thorax, each with ten entire rows and a scutellar row of rather fine punctures. Length $5-6 \mathrm{~mm}$.

Throughout the State; frequent. April 29--Juiy 28. Occurs on grasses and sedges in moist meadows.

S. collaris Baly, length $6.5-7 \mathrm{~mm}$., was described from Oklahoma.

\section{Tribe XII. CASSIDINI.}

Small or medium-sized, oval or circular, usually subdepressed beetles, having the margins of the thorax and elytra expanded and flattened, beneath which the head and logs are retractile so as to be almost wholly concealed in repose. On account of their form they are often called "tortoise" or "turtle-beetles," and are for the most part very prettily colored, sometimes being bright golden in hue 
during life, but rapidly fading after being kept in the cabinet a short time.

The larvie are oval, flattened, prickly grubs, feeding upon the surface of leaves, often in company with the adults. They occur mostly upon the morning-glory, wild sweet potato and other members of the Convolvulus family, and sometimes do much damage to the foliage of the cultivated plants. From the rear end of the body they often extrude a long forked process which is bent forward over the back and to which they attach pieces of their cast-off skins and excrement, thus forming a sort of parasol to protect themselves from birds and other natural enemies. Of the six genera recognized from the United States, four are represented in Tndiana.

\section{KEY TO INDIANA GENERA OF CASSIDINI.}

a. Thorax rounded in front, head concealed.

b. Thorax with the extreme margin thickened; form oval, convex; larger, 9-11 $111 \mathrm{~m}$.

LXXVIT. PHYsonota.

bu. Thorax with simple flattened margins; smaller, not over $7 \mathrm{~mm}$.

c. Antennx short, not reaching beyond the base of thorax.

LXYYTIT. Cassida.

cc. Antenne longer, extending beyond the base of thorax.

TXXIX. COPTOCYCLA.

aa. Thor:ax less rounded in frout, bisinnate at base; head partially exposed; larger, 9-11 $\mathrm{mm}$.

ixxi. Ghelymorpha.

\section{Physonota Boh. 185t. (Gr., "swollen + back.")}

One large oblong-oval, strongly conver species belongs here.

2276 (7096). Physonota unipunctata Say. Journ. Phil. Acad. Nat. Sci., III, 1824, 434; ibid. II, 206.

Oblong-oval, convex. Pale greenish-yellow; thorax with three black dots, the middle one oblong; apical half of antemæe, meso- and metasterna, and abdominal segments in part, black. Thorax smooth, the hind angles rounded. Elytra fine, sparsely and irregularly punctate. Length 9-11.5 mm. (Fig. 548.)

Lake and Vigo counties; scarce. June 5-Angust 14. Oceurs on flowers of Cratagus, on the horse-mint (Monarda) and the rosin weed (Silphlinm), both larve and adults feeding on the latter.

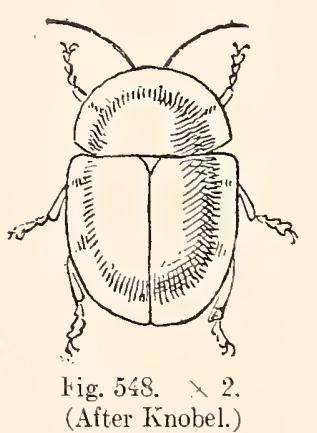

\section{T.XYVIII. Cissid Linn. 1735. (NL., "helmet.")}

'The members of this genus are known as "helmet-beetles," the rord Cassida being a Latin term for helmet or shield. They are oval in outline and have the head wholly concealed, the antemna 
short, the bodr more convex than in the nert genus. Five species probably occur in the State.

\section{KEY TO INDIANA SPECIES OF CASSIDA.}

a. Elytra with black spots or stripes.

b. Elstra each with three small, obscure black spots near the middle, two of these sometimes absent.

c. Dull red; larger. 6-7.5 $\mathrm{mm}$.

cc. Dull sellow; smaller. not over $5.5 \mathrm{~mm}$.

227i. NIGRIPES. 227S. ATRIPES.

6b. Elytra dull rellow, each with sutural line and two stripes black; thorax reddish-sellow.

2279. BIVITTAтA.

a a. Elytra uniform green or greenish-rellow without spots or stripes.

d. Under surface black; elytral punctures confused.

THORACICA.

dd. Under surface pale: elytra each with nine rows of rery coarse punctures.

22S0. PALLIDULA.

227 (7097). Cassida nigripes Oliv., Encyc. Meth., V, 1790, 34 S.

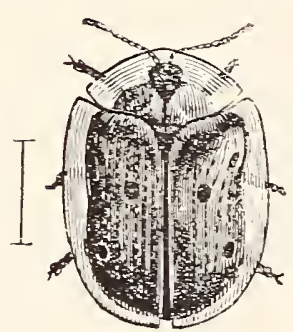

Fig. 549.

Broadly ovate. Dull ied; elytra each with three obscure black dots near the middle; under surface and legs black, shining: base of antennæ, tibice in part and tarsi reddish. Thorax twice wider than long, broadly rounded in front, smooth. Elstra with edges thickened and reflexed, base deeply emarginate, the humeral angles prominent; each with nearly regular rows of fine, scarcely impressed punctures. Length 6-7.5 mm. (Fig. 549.)

Throughout the State; scarce. April 26-September 28. Occurs on wild morning-glory and sweet potato vines.

\section{7 (7097a). Cassida atripes Lec.. Col. of Kan., 1S59, 28.}

Smaller and less broadly oval than nigripes. Color (after death) dull sellow, the elytra each with a small, round black spot near middle of disk and usually two oblong ones on sides. Thorax shorter and proportionalls wider than in nigitipes, the hind angles much less rounded than there. Elytra as in nigripes except that the sides on basal half are less abruptly declivous or sloping; interrals finels alutaceous. Length $5-5.5 \mathrm{~mm}$.

Taken in small numbers by Wolcott near Pine and Iillers, Lake County. Mar 21-May 30. Described from Long's Peak. Listed as a rariety of nigripes, but in my opinion distinct.

*2279 (7098). Cassida birtttata Say, Journ. Phil. Acad. Nat. Sci., T, 1826. 295 ; ibid. II: 341.

Oral, convex. Thorax rellowish, with a large triangular brownish-red space at base; elstra dull sellow, with the suture and two stripes on each, connected at apex. black or dark bromn; under surface and legs piceous. Thorax coarsely, sparsely and shallowly punctate. Elytra with regular rows of rather coarse, deep punctures.

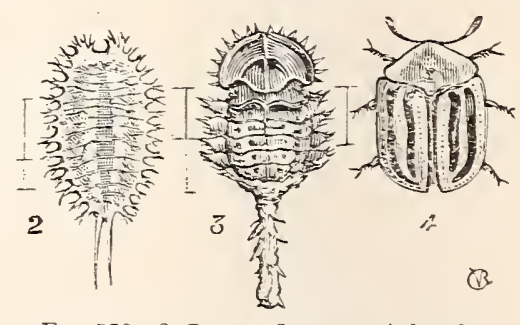

Fig. 550. 2, Larra; 3, pupa; 4, beetle. (After Riley.) those of the submarginal row larger and black. Length 4.5-6 mm. (Fig. 550.) 
Throughout the State; common. February 8-December 22. Hibernates beneath mullein leaves and rubbish. Occurs on sweet potatoes and wild members of the Convolvulus family, often doing much injury to the former. The leaves only of young plants should be dipped in a strong solution of arsenate of lead.

C. thoracica Ill., length $7 \mathrm{~mm}$, is known from Illinois.

*22S0 (7100). Cassida pallinuta Boh., Mon. Cass., II, 185S, 457.

Oblong-ovate, sides nearly parallel. Uniform dull green or greenishyellow; antennie with last three joints piceous. Thorax twice as wide as long, the angles all broadly rounded; margin very broad, flat and translucent. Elytra with humeral angles prominent, margins broadly flattened, punctures very coarse and close-set; intervals narrow. Length $5-5.5 \mathrm{~mm}$.

Vigo and Perry counties; scarce. February 11-December 29. Riley records it as attacking egg-plant, the horse-nettle and other species of Solanacex.*

\section{Coptocych Chev. 1834. (Gr., "cut+circle.")}

The members of this genus are known from those of Cassida by their longer antennx and more depressed form, with broader and more flattened margins of thoras and elytra.

KEY TO INDIANA SPECIES OF COPTOCYCLA.

a. Elytra without black spots or dark markings.

b. Elytra wholly golden yellow (dull reddish-yellow after death), not alutaceous.

bb. Elytra brownish-red, very finely granulate or alutaceous.

22S1. BICOLOR.

2282. PURPURATA.

a . Elytra with black spots or marks, sometimes wholly black, except the margins.

c. Disk of elytra with numerous tubercles or elevations, the margins pale at middle and apex.

22S3. CLAVATA.

c. Disk of elytra without distinct tubercles, the margins pale from near humeral angles to apex.

r. Dark discal space of elytra broken by numerous yellow or pale spots.

dr. Dark discal space without spots, black, shining.

22S4. SIGNIFERA.

2255. PLICATA.

$22 S 1$ (7102). COPTOCYCia BICOLOR Fabr., Syst. Eleut., I, 1S01, 369.

Broadly oral, subdepressed. Above brilliant brassy or' greenish-golden in life; dull reddish-yellow after death; under surface and last four joints of antennre black. Margins of thorax and elytra broadly expanded, very thin and translucent. Elytra each with a small, rounded, depressed space on disk, a large oblong one (often interrupted at midale) near margin, and with about ten rows of small, feebly impressed punctures. Length 5.5-6 mm. (Fig. 551.)

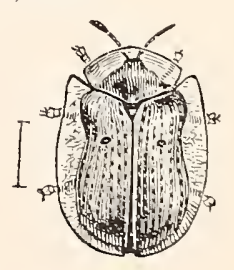

Fig. 551.

*Amer. Nat. XVI, 1882, 679.

$[78-23+02]$ 
Throughout the State; frequent. May 21-October 23. Occurs on morning-glory, bittersweet and sweet potato vines; commonly known as the "gold-bug" and in life one of the most brilliant of our beetles. Of it Harris says: "When living' it has the power of changing its hues, at one time appearing only of a dull yellow color, and at other times shining with the splendor of polished brass or gold, tinged sometimes also with the variable tints of pearl. The wing covers, the parts which exhibit a change of color, are lined beneath with an orange colored paint, which seems to be filled with little vessels; and these are probably the source of the changeable brilliancy of the insect."

$22 \$ 2$ (7105). Coptocycla purpurata Boh., Mon. Cassid., III, 1S57, 300.

Broadly oval, more convex than bicolor. Abore uniform dull red, the margins less expanded, translucent; under surface black; antennie, tar'si and front tibire pale. Elytra minutely granulate or alutaceous, each with a small inpression on middle of disk; the rows of punctures fine, feebly impressed. Length $5-5.5 \mathrm{~mm}$.

Martin County; 1are. May 16. Ranges from Pennsylvania to Kansas.

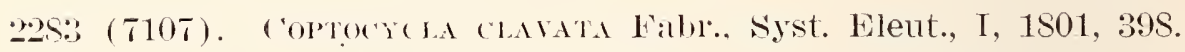

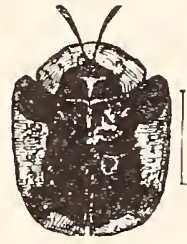

Fig. 552 .

froadly oval. Base of thorix and disk of elytra brown; margins of elytra with pale spot near middle and another much smaller at apex; under surface pale rellow. Elytra with numerous conical elevations or tubercles, the largest on suture in front of middle. Length $7-7.5 \mathrm{~mm}$. (Fig. 552.)

Lake, Wells, P’utnam and P'osey counties; scarce. March 20-September 17. Beaten from linden and oak foliage. A large and easily recognized species.

2284 (7104). Coptocycla signifera Herbst., Kafer, VIII, 1791, 313.

Broadly oval. Dull yellow; base of thorax usually with a large black spot, enclosing two pale ones; disk of elytra black with irregular yellow spots, margins pale except near humeral angles; under surface black, its sides yellow, except two joints of antennie dusky. Margins of thorax and elytra as in bicolor. Elytra finely alutacesus. the discal depressions and rows of punctures more irregular than in bicolor, the punctures coarser. Length 5.5$6 \mathrm{~mm}$. (Fig. 553.)

Throughout the State; common. February $1 \frac{1}{4}$

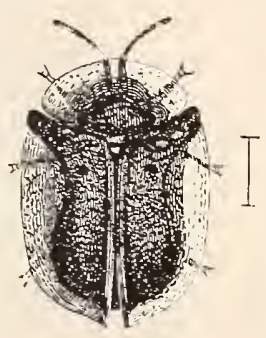

Fig. 553. (After Riley.) september 25. Occurs on foliage of thorn, buckere and especially cn that of members of the Convolvulus family. Hibernates beneath mullein leaves and rubbish. Listed as C. guttata. 
2285 (-). Coptocrcla plienta Bon., Monog. Cassid., III, 185T, 49:3.

Form of bicolon: Above black, shining, the margins of thorax and elytra, except humeral angles of latter, pale yellow. Under surface pale, the center of abdomen darker. Elytra each with a round, deep fovea on mirtdle; punctures coarse and shallow. Tarsal claws pectinate at base. Length 6- $7 \mathrm{~mm}$.

Throughout the State; scarce. May 12-June 10. Swept from roadside herbage.

\section{Chempmorpha Chev. 1834. (Gr., "tortoiso+shape.")}

This genus contains large convex specios, with the margins of thorax and clytra comparatively narrow, the former bisinuate at base and emarginate in front so as to leave the head partly visible. 'The prosternum is grooved and prolonged behind the front coxæ, the apex fitting into a notch in the mesosternum. One of the two recognized species occurs in the State.

2286 (7109). Chelymorpha argus Herbst., Col., VIII, 1801, 278.

Oblong-oval, convex. Bright brick red; thorax with four black dots arranged in a transverse row, and often two others behind them; elytra each with six black dots and a common sutural one near the scutellum; under surface, legs and outer antennal joints black. Thorax and elytra alutaceous, the former finely and sparsely, the latter more coarsely and rather densely punctate, the punctures not in rows. Length $9.5-11.5 \mathrm{~mm}$. (Fig. 554.)

Thronghout the State; frequent. April 7-Angust 11. Occurs on milkweed and on wild potato (Ipomoea pandurata L.). It is well fitting that this

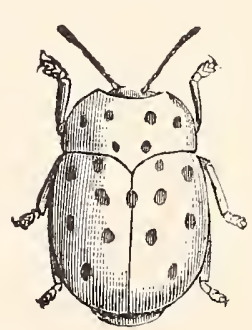

Fig. 554. $\therefore 2$

(After Forbes.) large and difficult family should olose with this prettily marked species, which is among the largest and most striking of our native Chrysomelids.

\section{Family IIV. BRTCHID E.}

\section{The Pea and Bean Weevils.}

A small family of short, thick-bodied beetles, all but one being less than one-fourth of an inch in length. They are closely allied to the Chrysomelidx, but differ from most species of that family in having short serrate antenne and the tip of the abdomen exposed, and from all in having the mentum listinetly pedunculate. They also resemble very closely the Anthribide, a family of the Rhynchophora or snout beetles, but the labrum and palpi are of the ordinary form and the head is but little prolonged in front. 
In addition to the characters mentioned the Bruchidx have the mentum transverse, more or less emarginate in front, its base supported by a peduncle; maxillary palpi four-jointed, the terminal joint slightly oval; head free, usually deflexed; eyes large, more or less emarginate in front; antenni 11-jointed, dentate or pectinate, inserted at the side of the head in front of the eyes; thorax margined at the sides; elytra entire or truncate, pygidium always exposed; front coxæ oval, moderately prominent, the cavities closed behind; hind coxæ transverse, narrowly separated; abdomen with five free ventral segments; front and middle legs of moderate length, their femora not dilated; hind femora usually dilated and often toothed; tarsi with the first joint elongate and with the two following densely clothed beneath with spongy pubescence, the third joint deeply bilobed; tarsal claws usually broadly toothed at base.

The larvæ of these weevils live in the seeds of leguminous plants, especially those of peas and beans, to which at times they cause great injury. The eggs of the pea-weevil are laid upon the pod while the peas are quite small, and when hatched the young bore through the pod into the young peas and spend most of their lives within the latter. Every person who eats peas in quantity has doubtless swallowed hundreds of these small worms, but "where ignorance is bliss 'tis folly to be wise." The larva, before transforming, eats a circular hole on one side of the pea, leaving only a thin scale, which is easily pushed away by the mature beetle. The latter usually remains in the pea until spring and is often planted. The seed peas should be placed in water and those which float picked out and destroyed; or the peas should be placed in a close receptacle and exposed for a few hours to a smail quantity of carbon-bisulphide.

The principal paper treating of the North American species of the family is by

Horn.-- "Revision of the Bruchidx of the United States," in Trans. Amer. Ent. Soe., IV, 1873, 311-342.

In this paper 55 species are recognized and distributed among three genera; while one genus and about half a dozen species have since been described.

KEY TO INDTANA GENERA OF BRUCHIDA.

a. Hind tibire with two slender jointed spurs; front coxre entirely separated by the prosternum; size larger, $7-8 \mathrm{~mm}$. I. Spermophagus. aa. Hind tibiæ without jointed spurs; front coxæ very prominent, contiguous; smaller, not over $5 \mathrm{~mm}$.

II. Bruchus. 


\section{Spermophiaus Schon. 1833. (Gr., "seed + eating.")}

This genus is represented east of the Rocky Mountains by a single medium-sized oval species having the hind tibix compressed, cylindrical and armed with two unequal jointed spurs, the inner one short and placed at right angles to the tihia.

2287 (7111). Spermophagus robiniz Fab., Sjst. Eleut., II, 1801, 397.

Oblong-oral, feebly conrex. Dull reddish-brown, clothed with grayishyellow pubescence; thorax clouded with piceous; elytra with small black spots arranged in five irregular transierse rows. Thorax nearly semicircular, truncate in front, base at middle truncate, bisinuate each side; surface sparsely and rather coarsely punctate, with dense fine punctures in the intervals. Elytra broadest at middle, their tips broadly rounded; surface striate, the striæ punctate; interrals feebly conrex, densely punctate. Length $7-7.5 \mathrm{~mm}$.

Throughout the State, frequent; more so in the southern counties. March 11-November 7. Probably hibernates. The larvæ live in the seeds of the black locust and the honey locust or thorn, and the adults usually occur on the foliage or beneath the bark of these trees.

\section{BRUCHUs Linn. 1767. (Gr., "a locust without wings."')}

A large genus of small, robust oval species, quite variable in color and separated by Dr. Horn mainly by the armature of the hind femora. The beetles must therefore be mounted so that the femora can be readily examined. Of this character he says: "The tooth of the hind femur is situated near the outer end at about one-fourth from the knee, on the lower edge and (except as noted in ker) on the inner side. Between the tooth and the knee is an emargination of greater or less depth in which the denticles are

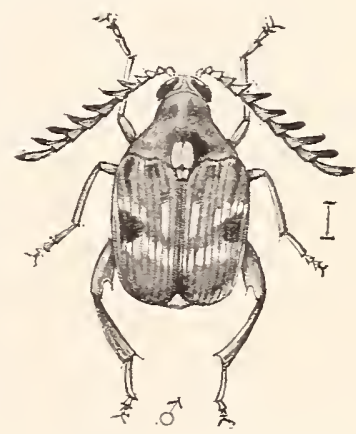

Fig. วัว๊. Bruchus chinensis Linn. Male. (After Chittenden in Bull. 8, X. Ser., U. S. Div. Ent.) situated." The following species have been taken or should occur in the State:

KEY TO INDIANA SPECIES OR GROLPS OF SPECIES OF BRCCHUS.

a. Thorax with tooth at middle of sides; hind femur with tooth on outer side only.

aa. Thorax not toothed on the sides.

22SS. PISORUM.

b. Disk of thorax elerated, with a median groore; hind femur with a strong tooth and three denticles.

bb. Disk of thorax simply conrex. not elerated.

2259. MrIICS.

c. Hind femur without tooth or denticles; elstra black with a large red space on each near the sides. 
cc. Hind femur with either one or two teeth or denticles, or both.

d. Hind femur without denticles; one or two teeth always present.

Group $A$.

dd. Hind femur with denticles and usually a single tooth present.

Group $B$.

22SS (7115). Brtches PISorum Linn., Syst. Nat., II, 1765, 604.
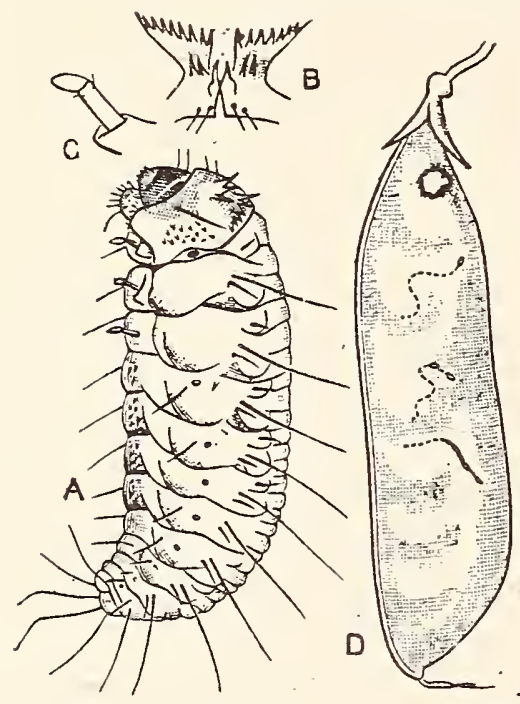

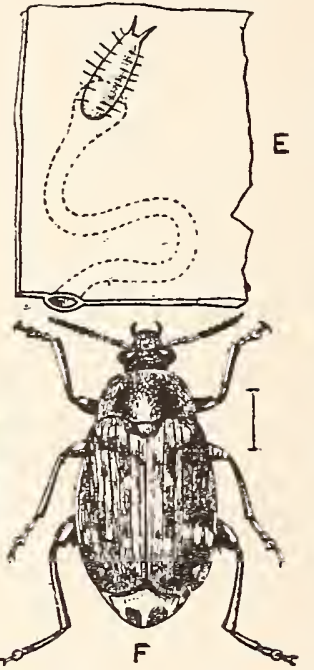

F

Oblong-oval, subdepressed. Black, feebly shining; above, densely clothed with red dish-brown and whitish hairs; thorax with a triangular whitish space in front of scutellum; elytra with yellowish, grayish and whitish hairs, the latter forming an oblique band behind the middle; pygidium covered with gray hairs except two oval black spots near apex; antenn:e black, the three basal joints rufous; legs black, front

Fig. 556. A, young larva; $B$, prothoracic spinous process; $C$, iarva greatly magnified; D, pea-pod, with tracks of entry; E, portion of pod, with egg, and the track made by larva; F, mature beetle. (After Riley.)

tibiæ and tarsi rufous; under surface black, shining. densely punctate, sparsely clothed with fine grayish hairs. Thorax broader than long, coarsely and densely punctate. Elytra slightly longer than broad, striate, the striæ finely punctate. Length $4.5-5 \mathrm{~mm}$. (Fig. 556.)

This is the "pea weevil" and occurs in abundance throughout the State wherever peas are cultivated. Its habits are given above under the family hoading.

2289 (7116). Bruchus mincs Say, Des. of N. Amer. Curculionidæ, 1S31, 2 ; ibid. I. 260.

Robust, subquadrate. Brownish, rariegated with gray, black and white pubescence; sides of median ridge of thorax black or dark brown at summit, divided by a small white spot; elytra with a common heart-shaped blackish spot behind the scutellum and with numerous small, black, oblong spots tipped with white at their basal ends; antennx and legs pale reddishbrown, the hind ones banded with piceous; pygidium clothed with whitish hairs, male, or with a large, smooth, oval, brown space, female. Thorax bell-shaped, disk with two median ridges separated by a narrow groove and with a tubercle each side near base. Flytra nearly as broad as long, striæ punctured; intervils flat. densely punctulate. Length $3 \mathrm{~mm}$.

Throughout the State; frequent. April 23-October 15. Occurs on flowers, especially those of red and black haws; ox-eye daisy and Eupatorium. It; as well as other members of the family, feign reath and tumble to earth when disturbed. 
B. discoideus Say, Ioneth :3-4.5 mm., is recorded from Ohio, Kansas and Colorado.

Group A.

KEY TO SPECTLS OF GROL'P A.

1. Hind femux with a tooth on both inner and onter mangins; that on inner side larger.

b. Median basal thoracic lobe with elevated ivory-like spalce. (Fir. 555.)

CIINENSIS.

bb. Median basal lobe with whitish hairs only. (Fig. 557.)

au. Hind femur with one tooth only on inner margin.

c. Elytra biack with red spots on the spaces.

1. Suture depressed; elytra each with a red spot on middle which touches the side margins.

2290. BIVULNERATCS.

dd. Disk of elytra flat, the suture not depressed; elytra more black than rufous, the red spot near outer apical margin.

cc. Elytra wholly black, hind fenora and tibize bicolored.

CRUENTATCS.

B. chinensis Linn., antennæ of male strongly pectinate, length $3-4 \mathrm{~mm}$., is known as the "cowpea weevil," as it lives in seedis of cow-peas, beans, ete. B. quadrimaculatus Fab., longer, less robust, with broader thorax, black with gray and white pubescence, length $3-4.5 \mathrm{~mm}$., is known as the "four-spotted bean weevil," and also lives mainly in cow-peas. Both are widely distributed, have been introduced in seeds and are likely to oceur any place in Indiana.

NISRTNES.

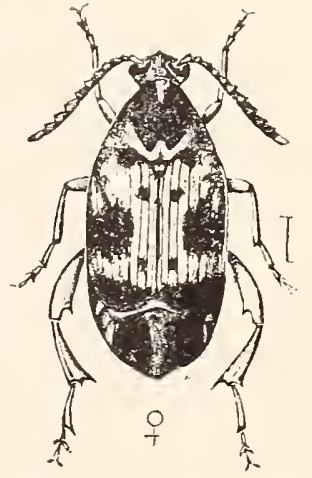

Fig. 557. Bruchus quacrimaculatus Fab. Fin ale (After Chittenden.)

2290 (7128). Bruchus Bivulneratus Horn, Trans. Amer. Ent. Soc., IV, $1873,325$.

Oval, robust. Black, feebly shining; elytra each with a large red spot at middle which reaches the margin but not the suture. Head elongateoval, densely punctured. Antennæ as long as head and thorax, the three basal joints reddish. Thorax shining, one-half broader at base than long. sides feebly curved and gradually narrowed to apex, base lobed at middle. surface densely and rather coarsely punctured. Elytra as broad as long. deeply striate; intervals flat, densely and rugosely punctate. Length 3$3.5 \mathrm{~mm}$.

Southern two-thirds of State; frequent. May 15-October 14. Oecurs on flowers of milkweed and white snakeroot (Eupatorium). The larva are said to breed in the seeds of wild senna (Cassia marilandica L.). 
B. cruentatus Horn, length $3 \mathrm{~mm}$., was described from Georgia, Illinois and Texas; B. nigrinus Horn, length 3-3.5 mm., is known from the "Middle States."

Group B.

KEY TO SPECIES OF GROUP B.

a. Hind femur with a tooth in addition to denticles.

b. Hind femur with one tooth and two denticles.

c. Elytra dull reddish-yellow; body beneath black, abdomen reddish.

cc. Elytra entirely black or dark piceous.

2291. PECTORALIS.

d. Legs all black.

c. Scutellum round, densely clothed with white pubescence.

ee. Scutellum more or less elongate.

2292. ALBOSCUTELLATUS.

$f$. Pubescence of elytra variable in color, grayish; interrupted on intervals, which are coarsely punctured.

2293. Distinguendes, male.

$f f$. Pubescence uniform in disposition and color, that of elytra very sparse.

2294. Calvus.

dd. Legs bicolored, front and middle ones reddish, hind femora black in part.

g. Abdomen reddish or brownish-yellow.

2295. овTECTUS.

gg. Abdomen and entire under surface black.

h. Pubescence of elytra interrupted on the intervals by darker spots; spur of hind tibiæ of normal length.

$i$. Thorax roughly punctured; elytral intervals with coarse punctures.

2293. Distinguendus, female.

ii. Thorax not roughly punctured; elytral intervals finely punctulate.

2296. HIBISCI.

hh. Pubescence sparse, forming an X-like design; terminal spur of hind tibiae nearly half the length of the tibia itself.

2297. Longistilus.

bb. Hind femur with one tooth and three denticles.

j. Oval, robust; black, clothed with grayish hairs. 229S. mrusculus.

ji. Oblong-oval; black, the elytra in great part rufous.

a . Hind femur with a few small denticles only.

$k$. Antenna not as long as head and thorax.

ki. Antennse longer than the entire body.

2299. Exiguus.

2300. SEMiNulum.

2301. MACROCERUS.

2291 (7141). Bruchus pectoralis Horn. Trans. Amer. Ent. Soc., IV, 1S73, 333.

Oblong-oval, rather robust. Elytra and abdomen dull red, the former sparsely clothed with silken yellowish pubescence; head, thorax, meso- and metasterna black; antennæe black, three basal joints rufous; legs pale rufous, bases of hind femora and tibire piceous. Thorax scarcely as wide 
at base as long. sides nearly straight; surface densely and rugosely punctured. Elytra at base not wider than thorax, stric finely punctured; intervals flat, each with a row of coarse punctures on the middle. Length $3 \mathrm{~mm}$.

Poser County; rare. June 6. Described from Texas.

2292 (7144). Bruchus alboscutellatus Horn. Trans. Amer. Ent. Soc., IV, $1873,334$.

Oblong-oval, moderately robust. Black, sparsely pubescent with grayish hairs, those on intervals of elytra interrupted, forming short, quadrate white spots; under surface black, more shining than above, very sparsely pubescent. Antennie longer than liead and thorax, black, the four basal joints paler. Thorax broader than long, sides feebly curved, the apex but little narrower than base; surface coarsely but not densely punctured. Elytra slightly longer than wide, at base not wider than thorax, strie indistinctly punctured; intervals flat, minutely punctulate. Pygidium broadly oval, very convex, coarsely and sparsely punctured and finely rugulose. Length $2.5 \mathrm{~mm}$.

A southern form taken only near Tincoln City, Spencer County. May 24. Swept from roadside herbage. Breeds in the capsules of the water purslane (Luduigia palustris Ell.). Easily known by the round white scutelium. The elytra are mottled much as in the common hibisci. From the latter it is easily separated by the black legs and antennx, as well as by the form of the sentellum.

2293 (7146). Bruchus distinguendus Horn. Trans. Amer. Ent. Soc.. IV,

1873,336 .
Broadly oval, robust. Black, rather sparsely clothed with grayish pubescence, that on the elytra interrupted on the intervals with indistinct darker spaces; legs all black, male; front and middle pair reddish-brown, female. Antennie somewhat longer than head and thorax, subserrate. Thorax bell-shaped. slightly broader at base tlian long, base feebly lobed; surface coarsely and sparsely punctured. Elytra together as broad as long, sides broadly curved, at base becoming rapidly broader than thorax; surface striate; intervals flat, each with a row of coarse punctures. Length 2.5-2.8 $\mathrm{mm}$.

Lake, Martin, Knox and Clark counties ; rare. June 30-August 8. Four specimens were taken from the ripening pods of the catgut or goat's-rue, Cracca virginiana L. A southern form described from Georgia.

2294 (7147). Bruchus calvus Horn, Trans. Amer. Ent. Soc., IV, 1ST3, 336.

Oblong-oral. Uniform black, very sparsely pubescent with grarish hairs. Antenne as long as head and thorax, subserrate. Thorax slightly broader at base than long, sides moderately curved and gradually narrowed to apex; surface finely and rugosely punctate. Elytra together less wide than long; surface shining. finely striate, the stria indistinctly punctured: intervals flat, finely punctulate. Length 2-2.5 $\mathrm{mm}$.

Northern half of State, frequent; Knox County only in the 
south. April 20-October 25. Occurs in numbers along the borders of marshes, especially on the flowers of the black choke-berry (Aronia nigra Willd.).

2295 (7150). Bruchus obtectus Say, Des. N. Am. Curc., 1831, 1 ; ibid. I, 259.

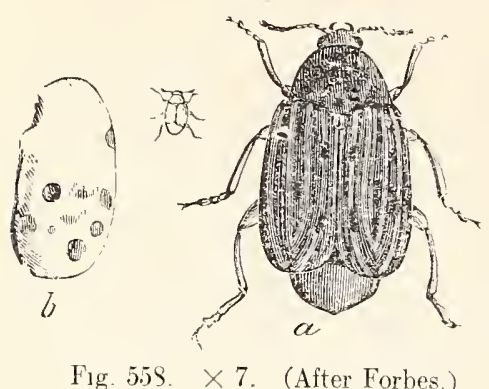

Oblong-oval, moderately robust. Black or dark piceous, clothed with dark grayishyellow pubescence, that of elytra interrupted by transverse bands of darker color; abdomen dull reddish-brown; antennæe black, the four basal and apical joints rufous; legs reddish-brown, under side of hind femora piceous. Thorax one-third wider at base than long, sides curved and gradually narrowed to tip, base lobed at middle; surface coarsely and sparsely punctured. Scutellum subquadrate, emarginate at apex. Elytra together not longer than wide, at base not wider than thorax, stria punctured; intervals tiat, densely punctulate. Pygidium rufous, broadly oval, coarsely punctured, sparsely pubescent. Length 2.5-3.5 mm. (Fig. 558.)

'This is the well-known "bean weevil," and probably occurs in numbers throughout the State, though taken only in Lake and Marion countios, where it is common in heans in the seed stores. March 9-.July 14.

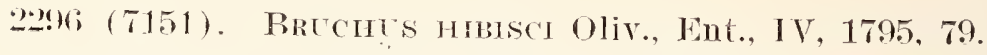

Broadly oral, robust. Black, moderately shining; sparsely pubescent with grayish-yellow hairs which on the elytra are frequently and irregularly interrupted by transverse bare spaces; antenna pale reddish-brown. joints $t-9$ often slightly darker ; front and middle legs rufous; hind femor: black, red at tip. Thorax twice broader at base than long, rapidly narrowing to apex; surface sparsely punctured. Scutellum whitish, bifid at tip, median line distinct. Elytra together as broad as long, disk convex, finely striate, the strice punctured; intervals flat, marked with fine and coarse punctures intermingled. Pygidium black, broadly oval, sparsely punctured. Length 2-2.5 $\mathrm{mm}$.

Southern two-thirds of State; common. April 13-November 1. Breeds in the seeds of the rose-mallow (Hibiscus), the beetles emerg. ing from seeds kept in vials from October 15 to November 1st. Occurs in spring and summer on fiowers of red-bud, dogwood, red haw, ete. This is our only speries having the denticles of the hind femur on the vertical face of the tooth itself.

2297 (7152). Brechus longlstulus Horu, Trans. Amer. Ent. Soc., I $r$, 1873, 339.

Oblong-oval. Black, shining, sparsely pubescent with whitish hairs, which on the elytra are arranged in an X-like design; tibia pale reddish- 
brown ; femora piceous at base, tarsi piceous; antenna black, slightly longer than head and thorax, gradually thicker to tip. Thorax wider at base than long, sides rather strongly curved and gradually nalrowing to apex; surface densely punctured. Elytra longer than wide, broader behind the middle, striæ finely punctured; intervals flat, densely punctulate. Leugth 2 mm.

Lake and Crawford counties; rare. May 25-May 28. Said to breed in the seeds of mallows.

2298 (7155). Bruchus musculus Say, Desc. N. Am. Curc., 1831, 3 ; ibid.

Oval, moderately robust. Black, sparsely clothed with grayish hair; antennæ usually entirely reddish, often with joints 6-10 piceons; legs reddish-yellow, middle femora at base and hind femora and tibix piceous. Head coarsely punctured; eyes very deeply divided. Antennie longer than head and thorax, gradually thicker to tip. Thorax one-third wider at base than long, rapidly narrowing from base to apex, coarsely and densely punctured. Elytra subquadrate, disk flattened, with rather deep punctured striæ; intervals flat, densely and finely punctulate. Length 2-2.5 $\mathrm{mm}$.

Marshall, Knox, Lawrence, Posey and Crawford counties; rare. June 2-September 4.

2299 (7157). Bruchus mxiguus Horn, Trans. Amer. Ent. Soc., IV, 1873, 341.

Oblong-oval. Black, sparsely clothed with short, fine grayish-yellow pubescence; elytra in great part dull reddish, their sides and suture narrowly piceous; antemme black, four basal joints paler; legs pale reddishbrown. Thorax one-third wider at base than long; surface coarsely and densely punctured. Elytra gradually broader to apex, finely striate, the striæ indistinctly punctured; intervals tlat, densely punctulate. Pygidium reddish, rather convex, coarsely punctured and pubescent. Length $2 \mathrm{~mm}$.

Vigo, Posey and Jennings comntios; scarce. April 27--July 11. Occurs on flowers of the yellow puccoon and wild parsnip and said to breed in the seeds of the false indigo (Amorpha fruticosa L.).

2300 (7158). Bruchus seminulum Horn, Trans. Amer. Ent. Soc., IV, 1873. 342.

Narrowly oblong-oval. Black, sparsely clothed with pale gray pubescence. Antennæ not longer than head and thorax, the latter wider at base than long, sides very feebly curved and gradually narrowing to apex, surface coarsely punctured. Scutellum small, oval. Elytra gradually wider from base to apex, finely striate; intervals flat, densely punctulate, each with a row of distant coarse punctures. Length $1.5 \mathrm{~mm}$.

Vigo County ; rare. June 15. Taken froin flowers of dogwood Our smallest and most slender species.

2301 (7159). Bruchus macrocerus Horn, Trans. Amer. Ent. Soc., IV, 1Si3,

342.

Oblong-oval, rather robust. Uniform black, moderately shining, rery sparsely clothed with whitish pubescence. Antenne one-fourth longer thau 
entire body, subserrate. Thorax a little wider at base than long, sides feebly curred, surface densely punctured. Elytra slightly wider at base than thorax, together nearly as wide as long; strix indistinctly punctured, interrals flat, finely and rugosely punctured. Length $2-2.5 \mathrm{~mm}$.

Floyd County; rare. June 2:3. Readily known by the great length of antennæ.

\section{Series VI. HETEROMERA.}

This series is sharply limited and is distinguished primarily, as the name implies, by the different number of tarsal joints, those of the front and middle legs always having five, while the hind legs have but four." The food of the larva is exceedingly variable, but consists for the most part of decaying vegetable matter, as rotten wood and fungi. Some, however, are carnivorous or parasitic. The following families of the series are represented in Indiana:

KEY TO INDIANA FAMILIES OF HETEROMERA.

a. Front coxal cavities closed behind.

b. Tarsal claws simple.

c. Next to last joint of tarsi not spongy beneath; front coxie short, not projecting from the cavities; tarsi without lobes beneath; antennx usually more or less bead-like, as long as head and thorax; color almost always black or dark brown.

Family LT. Tenebrionid e, p. 1243.

$c c$. Next to last joint of tarsi spongy beneath; front coxæ more prominent; form elongate, slender; thorax in our species subcrlindrical, narrower than elytra ; length $7-14 \mathrm{~mm}$.

Family LTII. IAagridde, p. 1284.

bъ. Tarsal claws pectinate or comb-like; form usually elongate-oval, convex; thorax not narrowed behind and usually as wide at base as elytra, its side margins distinct; color usually brownish; length less than $12 \mathrm{~mm}$.

Family LII. Cistelide, p. 1270.

aa. Front coxal cavities open behind.

d. Head not strongly and suddenly constricted behind the eyes.

e. Middle coxie not very prominent.

f. Thorax margined at sides, broad at base, its disk with basal impressions; form usually elongate, loosely jointed; maxillary palpi usually long and pendulous, with the joints enlarged.

Fimily IATII. Melandride, p. 1:sti.

ff. Thorax not margined, narrower behind, disk not impressed at base; form usually long and narrow; head sometimes prolonged into a beak.

Family LIX. Pithid.e, 1) 1:02.

*It would seem that the family Sphindidæ should be placed here, though usually classed with the Serricornia. 
ee. Middle coxie very prominent; thorax narrower at base than elytra. its sides romuded and without a sharp edge; next to last tarsal joint broad, slightly bilobed; body corering rather flimsy in tex$\{?: \cdots$

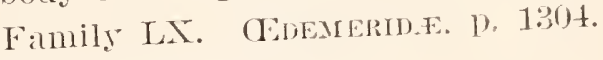

d d. Head strongly and suddenly constricted behind the eyes.

g. Thorax with a sharp edge at sides. its base as wide as elytri.

h. Antennie filiform.

$i$. Hind coxie with plates: head with verter lobed ol ridged behind. so that in extension it reposes on the front edge of the thorax; abdomen usually prolonged in a style or pointed r-ress.

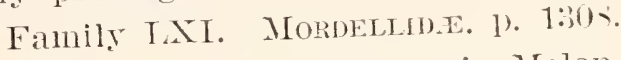

ii. Hind coxie withont plates; characters otherwise as in Nelandrevide; length less than $5.5 \mathrm{~mm}$.

Tribe (LTII). seraptiini. p. 120).

hh. Antennae flabellate (male), subserrate (female): characters otherwise as in Rhipiphoridie.

Genus (LAY). Pelecotona, p. 13
gg. Sides of thorax more or less rounded and without a sharp edge.
j. Thorax at base narrower than elstra.

k. Hind coxie not prominent; tarsal claws simple; antennæe filiform and simple: head with an abrupt narrow neck: length less than $12 \mathrm{~mm}$.. usually less than $5 \mathrm{~mm}$.

Family TAII. Axthicide, p. 1326.

lik. Hind coxie large, prominent.

l. Tarsal clans simple; head horizontal; antenne usually branched in male, serrate in female; next to last tarsal joints very broad.

Family LXIII. Prrochrom e. p. 1346.

71. Tarsal claws cleft or toothed; front rertical; elytra and sides of abdomen without coadaptation; length $6 \mathrm{or}^{\circ}$

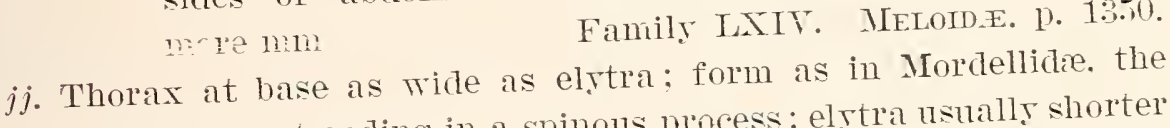
abdomen not ending in a spinous process: elçtra usualls shorter than abdomen and narrowed behind: antennie pectinate in the males. frequently serrate in the females.

Family TAT. RHIPIPHORID. 1). 136 .

\section{Family LT. TENEBRIONID.E.}

\section{The Darisling Beetles.}

A laroe family whose species vary greatly in size and form of body. In color they are mostly black or dark brown, whence the name of the trpical genus, Tenebrio. which is derived from a Latin word meaning" "darkness." The larger forms have a peculiar loosejointed appearance and lono, rather chmst and awkward legs. The 
antennæ are usually bead-like or moniliform, and the mouth parts rather small and not prominent. Onr species occur for the most part on fungi or beneath bark, but in the desert regions of the West, where the family is richly represented, they take the place of the Carabidxe and are found on the ground, beneath cover of any kind.

In addition to the general characters given above, the Tenebrionidie have the head narrower than thorax; mandibles short, robust and furnished with a basal tooth ; eyes usually transverse, with their front emarginate; antennæ inserted under the sides of the head, 11(very rarely 10-) jointed; front coxæ short, globose, separated by the prosternum, their cavities entirely closed behind; elytra rounded at tip, covering the abdomen, the latter with five ventral segments, the first three more elosely connected than the others ; first joint of hind tarsi almost always longer than second; tarsal claws simple.

The larve are long and slender, with the body often flattened, somewhat like a wireworm, and of a hard, horn-like texture. Six thoracic legs are present, and in addition, a short prop or pseudopod on the under side of the anal end. They are for the most part scavengers, living in dead or decaying wood and dry vegetable products or fungi. Some of them, as the "meal-worm," are injurious, though none attack growing crops. About 10,000 species of Tenebrionidæe are known, 750 of which are listed from the United States. As already mentioned, the vast majority of these occur only in the Western and Southwestern States, where they often form the most striking feature of the Coleopterous fauna. In Indiana but one of the three subfamilies into which the family is divided is represented, and this only by 52 known species. The principal paper and the only one treating of the North American species of the family as a whole is by

Horn-- "Revision of the Tenebrionida of America," in Trans. Amer. Phil. Soc., XIV, 1870, 253-404.

A number of genera have since been treated separately by Horn, Casey and others and the papers will be mentioned under their respective tribal or generic headings.

\section{Subfamily I. TENEBRIONINAE.}

In this subfamily, to which all the Indiana representatives of the family belong, the hind margin of the third and fourth ventral segments is leather-like or coriaceous in texture; the middle coxæ are usually provided with a distinet trochantin and their cavities extend outward to reach the epimera. The inner wings are more often 
present than absent and the tarsi are pubescent beneath. Nine of the 17 tribes recognized by LeConte and Horn are known to be represented in the State.

KEY TO INDIANA TRIBES OF TENLBLIONINA.

a. Front of head entirely corneous or horn-like in texture, never hinged with a leather-like clypeus.

b. 'Tarsi not compressed, their first joint moderate or elongate, never rery short; cheeks not sulcate.

$\therefore$ Eyes less prominent than the sides of front, more or less trinsverse, always emarginate in front.

d. Next to last joint of tarsi entire.

e. Front coxie rounded; middle coxie with trochantiu; antenuic with third joint usually longer than those following.

f. Front feebly dilated at the sides; tarsi with silken pubescence beneath; form elongate, rather slender; size large, usually 12 or more mm.

Tribe I. Thantiolon!n, 1. 1245.

$f f$. Front broadly dilated at sides, emarginate in front; front tarsi of male dilated; form short, oval; smaller 6-10 mm.

Tribe II. I'EDinint, 1) 1:251.

ce. Front coxie subtransverse; middle coxire without trochantin; third joint of antennie siort; tarsi pubescent, the last joint long; form oral or clongate; length less than 12 $11 m$.

Tribe III. Ulomin1, 1. 1253.

1d. Next to last joint of tarsi bilobed; surface coarsely punctured; lergth less than $6 \mathrm{~mm}$. Tribe IV. HeTerotarsint, T. 125s. re. Eyes more prominent than the sides of front, usually rounded, fecbly or not emarginate; form nsmally oval or lounded, convex; length less thin $T$ mm.

Tribe V. Diaperint, 1. 1260.

b). 'Tarsi compressed, their first joint short; cheeks sulcate; surface rery rough.

Tribe VI. Boletophagni, p. 1266.

ua. Front with a coriaceous or leather-like margin, or a coriaceous band between it and the labrum; third joint of antennæ long.

$g$. Sides of front not obliquely elevated; abdomen not pedunculate; outer joints of antenne broader; head not deflexed.

Tribe VII. Hecopini, p. 1268.

gg. Sides of front obliquely elerated.

$h$. Inner wings wanting; metasternum rery short; body robust, conrex.

Tribe VIII. Meracanthini, p. 1260.

h.h. Inmer wings present; metasternum long; body slender.

Tribe 1.5. strongrtini, p. 1270.

\section{Tribe I. TENEBRIONINI.}

Rather elongate, uniform black or piceous species of medium or large size, having the head prolonged, but scarcely narrowed behind, 
not received in the thorax as far as the eyes, which are transverse and emarginate; front feebly dilated on the sides, covering the base of mandibles; antennæ gradually thickened toward tips; elytra embracing feebly the fianks of the abdomen; legs long; tibial spurs small. Seven of the 18 recognized genera are known to be represented in the State, while members of another perhaps occur. They live, for the most part, beneath the bark of dead trees.

KEY TO INDIANA GENERA OF TENEBRIONINI.

a. Tarsi densely clothed beneath with fine. short, silken pubescence.

b. Antenne distinctly shorter than head and thorax, their outer joints transrerse, the last joint subquadrate, rounded at tip.

c. Epipleurie entire. narrower at apex; length 15 or more mm.

d. Sides of mentum with small inflexed lobes; thorax not narrowed at base.

I. Nictobates.

dd. Sides of mentum without lobes: thorax narrowing behind and crenulate on the sides.

cc. Epipleure not reaching the tips of elytra.

Iрнтнілет.

$e$. Femora strongly club-shaped. black, shining; larger. 18-26 mm.

II. Merinus.

ee. Femora slender, in our species reddish-brown; smaller, not orer $11 \mathrm{~mm}$.

III. HAPLANDRUS.

bb. Antenna more slender, as long as or longer than head and thorax, the outer joints triangular, the last one oral, more or less acute.

$f$. Front margin of front of head thickened and slightly reflexed.

ff. Front margin of front not thickened or reflexed. T. XrLopints. aa. Tarsi rather sparsely clothed beneath with coarse pubescence.

g. Epipleurie entire; form more or less convex; length 10 or more mm.

VI. Tenebrio.

gg. Epipleuræ abbreviated; head transrerse; form much flattened; length 5-6 $\mathrm{mm}$.

VII. Doliena.

\section{Nyctoвates Guerin. 1834. (Gr., "night+ walker."')}

Large black or piceous elongate forms, separated from allied genera only by the characters given in the generic ker. Two of the three known species occur in the State.

KEX TO INDIANA SPECIES OF NXCTOBATES.

a. Under side of mentum smooth: elytral lows of punctures fine.

2302. PEXXSTLIATICA.

a a. Under side of mentum with a tuft of rather long rellowish hairs; elstral punctures much coarser.

2303. BARBATA. 


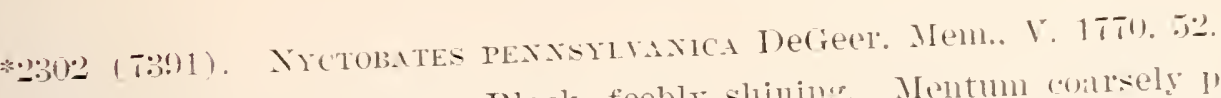

Elongate-oral. convex. Black, feebly shining. Mentmu contrely punctate. Thorax subutadrate. slightly narrowed in frunt, hind ancles rectansulirr: surface finely and sparsely punctate. Elytra faintly alutaceons. nuarker with rows of fine punctures: intervals feebly convex, minutely and suasely punctulate. Length 20-20:3 mm.

Throughout the State: common in the southern counties. less so northward. Gregarions in winter beneath bark and logs. February 11-December 11.

2303 (7391a). Nrсtobates Barbata Knoch. X. Beitrag.. 1S01. 166,

Resembles pensiglinuicu but usually smaller and piceous rather than black in hue. Thorax a little broader than long. less narrowed in front. the sides more strongly rounded. Sulface more distinctly alutaceous. the punctures of both thorax and elytra coarser. Length 1i-20 mul

Lawrence. Spencer and Posey counties; rare. April 15-July 27. A southern form which probab!y cecurs only in the southerm thire of State. Listed as a rariety of pennsyluarica but. in my opinion. aistinct.

Iphthimus opacus Lec. black. opaque, head and thoras coarsel: and confluently punctured. elytra with deep. interrupted strix. length $15-20 \mathrm{~mm}$. is known from New England and Canada and may occur in northern Indiana.

\section{Merrats Lec. 1862. (Gr.. "thigh + curve.")}

Here belongs the largest member of the family found in the State an elongate black form having the epiplenr? extending berond the last rentral suture. but not reaching the tips of elrtra: mentum with the middle lobe prominent along the middle. the side lobes with acute front angles: hind coxp rather widely separated. the intercosal process oral. rounded in tront.

$230 t(7+00)$. MERINUS L ETIS OliT.. Ent.. III. 1795. 10.

Elongate-oral. Black, feebly shining. Thorax about as long as wide. slightle narrowed in front. sides strongle curved. hind angles obtuse. surface rers finels and sparsely punctate. Elytra with rows of rerry minute punctures: inteltals faintly conrex. smooth. Males with the hind tibire much curved and with an acute tooth near the tip. Length $15-26 \mathrm{~mm}$.

Throughout the State: scarce. March 2:3-Tuly 9. Occurs beneath bark. Tery apt to be confused with Y. pemsigluanica. hut readily distinguished by the cho-shaped hind femora and the peculiar hind tibire of male.

[7. - 23402] 


\section{Haplandrus Lee. 1862. (Gr., "plain + man.")}

Medium-sized black or piceons species having the mentum trapezoidal, truncate in front, narrower behind and inserted upon a narrow peduncle; epipleuræ as in Merinus; femora slender, tarsi short; head rather strongly deflexed. One of the three known species occurs in the State.

*2305 (7402). Haplandrés fenoratus Fab., Syst. Eleut., I, 1801, 154.

Oblong-oval. Piceous, opaque; femora reddish-brown. Third joint of antennæ longer than fourth, twice as iong as second. Tliorax nearly square, sides almost parallel, angles rectangular; surface, as well as that of head, densely and confluently punctate. Elytra each with one scutellar and eight entire rows of elongate, deeply impressed punctures. Length $7.5-11 \mathrm{~mm}$.

Throughout the State, but scarce. Oceurs beneath bark and logs, especially in sandy localities. Hibernates. Jannary 13-December 7. H. concolor Lec., having the third joint of antennæ short, legs wholly black, length 8.5-9 mm., occurs in "Canada and the Lake Michigan region," and may yet be found in the northern counties.

\section{Sсотоватеs Horn. 1875. (Gr., "dark or obscure + walk.")}

Rather large black species having longer antennæ than any of those preceding, and the front margin of the head thickened and slightly reflexed. The males have an elongate patch of yellow hairs on the ander side of the front femora near the base, and the front tibiæ armed with a short blunt tooth near the middle. One of the two known species oceurs in the State.

2306 (7411). Sсотоватеs calcaratus Fab., Syst. Eleut., I, 1801, 159.

Elongate-oval, convex. Black, shining with a bluish metallic lustre. Thorax slightly broader than long. sides feebly curved; front angles obtuse. hind ones rectangular; surface finely, rather sparsely and irregularly punctured. Elytra with punctured strixe; intervals feebly convex, minutely punctulate. Length 14-17 $\mathrm{mm}$.

Throughout the State; frequent. May 31-August 12. Occurs beneath stones, logs, bark, ete.

\section{Xylopinus Lee. 1862. (Gr., "wood + be hungry.")}

Elongate, slender black or piceous forms, having the front margin of head truncate or feebly emarginate, not thickened. Males with the front and middle tarsi more distinctly dilated than in Scotobates, the front femora smooth beneath. Three species are known from the United States, two of which have been taken in the State, while the other may occur. 
KEY TO INDIANA SPECIES OF XYLOPINUS.

a. Body black, not metallic.

b. Legs black.

6b. Legs reddish-brown.

aa. Body brown with a brassy tinge.
2307. SAPERDIOHES.

RUEIPES.

2308. ANESCENS.

2307 (7413). Xrlopinus saperdoIdes Oliv., Ent., III, 1795, 11.

Elongate, subparallel, convex. Black, feebly shining; antennx and tarsi piceous. Thorax nearly square, slightly narrowed in front, sides feebly curved; front angles rounded, hind ones acute; surface densely and rather coarsely punctate, with an impression each side near the base. Elytra elongate, parallel; striæe coarsely and closely punctured; intervals moderately convex, sparsely and finely punctured. Length 12-16 $\mathrm{mm}$.

Throughout the State; frequent. J!nne 16-August 26. Occurs especially beneath the bark of oak.

$X$. rufipes Say, length 11-16 mm., is said to have the same range as saperdioides and is probably only a variety of that species.

2308 (7415). Arlopinus æenescens Lec., New Sp. N. Am. Col., 1866, 120.

Elongate-oval. Brownish or piceous, bronzed, shining. Thorax onethird broader than long, sides broadly rounded; surface finely and rather sparsely punctate and with an impression each side in front of base. Elytra more dilated behind the middle than in the preceding, their strix less impressed and less strongly punctured. Tooth of front tibiæ of male much less prominent. Léngth $13-15 \mathrm{~mm}$.

Narion County; rare. May 24. Occurs in the "Middle and Western States."

\section{Tenebrio Linn. 1758. (Gr., "darkness.")}

Medium-sized black or brownish, elongate-oval or parallel, feebly convex forms having the tarsi clothed with a coarser, less dense and more rigid pubescence than in the preceding genera; antennæ gradually thicker toward the tip; palpi and tarsi short. Four species are known from the United States, all of which occur in Indiana.

KEY TO SPECIES OF TENEBRIO.

a. Trochantin of middle coxie very distinct; form elongate, narrowly oval or parallel.

b. Surface dull, opaque; length 14-17 $\mathrm{mm}$.

2309. OBSCURUS.

bb. Surface more or less shining.

c. Thorax broader than long; length 13-16 $\mathrm{mm}$.

2310. MOLITOR.

cc. Thorax nearly square; length 9-10 $\mathrm{mm}$.

2311. CASTANEUS. $c c$. Thorax nearly Trochantin of middle coxie rery small; form more broadly oral; length
2312. TENEBRIoIDEs. $12-13 \mathrm{~mm}$. 
*2309 (7416). Tenebio obscu hi s Fab., Syst. Eleut., I, 1801, 146.

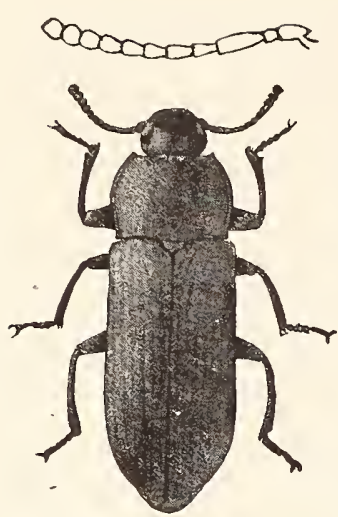

Fig. 559. $\times 2 . \quad$ (After Chittenden in Bull. JV, N. Ser., U. S. Div. Ent.)

Elongate, narrowly oval. Piceous or dark reddishbrown, opaque. 'Thorax subquadrate, slightly narrowed in front; sides feebly curved, margins rather wide, reflexed, hind angles acute; surface, as well as that of head. densely and granulately punctate. Elytra nearly parallel, surface with rows of fine punctures; intervals finely and densely granulate. Length 14-17 mm. (Fig. 559.)

Throughout the State; frequent. January 1-June 9. Both this and the next are introduced species and live in granaries, storehouses, barns, etc. 'Their larva are the "meal-worms" which are apt to occur wherever there is a heap of grain remnants or debris. By removing or changing such refuse their breeding places will be broken up and the beetles kept in check. When its use is practical carbon bisulphide will kill both larvæ and adults.

*2310 (7417). Tenebrio molitor Linn., Faun. Suec., $1761,224$.

Resembles obscurus in form. Piceous, shining. Thorax broader than long, less narrowed in front; margins broader, more strongly reflexed; front angles more prominent, hind ones less acute; surface finely and rather densely punctate, the impressions each side near base more distinct than in obscurus. Punctures of elytral strix indistinct; intervals convex, finely and rather closely punctate. Length 13$16 \mathrm{~mm}$. (Fig. 560.)

'Throughout the state; frequent. January 11-July 14. Occurs with the preceding.

2:211 (7418). Tenebrio castaneus Knoch., Nene Beitrag., 1801, 171.

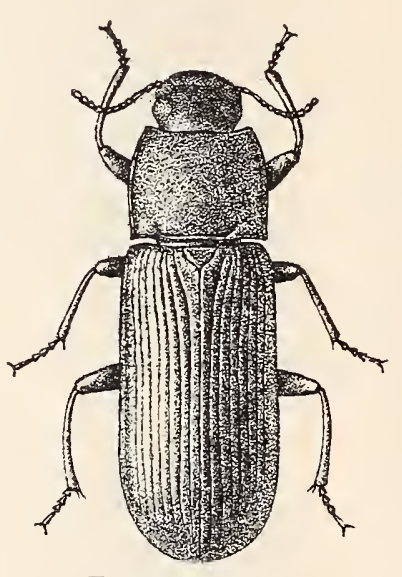

Fig. $560 . \times 2 \frac{1}{2}$. (After Forbes.)

Elongate, parallel. Blackish- or reddish-brown, feebly shining. Thorax nearly square, truncate at base, distinctly emarginate at apex; sides nearly straight, margius wide, strongly reflexed; front angles prominent. rounded, hind ones rectangular; surface finely, deeply and rather densely punctate. Elytral striae rather deep, strongly punctate; intervals finely and spirsely punctate. Length 9-10 $\mathrm{mm}$.

Throughout the State; common. March 12-November 23. Probably hibernates. Occurs beneath bark and logs, especially in low, open woods; gregarious in early spring. Fresh specimens have the upper surface finely prominose.

*2312 (7419). 'Tenebrio tenemioides Beauv., Ins. Afr. et Amer., 1805, 121.

Elongate-oval. Black or dark reddish-brown, shining. Thorax onethird broader than long, sides feebly curved; margins narow. scarcely re- 
flexed; base sinuate angles not mominent; surface with coarse and fine punctures intermixed. the coalse ones more numerous on the sides. Eitytral strie closely and demsely punctite: intervals sulveonvex, tinely and rather densely punctulate. Length 12-1:3 11111 .

Throughout the State; common beneath bark. Hibernates. February 20-December 8 .

\section{Dolmena Pase. 1860. (Gr., "insidious.",}

Small, pale, very flat species having the antenne graduall: thickened towards the tip. The males have a small triangular horn or tooth each side of the head in front of the eyes. One of the two known species occurs in the State.

2313 (7421). Dolieara Pallida Say. Jemm. Phil. Acad. Nat. Sci., III. 1\$24. 271 ; ibid. II, 160.

Oblong, parallel, much depressed. Pale reddish-brown. Lead concare between the eyes; dypeus emarginate. Thorax obcordate, much narrowed behind the middle, apex broadly and deeply emarginate; front angles rounded, hind ones rectangilar: surface finely and sparsely punctured and with a short impressed line each side near base. Elytra with rows of minute punctures, the side margins slightly elevated. Length $4.5-5 \mathrm{~mm}$.

Crawford County; rare. September S. Occurs beneath bark. Resembles a Cucujid in form and general appearance. Tisted as Adelina pallida.

\section{Tribe II. PEDININI.}

In this tribe the body is oval. not very convex; front short and broadly dilated on the sides; clypeus emarginate, covering the base of mandibles; labrum prominent; elytra feebly embracing the sides of abdomen; middle coxa with distinct trochantin; hind coxa well separated; front and sometimes the middle tarsi of males dilated and spongy beneath. But two of the six recognized genera are represented in the State.

KEY TO INDIAXA GENERA OF PEDININI.

a. Eyes not entirely divided: mentum trilobed in front; length $\mathrm{S}-10 \mathrm{~mm}$. an. Eyes completely divided, the upper portion large, rounded; mentum not trilobed; length less than $7 \mathrm{~mm}$.

IX. BLapstixios.

VIII. Hopatrines Tatr. 1829. (Gr., "also + a senator.'”)

To this genus, as above limited, belong three species, one of which ocenrs in Indiana. 
*2314 (7425). Hopatrinus notus Say, Journ. Phil. Acad. Nat. Sci., V, 1S26, 237 ; ibid. II, 304.

Oblong-oval. Black or brownish-black, opaque; antenne and tarsi piceous. 'Thorax one-half wider than long, slightly narrowed in front, sides nearly straight; margin slightly thickened, hind angles long, subacute; surface densely and rather coarsely punctured. Elytra not striate, but with rows of large, deeply impressed punctures; intervals with minute punctures, each bearing a very short, prostrate yellow bristle. Length $8-11.5 \mathrm{~mm}$.

Southern half of State; frequent in sandy localities beneath chips, bark, logs, etc. Hibernates. February 14-December 12.

\section{Blapstinus Latr. 1829. (Gr., "to injure + to attempt.")}

Small oblong or oblong-oval, black or piceous species, having the base of thorax bisinuate and as wide as base of elytra; inner wings always present, sometimes very rudimentary; front tibiæ straight, not produced at apex; antennæ stout, joints 4-8 longer than broad; upper portion of eyes large and rounded. Of the 40 or more species listed from the United States by Casey, but three occur in Indiana. For a synoptical table and description of the North American species see:

Casey--In Ann. N. Y. Acad. Sci., V, 1890, 416-462.

KEY TO INDIANA SPECIES OF BLAPSTINUS.

a. Elytral strice not interrupted; pubescence persistent; hind angles of thorax somewhat prolonged backward.

2315. MGESTUS.

aa. Elytral strice more or less interrupted; pubescence scant, easily removable, often almost absent.

b. Surface lustre rarely bronzed; color piceous-black, the elytra slightly paler; elytral strise more finely punctured and less interrupted.

2316. INTERRUPTUS.

b7. Surface lustre strongly bronzed; elytral strix more coarsely punctured and widely and frequently interrupted; thorax more sparsely punctured.

2317. METALLiCUS.

*2315 (7442). Blapstinus mastus Melsh., Proc. Phil. Acad. Nat. Sci., III, $1846,65$.

Oblong-oval, moderately convex. Black, shining; rather sparsely clothed with fine, short, yellowish, prostrate pubescence. Thorax one-half wider than long, feebly narrowing from base to apex, hind angles subacute, prominent; surface sparsely and deeply punctate at middle, more closely and coarsely at sides. Elytral strie feebly impressed near suture, more deeply on sides, where their punctures are coarser; intervals finely and sparsely punctured. Length $4.7-5.4 \mathrm{nmm}$.

Lake and Vigo counties; frequent beneath rubbish and other cover, especially cacti in sandy localities. March 7-October 1. 
2316 (7444). Bhapstines interiuptus Say, Jomm. I'hil. Acall. Nal. Ści., III, 18:4, 264 ; ibid. II, 155.

Oblong, rather robust and convex. Black, finely alutaccous; elytra piceous, obscurely tinged with bronze. Thorax thee-fourths wider than long; sides straight to near apex, then converging to the apical angles; avex broadly emarginate, hind angles acute; surface lather densely and coarsely punctured, the basal fovere well marked. Flytra together about one-half longer than wide; stria feebly impressed, very finely and closely punctured, the rows more or less interupted; intervals sparsely and ratlier coarsely punctured. Length $4.5-5 \mathrm{~mm}$.

Throughout the state; scarce. April 23-May 29. Several specimens were taken from a dead hen and others from cement sidewalks and beneath rubbish, usually in sandy localities. Broader and more oblong than the next.

2317 (7445). Blapstinus metaliticus Fabr., Syst. Elent., I, 1801, 143.

Oblong-oval, convex. Bronzed, rather strongly shining. Thorax as in interruptus, except that the disk is more finely and sparsely punctate at middle. Elytral punctures coarse and widely interrupted in sets of one to four or five, thus causing the surface to appear rugose; intervals flat, sparsely and very finely punctate. Length $4-4.8 \mathrm{~mm}$.

Lake, Marion and Vigo counties; frequent. March 26-October 1. Occurs with mostus and probably hibernates. Often attracted by light.

Tribe III. ULOMINI.

Elongate or oval, usually somewhat depressed species having the head immersed in thorax to eyes, which are transverse and emarginate; front dilated to cover the base of mandibles; antennæ 11 jointed, the outer joints more or less thickened; middle coxæ without trochantin, hind coxie slightly separated; tarsi pubescent beneath, the last joint much elongated. They live under bark, in fungi or in dried vegetable products. Representatives of but five of the 16 genera have been taken in the State, though those of three others perhaps occur.

\section{KEY TO INDIANA GENERA OF ULOMINI.}

a. Antenna with the last two or three joints suddenly broader (except in Tribolium confusum) ; length less than $5 \mathrm{~nm}$.

b. Club of antenne 3-jointed; epiplemra very narrow at tip.

bb. Club of antenne 2-jointed; epipleura distinct at tip. X. Xr. Dicnus. aa. Antennal joints gradually broader to tip.

c. Base of thorax not margined, the hind angles never covering the humeral angles of elytra.

d. Last joint of maxillary palpi oval; length less than 4 mm. 
e. Head of male unarmed; scutellum broadly transterse: eye. rounded. entire.

NII. Cexocorse.

ec. Head of male armed with two pointed tubercles: scutellum little wider than long: eyes transterse. dirided. Gsathocerts.

de. Last joint of maxillary palpi triangular; head of male not tuberculate: length more than $6 \mathrm{~mm}$.

f. Epiplenrie entire; front tibice more or less dilated. finely toothed; last joint of antemie oral.

ff. Epiplenre abbreviated: color dark reddish-bromn.

y. Front tibia slender ; first joint of hind tarsi short: form elongate. subdepressed.

yg. Front tibie broad. serrate: form broad. subconvex.

THARSUS.

IIV. Cloma.

cc. Base of thorax margined. the hind angles covering the humeral angles of elstra ; front tibie slightly dilated. finely denticulate.

Evtochia.

\section{Tribolium MicLear. 1825. (Gr., "thrice pointed.")}

Small elongate parallel species having the antennæ slender, the last three joints suddenly dilated to form a Hattened club; mentum nearly square with rounded front angles; last joint of maxillary palpi elongate-oral, truncate at apex. Two of the three listed species occur in the State.

IEET TO INDIAXA SPECIES OF TRIBOLICM.

a. Head not expanded besond the eres at the sides: antennal club distinctls three-jointed. (Fig. 561, f.)

231S. FERRLGINECM.

a . Head expanded each side of front of eye; antemnal joints gradually broader to tip. (Fig. $5(61$, e.)

2319. CONFUSCM.

\section{*2318 (7463). Tribotidar ferregixecur Fab., spec. Ins., I. 17S1. 324.}

Elongate. slender, parallel. Reddish-brown. shining. Thorax one-half wider than long. sides feebly curred. hind angles rectangular; surface finely and rather sparsely and deepls punctate. Elrtra with the interrals represented by rery narrow. fine laised lines. the strice with rows of minute punctures. Length $4.5 \mathrm{~mm}$. (Fig. 561.)

Southern half of State: common in meal. grain and other vegetable products. Hibernates. February 2-November 22. Both this and the next species are commonly known as "flour beetles" or "flomr reevils," and "live mpon cereal and other seeds and various other stored products, but generally prefer flour and meal and the so-called 'breakfast foods.' Their ewos are often deposited in the flour in mills. and these and the larre they produce. being minute and pale in color. readily escape notice; but after the flour has been harreled or placed in bags and left unopened for any length of time the adult beetles make their appearance. and in due course the flour 
is ruined, for when the inserets have time to propagate they soun convert the flour into a gray, useless mass. I part of the annoyance to purehaser, dealer and manufactmer is due to the fact that
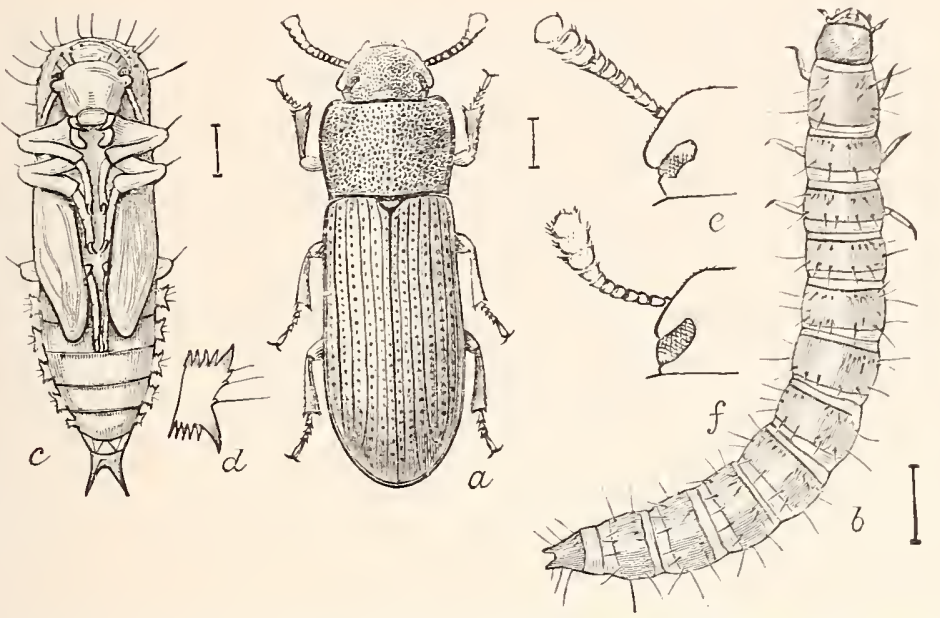

Fig 561. Tribolium confusum; $a$, beetle; $b$, larva; $c$, pupa, $d$, side lobe of abdomen of pupa; $e$, head of beetle, howing eye and antenna; $f$, same of $T$. ferrugineum. (After Chittenden in Bull IV, N. Ser., U. S. Div. Ent.)

the insects are highly offensive, a few specimens being sufficient to impart a disagreeable and persistent odor to the infested substance."

2319 (10,617). Tribolica confusum Dural, Gell. Col. Eur. Cat.. 1868. 181.

Slightly larger, darker and more depressed than ferrugineum. from which it can be easily sepalated only by the characters given in key. Thorax more coarsely and shallowly punctate. with the hind angles more prominent and the basal impressions wholly absent; punctures of elytra less distinct. Length 4.5-5. (Fig. 561.)

Marion, Orange and Vigo counties; frequent. January 17-November 25. On January 17, 1896, I received from Dr. Robert Hessler, of Logansport. Ind., a pillbox of Cayenne pepper in which were a dozen or more adult specimens of this beetle. The box was placed in a drawer of my desk and not opened again until Narch 20 , when the beetles were as lively as ever. On September 14 it was opened for the third time. Two living adults and numerous halfgrown larva were found therein, together with the uneaten bodies of the dead adults. 'The pepper being' perfectly dry, the question arises: How did the inserts secure sufficient moisture to live and flourish when enclosed in so small a box? Both this and the preeeding are imported species, and both are occasionally muse:m? pests, preving upon dried insects, ete. 'The best remedy is the bisulphide of carbon treatment, as deseribed on preceding pages. 


\section{Difedr Lei. 1862. (Gr., "two - strellings.")}

Here belongs a single small oblong reddish-brown species having. the last two antennal joints suddenly broader. compressed and pilose, the last one being the larger: epipleura entire, as broad at apex as at middle: mentum trapezoidal. narrotrer behind. its front angles distinct.

\$2320 (7465). Dicnes prxctates Lec. New Sp. X. Am. Col.. I. 1S66. 131.

Oblong. conrex. Dark reddish-brown, glabrous, shining. Thorax onethird broadel than long. scarcely narrotred in front; sides feebly curred, strongly but narrowly margined. hind angles rectangular: surface coarselr. rather sparsels punctate. Elrtra each with eight deep, coarsels punctured stria : intervals conver. minutely punctulate; scutellar stria wanting. Length $3-3.5 \mathrm{~mm}$.

Tigo and Crawford counties: scarce. April 12-December 25. Cecurs heneath logs and bark of pine.

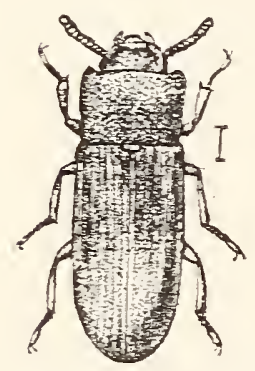

Fig. 562. (After Chittenden in Far. Bull. 45, C. S. Dep. Agr.)

\section{NII. C.mxocorse Thom. 1859. (Gr..."common.")}

Small oblong species having the eyes rounded. prominent. entire: antennæ rather robust, the joints gaduall: but feebly enlarged toward tip; first joint of hind tarsi but slightly longer than second and third.

2321 (一). C.exocorse ratzeblrgi Wissm., Stett. Ent. Zeit., IX, 1Sts, 7 .

Elongate-oblong, slender. parallel. Reddish-bromn. shining. Thoras conrex. nearly square, slightly narrowed behind, sides almost straight; surface minutels alutaceous, finels and rather closely punctate. Elrtra striate. the sutural and adjacent strice rather deepls impressed, finely and deelly punctate; interrals flat. rerr minutels and rugosely punctate. Length $3-3.5 \mathrm{~mm}$. (Fig. 562.)

Knox Countr: rare. May 6. Taken by sifting. Probably occurs throughout the southern third of State. It is known as the "small-ejed flowr beetle" and occurs in feed stores, bakeries and other places where cereal products are kept.

An allied species, Gnathocerus maxillosus Fab. (Fig. 563), feeds especially on corn and corn meal. and is often injurious in the Southern States. It has been recorded from Cincinnati. NiII. Alphitobits Steph. 1832. (Gr., "barley Fig. 563. (After Chitmeal + to live in."')

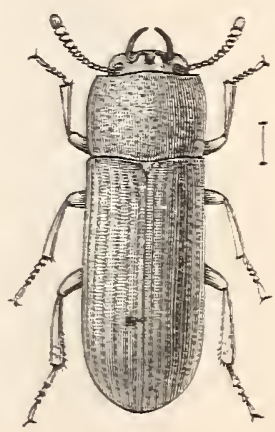
U. S. Dep. Agr.)

Tro medium-sized introduced black or piceous species belong here, one of which has been taken in the State. 


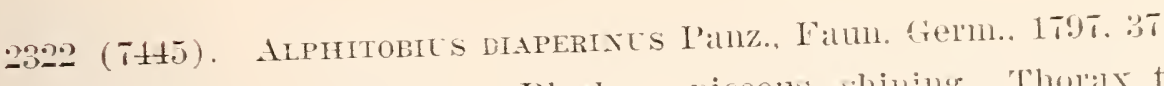

Oblong-oval, subconvex. Black or piceous. shining. Tholdx twice as wide as long. sides nearly stratght; apex deeply emilrariute. flont ansles prominent. rounded. base bisinuate: sulfice. as well as that of head. lather finely and sparsely punctured. Elytral strie slightly impressed. finely and shallowly punctate: intelvals feebly convex. distincty punctate, the punctures nearly as lalge as those of the striae. Length $6.5-7 \mathrm{~mm}$.

Vigo County; scarce. Warch T-April 12. Taken from barn where grain was stored. It resembles some of the larger species of Platydema, but is easily distinguished by the less prominent eves and large punctures of elrtral interrals.

Tharsus seditiosus Lec., elongate, depressed. reddish-brown, shining, length $5 \mathrm{~mm}$.. is a southern form which has been recorded from Cincinnati.

\section{Uroma Cast. 18t0. (Gr.. "destructive.")}

Medium-sized, reddish-brown species, easily distinguished by the short epiplenrie and dilated and toothed front tibiz. Three species have been taken, while a fourth mar occur.

\section{KEI. TO IXDIAXA SPECIES OF LLOMA.}

a. Lomer edge of front femora groored for their full length.

b. Last joint of antennie rounded at tip.

c. Elrtral interrals rers minutely and sparsels punctured; middle plate of mentum elongate-oral. 2323. IMPREss.

cc. Elytral intervals densely punctulate: middle plate of mentum transrersels oral.

2325. PLXCTLLATA.

6b. Last joint of antennre oblique, pointed: middle plate of mentum transrerse.

2324. IMIBERBIS. a a. Lower edge of front femora not groored but with a rather broad pit near the tip.

*2323 (7 151 ). Uloma impressa Melsh. Proc. Phil. Acad. Nat. Sci.. III. $1 S \pm 6.6 \pm$.

Oblong. subparallel. Chestnut-brown. shining: legs reddish-brom. Front of head with a deep curred impression. Thorax one-third wider than long. as wide at base as elytra: sides feebly curved. hind angles obtuse: surface finely and sparsely punctate, the males with a broad. deep impression behind the middle of the front margin. Elrtra almost parallel. rather deeply striate, the strize with punctures on the sides: intervals subconrex. minutely punctulate. Length 11-12 $\mathrm{mm}$.

Throughout the State: frequent. February 1t-October 12. Occurs especially beneath the bark of oak and beech.

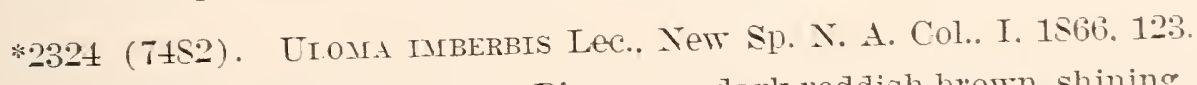

Elongate-oral. subconvex. Piceous or dark reddish-brown. shining. Head as in impressa. Thoras one-half wider thạ long, slightly narrowed in 
front of hind angles; sides distinctly curved: surface finely and sparsely punctate. Elytral strie more coarsely punctured than in impressa; the interrals more distinctly punctulate. Length $8.5-9 \mathrm{~mm}$.

Throughout the State; common. February 11-October 20. Readily known from impressa by its smaller size and form of terminal joint of antenne.

\section{5 ( 7 tS.5). Uloma penctulata Lec.. New Sp. N. A. Col.. I, 1866. 124.}

Elongate-oral, subparallel. Uniform pale reddish-brown. Sides of tholax parallel belind the middle. Intervals of elstra finely and densely punctulate. Male with thorax not impressed near apex, and middle tibic mucronate. Otherwise as in immressu. which it closely resembles. Length 7 8.5 $\mathrm{mm}$.

Lake County; scarce. July 21. Occurs beneath bark of pine. Known heretofore only from the Sonthern States.

Uloma mentalis Horn, dark reddish-brown. length $8.5 \mathrm{~mm}$., was described from Texas and Kansas and has been recorded from Cincinnati.

Eutochia picea Melsh., black, shining, length $8.5 \mathrm{~mm}$., is said to "occur rather abundantly in the Middle States."

\section{Tribe IT, HETEROTARSINI.}

Small oral winged species, having the upper surface very coarseby punctate and usually sparsely clothed with erect hairs; head not received in the thorax as far as the eyes, which are large and coarsely granulated; front slightly dilated orer the base of the mandibles; epipleure narrow, extending to tips of elytra; front coxæ globose; middle ones with a distinct trochantin; hind ones slightly separated; tarsi coarsely pubescent beneath. Three genera are recognized, all of which are probably represented in the State.

IEY TO GENERA OF HETEROTARSINI.

a. Antennse gradually thicker toward apex: body pubescent.

aa. Antenne with the last three joints distinctly larger.

XT. AxEdus.

b. Margin of thorax toothed: body pubescent.

b7. Margin of thorax simple; body without hairs.

Nir. Paratenetes.

Prateus

\section{ANæDts Blanch. 18t5. (Gr., "shameless.")}

To this genus, as above limited, belong but two species, one of which occurs in the State.

*2326 (748S). Axædes betrater Ziegler. Proc. Phil. Acad. Nat. Sci.. II. 1844,45 .

Oblong-oral, subdepressed. Dark reddish-brown, sparsely clothed with rather long, erect yellowish hairs; antemne and legs paler. Head coarsely 
punctate and with a rounded elevation alove the base of antemin. Thorax twice as wide as long. abruptly nallowed ealch side in front of himb angles, the latter acute; margins distinct, reflexed ; sulface coaldely and lathel sparsely punctured. Elytra with coarse, deep, irregular pumctures. Iangth 5-5.5 $\mathrm{mm}$.

Throughout the State; frequent in sandy localities beneath bark, logs and stones. Hibernates. March 19-December 25.

XVI. Paritenetus Spin. 184t. (Gr., "close together to ex-

Small, oval convex brownish species, easily known by the characters given in key. The thorax is narrower than the elytra and has the side margins distinctly toothed. Two species are known from the State, while another may occur.

\section{KET TO INDIANA SPECHES OE PARATENETUS.}

a. Sides of thorax with five to seren teeth; elytra moderately convex.

b. Sides of thorax rounded in rront. gradually narrowing behind the middle.

bb. Sides of thorax strongly rounded from the front to the hind angles.

aa. Sides of thorax with three teeth; elytra strongly conrex.

2327. FUSCUS.

P. punctatus Spin., reddish-brown, length 3-4 mm., occurs in the Middle and Eastern States, and has been recorded from Cincinnati.

2327 (7491). Paratenetus fuscus Lec., Agass. Lake. Sup.. 1850. 223.

Elongate-oral, convex. Dull reddish-brown, sparsely clothed with fine. silky, yellowish pubescence; club of antenne piceous. Thorax slightly broader than long, convex; surface, as well as that of head. conrsely densely and confluently punctured. Elytra with sides parallel for three fourths of their length, thence rounded to apex; surface coarsely, densely and irregularly punctured. Length 2-2.5 $\mathrm{mm}$.

Southern half of State; scarce. May 11-June 20. Taken by sifting dry leaves. Its range is given as "Canada and the States bordering the Great Lakes."

2328 (-). Paratenetus gibbipennis Mots.. Bull. Mosc.. 1S6S. 193.

Narrowly oral. strongly convex. Piceous or dark ledlish-brown. sparse1y pubescent; antemne and legs paler. Thorax convex. sides rounded on apical two-thirds, parallel and a little narrowed toward the base: margins each with three blunt teeth near middle; surface rery coarsely and densely punctate. Elytra very strongly conrex or gibbous; surface coarsely and rather closely punctate. Length 2-2.5 $1 \mathrm{~mm}$. 
Starke and Steuben counties; scarce. June 16-June 17. Sifted from sphagnum moss about the margins of marshes.

Prateus fusculus Lec., piceous, shining, strongly punctured, length $3.5 \mathrm{~mm}$., ranges from New York to South Carolina and has been recorded from Cincinnati.

\section{'I'ribe V. IDAPERINI.}

Oval or rounded winged species of medium or small size, having the head received in the thorax as far as the eyes, which are transverse and coarsely granulated; front somewhat dilated at the sides, covering the base of the mandibles; antennæ more or less thickened towards the tip; elytra with narrow epipleuræ; front coxæ transverse, middle ones with distinct trochantin; tarsi pubescent beneath. Six of the eight genera are represented in the State, while a member of another may occur in the northern third.

KEY TO INDIANA GENERA OF DIAPERINI.

a. Body broadly oval or elongate-oval; pygidium corered.

$b$. Eyes emarginate in front; length 3 or more mm.

c. First joint of hind tarsi not longer than second; body broadly oval, strongly convex.

XVII. DIAPERIS.

cc. First joint of hind tarsi longer than second.

d. First joint of hind tarsi not longer than second and third together; form elongate-oval; length $3-3.5 \mathrm{~mm}$.

XVIII. ARRHENoplita.

dd. First joint of hind tarsi longer than second and third together.

$e$. Epipleuræ entire; process between the hind coxæ acute.

$f$. Last joint of maxillary palpi broadly triangular; body broadly oval, strongly convex; length 4 or more mm.

XIX. Platydema.

$f f$. Last joint of maxillary palpi elongate triangular ; form elongate-oval; length less than $3 \mathrm{~mm}$.

XX. Phylethus.

ee. Epipleuræ short; intercoxal process truncate; thorax narrower at base than elytra; color greenish-bronzed, shining.

SCAPHIDEMA.

bb. Eyes not emarginate; last five joints of antennæ forming a loose club; length less than $3 \mathrm{~mm}$.

XXI. Pentaphyllus.

aa. Body cylindrical; pygidium exposed; length less than $4 \mathrm{~mm}$.

XXII. Hypophløus.

XVII. Dinperis Goeff. 1762. (Gr., "through + to pass.")

To this genus as limited above belong two species, one of which is common in the State. 
2329 (7506). Diaperis inaculata Oliv., Encyc. Meth., VI, 1791, 273.

Broadly oval, convex. Black; head between the eyes and elytra, in great part, orange-red; the latter being marked with black as follows: a sutural line not reaching scutellum and wider on apical half, a rounded spot on middle of basal third and another elongate and smaller one near the margin, a large irregular spat on apical half reaching from margin nearly to sutural line. Thorax nearly three times as wide as long, finely and sparsely punctate. Elytra with rows of rather fine, feebly impressed punctures: intervals

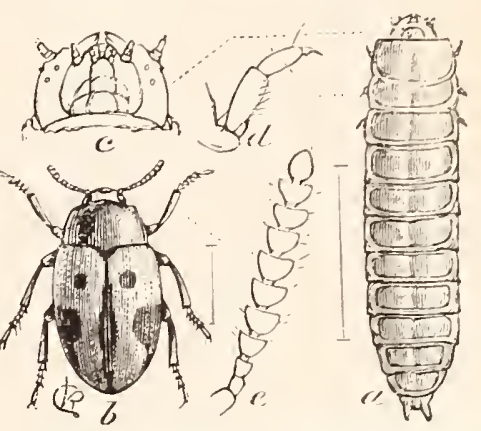

Fig. 564. $a$, larva; $b$, beetle; $c$, under side of head of larva; $d$, leg of same; e, antenna of beetle. (After Riley.) flat, minutely and sparsely punctulate. Length 6-6.5 mm. (Fig. 56t.)

Throughout the State; common and gregarious beneath bark, especially that of elm, and in fungi. March 16-September 9.

XVIII. ARrhenoplita Kirby. 1837. (Gr., "strong + reapon.")

Small elongate-oval, bluish or greenish species, having the epipleuræ abbreviated and the males (in our species) armed with two short horns on clypeus and two longer ones on vertex. Two of the three recognized species occur in the State. Formerly listed under Hoploceptrala.

2330 (750S). Arrhenoplita viridipennis Fab., Syst. Eleut., II, 1801, 586.

Elongate-oral. Thorax, legs and under surface, except abdomen, orangered; head, abdomen and apical half of antenne piceous; elytra green or blue, with metallic lustre. Thorax nearly three times as wide as long, sides feebly curred, hind angles rounded. surface finely and rather sparsely punctate. Elytra finely striate-punctate; intervals nearly flat, minutely punctulate. Length $3-3.5 \mathrm{~mm}$.

Posey County; scarce. April 13. Taken from beneath bark of fungus covered log. Probably throughout the southern third of State.

*2331 (7509). Arrhenoplta Bicornis Oliv., Ent., III, 1795, 55.

Differs from the preceding in having the whole upper surface bluishgreen, the thorax sometimes varying to brownish; under surface, except prosternum, usually piceous. Elytral strice more coarsely punctate. Length 3-4 mm.

Throughout the State; very common on fungi of various kinds. Hibernates. February 25-October 11. The head of female in both species is wholly devoid of horns or tubercles. 


\section{NIX. Platrdema Lap. 1831. (Gr., "hroad-bodr."')}

Small or medium-sized. broady oral conrex species having the first joint of hind tarsi longer than the tro following together: epipleura entire: mesosternum concave: last joint of maxillary palpi broadly triangmlar, its inner and outer sides nearly equal; intercoxal prccess of ahdomen triangular. acute. Theí occur especially on fleshy fungi about the bases of stumps or trees or beneath bark. About 16 species are known from the United States. ten of which are known from Indiana, while another may occur.

FEY TO IXDLAXA sPECIES OF PLATrDENA.

a. Head mith horns or tubercles: front concare.

Ђ. Tpper suriace black, shining.

ut. Cpper surface piceous or dark reddish-bromn. opaque.

a $\alpha$. Head without tubercles or horns.

2333. ERITHROCERA.

c. Thorax dull red. elrtral black.

ce. Thorax and elrtra black.

2334. RLFICOLLE.

d. Surface opaque.

e. Elrtra without red spots.

f. Antemie wholls pale.

ff. Antenna black. three basal joints pale.

ee. Elstra each with an oblique red spot on basal half.

dd. Surface shining black.

2335. RTFICORNE.

2336. FLATIPES.

2337. ELITPTICLM.

ø. Prosternum horizontal. its aper prominent.

$h$. Head with distinct transrerse groore and frontal impressi ri.

$h h$. Head without transrerse impression.

AMERICANCM.

$i$. Thorax rers sparsels punctured.

233S. L.ENIPES.

ii. Thorax and interrals of elrtra densels punctured.

2389. MICATS.

gg. Prosternum conrex between the coxie, its apex deflexed and obtuse.

i. Elongate-oral: black with a bronzed tinge: smaller, not orer $5 \mathrm{~mm}$.

j. Broadle oral: larger. $6-7 \mathrm{~mm}$.

23 40 . PICILABRLM.

2341. SLBcostatti.

*2332 (7510). Platrdema Excaratear Say. Joum. Phil. Acad. Nä. Sci. III, 1S24. 267: ibid. II, 157.

Broadls oral, conrex. Black, shining: antennz and legs reddish-brown. the latter sometimes piceous. Head of male with two parallel. prominent. crlindrical horns between the eses: front deeply concare between the bases of the horms: head of female with tubercles instead of horns. Thorax more than twice as wide as long. narrowed from base to apex. surface finely and sharsels punctate. Elytra with rather finels punctured strise: intervals feehy contex. minutels punctured. Length $4.5 .5 .5 \mathrm{~mm}$.

Thronohout the State: common. Januart 11-Octoher 11. 


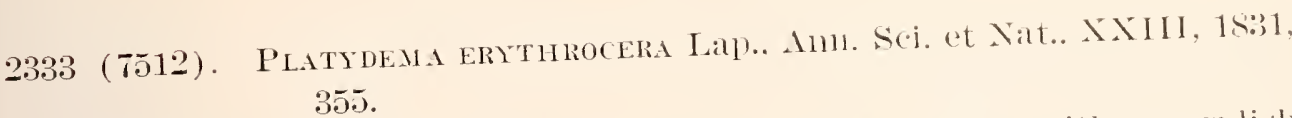

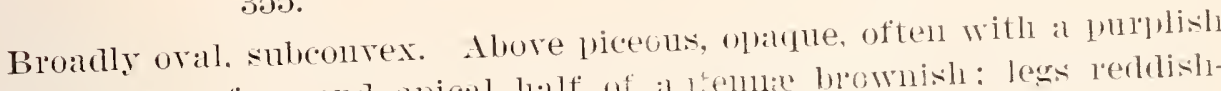

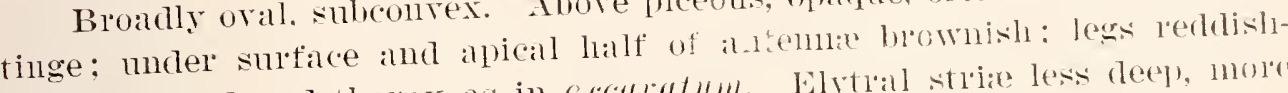
brown. Head and thorax as in excaldum. Flytral strie less deep, more

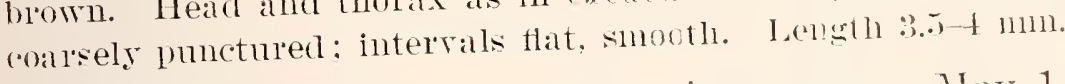

Putnam, Vigo and Posey counties; scaree. May 11-Oetober ?.

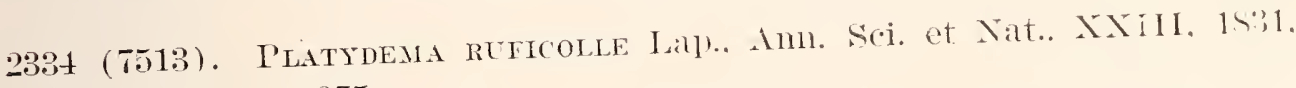
375.

Oral. convex. Black or dark reddish-brown. suboparque; thorax, antemme and legs dull red. Head minuteis punctured. Thorax nearly three times as wide as long, base bisinuate, apex deeply emarginate; surface finely and sparsely punctate. Elytral strie rather deep and coarsely punctured; intervals flat or nearly so. smooth. Length $3-4.5 \mathrm{~mm}$.

Lake, Posey and Perry counties; rare. April 21-September 27.

*2335 (7514). Platydema ruficorae Sturm Cat.; 1526, 6S.

Very broadly oval. I3lack. oparque or piceous, with a purplish tinge: moler surface and legs dark browni-h-yellow; antenne wholly pale reddishrellow. Thorax more than twice as wide at base as long. thence regularly narrowed to apex: surface very finely and sparsely punctite. Elytra finely striate, the strixe with small, rather closely placed punctures; intervals flat. very minutely punctulate. Length $4-5.5 \mathrm{~mm}$.

Throughout the State: very common on fleshy fungi and beneath bark. Hibernates. March 12-Deceniber 8.

2336 (7515). Pratidena Flaripes Fab., Srst. Elent., II, 1S01. 567.

Resembles ruficornc but more elongate. Black or piceons. opaque; antenne black except the three basal joints. which. with under surface and legs, are reddish-brown. Thorax feebly and sparsely punctate at middle. more densely and coarsely on sides. Elytral punctures coarser than in ruficorne; intervals feebly convex and with more erident punctures. Length 4-5 $\mathrm{mm}$.

Clark and Posey counties: rare. May 5-September 25.

2337 (7518). Platrdeara eldiptictar Fab., Syst. Eleut., II, 1S01, 568.

Flongate-oral. Black, opaque: elytra each with an oblique, rery irregular reddish spot. extending from lumerus to suture. Thorax finelș and rather sparsely punctate. Elytra tinely striate. the strie with tine distant punctures. Length $5 . \overline{5}-\tau \mathrm{mm}$.

Southern half of State; frequent. Narch 20-October 1t. Occurs beneath bark on fungus rovered logs.

$P$. americanum Lap., length $5-6.5 \mathrm{~mm}$., is said by Horn to be abundant in the "Northem states and Canada."

[s0-23402] 
2338 (7521). Platydema lavipess Hald., Journ. Phil. Acad. Nat. Sci., I, 1842, 101.

Rather broadly ovai. Black or piceous, shining; elytra often brownish; antennie and legs reddish-brown. Thorax about three times as wide at base as long, feebly narrowed from base to apex; surface faintly alutaceous, very finely and sparsely punctate. Elytra deeply striate, the striæ with fine, not closely placed punctures; intervals subconvex, minutely punctulate. Length $5-6 \mathrm{~mm}$.

Fountain, Vigo, Crawford and Posey counties; scarce. April 14-July 9.

2339 (7523). Platydema micans Horn, Trans. Amer. Phil. Soc., XIV, 1870, 383.

Broadly oval. Black or piceous black, strongly shining; antennæ and tibia pale reddish-brown, femora darker. Thorax more than twice as wide at base as long, sides nearly straight and converging from base to apex; surface rather densely and finely punctured and with a small impression each side at base. Elytra with rows of moderately coarse punctures; intervals rather densely and finely punctured. Length $3-3.5 \mathrm{~mm}$.

Lawrence County; scarce. July 29. Several specimens were taken from decaying fleshy fungi. Resembles the female of excaratum in color and form, but easily distinguished by the lack of tubercles and more dense punctuation. Known heretofore only from the Gulf States.

*2340 (7524). Platydema picilabrum Melsh., Proc. Phil. Acad. Nat. Sci., III, 1846, 62.

Oblong-oval. Black with a brassy or greenish tinge; antennæ and legs reddish-brown. Head with a shallow transverse groove in front of eyes. Thorax two and a half times as wide as long, surface densely and rather coarsely punctate, and with a large shallow fovea each side near base. Elytral stria rather deep, marked with coarse punctures; intervals flat, finely but distinctly punctulate. Length $4.5-5.5 \mathrm{~mm}$.

Putnam, Vigo and Posey counties; scarce. March 4-November 7. Occurs especially heneath bark of elm. The oblong form, brassy lustre and larger impressions at base of thorax serve to distinguish this form from all its allies.

*2341 (7025). Platydema subcostatum Lap., Ann. Sci. Nat., XXili, 362.

Broadly oval. Black, shining; antennæ reddish-brown; legs darker, almost piceous. Head with a transverse impression in front of eyes. Thorax three times as wide as long, sparsely and finely punctate. Elytral striæ feeble, the punctures fine; intervals flat, minutely punctulate. Length 5.5$6.5 \mathrm{~mm}$.

Throughout the State; common. January 11-October 23. 
XX. Phylathus Meg. 1821. (Gr., "member of a tribe.")

Small oval species having the last joint of the maxillary palpi elongate triangular, its outer side much the longer; epipleurx entire; prosternum not produced. The males are smaller than the females and have the front of head marked with three deep grooves and two ridges, the clypeus with a median impression and an elevation each side. One species occurs in the eastern United States, including Indiana.

2342 (7526). Phylethus bifasciatus Say, Journ. Phil. Acad. Nat. Sci., III, 1S24, 268 ; ibid. II, 158.

Elongate-oval. Reddish-brown, antennæ and legs paler; elytra dull yellow, with the suture, a broad band near middle and a narrower one near apex, dark brown or blackish. Thorax twice as wide as long, convex, the surface finely and densely punctate. Elytra with feebly impressed, finely punctured strix; intervals flat, densely punctulate. Length 2-2.5 $\mathrm{mm}$.

Lake, Marion, Lawrence and Vigo counties; scarce. May 29October 19. Occurs beneath bark and in fungi.

Scaphidema ceneolum Lec., dull greenish-bronzed, shining, length 3.5-4.5 mm., is a boreal species which may oceur in northern Indiana.

XXI. Pentaphyllus Meg. 1821. (Gr., "five + leaf.'")

Small oval brownish species, having the eyes entire and the front tibiæ not dilated. The males have two small blunt tubercles on the front between the eyes. One of the two species occurs in the State.

2343 (7538). Pentaphyllus pallinus Lec., New Sp. N. Amer. Col., I, 1S66, 126.

Elongate-oval, convex. Uniform pale reddish-brown, minutely pubescent with yellowish hairs. Thorax as wide at base as elytra, thence feebly narrowed to apex, hind angles obtuse; surface very finely and closely punctate. Elytra not striate, the punctures fine, irregular and rather dense. Length $2.5 \mathrm{~mm}$.

Marion, Monroe, Dubois and Spencer counties ; scarce. Nay 12June 12. Taken by sifting the debris of beech and maple stumps.

XXII. Hypophlaus Fab. 1790. (Gr., "under + bark.")

Small subcylindrical species, having the antenna gradually thickened; tibix somewhat broadened; epipleurse short. Two species have been taken in the State, while two others may oceur. 
KEY TO INUANA SPECIES OF HYPOPHLQUS.

u. Thoratx regulatrly convex.

b. Thorax emarginate in front, its flont angles distinct; color miforin pale reddish-brown.

bb. Thorax truncate in front. its front angles obtuse.

2344. PARALIELES.

c. Disk of thorax finely and sparsely punctate; upper surface bicolored.

2345. THORACICUS.

cc. Disk of thorax with longitudinal wrinkles; upper surface uniform dark browil; length $3.8 \mathrm{~mm}$.

RUGOSUS.

au. Tholax depressed with a broad longitudinal excavation; head and tholax reddish-brown, elytrat blackish; length $3.8 \mathrm{~mm}$.

CAVCS.

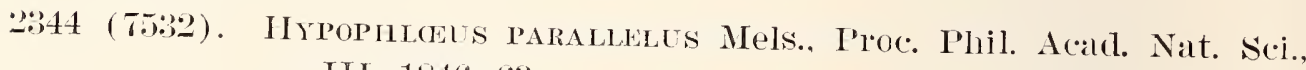
III, 1846 , 63.

Elongate. subcylindrical, parallel. Uniform reddish-brown, shining. Thorax as long as wide, front angles prominent, acute, hind ones rounded; surface finely; rather closely punctate. Elytra not striate, the punctures fine and rather dense. Length 3.5-4 $\mathrm{mm}$.

Lake County; scarce. July 23. Occurs beneath bark. Ranges from Canada to Arizona.

2345 (7535). Hrpopilleus thoracicus Melsh., Proc. Phil. Acad. Nat. Sci., III, $1846,63$.

Elongate, subcylindrical, convex. Reddish-brown; elytra black, sparsely pubescent with erect rellowish hairs. Thorax slightly longer than wide, sides almost straight, angles all rounded; surfuce finely and sparsely punctate. Elytra little more than twice as long as thorax; sparsely and finely punctured. Length $3-3.5 \mathrm{~mm}$.

Marion County ; rare. July 11. Occurs from Canada to Georgia.

$H$. cavus Lec. was described from Kentucky and $H$. rugosus Dury from Cincinnati. Both probably oecur in the southern third of the State.

\section{Tribe YI. BOLETOPHAGINI.}

Oblong, opague, winged species having the surface roughened with tubercles; head received in thorax as far as eyes, which are coarsely granulated, deeply emarginate and with a large groove beneath them for the reception of the base of the antennæ; epipleuræ narrow; front coxæ transverse middle ones with a small but distinct trochantin; hind coxie well separated, the intercoxal process triangular; tarsi pubescent beneath, the last joint longer than the others united. Two genera are known, both being represented in the State. The species occur on woody fungi which grow on the sides of trees or stumps or beneath baris. 
THE DARKLING BEETLES.

FEY TO GEXERA OF BOLETOPLIAGN

1. Antennie 10-jointed : eyes not entirely dirideal.

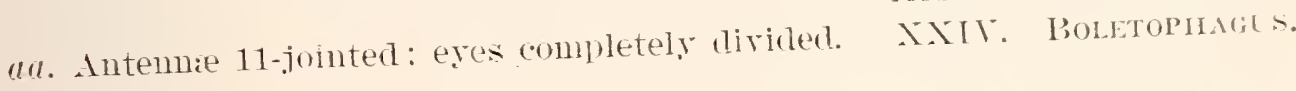

XXIII. Boletotherts Candeze. 1861. (Gr., "fungus-to
hunt."

In this genus the males have two horns. slightly curved and broader at tip, projecting forward from the thoras. and a short horn. bifid at tip. on the clypens. The fenales have the thoras strongly tuberculate. One species is known.

$2346(7540)$. Boletothert's BIflncts Fab.. Ent. Srst. Supp.. I, $1798,40$.

Oblong. robust. Black or brownish-black. opatue. Thorax three times as broad as long. margins broadly flattened and serrate with rounded teeth: the disk with horms or tubercles as above mentioned. Elytra each with four rows of large. irregular tubercles with smaller ones on the inter-

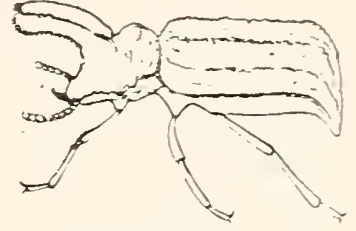

i ig. $565 . \quad$. 2 . (After Emiecns) rals. Length 10-11.5 $\mathrm{mm}$. (Fig. 565.)

Throughout the State: frequent. May + -October 17 . When disturbed they feign death. their form and roughened surface blending with the irregularities on the surface of the fungi in such a manner as to render the beetles almost invisible.

XXIT. Boletophigus Illig. 179s. (Gr.. "fungus + eating." )

Two species are known from the eastern Lnited States, both of which probably occur in Indiana, though but one has as yet been taken. The head and thorax are not horned in either sex.

\section{KEI TO SPECIES OF BOLETOPHAGTS.}

a. Thoracic disk with numerous tubercles: the margin strongly crenulate and deeply notched in front of hind angles. an. Disk of thorax coarsely punctured. not tuberculate: sides regularly rounded. not crenulate.

$23 \pm 7$ ( $7+1)$. Boletophages conticol sis. Joum. Phil. Acad. Nat. Sci.. V. 1S.20, 239: ibid. I, 115.

Oblong. robust. Black or brownish-black. opaque. Head with sides prominent. the surface granulate. Thorax three times as broad as long. deeply emarginate in front: surface with numerous granules or small tubercles. Elytria with rows of widely interrupted elerated lines or elongate tubercles. with smaller ones in the interrals. Length $\$-\$ .5 \mathrm{~mm}$.

Lake County : scarce. May 28. Taken from beneath bark of birch and pine. 
$B$. depressus Rand., color of corticola, elytra finely costate, intervals with a single row of coarse punctures, length $5-7.5 \mathrm{~mm}$., is said to occur in the Eastern and Middle States and Canada.

\section{Tribe VII. HELOPINI.}

In this and the following tribes the front of head is separated from the labrum by a short transverse clypeus of leather-like texture. The present tribe is composed of medium-sized oblong or oval species having the head immersed in thorax almost to eyes, the latter transverse, emarginate and coarsely granulated; antennæ gradually thickened from base to apex; front coxæ rounded, 'middle ones with distinct trochantin; hind coxie narrowly separated, the intercoxal process triangular; tarsi pubescent beneath, front and middle ones of males usually dilated. The tribe is represented by the single genus:

\section{Helops Fab. 1775. (Gr., “a nail + face.")}

Dark metallic species, usually with a strong lustre. About 35 are known, chiefly from the. West and Southwest. But three have been taken in the State, though two others perhaps occur.

KEY TO INDIANA SPECIES OF HELOPS.

a. Inner wings present.

b. Side margins of thorax not undulated.

c. Elytra finely striate; intervals finely and sparsely punctured; apex of last ventral segment with a depression. 234S. MIcANs.

cc. Elytral strix deep; intervals convex, almost without punctures; apex of last ventral without depression.

bb. Side margins of thorax undulate; form narrover ventus. elytral strixe deep.

aa. Inner wings absent.

2349. AMERICANUS.

d. Side pieces of prosternum with numerous shallow grooves.

$d d$. Side pieces of prosternum coarsely punctured.

2350. AREUS. CISTELOIDES.

2348 (7546). Helops micans Fab., Syst. Eleut., I, 1801, 157.

Elongate-oval, convex. Blackish-bronzed, shining; elytra with indistinct bluish and greenish-metallic stripes. Antenna slender, half the length of body, the three outer joints shorter. Thorax one-half broader than long, emarginate in front, margins feebly sinute, angles rectangular; surface coarsely, rather closely and irregularly punctate. Elytral strixe fine, indistinctly punctate; intervals flat, finely and sparsely punctate. Apex of last ventral with a broad hairy depression in male; a longitudinal and narrow one in female. Length 10-17 mm. 
Throughout the State; frequent. April 9-June 30. Occurs in colonies beneath loose bark of old snags, especially those of red and black oak. Our most brilliant member of the family.

H. venustus Say, color of micans, length 9-9.5 mm., is said by Horn to be "not abundant in the Middle and Southern States."

2349 (754S). Helors americands Beauv., Ins. Afr. et Amer., 1805, 122.

Elongate-oblong. Black. bronzed. Antenne with terminal joints less compressed than in miculs and scarcely shorter than those preceding. Thorax almost twice as wide as long, margins distinctly undulate, angles rectangular; surface coarsely and densely punctate and with a small depression each side near base. Elytra rather deeply striate; intervals subconrex, sparsely but distinctly punctate. Length 10.5-13 $\mathrm{mm}$.

Dubois and Crawford counties; scarce. May 15-May 19.

2350 (7565). Helops AREus Germar., Insect. Sp. Nov., 1S24, 159.

Short, oval, strongly convex. Blackish-bronzed, shining. Antennæ with last three joints subequal and shorter than those preceding. Thorax conrex, one-half broader than long; front angles subacute, surface densely and equally punctured. Elytra with rows of fine, scarcely impressed punctures; intervals flat, smooth. Length $7-9 \mathrm{~mm}$.

Throughout the western half of State; common beneath bark. April 5-June 14. Gregarious. Resembles Meracantha contracta in form, but much snialler. Easily distinguished by the numerous grooves on under side of thorax.

H. cisteloides Germ., elytra bronzed, with rows of fine punctures, intervals flat, smooth, length 10-12.5 mm., is a southern species which has been recorded from Cincinnati.

\section{Tribe VIII. MERACANTIINI.}

Ovate, strongly convex wingless species, having the head received in the thorax nearly to the eyes, which are large, transverse and emarginate; sides of head dilated over the base of antennæ and obliquely elevated; antennx long and slender, the outer joints very slightly thicker; last joint of palpi strongly hatchet-shaped; front coxæ rounded, middle ones with distinct trochantin, hind ones widely separated; front femora armed on under side with an obtuse tooth. The tribe is represented by a single gemus and this in turn by a single species, which occurs east of the Mississippi River.

XXVI. Merscantul Kirby. 1837. (Gr., "thigh + spine.")

2851 (757S). Meracantha contracta Beauv., Ins. Afr. et Amer., 1S05, 122.

Broadly ovate, robust, strongly convex. Blackish-bronzed; antennæ and legs piceous. Thorax subquadrate, convex, coarsely, irregularly and rather' 
closels punctate. Elstral strixe feebly impressed, rather finels punctured: intervals almost flat, thickls punctulate. Length 11-1:3 mm.

Throughout the State: frequent. Mar 18-September 18. Occurs singly beneath logs and bark, especially that of oak.

Tribe IX. STRONGYLINI.

Elongate, rather slender. conver species, having the head dilated on the sides, the eyes and antenna as in the preceding tribe; hind coxie narrowly separated: inner wings present. The tribe is comprised of the single genus:

\section{Strongrliur Kirby. 1837. (Gr., "round.")}

This genus, as characterized above, is represented by six species, two of which have been taken in the State.

KEY TO INDIANA SPECIES OF STRONGILIUM.

a. Thorax as long as wide, without a menian gloore. 2:5.2. TENLICOLLE. au. Thorax broader than long, with a shallow median groove.

235:. TERMINATLM.

2:52 (7579). Strongrlium tenticolle Say, Joum. Phil. Acad. Nat. Sci.. T, 1S26, $2 \pm 1$; ibid. II, 306 .

Elongate, conrex. Brownish-black or piceous, shining: last joint of antennæ sellowish. Thorax subcylindrical, narrower than elptra, as long as or slightls longer than mide; sides feebls curred, surface finely and rather closely punctured. Elytra with deeple impressed punctured striæ; interrals conrex, smooth. Length $1 \pm$ mm.

Lake County ; scarce. July 16-July 21. Taken at Hessville and Lake beneath bark of pine.

2353 (7580). Strongrlum termixatum Sag. Jourm. Phil. Acad. Nat. Sci., III. 1S24. 267 ; ibid. II, 157 .

Elongate, parallel, conrex. Blackish-brown; last joint of antennæ rellow. Thorax broader than long. front angles rounded: surface finels, lather closely and irregularly punctured. Elytra as in tenuicolle. Length 11-
$12 \mathrm{~mm}$.

Putnam and Crawford counties: scarce. June 28-July 1.

\section{Family LTI. CISTELID.E.}

The Comb-Clatwed Bark Beetles.

This family embodies in North America about 100 known species of brownish beetles without spots, which live, for the most part, beneath bark or on flowers and leares. In form they are usually elongate-oral, quite convex, and clothed above with minute hairs which give a silken gloss to the surface. Although closely allied to the Tenehrionida, they are readily separated by the comb-like or pec-
tinate tarsal claws. 
In addition to the above-mentioned characters, the members of the family have the maxillary palpi 4-jointed and often long an 1 much dilated; head suddenly but moderately narrowed behind the eyes, which are usually large, transverse and emarginate; clypeus not distinct, labrum prominent, mandibles short; antenna long, more or less serrate, 11-jointed, the joints, except three or four of the basal ones, studded with large eircular, sparsely placed pits or pores; thorax with the side margins obvious: mesosternum short, the side pieces reaching the coxal cavitie; metasternum long; elytra rounded at tips; abdomen with five or six ventral segments, the third and fourth of which are prolonged backwards and with their hind margins leather-like; middle coxw with distinct trochantins; hind coxx transverse, not widely separated, the intercoxal process in the Indiana genera being narrow, acute and angulate; tarsi often lobed beneath, the front and middle ones five-jointed, the hind one: 4-jointed.

The name of the family is derived from that of the typical genus Cistela, which is a diminutive of the Greek kiste, a "little box or chest,' and probably refers to the form of the insects. The larvæ, as far as known, somewhat resemble wire-worms in shape, live in rotten wood and have no special economic importance.

The principal literature treating of the North American forms is as follows:

LeConte.-"Synoptic table of the genus Hymenorus," in New Sp. N. Am. Col., I, 1866, 135.

LeConte.- "Synoptic table of species of Mycetochares," in Proc. Amer. Phil. Soc., XVIT. 1878, 616-617.

Casey._- "Synopsis of the Cistelidx of the U. S.," in Ann. N. Y. Acad. Sci., VI, 1891, 69-170.

Casey in his Synopsis recognizes 14 genera as belonging to the
family. Of these representatives of seven have been taken diana, while those of another perhaps occur.

KEY TO INDIANA GENERA OF CISTELID E.

a. Tarsi lobed beneath.

b. Head in repose resting against the prosternum and coxie, the former strongly slanting downward in front of the coxie. I. AlLECULA.

b7. Head in repose free, the prosternum longer and less slanting in front of coxa; thorax rounded at apex, its hind angles rectangular: body oblong and parallel.

II. IIYMENORT'S

al. Tirsi not lobed benenth.

c. Last joint of maxillary palpi elongate, triangular; mandibles distinctly notched at apex, their tips acute and subequal: antennie more or less compressed and serrate.

iII. Cistela. 
cc. Last joint of maxillary palpi broad, triangular.

d. Third joint of antenne nearly or fully equal to fourth.

e. Form oral; punctuation and pubescence usually minute and dense; front tarsi as long as the tibiæ; antenne slender.

ee. Form oblong. subparallel; punctuation and pubescence ISosira. coarse and sparse: front tarsi shorter than the tibige; generally shorter and stouter, the joints obconical.

dd. Third joint of antennie alwass distinctly shorter than fourth, but longer in the female than in the male.

f. Mandibles emarginate or truncate at apex: front tarsi more or less dilated in the male.

$g$. Legs short, the tarsi distinctly shorter than tibir; mandibles obliquely truncate at apex, feebls and obtusely bilobed.

gg. Legs long and slender, the tarsi as long as the tibire: mandibles deeply notched at aper, the lobes acute and subequal.

VI. CAPxochroa.

ff. Mandibles acute at tip ; front tarsi of male not dilated, but elongate and distorted; antennx long and filiform.

VII. Axdrochirus.

\section{Allecula Fab. 1801. (L., "by another way.")}

Oblong-oral species, gradually pointed behind, and having the tarsal lobes, especially the one on the next to the last joint, highly developed; apical side of last joint of maxillary palpi longer than the outer side; punctures of elytral strie finer toward apex. One species has been taken in the State, while another may occur in the northern counties.

KET TO INDIANA SPECIES OF ALIECULA.

a. Larger, 9-10 mm.; eses of female separated by about one-half their width, those of male not quite contiguous.

23อ4. PENCTULATA.

aa. Smaller, not orer $S \mathrm{~mm}$. : eses of femaie separated bs fulls their own width.

ATRA.

2354 (7599). Allecula puxctulata Melsh., Proc. Phil. Acad. Nat. Sci., III, $1846,59$.

Elongate-oral. Dark chestnut-brown to black, sparsely clothed with tine sellowish pubescence; antennre and tarsi reddish-brown. Thoras onehalf wider than long, sides distinctly converging and nearly straight from base almost to apex, hind angles rectangular, base broadly and deeply sinnate; surface coarsely and rather sparsely punctate and with a faint basal forea each side. Elytra scarcely wider than base of thorax. gradually narrowed from middle to apex; surface deeply striate, the striae with coarse. rather distant punctures; intervals subconvex. distinctly punctate. Nale 
narrower than female and with four basal joints of front tarsi strongly lobed beneath. Female with tlree basal joints of front tarsi simple, the fourth strongly lobed. Lengtlı!)-10 11111 .

Throughout the State; scarce. June 12-August 11. Occurs on dry twigs and beneath bark.

A. atra Say, black, shining, tarsi paler, length $7.5 \mathrm{~mm}$., is a member of the Alleghanian fauna.

II. Hrmenorus Muls. 1851. (Gr., "membrane + margin.")

Smaller oblong or oval species, having the last joint of maxillary palpi in the form of a right angled triangle with the apex and outer sides subequal in length; lobes of the tarsal joints less developed than in Allecula, the front and middle tarsi never having more than two joints lobed and the hind tarsi with but one. Seven species have been recognized from Indiana, while another may occur.

\section{KEY TO INDIANA SPECIES OF HYMENORUS.}

a. Thorax sparsely and usually rather finely punctured; upper surface shining.

b. Third antennal joint of male equal or subequal in length to fourth. c. Elytral strice obsolete toward the apex.

d. Elytra with a large reddish spot each side at base; length $4.5 \mathrm{~mm}$.

dd. Elytra uniform in color throughout.

e. Femora dark brown, tibice and tarsi paler; antennæ one-half as long as body; larger, $7-S \mathrm{~mm}$. 2355. PILOsUs. ee. Femora reddish-yellow, tibice darker; antennie two-fifths the length of body; smaller, 5-6 $\mathrm{mm}$. c. Elytral striæ distinct to apex; antennæ and legs reddish-brown.

2357. MELs HeIMERT.
b7. Third antemal joint of male distinctly shorter than fourth.

f. Antenne fully one-half as long as body, the third joint of male twothirds the length of fourth: thorax narrower than base of ely235S. PERFORATUS.

ff. Antennie slorter, about two-fifths the length of body, the third joint of male but slightly longer than second; thorax at base equal in width to elytra. a a. Thorax densely and rather coarsely punctured; upper surface less shining.

$g$. Antenne stont, third and fourth joints subequal; eyes large in male, separated by a distance less than one-third their width; piceousblack throughout.

2360. DISCRETUS.

gg. Antennæ slender, third joint distinctly longer thin fourth; eyes smaller, always separated by more than half their width; elytra piceous or dark reddish-brown, the head and thorax usually darker. 2361. DENSUS. 
H. humeralis Lec., piceous, antenna fuscous, legs pale yellow, was described from Kentucky and has been recorded from Cincinnati.

295. (7591). Hyanenorus 1'moses Melsh. Proc. Phil. Acad. Nat. Sci., III, $1846,5 S$.

Oblong-oral. Dark reddish-brown to piceous, shining; antennie, tibix and tarsi paler. Eyes separated by more than their own width. Thorax as wide at base as elytra, nearly twice as wide as long, the sides rounded into apex; hind angles rectangular; surface strongly sloping on the sides, rather coarsely, deeply and sparsely punctate, with a shallow transrerse impression each side near base and another in front of scutellum. Elytra nearly four times as long as thorax, the sides parallel; surface with rows of scarcely impressed punctures; intervals feebly convex, sparsely and finely punctate, rugulose near the apex. Length $7-8 \mathrm{~mm}$.

Throughout the State; frequent. Nay 16-August 10. Oceurs on and beneath the bark of the black willow, Salix nigra Marsh.

2356 (7594). Hymenorus Niger Melsh., Proc. Phil. Acad. Nat. Sci., III. $18+6,59$.

Elongate-oral, rather slender"and parallel. Black or piceous, shining; femora pale, antenne and tarsi piceous; pubescence ash-gray and rather fine. Eyes separated by a distance equal to their width. Thorax threefifths wider than long, sides straight and parallel almost to middle, thence rounded into apex; surface finely and sparsely punctate, without impressions near the base. Elytra not wider than thorax, their sides parallel and nearly straight; surface with rows of small, deep punctures, which are impressed only on basal half and become obsolete near apex; intervals finely, (leeply and sparsely punctate. Length $5.3-6 \mathrm{~mm}$.

Throughout the State; frequent. June 2-July 6. Occurs on the dead branches of oak.

2957 (10,642). HYanenorus melshemeri Casey, Ami. N. Y. Acad. Sci. VI, $1891,92$.

Elongate-oblong, parallel. Piceous black above; antennæ and legs pale reddish-brown. Eyes separated by slightly more than their own width. Antemne short, stout, not more than one-third as long as body. Thorax nearly twice as wide as long. sides parallel and feebly curved beyond middle. thence broadly rounded into apex; surface finely, sparsely and deeply punctate and with a faint impression on middle of base. Elytra equal to thorax in widtl, sides larallel, nearly straight; disk with inpressed rows of fine. rather distant punctures; intervals minutely and spalsely punctate. Length T-S $11 \mathrm{~m}$.

Lake and Kosciusko counties; rare. July 12-July 21. Described from Michigan. 
2358 (10,644). Hymenorus perforates Calsey, Mm. N. Y. Acall. Sci., Ýt, $1891,95$.

Elongate-oblong. Dark ficeous-brown, shining; legs and antemine slightly paler; pubescence pale, ratler coarse, semi-erect. Lyes reparated by about their own width in males. Antemne one-half as long as body, the joints very coarsely pitted. Thorax three-fourths wider thin long, sides broally curved into apex; surface coarsely and deeply punctate and without basal impressions, the punctures separated by twice their own diameter's. Elytral one-fifth wider than thorax and about four times as long, sides parallel and nearly straight; disk with rather strongly impressed rows of coirse, deei punctures; intervals subconvex, finely, sparsely and movenly pumctured. Length $\mathrm{i}-\mathrm{S} \mathrm{mm}$.

Kosciusko, Marion and Vigo counties; scarce. June 2-July 5. Occurs on leaves of maple. Described from Pennsylvania, Indiana and North Carolina.

2359 (7592). Hrmenores obscurus Say, Journ. Phil. Acad. Nat. Sci., Y, 1827, 242 ; ibid. II, 307.

Oblong-oval, strongly convex. Pale reddish to blackish-brown, shining, sparsely clothed with grayish-yellow pubescence; antemne, legs and abdomen reddish-brown. Eyes separated by about their own width in both sexes. Antenne with third joint equal to fourth in female, one-half as long sexes. Antenne with third joint equal to fout almost semicirculinly rounded
in male. Thorax one-half wider than long, alsely punctate, with faint im-
in front; disk rather finely, deeply and sparsely pressions each side and at middle near base. Elytra with sides almost parallel; disk with rows of strongly impressed. small, rounded punctures; intervals closely punctate in female, more sparsely so in male. Length 6-7 $\mathrm{mm}$.

Hamilton, Marion and Vigo counties; scarce. May 30--June 27. Taken on leaves of thorn and beneath logs.

2360 (10,657). Hrmenorts mascretus Casey, Amm. N. Y. Acall. soi., VT,

Oblong-subparallel. Piceous biack, feebly shining: antennse. legs and apical portion of abdomen reddish-brown; pubescence rather coarse. sparse and semi-erect. Eyes of male separated by less than one-fourth their width of female by two-fifths their width. Antemne notably stont, two-fifths as long as body. Thorax nearly twice as wide as long, the apex broadly curved and continuous with the sides; widest one-third from base, broadly flattened near hind angles, which are obtuse: surfice coarsely and densely punctate, faintly impressed each side near base. Elytra equal in width to thorax, sides palallel in basal two-thirds; surface with feebly impressed rows of rather small punctures; intervals fincly ancl slinsoly pumctite. Length $6.5-7.5 \mathrm{~m} 11111$.

Marion and Crawford connties; scarce. June 2-.July 2. Sereral specimens were taken from an old coat lying on the ground in the back yard of a city residence, by Philip Baker. 
2361 (7598). Hrmenorus nensus Lec., New Sp. N. Am. Col., I, 1S66, 138.

Elongate-oval. Piceous or dark reddish-brown; tarsi and two or three basal joints of antenne paler; pubescence short, coarse, pale and conspicuous. Antenne one-third the length of body, the third joint slender, slightly longer than fourth. Thorax one-half wider than long, sides straight to beyond middle, thence rounded into apex, hind angles rectangular; surface finely and very densely punctate, without basal impressions. Elytra slightly wider at base than thorax, widest at middle; disk with feebly impressed rows of small, rather close-set punctures; intervals very finely and densely punctulate.

Vigo County; rare. June 12. Taken from fungus on beech tree. One also in Webster collection.

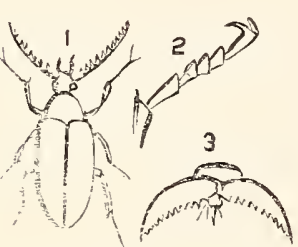

Fig. 566. 1, Beetle; 2, tarsus; 3 , tarsal claws. (After Westwood.)

\section{Cistela Fab. 1775. (Gr., "a little box.")}

Rather broadly oval or oblong beetles having the antennæ more or less compressed and serrate, with the third joint very short in both sexes; fourth joint of maxillary palpi slender, triangular; pubescence dense, short and inconspicuous. (Fig. 566.) Two of the six recogin the State.

2362 (7602). Cistela brevis Say, Journ. Phil. Acad. Nat. Sci., III, 1S24, 269 ; ibid. II, 158.

Elliptical or broadly oral, convex. Head, thorax and under surface black; antennæ and legs pale reddish-brown, the former dusky toward tip; elytra usually fulvous or tawny, sometimes black. Head with a lengthwise groove. Thorax two-thirds wider than long, apex truncate. one-half as wide as base, the latter broadly and strongly bisinuate, hind angles acute; disk finely and densely punctate. Elytra finely but deeply striate, the striæ with fine, close-set punctures; intervals subconvex, densely and minutely punctate. Males with the front tarsi compressed. the fifth joint strongly bent and thickened at base. Length $7.5-9 \mathrm{~mm}$.

Throughout the State; scarce. May 10--June 3. Occurs on flowers of wild hydrangea, linden, etc. All four specimens in the collection have pale elytra, though the ones with black elytra are said to be usually the more common.

2363 (7627). Cistela Amena Say, Journ. Phil. Acad. Nat. Sci., III, 1S24, 269 ; ibid. II, 158.

Oblong-oval, subdepressed. Black, shining; thorax and under surface pale reddish-yellow. Head with a transverse impressed line between the antenne. Thorax short, transrerse, more than twice as wide as long, the apex broadly rounded into the sides, hind angles rectangular; disk finely and rather sparsely punctate, more or less flattened on the sides and with a feeble impression each side and at middle near base. Elytra at middle 
distinctly wider than thorax, sides subparallel; surface with rather deeply impressed rows of close-set punctures; intervals nearly flat, finely and densely punctate. Male with stouter antennie and with last ventral segment deeply excavated. Length $6-\mathbf{T} .5$. mm.

Marion, Hancock and Putnam counties; rare. May 30-July 15. Occurs beneath bark. One of the three specimens has the legs wholly reddish-yellow. In the other two the front and middle femora and tibiæ are piceous.

\section{Isomira Muls. 1856. (Gr., "alike + part.")}

Rather small, oval brownish species, having the antennæ slender and filiform, the third joint asually nearly equal to fourth. Of the thirteen species recognized from the United States the following have been taken or should occur in the State:

$$
\text { KEY TO INDIANA SPECIES OF ISOMIRA. }
$$

a. Above bicolored; head and elytra piceous-black, thorax reddish-brown.

aa. Color above uniform or nearly so.

b. Fourth joint of maxillary palpi long and slender; elytral punctuation and pubescence exceedingly dense; color pale ochreous yellow throughout.

2364. SERICEA.

bb. Fourth joint of maxillary palpi robust, the outer side but slightly longer than apex.

c. Elytra without impressed lines on basal half, their punctuation sparse; third and fourth antennal joints equal in the sexes, $01^{\circ}$ the third slightly longer than the fourth.

d. Eyes small, separated by three times their width; lengtli $6.5 \mathrm{~mm}$.

2365. QUADRISTRIATA. al. Eyes large, coarsely granulated, separated by less than twice their width; length $7 \mathrm{~mm}$. 2366. SIMILIS.

cc. Elytra with fine but distinct impressed lines throughout the full length, their punctuation dense; third antennal joint one-fourth shorter than fourth.

2367. OBLONGULA.

1. ruficollis Ham., length 4.2-5.2 mm., is known from near Allegheny, Pennsylvania, and Cincinnati, Ohio.

2364 (7607). Isomira sericea Say, Journ. Phil. Acad. Nat. Sci., III, 1S24, 270 ; ibid. II, 159.

Elongate-oval. Pale brownish-yellow throughout, feebly shining; clothed with fine, dense and short pubescence. Antenne two-thirds as long as body. the third and fourth joints equal. Thorax one-half wider than long, sides straight and parallel to middle, thence rounded to apex, which is truncate and one-half the width of base; surface, as well as that of elytra, densely and finely punctured. Islytra with two or three feebly impressed striae near the suture, these more strongly marked near apex. Length $5-5.5 \mathrm{~mm}$.

Throughout the State; common. Nay 11-September 12. Occurs on flowers of Jersey tea, wild hydrangea, etc. 
2065 (7609). Isomira quadristriata Coup., Can. Naturalist, 186.5, 62.

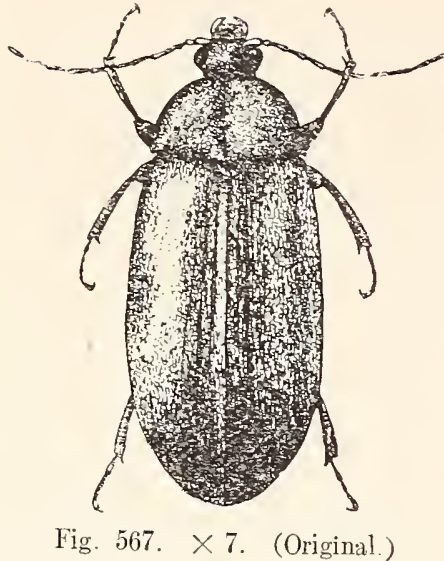

Rather broadly oral, convex, feebly shining. Dark reddish-brown to piceous, the head and thorax sometimes almost black; antemne and tibia usually paler, the former one-half the length of body. Thorax nearly twice as wide as long. sides rounded on basal half, converging toward apex, which is two-thirds as wide as base; disk finely and densely punctate. Elytra at middle one-fourth wider than thorax; surface finely and sparsely but distinctly punctate, each with two stribe plainly visible only on apical half near the suture. Length $5-6.5 \mathrm{~mm}$. (Fig. 567.)

Throughout the State; much more common in the northern counties, where it occurs aboundantly on huckleberry and other shrubs along the borders of marshes. May 11-August 15. The last joint of the maxillary palpi is much more broadly triangular than in sericea.

2866 (-). IsOMIRA SIMILIS sp. riov.

Elongate-oral, convex. Dark reddish-brown. feebly shining; antenna and legs paler: pubescence fine, slort. yellowish. rather dense. Head small. less than half the widtil of thorax. finely and densely punctate. Antenne slender, one-half the length of body; second joint one-fourth the length of third. the latter a little longer than fourth. Thorax twice as wide as long. strongly narrowed from base to apex; sides evenly rounded. base bisinuate. hind angles rectangular: surface finely and densely punctate and with a fine impressed median line on basal third. Elytra at base but slightly wider than thorax; surface finely and rather sparsely punctate, the sutural stria extending three-fourths to base. the others evident only near apex. Prosternum densely and roughly punctate; abdomen finely and rather closely punctate. Length $7 \mathrm{~mm}$.

Posey County ; rare. July 9. The larger size and much larger eyes easily distinguish it from 4-striata.

2367 (10,693). Isomira oblongula Casey, Amn. N. Y. Acad. Sci.. VI, 1891, 151.

Elongate-oblong, subparallel. Uniform dark reddish-brown to piceous, clothed with short, dense, pale pubescence. Thorax three-fourths wider than long, sides nearly straight except on apical fourth, where they are rounded into the apex. hind angles obtuse; surface finely and rery densely punctate, with a wide but feeble impression each side near base. EIytra four times as long as thorax; disk finely and densely punctate and with distinct but slightly impressed striae, without rows of punctures. Length 6.7$7.2 \mathrm{~mm}$.

Starke, T'ippecanoe and Orange counties; scarce. June 1-June 21. Beaten from oak. 
THE COMB-CLAWED BIRK BEETLES.

V. Mrcetochares Latr. 1829. (Gr., "fungus t to (lelight in.")

Small oblong brownish species, usually having the humeri of elytra dull red, and the last joint of maxillary palpi a robust rightangled triangle. They feed on fungi and oecur beneath bark. The outer covering is very brittle, breaking easily when handled. Casey recognized 22 species, seven of which have been taken in the State, while several others doubtless occur.

KEY TO INUIANA SPECIES OH MYCLTOCHARLS.

u. Front coxie separated by a distinct prosternal sulue,

b. Elytra each with a pale redash spot on hmmerus or hear balis.

c. Elytra without distinct rows of punctures; thorax as wide or matrly as wide as the base of elytrat.

d. Eyes small, separated by two to four times their widtl.

e. Pubescente rery short, sparse and inconspicuous; form natrow and convex; two stria evident neal the suture.

236S. HALUEMAN1.

ce. I'thescence normal f form broader and more depressed; sutural striae very faint.

2369. NRATERNA.

dd. Eyes very large, reparated by less than their own winth ; elytral lines impressed on inner half.

$2: 370$. MEGALOH'S. cc. Elytra with distinct rows of rather large puntetures; thorax at base narrower than the elytra.

f. Elytra fwice as long as widle; thorax with three basal inpressions.

2371. FOVEATA.

ff. Elytra distinctly more than twice as long als wide; thorax witl two basal impressions.

2372 . TENUIS.

b6. Elytra without pale humeral spot.

g. Thorax much narrower than elytra, but slightly wider tham head. GRACILIS.

yg. Thorax scarcely narrower than elytra, much wider than head, coarsely and densely punctite.

aa. Frout coxa contiguous or separated by a rery thin prosternil spine.

h. Elytra with a red humeral spot.

$i$. Thorax narrowly and abruptlysfattened at the sides. MARINATA.

ii. Thorax not flattened at the sides.

$j$. Eyes rather small, separated by twice their width; thorax equal in width to elytra.

2.37:. BINOTATA.

jj. Eyes larger, separated by slightly more than their witth: thorax narrower than elytra. h.h. Elytra without humeral red spot: thorax coarsely. rather densely punctured.

k. Eyes separated by at least twice their wirlth: color piceous-brown to black.

1. Thorax not flattened at the sides: antenne, legs and under surface reddish-brown. the last two rentral segments paler.

ANALIS. 
1l. Thorax flattened on the sides near base; under surface piceous, the anal segments not dirker.

LCGUBRIS.

ki. Eyes much larger, separated by not more than their width; color bale brownish-yellow, head and thorax darker. HORNI. 2368 (7615). Mrcetochares naldemani Lec., New Sp. N. Am. Col., I,
1S66, 140.

Oblong, subparallel, convex. Blackish-piceous, strongly shining; elytra each with a large oblique reddish spot extending from near the suture to humerus; tibix, tarsi and basal portion of antennse reddish-yellow. Eyes small, separated by four times their width. Thorax nearly twice as wide as long, convex, sides strongly rounded; surface, as well as that of elytra, very finely and sparsely punctured. Elytra parallel to basal third, thence rather acutely narrowed to apex. Length $4-4.5 \mathrm{~mm}$.

Marion, Vermillion, Dubois and Perry counties ; rare. May 23June 11. Our smallest form, easily recognized by its almost smooth, polished surface.

2369 (7616). Mrcetochares fraterna Say, Journ. Phil. Acad. Nat. Sci., III, 1823, 270; ibid. II, 159 .

Elongate-oblong, parallel, subdepressed. Piceous-black, shining; antennæ, palpi and tarsi reddish-brown; elytra with an oblique, pale yellowish spot on basal third; pubescence fine, short and sparse. Eyes separated by a little more than twice their width. Thorax twice as wide as long, as wide or slightly wider than base of elytra, sides broadly curved; surface rather finely and sparsely punctate, with a broad, distinct impression on middle near base, and a more feeble one each side. Elytra rather finely and unevenly punctured, with one or two vague strixe near the suture. Length $4.5-5.5 \mathrm{~mm}$.

Marion, Putnam and Dubois counties; rare. March 23-June 29.

2370 (10,679). Mycetochares megalops Casey, Amn. N. Y. Acad. Sci., VI, 1891, 129.

Elongate-oblong. subparallel, subconvex. Black, shining; under surface piceous; legs and antemne dark reddish-brown, the latter paler at base. Eyes as described in key. Thorax not quite twice as wide as long; sides nearly straight and subparallel on basal third, thence broadly rounded to apex; disk finely and sparsely punctate, the impressions more feeble than in fraternu. Elytra equal in width to thorax, parallel to apical third, thence obtusely rounded to tips; surface sparsely and rather roughly punctate, the strice eviclent on inner half, obsolete or nearly so on sides. Length $4.5 \mathrm{~mm}$.

Lake, Kosciusko and Marion counties; rare. May 22-June 19. One taken from an old coat in the back yard of a eity residence by P. Baker; also bred from willow. The larger eyes and less strongly rounded sides of thorax distinguish this from fraterna, which it otherwise very much resembles. 
7616). Mycetochares foventa Lec., N. Sp. N. Amer. Col., I. 1 S6ri,
140.

Elongate, suboval. Dark reddish-brown to piceous, shining; antenne and legs reddish-yellow; elytra with a small, pale reddish spot on humeri; pubescence short, fine, sparse and semi-erect. Eyes small, separated by nearly four times their width. 'Thorax one-third wider than long; sides strongly rounded at middle, thence converging to apex, hind angles rectangular; disk distinctly sloping on sides toward front angles, finely, deeply and sparsely punctate; basal impressions on sides deep, rounded, the one at middle linear, more shallow. Elytra with feebly impressed rows of rather coarse, close-set punctures; intervals each with a single row of very fine punc-

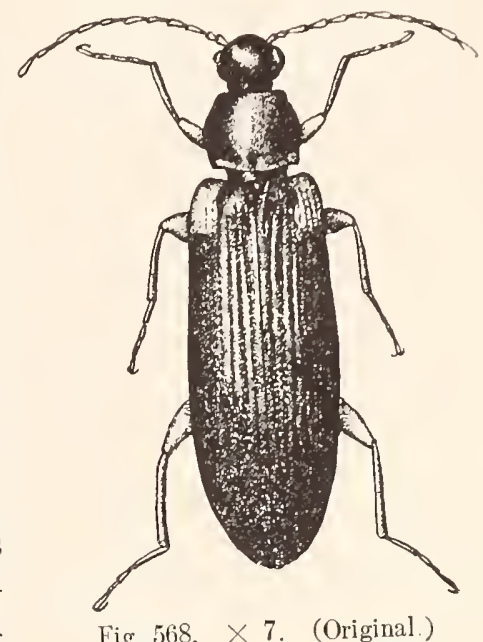

Fig. 568. $\times 7$. (Original.) tures. Length 5-6 mm. (Fig. 568.)

Throughout the State; frequent. April 25-July 24. Occurs especially beneath the bark of maple and walnut.

2372 (7618). Mrcetochares tenuts Lec., New Sp. N. Amer. Col., I, 1866, 140.

Elongate, slender, parallel. Piceous-black, shining; legs and base of antennæe pale reddish-yellow; elytra each with a small reddish spot near humerus; pubescence fine, short and inconspicuous. Eyes rather large, separated by two-thirds more than their width. Thorax one-fourth wider than head, about one-third wider than long, sides parallel and straight on basal two-thirds, thence rounded to apex; disk rather coarsely but sparsely punctate and with a deep impression each side near base. Elytra more than half as wide again as thorax; surface with rows of feebly impressed, rather fine punctures; intervais each with an irregular row of punctures almost as large as those of strix. Length $5.5-6 \mathrm{~mm}$.

Marion, Monroe and Posey counties; scarce. May 1--May 30. This species and foveata are often found together beneath bark. They run very rapidly when uncovered and attempt to hide in any dust or other debris which is present.

M. gracilis Lec., black, shining, legs black, length $5.5 \mathrm{~mm}$., is known from Michigan and Ohio; M. rufipes Lec., dark piceousbrown, legs yellow, length $4.5 \mathrm{~mm}$, is recorded from New York and near Cincinnati. M. marginata Tec., color and size of gracilis, was described from Michigan.

2373 (7624). Mrсетосhares binotata Say, Long’s Exped., II, 1S24, 285 ; ibid. I, 189.

Elongate-oblong, parallel, moderately convex. Piceous black, shining: two basal joints of antenne, tibie and tarsi paler. Elytra each with a large, rounded, pale reddish spot. Thorax nearly twice as wide as long. 
sides almost straight on basal third. thence rounded and converging to apex. which is two-thirds as wide as base: disk rather consely. deeply and sparsey punctate, with a short impressed line at midlle of base and a rounded, shallow forea each side. Elytra palrallel to apical third. thence rounded to tips; surface with feebly impressed rows of ratler coarse. close-set punctures which become obsolete near apex : intervals finely, sparsely and irregularly punctate. Length 6.S-7.5 mm.

Laporte and Kosciusko counties; rare. June 22-July 1. Taken by Dury at Cincinnati. Probably occurs throughout the State. Our largest species; readily separated from those preceding by the prominent and contiguous front coxæ.

2374 ( 7625$)$. Mrcetochares longlla Lec.. Proc. Amer. Phil. Soc., XVII, 1S7S, 618.

Elongate. parallel. Color as in binotuta; pubescence fine, rather long and sparse. Antenne stout, two-fifths as long as body. Eyes much larger than in the preceding, separated by less than their width. Thorax distinctly narrower than elytra, about one-half wider than long, broadly rounded on sicles; disk strongly sioping on sides in front, rather coarsely and somewhat densely punctate and with a median and two small lateral impressions near base. Elytra with feebly impressed rows of small punctures; intervals finely punctate. Length $5.5-6 \mathrm{~mm}$.

Steuben County; rare. Nay 22. The more narrow, elongate body, larger eyes, stouter antenna and narrower thorax, with more sloping sides, at once distinguish this from binotata. Known heretofore only from Detroit, Michigan.

I. anatis Lee., length 6.8-7.6 mm., is recorded from New Jersey and Michigan; M. Tugubris Lec., length $6.4-7 \mathrm{~mm}$., is known from New York and Kansas; M. hormi Dury, length 7.8 mm., was described from Cincinnati.

\section{C.spochroı Lee. 1862. (Gr., "smoke+color."')}

This genus is represented in the eastern United States, including Indiana, by a single rather large brown species, having the antenna elongate, compressed and filiform, the third joint longer than the second and one-half the length of fourth.

2375 (762S). Caprochroa fuliginosa Melsh., Proc. Phil. Acad. Nat. Sci.. III, 1S+6, 59.

Elongate-elliptical. Dark chestuut-brown to piceous; antenna and talsi later"; puluescence rely short. rather dense on thorax, sparse elsewhere. Tholax nearly twice as wide as long; sides parallel and nearly straight on basal half, thence curved and strongly converging to apex, which is trun"ate and less than one-half as wide as base; hind angles rectangular; surface finely and densely punctate and with a small inpression each side near 
base. Elytrat slightly wider than tholax, very gradually subacute an apical third; disk with deeply impressed rows of rather fine, close-set punctures;

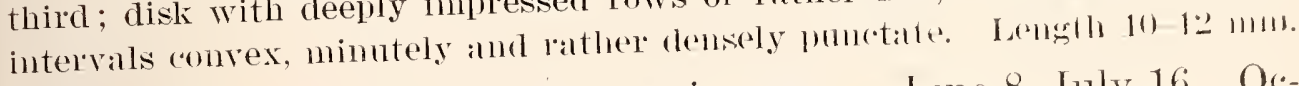

Lake, Kosciusko and Vigo counties ; rare. June 8-July 16. Occurs usually on bushes and twigs and probably to be found sparingly throughout the State.

VII. Annrochirus Lec. 1862. (Gr., "a male + hand."')

Medium-sized black or brown species, having the legs and antenna long and slender; terminal joint of maxillary palpi slender, triangular, its very oblique apex almost as long as the outer side; hind angles of thorax, especially those of female, acute and much prolonged backwards. One of the two recognized species has been taken in the State, while the other may occur.

\section{KET TO SPECIES OF ANDROCHIRUS.}

a. Deep black; femora reddish-brown, the tibixe and tarsi piceous.

FEMORATUS.

aa. Grayish-black; legs pale reddish-yellow throughout.

2376. ERTTHROPUS.

A. femoratus Oliv, length $9-10 \mathrm{~mm}$., is a southern species which has been recorded from Cincinnati.

2376 (763i). Androchirus erithropus Kilby, Fami. Bor. Amer., IV, 18:7. 239.

Elongate-oval, strongly convex. Color given in key; not shining; pubescence very short and dense. Eyes small, separated by one-half more than their own width. Third antennal joint twice as long as second, threefifths as long as fourth. Thorax one-half wider than the median length; sides converging from base to apex; disk very finely, deeply and densely punctate without basal impression; base strongly and broadly bisinuate. Elytra equal in width to thorax; sides parallel and nearly straight to middle, thence narrowing to a subacute apex; disk finely and deeply striate, the strixe finely punctate; intervals convex, minutely and densely punctate. Length 9-10 $\mathrm{mm}$. (Fig. 569.)

Throughout the State; scarce. May

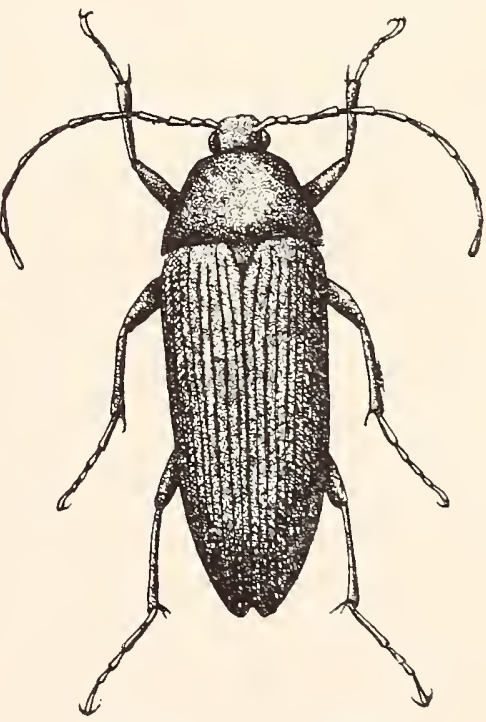

Fig. 569. $\times 4$. (Original.)

8-July 13. Occurs on stumps and bushes, ustually in moist places. A. fuscipes Melsh. is said by Casey to be a synonym of erythropus. 


\section{Family LVII. LAGRIID A.}

The Lagritd Bark Beetlles.

This family comprises a few elongate, slender beetles, having the thorax subcylindrical, narrower than elytra and the color more or less brassy or bronzed. From the Tenebrionidæ, to which they are closely related, they are separated only by having the front coxæ much more prominent and the next to last joint of tarsi dilated and spongy beneath. They oscur beneath bark and on leaves, the larvæ feeding freely on foliage and being much less retiring in habits than those of the Tenebrios.

In addition to the characters mentioned, the Lagriidæ have the head prominent, horizontal and more or less constricted behind the eyes, which are transverse, emarginate and rather coarsely granulate; antennæ 11-jointed, nearly filiform and inserted under very small, oblique frontal ridges, the terminal joint as long as the three to five preceding together; front coxal cavities closed behind; elytra rounded at tips, covering the abdomen, which, in our genera, has six ventral segments visible; legs siender, the next to the last joint of all the tarsi dilated, emarginate and clothed beneath with a dense bunch of hairs; tarsal claws simple. But eight species of the family are recognized from the United States. These are distributed among two genera and are treated in the single paper:

Horn.- "Miscellaneous Coleopterous Studies-Lagriidæ," in

Trans. Amer. Ent. Soc., XV, 1888, 28-32.

KEY TO THE GENERA OF LAGRIIDA.

a. Head not constricted to a neck; elytra very coarsely punctate, without definite strix; eyes transverse, reniform, not prominent.

I. ARthromacra. aa. Head constricted behind the eyes; elytra distinctiy striate; eyes large, convex and prominent.

II. Statira.

\section{Arthromacra Kirby. 1837. (Gr., "a joint + long.")}

This genus, sufficiently characterized in the key, is represented in the State by two species.

2377 (7637). ARthromacra TeNeA Say, Long's Exped., II, 1824, 287 ; ibid. II, 191.

Elongate, slender. Body beneatl and legs dark bronze; surface above brilliant metallic blue, green, cupreous or dark bronze; antennæ reddishbrown, the terminal joint usually darker; tarsi pale. Thorax cylindrical, one-third louger than wide, without side margins or angles; surface, as well as that of head, coarsely and rather closely punctate. Elytra parallel on basal half, then feebly but distinctly widened to apex; surface coarsely, closely and rugosely punctate, with vague strixe only on apical third. Length 9.5-13.5 mm. 
Throughout the State; scarce. June 11-October 12. Beaten from foliage of shrubs and trees, usmally along the borders of marshes.

237s (-). Arthromacra GLABricolits SP. nov.

More slender and parallel, the elytra not at all widened on apical half. Metallic cupreous or piceous, legs and antenna paler. Head finely and sparsely punctate. Thorax more slender, less convex on sides, longer in proportion to its width than in cenea; surface almost smooth, highly polished. Elytra each with four or five evident but indistinct costre extending from apex almost to base; intervals $r$ ather coarsely and not densely punctate. Length 10-13 mm. (Fig. 570.)

Posey County. June 4. Described from five specimens. The almost smooth thorax and much less roughly punctate elytra readily distinguish this from anea.

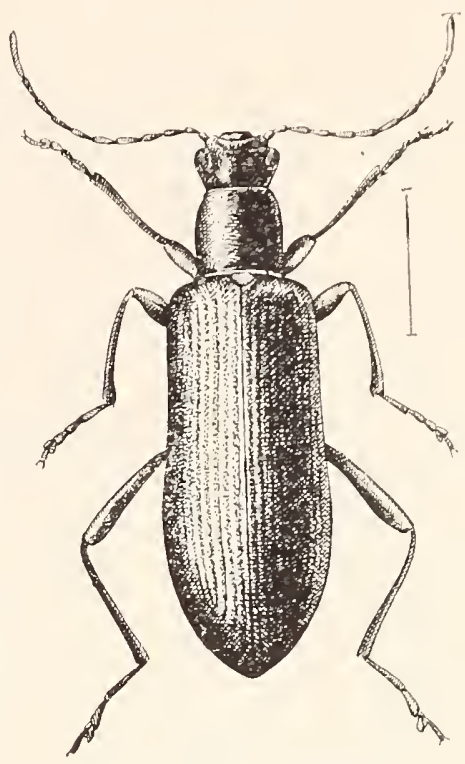

Fig. 570. (Original.)

II. StTatira Serv. 1825. (Gr., "a Jewish coin.")

Horn recognizes seven species as belonging to this genus, but some of them run very close together. Our two species have the tibiæ rounded, not sulcate on the outer edges and the first interval without setigerous punctures.

2379 (7639). Statika Resplendens Melsh.. Proc. Phil. Acad. Nat. Sci., II, 1845, 311.

Elongate, slender. Dark brownish-yellow to piceous, shining; thorax and legs reddish-yellow; elytra with a feeble bronzed lustre. Antennie half the length of body. Thorax subcylindrical, one-fourth longer than wide, sides finely margined, feebly curved, hind angles very small, acute; surface minutely and sparsely punctate. Elytra twice as wide as thorax, deeply striate, the striæ finely and closely but not crenately punctate; intervals feebly convex, almost smooth, the third and fifth with a few setre-bearing punctures. Length $\mathrm{i}-\mathrm{S} \mathrm{mm}$.

Putnam, Crawford and Posey counties; scarce. May 25-July 9. Beaten from the flowers of linden and foliage of shrubs.

2380 (7640). Statira gagatina Mels., Proc. Phil. Acad. Nat. Sci., II. $1 S 45$.

311.

Form of the preceding. Uniform piceous, shining: antennie and tarsi reddish-brown; elytra with faint metallic lustre. Thorax about as wide as long, more sinuate behind the middle than in resplendens, surface very finely 
alutaceous, almost smooth or with a few punctures near the base. Elstra as in resplendens. Length $6.5-8 \mathrm{~mm}$.

Southern two-thirds of State; frequent. May 24-July 10 Beaten from oak and other foliage.

\section{Family LVIII. MELANDRYID E.}

T'he Melandryid Bark Beetles.

This group comprises about 70 known North American species, varying much in form and size, thongh usually elongate and loosely jointed, with the thorax margined at sides, broad behind and often marked with two basal impressions. They occur beneath bark or in dry fungi and are black or brown in color, often thickly clothed with fine silken hair, only a few species being marked with paler spots or bars. The larva are slender, cylindrical in form and occur in the same places as the adults. The name is derired from that of the typical genus Melandrya. meaning "black t-oak or tree." and was so called because the insects live chiefly under the bark of trees.

In addition to the characters above mentioned, the Melandrride have the maxillary palpi 4 -jointed, usually long, more or less enlarged in the form of saw-teeth, the last joint being the longest and hatchet-shaped; head usually defiexed, rarely constricted behind the eyes, the latter emarginate or entire and rather coarsely granulated; antennæ 11-jointed. usually filiform; thorax in most genera as wide behind as the base of elytra, which are rounded at tips and cover the abdomen, the latter with five free ventral segments; front coxæ large, oval, the cavities open behind; middle coxæ with distinct trochantins; hind coxæ contiguous or nearly so ; first joint of hind tarsi always much elongated; tarsal claws variable in the tribes.

No paper dealing with the North American species of the family as a whole has been published, only isolated genera having been treated from time to time. These, as far as known to me, are as follows :

LeConte.- "Srnoptic Table of Hallomenus." in Proc. Amer. Phil. Soc.. XVII, 1878, 619.

Horn.- "Notes on the Mycteridx and other Heteromera," in Trans. Amer. Ent. Soc., VII, 1879. 336-339.

Horn.- "Miscellaneous Coleopterous Studies," in Trans. Amer. Ent. Scc., XV, 1888, 32-44. Contains a table of the tribes composing the family and synopses of several of the genera.

Casey.- "Review of the Tribe Tetratomini," in Journ. N. Y. Ent. Soc., VIII, 1900, 166-172. 
Horn, in his latest paper above eited, divides the family into ten tribes. Of these representatives of seven have been taken in Indiana, while those of two others probahly occur.

KEY TO INUIANA TRIBES OF MELANIRYIII:

a. Next to last joint of all the tarsi simple; iront tarsi of males not dilated: thorax as wide at base as elytra.

b. Antennae with last three or four joints suddenly larger, forming it lose, strongly developed club; length less than $6.5 \mathrm{~mm}$.

Tribe I. Tetratomine, 1\%. 1257.

bb. Antenne gradually thicker or filiform.

c. Front coxal cavities with an outer fissure or cleft.

d. Third joint of antenne as long as fourth and fifth together; form broadly oval.

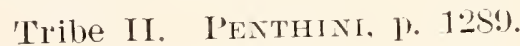

dd. Third joint of antenne not nuch longer than fourth ; form elongate.

e. Front coxie not prominent, rather widely separated; species strongly resembling Melanotus; length 10-11 mull.

Tribe III. SrNchromin. 1\% 1290.

ee. Front coxa moderately prominent and nearly c ntiguous; color piceous: length 6-8.5 mm. Tribe IV. Maromstri, p. 1291. cc. Front coxal cavities without fissure; form oral or oblong, conrex. Tribe V. Orchesins, p. 1*9291.

cia. Next to last joint of front and middle tarsi excavate and emarginate. more or less lobed beneath: front tarsi of males diated,

$f$. Tarsal claws simple or very slightly broader at base; thorax as wide at base as elytra.

g. Head not constricted behind. Tribe VI. Melandryini, p. 1295.

g. Head suddenly constricted behind the eyes: small species, not orer $5 \mathrm{~mm}$. in length.

Tribe VII. Scraptuni. p. 1209.

$f f$. Tarsal claws with a broad tooth or lobe at base.

h. Middle coxal cavities open on the outer side; head not prolonged; thorax as wide at base as elytra, its side margins entire, acute.

Tribe VIII. Nothixi, p. 1301.

hh. Niddle coxal cavities enclosed by the sterna; head more or less prolonged in a beak; thorax not as wide at base as elytra. its margin erident at base only.

Tribe IX. MICTERINI. P. 1302.

\section{Tribe I. TETRATOAINI.}

This tribe comprises small, oral convex forms living in fungi and having the last three or four jeints of antenne much enlarged, nearly equal in size and forming a loose club; tibial spurs small: next to last tarsal joint not lobed, claws simple, coxie all separated by their respective sterna. Casey, locality eited, has divided the tribe into five genera, three of which are represented in the State, while a single species of another may oceur. 
KEY TO INDIANA GENERA OF TETRATOMINI.

a. Antennal club composed of four joints.

7. Margins of thorax not reflexed at sides; larger, 5-6 $\mathrm{mm}$.

I. Tetratoma.

bb. Margins of thorax rather broadly concave and reflexed, the edge unevenly crenulate; length less than $4 \mathrm{~mm}$.

c. Basal segment of abdomen as long as the next two combined; color above mottled, black and pale.

II. Amstrulia.

ce. Basal segment of abdomen but little longer than second; color above blackish, not mottled but elytra with an indefinite, oblique yellowish streak.

INCOLIA.

aa. Antennal club composed of three joints; eyes smaller, very short and strongly transverse; length about $3 \mathrm{~mm}$.

III. Pisencs.

I. Tgtratoma Fab. 1790. (Gr., "four + joints.")

This genus, as limited by Casey, contains two species, one of which occurs in the State.

2381 (7646). 'Tetratoma truncorum Lec., New Sp. N. A. Col., I, 1866, 145.

Elongate-oval, strongly convex. Thorax, legs and under surface reddish-yellow; head and antennæe black; elytra steel blue. Antennx twofifths as long as body, the club as long as the basal portion. Thorax twothirds wider than long, sides rounded from base to apex, hind angles obtuse; surface sparsely, deeply and rather coarsely punctate, the basal impressions small, deep, rounded. Elytra parallel to apical third, thence rounded to apex; surface sparsely, irregularly and deeply punctate. Length $4.5-6 \mathrm{~mm}$.

Southern half of State; scarce. March 6-December 21. Occurs in dry fungi and beneath bark of fungus-covered logs, more especially those of beech.

\section{Abstrulia Casey. 1900.}

Small oblong-oval species having the margins of thorax wider and more reflexed, its basal foveæ larger, deep and less punctiform than in Tetratoma; scutellum smaller and more quadrate; elytra mottled instead of unicolorous as there; surface sparsely but distinctly pubescent. Three nominal species are recognized by Casey. One of these is in the collection at hand, while another he described from the State.

KEY TO INDIANA SPECIES OF ABSTRULIA.

a. Basal joint of hind tarsi very much shorter than last joint; yellow of elytra greater in extent than the black.

2382. TESSELLATA.

a a. Pasal joint scarcely shorter than the last; black of elytra much greater in extent than the yellow. MACULATA. 
2382 (7647). Abstrulia thssellata Melsh., I'roc. I'hil. Acad. Nat. Sici., II, $1844,114$.

Oblong-oval, convex. Piceous, feebly shining; antennar and lexs dull yellow; elytra each with about ten sinmous, nore or less connecter gellowish spots, one of which is a reversed crescent or O close to suture on midllle third. Antenne scalcely as long as head and thorax, the club disinctly shorter than stem, the third joint as long as the next two combined. 'l'h rax nearly twice as wide as long, sides broadly rounded, the base and alyes equal in width; surface deeply and rather coarsely and clocely juncotite. Elytral two-thirds longer than wide, more coarsely and siblisely punctate than thorax. Length $3.5 \mathrm{~mm}$.

Laporte and Lawrence counties; rare. June 10-June 14. Occurs on decaying twigs. Casey's type of $\Lambda$. maculata was from Indiana-Levette collection-without definite locality. It is probably of not more than varietal rank.

Incolia longipemis Casey, elongate, parallel, blackish, sides of thorax and streak on elytra paler, length $3.8 \mathrm{~mm}$., was described as being doubtfully from Indiana.

\section{Pisentus Casey. 1900.}

To this genus Casey ascribes two species, one being that usually listed under the Mycetophagidi as Triphyllus humeralis Kirby. The club of antennæ is loosely three-jointed; thorax not flattened at sides, the base broadly lobed at middle and as wide as the base of elytra, so that the sides of both form a continuous are; eyes small, very short and strongly transverse.

2383 (3402). Pisenus humeralis Kirby, Faun. For. Amer., IV, 1837, 112.

Elongate-oval, convex. Blackish-piceous. shining, sparsely clothed with short, silken. yellowish hairs; legs and antennxe dark reddish-brown; humeri of elytra obscure reddish. Thorax nearly twice as wide as long, sides feebly rounded; surface finely and rather densely punctate and with a feeble impression each sicle at base. Elstra thres times as long as thorax, nore coarsely and sparse1y punctate. Length $3-3.5 \mathrm{~mm}$. (Fig. 571.)

Throughout the State; common on leathery fungi, especially those growing on beech and

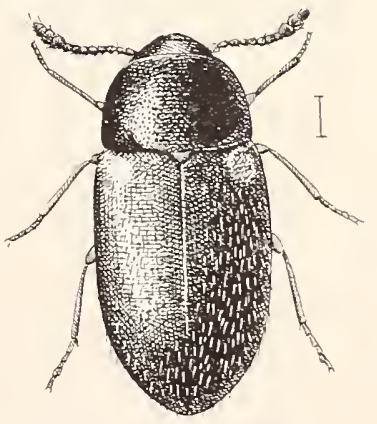

Fig. 571. (Original.)

March 10-Novemmaple stumps. Probably hibernates as imago. her 9 .

Tribe II. PEN'THINI.

This tribe is represented by the single genus: 


\section{V. Pentue Newm. 1838. (Gr., "in mourning.',)}

It comprises two medium-sized velvety-black, flattened oval species, having the front coxal cavities widely open behind; antennx not thickening externally, the third joint as long as the fourth and fifth together, joints 7 to 10 rounded, 11th a little longer and pale at tip ; front coxa oval, not prominent, separated by the prosternum.

\section{*23St (7649). Penthe obliquata Fab., Syst. Eleut., I, 1701, 162.}

Broadly oral, subdepressed. Velvety black, feebly shining; scutellum covered with long. orange yellow hairs. Thorax more than twice as wide as long, hind angles rectangular; sides nearly parallel on basal half, thence rounded to apex, base bisinuate; surface densely and finely granulate-punctate and with a deep oblong impression each side near base. Elytra with closely placed rows of deep, round punctures; intervals narrower than the rows of punctures, densely granulate-punctate. Length 11.5-14 mm.

Throughout the State; commion. April 12-December 5. Occurs on woody fungi and beneath bark of decaying wood.

\section{*2385 (7650). Penthe pimeria Fab., Syst. Eleut., I, 1701, 40.}

Readily known from the preceding by having the scutellum black, not orange yellow. The thorax is slightly shorter and wider, its hind angles much more acute and surface densely and more or less confluently punctate without granules. Length 10-14 mm.

Throughout the State; more common than obliquata. February 23-December 8. Both species are gregarious in winter, and hibernate beneath partly buried logs, especially those of beech in open upland woods.

\section{Tribe III. SYNCHROINI.}

To this tribe, as limited in the key, belongs the single genus

\section{Sinchrod Newm. 1838. (Gr., "uniform in color."')}

This in turn is represented in the eastern. United States by a single brown species having the head prominent and horizontal; maxillary palpi moderate in length, but slightly dilated; antennæe long, slender and feebly serrate, the second joint one-third the length of third, the latter slightly longer than fourth; tarsi filiform, claws simple; tibial spurs long.

\section{6 (7651). Synchroa punctata Newm., Entom. Mag., V, 1838, 378.}

Elongate, slender. Dark brown, rather densely clothed with ash-gray pubescence; antenne, tibire and tarsi paler. 'Thorax one-half wider at base than long. sides nearly straight, converging from base to apex: hind angles subacute; surface finely and rather sparsely punctate and with a deep impression each side near base. Elytra with a sutural groove on apical third; surface finely, sparsely and irregularly punctate. Length 10-11 mm. 
Throughont the state: frepuent. May 12-July :31. ()e.ms beneath bark and on dead limbs. The prostermmon is prolonered nearly as much as in the elick beetles of the genus Melanolus, some of which it closely resembles. Howerer, the arity in the mesosternum is much more shallow.

\section{Tribe IT. MALLOHRIINI.}

This tribe is also represented by the single genus Mallodrya Horn, formed for a "rather inconspicnous species, . subuncu IIorn. resembling a depressed Helandrya or an Emmesa. from which it differs by the slender tarsi, the penultimate joint not being excarate-emarginate and the front tarsi not dilated in the males." It is oblong, piceous, with faint rneous surface lustre, and 6 to 5.5 mm. in length. The types were taken by Dury near Cincinnati. who found them rather abundant on the branches of dead honerlocust. It probably oecurs in the southeastern part of Indiana. but no specimen has been seen from the State.

\section{Tribe V. ORCHEsIINI.}

Rather small oval, convex forms. having the head rertically defiexed; antenni 11-jointed, the joints gradually thickened. except in Microscapha. where they end in a distinct elub: front coxie oval. separated by the prosternum : tarsi filiform. claws simple. Four of the five genera, recognized by Horn as composing the tribe, are known to be represented in the State, while the single species of the other may occuí.

\section{KEY TO MNDIANA GENERA OF OHCHESIIXI.}

(4. Sums of hind tibie small or moderate, not serate, but of ten with trats: rerse lidges.

7. Hind coxie not oblique: form oral.

c. Elytra with rows of moderate or coarse punctures: prostermin narrowing to a point and not prolonged behind the coxie.

VI. Etstrophts.

cc. Elrtra finely and irlegularly punctured: prosternum prolonged behind the coxie and separating them. the apex slightly broader.

VII. HOLOSTROPHCs.

bb. Hind coxie oblique: form oblong-oval: length less than $5 \mathrm{~mm}$.

Viti. Hallodexts.

at Spurs of hind tibie large. the inner one rery long. peetinite.

d. Second antennal joint normal.

IX. Orenesta.

dd. Second anteminal joint thickened; antennie strongly clarate.

Microsc.PHA. 


\section{Eustrophus Ill. 1807. (Gr., "well + twisted.")}

Black or brown. oral. strongly convex species, separated from those of allied genera only by the character's above given. Six species are recognized, three of which have been taken in the State. while two others may occur.

KEI TO INDIANA SPECIES OF EUSTROPHLS.

a. Eves narrowly separated. sometimes almost contiguous on the front.

b. Middle and hind tibire with distinct transrerse ridges on their outer edge; under surface and legs reddish-brown.

c. Form distinctly narrored behind the middle; thorax wholly black.

2357. BICOLOR.

ce. Form much less narromed behind the middle; thorax with a brown marginal band on sides and front.

BRUXNEIMARGIXATCS.

67. Middle and hind tibire without tiansrerse ridges; under surface and legs piceous.

23SS. REPANDCS.

a a. Exes widely separated on the front; form rers little narrowed behind the middle.

d. Piceous black; thorax beneath shining, closely but not roughly punctured.

CONFINIS.

dd. Bromn; thorax beneath densels and roughly granulate-punctate.

23S9. TOMENTOSt'.

*2357 (7679). Eustrophus bicolor Fab., Ent. Srst., J, 179s, 497.

Oral. conrex. distinctls narrored behind. Black, shining, sparsels pubescent; abdomen and legs reddish-bromm; antennæ black, four basal joints reddish, terminal joint. wholly reddish-rellow. Thorax finely and closels punctured, the basal impressions rague. Elytra with rotrs of feebly impressed, rather coarse punctures which become finer towards apex: interrals flat, closels punctate. Length $5-6 \mathrm{~mm}$.

Throughout the State: common. January 19-September 20. Occurs beneath bark, especially that of fungus-corered logs. In two specimens from Tippecanoe County the under side of abdomen and femora are wholly black. but otherwise I can note no differences of importance.

E. brunneimarginatus Durr. black. head rufous, thoras and elytra each margined with brown. length 3.7-4.8 mm.. Tas described from near Cincinnati.

$238 S$ (10.710). Eustrophes Repandes Horn, Trans. Amer. Ent. Soc.. IT. 1S58, 33.

Differs from bicolor bs characters giren in ker. The antennie are darker, with onls the apical half of terminal joint pale. Punctures of elstral rors much finer on apical third. Length $6-\bar{r} \mathrm{~mm}$.

Throughout the State: common. Narch 26-Norember 17. Occurs with the preceding. more commonly on fungi, and like it probably hibernates as imago.

$E$. confinis Lec., length $6 \mathrm{~mm}$, is known from Canada, Wisconsin and Nebraska. 


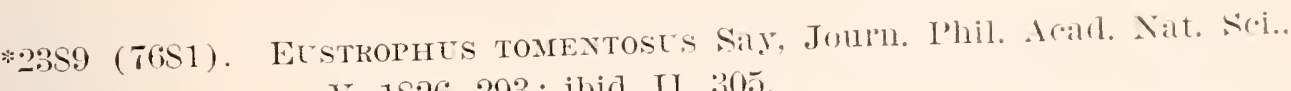

$$
\text { T, 1S26, } 293 \text {; ibid. II, } 305 .
$$

Oral, moderately convex, equally obtuse before and behind. Brown. feebly shining, rather thickly clothed rith short yellowish lubescence; alltemne, under surface and legs reddish-brown. Eyes separated in front by a distance one-fourth greater than their own width. Thorax rather closely and finely punctate, the basal impressions very fint. Elytra with rows of fine punctures. Which become much smaller near ajex; intervals densely and somewhat roughly punctate. Middle and hind tiblac with ridges as in bicolor. Length $4.5-5 \mathrm{~mm}$.

Southern tro-thirds of State, frequent; probahly throughout. February 6-September 13. Imagoes inst energing were taken on the later date. Oceurs beneath bark and in dry fungi. Hibernates in small numbers beneath deeply buried logs.

VII. Holostrophus Horm. 188s. (Gr.. "entire + nourished"'; i. e., well-fed.)

Small oral species which, besides the characters given in key. have the eyes very widely separated, scarcely emarginate in front; last joint of maxillary palpi oval, oblicuely truncate; fourth joint of antennæ not shorter than fifth. One of the three known species occurs in the State.

2390 (7680). Holostropht's bifasciatts Sar. Long's Exped., II. 1S24, 2\$2; ibid. I, 186.

Oral, convex, distinctly narrowed behind middle. Reddish-brown, shining, clothed with short. reddish pubescence; elstra piceous. with a broad, yellowish band on basal and another on apical third. these interrupted at suture; antemne pale reddish-brown. Thorax finely and closely punctate, the basal impressions short and linear. Elytra finely. densely and irregularly punctate. Length 4-5.5 $\mathrm{mm}$.

Throughout the State: frequent. April 7 -October 9. Occurs in and beneath rotten logs and in dret fingi in dense roods. Ranges from Massachusetts to Virginia and Tennessee.

\section{Hallonentes Panz. 1793. (Gr.. "to leap.")}

Small elongate or oblong species having the spurs of hind tibiz moderate in size and the hind coxæ oblique. Tro of the four recognized species occur in the State.

\section{KET TO IXDIANA SPECIES OF HALLOMEXES.}

a. Piceous or dark reddish-brown : antemne. legs and base of elptra dull brownish-yellow: length $4-4.5 \mathrm{~mm}$.

2:)(1) SCAPTLARIS. a $a$. Pale brown; head fuscous: smaller: $3 \mathrm{~mm}$. 2392. DEBatas. 
2391 (7683). Mallonents scapularis Melsh.. Proc. Phil. Acar. Nat. Sci.. III. $18+6,57$.

Oblong-orate, subconvex. Color giren in key; sparsely pubescent with rellowish hairs. Thorax one-half widel than long: sides parallel on basal hird. thence rounded to apex: surface finely and densely granulate-punctate. with a deep impression each side near base. Elytra more sparsely and less roughls punctate than thorax. Length $4.5-5 \mathrm{~mm}$.

Marshall, Wells and Vigo counties; scarce. May 19-October 2:3. Occurs on fungi, especially Polyporus sulphureus Fr.

2392 (i6S6). Halloments debilis Lec, New Sp. N. Am. Col., I, 1866, 152.

Obiong. Dull brownish-rellow, pubescence paler. Antenne stout, slightly longer than the head and thorax, third joint much longer than the second and fourth together: the joints more closely united than in scapularis. Thorax and elytra more densely punctate than there, the basal impressions of the former smaller. Length $3 \mathrm{~mm}$.

Putnam County ; rare. August 12. Occurs beneath logs and on fingi.

\section{Orchesia Lat. 1807. (Gr., "a dancer.")}

Small elongate, convex species having the spurs of the middle and hind tibix finely pectinate on their inner or lower edge. Our species are chestnut-brown in color and have the eres rather close together on the front. Two of the three species have been taken in the State. When uncovered they leap and tumble in grotesque fashion in their endeavors to escape.

KEY TO INDTANA SPECIES OF ORCHESIA.

a. I'rosternum between the coxie very narrow and acute at apex.

2393. CASTANEA.

a . Prosternum between the coxre broader and parallel, the apex obtuse.

2394. GRACILIS.

2898 ( 76 ) ). Orchesia castanea Melsh., Proc. Phil. Acad. Nat. Sci., III. $18+6,57$.

Elongate. convex. Unitorm dark chestnut brown; antennie and legs slightly paler: pubescence silky brown. Thorax one-third wider than long. lather coarsely and densely punctured near the base, more finely in front. the basal inluressions erident but shallow. Elotra punctured like the thorax. Length 4-5 inm.

Southern half of State; frequent. NIar 4 -November 9. Occurs beneath chunks and in woody fungi.

2394 (7rss). Orchesia gracidis Melsh.. Proc. Phil. Acad. Nat. Sci.. III. 1846.57.

More slender than costanca and more narrowed behind the middle. Punctures of thoiax and elytra more coarse and lugose, the basal impressions of former very vague. Length $3.5-4 m$ m. 
Kosciusko and Putnam counties; rare. March 20-.June 22. sifted from dead leares in low moist places. Ranges from Pennsylrania to Louisiana.

Hicroscapha clucicomis Lee., oval, convex, black, shining, head, base of antenna and front legs paler, length $2.8 \mathrm{~mm}$., was described from Illinois and Georgia.

\section{Tribe YI. MELANTRYIXI.}

The genera comprising this tribe, as at present limited, agree in having the next to last joint of at least the front and middle tarsi excavate beneath, emaromate and lobed; front tarsi of males diInted; front coxre contiguous; tarsal claws simple; thorax as wide at base as elytra; head not constricted behind.

Representatives of the following genera are known to occur or probably occur within the State:

\section{KEY TO INDIANA GENERA OF MELANDRYIXI.}

a. Front coxil carities with an onter fissure or cleft.

b. Frontal suture (between front and clspeus) distinct; trochantins of front coxie distinct: length 7 or more mm.

c. Elytra deeply striate: tholax with three groores on basil half.

cc. Elytra punctured. not at all striate; joints 2 and 3 of antennie together not longer than joint $t$ XI. EMaresa.

b). Frontal suture and trochantins of front coxie not risible.

d. Niddle coxie contiguous; antennie slender; fourth joint of maxillary palpi large, hatchet-shaped.

Irlita.

dd. Middle coxie separated by the mesosternum.

e. Maxillary paipi with fourth joint wider than the second and third: pubescence prostrate.

f. Antennie thick, outer joints wider than long; last joint of maxCarebara. (last joint of maxillary palpi elongate, cultri$f f$. Antenne slender ; lake a pruning knife: length less than $4 m m$.

XII. SPILotTs.

ce. Maxillary palpi with fourth joint not wider than second and third.

\%. Maxillary palpi not serrate or serriform, the fourth joint elonarte: color uniform brown : length more than $11 \mathrm{~mm}$.

NiI. Exchodes.

90. Maxillary palpi more or less serrate or serriform. the last joint elongate. cultriform: thorax elongate. its side margins effaced in tront. obsolete behind. a a. Front coxal carities entirely closed on the onter side. i. e.. without an outer fissure or cleft.

9. Maxillary palpi with last joint cultriform or pruming-knife shaped: length 6 or more $n$ min.

XIV. IHLEOTRIA.

[s2-23402] 
gg. Maxillary palpi with last joint hatchet-shaped; length less than $4 \mathrm{~mm}$.

h. Spurs of middle tibi:e small, equal; second joint of antennæe shorter than third.

hh. Spurs of middle tibie rery unequal: third joint of. SYmpHorA. longer than second.

A NISOXYA.

\section{Melinderya Fab. 1801. (Gr., "black+oak.")}

This and the next genus have the head inclined, never vertical: suture between front and clypeus distinct; last joint of maxillary palpi wider, hatchet-shaped; front coxre conical, contiguous with distinct trochantins; middle coxe contiguous. Melandrya, the typical genus of the family, is represented in the United States and Indiana by one species.

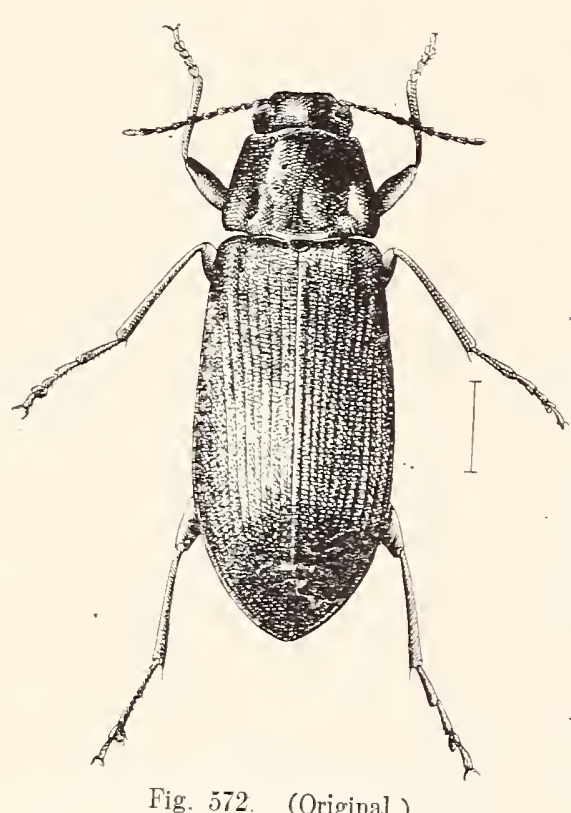

Fig. 572. (Original.)

2995 (7653). Melandrya striata Say, Long's Exped., II, 1823, 286 ; ibid. I, 190.

Elongate-oral. Black, shining; terminal joints of palpi and antenna reddishbrown; pubescence rery fine and sparse. Thorax gradually narrowing from base to apex, where it is but slightly wider than the head; surface finely and sparsely punctate and with three wide, shallow groores on basal half, the middle one the longest. Elytra gradually broader from base to apex, widely and deeply striate; intervals convex, sparsely and irregularly punctate. Length $7.5-15 \mathrm{~mm}$. (Fig. 572.)

Throughout the State; common in the southern counties, less so northward. April 9-June 18. Occurs beneath bark.

XI. Enmesa Newm. 1838. (Gr., "intermediate.")

One of the two known United States species occurs in the State. 2396 (7655). Emamesa Labiata Say, Long's Exped., II, 1823, 287; ibid. I, 190.

Elongate, subparallel. Black, shining, sparsely and finely pubescent; labrum, terminal joints of palpi and tips of last joints of antennæ reddishbrown. Thorax one-third wider than long, sides feebly curved from base to apex; disk finely and rather closely punctate and with a deep, wide, oblique impression each side on basal half and a narrow one at middle. Elytra closely and rather finely punctured, each with two or three indistinct raised lines. Length 9-11 mm. 
Marion and Crawford counties; rare. May 2t-May 25. Oecurs on leaves of plants and shrubs.

Tylita levigata Hellw, black, hasal half of elytra piceous or rufo-piceous, length 5-7 mm., ranges from Maine to Lake Superior and has been taken at Cincinnati.

Carebara longula Lec., elongate, depressed, piceous, length 6.5 mm., is said to occur rarely in the "Middle States."

\section{Spilotus Lec. 1862. (Gr., "spotted.")}

The members of this and the next genus have the head inclined or vertical, frontal suture not distinct; front coxæ conical, contiguous, without trochantins; middle coxre not contiguous. Spilotus is represented by a single species having the antennæ somewhat thickened toward apex.

2397 (7662). Spilotus Quadripustulatus Melsh., Proc. Phil. Acad. Nat.

Sci., III, 1S $46,57$.
Elongate, slender, convex. Blackish-piceous, sparsely and finely pubescent; tibire, tarsi and basal halt of antenne redđish-yellow; elytra each with two dull yellow spots, one large, oblique, near base, the other, smaller and more rounded, on apicai third. Thorax one-half wider than long, sides rounderl, hind angles cbtuse; disk finely and densely punctate and with a faint impression each side near base. Elytra more sparsely punctite than thorax. Length $3-3.5 \mathrm{~mm}$.

Kosciusko and Vigo counties; rare. June 5-June 6. Beaten from leaves of walnut.

XIII. Enchodes Lec. 1866. (Gr., "lance + appearance.")

This genus is represented in the Middle and Western States by one species.

2395 (7665). Enchodes sericea Hald., Journ. Phil. Acad. Nat. Sci., I. 1S49, 98 .

Elongate, slender, subdepressed. tapering behind. Tniform reddish- or chestnut-brown. rather densely clothed with rery fine, prostrate, rellowish pubescence. Thorax about as wide as long, widest at middle; hind angles acute, base bisinuate; disk rery finely and densely punctate and with a wide, triangular impression each side near base. Elytra gradually but distinctly tapering from near base to apex. not striate, finely and densely punctate. Length 12-14.5 $\mathrm{mm}$.

Vigo and Poser counties; rare. Nay 21-June 10. Taken from beneath bark of the downy poplar. Populus heterophylla L.

Mystaxus simulator Newm. dull rellow, thorax and elytra marked with black, length $7 \mathrm{~mm}$., is known from Ohio and Canada. 
XIV. Phlleotrya Steph. 1832. (Gr., "bark + to bore.")

This genus includes those species usually listed under Dircaa. They are of medium size, have the head vertical; prosternum short, not separating front coxar: males with front tarsi rather widely dilated and the last ventral segment truncate or emarginate. Two of the seven species recognized by Horn have been taken in the State and another perhaps occurs.

\section{KEY TO INDIANA SPECIES OF PHLEOTRYA.}

ル. Antennie slender, joints longer than wide; length $T$ or more mm.

b. Thorax shining. simply punctate: elytra each with two yellow spots of ir'regular shape.

2399. QUADRIMACULATA.

bb. Thorax opaque, rugulose; elytra uniform brown or piceous.

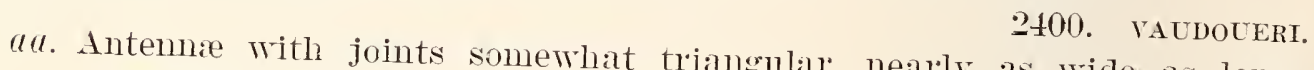
nular. nearly as wide as long; CONCOLOR.

2399 (7669). Phlqotria quadrinacliata Sity. Long"s Exped., II, 1S2:3, $28: 3$; ibid. I, 187.

Elongate-oral, conver, narlower belind the middle. Dark reddishbrown or piceous, feebly shining. spirsely pubescent; antennie, palpi and front margin of thorax pale; elrtra each with a rellowish. irregular, $H$ shaped spot on basal third and a rery irregular one on apical third. Tholax slightly wider than long. disk with sides strongly sloping. finely and densely punctate. Elytra more sparsely punctured, the punctures on basal half unequal and coarser than those near apex. Length 7.5-11 mm.

Lake, Putnam, Marion and Crawford counties: scarce. May 28July 15. Occurs on moss of beech and maple trees. Commonly listed as Dirccea Titurata Lee., hut Say's name has priority, as it was thrown aside by LeConte only on the ground that it had been preoceupied under Serropalpus.

2400 (7671). Phleotrya vatboteri Muls. Col. Fr. Barbily. 79.

Elongate, subcylindrical. slightly depressed. Dark brown to piceous, feebly shining. sparsely clothed with short. brown pubescence: labrum. narrow front margin of thorax. antennie and legs reddish-brom. Thorax a little longer than wide. sides rounded into apex: surface finely. densely and more or less rugosely and confluently punctate, the basal impressions rery faint. Elytra with two or three rague costie. the surface of basal half more sliarely and coarsely punctured than thorax. Length $7-9.5 \mathrm{~mm}$.

Perry County; rare. May 31. Occurs beneath bark.

$P$. concolor Jec, dark brown, antennæ piceous, legs fuscous, the tarsi paler, is known from P'ennsylvania and near Cincinnati.

$$
\text { XV. SYriphor L Lec. 1866. (Gr., "joined.") }
$$

Here belong two small. elongate, brownish or piceous species having the head scarcely deflexed, not constricted behind the eyes; 
antenna filiform, third joint more than double the length of second and nearly equal to those which follow : maxillary palpi with second and third joints short. the fourth dilated. hatrhet-shaped: front coxie contiguous. Both ocerur in Indiana.

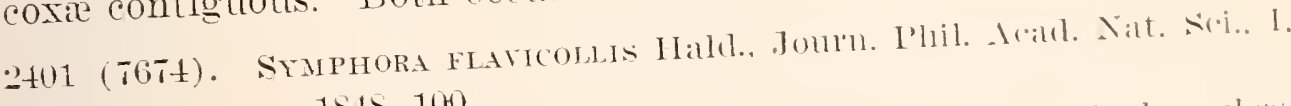
1sts. 100 .

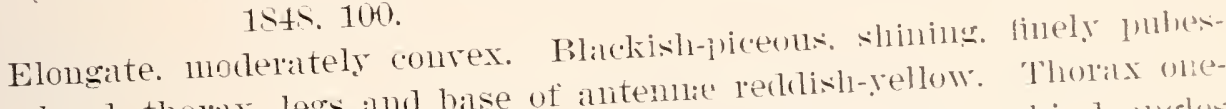
cent; head. thorax. legs and base of antennite redhish-yellow. Tholid onethird wider than long. sides broadly rounded. aljex truncate. linin angles

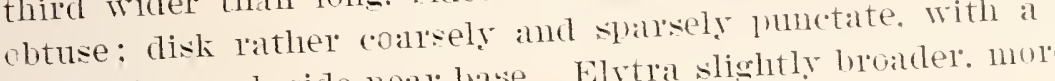
impression each side near batse. Elytra slightly hroaler. more coarsely ant sparsely punctate than thorax. Length :3-3.5 $111 m$.

Throughout the State: frequent. April E-.July 3. Occurs beneath bark and on foliage.

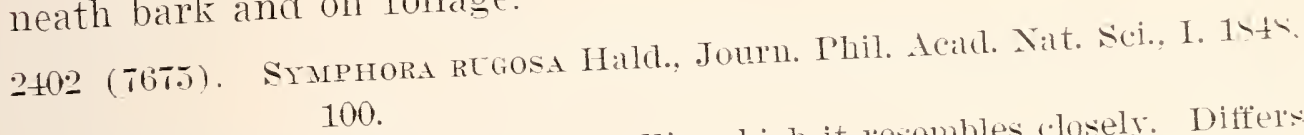

Usually more slenter than furicollis. which it resembles closely. Difters in being uniform pale chestnut-brown to dark fuscoms, less shining: an temie and legs paler Thorax less convex and more densely punctate. it outer margins contimus with those of elytril. Length 2.5-3.2 $\mathrm{mm}$

Throughout the State: common. June 2-.July 11. Taken by beating : also on fungi.

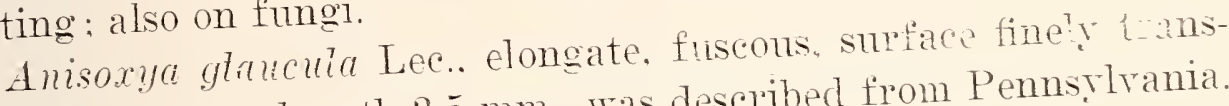
versely aciculate, length $3.5 \mathrm{~mm}$. was described from Pennsylrania.

\section{Tribe VII. SCRAPTIINI.}

This tribe is composed of three genera of small species having the head inclined. suddenly constricted a short distance behind the eres into a small neck; labial palpi with the last joint hatchetshaped; front coxie large, conical. contigrous, with distinct trochantins; middle coxp contiguous. Pepresentatives of all the genera have been taken in the State.

$$
\text { KEI TO GENERA OF SCRIPTIINI. }
$$

a. Last joint of maxillare palpi triangular.

6. Next to list joint of all the tarsi lobed: first joint of hind tarsi twice as long as all the others mited.

6b. Next to last joint of hind tarsi not lobed: first joint of hind tarsi shorter than the other three united.

a a. Last joint of maxillary palpi elongate. prtming XTII. Caxifa.

ATI. Scraptia Tatr. 1807. (Gr.. "an unchaste woman.")

Represented by a single small bromish species haring the antennx about two-thirds the length of bodr, not rery slender. third 
joint slightly longer than second, the two together not longer than fourth; last joint of maxillary palpi large, one-half longer than wide, the outer side broadly curved. $2403(7690)$. Scraptia sericea Melsil., Proc. Phil. Acad. Nat. Sci., III,
1846, 57.

Elongate, parallel. Uniform dull brownisll-yellow, sparsely clothed with silken, yellow pubescence; antenne and legs paler. Thorax one-third wider than long, sides broadly rounded into apex; disk rather finely and closely granulate-punctate and with three broad, shallow impressions near base, the median one reaching to middle. Elytra a little more sparsely and coarsely punctured than thorax. Length $4-5.5 \mathrm{~mm}$.

Orange and Perry counties; scarce. May 21-June 2. Occurs on flowers and foliage.

\section{AlLOPOD Lee. 1866. (Gr., "other + feet.")}

Represented by one small elongate, convex species having the antennæ about half the length of body, second joint half as long as third, which is equal to fourth; next to last joint of front and middle tarsi cordate and lobed; same joint of hind tarsi slender, not at all dilated and two-thirds the length of preceding.

2404 (7691). Allopoda lutea Hald., Journ. Phil. Acad. Nat. Sci., I, 1848. 100.

Elongate, rather slender, subdepressed. Pale dull yellow to reddishbrown, feebly shining, sparsely pubescent; elytra usually with a common brown spot on apical third, which often extends forward along the suture; antenne and abdomen dark brown; legs paler. Thorax slightly wider than long, sides rounded into apex: surface, as well as that of elytra, finely and rather closely granulate-punctate and with a small, round impression each side near base. Length $3-3.5 \mathrm{~mm}$.

Crawford County; scarce. June 2-June 27. Occurs on flowers of wild hydrangea and other shrubs.

\section{Canifa Lee. 1866.}

Antennx slightly more than half the length of body, second and third joints small, equal, the fourth as long as both united; last joint of maxillary palpi fully twice as long as wide; next to last joint of all the tarsi cordate and somewhat lobed; first joint of hind tarsi nearly twice as long as the others united. Four small, dull species represent the genus, all of which have been taken in the State.

KEY TO SPECIES OF CANIFA.

a. Color of thorax and elytra uniform.

b. Dark brown or fuscous; legs pale, dull yellow; basal impressions of thorax distinct. 
THE MELANDRYID BARK BEETIES.

bb. Black; legs pale fuscous; basal impressions very faint.

aa. 'Thorax and elytra more or less bicolored.

c. Head black; thorax and hasal portion of elytrat laredy dull yellow.

cc. Head and thorax black : elytra pale, dull yellow.

2407. PLAGIATA.

2405 (7695). Cantfa pallipes Melsh., Proc. Phil. Ararl. Nit. Sici., Ill, $1846,56$.

Elongate, rather slender, subdepressed. Color given in key; hear black, pubescence fine, sparse, yellowish. Thorax short, nearly twice as wide as long, apex and base truncate, sides rounder; disk minutely and densely granulate-punctate, basal impressions broad and rather shallow. Elytra widest behind the middle, a little more sparsely and coarsely and less roughly punctate than thorax. Iength $2-2.5 \mathrm{~mm}$.

Throughout the State, frequent in the southern counties; much less so northward. Nay 16-July 25. Beaten from foliage of various shrubs.

2406 (769)3). Cantfa pusilda Malr., Jomm. Phil. Acad. Nat. Sci., I, 1Sts,

More slender and parallel than pallipes. Black; elytra tinged witl fuscous, thickly clothed with fine, pale, yellowish pubescence. Length $2 \mathrm{~mm}$.

Putnam and Dubois counties; scarce. May 10-May 26.

2407 (7692). Canifa Plagiata Melsh., Proc. Phil. Acad. Nat. Sci., III, $1846,56$.

Form of pallipes. Head black; thorax and medial basal portion of elytra dull brownish-yellow; apical portion and sides of basal half of elytra blackish-fuscous. Basal impressions of thorax smaller, deeper, with usually a third one in front of scutellum; otherwise as in pallipes. Length 2$2.5 \mathrm{~mm}$.

Throughout the State, common in the southern counties; less so northward. May 11-June 24. Beaten from foliage of many shrubs and herbs, especially that of red bud, honey-locust and great ragweed.

2408 (7694). Canifa pallipennis lec. Proc. Amel. Phil. Soc., XVII, 1Sts,

619.

Elongate, slender. Head and thorax black; elytra pale, dull yellow. finely pubescent; under surface and legs pale yellow, antemnie and abdomen darker. Thorax twice as wide as long, surface finely granulate-punctate; basal impressions broad and distinct. Length $2.3-2.5 \mathrm{~mm}$.

One specimen from beneath the bark of dead pine near Millers, Lake County. July 14. Described from northern Michigan.

Tribe VIII. NOTHINI.

This tribe is represented in North America by the one genus: 


\section{No'thus Oliv. 1811. (Gr., "a bastard.")}

Our single species rosembles the Lampyrid, Telephorus bilineatus Say, in general appearanee. Besides the characters given in tribal key it has the head deflexed; antennx slender, subserrate; last joint of maxiliary palpi large, dilated, nearly eultriform; front coxil conical, contigunus. The males have the hind femora curved, the tibix armed with a sharp spine on the inner edge near the tip, and the tarsal claws cleft.

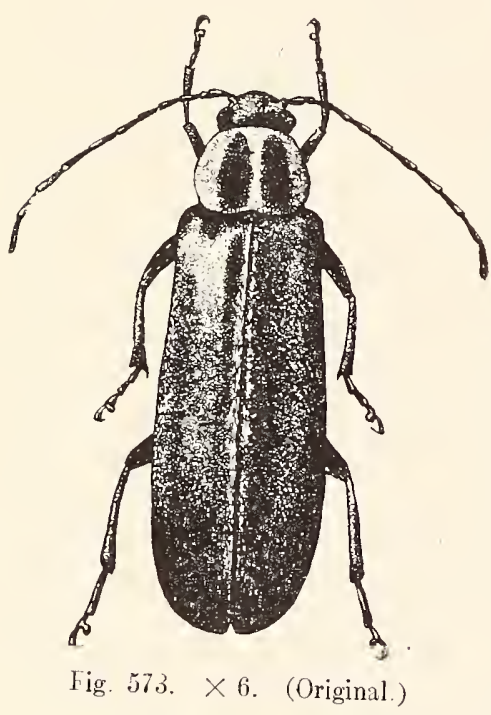

2409 (7698). Nothus varians Lec., New Sp. N. Am. Col., I, 1S66, 145.

Elongate-oblong, parallel. Piceous or blackish-piceous, sparsely clothed with fine, gray, prostrate hairs; thorax reddish-yellow, with-a broad, black stripe each side of middle, these often connected or eren confluent; antemne and legs usually piceous, sometimes in part or wholly dull yellow. Thorax suborbicular, slightly broader than long, its ansles all obtusely rounded; surface finely and rather closely punctate. Elytra finely, densely and rugosely punctate. Length $5-8 \mathrm{~mm}$. ( Fig. 573.)

Throughout the State; frequent. May 1-July 1. Occurs on flowers and foliage, especially those of Cratregus.

Tribe IX. MYCTERINI.

While no member of the tribe has been taken in the State, a single species of each of its two genera may occur. The genera are separated as follows:

\section{KEY TO GENERA OF MYCTERINI.}

a. Head short; epiplenre not reaching tips of elytra; first ventral segment short.

ar. Head prolonged into a beak; epiplemre reaching tips of elytra; first ventral as long as the second.

Lacconotus punctatus Lec., black, thorax reddish-yellow with median black space, length 4-5.5 mm., has been taken by Dury at Cincinnati. Mycterus scaber Hald., black, legs and antennæ yellow, lengrth $4.5 \mathrm{~mm}$., "occurs in the Atlantic States."

\section{Family LIX: PY'HID AE.}

The Pythid Bark Beetles.

A small family, represented in the United States by only about 20 species. They are separated from those of Melandryidx by hav- 
ing the thorax narrowed behind, racely mareined at the sides, its disk without basal impressions. In form they are usually long and narrow, either slightly convex or much flattened. They cerar beneath bark, usually that of pine, and have no special economic inlportance.

Other than the characters above nientioned, the Pythidie have the head prominent. not constricted behind the eyes, which are reither emarginate or finely granulate; antenni 11-jointed, slightly thickened toward the tips; elytra roundod at apes, covering the abdomen, the latter with five free ventral segments; front coxie conical, usaally contiguous, the cavities open behind; tarsi slender, never lobed, their claws simple.

Of the nine genera recognized hy LeConte and IIorn, representatives of but three have been taken in the state, while those of one other probably oceur. The only papers treating of any of the North American species are as follows:

Horn._- "Table of the species of Cononotus," in 'Trans. Amer. Ent. Soe., II, 1868, 136.

LeConte._" "Table of Rhinosimus," in N. Am. Entom., I, 1868, 4. Horn.- "Synopsis of the Genus Pytho." in Trans. Amer. Ent. Soc., XV, 1888, 45-46.

Wichlim.- The Pythick of Ontario and Quebee," in Can. Ent., XXXI, 1899, 57-61.

KEI TO INDIANA GENERA OF PYTHID.E.

(i. Middle coxie with distinct trochantins: last joint of maxillary palpi dilated: mandibles visible beyond the labrum: length 10 or more mm.

b. Third joint of antenne not longer than fourth; elytra not striate.

bb. Third joint of antennte longer than fourth: elytral striate; body much

a. Middle coxie enclosed by the sterua, without trochintins; last joint of maxillary paipi not dilated; mandibles not visible beyond the labrum: length less than 5 mm.

c. Beak of head broad and rery short.

I. SALPINGTS

cc. Beak prolonged.

III. RHIxosinl

I. Bonos Herbst. 1797. (Gir., "to shine.")

But one species from North America belongs to this genus.

2410 (gTOS). Bonos cxicolon Sar. Jouln. Phil. Acad. Nat. Sci.. Y. 1s.6. 238: ibid. II. 305.

Elongate. slender, subdepressed. Uniform piceons, shining. scarcely or not at all pubescent. Antenme one-third longer than head. Thorax oral. 
the sides evenly rounded; surface, as well as that of head. coarsely, deeply and rather closely punctate. Elytra much more finely and sparsely punctate than thorax. Length 11-13 mm.

Lake County; rare. October 22. One specimen from beneath bark of dead pine.

The range of Pytho depressus L. is such as to include Indiana. It is piceous or chestnut-brown, with a bluish or violet lustre, legs, antennæ and under surface reddish-rellow. Length 11-15 mm.

\section{SAlpINGUS Gyll. 1810. (Gr., "a trumpet.")}

One of the four recognized species occurs in the northern por' tion of the State.

2411 (7i17). Salpixgls ribescexs Lec. Agass. Lake Sup. 1850, 232.

Elongate, depressed. Greenish-black. shining; antennie reddish-brown. the last three joints piceous. Thorax slightly broader than head, widest one-fourth from apex, thence obliquely narrowed to base; hind angles rectangular, distinct; surface, as well as that of head, sparsely and rather finely punctate. Elytra broader at base than thorax, widening behind the middle; disk with rows of fine, feebly impressed, close-set punctures; intervals flat, smooth. Length $2.5-3 \mathrm{~mm}$.

Lake County ; rare: June 28. Taken by beating foliage of pine.

\section{Rhinostulus Latr. 1805. (Gr., "flat-nosed.")}

This genus is easily distinguished from the preceding by the much greater length of the flattened beak, the species in this respect resembling some of those of the family Rhynchitida. One of the three known species has been taken in the State.

2412 (7i23). Rhixosmes midifenets Rand., Bost. Journ. Nat. Hist., II, 1838, 23.

Elongate. Blackish-green. strongly shining; antennæe, legs and tip of beak brownish-yellow. Beak flat, trice as long as wide, narrowed at middle. wider at tip. Thorax slightly broader than long, narrowed behind, sides roumded in front; surface, as well as that of head and beak, coarsely but not densely punctured and with two irregular impressions each side. Elytra about twice as wide as thorax, marked with rows of scarcely impressed. rather fine punctures: interrals flat. the alternate ones each with a single row of distant punctures. Length $3.5-4 \mathrm{~mm}$.

A single specimen in the Trolcott collection, taken near Millers, Lake County. July 13. Occurs beneath bark of pine.

\section{Family LX. EDEMERID A.}

The Edeuerid Beftles.

A family of small or medium-sized beetles, usually rather slender, elongate and semicylindrical in form, with the head and thorax 
narrower than elytra, the former but slightly narrowed into a neck. The middle coxie are rery prominent; thorax without sharp edges at the sides, its lateral suture beneath ranting; elytra somewhat soft in texture and either smooth or with fine punctures and silky hair. They are found mostly on flowers or foliage, sometimes in crevices or on the ground near water. The larve live for the most part in decaying wood and are not of much economic importance. The name of the family is derived from that of the typical genus Edemera, which is the Greek of two words meaning "swollen"' and "thigh."

In addition to the characters mentioned, the nembers of the family have the palpi 4-jointed, the last joint dilated; head slightly inclined, the front somewhat prolonged; antennæ 11- rarely 12 jointed, nearly filiform; elytra covering the abdomen, which has five free ventral segrnents with a sixth sometimes visible in the males; front coxæ large, conical, contigrious, the cavities widely open behind; tarsi with the next to last joint dilated and furnished with a dense brush of hairs beneath; tarsal claws usually simple, rarely toothed at base.

The principal papers treating of the North American species are as follows:

LeConte.- "Synopsis of the Edemerida of the United States," in Proc. Phil. Acad. Nat Sci., VII, 1854, 20-22.

LeConte._- "Synoptic Tables of Copidita and Oxacis," in New Sp. N. Am. Col., I, 1866, 164-166.

Horn.- "The CEdemeridæ of Boreal America," in Proc. California Acad. Sei., VI, 1896, 382-421.

Wickham.- "The Edemerida and Yephaloide of Ontario and Quebec,' in Can. Ent., XXX, 1893, 149-152.

Horn, in his paper above cited, recognized 50 species from North America. These he distributes among 13 genera. Of these but five species, belonging to fom genera. have heen taken in the State, and a representative of another may occur.

KEY TO INDIANA GENERA OF EDEMERIDA.

a. Next to last joint of tarsi narrowly dilated; length less than $5 \mathrm{~mm}$. ; color brown.

I. Microtones. a a. Next to last joint of tarsi broadly dilated: length usually more thin $7 \mathrm{~mm}$. $7 \mathrm{~mm}$.
b. Front tibie with one spur; color above yellowish, elytra tipped with
black; antenna of male 12-jointed. II. Nacerdes.

7) b. Front tibiæ with two spurs; antennie in both sexes 11-jointed.

c. Both mandibles bifid at tip. 
d. ('latws simule.

('OPIDITA.

dd. Claws toothed at base: form very slender' color blackish. thordx wholly or in part regdish.

ec. Both mandibles simple: head short.

IIT. ASCLERA.

IT. Oxacis.

\section{Mickoronts Tuec. 1862. (Gr., "small + a thong.")}

Represented by a single small brown species having the head short, the front with distinct curred suture just before the eyes, which are rather coarsely granulate; maxillary palpi with last joint rather long, hatchet-shaped; antenn:e slender, one-half the length of body, the second joint one-third as long as fourth.

2413 (7726). Microtoxts sericaxs Lec.. Class. Col. of X. A.. I, 1862, 259.

Elongate. slender. convex. Brown. feeblr shining, sparsely clothed with short, silken. Jellomish hairs. Thorax nearly square, as wide as head. sides feebly rounded; hind angles acute; surface finels and densely punctate and with a rague depression each side near base. Elstra but slightly wider at base than thorax: surface closely. coarsely and irregularly punctate. Length $3.8-4.5 \mathrm{~mm}$.

Orange, Crawford and Perry counties; scarce. May 11-June 26. Occurs on foliage, especially that of elm.

\section{N.ACerdes Schmicit. 1846.}

One medium-sized, slender-hodied species belongs here. The antennæ are less than half the length of body, 12-jointed in male, eleven in female. Fourth joint of maxillary palpi elongate-triangular.

\section{4 (7333). Nacerdes yelaxtra Limn. Faun. Suec.. 1746, 205.}

Elongate. slender. parallel. subdepressed. Above dull rellow: elytra tipped with blackish purple: under surface and legs in great part piceous. Thorax dilated each side in front of middle, narrorred behind, rather coarsely and closely punctate. Elytra each with four narrow. slightly elevated lines; surface finels and densely punctate. Length s-12 mm.

Wells, Marion and Lawrence counties : scarce. May 29-July 12. Occurs about cellars. old boxes and lumber yards, probably in all of the larger torns of the State. Originally from Europe, it has been spread by commerce over the world. In one specimen from Larrence Countr the thorax has a large piceous spot each side.

Copidita thoracica Fab.. piceous, thorax reddish-rellow, elytra varying to purple or blue, length $5-\tau \mathrm{mm}$., is said to occur from the "Middle States southward." 
III. Ascters Sehmidt. 1846. (Gr., "not+harel.")

Elongate, slender blackish forms having the elytra distinctly costate; last joint of maxillary palpi triangular; tarsal claws toothed at base. Two of the six recognized species oceur in the State.

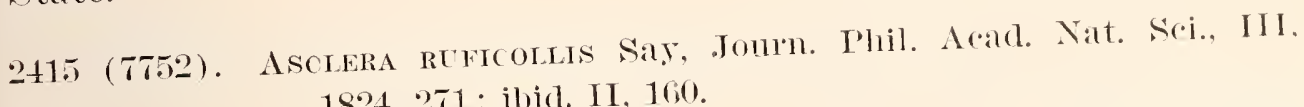
1824,271 ; ibid. II, 160.

Elongate, slender. Black, opaque; thorax wholly red. Thorax broadel than long. sides curved in front, oblique behind; disk smooth, except a rw of coarse punctures along the base and three broad fovex, one each side of midale, the other, more shallow, in front of scutellum. Elytra each with three well marked dorsal costre; intervals densely and minutely granulatepunctate. Length 5-6.5 $\mathrm{mm}$.

Throughout the State; frequent southward, much less so in the northern counties. April 7-May 23. Occurs on flowers, especially those of the yellow adder's tongue or dog's tooth violet (Erythronium ancricanm Ker.) ; also on those of willow, wild plum, black haw, etc.

2416 (7753). Asclera pi Notroolus Say, Journ. Phil. Acarl. Nat. Sci., III, 1S24, 27:3; ibicl. II, 161.

Form and color of ruficollis except that the thorax has a large central blackish spot and has the disk depressed at middle, without forea, finely and densely punctate. Elytra often with a slight purplish tinge, the costie distinct but less prominent. I aength $6.5-8 \mathrm{~mm}$.

Putnam and Posey counties; scarce. April 12-May 6. Oceurs on flowers of wild plum, ete.

$$
\text { IV. Oxucis Lee. 1860. (Gr., "sharp + edge.") }
$$

Iere belong about 15 slender species, having the antennie inserted close to the eyes, which are emarginate; mandibles acute at tip; claws usually simple. But one has been taken in the State.

$2417(\tau T+1)$. Oxacis Teniata Iec.. Proc. Phil. Acad. Nat. Sce.. YII. $1554,21$.

Elongate, slendel. Tull brownisll-yellow; thorax with the sides usmally piceous, often with a median blackish spot and a small rounted one ealch side in front; antemne dull yellow to piceoms. the basil joint longer than the third. Thorax obovate, longer than wide, without transrerse impression; rather finely and densely punctate. Elytrat finely and densely punctate without trace of costae. Length $T-!) 1111$.

Posey County ; rare. May 18. Beaten from flowers of the false indigo. A member of the Austroriparian fauna. 


\section{Family LXI. MIORDELLID A.}

'The Tumbling Flower Beetles.

This family includes a large number of small, wedge-shaped beetles having the body arched, the head bent downward and the abdomen usually prolonged into a style or pointed process. The hind legs are, in most species, very long and stout, fitted for leaping; the antennæ long and slender and the thorax is as wide at base as the elytra. The body is densely covered with fine silky hairs, usually black, but often very prettily spotted or banded with yellow or silvery hues. The adults occur on flowers or on dead trees and are very active, flying and running with great rapidity and in the net or beating umbrella jumping and tumbling about in grotesque manner in their efforts to escape. The larvæ live in old wood or in the pith of plants, and those of some species are said to be carnivorous in habit, feeding upon the young of Lepidoptera and Diptera which they find in the plant stems. The name Mordella, that of the typical genus, is from the Latin mordere or "bite."

In addition to the characters mentioned the Mordellidæ have the maxillary palpi 4-jointed, the last joint variable in form; head vertical and applied closely to the prosternum in repose, suddenly constricted immediately behind the eyes; antenna slender, 11-jointed, inserted at the sides of the front; thorax strongly narrowed in front, its lateral suture distinct; elytra narrowed behind, not truncate, leaving exposed the tip of the abdomen, the latter with five or six ventral segments; front legs short, hind ones usually long; front coxæ large, conical, contiguous, without trochantins, the cavities open behind; hind coxæ flat, contiguous, very large in most of our species; hind tarsi long, compressed; tarsal claws either simple or cleft to the base, with the upper portion comb-toothed in most species.

The principal literature treating of the North American forms is as follows:

LeConte.- "Synopsis of the Mordellidre of the United States," in Proc. Phil. Acad. Nat. Sci.. XIV, 1862, 43-51.

Smith, John R.- "A Synopsis of the Mordellidæ of the United States," in Trans. Amer. Entom. Soc., X, 1882, 73-100, Pls. I-III.

About 120 members of the family are known from North America. These are distributed among seven genera, six of which are represented in the State. One of the principal characters used in 
separating the genera and species is the number and form of the small black ridges on the outer face of the hind tibia and tarsi. 'The insects should be mounted with the hind legs straightened out and plainly visible, else their identification is impossible.

\section{KEY TO INDIANA GENERA OF MORDELLIDA.}

a. Abdomen not prolonged at tip; tarsal claws not cleft; upper surface of body very finely and transversely strigose.

b. Front and middle tarsi with third and fourth joints equal; antemne rather short, with the last five joints broader. I. Pentaria.

$b b$. Front and middle tarsi with the fourth joint ver'y small.

II. Andspis.
a a. Abdomen with the last segment prolonged, conical; tarsal claws cleft and pectinate; hind femora much enlarged.

c. Hind tibire with only a small subapical ridge; eyes finely granulated. d. Anal style short, obtuse; scutellum usually emarginate behind; eyes not reaching the occiput. dd. Anal style long and slender; scutellum triangular; eyes reaching the occiput.

IV. MORDElLA. cc. Hind tibire and tarsi with oblique ridges on the outer face; eyes coarsely granulated.

e. Hind tibire with one long ridge and no subapical one (Fig. 576, No. V. Glipodes. ee. Hind tibixe with subapical ridge distinct and usually one or more oblique ones in addition (Fig. 576, Nos. 15 and 17); length less than $6 \mathrm{~mm}$.

VI. Mordellistena.

\section{Pentaria Muls. 1856. (Gir., "five + thin.")}

Our species of this and the next genus are small yellow or yellow and black, finely pubescent forms, having the body fusiform rather than wedge-shaped; hind femora not or bit slightly dilated; last dorsal segment not piolonged; eyes oval, narrowly emarginate. Pentaria has the sixth ventral segment visible, and is represented in the State by one of the four known species.

2418 (7761). Pentaria trifasciata Melsh., Proc. Phil. Acad. Nat. Sci., II, $1845,316$.

Elongate, subdepressed. Head, thorax, legs and base of antennze dull reddish-yellow; elytra yellow, with base, tips and a broad band just behind the middle, black; abdomen, and sometimes the entire under surface, fuscous. Length $3-4 \mathrm{~mm}$.

Throughout the State, frequent; more so in the southern counties. June 4-July 30. Occurs on flowers, especially those of the dogwood (Cornus), wild hydrangea and black haw. The thorax is sometimes marked with fuscous and the bands of elytra are rarely connected along the suture. 


\section{Axuspis Geoff. 1762. (Gr., "without + shield.")}

Sixth rentral segment not risible: fourth joint of front and middle tarsi very small and received upon the third. which is slightly lobed; males with two slender appendages protruding from between the fourth and fifth rentral segments. Two of the eight recognized species have been taken in the State, while a third may occur in the northern counties.

KEI TO INDLANA SPECIES OF ANAEPIS.

a. Cpper surface entirely black: palpi, base of antemne and tront legs dull yellow; thorax twice as wide as long: length $3-4 \mathrm{~mm}$.

NIGRA.

a a. Upper surface, in part at least. rellow; thorax one-half wider than long. b. Head, thorax and under surface black: elytra pale brownish-rellow. 2419. FLAYIPENN:S.

67. Head fuscous or sellow: thorax and elytra dull reddish-rellow. 2420. RCFA.

A. nigra Hald., readily recognized by the robust form. is known from Termont and New York to Lake Superior.

2419 (7669). Axaspis flatipenxis Hald., Journ. Phil. Acad. Nat. Sci.. I 1StS. 100.

Elongate, slender. Color given in key; tibie. tarsi. mouth parts and base of antennx brownish-yellow. Length $3-4 \mathrm{~mm}$.

Steuben, Marion, Putnam and Jennings counties; scarce. April 9-Mar 25. Occurs on flomers, especially those of huckleberry and Cratcegis.

2420 (7770). ANaspis rufa Say. Jouln. Phil. Acad. Nat. Sci., T. 1826, 244; ibid. II, 309.

Elongate. slender. Head sellow or more or less piceous; antennæ and abdomen fuscous or dull rellow. Length $3+\mathrm{mm}$.

Kosciusko, Fulton, Putnam and Crawford counties; scarce. April 20-June 27.

\section{Tonoxis Costa. 185t. (Gr.. "joint+sharp.")}

In this and succeeding genera the body is more or less redgeshaped; hind femora rery large and flat; last dorsal segment conical, prolonged; sixth ventral not visible; body pubescent and rery finely punctulate. The species of Tomoxia are of a blackish color, raried with irregular grayish pubescence. They have the anal style short. obtuse: antennie serrate: last joint of maxillary palpi more or less elongate, triangular and thick, with the apical face concare. Two of the three recognized species have been taken in the State. 


\section{THE TUMBLING FLOWER BEETLES.}

KEI TO INDIANA SPECIES OF TOMONIA.

a. Last joint of maxillary palpi long. triaugular; scutellum emalleinate behind.

2421. BIIENTATA.

at. Last joint of maxillary palpi broadly hatchet-shalped: scutellum triangular.

2421 (7т3). Tomoxta bidextata Sag. Jouln. Phil. Acad. Nat. Sci. III 1524. 2TT; ibid. II, 164 .

Robust. wedge-shaped. Brown. varied with asli-gray lubescence as follows: four stripes on thorax radiating from the middle of font marein. which. with the side margins, is also ash-cray: elytria each with three or four stripes on basal half, a broken crossband behind midde and the anex ash-gras: a large rhomboidal brown spot on each near base. Iength 10$13 \mathrm{~mm}$.

Lake. Tigo and Posey counties; scarce. February 6--June $T$. Occurs on dead trees. T. Tineclla Lec., $5-7 \mathrm{~mm}$. in length, the elvtra marked with narrow ash-grar lines. is now recognized as the male of bidentata.

2422 (Ti6). Tomosta Hitaris Sar. Bost. Joum. Nat. Hist. I. 1S35. 190: ibid. II, 661.

Form wedge-shaped: more slender than bidentatu. Black, raried Tith ash-gray pubescence: elytra with a narrow sub-basal band of brownishrellow pubescence and a broader one behind the middle. the tro connected along the suture and margined with ash-gray pubescence. Length $9-13 \mathrm{~mm}$.

Described from Indiana. Two in Stein collection. probably from Pcsey County.

\section{Mordelda Linn. 1758. (L.. “bite."}

Rather large wedge-shaped forms having the scutellum triang'ular : anal strle usually long and slender : last joint of maxillary palpi long, triangular and obliquel truncate (except in the male of oculata). Nine of the 19 recognized forms have been taken in the state. while two others may occur.

\section{KEI TO IXDIATA SPECIES OF MIORDELLA.}

a. Amal strle short and truncate: dull black: thorax and elytra sprinkled with small spots of silrery pubescence. the latter with narrow interrupted band on apical third composed of confluent spots. Boreats.

un. Anal stryle long and slenter.

b. Last joint of maxiliary palpi triangular, the sides mequal.

c. Elytra dark. without conspicuous markings.

[S3-23402] 
d. Deep black. finely pubescent; base of thorax broadly rounded at middle.

2423. MELENA.

dd. Dull black, pubescence brownish; base of thorax much less rounded.

2424. SCUTELLARIS.

w. Elytra with distinct rellow or ash-gray spots or markings.

e. Elytra each with four spots of yellowish pubescence, the one at base broadly curred.

ee. Elytra with stripes or with more than four spots.

2425. осторUNCTATA.

f. Antemne and front legs biack; thorax marked with ash-gray pubescence and large black spots.

g. Elytra with small silrer gras spots, usually more or less confluent.

2426. MARGINATA.

yg. Elstra with a narrow sutural line and an oblique stripe from humerus toward the middle, ash-gray. 2427. LUxulata.

ff. Antenne and front legs dull sellow; tỉorax and elytra speckled with small, unequal yellowish spots; elstra with an interrupted band behind middle and the tips also sellowish pubescent.

2428. SERVAL.

00. Last joint of maxillary palpi either broadly hatchet-shaped or with the sides equal.

h. Head and thorax black.

$i$. Thorax sparsely clothed with yellowish pubescence, more densely at base; elstra with a broad basal band, enclosing on each a round black spot, and an interrupted band behind the middle yellowish or ash-gray.

ii. Thorax marked with ash-gray pubescence and large black spots.

j. Elytra with a broad basal band, including on each side two spots. and two oblique undulated bands of sellowish or ashgray pubescence.

2430. TRILOBA.

jj. Elytra with a broad basal band, including each side a rery large black spot, a band just behind middle and the tips ashgray.

UNDULATA.

hh. Head and thorax partls yellow: elytra with crossbands of black and rellow.

2431. DISCOIDEA.

U. boreatis Lee., length 3-4 mm., is said to occur in the "Norther'n States," and has been recorded from Cincinnati.

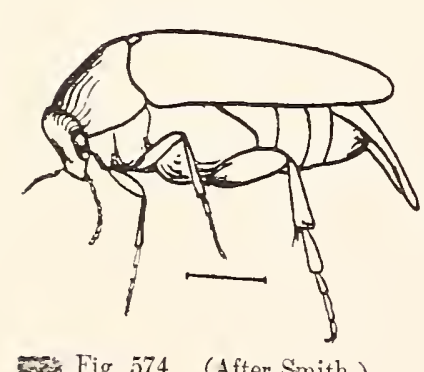

Fig. 574. (After Simith.)
2423 (7779). Mordella melana Germ., Insect Sy. Nor. 1824, 169.

Deep relrety black; pubescence at base of elytra and on sides of under surface often more or less iridescent; base of pygidium usually silvers pubescent. Length $5-\overline{\mathrm{mmm}}$. (Fig. 5it.)

Throughout the State; frequent. June 9August 1. Occurs especially on blossoms of wild rose. 
2424 (TSO). Mordella scteleldaris Fab., Syst. Eleut., II, 1801, 123.

Dull black, clothed with brownish pubescence; scutellum sometimes ash-gray ; sides of meso- and metasterna and front margins of rentral sesments more or less ash or silvery gray. Length :3-6 mm.

Throughout the State; common. June 2-September 2:3. Occurs in numbers on the flowers of Solidugo and other Compositx. U. irrorata Lee. is a rariety with single ash-cray hairs scattered orer the elytra, and with the under suretace dull black.

2425 (7782). Mordella octopexctata Fab. Syst. Eleut., II, 1SU1, 129.

Hear grayish pubescent: thorax with a network of lines of grayishyellow hairs; elytra as mentioned in key, the basal curved spots each partially enclosing a round black one, the subhumeral spot narrow and oblique; under surface spotted with ash-

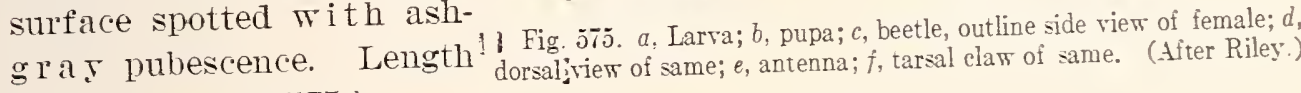
6- $7 \mathrm{~mm}$. (Fig. 5ั5.)

Southern half of State; frequent. June 2-August 7. Occurs especially on flowers of Jersey tea. The roung are said to feed on the rood of very rotten oak stumps.

2426 (7TS3). Mordella Margtrata Melsh., Proc. Phil. Acad. Nat. Sci.. II. $1845,312$.

Thorax with the margins. a narrow stripe each side of middle and a short one extending forward from base near hind angles, silvery or ashgray. Elytra with the spots rarying much in size and disposition. Under surface varied with silver-gras and black. Length $3-4.5 \mathrm{~mm}$.

Throughout the State; common. June 1-August 2. Occurs especially on flowers of dogwood, Jersey tea. and wild hrdrangea. The markings on the thorax are distinct only when held in a certain light.

2427 (7TS). Mordella ltxulata Helm. Proc. Phil. Acad. Nat. Sci., XTII. $1565,96$.

Head and thorax sparsels clothed with rellowish-grar pubescence: the latter with an indistinct stripe extending forward from base on each side more densely pubescent: under surface with sides and front margins of rentral segments with sparse ash-gras hairs. Length $4 \mathrm{~mm}$.

Orange County : rare. June 1 . The single specimen agrees perfectly with the descriptions of Hellmuth's troe collected in Illinois. the elvtra having the "narrow basal margin. humeral lumule and suture cinereous pubescent." In LeConte's obliqua. described from 
Detroit, there is an oblique stripe from the humerus to beyond the middle. Smith regards the two species as identical.

2428 (77S5̃). Mordella serval Say, Bost. Journ. Nat. Hist., I, 1835, 191 ; ibid. II, 662 .

Piceous brown, mottled with sellowish as mentioned in kes; elytra with a round black spot each side of scutellum, these bordered beneath with a rellowish spot much larger than the other's; under surface varied with ashgray and black. Length $4+4.5 \mathrm{~mm}$.

Putnam County ; rare. July 4 . Beaten from flowers of linden. Say's type was from Indiana, probably Posey County. A prettily marked and easily recognized species.

2429 (TiST). Mordella oculata Say, Bost. Journ. Nat. Hist., I, 1S35, 190 ; ibid. II, 662 .

Antennæ, tibiæ and tarsi clull red; basal yellowish band of elytra extending in a point almost to middle of each; under surface raried with ashgray pubescence, the hind margin of each rentral segment reddish. Maxillary palpi of male much larger than in female, and excarated at tip. Length $5-6.5 \mathrm{~mm}$.

Southern half of State; scarce. May 31-October 3. Occurs on the greater horseweed, Ambrosia trificla L.

2430 (77S9). Mordella triloba Say, Joum. Phil. Acad. Nat. Sci., III, 1S24. 276 ; ibid. II, 163.

Body black. Thorax with a three-lobed black spot, margined with rellowish pubescence; elytra with three undulating bands of dirty yellowish pubescence, the basal one enclosing a humeral and scutellar black spot; under surface rather thickly clothed with silvery gray hairs. Length $3-4 \mathrm{~mm}$.

Marion, Putnam and Posey counties; scarce. May 24-July 14. Taken from flowers of mullein and wild hydrangea.

II. undulata Mels., length $3 \mathrm{~mm}$., is recorded from Pennsylvania and Ohio.

2431 (7792). Mordella discoidea Melsh., Proc. Phil. Acad. Nat. Sci., II, $1 S 43,315$.

Black; antennæ, legs and top of head yellow; thorax yellow, with a large triangular black spot reaching from apex two-thirds to base; elytria black, marked with yellow as follows: an oblique stripe extending from humerus to a crossband before middle, a second band behind middle; apex. margin and suture behind the second band. Length 2-3 mm. (Fig. 5i6. No. 9.)

Posey County; rare. June 11. A small and prettily marked form, whose general range is southern. 
V. Gurpodes liec. 1862. (Gr., "slippery + foot.")

Rather large fuscous species, covered with dense silky brown pubescence; scutellum rounded, triangular; hind tibia carinate along the dorsal line and furnished with a long oblique ridge on outer surface, this connected with the dorsal ridge near tip; first joint of hind tarsi with two oblique ridges. (Fig. 576, No. 10.) One of the two known species has been taken in the State.

2432 (7793). Gimpones sericans Melsh., Jomm. Phil. Acad. Nat. Sci., II, $1845,312$.

Dark reddish-brown, densely clothed with silky yellowish pubescence; elytra usually darker than head or thorax. Labial palpi with last joint emarginate. Maxillary palpi of male with under side clothed with a dense brush of fine, soft hairs, the last joint bearing at base an onter jointed and forked appendage as long as the joint itself. Length $6-8 \mathrm{~mm}$.

Posey County; rare. Jume 14. Occurs in the "Middle and Southern States."

VI. Mordelistena Costa. 1855. (L., "'bite + narrow.')

A large genus of small, linear or wedge-shaped forms, having the scutellum rounded, triangular; anal style long and slender; hind tibixe with a subapical short transverse ridge* and from one to five oblique ridges on the outer face; hind tarsi with from one to five oblique ridges on first joint and often one to three on second and third joints. The beetles are often brightly and prettily variegated and occur on flowers of various plants.
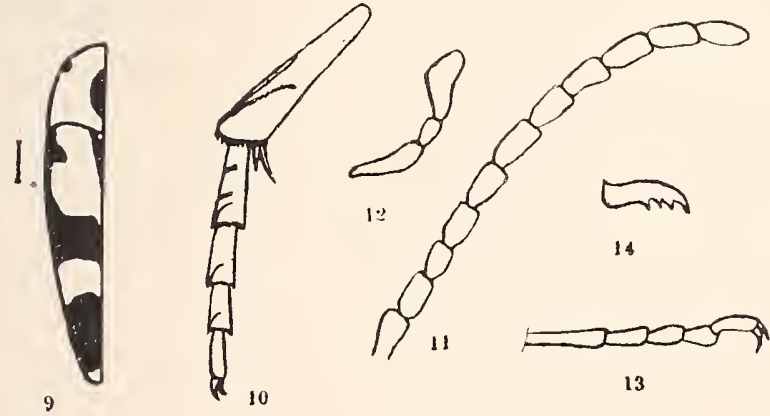

13
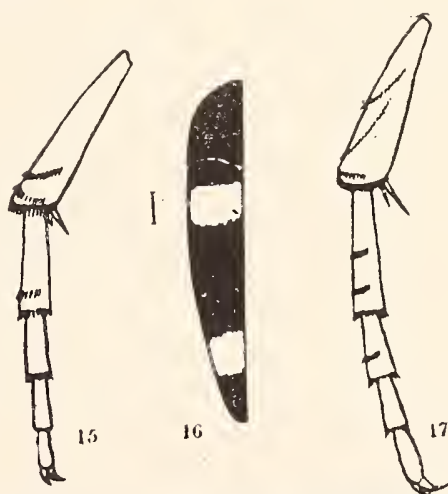

Fir 576 No 9. Mordella discoidea; 10, hind tibia and tarsus of Glipodes; 11, antenna of Mordellistena; 12 , 9. 13 ,

maxillary palpus of same; 13 , front tarsus of same; 14 , tarcinctella; 16 , elytra of same; 17 , hind tibia and tarsus of $M$. arida. (After Smith.)

On account of its large size, the genus is separated primarily into six groups, based upon the number and arrangement of the tibial ridges. These are as follows:

*This is not taken into account in the separation of the Groups below. 
KEY TO GROUPS OF INDIANA MORDELLISTENA.

a. Hind tibie and first joint of hind tarsi each with a single short, oblique ridge near tip. (Fig. 5i6, No. 15.)

aa. Hind tibia with two or more oblique ridges on outer face.

Group $A$.

b. Hind tibire with but two oblique ridges on outer face.

c. Ridges of tibia converging above. (Fig. 576, No. 17.) Group $B$.

ce. Ridges of tibixe parallel.

r. Ridges equal in length. (Fig. 5it, a.)

Group $C$.

1r. Ridges unequal, the upper one extending almost across the onter face of the tibiae. (Fig. 5is, a.)

7b. II ind tibie with three or more short, oblique parallel ridges.

e. Hind tibie with but three ridges. (Fig. 579, b.) Group $E$.

ce. Hind tibia with four or more ridges. (Fig. 5s0, a.) Gronl) $F$.

Group A.

This group is represented in the collection by two species.

2433 (7795). Mordeldistena bicinctella Lec., Proc. Phil. Acad. Nat. Sci.. XIV, 1862, 48.

Body narrow. parallel. Black; elytra with two yellow bands, first near base and interrupted by suture, second one fourth from tips; head, antenna and legs, except hind femora, dull yellow; thorix sometimes black, sometimes brick red. Length 2-2.5 mm. (Fig. 576. No. 16.)

Steuben and Marshall counties; scarce. June 11-July 6.

2434 (-). MoRdellistena CONFUsa sp. nov.

Very slender, parillel. Black, sparsely clothed with brownish pubescence; elytra with an oblong, dull yellow humeral spot; labrum, palpi, tarsi and abdominal process dull brownish-yellow. Length $2.5 \mathrm{~mm}$.

Martin County; rare. May 16. Resembles biplagiata in color, but much more slender and with but one ridge on tibixe and first tarsal.

\section{Group B.}

This group contains two uniform brownish-yellow species having the tibial ridges not parallel, but converging above.

KEY TO INDIANA SPECIES OF GROUP B.

a. First joint of hind tarsi with two second with one oblique ridge; ridges of tibia short, less strongly marked.

2485. LUTEA.

aa. First joint of hind tarsi with three. second with one oblique ridge: ridges of tibia long, very strongly marked.

2435 (7797). Mordeldistena Lutea Melsh., Proc. Phil. Acad. Nat. Sci., II, $1845,315$.

Slender, wedge-shaped. Uniform brownish-yellow ; elytra densely clothed with yellow pubescence. Length 2.8-3.2 $\mathrm{mm}$.

Marion, Orange and Posey counties; scarce. June 1-June 9. 
2436 (7796). Mordeblistena arida Lec., Proc. I'lil. Arad. Nat. Si.j., XIV, $1862,48$.

Larger and slightly darker than luted. Ridges of tibie and talsi longer and stronger than there, those of the first joint of hind tarsi nunch nurore oblique. Length $3.5-4 \mathrm{~mm}$.

Lake, Porter and Tippecanoe counties; scarce. June 27-. July 21. The specimens from Lake and Porter counties were taken from the flowers of the prickly pear cactus, Opuntia rafinesquii Engelm. Both LeConte and Smith state that arida has but two ridges on first joint, but all the specimens at hand have three. Dr. Smith pronounces them arida, stating that "the difference in the ridges is within the range of variation.' 'This is, of course true, but how about the keys, which are based on an unvarying number of ridges?

\section{Group C.}

In this group the tibia bear two equal oblique parallel ridges on the

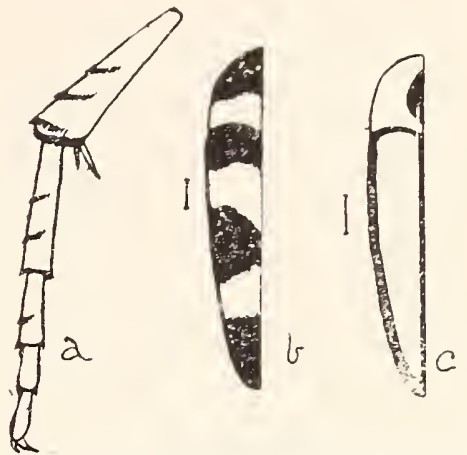

Fig. 577. a, Hind tibia and tarsus of Mordellisteno, trifasciatu; $b$, elytron of same; $c$, elytron of $M$. limbalis. (After Smith.) outer face. (Fig. 577, a.) The following species have been taken or should occur in Indiana:

\section{KEY TO INDIANA SPECIES OF GROUP C.}

a. First joint of hind tarsi with two oblique ridges.

b. Second joint of hind tarsi with but one oblique ridge.

c. Elytra black with two transverse yellow bands, the front one partly interrupted at suture bs a prolongation of the black band at base.

d. Body black; thorax black with basal margin and sides dull yellow.

2437. TRIFASCIATA.

dd. Body yellow; thorax yellow with a faint fuscous cloud on disk.

cc. Elytra without transverse yellow bands.

$e$. Color above wholly or in great part pale.

f. Thorax with front angles and a large spot on center of disk black.

2439. LIMBALIS.

ff. Thorax and elytra wholly pale clay yellow. 2440. VAPIDA. ee. Color above wholly or in great part black or piceous.

g. Elytra with a reddish-yellow oval humeral spot.

2441. BIPLAGIATA.

gg. Elytra without distinct lnmeral spot.

h. Head, thorax and legs, except the hind femoria, reddish-yellow. 
hh. Head, thorax and legs black or piceous; pubescence of elytra dark brown with light hair intermixed. INTERMIxta.

bb. Second joint of hind tarsi with two oblique ridges.

$i$. Body sellow; thorax with front half sellow with a median cloud, basal half black.

DECORELTA.

ii. Body black; thorax black with two small spots on apical margin reddish-rellow.

a a. First joint of hind tarsi with three oblique ridges.

$j$. Second joint of hind tarsi with one oblique ridge.

7. Piceous clothed with bromn silken pubescence: elstra paler.

7ik. Head, thorax and legs reddish-yellow.

PICIPENNIS

$j j$. Second joint of hind tarsi with two oblique ridges. FULTICOLLIS.

7. Elytra black with a reddish or orange-yellow humeral spot.

$m$. Head reddish-yellow.

$m$ m. Head black.

71. Elytra without distinct humeral spot.

n. Body reddish-sellow; base of thorax black.

m. Body black.

2442. ORNATA.

o. Head wholly or partly reddish; thorax brick-red, usually with an oblong black spot near base.

oo. Head and thorax black; pubescence brownish-gray.

MILITARIS. SCAPCLARIS.

443. COMATA.

2444. ASPERSA.

2437 (7798), Mordellistena trifasclata Say, Journ. Phil. Acad. Nit. Sci.. V, 15̣̂6, 243 ; ibid. II. 308.

Body narrow. nearly parallel. Color given in kes; head dull sellow; legs and abdomen tinged with same hue. Length 2.3-2.5 mm. (Fig. 5i , b.)

Putnam and Spencer counties; scarce. NJay 24-July 25.

2438 (7799). Mordeldistena lepidela Lec., Proc. Phil. Acad. Nat. Sci.. XIT, 1S62, 48.

Form of preceding. Color giren in key; elytra with three black and two yellow bands as in trifasciata; abdomen and hind tibire and tarsi raried with black. Length $2-3 \mathrm{~mm}$.

Pulaski and Monroe counties; rare. June 19-June 25. Taken from flowers of hercules club, Aratia spinosa L.

2439 ( 7800$)$. Mordelistena Limbalis Melsh.. Proc. Phil. Acad. Nat. Sci.. II, 1845,315 .

Slender. wedge-shaped. Large spot on front of head, disk and front angles of thorax. suture and side margins of elytra blackish; legs, metasternum and base of antenne rellow; mesosternum and abdomen blackish. Length $9 \mathrm{~mm}$. (Fig. 5iт, c.)

Lake, Tippecanoe and Knox counties; scarce. June $4-J u l y ~ 5$. 


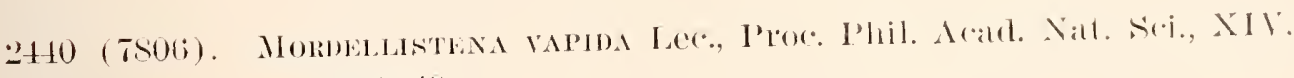
$181 ; 2,4 !)$

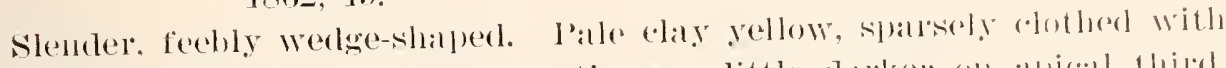

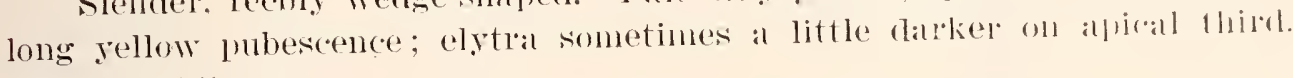
Lengtlı $2-3.511111$.

Orange County ; rare. May 28. Ranges eastward to Ner York. 2441 (7S03). Mordellistena Biplaghata Helm., Proc. Plil. Acarl. Nit. Ári.. XTI, 1864, 105.

Rather robust, wedge-shaped. Black, elytra with a redolish-yellow oval humelal spot: palpi. tibice, tarsi, basal joints of antenna and palt of alulomen, reddish-brown. Isength $3-4 \mathrm{~mm}$.

Throughout the State; frequent. May 3-October 23. Occurs in spring, especially on flowers of Crategus; in autumn rarely on fungus.

1I. dimidiata Helm., length 2-3 mm., was described from Tllinois; $M$. intermixta Helm., length $2.5 \mathrm{~mm}$., is known from Illinois and New York; M. decorella Lee., $3 \mathrm{~mm}$., M. bipustulata Helm., 2-;3 mm., M. picipennis Smith, $4 \mathrm{~mm}$., M. fulcicollis Melsh., 2-3 mm., and $\boldsymbol{H}$. militaris Lee., $2-3 \mathrm{~mm}$. in length, have all been recorded from Cincinnati; bipustulata and fulvioollis also from Thinois. $M$. scapularis Say, $4 \mathrm{~mm}$. in length, is said to occur in the "Niddle and Western 'States.'

2442 (7813). Mordellistena onnata Melsh. Froc. Phil. Acad. Nat. Sci..

II, $1845,315$.

Narrow, slightly wedge-shaped. Head and front half of thorax reddish-yellow: elytra each with a large triangular spot on basal half. suture and narrow margin or line behind middle, yellow. Length $3-4 \mathrm{~mm}$.

Throughout the State; searce. May 21-eJuly 13.

2443 (7S16). Mordeldistena comata Lec.. Proc. I'hil. Acad. Nat. Sci.. 1S5S, 75.

Linear, slightly wedge-shaped. Color given in kẹ: front and middle legs partly dull yellow. Length 2.8-3.2 mm.

Southern two-thirds of State; scarce. May 27-June 21. The Indiana specimens are of the rariety cervicalis Lec., and resemble marginalis Say very closely, differing only in having one less ridge on hind tibize and first joint of tarsi. If these ridges and color of thorax are variable, as some authorities claim, several of the forms with black body and reddish head will have to be combined under Say's name.

$2414(7817)$. Moroeldistera Aspersa Melsh., Proc. Phil. Acad. Nat. Sci.. II. 1S45. 314.

Narrow, slender. Black; pubescence rather dense and evenly distributed. brownish-gray in hue. Hind tibia with a trace of a third ridge. Length 2-3 $\mathrm{mm}$. 


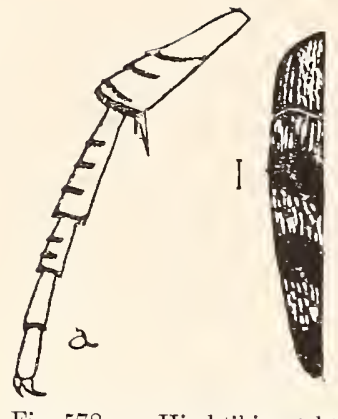

Fig. 578. $a$, Hind tibia and tarsus of $M$. grammica; $b$, elytron of $M$. infina; $c$, elytron of $M$. andrex; d, elytron of $M$. gram-
mica.
'Throughout the State; common. May 5-August 2. "The legs vary from pale brownish-yellow to dull black, the pubescence from brownish-black to ash-gray, and the head from deep black to dull red." (Smith.)

\section{GROUP D.}

In this group the hind

tibize bear two parallel ridges. the upper one much longer and extending almost across the outer face of the tibix. (Fig. 578, a.) The following species have been taken or perhaps oceur in Indiana:

KEY TO INDIANA SPECTES OF GROLP D.

a. First joint of hind talsi with two second with one oblique ridge.

b. Elytra black witl two rellow bands as in trifasciata.

AMICA.

bъ. Entirely black: pubescence grayish.

PICILABRIS.

aa. First joint of hind tarsi with inree or four, second with two oblique ridges.

c. First joint of hind tarsi with only three oblique ridges. (Fig. 57s, a.)

d. Body yellow; elytra yellow, with base, tips, suture and a large, oblong marginal spot black.

2445. GRAMMICA.

rr. Elytra not as abore.

c. Elytra and entire body pale brownish-yellow. 246. TEstacen.

re. Elytra in part or wholly black or piceons.

$f$. Elytra pale reddish-brown with the suture and margin black: body black.

ff. Elytra without distinct markings.

2447. VARIANS.

\%. Thorax wholly reddish-brown; elytra with reddish humeral spot.

SEMILSTA.

gg. Thorax black or piceous; elytra without humeral spot.

7. Head in part or wholly reddish: front and middle legs pale reddish-yellow.

i. Elytra with sage-green pubescence: front of head only reddish sellow.

DELICATULA.

ii. Elytra with brownish-yellow pubescence: head wholly reddish-brown.

RUFICEPS.

7h7. Body and legs entirely black.

244S. NIGRICANS.

ce. First joint of hind tarsi with four oblique ridges (Fig. 579. a) ; piceous, clothed with fine silvery pubescence.

SPLENDENS.

M. amica Lec., $2.5 \mathrm{~mm}$., and 1 . picilabris Helm., $2 \mathrm{~mm}$. in length, have been recorded from Cincinnati; the latter also from Illinois. 


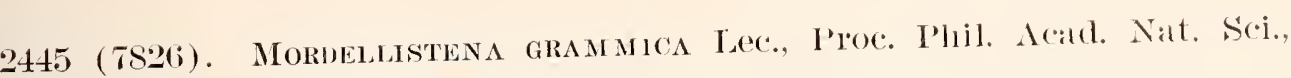
XIV, 1862, 50.

Elongate, subparallel. Head, thorax and body yellow; elytra as mentioned in key; abdomen of ten blackish. Length 2.5-2.8 1mm. (Fig. 578. 1.)

Marshall, Marion and Putnam counties; scarce. June 12-.July 8. Occurs especially on flowers of wild hydrangea. This includes the ustulata of LeConte, which differs only by being a little darker. yellow and having the marginal dark lines of elytra very narrow.

2446 (- - ). Mordellistena testacea s1\%. $110 \mathrm{~V}$.

Slender, parallel. Uniform dull brownish-yellow; puhescence rather close, paler yellow. Cength $2.31 \mathrm{~m}$.

Putnam County; rare. July 25. Taken from flowers of Solidago.

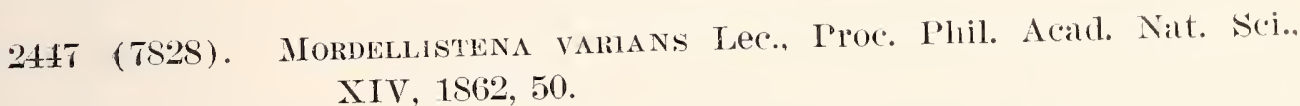

Form of grammica. Thorax black at base; front legs yellow; hind tibixe and tarsi dull yellow, the joints black. Length $2.5-3 \mathrm{~mm}$.

Marshall and Lawrence counties; scarce. June 4-June 13. In one specimen the metasternum is yellow and the thoracic dark spot small, thus forming a connecting link between this and grammica.

$M$. semiusta Lec., 2-3 mm. and $M$. delicatula Dury, $3.3 \mathrm{~mm}$. in length, have been recorded from Cincinnati. W. ruficeps Lec., 3 mm. in length, is said to occur in the Middle and Southern States.

2448 (7S33). Mordelistena nigricans Melsh., I’roc. I'hil. Acad. Nat. sici. II, 1845, 313.

Iinear. Blackish-piceous; elytra sparsely clothed with grayish-yellow pubescence; labrum, palpi and four bisal joints of antenne dull redilishbrown. Length $2 \mathrm{~mm}$.

Owen, Nonroe and Perry counties; searce. May 16-June 19. Beaten from flowers of Cornus.

M. splendons Smith, very slender, length $6 \mathrm{~mm}$., is known from Illinois, Ohio and Florida.

Group E.

In this group the hind tibia each bear three short, equal, parallel ridges in addition to the subapical one. (Fig. $579, \mathrm{~b}$.) The following have been taken splendens; $b$, same of $M$, pustulata; $c$, elytron er probably occur in the State:

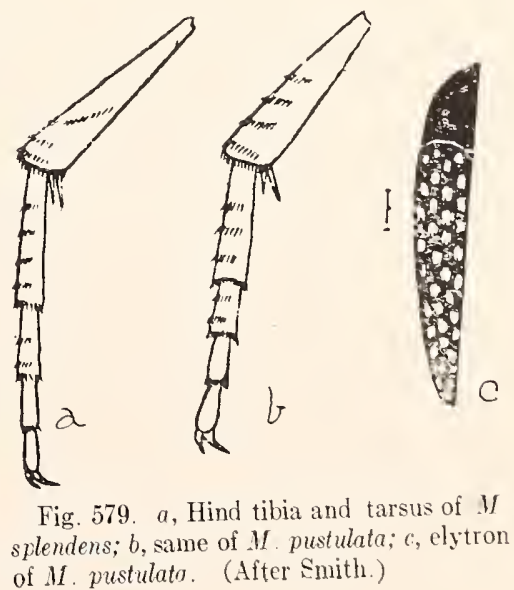


KEY TO INDIANA SPECIES OF GROUP E.

a. First joint of hind tarsi with two. second with one oblique ridge: elytra brownish-yellow, with six dark brown spots, the apical one transrerse.

a . First joint of hind tarsi with three or more oblique ridges.

SENNOTATA.

b. First joint with only three ridges. (Fig. 579, b.)

c. Second tarsal joint with one ridge; thorax black. eltrat reddishbrown.

cc. Second tarsal joint with two ridges. (Fig. 579, b.)

24t9. SMITHII.

d. Third hind tarsal joint without ridges.

c. Bodr black.

f. Elytra with numerous spots of silvery pubescence. (Fig. 579. c.)

2450. PCisTULATA.

ff. Pubescence of elytra not in distinct spots.

\%. Elytra with lines of brownish-gray pubescence, confluent behind.

2451. CONVICTA.

gg. Elytra with grayish-rellow pubescence. distributed mevenly orer the surface.

2452. MORLLA.

ce. Body fuscous or dark reddish-brown; pubescence silks brown.

2453. AMBपSTA.

dd. Third tarsal joint with two oblique ridges: reddish-brown. elytra black; pubescence fine and dark.

bb. First hind tarsal joint with four ridges.

SINGTLARIS.

h. Second hind tarsal joint with two ridges.

i. Cpper surface wholly piceous, corered with brown. silky pubescence.

2454. T TICOLOR.

ii. Head and thorax in part or wholly reddish-yellow.

j. Pubescence fine and dark; head and front legs in part black.

2455. MARGINALIS.

i. Pubescence dense, brownish-yellow; head and front legs wholly sellow.

2456. DIVISA.

hh. Second hind tarsal joint with three ridges; color wholly black.

EQTALIS.

M. sexnotata Dury, length 3 mm., was described from Cincinnati.

2449 (- - ). Mordellistexa smithin Dury, Journ. Cinm. Soc. Nat. Iist. XX. 1902. 17\%.

Subparallel. Piceous black; elytra dark reddish-brown. the resion of the humeri somewhat paler; front and middle legs dull brownish-rellow; pubescence coarse, rellowish. Length $3.5 \mathrm{~mm}$.

Putnam and Crawford counties: rare. June 28-July 4 . Described fron Cincinnati. In one specimen the hind angles of thorax and the hind legs are of the same hue as the elytra.

2450 (7S39). Mordemistena pestulata Melsh., Proc. Phil. Acad. Nat. Sci., II. $1845,314$.

Linear. Black: elytra spotted as mentioned in key. the spots often arranged in oblique bands. Length 2-3 mm. (Fig. 579. (.)

Throughout the State; common. May 13-July 14. 
2451 (7840). Mordellistena convicta Iec., Proc. Plil. Acad. Nat. Sci., XIV, $1862,50$.

Linear. Black; pubescence of elytra arranged in distinct llatrow lines. Length $3 \mathrm{~mm}$.

Marion and Perry counties; scarce. May 20-11ay 30.

2452 (7843). Mordelitstena morula Lec., P'roc. I'lil. Acad. Nit. Sci. XIV, 1862, 50.

Resembles pustulata in form and size, but the pulescence is rellowish and is scattered unevenly orer the surface. Length 2-3 $\mathrm{mm}$.

Lake County; rare. May 29-June 12. A member of the Alleghanian fauna.

2453 (7844). Mordellistena ambusta Lec., Proc. I'bil. Acad. Nat. Sici., XIV, 1862, 50.

Neariy linear. Dark reddish-brown, the head and thorax often slightly darker. Ridges of hind tibise longer and more oblique than usual. Lengtl 3-3.7 mm.

Vigo, Knox and Crawford counties; scarce. June 2-July 4.

II. singularis Smith, length $5 \mathrm{~mm}$. is known from Georgia and near Cincinnati.

2454 (7846). Mordellistena unicolor Lec.. Proc. Phil. Acad. Nat. Sci.. XIV, 1862, 50.

Slightly wedge-shaped. Uniform dark leddish-brown, thickly clothed with brownish-yellow pubescence. Length $3.4 \mathrm{~mm}$.

Marion and Putnam counties; rare. June 7-June 28. Differs from ambusta only by the additional ridge on first joint of hind tarsi.

2455 (7S47). Mordellistena marginalis Sily. Jomm. Plil. Acad. Nat. Sci..

III, 1824, 27S; ibid. II, 165.

Rather robust; redge-shaped. Black; head and thorax reddish-yellow, the former usually with a black spot: the latter either with base entirely black or with a quadrate oblong spot extending from middle to scutellum. and another on each hind angle. Tength $3-4$ min.

Throughout the State, common: much more so in the northern counties. May 29-September 25. 'Taken by sweeping. W. comata resembles this species closely and is apt to be confused with it.

2456 (-). Mordeltistena divisa Lec. Col. of Kan. and F. N. Mex.. $1860,17$.

Slightly wedge-shaped. Head. front and middle legs and front half of 
thorax bright sellow; elytra densely clothed with yellow pubescence. Length 2.5-3 $\mathrm{mm}$.
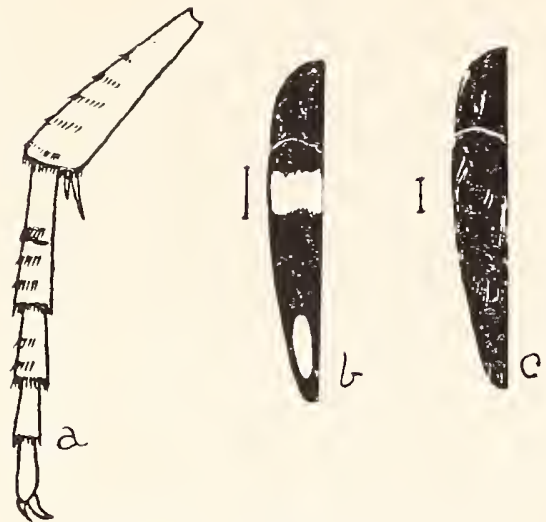

Fig. 580. a, Hind tibia and tarsus of M. scalaris; $b$, elytron of same: $c$, elytron of $M$. pubescens; $d$, elytron of M. bihumata. (After Smith.)
Lake County ; rare. September 22. Although Smith places divisa as a synonym of marginalis, yet the specimen at hand is very distinct by the much brighter yellow of head and legs and the character of the pubescence.

II. aqualis Smith, length $5 \mathrm{~mm}$., was described from northern Illinois.

\section{GROUP F.}

In this group the hind tibiæ are marked with four to six short, oblique ridges. (Fig. 580,a.) The following species have been taken or perhaps occur in the State:

\section{KEY TO INDIANA SPECIES OF GROUP F.}

a. Hind tibixe with only four ridges besides the subapical one.

$b$. Fourth ridge very small or: rudimentary; first joint of hind tarsi with three, second with two oblique ridges.

c. Body black.

d. Elytra with an undulated band before the middle and a large oblong spot near tip, fuscons. (Fig. 580, u.)

dd. Elytral markings of silken yellow, not fuscous, pubescence.

e. Elytra with a curved band from humerus to suture, a crossband behind middle and another at tip of silken yellow pubescence. (Fig. 580, c.)

2457. PUBESCENS.

ee. Elytra with two oblique bands connected by a line near margin, and also the apex yellowish pubescent.

2458. BIHAMATA.

ce. Body uniform bewnish-yellow; elytra with two very oblique bands of silken yellow pubescence.

bъ. Fourth ridge of hind tibise distinct.

2459. LITURATA.

$f$. First joint of hind tarsi with three. second with two oblique ridges; elytra fuscous, clothed with short, yellow pubescence.

2460. FUscata.

$f f$. First joint of hind tarsi with five ridges; second joint with three ridges, third with none.

h. Color reddish-brown.

2461. HOOSIERI. 
hh. Color black; suture of elytra very natrlowly graly.

246iz. SUTLLLLLA.

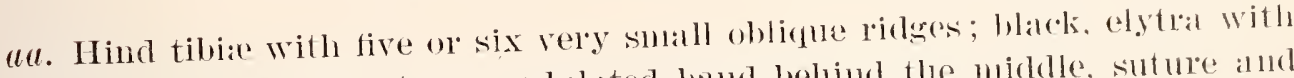
a long basal spot. an molulated band belind the middle, suture and tips of yellow silken pubescence.

DISCOLOR.

M. scalaris Melm., length $4 \mathrm{~mm}$., was described from Illinois.

2457 (7851). Mondellistena pubescens Fabr., Syst. Flent., II, 1801. 12:3.

Rather robust. Black, pmbescence brownish; thorax wholly black or reddish-yellow with a black discal spot; elytra with a humeral lunule and two bands of yellow pubescence as mentioned in key. Cength 2.5-? 1 mm. (Fig. $5 \mathrm{SO}$, c.)

Southern third of State; frequent. June 4-July 13. Swept from herbage.

2458 (7852). Mordellistexa bihamata Melsh. Proc. Phil. Acad. Nat. Sici. II, $1844,313$.

Differs from pubescens by the somewhat more slender form and hy having the elytra darker. with the yellowish pubescent bands comnecterl on sides

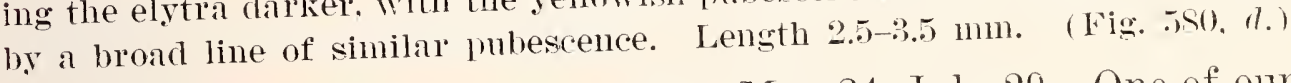

Southern half of State; frequent. May 24-July 29. One of our most handsome species. The spots which are enclosed by the bands of yellowish pubescence vary much in size and shape. The thorax varies in hue as in pubescens, and a large series will doubtless show that the two are the same, and are connected by the hebraica of LeConte which Smith has placed as a synonym of pubescens.

2459 (7853). Mondellistena liturata Melsh., Proc. Phil. Acad. Nat. Sci.. II, 1845, 314.

Slender, somewhat wedge-shaped. Thorax with three badly defined discal clouds. Elytra with a narrow marginal line and two oblique bands of yellow pubescence. Length $2-3 \mathrm{~mm}$.

Knox and Posey counties; rare. June 4-.July 6.

2460 (7505). Mordellistena fuscata Melsh.. Proc. Phil. Acad. Nalt. Sci.. II, 1S45. 313 .

Rather robust, wedge-shaped. Very dark reddish-brown or fuscous: front and middle legs and basal half of antennie dull reddish-brown. Lenoth 4-5 $\mathrm{mm}$.

Crawford County ; rare. June 28.

2461 (- -). MORDELLISTENA HOOSIERI sp. nov.

More slender and paler reddish-brown than fuscat sparser and a little longer: antennre. front and middle legs wholly dull reddish-rellow. First joint of hind tarsi with ive distinct ridges. Length $3.5-$ $4.5 \mathrm{~mm}$. 
Kosciusko County ; rare. June 19. Described from two specimens taken by sweeping low herbage in dense woods.

2462 (7S61). Mordellistena suturella Helm., Proc. Phil. Acad. Nat. Sci., XVI, 1864, 105.

Robust, wedge-shaped. Dense uniform black, except the suture, which is very narrowly gray. Length $4.3-5 \mathrm{~mm}$. Wolcott.

Tippecanoe County; frequent. June 21-June 25. Taken by

M. discolor Melsh., length 3.5-4 mm., occurs in the "Middle and Southern States," and has been recorded from Cincinnati.

\section{Family LXII. ANTHICIDE.}

\section{The Ant-like Flower Beetres.}

Medium or usually small-sized beetles varying much in form but agreeing in having the head drooping and strongly constricted behind the eyes into an abrupt slender neck; thorax narrower than elytra; hind coxæ not prominent; tarsal claws almost always simple. Some of them bear a striking resemblance to ants, and others are remarkable for a prominent horn on the front of the thorax. They occur for the most part on flowers, thongh some live in rotten wood, and others in burrows in sandy places near water. None of them are known to be in any way injurious. The name Anthicida is from that of the typical genus Anthicus, meaning variegated or "like a flower."

In addition to the characters mentioned, the Anthicidæ have the antennæ nearly filiform, rather long, 11-jointed, inserted before the eyes at the sides of the front; elytra rounded behind, covering the abdomen, which has five, rarely four or six, free ventral segments; front coxe conical, prominent, contiguous, the cavities confluent and (except in Dilandius) open behind; middle coxæ with distinct trochantins; hind ones transverse, nearly contiguous except in the tribe Anthicini; tarsi with the next to last joint usually emarginate.

About 1,150 species of Anthicidx are known, 265 of which are listed from North America, Casey having described 138 of them in a single paper. "The following is the principal literature treating of these North American forms:

LeConte.- "Synopsis of the Anthicites of the United States," in Proc. Phil. Acad. Nat. Sci., VI, 1852, 91-104. 
Leconte.-"Synopses of the Genera Eurygenius, Stereopalpus, Macralria, Corphyra and Iylophilus," in Proc. Phil. Acad. Nat. Sci., VII, 1855, 270-276.

Horn.-_"Synopsis of the Species of the Corphyra of the U. S.,' in 'Trans. Amer. Ent. Soc., III, 1871, 278-28.; ; V, 1874, 4043 ; X, 1883, 305-310.

LeConte.-"Table of the Species of Xylophilus," in 'Trans. Amer. Phil. Soc., XVII, 1878, 425-426.

Horn.-"Synopsis of the U. S. Species of Notoxus and Mecynotarsus," in Trans. Amer. Ent. Soc., XI, 1884, 165-176.

Casey.--"Synopsis of the Anthicidx of the U. S.," in Ann. N.

Y. Acad. Sci., VIII, 1895, 624-809.

The family is subdivided by Casey into six tribes, five of which are represented in the State.

KEY TO INDIANA TRIBES OF ANTHICIDE.

a. Abdomen composed of fire free segments; tarsus (except in Mceynotarsus) with the next to last joint lobed beneath; tibial spurs generally distinct; labial palpi minute.

b. Neck wide; eyes large, finely faceted and generally emarginate; size larger, $6-15 \mathrm{~mm}$.

c. Tarsal claws simple or slightly dilated at base; thorax constricted neal apex.

Tribe I. Eurgentint, 1. 1:327.

cc. Tarsal claws with a broad basal tooth on the inner side at base. its apical part abruptly bent; thorax not constricted near apex.

Tribe Il. Pedrini. p. 1329.

66. Neck narrow; eyes not emarginate; thorax constricted at apex; smaller, less than $5 \mathrm{~mm}$.

d. Eyes large, oval, rather fincly granulate; basal segment of abdomen elongate; hind coxie close together; tarsal claws with a broad basal tooth.

Tribe III. MacratritNI. 1. 1382. dd. Eyes small, rounded, generally coarsely granulated; balsal segment of abdomen not elongated; hind coxie somewhat distant; tarsal claws simple.

Tribe IV. ANTHIC1Ni. p. 13:3:. ad. Abdomen composed of four free segments, the first or basal one formed of two firmly united but with the suture sometimes evident; tarsi with the second joint from last lobed beneath; tibial spurs obsolete: labial palpi with the last joint large and more or less dilated.

Tribe V. Xrlophimisi, 1). 1:3t:

Tribe I. EULYGENIINI.

Elongate beetles, clothed with gray pubescence and having the mandibles broadly truncate at tip; maxillary palpi dilated; next to last joint of all the tarsi bilobed. Representatives of two of the fire genera occur in the State.

[84-23402] 
KEY TO INDIANA GENERA OF EURYGENIINI.

a. Lalst joint of maxillary palpi broad, hatchet-shaped; eyes narrowly and distinctly emarginate on lower side.

al. Last joint of maxillary palpi long. pruning-knife shaped; eses very slightly emarginate.

II. Stereopalpus.

\section{Retocomus Casey. 1895.}

This genus comprises most of the species formerly classed under Eurygenius Laf., which Casey states is confined to Brazil. But one of the five recognized species occurs in the State.

2463 (7869). Retocomes wildir Lec.. Proc. Phil. Acad. Nat. Sci.. VII, 1S55. 270.

Elongate, subcylindrical. Black, head and thorax densely clothed with hrownish-gray hairs; elytra each with five narrow rows of similar pubescence, these altelnating with narrow black stripes bearing small isolated patches of gray hairs; madei surface and legs brownish, densely clothed with gray hairs. Thorax subcordate, about as wide as long; disk densely and coarsely punctate and with a deep median impressed line. Elytra onehalf wider than thorax, densely and coarsely punctate. Length 10-12 mm.

Southern two-thirds of State; scarce. May 10-June 17. Beaten from flowers, especially those of the false indigo (Amorpha fruticosa L.) and osage orange.

\section{Strereophlpus Laf. 1849. (Gr., "solid + palpus.")}

Casey recognizes 11 species of this genus, seven of which he describes as new. Two well-known species occur in the State and rufipes. one of Casey's new ones, was described from Indiana. I have not seen specimens of it, but give his distinctions between it and the others as follows:

KEY TO INDLANA SPECIES OF STEREOPALPUS.

a. Elytral pubescence uniform in distribution and in general tint; head equal in width to thorax.

b. Upper surface uniform grayish-fuscous in hue, the elytra often slightly paler.

2464. MELLTI.

b7. Elytra light yellowish-brown, always distinctly paler than thorax.

2465. vestitus.

a . Elytral pubescence not uniform in distribution and hue, they being closely and finely mottled with small irregular clusters of slightly greater density; legs dull reddish-yellow. RUFIPES.

2464 (7S73). Stereopalpus meldi Laf., Mnn. des Anthic.. 1S4S, 5.

Elongate, slender, subcylindrical. Fuscous, thickly clothed with grayish pubescence; legs often varying to reddish-brown. Thorax bell-shaped. 
about as wide as long, widest in front of middle; surface densely and rather coarsely punctate and usually with a distinct median inyressed line. Elytra densely and coarsely punctate. Length $i-S \mathrm{~mm}$.

Northern third of State; frequent on alder and other shrubs about the borders of lakes. June 24-August 27.

2465 (7874). Stereopatyus vestitus Sily. Jomm. Plhil. Acad. Nat. Sci., III, 1824, 273 ; ibid. II, 161.

Broader and more robust than mellyi. Lead, thorax and under sulface fuscous; elytra and legs pale browu, the latter often tinged with fuscous. Thorax with median line usually obsolete or visible only ou basal half. Otherwise as in mcllyi. Length $8-10 \mathrm{~mm}$.

Throughout the State, frequent in the northern counties; much less so southward. June 12-August 6. Occurs with the preceding on foliage near water. Listed as badiipemis Lec. It is my opinion that mellyi will be found to be only a narrower, darker form of this species, those examples of mellyi with slightly paler elytra torming the intergrades. Say's name is the older of the two.

\section{Tribe II. PEUILINI.}

Very neat, oblong or elongate black (rarely brown) beetles having the thorax usually yellow, subglobose and polished; mandibles truncate; antennæ (in our species) slender and subserrate; maxillary palpi feebly dilated; next to last joint of tarsi bilobed. The males have six distinct ventral segments and often have the tips of elytra impressed and polished.

The tribe is represented by the single genus Corphyra Say. Casey has substituted for this the old name Pedilus, but Horn has given (Trans. III, 278) good reasons why Say's name should stand. so it is here retained.

\section{Corphyra Say. 1835.}

Horn in his latest paper on Corphyra (loc. cit.) lists 20 species as belonging to the North American fauna. Dury has shown that a number of these are very closely related and probably synonymous. The thorax in all species is elliptical with all the angles rounded; in the wholly black species it is somewhat wider and less convex than in the others. Eight of the 20 forms have been taken in the State, while another may occur.

KET TO INDIANA SPECIES OF CORPHYRA.

a. Thorax with a distinct impressed median line: elytra of males simply tipped with yellow, not impressed.

2466. CANALICULATA.

*Journ. Cincin. Soc. Nat. Hist., XX, 177. 
aa. Thorax without median line; elytra of males more or less distinctly inpressed at tips.

b. Head and elytra wholly or in great part black.

c. Elytral tips of male yellow.

d. Last two ventral segments of male yellow; less yellow.

da. Abdomen wholly black in both sexes.

2467. ELEGANS.

$e$. Thorax entirely red; legs black; elytra sparsely punctured.

ee. Thorax in part or wholly black.

246S. TERMINALIS.

$f$. Legs black.

$f f$. Legs pale.

cc. Elytral tips of male black.

NEWMANI.

2469. Fulvipes.

g. Legs yellow; thorax black at middle, its sides reddish-yellow.

gg. Legs entirely black.

2470a. var. PUlchra.

h. Clypeus pale yellow; thorax as in pulchra.

hh. Clypeus black; elytra with pruinose surface.

2470. LABIATA.

$i$. Thorax black; elytra rather densely punctured.

2471. LUGUBRIS.

ii. Thorax redish; elytra coarsely and sparsely punctured.

bb. Head, elytra and legs uniform brown.

2472. COLLARIS.

2473. BRUNNEA.

¿246 (7S85). Corphyra canaliculata Lee., New Sp. N. Am. Col., I, 1866. 143.

Black, feebly shining; thorax subopaque, reddish-yellow; two basil joints of antennie and palpi paler. Elytra rather coarsely and roughly, not densely, punctured. Length $5-6 \mathrm{~mm}$.

Marion County ; rare. May 2. Beaten from flowers of Cratregus. The female is said by Dury, who has collected them near Cincinnati, to be much more common than the male and to vary much in color, the thorax sometimes being black and the legs pale.

2467 (7SS6). Corphyra exegans Hentz., Trans. Am. Phil. Soc., 1830, 257.

Elytra piceous black with a bluish tinge, shining. Thorax, legs, two basal joints of antenne and palpi usually reddish-yellow. Elytra rather coarsely and sparsely punctate. Length $7-8 \mathrm{~mm}$.

Wells and Narion counties; rare. May 19-June 5. The thorax in the single male at hand is black, with the apical angles reddishyellow.

2468, (7S57). Corphyra terminalis Say, Journ. Phil. Acad. Nat. Sci., V, 1826, 247 ; ibid. II, 311.

Black, shining; thorax red. Elytra coarsely, deeply and sparsely punctured. Length 5-7 $\mathrm{mm}$.

Marion and Jackson counties; scarce. April 25-May 20. 
2469 (7S89). Corphyra futvipes Newin., Ent. Mas., V, 1s.3, :75.

Black, shining; thorax black (female) or lochlish with a darker (eenter (male). Elytra coarsely and rather densely punctured. I,ength $6.5-8$ mm.

$\mathrm{Knox}$ and Posey counties; scarce. May 20-June 10.

C. newmani Lec., length 6.5 $\mathrm{mm}$.; is recorded from Maine, Canada and New York. It is probably only a variety of fulvipes.

2470 (7S93). Cokphyra lablata Say,

Jourlu. P'hil. Acad.

Nat. Sci., V, 1826, 247;

ibid. II, 311.

riceous black, feebly shining; palpi, clypeus, labrum and two basal joints of antennse pale yellow; thorax reddish-yellow, with a broad median black space. Elytra densely and rather finely punctured. Length $6-7.5 \mathrm{~mm}$. (Fig. 5\$1.)

Southern half of State; fre-

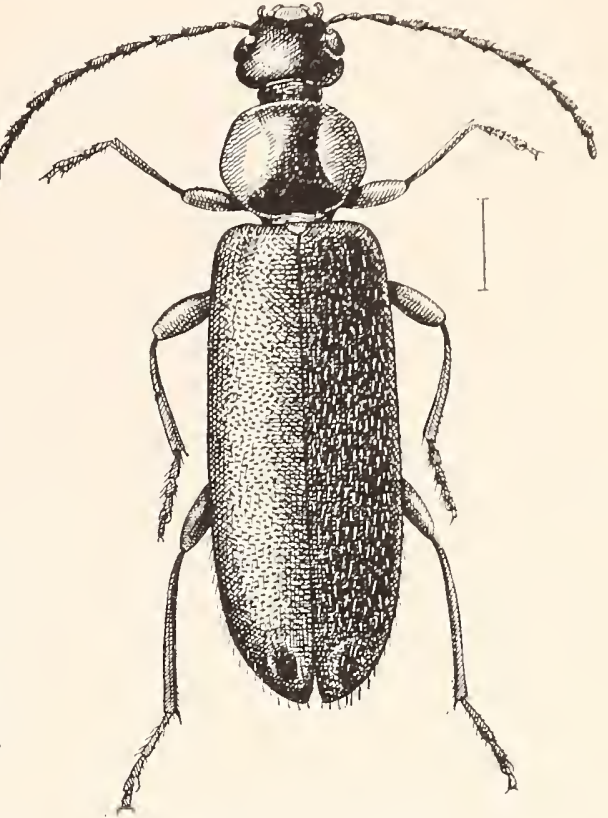

Fig. 581. (Original.) quent. May 16-June 13. Occurs on the greater horseweed, cup-plant, etc.

2470a (7S92). Corphyra labiata pulchra Lec., Jomll. Phil. Acall. Nat. Sci., I. 1848, 83.

A variety of labiata, differing only in having the legs yellow. Length 7-S $\mathrm{mm}$.

Lake and Posey comnties; scarce. May 28-August 1.

2471 (7894). Comphyra lugubris Say, Jomln. Phil. Acad. Nat. Sci., V. 1s.96, 246 ; ibicl. II, 310.

Color wholly black except the labrum. two balsal joints of antenne and tarsi, which are reddish-brown. Length $6-8$ mm.

Southern two-thirds of State; frequent. April 25-August 1. Beaten from foliage of buckeye and red haw.

2472 (7895). Comptrka collakis Say, Jomm. Phil. Acad. Nat. Sci. V. 1ミ27. 246 ; ibid. II, 311.

Black; thorax red. Elytra with coarse. deep, spalsely placed punctures. Length $5-5.5 \mathrm{~mm}$.

Vigo and Lawrence counties; scarce. Nay 6-Tuly 10. Oceurs especially on leaves of May-apple.

2473 (- ). CORPHYRA BRUNNEA sp. nor.

Thorax yellow: two basal joints of antemne brownish-yellow; otherwise uniform Van Dyke bown. feebly shining. Thorax mole transerse 
and shorter than in tcrminulis. Elytra finely and rery sparsely punctured. Males with elptral impression smaller. more oral and more distant from apex than in any of the other species. Length $4-5.5 \mathrm{~mm}$.

Vigo and Lawrence counties; scarce. May 6-July 10. Occurs especially on leaves of May-apple, Podophyllum peltatum L. Not an immature form, as at first supposed, the sparsely punctured elytra with wholly different impressions in males showing its specific rank.

Tribe III. MACRATRIINI.

This tribe is also composed of a single genus of narrow brown or black pubescent species, having the head deflexed, constricted far behind the eyes into a very slender neck; maxillary palpi compressed and dilated, the last joint large and hatchet-shaped; last three joints of antemni much longer than the others; first joint of hind tarsi very long; males with a sixth abdominal segment visible.

\section{Macratria Newm. 1838. (Gr., "long + three.")}

Two of the four known species occur in Indiana.

KEY TO INDIANA SPECIES OF MACRATRIA.

a. Pubescence of upper surface rery fine and dense; head rather finely and densely punctate.

247. ILRIXA.

ua. Pubescence rather coarse and sparse; head rery minutely and sparsely punctured.

2175. CONFLSA.

2474 (7915). Macratria mLrixa Fab.. Syst. Eleut.. II. 1S01, 91.

Elongate, slender, subcylindrical. Dark olive gray. densels clothed with fine, silken. rellowish hairs; antenne and legs dull yellow. the femora often piceous. Head subtruncate behind the eres; antennde with second and third joints nearly equal. 11th almost as long as 9th and 10th united. Thorax but slightly wider than head. one-half longer than wide, base strongly margined, angles all rounded. disk finely and densely punctate. Elytra with rows of fine. close-set punctures which are almost hidden by the dense pubescence. Length $4 . \overline{5}-\overline{5} \mathrm{~mm}$.

Marion, Floyd and Posey counties; scarce. June 23-July 9. Occurs on willow bushes and the foliage of water-willow along streams.

2475 (7914). Macratria confesa Lec. Proc. Phil. Acad. Nat. Sci.. VII. $1855,272$.

More slender and darker than murina. Head more rounded behind the eves. Thorax more slender. not wider than head. less narrowed in front. Elytral rows of punctures shallow, indistinct. Length 4-4.5 $\mathrm{mm}$. 
THE INT-LIKE FLOWFR PEETIES.

Lawrence County ; rare. June 5. The legs, in the single specimen at hand, are pale, whereas LeConte says that they are piceous, with the base of front thighs rufous. A member of the Austroriparian fauna.

\section{Tribe IV. ANTHICINI.}

To this tribe belong by far the greater number of species of the family. They have the neck very small; mandibles emarginate at tip; middle coxæ nearly contiguous; ventral segments five in both sexes. Casey has divided the tribe into 16 genera, representatives of ten of which have been taken in Indiana:

\section{KEY TO INDIANA GENERA OF ANTHICINT.}

a. Thorax prolonged near apex into a horn-like process.

b. Hind tarsi not longer than the tibiae.

bb. Hind tarsi much longer than the tibie.

r. Notoxis.

a a. Thorax not prolonged over the head.

c. Very small and slender ant-like forms, having the fiont coxal arities closed belind by a prolongation of the acute side pieces of the prosternum: head oblong, the eres rery small, placed in front of middle.

cr. Less ant-like in appearance: the front coxal carities widely open behind.

1. Sides of mesosternum more or less abmormally dilated: length not over $4 \mathrm{~mm}$.

e. Thorax deeply constricted or narrowed behind the middle.

f. Antenne thick, moniliform or bead-like; constriction of thorax extending across the dorsal surface. VIII. Tonodercs.

fi. Antenne long and slender; constriction of thorax not extent ing across the dorsil surface.

g. Last joint of maxillary palpi small or moderate. hatchetshaped; body very sparingly punctate and bearing long. erect setie or hair-like bristles.

IX. Malpores.

gg. Last joint very large and dilated. the sides equal: punctuition fine and dense without setie.

ec. 'Thorax not constricted except very feebly and near the base. the sides oblique and straight; antenne stout; femora club-shaped. the front ones strongly so. XI. Heansters. da. Sides of mesosternum not dilated but straight and slightly oblique. forming a point between the broad episternum and the coxie: length less than $3.5 \mathrm{~mm}$.

h. Thorax normal and erenly convex: head subquadrate or rounded behind.

i. Thorax moderately large, oblique at the sides near base: pubescence simple.

XII. IxthICQ⿻ 
ii. Thorax relatively small, not quite as long as wide, sinuate at the sides near base; antemne with an abrupt though feeble three-jointed club; pubescence consisting of two sets of hairs.

XIII. SAlintus.

hh. Thorax abruptly sloping and flattened in front; head strongls triangular; body stout and conrex. XIV. Amblyderus.

\section{Nотохus Geoff. 1762. (Gr., "back+sharp.")}

The members of this genus are easily distinguished by the thoracic horn which extends in a sort of hood over the head and by the short tarsi with the next to last joint slightly dilated. Five of the 32 species recognized by Casey have been taken in the State, while another may occur.

KEY TO INDIANA SPECIES OF NOTOXUS.

a. Elytra uniform purplish black.

aa. Elytra more or less rariegated in hue.

2476. BICOLOR.

b. Elytra black or piceous, with pale markings.

c. Elytra each with two large oblique spots of pale tint; elytral tips truncate in female.

247\%. TALPA.

cc. Elytra crossed by two pale crossbars, one before, the other behind the middle, these interrupted at suture; elytral tips rounded in both sexes.

2478. BIFASCIATUS.

67. Elytra pale, with a single black crossbar behind middle, which is more or less produced forward along the suture; usually also with other dark markings.

d. Dark crossbar of elytra placed at apical fourth and continued along the suture to the base; also usually an elongate dark spot each sicle.

2479. ANCHORA.

dd. Dark crossbar just behind middle, continued along suture but a short distance.

c. Thoracic horn broader, always distinctly but finely toothed on sides; elytra each with an irregular subapical dark spot and with two small spots near scutellum. 2480. MONODON.

ce. Thoracic horn narrower and more elongate, never toothed; elytral tips dark in color, the sides behind basal third also dark.

APICALIS.

2476 (7916). Notoxus bicolor Say, Amer. Ent., I, 1824, 21 ; ibid. I, 21.

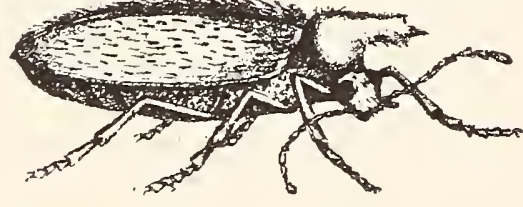

Fig. 583. $\times 9 . \quad$ (After Say.)

Head and apical half of antennæe fuscous; thorax, legs and under surface reddish-yellow; elytra purplish-black, clothed with a fine. prostrate, silken, gray pubescence. Thorax oval, slightly broader than long; horn rather broad, obtuse at tip, its sides coarsely toothed; its crest margined and finely serrate. Elytra with tips rounded and alike in the sexes; surface finely, not densely punctured. Length $3.5 \mathrm{~mm}$. (Fig. 582.) 
Southern two-thirds of State, frequent; not noted in the northern counties. March 25-November 28. Probably hibernates beneath leaves and rubbish, where it is taken by sifting in spring and fall; most abundant in May and June on flowers and foliage of various plants.

2477 (7918). Notoxus talpa Laf", Mon. Anthic., 1848, 50.

Thorax, antenne and legs dull reddishbrown; head, under surface and elytra piceous, the latter each with a large, oblique pinkish spot extending from humerus to middle of suture and another more narrow on apical third. Thorax oval, distinctly wider than long; hor'n rather widely margined and serrate, its crest abruptly and strongly elerated, distinctly margined and slightiy crenulate. Elytra with tips rounded and disk obliquely impressed behind humeri in male; tips truncate and disk scarcely impressed in female; surface finely but not densely punctate. Length $3.5-4 \mathrm{~mm}$. (Fig. 583.)

Northern third of State; frequent on foliage of hazel and oak along the bor-

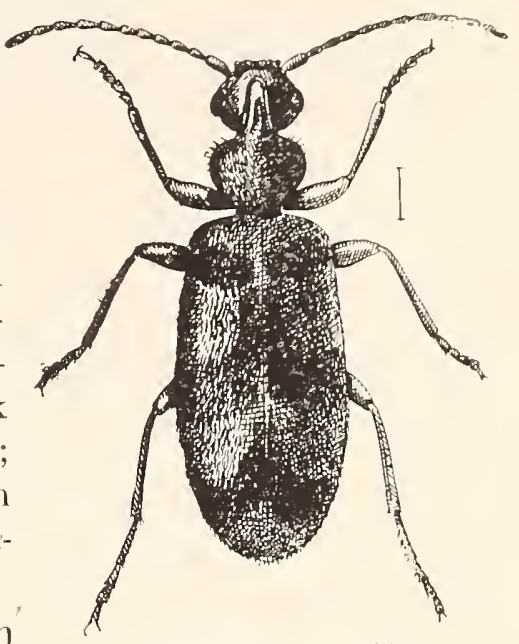

Fig. 583. (Original) ders of lakes and marshes. Jume 18-July 27. The pale spots of elytra vary much in size, sometimes exceeding the dark marking in area, but usually much less. It forms almost a connecting link between monodon and bifasciatus.

2478 (7919). Notoxus BIfasciatus Tec., Journ. Phil. Acad. Nat. Sci., I, 1848, 89.

Piceous, shining; antenna, thorax and legs usually reddish-brown; elytra with pale bar's as mentioned in key; pubescence fine and sparse. Thorax globose, slightly wider than long; horn moderate in length, distinctly margined, sides feebly serrate, its crest abruptly elevated and margined, not serrate. Elytra finely and rather sparsely punctate. Length $3-3.8 \mathrm{~mm}$.

Northern half of State, frequent; not taken south of Vigo County. June 9-July 15. Occurs especially on flowers of Cormus and wild cherry. Resembles talpa, but the pale bars of elytra are transverse, narrow and vary little in size.

2479 (7925). Notoxus anchora Hentz., Journ. Phil. Acad. Nat. Sci., V, 1827,375 .

Reddisli-yellow, sparsely pubescent, with erect hairs intermingled with the prostrate ones; elytra with dark markings as mentioned in key: head and thorax often in part fuscous. Thorax oval, not wider than long. rather densely and regularly punctate: horn narlow and long, both it and crest margined and toothed at the sides, the crest narrow. feebly elevated. Elytra with tips obliquely truncate in male, separately rounder in female; surface rather densely and finely punctate. Length 3-3.5 $\mathrm{mm}$. 
Northern third of State; scarce. June 13-July 23. Occurs in company with talpa on foliage about water. The black markings of elytra vary much in area, some specimens being almost wholly piceous, while in some the oblong black mark on sides is lacking. *24S0 (7923). Notoxus monodon Fab., Syst. Eleut., I, 1801, 289.

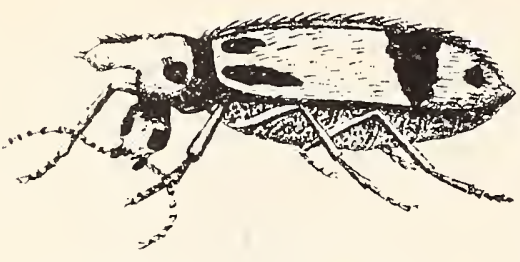

Fig. 584. $\times$ 9. (After Say.)

Rather elongate and slender. Dull brownish-yellow; elytra with a crossbar behind middle, two basal spots and often a subhumeral and subapical spot on each, piceous; head and thorax on sides often piceous. Thorax oval, slightly wider than long, sparsely and finely punctate; horı rather broad, margined and serrate at the sides, its crest in large specimens distinctly elevated and serrate, in smaller ones scarcely elevated and granulate. Elytra oblong, their tips rounded in both sexes; surface rather coarsely and densely punctured and with rows of erect hairs intermixed with the dense, prostrate, grayish pubescence. Length 2.5-4 mm. (Fig. 584.)

Throughout the State; frequent. January 11-December 28. Hibernates beneath $\operatorname{logs}$, mullein leaves, etc. In summer occurs on foliage, and often beneath cover in sandy places. As in the other species, the dark markings vary. The subhumeral spot on sides is more often present than absent, and sometimes forms a black marginal stripe connecting with the crossbar. The subapical dark spot is absent in several specimens at hand, but I do not follow Casey in considering them specifically distinct.

$N$. apicalis Lec., length $4 \mathrm{~mm}$., is said to occur from Michigan to Kansas, Texas and California.

\section{Mecynotanses Laf. 1849. (Gr., "elongate + tarsus.")}

This genus differs from Notoxus in having the tarsi of all the legs slender and much longer than in that genus, while the next to last joint is cylindrical, without lobes. One of the four species occurs in the State.

2481 (7930). Mecynotarsus candidus Lec., Trans. Amer. Ent. Soc., V. $1875,175$.

Uniform pale dull yellow, almost translucent, clothed with very fine silken pubescence. Thorax oval, broader than long, rather densely and finely punctate; horn triangular, suddenly narrowed at base, both it and crest margined and finely toothed, the latter narrow and feebly elevated. Elytra oval, very finely and densely punctulate, the tips rounded in both sexes. Length $2 \mathrm{~mm}$.

Vigo County; rare. May 29. One from beneath chunk in sand near border of pond. Known heretofore only from the Southern States. 


\section{Dilandus Caser. 1895.}

Of this genus its author says: "Peculiar in haring the acute side pieces of the prosternum behind the coxit more inwardly prolonged than in Anthicus, so that they coalesce at or near the middle, thus closing the coxal carities. The mesosternum extends in one extremely large unbroken polished plate from side to side of the bodr ; its lateral edges bearing a sparse fringe of long stiff, bristly setre." Two species are known, one of which was described from southern Illinois and has been taken by Dury near Circinnati.

2482 (-). Dilaxdus mrranecops Caseg, Am. X. I. Acad. Sci.. Tili. $1595,6 \pm 3$.

Very slender and elongate. Black. densels and minutely pubescent: basal half of antennie and legs paler; elstra with a narrow basal crossbal and a broader one at middle light brown, the hind one bordered in front by a narrow oblique bar of coarser, silvery white pubescence. Head rounded at base, coarsely and densels punctate. Antennze one-half the length of bods, the third joint longer than fourth. Thorax slightly narrower than head, much longer than wide, deepls constricted at basal third. the front lobe globular; surface. as well as that of elrtra. minutely and clensels punctate. Elrtra much longer than head and thorax, and twice as wide as latter; disk with a deep cross-impression near base. Length $2.8 \mathrm{~mm}$.

Posey County; rare. April $\rceil$. One specimen from beneath board in roodland pasture. Dury's specimen was taken from beneath a flat stone on November 17, so that it probably hibernates as imago.

VIII. Tomoderts Laf. 1848. (Gr.." "cut+neck.")

Robust, convex species, with antennx stout, bead-like, thickened and somewhat perfoliate near tips; fenora stout. club-shaped; eyes rather small, somewhat coarsely granulated: next to last joint of tarsi bilobed.

*2483 (7933). TOMODERes CONSTRICTtS Say. Journ. Phil. Acar. Nat. Sci.. V. 1826. 244 ; ibid. II, 309.

Dark reddish-brown to piceous, shining. sparsely pubescent: basal portion of elstra reddish-brorm. gradually merging into piceous; antennie dark reddish-brown, legs paler. Thorax strongls constricted behind the middle. the front lobe subglobose, much the larger, smooth or nearls so. Elytral punctures very tine and irregularly placed on apical half: coarser and in more or less distinct rows on paler basal portion. Length $2.5-3 \mathrm{~mm}$. (Fig. 585.)

Southern half of State, common: not taken

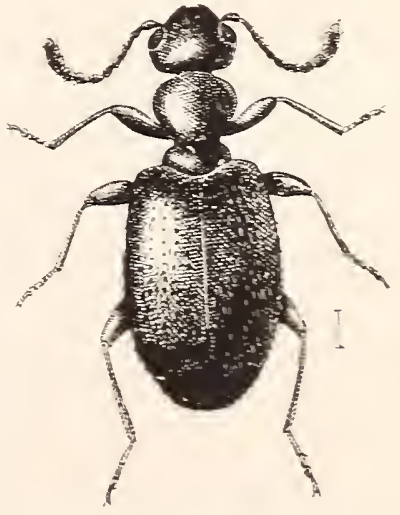

Fig. 585 . Line shows natural size. (Original.) 
north of Marion and Putnam counties, though probably occurs in fewer numbers. January 21-December 3. Most common in spring and fall beneath chips, mullein leaves, stones, etc., and hibernates in similar places. T. interruptus Laf. is a mere form in which the hasal portion of elrtra is more extended, with the rows of punctures less regular. Intergrades between the two are common in the collection at hand.

\section{Malports Casey. 1895. (Gr., "had + walker." )}

Rather slender, ant-like species, possessing the characters mentioned in generic ker and having the head more strongly rounded and the last joint of maxillare palpi smaller than in Lappus. Three closely allied species may occur in Indiana, though but two have been taken.

\section{KEY TO INDIANA SPECIES OF MALPORLS.}

a. Elytral punctures distinct throughout the disk, fine and remote toward apex. closer and coarse before the middle.

b. Thorax rery strongly constricted; bodr throughout more sparsely punctate; elstra without an apical pale spot. ForMICARICs.

b7. Thorax much less strongl constricted; bodr more densel p punctate: elstra more parallel, the pale crossband less basal, each with an apical pale spot.

an. Elrtral punctures limiter to the sub-basal transrerse impresto cractcs. is strong.

2485. PROPERLS.

$24 S 4$ (7941). Malports cINctes Say, Journ. Phil. Acad. Nat. Sci., III. 1S24, 27s: ibid. II, 165.

Dark reddish-brown, shining: elytra black or piceous. reddish at base. and with a pale, narrow crossband, interrupted at suture, in front of middle, and usually a faint pale spot at hargin of tips. Thorax narrower than head, much longer than wide, strongly constricted on sides behind the middle; the larger front lobe globose and sparsely punctured, the hind one rather coarsely and densels punctured. Elrtra with disk feebly, transrersely impressed on basal third, each with a distinct hump near suture in front of pale bar; surface punctured and with erect setie as mentioned in kers. Length $3-3.5 \mathrm{~mm}$.

Throughout the State; scarce. February 11-July 24. Occurs beneath logs and rubbish, especially in sandy places near water. Several dark specimens with apical pale spot lacking may be formicarius Iaf.: but I am unable to satisfactorily separate them as distinct. That species is said to occur from Rhode Island to Iowa. 2485 (-). Malports properts Caser, Amn. N. Y. Acad. Sci., MIII, 1895. 653.

More slender and somewhat paler than cinctus: eves larger and more convex; antenna more slender. Elstra with basal transrerse impression 
much stronger and without distinct punctures except a verg few within that impression. I Length $3.3-3.5 \mathrm{~mm}$.

Putnam County; rare. April 27. One specimen taken by sifting dead leaves. Described from Indiana and Iowa.

\section{Lappeus Casey, 1895.}

Casey separates four species from Anthicus and describes 14 new ones under the above name. The characters distinguishing them from Malporus and allied genera are given in the generic key. Two species have been taken in the State.

\section{KEY TO INDIANA SPECIFS OF LAPPUS.}

a. Body and legs deep black throughout; hind tibie of male not dilated or sinuate.

ac. Body and legs reddish-brown; abdomen and apical portion of elytrat usually black or piceous; hind tibire of male dilated and sinuate on inner side.

248\%. STLRMII.

2486 (7936). Lappes obsctres Laf., Mon. Anthic., 18ts, 116.

Black, shining; finely pubescent except on basal third of elytra, where the hairs become coarser and slightly paler. Thorax strongly constricted near base, front lobe erenly rounded, widest at middle, hind one cylindrical : surface as well as that of elytra, finely and densely punctate. Sub-

Orange and Posey counties; scarce, June 1-June 18. Beaten from wild grape and elder.

2487 (7938). Lappes sturmir Laf.. Mon. Anthic.. 1848, 304.

Reddish-brown, fineị pubescent; elytra piceous, the basal third reddish and with a distinct crossband of coarser gray pubescence. Thorax less strongly constricted. the basal lobe subcylindrical. its sides parallel. Subbasal impression of elytra distinct. Length $2.7-3 \mathrm{~mm}$.

Tippecanoe, Crawford and Harrison counties; scarce. June $14-$ July 5 .

\section{Henantus Casey. 1895.}

Sufficiently distingmished by the characters given in generic ker, "the mesosternum in our species dilated so as to extend more than half way between the coxa and elrtral humeri, its outer margin bearing a close fringe of long, fine decumbent hairs." 248S (7945). Henaxtus floralis Payk. Faun. Suec., I. 1798. 256.

Reddish-bromn, shining; head. abdomen and apical two-thirds of elytra piceous; pubescence extremely short and sparse. Vertex with a distinct notch or impression. Thorax widest near front angles, which are rounded: sides straight and converging to base; disk with a small double tubercle on 
middle near apex, its surface, as well as that of elytra, finely and rather closely punctate. Elytra rery faintly or not at all impressed behind the humeri. Length $3-3.5 \mathrm{~mm}$.

Posey County; rare. September 27. Occurs on flowers. A European species, widely distributed throughout the United States. 2489 (10,727). Hemantus Basillaris Say, Journ. Phil. Acad. Nat. Sci., III, 1S24, 279 ; ibid. II, 165.

Resembles the preceding but without the double tubercle on front of thorax and with a distinct impression just behind the humeri of elytra.
Length $34 \mathrm{~mm}$.

Lake and Marion counties; scarce. January 17-June 18.

\section{Anthicus Payk. 1798. (Grr., "like a flower.")}

A large genus of small species which, as limited by Casey, have the mesosternum normal and undilated; last joint of maxillary palpi moderate in size and hatchet-shaped; antennæ rather short and gradually enlarged toward apex, the last joint entire; pubescence consisting of but a single set of hairs in addition to the erect, tactile setw. About 60 species are recognized, of which the following have been taken or probably occur in the State.

KEY TO INDIANA SPECIES OF ANTHICUS.

a. Larger, 2.5 or more $\mathrm{mm}$. in length; sides of thorax broadly rounded in front, generally oblique and curved toward base.

b. Abdomen rather coarsely and sparsely punctured; body pale in color. c. Head densely and roughly punctate; elytra usually with a large ill-defined piceous spot.

2490. SCABRICEPS.

$c c$. Head sparsely, coarsely and simply punctate; elytra with a fuscous or piceous band at middle, interrupted at suture.

2491. EPHIPPIUM.

bb. Abdomen always minutely and more or less densely punctate; body usually dark.

d. Reddish-brown; elytra with a dark interrupted crossbar at middle and another near apex, the two enclosing a rounded pale spot on apical third.

dd. Elytra not as above.

2492. CERVINUS.

$e$. Color wholly black or piceous.

$f$. Head and thorax alutaceous and without pubescence; basal margin of thorax completely obsolete. coracisus.

$f f$. Head and thorax pubescent as usual; thorax with sides obtusely prominent near apex, thence straight and oblique to base ; elytra large, flat.

SODALIS.

$e e$. Body black; elytra each with a well defined pale spot near base and another near apex, these occasionally more or less confluent; thorax feebly constricted before the base; occiput impressed in middle.

g. Elytral punctures rather coarse and sparse, the surface shining. 
h. Larger, $4 \mathrm{~mm}$; ; elytral pubescence long and distinct.

hh. Smailer, not over :3 mm.; pubescence very short.

HEROICUS.

gg. Elytral punctures fine and very dense, the surface dull; basal spots of elytra elongate, not confinent; pubescence short.

SAUCIUS.

aa. Smaller, not over $2 \mathrm{~mm}$; sides of thorax oblique and straight from apical third to base; eyes very small and distant from base; color dull brownish to yellow.

2494. MELANCHOLICUS.

2490 (7951). Anthicus scabricep's Lec., Agassi\% Lake Sup., 1850, 230.

Elongate, rather narrow. Dark redish-brown to piceous, shining; pubescence dense and coarse. Head wider than long, truncate at base, both it and thorax densely and roughly punctate or minutely tuberculate. 'Thorax as wide as long, sides broadly rounded, converging behind. Elytra twice as wide as thorax, coarsely and sparsely punctate. Length $2.5 \mathrm{~mm}$.

Northern half of State; scarce. April 23-November 28. The elytra are for the most part piceous except at base and apex ; rarely they are wholly reddish-brown.

2491 (7956). Anthicus ephippium Laf., Mon. Anthic., 1848, 163.

Elongate. Dull brownish-yellow; head and thorax often reddish-brown; elytra with dark crossbar as mentioned in key; pubescence sparse, long and

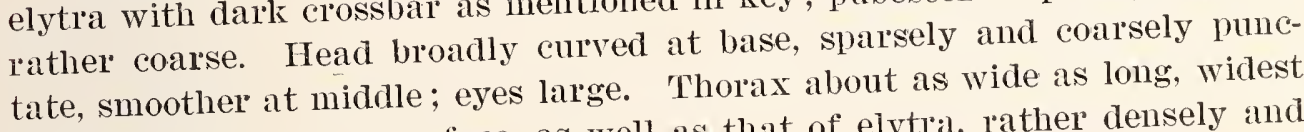
one-third from apex; surface, as well as that of elytra, rather densely and coarsely punctured. Length $3 \mathrm{~mm}$.

Lake, Parke and Vigo counties; scarce. May 13-December 28. Occurs beneath rubbish in sandy localities. According to Casey, LeConte's difficilis and confusus are both synonyms of this species.

*2492 (7959). Anthicus cervinus Laf., Mon. Anthic., 1848, 181.

Reddish-brown, feebly shining, sparsely and finely pubescent; antennæ and legs dull yellow; elytra marked with piceous as noted in key. Head broad, subtruncate at base, coarsely and rather sparsely punctate, smoother at middle. Thorax about as wide as long, the sides gradually but slightly converging toward base; surface, as well as that of elytra, finely and densely punctate. Length $2.4-2.7 \mathrm{~mm}$.

Throughout the State; frequent. January 7-October 9. Oceurs beneath rubbish, more commonly in sandy places. Hibernates as imago. The head is usually darker than thorax and the front black bar of elytra varies much in width, sometimes uniting with the other so that the entire apical half is piceous.

A. coracinus Lec., elongate, tibiie and tarsi pale, elytra parallel, strongly and coarsely punctate, length $3.5-4.2 \mathrm{~mm}$., is said to oceur in the "regions near the Great Lakes." 
2493 (7961). Anthicus haldemanni Iec., Proc. Phil. Acad. Nat. Sci., VI. $1852,100$.

Black or piceous; elytra each with a large, triangular spot on basal fourth and a small rounded one on apical fourth, reddish-brown; antenna and legs dull reddish-yellow. Head truncate and impressed at base, rather coarsely and closely punctate and with an entire smooth median line. Thorax as long as wide, broadly rounded on the sides in front; surface densely and finely punctate. Elytra much more coarsely and less densely punctate than thorax. Length 2.7-3 $\mathrm{mm}$.

Pine and Hessville, Lake County; scarce. April 16-June 4. The markings on elytra resemble some of the varieties of cervinus, but the head and thorax are both distinctly wider and the elytra more coarsely punctured.

\section{4 (79S0). Anthicus melancholicus Laf., Mon. Anthic., 1S48, 174.}

Suboval, convex. Color uniform. varying from piceous to dull brownish-yellow, sparsely pubescent; antenne and legs paler. Head with base truncate; surface finely and closely punctate and with a smooth median line. Thorax slightly longer than wide, its sides nearly straight and feebly converging to base; disk strongly convex, densely and finely punctate. Elytra with humeri somewhat rounded; disk coarsely, deeply and rather closely punctate. Length $1.8-2 \mathrm{~mm}$.

Marion County; scarce. October 11. Taken from beneath chunks in low, open woods. Easily known by its small size, uniform color and small, convex eyes. LeConte's spretus and latebrans are said by Casey to be the same as Laferte's species.

Casey (loc. cit.) described Anthicus sodalis black throughout, length 3-3.2 mm., and A. heroicus black, legs testaceous, elytra each with two large rufous spots, length $4 \mathrm{~mm}$., both from "Indiana," but I have seen no specimens. A. sancius Casey, length $3 \mathrm{~mm}$., was described from Iowa.

\section{XIIT. Safintus Casey. 1895.}

This genus includes ten species differing from Anthicus by the characters mentioned in key and by their having the body stouter, with relatively longer elytra and smaller thorax; epipleuræ wider; first joint of hind tarsi longer; tibial sp!rs shorter and much more slender. In addition to the erect "tactile setx," the elytral pubescence consists of longer and more erect hairs arising from coarse punctures, and shorter, rnore prostrate ones from minute punctures of the intervals. Our two species belong to the group having the eyes large and rather strongly convex and the body black or brownish-black. 
*2495 (7970). Sapintes plbescexs Laff.. Non. Anthic., 1S4S, 177.

Head and elytra dark brown to black, shining; thorax dull: legs piceous, the tarsi and basal half of antennie pale. Ilead finely and closely punctate, truncate at base. Thorax wider than long, slightly narrower thatl head, widest at apical third, the sides thence oblique and strongly converging to base; surface finely and densely punctate. Elytra convex, more than twice as wide as thorax, sides straight as far as middle; disk coarsely. deeply and rather sparsely punctate, with a distinct hump each side of scutellum; the coarser, suberect hairs sellowish. Length $2.7-3 \mathrm{~mm}$.

Throughout the State; scarce. January 13-.June 13. Occurs on ground beneath rubbish, hibernating sparingly beneath mullein leaves, etc.

2496 (7971). Sapixtus Fulvipes Laf., Mon. Anthic. 1848, 17.

Smaller and more narrow than pubescens. which it resembles closely. Legs and antenne wholly dull reddish-yellow. Thorax much narrower than head and more distinctly narrowed behind. Pubescence of elytra fine, short. pale and conspicuous. Length 2.3-2.5 $\mathrm{mm}$.

Lake, Lawrence and Dubois counties; scarce. May 5-October 6.

\section{Axblyderus Laf. 1848. (Gr., "obtuse + neck.")}

The members of this genus occur, for the most part, along the beaches of the sea and lakes. The strongly sloping front of the thorax and the stouter, more oval body readily distinguish them from Anthicus. - One of the eight species recognized by Casey has been taken in the State.

2497 (7976). Ambliderus Pallexs Lec., Agass. Lake Sup.. 1550, 231.

Stout, convex. Uniform dull, pale sellow, rather densely clothed with short, coarse, rellowish hairs. Head triangular, base truncate and distinctly impressed at middle, surface granulate, with a median smooth line. Thorax cordate. slightly wider than head. widest at apical fourth, thence much narrowed to base; surface finely and sparsely granulate-punctate. Elytra oval, one-half wider than thorax; disk finely. mot densely punctate. Length 2.7-3 mm. (Fig. 5S6.)

Lake and Porter counties; scarce. May 14 October 12. Occurs beneath rubbish on the sand beach and dunes of Lake Michigan, its hues so blending with those of the sand that the insects

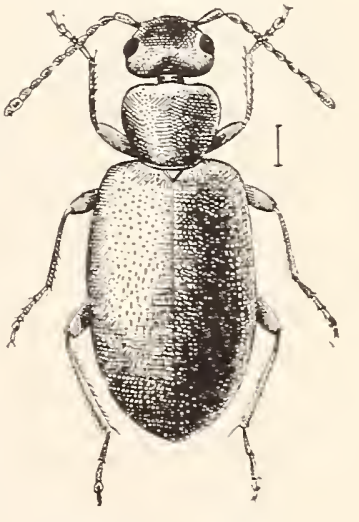

Fig 5S6. (Original.) are scarcely visible until they move.

\section{Tribe V. XYLOPHILINI.}

Small oval or oblong forms separated by the characters given in the tribal key and by having the head constricted close behind the emarginate, usually hairy and coarsely granulated eyes; head 
strongly deflexed, neck very small; last joint of maxillary palpi large and hatchet-shaped; first joint of hind tarsi in our species very long. Casey has divided the tribe into 13 genera, six of which are probably represented in the State.

KEY TO INDIANA GENERA OF XYLOPHILINI.

a. Eyes hairy, deeply emarginate.

b. Head deeply sinuate at base, its hind angles round, not prominent; pubescence of elytra short, matted and duplex. XV. ELonus.

bb. Head truncate at base; pubescence long, stiff and simple.

c. Antenna inserted within the deep notch or emargination of eye, those of male with fan-like processes; hind angles of head dentiform, setose.

cc. Antenna inserted just without the coarsely gramulated eyes, simple in both sexes.

a a. Eyes almost smooth, feebly emaroinate, the not solete.

d. Second and third antennal joints small.

dd. Third antennal joint elongate; 'rower than head; body ithout spots.

e. Antenne gradually and feebly enlarged towalds apex. VAnonus. ce. Antennse terminating in an abrupt parallel five-jointed club.

'T'A NILOTES.

\section{Elonus Casey. 1895.}

Oblong, opaque species clothed with short hairs intermixed with longer and more erect ones; head deeply constricted and strongly sinuate at base; last joint of labial palpi large, suboval, truncate and deeply concave at apex; antennæ with second joint short, wider than third, the last joint elongate, obliguely pointed or bent. Two of the three known species probably oecur in the State, although but one has been taken.

KEY TO INDIANA SPECIES OF ELONUS.

a. Brownish-black; elytra orange at base, without a zigzag median band.

a . Grayish-black; elytra with an angulated narrow band about the dle and an apical spot of gray pubescence.

2498. NEBULOSUS.

E. basalis Tiec., length $2.8 \mathrm{~mm}$., is known from Virginia and Illinois.

2498 (7900). Elonus nebulosus Lec., Trans. Amer. Ent. Soc., V, 1875, 175.

Grayish-black, opaque; abdomen and elytra brown, the latter reddishbrown at base and marked with grayish pubescence as mentioned in key; tarsi and palpi pale. Eyes very large, separated by about one-third their width. Thorax slightly longer than wide, the apex three-fifths as wide as 
base, sides feebly rounded, disk very densely punctate. Elytral twice as wide as thorax, parallel, deeply and coarsely punctate. Male with hind thighs dilated and last joint of antenne as long as the three preceding united. Length $2.5 \mathrm{~mm}$.

Posey County; rare. May 28.

\section{XVT. Enelinus Cascy. 1895.}

Eyes very large, sub-basal, coarsely faceted; antenne two-thirds as long as body, those of male with third joint elongate and joints 4-11 each with a long appendage on inner side; third joint of female scarcely longer than fourth, joints 4-10 equal, without appendages; basal joint of tarsi long and slightly bent near base.

2499 (7898). Emelinus mershemeri Lec., Proc. Phil. Acad. Nat. Sci., ViI, 1855, 276.

Rather slender, convex. Head, under surface and femora piceous; thorax reddish-brown, with three irregular blackish spots: elytra dull brownish-yellow, with sides and three uneven crossbars blackish, sparsely clothed with long yellowish hairs; antennæ, tibix and tarsi dull yellow. Head finely and sparsely punctate; eyes separated by one-third their width. Thorax quadrate, narrower than head, sides parallel, disk finely and densely punctate. Elytra parallel, twice as wide as thorax, marrowly impressed each side of suture, coarsely, deeply and closely punctate. Length $2-2.5 \mathrm{~mm}$.

Marion County; rare. September 5. Known from Illinois and Pennsylvania.

\section{Zonanies Casey. 1895.}

Eyes large, coarsely granulated, piaced close to base of head, which is entire and truncate. Antennse with second and third joints of subequal length, eleventh swollen at middle and obliquely pointed. Two of the cight species have been taken in the State.

2500 (7902). Zonantes fasciatus Melsh., Proc. Phil. Acad. Nat. Sci., III, $1846,55$.

Suboval, convex. Black; antennie, palpi, legs and tips of abdomen dull yellow; elytra black, each with a large humeral spot and apical fourth reddish-yellow; pubescence long, rather coarse and sparse. Thorax as wide as head, subquadrate, sides parallel; disk finely and rather sparsely punctate, feebly impressed along the median line. Elytra one-half wider than thorax, parallel, coarsely but not densely punctate. Length $2-2.5 \mathrm{~mm}$.

Throughout the State; scarce. June 1-June 20. Taken by beating flowers and foliage.

2501 (7904). Zonantes stbfasciatus Lec., Trans. Amer. Ent. Soc. Y.

Suboral. convex. Dull reddish-yellow: head fuscous: elytra with a nar'ow median piceous bar. slightly wider at the sides: pubescence long. 
coarse and sparse. Thorax subquadrate, one-third wider than long, finely and densely punctate and impressed along the median line. Elytra onehalf wider than thorax, densely. deeply and rather coarsely punctate. Length $1.5-1.7 \mathrm{~mm}$.

Dubois County; rare. April 29.

\section{Phomalus Casey. 1895.}

Eyes large, rather widely separated, very coarsely granulated and with a small rounded emargination; placed close to base, which is strongly arched and elevated: eleventh joint of antenna rather small and obtuse; thoras transverse, with sides parallel; abdomen with basal segment more than equal to the others combined. One of the two species occurs in the State.

2502 (7910). Phomalus brundipendis Lec., Trans. Amer. Ent. Soc., V, $1875,176$.

Elongate-oblong, conrex. Dark brown; head, thorax and middle and hind legs piceous; pubescence grayish-yellow, short and rather dense. Thorax wider than long, apex rounded; disk convex, slightly uneven, finely and densely punctate. Elytra nearly twice as wide as thorax, oblong, parallel, finely and densely punctate and with a faint oblique impression on basal third. Length 1.7-2 $\mathrm{mm}$.

Vigo County ; rare. April 16.

Tanomus piceus Lec., black, legs and antennæ dark reddislbrown, eyes separated by twice their own width, length $1.7 \mathrm{~mm}$, is known from Pennsylvania, New York and Wisconsin.

Tanilotes lacustirs Casey, black, eyes separated by three times their width, length 1.6 mm., was described from Wisconsin.

\section{Family LXIII. PYROCHROID E.}

\section{The Fire-colored BeEtlis.}

A small family of moderate sized, broad depressed beetles having the elytra rather soft in texture, usually widened behind the middle and remarkable for their relative size. The head is almost horizontal and constricted behind the eyes into a rather slender neck, both head and thorax being much narrower than the elytra. Most of our species are conspicuons for the rufous thorax, which contrasts with the black elytra and for the prominent antennxe which are serrate or subpectinate in the female and usually with 
long, comb-like processes in the male. 'The name is from that of the typical genus Pyrochroa, meaning "fire + color," and was probably suggested hy the presence of red or yellow in their coloration, some of the foreign ones being almost wholly red. Our species live in all stages under the half decayed bark of trees and have little economic importance.

In addition to the more prominent characters mentioned, the Pyrochroidæ have the eyes emarginate, rather coarsely granulate and sometimes very large; antennie 11-jointed, inserted at the sides of the front just before the eyes; elytra wider than the abdomen, rounded at tips, the epipleure visible only near the base; abdomen with five free ventral segments, the fifth emarginate, exposing the tip of sixth in male; front coxe large, conical, contiguous, the cavities widely open behind; middle coxæ with distinct trochantins; tarsi with next to last joint dilated, claws simple.

The principal papers treating of the North American species are as follows:

LeConte.- "Synopsis of the Pyrochroides of the United States," in Proce. Phil. Acad. Nat. Sci., VII, 1855, 274-275.

Hom.-." "Synopsis of Dendroides," in Trans. Amer. Ent. Soc., XV, 1888, 46-48.

The 11 known species from North America are divided among four genera, all of which are represented in Indiana.

\section{KET TO GENERA OF PYROCHROIDA.}

a. Eyes moderate in size, well separated.

ъ. Antenne simple; color dull yellow; thorax and elytra strongly carinate.

I. IschaLIA.

bb. Antennx serrate or branched; the branches more or less rigid.

c. Last joint of maxillary palpi long, pruning-knife shaped; length 13 or more mm.

II. PrrochroA. cc. Last joint of maxillary palpi long, oval; smaller. not over $\mathrm{S}$ mm.

III. Schizotus. a a. Eyes very large, sometimes nearly contiguous: branches of male antemn:e very slender and flexible.

\section{Iscmalia Pase. (Gr., "dried up.")}

This genus is represented in the eastern United States by a single small species which, on account of its peculiar sculpture, is very different in appearance from any other Indiana beetle. The body covering is much firmer than in other genera of the family and the last joint of the maxillary palpi is large and liatchet-shaped. 
2508 (7990). Ischalia costata Lec.. New S1). N. Am. Col.. I, 1866, 142.

Oral, subdepressed. Dull brownish-yellow; head, abdomen and antemne, except the last two joints, brownish-fuscous; elstra dusky with a long stripe on side and tips pale. Thorax bell-shaped, withont punctures. sides thickened and reflexed: hind angles acute: disk with a strong median carina ending in a point at the base. Elytra elongate-oval, very coarsely punctured: each with a high ridge extending from humerus nearly to tips and another. much feebler. very near the margin and reaching from near the base to the tip. Iength $4.5-5 \mathrm{~mm}$.

Tarshall Comuty: rare. May 3. One specimen from decaring cettonwood.

\section{Pyrochro Geoft. 176t. (Gr., "fire +color."')}

Four species of large black and yellow forms belong here. Tiro of the four occur in the State.

2504 (7991). Pyrochroa Flabeldata Fab., Ent. Syst. Supp., 1798, II, 105.

Elongate, subdepressed. Reddish-yellow; antennæ. except the two basal joints, piceous; elytra black, sparsely clothed with short, suberect pubescence. Thorax twice as wide as long. distinctly wider than head; sides and angles romded, disk smooth, with a broad median impression at base. Elytra distinctly wider behind the middle, finely and densely granulatepminctate. Male with head broadls concare between the ejes and antemme with joints 5 to 10 more strongly pectinate than in female. Length 15 $17 \mathrm{~mm}$.

Throughout the State, frequent in the southern counties; much less so northward. June 2-July 7. Occurs on foliage, especially that of ironwood, in open woodland; also often beneath chips and bark. A half dozen specimens were, on one occasion, found feeding on a pungent, sourish sap which was exuding from a crevice in a white oak stump.

2505 (7992). Prrochroa fexroralis Lec., Proc. Phil. Acad. Nat. Sci. VII. 1855. 274 .

Resembles the preceding in form and color except that the under surface, palpi, all the tibire and tarsi and part of middle and hind femora are blackish. Thorax much narrower than in flabellata, scarcels wider than head. Male with a rery deep double forea between the eyes and with the branches of antemnal joints much longer and more slender. Females with a broad, shallow excaration between the eyes and the antemnæ about as in the males of flabellata. Length 14-16.5 $\mathrm{mm}$.

Marion, Crawford and Perry counties; scarce. May 14-June 5. The elytra are much more shining and less rough than in flabellata. 
THE FIRE-COLORED BEETILE.

\section{Schizotus Newm. 1838. (Gr., "cleft+back.")}

A single rather small. dull species represents this genus in the Eastern United States.

2506 (7993). Schizotus cervichlis Newml. Lntom. Mag.. $Y$, 1S:39. 375.

Elongate, suboral. depressed. Dull blackish-piceous, sparsely clotled with fine. prostrate, grayish-yellow hairs: thorax, front of head and rery narrow sutural and marginal lines of elytra. obscure reddish. Thorax onehalf wider than long. sides and angles rounded; disk uneven, rery finely and densely punctate and with a wide, deep median groove. Elytra feebly widened behind the middle, finely and densely granulate-punctate. Head of males with a deep forea each side at base and with the branches of antennir long and slender.

Lake Countr; rare. Nay 28. Taken from beneath the bark of dead birch in the Kankakee Valley near Shelby. A member of the Alleghanian fauna.

\section{DExDRoides Lat. (Gr., "branen or tree + like.")}

Nedium-sized species, readily known by the very large eyes which, in the males, almost meet on top of the head, and in the female are but slightly separated. Two of the four species recognized by Iorn occur in the State.

2507 (7994). Dendroides bicolor Netrm.. Ent. Miag., T, 1838, 375.

Elongate, slender, subparallel. Reddish-yellow; head, antennæe and elytra piceous. Thorax about as wide as long, widest at middle, the sides strongly converging in front, slightly sinuate near base; disk sparsely and coarsely punctate, with a median impression on basal half. Elytra rearly parallel in male, distinctly wider behind in female, coarsely and wider behind in female, 587 , Iarra; b, pupa;
rather closely punctate. Males more larged anal horns of larra; $e$, en
slender, with a narrower tholax and antenna of male. (Atter Riley.)

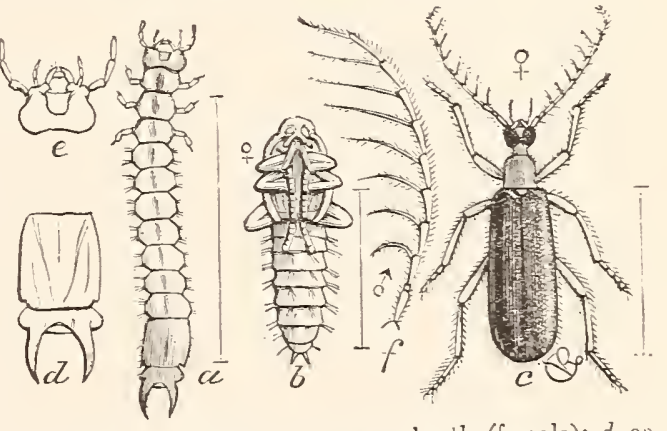

Fig 587 a Tarva: $b$, pupa; $c$, beetle (female); $d$, ena enlarged head of same; $\dot{T}$. ntenna of male (After Riley.) with branches of antennal joints rery long and slender. Length 9-13 mm. ( Fig. 3, No. 5, and fig. 5ST.)

Throughout the State: frequent. May 21-August 17. Occurs beneath bark.

250s (7995). Dexdrotnes coxcolor Newm.. Ent. Mag.. T. 1S38, 375.

Elongate. slender, parallel. Uniform pale brownish-yellow. Thorax distinctly longer than wide, narrower in front; disk smooth and shining. 
the median impression visible at base only. Elytra parallel, coarsely and rather closely punctate. Male antemne with last joint as long as the five preceding, their branches as in bicolor. Length 11-13 $\mathrm{mm}$. pine.

Laporte County; rare. May 25. Taken from beneath bark of

\section{Family LXIV. MELOID A.}

\section{The Oil and Blister Beetles.}

Medium or large-sized beetles of variable color, having the thorax narrower than either head or elytra; the bodies soft in texture, often loose-jointed and sprawly in appearance and usually slender and subcylindrical in form; antenne of moderate length and in the male sometimes curiously knotted or otherwise modified; head broad, vertical and abruptly narrowed into a neck; elytra and sides of abdomen with little or no co-adaaptation; tarsal claws cleft or toothed, each claw usually bearing a long appendage closely applied beneath it.

The name Meloidx is of uncertain derivation. The larger, more bulky species, belonging to the genus IIeloe, when alarmed exude from the joints of the legs a yellowish oily liquid, whence the name "oil beetles," often applied to them. To our more common forms the name "blister beetles" is given, on account of their possessing a peculiar principle called cantharidine which, when extracted and applied to the human skin, possesses the power of raising blisters.

In the adult stage the blister beetles are often injurious, since they feed on cultivated plants such as beets, potatoes and tomatoes, and a number of them are called "old-fashioned potato beetles," a term in use only since the Colorado potato beetle invaded the East. In the larval stage. however, many of them are very beneficial, as they feed upon the egg-pods of our common grasshoppers, thus greatly lessening the numbers of these insects. The larvæ of the blister beetles are also peculiar in that they undergo several more changes than do ordinary beetles before reaching the adult stage, a pseudo-pupal or inactive stage following the usual three or four moults of the larval form, this being succeeded by an active stage, which in turn is followed by the usual pupal stage preceding the final moult. The larva of the "oil beetles" ive in nests of bumbleand other bees, feeding upon the honey stored for the young bee. and hence are also injurious in this stage.

In addition to the more important characters mentioned, the 
Meloidae have the antenna 11-jointed, inserted at the sides of the front, before the eyes; elytra variable in form, but when short never truncate; abdomen with six free ventrai segments f front and middle coxa large, conical, contiguous, the front cavities widely open behind; next to last joint of tarsi cylindrical, except in T'elraonyx.

About 200 species of Meloidx are known from North America, the great majority of them being from the Western and Southwestern States. These are treated in the following papers:

LeConte._"Synopsis of the Meloides of the United States," in

Proc. Phil. Acad. Nat. Sci., VI, 1853, 328-350.

LeConte. "Synopses of the genera Pyrota and Pomphopoa," in New Sp. N. Am. Col., I, 1866, 159-161.

Horn.- "Revision of the species of several genera of Meloidie of the United States,' in Proc. Anner. Plil. Soc., XIII, 187?, 88-117. Gives synopses of Macrobasis, Epicauta, Pomphopoea and Cantharis.

Hom.- "Synoptic tables of Zonites and Calospasta," in 'Trans.

Amer. Fint. Soc., V, 1875, 155; VII, 1878, 60.

LeConte._'Synoptic table of Ncmognatha,' in Trans. Amer. Ent. Soc., VIII, 1880, 212-215.

Horn.- "Studies among the Meloide," in Trans. Amer. Ent.

Soc., XII, 1885, 107-116. Gives synopses and descriptions of Macrobasis, Pyrota and Tetraonyx.

Hoin.- "Revision of Calospasta," in Proc. Amer. Phil. Soc.,

XXIX, 1891, 99-102.

Wickham, H. F._- "The Meloidx of Ontario and Quebec," in

Can. Ent., XXVIII, 1896, 31-35.

Fall, H. C.- "Notes on Cantharis, with Synoptic Table," in

Trans. Amer. Kint. Soc., XXVII, 1901, 293-304.

The North American species of the family may be divided among two subfamilies, both of which are represented in the State.

KEY TO SUBFAMILIES OF MELOIDA.

a. Side pieces of meso- and metathorax covered by the elytral inflexed portion of elytra very wide; inner wings absent; elytra (in our species) short and overlapping the suture and leaving most of the abdomen exposed; body large, clumsy.

Subfamily I. MELolx.E. 1). 1:5:-2. a $a$. Side pieces of meso- and metatholax visible; inflexed poltion of elytril nalrow; wings usually present; elytrat long, almost ol quite covering the abdomen (excent in siturimi), not overlapling at sutule.

Subfamily II. CANTHARIN.E. 1. 1:25:?. 


\section{Subfamily I. MELOINAE.}

The members of our single genus of this subfamily are known as "oil beetles." They are large, clumsy black or bluish forms with short elytra, which do not cover the unwieldy abdomen. They have the tarsal claws cleft, the upper and lower parts equal, and the antennæ of the males are curiously dilated near the middle. (Fig. 588.) Being wing- Fig. 588. Ireloo sp. ?1, male beetle; 2, larra; less, they are found on the ground or low

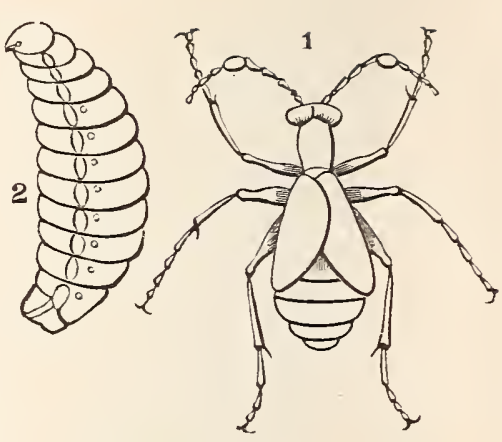
(After Packard.) herbage, and are more common in late autumn or spring. When disturbed they emit a disagreeable fluid from the joints.

\section{Meloe Linn. 1758. (Gr., "small animal.")}

Three of the 14 species have been taken in the State and one other perhaps occurs.

KEY TO INDIANA SPECIES OF MELOE.

a. Thorax not longer than wide.

b. Color dull black; thorax with an impression on basal half of median line.

2509. IMPRESSUS.

6b. Color blue or bluish-black; thorax not impressed.

c. Thorax rathei densely punctate; elytra not roughly sculptured.

NIGER.

cc. Thorax coarsely and deeply, not densely. punctured; elytra coarsely sculptured; color more decidedly blue and more shining.

2510. AMERICANUS.

a a. Thorax longer than wide, sparsely and irregularly punctate; color deep bluish-black; elytra finely rugose.

2511. ANGUSTICOLLIS.

2509 (S006). Meloe mpressus Kirby, Faun. Bor. Amer., 1S37, 241.

Dull black with a faint bluish tinge. Thorax about as wide as long, widest at apical third, thence feebly narrowed to base; disk coarsely and sparsely punctured and with an impression just behind the middle. Elytra rather densely and shallowly rugose. Length 11-14 $\mathrm{mm}$.

Vigo County; rare. May 12.

1. niger Kirby, blue-black, feebly shining, length 12.5-15 mm., is known from Canada.

2510 (S013). Meloe Americanus Leach. Limn. Trans., XI, 1815, 251.

Bluish-black; elytra more decidedly blue in male. Thorax about as wide as long, but slightly narrower than head; rather densely punctate on apical half. much more sparsely so on basal portion. Length 16-24 mm.

Southern half of State; scarce. April 10-December 25. Noted only in late autumn and early spring. On October 28 I once found 
six of these beetles close together near the margin of a wheat field. One female had the abdomen partly buried in the soft, recently ploughed earth, and on removing her I found a circular mass of yellow eggs, 150 or more in number. Say states that americanus is "not uncommon and is sometimes gregarious in great numbers."

2511 (S012). Neloe a Ngusticolis Say, Journ. Phil. Acad. Nat. Sci., III, 1S24, 280 ; ibid. II, 166.

Head and thorax dark blue; elytra and abdomen violaceous. Head alutaceous, finely, deeply and very sparsely punctured. Thorax one-half narrower than head and nearly one-half longer than wide; sparsely and deeply punctate and, in male, with two small impressions each side of middle. Elytra finely and shallowly rugose. Length 12-15 $\mathrm{mm}$.

Vigo County; scarce. September 18. The adults are said to feed upon the leaves of the buttercup. This and the preceding species are often confused in collections, and Nickham evidently has the names transposed in his table of Canadian species. Say states that both head and thorax of angusticollis are "strikingly narrower than the body," while LeConte says that the thorax is nearly onehalf longer than wide, both of which statements are true of this, but not of americamus.

\section{Subfamily II. CANTHARINAE.}

In addition to characters given in the key, the species of this subfamily have the body much more slender and the elytra meeting evenly along the suture; claws cleft to base, the upper portion sometimes pectinate. Representatives of four of the five tribes (subtribes) and seven of the 24 genera, recognized by LeConte and Horn, occur in the State.

KEY TO INDIANA TRIBES OF CANTHARINE.

a. Front not prolonged beyond the base of antennse; labrum small, scarcely visible; elytra (in our species) dull red.

Tribe I. HorIint, 1. 135t.

aa. Front prolonged; frontal suture and labrum distinct.

b. Mandibles prolonged beyond the labrum, acute at tip.

c. Elytra entire; tarsal claws cleft.

Tribe II. Nemogxathisi, p. 1355t.

cc. Elytra rudimentary; wings wanting; tarsal claws simple.

Tribe III. StTanixi, p. $135 \pi$.

bb. Mandibles not proionged, obtuse: elytra entire; antennæe straight. not thickened toward the apex. Tribe IV. CAxtranixi, P. 1:56. 
Tribe I. HORIINI.

In this tribe the head is large, squarely truncate behind; antenna not very long and not thickened toward apex; eyes transverse, kidney-shaped; claws of tarsi cleft to base, the upper portion with fine comb-like teeth, the lower one rery slender. One of the two genera is represented in the State.

\section{Tricrinda Lec. 1860. (Gr., "three times + head.")}

Head triangular; last joint of maxillary palpi longer than third; mandibles not toothed; hind tarsi one-half shorter than tibire. One of the three species occurs in the State.

2512 (S021). Tricraxia saxgutipexis Say, Journ. Phil. Acad. Nat. Sci.. III. 1824,279 ; ibid. II. 166.

Elongate-oblong. Black. sparsely clothed with short, erect hairs; elytra uniform brick red. Thorax subquadrate, about as wide as head. onethird wider than long; surface. as well as that of head, densely, coarsely and roughly punctate. Elytra densels and rather finely rugose. Length
$7.5-9 \mathrm{~mm}$.

A few specimens taken by Wolcott near Hessville, Lake County. April 15-May 1. Occurs on sorrel and beneath cover in sandy
localities.

\section{Tribe II. NEMOGNATHINI.}

Our members of this tribe are rather small, oblong species, having the head triangular and squarely truncate behind; maxillary palpi not dilated, the fourth joint longer than third; tarsal claws cleft to base, the upper portion with strong, comb-like teeth, the lower one equal in length, acute and generally more slender than the upper. T'wo of the three genera are represented in the collection
at hand.

\section{KEY TO INDIANA GENERA OF NEMOGNATHINI.} a. Maxillie with the outer lobe prolonged. bristle-like; antenna not thick-
ened toward apex.

aa. Maxillæ with outer lobe not prolonged.

III. Nemograthi. IV. Zoxitis.

\section{Neגiogratha Ill. 1807. (Gr., "a thread + jaw.")}

In this genus the outer lobe of the maxillæx is prolonged into a slender, flexible process, sometimes nearly as long as the body, which resembles somewhat the sucking tube of a butterfly. Four of the 18 species recognized by LeConte have been taken in the State, while
two others may occur. 
KEY TO INDIANA SPLCIES OF NEMUGNATHA.

a. Palpi rather short, not very slender, hairy; spurs of hind tibiac equal in size, rather slender.

b. Elytra finely and very densely punctured; thol:ax not wirlar behind.

c. Thorax quadrate; maxillar two-thilods or luole the length of body.

a. Thorax densely punctured; color variable.

PIEKA'TA.

dd. 'Thorax sparsely punctured ; elytra either wholly yellow or brownish-yellow, with a black stripe.

cc. 'Thorax nearly oval, yellow, with black spots, finely and rather' sparsely punctured; maxillae half the length of body.

2514. NEMORENSIS.

bb. Elytra less tinely and less densely punctured, rellow, with a wirle black stripe; thorax yellow, rather sparsely punctured.

CRIBRARIA.

a. Palpi longer and more slender, not hairy but only pubescent; maxillab less than half the length of body ; spines of hind tibiae broarl, obtuse.

$e$. Thorax rather finely and densely punctured; elvtra wholly orange yellow or rarely with a broad black stripe. 2515. TrTTIGLRA. $c e$. 'Thorax very coarsely, sparsely and irlegularly punctate; elytra yellow or dark brown.

2516. CRIBRICOLLIS.

N. piezata Fab., male with fourth ventral broadly sulcate, fifth impressed, length 7-11 mm., is said to oceur from the "Atlantic Regions to Colorado and Montana."

2513 (S032). Nemognatha puncturata Lec.. Proc. Phil. Acad. Nat. Sci.. VI, $1553,347$.

Elongate-oblong. Orange yellow, sparsely clothed with yellow hairs; antenna (except at base), tarsi and greater part of under surface blackish. Head finely and densely punctate, with front flat; occiput swollen. Thorax one-third wider than long, sides almost straight, disk sparsely. coarsely and irregularly punctate. Flytra minutely and very densely punctured. Length $\mathrm{S}-11 \mathrm{~mm}$.

Jackson County; rare. July 16. The form described is var. flavipennis Uhler. In the typical form the upper surface is brownish-yellow, the elytra with a black stripe.

2514 (S034). Nemognatha Nemonensis Hentz., Trans. Amer. Plil. Soc..

$$
\text { III, } 1830,25 \mathrm{~S} .
$$

Elongate-oblong. Black, rather thickly clothed with short, erect blick hairs; mandibles, middle of head and thorax yellow, the latter usually witl two black spots on basal half which are often mited. Maxillae one-half tise length of body. Tength 6.5-7.5 $111 \mathrm{~m}$.

Crawford County; rare. June 2-June 28.

$N$. cribaria Lec., male with fourth and fifth ventrals impressed and with median tufts of black hairs, length 6.5-8.5 mm., ranges from "the Middle and Western States to New Mexico." 
2.j1.j (8040). Nemognatia vittigera Lec., Proc. Phil. Acad. Nat. Sci, VI, $1853,348$.

Elongate, subcylindrical. Reddish-yellow; elytra usually with a broad discal black stripe; antenne, tibixe and tarsi blackish. Thorax as wide as long, sides almost straight, apex rounded. Elytra densely, roughly and confluently punctate. Length 9-11 mm.

Two in Webster collection labelled "Ind., Baker;' probably from St. Toseph County. Recorded from Illinois, Missouri and Texas.

2516 (8041). Nemognatha cribricolis Lec., Proc. Phil. Acad. Nat. Sci., VI, 1853,348 .

Oblong. Color exceedingly variable, in the type dull yellow with antennie and tarsi brownish: in the specimens at hand (fuscipemis Lec.) dark brown with head and thorax reddish-yellow. Thorax but slightly broader than long, sides rounded. Elytra rather coarsely, densely and confluently punctured. Length 5-9 $\mathrm{mm}$.

Lake County; rare. June 29-July 4.

\section{Zonttis Fab. 1775. (Gr., "girded or banded."')}

Small oblong species with the maxillæ not prolonged; antennw filiform, the first and third joints equal, the second a little shorter. 'Two species have been taken, while another may occur.

KEY TO INDIANA SPECIES OF ZONITIS.

a. Antennie not over half the length of body; eyes widely separated, not extending beneath the head.

b. Thorax without a median impressed line; elytra yellow, each with a median piceous stripe which is abbreviated at base and apex.

2517. BILINEATA.

67. Thorax with a distinct median impressed line; elytra brown with suture and margins narrowly yellow. 2518. sulcicollis.

aa. Antemure bristle-like, nearly as long as the entire body; eyes large. rather close together and extending beneath the head; thorax and elytra very densely punctured: elytra brownish-yellow. with suture. margin and narrow median stripe paler. LONGICornis.

2517 (8049). Zonitis bilineatus Say. Joum. Phil. Acad. Nat. Sci., I, 1817. 22 ; ibid. II, 3.

Elongate-oblong. Dull brownish-yellow. Elytra usually with piceous stripe as mentioned in key, this sometimes wanting; antenne, tibix and tarsi in part or wholly fuscous. Thorax subquadrate, slightly wider than long. front angles rounded, hind ones obtuse ; disk coarsely and very sparsely and irregularly punctured. Elytra with distinct, rather coarse and sparse punctures. Length $7.5-9 \mathrm{~mm}$.

Wells and Putnam connties; rare. June 11-July 29. Taken from blossoms of wild rose. 
Elongate-oblong. Antennic, occiput, tibiar, talrsi and meste and netalsterna brown; thorax, front of head, fenoral. prosternum and ablomen yellow; elytrat as mentioned in key. Itead coancely and lather closely punctate, the middle of occiput smsother. 'Thorax slightly wider than long: sides and all the angles strongly rounded; disk uneren, spalsely and coarsely punctate and with a deep median impressed line. Elytra scabrous or rugose without distinct punctures. Abiomen finely and densely punctate. the apex of fifth ventral broadly and deeply concare. Length $\mathrm{s} \mathrm{mm}$.

Lake County ; rare. July 29. Taken from blossoms of the yellow flowered thistle, Cnicus pitcheri Torr. Tery distinct from bilineata in color, difference in sculpture of elytra and in having thoracic inpressed line.

$Z$. longicornis Horn, head nearly black, thorax darker at middle. legs and antennæe pale, length $10 \mathrm{~mm}$., was descrihed from Central Illinois.

\section{Tribe III. SITARINI.}

To this tribe belongs a single North American species, Hornia mimutipennis Riley, which is parasitic upon a ground-bee (Anthopora sp.), which builds its nests in perpendicular clay banks. The abdomen of the beetle is very large, as in Meloe: elytra very small and wings wanting. 'The head is triangular, thorax elongate, tarsal claws cleft; male with a double row of horny plates on abdomen. It was described from near St. Louis, doubtless occurs wherever its host lives, and should be looked for in early spring.

\section{Tribe IT. CANTHARINI.}

Elongate, rather slender, suberlindrical beetles, having the front marked with a distinct transverse suture prolonged beyond the insertion of the antennæ; tarsal claws cleft to base, the upper part not serrate, the two parts

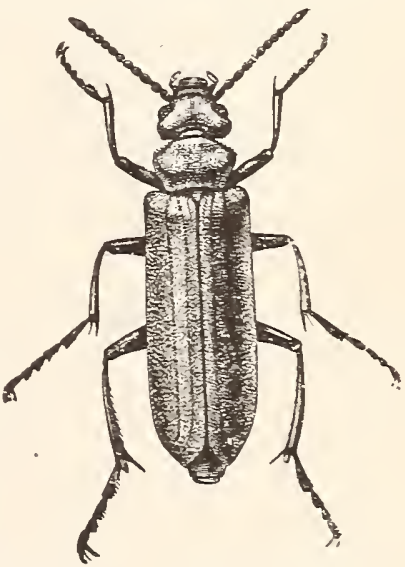
in our genera subequal. (Fig. 589.) Four of Fig. 589. Cantharis nuttalli Eay. the trelve genera are represented in the collections, while members of two others perhaps occur.

KET TO INDIANA GEXERA OF CANTHARIXI.

a. Second joint of antemne at least one-half as long as third.

a $a$. Second joint of antenne much less than half the length of third

b. Next to last joint of tarsi bilobed.

TETRAOXYX.

bb. Next to last joint cylindrical. 
c. Front femos:a with a silken, hairy spot on the under side; second joint of antenne rery short: mandibles short. VI. EPICACTA.

“. Front femoral withont a silken, hairy suot.

a. Antenne filiform, the outer joints cylindricall. VII. I'rota.

d. Antennie thicker toward apex. the outer joints oval or rounded.

e. Labrum deeply emarginate.

ee. Labrum slightly emarginate.

VIII. POMPHOPEA.

CANTHARIS.

\section{Macrobasis Lec. 1862. (Gr., "long + a base.")}

Our species of this genus are elongate, subcylindrical, black beetles clothed with gray pubescence and having the first joint of antennip of male elongate and the second joint always more than half the length of third; last joint of maxillary palpi triangular and cbliquely truncate; front thighs with spot of pubescence as in Epicanta, to which the genus is very closely related.

KEY TO INDIANA SPECIES OF MACROBASIS.

a. First joint of antennie unlike in the sexes. that of the male being much thickened and longer than the next two; second joint of male equal to third and fourth together; length not orer $15 \mathrm{~mm}$.

b. First joint of male antennae more or less s-shaped or with a distinct sinuation on under side near apex: front tibire of male with one terminal spur.

bb. First joint of male antemne not sinuate or s-shaped. but 2519. ToRsA.

tened and feebly curved; front tibire of male with tro spurs.
c. Pubescence less dense. ang and wider, reaching the occiput: femora without long hairs behind in either sex.

2520 . UNicolor.
cc. Pubescence more dense and with a distinct rellowish tinge; basal joint of mile antennie not reaching the occiput; femora of male. especially the hind ones, clothed with long hairs on their hinder margin.

2521. FLA YOCINERELS.

a a. First joint of antennie similar in the sexes and not in either sex longer than the next twro; second joint in both sexes not longer than third; length $13-23 \mathrm{~mm}$.

2522. IMMACULATA.

2519 (S060). Macrobasis torsa Lec.. Proc. Phil. Acad. Nat. Sci.. VI, 1853, 343 .

Elongate, slender. Black. sparsely clothed with short, grayish pubescence; antenna and legs black. Thorax slightly broader than long. sides nearly parallel. curved at apex, median line impressed. Elytra subparallel. more or less pruinose, moderately punctured. Male with second joint of antennie cylindrical. compressed, and with first joint of front tarsi shorter than second, narrow at base and more or less rilated. Female with second joint of antenna slightly longer than third. Iength 11-15 $\mathrm{mm}$.

Crawford County; rare. June 11. Known heretofore only from Texas. Easily distinguished from unicolor by the contorted first joint of male antennæ. 


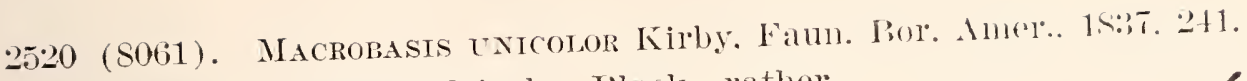

Elonit a subcylindrical. Plalck, rather densely rlothed with gratyish hail's which give an asilen hue to the upyer surface. Thorax slightly longer than broad, otherwise as in torsa. Second joint of male antennæ slightly longer than the next tro and nearly twice as wide; in female one-half longer than third. Length S$15 \mathrm{~mm}$. (Fig. 590.)

Throughout the State, frequent; more so in the northern counties. May 21-August 6. Commonly known as the "ashgray blister beetle" and occurs on false indigo, Kentucky coffee tree and other legumes: also on potatoes and ironweed, it tenna of male much enlarged. (After and cne or tro species of Epicalla being among the few living creatures which will attack the leaves of the last-named plant.

2521 (-). MaCrobasis FLAVOCINERETS sp. nov.

Slightly narromer and more parallel than nnicolor. Pubescence rellowish-gras. Second joint of male antenne shorter and not much wider than the next two: of female scarcely longer than third. Maxillary palpi much longer and stouter than in unicotor. All the femora of male. and especially the hind ones, with a fringe of long hairs on the hind margins. the hairs curred near tips. Length 12-13 $\mathrm{mm}$.

Starke Counț ; rare. July 1 . Tery distinct from unicolor in the form of antennal joints and pubescence of femora of male.

2522 (S068). Macrobasis manactlata Say. Journ. Phil. Acad. Nat. Sci..

III, 1824.304 ; ibid. II, 170.

Elongate, male rather robust. Black, densely clothed with rellowish or grayish pubescence. Thorax slightly longer than wide otherwise as in torsa. Elstra gradualls broader behind the middle. especialls so in male. First joint of male antenne less than half the length of head; second joint shorter than third. Female with second joint as long as or sightly longer than third, and the first more slender than in male. Length $13-23 \mathrm{~mm}$.

Southern half of State; scarce. May 2t-August 2. Occurs on goldenrod and wild morning-glory.

Tetraomyx quadrimaculata Fab., head black, elrtra rellowish. apical third and large humeral spot black. length $10 \mathrm{~mm}$., is known from Georgia and North Carolina, and may occur in southern Indiana.

VI. EpIC.ıтTA Redt. 1849. (Gr., "upon+burn.")

The members of this genus closely resemble those of Macrobasis in form and are separated only by the ditference in the basal joints $[81 ;-23402]$ 
of the antemnix. The first joint is usually shorter, rarely equal to,

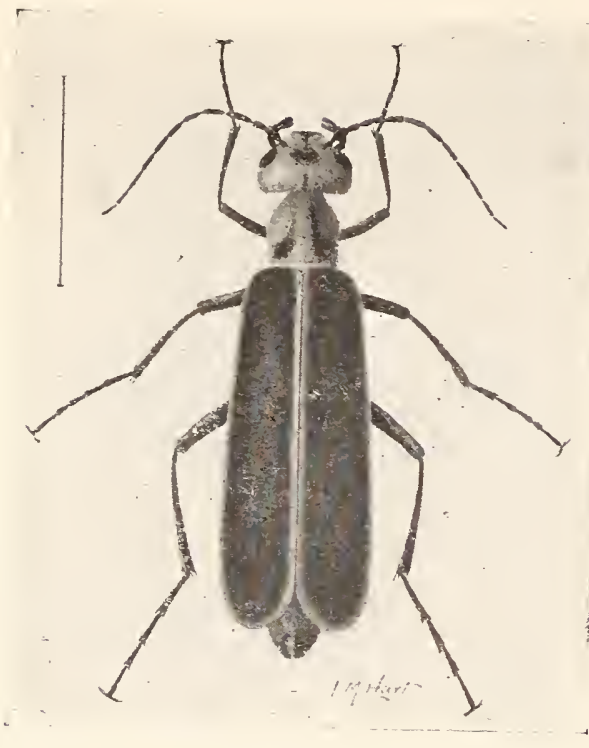

Fig. 591. (After Forbes.) and never longer than the third, and the second joint is never greater in length than half the third. Epicauta rittata and $E$. marginata (Fig. 591), are both known as "old-fashioned potato bugs," and frequently appear in swarms in late summer and sweep through a garden or field before the farmer realizes the nature of the attack. They especially favor beets and certain Composite when in flower. As a rule they disappear as suddenly as they come, some species being found in strarms on one day only. Others remain a week or two and are then best gathered into kerosene pans, if at all possible. The arsenites kill them slowly, and a swarm that feeds for a day or two before application is made and a day or two before the specimens die has done about as much injury as would have been caused without treatment of any kind. Driving them off with bushes wielded by hand is sometimes practiced with fair suceess and may be resorted to when circumstances favor the method." Six species of the genus have been taken in the State, while one other may occur.

KEY TO INDIANA SPECIES OF EPICACTA.

a. Antennal joints of equal thickness throughout, cylindrical and closely united; eyes nearly as wide as long, feebly or not emarginate in front.

7. Head less densely punctured than thorax, usually brick red behind the eyes.

2523. TRICHRUS.

7b. Head and thorax similarls punctured, the former always black; elstra clothed with dense gray or grayish-yellow pubescence.

c. Thorax longer than wide. densely pubescent with a dark line each side of middle.

STRIGOSA.

ce. Thorax as wide as long. moderately shining, rather coarsely and densely punctured.

2524. FERRUGINEA.

at. Antennal joints on apical half always more slender, loosely united and more or less compressed; eyes always longer than wide. emarginate in front, more finely granulate and less prominent than in those preceding.

r. Elytra clay yellow, each with two black stripes. 2525. ritTata. 
dd. Elytra black without stripes on disk.

e. Body beneath clothed with gray pubescence; elytra in part or wholly gray-pubescent.

f. Elytra wholly clothed with uniform gray pubescence.

ff. Elytra black, the narrow margins and suture only gray,

ce. Borly above and beneath wholly black; surs of hind tibia unequal. the outer one broader.

252S. PENXSYWANICA.

2523 (8079). Epicauta trichrus Pall., Icon. Ins.. 1798, 100

Elongate. subcylindrical. Black, opaque; clothed with short. rather dense. recumbent, black or gray pubescence, the gras often forming a marginal stripe and rarely a sutural line on elytra; head behind the eyes usually red, though often wholly black or with a small red spot in front. Thorax narrower than head, one-half longer than wide, coarsely and densely punctured and with a fine median line. Elytra finely and closely granulate-punctate. Nale with head less shining and more sparsely punctate than female. Length $8-11 \mathrm{~mm}$.

Throughout the State; scarce. June 3-August 4. Occurs especially on the hedge bindweed. Convolvulus sepium I., also on Jersey tea, sweet potatoes, etc. 'The specimens with head wholly black are apt to be confused with pennsyluanica, but the different punctuation of head and thorax will at once distinguish them.

E. strigosa Seh., thorax usually with two black spots and elvtra each with two black lines, Tength $7-10 \mathrm{~mm}$., is said to occur from "Pennsylvania to Georgia.",

2524 (Sos2). Epicauta ferregixea Say, Jomrn. I'hil. Acad. Nat. Sci., III. 1S24. 298 ; ibid. II. 167.

Elongate. slender. Black, elytra densely clothed with grayish or clay-yellow hair. Head shining. rather sparsely and finely punctured. Thorax slightIs wider than long. coarsely but not densely punctured. Elstra finels granulate-punctate, the sculpture almost hidden by the pubescence. Length 4 $9 \mathrm{~mm}$.

Knox County ; rare. July 10. Its range is given as Dakota to New Mexico.

25:5 (S093). Epicalta vitTata Fab., Syst. Ent. 1798. 260 .

Elongate, slender, subcrlindrical. Under surface black, densely clothed with short. prostrate hairs: head. thorax and elytra dull clas-yellow. each with two black stripes. Head broader than thorax, the latter longer than wide. Length 121s $\mathrm{mm}$. (Fig. 592.)

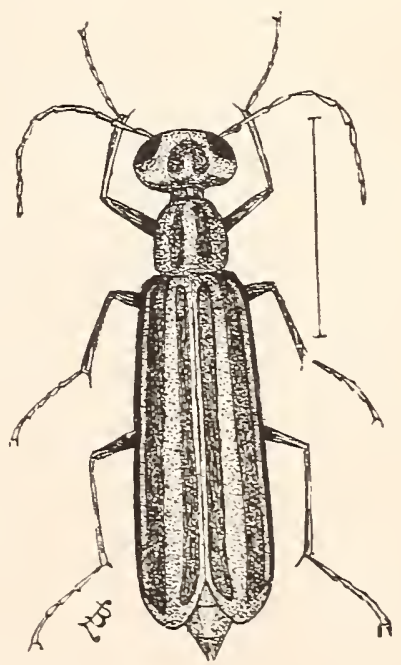

Fig. 592. Line shows natural length. (After Forbes.) 
Throughout the State; common, but apparently much less so than a score of years ago. June 11-July 20. The best known of the "old-fashioned potato bugs," or blister beetles. Feeds on tomatoes, potatoes and various weeds in low grounds. The writer's father, H. S. Blatchley, of Bainbridge, Indiana, always raised a great many potatoes, which each season were more or less damaged by these beetles. On one occasion, after sprinkling with London purple and trampling and mashing five bushels, more or less, of the beetles into the ground, he wrote of his experience as follows: "On the next day, for every one that had been killed a dozen had come to their funerals. A dashing rain having washed the poison from the vines, the bugs went for them again and not until after they had devoured the last leaf and sucked the juice from the stalks did they leave for greener pastures. I have heard some people hint, in a sly kind of way, as though they were fearful of offending some angust personage, that these blister beetles were the devil's own. This I have come to believe, and

"It's my firm conviction and it makes me free to say

That we re indebted for their visits to 'Old Scratch.'

I judge from observation that from every egg they lay

A dozen little blister beetles hatch.

If ever they should risit you, you'll find they've come to stily,

And there's nothing that their greediness can match.

If you undertake to hustle 'em it's 'possum they will play.

And a bushel in a minute you can catch.

The devil take his tater bugs, if I could have my way.

I'd tumble into Tophet the whole batch.

If such a blistering avalanche old Satan should dismaly,

He probably would hump himself and scratch."

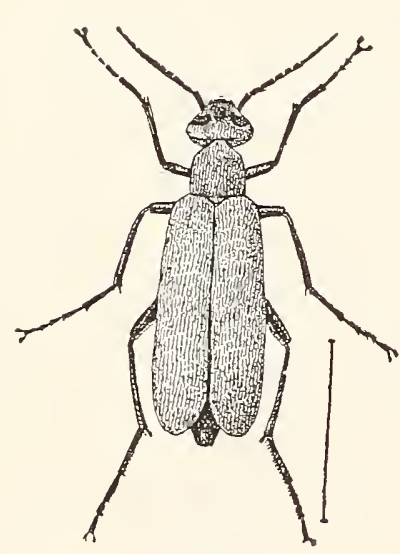

Fig. 593. (After Chittenden in Bull. 43, U. S. Div. Ent.)

elytra given in

17 mm. (Fig. 591.)
2526 ( 8097 ). Eiricauta cinerea Forst., Nov. Spec Ins., 1771, 62.

Elongate, rat her robust. Black, uniformly clothed with gray pubescence. Head and thorax densely and finely punctured. Elytra finely granulate-punctate. Length 10-17 mm. (Fig. 593.)

Vigo County; scarce. September 22. Krown as the "gray blister beetle."

2527 (—). Epicauta marginata Fab., Syst. Ent., $1775,260$.

Elongate, robust. Black; head and sides of thorax densely clothed with gray pubescence, the latter with a large triangular discal space black, this divided by a gray median impressed line. Color of
Sculpture of upper surface as in cincrea. Length $12-$ 
Throughout the State, common; more so in the southern counties. July 1-September 18. Known as the "margined blister beetle," and occurs especially on Clemalis, but also on beets, tomatoes, ete., and in later years seems to have taken the place of vittata.

2528 (8104). Epicauta pennsyluanica Deg., Mem., $\mathrm{V}, 1775,15$.

Elongate, slender. Uniform black, opaque, clothed with fine, short, prostrate black hairs. Thorax quadrate, the front angles rounded; surface (as well as that of heid and elytra) finely and densely punctate and with an impressed median line. Lengtl T-13 1nm. (Fig. 594.)

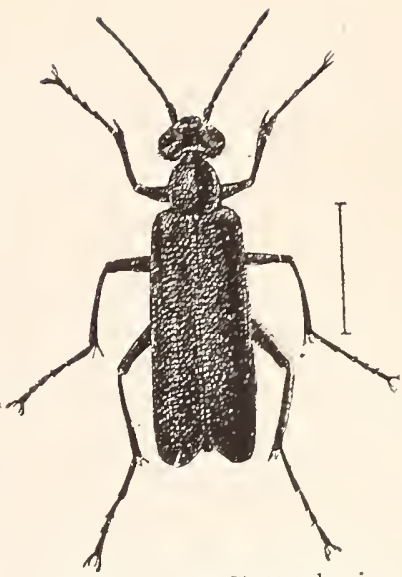

Fig. 594. (After Chittenden in Bull. 43, U. S. Div. Ent.)

Throughout the State; common. August 19-October 9. Occur's especially on goldenrod (Solidago), also on thoroughwort and rarely, with the preceding, on ironweed. It is essentially an autumn insect, as the above dates will show.

\section{Pyrota Lec. 1862. (Gu"., "fire.")}

This genus is separated from its allies by the form of the antennal joints, which are all slender and cylindrical; the second. joint about one-fourth the length of third. The males have the last joint of maxillary palpi transversely oval, with the mider side concave; in the female it is elongate and truncate at tip. In the former sex the last ventral segment is notched.

2529 (8109). Prrota engelmanni Lec., Journ. Phil. Acad. Nat. Sci.. I, $1847,91$.

Elongate, robust. subcylindrical. Dull yellow; antenuse, tibise and tarsi, hind angles of head and six spots on thorax, black; elytra with three lather wide black bars, the front and middle ones interrupted at suture, the former composed of two oblong black spots which are often confluent; under surface in part black. Head convex, sparsely punctate. Thorax longer than wide, narrower at apex: surface very sparsely punctate. Elytra each with two $01^{2}$ three fine raised lines; very finely and densely punctate. Length $17=20 \mathrm{~mm}$.

Starke and Wells counties; scarce. August 15-August 20. The spots of thorax are arianged one on each side of middle of disk, one slightly in front of each of these on the sides and two on the front margin. Its range has heretofore been recorded as "Missouri to Texas." 


\section{Pомрнорєц Lec. 1862. (Gr., "'a blister.')}

The only characters separating this genus from Pyrota and Cantharis are those set forth in the key. One of the five species occurs in the State.

2530 (8124). Pomphopea anea Say, Journ. Phiī. Acad. Nat. Sci., III, 1824, 301 ; ibid. II, 168.

Elongate, slender, subcylindrical. Under surface, head and thorax greenish, rather thickly clothed with long gray hairs; elytra bronzed and with a few short, scattered hairs; antennæ black; legs reddish-yellow, the knees and trochantins black. Upper surface alutaceous, the head and thorax sparsely, irregularly and rather finely punctured. Thorax bell-shaped and with distinct median impressed line. Elytra finely rugose, not distinctly punctate. Front tibire of male straight and with two spurs; hind tibial spurs unequal, the outer broader. Length 10-16 $\mathrm{mm}$.

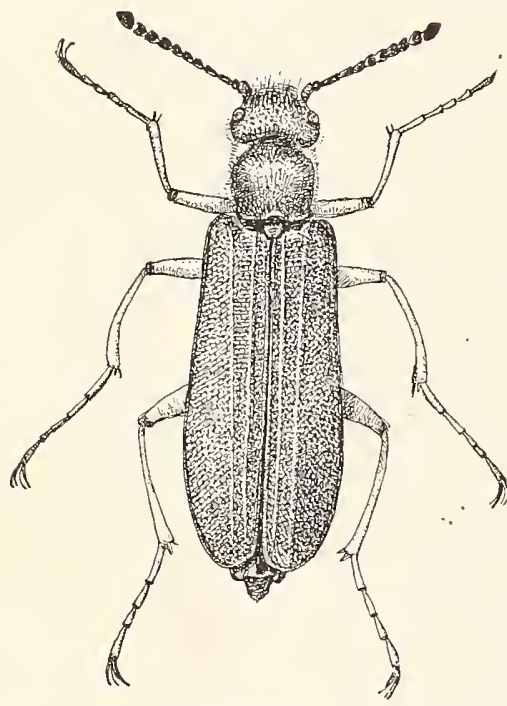

Fig. 590. Pomphopcea Sayi. $\times 2 \frac{1}{2}$. (After Chittenden in Bull. 38, U. S. Div. Ent.)

Putnam and Vigo counties; rare. April 20-May 4. Occurs on blossoms of apple, pear, etc.

P. sayi Lec. (Fig. 595), length 15-18 mm., and $P$. unguicularis Lec., length 18-20 mm., were both described from Illinois and may oceur in Indiana. According to the descriptions, they differ very slightly from cenea, the elytra being glabrous and the legs more or less blueblack In unguicularis the hind tibiæ of male are dilated toward apex and strongly compressed, while in sayi the tibix are normal.

\section{Family LXV. RHIPIPHORID E. \\ The Rhipiphorid Beetres.}

A small family of wedge-shaped beetles resembling the Mordellide closely in general appearance, but having the sides of thorax without a sharp edge; hind body not terminating in a spinous process as in most Mordellids; elytra usually shorter than the abdomen and narrowed behind, with the inner wings longer and usually more or less projecting; antenna pectinate or fan-shaped in the males, frequently serrate in the females. The adults occur on flowers and are much less common than the Mordellids. The larvæ that are known are parasitic, some in the nests of wasps and others on cockroaches.

In addition to the general characters mentioned, the Rhipiphoridæ have the head vertical, the neck very slender and entirely im- 
mersed in the thorax; eyes laxge, usually very finely granulated; mandibles not emarginate at tip: maxillar with the upper lohe often filiform; antenna 11-jointed (10-jointer in certain females); thorax as wide as the elytra at base, much narrowed in front; abdomen with a variable number of free ventral segments; front coxæ large, conical, without trochantins, the eavities open behind; hind coxie transverse, lamellate, contiguous; claws pectinate or toothed, rarely simple.

Only about twenty-five species of the family are known from North America. These are treated in the following works:

LeConte.-"Notes on the species of Myodites inhabiting the United States,' in Proc. Phil. Acad. Nat. Sci., 1865, 96-98. Horn.- "Notes on the species of Rhipiphorus of the United States," in Trans. Amer. Ent. Soc., V, 1875, 121-125.

Leconte.- "Synoptical table of Nyodites, with descriptions,"

in Trans. Amer. Ent. Soc., VIIT, 1880, 210-212.

Hom.- "Synoptic table of Myodites," in Trans. Amer. Ent.

Soc., XIX, $1892,48$.

By LeConte and Horn the family is separated into four tribes. represented by five genera. Nembers of but two genera have as yet been taken in the State, though single species of each of two others probably oecm.

KEY TO INDIANA GENERA OF RIIPIPIIORIDE.

a. Flytra as long as the abdomen. not separited toward apex: eyes oval. feebly emarginate.

Pélecotoma.

a a. Elytra shorter than the abdomen.

b. Mouth organs perfect.

c. Scutellum covered by a lobe of the base of thorax; elstra not much shorter than abdomen; miclle coxe almost contiguous.

I. RHIPIPHORES. cc. Scutellum not corered by the thorax; elytra rery small; middle II. Mrodites. $b b$. Mouth organs atrophied; female larviform, witbont elytra and wings (species parasitic upon the croton bug, Blatella germanica L.)

Rhipidics.

Pelecotoma Fisch. 1809. (Gr.. "ax + to cut like.")

The single species of this genus, $P$. faripes Melsh., occurs in the eastern United States and has been taken at Cincinnati. It is black, with antennæ, palpi and legs yellowish, length $4.5 \mathrm{~mm}$.

I. Rhipiphorus Fab. 1792. (Gr., "a fan + bearing." )

Rather small, wedge-shaped forms having the antenne bipectinate in males, serrate in females; elytra pointed behind and sepa- 
rated along the suture; tarsal claws hifid at tip. The larvæ are parasitic on the young of wasps. Four of the eight recognized spe(des have been taken in Indiana, while three others may occur.

\section{FET TO INDIANA SPECIES OF -RHIPIPHORTS.}

a. Front coxie not separated by the prosternum.

7. Front tarsi of male spinulose beneath; elytra rers acute.

c. Basal lobe of thorax with a strong eleration; male elstra wholly rellow, the abdomen black: female elstra rellow. tipped with black. abdomen red.

c*. Basal lobe of thorax transversels notched at tip: elstra of male rellow with black margins and tips: of female rellow with apical third black.

b7. Front coxae of male with three joints pubescent beneath.

1. Second joint of hind tarsi shorter than third and flat abore.

c. Basal lobe of thorax with an obtuse eleration and a deep pit each side: elotra brownish-black at base. BIForEATCs.

cc. Basal lobe of thorax not elevated. its surface regularly conrex; punctures of metasternum separated br at least their own dianneters; color rariable.

dd. Second joint of hind tarsi longer than third. subcrlindrical; lobe of thorax neither carinate nor notched.
2.533. cRLExtus.

ar. Front coxie separated in nearly their entire length by the slender process
of prosternum. of prosternum.
Second joint of hind tarsi longer than half the third and not flattened abore; piceous. iridescent.

ff. Second joint of hind tarsi shorter than hal head and thorax reddish-rellow, the latter with black oral spot.

2534. LIMBATCS.

2.591 (S174). Rhipiphorts dimiates Fab., Spec. Ins., I, 1781. 332.

Black; elrtra pale rellow with tips and sometimes the outer and sutural margins black in male: apical third black in female; antennse of male pale rellow: of female piceous. the two basal joints reddish. Thorax without apical impression. the hind lobe emarginate; surface coarsels and densels punctate; elytra flat. sparsely punctured. rapidly narrower and rer $r$
acute at tip. Length $5-9 \mathrm{~mm}$.

Vigo, Knox and Gibson counties; scarce. July 10-August 11. Occurs especially on the flowers of the narrow-leaved mountain mint, Pigcnanthemum Tinifotium Pursh. The male is evidently rare, as but one of the ten specimens at hand is of that sex.

\section{2 (8177). Rhipiphores Pectixates Fab.. Srst. Ent.. 179s. 263.}

Color exceedingly variable. ranging from bod entirely black. except a reddish abdomen. to black with thorax and elytra reddish-rellow: antennse of male usually reddish with the branches black: those of female black with tro basal joints reddish. Structural characters as given in key.
Length 4-7.5 $\mathrm{mm}$. 
Lake, Fulton and P'utnam counties; scarce. July 4-July 31. A single female of var. tristis Fab., wholly black, was taken in Putnam County, July 25.

2533 (8178). Rhipipiorus cruentus Germ., Ins. Spec. Nov., 1824, 168.

Color variable; in typical cruentus, body and legs entirely black; elytra red, apex and narrow basal margin black; antenne and abdomen black, the latter very rarely red (male), abdomen red, very rarely black (female) ; in var. rufus Lec, body above, beneath and legs reddish-yellow; antenne black with pale basal joint. Elytra contiguous for nearly half their length, then obliquely narrowed, not acuminate at tips. Length $5-7.5 \mathrm{~mm}$.

Perry County; rare. June 17. Our only species having the second joint of hind tarsi longer than third. A member of the Austroriparian fauna.

2534 (8179). Rhipiphonus mimbatus Fab., Ent. Syst., II, 1798, 112.

Head, thorax, under surface, femora and middle and hind tibire reddish-yellow; thorax with an oval black spot on disk; elytra either wholly black or pale yellow with the margins and suture black; antenne, except the two basal joints, tarsi and front tibiæ, black. Vertex smooth, convex. Thorax with hind angles and basal lobe much prolonged, the latter not notched at tip; surface sparsely and shallowly punctate. Length 6-10 mm.

Southern two-thirds of State; scarce. July 10-August 17. Occurs on flowers of various Compositce. The top of head and sides of meso- and metasterna are often black.

R. Alavipennis Lec., length 7.5-10 mm., is known from Pennsylvania, Georgia. Illinois and westward; $R$. bifoveatus Horn, black, elytra brownish, darker at base, with small pale spot one-fourth from humerus, length $11 \mathrm{~mm}$., was described from Illinois; R. linearis Lec., Jinear, length 4 mm., was described from Kentucky.

\section{Mrodites Latr. 1819. (Gr., "like a mouse.")}

Wedge-shaped species having the elytra very short, wings not folded; antenne fan-like in both sexes. They occur on the flowers of goldenrod and other Composite in August and September. One species is known from the State.

2535 (8187). Mrodites Fasciatus Say, Journ. Phil. Acad. Nat. Sci.. III, 1824, 274 ; ibid. II, 162.

Black, feebly shining: legs and elytra yellow, the latter with base and spot near apex fuscous. Vertex prominent with a median carina. Thorax conical with a median impressed line; surface, as well as that of head. finely and densely punctate. Elytra one-third the length of abdomen. widely separated, sparsely punctate. Length 4-6 $\mathrm{mm}$.

One specimen in Webster collection labeled "Ind." Taken by Dury near Cincinnati; also known from Illinois and Pennsylvania. 


$$
* * *
$$

It will be seen that, exclusive of the Rhynchophora, 2,535 species of Coleoptera are known to have been taken within the bounds of Indiana. In addition, 777 species have a known range which renders it probable that they may also occur within the State. These have been included in the keys and, in most instances, brief mention has been made in the body of the text of their color, length and range. They can, therefore, for the most part, be readily identified by future collectors.

While the number of species which may occur but have not been taken may seem very large, it must be remembered that no continuous collecting by trotined coleopterists has been done, but only such species taken as time and opportunity afforded during the intervals from other work. It is very probable that two or three seasons devoted solely to collecting would raise the number of species, aside from the Rhynchophora, to more than 3,000.

The following table of families shows the number of species of each which are known to occur, and are therefore listed and described; also the number of species of each family which are included in the keys as being of probable occurrence within the State. The forms listed as varieties are not included:

\begin{tabular}{|c|c|c|c|}
\hline I. & $\begin{array}{ccc}\text { Family. } & \ddots & \text { No. } \\
\text { Cicindelidxe } & \ldots \ldots \ldots \ldots \ldots\end{array}$ & $\begin{array}{l}\text { f Species } \\
\text { to Occur. } \\
16\end{array}$ & $\begin{array}{c}\text { No. of Species of } \\
\text { Probable Occurrence. } \\
1\end{array}$ \\
\hline II. & Carabidx .............. & 366 & 75 \\
\hline III. & Haliplidie .............. & 10 & 1 \\
\hline IV. & Dytiscidæ .............. & 70 & 23 \\
\hline V. & Gyrinide $\ldots \ldots \ldots \ldots \ldots$ & 15 & 4 \\
\hline VI. & Hydrophilidre .......... & 54 & 14 \\
\hline VII. & Leptinidx .............. & 1 & 0 \\
\hline VIII. & Silphidr .............. & 35 & 17 \\
\hline IX. & Scydmænidæ ........... & 21 & 19 \\
\hline $\mathrm{X}$. & Pselaphidx ............ & 41 & 42 \\
\hline XI. & Staphylinidr ........... & 304 & 119 \\
\hline XII. & Trichopterygidæ ......... & 8 & 12 \\
\hline XIII. & Scaphidiidr ............ & 13 & 5 \\
\hline XIV. & Phalacridæ ............ & 9 & 2 \\
\hline $\mathrm{XV}$ & Corylophidre ........ & 8 & 9 \\
\hline XVI. & Coccinellidx $\ldots . . \ldots$. & 49 & 4 \\
\hline XVII. & Endomychidre .......... & 10 & 2 \\
\hline XVIII. & Erotylidx ............. & 22 & 4 \\
\hline XIX. & Colydidx $\ldots \ldots \ldots \ldots \ldots$ & 14 & 10 \\
\hline $\mathrm{XX}$. & Rhyssodidx ........... & 2 & 0 \\
\hline XXI. & Cucujidæ .............. & 17 & 8 \\
\hline
\end{tabular}


No. of Species

Fanily.

XxiI. Cryptophagidie ..........

XXIII.' Mycetophagidæ ........... 12

XXIV. Dermestidx ............ 18

XXV. Histeridx ............. $60^{\circ}$

XXVI. Nitidulidæe ............. 49

XXVII. Lathridida ............. 14

XXVIII. Trogositidie ............

XXIX. Monotomidie ..........

XXX. Derodontidx ...........

XXXI. Byrthida ............. 8

XXXII. Georyssidx ............ 0

XXXIII. Parnidie .............. 7

XXXIV. Heteroceridie ........... 7

XXXV, Dascyllidie ............. 15

xxxVI Rhipiceridæ ............ 3

XXXVII. Elateridx .............. 148

XXXVIII. Throscidre ............ 5

XXXIX. Buprestidx ............ 56

XL. Lampyridx $\ldots \ldots \ldots \ldots$. $6 \mathrm{~S}$

XLI. Malachiidx ............ 17

XLII. Cleridx ............... 28

XLIII. Ptinidx ............... 35

XLIV. Bostrichidx ........... 13

XLV. Cupesidx .............. 1

XLVI. Lymexylonidx .......... 2

XLVII. Cioidæ ................ 14

XLVIII. Sphindidx ............ 1

XLIX. Lucanidx ............. 8

L. Scarabæidæ ........... 150

LI. Spondylidx ........... 2

LII. Cerambycidx ........... 147

LIII. Chrysomelidx .......... 265

LIV. Bruchidæ ............. 15

LV. Tenebrionidx ......... 52

LVI. Cistelidæ .............. 23

LVII. Lagriidæ ............. 4

LVIII. Melandryidx ........... 29

LIX. Pythidx .............. 3

LX dedemerida ............ 5

LXI. Mordellidx ........... 45

LXII Anthicidx ............ 40

LXIII. Pyrochroida .......... 6

LXIV. Meloidx ............ 22

LXV. Rhipiphoride ........ 5

2,535
No. of Species of probable occurrence. 


\section{GLOSSARY OF TERMS USED IN TEXT.*}

Abbreviated.-Cut short; not of usual length.

Abdomen.-The third or hindmost division of the insect body; see page 18 . Abdominal.-Belonging or pertaining to the abdomen.

Aberrant.-Unusual; out of the ordinary course.

Aborted.-A structure developed so as to be unfit for its normal function.

Abrupt.-Suddenly or without gradation.

Accessory.-Added, or in addition to.

Acicular.-Needle-shaped; with a long, slender point.

Aciculate.-A surface that appears as if scratched with a needle.

Acuminate-Tapering to a long point.

Acute.-Pointed.

Adult.- The stage when an insect is sexually mature and ready to repro-

duce normally.

Aneous.-Shining bronze or brassy.

Alleghanian faunal area.--That part of the Transition life zone comprising

the greater part of New England. New York, Pennsylvania, Michigan,

Wisconsin, Minnesota, and the Alleghanies from Pennsylvania to

Georgia ; also a part of the northern thirds of Indiana and Inlinois.

Alutaceous.-Covered with very minute cracks or wrinkles.

Ambulatorial setw.-Specialized hairs or bristles situated on the rentral

segments of the abdomen of some beetles.

Angulate.-Forming an angle; when two margins meet in an angle.

Anmulate-Ringed or marked with colored bands.

Ante.-Before; used as a prefix.

Antenna; pl., Antennc.-Two jointed, sensory organs, borne, one on each

side of the head. commonly termed horns or feelers; see page 11.

Antennal groores.-Carities in which the antennie are located or concealed.

Apex.-That part of any joint or segment opposite the base by which it is

attached.

Apical.-At, near or pertaining to the apex.

Appendiculate.-Bearing appendages: said of tarsal claws that have processes at base.

Appressed.-Closely applied to.

Apterous.-Without wings.

Aquatic.-Living wholly in water.

Arcuate-Curved like a bow.

Attenuated.-Drawn out; slender; tapering.

Austroriparian faunal area.-That part of the Lower Austral life zone correring the greater part of the South Atlantic and Gulf States. It extends over the southern third of Indiana, overlapping the Carolinian faunal area of the State.

*The definitions of the terms here given, are, for the most part, taken from a little work entitled "Explanation of Terms Used in Entomology," by Prof. J. B. Smith, State Entomologist of New Jersey. 
Band.-A transverse marking broader than a line.

Bar:-A short, straight band of equal width.

Basal.-At or pertaining to the base or point of attachment to or nearest

the main body.

Base.-Jhat part of any appendage which is nearest the body; on the thorax that portion nearest the abdomen; on the abdomen that portion nearest the thorax.

Beak:-Any notable prolongation of the front of the head.

Bicolored.- With two colors that contrast to some extent.

Bidentate. - Two-toothed.

Bifid.-Divided into two parts; split.

Bipectinate.-Antenne having comb-like processes on each side of each joint. Boreal.-From or belonging to the north.

Borer.-Applied to an insect or larva that burrows or makes channels in woody or other regetable tissue.

Brassy.-Yellow, with the iustre of metallic brass.

Bristle.-A stiff hair, usually short and blunt.

Bronze.-The color of old brass.

Canaliculate.-Channelled; longitudinally grooved.

Capillary.-Long and slender like a hair.

Carina; pl., Carinc.-An elevated ridge or keel, not necessarily high or acute.

Carinate.-A surface having carinæe.

Carnivorous.-A feeder upon flesh food.

Carolinian faunal area.-That area of the Upper Austral life zone, including nearly all of Iowa, Missouri, Illinois, Indiana, Ohio, Maryland and Delaware; more than half of West Virginia, Kentucky, Tennessee and New Jersey and large areas in Alabama, Georgia, the Carolinas, Virginia, Pennsylvania, New York, Michigan and South Ontario.

Cartilaginous. - Of the consistency of cartilage or gristle.

Chelate.-Bearing a chela or claw; applied when claws are capable of being drawn down or back upon the last tarsal joint.

Chitin.-The material forming the hard parts of the insect body.

Cicatrix.-A scar; an elevated, rigid spot.

Ciliate.-Fringed; set with even, parallel hairs or soft bristles.

Cinereous.-Ash-colored; gray tinged with blackish.

claws. - The claw or hook-like structure at the end of the foot or tarsus.

Cleft.-Split; partly divided, longitudinally.

clypeus. - That portion of the head before or below the front, to which the

labrum is attached: see page 9.

coadapted.-Formed so as to work together to one end.

Common.--Of frequent occurrence; occurring on two adjacent parts ; a band

or fascia is common where it crosses both elytra.

Concave.-Hollowed out.

Confuscl.-A marking with indefinite outlines; a rumning together as of

lines and spots without definite pattern.

Conical.-Cylindrical, with a flat base, tapering to a point.

Connate.-United at base, or along the whole length. 
Contiguous.--So near together as to touch.

Contracted.-To draw or drawn together; to reduce, or reduced in size by contraction.

Cordate.-Heart-shaped.

Cordiform.-Cordate.

Coriaeeous.--Leather-like; thick, tough and somewhat rigid.

Corneous.--Resembling horn in texture.

Costa.-Any elerated ridge that is rounded at its crest.

Coxa; pl., Coxa.-The basal segment of the leg, by means of which it is articulated to the body.

Coxal cavity.-The opening or space in which the coxa articulates; see page 15.

Crenate--Scalloped, with rounded teeth.

Crenulate.-With small scallops, evenly rounded and rather deeply curved.

Crest.--A prominent longitudinal carina on the upper surface of any part of the head or body.

Cupreous.-The metallic red of pure shining copper.

Cylindrical.--In the form of a cylinder or tube; round, elongate, of equal diameter throughout.

Deflected.-Bent downward.

Deflexed.-Abruptly bent downward.

Dehiscent.-Separating toward the tips.

Dense.-Thickly crowded together.

Dentate.-Toothed; with acute teeth, the sides of which are equal and the tip is above the middle of base.

Denticle.-A small tooth.

Depressed.-Flattened down vertically ; opposed to compressed.

$D i$-As a prefix $=$ two.

Dilated.-Widened, expanded.

Disk.-The central upper surface of any part; all the area within a margin.

Distant.--Remote from; standing considerably apart.

Diurnal.--Such insects as are actire or habitually fly by day only.

Divarieate.-Spreading apart; tarsal claws when arising at opposite sides of the joint and separating widely.

Divergent.-Spreading out from a common base; tarsal claws when they spread out only a little.

Dorsal.-Of or belonging to the upper surface.

Dusky.-Somewhat darkened; pale fuscous.

Elliptical.-Oblong-oval, the ends equally rounded.

Elongate.--Drawn out; lengthened; much longer than wide.

Elytra.-See page 15 .

Elytron.--Singular of elytra.

Entire.-With an even, unbroken margin.

Epimeron; pl., Lipimera.--See page 14.

Epipleura; pl., Epipleura.-The deffexed or inflexed portions of the elytra immediatèly beneath the edge.

Episternum.--See page 14.

Equal.-Of the same length, size or shape. 
Erect.-Standing upright; not necessarily perpendicular

Evaneseent.-Disappearing; becoming gradually less.

Evident.-Easily seen or recognized.

Expanded.-Spread or flattened out.

Explanate.-Spread out and flattened; applied to a margin.

Lxserted.-Protruded; projecting beyond the body.

Exude.-To ooze or flow slowly througl minute openings.

Faeet.-A small face or surface; one of the parts, areas or lens-like divisions of the compound eye.

Family.-A division of classification including a number of genera agreeing in one or a set of characters and so closely related that they are ayparently descended from one stent; opinionative and indicated by the termination $i d \propto$.

Fuseia.-A transrerse band or broad line; it is common when it crosses botll wings or wing covers.

Fauna.--The assemblage of animals inhabiting a region or country.

Femur; pl., Femora.--The thigh; see page 17.

Ferruginous.--Rusty red-brown.

Filament.-A thread; a long, slender process of equal diameter throughout.

Filiform.-Thread-like; slender and of equal diameter.

Flabellate.-With long, flat processes folding like a fan.

Flavo-testaceous.-Light yellow-brown.

Flying-hairs.-Very long. slender surface lairs set in punctures.

Fossurial.-Formed for or with the habit of digging or burrowing.

Fovea; pl., Forea.-A shallow depression with well marked sides; a pit.

Fragile.-Easily breakable; thin and brittle.

Free.-Unrestricted in movement; not firmly joined with or united to any

other part.

Front.--The anterior portion of head; see page $S$.

Fulvous.--Tawny; light brown with much yellow.

Funicle.-The joints between the scape and club in elbowed antennse.

Fuscous.-Dark brown, approaching black.

Fusiform.-Spindle-shaped; tapering gradually to each end.

Gena; pl., Genc.-The cheeks; includes that portion of the head on each

side below the eyes, and extends to the gular suture.

Geniculate.-Elbowed; abruptly bent in an obtuse angle.

Genus.-An assemblage of species agreeing in some one character or series of characters; usually considered as arbitrary and opinionative.

Glabrous.-Smooth; free from all vestiture.

Glancus.-Shining sea-green; whitish-blue inclining to gray lavender.

Globose.-Formed like a globe or sphere.

Gramulated.-Covered with small grains.

Gramule.-A little grain or grain-like elevation.

Gregarious.-Living in societies or communities; but not social.

Griseus.-Light gray; a mixture of white and black.

Group.-A division of classification used indefinitely for a series of allied species, genera or larger assemblages.

Gular suture.-The line of division between the gula or throat and the genie or cheeks. 
Habitat.-The region or place which an insect inhabits.

Head.-See page S.

Hemi.-As a prefix means half.

Herbivorous.-Feeding upon plant tissue; a leaf feeder.

Hetero.-As a prefix, unequal; different from.

Heterogeneous. - A mixture of different forms ; abnormal.

Heteromera.-Coleoptera in which the front and middle tarsi are 5-jonted and the hind ones 4-jointed.

Hibernate.-To pass the winter in a dormant condition; usually applied to the imago.

Hirsute.-Clothed with long, strong hair; shaggy.

Hispid.-Bristly; sparsely set with short, stiff hair.

Hoary.-Corered with a fine, white, silvery pubescence; pruinose.

Homogeneous.-Of the same kind or nature; similar in texture or parts.

Humeral.-Relating to the shoulder or humerus.

Humeral angle.-In Coleoptera the outer front angle of elytra.

Humeral carina.-An elevated ridge or keel on the outer front angle of elytra.

Humerus; pl., Humeri.-The shoulder; the basal front angle of elytra.

Imago.-The adult or sexually dereloped insect.

Incised.-Notched or deeply cut into.

Inferior.-Beneath, below or behind; a term of position.

Inflected.-Bent inward at an angle.

Infra.-Below or beneath; opposed to supra.

Infuscated.-Smoky gray-brown, with a blackish tinge.

Insectivorous.-Feeding upon or devouring insects.

Insertion.-The point or place where a part is inserted.

Interocular.-Between the eyes.

Interrupted.-Broken in continuity, but with the tips of the broken parts

in a right line with each other.

Interval.-The plane surface between the elytral striæ.

Intricate.-Irregular; confused; applied to markings and sculpture.

Iridescent.-A surface which reflects a play of changeable colors.

Irregular.-Unequal, curved, bent or otherwise twisted or modified; without order or symmıetry.

Key.-A tabular or other arrangement of species. genera or other classification according to characters that serve to identify them.

Knee.-The point of junction of femur and tibia.

Labial.-Referring, pertaining or belonging to the labium.

Labium.-The lower lip.

Labrum.-The upper lip; covers the base of the mandibles and forms the roof of the mouth.

Lamella.-A thin plate or leaf-like process.

Lamina; pì., Lamince-A chitinous plate or plates.

Laminate.-Formed of thin, flat lavers or leaves.

Lanceolate.-Lance- or spear-shaped; oblong and tapering to the end.

Larva; pl., Larva.-The second stage of insect development.

Lateral.-Relating. pertaining or attached to the side.

Leathery.-Haring the appearance or texture of leather. 
Ligula.-see page 10.

Line.-A narrow streak or. stripe.

Lincar.-straight; in the form of a right line.

Lobe-Any prominent, roundea mocess or excrescence on a margin.

Longitudinal.-In the direction of the long axis.

Lumulc.-A lunate mark or crescent.

Luteous.-Pale clay rellow.

Waculate.-Spotted or marked with figures of any shape. of a color differing from the ground.

Mandibles.-The lateral upper jars of a biting insect.

Iargin.-That portion of a surface within the edge, bounded on the inner. side by the submargin and consisting of a more or less dilated imaginary line.

Marginal.-Of. belonging to or near the margin.

Marilla; pl.. Maxilla.-See page 9.

Kaxillary patpi.-The first pair of palpi, borne on the maxilla.

Membranous.-Thin, skin-like, semi-transparent, like parchment.

I cutum.- See page 10.

I ceso.-Midale.

Ucsosternal cavity.-In Elateriare, the opening into which the prosternal spine is fitted.

Mcsosternat cpimera.-The narrom pieces separating the mesosternal irom the metasternal episterna.

Mesosternal episterna.-On each side of the mesosternum between anterior border and epimera; generally separated by a distinct suture.

Mesostcrmum. - The under side or breast of the mesothorax.

Mesothorax.-The second or middle thoracic ring; bears the middle legs and the front wings.

leta.-Posterior.

Wetal7ic.-Having the appearance of metal; applied to a surface or color.

Mctathorax.-The third thoracic ring or segment; bears the hind legs and second paix of wings.

W.L.-Millimeter : .001 meter $=.089$ of an inch; roughly, $25 \mathrm{~mm}$. are counted to an inch in measuring insects.

Moniliform.-Beaded like a necklace.

Wucronate.-Terminated in a sharp point.

Iuricate._-Armed with sharp, rigid points.

Tahed.-Not clothed: lacking restiture.

Tcck.--The slender connecting suture between head and thorax of such insects as hare the head free.

Noctm*nal.-Species that fly or are active at night.

Tormal.-Of the usual form or type.

sotched.-Indented. cut or nicked; usually a margin.

obconic.-Conic, with the apex pointing downard.

obcordate.--Inversely heart-shaped.

Obtiquc.-Any direction between perpendicular and horizontal.

oblong.-Longer than broad.

oborate.-Inversely egg-shaped; the narow end downmard.

[87-23402] 
Obscure.-Not readily seen; not well defined.

Obsolete.-Nearly or entirely lost; inconspicuous.

Obtuse.-Not pointed: an angle greater than a right angle; opposed to acute. Occiput.-That part of the head behind the rertex.

Oeellus.-A simple eye, consisting of ar single convex or bead-like lens.

Omnivorous.-A general feeder upon animal or regetable food. or both.

Opaque.-Without lustre; not transparent.

Orbicular.-Round and flat.

Outer margin.-The outer edge of wing. between apex and hind angle.

Oripositor.- The tubular or valved structure by means of which the eggs are placed; usually concealed.

Palpi.-Plural of palpus.

l'alpus. - A mouth feeler" tactile, usually jointed structures borne by the maxille (maxillary palpi) and labium (labial palpi).

Pectinate-Comb-shaped; with even branches like the teeth of a comb.

Penutimate. Next to the last.

Perfoliate-Divided into leaf-like plates; applied to antennæ with disk-like

expansions connected by a stalk passing nearls through their centers.

Perpendieular.-Upright; at right angles to horizontal.

Persistent.-Remaining constantly; always present.

Phosphorescent.-Shining or glowing in the dark. like phosphorus.

Piceous.-Pitchy black.

Pilose.-Clothed with down, or dense pile; with long. sparse hair.

Plane.-Level, flat; applied to a surface.

Plicate.-P̉laited; folded like a fan.

Pluri.-Used as a prefix, means many.

Poly.-Many, much.

Pore.-Any small, round opening on the surface.

Posterior.-Hinder or hindmost; opposed to anterior.

Pre-apical.-Before the apex.

Predaceous.-Applied to insects that live by presing upon other organisms.

Prehension.-Structures fitted for grasping or holding.

Process.-A prolongation of the surface, margin or an appendage.

Produced.-Drawn out; prolonged; extended from.

Prolonged.-Extended or lengthened beyond ordinary limits.

Prominent.--Raised or produced beyond the level or margin; standing ont

in relief by color or otherwise; conspicuous.

Pronotum.-The upper or dorsal surface of thorax.

Propygidium.-The dorsal segment or tergite in front of the pygidium. some-

times left exposed in Coleoptera.

Prosternal.-Belonging to the prosternum.

Prosternal grooves.-Occur laterally in some beetles to receire the antennie.

Prosternal lobe.-In some Coleoptera an anterior prolongation of the pro-

sternum which more or less conceals the mouth from below.

Prosternal spine.-The curred spine which extends backwird into a mesosternal cavity.

Prosternal suture.-That suture of prothorax which separates the sternum

from the pleural pieces.

Prosternum.-The fore-breast: the sclerite between the fore legs. 
Prothorux.--The first thoracic ring or segnent; bears tlue front legs but no wings; in this work referred to as "thor"ax" nierely.

Pruinosc.-Hoary; as if covered with a fine frost or' dust.

Pubcscent.-Downy; clotlied with soft, sliolt, fine, closely set hail.

Punctate.-Set witl impressed points or punctures.

Puncture.-An impression like that made by a needle.

Punctured.-Marked with small impressed dots.

Pupa; pl., Pupa.-The intermediate stage between larva and adult.

Pupate.-To become a pupa; the act of becomins a pupat.

Pyyidim.-The last dorsal segment of abdomen left exposed by the elytra.

Quadrate.-Square or nearly so.

Quadrilateral.-Four-sided; formed or bounded by four lines.

Ramify.-To branch out in every directioll.

Rapacions.-Predatory ; capturing and eating prey.

Rare.-Seldom seen or found.

Rectangular.--In the form of a right or rectangle.

Recumbent.-Lving down; rectining.

Recured.-Bowed backward.

Reflected or reflexed-Angularly bent backward.

Remote.-Further remored than distant.

Reniform.-Kidney-shaped.

Restricted.-Confined to a limited area.

Reticulate.-Like net-work.

Retracted.-Drawu back; opposed to prominent.

Retractile.-Capable of being drawn in or retracted.

Rhomboidal.- Having the form of a rhomb. or quadrangular figure haring its four sides equal and its opposite lines parallel, with two opposite angles acute and two obtuse.

Rufous.--Brick-red.

Rugose.- Wrinkled; with irregular wared elevated lines.

Rugulose.-Minutely wrinkled.

Scabrose.-Rough like a file, witl small rilised points.

scape.-The long basal joint of an elbowed antenua in Coleoptera.

scrobcs.-Grooves on the sides of the mandibles.

Sculpture.-The markings or pattern of impression or eleration on an ely-

tra or other body surface.

Scutptured.-A surface. when marked with elevations or depressions or

both, arranged in some definite manner.

Scutcllum.-The triangular piece between the elytra it base.

Securiform.-Triangular-compressed: like the blade of a hatchet.

segment.-A ring or division bounded by incisions or sutures.

scmi.-Half.

scmicircular:- Like the half of a circle.

semi-cylindrical.-Tike a groove or half a cylinder.

sequence.-The order in which things follow.

series.-A group of species. genera or families. arranged to show agreement

in a common character which is not of sufficient importance to warrant the next higher division.

[SS-23402] 
servate.-Saw-toothed, the teeth set toward one end.

scrulnte. With numerous little saw teeth.

Seta; pl., seta.-A pointed bristle or long, stiff hair; slender, hair-like áppendages.

Sctaceous.-Bristle-shaped; slender, gradually tapering to a tip.

S'etiform. - In the form of a bristle or seta; when a slender, short bristle arises from a thicker basal joint.

Setigerous._-Bearing setre or bristles; e.g. punctures.

sharp.-With a pointed tip or thin edge; opposed to blunt.

simuate.-Applied to lines and margins with an in and out culve.

Simuato-truncate.-Truncated, with the mal'gin sinuate.

Smooth.-A surface without elevations or indentations.

Sparse.-Scattered; single hairs, scales or punctures set well apart.

Species.-An aggregation of indiriduals alike in appearance and structure, mating freely and producing young that themselves mate freely and bear fertile offspring resembling each other and their parents ; a species includes all its varieties and races.

Specific character.-A feature common to all individuals of a species, by means of which they may be distinguished from all other individuals of other species.

spherical.--In the form of a sphere; a body in which all diameters are equal.

Spindle-shapel.-Cylindrical, elongate, thicker in the middle, tapering to each end; fusiôtolm.

Spiniform. - In the form or shape of a spine.

Spinose. - Set with acute processes or spines.

spinules.-Little spines.

Spiracle.-A breathing pore; in the plural the lateral openings on the segments of the insect body through which air enter's the trachere.

Spur.-A short, stiff, generally blunt process, usually not articulated at its base.

Stage.-Refers to the period of development; e.... larval, pupal, etc.

sternum.-The breast: the middle portion of the under surface of thorax between the coxal cavities.

Stigmata.-The suilacles.

Stria; pl., Strice.-A longitudinal depressed line or furrow, frequently punctuled.

striate.-Marked with parallel, fine, implessed lines.

Stridulate. To make a creaking noise by rubbing together two ridged or loughened surfaces.

stripe.- I longitudinal streak of color different from the ground.

sub-clackte.-Somewhat thickened toward tip; but not quite club-shaped.

Subequul.--Similar but not ruite equal in size, form or other characters.

Subfamily.-A division of classification containing a group of closely allied

genera; different from other allied groups, ret not so as to make a family series, ending in ince.

Submarginal.-An imaginary portion of a surface outside of the disk and within the margin.

Subparallel.-Nearly parallel.

Subulate.-Awl-shaped; linear at base, attenuate at tip. 
sulcate.-Grooved: furrowed with broad. concare, parallel implessed lines. sulcus.-A furrow or groore.

Nirma.-Over ; above.

smoru-(orbital.-Situated above the eye.

suture-Tine line of junction of the clytra.

symmetrical.-Frenly developed on botlu sides.

Synomym. - A name applied to a species or genus that has been previously described and named.

T'arsal.- Relating to the tarsi or feet.

'incal lobes.-Membranous appendages arising from the under side of the taisil joints.

'T'arsus; pl.. 'T'ursi.-The foot; see page 17.

Tentacle. I flexible semsory or tactile process; in some cases retractile.

Terminal.- Situated at the tip or extremity; opposed to basal.

Terrestrial.-Liring on or in the land: opposed to aquatic.

Testuceous.-Dull yellow brown.

T'ctra.-Feur ; a combining form.

Thoracic.-Belonging or attached to the therax.

Thorax.- The second or intermediate region of the insect bodr, bearing the true legs and wings; made up of three rings, named in order, pro-. meso- and meta-thorax.

Tibia; pl. Jibia.-See page 17.

T'ip.-The extremity; the part furthest removed from the base.

Fomentose.-Corered with fine hair, so matted together that particular hairs annot be separated.

Tooth.-An acute angulation; a short, pointed process from an apyendage or. margin.

Transition sone. - The transcontinental belt in which the austral and boreal elements overlap.

Transhucent.- Semi-transparent; admitting the passage of light but not of vision.

Transparent.-So clear as not to obstruct vision.

Transtcrsc. - When the longest diameter is across the body.

Trapezoidal.-A four-sided plane of which two sides are parallel and two are not.

Tribe.-A term of classification less than a subfomily: usually ending in imi. Tricarinate.-With three keels or carina.

Trifid.-C'left into three parts or ellds.

Trochanter.-A segment, sontetimes divided, between the coxa and femur. sometimes fused with the fenur.

Trochantin.-The basal part of the trochantel when it is two-jointed: in Coleoptera, a piece often present on the outer side of and sometines movable on the coxa.

Trumcute.-Cut off squarely at tip.

Tuberele.-A little solid pimple or small chitinous button.

Tubcrulate.-Formed like a tubercle; a surface corered with tubercles.

Type.-A unique or single specimen selected from a series and labelled by the describer to represent his mame and description.

Typiral. The normal or towal form of a species: agreeing with the type form. 
Umbilicate.-Navel-shaped, or resembling a navel.

Umbone.-An embossed, elevated knob situated on the humeral angle of elytra.

Unarmed.-Without spurs, spines or armature of any kind.

Undulated.--Obtusely waved in segments of circles.

Unequal.-Unlike in size, form, development or other characters.

Unicolorous.-Of one color throughout.

Unique.-One only; unlike any other.

Tariety--Any departure from the normal type of a species which, while retaining the specific characters, is yet recognizably different because of the climatic, seasonal or other influences; may occur with the type form or as a geographical race.

Ventral.-Pertaining to the under surface of abdomen.

Vermicular.-Worm-like, tortuous; resembling the tracks of a worm.

Verrucose.-Having little hard lumps or wart-like elevations.

icrtex.- The top of the head between the eyes, front and occiput.

Festiture.-The surface clothing, whether of a hairy or scaly character.

i iolaccous.-Violet colored; a mixture of blue and red.

Vitta.-A longitudinal colored line.

Vittate.-Striped.

Whorl.-A ring of long hairs or other appendages arranged around a center like the spokes around the hub of a wheel.

Yellow.-Used without modification is sulphur or lemon yellow. 


\section{INDEX TO FAMILIES AND GENERA.*}

Abstrulia, 1288.

Icanthocinus, 1079.

lcanthoderes, 1070.

1cholerops, 304.

Achryson, 1021.

t cidota, 477 .

Acilius, 233

Acmæodera, 793

Icmaops, 1049.

tcritus, 626.

Actenodes, 792.

lctium, 332.

Actobius, 391.

Acupalpus, 190.

Acylomus, 499.

tcylophorus, 368.

tdalia, 515

Idelocera, 713 .

Adelothyreus, 707.

tderocharis, 430 .

idoxus, 1135 .

Adranes, 306.

Egialia, 921

Eletes, 627 .

Igabetes, 224

lgabus, 224

Agathengis, 579 .

Agathidium, 289

Agelasa, 1164

dolvptus, 290

gonoderus, 175

Agrilus, 796

Agriotes, 739.

Alaus, 717 .

leochara, 363

Alindria, 663.

Allecula, 127.2.

lllopoda. 1300.

Ilorthina, 996.

iphitobius, 1256 .

llymeris, $8+6$.

Amara, 102.

I marochara, 361.

Amblyderus, 1343 .

Amphicerus, 889.

Amphicrossus, 646 .

Amphionycha, 1095.

Anædus, 1258 .

Anamorphus, 58.

Inaspis, 1310

Inatis, 516.

inatrichis, 171

Inchastus, 726 .

inchylarthon, : :-2.

Anchytarsus, 68?

Ancyronyx, 682.

Androchirus, 128.

Anillus, 79.

Anisodactylus, 193

Anisosticta, 510

Inisotoma, 285.

Anisoxya, 1299.

Anobium, 871.

inomala, 981.

Inomoea 1113.

Inomoglossus, 169 .

Anophthalmus, 88 .

Anthaxia. 786.

Antherophagus, 574 .
I NTIICIDA, 1326

Inthicus, 1340.

Inthobium, 481.

inthocomus, 842 .

inthrenus, 595.

Apenes, 154.

Iphodius, 927.

Aphonus, 992.

lphorista, 538.

Aphthona, 1195

Apocellus, 472.

pristus, 149.

Ardistomis, 62.

Arhopalus, 1035.

irpedium, $47 \%$.

trohenoplita, 1261.

Arthrolips, 505.

Arthromacra, 1284.

Asaphes, 769.

Asclera, 1307.

Asemum, 1014.

Ispidoglossa. 61

itæuius, 924 .

Atheta, 352.

Athous, 759

Atimia, 1041.

Atomaria, 579.

Atranus, 137.

ittagenus, 592.

Attalus, 843

Aulonium, 554.

Axinopalpus, 151.

Axion, 518.

Babia, 1114

Bacanius, 625.

Bactridium, 669.

Badister, 117.

Brocera, 492.

Bassareus, 1117.

Batrisodes, 322.

Batyle, 1031

Bellamila, 1051.

Belonuchus, 379

Bembidium, 67 .

Berosus, 258.

Bibloplectus, 33:.

Bidessus, 212.

Bladus, 761.

Blanchardia, 826.

Blapstinus, 1252.

Blechrus, 150.

Bledius, 463.

Blepharida, 1207.

Blethisa, 50.

Bolboceras, 936.

Bolbocelosoma, 937.

Boletobius, 452.

Boletophagus, 1267.

Boletotherus, 1267.

Bolitochara, 344 .

Boros, 1303.

BOSTRICHIDA. 886 .

Bostrichus, 888 .

Bothrideres, 556 .

Brachyacantla, 520.

Brachyoluta, $31 \mathrm{~s}$

Brachylobus, 170 .

Brachyuus, $15 \%$.
Prachypterus, (2:80.

lirachys, 806 .

Iiradycellus, 191.

brontes, 568 .

BRVCHIDA, 1238.

Bruchus, 1235.

Bryaxis, 818 .

Bryoporus, 456.

BUPRESTIDA, 76 .

Buprestis, 78:,

BYRRHID 6,671 .

Byırhus, 673.

Bythinus, 317

Byturus, 589 .

Cacoplia, 1066.

Cienocala, 883.

('enoscelis, 578.

Canocorse, 1256

Calathus, 120.

Calitys, 666 .

Callida, 151

Callidium, 1018.

Calligrapha, 1154.

Callimoxys, 1029.

Calloides, 1035.

Calochromus, 815.

Calodera, 361.

Calopteron, 810 .

(alosoma, 46.

Campylus, 759

Canifa, 1300 .

Cantharis, 135s.

Canthon, 912.

Canthydrus, 208.

Capnochroa, 128:.

Carabide, 36.

Carabus, 44.

Cardiophorus, 720

Carebara, 1297.

Carpophilus, 6:1.

Cartodere, 655.

Casnonia, 138.

Cassida, 1229.

Cathartus, 563.

Catogenus, 564.

Catorama, 879 .

Cedius, $: 312$.

Celetes, 811 .

Celina, 214.

Centrodera, 1048

Ceophyllus, 309.

Cephaloscymnus, 531 .

Cephennium, 302 .

Ceracis, 900.

CERAIIBYCID 1007.

Ceratographis. 1079

Cercus, 630.

Cercyon, $26 \overline{5}$.

Cerotoma, 1163

Ceruchus, 907.

Cerylon, 557 .

(hotarthria. 25:.

chetocnema, $120 \mathrm{~s}$

Chalcolepidius. 717

Chalcophora. 7 .

Chalepus, 1226.

Chariessa, 859.

Charistena, 1225.

* Family names are in small capitals, generic names in Roman. 
Chauliognathus, 827 .

Chelsmorpha. 1233 .

Chennium, 309.

Chilocorus, 518 .

(hion. 102:2.

Chitalia, $3+6$.

Chlænius, 163.

Chlames, 1115.

Chceridium, 915.

Cholera. 2-s.

Chrissobothris. 7ss.

Chrysochus, 1141 .

Chrrsodina, 1149 .

Chrysomela, 1158

CHRYSOAELID. 109.5

Cicindela, 29.

CICINDELIDA, 27

Cinyra, isร.

CIOIDE, 895 .

Cis, 897.

Cistela, 1276 .

Cistelin $\mathrm{x}, 1 \geq 70$

Clambus, 291.

Cleride, St6.

Clinidium, 559.

Clirina, 59.

Clceotus. 940.

Clstanthus, i039.

CIrtus, 1040.

Cnemidotus, 203 .

Corcidula, 533.

Coccinella. 513.

COCCINELIDE, J06.

- Colambus. 214

Colostethus, s72.

Colaspis, 1147.

Colastus, 633

Colenis, 286.

Collops, $8+1$.

Colon. 28:.

Colydide, 549

Colrdium, 55t.

Colsmbetes, 229.

Coninomus. 654 .

Connophron, 296.

Conosoma, 449

Conotelus. 635

Copelatus, 223.

Copidita. 1306 .

Copris, 915.

Coptocrcla, 12:31.

Coptodera, 149.

Coptotomus, 2.28 .

Corphyra, 1329.

Corticaria, 656 .

CORILOPHID. 501.

Corrylophodes, 503 .

Corrmbites, 763.

Coscinoptera. 1113.

Cotalpa. 9s6.

Cotinis, 996.

Coxelus, 553 .

Cratacanthus, 175

Cregya, 859

Cremastochilus. 90s.

Creniphilus, $26+$.

Creophilus, 374

Crepidodera, 1212.

Criocephalus. 1014.

Crioceris, 1112.

Crosimus, 574 .

Crsptarcha. Gis.

C'rptobium, 417

('riptocephalus, 1120 .

Cryptohypnus, 722 .

CisptopHagide. Jfi?.

('rptophagus, 575.

Cryptophilus. 57:.

crsptopleurum. 270.

Cryptorhopalum, 594.

CLCLJIDE, 560.
Cucujus. 565.

Cupes. 89:3.

CTPESIDE, 89:.

Crbister. 235.

Cyocephalus, fitz.

Cychramus, $6+\bar{\imath}$.

Crchrus, 41.

Crsolocephala, os?.

Crllene, 103:.

Crmatodera. 849.

Crmbiodrta, 261 .

Crmindis, 153

Crparium. 491

Crphon. 695.

Critinus, 106:2

Crrtophorus, 1040 .

Cirtusa, 2ss.

Crtilus, 673.

I)acne. 544 .

DASCTLLIDE, 688

bearthrus, 592 .

I ecarthron. 316 .

Tectes, $107 \%$.

relius. 302.

Delphastus, 519 .

Ileltometopus. 704.

Dendroides. 1:4t9.

Dendrophagus, 566 .

Dendrophilus. 615.

Dermestes, 500.

JERMESTID E, ST.

IERODONTID, 670.

Derodontus. 670 .

Deronectes, 216 .

Desmocerus. 1044.

! Jesmopachria. 212.

Diabrotica, 1171.

Diachus. 1138.

Dianous. 407.

biaperis. 1260

Itibolia. 1221.

Dicælus, $11 \%$.

Dicerca iso.

Dichelontcha. 9.1.

Jicranopseiaphus. 1993.

Dicrepidius. 729.

Dilandius. 1337.

Dineutes, 240 .

Dinoderus, 890.

Iinopsis, 337.

Iiochus, 400 .

Dicedus. 1256

Tiphaula:a, 1204.

Diplochila, 113

Diplocolus, $57 i$.

Diplotaxis. 954.

Discoderus. 17s.

Disonceha. $11 \mathrm{~s} 6$.

Distenia, 1043.

Isitemnus, $8: 3$.

Initoma. is.

Doliema. 1251.

Dolopius, 742 .

I)onacia. 1099

Dorcaschema. 1065

Dorcatoma, s.:.

Dorcus, 906;

Drapetes, 774 .

I) rasterius, 73.5

Tromæolus, 70.5 .

Dromius, 149.

I) ryobius. 1021.

loryops. 67s.

1) rnastes, 093.

Iisschirius, 56 .

Trscinetus, 990

Disphaga, 1095

DITISCID E, 204

Drtiscus, 230.
Fburia, 1022.

Ectopria, 692

Eesrus, 1081.

Edaphus, 458

Elaphidion, 1023.

Elaphrus, is.

Elater. 730

ElATERID.E, 699.

Eleusis, 483.

Ellipotoma. 859.

Ellychnia, 81s.

Elmis, 679 .

Elonus, 1344.

Iimelinus, 1345

Emmesa. 1296.

Enchodes. 1297.

Enerclops, 1045 .

Endecatomus, SST.

ENDOMICHIDE. 533.

Endomschus, 537 .

Enicmus. 654.

Ennearthron. 900 .

Enoclerus. 852.

EntomophthaImus. 709

Ephelis, 481.

Ephistemus, is1.

Epicauta. 1359.

Epierus, 614.

Epilachna, 532.

Epitix. 1216.

Epuræa, 636.

Erchomus, 449.

Ernobius. 568.

Elos, 812.

Erotylathris. 556 .

EROTYLID玉, 53:.

Esthesopus. 7.2.

Eursthetus, 458

Eucicones, 502 .

Eucinetus, 691.

Eucnemis, 704.

Euconnus, 293.

Eucrada, s67.

Enderces, $10+0$.

Eudesma, 5.5?.

Eumicrus, 303.

Eupactus. 8Ts.

Euphoria, 997.

Euphorticus, 137.

Euplectus, 331.

Eupogonius. 10s?

Eupristocerus, 796 .

Eupsenius. 322.

Europs, 669

EurTgenius, 132s.

Eurppogon, 689.

Eurysphindus. 902.

Eustilbus, 500 .

Eustrophus, 1292.

Euptheia. 30s.

Euthiodes. 303

Eutochia. 12.5.

Eutplistus, Ss.

Erarthrus, 99.

Exema, 1116.

Exochomus, 518.

Falagria. 346.

Fidia. 1142.

Folnax, 0 -

Fustiger, 307.

Galerita. 140.

Galeruca. 1164 .

ralerucella, 1166.

Gastroidea, 1159.

Gaurotes. 1050.

Geodromicus, 47.

Geopinus. 174.

GEORTSSIOA 6T

Georrssus, $6 \overline{7}$. 
Geotlupes, 93s.

Gibbium, S64.

riliporles, 127

Glyphonyx, $7+2$.

Glyptina, 1194.

(iliptoma, 454 .

Glyptoscelis. 1136.

Ginathocelus. 1256.

(inorimus, 1602.

(in rpeta. 348 .

Goes, 1066.

(iracilia 102:2.

Graplisurus, 107s.

(i)aphoderes, 2:34.

(ilaphols, 114 .

(tivibulius, 1124.

(ronerus, $50: 3$.

Grynocharis, 666.

Grnandropus, 179.

Gyretes, 242.

GYIINTE 236.

Grvinus, 238

Gylonycha. 339.

Gyrophæna, $3+0$.

Habrocerus, 457 .

Hadrobregmus. ST1

Hæmonia, 1107.

HALIPLID E, 200.

Haliplus, 201.

Hallomenus, 1293.

Haltica. 119?.

Hamotus. 313.

Hapland $1 \mathrm{~s}, 12 \pm 8$.

Hartualus, 179

Helluomorpha. 15.5.

Helochares, 261.

IIelocombus, 262.

Helodes, 693.

Helophorus. 250.

Helops, 1268.

Hemantus. 1339.

Hemirhipus, $71 \mathrm{~s}$

Henoticus, 577.

Hesperobænus. 669

Hesperobium, 41?.

Hetrius, 614.

Heterachthes, 1026.

HETEROCELID F. 6S2.

Heterocerus, 65:.

Heterotlops, 368 .

Hetøemis, 1066.

Hipporamia, 511.

Hippopsis, $10 \$ 3$.

Hister, 602.

HISTERID $59 \mathrm{~S}$

Hololepta, 600.

Holoparamecus. 6.52

Holotrochus, $4 \overline{\mathbf{T}} 4$.

Holostrophus. 1293.

Homalium, 479 .

Homalota, 342

Hopatrinus, 1251.

Hoplandria, 350.

Hoplia, 949

Hoplosia, 1050.

Horistonotus, 721.

Hornia, 1357.

Iydaticus. 23:2.

Hrdnobius, 285.

Hrdnocera. S5.

Hydræua. 2.54.

Hrdrobius, 262.

Hidrocanthus. 208.

Hydrocharis. 257 .

Hidrochus, 25 i.

HYDROPHILID.E. 247

Hydrophilus, 254.

Hydroporus, 216 .

Hidroratus, 211.

Hrlecoetus. 894.
Ifrochares, To?.

Hylotiujes, 101!)

Hrmenorts, 1:7:3.

Hyperaspis, 521.

IIyperplatys, 1077 .

Hypnoidus, T2:3.

Hipocolus, 711.

Irypolampsis, 1206.

IIypophlous, 1265.

llybiosoma, 224 .

Ilybius, 222.

Incolia, 1259

Iphthimus, $12+7$.

Ips, 648 .

Isclualia $13+\mathrm{T}$

Ischiodontus. 729.

Ischylus, its.

Isomila, 127 .

Isoplastus, 2s?.

Labidomera. 11.5.

Lascobius, 259.

Iacconotus, 1302.

Laccophilus, 209.

Lacnocrepis, 170.

Lachnosterna, 9.5.

Lacon. 716.

Lactica, 1204 .

[æmophlveus, 566.

LAGRIIDE, 12St.

I amprohiza, 82:

I IIPYRID F, SOT.

Lansuria, $5+1$.

I appus, 1389

Lasconotus, $5.5:$

Lasioderma, 875

Lathrobium, 421.

I.ATHRIDIID.E, 651

Lathridius, 6.53.

Lebia. 143 .

Lema. 1110.

Leptacinus, 398

IFPTIYID.E, 271

Leptinotarsa. 1152.

Leptinus, 272 .

Ieptogenius, 436 .

Leptolinus, 398.

I.eptoschema, 761

Leptostrlus, 1071.

Leptotiachelus, 138.

Leptira. 1053.

Leptul'ges. 1075 .

Leptusa. 342.

Lesteva. 476 .

Ligrutus, 991.

Limnichus. $6 \bar{\imath} 4$.

Limonius, 7.5.).

Limulodes. 487.

Lina. 1160.

Liodes, 296.

Liopus. 1078.

Lispinus, 4S3.

Listotrophus. $37 \pm$.

Litargus, 5ร5.

Litochrus, 501

Loberus, 573.

Longitarsus, 1191.

Lopheros, 811.

Loxandrus, 110 .

LTCANID.E, 903.

Lucanus, 905.

Lucidota. S17.

Ludius, 736

Luperaltica. 1203.

Luperodes, 1176 .

Lutrochus, $6 \mathrm{~T}$ s.

Lrcoperdina, $53 \mathrm{~S}$.

Lictus. 891.

LTUEXYLONID.E, 894.

L.smexylon, $\$ 95$.
Vacratrid, 1,...2.

Jacrobasis, 13...

Marelodactylus, ?):?

Iaceonychus, (;5:.

yarelopogon, lise)

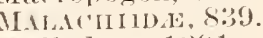

Mallodrya, 12!sl.

Ialporus, $13: 35$

Malthinus, s:is.

Maltliodes, s:3s.

IIantura, 121?.

Iastogenius, 79.

Matus, 2.2?.

Mecas. 1090 .

Uecynotarsus, 1:3:60.

Megalodacne, 54 t.

Megalops, 462.

Iegapenthes, $7: 36$

IIegarthrus, 482.

Megastilicus, 436 .

Megilla, 510

Mexorama, 876

Melanactes. 770 .

Melandrsa, ragf

IELANDRYIDE, 12S6.

Melanophila, is.

Melanophthalma, 658.

Melanotus, $7+4$.

Melasis. 70 :

Melba. $3: 38$.

Meligethes. 644 .

I leloe, 1352.

MELOID E, 1350 .

Meracantha, 1269.

Jerinus, 1247 .

Jelium, 101?.

Meronera, 349.

Vetabletus, 151.

Ietachroma. $114 t$

Mezium. S6t.

Microbregma, 872.

IIicrocara. 69:

Iicroclytus. $10+0$.

Iiclomalthus, s.94

Iicropeplus, 48.

Microrhopala. 1224 .

Microrhagus, 707

Microscapha, 1295.

Vicrotonus. 1306.

Molamba, 504 .

Molorchus, 102s.

Iona shus, 1132.

IIonocesta, 1164.

Monocrepidius, 727.

IIonohammus. 1063

Inonophylla. \&49.

IIonotoma. 667 .

VIоуото IIDE, 666.

ILonoxia, 1171.

yordella, 1311.

IIORDELLID E, $130 \mathrm{~S}$.

Iordellistena, 1315.

Morio. 66.

Murmidius, 558.

Mras. 89.

Iricetina, $53 \mathrm{~s}$.

ircetochares. 127?

MICETOPHAGID. 58.

Yrcetophasus 58.

irycetoporus, 4.5.

Mirchocertus, 5.5.

Ircotietus, $5+6$.

ircterus, 1302.

Myllæna. $38 s$.

IFoclirous 1186.

irodites, 1367.

Iystaxus. 1297.

Nacerdes, 1306.

Yanosella. 48T.

Narthecius. 566 . 
Nausibius, 564 .

Nebria, 52.

Necrobia, 861 .

Necrophilus, $27 \%$.

Necrophorus, 273

Necydalis, $10+4$.

Neladius, 302.

Nematodes, 710.

Nemognatha, 1354

Nemosoma, 662.

Nemotarsus, 143.

Neoclytus, 1037.

Neomysia, 516.

Nephanes, 489 .

Nicagus, 908 .

Nisaxis, 317 .

Nitidula, 640.

Nitidulin A, 628 .

Nodonota, 1147.

Nomaretus, 41.

Nomius, 66.

Nosodendion, $67: 2$

Nossidium, 486.

Nothodes, 762 .

Nothopus, 174.

Nothus, 1302.

Notiophilus, 51.

Notoxus, 1334

Nyctobates, 1246.

Oberea, 1091

Obrium, 1027

Ochodæus, 935

Ochrolitus, 501.

Ochthebius, 253.

Octotemnus, 901.

Octotoma, 1225.

Ocypus, 378 .

Odontreus, 938.

Odontonyx, 689

Odontosphindus, 902.

CEDEMERIDA, 1304.

Adionychis, 1180.

OEdostethus, 726.

Olibrus, 499

Oligomeris, $\$ 69$.

Oligota, 339

Olisthrrus, 458.

Olisthopus, 136.

olophrum, 478.

Omethes, 825 .

Omophron, 39.

Omosita, 643.

Oncideres, 1083.

Onthophagus, 917.

Oödes, 171.

Opressus, 302.

Orchesia, 1294.

Orphilus, 598.

Orsodacna, 1108.

Orthaltica, 1215.

Orthocis, 899.

Orthoperus, 505.

Orthopleura, 861.

Orthosoma, 1010.

Orthostethus, 737.

Osmoderma, 1001.

Osorius, 473.

Oxacis, 1307.

Oxygonus, 768 .

Oxypoda, 361.

Oxyporus, 459.

Oxytelus, 467 .

Pachybrachys, $112 \pi$.

Pachyonychus, 1207.

Pachyscelus, 807.

Pachyta, 1049

Prderus, 437.

Palaminus, 441.

Pallodes, 646.
I'anagæus, 65.

I'aramedon, 431.

Parandra. 1007.

Paratenetus, 1259.

['aratriarius, 117:

I'aria, î138.

PARNIDA, 675.

Paromalus, 615.

Pasimachus, 54.

Passalus, 908.

Patrobus, 87.

Pediachus, 566.

Pelecotoma, 1365.

Pelidnota, 986 .

Pelonomus, 678.

Peltis, 666.

Pentagonica, 154

Pentaphyllus, 1265.

Pentaria, 1309.

Penthe, 1290.

Penthelispa, 55.5.

Perigona, 136.

Perothops, 773.

Petalium, 877 .

Phalacrid $2,497$.

Phalacrus, 498.

I'hanæus, 917.

Phengodes, 824.

Phenolia, 642.

Phileurus, 994.

Philhydrus, 259.

Philonthus, 379

Philotermes, 243

Philothermus, 557.

Phlegon, 712.

Phlœepora, 360.

Phlootrya, 1298.

Phœnonotum, 270.

Phomalus, 1346.

Photinus, 821.

Photuris, 8.2.

Phylethus, 1265.

Phyllecthrus, 1177.

Phyllobrenus, 858.

Phyllobrotica, 1174

Phyllodecta, 1161.

Phyllotreta, 1196.

Phymaphora, 536.

Phymatodes, 1017

Physocnemum, 1017.

Physonota, 1229.

Phyton, 1027.

Pilopius, 311.

Pinacodera, 152.

Pinodytes, 277.

Pinophilus, 440.

Pisenus, 1289.

Pityobius, 759

Placusa, 341.

Plagiodera, 115?.

Plagionotus, 1034.

Platandria, 350.

Plateros, 814.

Platycerus, 907.

Platydema, 1262.

Platynus, 121.

Platystethus, 467.

Plectrodera, 1068.

Plegaderus, 624 .

Pleurophorus, 9:2.

Plochionus, 152.

Pløosoma. 544.

Pocadius, 643.

Podabrus, 828.

Poecilonota, 783.

Pogonocherus, 1080.

Polemius, 836.

Polyclasis, 817.

Polymøechus, 987.

Pomphopœa, 1364

Prasocuris, 1150 .
Prateus, 1260.

Priocera, S51.

Prionochæta, 280.

Prionocyphon, 693.

Prionus, 1011.

Prometopia, 642.

Protheca, 882.

Protinus, 48 ?

Psammodius, 922.

Pselaphide, 305.

Pselaphus, 314.

Psenocerus, 1062.

Psephenus, 677.

Pseudobæus, 842.

Pseudomedon, 432.

Pseudopsis, 458.

Psilopyga, 645.

Psylliodes, 1222.

Psyllobora, 517.

Ptenidium, 486.

Pterostichus, 90.

Pteryngium, 577.

Pteryx, 488.

Itilinus, 885.

Ptilium, 486.

Ptilodactyla, 690.

Ptinella, 490.

Ptinellodes, 488.

PTINIDA, 862.

Ptinus, 865.

Ptomophagus, 281.

Ptosima, 794.

Purpuricenus, 1030.

Pycnomerus, 556.

Pycnophus, 296.

Pyractomena, 820 .

Pyrochroa, 1348.

Pirochrolda, 1346.

Pylopyga, S19.

Pyrota, 136:.

Pyticera, 860 .

PYTHIDA, 1302.

Pytho, 1304.

Quedius, 369.

Rafonus, 329.

Ramecia, 330 .

Reichenbachia, 319.

Retocomus, 1328.

Rhabdopterus, 1147 .

Rhagium, 1048.

Rhanis, 536.

Rhantus, 228.

Rhexidius, 230 .

Rhexius, 329.

Rhinosimus, 1304.

RiI 1 PICERIDA, 696.

Rhipidandrus, 901.

Rhipidius, 1365.

RHIPIPHORID $A, 1364$.

Rhipiphorus, 1365.

Rhizophagus, 650 .

Rhopalophora, 1029.

Rhopalopus, 1017.

Rhymbus, 535 .

Rhyssodes, 559.

RHYSSODID无, 558 .

Romaleum, 1023.

Rybaxis, 317 .

Sacium, 504

Salpingus, 1304.

Sandalus. 698 .

Saperda, 1084.

Sapintus, 1342

Saprinus, 617.

Sarpedon, 710.

Saxinus, 1114

Scaphidema, 1265.

SCAPHIDIIDE, 490 . 
Scaphidium, 491.

seaphiomicrus. 497

sicaphisoma, 495 .

S:ARABXIDE, 909.

carites, 55.

Schizogenfus. 61.

schizophilus, 712

schizotus, 1349

sciocharella, 431.

Sciocharis, 430 .

sicirtes, 69t.

Scoprus, 43.3.

Scotobates, 1248 .

Scraptia, 1299

Scutopterus, 2:s.

SCYDUEXID.T, 291.

scydmænus, 301.

scrmnus, 525.

Selenophorus, 186.

Serica, 956.

Sericoderus, 504 .

Sericus, 762

Siagonium. 483.

Silis. 831

Silpha, 275.

SILPHID.E. 272.

Silvanus, 561.

Sinoxylon. $88 \mathrm{~s}$.

Sitodrepa, 870.

Smicrus, 489 .

smilia. 524.

Smodicum, 1015.

Soronia, 643.

spermophagus, 1235.

Sphridium, 265.

Sphæroderma, 1205.

Sphenostethus, 1012

SPIIINDIDE, 901.

Sphindus, 902.

Spilotus, 1297.

SPONDYIIDE, 1006.

STAPHYLINID $2,334$.

Staphylinus, 375 .

Statira, 1285.

Stelidotta, 611 .

Stenelmis, 680

Stenispa, $122 \mathrm{~s}$.

Stenolophus. 187.

Stenosphenus, 1031.

Stenotarsus, 539 .

Stenus, 401.

Stereopalpus, 1328.

Stetholiodes, 2ss.

Stethon, T03.

Stethorus, 531.

Stictocranius, 459 .

Stilicopsis, 439 .

Stilicus, 434 .

Strangalia. 10.51 .
Striooderma, 98.5

Stromatium, 1022.

Strongylium, 1270.

Sunius, 438.

Symbiotes, 536.

Symphora, 1298.

Synchita, 551 .

Synchioa, 1290.

Syneta, 1110 .

Systena, 1219.

Tachinus, 443 .

Tachycellus, 192.

Tachyporus, 446.

Tachys, 80.

Tachyusa, 347.

Tanilotes, $13 \pm 6$

Taphrocerus, soi.

Telephanus, 569 .

Telephorus, \$32.

Telmatophilus, $\div 73$.

Tenebrio. 1249 .

Tenebroides, 66 ?.

TENEBRIONID E, 1243.

Teretrius, 625 .

Tetracha, 28 .

Tetragonoderus, 142

Tetraonyx, 1359 .

'Tetraopes, 1093.

Tetratoma. 128s.

Tetropium, 1015.

Tetrops, 1093.

Thanasimus, 854 .

Tharops, 703.

Tharsus, 1257

Theca, 879.

Thermonectes, 234.

Thesium, 332.

Thinobius, 472 .

Thrimolus, 587.

THROSCIDE, 773 .

Throsins, 775 .

Tillomorpha, $10+0$.

Tillus, $8+9$.

Tinotus, 349

Tisactia, 581 .

Tmesiphorus. 310.

Tomarus, 574.

Tomoderus, 1337.

Tomoxia, 1310 .

Toxidium, 49.5.

Toxotus $10+6$

Trachysectus, 431 .

Tragidion. 1030 .

Trechus, 87.

Triachus, 11:34.

Tribalus, 614.

Tribolium, 1254.

Trichaitica, 1201.
Trichius, 1008.

Trichiusa, 351 .

Trichodes, 8.51.

Trichorlesma, 871 .

Trichopsenius, $44: 3$.

TRICHOPTERTEID.T, 48.5.

Trichopteryx, 4ss.

Tricrania, 1354

Triga, 48:3.

Trimiomelba, 3:32.

Trimioplectus, 338.

Trirhabda, 1164.

Tritoma, 547 .

Trogoderma, 593.

Trogophlous, 469.

Trogosita, 603.

TrogositIDE, 661.

Tropisternus, 255 .

Trox, 941.

Trypherus, 838.

Trypopitys. 872.

Tychus, 314 .

Tylonotus, 1026.

Tymnes, 1141 .

Trphoea, 587.

Typocel'us, 1052.

Typophorus, 1138.

Tyus, 313.

Tytthonyx, 824 .

Cloma, $125 \%$.

Valgus, 1004.

Vanonus, 1346.

Teraphis, 303.

Xantholinus, 394 .

Xanthonia, 1142 .

Xenistusa, 443 .

Yenodusa, 359 .

Xenorhipis, 787.

Xestobium, 868 .

Testocis, 899 .

Testurida, 350.

Xyletinus, 873.

Xylita, 1297

Xylopinus, 1248.

Xyloryctes, 992.

Xylotrechus, 1036.

Zamodes, 1027 .

Zenoa, 697 .

Venodusus, 855 .

Zeugophora, 1109

Zonantes, 1345

Zonitis, 1356.

7uphium, 140.

Zygogramma, 11ธ

Zyras. 358. 


\section{INDEX TO NEW SPECIES.}

Aleochara rufipes. 365.

Amarochara fencesi. 361.

Inomala pubescens. 984 .

Aphodius rolcotti, 932.

Arthromacra glabricoliis. 1285.

Atheta cariceps. $35 \pm$.

laurentiana. 357 . punctata. 355.

sulcata. 355.

Brocera punctipennis, 494.

Ladister laticeps, 118.

Bianchardia gracilis. \$26.

Bledins borealis, 465 .

Prachrnus gracilis. 160. pulchellus. 161.

Caloctera infuscata, 361.

Cathartus longulus. 564 .

Cis confusus, 899.

cornutus. 898.

falli. 898 .

Colon oblongulum. 283.

Conosoma carinula, 451. elongata, 450 .

colphyra brimnea. 1331.

Ditemnus latilobus. $\$ 37$.

Ditoma granulata. 552.

Donacia megacornis, 1103.

Enmearthron oblongus. 900.

Epurea durтi, 639.

Euconnus similis. 295.

Glyntoscelis liebecki, 1137.

Grrinus piceolus, 240.

Haltica æenescens, 1202. cuprascens. 1202. knabii. 1203.

Hister osculatus, 607.

Hydrochus sranulatus. 253. Hydroratus indianensis. 212.

Isomira similis. 1278 .
Lathrobium insanus. 424.

Leptusa elegans. $3 \pm 2$.

obscura, $3 \pm 3$.

Macrobasis flarocinereus. 1359.

Melanotus carinus, 752.

cribriventris. $\bar{\tau}+\bar{\tau}$.

debilis. $75 t$.

difficilis. 751.

divarcarinus. $75-1$.

lixus. 754 .

longicornis. $i t i j$.

pilosus. 751 .

prasinus. 752

Mordellistena confusa. 1316. hoosieri. 1325. testacea. 1321.

Ochthebius putnamensis, 253.

Oxтрoda palustris. 362 .

I'achrbrachrs elegans. 1127. sticticus. 1130.

Paramedon falli. 432.

Philonthus multipunctatus. $3 \$ 9$.

Phyllobrotica lengi. 1175.

Prasocuris oralis. 1151.

Rhantus confusus 229.

Saprinus lakensis. 623. oviformis. 622 . simulatus. 621.

Scaphisoma distincta. 196.

Serica carinata. 957 . intermixta. กร:

Stenelmis sulcatus. 681 .

Stenus similiatus. 404. suspectus. 408 .

Tachrporus pulchrus. 447 .

'Telephorus simpliunguis. 836 .

Trogophlœus poserensis. 471.

Xantholinus indianensis. 396. linearis, 395.

Zonitis sulcicollis. 1357 .

(Date of issue of this volume. September 20, 1910.) 


$$
\cdot
$$

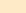





